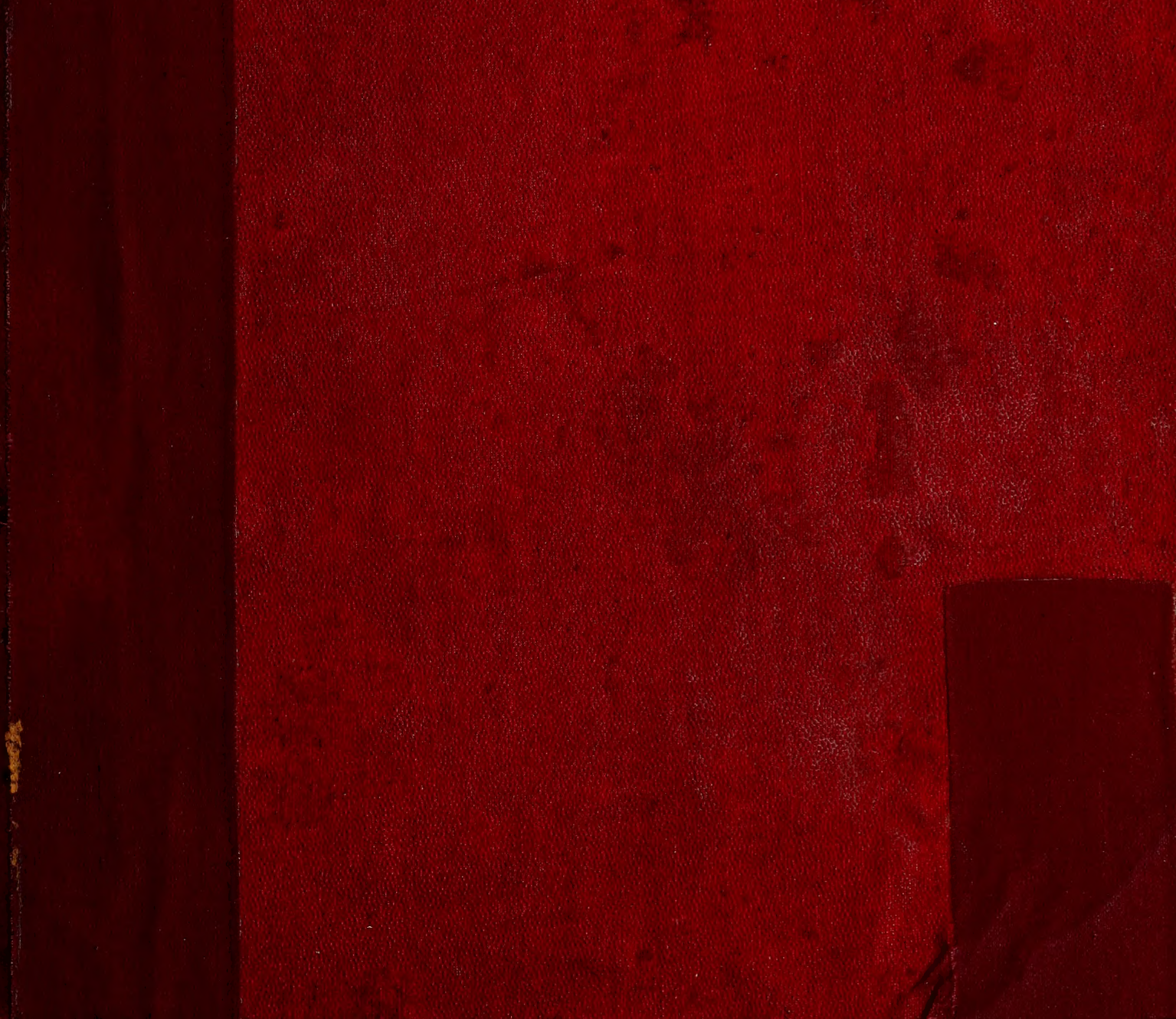




\section{C/4.35.-}

sutts

6. 2.2

$x>-2$

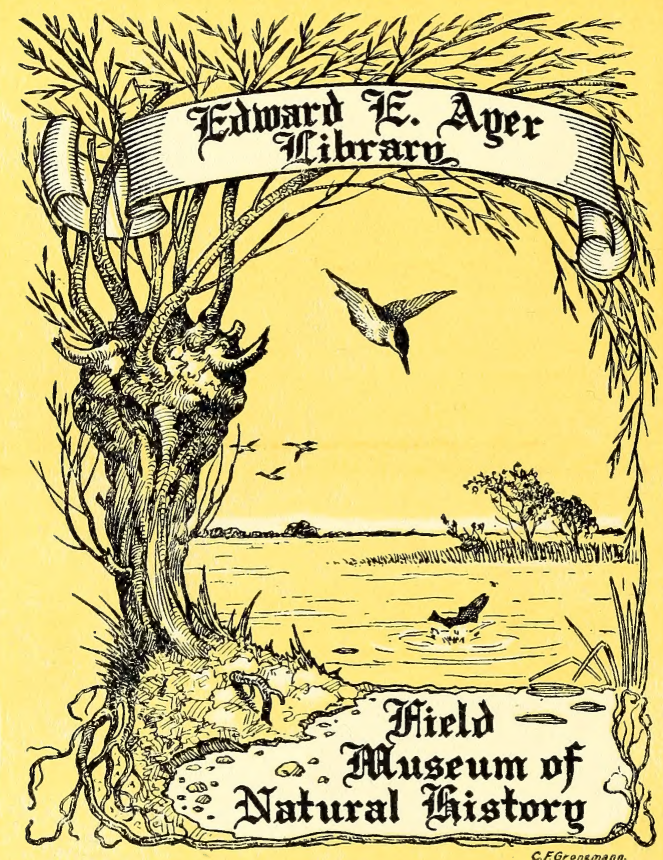



2 sole.

mHL

62,23 
$\%$ 
Taf. 4.

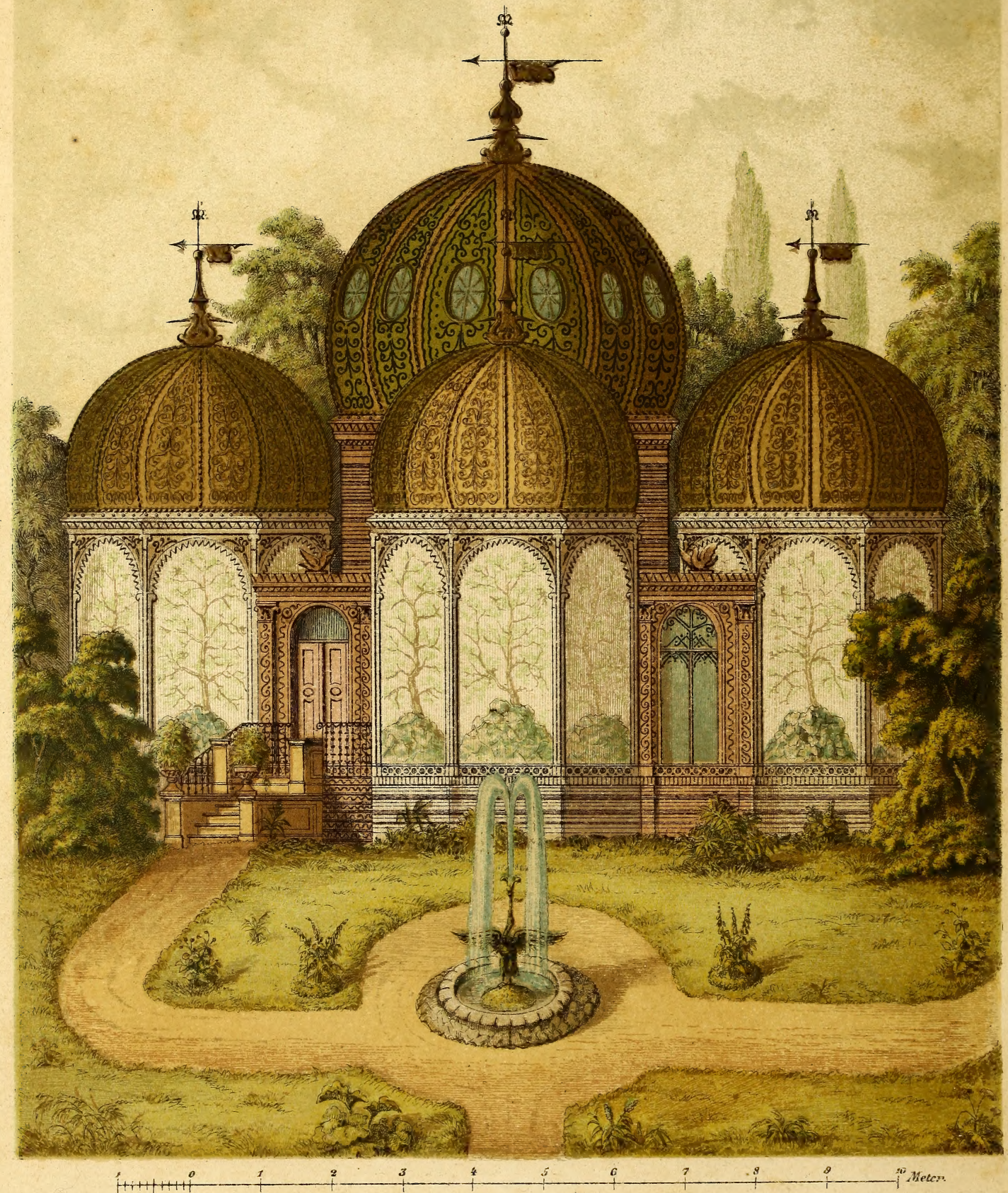

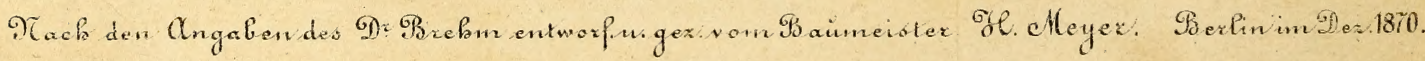
Ansicht des Thoggebauers. 


\title{
Èefantgeme כ̧öghel.
}

\author{
(5in $\mathfrak{5 a n d}=$ und Lefrbud
}

fïix

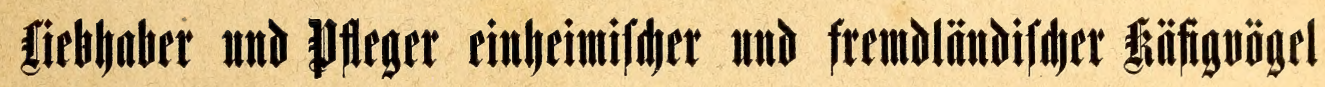

von

\section{4. (5. $25 \mathrm{rbm}$,}

in Berbinbung mit Bafbamus, Bodimts, Bolle, Eabmis, Eronau, Fiedter, Finid,

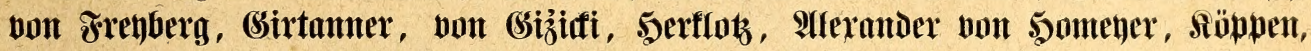

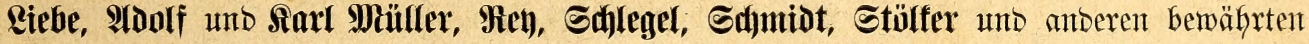
Bogeftrirten bes $\mathfrak{I n}=$ und $\mathfrak{A}$ Halandes.

\section{(Eriter Teil.}

Eriter $\mathfrak{B a n d : ~}$ pfleger und pfleglinge, Sittidne und fä̈rnerfrefler.

Mit 4 Iafelth.

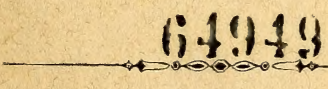

Leipzig unb soibelberg.

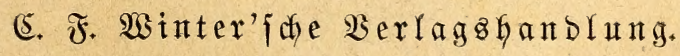

1872. 
R.B

Ayer

0,89

i 1

V.I
SF

461

B 81 .

Arfe Redhte vorbehalten. 


\section{(Geratdus frederik Wefterman,}

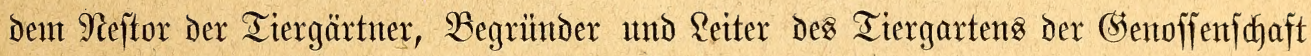

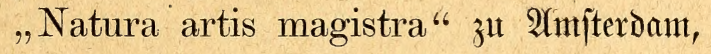

Dem eifrigen Förderer der Wiffenfdaft, dem erfahrenen Iierpfleger, dem liebenz= mürdigen Berufegenoffen utto Freutnde, 
als ein idymades Zeident feiner Berehrung, Freundjdaft und Riebe gemismet von Dem $\mathfrak{B e r f a f f e r . ~}$ 


\section{Bormort.}

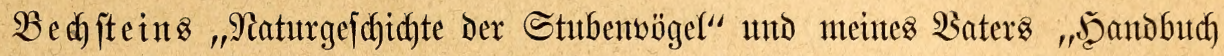

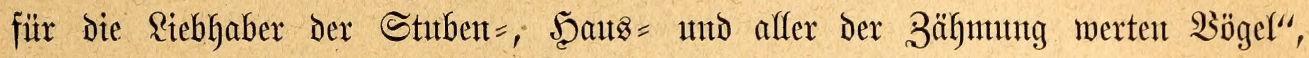

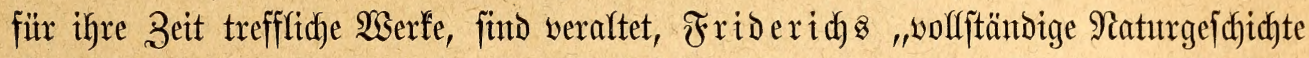

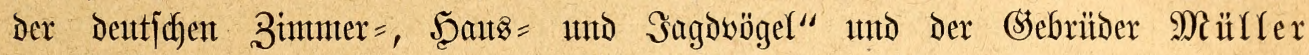

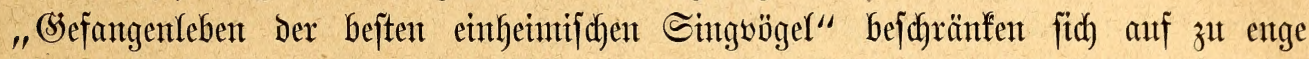

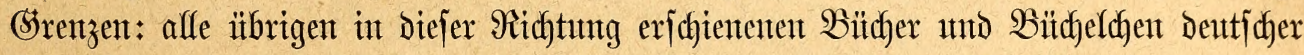
Spradhe, won Denten id̆ Sintoe erlangt habe, werbienten faum Der Errwähmung, weil fie. entweder mutr mit einigent Der befantepten Stubenvögel fith befaffent oder einte

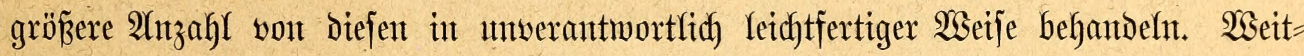

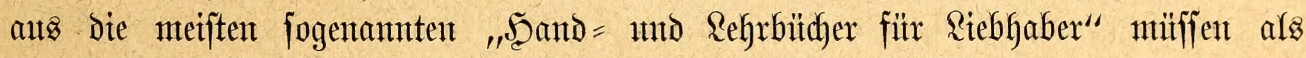

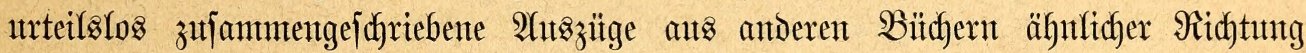
bezeidntet werden; Die übrigen bieten Dürftige Beobadhtungen mit einer Selbjt= itberhebuntg, welde mur in Dem Mangel an Rentnis Des ftreng wiffenidaftlidyen

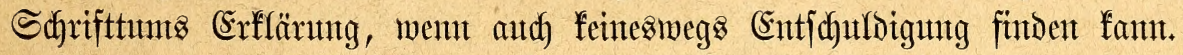

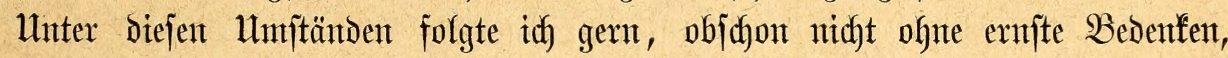

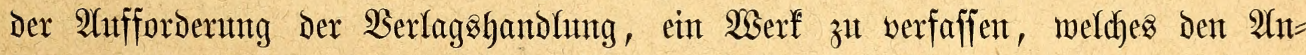

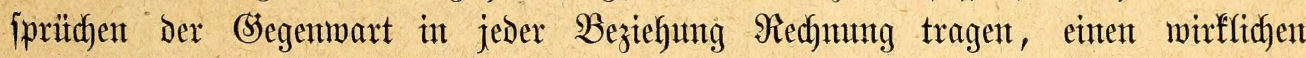

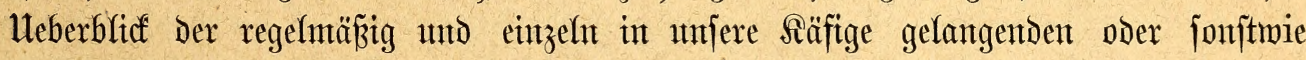
irgettomo unt von irgenowem in (Sefangenfdaft gefaltenen $\mathfrak{B}$ ögel gemähren, gentatere Bejdreibung affer in Frage foumtenden $2($ rten bieten unt ïberhautpt aflez in biejer

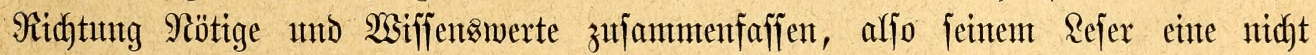

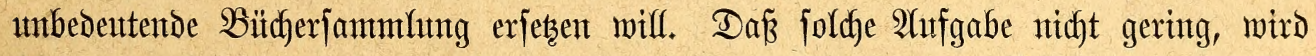
Seder ermeffen fönten, weldher die zeitratbende $2 \mathfrak{l}$ rbeit unto Miühe der einfachen

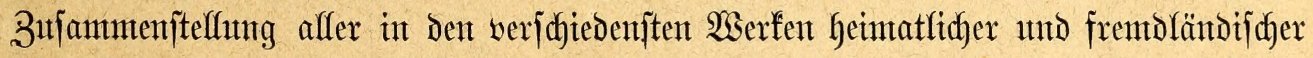
Sprachen aufgefübrten Säftg = ober ïberhautpt gefangen gehaltener Bögel fenut,

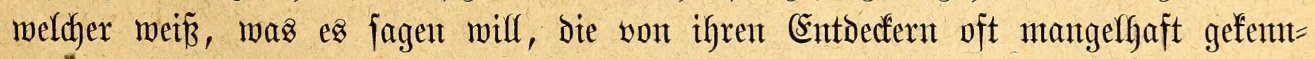

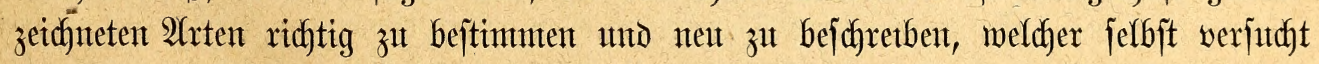

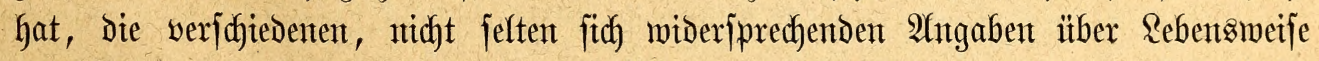

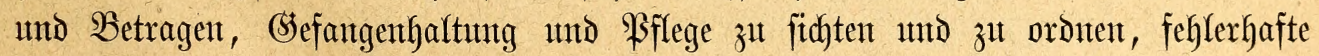

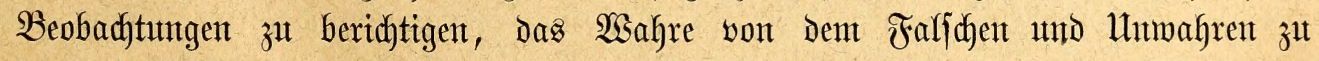

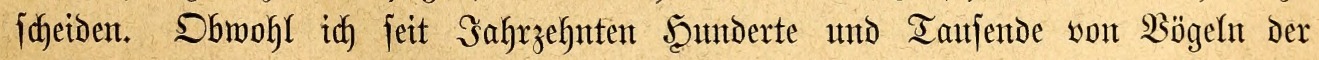

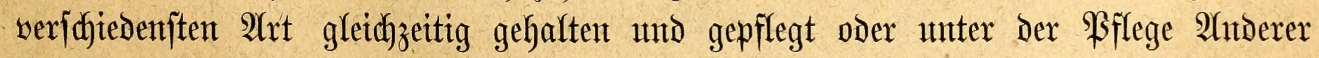

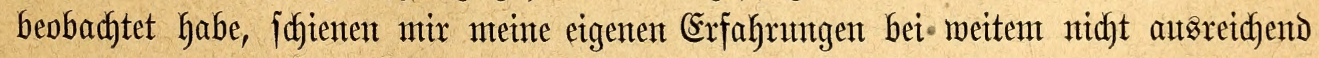

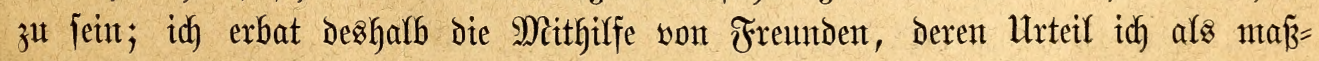
gebend amfehe, unto fanto bei alfen freutndliches Entgegenfonmen unto merftätige

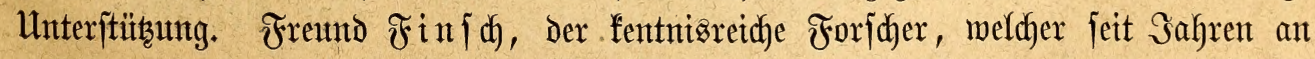

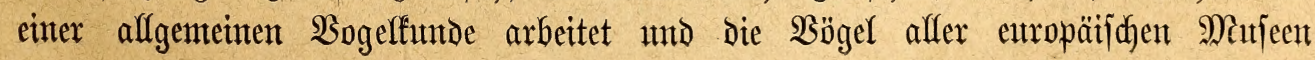




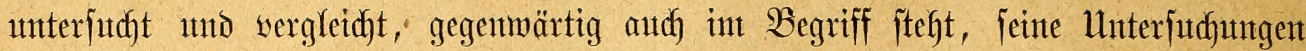

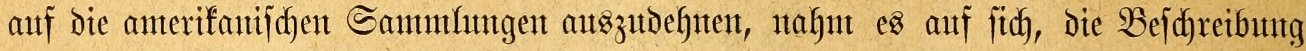

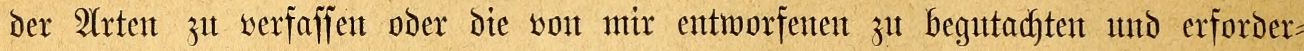

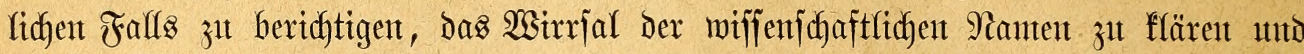

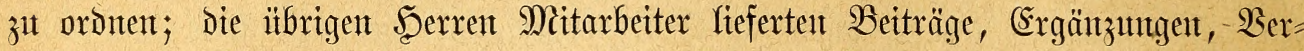

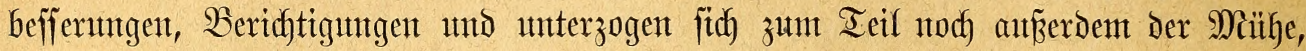

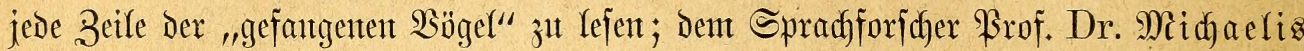

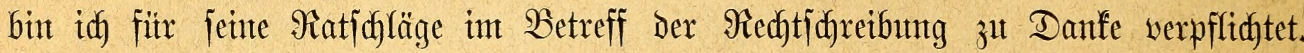
Seder Bzogent mutrde einem größ̈eren Teile der Şerrent Mitarbeiter wor Dent Drutde

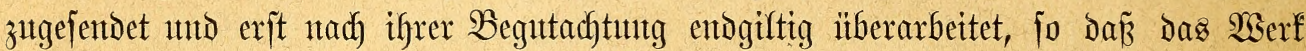

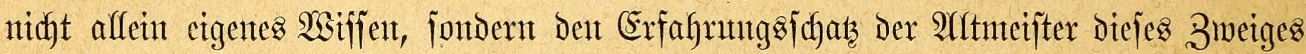

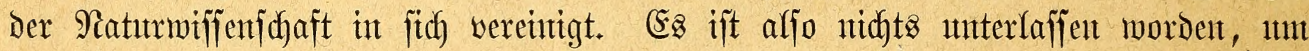

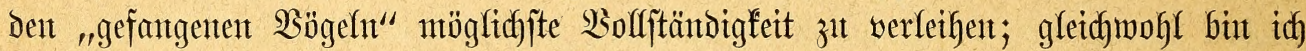

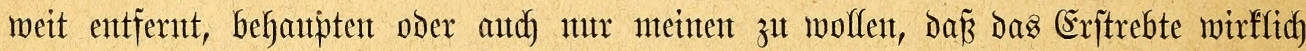
erreidgt morden märe. Sedes Safhr, jeder Iag fajt bringt für die Siebgaberei neute

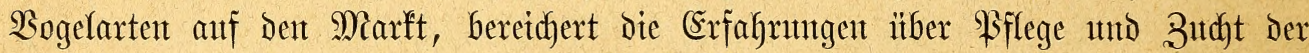

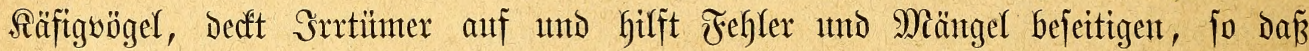

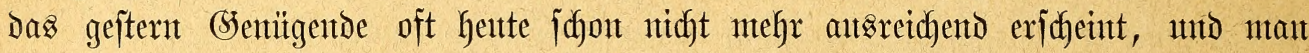

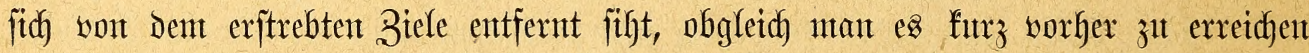
geglautbt hatte. Demuntgeadfet dorf idy $\mathrm{ez}$, Danf ber eifrigen Mithiffe jo vieler

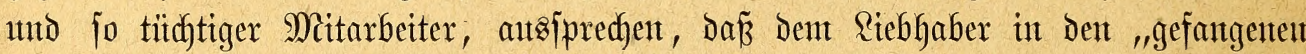

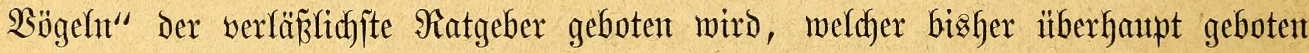

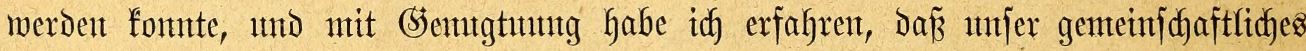

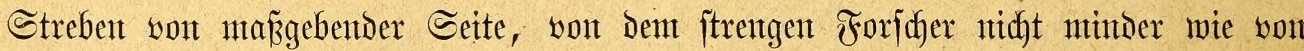

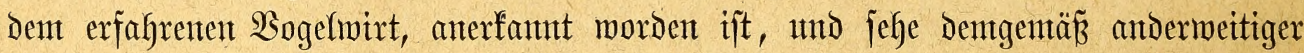
Beutreilutng ofyte Sorge entgegen.

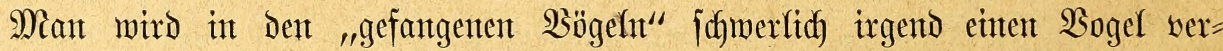

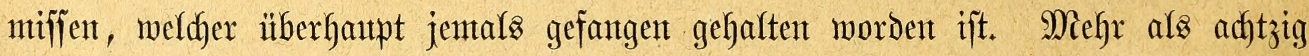

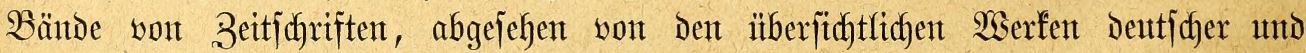

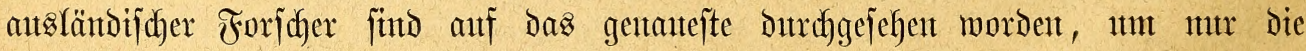

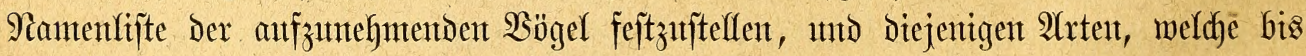

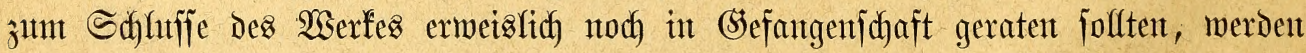

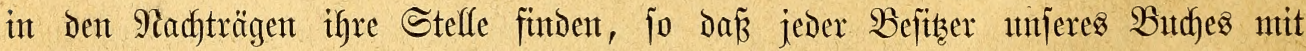

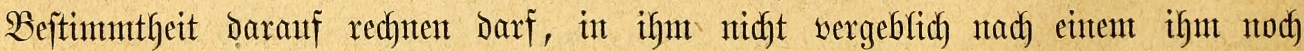

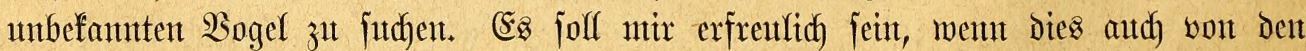

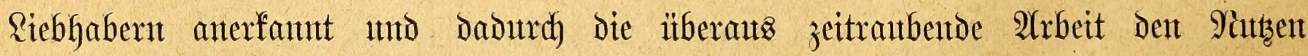
gemährent wiro, weldent idy eriftrebt habe.

Berlin am 8. Jึษน 1872.

Der $\mathfrak{U e r f a n t e r}$. 


\title{
Inbaltsüberfid)t.
}

\author{
Errfter Abridnitt.
}

\section{Bifleger und Rifleglinge.}

Siebgaber uno $\mathfrak{B}$ g̈gel

\begin{tabular}{r|} 
Seite \\
3 \\
9 \\
17 \\
21 \\
32 \\
37 \\
46
\end{tabular}

Geite

Eingemöhnung แก๖ 3ähnumg . . . . . . 52

Bebauter

Erziehung und unterridat

Empfang und Serjand

Bogelgäujer und Fluggebauex .

Irantheiten und Sirantenpflege

Sogelkandel uno $\mathfrak{s}$ ogelkänbler

\section{Bweiter Abrdnitt.}

\section{Sittiaje vier \$apageien.}

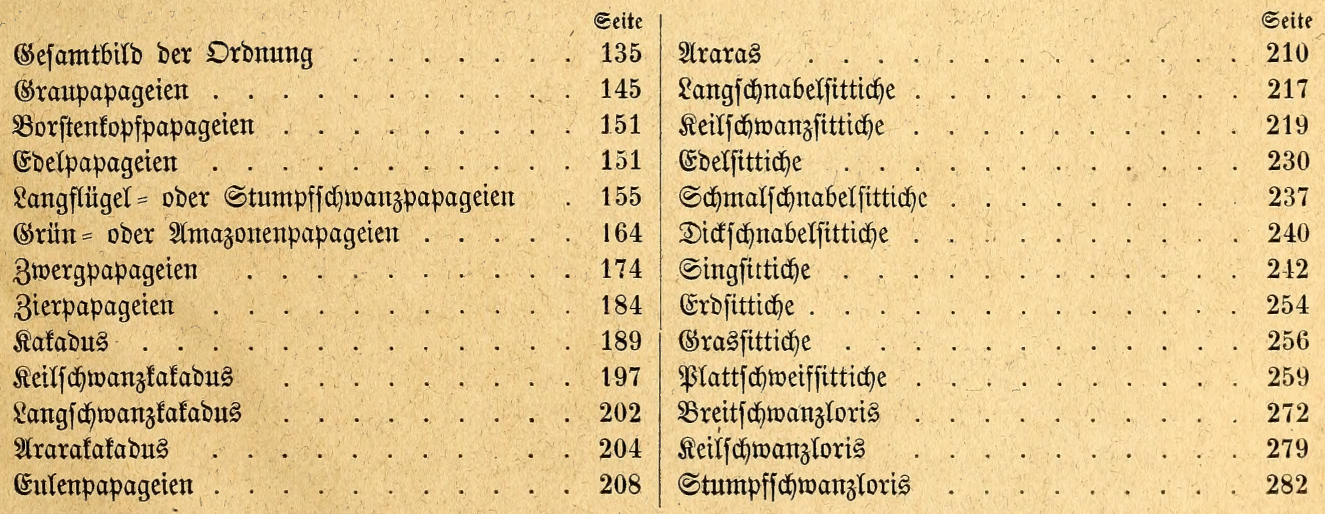

\section{Dritter Ab/dmitt.}

\section{Säruerirefier.}

3ur Meberficht ber Bejantheit . . $\quad \begin{array}{r}\text { Seite } \\ 287\end{array}$

Лreuzichnäbel

Bimper

Şatengimper
289

296

303
Rarmingintwel

Sirrlike

Felogimper 


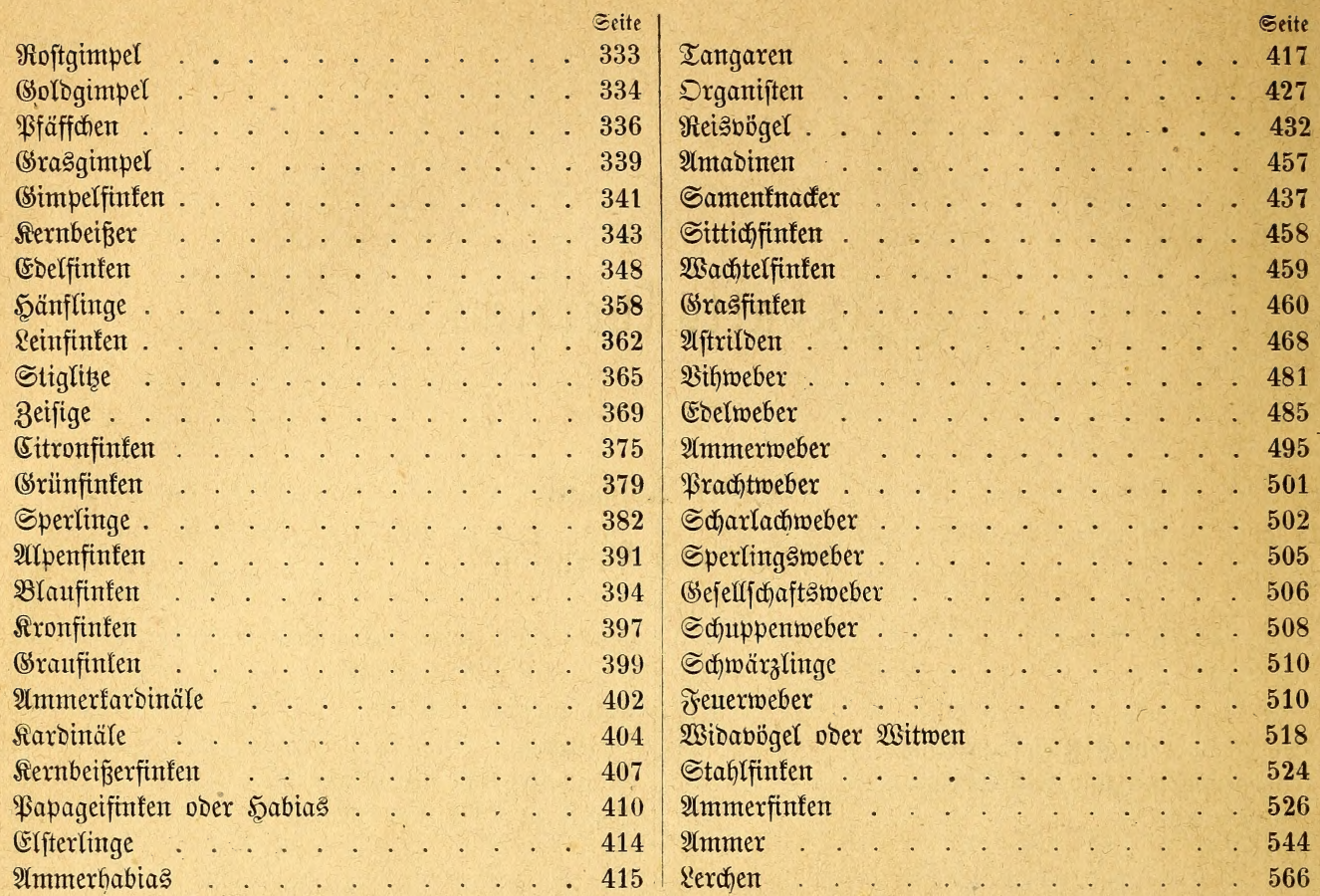


(Eritter $\mathfrak{A b j ( d ) n i t t . ~}$

\section{Bffeger und Bfleglinge.}





\section{Pitelohatuet unto Dögel.}

Das Märchen aus Den Sintbgeitatagen ber Menjchbett, weldfes von bem intuigen Jreunbjchaftabumbe zwijchen bem Erbenteherjcher unọ ben Tieren berichtet, verwirflidyt fich

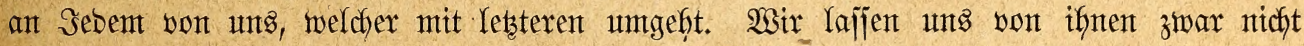
mefgr zunt Böjen verlocfen, wie Eva vont ber Shalange, ober zum Sutent füfren, wie Bileam von bent Ejel, jefen in ifnen nidyt mefr bie $\mathbb{U r}=$ ober $2 \mathrm{Hb}=$ unto Sinnbilber ber

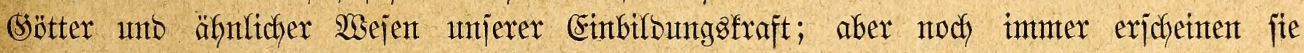

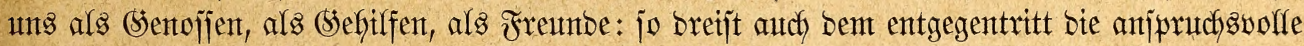
unto bodh äuserjt wohlfeile Weisheit Einzelner, welche unts bie Tiere fentzeidynen will als

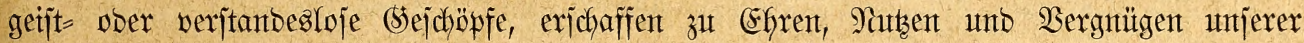
jelbit, gezmungen, auf "höheren Befehl" für uns zu wirfent unb zu arbeiten, geleitet vont

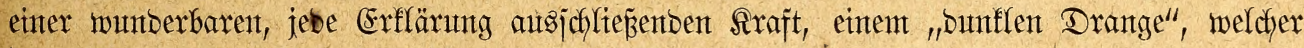
ber (S)lieberpuppe bie rechten $\mathfrak{B}$ ege gehen Keipht.

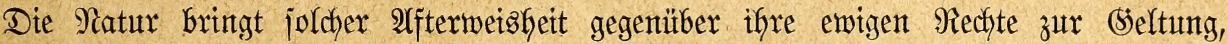
unto bie Forjchung beweijt unts überzengenter als jebes fünifliche Syjtem jener zmeifelfaften

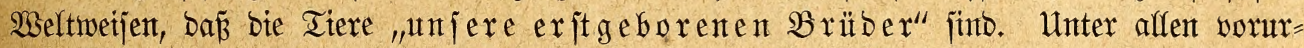

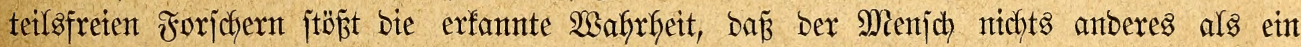

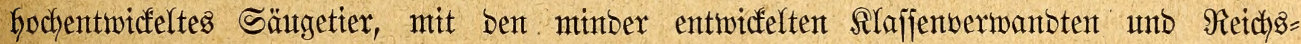
angehörigen aljo in ber Iat verbuntoen unb verbrübert ijt, auf feinen Witberipruth; bent

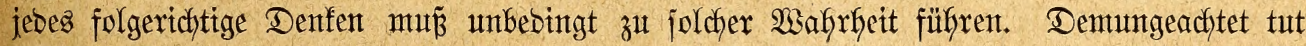
es not, fie immer und inmer wieber auszujprectsen, inzbejondere in einer Beit wie bie unjrige, in welcher fich bie grofanartigite alfer Umwälzungen auf geifftigent (Sebiete unauf = haltiam bollzitebt.

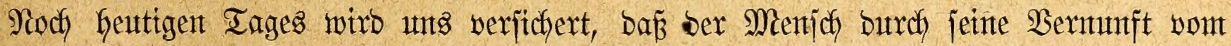

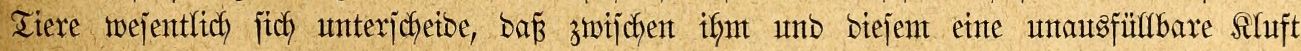
fich tiefe und breite. Im (Segenjake zu biejer Bermunft ipricht man bem Tiere "Snjtinft", günjtigen Falfs audf wohl ein wentig Serjtant zu. Nebenbei rebet, prebigt unb jafreibt man vont ber "unjterblichen Sele" Des Menjchen, läß̈t aber in biejer Şinjictst bas Tier

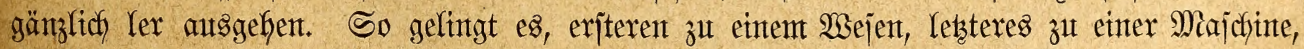
jenten zu eittem Şalbgott, Diejes zu einem nichtsbebeutenden (Sejchöpf zu jtempeln. (S)lücflicher Weije läßjt man das retbliche Reben Des Tieres als noch bejtehento gelten und erleichtert es uns baburch, Syjtem und Weiaheit zu prïfen.

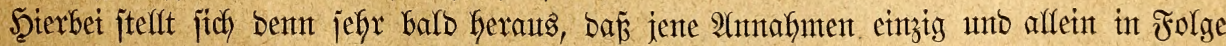
mangefnoen $\mathfrak{B}$ erjtäntonifjes bes tierijchen Reibes unto jeiner Srgane entjtanton jein föntent. Die Forjchutng gewäfyrt ifnen nicft bie geringjte Unterjtübzutg; Die Forjcher verwerfen fie bemgemäŕ inżgejammt als gänzlich Gartlos. Durch taujenbfältig mieberfolte Berjuche, burch bie gejammelten Exfahrungen haben fie erfennen gelernt, baj geiftiges Sein ofnte leibliches 
Reben nicht bejtehen fannt, ba bas geiftige Reben nichts antoeres ijt als eine Tätigfeit bes (Sefhirns. Dieje Iätigfeit mag mun zmar eine jebr verjefiedene jein; ifrem WSejen nach ijt

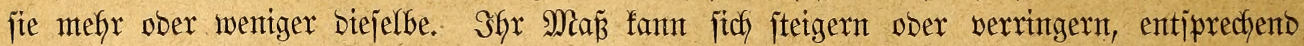

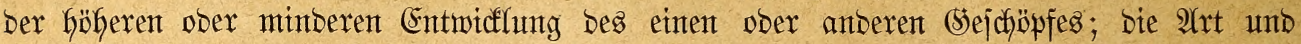
Weije aber, in welcher fie fich äußzert, bleibt fich gleidh. Sijt ein (Sefjirn vorhanden, io

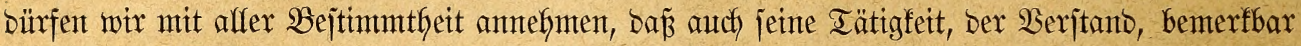
jein wirb. Entiprechento bem am höchjten entwicfelten Şirn bes Mienjichen mag man bei

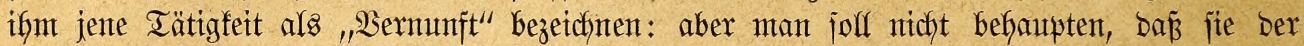

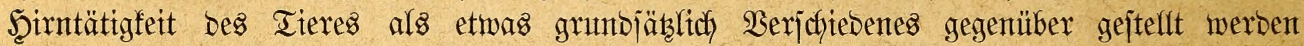
müije ober sürfe. Şier wie da fint biejelben Rebensbebingungen maßjgebend, Gier wie ba

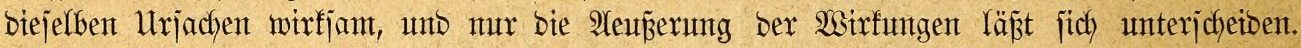

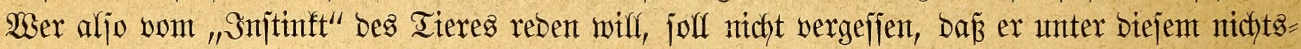

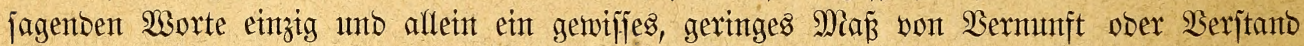

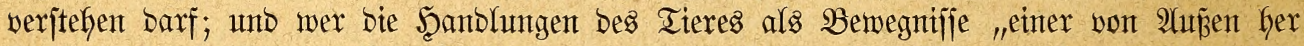

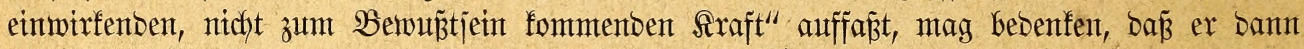
nicht beredstigt ijt, bie geifitige Freifyeit bes Menjchen anzunefymen.

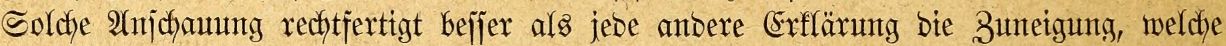
afle, bie fie fenten, für bie Itere empfinden. Einen Freundichaftabunt, wie ex żoijchen

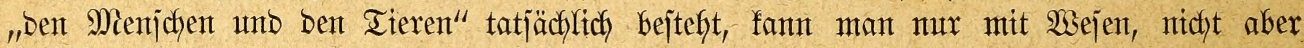
mit Majuftnen eingefgen. Rebere Iajjen fich anjtaunen, nicht zu Jreunben geninnen. Man

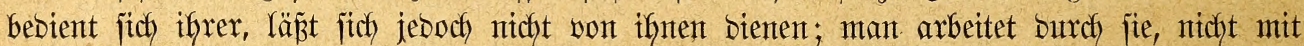
ifnen. Die Tiere aber bedienen 1218 und arbeiten mit und für uns tagtäglich mit ifyren leiblichen umb geiftigen Sräften, und wer fie herabmüroigt, macht fich einer Itngerechtigfeit jchulbig, weldhe in feiner Weije bemäntelt merben fann, Den Menjichen auch feinesెwegs zum Salbgott erbebt, mie Manthe vielletdyt mähnen. Wenn wir gegen bie Tiere, unjere Mitmejen, gerecht jein wolfen, müfjen wix uns bemühen, fie zu uns empor zu zieben, wie mix bie edleren Scaustiere in Wirfltitjeet zu uns emporgezogen haben.

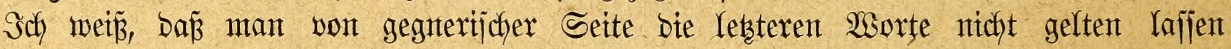
wirb, habe midh beshalk aber nidyt int geringiten bebadyt, fie auszujprechen. Seber siebhaber

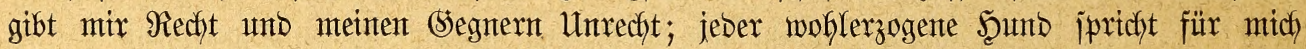

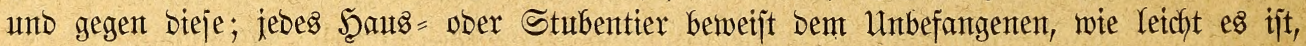

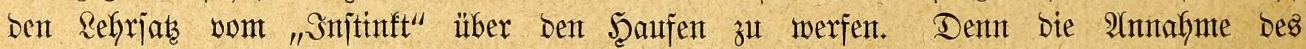

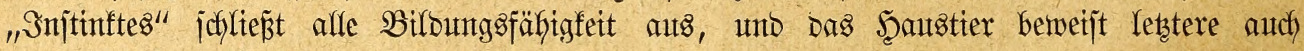
Dem blöbejten Berjtande.

In wie hohem (Srabe bilbungsfäfgig bie Tiere fint, befunben afle, weldye burch ben Menjicten in ihnen uriprünglich frembe Serbältniffe gebracht murben, inabejonbere auds

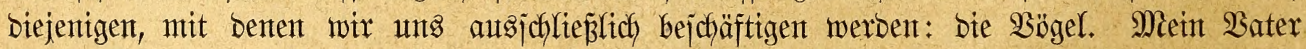
hat bereits vor vierzig Gafren hierauf fingemiejen. "Sch behaupte breijt", jagt er in ber

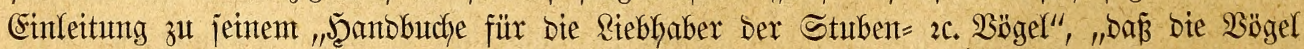

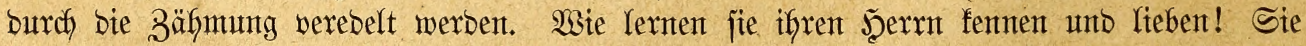

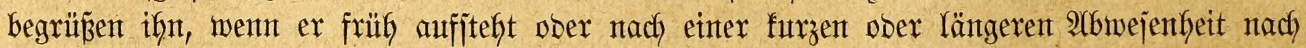

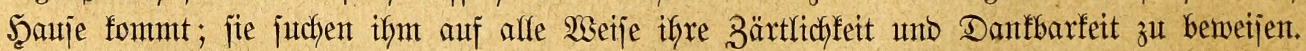
Sie zeigen ifm an, went einer ifrer Mitgefangenten jeinem Säfige entfliebt ober went

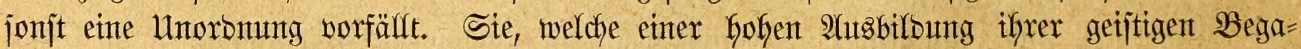
bungen fäfrig fintb, erhalten bieje burch Den Ungang mit Dem Mienjchent. Sie werben zärtlich,

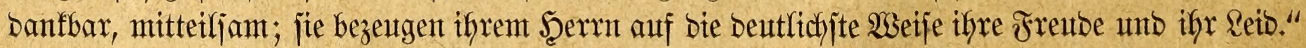

2lnbers urteilen, wie leicht erflärlich, bie Begner. Der ફ̧err Dr. Arltumt z. $\mathfrak{B}$.

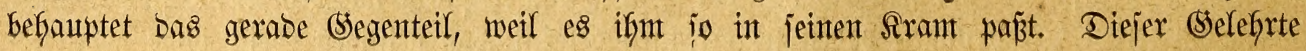




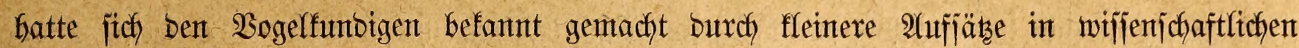

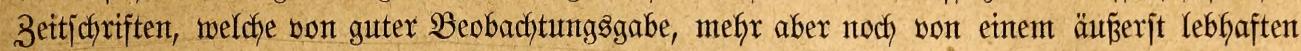

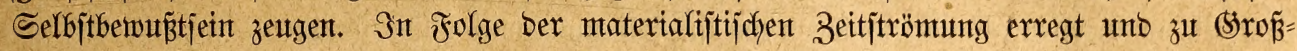

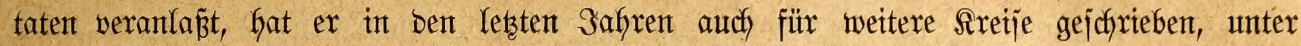

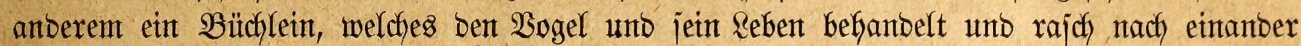
mefrere Aluflagen erlebt, aljo \&ejer gefunben hat. Diejes SBüchleint, ein in ber Iat nicht

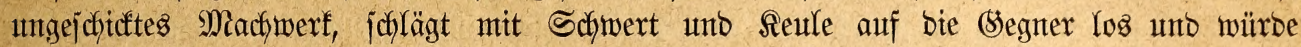

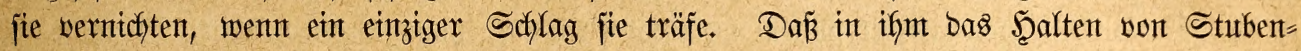

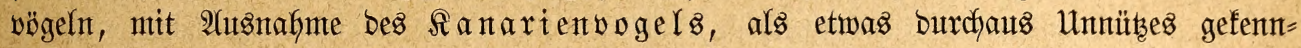

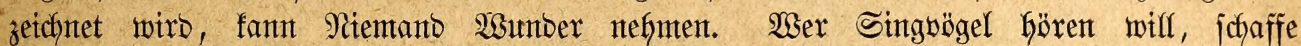

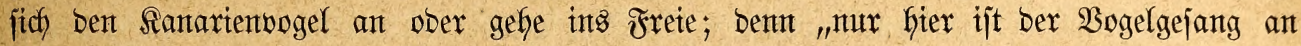
letner Stelle, mur Gier wermögen wix ifn zu verjtefen." Damit wiro bie Sache abgetan unto ber Rebhaber zux Ruhe verwiejen.

Bon jeintem Standpunfte aus hat ber weije Mann volffommen Recht. Die Riebhaber

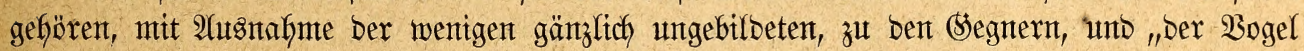

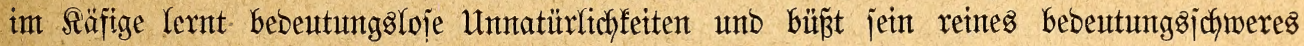
seben ein"; folglich geichifgt ifgm Unreefst, und Senem - brautdyt eben fein Recht zu

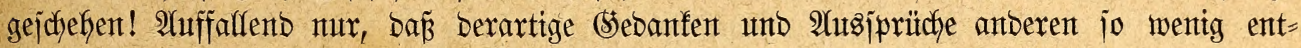

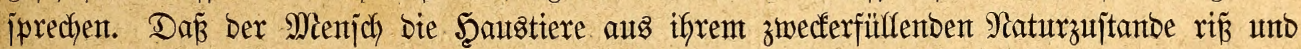

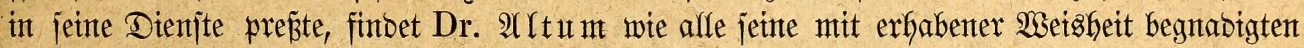

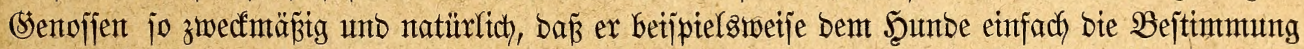

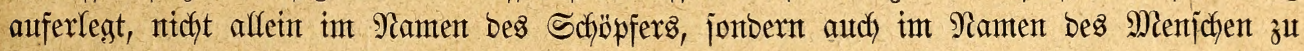

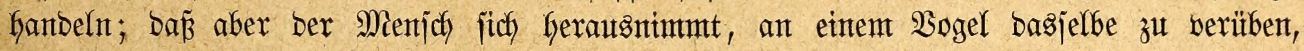
was er am Şumbe tat, tịt naturwibrig!

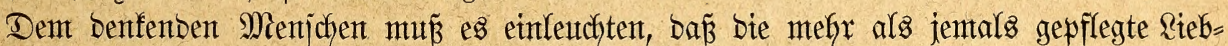
Gaberet für Stubentögel etwas ganz anderes ijt als ein plumper (Etngriff in bie Ratur. Der

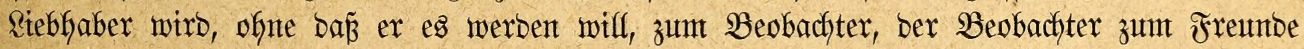

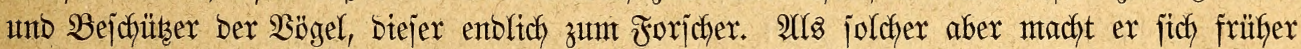

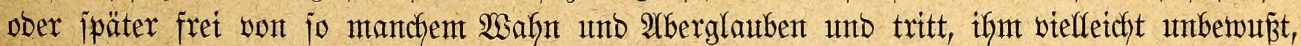
affmäblich auf Die Seite Der Borgejdyrttenten jeiner Beit. In biejer unleugbaren Tatjache finbe ich eine Rechtfertiguntg Der Riebhaberet, wie fie beffer nidft auggejprodyen werben fann. Wir jtreben nidft mefr bantach, "Dem Teufel einte Sele zu rauben", wohl aber geizen wir

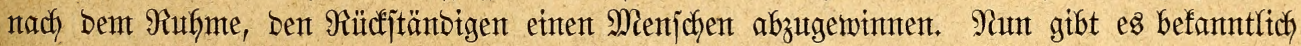
fein geeignteteres Mittel, unflare Röpfe zu erleudften ober jofwache (seijter zu ftärfen, als bie Raturmifjenjchaft; folglich juchen wix fie zu verbreiten unb zur (s)eltung zu bringen, wo unto jo viel wit bermögen. Unjerem Zwedfe fann jeber Stubenvogel bienten, und ein jeder

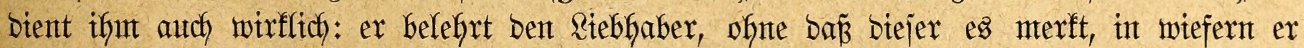
Yernt. Man beobachte ifnn mur, Durdfgeiftige bas Beobachtete unto benfe unb folgere weiter: bie Wirfung wirb wafhrhaftig nitht ausbleiben!

Bon biejem (Sejichtspunfte aus betrachtet, exjcheint mix bie Riebhaberet jo hod) erfabent

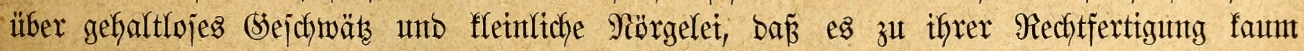
weiterer Worte bebarf. Denungeadytet will ich auf anbere Eintwänbe, weldhe man erfoben hat unb noch erhebt, eingehen, um zu prüfen, wie viele Wabrheit bent eigentlich in ifnen enthaltent ijt.

Fioch inmtex vernimmt man von empfinbjamen Seuten bie vormurfisoffe Bemterfung,

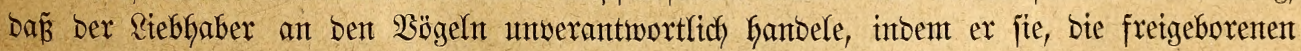
unt freifeitliebentoen, einfängt unb in ben engen Säfig jtedft, ihnen zux Sual unto zum

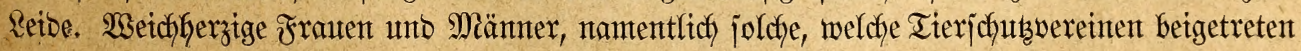


fint, werjeben jich) in (sejühlsjichmangerfeit, bringen aber mur jelten etwas Befferes als

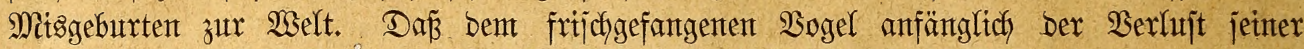
Freifeit in Gödjiten Srabe unangenefhn ift, jolf unt fann nicht in Albrebe gejtellt werben;

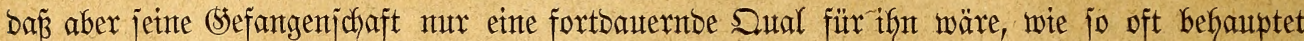

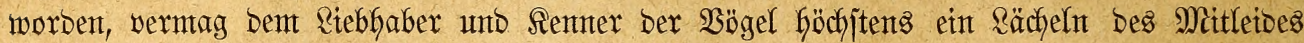

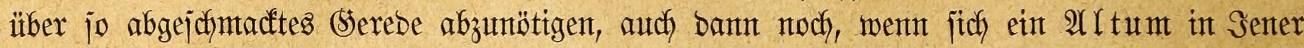
Sinte ausipricht und in jeiner 2 rt von ber Rebensverfürzung und ber Einbure fajelt, weldhe bie Stubentögel erletben joflen, weil bas (Sefteber einiger wentiger 2rrten bei längerex

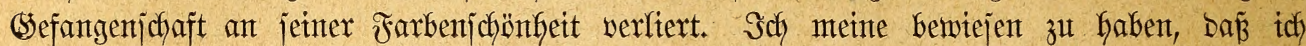

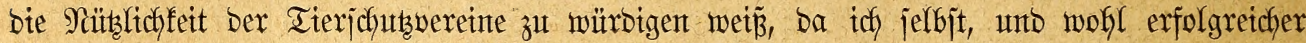

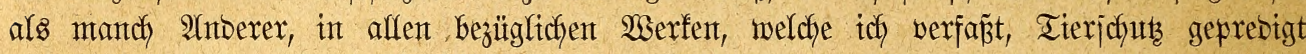

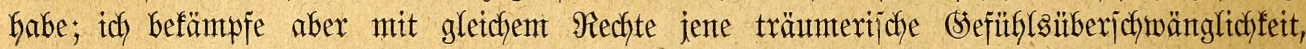
weldye im leren Wortichwall ify (Stenügen fintoet und burch hofltönendes Wortgeflingel zu belef̧ren wäfnt.

Der im Räfige ober in Sejelfichaftbbauter, im Farf ober auf Dem Weifyer gefaltene

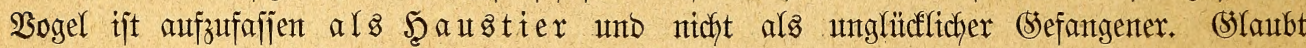

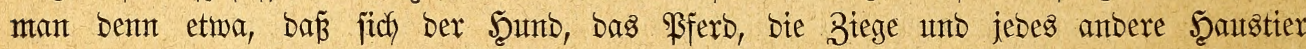

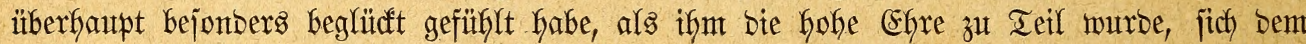
Bitlfen Des Menjchen beugen zu mülfen? Doer wähnt man, bas Jü̈lfen jehe es für ein beneibenswertez 208 an, einen Sattel aufgelegt zu erfalten, bezüglidy bor ben Waagen

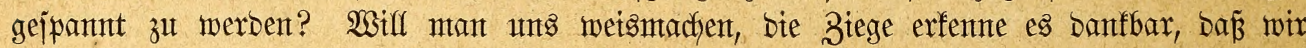
fie gezmungen, ifyre Kuftige Bergheintat mit Dem Stalle zu vertaujchen? Affe unjere Şaus: tiere haben jich mur mit Wiberjtreben unjerer (Semalt gebeugt; beshalb jagt man ja eben, baßj fie gezäfmt worben fund. Naun, gezähmt wirb auch Der Stubenvogel, ber eine leidhter unt mebr, ber anbere jchwieriger und weniger; und wie jente uns bienten, jo bient audch er bem Stärferen, Mä̈btigeren. Uno mahrlich, ex befintoet fïch minbeitents ebenjo wohl in ben ifm aufgezmungenen Serbältnifjen als jebes antere Scaustier. Shn pflegt

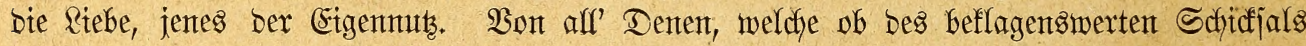
ber Stubentögel iffre Scirnabfülle an ben Mant zu bringen judten, johent fich feinter und

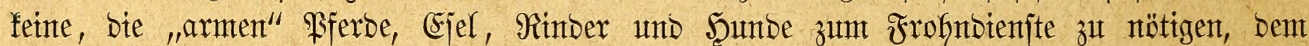

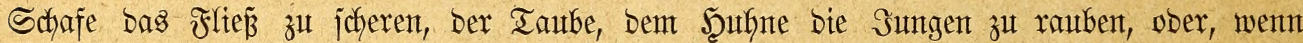
fie alfe, Die Scaustiere, zux Stenüge gebient, Das Iobesurteil über fite auşujprechen, fie ber

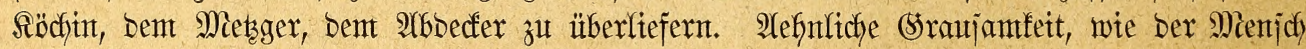

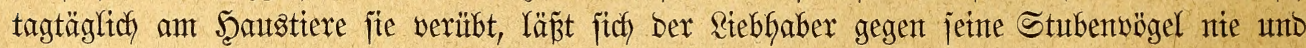
"nimmer zu Schulben fommen. Dort ift ein meites Feld für Die Bmecfe Des Tierjuhues und ber Menjchweredelung: Gier bemühen die Bereinler fich vergebens; Dent wir Riebfaber

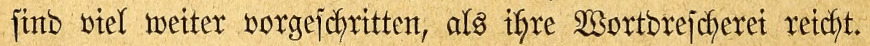

Das Recht Des Stärferen, weldjes fich wohl wereblen fann, niemals aber jeine (seltung berlieren wirb, wenten wir an unb füfren wir aus, went wir uns einen Bogel fangen, bie Iffrgemalt Der Riebe, went mir verjuctjen, ifn zu zäfnten. Und bieje Riebe trägt jebr

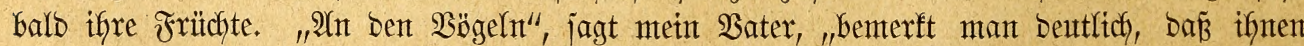

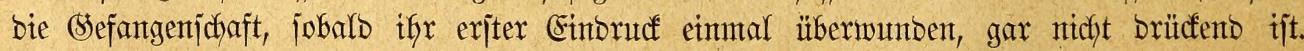

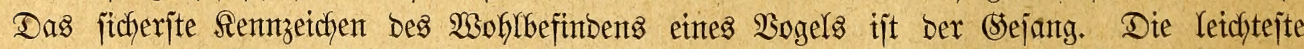

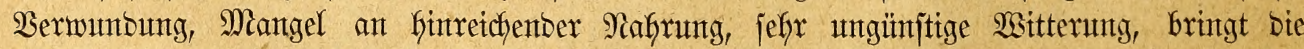
Singwögel balo zum Schweigen. Man vergefie bes Morgens einen Stubenvogel zu füttern,

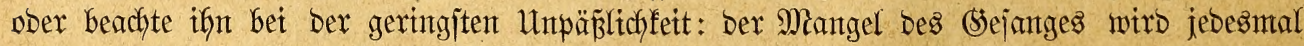

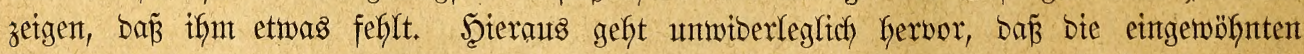

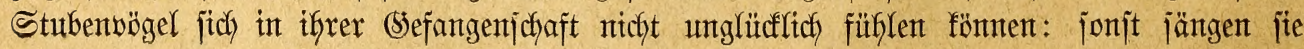


nicft." Der Begriff ber Sraujamfeit finbet auf Das Berkältnis, welches zmijchen bem Siebbaber unto jeinen Bögeln bejteft, feine 2Ytnendung.

Ernjter gemeint ijt bie Befauptung, bie Riebfaberei beraube bie Wälder, Scaine unto

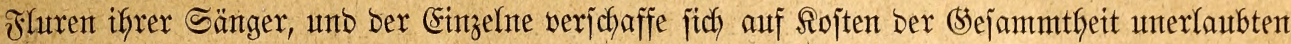

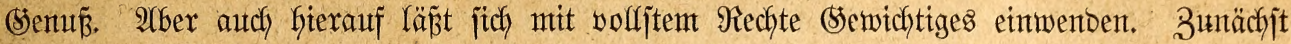

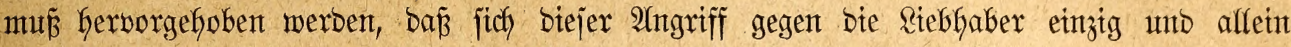

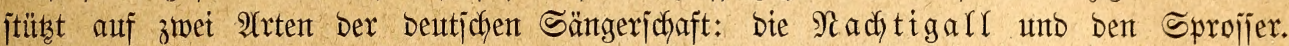

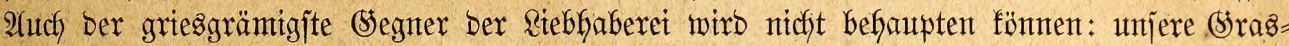
mücfen, Rot= uno SBlaufefldchen, Sartenjänger, Droljeln, Feld= und Şaibelerchen, Zaun=

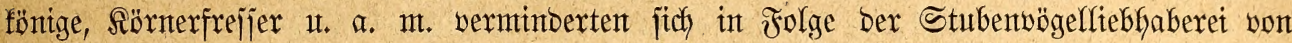

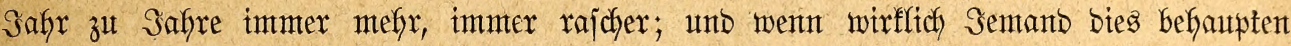

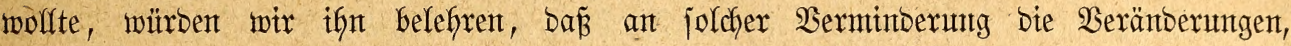

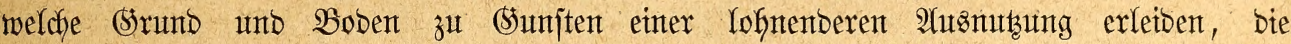

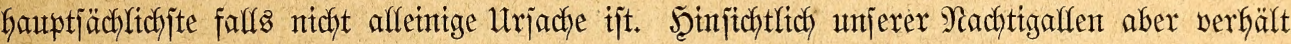
fich Die Sadye 10: ben Sproffer füngt man mur in Dejterretch, nirgends andersino in Deutichland, aus bemt einfachen (stumbe, weil fowohl ber mäbrijche als ber pommeriche Sproffer von bent fienter wentg gejchäbst werben, unt bie Rachtigall ijt ba, wo je lebt

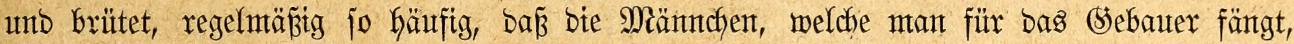
unt wären es funterte, ofnte merflidfen Nadjteil gefangen werben bürfen, weil fie

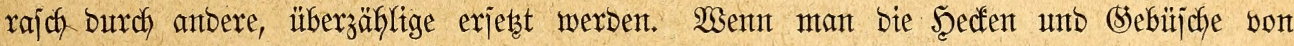

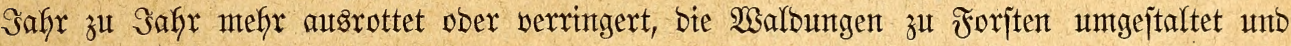

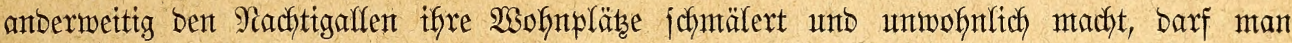

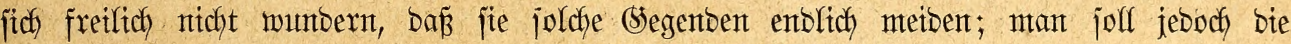

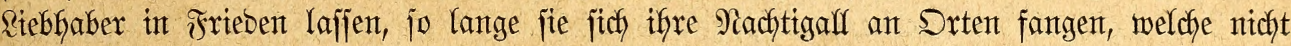
als ein Dem Einzelnen ober ber Sejammtheit angehöriges (Sehege angejehen werben fönten.

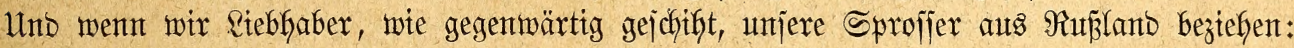
welcher bernünftige Menjich wifl uns bas wefhren? Sjt es jolchen Iatjachen gegenüber nicht, gelinbe geiagt, eine arbernkeit, wenn gemifje Schönjdyriftler, weldye ifhr armjeliges Sdyrift=

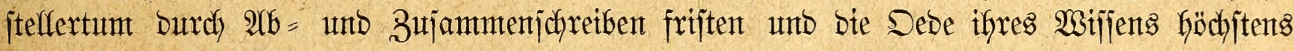
mit gejüblg̈jeliger. Wortmacherei überfleijtern, - went joldhe seute, jage ich, fich bis zunt

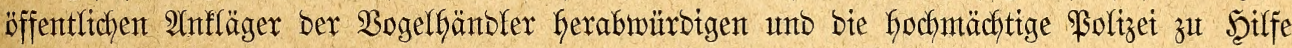
rufen, Damit momöglich ber ungarijche ober rufitiche Sprofjer weggenommen, fretgelafjen und von ber eriten bejten Sakze ober bem Sperber gefangen und aufgefreffen werde.

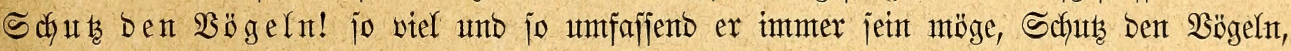

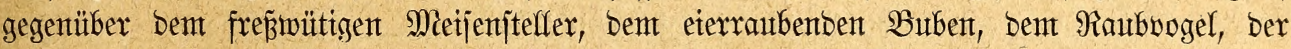
Wohnungant: aber Schuts ober bods Frteden auth einter Riebfaberei, weldhe, went fie bie mafjre, niemals jofabet, viefmefr jenten Schuts mit Eifer und Serjtäntonis predigen und ausfübren bilft.

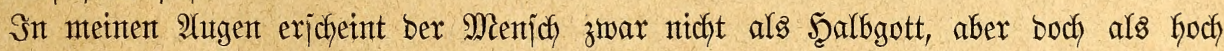

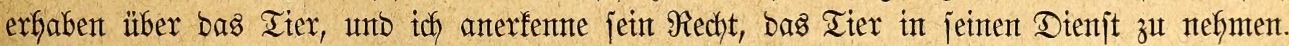
Somit ipreche ich ifym auch bie SBerechtigung zu, fich bie Rajt Der Arrbeit, welche ifhn an

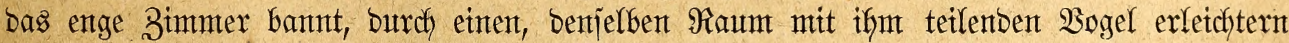
zu Kafjent. Wer finto bent eigentlich Die Riebhaber? Die Bautern etwa, bie Forjtleute, welche tagtäglich int Freien bie $\mathfrak{B o ̈ g e l ~} \mathfrak{m}$ fich Gaben? Soer bie zur 2Trbeit im Zimmer genötigten,

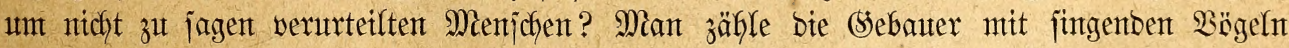

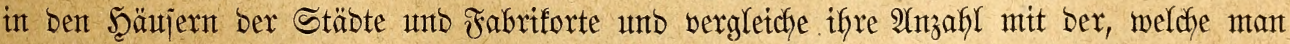

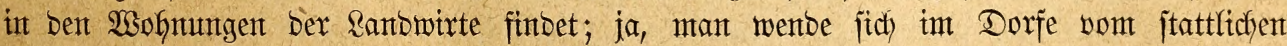

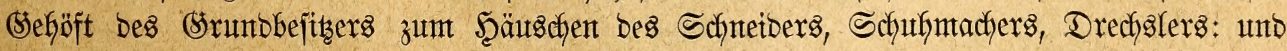




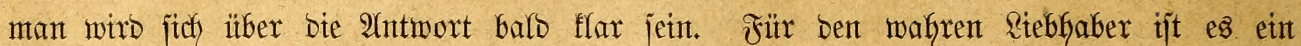
Beouitrfntis, jeinen $\mathfrak{B o g e l}$ um jith zu Gaben; bent ber Bogel Gilft ifm arbeiten, fitft ifm leben! Er jifht in biejem feinen "armen Befangenten", jonbern einen Benofien, einen

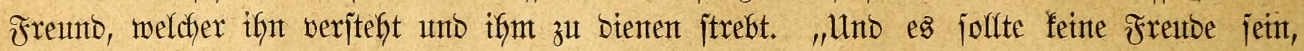

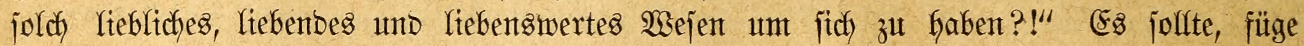

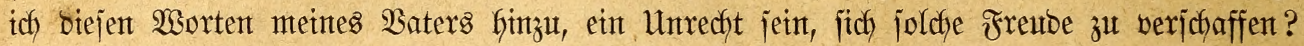

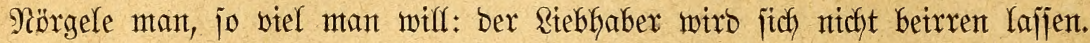

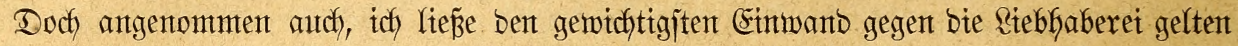

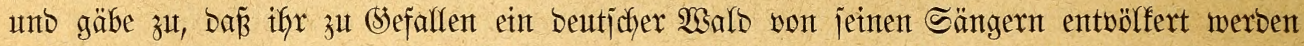

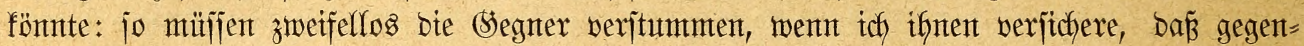
märtig weit mefr auşä̈ntijche als inläntijche $\mathfrak{B}$ ögel gefangen gefalten werben. Sion ber (Srofiartigfeit unjeres berzettigen Bogel= ober Iterfanbels überbautpt haben Diejentigen, weldhe

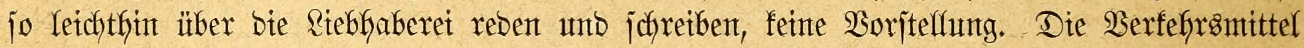
unjerer Iage überbrittfen bie $\mathfrak{B e l t m e e r e , ~ D u r d f b r i n g e n ~ b i e ~ U r w a ̈ l d e r , ~ f r e u z e n ~} \mathfrak{B u ̈ j t e n ~ u n o ~}$

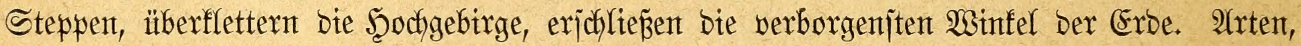
melche unjere $\mathfrak{B a ̈ t e r ~ G o ̈ c h j t e n s ~ a u g g e j t o p f t ~ i n ~ u n j e r e n ~ M a j e e n ~ j a f b e n : ~ w i r ~ e r b a l t e n ~ f i e ~ l e b e n t o ~}$

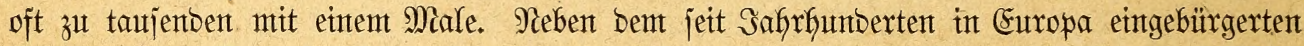
Sänger von Santaria fant jeber nur eintgerntaß̧en Bentittelte afrifantijche, afitatijche, aujtralijche, amerifantijche Finfen in Bintuter züchten; benn ex ijt int Stanbe, für mentige

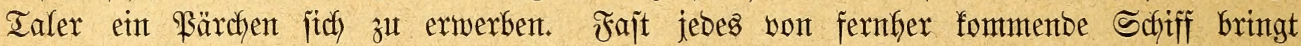
gefüfllte Säfige mit fith, unb gar mandhes nimmt joldhe von uns mit. Sebes Sahrzebnt

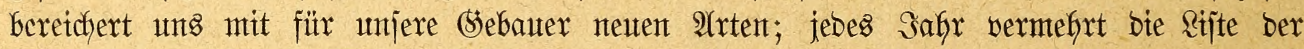

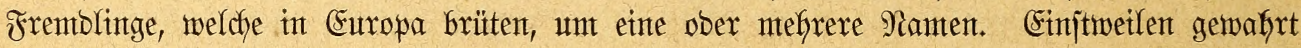
man bieje Fremblänber mur in Den Räfigen ber Riebhaber exjten Ranges; nicht lange wiro

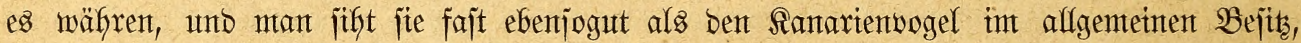
züchtet fie unto vermefyrt fie weiter. So jofwer es bält, unjere einfeimijchen Bögel im Räfige zur Fortpflanzung zu bringen, jo leicht gelingt bies bet vielen ausländijchen 2 rten.

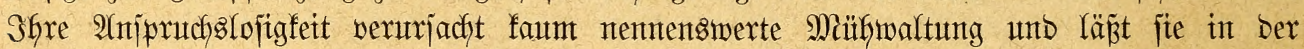

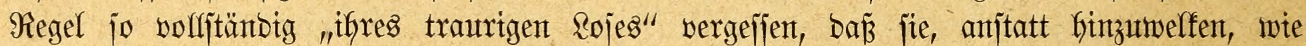
armjelige Schwäter ifnen nachjagen, in bes sebens böbjiter sujt erghüben, lieben, nijten, iich) vermefyent.

Was haben bie weisheittriefenten (steghter Gierauf zu ermibern? (Sreifen wix burch bas

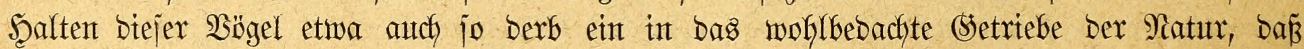

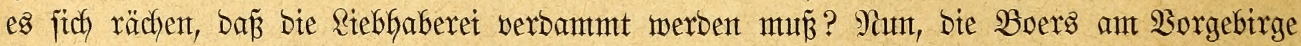

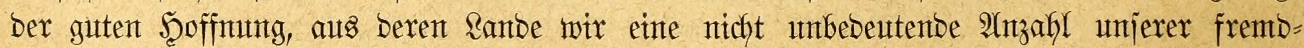
Yänbijchen Finfen beztehen, Denfen anders: jite vernidyten bieje Finfen, weil fie in ifgr Setriebe

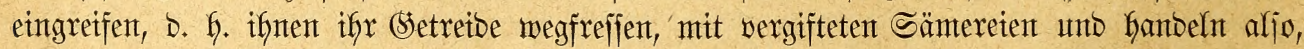
objchon mit mefyr Berectitigung, boch ebenjo nieberträchtig, als ber beutjche BBubentäger, weldher mit ftrtydhningetränfften 2 seizenförnern auf bie Sago ber Steppenfühner ausziefgt,

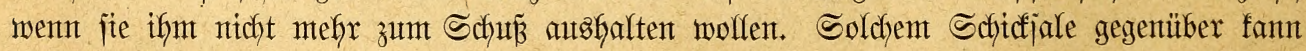
boch Das Ros ber gefangenen Stüdfe bieier won Meutchlerbanto bebrobten 9 (rten jo ichlimm

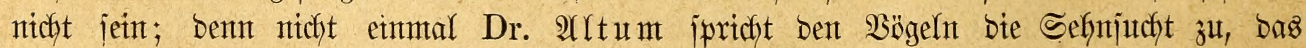
"irbijche Sammertal" mit einter "befjeren $\mathfrak{B e l t " ~ z u t ~ v e r t a u j c h e n . ~}$

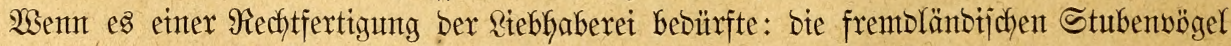

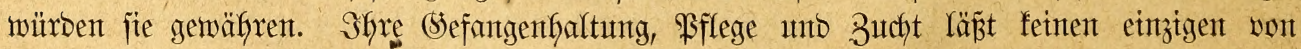

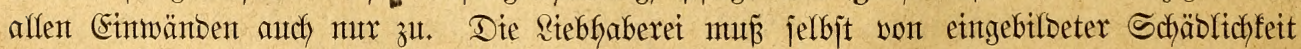

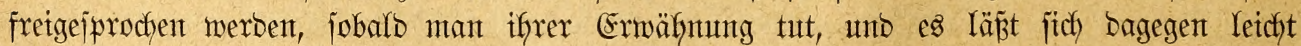

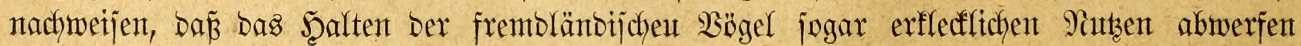


fant. Ebenjogut als ber eine gelbe $\mathfrak{B o g e l}$ von Ranaria jetjon gegentoürtig taujente von Talern in arme Bebirgsoörfer bringt und frohen, heiteren Sinn bazu: ebenjogut fömtent

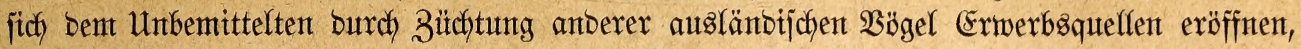
weldye reichlicher fließen alz andere, althergebrachte, unt nicht, wie bieje, (Seijt und (Semüt ftumpfen unt nieberbrücfen, jonbern aufridften unb exheben, weil ber freunblidje sajt imt 3immer reblich bas Seinige bazu beiträgt, ein armes, trauriges Mienjchenfherz aufzuheitern unto zut beglürden.

Wer fich burdyaus berufen füflt, bie $\mathfrak{B e l t}$ mit etner $\mathfrak{B e t s h e i t , ~ w i e ~ f i e ~ i m ~} \mathfrak{B}$ orjtehenden angebeutet, zu bereicfern, laffe uns stebfaber aus bem Spiele. Wir haben für ifn, ex bat für uns fein Berftänonis. Wer uns beutrteilen will, muß etner ber Unjrigen jein. Unt jo lange nodh ein Einziger unjer bleibt, jo lange wirb ex ftreben, bie lieblichen $\mathfrak{B o ̈ g e l}$ um jich zu verjammeln, burdh fie ben Winter fich zum Jrïblinge zu gejtalten, jie unt iffr Reben zu exforjchen, unt fidh bes eigenten wahrhaft zu erfreuen und mefr unt mefr

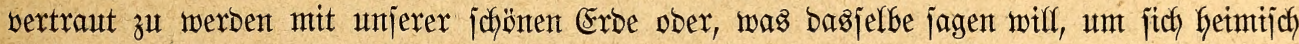
zu madjen in unjerer wirflichen Seintat.

\section{(Gelunter.}

Ein mangelfafter Räfig ijt ein Rerfer, ein wohleingeridfteter einte Wohnung bes

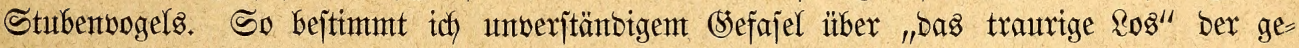
fantgenen $\mathfrak{B o ̈ g e l ~ e n t g e g e n t r e t e , ~ j o . ~ e n t i c h i e d e n ~ v e r l a n g e ~ i d f ~ w o n ~ b e m ~ R i e b f a b e r , ~ b a j ~ e x ~ j e i n e m ~}$

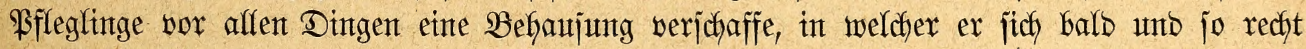

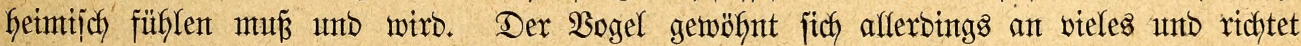

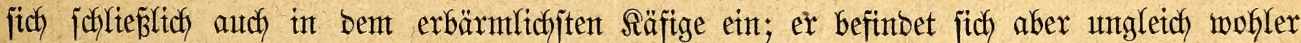

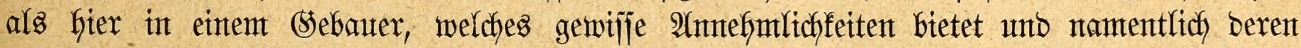
größzte, bie Reinlichfeit, gemährt ober ermöglidyt. Weer jeine $\mathfrak{B}$ gel lieb hat und bie

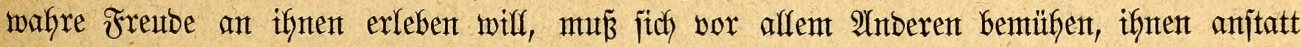
eines (Stefangenwärters ein freunblicher Wirt zu jein; wer überbaupt Bägel Galten will, folf jich vorfer geeignete, zwedfentiprechende stebauter anfertigen lafjen.

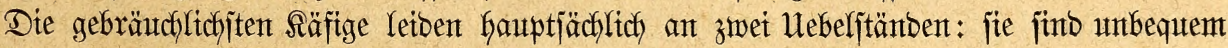
unb raffen fidh jobner unto mangelfaft reinigen. Şierzı treten oft nod) ungeeignete Futter=

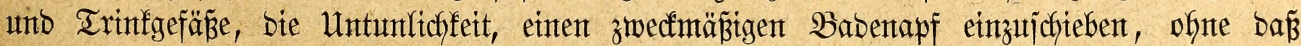

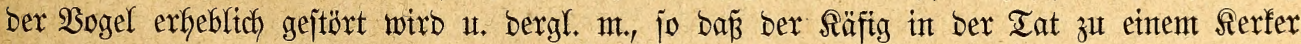

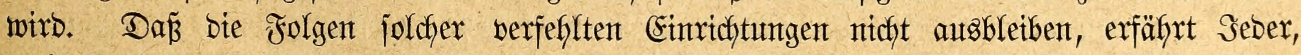

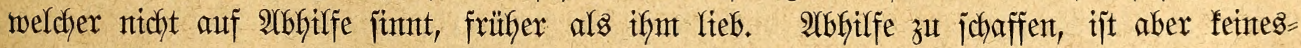

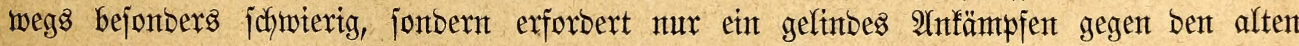

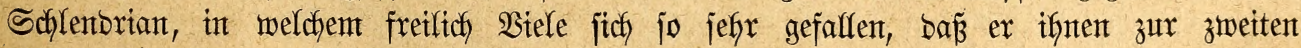
Ratur getworben.

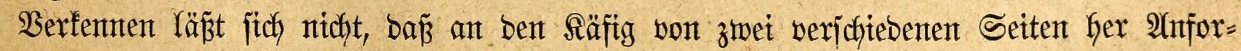

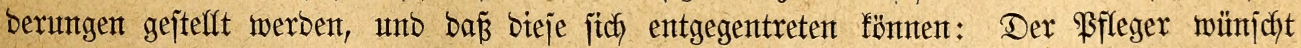

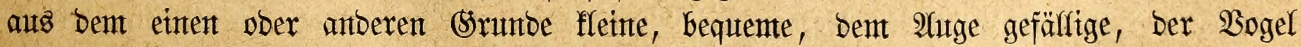
berlangt geräumige, ifm befaglich eingerichtete, gegen 3ugluft unt ifm läjtiges Bejchauen

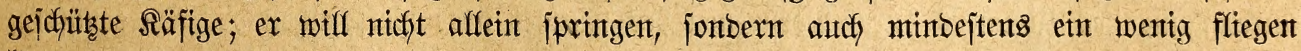

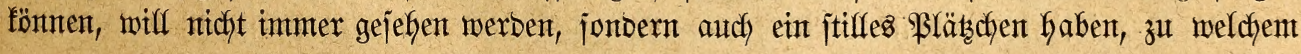




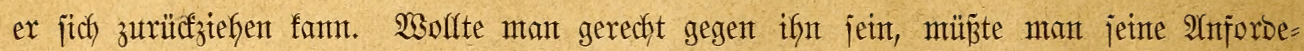
rungen bevorzugen; Das aber ijt in vielen Fällen faum möglich unt baher ein ausgleichender Mittelweg jchwer zu finbent. Eine 2 (nforberung fant man ftets gewäfren, nämlich), jebem

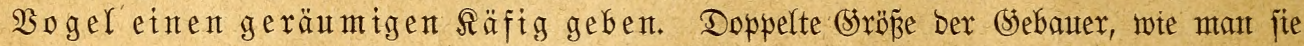
gemöhnlich angewentot fift, erjcheint meinen funbigen Freunben unt mir unter aflen

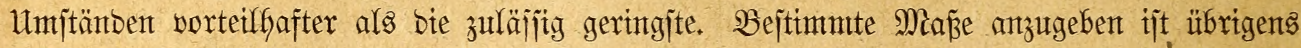

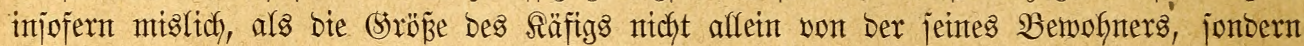

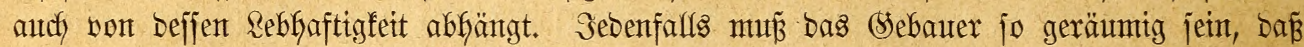

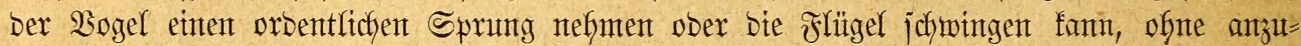

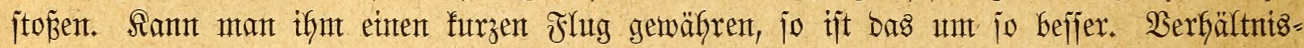

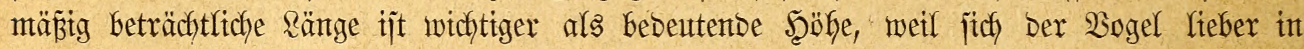

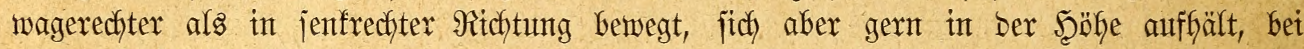

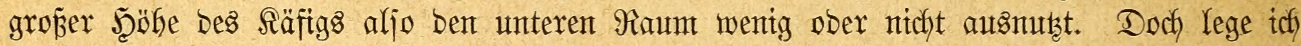
auf bie form weit wentiger (semidyt als auf Die Seräumigfeit. Sie gejtattet freie Beme=

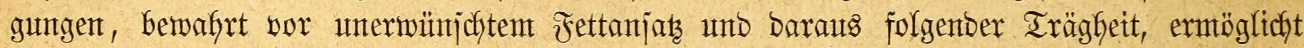
eg bemt Stefangenten, jein Sefieber in volfer Schönfeit unt Dronung zu erhalten, bringt

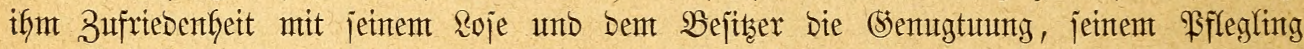

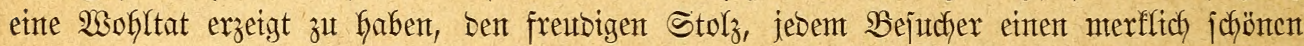

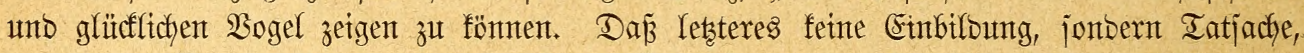

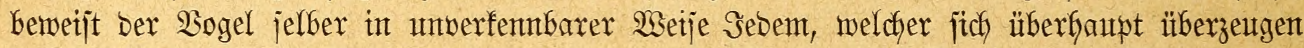
Iaffen, nicht aber vorgejaj̧te 2(njichten unter affen Umitänben zur (Sieltung bringen wilf.

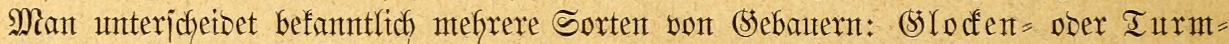

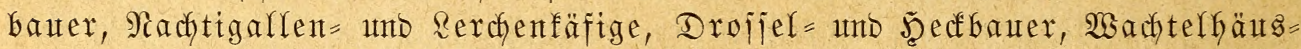

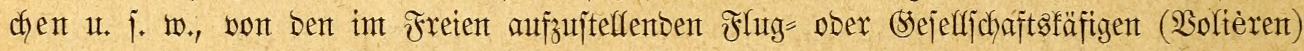

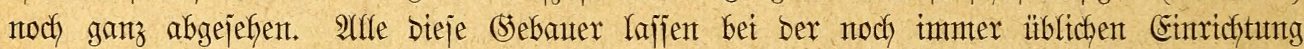

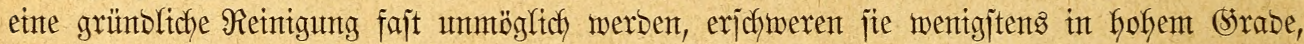
und bies einzig unt alfein besfall, weil ber Socfelteil ungejfyidft gebant ijt. Um biejem Ulebelitanbe abzubelfen, habe ich einen Säfig, wie nachjtefent beichrteben, anfertigen laffen.

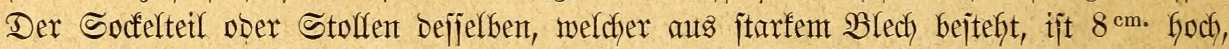

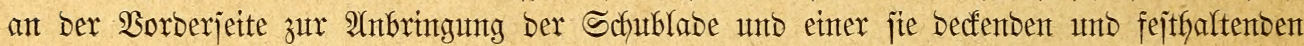

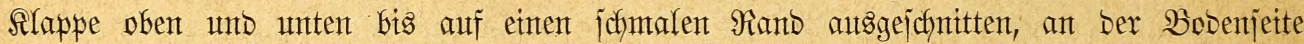
aber nidft burch ein fejtgentageltes Bretchen ober eine aufgelötete Blectrafel gejchlofien,

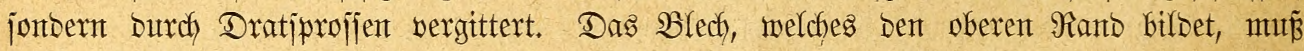

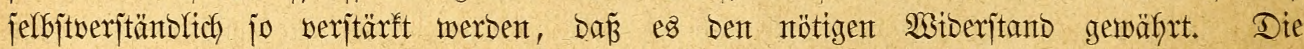

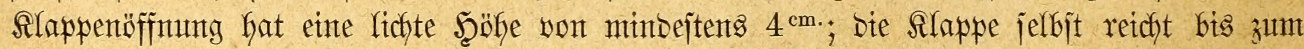
unteren Ranbe bes Sodfelgejtells herab unt wirb fier an ifm burdh einten wageredit

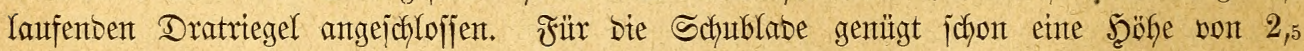

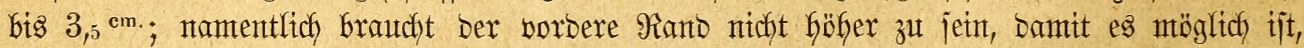

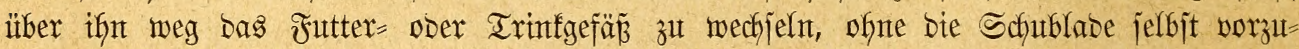
ziehen. Dieje bejteht untabänberlich aus mitteljtarfem B Blech, welches burch breintaligen

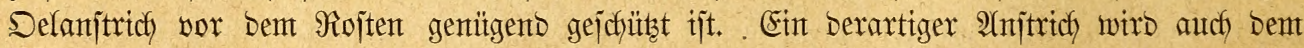
ïbrigen Sodfel gegeben, um ifht zu berjichern unt entiprechent zu zieren. Arls mejentliche

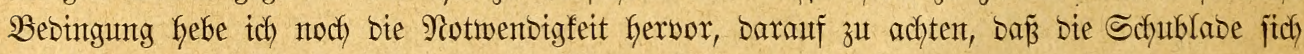
jo leicht als möglich auszziehen und einjchiebent lafje.

Dem funtigen Riebhaber merben bie Sorzüge biejer Eintichtung alsbald einleuthten. Die hofen 2 änbe bes Untergejtellz verfinbern bie bejonters fratten wiberwärtige $\mathfrak{B e r}=$ unreiniguntg Des Zimmers burdy Seritreutt Des Futters ober Beriprïtzen bes Babemaffers, ba alfe ober fajt alfe Stoffe, weldhe ber $\mathfrak{B}$ ogel aus bem Sejchirre wirft, in ber waffer= 


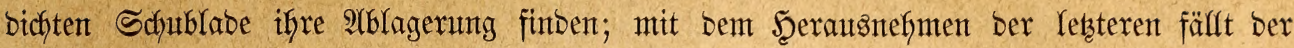

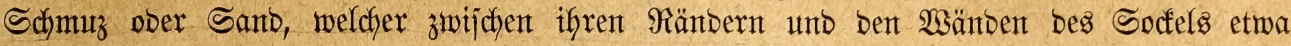
eingebrungen jein möchte, won jelbjt burch bas (sitter auf ben Boben herab ober Yäj̈t fich boch burdh einen einzigen Bärjtenjtrich wegfegen; mit ber Schublabe entfernt mant gleich=

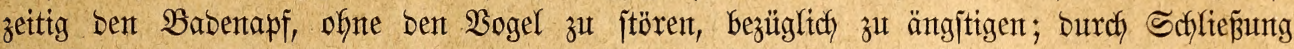

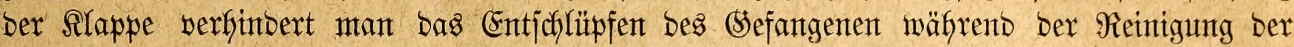

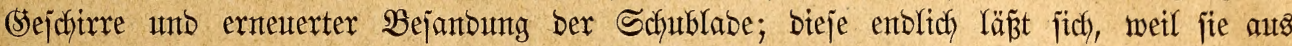
Blech bejteft und mit Delfarbe gebecft ift, ofne jonberliche Mühe mit Waijer abjpillen

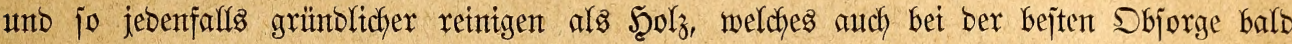
einten wibrigen (Serutch antummt.

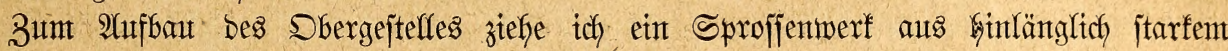

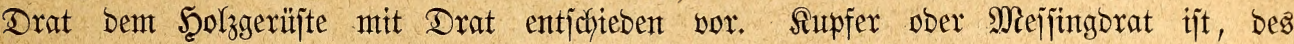
(Srünjpants halber, gänzlich zu vermeiben; verzinfter Draft, weldher gegentwärtig viel= fache Serwentung finbet, hat Manthes für fich, einten Şauptithelftanto aber gegen fich: ex

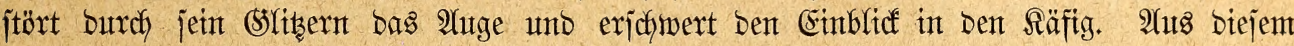
(Sruntbe lajfe ich) Das Dratgerïjt mit Selfarbe ftreidfen unt fwar mit Sdywarz, Dunfel= braun ober Dunfelgraut, Den einzigen Farben, welche benten bes Bogels wentig Eintrag

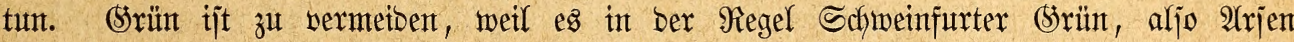

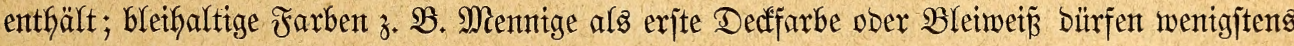
für jolche $\mathfrak{B}$ ögel, welche bie Sprofjent benagen, unter feiner Bebingung angementet werbent,

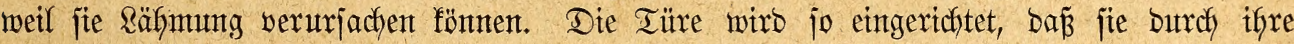

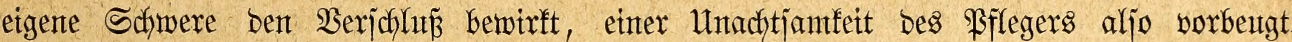
Wenn fie gut gearbeitet wurde, ijt eine bejonbere Schliefsorridstung nicht mebr exfor

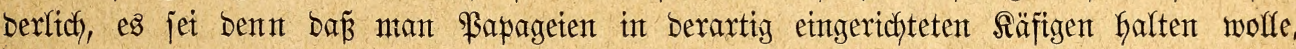

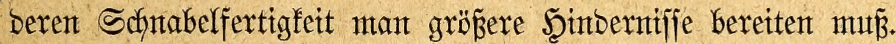

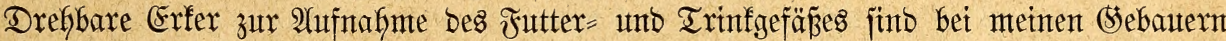
nicht unbebingt nötig, weil man bequen unto mit geringer Befelfigung für ben $\mathfrak{B}$ ogel bie (sejchirre burch bie fllappe einbringen unt herauszieben fant; fie finto aber eine eriprießsliche Bugabe, weil jie eine Bejchmuzung bes Futters burdh Den Miijt Des $\mathfrak{B}$ ogels verhinbern. Ins

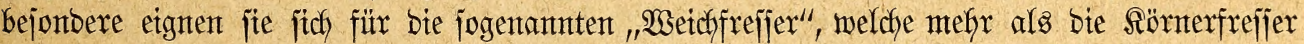

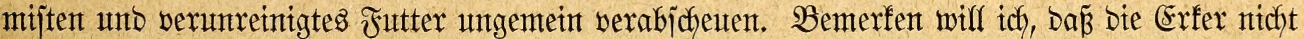

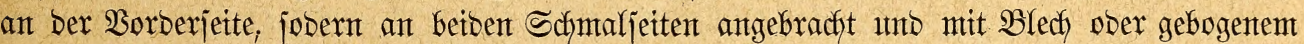

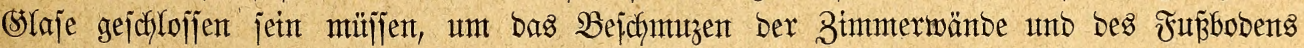
unmöglich zu madyen ober boch zu verringern. Reţteres halte ich für jebr beachtensmert; bent bie "waltente Sausfrau", ja jelbjt bie bejenfïfrente Meago jprechen bei ber

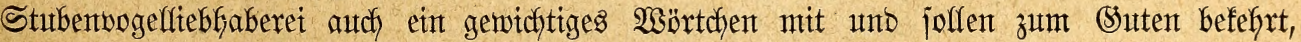
nicft aber zum $2(u f r u t h r$ geführt werben.

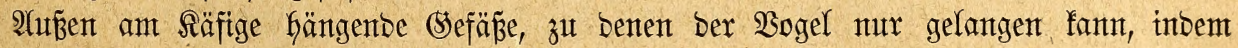
ex jeinen Siopf Durch ein enges \&och zwängt, finto mix ein (Sreutel; 3ugworrichtuntgen, weldye

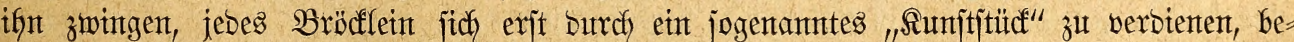
trachte idy als läppijdye Spieleret alberner शarren; bie fier und ba ïblidhe Eintrichtuntg, jeberjeits vorn ein langes frippenartiges (Sejfjirr für Jutter uno Wafjer einzujfjieben,

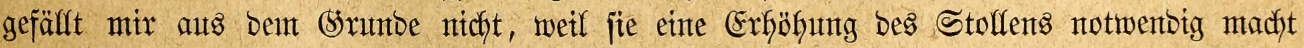

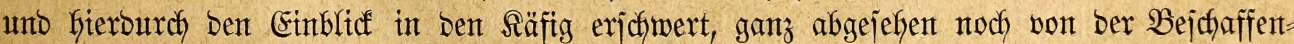
Geit ber Sejefinre jelbjt, welche in ber Regel eine feblerbafte ijt.

Futter=, Trinf= umb Babenäpfe mitifien aus (Slaz ober Forzelfan, bezüglich gut ver= glajtem uno gebranntem $\mathfrak{T}$ on bejtefjen; jebes anbere Material ijt zu verwerfen. Scolz nimmt

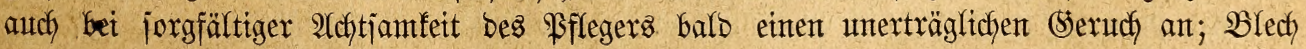




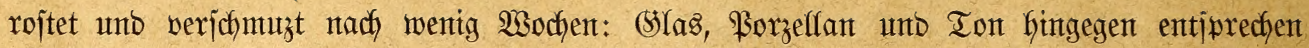
allen 2 Anforberungen, wèldhe man an bergletchen (Sejchirre jteflen fann. Futter= ober Trinf: näpfe aus \$Slas fant man gegentwärtig in jeber F̧andlung zum Preije von 1 bis $1 \frac{1}{2}$ Sgr. für bas Stüuf erfalten ober boch burch fie bezieben; zu Babenäpfen ijt jebe Untertajie ober jeber Ielfer zu verwenden: jolche mit Unterjats zum 2Hfffangen ber nebenjpritzentoen Tropfen habe idy Durch Schomburgf in Berlin aus \$orzellan anfertigen lafjen.

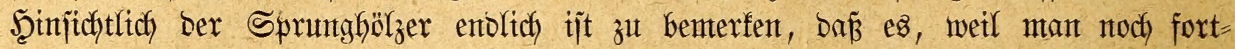
mährent bagegen jünbigt, gar nicht bringento genth empfohlent werben fant, jie jo bid zut

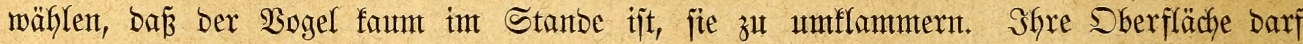

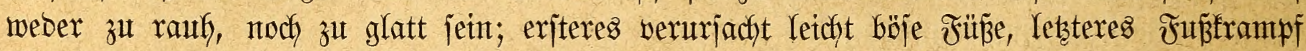
ober boch ein bejchwerliches Fusen. Sehr zu empfeflen ijt bie Exfindung eines Riebfabers,

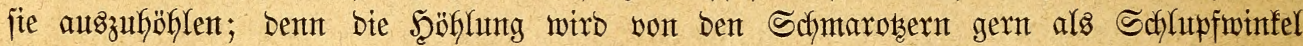
benutzt unt baburdh bem Pfleger (stelegenteit gegeben, bie läjtigen Feinbe jeiner Rieblinge

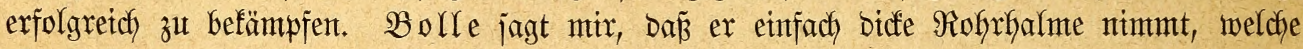
ebenjo jauber ausjehen, als jie leidft zu haben unt zu reinigen fint, auch gerabe benjentigen

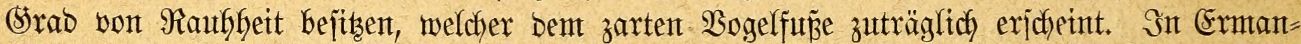

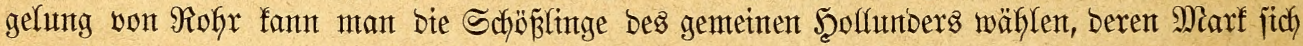

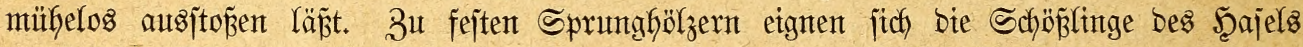

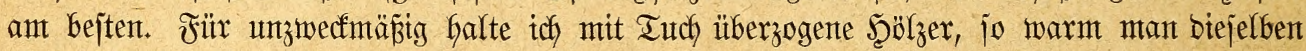
für zartfüßjige Bögel auch angepriejen hat, und zmar aus bem (Srumbe, weil baz Iuch bocks

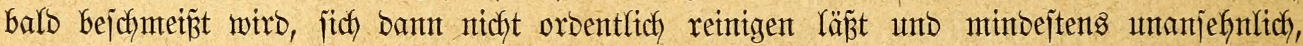
nicht jelten aber in Folge bes auf ifm haftenten Siotes Gärter unt rauker wirb als ein=

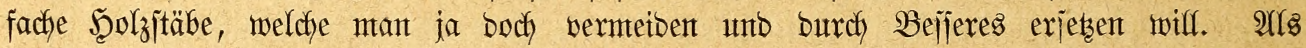

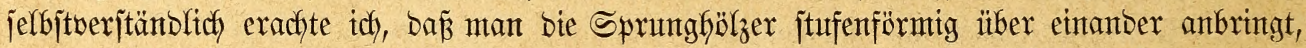
um bem $\mathfrak{B o g e l}$ einen bequemen Sprung zu geitatten unb, falls man mefrere zujammenhält,

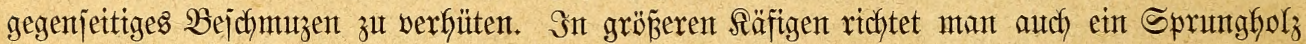
Der sänge nach her, weil burch ein joldyes ber Sprung bes Bogels wechjelvolfer und ifym angenefiner wirb.

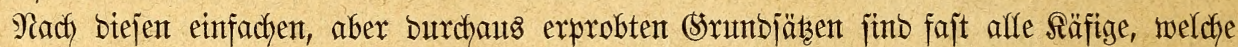
ich) gegenwärtig werwentoe, gebaut unb eingerichtet. Sie fommen höher zut fteben als bie meiften, welche bisher im (sebrauth) waren, übertreffen bieje aber audy bebentent an 3wed"=

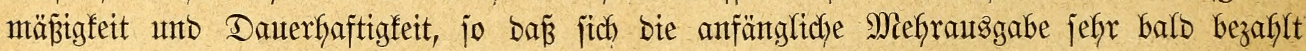

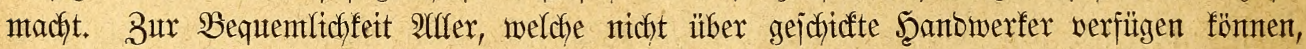
Gabe ich einen Giejigen Fabrifanten bejtimmt, Die gebräuchlichjten Sorten anfertigen zu Yajןen

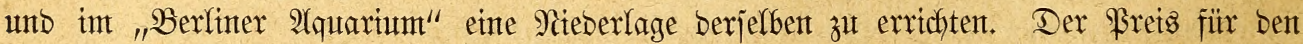

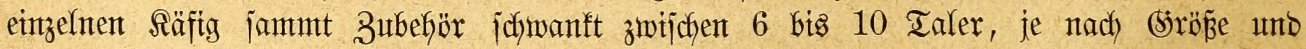

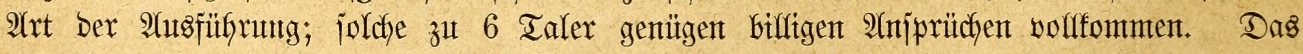

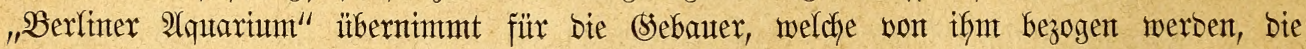
Berjicherung ber vorjdyriftsmääpigen und orbentlicten Seerjtelfung, und tragen afle Räfige

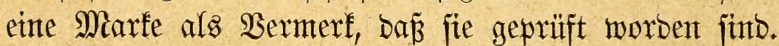

In ben bejdyriebenten Räfigen Galte ids ofne Bebenfen audh Bugbögel, jelbjt Sprofier,

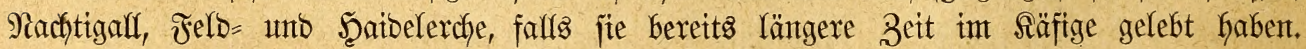

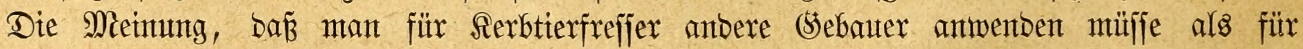

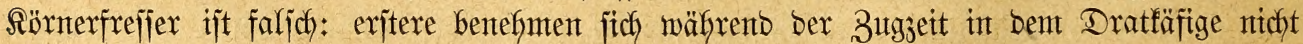

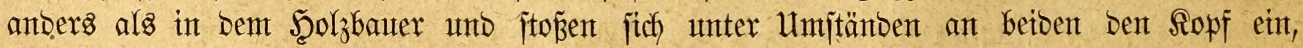

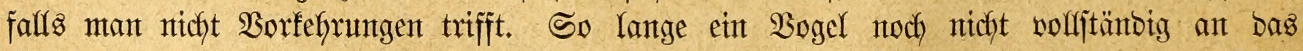

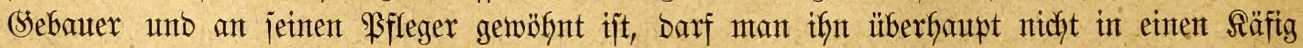
bringen, in welchem ex jidh jchaben fann; unt ebenjo muz man Bebacht nefgmen calf bie= 


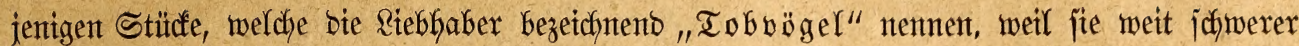
als anbere eingemöbnen, bei jeber (selegenheit umberflattern unb wäfrento ber 3ugzeit oft wie unfinnig fich gebärben. Die einen wie bie anberen müjfen nicft affein in bejonberen Räfigen, jonbern auch unter bejonberer $\mathfrak{P f l e g e}$ geffalten werben, wie bies weiter unten aus= gefübrt werben joll.

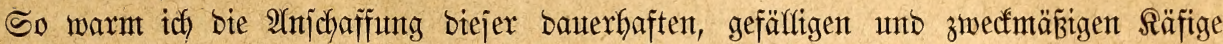

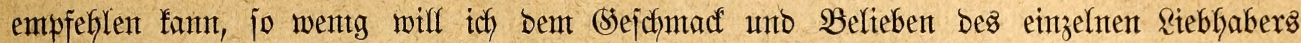

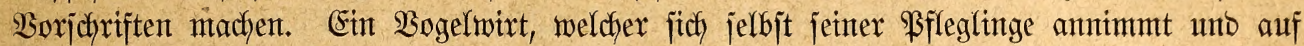
bie Reinigung Der Ssebauter bas gebürende (Semiddyt legt, wiro audb, went er Räfige mit

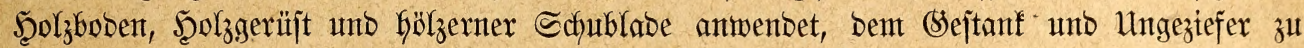
begegnten im Stande jein, zumal, wenn ex fich für jebes Bsebauter zwei gut angejtricfjente Schublaben anjchafft unb bieje täglich wedjjelt und frijch bejandet, bie Räfige jelbjt in Sromung Gält, fite zeitwetlig mit Reinöl bejtreicht unb alles tut, was weiter unten, als zur Wartung geförig, gejagt werben joll. Gch habe bet metnem Freunbe Fieblex in Algram

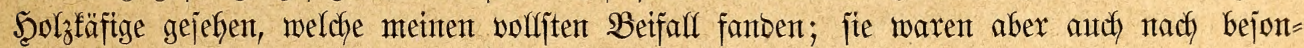

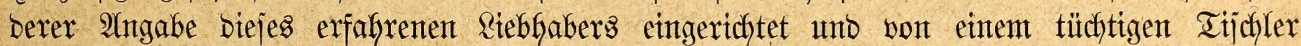
ungemein jauber gearbeitet.

Unter allen hölzernen Bebautern gefallen mir am bejten bie $\Re$ ijtenfäfige, wie wir

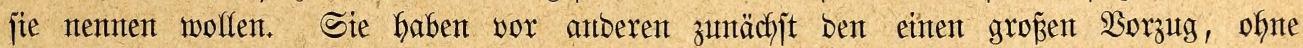

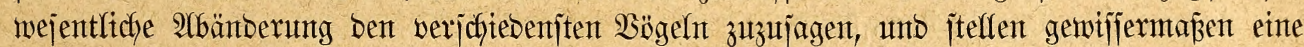

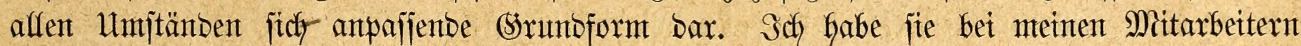
(Sirtanner und Stöffer in ber Schweiz fenten gelernt. Sie bejtefen aus einer leidhten

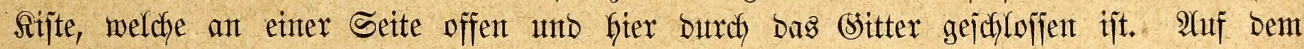

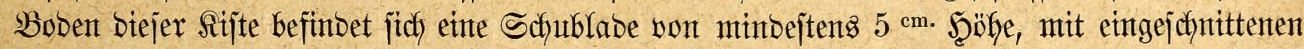

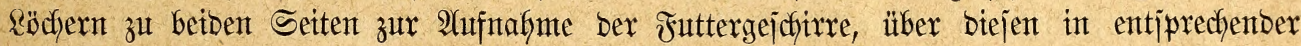
Şb̈he je ein jofief nach intmen unto unten genteigtes Bretchen als Decfe, zur 2(bbaltung won herabfalfendem Unrat, aufgeworfentem Sande unb Dergleichen; ein ähnlliches, mur jofłmäleres

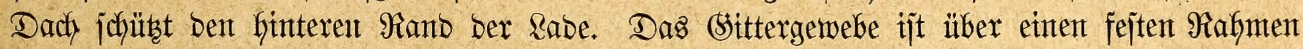

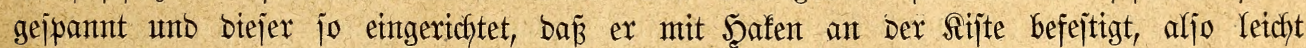
abgenommen unt mieber aufgejetzt werben fant. Sebe Seitenwand bejitst eine von unten

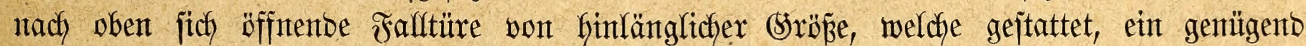

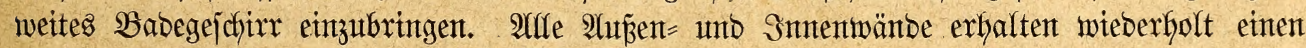
gebiegenten Selanjtrich und fint in ben Fugen nody bejonbers burch Sitt vor bem jich jonjt vielleidht einnijtenden Untgeziefer gejchütst.

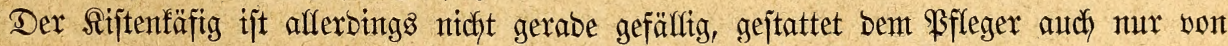
einer Seite Einblicf, hat aber boch mandje Borzüge vor anteren Bebautern. Der in ifym haujente Boget fühlt jich vom 2Anfange an ficherer als im Sprojienfäfige, wirb beshalb

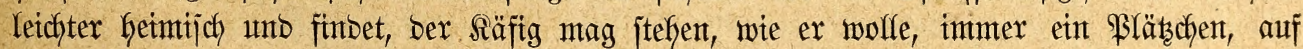
meldyem er fïh) vor $3 \mathrm{ug}$ vollfommen jchützen fann. Afuch verntag man ofyne jegliche SBejdränfunt Sprunghölzer in beliebiger $2(n z a h) l$ unb gerabe ba zu befejtigen, wo man es

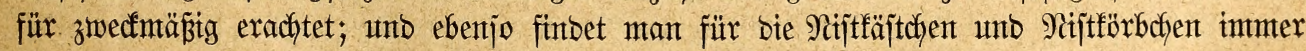
ein berjtecftes \$rläbchen, am einfachjten in ben beiben finteren Ecfen, mojelbjt man bant

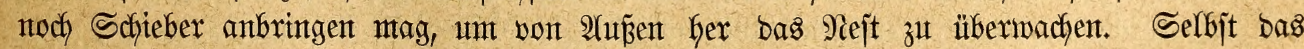

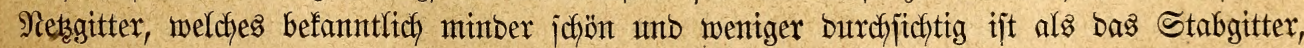

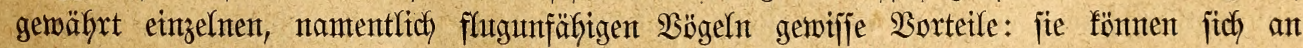
ifym leichter in bie Şähe helfent als an jentem. Bubem ijt es haltbarer unto bifliger als

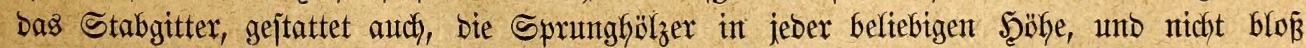
auf ben Duerjtäben anzubringen. Jutter=, Irinf = uno Babegejcfirre lafjen jich ebenjo 
leidyt einjichteben, wie in Den von mir erbachten Räfigen. Die Reinigung verurjacht audh nicht bejonbere Schwierigfeiten, weil man Yeidyt zmei gleiche Säfige mit entjprechent geöfineten Türen neben emanber ftelfen, ben $\mathfrak{B}$ ogel won bem einen in bas anbere (sebauter über= ipringen lafjen fann unt bas betreffentbe bann jo grünblich, als erforberlich ijt, zut reinigen vermag. Fallz bie Bögel nidft gerabe brïten, nimmt man bie affgemeine Reintigung vor, jo oft fie fich nötig madft; Denn jene merfen bie berurjachte Störung faum ober nicft,

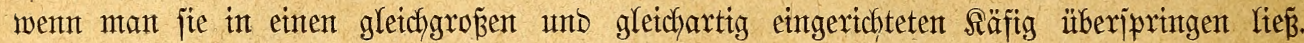

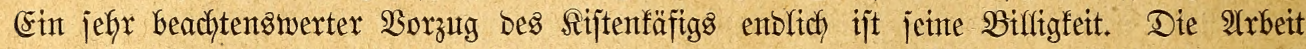
ift jo einfach, bas (Sitter, weldjes recht gut ein Semebe ober Majchinengeflecht jein barf,

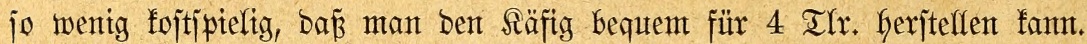

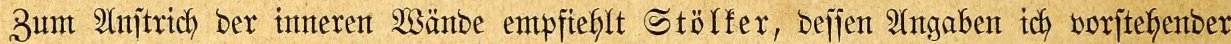
Bejchreibung zu Srumbe gelegt habe, ein bunfles Braun, weil fich von biejer Jarbe bie

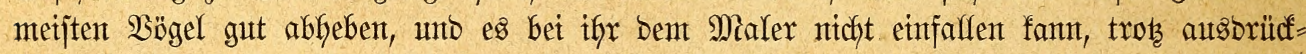
lichen $\mathfrak{B e r b o t e g ~ g i f t i g e ~ F a r b j t o f f e ~ z u ~ v e r w e n b e n . ~ D e r ~ a ̈ u p e r e ~ 2 f n j t r i c h ~ f a n t ~ b e m ~ b e r ~ Z i m m e r ~ = ~}$ geräte ähnlich gef̧alten werbent.

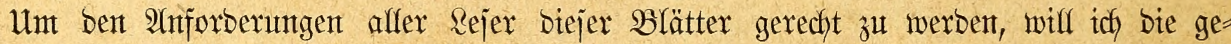

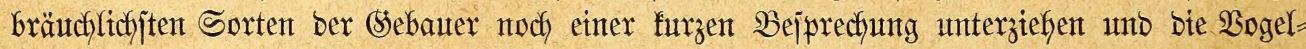
familien angeben, weldse in bem einen ober anberen Räfige gemöfnlich gefalten werben.

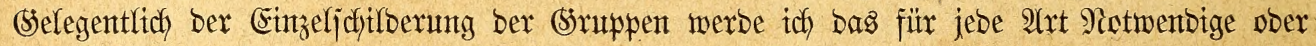
Eriprieß̧liche noch bejontoers anfü̈fren.

Dbenan jtelle idy ben Finfenfäfig, wie idy ifnn nemten will, ben Säfig Dex Räfige. Er bient mix für affe Finfen im weitejten Sinne, für bie meijten ferffreffer, für jämmt= lidye fleme Papageten, für bie Tangaren unb anberent Schmudföger, Meijen 2 c, jelbjt für

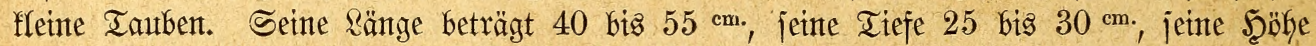
$35 \mathrm{biz} 45 \mathrm{~cm}$; Bau uno Eimrichtung fint bie ber worjtebento gegebenen Bejchreibung; bie

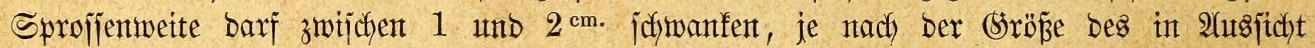
genommenten $\mathfrak{B o g e l}$. Eine $\mathfrak{B e i t e}$ von 1 bis $1,5 \mathrm{~cm}$. entiputicht bent gewöhnlicthen Bebürfniffe.

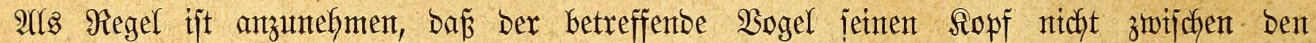
Sproffen burchjtecfent fann, wie ex gern berjucht, zumal ment bie Sproffen nicht miber=

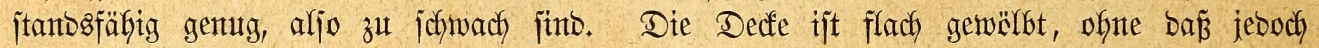
fierauf (Semidyt gelegt wirb; bent jie fant ebenjo gut auds wageredyt jein. Drei Sprumghëlzer, eints oben in ber Mitte, brei 3oll über ben untern unt je eins vier 3olf von jeber Seitentwand angebradft, ein Futternapf unb ein Irinfnapf aus (5) Ias, jonte ein

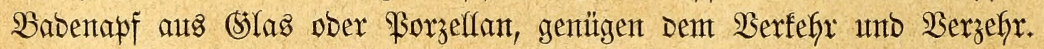

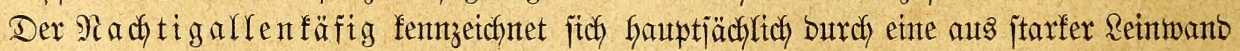

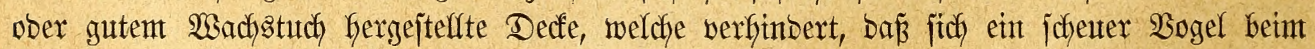

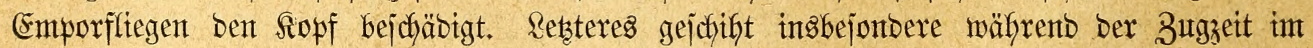

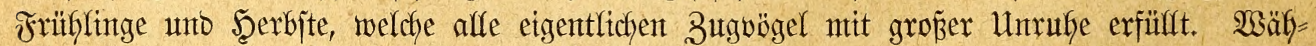

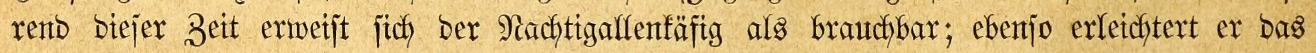
Eingemöhnen frijdgefangener $\mathfrak{B o ̈ g e l ; ~ e n d l i d y ~ g e m a ̈ h r t ~ j e i n e ~ D e c f e ~ e i n ~ S c h u t z ̇ a c h ~ g e g e n ~ b i e ~}$ Sonmenitralen, für ben Fall, baj man jeinen $\mathfrak{B}$ ogel vor bas Fenjter Gängen wilf. Da=

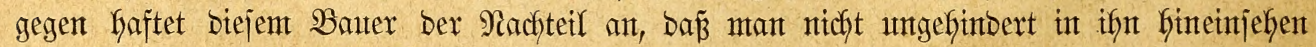
und iffn niemals orbentlich reinigen fant, jonbern im (siegenteile in jeinter Bebacfung für

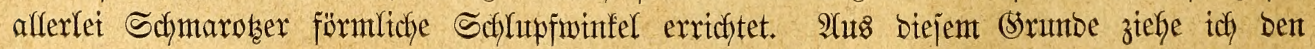

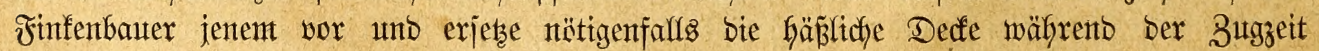

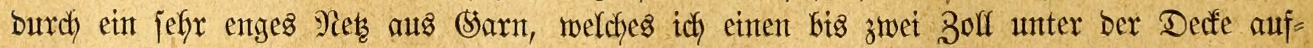
ipante, nach ber 3ugzeit aber mieber abnebme. WSer jente Niachtigaffen in Sommter

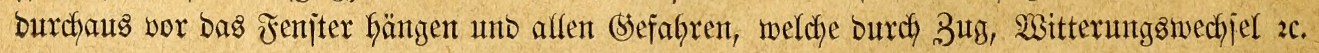


entitefyen, preiżgeben will, mag fich bes̀ veralteten Nachtigaflenbauers bebienten, fann aber ebenjo gut autch ben Finfenbauter zeitweilig mit Wadfstuch überbedfen. Mich jtört bie

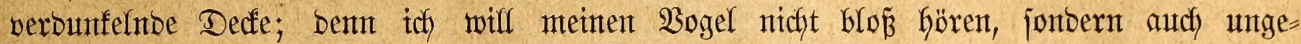
hinbert jebent.

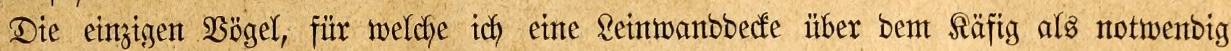
eractite, fint bie Rerchen, weil fie währent bes Singens, won ber Begeifterung hingeriffent unb wie in ber Freifeit gemöfnt, empor zu jteigen pffegen. Da jie nun auserbem \&auf = bögel finto, fommt man ifren Beoürfniffen eintigermaken nads, went man ifnen einen längeren Siäfig gibt, als jolchen anbere Bögel erfaltent. Der serchenfäfig, wie man

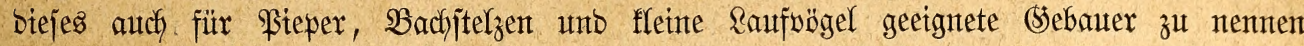
pflegt, hat einte Ränge von $40 \mathrm{biz} 65 \mathrm{~cm}$, eine Tiefe von $25 \mathrm{biz} 30 \mathrm{~cm}$. unt eine Sitterföhe (ofne Ulntergejtell) von 22 biz $26^{\mathrm{cm}}$, ijt mit Reinwand gebecft, bejizt Erfer (nicht aber bie

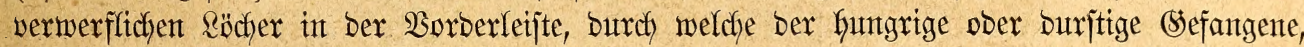

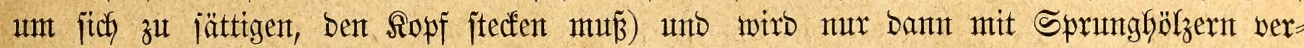

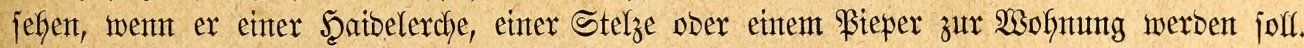

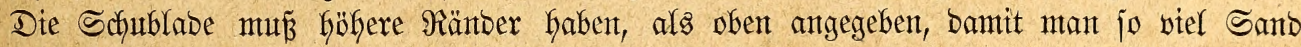

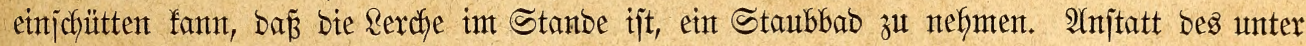
Der Sifublabe befinblichen (sitters bringt man einten Blechboben an, weil bie serchen an einem (Sitter, auf weldyem fie wenn auth) nutr furze Beit laufen müffen, in Folge ifyrer langen Befjen oft Gängen bleibent unb bann jich leidst bie Beinte brechen fönnen, zumal

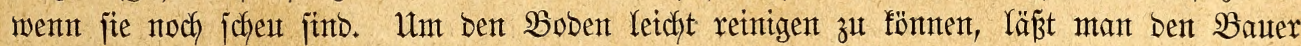

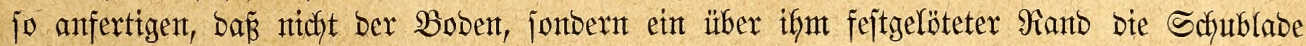
trägt, ber Boben jelbjt finten in 2Angelnt geht, vorn aber vermittelo Şafen am Sodfel befejtigt mird, aljo jich nieberflappen läßjt.

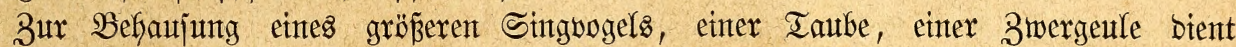

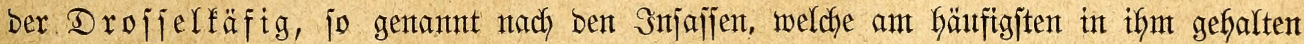
merbent. Er ijt ein mit Erfern berjefener Finfenbauer int Srožen. Die Ränge fant

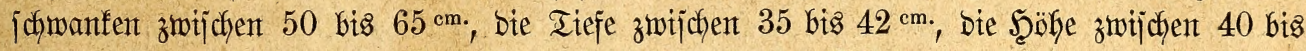

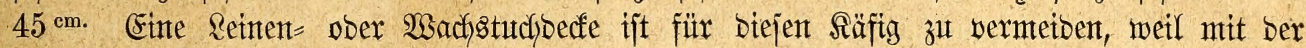

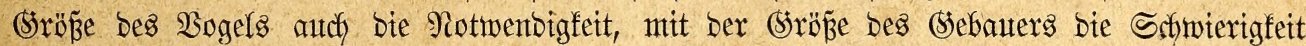
offerer Reinigung zuntmmt.

Ein Bauter, weldjer nur jefhr ausnahmsweije zwedfentiprechent hergejtellt miro, ijt bex (5) lo dfent = ober Iurmbauer. (Semöhnlich. fertigt mant ifgn biel zu flein an, in ben

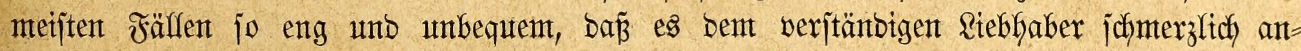

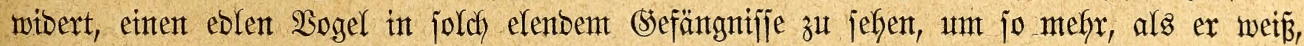

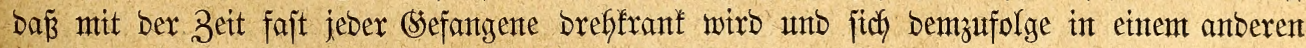
befieren Säfige gar nicht mehr zurecht finben fant. Das runbe, jechs = ober achtedfige

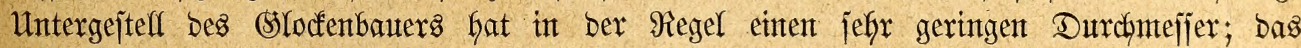

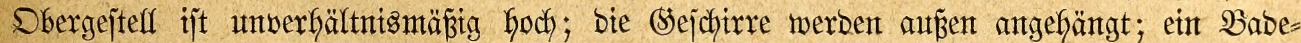
napf galt für untötig; bie Reintgung läß̈t fich nux betwerfftelfigen, nachbem man ben

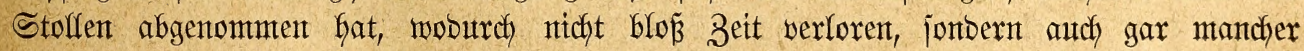
Bogel unabjichtlich in Freifeit gejeşt wiro - Den Satsen zur beinafy ficheren Beute. Ein joldjer Säfig ijt unbebingt zu verwerfen: ex ijt ein abjecheultcher fierfer unt zugleich ein

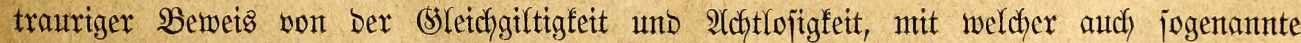
Stebfaber igre Bögel befandeln. Nar ber alte Schlentorian, Die Denffaulfeit bes Berfer=

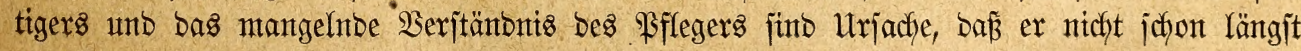

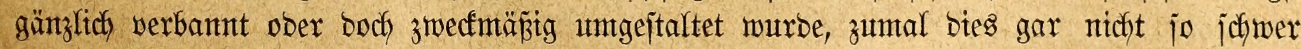
Gält, als man zu glauben jcheint. Allen Uebeljtänden unt ber Jormlofigfeit bes (slocfen= 
bauers läßjt fich abjelfent, went man bas Sechsecf zur Srumbform nimmt, Den Durdjnteflex auf minbejtens 35 , beffer noch auf $40 \mathrm{~cm}$. erhöht, ein Biertel bis ein Drittel biejer Maßze mefyr auf bie Şöhe rechnet unt an zwei jich gegenüberitehenden Seiten Erfer anbringt. Wex zu zeicfnen veritefft ober jich an einen bilbenben Sïnjtler wenben fann, ijt im Stanbe, biejem jonjt jo ungejchictenten Säfige eine jehr anjpredfente Form zu geben und ifn zu einer wafhen Bierbe Des Bimmers zu gejtalten. Der (\$)locfenbauer, in weldyem man

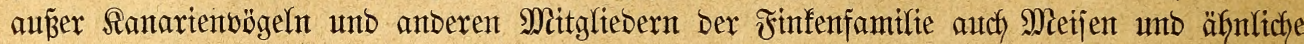
Sletterfünftler zu halten pflegt, läß̈t fids, pafjenter als jeber anbere, an bie Decfe hängen und ebenjo auf einem runben Iijdydyen mit Bhlumen in Berbinbung bringen: - es fift

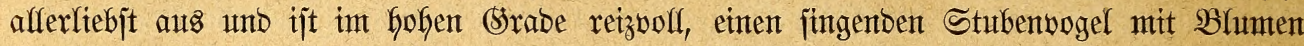
zu ungeben; es ijt, als verjob̈nere man baburdy iffn und jeine seieber.

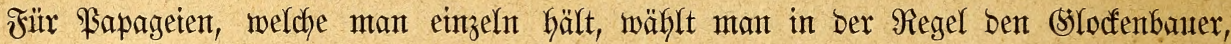

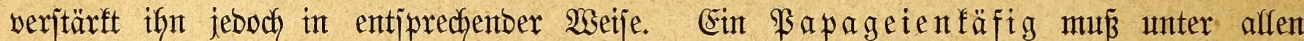
Umitänben auts Metalf gebaut jein, weil fich jeber größęere Sittich ofne Berzug an bie Zerjtörung affer nicht niet= unb nagelfejten Ietle jeiner Behaujung madyt, uno in ber Simjt zu vernichten Erfferfliches leiftet. Der Durchmejier eines joldhen (Sebauterz Darf nicht unter $65^{\mathrm{cm}}$, bie Şöhe nicht unter $85^{\mathrm{cm}}$. betragen.

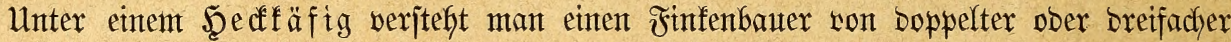

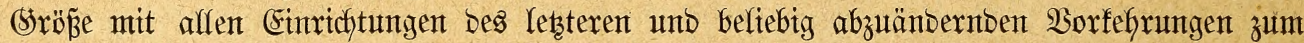

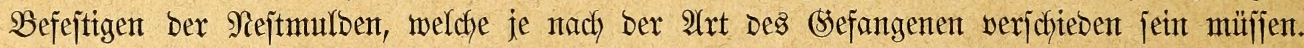

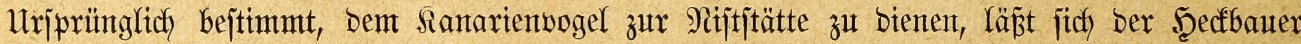
aud) für anbere Finfenarten, welche man zur Fortpflanzung zu bringen wünjot, mit Exjolg

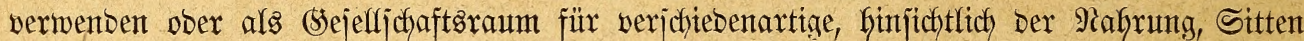

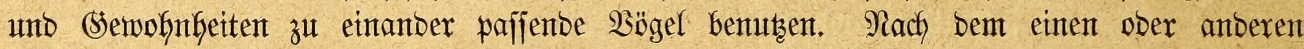

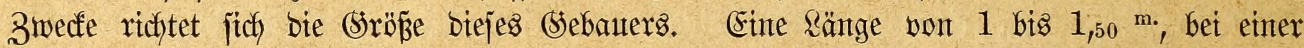

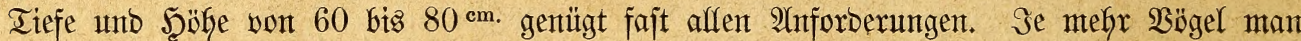

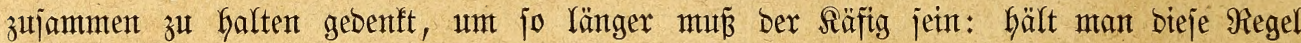

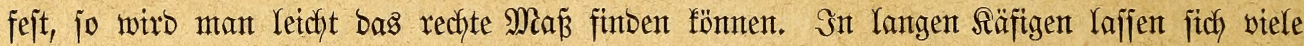
Sprunghölzer anbringen and bamit mandhe Unzuträglichfeetten, afs bie find: gegenjeitiges Bejdymuzen, Zanf und Streit um ben bejten Sibplats zux Nad)trube zc., exfolglich vermeiden,

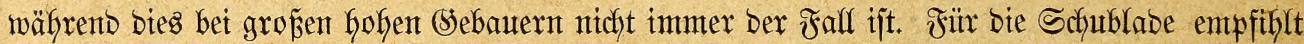

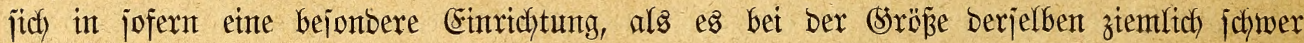

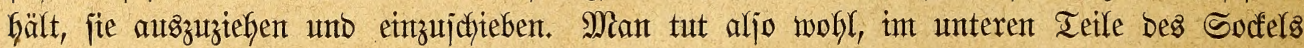
zu betben Seiten idfwache Eijenjchienen und am Boben ber Schublabe fleine eijerne Rolfen anbringen zu lafjen, welche auf jenen laufen. (Serabe bee $\mathfrak{B o ̈ g e l n , ~ w e l c h e ~ b r u ̈ t e n ~ j o l f e n , ~}$

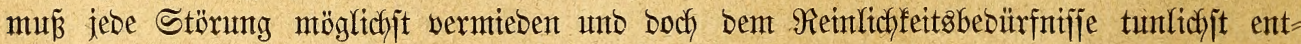
iprocten werben; eine Derartige Errleichterung trägt bemgemä̈ jtets ifgre Früchte.

Benaueres Eingehen auf bie Einrictutung biejes (Siebauters zum Brutraum ijt fier nicht

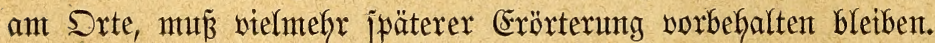

Wollte ith noch won alf ben übrigen Räfigen iprechen, weldhe in biejer ober jenter

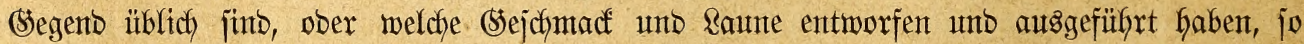

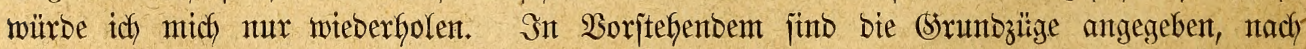
benen man berfafren fann, unb bleibt es bem Ermeffen bes Estzelnen überlaffen, zu änbern, jo viel er wifl, Der Errahrung Des benfenten siebhabers ankeintgejteflt, zu beffern,

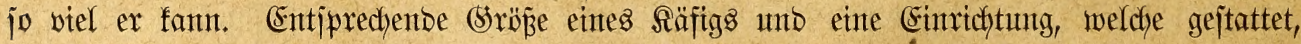

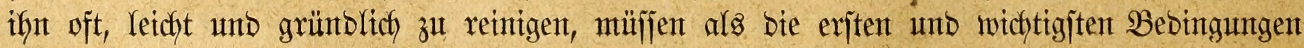
angejełen meroen. 


\section{Die Wogelftulbe.}

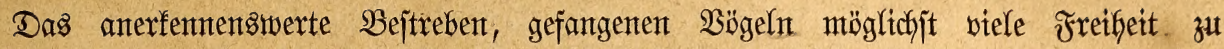
gewähren, hat einzelne Riebfaber beítinmt, ifyren \$ffleglingen ganze Zinmer einzuräumen, unt bieje zu einer jogenannten "Sogerfjtube" zu gejtalten. Sn ber Nenzeit ijt über bie Borzüge und Freuben einer jolchen 2 ogelftube viel gejdfrieben morben; idy habe jeboch in

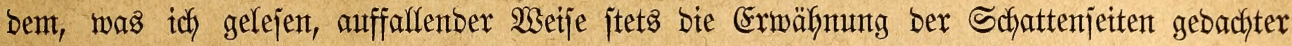

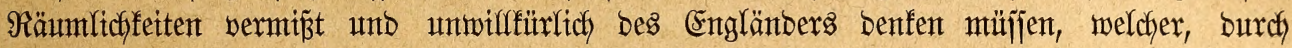

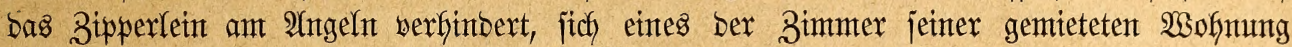

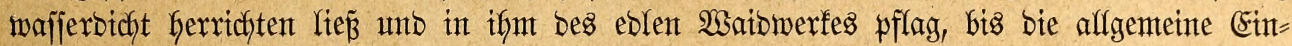

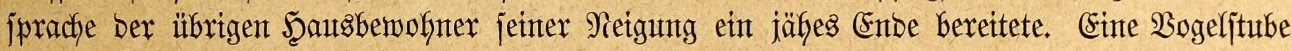

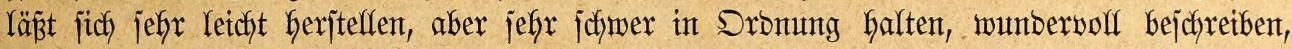

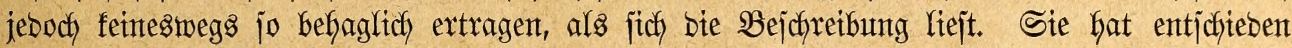

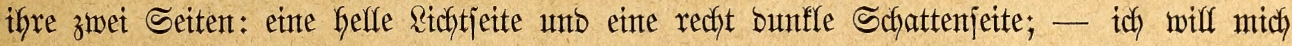
veritänolidy) zu machen juctjen unt beibe nebenteinantoer fteflen.

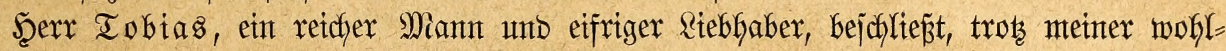

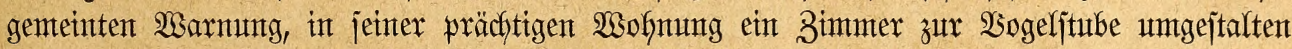

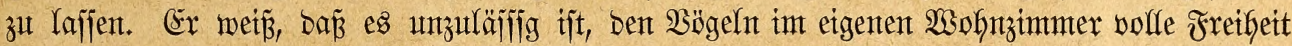
zut geben; Dent ex hat bie nachjtehenben 2 sorte meines Baters gelejen unb wohl beherzigt:

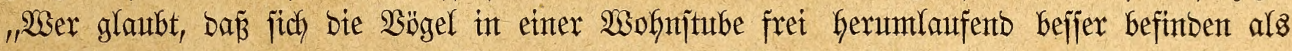

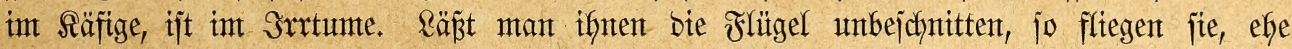

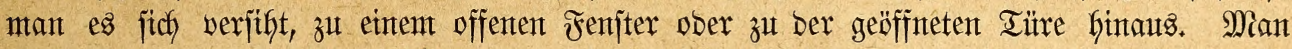
famt fierbei gar nicfft borfictfig gemug jein uno befinbet fich noch in ber traurigen Not=

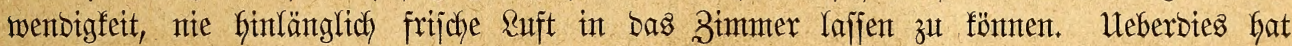

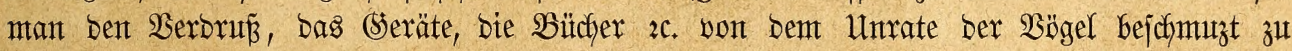

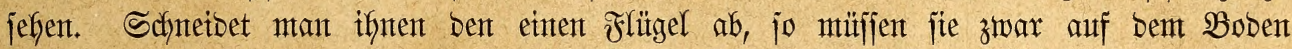

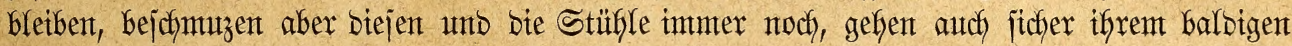
Untergange entgegent. Der einte wirb vont eittem utterwartet Gereingefommenten Scunbe

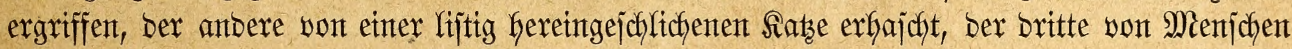

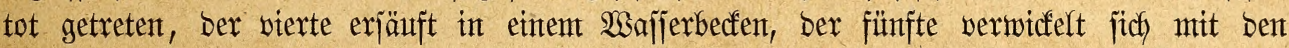

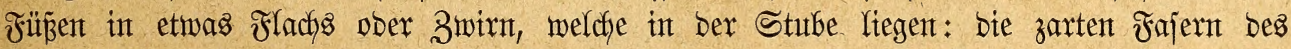

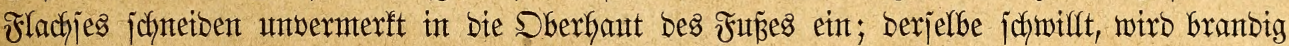
unt bringt bem $\mathfrak{B}$ ogel ben Untergang." Dieje wafhen, auf Erfafrumg begrünbeten 2 Sorte

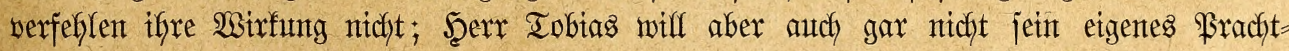

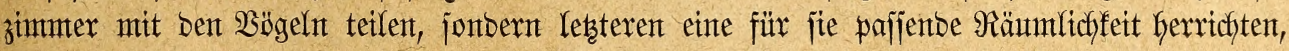

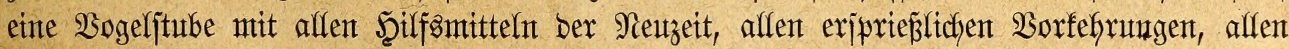
Atrutefyntlidsfeiten Gerftelfent.

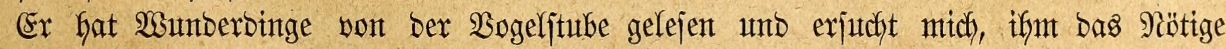

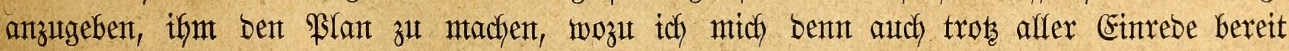

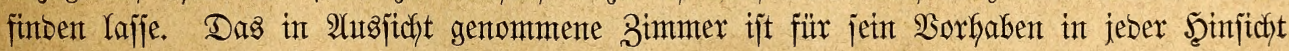
geeignet. Es liegt nach) Sinben, ift jefy geräumtig, hat zwei hohe, helfe Fenjter, mur einen

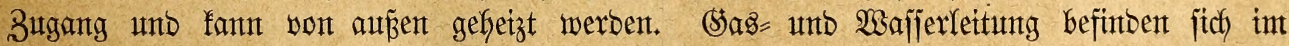

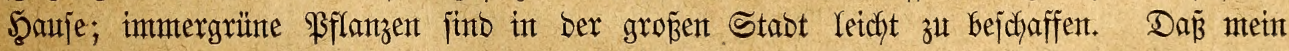

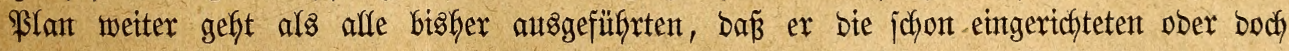

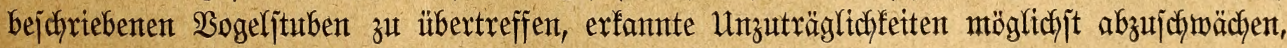
Serbefferungen einzufüffren jutht, veriteght fich von jelbjt. 
Die Arbeit beginnt, unt nichts miro gejpart. Man bringt bor betoen Fenftent zierliche Dratgitter unt in je eintem Flügel einte Rüftuntggflappe ant, nagelt eine B̧lechbecfe

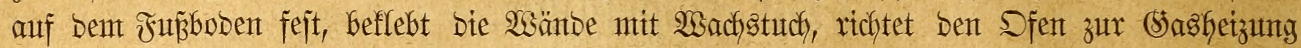

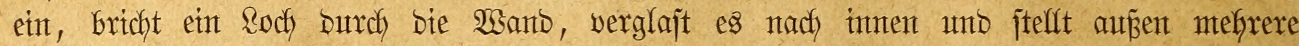

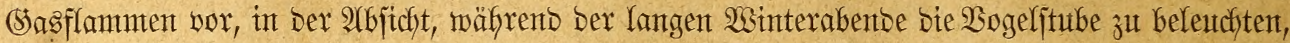

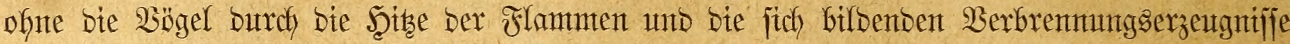

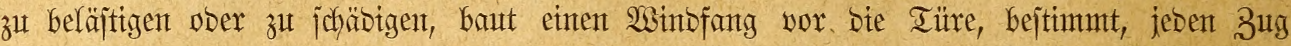

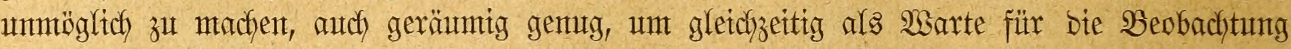
zH Dienen, exridftet in ber Mitte Des 3immers einen Springbrumten mit flacher Schale

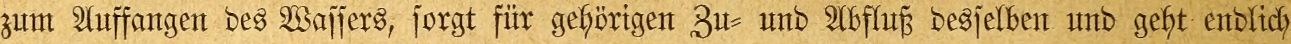

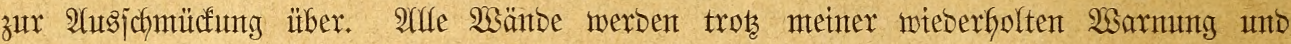
Einjprache mit Ephen und anderen Edylingpflanzen begrïnt, bie Ecten gejchmadtuolf nit

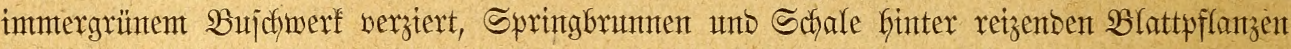

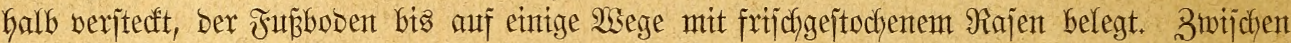
bie Schlinggemädbje hängt man SBrutfäftchen, geflodjtene Strof = und Weidenfürbchen, die einen oben geöffnet, bie anberen bis auf ein Flugloch gejolofifen, fleine (sebauter unb jonjtige Unterlagen für bie bon ben Bögeln jelbjt zu erbautenbent গiejter. Es feblt nichts, was zur

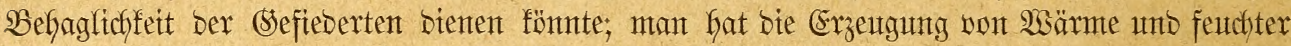

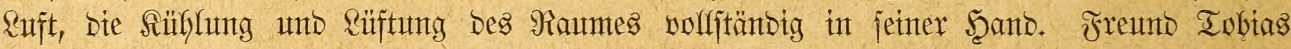

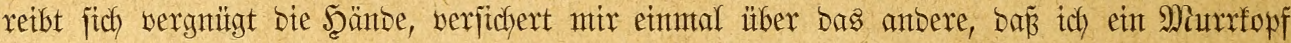

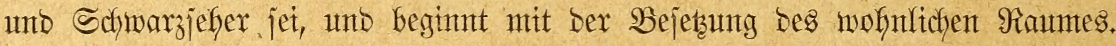

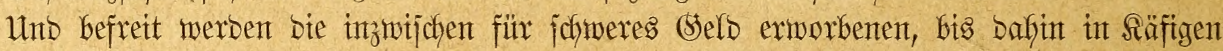

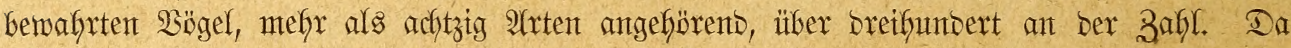

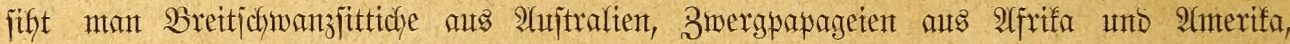
Biteritticte aus Sndien, Roris, Safadus und andere Sitgfteber Der Sronutg, afrifanijche, ajiatijche, aujtrafijche \$rachtfinfen, europätjche unb anterifantjche Sïrnerfreffer; man gemahrt Starvögel, Slanzoroffeln, Drofjeln, Spottoögel uno befauntere Esoljänger, fleme Inuben,

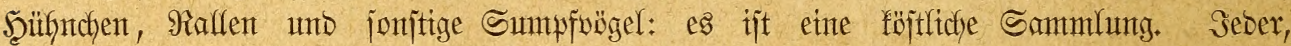

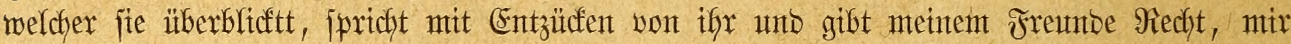
aber unredft.

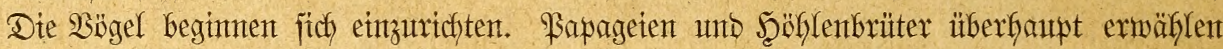

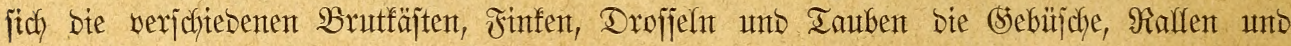
anbere Sromungaverwandte bie Itefe. Eintge fangen fichon nach wentgen Iagen mit bem Bau ifyrer Nejter an, - Die Bapageten and mefrere ber frärferen Finfen bereits menige

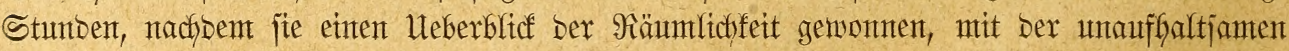

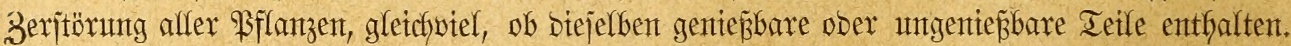

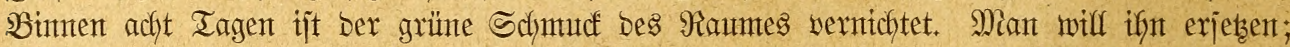

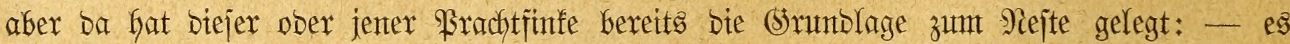

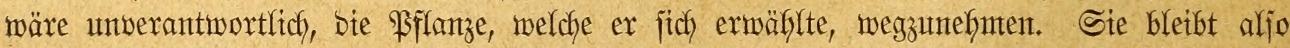

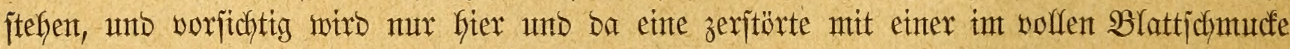
prangentont vertaujcht; aber lebere fifft bald genth wieber genau ebenjo auts wie bie

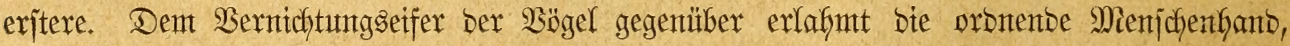

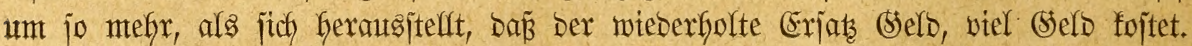

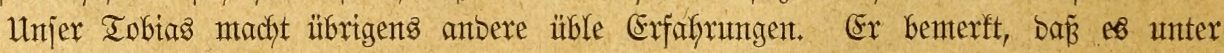
\$apageten unb Finfen enticfiebente Störenfriebe gibt. Şalbfertige ober bereits volfenbete

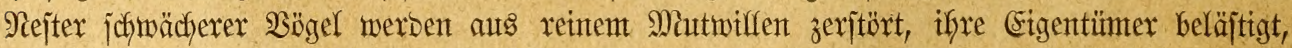
verfolgt, gebifjen, getötet. Eine harmlos erjchententoe Raffe bejchäftigt jich zu nticht geringent

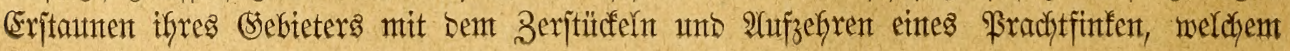




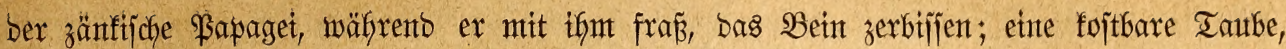

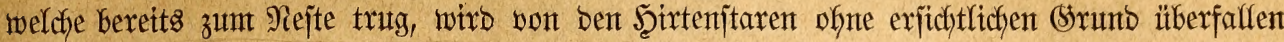

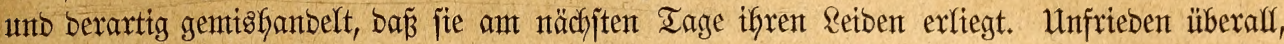

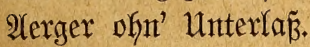

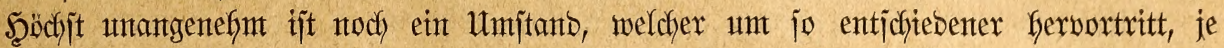
länger bie Sogelitube bejteft. So viele Sorgfalt man audh auf bie Reintgung nermentete, io untoolffomment gelingt fie. Wänbe unto Fuß̧Goben jeben bald abjcheulich aus; in jedem Winfel, auf jebem Borjprunge jantmelt fich ein Mijtffaufen. Das Sras bes gelegten Rajens ijt längit beroorben unt trägt, weil es aflen Utnrat in jich aufnimmt, jefrx rejentlich bazu bei, üble Serüche zu verbreiten, welche feinte süftung mebr bannen wilf. Surz, nach

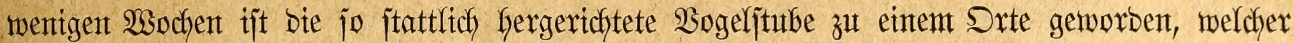

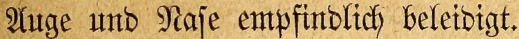

Die Erzählung ijt erfuntben; Denn idh fente feinen Sogeltobias, welcher ez fich jo viel (Selb bätte fojten lajfen, als bie Eintidfuntg joldfer Sogelitube exforbern mürbe: abex ber Scergang in einem mit $\mathfrak{F f l a n z e n ~ g e j d y m u ̈ c f t e n ~ u n t ~ m i t ~ g e n a n n t e n ~} \mathfrak{B}$ ögefn bejebzten

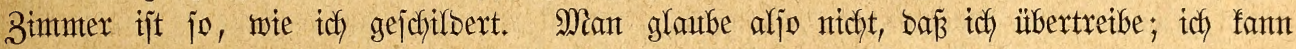
jedes meiner 2 orte Durch gemadfte Erfahrungen belegent. (58 geht inmter jo unt fann

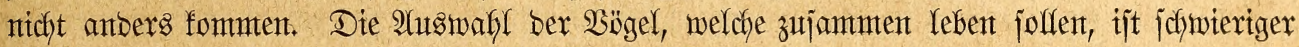
als man glaubt; Das Ergebnis aud ber jorgfälttgitten Wabl feineşwegs immer basjelbe;

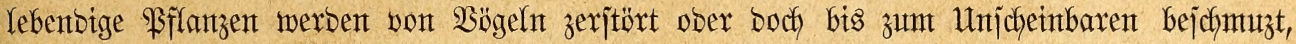

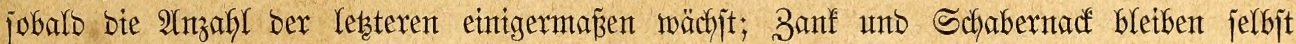
unter ber Garmtojejtent (Sejellichaft ber Sefieberten nidyt aus.

2lngenommen aber auth, ber Streit wäre bejeitigt, biejer ober jente Störenfrieb unt=

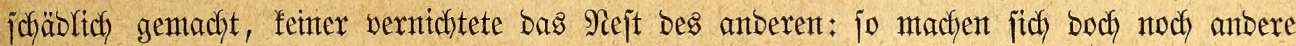
Unzuträglidffeiten geltent. Die Bögel in joldyem Raume verbittern Dem Sogelwirte bie

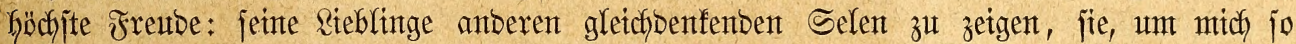

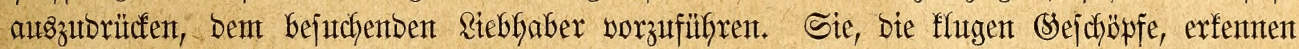
ben Fremben fofort, werben unruffig, fobald ex fich zeigt, flattern ängitlich umber ober

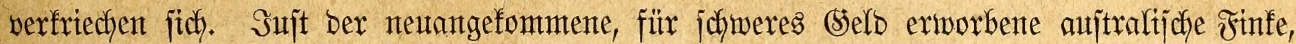
wegen beffen ber Freumb jith auf Den $13 e g$ gemtacht, ijt nirgentos zu finben, menn biejer ifn jefen mifl: - unto man mollte boch mit SBewubtjein ifn zeigen! Saat man an ber einen Want eine Warte für bie Beobachtung errichtet, jo bleibt bieje Want auper Sicft,

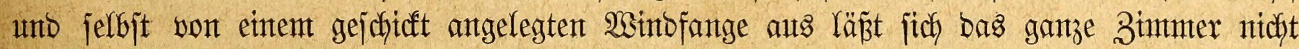

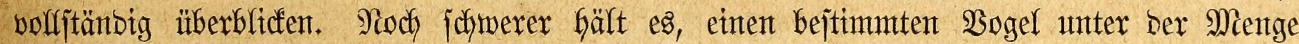
Gerauszzufangen, jet es, unt ifynt bie Nägel zu bejchnetben ober, weil er leibent, zu behanbeln.

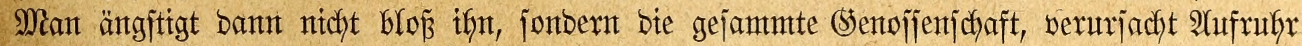
unt Serwirnung, unt bringt fich um bereits erzielte Erfolge ber Zäfmuntg. Frantfe Dögel

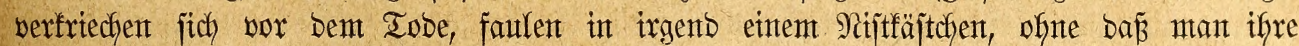

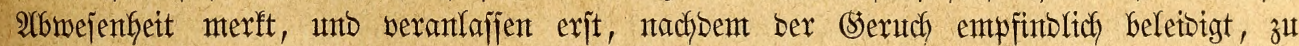

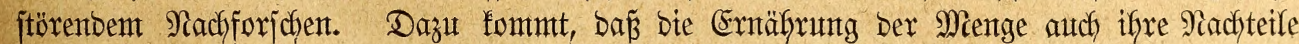
hat. Son bem für bie $\mathfrak{B}$ eidjfrefjer unto zarten Finffen bejtimmten Futter jobmarotzen bie

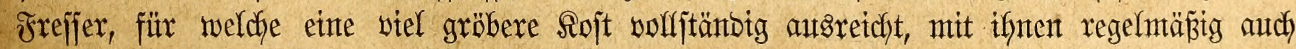
bie Miäuje, weldje in ber Sogelítube ebenjo fidfer fith einnijten wie im Fluggebauter unto in ben Butfäitchen Gerrliche Sexjtecfpläţe finben.

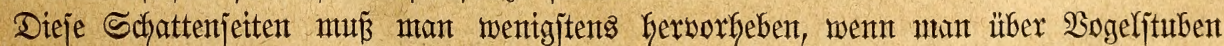

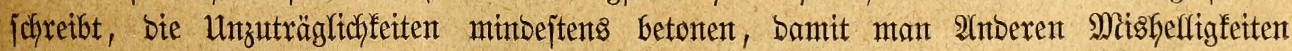
erjpare, weldje man jelbit exfafiren ober bodh fennen gelernt haben jolfte. Maan mödte

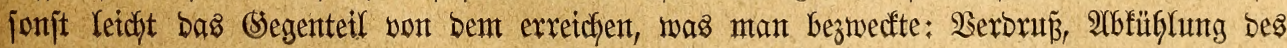




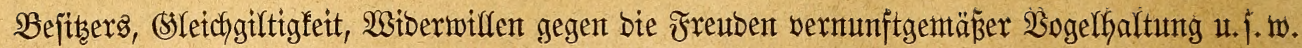

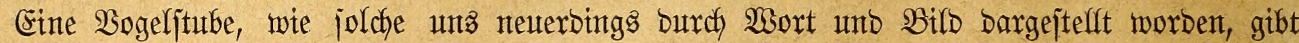

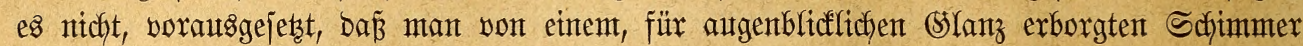

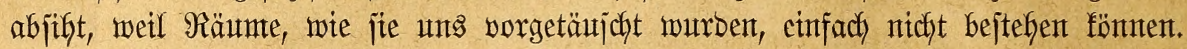

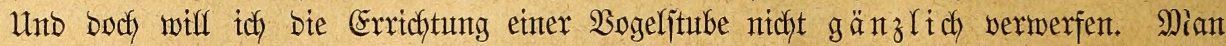

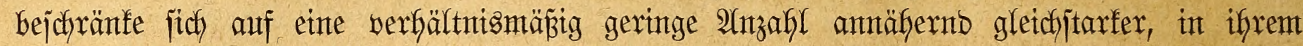

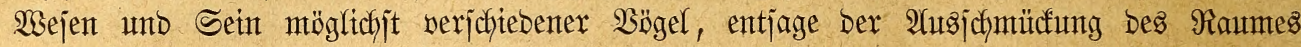

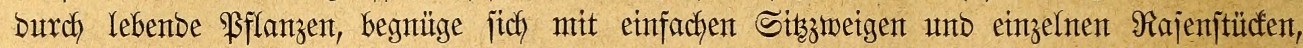

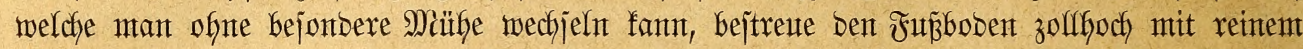

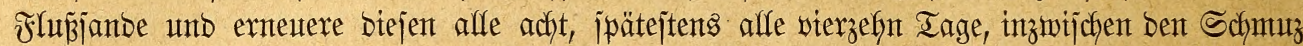

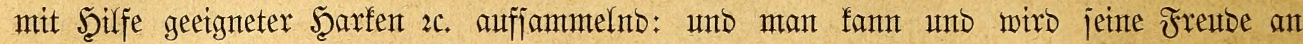

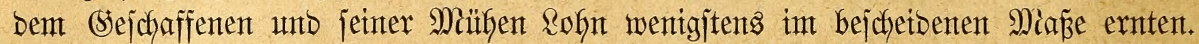

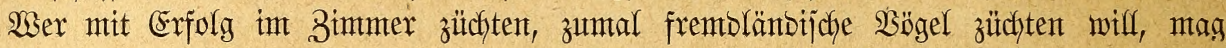

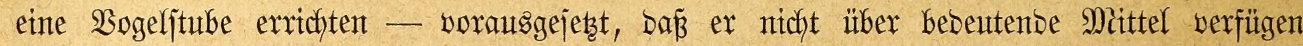

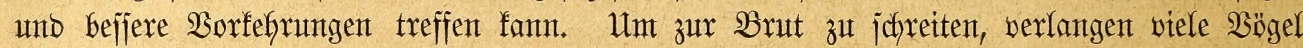

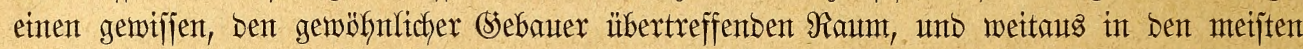

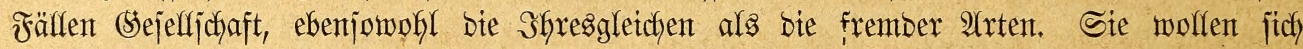

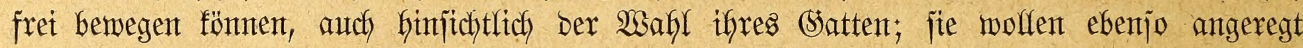
werben. Der (sejang bes einen Miäntchens medt bie Eiferjutcht Des anberen, unb auts jolcther Eiferjucht entipringt jefł häufig Riebes= und \$arungslujt. Soldche Bebingungen exfüllt für

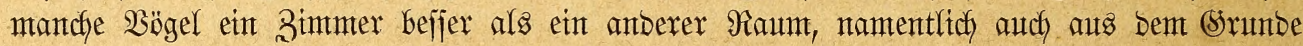

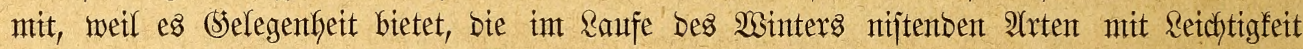

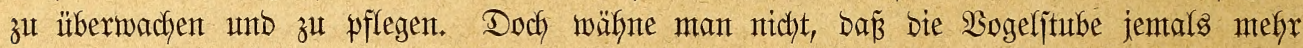

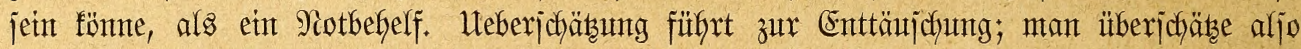

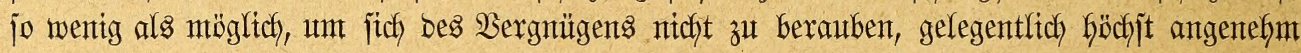
überrajcht zu werbert.

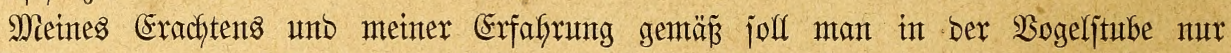

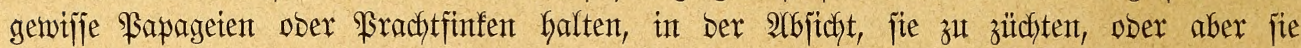

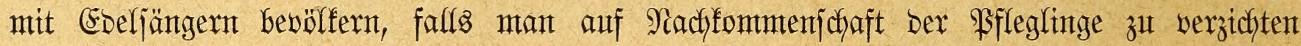

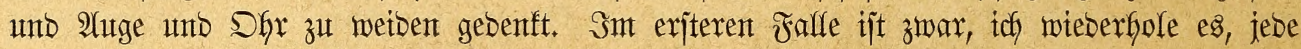

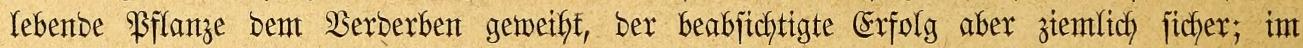

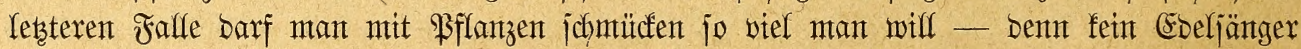

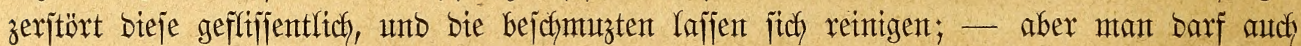

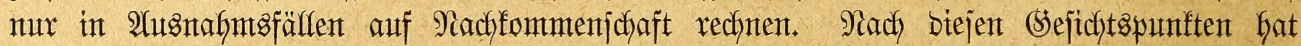
man fidf zu enticheiben.

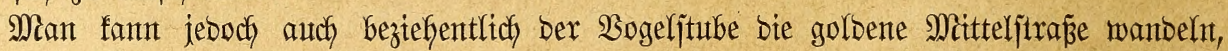

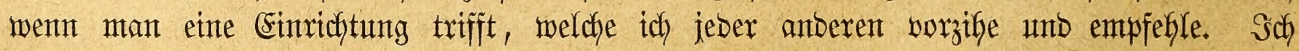

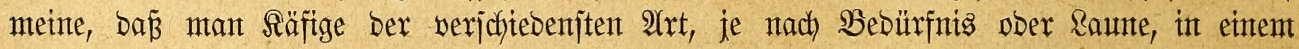

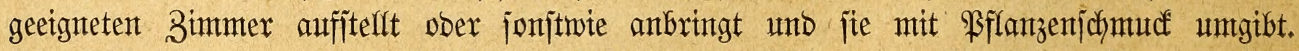

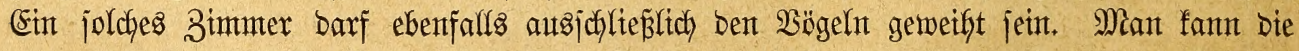

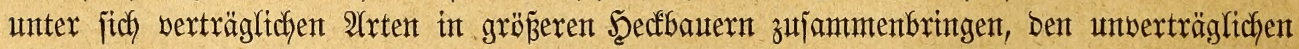

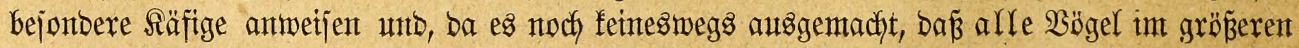

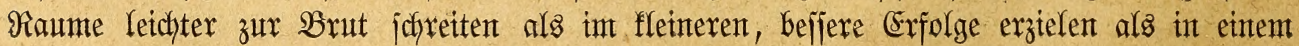

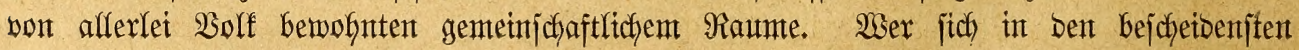

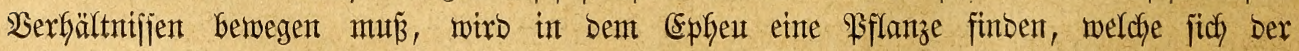

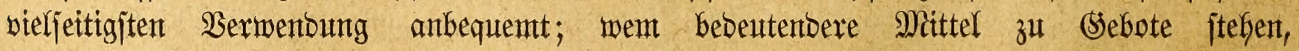

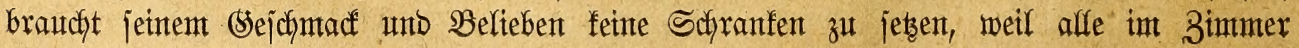

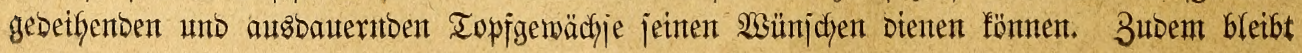


es Sebent utrbenomment, etwaigen Wünjdjen nach jonjtigent Schmud burdy Mujichelzier, Bilbjäuten unto bergleichen Redynung zu tragen.

Einte Derartige $\mathfrak{B}$ ogelitutbe getwährt unter alfent $\mathfrak{u m i t a ̈ n t}$ en einten angenefmen Eintorud,

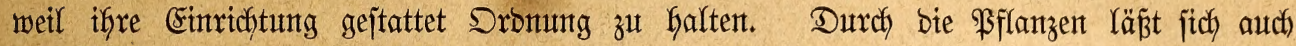
Der Räjtg zu eintem behaglichen Rämmterchen ungejtalten; und bie burch jente gereinigte

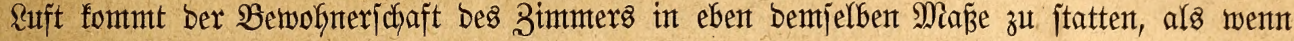

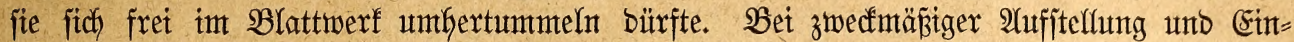
ridftuntg Der Räfige fant mant lüften, jo viel man wifl ober für gut hält, bie reintgende Şanto anlegen, ofnte wejentliche Stönung zu verurjachen, bequent unto jicher beobadjten, ofite Scheut unb Furdbt zu erregen ober aber, wie weilant Iobias ber Afeltere von ber

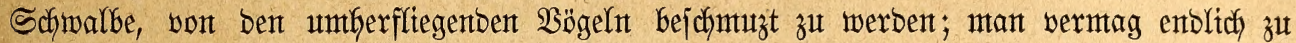
zähnten, bezüglich, bereits erlangtes Bertrauen jich zu erfaltert. Fajt von aflen Stubentö̈gelth

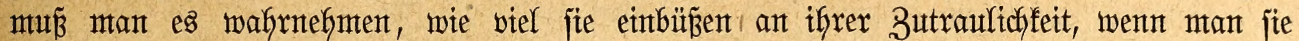
bont Säfige in bas 3intmer läß̆t; gerabe bie vollite Bemöhnnng an Dent Pfleger aber bietet

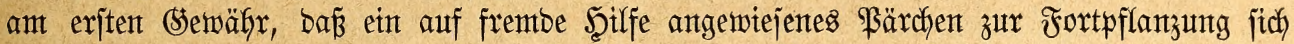
anjchicft. Fïr biejes fant mant in eintent pajjenben Räfige ungleich leichter jorgen als in

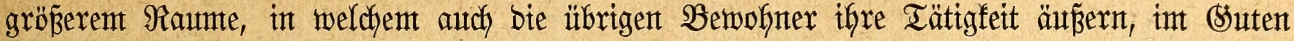
wie int $\mathfrak{B b ̈ j e r t . ~}$

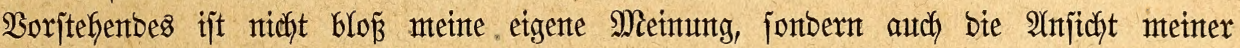
funtigen Freumbe, beren Mitfilfe idh mich erfreute. Unto beshalb barf ich fühn jein

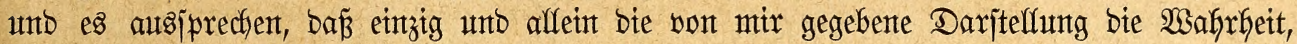

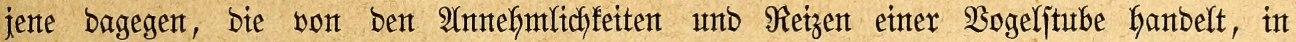
welcher bie gejammte Bemofnterjchaft burcheinantoer tobt, eben mur ein Sebtlo ungezügelter cinbiloung ift.

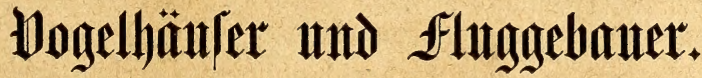

Durch bie Titergärtnterei haben mix gelernt, bie Sefängnifie unjerer gefteberten Rteblinge

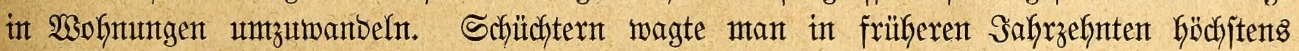

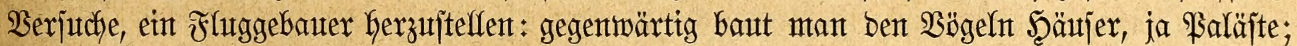
vormals pferchte man fie in vorhanbente $\Re$ äımte ein: jebst errichtet man für fie Baulfichfeiten, welche ifyen $\mathfrak{B}$ ebürfnififen angepaß̧t werbent.

Mit biejen Worten ijt ber Durchgreifente Unterjchied znijchen Bogelitube unto Bogelfauts,

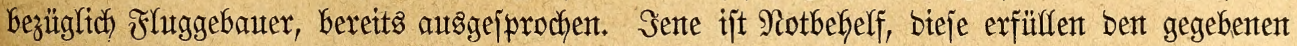

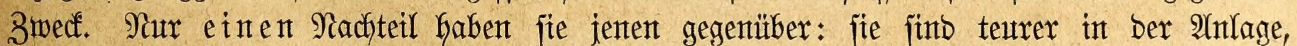
weil fie erjt gejchaffen werben müjjen, währento für jente ein Geizbarer Raum, etwas ssenijt unb (Seftänge unt eintge Brutfajtent ober Nitítgebauter ausretchen. Sie jeben einen Bejüber voraus, wäfrento jente fich aud ein Miteter verichaffen fant.

Wer wie idy alfe bebeutemberen europäijchen Iiergärtent wieberbolt bejudfft unto bie verichiebenjten Fluggebauter einzelnter Riebhaber bejichtigt hat, verifeft, wie jojwer es ift, bas

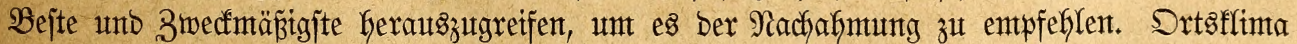

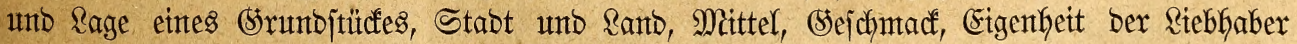
unt noch Gumbert anbermeitige Sefichtspunfte folfen ober fönten zut Ermägung fommten, went es fich barum hanbelt, ein $\mathfrak{B}$ ogelfaus, ein Fluggebauter anzulegent unt einzuridyten. 


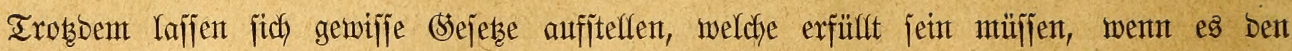
Bemofnern, für weldhe ber, Bau bejtimnt, gefaflen jolf ober, was basjelbe, wenn man

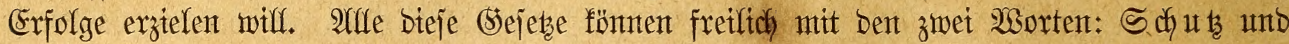
Behaglichfeit, auggebrücft werben; ifre Erfüflung ijt aber feinesmegs jo leicht, als man

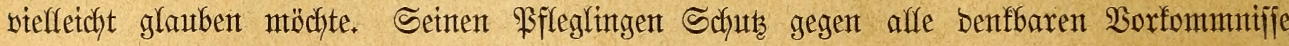

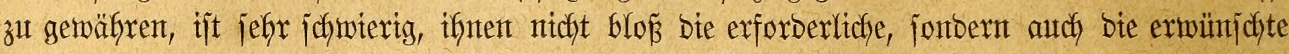

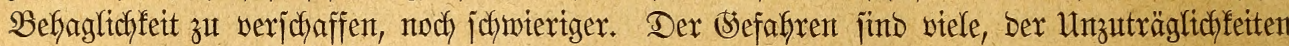
faum wentger für siefangene, weldye gezmungen fint, in eintem ifgnen aufgebrungenen Raume fich einzurichten. Unt jojon jebt auf Das finzudenten, was idh zu jagen faben werbe,

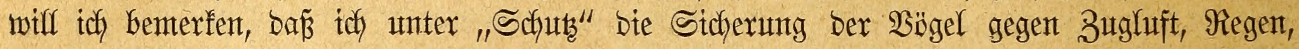

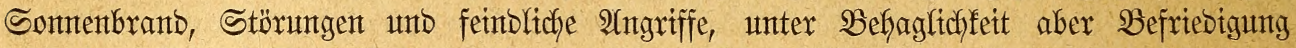
berjentgen Bebürfnifje veritehe, weldye ber ßffleger jeinen \$fleglingen - exjt abzujehen hat.

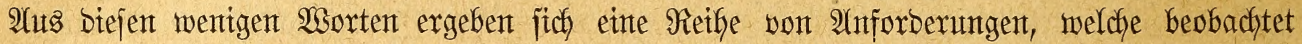
werben miüffen, falls $\mathfrak{B}$ ogelfaus und Fhthgebauter ifrem 3wedt entiprechen jolfen.

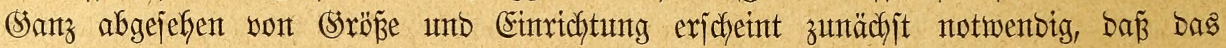

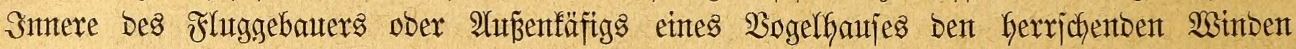
ntcht auggejebt jei. Der Bogel, bas fint ber suft, in meldjem bieje jo zu jagen zux

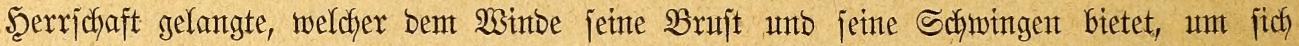
von iffm tragen zu lafjen, weldher fich, abweichent won ben meijten anberen Tieren, aus=

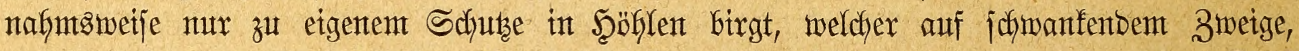

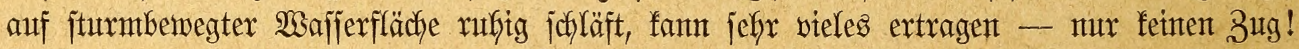

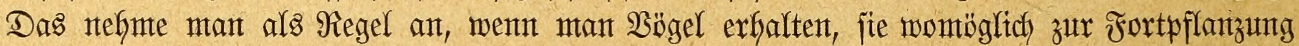

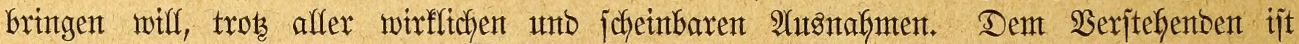
fiermit bie etwaige Rage jeines Sogelfaujes ober Fluggebauters unt eit guter Ieil ber Eintidytung gegebent.

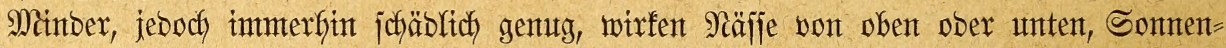

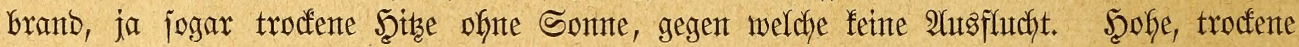
Rage bes Fluggebauers unt ein genẗgenbes Schubbach mögen aljo als anberweitige Şaut: bebingungen ben ïbrigen vorangeitellt werben.

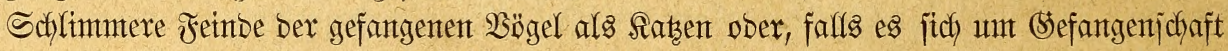

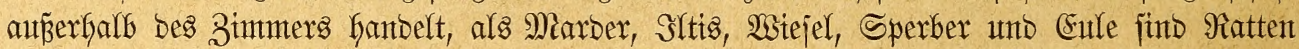

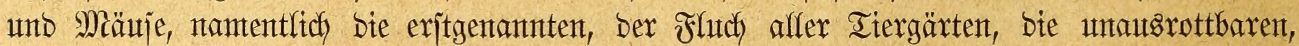
nicht zu vertreibenben Sifymarotzer an bent Iijche bes gefitteten unb ungejitteten Menjichen, bie jchäblichjten aller uns befannten Iitere. Sie ober bie Mäuje nijten fich ein in jebent Bogelfauje und werben um jo breifter ober ridftiger frecher, je mefr fie fich vergemififern,

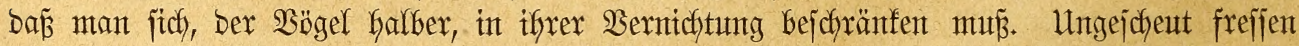
fie mit ben wefrffaften Snwohntern bes Bogelfaujes aus einer Schüffel; mörberijch falfen

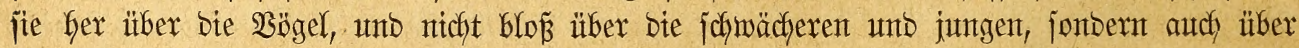

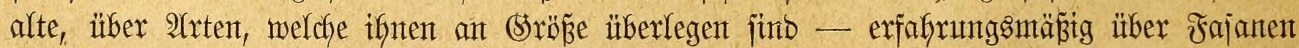

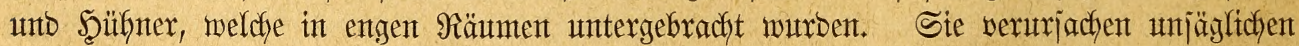

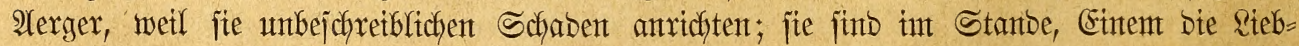

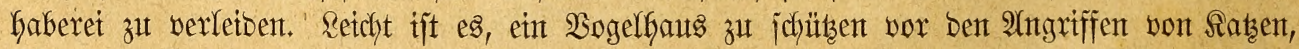
Marbern, Euten, ungentein jofwierig, es zu bemafren vor jenen zubringlichen Störenfrieben. Sie erfuntoen jebe Rüffe und wiffen jich an hunbert Stelfen Eingang zu verjchaffen; fie

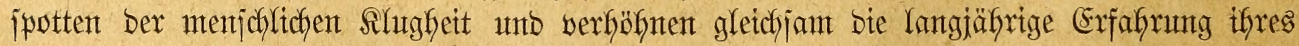
gezmungenen Brotherrn. Sch halte fie, bie einen wie bie anberen, für bie jollimmiten uno

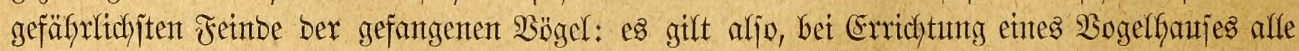

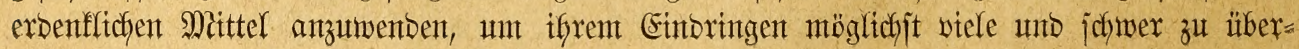




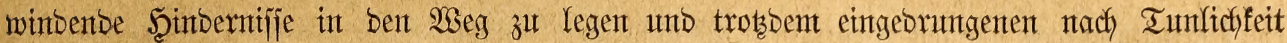

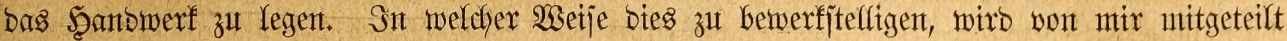

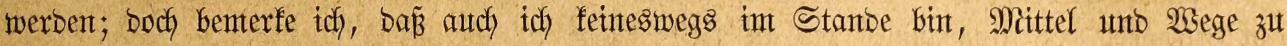
gentigenter sabwebr anzugebent.

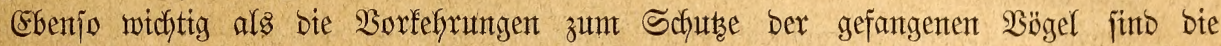
Eintrichtungen, weldye bezmedfen, ifynen Die nötige unb erwünjdyte Bebaglichfeit zu werjchaffen. Dieje Eintichtungen haben fich zu beziehen auf bie gejantmte 2 Antage, injofern es fich hanbelt

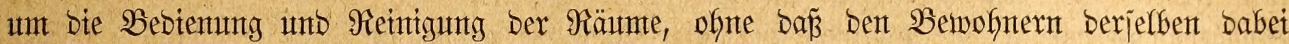

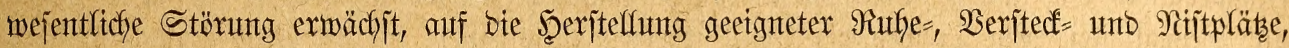

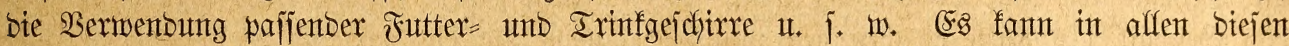
Beziefungen redyt vieles mit wenigen Mitteln gut unto ebenjo vieles aud mit bebeutentemt Rojtenaufwantbe jefr mangelfaft und jolledht gemadht werben.

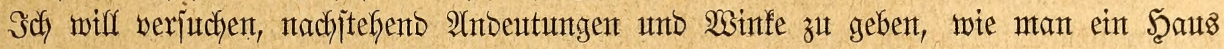

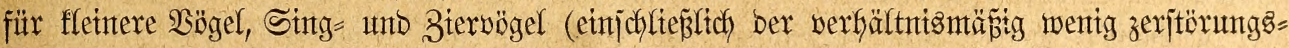
lujtigen Sittiche meintwegen) einzurichten hat, und midch babei itätig bezigen auf bereits ausgeführte ober von mir entworfene (sebäube, ofne jeboch eigentlich zur unjelbjtäntoigen

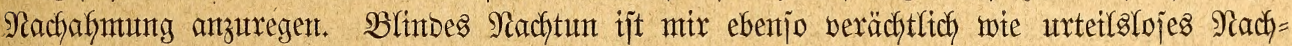

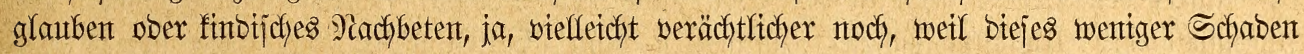
bringt als jenes. Ein Rtebfaber, welcher nidft fäfitg ijt, eigente Wege zu gefen, ijt audch

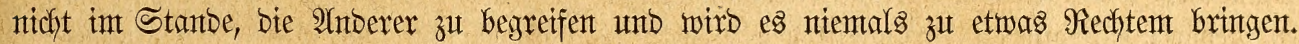

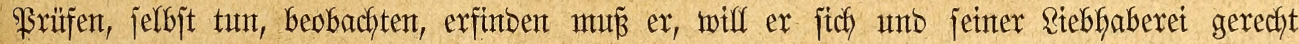

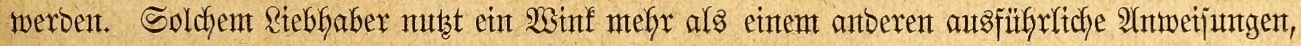

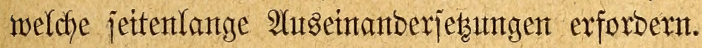

2hu einfache unb biflige 2 Beije fann man ein 2 ogelfaus Geritelfen, went man über Dent ober einen gewifjen Raum eitte Goken fiefler= ober niebrigen Erogejchofies zu verfügen bat. Smt erjteren Falfe ertweitert mant bie in Frage fonmenten Scalbfenjter jeitfich, jo weit bie Den Pfeilern aufgebürbete Rajt es gejtattet, bringt an jenen Fallgitter bezüglich Fallfenjter an, melche mittels einer über Roflen laufenben fiette vom inneren Sorraum aus gejchlojien werben fönten, errichtet vor bem berbreiterten Fenjter eine, in gleicher

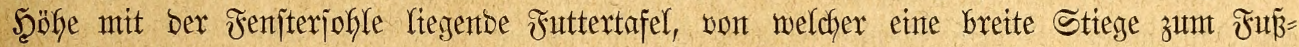

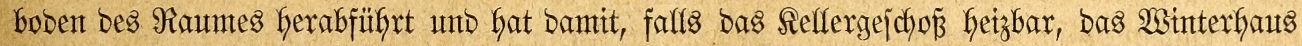
fix und fertig. Sor Dem Seauje untb bezüglich ben verbreitertent Jenjtern jtedft mant fich in berfï̈gbarer Ränge (Brette) unb minbejtens 2,50 , womöglich 4 m. Titefe Den $\mathscr{2}$ hebt ben Maurngrund wenigftens $75 \mathrm{~cm}$. tief aus und erridftet auf einer 9 bis $12 \mathrm{~cm}$. Gofjen Rage won fejtgeitampften (Slas: = unt Iopficherben in Eentent gemörtelte

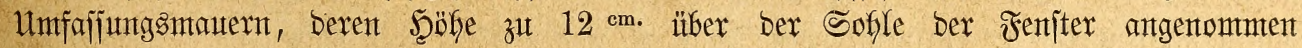

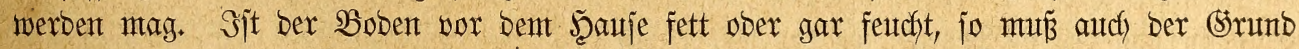

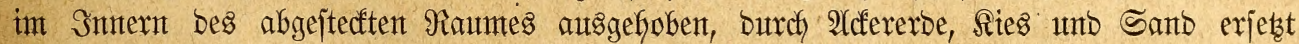

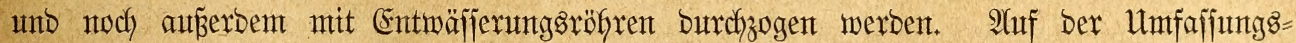
mauter errichtet man ein Seriijt von Säulen unb Stänbern, weldhe am bejten aus Eijen

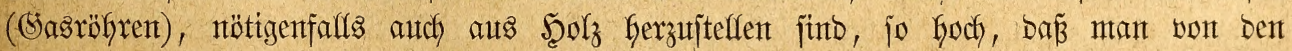

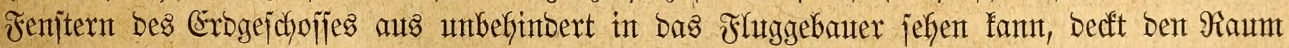

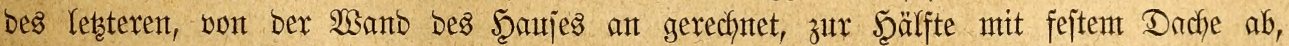
vergittert bas ïbrige Dach wie bie Wänbe mit gemebtent Dratgeflecfyt von erwünjffter,

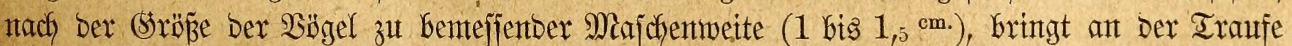
bes feiten Daches einte Regentrinte, an ber Seite, meldye am wentgiten in bas 2luge fällt,

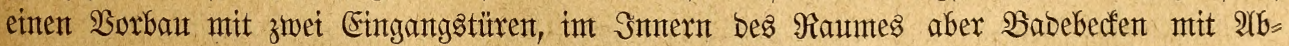

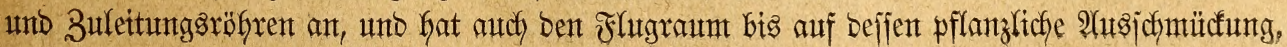


bie Şeritelfung Der nötigen Brutfajten 2 c. volfenbet. Falfs man nutr ein Erogejchoß zur Berfïgung Gat, Gricht man bie Fenjter besjelben bis zur Fußbobenthöhe nieber unto jchüttet

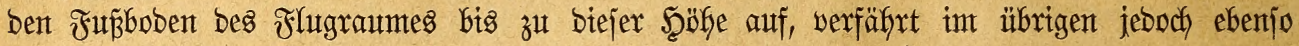
ober gantz ähnlitdy.

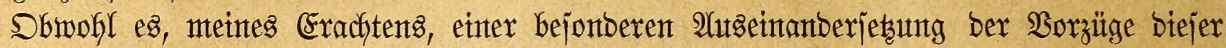

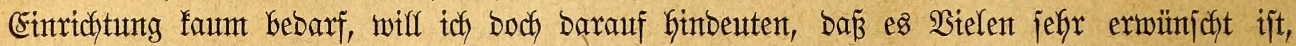
vom 2 (rbeits = ober besorzugten 2lufentbaltszintmer aus burdh bie Fenjter in bas Sntere bes Fluggebauers wie in eine Beranba zu blicfen unb (Selegenfyeit zu Gaben, mit aller Muke

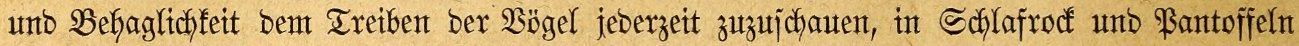

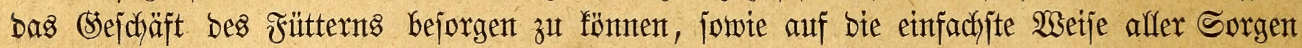
für Unterbringung ber zarteren $\mathfrak{B o ̈ g e l ~ w a ̈ h r e n t ~ b e s ~} 2$ inters überboben zu jeint.

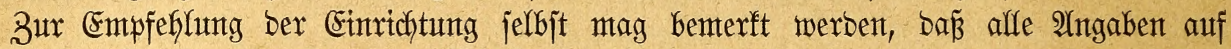
gejammelten Erfahrungen berufhen. Ein Fallgitter am Fenjter, weldyes von fernfer geöffnet ober gejdyloffen werben fant, exletdftert bas Einfangen und Einjperren ber vorjidftigen,

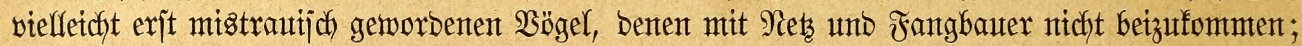

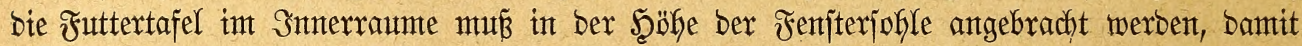
bas Futter ben $\mathfrak{B}$ geln leidft in bas 2 luge falle; bie Scherben, welche mant audh an ber

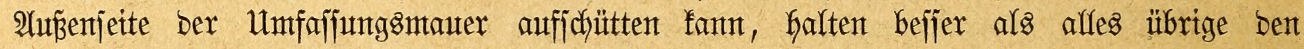

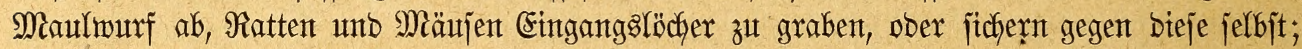

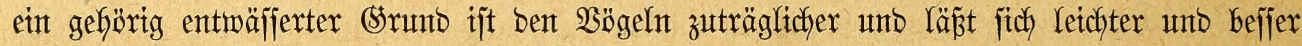
reinigen als feutchter; bie angegebente Şb̈he bes Flugraumes gejtattet, Denjelben jo zu gejtalten,

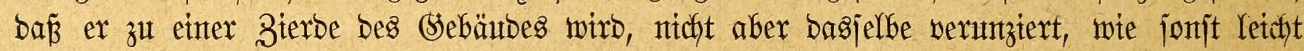

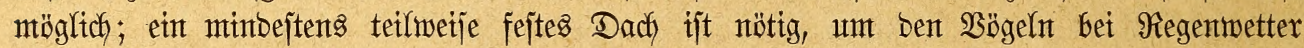
trodene Simpläbe zu gemähren; Die boppelte Türe verhinbert ein Entichlüpfen ber einge=

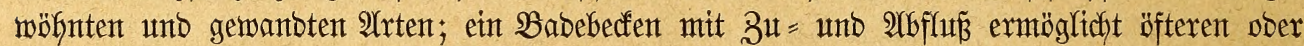

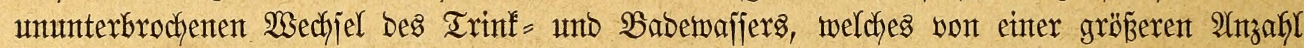
gefangenter $\mathfrak{B o ̈ g e l}$ in furzer Frift verumretnigt unt werborben wirb. Alles anbere bebarf

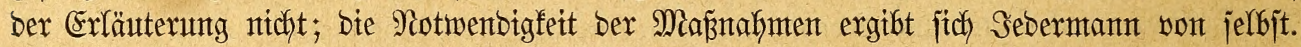

Fajt ebenjo biflig und in mefyr als einer Seinjicht vorzïglicher als ber gejchilberte ijt ein Bau, welcher Bogelfauts unt Fluggebauter in fich vereinigt. Er eignt fich bejonbers für Srrumbititufe in Stäbten, beren Şauggärtent ofnefin mit Mautern ungeben finto. Şier

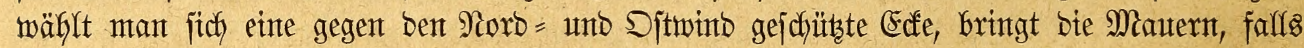

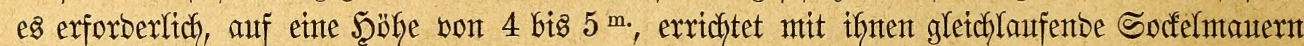

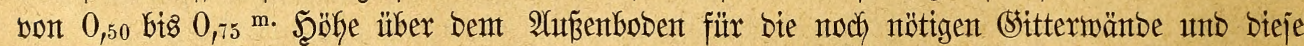

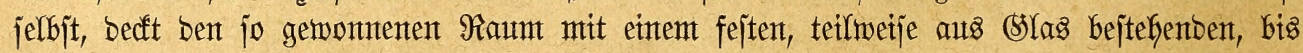
auf minbejtens $0,75 \mathrm{~m}$. vorjpringenten Dache ab unb verfäfyrt mit Sicherung ber Mautern, Entwäfferung Des Fuß̣bobens, welcher bis beinah zur Sberfante ber Sodfelmautern aufgefüflt

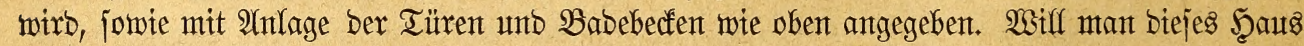
zum Ueberwintern wärmebebürftiger $\mathfrak{B}$ b̈gel verwenton, jo ftellt man ben an eine ber Mautern fich antefnemben Teil ber zut erbautenden Umfafjungswanto auts Steinen Ger, bringt hier bie

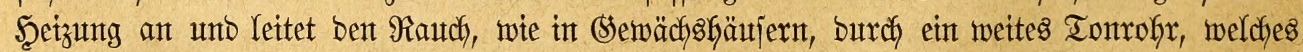

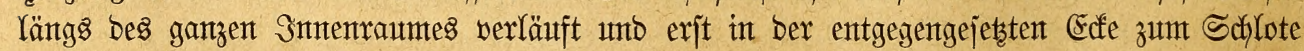

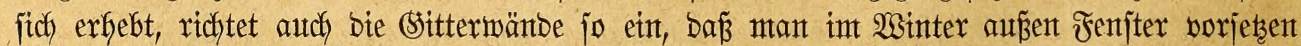

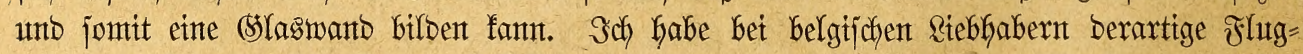

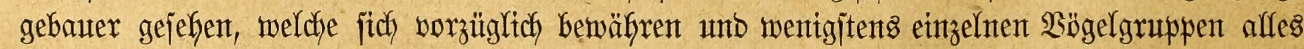
bieten, was bieje berlangen.

Wer über genẗgente Mittel zu werfügen hat, fann einen Schritt weiter gehen unto

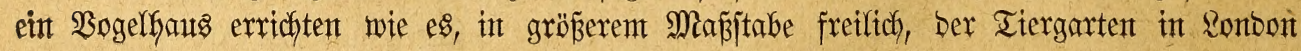




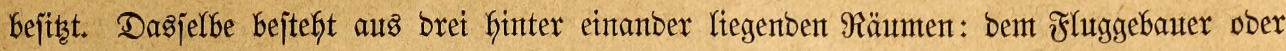

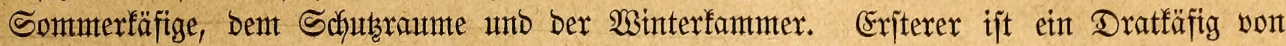

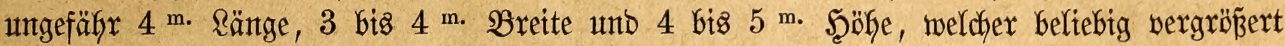

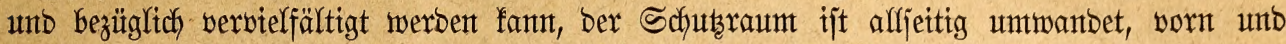

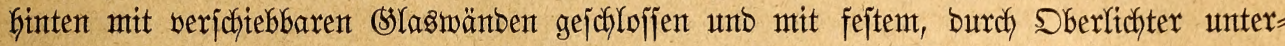

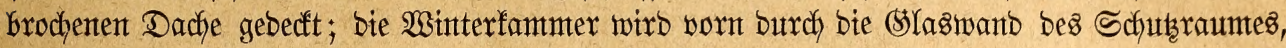

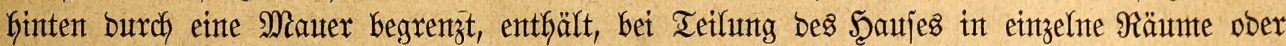

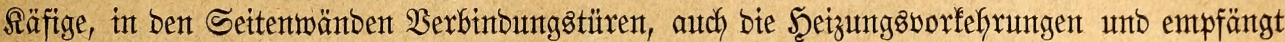

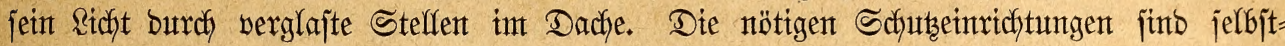

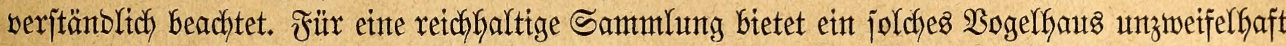

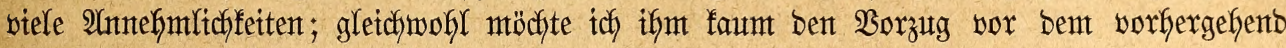
bejăjriebenten eintüutmtent.

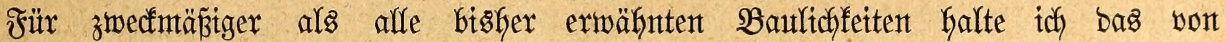

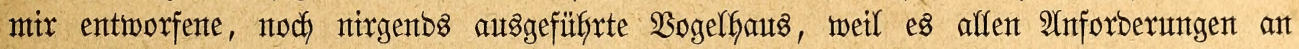

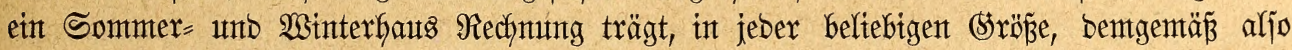

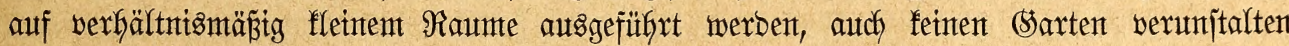

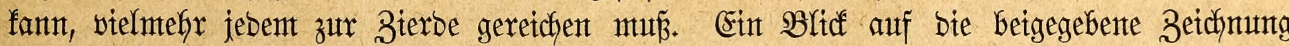

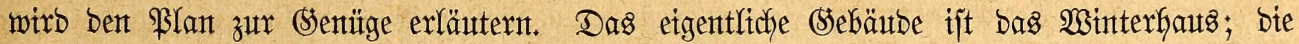

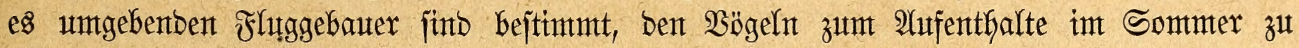

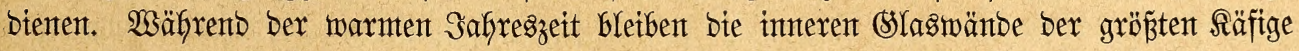

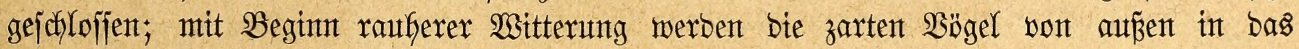

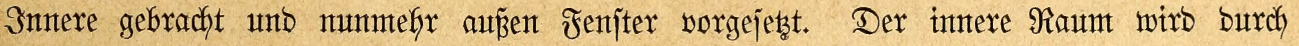

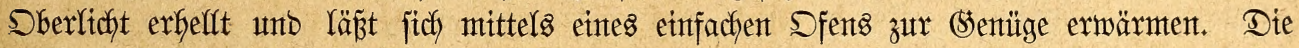

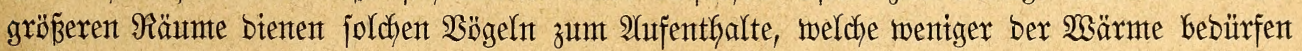

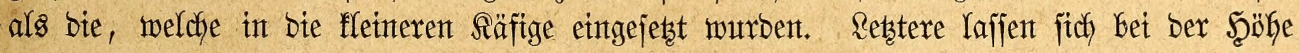

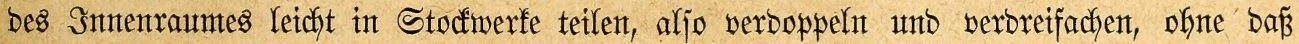

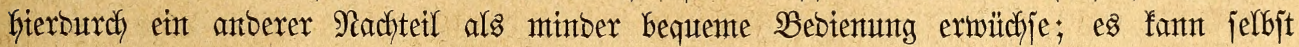

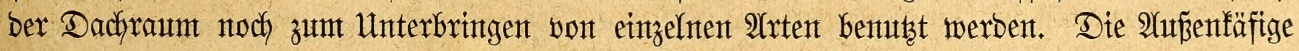

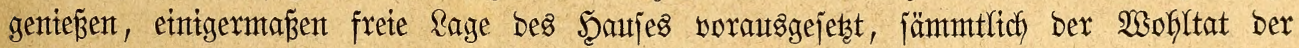

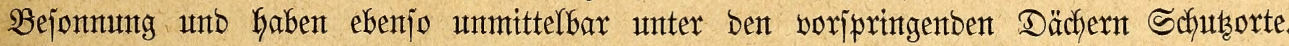

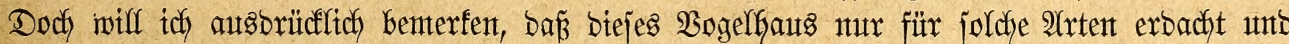

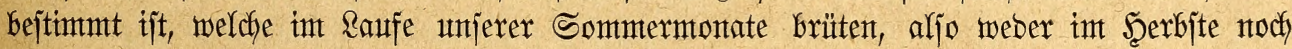

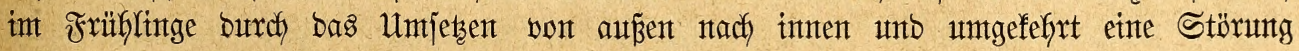
währent bes brutgeidä̈tes zu fürdytent Kabent.

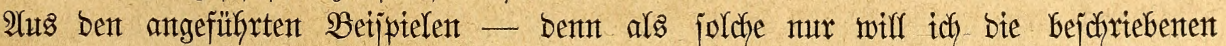

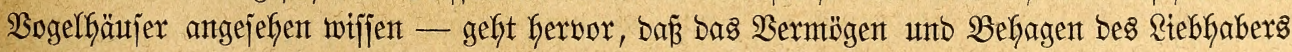

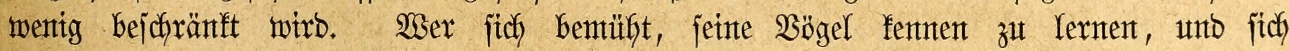

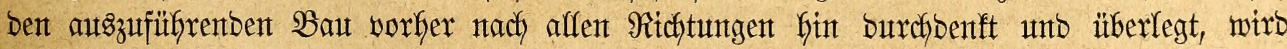

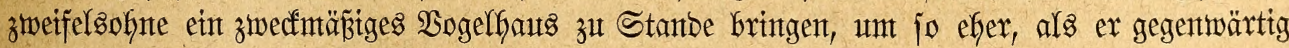

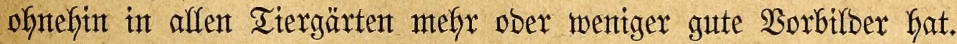

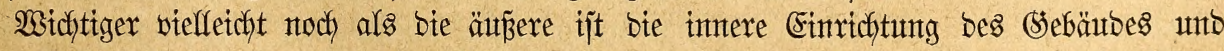

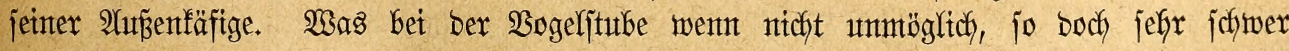

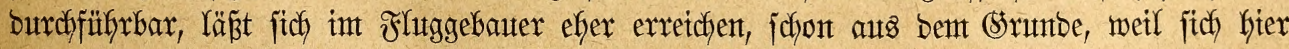

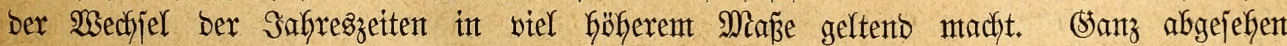

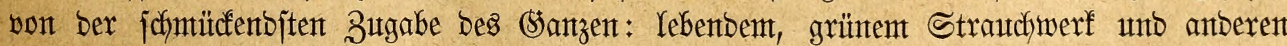

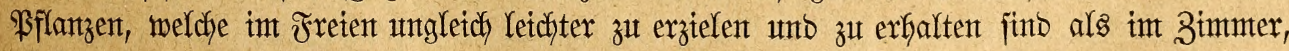

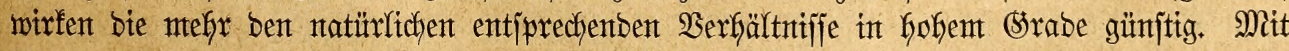

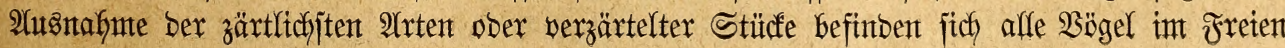




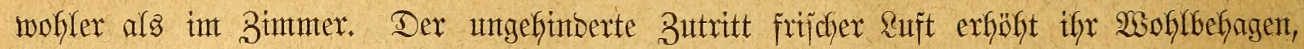

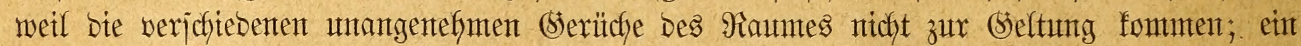

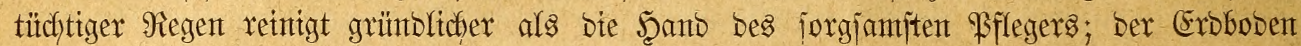
ift wifliger zut 2lufnahnte son afferlet Untrat als ber SBoben bes 3immers; bie alfbelebende, jdfaffende Sonnte wirft braupent fräftiget als brinten. Das fint Sorzïge bes Fluggebauters ber Bogelitube gegenüber, welche aud butch bie eifrigite Sorgfalt nidht aufgemogen merben föntutt.

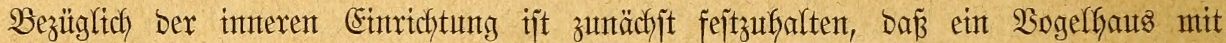

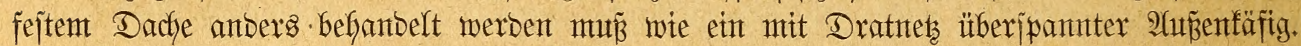

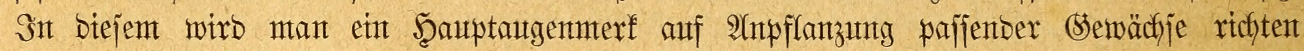

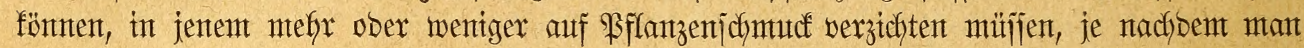

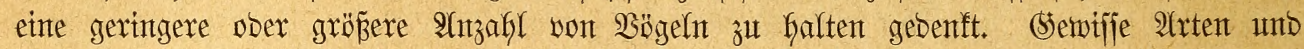

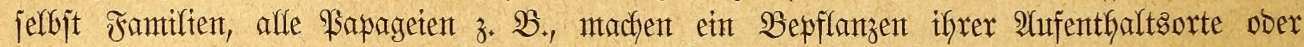

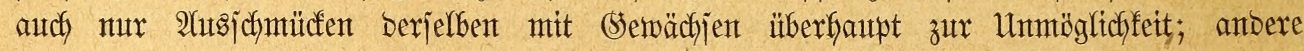
bejchmuzen, went jie in größerer 2 (nzafl gefalten werben, wentgitens bie Blätter, 3wetge und

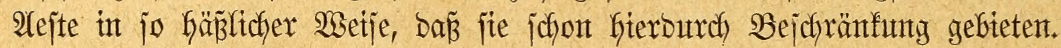

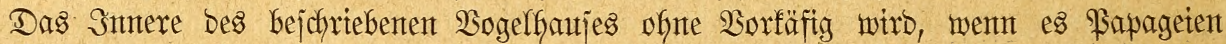
ober Srracftfinfen ober beiben zugleich Dienen jolf, eingeridytet wie folgt.

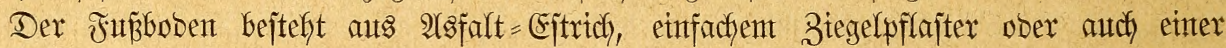
feitgejchlagenten Refmentente; ex ijt nach einer Seite fint genetgt, etwa $15 \mathrm{~mm}$. auf ben

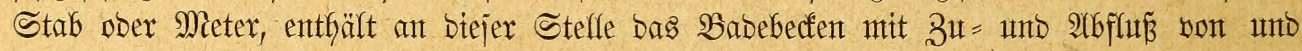

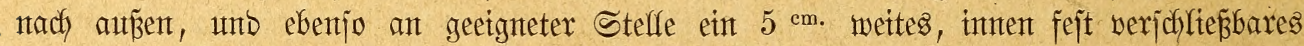

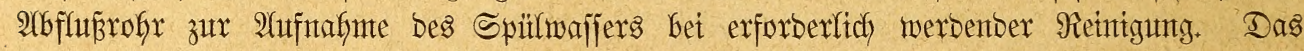

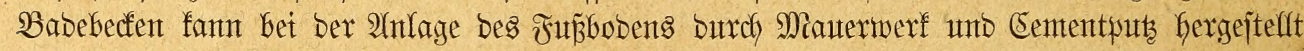

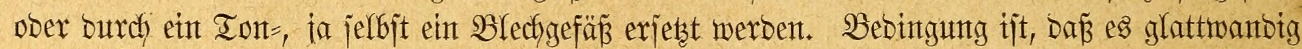

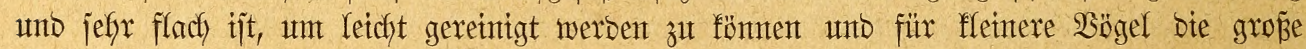
(Sefahr bes Ertrinfens zu. verminbern. Ein 2 Safferitanto von 35 bis $45 \mathrm{~mm}$. ant ber tiefitent

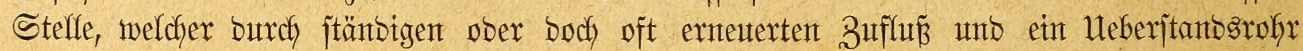

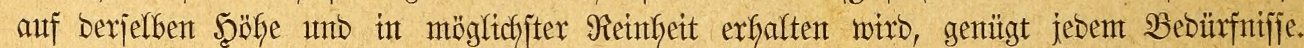
Berfügt man über Wajjerleitung, io berbinbet man bas Buflufirofyr mit biejer; entbefort

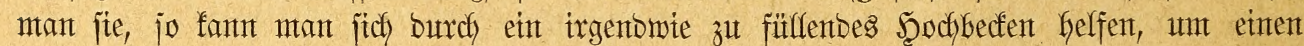

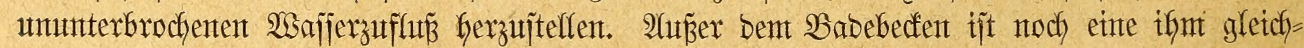
gejtaltete Marbe ermünjidt, weldfe amitatt mit $\mathfrak{B a f j e r}$ mit gejtebtem feinen, trodenten Sanbe

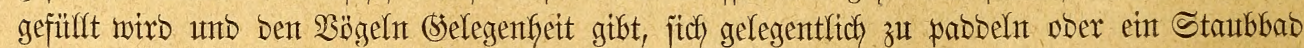

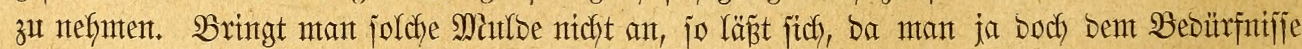

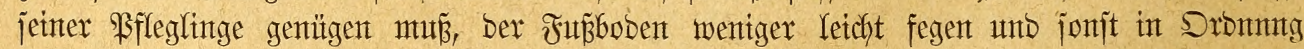

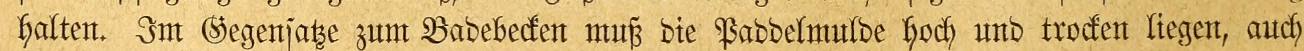
bejtäntotg trocfen erhalten merben.

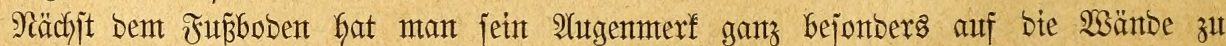

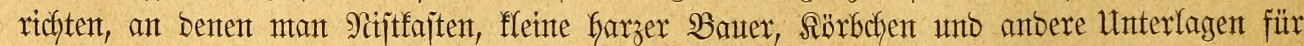

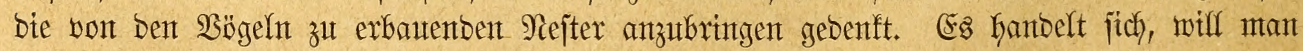

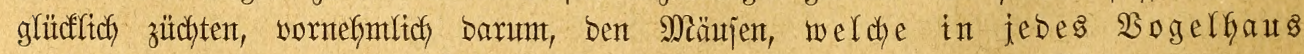

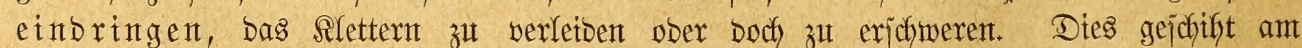

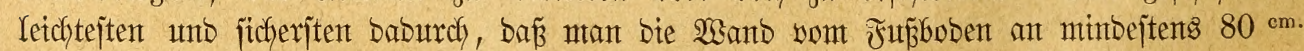

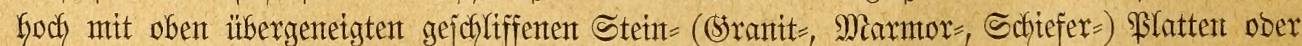
mit Blech befletbet, unb eine ähntliche Sdyutwehr auch oben unter ber Decfe, jowie überalf ba anbringt, wo bie $\mathfrak{3 a n t b}$ von ben Mäujen exretcht unt beztefgentlich begangen werben fantn. Man unterichäţe bie Miäuje ja ntcht, weber was ifre Siletterfähtgfeit umb Sprung= 
fertigfeit, noch twas ibre Zerjtörungshujt und Morbjucht ober bod Schäblichfeit anlangt!

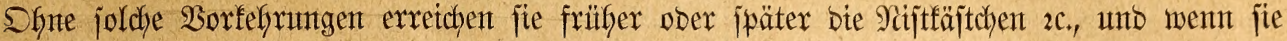

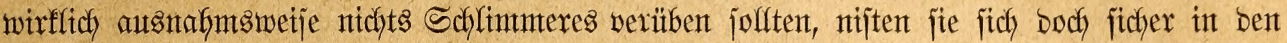

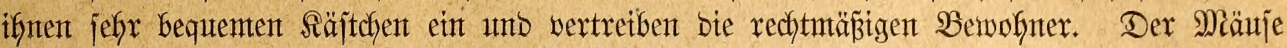

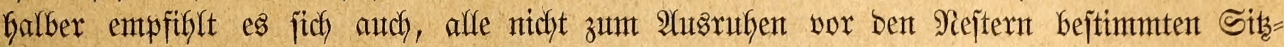
anjtalten, als ba finto Sprunghölzer, Sibjtangen, Bäumtchen u. Dergl. immter uno überalf

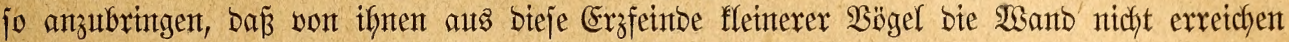

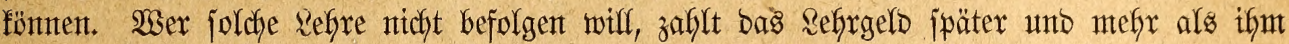
lieb jein bürfte.

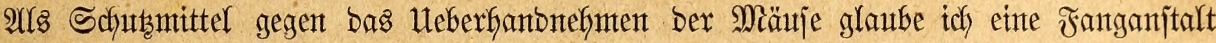
emtpfeblen zu bürfen, welche in wejentlichen ben bei Fajanterien gebräudblichen Marberfallen nachgebilbet ift ober boch auf benjelben (stunbzïgen berufht. Man bringe im Mauterwerfe

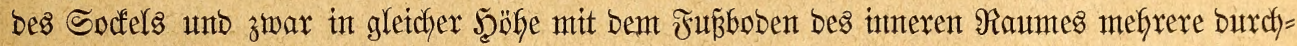
gehente rumbe Röcher an, eben gró gentg, um einter Maus bas Durchjchlïpfen zu gejtatten unt befejtige vor thnen an ber äuß̌eren Seite ber Socfelmauter jelbjttätige fajtenfaflen berartig,

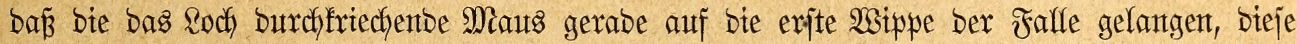
beim Weiterfaufent nieberbrücfen, jith bie Umfefr verjperren, jobann über bie zwette Wippe weglaufen unt in ber finteriten fammer fich fangen mur. Went joldfe Faffe gut eingeridftet,

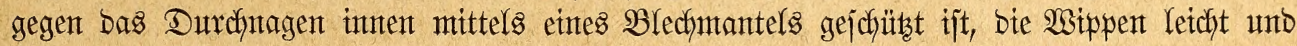
ficher ipielent, Der Sajten bequem abgenommten unto wieber an bie rechte Stelfe gebradjt werben fant, leijtet fie treffliche Diente; Dent jede Maus benutbe ein Schlutpfloch ba, wo

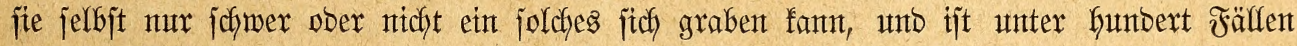

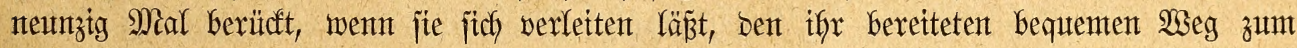
Berberben zu betretent. Sn alfen übrigen Fallen fängt man jelten mebr als einte Maus

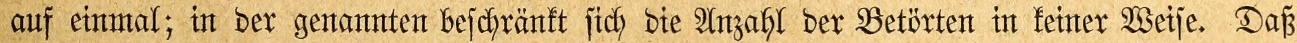
ntan aukerbent forbfalfen mit Duftigem föber Ḧberalf ba anbringent fant, wo man bie Bögel nicht ftört ober gefäfrbet, werjtefgt jich von jelbjt.

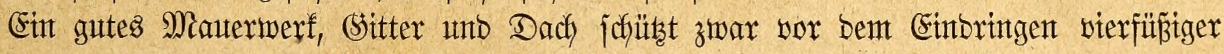

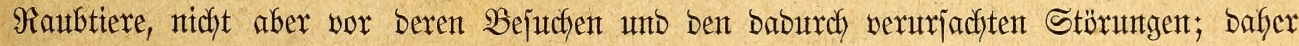

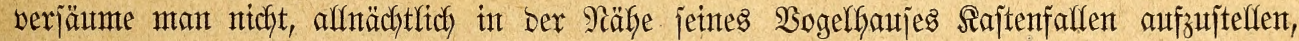

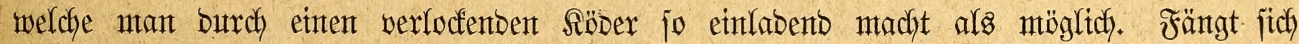
ein Marber, Slti̊, Witejel, fo "gilt ber $\mathfrak{B a l g " , ~ f a ̈ n g t ~ f i c h ~ e i n e ~ S a ł z e , ~ w e l d j e ~ m a n ~ u n g e r n ~}$

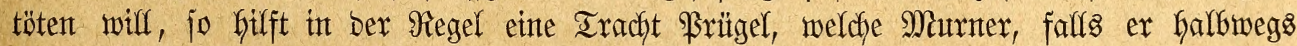
lenbenlafynt geichlagen wourbe, in ben meiften Fällent beherzigt unto für bie Folge als mofil= beritantone Warmung betrachtet. Erjcheint ex trotzalfedem wieber jchleidhend, Glinzelnto,

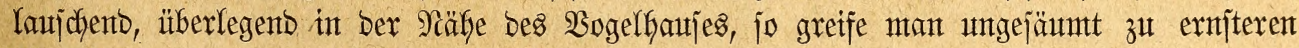

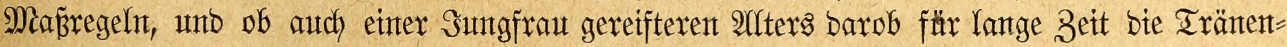

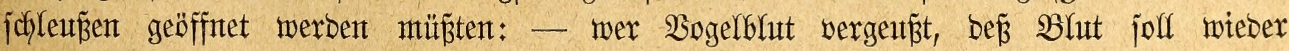
vergofjent werben!

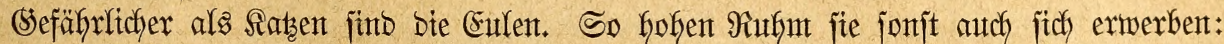

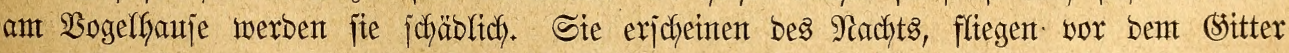

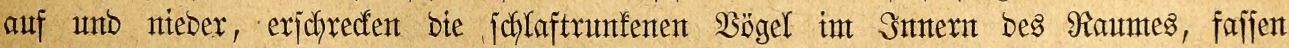

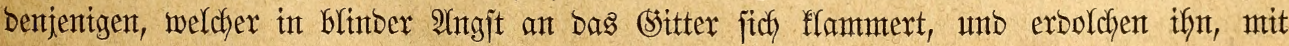

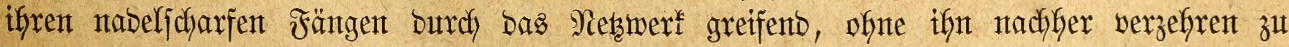

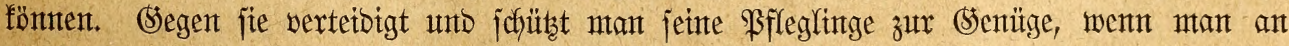

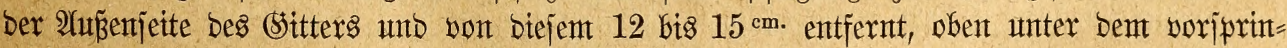

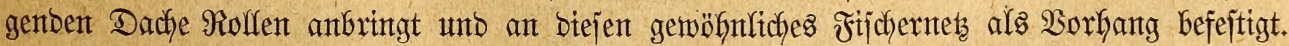

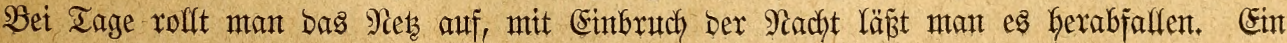




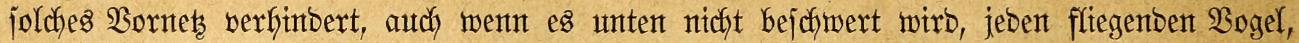

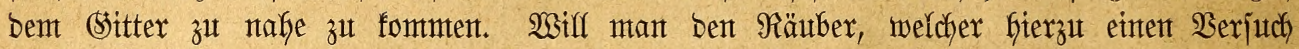
madft, nidft blos abmefrent, jonbern aud fangen, jo bängt mant einfach ein Silebentebs vor Das Bitter.

Die Aftwentung affer biejer Sdyutborfefrungent fichert zwar immer nody nicht

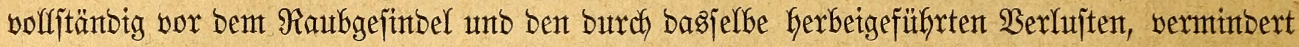

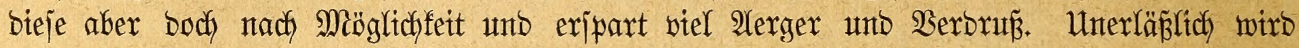

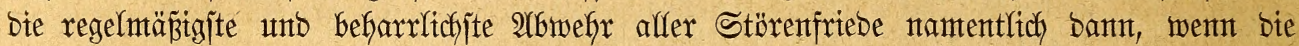
Brutzeit ber $\mathfrak{B o ̈ g e l}$ Gerannaht; bent bieje brüten mur ba, wo fie fich jither füflen, und

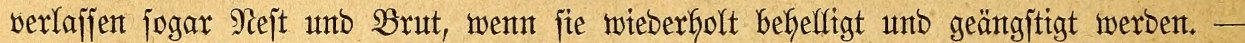

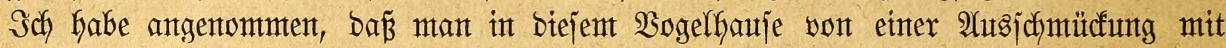
intmergrïnen $\mathfrak{B f l a n z e n t}$ abjifgt, weil Gier notwentiger $\mathfrak{B}$ eije bie gejchilloerten Uebeljtänbe ber

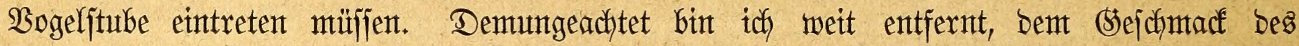

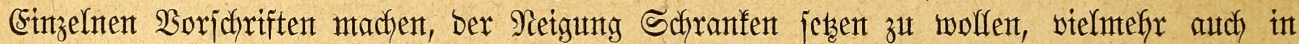

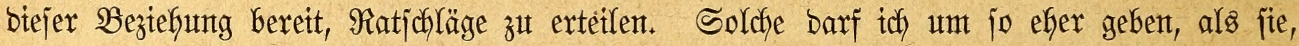
wie alfes nadjjtefent über Bepflanzung (Sejagte, bie meines wertent Freunbes Borle fint,

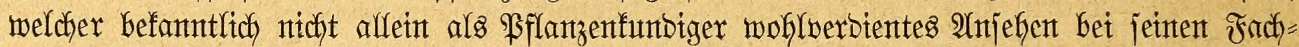

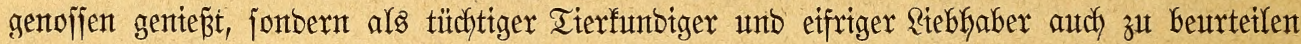
unb abzumägen weî́, umt was es fich hanbelt.

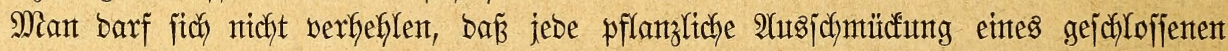

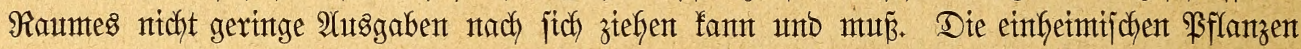

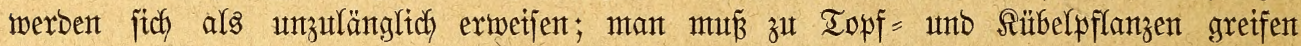

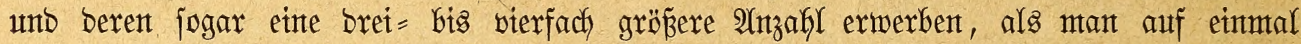

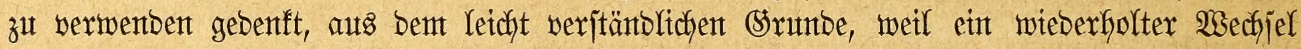
zur Notwentigfeit wirb. Entgegengejebten Falls würben alfe \$fflanzen balo jo unjchetnbar

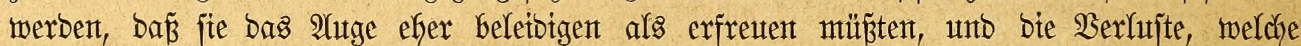

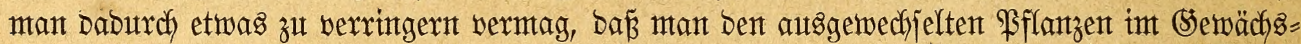
hauje ober int Freien selegenteit zur Erfoluntg gibt, bürftent balo allzu entpfintolich fein.

Der Wafhl bes Riebfabers exoffintet fich fier ein jefr meites Feld; ftets jedody wiro

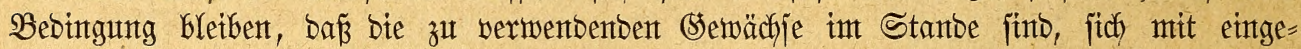

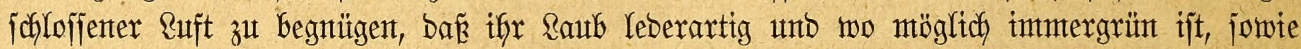

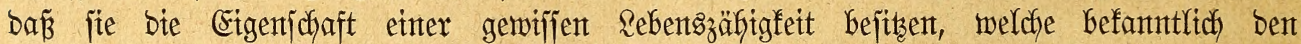

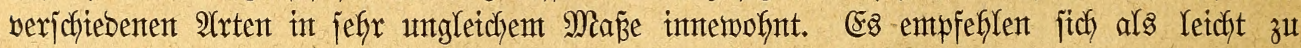
erlangen ber Rorberbaum, ber \&aurustinus, eintge Stechpalment un bas japantijche ß̧faffenfütchen (Evonymus japonicus); will mant bifliger megfontnten, Epheu unto Gaumartiger Butchbaum. alfle blattabwerfenton Bflantzen werben wentger unb Gödfjtens bet

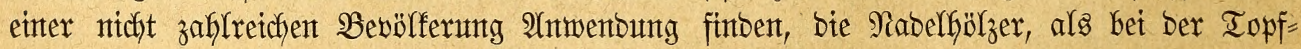

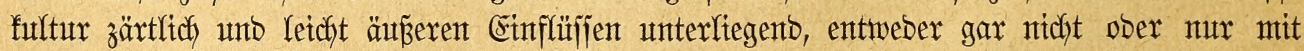
Borjicht als antwentbar in Betradjt fomment fönten.

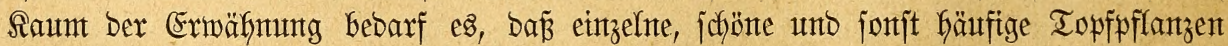
wie z. $\mathfrak{B}$. Der Sleatber, Der Sirjchlorber, gänzlich zu verwerfent fint, weil ber igre Senebe

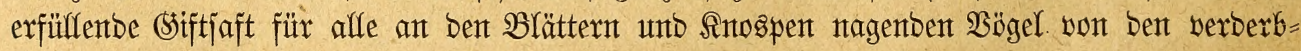
lichjten Folgent jein bürfte.

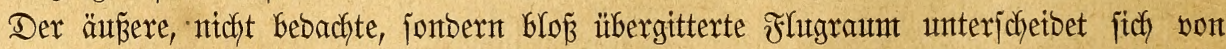
bent mit feitem Dache gebecften, zimmterartigen vorzuggmetje burch bie Bepflantzung. Seaupt=

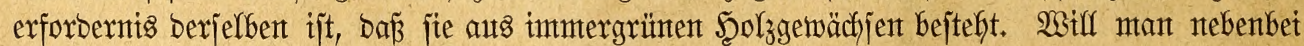
anbere verwentoen, jo hat mant joldfe zu wählen, weldhe vermöge ifyrer Wä̈djigfeit etwaige Zerjtöruntgen leidyt erjetzen. Son biejen barf ber jujwarze Flieber (Sambucus nigra) 


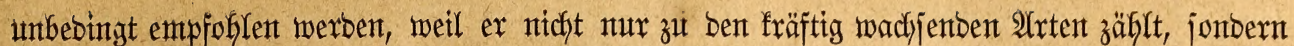

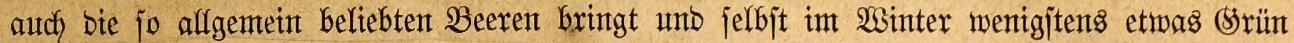

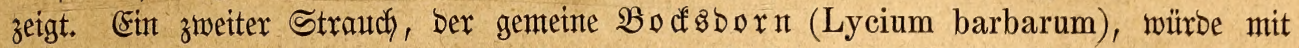

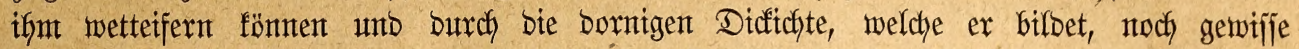

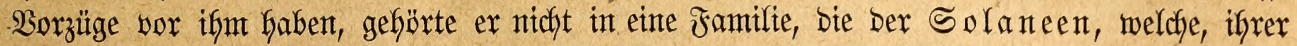

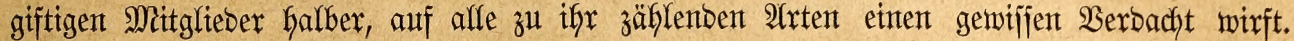

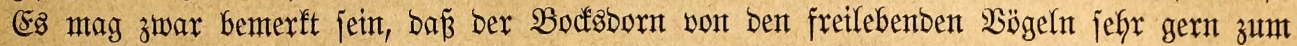

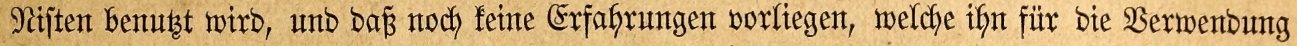

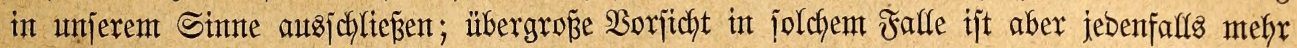

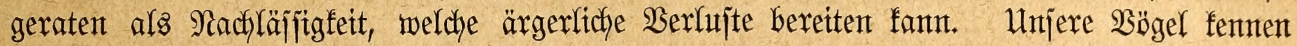

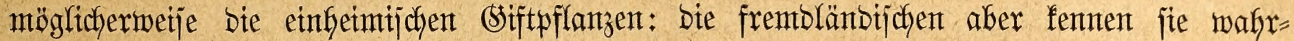

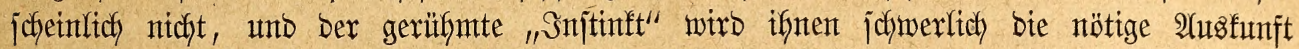

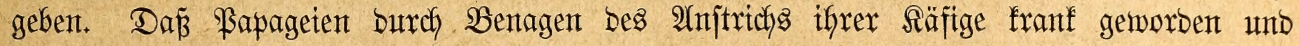
gejtorben finto, wiffen wir, baß̈ fie \$fflanzengifte ebenjo wentg vertragen fünnen, fteft eben= falls feit: warum alio joll man, fie einer (sefafyr und fich jelbjt bem 21erger ausjetzen, fie

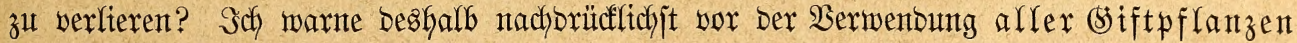
3u unjeren Zwedfen, mögen jie heiß̈en unb heritammen wie unt woher fie mollen.

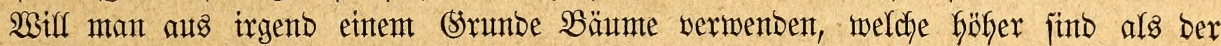
Flugraum jelber, jo pflanze man vor aflen anberen bie Eberejdye ober ben $\mathfrak{B}$ ogel= berbaum (Sorbus aucuparia), weil fie außer ber Schäntheit iffrer Irone unb bez

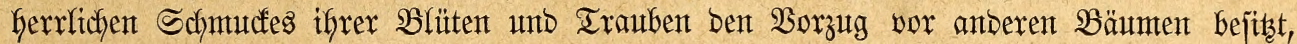

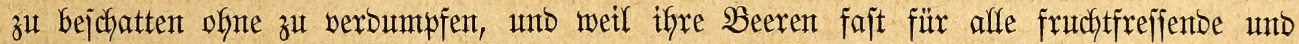
viele anbere 2 b̈gel eine beliëbte Speije bilben. Den Stanbort bes Baumes wäflt man jo,

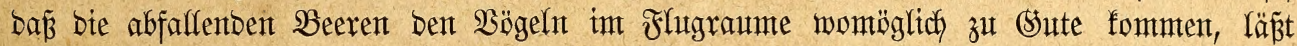
aljo unter Umitänben Den Stamm felbjt bie Sitterbecfe burchyaddjen, bantit bie Sirone über

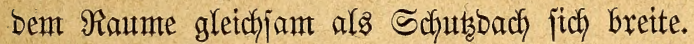

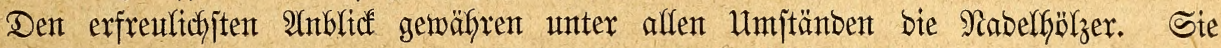

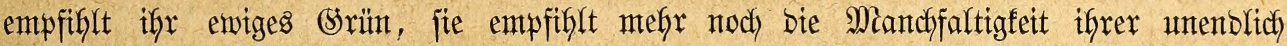

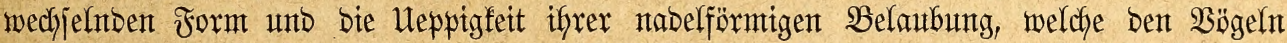

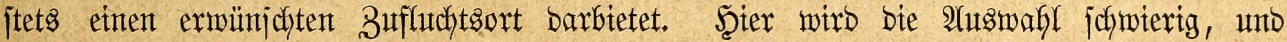

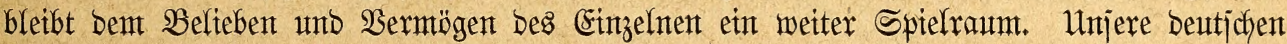
Tanten, bie githte wie bie Ebeltante, find am geeignetften, in groß̌en, hohent Mä̈umen

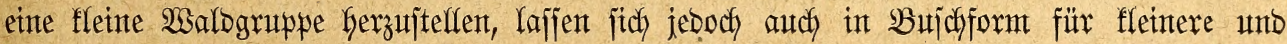

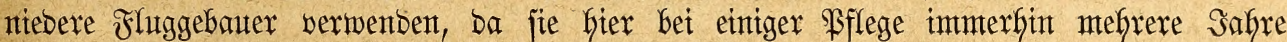

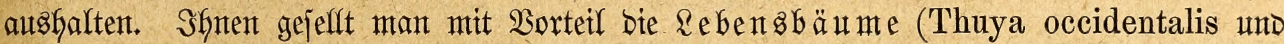

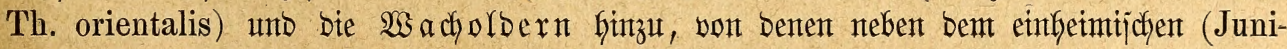
perus communis) ber virginifdje ober bie rote (Eeber (J. virginiana), Yetztere von fïherent

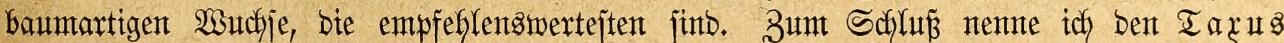
(Taxus baccata), weldder mit jeinemt bunffen Raube gegen bas helfere Srün ber genannten 2trten angentefm abjticht.

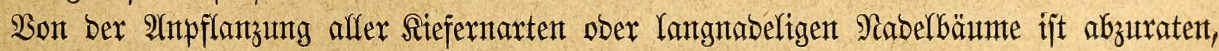

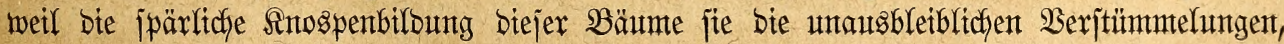

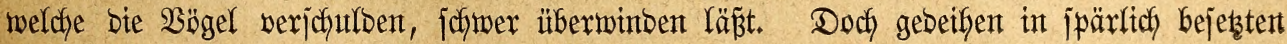
Bogelfäujern einzelne 2(rtent biejer siruppe redft gut.

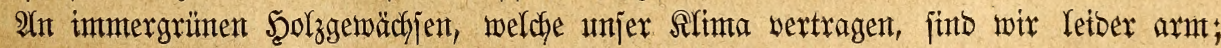

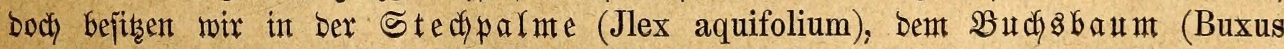
sempervirens) unt bem (Ephe th (Hedera helix) inmer noch reidfent Stoff, umt jelbjt

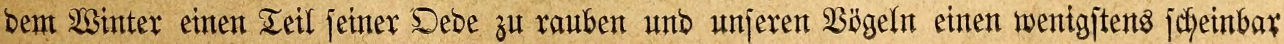




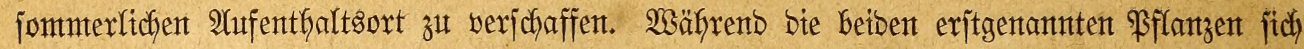

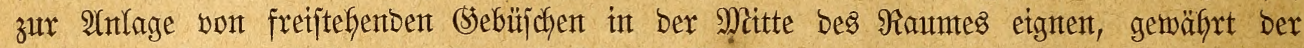

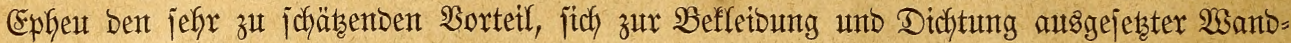
fläctyen gebrautchen zu raffent.

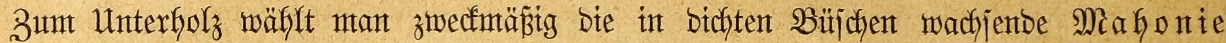
(Mahonia aquifolium) und zur teilweijen Befleibung und Fejtigung Des Bobents jomie zu Brutjtätten für ant $\mathfrak{B}$ oben nijtende $\mathfrak{B}$ g̈gel bie zwergartige Spielart Des $\mathfrak{B}$ utchabaumes, welche burch ifre Berwentung zu Einfajiungent in Särten zur Ssenïge befannt ijt.

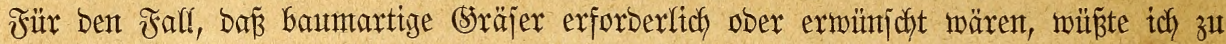

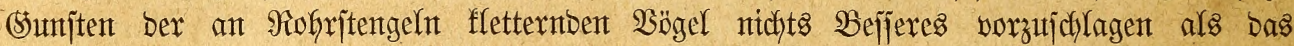

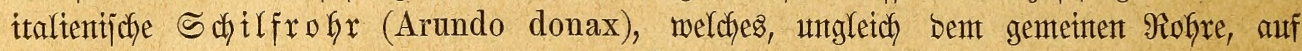

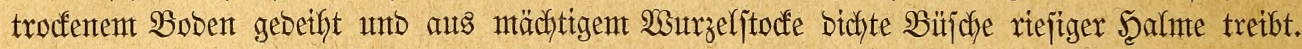
2fferbings jterben biejelben alljäfrlich ab, unt es bebarf bie \$fflanze, um nicht zu exfrieren,

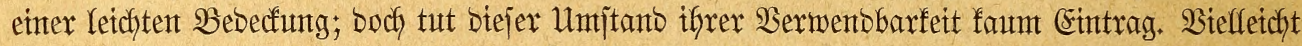

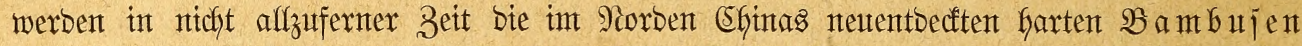

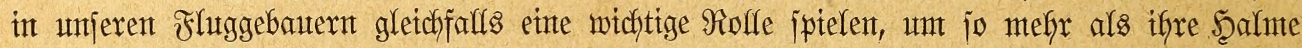

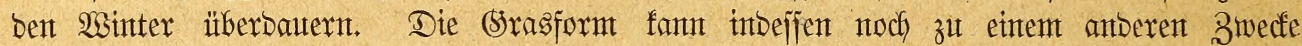

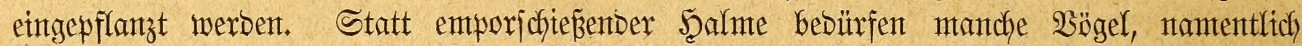

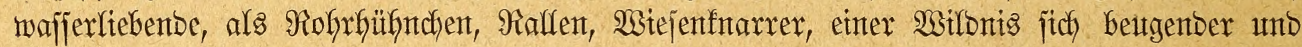
mit einanber verichlingenber feiner Blätter, jogenannter Sragfufen ober fiaupen. Unjere cinfeimijche Flora bilbet biejelben vorzugsmeije auts ber artenreichen Familte ber Ritegräjer (Carex). Die empfeflungşwerteren unter benjelben (Carex maxima, riparia, vulpina, pseudocyperus) funt jebodh jämntlich Waffergenächje, mintbejtents Pfflanzen eines jebr feudjtent Stanbortes. Mian mag fie verwenden $b a$, wo es angeft; fie werben aber in ifyer Wirtfjamfeit weit übertoffent bont eintgen riefigen Sräjern, Deren Wanzelblätter Denen ber

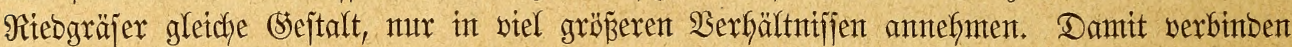

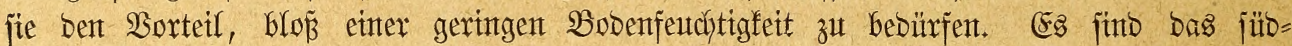
amerifanijdje $\mathfrak{B} a m p a s g r a s$ (Gynerium argenteum) und das Dem fllma Sïbeuropas

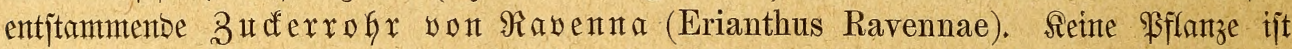

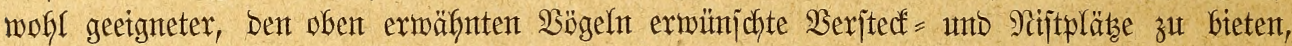
als bieje beiben leicht zu erlangenden und mit geringer Sorgfalt burch unjeren 2 sinter zu

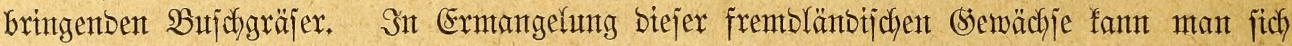
Des Bantograjes (Phalaris arundinacea picta), einex jefneff mudchernden Pfflamze bebienen; nur geitaltet fie weber fo hohe noch jo rumbe und gemölbte Binjche als jente betoen.

Meben Dent angefüfyrten Bflanzenarten Gaben mir noch eine Sruppe zu nenten: bie ber Sdylingpflanzen ober Rianten, mit weldyen in fürzeiter Beit in Ermangelung der

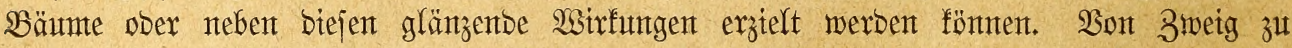

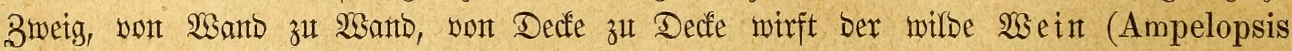

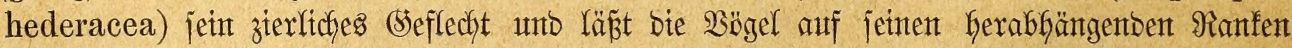

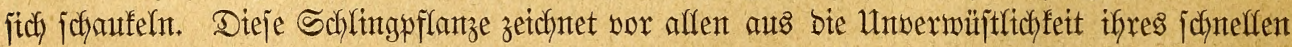

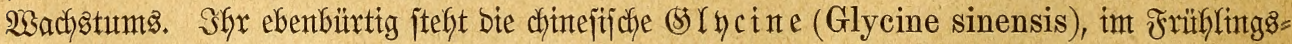

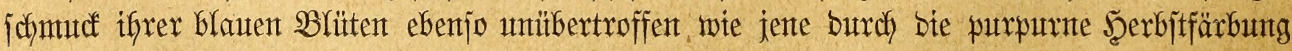

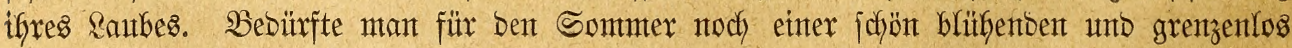

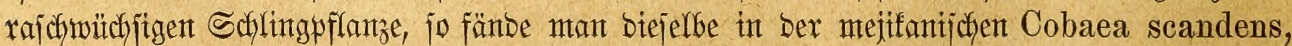

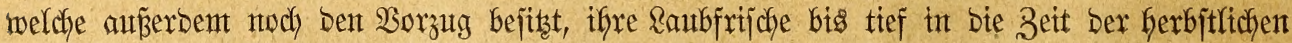

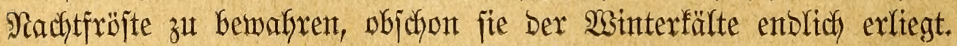

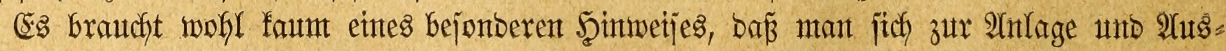

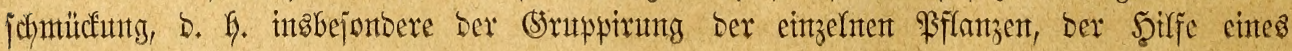




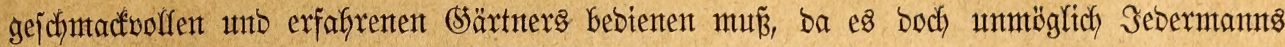

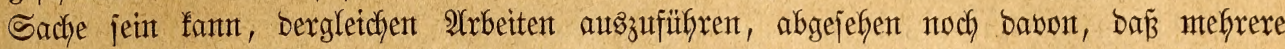

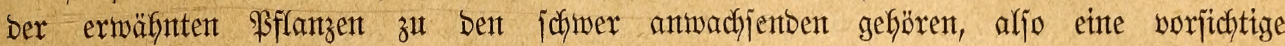

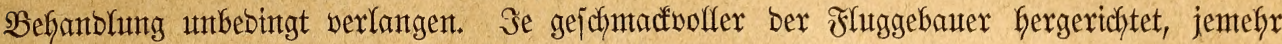
ex ein flemer Bartent int Sarten ift, um jo mefyr wiro er auth ben $\mathfrak{B}$ b̈gefn behagen, weil

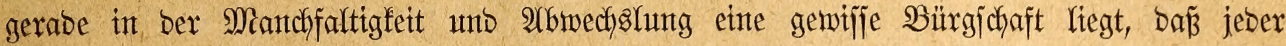

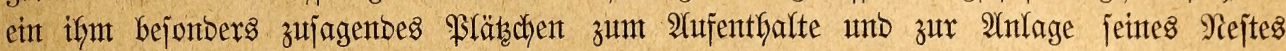
fintoent werbe.

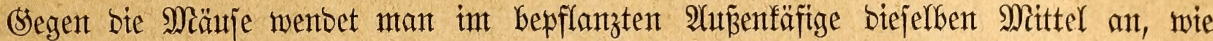

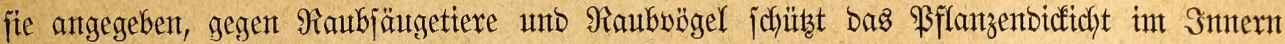

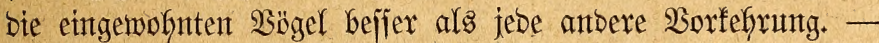

Fortwährenber Erjats alfer unbrauchbar gemorbenten Teile eines Bogelfaujes, Injtanto=

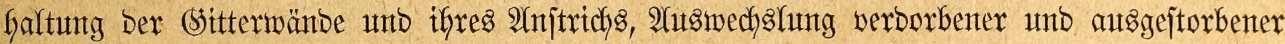

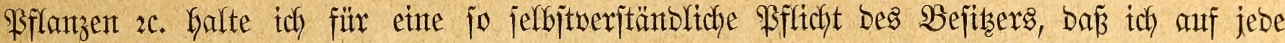

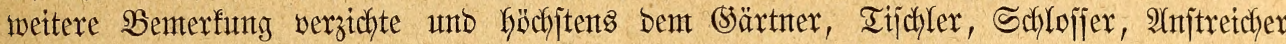

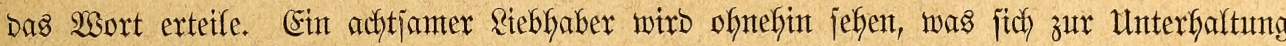
Des (sanzen als nötig erweift, und einemt unadjtianten Bogelwirte gegenüber ijt ja bod alle Belebrung vergebens.

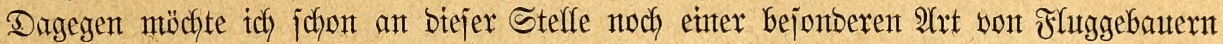

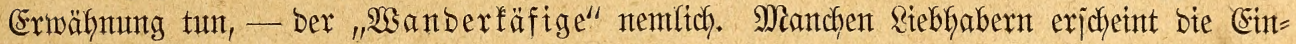
richtung eintes Fluggebauters aus bem (Srumbe unxatjam, weil fie finfitctflidh Des 2 sofynortes won ifrem Berufe abfängen, plöblich verjebst werben fönten unto bant affes im Stidje laijen müfjen. In fajt berjelben Rage befintoen fich bie Wobnungsmieter, Deren zeit= weiliges Bejitztum audf) über einen (Sarten fich erjtrecft. Den einen wie ben anberen

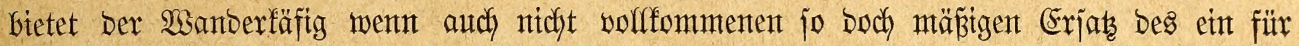
allemal feititebentoen $\mathfrak{B o g e l f a r j e s . ~}$

Der Wanberfäfig wird aus Bretern, eijernen Irägern unto mit Drat itberjpanntent Rabmen zujammengejesct unb überaff Durch Schrauben berbunben. Der gebecte Raum

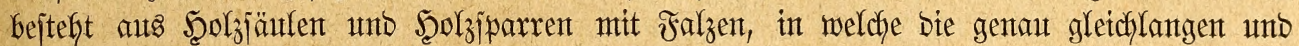

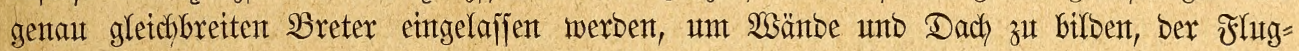

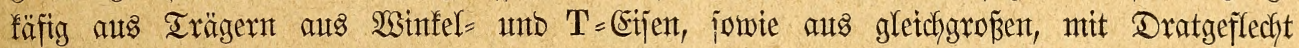

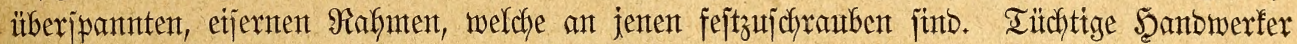
vermögen einen folchen Flugfäfig jo jorgfältig und genau zu fertigen, baß̉ ifn eintge geichicfte $\mathfrak{A r b e i t e r}$ in fürzefter Frift auseinambernefmen und wieber aufiteffen föntnen. Das

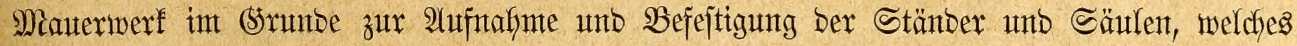

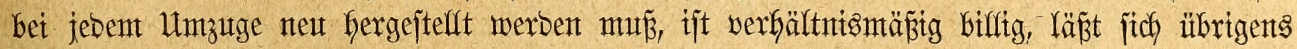

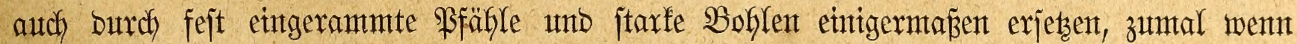
matt es an (5lazjcherbent zu beiben Seiten ber in Den Srumb eingelafjenten Breter nicht

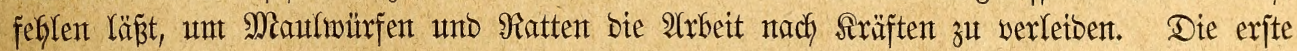

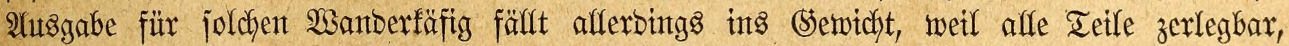
aljo jefy gentau gearbeitet jein müffen; bei wobberfolten untzügen aber macht fich jente

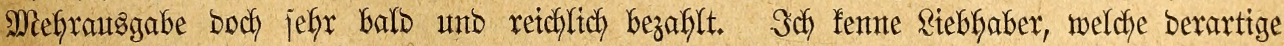
Jluggebauter bejizen, biejelben jojon mebrmals verjetst Gaben unto mit ifnen in jeber

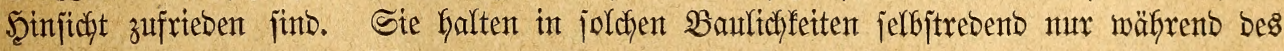

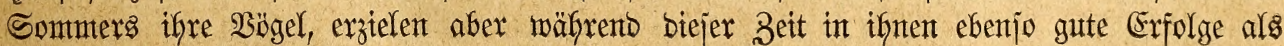
2lttbere in fejtitefyenden Şäujern.

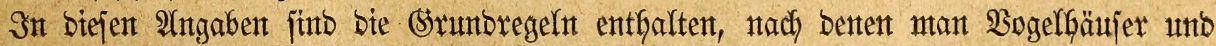

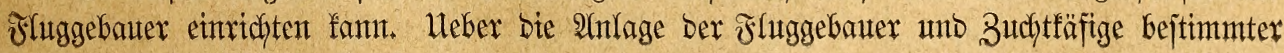




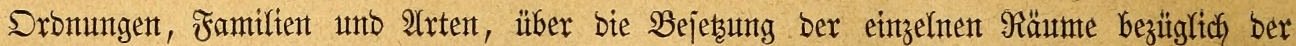

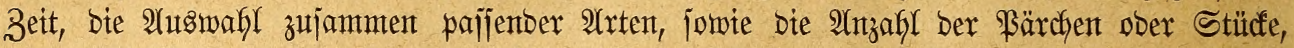

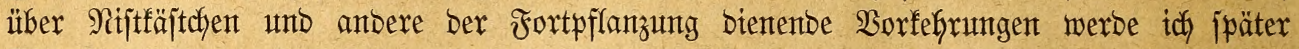

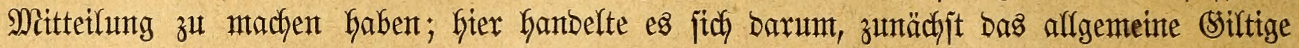
孔t gebent.

\section{Ameiโenpuppen unto Atlehlwuïrmer.}

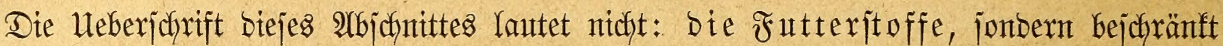
fidf) auf zwei won ifgnen, aus bent einfachen unt wohl autch als giltig anzuerfennentoen (Strutbe, weil über bie anberen went nicht bie Şausfraut, jo boch jeber Ranbmirt ober

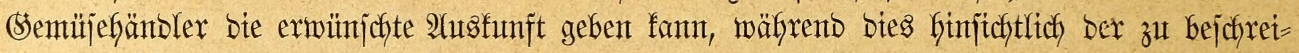

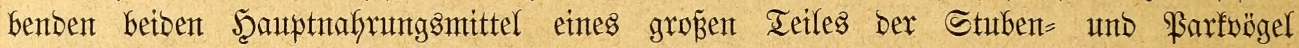

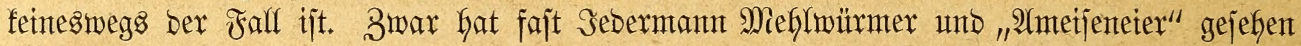

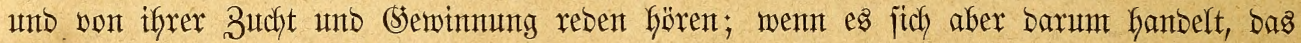

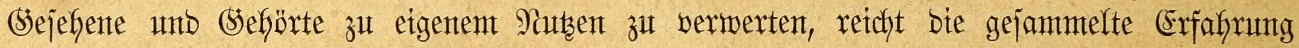

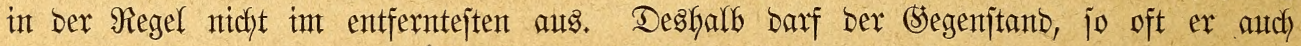
jeffont bejprochen worben, ant biejer Stelfe nicht fehlen: nübzt bas (sejagte nur einem Einzigen, io ijt es aflen 2 (ntweren gegenüber entichulbigt unt gerechtfertigt.

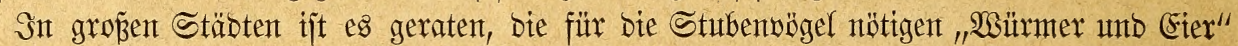

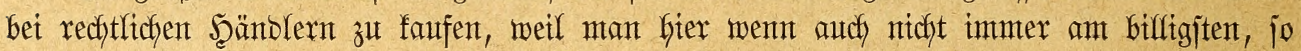

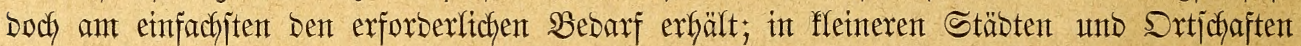

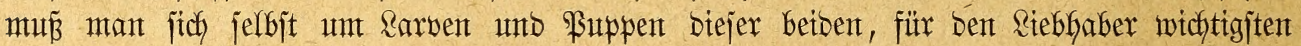
aller Serfe bemühen, fafls man fie ftetz in genügenber Mienge bejchaffen witf. Es ift

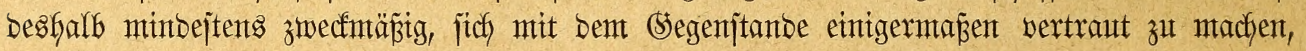

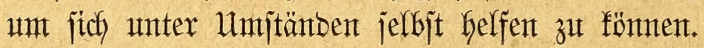

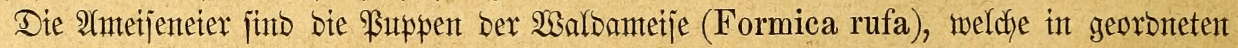
Serbänben ober Staten vorzugsmeije in ben Nabelwälbern, zumal in benten bes Norbens

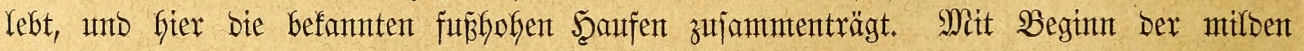

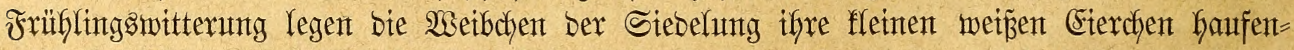

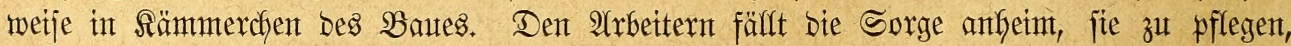

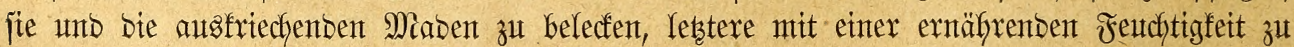
weriegen unb je nach bem Stante ber $23 i t t e x u n g$ in ben oberen ober unteren Teil bes Bautes

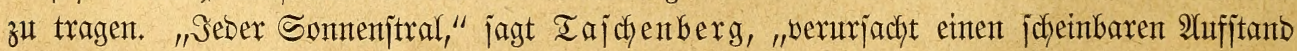

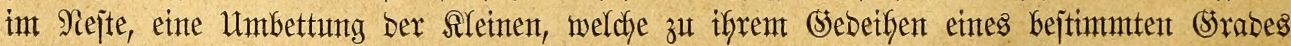
ber Wärme unto Feuctitigfeit bebürfen."

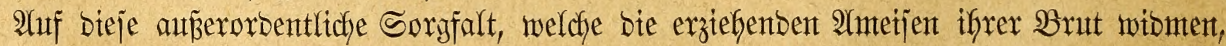

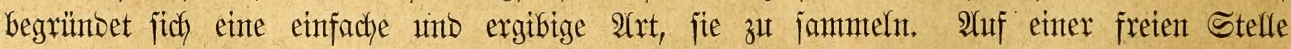

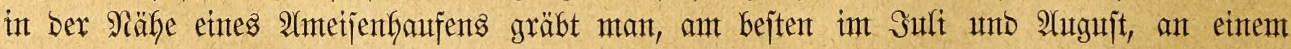
jomigen Mittage - Dent bei trübem 23 etter arbeiten bie $2(m e i j e n$ joflecfft - eine (5rube

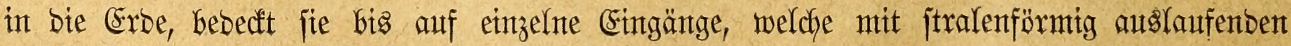

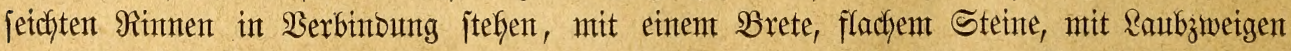

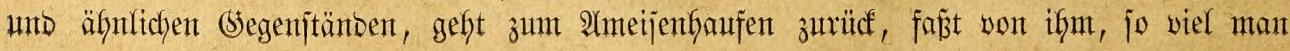




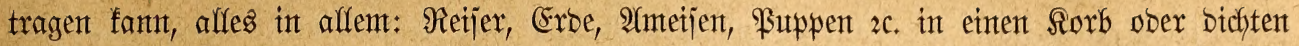

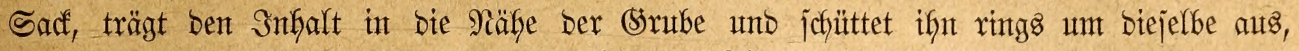

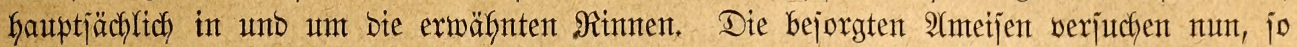

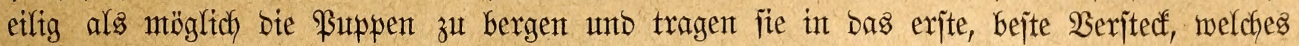

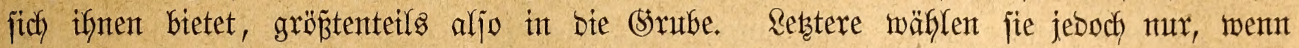

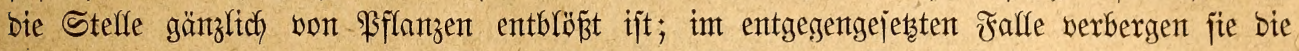

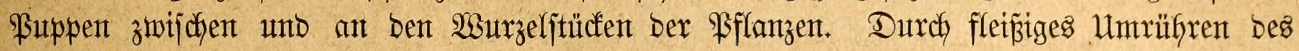

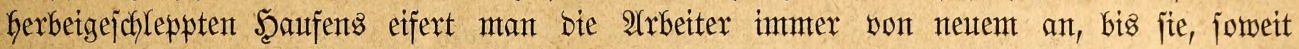
erjichtlich, ifyx (sejchäft beenbet haben. Dant nimmt mant bie zujammengetragenten \$uppen mit einem Röffel aus der (srube und trägt fie getrojt nach) Şauje. Den übrig bleibenden Benifthaufen jammt jeinen Bemohnern bringt man nieber zum Stodfe zurüct, um biejem

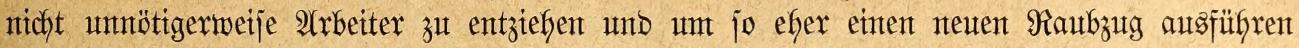
孔ั föntกn.

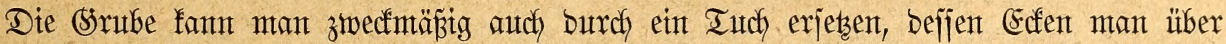

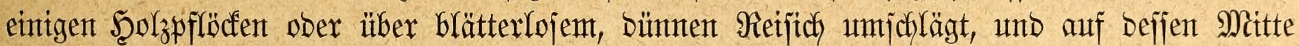

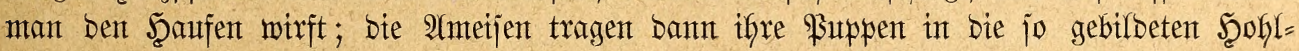

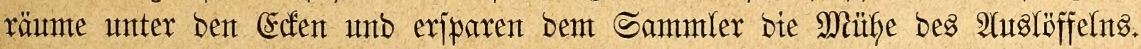

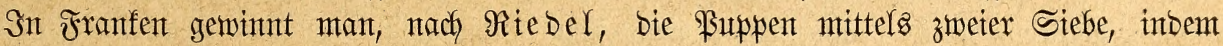

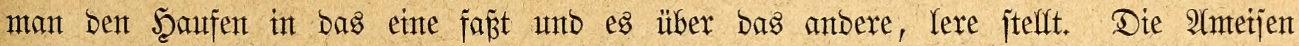
tragen fierauf ifyre \$uppen in Das untere, bejonbers, went basjelbe niebrig ift; es fäflt gleidzzeitig aber audf eine Mienge von (Erbe $2 c$. mit burd) und berunreintgt bie Puppen.

So ganz ofne Şinberniffe geft ein Derartiger $\mathfrak{B}$ eutezug übrigents nicht ab. Die erbojten Serfe webren jich nach Siäften, unt wenn ifrer viele über Einten fomment, hat mant feine

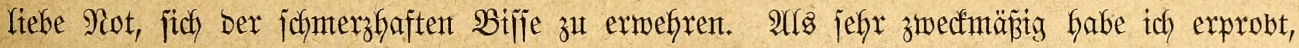
bie Stiefeln, ben Stiel Der Schaufel, weldhe man zum Einpacfen bes Şaufents vermentet, unto bie Stange, an weldyer man (jelbanber) ben Sorb ober Sacf von bannen trägt, teilmeije

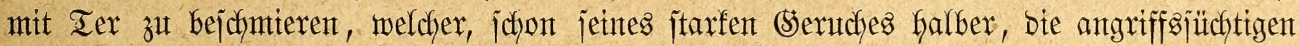

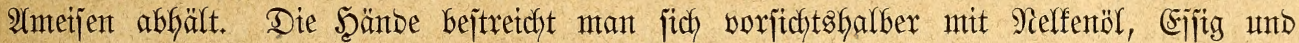
antoren itarfriectjenten Stoffent.

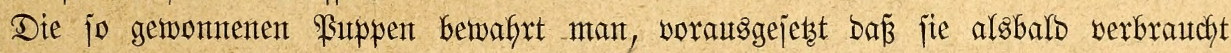

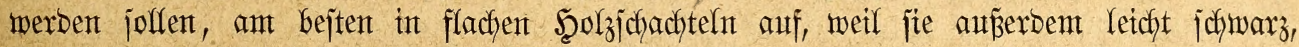
bezüglich) reif werben ober verberben (zujammenfleben unt ifgre gelblichmeize Färbung ver= lieren), mentgitens jofwitzen und iffen guten (sejdymad einbüren. Deshalb ijt es autfy wohlgetant, fie täglich ein bis zwei Mal Yeife umzujchüttelnt, bamit bie \&uft an alfe treten

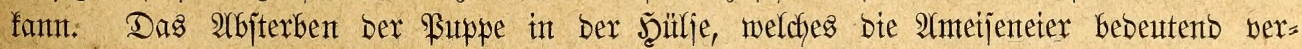

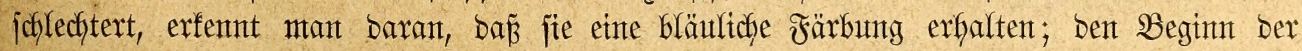

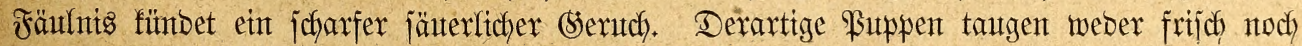
gebört zum Futter unto müffen weggetworfen werben.

Für Den Winterbebarf bört man fich bie 2(meijenpuppent in einter über Sioflenfeuter

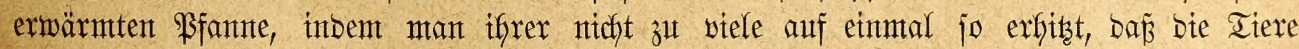
getötet, nidfyt aber geröjtet werben, breitet fie jobant auf Bretern (Sutchentecfen) auts,

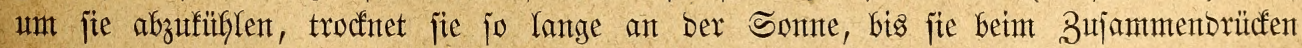
feinen Eaft mefy yon fich geben, untb bewahrt fie in flachen (sefäp̈ent auf. (S)röpere Miengen tötet man auf Rutchenblectent int Bacfofen und bourt fie jobann vollentos in ber Sonne, Gat fierbei aber jefr genau $2(d y t$ zu geben, um fie rectzzeitig wieber aus bem Dfen zu bringen. (5) räßner rät nach) benäbrter Exfafyung, zum 2rbtöten einen B̧lechtopf zu nefymen,

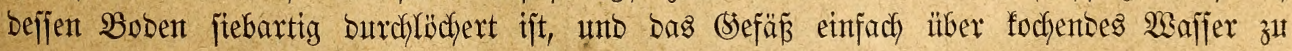
Galten, bis alle \$uppen abgejtorben jind. Sie trocfnen freilidy fdyerer als bie geoörten, 


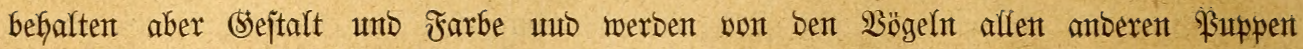
enticfieden vorgezogen.

Begreifflichertweije ijt bie mit ber Bejchaffung and weiteren Befhanthung bex 2Ameijen= puppen verbunbene 2 trbeit nux einem Stebhaber zuzumuten, welcher in einer fleinen Stabt

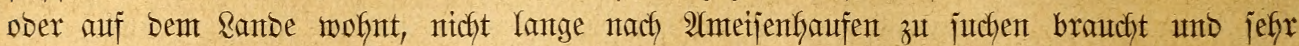

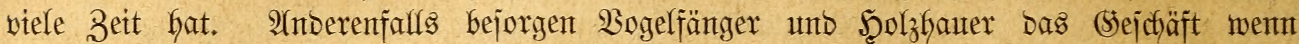

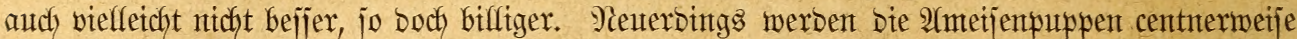

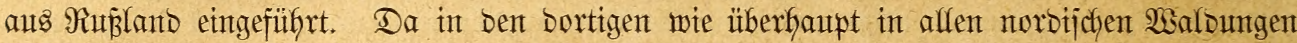
bie betreffente Afmeife ungleich) bäufiger unb bie 9trbeit bitfiger ijt als fier zu Ranbe, erfält man jeinen Bebarf zu jefy mäp̈tgen Freijen. Die Bogelfändlex Staber \& Comp. in Mosfau jint in Der Rage, jede beliebtge Menge von Âmeijenpuppen zu bejorgen, reijten

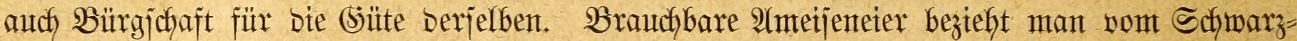
malbe, vom Saarz und türtnger Walbe, ganz aużgezetantet gute aus Witen unt anderen grö̈eren Stäbten Dejterreidfs, wentger gut gebörte aus Der Segento von Salzmedel

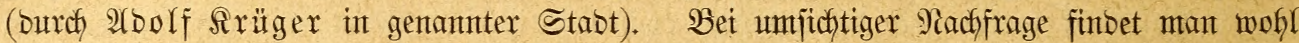

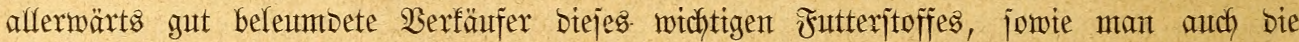
letchtfertigen Şänbler balo fenten lernen fann. (Semifijenthafte Şänbler verfaujen nur joldhe Imteijenpuppen, welche unntttelbar nad) bem Eimjantmeln gebönt murben, genifientoje

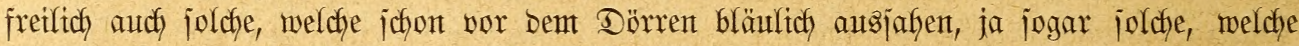
jäuerlich rochen, als fie über bas geuer famen. Den reintweip̌en Fuppen hat man jtets zu mistrauten, meil betrügerijche Reute bieje Färbung Durch Schwefeln heroorzumfen mifjen,

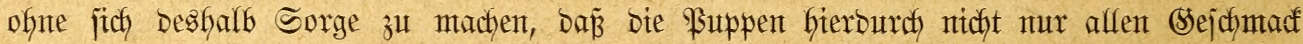
verlteren, jonbern aud jchäblich wirfen.

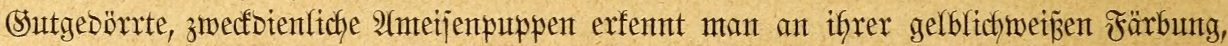
einem eigentümlich würzigen (sieruche, ifrer noch zientlich gut erfaltenen (sejtalt unto endlich

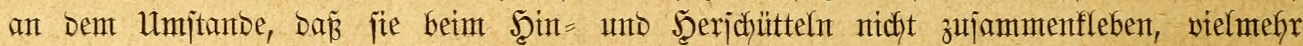
letcht "rolfiren", wie mant zu jagen pflegt. Soldfe \$uppen bemafyrt man in flachen Schachteln auf unt fchüttelt fie won acht zu adht Iagen etwa einmal bei ungefintoertem 3utritte von \&uijt geförig Durchetnanber. Ebenjo zmedmäpig als Schacfteln ermeijen fidh bünne Säcthen, melche Den Butritt von \&uit gejtatten und boch bie Bertilger abhalten. Bet joldher Behanblung haltent fith die \$uppen ein Sabr lang und Darüber, berfieren aber mit ber Beit mehr und mehr an (Süte, milijen aljo jebes Gafhr erjezt werben.

Die joblimmjten Beritörex Der gebörrten \$uppen fint fleme Mitlben, welche jich jehr letcht einnijten und bebeutenben Echaben antichten. Durdy jie Keimgejuchte Fuppen werben

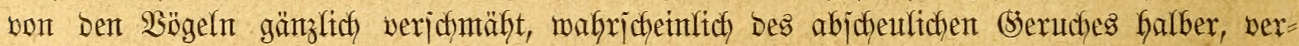

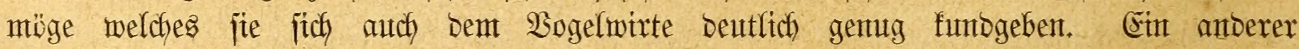
Schabenbringer ijt bie Rarbe bes Spedfäfers; fie vernichtet jeodh mentigitens nidft ben ganzen Borrat, jonbern nur biejentgen \$uppen, welche fie verzefrt. Bor betoen

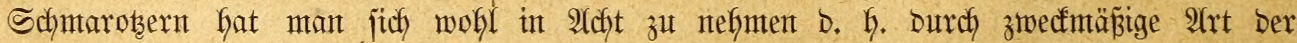
Áffbemafyung jeiner \$uppen möglichjt zu jchütsen.

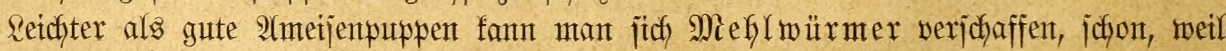
man fie in bex erforberficten Mienge zut züchten int Stande ift. In groben Stäbten fauft

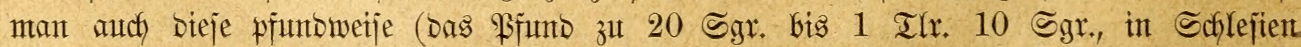

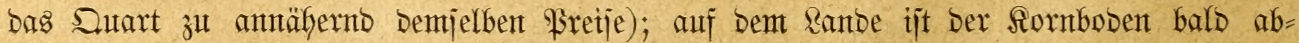

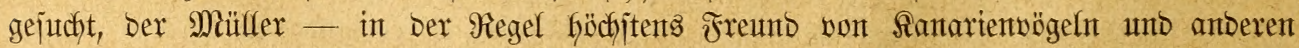
Samenfrefiern - binnen furzem ebenfalls ausggebeutet; es gilt bafer, bas SBebürfnis ourch eigene Mittel zu becfen. 3u bieiem 3medfe legt mant fich ben Mieflmurmiak ober bie Mehlinurmbecfe an. 


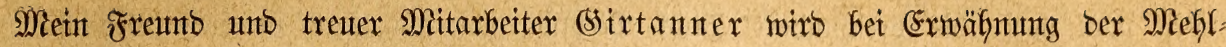

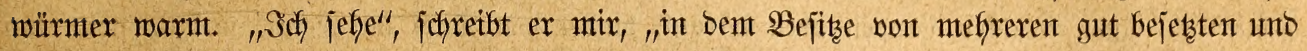

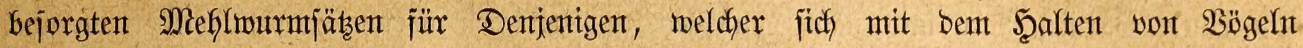

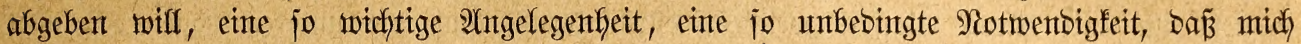

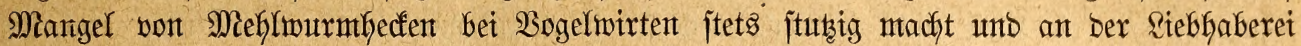

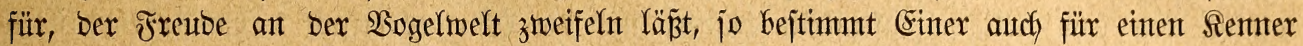

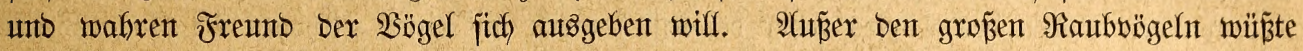

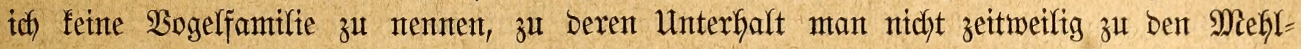

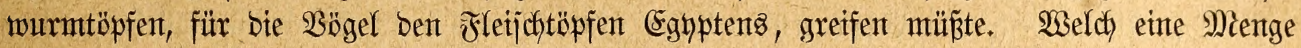

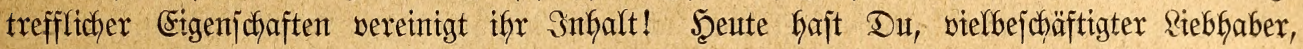
unmtöglich Beit, Die langmeifige 2 rebeit ber Futterbereitung für Deine Machtigaflen aus= zufüffren: - woflan Denn, greife зum Iopfe, reidge ben Şungrigen ein halbes Sdjodf

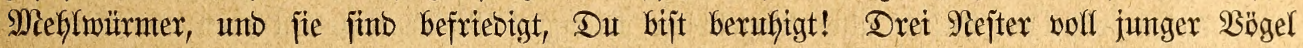
bringt mir ber Fänger, Yeiber aber feine 2(meifenpuppen mit, unb bie meinigen fint audt

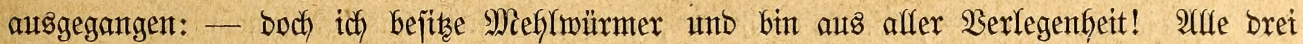
Watebefopfe maren glürflich burdjgegangen; mit, ifren gejdjiften Edynäbeln hatten jie bas

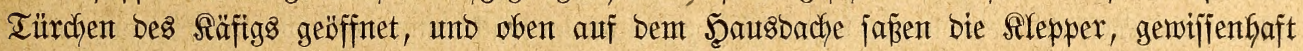

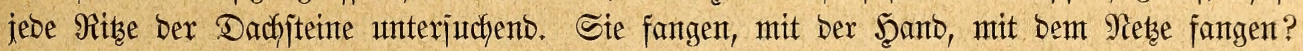

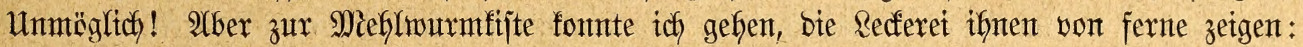
und vom Dache herab famten fie geflogen - nicht aus Seffijucht zum Säfige, jonbern aus

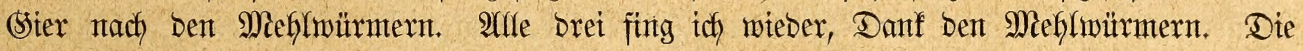

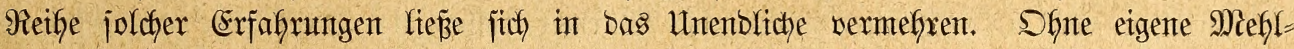

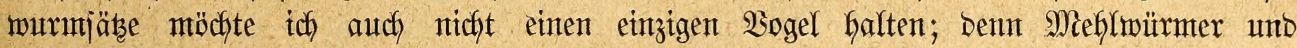
Stubenvöger finto mix untrembare begriffe gemorbent. $2 \mathfrak{S a s}$ wäre aus meinen fieben Mauterläufern geworben, ofme Meflmürmer? 2 as woulte man ofgne fie beginnen mit

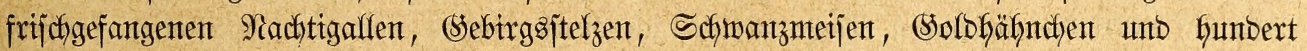

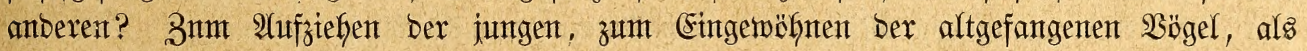

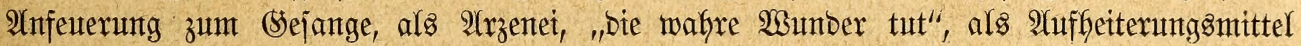

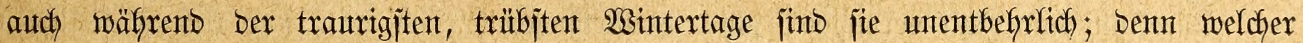

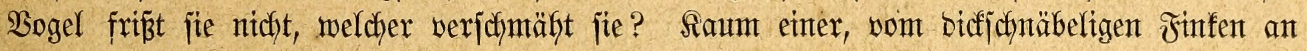
bis zum Röffler Gerab!"

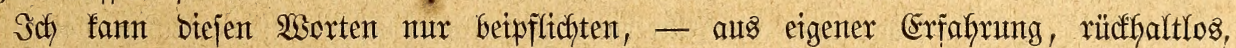

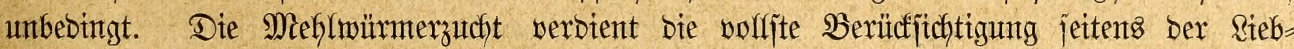

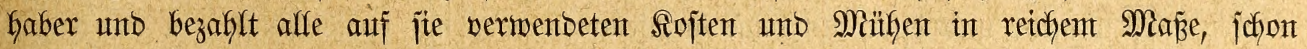
weil fie unabhängig macht von taujenb Bufärligfeiten. Sch fant fie bem 2 bogelwirt gar

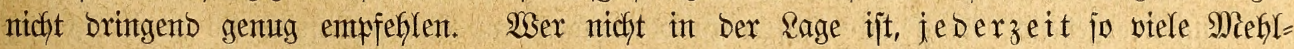

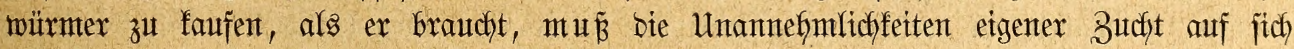
nefgmen; unt wer bies nidft tun wilf, "berbient gar nicht, einen 20 gel zu befitzen", wie Freund (sirtanter noch finzufügt.

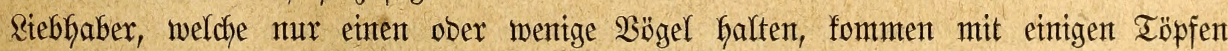

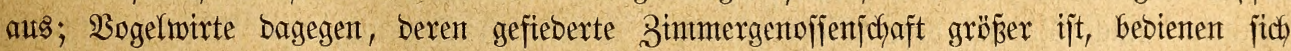

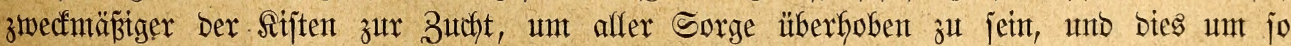
lieber, als fich in ben Sijten weniger Mitiben unb Miotten einfintben als in Töpfen. Es

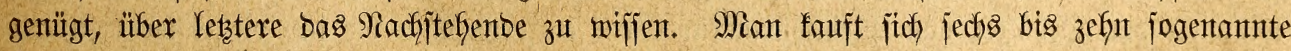

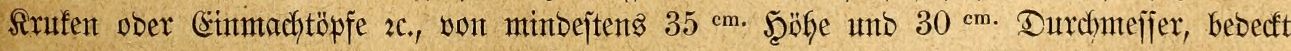

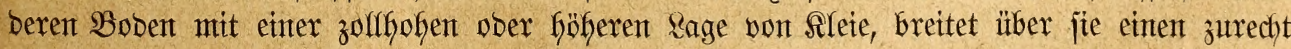

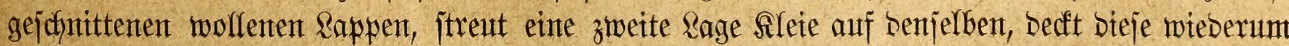

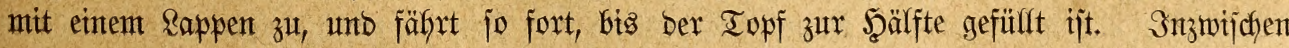


mirft mant zwei = bis breifumbert Stüd Meflnürmer als Sats in bieje Behaujung, legt

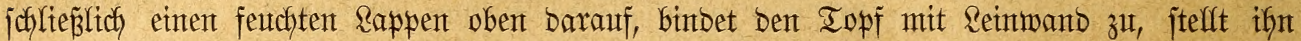

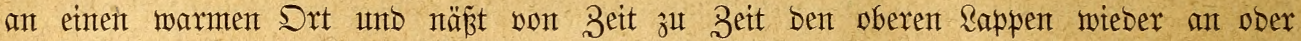

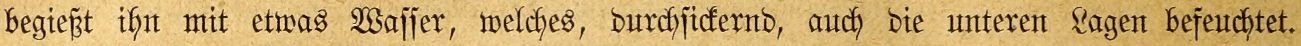

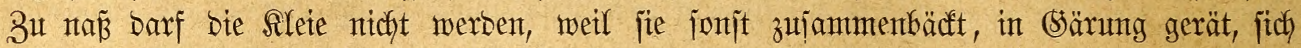
erfitst, Den jefr nötigen \&uftzutritt Ginbert unt bie Wä̈mer erjticft. Einige Bogelwirte bebecfen ben $\mathfrak{B}$ oben bes Iopfes (ober ber Rijte) znexit mit einer zollfohen Sandlage, welche bie Feuthtigfeit auffaugt, ofne ben barüberltegenden Jutteritoffen zu jchaben.

Die Siften bejdyreibt (sirtanter befjer als idh, weil mein Bebarf an Meflmürment

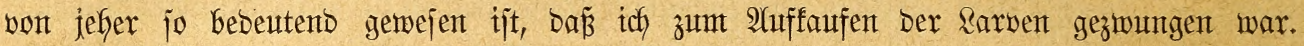

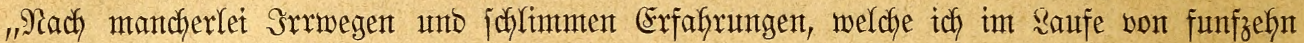
Safyren gegangen und gejammelt, bin ich zu einter wentgitens für mich endgiltigen Einjicht über biejen widftigen $\mathfrak{B} e$ helf alfer $\mathfrak{B}$ ogelwirte gelangt. Meine Siften werben aus Iannen= holz und zwar aus $1,5 \mathrm{~cm}$. Dicfent, mögltchjt ajtfreien 2 retern gefertigt. Die Ränge beträgt $60 \mathrm{~cm}$, Die Breite $45 \mathrm{~cm}$, Die Şöhe $30 \mathrm{~cm}$; größ̈ere Sijten füto unbequem, fletnere nicht ausretchend, thefere in jeber Beziefung unvorteilffaft, weil ber Sats in ben unteren Echidften

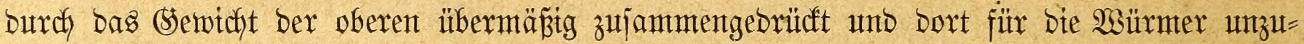

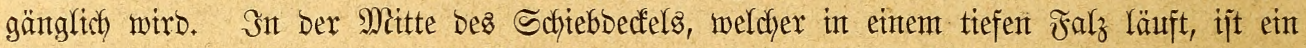
Soch von $15 \mathrm{~cm}$. int (Sebiert ausgejchnitten mo Darüber ein feines Dratjieb befejtigt, welches

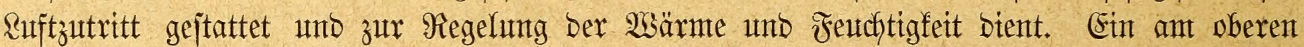

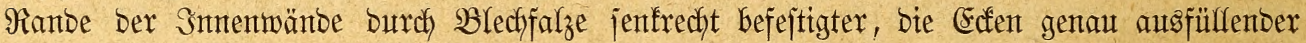

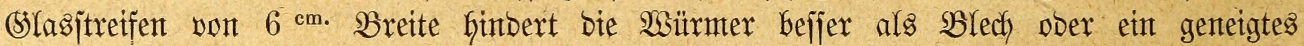

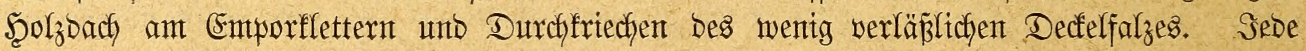
Rijte wirb vor bem (sebrauche genau bejichtigt, hierauf in ber oben angegebenen 2 seije bis zu etmas mefyr als halber Şähe mit Sand, Slete, Miehl und Rappen vorgeridftet und mit 500 bis 600 Mefhlwürmern bejest, weldye idh Durdy Sieben von aflen Beijtoffen jondere, umt etne Ulebertragung von Mitfbentern, Specffäfern 2 . mögfichjit zu vermeiben. Son jebzt

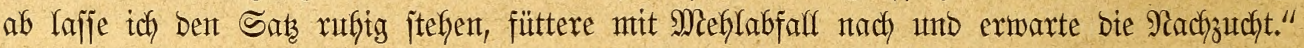

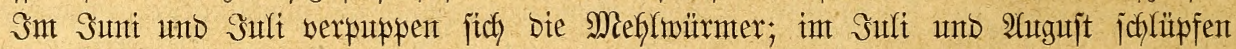
bie vermantolten Meglfäfer aus. Nummefr ijt es an ber 3eit, noch mögltchjt viele ber

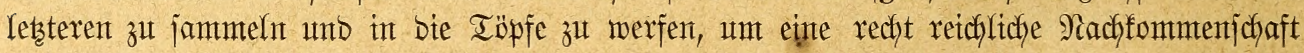
zu erzielent. Şierzu trägt auch bie Jätterung ber Räfer bei; man verjäume baher nicht, für Dieje Fleijch (tote Bögel $2 c$.) in Die Töpfe zu werfen und fie zu tränfen, D. h. Den oberen Rappen mebx unt öfter als jonjt anzufeuthtent ober mit etwas 2áfjer zu bejprengen. Dodh Güte man fich, betiptelsmeife audh beroorbentes Bogelfutter ober anbere lecht in

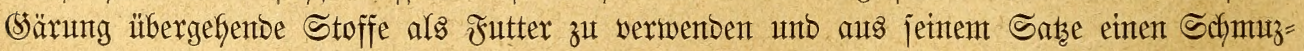
haufent zu machen, in weldhem Das wertwolle Sierbtier in allen Entwicfelungsitufen jeines

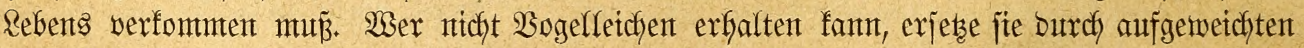

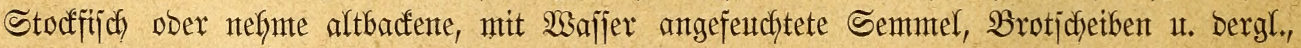
weldje Räfer und Rarven gern freffen, und weldhe leidht erjetst ober weggeräumt werben

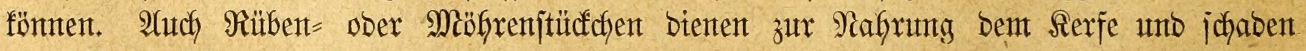
bent Sake nicht.

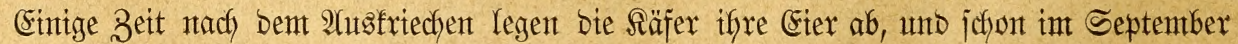

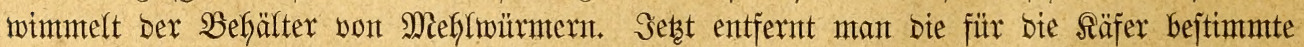

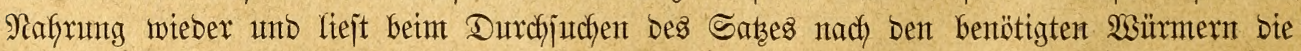
abgeitorbenten Erzeuger ber lebtgenanten mit aus.

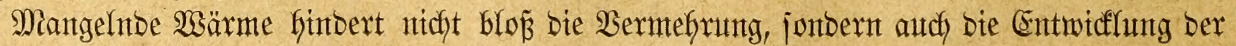
Mebrffäfer und ifrer Rarben. Man itelfe bebfalb ben Satz immer an einent Drt, tomöglich 
10, Dẩ bie Wärmte von untent eimjtralt, und gebe ben Sitjtent exforberlichent Falls einten bem 2luge gefälfigen 2 fnjtrich, unt jie jelbjt int Bintmer auf ober Ginter Dem Dfen unterbringen

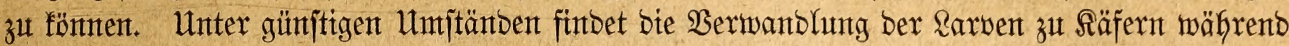
bes ganzen Sahres ftatt, vorausgejest natürfich, baß man wentgitens einen Ieil ber er=

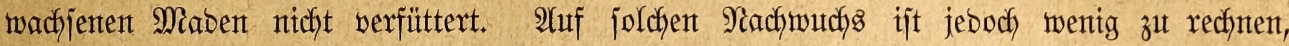

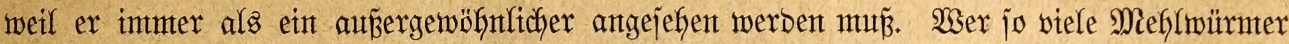
füttert wie ich, mur auf jeben eblent Sänger einte Sijte rechnten, auf größzere 2 (rten, Spott=

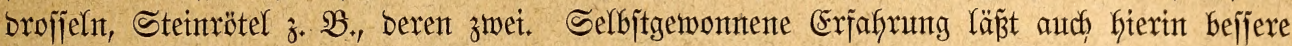
und ridftigere Erffentntití gemintmen als alle Refre.

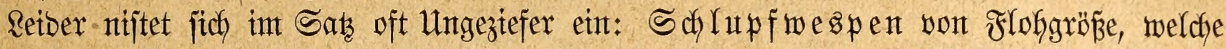

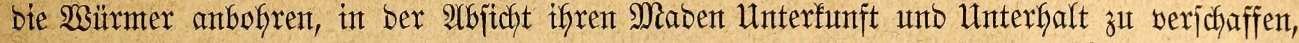
jente baburch aber untbringen, Milben, welche zwar nicht ben Würmern jchaben, jebody bie

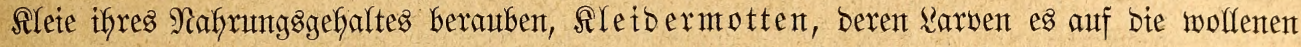

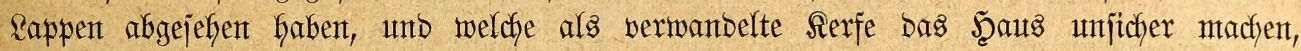
Spedffäfer unb anbere. Sie judft man nach Mïglidffeit zut entfernen, am bejten baburch,

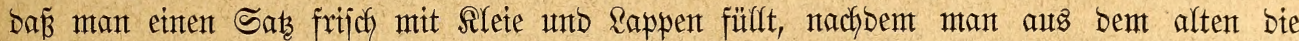

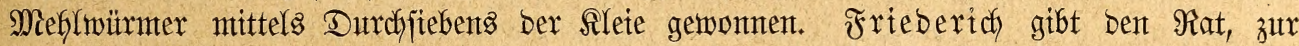
Bertreibung Der faum fichtbaren Feinto etwas Rampfer in ein Räppchen zu binben unto biejes ant einem Sidhnürchen jo in ben Topf zu hängen, bá es bie Mafje bes Sakes nicht

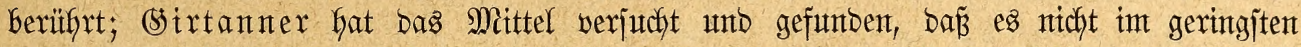
nübst. Die Mitlben, Deren Entwicffuntg burch Fenchtigfeit und Wärnte bejonbers begünjtigt

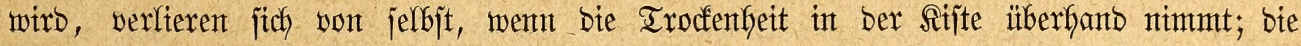
Mottent aber, welche int Ei= ober Rarbenzujtanto int ben wollenen Rappen in ben Sats

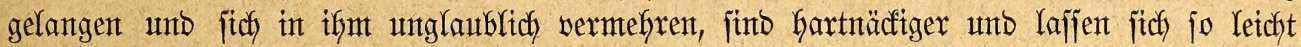
nicft bertreiben. "sfynen gegenüber", idyreibt (Sirtanter nodh, "ftreiche idh bie Segel.

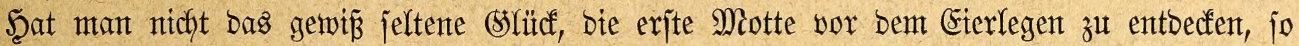
barf mant entweber ben Sab verloren geben ober mit $\mathfrak{B}$ ejtimmtheit erwarten, bas ganze

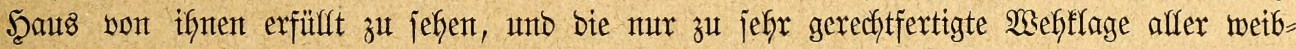
lichent Bewofnter bes lebsteren zu vernefymen. Saltlächelno fajfe man bie mottige Sijte, fiebe ifren Snthalt unter fretent Scimmel aus, jammle bie Mieflwürmer auf, werfe fie in frijche Silete, bamit fie fhter fich reintgent und jetze jie von neuent an, ober befifer: man jetze

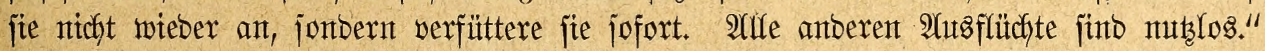

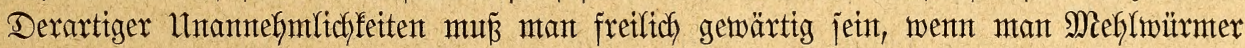
züchten wifl; bie Beruffigung aber, weldye bie Butfyt Der untentbehrlicfyen fierfe gemährt, macht fie ertragen helfen. Эch wieberfole: ofnte Mieflwurmiäbe ijt ant bie Unterfaltung

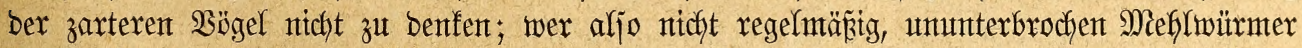

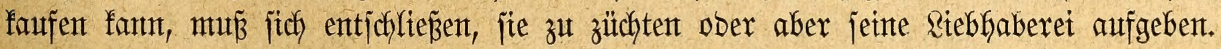

\section{Donelfutter.}

Wolfte mant verjuchen, affen $\mathfrak{B}$ g̈geln int Stebauter bas Futter zut retchen, weldyes fie int Freien juthen und finben: es mörbe fajt unmöglich jein, Stubenvögel zu Galten. Seintent

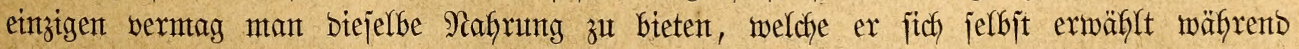
jeines Freilebens; man ijt, gümitigen Falfs, in ber sage, ifmt einen Ieil jeiner natürlichen 
Speije zu bieten, nicht mebr, oft noch weniger. Die alusnafmen, meldhe mir jefr mofyl betwupit fint, bejtätigen nur die Regel.

Nod) mehr: man Darf Den gefangenen $\mathfrak{B}$ ogel, auch menn man fant, nicht gentau ebenjo fïttern, wie er fich) nährt, fo lange ex fich ber golbenen Freitgeit exfreut; man fann höch)=

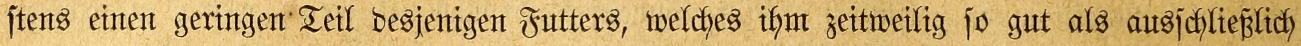
zum Unterfalte bient, ber Befangenenfojt zujesen. Snt allgemeinen ijt es freilich ricjtig,

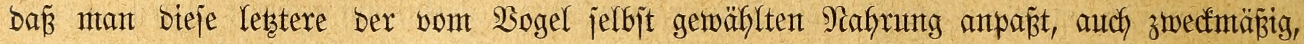

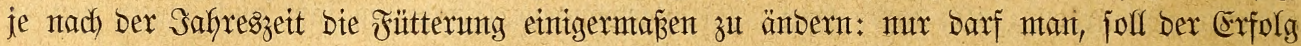

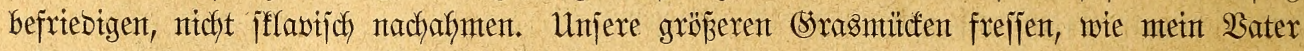

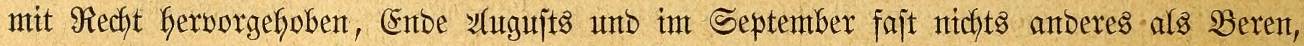
namentlich Flieber = unto Faulberen, bie Drofieln in Winter, menn bie Wacholberiträutde

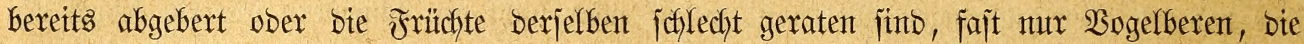
bet uns ïberwinternben Seibenfchmänze mochenlang hauptjächlich Fautlberen: aber man ver:

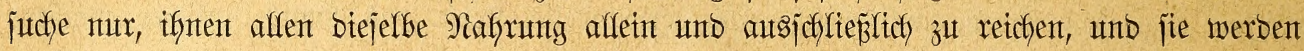
berfïmmern, werbent fterben. Nodh fint wir nidfyt jo weit, Das Warum mit unbebingter

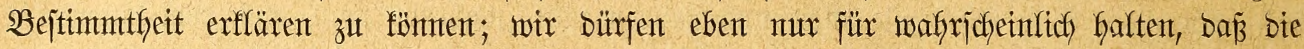
veräntoerte Rebenşweije Des Stubenvogels vortwaltend bie Hrjache biejer Erjcheimung ijt.

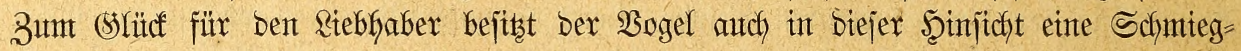

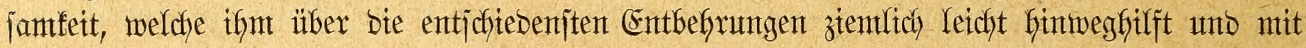

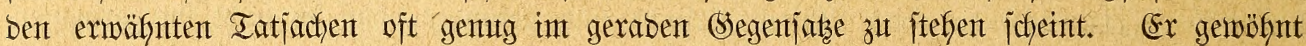

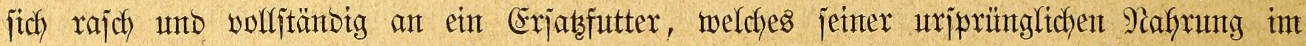

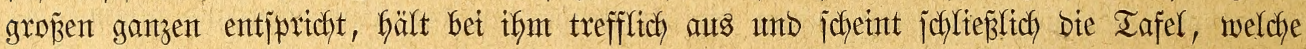

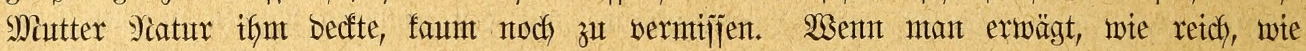

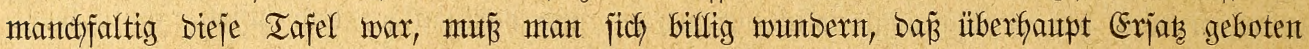
merben fant; ebenjo aber wird man begreifen, daß für viele $\mathfrak{B}$ ögel ifn zu finten.

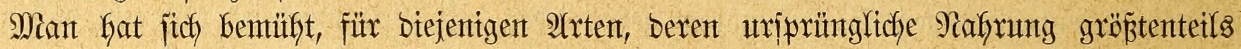
aus Serbtieren bejteht, berjchiebene Stoffe zu einem jogenannten "Untwerjarfutter" zujammten zu mijchen und bald bie einte, bald bie andere Mitjchung empfoflen oder getabelt, je nach=

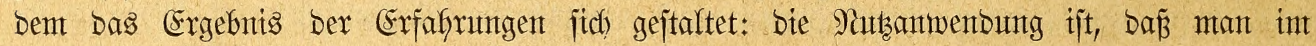
affgenteinen mit einfacherem Futter günjtgere Erfolge erzielt als mit einem auts alferlei Stoffen zujammengejetzten, jo wohlïberlegt bie 3ujammenjetzung audh gejdyehen mochte.

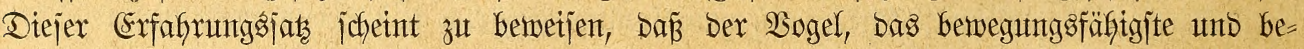

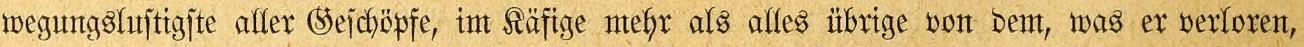

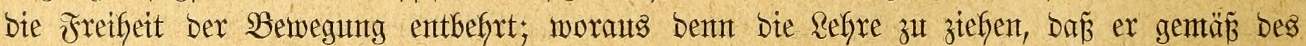
in Folge jeiner Einferferung bebeutend bejchränften Stoffinedjels behandelt, aljo lieber bei

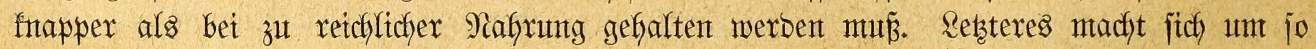

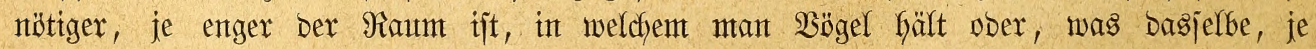
wentiger fie im Stande finto, fich ausgibig zu bewegen. Man barj es als Bejets anjeben,

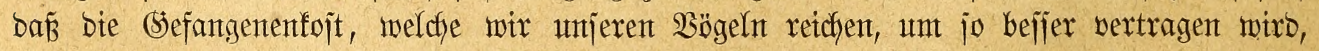

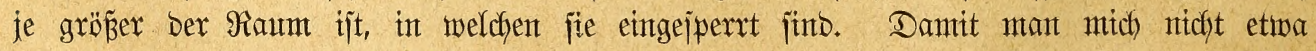

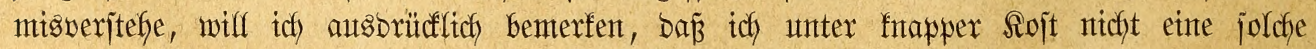
gemteint wijfen wifl, welche aus geringen ober gax werborbenen Bejtantoteilen Gergejtelft

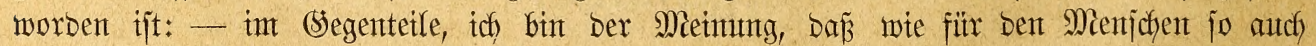
für ben Sogel bie alferbejten Jutteritoffe beziehentfich auth bie alferbifligiten finto. Es joll aljo "fnappe fojt" mur bebeuten, Dañ man jeinten Befangenen nitht inmer io viel von ifrem \&ieblingsfutter geben Darf, als jie frefien mögen, fie vielmebr wentgitens zeitweilig in

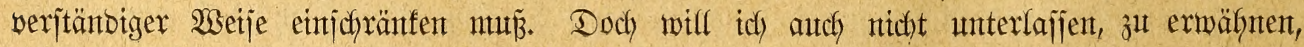




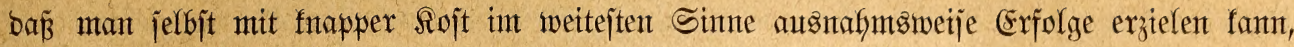
melche man nicht für möglich Galten möchte. Ein exfindunggreicter Sdyneiber, ben ich fennen gelernt, füttert, um nur ein Beijpiel anzugeben, Srasmücfen, Droffeln, WSiedefopfe, Regenpfeifer, Sibibe beharrfich mit einem unb bentjelben Futter: gefochten, geriebenen Siartoffelt und in Wafjer aufgemeichter Semmel; unb bod erbält er jeine Bögel jafbrelang - freilich

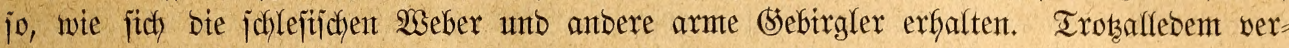

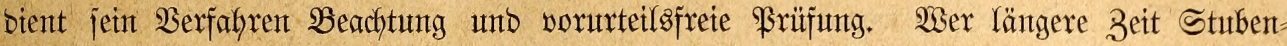
vögel gepflegt bat, miro mir beiftimmen, wem idh jage: weit mebr als won ifnen an all=

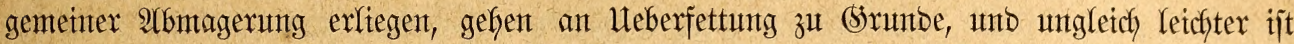
eB, eintent mageren $\mathfrak{B o g e l}$ zu feiften, als einen aflzufetten zurücf́ zu füttern.

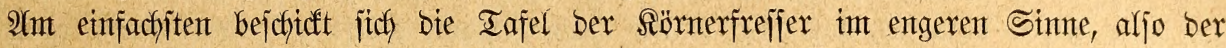
Finfenvögel unb ifgrer Serwanbten, wie ber zu ifnen zählento, affgentein verbreitete fiana= rienwogel zut (sentigge betweift. Nitcht wentge von ifnen balten bet einem und bemjelben Futter viele Gabre int Säfige aus, ohne Entbebrung merfent zu lafien; anbere ver=

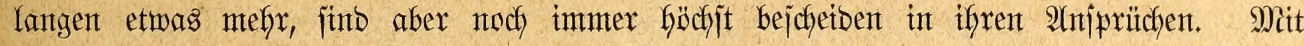

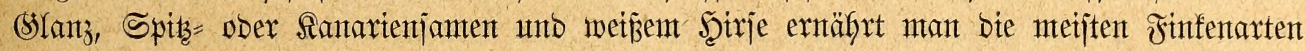

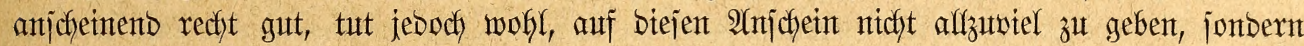
rechtzeitig noch andere Futteritoffe zuzujetzent. Der freilebende Bogel nimmt, wie bie meiften Titere ïberbaupt, eine biel mandffaltigere Speije zu fich, als man gemöfnltich meint.

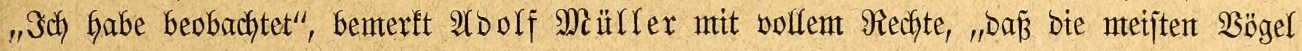

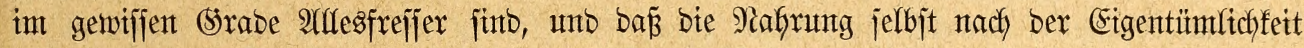

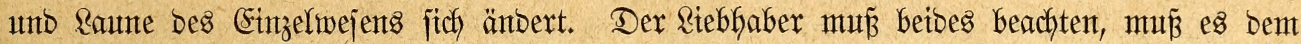
Bogel abjeben, was or will, muz ifym abzulaufchen wifjen, welche Nafyrung er ber anberen vorzigt." Wer aljo Sörnerfreffer alfein im engen Säfige Gält, verjäume nitdft, bem haupt=

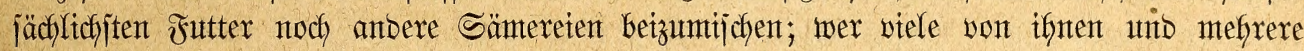
2trten in ein unb Dasjelbe Fluggebauter bringen wifl, retche ifnen verjdjiebente sejämte in bejonberen Futternäpfen. (S)lantz, weif̧er Şirje - nicht gelber, welcher ıngern gefrejien

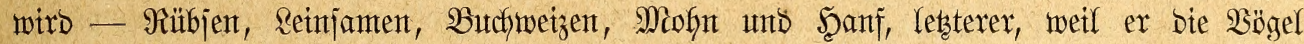
reidyt zu fett madjt ober ifyr (Sefieber fdywärzt, jtets nur in jefr geringer, abgemogener Menge, finto bie widftigiten Sämereien, weldhe überfautpt Berwentung finden; Fichten=, Tanten= ober Ritefernjamen bilben baz bejte Futter für freuzidyäbel, Erlen= und Birfen=

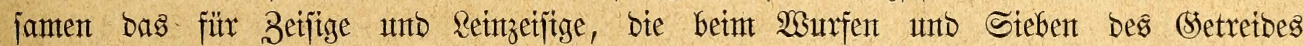
ausfalfenben Unfrautjamten, in Türntgen Scheuterngejänte genannt, ober bie auf bent

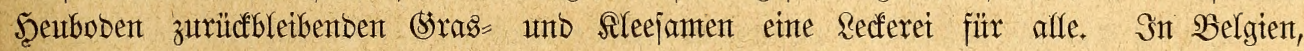
Jranfreich und Stalten reidyt mant anjtatt bes weifen vorzugsmeije ben Sogelfirje (Panicum italicum); jowofhl Das (sejäme als bie nod) untentlerten folben, welche mant

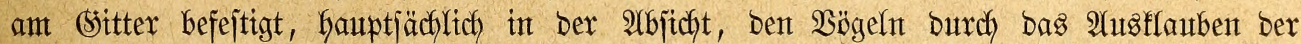
Sörner eine Zerjtreuntg zu verjchaffen. Der Sogelfirje witro von bemährten \&iebfabern höher gejchäbst als andere Sorten, weil fie beobachtet haben, baj viele Bögel ifgn jenten

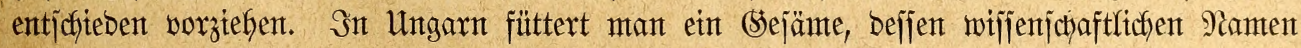

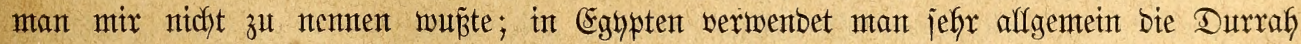

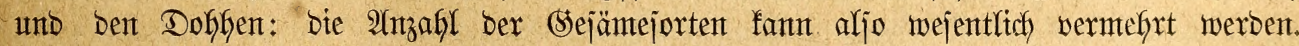
Unto noch ijt mit ifnen ber Speijezettel ber förnerfrefjer nicht gejchlofien. Weitats die meijten Finfentögel bebürfen (Srünzeug: $\mathfrak{B}$ ogelmiere (Alsine media), Siofl, Salat $2 x$, manche serzefren $\mathfrak{B l a ̈ t t e r}=$ nnto Blütentnospen, Blätter, unreife Jrüchte, einzelne jelbjt

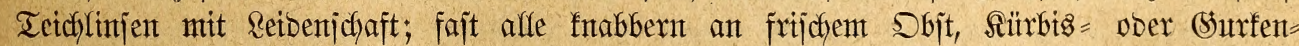

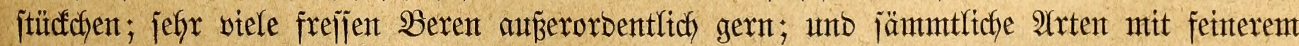
Sdynabel müfijen wentgitens eintge Meflwürmer, 2fmeijenpuppen, etwas Eitootter, Räjequarf, 


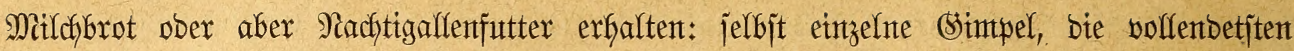
affer befannten Samtenfreffer biejer Sronutg, gemöfnen fich an Serbtiernafrung ober beren

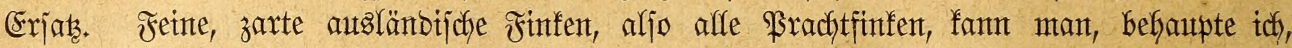
ofyne tierijche Nafhrung nicht lange an Reben erbalten, faum zum Brïten bringen und ifre

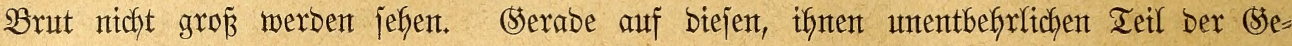

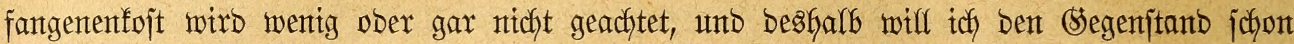
Giex nadforiucflichjt betont Gaben.

(Ebenjo leidht als bie flemteren Samenfreffer Galten fich Fapageien, weil fie Sïnter=

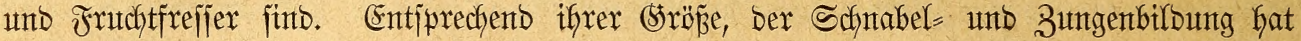
man ifnent aber boch verjchtebentes Futter zu reichen. Die gropen, ftarfjchnäbeligen, platt=

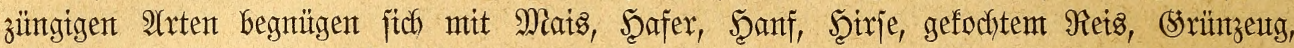
nefymen aber gern noch Mitchbrot an; Die fleineren 2(rten, insbejonbere bie Breitjchwantz= fittiche pflegen bas lebstere zu verjchmähben, machen fich meijt auch wentg aus Früchten, beampruthen bagegen zeitweilig 2(mteijenpuppen; bie Roris verlangen zartere Speije: gefoctent

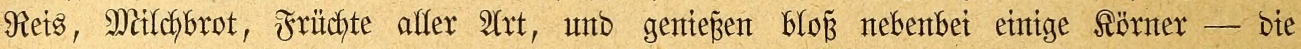
eigentlichen \$injelzüngler fömten wix mit verjüßtent Mitldyrets unto getrodfneten Feigen,

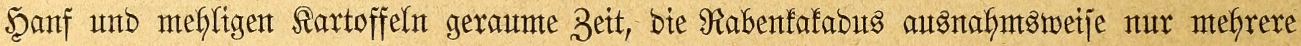

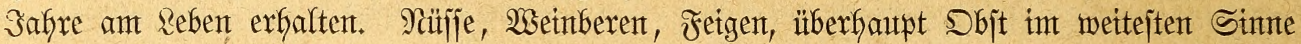

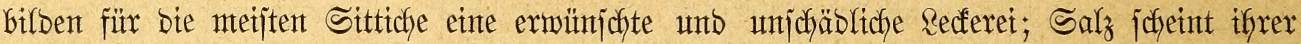
(sejundfeit jefr zuträglich zu jein, Darf ifnen jebenfafrs ntidht feglen; bittere Mandeln unt,

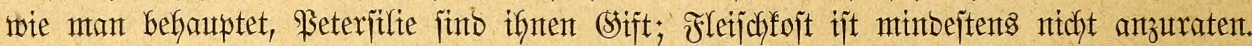

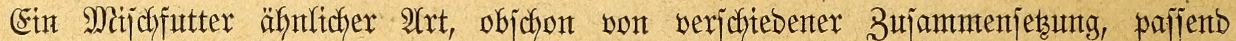
"sexchenfuttex" genant, Dient zur ExnäGrung Der feinjchnäbeligen Samenfreffer: unjerer unto fremblänbijcher Ammerarten, Rerchen, Stärfinge, zarten Şüfnter unto äfnlticher Bögel. Sie wollen Setretbe, namentlich Weizen, Şafer, feinere Sämereien, (Srïnzeug unt Serbtiere Gaben, Dieje Die leţteren mehr, jente wentger, Die einen meblige

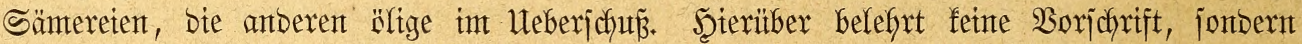

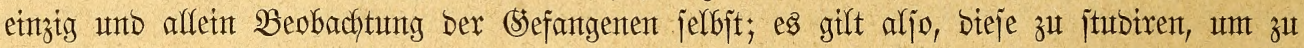
exfahren, in welcher Weije man bas serchenfutter zujammenzujetsen Gat. Fein gebacter

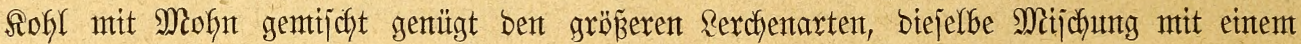
3ujake von 2(mteijenpuppen auth ben fleinteren, Geijpielsmeije ber zarten Setbelerche. Alls

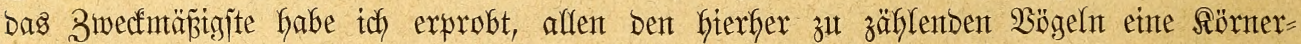

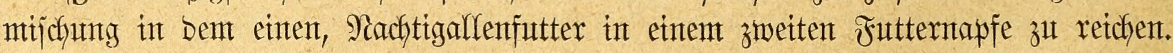

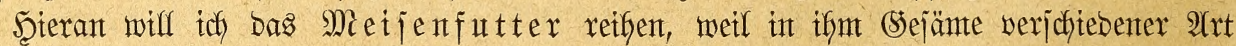

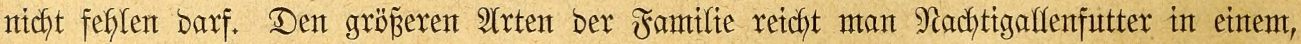
Şafer, Budfweizen, Sontenblumenjamten, Siürbisferne, Şanf unto Miofn int eintem zweiten Jutternapfe; für bie flèten, zarten unt langjchwänżigen 2 trten wäflt man lieber \&aub=

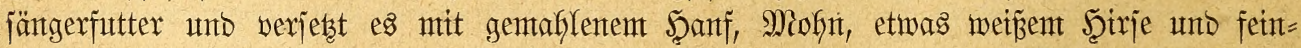

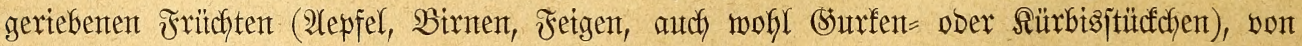
benten man jeboch inmter nut wentg zugeben barf.

2(uf Die ferbtterfreffenden Singü̈gel hat man unter alfen Umitänben größ̈ere Sorgfalt zut berwenten als auf bie bisher genannten 2(rten. Die Droffeln fint bie antprudchlojeften,

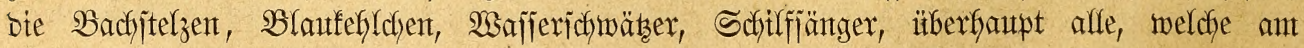

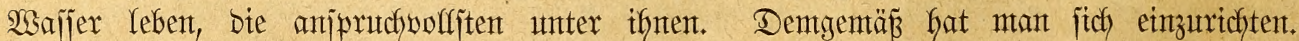
Solange man itber frijche 2(mteijenpuppen nad) Belteben berfïgen fant, gibt man bieje als

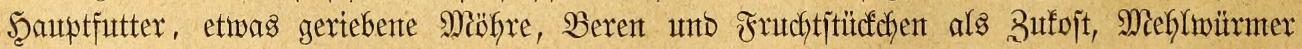
als Sieblinggnafrunty; anders aber geitaltet fich ber Speijezettel im Winter ober unter

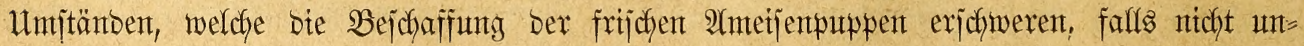




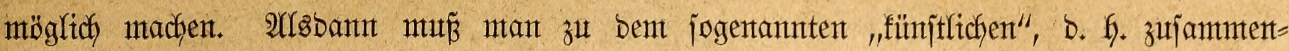
gejesten Futter greifen. Sch will einige Bujammenjetsungen hier angeben.

Man nimmt eine alte gut augigebacfente Senntel, weidft fie fo lange in frifchent

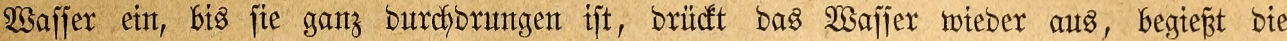
Semmel mit Mitldy unto mengt bann nody mefr ober mentiger, bis auf zmei Drittel fteigendes, griesartig gemtaflentes unto von alfen Seitljen befreites Berjtenjchrot ober, nody beffer, flaren Weizengries bet."

Dies ijt $\mathfrak{B} e d j$ ftein's Drojjelfutter, ntit jetnent eigenten Worten bejdrtebent.

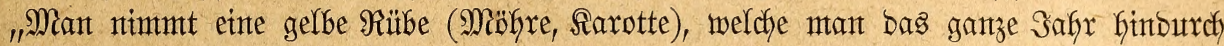
int Reller, in Santo gejcharrt, frijh erfaltent fant, reibt fie auf eintem plattent Reibeijent, weldyes jogleids wieber rein abgebüritet wirb, quellt eine \$ffentigjentmel in Wafjer ein,

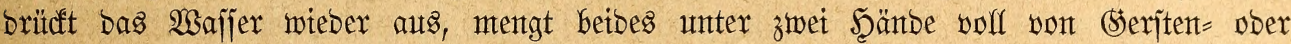
Weizenidyrot unto reibt alfes in einent Napfe mit einter Sieule recht unter einantoer."

Dies ijt Baedjitein's untwerjalfutter.

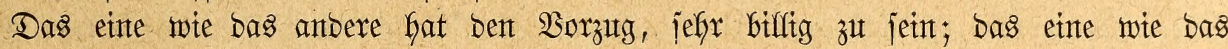
anbere erfält autch gröbere Rerbtierfreffer - meiner 2nfjicht nach aber nidfyt zartere,

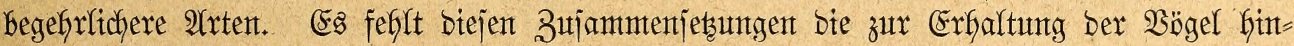

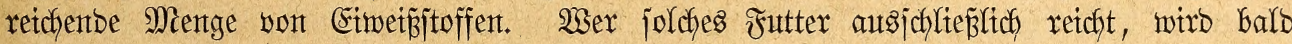

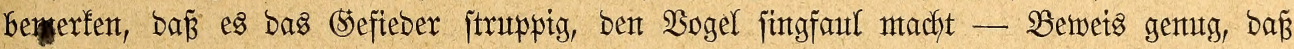
in ifm genẗgente Nafhrung nicht enthaltent ijt. Dagegent werbient ein Pflanzenjtoff als Betmijchung zum Drofiel $=$ unt jebem anderen Futter für ferbtierfireffer empfohlent zu werben, io jonberbar bies vieffectht ficheinen mag. Sch meinte gut gequetichten ober ge=

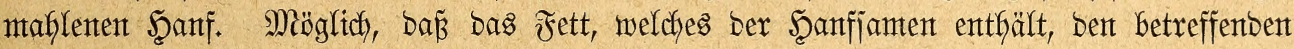

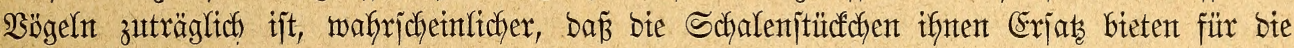
Garten Teile ber Sierfe unto zur Bitbung von Stemöllen bienten. Sparjante Sogelwirte

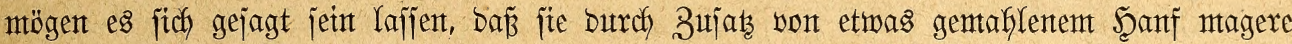

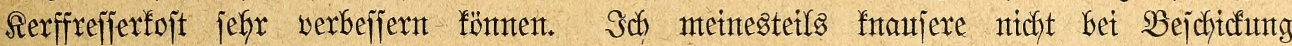

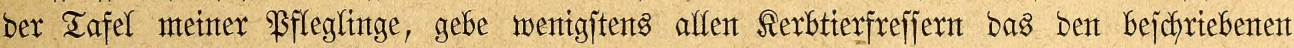
(s)eridytent entichieben Fehlento.

Meint Droffelfutter bejteft aus rohent ober gefochtem Serz, bezüglidy jaftigent, mtageren Fleijche, Mëhren unt Sentmelgrtes (geriebenter Sentmel) ober gejtopentem $\mathfrak{W e t} \tilde{\beta}=$

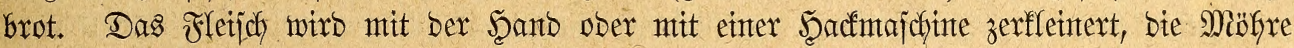

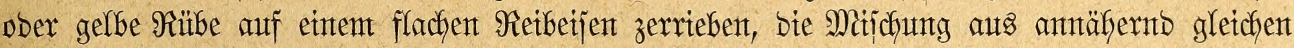

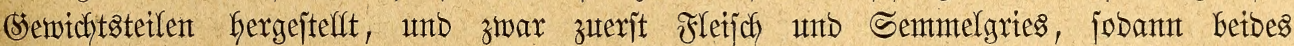
mit ber geriebenten Miöfre vermengt, bis bas (5anze meber zu troden, noch zut feutcht

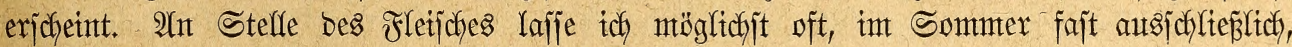

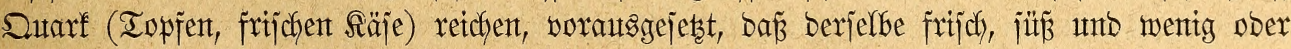

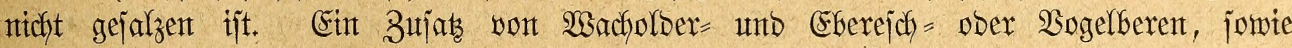

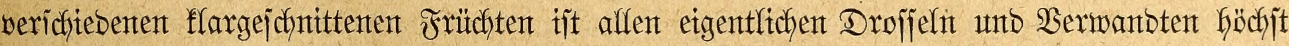

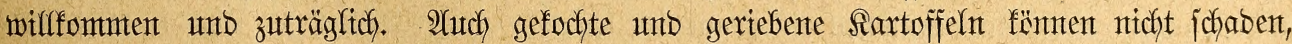
jelbjt went fie in namflafter Menge unter bas Jutter gemticht werben. WBer es int Stande, fant int Sommer jo biele frijche 2tmteijenpuppen zujetsen, als bie B̈̈gel frefijen wollen, unto bant Fletich unt Duarf weglafjent, währento bies nicht zu empfeflen ijt, went man bloź Semmelgries unt Mëhren füttert, wie etnzelne siebfaber zut tut pflegen.

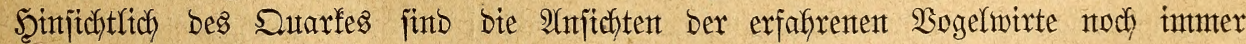

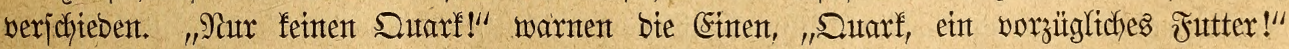
rüfyment bie 2Anderent. Sch trete benten bei, weldhe bent Duarf emtpfeflent. WGer blos einten ober Gödhitens ein Dubent Rexffreffer zu füttern hat, mag ifnt weglaffen; wer mehr als 
Gunbert fungrige Magen ittllen muß̂, wiro ifn faum entbefren fönnen unt faum entbefyren

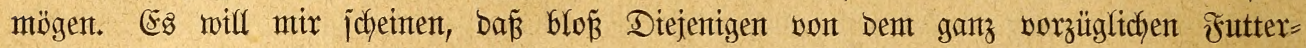

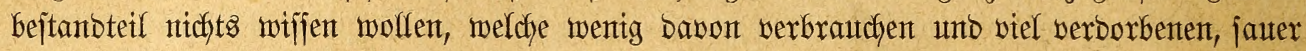
gemorbenten Suarf megwerfen müifen. Shnen wifl idh nidft Unrecht geben, fie aber burch

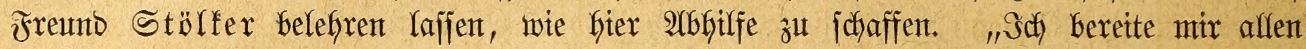
Suarf, weldyen idf berbraudbe, jelbjit, indem idy gute Mitldy an einen warmen Srt jtelle,

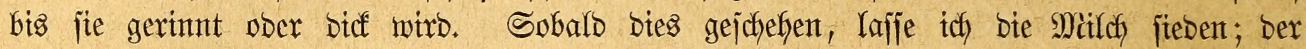
Säjejtoff fällt als fejte Maffe zu Boben, wirb Durch Albjeifen gejchieben, gut geprefit und jobann berfïttert. Saure Brechungsftoffe vermetbe ich, um Das Sauterwerben bes Duarfes 子ł verfüten." Sauren Duarf verfüttere ich ebenfalls unter feiner Bebingung; meine Dreifundert Duarffreffer laffen es aber audb gar nidht bazu fommten, verzebren heute vielmetgr regelmä̈̈ig bie Menge, welde gejtern eigens für jie bereitet nurbe.

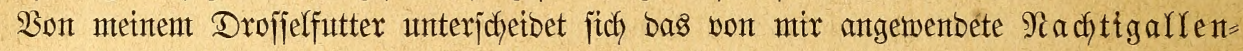

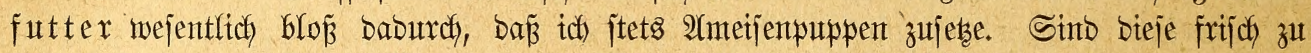

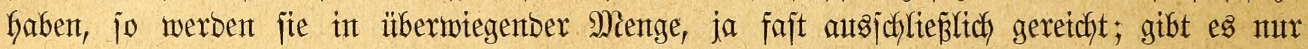
getrodfnete, jo bejchränfe ich bie Mienge derjelben auf etwa ein Biertel bes (sanzen. Fallz

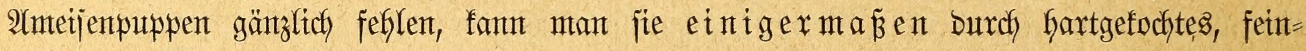
geriebenes Eitotter exjeben.

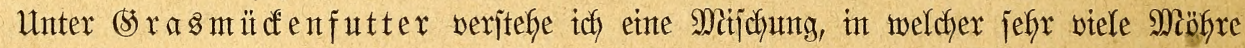
entGalten ijt, unto bieje noch burch Jrïbste unt Beren ergänzt wiro. Es bejteft arjo bas

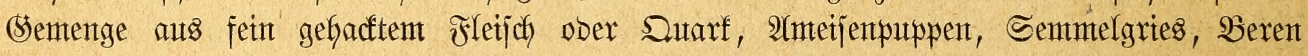
(Flieber = ober Şolder $=$, Gohannis = und Weinberen, fiorinten, weldhe vorfer in Waffer

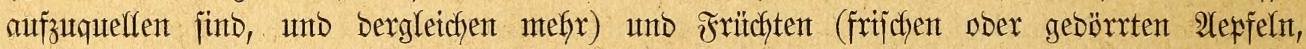
Bimen, Pflaumen, Airjchen, Feigen, Datteln zc.), weldhe fein gefjactit beigegeben werben.

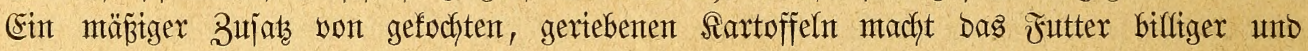
jofyabet nicfft.

Eintige ferbtierfreffer verjchnähen \$flanzenfoit, lieben fie wenigitens nicht. Für fie

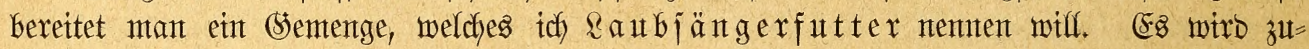
jammengejest aus gejtopenem, mit eintigen Iropfen guten $\mathfrak{B}$ aumb̈ls angefeuthteten 3 wiebact, 2(meijempuppen, Duarf, jefr fein gebactem Fleijch ober zerriebenem Eibotter, und fein= gemaflentent Şanf, alles zu antäberno gletchen Teilen abgemogen.

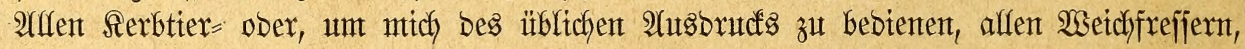

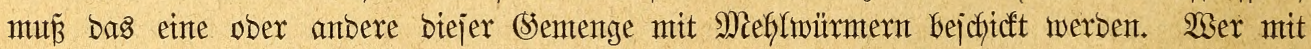
Diejen trefflichen Serflarben nitht zu iparen braudst, Darf ofyne Bebenfen jo viele von ifynen füttern, als bie $\mathfrak{B}$ g̈gel mögen; Denn es ijt nicht wahr, was jo Biele behaupten ober bods

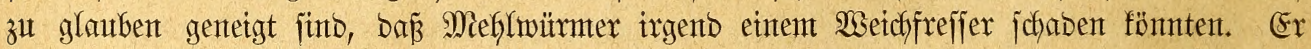

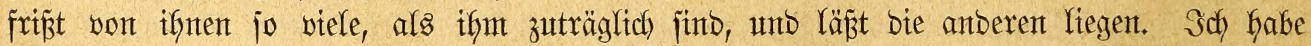
Sproffern und Nachtigaffen täglich fünf bis jechzig Stücf gereicht und niemals bemerft,

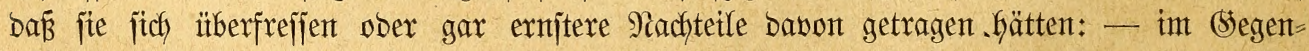
teile, meine Sproffer befanden fich um jo wohler, je retchlicher idy ifnen bieje ifyre Rieblingafoit gegeben.

Waer in fleinen Stäbten ober auf bem Ranbe wohnt, bezüglich bas greie Yeicht erreichen fann, ijt in ber Rage, währento bes Sommers jeinen Rieblingen nod) bejondere Stenüfje zu verjchaffen, intoem er, mit Sdjöpfer ober Säticher, Schirm uno Rlopfer ausgeriijtet, zur

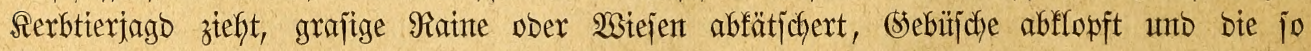
gemontene Beute unter jeine Bffegebefohlenen berteilt. Shrwürmter werben von ben meiften Wetdfreffern ebenjo gern gefreffen mie Megltwïrnter; Regentwürmer - bie

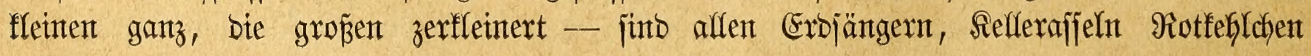




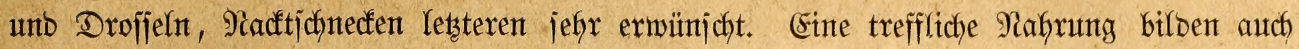

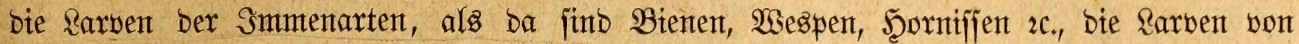

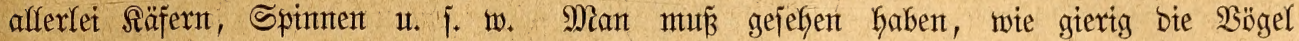

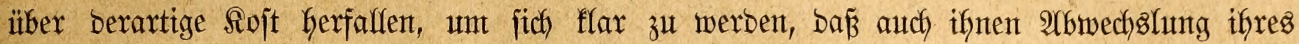

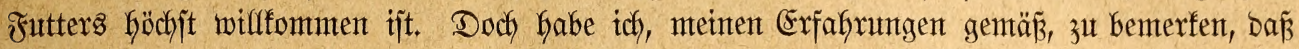

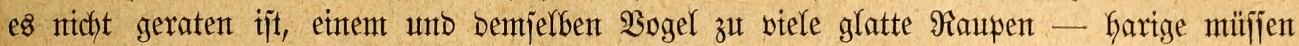
gänzlich gemieben werben, fafls man nicht für einen futfuf fammelt - zu füttern, jo berlocfent bies auth bei ber seidjtigfeit, fie zu erbenten, fein ober jocheinen mag. Eine

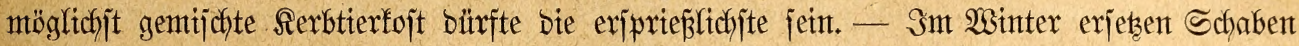

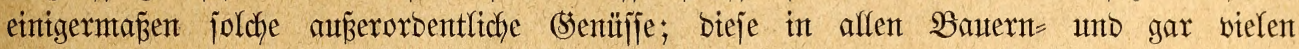
ftäbtijchen Stuben nux zu bäufigen Serfe werben von ben nteijten Wetdyfeffern jefy gern gentominten.

Shwohl bie bejartebenten Futtermijchungen wolfommen ausreichen, um affe Rerbtier=

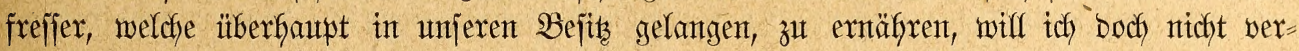
jäumen, auch anbere Bujammenjetsungen fier aufafiübren, joweit jolche mir befannt ge=

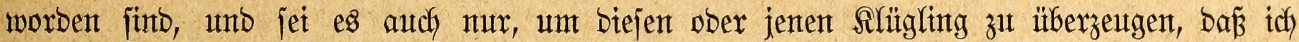
nicht alfein bie in verjchiebenen Büdsern aufgefüfyrtent Sientenge zur Stentige fenne, jontern burch meinte Freumbe audf nodh über andere 3njammenjebungen unterridytet worben bin.

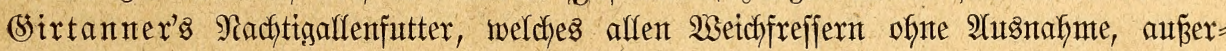
Dem ben Meijen, Serchen unb - als 3ufojt - Den zarten Finfen gereidft wirb, ijt zu=

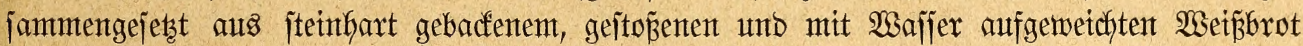
(Semmel, Zrotebad), bem gleidyen Raumteile geriebenter Mähre, ebenjovielent gefodjten, auf

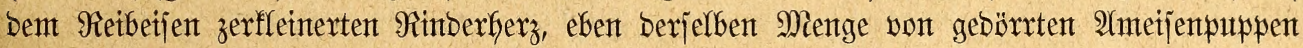

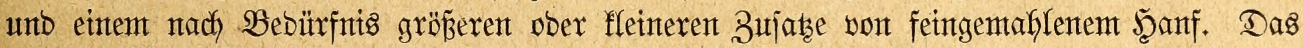

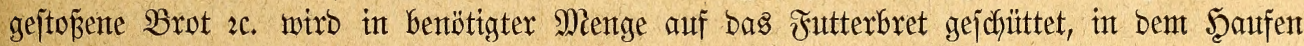

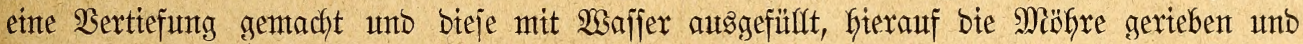

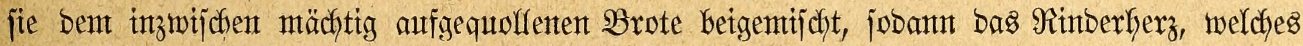

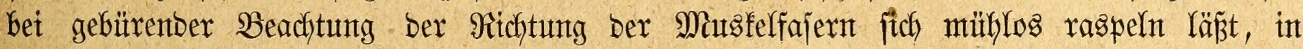

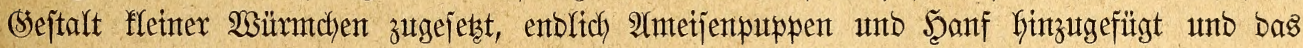
(Sanze jo lange gentengt, bis es eine locfere, buftige Majje bilbet, bezüglidy bis bie 2 Ameijen= puppen jo viele Feudjtigfeit eingejogen haben, Daß̉ jie jelbjt aufgequolfen jint.

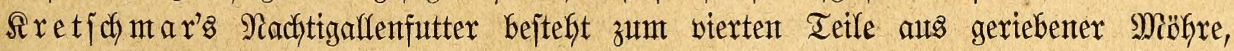
zum gleidjen Ieile aus gut getrodfneten jdywarzen Märzameijen, zur Şälfite aus getrodfneten

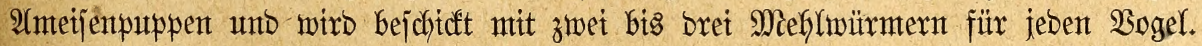

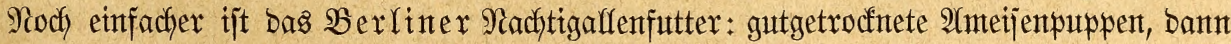
unb want mit etwas gertebenter Miöhre bermijcht, bazu Mefflwürmer, int Sommer aus=

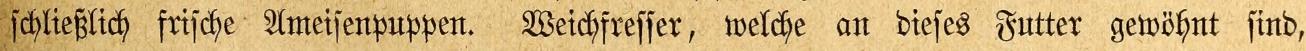

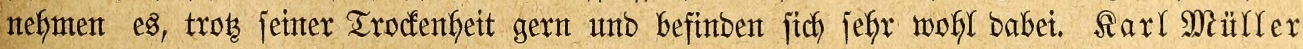

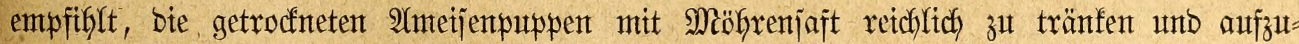

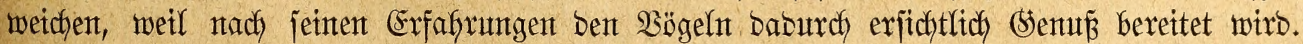

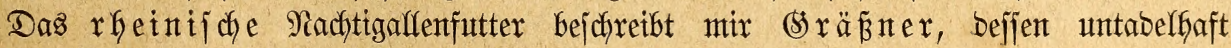

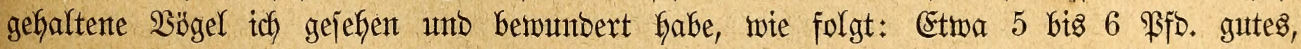

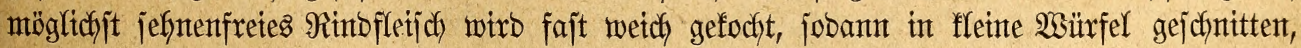

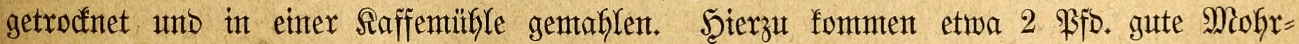
rüben, weldhe frijch gerieben unb ebenfalls geoört unb gentaflen werben, unb ungefäfyr 15 sot geitopienex Zntebad ober Semmelgries, bezïgfich noch 10 bis 12 zerffeinerte, ge=

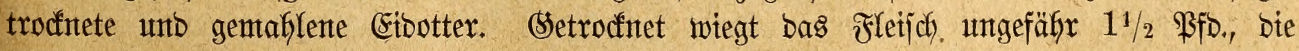
Miöhre 9 Rot, norauf man noch adjten fann. Die Mijachung roird mit gutem Baumöl 


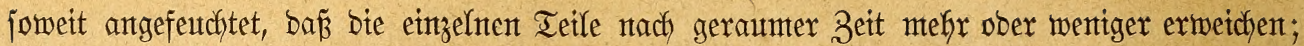

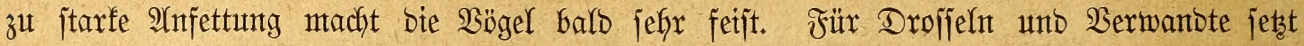
man ber Miijchung etwa ein $\mathfrak{B t e r t e i l}$ Steritentgrübe zut.

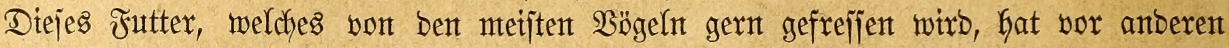

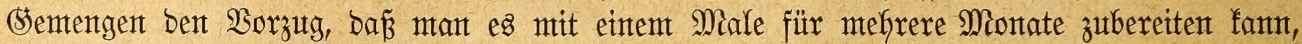

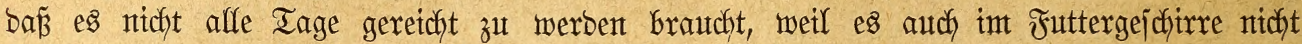

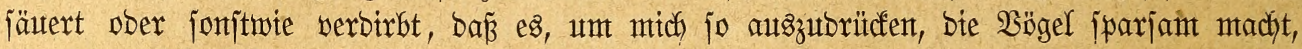
überfhautpt jefre Gillig unto bequent iłt.

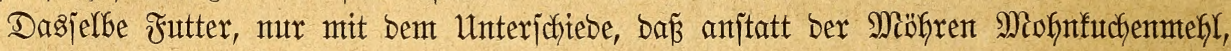
anjtatt bes Bauntüles Schlyeinteichntalz verwenbet wiro, benutbeen bie Şäntoler, unt bei weitent

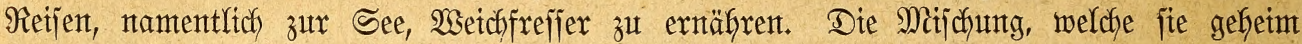

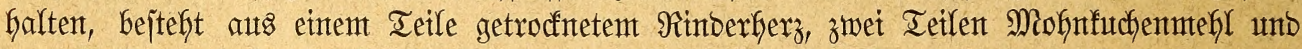

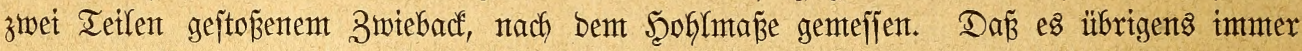

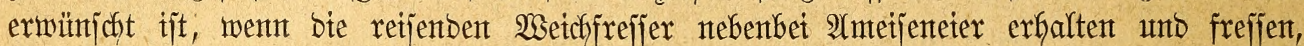

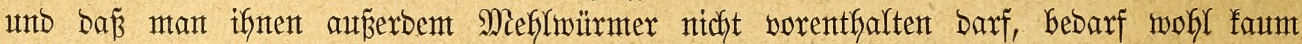
bejonberer Errwäfnutg.

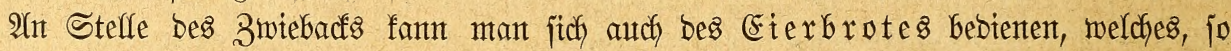

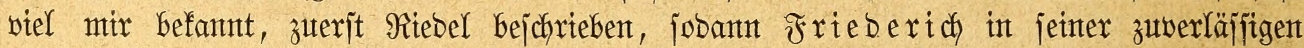

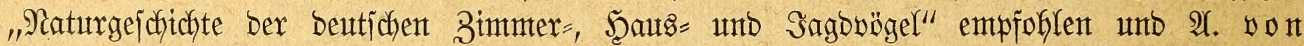

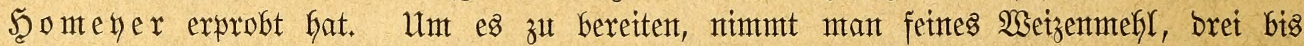

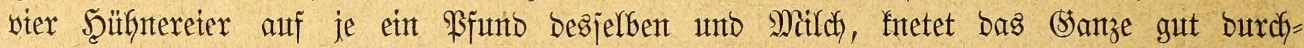

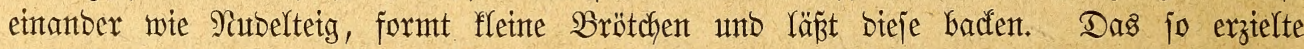

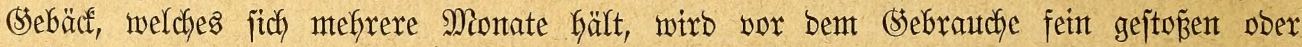
gerieben.

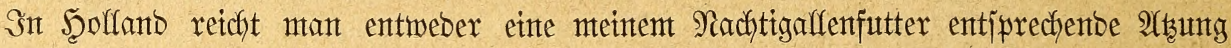

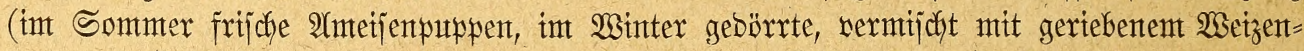

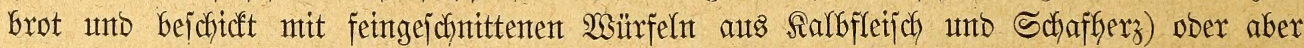

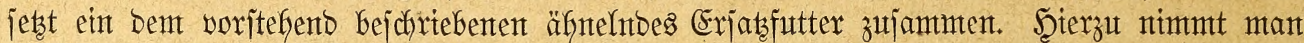

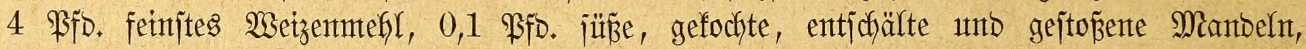

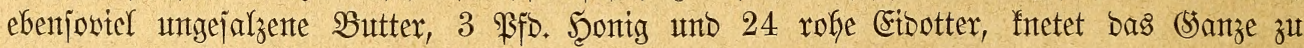

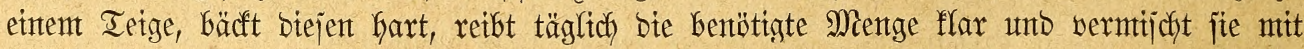
angefeutchtetent 'Tmeijempuppen.

Jranzojent unt Belgier geben jich joldhe Meüge nicht. Sie füttern ifgre Weidffrefjer mit

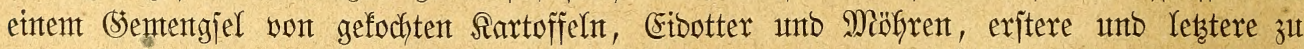

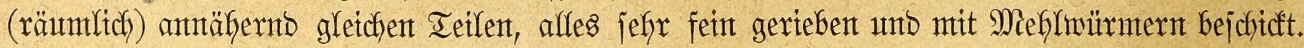

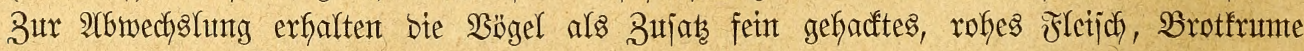
into gemtaflentent Şanf.

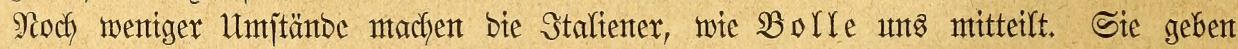

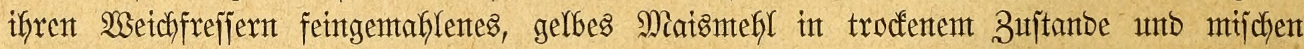

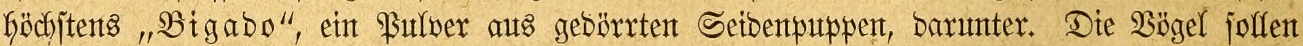

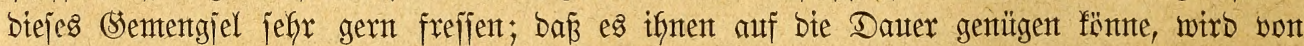
Boffe mit Recht bezmeifelt. Dagegent empfifift friebertad, bas Miaismefil mit ge=

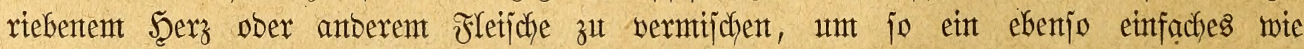

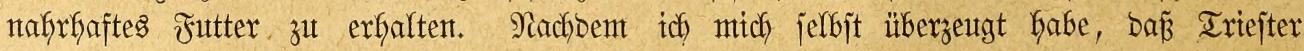
Siebfaber bas gelbe, grobe Miatsmefl mit bejtem Erfolge verwentoen, nachbemt id erfafrent,

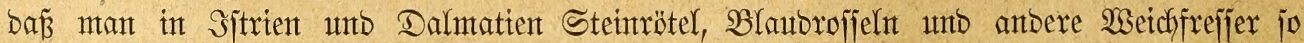

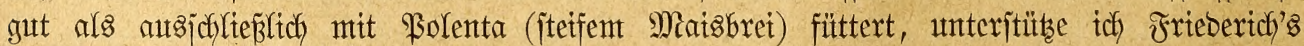

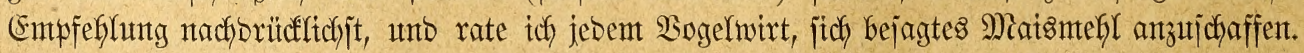


Die Spanter ernährent ifre gefangenen Sierffrefier hauptjächlich mit eintem Semengiel

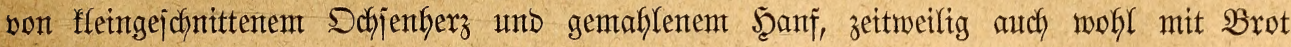
und Milch. Meflinürmer und 2(meijenpuppen find ifnen unbefannte Dinge.

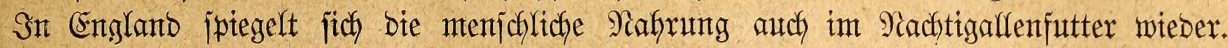
Rohes Rumpiteaf gilt als Das bejte; auf bie Zartheit und Frijche Des Fleijches wird

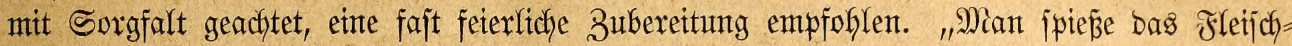
ftüd an eine jillberne (Sabel, lege es auf eine reingejpülte Marmorplatte und johabe es mit einem fleinen jcharfen Stahlmeffer, halte aber bie Şämbe adhtungsovolf entfernt. Das (5)e= ichabte feuchte man mit etmas Sueffmajfer an und vermijche es jobant mit bem flarge=

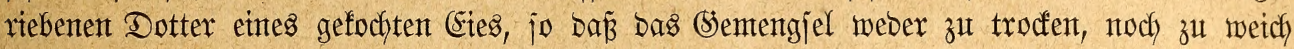

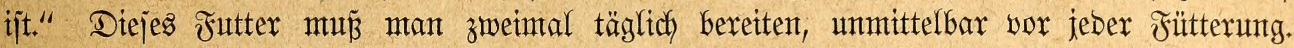
"Irots aflem, was man jagen mag", meint mein (Semährsmann, "ijt rohes Rumpiteaf bie

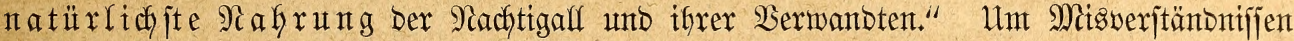

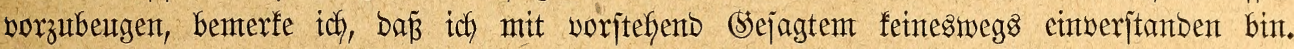

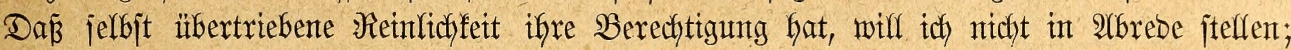

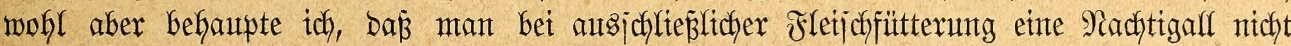
lange am Rebent erfält, und zwar beshalb meil bie harten, gemöllbilbenden Ieile ber Serbtiere, weldye Dody erjebt werben jolfen, Den Fleijdjajern fehlen.

2łnbers verhält es füch bet. Bögeln, welche vom Şauje aus Fleijchfrejfer jints.

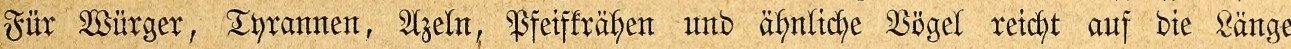
ber Beit weber bas Droffel= noch Das Nadftigallenfutter aus, weil es zu wenig Fleijch

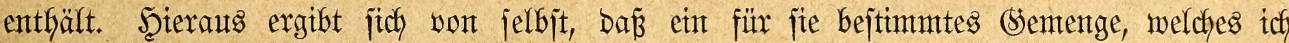
Bürgerfutter nenten will, nody bejonbers mit flemen 2 sürfeln bon robem Fleijche

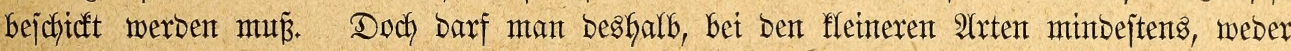

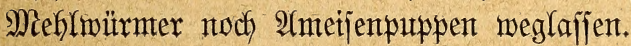

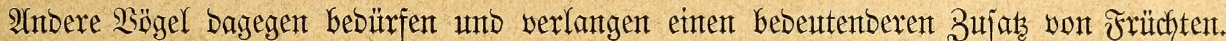
Shnen lajje ich Siachtigaflenfutter reichen, weldyes mit gefochten und geriebenen fartoffeln,

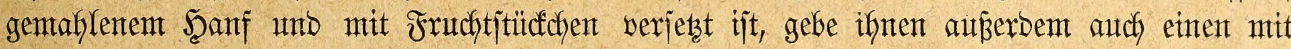

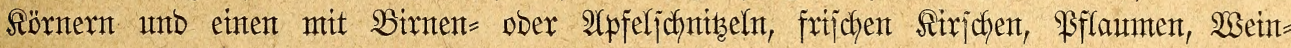
beren zc. gefüflften Napf in bas Sebauter. Die Iangaras oder Jarbenfinfen, nteijt jefy prachtwoll gefärbte Bögel SüD= unt Norbamterifas, welche neuerbings in jtetig wachjentoer

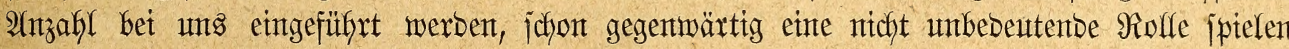
unb erföhte Bebeutung erlangen bürften, bilben, um mich jo auszubrïffen, ben fiern ber

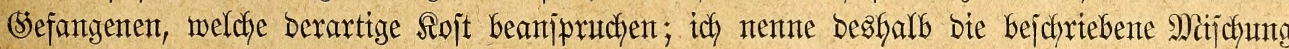
Iangarafutter.

In Englant, Scolfand unt Belgien reidyt man Den Iangaras ein aus geriebenten

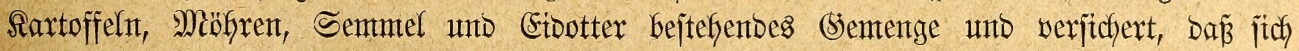
Die $\mathfrak{B}$ ögel babei vortrefflich Galten; meinen Beobachtungen zu Folge żehe ich Die exjterwähnte Mitichung jeboch entichieden vor, weil jefy biele, falfa nicht bie meijten Iangaras in bem= jelben Srabe Serbtier = wie Samen= ober Fruchtfreffer jint, ber geringfügige 3ujat bon Eibotter, weldher bie Sierbtiere zł exjeben bejtimmt ijt, ifnten aljo für längere (sefangen= ichaft faum genügen möchte.

Pflanzliche und tierijche fojt beamiprutchen auch antbere \$rachtoögel, beijptelameije

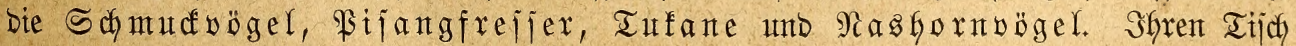

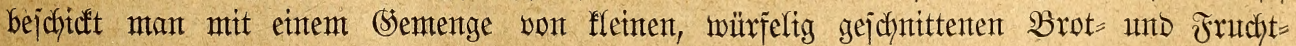

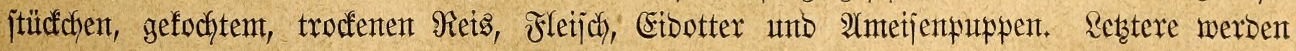

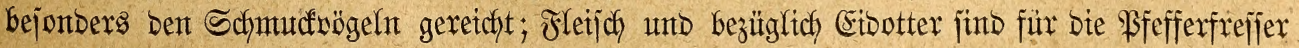

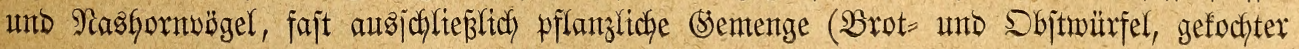




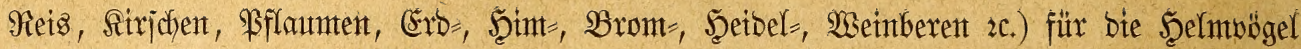

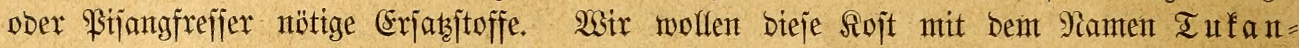
futter bezeidynen.

Mit Den voritebento erwäfnten (Semengen, Demt jogenantenten "fünjtlicken Futter" im meitejten Sinte fant man alle eigentlidyen Stubenbögel exhalten; mobei freilich

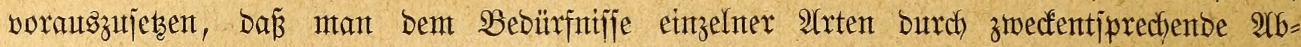

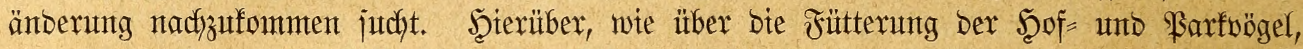

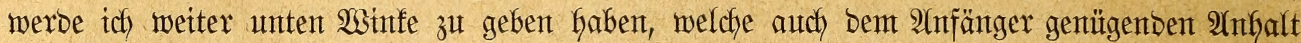

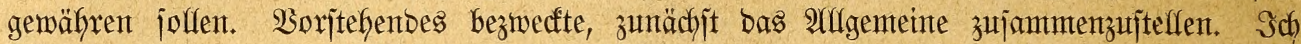
Gabe nichts aufgentommen, bezüglich wiberjpruchslos angefüfyrt, was nicht ourch mich ober Alnbere finlänglich erprobt morben wäre, barf aljo Sertrauen ermarten.

\section{Wurtuma.}

Den exfafrenten Riebfabex erfennt mant an jeinen 2 b̈geln. Waer viele von biejen

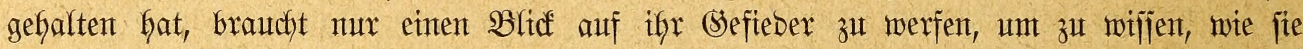

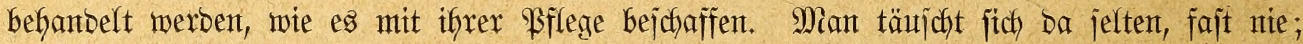
man jifht Den Bögeln, um mich fo auszubrücfen, Durch das Sefieber ins Eingemeibe.

(Eigentlich jollte man meinten, es verjtehe fich für ben stebfaber ganz von jelbit, jeine

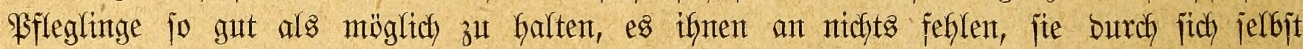
puzen zu laffen: — Dies aber ijt mur zu häufig nicht ber Falf. Sch habe von Sintheit an unter Der Reitung meines exfafrenen Baterz Bögel gepflegt, in ben nieberen Stuben

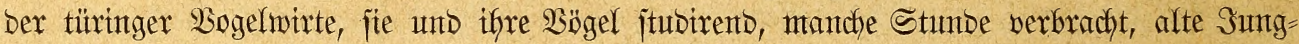

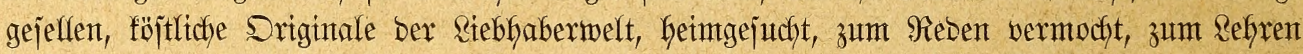
halb gezmungen, Dann jelber Den Refjer gejpielt und manth tüchtigen Schüler erzogen: und

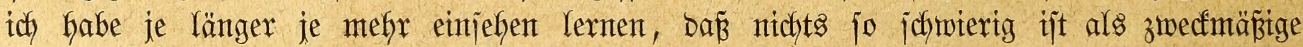

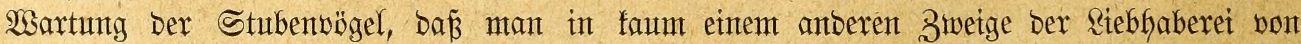

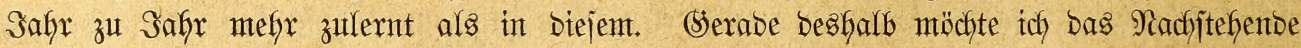
meinen Rejern ganz bejonbers empfeflen, obgleich ich audf fier eben nur winfe geben will und fant.

Schon Das eine, wie und wohin man ben Säfig hängt, ijt feinesmegs gleichgiltig. Bor allem hat man wohl zu beferzigen, Daj ber Bogel io viel als irgent tunlich vor jeglichem suftzuge gejichert jet; Dent mefyr noch als im freijtebenden Fhiggebauer bebarf

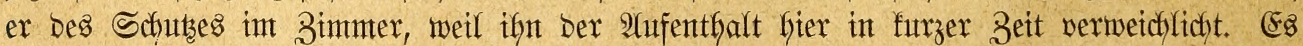
ijt nicht immer leidft, einte für ifn falfenbe Stelle int Bimmer auşfindig zu mactien, on es ja boch nicht Sebermanns Sache ijt, Dagjelbe regelmäß̄ig zux Sogelitube umzugeitalten; man

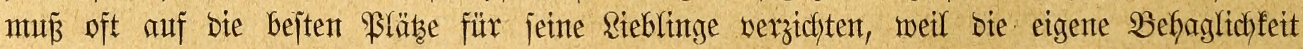
ober Dex Sromunggfint Dex Şaugfrau joldhes gebieten: Die eine Srumbbebingung aber barf

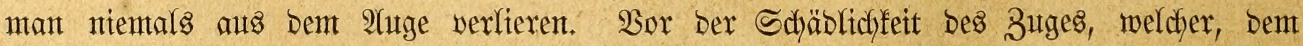
Bejthauthe vergleidjbar, bie meijten Sterbefälle unter ber gefieberten Zimmerbemofgnerjchaft

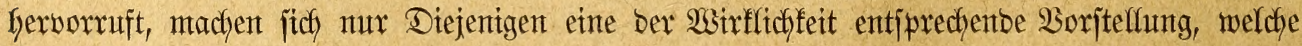
burch eigene ober 2lnberer Exfahrungen getwitgigt worben finb. Man verfäfrt in biejer Seinjicht gerabezut finnlos, als ob ber Bogel auts Stafhl und Eijen gebaut wäre, mumbert 


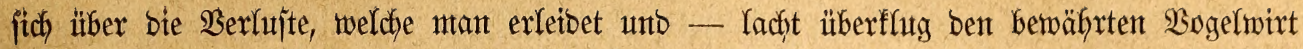
aus, welcher bie Uriache ber Werluite erfennenb, warnte, wie ich es Giermit mit affem

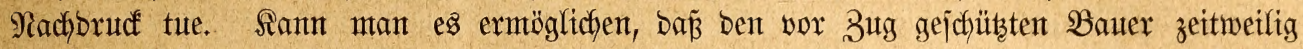

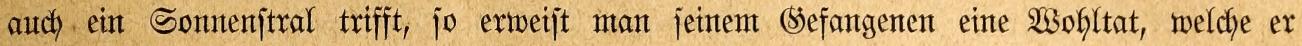
Danfbar anerfentut, Deren Jefhlen er wenigitenz enticfieben vermijift.

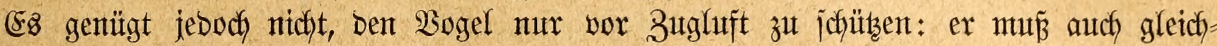

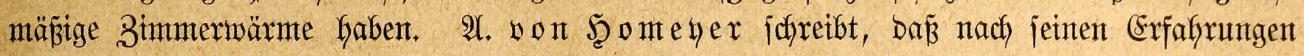

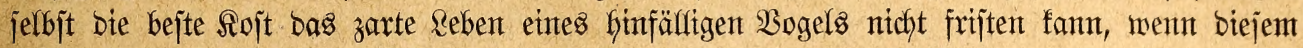

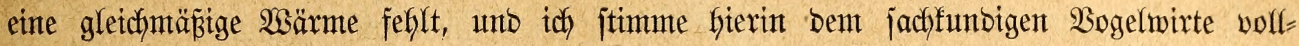
ftänbig bei. Waärnte ijt Rebensbebingung für affe umjere Zugvögel, Rebenzbedingung für

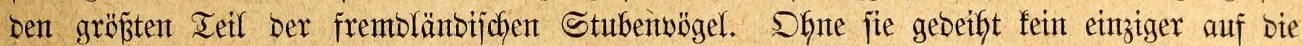
Ränge ber Zeit, möge man jonjt ifgn halten wie man woffe. $2(m$ menigiten erträgt er jähen

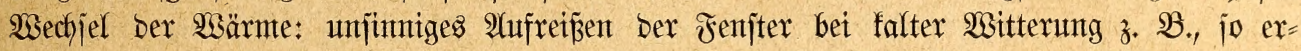

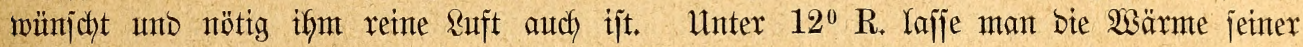

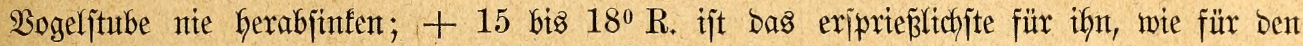
Mienjchen. Soldhe 2 särme behagt allen, jelbjt Den zarteiten Süblänbenn vortrefflidy; es

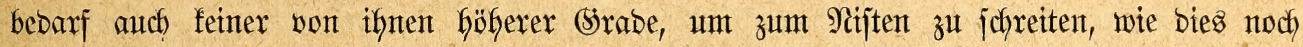

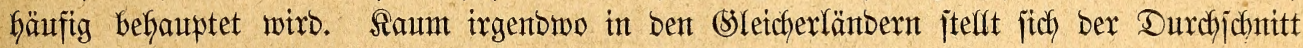

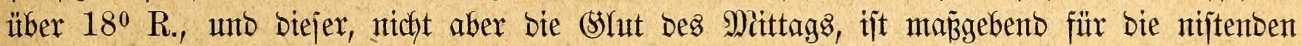

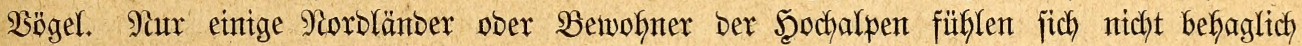
in einem wie angegeben exwärmten Bimmer ober Bogethauje, obgleidh auth fie bier fidt eingemöhnen.

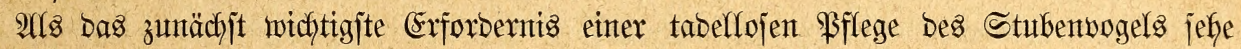
idh Das unabläjifige Bejtreben Des Bogefwirtes an, bie affen gefiebertent bejejüpfen ange=

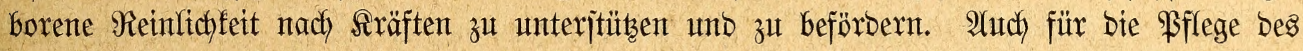

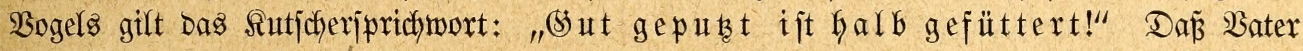

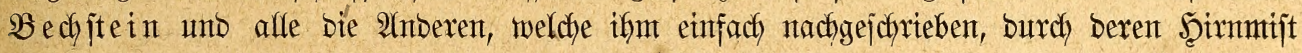

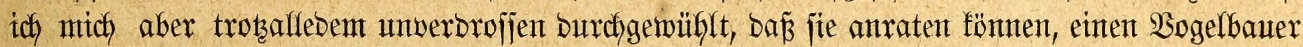
etwa affe vierzegn Iage einmal zu reinigen, ijt mir gänzllich umfaß̉lidy. Sadh barf bod

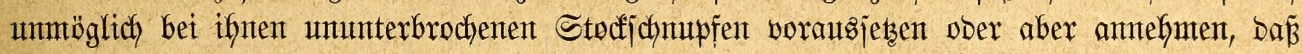

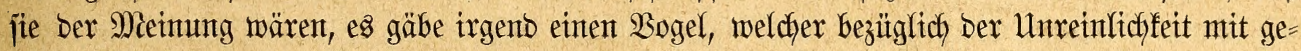

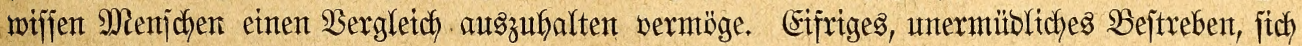

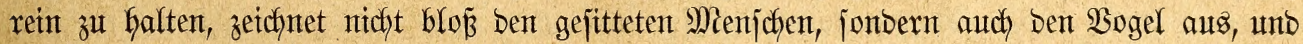

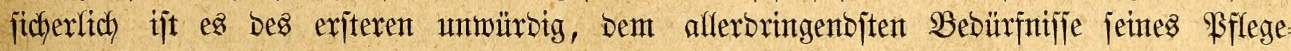

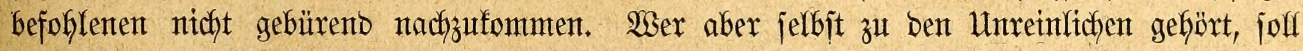

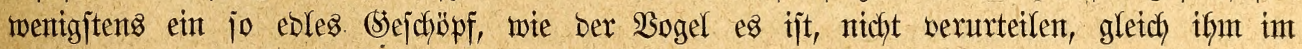

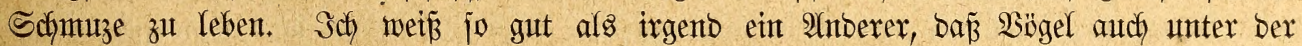

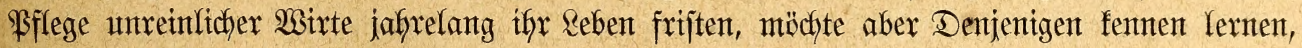

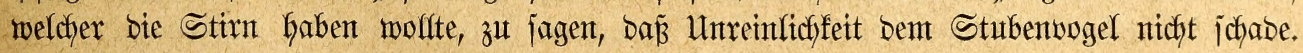

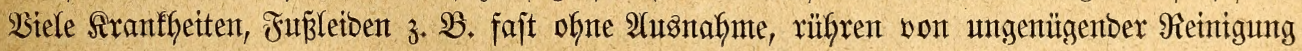

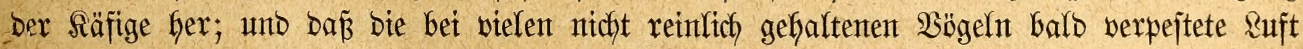
Des 3immers biejent ebenfo wentg förberfict ober-angentehm fein fann als ben Mienjchen,

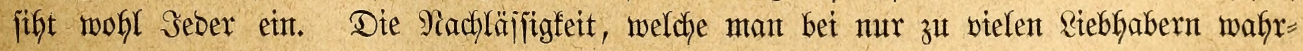

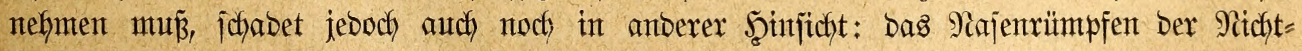
liebbaber über bå 5̧alten von Stubentwögefn, bie Rifagen nicht beteifigter, jonbern nur

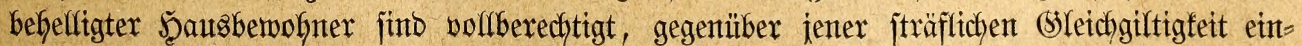
zeltner Soggelwirte, weldhe bie übrigen unb bamit bie Siebfaberei förntlich in Serruf gebradit haber. 


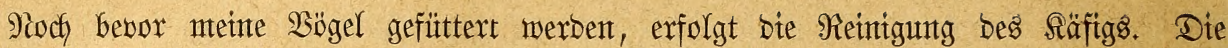

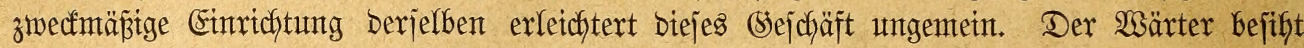
zunächjit bie Sitzitangen, entfernt biejentigen, welche befotet, bejchmuzt ober mit Itngeziefer

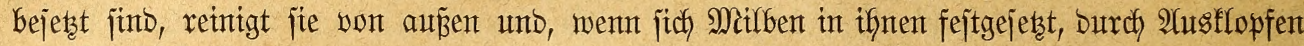
und 2 Utsblajen aud bon innen, bringt jie wieber an ifre Stelle, nimmt jobann aus beiben Drefrolfen oder Erfern Futter = unb Babenapf, jäubert erjtere mit eintigen SBüritenjtrichen, żeft, falls es nötig, die Schublabe herbor, jifht nach, ob Sdymuz ober Sand im Stolfen hängen geblieben ijt, fegt auch biejen weg, johliểt bie filappe und geht mit Schublabe unto (Sefäв̈en des einen, bezüglich alfer Sebauter zum Spültroge. Scier jofüttet er das noch übrig gebliebente Jutter Des Napfes wie Den Sand ber Schublabe aus, legt bieje und bie

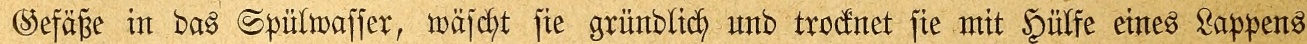
jorgfältig ab. Şierauf füllt er bie Schublade mit frijchem Sambe ober mit Sartenterbe und Sant, je nach Der 2Trt Des Sogels, jtrent noch eintge Sïrndyen Salz unt einige Stäubchen

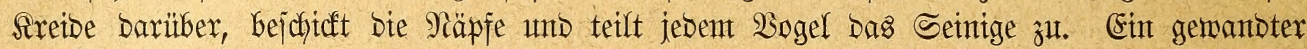

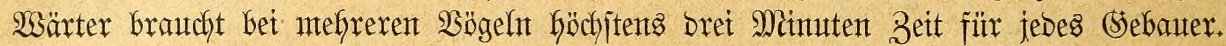

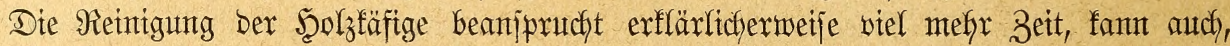
affer Sorgfalt ungeadhtet, nie jo vollitänbig bewerfitelfigt werben als bei ben won mir empfoflenen (Sebauern. (Sraf (5) ourcy, Der Mitarbetter an meines Baters „Sूandbuche

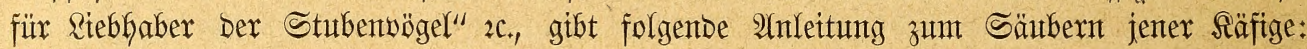
"Die Sdyublabe mird mit frijdyem \&öjdypapter belegt und mit ziemlich viel Sand bejtreut. Dieljährige (Exfahrung hat midh belehrt, Dak̉ bie Bogelbauter jo ant wentigiten jtinfen. Riegt

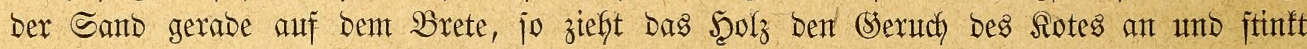

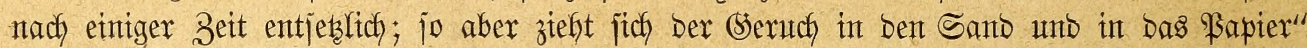

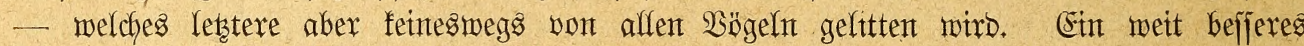

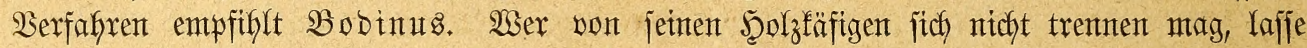

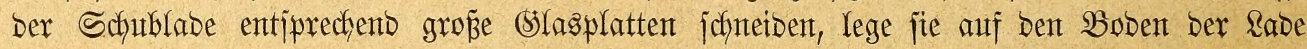

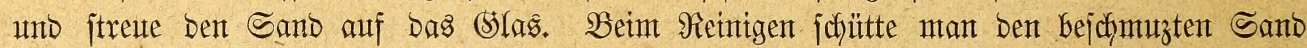
weg, wajche bie (5)lasplatte gehörig ab und verfahre, nachoem jie getrocfnet, wie worker. - $\mathfrak{B}$ ei meinen (Sebautern fommt ein merfficher (Sejtanf gar nicht zut Seltung.

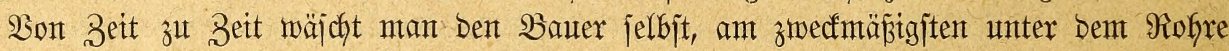

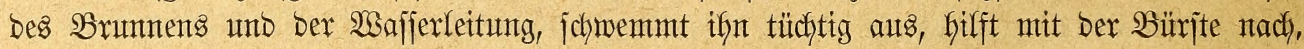
no es nötig, erjebt bie Wadfbletnendecfe Durch einte andere und gibt bem Berïjt einen

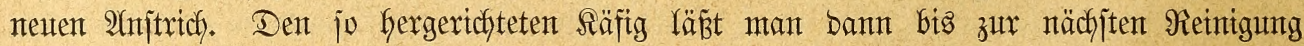
jtefsen. Diejer Rat verurteilt zwar nodymals bie erbärmlichen Fabriffëfige, welche bei einer tüdhtigen Wäjche unbebingt aus bem Seime geben, verfangt aud) einige überzählige (sicbauer, ijt aber wolfer Befyerzigung wert.

Merft man, Daj Dex Sefangente an Ungeziefer leibet, jo nefhme man unverz̈̈glich eine

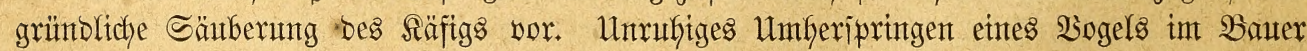
bald nach Sontemuntergang gilt als ziemlich ficheres Beichen, Daís Die Mitlbenbrut, weldhe jidf) bei Tage berjtedfte, über ben armen Schächer hergefallen ijt und ifynt Den Sablaf raubt.

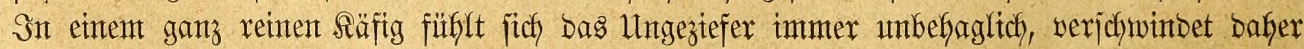

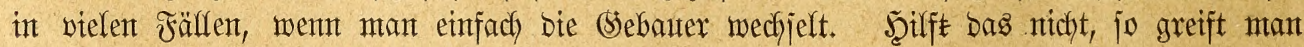
zu anderen Mitteln, um ę zu vertilgen.

Den Babenapf füllt man am bejten in ben ipäteren Sormittaggitunbent, weil fie unb

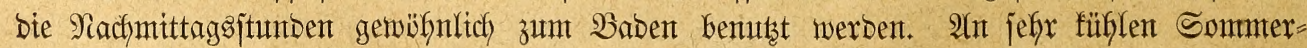

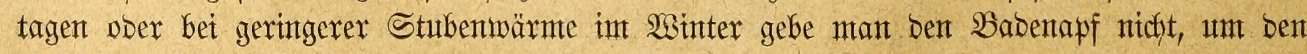
Bogel nicht ber (sefafy augzujetzen, fich zu erfälten; lieber warte man wärmeres wetter ab, obet erföge man bie Stubenmärnte auf fünftlichem 2 ege. Babet ber Bogel ntcht, io 
miro ber Babenapf nach geraumer 3eit wieber entfernt, weil jenter ifn jonjt leidft ver=

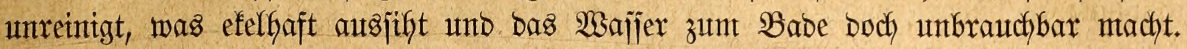

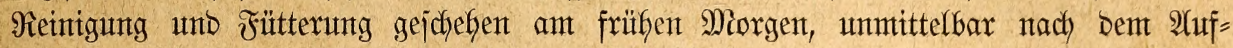
ftehen, womöglich balo nach Sonnentaugang, im Sommer aljo mentigitens vor jects, int Winter zmijchen fieben unt acht $\mathfrak{u b r}$; Denn ber $\mathfrak{B}$ ogel ermadyt mit Tagesanbruch und geht

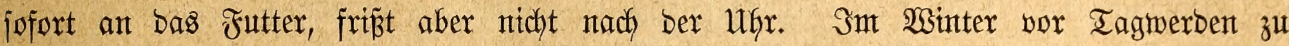

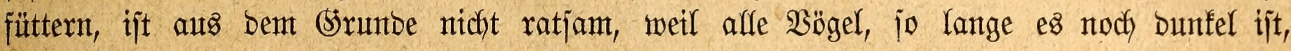

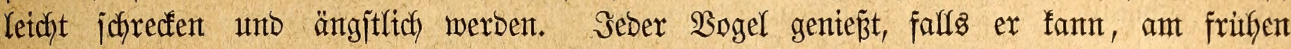

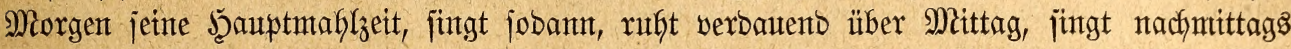
wieber und pflegt abentos vor Dem Sdylafengeben nody einen Smbíz zut nefmen. Mant bejchicft baher an Miorgen Den Iijch bes (Sefangentent reichlich, gibt mittags, nachbem Das Mitjchfutter im exjten Scunger fajt aufgezehrt worben, bie betreffente Menge won Mefhl= würmern ober bejonbere (Steridyte überfaut, bie Ergebniffe eines $\mathfrak{B}$ eutezuges z. $\mathfrak{B}$., getwiffer=

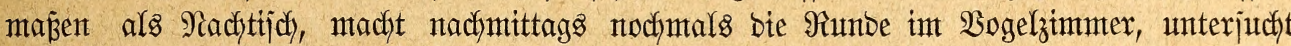

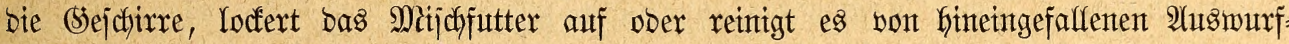

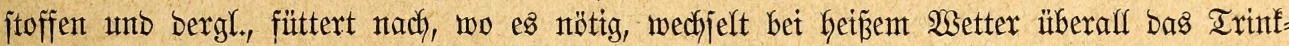

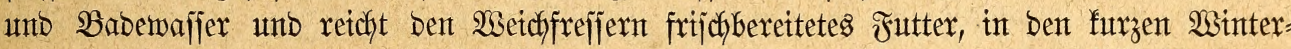

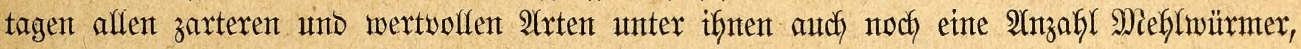
bamit fie fich vor bem Schlafengeben orbentlich jatt freffen und bie lange Nadjt ofhe (sefährbe oder Bejdwerde überjtehen föntent.

Afles übriggeblitebene jutter fant noch $\mathfrak{B}$ erwentuntg finben, mit frijchem untermijcht zur Ernährung Der Droffelt und fleinteren Stelzbögel, fo, wie es aus ben アäpfen fommt, zur Fütterung Der ŞofGüfner unt anderen (5robzeuges. Die Rörner werben burdigefiebt, autgejpelzt unt wieber mit berteilt.

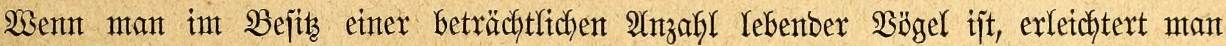

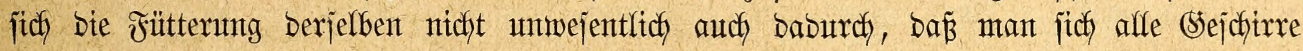

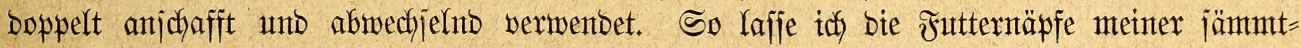
lichen Samenfreffer johon in Den Nadfmittaggitumben Gerrichten und anberen Iages eben mutr wechjeln, um allen jo rajch als möglidy ifyre Nafrung zu verjchaffen. Das Futter ber

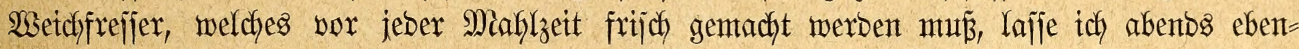
falls vorbereiten, in eintemt reinten (Sefäß̈e nemlich Duark und 2(meijempuppen vermijchen, bamit bie lebzteren bis zum Morgen, "anzieben", D. h. Die Feudytigleit bes Duarfes in jich auf= nefgment und erweichen. Bei reinlicher Behanolung jäuert Der Suarf io nicht nur nicht nach), jonbern wirb gleidfzettig auch bröcfelig unb jomit für bie jpäter vorzuntymende Mijchung geetgneter. Sn Ermangelung bes Suarfes wentet man Mithy an, welche man

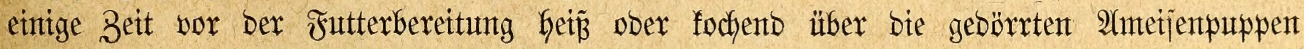
gieß̉t und wegichüttet, nachbem fie bieje aufgeweicht hat; fie erjetzt ben Duarf fajt volljtändig unto hat ben gropen Borzug, bie \$itppen "faftiger" zu machen als irgent eine andere

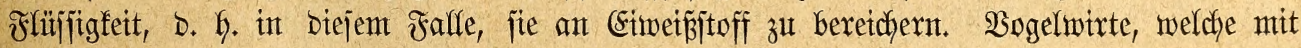

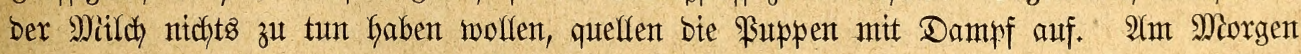

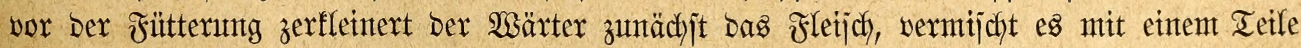

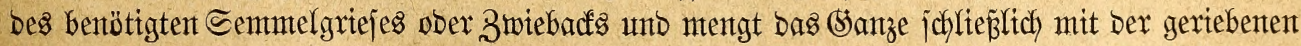
Möhre, bez̧üglich ben exforberlichen Fruthttetlen uno SBeren zujammen, bis bie Mitjdynt

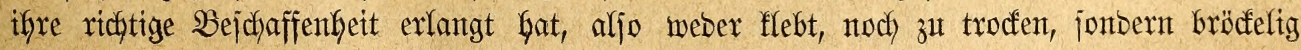

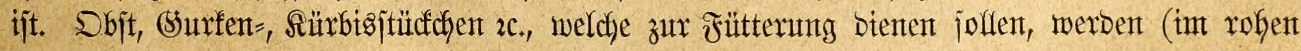
Bujtande) ganz fein geichnitten ober gejdfabt, frijche Beren gemajchen, getrocfitete in Wajjer

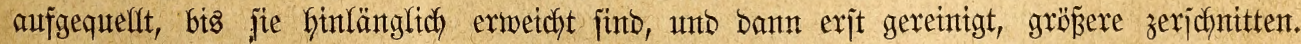
2fle (Seräte unt $\mathfrak{B}$ erfzeuge, welche bei ber Jutterbereitung gebraudbt werben, fint unmittelbar 


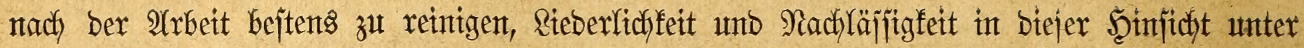

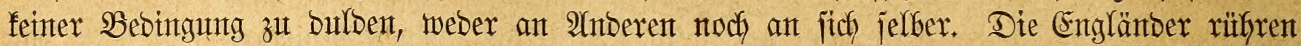
Das für ifyre Wetchfreffer bejtinnte Mitjchfutter niemals mit ben Şänden an, jonbern

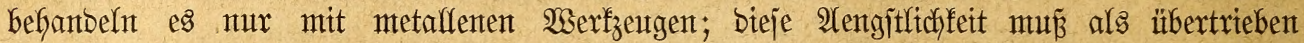
erjcheinen: ber Strunbjaz aber, won weldhem mant ausgeft, ijt richtig.

Bezüglich ber Beren mag benterft jein, baj frịche in bejonberen शäpfen ober it Irauben, ntcht aber vermijaht mit bem übrigen Futter gereicht werben, weil biejes jonjt

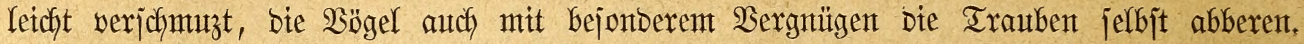

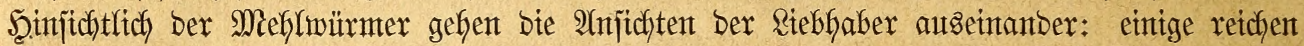
fie tot, anbere brütfen ifnen ben Sopf ein, bamit fie fich nod betwegen, bent Bogel baburdh reizen unb bods nidyt entfommen fönmen, anbere geben fie lebento. Unt jie raja zut töten,

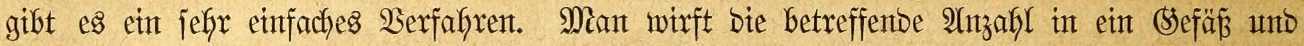

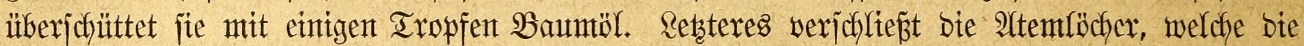
äıpere Deffmung Der \&uftröbren (Iracheen) bilben, unb exitift baburdh bie Rarben binten wentgen Minuten. Tote Meflinürmer zu reichen, ijt übrigens burchauts nidfyt nötig, ba fajt afle Bögel bie lebentben Rarwen lieber nefymen, bieje fich auth im Jutter verfriedjen und Dann jpäter gefumben und mit exneutem Sergntïgen verjpeijt werben. Sdh habe niemals tote Bürntrer gefüttert.

Sauer gemorbenes Meijchfutter ijt jtrengitens zu vermetben; es jchabet ben $\mathfrak{B}$ ögeln unbebingt. Ueberbaupt Güte man fich vor verborbenen unt jcharfen Futterjtoffen, aljo auds

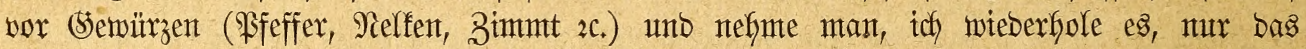

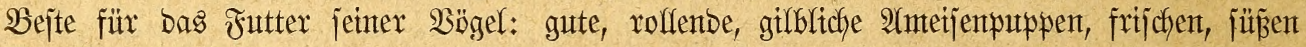
Suarf, burchauts unverborbentes Fletjch, reine, altgebacfene Senmel ober beren Sries, jaftige

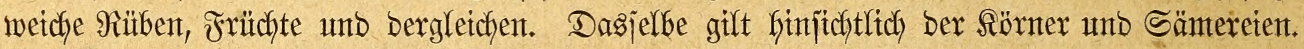
Die Bögel unterjcheiben jebr genau zwijchen guter unto joblechter Nafyung und lafjen bas

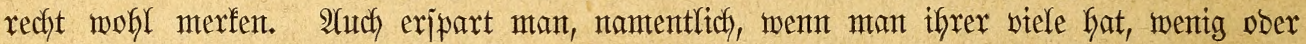
nichts burch Cinfauf geringen Futters; Denn man verltert in Folge besjelben an Bögeln melyx, als bie joheinbare Erjparnis ausmadyt.

Sand im Säfige ijt aflen $\mathfrak{B o ̈ g e l n}$ unentbefyrlich). Feiner, weiner Sand taugh jelten

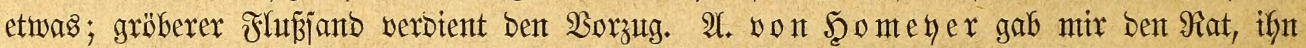

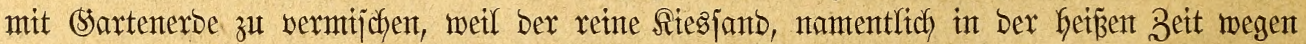

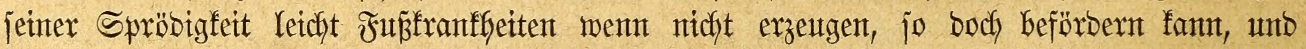

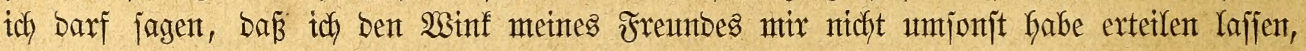

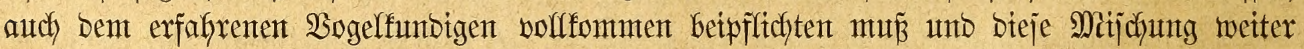

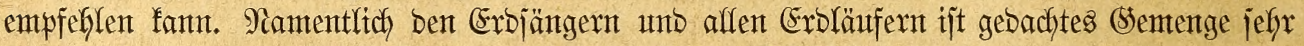
wilffommen; man meint ifhnen anzujefgen, baj es ifnten beffer behagt als reiner Sant, auch went berjelbe vorker gut burdjgejiebt wurbe. Für Rerchen, Fiteper unb andere Eros

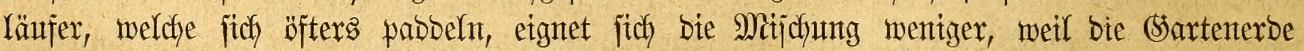

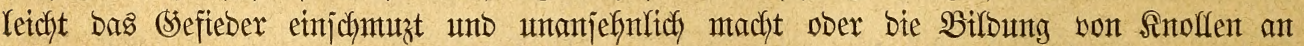

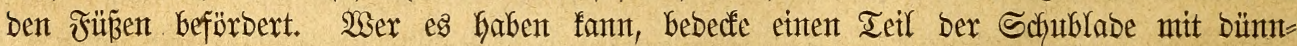
gejtodjenem Rajen, welchex Den meijten $\mathfrak{B}$ g̈geln jehr zujagt.

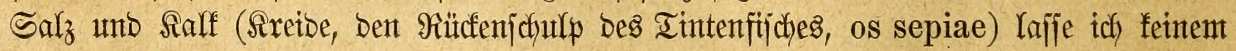
meiner Bögel feblen. Erjteres werlangen weit mefgr won ifnen, als man glaubt, Salf ge=

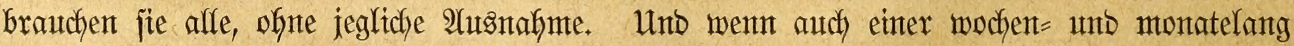

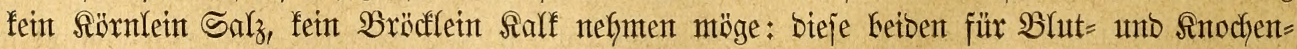

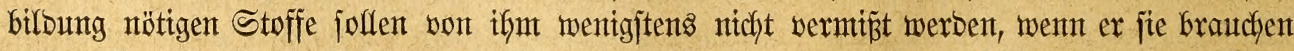

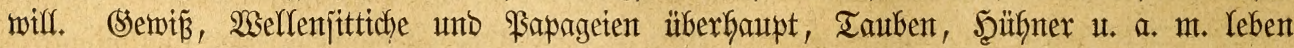
monate = und jahrelang unter ber $\mathfrak{P f l e g e}$ won Riebhabern, welche niemtals bie Bejtandteile 


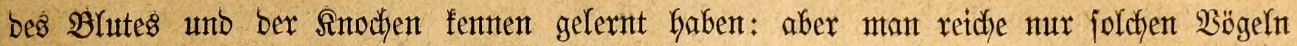
bas eine wie bas anbere, und man wirb jeben, wie bald und wie begiertg fie barüber her falfen, wie fie picfen, twie die \$apageten bas Rönterjalz auflejen, das Steinjalz belecten! Soldye Beobachtungen müffien zu Jingerzeigen werben.

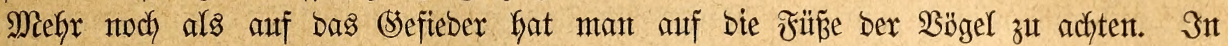
Folge ber meijt zu bünnen, zu glatten obex zu rauben, fantigen, fnotigen Sibjtantgen be= fommen bie Şaumbögel Keidjt Seüfyneraugen unb Recthbornent, in Folge ber im Räfige febr

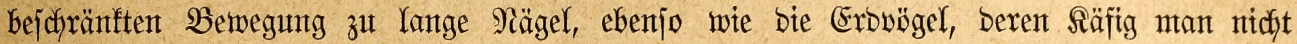
mit ber bejdyriebenen Sorgjamfeit jo oft als erforberlich reinigt, fich ifyre Füre mit Rot

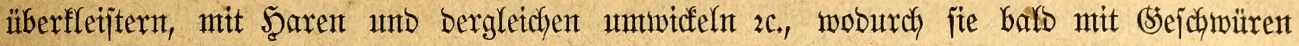
befaftet werben und Rafmbeit, Fußjgicht unb anbere Sranffeiten Dawon tragen. Unter

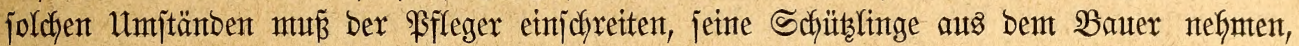

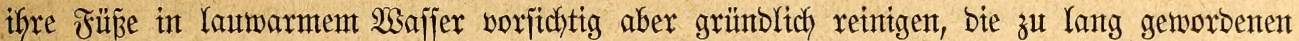

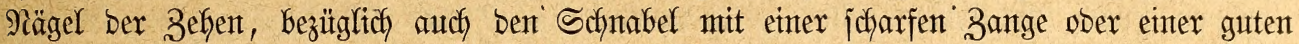

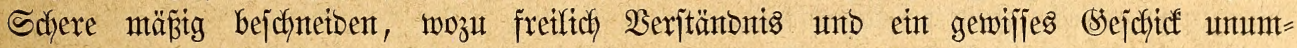

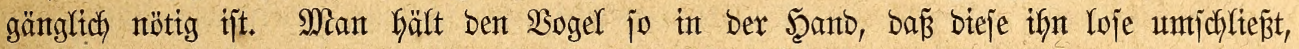

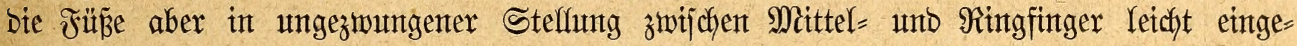
flemmt werben. Soldjerart jitjert man bas Iter ebenjo vor Drud unb Unbehagen als

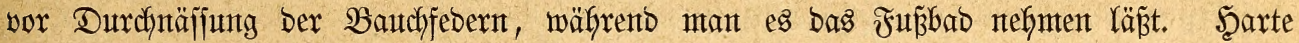
Snollent meicft man gebörig auf unt löjt fie jobann jorgfältigit ab. Betm Bejchneiben

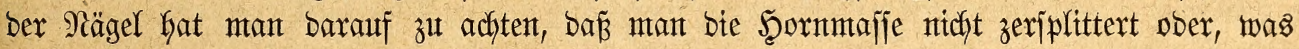

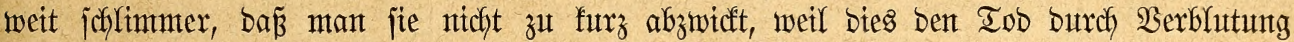
Gerbeifüfren fant. Reicfoornen betupit man mit (S)lycerin, munbe Steflent, Sejchmüre zc.

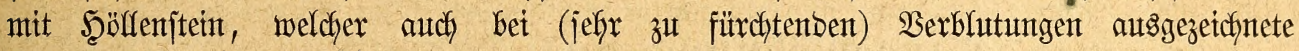
Dienjte reijtet.

Reibet ber $\mathfrak{B f l}$ legling an Ungeziefer, inßbejonbere an ben jogenannten ,Räujen", Den bereits erwäfnten Mitben, unb hat ein ober mefrnaliges Untjeben nicjts gefolfen, jo bläjt

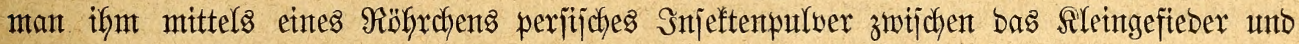

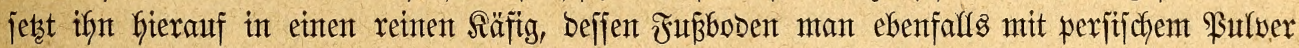
bejtreut hat. Das lektere tötet bie Mitlben jicher, ofyne Dem (sefangenten zut jchaben.

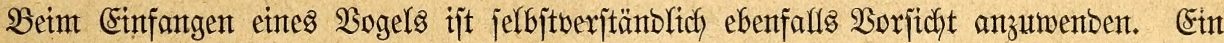
ungejchiffter Bfleger fängt jelten einen aus bem Bauter Gerats, ofnte ifym einte Sijwinge ober Steuterfeber aušzunupfen. Sn ber eigentlichen (sejangzeit hat bies oft bie Folge, bañ ber $\mathfrak{B o g e l}$ jofort zu jingen auffört; mandfunal aber erfäfrt man nod) Schlinmeres. Sch habe

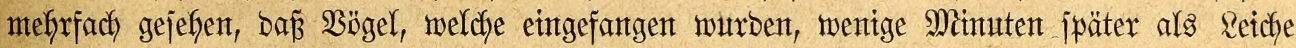
in ber Şant bes Fängers lagen, unt nicht afletn in ber eines ungejdfidften, jonbern in (Segenteile audh eintes gejdjifften Mannes. Die Alufregung, ber Sdyrectent über bas ifynen

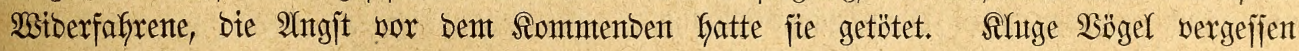
eine joldye Bsemütsbewegung nie, extntern jich vielmefyr berjelben bei jeber entiprechenden (Selegentgeit und werben von neutem ängitlich). Unt joldyen Witberwärtigfeiten vorzubeugen, nimmt man bei jcheueren Stücfen bie Springjtangen ats bem Säfige, woburdy man erwirft,

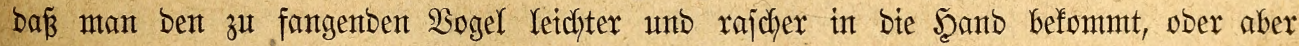
bectit ben Bauter mit Iüchern zut unb verbutst jenten burch foldhe Serounflung. Beim

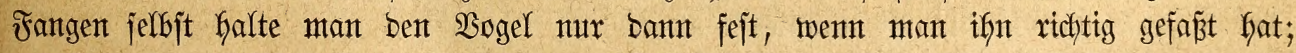

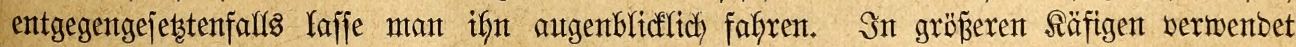

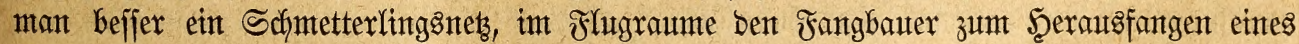
Bogels. Unt bas fretwilfige Heberipringen zu bewirfen, fteflt mant zwei Räfige mit geöffneten Türen gegeneinanber, becft ben verjednuzten mit einem Tuche zu unb fobbert in 
bem reinen mit irgent einer sieblingsjpeije. Der Bogel geht nach fürzeremt ober längeremt Bejünten jebesmal bon jelbjt in Den betreffenben Säfig, ofyte fich zu jobeuten ober zut ängjtigen.

Wäfrend ber Maujer Darf man, ofne bie auggeiprodjenjte Notwentigfeit, einen $\mathfrak{a g e l}$

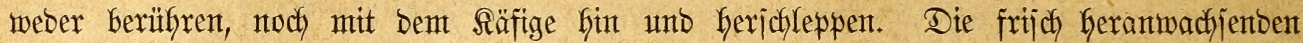
Febern fönnen, unt Berfrüppelungen Derjelben zu verfüten, gar nicht vorjichtig genug be= Ganbelt, bie maujernben $\mathfrak{B}$ gel jelbjt nicht jorgfältig gentg ernährt, gepflegt, vor alerger unt 2 (1ufregung betwaknt werbent.

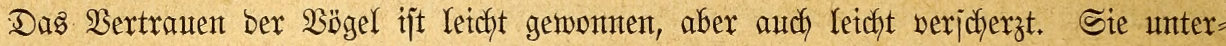

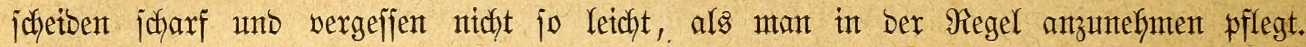
Bapageien erinnern fich einer erlittenen Mishanblung nody nady vielen Gafren, unto einzelne von iffnen wenben iffe 3umetgung bem, welcher fie verlor, niemals wieber zu. Mant unterjyäze dieje Worte nidyt, jie berufgen auf Erfahrung und jollen zum Echluz nur noch mafnen, nach Miögfichfeit affes zu vermetoen, was das Mitstrauten ber gefteberten Pfleglinge ermedfen und befejtigen fanm.

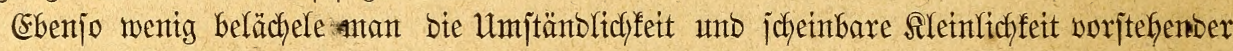

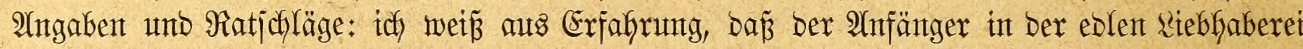
für Mitteilung eines Derartigen, Durch langjährige llebung unt ફૃanbhabung erlernten unto befejtigten Berfafrens oft recht banfbar ijt unto jein fant.

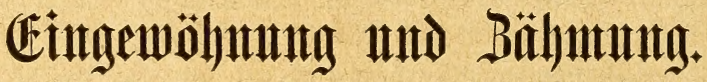

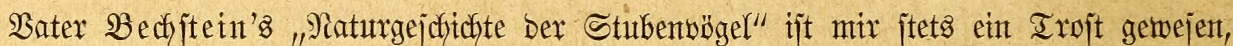

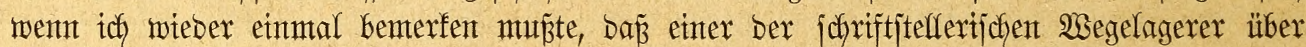
eintes meinter geiftigen fintlein hergefallen war, es beraubt und bas ifm (sntnommene, nady

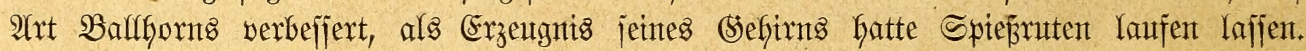
Sch mill jagen: Bechjtein's $\mathfrak{B}$ ogelbuth ijt viele Safre lang eine Sutfe für jentes Sejundel

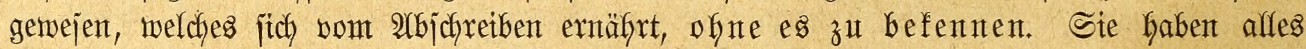
genommen, Das Edjte mie Das SBlinfende, Das Duftige wie bas Stinfende. So darf es̊

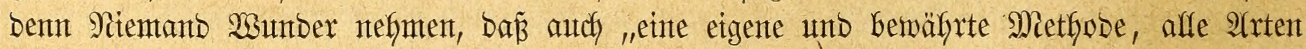
von Stubentü̈geln in einer bis zwei Stunden zafm zu machen" $2 c_{.}$, in Den unzäbligen

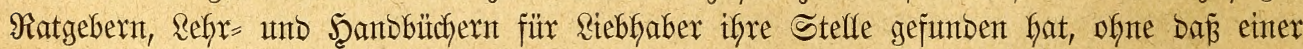

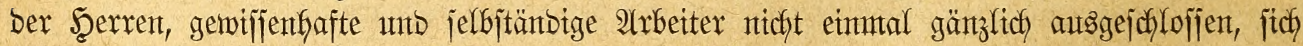
die Mäfye gegeben, über bie bewäfrte Metfyobe nachzubenfen. Dieje bejtegt nun aber barin,

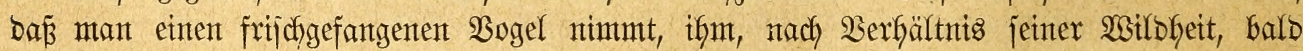
mefrx, bald wentger von ber interen Jafhne ber Sifyingen wegidhneibet, bamit er beint 23egfliegen von ber Şanb feinen Schaben Yeibe, unto bie Flügel boch ifre geförige (sejtalt behalten, ifm bant bie (Segento ber Najenlöchex mit Bergamtotten= ober anberweitigem jtarf:

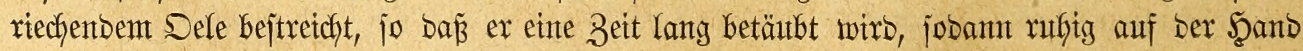

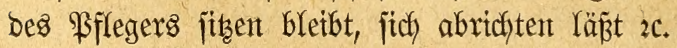

Bechjtein war fein 2 bjichreiber, jontern ein Beobachter; bas von ifm angeratente

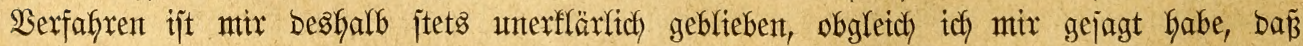

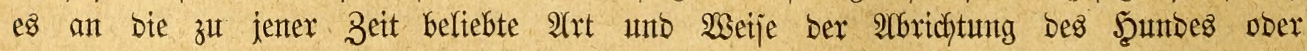

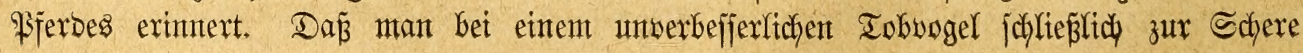


greift unb ifm bie Schwingen in ber angegebenten Weije beichnetbet, um bent Selärm unt (Beflatter ein (Enbe zu mactien, bermag id) zu begreifen; wie man aber eitten $\mathfrak{B}$ ogel, welcher fich ben veränberten Umitäntben ntiḑt fügen mill, burch) Betäubung zu beffern glaubt, ijit

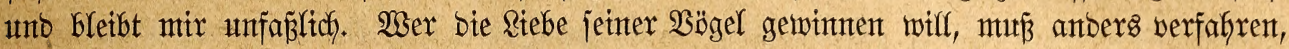
als Bechjtein angibt; milbe Befhanblung füfhrt jicherer unto eher zum Biele als jebe

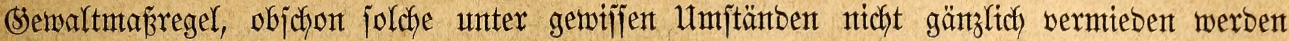
fant. Die "Miethobe" Bechjteins ijt bielfetcht - ich Gabe fie nie erprobt - tatjächlich "bemährt", ficherlich aber untötig unto jomit verwerflich).

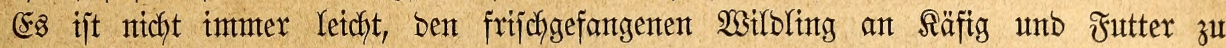
gemöhnen, am wentigften, went es fich nur um einen, ntcht um mefrere hanbelt. Mandfie Sögel gebärben jich anfänglich wie unfinntg, toben in Räftge umther, prallen gegen Decfe

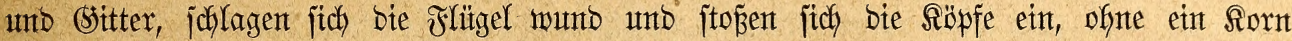
ober eitren $\mathscr{B}$ ifjen bes ifnen vorgejesten Futters anzurïfren. Shnten verbüftere man zunächjt ben Räfig, jobant jeşe man ifnen in flachen Dunflen (Sefäß̈en Irinfwajfer in ify Bebälter unt werfe thnen, nachbent fie eine Beit lang gefungert, entjprechenbe Nafhung, insbejonbere

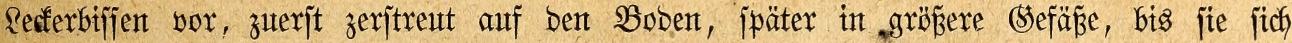

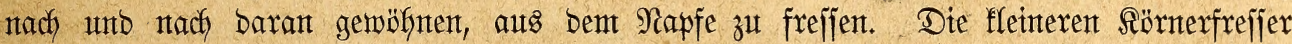
gehen meijt whne afle Umitänbe an bas Jutter, fleintere Weichfreffer troken oft lantge, verfungern audf) angejichts bes gefüfllten Futternapfes, falls mant es nicht gejojicft anfängt,

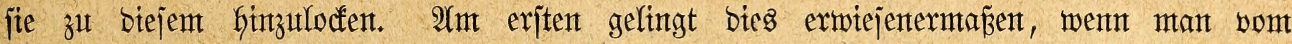

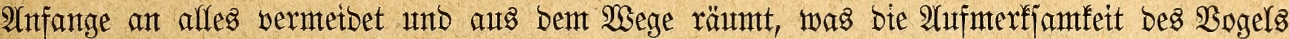

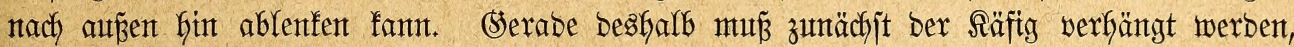
entweber mit bidftem (sezmeige ober befier nodh mit Iüchern, welche zmar etwas sidft

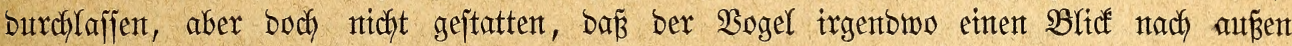
werfen fönne. Se gleichmäp̈iger man bie Wänbe bes Räfigs heritellt, bezügltich verbunfelt, Int jo wentiger wiro Der Befangente baran benfen, in bent Bejtreben, jeinte Jreifeit wieder

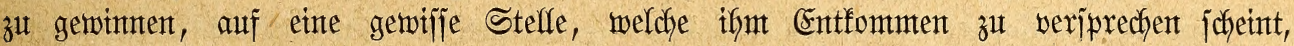
jein 2Yugenmerf zu richten, bejtändig auf jie logzzuftürzen unto barïber alfes anbere,

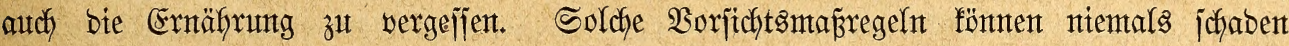

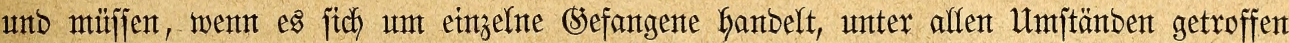
werber.

Stebhaber, weldye jelbjt fangen ober bodh öfters watblinge eingewöbnen, werben gut tunt, fich einten befonberen Räftg Kerzujtellen, in weldhem ber Neuling bie exjte Beit ber

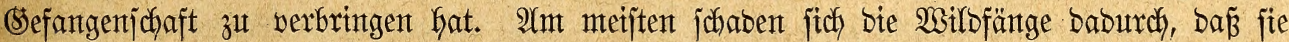
fich mit Schntabel unto Borberfopf zwijchen ben Sprofjen ober Maichen bes Säfiga burch)=

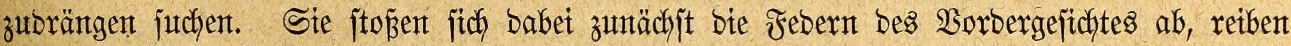

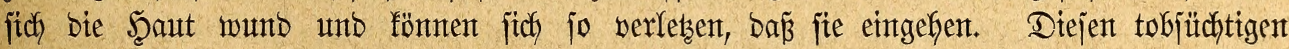
Berjuchen joll unt fant ber Eingenöhnungäfäfig vorbeugen. Wer feinte Beit zu verfteren Gat, wanbelt jeben Säfig zwedfentiprechent um, inbem er ifn bis auf ben Raum für Cin=

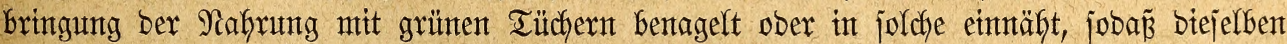
überall itraff anliegen; wer für bie Bufunft baut, nimmt eine oben offene fijte, bringt an einer Seitentwant berjelben einten Schieber, innen ein einziges Sprungholz an, benagelt fie oben mit feinem Drat= ober Reinennets (baze), burch weldhes ein rufiges Ridht in bas Sntmere fällt, unb hat jeinten Eingemöhnutgoraum fertig. Sarl Mïller wenbet jeit Safjren mit bem bejten Erfolge einen Säfig an, welcher jeiner Einfactbeit halber alfjeitig

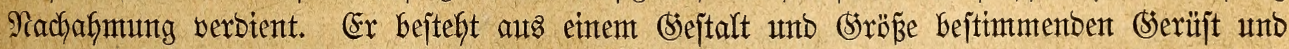

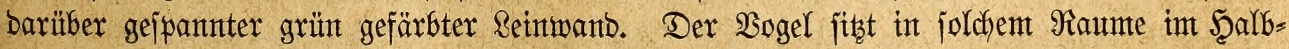

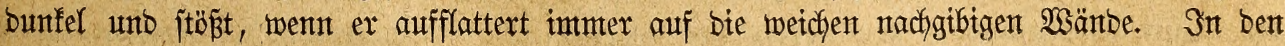




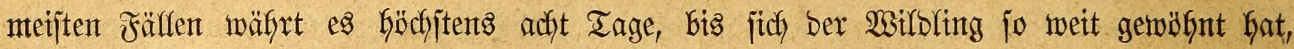
baß̉ er in einten gemöfnllichen Räfig gebracht werben fant.

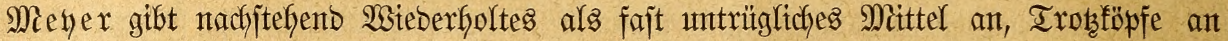
bas Jutter zu gewöfnten: "Man bringe ben $\mathfrak{M o g e l}$ in einem Räfige bafin, wo er fich

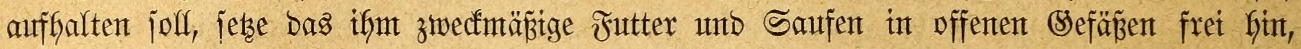

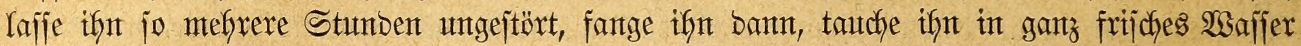

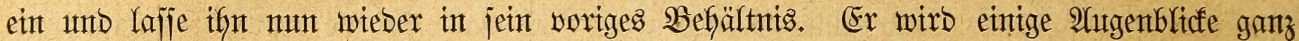
erjechöpft bajtzen, jidh aber bald wieber erfolen, fidh zu putben beginten, nach einigen

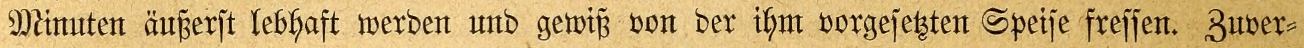

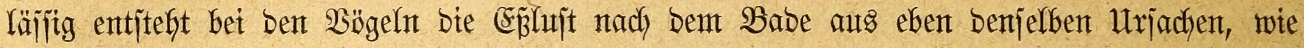
bei bent Mienichen."

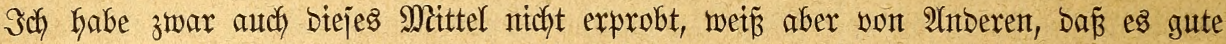

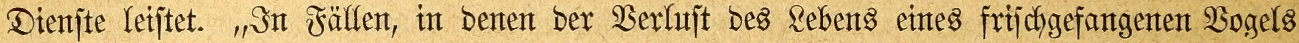

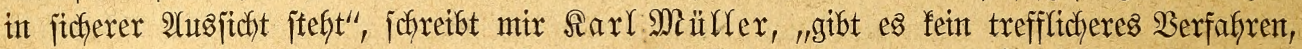
als bas von Meyer angefüfyrte. Sch habe Droffeln, welche int Sommer beim Nejte ge=

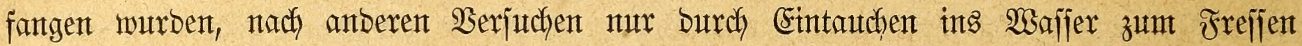

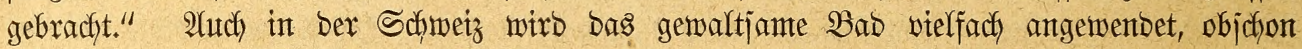
mentger, um Den Watloling zum Freffen zu vermögen, als um tobjüchtige Befreiungg̈verjuche zu brectjen. "WGie jefyr man", bemerft \$irtanter, "einem Ranboggel ichaben fant, weldyer

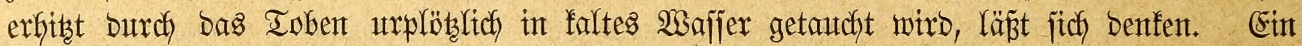
bemährter Sogelmirt, won weldyem idd biejes Serfahren zuerjt anwentoen jah, hatte es

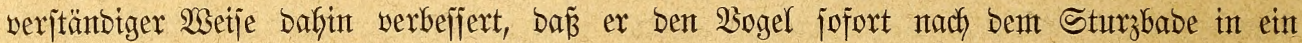
Iuch) einfü̈flte, unter jeinte Bettbecfe jtecte und erjt jpäter in ben Räfig jebzte. So viel ijt nad) meinent eigenten (Exfafhungen Iatjacte, baj ber getwartiam gebabete Bogel,

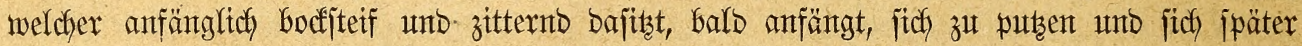
aus irgent weldyent Srutnde viel verjtäntiger benimmt als früfher."

So lange man anbersmie burchfommt, brautdyt man bas Sturzkad nidft anzumenten. Schon mein Sater hat ein weit befjeres Berfahren, frijdgefangente Weichfreffer an bas

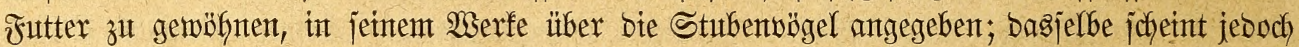
noch intmer nicht gentïgend befgerzigt zu werben, obgleidh es won Bechjteins unt meines

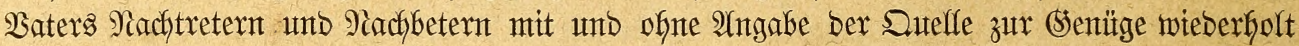
worben ijt, und aus bem eben mitgeteilten (smunbe audf bon mir wieberfolt werben foll.

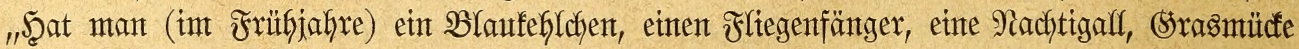
unt bergleidjen frijh gefangen, jo jest man jie - bie wilben mit verbunbenten Flügeln in einten verbecften nicht zu fleinen Säfig, in welchem fich ein Saufnäprchen befindet. Şat ber $\mathfrak{B}$ ogel einte Zeit lang, etwa zwei Stumben int (Sanzen gefungert, fo wirft man ifm einige nodh Galb rebende Meflwitrmer auf ben SBoben bes Säfigs. (Ein Yebentiger Meehl= wurm ijt für einten fungrtgen ferbtierfrefienten $\mathfrak{B}$ ogel basjelbe, was ein Stïtf neubadenes Brot für einten funtrigen (Sefangenen, weldher Den Scungertod jterben wilf. Beide fönnen

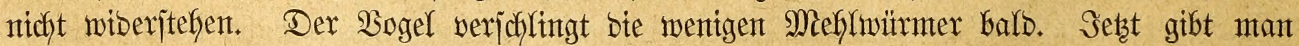
ifgn mefrere unt unter ifnen einige ganz tote; liejt er eimmal bie lebentigen auf und finbet feine mefrr, fo ninmt ex bie toten auch mit. Scat ex jid einmal an bieje gemöbnt,

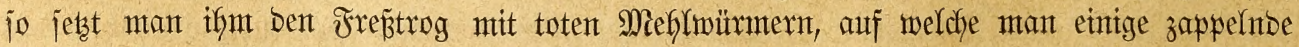

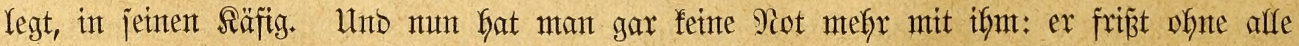

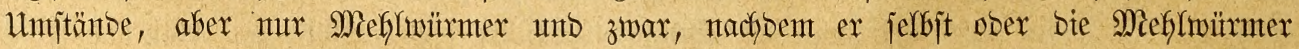

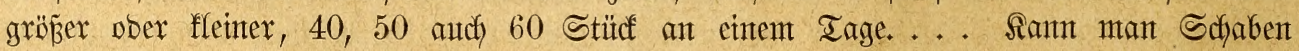

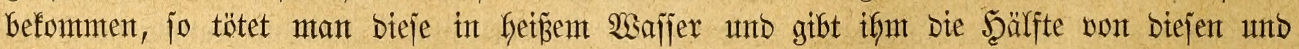
bie Şälfte Meghlmürmer. So nähert fich bie Zeit, in iveldher man frijche Amteijenpuppen 


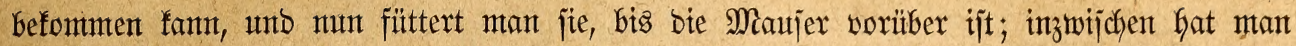
ben Weidjfreffer alfmählich an jein bejtändiges Stubenfutter. gemöfnt."

Diejes Serfafren ift alferbings untrüglich, jeboch etwas langmeilig. Sidf wifl besfalb noch ein zweites, ebenjo jidjeres, za Pats unt Fronmen affer Bogetwirte hier angeben.

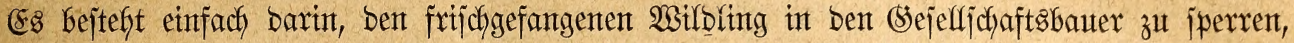

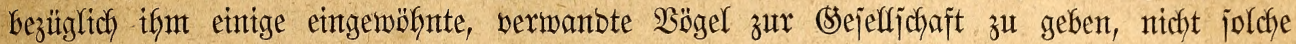
berjelben 2 trt, falfs man nur einen bereits gezähntten hat, jonbern beliebige anbersartige,

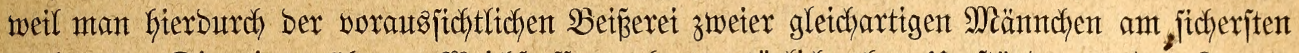

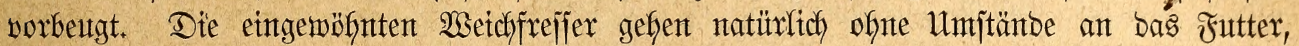

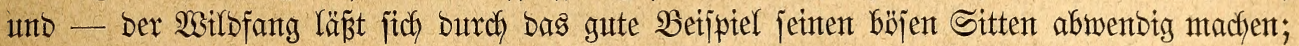

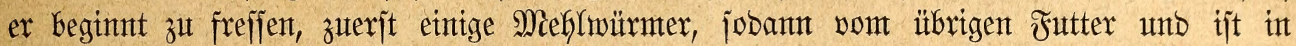
wentig Iagen burch bie (sejeflent weiter gefradyt worben als burth wochentange Einzelfaft.

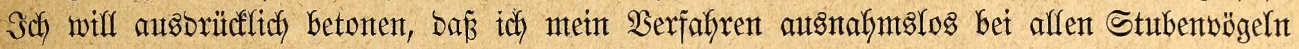

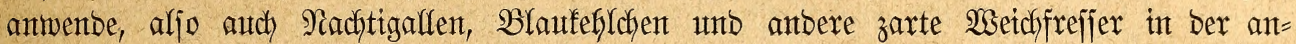

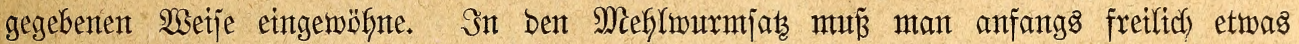

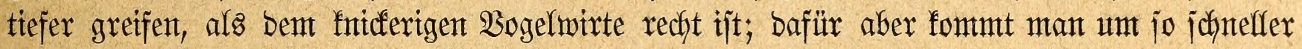

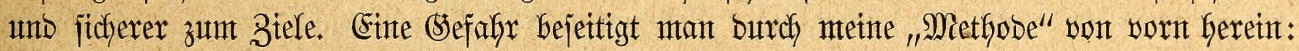

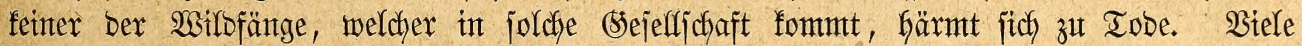

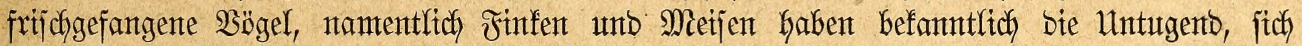

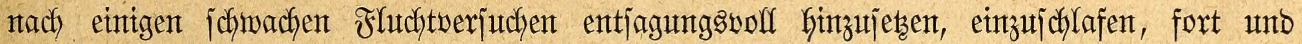

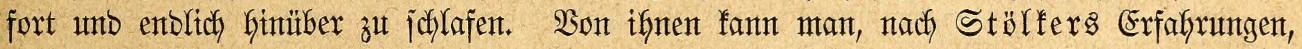
manche retten, wenn man fie steberfyolt erwectit, bie meiften, went man fie in hufftige

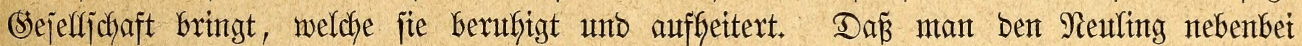

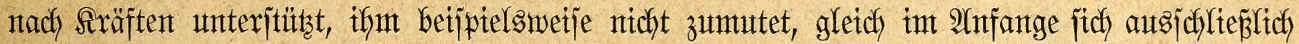

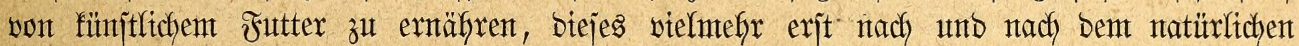

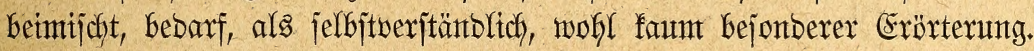

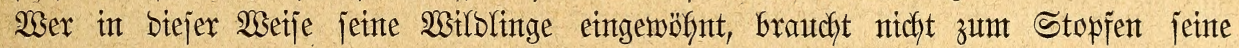

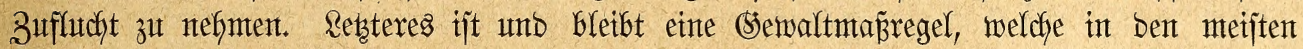

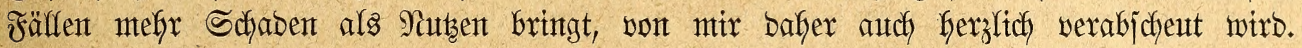

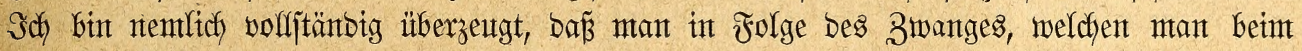
Stopfen alter Dögel auf fie ausübt, minbejtens ebenjo biele won iffnen werfiert, als went

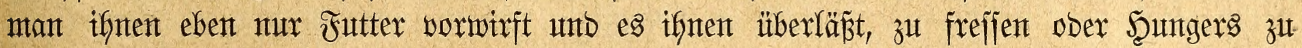
fterben. Heber bas Stopfent ber (sänje fajitt man, bas Stopfen ber zantent Sänger heiß̄̆t man gut, wäfreetro boch bie Semalttat Gier wie bort wejentlich biejelbe iit. Soldche

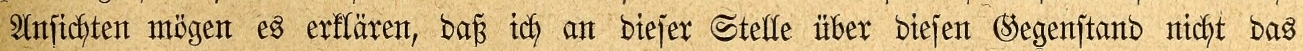
Beringite vermelbe.

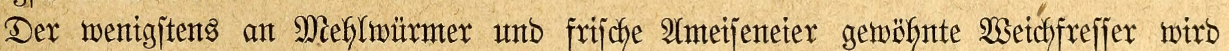

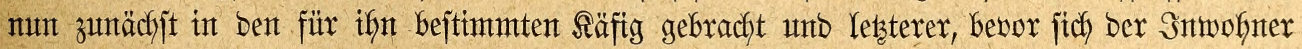

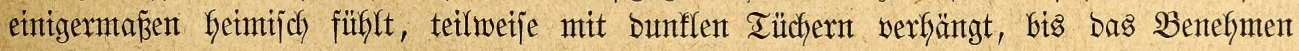

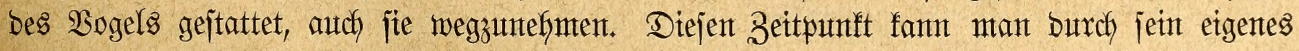

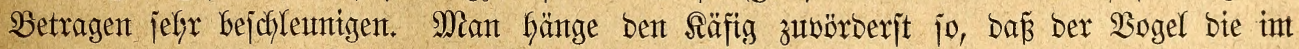

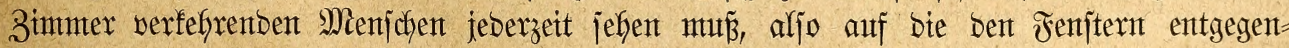

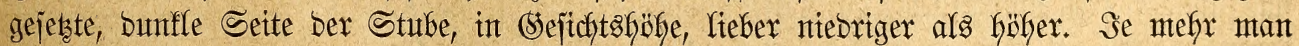

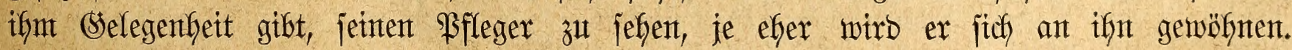

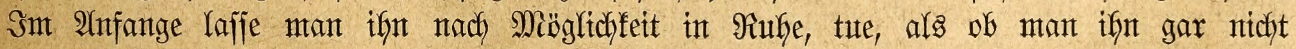

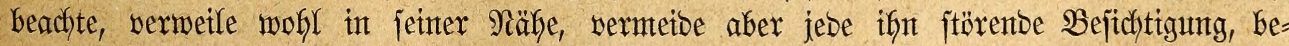

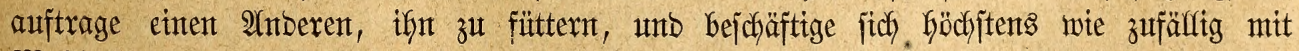

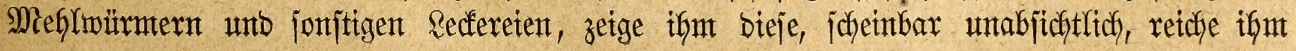




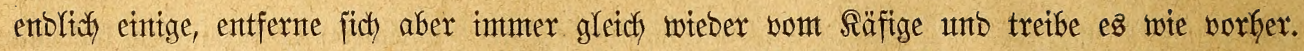

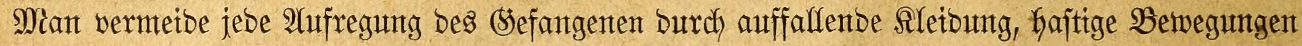

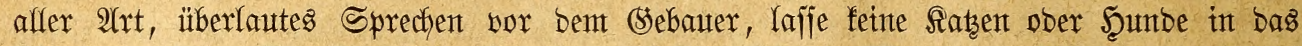

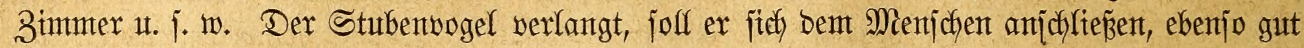

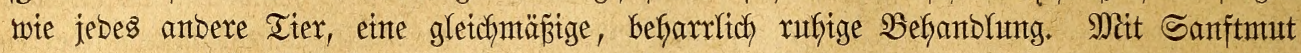
fonmt man unzmeifelfaft biel ficferer und efer zum Biele als mit jebem jonjtigen Mittel. Bejitzt mant jie nicht, fo nefyme mant jie an, heuchle jie meinetwegen, bes guten Zwectes

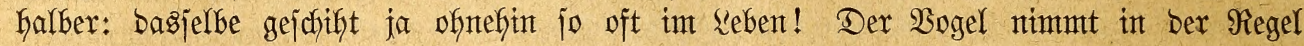

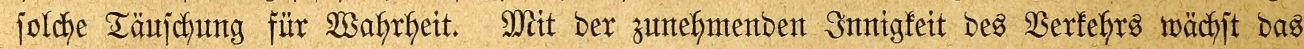

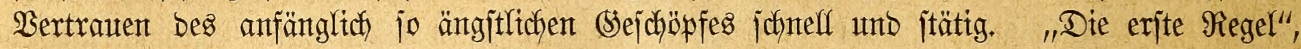

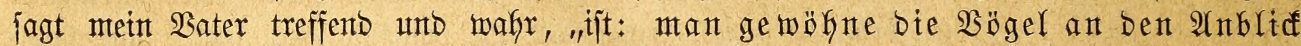
ber Menjchen, trete oft zu ifnen, jprectse mit ifnen, itecfe ifnen ben Finger in ben Säfig,

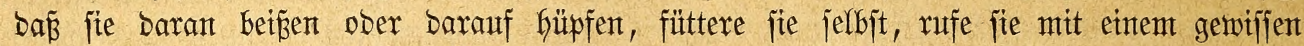
Namen unt gebe fich viel mit ifynen ab. Sind fie num im Räfige gantz firre, jo lafije man fie, nadjoem man fie womb̈glich auf bem Fintger aus bem Säfige getragen hat, auf

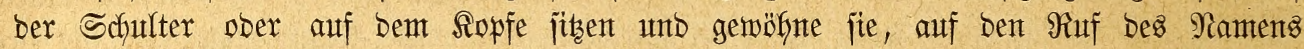

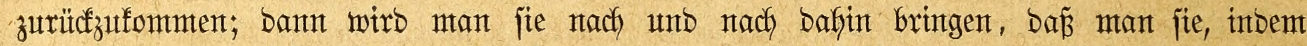
mant fie auf ber Şanto ober Schulter trägt, mit ins Jreie nefymen fant, ofgne fie zu berlieren."

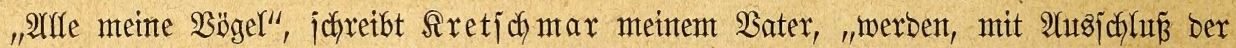

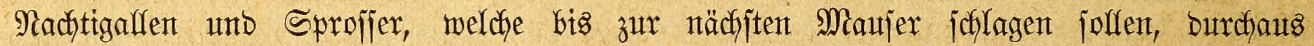
nicht berfängt, oft von mir bejudht und an einten anberen Srt gebradjt. Sch fä̈nge audf) meinte zartejten Bögel bald hodh, balb tief, bald zu Diejem, bald zu jentem Nacjbar, und

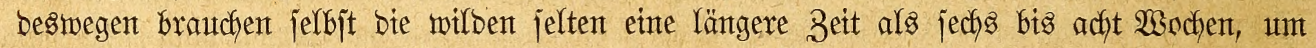
fich afles Flattern abzugewöhnen, wenn thy ober Befannte Ginzutreten. Alfe nefmen

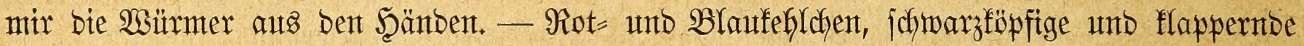

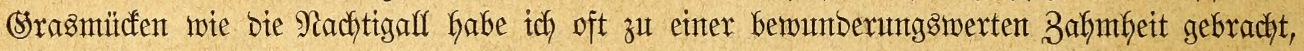

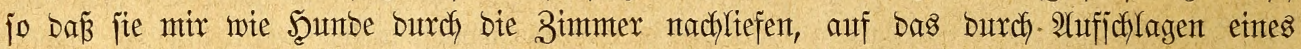

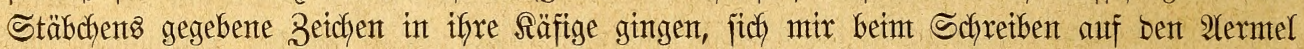

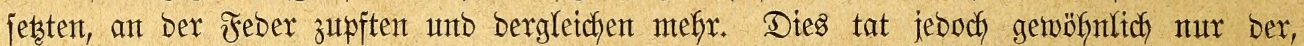
weldher eben ber Riebling war unto yor ben anberen bejonbers ausgezeichnet nurbe. Einjt

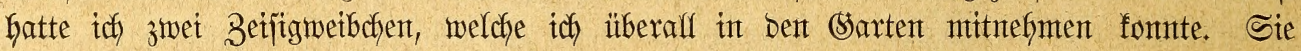
flogen auf bie Bäume, Güpften auf ifnen eine Zeit lang umber, jeşten jich aber ftets betm janften Pfeifen auf Der Goflen Scanb, in weldyer etwas Futter lag, mieber auf ben 2 rm

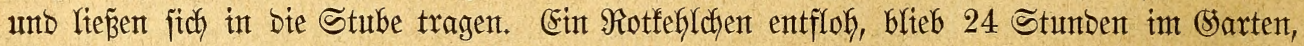
flog aber bod burch ein offentes Fenjter wieber in bie Stube unto fefrte jogleidh in jeinen

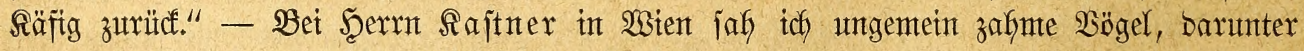

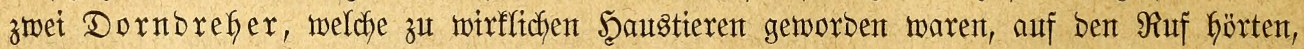

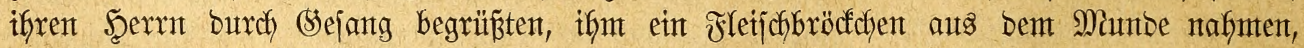

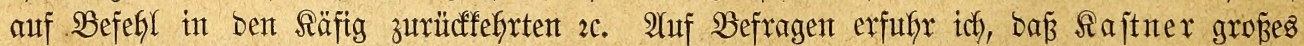
(S)emidyt barauf legt, fite, unt fie balb zafmt zut madjen, täglich einte Stumbe unt barüber im Zimmer frei umberfliegen zu lajfen, ifnten bei Tijoh von affen Speijen anzubieten unto

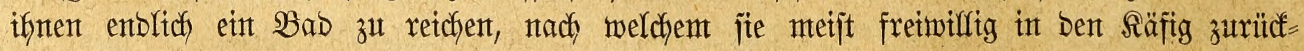

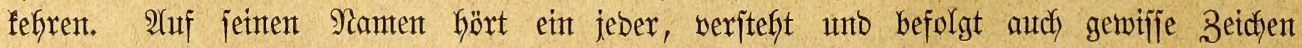

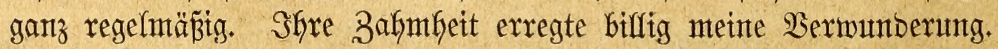

Trotzoem mag ich Niemand ermutigen, äfultiche Berjuche zu machen. Daz Enbe pflegt

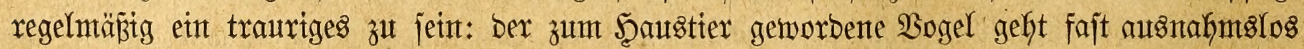

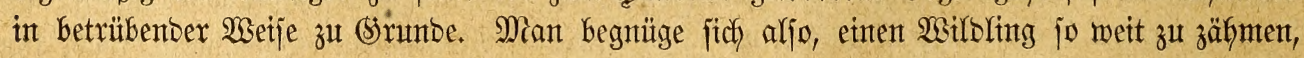




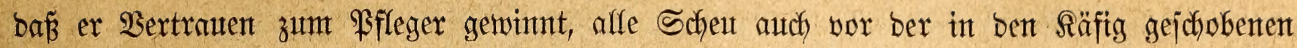

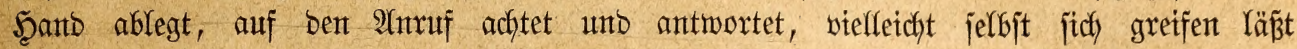

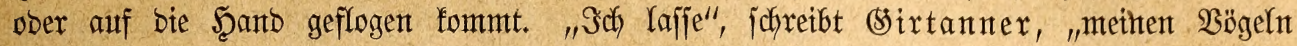
im Räfige jo biel als mögltch von ifrer Natürltchleit. 2(ber ofnte bejontoere 2Ats= ftrengungen meinerieits werbent fie mir nterfwürbig zugetan, weif idf mit ifnen rebe, freunblich ober barich, je nach Bebürfnis, - weil ich thnten täglich jelbit Futter unto Waffer bejorge, weil ich zuverläjifg bin bezüglich ber Beit ifyrer Fütterung unt freigebig

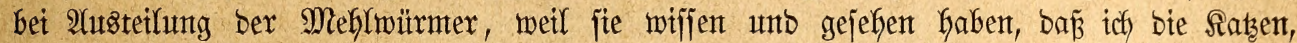

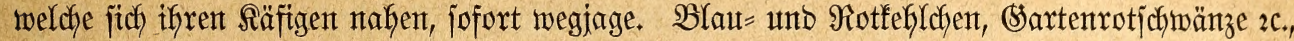

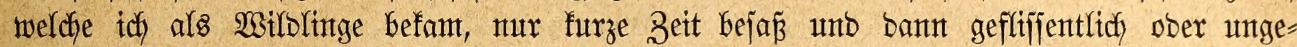

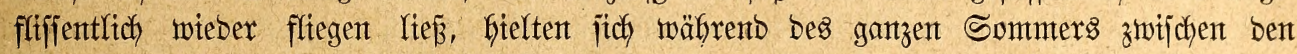
ßfflanzengruppen metnes offenten Erfers auf, fament aber mur, went idf, midh nakete, zum

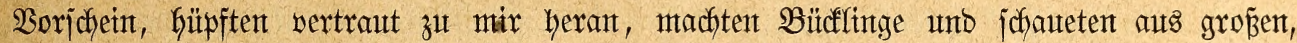

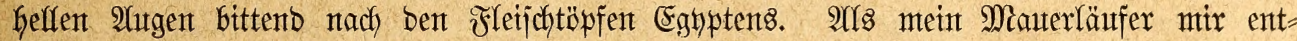

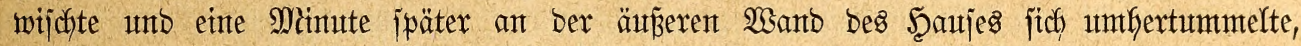
gab ich ifn nicht verloren, holte ftifl mein Fanggann und einige Mieflwürmer, verbarg bas eritere, zeigte bie letzteren, pfiff unto murbe veritantoen, locfte unt wurbe mieber gegrïfft, bis

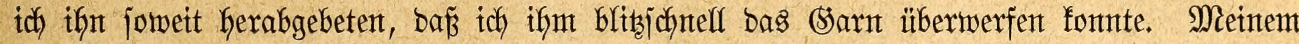

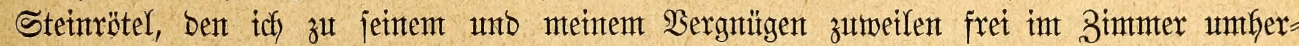

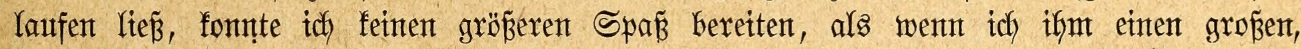

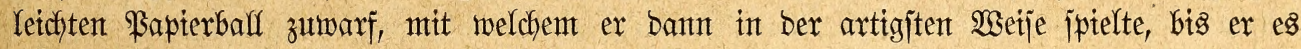
fatt hatte, zu mix fam unto mit Snixen unto Schwanzmippen um anberen Unterbaltungsitoff bat. Soldhe 2 Anthänglichleit, weldhe nidfyt bas Ergebnis einer regelrechten Albrichtung ijt,

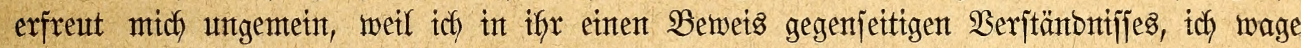

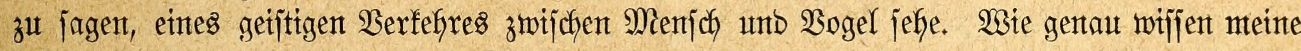
Pfleglinge freutbliche unto Grate Worte zu unterjcheiben; wie ungebulbig melden fie fich, went bie Zeit ber Darreidfung von Futter ober von Meflyürntern vorüber! (Semin, fie

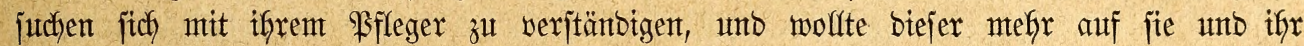

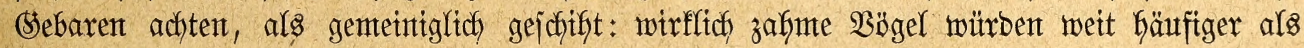
gegentwärtig zu jehen jein."

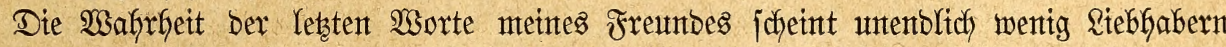

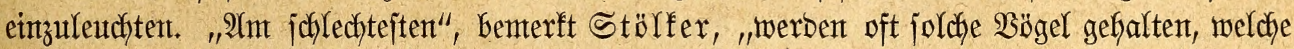
bie bejte Belegenţeit zur Zähmuntg bieten, weil fie vereinzelt in eintem Bimmter Gängent uno bie ungeteilte âtumerfjamfeit auf fich lenfen fönnen. Es fint zumeijt joldje, beren Pflege fajt gar feine Më̈fwaltung exforbert, aber trotzbem vernachläjfigt witro. Seterburdy

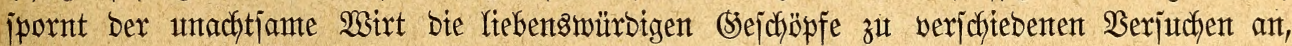
bie Beadstung bes sebteters auf fidh zu ziehen; jie fingen lebhafter als jonjt, lafjen eigene

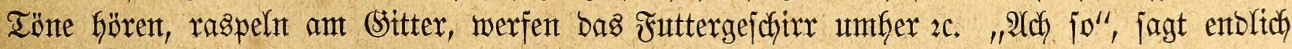

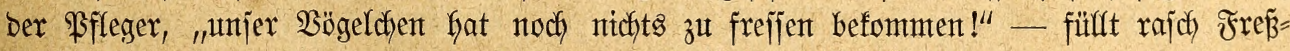

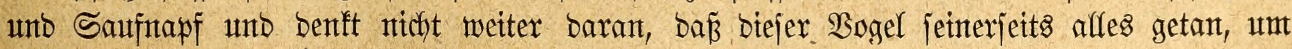

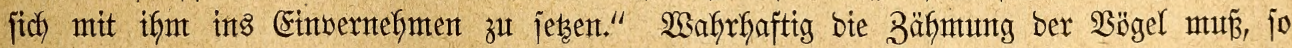

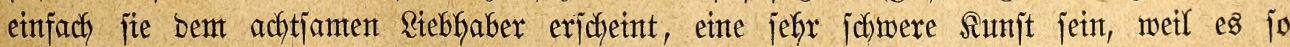
Bielen nidbt gelingen will, mit ben Groch begabten unb antjänglichen (sejchöpfen in innigen Serfehr zu treten.

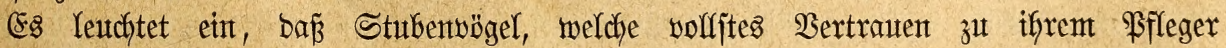

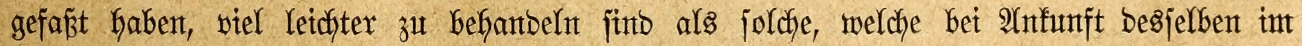
Räftge umbertoben, fich bie Flügel wuto fdylagen uno in gewaltige 2lufregung geraten. 2. von Şonteyer nimmt feine Steinrötel unb Blaunterlen mit ber Şant aus bem Säfige, 


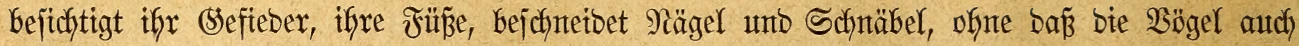
nur verjucthen fich ungebärbig zu zeigen. Meein Bruber und id haben oft ebenfo zafyme Bögel gefabt, weil wir thre Scheu Durch verjtänotge Befpanbluntg bintten furzem zu bejiegen wušten.

Sbgleich ich es nach Dem oben Mitgeteilten faum für nötig exachte, wiff idh boch noch

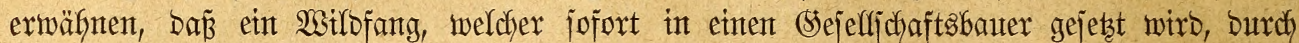
bie früberen $\mathfrak{B}$ emofner besjelbent nicht alfein balo an bas Jutter gemöfnt, jonbern auds

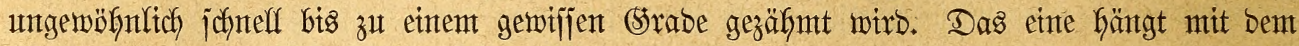

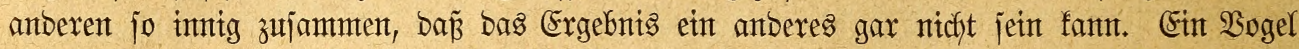

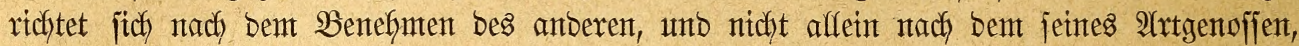
jonbern audf nach bem Betragen ber (sejammtheit; er läß̈t jith burch bieje beruffigen ober warnen, er vertraut unb mistraut wie fie. $\mathfrak{B o r}$ wentig Iagen gefangene Stranbobigel,

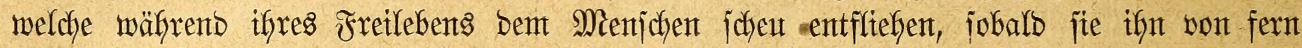
jeben, benafmen fich in meinen Jluggebattern, nacfoem fie von ifyren afrtgenoffen begrü̈st worben waren, von ftunban genau eben jo rufig unt verjtändig wie bieje. 2lffe übrigen Sögel hanbeln faum ober ntrfyt antbers.

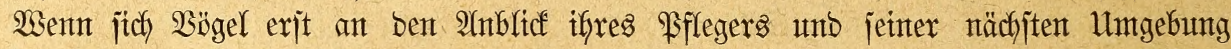

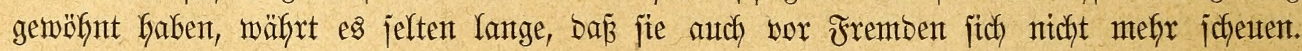
2lnfänglich pflegen jue ify Mitsfallen über jebe unbefante Erjcheimung jebr beutlich zu er=

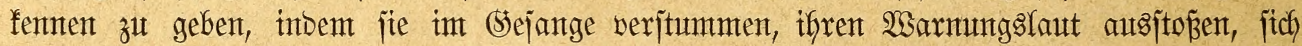
ängitlich gebärben, flattern H. . . w. Dodb berufigen fie jich bald wieber, went fie jefgen,

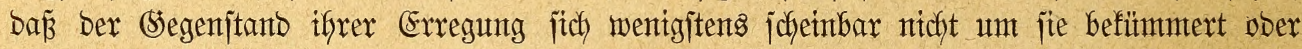
aber als Sachwerjtänbiger jich befunbet. Sn İergärten unb anberen 2 (njitalten äfnlficher

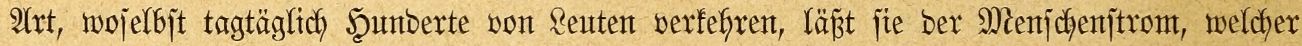

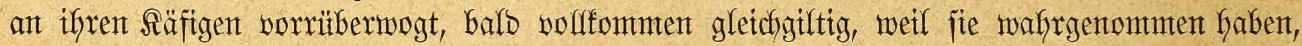

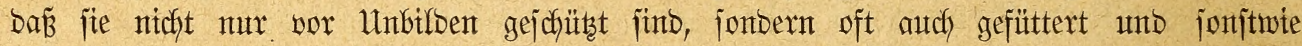
gehätjchelt werben. (stöpere Barfbögel, welche jïch bie alfgemeinte Buneigutg zu erwerben

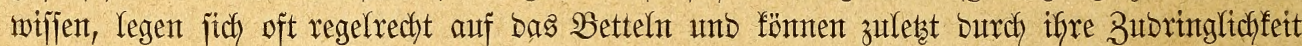
beläjtigen.

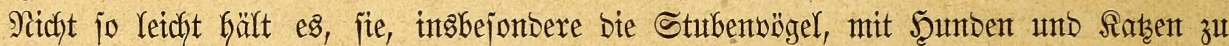
befreuntoen. Sie erfenten in betoen bas Raubtier jefr mofyl und befharren lange Beit in

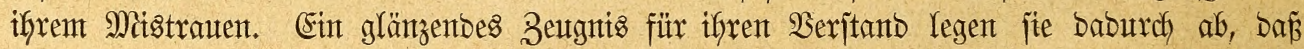
fie weit früher mit Der Segentwart bes Şutbes als mit ber einer Satze fich ausjöhnen, ja, mit erjterem, nadjoem fie ifn längere Beit beobachtet, einten wirffichen Freumbjhaftabunto

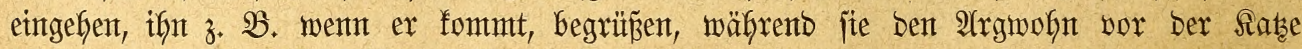

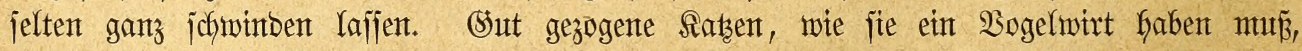

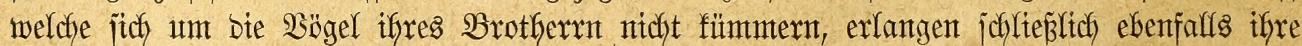

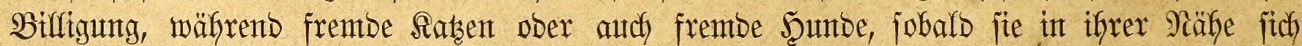

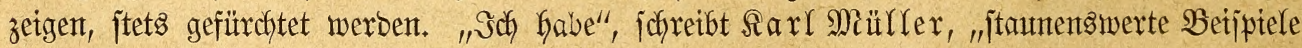

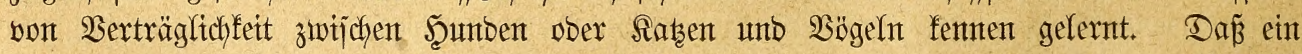
Seunb ein Rotfeblchen auf alfen Ietlen jeines Rörpers untherjpringen unt jich von thm bie

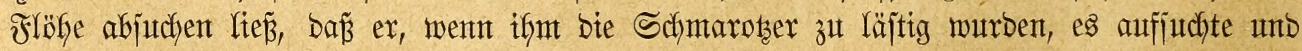
gleidjiant aufforberte, ifgm ben getwofnten Riebesbienjt zu ermeijen, erjcheint mir ein un= widftiger $\mathfrak{B}$ eleg fïr joldhe Freunbjchaften zu jein, gegenüber folgenber Beobadjtung. In

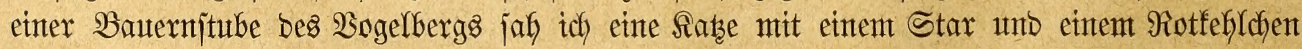

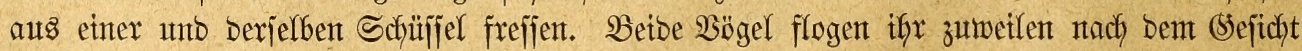

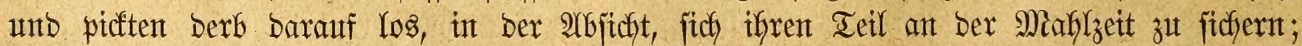

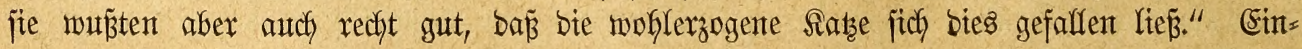




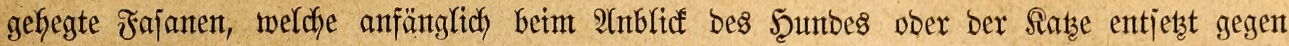
bie Dedfe ifyres sebauters jtürmen, rüfren fich ipätex gar nidyt mefyx, went Yetztere über

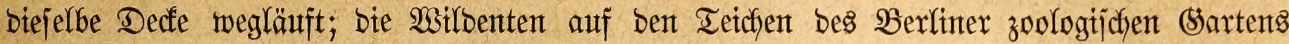

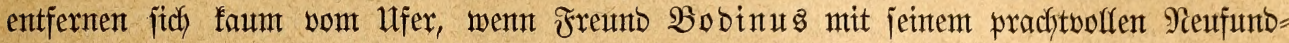

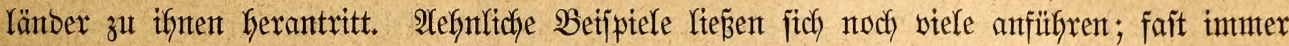

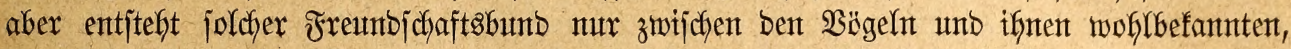
Demjelben Şauje ober Şerrn angehörenben, nicht aber fremben Säugetieren.

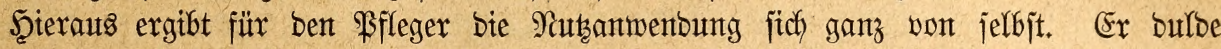
nie, baß̃ unverjtänbige, hajtig gehenbe ober jonjtwie fich heftig bemegenbe Menjchen of nte

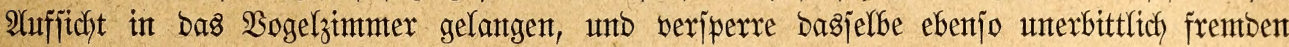

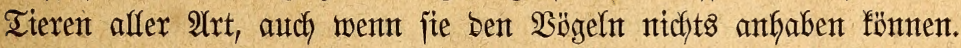

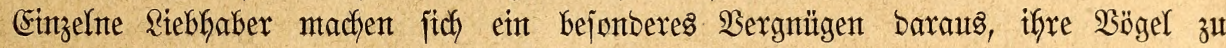

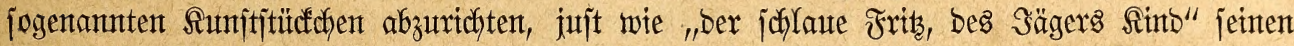
berïfmten Scumb \$antalon. Sch Gabe fein Berjtänonis für Derartige Bejtrebungen und

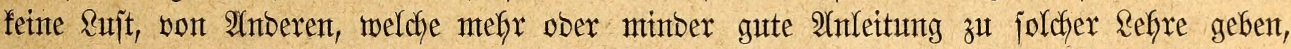

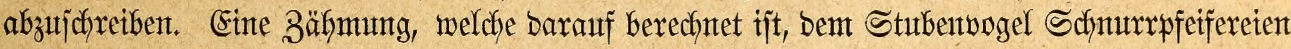
zu Kefren, ift mir in tiefiter Sele verfap̧t. Der $\mathfrak{B}$ ogel verltert im Säfige vfhnefin mefr

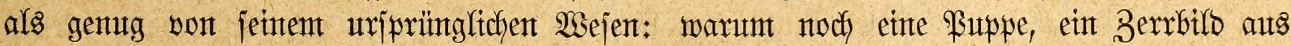

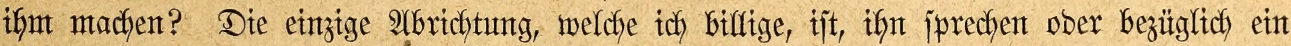

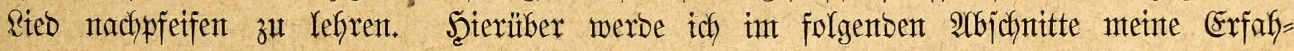

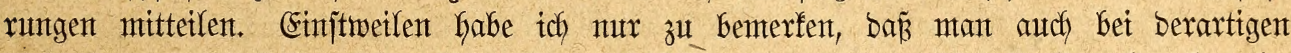

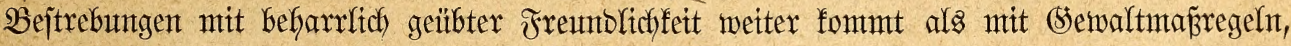

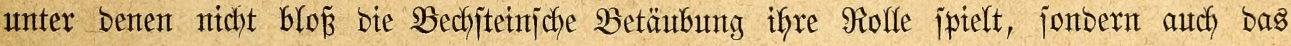
"Röjen ber Sunge", eine ebenjo unjuntge als untötige Suäleret, geïbt von gebanfentojen

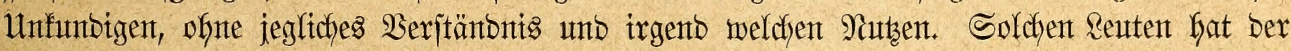
wahre Riebhaber entgegenzutreten, nicht aber jogenannte Refrent zu geben, welche fie boch

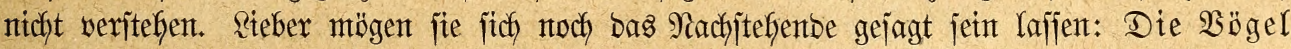
jind eble, verjtändige bejchöpfe and wollen verjtänbig behanbelt jein. In

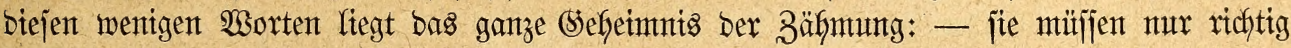
veritanden unt fortwährend behergigt werben.

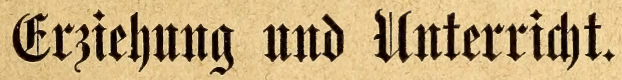

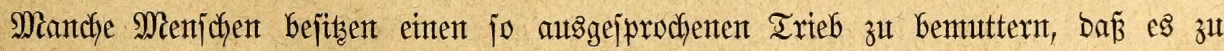

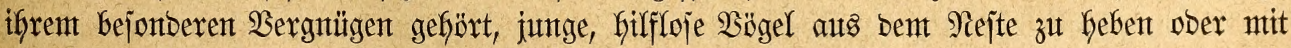

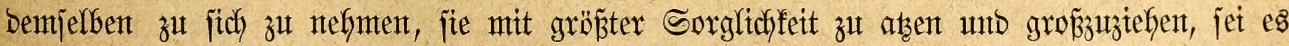

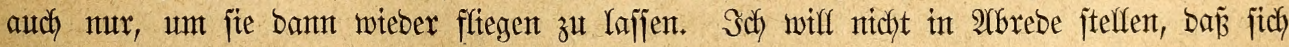
foldje $\mathfrak{B f l e g e ~ m e f r x ~ f u ̈ r ~ F r a u t e n ~ a l s ~ f u ̈ r ~ M a ̈ n n e r ~ e i g n t e t , ~ f a u t n ~ a b e r ~ e b e n j o w e n t g ~ v e r f e n t e n , ~}$

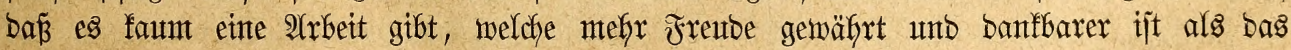

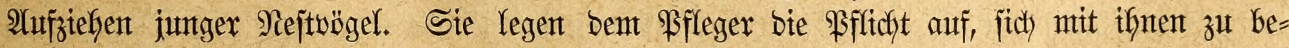
jchäftigen; man lernt mährento ber গiiftzeit mit ber Sonne aufiteken unto bas (sefüf)l erfreutenber Shjorge fenten, Da man vom 2lufgang bis zum Nitebergantg ber Sonne fich mit

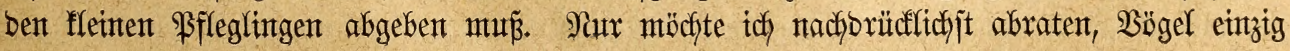




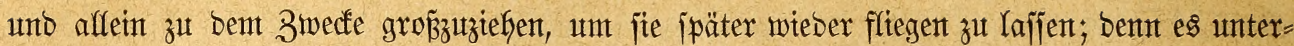

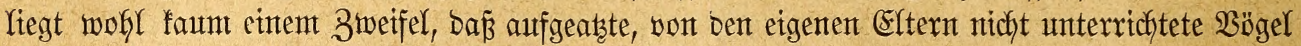

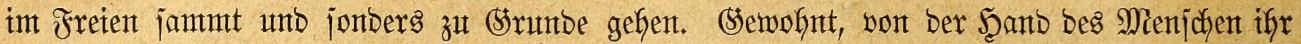
Brot zu empfangen, Gaben fie nidht gelernt, joldfes fich zut erwerbent und verfungern; im

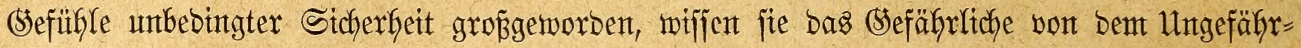
lichen nicht zu unterjcheiben und falfen ber eriten bejten fiake zum Dpfer; im Bimmter

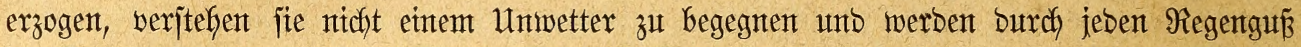
in Tobesgefafyr gebradyt. Wer aljo bas 2sergnïgen, Nejtbögel unter feiner Dbjorge grofswerben zu feben, fich bereiten will, möge fie audb bebalten ober aber jeine Pflegelujt unterbiücfert.

Für ben Siebhaber wirb bas von Einzelnen zmedfos auf fich gentommene Bejchäft

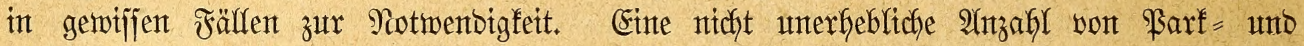

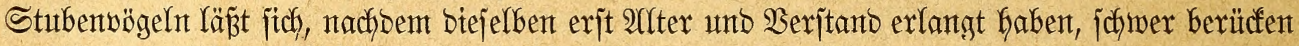

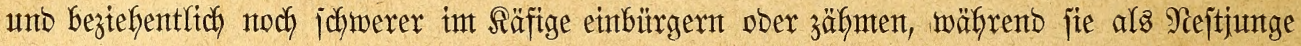
retchter zu erlangen und eher an $\mathfrak{B a t e r}$ und Siefangentenfoit gemöhnt merben fömen. Sogar

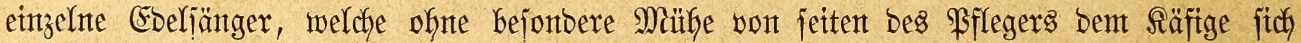
einbürgern, müffien unter $\mathfrak{H}$ mitänben von früfejter Sugento an auferzogen werben, went fie bejtinmten Zwecfen bienten jollen. Torkeit wäre es, fie als unreife Sunge in ber

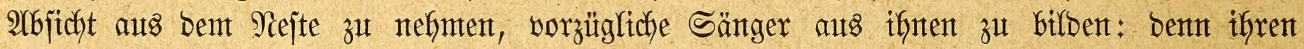
Naturgejang lernen bie im Freien gropggetworbenten ungleich leichter, beffer unto volljtänbiger als bie fïnftlich erzogenen; wohl aber erforbert bie albridgtung zum Erlernen ber von bem

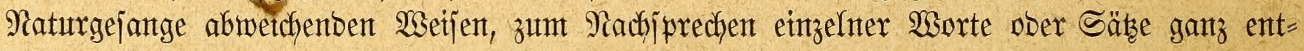

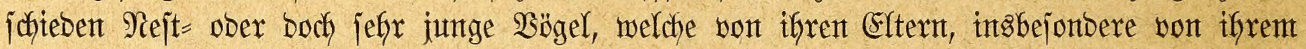
Sater, noch mentg ober gar feinten Unterricht genofjen haben. Das (Sejdjidf, Rejtoögel auf=

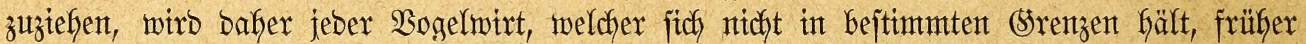
ober jpäter fïch anteignten mülfien.

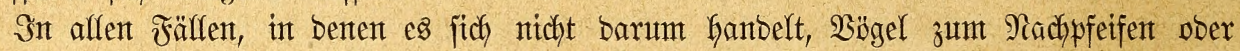

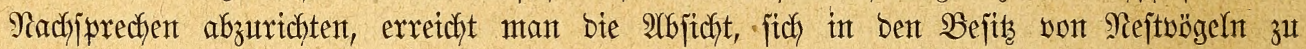

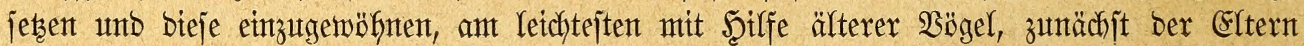
Der betreffenbent Sungen jelbjt. Die unbegrenzte Riebe ber allten zut ifrer SBrut erleidftert

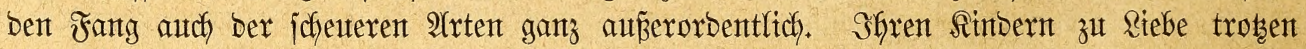

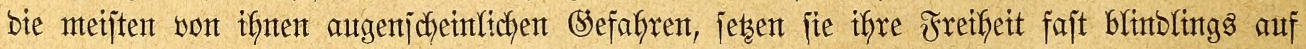

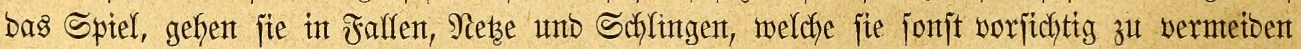
wififen, unt wenn wirflich eine Fangart an ifnen fich nicht bemährte, fallen fie einter anberen zum Spfer. 2łusinafmen, weldhe weiter unten nod) bejonbers erwäfnt werben jollen, gibt es freilich auth Giertn: einzelne Bögel, betjptelsweije bie son jefger in ber Regel faljeh beurteilten Iauben, werlafjent augenblidflich (Eier unto Brut, went fie fich gefäbrbet jeben, anbere putsen bie ifnen gejtelften Schlingen jefr gejhidft weg, nieber anbere werfen ben

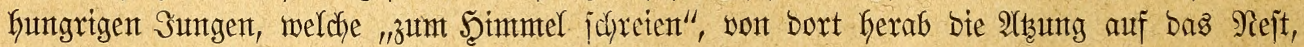
um bie brohenten Fallen zu vermetben; bet ber groken Miefrzabl aber ijt bie Echwierigfeit, fie auf bem Rejte zut fangen, einte faum nententwerte.

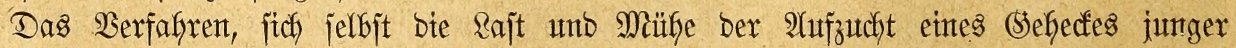

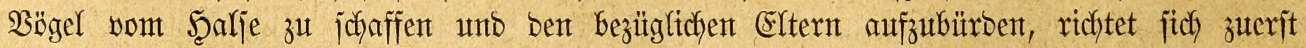

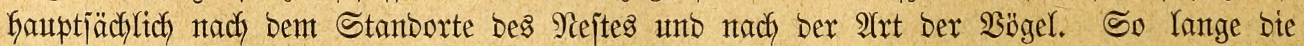

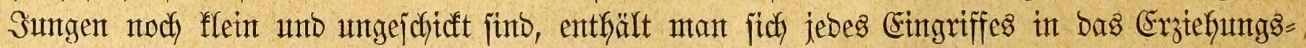

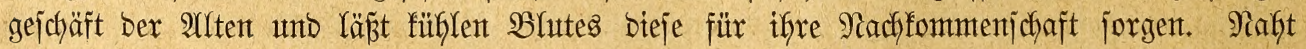

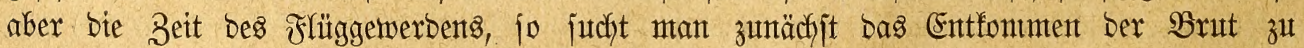

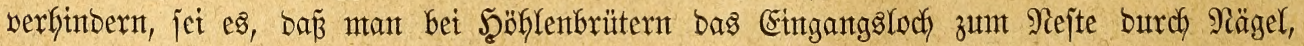




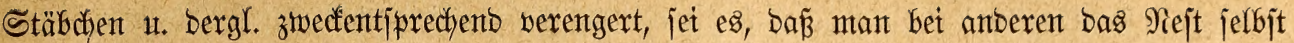

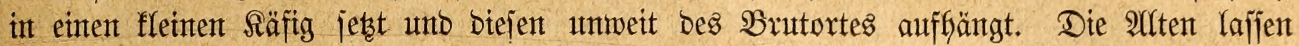

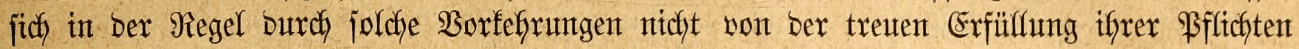

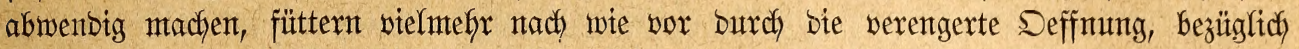
bie Sprofifen Des Räfigo fort ober fliegen in Yesteremt ein unt aus. WSenn man nicht

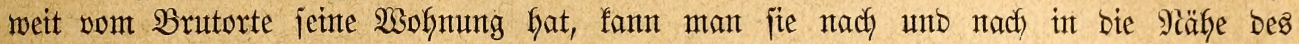
5̧aujes locfen uno zu rechter Zెeit wegfangen, went bies nicht ber Fafl, jeberzeit mittelz Des Fangbauters in jeine Seewalt befommen. Nuntmefr bringt man bie Familfe in einen

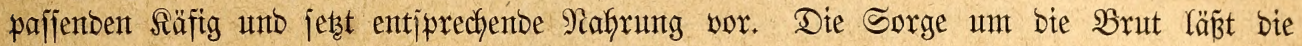

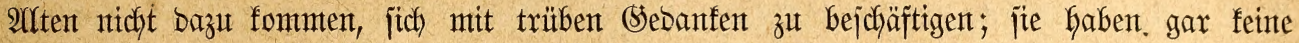

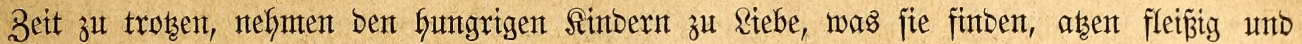
gemöhnen jich babei jellbjt an Stubenfojt uno Befangenjifaft.

Die Riebe ber alten $2 B ̈ g e l$ zu ben jungen bejdyränft fitch jeboch nicht affein auf bie

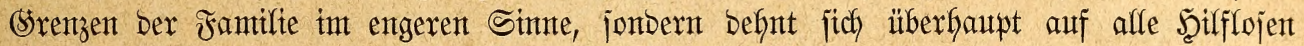

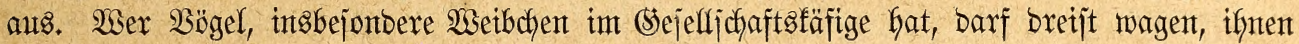

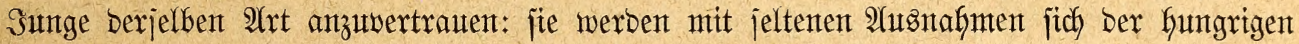

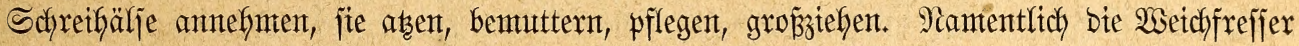

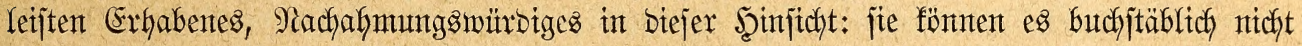

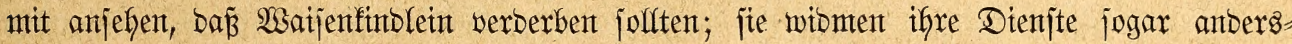

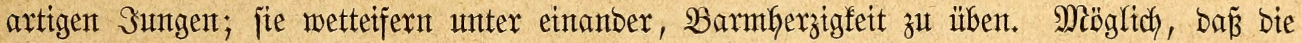

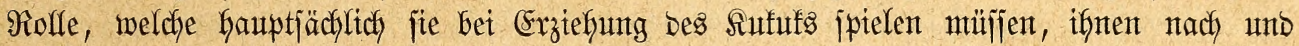

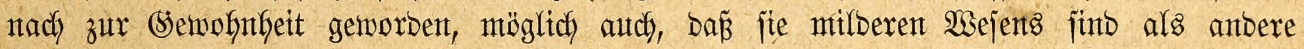
Sögel: jebenfalfs eignen fie fich am bejten zu

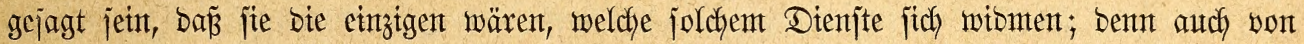

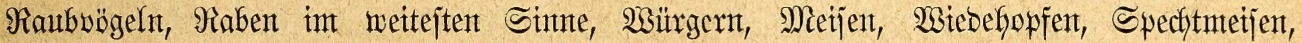

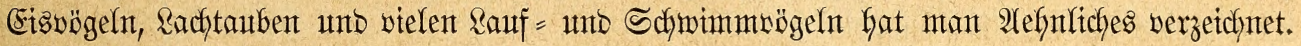

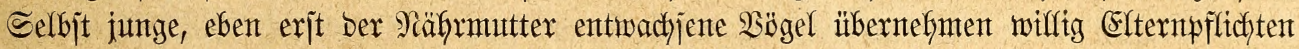
gegen jüngere iffrer 2 (rt ober gegen anbersantige, went fie beren Şifflojigfeit exfennen.

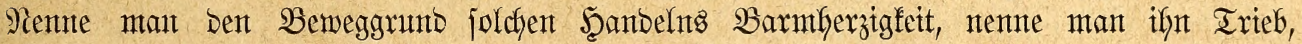
benumbere man bas (semüt, doer fajefe mant über "Snjtintt": Das Ergebnis bleibt basjelbe;

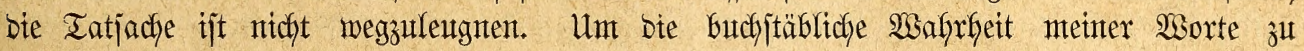
erfhärten, witl ich von ben sielen mir befannten $\mathfrak{B}$ eijpielent mur eines mitteilent, eine Beobactutung, weldye ich int vortgen Saffre madyte.

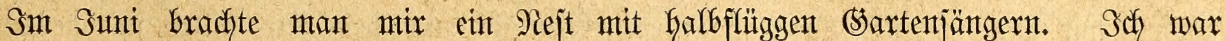

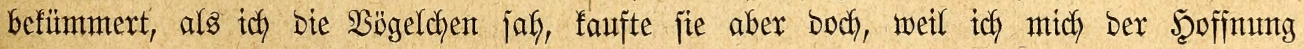

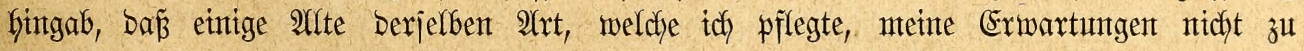

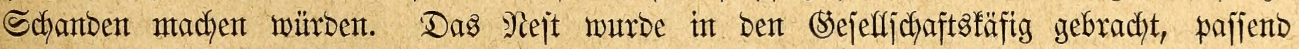

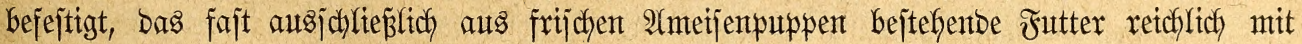

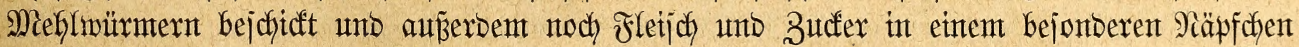

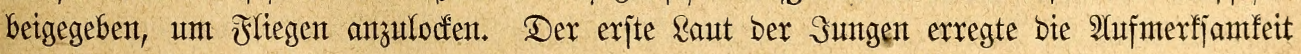
ber alten Sprachmeifter. Sie unfflatterten einige Mare Das Nejt unt begannen jofort

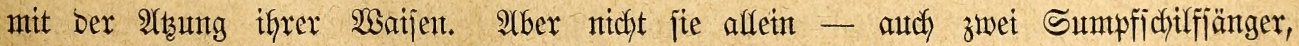

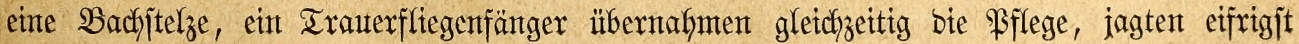

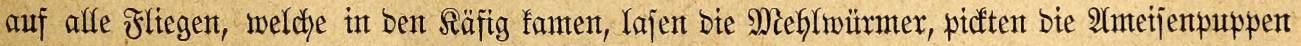

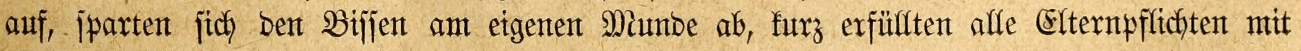

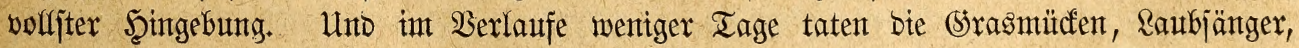

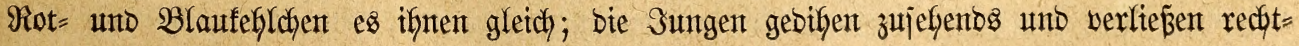
zeitig bas Niejt. 


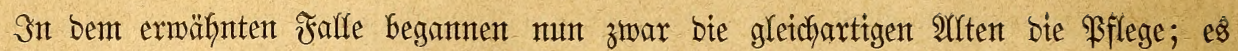

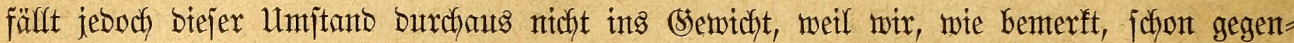

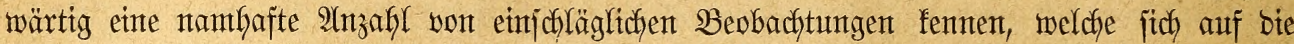

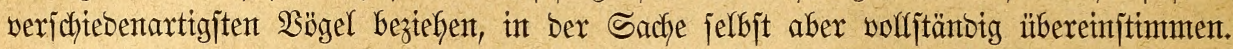

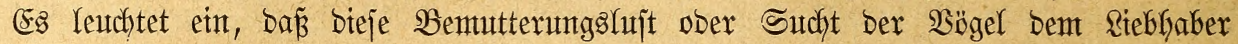

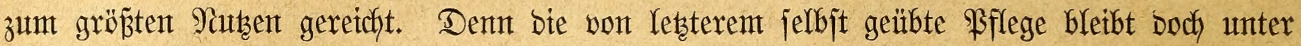

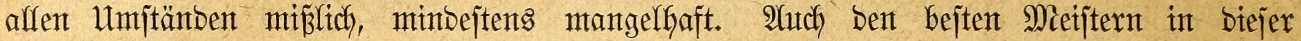

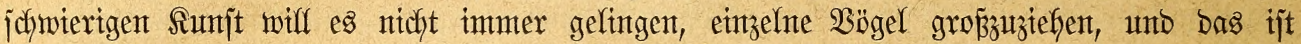

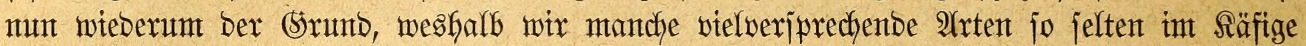

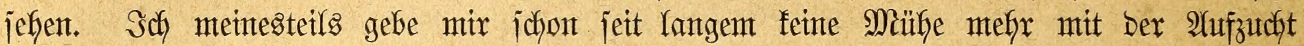

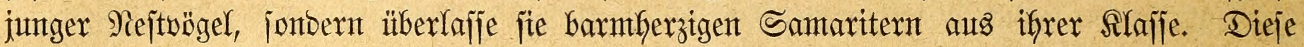

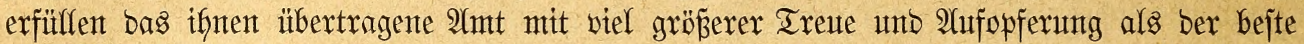

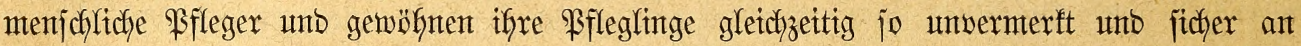

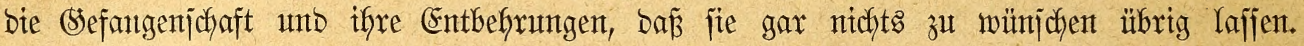

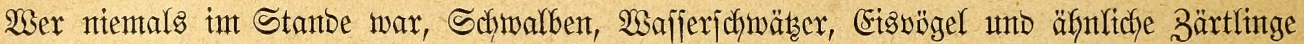

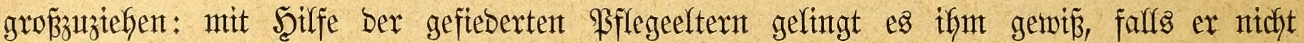

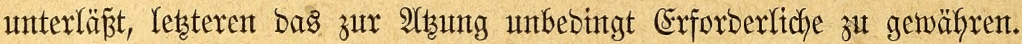

Snbeffen tritt an biejen ober jenen 20 gelwirt in einzelnen Fälfent boch auch bie Mot-

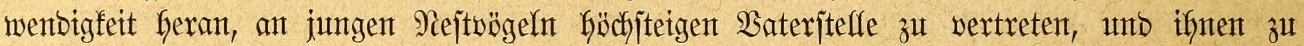

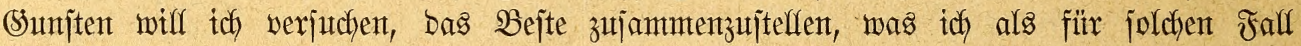

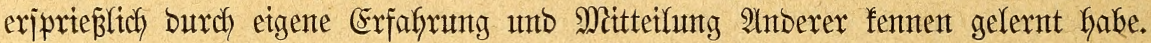

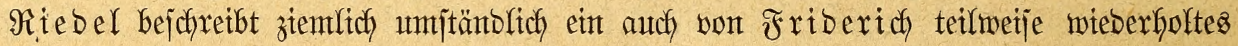

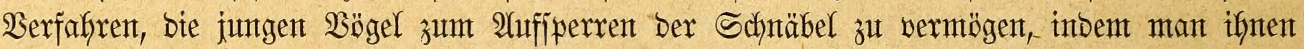

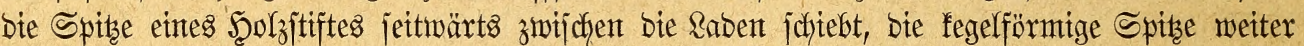

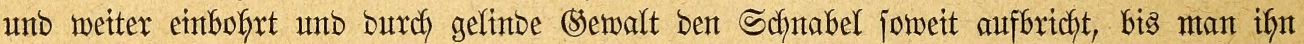
mit ben Fingern wollenbs iffnten fann. Das vorker bereitete Futter bringt mtan ben Sungen

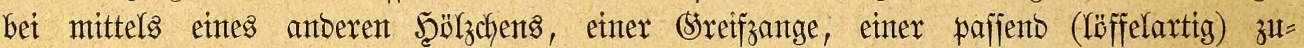
gejdynittenten Feberipule, eintes angefentdeten feinen \$injels, weldh leţteren Friberich und wofl mit Recht bejonbers empfithlt.

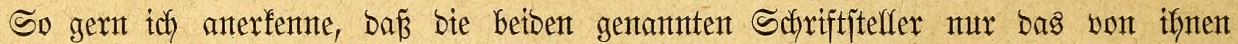

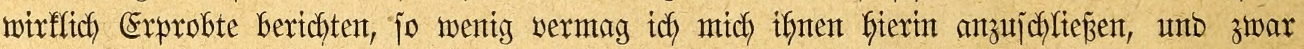
weil idh in meinen Freunben (sirtanner unb Stölfer Mieifter in ber fraglichen Sumit

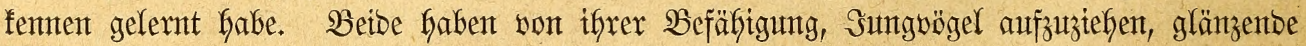

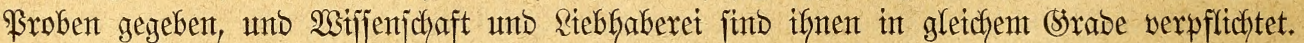

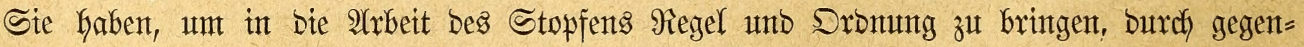
jeitiges Refren unto Rernen nach unto nach ein Serfafyren ausgebitlbet, meldyes fo recht

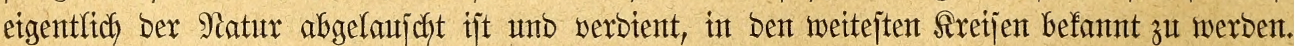

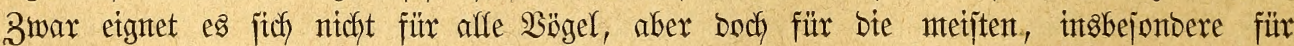

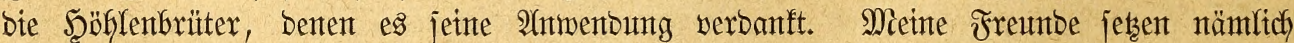

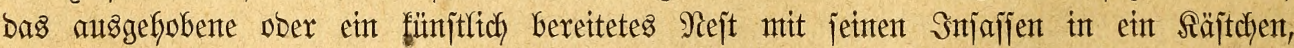

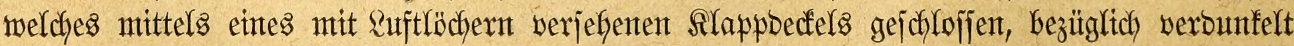
werben fautn. So lange ber Decfel gejd)lofien, fitzen alfe ruffig unt ftilf, fo wie er aber

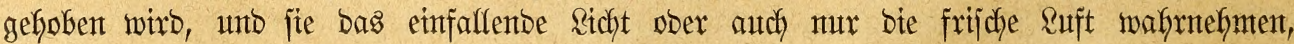

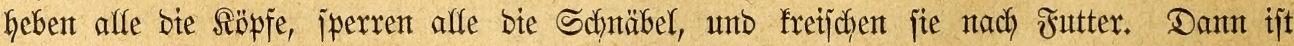
es natürlich ein Reidftes, ifynen mittels einer vorn etwas verbreiterten ober löffelförmig

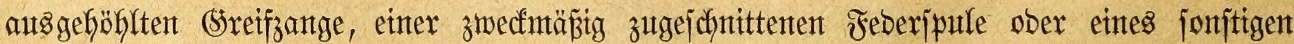

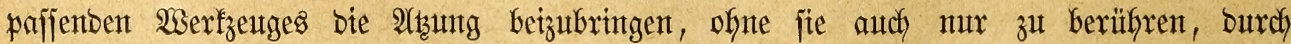

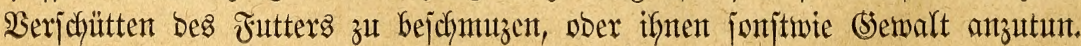




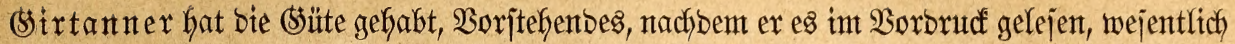

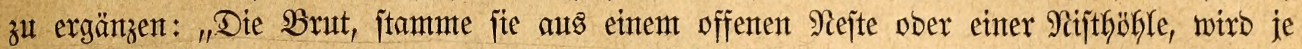

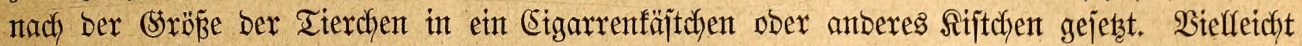
ift es bndf notwentig, zu Genterfen, bả man fierbei, wie bei ber

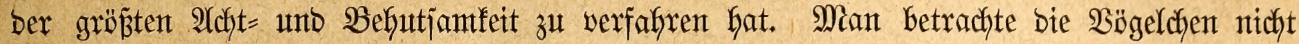
als Eptelzetg, jontoent als hodfbegabte Mitgejchäpfe, welche burch unjere Sdjulb hilfloz

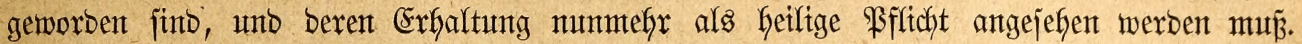

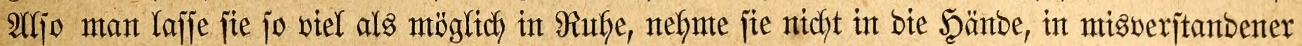

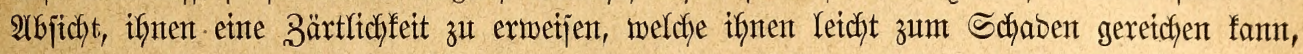

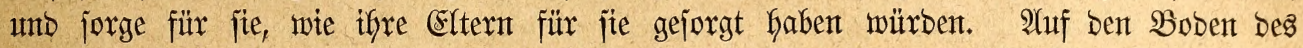

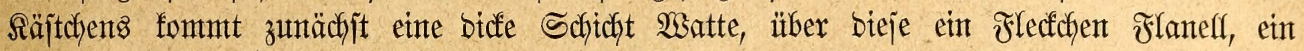

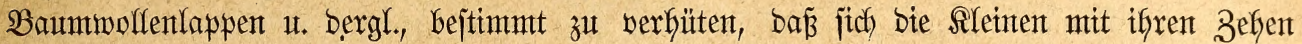

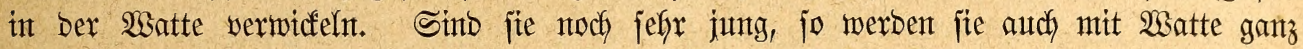

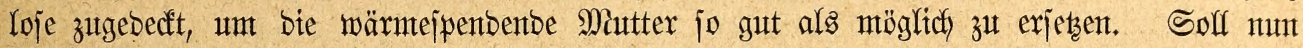

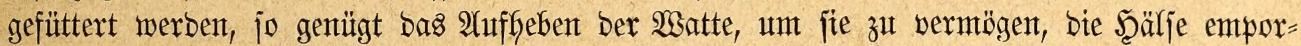

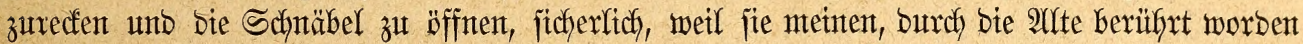

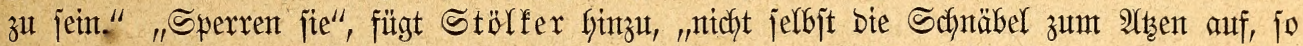

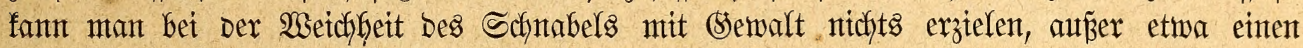

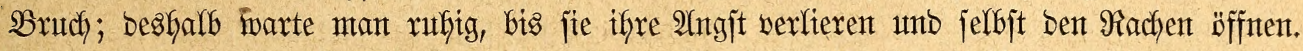

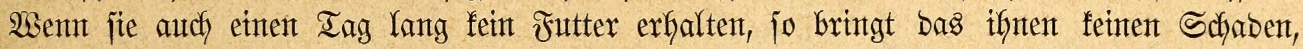

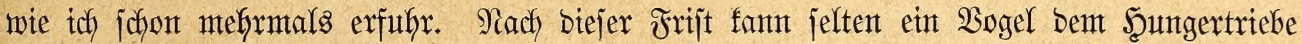

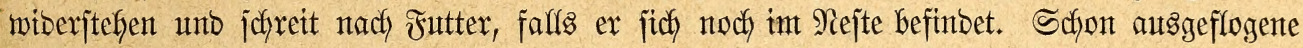
Sunge bagegen fint felten zum 2 urfiperren Des Sdynabels zu bringen und gehen eber zu (5rutulo."

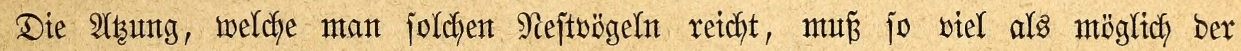

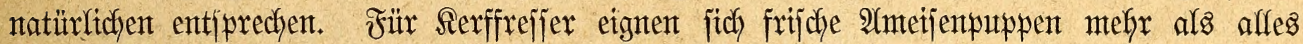

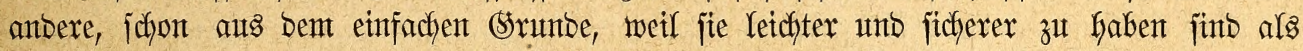

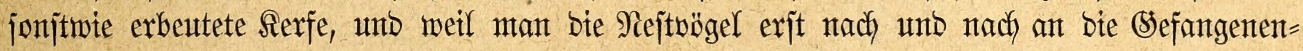

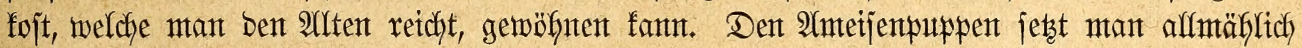
Sutarf, Fleijach ober Eibotter, aufgemeidyten Semmelgries und enblidy aud Miöfre zu, je

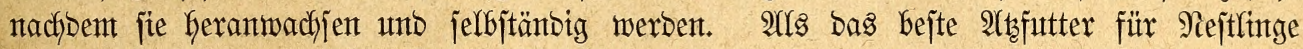

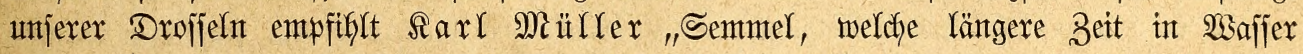
gelegen hat unb ausggebrüaft morben ijt, Dannit bie Seefe entfernt werbe, unb mun mit fübfler

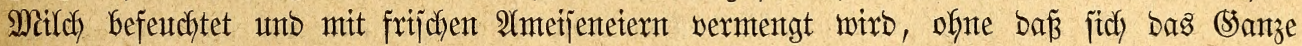

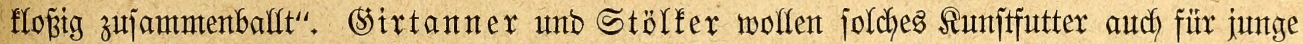

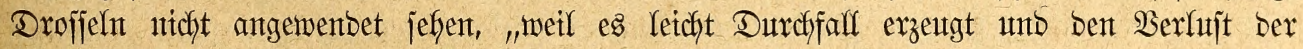

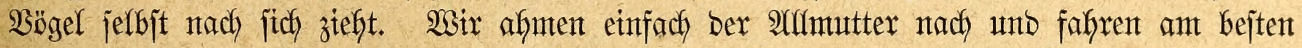

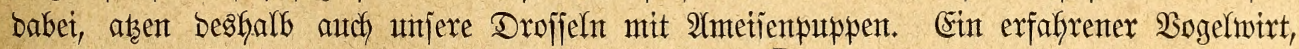

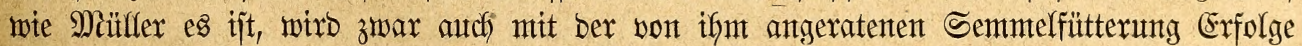

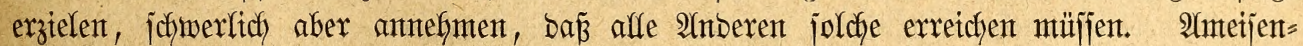

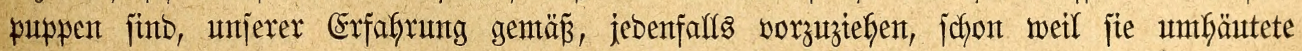
Sotbaflen erzetugen, was bet Süniffutter nientals ber zall ijt." Dent Samtenfrefifern reidght

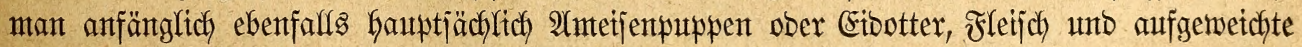

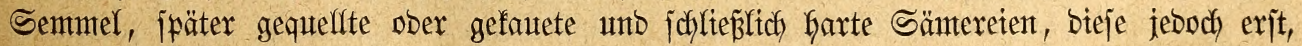

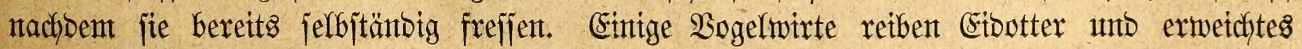
Mitchbrot zu gleidgen Teilen zujamment unb aţen zarte Santenfrefifer mit biejer Miijffung,

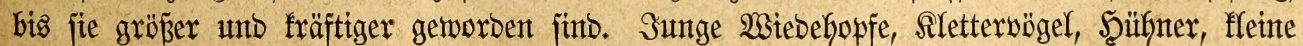

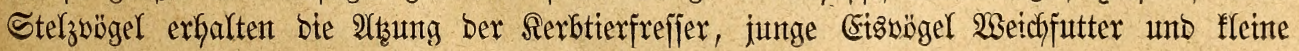




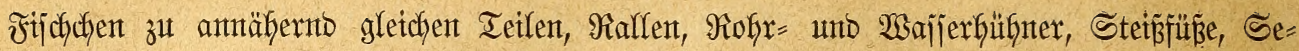

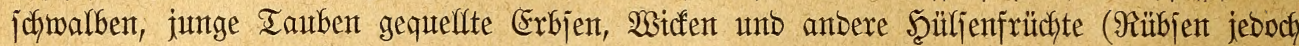

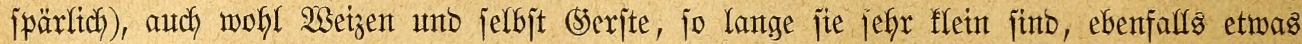

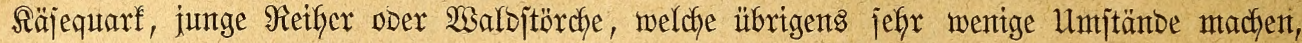

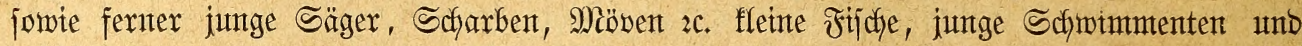
Willogänje das Futter ifyrer zafmen Berwanden, io lange dieje Sïtclein jüb, junge Taudsenten ein (semijich bon Fijch unto pflanzlichen Stoffen, namentlich Brot, Ietic) =

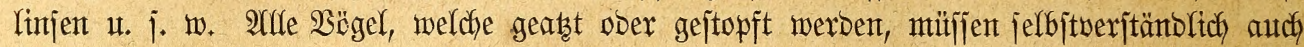
Wafjer zum Irinfen erhalten, Die fleineren einige Iropfen, welche mant ifnten mittels einer Feberjpule einflöß̈t, bie größeren mehr, ein jeber nach Bebürfnis, niemals zu viel, eher nody etwas zu wentg. Serbtierfrefjer bebürfen, jo lange fie einzig und alfein frijche âtmetjen=

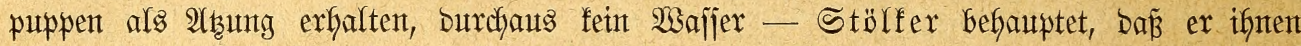

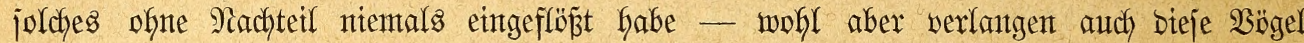
getränft zu werben, jobald jie anfangen bon bent Mitjeffutter zu frefjen. Sörner= und

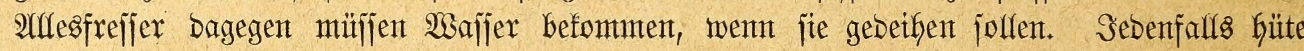
man jitch vor zu reichlicher Iräntung und Einnäjjung Des Sefteders oder Nejtes.

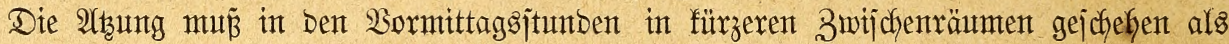

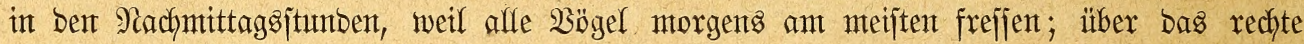

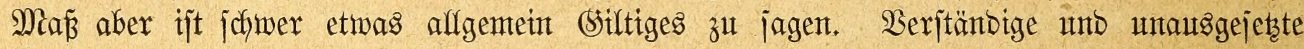
Beobachtung lefrt bald Das Rechte fennen und tun, näntlich bas Gungerige freijchen unt

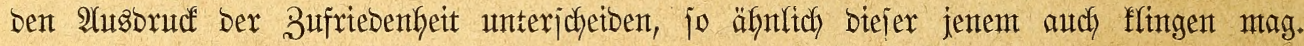

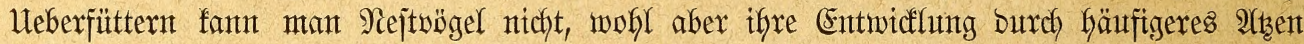
bejchleunigen. "Maan jei", rät (sirtanner, "weber nachläjïtg, noch ängjtlich pünttliç).

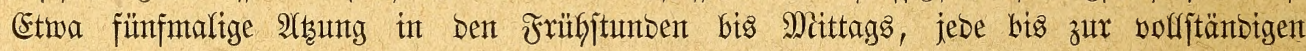

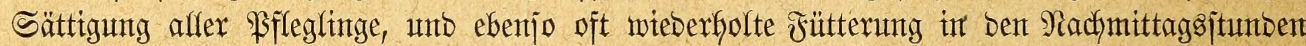
reichen jelbjt bei ben Ginfälligiten Arten solffomment aus. Wer über jeine Beit nach

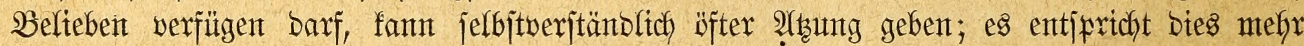

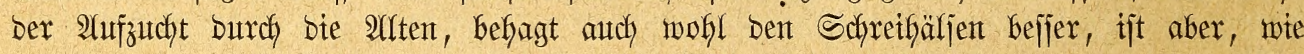
gejagt, nidyt unbebingt nötig und für Den $\mathfrak{B f f e g e r}$ ungemein zeitraubend. Bejonberes

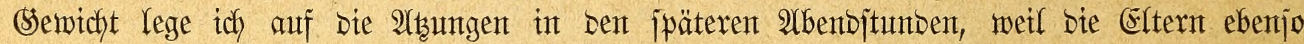
berfahren unb bie Nacht Dem flemen Sejintel immerfin lang genug werben mag."

Ebenjo wichtig für bie Erziehung Der Sungyögel wie bie Fütterung fint Wärnte unt

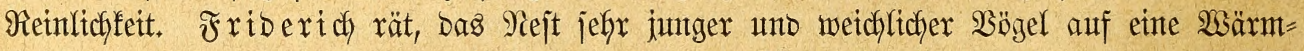

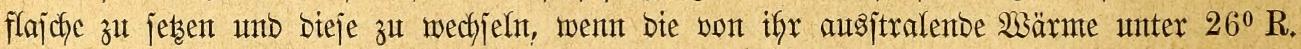
gefallen ijt: eine auf Diejem Wege hervorgerufene Erwärmung ber jungen Nejtwögel wirb aber, went man bieje in gejchloffenen Räjtchent erziefst, mux in jef̧r jeltenen fällen notwentitg werben. Das junge $\mathfrak{B}_{\mathrm{olf}}$ erwärmt fidh gegenjeitig, unb aud ber einzelne miro

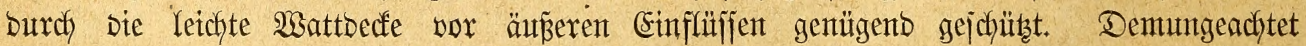

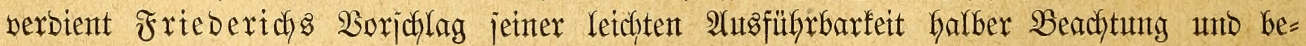

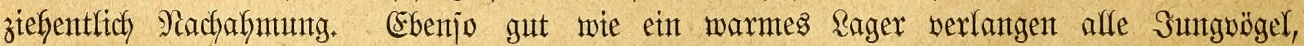

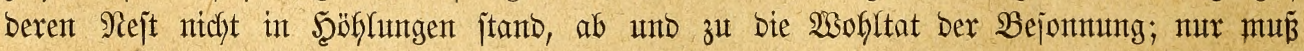
mant fierbet vorjicftig verfahren, unt fie weber zu lange noch in ber grö̈sten Iageshitze Der Sonne augjęzen. Den Intrat entfernt man mit berjelben Sorgfalt, wie bie Ertern es tun, und Gat bies audh feinte Sdymterigfeit, weil jie ifgn, fo lange fie fich wohl füblen, in

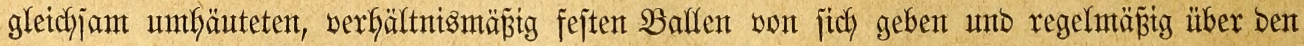

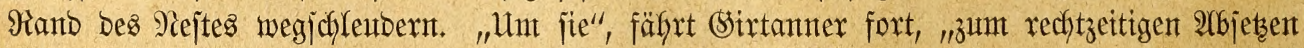

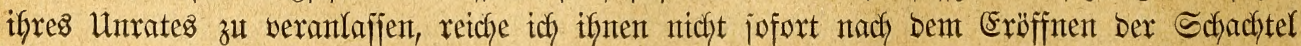
bie Nahrung, jobern reize jie erjt Durdh Sorbalten ber 2 tzung, mit ber fie enthaltendent 


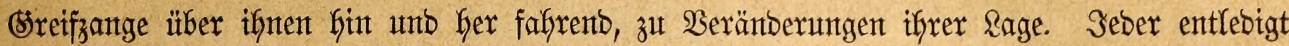

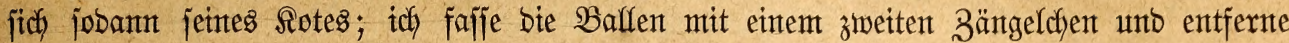

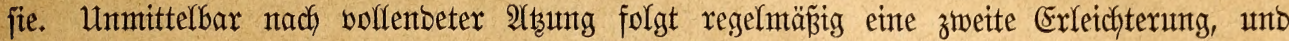
bas Nejt bleibt inmter rein."

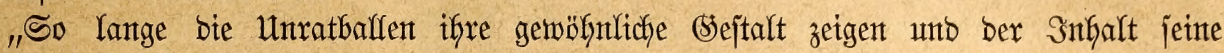

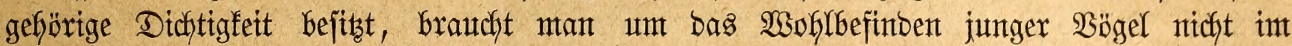

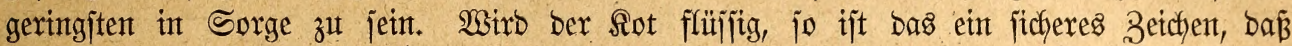
bie Tierchent nicht risftig. gefüttert ober zu fart geffaltent werben." WSent fich wirfflicher

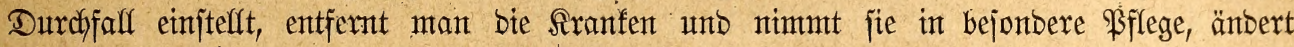

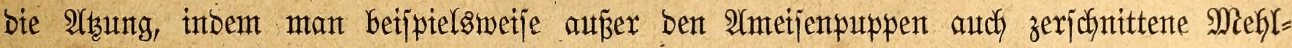

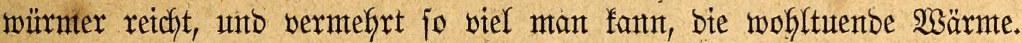

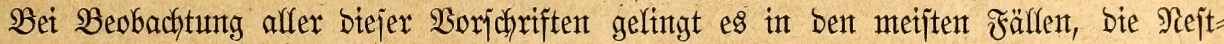

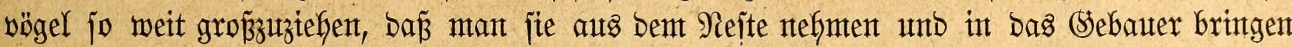

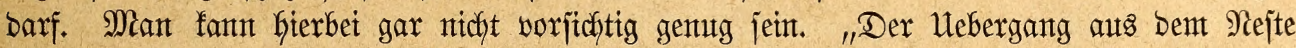

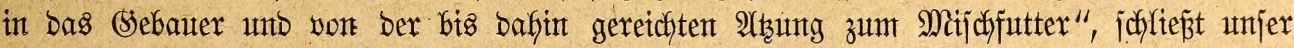

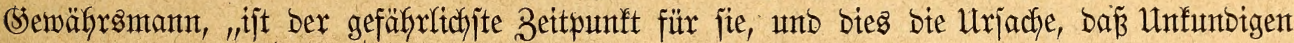

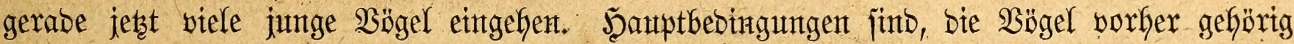

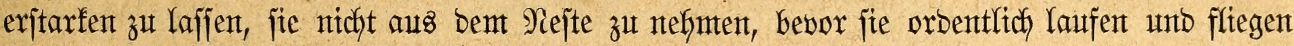

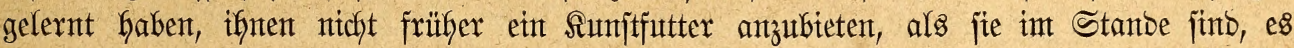

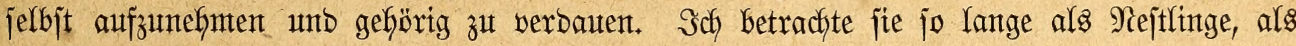

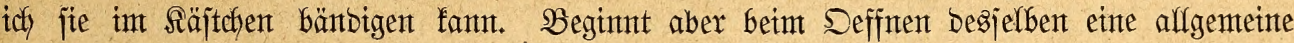

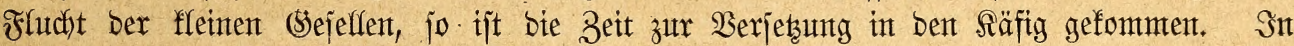

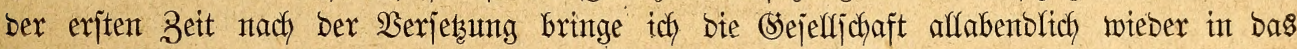

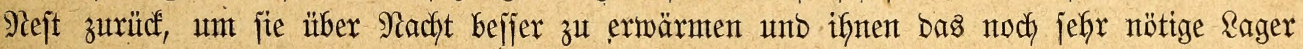

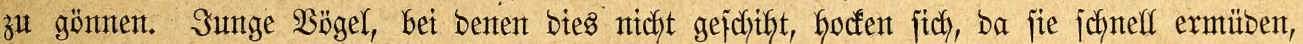
Derartig auf Den Sitjitangen Des Räfigz nieber, bẩ fie mit bem Ramme Des Brujtbeins auffiegen, brücfent biejen frummt, wertümmtern überfgaupt leidht an biejemt ober ienem Teile

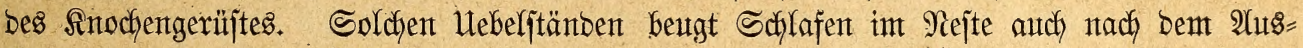

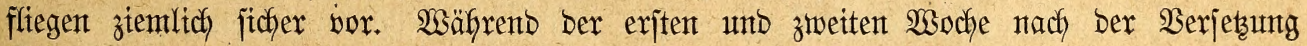

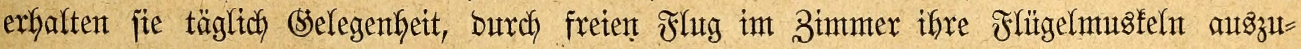
bilDen, fich gewanote Benegung, Fltrgfertigfeit unb - Selbjtänbigfeit anzueignen. Mit gröster Sorgfalt müffent insbejonbere eben flïğg geworbene Rletterbögel befgandelt werbent,

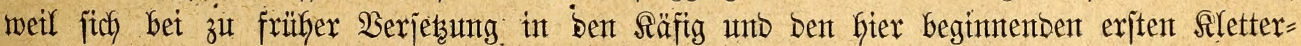

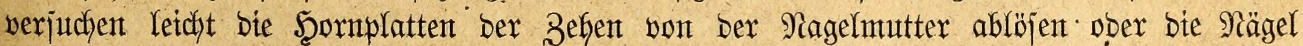

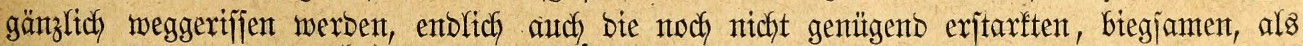

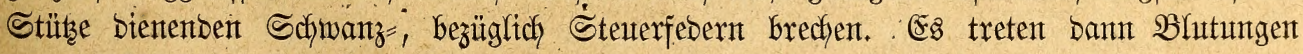

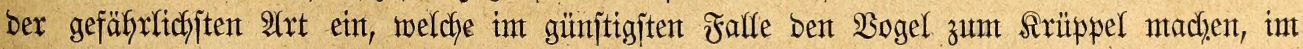

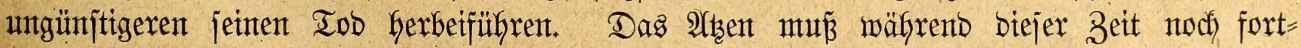

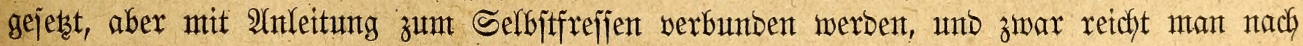

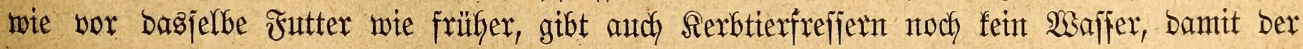
Uturat nicht vorzeitig veränbert merbe. Eine gemiffe 2futfeitung zum Selbiffrefijent ift aus

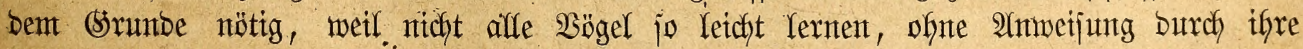

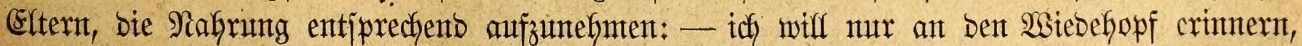
meldser geraumte Zeit braudft, bevor er fich bie Jertigfeit angeeigntet Gat, Miehfruürmer,

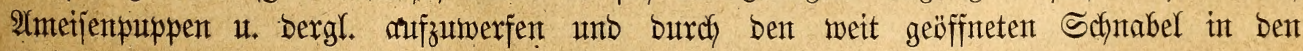

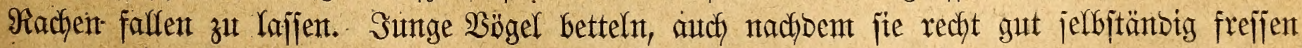

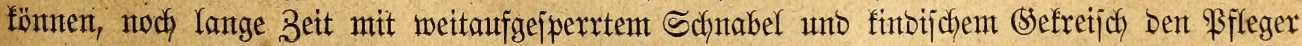

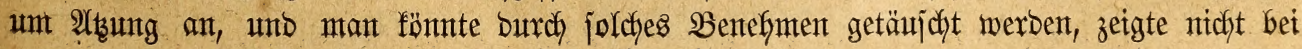




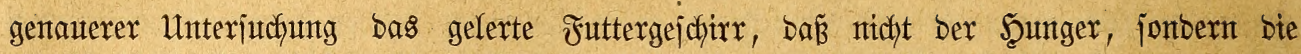
Macht jüfer SEemofnheit Die Triebfeder ifrer Bettelet ijt. Man Gelfe baher nur no es

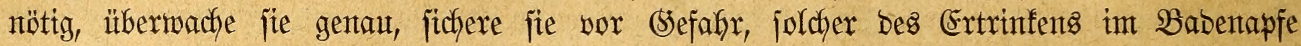
3. 2 ., unteritütze fie einerjetts, zminge jie anbererjeits zu jelbjtänbigent Scanbeln. 2affes Betajten, Berüfren ober Exgreifen, vieflectht unt jte von eintem Räfige in Den anberen zu bringen, unterlafje man auch jetzt nod, umjomefy als vorgehaltene ober vorgeworfente

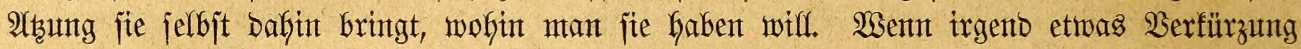
Des rebents eines Stubentogels bemirfen fant, jo ijt es biejes in Den nteiften Fäflen Durct)=

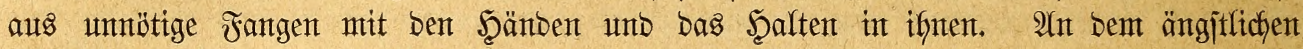

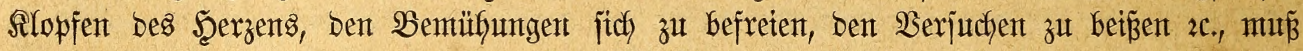
man mahnefgmen, wie unangentefm alfen $\mathfrak{B}$ ögeln biejes Umthanten ijt."

In einzelnen Fällen fant es von Widchtigfeit jein, bas (Sejchlectst ber jungen $\mathfrak{B}$ ögel

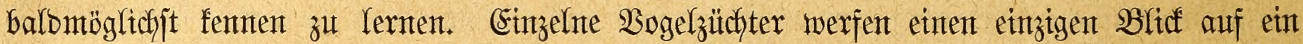

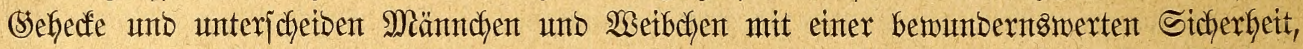
fie aber fint Metifer in iffer 3unft, wont benten es nux jefr wenige gibt. Der Minber=

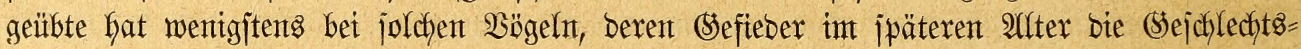
unterichiebe befuntoet, ein einfaches Mittel in ber Şant, fich balomöglichjt alfer 3weifel zu entichlagent, inbem er an joldyen Stellen bes Seftebers, welche ipäter bie bezeidynente Färbung erlangen, einige Febern auszieht unb Darauf achtet, wie jie nachwachjen. Entgegengejetzten Falls, aljo bet allen Bögeln, weldhe auch als ermachjene in beibent (sejchlechtern gleich gefärbt jint, bleibt, um ficher zu geben, nichts anderes übrig, als bie ganze Sbrut jo lange zujammen zu Galten, bis bie Miänndyen mit ifrem eigentfichen (sejange beginnen, bezüglich ihre Borjtubien beendet Gaben.

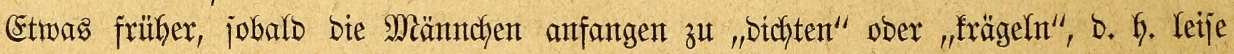
zut zwitjchern, ijt bic Zeit gefommen, in weldher jie einten bejtimmten Bejang, eine Weije Doer Worte ant bejten behalten und am leichtejten machpfeifen ober nachahmen lernen. Wex mut \&ujt hat, die geeignetiten unter ifnen zu lehren, mag vor allem zunächjt bebenfen,

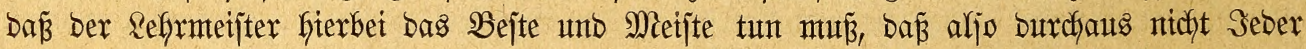
fiterzu taugt, gute Bogellehrer im (Segenteil jujt eben jo jeltent jüb, als tüchtige Sintberlehrer.

Heber bie Rebre Der als Rejtjungen gefangenten unb aufgezogenten (Simpel, weldse ebenjo auch für 2imtjeln, anbere Drojjeln, Stare, Flötentögel, 2Bürger, angemenbet werben

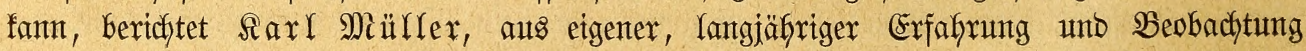

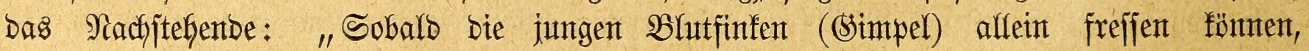
merben jie in Unterridyt genommen. Der Sefrmeijter pfeift ifnen bas Riedchen vor. Setzt bürfen fie noch in einer Stube bereinigt jein. Sobald fie aber anfangen, bie Melobie nachzupfeifen, müffen fie einzeln verkängt merben unb zwar jo, baj̃ jeber $\mathfrak{B}$ ogel auf fich und jeinen Refrex bejabränft ijt uno feine auffallenten Stimmen anderer Bögel ober gar

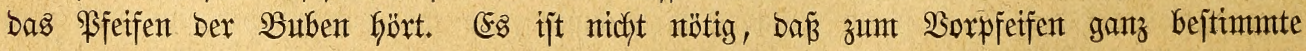

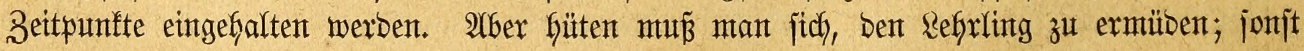
wirb ex unaufmerfjam und emtpfängt ben Reforer nicht mit ber geförigen siebe und bem

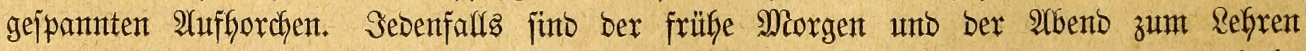
bejonbers geeigntet. Ein zu helfer Blats ober ein Stand, von weldyem aus bent Bogel ein meiter $\mathfrak{B l i c f}$ ins Frete gejtattet wirb, taugt nicht: ein fitilles, büjteres Ecfchen ijt immter ant förberlichjten für jeine jugendlichen Stubien. Reije, wie bas SEeztwitjcher bes jeiten Siejang einübentben Wilbfangs, beginnt auth) bas Stubium bes jungen, Yernenten Bhlutfinfen. Dent es ijt nicht mux bie Mielobie, Deren Bortrag ifm Schnterigfeiten bexurjacht, jondern es bilbet jich auch nach und nach erjt ber Ion an jich aus. 2(nfü̈nglich entbefyrt biejer ber Sidjerbeit unb Des Silanges. Der Sortrag gleidyt einem johwanfenben Unthertajten. Das natürfiche 


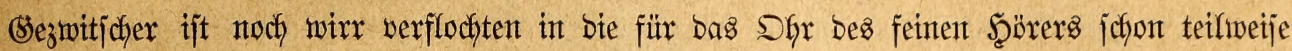
fich) Kerworkebende Mielobie. Smmer mefyr rumbet bieje aus bem (Sejtaltlojen jich ab. Eines Iages extönt bie erjte Strophe Deutfich, aber immer noch, wie es jicheint, ängitlich

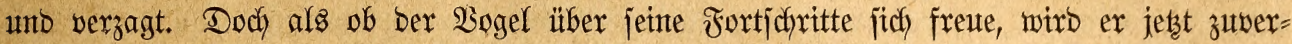
fichtlicher unt lauter. Ein Beitpunft ijt hiermit eingetreten, in melchem ber junge Stubent

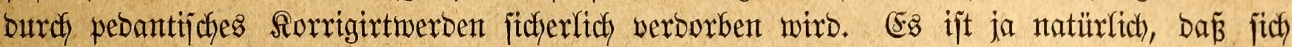
zunächjt ein Ieil und weiterfint exjt bas (sanze jeinem (sebächtnifje einprägt, unto mit biejer Eimprägung ftimmt genau bas Wiebergeben itberein. Er trägt aljo bie erjte Strophe wor, Gält inte, wieberholt biejelbe unb läß̈t viefleidft audf fdjon ein par Iönte ber nächjten Gören. Wenn jetzt Der Borpfeifer mit Dex zmeiten Strophe beginmen ober ba fortfahren mollte, two ber $\mathfrak{B}$ ogel jtehen geblieben ijt, würbe biejer in ber Folge nicht das sieb in einem నuge autsfüfren, jonbern jebesmal nach Bollentung ber erjten Strophe eine Bauje machen ober gar von vorn anfangen unb nach abermaligem 3̈̈gern erjt bie Mielobie zu Enbe bringen. 2In jeber Stelfe, two man ifn auf bie oben erwähnte waetje zurechtfügren wollte, würoe jich ganz gemiź stejer Mangel einjtelfen und aus bem Refrlinge niemals ein

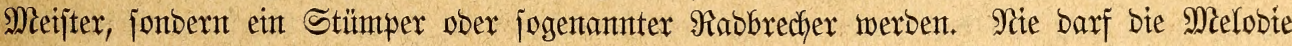

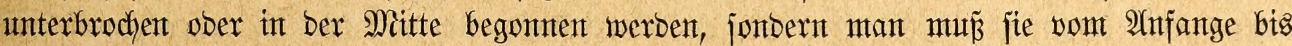
zu Enbe burdyfeifen. Die einzelnen Sdhwierigfeiten übermintoet Dann ber Bogel von jelbjt.

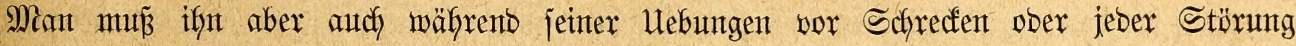

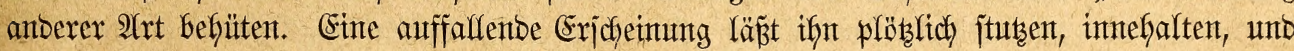
jobald bies öftex jich mieberbolt, gemöhnt er bie Untugend bes albjebents fich an, wiro irre,

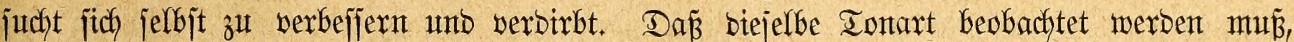
werjtefyt fich won jelbit; wer baher ben Ion nicht genau zut treffen weiz, hat fich ber Stimmgabel zu bebienen. AYtch Darf bie zu refrembe Melobte in feiner weije eine extreme Rage haben ober burdy kejonbere \$ajjagen allzugrope Schwierigfeiten bereiten. Ein einfaches furzes in mittleren Tönen jich benegendes sieb ijt immer vorzuziefen."

Mandhe Refyrmeijter bebienen fich zum Unterricht ber Sogelorgel; weldhe ben einen

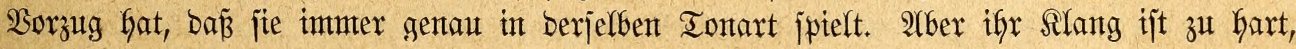

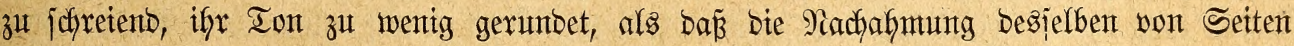
bes gelefrten $\mathfrak{B o g e l s}$ befriebigen fönte. Ungleich) bejier wirft bie Flöte, objchon audf fie nicht verglichen werben barf mit bem einfactjiten und natürfichjten Werfzeuge: bem Mande Des geübten Refirmteijters. Alber jelten mur finbet man einen Simmelzüdfter, meldyer entjchieden rein pfeift. "Es hat", jagt Mi üllex, "mit bem richtigen \$feifen eine eigente Bemantotnis. Fein gebilbete Majifer pfeifen, ofne es zu merfen, zuweilen nicht ganz rein, wäfhrent fie

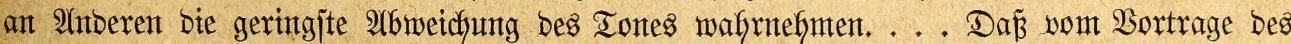

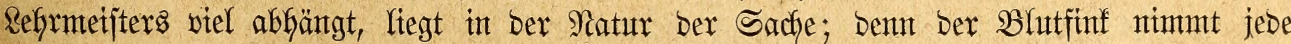
Tugento ober Untugent besjelben an, unt im alfgemeinen fant man alferbings nur jagen,

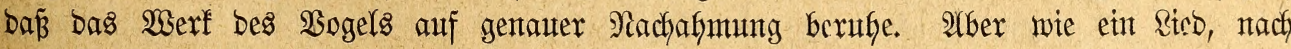

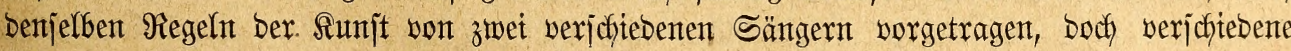
Winfing herworbringt, weil ber Eharafter ber Stimmen verichteben ijt, jo finbet etmas Berwanbtes, wenn auch in weit geringerem (Strabe, bei ben befieberten Sängern ftatt. Unter ben bejonbers begabten Blutfinfen gibt es joldhe, welche zwet sieber volritänbig

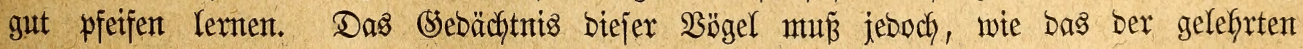
B̧lutfinfen überfhaupt, von Beit zu Beit aufgefrijdht merben. Die Maujer ijt für

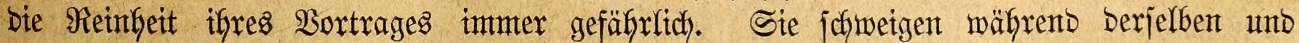
vergeffen in Folge beffen einzelne Ieile ber exlernten Weijen. Maan pfeift ifnen beshalb täglich mieber vor. Dies barf aber nur in ber einmal gelefyrten urjprünglichen 2 frt gejcheben,

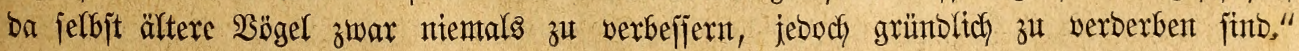




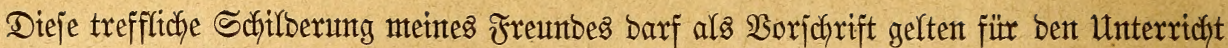

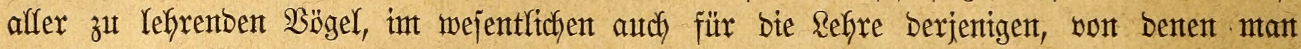

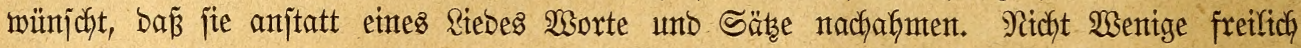

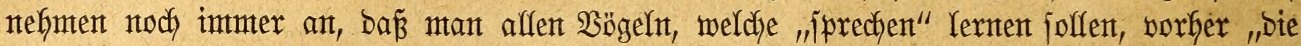

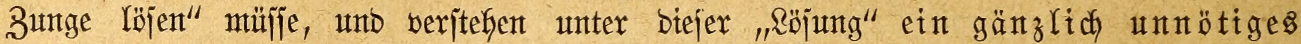

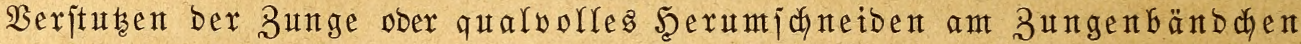

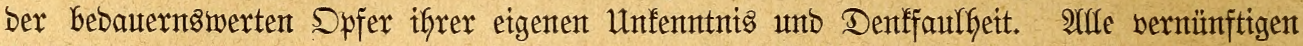

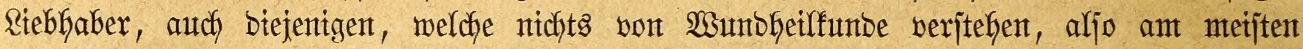

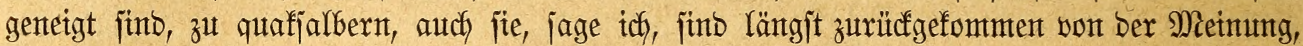

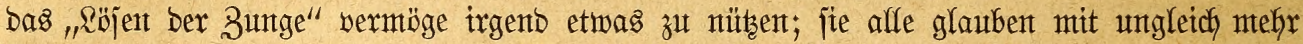

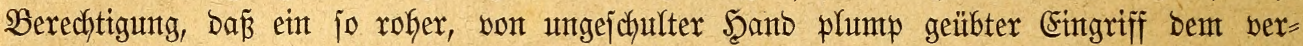

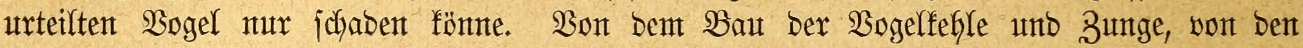

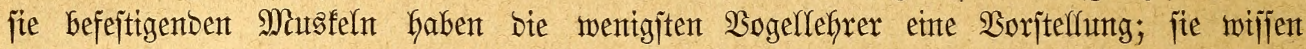

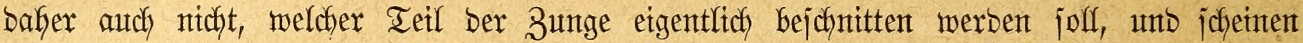

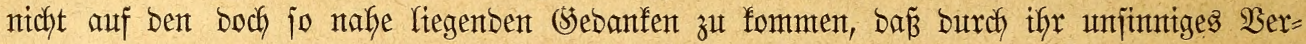

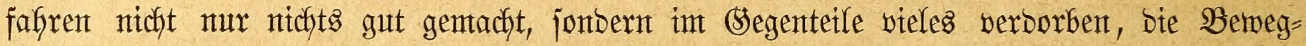
Yichfeet ber Bunge int Gohent (Srabe beeinträchtigt merben fantr. 2tbergläubig greift Diejer

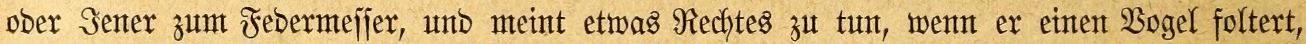

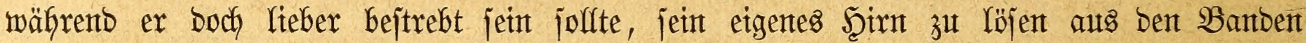

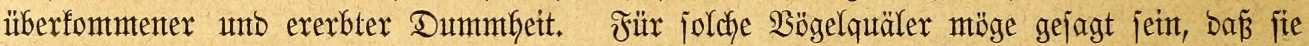

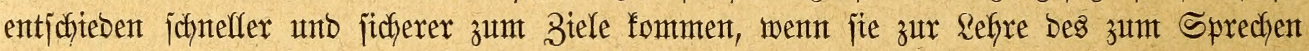

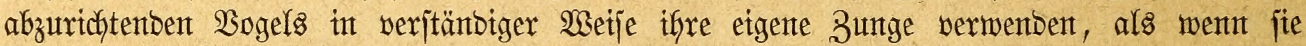

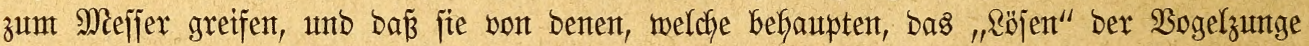
jei erforberficd, einfach belogen worben fittb.

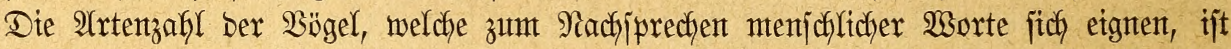

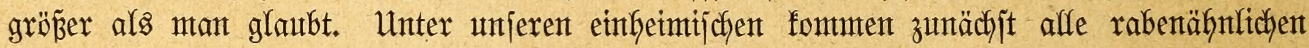
unb ber Star in Betradyt, unter ben fremblänbijachen ftefhen bie Sittiche in tweitent Umfange,

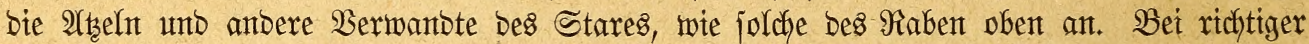

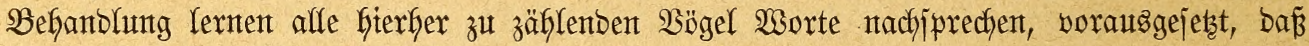
fie in ifyer Sugenb in bie Refire genomment werben fönnen. Einzelne \$apageient unt der

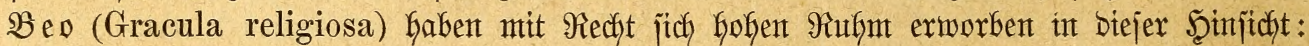

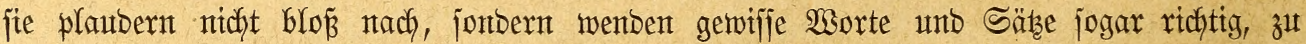

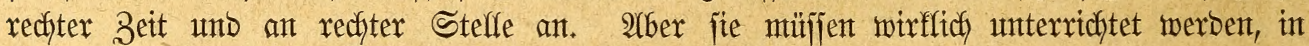

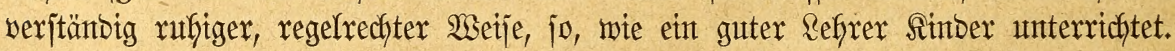

Wie unter ben Mienjchen, finbet man audd unter ben Bögelf begabte unto minber begabte. Mit Yetzteren gibt mant fich oft vergebliche Miühe, erjtere Iernen jpielend, umt jo

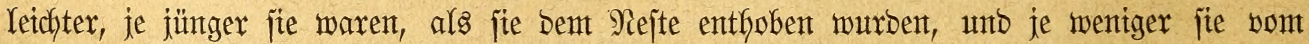

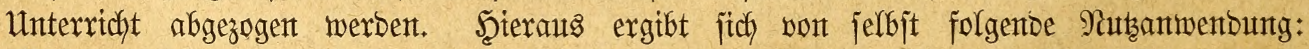
Mian wähle zunt Unterridht nux jefr junge $\mathfrak{B}$ ögel, womöglid Männdyen,

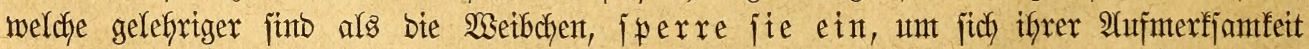
zut verjichern, und Galte fidh won Mithelfern frei, b. Ko. unterrichte mur jelbift oder

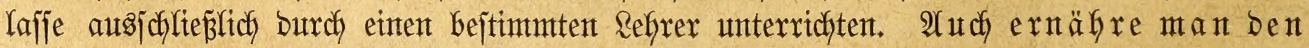
Wogel gut, füttere ifgn weber zu bürftig noch zn fett, weil er jonjt reicht ben Mut ober Die Rujt zunt Rernent werfiert. Dieje 2 Sinfe Gat jchon ntein 2 ater gegeben, unt zwar nadh eigenter, Yangjäfriger Erfafruttg.

Bevor man afjo mit ber \&efre beginnt, muß man fich bie Bemogenfeit, bie ₹reunbjdyaft

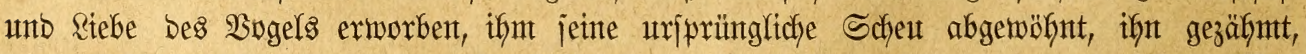
feiner früferen (Senofienjchaft entfrembet Gaben. Nammefgr berfährt man, wie folgt: Mant 


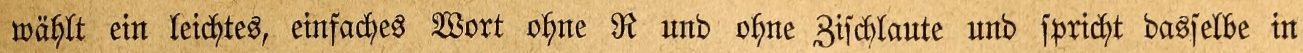

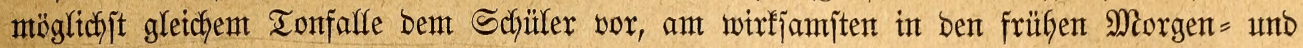

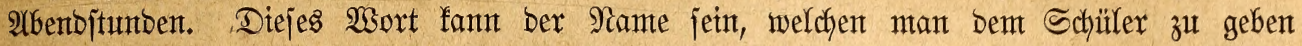

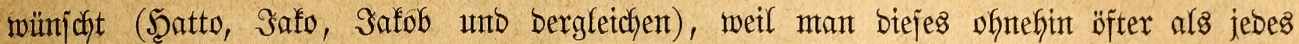

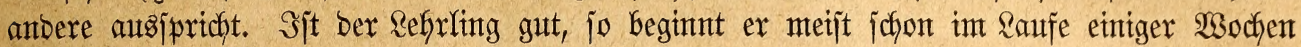

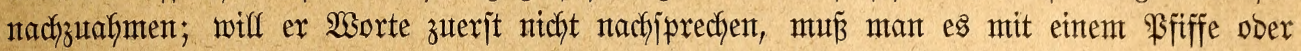

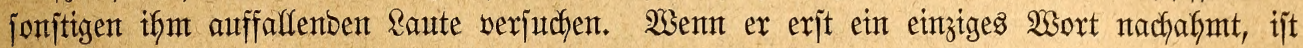

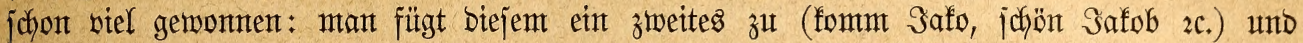

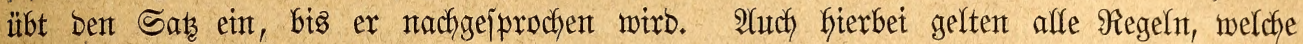

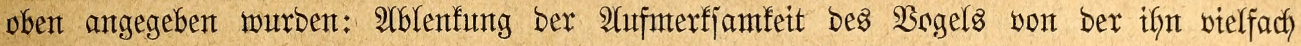

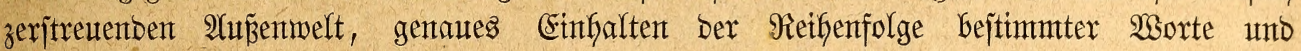
Sä̉ze, imunterbrochenes Einüben unt beharrfiches WSteberfolen, bis er affes recht begriffen

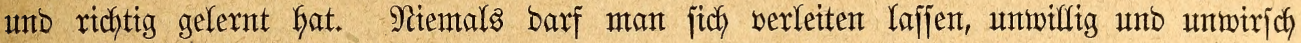

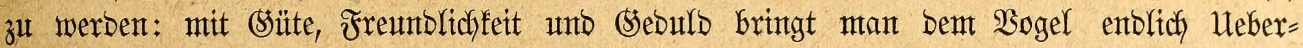
rajdentbes bei, mit semalt wenig ober nichts. Spridgt er bereits ntefrere 230 orte uno

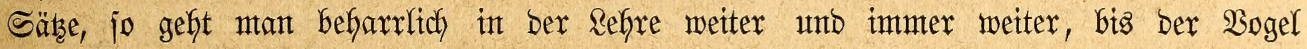

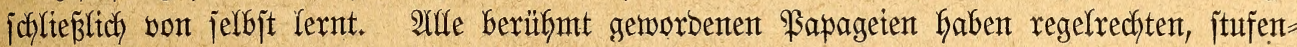

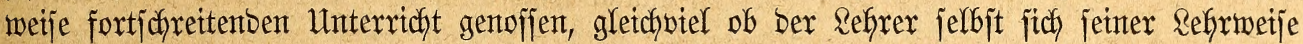
betwuşt war ober nidht. 2Ulte Sunggejellen find bie bejten Refrnteifter, alte Sungfern tautgen

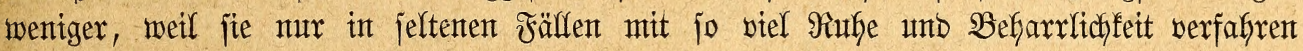
wie jente, für weldhe ein foldher $\mathfrak{B}$ ogel oft bas einzige $2 B e j e n t$ itt, an weldhem bie ganze Sele

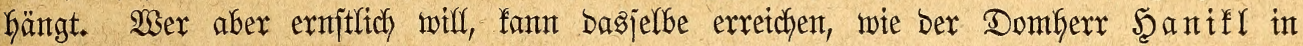

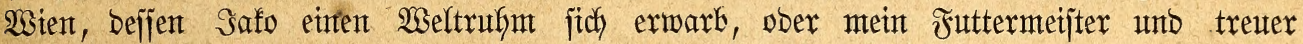

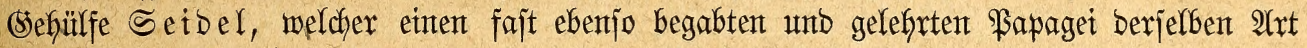

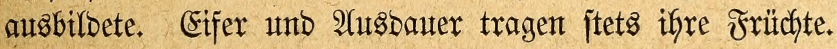

\section{Empfanta Mtid Der/ando.}

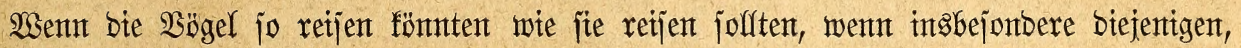
weldhe aus überjeeijdjen Ränbern zut unts gelangen, unterwegs jorgjältig bebient, mit $\mathfrak{A} u \tilde{f}=$ merffjamfeit gepflegt würben: wir Gätten affe, welche überhautpt in Jrage fonmen fönnen, idłon längjt in unjeren Räfigen unt Fluggebauern, währent wir uns gegenwärtig noch

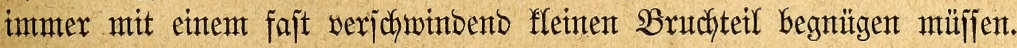

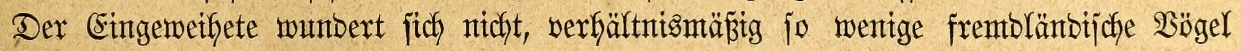
auf bem europäijichen Marfte zu jehen, jonbern im Segenteile eher barüber, Dá̉ ifhrer noch is viele bie Entbefrungen und Reiben aushalten, welche ifgnen Unfenntnis und faljde Sparjamfeit aurier ben notwendigen ober bodf entjdyulobaren Bejchwerben ber Reije auf=

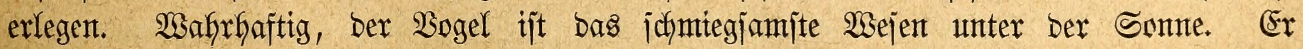

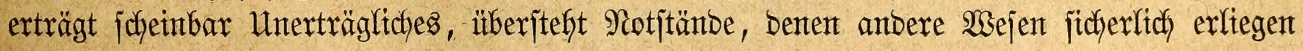
würben, unto vergiß̄t Trü̈bjal uno Hngemadh, jobald jie vorüber.

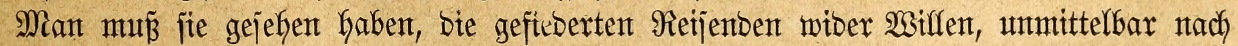

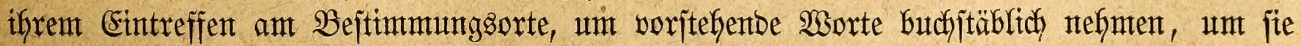

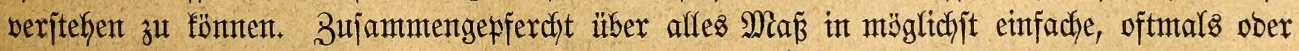

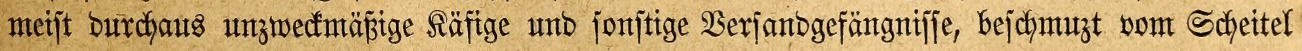




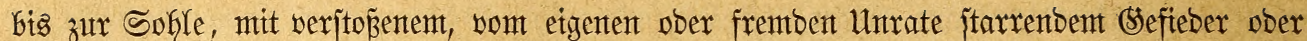
aber teils, ja jelbjt gänzlich feberlos, jtinfent, abgentagert, halblafhm, fur = unto flïgeljchwach, leiblich und geiftig ermattet unb niebergebeugt: jo fommen jie an - wenn nicht alfe, jo body Diejentigen, weldye nithyt von geïften Seänblern ober Sermittlern verpadft unto begleitet murben. Biele lafjen fidh ntidft ober faum noch erfenten, jo hat ifnen bie Reije mitgeipielt; anbere ermedfen nicht einmal bie Şoffnung, fie jentals fenten zu lernen: fie

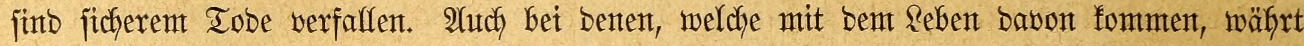
eB geraume 3eit, bevor fie wieber zu fraft unto Anjefn gelangen. Shre Berbauntg ift in

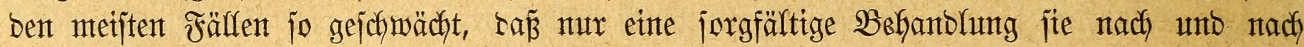

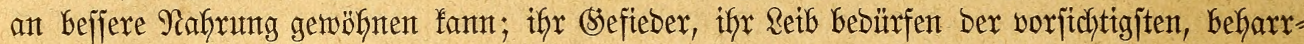

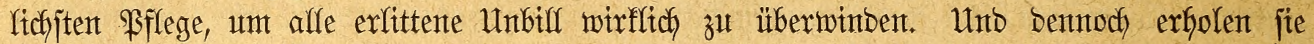
fich oft in unglaublich furzer Zeit und volrftänbig wieber, legen ein neuez Sleio an, puben fid heraus, fingen Geiter wie vorker unt betätigen jogar bie burch Den Sejang angefündigfe

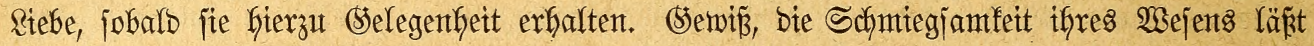
gar nichts zu wünichen ïbrig.

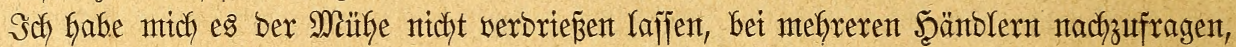
mit welchem Futter bie befanntejten frembländijđen Stubenwögel wäbrend ber Seeretje ernährt werben, weil bies zu mifjen für bie anfänglidye behanblung frijch eingefübrter Bägel von Watchtigfeit ijt. Ergebnis diejer Erfunbigungen war, zu erfahren, baj man noch

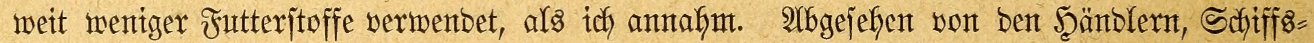

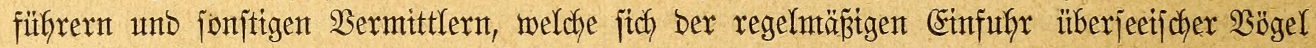

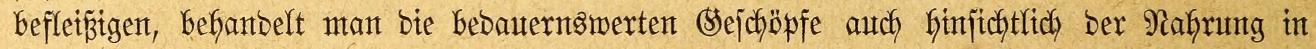

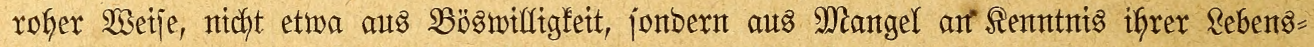

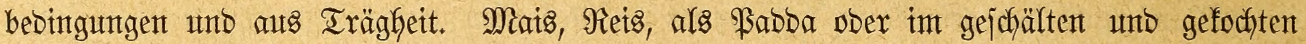
3ujtande, Schiffszmiebad, troden ober angefeudstet, fint bie Nafrungsitoffe, welche vorzugstweije gereidft werben; falls zu ifnten nod) Scirjent unto (S) fanz fommen, Deutet bies jchon auf eine höhere Stufe Der 2htabiloung bes Pflegenten. Mais und eingemeidfter

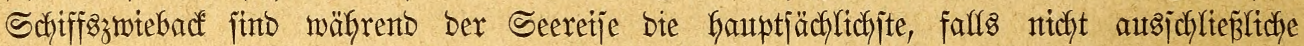

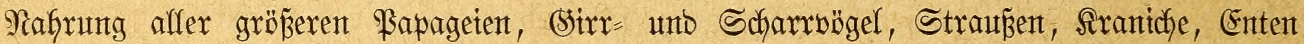
unto jonjtiger Sdywimmbögel, eingemeidyter Schiffszmiebad, meijt ofyne alfe 3ufoit, Das

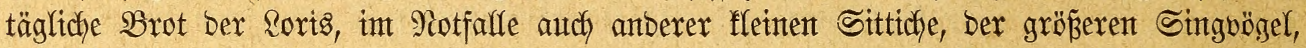

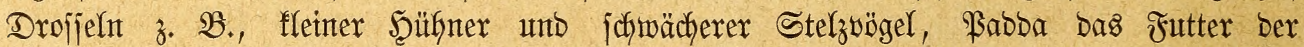

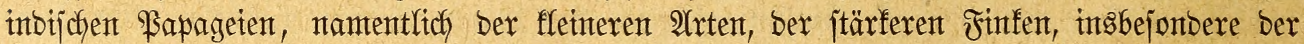
Reţvögel, ber grauten unt grïnen Sarbinäle, ber förnerfreffenden flemen Iauben, gefochter

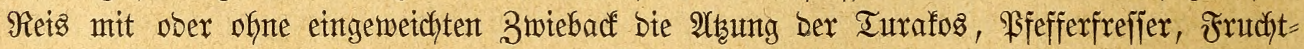
tauben, Şirjen unto (Slantz endlidy bie Sojt bez übrigen Aleingeflitgels, mit alleintiger

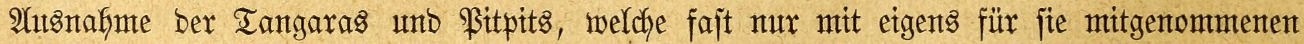

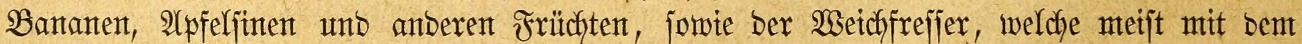

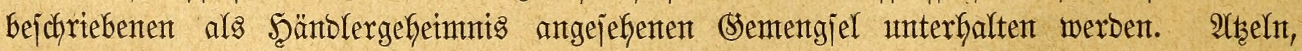
Seirtentatare unto andere in Snbien vielfach eingebauterte $\mathfrak{B o ̈ g e l , ~ S t a ̈ r l i n g e , ~ S c h w a r z = ~ u n t o ~}$ (Silbvögel, empfangen oft bie Brojamen, welche von bes Scerm, Giter bes Sdjiffers Itjche fallen, D. h. werben geipeijt wie bie Sdyiffintannjchaft jelber; berjelben Wobhtat madht man Bapageten teilfaftig. Reijende Şändler unb mit ber Bogelpflege vertraute Sdhiffer, beren es aber leiber noch jefjr wenige gibt, füttern natürlich jachgemä̈веr, geben fïch reoliche

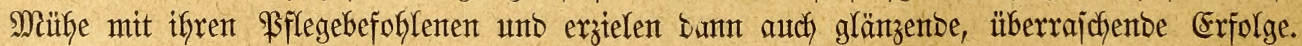

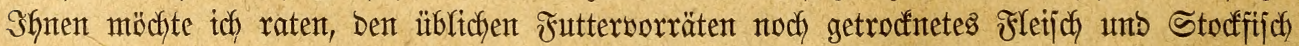

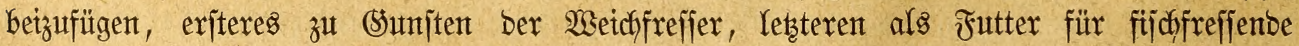

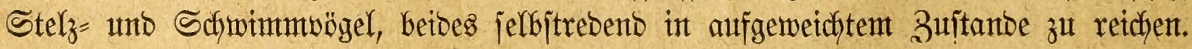




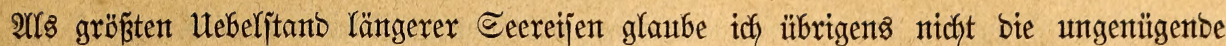

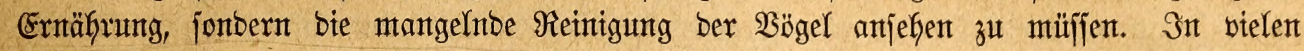

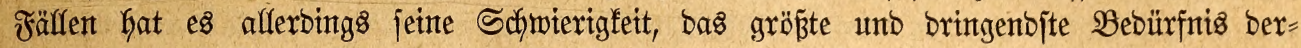

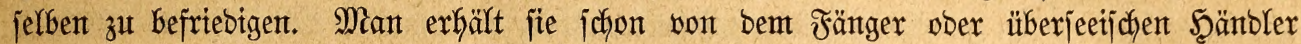
zu bicht zujammengepfercht, in Räfigen, weldhe ungejdjicft gearbeitet find, namentlich einer

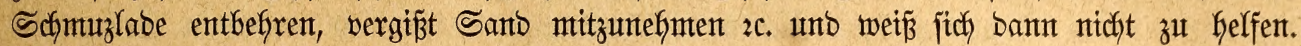

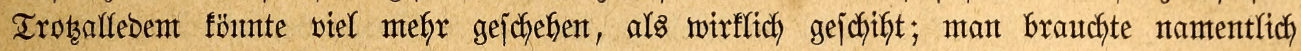

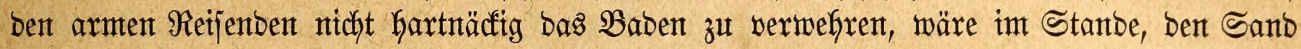

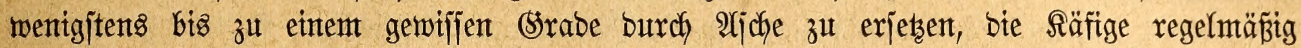

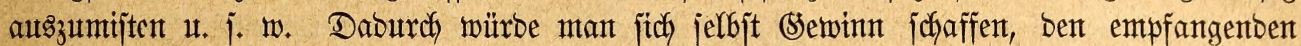

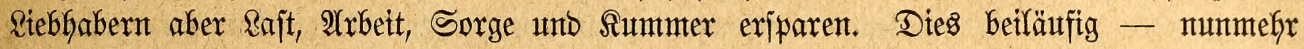
zux $\mathfrak{A}$ urfgabe.

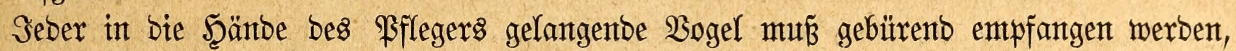

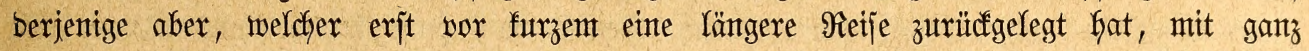

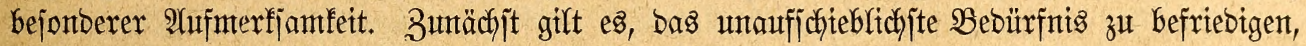
aljo Speije uno Iranf zu reichen. Die Böger, melche eben von Der Reije fommen, find

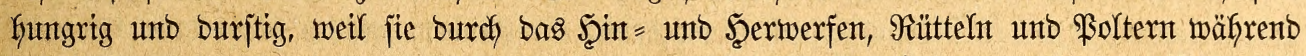
ber Reije verbutst morben fint unb wentg ober ntcht gefrefjen haben, audf went fie wohl= berjorgt waren mit Futter und Waffer. Sie pflegen aljo, nachbem fie wieber zur Ruke gefommen, gierig über bie Nahrung Kerzufallen, fich aud wentg ober nicht vor bem Menjchen zu jchenen, ant wentigjten wenn jie unterwegs arg Yeiben muß̈ten. Soldhe unnatürliche

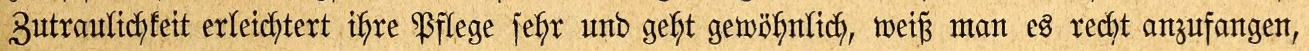
in benuß̧stes $\mathfrak{B e r t r a u t e n ~ u ̈ b e r . ~}$

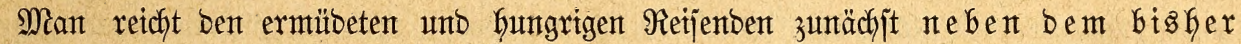
gewohnten Futter bie nafrhaftejte unb beliebtejte Speije, melche man als für jie zuträglich

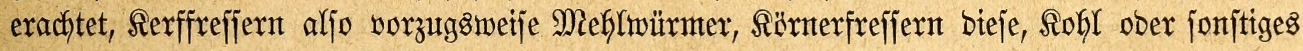

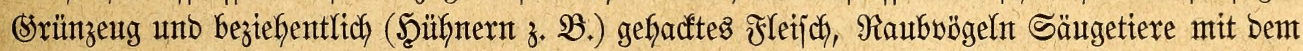

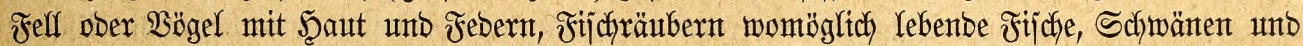
(Sänjen frijches (Sras und jonjtiges (Srünzeug, Enten ein (Semenge von Teidjlinjen, gebrofftent Brot, gef̧acftem Fleijch, zerjtïffelten Fijchen $2 c$. Dieje Fetertagsfojt gibt man jeboch nicht in genẗgenter Menge auf einmal, fonbern in 3mijchenräımen, welche man jorgfältiger $\mathfrak{B} e o b=$

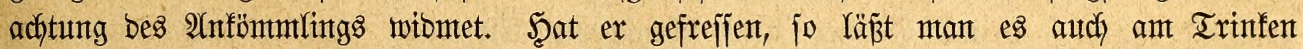
nicht feflen, vermefret ifgm aber einjtweilen nody bas $\mathfrak{B} a b e n$, füttert vielmefyr wieber unto in Faujen immer wieber, fo lange er freffen will, erforberlichen Falfs bet Beleuthtung bis tief in bie Nadht, unb ob man es jich aud ben Schlaf fojten laffen mïffe. Bei falter

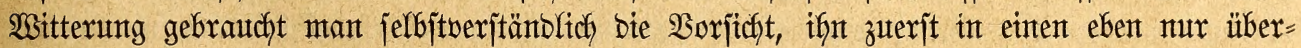

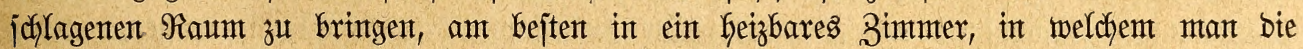
wärme nach umb nach, aber jefr allmählich, biz zur Bebaglichfeit jteigern fant.

Sit ex orbentlich gejättigt uno burchnärmt, jo fann ifm bie 2 ofhltat eines $\mathfrak{B a b e s}$ gewährt werben; er werlangt nach biejem balb mefy als nach Speije und Iranf. Se

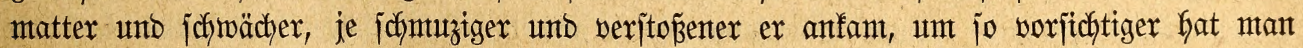
hierbei zu werfafyen. Das Bimmer miro geförig erwärmt, Das Babewafjer auf etwa $+10^{\circ} \mathrm{R}$. gebracht, ber Babenapf nidft volfjtänbig gefüflf, unb wieber weggenommen, noch

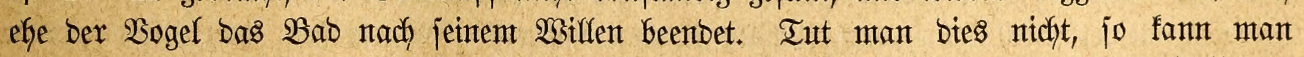

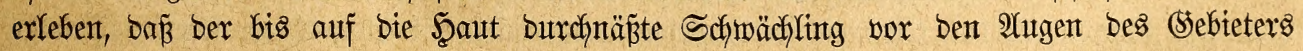

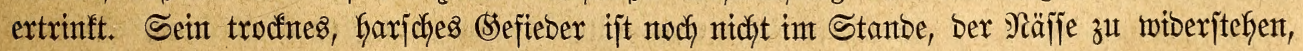
erfältet ifn int gïmitigeren boer zieft ifnn niteber im ungünjtigerent Fafle: idh babe

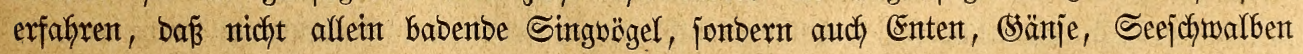




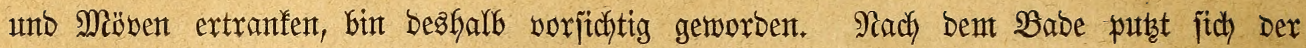
Bogel, jo gut ex einftweilen es vermag, bearbeitet bas sefieber und fettet es ein, fo weit jeinte Bürzeldrüje ben fierzu exforberlichen Stoff hergibt. Das Bab erregt jeine Jreß̉̆ujt, barf bafer niemals in ben $2(b e n t j$ tunben geitattet werben, weil ja noch eine tüchtige Füttentung

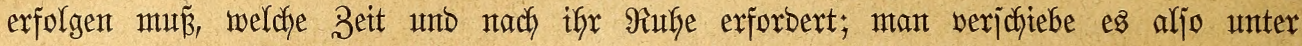
Umiftänden lieber bis zum nädyten Morgen. Sollte bas (Sefieber in geraumer Beit nteft

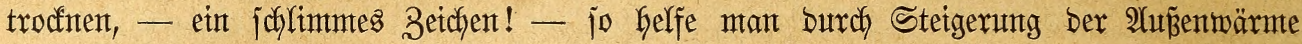

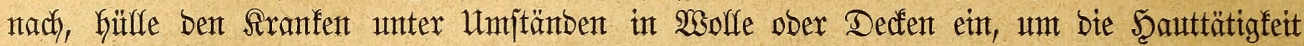
anzujpornen. Derartiges Eingreifent erzielt oft überrajdyende Ergebniffe. 2 . von Jૃomeyer

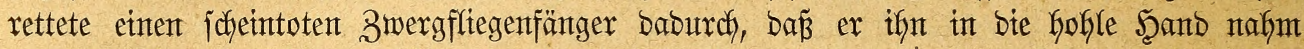
unt mit bem Şaudje jeines Mimbes erwärmte, gletchzettig audf bas (sefieber mittels Watte trocfnete. Freunt $\mathfrak{B}$ odinus unt ich wenten in äfnlichen Fällen jtets unb zunächjt bie Wärme als Mittel an, meijt mit trefflichem Exfolge.

Erfä̈lt man einen eintheimifchen $\mathfrak{B o g e l}$, weldfer mit Reim gefangen murbe, jo hifft man ifgm jein sefieber jäubern, meil bies ifgm jelbjt ganz unmöglich ijt. WBenn mur

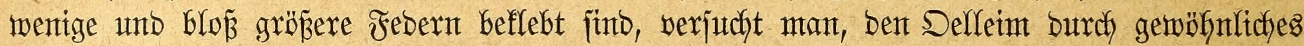
ober Baumöl, Den Mijtelleint Durdy Terpentintöl aufzulöjen, wijeft und trodfnet biejes jobann auf, entfernt es überhaupt jo viel als erretchbar; went bagegen viele Febern bejchmuzt füt, muz man jchon zur Schere greifen und jente jo weit als exforderlich be=

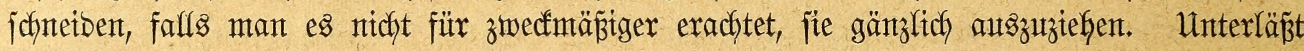
man es, bem Bogel beizujtehen, fo ermïbet mant ifgn nicht mux zmedflos, jonbern jechabet

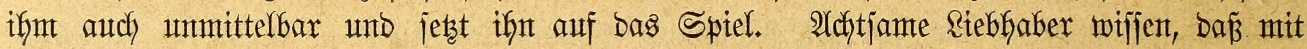

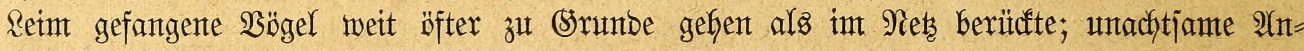
fänger exfafren bald gemtg baģjelbe.

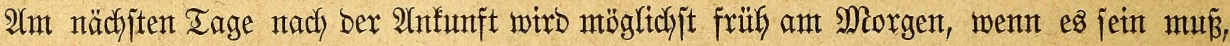

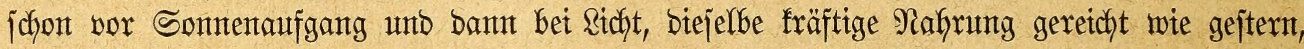

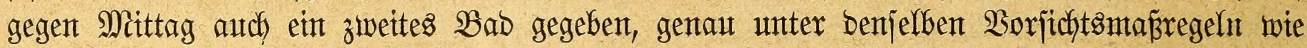

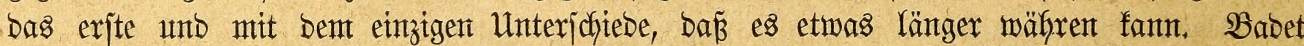
ber $\mathfrak{B o g e l}$ nidft, jo babet ex morgen; jebenfalls barf ber Babenapf nicht bis zum ipäten Nachymittage in Säfige iteben bleiben.

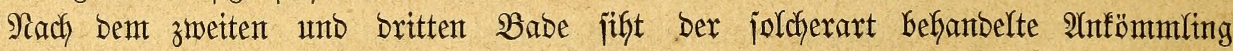
gemöhnlich johon ganz anbers aus als am Tage jeiner 2lntumft. Seine Jettlabe auf bem Bürzel ijt in Folge Der guten und reichlicken Nafrung jowie ber wieberfolten Entlenungen in regere Tätigfett verjest worben und liefert ben zum Rodfern und (s)lätten bes (Sefiebers unumgänglich nötigen Stoff in genügenter Menge; Das Sefieber hat einen Teil jetner Schönbett mieber erfalten, fletbet, Decftt und wärmt beffer; Der Bogel befindet fitch wohler, befaglicher, füflt fich freter anto beginnt jeine aughgeitanbenten Reiben zu vergeffen. Nodh einige Tage guter $\mathfrak{P f l e g e , ~ u n d ~ e x ~ i j t ~ g e r e t t e t ~ u n t ~ g e e i g n e t , ~ i n ~ b e n ~ f u ̈ r ~ i f n ~ b e j t i m m t e n ~ \Re a u m ~}$ gebracht unt ganz alfmäblich an bie ifgm bejtimmte zuträglichere Befangentenfojt gemöhnt zut werben.

Punmefy hat eine neue Befichtigung itattzufinden. Der $\mathfrak{B}$ gel wirb zubörberjt an Schnabel und Beinen genau unterjucht, da wo es nötig bejchnttten, an munben Stelfen ber

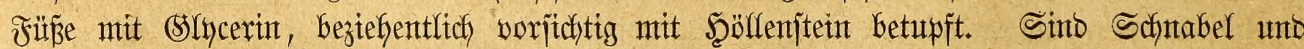

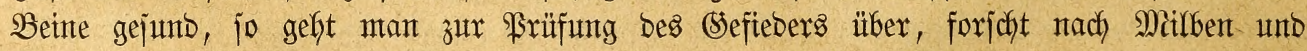
jucht jie, woie angegeben, zu bertreiben; bemerft man feine Schmaroker, jo erwägt man, ob es mofyl geraten, bie fünjtliche Maujer einzuleiten, um bem Bogel jobalo als möglich zu einem volfen 尺leibe zu verhelfen. Erjte Bebingung zur Rechtfertigung jolcher (semalttat

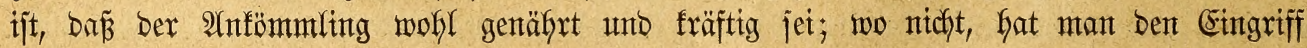


noch zu verjafieben, weil bie Maujer ober ber Feberwedyjel bie volle Siraft bes Bogels beanjprucht ober, was basjelbe, einen äußzerjt regen Stoffwedfjel und mandherlei Untbefags= lichfeit bebingt. Einem gejumben, fräftigen $\mathfrak{B}$ ogel jchabet bie natürliche Maujer ebenjomenig als bie fünftlich eingeleitete; benn ber Feberwechjel tiłt feinte Sranffgett, wie Siele wäfnen, jagen und jadreiben, jonbern einte Serjüngung: ex barf wofjl mit bent Şäuten ber Schlange, nicht aber mit bem Schälen ber 5̧aut bes Scharlachtranfen verglichen werben. Die fünjtliche Maujer mun beminft man einfach baburch, baj man mefjrere - nicht jämmtliche - ber

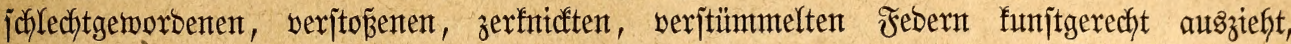

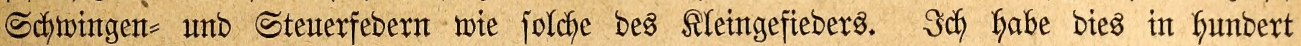

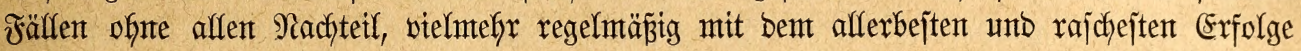
getan, fann aljo Bïrgichaft Yeijten füx meine 2 (ngaben, wifl jeboch auch Gierbet nicht unter=

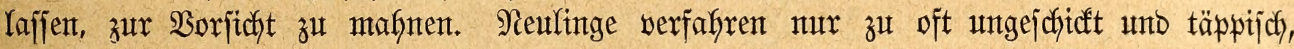
ofhe es zu wolfen, bezüglich ofne zu wiffen, woburch fie fündigen. Maan fann einem

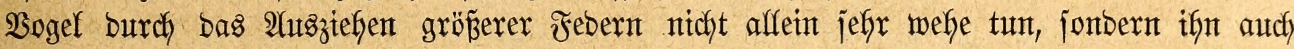

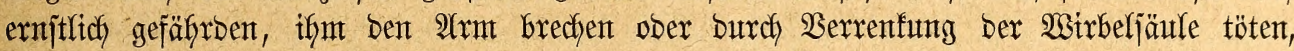

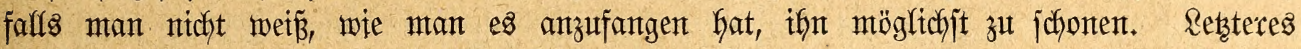

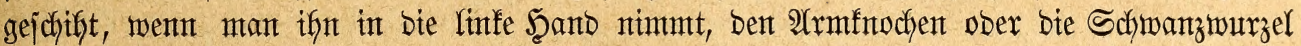
mit. Daumten unt Beigefinger fejthält unt ifym nun bie Feber befutjam unt in ber Richtung, meldhe jie Kat, aljo meber ructweije noch jeitwärts, auszieft. Won ben alten

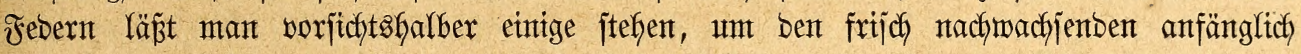
Schut und Stïtze zu gebent. Unt bie jtefenbleibenden brautd)t man fich nicht weiter zut fümmern; fie falfen redhter Beit von jelbjt auts. Sinto beibe Flügel in annäherno berjelben Weije bejchäbigt, io afynt man ben natürltchen Scergang ber Maujer injofern nach, alz mant immer bie fich entjpredyend gegenüberjtegenden Schwingen auszzieft. Bei Beadjtung

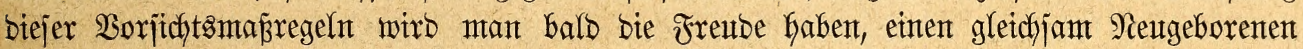

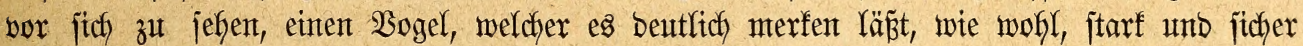
ex jïch in jeintem volljtändigen uno reijtungafähtgen Aleibe füf)lt.

Bögel, weldye gänzlich ober fajt gänzlich nactend anfommen, trennt man fofort bon ben übrigen, exjebt ifgnen aber bie Wärme, welche bieje ifhten jpenten, went bie feberlojen

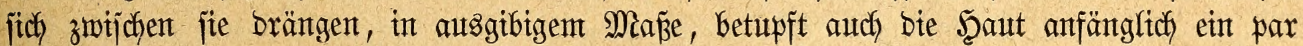
Mal mit einem ölgejättigten Sdywämmthen ober, wenn bies nichts fruchten will, mit peru=

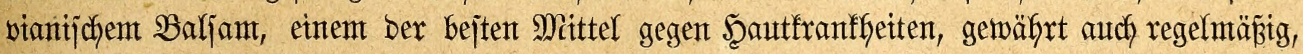

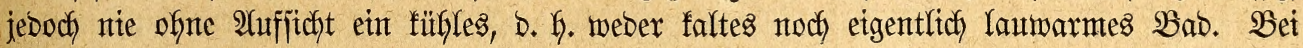
reichlichem unto fräftigem Futter, genügender Wärme unb etwas milbem Sonnenjchein am

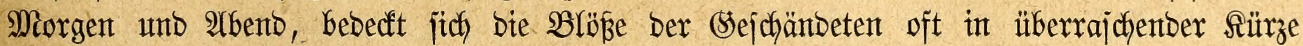

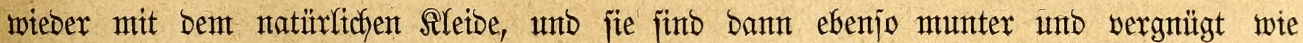

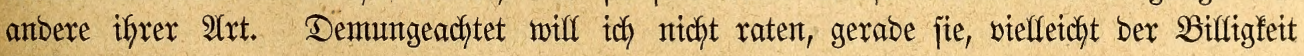
Galber, zut faufen.

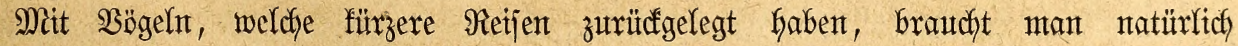
wentger Umjtänbe zu machen: einte tücftige Maflzeit, ein guter Trumf und ein füfles $\mathfrak{B a b}$

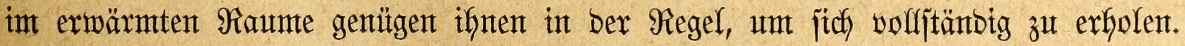

Bei $\mathfrak{B}$ eobactutung biejer Maßjnafmen wirb. man jelten einen von ben angefommenen

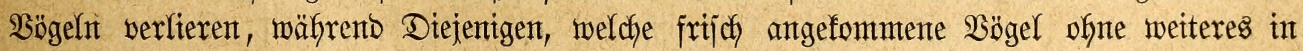
bie (s)bauer jeben, ifnen Speije, Irant uno Babemafjer retdyen, übrigents aber es ifnen

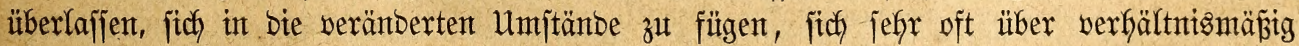
bebeutende Berlujte wumbern unto fich beflagen, weil jie überzengt fint, bas 80s iffrer Pfleglinge entijfjeben verbefjert zu Gaben. Rebsteres ijt mun afferbings ber Faff - vorausgejezt

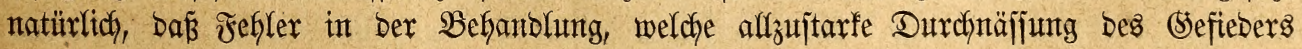


unt Ertrinfen ober mindejtents Erfältung zur Folge Gaben, verntieben wurben; Dex plöblicke Hebergang aber von ber gemofnten sebenzweije zu einter anberen, unt jei jie gleidf eine beffere, wirb ben Bögeln berberblich: fie fönten bas Wofhlleben ebent noch nidft ertragen. Mañ man boch jelbjt bei benten vorjidhtig jein, weldhe moblbeleibt unb gutbefiebert anlangen, aber an ein anberes unt zwar geringeres Futter gewöhnt jint, als mant ifnen zu bieten gebenft: um mie biel mehr aljo mit joldhen, benten mant burch Futter, Reinigung, Wärme

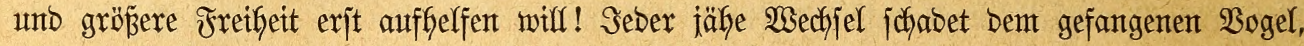
möge er jich bezieben, auf was immer es jei: biejen unantajtbaren sebrjacs wolfe man jeberzeit berürffictitigen!

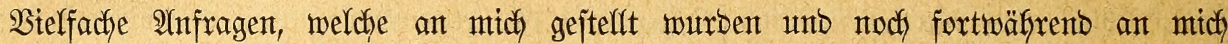
gejtellt werben, bejtimmen mich), Sorjtehenbem einiges über zmectmäp̈igen Serjant lebender Bögel beizufügent.

Wenn es jich um Reijen von geringer Dauter hanbelt, verurjacht ber Berjant feinerlei erwähntenswerte Borbereitung. Man nimmt einen entjprectento grofien, gut gearbeiten Sorb, welcher ja alferorten zut Gaben, ant bejten joldjen mit flachen Boben, näht eine Seinwanbbedfe an jeinem oberen Ranbe bis auf eine ffeine Deffnung fejt, jtecft Durch bieje Den $\mathfrak{B}$ ogel in Den forb, näht volfenbs zu, bezetchntet, fayretbt auf ben Segleitbrief: „Rebende $\mathfrak{B}$ öger; jofort zu bejtellen!" unt übergibt biejes Frachtftücf ber \$ojt zux Beförberung. Sịt bie Witterung ungünitig, z. 20. jefr falt, jo hängt man bem forbe einen Bettel an und jadreibt auf biejen bie Bitte an bie Scerren Fojtbeamten, Den Rorb freunblichjt in bem Eijenbafyn=

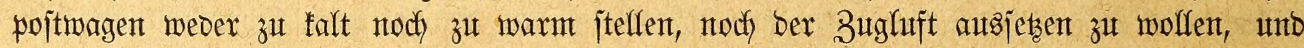

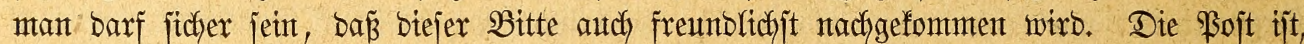
falfs man nidht einten Begleiter jenben ober geminnen fant, jeber anberen Berfehrsanjtalt borzuziehen, weil fie nicht mur am rajchejten, fonbern fleinere, wentg wiegenbe Senbungen audh am billigiten beförbert, billiger jebenfallz als Eijenbafnen, weldhe, wenn man Serjenbung mit ben Schnelfzügen beanjprudft, jefr hohe Jradft verlangen. Wer fojtbare Bögel zu verjenten hat, wirb übrigens immer gut tum, Den Empfänger worker von ber 3eit Des 2 flbganges in Sienntnis zu. jebert.

Wäfynt bie Reije unter zmölf Stumben, jo ijt nicht einmal Beigabe von Futter uno Trinfen nötig; währt jie länger, jo jtreut man biejes, (für Weidhfreffer 9 (meijenpuppen unD getötete Mehlmürmer, für förnerfreffer (Sejäme, für anbere Bögel nach Bebarf möglichjt trocfene Rafyrung) in ben Sorb unt heftet an ben Seiten besjelben einen Babejdmamm

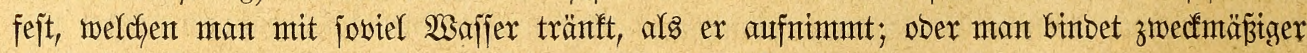

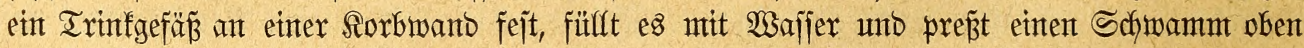

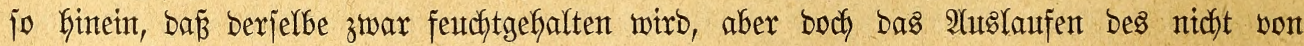
ifm aufgejogenten Wafjers verfinbert. Ein joldher Sdywamm, welcher audh Die Berbunjtung bes Wajfers verlangjamt, leiftet treffliche Dienjte, mur jeboch, bamit ifyn ber $\mathfrak{B}$ ogel nicht Gerauszitehen fann, Durdy zwei freuzweije über ifn meglaufende Dräte im Irinfnapfe befejtigt

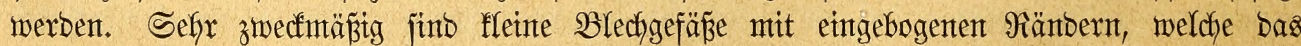

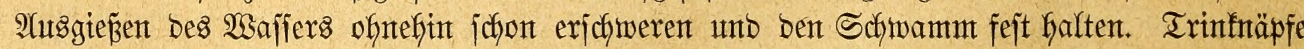
ofhe $\mathfrak{B a b e j} d$ wanm in ben forb zu jtellen ober in iffm zu befejtigen, ijt nicht ratjant, weil

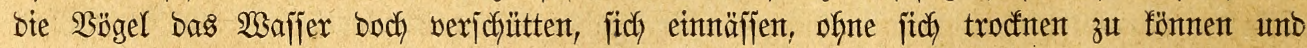

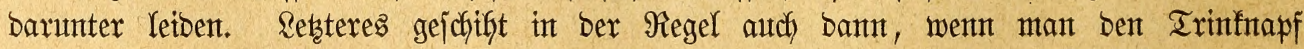

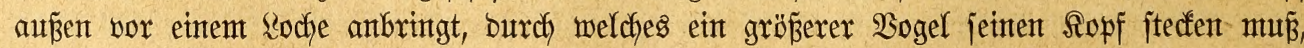

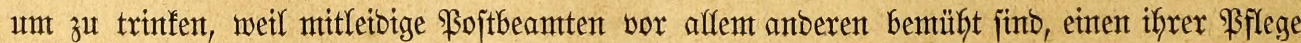
ausbrüdflich ober nticht ausbrüfflich) übergebenten $\mathfrak{B}$ ogel nicht Durit Yetben zu Yaffen. Etrwas

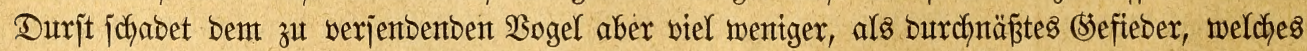
er nicht zu trodfnen vermag. $2 \mathfrak{A}$ Den Folgen joldyer Durchnäjiung uno Erffältung jterben 
weit mehr gezmungen reijenbe $\mathfrak{B}$ ögel, als man glaubt, an ben Folgen bes Durjtes, benen man ja übrigens auch auf einfache Beije burd) Mitgabe von jaftigen Früthten, (srïnzeug, eingeweichtem Srote it. bergl. begegnen fant, nur in ber größ̈ten Sommerfitze einer unb ber anbere.

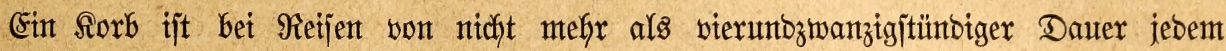

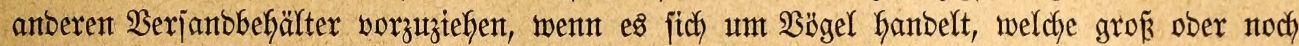
jefr icheu find ober bie Bemohnheit haben, bei Erregung nach oben zu fahren, weil bie einen wie bie anberen in ifm fich Den wentgiten Schaben zufügen fönnen. Bebor mant jith jeiner bebient, hat man ïbrigens nachzujeben, ob nidht etwa fier und ba bas jafarfe Enbe

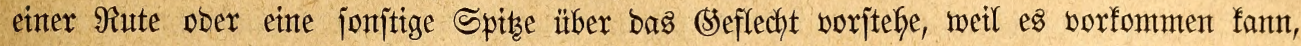

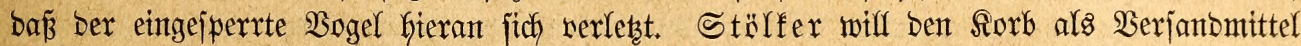

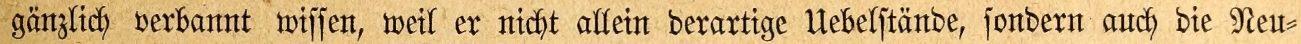
gierbe ber \$ojtamten fürchtet, weldfe jogar in Durchlöcherung ber Reinmanto Befriebigung

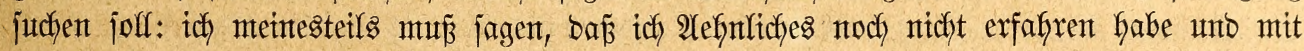
ben fïrben immer jebr zufrieben gemejen bin.

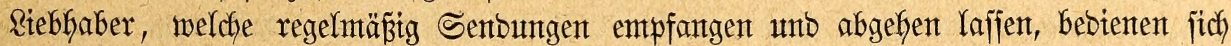

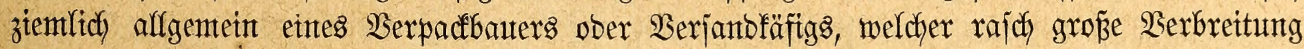

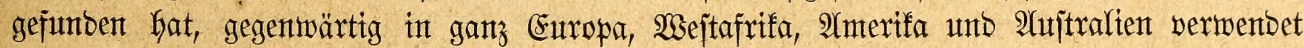
wirb unb burch leidste Boljterung jeiner Dedfe auds für bie Scimmeljtürmer unjchäblich

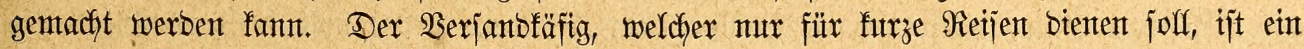

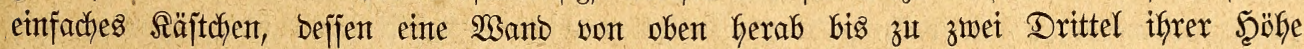
vergittert uno mit einter Göchjt einfachen, im (sitterwerf angebrachten Schjebetüre verjefjen

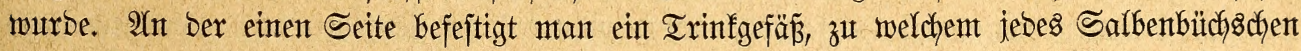
bienen fann, füflt es mit $\mathfrak{B a f f e r}$ unb einem entiprechenten Babejhwamme, in ben Stolfen, welcher burdh bas nidft bis zum Boben Kerabreidhende (sitter gebilbet wirb, ftreut man

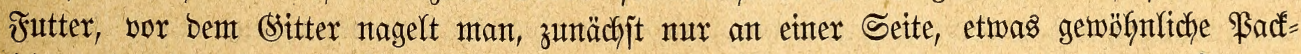

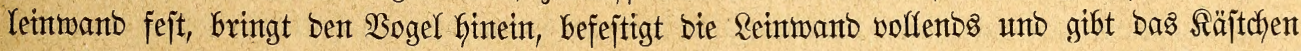

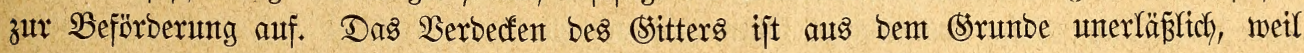
man bem $\mathfrak{B}$ ogel bamit ben $\mathfrak{B}$ licf nach auren verwefirt, iffn alfo vor ftörenben ober beäng= fitigenten Einbrüdent bewahrt unb auf jich jelbjt bejdyränft, wie alf biejes ja auth int

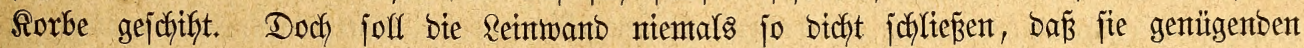

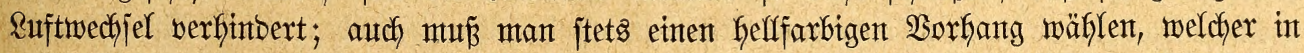

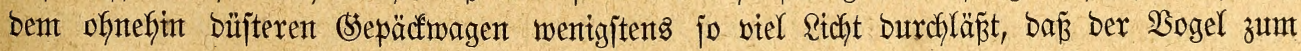
Futternehmen nodh Ginlängliḑ jehen fann. Ein Sprungholz barf bem Berpadfbauter nur

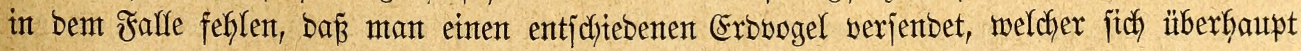

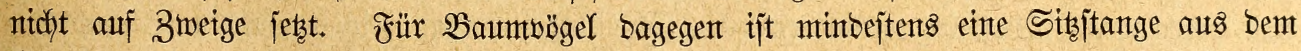

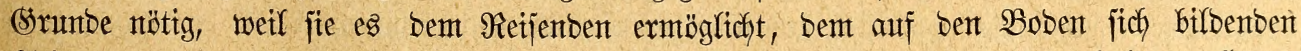

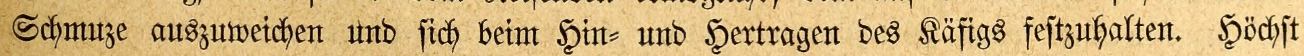

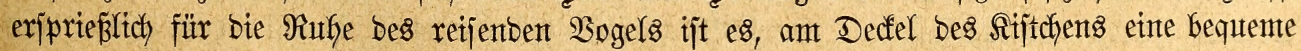
Scanbhabe anzubringen, nact) welchem ber \$ojtbeamte ober Iräger untwilffïrlich greifen wirb. Entgegentgejebsten Falfs biurfte ein 2 erjanbfäfig von biejem ober jentem bod) als einfaches Sijtchen behanbelt unb mehr umbergetworfen werben, als bem $\mathfrak{B}$ ogel unb bem Empfänger rieb ifit.

Bei weiteren Reijen unb Berjentung einer zahlreidfen Sejellichaft fleiner, gletchartiger ober bodh berträglticher $\mathfrak{B}$ ögel wentot man ben franzöjijchen Serfactbauter an. Er ijt

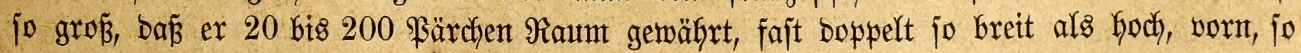
weit bas (sitter reidft, abgejdyrägt, hat bie Tïr an ber Seite, in ber Rajtenwant, unto

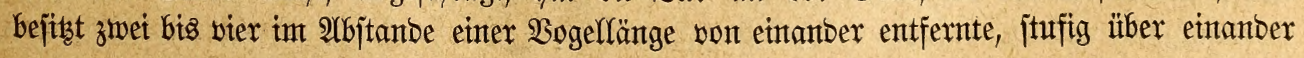




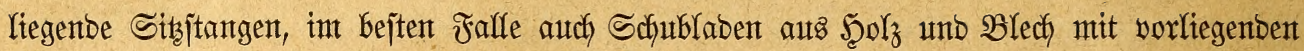

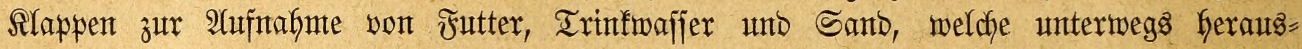
genontmen, gereinigt unb frijch gefüflt werben joflen. Die Reinwanbbecfe befeftigt man bei

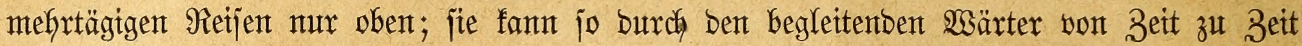
zurücfigejchlagen werben, um ben $\mathfrak{B o ̈ g e l n}$ zu frijcher \&uft, zu \&icht und Sonnenichein zu

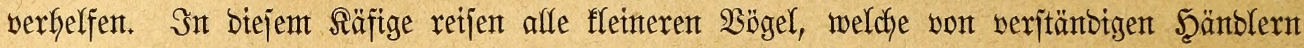
berjenbet und beziehentlich begleitet werben; in ifgn erfhalten wir mit jefr unbebeutendem

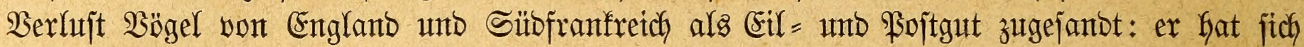
in jeber Beziefung bemährt, werbreitet fich immer mefyr umb zählt zu ben unerläßjlichen

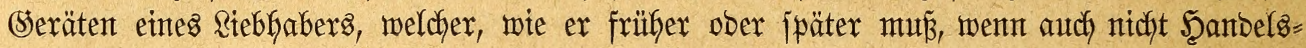
jo body Iaujchgejchäfte betretben wifl. Iraut mant Dem Srtstijchler nicht zu, nach vor= jtebenber Bejdyreibung einten $\mathfrak{B}$ erjanbbauter anzufertigen, jo ntmmt man eine einfache, inten

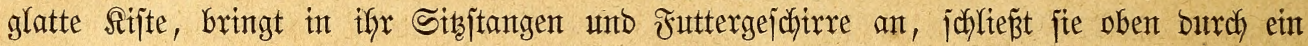
Sproffentwerf aus 5ुolzleijten ober burch Dratgitter unto gibt fie auf bie Reije.

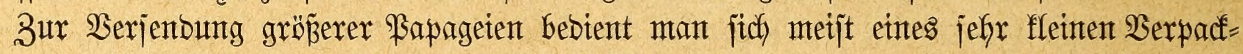
bauters, welcher ben Sogel eben aufnimmt, ifm jeboch faum ober nicht gejtattet, jich umzubreben. 2Auf Dem Boben ijt ein Suerfolz zum Sizen aufgentagelt, bie (sitterjeite, vor Dem (Sejicht Des Sittichs mit Blech bejchlagen, bas (sitter felbjt aus jtarfem Drat gefertigt und wohl befejtigt, ein Futternapf und ein Iränfbüchschen mit Schwamm inten mittels Drat an bas (sitter gebumben. Trots biejer Sorfefyrungen, weldhe midh jtets an ben Sierfer eines Bellengefängnifjes erinnern, uno meldhe vielleidht noch joblimmer find als bieje, weil fie bem $\mathfrak{B}$ ogel faum eine $\mathfrak{B}$ emegung exlauben, bringt es ber reijenbe $\mathfrak{B a p a g e t}$ oft binnen

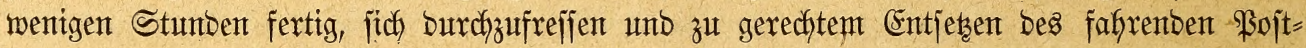

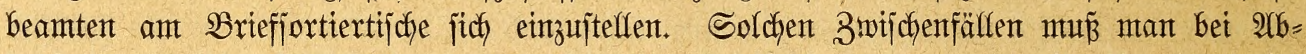
fertigung größ̈erer Sittidfe inmter entgegenjeben, bet Berjenbungen auf meite Strecfen baher nach bejten firäften vorzubeugen juchen. Sileinere Sittiche fann man ofne alfe Bejorgnis in gemöbnliche Serjanbläfige iperren, insbeionbere wenn man fie par= ober gejelljchafts: meije verichidft. Sie finden Dann faum 3eit, unterwega ifye ofnefin fraftlojen Schnäber

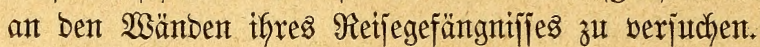

Für ben Berjand wäbrent ftrenger Winterfälte hat Stader eine vorzüglidche (Eint= ridjtung getroffen. Er jebt einen gropen Berpacfbauer, mit jentrechtem (sttter und am

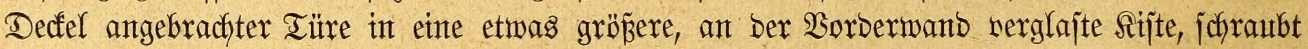

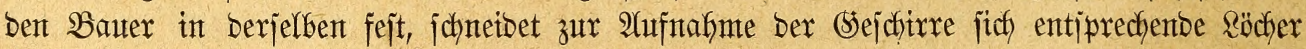

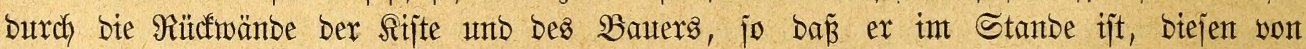
außen zu veriehen, bringt hierauf bie $\mathfrak{B}$ g̈gel in ben Bauer und nagelt ben mit eintigen \&uftlöchern werjegenen Rijtenbecfel fejt zu. Es bilbet jich jomit rings um ben Baauer eine

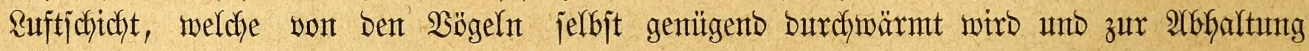
ber äuß̧eren Sälte bient. Staber hat in jolcherart burchbeizten Reijegefängntifjen während Der itrengiten Rälte bes Winters von 1869 zu 70 \$rapageien ofne Derlujte von Deutichland Itach) Miosfaut gebradjt, jeine Berjanbfäfige aljo genẗgent exprobt.

Ein Sogelwirt, weldjer Sorjtehentes aufmerfiam gelejen, wiro ben Berjant affer

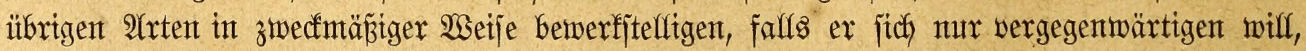

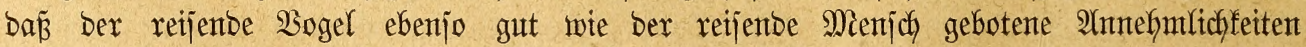

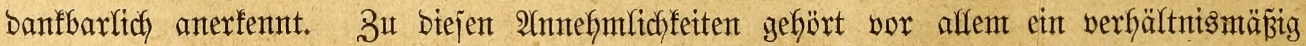
geräumiger Siorb ober Bauter, weldher namentlich im Sommer bas 2 ohlbefinton bes

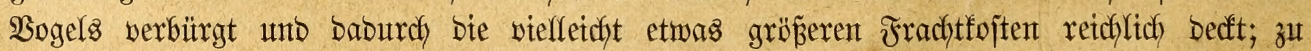

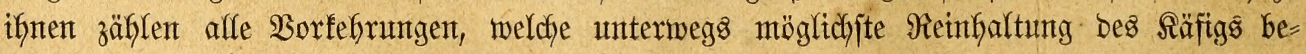
zwedfen u. D. m. Ein jallecht bejorgter Sogel läuft Befafyr bet jeber Hebertragung von 


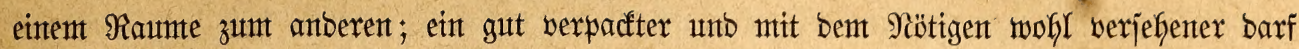
ofyte Bebenfen auf jefr weite Strecfen verjentbet werben.

\section{Wogelindil.}

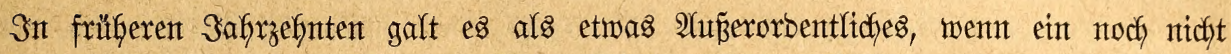

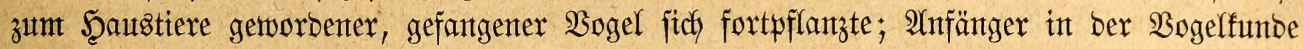
voer angekende RiebGaber jutto heut zu Tage nodh berjelben Meinung. Wir benfent antoers. Settbem jelbjt gefangente Strauke bet uns zu sanbe fid bermefyrt haben, fint wir ab= gejtumpft worben gegen bas (sejchret, weldjes Diejer ober Gener erhebt, went ifym bas

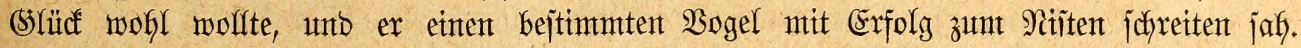

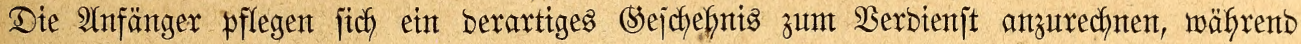

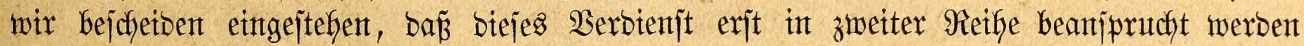
barf. Damit joll jelbjtwerjtänolich nidht gejagt jein, baj das Butun bes Pfflegers be=

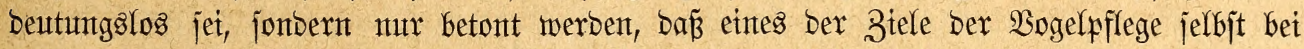
nicht jachgemäßęer $\mathfrak{B}$ ehantblung Der gefangenen $\mathfrak{B}$ ögel erretdyt merben fant.

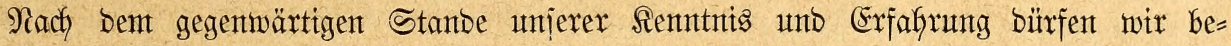

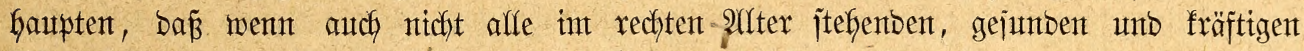

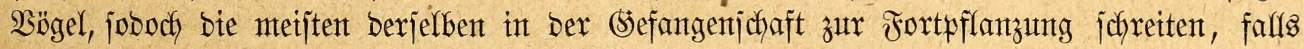

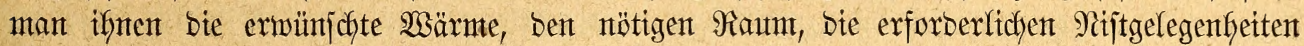
unto yor alfem bie eriprieplichjte Nafyrung bietet und fie übrigens fo viel als möglide

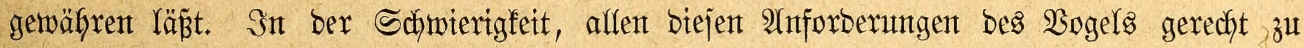
merben, fie vereinigt zu exfülfent, ijt bie Erfflärung ber Mitzerfolge zu juchen, über welche

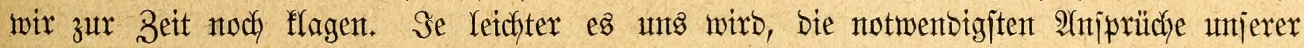
gefieberten $\mathfrak{B f f e g l i n g e}$ zu erfüffen, um jo jicherer wirb in ifynen ber natürlichjite alfer Iriebe fich regen, unt jo gewifjer ber Erfolg unts lofnent.

Mefor als alfes übrige tritt uts nodh immer bie Schwierigfeit, unjere gefangenen

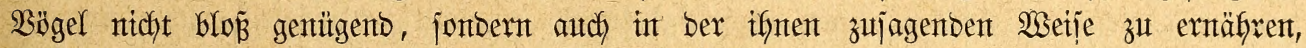

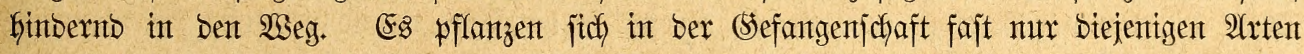
fort, Denten wir ein Exjabfuttex, weldyes ifyrem natürlichen möglichjt entjpricht, zu reichen

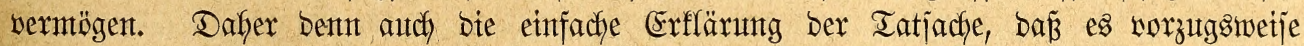
bie Sïnnerfreffer fints, welche int Bebauter nijten, unb, Daraus folgernb, für ben angehentent

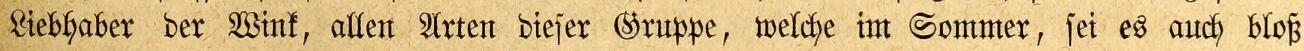
nebenbei, Rerfe freffen, bieje, went bie SBrutzeit Gerantühtt, jo viel als möglich zu erjetzen.

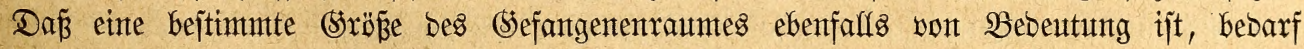
faum Des Bemeijez; Dá̉ man Bögeln, welche fich fortpflanzen jollen, afle Störungen

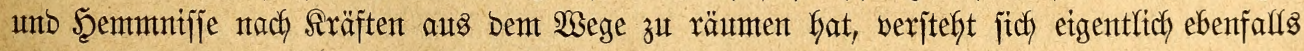

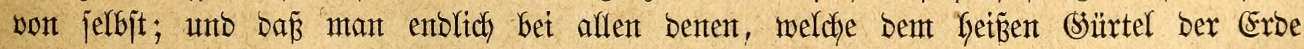
entitammen, wäkrento ber Brutzeit mentgitents für eine gemiffe, insbejonbere für gletch =

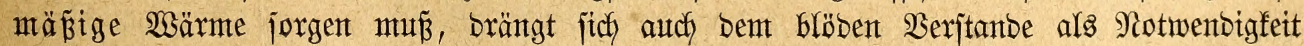

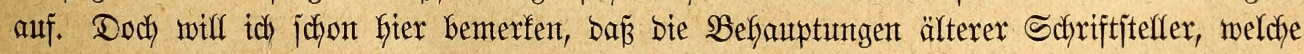

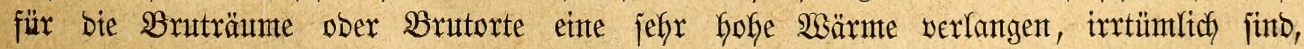
twentgitens zu ben für uns übermunbenten Standpunften gehören. (Sleidymäp̧igfeit der

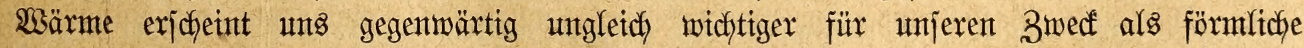
Sige, twie jene fie für nötig Gielten. Wer bie in Jrage foumenten Stubentögel bet 
+15 bis $18^{\circ} \mathrm{R}$. nicht zur Fortpflanzung jedreiten jifgt, wiro wohl in ben meijten Fälfen vergeblich ftärfer Ketzen, fallz er nicht gleid)zeitig antbere Miängel jeiner Einrichtunty uno Behandlungģweije bejeitigt. Für bieje metne Befaututung füfre tch bie $\mathfrak{B}$ ögel ber jüblichen Şalbfugel ant, beren Früfling und bezïglich Sommer in unjeren Scerbjt uno Winter falfen, melche aber bennoch bet uns mit Erfolg fich fortpflanzen, und nicht bló im gebeizten

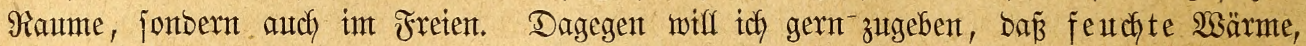

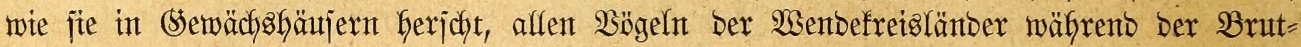
zeit hödjit miflfommen, für jie alfo aud ântrieb jein mag, fich zu paren unt zu begatten.

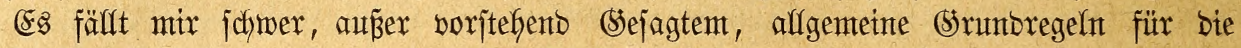

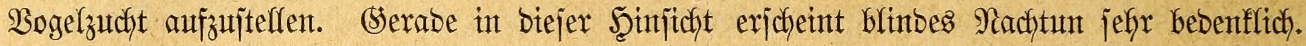
Der Riebfaber hat nicfyt bas Recht, einen bejtimmten Falf als Beję̧ anzulehen, viel=

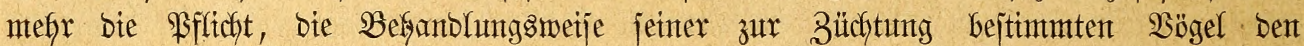
jetweiligen Umitänben entiprechento einzurichten, jene genau zu beobachten, ifye 2 sünjche,

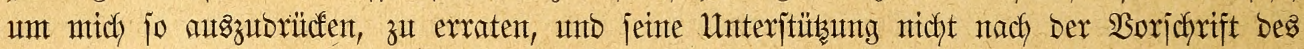

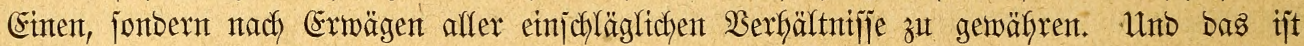
feineswegs leidft, im segenteile oft recht ichwierig. Es exforbert vor alfem einen jelb= ftänbigen, richtig beobactytenben, Denfentoen unb folgernben Menjecten, feinten blinben Nachbeter,

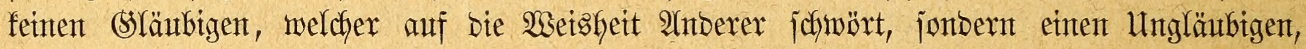
welcher zwar alles Begebente bentht, aber auch alles prïft, unterjucht, abänbert, verbeffert

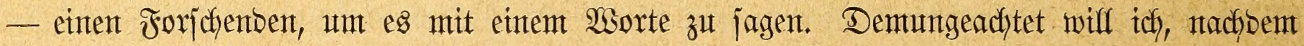
ich) Goffentlich alles und jebes alpoiteltum von mix abgeichüttelt, für Diejentgen, welche cs

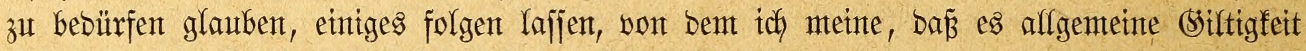
haben fantn. Selbjtwerjtäntlich berufgt alfes, was tch jagen werbe, ebenfalfs auf (Exfah)= rungen, went nidyt eigenten, jobody joldfen won 2 tnderen.

Erites Exforbernis zux Exreidfung bes 3medfes ijt in meinen 24tgen einte ben natür=

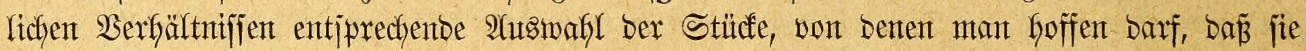
nijten. Mant ermerbe ober vereinige bló̉ volffommen gejumbe, ourchaus febierfrete Bögel, falls irgento möglich mefrere, beobadyte fie genau, achte jorgfältig auf bie beginnende $3^{u=}$ neigung zwijchen eintem Meäntchen unt einem Weibchen, unterjtübe Diejelbe nach Befinton unto trente biejentgen, weldfe fidf gepart Gaben, unter feiner Bebingung. Einte fretmillig

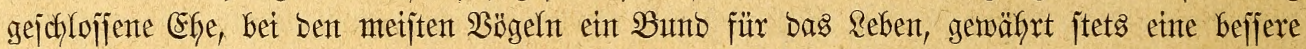

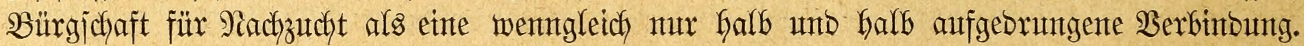
Soldhe gehen unter Umitänben aud bie $\mathfrak{B}$ ögel ein, meijt mit jcheinbar berjelben Begeijerung:

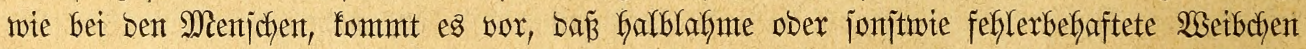
ummorben, geeblicht, befutdstet merben und Sunge bringen; es gejchifht jogar, bafis fich Männtfen mit anbersartigen Weibdjen paren unb Błlentlinge erzeugen: Die Ergebniffe

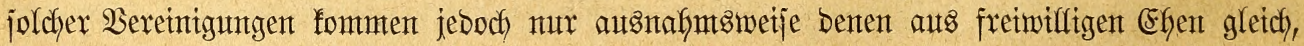

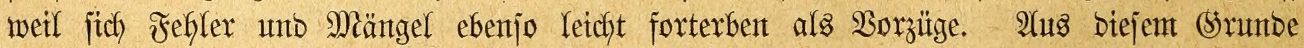

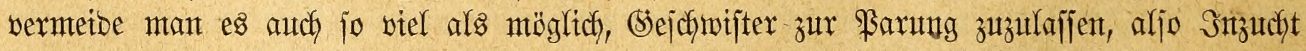

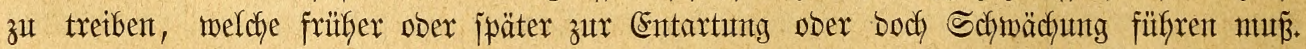
Es ijt fier ntidjt Der Srt, für bieje Warnutg Belege beizubringen; ich werbe bies jeodch

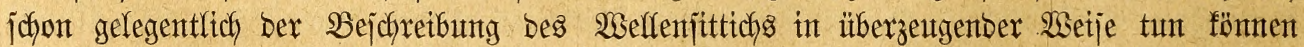
und berweije auf bie betreffende Stelfe.

Befangene $\mathfrak{B o ̈ g e l}$ nijten um jo efer, je mebr bie Umitünte, unter Denen fie Yebent,

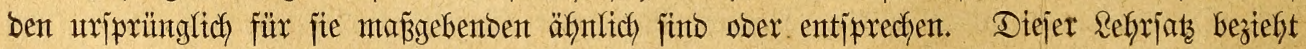
fidy nidft alfein auf bie bereits heroorgehobenen Bebingungen, jonbern aud auf bie $\mathfrak{B e r}=$

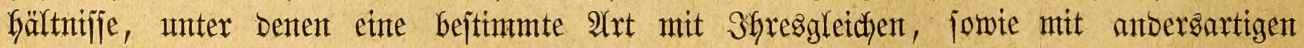
Bögeln Yebt. Es ijt Daher Durchaus nidht gletdygiltig, ob man bie 'Sefantgenten, Deren Ber= 


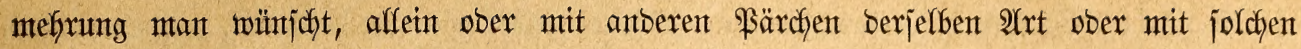
frember 2 rten zujammentoringt.

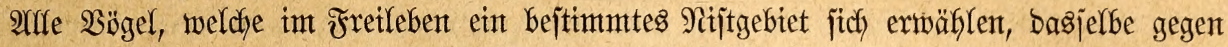

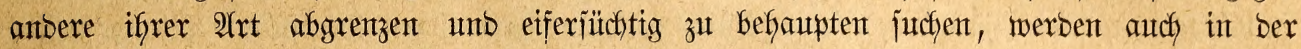
(s)efangemichaft einzeln gebalten werben müijen, am allerwentgiten aber mit nur noch einem \$ärchen zujammengebracht werben bürfen. In biejem Falfe nefonten Streit unt 3meifampf unter ben parungshluitigen Meäntchen fein Enbe, unb verfindert bie baburch Gerbeigefüfyrte Störung fehr oft bie Fortpflanzung. Eלger noch läp̧t es jich ausfüfbren, bret, fünf oder

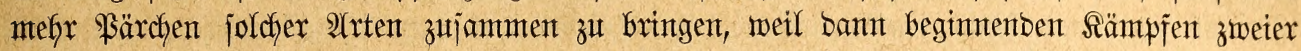

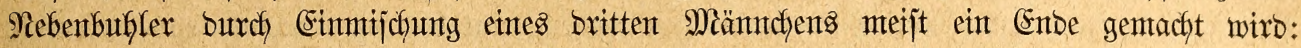

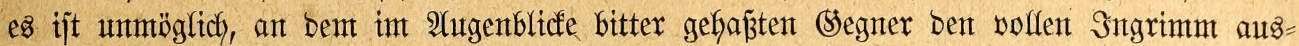
zulafien, went ein Dritter bazmijchen tritt und wafllos biejem ober jenten auf ben Slopf

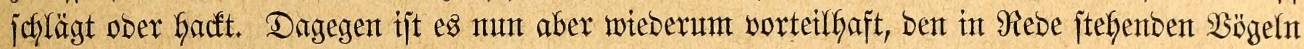

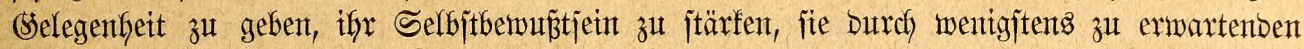

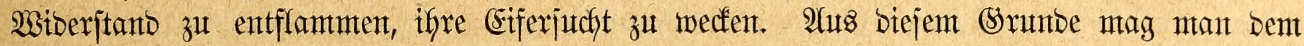

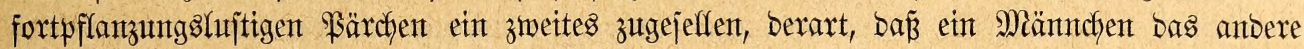
fiht ober hört, ofne zu ifm gelangen zu fönten. Seber 24tsobut ber begeijterung, weldyen bas einte wernebmen läp̧, erregt die bes anberen, unb je höher bie Erregung, um jo eher, unt jo gemifjer ber Erfolg, um jo ftürmijcher bie Riebesmerbung bes Meäntchens, um jo zHoorfommentber Die Şingebung Des Weibchens. Darin aber gerabe be= grünbet ficf zum guten Teile Das Ergebnis Der Farung: befrucftete Eier, fräftige Iunge - und joldye finto es ja boch, meldye man erzielen will.

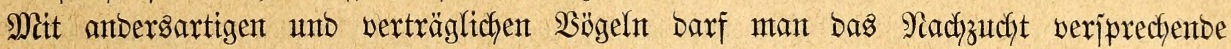
Bärchen ofne Bebenfen zujammenbringen. Unter einer gemijacten (Sejelfichaft fried=

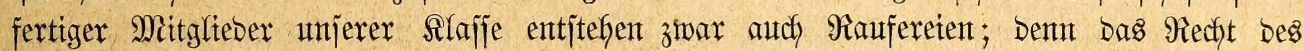
Stärferen fommt in ber Iterwelt ntoch bebingungslojer zur (Seltung als unter ben Menjchen:

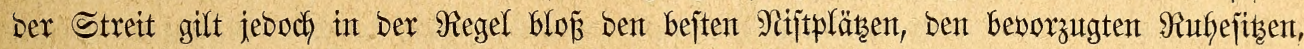

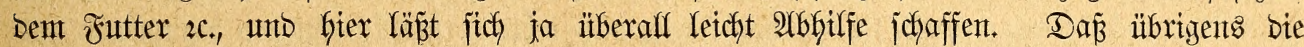
(Sejeflichaft mit anbersartigen $\mathfrak{B}$ geln ebenfalfs wejentlich bazı beiträgt, ein günjtiges Buchter= gebnis zu exzielen, unterliegt feinem Zweifel. Wenn im Bejelfchaftšäfige ein \$ärchen mit

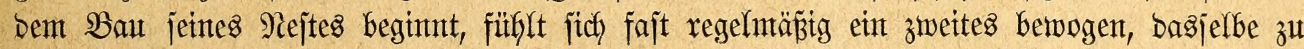
tum, und es wirft bant bas gute Beijpiel verlodfend für bie übrigen. Dafer foll man, falls es möglich, nux joldhe Arten zujammenbringen, weldye einen und benjelben Früfling, eine in biejelben Wochen ober Minate faffentbe Şodyzeit Des Rebens haben. Diejen Wint hat man beijpielsmeije zu beherzigen bei ßapageien, Finfen, Şïfntern, Enten, welche befanntlich ben Früfling ifrer Setmat mit in Die Frembe nefymen, D. G. in Denjelben Mionaten zux Fortpflanzung joyreiten, in Denen fie ober ifre Borfahren im Seburtslande es getan. Es

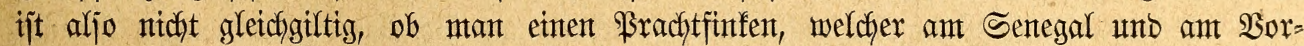

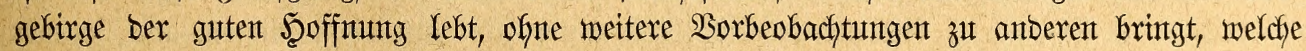
Dasjelbe Berbreitungsgebiet haben; Denn ber am Senegal geborene legt nidyt zu Derjelben

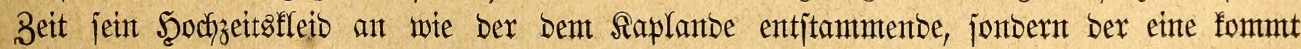

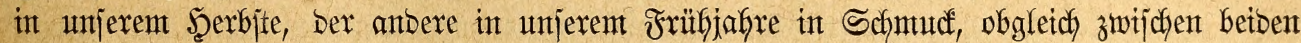

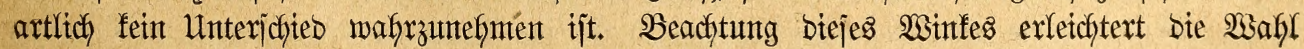
Der sejelljchaft ober bilfft bazu, jie zu regelnt.

Das bisker Bemerlte gillt in höherem Maßje noch für bie gejelfig lebentben Bägel. Bei

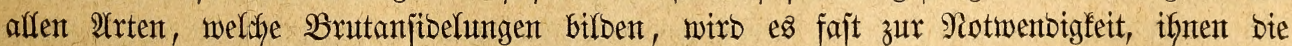

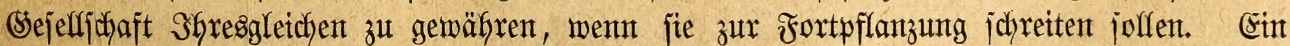

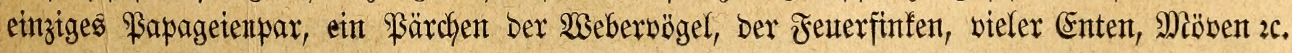


brïtet wobl ebenfalls in Sefangenjchaft, entichteden aber wentiger bejtintme, als went man

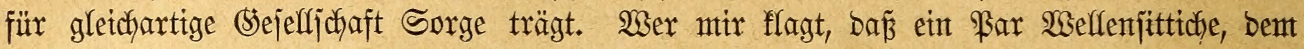

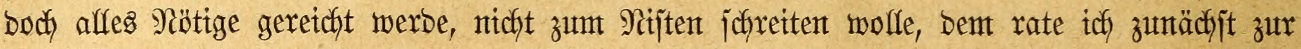

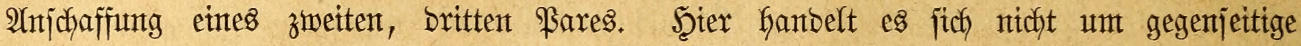
Eiferjuct, jonbern nur um wedjjeljeitige Nacheiferuntg: bieie aber vermag viel, went fie

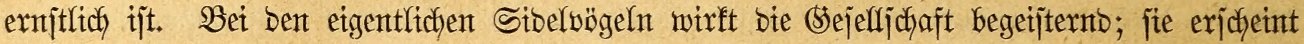

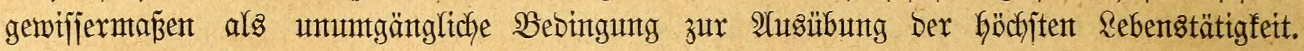
Ein Weberwogelmänthden nimmt, jheinbar aus Spieleret, einen (5rabhalm, einte Fajer unb beginnt zu bauten; Das zweite jifht es, afynt jofort bas gute Beijpiel nach; bas britte

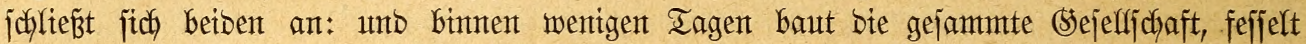
baburch bie 2 htfmerfjamfeit ber Weibchen, unt auth Dieje tun, was ifnen zufommt. Das fint Iatjacthen, welche wobl berotenen, gebürento ermogen unt beziebentlich bentşt z werbert.

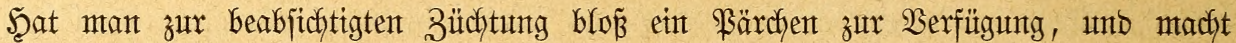

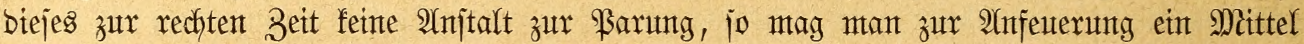

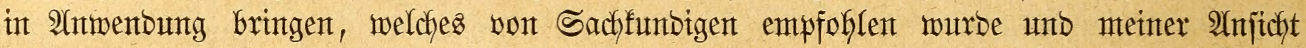
nach in vielen Fällen wirfjam jein bürfte. $5 s$ bejtefgt barin, bie liebesfaulen (sattent zeitweifig zu trennen, bie Stebauer jeboch jo zu jtellen, baj fich beibe bejtänbig jehen und

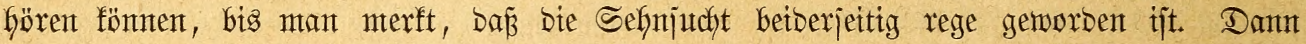

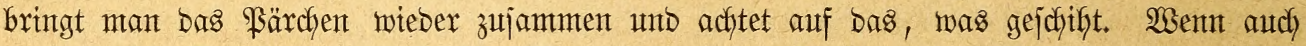

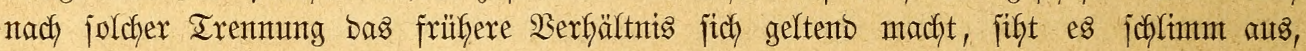

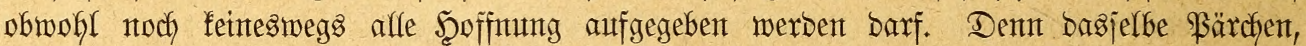
weldyes in zwet ober bret Gafren fein (5it legte, fant int vierten Gahre eifrig brüten.

Şanbelt es fich unt Bögel, weldhe jafyraus, jafyrein im Freient leben, die Untbilben

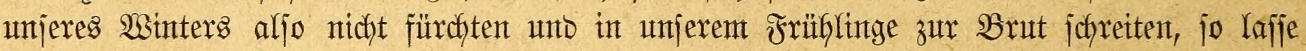
man ifnen ben Frübling auch werben. Man bringe jie alfo, falls man es wirffich für

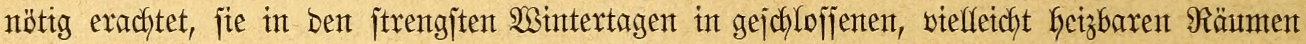
zu Galten, jobalo als irgend tunlich ins Frete, Damit ifnen ber Unterjajied zwijchen Winter unto Jrüfling merffear werbe, bamit ifnen ber belebente Şauch Des Renzes zu Sute fomme, ber erjte milbe Sonnenitral \&ujt zunt Reben unt Rieben in ifnen wedfe, Damit ein fräftiges, unverzärteltes ßar auch einen fräftigen Nachwutchs erzetgen möge. Mit innigitem Eint=

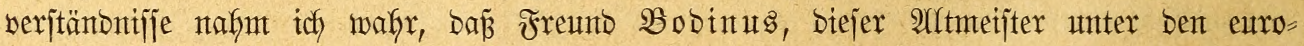
pätichen Sogelzüchtern, jeine fojtbaren (Slantzajanten noch mitten int Winter auf ben

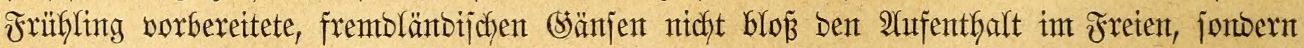

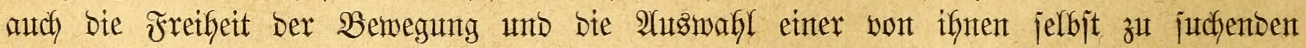

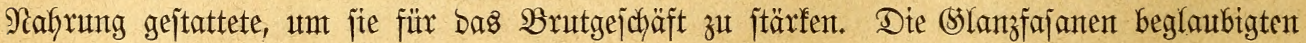

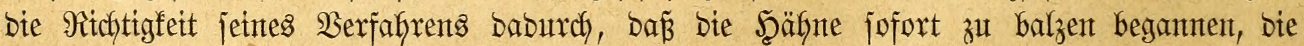

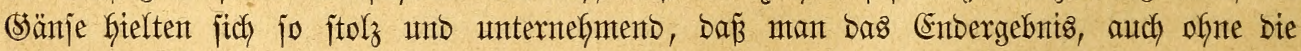
(Sabe ber Weiffagung zu bejitzen, wohl norausjagen Durfte. Bei allen Sdimimmbögeln, von

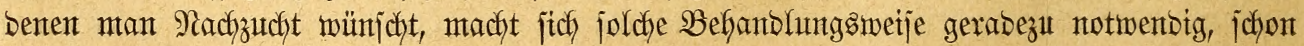

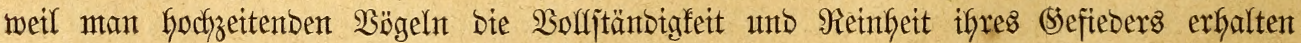

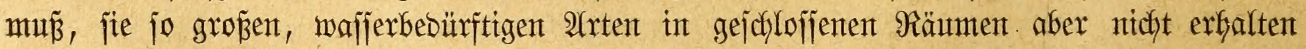
fant. Unter ifnen gibt es wentige, welche nichyt im Stanbe wären, einen gemöhnlicken

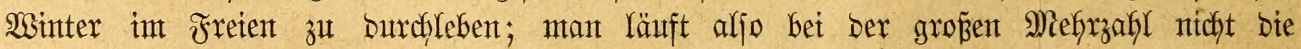

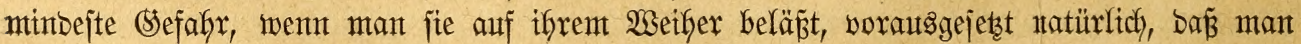

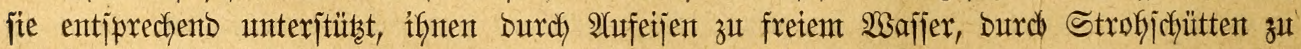

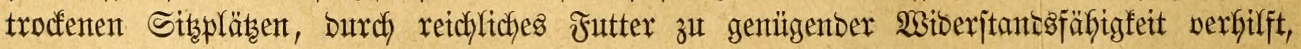

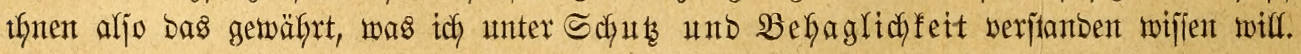




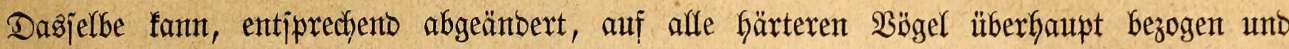
angewentibet werben.

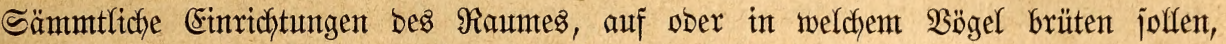

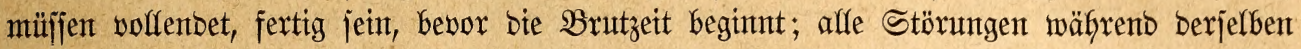
fint zu vernteiben. SBei benjenigen 2 trten, welche int Jreten ober in Einzelfäfitgen nijten, läß̈t fich bieje Bebingung unichwer erfü̈flen, bei benen Gingegen, meldhe int Ffluggebauter zux Fontpflanzung ichreiten joflen, nicht intmer jo leidft burchfüffrent, weil man bie Bebürfnifje

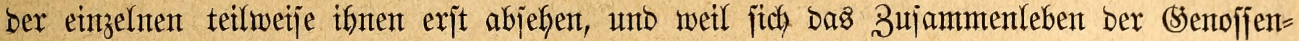

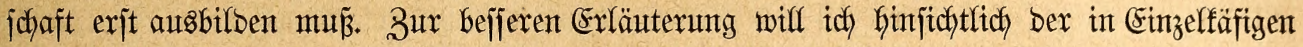

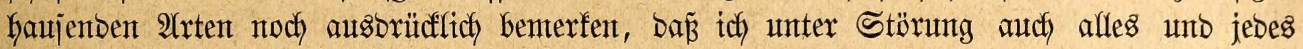

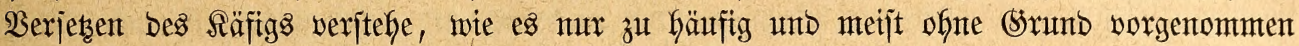
wirb. Wer aljo auf Exfolg hoffen will, ridyte jeinen Seecffäfig vor ber Bratzeit her, be=

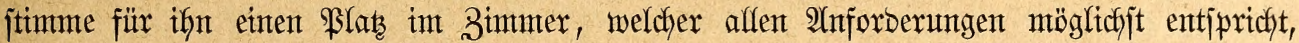

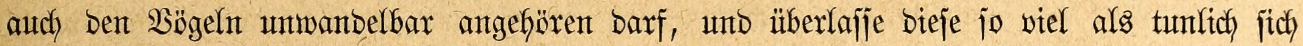

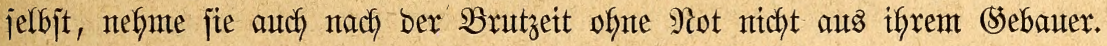

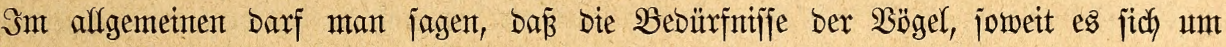

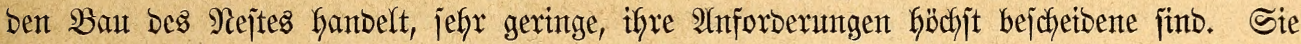

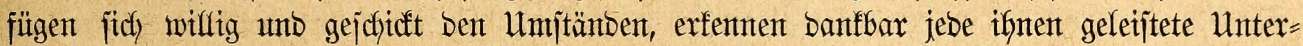

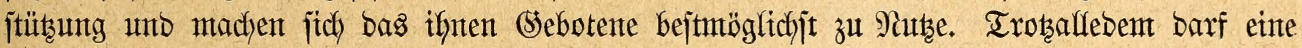

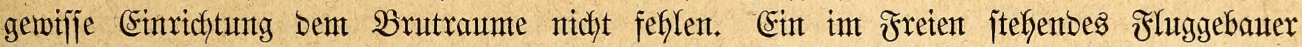

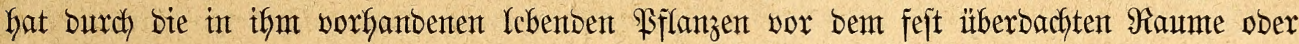

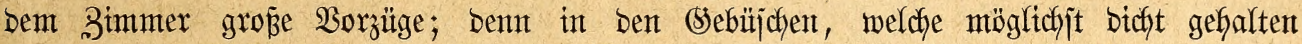

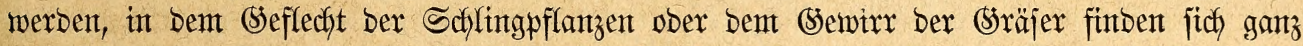

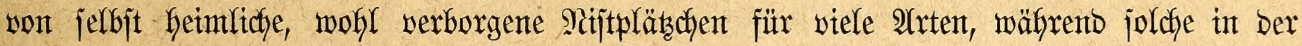

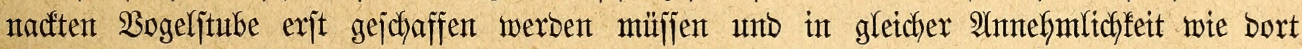

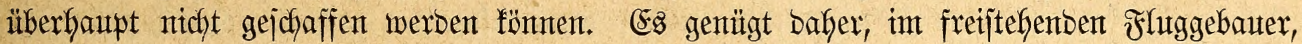

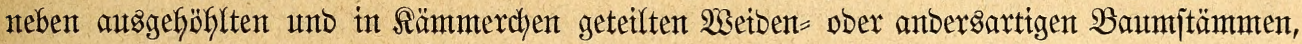

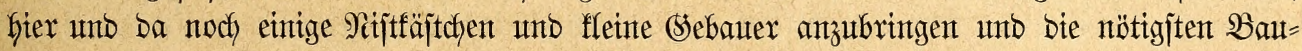

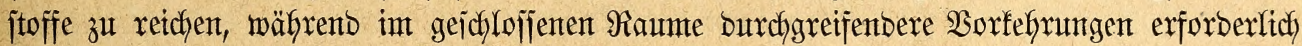

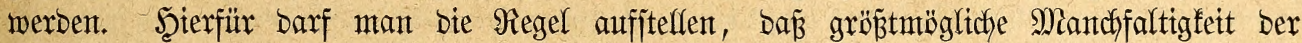

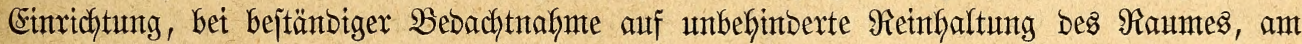

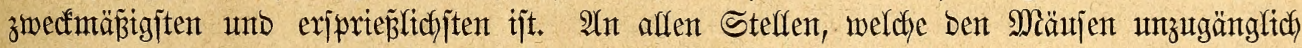

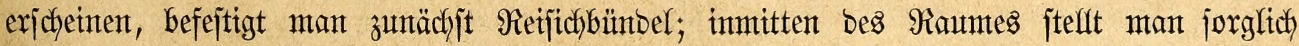
borgeriçftete, Niijtbäume auf; an ben Miautern unb gejichertent (Sitterwänbent bringt man

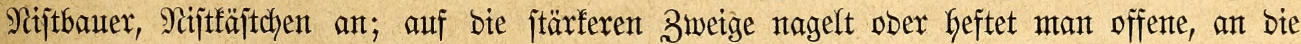
Decfe Gängt mant gejd)lojiene Sïrbchen, ant bejtent mittels eintes längerent Drates.

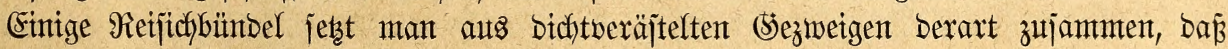

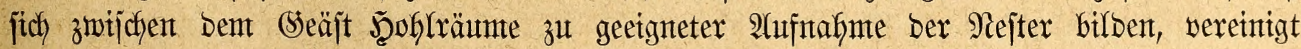

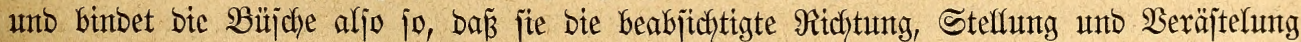
ein für allemal behalten, unt bedient fich, umt jicherer zut gehen, Des Eijenbrates als bBinbe=

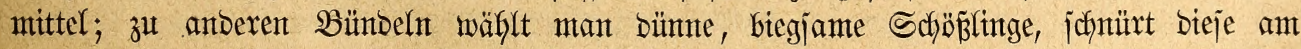

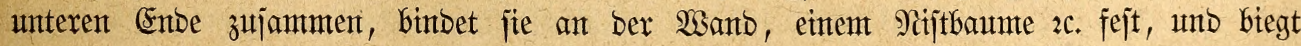
ihre Sppizen auseinanber und nad) untent Kerab, um alfen Şängentejtfern zutnt baut ihrer

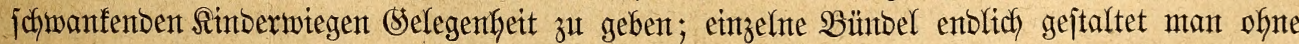

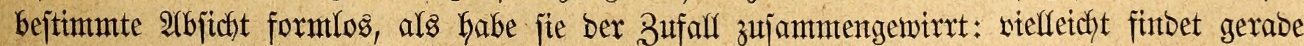

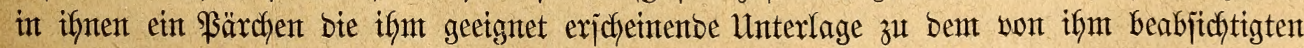
Baute. Nod) einlabender madjt man bas Reifich, wetn man es teil(weije mit einem

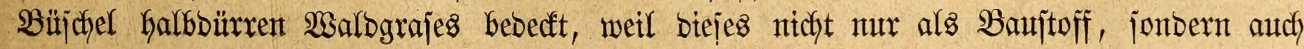




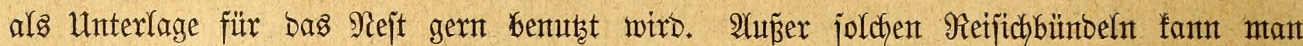
fïr alle biejenigen $\mathfrak{B o ̈ g e l , ~ w e l d y e ~ i f h r ~ \Re e j t ~ b i d f t ~ u ̈ b e r ~ b e m ~ B o b e n ~ a n l e g e n , ~ e i n i g e ~ B i n j e n t = ~}$

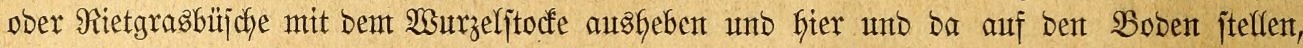

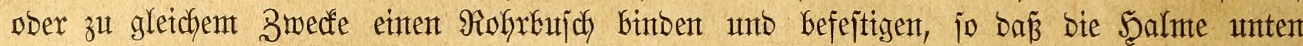
bicft bereinigt find, oben bagegen ben zux 24tfnafyme bes Rejtes erforberlicfent Spielraum

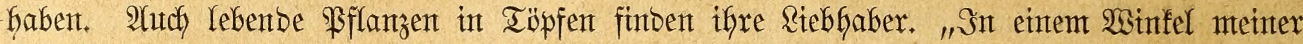

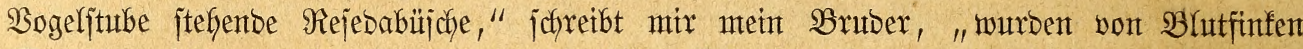
(Pytelia minima) aflen Säjtchen unt jonjtigen Nijitgelegenfeiten vorgezogen unt mit eintem

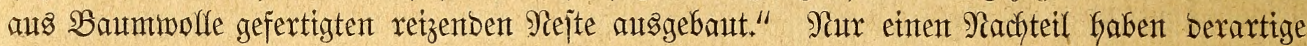
B̧üjche: jie merben won ben Miäujen arg heimgejutcht.

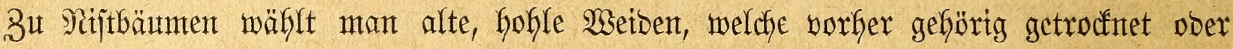
beffer gebörrt twurben, um ben ifnen anfaftenben, vielen Sögel fyöchjt unaugenefymen (s)eruch zu mildern, und welche man jobann in Sntern entiprechent vorrichtent läpt. Dies gejchifht ant einfachjten, indent man den ganzen Stamm jeiner Ränge nach) auseinanberiägt, aljo in zwei Scälften teilt, in jeber berjelben io viele, affjeitig gejchloffente Sämmerchent mit Fluglb̈chern anbringt, als fich anbringen laffen, hierauf aber

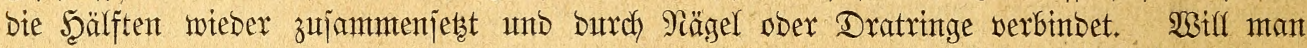
bie Eintichtung berbolffommmen, jo berjift man jebes fiämmerchen finten mit einem gut

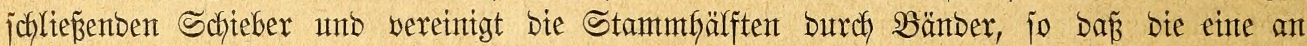
ber anderen jich bemegt, wie eine Türe in ifren 2 (ngeln. Seterdurch erlangt man ben Borteil, jebes einzelne Sïmmerchen nötigenfalfs bejichtigen und jetner Beit reinigen zu

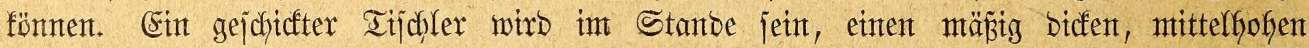

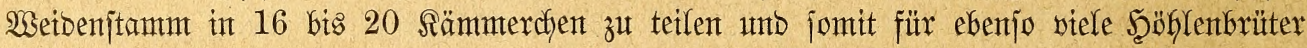
Nijträume Gerzufteflent. Bemerft mag noch merben, baß̉ jebes Rämmerchen nicht breiter als 15 bis $20 \mathrm{~cm}$, nicht Göher und nidjt tiefer als $10 \mathrm{bis} 12 \mathrm{~cm}$. zu jein braudft, falfs es

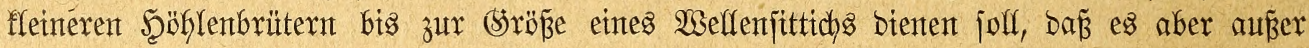
Dem Fhugloche, weldyem man einen Durdymeffer bon $4 \mathrm{~cm}$. gibt, anberweitige 3ugänge nicht

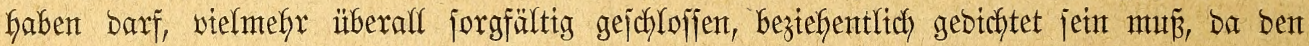
Br̈geln jeber sidftitral, weldyer an einer anberen Stelle als burd, bas Fluglod, eintringt,

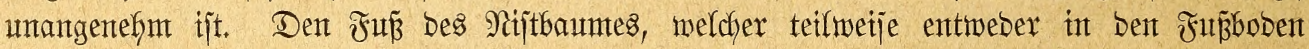

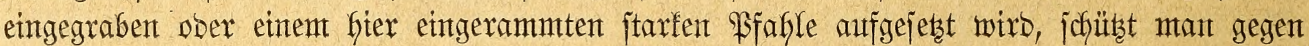

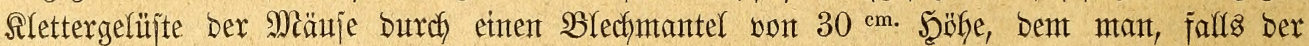

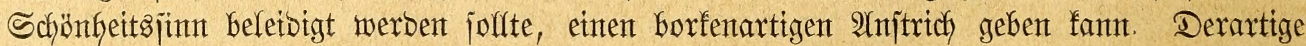

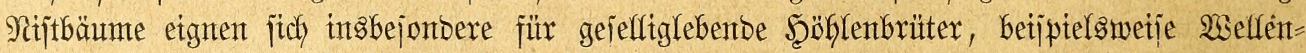
fittiche und anbere fleine ßapageten; fie bilben in Den belgijchen Fłthggebautern, in benten man alliährlich fumberte Dex erjtgenamnten züthtet, Dexen einzige Nijtgelegentheiten. Shre

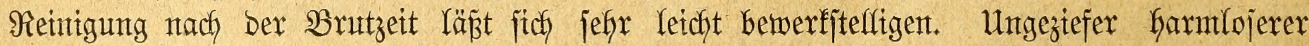
A(rt (Mitben) nijten jich, wohl Des Matmgeruchs Galber, wom Scauje aus mentiger in ifnen ein, unb ben Miäujen fommt man in ben einzelnen Sämmerchen viel leichter bei alz in anberen Ş̋̈hlungen.

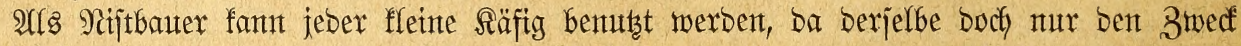
Gat, Dem Silejte zur Unterlage zu bienen. 2(m häufigiten verwenbet man Şarzer Bauer und

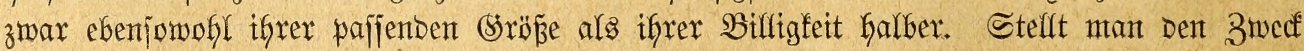
ber Büchtung alfen übrigen woran, fo nagelt man bie $\mathfrak{B}$ auterchen auf ein glattgefjobeltes $B$ ret,

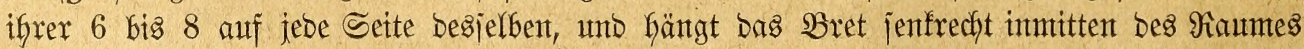
auf; bieje Einrichtung jift zmar nicft gerabe hübjch aus, gemährt aber ausigezeidynetent Schut vor Miäujen unt aurerbent nody ben Sorteif, nach ber Brutzeit ofnte irgentowelche ธtörung ber Bögel entfernt merben zu fönten. Wemt man bas Bret nur auf cinter 
Seite mit Şauerchen benagelt unt an einer glatten Wanb auffängt, wirb bas 24tge

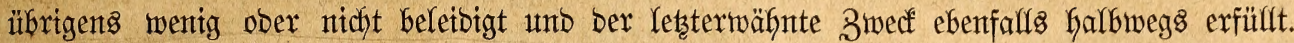

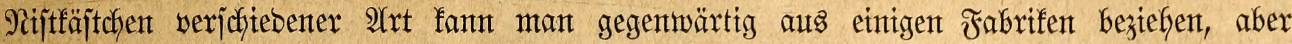

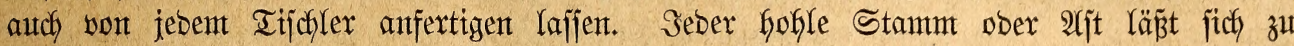
iffnen verwenten, wenn man ifgn oben unt unten gerabe abjdynetbet, mit Decfel unt Boben berjitht unto ein Flugloch einbofgrt; joldche gleichjam natürliche Nijitgelegentbeiten

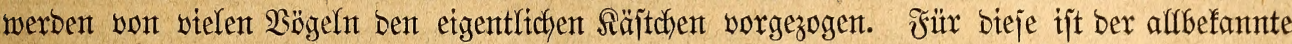

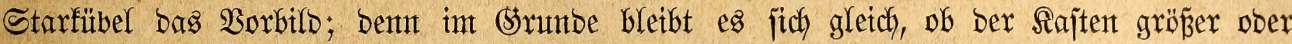
fleiner, höher ober niebriger ift, ob ex jenffedyt ober wageredht aufgehangen miro, unb ob bas Jlugloch jeitlidf ober vorn eingeidynittent wurbe. In einent mit serjcfiedenen ârten bejebtent

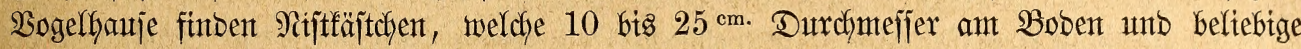

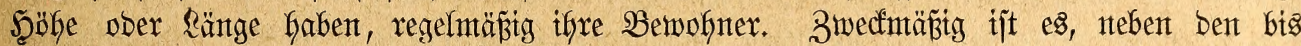

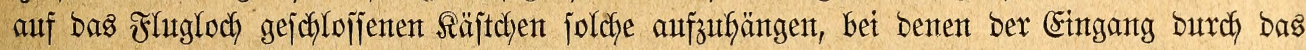
Jeblen bes oberen Drittels einter Seitenwanto gebilbet wirb, weil man audy ben Raunen eines

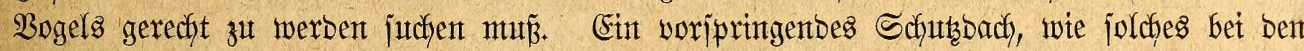

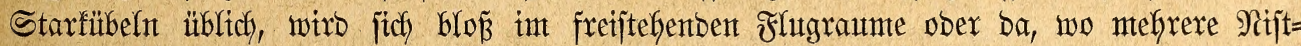
fäjtchen über eintanber angebractyt werben, als notmenbig ober boch paffent erweijen. 2Yuf

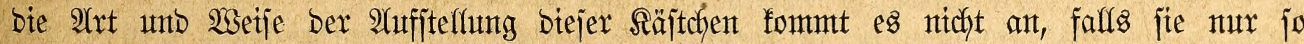

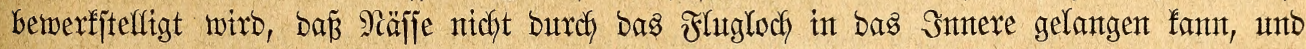
falfz man ferner bie Meäuje nicht aus ben 2Yugen verliert. Die $\mathfrak{B}$ ögel fügen fich, went

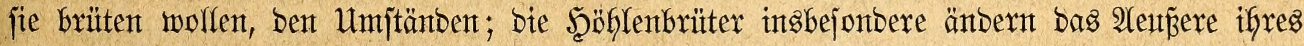
Nejtes je nach ber Şöflung, in weldyer es jteft, entiprechento ab. Schwieriger als bie

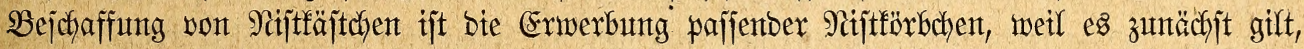

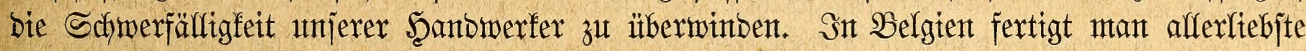

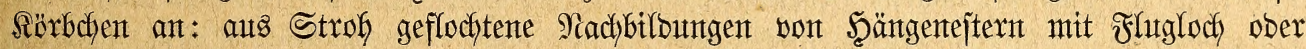
Jlugröhre, welche man an einemt Drate einfach aufzufängent brautht, umt bie Bögel eint=

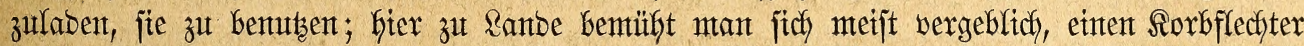
zu veranlafjen, berartige 2 trbeit zu liefern, uno went ex wirflich bereit ijt, erbält man unbrautchbare Ware. Bló bie fleinen oben offenen Malben, welche zur Unterlage ber Nejter bes Ranarienbogels bienen, finbet man vorrätig, meijt aber audch mur in jefr jojlechter Bejchaffenheit. But gearbeitete, D. h. Didyt geflochtente Rürbchent werben von ben $\mathfrak{B}$ g̈geln

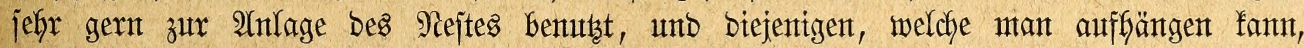

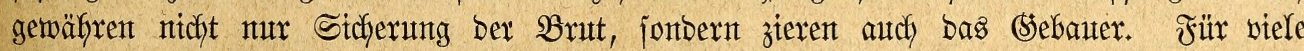

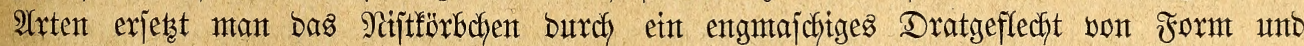

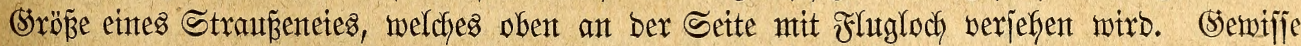

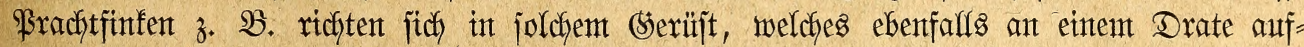
gebängt werben fant, jefr befaglid ein, intoent fie Sbauftoffe in bas Snnere tragen uno

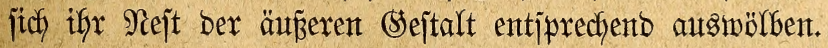

Bei einemt belgijdyen, wohl exfahrenen Siebhaber, bem jetzigen Borjteher bes Briujfeler

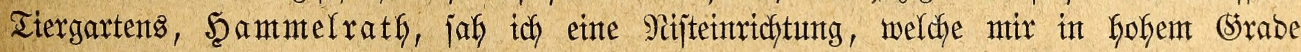

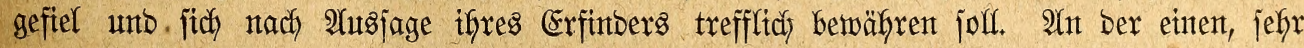
jorgfältig geglätteten, fejt überbadyten Want bes Fluggebauters war über eingemauterte,

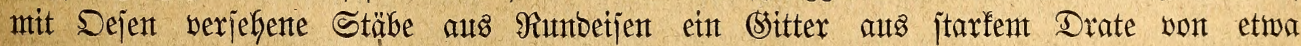

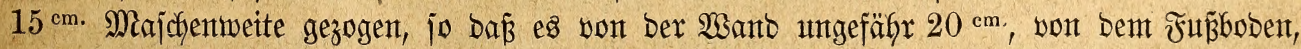

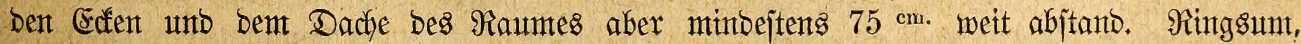
zur $\mathfrak{B a n t b}$ jenfredft ftefjent, zog fich über Die äußerjten Stabreiben eint enges Dratgitter,

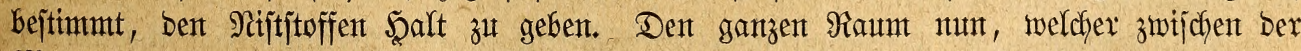
Mauter unb bem weiten (sitter gebilbet unb burdy bas Dratnets umidhlofien wurbe, hatte 


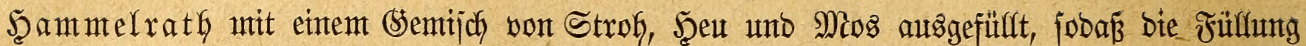
gleichjam eine fejte Wand Darjteflte. In biejer waren burch jorgfältiges Aluşupfen ber Mitjtitoffe bacfofenförmige Şöhlungen hergerichtet worben, ant jeber Majche Des weiten

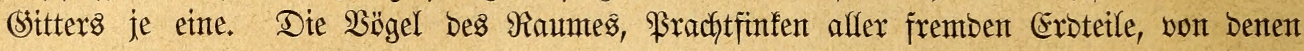

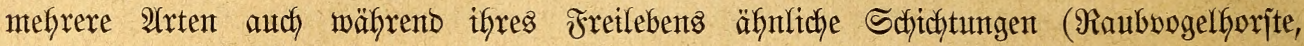
Wänbe von Strohgütten) zum Siijten benuben, Gatten Die Eintichtung bejtens angenommen. Man jaf überalf Dic zierlich zugebauten Eingänge zu Den Nejtern unb bieje auch von joldyen Arten bebolfert, welche bie Benubung einer berartigen $23 a n b$ unzweifelfaft erjt anberen abgejehen und nachgeabmt haben muraten.

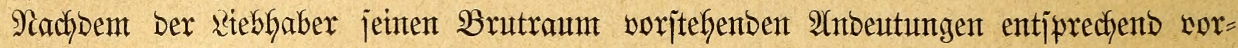

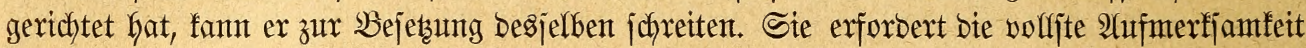

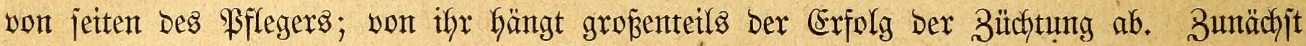
überlege man es jich genau, weldye 2rrten man gemeinjchaftlidy in einem umb bemjelben

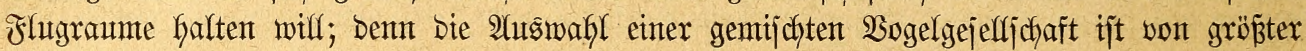

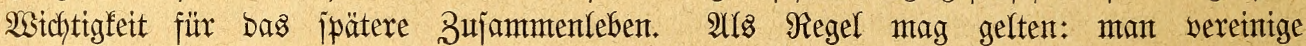

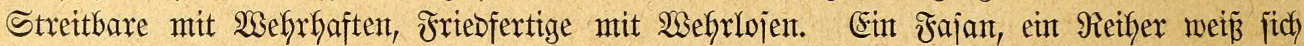

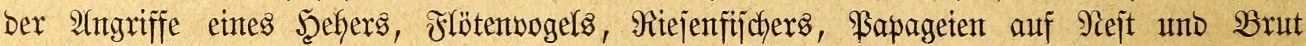

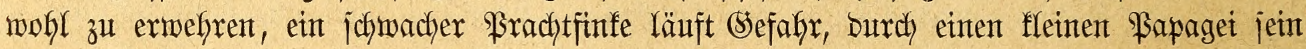

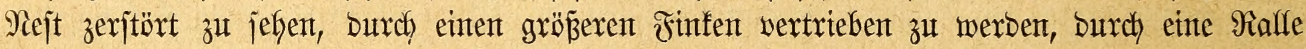

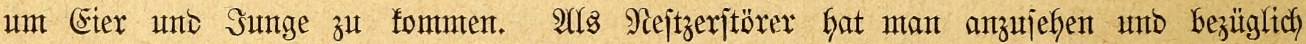

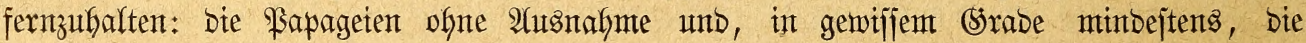

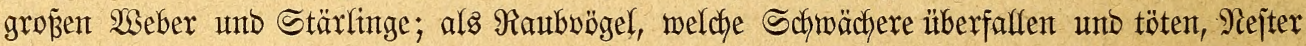

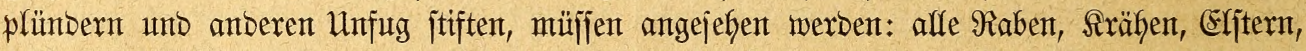

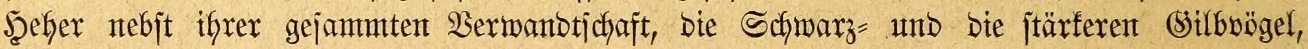

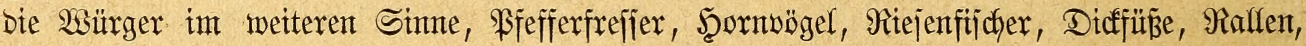

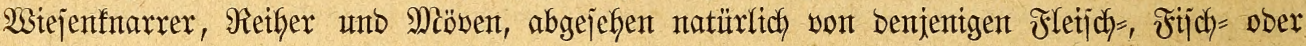
allesfrefjern, welche man ofnefjin nicht im Fluggebauter zu halten pflegt; entjchiebente

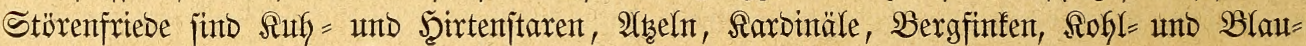
meifen. Site alle verbante man aus ber (Sejelljchaft ber Schnächlinge, will man fie vor

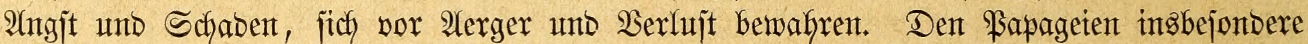

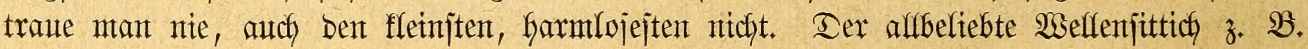
ijt, wie Freund Fiebler und idh mieberfolt exfufren, einer ber abjcheulichjten Stören=

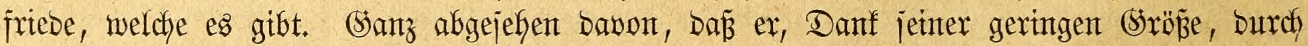

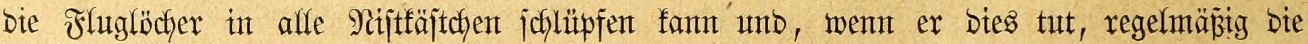

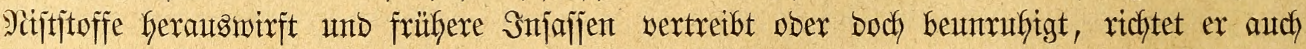
jonjt vielen Echaben an, wie tdh weiter unten ausfühyren werbe. Shn jollte man jtets nux in Sejelljchaft von Seinesglechen halten; ex mirb jogar ftärferen Sittichent läjtig. Dagegen

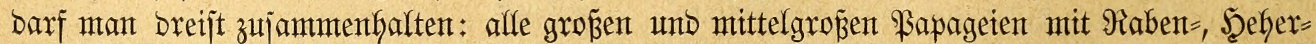

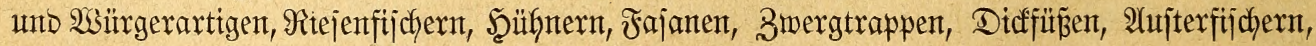

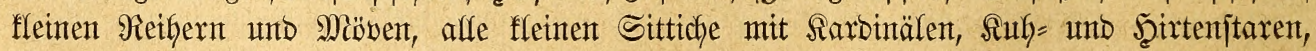

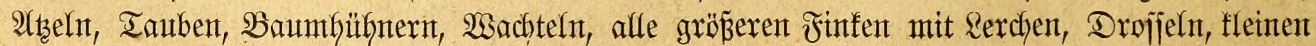
Tauben, Regenpfeifern, Wajjer =, Strand $=$ ufer = und Schlammläufern - Dem Strand = gemimmel, wie ich, lekztgentannte (sejelfichaft vereintgent, mich auszubrüdfen pflege, - See=

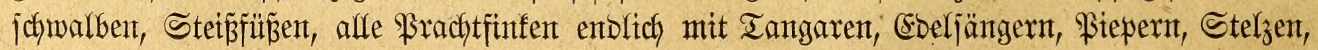
fleinen Meijen, Schwalben, Fliegenf́̈̈ngern, Den fleinjten Stranbläufern und anberen wehr = und barmlojent Stubenoögeln.

Eine golbene Regel ijt, Die gejammte Bemofnerichaft einer Afbteilung Des Fluggebauters

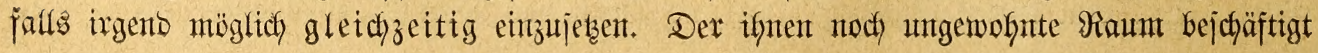


affe anfänglich weit mebr als ifgre stenofjenjchaft, unto wäfrend jie jitch bejtreben, im Raumte Geimijach zu werben, Yernen fie alfgemach jidh fenten. Iritt jpäter ein Stüdf,

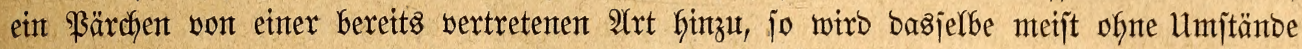
auf = unb angenommen, währeno bei Bermefrung ber eingewofgntent und eingelebten Bejell= jidaft burch ein neutes, anbersantiges Mitglieb Das Entgegengejetzte itattfinbet, bie gejammte (Sejellichaft in Alufregung gerät, Gerbei geflogen fommt, ben Neuling neugierig betrachtet, autch wohl mit Schntabelfiteben und äfnltichen Zeichen einex gemifjen Feintojeligfeit entpfängt, unto jei es nur, unt ben Uebermut an bem anfänglich verblïfften Sdjächer auzzulafjen.

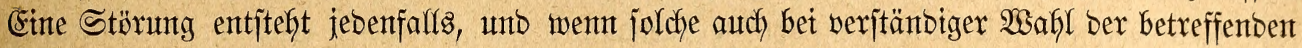
2)rt wentig zu bebeuten Gat, ijt es boch nicht erwünjcht, fie herbeizufüfren.

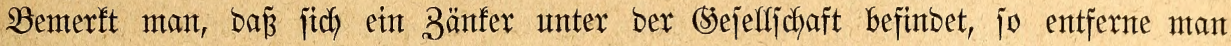

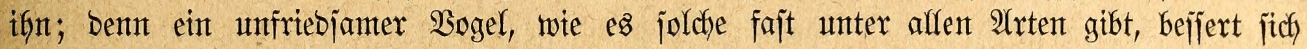

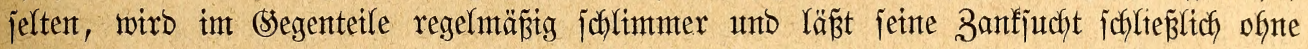
erjichtlichen (srumb auch an ben harmlojejten (sejellen aus. Ebenjo fant mant in die sage

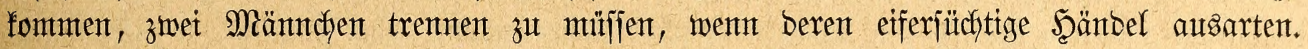

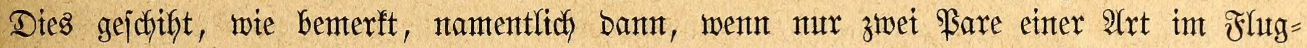
gebauter jich befintoen, unt es läß̈t jich bafer in vielen Fälfen burch Şinzufügung eintes

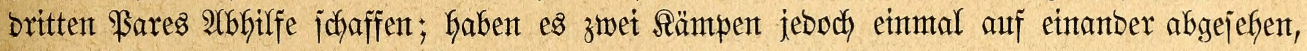

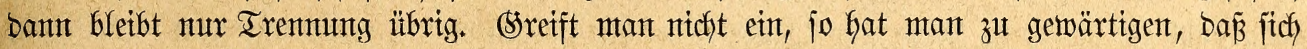
Die erbittertent Streiter, und zäf)len jie gletch zu ben webrrlojen, gegenjeitig ärger zurichten,

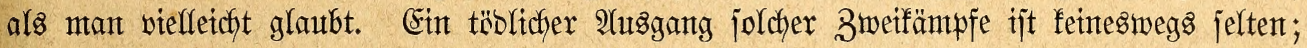
Berwumbungen, weldye zeitweije zur Farung unfähig machen, fommen noch öfter vor. (Santz anbers verfält fich natürlich bie Sache, went ein Bärchen ofne frembe Eimmijchung in Streit gerät. Der 2 (nfränger lafje jich burch bas gegenjeitige Sagen ober Ireiben nicht irre machen ober berfüfyren, ben jubringlich erjcheinenben (Sattent unb went audf mur zeit= weilig zu trenten: biejer bezwedt nichts anderes, als jein Stejpons zux Riebe zu entflammen,

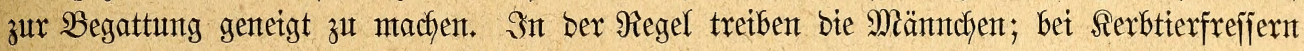
fommt jeboch auch bas Entgegengejetste vor.

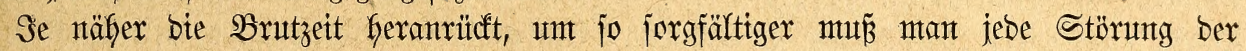

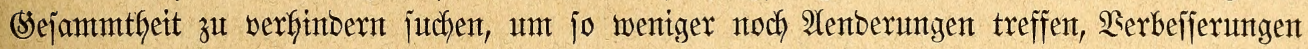
einfübren molfen, umt jo aufmerfianter und unabläjifiger beobad)ten, bamit man sorfommenden

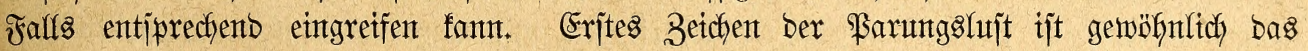

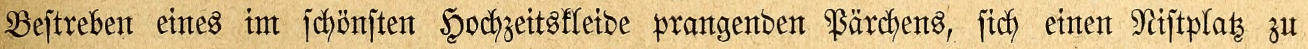

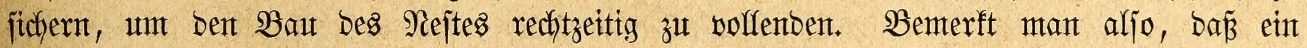

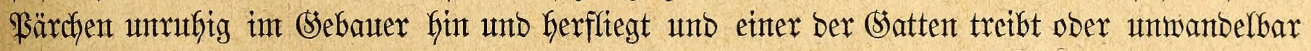

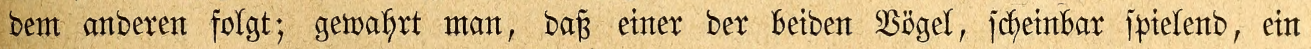

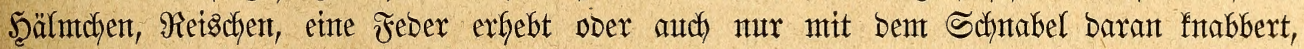

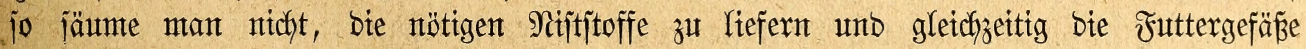
reich)lich und zmedfentiprectiend zu bejchicfen.

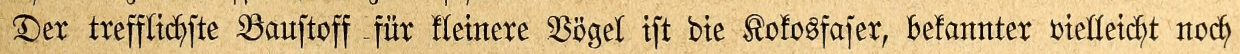

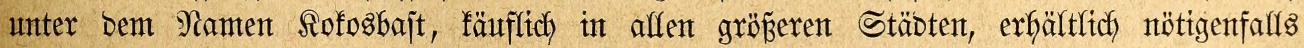
burch Berfajern einer aus ifyr geflochtenen Fuñmatte. Sie eigntet fich insbejonbere für ben

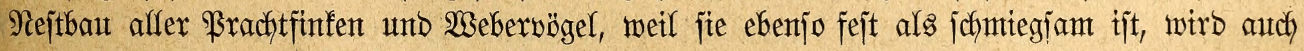

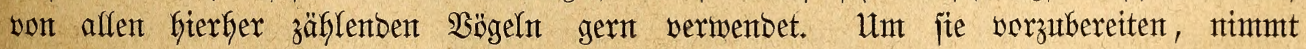
man einen Baflen, zerfajert ifn, bis ex ganz locfer geworben, unb legt ifn in einen fleinen

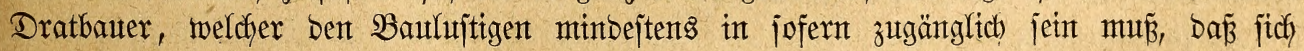
jeber bie benötigten Fäbent zwijchen Den Sprofjen Kindurdy ausziehen fann. Winft man bie Fajer auf bent Boben, jo wirb ber $\mathfrak{B a f l e n , ~ a b g e j e f e n ~ b a v o n , ~ b a j ~ e r ~ u n t e r ~ U m i t a ̈ n t o e n ~ e i n t e n ~}$ 
Zantapfel bilbet, fin und Gergejchleppt, bejchnuzt und jonjtwie verborben ober, faflz er nicht

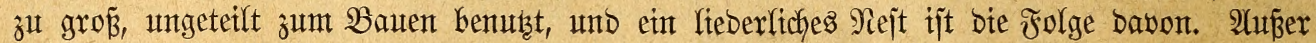

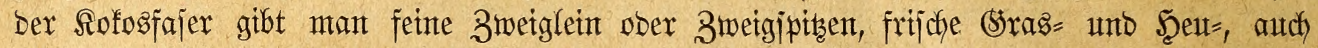

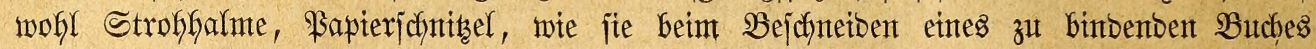
abfallen, feine Birfenichale, trodfenes Mos, Fledjten, B̧lütenfajern won ben Rolben bes Mais, zumal bes fleinföntigen, italientichen, Samtenwolfe von Dijteln, Weiben, Espen, Schwarz=

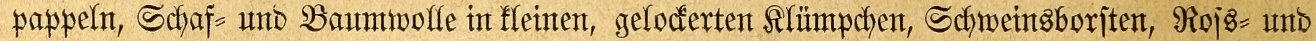
Sälberfare jomie endlich Febern fleinerer und mittelgroß̈er $\mathfrak{B o ̈ g e l , ~ b e z i e h e n t l i d y ~ a u t h ~ D u n e n . ~}$

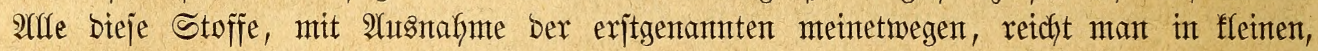
oben offenen, leidyt zugänglichen, vor bem Bejchnuzen tunlichjit gejchütsten Sïrbchen, bie zujammentpaffenden beretnigt in je einem; baburd bermetbet mant nidyt affein untötige Berlujte, fontern geminnt audf eine reidjtere und befjere Ueberjicht bes Serbrautchten, fann aljo jeberzeit helfen, wo es fefjit. Die berjchiebenen Stoffe in einem einzigen forbe zu

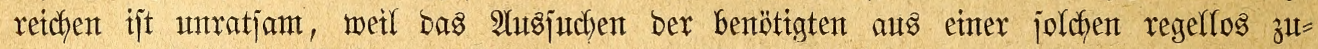
jammengejchidfteten Maffe Den $\mathfrak{B o ̈ g e l n ~ u n n u ̈ b e ~ M a ̈ h e ~ m a d h t ; ~ e h e r ~ e m p f i b l t ~ e s ~ f i c h , ~ i f n e n , ~}$ went mant fie eifrig tragen jift, nach SBebürjnis einen fletnen Ietl Derielben zerjtreut auf

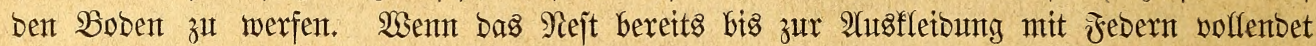

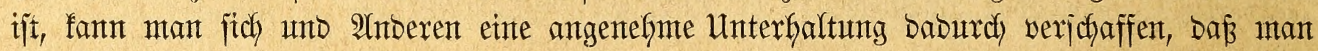
ausgejucht ichöne, D. h. fleine uno meidfe Feberchen in Den Raum miryt uno einen Wetteifer,

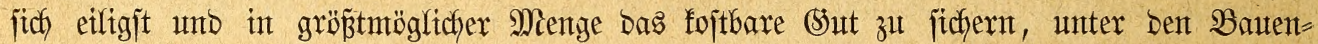

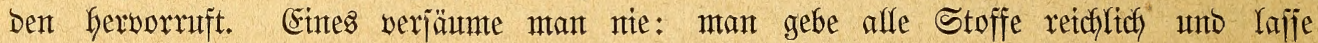

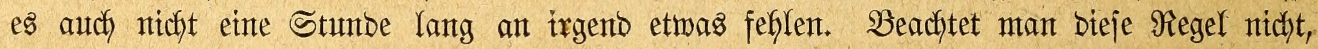

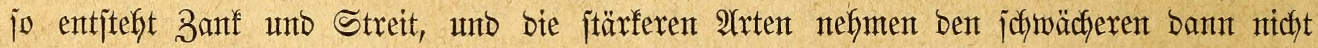
allein bie Banitoffe meg, jonbern zerjtören auch bie bereits halb ober ganz fertigen গiejter,

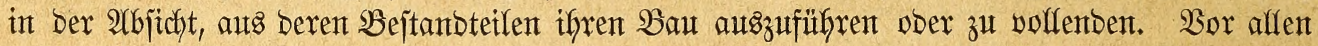

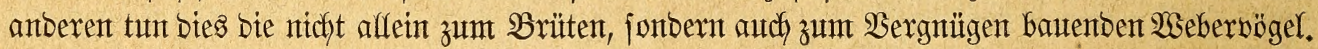

(Sröß̈eren, ungejchifften Wögeln, beijptelsmeije Denen, welche auf Dem Boben nijten, fommt man beim $\mathfrak{B a u t n}$ zu Scilfe ober bereitet ifnen bas volfjtänbige Nejt, wie jeber

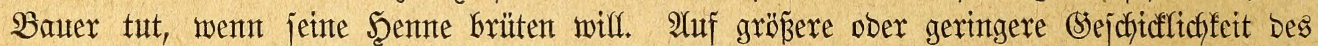
Selfers fonmt es babei nidht eben an; Der brïtluftige 2 ogel jolf in bem ifym bereiteten Miejte eigentlich mur eine Einlabung jefen, Dafinein jeine Eier zu Yegen. Will ex ber Eint= rabung nidft Folge leijten, vielleidft jeinen eigenten Willen zux Beltung bringen, jo lafie man ifn einfach gemähren, jchon um ifn nidbt ängjtfich zu machen ober zu vermirren; legt er, wie oft gejofifgt, ein Ei bortfin, Das andere hierfin, jo janmelt man bie Eier entweder

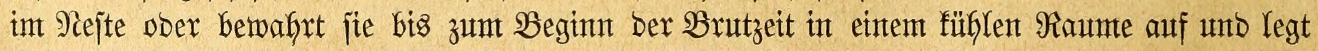

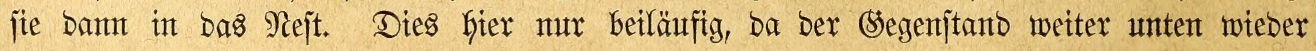
aufgentommen utb ausfüfrlich befjandelt werben wirb.

Das Futter, weldyes man brütlujtigen $\mathfrak{B}$ ögelnt retcht, mußs barauf berechntet jein, fie jo gut als möglich zu nähren. Şat man Rörnerfreffern bis bafin weber Mefltwürmter nodh S(meijenpuppen gereidjt, bon jest an unterlajje man es nicht, füge aud jo viel anbere Serbtiere finzu, als man erlangen fanm. Der brïtende Bogel nimmt fich wentg Beit zum Freffen, mun baher afles ifym sötige funben unb fich in fürzejter Frijt jättigen fönnen.

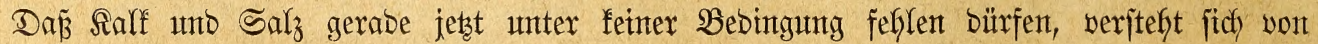
jelbjt; es empfiblt jich jogar, exjteren bem Jutter gerabezu beizumijchen, am einfachjten, inbem man zwei Stüdfe Sreibe ninmt und Dieje über Dem Futternapje gegeneinander reibt, biz ber jo entitefentbe feine Staub auf letzterem fichtbar wirb, ober aber intom man in einem bejonberen शapfe zerbrödelten Mibrtel aus altem (semtäuer barbietet. Salz retcht ntan um jo öfter und mefrx, je wentiger ber Sogel (selegentheit hat, jich jelbjt Damit zu verjorgen, 


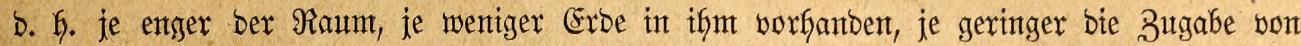
Fleijch int $\mathfrak{s u t t e r}$ ift.

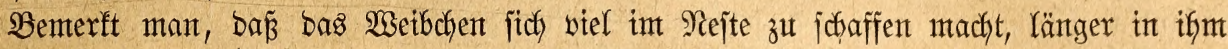

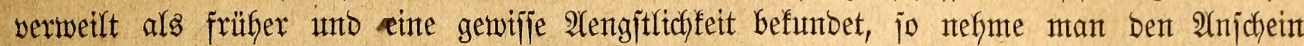
gröbter Unachtjamfeit an, tue, als jefe man bas Nejt gax nicht, nahe fid bemjellent

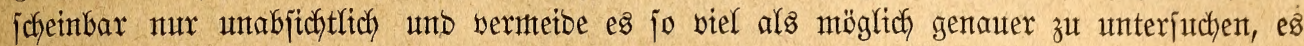

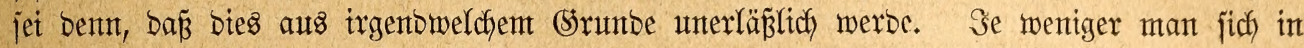

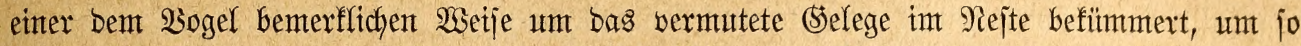

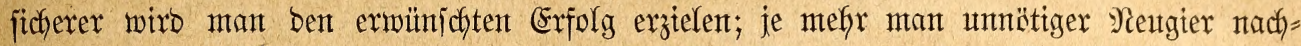

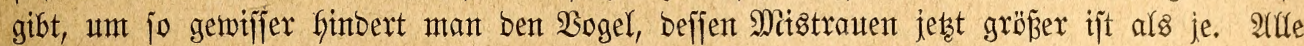
Riebhaber, weldhe jeberzeit ganz gentau wiffen, wie viele Eiter biejes, wie biele jentes \$ärchent

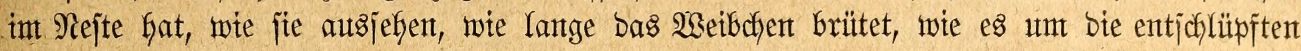

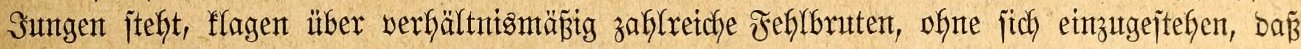

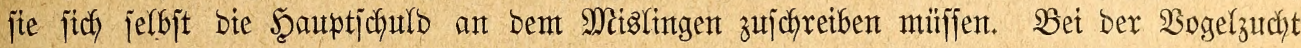

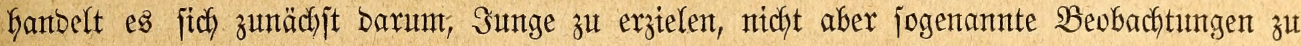
machen, was gemöfnlich nichts anberes jagen witl, als ber unbejieglictent Neugier frönent. Der exfafrene Soggelwirt beobactlet audd, aber ofgne zut ftören, greift ein, went es er=

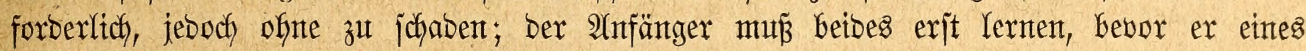

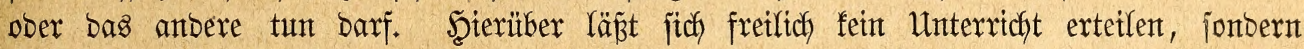

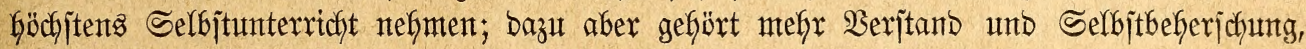
als bie Miefrzzafl wähnt.

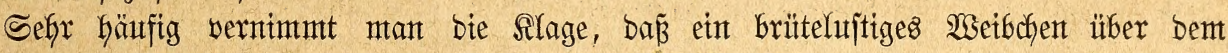

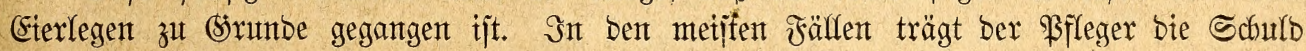

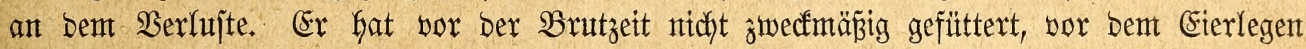

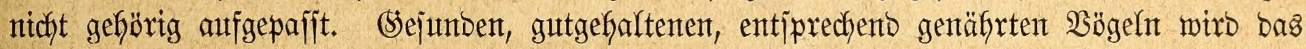

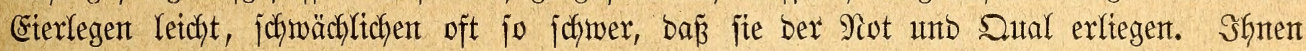

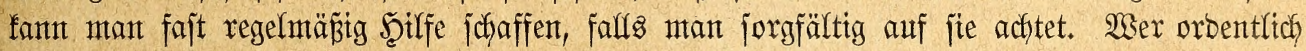

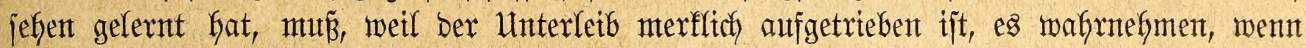

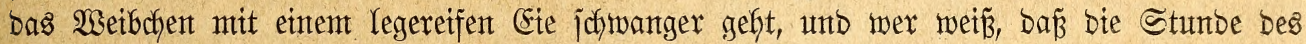

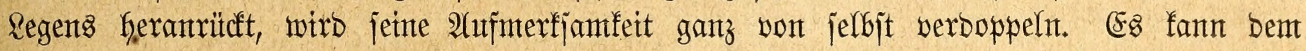

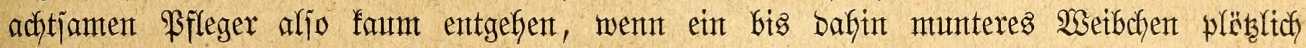
Beichent bes Untmoflieins befuntet, fich mit gejträubtent Befieber jitif auf bas erjte bejte

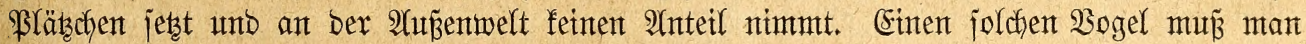

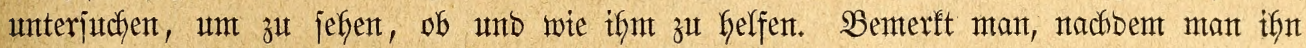

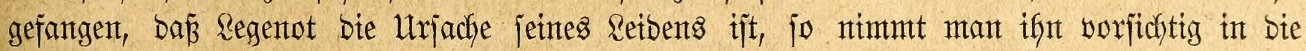

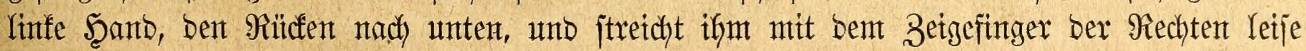

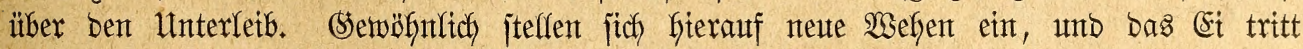

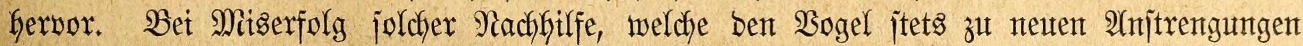

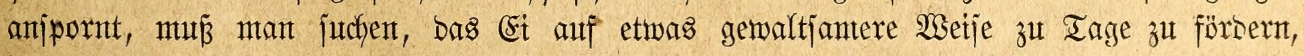

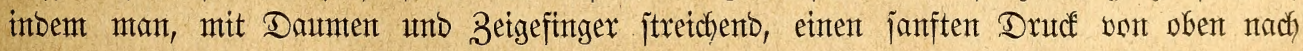

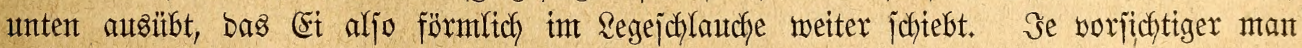

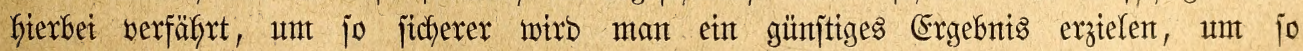

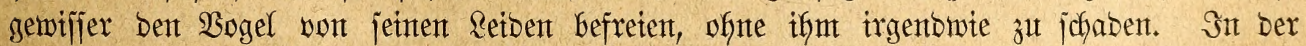

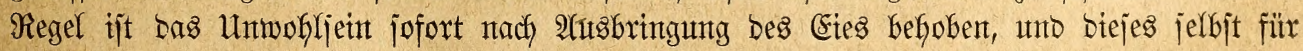

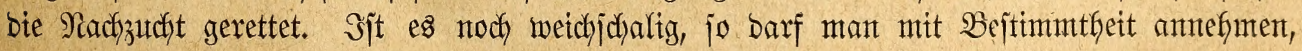

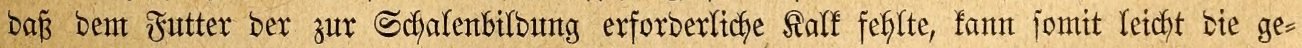

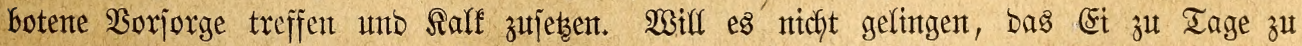

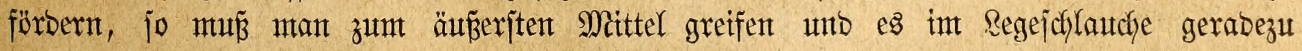




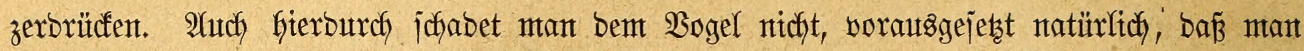

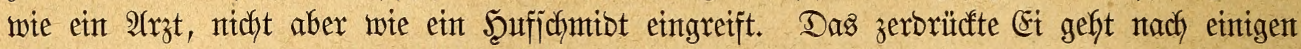
Mimuten ab, und bie etwa noch feflenten Splitter ber Schale werben ipäter augigejujieden. Sollte bas burdh bie Regenot ermattete Weibchen nach ber gewaltjanten Entbinbung framtsf= Gafte 3ufälle befommen, jo tut ein faltes Bad vortreffliche Dienjte. - Bei größ̈eren

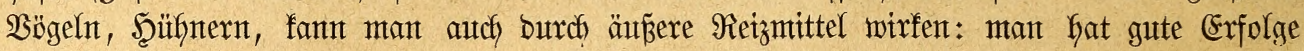

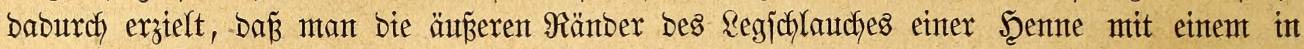
Terpentinül getaudsten Binjel betupfte unt baburch erneuterte, fräftige Weben Gerworrief.

Währento ber Brutzeit jelbjt muß man noch jtrenger als jonjt jebmede Störung ser= meiben unto auf alles achten, was nachteilig ober förberlich jein fant. Dem gewöhntlichen

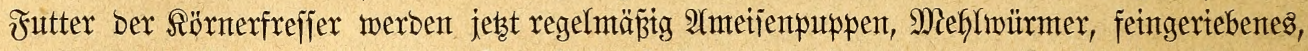

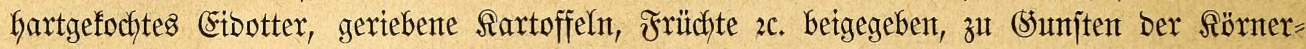
wie Dex Wetchfreffer auperbem noch tägliche Beutezüge zur Exlangung beionberex \&ecfereien

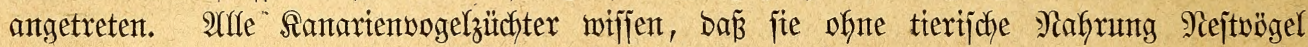
nicht großz zieben fönten, und juthen das Fehlende zu erjezen, und alfe Beobachter werben

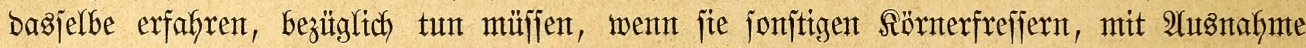
ber Tauben, gerecht werben wollen. Bei flemeren 2 B̈geln fann in biejer Şinficht zu viel

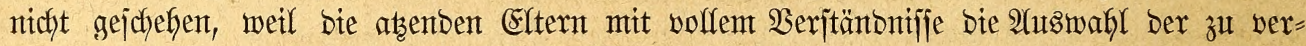
wententoen Stoffe übernebmen; bei größ̈eren Bögeln bagegen, namentlich bei alfen গiejt= flücftern, fann leidft das (segenteil ftattfinten, - boch barüber ipäter.

So gejellig und friebfertig gemiffe Bögel unter fidh leben, jo abjcheulidy bebantoeln fie zuwetlen bie eben auggeflogenen Sungen ifyrer eigenen ober einex fremben 2 rrt. Es ijt

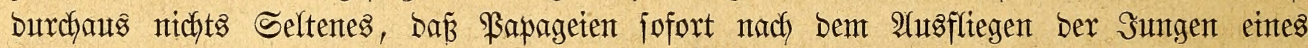
anberen Bärchens über bie fitlf = und wehrlojen Slleinen Gerfalfen, jie mishandeln und, falls

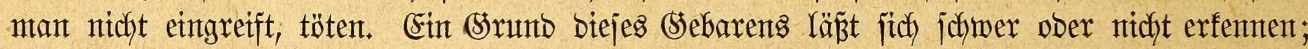

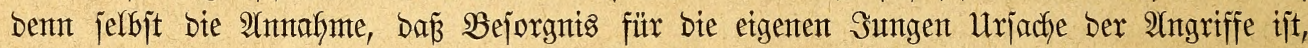
trifft nidyt immer zu. Sch habe Wellenjittiche gepflegt, weldye bas Afusfliegen mefrerer Bruten rubig hatten geicheben lajfen und Dann plöblich eine Brut umbractsten; ich habe

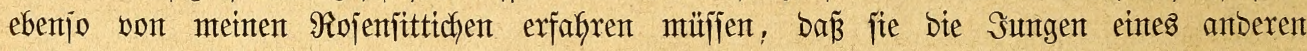
Färdhents angriffen, währent jie mit Den Estern im bejten Einvernebmen gelebt hatten und fortlebten, unb idf bin in beiben Fällen nicht im Stande gemejen, bas mir rätjelbafte

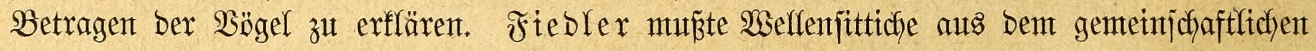

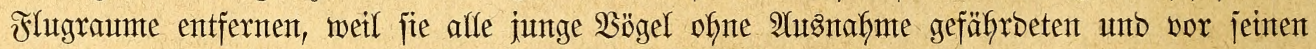

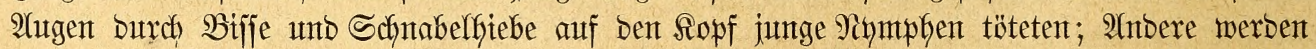

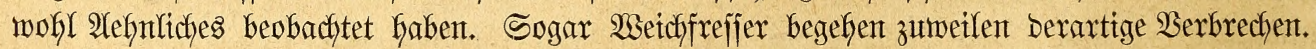

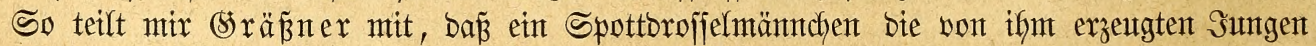

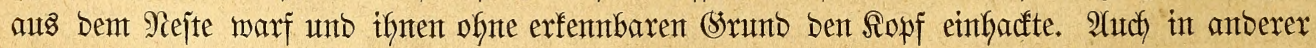

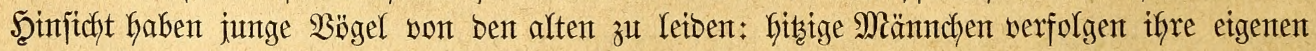
Sintoer jogar mit fdynöben (selüjten, mafyrjheinlidf; weil ite bie Aleinen ifyres Sugentfleibes Galber für neu binzugefommente 2 setbdyen Galten. Sie töten bie Sungen zmar nidft, merben ifnen aber Dod jefr läjtig und fönten immerbin unbeil herbeifübren. Sn beiben Fällen ijt es nötig ober body wofilgetan, bie Sungen in einen fleinen fäfig zu jetzen und biejen im Flug=

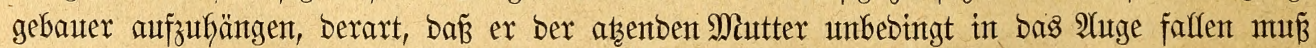

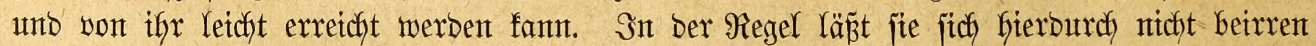
uno füttert weiter; es fann jeboch audy bas Ungefeforte ftattfinbent: itätige Beobadjtung ijt aljo

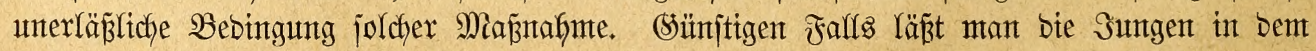
Bauerdyen, bis fie affe und jebe Bemutterung entbebren fönten, unto bringt jite jodann in einem bejonderen Räfige unter, unt jie aud fernerbint zu jitbern. 


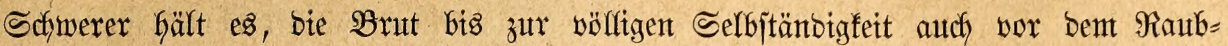

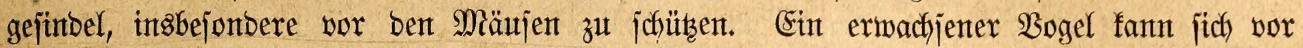

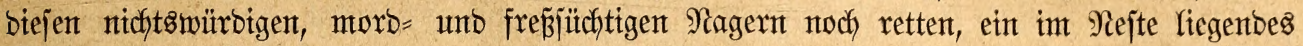

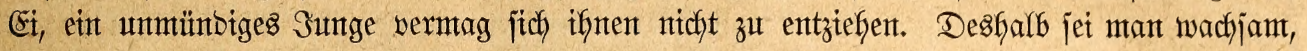

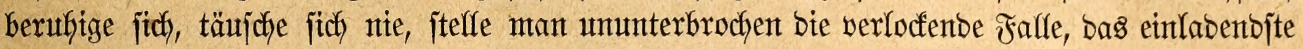

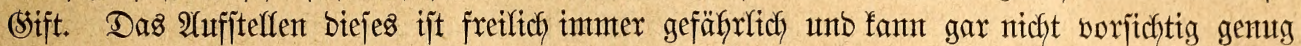

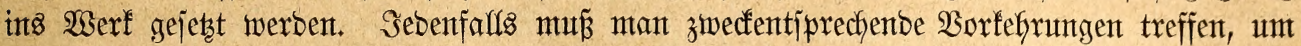

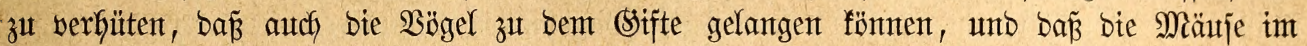

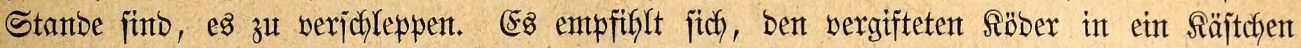

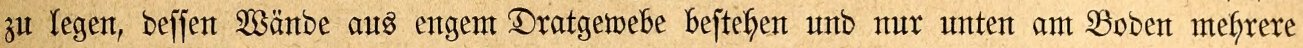

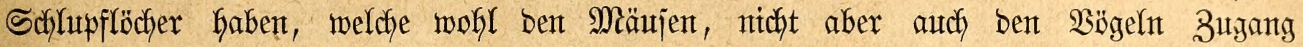

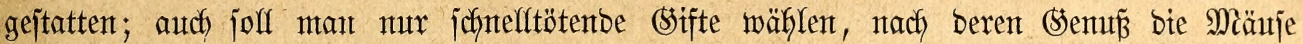
jofort Yiegen bleiben, nidft aber nodh Zeit Gaben, itgren Schlupfwinfel zu erreichen, weil

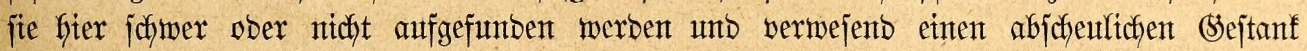
verbreiten. Strydgin jteht nach meinem Erfafynugen oben an; es tötet umfehlbar uno

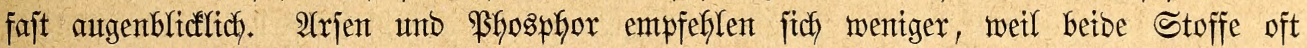

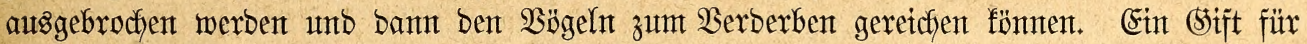

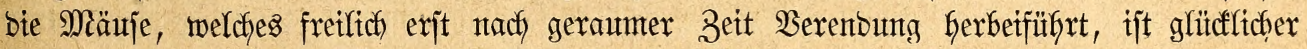

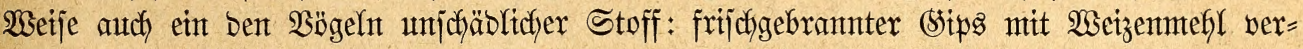

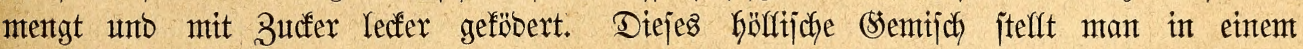

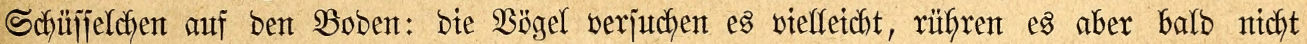

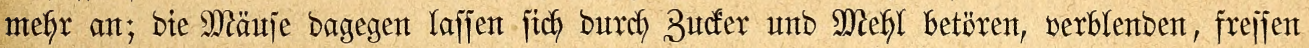
mit beiben aucd) (Sips, werben burjitig, trinfen unb - faben wentge Mimuten jpäter anjtatt

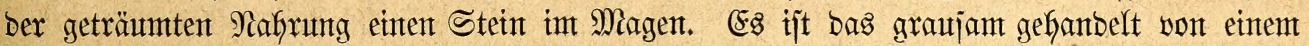

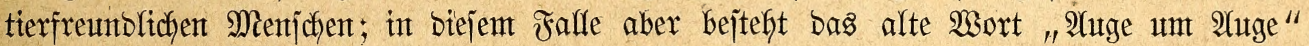

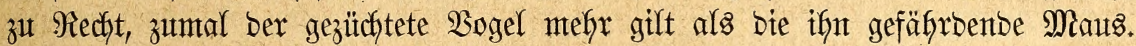

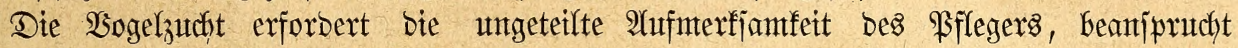

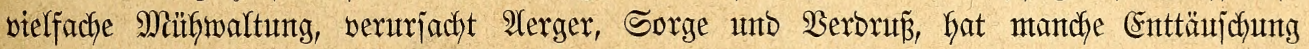

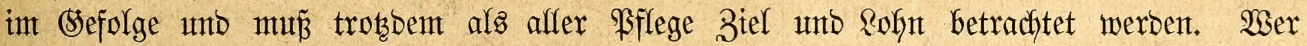
fie mit bem rechten Eifer betreibt, bejdetben ijt in jeinen Erwartungen unb bejcheiben bleibt

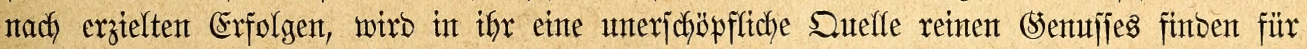

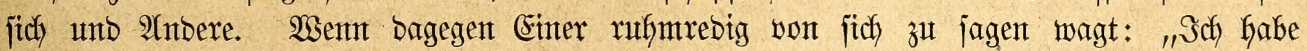
biejen ober jenten Sogel zur Fortpflanzung gebradh", jo berweije idh ifgn jtatt alfer

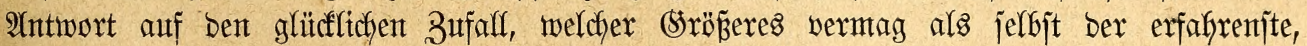

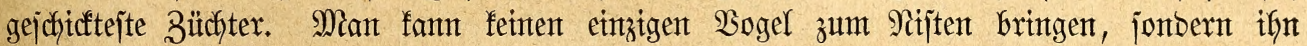

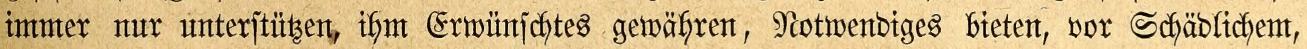

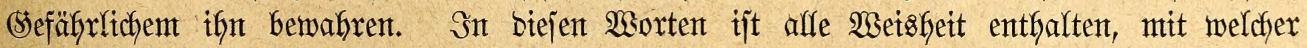

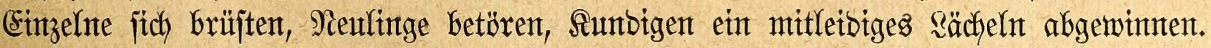

\section{farankheiten und farankenpflear.}

Dem erfafrenen Riebfaber wirb es web umb Seerz, went er einen jeiner gefieberten

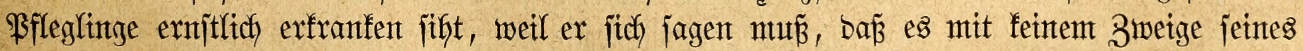

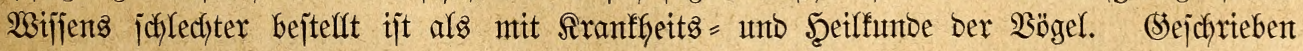


unto gejprodsen wiro genug über biejen (segenjtand, gequadjalbert nicht minber, erreidjt untrnblich wentg. 3ux Beit mangelt es noch an affemt. Der geringfügige Stoff ijt nicht gejammelt unt gejichtet, D. h. gereinigt von bem ifyt anthängenton Unjün, einer notwendigen

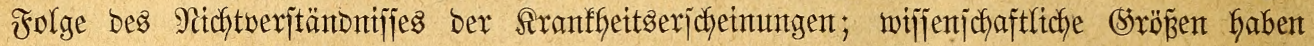

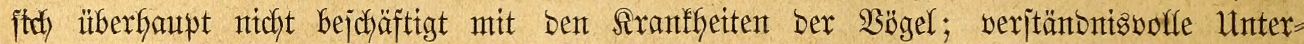
jucfungen bex an verjchiebenen Sranffyetten zu Stunbe gegangenen $\mathfrak{B}$ g̈gel werben mur von Wentigen gemadht, unto Diejen $\mathfrak{B e n t i g e n}$ fehlt $e \mathfrak{B}$ in ber Regel an Belegenheit, einte gentügentoe

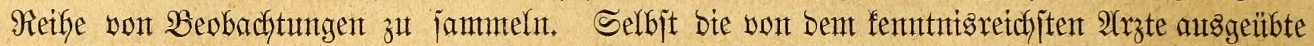
Befyanthutg franfer $\mathfrak{B o ̈ g e l}$ ijt faum mefgr afs ein Tappen im Dumfeln, erinnert noch jtarf an Das Urinbejchauten der Duacfjalber unt "ffuger Frauen" vergangener Beiten. Welcher

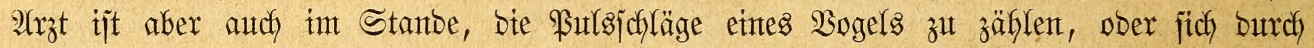

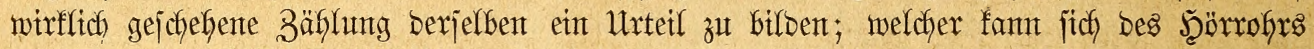

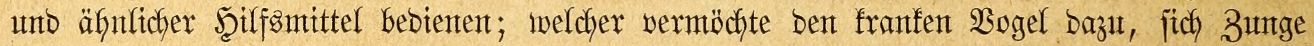

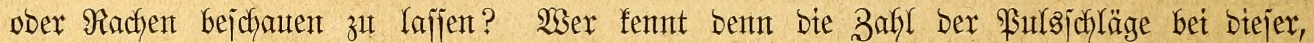

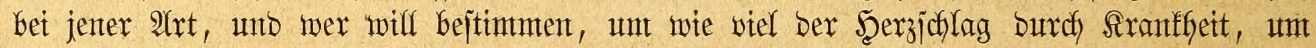
wie viel er burch Unterjutchen, Betajten, Ergreifen bes Sogels bejchleunigt wiro? Unto

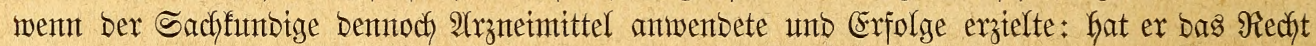

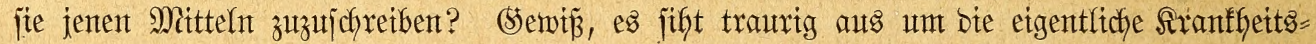
unt Sceilfuntbe Der Bögel: in biejer Berficherung ftimment Diejentgen meiner Mcitarbeiter,

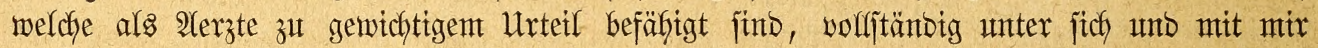
ïbereitr.

Dem ungeachtet ftehen wir Den frantheiten ber $\mathfrak{B}$ ögel nicht machtlos gegenüber. Mit Eingeben unt jonjtigent $\mathfrak{B e r m e n b e n ~ v o n ~} \mathfrak{A}$ żneien vermögen wir freilich wentg auszurichten;

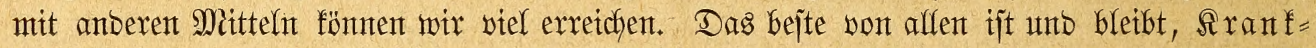

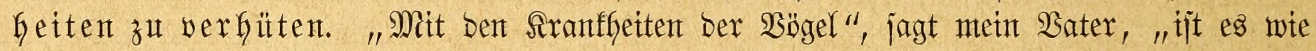
mit ber ajtatijchen sholera: jie jutb retchter zu verfüten als zu heilen, und bes Freundes

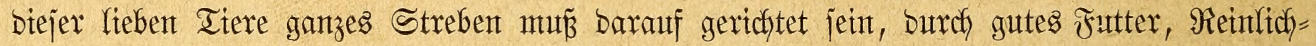
feit unb zwedfuäpige Wartung Die Sranffetten zu verringern." Wer wirflich Exfahrungen in ber Bogelpflege gejammelt hat, wirb biejen und ben nadffolgenten Wortent (\$) ourcy's unbedingt

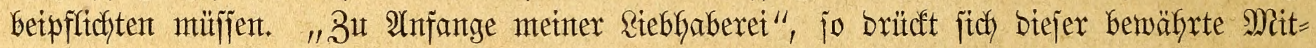
arbeiter meintes Saters aus, "jtarben mix jefr oft eintige metner lieben Titerchen, Diejer am Sdylage, jenter an Der Darre, ein anberer an gejdywolfenten Fünen $2 c$. Seitbent idfs

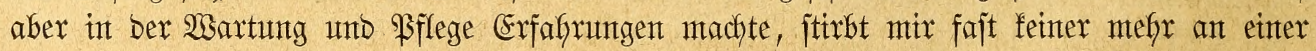

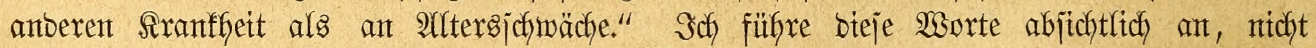

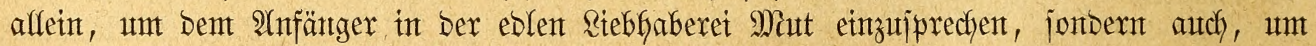

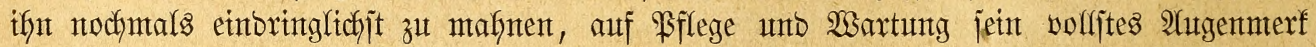

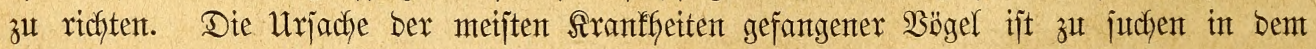
unpajfenten ober ungenẗgenben Jutter, in Der berfehrten Wartung und $\mathfrak{B f l e g e , ~ i n ~ D e n ~}$

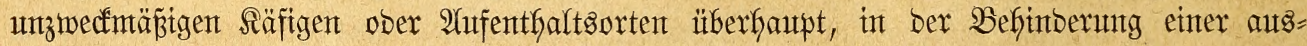
gibigen $\mathfrak{B}$ envegung, in bent Mantgel an frijcher, reinter \&uft, an Sidft, Sonte, an entiprechen=

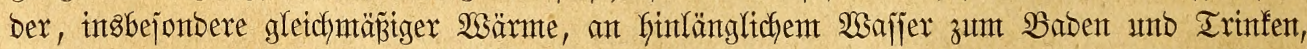
Sand auf bem Boben bes Bebauters 1t. Dergl. m. Wex eifrig, unabläjitg bejtrebt ijt, alf

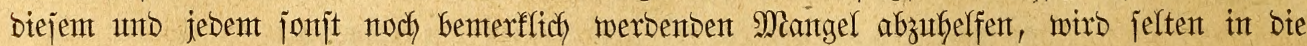
Berlegentheit fonmen, Arzmeien anzumenten, beren Exfolg, wie angebeutet, inmter fö̈bjt zweifelfaft ijt.

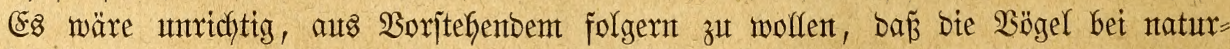

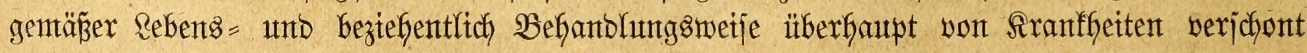

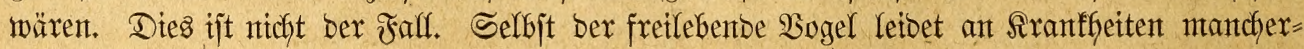




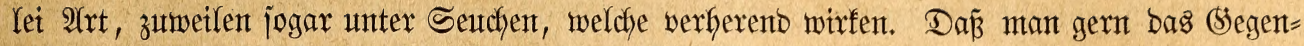
teil annimmt uno glaubt, läßjt jith in eimfactjiter 2 Seije erflärent. Selten mur fiht man int Jreien einen franfen $\mathfrak{B}$ ogel; faum häufiger fimbet man eine $\mathfrak{B}$ ogelfeidtye. "Der fich franf füfylenbe $\mathfrak{B o g e l} "$, bemerft (sirtanner, "ziteht fich ints Didfidft zurüd, ba wo es am bidfteiten

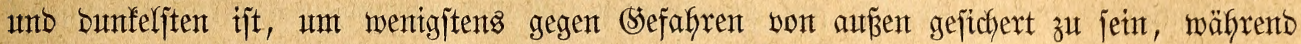

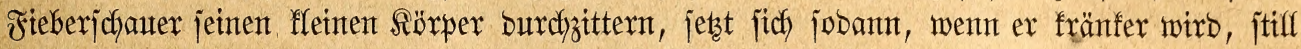
auf ben Eroboben und ftirbt ruffig bafjin. Zufälfig habe tidh fier untb bort im Walbe recht franfe $\mathfrak{B}$ g̈gel angetroffen, und oft genug habe ich von Sinbern jolche erfhalten, welche beim Berent, Mlos = unt Raubjuthen gefunben worben waren." Heber bie Retchen Derjentgen aber, welche nicht gefunden merben, falfen verjefiebenartige fierbttere her unb verzefyren fie

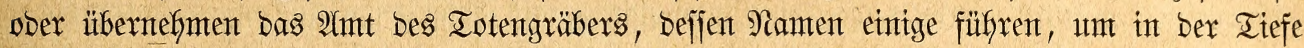

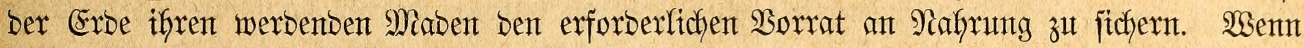

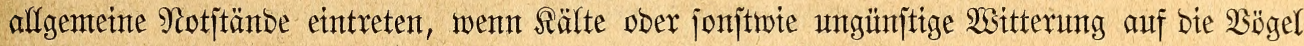

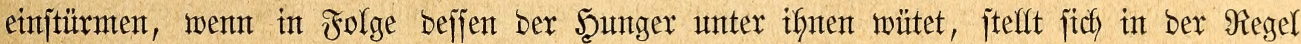
bieje ober jene Seuthe ein, unt ber Iob bält retche Ernte. Sebenfalfs ijt man nicht be=

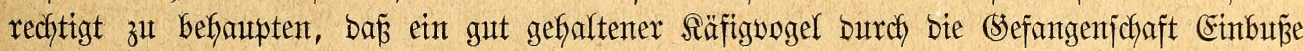

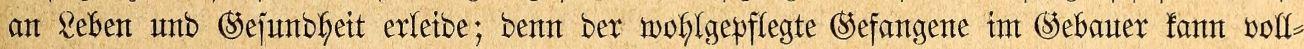
ftänbig ebenjo alt werben wie in ber Freifeit. "Âttch Der gutgefaltene Stubenwogel", fäbrt (Sirtanner fort, "iijt mifreitig mandserlet Einffüfjen ausgejebt, weldye, ,ant jeinem Reben nagen", unto benen ex in ber Freigeit entgangen jein würbe - Einflüfjent, welche recht

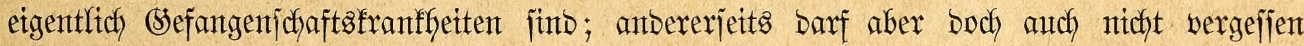

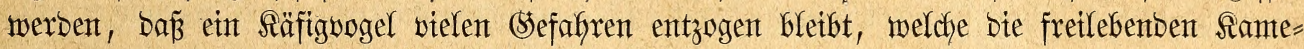
raben afltäglich und alfnächtlich bebroken. Ex fennt feinten Futtermangel, feine jchutsloje

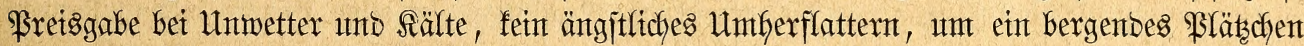

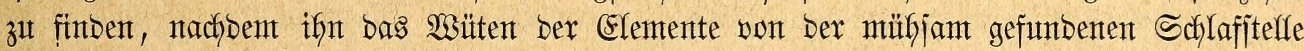

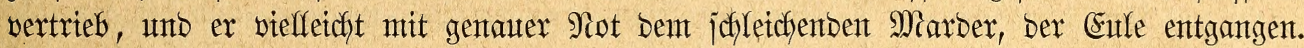

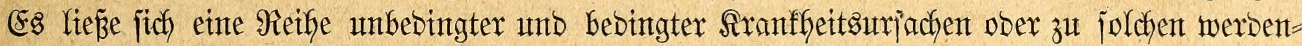
Der Einflïfje anfüfren; jeben bentenben Beobadfter aber bringt eigente Heberlegung bafin,

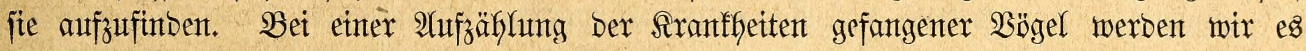

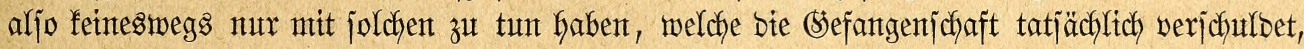

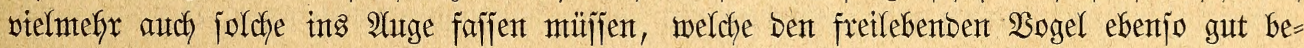

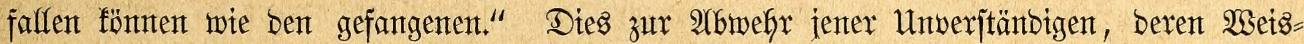
Geit barin gipfelt, in jebem franfen Räfigwogel ein beflagenswertes Dpfer ber (sefangenjchaft zu exblicfent.

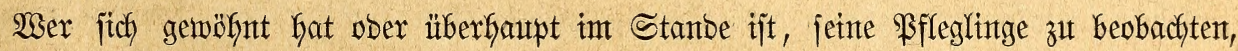
merft augenbliffitch, went einem berjelben etmas fefilt. Der franfe $\mathfrak{B}$ ogel ijt bas gerabe (Segenteil bes gejunbent. Wäfrend biejer fich gern, viel und fräftig bemegt unt auth in

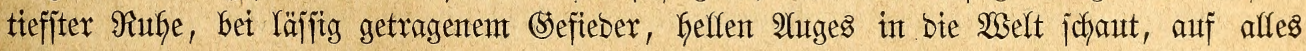
acftet, was unt ify vorgeht, unb, angeiprochen ober jonjtwie angeregt, augenblifflich jeine gemöhnltiche Şaltung anntmmt: jitzt jener jtill auf einer unt berjelben Stelfe ober bü̈pt langjam unto matt von eintem Srte zum anteren, fträubt bas (Sefieber ("Fuctet Den Wanber= Günbel auf", wie unjere Türinger Bogelfteller jagen), zieft bie Iltgenliber zujammen, wo= burch ex ein mirflich trauriges (sefidyt exfält, jtedit fpäter ben fiopf unter bie Schulterfebern,

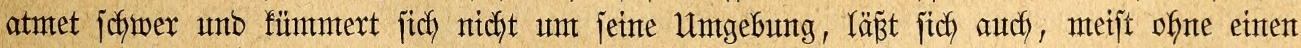
Berjuch zum Wegfliegen zu madhen, mit Dex Seand aufnefment ober boch mux jdywer zu einer

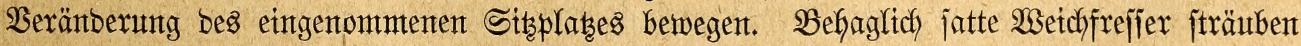

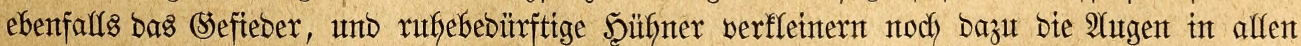
(Sraben: betber 2 ntblid ift aber, ein ganz anberer als ber eines franfen 2 bogels unb wirb 
wohl niemals einen beobadftenben Bogelmirt bejorgt madjen fönnen. Der franfe Bogel ber=

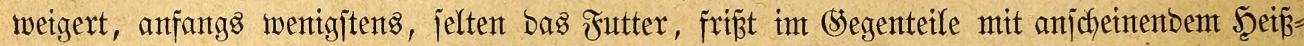
Gunger und erregt bann bei bem exfahrenen Pfleger bie gerechtejten und ernjtejten Bedenfen.

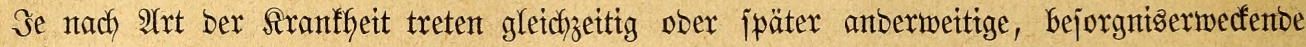

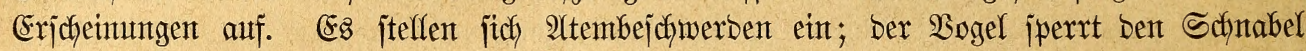

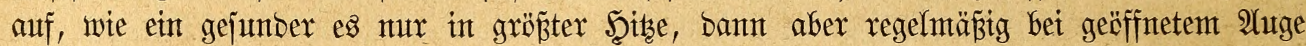
zu tut pflegt; man bernimmt beim 2Atmen ein ftönenbes ober pfeifendes (s̈eräujc); ber Iltem ijt, wie man an ber Bemegung ber Baatchfebern zu exfenten bermag, lebhaft, furz

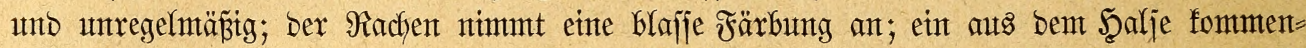

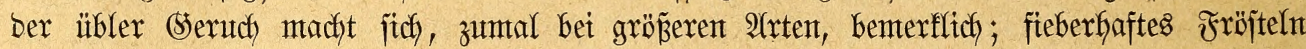
überfommt ben Reib unb wieberholt fich offter und öfter; frampfhafte 3udfungen treten finzu und - von ber Sitjitange herab fällt, auf Dem Boden liegt ein Reichnam. In biejer Weije

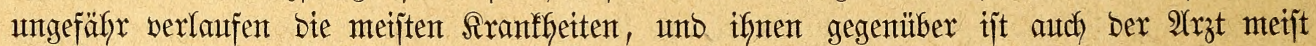

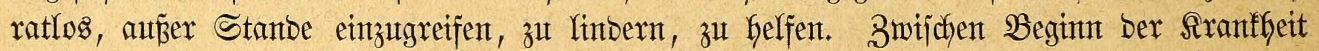
unt bem $\mathfrak{B} e r e n b e n$ liegen jelten mebrere Iage, meijt wentige Stunbent.

"Weitaus bie meijten gefangenen $\mathfrak{B o ̈ g e l " , ~ j u f r e i f t ~ S t o ̈ l f e r , ~ " g e h e n ~ w o h l ~ i n ~ F o l g e ~}$

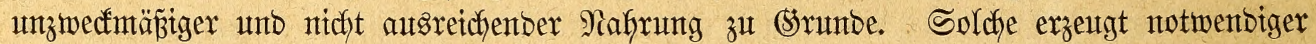

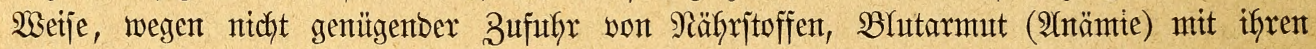
Folgezuitänben: Albmagerung, Schwäche unb unterleibsbejchwérben, — ein Aranffeitabilo,

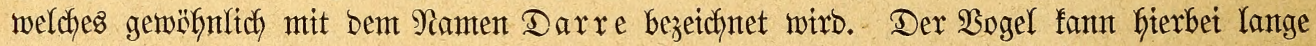
3eit anjcheineno munter jein. Er frij̧t won Dem Dargereidyten Futter; man merft es ifm

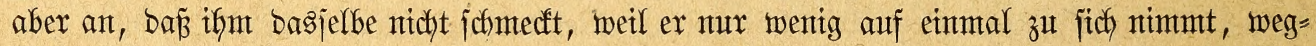
fliegt und balb baxauf mieberfefrt. Er fÿrt auf zu fingen, fträubt bas (sefieber immer

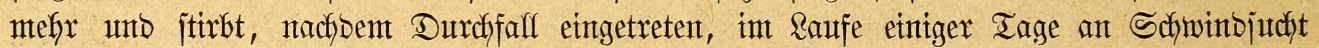
bafin. Rangjamter verläuft bie Darre, went ify Schninbjudft und alfgemteine Arebanteigung (Tuberculoje unto (Sarcinoje) ober bäıfig fich mieberholende unterleibsübel (Intejtinal=

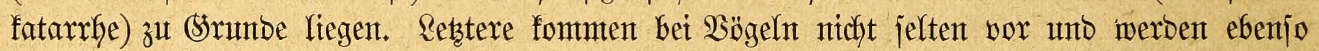

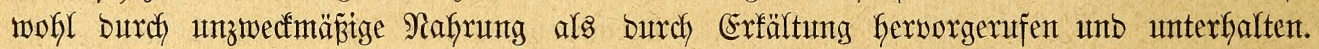

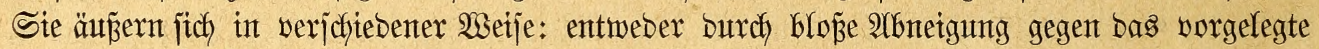
Futter - io bei Raubwögeln, weldhe längere Zeit ununterbrochen biejelbe Fleijchjorte ex= Galten, Scare und Febern aber entbehren müfjen - ober burch Serjtopfuntg und Durchfalf. Şierbei fann bie Freß̉lujt fich gleich) bleiben, fich minbern ober jelbjt vermebren. Die fot=

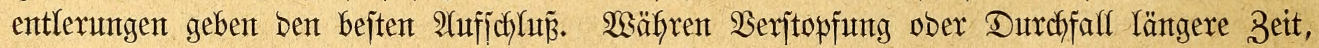

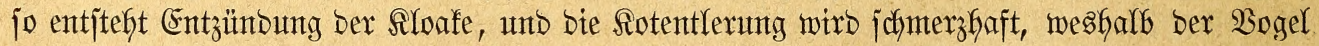
nach) jeber Entlenung mit Dem Steip̧e zudft, bezüglidy mit Dem Sifwanze wippt. Durdffall

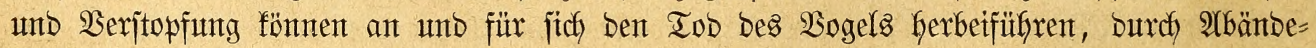
rung Des Futters anfänglich jeboch Yeicht behoben werben."

2lus biejen Worten meines Mitarbeiters geft flar Gerbor, baj man unter Darre

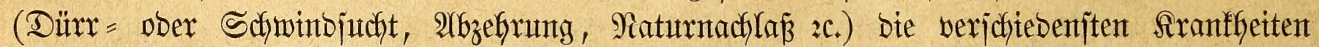
begriffen hat. Şierin ftimmt aud (Sirtannex mit Stülfer vollftändig überein: „Was man unter biejer Bezeidfuntg veritehen joll", jagt Der Eritgenannte, "ijt nicht jo leicht zut

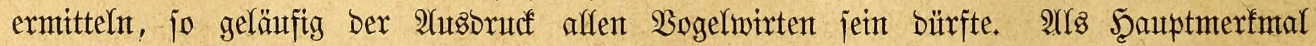

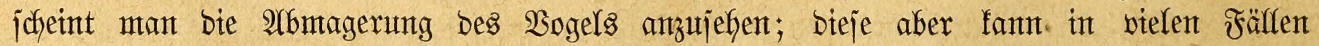
in Rungenjudft (Iuberculoje) ober alfgemeiner tuberculöjer Erfranfung ifren (S) runto unto

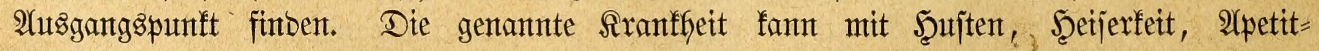

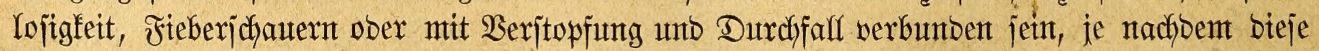
Doer jene Srgante ergriffen jüto, unto fönnen aljo Sdymufen, Scujten, beijerer Siejang, weldye

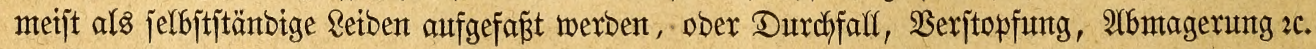




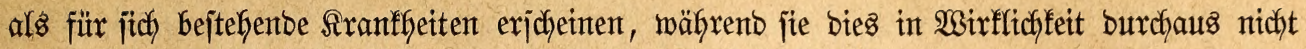
fint. Beigt fid bie jogenannte Darre beijpieläweije bei einem $\mathfrak{B}$ ogel, weldfer unter pajfentor

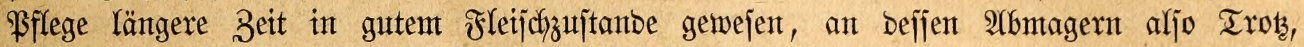
Trübjinn, Stürung burch Menjacten unb anbere Tiere $\mathfrak{u}$. Dergl. m. nicht fachuld jein fünnen;

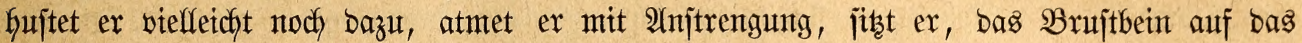

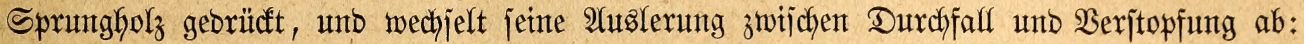

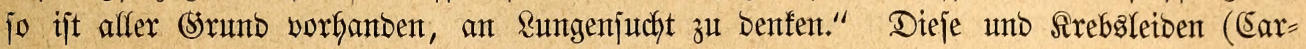

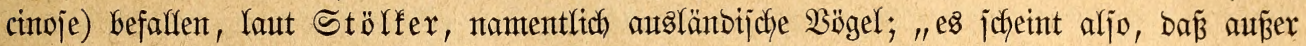

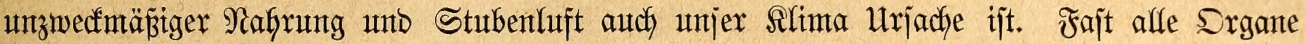

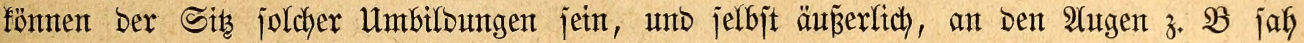

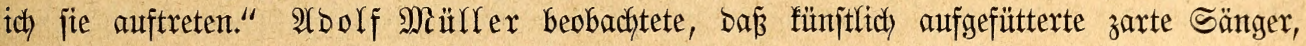

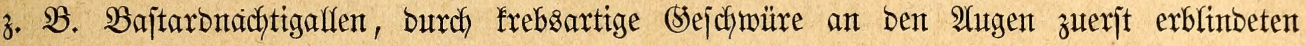

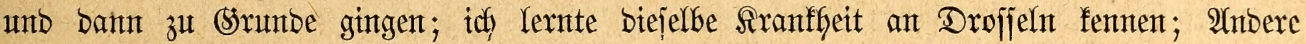
Bogelwirte werben unzmeifelfaft ähnlliche Errfafruntgen gejammelt baben. Utnter joldhen

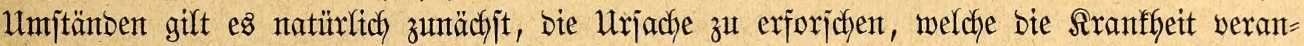

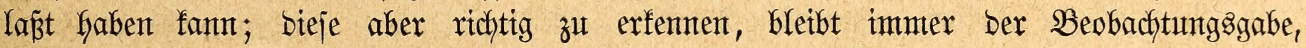

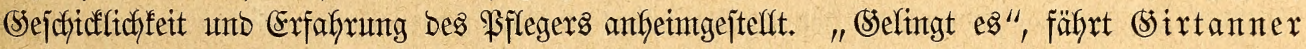
fort, "Die Rrantfeitsurjache zu entfernen, jo ijt bamit oft gefolfen, anberenfallz aber audy

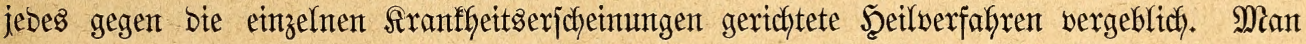

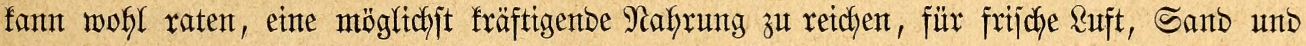
Babewaffer zu jorgen, bies aber boch mur in bem Jalle, bá ber $\mathfrak{B}$ ogel alles vorfer entbehrt

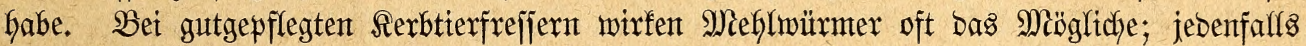

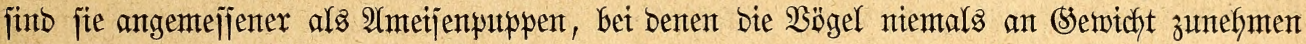

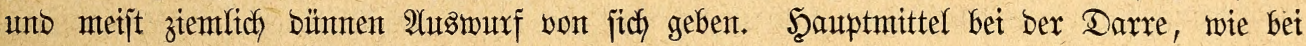

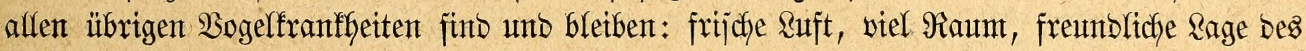
Fluggebauters, bezüglich Stanbort bes Räfigs, Butritt ber Sonne, jowie anbererjeit \$a audd

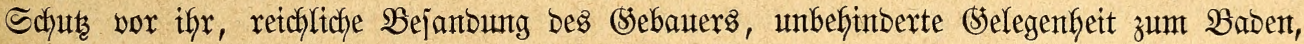

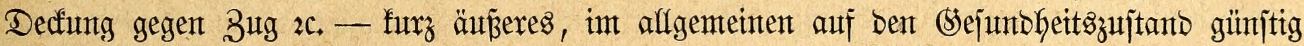

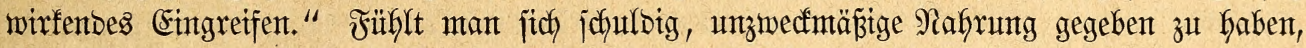

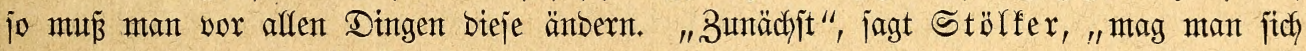

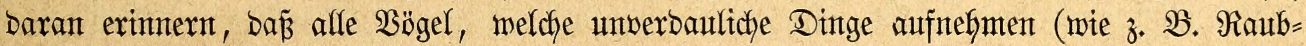

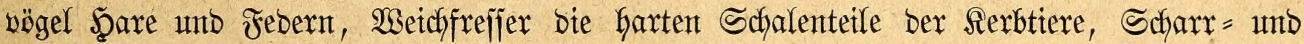

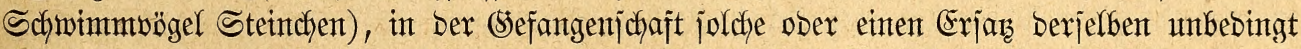

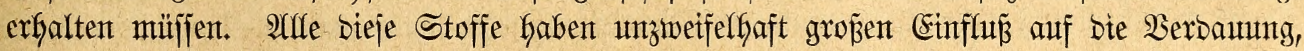

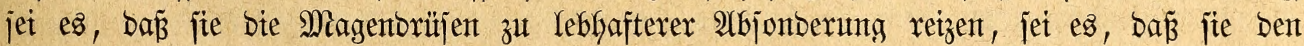

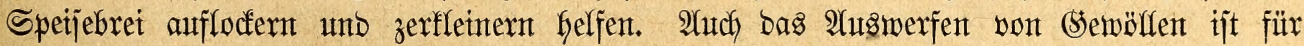

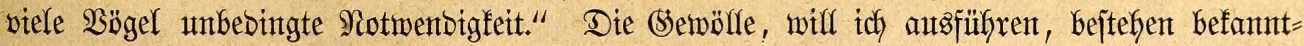
lich) aus bent zut rumblichen Baffen zujammengejchidfteten unverbaulfichen Speijerejten, nament=

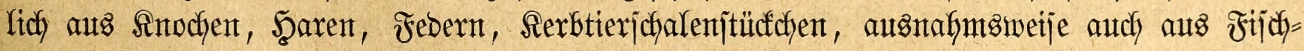

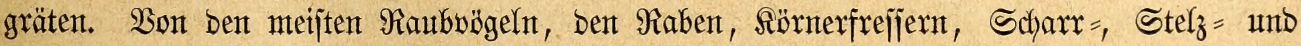

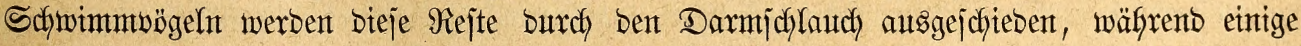
Falfen, bie Eulfen unb, joweit befant, alfe eigentlichen Rerffrejijer fie als bienölfe aus=

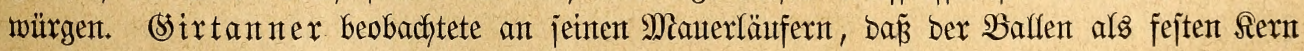

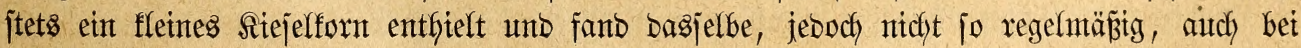

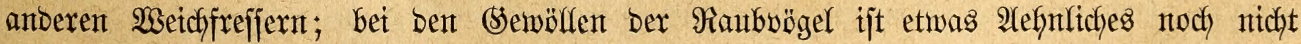

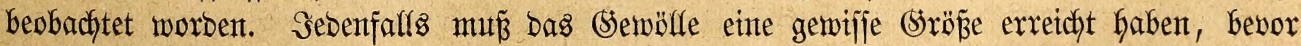

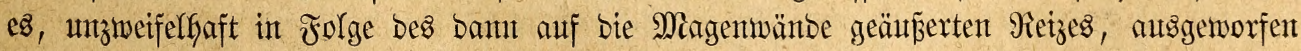

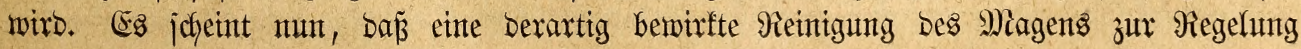


Dex Serbautntg ber betreffenben 2Irten mejentlich beiträgt, weil alfe biejentgen $\mathfrak{B}$ ögel, welche

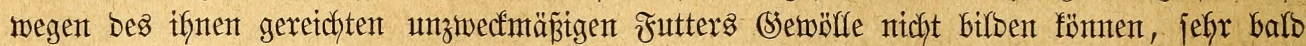

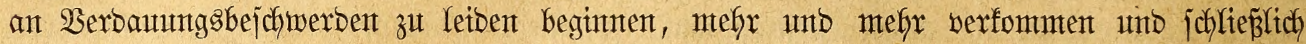

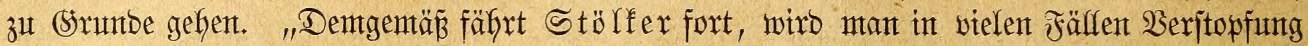

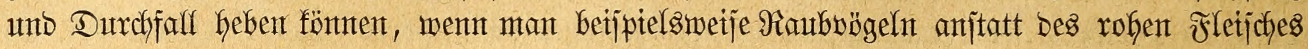

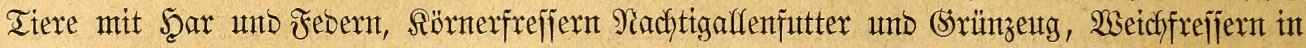

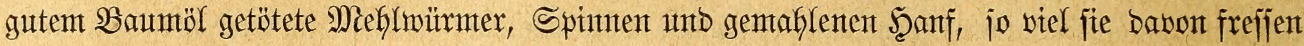
wolfen, und abgefochtes unt mieber abgefüfyltes Wajfer zum Irinfen reidyt, ifnen audy beziełentlich Den SBabenapf zeitmeilig megnimmt. In Den meijten Fällen fommt man mit einem io geregelten Futter meiter als mit allerlet Salben (B̈utter, Del, Schntalz 2c.) Alyjtiren, und jonjtigen Sutaffalbereien, wie man fie in vielen Büthern angezeigt findet."

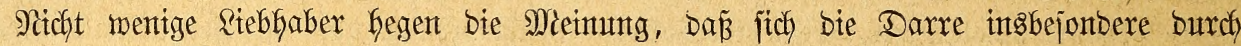
Berfärtung Der Bürzelorïjen, aus Denten Der $\mathfrak{B}$ ggel Das zux Einölung Der Febern nötige Fett nimmt, äunere, ober aber, bafi jie ntchts anters als eine Erfranfung Diejer Drïjent jet. Sie glaubent Deshalb günjtig einwirfen zu fönnen, went jie bie Drïjen mit Dem Nagel

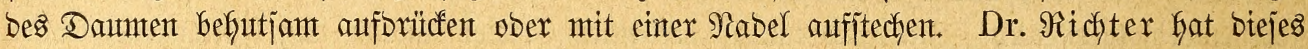
Berfafyen jchon wor vierzig Safren als bas gefentzetchntet, was es ift: als reinen Unjinn!

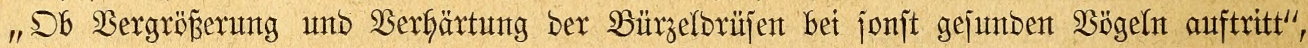
jagt (sirtanner-ferner, "ijt mefre als zweifelfaft, mix jebenfalls nicht befannt. Unt=

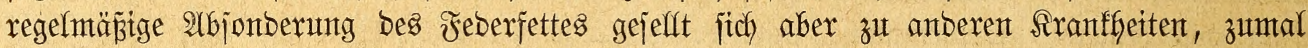
jolchen, welche Folge ungen̈̈gender Ernährung find. Die Fettabjontoentung fant jo ver=

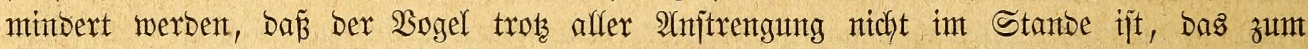
(5)lätten jeines (Sefitebers nötige Fett auszupreffen, weshalb er bant nady eintem Babe nicht

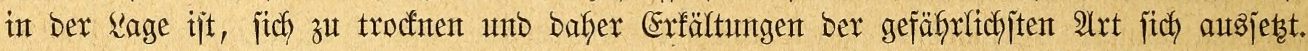
2(nbererjeits wirb bei alfgenteiner Fettjucht aud biejes Drüjengebilbe in Mitleibenjchajt

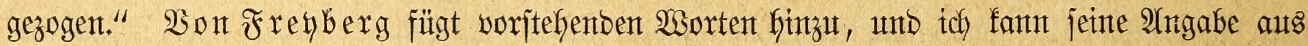

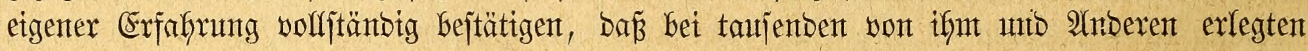

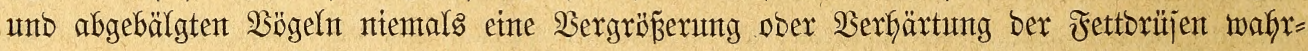
genommen twurbe. Für bie von einzelnen Riebfabern beliebte $\mathfrak{B} e=$ ober richtiger Mishand= lung ber SBürzelbrïje liegt aljo nicht Der geringite 2 (nthalt vor. "fiommt trobsem Dex Bogel glüdflich burdh", bemerft von Freyberg jefy ridytig, "jo sernarbt bie Wumbe unto

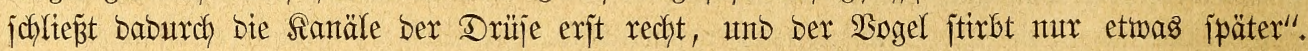
Dex Eingriff, weldyen mant fidh bei wirflidfer Erfranfung. Der Drüje erlauben Darf, hat

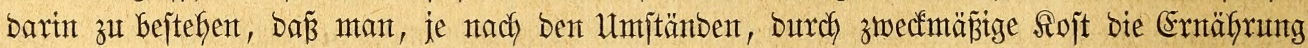
regelt, arjo zujebt ober abbricht. WSifl mant mefyr tun, jo mag mant fich noch bes linbern= Den Seles bedienen, D. \%. jolches oder ungejalzentes Fett mittels einter weichen Feber behut= jam über bie Drüje jtreichen: Damit jchabet man menigitents nicht. Bei allgenteiter $\mathfrak{B} e r=$

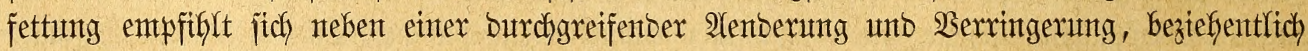

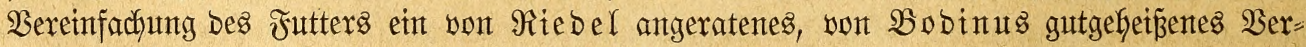

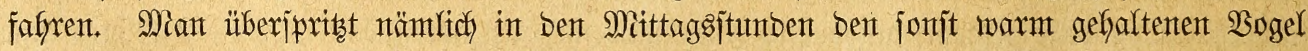
mit eintent Sprïfregen laumarmen $\mathfrak{B a j j e r s , ~ a n t ~ b e j t e n ~ m i t t e l s ~ b e s ~ M i m b e s , ~ u n d ~ n o ̈ t i g t ~}$ ifgn hierburch, fich zu reinigen, jein (Sefieber neu einzufetten und fich fierzu jeiner Drüje 3H bebientent.

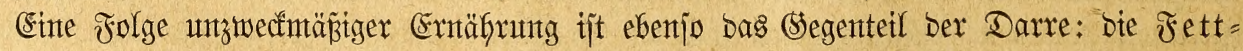

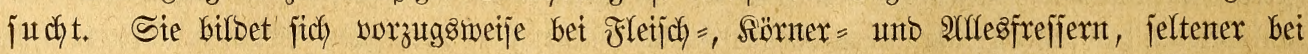
Weidf = und Fijchfrefjern aus, insbejonbere bet joldhen 2 sögeln, weldye ronig Bemegung

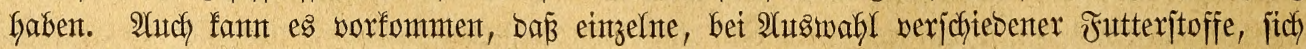

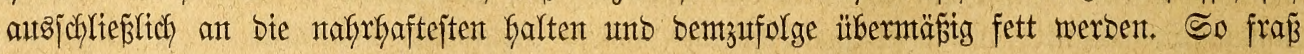




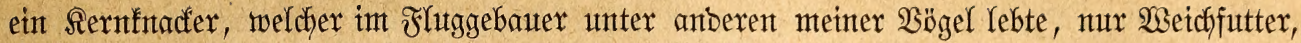
am liebjten Fleijh, und mutrbe bavon binnen menigen Wodjen fo fett, baj ex bie meijten Febern werlor, faum noch hüpfen, gejdyweige bent fliegen fonnte, bejtändig Den Scfnabel

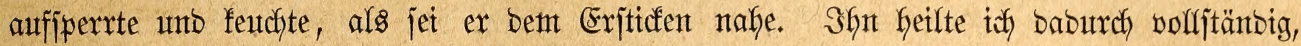

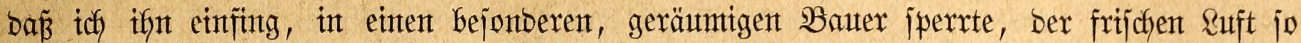

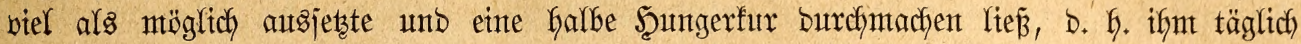
mur eine gentau bejtimmte, alfmäblich geringer werbenbe Mienge von Sörnern, Dagegen aber (Srünzeug nach Belieben und ziemlich jtarf jalziges Wajier reichte. So lange die Fettan=

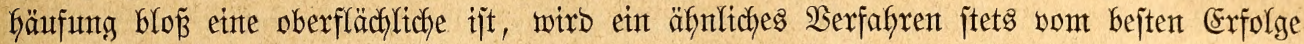
gefrönt jein, falfs man bie notwentige Sorjicht gebraudft, mit bem 2(bbruch Der Nafyunt, ebenjowohl was bie Bejchaffentheit als was bie Mienge anlangt, nicht zut rajd worzugeben.

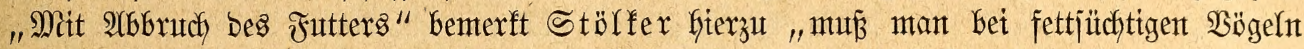
ftets mit größ̈ter Sorjicht verfahren, weil bei vielen, zumal bet Sierbtierfrefjern, bie Jett= jucht, jelbjt bet fortgejebter Darreichung Derjelben Futtermenge, in Folge Entartung Der Berbautngswerfzenge, insbejonbere Der Reber, in bas (Segenteil umichlagen unt rajdhe

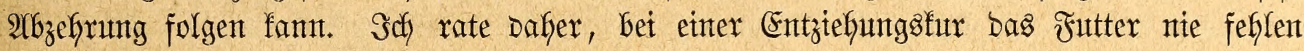
zu lajfen, jonbern nur ein wentger nafreaftes zu geben, bamit ber $\mathfrak{B o g e l}$ niemals zu wollitänbigem Fajten gezmungen ijt; ia ich möchte jogar veroronen, Daj ifym morgents und abents nody eine fleine Mienge gutes Jutter gegeben werbe. Bei fïrnerfreffern bürfte

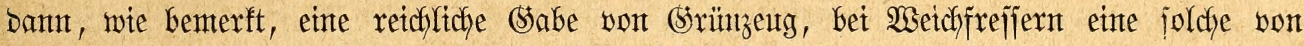

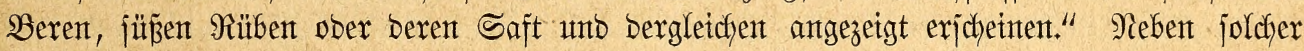

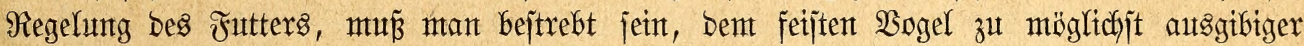

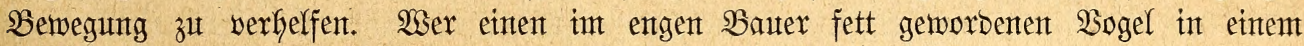

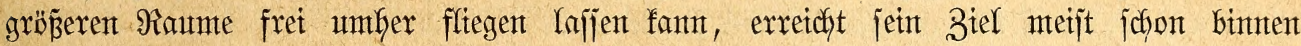

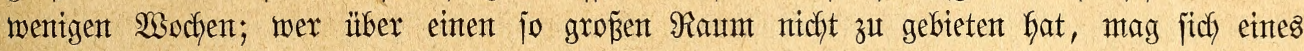
von $\mathfrak{A}$ bolf Mïllex vorgejd)lagenen Mittels bebienten. Dasjelbe bejteft barin, nach (se= mährung eitter mäpigen Mafblzett vor ben noch halb gefüllten Futternapf ein (Sitter zu jofieben, welches Dem $\mathfrak{B}$ ogel gejtattet, bas Futter zu jefien, ifm aber werwebrt, Dawon zu frefien. "Эch berurjachte bamit", jagt Mïller, bei bent Faulenzer unter Ifnjpornung

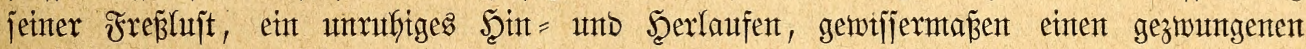

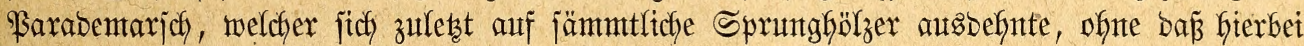

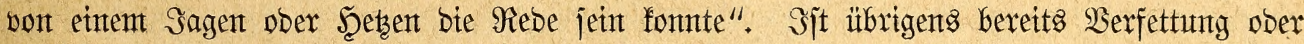
fettige Entartung ber interen Srgane (Serz, Reber, Nieren, Netz zc.) eingetreten, io er= reicht man, wie (Sirtanner herworkebt, ,mit affen biejen unb anberent entjpredsenten Mitteln

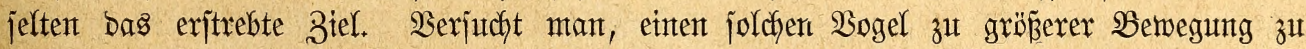
zwingen, als ex jelbit jie ausführen wiff, jo berurjacht mant ifmt regelmäpitg heftiges

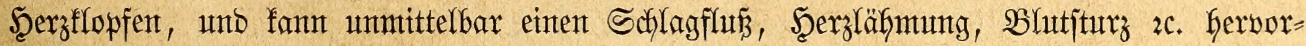

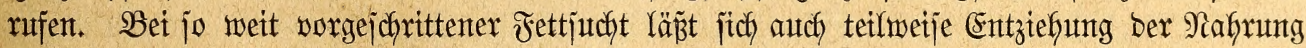
nicht Durchjüfyren, weil bie erfranften Drgane ofnefint nur mit jefr vermintoerter "Fäbigfeit tätig füt. Solche Siranfe gehen ficherent Iobe entgegen anto bürftent am bejten jo wentg alz möglid beläjtigt werben."

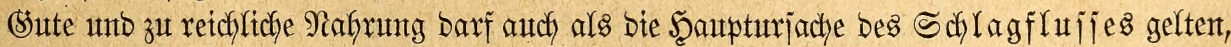
welcher bent Bägeln oft genug ein jäfes ertbe bereitet unb zwar ben freilebentoen ebenjo gut mie ben gefantgenen. Wäfrend bes eifrigiten Singens ober beint Jreffen, int Schlafe, jtürzent fie plötlich zu Bobent unb verenben meijt nach wentigen Secunben. Sine zu üppige Er=

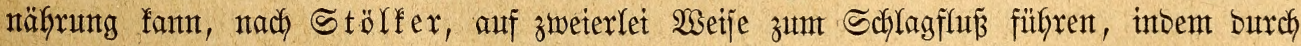

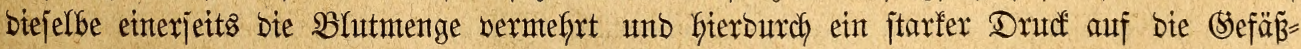
manbungen autgeübt wirb, unt inbent anbererjeits burdh bie affgenteine Berfetitung bie 


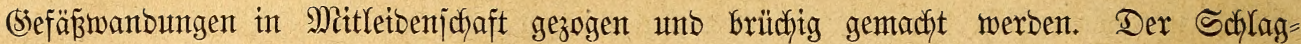

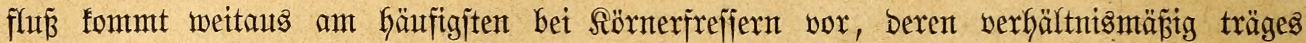
Wejen befanntlich aud Berfettung jebr begünjtigt. "Manthmal", jagt $\Re$ ichter, "rettet man nod) einen bawon befaffenen $\mathfrak{B o g e l , ~ w e n t ~ m a n ~ i f m ~ b e n ~ \Re a g e l ~ b e r ~ f i n t e r e n ~ 3 e b e ~ j o ~}$

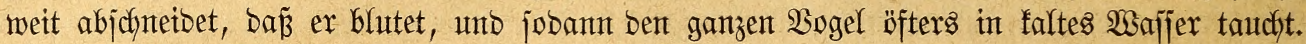
Ein Derartiges હturz̧bad tut unter biejen und äfnflichen Umitänben überfautpt meijt vor=

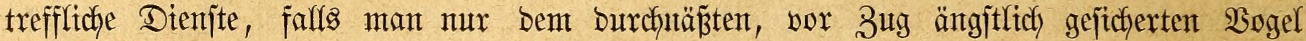
(5)elegenbeit gibt, jich) rajch unb volljtänbig wieber zu trocfnen.

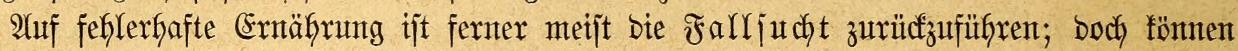
aud) Scirnletben und Eingemeibemürmer in Frage fommen. Dieje traurige Sranflyeit, weldye

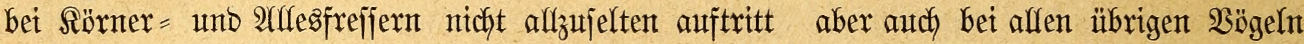
beobachtet wiro, ijt fo gut als unheilbar; Denn alle bie unzähligen Mitter, weldye mant

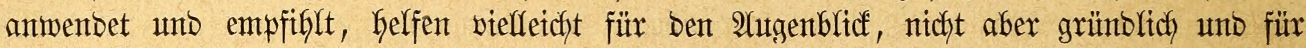
immter. Das Bejte ijt unto bleibt, einen mit ber Falljucht befafteten Boger, Deffen Sealten Einem ofnefjin bald gänzlich verletbet wirb, irgendwie zu entfernen. "Jebenfalls", meint Stirtanner, welcher augbrüdflich bemerft, baj er fein Sceilmittel fenne, "jonbere man

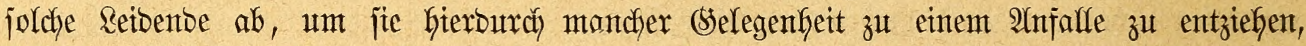

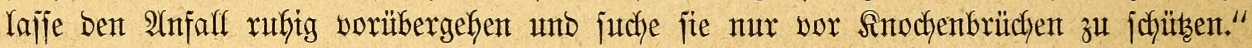

Wite viele erfannte und nicht erfannte Bogelfranffeiten auperbem burch ungentïgende

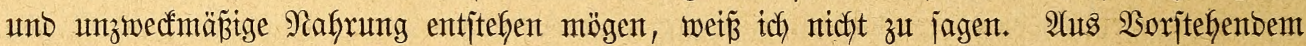

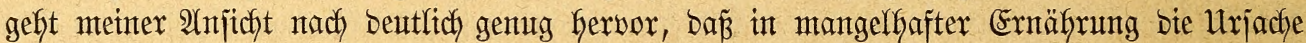

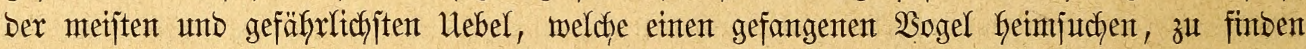

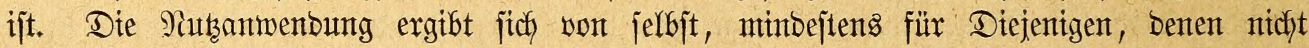
ein unbejteglither Drang zu quactjalbern innemoknt.

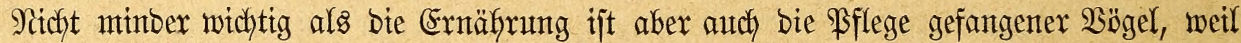

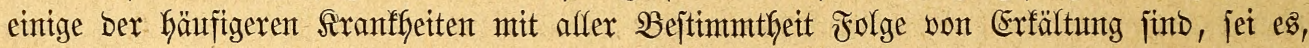

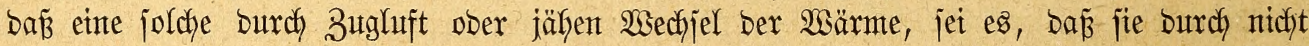

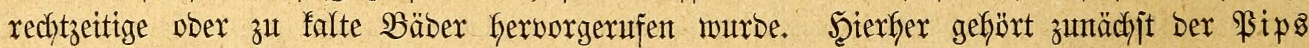

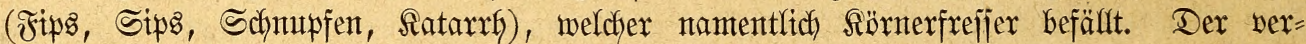

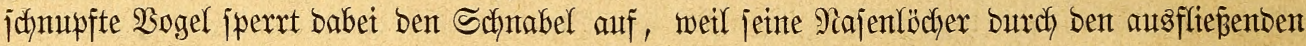
Shleim berjtopft werben, niejt (Gujtet) won 3eit zu Zeit, in Der 9lbjicht, bie verjchleimten शajengänge zu s̈finen, feudft, fträubt bie fopffebern, wiegt mit Dem Scaupte fin und hex

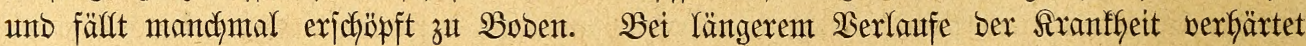
fidh bie Dberhaut ber 3unge und bes Schlunbes, entzünbet fidh aud wohl, und es treten Dann alfe Erjcheinungen eines heftigen Schmpfenfiebers ein. Diejentgen âtren, Deren

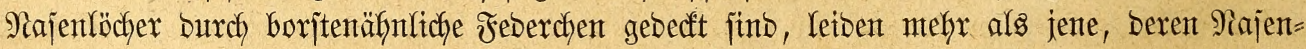
lödjex fret in ber Wadhghaut ober nodh weiter vorn am Sdynabel fich öffnen, weil bie er=

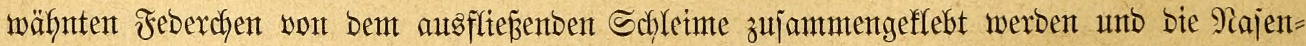

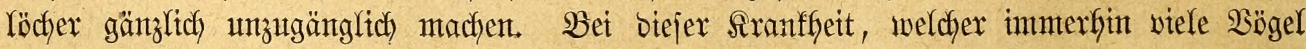

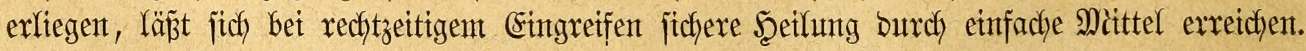
Das erjte und michtigite ijt, Den leibenden $\mathfrak{B}$ ogel zunächjt in ein jonntiges Zimmer zu

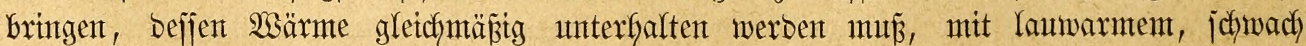

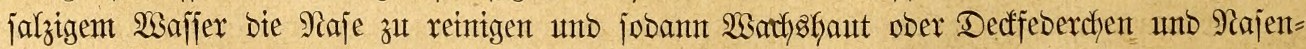
röbjer mit Baumöl geltnde einzureiben, ifm ben Babenapf zu entzieben und leichte fiojt zu.

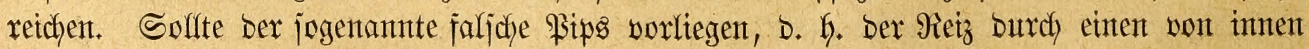
ober außen in bie Rajenlöcher georungenen Sïrper Gerrïfren, jo hat man "jelbjtwerjtäntich

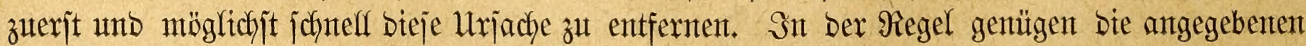
Mitter volffommen, um Den ßips zu Geilen, unb braudst man nicht zu anberen zu greifent. 
Entichteben verwerffich, weil eher hinberno als förberno, ịt bas bei vielen Riebfabern jehr.

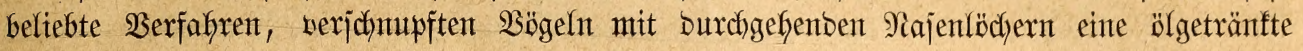
Feber Durch bie Naje zu zieken oder bie Feber jogar einige Iage jtecten zu Iafjen; Dent bieje reizt mefyx, als bas Sel berufjigt. Noch weit jojäblicher ijt ein gemaltjamer Eingriff, welcher ebenfalls angeraten und von ungejdyicfter Şanto nux zu vft ausgefüfyrt wiro: Demt franfen $\mathfrak{B}$ ogel "bas Bungenbäutchen abzulöjen", wie man jich ausbrücft, D. h. Die entzünbete

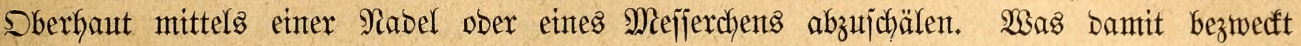

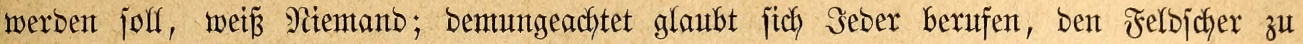
ipielent. Sch meinestetls fant vor berartigen Ëingriffen nur nadjorüdfficfjt marnen. Da=

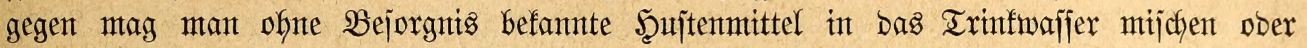

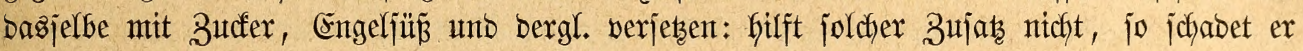

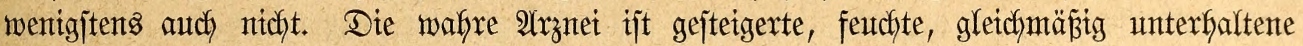

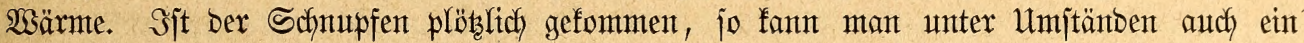
Sdymitzbad berorbnen unt antwenden, inbem mant ben $\mathfrak{B o g e l}$ in einen feudften wollenen

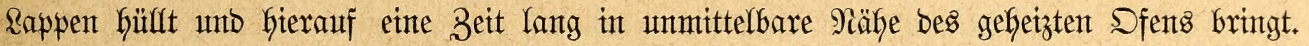

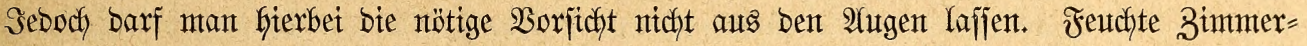
wärme, welche man burch Şeizen unb Serbampfen einer fintünglichen Mienge von Waffer jeberzeit erzengen fann, wirft, vielleidyt etwas langjamer, jeboch ebenjo jicher und minder gemaltiam als joldjes Schnibzad.

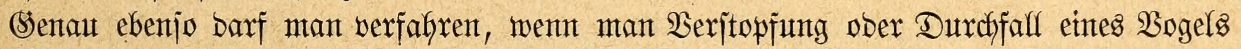

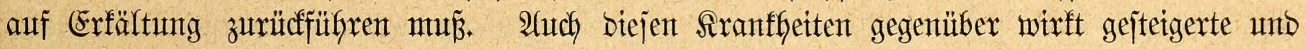

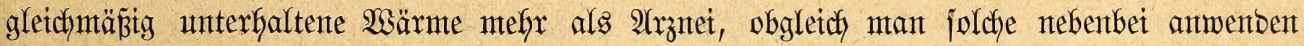
fant. "Somie ein $\mathfrak{B o g e l}$ trautert", jagt von Freyberg, "jollte ber \$ffleger wor alfen

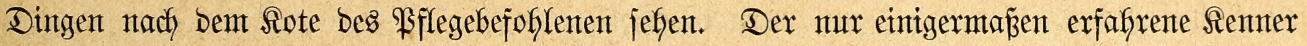

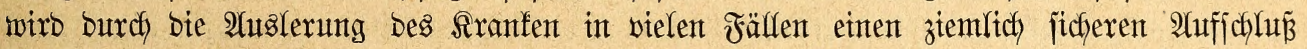
über Den Siranffeitsfalf geminnen fönnen. Der zmeite Blicf jet Dem 2 fter bes $\mathfrak{B}$ ogels ge= wibmet. Bei flüifitigem flote werben jefr häufig bie Febern rings um ben affter zujammen=

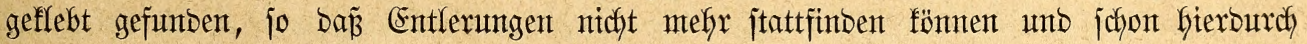
bas reben exnjtlichjt gefährbet erjcheint. Das Männdhen fyält eine Derartige Berjtopfung 24 bis 30 Stutben, Das $\mathfrak{B e i b c h e n ~} 40$ bis 45 Stutben aus, bas eine wie bas andere

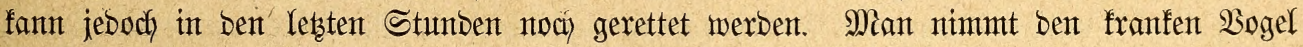

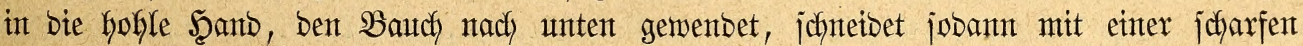
Schere bie zujammengeflebten Febern vorjichtig ab unb bejtreicht endich ben Alfterrand mit etwas Sel ober ungejalzenem Sdymalz". Nebenbei fant man mit interlichen Mitteln

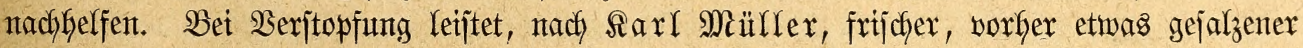
Specf oft überrajchenbe Dienjte; er barf jeboch nicht bei aflen Bögeln angemenbet merben, weil ex für einzelne, namentlich für bie Eulen, gerabezu als (sift exjcheint, D. hy. unbebingt

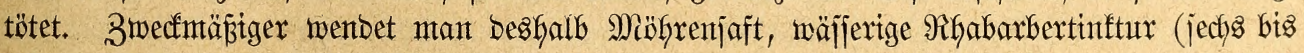

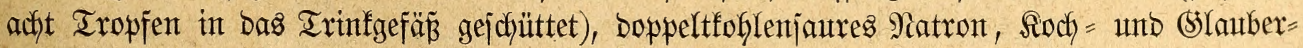
jalz att. Bei Durdyfaff empfifylt es jich, etwas boppeltfoblenjaures Patron, bielleteft noch ein, afferföbjitens zmei Iropfen Raubanum in bas Itinfwaffer zu geben. Unter alfen $\mathcal{U m}=$ ftänben aber änbert man aud bas Futter in ber bereits angegebenen Weije ab.

(Sichtijche Reiben, weldye Stubenbögel in böherem Allter zumeilen befaffen, mögen in Den meijten Fällen eberifallz burch Erfältung herbeigefüfyrt werben, find minbejtens feinen=

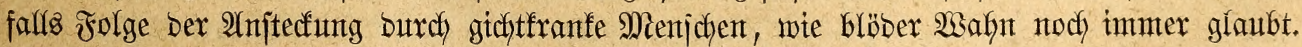

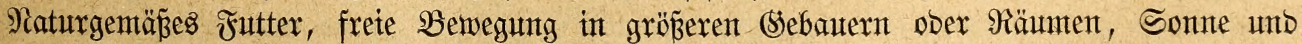
reine, frijche suft, gentügendes Waffer zum Baben, fint bie fyauptjächlichjten und allein rictitigen Şeilmittel Dagegen. 
Starfe Erfältungen bewirfen zumeilen eine Eritarrung, ja förmlichen Sibeintob ber

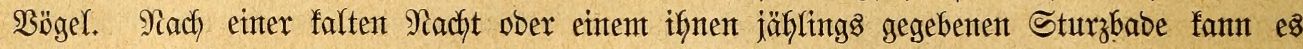

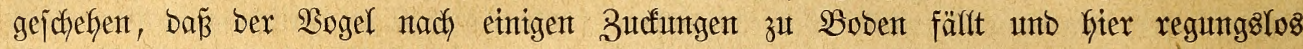

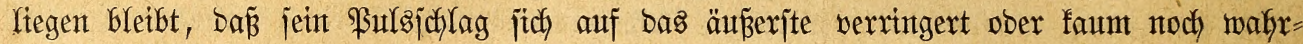

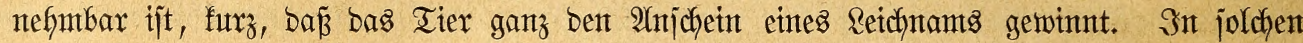

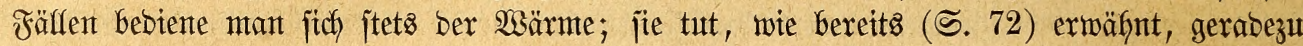
Wunber und rettet $\mathfrak{B o ̈ g e l , ~ w e l c h e ~ j o n j t ~ j i c h e r e m ~ I o b e ~ b e r f a f f e n ~ j e i n ~ w u ̈ r b e n . ~}$

Unter Den Siranffeiten, weldye man mangelfaft eingerichteten Räfigen zux Rajt legen

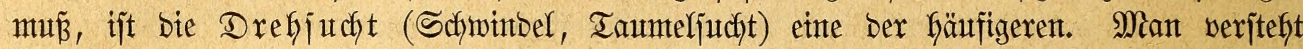

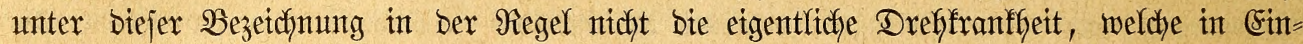
gemeibemürment Des (Sefirns ifren (S)umb hat und unheilbar ijt, jonbern ein burch längeres

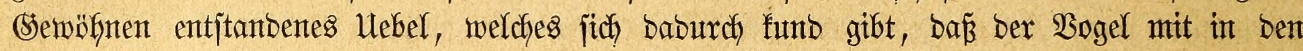

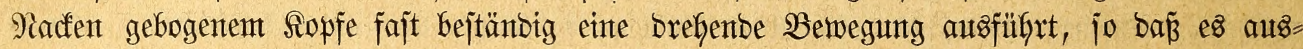

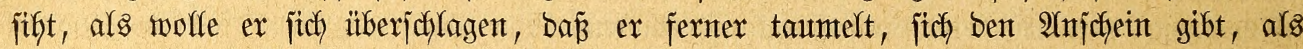

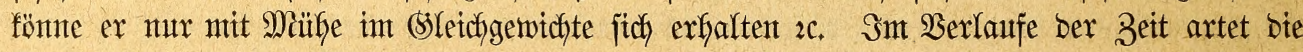
Drefjucht aus; ber Bogel fäflt, mantdmal unter frampffiaften Budfungen, wirflich von jeinex Sitzitange unb bletbt bann minutenlang wie finnlos auf bem

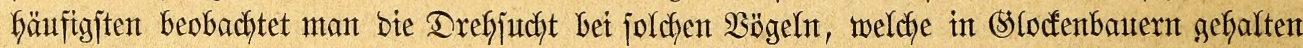
merben ober ridfiger eingeferfert find, zumal wenn man fier bie oberjte Sitjitange zu foch angebracht Gat. Drehfranfe Bögel, im ftrengiten Sinne bes 2 ortes unglürffiche Spfer ber

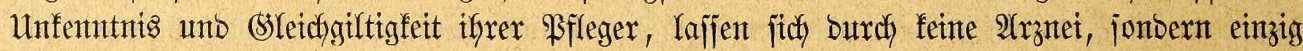

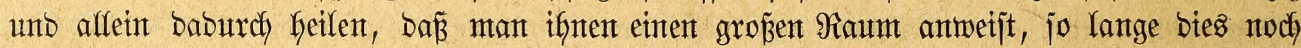
nicht zu jpät ijt. Snt entgegengejesten Falle jinb jie für ben

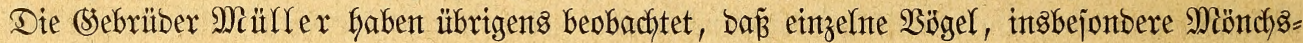
unt Şartengrasmünfen, ofne wurmfranf zu jein, bie Unart bez Drebents vom exjten Iage

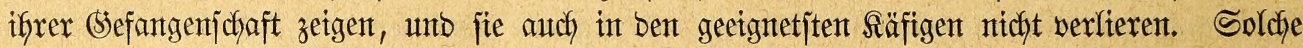
Bögel mag man je efger je lieber fliegen lajjen, wetl jie in futzer Beit unerträglich werben.

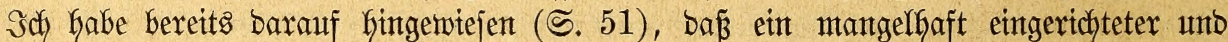

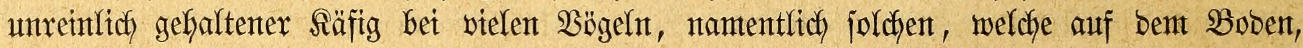
bezüglich auf Feljen leben, Fuß̧א bölzer fann jolche in Sefolge haben. "sachtigallen, Sprofjer, Blaufebleben, Baunfönige ze,

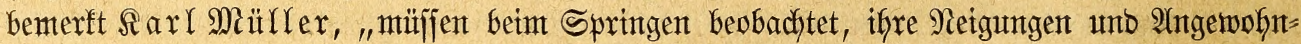

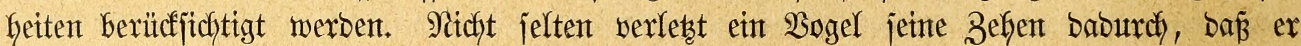

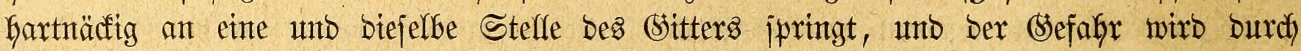
einfache Serjetung eines Sprungholzes ober burch 2Anbringen eines Rappens und bergleityen

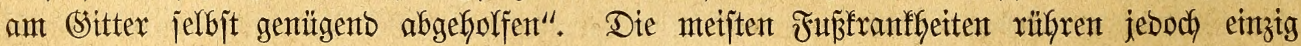
unb alfeit bon bem fote her, weldyen faule Bogelmirte am Boben bez Räfigs wochenlang fidc) anjammeln lafjen; biejer mefhr ober wentger äbenbe Schmuz jebst fich an bie und zmijchen ben Beben fejt, bilbet Slumpen, greift bie Sberhaut ber Befent an und ruft unter berjelben (Sejchwïre heroor, welche minbejtens zeitweilig \&ähmung im Sefolge haben

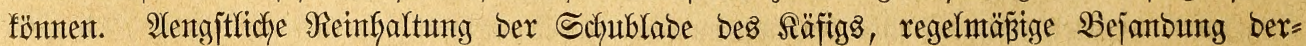

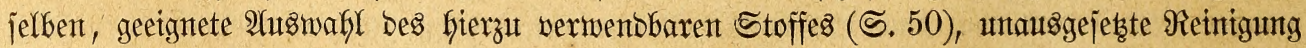

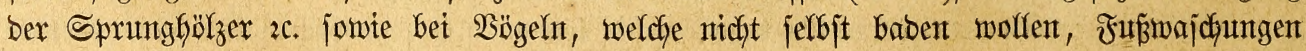

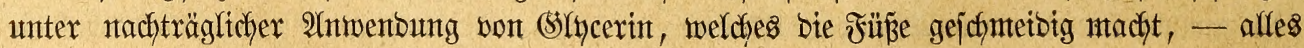
mit Beobachtung ber angegebenten Sorjichtsmtañegeln: bas fino bie Mitter, um jolche

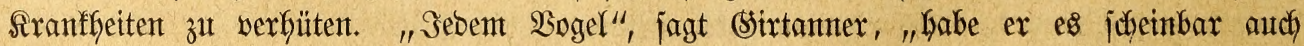
nicfyt nötig, folften von Zeit zu Zeit bie Jüpe in fauwarment Wajfer gebabet werben.

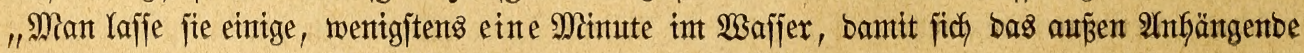




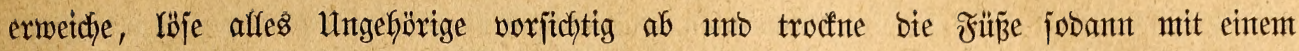
reinen unb linben Tudbe, bamit jie nicht, wie nach jelbjt genommenten $\mathfrak{B a ̈ b e r n ~}$ leiber ge=

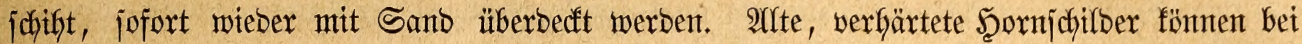
biejer (selegentheit ebenfalfs ofne Bebenfen entfernt werben, da jie body bereits abgejtopenen, minbejtens gelocfert jintb.

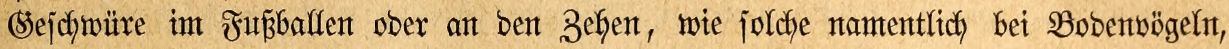
(Nachtigallen, Droffelth, Stelzen, Piepern, Rerchen zc.) vorfommen, verurjachen Den Damit

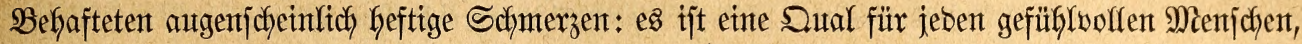

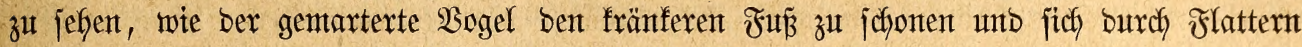
auf bem gejünberen zu Galten, wie er jenten int Befieber zu bergen judft, und wie er jith entlich, went audb ber anbere mefir unb mebr erfranfte, auf ben SBauch legt, unt jeine Schnterzen wenigitens eintgermaß̧en zu linbern. Dem nichtżntzigen (Sefangentwärter, welcher burch jeinte eigene Itnreinlichfeit ein ebles (sejchöpf zu jolchen Reiben verurteilte, jollten von

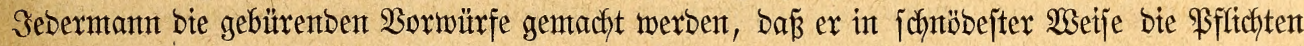

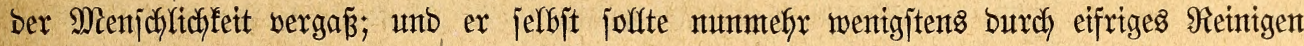

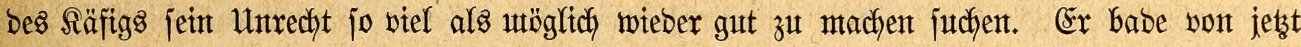

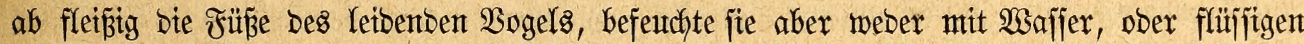
Árzneien, nodh mit Del und anderen Sdymierereien, fonbern trodfne fie, wie angegeben, ab unt äßze bie (Sejçwüre, je nach ben Umitänben oberflächlidy ober tiefer mit Së̈lfenjtein ober bepinjele fie mit einer 2Yuflöjung besjelben, balte ben $\mathfrak{B}$ ogel in ber Şand, bis bie \&öjung ein= getrocfnet, unb bringe ifn hierauf in ben Säfig zurüd, wo möglid unmittelbar auf eine Sits= jtange, auf weldyer er, ber Sdymerzen halber, eine Beit lang jtill zu jizen pflegt. Sch babe

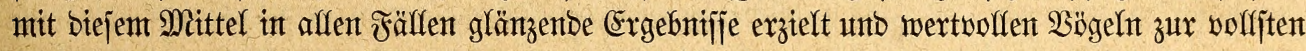

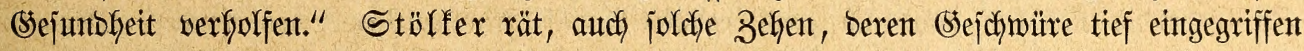

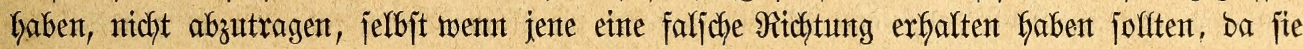

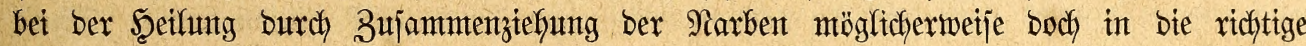
Steflung zurücfigefüfrt werben fönnten.

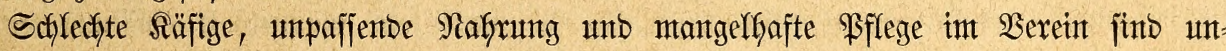

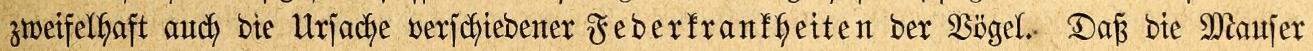
ober Maure nicht eine Rranffeit, fonbern einte regelrechte unt notwentige Şauttätigfeit ober

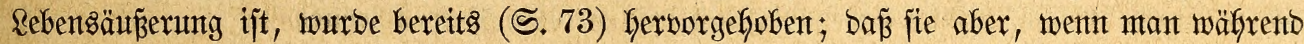

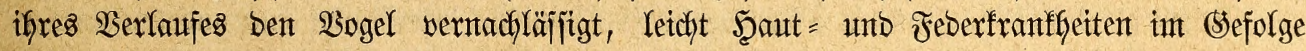
faben fant, folf nidyt bejtritten werben.

Die Maujer umjerer einflemtijchen Stanboügel fällt in bie Monate Sult bis September, bie ntandjer 3ugvögel in bie Mlonate Sftober bis Februar. Einzelnte maujern zweimal, baz eine Mal in ber Sceimat, bas anbere Mal in ber Frentbe. $\mathfrak{B e t}$ vielen $\mathfrak{A}$ Halänbern fintot

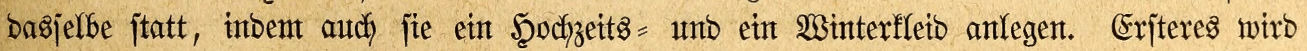

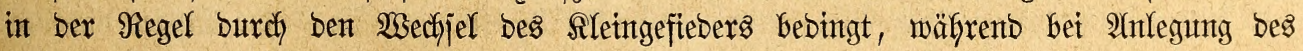
rebzteren fich bie Sifwingen unb Steuerfebern ebenfalls ergänzen. Raubbögel mautjern in einem Safjre nicht volfitäntig aus; ber Erjatz ifyrer Schningen unt Steuerfebern beanjprudbt im

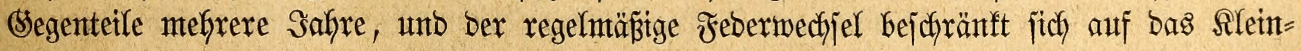
gefieber. Die Umitände, unter benen bie Mianjer eintritt, bie Beit, in welcher jie beginnt und berläuft, bie Dauter, weldhe fie beanjprudft, fönten aljo jefy verjodjeben fein. Etwas Bejtimmtes über ben Beginn ber Maujer zu jagen, ijt unmöglidy, namentlidy twas bie

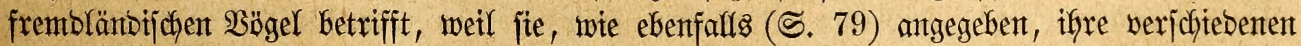

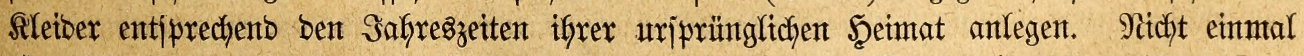
für einen unb benjelben $\mathfrak{B}$ oger fann eine unabänberlidbe Maujerzeit feítgefteflt werben; benn eine unb biejelbe Nactitigall maujert in biejem Safre früber, in jenem fpäter. Der 


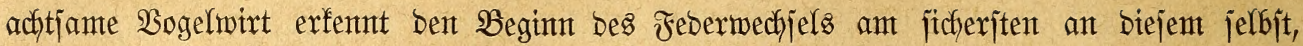

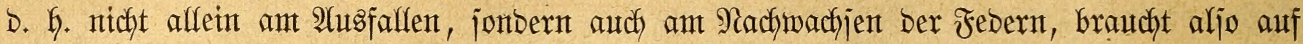
bie Maatjerzeit nicft bejonbers aufmerffam gemadht zu werben.

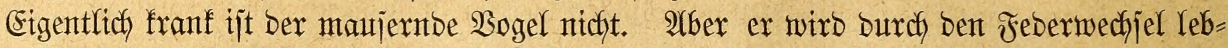

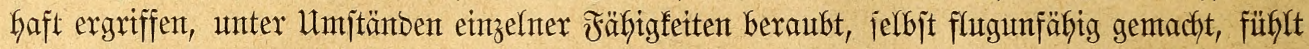

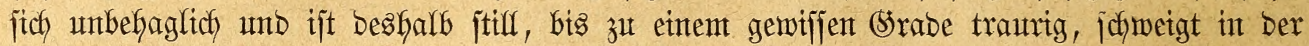
Regel - feintesmegs aushafymslos - mit jeinem (Sejange, fibst biel auf einer unb berjelbent

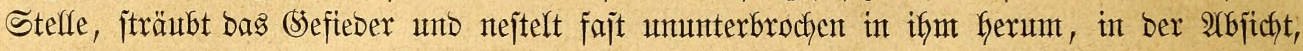

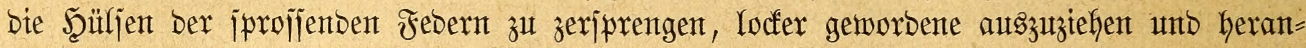
wadfjenbe gef̧örig einzufetten. Diejer Bujtant, Diejes Stebafrent bes Iteres ift jo augenfällig,

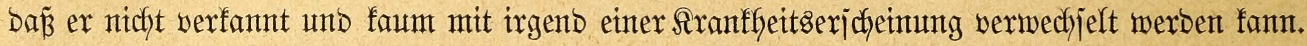

Eine gemifife Beffanthlung num erforbert bie Maajer jebenfalrs; nur Darf man unter joldjer nidft etwa ein jinnlojes Suadfalbern werjtehen. "WSer jeine Bffleglinge", bemerft (sirtanner treffend, "überfgaupt fo gut hält, baß̉ er ifgre Rage faum ober nicfft verbeffernt

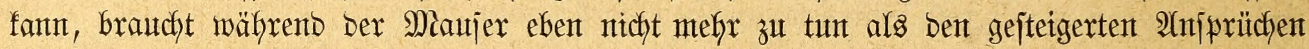
an nafrbaftez Futter nachzutommten; wer bagegen biz zum Beginn ber Miaujer jeine Bägel

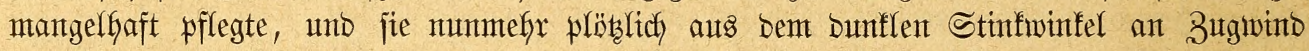
und Sonnenfitze bringen unb gut füttern wifl, wiro ifynen fdjwerfich bienten. Mian beginte

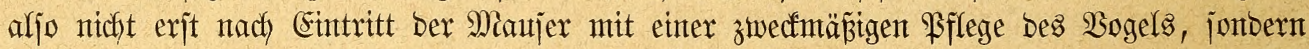

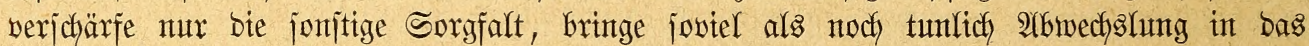

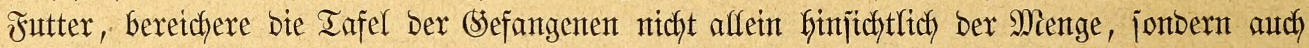

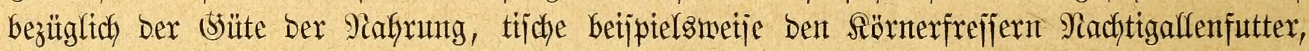

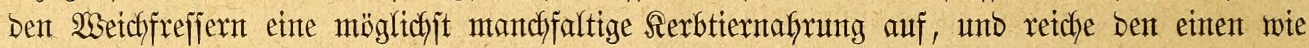
Dent antoeren zu verichiebenen Iageszetten jo viele Miefinürmer, alz jie frefifen wolfen, beziehent= lich als man ifgnen reidhen fann, gewäfre wollfte (belegenfgeit zum SBaben, gebe recht viel

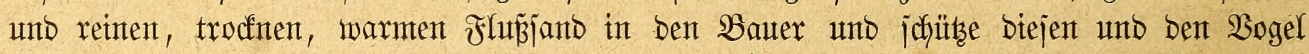
lieber mit zu viel als zu wenti Sorgfalt vor jeglicher Störung, bor äußeren Einflüfien,

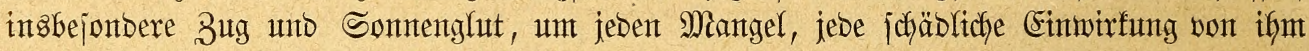

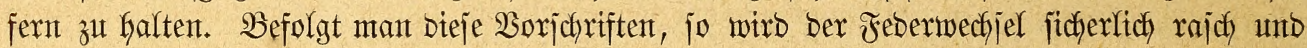

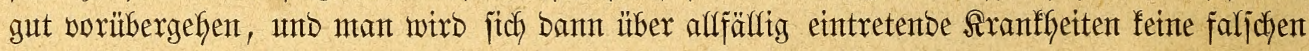
Dorriteflungen machen unto afles Hnbeil auf bie Miaujer jafiebent wollen."

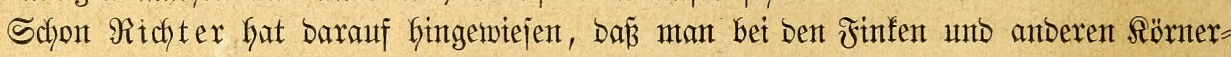
frefjern oft eine Serfrüppelung Der neu Geranwachjenben Febern benterft, inbem namentlich bie

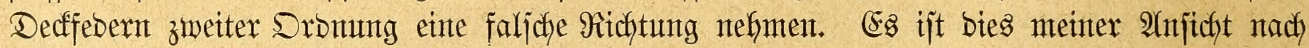
Folge einer ungenügenten Ernäfrung, vorzugameije aus Maangel an Serbtierjutter. "Itunter=

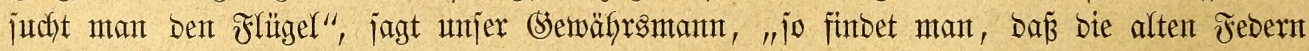

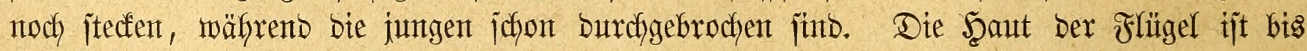

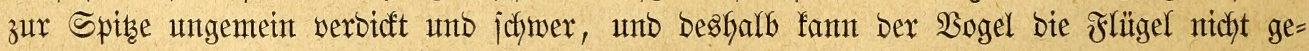

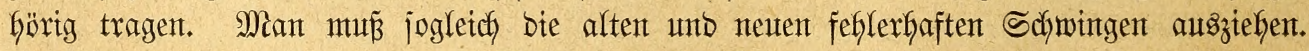

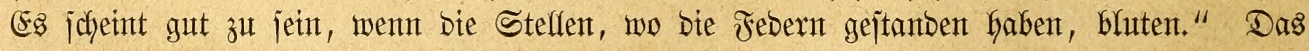

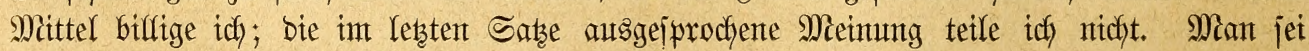
Itets, in ber Miaujer aber boppelt vorfichtig beim 241 sziefen ber Febern unb verfaffe nach

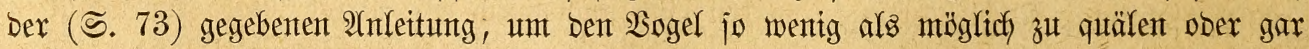

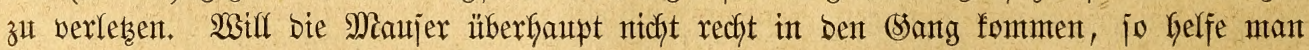

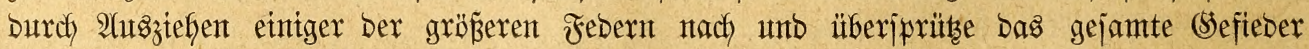

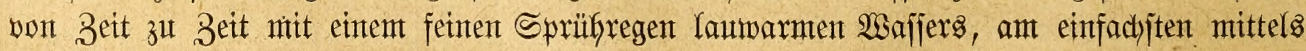

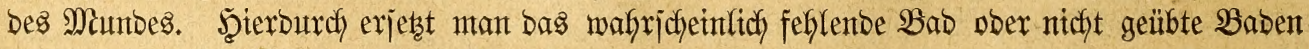
unb beminft ein retchteres 2tusfaffen ber Jebern. 
(Sar. nicht bringento gemug fann getwant werben, einen maujernben $\mathfrak{S o g e l}$ mit jeinemt

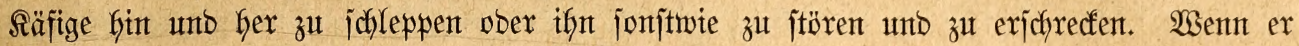
fich bie noch unreifen Febern Durch Flattern im Sebauter bejchäbigh, barf man fajt mit

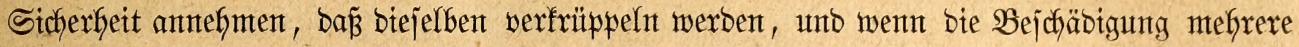

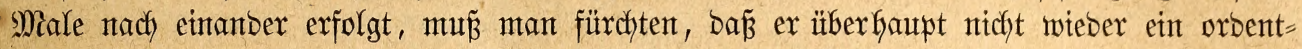
riches (sefieber erfält. Namentlich bie Schmingen erjter Sromung vertragen burdyaus feine Berletzung, jo lange ifre Riele nody mit $\mathfrak{B l u t}$ gefüllt jinto. Sch babe midh vergeblich be=

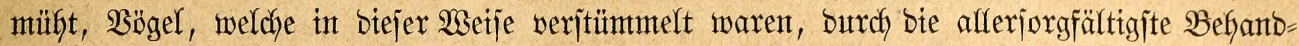
lumg zu Geilen: fie litten fortan, jo zu jagen, an einer ununterbrodjenten Maujer unt brachten es boch mur zu unteifen Febern, bluteten ba, wo biejelben entfeinten, unt blieben gejchäntbet für immer.

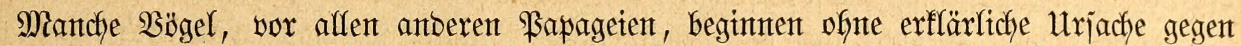

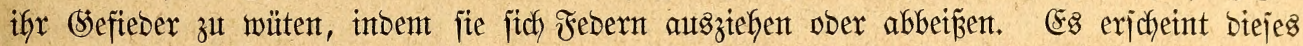

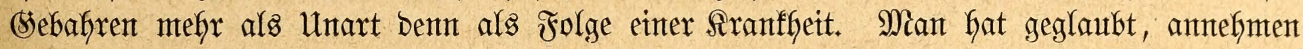

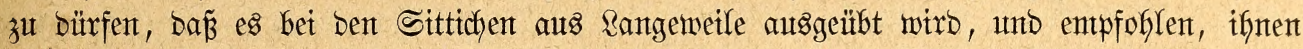
weiches $\mathfrak{S e l l}_{z}$ zum $\mathfrak{B e f n a b b e r n ~ z u t ~ r e t c h e n ; ~ f u ̈ r ~ b i e ~ u ̈ b r i g e n , ~ w e l c h e ~ b a s j e l b e ~ t u n , ~ h a t ~ m a n ~}$

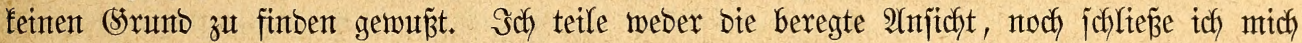

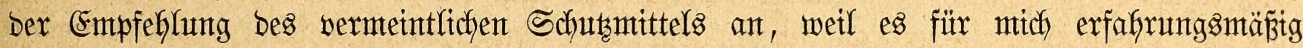

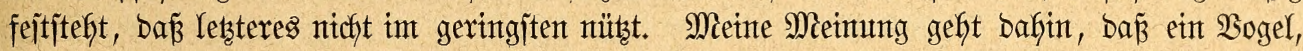
weldyer jein sefieber vernidytet, in gemifjem, bejchränftem Sinnte afferbings franf ijt, und

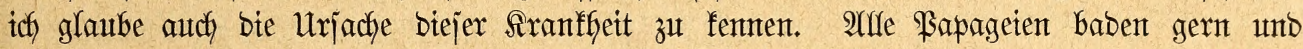
oft, unb affe, weldye baben fönnen, benfen, io weit meine Beobachtungen reidhen, gar nidft

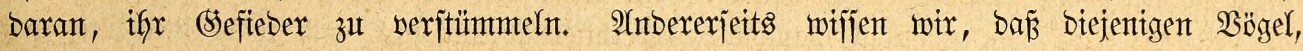

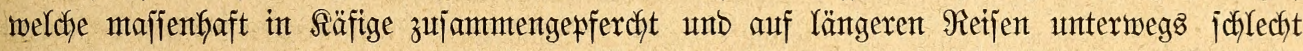
gepflegt, insbejonbere mux mangelkaft mit Sajjer verjeken werben, jefr oft in bem ( $\$ .69$ ff.)

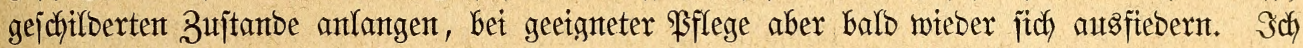

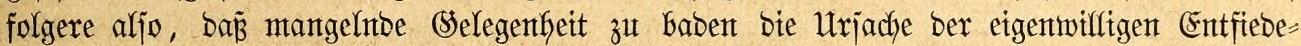

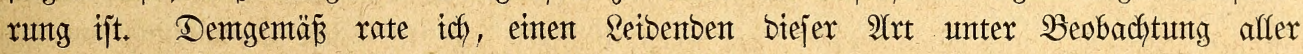

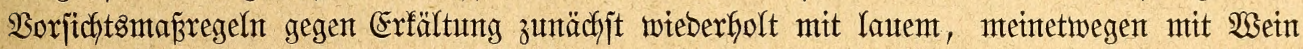

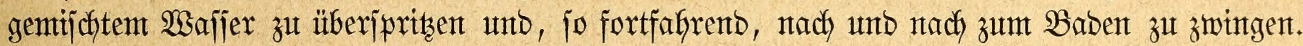

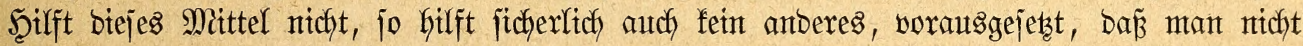

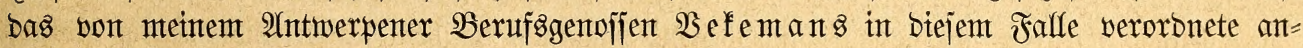
wenten will: Dem betreffenden $\mathfrak{B o g e l}$ ben Şals umzubrehen!

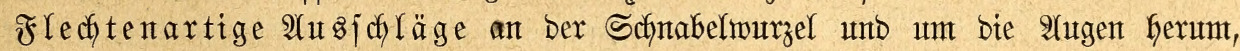

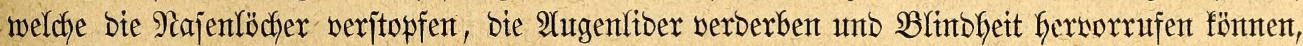

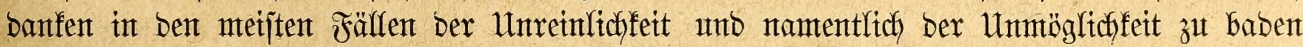

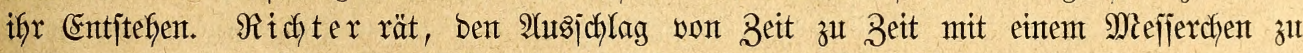

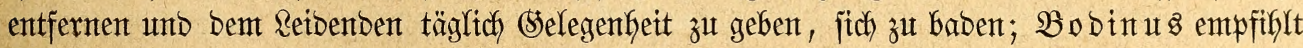
Wajadyungen mit einer Yetdften \&öjung von Scöllenjtein (1 bis 2 (stran auf bie Unze Wafjer) ałs bas einfachjte und jicherjte Şeilmittel.

Sefr viele $\mathfrak{B g ̈ g e l ~ K e t b e n , ~ a b g e j e h e n ~ v o n ~ b e n ~ b e r e i t z ~ ( \Im . 4 8 ~ u n b ~ 5 1 ) ~ e r w a ̈ h n t e n ~ M i t h e n ~}$ (Räıjen) an Sdymarotzern, zumal an Eingemetbemïrmern. Währento bie meijten von biejen

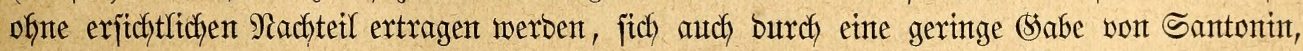

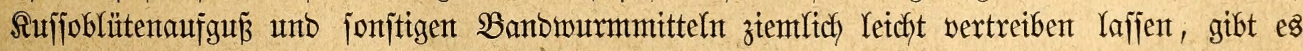

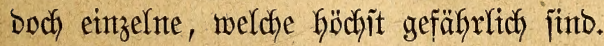

Unter ifnen jteft, joweit uniere bisherigen Beobachtungen reidhen, ber von Siebold zuerjt bejchriebene \&uftröhrenwurm oben an. "Diejem fürchterfichen Titere gegenüber", bemerft von Freyberg, "exjcheinen mir alfe übrigen Sranffeiten ber Bögel bebeutungalog. 


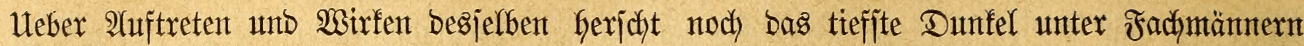
wie unter 2aien. 2Yuf beides wirb nicht geadjtet, beibes wiro nicht erfannt. Seber Beitrag

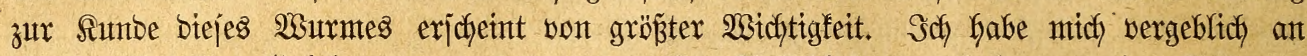

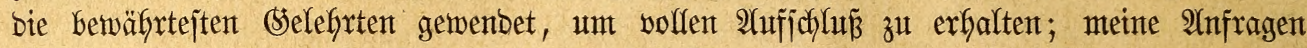
blieben unbeantwortet, bie Heberjendungen bes Iteres jelbjt ofhte mix befannt getworbentes.

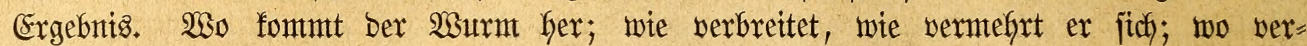

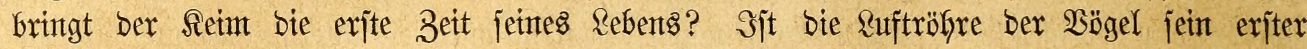

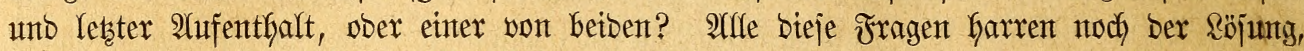

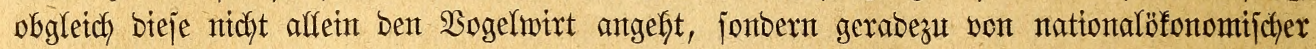

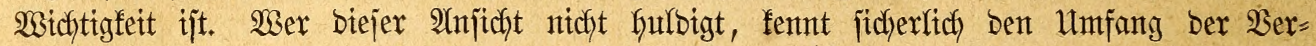
Gerungen nidft, weldye biejer Schmarotzer berurjadyt". Sch Gabe bisher letber, für mich)

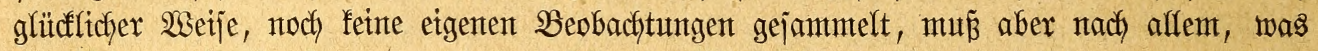
mix 2 (ntbere mitteilen fonnten, meinem erfahrenten Mitarbeiter vollítändig beijtimment unt möchte beshalf mit ifm in Serein nodfutals bringento aufforbern, Dent Treiben bes $23 u r m e s$ bie volljte 2 (ufmerfjamfeit zu wibmen, um jo balb als möglidy über ifgn und jein Reben ins Silare zu fommten.

Der \&uftröfrentwurnt (Syngamus trachealis ober Sclerostomum syngamus) gefört

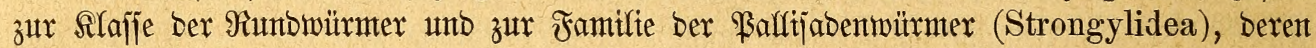
Sennzeichen in bemt verlängerten, rumblicten Rörper, Dem enditänbigen ober an ber Spize

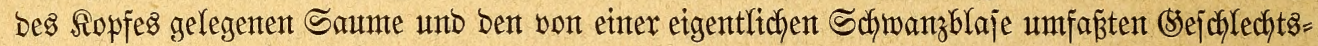
werfzeugen zu juchen find. Der \&uftröfrentwurn fentzeidynet fich burch folgende Mierfmale: Der Mimbjaumt ift freizrunt und mit jechs Wärzchen bejekt, bie Schwanzblaje zwälf = bis funfzefnitraltig; bie weiblidye in ber vorberen Reibeshälfte gelegene (sejdylechtsöfinung ijt eine wulfitig ummanbete Duterjpalte und füfrt in bie vielfach getwunbene Eiröhre; bie männlicken (sejchledhtswerfzeuge bejtehen aus zwei jenjenförmigen Stäbchen, weldye in einer zweiblätterigen Schetbe liegen. Das Männthent ijt etwa $7 \mathrm{~mm}$, bas $\mathfrak{3 e i b c h e n ~} 13$ bis $14 \mathrm{~mm}$. lang; ber

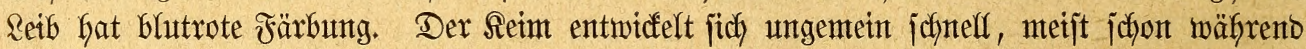

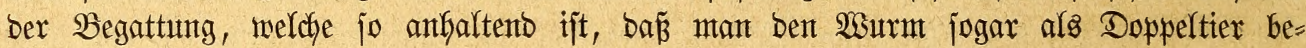
jatrieben hat.

Borzugsmetje finto es bie Scharrö̈gel, weldye ber Sdymarober heimjucht; ex bejdfränft jich jeooch feinesmegs auf jie afleit, wirb bielmefr audy leidht auf antbere Bögel übertragen

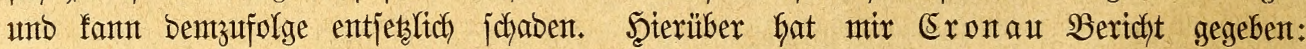

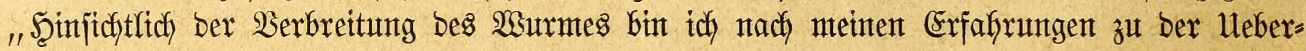

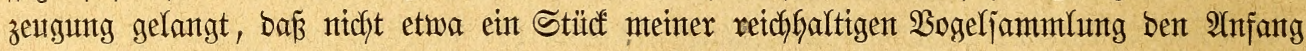

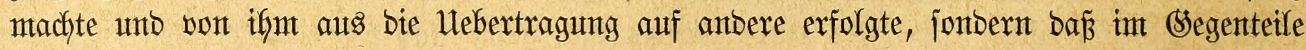

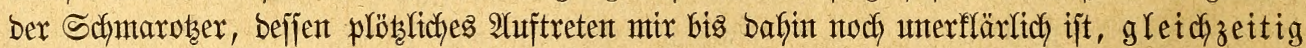
in mefreren, ziemlidf weit von einanber entfernten Fluggebautern fidf einjtellte unto ifrer

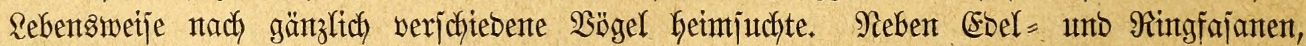
Fajanentyüfnern, wurben 9lfenbohlen, ein Sarbinal unt einzelne flemere Singuögel befallen,

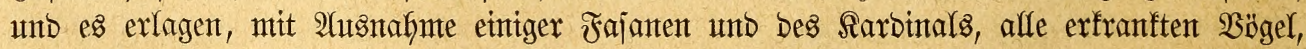
unter ifnen zebn Irlpendoflen, fajt mit einem Male. Sunge Silber = unb Solbfajanten, welche fich mit - Den exfranften Sjabelffajanen in bemjelben Raume befanben, wurben nicht

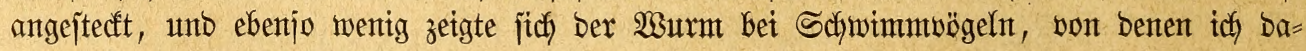
malz eine großse 2 (nzabl fielt."

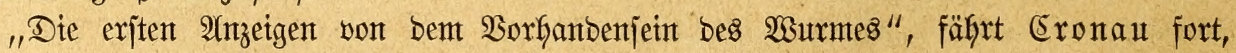

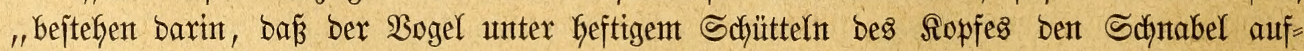
jperrt, feudst uno hujtet, fo bafis man mofl glauben fant, ex jei von eintem heftigen

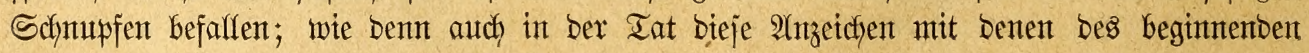




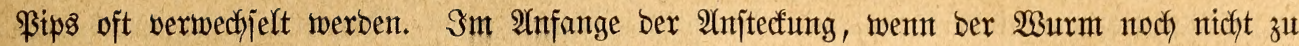

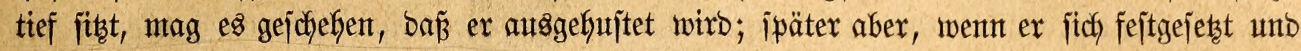

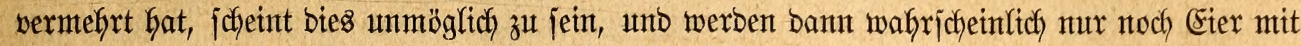
ben jefrt hartlebigen Reimten autsgeworfen. Die Sermefynung ift eine überauts rajche; bent

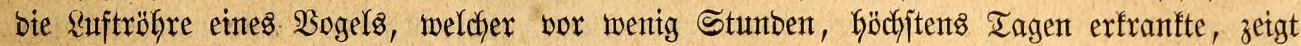

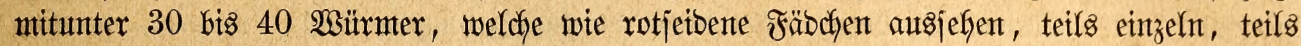

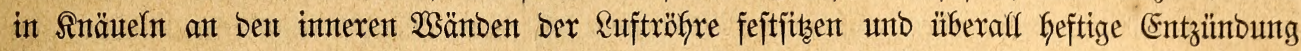
Gervorrufen. Nimmt man mit einer (Sreifzange einen foldchen 2 surm ab, uno legt man than

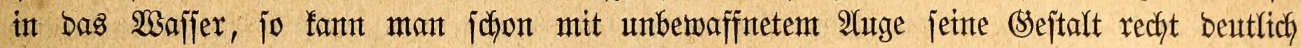
erfenten."

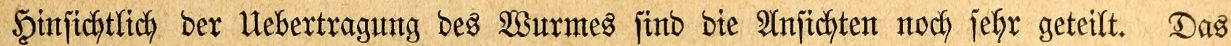

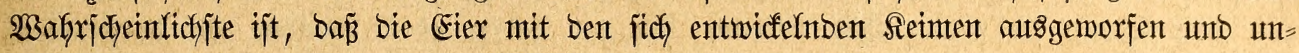
mittelbar aufgenommen werben; wieffeidft wirb audd ein unb ber anbere aubgefuftete \&uft=

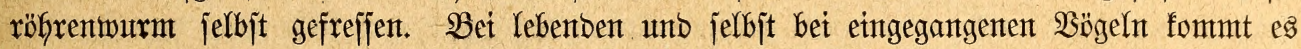

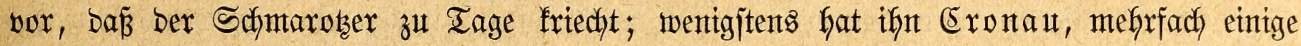

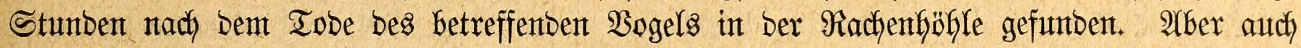

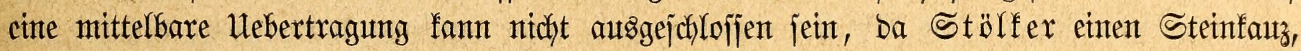

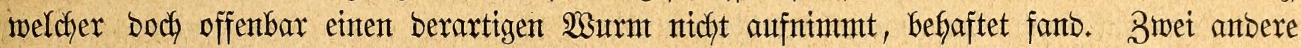
Steinfäuže, weldhe gebactiter Forjcher mit bem erwägnten zujammen fielt, GGleben ebenjo

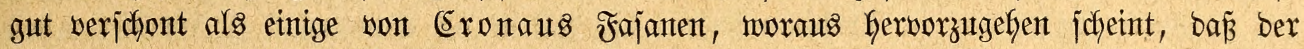

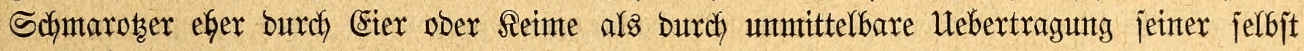

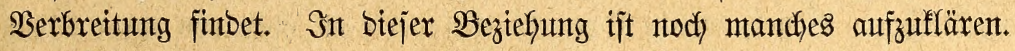

seiber bejitzen wir noch fein jicheres Mittel, weldyes einen von biejem furrdjtbaren

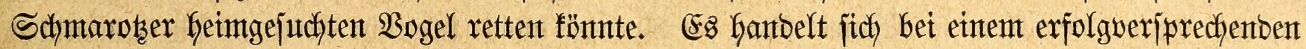
Eingreifen barum, ben gefährflichen $2 s u r m$ zu töten, uno bas ijt, wie- Yeidgt begreifflich,

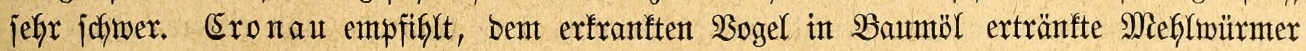

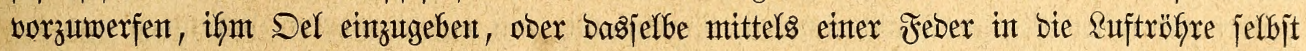

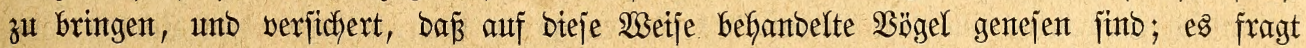

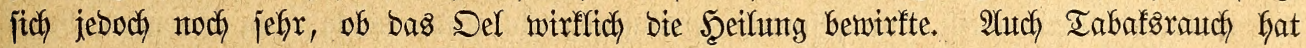

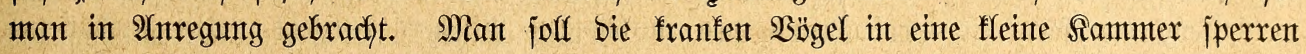

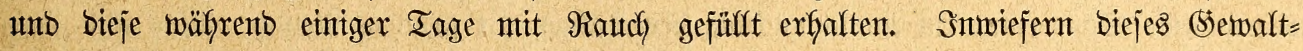

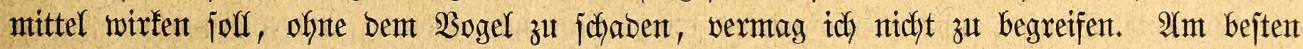
wiro man tum, weent man angejteçte Sögel jofort von ben übrigent trennt, afle Befeäß̈e,

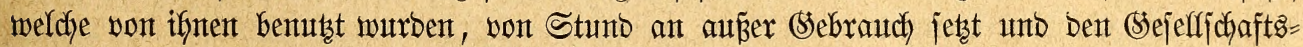

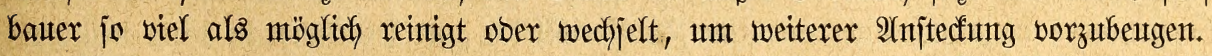

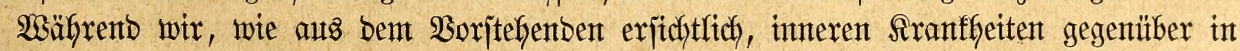

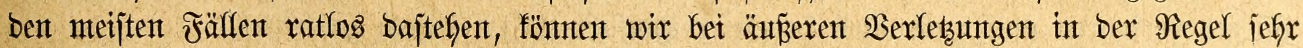
förberlid eingreifen. "Madd meinen Exfafrungen", beleffrt (jitrtanner, "yertragen bie

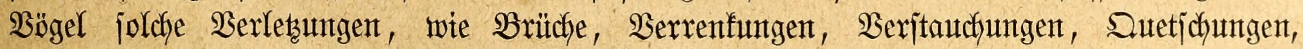

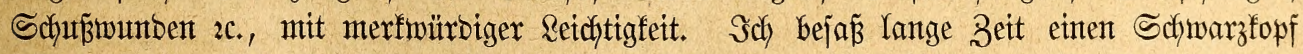

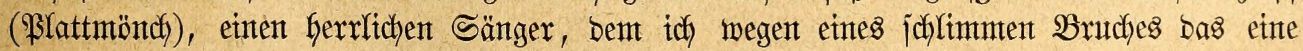
Bein abgelöjt hatte. Das anbere nafm int \&aufe ber Zeit eine ganz untgenöbynlidye Stärfe

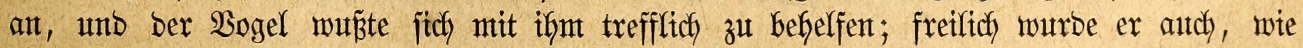

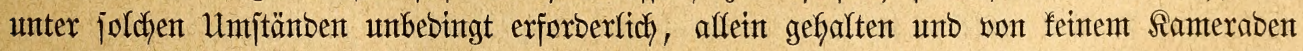
in feinen Bemegungen gejtört. Eine Steinfrähe, weldye Stölfer erfielt, werlor burde $\mathfrak{2} b=$

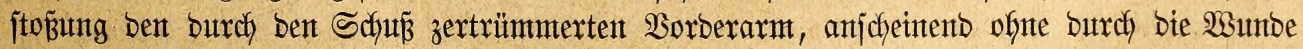

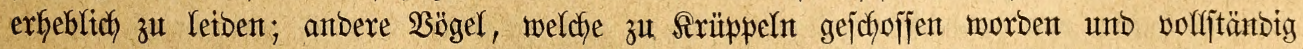

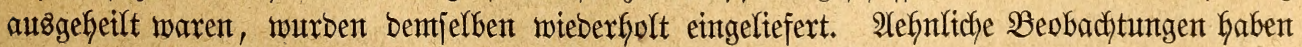




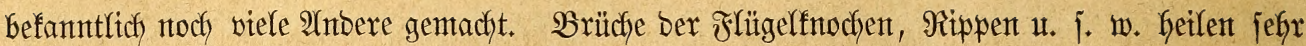

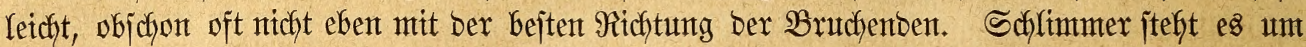

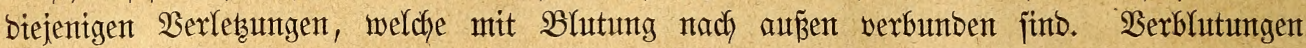
fommen viel Gäufiger vor, als man gemöbnlich annimmt; wer aljo eine B̧lutung itiflen

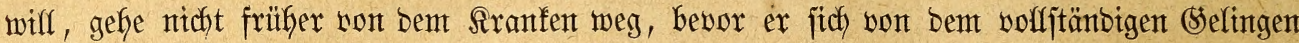

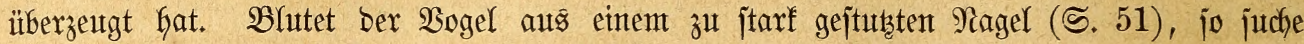

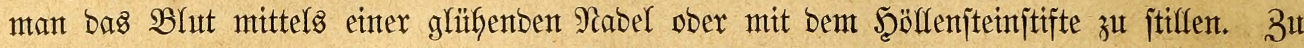

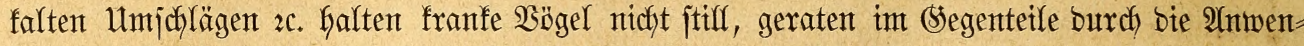

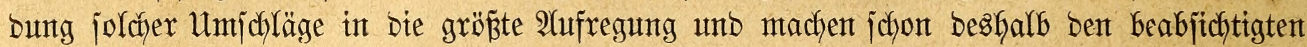

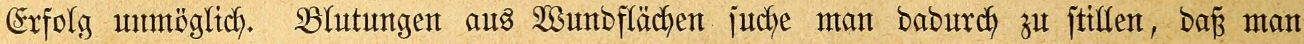
bieje mit einer jtarf gejättigten Röjung von arabiichem Siummi ober Solfobium bejtreicht unto bem Bogel bie Stelegentheit nimmt, fich zu baben oder jonjtwie zu burchnäjfen. Unter alfen Umitänben befalte man einen in Befandlung befindlichen $\mathfrak{B o g e l}$ möglichjt wentg

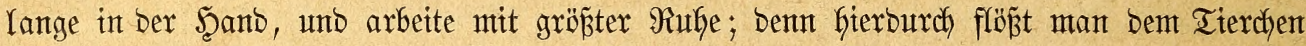
3utrauen zum $\mathfrak{B f l e g e r}$ und Einjicht in befjen wohltuende Tätigfeit ein. Bsemöhnlich wäfrt

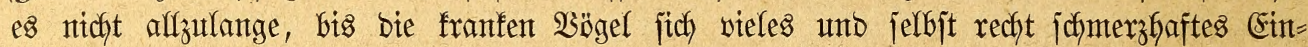

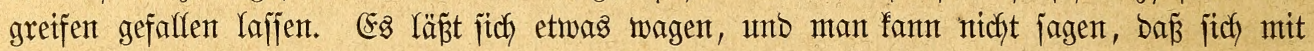

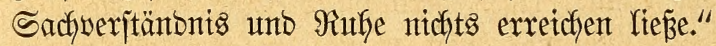

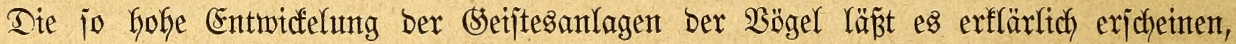

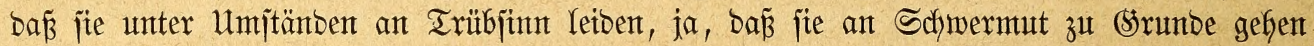
fönnen. Es liegen fierïber genügende Beobadtungen vor, weldye jeben 3meifel an ifrer

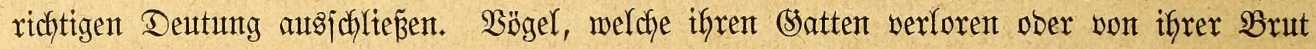

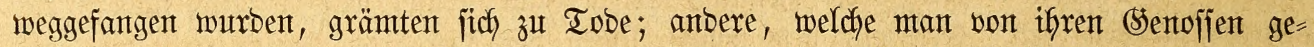
trennt hatte, verfielen in Schwermut; anbere bärmten fich ab, meil fie ifhre geliebten

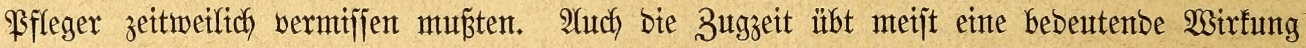
auf Den Semütşujtand aus, erregt, madjt unrufitg unb traurig. Sm eriteren Falfe er= Geitert unb rettet oft, jeboch nicht inmer, Sereintgung mit eintem anteren Meäntchen unt be=

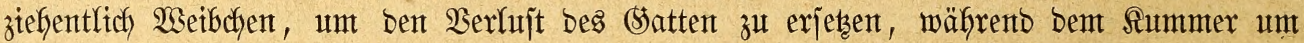

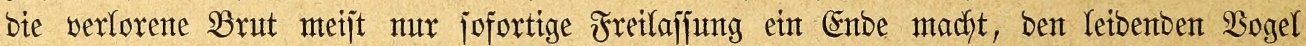
wenigjtens ber ferneren Beobachtung Des mitleidigen Bflegers entzieft. Bei minber tief

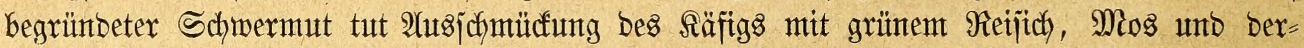
gleichen gute Dienjte, unb ebenjo wirfen frijche Ruft uno Sonne, âbwechshunt int Jutter,

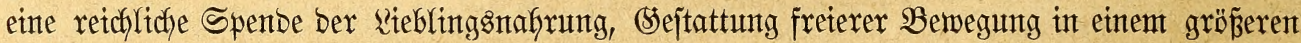
Räfige ober ßimmer erbetterno. -

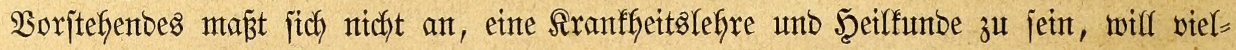
mefy nur bie (stumbregeln angegeben Kaben, nach benten ein jorgjamer Beobadjter und

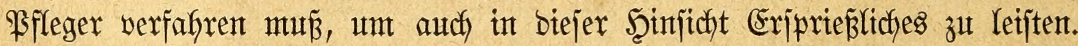

\section{Dougelhandel und bouglhäntiler.}

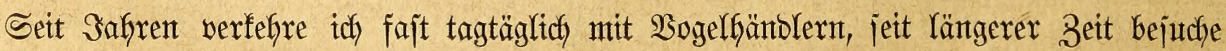

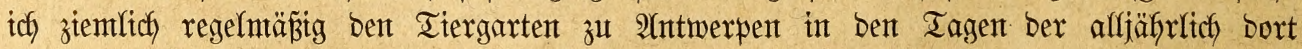
jtattfinbenten Berjteigerung, welche ich an einem anberen Srte bie Börje bes Tierhandels genannt Gabe: unt bennody ift es mir nicht möglich gemejen, mefr als ein ziemtid rich =

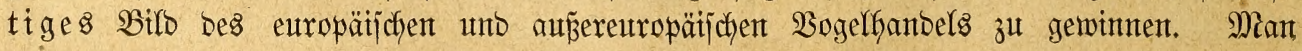


mü̈̈te, mollte man umfaffend über biejen Segenjtand berichten, felbít Şändler jein int eigentlichen Sintre bes Wortes, in einem ber hauptiächlichjiten Stapelpläbe einte größzere

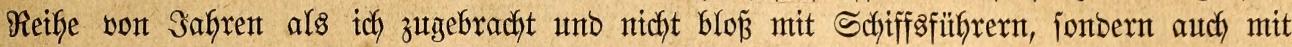
allen Den 3uträgern, welche Gierbei als werftätige Reute auftreten, verfehrt haben. Dem= ungeadtet bin idh int Stande, Mitteilungen zu geben, wie jolche bisher noch nicht ver=

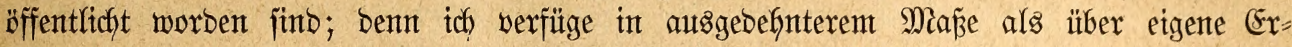

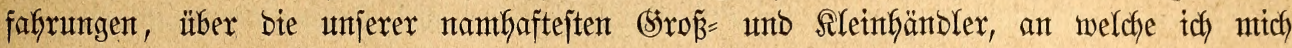
zu (Sumiten biejes 2 serfes bittend gewenbet, unb von benen idf einen gropen Teil bes Rachiftehenten erbalten habe.

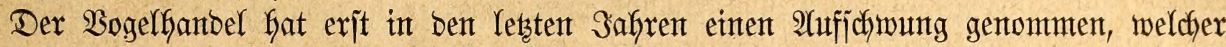

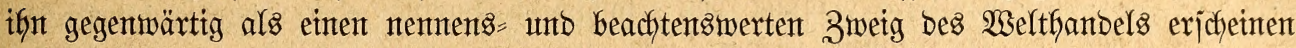

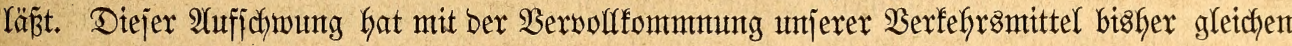
Schritt gefalten, verjpricht aljo, itetig zuzuthmen unt fich immer bemerflicher zu machen.

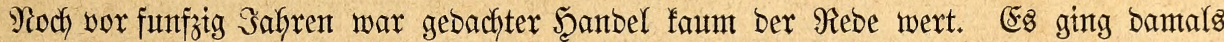

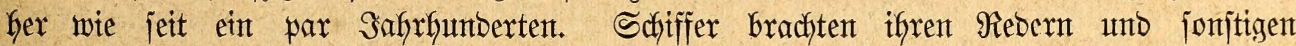
Befreunbeten einzelne fremblänbijche $\mathfrak{B} \not ̈ g e l$ mit, weldye fie zufällig in auß̈märtigen Şafen= orten ermorben hatten, lieferten audf wohl einmal cinten geringen Beitrag für bie un= bebeutenden $\mathfrak{B e r f a u f g l a b e n ~ b e r ~ S e a ̈ n b l e r . ~ D i e ~ E i n f u h r ~ w a r ~ g e r i n g , ~ a n ~} 2$ Ausfufhr bachte

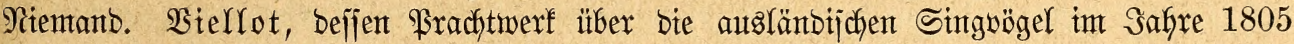

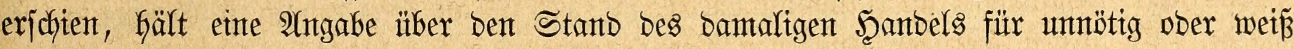

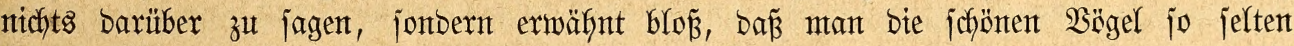
rebento nach Europa bringe. Noch zwanzig, breişig Safje ipäter war es faum anders als zux angegebenten 3eit. Exjt mit Dem Emporblüfen Der Titergärten begann audh bie Ent=

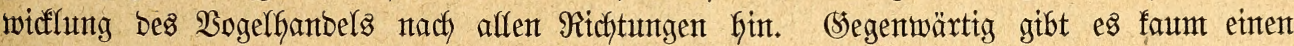

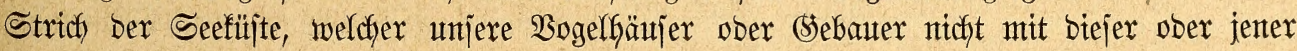
Art bejchenft hätte.

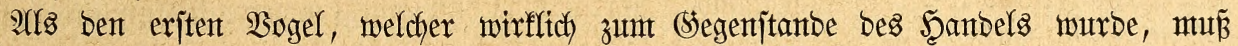
man bent Sänger von Sanarta bezeidfnen. Er hat tatjädylich Safyrfunberte lang ben Marft injofern befjericht, als er ber einzige war, meldyen man regelmtäß̈ig faufen fonnte.

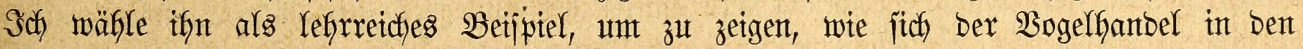

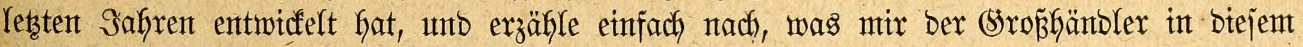

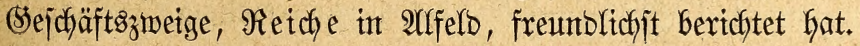

"Der ફ̧antbel mit Sanarienvögeln unb abgerichteten Dompfaffen nach auperbeutjchen

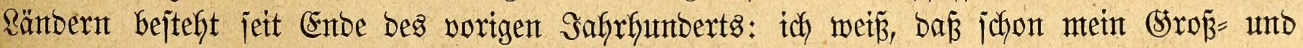
Urgropabater fich bamit befchäftigten. Beibe Gatten fich St. Betersburg zum Arbjatzorte

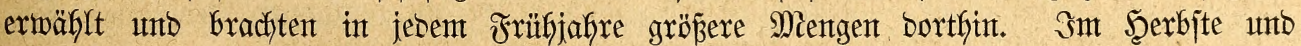
Winter bejucften fie zu gleichem Zrwedfe Scollanto unt Englant. Dodh wurbe bas Bejchäft

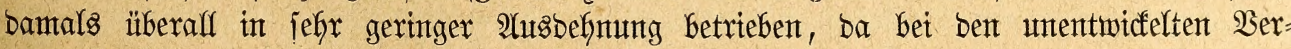

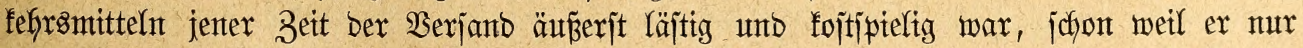

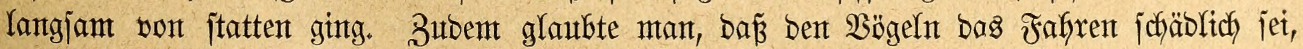

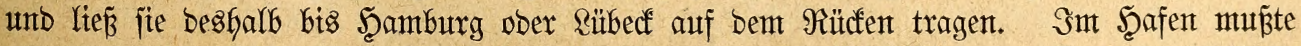
man nicht jelten wibrigen Wintoes falber wochenlang liegen bleiben, unb went entlich bie

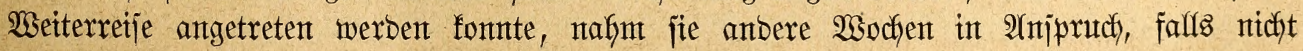

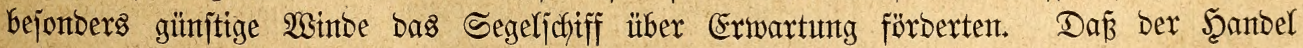
joldyen Şinberniffen gegentüber unmtöglidy gebeifgen fonnte, bebarf nidft ber weiteren 2 (1ts= einanderjebzung.

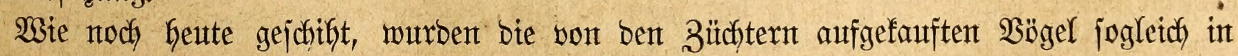

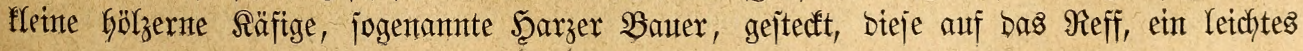


Traggejtell, geietzt, bis man bie Rabung von 160 voer 170 Bautern zujanmengebrad)t hatte, worauf man baz (Sarze funitgeredft mit Reintwand umbüflfte, unb ber Träger fidc) auf ben

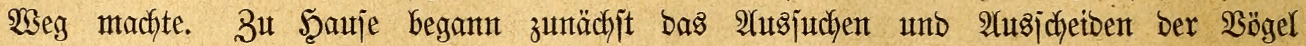

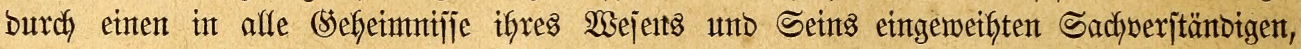

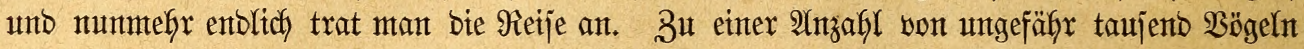

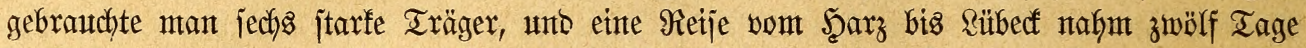

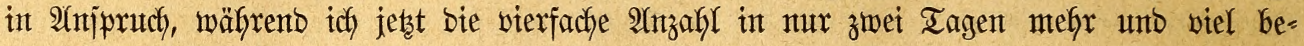

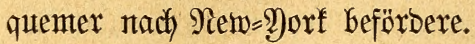

Man bradh bamals bereits eine Stumbe vor bent Iagmerben auf, legte bie erjite

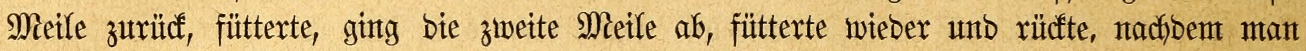

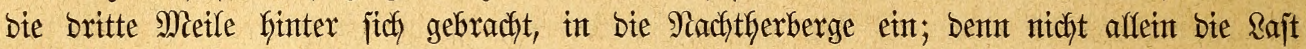

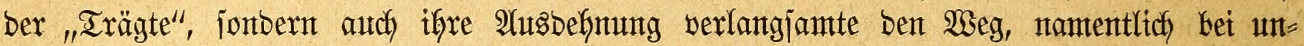

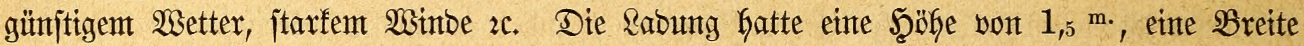

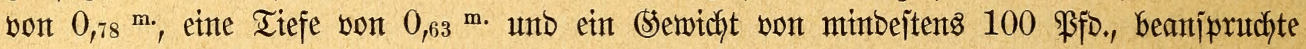

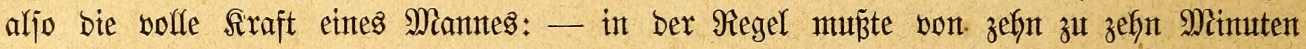

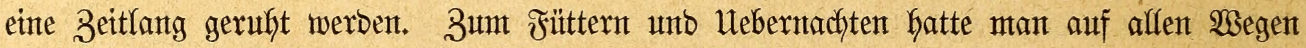

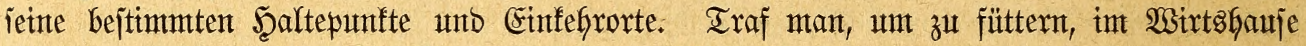

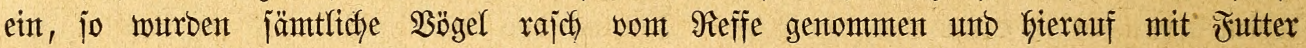
unto Trinfent verjorgt, jo gut bies ebent gehen wollte. Se fieben Bauter waren burch einen

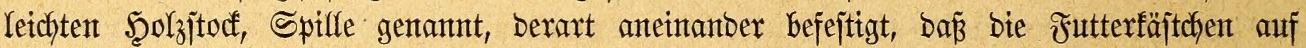
ber einen, bie Irinfuäpfchen auf ber antberen Seite fich befanben. Eine foldhe Reitge nach

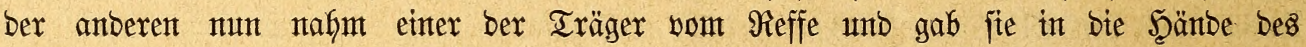

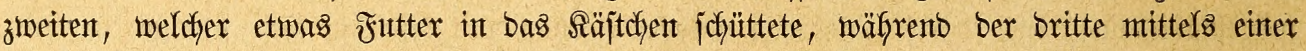

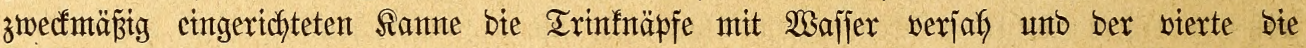

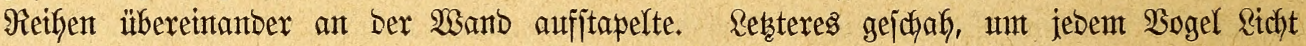

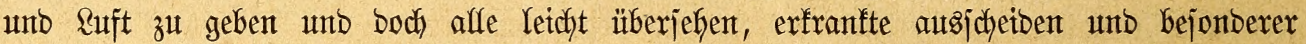

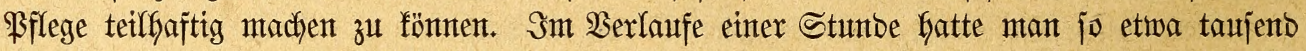
Bögel abgefertigt, lié̉ fie Gierauf eine fernere Stumbe ruffig jtefen uno frefien, erquicfte jith jellbjt mit Speife und Tranf, pactte auf unt trat bie näddjte Meile an. Se von.brei

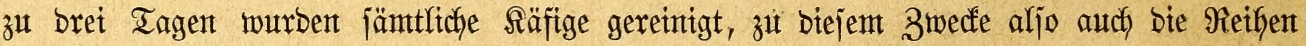
auBeinanbergenommen unto wieber zujammengejteft - eine 2lrbeit, weldye io viel Zeit wegnafm, bá̉ an biejem Tage nur zwei Mietlent zurülffelegt werben fonnten. Das jür

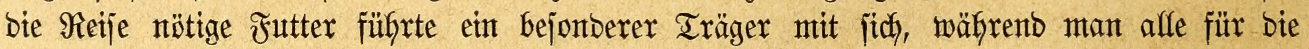

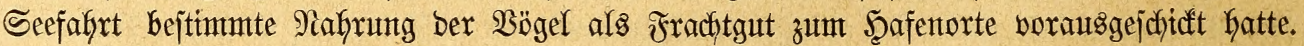

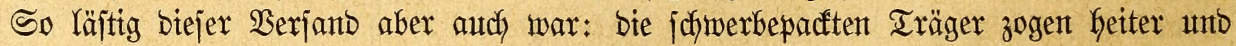
wergnügt iffres 2 Seges bafin, begleitet auf Sedritt unb Iritt won ben jodntetternben Riebern

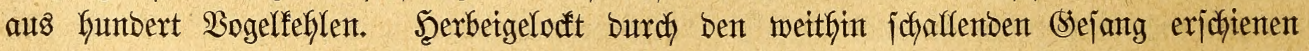

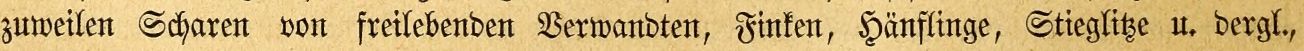

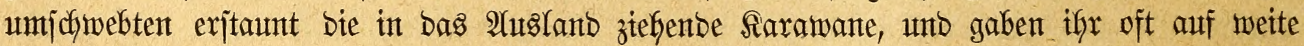

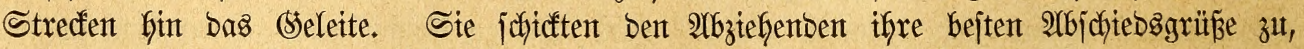

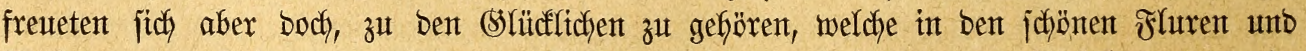

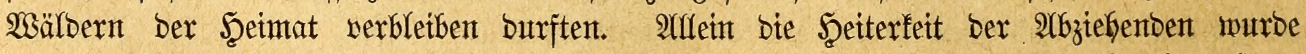

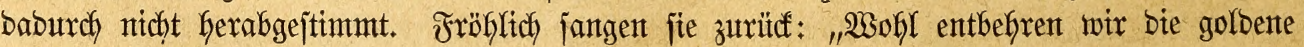
Ireibeit; aber Dafür ziefen audch bie Stürme bes Şerbites, bie bitterfalten Tage bes

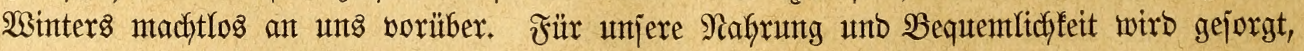

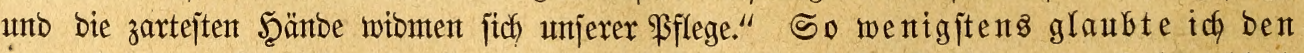

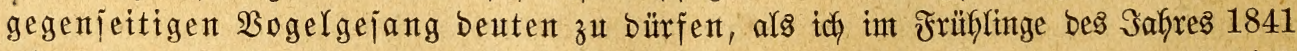

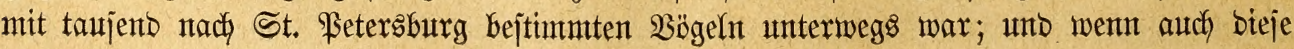


Dentung wofhl nidft ganz ridftig jein mochte: fie gemährte mir Freube, erleidfterte bie Büroe nno fürzzte ben $\mathfrak{B e g}_{\text {. }}$.

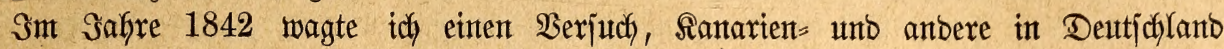
geborene $\mathfrak{B}$ g̈gel in Norbanterifa einzufüffren. (Es war bas erite berartige Unternefymen

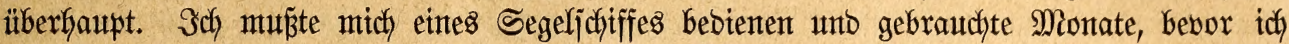

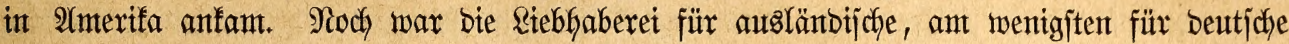

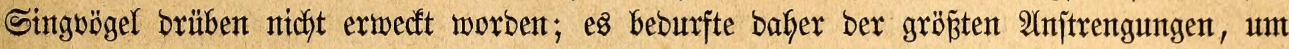

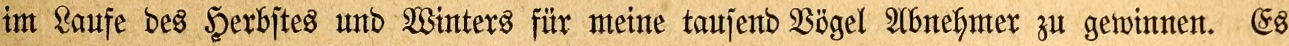

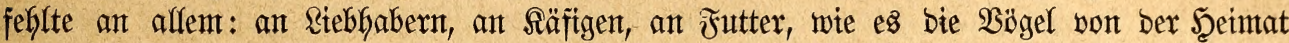

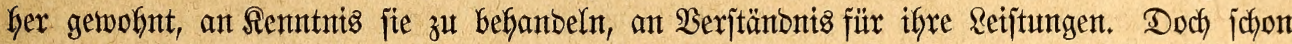

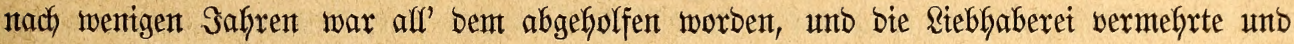
verbreitete fid von $3 a b r$ zal Safre.

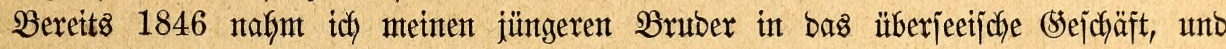
wir betrieben nummefir ben Sandel regelrecht unt in immer fich fteigernber 2 fu\&befnumg.

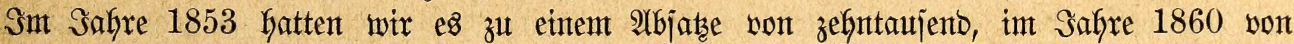

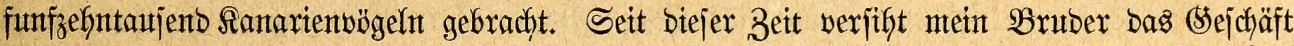

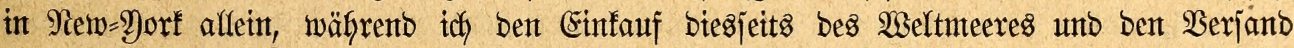
übernommen fabe; bent mur burdh bieje Ieilung ber 2 rrbeit find wir int Stanbe, ben 2Unforberungen unjeres 5̧anbels zu genügen.

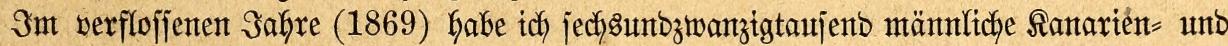

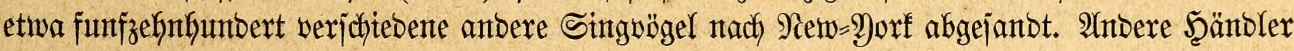
Gaben Denjerben Marft ebenfalls aufgejutfit unb zujammen in bent genannten Safhe etwa

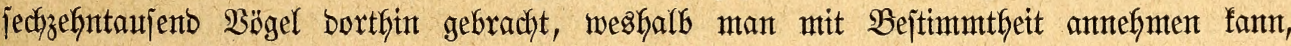

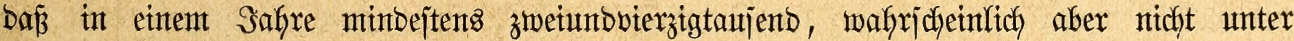

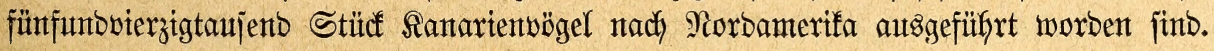

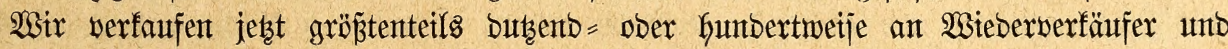

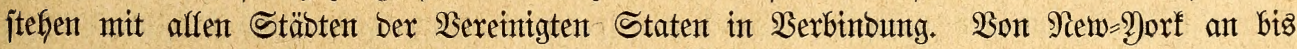

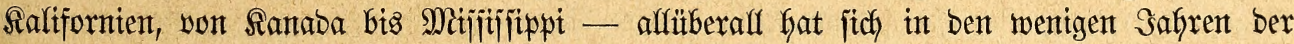

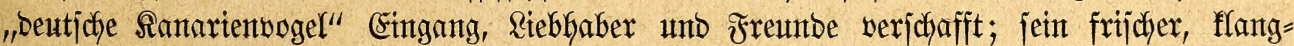

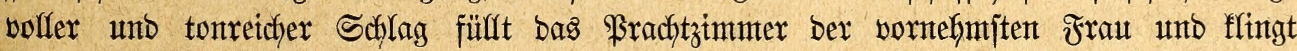
wieber im einjamen 2 Salbe, weldyer bas neuterridftete Bloctfaus noch umgibt. Sor Gafren

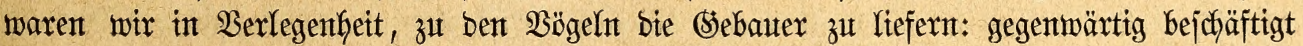
(Sïnther, ein Deuticher, in jeiner mit Dampfntajfinten verjefiebenter $\mathfrak{A}$ trt alsgejtatteten

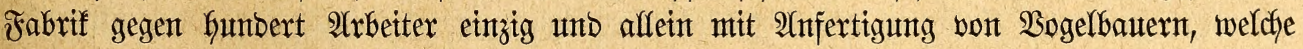
er aus $\mathfrak{B l e c}$ ) und Drat ebenjo gut als zierfich Geriftellen läp̈t.

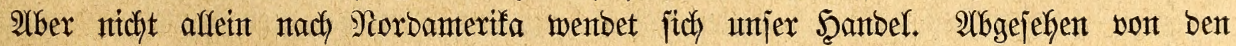

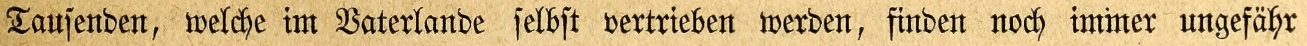

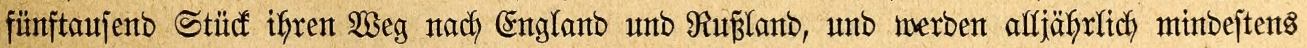

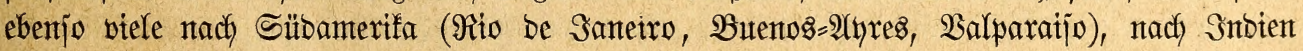

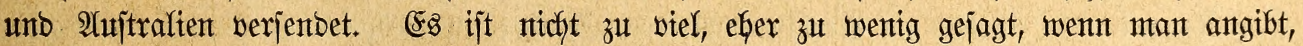

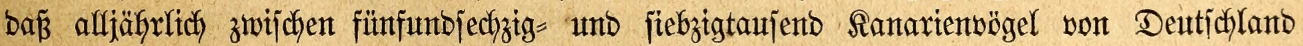

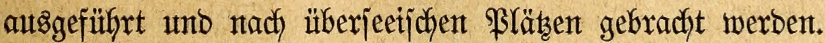

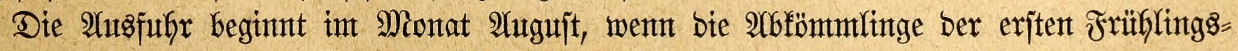

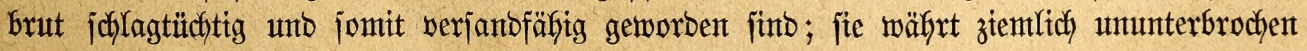
fort bis zum 2 (prit: Dann ift alfer $\mathfrak{B}$ orrat vergriffen.

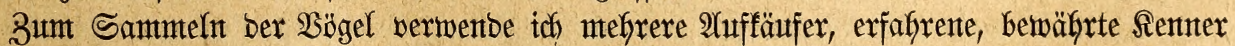

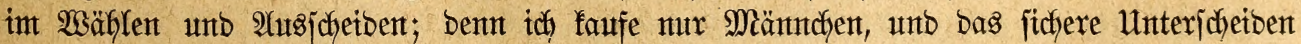

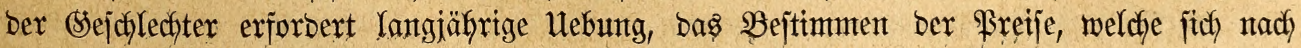




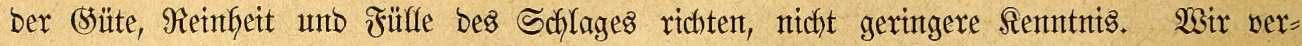

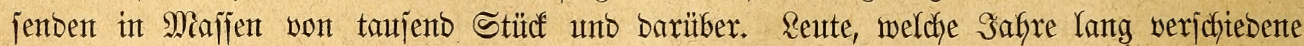
Bögel gepflegt haben und volffommen jeefejt geworben find, bejorgen unterwegs bie

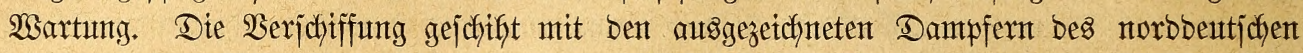

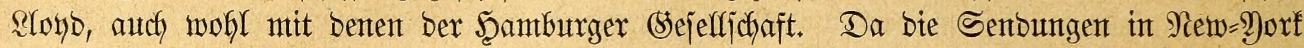
yon unjerem Sanje jofort nach Anfunft bes Sdfiffes in Empfang genommen werben,

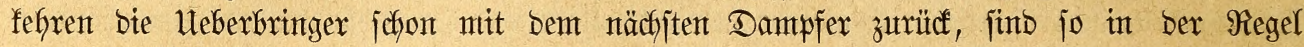

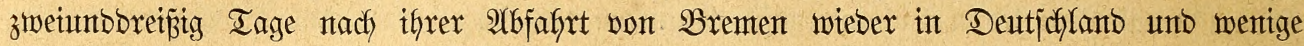
Tage ipäter zu einter neuen Reije bereit.

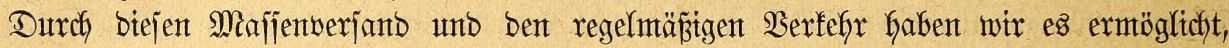

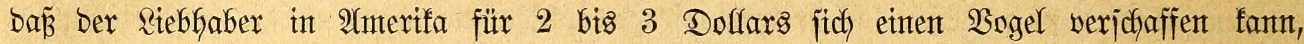
weldyer fajt taujend Meilen von jeiner Seeintat gezütdstet, won ben bejten Meijtern jeiner 2(rt zu eintem vorzüglidhen Sdyläger ausgebilbet unb über bas jtürmijche Weltmer gejenbet

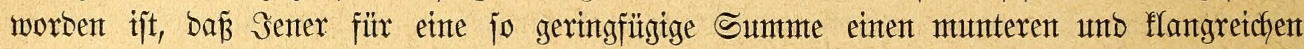
Stubengenofjen zu geminnen wermag, weldhen ex trots alfer ifym in hofhem (stabe eigenten

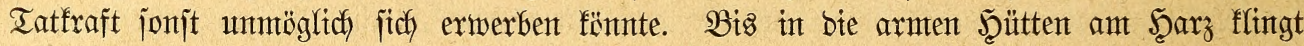
ber Danf von brüben Gerïber, flingt tatjächlidy in blanfem (Selbe wieber; Denn manthent

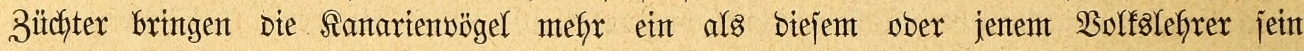
mïfyolles 9 Imt.

Bon Den freilebentben beutjchen $\mathfrak{B}$ g̈geln habe idy wenige zu nennen, welche in 2 mmerifa

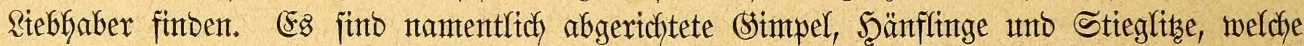
begehrt werben, währento wir Ebelfinfen unt Beifige inmter mur an wentge Riebhaber ver=

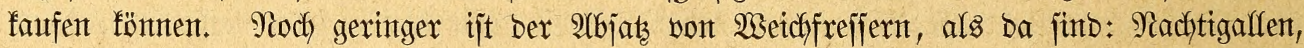

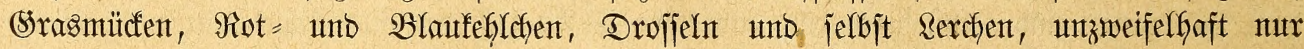
aus bem einen Srumbe, weil bie $\mathfrak{B f l e g e}$ gröpere Schwierigfeit, bie Fütterung mefyr Mïhle verurjacht.

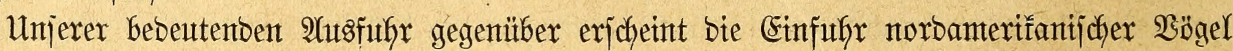

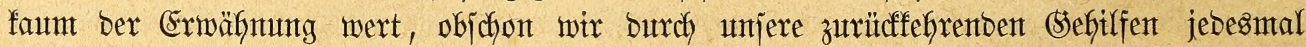
eine Sentung erfalten. Die Urjache muk in ben brüben uno Gier zu Sanbe Gerichenten (Selbwerfältniffen gejudht werben: Bögel, weldhe in eintent Ranbe aufgefauft wurben, in weldyem bas (Seld geringen Wert hat, werfaufen Da, wo bas (Segenteil ftattfintet, fick)

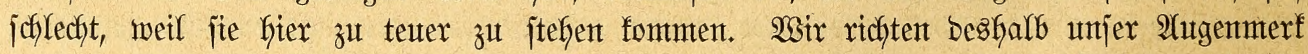

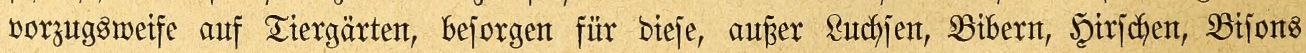

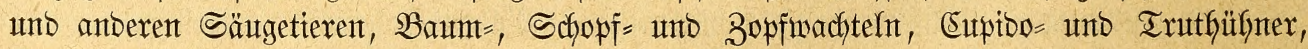
Sirantche, Enten, Schmänte 4. 1. w., für bie Riebbaber int engerent Sinne bagegen Rarolina= jittiche, Sarbinäle, ßabjt= uno Inbigofinfen, (Solbzeifige, Iangaras, Faperlinge, Rotflügel, Barttmorevögel, Spottorofjeln, Sałenvögel, Scüttenjänger u. bergl, alljährltch ungefäfr int Belaufe von bret= bis viertaujento Stücfen.

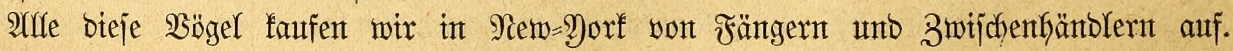
Der Fang finbet teilweije in Şerbjte, hauptjächlitch aber int Frühlinge währento ber 3ugzeit ftatt, unb zwar wentbet man fajt alle bet uns üblichen Fangmeijen ebenfalls ant. Sittiche uno Sarbinäle merben in ben füblidyen Staten, von Mitififippt bis Sübfarolina, in ben Monaten Dezember bis Februar gefangen und aufgejammelt, Spottorofieln ebento meijt Demt Nejte entnommen und aufgefüttert; Die übrigen exfyalten wir in Den Montaten Miärz bis Mai aus ben mittleren unb wejtlidfent Staten."

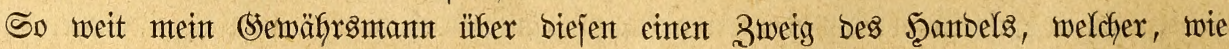

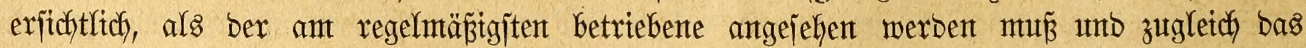

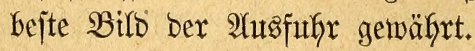


Dem Scambel mit Sanarienbögeln fann ber mit abgerichteten (s) impeln nicht zur Seite geitellt werben; bod, verbient aud ex immerfin $\mathfrak{B}$ eadjtung. "Mandjes arme

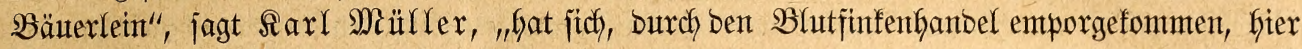

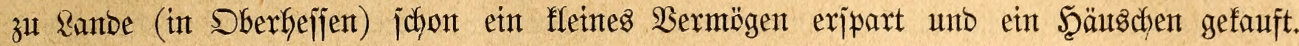
.... Sn vielen Dörfern Des Bogelberges merben, wie im Türingerwalbe, alljälfrlich

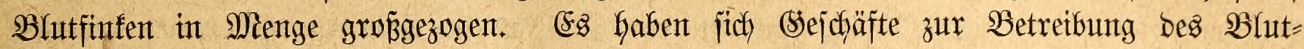

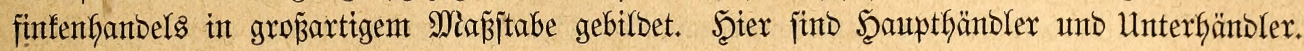

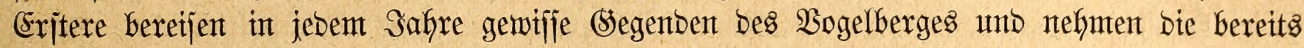
gelehrten Bhutfinfen in Empfang. Sind fie in Bejts einer ifyren Bweden entiprechenten Menge gelangt, jo reijen jie nach Englant, um bort einent möglichjt hoben Bseminn zu

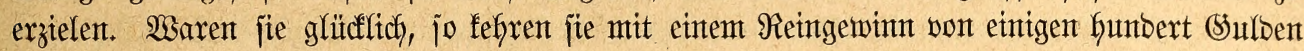

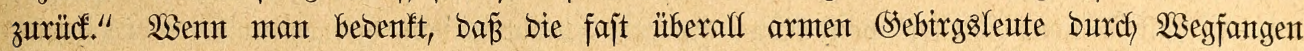
ober 2Uufziefgen ber (simpel in feinter Wetje Schaben bringen, erbält man wieberum einte Beleuthtung Des jo vielfach berzeterten $\mathfrak{B}$ ogelfantges, an weldye man faum gebacht Gaben mag.

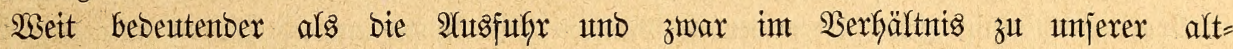
genurgelten, fejtbegrünbeten und verbretteten siebhaberei, ijt gegentwärtig bie sinfufr, ob=

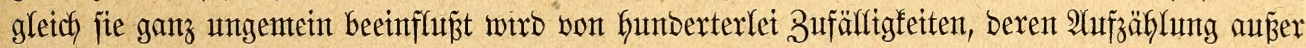

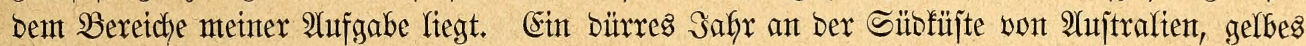

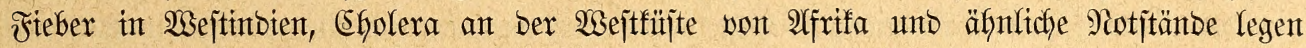

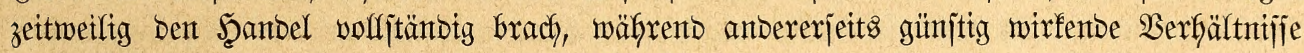
unjeren Marft zubeilen mit $\mathfrak{B o ̈ g e l n}$ gemifjer $\mathfrak{A}$ rtent gerabezu überfüflen. Daher Denn auds

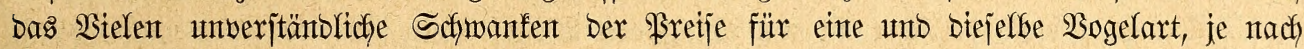

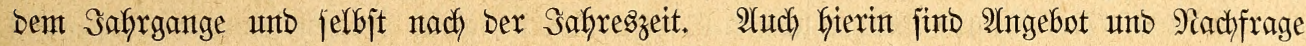

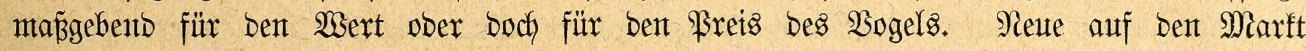

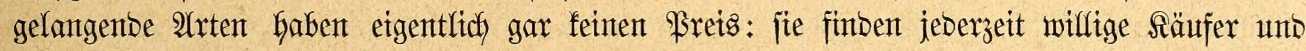
werben unt jo höher bezahlt, je letchter jie vorausjichtlidy zur Fortpflanzung jodreiten, und je

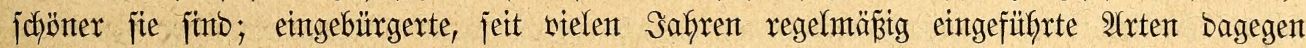
jhywanfen nur bann in ifrem bereits fejtgejtelften Werte, wenn bejondere Umjtände, wie bie erwäfnten, bie Einfufx ftören. Sie Gaben einten verbältnismäß̈̈g weiten Marft und

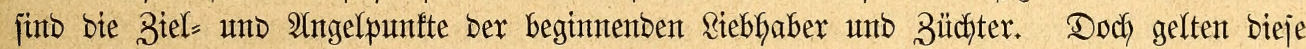
Benterfintgen nur für ben Srop̧handel; Denn ber Sertrieb im einzelnen ijt, wie jeber Sleinfander, unberechenbar.

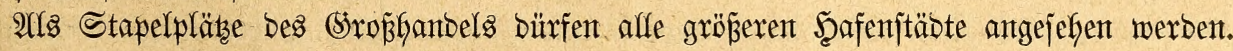
Sbenan jteft auch in biejer Scinficht Ronbon, auf Ronbon folgt Scamburg, auf Seamburg

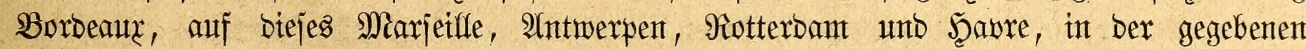

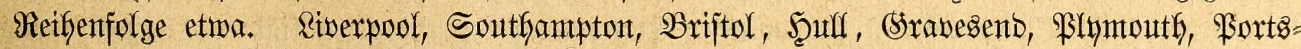
mtouth, ßeterkeab, Esinburg fint sonbon zollpflichtig, inbem fait alfe bort "auffommenton" Bögel an bie Ronboner (Srop̧bänbler gelangen; Bremerhaven uno \&übed jenben bie eingetroffenen

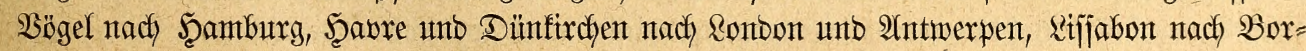

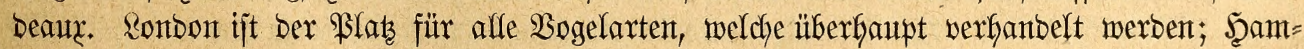
burg und Afntwerpen bilben Durch eigene (sinfuhx und $\mathfrak{B}$ ezug von Rondon mentgitens mittelbar einen ebenjo umfajjenden Marft; Borbeaux und Marjetlfe finb vorzuggrweije bie Bezugg=

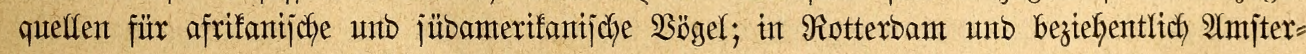
Dam treffen namentlich bie jübajiatijchen, zumal junbaijchen 2lrten ein, weldhe zu Den

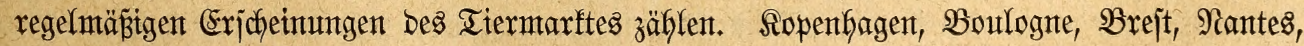
Ioulon, Die ipanijchen und italienijchen ફ̧äfen fint für ben Şanbel mit überjeeijchen und

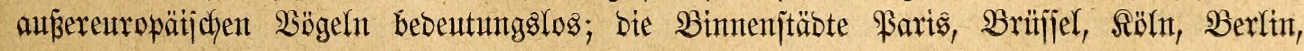




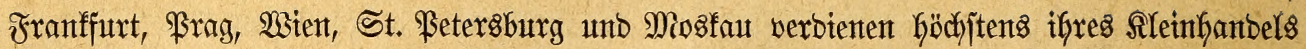

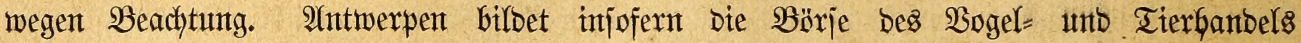

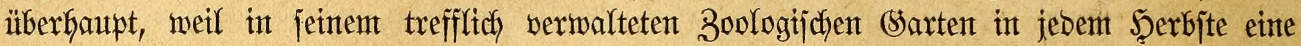

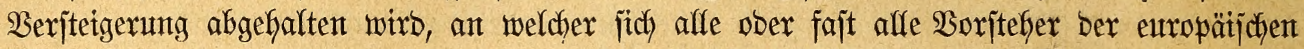
Tiergärten, bie nambaften Şäntbler unto bebeutenbjten RiebGaber zu beteilfgen unb bie bort

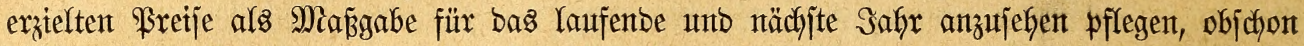

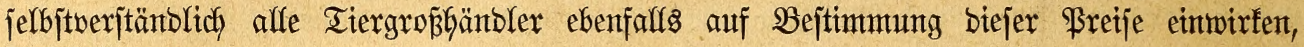
joviel fie vermögent.

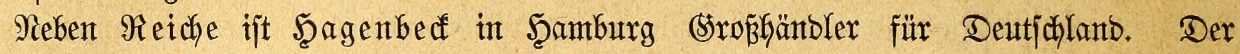
Sater bes noch jungen, jefre tätigen unt jtrebjanten Mantes begant im Safje 1852 mit

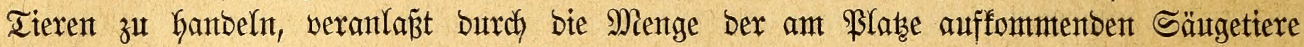

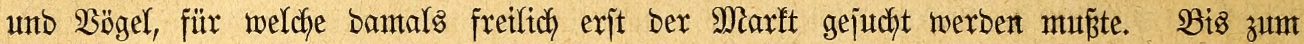

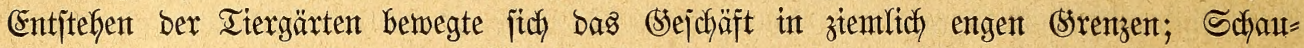

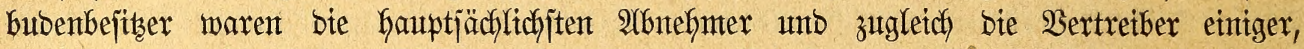
bereits in ber (sumft ber RiebGaber eingebürgerten 2 oggelarten. Der burch bie Tiergärten

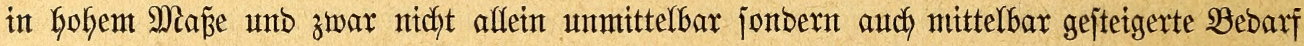

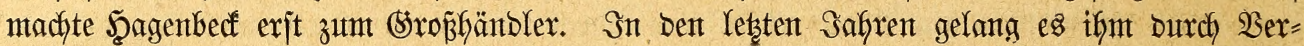

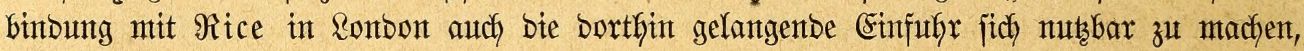

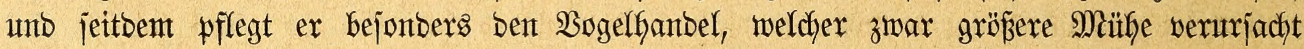
als ber Şandel mit Säugetieren, baf̣ür aber einen viel ausgebef̧nteren Miarft hat umb

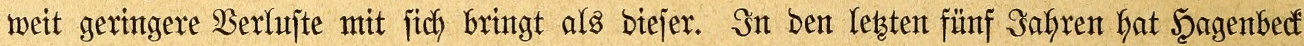

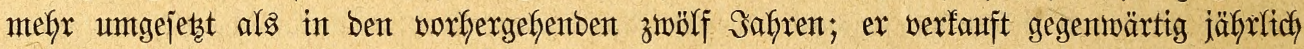

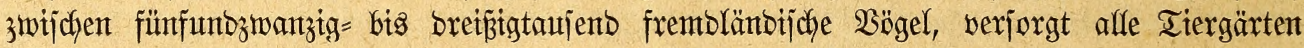

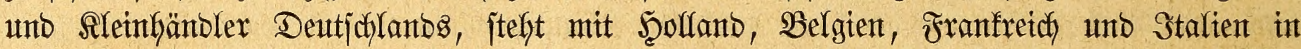

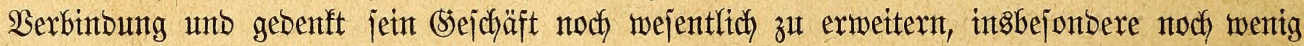

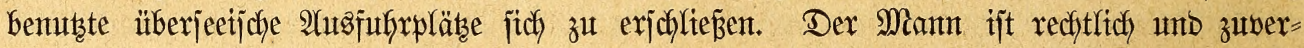

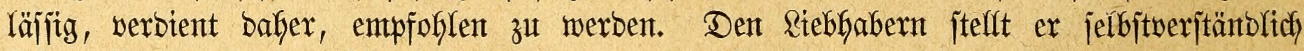

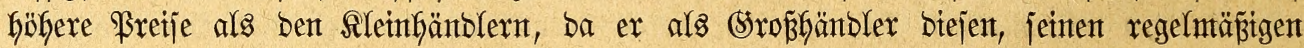

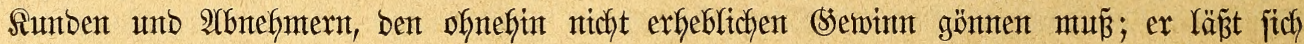

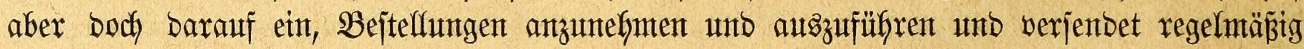
gute, gejunbe 2 b̈gel.

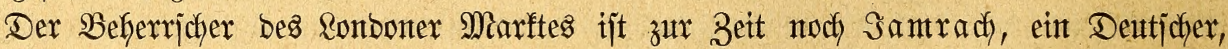

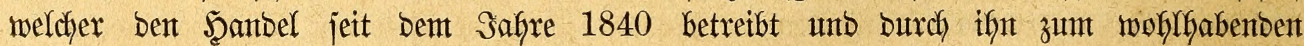

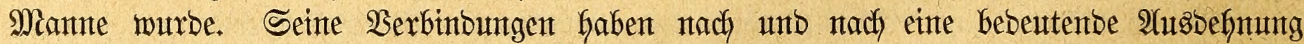

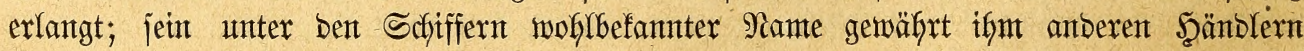

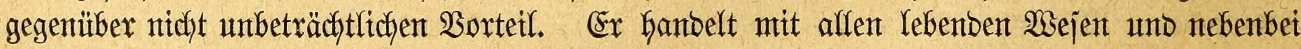

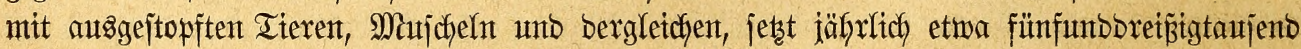

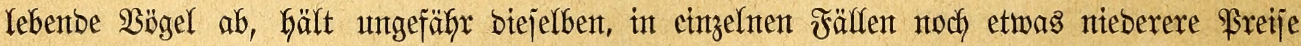

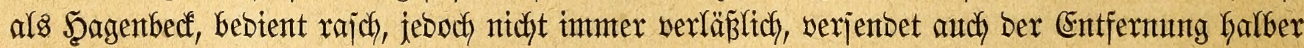
ungern nad) Deutfidflant, es jet bent an einzeltnte Tiergärten ober Şä̈tbler. Sn ben

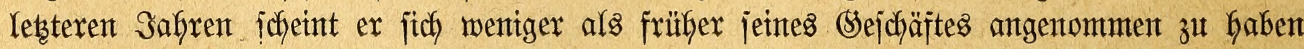

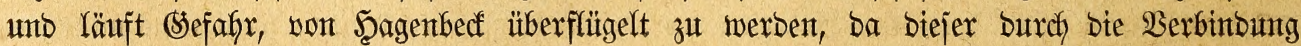
mit Ritce von ifgm fich utabhängig gemtadjt hat.

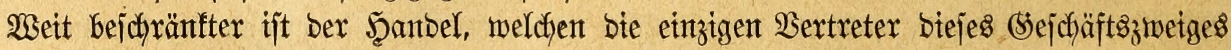

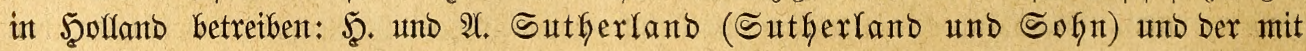

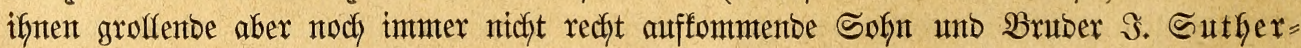

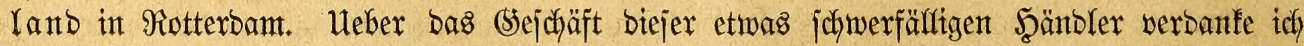

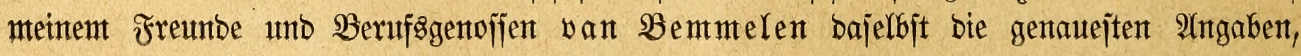


welche überhaupt zu erlangen waren. Die brei Sutherfantos exhalten alljährlidy zwijchen

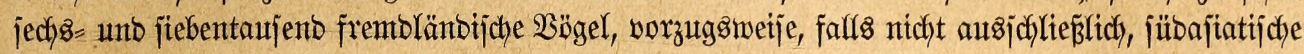

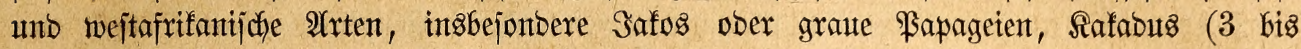
5 Ârten), Roris (6 bis 7 2rten), Unzertrennliche unb antere weitafrifantiche Bwergpapageien,

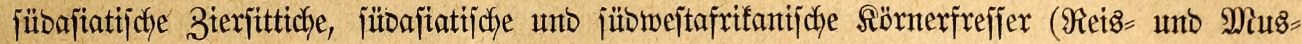

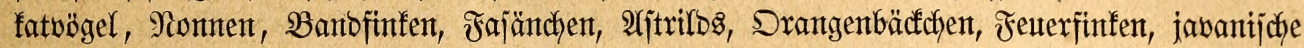

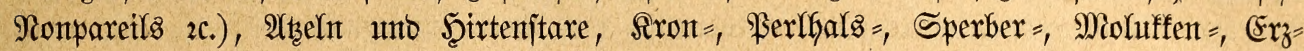

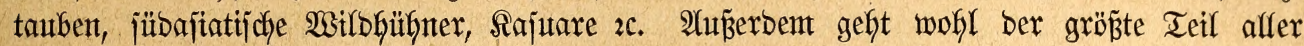
Bögel, weldfe in Şolfand gejangen unt in unjerem Sinne verwenbet werben, Durch bie

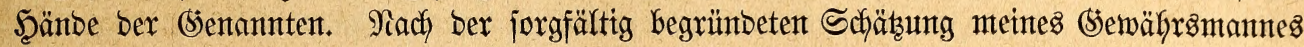

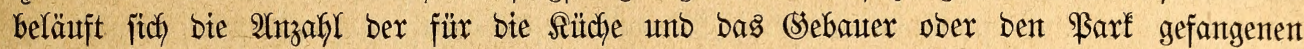

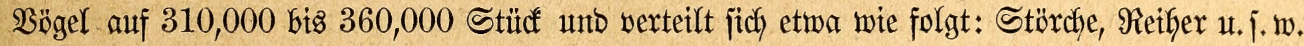
300, Finfentuögel unt Droffeln 100,000, fleme Stranbvögel 10,000 , Sdhwänte 50, (Sänje,

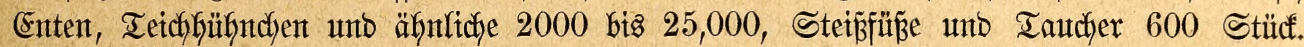
Bon biejem Fange werben burdh bie Sutherlanbs affe folfänbijchen, belgijdhen, englijchen

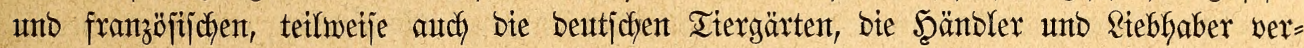

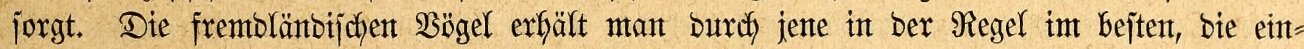
Geimijchen oft in traurigiten 3ujtanbe: in Sïrben eng zujammengepfercht, bejdhmuzt, halk berfungert unb überbaupt verfommen, worauf man aljo beziehentlich zu adjten hat.

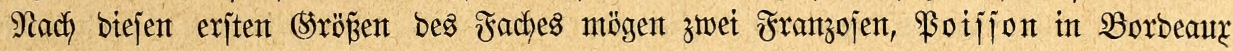

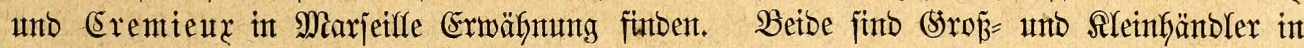
einer ßerjon unt liefern vorzugsmeije wejtafrifanijche unb jübojtamerifanijace Bägel, einzeln

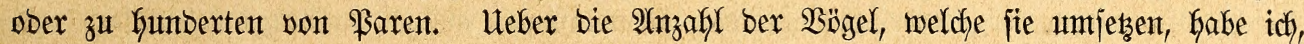

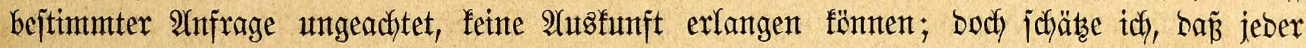

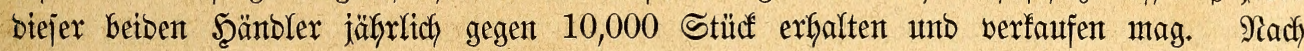

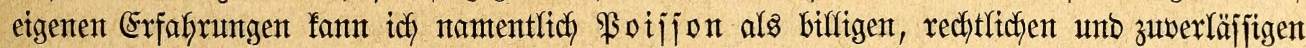
Seänbler empfeglent.

Sn ber affernetejten 3eit hat ber bereits erwäfnte Staber mit einem anberen

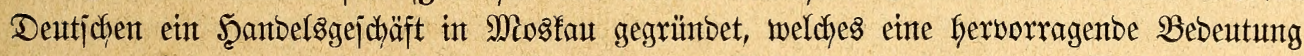
erlangen bưrfte und jebenfalfz bie Beachtung ber Stebfaber in bejonderem (Srabe verbient.

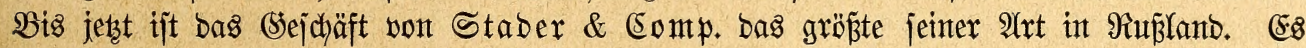

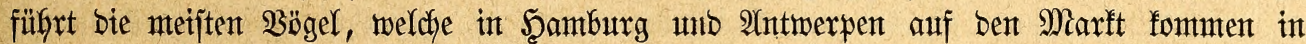

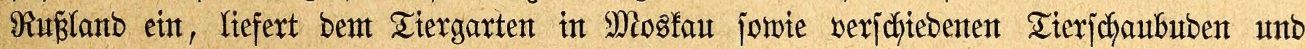

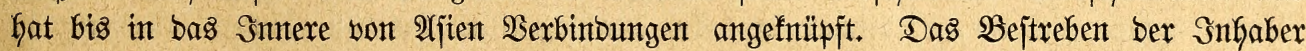

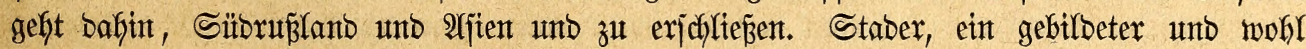

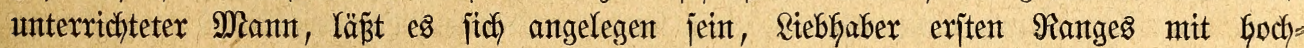

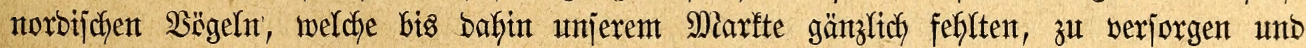

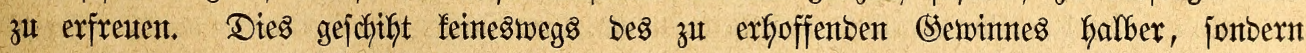

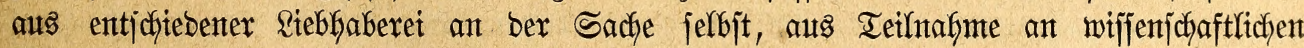
Bejtrebungen. Staber ftrebt nach bem Rufhnte, ber Erite unb Einzige zu jein, welduer

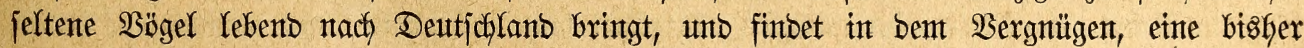
auf bem Marfte nicht vertretente $\mathfrak{A}$ xt eingefüGrt zu Gaben, Entjchäbigung für bie aufgemendete Mï̌lge, weldye burdy bie zu erzielenben Preije wahrhaftig nicht aufgemogen wirb. Das "Berliner 2lquarum" berbanft jeinemt Eifer Zwergeulen, Rajurmeijen, Wetbenammer unb

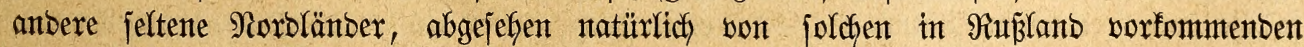
Irten, tweldye audi von anberen Seänblern eingeführt merbent.

Teben Den (sroß̈gänblern befaffen fich audy Tiergärtent untb anbere ber Tierfunbe bienenbe 2 (njtalten mit bem $\mathfrak{B}$ erfaufe von $\mathfrak{B}$ g̈geln, viele von ifnen übrigens, ofne eigentlich 


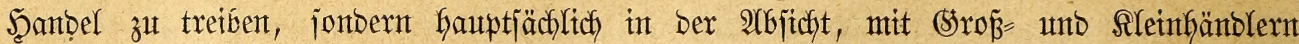
ununterbrochen int Serfebr zu bletben, fidh jeltnere Tierarten nidft entgehen zu Laffen und

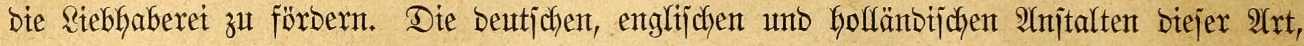

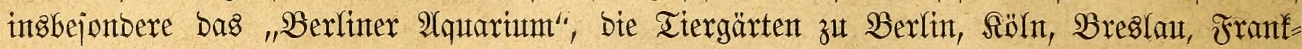

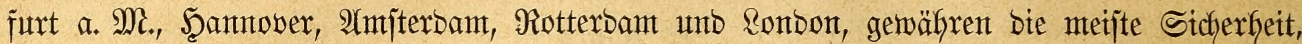

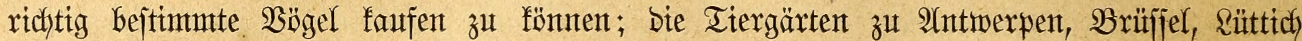
unt ber 2lfflimatijationggarten zu Paris jtellen ifre \$reije meijt niebriger als jene, geben

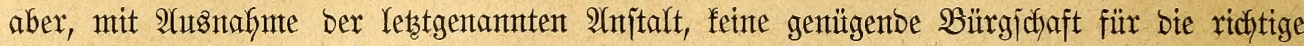

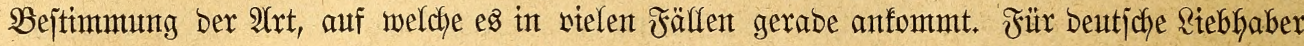
mirb es jtets geraten jein, ifren Bebarf won beutjchen, ber Tierfunbe bienenten 21njtalten zł entnefymen, weil auch int Bogelfandel bas Spridywort gilt: "Beffer betwafnt als beflagt."

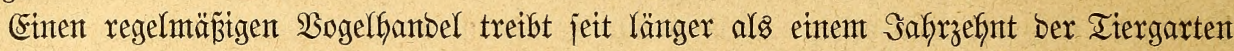

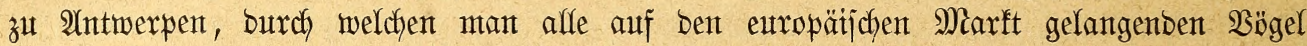
erbalten fant, bie Gier jo zu jagen eingebürgerten, D. h. alfjäfrlich auffommenden $\mathfrak{A}$ rten in beliebiger Mienge, anbere je nach ben Hmitänben. Heber bie 2 nzahl ber Bögel, weldye

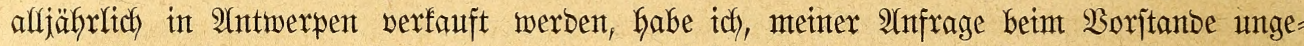

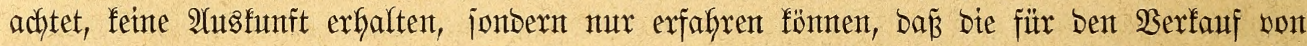

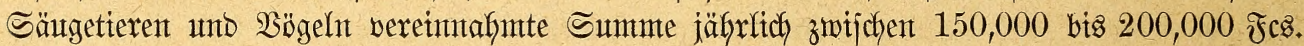

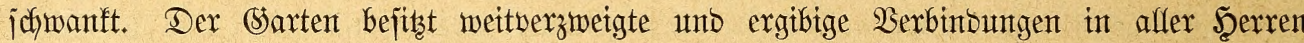

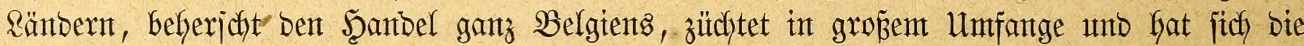

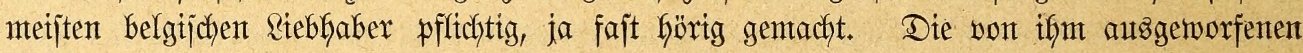

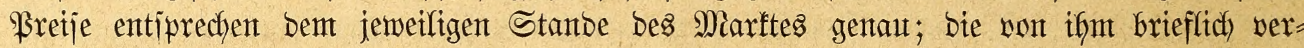

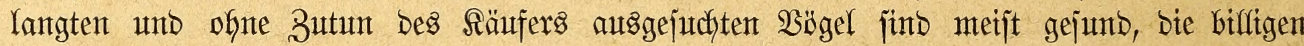
unt gemteinen auch feblerfret, währent man $\mathrm{es}$ Demjentgen, weldyer nach erfolgter eigenter Bejichtigung fauft, zu ïberfajjen pflegt, fich über ben Bujtand Der Stücfe jelbjt zu ver=

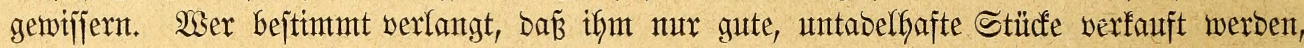
erhält joldhe, vielletdyt etwas teurex als bie übrigen, jeboch unter antefymbarer Bärgjichaft.

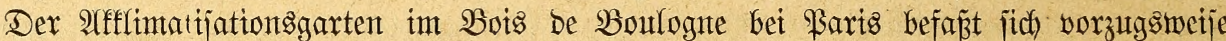
mit folchen Bögeln, weldye, wenn auch nur entfernt, bie Şoffmung gemähren, eingebürgert zu werben ober body zur Fortpflanzutg zu gelangen. Wiffentlich verjenbet bieje 2 (njjtalt

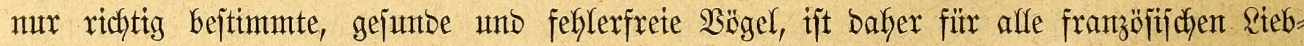
Gaber von größster Watchtigfeit. Die Summte, weldye in ben letzten Safren für verfaufte Bögel bereinnafymt murbe, beläuft fich auf burchjofntttlich 200,000 Fcs. Snmiefern bie Ereigniffe des rufgmretchen Jafres 1870 auf ben (Sarten eingeminft haben, D. h. ob Derjelbe,

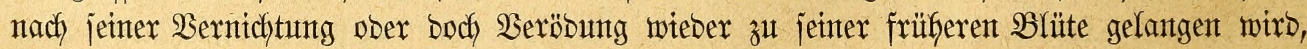
räßjt jich zur Zeit nidbt bejtimmen, ficherlich aber mïnjechen.

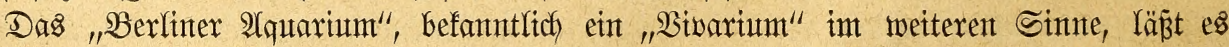

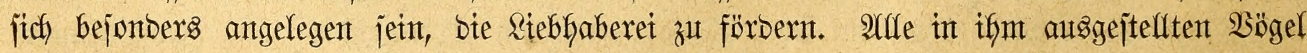
fint berfäuflich, nicht vorhandene auf fejte Bejteffung zu erlangen, jobalo dies möglich.

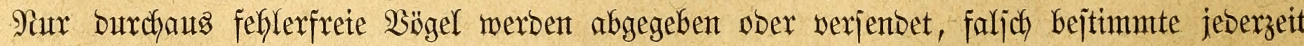
zurüdfgenommen und umgetaujdyt. Die Sretje jtehen mit benen, meldhe bie norbdeutichen 5änblern forbern, ungefähr auf gletcher ફ̧̋̈he, finto auth wohl noch etwas niebriger. Das

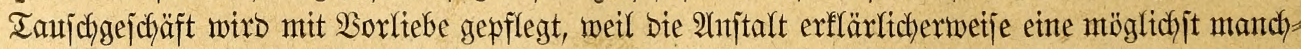
faltige und volfzählige Sammlung zu erzielen judft. Dex umjał ijt nod) niddyt bebenteno, jeboch in raichem Bunefymen begriffent.

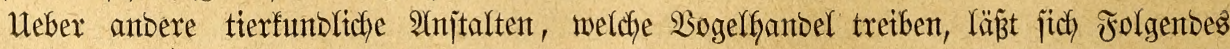
jagen. Der Itergarten zu Ronoon gibt nux überzählige 2 b̈gel uno bieje meijt zu jebr 


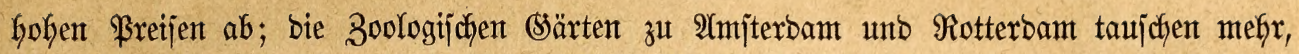

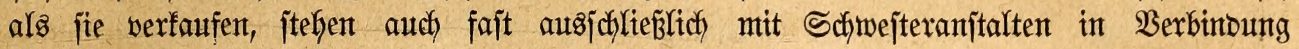

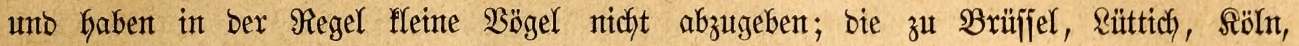

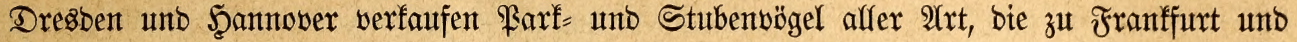

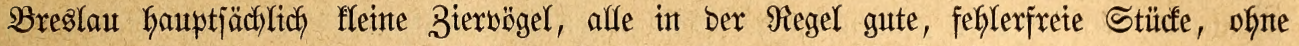

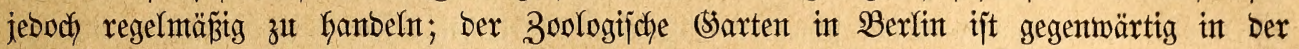
ungejtaltung begriffen unto nod) niddt in ber Rage; fidch mit berartigen (sejchäften abzugeben;

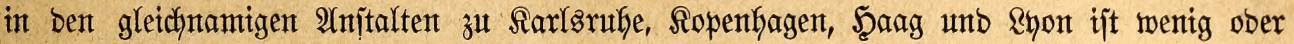

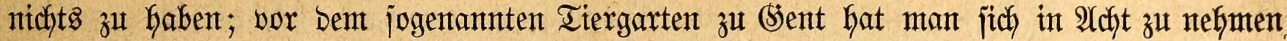

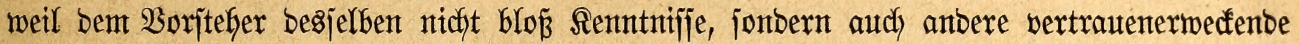
Eigenjidaften mangeln.

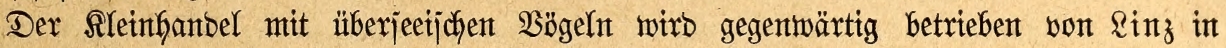

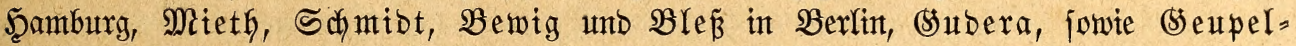
Whyte in Reipzig, 3utferfant in Dresben, Fordynter unb Schwarz in Breslau, (5hr. Wagner in Drbenburg, Sahreiber in Witen, Bocquet, Ehaparb, Thuent,

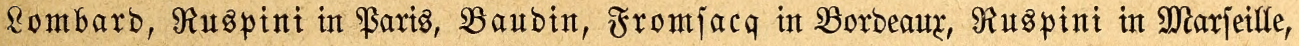

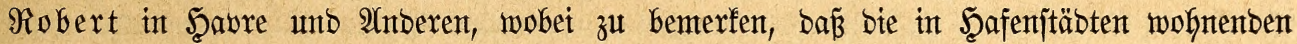

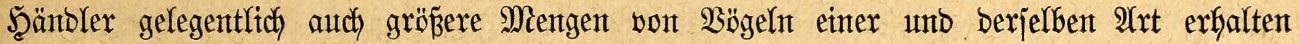

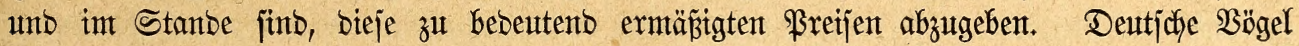

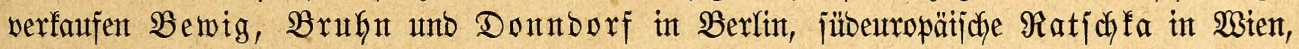

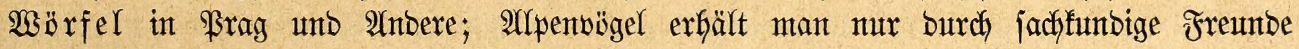
in ber Salpeiz, ba ber Grave Nager= Donazians in 2rnberntatt zwar hanbelt, aber

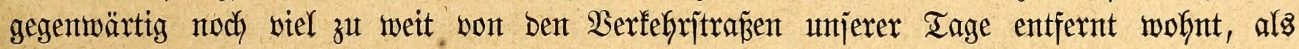

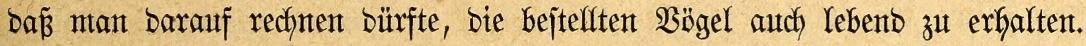

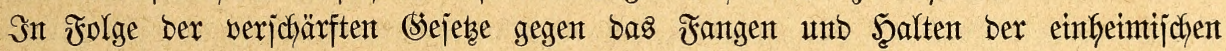

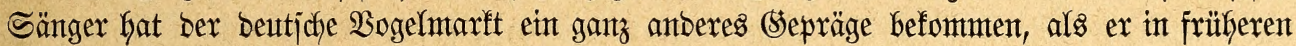

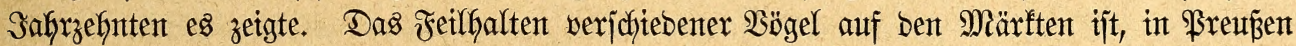

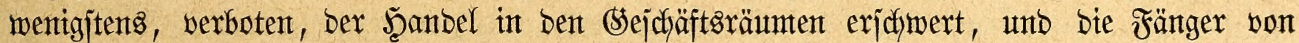

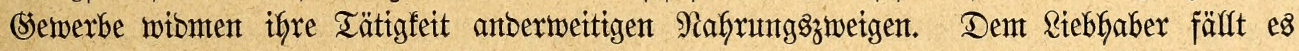

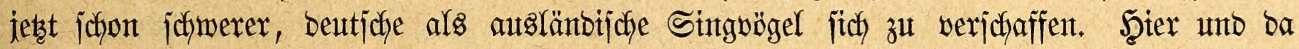
im (sebirge lebt woffl noch ein unt ber anbere Fänger vont echtem Schrot unb Rorne; jein

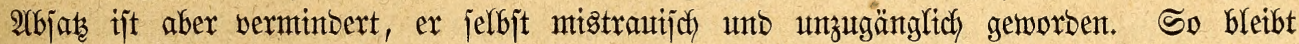
Demjenigen, welcher eintheimijache Sägel haltent wifl, faumt etwå anberes übrig, als jelbjt

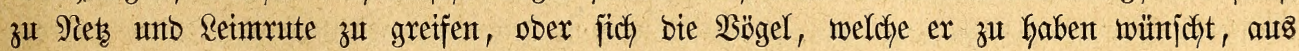

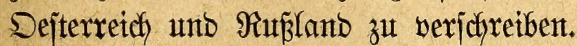

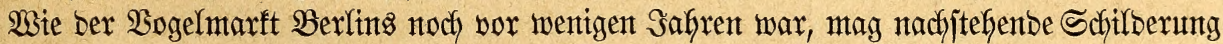

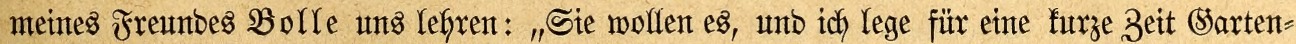
mefifer unb Spaten aus ber Şanb; ich greife zur ungewofint geworbenten Feber, um etwas

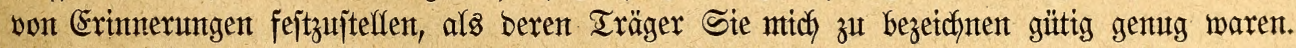

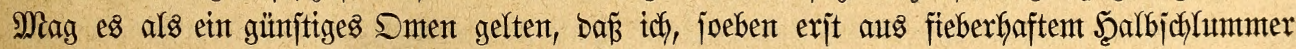

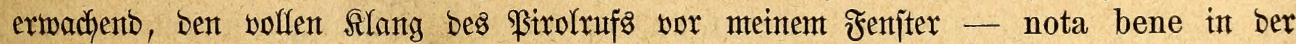

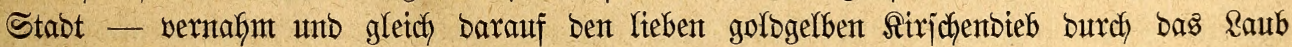
eines Jaulbaumes bidft am 5̧ofe gleiten faf. Sa, Bögel haben wir noch in Berfin, aber

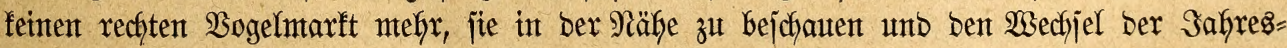
zeiten in ifren heiteren Bilbern unts zu vergegentuärtigen. Sie finto fajt jo unnahbar geworben, wie bie Sternte amt Firmament, wie Blüten, bie fich int Sityfel zut hoher Baum=

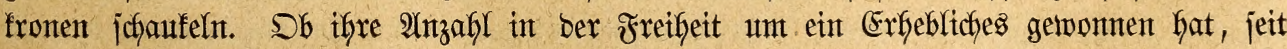

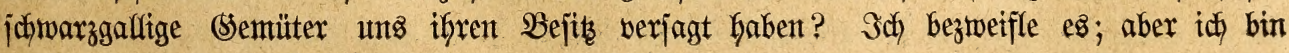




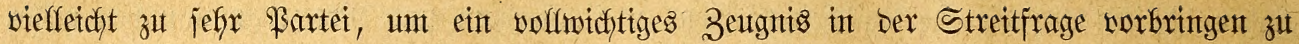

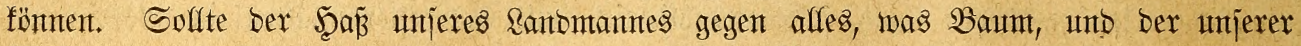

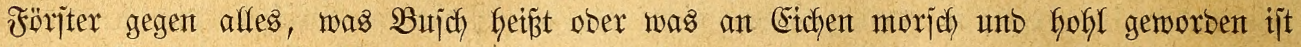
in ber Sienfeide, jolfte bie ftets mefr unt mefr um fidh greifenbe Eultur, bie feinten wilben

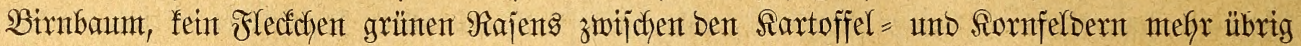
lafjen will, nicht bodh vielfeidft jefwerer wiegen in ber einent Seite ber Wagjichale als alfe (5)loger'jchen Brutfäjten unt alfe gejeb̧lichen Berbote in ber antberen?

snbes non ragionar, Güte Didf) zu raijonniren, ijt ein 2(usjputudy bes alten Dante, ber noch immer nicht zu gelten aufgehört hat, jeit wix aus \$reußen Norboeutjche geworben

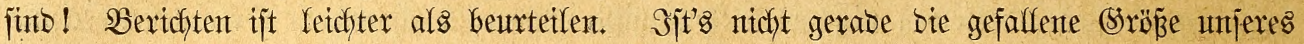
alten Berlinter $\mathfrak{B}$ ogelmarftes, von ber Sie fumbe burch mich berlangen, weil Sie zu pät

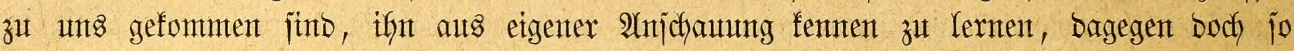
manthes barïber wernommen habent? Schenfen Sie mir baker (Stauben, went idf es von

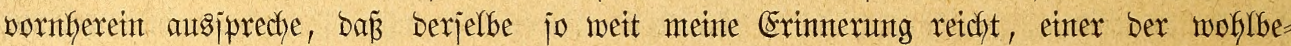

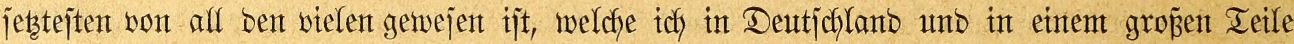
Des übrigen Europa ju jefauten (s)legenheit fanto. Selbjt went ich ifgn bes träumerijchen

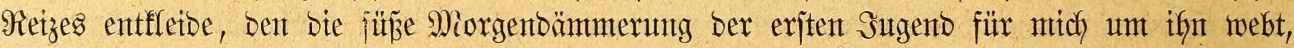

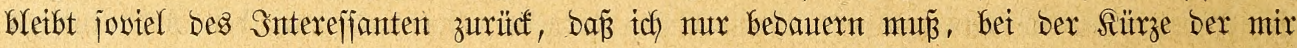
zugemejienen Beit meines (Segenjtantos jedwerfich) worffommen Meejter werben za fömten.

Diejer Marft wax audf in jeiner 2 rtt ein Seijpiel bawon, baj bie jüngjtuergangente,

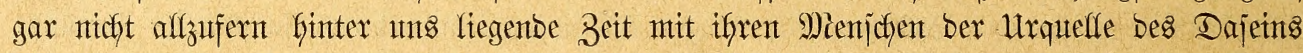

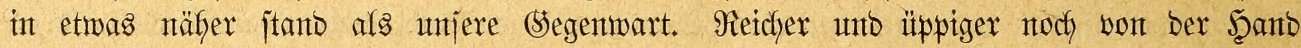
ber guten (söttin gejfymücft, prangte bie Natur jelbjt im Sanbe Der Miarfen, unb mas aus ifrem Füflforn ftrömte, fdhaute Der Sterblictle noch mit innigerem Befagen, mit bem geheimmisuollen 3uge ber Berwantijchaft und bes fajt gleichen Uriprungs. Die Frembe lag

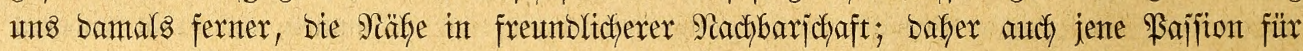

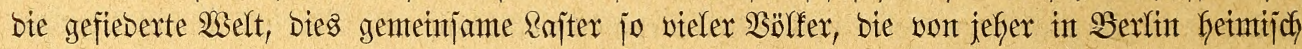
gemejen ijt. Âtnberenorts mag fie fich ausjchlieplictser auf Spectalitäten gemorfen haben; fier umfap̧te fie neben biejen, weldye wafhrhaftig nicht fefjlen, wie bie Sprojierliebhaberei betweift, mit gletcher Borltebe alfes, was ba fliegt unto jedwirrt. Die bejte \$robe bavon lieferte eben anjer Bogelntarft, bem nicfts feblen burfte won bem, was eingeboren ober

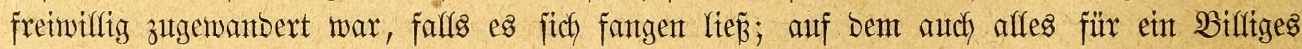
Säufer fant, bont gelernten Domtpfaffen an bis zum zufällig in etrte Reuje gefrochenen Wafjerfuffn ober bis zu bemt aus Gofem Iummejt gefalfenen Mauterjegler. War ja bodh

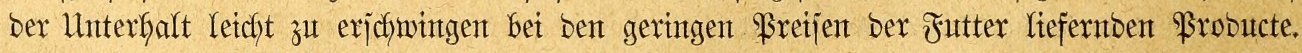
(5s würbe vergeblich jein, barnach zı fragen, was ats jenent zablfojen, bergejtalt ber Rieb= Gaberei geopferten Bögeldyen geworben jei. Biele bavon mögent in gute ફ̧änbe gefalfen

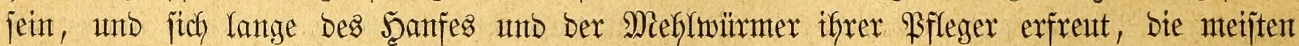

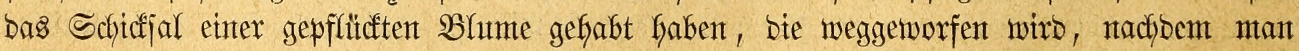

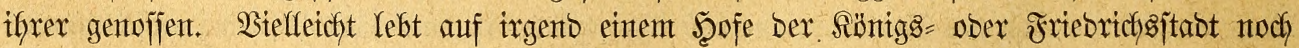

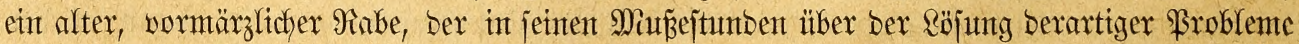
grübelt. Dodh int Ernjt: es lag einmal bei uns, wie anderwärts, ja biefleidft mefyr noch in Den Sitten, SB̈̈gel zu Galten, zu pflegen, zu faufen unto berfaufen, ja jogar gelegentfich zu beripeijen, was Keutigen Iags auf bie bejten Sänger, bie zufälfig zugletch bie wohl=

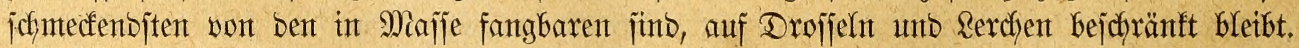

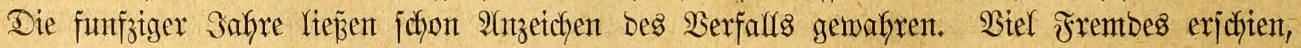
manches Einfeimijche marb jeltener. Dex alte (s) loger polterte auz ber untreinen Atmojphäre

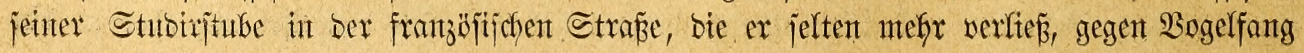


unto Bogelfiebhaberei wie gegen unnatürliche Sünben. Sch bin itets zu höflich gemejen, ifgm offent ins (Sejicht zu lacken, wie es ben Mioralijten auf ber Straß̃e gejchah, went

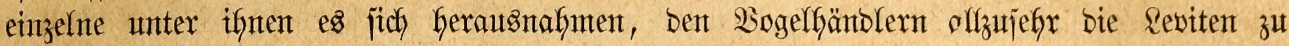
lejen. Nody war jelbjt bie $\mathfrak{B o l i z e t , ~ j t a t t ~ f e i n b l i c h ~ g e j o n m e n , ~ e f j e r ~ i m ~ g e h e i m e n ~ E i n v e r j t a ̈ n b n i s ~}$ mit ber s̈ffentlichen Mieinung, wenn es galt, ifgr jtets waches 9fuge ein wentig zuzubrücfen,

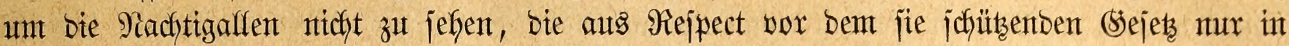
mit Iüchern berfängten Bauern feifgeboten . wurben. $2 \mathfrak{A}$ Dorkerjagungen, an trüben

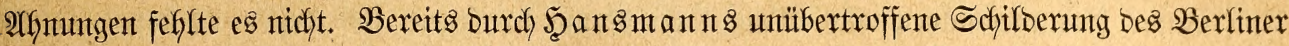
Bogelmarttes (1858) geht ein reijer unheilwerfünbenber 3ug. Das hat jo gebauert bis zum exiten Эamuar 1869. Damit war's vor ber Şant zu Ende.

Wer Gätte vorauछgejeben, Daß̃ wir, ofne Metfujalem zu jein, jie überleben würben,

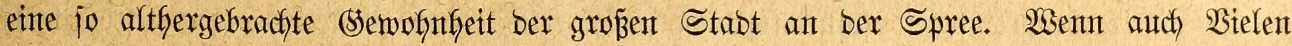
mebr, war ify $\mathfrak{B}$ ogelmarft ntdyt audh einz jener Spielzenge, ntit benen ein Ieil ifrer

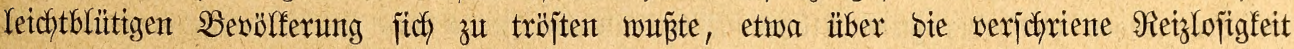
ifrer fanbigen Umgebung, über ein verregnetes Feuerwerf in Ireptom, über bie Scundejteuer voer über eine Seciferfeit ber Sirelinger? Man hatte ja bamals weber jechzehn Iheater, noch bas Drpheunt, noch brei Barlamente auf einmal. So begntïgte fich ber Stäbter etwas

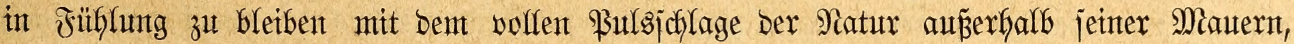

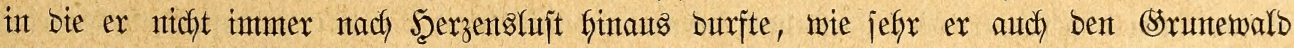
liebte und bie \$ichelsberge und ben Finfenfrug, wie gern ex auth unaufgörlich in iffer Iaufrijche ben Staub des Arftagglebens von fich abgeipuilt bätte. Da war es ifm benn lieb, went Einiges wentgitens zu ifym herein fam unt ifn einlut, auf bem \$lake jteken

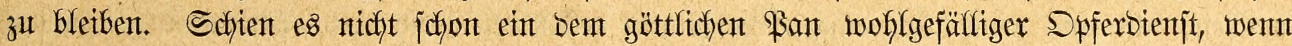

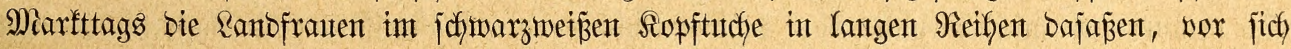

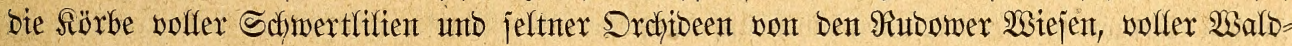
beren, Morcheln ober Pilzen, je nact) Der Safreszett, unto went vor ifnen bie weipen

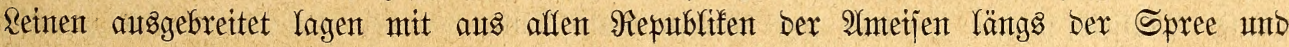
Şavel geraubten, belfjefimmernben, Miterentern", neben Sörben voll anberer nods appetit=

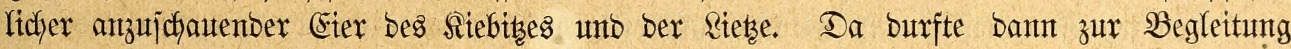
ein (Srrasmüufennejt nicht leidht fehlen, ober ein junger Suffuf ober ein (Sitter volfer Star= mäke, bie Der flachgharige Sunge vom Baume herabgeholt hatte, ehe jie ant J̧immelfahrtatane

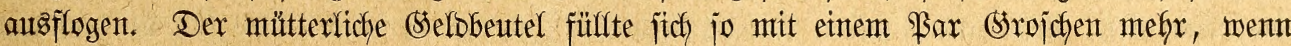
das Sobnchen nicht jelbjt \&ujt verjpürte, zux Stabt zu manbern und als ambulanter

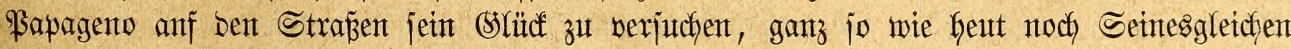

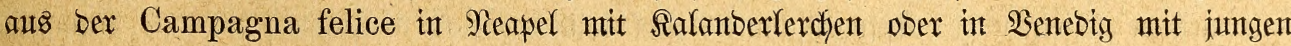
Stein = und Blauamjelit baujiren geben.

Dody bas war wentg, was jo berfauft warb. Das waren nur bie wilben, beren 3ufuthr im Bergleid) mit jenter ber Zünftigen zu nichtz zerram.

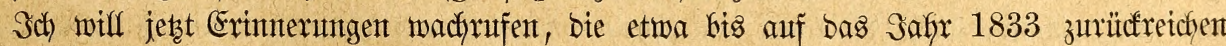

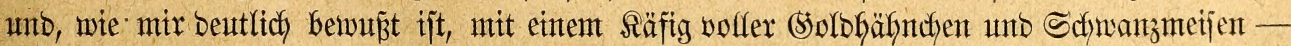

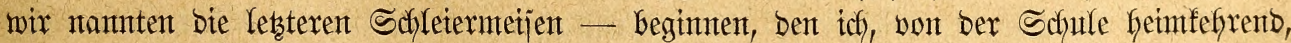
it Der Sharlottenftraje an einter Ecfe bes (Sensbarmenmarftes gewafhr wurbe, wo ein alter

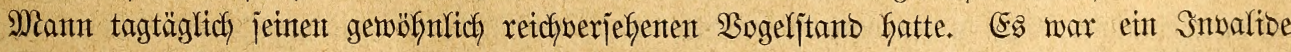
aus ben Freiheitßfriegen, Dex jtatt Der üblichen Bejtattung, Den Reierfajten im Iiergarten zu jpielen, zum Rofn für jeine firtegsbienjte fich bie Ertaubnis zum Bogelfants unto Bogel=

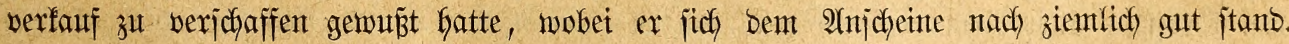
Durch bieje Entbeffung aufmerfjam gemorben, fing ids an Den Marft zu exforjchen und

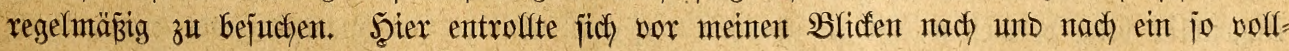




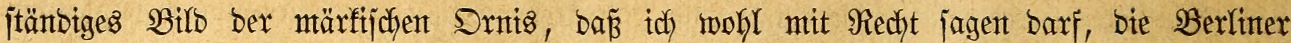
Bogeljtänto jenter Zeit jeten ein wahrhaftes Museum vivum getwejen. Sie warent es an $\mathfrak{B}$ g̈geln

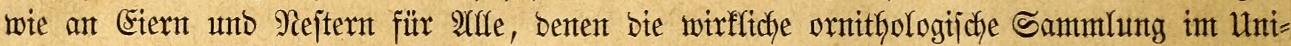
verjitätżgebäube, über weldyer \&idy tenjtein alz, „Sberjter ber Titere" mit Strenge waltete, nicht

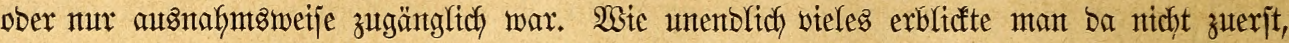

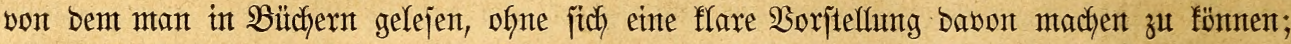
wie manches anbere hingegen trat $\mathfrak{u} 18$ ba zu alfererjt entgegen in ureigner Sejtalt, won

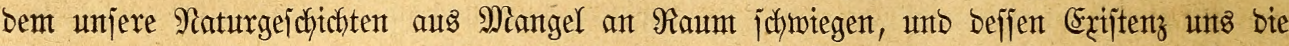

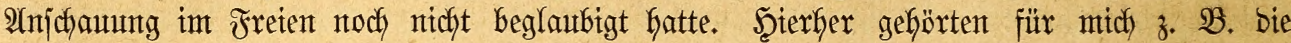

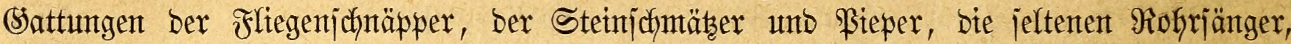

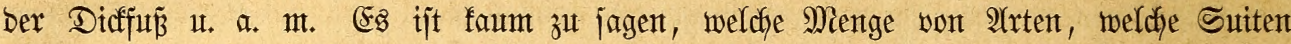

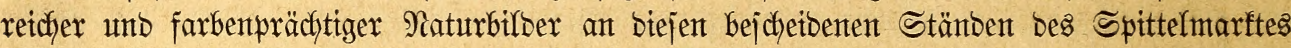

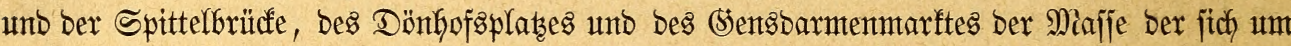
jie brängenten Riebfjaber jebes âtters, jebes Standes, jebes (Sejchlechtes bargeboten murben. Was ber Teltow, ber Barnim und bas Scavelland in ben Sitenteiben, im Birfentujich und

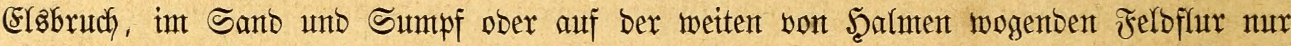
erzeugten, was fie über jich finmanbern jafjen auf ben Fittichen bes Wintes: Fier itellte es

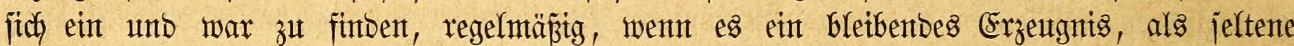
Erjcheinutng angejtaunt ober überjegen, went $e^{8}$ eine Rarität unb noch bazu vielfeicht eine unjcheinbare war. Was nicft fam, munt bas wax entweber int vielmeiligen Umfreije über= Gaupt nicht vorbantoen ober von ber afferauggejuthtejten Seltenflet, wenn überhaupt fangbar. Uno bies gar ntcht ober faum jemals 2(uftretenbe wäre eigentlich leichter nambaft zu

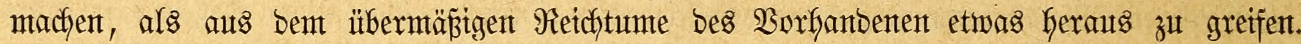
So erintere ich midh, ntemals bas Schwarzfeblchen, ben Wajferjtar, bent Wajferpieper, ben

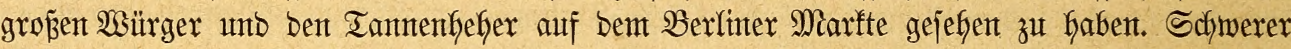

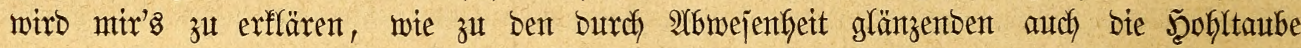
(unter Maffen junger Turtel= unto Ringeltauben) unt ber bei uns boch noch zientich zahlreich workanbente grof̉e Irappe, nadh meinen Exfahrungen gehören fonntent.

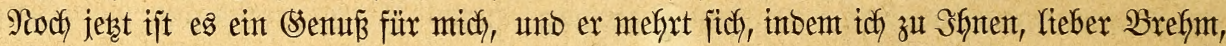
bavon ipreche, mix bie Stänbe zu vergegentwärtigen mit ifrer exjtaunlichen Mantbfaltigfeit an Bögeln uno Befältern, unter lebteren audy bie Schlagbauter, nicht aber, mie in Stalien, bie Reimnuten, Nebe unt anberen Fangapparate, Mayterien ber Sunjt, bie jich bei unts ben

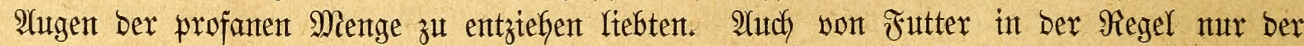

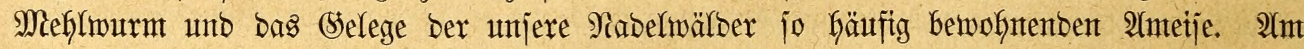

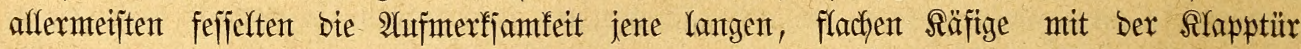
oben, Durch weldye bie Şanto bes Şänblers ober Der Seänblerin jo Yeidyt Gineingriff, menn

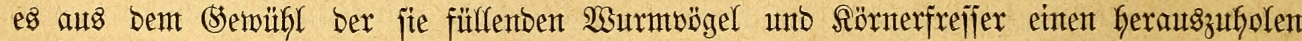

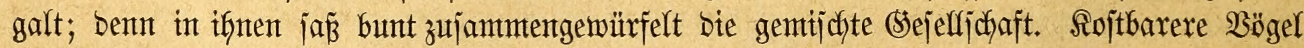
unto eingemöhnte, jolche bie jujon "int Futter" waren, befanton fich natürlich in Einzelfaft

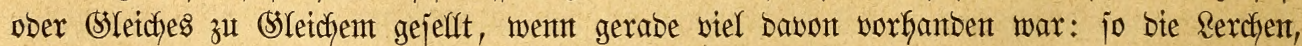
Die Meijen, bie Staren, Würger zc. Iffren Frijchgefangenten twaren bie Flïgel gebunben.

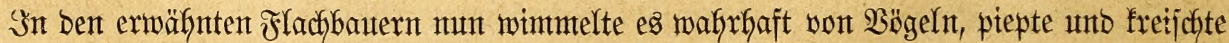

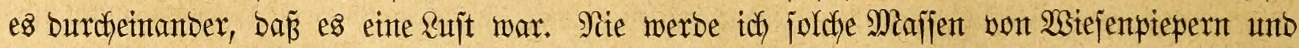

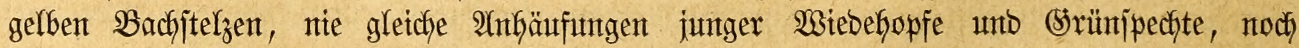

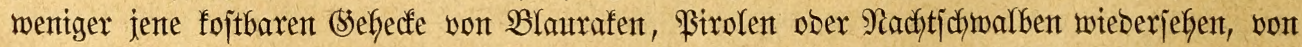

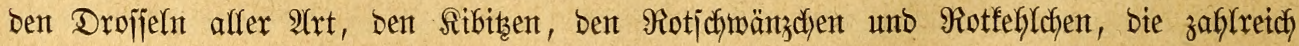
maren wie Santo am Mieere, gar nicht zu reben. Arber bet euch möge bie Erinnerung einen

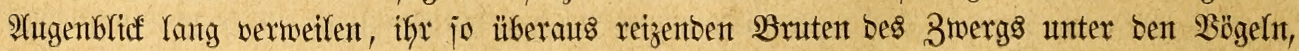




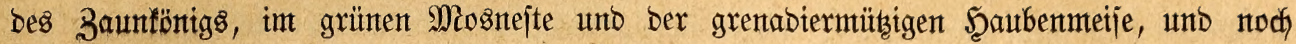
meniget will idd eurer vergeffen, ifhr meine Rieblinge, Sitnber bes Blaufefflchens, mit bent ftar=

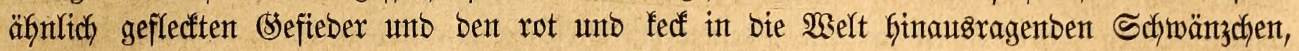

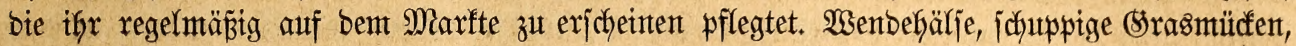
Sctjiffiänger, Wiejenjdmützer, jeltener vereinzelte $\mathfrak{B r a c t j p i e p e r , ~ i f y r ~ a f f e ~ w a r e t ~ j t e h e n b e ~}$

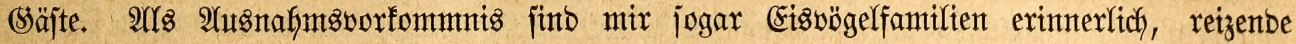

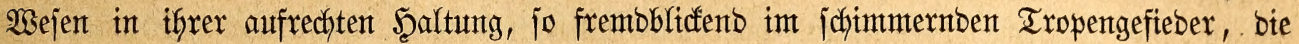

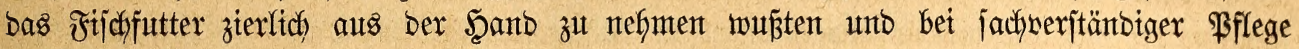
trefflich gebigent.

Wäfrent won ben $\mathfrak{A}$ ten aus Sropf unt Schnabel nach) Serzensluft gefüttert warb, gab es bagegen Regionent Sunger, bei benten ber Fänger jenten Gumanen Sprud ber ntoja= ifchen Bejebgebung befolgt Gatte, weldher verbietet, bie auf ben Sungen ober Etern fitzente Mintter mit biejen zugleich zut nefymen. Wenn bieje SYeinen mun ben Schnabel weit auf=

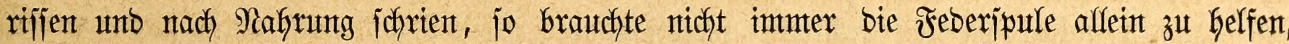

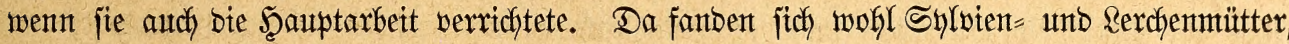
empig umberlaufento im Tumult ber Befangenjchaft, ben Samariterbiemit bez Brot=

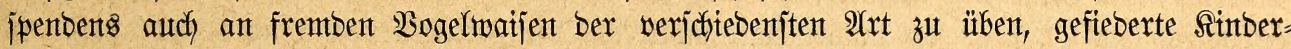

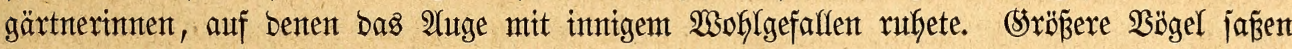

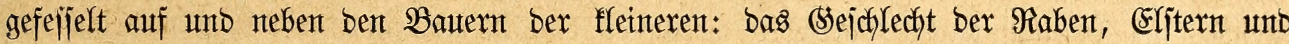

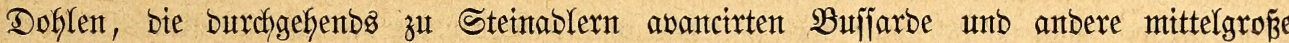

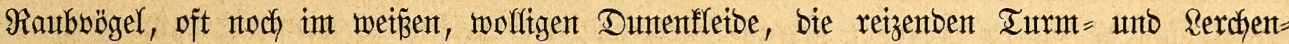

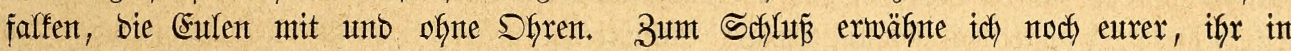

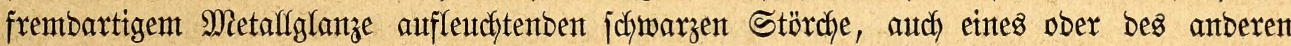

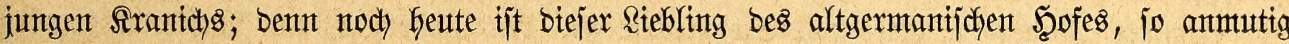

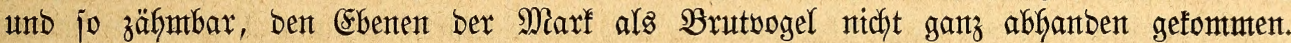

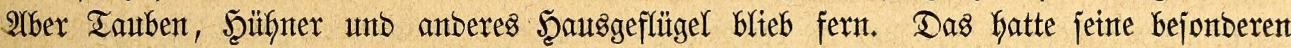
Stänbe unt meift auch jein bejonberes Publifum.

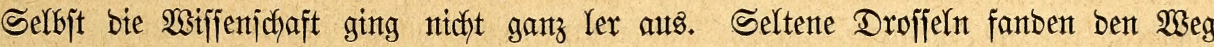
in Sammllumgen von $\Re$ uf, ein Raubjärger ber Şimalayaberge jogar ben vont Berfinter

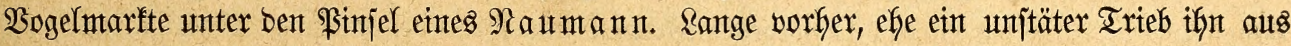

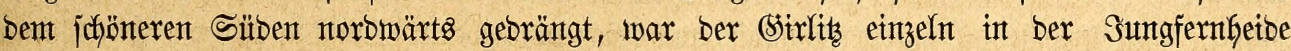
gefantgen worben. Die mündliche lleberlieferung bewafrte bas âtroenfen an bie Züge ber

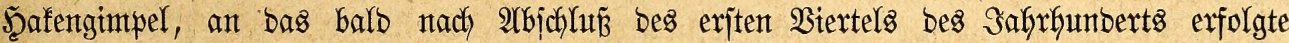

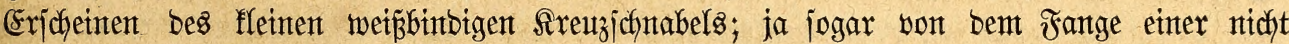
anbers als auf bie \&ajurmteife zu beutenben Seltenfeit ift mir Sumbe getworben. Den gelb=

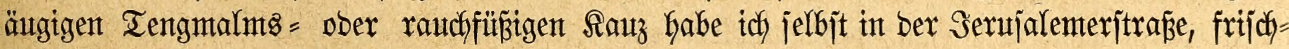
gefangen, feilbietent jefen.

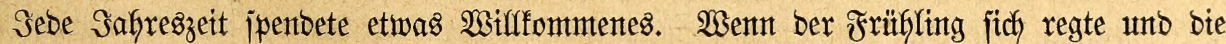

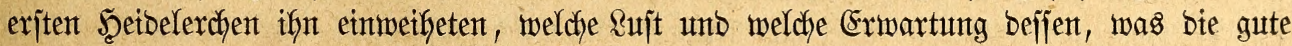

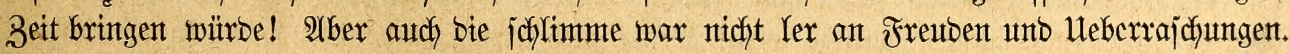
Bradgte fie ja bodh Waintergäjte: alfe par Safre bie Sadywärme Der Setbemjdyänze unto

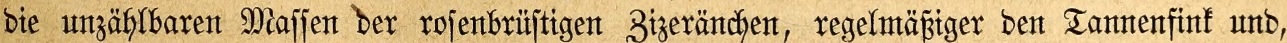
mefyr ober meniger zaffireidh, ben Dompfaffen, jowie jeltent auzbleibento, went auth ver.

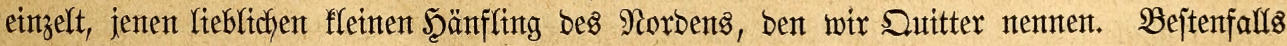

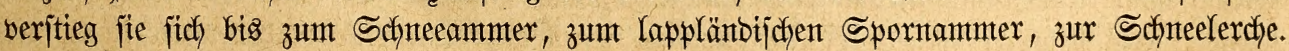

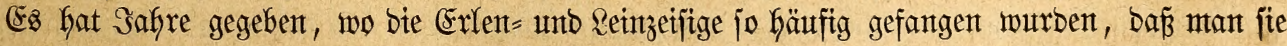

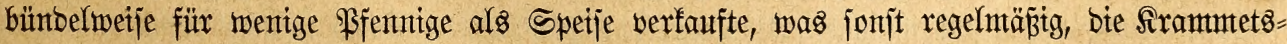
wögel abgeredgnet, nur mit (sold = unt (srauammern zu geidsefen pflegte, weil im alfgemeinen 
in Berlin für bas Gffen fleiner $\mathfrak{B o ̈ g e l ~ f t e t s ~ n u r ~ e i n e ~ j e f y ~ m i t t e l m a ̈ ß j g e ~ S o r l t e b e ~ g e = ~}$ herjcht hat.

Sprofjer, Ranartenfäfyne unb frembländijche $\mathfrak{B a ̈ g e l ~ - ~ Y e t s t e r e ~ b i s ~ z u ~ D e n ~ v i e r z i g e r ~}$ Safyren nicht Gäufig bei uns zu jehen - wurben nicht zu Marfte gebracht, jonbern ftanben

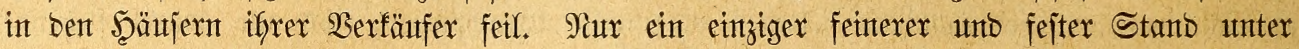

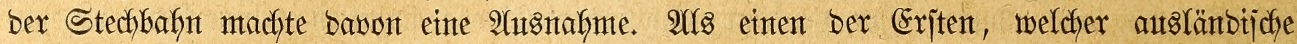

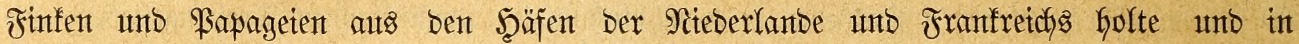

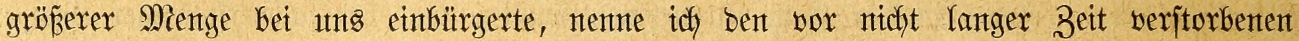

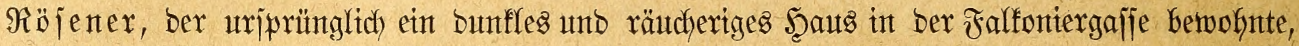
barin aber bie vornefmiten Bejuthe empfing. Sndem idf won ifm rebe, entferne ith mids jeoodh jofyon vom Rapitel bes Berliner Bogelmarfts int engeren Sinne. Ebenjo werbe idh mix faum erlautben bitrfen, von ber (Erbltedfeit bes Bogelfanges umb Bogelfantbels unter

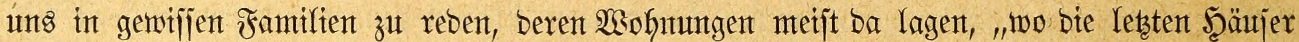

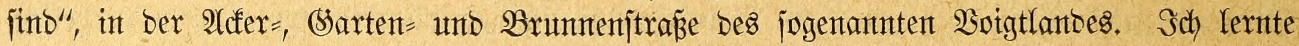

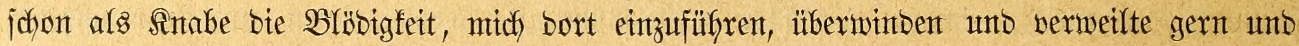
viel in ben weiten, aber nieberen Stuben, beren 2 änbe mit Bautern förntlich austapezirt

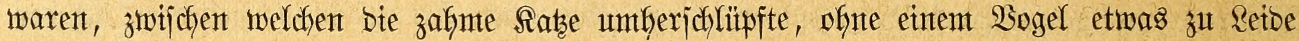
zu tun; hatte man fie boch in ber Sugent mit Riebfojungen und Nabeliftchen in bie शaje gelebrt, ifgr গaturell zu befämtpfen.

Da war bent freilich mefyr noch zu jefen unt zu bewumbern als auf bem Miarfte jelbit;

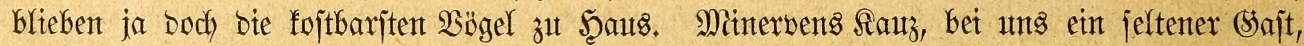
jaß gravitätijch in jeiner geräımigen $\mathfrak{B} e$ haujung.

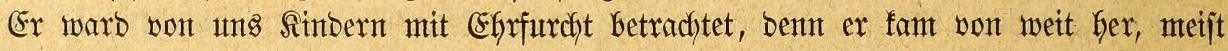
aus Türingen tnd war unverfäuflich ober nur zu einem für bie fleine Börje bes fnaben

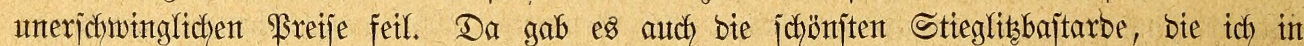
meinem Reben gejehen, und von ben aufgefïtterten jungen Rautdjichwalben erzäflte wohl bie

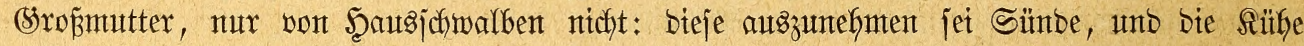

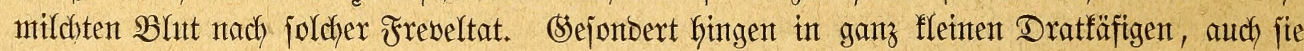
unverfäuflich), bie vieljäfrigen Rodfö̈gel, bie nur zum Fange Kinaus, nie auf ben Marft

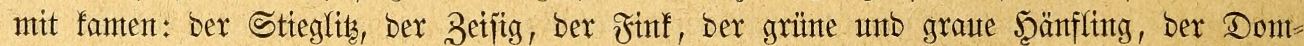

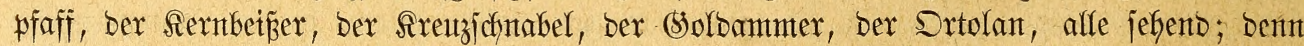
bie graujame Sitte bes $\mathfrak{B}$ ogelblenbens, obwohl in ber Marf nicht unbefannt, Gat in Berlin nie gegolten."

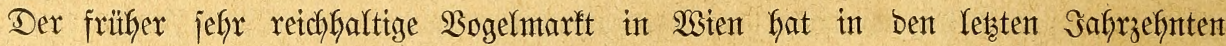

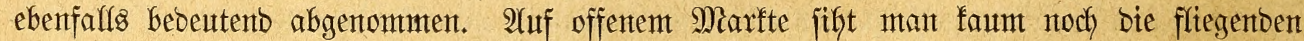
Sogelfä̈bler, benten bie Stebhaber und funbigen jo manthe Seltentheit verbanften; in ben

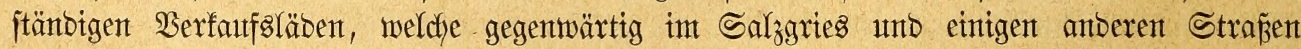

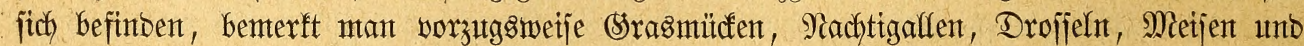

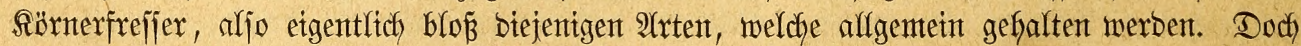
fant ein am Srte 2(ngejeffenter auf fejte Bejtellung burch Dieje Reute wentigitens nod) ver= jchiebene Räfiguögel erbalten und jo manthen guten Rauf machen. Sm Sïben bes ojter= retchijchen faijerreichs bagegen haben fich bie Berbältniffe wohl faum geänbert. Mant fä̈ngt

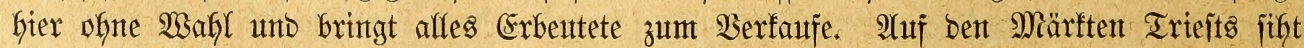

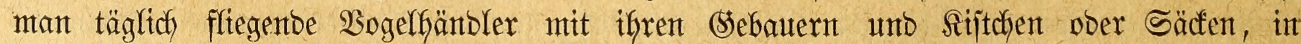

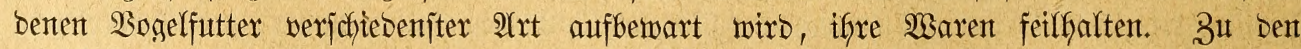
gewöbntichen Erjcheinungen unter ben Räfigwögeln zählen hier Stemtrötel unb Blaumerle, Ralanberlerche unto Sappenammer, unt unter ben gemeinen 2 (rten bemerft mant zumeilen groß̉e Seltentgeiter. Ralanberlerchen, Steinrötel unto namtentlich Şlaumerlen werben hoch 
im Bretje gehaltent, bie letzteren wohl audh Deshalb mit, weil fie in ben Şarems ber Türten als bie beliebteften Stubentögel gelten. Die Stetnrötel fommen, wie Freuts Fiebler midf belefrte, fammt und jonbers aus Sirain, fo zu jagen bem Mittelpunfte ifrer Sceimat, wojelbjt fie häufiger jüb ałs ingenomo antors. Eingeborente Säger, von Sugend auf geübt im $\mathfrak{B}$ ejteigen ber halsbrecherijchen Feljenwänbe, auf benen bie $\mathfrak{B}$ b̈gel brüten, betreiben Fang

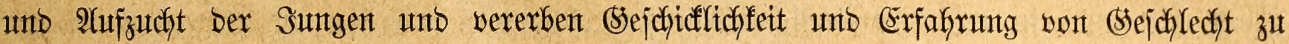
(Sejchlecht. Sie liefern bie an bas Futter gewöhnten $\mathfrak{B o ̈ g e l ~ z u m e i j t ~ n a c h ~ R a i b a c h , ~ w e l d j e s , ~ j e i n e r ~}$

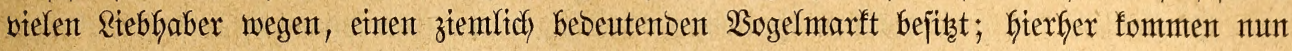
bie Triejter ફ̧ändler, um fich mit ber gejuchten Ware zu verjegen. Die B̧laumerlent erfalten Yetztere aus Cattaro, Carlopago unb 3ara. In ber Untgegento biejer Stäbte

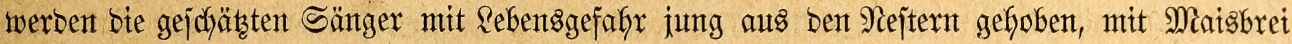
uno 2(mteijenpuppen aufgezogen uno jobann an bortige Scänoler billig verfauft. Witele bleiben int Ranbe, antore gelangen in bie Sänbe geminnjucthentber Schiffer unt burch bieje in bie

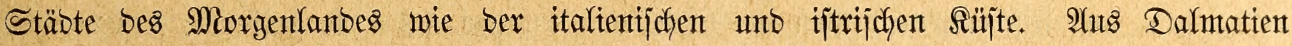
jtammen auth) bie Rappenammer, währent bie Ralanberlerchen umb bie, leiber jelbjt in ben Räfigen ber Iriejter Rtebhaber jefx jeltenen Mieijterjänger in Sitrien jelbjt erbeutet werben. Neben ben zünftigen Şänblern exjcheint biejes ober jenes Bäuerlein mit frijdhgefangenen Sögeln auf Dem Marfte, Geute auf bent einen, morgen auf Dem anberen. Bon foldyen Seuten fann man, fafls bie Sogelfänbler nicht zuworfommen, jefy biflig faufen, nidfyt aber auf jie rechnen.

Uleber ben Bogelfandel ber Schweiz teilen meine trefflicben Mitarbeiter Sirtanner unt Stulfer bas Nachjtebenbe mit. "Wir Gaben in ber ganzen Sdyweiz feinten orbent=

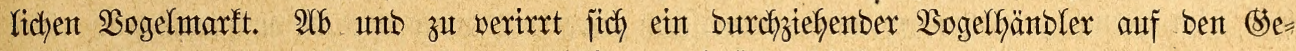

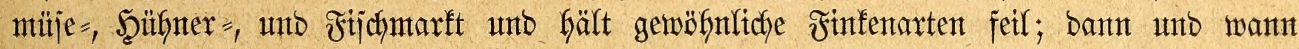

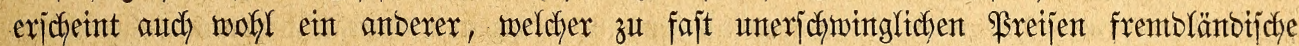

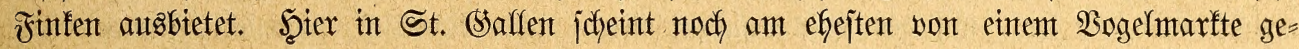

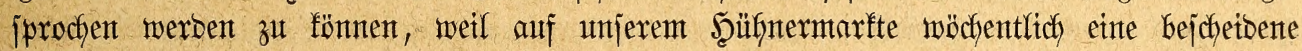

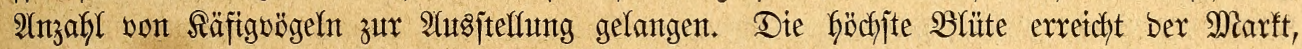
went ein Borarlberger Bogelfteller eintrifft, weldher nimmt unt bringt, was thm ins Nets läıft unb jein Setwerbe zünftig betreibt. Bejagter Mann bringt uns neben ben gewöhn=

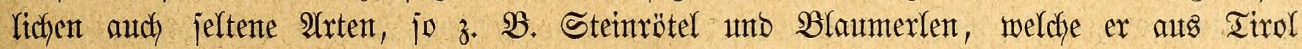

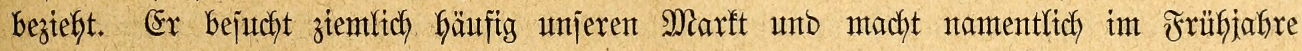

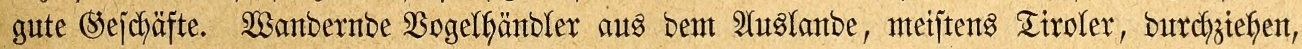

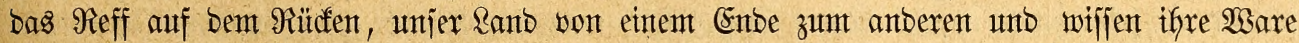

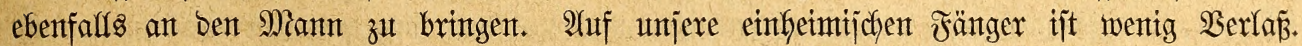
Es feflt ifnen an Senntnis ber geeigneten Fantgarten, an Berjanbmitteln unb an gutem

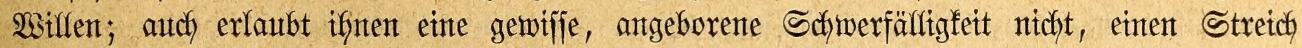
mefy zu arbeiten, als jie zu tum gewohnt jint. (sebirgsjäger wollen alfes liefern, was man verlangt, bringen aber fajt gar nichts oder mur erlegte Beute. Nager= Donazians

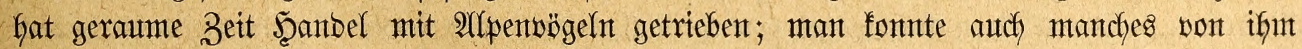

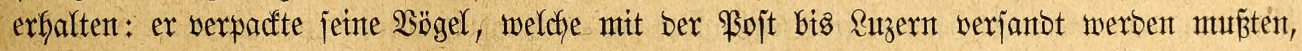

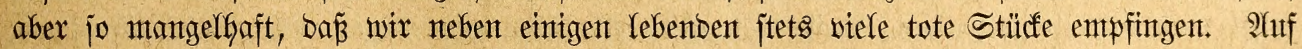
weite Entfermung fant Rager gar nidyt verjenben. Wenn wir für umjere Jreunbe int

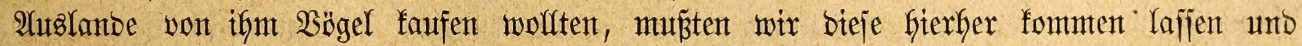
leiblich und geiftig aufrichten; erift bant fonnten wir fie, befjer serpacft, weiter jenten.

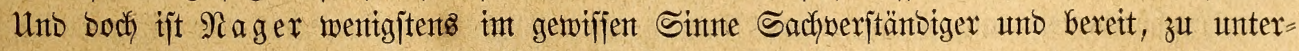
jtïben, währeno jonjt ber umjtänblichjte jabriftliche Serfefy faum ober nicht ausretcht, es vielmebr münblicher Sejprechung mit ben Aelplern jelbjt bebarf, un etwas zu erbalten. 
(Es hält aljo jajwer, jefr jabwer, bie jo vielfach) gejudtent Arlpentögel zu erlangen! Raum ein einziger Bejucher unjerer Altsjtelfung mag in Stanbe gemejen jein, bie unenbltche Meithe, welche uns bie ફ̧erbetichaffung unjerer Sammlung verurjacht hat, ridjtig zu beurteilen uno

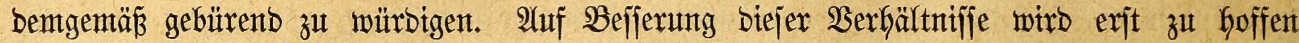
jein, wenn endlich eitter ber in Bajel, Zürich und Stenf geplanten Tiergärten wirffich ins Seben tritt und ein Yebhafter Iaujdyerfefy fich entwitfelt, wie ifn bie Sogelwelt umjerer Alpen ermöglicht.

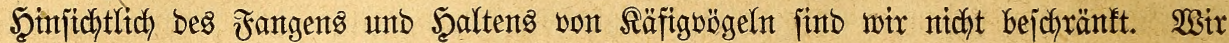

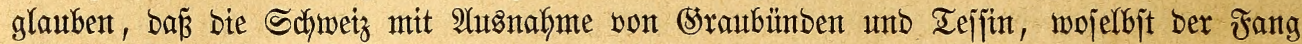
ber 3ugbögel ebenjo eifrig als in Stalien betrieben wiro, im Bez̆tg auf Fang unt Şantoel einen vernünftigen Mittelweg gefunben bat zwijchen blinolings verbieten unt blinblings

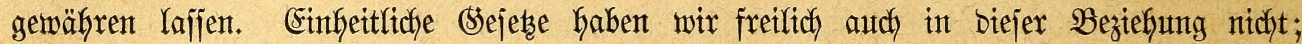
inbejfen wiro gegenwärtig in ber Sdjweiz tïchtig gearbeitet an einer aflgemeinen Regelung ber Sagd = und Fijchereivorjariften int weitejten Umfange. Frïffer befïmmerte fich feine einzige umferer zweiunbzwanzig Regierungen Darum, ob unt welche Sögel gefangen wurben; jest nimmt jith mebr als bie Bebörbe bie bffentliche Meinung ber Befieberten an. Wir Gaben wofl in aflen Stäbten einzelne Riebhaber, weldye nidyt ermangeln würben, Miłabräudche,

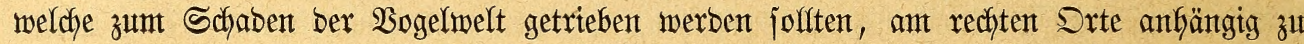
machen und zu verwebren. Indererjeits ftört audf Nientand ben wafyen Siebhaber Durch

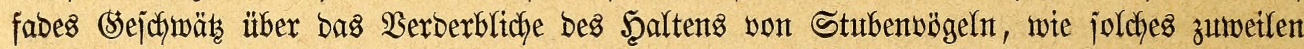
aus bent entpfindjamen Deutjcylant zu uns Gerübertönt, in jeinem Garmlojen unt bejcheibenten

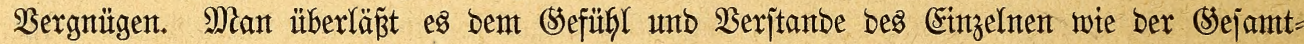

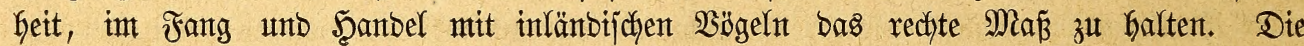

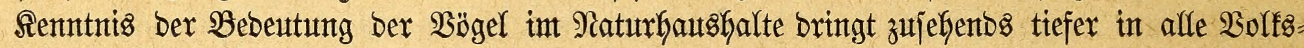
jedichten ein, unb bies wirb einer vernünftigen unb billigen Einjedyänfung bes ßogelfanges,

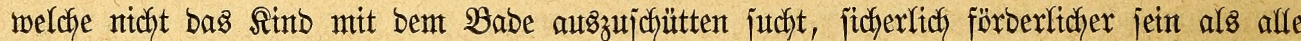
hodhtrabenben, auşrottungşüühtig gegen bie Riebbaberei anfämpfenben obrigfettlichen Bejehle, weldye ber Sache mefr jajaben als nüben.

Der alfwerbreitete Stubenwogel ber Sdyweiz ijt, wie überall, ber Sanarienwogel, weldyer

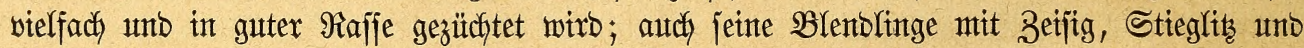
5̋änfling, jowie bieje jelbjt fimben viele Riebgaber, ebenjo Meijen, zumal bie trot ifrer Einferfe=

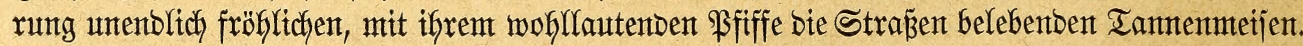
Sobant werben noch bejonbers gebalten: 2 mijeln und andere Drofjeln, serchen, Ssimpel, jeltner bie fetneren Sänger. Unter biejen jift man int Säfige am häıfigjten bas Rot=

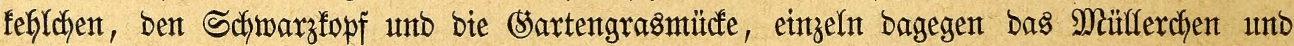

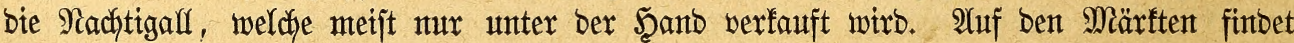

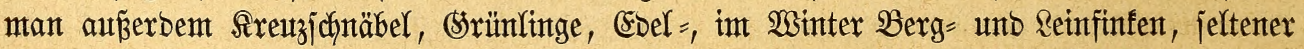

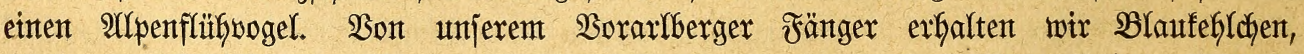

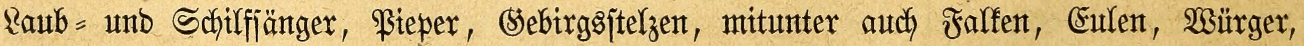
Rallen 2c. Die übrigen Räfigbögel ermirbt fid biejer ober jenter Bogelmirt burch etgene

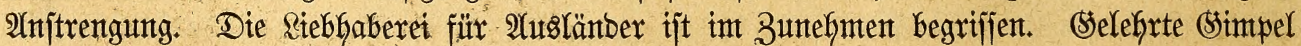

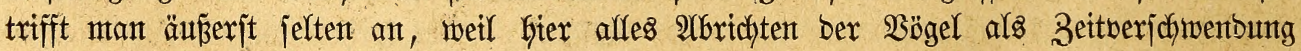

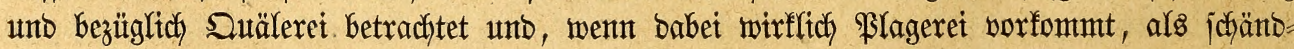
lidyes Beginnen unerbittlich berbammt wirb: - jidferfich ein tïdftiger 3 utg in unjerem Bolfischaraftex."

Srop̈britanien unt Srlanto, insbejondere aber England, zählt viele unt eifrige Rieb= Gaber unter jeinen Bewofnern. Die ausgezeichnteten Serbinbungen bes Ranbes, ber Reidftum ber vom (s)lüf Beborzugten unb bie allgemteinte Ieilnafgme, weldhe ben Tieren 


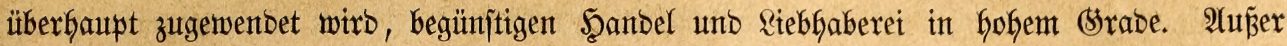

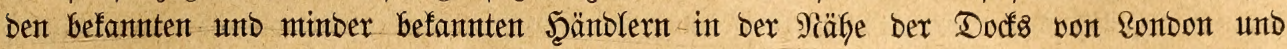
anberen ફ̧afenjtäbten lexnt man, went man fich erfunbigt, nodh zaflloje Aleintbänbler

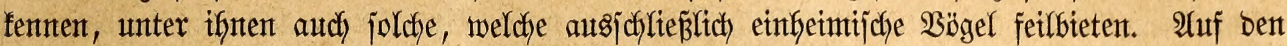

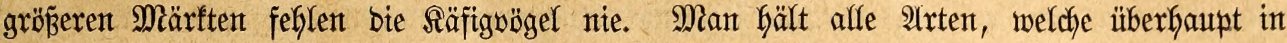
Frage fonmen fönnen, behanbelt jie, wie bie gefantgenen Tiere inggemein, jebr gut und züchtet

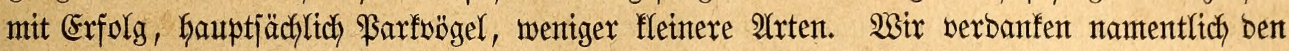
Englänbern bie jeltenteren Räfigü̈gel, weldye wir gegenwärtig halten, Gaben ifnen aber

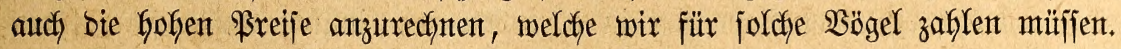

Sn Scolfanto gibt es auker ben Sutherlands nody mefrere Alemtjänder, aber feinen einzigen von irgenbmeldher Bebeutung. Der Fänger am Mieresjtranto, in ben Moren unb Sïmpfen, int Räfricht und $\mathfrak{B a l b e}$ bringt jeine Beute zu Marfte, bent gröpsten Teil tot, Den geringiten auf bejonbere Bejtelluntg lebento; ein Schiffer johlägt jeinen aus

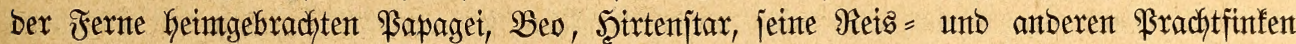

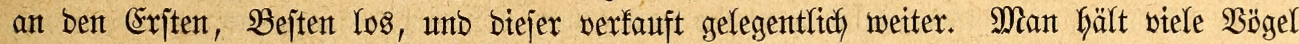

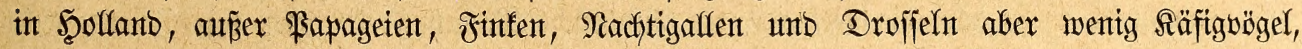
eher noch \$arfwögel affer 2 rtt, insbejonbere Fajanen unb Enten. Dods gibt es unter bent

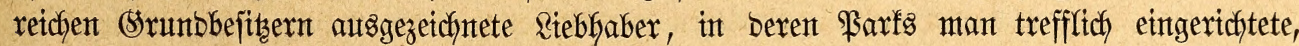

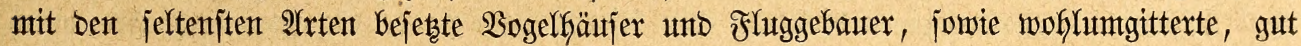
bewölferte Weifher und Behege fift.

Das fleinte Ranto Belgien bejust vier Tiergärten: bies allein johon bemeijt, wie verbreitet

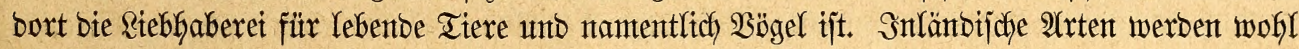

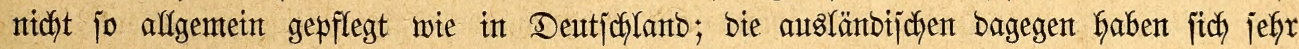

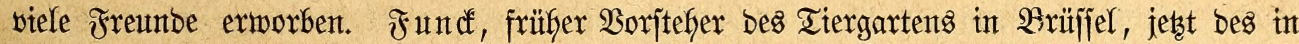

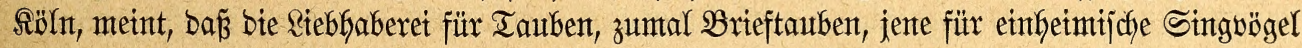

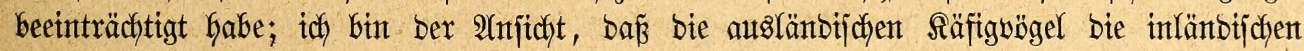
zurücfigebrängt haben. Won biejen hält mant bie Sänger, weldhe auth in Deutjchlanto bie

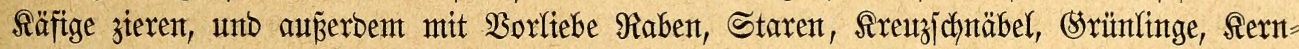
beižer, Solbammer, Seibenjchwänze unt Wiebehopfe, von jenten affe âtrten, weldye auf ben europäijchen Tiermartt gelangen.

Die Fluggebauter ber belgijchen Riebfaber fint zum Ietl wafre Majteranjtalten, ebenjowofil mas beren (Einricftumg als was beren Bejetzung antelangt. Mant züdftet ein= heimijche $\mathfrak{B}$ g̈gel fajt gar nicht, auslänbijche bagegen mit gropem (Eifer umb erzielt autzgezeichnete Erfolge. Selbjt bie fribher blithenbe Zudjt bes Sanarienbogels bat unter ber gegentwärtigen affgemteinen Beborzugung ber 2luslänber gelitten: mant bezieft jeţt bie Santarien ebenfalfz

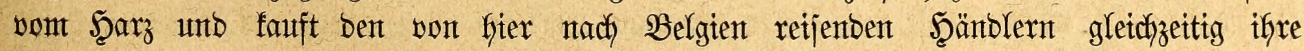

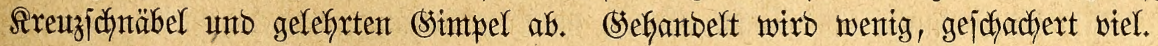

Seder einzelnte Riebfaber ijt in gemiffem Sinnte aud Şäntler unt feintesmegs inmer

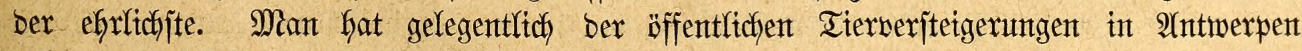

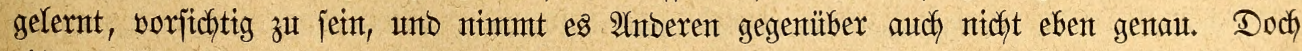

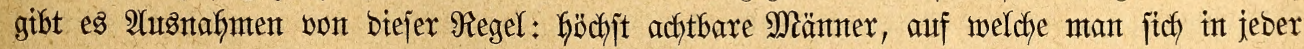

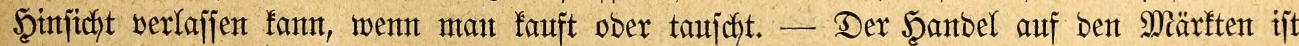
bebeutungslos. Albgejehen von ben Reuten in Seejtäbten, weldhe mit Sidjffern verfebren

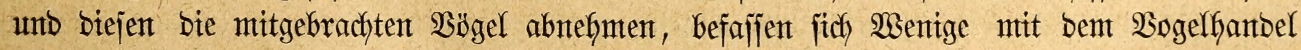

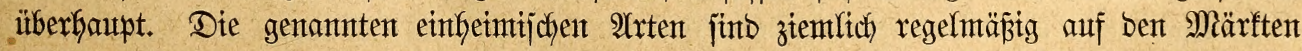
gröperer Stäbte vertreten, werben nantentlich Sonntags zwijchen $8-12$ Mhr 20 ormittags

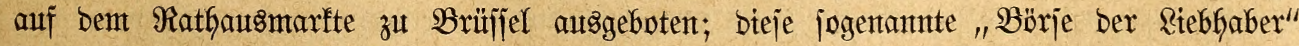

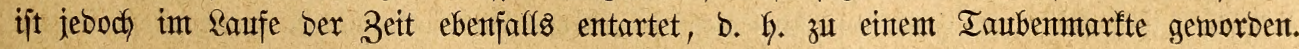


Was Ginjichtlich ber Riebhaberet von Englanto gejagt werben fann, gillt, vielleidht im

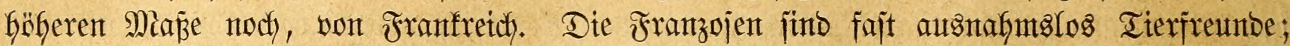

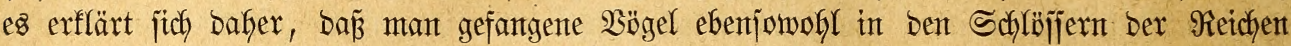

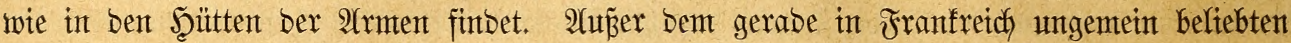

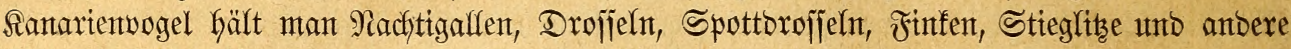

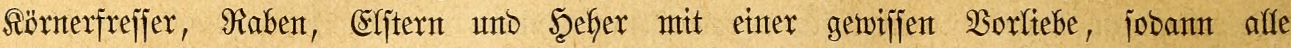
erlangbaren Iauben, Şü̈fner und Fajantenarten, Sänje, Enten u. a. m., furz bie gejamte Bogelmelt, welche fich ingentwie für bas Bebauter eigntet. Sn Den Seeitäbten verntmmt man bas Areijchen und PFeifen Der \$apageten in affen Straßen, in ben Bintrenjtäbten bent

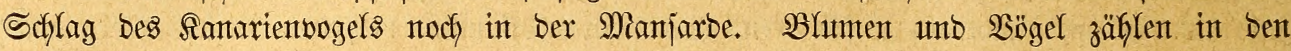

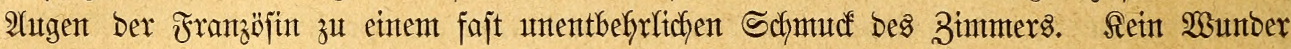

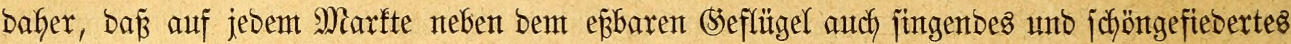

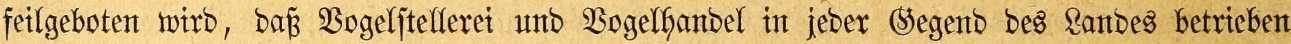

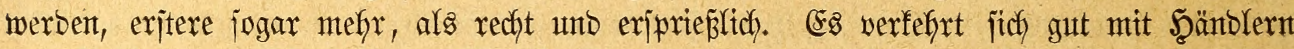

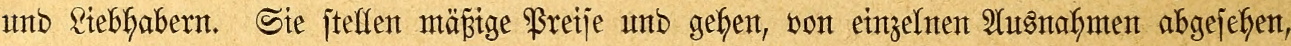
nticht barauf auş, zu überworteilen ober zu täujchen. Man hanbelt gern mit ifnen, weil man rajch, gut unto biflig fauft, hat auch faum Mrjache, einmal eintgegangene (sejechäfte = verbinbungen aufakeben.

Bezüglich Der allgemeinten Riebe zu ben Tieren bas gerabe Begenteil ber Jranzojen, jinto bie Spanter boch ebenfafls Freunbe gefangenter Bögel. Metn Bruber, weldyer bie bejte

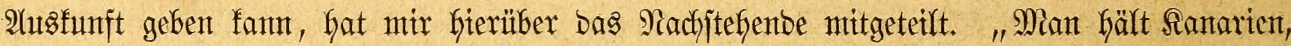

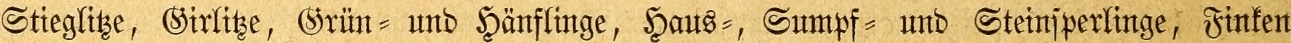

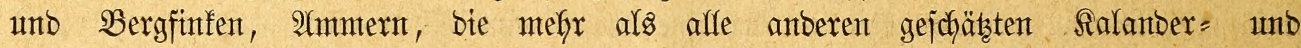
furzzefigen Rerchen, Flughüfner, Wadhteln in groß̈er 9 (nzahl, nodh Gäufiger jebods einzelne

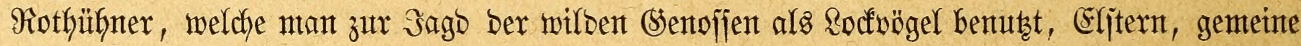

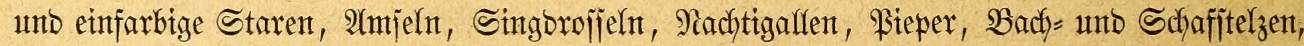

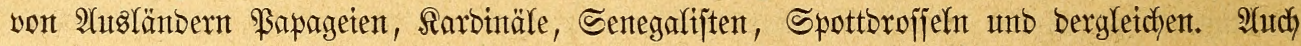
Raubvögel fommen oft auf Den Marft. Niemals wirb man ben Sperfingsfauz vermijien,

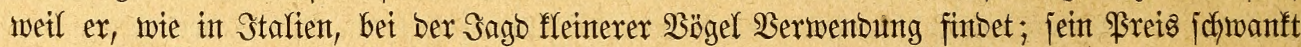

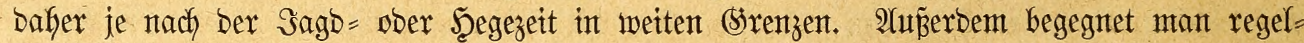

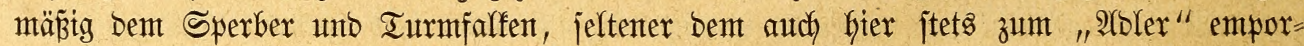
gehobenen Buffarb, zumeilen bem 3mergablex, mandymal bem Uhu, im Jrüfjahre ber 3wergofreule, meijt jungen, bem গiejte entfyobenen Stüden. Utm bieje Beit ericheinen

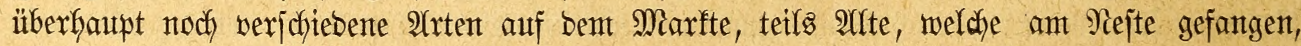
teils Sunge, welche ausgenommen unb aufgefüttert wurben; regelmäß̈ig gemafyrt man jebzt

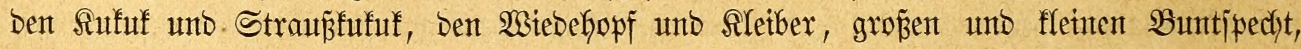

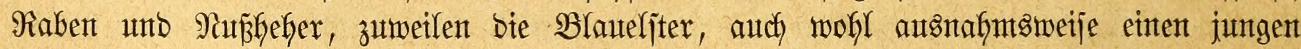

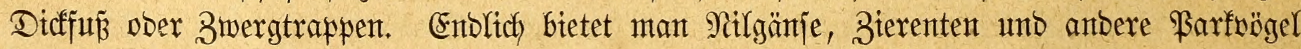

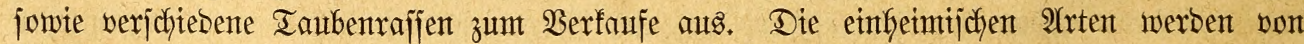
z̈unftigen Bogelifellern, auf Scerben, welche man balo bier, balb bort aufiftelft, jowte auf Reimruten gefangen, an Srt und Stelfe in elende Säfige gejtecft, auf ben Miarft gebradjt unto verfauft, bis bafin aber jo mangelfaft gefüttert, Dá faum ber zefinte Teil am reben

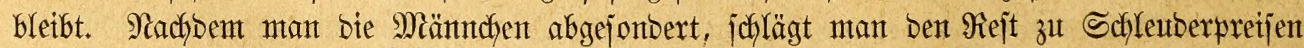

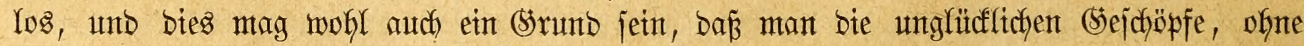
fich Sorge zut madhen, halb ober gantz verburjten läp̈t. Was nidft auf bem Marfte jelbjt

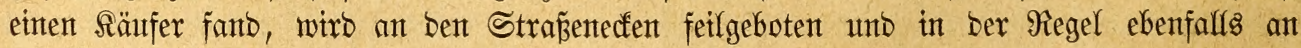

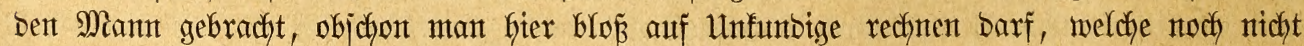

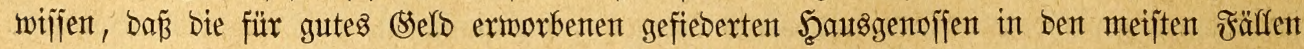




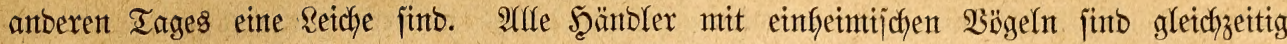

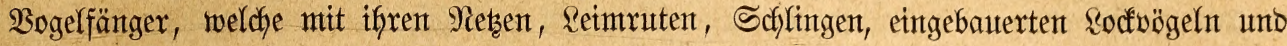
Berjanbfäfigen auf weitfin bas sand burctzitehen unto exjt mit volfer sabung heimferyren,

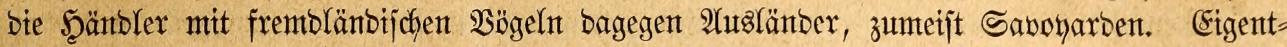
licke $\mathfrak{B o g e l m}$ ärtte gibt $e g$ nur in Mabrib, Barcelona unb Cabiz; erjtere haben weit mefyr Bebeutunty als Yetzterer. In Mabrib hatten bie Şänbler bis zum Safre 1869 auf eintent mitten in ber Stabt gelegenen \$laze jtehende Breterbuben, weldhe zum Berfaufe unt beg

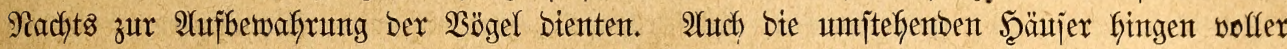

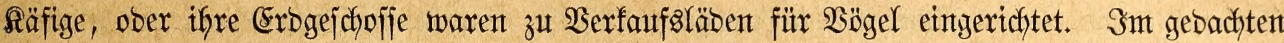
Safhre murbe bie Plazuela de Santa Ana zu eintem s̈ffentficten (Sarten umgemandelt, unto

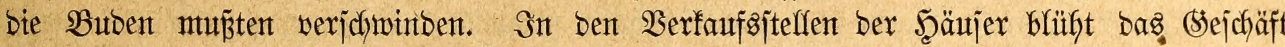
nach twie vor; bie fliegenton Şänbler aber mušten bis an bas Ente ber Stabt wandern unb fanben exjt auf bem "Strohmarfte" einte Stätte, auf welcher man ifynen erfaubte, fich

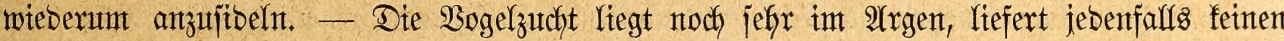
nentensmerten Beitrag auf Den Marft. Einzelne Riebbaber züchten Sanartenvögel, einige Galten auth antbere 2 (rten in ber Sgoffnung, jie jich fortpflanzen zu jeben; im affgemeineut

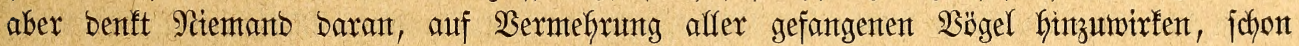
weil bent Spanter bie fierzu erforberliche (sebuld gänzlitch abgeft."

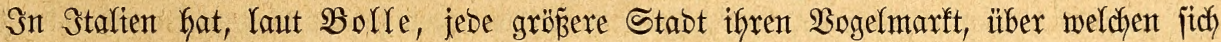
etwa başjelbe jagen läß̈t, twas ich won Iriejt bemerft habe. AUuf ben Marftpläben von

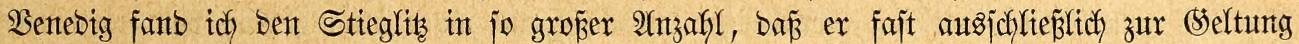

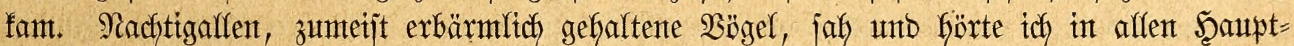

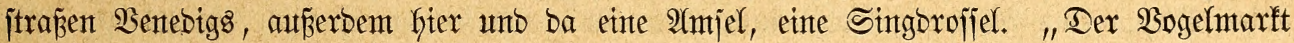
zu Mailand" jagt Boolle "gruppirt fich unt eine Seite bes weltberïfynten Dontes. Dort

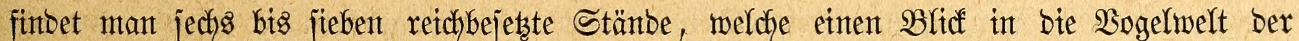
Rombarbei geitatten. Sch traf viele Sartenammern, Steinrötel uno Blaumerlen, unjere nörblichen (srasmülden, zumal bie ifres Bsejantges Galber am meijten gejdhäbten Miönchs:

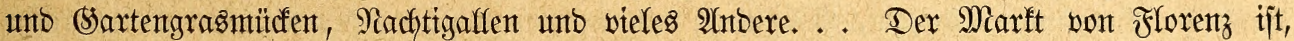
wie ber von ßija überreich mit getöteten fletnen $\mathfrak{B g ̈ g e l n}$ verjehen. Wag Febern hat, ab= märts bis zur Blaumeije, wiro gebraten unto mit ßolenta verjpeijt: faum ben Beifig jajützen bie Magerfeit jeines Rörperdhens, (Sejang, Buntbeit uno Zutraultidfeit. . . Bon

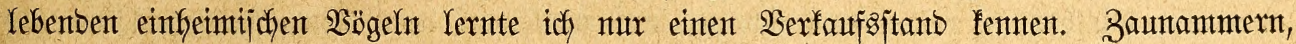
in jeltneren Fälfen 3ippammern, Cteit = unb Allpenjperlinge waren für midh bas mentiger (Semögnliche. Tieben ifnen tronte unwandelbar auf jeiner aufredsten, oben mit einent Politerchen als Sizz verjehenen Stange, Minervens Säuzlein, Eivetta genannt, bie jtraf=

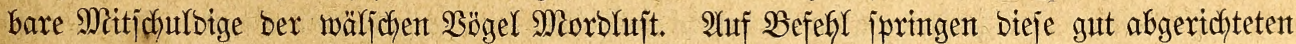

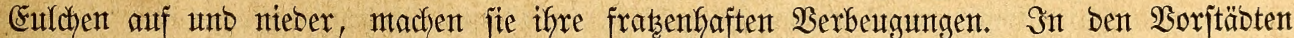
fiht man ifhrer viele in ben \&äben ber Seanbwerfer, Deren Sonntagserfolung bie Bogeljago

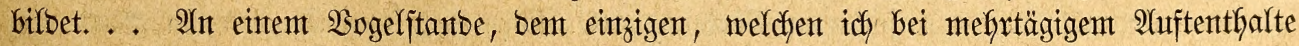

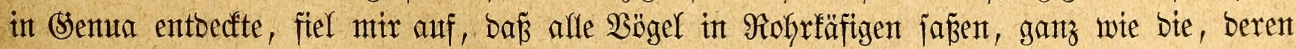
man fich auf ben body jo entfernten fanarijchen Injeln bebient." Mant fift aus biejen

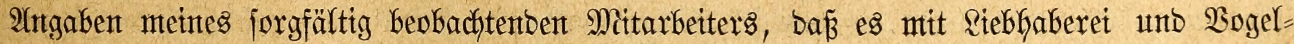
hanbel in Stalient eine ganz eigente Bemantonis hat. Mant fängt ebent vorzugsiweije für bie

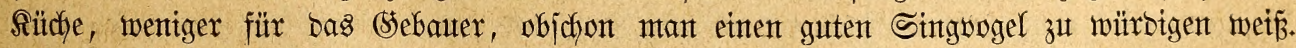
Der Şanbel mit frembläntijchen $\mathfrak{B o ̈ g e l n ~ i j t ~ f a u m ~ b e r ~ \Re e b e ~ w e r t , ~ w e i l ~ S t a l i e n ~ h a u p t j a ̈ c h l i c h ~}$ mit Ränbern verfefhrt, in benen bie Riebfaberei nodh in ben Wintoeln liegt ober gar nidft

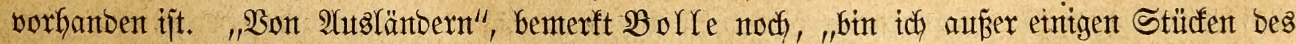

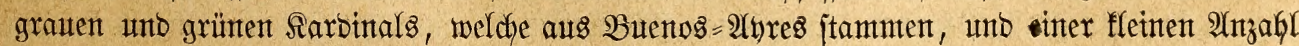




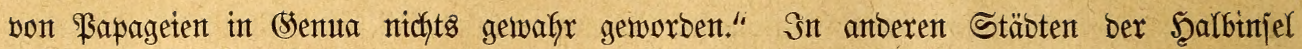
verbält $\mathrm{es}$ jich ebenjo.

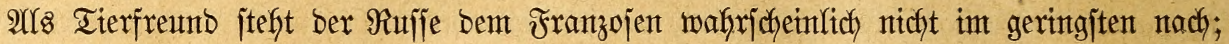
als Riebbaber fant und nuts er noch von affen bereits genannten Europäern lenten. Stader in Mlosfaut hat mit Giterïber jäätzenswerte Mitteilungen gentacht. "Man fängt

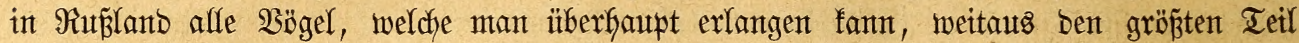
für bie Sïhthe, einte fefr beträdhtlictie Mienge aber ebenjo für baś (s)ebauter. Zut bem

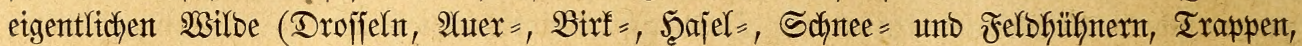

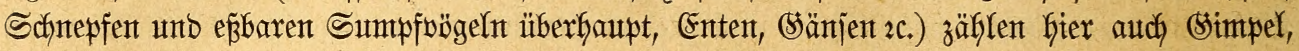

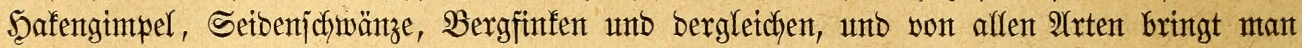
Majien auf ben Marft, Seajel= unb Sdyneehüfner jogar von Arrdjangel her: bie Sirgänten, ein mongolijcher Stamm in ber Nähe gebadjter Stabt, bezahlen ifyre Steutern in gefangenten Şithnern, weldhe jie int gefrorenen 3ujtantbe auf Sdhlitten vom Etsmere nach Mosfau

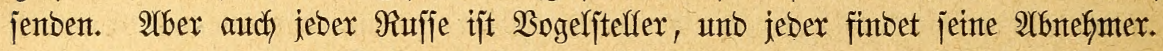

Schon jeit vielen Sabrent bejteht in Mogfau ein eigenter, ftänoiger Bogelmarft, auf weldyem wöchentlich Sutuberte von Bögeln abgejebt werben. Diejer Marft befinbet fich auf einem ber gröperen freten $\mathfrak{B l a ̈ b e ~ i m ~ M i t t e l p u n f t e ~ b e r ~ S t a b t . ~ Z w e t ~ \Re e i f e n ~ e l e n t o r ~} \mathfrak{B r e t e r}=$

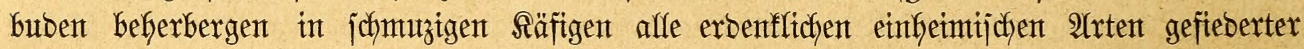

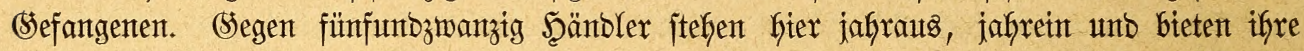
Ware feil. Sn Den $\mathfrak{B o r m i t t a g g f t u m b e n ~ b e r ~ S o n n t a g e ~ h e r j c h t ~ e i n ~ r e g e s ~ R e b e n ~ a u f ~ b e n t ~ M a r f t e . ~}$ Şänbler vom Ranbe fint von aflen Seiten herbeigejtrönt unb juchen ben int Raufe ber ver= gangenten $\mathfrak{S}_{0}$ che erbeuteten Fang an ben Mann zu bringen. Man errichtet reifentweije fafle Bäımte unt bebängt fie über unt ïber mit einemt bunten (Semtijc) von Räfigett afler 2(rt. Dex Mann aus bent $\mathfrak{B}$ olfe finbet fiter fich ein, umt fich einen billigeren $\mathfrak{B}$ ogel zu faufen, als bie von Dentjchlanto eingefübrten Rerchen und Sanarientögel es finto und jein

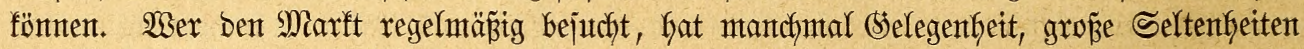
für wentg (Selb zu erwerben. Şier finbet man neben ben regelmäp̈tgen Ericheinungen, als

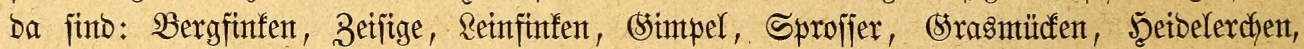

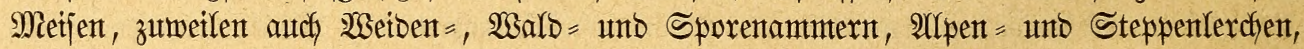

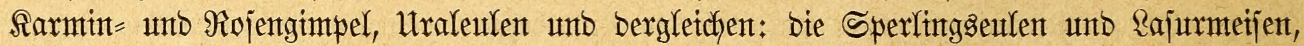
weldye idh Dem Berliner Alquartum geliefert, wurben auf biejem Marfte eingefauft. Alber man mun jith beeilen, went man nidht ler autgehen wiff; benn an fauflujtigen Riebhabern

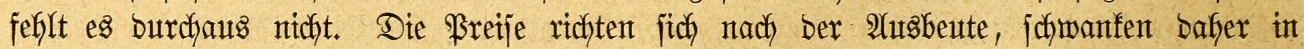
weiten Srentzen. $\mathfrak{W a s}$ am Sonntage nicht verfauft mirb, trägt man in ben Wodhentagen unter lautent 9 (1tsirufen burch bie Strapent.

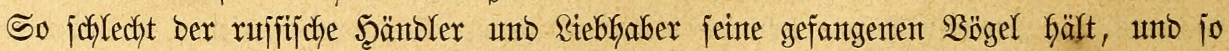

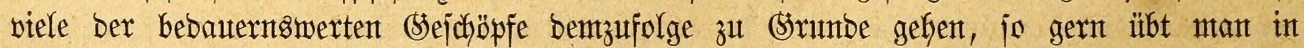
gemififer Weije Barmberzigfeit gegen bie eblen Wejen. Wie auf bem Marfusplabe in

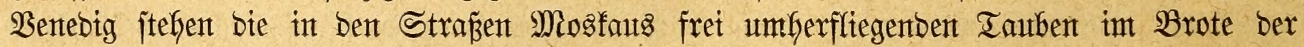
Mitlotätigfeit, unto babei fälllt benn auth ein Scherfletn für arme alte Frauten ab, benen man bie Fütterung ber $\mathfrak{B}$ ögel überträgt. Sn ber Faftenzeit unt zwar am Tage ber $\mathfrak{B} e r=$ fünbigung Marias, weldyer auf ben 25. März ruifijchen Stiles fällt, żeht Bornefm uno (Sexing, allt und Sung nach bem Bogelmarfte; Seber fauft, je nach Sermögen mefr ober wentger, frijc) eingefangene $\mathfrak{B}$ ögel uno johenft ifnent unter alfgenteinem Subel ber $\mathfrak{B}$ eteiligten

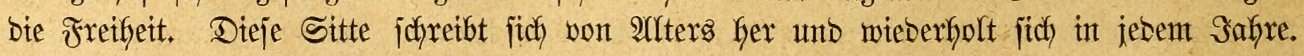

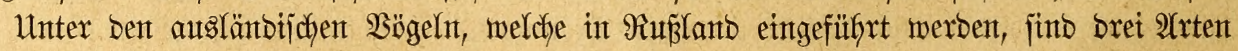
bejonbers beliebt: Der Ranarienbogel, bie Felblerche, fier "Danziger Rerche" genant, uno ber Safo ober graue ßapagei. Won ifnen finbet man fajt in jeber Familie einen ober bent 
anberen. Sbenan itefht ber Ranarienvogel, welcher afljäfyrliç) zu bejtimmter Zeit won Rübedfer, Berlinter unto Danziger Şänblern auf Den Marft gebracht wiro. Zwwar züchtet

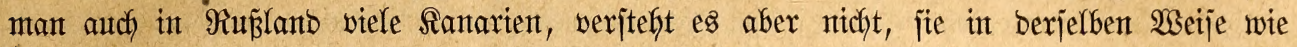

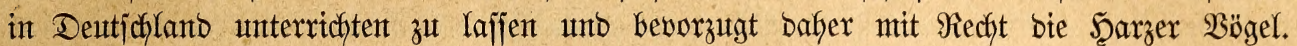
Die meijten Riebhaber funt Sienter bes (sejanges unt zaflen unter Umitänben für aus: gezeidhnete Schläger ofne Wiberjtreben einte Summe von 50 bis 100 Rubelnt. Die Danziger-Rerche exfreut fich ebenfalfs affer Srten einer freunblicken 2 (ufnafyme und wiro namentlich in Mozfau viel gefalten. Şier trifft brei bis vier Miale im Jahre Der Şändler $\mathfrak{B}$ ehren $\delta$ a a

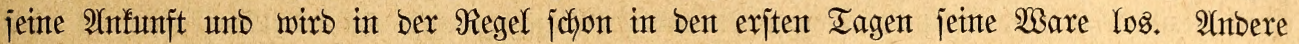

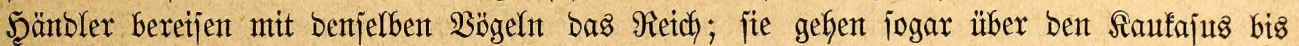
Iiflis. Althe verjentet man von fier aus viele Bögel in bie \$rovinzen. Der graue

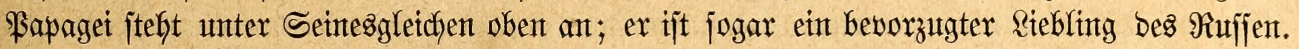

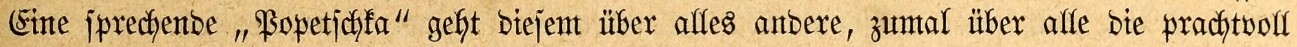

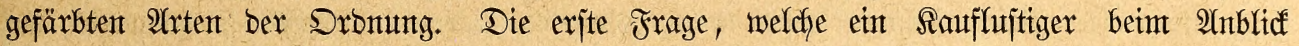

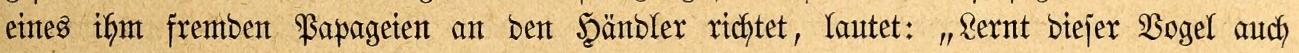

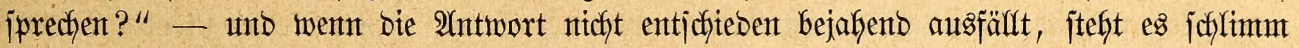

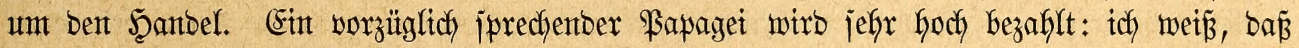

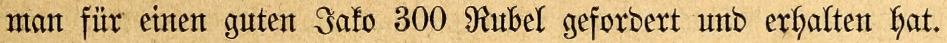

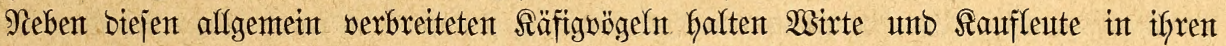

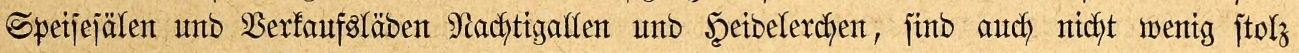
auf gute Bögel. Wir hoffen, noch bie Spottorofifel unto ben Sarbinal einzubürgern unb

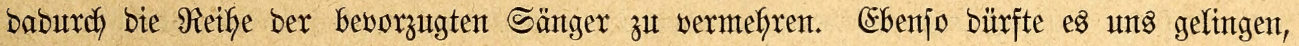
bem $\mathfrak{W e l l e n j i t t i d j e ~ F r e u n b e ~ z u ~ v e r j o d a f f e n , ~ b a ~ b e r j e l b e ~ z u ~ n t c h t ~ g e r i n g e n t ~ E r j t a u n e n ~ f i e r ~ i n ~}$ umjerem Bogelzimmer gebrïtet hat."

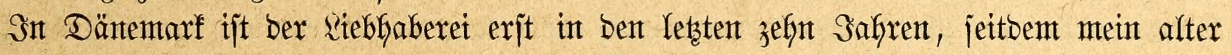
Freunb $\Omega$ järbörling in Sopenthagen jeinen Tiergarten errichtet, Teifnafme gemorben; früber fielt man auker ben gewöbnlichjten einbeimijchen Singoögeln hödyjtents nody eintge

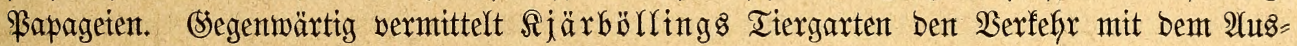

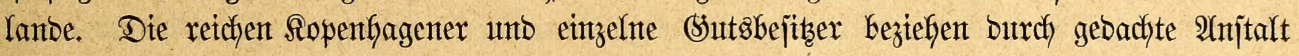

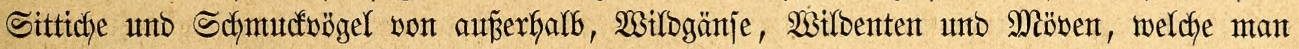
jeboch mur jefr vereinzelt in ben ßarfs zu jefen befommt, von intmerbalb. Aluzerbemt

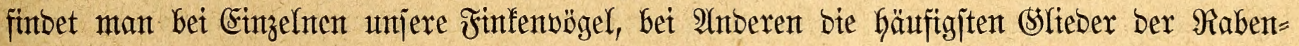
familie im (sebauter und im Beföft. Der Fang ber Ebeliänger, welder jebt jtreng wer= boten ijt, wurbe früher Gauptiächlich von ben "Sjouter", mjeren Ecfenjtehern, ber Şanber mit ber eingelieferten Beute von zwet Ropentyagenter Sifujtern betrieben. Rjürbörring

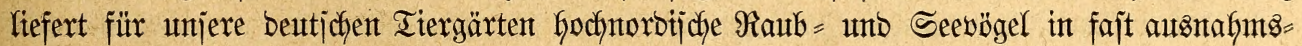
los untabelfaften Stïtfen unb zu mtäß̄igen \$reijen.

Was jitch bon Däntentarf jagen läß̈t, barf man feinesmegs audf auf Schmeden beziefjen. Scter jteht bie Riebhaberei fait auf Dentjelben Stanbpunfte wie in Striechenland unt in ber

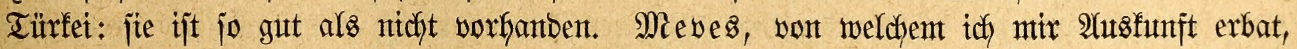

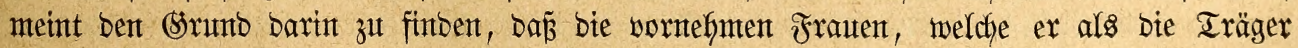
ber Siebfaberei anjift, Den Sommer auf bem sanbe zuzubringen pflegen unt fich vor

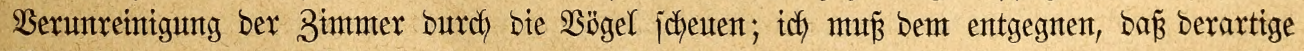
Bebenfen-meiner 2 (njidyt nach gar nidyt in Betradjt fommen fönnen, wenn von Rieb= Gaberei gejprochen wiro. "Untwerfeiratete Meänter", jajreibt Meves, "Galten noch am

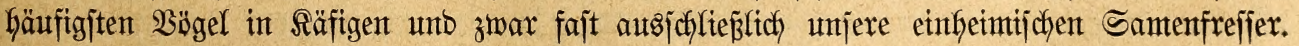
Bon Eoeljängern findet man in gantz Stodfyolm feine zwanzig Stücf im Sebauter; Droffeln 
jind faum fyäıfiger, Stare in etwas gröвerer $2(n z a b l$ vertreten. Eintige bringen fith Sittiche, meijt (Strumapageten und Welfenjittiche, Frachtfinfen, Sarbinäle, WBeberbögel, vom 2luzlanbe mit; won einer Einfufhr ijt aber ebenjo wenig zu reben als von einem Bogelfanbel.

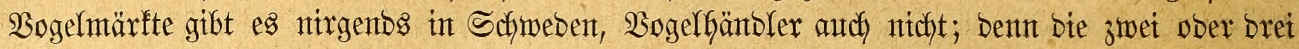

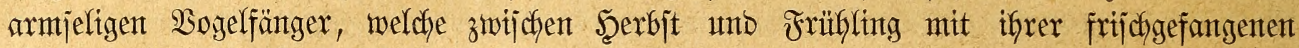
Beute in ben Straß̉en umberlaufen, fönten mofl nitht unter bie Seändler gerechnet werben.

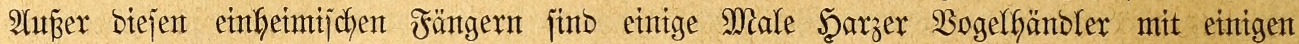

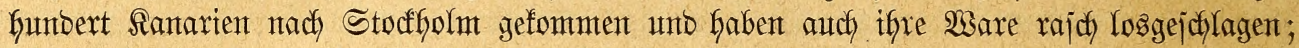

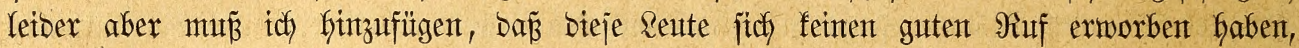

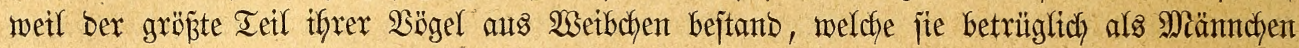
autigegeben hatten."

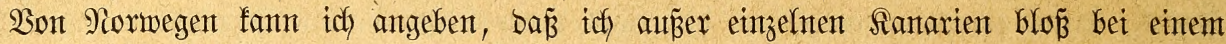

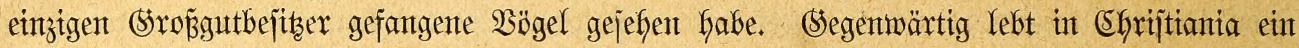

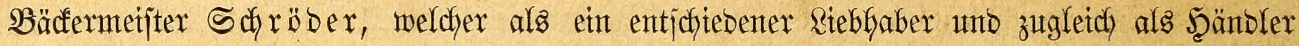

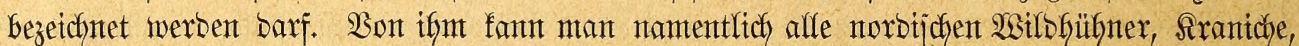

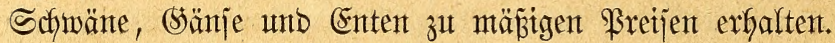

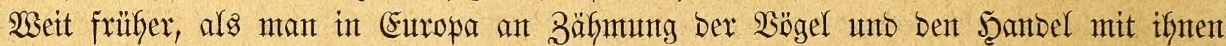

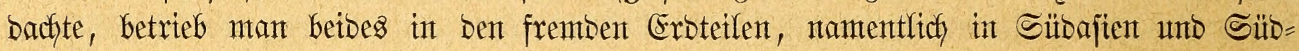

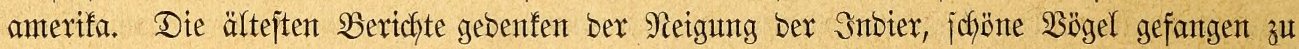
Galten; die Entbecfer Âmerifas erwäfnten ber gezäfimten $\mathfrak{B}$ g̈gel, meldhe die Eingeborenen ihnen als (Sejchenfe überbrachten. Şter wie bort reicht Die Werbrüberuntg Des Mienjchen unb Des $\mathfrak{B}$ ogels bis in bas grauejte Âttertum zurüdf. Sn Egypten hat mant wentigitens fich

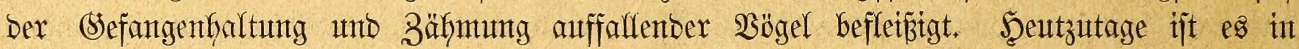
Sübajien und in Sïbamerifa noch genta ebenjo, wie es vormals wax, wäfrent fict) in

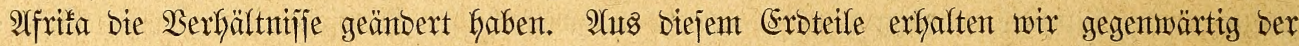

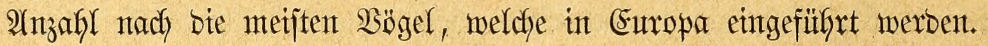

Bor affen ïbrigen jutno es bie sänber an Senegal, welche uns afrifanijche sögel liefern; bie 2Yusfuffr, weldhe uns aus ben jübwejtlichen und jüblichen Ietlen Des Eroteils

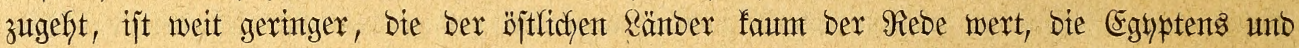
Alfgiers erjt im Werben begriffen. Zwijchen bem Senegal unt Marjetfle ober Borbeaux jowie siwerpool bejtefen jeit Eintridftung Der Dampferlinten regelmä̧̈ige Serbindungen unter ben be=

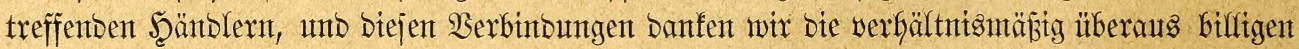
Freije ber gemöfnlicheren $\mathfrak{B}$ ogelarten jener (Segenben. Die fïjtenfafyrer faufen bie $\mathfrak{B}$ g̈gl auf unto geben jie an bie Schiffe ab, weldye wom Borgebirge ber guten Scoffintug nach

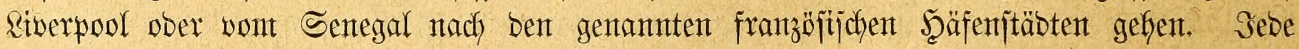
biejer sinien ijt für bie mejtafrifantichen $\mathfrak{B}$ g̈gel son bejonberer bebeutung. So erfalten

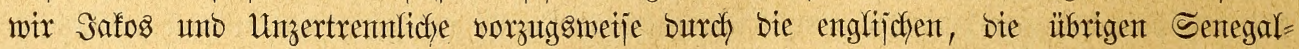

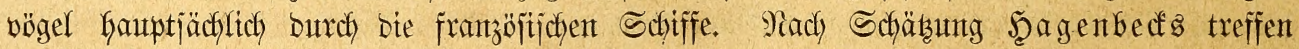

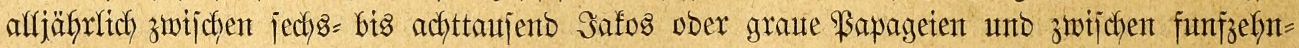
humbert bis zweitaujend $\mathfrak{B a ̈ r c h e n ~ " U n z e r t r e n n l i c h e " ~ i n ~ S i v e r p o o l ~ e i n . ~ E s ~ g e f o ̈ r t ~}$

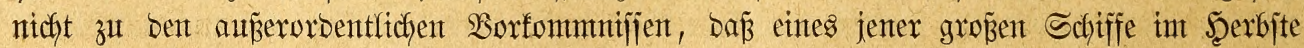
taujent Stücf Safos won einer Reije mit bringt und in Riverpool abjetst; Dent went Der

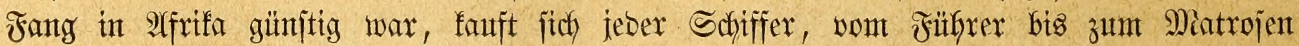
Gerab, eintige ober mefrere Dubend biejer alfbeliebten, jtets begeforten, reicht verfäufflichen

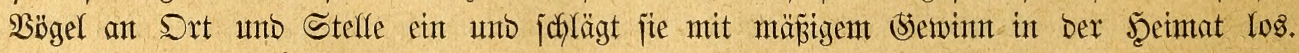
2fudf) von ben Unzertrennlichen gelangen mandymal zmei = biz breifunbert Pare gleidzzeitig

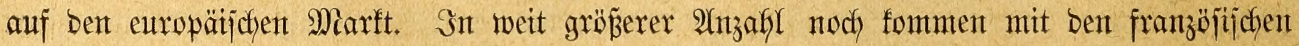
Dampfern bie Eenegalipten in Borbeaur unt Marjeifle an. Iaupend Fare lobnen faum 


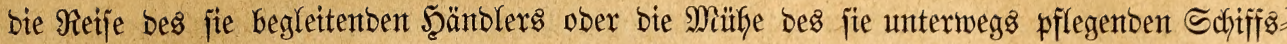
füfhrers; Desmegen nimmt man, falfs es möglich, z'wei = bis breitaujento Pärchfent mit einem

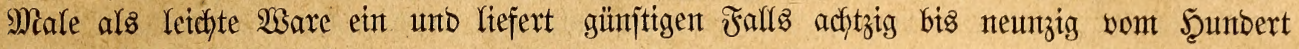
im Keimijichen Şafen ab.

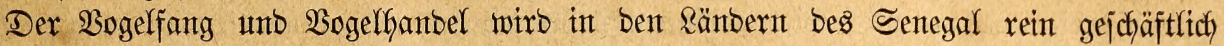
behantbelt. "Bejonbere Réebfaberei für Stubentuögel " idfreibt mir $\mathfrak{5}$. Dof

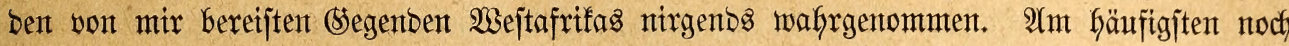
fano idf ben grauen \$apagei gezähnt unt zut Sprectjen abgericftet vor, auß̧erbent ein

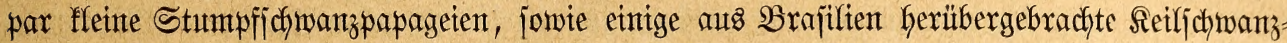

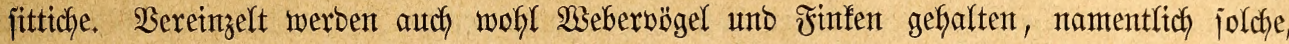

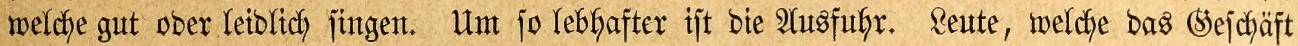

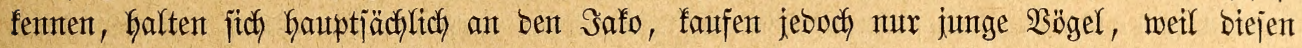

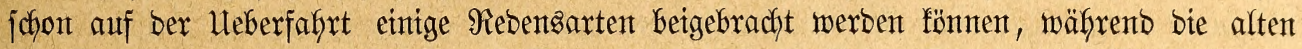

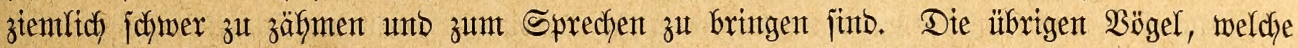

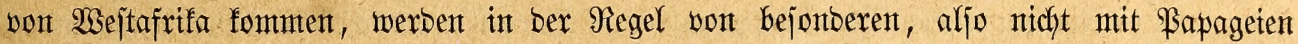

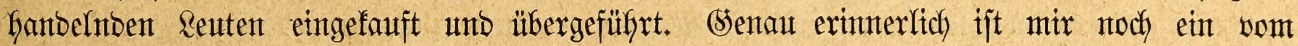

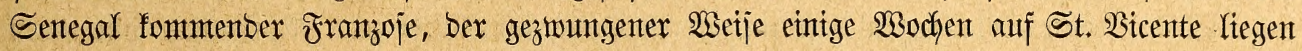
blieb, weil ber \$ojtbantpfer, weldfer bie $\mathfrak{B}$ seiterbeförberung nach (Europa übernefhment jollte,

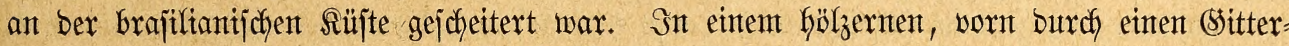

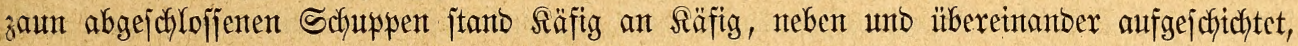

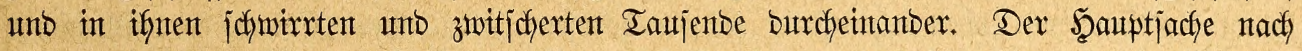

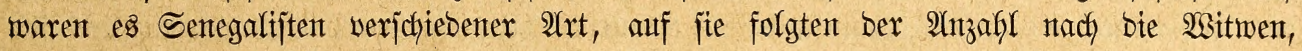

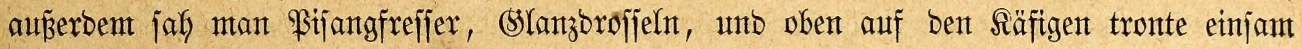

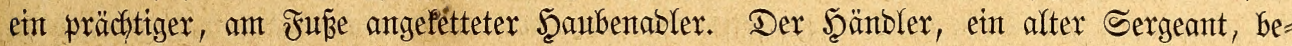

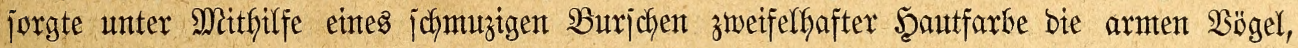
reinigte bie Räfige, wowon freilich wenig zu bemerfen, ichrotete Negerfirje unb anbere

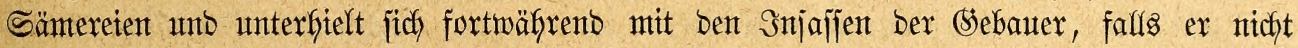
fonjt Semanbes fabbaft werben fonte, bent gegenüber ex bie Sdjleujent feiner Berebjamfeit

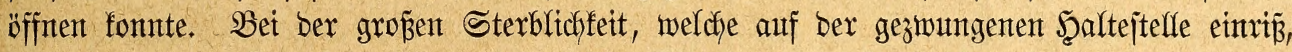
geriet ber arme Teufel täglich in jefhr trïbe Stinmung; aufs höbljite aber murbe bieje ge= jteigert, als er eines Morgents meffrere jeiner Räfige geäffintet unt faít ler fanto. Die

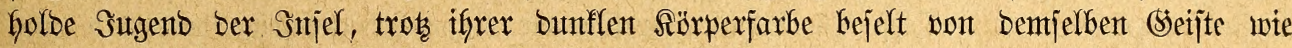

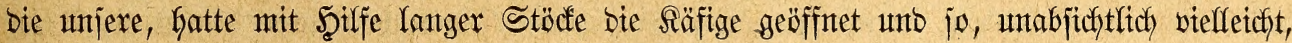

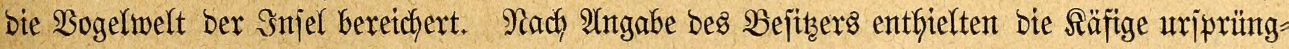
lich 12000 Bögel, won benen gegen 4000 verloren gingen.

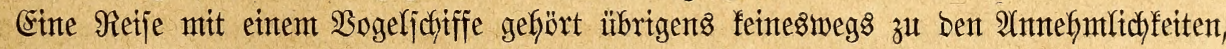

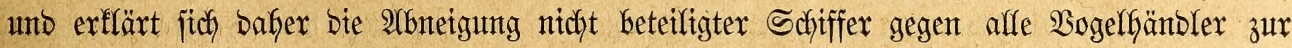

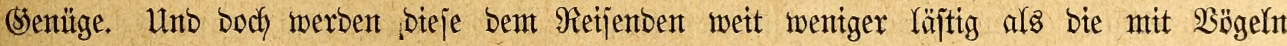

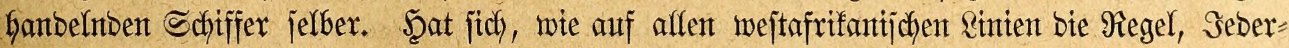

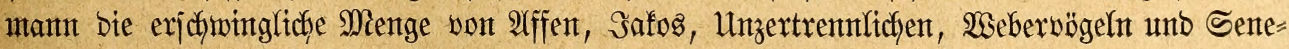
galijtent zujammtengefauft, io fant ber 2Yufenthalt auf foldhem Schiffe gerabezu uterträglich merben, wie idy bies, vont Fieber im G̈̈bjften (Srabe mitgenommen, "am eigenen Reibe"

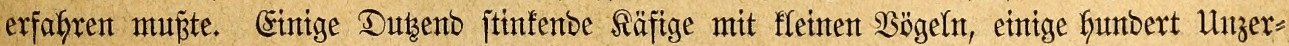

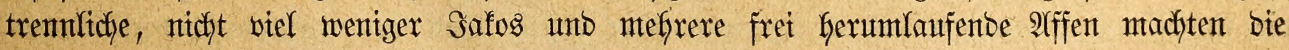

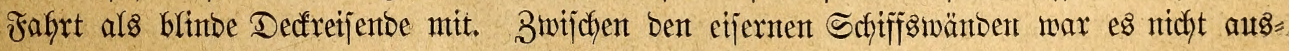
zuthalten; obent auf Deff gab es von Sontenauf = bis Sonnennieberganty nidft eine einzige ruffige Minute. Unangentefm genug für meinen 3uitanto war bas (Sezirpe unt (Sezłitifher ber Iaujentbe von fleinen Singvögeln, gerabeju unerträglich aber ber tägliche Hutterricht ber. 
Fapageien, welche, für Englano bejtimmt, fant unt jonbers zunädjijt "pretty Polly" Yernen joflten, Wrorte, Die ifnten von ben bezüglichen Eigentümern ober Refrmeiftern

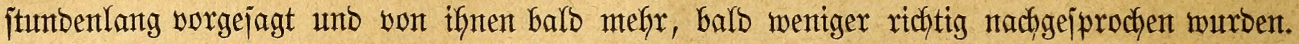

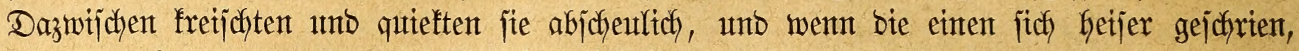

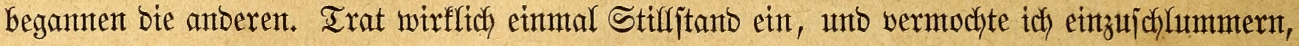

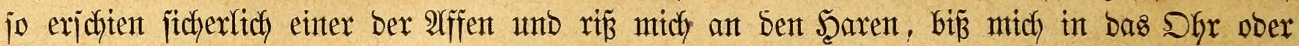
nach eintemt meiner Finger, war, efge idf midch recht bejinnent fonte, wieber oben in ben

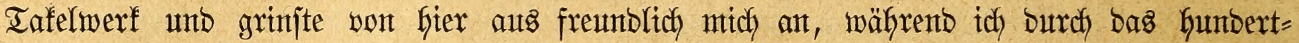

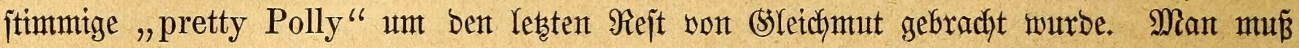

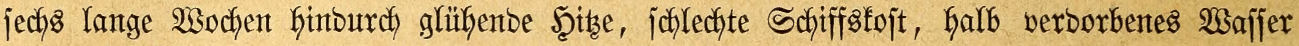

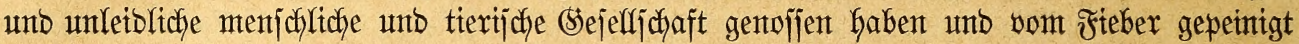

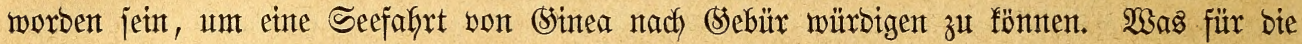
(sejunben langweilig, wiro für ben Sranfen zur Maarter."

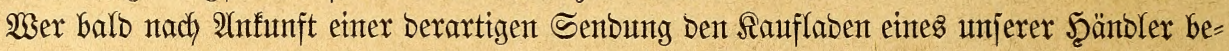

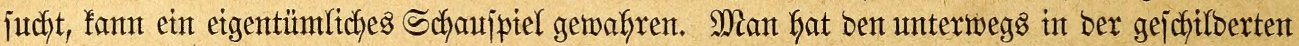

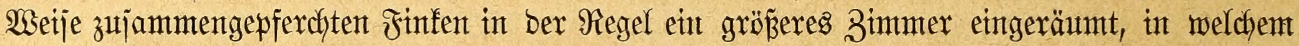

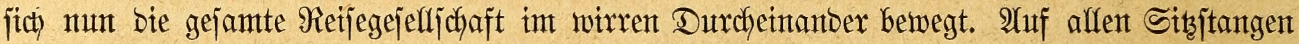

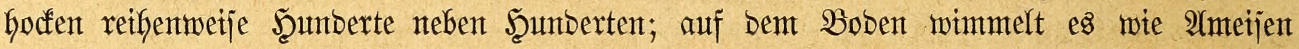

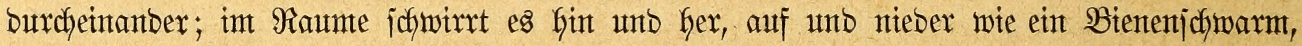

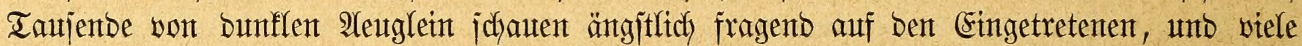

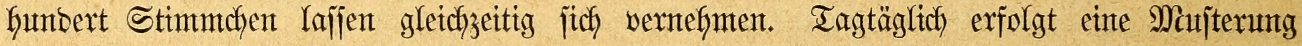
Dex (Sefangenten; Dent tagtäglich) gibt es Sranfe, tagtäglich) fintbet mant Reichen, bis bie

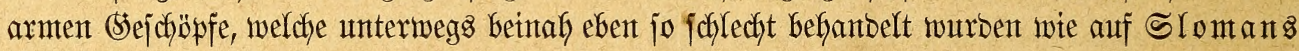

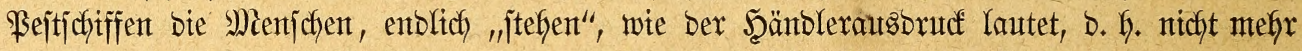
Dutzentweije Den auggeftanbenten Reiben exliegen unt in bie zweite Scanto gegeben werben

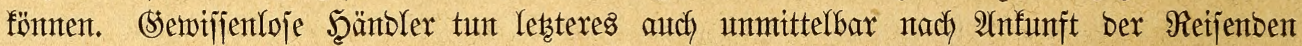

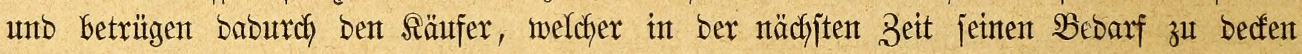

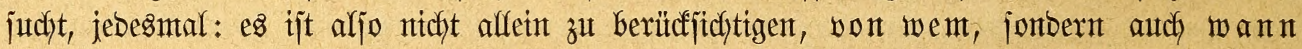
man fleine $\mathfrak{B o ̈ g e l ~ f a u f t . ~}$

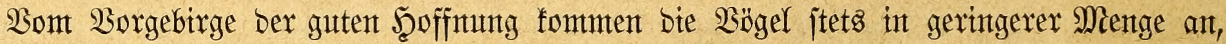

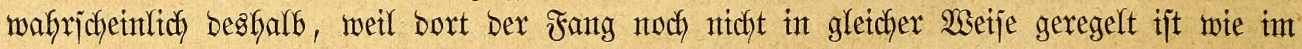

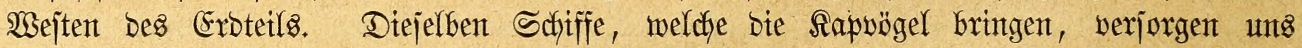

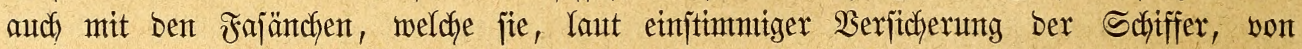

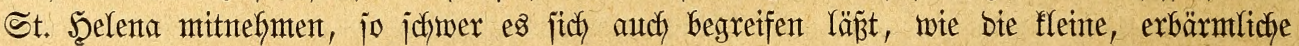

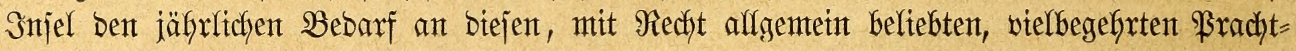
finfen zu becfen vermag.

2U1 Egypten erfalten wir zur Zeit fait mur Flammings und Futhsenten, aus

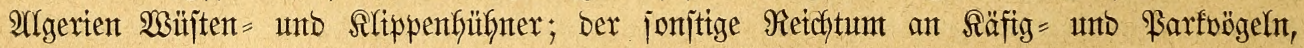

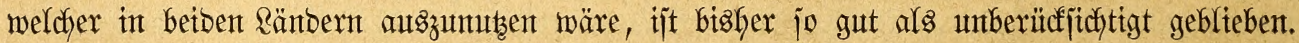

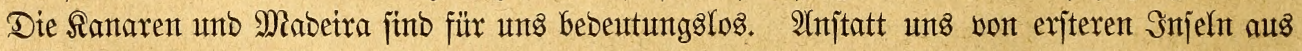

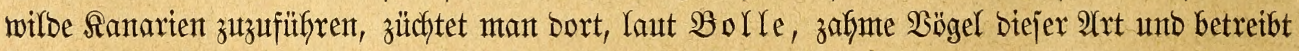

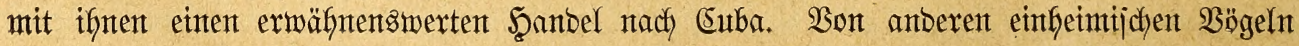

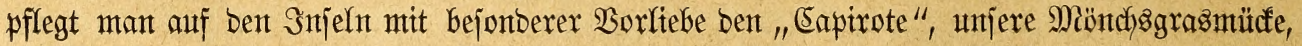

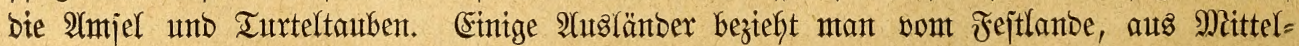
anterifa uno von ben \$GGilippinen. Untgeadtet ber regen Siebfaberei gibt es feine anberen

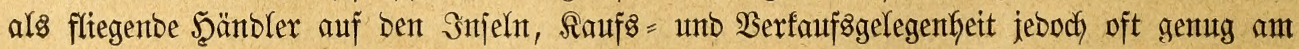
Borb ber antanbenben Sdjiffe. Miabeira übertriffit finfictetlich ber Siebfaberei bie Ramaren,

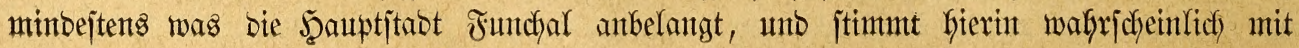




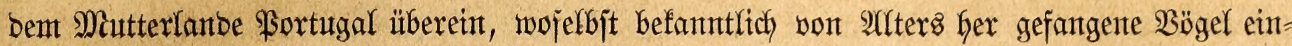
gefübrt nno gepflegt wurben. Maan finbet in Funchal fremblänbijche Bögel aus aller

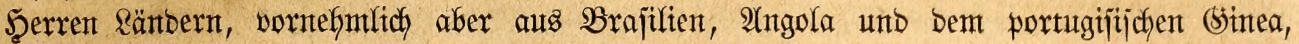
betreibt bort audf eine unbeabjichtigte 3ucfft berjelben, ba fich fajt affe 2(xten, welche in Frage fommen fömen, hier unt auf ben fianaren ungleich leichter fortpflanzen als im ge= mäpitgten Europa.

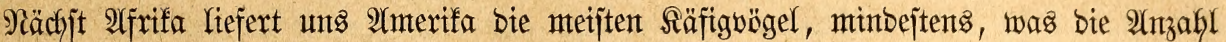

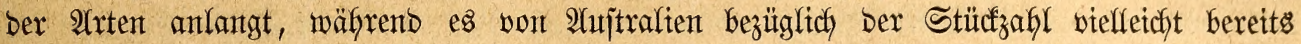

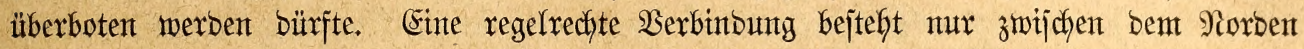
bes Exoteils unb Europa; vont Süben her bereichert einzig und aflein ber Bufafl unjeren

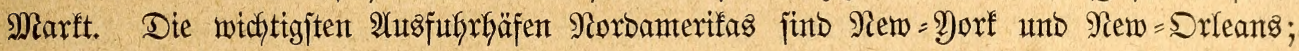
afle übrigen haben eine untergeoronete Bebeutung. Sarbinäle, ßabitfinten, Intbigobögel,

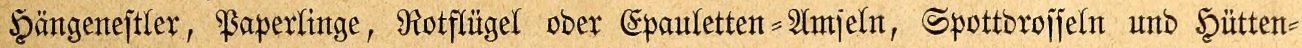

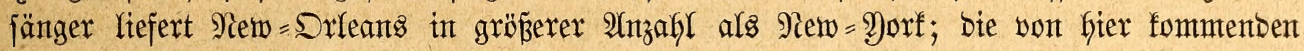
Bägel berjelben 2 rten banfen aber $\Re$ eiches geregelten Eintichtungen einte unverbältnismäp̄ig

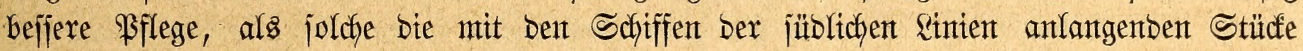

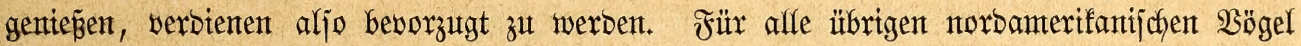

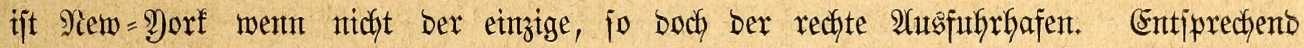

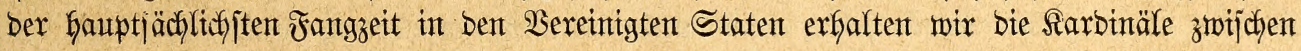

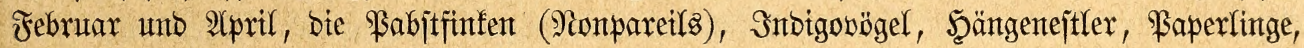
Irauteritteglize ober Solbotitelfinfen unt bie übrigen Gänftgeren 2 rrten in ben Monaten Mai und Suli, Spottbrofleln, Schopf = und andere Baumwadyteln, Sranidye, Enten $2 c$.

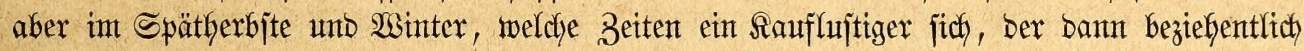

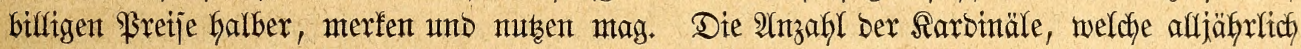
3u uns fommen, jtellt jich Durchjchntttlich ungefähr auf taujent Stüdf; Doch unterliegt bie Einfuhr bebeutenden Sdjwanfungen. Währento bes amterifantichen Sirieges bätte man jie in Europa mit (\$olb aufwiegen mögen; im Эahre 1869 bagegen warf ein einziger Şänbler aus $\Re$ iem $=$ Drleans über taujent Stücf auf umjeren Itermarft, unb belief jich bie gejamte Einfufyr zmijchen 2500 bis 3000 Stülf. $\mathfrak{B a b j t f i n f e n ~ u n d ~ I n d i g o s ~ f o m m e n ~ i n ~ f l e i n e r e n ~}$ Senoungen von 200 bis 300 Stüdf, affe übrigen mur butsenbmeije an; Spottbrofjeln

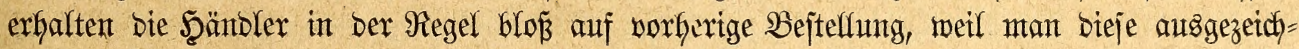

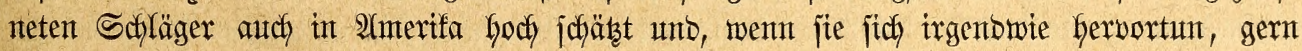
mit 30 bis 40 Dolfars bezahlt.

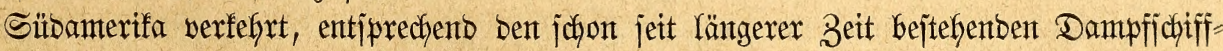
verbintuntgen, vorzuggrweije mit England unb Jranfretch. Aflfe von bort itammenten Bögel,

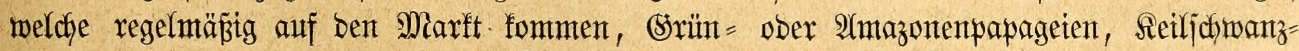
jittiche, Sperlingapapageten, Atraras, graute Sarbinäle, Safranfinfen und Iangaras z. $\mathfrak{B}$., treffen in fleinen Senbungen bei unz ein, bie gröperen Sittiche meijt mur einzeln und unregelmäß̄ig als gemejente Reijebegleiter Geimmärtżfefyrenber Matrojen, bie übrigen burch Bermittelung ber Jüfrex, Steuerleute und Wirtjchaftabeamten ber größ̈eren Dampfichiffe. Senbungen, weldje Dreişig ßare won einex biejer Bogelarten enthalten, gefjüren zut Den

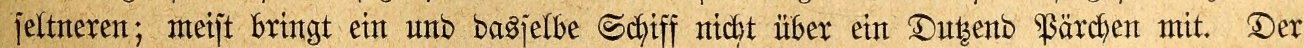

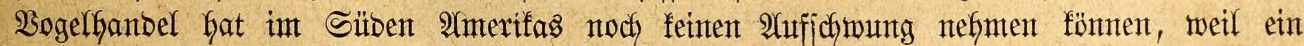

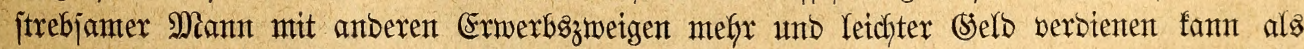
mit biejem (Sejdjäft, weldyes immerfint einte gemifje Sienntnis unt namentlich) (Sebuld ex=

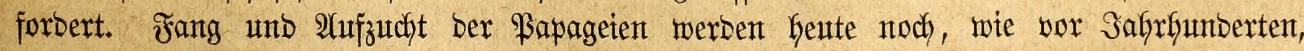
von ben Inbiantern betrieben: Der jübamerifanijche Sittich, welcher umjer Brachtzimmer ober Fluggebauer ziert, jaymürfte und belebte einjt die Seütte bes roten Manmes und gelangte 


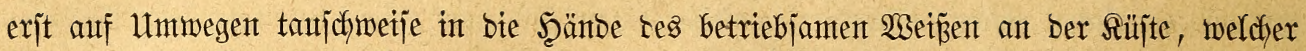

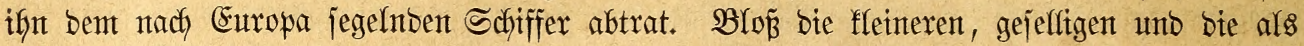
Feinte ber $\mathfrak{B f l a n z}$ ungen auftretenten 2 (rten ber Dronung, bie Finfen unb Tangarab, werben nicht von ben Ranbesureinwohnern, fonbern von freigemorbenten unt jonjt arbeitşchenen

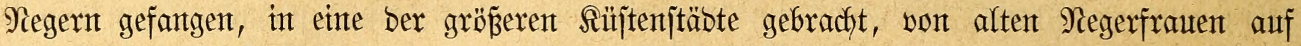

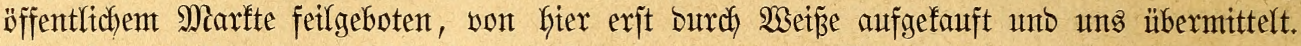
Der Şanbel ijt aber vollitänbig regellos und mur bem 3ufall untermorfen. Aluf bem Gejonbers retchfaltigen Marfte Bafins finbet man unter ben verjobiebenartigiten Erzeugnifien bes Ranbes, weldye fier aufgejtapelt wurben, Geute stelletcht ein Dubent prachtwolle Pfeffer=

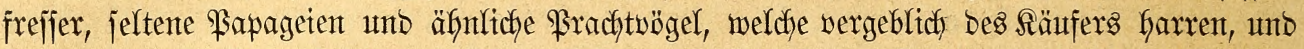
jucht mant adbt Iage ipäter möglicher Weije umjonjt nach ber Iangara, weldye zut Iaujen=

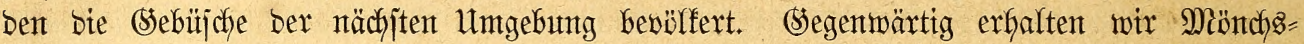
uno Sperlingspapageien, graute unb grüte farbinäle jowte Safranfinfen vorzuggtweije

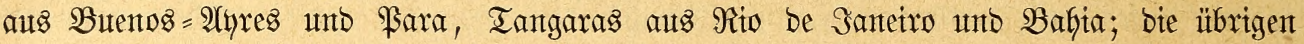
Şäfen liefern wohl einzelne größ̈ere \$apageten, fleittere Bögel aber mut in jefr geringer

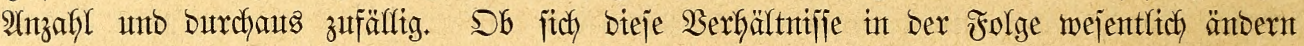

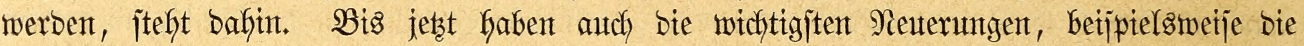

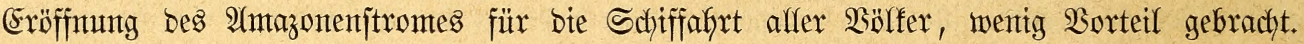
(5:s feflt in ganz Sildamerifa leiber nody immer alfzujegr an Reuten, melche ber herlichen Bogelwelt bes Ranbes die unjeren Wünjchen entjprectente Ieilnabme abzugeminten ver=

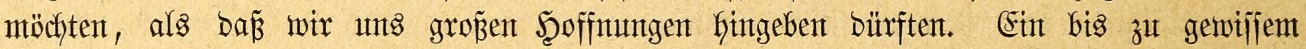

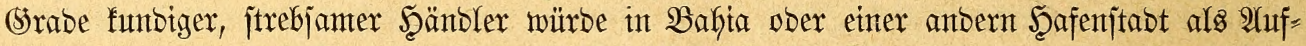
fäufer Der von Den Negern gefangenten $\mathfrak{B o ̈ g e l ~ i n ~ f u r z e r ~ B e i t ~ e i n t e ~ p r a c t y t o o l l e ~ S a m m l u n g ~}$

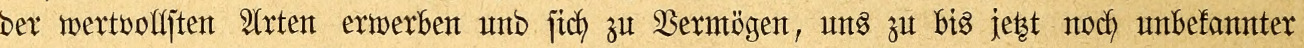
Räfigzierbe verhelfen fönnen.

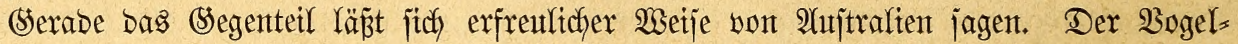

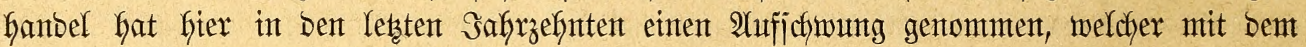

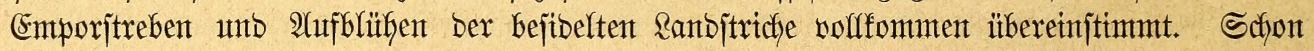

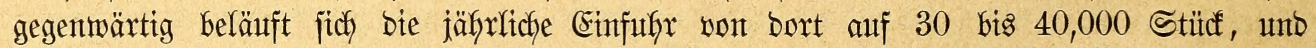

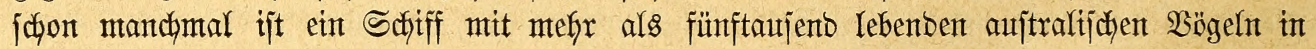
einemt englijcten Scafen eingelaufen. Sm Safyre 1867 jah idy in einem groken, jalartigen

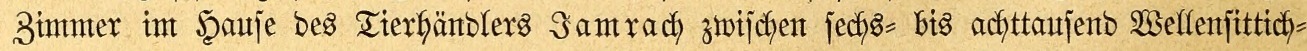
pare vereintigt, zwijchen zwölf= bis jechszefhntaujent Bögel auf jtufenförmtg über = uno hinter= einanber angebradjten, burch bie ganze Ränge bes Zimmers gebenben Sitzitangen aufgereibt,

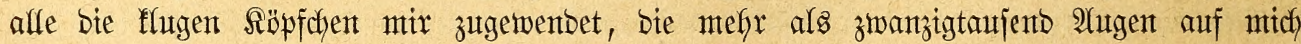
geridftet. Es war bas Sdfaujpiel, weldhes bie Sentegalijten bieten, wieberfolt, etweitert,

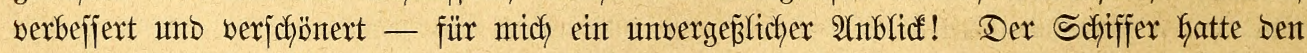

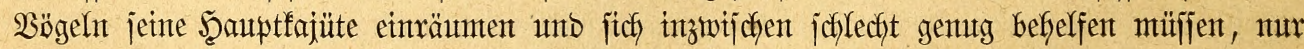
um jie unterwegg zu beherbergen. Untgeadjtet biejer Borjorge jtarben nachträglich bie meiften biejer Sittiche: Der gröp̈te Raum, weldyen bas Sdjiff bietent fonnte, war ifnen boch viel zu eng gemejen, unb Mangel an sidfyt und suft hatten unter ifnen ben Reim zu töblidjer Sranffeit gelegt. Ein joldjes sejchefnis entmutigt zmar einten Schiffer, wizigt aber bie übrigen uno lefrt jie, ifyre $\mathfrak{B}$ b̈gel befjer zu befgantbeln.

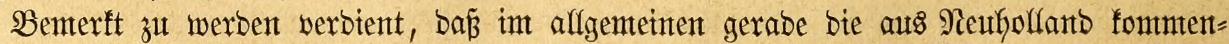
Den $\mathfrak{B a ̈ g e l}$ unterwegs entiprechent gepflegt werben, beshalb auch meijt in jefr gutem $3^{\mathfrak{u}=}$ ftanbe bei uns eintreffen. Dies banfen wix zunädyjt benjentgent Seänblern, welche mit ifyrent Bögeln reijen. Urjprünglich unternafymen fie bie Reije hauptjächlich bes Ranarientbogels

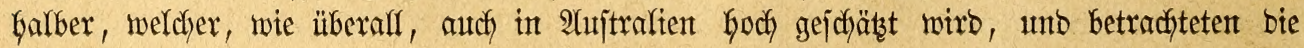




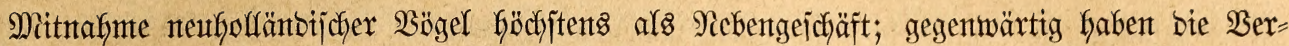

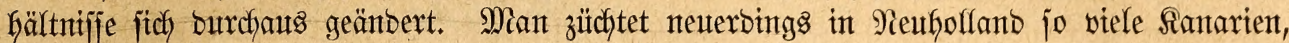

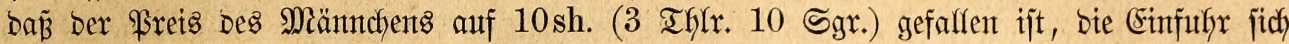

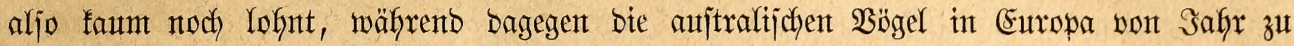
Safyr mefyr siebhaber geminnen. Die Scänbler, grop̉enteils Deutjche, bereijen das Sntmere Des Rantbes nitht, jonbern faufen in ben Bogelläben, welche man in alfen Seeptäbten finbet,

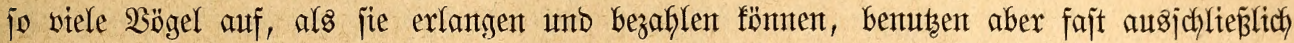

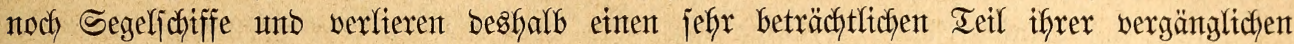
Ware. Setr $\Re$ awerau, bem idf vorjtehende Mitteilungen verbanfe, reijte im Safye 1867 mit eintem beutjchen Şänoler nach Şauje, welcher jojon zunt fünften Male unterwegs war,

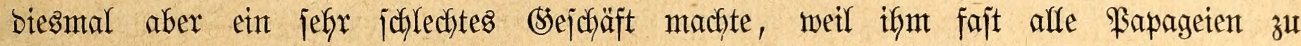

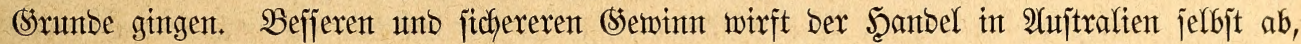
weil bie 2 Geizen alfgemein ben einen ober anbexen $\mathfrak{B}$ ogel Galten unto boch nicht jämtlich

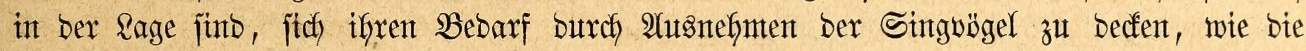

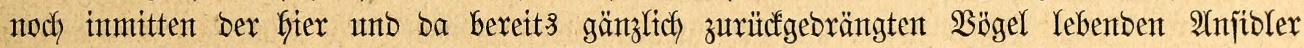
es tun. ßapageten uno Flötentögel fino bejonbers beltebt, weil fie fich abrichten lafjen;

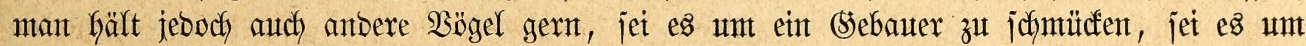
bas (seböft zu beleben; - ich werbe auf bie beworzugten Ârten zurüdfulfommen haben.

Der Şauptfang finbet alfjäfrlich währent bes Frïflings, umjerent Şerbjte, und nach

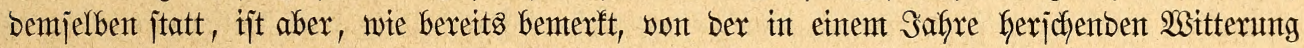
burchaus abfängig. Nitcht in jebem Jrüflinge exjdjetnen bie Wanberbögel im Sïben auf Den befannten Brutpläben; oft genug bleiben fie aus, wenn Mangel an Regen einen Rands

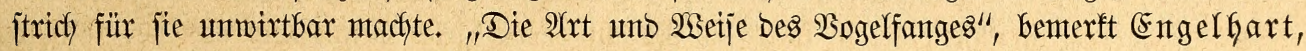
weldyer mix Göchjt anżehentbe Beobachtungen mitgeteilt hat, "iït wohl überafl, wo Europäer leben, mefhr ober mentiger biejelbe; aber afferorten exforbert ex, baß̃ ber Fänger, welcher

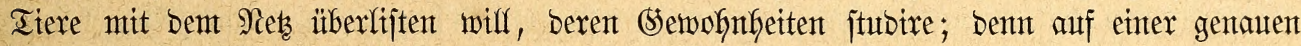
Renntnis ber Rebensweife berubt jein Erfolg. Ein jo merfwürbiges sant wie Silbauftralien, befien alima jo unbejtäntig ijt, beffen (Srasmudts unmittelbar abbängt von ber Mienge Regenwafjer, welche in jebem Sahre herabfällt, hat audy jeinen Bögeln ben Stempel ber

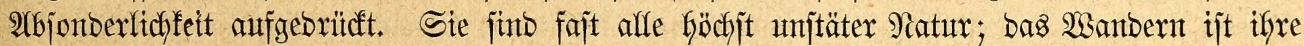
sujt jo gut als bie bes Müffers. Sie ridyten ifye wantorzüge nach) bent jemeiligen Stanbe ber Bräjer ein unb exjcheinen beshalb an gemiffen, vom Waaffer begünjtigten

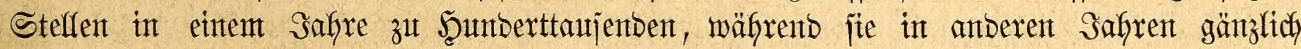

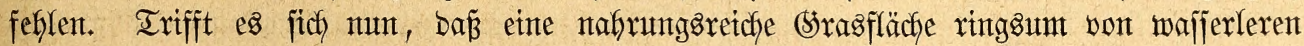

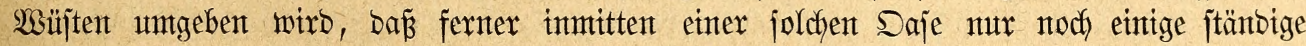
Sajferläufe allen in ber Saje vereintgten Bögeln zut Iränfe bienten müfjen, jo entgeht

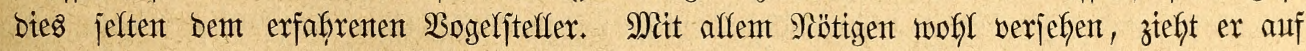

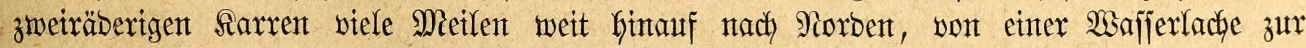
anberen, beobachtet genau bas Ireibent ber $\mathfrak{B}$ g̈gel unt beginnt jeinen Fantg. Sjt biejer

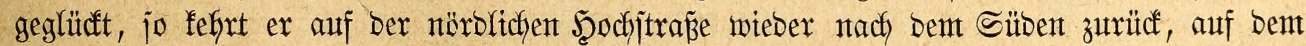

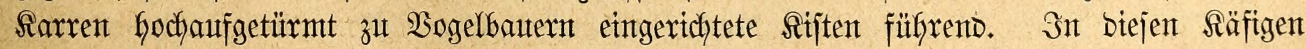

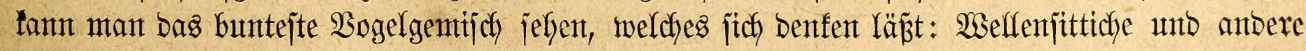
Bapageten, Bebrafinfen, Diamantbögel, Schopf=, Bronzeflïgel= unb anbere Tauben - alle

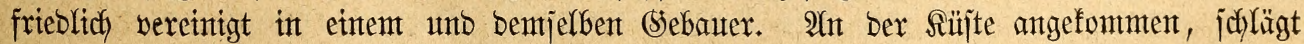
Der Fänger jeine Beute entweber rajh an bie Sä̈nbler los ober bietet fie einzeln aus, finbet auth intmer und balb willige refonefymer."

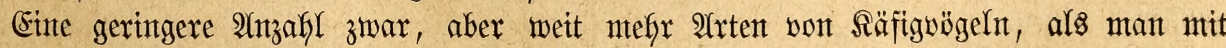
Rekzen fängt, werben von Schäfern unb Ranbbauern ober vielmebr beren hoffnumgsbolfen 


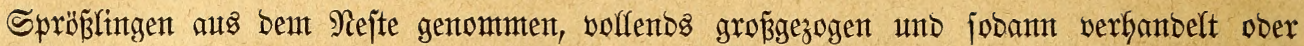
won ben noch vorthanbenen Utreinwognern in berjelben 23 eife erbeutet unto nach ben Sibe=

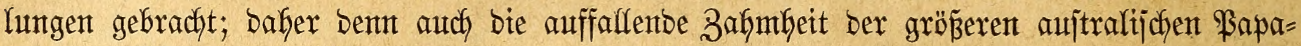
geient, welche ztt uns gelantgen.

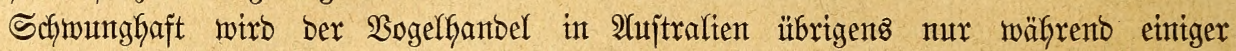

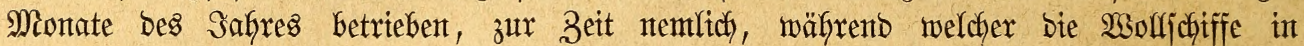

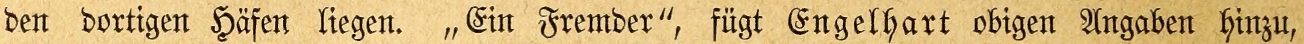

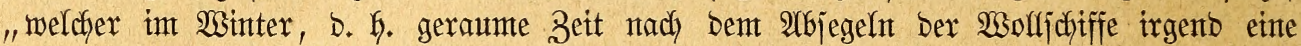

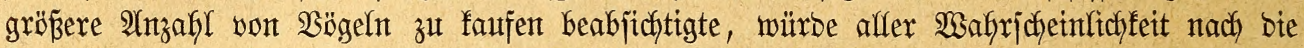
Räbent ber Şänbler ler unb bieje jelfjt anbermeitig bejchäftigt finbert. Surrz bebor bie

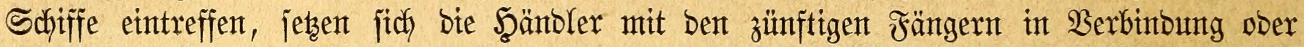

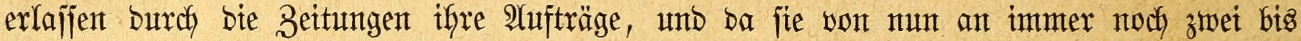
brei Mionate Zeit Gabent, bevor fie bie benötigte Mienge abliefern müffen, fällt es ihnen in

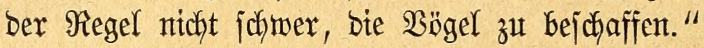

Das reiche 2(fjent liejert uns gegenwärtig überaus wentg, jo erwünjecht auch affe vont

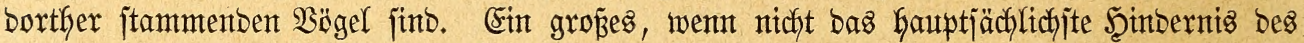

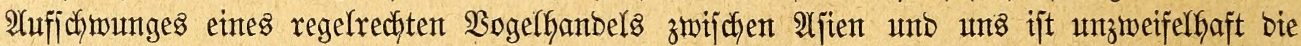

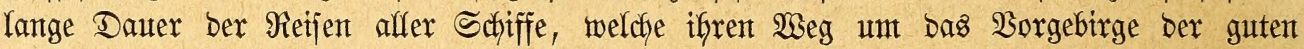

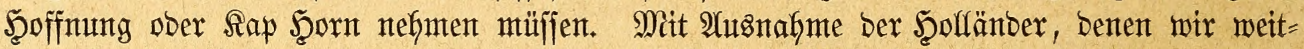

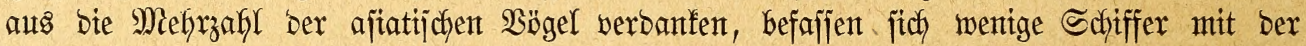
Ueberbringung unjerer Rteblinge, jo erfeblich audd bie Sinmmen fint, weldhe Tiergärtner

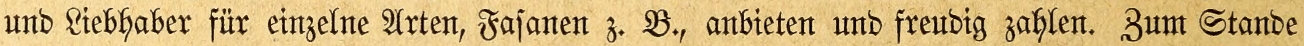

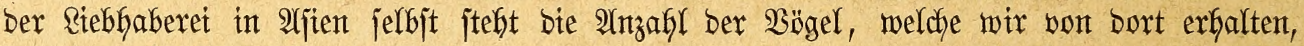

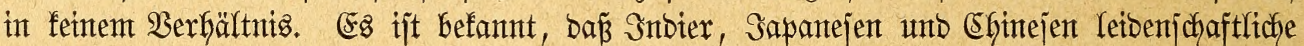

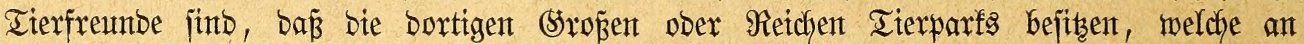

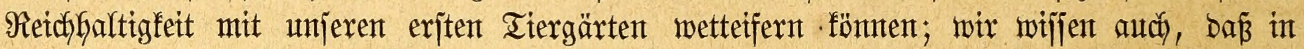
Den genannten Reidfen, wie in ben übrigen jübajiatijchen Staten ein regeirechter Şanbel betriebent wirb: wir erfalten aber won borther, abgejehen wont benjentgen 2 (rten, weldhe uns eifrige Ranbaleute vermittelf, immter mur bie jeit Safhrhumberten in Europa lebent einge=

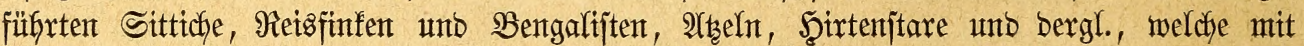

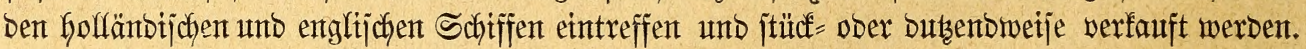

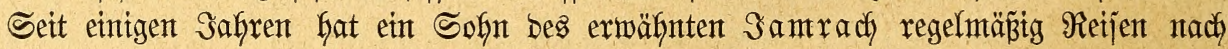

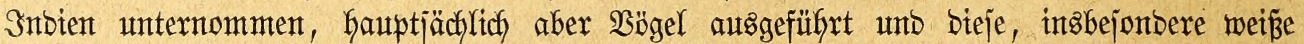

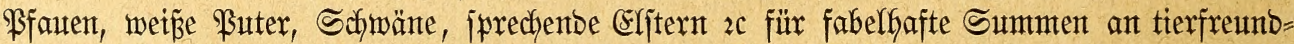

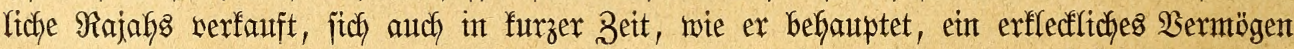

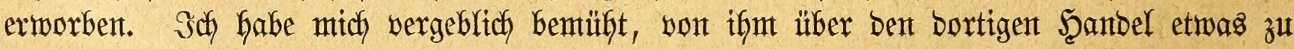

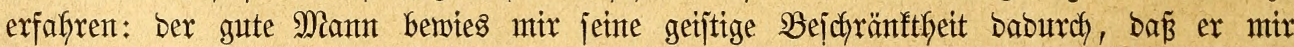

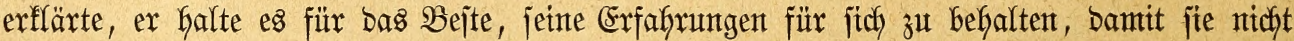

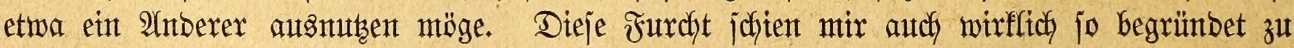

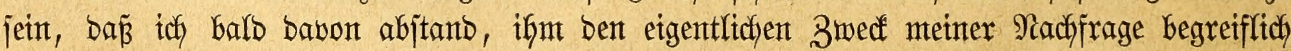

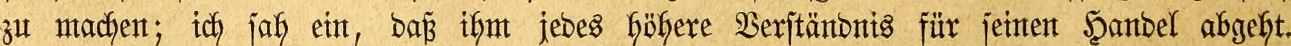

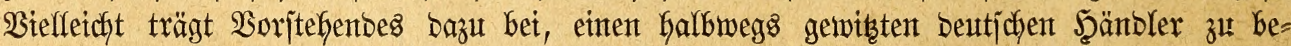

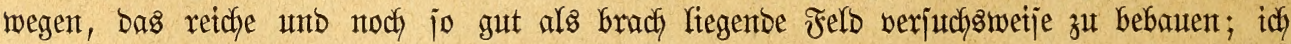

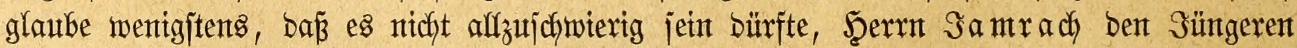

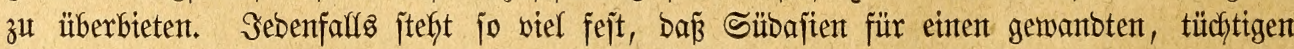

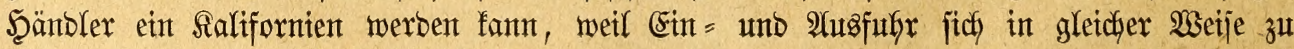
lohnen jojeinen. 
3weiter $\mathfrak{A}(\mathfrak{b}$ ids)nitt.

\section{Sittide ader $\mathfrak{B a p a g e i e n .}$}





\section{(befaumtbild der (D) rommuta.}

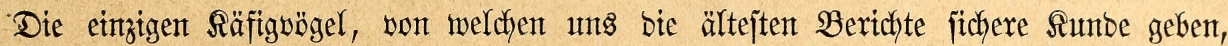

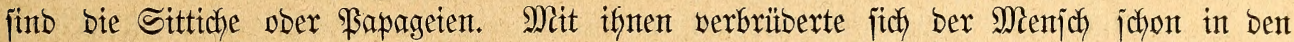

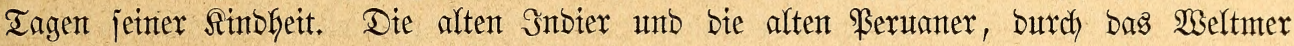

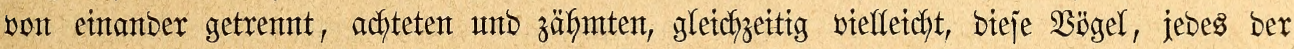

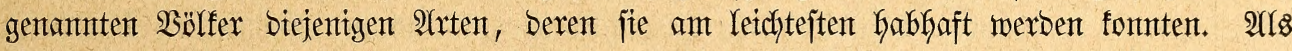

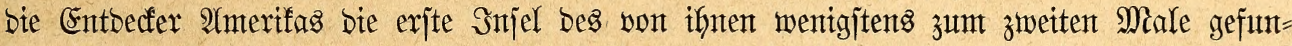

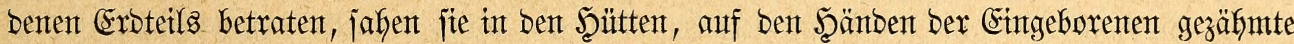

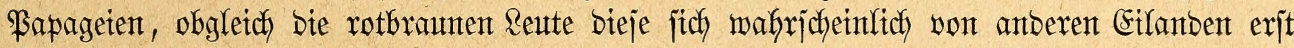
werichafft Kattent, ba man gegenwärtig annimmt, baßj bie erjte Snjel, weldye Colon mit

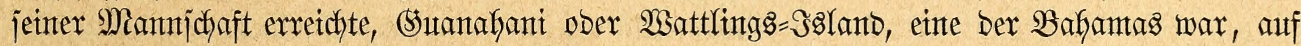

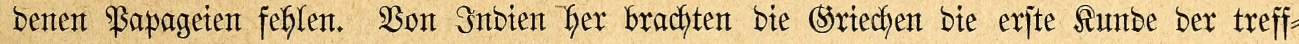

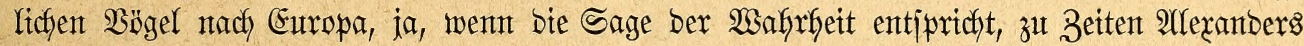

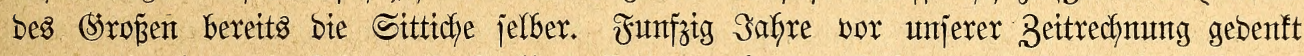

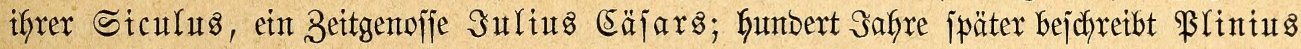

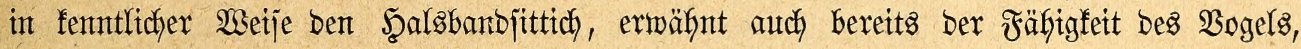
menjchliche Worte nactzuafinten.

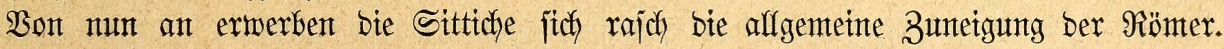

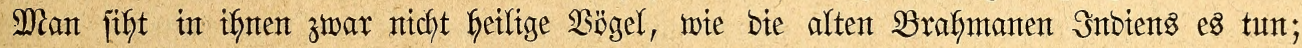

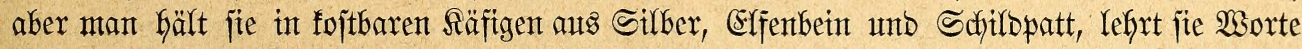

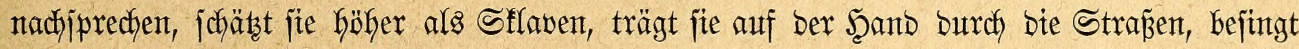

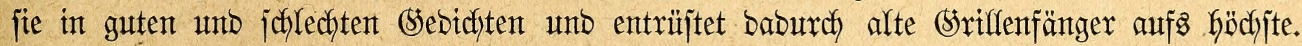

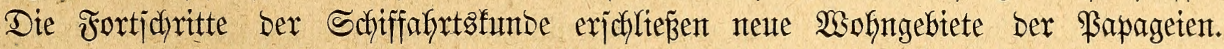

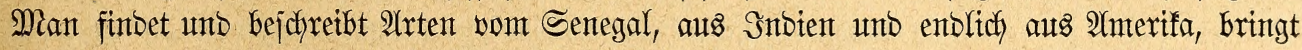

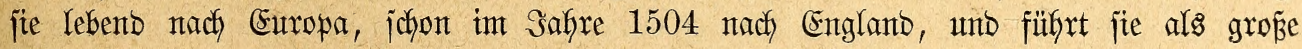
Seltenfeiten im Ranbe umber, verwendet fie, neben Rammerferren und Edelfnaben, neben

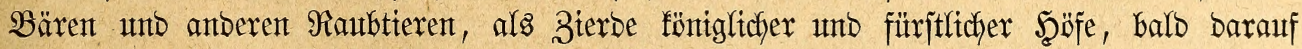

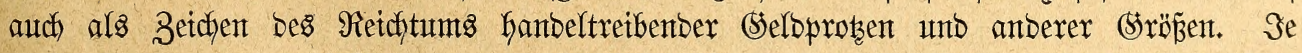

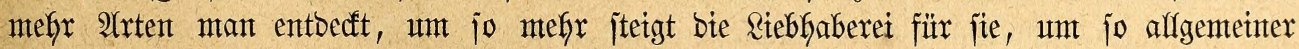

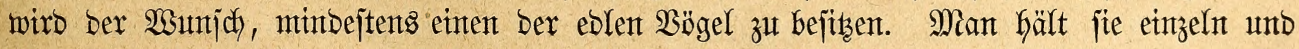

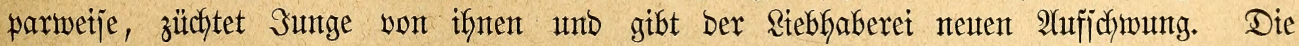

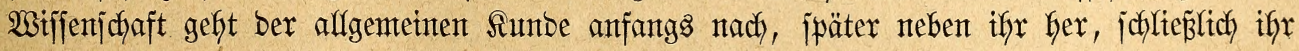
voran. Mian bejdyreibt und bilbet ab, bejdreibt wieber, werwirrt bie Maturgejefidute, wer=

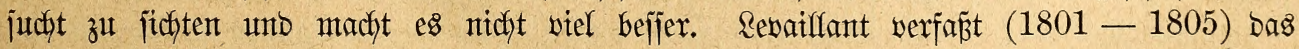

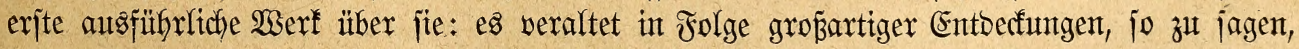

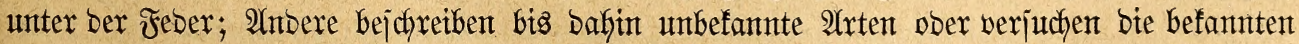

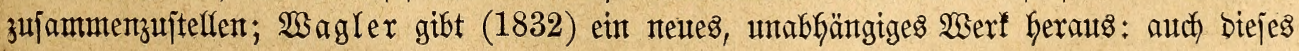




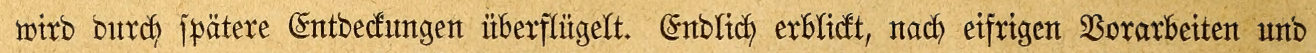

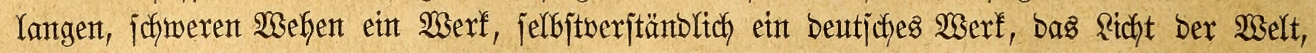
bas bejte, weldyes jentals ïber biejen Segenjtand gejdyrieben worben, bas bejte, welches wir Gaben: Die \$apageien, monographijh bearbeitet von Dtto Finja zc. Reiben, bei Brifl, 1867 u. 68. Mit biejemt trefflichen Buthe, weldyes jeber Papagetenltebfyaber, will

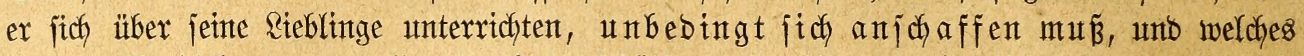

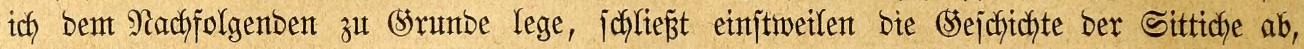
nicht aber auth ifre Sunbe, an beren Förberung unt Sermefyrung gegenwärtig fleip̈tger gearbettet wirb als je. Bom vergolbeten (Seftell am Fürjtenfofe, aus ben Tierjchaububen Into Tiergärten finto fie allmählich biz in bie Räfige ber Riebfaber gelangt und haben fier ifre wafren Freutibe, ifre untermitolidyen Beobacter, eine zweite Sceimat gefunben. Shre

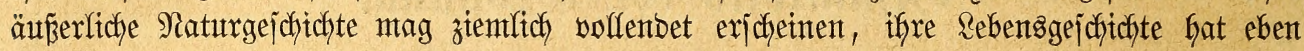
exjt begonnen.

Die Sittiche jüto, größ̈tenteils mentgitens, in ben Ränbern zwijchen ben Wenbefreijen Geimijch. Bon ben 355 Arten ber Dromung, weldye Finjdy bejdyreibt, hat man biesjeits bes Wentefretjes des Arebjes in afjen 6 , in Armerifa 2 Arten, jenjeits des Wentefretjes

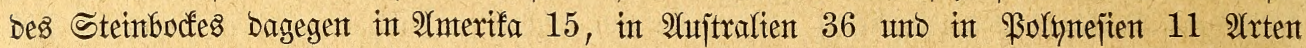

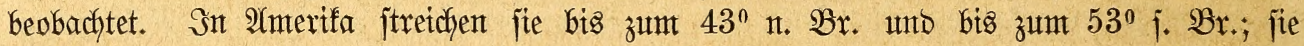
würben aljo noch recht gut in Europa gebeigen fönnen. Shre eigentliche Seintat ift 2(merifa; es jtefjt mit 142 befannten $\mathfrak{A}$ rten unter ben übrigen Sebieten oben an. Das Ssebiet ber

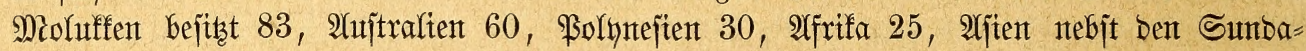

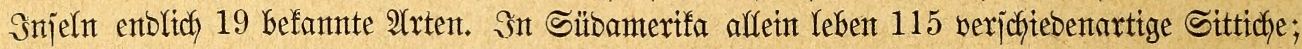

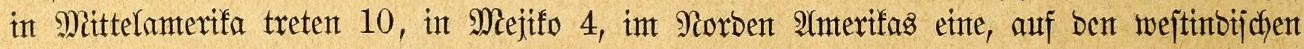

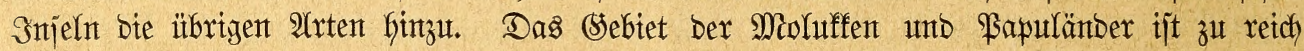

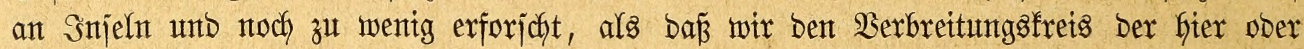

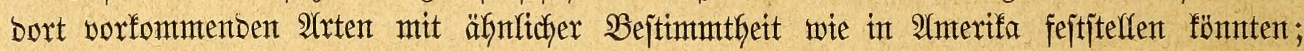

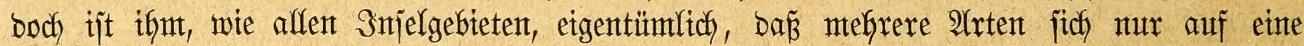
Injel ober mentige benachbarte Eilantbe bejdyränfen. Die Mefrzahl aller in biejent Bebiete

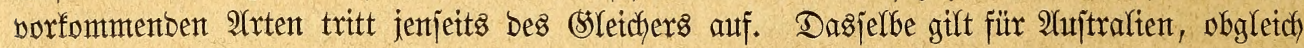

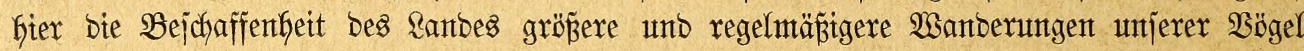
bebingt, als bieje fie anderswo auszufüfren pflegen: won ben 54 befanten 2 rtten fommen 36

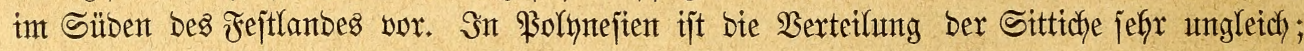

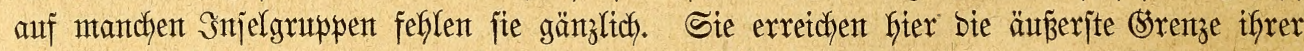

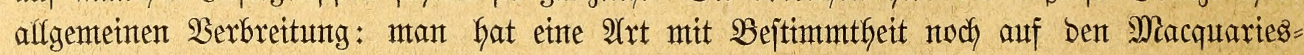

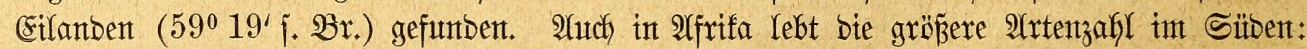
nach Norben fin bilbet ber $16.0^{\circ}$, nach Sïben fin ber $34 .^{\circ}$ bie (Strenze ber von ifnten bewohnten

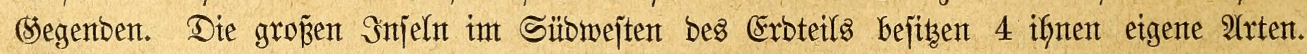

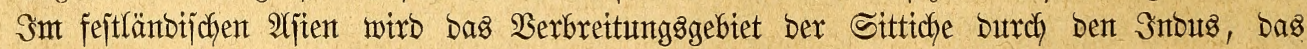

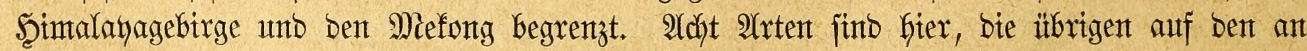
umjeren $\mathfrak{B}$ b̈geln auffallent armen Sumba $=$ Snjeln beobachtet worben.

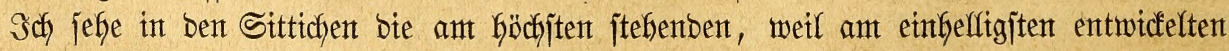
Böger, und habe biejer Injicht jubn vor einigen Gabren int "Tierleben" Worte geliehen.

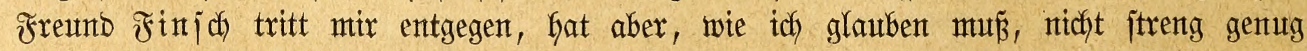
feitgefalten, baj ich ein Sejamtbilo ber Dronung (in jeinen Âgen Framilie) zut ent= werfen vexjucht hatte. 2(uch meint Finj

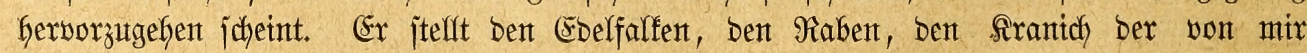
hocherbobenten Sittichgentijenjchaft gegenüber, anjtatt bie Raubvögel inggemtein, bie jämt=

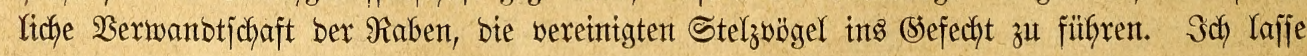




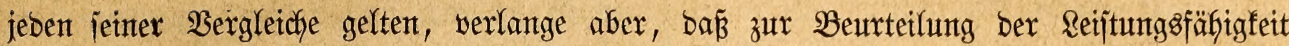

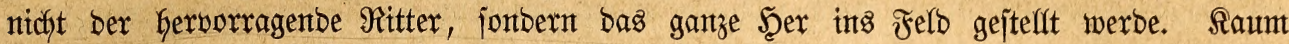

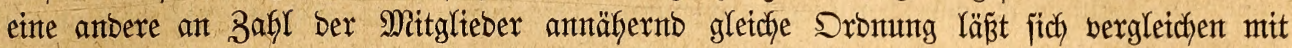

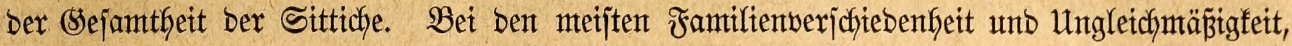
Gier Hebereinitimmung unt Einfeefligfeit: Die ganze Sruppe wie aus einemt. Sulfie, bie

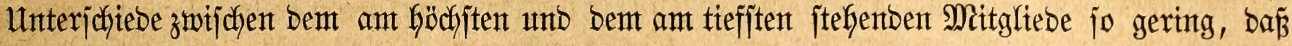
es jelbjt meinem alles und überall vergleidfenten Freutbe, ebent unjerent Meijter Fintid,

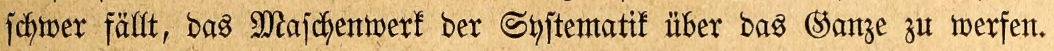

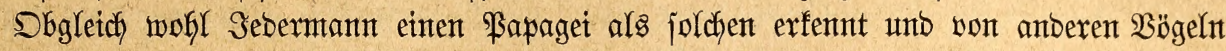

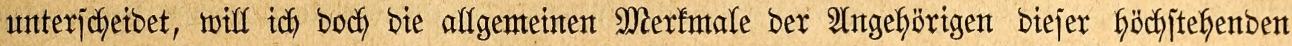

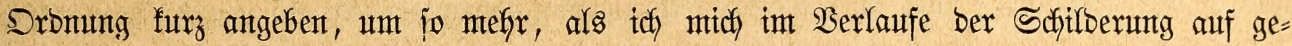

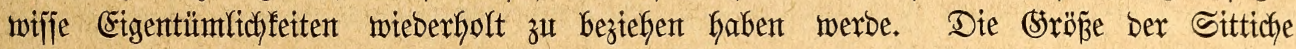

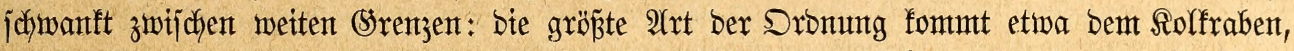

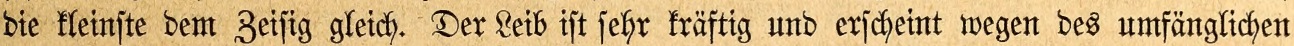

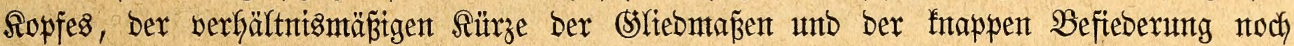

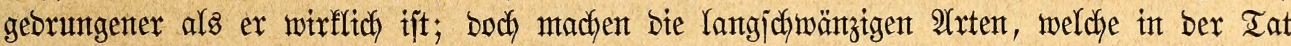

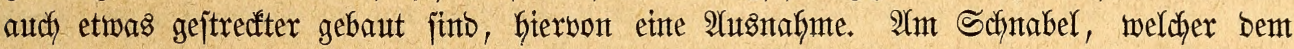

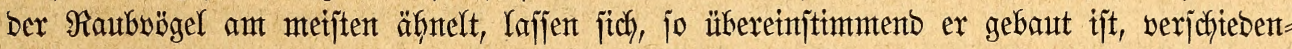

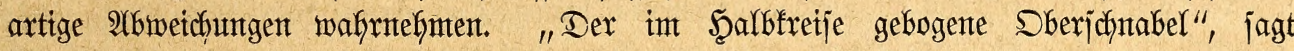

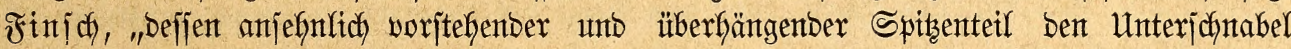
bebeuteno überragt, ift jeitlich flach gemölbt, ebenjo ber an ber $23 u r z e l$ jefjr hohe Unter=

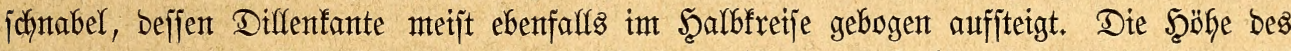
Sdynabelz an ber 23 urzel, weldye hier bie Breite meijt um noch einmtal übertrifft, ift baher

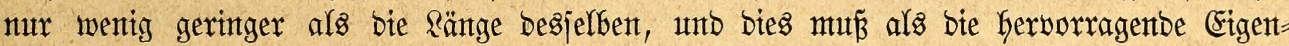
tümlidffeit bez Bapagetenjdynabelz betradytet werben." Sei ben eiren ijt ber Sdynabel fürzer, bei ben anberen länger, bei biejen ntefr abgerunbet, bei jenen jeitflich zujantmten= gebrüuft utto bann meijt auf ber Firijte fantig audf woffl janft gefurcht 2 . Die Riefer=

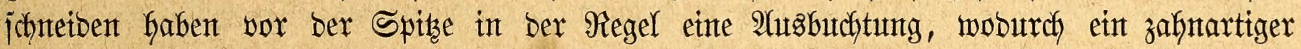

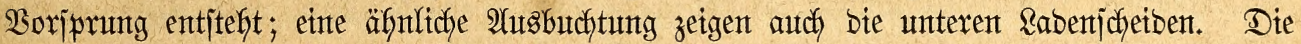

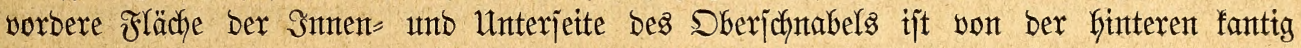

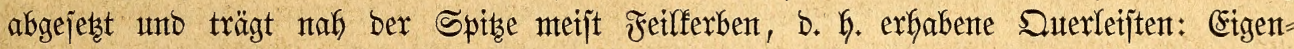

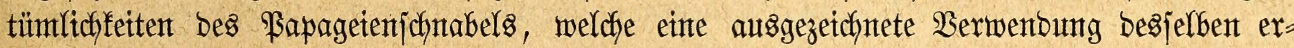

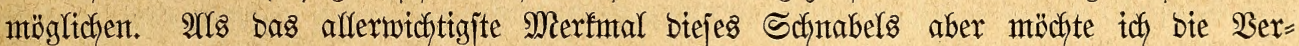

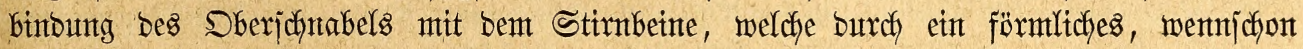

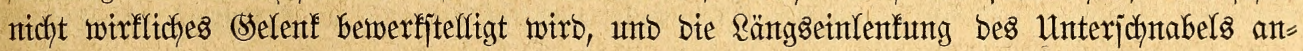
jeken - zwei weitere Eigentüntlichfeiten, weldhe ben Edynabel ber Sittidfe vor bent alfer

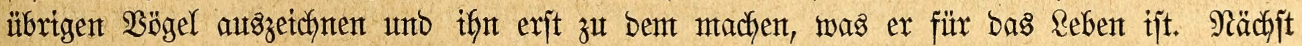

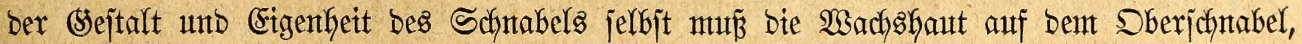

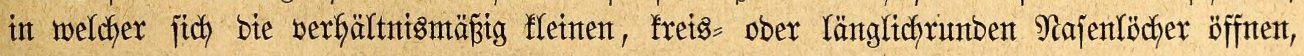

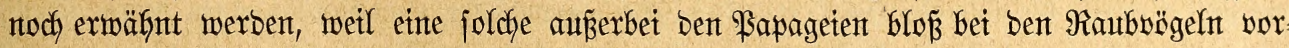

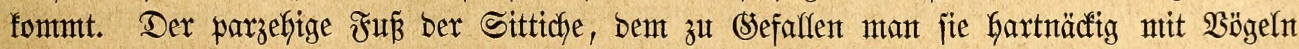

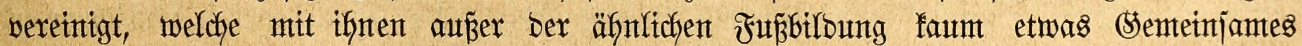

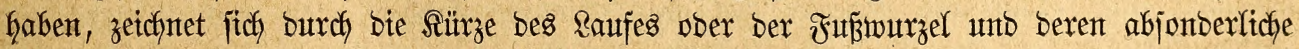
(Sejtaltuntg auz; unter ben Zefent ijt bie äuneere, vorbere meijt bie längíte, bie innere fintere Die fürzzejte; bie Srallent finto fräftig, jtarf gefrümmt unto jpitzig; bie äuñere befleibunt

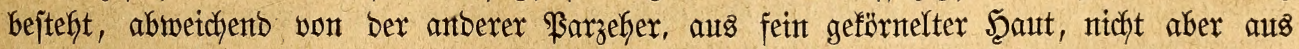

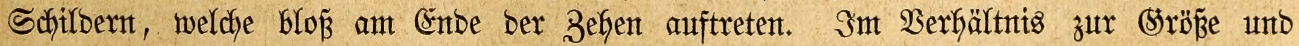
Sdywere ber ßapageien ericheinen bie Flugwerf 


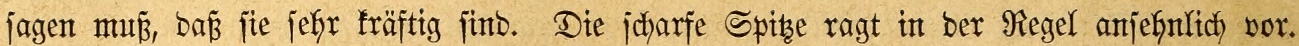

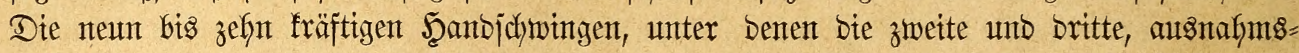
meije bie britte und vierte, bet einer 2 (rt jogar bie jechjite und jiebente bie übrigen an Qänge überragen, haben berbe Schäfte, breite Fafnenbärte unt finb am Ento verjdymälert, jelten verengt ober autggejdnttten unt iptb, ober aber breiter unb bann ab= unt zugeruntet;

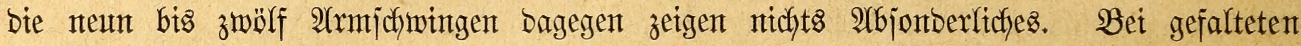
Flügeln exreithen bie längiten Sdymingen gewöhnlich bas Entoe ber oberen Sdywanzbect= febern, ragen auch wobl noch etwas barüber finaus. Arfle Fapageten haben unabänberlich zwölf Schwanz= ober Steuerfebern, beren Ränge unb Jorm freilidh, entipredyent ber Bitoung

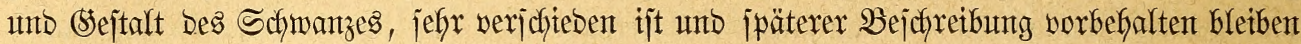

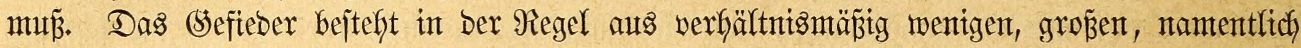
gegen Das Enbe werbreiterten und beshalb abgejtutzt erjcheinenben Febern, beren Fafnen meijt bicht, jeltenter weitjtralig jinto; es fommen jebodh, zumal am Siopfe und Saalje, auds iptis zulaufente, und eigentümlich gebogene, an ber Spize zerjchlifjene, ja jogar fafnenloje Febern vor. Unter bem Sbergefieber itehen nicht jelten bidyte, oft lebbaft gefärbte Dunen.

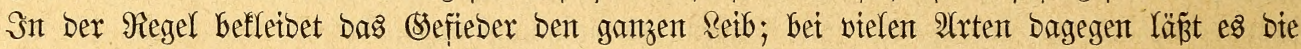

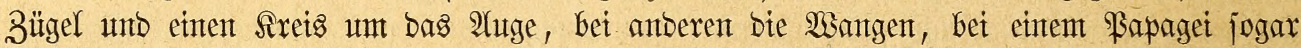

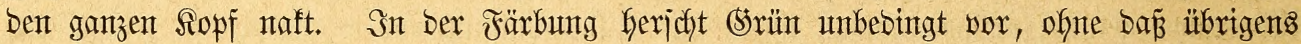
anbere Farben ausgejchlofien mären. Weitaus bie meiften Alrten jind buntfarbig, biele

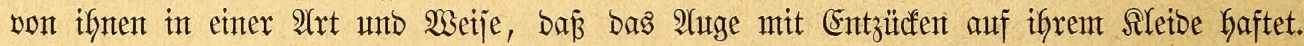

Die Bemegungen ber Sittiche entiprechen ber Bitbung ifrer Stliebmaß̉en auf bas

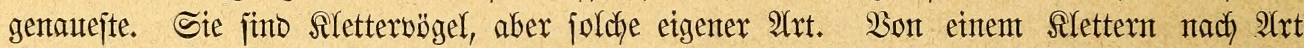
Der Spechte fann bei ifnen feine Rebe jein. Mit ifrem jofarffralligen fllammerfüe um=

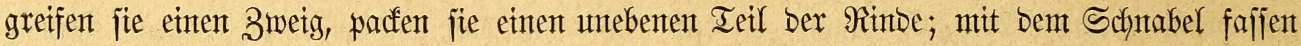
fie einen anberen 3weig ober jonjtigen 2 (nhbaltspunft, weldhen fie erreichen fönnen, zieben

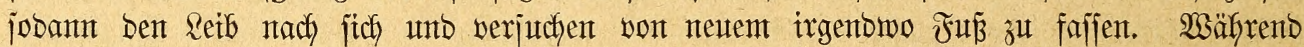
bei alfen übrigen Sletterbögeln ber jü bie Şautptrolle jpielt, ijt bieje bei ifnen Dent

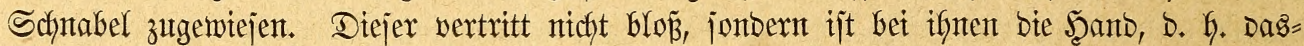

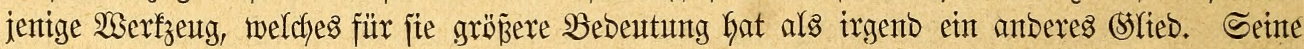

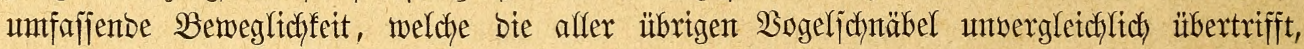
gejtattet bie ausgibigjte Berwendung. Er Dient feineswegg zum Ergreifen, zum Alettern alfein, jonbern audh zum Benagen, Bejdyaben, Meiß̈elnt, Bohren, zu Gunberterlet $\mathfrak{B} e r=$ richtungen überfaupt. 2Anbere Bögel fund ntcht im Stanbe, ifren Sberjonabel in jich jelbjt zu betwegen: bie Sittiche biegen ifg nach oben und jofieben ifhn üfer ben unteren vor nach Belteben; fie jimb fähig, mit ifm allem einen (segenjtand zu ergreifen, feitzubalten und heranzuziehen: man möchte ifn mit einem überaus fräftigen Finger vergleichen. Sn

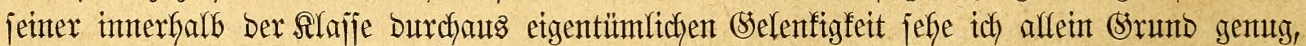

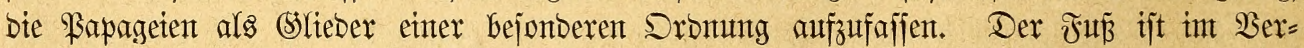
gleiche zu bem Sifnabel minber betweglich, vorzugsmeije auth mux gejdjidft zum Silettern in Der geidfilberten Weije und zum Ergreifen eines (Segenjtandes. Won wentigen Âtusnabmen

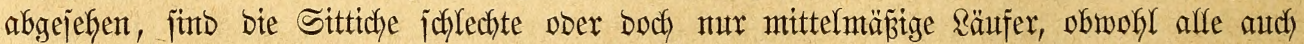
auf flachem $\mathfrak{B}$ oben gehent jich zu betwegen wifjen umb einzelne zu förmllichen Bobentö̈geln

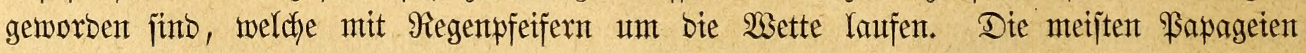

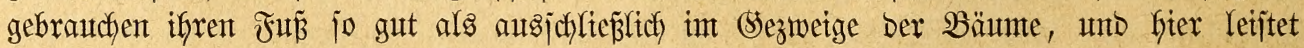
ex ifnen alfe Dienjte, Deren jie bebürftig jund. Heber ben Flug läp̈t jïh im alfgemeinen

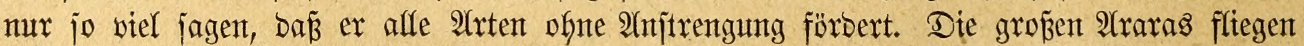

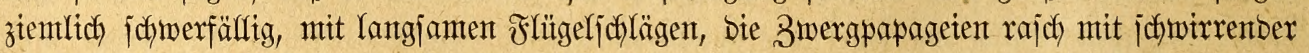

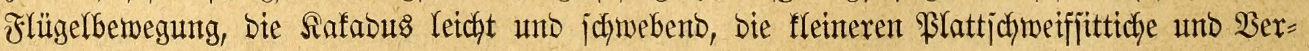




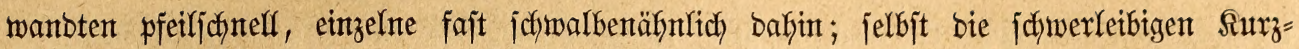

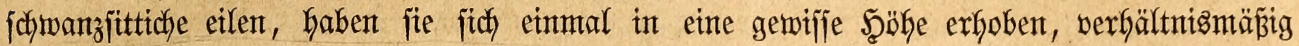
rajd) ifres Weges fort.

Ueber bie höheren Fähtgfeiten fönnen bie Meinungen geteilt jein, unterjä̈üben wirb

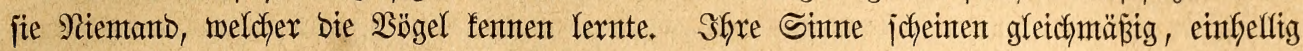
entrwidélt zu fein; verfümmert ijt fein einziger. Die geiftigen Eigemijdaften fint ein wun=

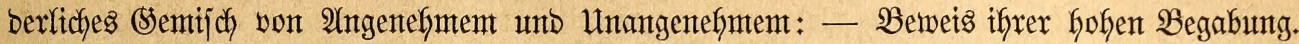

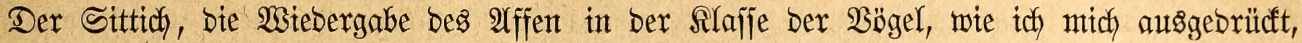

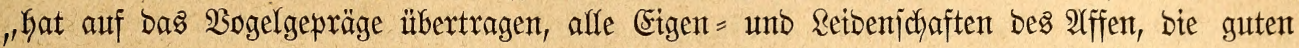
Seiten besjelben wie bie jeffect)ten, Das siebenswerte wie bie Ultarten. Er ijt ber flügite

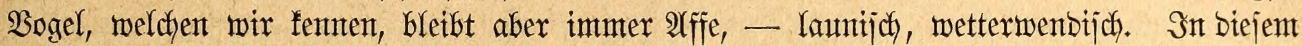

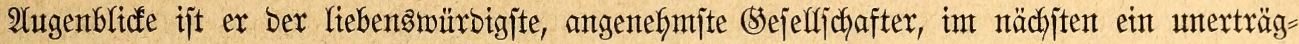

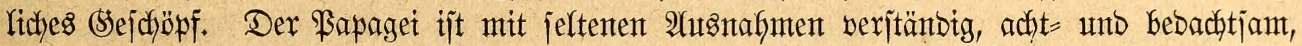

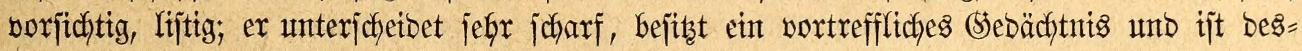

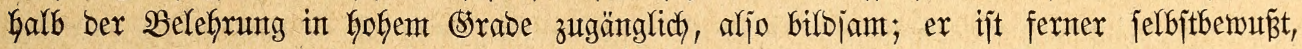

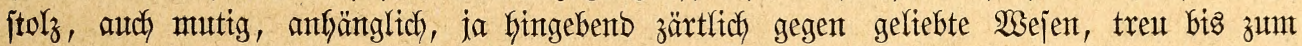

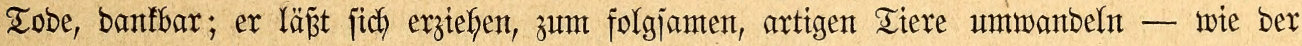

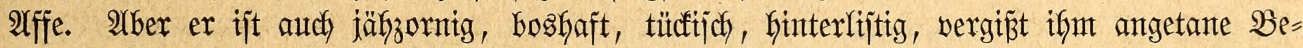

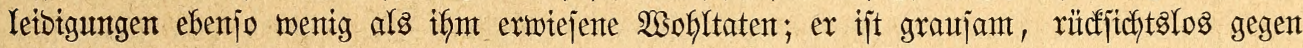

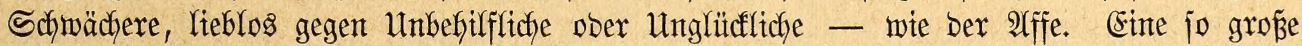

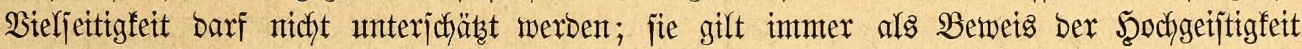
eines (sejüjofes."

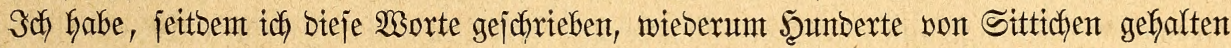

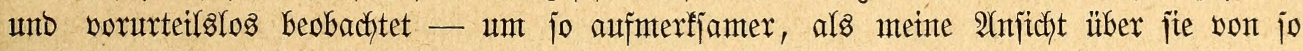

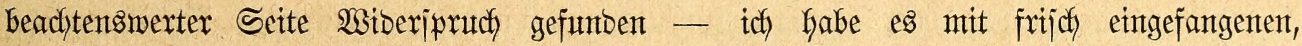

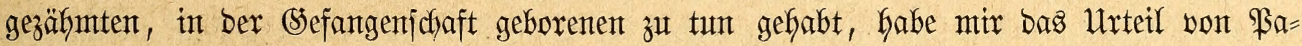

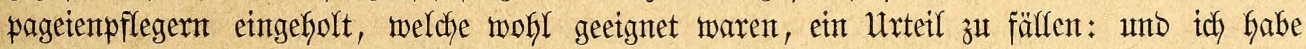

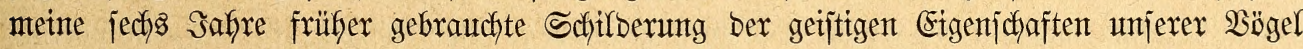
in ber Heberzengung, Dẩ fie rifftig ift, an biejer Stefle wieberfolt.

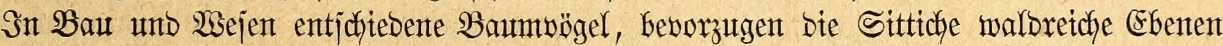

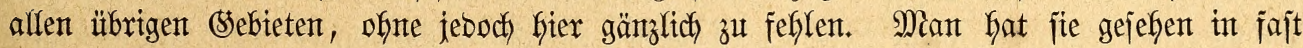

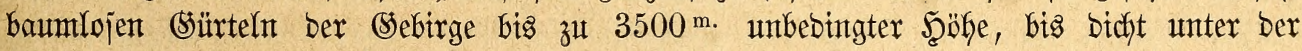
Schneegrenze munter umberfliegent; man hat fie ebemijo beobadytet an aben Feljengejtaben,

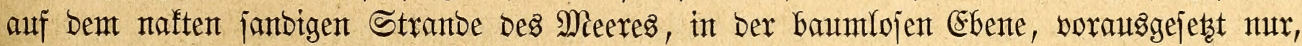

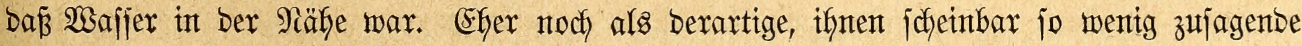
Dertlidbfeiten metben fie bas Snnere meit ausgebefynter, umunterbrodjenter Hrwälber. Die

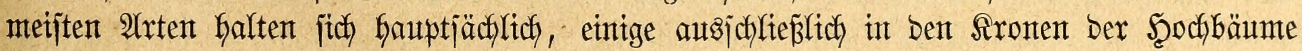
auf; nidyt menige aber fonmen oft unb gern zum $\mathfrak{B}_{0 b e n}$ herab, unto einzelne verlafjen benjelfen mur, wenn fie von einer Stelfe zur antbern flegen, ober aber went fie, aufge=

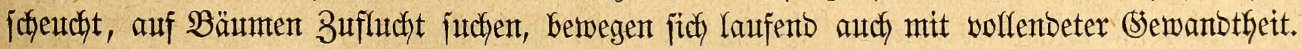

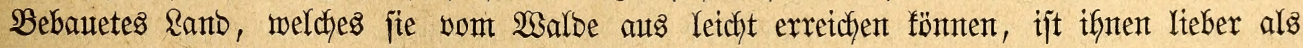

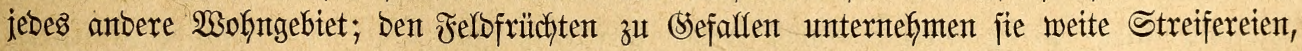

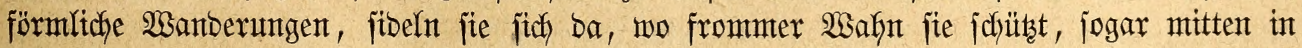

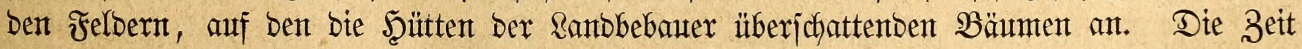

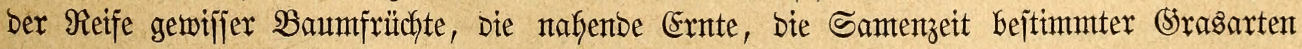

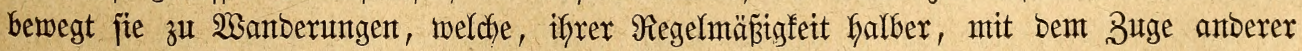

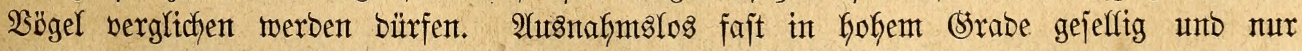

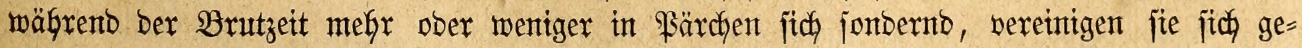




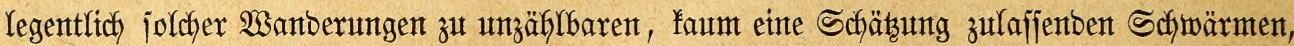

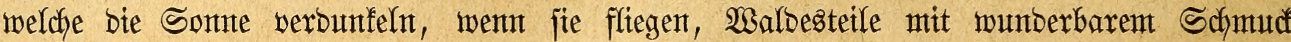

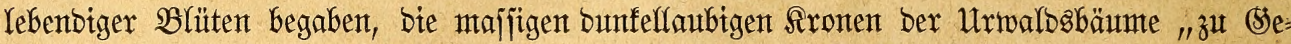

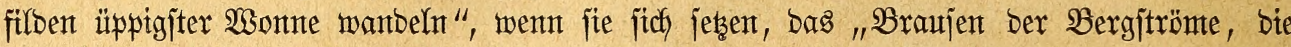
von Fels zu Feljen jtürzen, übertönen", wenn fie genteinjchaftlich ifyre Stinme erbeben.

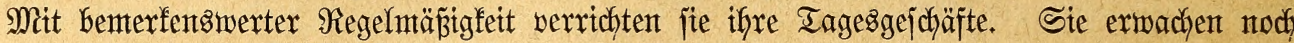

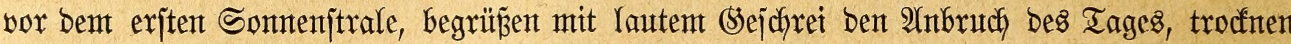
und puzen bas vom Nachttau genäp̆te und gefräujelte (sefieber, erbeben fich jajreiento unb ziehen par = ober truppweije nafrumguerkeizenden Stellen zu, ba wo bas Sselänbe

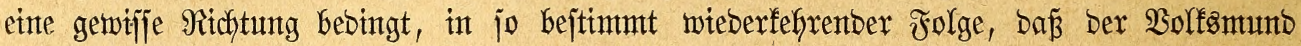

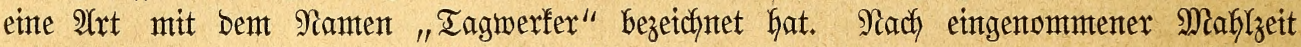

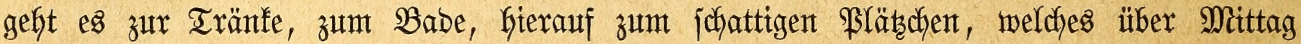

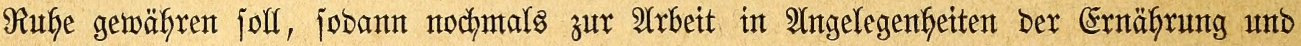

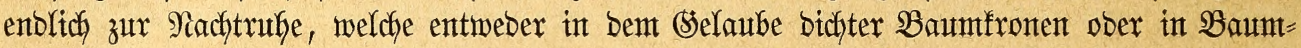

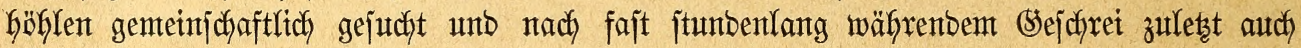
gefunbent wirb.

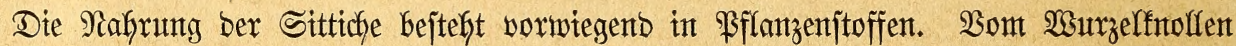
bis zur Frudft, vom Samenforn bis zum Blütenjaft ift ifnen alles Bentep̧bare, meldjes

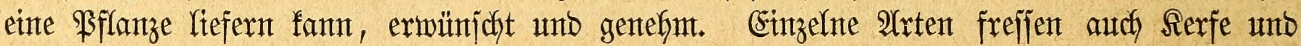
anbere tierijche Stoffe, mebrere joldye nebenbet. Shr mä̈dtiger unb bemeglicher Schnabel

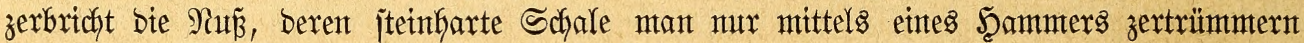

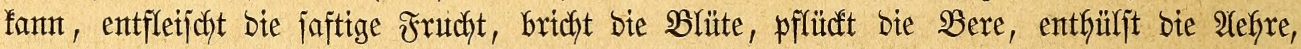

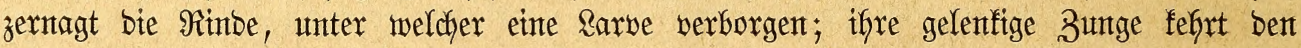
Staub aus bent B̧lütenfeldhe, jaugt Den Şonigjaft ber Eufalyptent unt Şonigbäume auf.

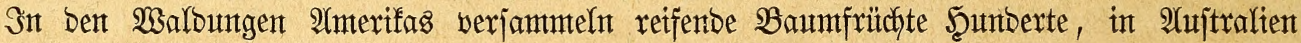

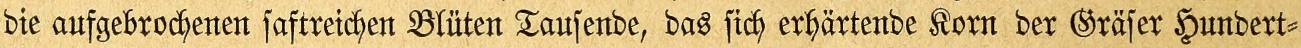
taujente von ifnen; alfüberalf, wo ber umwofntente Menjidy bas Ranto urbar gemacht, einte Pfflantzung angelegt, bas nährentbe forn gejät hat, fallen fie ein, jtehlento, plïntoento,

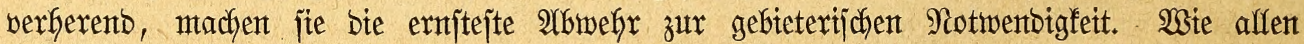
pflanzenfreffenden Tieren jheint Das Salz ifnen Bebürfniz zu jein; fie finben fich bem zufolge, nacy âtrt ber fönerfrefjenten Tauben, auf alfen Sulzen ein ober trinfen jalz=

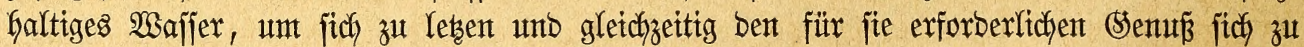
berichaffent.

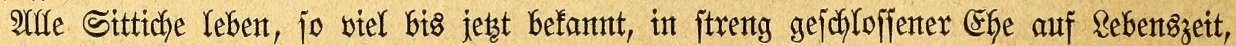

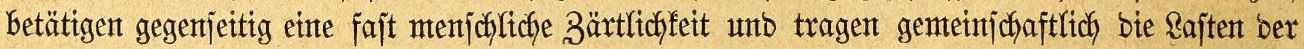
Brutpflege. Aludh int bichtejten Sdhwarme laffen bie bereinigten Färdjen an ifrent treu=

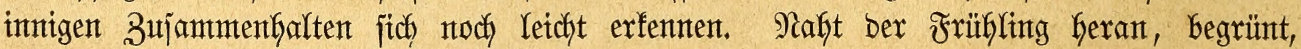

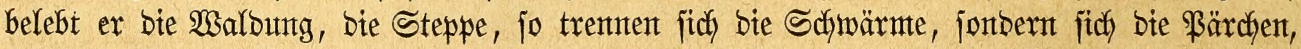

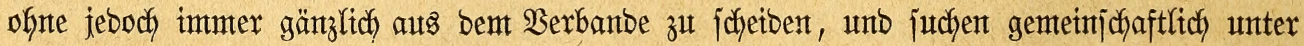
zärtlichem unto anmutigent Siojen bie Brutjtätte fich aus. Sn ber Regel ijt bieje ein vor=

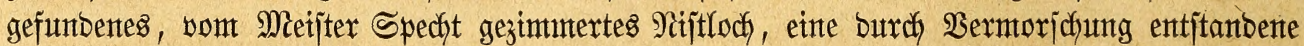
Baumböhlnug, weldhe vielfeidst nodh etwas zuredht gemadjt, an ber Deffnumg ermeitert,

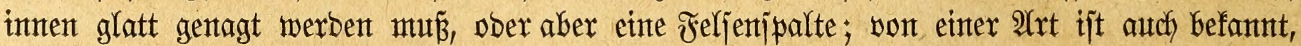

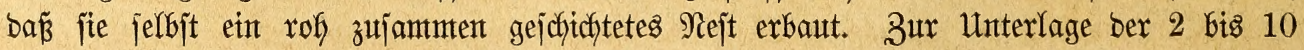
weipen, jef̧r abgerumbeten, glattjafjaligen Eier bient meijt ber abgenagte Matm ober jelbjt ber nafte Feljen; boch gibt es ebenjo Ârten, wahrjedeinlich weit mefr, als mant zux

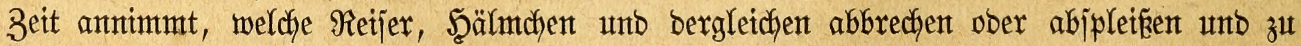
Nejte tragen, jogar in hödfjt eigentümlicher, in ber ganzen Bogelwelt beijpiellojer 2 Beije: 


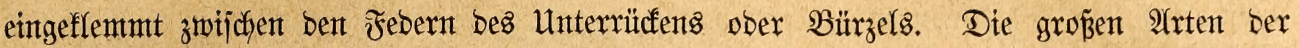

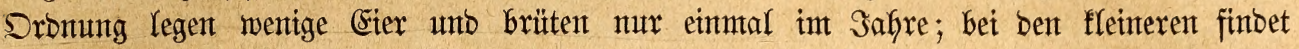

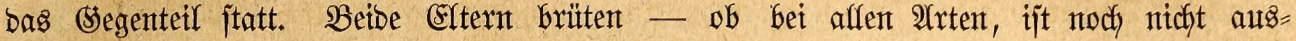

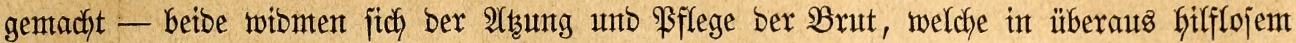

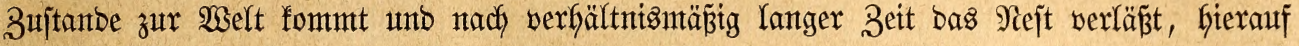

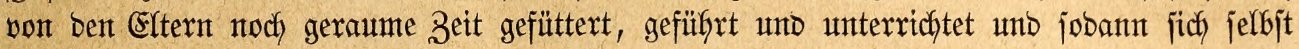

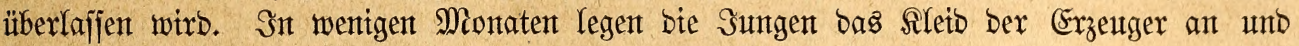
Gaben bamit ifyre Mannbarfeit unb Fortpflanzungsfäffigfeit erfangt.

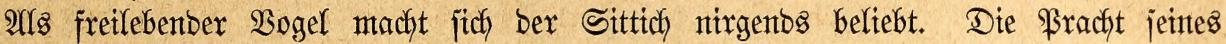

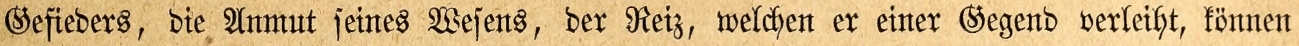

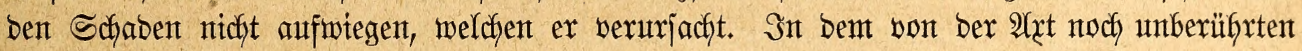

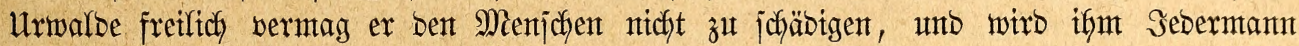

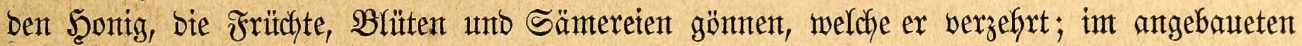

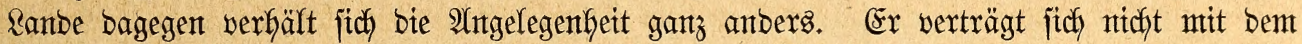

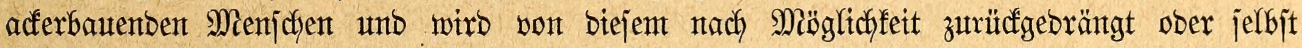

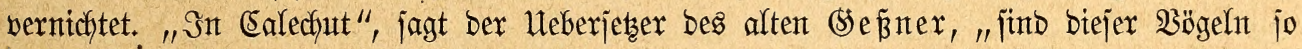

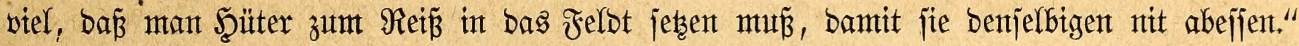

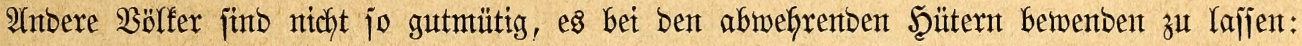

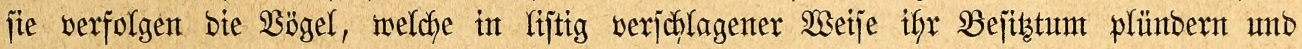

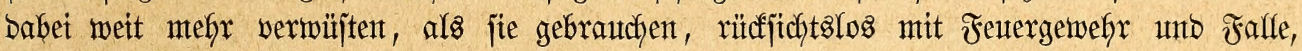

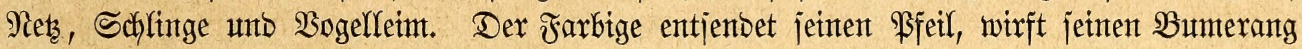

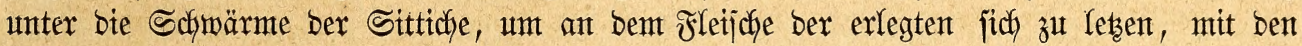

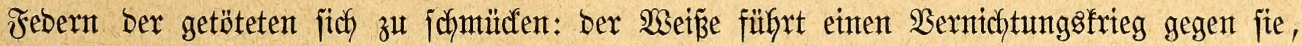

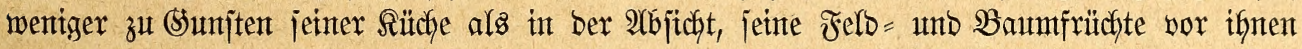

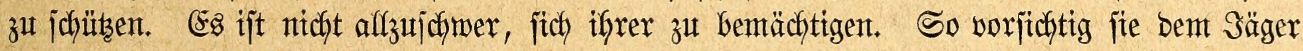

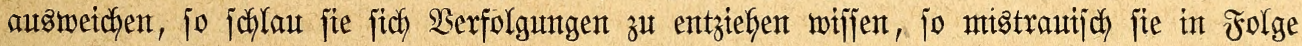

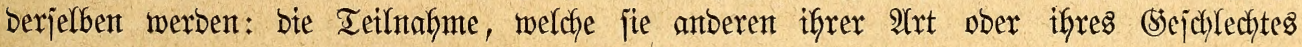
befuntben, Die 3utnteigutug, weldhe fie gegent Die Ssefährten betätigen, bringt fie maffenffaft in

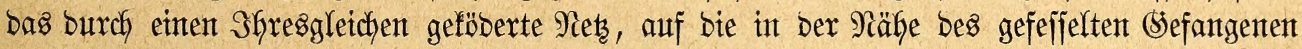

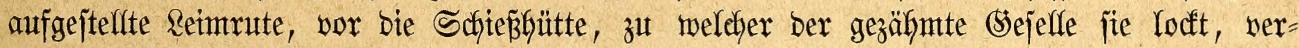

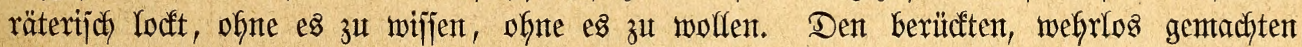

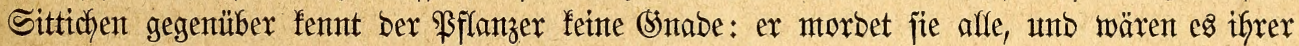
viele Taujenbe.

2(nbers verfähnt ber Fänger, weldher für unz \&iebGaber arbeitet - ber Snbianer, weldfer

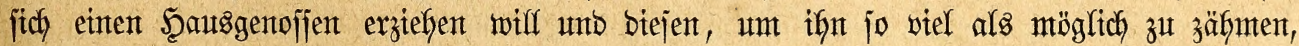

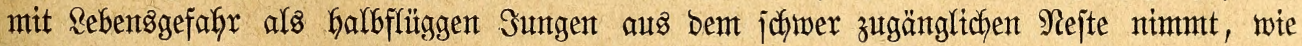

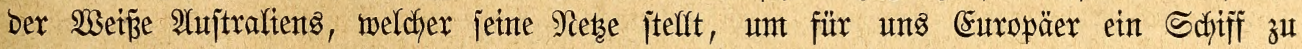
befractiten. SGhten, bemt einen unb bent anberen, jowie bent nidyt aderbantenben Eingeborenten

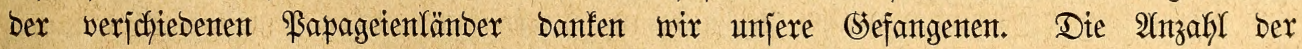

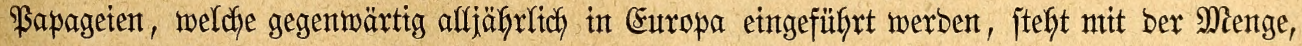

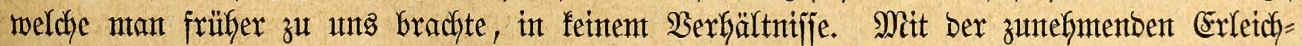

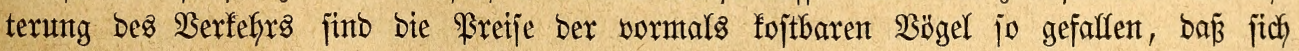

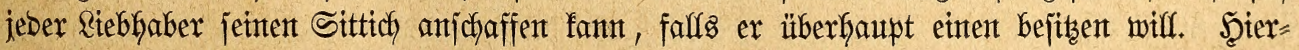

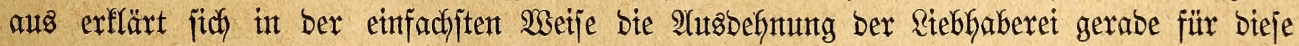

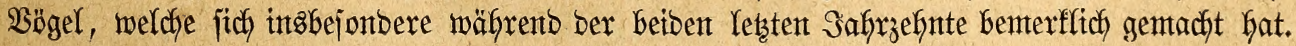

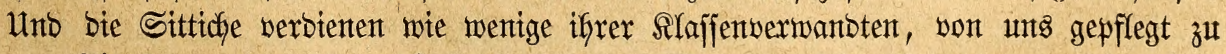

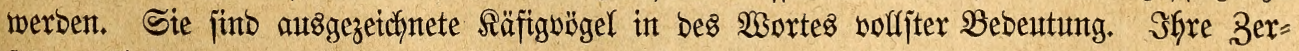

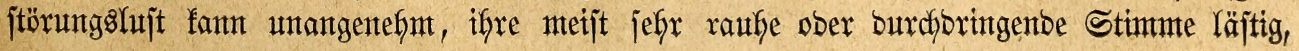




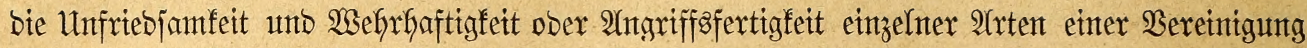
mit anberen $\mathfrak{B}$ ögeln hinberlich werbent: in einemt zmedfentipredhent für fie eingeridfteten Fluggebauter, in Sejelfichaft mit Shresgleichen ober mit verwanden gletchjtarfen 2 trten

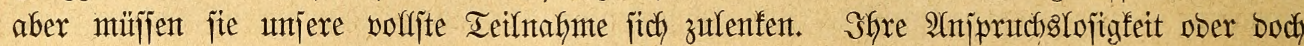

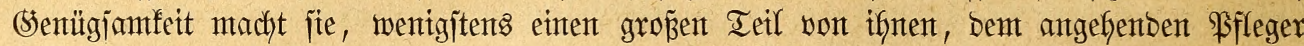
wert; ifre Ranglebigfeit erkebt fie ober bodh einzelne fajt zu (sliebern ber Jamilie; ifyre

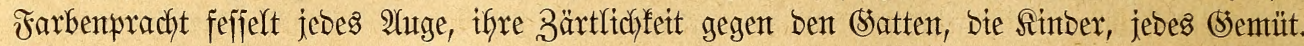
Man mag über fie urteilen, wie mant wolfe: fie nefmen unts früGer ober fpäter für fich

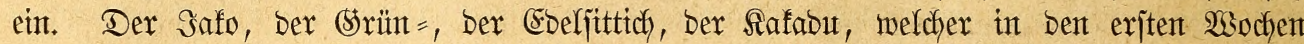
nach jeiner Afnfunft in Europa ein unleiblicher Bogel zu jein jofien, Sebwebem, weldyer ifym jich nahete, mit gräultichem (Sejchnarr, ärgerlidjem (Sejchret, brokento erbobenter Scaube

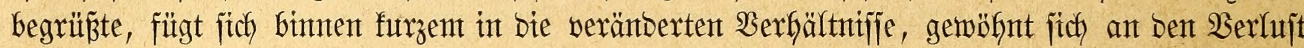
jeiner Freibeit, befreunbet fich mit bent Menjeden, entfrembet fich jeiner Unarten, nimmt

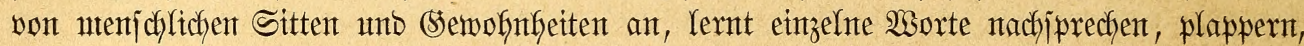
biz zu eintem gentifen (Srabe jogar reben, wirb mitteiljant, zärtlich, Gingebento, befumbet Anteil an Freube und Reid, betrautert tief und lange Sejchtedente und begrüß̈t bocherfreut Burüdffebrende: - er wirb zum Scaustiere in bejtent Sinne. Der fleinere Sittich, möge

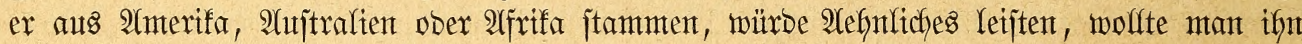
mie jeine beworzugten $\mathfrak{B}$ erwanten befandeln; er genügt aber audh ofnebem ben 2Injprïchen, welche wix an ifnt jtelfen. Bei geetgneter Einrichtung jeines afufentfyaltsortes und ent=

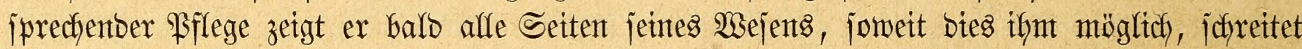

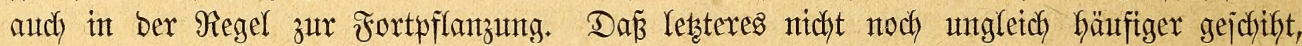

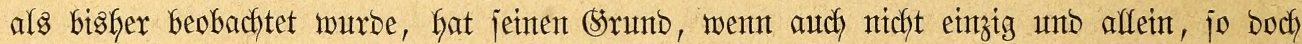

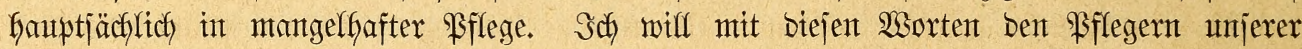
Bögel feinten Bormurf machen, jonbern je mur zu bemegen juchen, fortbauterno neute Ber= juche zu madfen, wie und moburch bieje $\Re$ flege zu verbefjern jein möchte. Unjere Renntnis

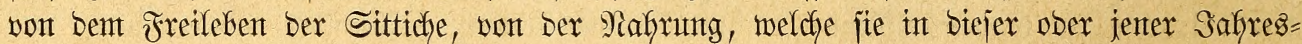

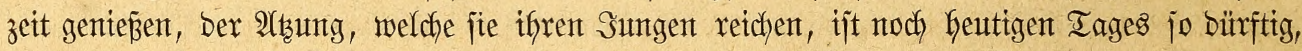

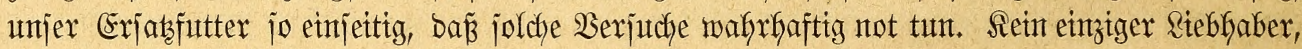
weldher wirflich int Stantbe ijt, Sittidfe zu beobadhten unt zu pflegen, wirb mix miber=

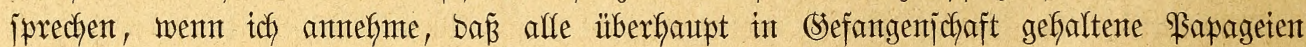

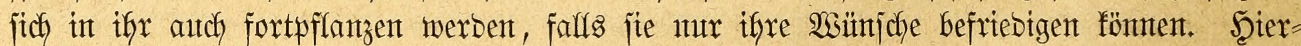

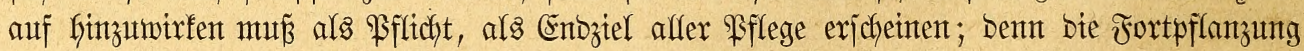

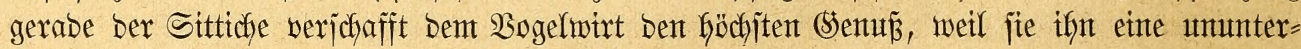

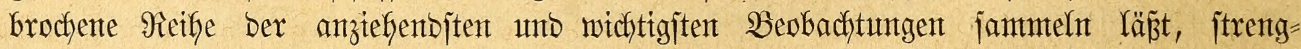
genommen, ifyn jeine Sfleglinge exjt fenten refgrt. Sn ber Neuzeit ijt viel getan morben in biejer Şinficht; aber noch weit mefhr mußs gejchefen, um zum Siele zu gelangen.

Retber balten feinesmegs alle Sittiche jo leicht und bauerno in ber (sefangenjchaft aus,

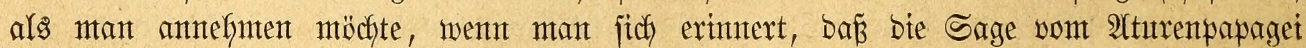

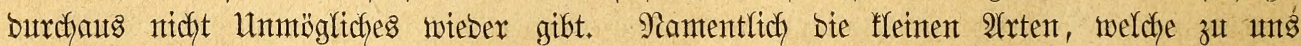
gelangen, finto fajt jämtlich in beflagenşwertem (strabe binfällig; jie exliegen an biejer ober jenter Sranffeit trots ber bejten Bflege, weldhe wir ifnten angebeihen laffen fönnten. Seuchen, welche zumeilen berferento wüten, fint unter Sapageien nidft eben jelten und befaffen mitunter audy biejentgen 2 rten, beren Rebensbanter unjerer menjoyitchen mintbejtens gleidffommt. Darre in affen Formten, Sdywindjudyt und Srebsfranffeit, böвartige Utnter=

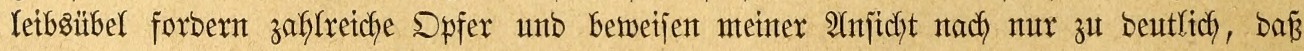
wir noch weit entfernt fint, zu wifjen, weldyes Jutter biejer ober jenter 2(rt eigentfich

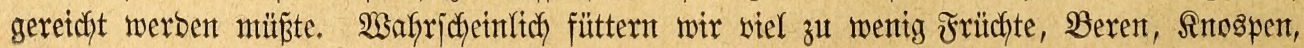




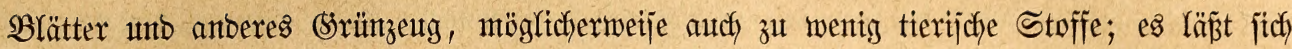
fierüber jebody jefr jefwer ein genïgend begründetes Mrteil geminnen, weil bie Sittidfe zu entjcheibenden Serjuchen benn boch nodh zu fojtbar fint. Die Unart ober Sucfjt vieler, insbejonbere ber größ̈eren 2̂rten, fich jelbjt bie Febern abzubeizen unt auszurupfen, glaube

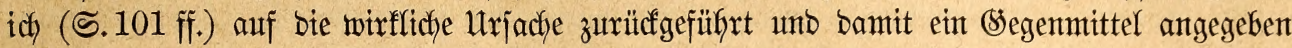
zu haben, welches jicherlich erjprieß̧licher jein bürfte als jebes anbere bisher vorgejchlagene.

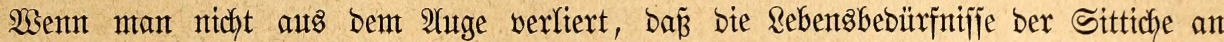

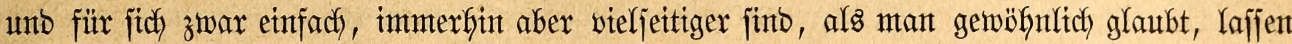

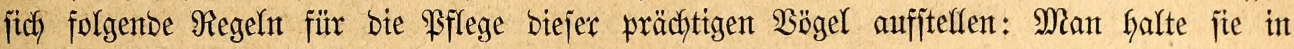

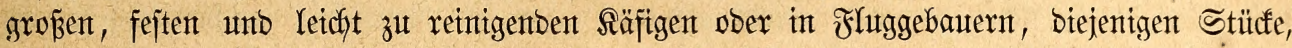
meldhe mant zum Sprectjen abrichten will, einzeln, bie übrigen wo möglich partweije ober

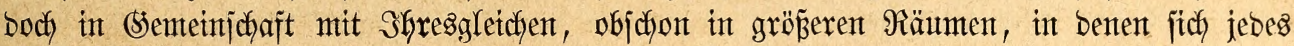

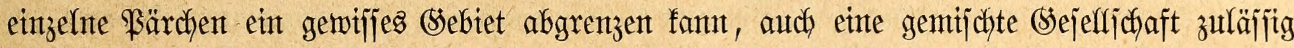

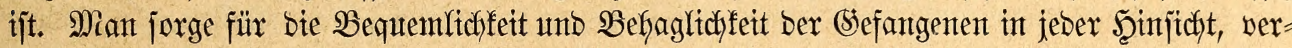
Damme fie nicht Daz̧u, umunterbrochen auf metalfenen Sprutghölzern zu jitzen ober in joldyen

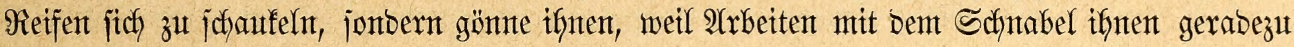
Bebürfnis zu jein jcheint, bas $\mathfrak{B}$ ergntïgen, ifyre Sitzjtangen unt anbere Şälzer zu benagen,

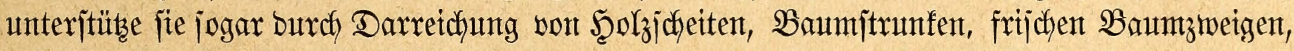

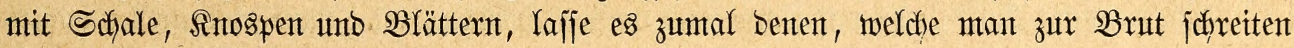

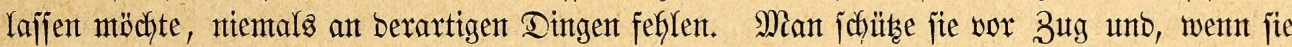

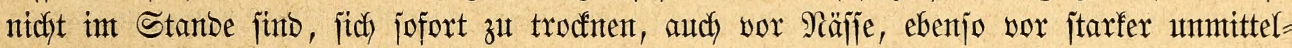

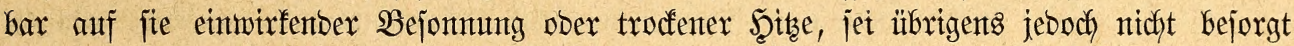
um fie. Biele von ifnen vertragen ziemlich bebeutenbe Rälte vfgne allen Schaben, unto bie meiften betrachten bei warmer Bitterung einte tïchtige $\mathfrak{B}$ eregnung als ein erquticfentes $\mathfrak{B a b}$ uno geben fich orbentlich Müfge, affe Ieile ifyes (sefiebers zu burdynäfjen; nux verjäunte man nie, ifyen nach jolchent Babe jtets (selegentheit zu verjchaffen, fich rajch und volljtänbig

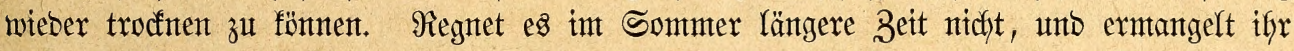
2Ufentfyaltsort eines Springbruntents ober Wajferfalles, jo überjprütze mant jie mit über= jchlagenem Wajfer: es befagt bies ifnen beffer als jebes andere Bab, ijt aud rätlicher,

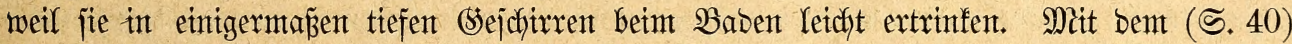
im alfgenteinen angegebenten Futter endidy mechsle man zeitweilig ab, weil jie, mefyr als

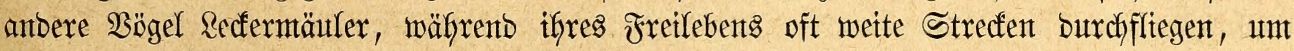

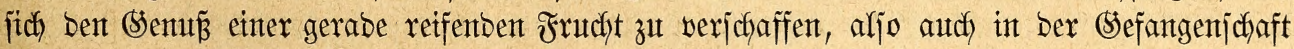

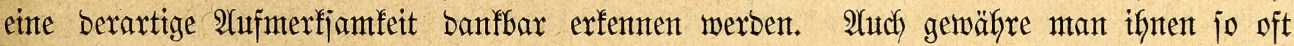

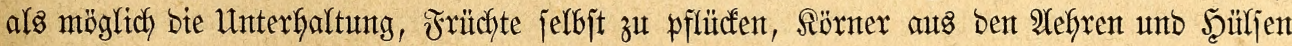

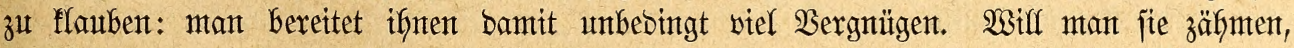
io beleibige man fie nie; benn fie vergeflen bies nidjt unt bewahren Sabre lang Mitstrauen unb (Srolf. Mant bejchäftige jich viel mit ifnen, unterridste vom erjtent Tage an biejentigen

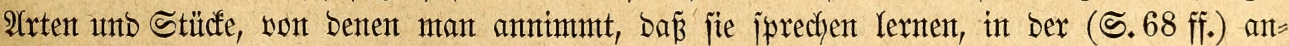
gegebenen Weije, füttere jie jelbjt, Galte ifnen secfereten vor unto verantajje jie, biejelbent aus ben Fingern zu ntefmen, jtreidfle fie von Zeit zu Zeit leije und zudfe nicht zurücf,

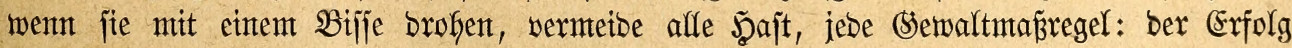
iịt jicher.

Bet ber aufierorbentfichen Hebereinjtimmung alfer Merfmale ber Sittiche bălt es jdjwer, bie Sromung in Familien unb Sippen zu trenten. Finj $j$, weldyer in ben \$apageten mur

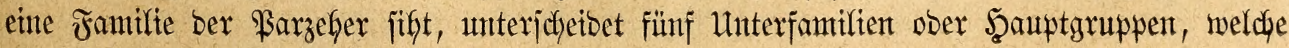


audy wir, objchon nidft in Derjelben Rethenfolge, antefmen, unto beren Merfmale wir von bem bemährten Meijter uns Yehren lajien wollen.

Die exjte biejex Şauptgruppen, in meinen 24tgen Familien, umfap̃t bie ßapageien (Psittacinae). Sie fentzeidfnet ifre gebrungente (Sejtalt und ber furze ober mittelfange, gerabe ober etwas abgerundete Sdywant. Bu ifnen gefören bie (5rau=, Boritentopf $=$,

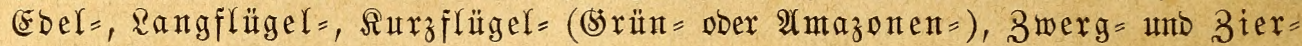
papageien.

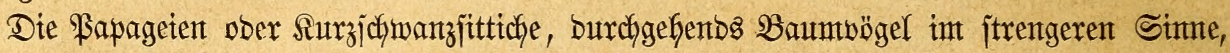

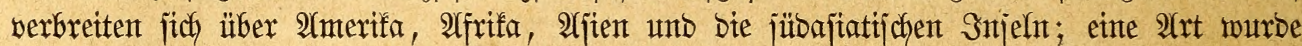

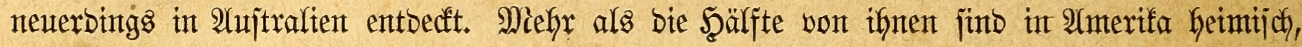
unt fajt alfe afrifanijchen Papageten zäflent zu ifnen. 3wei Sippen haben in ber alten und neuten Welt ifre Bertreter.

Die zweite Familie ijt bie der $\Re$ af adus (Plictolophinae). (Es zeichnen fich bie fier= her gehörigen Sittiche aus burdh einen aufrichtbaren Feberjchopf auf Stirn ober Scheiter, fräftigen Schnabel, jefr entwidfelte Schwingen unt einen meijtentetl\& furzen, geraben Schwanz.

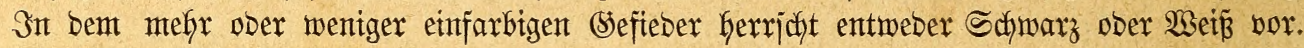

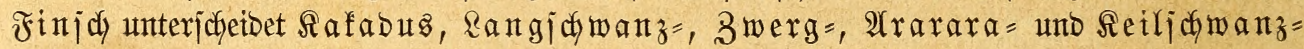
fafabนs.

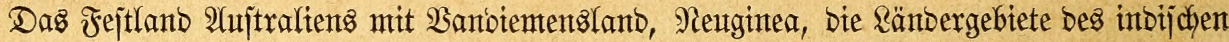

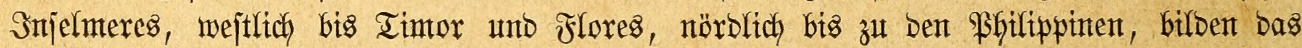
Berbreitungsggebiet Der Safabus, welche in gletchem Srabe wie bie vorigen Baumbögel jinto.

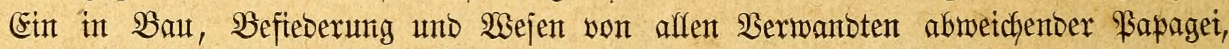

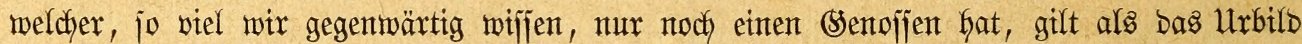
Der शaachtpapageien (Stringopinae). Familienmerfmale find: Eulengefieber unb halber Feberja)leier int (Seficht.

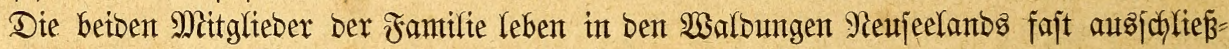
lich auf bem $\mathfrak{B}$ oben.

Sittiche (Sittacinae) Keiß̄en bie 2Ungehörigen ber vierten Familie. Sie fentzeichnet ber mefyr ober weniger lange, Ketfförmige ober abgejtufte Edfwanz. Die Jamilie, weldhe

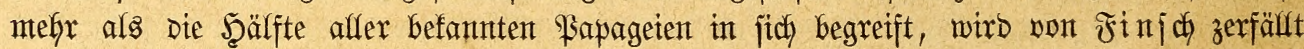

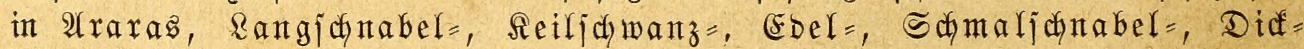

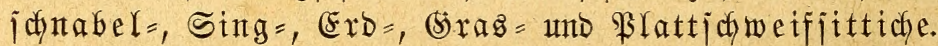

Die Sittiche fehlen nur in Europa. ATmerifa und 2 lujtralten beherbergen bie meijten,

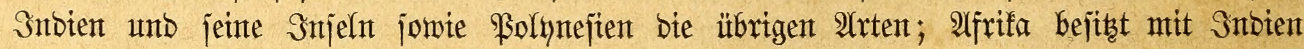
zmei $\mathfrak{A}$ rten gemetnichaftlich. Die Mefrzahl zählt zu ben Bammögeln; bod) gibt es auch ecfite Erovögel unter ifiten.

In ber fünften Familie enblich vereinigen wir bie Roris (Trichoglossinae). $3 \mathfrak{g r}$

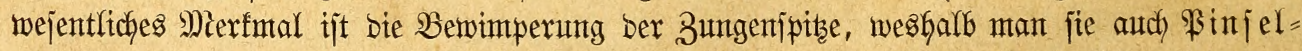
zungenpapageien gentannt hat: auzerbem fennzeidnen jie fich burch jeitlich zujammen=

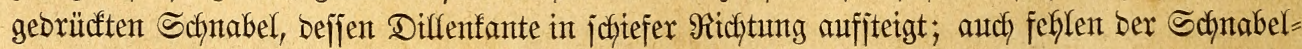

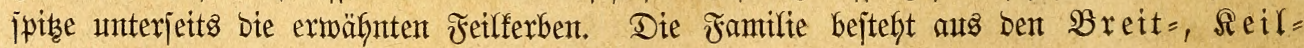
und Stumpfidyanzlorts.

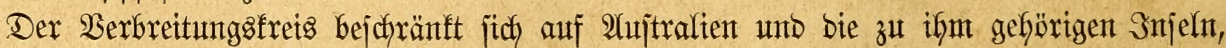

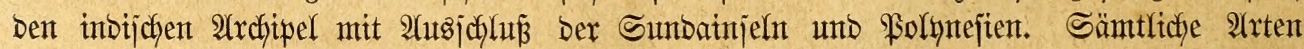
jint Baumtoögel.

So viel vorläufitg zum exjten Heberblicf ber formen = unb artenreichen (Siejantheit,

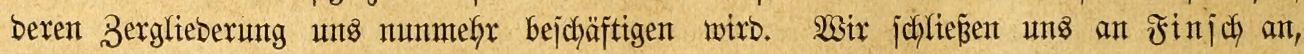

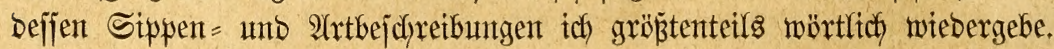




\section{(braupapageien.}

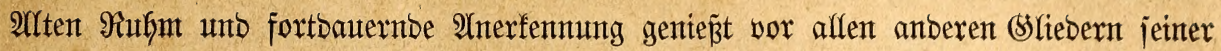

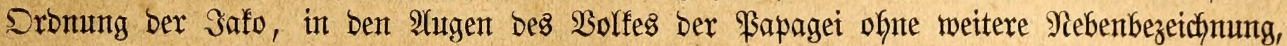
mit einem neuerbings entbecten Serwandten ber einzige jeines (sejchlechtes, welcher ben ifym

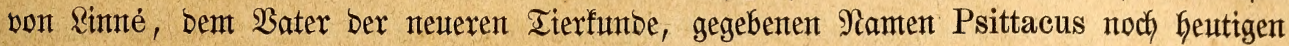
Iages füffrt, ber eigentficfje Bertreter ber (5raupapageten. Wir verjtehen unter biejem

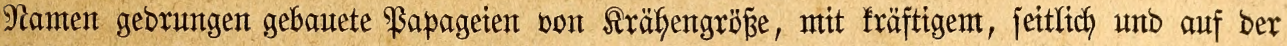
Sirjte abgerumbetem Schnabel, weldyer vor ber furzen ober nur mäß̈tg verlängerten Spike

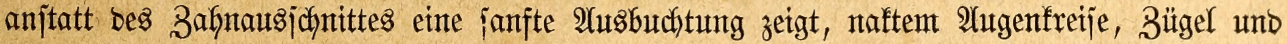

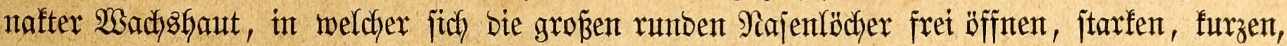

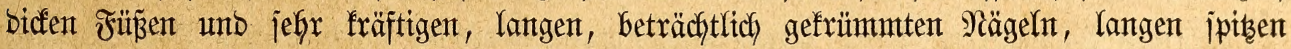
Frügeln, weldye bis zur Şälffe ober bis zum Entoe bes Schwanzes reichen und unter beren Schningen bie britte ober vierte bie längiten find, breitem, Gödjittens mäpiglangem, fajt gerabe abgejtutzem ober etwas abgerumbetem Schmanze und weidyem Sleingefieder, beffen Febern ant Enoe breit, wie abgejdyntten, exjdeinten, unt in befjen Färbung (Srau, Braun ober

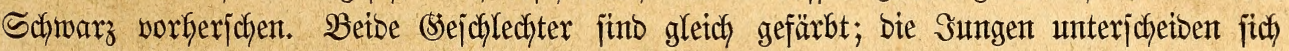
faum merflich von ben arlen.

Mefhrere Forjcher trennen, Dem Worgange Waglers folgent, bie mentgen fierker

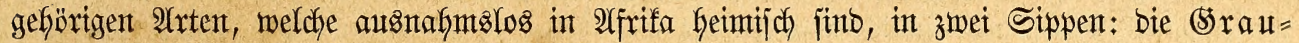

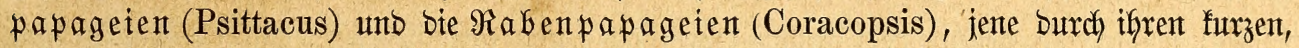
bieje burdy ifyren langen Sdywanz und bidferen Sdjnabel fentzetdjnent. 3u erjerer Sruppe gehören:

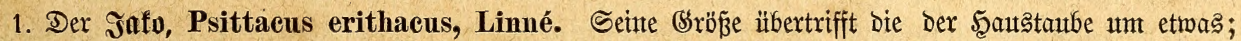

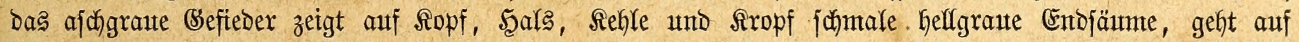

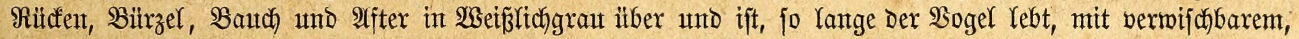

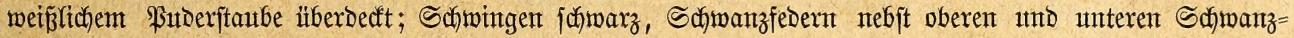

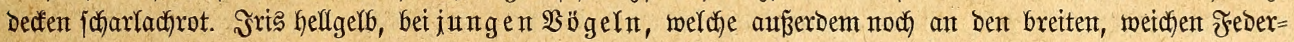

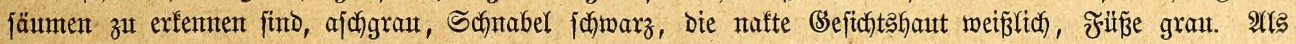

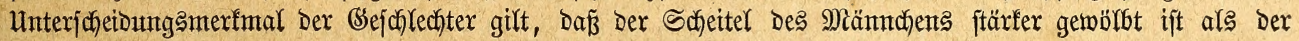
Des 2 Seibchents.

Eine Spielart (Ps. ruber) ift mur an Iopfe, Şaffe uno anf Den Sdfwingen grau, übrigents rot; bei

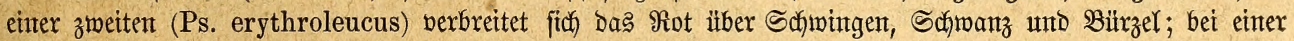
britten (Ps. rubrovarius) tritt es fledtig im ganzem (Befieber auf; bei einer vierten (Ps. cinereus) fefit es gäızlich). -

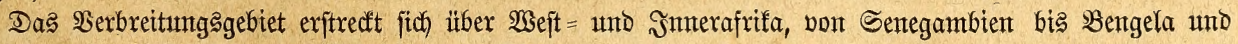

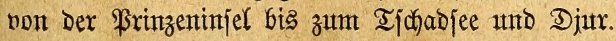

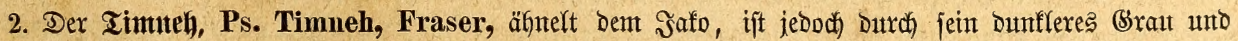

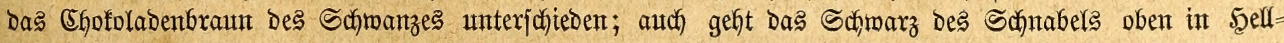
hornfarb über.

Der bezüglich feiner 2 trtferbftändigteit noch zmeiferhafte $\mathfrak{B}$ ogel ift vom Babum unb von Sierra Reona gebradjt worben.

Mitglieber ber zweiten (siruppe finto:

3. Der Samarzpapngei, Ps. (Coracopsis, Vaza, Vigorsia) niger, L., (fuscus)*). Dą ganze

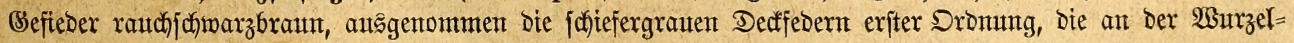

*) Die eingeflammexten Worte, meld)e bei WSiederhohungen verfïrzt gegeben werden, bezeidfnent bie

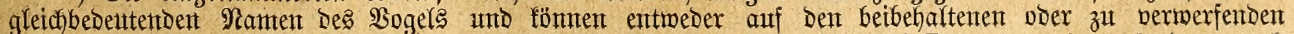

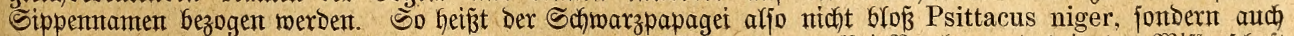
Psittacus fuscus, Coracopsis nigra, Vigorsia nigra, Vaza nigra. Bei Beachtung Des it Dex $23 i j$ enjichaft B re $\mathfrak{h m}$, gefangene Büget. I. 


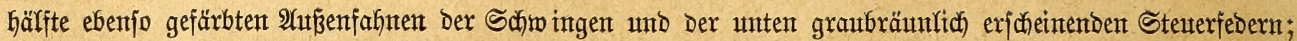

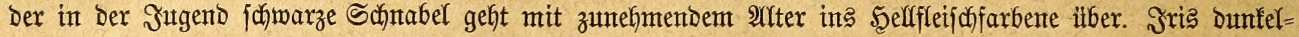

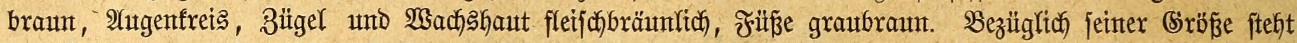

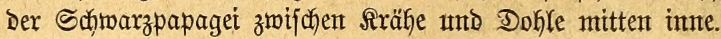

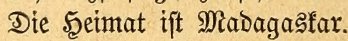

4. Der Doffempapagei, Ps. (Cor.) Barklyi, Newton, Sertreter Des vorigen auf ben Setheffen unt

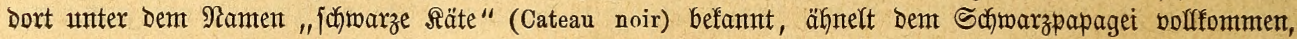

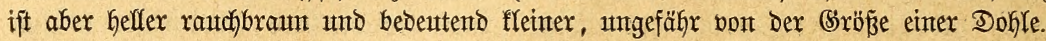

5. Dex $\mathfrak{B} \mathfrak{a} \mathfrak{a} \mathfrak{a}$ ver $\mathfrak{B} \mathfrak{a} \mathfrak{a}$, Ps. (Cor. Vig.) Vaza, Shaw (melanorhyncha, obscura). Atud biefe $\mathfrak{A}$ rt

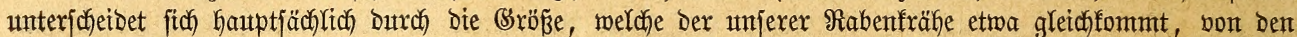

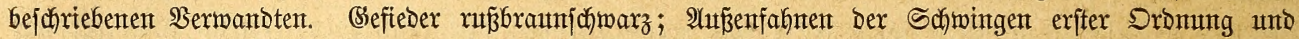

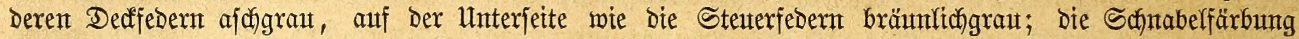

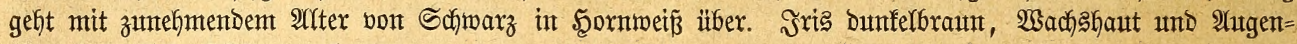

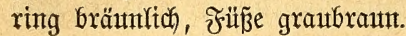

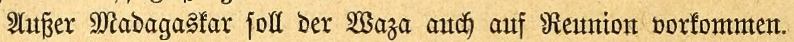

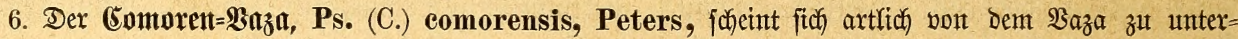

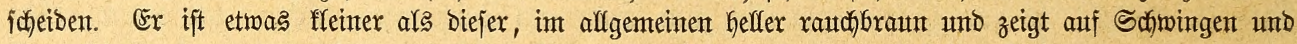
Stetterfedern einent namentfich unter helfer Beletteftung heroortretenden grünlidchen Schinmer.

Der Name Dentet Die Seeimat ant.

7. Der Miafen= $\mathfrak{B} \mathfrak{a} \mathfrak{a}$, Ps. (C., Mascarinus) madagascarensis, Lesson (mascarinus, obscurus),

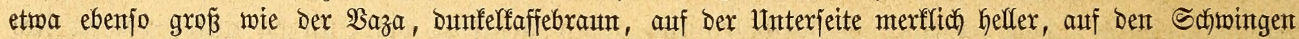

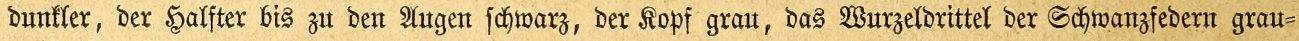

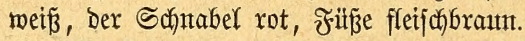

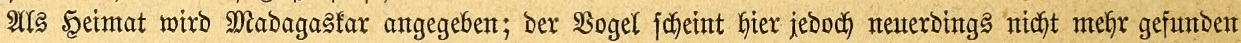
worben zat fein und ftammt vielfeidft antbersmo her.

Uleber bas Freileben Der Srraupapageien feflt unts noch inmter gentïgentbe Sunbe; wir jinto nach ben unts getworbenen Mitteifungen noch nicht einmal int Stanbe, ein ausfüüfrfiches

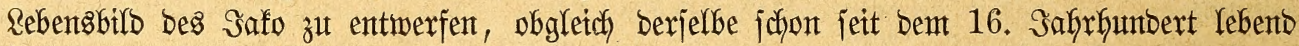
in Europa eingefüfrt wirb und $D a$, wo ex vorfommt, in zafllojen Schwärmen auftritt.

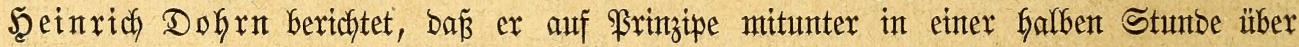

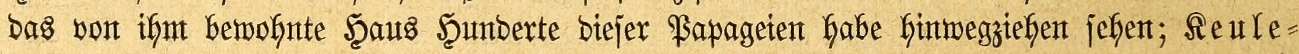
mans, welcher für Dofrn jammelte, bemterft fernter, baźs ber Sogel affabentlich nach einem $\mathfrak{B}$ erge, Dem "Pico de papagayo" fich begebe, um bort mit ben von alfen Seiten

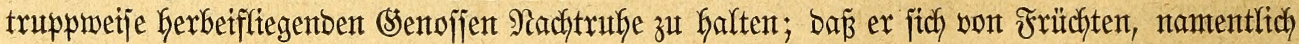
Bafmnüifjen unb Sämereten ernäfre, nach Der Regenzeit, int Dezember, oft mit mehreren

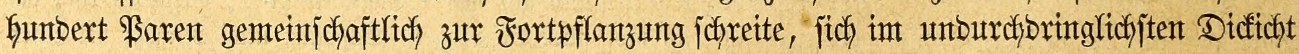

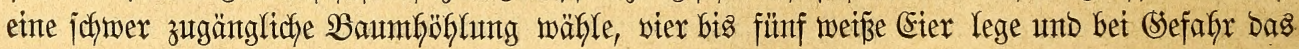
Nejt mutig verteibige, auth von jeinten Rameraben tapfer unterjtüht werbe. Das (5leiche

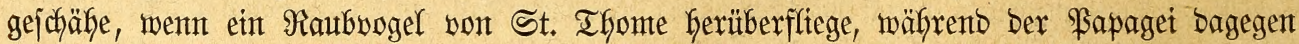

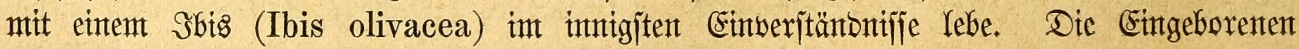

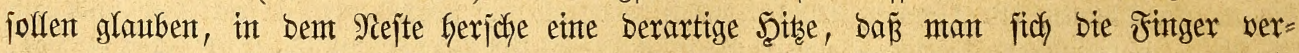
brenten würbe, falfs man bie Sungen ausnehmen wolfe. Sie ziehen es beshalb vor, bie

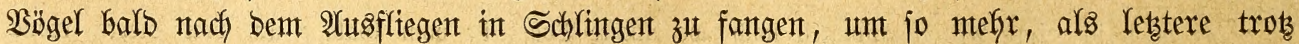

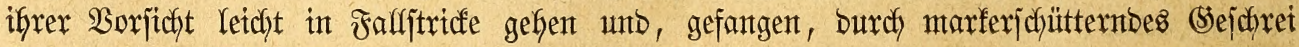

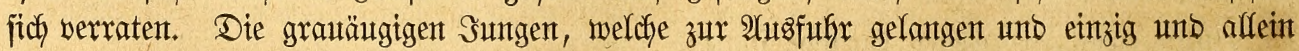
gejucht merben, berfauft man zum \$reije von Gödjitents eintem Dolfar für bas Stücf an

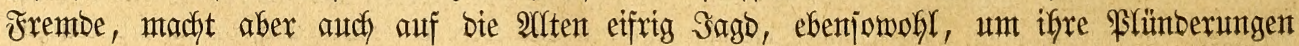

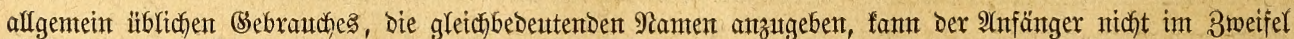

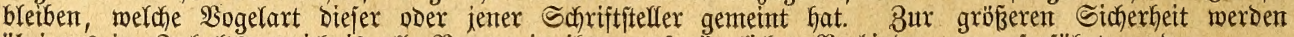

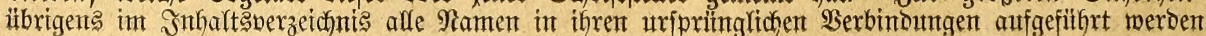




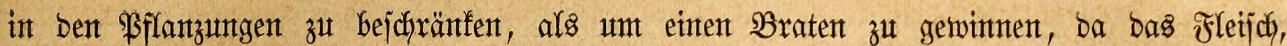

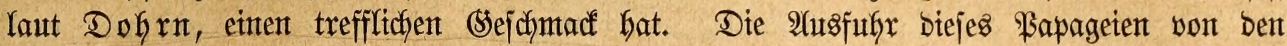

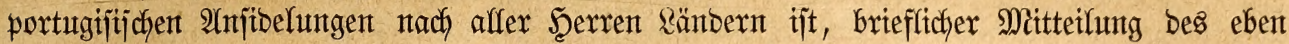

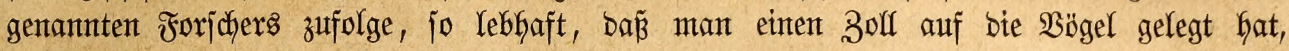

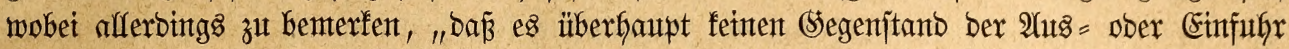

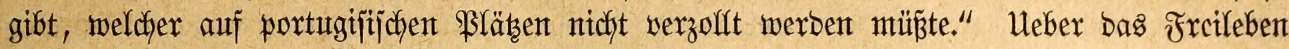

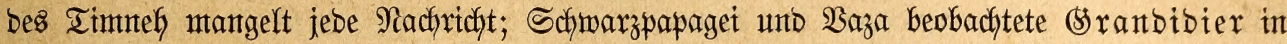
Flügen von 10 bis 50 Stüdf, gemeinjchaftlich rebent, bäufig auf ber ganzen Injel Maba=

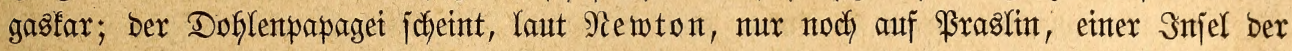

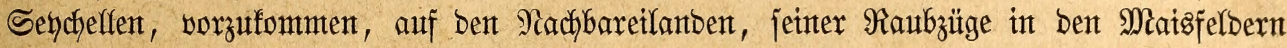

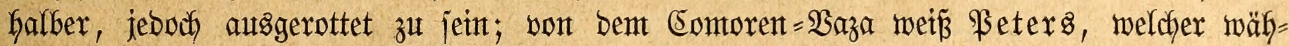
rent jeines furzen Bejuches auf ben Snjeln ben Bogel nur einmal an jith vorüberffiegen

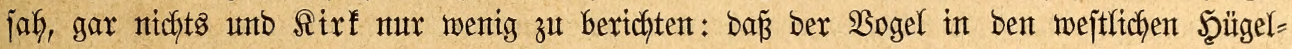

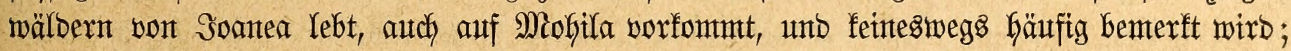
won Demt Miasfen = $\mathfrak{B} \mathfrak{a} a$, welcher einige Miale lebento nach Europa gelangte, fann man mit Bejtimmtheit nidfyt einntal bas Saterfand angeben.

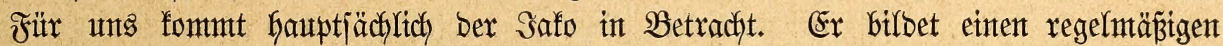

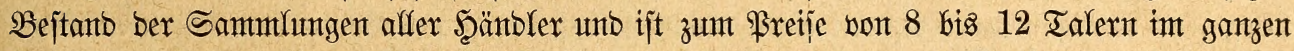

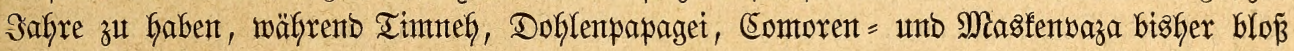

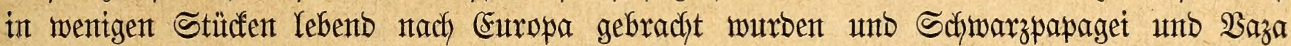
zu bent entichieden jeltenen Erjcheinungen bes europäijchen Tiermtarftes zäblen, ifyrer Unjichein= barfeit ungeadjtet immerfin mit 16 bis 24 Talern bezaflt, und bentgentäß meijt mux für

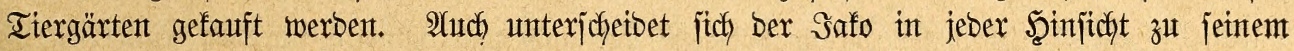

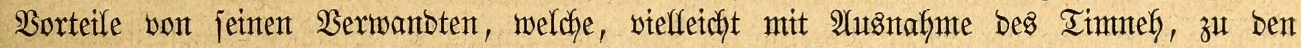
langmeifigeren ßapageien gehören. Bevaillant rühmt zwar Dent Schwarzpapagei megen

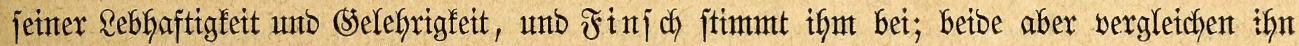
boch nur mit bem $\mathfrak{B a z a}$, iprechen aljo bebingungsivetje. Sch habe ben einent mie ben

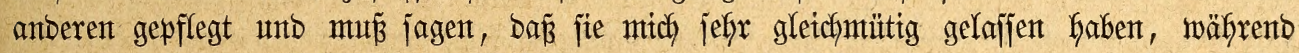

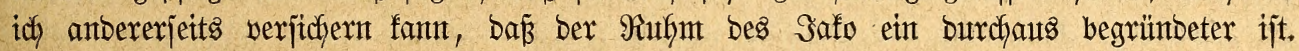
Deshalb baxf ich mich im Nachjtefyenden auf lebteren bejdyränfent und zwar umt fo mefri, als Fütterung, Wartung unt $\mathfrak{B f l e g e ~ a l l e r ~ ( 5 r a u p a p a g e t e n ~ g e n a u ~ d i e j e l b e n ~ j u ̈ t o . ~}$

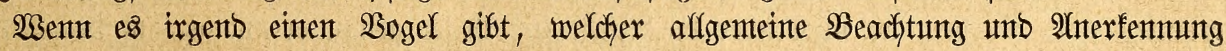

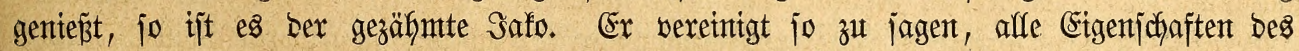
Bapageien in jich. Sm 2lnfange jeiner (sefangenjchaft freilich zeigt jich ber noch ungejchulte Refyrling burchauts nicht von ber angenefymitent Seite. Mit wiberwärtig gurgelnbem (Befnarr

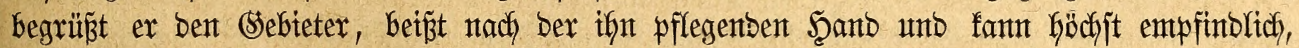
ja itt gefälyrlicher Weije verleben, zernagt alles, was ifnt erreichbar, fallz es ntcht niet= unto nagelfejt, betracjtet jebes (s)lieb ber Familie mit bem entjdyiebenjten Mitstrauten, jheint

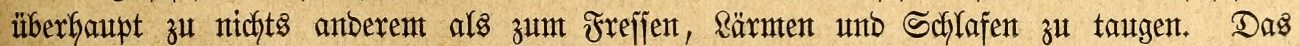

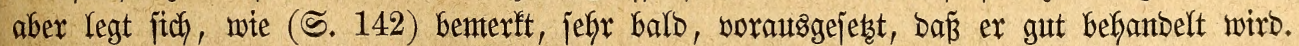

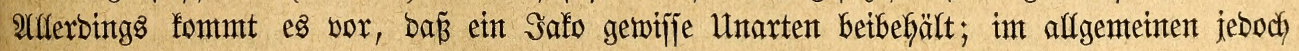
baxf man antefymen; Dẩ man aus jebem Sungen einen artigen Stubengenoffen erziehen fant. 2fber freilich, junge (grauäugige) Bögel muñ man wäblen, wenn man etwas aus ihnen machen wilf, nicht alte (gelbä̈rgige), welche mögltcherweife jchon veroorben fints.

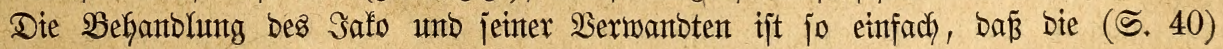
gegebenen $\mathfrak{B i n f e}$ bolffommen ausireichen bürften. Alfe Srraupapageten gefören zu ben aušbauternbiten Räfigub̈geln, weldje wir fenten, fint aber jefr empfinblich gegen Rälte und

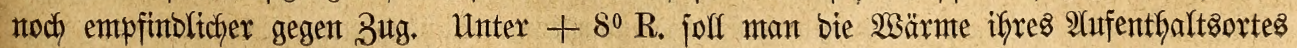


nicht finfen Yajjen, am wenigiten bes Nadjts, gegen beren Süf)le jie jich im Freien baburch

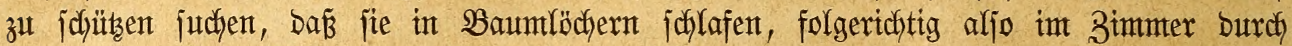

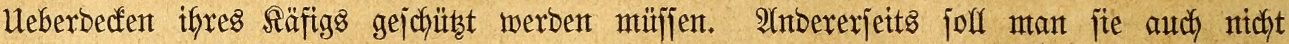

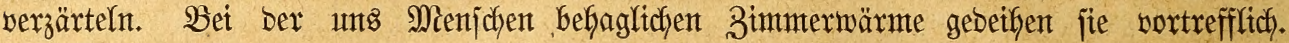
Sm Sommer bringe mtan fie jo viel alb möglich ints Frete, im Winter gönne man thnen jeben Somenblidf am Fenjter: bas eine wie bas anbere erbettert jie ungemein. Mit Waffer farge man nie, zwinge jie eher zum Baben. Sm Sommer jebe man fie auf furze Beit

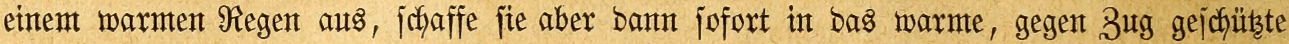
Simmer; im Winter näfje man ifnen, etwa affe bre Iage eimmal, bas Siefieber mittels Des Mumbes ober einer Sprize zienlich berb ein, jeboch nur in ben Sormittagsitumben

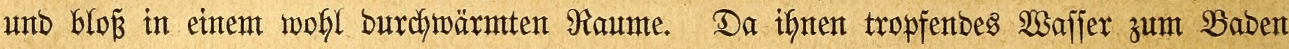

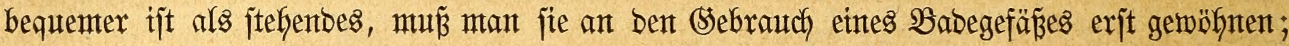
hat man bies einmal erreidst, jo braudft mant jie natürlich weber beregnen zu laffen, nodh

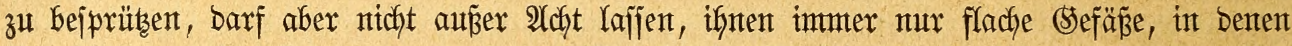

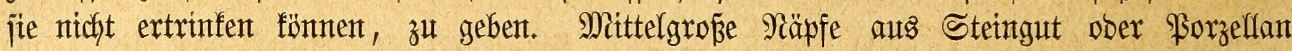
fint, Demt afles vernidytenten \$apageienjdynabel gegenüber, twegen ifrer Sealtbarfeit und ebenjo ber Reichtigfeit, jie rein zu balten, jebr zu emtpfeblen, haben aber, wie von Freh=

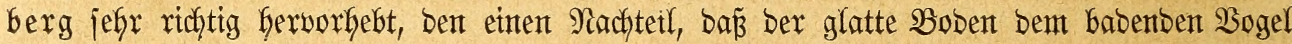

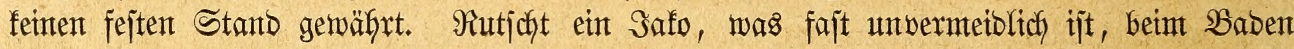

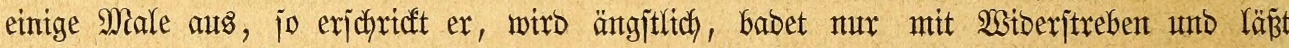

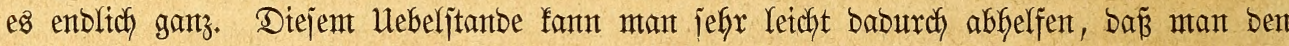
Boben Des Befäß̈es nit einemt feinmajchigen Nebs aus Eijengarn ober in Erntangelung

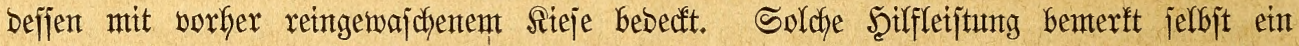
mistrautich gemorbener Safo bald und fonmt bann von jelbjt wieber zum Baben. Man

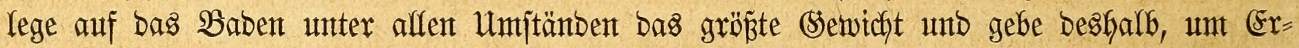
fältungen zut verfüten, auch jtets überichlagenes wajjer, D. h. jolches, melches 12 bis

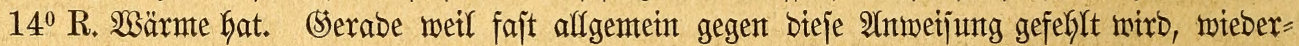

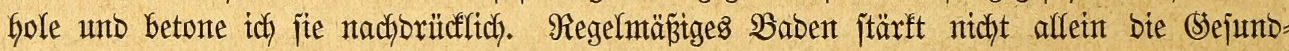

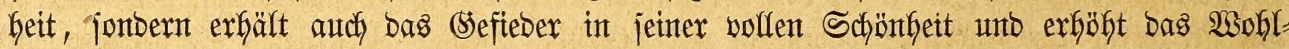

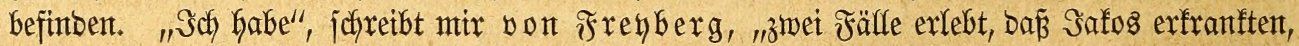

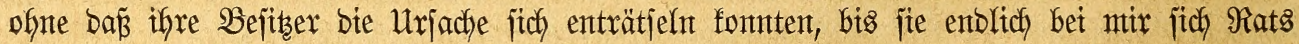
erholten unt, nachbem ich mich über bie Bffege ber $\mathfrak{B o ̈ g e l ~ g e n a u ~ e r f u n b i g t , ~ a u f ~ b e n ~ M a n g e l ~}$ einter zwedmäß̈igen Babegelegenfyeit aufmerfjam gemtadyt werben fonnten. SBinnen furzem

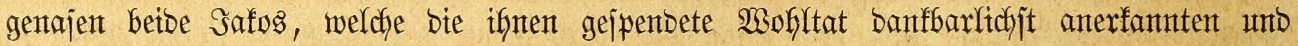

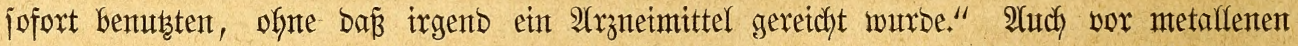

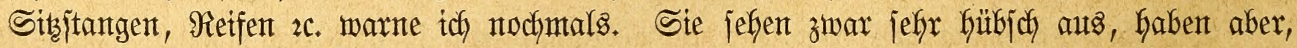

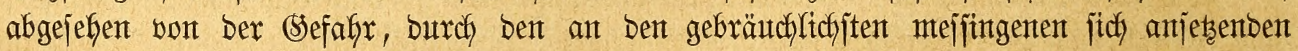

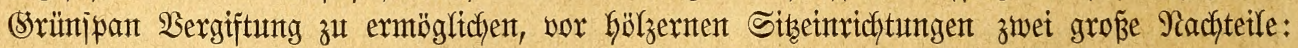
jie jünd gute 2 ärmteleiter und nicht raut gentg. Erjtere Etgenjchaft fann bie Urjache

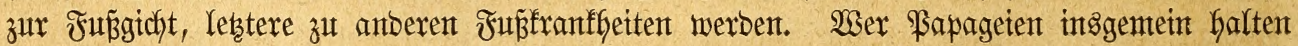

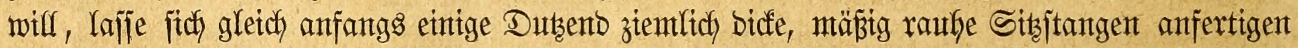
unb erjeze nötigen Fafls bie zernagten burch unveriefrte: bies verurjadjt wenig sojten,

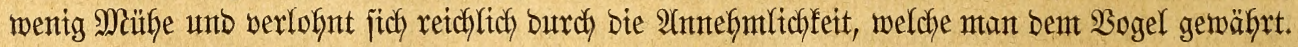
Son Freyberg rät aus guten (Stünben, bie Sitjitangen weber von gleicher Form noch)

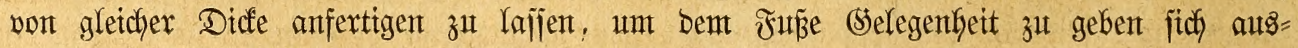

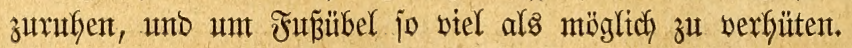

Sbichon man bie (Sraupapageien jo ztemtich an affes gewöhnen fann, was ber Menjch

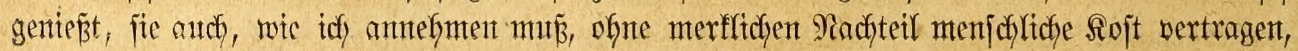


if́t boch anzuraten, fie jo einfach als möglich zu falten. Sie find borzuggiveife Rïrner=,

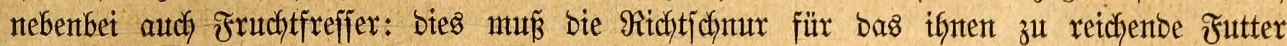
fein unt bleiben. Miais in Solben ober entförnt ijt wohl aflent übrigen vorzuzieflen, weil

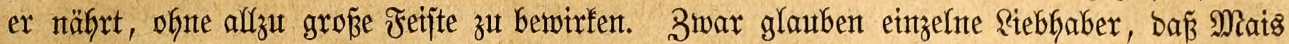

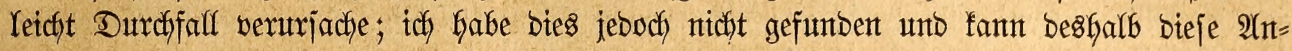

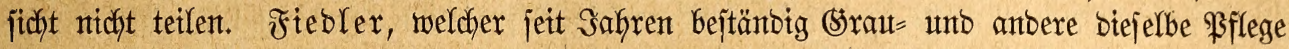
beanjpruthenbe \$apageien bălt, rät, ben Maàs mittelmeich zut fochen, ifn falt werben zu lajfen unt jobant exjt ben Bögeln zu reidhen. Sie getwöhnen jidh rajch an biejes Futter

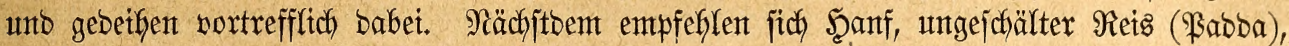

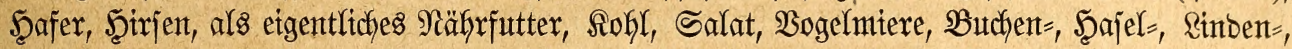

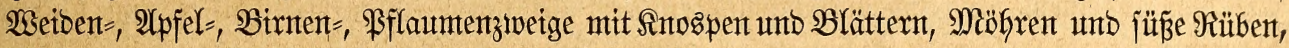
Melonen = utto Rürbişjtüctchen, gefodjte Rartoffeln als Zutojt, auslänbijche wie inlänbijche

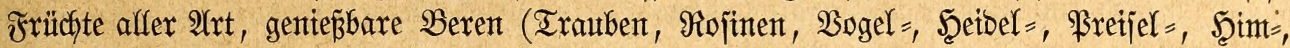

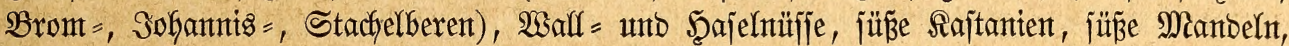

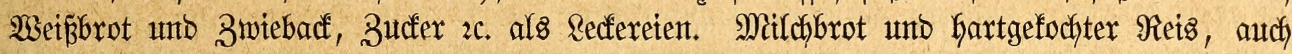
Mitldyreis merben gern genommen, entwöhnen aber leidht von bem exjprieß̧lichen Sïrnerfutter; Butterbrot, gefochtes und gebratenes Fleijch, welches einzelne Safos Yetbenichaftlich gern

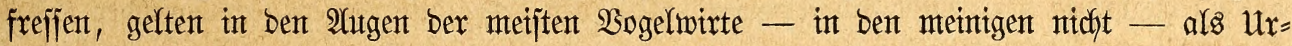
jache bes eigenjumigen Feberrupfens, mögen baker vorjichtsfalber vermieben werben. Darf mant aud bieje Jrage als einte zur Beit nod, offente behanbeln, fo ijt body unzweifelfaft,

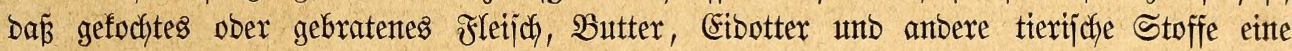

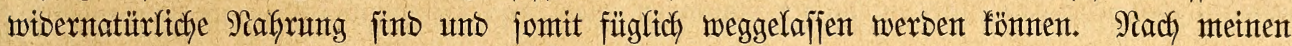
Erfahrungen ijt nicft einmal Mitldy eine exjucftlich zujagende 3utat zum Futter; ich, habe

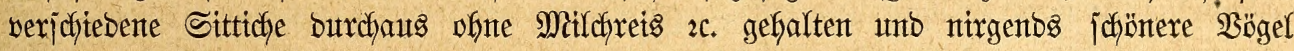

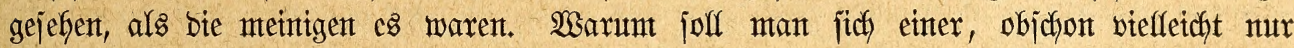
eingebilbeten (Sefahr ausjeben? Die Spetjefarte ijt audh ofne tierijdye Stoffe retchfaltig

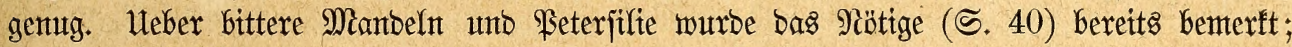

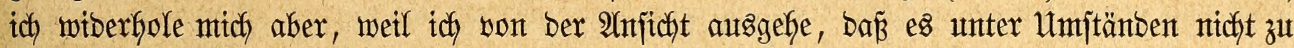
viel ijt, einem angebenden Riebfaber ein unb basjelbe zweimal zu jagen. Salz reicht man

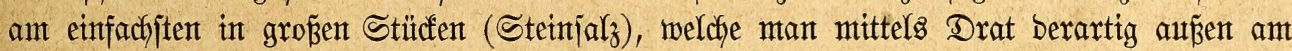

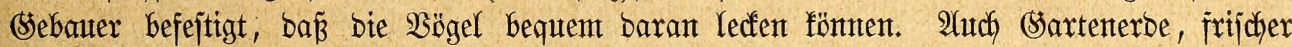
ober altex, jalzhaltiger sefgm wiro won ifnnen jefy gern benagt unt teilweije gefrefjen, mag baher nebentbei gereidft werben. Bei einiger 2ldhtjamfeit merft man barb, weldjes Futter ifnnen bejonbers zujagt, unb barf bann mit berjtänbiger Bejchränfung ifyren Wünjchen woblinollento nactigebert.

Mitt Der Erzitefyutg unb Dem Unterrichte beginnt mant fo balb als möglich. Butächjt

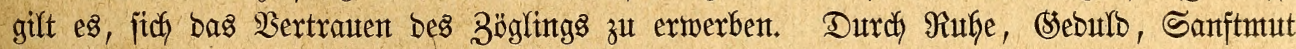
unto Beharrlichfeit erreicht man alles, Durch zornige Strenge gar nichts. Eine rechtzeitig

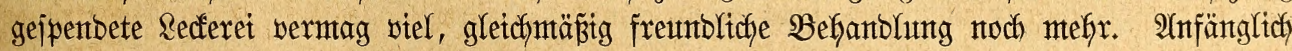

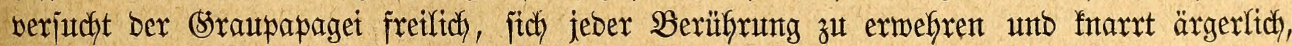
jobalo man verjucht, ifgn zu fajjen; bletbt ntan aber faltblütig, went ex brobt, ftraft mant

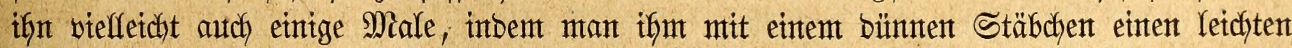

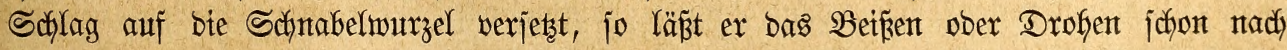

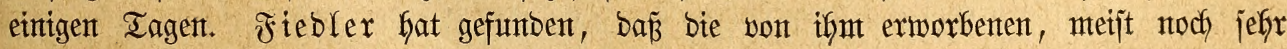
icheuen unt mistrautichen \$apageien am exiten zabnt wurben, went ex fie nicht in ein

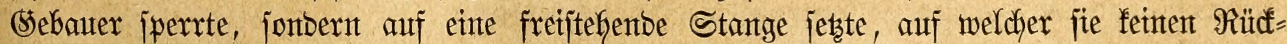

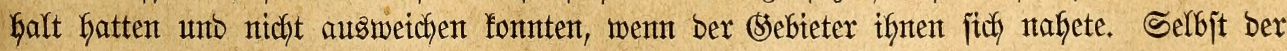

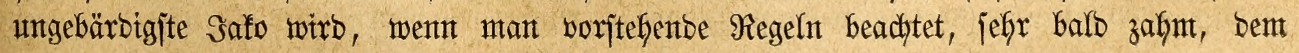




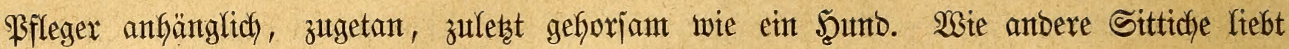

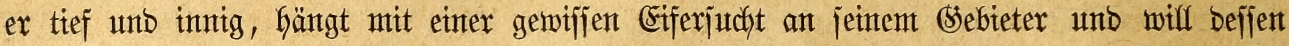

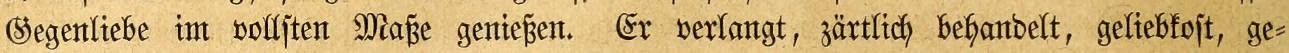
Gätfchelt zu werben, erwiebert audd Siebfojungen in artiger WSeije, gibt ein Rürschen,

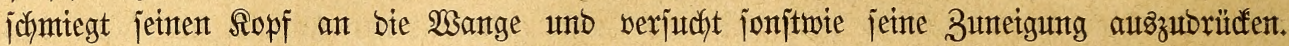

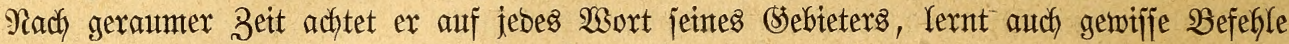

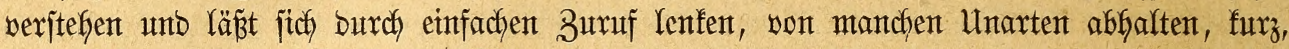

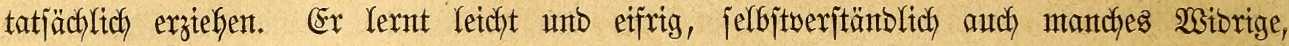

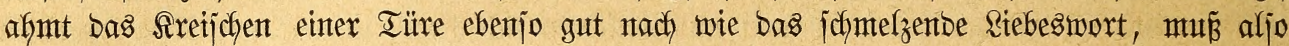
jorgfälttig befütet werben vor affen unangenefhmen (seräujchen ober volfentos vor gemeinen

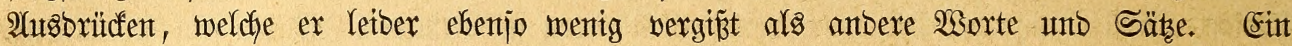

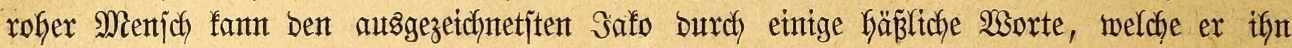

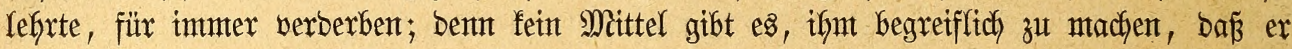

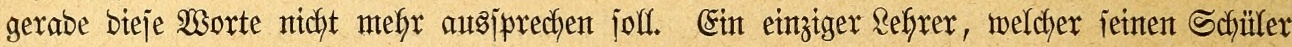

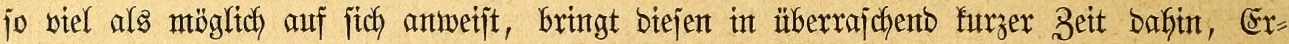

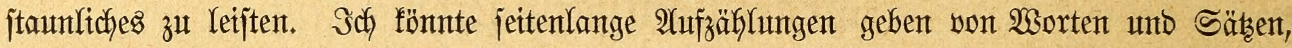
weldhe Strautpapageien nachjprechent gelernt, halte bies aber für burchaus unnötig, weil eine (5renze von bem, was jolcher 2 bogel Kernt, überfhaupt nicht zu bejtimmen ijt. IAmt eifrigiten

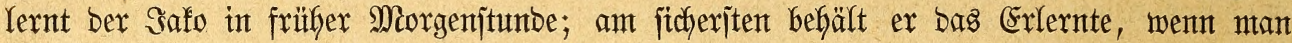

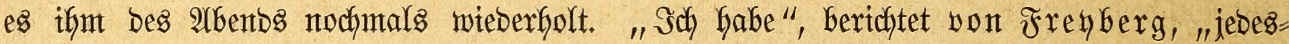

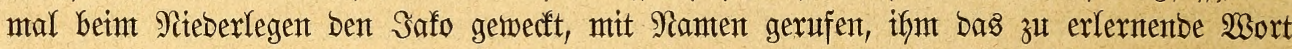
einntal vorgejagt unt ifgm bann bie 9iufe gelafien. Dabei habe idf midf afferbings be= ftrebt, ber Stimmte ftets bie gleiche Betonumg zut geben, Den 2 ogel aud niemals unter= ridftet, went idy jelbjt nicht in rectjer Stimmung war. So hat jeber 2 sogel bard bas

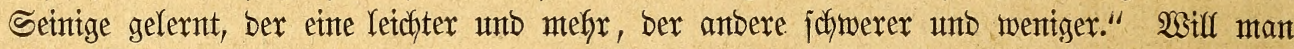

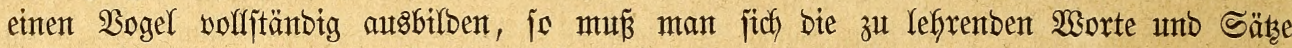

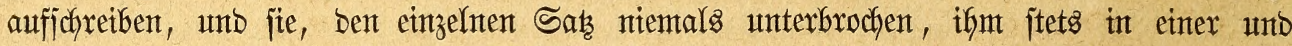

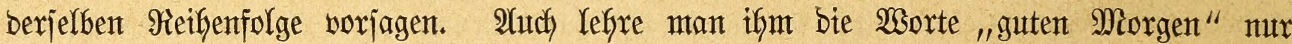

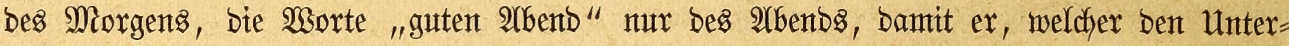

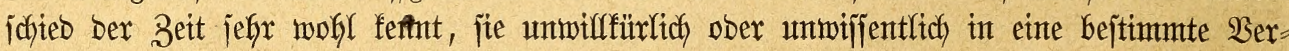

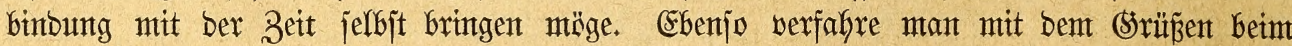

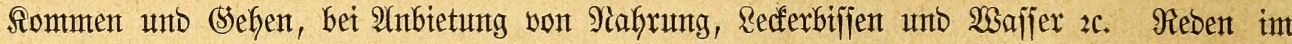

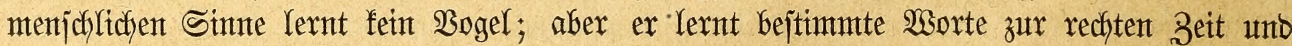

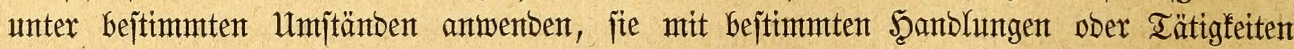
werfnüpfen, woburdy es ben 2 (nijchein gewinnt, als wiffe ex genau, was er jagt. So lexnt

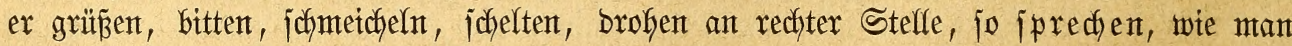

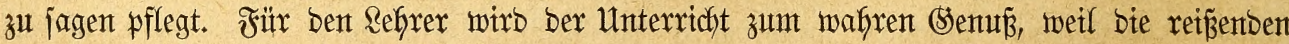

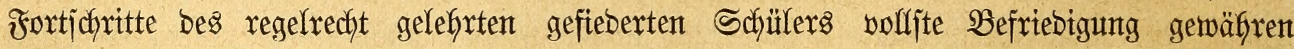
muîfifen. "Es ijt", jagt Sace, "nit bemt Saffo, wie mit bem Şunbe. Mian wirb nidgt

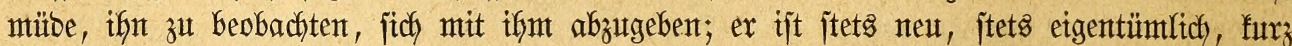
ber anziefentojte Stubenoggel unter ber Sonne."

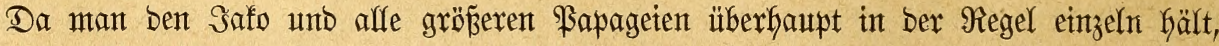

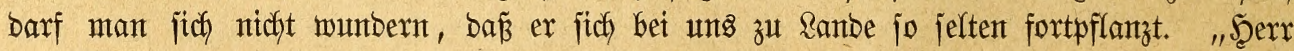

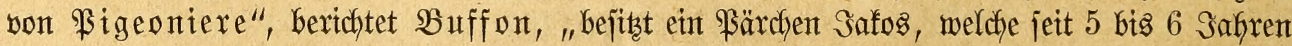
in jebem Früfflinge gebrütet unto gemeinjchaftlich bie Sungen erzogen haben. Sebe Brut bejtand aus vier Eiern, untern benent regefntäping brei befructitete waren. Unt fie zumt Brüten

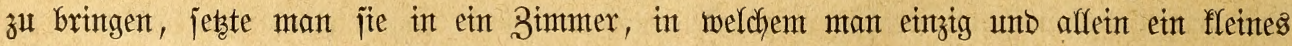

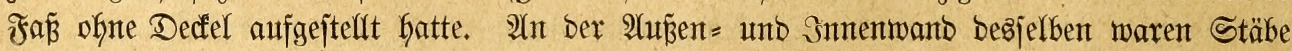


angebradjt morben, welche bem Meändhen einen Bejudh jeines inten brütentoen $\mathfrak{W e i b d j e n s ~}$

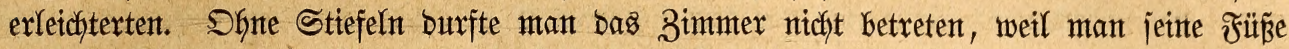

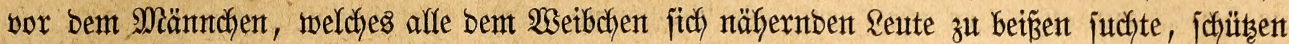

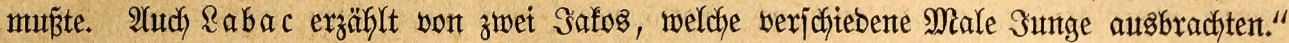

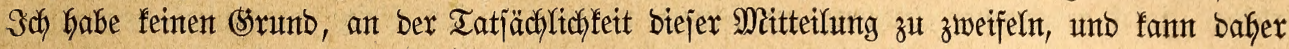
nur zu weiteren $\mathfrak{B} e x j u c h e n$ in biejer Richtung anjpornen.

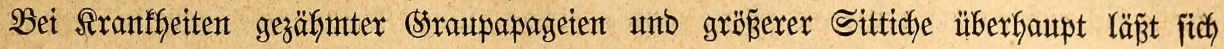

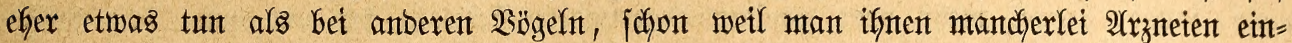

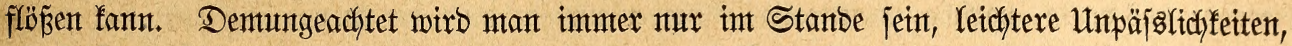

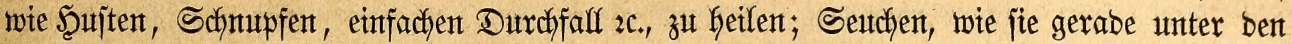

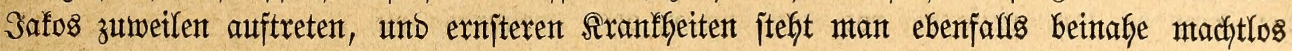
gegenitber.

\section{Rorftenkopfpapageten.}

Die 2lbficht, alle Bögel, welche ermiejenermazent in Sefangenjdyaft gehaltent wurben,

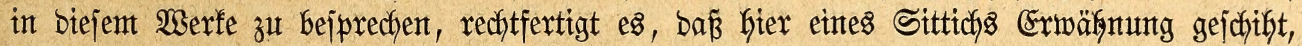
von welchemt wir bis jest noch nicht einmal bas Baterlant fenten. Siebachter gelangte in eintgen $\mathfrak{B a ̈ l g e n ~ i n ~ b i e ~ e u r o p a ̈ i j c h e n ~ M a j e e n ~ u n b ~ e i n m t a l ~ K e b e n d ~ i n ~ b i e ~ b e r u ̈ f h m t e ~}$ Snowsly = Menagerie Des Rorb Derby, berbient aljo mit Fug unb Recft fier feine Stelle.

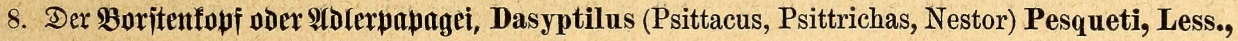

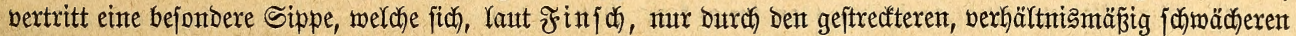

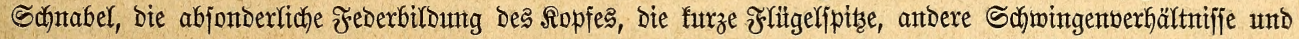

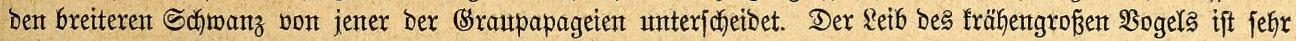

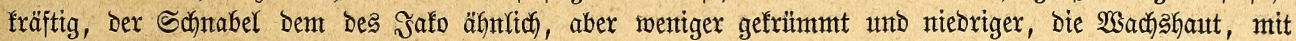

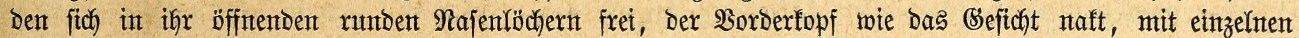

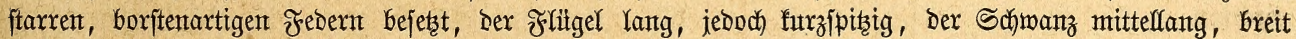

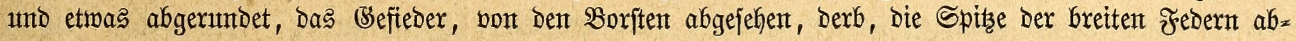
gefturtict.

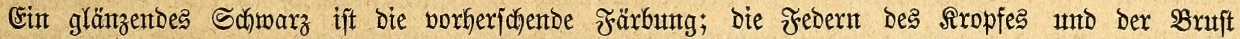

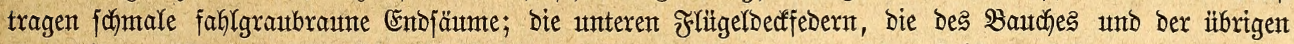

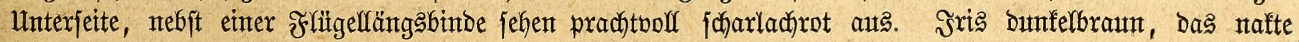

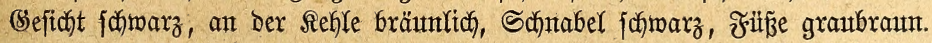

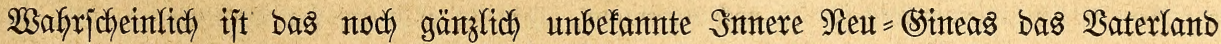
biejes jeltenten $\mathfrak{B o g e l}$, unt wurben von Gier auts bie wentgen Stüdfe gebradjt, weldhe mant auf Ternate unb Salamatti als Stubentubgel bei ben Eingeborenten gefunben unt teilmeije ermorben Gat: eine 21mafme, welche burch bie befannte Iatjache, baj bie Bemofner ber

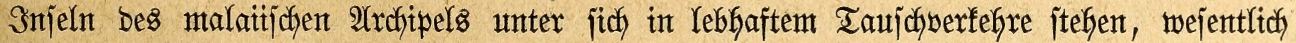

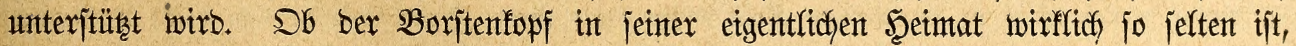
als man glaubt, läßjt fich bezweifeln.

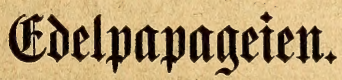

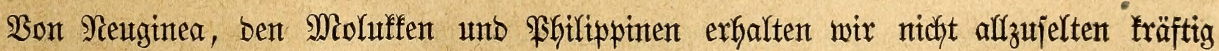

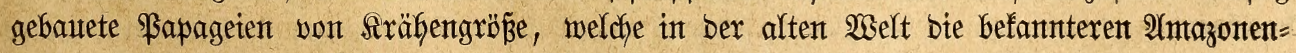
papageten zu vertreten jcheinten. Sie fentzeidynen fidy burch folgende Merfmale: 
Der jefr fräjtige; bidfe unt breite Sclynabel biegt fich von ber 2 Surzel an jtarf nact)

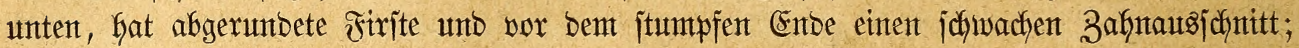
bie fletnen numben Najenlödjex nebjt ber Wadjshaut merben gänzlich ober fajt gänzlich von

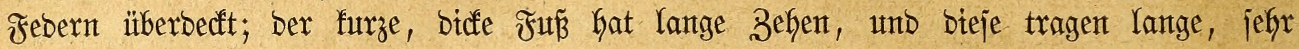
fräftige, jtarf gefrïmmte Srallen; Der Flïgel ijt lang, jeine Spibe anjehnlich borragent, bie britte ber am Entbe ftumpf abgeruntbeten Sdymingen bie längite, bieje mie bie bentachbarten (zweite bis vierte ober britte bis fünfte) außen etwas, inten faum ausgejejnitten; ber mittel= mäßjig fange, breite, mefyr ober weniger abgerumbete Schwantz hat ant Enbe jefy breite

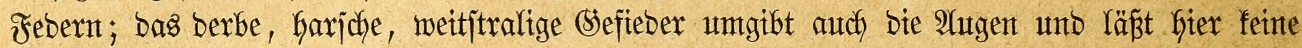
nafte Stelfe fret; jeinte vorferjachende Färbung ijt ein jefr lebfaftes (Srün ober Duntelrot; ber Schnabel fann einfarbig rot ober jaywarz ober zmeifarbig jein.

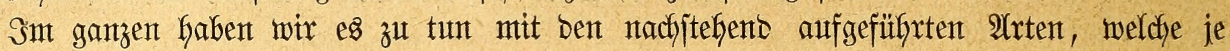
nach bex Färbung in bret Srutppen eingeteilt werben mögen. Borkerjchento grün gefärbt finto:

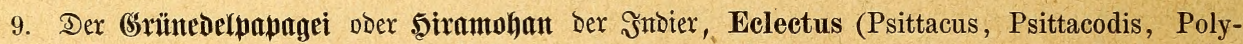
chlorus, Mascarinus) polychlorus, Scopoli (sinensis, pectoralis, aurantius, magnus, viridis, lateralis,

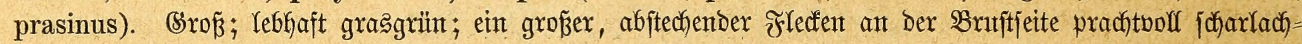

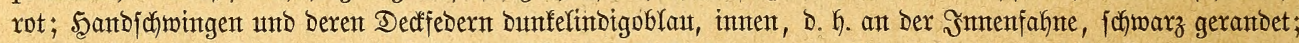

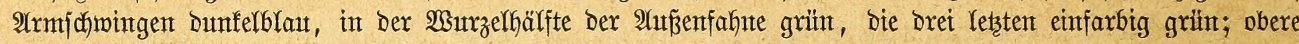

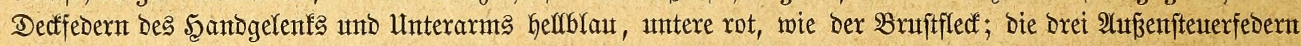

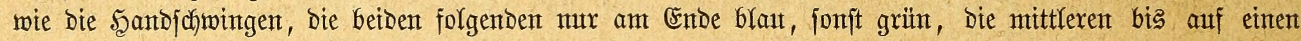

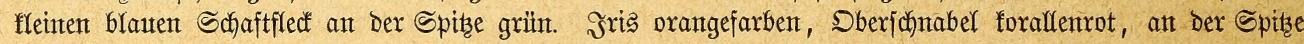

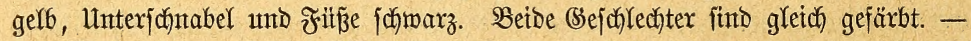

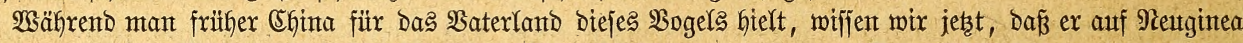
umb Den öftlichen Mioluffen Keimifich ift und, wie es fajeint, an geeigneten Srtent nidift felten aufftritt.

10. Dex Mitteledelpapagei oder Sintermanf Dex Raninfutantex, E. (Ps., Pol. Masc.) intermedius,

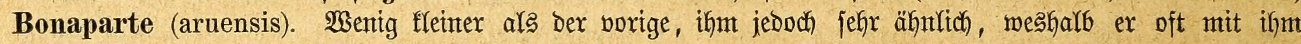

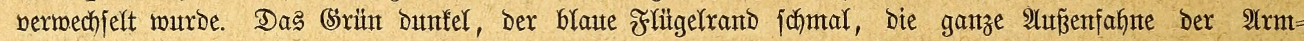

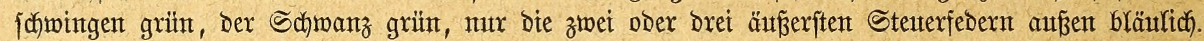

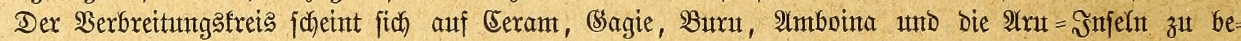
\{chtüntuetr.

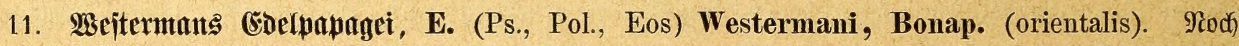

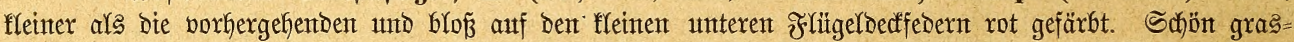

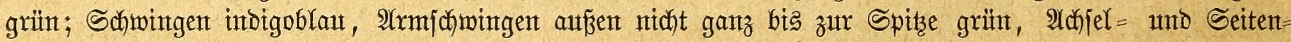

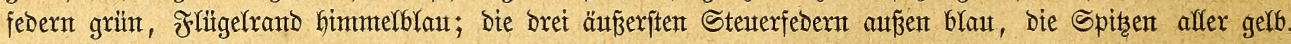

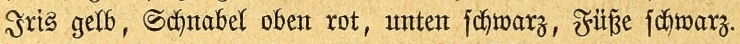

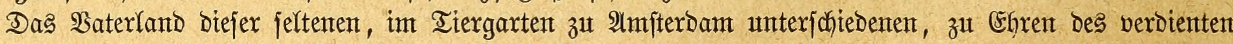

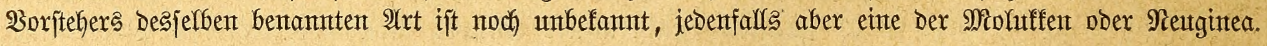

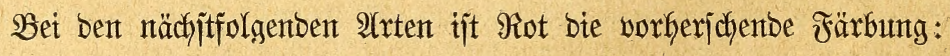

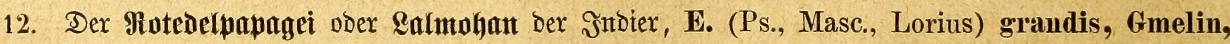

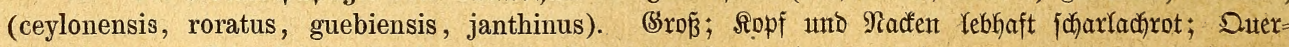

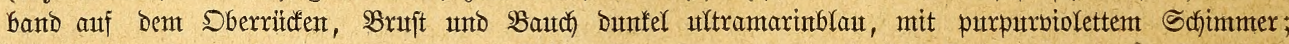

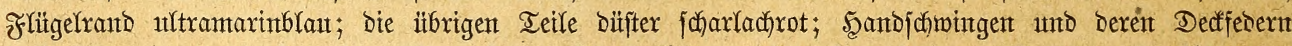

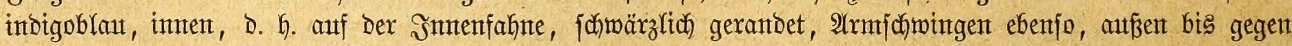

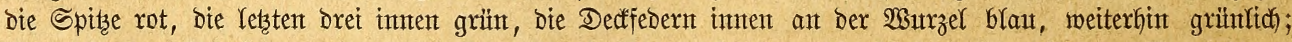

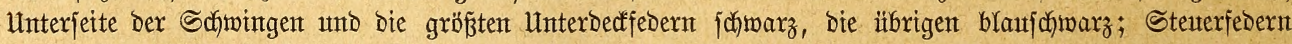

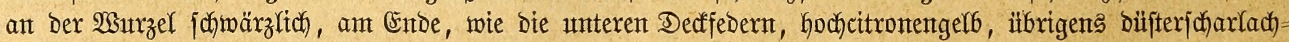

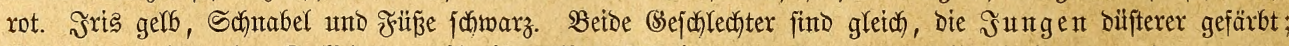
Spielarten mit gelben Decffedern, teifweife gerbent Schwingen 2c. fontmen vor.

Satmakera, Iernate, Batjan unt Morotai fint als Seeimatorte nadjgewiejent worben.

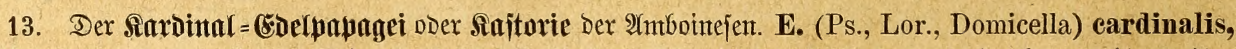

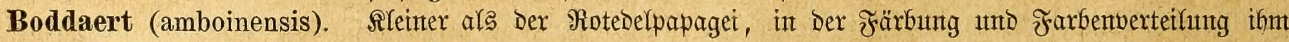

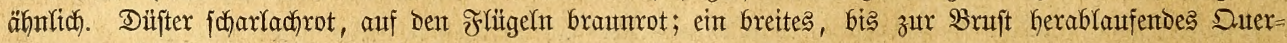




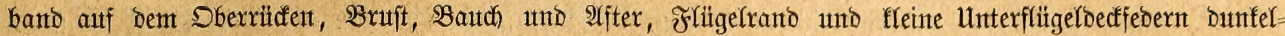

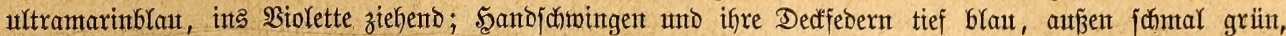

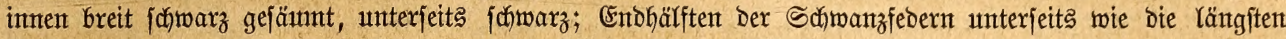

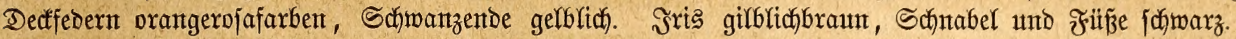

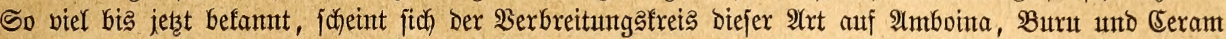
zu bejổränfent.

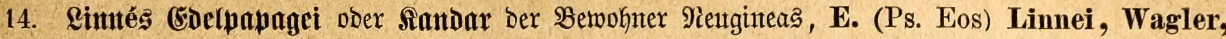

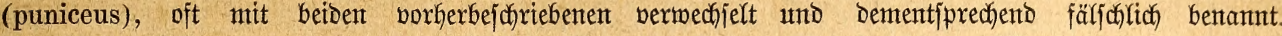

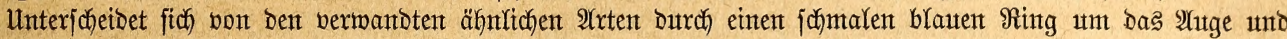

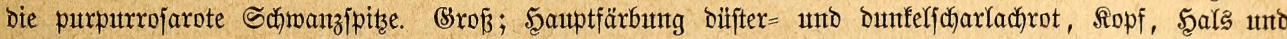

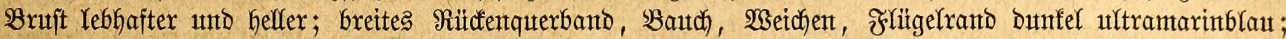

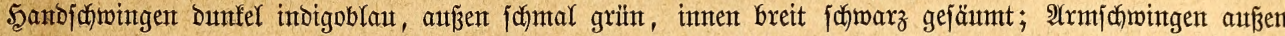

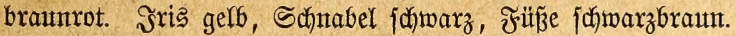

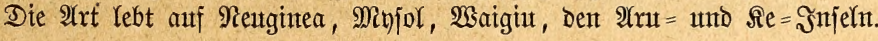

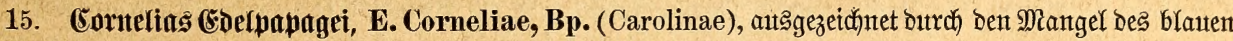

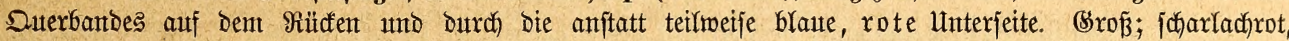

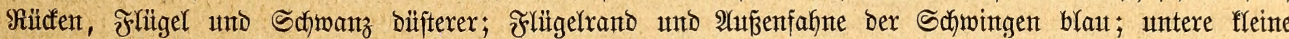

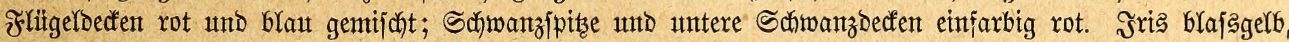
Santabel fadinarz, Füne Dunfelbraun.

$\mathfrak{B}$ aterlando unbefannt.

Die übrigen $\mathfrak{2}$ (rten ber (Sruppe werben neuerbings gewöbnltich) in einter bejonberen Sippe

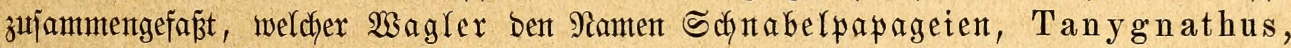

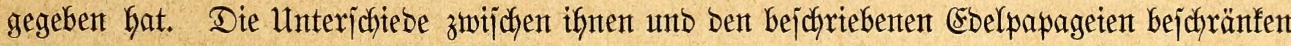

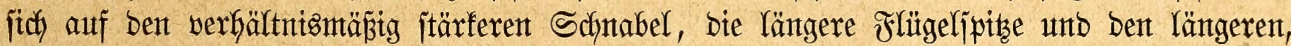

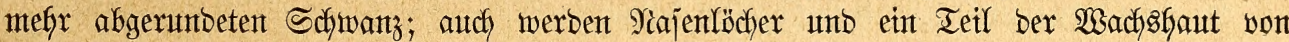

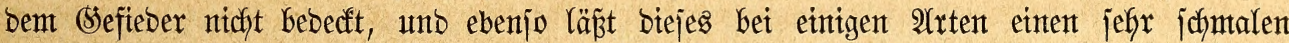

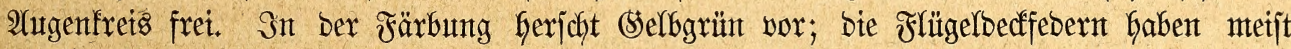
farbige Säume; ber Schnabel ift gemöfhnlide einfarbig rot. Finfid bällt bieje Unter=

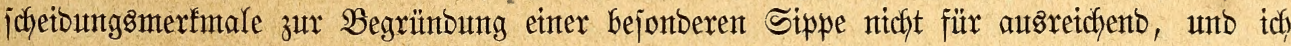

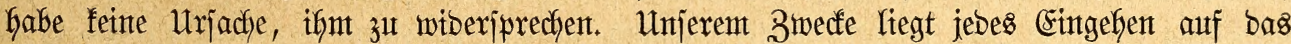

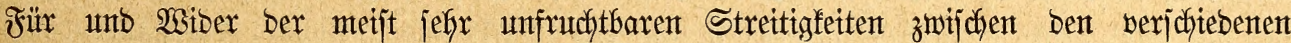

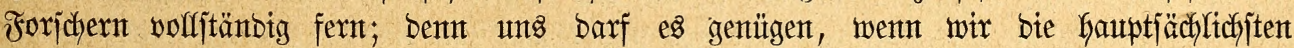

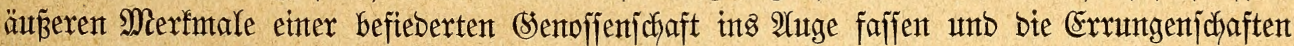

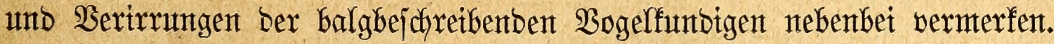

16. Dex Sinwarzidultex = Boelpapagei ober Burah ber Boramejen, Salea anderer Eingeborenten, E. (Ps., Mase., Tanygnathus, Erythrostomus) megalorrhynchus, Bodd., (macrorhynchus, marginatus,

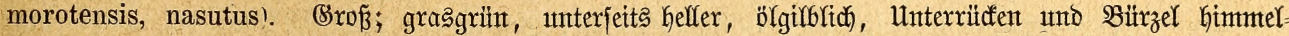

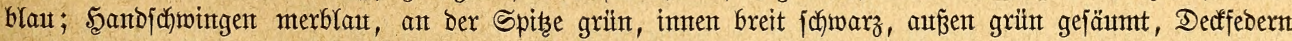

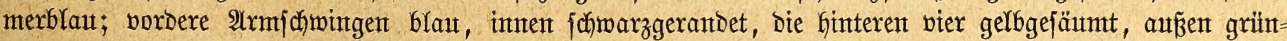

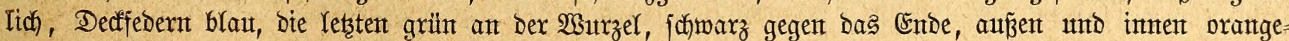

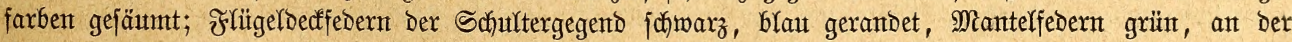

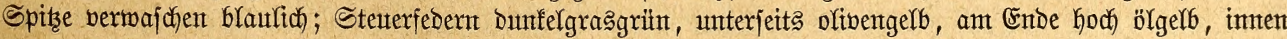

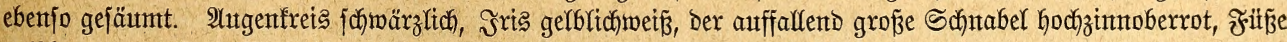
gelbbraut. - Das $\mathfrak{W}$ eib chen ijt merflich fleiner.

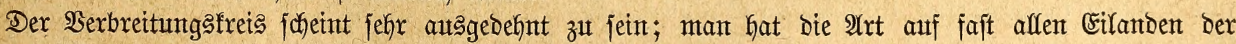

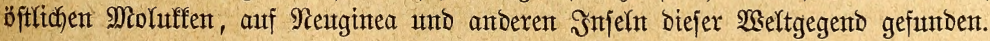

17. Der (Srünidulter = (5)elpanagei, E. (Tan.) affinis, Wallace, (intermedius). Unterjd)eibet fitc) bon Den vorkergehenden augenfälftg Durch bie grïnen Sdutlterfebern unt Sdjwingent. Rlein; grasgrün,

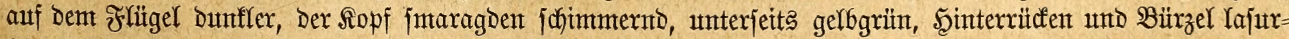

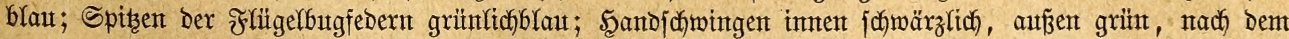
Schafte zu blaulich), fámal ginbliç) gejäımt, unterjeits gelb, graut berwajchen, ifhre Dedfebern blaugraut,

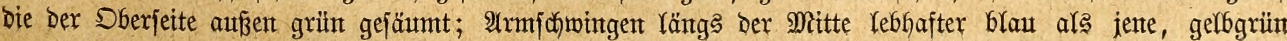




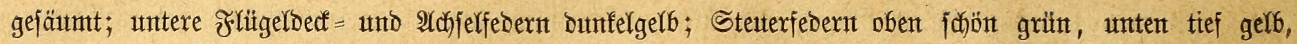

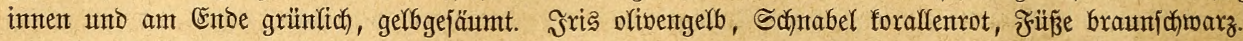

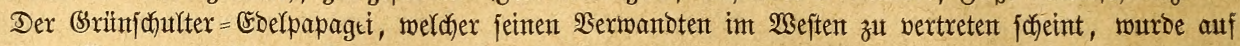

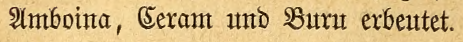

18. Müllers Conelpapagei, E. (Ps., Psittacodis, Tan.), Muelleri, Temminck (sumatranus,

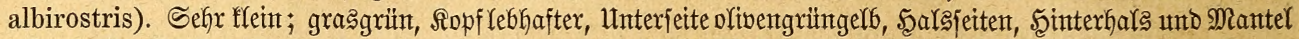

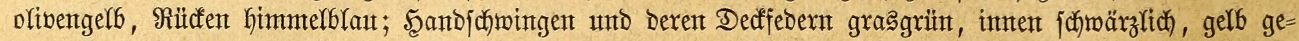

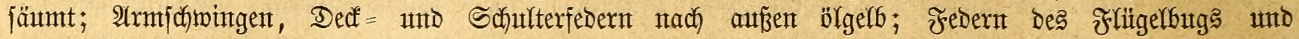

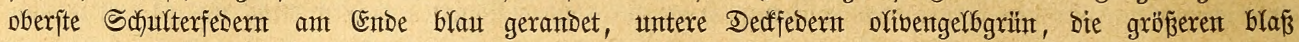

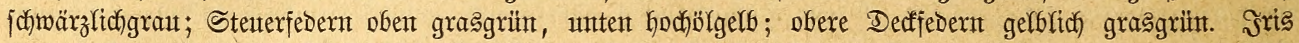

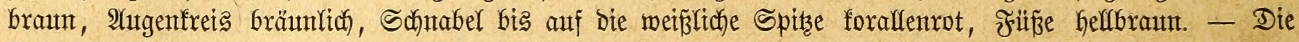

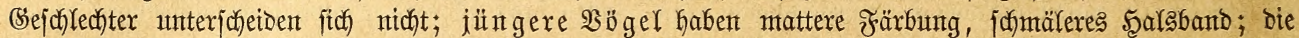

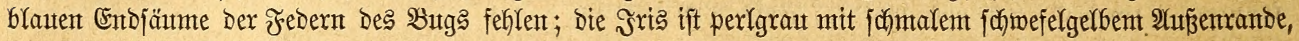
Der Sdjutabel hell fleifdofarbent.

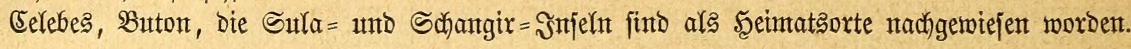

19. Dex Blatideitel=(5oelpapngei ober Rilafil bex \&uzonejent, E. (Ps., Tan., Arara) luconensis, L. (lucionensis, pileatus, marginatus, gala, olivaceus, phrygius). Seff flein; gra grgün, auf Ropf, Bruft,

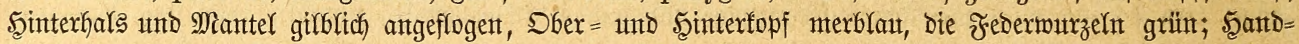

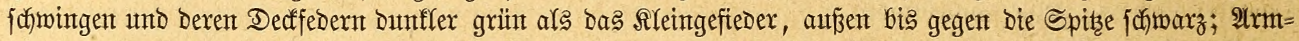

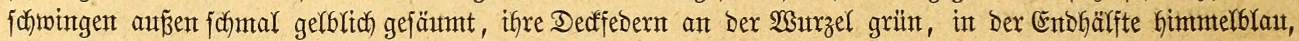

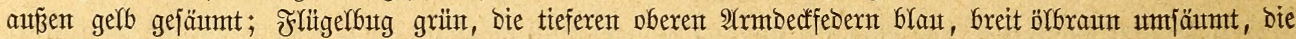

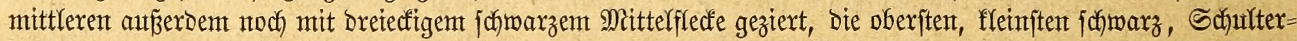

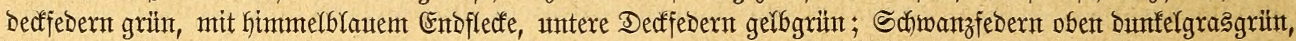

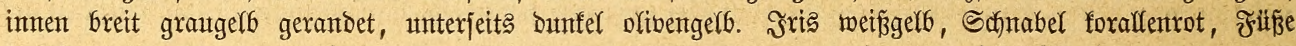
bornbrautgraut.

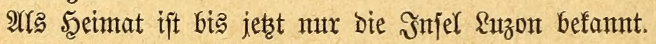

Unjere Renntnis Der Ebelpapageien begrünbet jich hauptjächlidy auf Räfigob̈gel; Denn

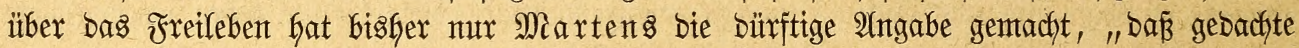
Papageien mehr einzeln als in Scharen in Den Walbungen leben." Die Eingeborenen ber

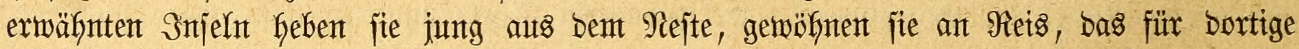
Segenden einfachjte und billigite Futter, zäfmten fie bis zu einem gemifjen (Srabe, ofhne fich mit ifyrer Refre abzugeben, bringen fie auf ben Marft und endlich in bie Scänbe eines

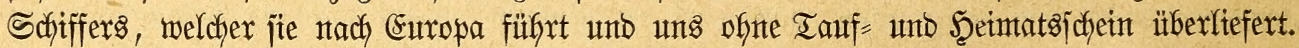

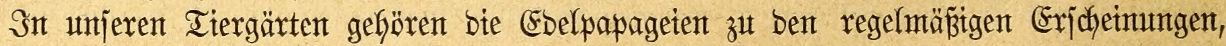

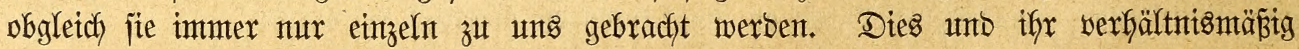

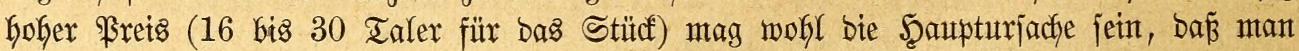
fie jelten in $\mathfrak{B}$ ejits bes Riebhabers finbet. Ein anberer Umitand trägt alferbings ntoch bazu bei, ifre Berbreitung als Siäfigügel zu bejdyränfen: fie zäflent ntidft zu ben bejonbers an=

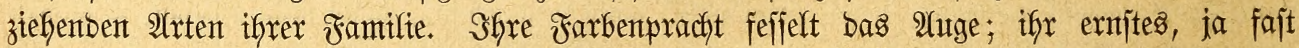

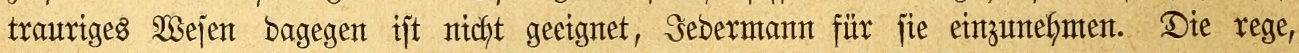

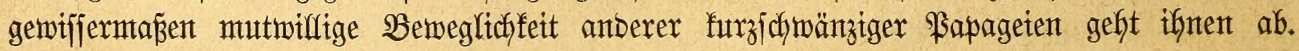
Still unb rufitg, meijt mit etwas gejträubtem (sefieber jitsen fie auf ifrer Stange ober in ifyemt (sebauter, unto went fie cinmal flettern, tun fie es gleichjam veroroffen, mintoptents

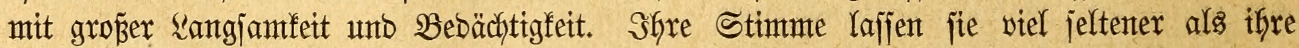

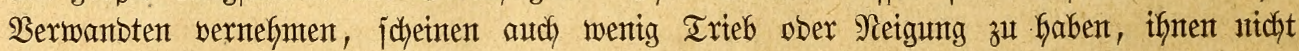

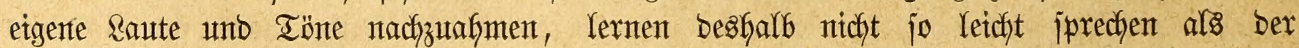

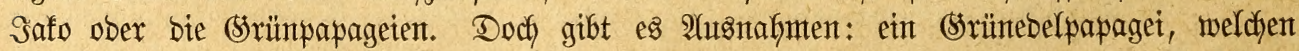

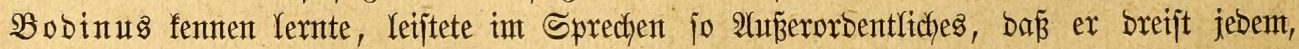

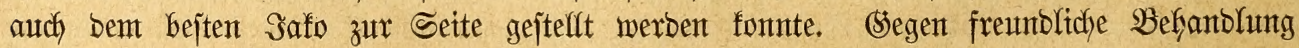
jint fie jefr empfänglich, werben baher bei geetgneter Wartung ebenjo gut zafm als andere

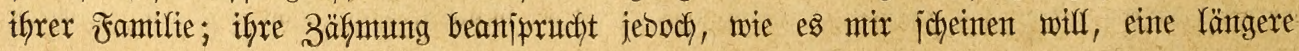


Zeit alz bie anberer $2(x+e n$, weil jich bas entichiebente Mistrauen, welches jie anfänglich

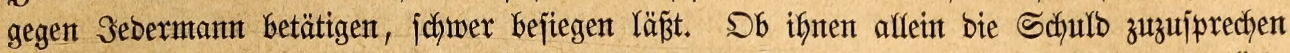

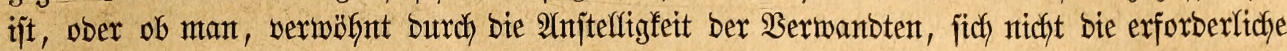

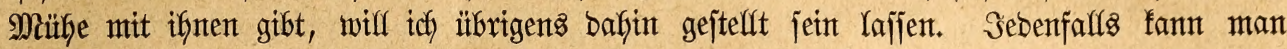

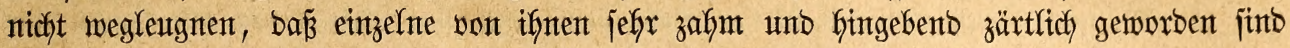

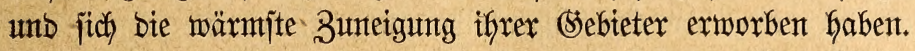

Bffege unt $\mathfrak{B a r t u n g}$ ber Ebelpapageient haben ifyre Edjwierigfeiten, nidyt jowofgl was

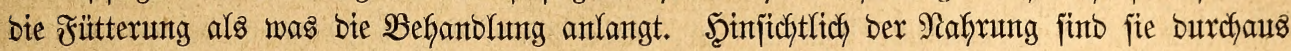

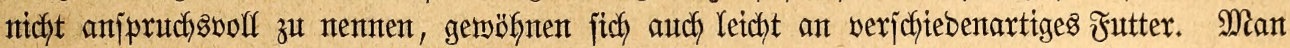

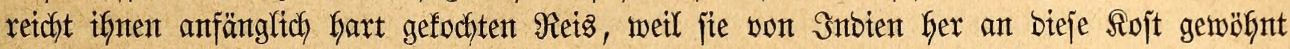

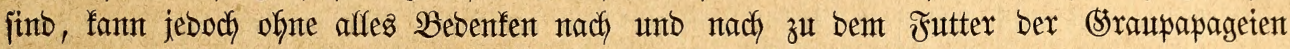

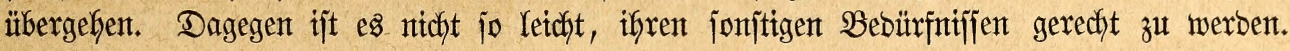

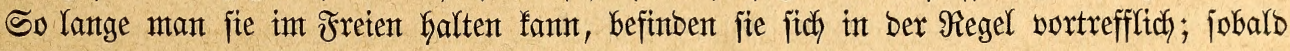

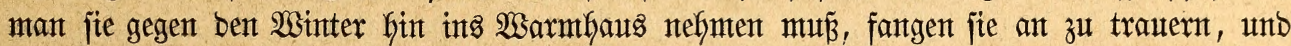

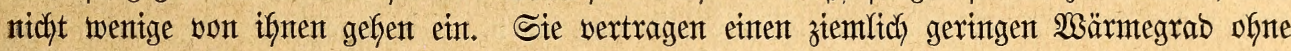

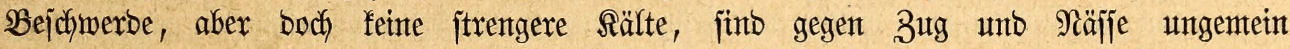

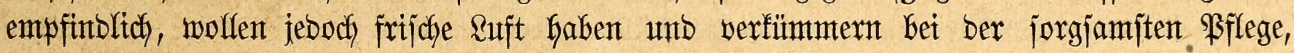

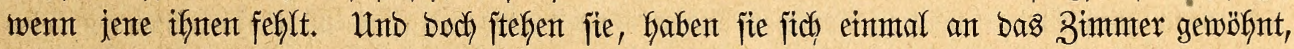

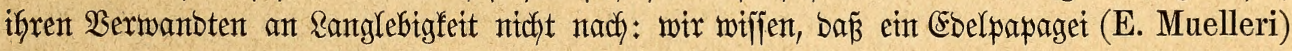

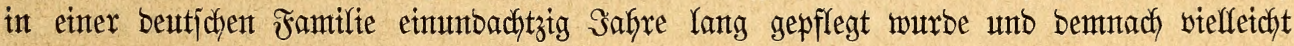

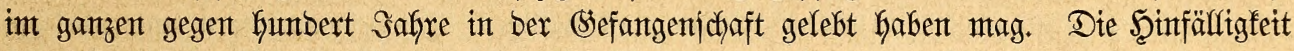

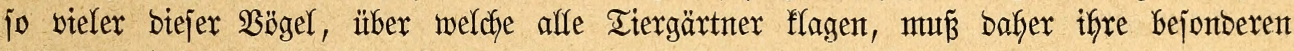

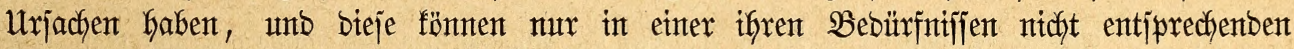

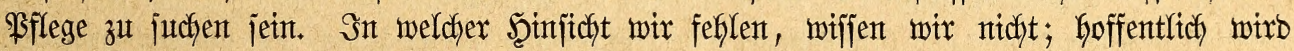

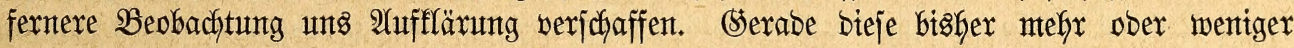
vernachläjfigten $\mathfrak{B}$ b̈gel veroienten volfifte Berücffichtigung.

Die Şauptbezuggquelle für afle Ebelpapageien ift ફ̧ulfanto, wojelbịt autch bie meiftent zu bleiben jecheinert.

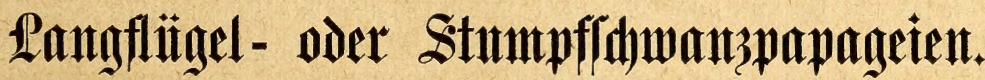

Snbem wir Finj dh weiter folgen, bürfen wir eine nambafte 9 Inzafl won mittelgroben, jefri gebrungen gebauteten, bičleibigen Bapageent in eine unt unt biejelbe Sippe vereinigen, obrwofl fie fich über brei Exbteile verbreiten unto, entfprectento ber verjdjebenten Şeintat,

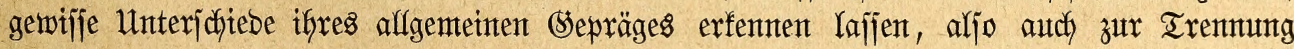
in Unterabteilungen berectitigen.

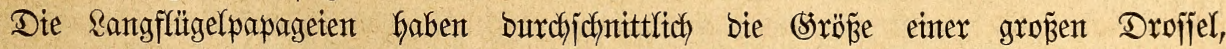
jefhen aber, bes Stumpfichiwanzes Gafber, viel fräftiger unto gebrungener aus, wiegen audch

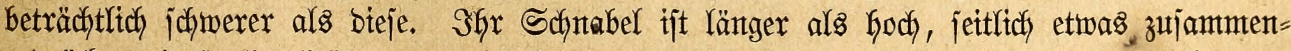

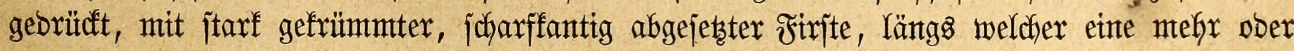

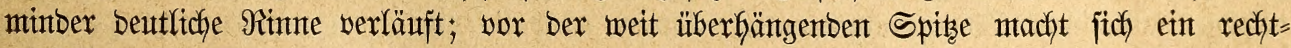

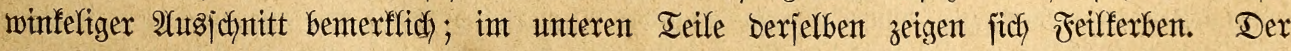
Unteridgnabel ift io Goch als ber obere, hat eine breite, abgerunbete Diffenfante, auf

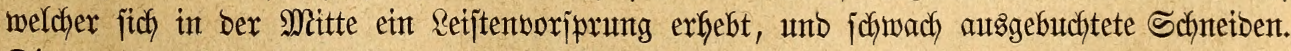
Die rutben Najentëcffer liegen ftets frei in ber entweber mit furzzen Boriften ober mit

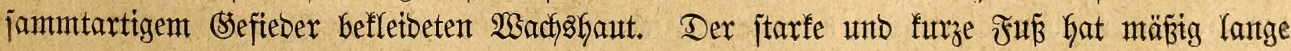




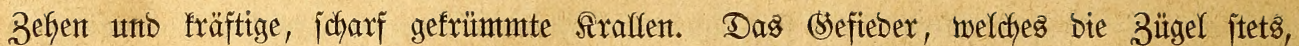

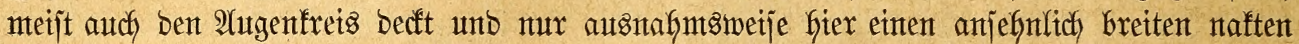
Ring freiläpit, bejteft zumeijt auts breiten, bet ben einen meidyen, bei anberen barten, bei

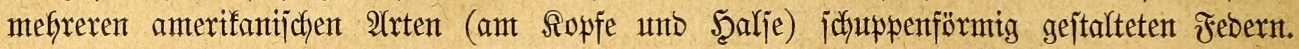

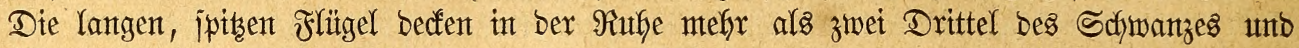

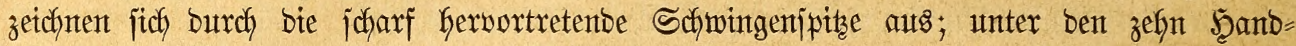
jchningen, beren zweite ober britte bie längiten, jinto bie exjten brei ober bie auf bie zmeite folgenben vier aufen etwas ausgejdyntten. Dex furze breite Schwanz ijt bei ben meiffent Irten gerabe abgejdyntten, bei einigen jeitlich ein wentg zugerunbet; Die Stenerfebern funto ant Enbe meijt flammerförmig gejtaltet, jeltener abgerunbet. Die alfgemeine Färbunt ijt

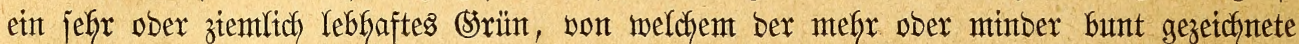

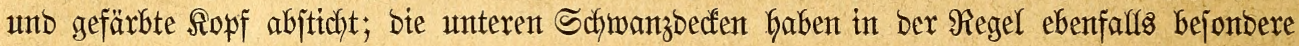
Färbuttg; auf ben Flïgelnt bagegen feblt jolche jtets.

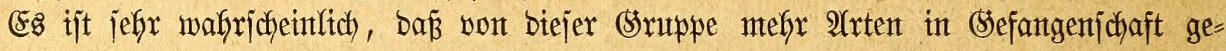

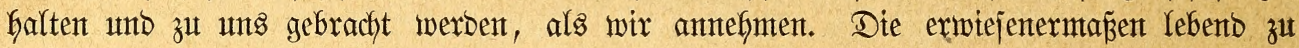
uns gelangten und eintge, welche wir frïfyer ober fpäter bejtintmt ertwarten bürfen, babe idy nachitebento berzetdynet.

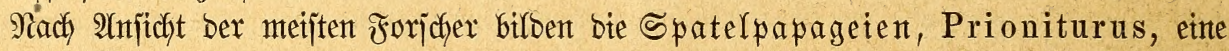
bejonbere Sippe, weil fie jith won ben ïbrigen Rangflïgel= unb Surzichwanzpapageten über= Gaupt burdh bie betben, beträchtlich werlängerten, in Der Sugento vollbartigen, im SYlter bis auf bie jpatel = ober jubeibenförmige Enbfafne naftichaftigen Mittelichwanzfebern untericheiben. $3 \mathfrak{i t h n e n}$ gehört:

20. Dex Motmtut=\$apagei ober Strity unto Sli ber Eingeborenten ber Mitrabafia utto Gorontalo, Pionias (Prioniturus, Ps., Ecl.) platurus, Tem. unt Kuhl (setarius, discurus, spatuliger, Wallacei).

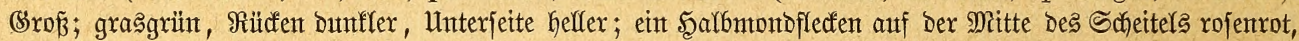

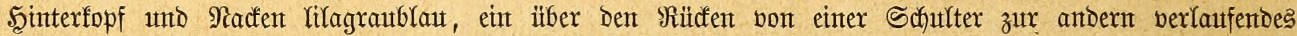

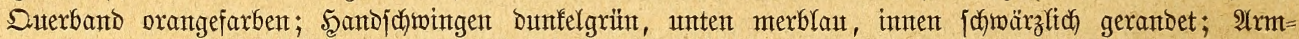

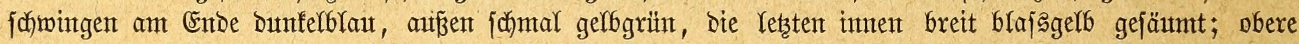

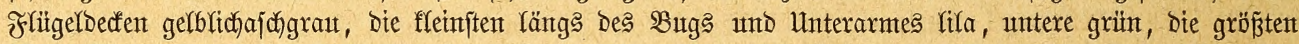

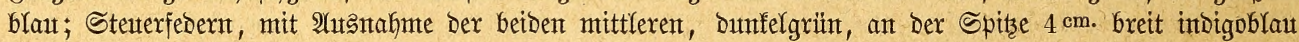

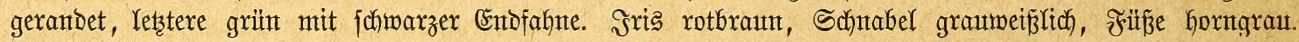

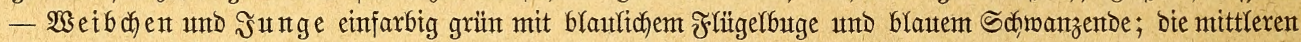

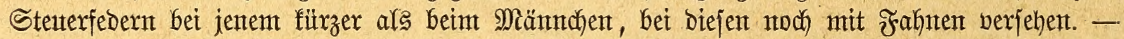

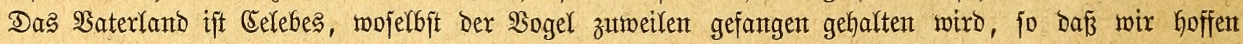

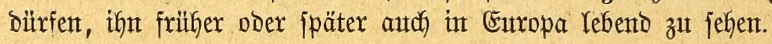

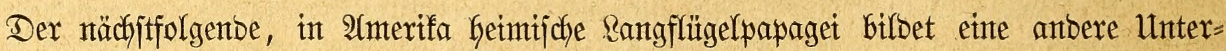
abteilung, weldyer ber Rang einer Sippe, Triclaria, zugeiproctjen worben ijt. Die

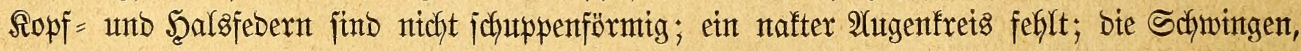
unter benen bie britte bie Yängite ift, laufen jefr ipizig zu; bie unterent Sdywanzbecffedern finto grün.

21. Der Blaubmud oder die Sabiafiteca ber $\mathfrak{B r a f i l t a n t e r , ~ P i o n i a s ~ ( P s . , ~ T r i c l a r i a , ~ C h r y s o t i s , ~ A m a - ~}$ zona) eyanogaster, Prinz Max von Neuwied, (malachitaceus). (Sroß̋; glänzenঠ Dunfel grasgrünt,

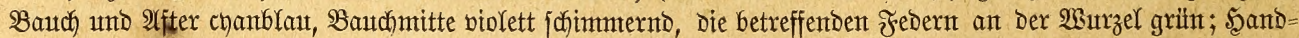

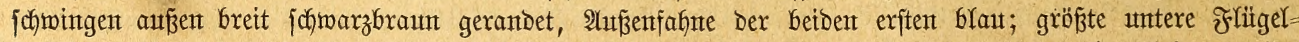

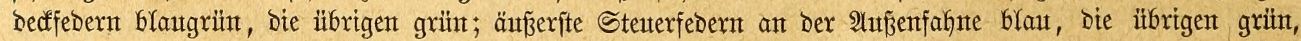

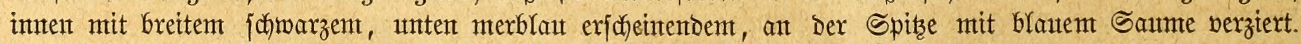

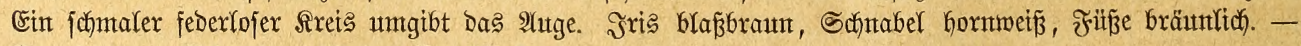
Den jutngen $\mathfrak{B}$ p̈geln feflt ber Bautufflectent.

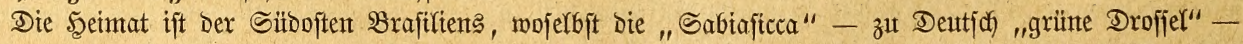

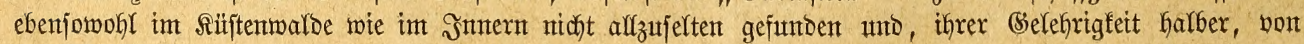
Dent Eintwohnern mit $\mathfrak{B} 0 \mathrm{rfiebe}$ gefangent gefalten miro. 


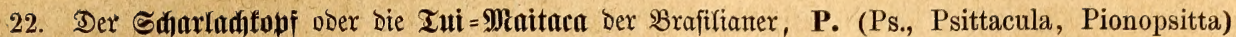

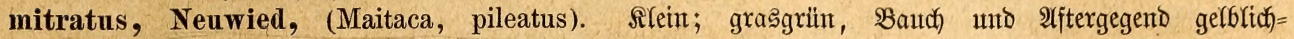

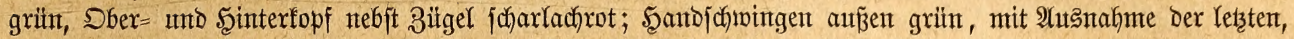

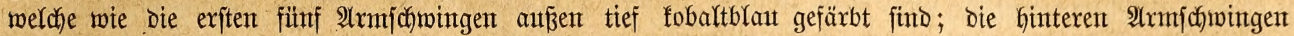

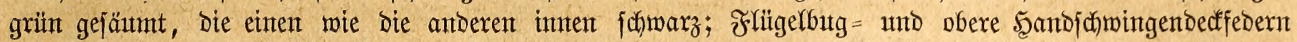

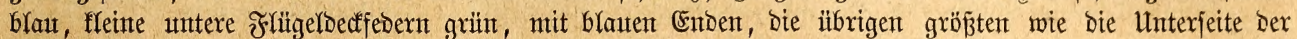

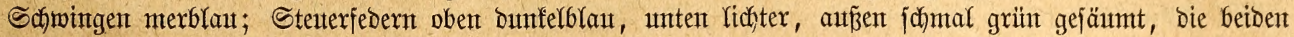

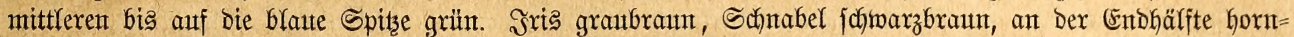

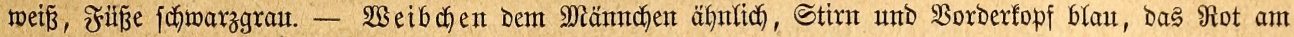
Ropfe mur angebentet ober nicht borhanden. Sunge $\mathfrak{B}$ ögel einfarbig mattgrün, Scheitel bräumflich über-

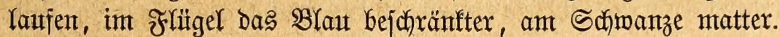

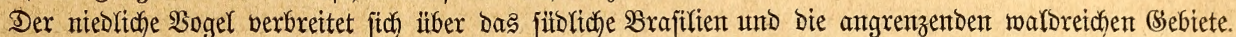

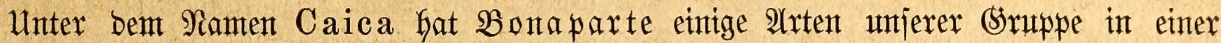
bejonberen Sippe vereinigt, weil ifyr Sannabel etwas Göher, ber Flügel jptizer unb Der Schmanz mefy abgeruntoet ijt als bei ben übrigen. âls ifnen eigentümtlich mag ferner

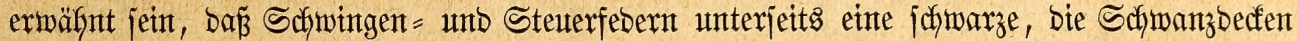
eine gelbe Färbung zetgent.

23. Der Sanpen = \$apagei, P. (Ps., Am., Caica) histrio, Bodd. (caica). Mittelgroß̃ ;

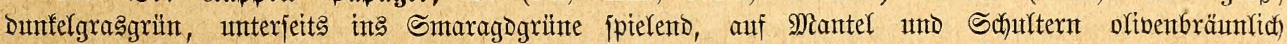

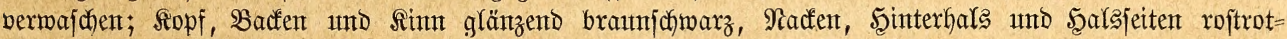

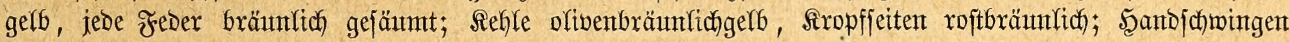

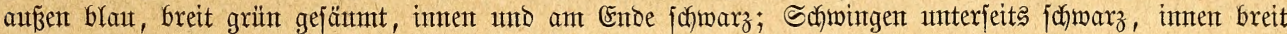

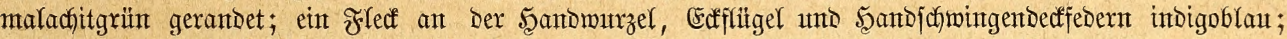

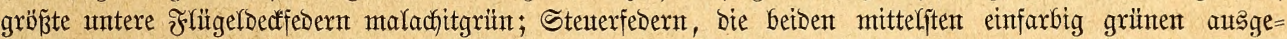

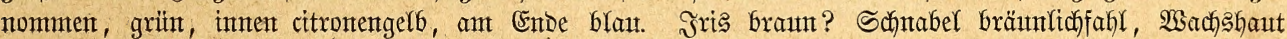

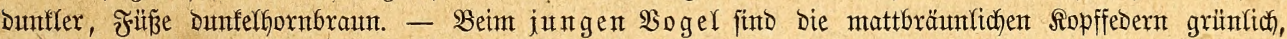

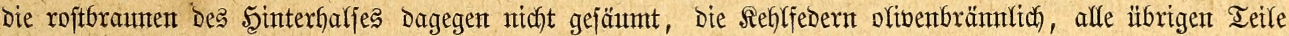
Dem Altersfleibe gleidy ober febr ähnliç gefärbt.

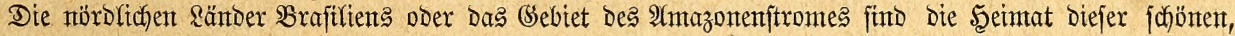

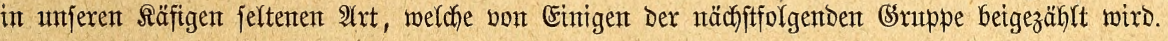

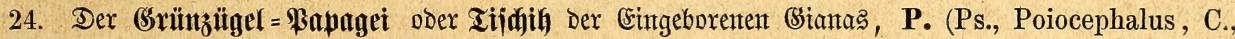

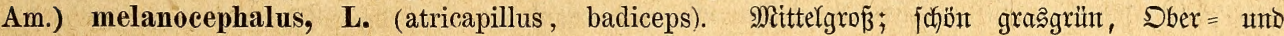

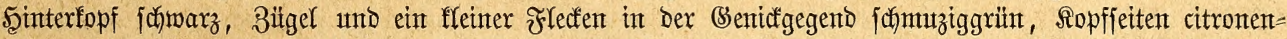

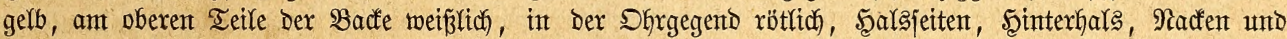

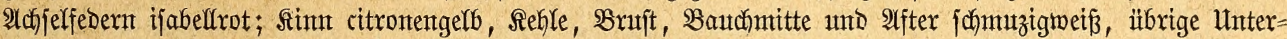

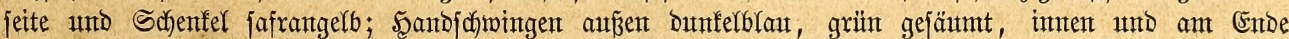

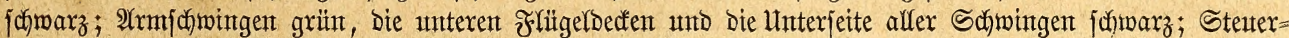

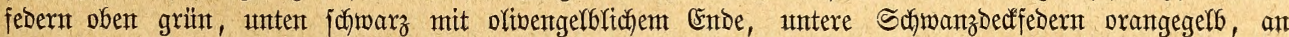

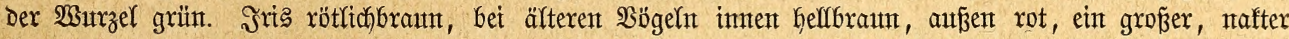

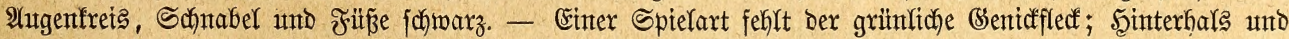

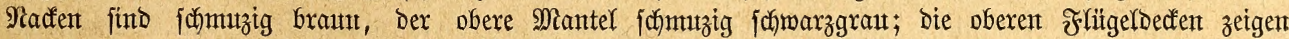

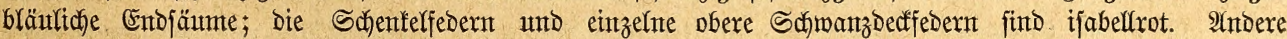

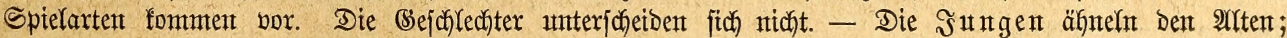

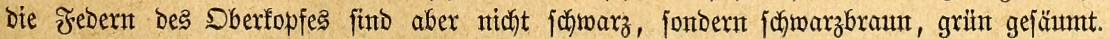

Der in umferent Sanmthntgen nod) feltene Wapagei gefört Dent nörolidenen Ieifen SïDamerifas an, ift

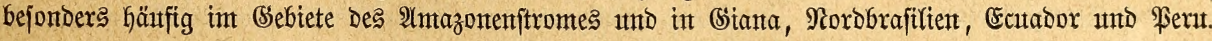

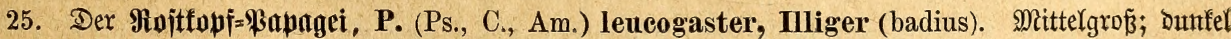

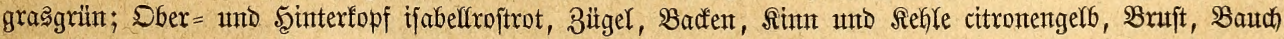

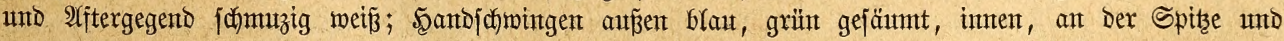

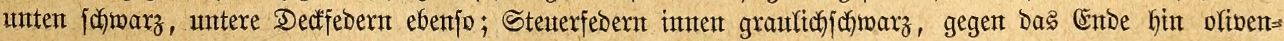

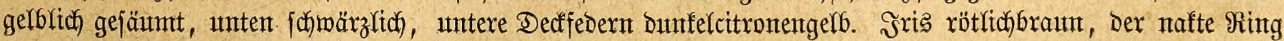

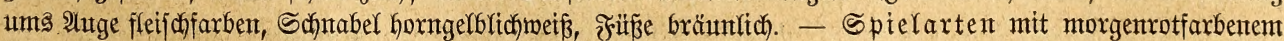

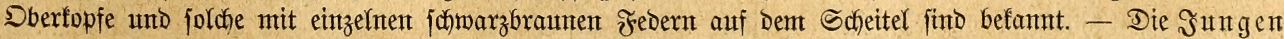

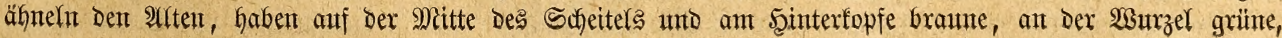




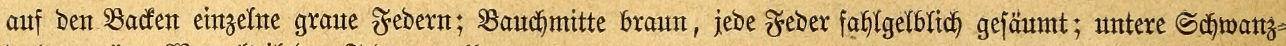
becten grün, 2 surzelteil ber Federn gelb.

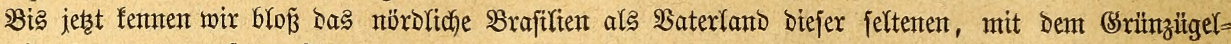
papagei zufammengemorfenen $\mathfrak{A}$ rt.

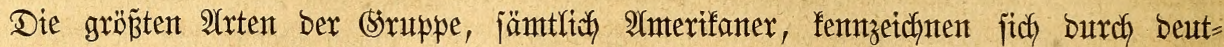

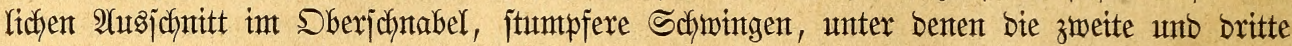
bie längiten, gerabe abgejdyntttenen Schwanz, Defjen Febern an Enbe flammerförmig fint, eigentümlich jahuppenartige Febern ant Sopfe unt Şalje unb rote Unterjchmanzbedfebern. Sie

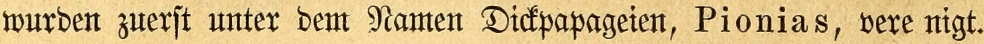

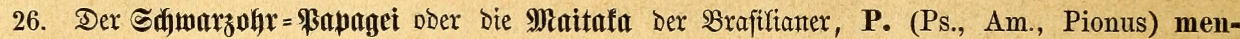

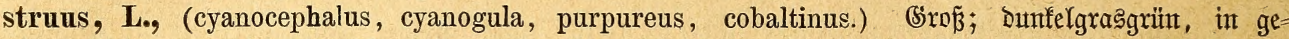

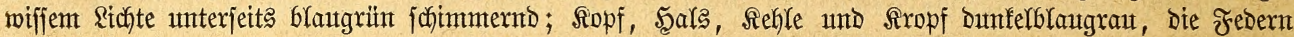

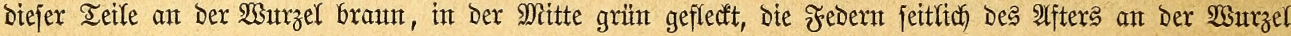

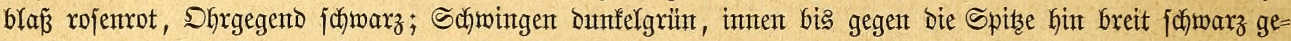

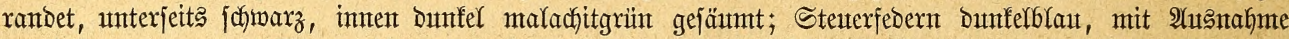

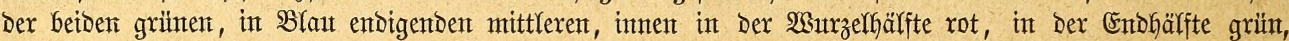

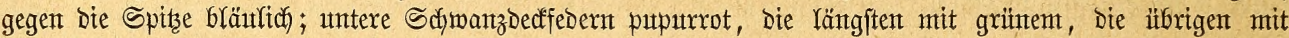

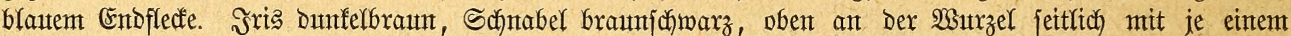

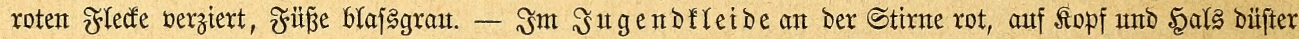

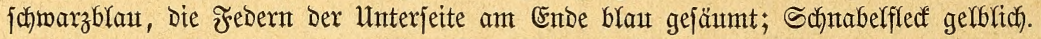

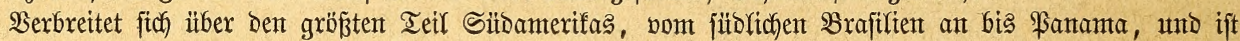
überall häuftig.

27. Maximilians \&angflügelpanagei, P. (Ps., P., Am.) Maximiliani, Kuhl, (flavirostris,

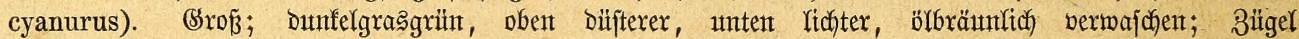

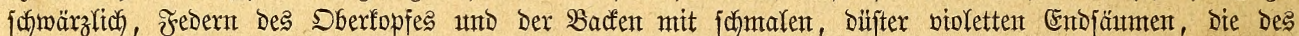

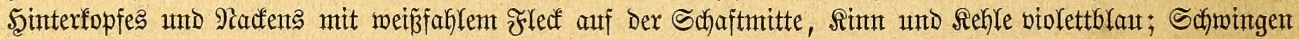

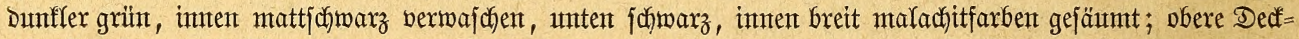

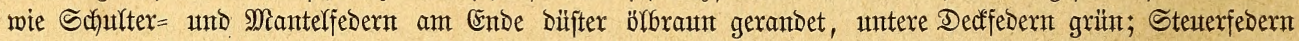

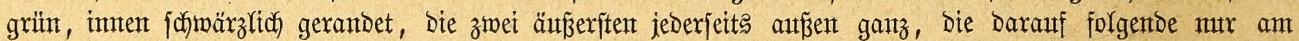

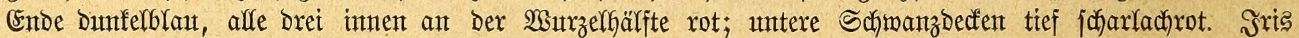

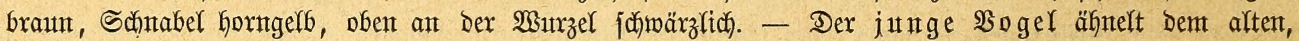

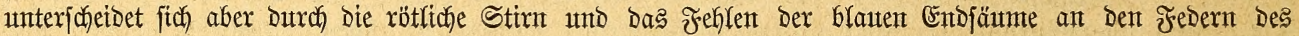
Sberfopfes.

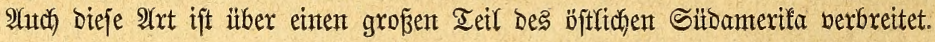

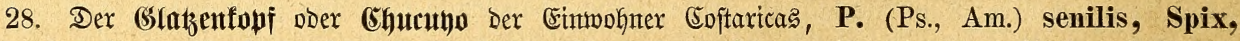

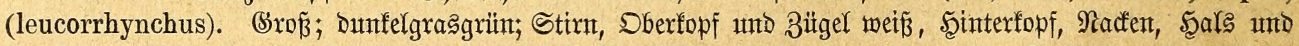

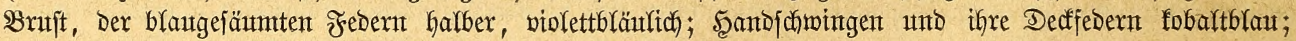
alfe Sdhwingen unterfeits fafmarz, innen breit malachitgrün gefäınt; untere Dedfedern grün; Stenterfebern

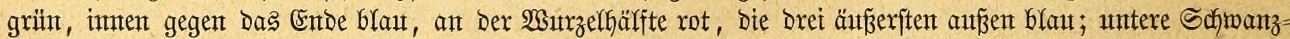

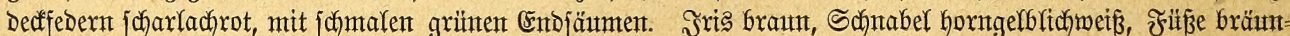

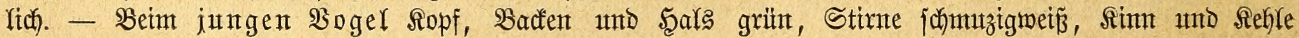

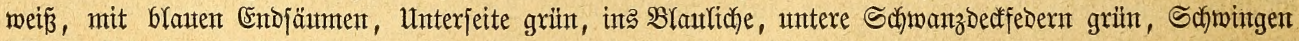
błau, mit grünemt Entoe.

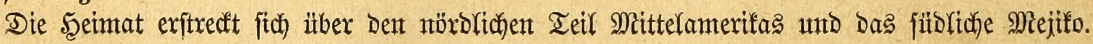

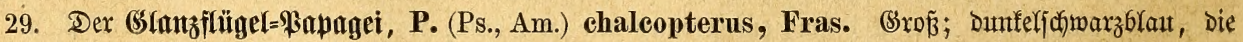

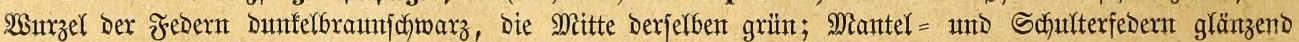

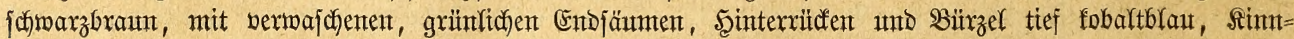

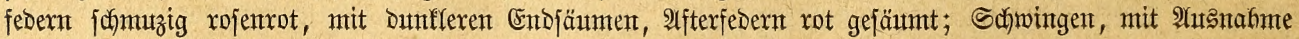

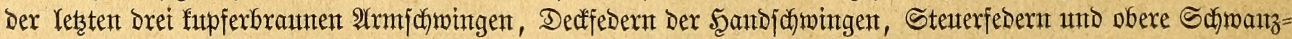

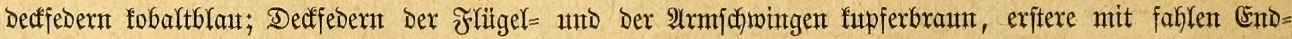

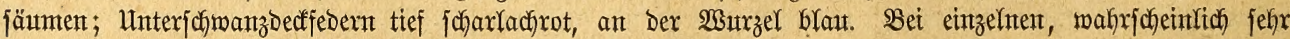

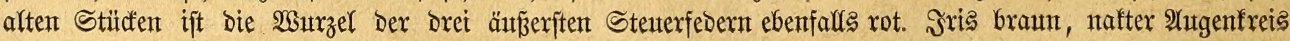

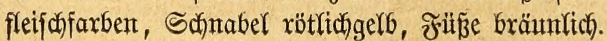

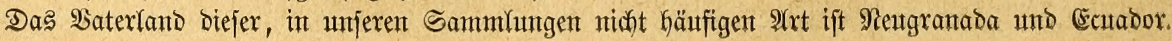


30. Dex Beildien = \$apagei, P. (Ps., Am.) violaceus, Bodd., (fuscus, infuscatus, cyano-

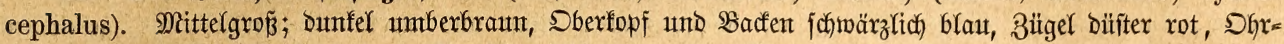

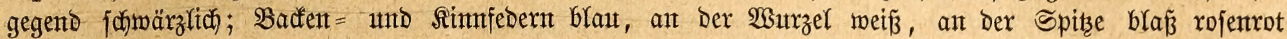

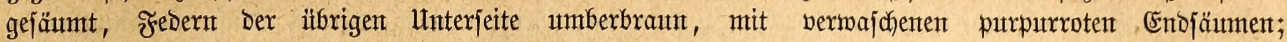

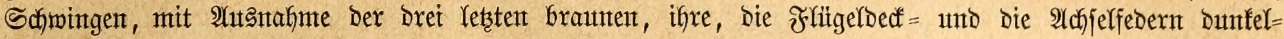

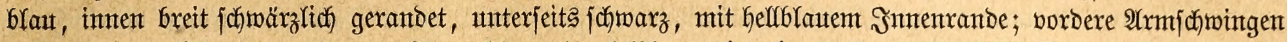

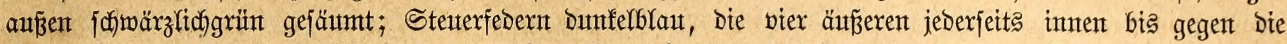

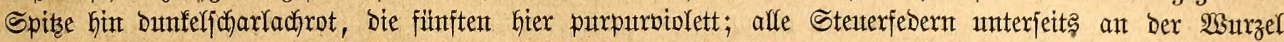

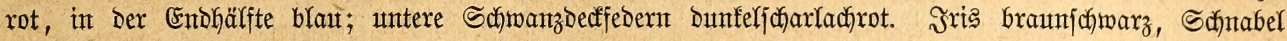

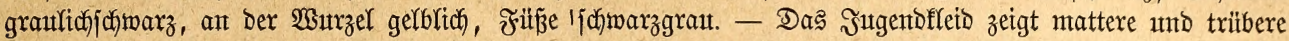
శrarbent.

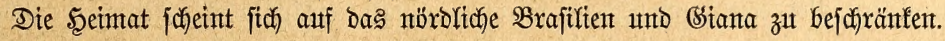

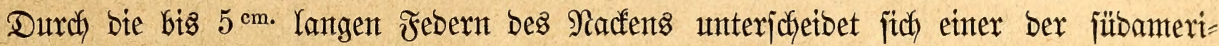
fanijchen Rangflügelpapageten exjicftlich bon ben Bermanbten und wirb beshalb von ben meijten Forjchern als Bertreter einer bejonberen Sippe, Der Fädjerpapageient, Deroptyus, angejehen.

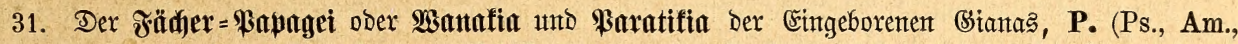
Deroptyus) accipitrinus, L. (elegans, Clusii, coronatus). (Sroß̃; Dunfelgraggrün; $\mathfrak{B}$ order = unt Dber $=$

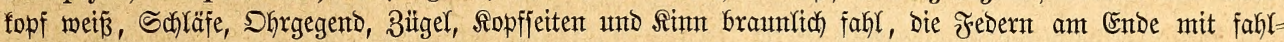

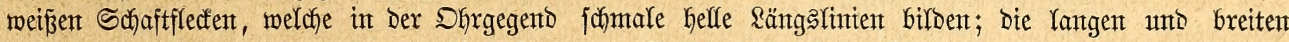

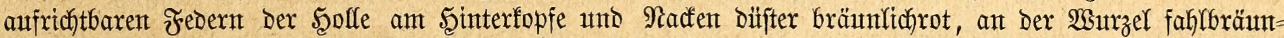

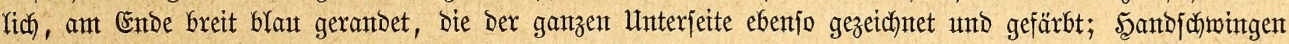

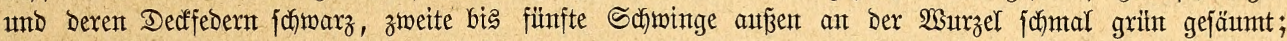

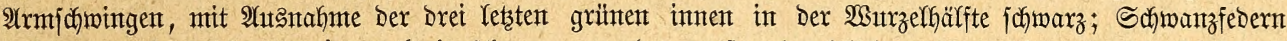

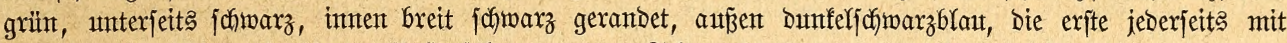

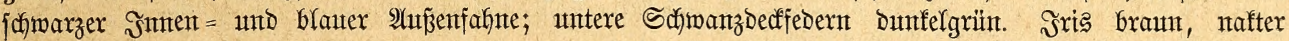

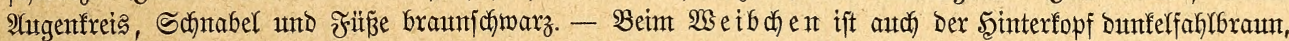

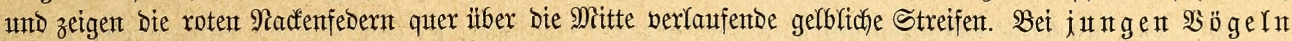

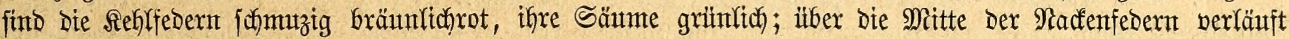
ein orangegelber Streifent.

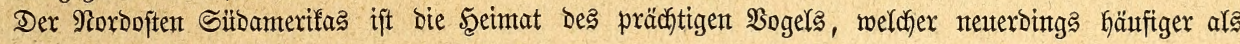
frïher zut uts gebracht wiro.

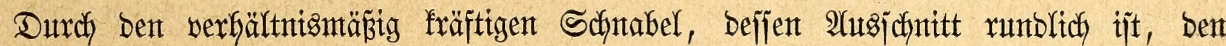

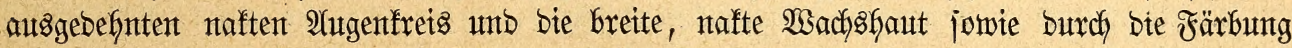
meichen bie afrifantichen von ben amerifanijchen 2raten ber Sruppe, benten jie jonjt burchaus ähneln, einigermtaß̧en ab. Das (sefteder bes fopfes unt Şaljes iit nicht jchuppenfürmig wie bet ben worjtehento bejdyriebenten 2Irten, bie Febern haben vielmebr eine mebr herzförmige (sejtalt. Slivengrün, Die vorkerjchente Färbung, geht auf bent Ropfe und ben Schmingen meijt in ein büjteres Delbraun ïber, währento ber Bauds unto bie unteren Flügeldecten in

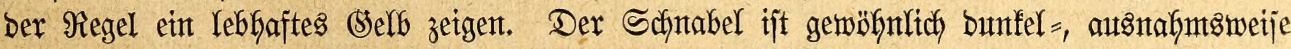
zmeifarbig. Man Gat audh fie unter bent Şändlentanten Miofrenföpfe, Poiocep halus, zu einter bejonberen Sippe erfoben.

32. Der grof̧e Mtohrenfopf, P. (Ps., Poiocephalus, Phaeocephalus) fuscicollis, Kuhl (pachyr-

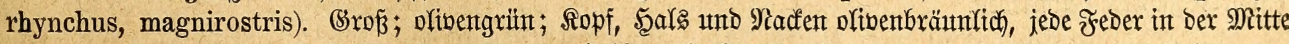

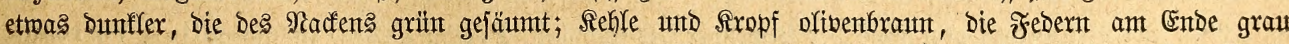

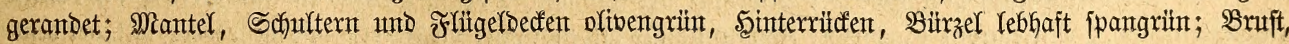

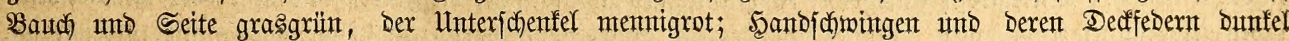

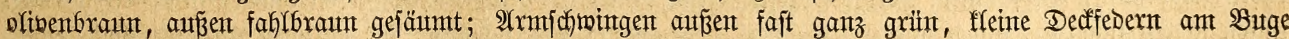

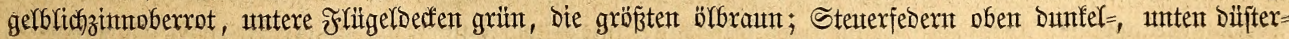

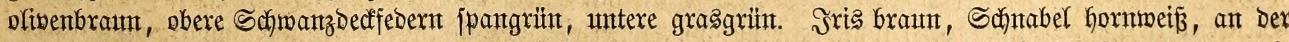

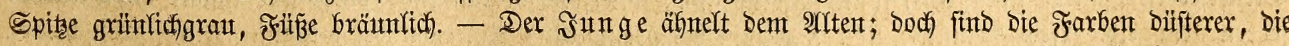

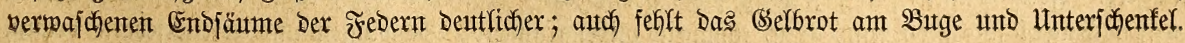

Beftafrifa, vont Senegal bis zum Babut, ift ałs seemat befannt gemordent. 
33. Der Sịp= ober \&evaillantg Bapagei, P. (Ps., Am., Poioc.) robustus, Gmel., (flammiceps,

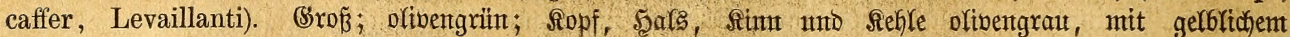

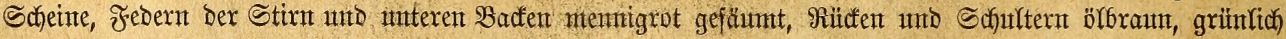

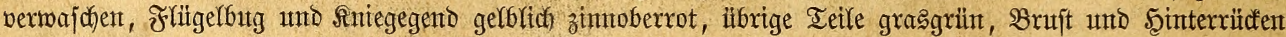

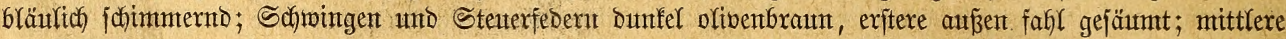

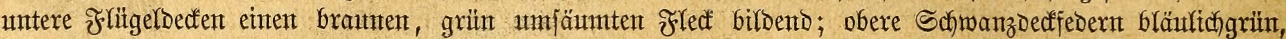

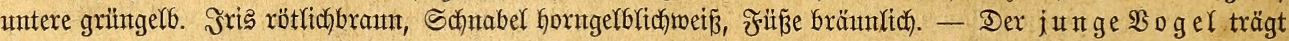

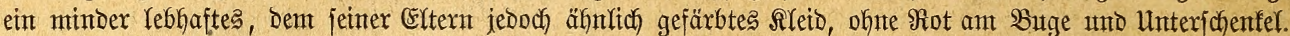

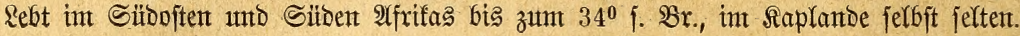

34. (Sultiefmis $\mathfrak{B a p a g e i , ~ P . ~ ( P s . , ~ P h a e o c . , ~ P o i o c . ) ~ G u l i e l m i , ~ J a r d i n e ~ ( A u b r y a n u s , ~ L e c o m t e i ) . ~}$

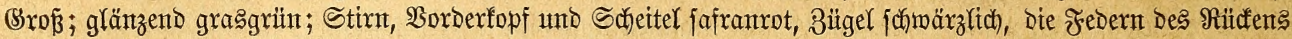

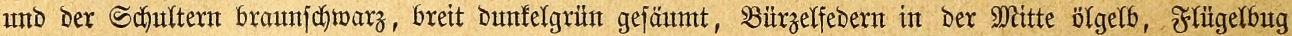

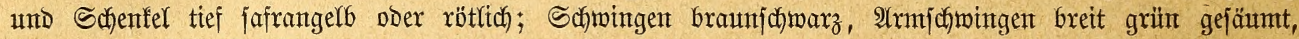

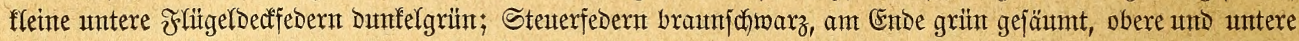

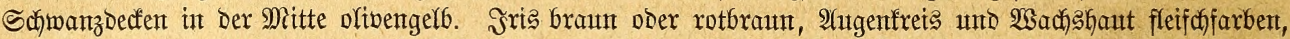

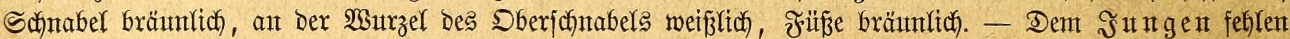
Die roten Fredern an Bitg und Schenfel.

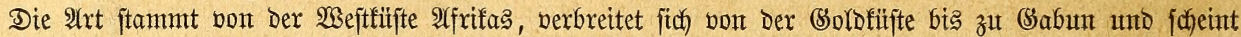
Dort häıfig zu fein, weil fie nid)t allžlfelten zu ınt gelantgt.

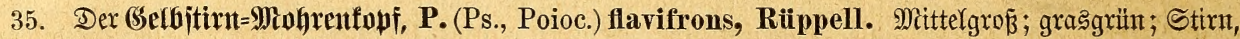

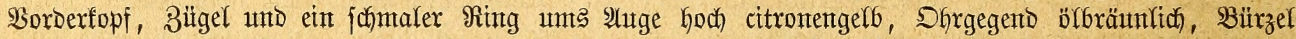
glänzeno grün, am Unterfobenfel einige gelbe Federchen; alfe übrigen Teile olivenbraut, Die Federn an

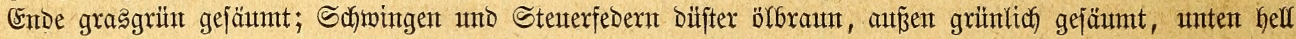

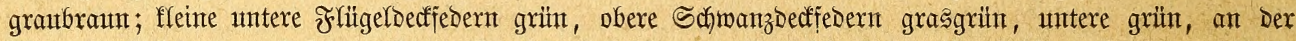

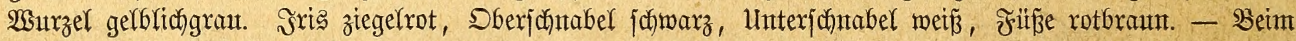
iungen 2 ogel find alle Farben matter, unt das (Selb Defint fich bis zum Şinterfopfe auts.

Rebt in Den Gebirgąwäldoern bon Şabejón.

36. Der Rotbaud = Mohrentopi oder Donforo der 2(fiffinter, P. (Ps., Poioc.) rufiventris, Rppl.

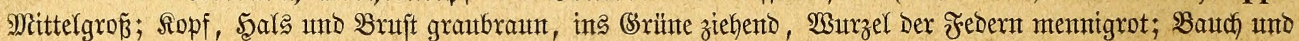

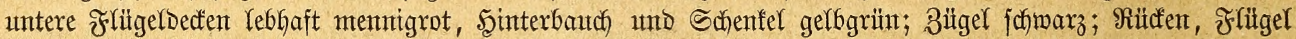

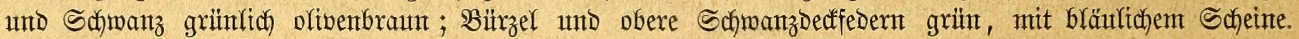

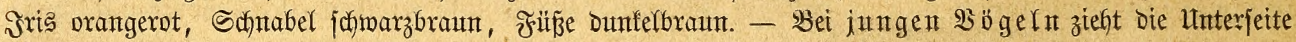
ins Brautne.

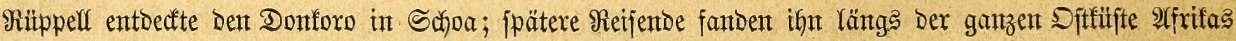
bis zum $6^{0}$ †. Sir. auf.

37. Der Mtohrentopi, P. (Ps. Psittacula, Poioc. unt Phaeoc.) senegalus, L., (senegalensis,

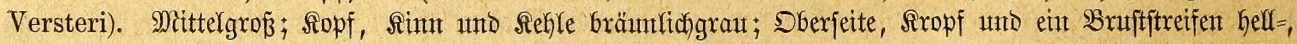

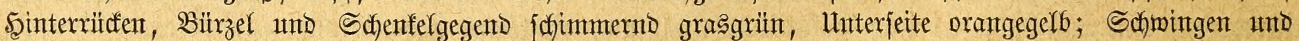

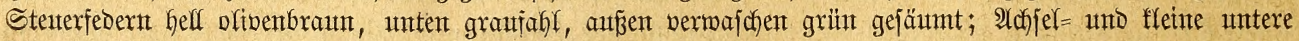

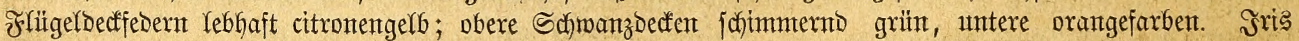

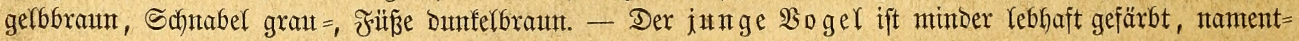
lich) auf Der Unterjeite bläffer.

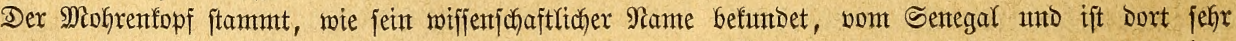

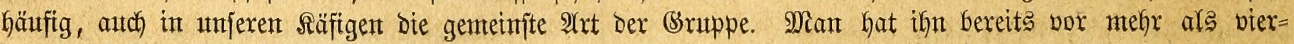
humbert safuren bejdriebent.

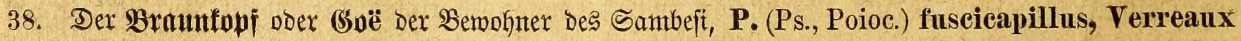

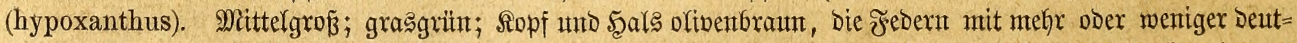

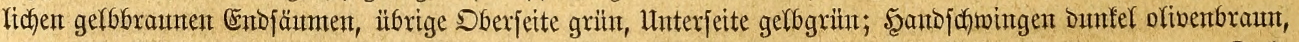

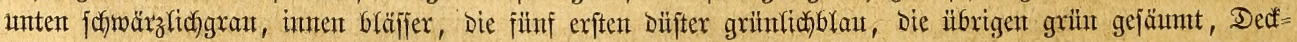

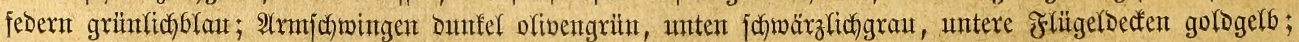

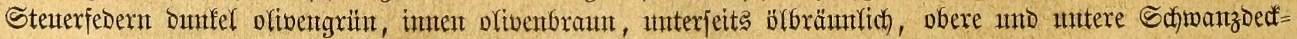

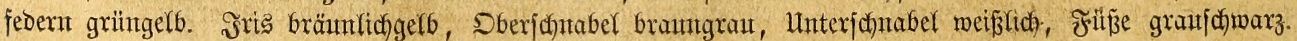

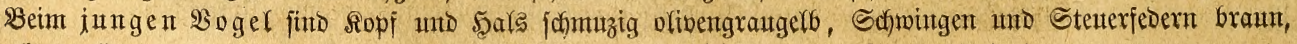
ofibengrïn gerantet. 


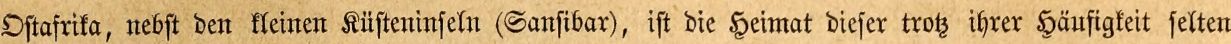
zu uth gelangenden $\mathfrak{A r t}$.

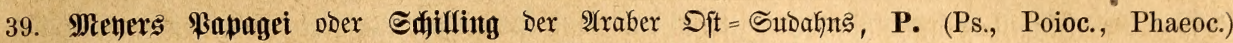

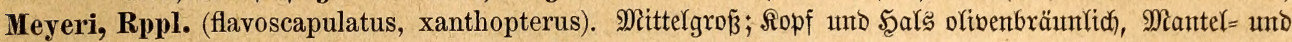

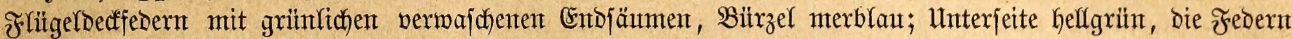

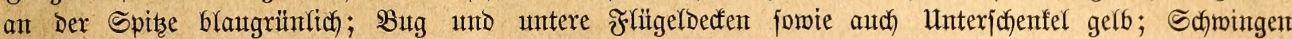

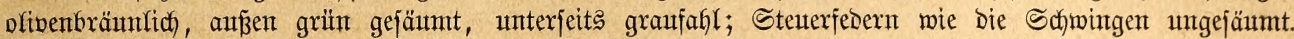

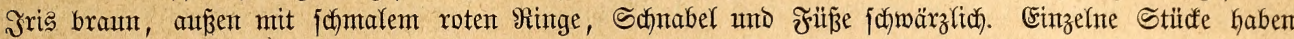

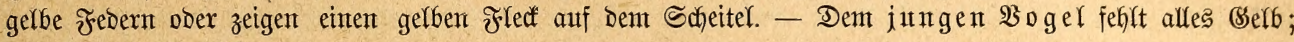
Das Befieder ift büfterer.

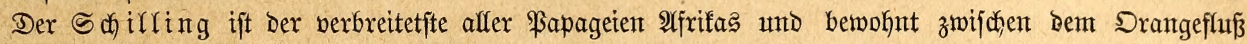

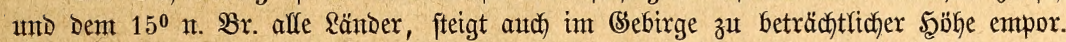

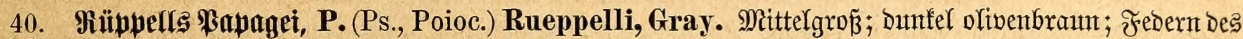

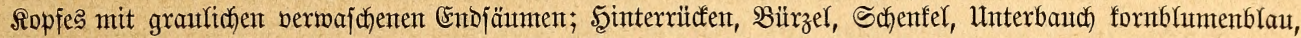

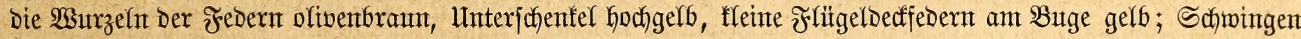
und Steuterfedern einfarbig fofmarzbraun, unten graubraunfid), untere Decffedern der erifteren gelb, obere

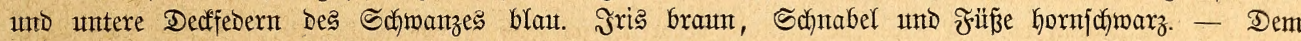

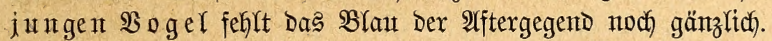

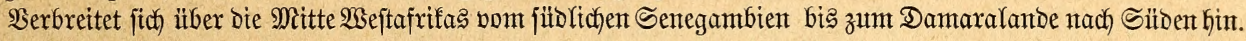

setber liegt auch bie Rebenafunbe ber in brei Eroteilen artenreich auftretenden

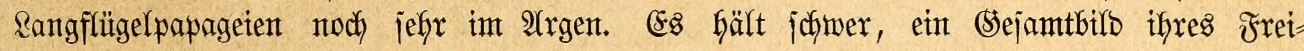

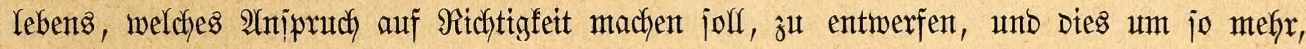

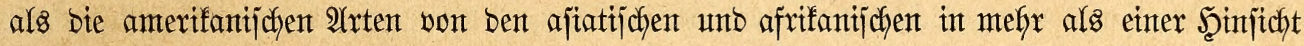

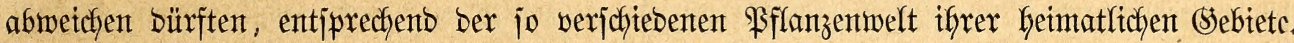

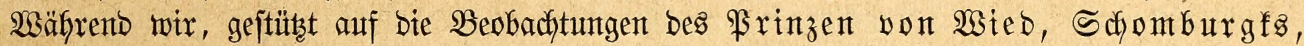
Burmeijters und anberer Forjcher, bie amerifanijchen Rangflügelpapageten in bemjelben Sinne wie bie meijten übrigen (S)lieber ifrer Sromung als Walbuögel bezeidynen fönnen, müffen wir bie afrifanifden Mohrenfïpfe wahrjcheinfich Baumbögel nennen. Sie binben

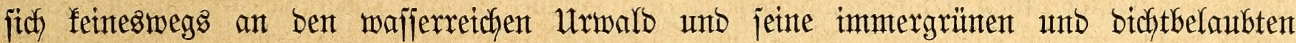
Bäume, jonbern fommen auch in bie Steppe heraus unto treiben fich, vorjichtig zwar, aber bod) ziemlich) ungebecft, jelbjt auf ben winterlich blätterlojen Bäumen umber, mit $\mathfrak{B o r}=$

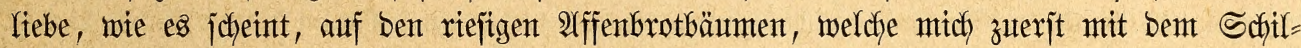
ling, Şeuglin mit einer von ifm entbecten, noch nicht in unjere fäfïge gelangten 2 (rt

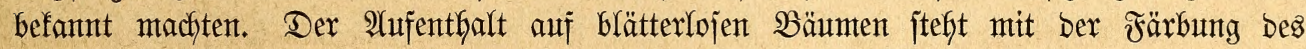

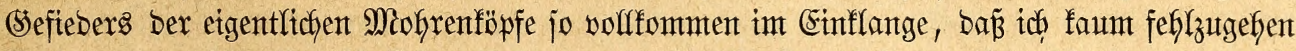

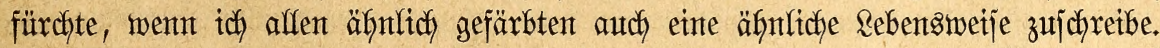

Dex gebrungente Baau ber Rangflügelpapageien, weldher burch bas bei ben meiften Ârten

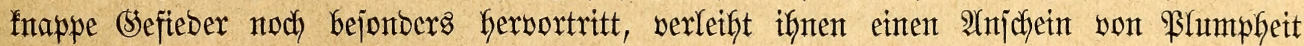

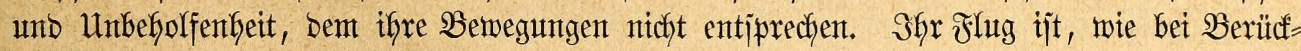
fidftigung ber fräftigen (sejtalt und jdymalen Sdywingen von vorn herein zu bermuten,

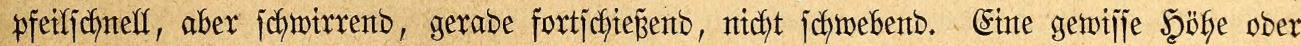

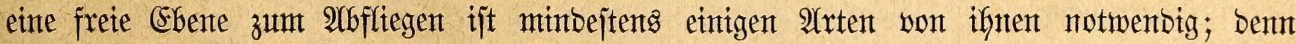

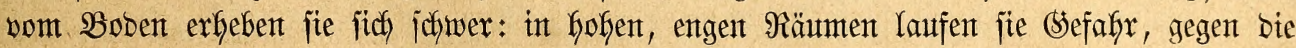

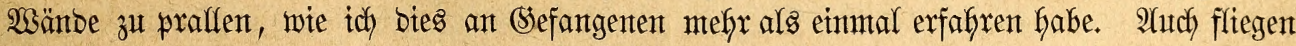

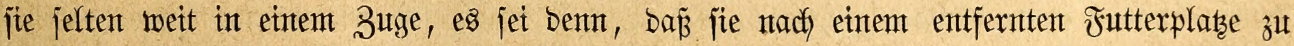

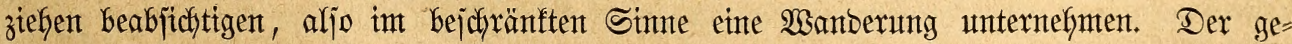

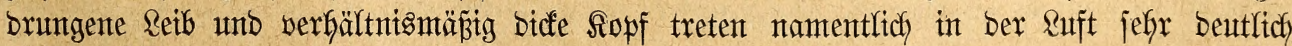
Gervor. Sm Silettern fommen fie, joweit meine Beobadjtungen reichen, ben übrigen Surz=

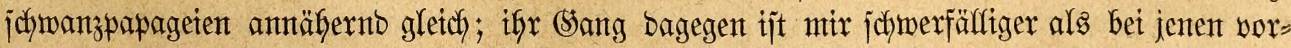

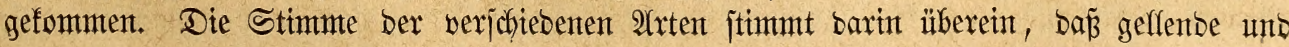
3 r e hm, gefmgene $\mathfrak{B o ̈ g e r . ~} \mathrm{I}$. 
burdforingenbe Raute vorferjichen; auch fnarren fie, bie einen, unt jich gegenjeitig herbet zu rufen, bie anberen, unt iffre Erregung auszutbrücfen; Das wiberwärtige Arreijchen ber

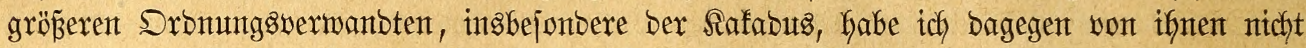

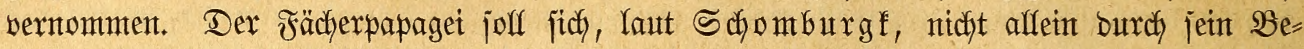

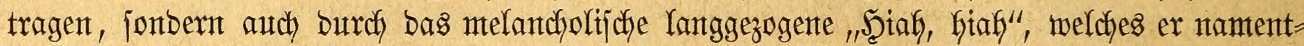

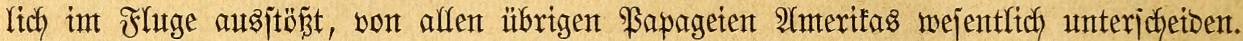

Heber ifyre geiftigen $\mathfrak{A}$ (ntragen finto bie Meinungen geteilt. Mefyrere Arten werben als geiftloje (Sejchëpre gejditbert, won anberen, namentfich von ben Mofrenföpfen, ber Maitafa unb bent Fädherpapagei fant idch bas gerabe (Segenteil befautptent. Eintige ameri=

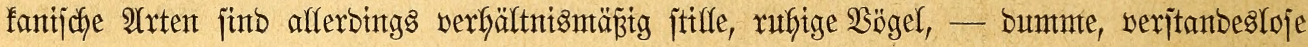

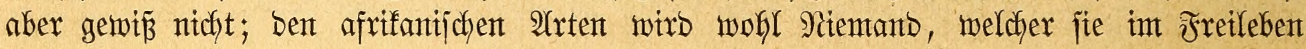
ober in ber Befangenjidyaft fenten gelernt hat, Seerjtand abjprecten molfent.

Währent Der $\mathfrak{B}$ rutzeit leben, jo viel bis jeţt befannt, affe Rangflïgelpapageien par=

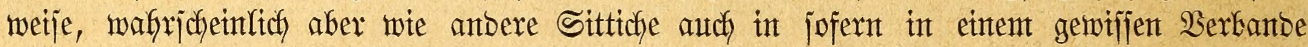

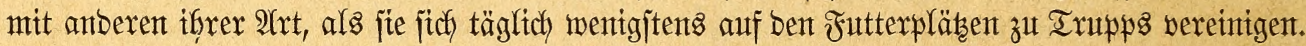

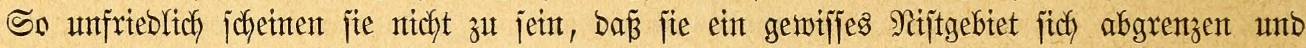

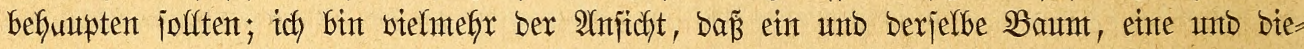

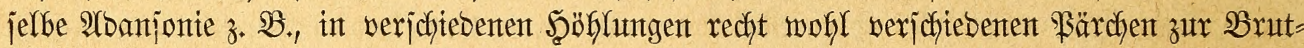

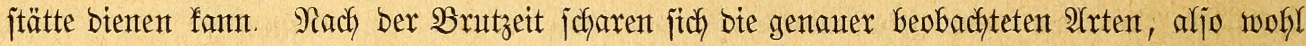

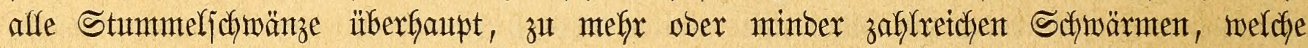
fortan bes Iages Rajt und Freube gemeinjchaftlich tragen. Nach Reyairfants Erfafrungen

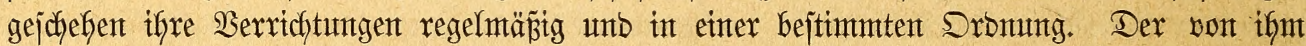
ausfüffrlich gejchilberte Stumpfictwanzpapagei (P. robustus) berjantmelt fich mit bem

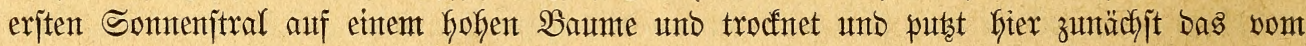

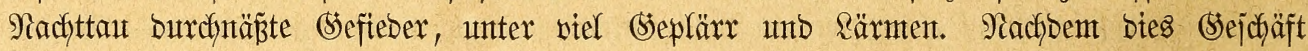

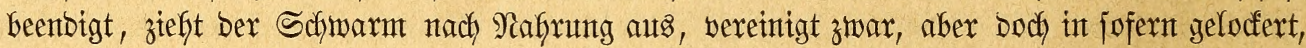

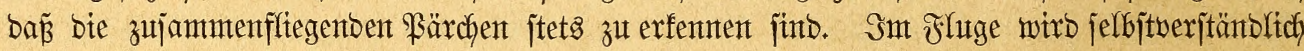

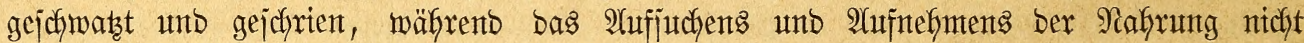

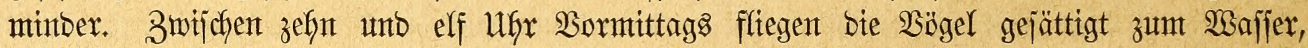

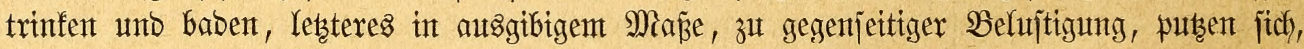

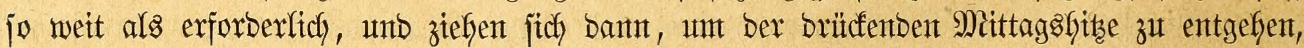

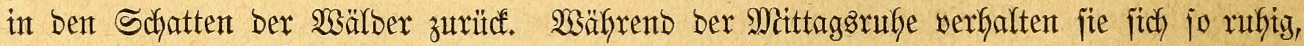

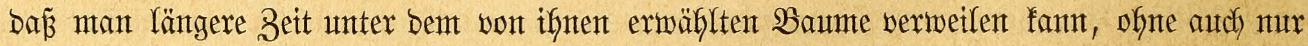

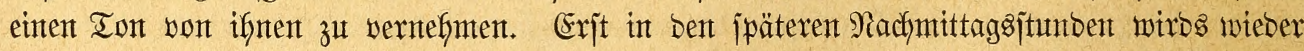

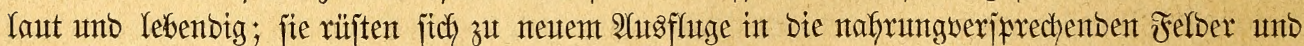

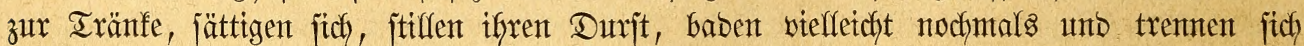

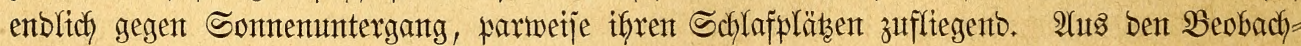

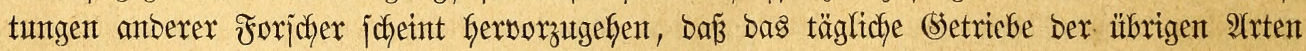

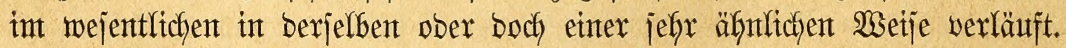

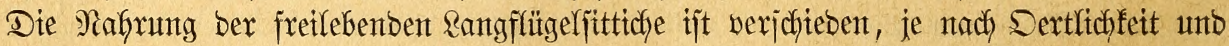

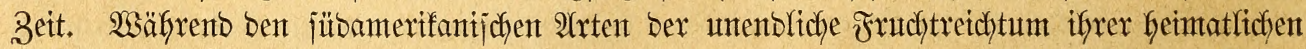

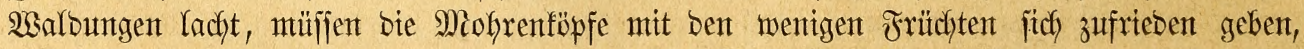

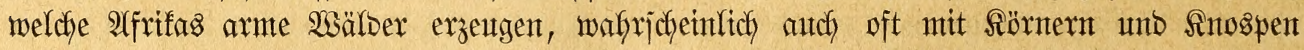

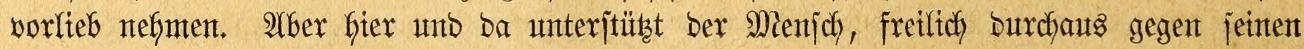

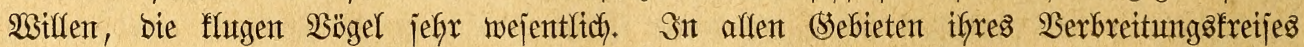

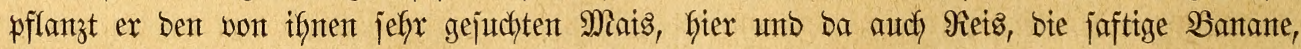

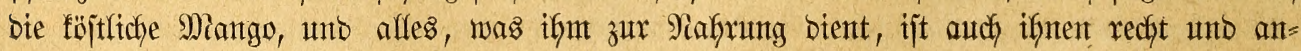
genefymt. "Sie fadaben ben \$fflanzungen", flingt es von überafl her zu uns Gerüber; "fie 
zitefyen ben reifentont Früchten meilentweit nach, erjcheinen in ber Tiefe, an ber Seefüjte, in

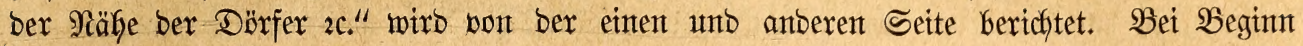

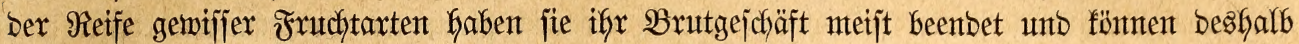

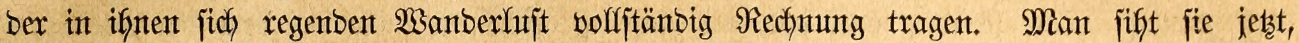
machbem man burch ifyr emiges (sejchret auf fie aufmerffant geworben, in hoher suft pfeil=

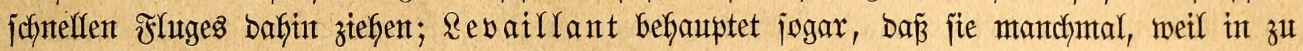

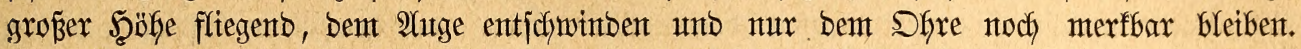

Mit bem Früflinge bes betreffenten Ranbes ober noch ein wentg früher regt jich ber Jortpflanzungstrieb in ifnen. Die Schwärmte zerteilen fidh in \$ärchen, unt bieje juthen

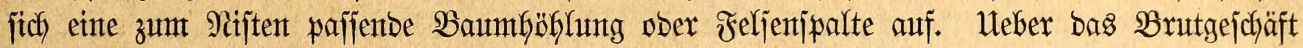

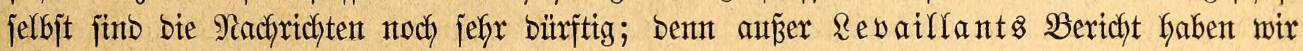

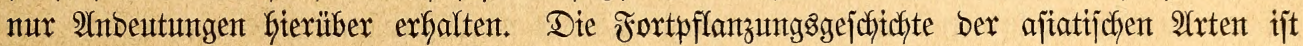

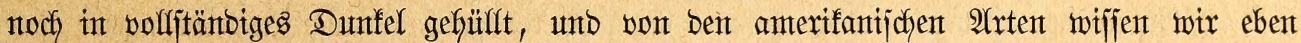

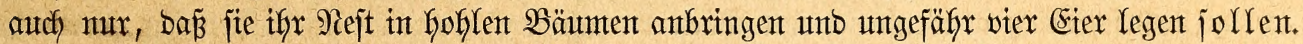

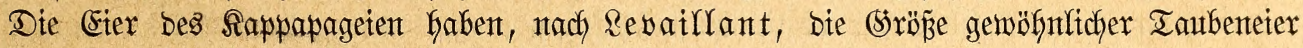
unb, wie affe Fapageienteter ïberbaupt, weiṕe Färbung. Beibe (Sattent bebrïten fie ab= medjjelno ungefähr vierunbzwanzig Iage lang, nefhmen fich auth genteinjchaftlich ber Sungen

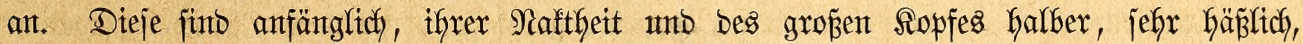
exfalten jebody balo bas exjte Dunenfletb, aus weldyem bereits nach fümf bis jechs Iagen

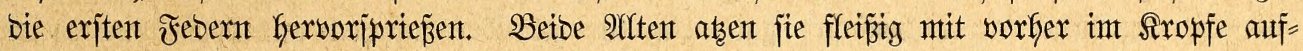

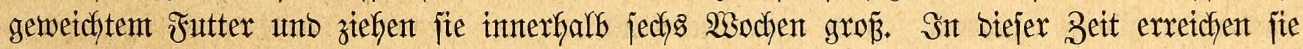

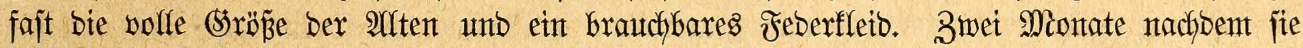

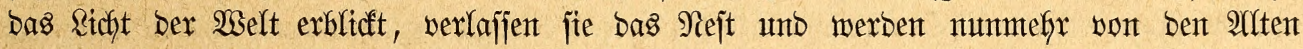

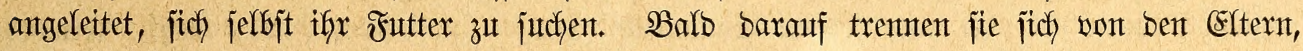

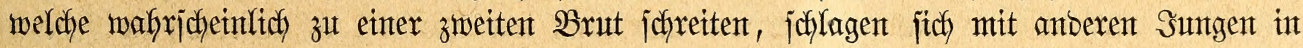

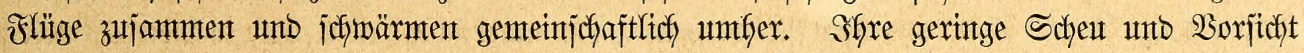

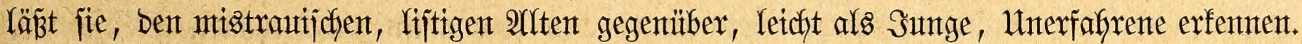

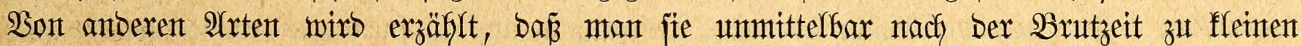
Ixupps bereinigt fiff: wafyicheinlich hat man es bann mit Familien int menjoblichen Sinne, D. h. mit Den Elttern unb ifyen vor furzem ausgeflogenen Sungen zut tun.

Allü̈berall, two bie Rangflügelpapageten in grö̈Berer Mienge auftreten, forbern fie bent

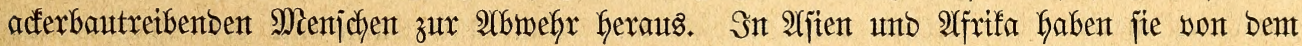

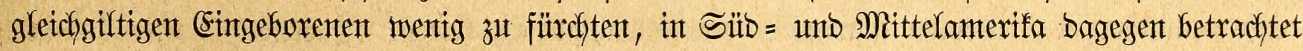
fie ber $\mathfrak{B e i \beta e}$ entweber alz Ungeziefer ober als Wilb für bie Siüche. Şier unb ba gebrautht man alfe Mittel, um jie zu vertilgen. Mit Şilfe von Rodfögeln, benten jie fajt blindlings

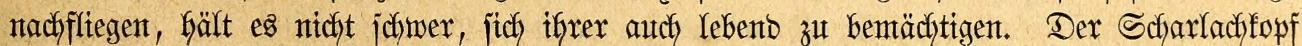

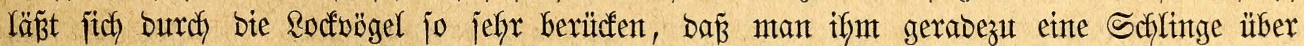

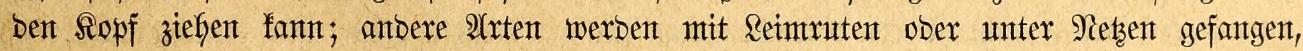

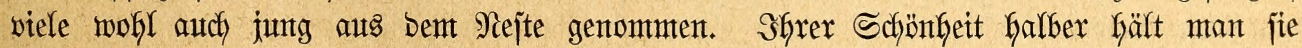
überalf gern in Befangemidhaft. Mit ben afiatijchen 2 (rten treibt man einten ziemlich regen Iaujchbanbel, fängt fie fier unto ba auth wohl einżig unto allein zu bem Zwedte, fie gegen bares (selo an europäijche Sdjiffer zu verfaufen, unto betwafyrt fie bis bafin, mittels

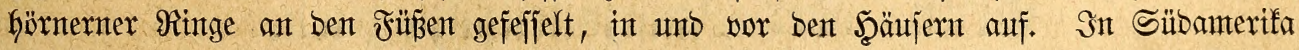

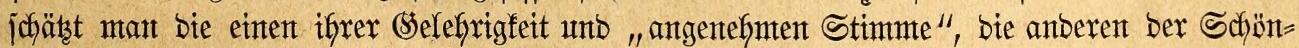
heit ifres Befiebers wegen als 3inmerbögel hod unt fift fie beshalb ebenjowohl in ben

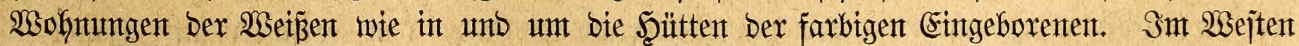

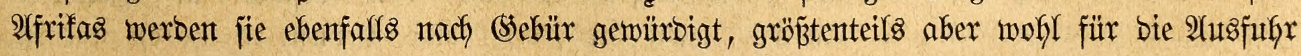
gefangen; im Siten bes Eroteiles bagegen jdyeint man jie wentig ober nicht zu actitert. Bon 


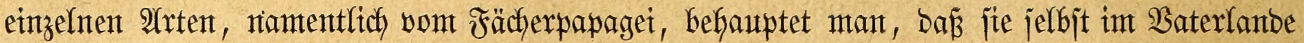
jđjwierig zu halten wären, unb glaubt barin bie Urjache ifyrez feltenen Borfommens auf umjeren Titermärften juchen zu bürfen; bie in Europa gemadhten Erfafhrungen lafjen jene Beflauptung jeboch als irrig ober boch als einjeitig erjeceinen, wie mir auch ber Meinung,

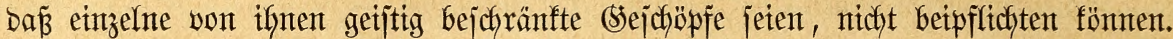

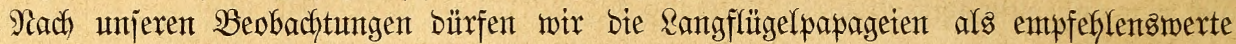
Räfigö̈gel bezeichnen. Die meiften von ifnten bautern bei geeignteter $\mathfrak{B f f l e g e}$ gut int

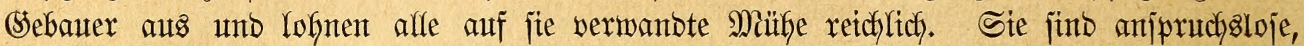
genügjame $\mathfrak{B o ̈ g e l , ~ w e l c h e ~ f i c h ~ m i t ~ e i n f a c t j e m ~ F u t t e r ~ z u f r i e b e n ~ g e b e n , ~ f o ̈ n n e n , ~ f a l l s ~ m a n ~ j i e ~}$ mur gegen 3ug gehörig gejđjützt hat, eine ziemlich geringe Wärme ohne Nachteil ertragen,

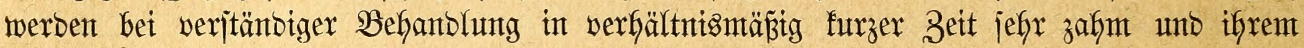
Bfleger anfänglich, Yernen auch, went jie juntg aus Dem Niejte genommen murben, Worte unt Sätze nachjprechen, würben vielfeicht gerabe bierin eine groß̉e $\mathfrak{B}$ egabung befutben, wollte man jich mur ofne Borurteil ebenjoviel mit ifnen bejcjäftigen, als man jich mit einemt zu regel=

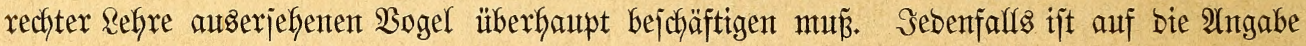
einiger Sifyriftitelfex, Diejer ober jenter Rangflügelpapagei lerne nicht jprectyen, wentg zu geben, weil ber Beweis für eine berartige Befauptung nicht erbradyt merben fant. In einzelnen

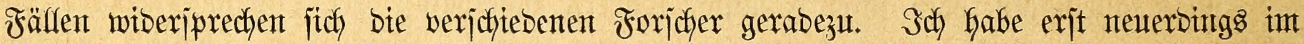
Berliner zoologifchen Barten einen Fächerpapaget beobachtet, weldyer jo verjechiedente,

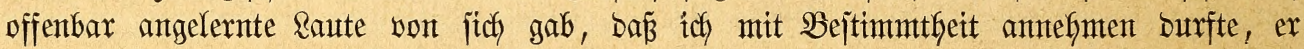
müroe bei gutem Ilnterricft iprechen gelernt haben.

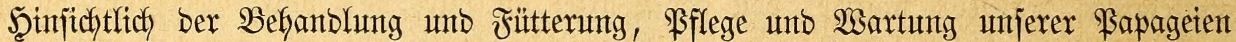
gilt im allgemeinen bas (\$. 143 und 147 fi.) bereits (Sejagte, höchjtens mit bem Unterjchiebe,

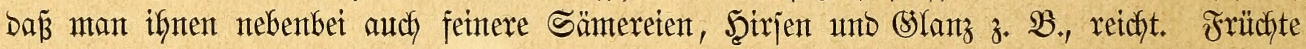
und Blattfnospen lieben jie jehr; erjtere und bann unt wann frijh abgebrodjente Zlweige

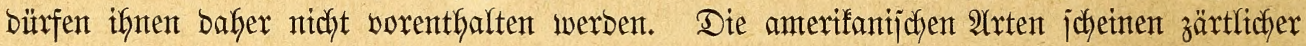
zu jein als bie afrifanijhyen; ifnen gegenüber ijt aljo eine umfithtige Beflandlung bejonbers anzuraten. Die häßlidye Unart ber Selbjtwerjtümmelung ifres (Sefiebers ijt leiber auch

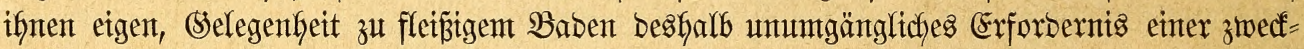
mäß̄igen ßffege.

3u ben regelmtäp̈tgen Erjchemungen auf mierem Tiermarfte zählen bie Surzjchwanz= papageien nidst. Sie treffen Gier unb ba und bant und wann mit ben Schiffen ein,

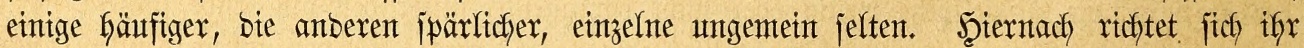
\$reis. Währento man Den Miofrenfopf ntandymal mit 4 bis 5 Ialern faufen fann, wiro man (sutlelmis \$apagei faum unter 8 Ialerm, bie Maitafa nicht unter 10 Ialern erlangen.

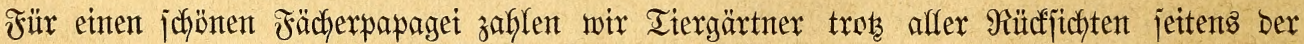
Şänoler unweigerlich bis 40 Ialer, für einen Motmotpapagei minbejtents ebenjoviel, wenn nidjt mefr. Einte Summe von 8 Ialern barf jür bie meiften 21rten als Durchjidnittsprets angejehen werben.

\section{(Griitl- oder Amazoutenpapatgetet.}

Die Ufermalbungen Des mächtigiten Stromes ber Erbe gelten, nicht ganz mit Unrecht, als bie eigentliche Şeimitätte einer ßapageiengruppe, welche von Jorjchern unt Şäntlern

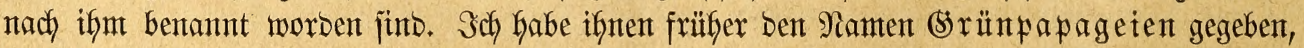

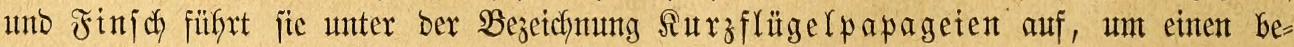


merfenswerten Unterjejteb Gerworzubeben, weldyer zwijchen ifynen unb ben Rangflïgelpapageten

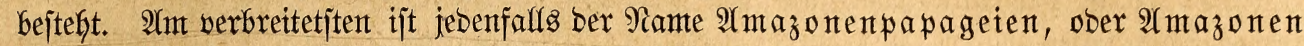

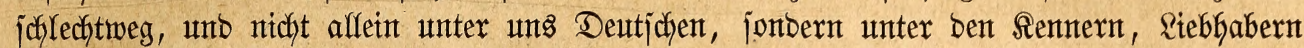
und Şänblern affer \&änber überhaupt.

Die 2 mazonenpapageien bilben eine berjentgen (Sruppen ifyer Dromung, innerbalb beren

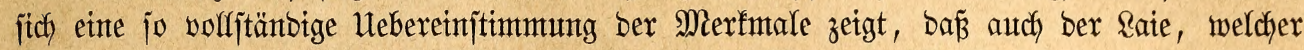

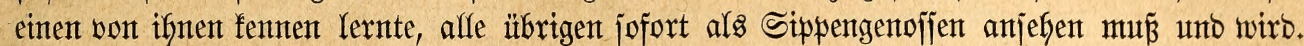

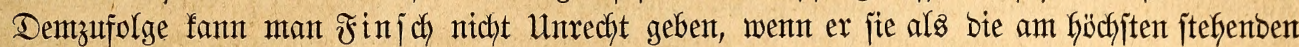
affer Sapageien betrachtet. "Sie entiprechen", jo brüctt ex jich ausి, "am bejten ben $\mathfrak{B} e=$

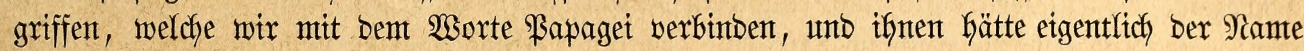

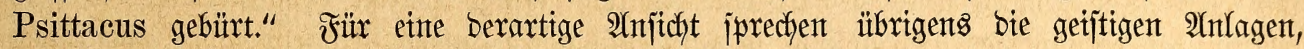

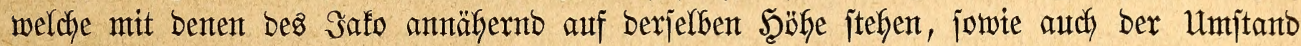

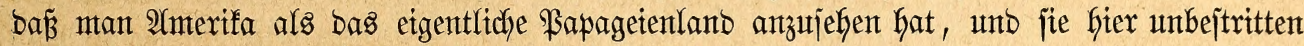
bie höchjte Stelfe unter ifyren Dromungsuerwandten einnefmen.

In 2 fijen merben fie, wie bereits bemerft, burdy bie Ebelpapageien erjetzt; in ben übrigen Eroteilen Dagegen finden fich feine Sittiche, melche mant als wirfliche $B$ ertreter wont ifnten betrachten fönnte.

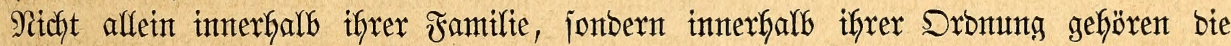

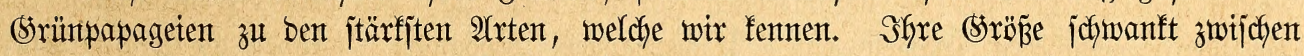
Der einer Dohle unb ber einer Arähe; einzelne Ârten übertreffen bie leztgentante wohl noch ein mentig, an Sentidft jebenfalls. Shre Sejtalt ijt jefr gebrungen gebaut, ber Siopf

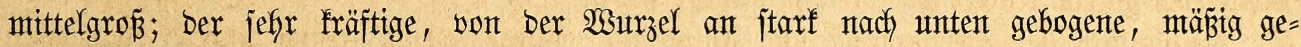
wölbte Schnabel auf ber Firjte mur nach finten jayarffantig abgejetst; vor ber Spize bes ant=

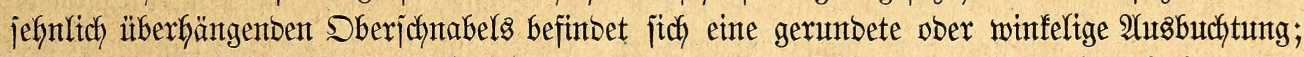
ber Unterjantabel ijt jo hoch als ber obere, und jeine Dillenfante bilbet eine breite abge= runbete Fläche; bie Feilferben in ber Sberjanabelipitze treten beutlich Kervor. Die gropent

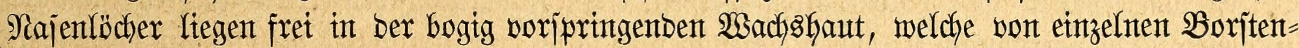

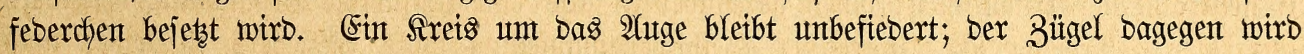

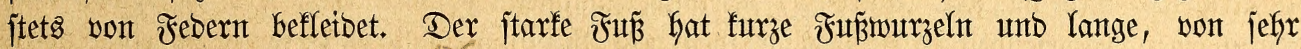

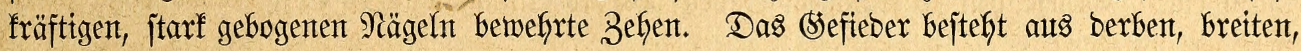

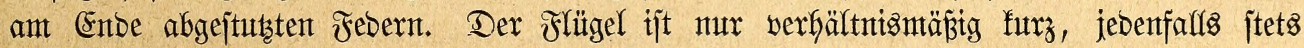

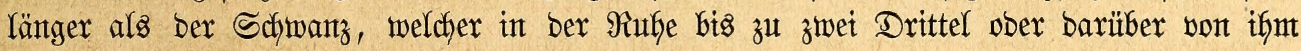
bebectt witro, bie Flïgelipitze wentig ober nicht vorragent, unter ben am Enbe iptzen, vorn (erjte bis britte Feber) innen, weiter Ginten (zmeite bis fümfte Feber) außzen beutlich aus= gejdhnttenen Sdywingen bie zmeite ober britte bie längjte. Der Sdywantz ijt futz, länger alz bie ફ̧älfte bes Flïgels, breit, abgerunbet, an jeinten äuß̌erjten Febern etwas verfürzt; bieje

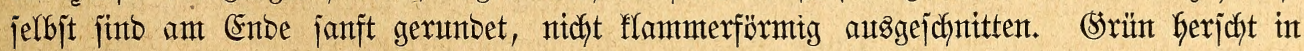
ber Färbung unbebingt vor, objchon es aud bunte 2 rten gibt. Sopf und Flügelbutg fint meijtens

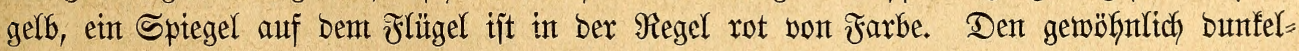
farbigen Sdynabel żert bei einzelnen 2 (rten ein an Der $\mathfrak{B u r z e l}$ bes Sberidynabels jtehentor

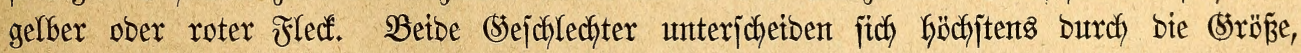
unto auch bie Sungen zetchnen jich bló̉ burch etwas mattere Färbunt ithres (Seffiebers aus, befien Gervorjtechento Teile bereits unverfennbar auşgeprägt zu jein pflegen.

3ur befieren Ueberjicht ber zahlreichen ânten ber Sippe teilen wir bieje nach ber Färbung Der Flïgel unto bes Sopfes in brei Sruppent eint.

Blaue Dedffedern ber Şandichwingen zeigen:

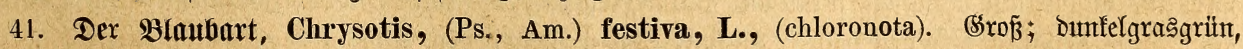

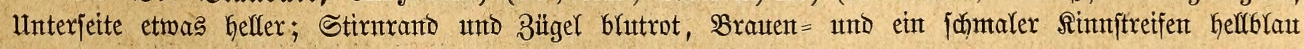




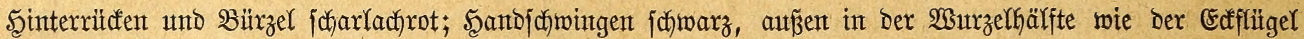

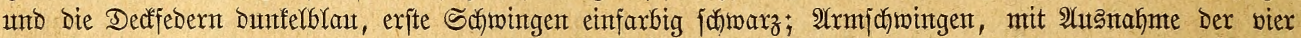

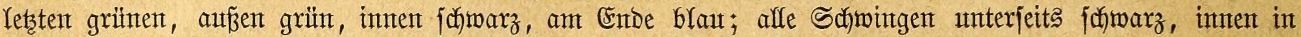

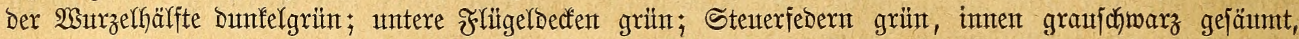

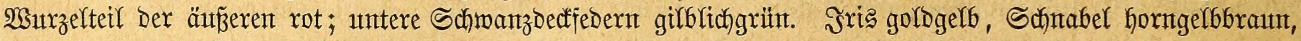

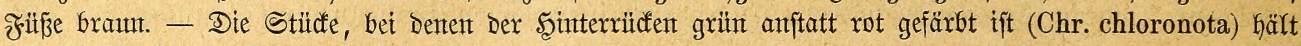

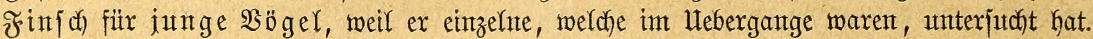

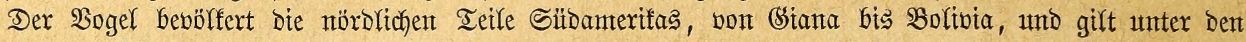
Eingeborenten als ber gelehrigite affer ßapageient des \&antoes.

42. Die Blaufronte, Chr. (Ps., Am.) Sallei, Sclater, (martinicanus, ventralis). Mittelgroßß;

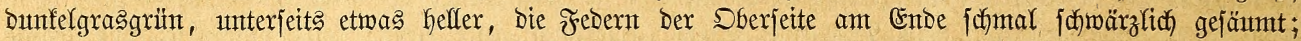

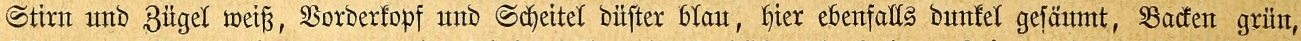

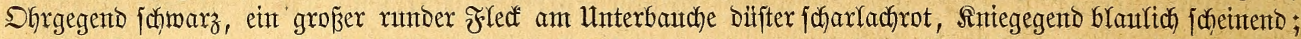

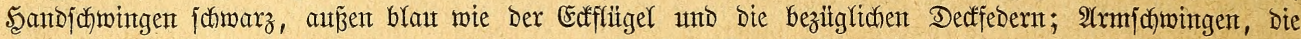

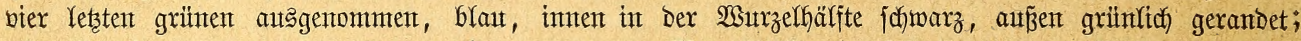

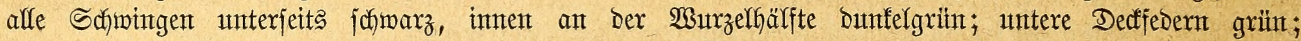

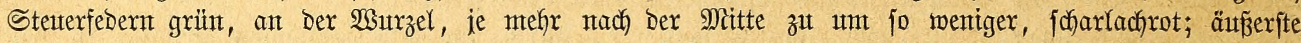

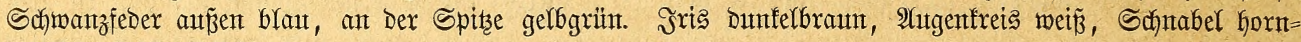

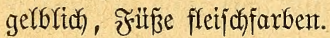

Die Blauffrone ftammt won St. Donningo unt murbe bis jeţt weder auf einter anderen 2 (ntilfe, nod) auf Dem Fefittande beobachtet.

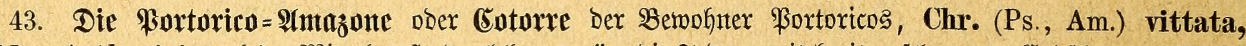

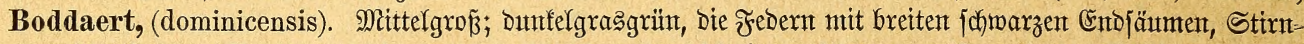

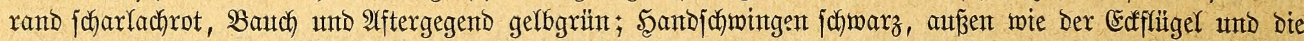

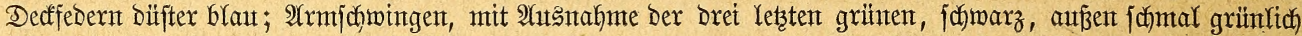

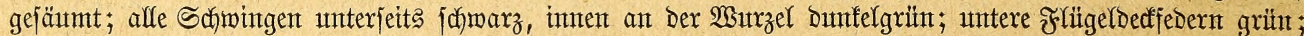

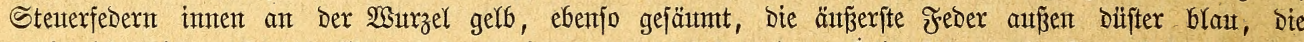

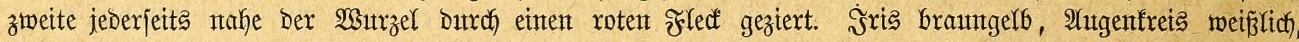

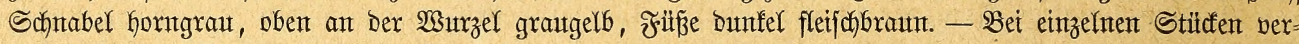

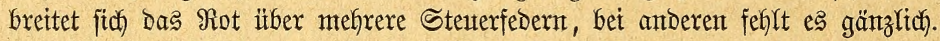

Die Cotorre ift Der einzige auf Fortorico vorfommente, mintoftents von Dorther betantte Papaget und

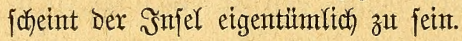

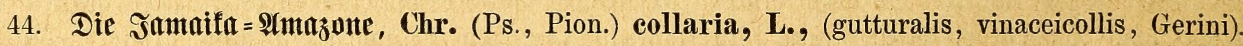

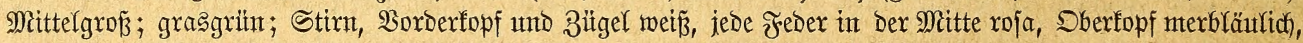

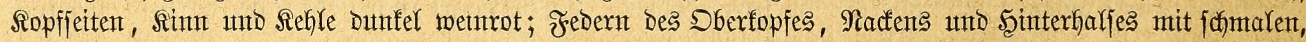

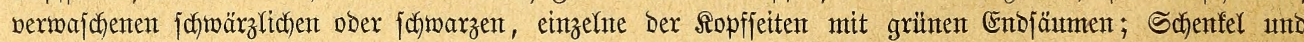

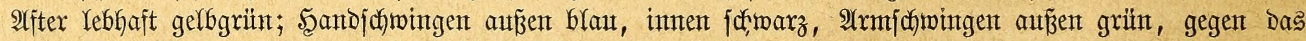

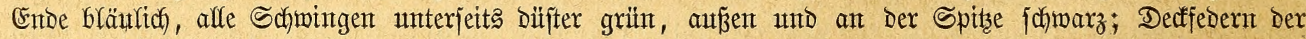

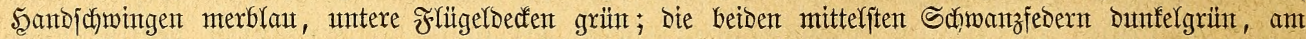

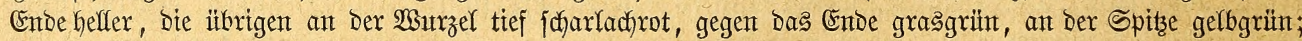

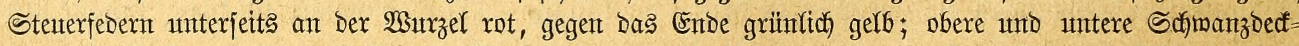

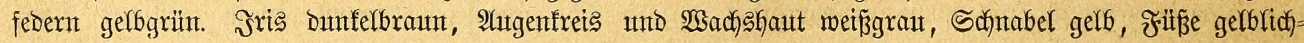
fleifadfarbett.

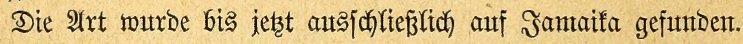

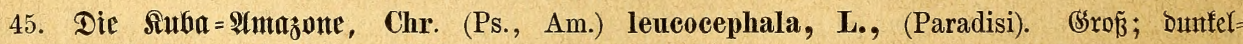

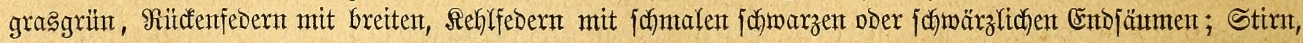

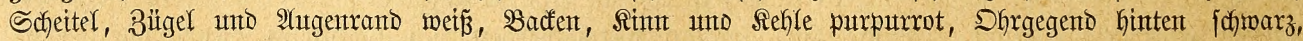

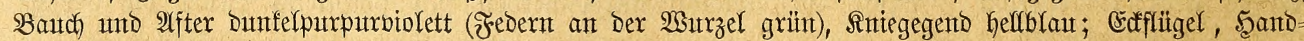

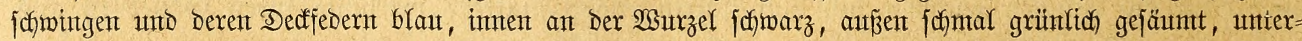

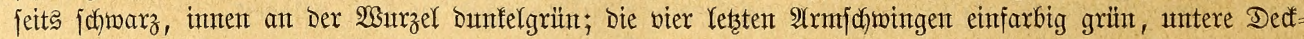

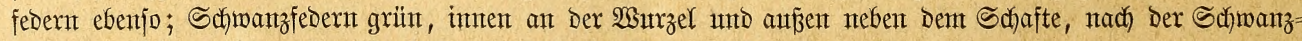

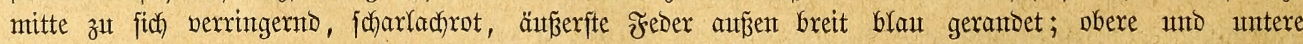

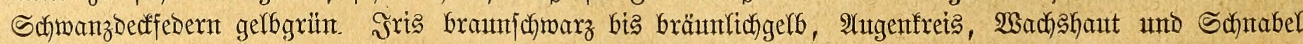

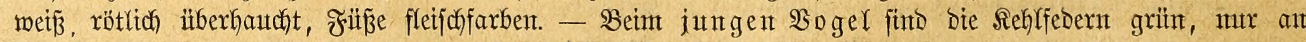

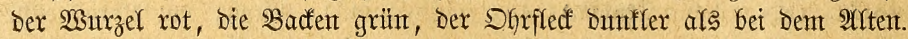

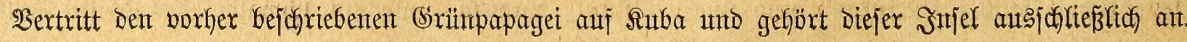




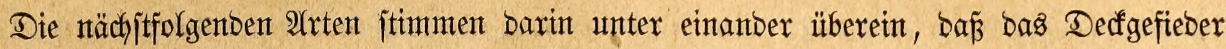
ber Şanbjdywingen rot ober grün, ber Edfflügel rot ijt unb ber Sopf́ ebenfalls mebr ober wentiger $\Re$ ot zeigt.

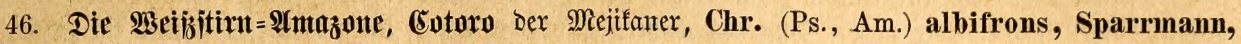

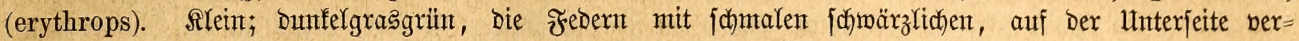

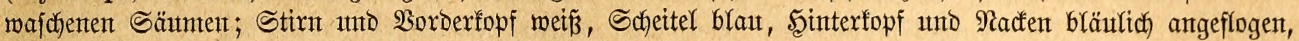

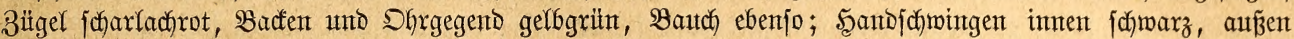

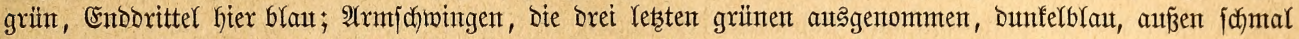

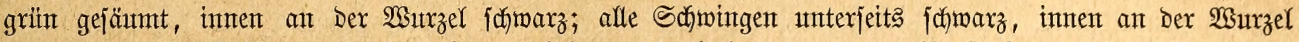

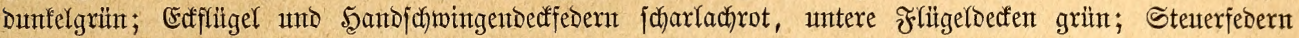

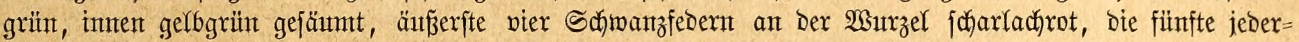

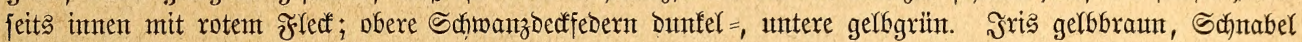
wachsgelf, an Der Spitze graut, F̌lïße bleigraut.

Schon ber alte Şernandez gebentt biejer in Miejif́, Şonduras, Bitatemala und Ricaragna vor=

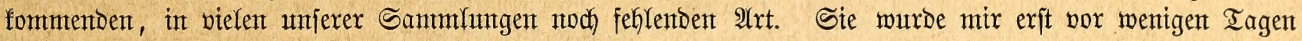
lebent gebradgt utto Darf fortan wohl audh auf umferem Tiermarfte erwartet werdent.

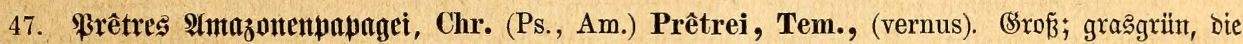

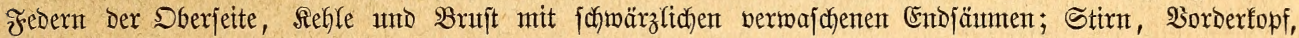

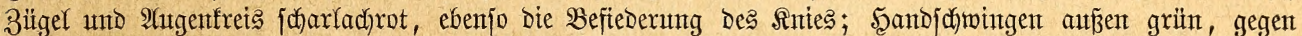

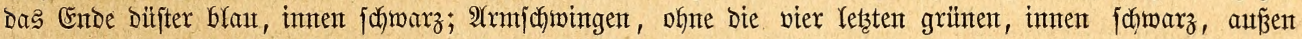

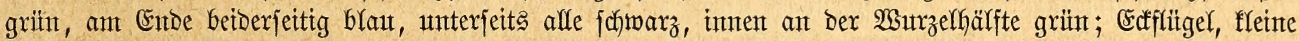

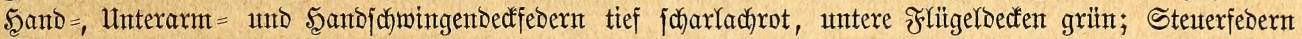

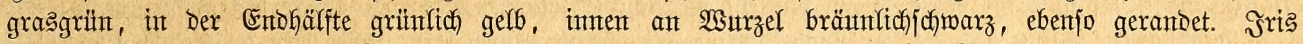

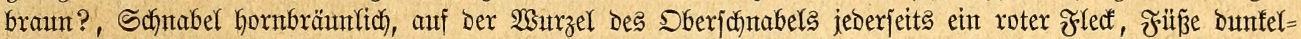
horutbraut.

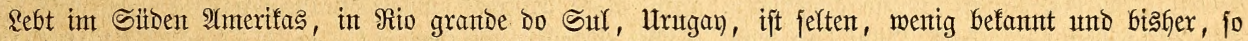

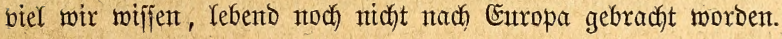

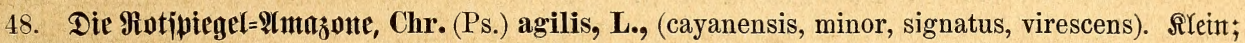

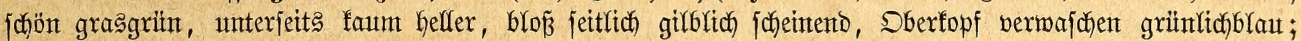

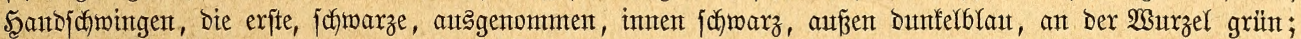

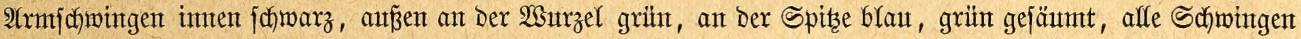

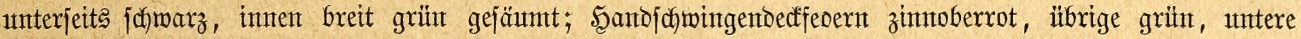

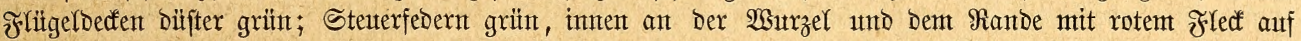

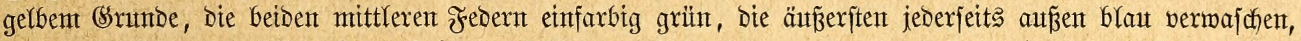

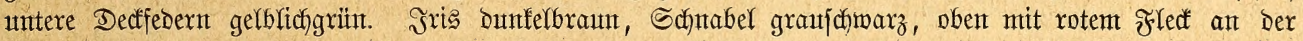

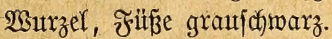

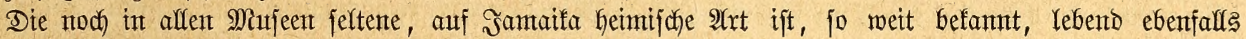
noch) midft nad) Entropa gefomment.

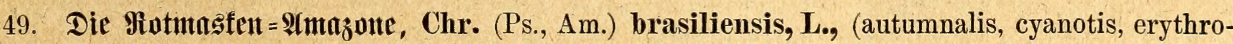

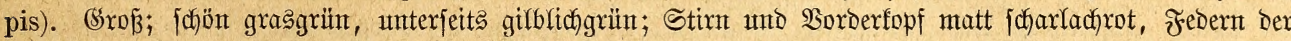
Bacfen unt Shrgegent, am Simm unt rings um Den Huterfantabel mutr an Der 2 Surzel mattrot, am Ende

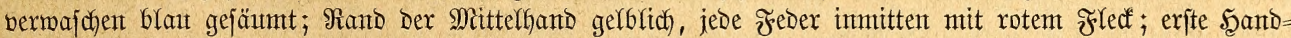

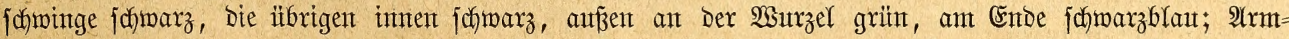

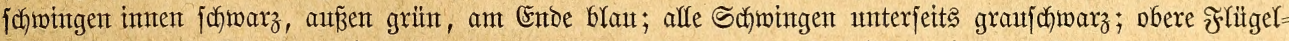

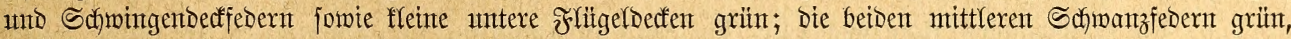

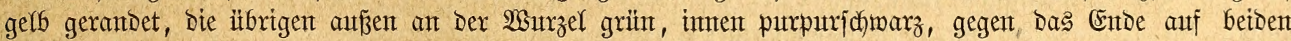

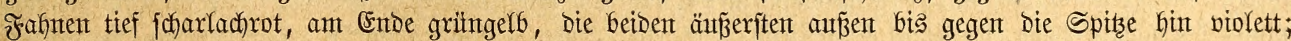

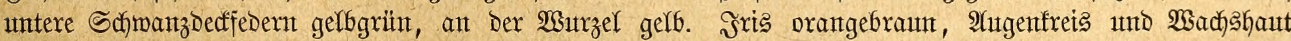

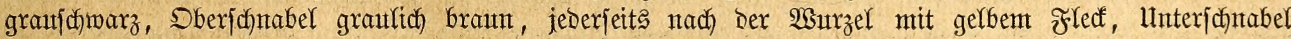

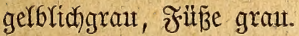

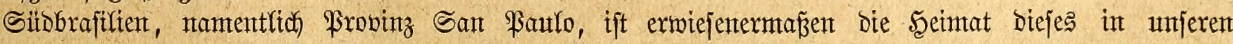
Sammllungen nod) feltenen 2 ogels.

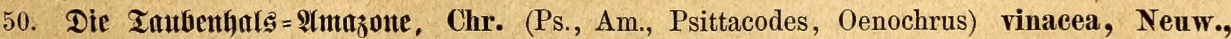

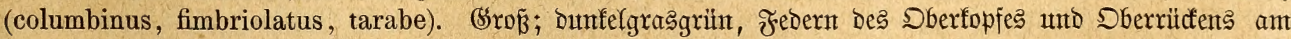

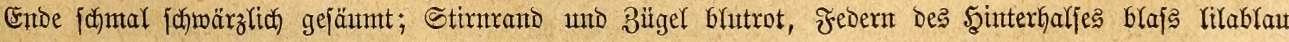




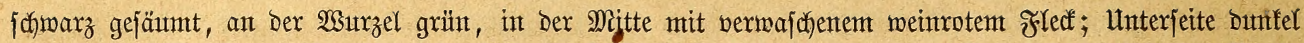

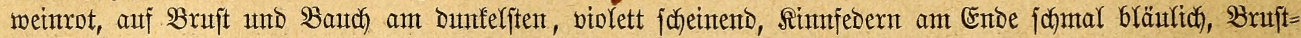

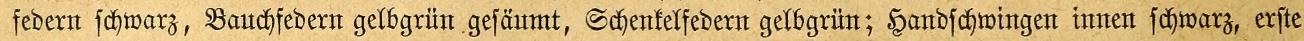

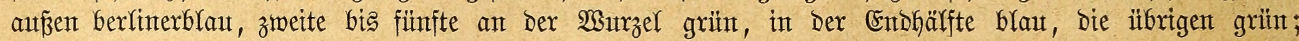

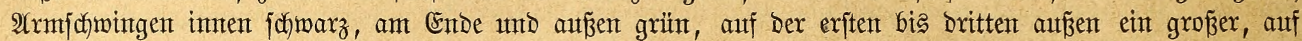

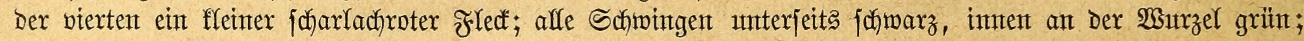

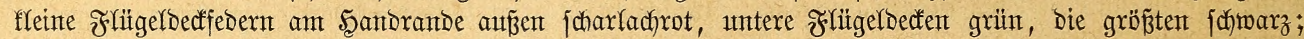

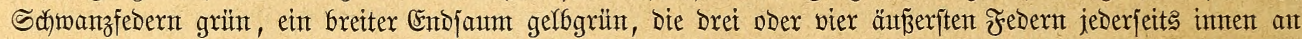

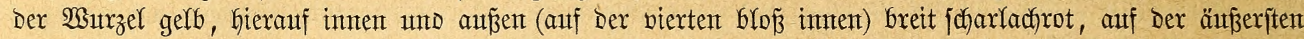

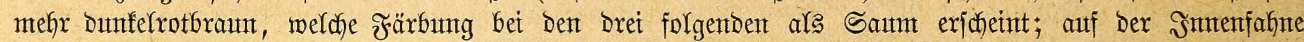

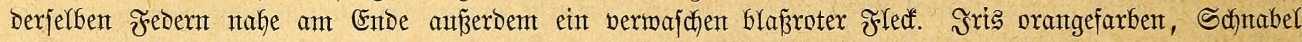

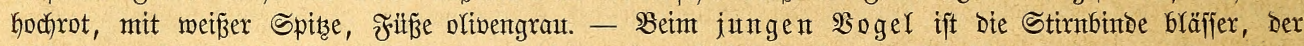

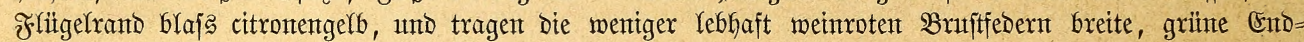

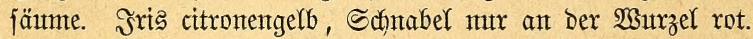

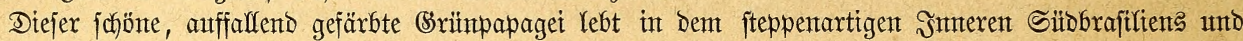

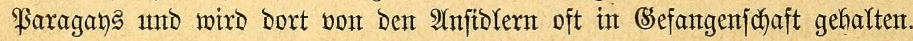

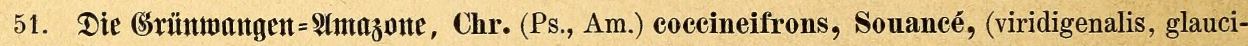

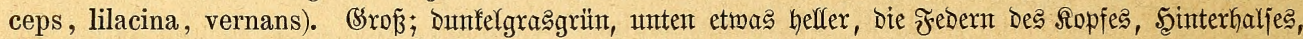

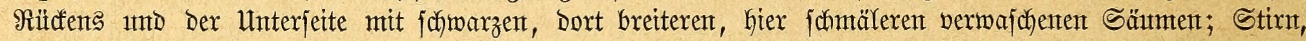

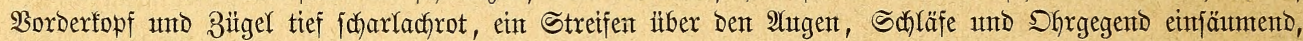

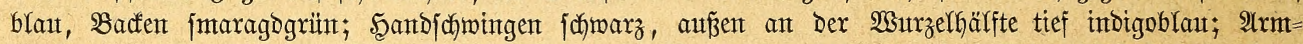

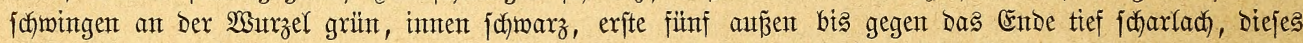
blaut, vierte unt fünfte vorher grün, heller gejäınt, bie leţten brei einfarbig grün; affe Sd)wingen unter=

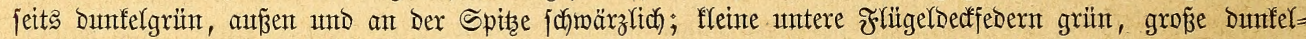

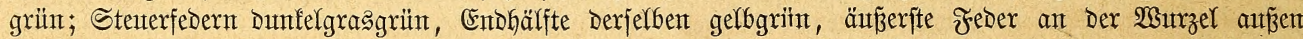

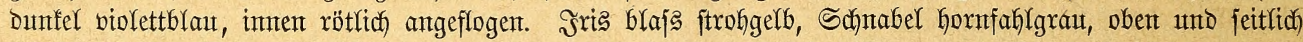

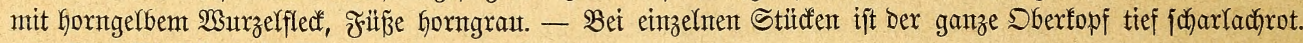

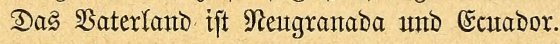

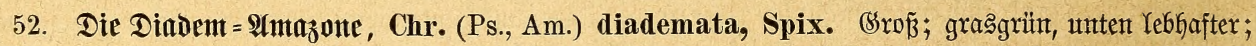

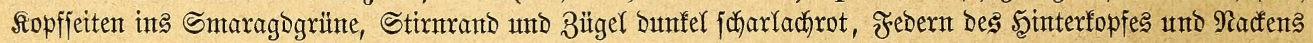

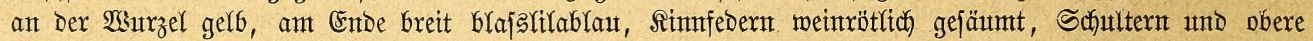

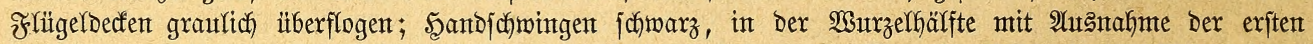

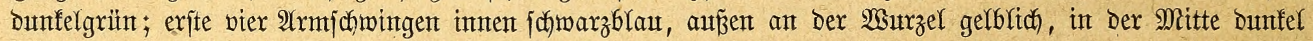

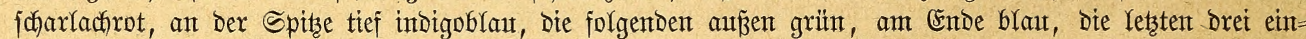

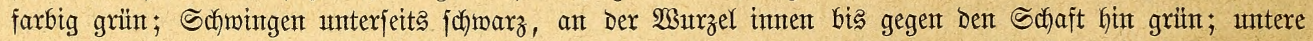
Glügeldectent grün, Die größ̈eren mit gelbliderer Spitze; Stenerfedenn grün, gegen Das Endoe hin lebhaft gelb=

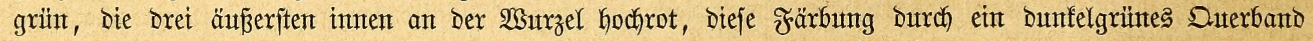

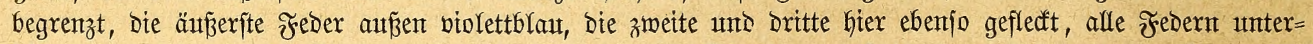

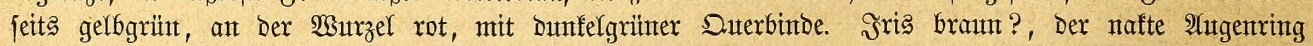

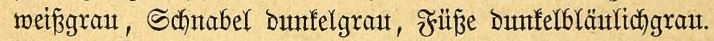

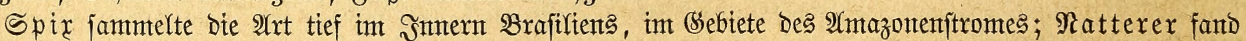

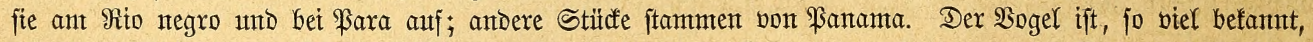
lebento ebenfalfs noch nidft nach Guropa gebracht worden, fant aber mit jebem von Para auslaufenden Scjiffe zut unts gelangen.

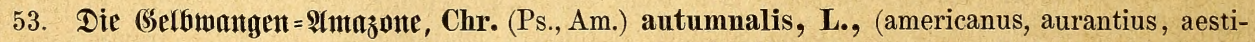

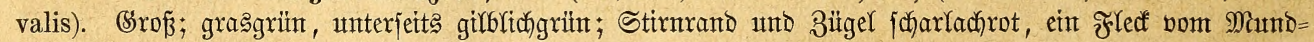

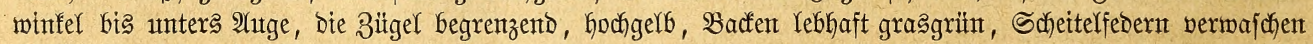

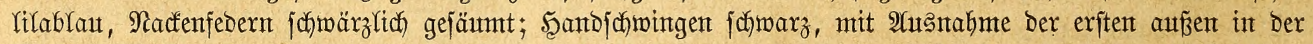

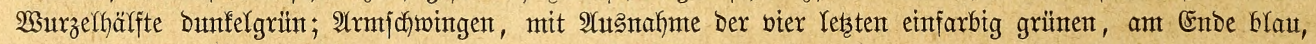

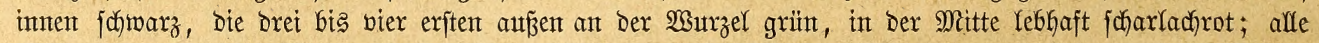

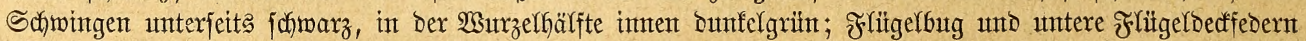

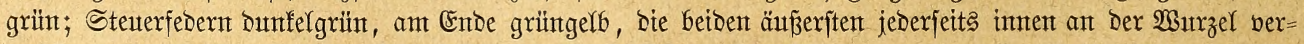

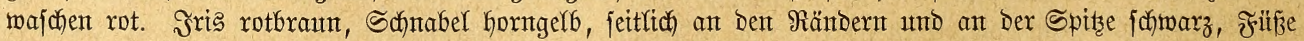

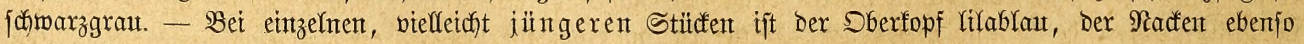

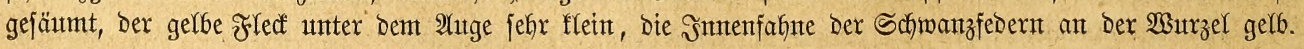




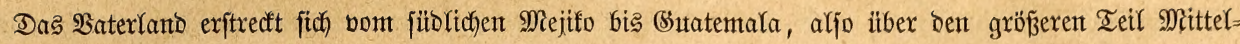
amterif́ă.

54. Die $\mathfrak{A f a m u t a n g a ~ b e r ~ E i n g e b o r e n t e n ~ B r a f i l i e n s , ~ C h r . ~ ( P s . , ~ A m . ) ~ D u f r e s n e i , ~ L e v a i l l a n t , ~ ( c o - ~}$

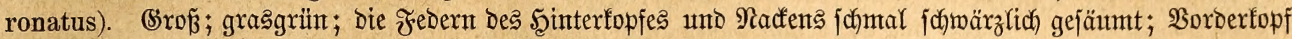

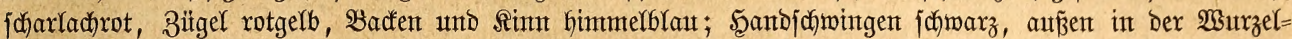

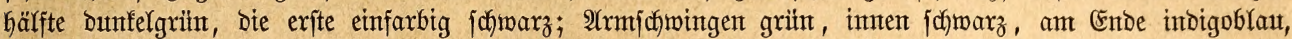
erfte bis britte außsen in Der Mitte zinnoberrot, Die vier leţten einfarbig grïn; affe Sdjwingen unterjeits in

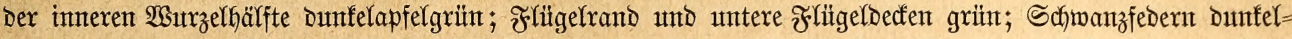

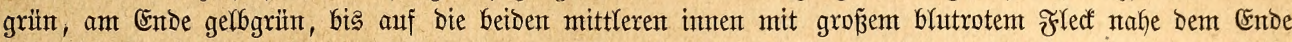

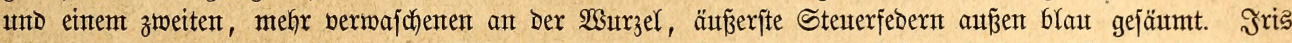

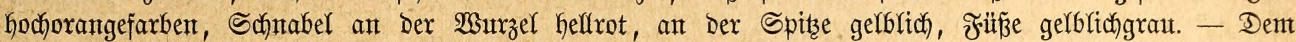

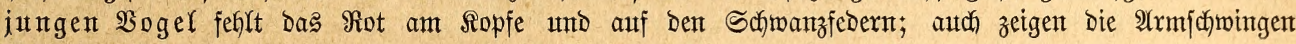
Drange amftatt $\Re$ ot.

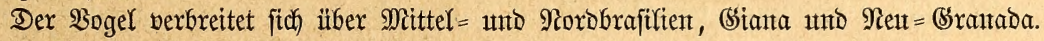

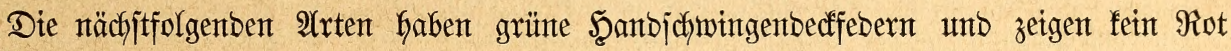
am Sippfe.

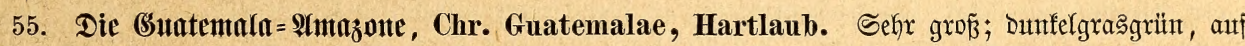

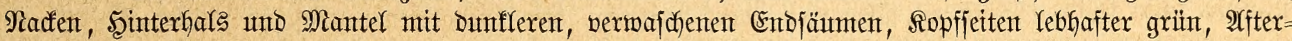

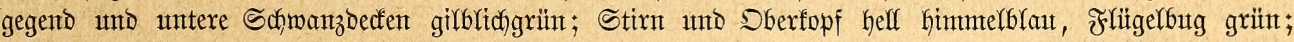

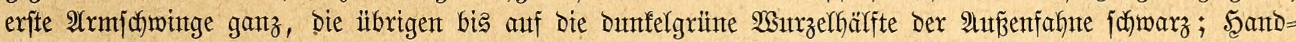

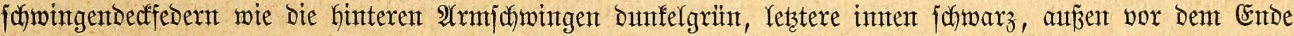

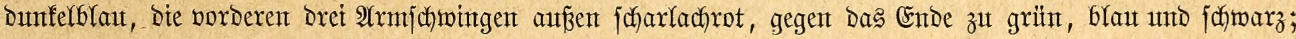

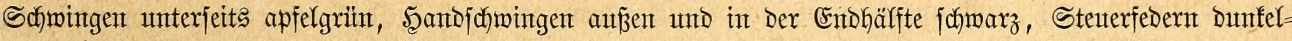

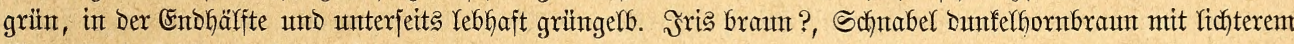

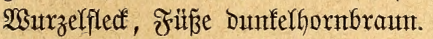

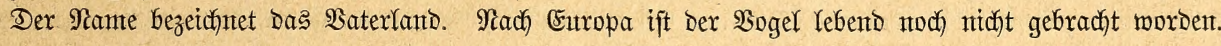

56. Der Blaufopf doer (Gicero Der Dominifaner, Chr. (Ps., Am. Oenochrus) Augusta, Vigors.

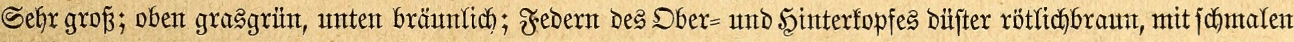

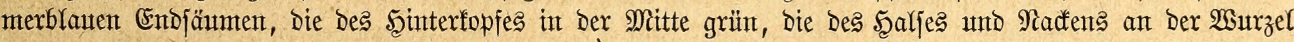
Düfter bräunlide unb vor Dem fadwarzen Entoranbe mit verwajchenter, violetter unt grüner Entobinde; Febern

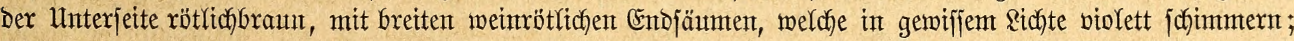

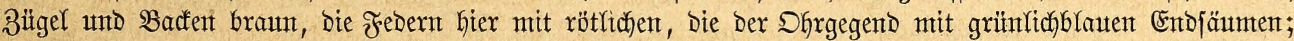

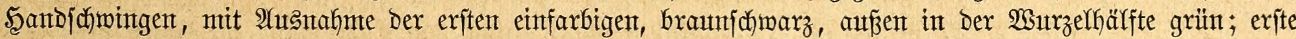

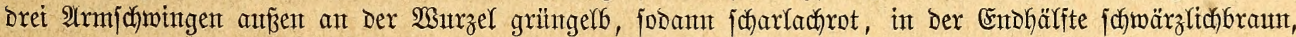

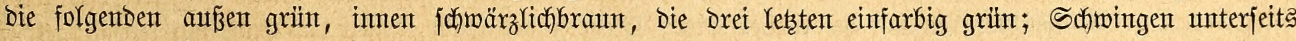

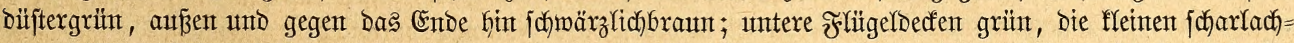

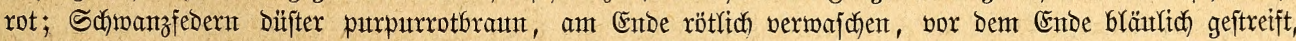

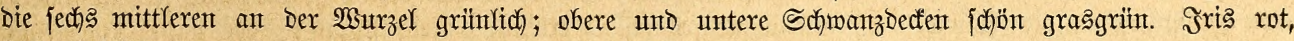

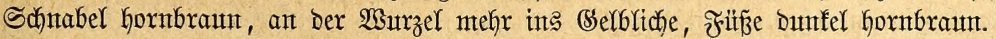

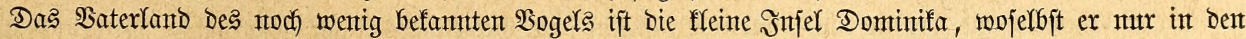

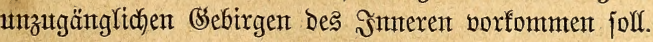

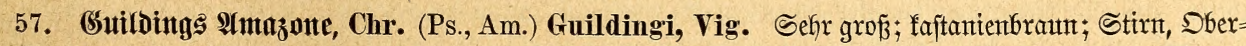

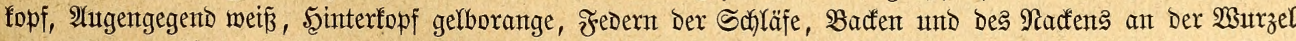

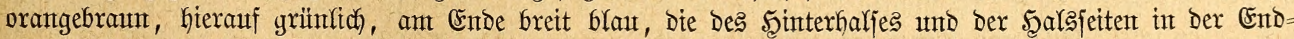

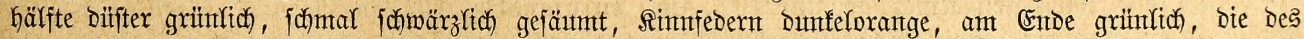

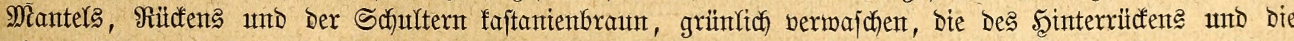

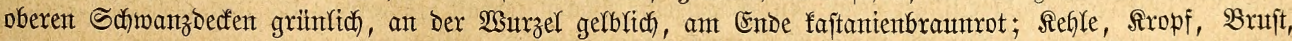

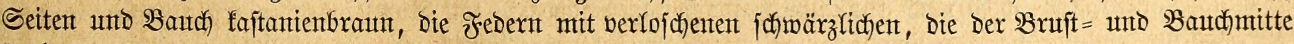

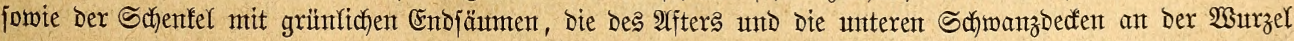

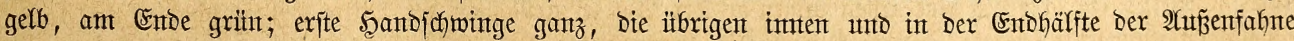

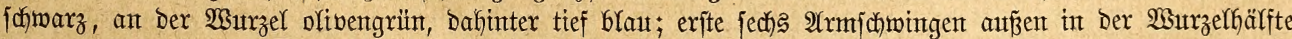

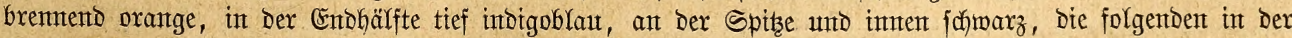

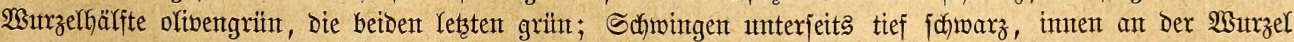

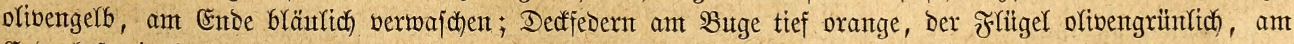

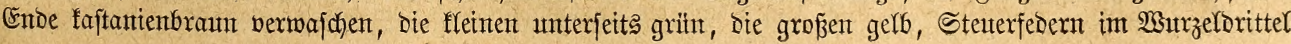


tief, int Entobrittel Gefl orange, in Der Mitte blan, inten fajwarz, unterjeits wie oben, in ber Mitte jeboch

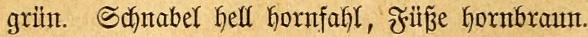

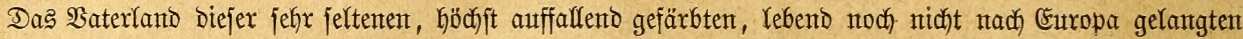
Atmazone poll St. Sincent feint.

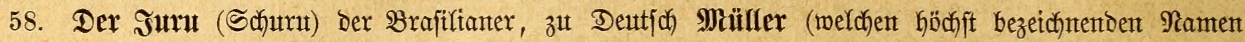

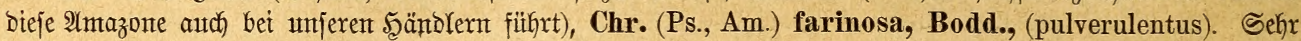

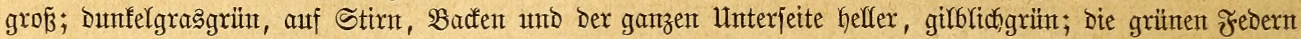

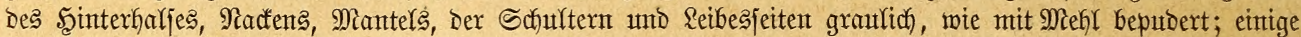

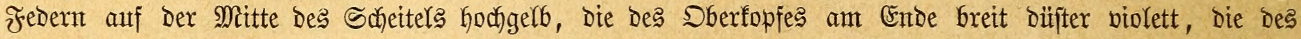

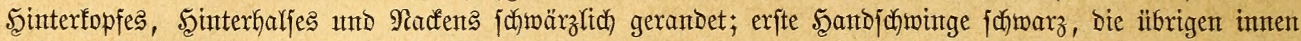

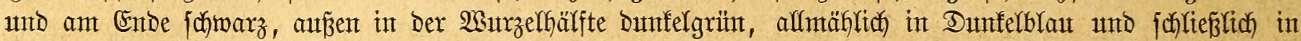

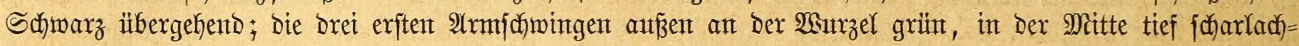

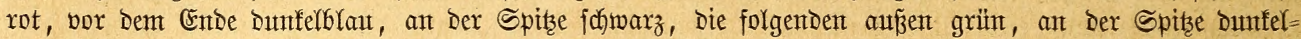

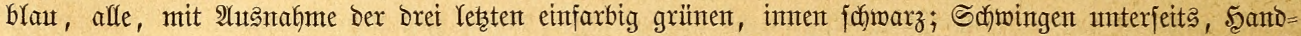

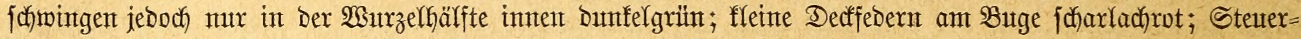

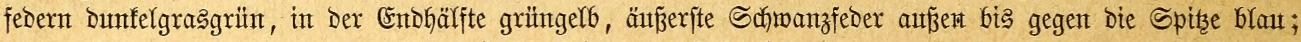
untere Schmanzoectfedern grüngelb. Sris Dunfelfraut, Schnabel horngraut, oben unt unten jeberfeits mit

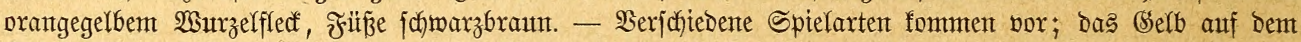

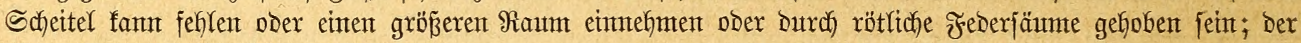

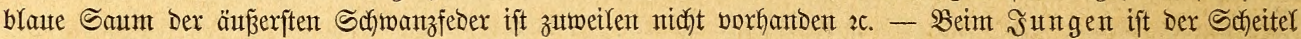
graublaut ïberlantfert.

Ein groperer Ieil Sïbanterifas, vom mittlexen Braftlien bis Biana, Bantanta, Ecuador, Bolivia, ift

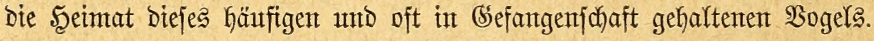

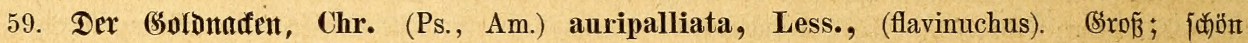

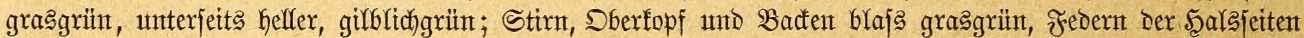

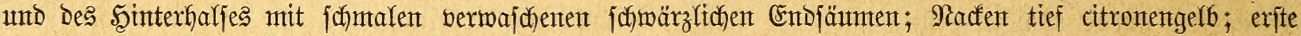

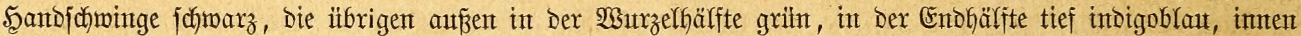

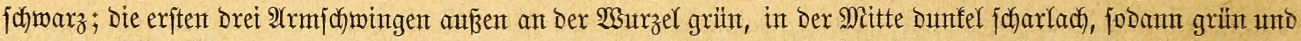

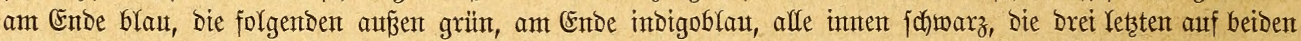

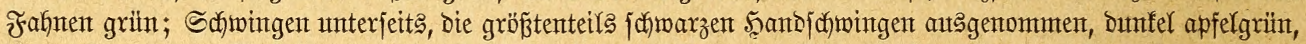

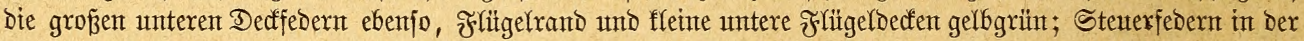

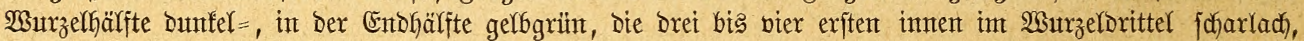

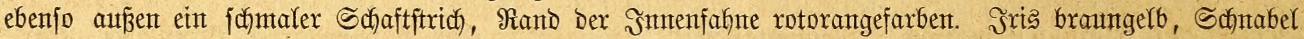

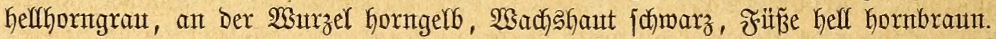

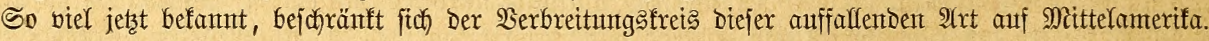

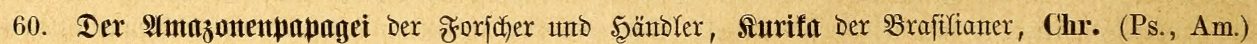
amazonica, L., (aestivus, Aourou, jamaicensis, luteus, luteolus). Mittelgroß;' Dumfelgraggrï̈n, unter= feits faum helfer; Stimnant unt Bügel bis finter bas Atuge fitablau, Ropf nebft Bacfent hod)gelb;

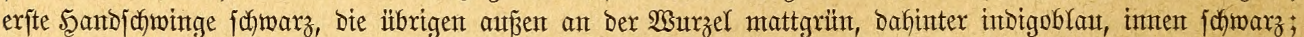

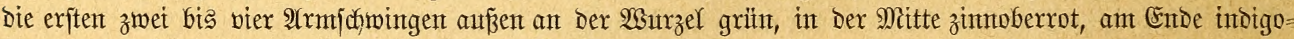

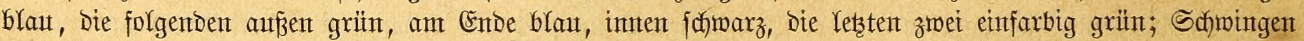

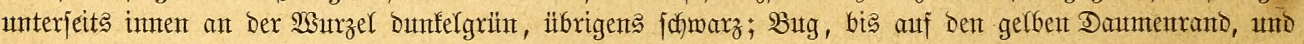

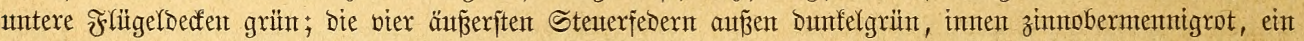

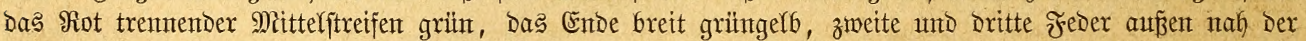
Wurzel mit rotem Fled", bie fünften Steuterfedern iederfeits inten grün mit rotem Fledf; untere Sdjwanz=

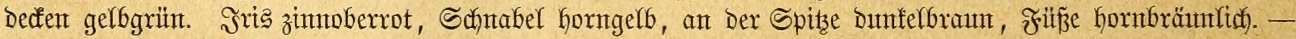

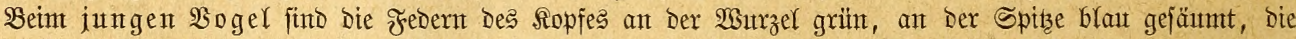

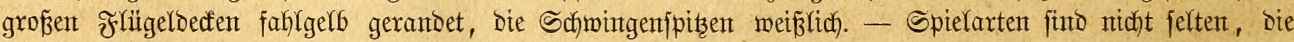
Farbenabänderungen jeDod) meif́ Folge längerer (Sefangenfdcaft. *)

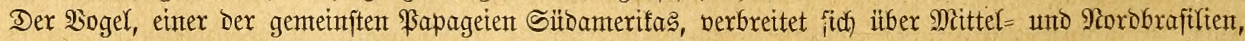
Bstana, Sienez̧uela, Sogota utto Ecutador.

61. Die Gelbflügef=91mazoute, Gelbfopf Der Şändler, Chr. (Ps., Am.) ochroptera, Gml., (icterocepha-

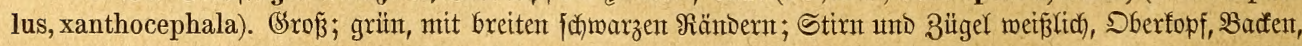

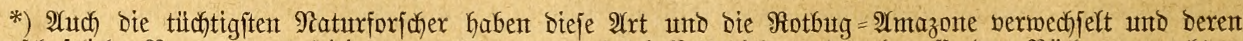

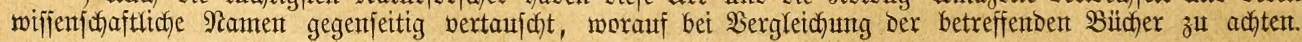




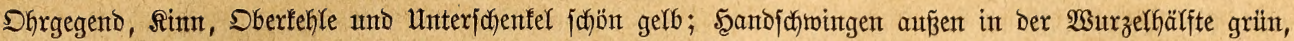

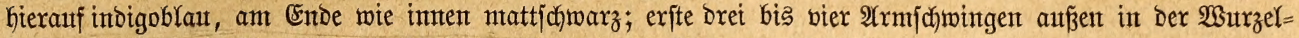

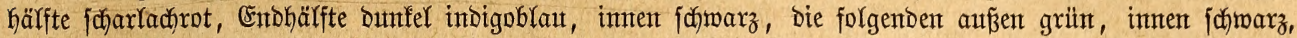

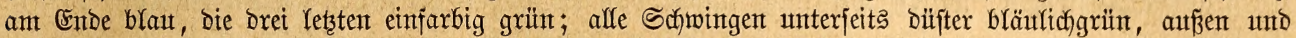

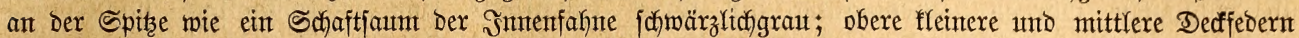

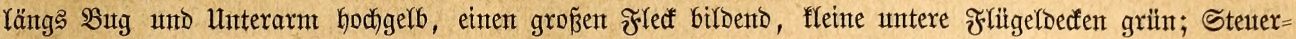
federn grïn, die mittleren einfarbig, die übrigen in ber Embfälfte hell gelbgrïn, das Wanzeldrittel dex

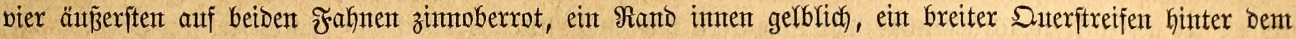

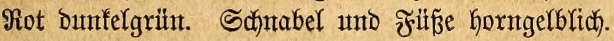

भIS Saterland ift Silomejifio nachgemiejen morben.

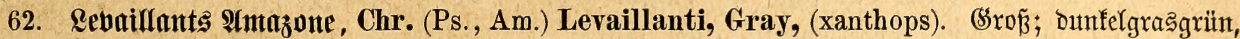
unterjeits Geller, Federn bes Seinterfarjes und Mantels mit fdhnalen verwajdhenen Dunflen Endjäumen;

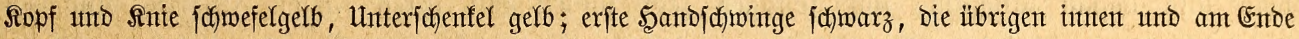

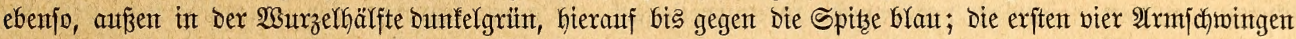

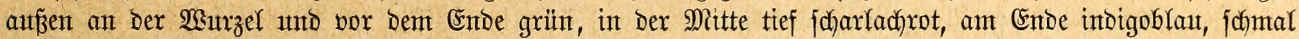

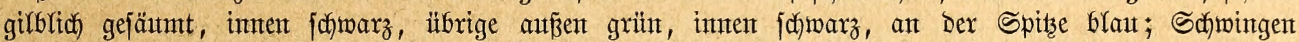

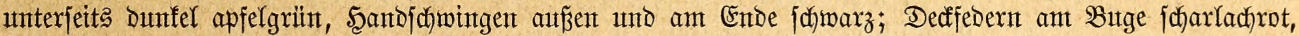

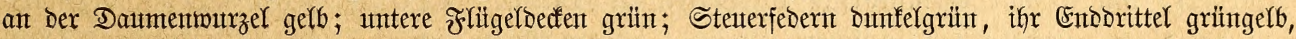

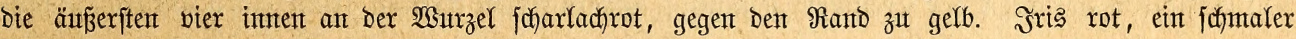

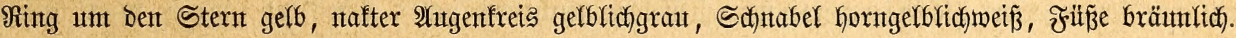

Der $\mathfrak{B o g e l}$ lebt in Slld = unto $\mathfrak{B e f t m e j i f o . ~}$

63. Die (Selbjđeitel=\{lmazune, Chr. (Ps., Am.) ochrocephala, Gml., (poecilorhynchus, flavifrons).

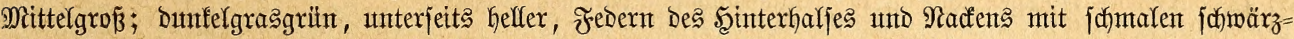

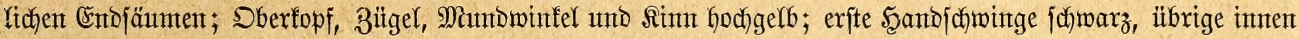

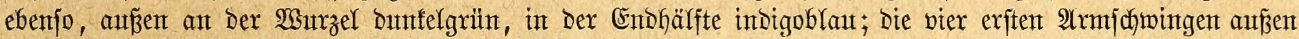

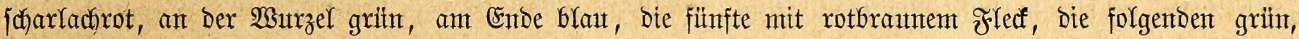

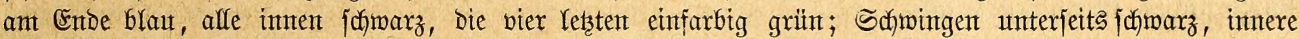

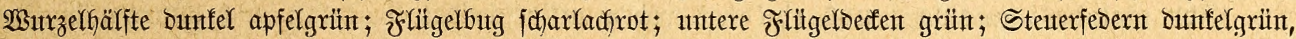

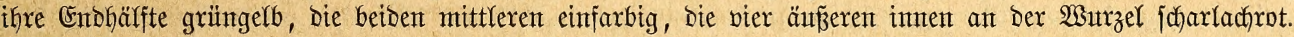

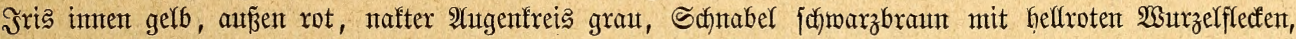
Füfß̉e bräuntić).

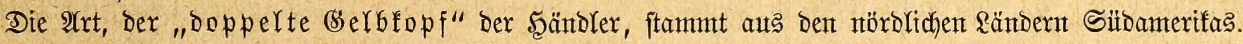

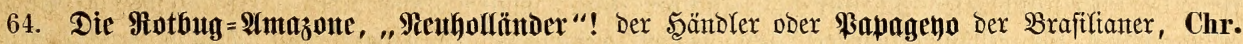
(Ps., Am.) aestiva, Latham, (amazonica, decorus, guttatus, aurora). Mittelgrof́; Dunfelgraggrït, ınter=

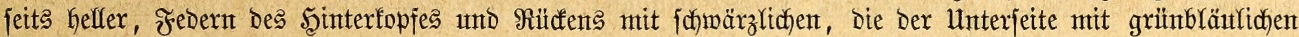
Endfäumen; Stirnxand himmelblau, Scheitel, 3̈̈gel, Bacten und Sint hod)gelb, Unterjahenfel gelb; erfte

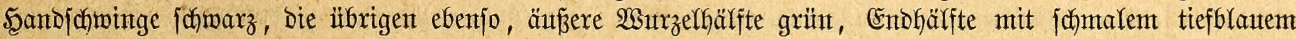

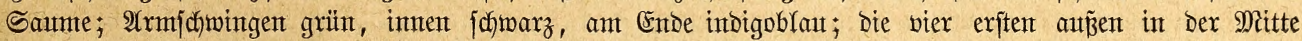

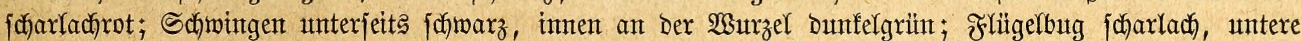
Fłïgeldecten grïn; Die beiden mittleren Steuterfedern einfarbig, bie ïbrigen an ber Wurzel bunfelgrün, thre

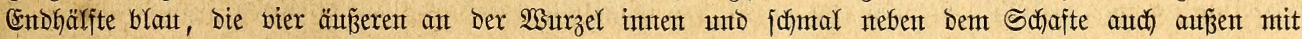

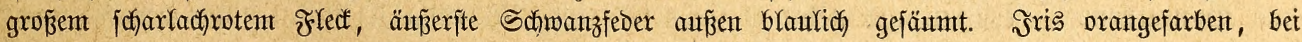

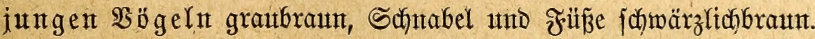

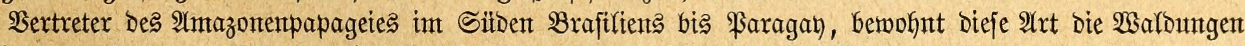
bes inneren Ranbes und fommt nidht an bie Ritite.

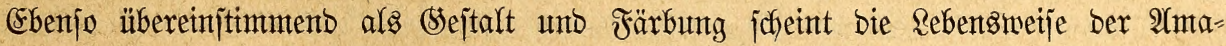

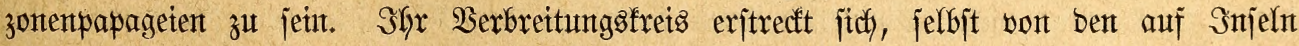

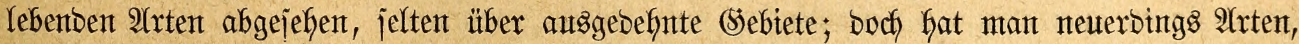
beren $\mathfrak{B o r f o m m e n t}$ nur für gewiffe Begendent befant war, aud in weit bavont entferntent

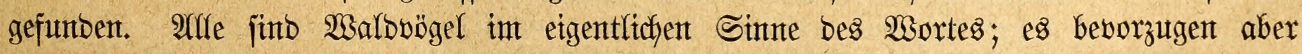

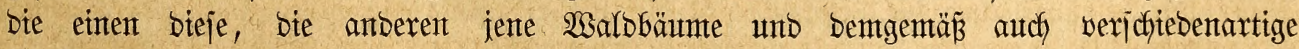

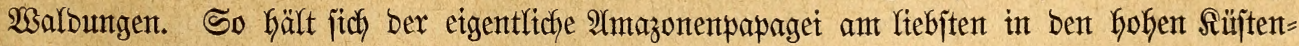

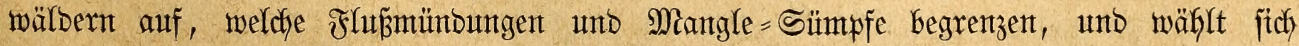

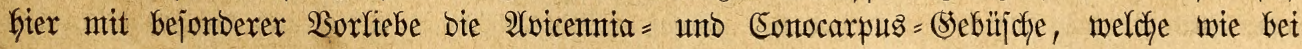




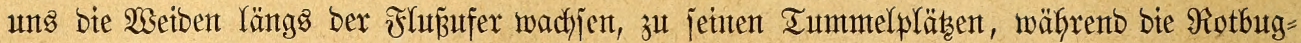
Itmazone erjt in ben böher gelegenen Steppenwalbungen gejumben wirb. Wie hodh fie im

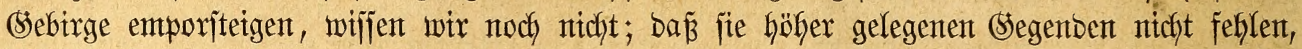

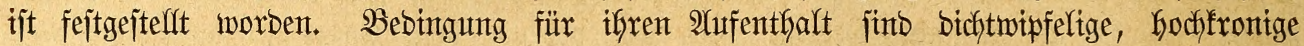

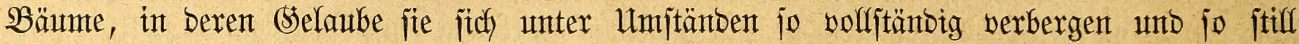

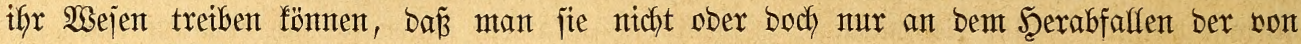
ifnen abgepflücften unb auggefrefienen Frütdyte wahrnimmt.

Sn ifren Bewegungen äfnteln jie Den Sraupapageten am meijten. Sie fint lantgjamte aber ausbauternbe Aletterer, jw)lechte ¿äufer und juberfällige Flieger. Miorib vergleicht ihren Flug mit Dem idywanfenden einer Ente; Der Srinz von Wied jagt: "fie fliegen

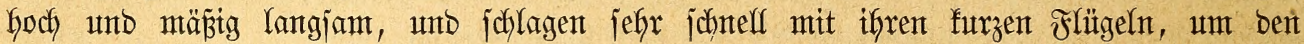
bicfen, furzen, jofweren Rörper fortzutreiben." Dabet jobreien fie unaufgorlich und in unerträglicher $\mathfrak{B e i j e , ~ w e i l ~ f e i n ~ e i n z i g e r ~ e i n e ~ a n m u t i g e ~ S t i m m e ~ b e j i t z t , ~ u n b ~ b a s ~ v e r e i n i g t e ~ ( S e j c h r e i , ~}$ weldjes "Den Wald erfülft", zwar "merfwürbig anzubüren" ijt, aber body Nerwen von Stafyl

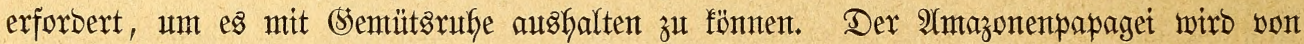

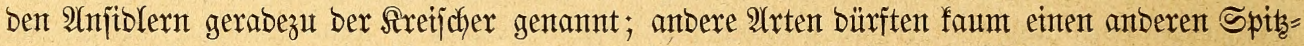

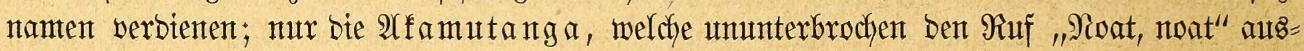

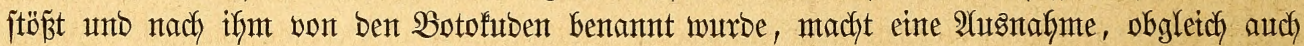

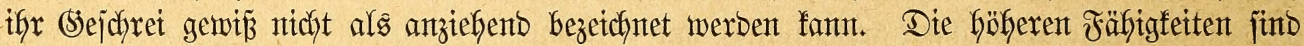

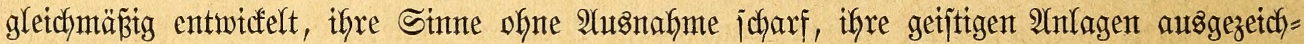
neter $\mathfrak{A}$ rt. Sie zäflen unbebingt zu Den flügjten $\mathfrak{B}$ ögeln Der erbe und zeidynen jidc ebenjo

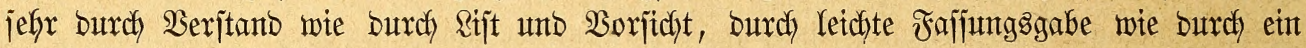
vorzïgliches ssebächtnis aus.

Shr tägliches, gejelliges unb eheliches Reben unterjchetbet fie faum von anberen $\mathfrak{B a p a}=$

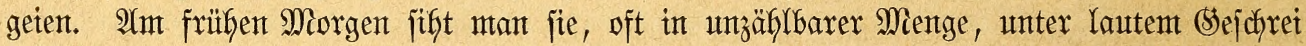

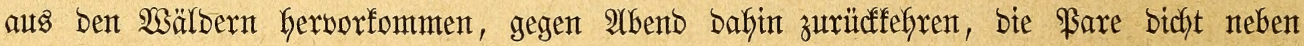

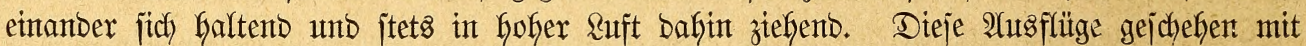

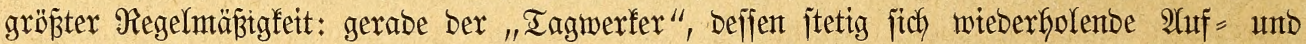

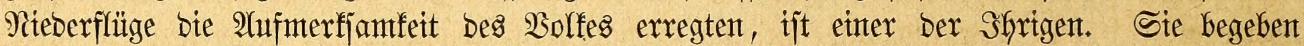
jich zunädyjt zu ifyren Futterpläłzen, weldhe je nach Der Sahreszeit verjchieben jind, und treiben Gier igre Sejchäfte ebenjo jtill, als jie früher laut waren. In ben Wälbern fallen je, um

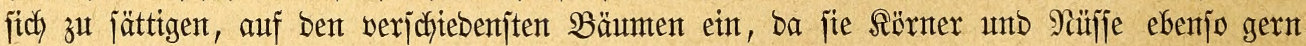

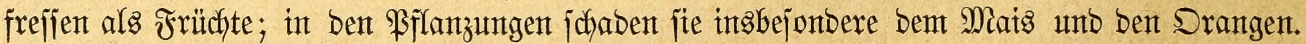

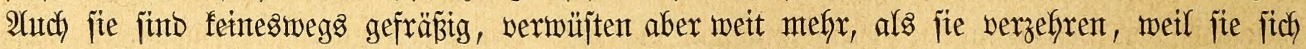

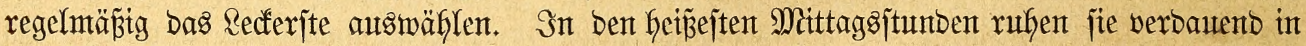

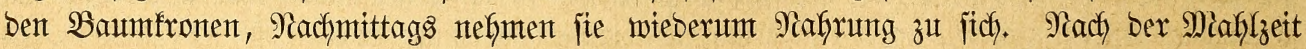
pflegen jie zu trinfen, jalziges Wajfer ebenjo gern als jüfes, am liebjten, intom jie fich von niebrig über bem Wafjer hängenton 3wetgen zu biejem Gerabbiegen. Wäbrent eines Regens jifht man fie auf Dent höbjten 3weigen fitzen, um fich Der Wobltat eintes Babes

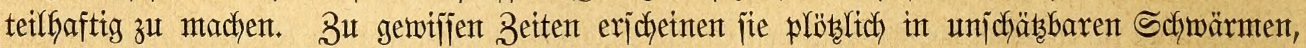
beren Borüberflug viele Minuten währen fann, an ber Süjte, in Den Bflanzungen 2 ., werjchwinton audh ebenjo untwerjehents wieber, als jie gefommen.

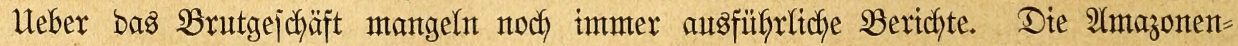
papageien trenten jich furz vor Derjelben in \$are, juthen fich einte vom Spedyt gezimmerte ober jonjtwie entitandene Baumb̈̈hlung aus, richten biejelbe im Snnern bürftig her und

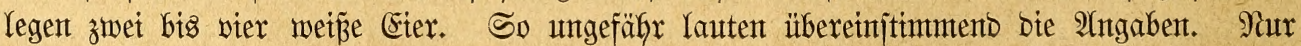

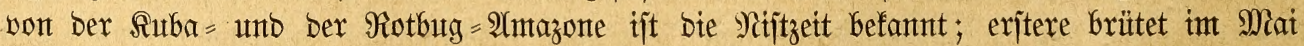

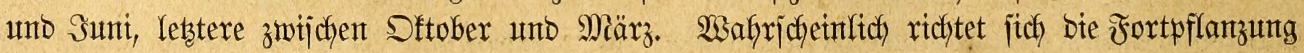


gentau nach bemt Frühlinge ber betreffenben Ränber. Die Sungen werbent bon betben EItern gepflegt und bis zum 24usfliegen aus bem Siropre gefüttert. "Sch beobachtete"; jagt

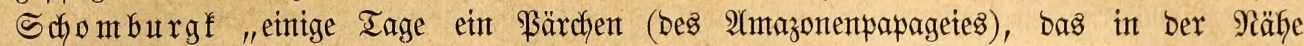
unjeres Ragers am Ramufu =\$ebirge in einem hohen, aber eingegangenen $\mathfrak{B}$ aume Nejt unb Sunge Gatte, weldfe letzteren fie nur zweimal fütterten, uno zwar um $11 \mathfrak{H h r}$ Sor=

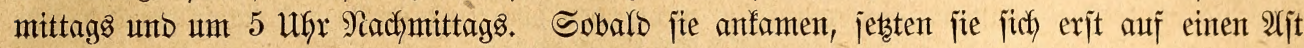

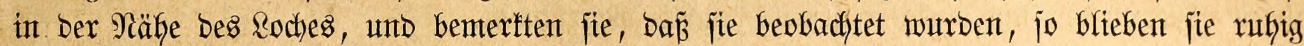
auf biejem jutzen, bis ifnen bie (S)legenkeit günjtig jeften, unbemerft in bie Seffnung zu

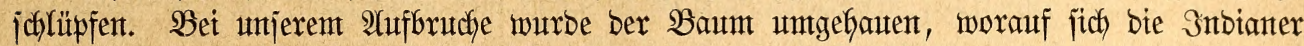
in Bejitz Der Sungen jebten; ein Mittel, zu bem jie immer ifyre 3ufludbt nefyment müljen, ba bie \$apageten gewöhnltich in hohe und unerjteigbare Bäume bauten."

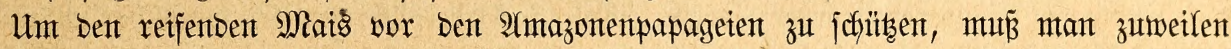

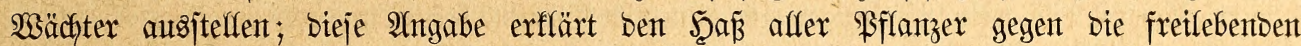
Bögel und bie $\mathfrak{B} e r f o l g u n g$, welche bieje zu erleiben haben. Snbes trägt audf nodh ein antberer

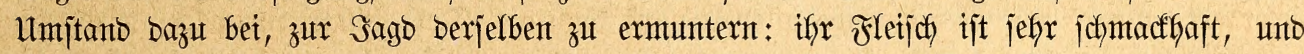

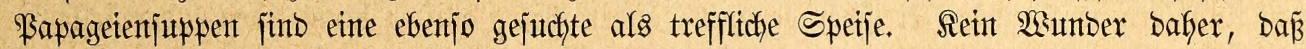
man, jo oft $e 8$ möglich, zu ifyrex Sago auszieft umb zuweilen Mafjen von ifnten

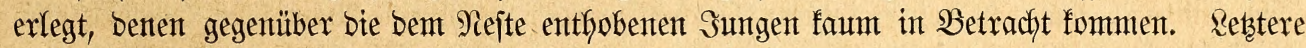

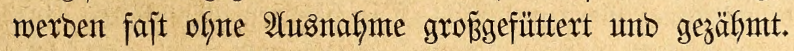

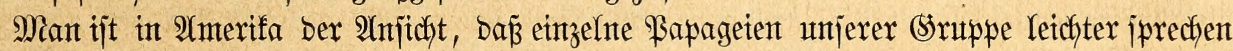

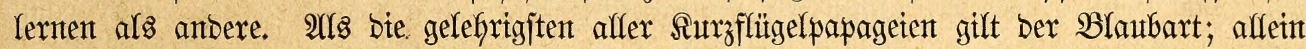

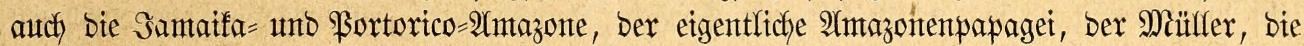

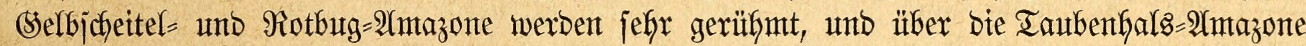

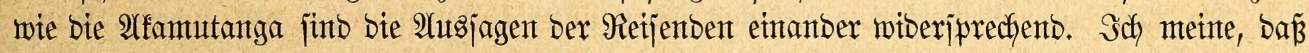

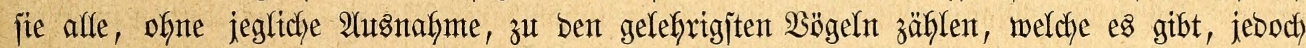
nur in jeltenen Fäflen einen Refyrmeifter finben, welcher ifnen etwas Tüdhtiges beibringt; es

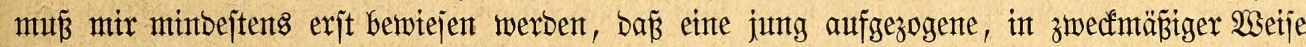
unterrichtete 2 mtazone nichts gelernt hat, bebor ich won bem Mangel ifher befäfigung überzengt jein joll. Sie jüto alle gut unb beshalb gantz bejonbers für biejentgen Riebfaber geeignet, weldhe an "iprecthenden" $\mathfrak{B}$ g̈geln Sefalfen fintoen. Wer über genügente Mittel zu verfügen hat, mag immerhin für eine ber grö̈̈eren und joföneren $\mathfrak{A}$ rten 20 biz 30 Ialer aufwenben; wex fich bejdyränfen mut $\tilde{3}$, fintoet in ben fleineren, mefy ober wentger unjchein= baren Ârten, Deren $\mathfrak{B r e t z ̇}$ zwij weidsent won ben Sraupapageten fommen bie von ben tierfreunblichen Inbianern auf=

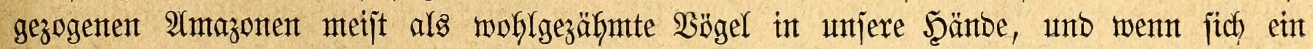

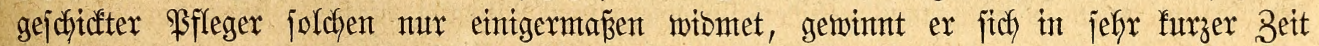
einten jefyr liebensmürbigen, für freuthliche Behanblung in hohem (Srabe empfänglichen,

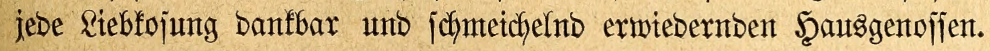

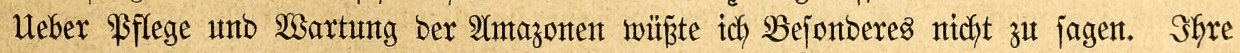

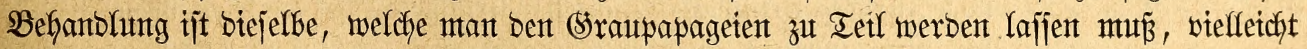

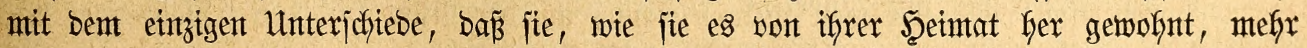
Früchte erbalten mögent alz jene. Zur Fortpflanzıng int Räfige hat man fie meines : nody nidyt jajreiten jeben, jie aber audy mur ausnabmsmeije in \$aren gehalten. Sebenfalls

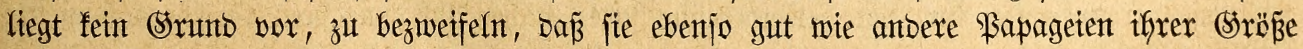
in ber Befangenjichaft fich fortpflanzen bürften, falls ifnen alfe Exforbernifife gewährt werbent.

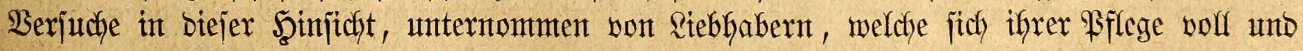

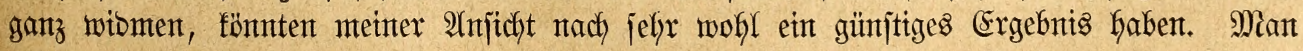

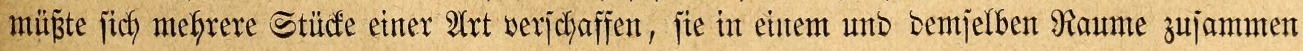




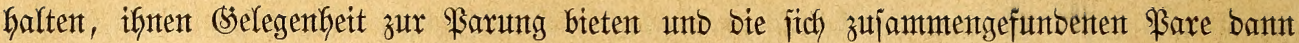

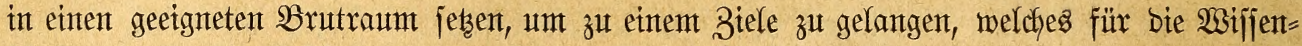

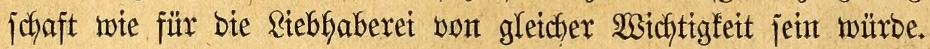

\section{Bmertapapageter.}

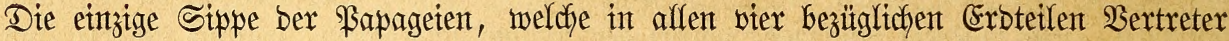

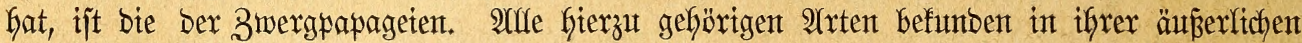

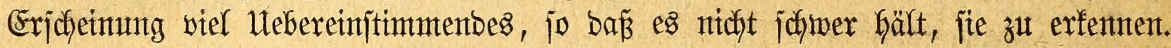

Shre (s)räßje jdjwanft zwijdyen ber eintes Stares unto ber unjeres Sperlings. Die

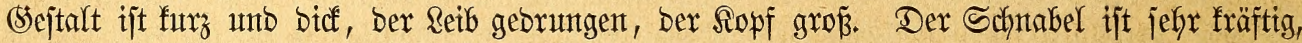

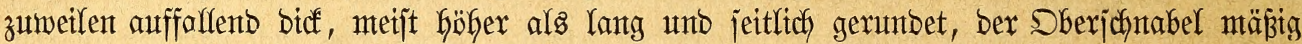

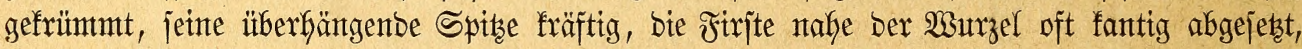

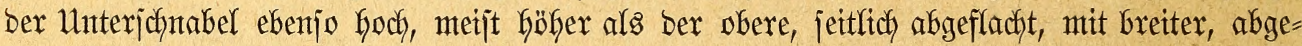
rumbeter, int Bogen auffteigenber Diffenfante, auf beren Mitte zutweilent eine erhabente Ränggleif́te verfäuft; yor ber Spitze bes Sberichnabels befintoet fich eint beutlicher recht=

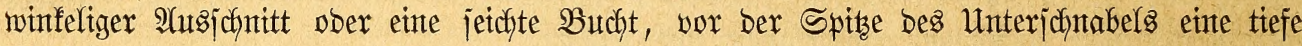

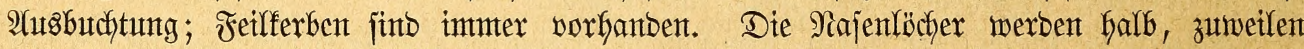

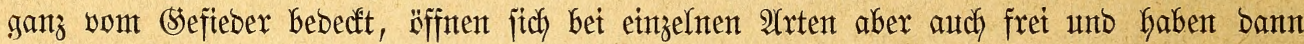

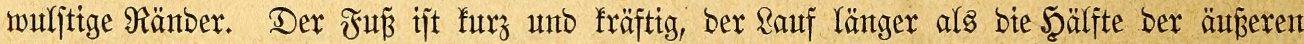

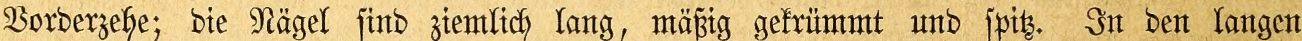

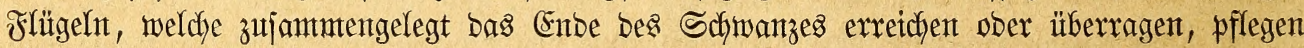

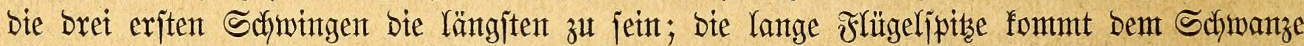

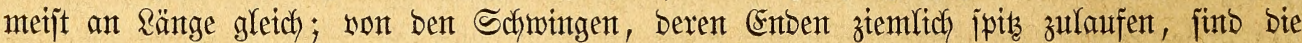

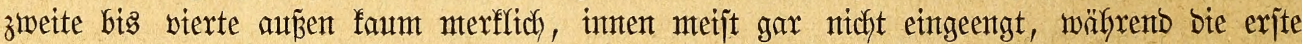

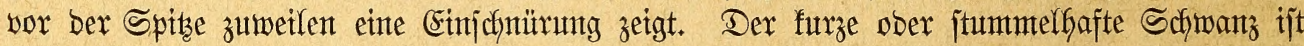

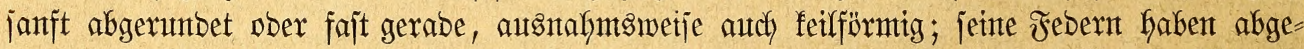
rumbete, feltenter zugejpitzte Enben; bie oberen Deedfebern, Deren mittlere manthmal megen iffrer Breite ben Steuterfebern äfneln, erreidfen das Schmanzenbe unb zeidynen fich burth

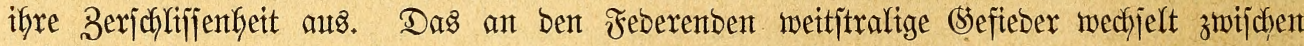

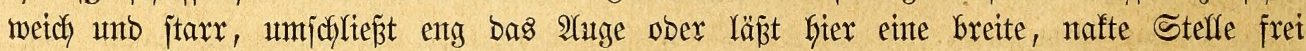

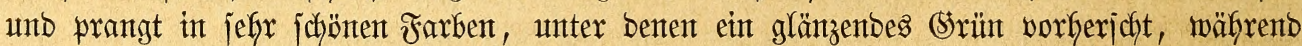
ein janfteres ober grelferes grot am Ropfe, ein lebfaftes Blau auf bem Bbürzel unb eine ¡dÿ̈nfarbige Fleefenzeidynung auf Dem Sdymanze zur bejonberen Zierbe wirb.

2utch bie Sippe ber Zmergpapageien ift in mefrere Unterabteilungen zertrent morben,

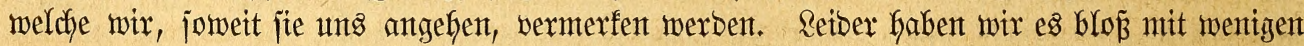

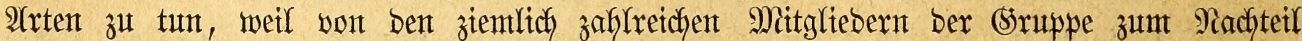

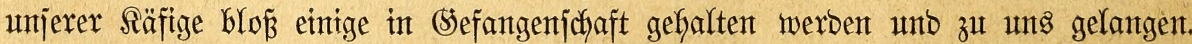

$3 \mathfrak{u}$ ben 2 trten mit abgerunbetem, einfarbigem Schwanze, Deren Şanbjdiwingen unb

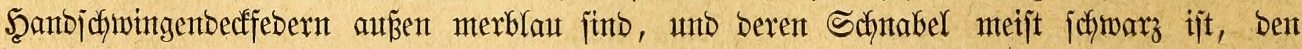
3wergpapageien (Psittinus), gefört:

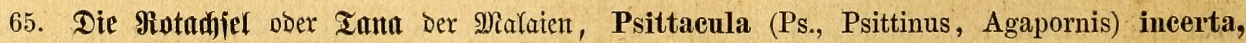

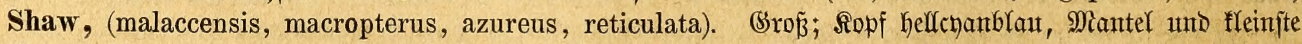

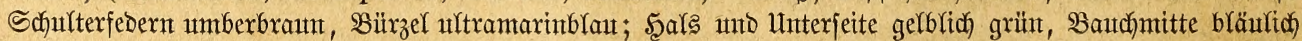

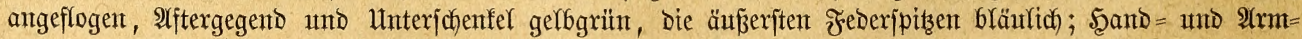

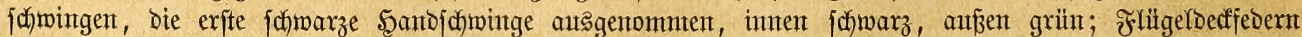

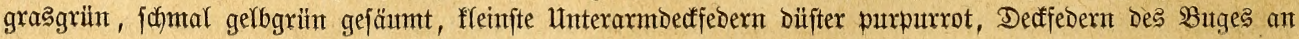




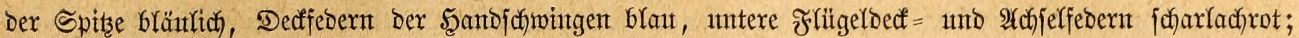

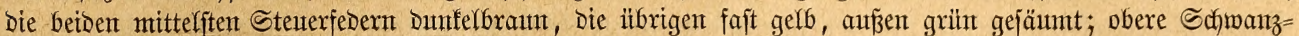

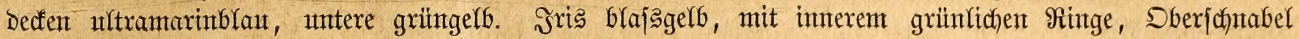

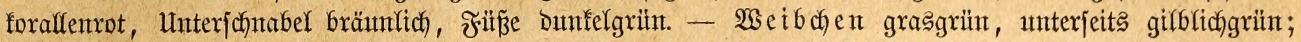

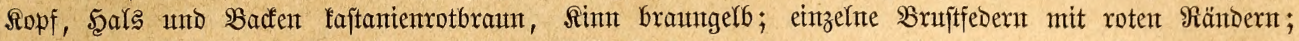

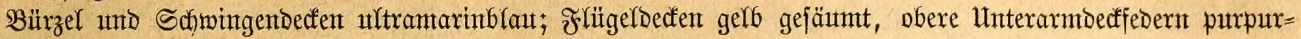

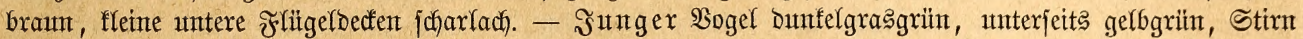

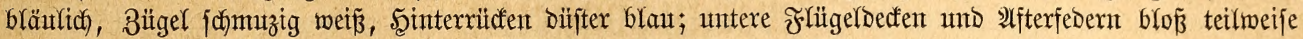
rot; Sdymanzfedern grïn, intent olivengelb; Schnabel hornbräınlič).

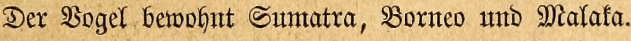

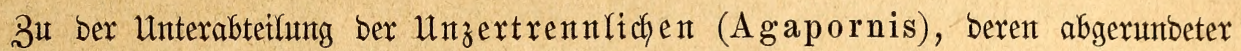
zwei = poer breifarbiger Sdywanz eine jojwarze @uterbinbe befitzt, unb beren Sedfnabel in

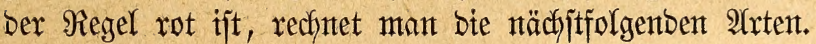

66. Der Unzertrentlidje (Infleparable), Psa. (Ps., Agapornis) pullaria, L., (minor, minimus, guineensis, rubricollis, xanthops). Mittelgrof́; Yebhaft graפgrün, unterjeits richter; Borberfopf, 3ügel,

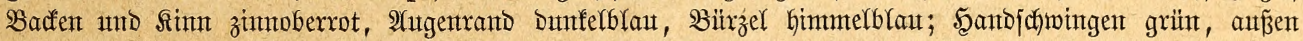
\{d)mal gelblich gejäımt, inten ıno an Der Spitze oliventbräınlich; Sdymingen unterjeits ınto untere Flügel=

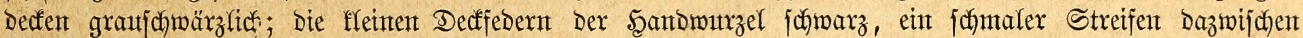
blau; Steuterfebern, Die betben mittleren grünen auggenommen, an Der Wurzel und im Endorittel grüm, in Der Mitte Dunfel zinnoberrot, vor Dem grïnen Ende mit breitem, fandarzem Duterbande; obere Sdhwanz=

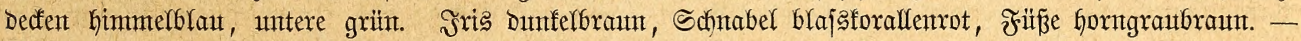

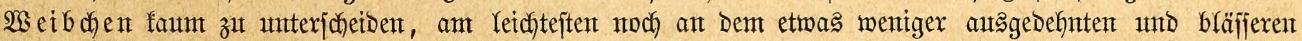

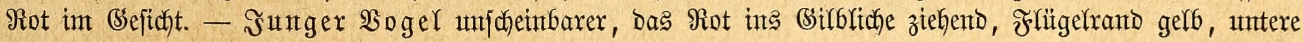
Fłïgeldecfen grïnt.

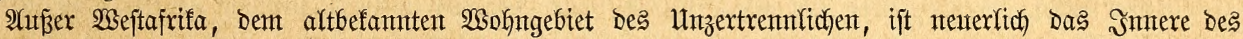
ExDteiles ars Defien Sceimat nachgemiejen morbent.

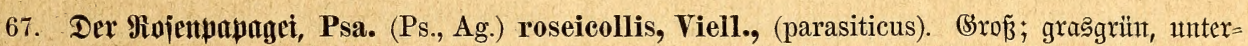
jeits helfer, Stixn und Angenbrauten blajs joharlach, Bügel, Bacten, Shrgegend und Rimn blajs rojen= ober

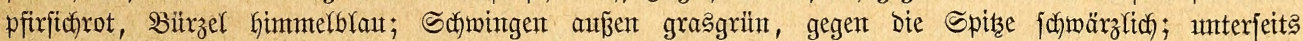

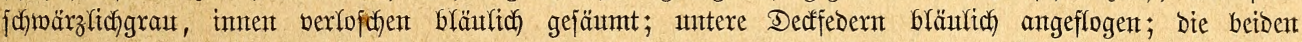

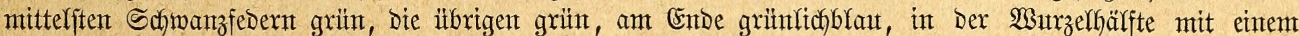

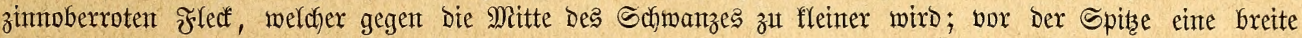

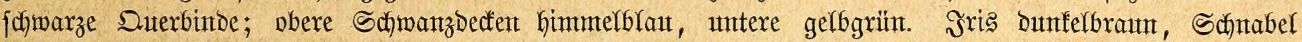

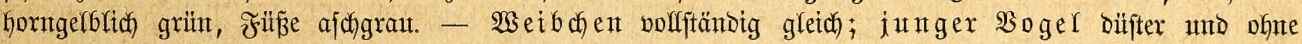

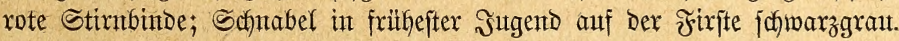

Das $\mathfrak{B a t e r l a n d}$ ift Der Silden und Sildmeften 2 frifas.

68. Das (Grauföpidien, Coruf́ der Mabagaffen, Psa. (Ps., Ag., Poliopsitta) cana, Gml.,

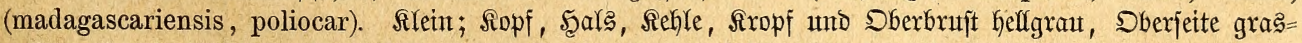
grïn, olivenfarben verwajchen, Bïrzel fdjön graggrïn, Unterjeite Yebhaft gelbgrün; Sd)wingen inten uno

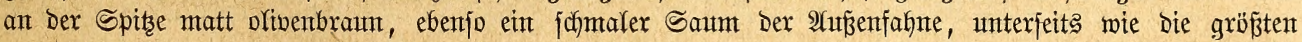
unteren Deden mattjahlbraun; Steuexfebern grün, innen an ber $\mathfrak{W}$ mzel gelb verwajchen, vor bem Ende

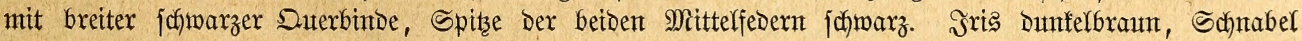

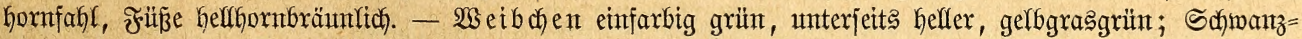
zeichnung wie beim Männch)ent.

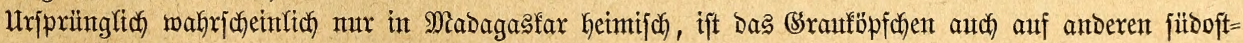

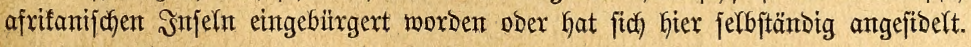

Эn ber Unterabteilung ber Sperlingspapageien (Psittacula), vereinigt man bie Irten mit ftärfer abgerumbetem, einfarbigem Schyanze, befifen Febern am Enbe zugeppiz̧t

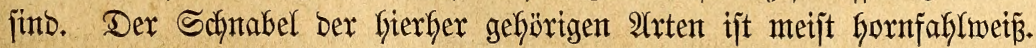

69. Der Sperfintgenangei, Psa. (Ps., Ag., Psittaculus, Conurus) passerina, L., (cyanopterus, gregaria, modesta, capensis, guianensis, Sancti Thomae, cyanochlora, xanthopterygius, viridissima, chrysogaster, leucophthalmus, simplex). Silein; Dunfelgrasgrün, unterjeits mehr gelbgrïn, Scinterrïđfen

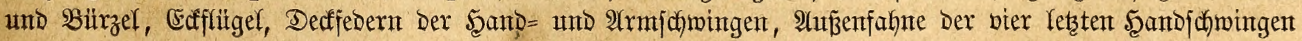

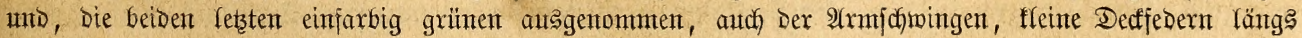




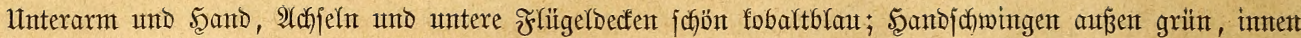

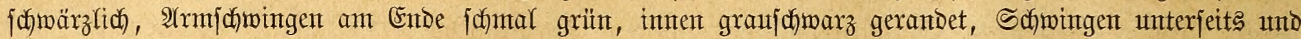

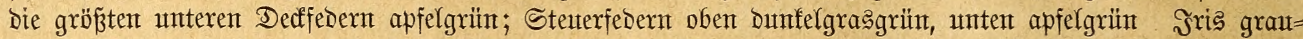

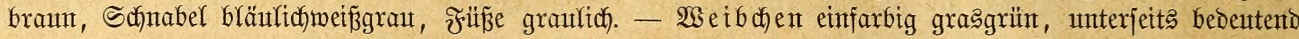
heffer, Sdfwingen und Deren Deffeesent etwas Dunffer, Bürzel glänzent grasgrïn; Şandfdhwingen innen

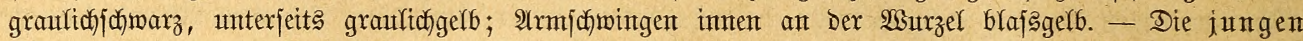

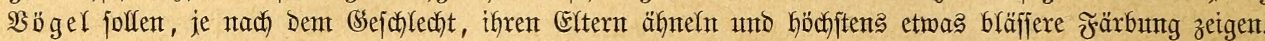

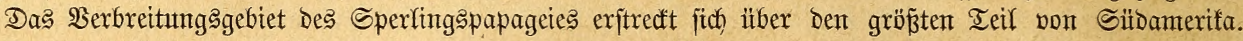
Auf Barbados ift ex Der einzige hier vorfommende $\mathfrak{B}$ apaget.

Die lebste Unterabteilung, welche Bonaparte mit bem Namen Simpelpapageien (Pyrrhulopsis), bezeidynet, bejteft aus 2(rten mit gerabem Schmanze, befien Jebern am

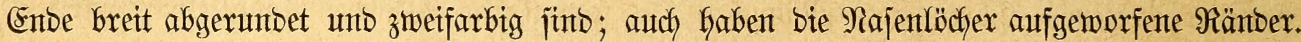

70. Der (Sürtelpapagei, Psa. (Ps., Pyrrhulopsis, Urochroma) cingulata, Seop., (batavica, mela-

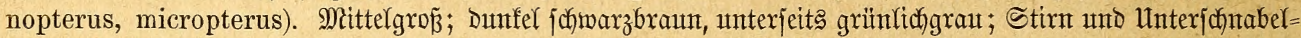

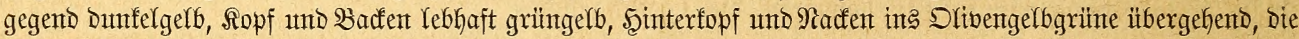

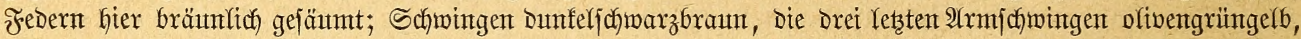

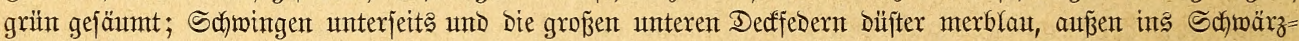

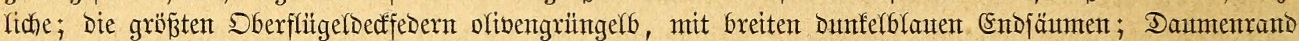

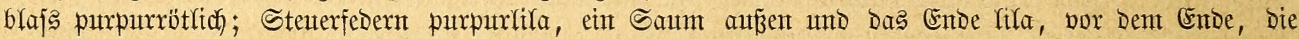

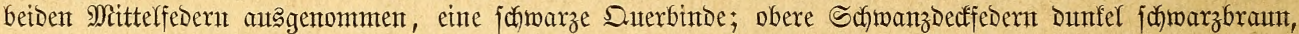

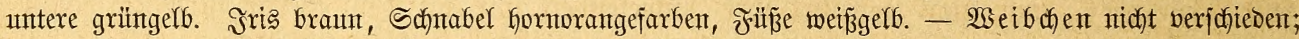

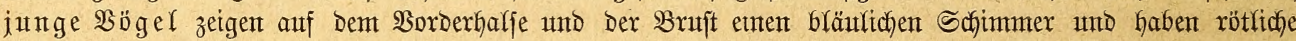
Schmanzfedern.

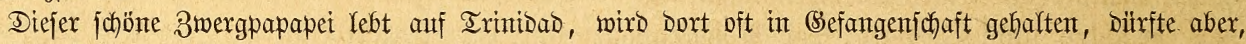

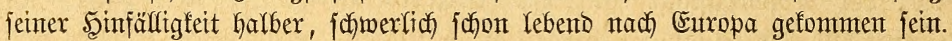

Sbgletch bie 3wergpapageten afferorten, wo fie vorfommen, fä̈ufig auftreten unt

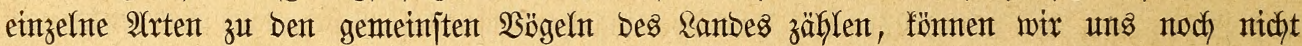
rüfgmen, ein umfajfendes und flares Bilb über ify Freileben gemonnen zu haben. Sie betwofnen ebenjo wohl die büjteren als bie lidyteren Waldungen und Bebüjche und bewölfern

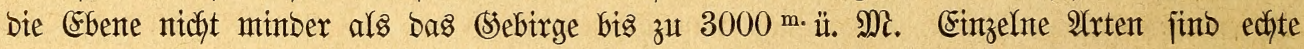
Sebirgsuögel, welche unter $100 \mathrm{~m}^{\mathrm{m}}$. unbebingter Şb̈he gar nidht vorfommen; anbere gehören

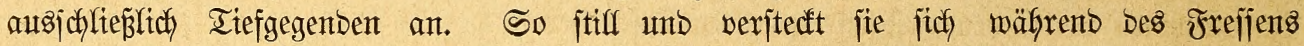
zu Galten pflegen, jo bemerflid) machen jie jiats, jobald jie jich gejättigt Gaben. Manche

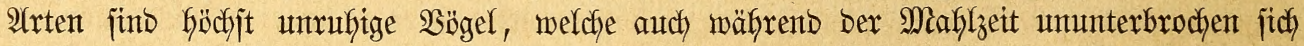
bewegen; anbere fingegen exjcheinen, minbejtents in ber (Sefangenjchaft, als träge, trübjelige

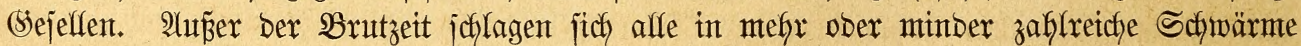

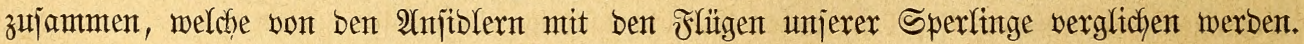

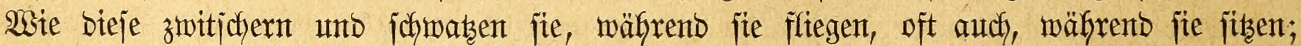
mie bieje fonmen fie in bie Särten ber Sibelungen; wie bieje überfallen fie die reifenden Baumfrüchte. Âtndere Beobachter vergletchen fie mit unjeren Staren. "Uleberall", bemerft Schott, „ftreidht Der niebliche Zwergpapaget in groß̈en Flïgen utmber. Der Rärm, welchen bieje berurjactjen, went fie zujammen in eine bidftbelaubte Baamtrone einfalfen, erinnerte

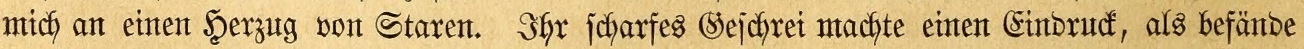

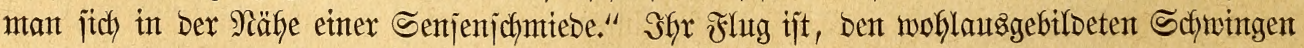

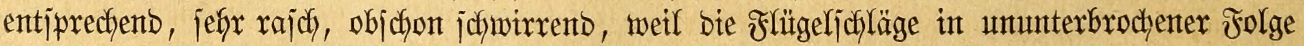
geichehen müjfen, um ben immerfin jchweren Reib zu förbern. Im Slettern jtehen jie Ginter

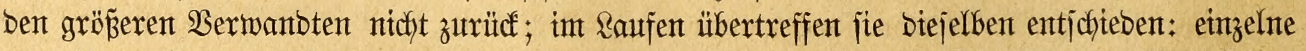
von ifnen betwegen fich jogar ziemlich eilfertig, fajt rentent. Die höheren Fähtgfeiten

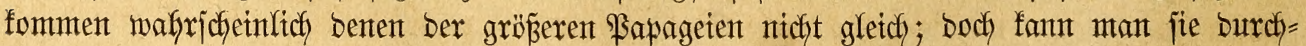

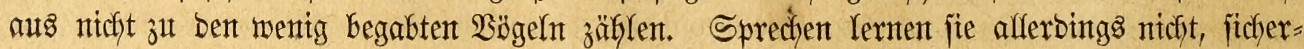


lich aber nicht aus Miangel an Berjtant, jonbern mux besfalb, weil ifyre Stimme, ein mefhr

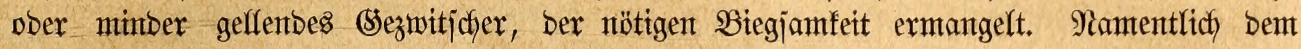

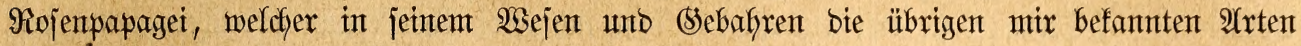

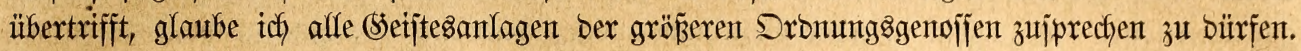

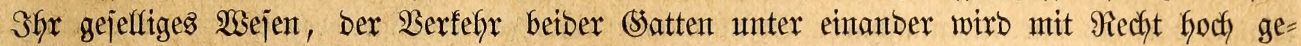
rüfymt. "Die Deutjchen Didfter", jagt Schomburgf, "finnten bie zärtliche Riebe nicht,

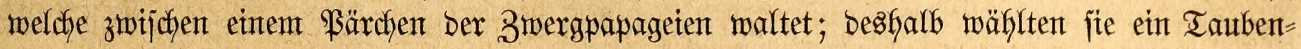
par zum Sinnbild Der ionllijchen siebe. Ifllein mie weit bleibt ein joldyes in jeiner Zärt=

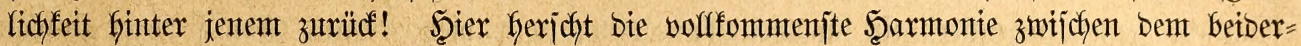
jeitigen $\mathfrak{W o l l e n}$ und Iun: frip̌t bas eine, jo tut bies audy bas anbere; babet jich biejes, jo

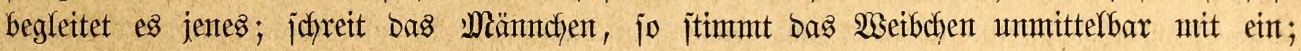
wirb biejes franf, jo füttert es jenes: und went ifrer noch jo viele auf einem Baume ver=

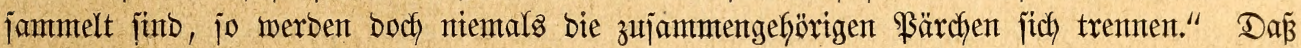
bieje Schilberung richtig ijt, beweijen bie Serangenen.

Die Nahrung Der 3wergpapageien bejtefgt ebenjo mohl in Früdften als in Sämereien,

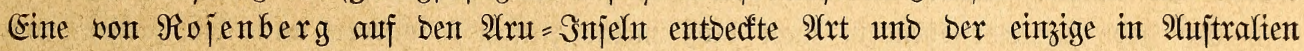
aufgefunbente 3mergpaptagei hatten bie Aröpfe mit bem jaftigen Intmern milbwadyjenber Feigen

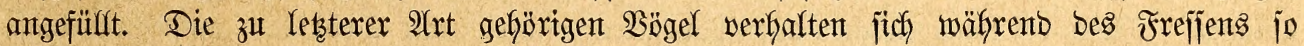

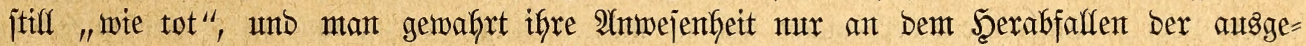

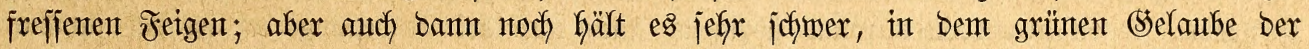

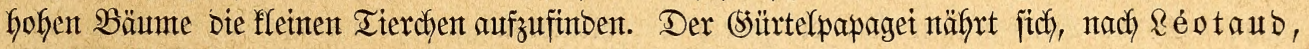

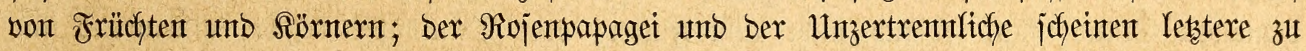
bevorzugen, uno audé in Dem Magen einer in Brajilien häufigen, erweizlich lebento noch nicyt nach Europa gelangten ober überhaupt gefangen gehaltenen $\mathfrak{A}$ rt (Psa. melanota), fand

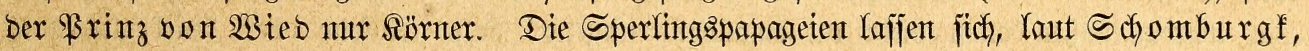
vorzüglidh gern auf bie Inmarinbenbäume nieber, Deren Blïte und reife Schoten jie jefr zu

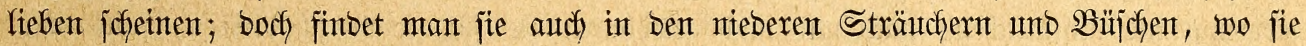

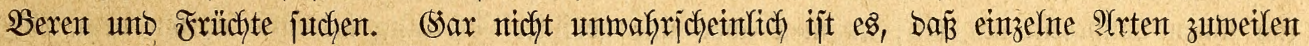

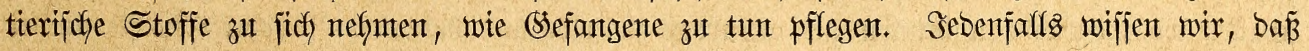
jie einen mit berjdjiebener Speije gebecten Iijdy lieben.

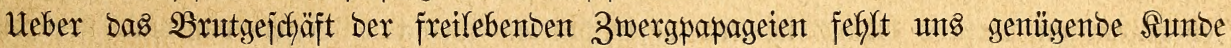

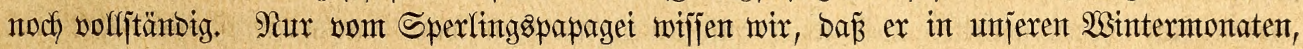

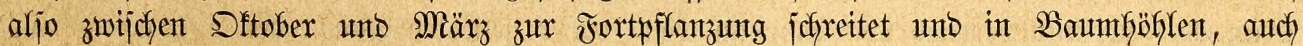
wohl in ben fünftlichen Iofnntejtern bes Topperoggels brütet. (S)lüdflichermeije hat unz das

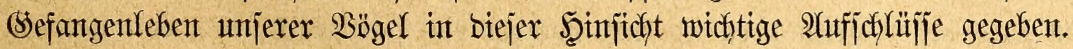

Alfe reijenben Forjcher, weldye bie Zmergpapageien in ifrem bezüglichen Saterlanbe

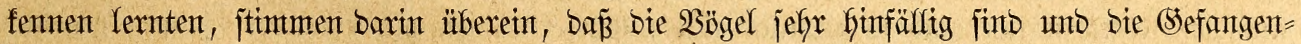
jchaft johmer aushalten. Bebingungsmeije ijt bies volffomment ridhtig, barin aud jebenfalfs ber

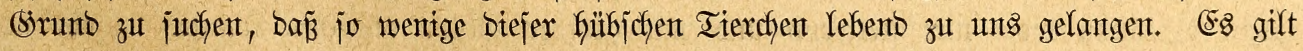
bei affen Sadyerjtänbigen als jobwierig, fleine \$apageien inşgejamt am \&eben zu erfalten,

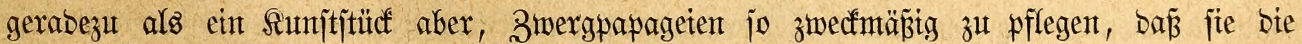
(Sefangenjichajt längere Beit extragen. Id erintere mich zwar, bie unbedingte Befgauptung Des geraben (Siegenteils voritehenber Bemerfung gelejen zu haben, mödyte mente sejer jedoch

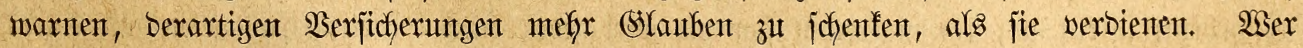
Dutzente ober Şunberte von Zwergpapageten gepflegt hat, lernt anbers ïber jie urteilen als ein Şalbfumbiger, weldyer, weil ifym ber 3ufalf wohl wollte, leidyt fertig mit bemt

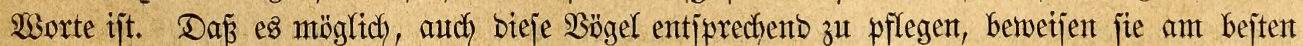
burdh ifre Fortpflanzung in ber (Sefangenjedaft; bebenflich aber bleibt ber 2lnfauf frifidy= 
angefommenter \$ärchen unter alfen Umitänben, weil bet ben meijten won ifynen fichon in bent eriten Iagen iffrer Sefangenjchaft unt mährend ber Seereije der fieim bes Iobes gelegt

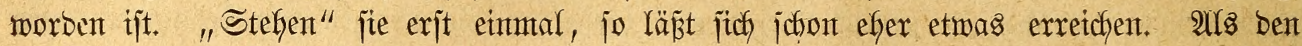

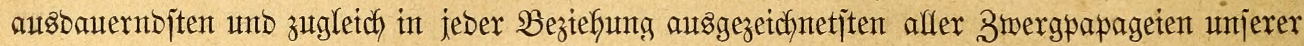

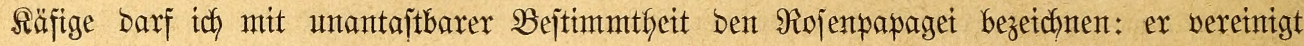

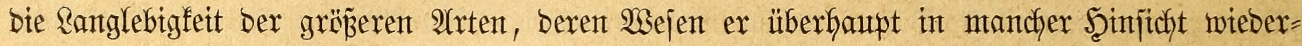

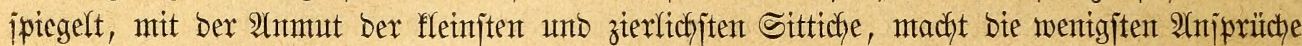

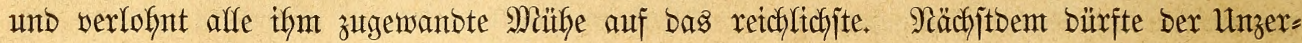
trennlidje, jentem gegenẗber ein langweiliger Bejell, zu empfeblen jein, jofon weil er unter= wegs am bejten gepflegt miro, wäfrent ber Sperlingspapaget erit Die leţte Stelle einnmmt.

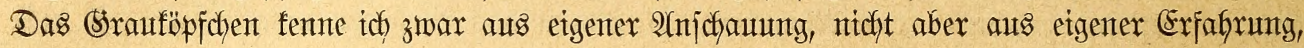
und fant beshalb nur jagen, baj mix jein Wejen und Betragen int Räfige recht wohfl

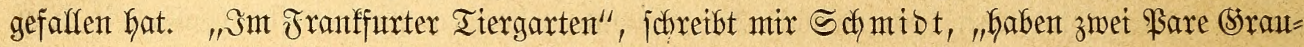
föpfchen etwa brei Gafre gelebt, und ein Weibdjen hielt fich fajt jechs Jahre lang. Sie waren jefr lebhaft, zeigten aber feine গietgung zur Fortpflanzung."

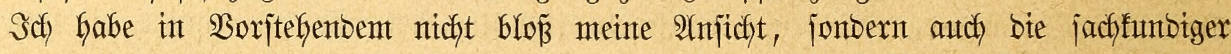
Freunbe ausgeiprodien, namentlich was ben von Einzelnen hoch gerüfenten Sperlingspapagei

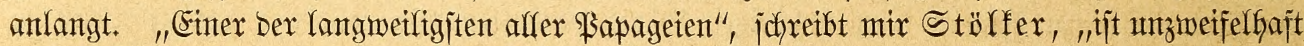

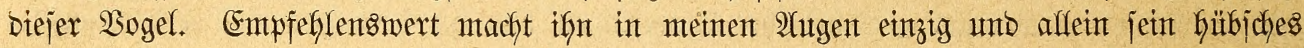

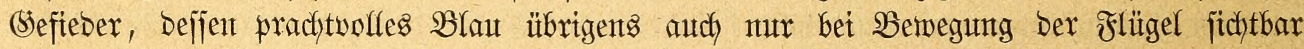
miro. Soldhe betwegungen übt ex jeboch verfältnismäpätg jefy mentg, ba ex einen und Demjelben Stand, fafls ex jich nicht zum Jutter = ober Irtufnapfe begibt, andauternt und träge inne zu halten pflegt. - Sm Sabre 1867 empfing ith zwet Miännchen, welche bis zum Spätiommer 1869 aflein Glieben. Sie fielten ftets treu zujammen, als ob fie ein

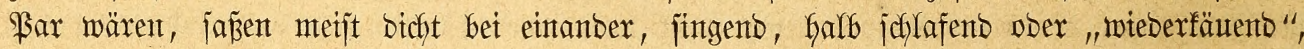

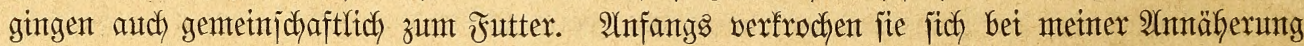
jedesmal ins Nififfäftchen; nach und nach gemöbnten fie fich fitsent zu bleiben, falls man fich ifgnen vorjichtig näherte, nafmen aber eine gebücfte Steflung an und fefrten bem $\mathfrak{B} e=$

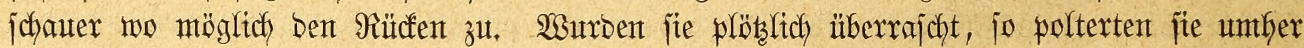

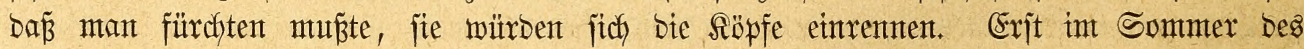
retztgentanten Safyes erfielt ich ein verfrüppeltes 2 Seibchen, beffen einjtmals zerbrochentes

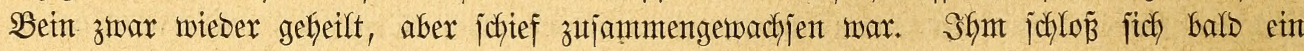
Männdyen an uno vertrieb von mun an ben früher geliebten Sameraben eiferiüchtig auts

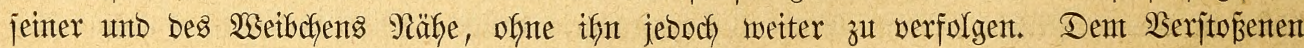
jollte es übrigens balo befjer geben, ba idy furz nadhger ein \$ärchen faufte, won weldyem id) mur bas ferngejumbe Weibchen befjelt. Naunmefyr blieben beibe Bärchen itreng zu= janmen, lebten fortan aud in żemlide gutem (Einverntymen mit einanber, frapen gemein= ichaftlich und johliefen neben einanber auf ber Göchjten Sibjitange im Säfige, obgheich Das

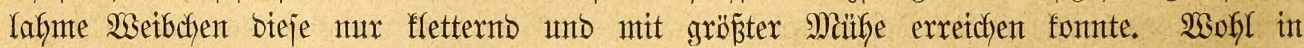

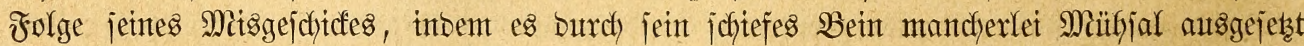

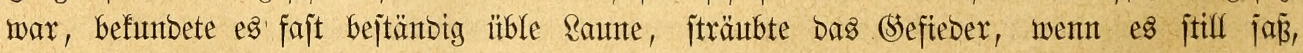

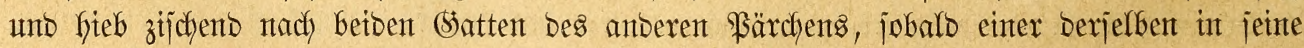

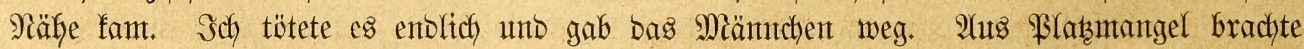
ich Gierauf in eintem geräumigeren Siäfige bie übriggebliebenen Sperlingspapageien mit einem

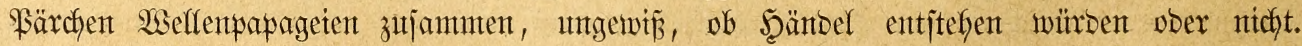

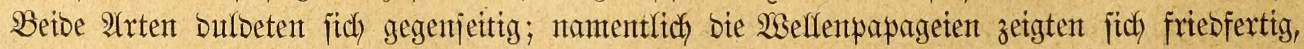

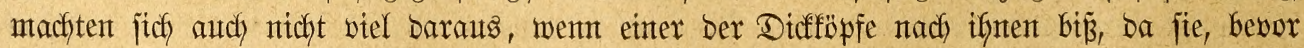
Der Schnabel traf, meijt jchon längit entflohen maren. Das wejen ber Sperlingspapageien 
trat jeşt, als ich fie mit bent immer betweglict)en und Geiterent 2 seflenjittichen vergleichen

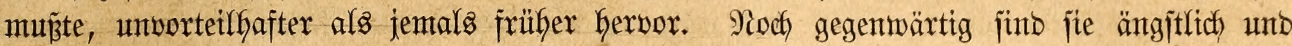

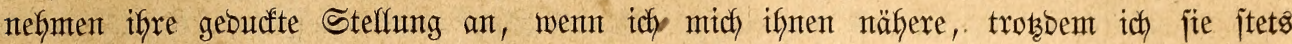

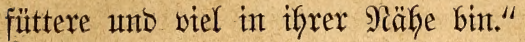

In etwas günjtigerem Richte erjoheinen bie Unzertrennlichen, obgletch audch fie, wie be= merft, zu Den langweiligen \$apageten zählen uno in alfem mejentlichen Den Sperfingspapageien

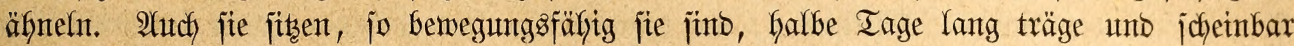

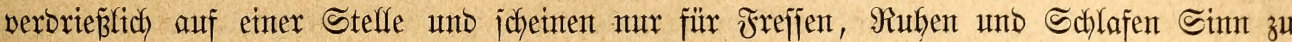

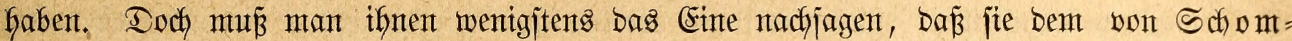

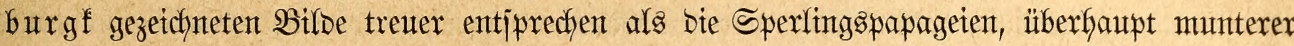

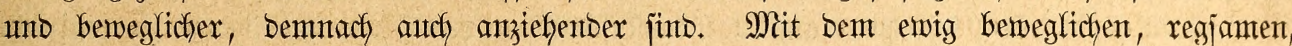
tätigen uno flugen Roientpapagei lafjen jite jith alferbings nidft vergletchen; ifym jtehen aber

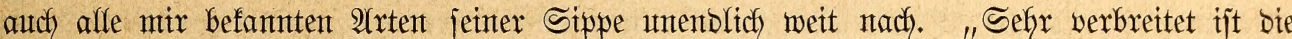
Meimung", fügt Stölfer finzu, "Daß̉ Der \$atte eines Bärchens Der Unzertrennlichen, zu benen mant bem Sinte nach aud bie Sperlingspapageten redyntet, Den Iob Des anberen nicht überlebe. So alfgemein barf bies burdhaus nicht bingejtellt, am wentgiten aber als Folge eines tiefen srames aufgefaß̧t werben. Es fommt eben jefr barauf an, weldje Hrjachen Den Iod Des einen (Satten herbeifüfyrten. Sit Das albleben Folge eintes Untglüdf', Der Sege= not $2 c$, jo bleibt ber anbere Statte ebenjo wohl als bisher; waren bagegen betbe benjelben jchäblichen Einflitijen ausigejetzt, muß̈ten beibe hungern ober boch barben, wurben fie un=

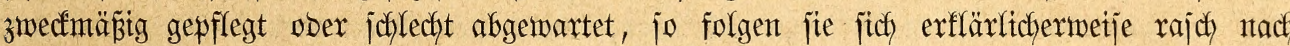
einanber." Dá̉ bieje BBemerfung meines Freunbes, auf weldhe idh nicht gefommen mar,

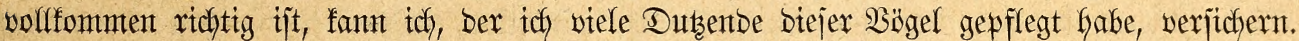

Reine einzige \$apageienjippe verlangt eine jorgjamere Bflege, leine ein jo verjefieden= artiges Futter wie Die 3wergpapageten. Sch lafje ifnen alle bet mir überfaupt verfüttert werben, und habe bamit bie bejten Erfolge erzielt. Einzelne

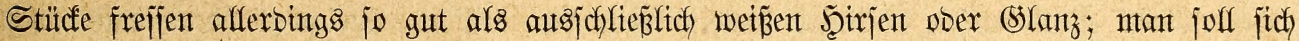
burch foldfe Beobadytung aber ja nidyt berleiten lafjen, allen nux biejes eine Futter zu

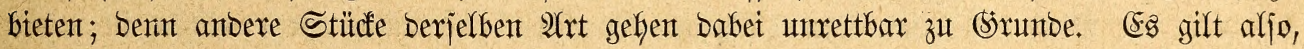
zutächjt zu verjuchen, weldyes Futter an liebjten genommen wirb, unt barnach bie Ernäfyrung zu regeln. Şirje, (S)lanz und ein wenig Şanf mögen als (Srundlage Des Futters angejeben merben; Diejen Sürnerjorten fann man jeboch nodh viele andere Stoffe łujetzen: Şafer, Butch= weizen, Sonnenbluntenförner, Sras = unb Dogelfirjenrispen, Galbreifen Mais in ben Solben,

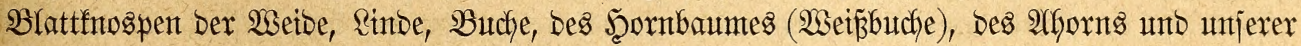

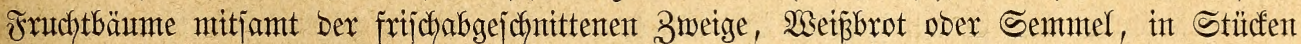

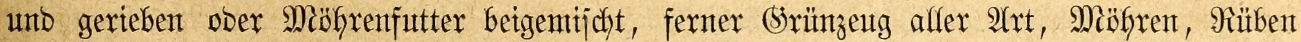
Beren, joweit fie als nicht giftig ober umjchäblich in Frage fommen fönnen, unto entlich

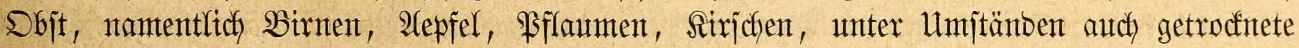

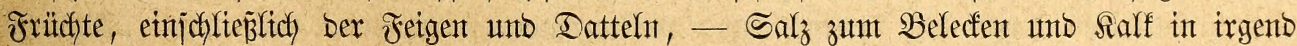
meldyer Form, am einfachjten gepulwerte Aretbe, niddt zu vergeifen. Währento ber Fort=

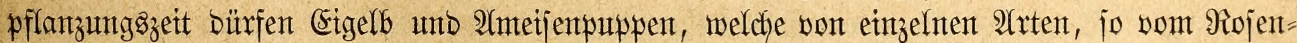

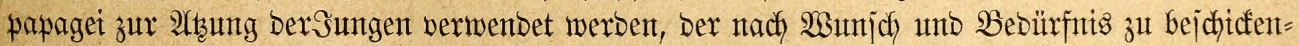
Din Iafel nicht feflen. Der eine Zmergpapaget betrachtet biejen, Der antere jenten Futterjtoff als wifffommente Bugabe zu ber ofnehin jo einförmigen (sefangenenfojt, entbehnt wentgitens

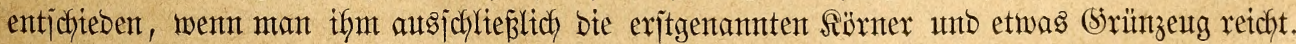

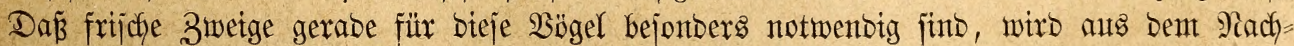

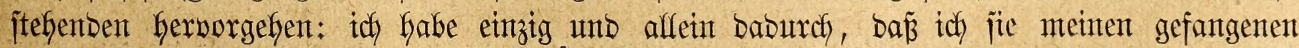

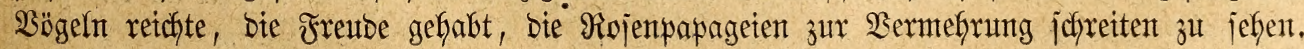




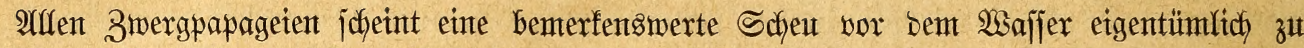
iein. Man jifht fie jelten trinfen, noch meit jeltener aber baben; einzelne \$ärchen benuzen ifre Babenäpfe in Sahren nidft ein einzige Mal. Wahrjheinlich laffen jie fich im Freien auch nur beregnen.

Bon ben aufgefüfrten Arten Gaben fich ifrex brei in unjeren Räfigen fortgepflanzt,

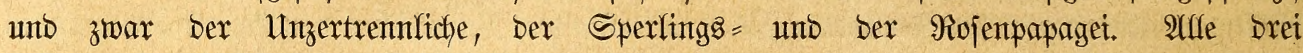

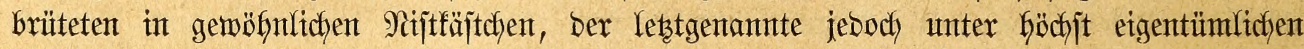

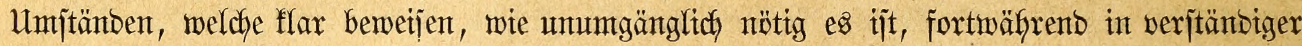

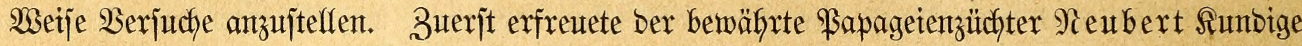

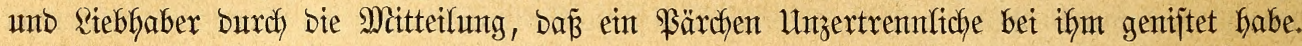

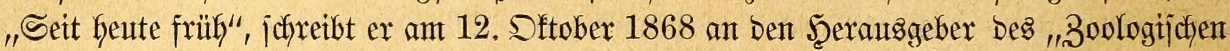
(Sartens", "bin ich Der jebr beglüfte \$flegebater ber erjten Jungen von meinen Imjeparables.

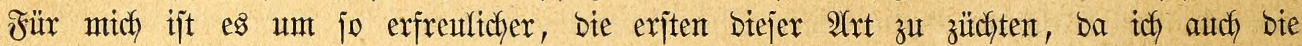

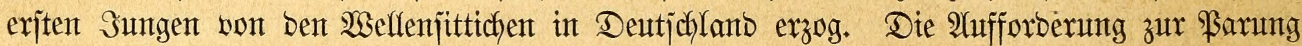
ging won bem $\mathfrak{B e i b c j e n ~ a u s , ~ w e l d h e s ~ j i ł h ~ m i t ~ m a h r e m ~ S e u j z e n ~ a n ~ b a s ~ M a ̈ n n d j e n ~ m a n b t e . ~}$

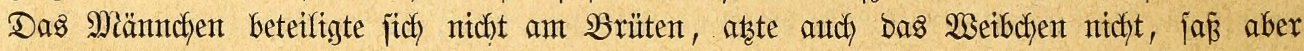
Den ganzen Iag vor Dem Schlupfloche Des Nitiffäjtchens und hütete mit famtpfgieriger (Eifer = jucft Das Weibchen; jelbjt Den bei weitem größeren fïnigslori (Platycercus scapulatus) jagte $e \mathfrak{s}$ in bie Flucht. Das exjte (ët wurbe gelegt am 15., bas zweite am 17, bas britte am 19. September. Das $\mathfrak{B}$ eibchen blieb vom exjen Ei an in Räjtchen jüzen; es würbe aljo von ba an gerechnet bie Brütezeit 27 Tage, vom britten Ei an aber 24 Tage betragen. In nue meit bie vorgerüdfte fühlere Gafreszeit bet bem 2(ufenthalte in bem Fluggebauer in

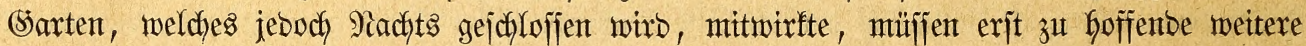
Sbrütungen exflären*). Die Injeparables jah tch noch ntemals etwas anderes freffen als Sanarienjamen ((S)fanz), Semmel unb Salat. $2(1 z$ Sijtiftofi maren meidje, feinte Sägejpäne

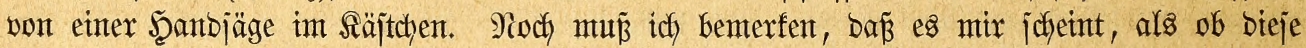
Bögel einen etmas tiefen গiiftraum lieben; Denn bas brütende 2 Seibchen hatte immer ben Siopf gegen Den Dunflen Şintergrumb geridhtet." Die Beobachtungen, welche Fie bler ge= legentlich Dex $\mathfrak{B r u t}$ entes von ifym gepflegten Bärchents gejammelt Gat, weichen in jofern

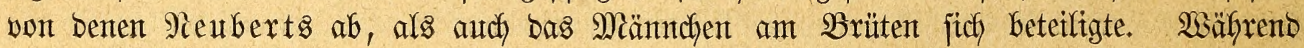

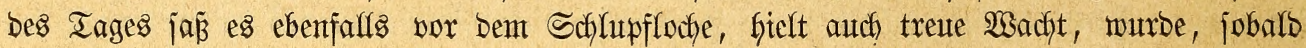
fich Semant Dem (sebauer näherte, unxufig, jobrie und zeterte unb froch bann zu bem Weibchen in ben Räfig, anjcheinenb in ber 9fbjicft, biejem über bie Störung Beridyt zu

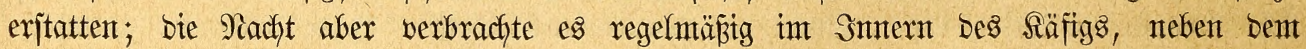
Beibchen jitzento und gemeinjchaftlich) mit biejem brütend. Reiber zeigten fich bie (Eier nach)

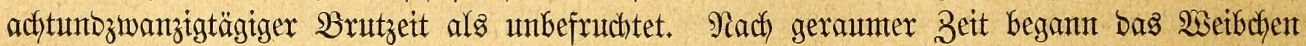
mieber zu legen; Weiteres fonnte mix Fieblex bei a(bjchluź biejes SBogens nicht mitteilen.

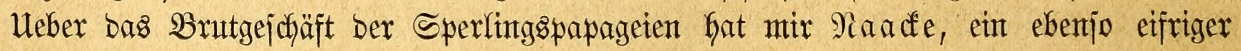

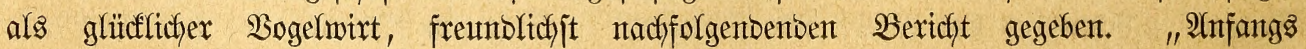

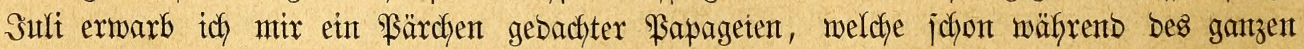

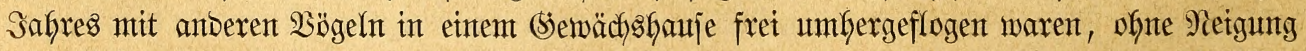

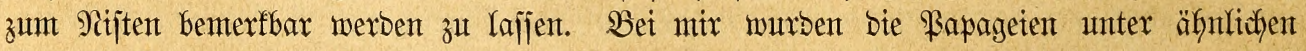

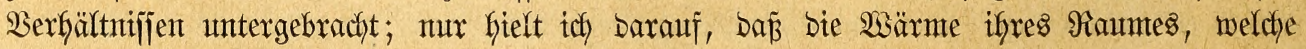
Durdyjdynttllidy $18^{\prime \prime}$ R. betrug, eine gleidymäß̈̈ige Glieb und jelbjt an falten Sommertagen

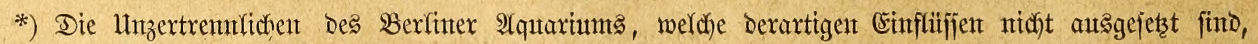

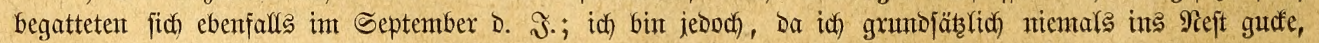

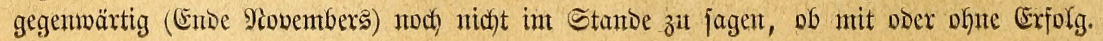


nidft unter $15^{n} \mathrm{R}$. Gerabjant. Schon im $\mathfrak{B e r f a u f e}$ ber erfiten acjt Tage, nachbem bie

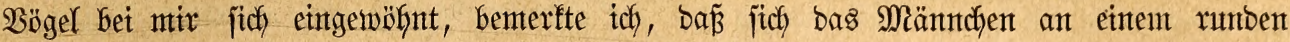
Brutfajten son $35 \mathrm{~cm}$. Sëhke unto $12 \mathrm{~cm}$. Dutrdimtejfer, weldyer unter vielen anberen gegen

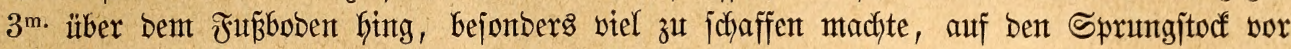
bem Schlupfloche flog und balo auch bas Weibdjen bewog, ifmt nactzutut. Beibe begaben fid) mun abwechjelnto etwa vierzehnt Iage lang jefre oft auf bas Sprungholz unt lugten von Demjelben aus in bas Intere des Nififfäjtchens, ofne baz eintes von beiben einzujchlïpfen

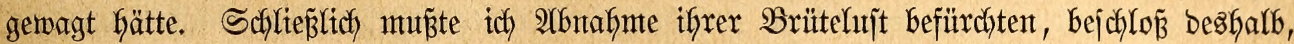
ifyten ben Sajten einlabenter zu madien ober bas (Eimjchlüppfen zu erletchtern, unto füflte

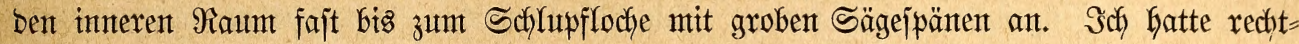
zeitig ifnen bie Brücfe geichlagen; Dent nodh an Demjelben Tage gingen beibe Sperlings= papageien mit überrajchenter Rebhaftigfeit ans Werf, flogen umutterbrodjen aus unb ein

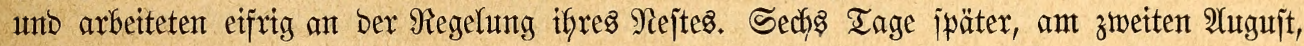
fantb ich Das erjte (Ei im Rajten; am bierten 2 hugujt lagen beren zwei im Nejte, unt bas 23eibchen blieb von jebzt ab auf bem Selege jitzen, obgleidy biejes erjt am vierzefnten 2lugujt mit adyt Eiern bollzählig wurbe. Snterballb biejer zmolf Iage waren alle Eier gelegt worben - ob in regelmäß̈tgen ober unregelmäß̈̈gen 3wijchenräumten, fonnte idy nidft

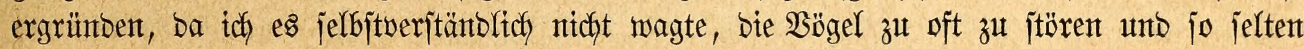
als möglich ints Rejt jaf.

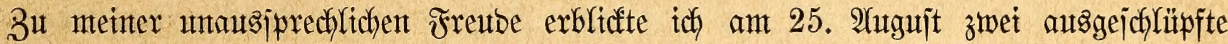
Suntge; am zweiten September waren beren jieben vorhanben, welche zum Teil bereits recht jtarf und fräftig ausfaken. 2(m vierten September unterjuchte idh bas Nejt wieberum, unto ba idh bas achte (Ei audh) jetzt noch vorfanto, muşte ith es begreiflichermeije für taub Galten, umjomefyr als bas Weibchen nicht mefr brütete. Sorjichtig zerbrach ich bie Schale; aber fiefse ba: ein volritändig entwicfeltes Sunges fant mix entgegen, unb eiligit wurbe baš =

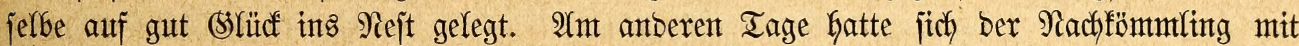

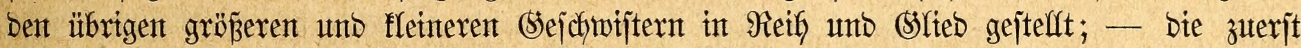

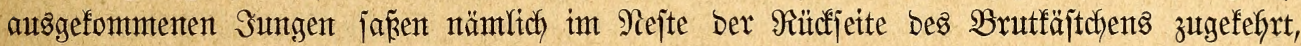

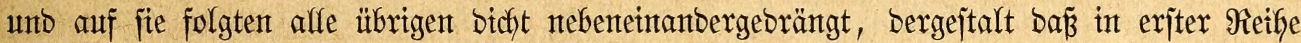

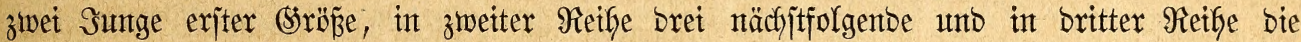

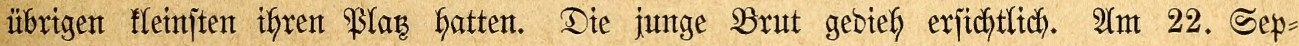
tember erjcfitenten fajt gleicfzettig bie exjten betben, zwei Iage fpäter zwei anbere Iunge;

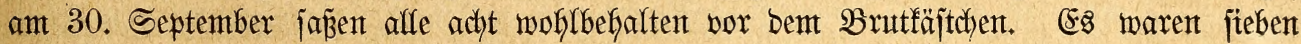
Miännţen unt ein $\mathfrak{W e t b}$ chen.

গux Das Weibchen meines Bärchens brütete; bas Mäntchen übernabm mährentom

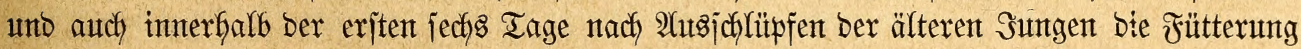

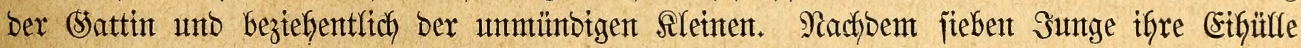

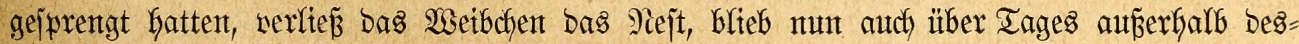

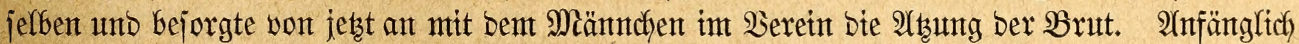

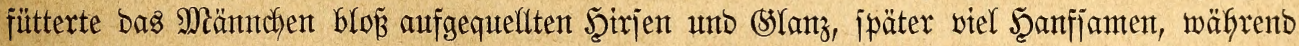
bas Weibchen fajt ausichließ̧lich fein gejtopenene und angefeudstete Semmel unt etwas hart= gefochtes und zerriebenes Eigelb ober mit bem (Satten gemeinjdyaftlich gebörrte 2imeijen= puppen und frijche 2 ogelmiere ben Sungen zutrug. Bum Trinfnapfe famten beibe âten

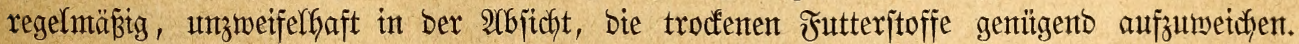
Sobalo bie Sungen ifyr Befieder erfalten hatten, murben jie von ber Sitjitange auts ge=

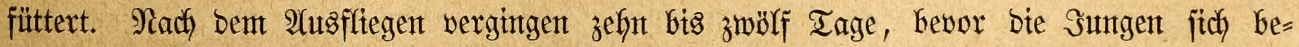

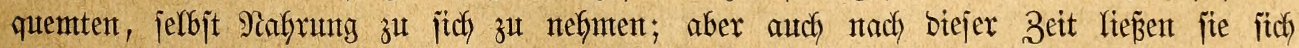
minbejtens noch zwei Wodjen lang bont ben 2 (lten atzent." 


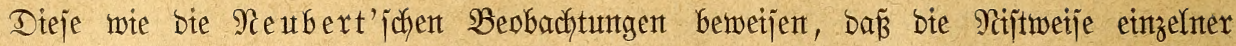

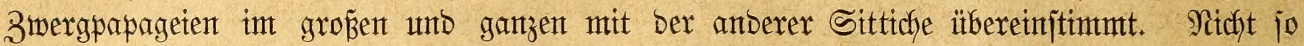

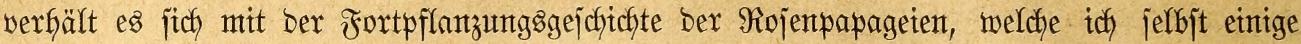
Male werfolgen fonnte.

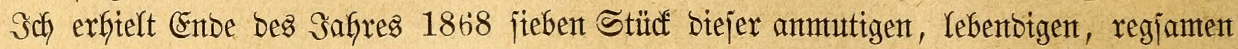

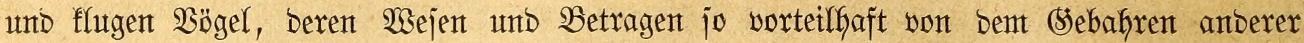

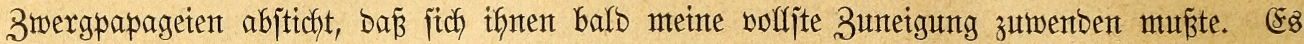
maren, wie fich burdh bas gegenjeitige Bujantmentyalten herausjtelfte, brei Bärcheft unt ein Ueberzähliger, Deffen (Sejchlecht wegent Der volfjtänbigen (S)leichartigfeit Der Mä̈nnthen uno Weibchen nicht feitgejtellt werben fonnte. Die Bögel wurbent, went fie zu zwei und zwei

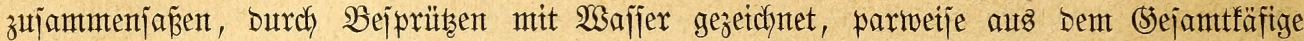

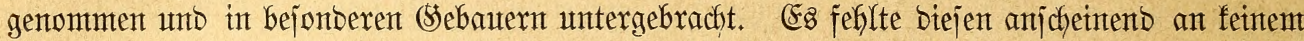

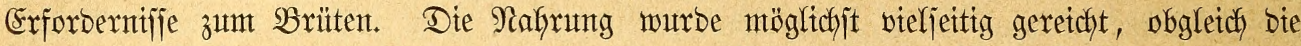

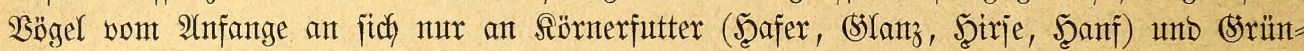

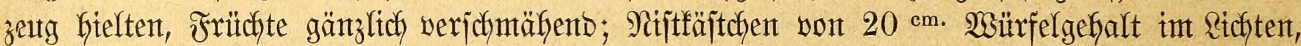

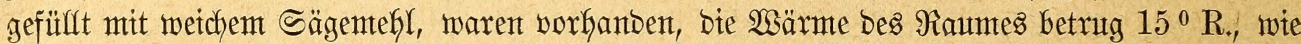

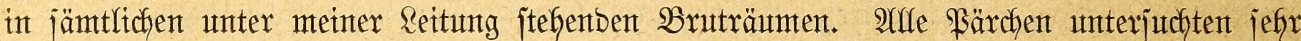
balb bie Räjtchen, flogen in ifnen aus und ein, warfen Sägeipänte Geraus, überbäuften fith gegenjeitig mit Bärtfichfetenten, niffeten jebody nidyt. Dies ging jo fort bis zum Mai bes

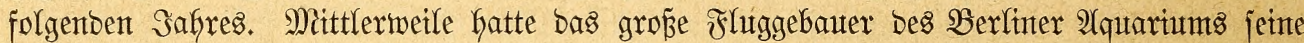

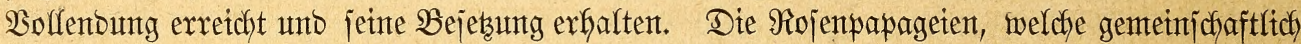
eine ber Afbteilungen betwofnten joflten, ridfteten fich rajd in berjelben ein unb warfen fich binnen furzent zu Beherjchern des Raumes. auf. Jriebfertig unter fich, lebten fie body mit ben flemen Pradhtfinfen, ifren Senofjen, in einjeitiger Feboe, bifijen fie von ben Futter=

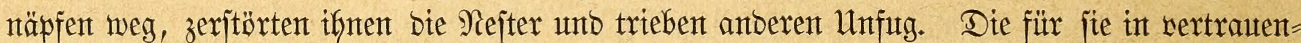

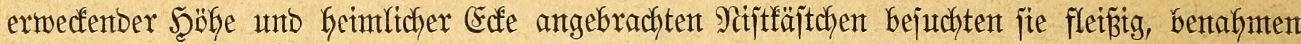
fich jebodf autch fiex mie früfer. Sch begriff ntidgt, warum jie ntcht brüten mollten, wohl aber, Dẩ thnen etwas feflen müfife, vermeinte Den Mangel in bem bisher gereidyten Futter

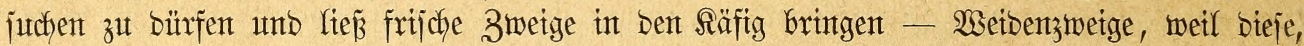
zur Nahyung Der Biber bejtintmt, regelmä̈̈ig geliefert mutben. Wentige Minutent nach

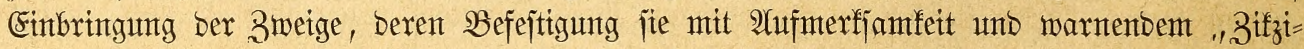

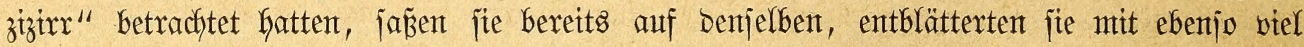

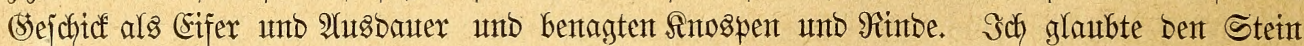

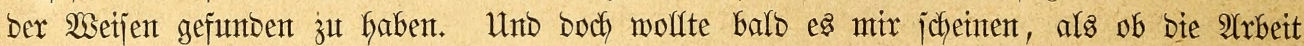
eher aus \&ujt zum Beritören benn um jich zu ernäbren unternommen werbe. Áufmerfjam

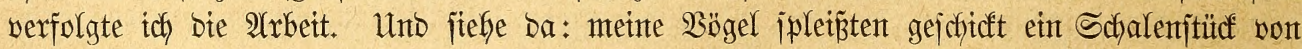

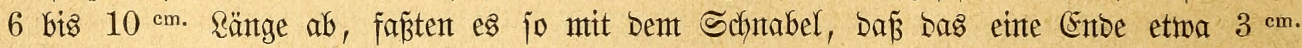

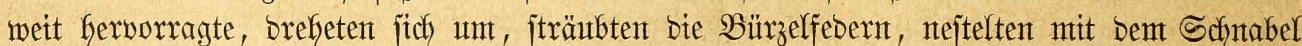
in ifnent herum unt -- Der Splitter blieb zmijchen bent wieber geglätteten Federn haften. Ein zweiter, britter, jechjter, achter wurbe in berjelben Weije abgelöjt unto ebenjo- befejtigt; manth etner fiel babet zum Boben herab, ofne weitere Beadhtung zu finben, mand einer wurbe yout Dem alfzu bienjteifrigen (Sentifen wieber zmijchent ben Febern hervorgezogen:

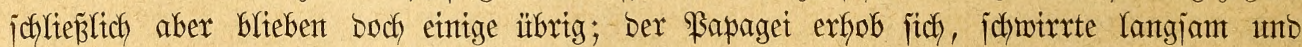

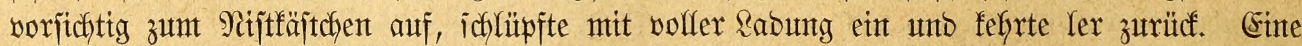
Rätielaufgabe für $\mathfrak{B g g e l f u n t b i g e ~ h a t t e ~ j i c h ~ g e i t a l t e t , ~ n a c h o e n t ~ b i e ~ \& o ̈ j u n g ~ g e f u n b e n ~ w o r b e n ~}$

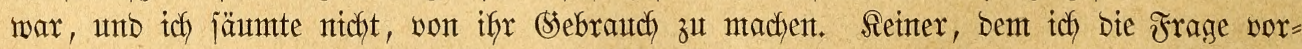

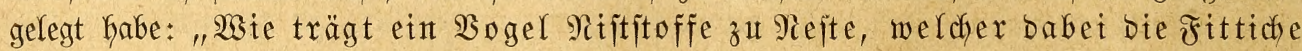

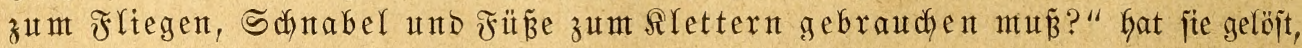




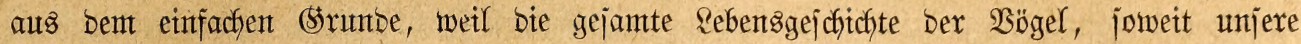
bisherigen $\mathfrak{B}$ eobachtungen retchen, etwas 2 fehnliches nidft aujweijt. Deshalb Denn audh hier

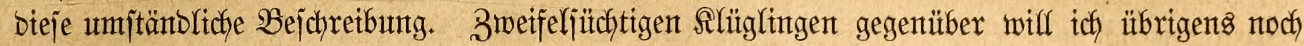

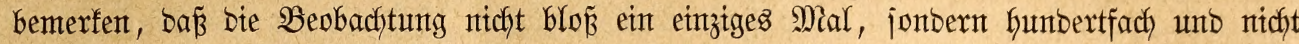
alfein von mir, jonbern aud von anberen Sunbigen gentadyt wurbe und zu rechter Beit von

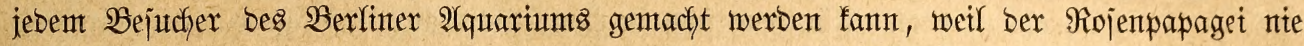
antoers baut.

Wentige Tage nach Beginn bes Eintragens ber jomit glücflich gefundenen Nijtjtoffe ex=

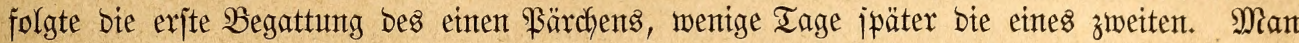

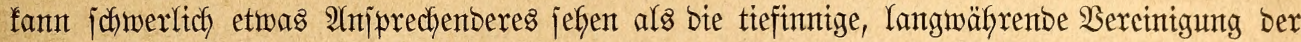

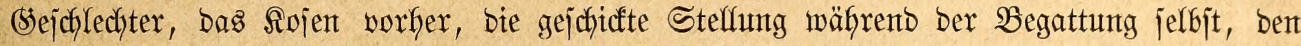
ermiten Eifer bes Më̈ntchens, das hingebende Sichjelbjtuergeffen bes Weibchens, bie Freudig= feit nach vollzogener \$aruth, Die zärtlidfe Danfbarfeit Des einen (Satten gegen Den anderen! Want Das erite Ei gelegt wurbe, wie lange bie Srï̈tezeit, wie lange bie Wienenzeit ber

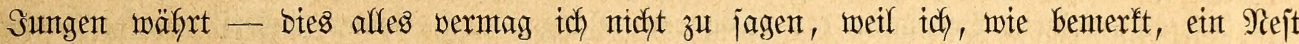

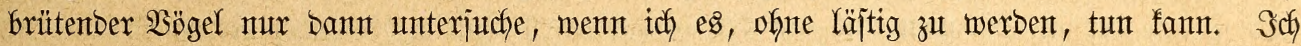

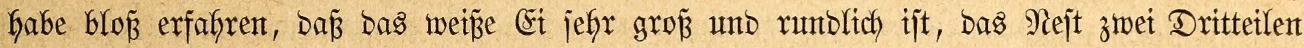

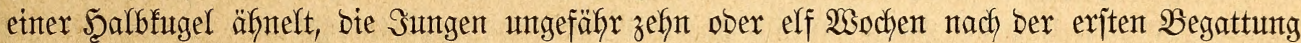

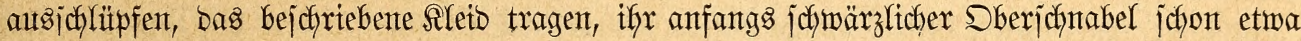
vier Bochen nach bemt 2 (tuffliegen verbleicht, jie im britten ober vierten Monate ifyres Rebens ourch Serfärbuntg Den Eltern ähnlich merben, im achten ober neunten Mionate ifyrez Sebenz aber zum eriten Male maujern. (Seabt murben fie, wie thy beobachtet zu Gaben glaube, won beiben Eltern und zwar feineswegs allein mit Pffanzenjtoffen, jonbern, wie bemerft,

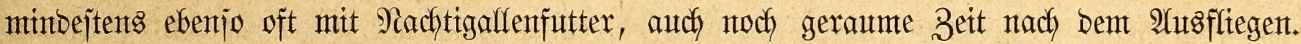

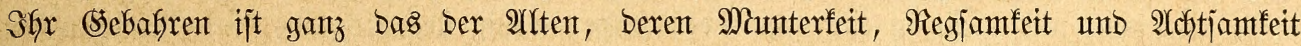

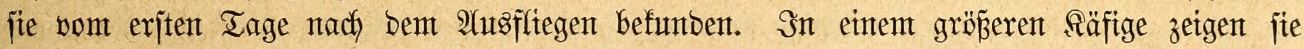

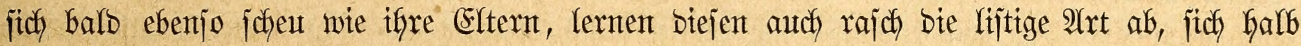
ober ganz zu veritedfen, jobald jie (Sefafyr fürchten ober überhaupt jich beobachtet jeben. Sn ben Räfigen unjeres Fluggebauters berfriechen jie jith zuweilen wie Mäuje; bei Freuno Fiebler, welcter vier won ifnten erfielt uno mit verotenter siebe pflegt, treiben fie es

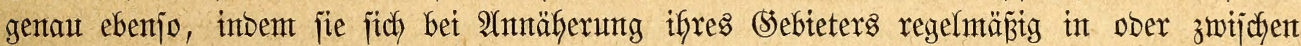
ben $\mathfrak{B}$ rutfäftchen berbergen. Antbere $\mathfrak{B}$ ögel flattern wie unjuntig im fäfige umber, fie jofonen iffr (sefteder und erreichen boch, mas jie exjtreben. Unmittelbar anf bie erjte Brut folgte eine zweite, unt genau basjelbe ijt in biejem Gafire ber Fall gemejen. Doch begannen bie Rojenpapageten biesmal exjt Entbe Sults mit ber erjten und Mitte Sftobers mit ber

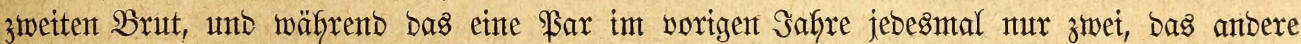

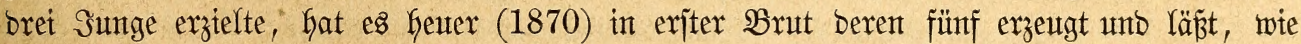

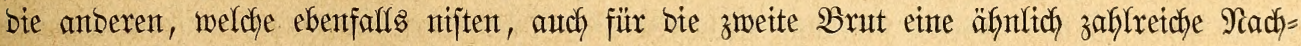
fommenjidsaft exhoffen.

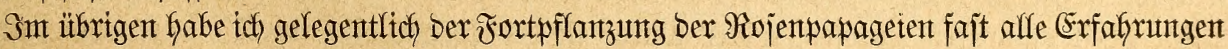
gejammelt, weldye mant an brütenden \$apageten zu machen pflegt: ungemein grop̌e Zärt=

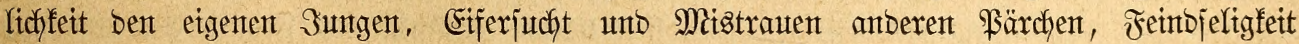
beren Sungen gegenẗber (ธ. 88), Regenot, Feflichlagen einer Brut $2 c$. So viel aber

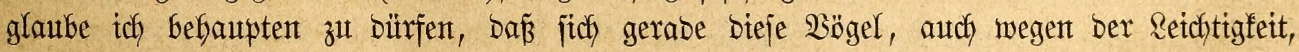
mit weldyer jie fich fortpflanzen, mefyr als alfe übrigen Zmergpapagetent für bie Befangen= ichaft emprefilent.

Sperlingspapageien und Unzertrentulidfe fomment in Der $\Re$ egel in Den Yetzten Sommer= ober exjten Serbjtmonaten auf ben Tiermarft; mtant bürfte jeboch, aus bent angegebenten 
Brïnben wohltun, jie erjt jpäter zu faufen, un möglichjt jitcher zu jein, ausbauternbe $\mathfrak{B o ̈ g e l}$

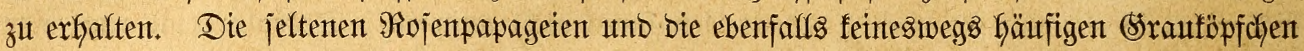
treffen bloz zufällig cinmal lebeno bet uns ein; auf jie aljo ijt nicht zu rechnen. Fïr erjtere Darf man, falls jie gejund und fchön füto, 8 unb bezüglich 10 Ialer für bas \$rärchen auf=

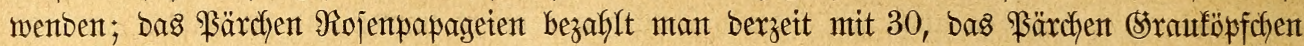

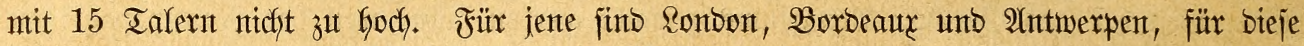

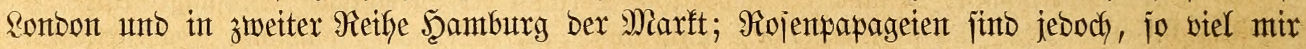
befannt, bis jebst bló zweimal lebent nach Europa gebradyt worben.

\section{Bìrpapangien.}

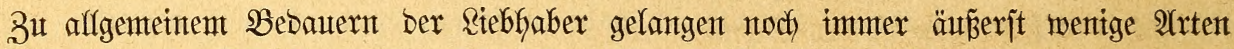
unt Stïcfe ber in Sildajien unto auf Den benachbarten Snjeln heimijchen Zierpapageien auf unjeren Marft, obgletch Die betreffenden Tierchen an Drt unt Stelle regermäß̈ig in (Sebauter

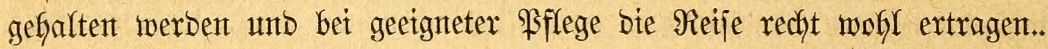

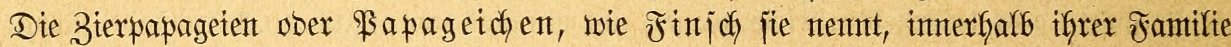

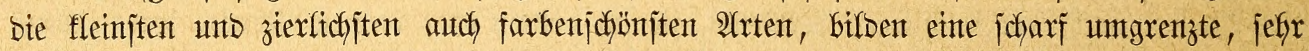
übereinjtimmende und Deshalb leicht fentliche Sruppe. Shre (srö̈ß̈e fommt Der unjeres Sperlings annähernd gleidh, bleibt jebody bet einzelnen 2 (rten nod wejentlich Ginter berjelben

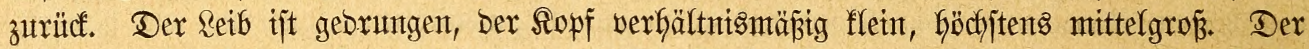

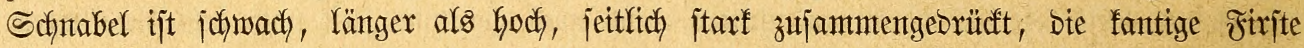
janft gefrümmt unb meijt in eine weit vorragenbe, wentg überfängento bünte Spitze aus= laufent, vor weldyer innen beutlich jichtbare Feilferben jich befinden, ein 3abnausjofnitt nicht worfanben, ber Unterjchnabel ntebriger als ber obere, jeitlich abgeflacht, bie in Sbogen

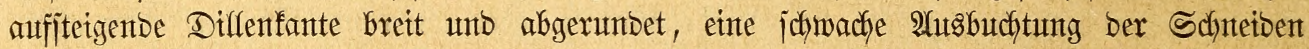

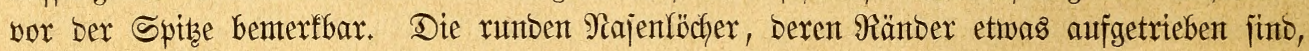

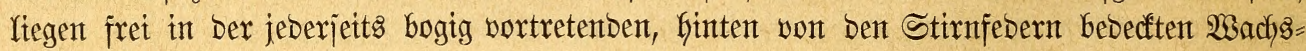
Gaut. Der Fun ijt furz und fräftig, Der Rauf etwas länger als bie Scälfte ber vorberen 2lukenzehe, weldye mit ber finteren gletăje seänge hat. In bem langen Flügel, weldyer in

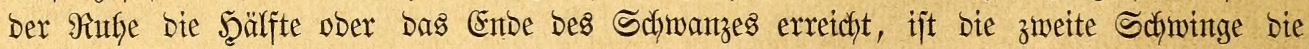
längite, Die Flügeliptbe lantg, Der Şälfte Des Dberflïgels etwa gleichfommento, Das Ende Der gleidymäp̈ig zulaufenden Sdyningen jtumpf abgerundet. Die Steuerfedern bes furzen, etwas abgerumbeten Schwanzes, weldher ungefähr bie Şälfte ber Jlïgellänge Gat, laufen ebenfalfs gletdymäß̄itg zu, zeigen aber iptze, wenig zugerunbete Enden; Die oberen, jefr

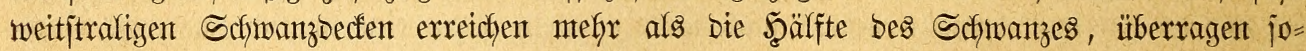
gar mandfhtal befien Ende, Die unteren fommen ben Steuerfebern nteift an Ränge gleidf.

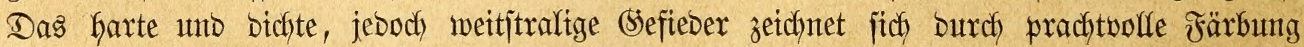
aus. Ein lebhaftes (Srün herjdyt vor; von ifm heben fich rote, gelbe ober blaue Flecte auf Sopf und Siefle ab; bie Bürzel= und oberen Sdywanzbeffedern juto jtets jedjön rot, bie Schwingen und Steuerfebern unterjeits jtets merblaut gefärbt. Beide Bejchled)ter unter: icheiben jich bei einzelnen 2 (rten nicht, bet anberen jefyr mejentlich; junge $\mathfrak{B o ̈ g e l ~ t r a g e n ~ e i n ~}$

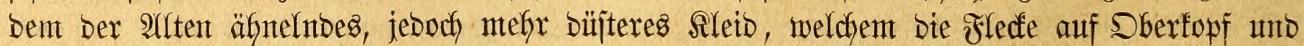
Sefle meijt noch fehlen.

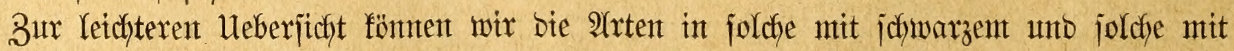
rotem Sifnabel einteilen. Son erjteren Gaben wix die nadjitebeno bejdyriebenen aujzuïfyren. 


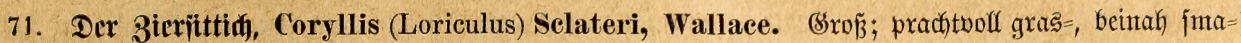
ragogrün; Mantel unt Schuttent tief gologelb oder hodforangefarben, einzelne Federn rot gejäınt; eint

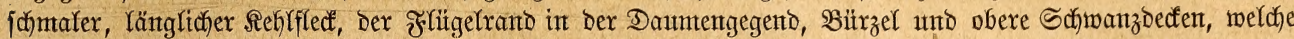

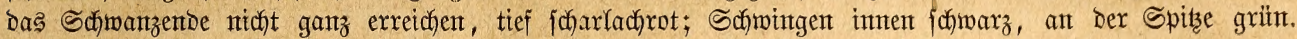

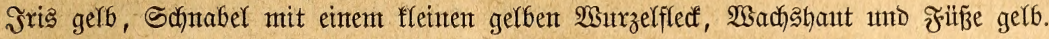

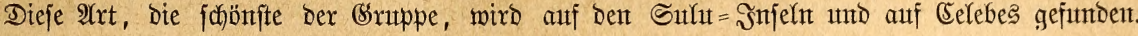

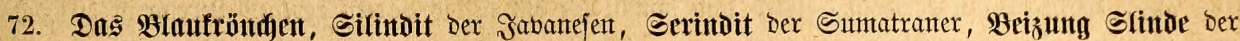
Malaien, C. (Ps., Psa., Psittaculus, Lor.) galgulus, L., (flavigulus, pumilus, cyaneopileata).

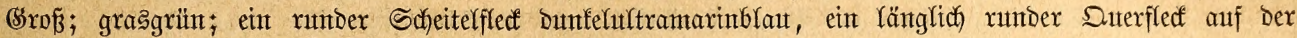

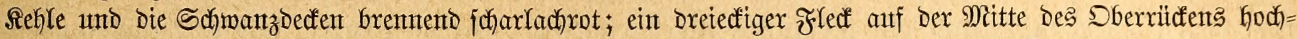
orange; ein fabmalex Streifen ïber Den Bürzelfedern hod)gelb; Sdjentelfedern feitlich) Gochgelb gejäumt;

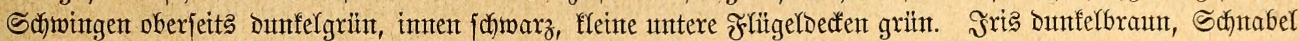

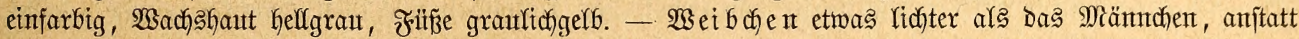

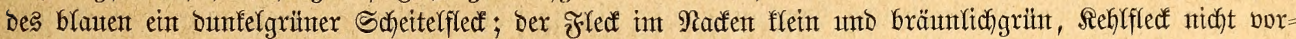

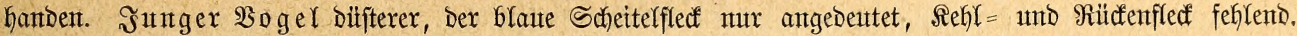

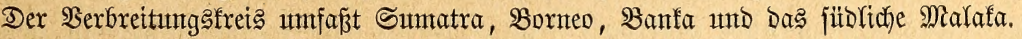

\section{Bei ben folgenten ift Der Sifntabel rot.}

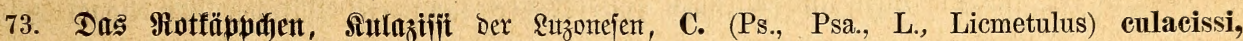
Wagl., (philippensis, rubrifrons, melanoptera). (Srop̧; Kelfgraggrïn; Stirn und Sorberfopf zintoberrot,

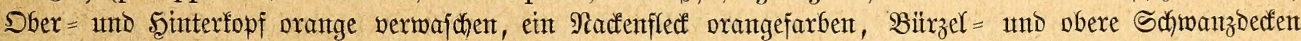

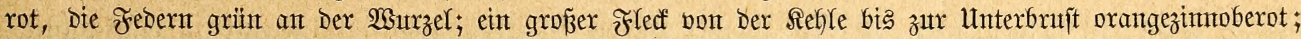

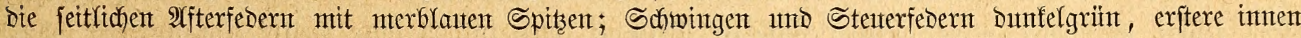

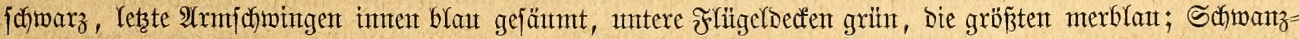

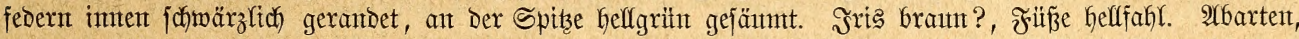
welche jebod) alfe widhtigen Merfmale zeigen, fonmen vor. - Beim jungen $\mathfrak{B}$ ogel ift bie Stirn blafjrot

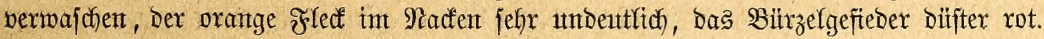

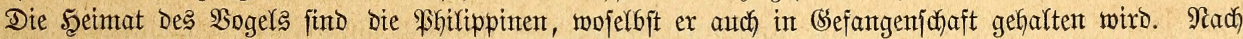
Enropa fdeinten Yebende Stïlfe nod) nidjt gefonmen zu jein.

74. Dex Bhuntenpangei, $\mathfrak{B o l}=(6 i r m w a$ der (Set)lonefent, C. (Ps., Psa., L.) indiea, Kuhl, (asia-

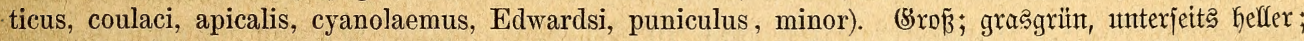

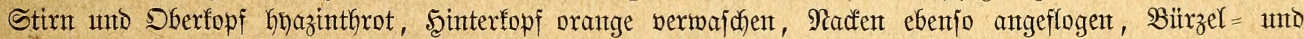

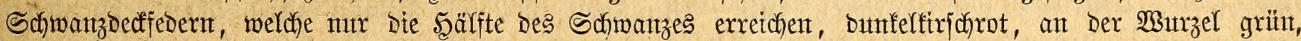

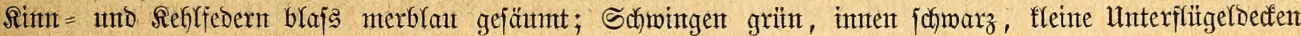

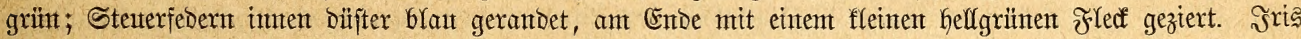

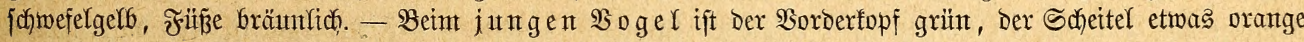

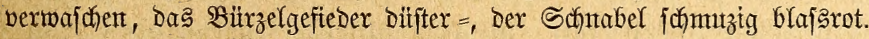

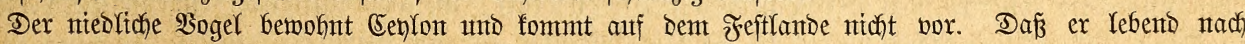
Eitropa gebracht minde, barf angenommen, fann mit Sicherbeit jeboch nidyt feftgeftellt merden.

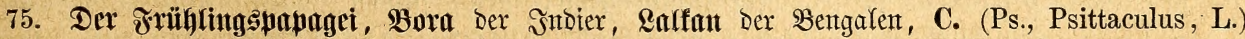

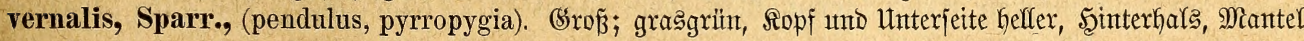

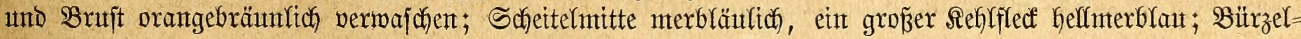

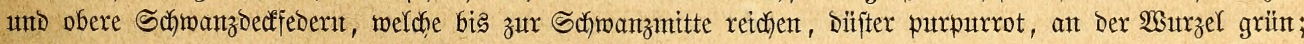

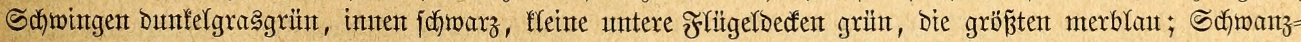

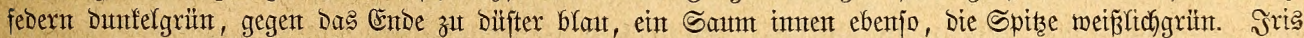

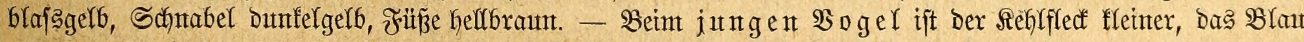

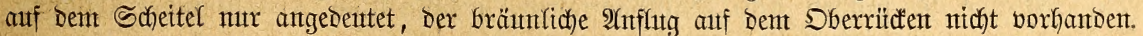

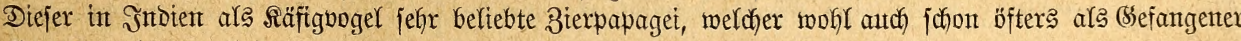
naci) Europa gelangte, reft mux auf Dem Jeftlande.

76. Der (Elfenpapagei, Ijeliùit Der Gabatefen, C. (Ps., L.) pusilla, Gray, (amoenus). Mittelgroß̈; glänzeno grasgrïn, unterjeits heller, auf Den Dberrïden orange verwajden; ein grop̃er number Reflfledf hod)gelb; Bïrzel= und bie bis zum Sdymanzente reidhentent Sdhmanzbedfedern brennent zinnoberrot; Sd)wingen

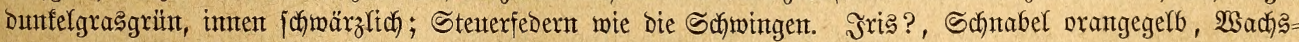
Gaut und Fünße blaj̧gelb. - Dent jungen $\mathfrak{s}$ ogel fehlt Der Reblflect.

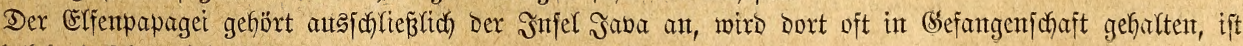
jebod rebento jabmerfich fidon nach (Entropa gefommen. 
77. Der Riliput, C. (L.) exilis, Schlegel. Sefr flein (neben Dent 3roergfafadu Der fleinfte afler

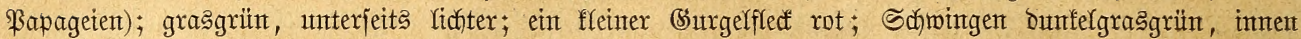
fajwarz, unterfeits merblau; Steterfedern wie bie Schmingen; BBürzel und bie oberen bis zum Schmanz=-

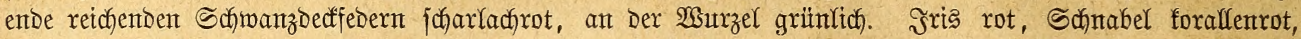

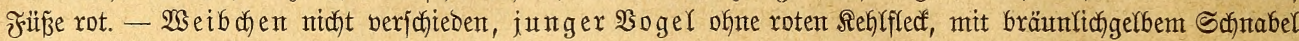

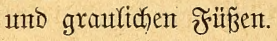

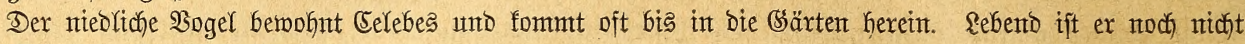
nach) (Europa gebradyt worben.

Retber trifft bie allgenteine Silage bezügltich unjerer Unfunbe über bas Freileben ber Fapageten überfaupt auth bie nieblichen Zierpapageient. Schon Rinn é fannte bie 2Hbjonber= lichfeit won ifnen, fich int Schlafe flebermauzartig an ben Betnen aufzufängen, - ein

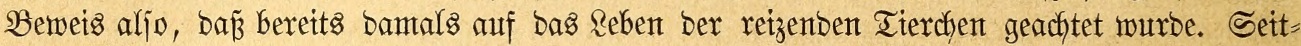

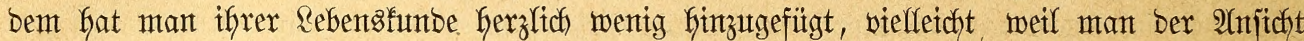

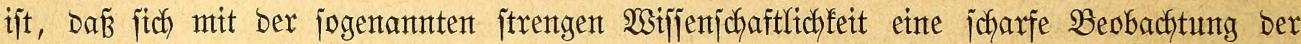
Zebenşverfältniffe eintes Tieres nicht verträgt, jente vielmefyx einzig und alfein in gentauer

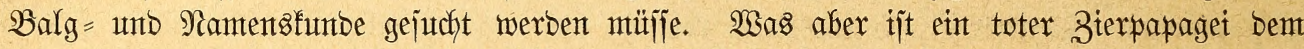
Yebenden gegenüber! Seitbent id über zmet Gahre lang ein \$ärchen ber Bögel gepflegt Gabe, Grente tid fait vor Begierbe, über ifr Freileben unterrichtet zu merbent.

Die Bierpapageien jinto, wie alfe Berichte meloen, in ifrer bezüglichen Seimtat feinte $=$ wegs jeltent, in Den meijten ber für jie geeignteten Dertftchleiten im (segenteife jefr fräufig.

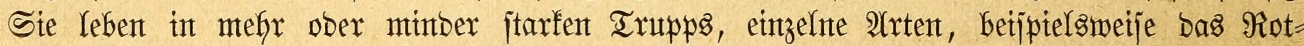

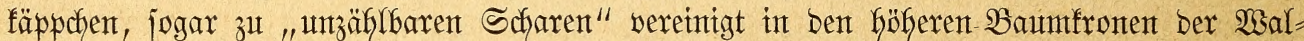

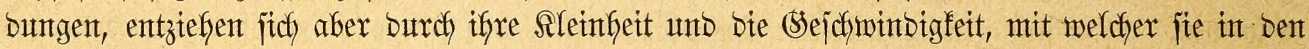

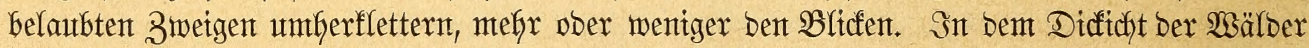
ijt ihr liebjter Alufenthalt, unt mur ungern machen fie von ifren Flugwerfzeugen (sebrauth).

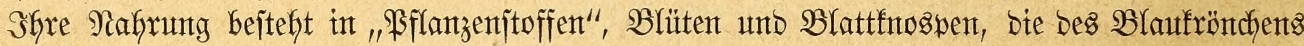

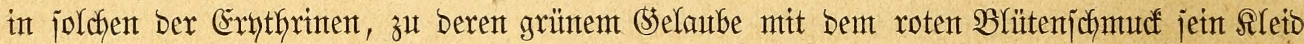

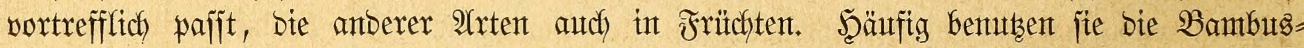
röhren, welche bie Eingeborenten zum 2tuffangen des \$almiaftes aufbängen, zu ifren

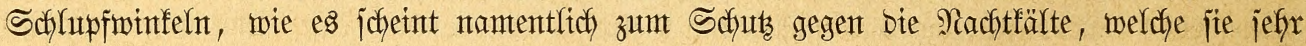

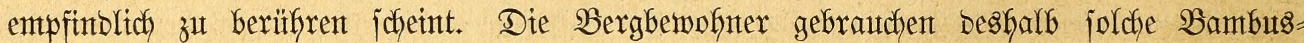
röhren als Faflen, in Denten fie bie Bögel fangen. Heber bas Fortpflanzungägejchäft Gaben

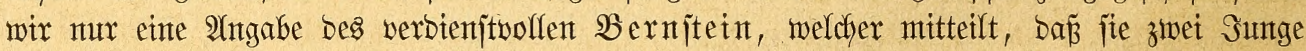
erzithen. Dies ijt alfes, was idh in bem Werfe unjeres Meijter Finjof, weldher wafhr=

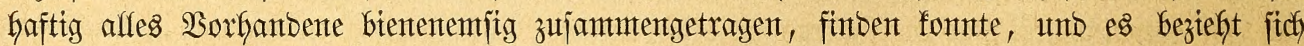

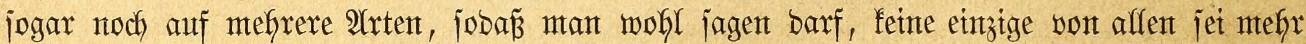
als Gübdjt oberflächlich beobachtet worben.

Etwas mebr wiffen wir über bas Befangentebent unjerer $\mathfrak{B}$ g̈gel Snt ganz Snbien nebjt (Seylon, jonte auf Den Sumba= Injeln unt \$shilippinen jcheinten bie Bierpapageten zu Den beltebtejten Räfigbögeln zu gehören. Mant Gält jie par = unto gejelljchaftomeije in fleinten

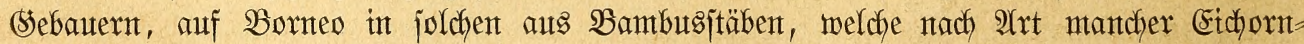
fäfige gebaut finto, D. G. einte Walze Darjtellen, weldhe fich unt ifyre 2ldjje brefgt unto vont

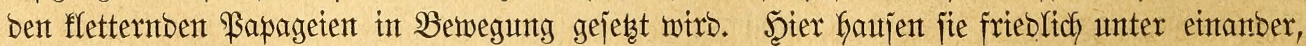

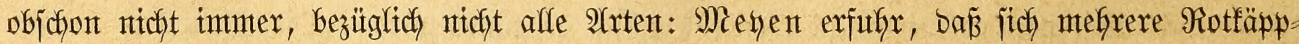

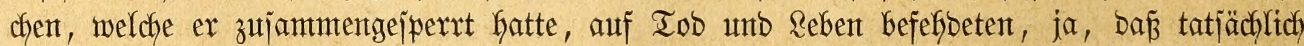
einer ben anberent tötete, weshalb Der Beobachter ifnen ein "wildes Raturell" zuidyreibt

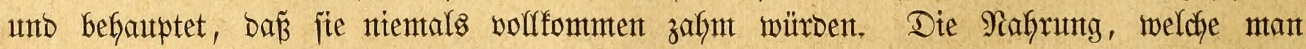

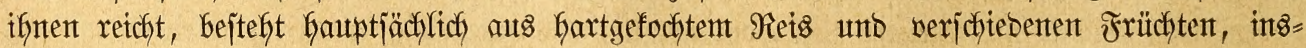
bejonbere Banantent. 


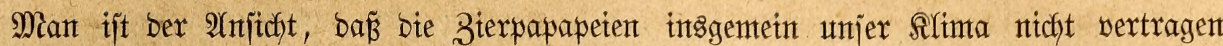
föntnen uno besfalb jo jelten lebento zu unz gebradjt merbent. Sch sermag es nidyt, biejer Meinung beizupficten. Es malten bei biejen aflerliebjten (Sejwöpfen unzmeifelfaft biejelben Uniftänto ob, welche ich bei Schilberung bes (Sefangentebens ber Zwergpapageien ( 5.177 ) herworgehoben habe: jie geken unterwegs aus Mangel an entjprechenter Pflege, in Europa

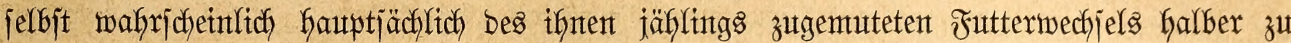

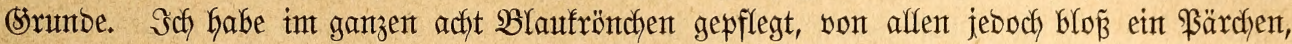

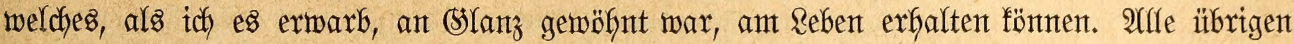

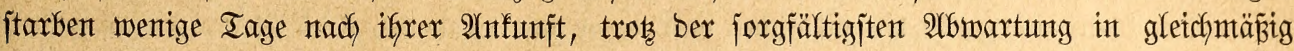

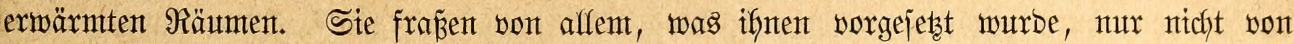

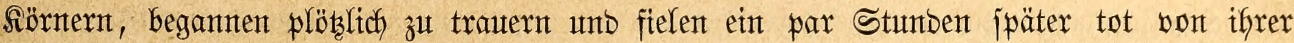
Sił = ober ફ̧ängeftange Gerab. Senes \$ärchen Gingegen Gält fïch vortrefflich im Wobnt=

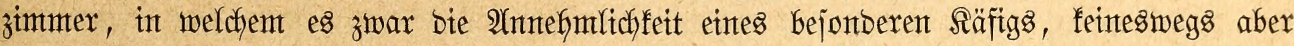

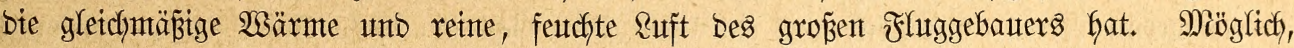

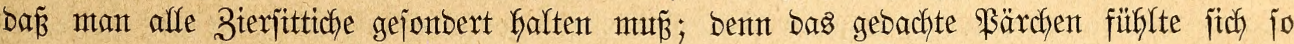

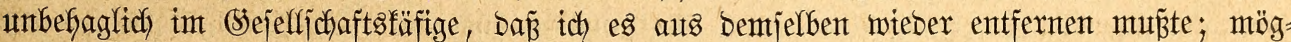

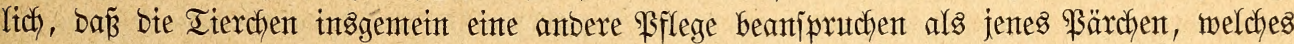

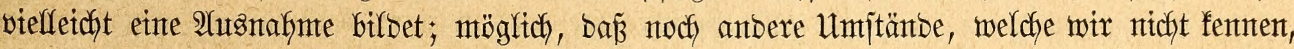

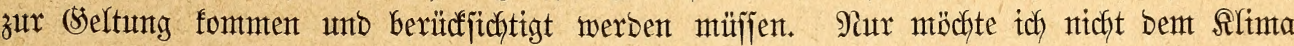
alfe Sdjuld unjerer bisherigen Mits = ober Seringerfolge zujdyreibent ober ben Bierjittichen

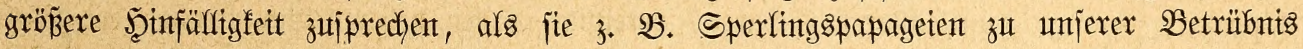

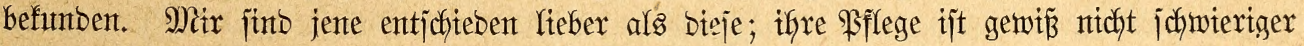

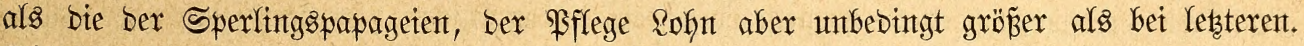
Dies beweijen wentgitents meine Siefangenten zur (stentïge.

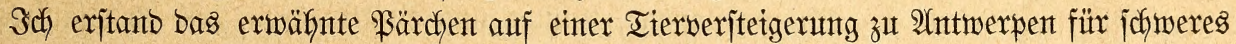

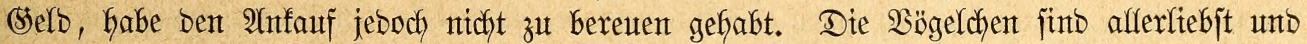
gehören unbedingt zu ben liebentsuürbigiten affer \$apageien. Sie befunbent eine Garmtoje

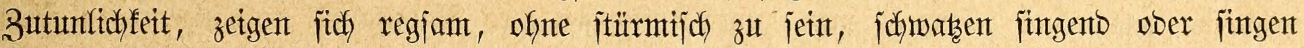

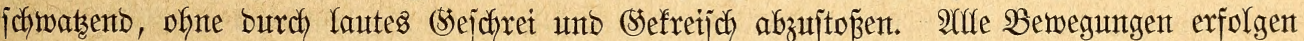

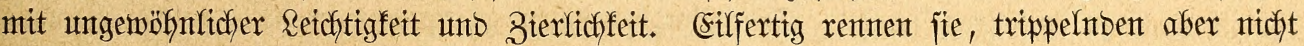
matjcyelntben Sdyrittes, über ben Boben hin; ofne Bebenfen magen fie einten Sprung von einter für bie furzen Beinthen beträaftlithen Weite, rajch und gemant flettern fie, Schnabel unto

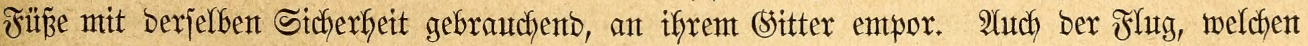

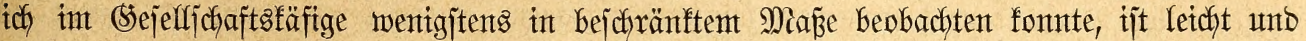

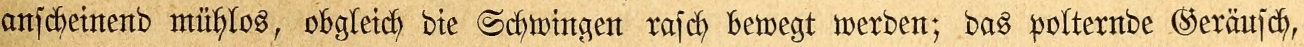

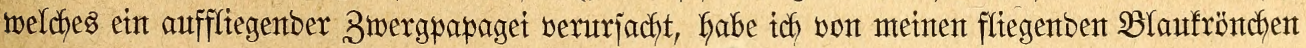

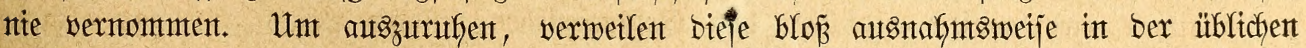

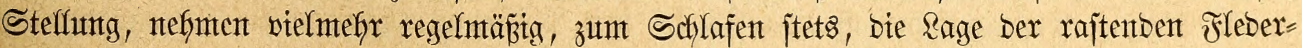
mauts an, intoem fie fich mit Den $\mathfrak{B}$ einten an bem Dacke bes Säfigs ober eintem bünnen Sits= zweige anflammern unb nicht bloź ben Reib, jonbern audb ben fiopf gerabe berabbängent lajfen,

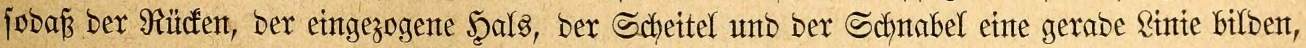

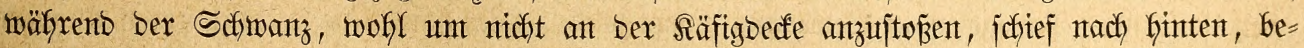

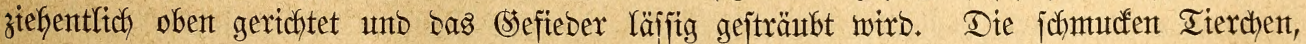

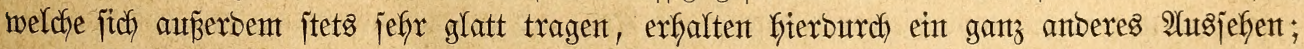

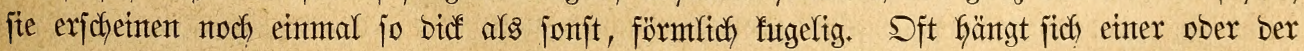
andere nur an einem $\mathfrak{B}$ einte auf und zieht bas zmeite jomeit ein, bá bie gejdyloffente Slaute

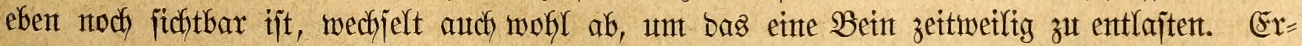

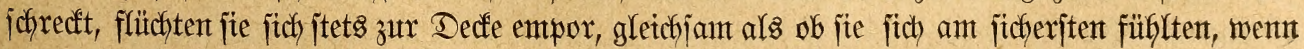




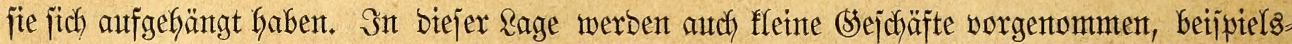
weije bie Febern ein wentig georonet, ebenjo eintge Befaglichfeit füntente Raute Gergeplaubert,

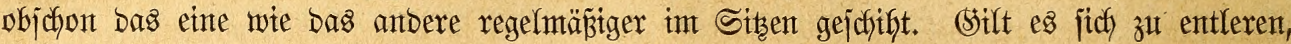
fo wiro ber Schwanz mux ein wentig mefy gejtelzt, ber Reib etwas gebogen unt hierauf ber

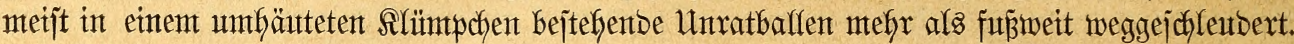

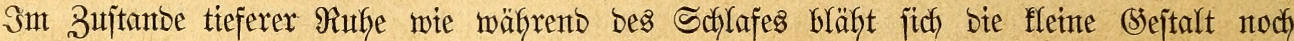

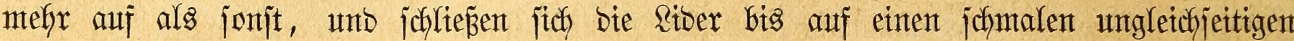

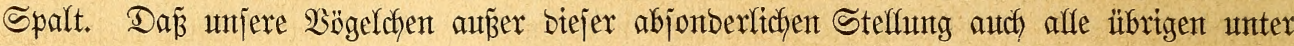
Fapagetent üblichen ober biejen möglichen unt zwar mit ipielenter Reidytigfeit antebmen, be= barf wohl faum bejonberer Erwähnung: fopfoberjt, fopfunterjt gilt ifnen volljtänbig gleidh.

Die geiftigen 2 nnlagen Der Bierjittiche bürften mit Denen ber flügeren 3wergpapageien annähernto auf einer und berjelben Stufe jtehen. Meine Blaufrönchen füto Garmlos uno

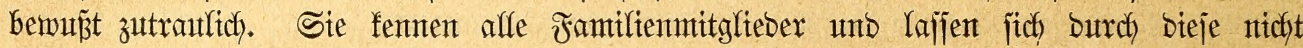

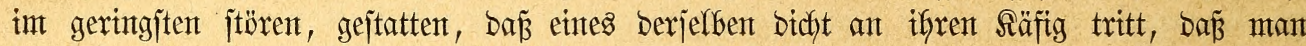
Yezzteren bint unb Ger trägt, ofne zu flattern ober jich jomittwie ängitlich zu zeigen, ja jogar, ofne aus ifyrer fängenten in eine anbere Stellung überzugehen. Sie erfennen Frembe als

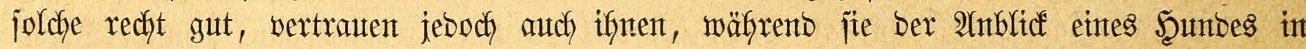

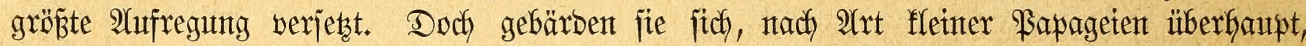

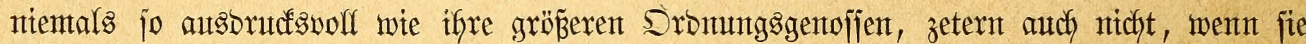
erregt werben, wie bies beijptelsweije bie Rojenpapageten tun. SGr Betragen ijt in jeber $\mathfrak{B} e=$ ziefung rubig, geffalten; jie leben, wie man zu jagen pfllegt, ittlf wor fich fin. Beide

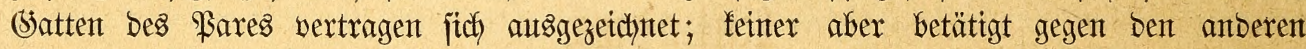

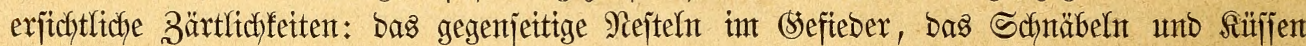
anberer Fapageien Gabe idy bet ifnen niemals beobadytet. Einte Sejellichajt gleichartiger 3ierjittiche, weldhe idh jah, lebte ebenfalls im tiefiten Frieben zujammen; als idh jebody zu meinem Bärchen noch ein Meänndjen jetzte, gebärbete fich jentes twie tolf, anjcheintento aus

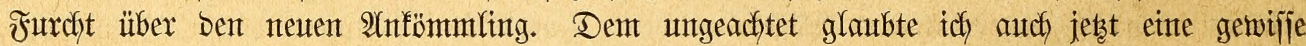
Reugier, wie joldbe überfant ifnent eigen, wahrnefmen zu fönten.

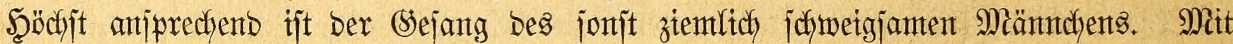

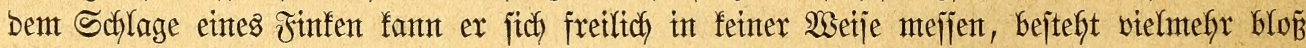
aus jchwatzenten, jchwirrenten, zmitjchentoen unt entigen pfeifenten Rauten, wirb aber mit jo viel

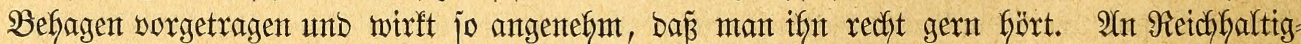
feit Der Raute, an Wentungen unt Sertönungen jtefht er bem Stejange bes Welfenjittichs

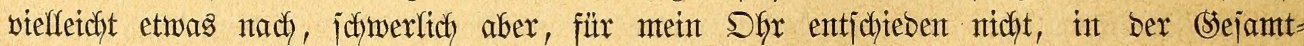

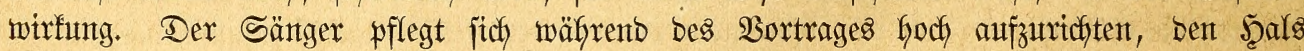

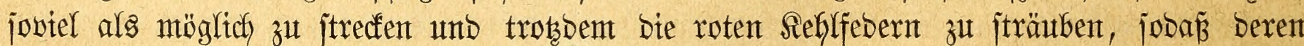
Bemegungen jente ber Reflntubfeln gentau wiebergebent ober boch anbeuten. Der einzelne Sortrag wäfrt einte bis zwei Minuten; Dant tritt einte furze \$auje ein, unb bas jünentbe

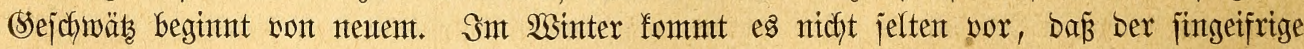
Sogel, nachbem er itunbenlang gejchwiegen, wobl audb gejchlafen, noch in ppäter albento=

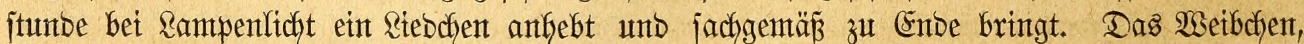
welches bann unt wann benjelben Rodton wie bas Männthen, ein leijes aber joharfes "Bit"

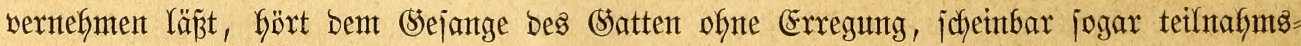

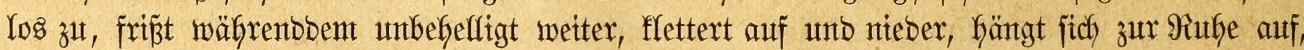
putbe fich, futrz treibt es ganz nach Belieben, ofne bas Miänthen zu beirren, Da biejes, wie

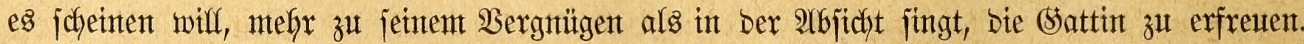

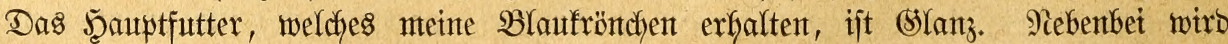

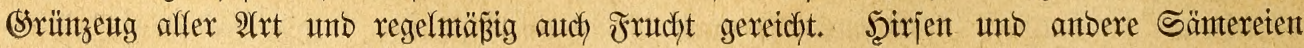




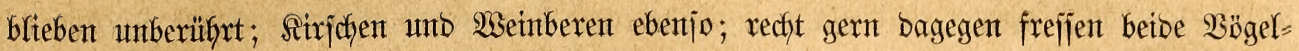

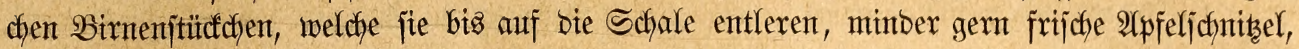
faum ober nicht gebörrtes Sbjt, unb wafrhaft gierig fallen fie über frijche 2fmeijenpuppen her,

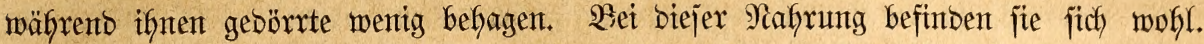

Sie haben bereitz zweimal bie Maujer überjtanden. Boriges Gahr begann bieje Ende Novembers, in biejem Sahre jhon in Sftober. Sie geht, wie bei ben meijten

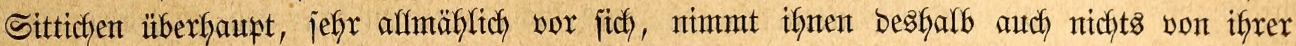
Rebhaftigfeit; jelbjt Der (sejang Des Miännthens mirb burch ben Feberwechjel faum beeinflufist.

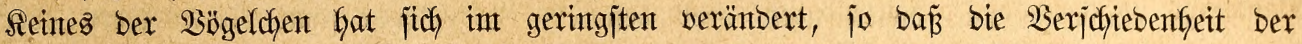
(s)ejchlechter mindejtens bei biejer 2 rt für mich volffommen erwiejen ijt.

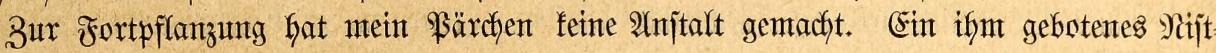
fäjtchen wirb nicht bejucht, jo oft auch ber eine ober ber anbere auf bem Sprumgholze vor Dem Eingange Plaţ nimmt. Miöglidyerweije ijt bie teilmeije Beritümmelung bes einten Flügel\& beim Männchen bie Urjache jeiner Enthaltjamfeit.

গur ber 3ufall bringt 3ierpapageten auf unjeren Titermarft. Sie fommen in fleinen (Sejelfichaften in Scolfant unt Englanto an und werben von bort weiter verjentet. Shr

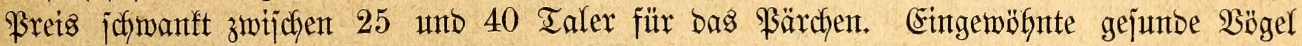
merden Damit burchaus nicht zu hoch bezahit.

\section{fakknous.}

Wentg anbere $\mathfrak{B}$ g̈gelgruppen Yiejern uns ifyre Mitglieber jo vollzähltg in unjere Räfige als bie Sippe ber Safabus. Wir erfalten alfe überhaupt befannten 2 (rten Yebend und haben

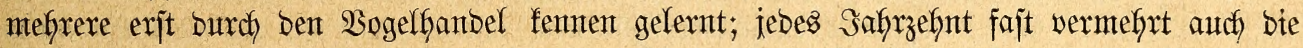

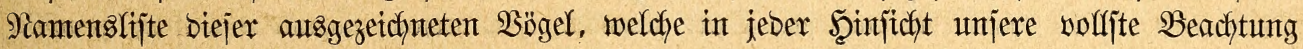
verbienen.

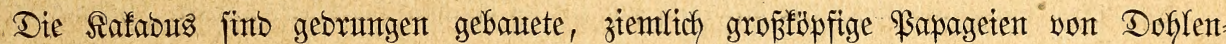
bis Sxähengrößze. Dex jebx fräftige Schnabel ijt meijt ebenjo hoch, jelten höher als lang, jeitlich flach, nur gegen bie Spitze zu mefy gemölbt, bie Finjte, in weldyer bei einzelnen Arten einte johmache Rängsrinte verläuft, flächenartig breit, etwas abgerumbet, Der Sber jchnabel jtarf in Bogen, mit ber Spize einmärts gefrümmt, bie Spize, melche inmen beutfiche Feifferben zeigt, meijt anjefnltidf, zuweilen auffalfent weit worragent unto über=

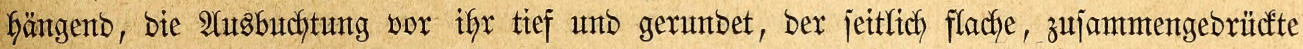
Unterjanabel niebriger als ber obere, bie Diflenfante, weldye eine zu betben Seiten gleid)= laufende breite Fläche bifbet, bogig aufiteigent, ber Schneibenrantb gerabe, mit bent End= teile jharfbogig jich aufwärts biegent. Die fleinen rumben Najenlöbher liegen entweber

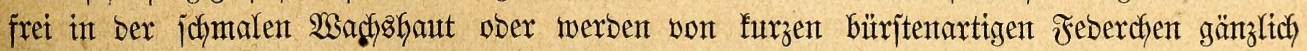
bebefft. Der jebr jtarfe, furze unt bidfläufige Fuß hat fräftige 3ehen von fajt boppelter \&auflänge, mit jtarfen, jichelförmigen Arallen. Dex lange, jpitze Flügel becft, zujammen= gelegt, mehr als bie Scälfte bes Sdhwanzes; bie wentig ober mefyr vorragenbe Spitze ijt nicht ganz Galb fo lantg als ber Sberflïgel; unter ben gegen bas Enbe iptz zulaufenden Şantojdfwingen ijt bie britte ober vierte am Yängiten, bie erjite, fünfte ober jechjite vom Wurzelorittel an auren, bie erjte bis vierte ober fünfte innen ausgejdyntten; bie jefyr langen unb breiten $\mathfrak{2}(r m j$ d)wingen pflegen am Enbe zugerumbet, jeltenter auggejdyttten zu jein. Der Schwanz ijt fürzer, mandfymal ebenjo lang alz bie Şälfte bez Flügelz, breit, am Entbe gerabe

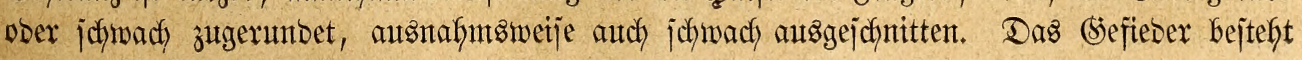


aus gropen und breiten, am Enbe abgerunbeten, fetbenweichen Febern, Deren 2 surzel bet

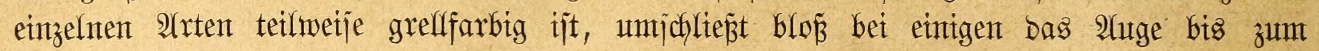

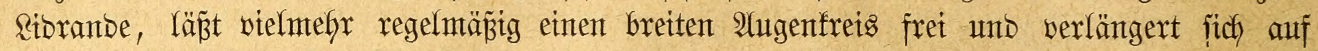
Stirn und Sberfopf zu einer jefyr verjchtebenartig gebilbeten Saatbe, weldye gemöfnltids aus zwölf Febern bejteht und bei fentzeidhnung ber Afrten gentuer bejdyrieben werben miro.

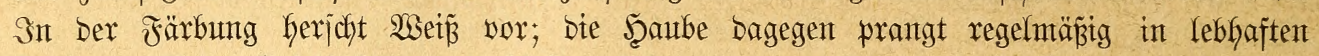
Jarben. Beibe (Sejchlechter unterjcheiben fich nicht won einanber, bie Sungen, mit einer einzigen 2̂tıntafme, ebenjo wentig von Den âlten.

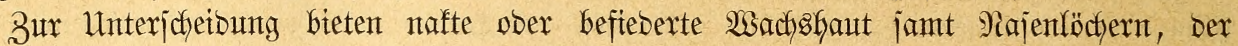
Dunfle ober Gelle Schnabel unto bie Bejchaffentheit ber Saube gute Mierfmale.

Nafte Wachshaut, johwarzer Schnabel und eine breite, lange, nach Ginten herabhängende Şaube Gaben:

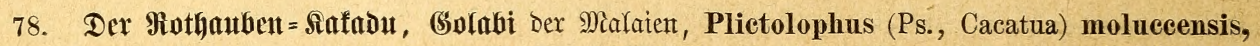

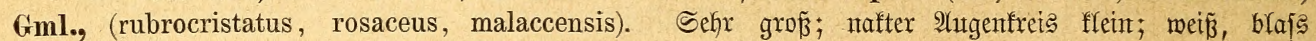

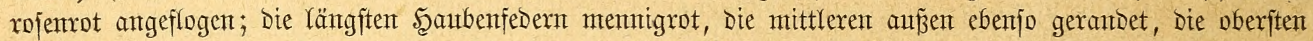

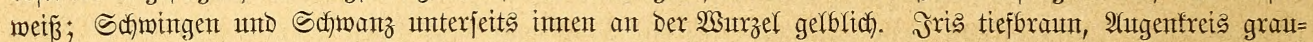

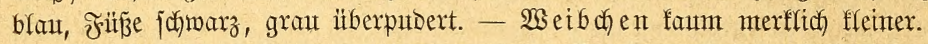

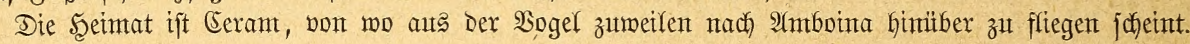

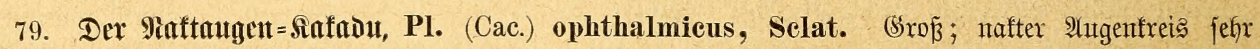

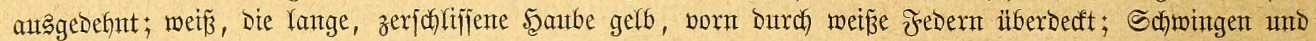

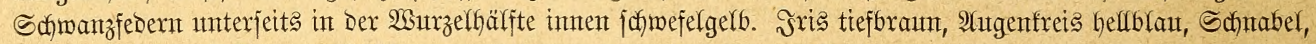

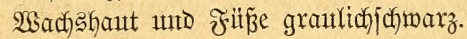

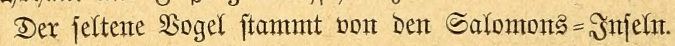

Schmarzen Sdynabel, nafte $23 a d y$ byaut und eme gerabe, aufredyt jtehende, aus breiten Febern gebillote Şaube hat:

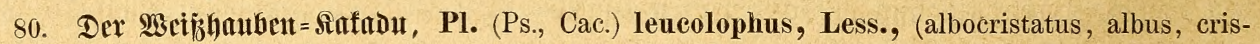

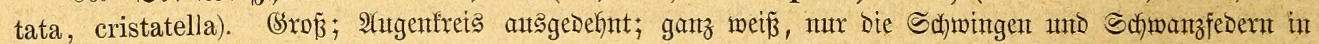

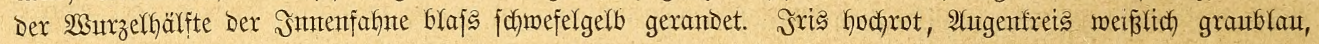
Fुïre graut beputbert.

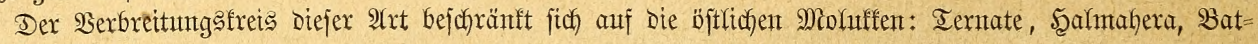
jan unt Tidore.

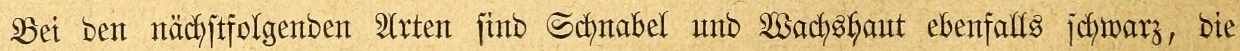
mebr ober wentger zerjchliffenen ફ̧aubenfebern aber zmeizeilig georonet, aufgerichtet und mit Der Spitze nadh vorn gefrümmt.

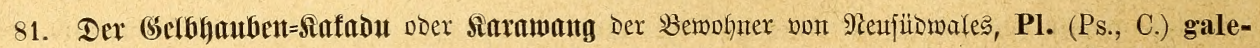

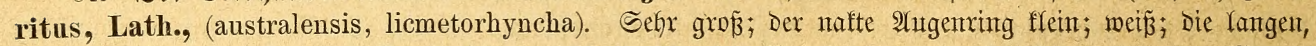

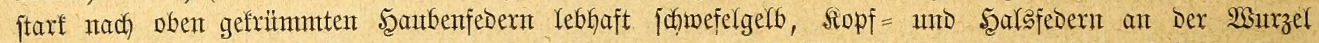

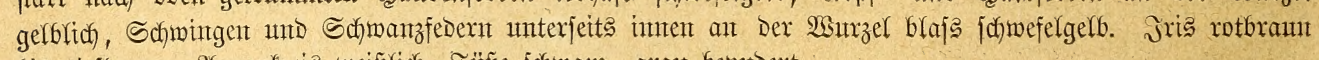

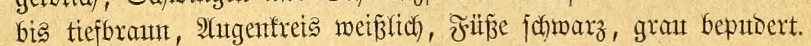

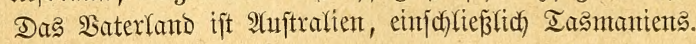

82. Der Iritun, PI. (C.) Triton, Tem., (cyanopsis, macrolophuse Eleonora). (Eroß̉; Der nafte

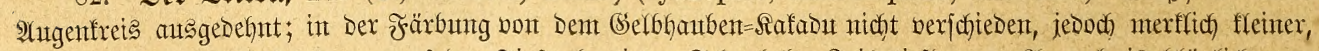

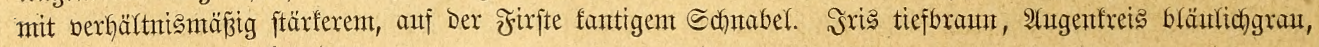

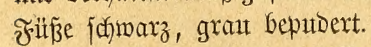

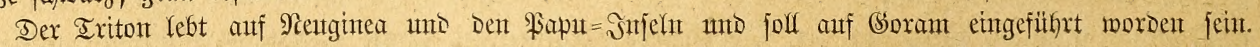

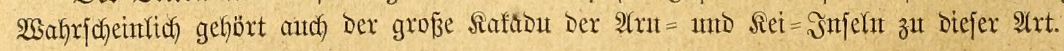

83. Der (Selfmangen= Sinfudu, PI. (Ps., C.) sulfureus, Gml., (luteocristata, aequatorialis).

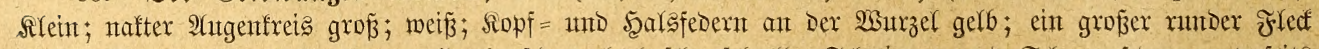

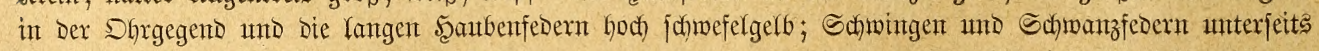

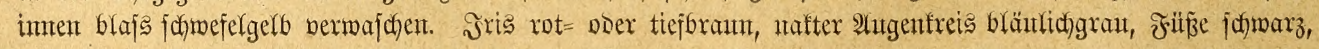
grau beputiert. 


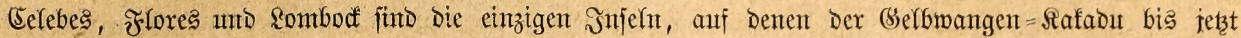
beobaditet mutrbe.

84. Buffouts Siafadu, Pl. (C.) Buffoni, Finseh, (parvula). Sefy flein; Der nafte Alugenfreis

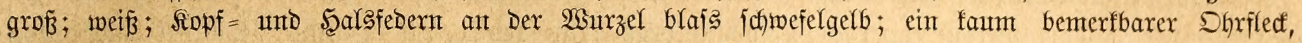

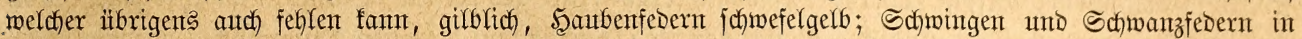

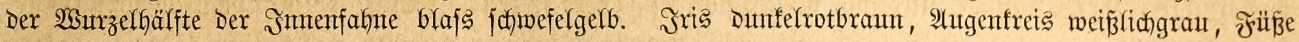
jđjwärzlich, grau bepubert.

Der Serbreitungstreis fcheint fich auf Timor ıtto Samao zu bejd)ränfent.

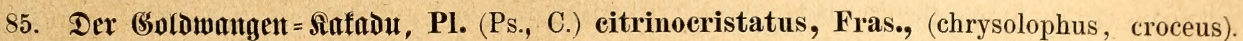

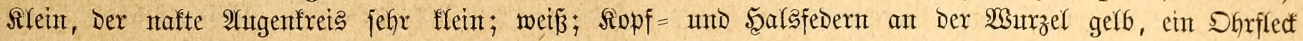

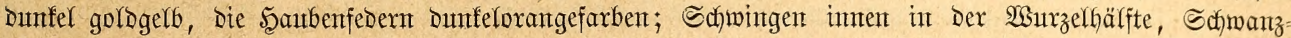

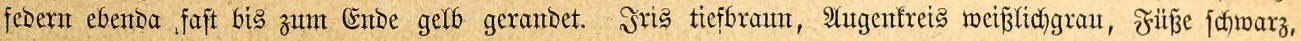
grau bepubert.

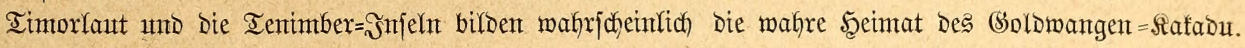

Der jubnjte alfer Siafabus hat befieberte Wadjahaut, lichten Sdynabel unt eine aus jectzebn ipts zulaufenton, worn übergebogenten Febern beftehende Şaube.

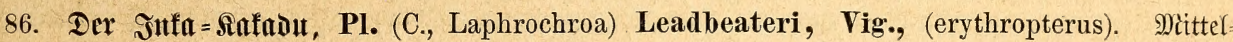

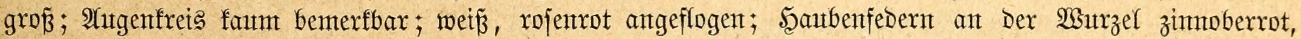

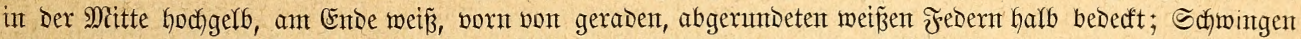

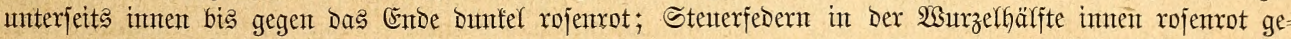

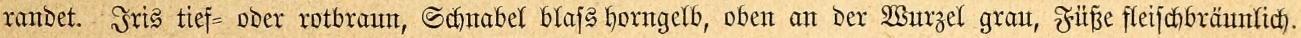
- $\mathfrak{B e i b}$ d)en ein mentg fleiner umo faum merffich bläffer.

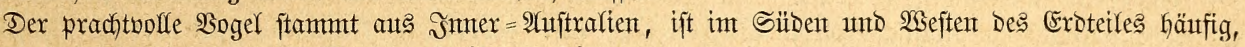
fheint aber über Das ganze Feftland verbreitet zit feir.

Befieberte Wadhahaut, hellfarbiger Schnabel und ente furze, abgerumbete Şaube fenn zeichnen bie näidyitfolgenten 2 (rten.

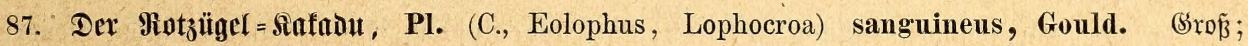

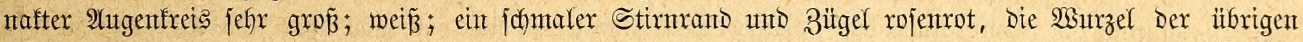

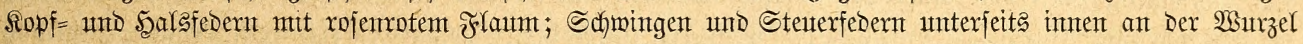

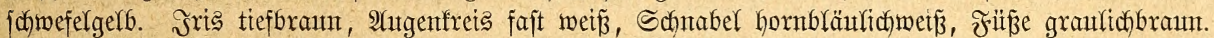

Ituftrafien ift Die Şeimat des $\mathfrak{s}$ ogels.

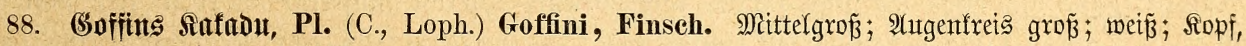

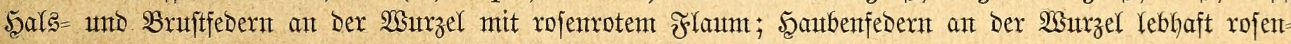

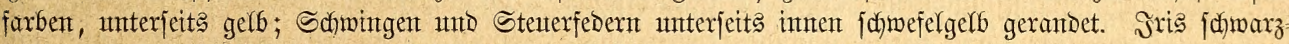

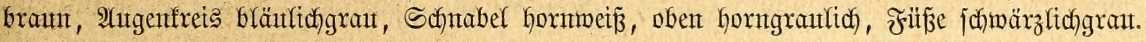

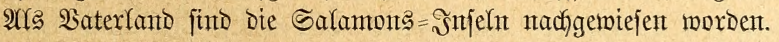

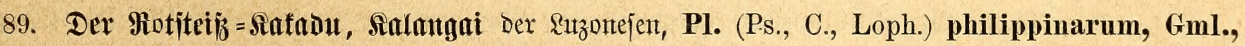

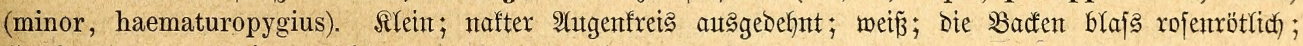

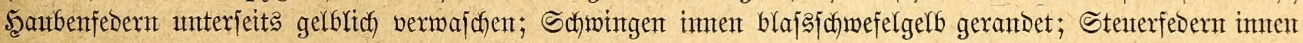

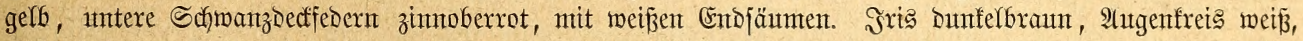

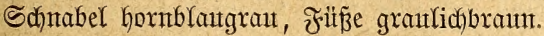

Die 2 frt berwohnt bie \$shilippinten.

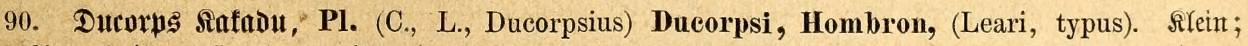

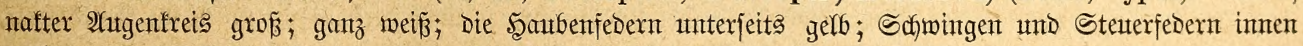

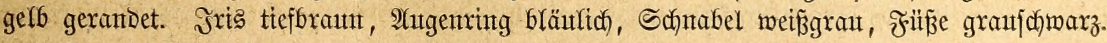

Stanmt bont Den Salontons = Snjelit.

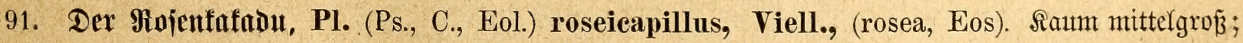

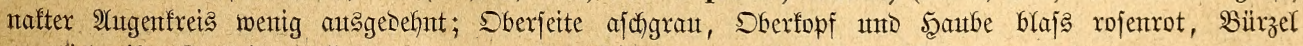

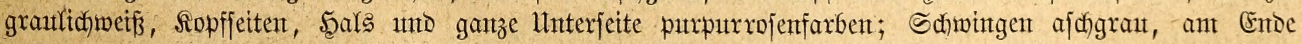

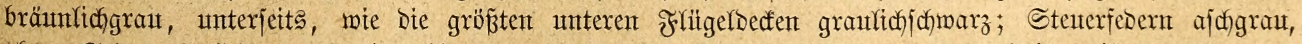

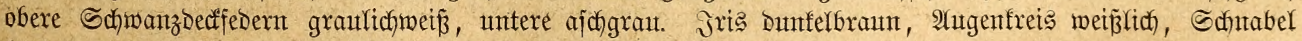

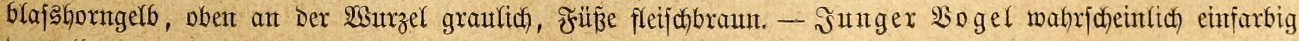
Dunfelfrautt. 


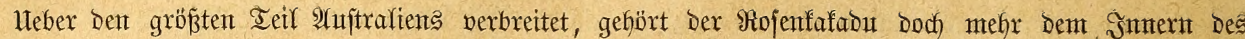
Feftlandes als Dex Rilite an.

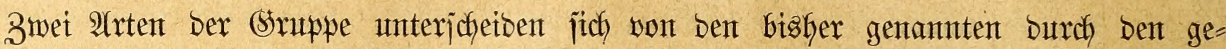

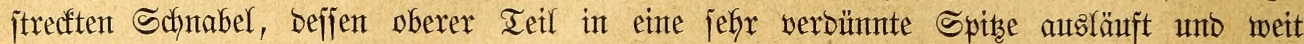

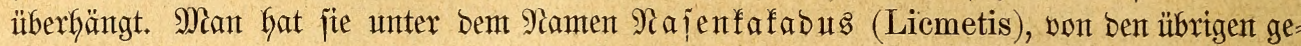
trennt unt bierzu injofern eine gemifje Beredftigung gefabt, als jie audh eine abwetchende Rebensweije füfren.

92. Der Majenfafadu, Pl., (Ps., C., Licmetis) nasica, Tem., (tenuirostris). Mittelgroß;

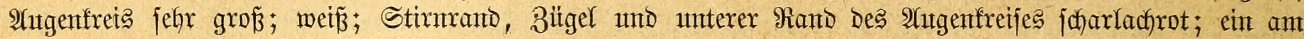

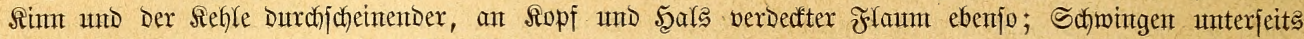

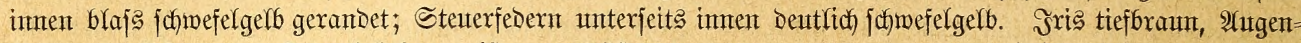

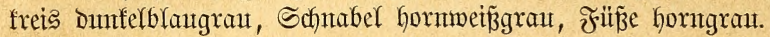

Bemofnt Sübauftrafien, Das Innere mehr als die Rüifte.

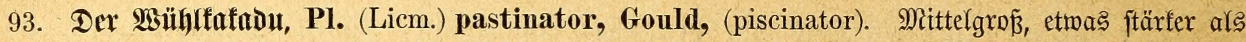

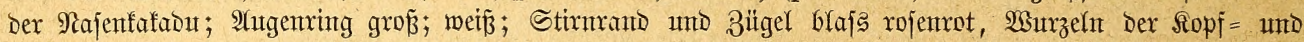

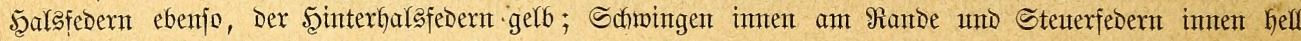

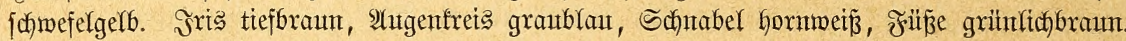

Scheint auf 2 seftauftrafien bejohräntt zu fein.

Die vorjtefent gegebenen Mitteilungen über bas $\mathfrak{B a t e r l a n d}$ ber einzelnen 9 arten be= zetchnen bas Serbreitungsgebtet Dex Rafabus auf das genauejte. Sie gehören Âtutraften. im meitejten Sinne an unb zählen zu Denjentgen Titeren, weldhe biejen Eroteil richtig $a b=$ grenzen Kelfen, jo vielfach jolche Begrenzung mit vererbten Afnjifyaungen Der Erofunbigen

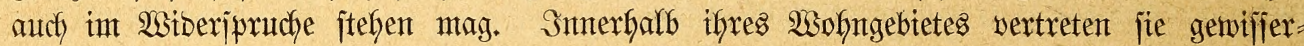
maß̈en bie gropen \$apageien ber anderen brei Eroteile, beren Rebensmeije fie im gropen und ganzen wiederipiegeln.

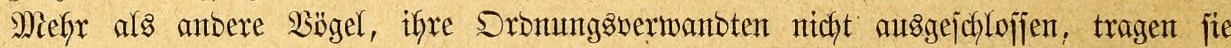
zux Belebung Der Ranbjchaft bet. Shre Schwärme, welche zu gemiffen Beiten Des Safhres

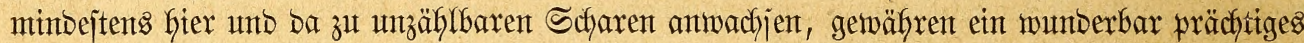
Schauppiel und begeiftern auch Den nüchterniten Mienjchen zu 24usbrïcfen bes Entzüffens. "Man mus", jo habe ich mich früher ausgebrüctet, "jelbjt umptricft worben jein von bem 3auber, welchen bie Pfianzentwelt unter ben Wentefretjen auf Den Norblänber übt; man

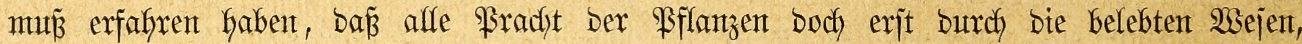

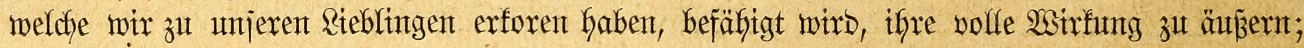

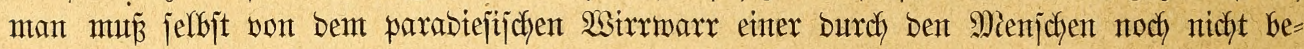

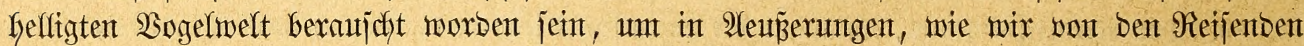

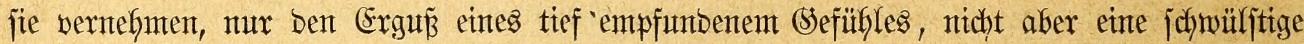
Uebertreibung zu erfentent."

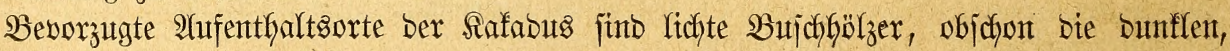
in emigem (strün prangenden Urwälder ebenfalfs von ifnen bemohnt werben. Wie goch fie

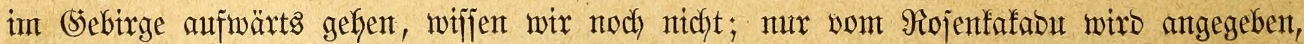

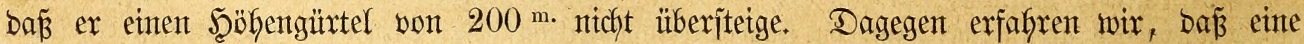

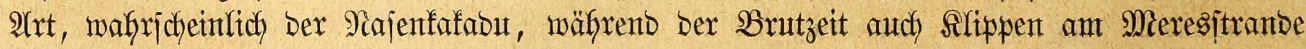

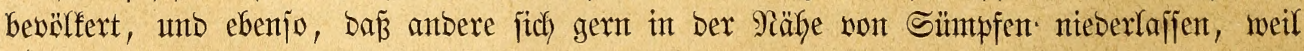

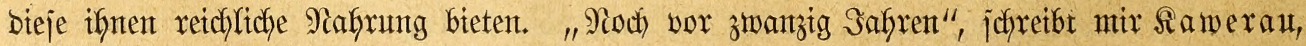
"fanten bie Saffabus (Pl. galeritus) in Schwärmen von vielen Iaujenben bis in bie un= mittelbare গähe von Mielbounte; gegentwärtig haben fie fich vor ben zafjlreicher geworbenen Bemofnern bes Ranbes ganz zurüffigezogen unb nach ben nody unangebauten Ieilen Des

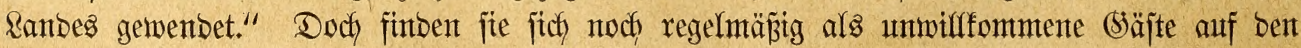

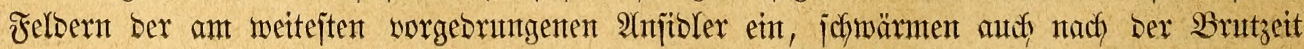


ziemlich weit in bas angebaute Rand finaus. Bux Beit bex Ernte werben fie fitex unt ba zur Ranbplage. Züge von Şunberten und Taujenten erjcheinen, von tweitem burch be=

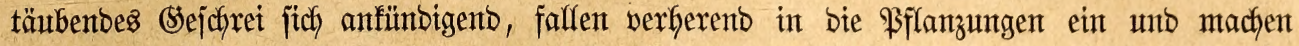

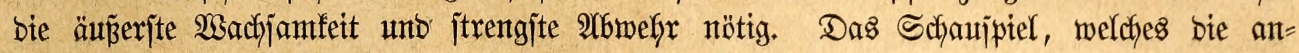

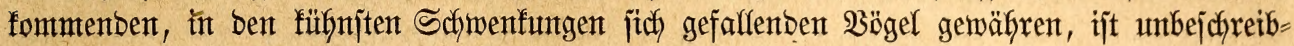

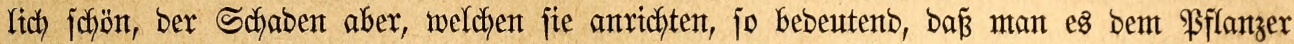
nicht verbenfen fant, wenn ex für jenes Schaujpiel fein âtuge hat, jonbern mur ben

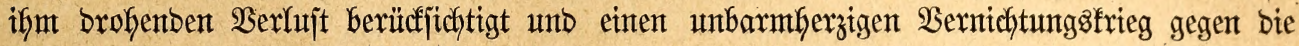
herlictyen $\mathfrak{B}$ öger eröffitet.

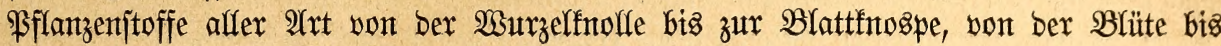

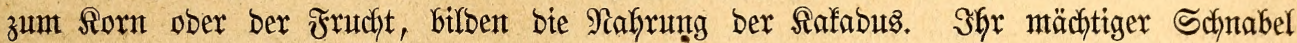
bient ebenjo zum

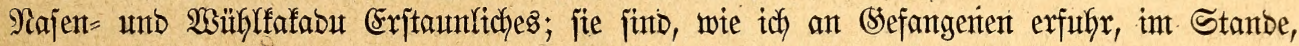

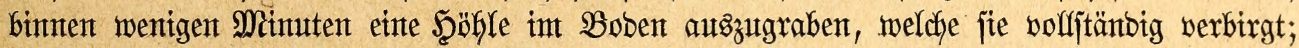
fie Durchnagen, nach meinen neutejten Beobachtungen, in jebr furzer Zeit Garte Salfjteine unb haben mich. baburch zu ber Meinung geleitet, Dá jie und nicht bie Selbhaubenfafabus es fint, welche in ben Slippen nifiten unb fier, wie bie Berichte lauten, augigebefnte

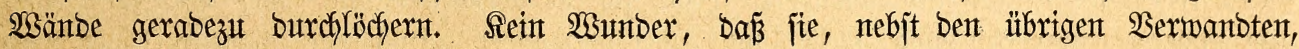
ben Pflanzer gegen jich aufbringen; Dent vor ifnen ijt bas bem Boben antwertrautete Sorm,

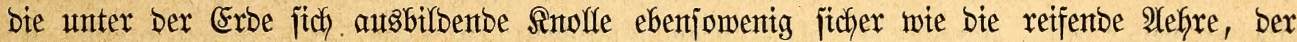

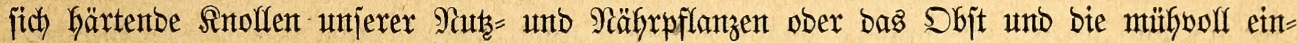
gebürgerte Sïbfurdyt int Sarten. Neben pflanzlichen Stoffen nefmen fie übrigents auch fleine. Steine auf, und auf Salz fint fie mafrifaft erpicfft.

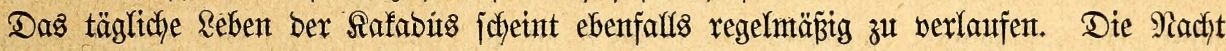

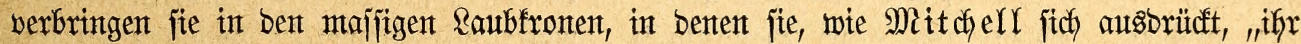

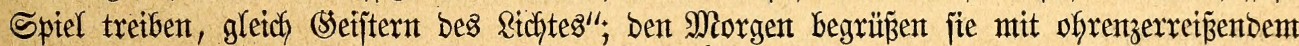

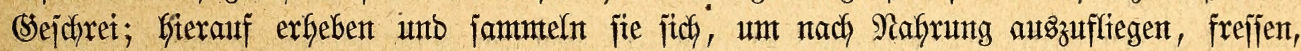
bejuctjen Sulfen, trinfen, baben unb fefren zum Walbe zurüd, um eintige Stunben ber

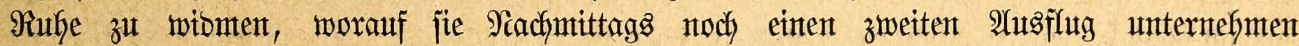

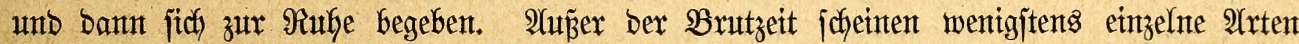
bon ifnen mebr ober mintor regelmä̈̈̈ge Wanberungen anzutreten, währenb berjelben es

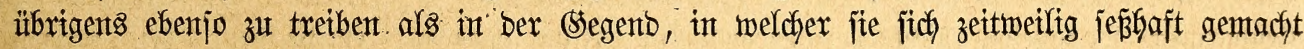
haben, unt zu brüten.

Heber bie Fortpflanzung Gaben wir mur sont brei 2 trten, bent Selbhauben=, Rojen=,

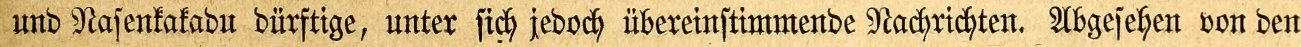

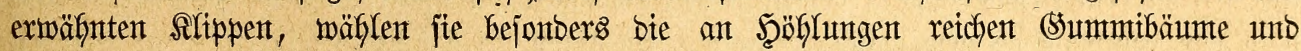

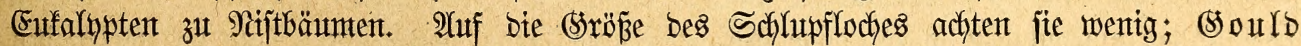

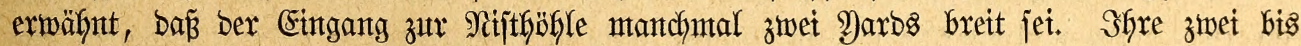
brei gropen, runblichen, grobförnigen Eier werben auf ben Miulm ber Mitjthöble unto

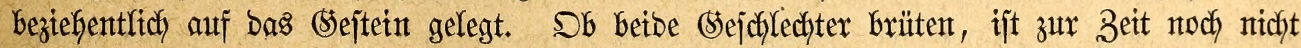

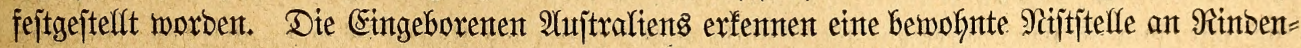

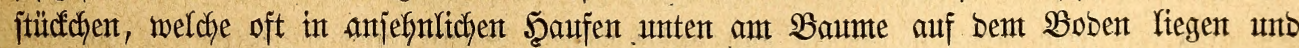

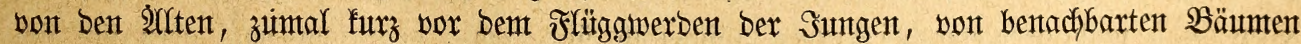

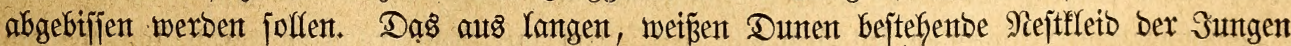

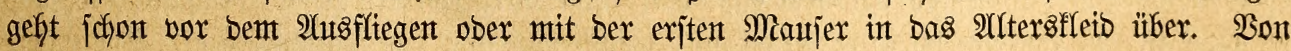
Mitte Nowember an bietet man, laut $\Omega$ awerau, in Mielbourne junge Sielbhaubenfafabus

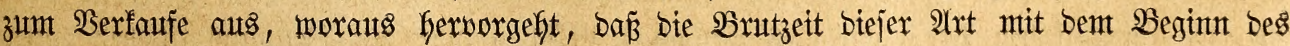
aujtralijchen Früblings zujammenfällt. Für bie auf ben Snjeln int Norben bes Frejtlanbes 


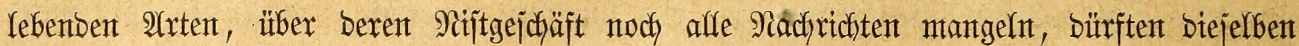

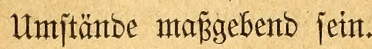

Sago unt Fang Der fiafabus jowie ber Şandel mit gezähmten $20 ̈ g e l$ merben won ben Eingeborenen ber oben ermäfnten Injeln jeit uralter Beit betrieben. Sijon ßigafetta

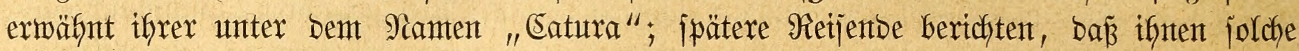

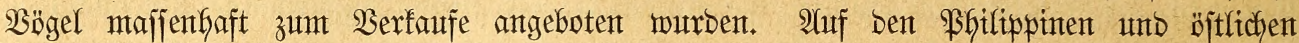
Moluffen hält man jie häufig in Sefangenjchaft; unter Den \$apus gelten Die Saubenfedern Des Iriton als bejondere 2 Utzzeichntung Der Tapferen, bürfen nux von ben Sorfämpfern unt Dententgen friegern, weldhe mit eigener Şant einen Feint erlegten, getragen werben und

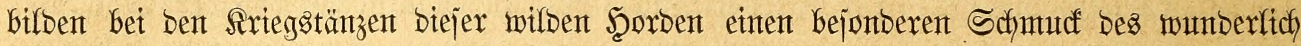

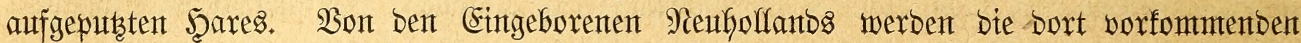
2lrten einzig unb aflein zu Sumpten ifyres emig beflenten Magens, jeboch in Gödjit eigen= tümlicher Weije gejagt. Der armjelige Schmarze ijt johlaut gentg, bie herlichen $\mathfrak{B o ̈ g e l}_{\text {zut }}$

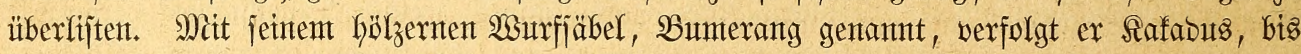

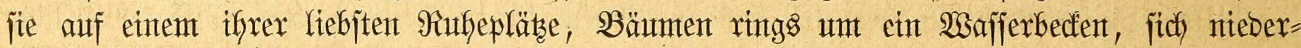

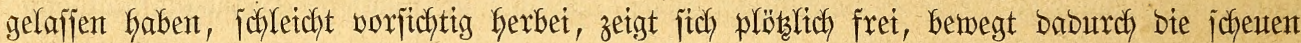
Bögel zu eiliger Fludbt und fchleubert, jobald jie jids erfoben haben, einen Wurfiäbel nady bent anberen unter ben Flug, Diejen unt jenen verwutbent, im Fłhge lähment, bevor nods

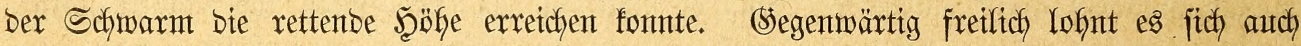

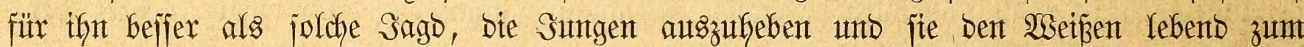
Berfauf anzubieten; Der brave "Dunfle Sitabe" erbält Dafür zunädjjt von Den 2(njtblern etwas (sift in (Sejtalt von Brrantwein, jobann Brot und endlich Seiebe - für ifn, nach

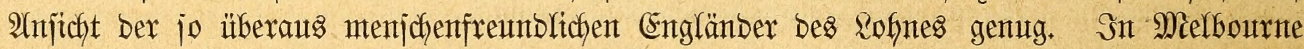
zahlt man für gejunde, fehlerfrete Safabus 4 bis 5 Ialer, für die jeltneren âtrten mebr; ber Ânjtblex, weldher aus exjter Şand faufte, madht arjo immterfint nod ein zitemlich gutes (sejcjärt.

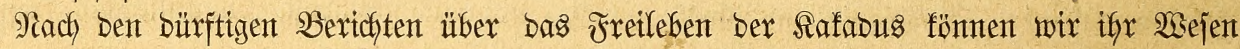
Göchjtens erraten; nach Den $\mathfrak{B}$ eobachtungen, welche wir von (Sefangenen gejammelt haben, funto

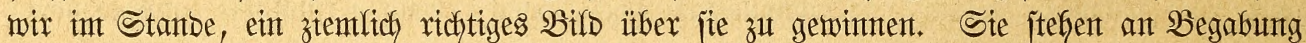

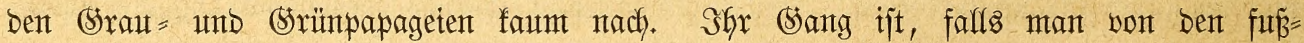

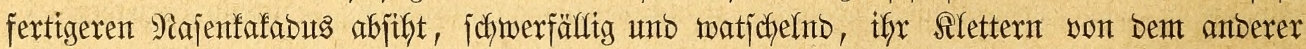

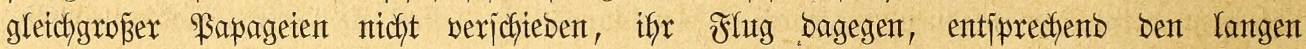
unb breiten Flïgeln, ebenjo idnelf als leidjt, namtentlich went es fich um Schwent=

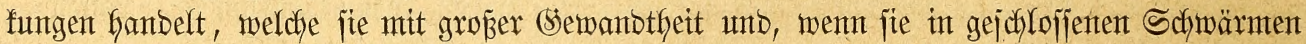

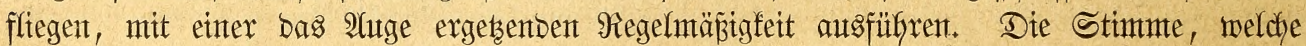
man von ben Safabus gemöhnlich vernimmt, ein faum erträgliches sireijchen, ofne jeglichen Wohlflang, um nidft zu jagen, ofne jeglichen אlang, mag, wenn ibrex Iaujende gleidzzeitig

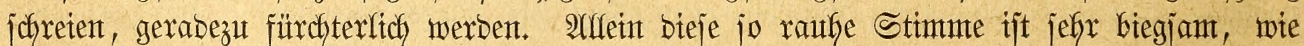

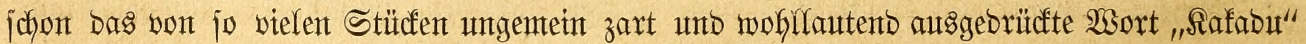
gentugiam bemeijt. Bernjtein, weldyex Saffabus vielfach in ber Jreifeit beobadjten fonte,

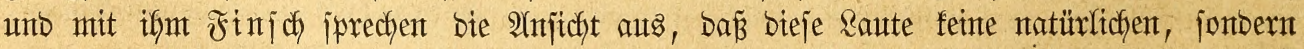

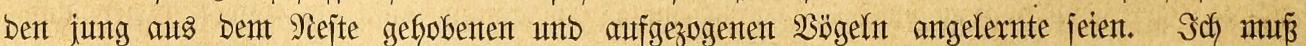

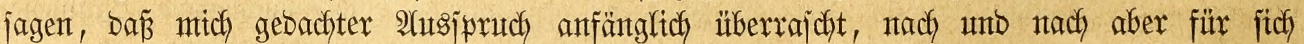

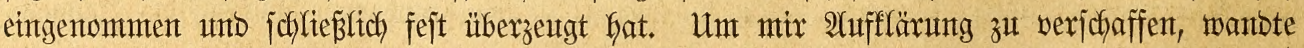

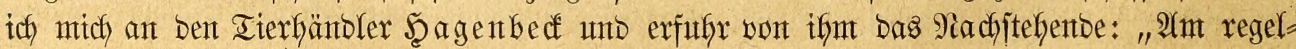

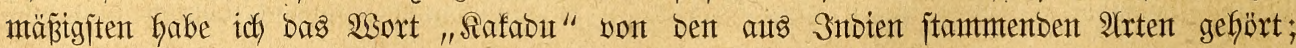
aber bie auftralijchen 9 (rten jagen es ebenfalls; ja ich glaube mit Bejtimmtheit bebaupten z̆ fönten, Daj es von affen 2 trten überhaupt vernommen mird. Sebod) waren es immer 


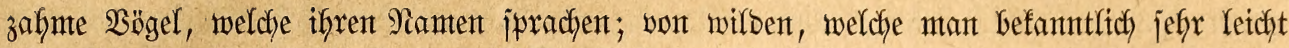
als alt gefangene ober boch vernachläffigte erfennt, Gärte idh ifyn nie, unto zwar ebenjowentg

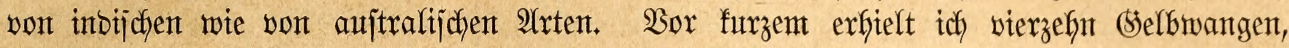

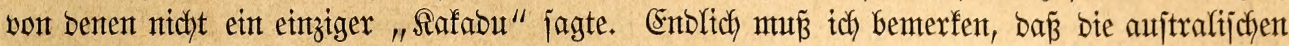

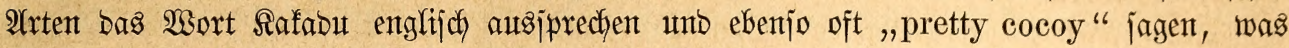

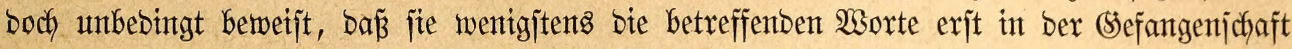

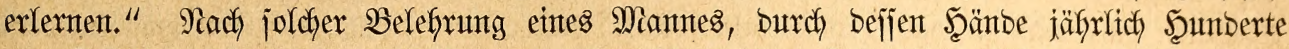

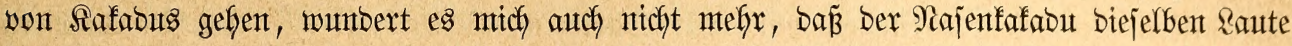

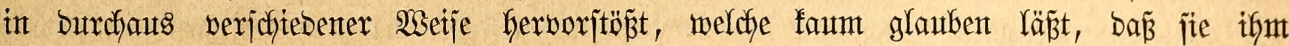

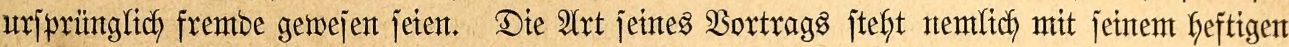

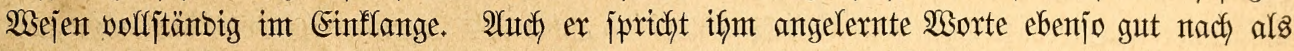

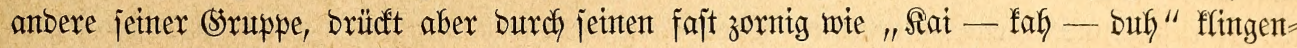

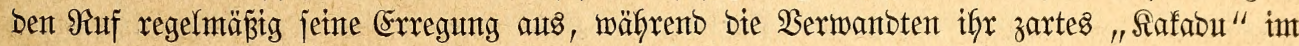
Begenteile bei guter Raute unt janftntütiger Stimmutng berneffntent laffent.

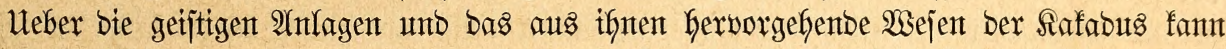

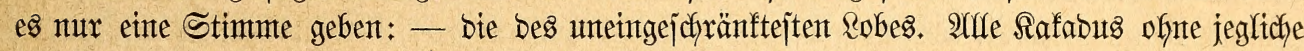

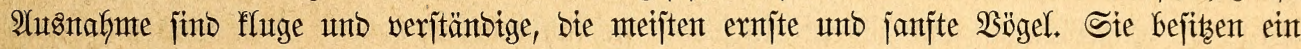

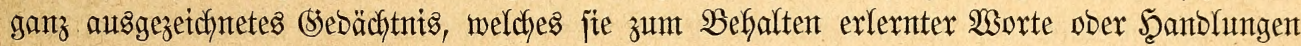

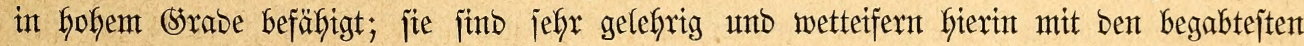

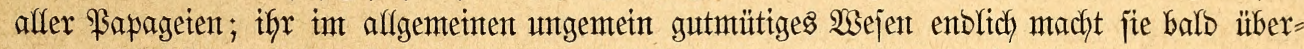
auts antfängfich und zärtlicty. Sie wollen lieben und gefiebt jein; bies befunben jie ifyremt

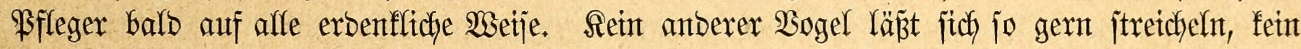

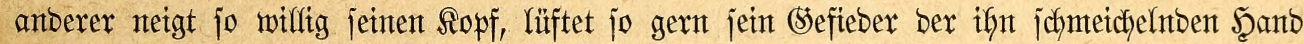

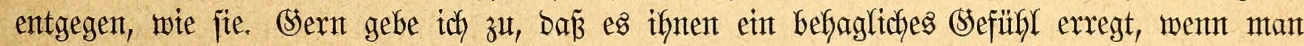

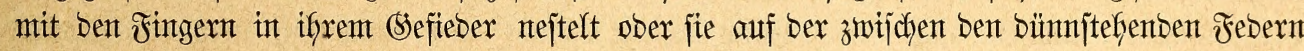

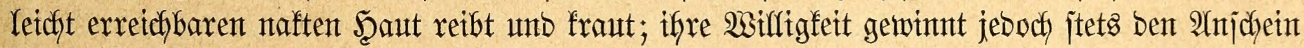

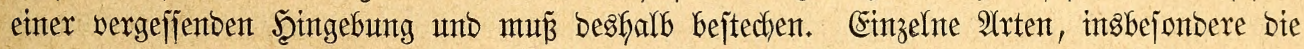

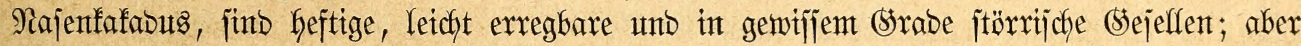

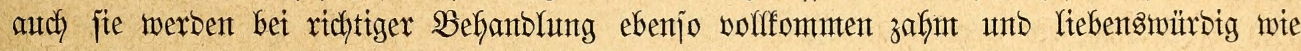

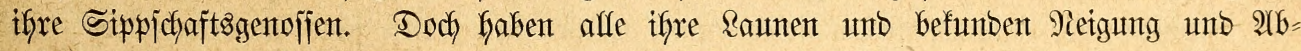

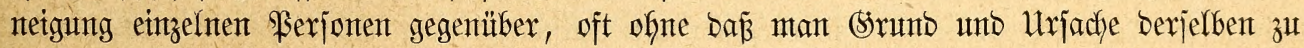
erfennen vermübthte. Shnen angetante Beleibigungen vergefient fie jelten, joldhe, weldhe

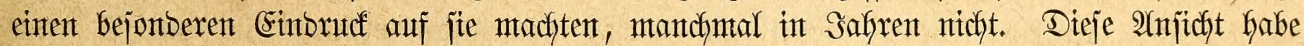

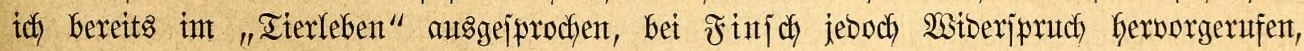

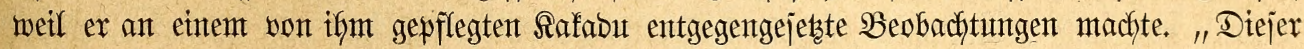

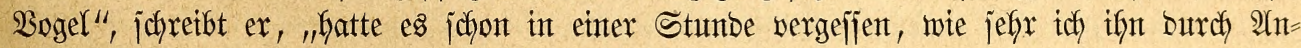
blajen won Iabafzrautch zum Zorn gereizt hatte. Dagegen zeigte er fith gegen cin Miäbchen, welches ifgn nie beleibigt hatte, jtets bäsartig." Sch will es baffin gejtelft jein laffen, wb

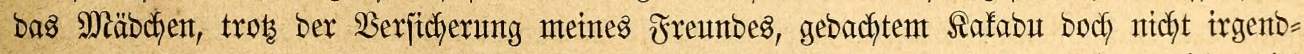
wie zu nahe getreten ijt; Denn id meinesteils habe Exfafhungen gejanmelt, welche midch

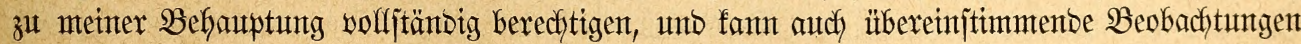

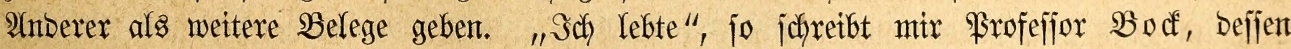

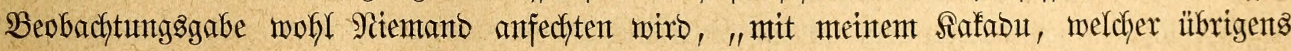

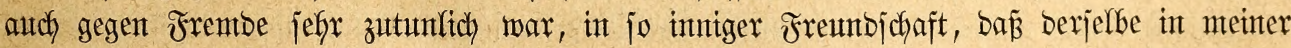
Stubiritube, währeno idh arbeitete, frei umberflog uno fich in ber 9iegel auf meiner Edfulter

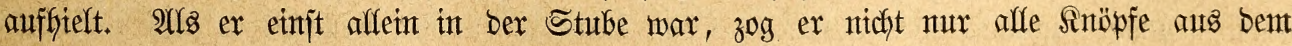
Sopha, jonbern trennte aud Den Heberzug Desjelfen ab. Sad bejtrafte Den Mififetäter Dafür

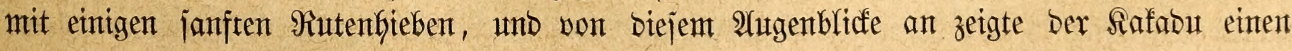




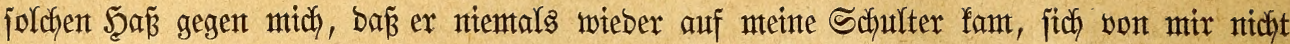
einmal ergreifen liéz und, jobald ich in bas 3immer trat, zu meiner Tochter flog. Heber

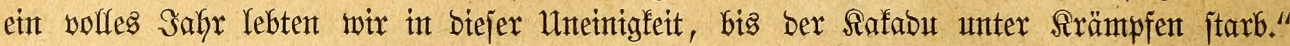

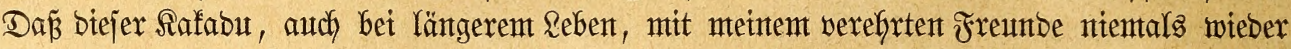
Frteben gejchlojien haben würbe, unterliegt für ntich feinem Zweifel: ich habe zu viele biejer

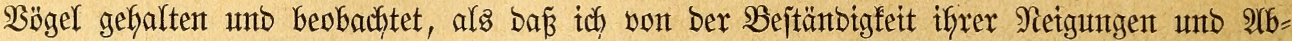

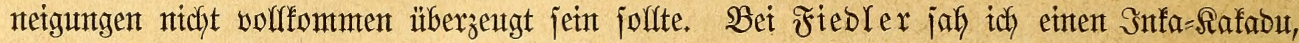

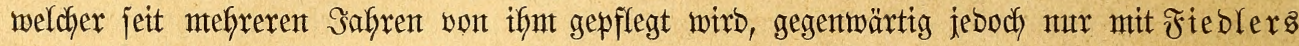

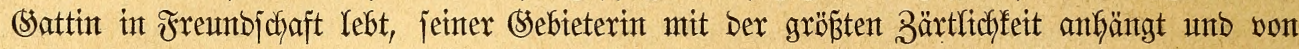

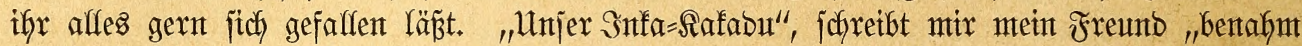

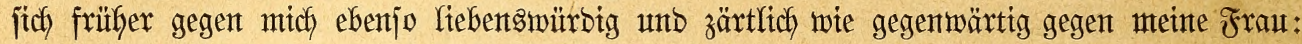

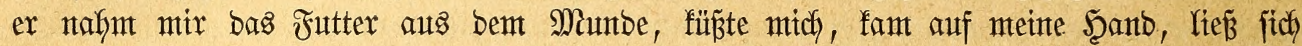
ftreicheln 2c. Wir haben uns aber vor ein par Safrent veruneinigt unb leben jeit biejer Beit zu meinem $\mathfrak{B} e$ datern in Unfrieden mit einanber. Der Srumb bes beflagenswwerten Swijtes ift folgenter. Freunt Safabu Gatte bie Unart, jebe Rette, welche ifgn an jeinen

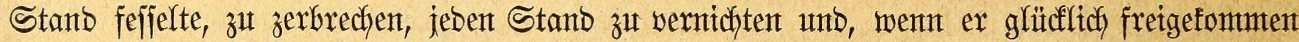
war, int Binmer nach jeinem Ermeffen, aber zu meinem Sdyabent zu wirtichaften. Utm

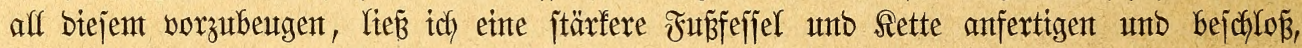

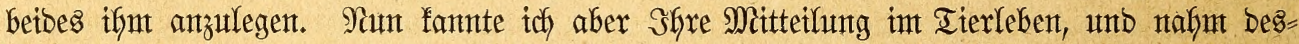

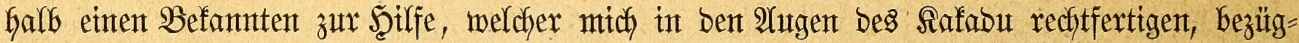

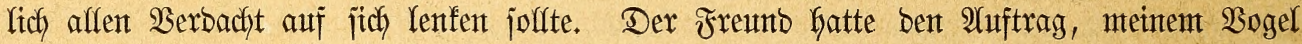
ein Iuth überzumerfen unt ifhn währento ber Feffelung in unt unter bemjelben feitzufyalten.

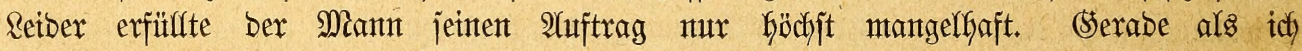

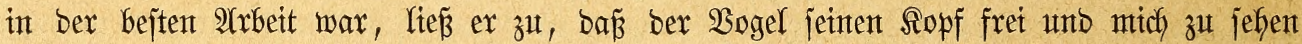

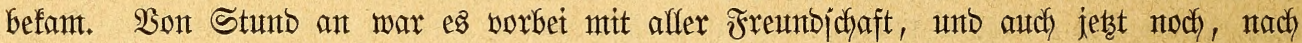
vier Safyen, barf ich mich ifgn nicht näfern, ofgne baj ex in ben Geftigiten 3orn gerät."

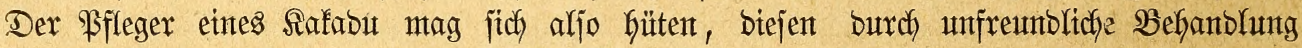

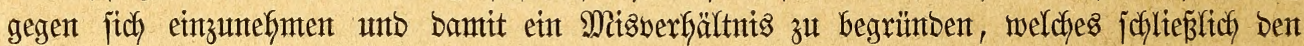
Bogel auth bem gebulbigiten Riebbaber verleibet.

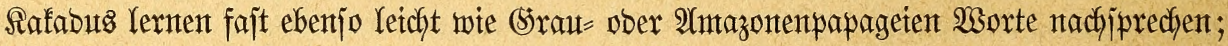
ify Sortrag ijt aber jelten ebenjo gut, D. G. Die Wiebergabe ber 2 orte ebenjo beutlich wie won biejen. Doch fommt auch bet ifyrem Unterrichte vieles, wenn nicht afles auf ben Sebrex

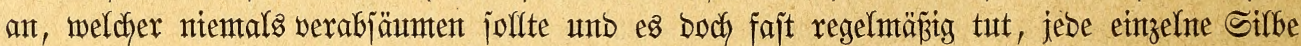

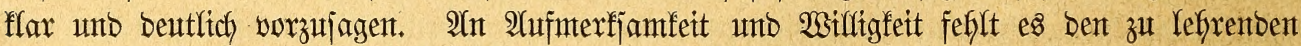
Sögeln nicht, unb wenn man Sunge in ber angegebenten 2 seije (ङ. 68 unb 150) unter= richtet, baxf mant Des Exfolges ziemlich jicher jein.

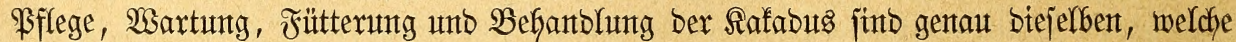
(Srau = und Srünpapageien beanjpruchen. Die meijten ârten vertragen einen ziemlich geringent Wärme =, bie auftralfijchen jogar einen mäß̈̈gen fältegrab ofne affen Nadjteif, nicht aber

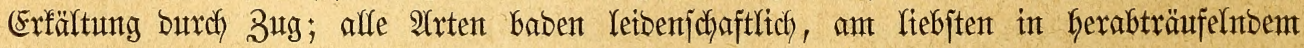
Baffer unt entbefren, went ifnent bie Selegentfeit zum Baben mangelt. 2(nt bas Futter

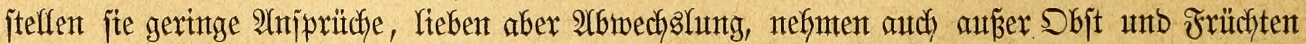

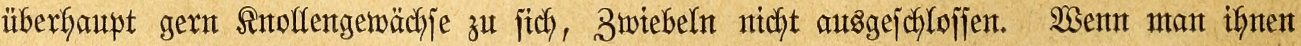

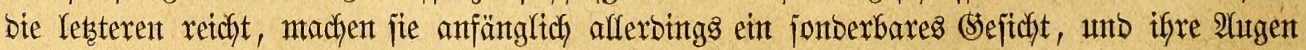
ermeijen fich faum mintber emtpfintolich als bie ber Mienjichen gegen baş flüchtige Sel biejer

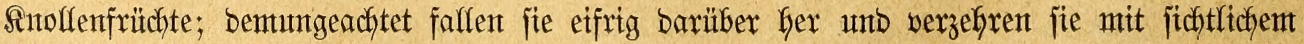

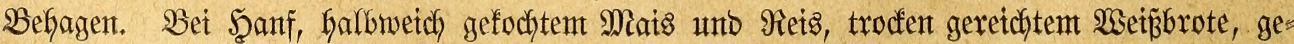
fochten Sartoffeln, Mäfren unt Srïnzeug gebeifen fie vortrefflich; int Mitldy getweidstes 
Brot halte ich efher für jchäblich als nüblich, Sucfer für untötig, Sbjt für eine gejunbe

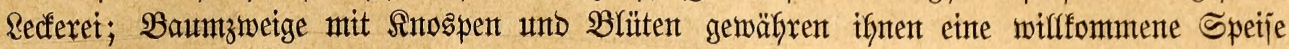

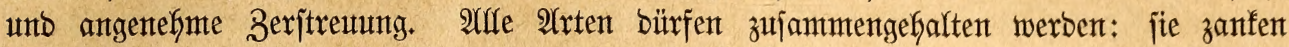

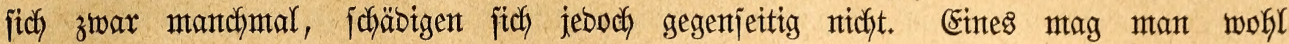

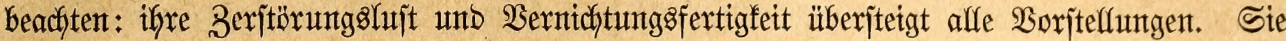
zernagen, wie ich aus eigener Erfafrung verbürgen fann, nidft alfein Breter, jonbern audh bidfe Balfen, nicht bló̉ Scolz, jonbern jogar Eifenbledy von $1 \mathrm{~mm}$. Didfe; fie zerbredjen

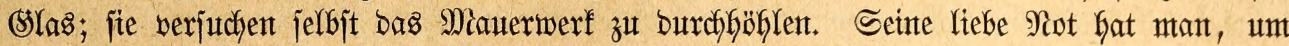
fie auf einemt Stänber jo zu fefjeln, baß̃ fie jidh nidgt befreten fönnen. Sie machen, um

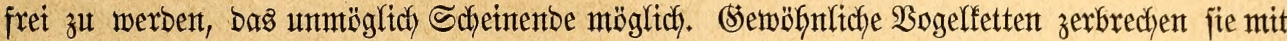

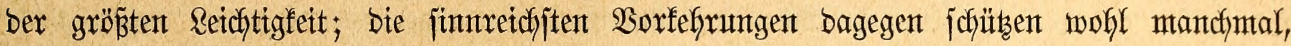
feinesmeges jeboch inmer. "Man mur es", benterft Fiebler, "jelbjt gejeben haben,

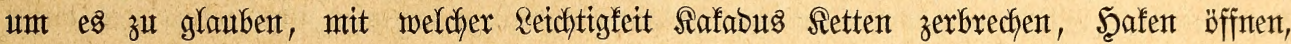
Schrauben auforehen und antbere Feffeln löjen, weldye man ifnen anlegte. Mein Sntfa = Safabu

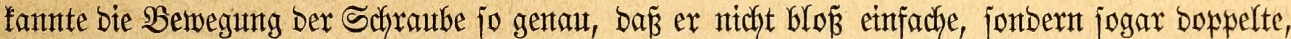

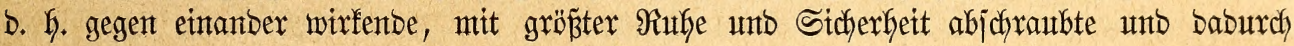
regelmäß̈tg fich befretete. Selbjt das ebenfafls angejdyraubte Futtergejchirr wubte ex zut entfernen, weil es ifn Gindorte, ben Enbring jeiner Fußffette vont Stä̈toer abzujtreifen." Wet Safabus halten will, mag fidd auf joldye und äfnlliche Sumptfertigfeiten gefajt machen.

SBis jebst baben, joviel mix befant, gefangene Safabus noch feine Sungen erbrütet

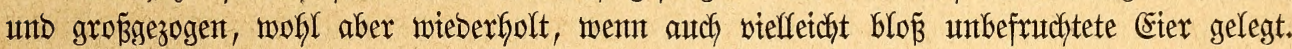

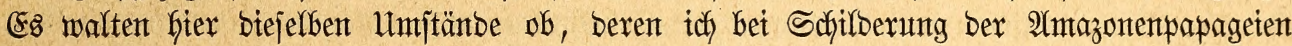

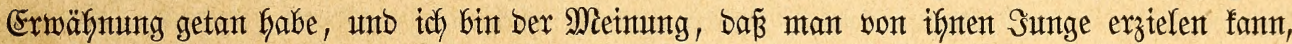

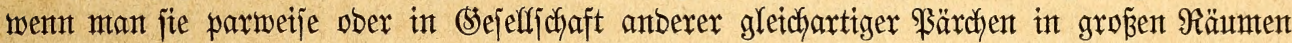

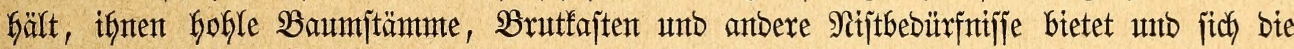
teilmeije Zerjtönung berjelben gleidymütig gefallen läß̈t.

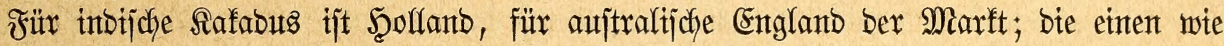
bie anberen feflent febody audch ben Scänblern bes Bintenlantes jelten ober nie. Man bezafilt

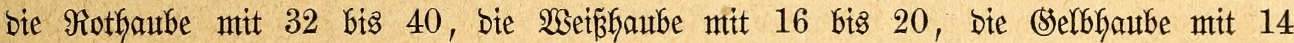
bis 18, bie Selbmange mit 10 biz 12 , bie Solbmange mit 12 bis 15 , ben Snfa= Siafabu

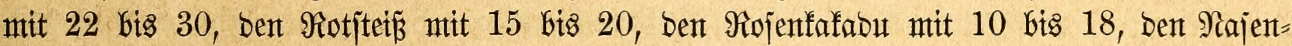
fafabu mit 24 bis 30 Talern nidft zu hody unb barf für zafme, vielleidft jogar einige

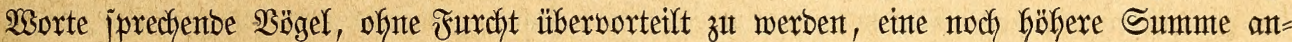
legen. Die Schwantungen ber \$reije finden ifyre Erffärunts in bent jemeiligen Stanbe bes

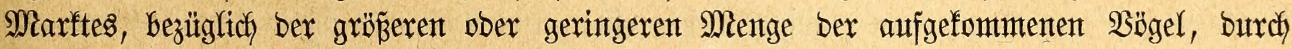
weldye bie Şänbler mefrr beeinflufist werben, als jie thre arbntefmer füblen lajfen fönten.

\section{faillidmwankakadus.}

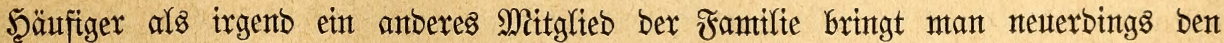

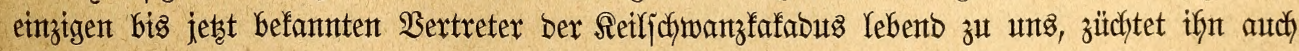

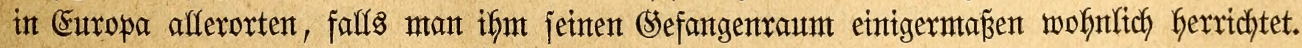
Der Bogel verbient beshalb vollftänbig bie Beachtung, weldye er bei allent mit ifym befannten Riebhabern genieß̄t.

2(bweidhenb von jeinen Familienwerwanbten hat ber Reifjchmanzfafabu einen gejtredten,

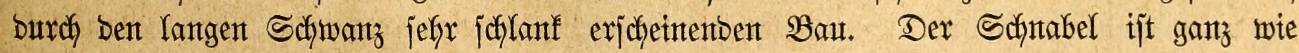




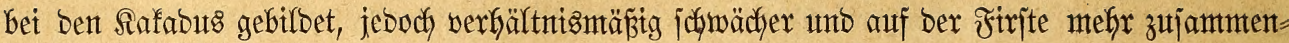
gebrüfft, baher fantiger als ber gebachter Serwanbten. Die rumben Rajentöcher, beren

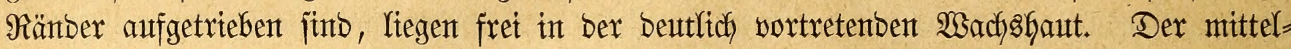

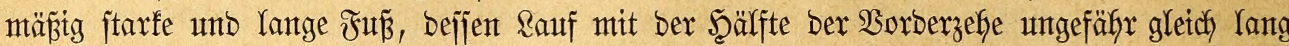

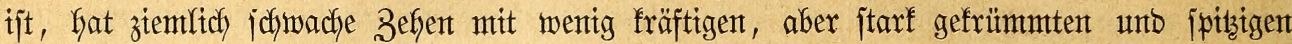
Sraflen. In bem ungemöhnlich langen und jcharf zugejpitzen Flïgel, welcher, zujammen= gelegt, bie Scälfte bes Schwanzes bedit, ijt bie Flügelfpitze aukerorbentlich lang, bem Sber= flïgel gletchfonmento, unter ben ant Enbe abgerumbeten Schningen, won benten blok bie zweite unt britte aujent eine jodntale $\mathfrak{B e r e n g u n g}$ zeigen, bie zweite bie längite. Der Sdywanz ift etwas fürzer als ber Flügel unt feilförmig; jeine Febern, unter benten bie beiben mittleren anjefnlid, vorragen, verjdymälern fich ein wentg gegen bas abgerunbete Ende fin. Das jefy

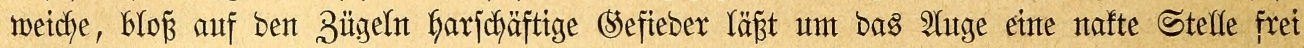
unt verlängert jich auf Dem Sberfopfe zu einter langen, jdymalen, fanft nadh oben ge= frümmten, aus weitfajerigen Febern bejtebenden ફૃaube.

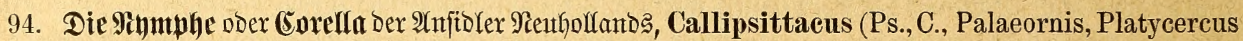
Leptolophus, Nymphicus, Calopsitta) Novae-Hollandiae, Gml., (auricomis). (Grö̈ß̈e einer Droffel, jeboch

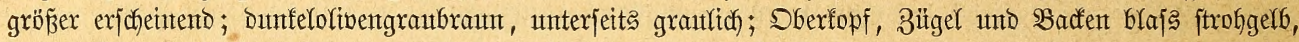

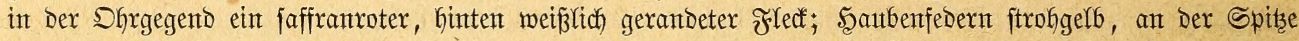

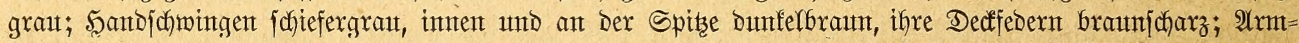

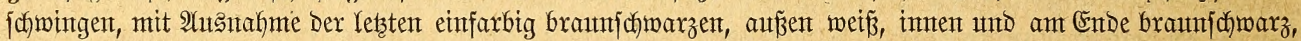

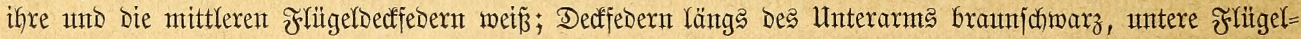

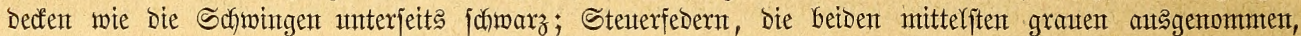

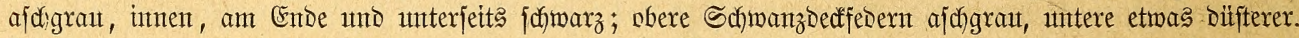

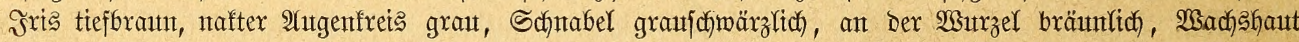

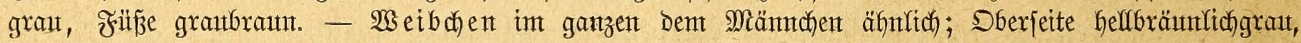

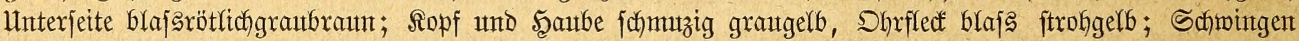

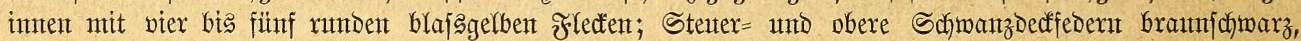

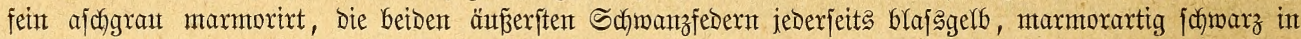

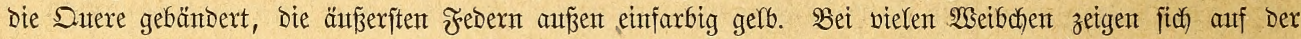

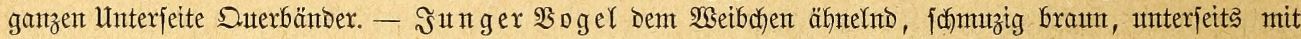

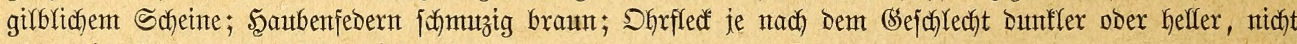
aber rein, fortoern ftets fofmutzig gelb.

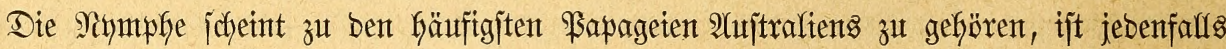

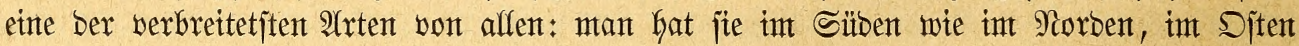

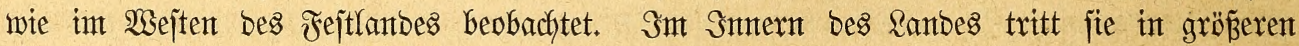

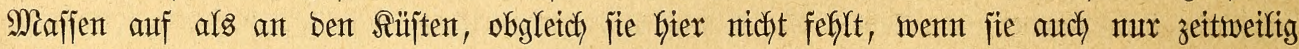

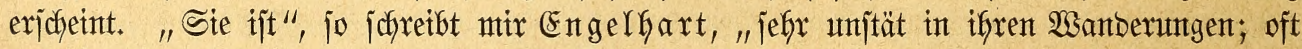

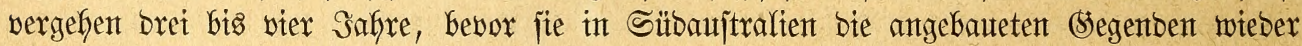

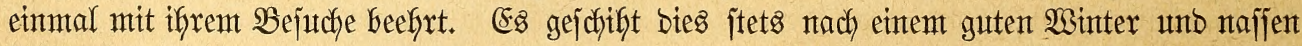

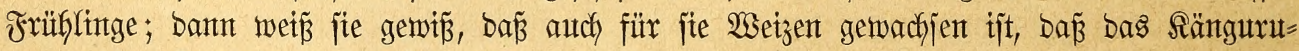
unto willo Sanartengras retchen Samen für ifre Stungen liefern miro. Unt bie Beit,

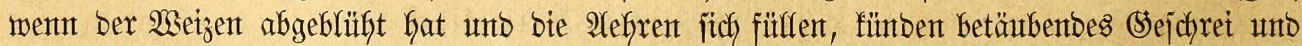
Durchbringentbe, auf weitfin Görbare socftöne ifre Ifnfunft an, und unmittelbar barauf benterft man, Daßj fie fich inmittent ber Ranbgüter ntebergelaffen hat, ofnte im Bezug auf ben Wofnbaum bejonders mäflerijch zu jein. In manthen Safren exjcheinten unjchäţbare

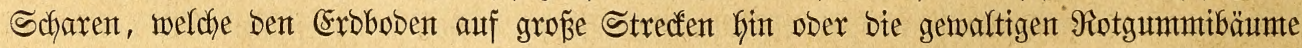
buchjtäblich bebecfent.

Unjer Bogel exfreut fich einer ungletch grö̈Beren Beadytung als irgent eint anberer jeiner

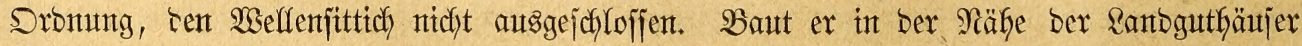

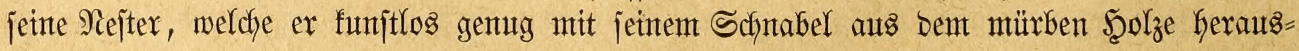




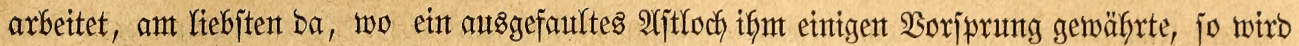

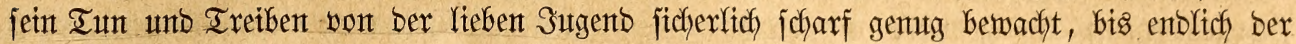

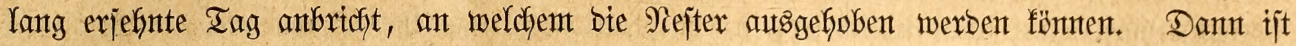
ber Subel groṕ allüberalf. Seber Ranbbebauter Gat fortan jein Färchen "Safabupapageien",

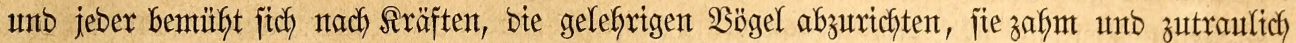
zu machen, fie bas Nachpfeifen eines Rtebes zu Yefren, was afles mur wentg 2̂njtrengunts exforbert. Afuch bringt man jeşt Şunberte unb Iaujente von Sungen zux Stabt, um fie

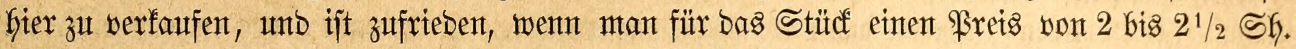

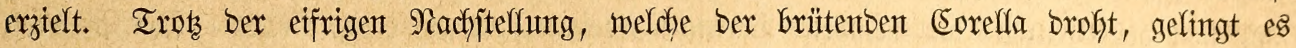

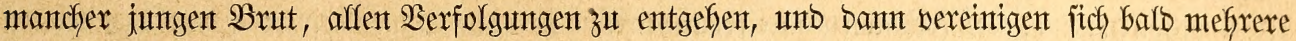

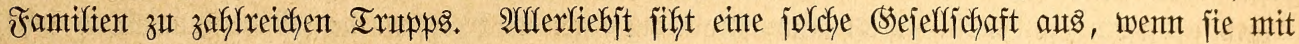

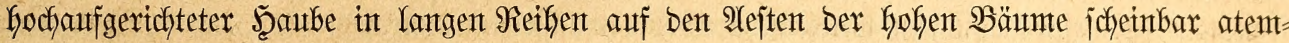

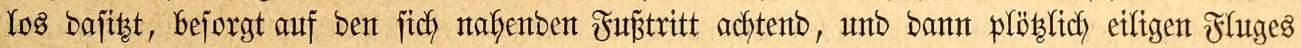
bas $\mathfrak{\text { Seite judjt. }}$

Die erjte $\mathfrak{B}$ rut ber (Sorella fällt wie bie jo vieler $\mathfrak{B} \ddot{g e l}$ Silbaujtraliens in ben Sltober,

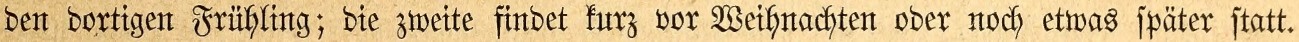

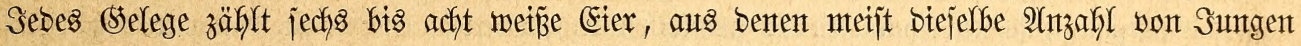

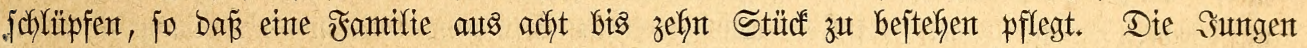

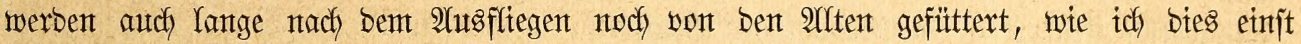
genat beobadjtent fonte, als jid Sorelfas bidjt vor meinem Fenjter angejibelt hatten. Sie

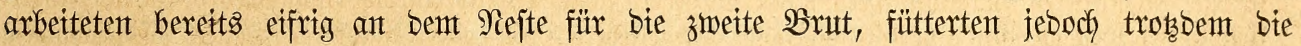
Galberwadyjenen Singen ber erjten noch fort.

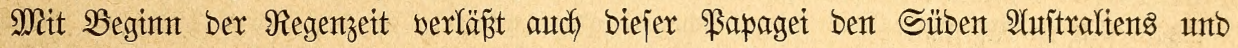
bricht in ungeheuren Scharen nach bemt Norben bes Feftlantes auf."

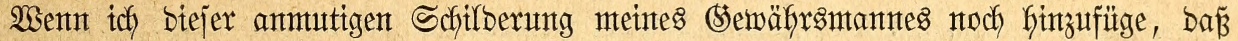

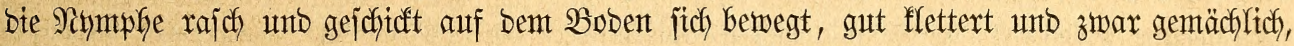
aber leicht unto ausbauternto fliegt, fich wenig vor bem Mientichen jochent und beshalb unichwer berücft wirb, habe idy wofjl afles mitgeteilt, was uns über bas Freileben berjelben befant getworben i $i$ t.

Für bie Sefangenjchaft eignet fich bie Corelfa in bejonberent Srabe. Sie ijt anjprutchglos

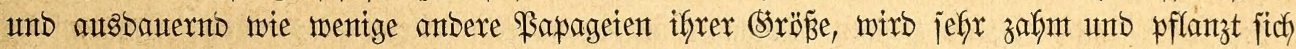

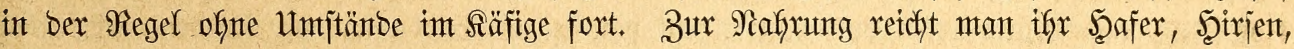

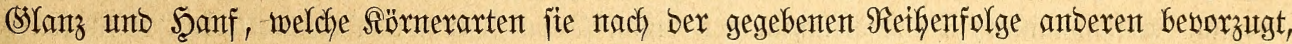
fügt etwas (strünzeng, vielfeidyt autch gejdynittente ober geriebente Miohren, vor und währent

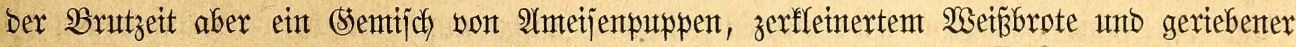

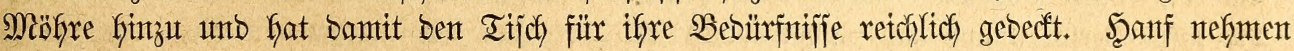
bie wentgiten Stücfe, und went jie $\mathrm{es}$ tum, gewëhnlich in geringer Menge zu fich; mefil= Galtige Sïnner jün ifnen entichteben viel lieber als fettige ober ölige Sämereten. Manche

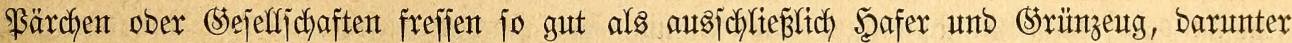
auch junge Sat ober frijches, zartes (Sras; anbere, welche nuf ber Reije bermöhnt wurben,

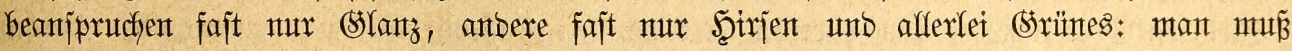
aljo bei Empfang neu erworbener Nismphen exjt erfunben, weldse Sörnerart ifnten ant

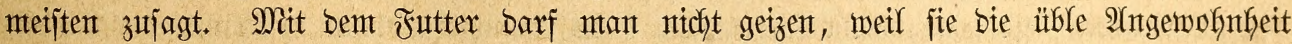
Gaben, bie Sïnner nicft rein augzujpelzen, jonbern bloz in ber Mitte anzufrefifen und ben Rejt Yiegen zu Yafjen, aljo mebr verbrautchen, als man int Berbältnts zu ifyer (strö̈̈e von vorn= Gerein annimmt. Ulebrigents barf man mit Den Garten Bögeln wentg Hatiänbe machen. Sie bertragen, falfs fie nut bor 3 tg fich fidübent fönnen, ziemlich niebrige Wärmtegrabe

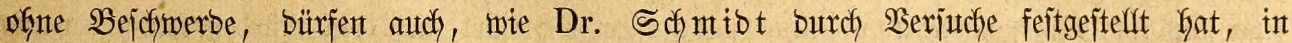




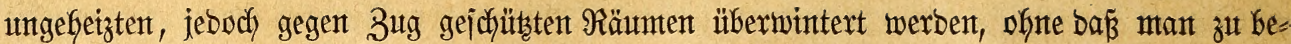
jorgen hat, fie zu verlieren, brüten Gier jogar, bererbter semolnhyeit folgent, wäfrent ber

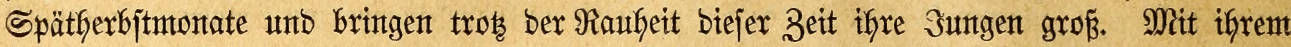
Unterrichte gibt ntan jich bei uns zu Ranbe nicht ab, obmobl bie aus গeuffollanb uns zu=

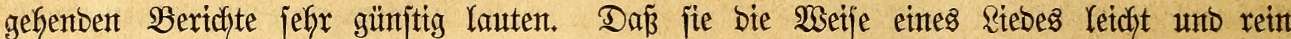

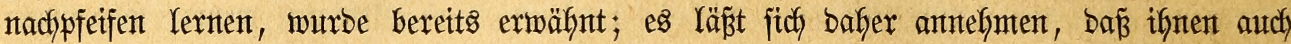

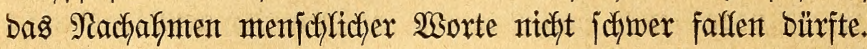

Un jo eifriger betreibt man bie Butdt ber Siymphe, meijt aud mit bem bejten Erfolge, wbjchon bie Brutzeit, wie bemerft, eigentlich in unjere Wintermonate fäfllt. Doch genöhnen

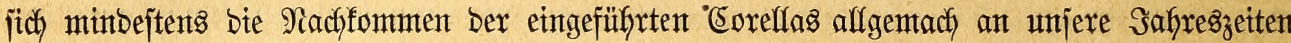

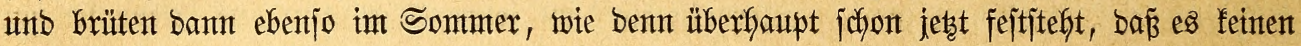
Montat in Safyre gibt, in weldhem ein ober bas anbere \$ärchen nicht zur Fortpflantzuntg gejarttten wäre. Unter günjtigen $\mathfrak{B e r f a ̈ l t n i f j e n ~ n i j t e n ~ a l t e ~ C o r e l l a s ~ m i n b e f t e n s ~ z m e i n t a l , ~}$

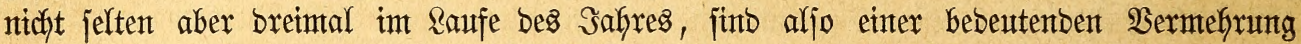

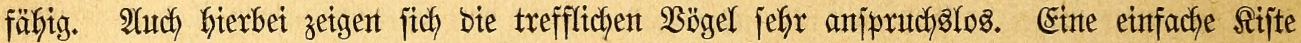
von $30 \mathrm{~cm}$. in $\mathfrak{W u ̈ r f e l , ~ b i s ~ a u f ~ e i n e n ~ S c h i e b e r ~ u n d ~ e i n ~ r u t t b e s , ~} 6$ bis $7 \mathrm{~cm}$. im Durch)= mefijer haltentes Sallupfloch alfjeitig gejhloffen und unten mit einer Rage von grobem Säge=

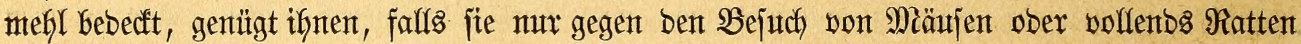

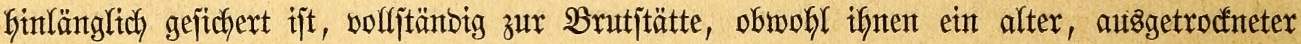
voer frijdyer Weibenjtamm, beffen Gofiles Snnere fie nach Sefalfen benagen föntnen, entjchieben

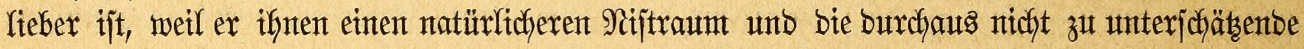
EIternfreube gewährt, burch eigene, vorjorgliche $\mathfrak{A}$ rbeit für bie fommenbe SBut bie Sinber= witege jich zu jafaffen.

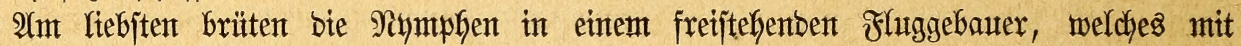

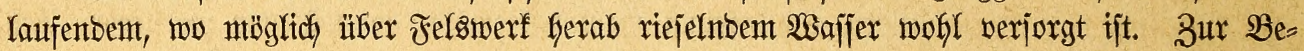
pflanzung besjelben eignen fich bejagte Weiben, beren Berjebung freilich ifre Schivierig= feiten hat, aus bem (Srunbe in bejonberem Srabe, weil ifre idfwantenben Zweige antge=

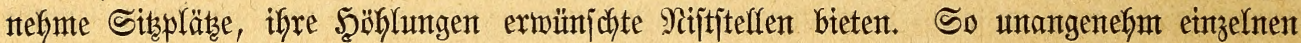

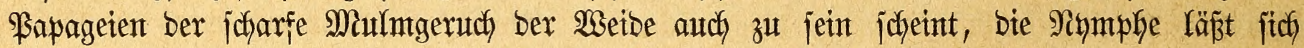
baburch nicht abjdyredfen. "Wite viele andere Ş̈̈hlenbrütex", bemerft Freyberg, "legt fie ifye Eter auf verfaultes $\mathfrak{S c l}_{z}$, gleidyoiel ob in joldfes lebentoer ober toter "Bäume, mit Borliebe auf Maulm, weldyer feuddt ijt, jo baj ich auf ben Sebanfen geführt worben bin,

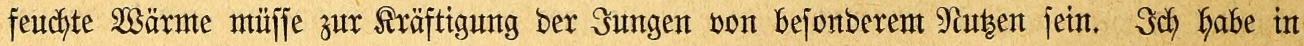
freiftehenben Fluggebautern Corelfas gezüdhtet, obgleidh bie Eier fajt jtets ná̉ gelegen hatten

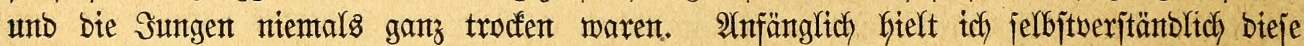
Brut für verloren unb gab fie auf; aber fithe ba, alfe vier Sungen gebifgen herltidy und murben jtarfe, fräftige $\mathfrak{B o ̈ g e l , ~ w a ̈ f r e n t ~ a n b e r e ~ i n ~ B i m m e r ~ g e z i ̈ c h t e t e ~ a n ~} \mathfrak{B}$ lutarmut litten und im vierten ober fünften Monate zu Srunbe gintgen. Seitben ich bieje Erfafrung ge=

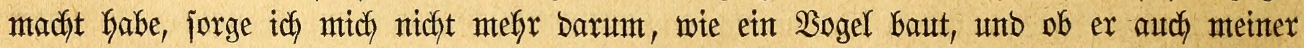

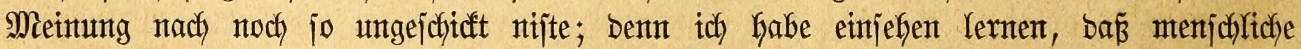

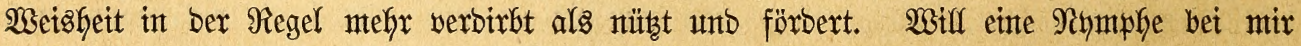
auf feudften Mutm ober Sartenerbe Yegen, jo Yaffe idy fie gewäbren unb berufige mich mit bem (sebanfen, fie werbe wohl eine feudte Brutitätte nötig haben." Derartige Nij̄tpläßze

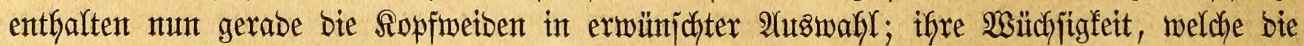
Der meijten $\mathfrak{B a ̈ u m e ~ u ̈ b e r t r i f f i t ~ i j t , ~ e i n ~ a n b e r w e i t i g e r ~} \mathfrak{B}$ orzıg, went fie mit ber Beritörungs =

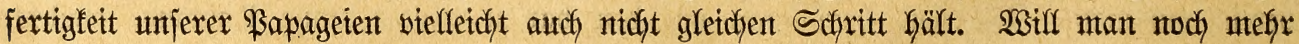

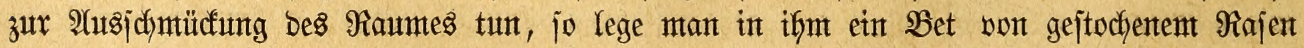

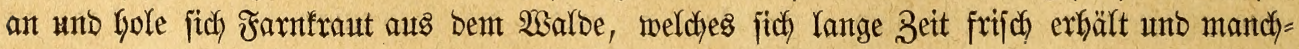


mal nicht angefochten wirb - eines weiterent \$flanzenjdyntutés bedarf minbejtens bie Niymploge nicht.

Mian tut gut, bie Erfafrutg Fieblers (ভ. 88) gebürenb zu würbigett, Corellas

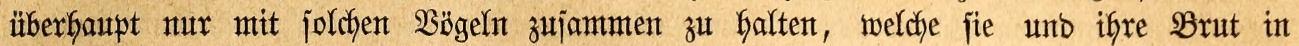
feiner $\mathfrak{B}$ seije behelligen, weil jegliche Störung, wie bereits zur Senüge erörtert, ben Erfolg ber Züchtung in Jrage ftelfen faum. Dagegen barf mant of

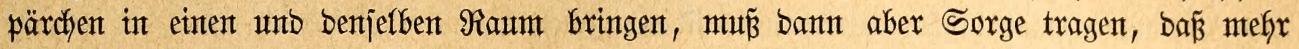

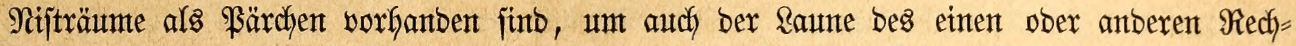

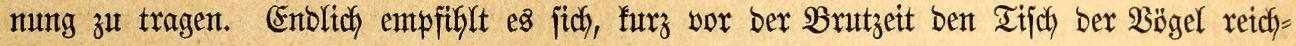

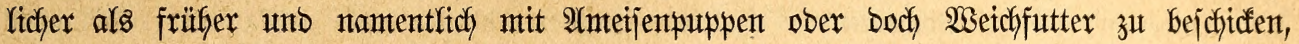
weil man fie baburd zux Fortpflanzung anregt. Die redjte Beit für joldje Maántafynte ijt

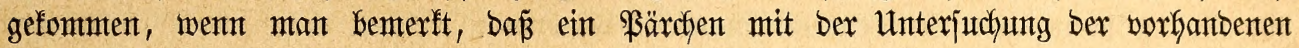
Niiftfaiten beginnt.

Die Cier werben einen $\mathfrak{T a g}$ unt ben anberen gelegt, went bie 2 Sitterung rauf boer fiityl iit, vont eriten an bebrütet unb innerfall zwanzig bis zweitubzwanzig Tagen gezeitigt.

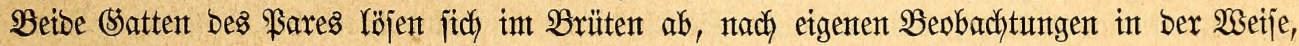

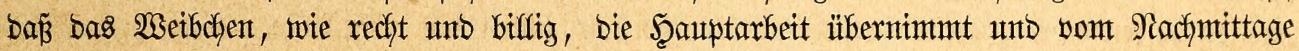

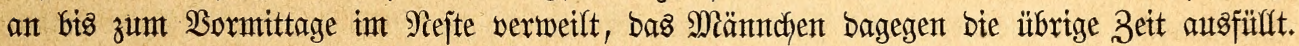

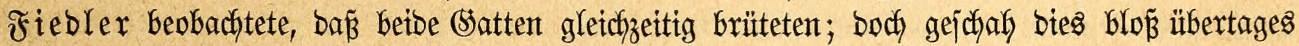

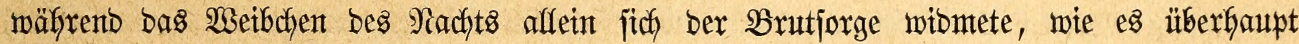

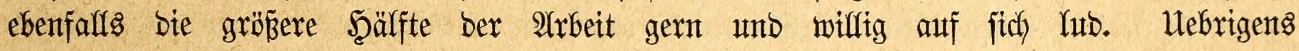

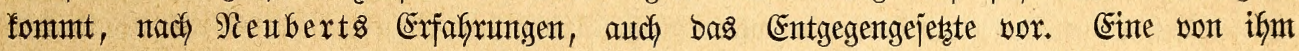

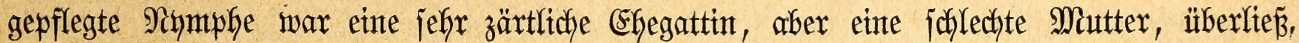

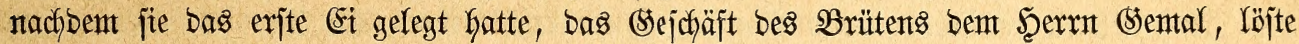

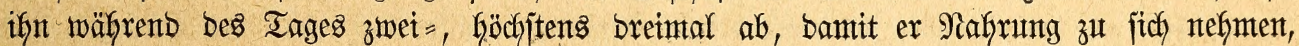

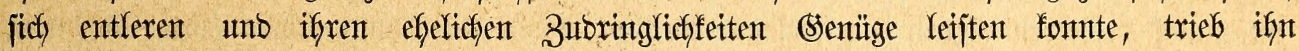

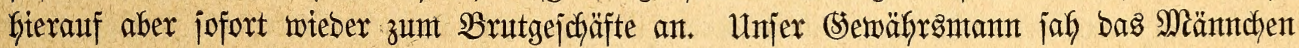

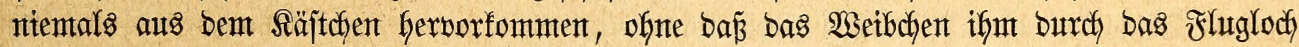

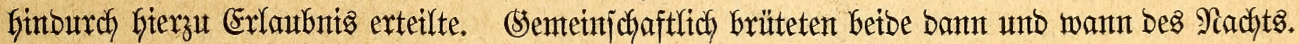

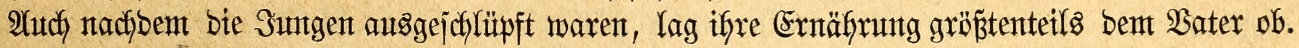

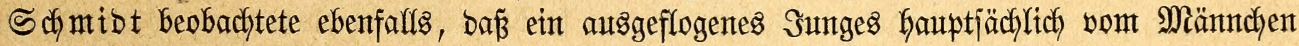

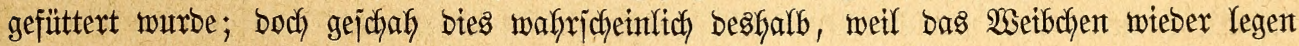
wollte, in weldsem Faffe ber $\mathfrak{B a t e r}$ unter alfen $\mathfrak{H}$ mitänben ben Sungen ber eriften $\mathfrak{B}$ rut bie

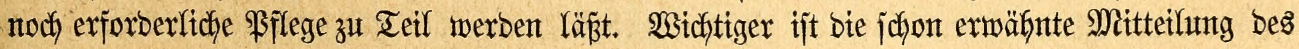

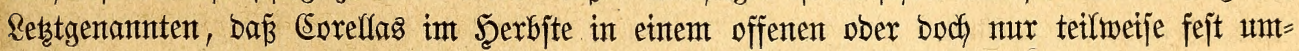

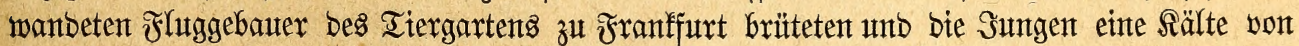

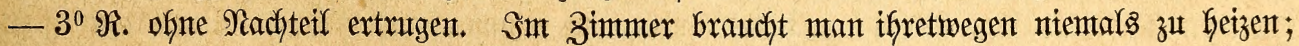

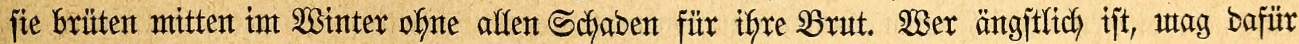

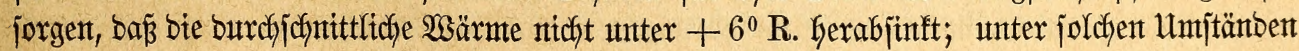
hat $\mathfrak{B}$ ald anus jutnge Corelfas gró

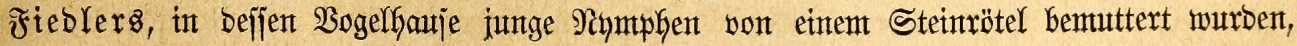

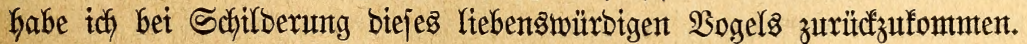

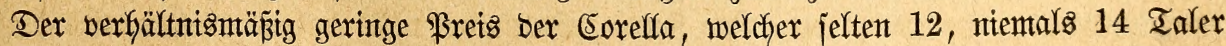

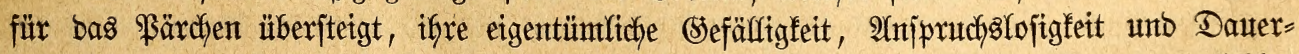

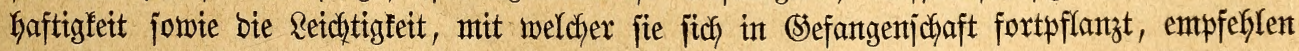

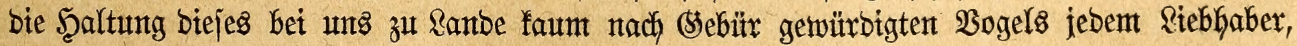

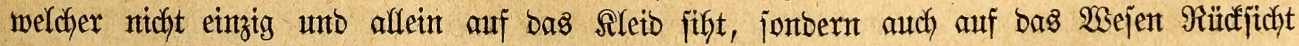
nimmt, in bejonberem srabe. 


\section{Aantafdhwankakandts.}

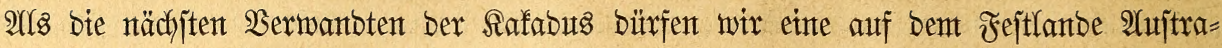

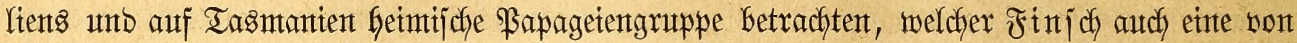

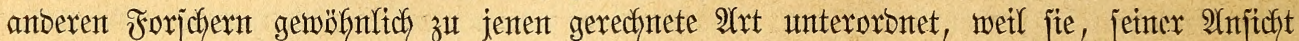

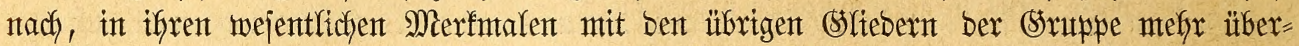
einjtimmt als mit Den bisher aufgezählten Familtentwermantoten.

Die Rantgichwanzfafabus fint fräftig gebaute, ifyres lantgen Schwanzes balber jedoch

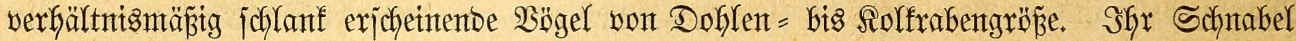
ijt jefr jtarf, böker als lang, int Scalbfretje gebogen, bie furze, wentg vorragende, intuen mit uttbentfichen Feifferben verjebene Spitse nach innen gefrünmt, Dex Sberjanabel

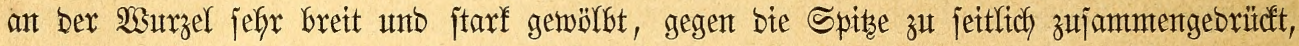

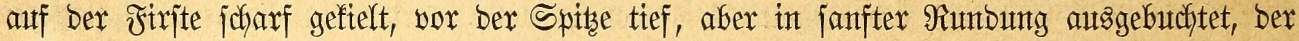
Unterjanabel niebriger als ber obere, jefr, bie Diffentante auffaflento breit unt abgerunbet, bie Diffe tief auggebuthtet, Die Schnteibe gerabe, mit ber Spitze hafig in bie Scöhe gebogen.

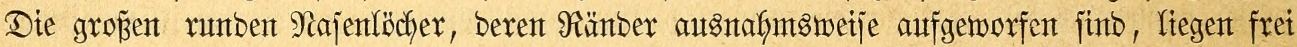
in einer jeberjeits bogig vortretenden, mandymal mit feinen Borjten bejetsten, autinafynts=

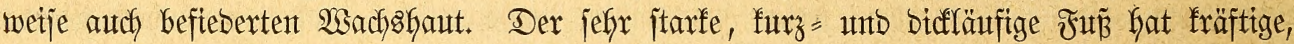
mit langen, itarłen Sichelfrallen bejebte Befen. In Dem langen, ipizen Flügel, welcher, zujammengelegt, zwei Drittel bes Sdymanzes ober nod etwas mefr bebecfit, ragt bie ber Şälfte Des Dberflügels an sänge ungefäfy gletchfonmente Spitze anjefnltch vor; unter ben Sdywingen ijt bie britte ant längiten unb bie zweite bis fünte in ber Enbfälfte ausen, bie exjte bis britte ober fümfte inten jtarf auggejdyntten. Der Sdywanz, Defjen \&änge bie bes Sberflügels erreidft, ift breit unb ftarf abgeruntbet unt wirb aus breiten, am Ento abgerunbeten Febern zujammengejebst. Ebenjo geitaltete Febern bilben bas übrige Sefieber,

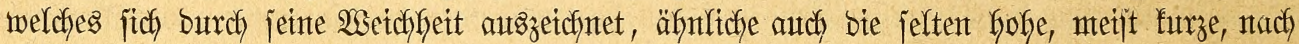

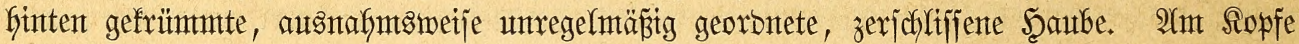

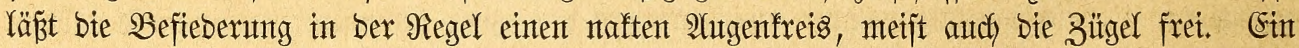
ftaflglänzentes Sibwarz, won weldyem jidh eine breite rote ober gelfe Sdymanzbinbe, ein gelber Shrflecf ober ber rote Sopf Kebfaft abheben, ijt bie vorferjchente Färbuntg Des allters= fleibes, wäfrend bas Sigentofleto geflecft, geweflt und punftirt zu jein pflegt.

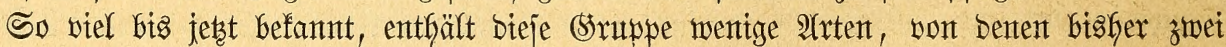
lebento nady Europa gebradyt wurben. Die Unterabteilung ber Schönfopffafabus bilbet:

95. Der 5ermtfafadu, Calyptorrhynchus (Ps., C., Pl., Corydon, Banksianus, Callocephalon, Callicephalus) galeatus, Lath., (fimbriatus, phoenicocephalus, australe). Silein; Dunfeljchieferjobnarz, jebe

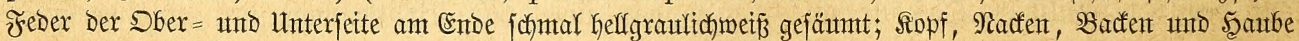

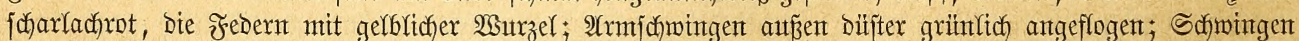

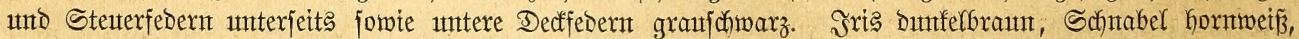

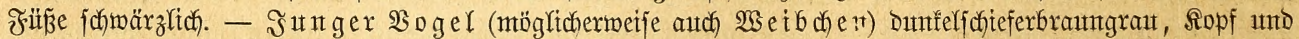

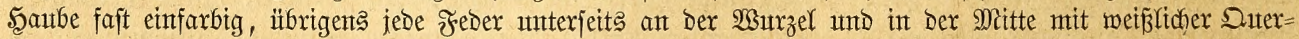

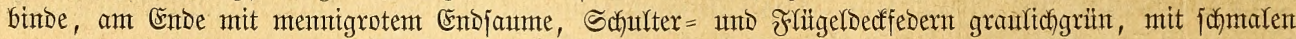

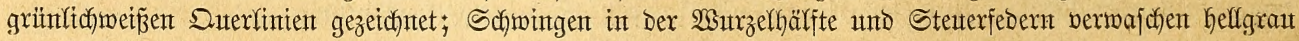
quergebäntort.

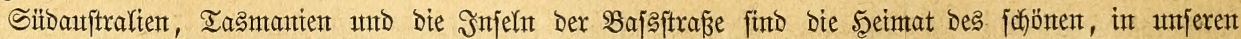
Sammlungen feltenen $\mathfrak{s}$ ogels.

3it ben eigentlitchen Rangichrwantzfafabus gefjört:

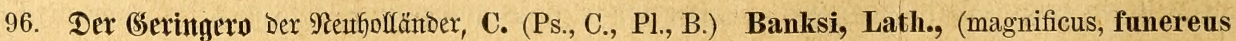
australis, Leachi, Cookii, Temminckii, macrorhynchus). Sefr grof́; tieffichnarz, ftaf)lgriłn glänzento; Stetter= 


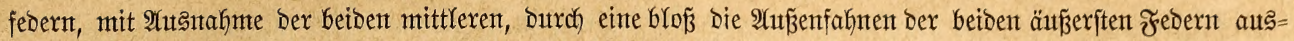

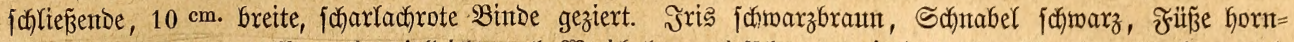

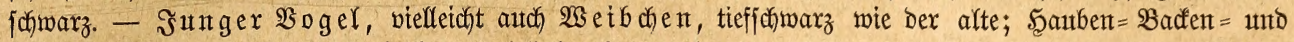

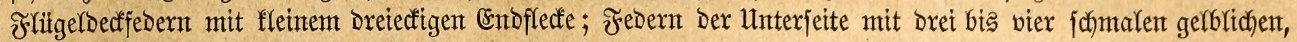
auf Den unteren Sdymanzbefen rötfichen Duteritreifen; Sdynanzbinde gelb ober rot, fámarz marmorirt uno quergeftreift; das jabarze Sdwanzente fdhmal zintoberrot quergeftreift. Sannabel horngelb, ant der Spitze bräunliç).

Dex (Seringero fcheint in ganz Âtiftalien vorzutionmen.

2lle Rangjchmanzfafabus fint echte Baumbögel, weldye jelten zum Soben Kerabfomment.

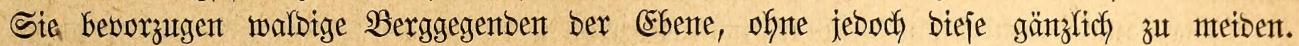
Mant fift jie in ber Regel blop̉ in fletnen Irupps von vier bis adft Stüdfen langjant unto

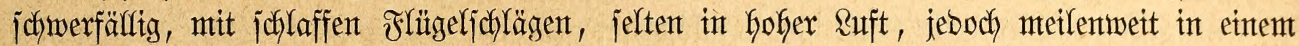
Fluge bafinziefen, ober bemerft fie fletternd in ben Wipfeln ber Gödjitent Bäunte bes Ranbes. Der Scelmtfafabu billoet wie in Siejtalt unt Färbuntg fo autch in jeinem

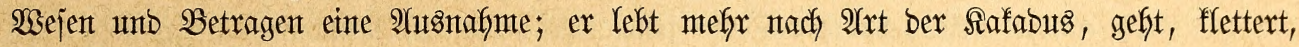
fliegt fajt wie bieje unt jochart fich zu gröperen (sejelljchaftent zujammtent. Die Stinmte bes

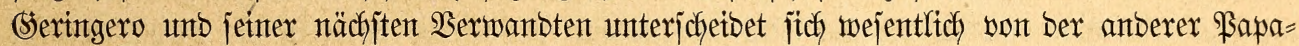
geien; namentlidy gilt bies für bie weinterlidy flitgentben Raute, weldye fie int Fliegen auts=

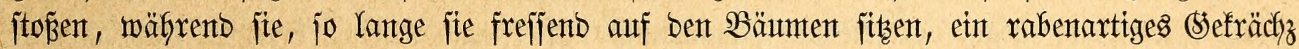

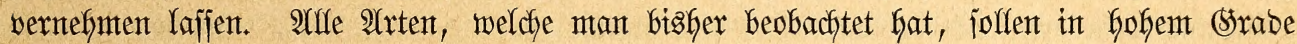

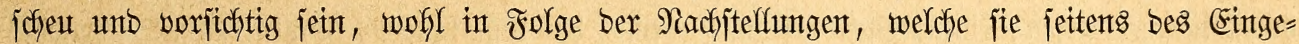
borenen wie bes Weipen zu erletben Gaben. Dody vergefjent jie, währent jie frefjen, zu=

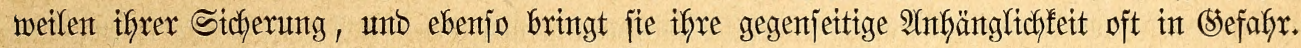

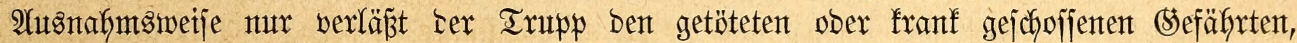

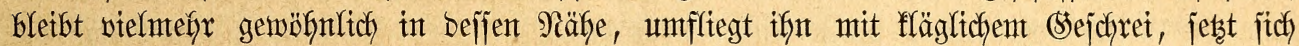

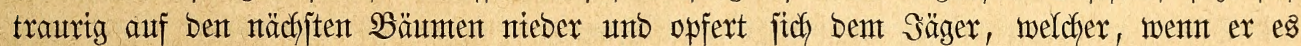
recht anjängt, nach unt nach ben ganzen Flug erlegen fant.

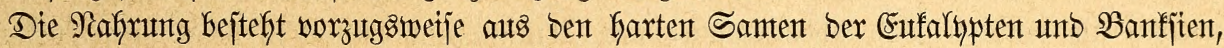
weldye ber getwaltige Sdynabel mit Reidftigfeit zertrümmert. 2(uperbem freffent alle

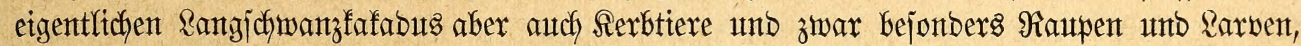
welche in mürbem Scolze ober unter ber SBaumrinbe leben, unt zernagen, um zu ifytt z॥

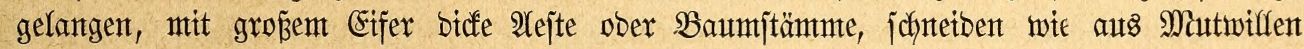

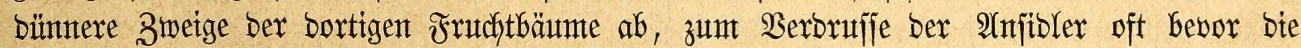
Frïtchte gereift fints.

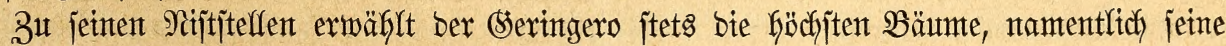
geltebten Eufalyptent. Eine vorgefunbente, nötigenfalfs ermeiterte Ş̈̈hlung in bebeutender

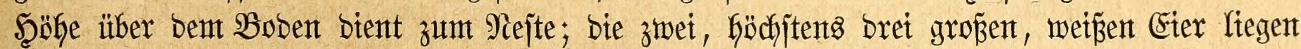

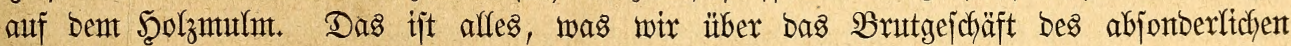

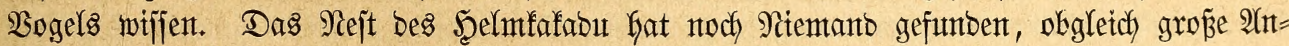
ftrengungen gemadyt worben find, es fennen zu Kernen. Selbjt bie Eingeborenten haben über

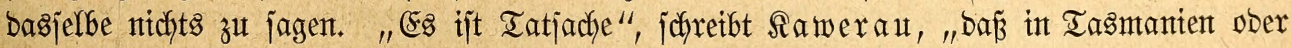
Bantemenzlant zur Zeit, als bortfint nodh Sträflinge gebradyt wurben, benjentigen von biejen, welche gegen "tickets of leave" in ben Sibelungen arbeiteten, bie volfe Freifheit

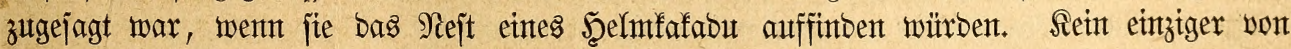
allent hat bieje hohe Belofintng fich werbient."

In unjeren Sammllungen zäflen bie Rangidymanzfafabus zu ben jeltenjtent Exjcheinungen

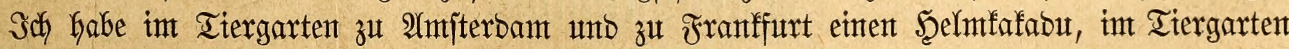

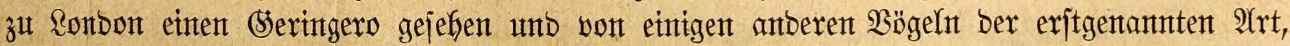
weldhe lebento nach Europa gebracht worben waren, vernommen. Die Schwierigfeit, jie in 


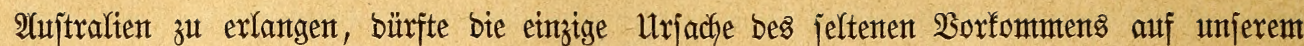
Tiermarfte jein; Denn bie fierbtiernaforung, weldye fie nebenbei gentejent, fann man ifnen

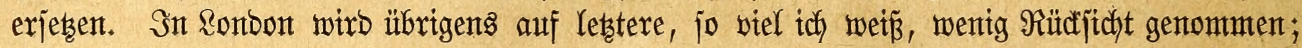
ber bortige Seringero erfält gemöhnliches ßapagetenfutter mit gefochten Sartoffeln unto etwas Weipbrot in Milch). (Sanz ebenjo wirb ein Sefangenter bes Afmiterbamer Tiergartents

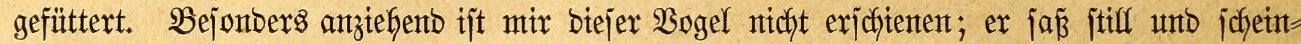
bar verbrofjen in jeinem Räfige, whne nach anberer \$apageien $\mathfrak{A}$ tht fich zu betwegen ober einten Raut vont fich zut gebent.

Der Şelmtfafabu benimmt jich ganz äfnlich wie bie eigentlichen §affabus, wirb jelten orbent= lid) zafm, lernt aber, wie ber Sefangene in Tiergarten zu 2 (m) einzelnte Worte nachjpredjen. Mein Berufggenoffe Sdymibt hat mix über ben von ifm

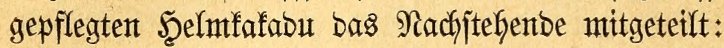

"Schon länger als acht Sabre bejiżt Der Giejige (Jranffurter) zoologijche Sarten einten

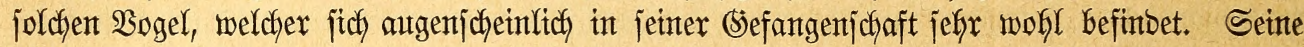
Nahrung bejteft vorzuggmetje aus Sanarienjamen, mit geringent నujake von Scanf unt ge=

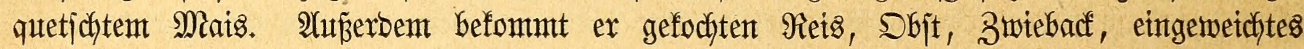

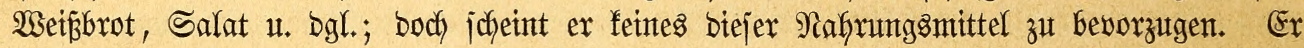

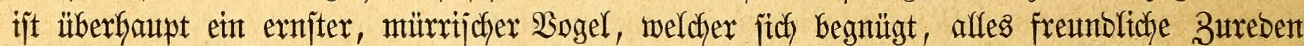
unb Darbieten bon Redferbiffen mit einem furzen finarrenten Tone zu beantworten, unto föbjitens gegen ben vorgebaltenen Finger einige wudftige Sdynabelfiebe füfrt, von benten

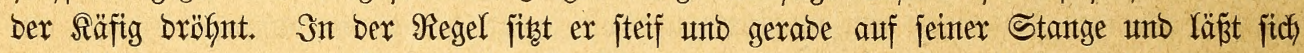

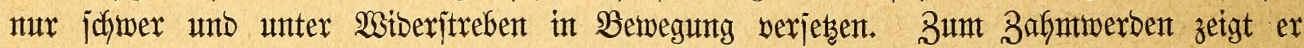

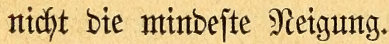

Mittels jeines furzen, jteilgemölbten Schnabels pflegt er, wenn ex fid unbeobachtet wäfnt, bie in jeinem Säftge angebrachten Sikjitangen in Splitter zu beiß̈en. A(nfänglich glaubte ich biejem Hebelítante am mirfiamjten baburch abzufelfen, baj ich bie Stangen

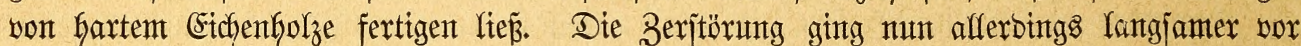
jidy, aber jie war bem Sogel aud zu mühjam. Ex jaf jidf aljo nach einem wetcheren Stoffe um und hatte biejen alsbald in jeinem stefieder gefunden. Eines Tages biźs er fich

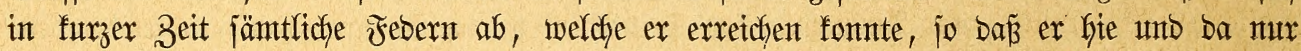
nodh mit graulidjem Flaume bebecft war; an mandben Steflen hatte ex audh biejen nidgt ge= jdyont. Sofort wurben mun bie harten Stangen wieber entfernt unb burdh joldye aus weichem Iannenfolze exjezt, über welche er mit wahrem Eifer herfiel. Sebesmal im Berlaufe von vienunbzanzig Stumben wurbe eine Stange von $1 \mathrm{~m}$. Ränge unt $4 \mathrm{~cm}$. Didfe in fletne

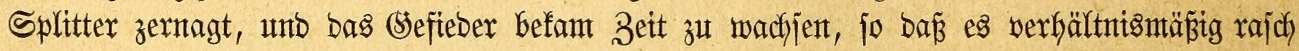
wieber jeine früffere $\mathfrak{B}$ olf ftänbigfeit erreidyt hatte. Seitbent wirb bafür Sorge getragen,

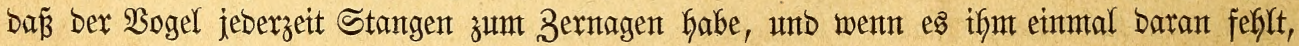
rädjt er bies jofort burch Zerjtönung feines Sefteders. Merfwürotger Weije hat ex nie bie

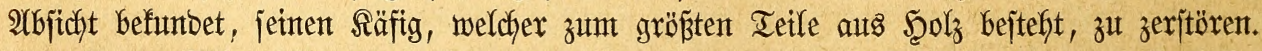

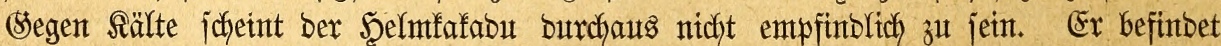
fich) bei uns in einem Şauje, weldyes wentg geheizt wirb unb beffen Türen fajt ben ganzen

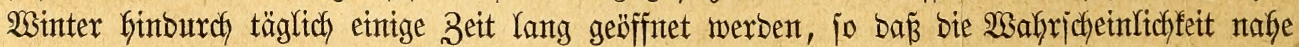
liegt, ex fönne ofne Befahr im Jreien überwintert merben."

\section{Ararakakadus.}

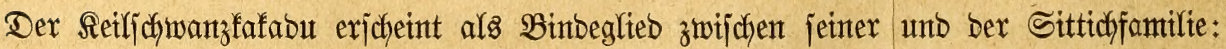

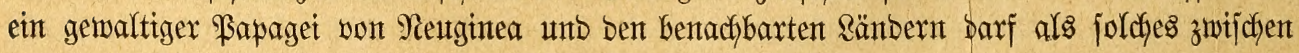




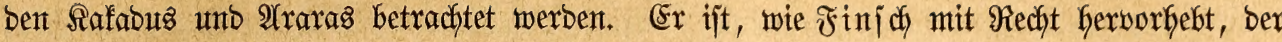

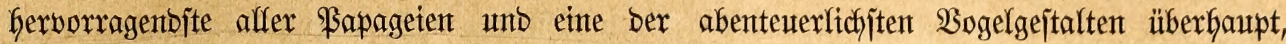

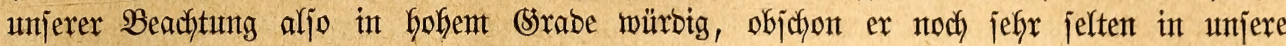
Räfige gelangt.

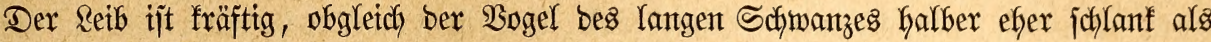
gebrungen gebaut zu fein fajeint, Der Sopf groß̧, Der Schntabel riefïg, Yänger alz ber Sopf

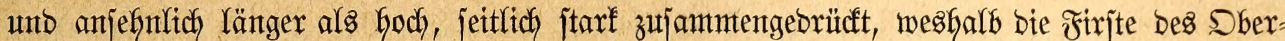

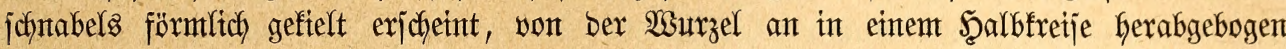
unt mit ber verbünnten, weit vorragentoen Spiłze, vor melcher fidy inten tiefe Feifferben

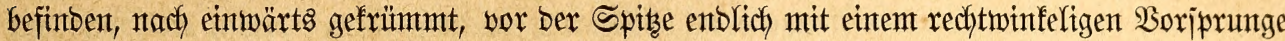

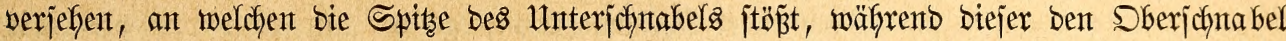
jomít niddt berüfrt; ber Unteridynabel ijt niebriger als ber obere, aber wiel breiter, bie

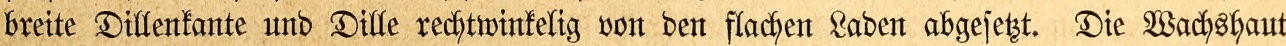
wirb von furzen jammetartigen Feberchen beffetbet, jo baj jie faum unterjafieben merben

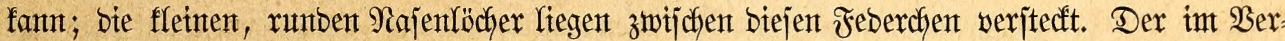

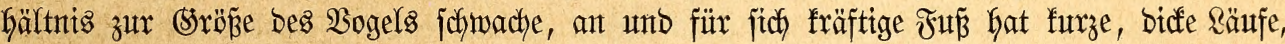

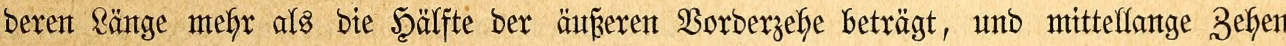

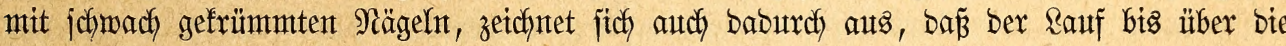

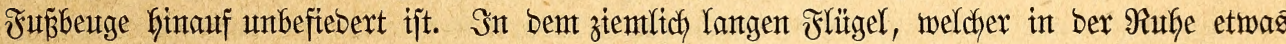

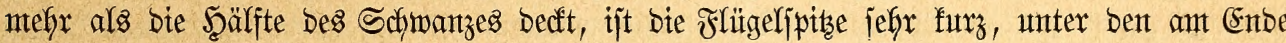

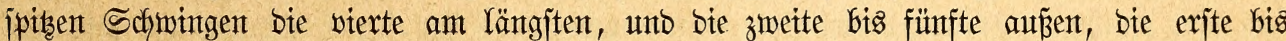
fünfte inten aubgejdynitten, Der lange, bent Dberflügel Gierin jeboch nicfft gleidffonmtente,

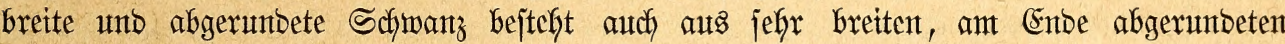

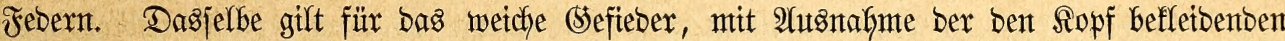

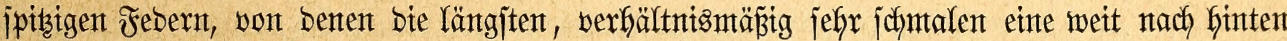
Gerabfängentbe Şaube bitbent. Die $\mathfrak{B a n g e n t}$ finto naft.

Bejonbere Errwäfhnung verbient bie Bunge, weil fie von ber afler übrigen Papageient

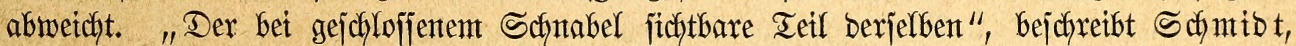

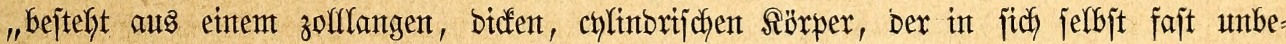

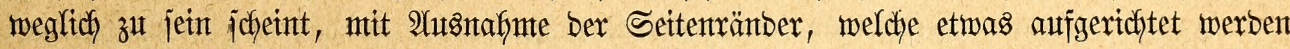

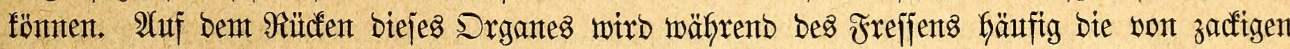
Ränbern begrenzte Stinmmrize fichtbar. Seberjeitz ijt biejer Teil ber Zuntge mittelz einez

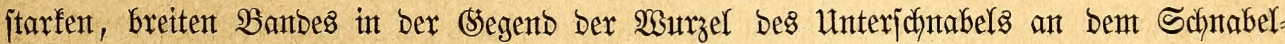

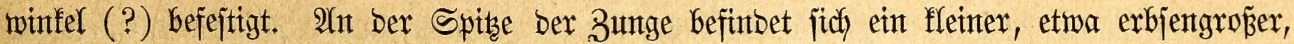

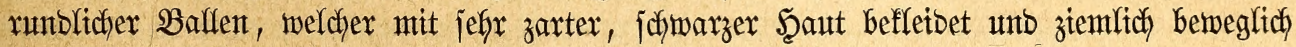
ijt. Diejer Teil ijt als bie eigentlidhe Bunge zu betrachtent."

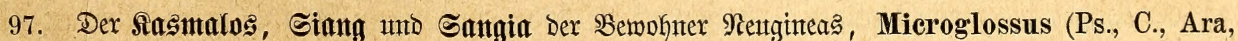
Solenoglossus, Macroglossus,) aterrimus, Gml., (ceylanicus, alecto, intermedia, Goliath, griseus,

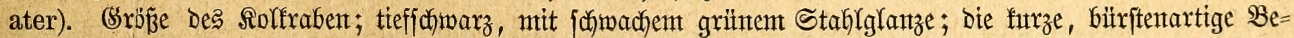

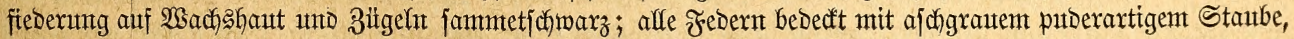
weldher nach bem Iode abfällt; bie naften $\mathfrak{W a n g e n t}$ blutrot, mit hellerem, fleifoffarbenem Beäber. Sris tief=

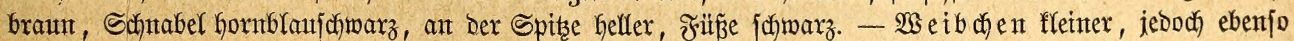

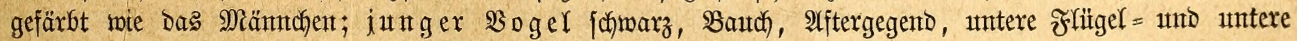

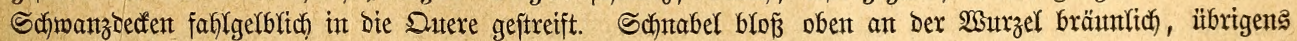
horngelblicy)eiñ.

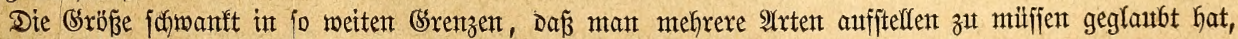

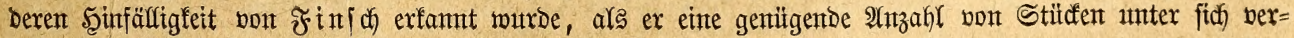
greidfent tonnte.

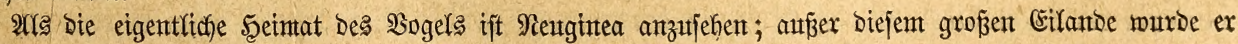

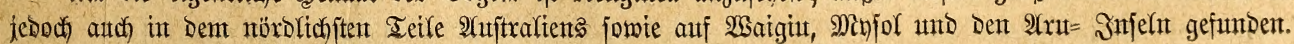


Heber bes Freileben bes Saṡmalos haben mix erjt in ber neuteften Beit burch Mac (Sirlioray, Rojenberg und Baflace Bericht erfalten. Ex bemofnt einzeln ober par= weije bie hödhiten Eufalypten mie bie niebrigen Steflen bes $23 a l b e s$, ijt munter unto be=

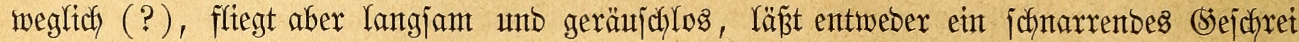

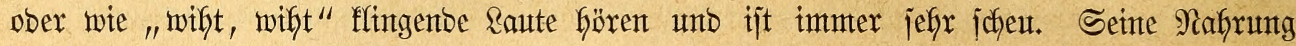

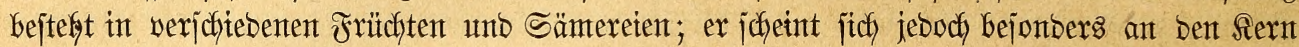

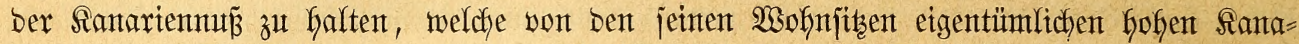

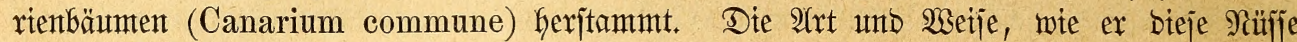

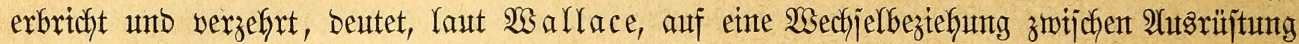
unto Semofntheiten, weldye bie Ranarien als jeine eigentliche Nafrung exjcheinen läpt. So

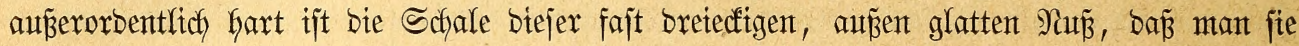

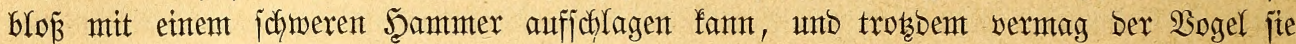
zu öffnen, wenn audb auf jeltjame Weije. Er nimmt ein Ende in jeinent Schnaber, hält es Durch einen Drudf jeiner 3unge fejt und johneibet jobann mittels jeitlicher, jägenter

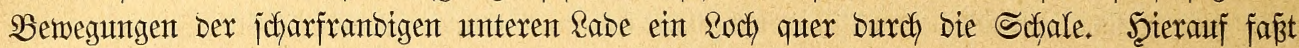

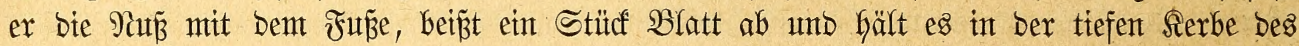
Sberfiefers fejt, ergreift jobant bie $\Re$ in

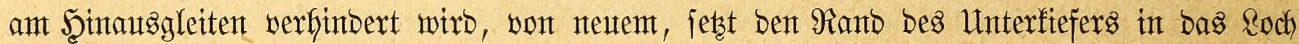

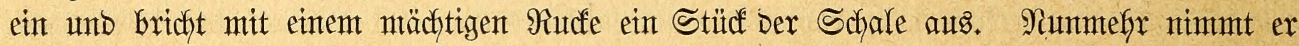

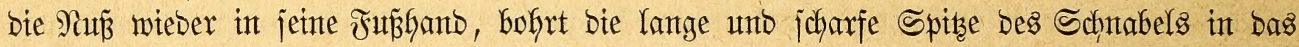

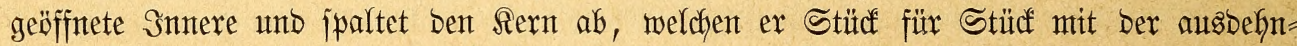
baren Zunge Gerausholt unt veripeift. So joheint jebe Einzelfeit ber Form und bes Baues

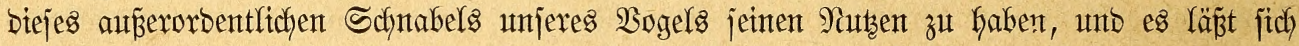

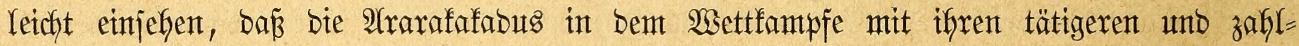

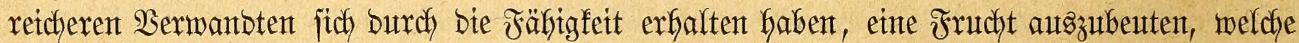

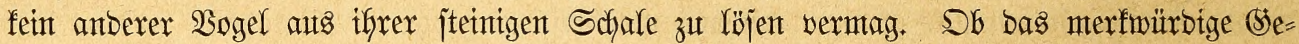
jchöpf neben pflanzlichen Stoffen Serbtiere zu jich nimmt, ijt zux Zett noch nicht fejtgejtelft;

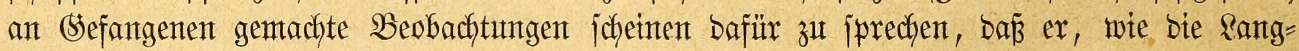
jumanzfafabus, Sierfe nidjt verjdymäht.

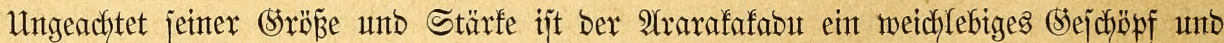
fant burch eine verfältnismäp̈ig lecthte 2 mumbe getötet merben. Die Eingeborenten jtelfen ifm eifrig nach, ganz bejonbers aber jeinen Sungen, welche jie aus Dem Nejte Geben, um fie aufzuziefen und fpäter für bie geringe Summe von 20 bis 25 (sulben zu verfaufen.

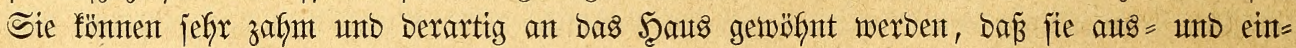
fliegen. Rojenberg lernte zu 21mboint einen biejer Safabus fennen, welcher Den Iag über

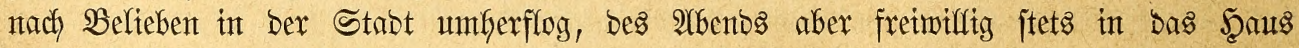
jeines Ssebieters zunücffebrte.

Die mentgen Sasmalos, welche lebento nach Europa gebracht unt zu hohen fretien $(200$ - 250 Ialer für Das Stüdf $)$ erworben murben, mïffen in ber Regel exjt mit ber

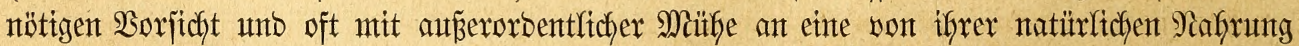

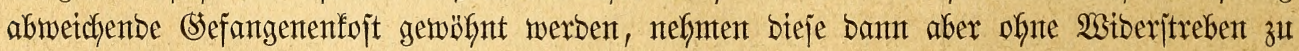
fich und befinden fich wohl babei. Sie freffen bejonbers gern Şanf, genieken aber aud memichliche Siojt in weitem Umfange. Ein (Sefangenter, welcher jeit vierzebn Safyren im

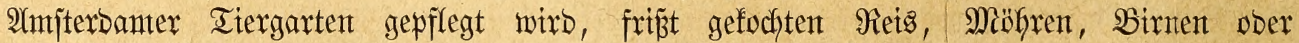
2lepfel unb jeben Iag etwas von bem, was bie Rïche auf ben Itid bringt. "Drei Gahre",

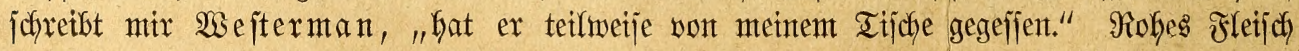

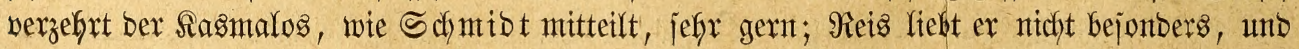
von Dem Mais nimmt er nur ben interften, zarten und mefligen fiern Geraus. Brot, 


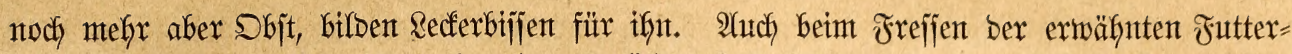
ftoffe finbet, laut Sdymibt, ein eigentüntliches 3ujanmentmirfen bes Sdynabels mit ber 3unge jtatt. Die Nafrung, ein Şanfforn $3 . \mathfrak{B}$., wiro unter ftetem Betajten mit ber 3unge

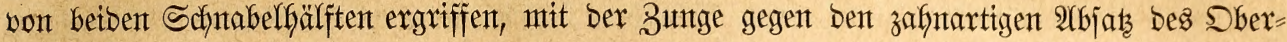
jcynabels gejtemmt unt burch bie untere Rabe aufgefinacft. Nam faffen Unterjcynabel unt

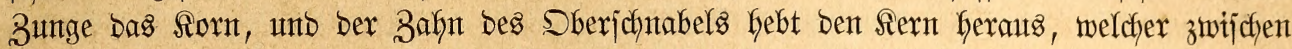
beiben Schnabelfälften unter ftäter Mitminfung ber 3uttge vorfichtig zerorücft und zerrieben

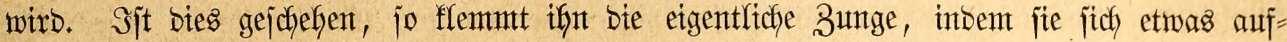
richtet, zmijchen fich und ben Bungenbeinapparat in bie bort befindliche Duerfurche. Nun mirb rajh bie 3unge zurüdfgezogen, Der Bifijen gegen ben (saumten geführt und, inbem bie 3unge wieber vorjdynellt, an ber vorberiten Suerwuljt bes (saumens abgeitreift, wobei ex über bie Stimmrize finweg in ben Bereich Der Schlunbfopfmusfeln gelangt. Wä̈hrend des

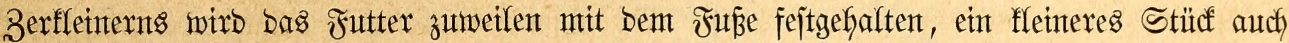

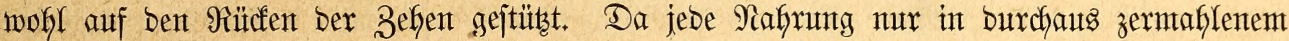

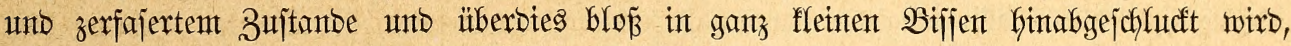
bauert bas Frefjen jebesmal jefr lange. Beim Irinfen jtecft ber Sogel ben vorberen Ieil bes. Unterjanabels in bas Wajfer, Gebt Giterauf ben Sopf rajch jchief vormärts nach oben und jubëpft jich jo förmlich jeinen Trunf.

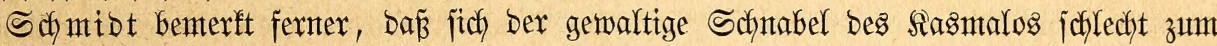
Slettern eigntet, weil jeinte Seitenränber fierz̆ jo gut als nicht bentzht werben fönnen, und

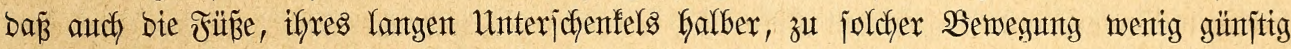
gebaut exjcheinten. Die Stimme bes $\mathfrak{B}$ ogels eximtert nach ifm an bas finarren einer Türe unt läßst fid antäfrend burch bie Raute $\mathfrak{S}=\mathfrak{r a}=\mathfrak{a}$ miebergeben. Wenn ber Ion leije

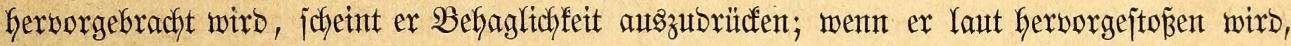

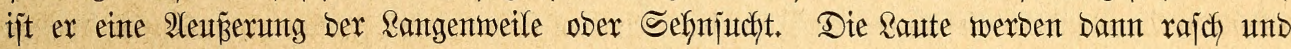
wieberholt ausgejtopent unt exintern an bas Bsejchret ber gemeinen Mafafent.

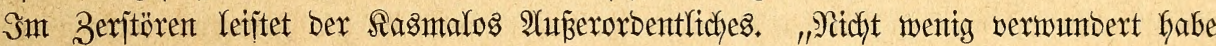

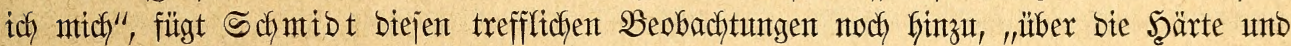

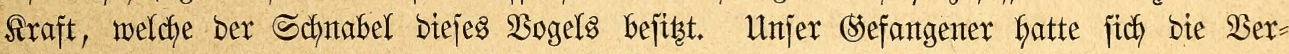
nichtung jeiner Futtergejchirre zux Rieblinganfigabe erforen unb leijtete Darin fajt unglaub=

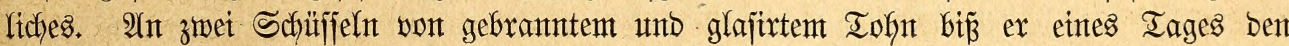

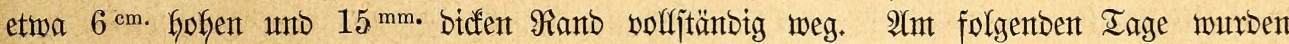

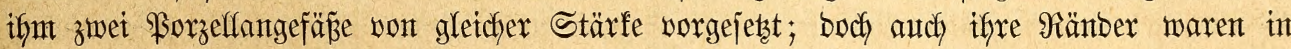

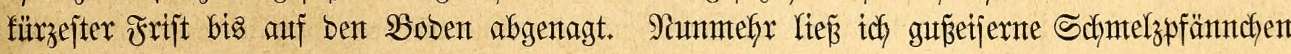

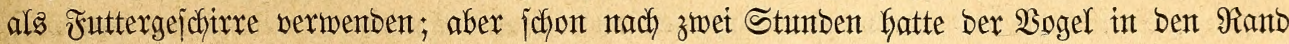

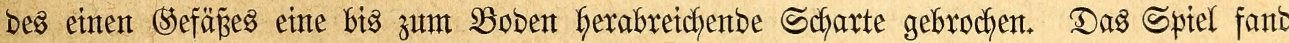

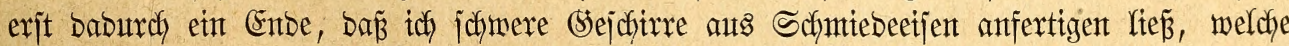

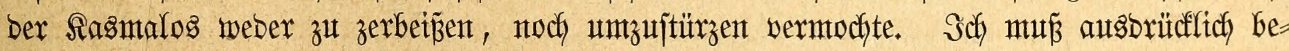

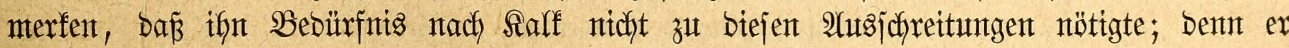

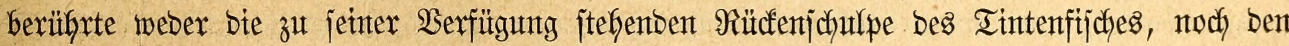
jeinemt Schnabel erretchbarent falfanturir ber Want.

Retber ging bas merfmürbige Iter, nachoem es mur brei Safre bei uns gelebt hatte, an 2 (Fzebruth ein."

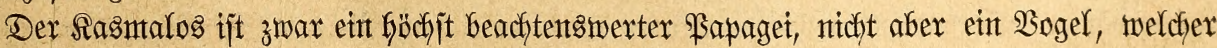

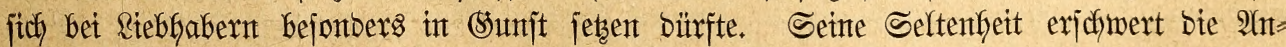
jchaffung und jein hoher \$reis entjpridyt eben mux jenter, nidft aber herworragenten Eigent= jofaften bes abjonberlichen (sejchöpfes. Sb ex iprechen lernt, ijt fraglich; Der Bau jeines

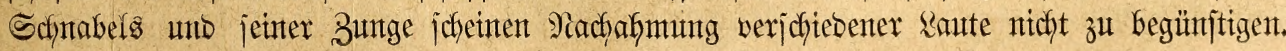




\section{(Enlenpapaneten.}

Das an auffallenten $\mathfrak{B o ̈ g e l n t ~ r e i c h e ~ M e n j e e l a n b ~ b e h e r b e r g t ~ z w e i ~ \Re a p a g e i e n , ~ w e l c h e ~ v o n ~}$

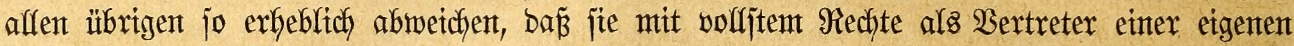

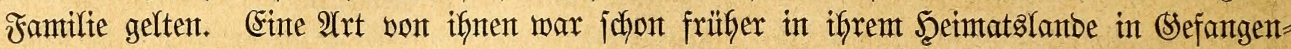
jafaft gehalten worben und ijt mun endlich lebend nach Europa gelangt; eine zmeite 2rat jofeint bereits von iffrem enblichen Schicfjale erreidst worben und ausgejtorben zu

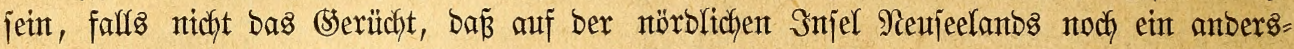
artiger Eutenpapaget lebe, fich gerabe auf fie beziegt. Went mut aud faum zu hoffen

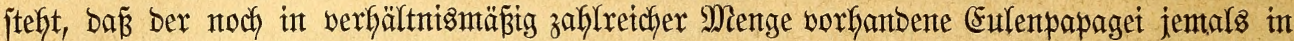

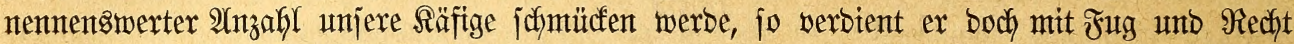

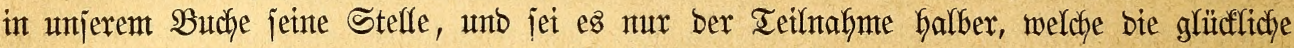

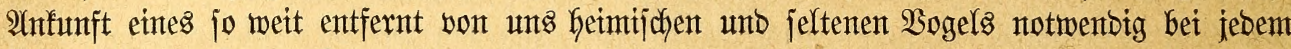
Riebraber erwecten mur.

Die Eulenpapageient fint gebrungen gebautete, grop̈f̈̈pfige Bögel, welche, Danf ifrer Feberfüfle, unjerem Rolfraben an Srö̈ß̈e mindejtens jcheinbar gleichfommten. Der Schnabel ijt bict und fräftig, häher als lang, jein oberex Ieil an ber Wurzel ebenjo hoch als breit, bie Sixjte abgerunbet, bie Spibe furz unb jtumpf, inten mit beutlictjen Feilferben verjeben,

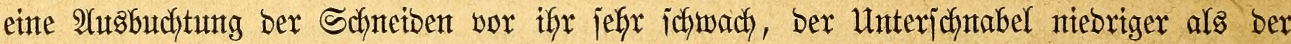
obere, mit abgeflactiten, ntdyt auggebudfteten Rabenjchneiben unb breiter, im Bogen auF= jteigenter Dillenfante, auf weldfer vier tiefe Ränggifurctjen berfaufen. Eine eigentliche

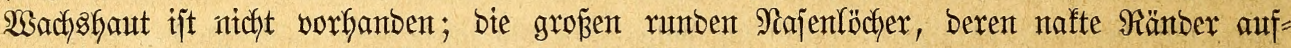

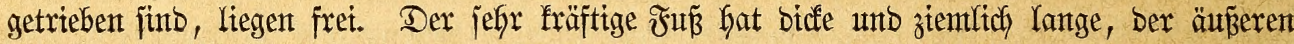

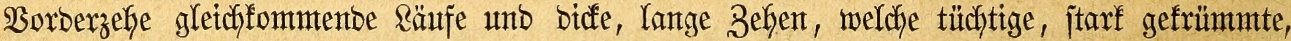

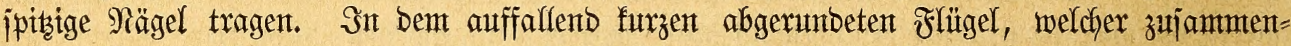
gelegt bis zux Schwanzmurzel retdyt, ijt bie fünfte Schwinge bie längjte ber neum \$ุant = jefiningen, welche nirgentos verengt, breit unb ant Ento abgerunbet fint. Der lange, bem Dberflügel etwa an Ränge gleidjfommende, abgerunbete Schwanz bejtefht aus breiten, am Enbe etwas verjchmälerten, iptis zulaufenben, bas harte Sefteder auts weitjtraltigen, breiten, am Enbe abgerunbeten Febern; bieje gehen jeboch auf ber Stimn unb ben $\mathfrak{B a c f e n}$ in jolche mit verfängerten, baräbnlichen Schäften, ichntalen, fajt zerjchlifjenten Fafhnen über, umgeben ftralig bie Sdynabelwurzel und ftelfen einen unvolffommenten Schleier her. Die grüne (Srunbfärbung ber Febern wirb burch bunfle Bänber und Miarmelflecfe gezeichnet.

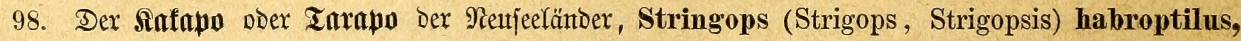

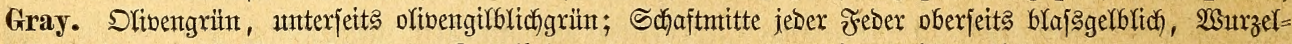

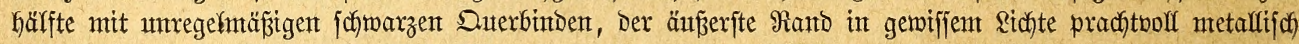

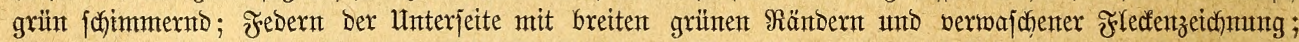

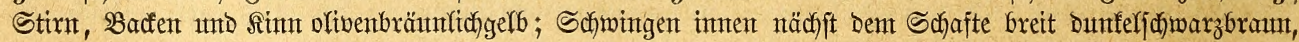

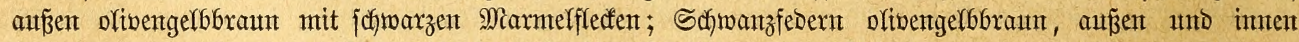

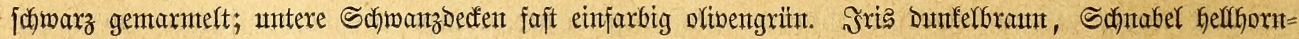

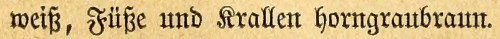

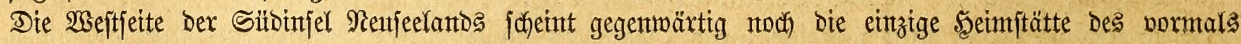

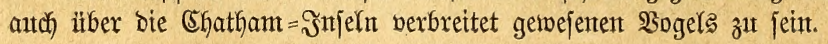

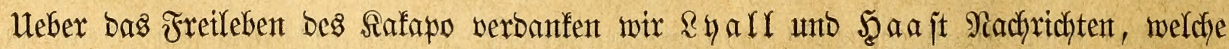
faumt etwas zu wünjchen übrig lajfen. Irodtente Şügelabbänge, ober flache Stelfen an Fluß $\tilde{z}=$ ufern, welche mit Şodjwald bejtanton unt einigermaf̧en frei von Unterfolz und Farnfraut, aber mit Mios betwachjen jimb, vom Seejtrande an bis zu $1300 \mathrm{~m}$. ü. Mi. Gilden bebor:

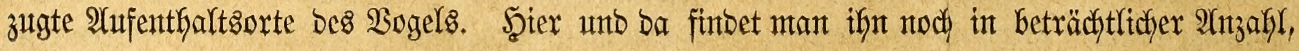


nteift zwar nut einzeln, zumeilen jebodh aud in fleinen (Sejelljdaften. Tief in bas Mios

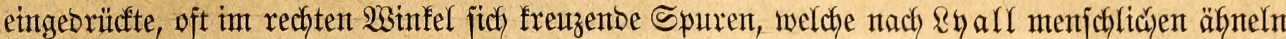

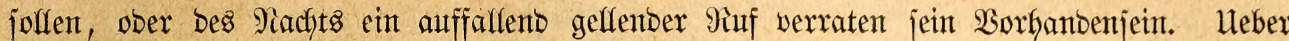

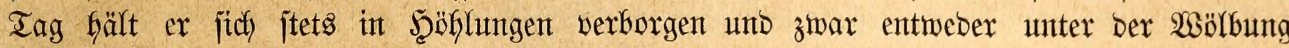
überfyängenter Feljen ober unb lieker in joldfen unter bem Benurzel ber Bäume, wie fie

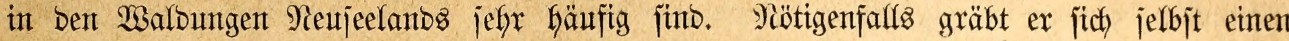
Bau. Stusnafmmstweije fltmmt ex wohl auch im Interen eines hohlen Baumes empor ober

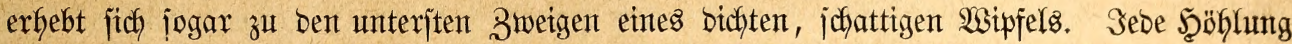
wiro bloß̧ von einem Stücfe bemohnt; bie Pärchen leben jedoch nah bei einander und ver= einigen jich bes Siachts, um gemeinjedaftlich umberzujtreifen.

Wie afle Nachtwögel erjcheint ber Safapo zuweilen jofon vor Somenuntergang vor jeiner

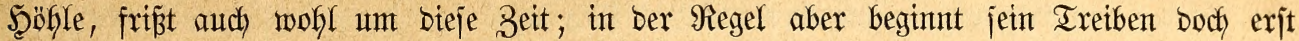
etma eine Stumbe nach (Einbruch Der Nacht. Dann vernimmt man zuerjt jeinen Sijurei, ein heijeres frächzen, welches bei Erregung in mistöntges fireijchen übergeft und, wenn eg von vielen zugleich auggeítoßßen wirb, betäubend wirfen fann. Er ijt ein ecfter (Erobogel, welcher nur im äukeriten Potfalle von jeinen Flügeln einigen (Sebrauds madht, öfter viel= leidfyt jie benubst, um fidh bei jdynelfem saufen im (B)leidgemidyte zu Galten. syarl hat ifgn aber boch fliegen jeben, objobon mux bann, ment ex, berfolgt, im Intern eines

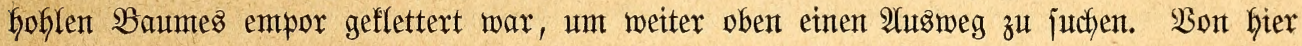
aus jtrich or unter unbebeutenden, ja faum wafhnebmbaren Flügelbemegungen nach tiefer

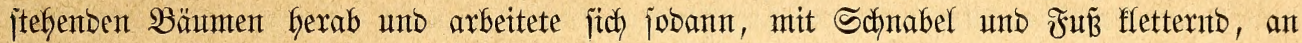

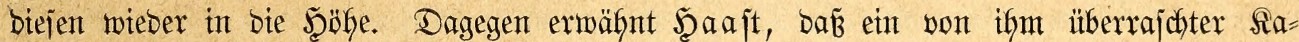

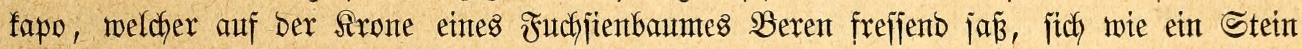
bon oben herabfallen lies, ofne jidh jeiner Schwingen zu bebienen. Ein Flieger ijt ex aljo

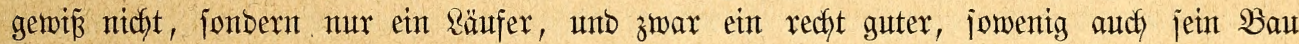

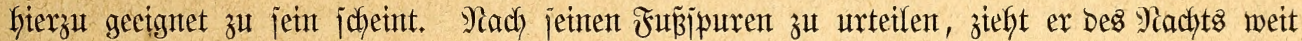
im Warbe umber. Heber bie geiftigen (Eigenjchaften bes abjonberlicjen Bogels verfautet nur (Sutes. Er ijt wachjam unt vorjidytig, gejelfig, friebfertig, 2(ngreifern gegenüber mutig, gemöhnt jich auth leidft an ben Mienjechen und wirb biejem bald in hohem Srabe zugetan, furz betweift viel und einen jebr bilbjamen Serjtant.

Die Nabrung bejteft vorzugsmeife aus Mlos, won melchem ber Siafapo, um fich zu

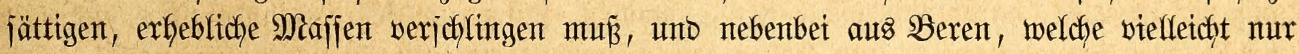

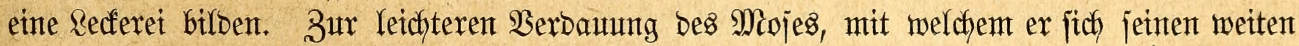
Sropf wollzuftopfen pflegt, bebarf ex eines reidylichen Inunfes; Dafer wohl jeine Borliebe

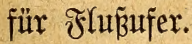

Die $\mathfrak{B r u t z e i t}$ fällt in bie lebzten und exiten Mionate Des Gahres. Ende Februars und

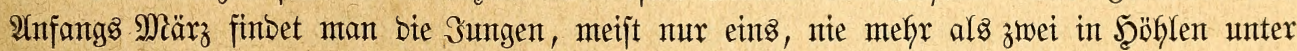

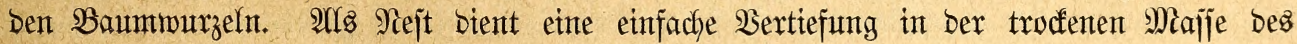
vermoderten 5̧olzes. Die Eiter gleicten Denen Dex Şaustaube.

Seitbem auf গeujeeland Şunbe eingefüfyrt worben find, geht ber Rafapo wentgitens

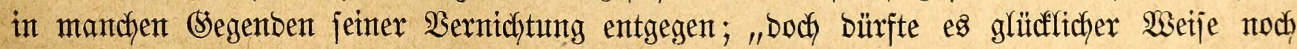
lange währen, bevor jeine leţte Stunbe gejalagen haben wirb, Da nodh Taujenbe von (Seviert=

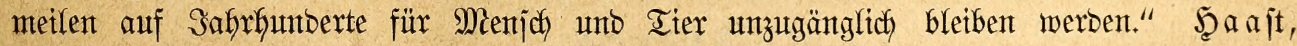
welcher vorjtehende Bemerfung in einem an Finjch geridfteten Briefe madyt, fährt jobann

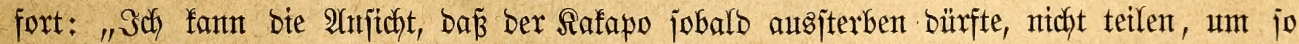
mefr, alz ex von bem Mieresufer an bis zน einter Şähe von $1100^{\mathrm{m}}$. vorfommt. Solfte er jelbjit in bem tiefer liegenben Sürtel augigerottet werben, jo bleiben bie oft nur mit ben

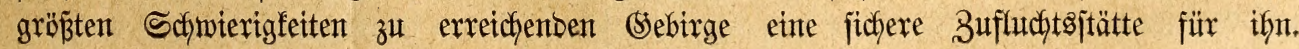




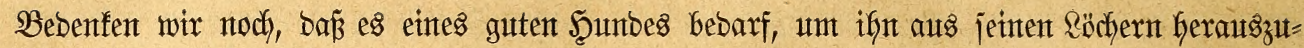

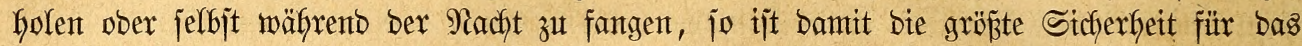
Fortbejtehen ber 9 Art vorhanben." Won ben Eingeborenen wurbe er vormals hart verfolgt:

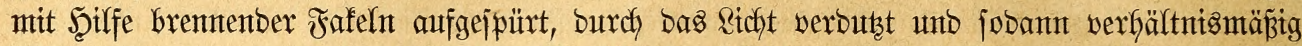
leidbt gefangen, ober aber in Geffen Montojcheinnächten zur Beit ber Beremeife bes Tutu=

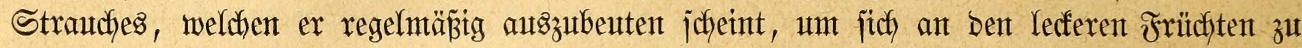

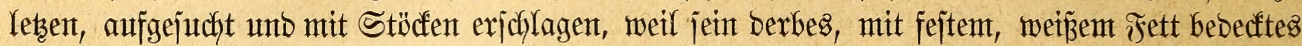

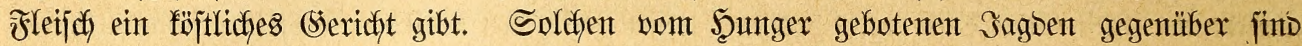
biejentigen, welche bie wenigen 2 (njtbler unternefgmen, faum von Belang, und bürfen wir

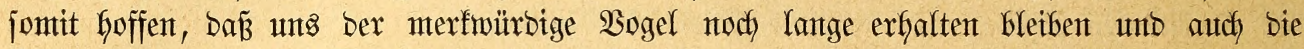
Säfige Kervorragender Itergärten zieren wirb.

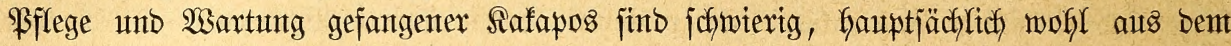

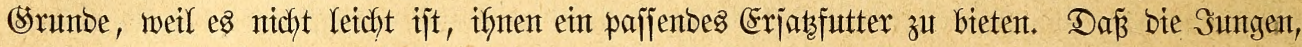
meldye syarl mit eingeweichtem Brote und gefochten Siartoffeln fütterte, nicht lange am Seben bleiben fonnten, wirb Niemtanb Wunber nefymen; aber biejentgen Stüdfe, welche man

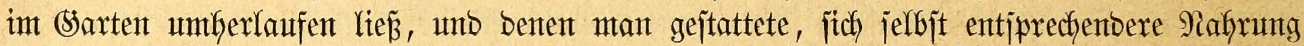

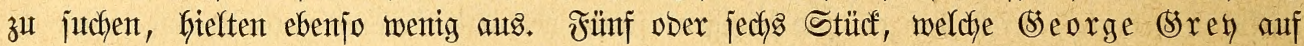

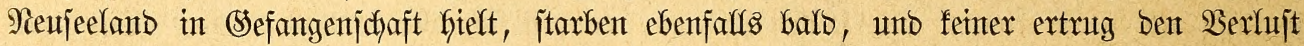

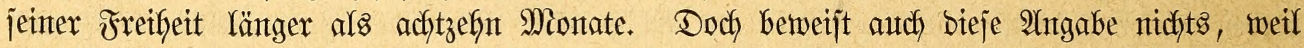
auş ifyr nicht hervorgeft, ob ben (Sefangenten bas rechte Futter gereidft tourbe. Ein Safapo, weldyer ber englijchen Siüjte biz auf jechghunbert Seemeilen nahe gebradjt murbe und burch

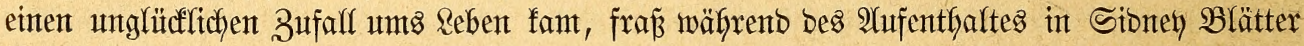
ber Banffien und Eufalypten, Siüjje und Manbeln und lebte wäfrent ber lebsten Zeit fajt

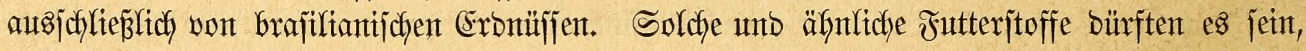
meldye gefangenen (sulenpapageien gereicht werben müjjen, um ifnen Exjaz für ifgre natürfiche গabruntg zu bieten.

Bon jeinen gefangenen Rafapos jpridyt (5) rey mit Wärme. Er jofjilbert fie als jefrx

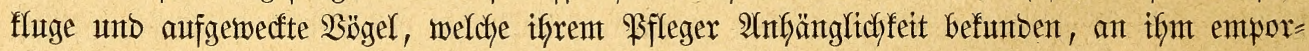
flettern, jich an ifn anjchmiegen, befjen (Sejelfichaft juchen und zum Spielen aurgelegt jumb.

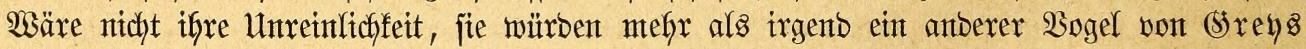

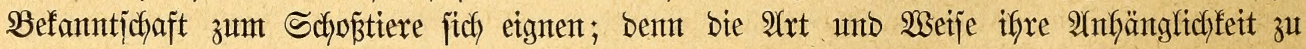

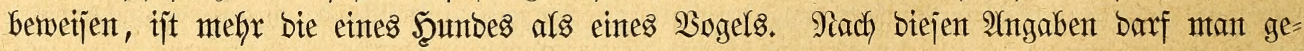
ipannt jein, Eingehenderes über ben Befangenten zu vernehmen, welcher int saufe diejes Sommters nach England gelangte. Für ben zoologifichen Sarten in Regentparf murbe ex leiber nidft erworben. "Wir fonnten", jdyreibt mir Sclater, "Den Eulenpapagei nidft faufen, meil ber (Eigentümter 100 \&. für ifgn berlangte unb wir ber 2 Anjicht maren, baß̃ bies zu biel jei." Sich bermag nidht, bieje IInjicht zu teilen; benn jenter (Sarten ijt reids unt hat meines Eradjtens bie Berpflidytung, ein jo merfwürbiges (sejdyöpf zu erwerben, jei es auch nux, umt eingehenbe SBeobachtungen über basjelbe anzujtelfen.

\section{Arotas.}

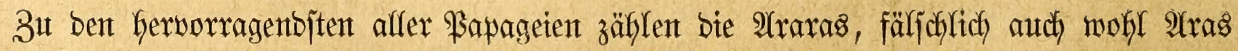

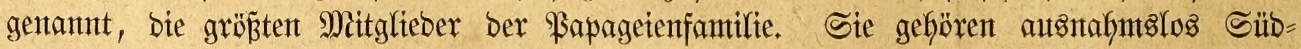
und Mittelamerifa an und werben von bort aus johon jeit ber Entbectung bes Ranbes regel= 


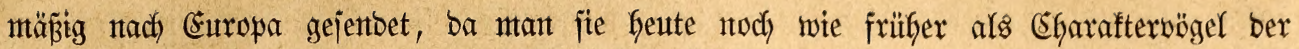

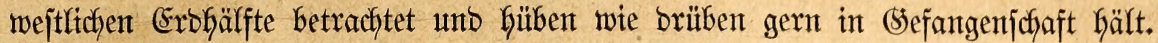

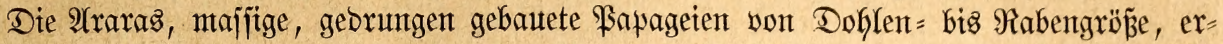

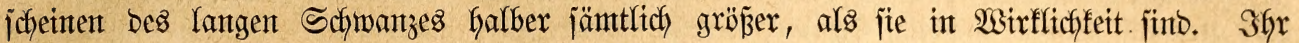

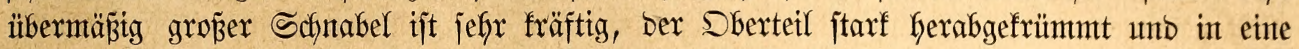

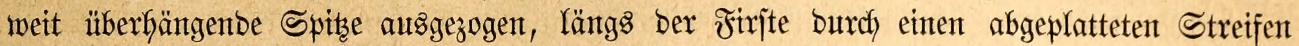

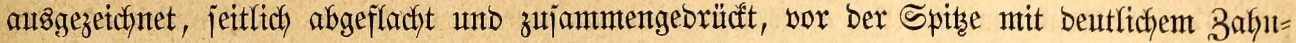

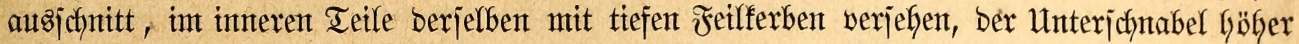

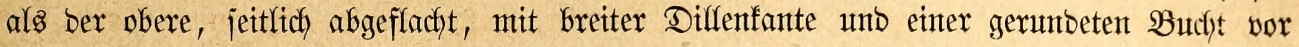

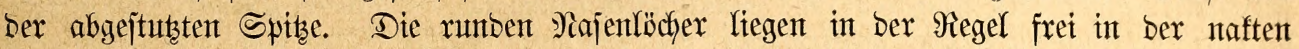

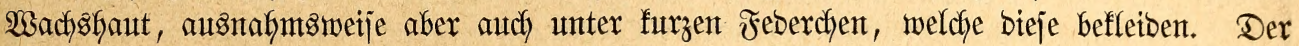

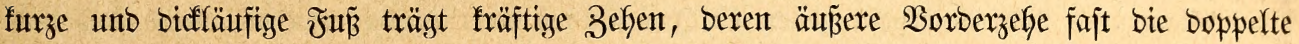
Rauffänge hat, und jtarfe Siraffen. Sn bemt langen unt jpitzent Flügel, weldher jelten bem

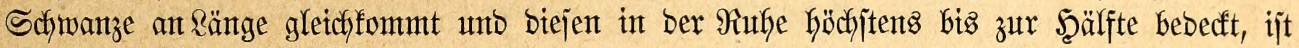

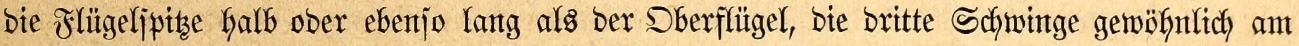

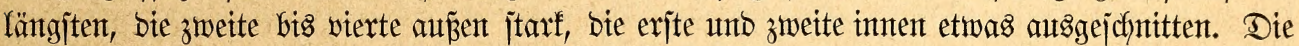

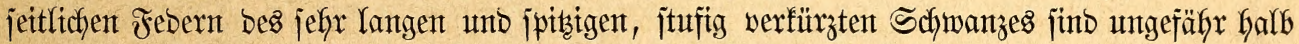
jo lang als bie mittleren; afle laufent jpitz zu, rumben fich aber amt Entoe ab. Das aus

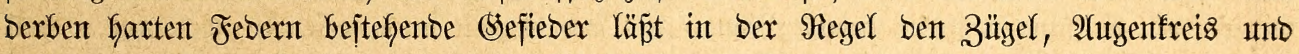
vorberen Teil ber Bacfent naft ober bejeķt bieje mit furzzen, in Reigen georbneten Febern

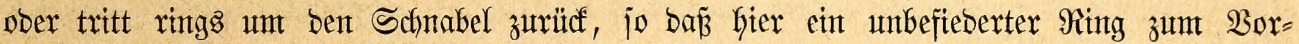

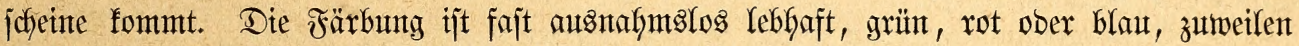
einförmig, in ber Regel aber butt.

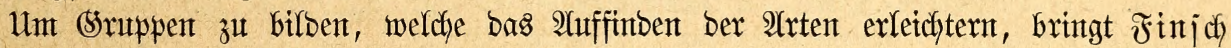
audh bieje Sippe in Unterabteilungen, welche teilmeife von anberen Forjdhern ebenfallz an= genommen, meijt jebody als bejonbere Sippen angejefen morben finto. Eine joldse Unter= abteilung bifsen bie Riejenararas, Anadorhynchus ober Cyanopsitta früherer Boget=

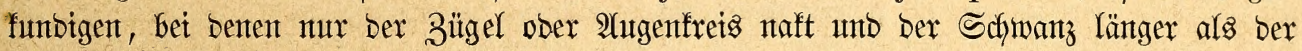

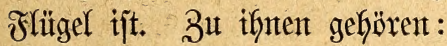

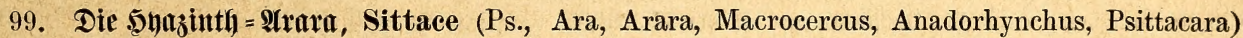

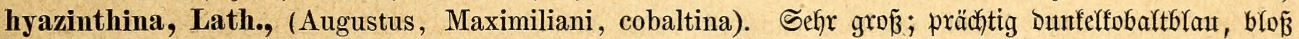

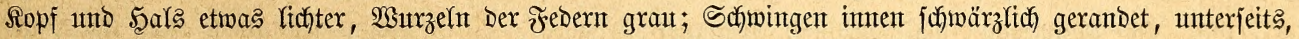

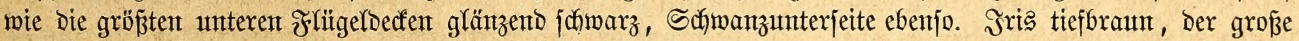

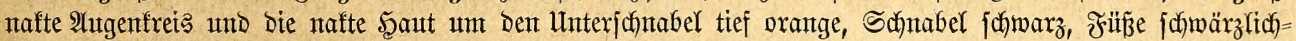
brautt.

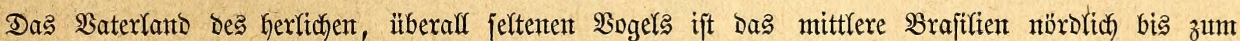
शmazonenitrome.

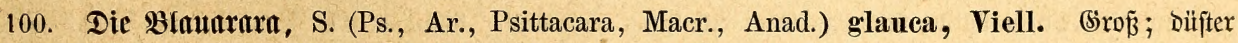

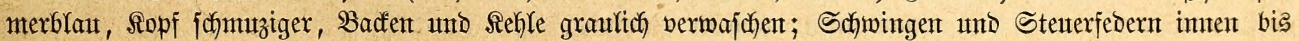

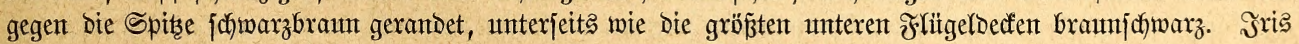
braun, Schnabel und Jünje hornjoftwarz.

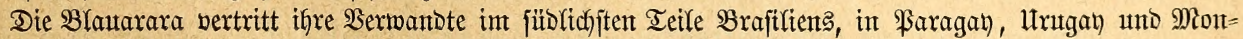
tebibeo.

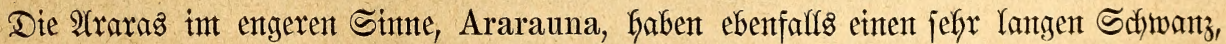
aber unbefieberte Bügel uno nafte $23 a n g e n t$ mit idjmałen Feberreifgen. Die Unterabteilung wirb von ben in unjeren Sammlungen häufigiten 2 rtten gebilbet.

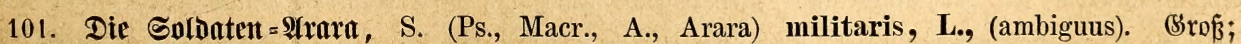

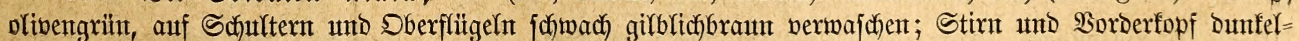

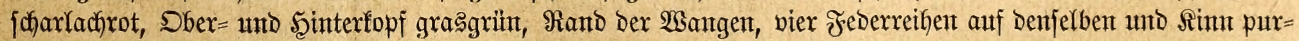

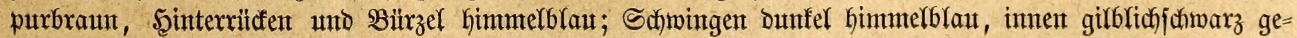




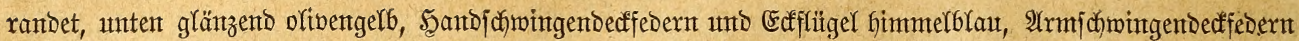

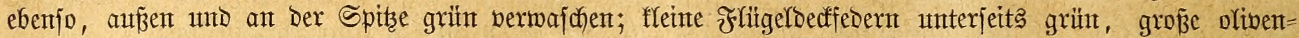

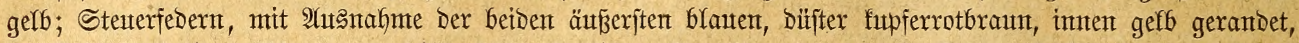

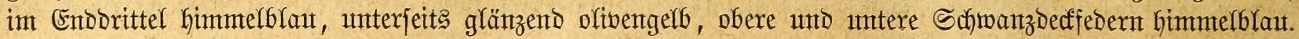

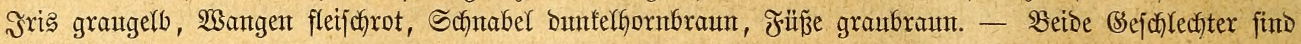
głeidh) gefärbt.

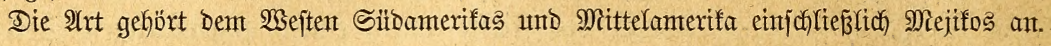

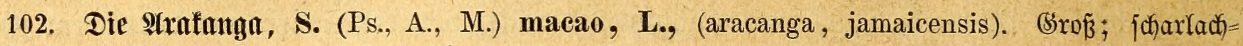

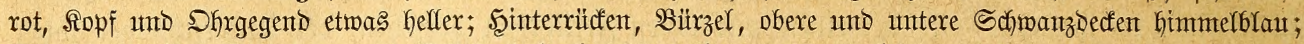

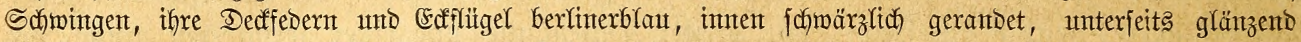

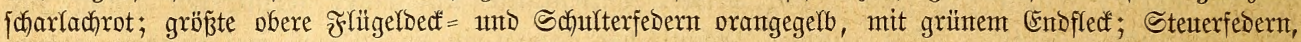

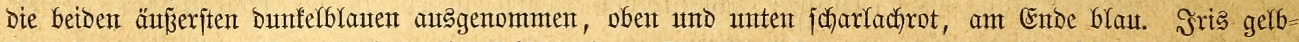

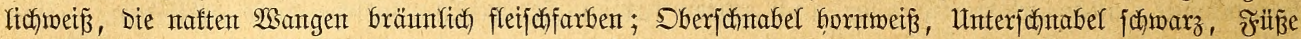

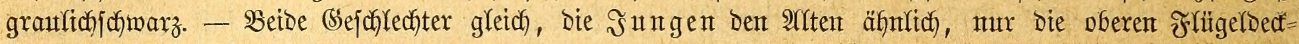
febern teilfweife grün, anftatt Durchauts gelf.

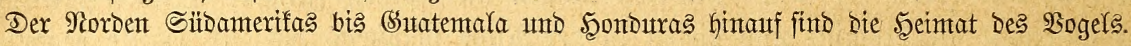

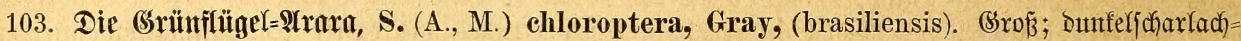

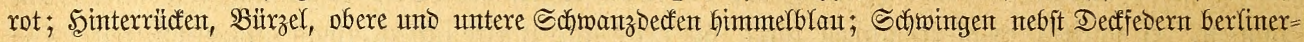

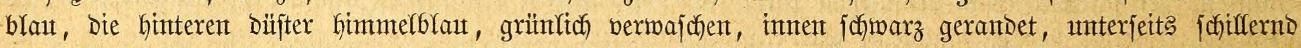

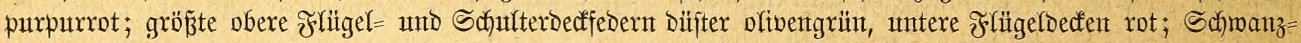

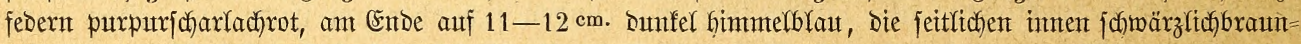

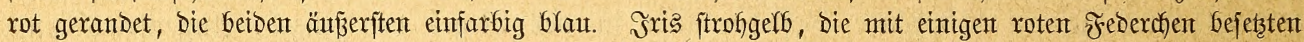

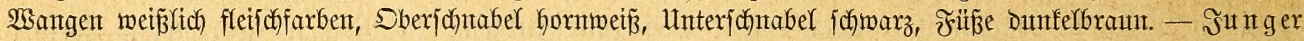

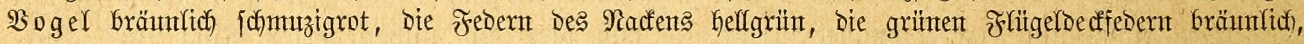
gefbrich ober rötfich itmrantoet.*)

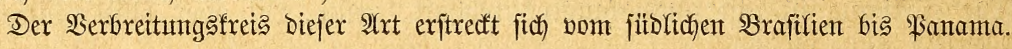

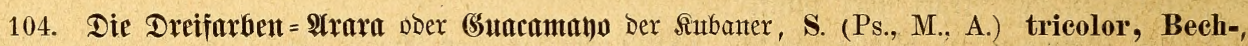

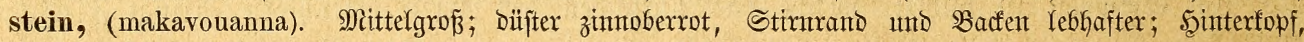

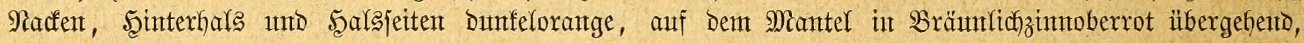

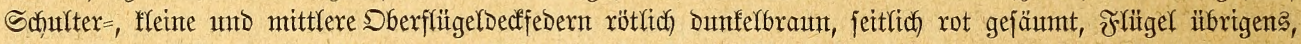

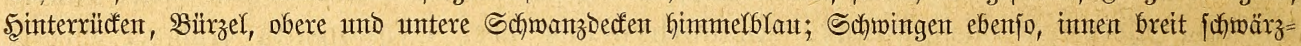

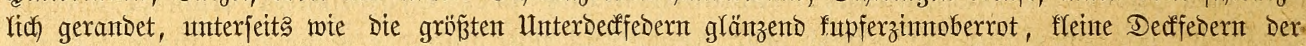
Flügefunterfeite zimnoberrot; mittlere ebenfo, gelb gejäumt, Steuterfedern bräıthlid) fupferrot, im Endobrittel

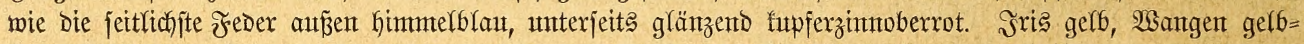

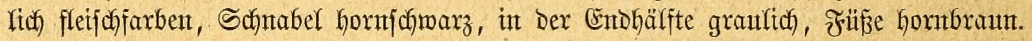

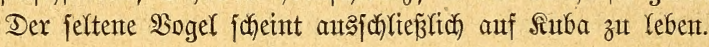

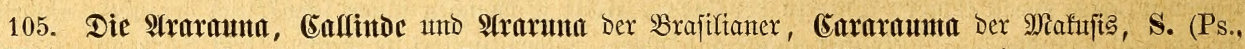

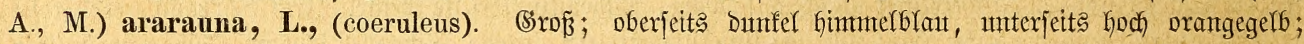

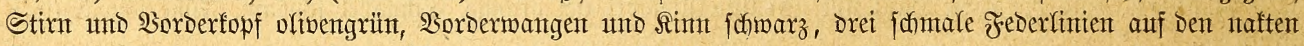

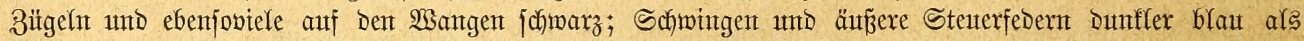

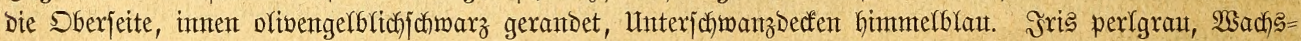

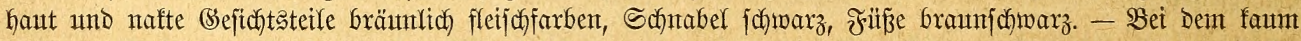

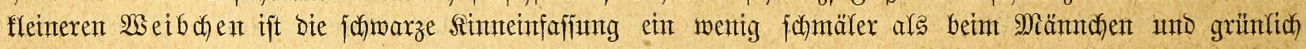

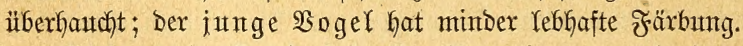

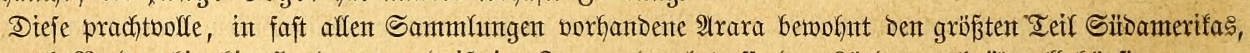

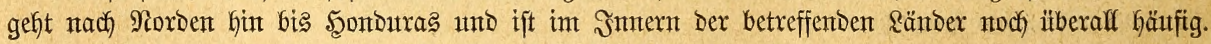

Die übrigen $2(r t e n$ Der (Sruppe, Sittace, haben ebenfalfs nafte Bügel und 2 antgen, aber

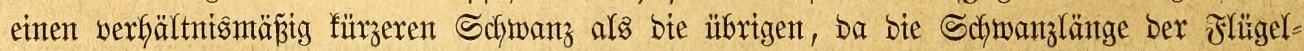

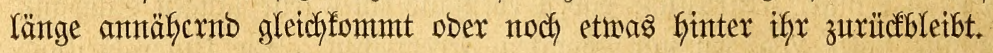

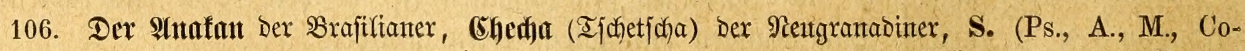

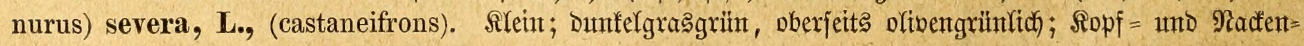

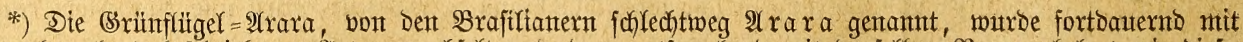

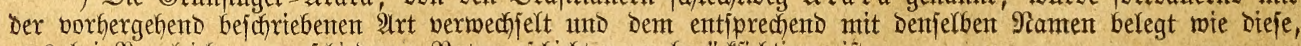

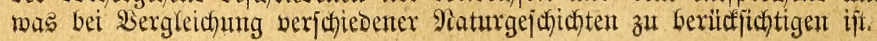




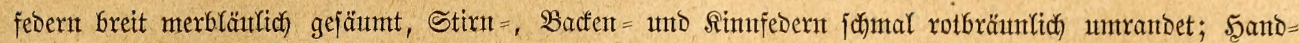

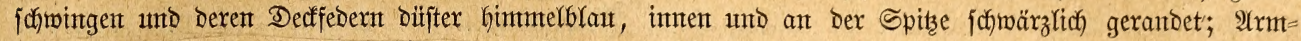

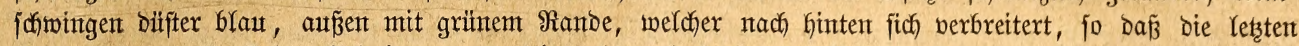

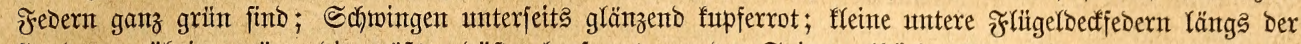

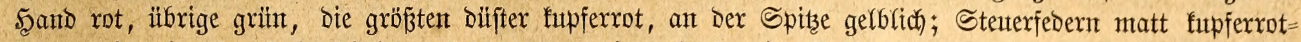

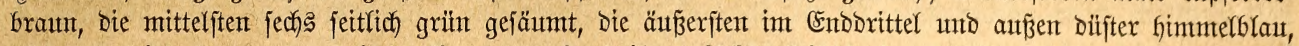

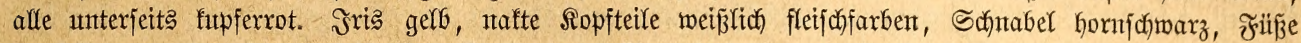

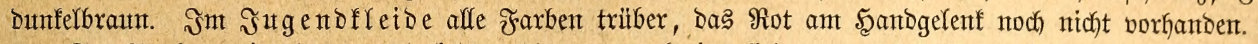

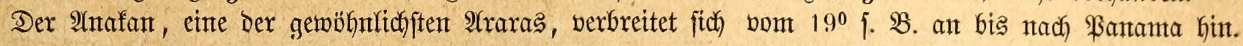

107. Die Maxnfana, S. (Ps., A., M., Con., Psittacara) maracana, Viell., (Illigeri, makavuanna, purpureodorsalis). Slein; olivengrasggrïn; Dberfopf büfter grïnlichblau, Stirn, Scinterrücfen uto

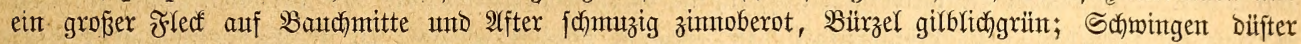

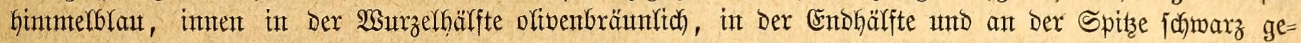

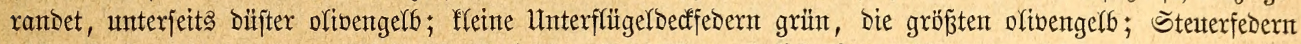

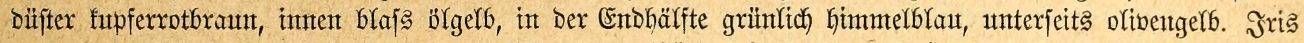

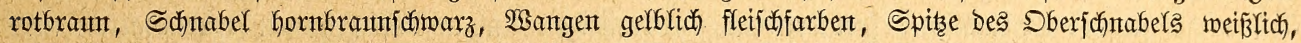

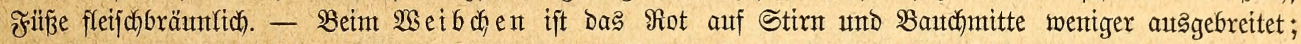

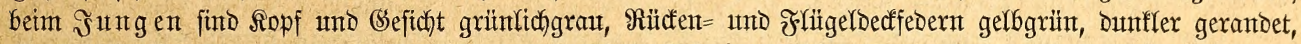

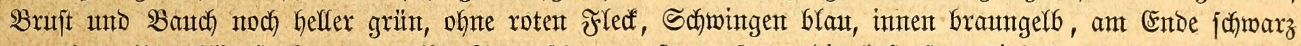
geranbet, Unterflïgeldecfen mattgelb, Steuterfedern außen roftrot, bie äußerften mindeftens ebenfo gejäumt in Der Enohälfte blat, an ber Spitze meî̉ gejäumt.

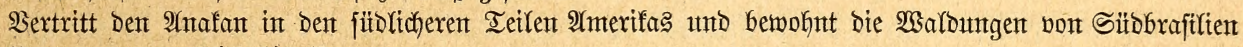
und Paragay ant weftlich bis Perut.

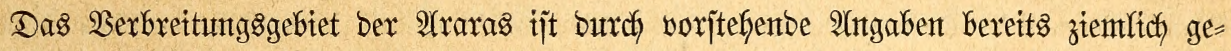

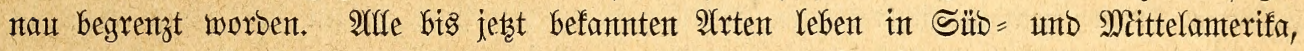

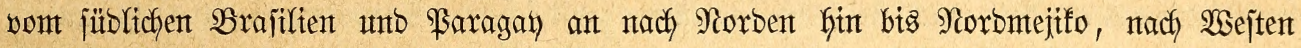

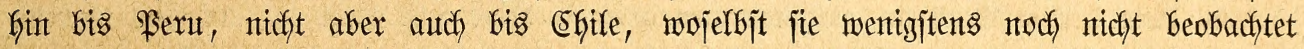

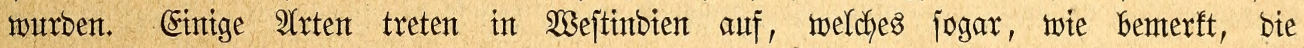

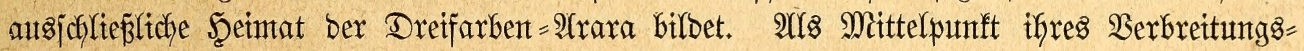

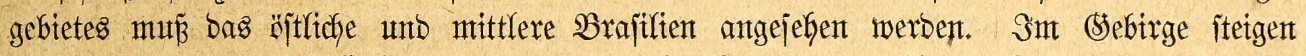

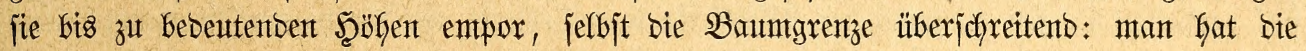

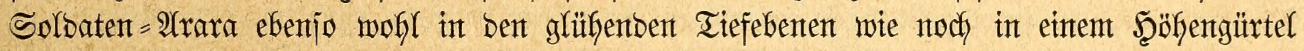

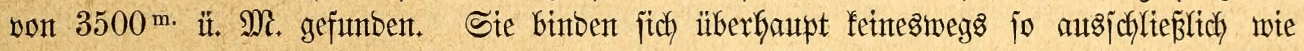

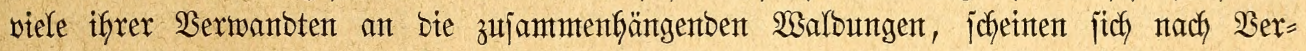

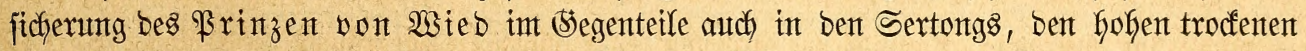

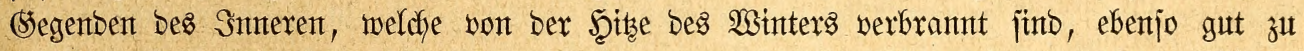

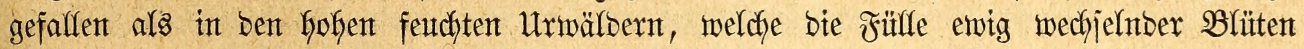

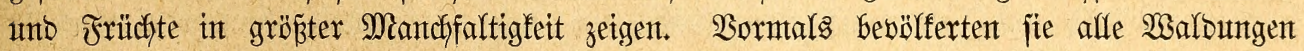

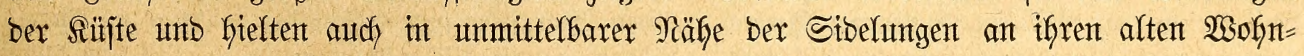
fitzen fejt; gegentwärtig habent fie fich vor bent weiter unt weiter vorbringentben weisent Mienjchent mefyr in bas Smtere ber tiefen 2 safbungen ober bodh bes unbevälferten Ranbes

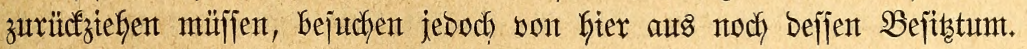

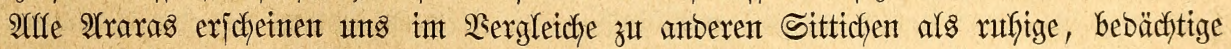

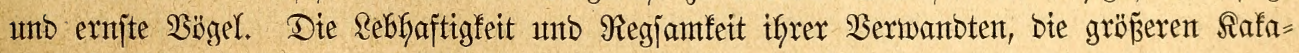

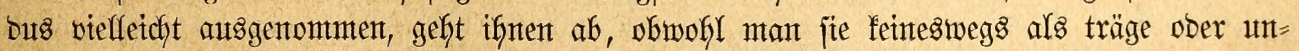

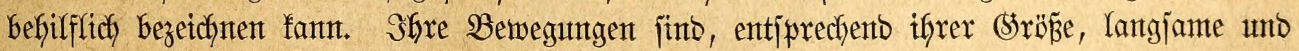

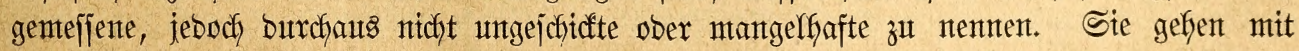

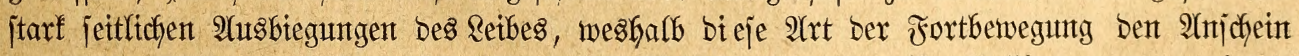

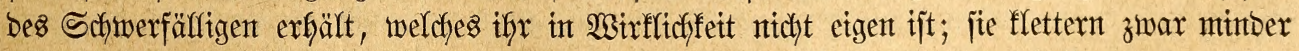

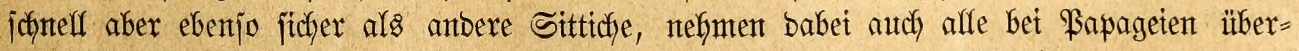

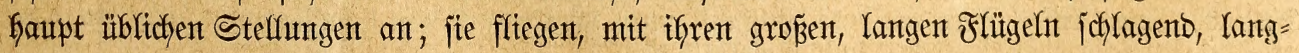




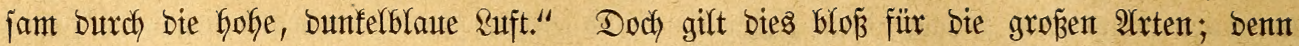
bie flemeren $\mathfrak{A}$ raras fommen in affen ifyren $\mathfrak{B}$ emegungen in wejentlichen mit anberen Sittichen überein und zeidynen fich insbejonbere burch reiźend ichnelfen frug auss. Die Stimme bejteht aus mentgen rauken Rauten, weldhe ber Name unjerer $\mathfrak{B}$ ögel als salang= bitlo ziemlich treu wiebergibt; fie ijt aber ebenfalls biegjam unt ermöglicht es, menjchliche

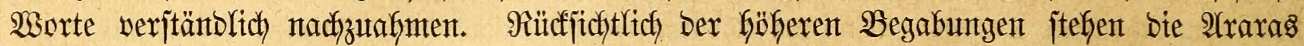
finter anberen \$apageten faum zutüd. Shre Sinne find ausnafmslos wohl entwicfelt,

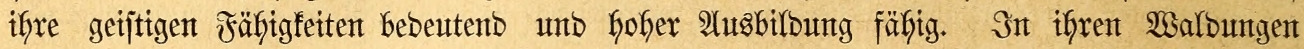

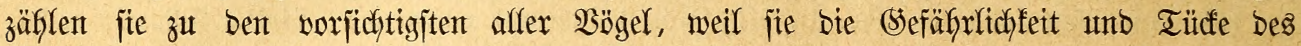

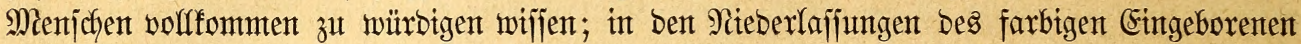

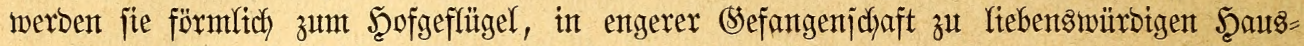

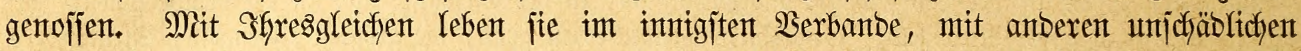
Bögeln ober Tieren überhaupt im tieffiten Frieben. Shr Wejen madyt jie liebenşwert. Sie

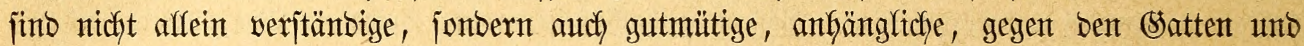
Die $\mathfrak{B}$ rut Gintgebento zärtfiche $\mathfrak{B}$ ögel.

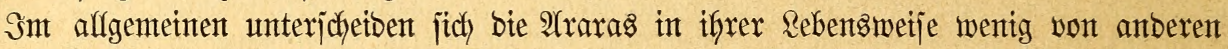
Bapageien. Sn ben wilben, felfigen Sebirgen ber inneren Sertongs von Brafitten ijt nady

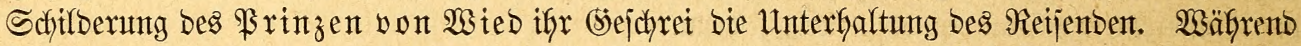
man auf ben Flüffen burch bie Rüjtenmälber idjifft, erbficft man bie jtolzen Bögel und ex= fennt fie augenblifflich an ifyer Stinme, Srö̈ße unto bem langen Schweife ober ifrem

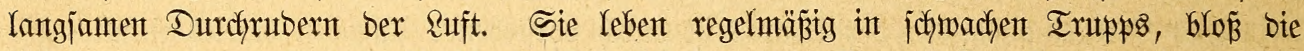

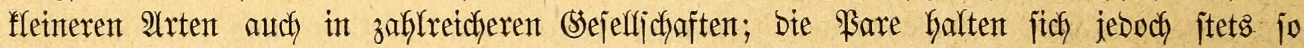
innig zujammen, baß man jie jelbjt in einent zahlreicheren Schwarme redjt wobjl unter=

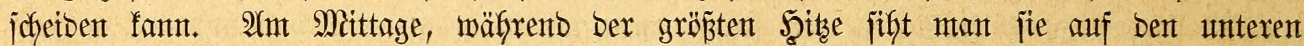

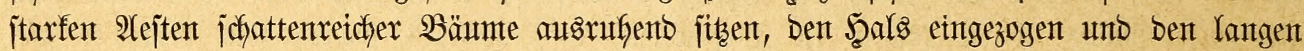

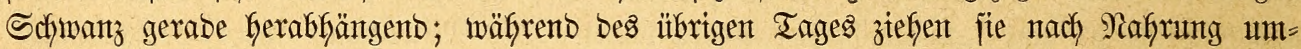
her voer bejdäftigen fidh mit Einnefmen berjelben. So laut jie jonjt zu jein pflegen, jo

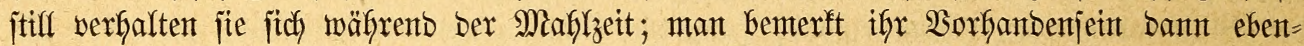
falls mur an bem Şerabfallen ber zerbiffenen Jrudththüljen, falls man nicht bejonders auf bie leijen Töne adytet, weldye fie beim Frejien zu Gören geben, unb weldye an eine menjed = liche unterfyaltung erinnern. (Segen 2 (lbent fliegen fie wieber nach ben 2 arbteilent zunüf, won Denen fie ant Morgen gefommen waren. Zu gewifjen Beiten unternefnten fie weitere

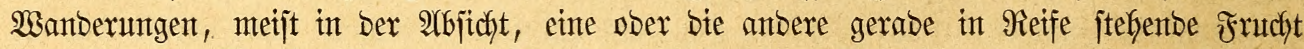
auszubenten. Einzelne 2Yrten erjoheinen bann, möglichermeije nicht ganz aus freien Stücfen, jonbern als halb und halb verjdhlagene (säjte auf Injeln auperbalb igres Serbreitungs: freijes, wie $z . \mathfrak{B}$. Die Solbaten= 2(rara in Den $\mathfrak{B}$ ergwälbern Samaifas. Für ein $\mathfrak{B} e r=$

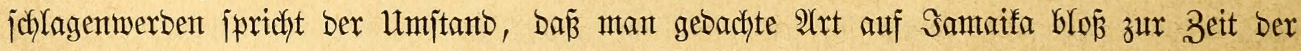
Geftigen Dftoberjtïrme, weldye Taujento von $\mathfrak{B}$ g̈geln mit jidh fübren jollen, Geobachtet bat.

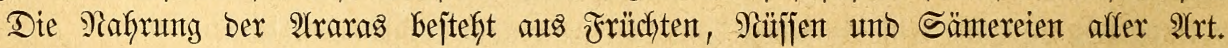

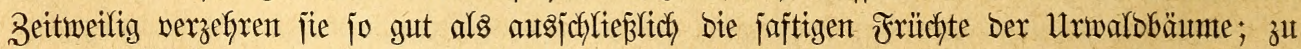

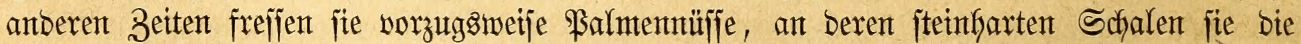
gewaltige Sraft ifyrer Schnäbel bemeijen, ba jene Siüjije von Menjchen nux vermittels eintes Şammers zertrümmert werben fömen; zumeilen balten fie fich mehr an bie Samenferne einzelner Sdylingpflanzen, in Deren Ranfenwerf fie gejdyidt umberflettern, unb mit beren

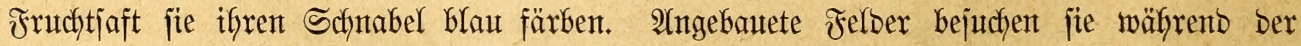

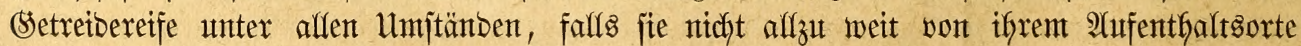
entfernt Yiegen, Dbjt= unb Frutdftpflanzungen nidht minber. "IFinben fie", jojilbert Schom= burgf, "ein reifę Feld auf, jo werben runb Gerum auf ben nädjiten $\mathfrak{B a ̈ u m e n ~} \mathfrak{B a c h e n ~}$ 
auşgejtelft; Das jomjt immermäfrente Selärm und Sefretjch ber rauben Stimmen ijt ver= ftument; nur Gin und wieber Gört man einten ballb unterbrüdten fnurrenten unto mux.

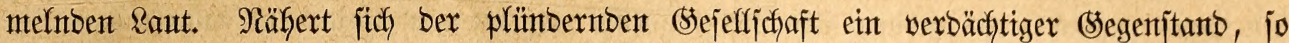

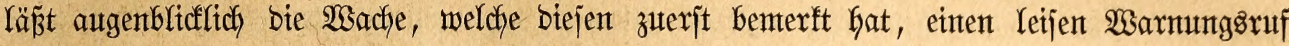

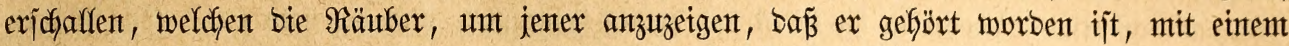
halb unterbxïctten Srächzen beantwortent. So wie bie Sefahr bringenter wirb, fliegt bie

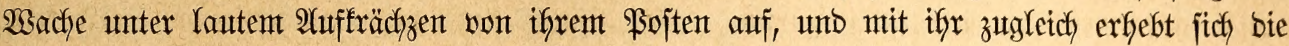

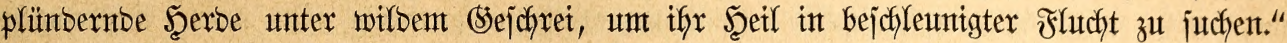

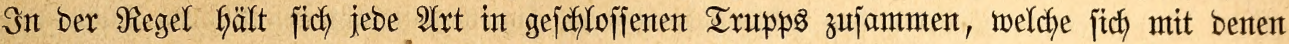
ifrer Serwanbten nicht wermijichen; Doch fant auch bas Entgegengejebte vorfommen, went ein gemeinjames $\mathfrak{B e u t e z i e l ~ i f n e n ~ w i n f t . ~}$

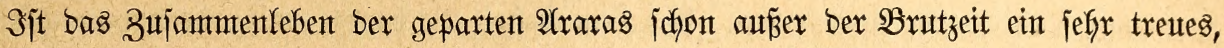

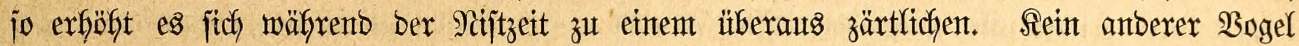

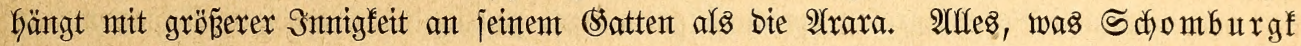
von ben Sperlingapapageten gejagt hat, Yäjt jich auch auf fie beziehen. Die Satten eines

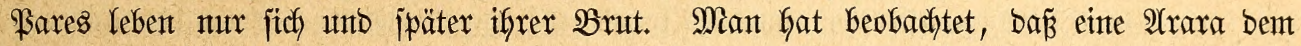
Säger, weldyer ifyren Satten getötet unt an jeinem PFerbe befejtigt batte, flagent bis in bas Sntnere einer Stabt folgte, fidh zu bem verendeten Senvijen herabjenfte, Tage lang in

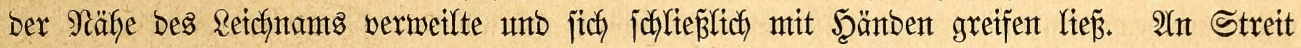
ober audh mux Uneinigfeit zwijdjen ben (satten eines \$ares ijt ntidyt zu benfen; jeber joheint

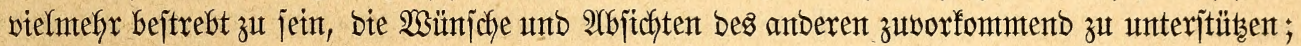

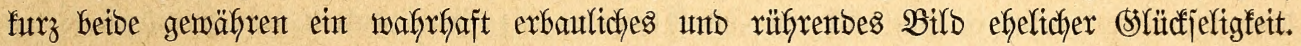
Sn ber Fortpflanzungazeit pflegt jebes $\mathfrak{P a r}$ ben $\mathfrak{B}$ nutort ober Stant, weldjen es jich einmal erwäflt hat, wieber aujzujuchen, wentgitents bann, went es bajelbjt nidgt Geunruffigt worben ijt. Man jifht es baher lange Gabre an einer unb berjelben Stelle; ja gewiffe Nifjtbäıme waren joyon ben alten Peruanent befannt unt für fie einte Duelle bes Erwerbes, wie anbere noch Gentigen Tages eine joldje für bie Snbianer Brajiltents unt Stianas find. Bon

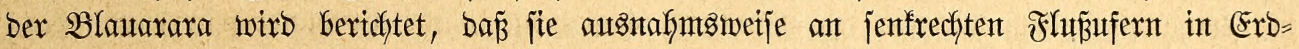

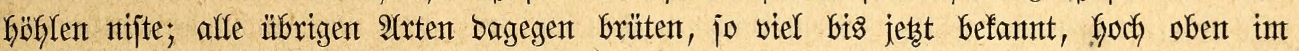
Stamme ober einem mädstigen âfite riefiger Walobäume, und zwar in vorgefunbenen ober jelbjt ausgearbeiteten Së̈hlungen, aus benen bex lange Schwantz verräterifch vft weit hervor=

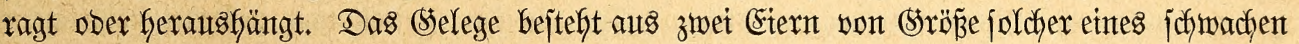
Scausfufgnes, bas ber fleineren $\mathfrak{A}$ rten, über beren Fortpflanzungsgejchäft noch feinte $\mathfrak{B} e=$ obachtungen vorliegen, viefleidyt aus beren brei, hödyjtents vier. Wafhrcheinlich brüten betbe

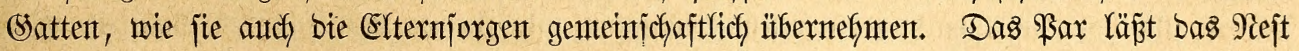

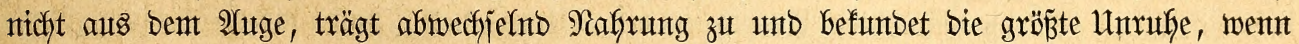

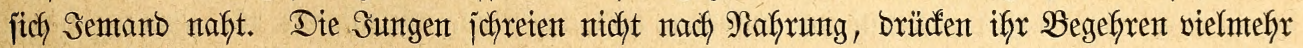
burch Silopfen mit bem Schnabel aus, fint anfänglich itberaus bäßlich unto unbefifflidy unto

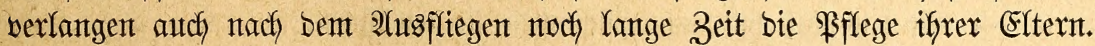

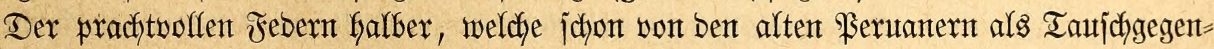

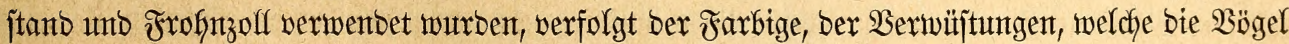
in Felbern unt Pflanzungen anrichten, untb bes guten, fräftigen Fleijches wegen ber Weißé

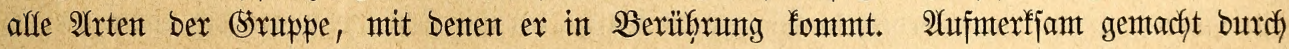

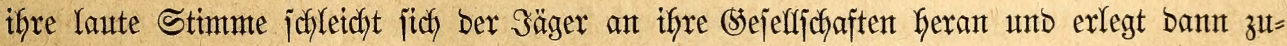
weilen mefrere mit einem Schuffe, befommt aber boch mux bie jofort getöteten in bie J̧anto, weil bie verwumbeten fich oft noch im Şerabfallen an einem Zweige anflammern unto fich in joldjer Stellung bis zu ifrem Tobe exfalten. Sie verlangen einen jebr jtarfen Sdfur,

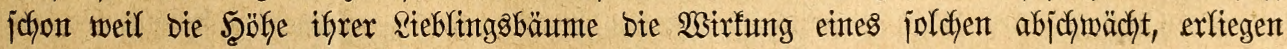




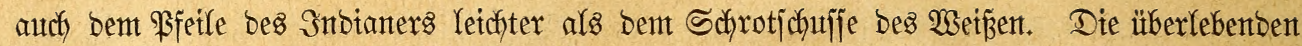

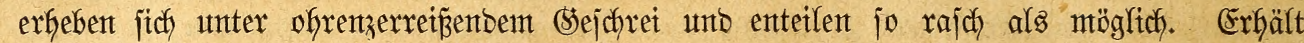

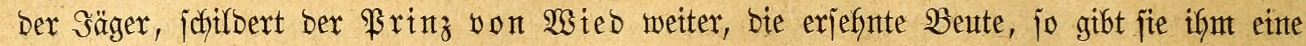
ermünjchte Speije, namtentlich eine fräftige Brïhe. Das Fleijch gletcht bem Rintofleijche, uno bas von alten $\mathfrak{B o ̈ g e l n ~ i j t ~ h a r t , ~ i n ~ b e r ~ f a l t e n ~ G a b r e s z e i t ~ a u t h ~ o f t ~ f e f r ~ f e t t . ~ D i e ~ j o j o ̈ n e n ~}$ Febern werben vielfältig bentust, yon ben Brajiltanern teilweije zum Schreiben, von an=

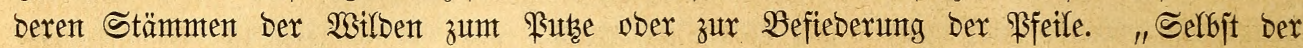

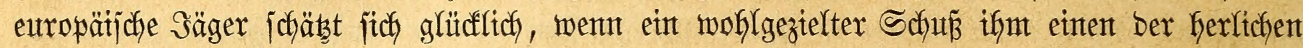
Bögel in bie Scände licferte, und jebesmal wirb er jeinen Scut mit ben jefönen Schwuntg= unt Schwanzfebern zieren." Berjchtebene Stämmte arbeiteten efhemals mantherlet \$uzgegen=

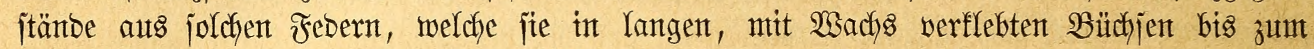
jebesmaligen (sebrauthe verwahrten. Bei bemt Fejte, welches vor bem Erichlagen und Ber= zefren eines gefangenten, feindlichen Artegers von ben Tupinamben begangen wurbe, erjofien

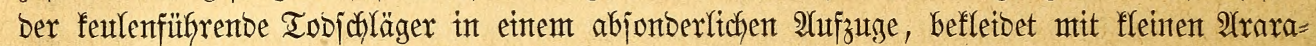
febern, welche mittels eines (s)ummifyarzes auf bem naften fiörper fejtgeflebt maren, into mit einer aus $\mathfrak{A}$ rarajdymanzfebern gebilbeten Arone auf jeintem Seaupte. Ararafebern waren bei ifnen Beidyen bes Srieges.

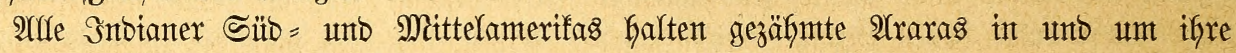

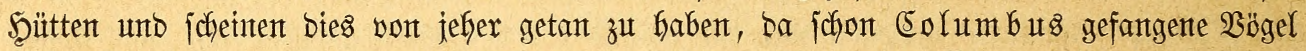

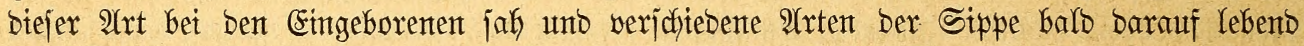

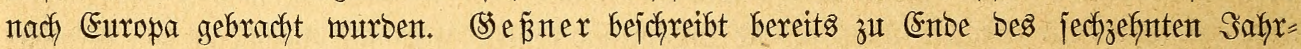

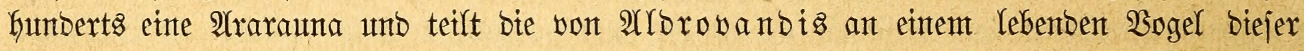

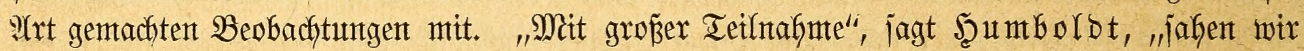
um bie Şütten ber Sndianter zafyme 2(raras, weldye auf Den Felbern umberflogen, wie bet

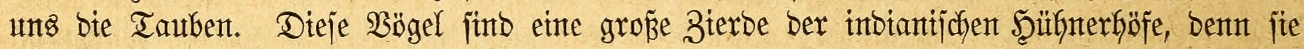

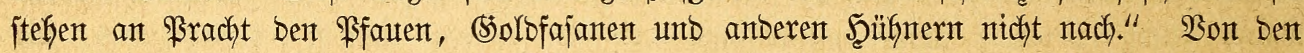
rotbraumen Reuten erfalten wir nod heutzutage umjere Sefangenen, junge wie alte Bögel,

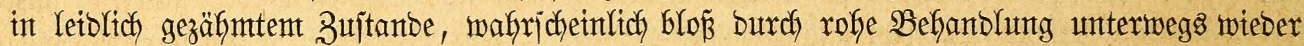
berwilbert. Bei gectgneter befandlung werben jie fefr balb ebenjo zafim, zutraulteds unto antyänglich wie anbere gröbere Fapageten, Yernen auch, went fie juntg in bie rechtent Scänbe gelangten, ziemlich gut iprechen. Ein Freumb nteines Baters, Siebhof, bejá eine 2lrara, weldye von einer iprechentoen Eljter Yernte, in furzer Zeit ber Refyrmteijterin afles abgelaujdyt Gatte, was bieje jelbjt wuinte, bann aber rajch noch bieles finzullernte. Sch Gabe mehrere gut iprectiente $2 \mathfrak{r a r a s}$ gejefen und viele von ifnen gepflegt, welche, wentiger unter

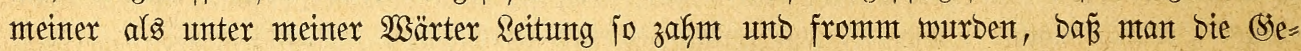

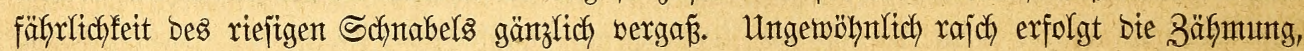
went mant jebe Alrara getrennt von anberen bält, weil bie Bejelligfeit mit anberen iffer 2(rt jie jonjt letdft von bent \$fleger ablenft; boch ijt einte berartige Albjonberung feineswegs exforberlich, um fie an ben Umtgang mit bem Mentchen zut gemöhnen.

Unter fidh Yeben bie Stefangenen in bejtem Einvernebmen, auth ment bie Beiellichaft

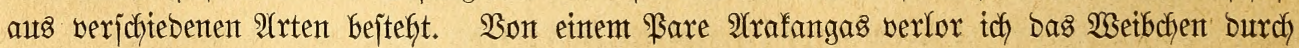

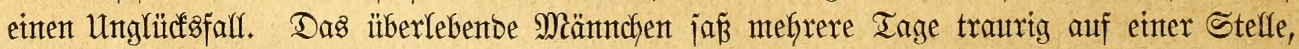

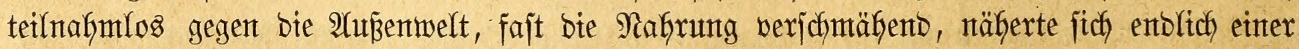
2(rarauna uno fnüpfte mit biejer ein Freuntojchaftżyerkältnis an, meldyes nach unto nach

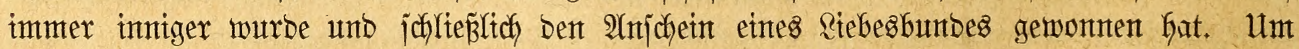

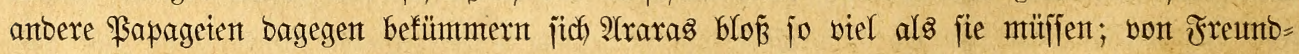
ichaftsbezetguntisen zwijhen jenten und ifynen babe idh niemals etwas bemerft, efjer noch ein ge= mifjes Bejtreben, fich joldje Sejellichaft fern zu halten, wahrgenommen. Demungeadjet 


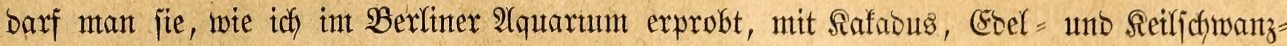
fittichen jonte mit $\mathfrak{A}$ ngehörigen anberer Dronungen ofne Bebenfen in einen gröBeren Raumt zujammenjperren. Sie jelbjt jint friebfertig und wiffen jich bei ber ïbrigen (sejelfjchaft bie

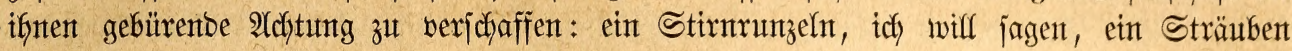
iffrer Ropffedern genẗgt, um jente int Baume zut haltent.

Die Grntäfruntg ber prächtigen $\mathfrak{B o ̈ g e l ~ v e r u r j a d y t ~ f e i n e r l e t ~ S c h n t e r i g f e i t . ~ S i e ~ f r e f f e n ~ a l l e ~}$

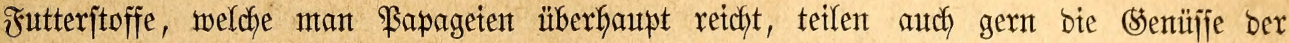
menjchlithen Iafel. Wenn man bie bei Schilbenung ber Sraupapageien und Safabus ange=

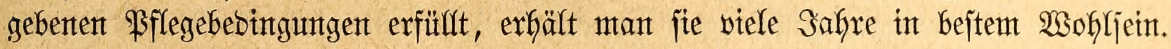

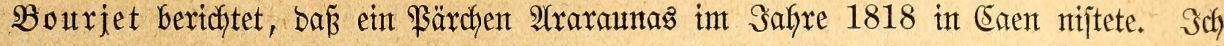

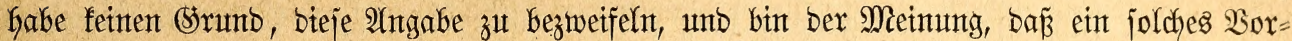

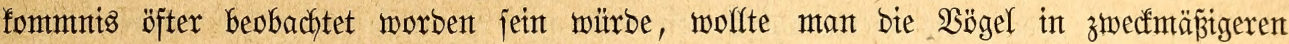

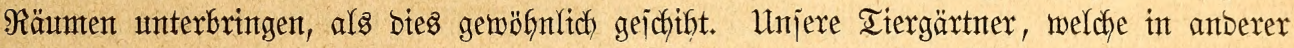
Şinficht jo groß̉e Fortjdyritte gentadyt Gaben, Gängen aber unbegreiflichermeije in manther

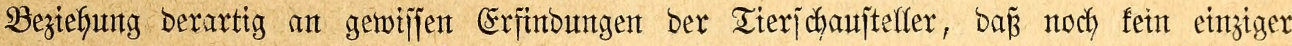
von thnen auf ben (Sebanfen gefommen ijt, ein zwedfentjprechenbes \$apageienthauts zu errichten, obgleids ein joldyes nicht alfein ber zaflenten Bejucherjchaft, fonbern auds Naturforjchern

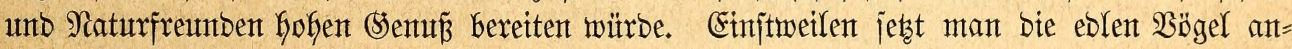

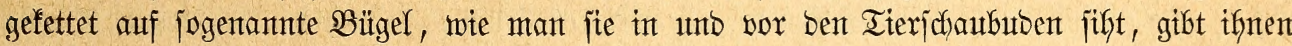
jabrauts, jafrein basjelbe Futter und glaubt damit bas Seinige getan zu haben. Dap ber= artiy gemishanbelte $\mathfrak{A}$ raras nidht an Fortpflanzung benfen und jich hödjtens bon fernther gegenjeitig Riebesblicfe zutwerfen fönnen, bebarf nicht weiterer 2(useinanberjetzung. Züthtung

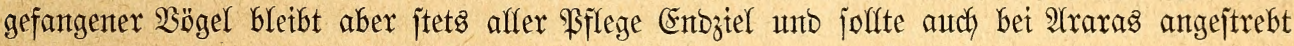

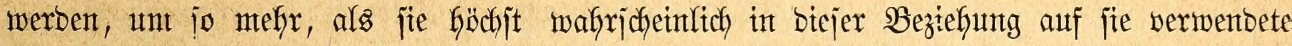

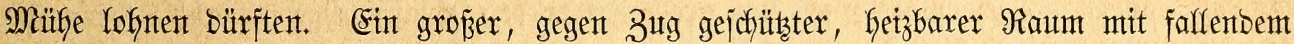

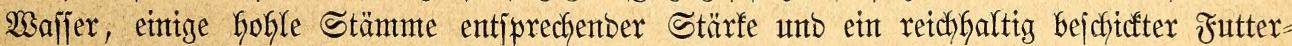

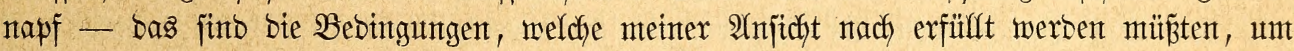

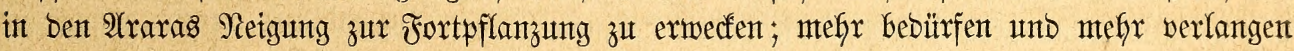
jie jebenfalfz nicfyt.

2raras treffen einzeln unt zu jeber Sabreszeit in aflen Einfuthrfäfen Europaz ein, am Gäufigiten wohy in Sonton ober Soutfampton utb Borbeaux. Shr Frets ijt geringen Schwanfungen unterworfen. Şyazinth = unt Blauarara werben bis zu 200 Talern für bas

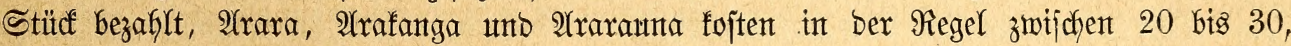
bie Soldaten=21rara zwijchen 25 biz 40 Taler; 2 tnafan unt Marafana fommen erfeblicts bifliger zu ftehen und fönnen unter untitänden für 12 bis 15 Taler erworben weroen.

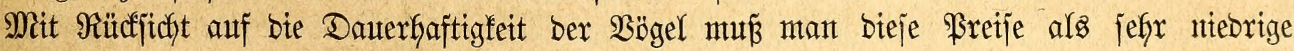
anjeben.

\section{Pand (d)}

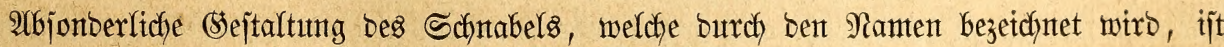
Beranlajiung gewejen, einen jübamerifantijchen Sittich von alfen ïbrigen zu trennen unto zum Bertreter einer bejonberen Sippe zu erfeben. Der Bogel wirb zwar bis jetzt nody

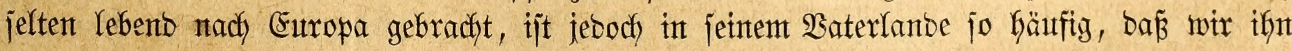
für bie Folge unzweifelfaft öfters in unjeren Säfigen jefen bürften, unto ifm fier unbebingt eine Stelle antweijen müfijen. 


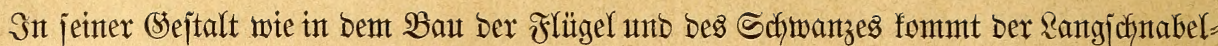
jittich am meijten mit Der reidfhaltigen Sippidgaft ber Reilfichwanzjittiche ïberein, unter=

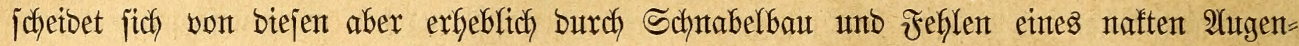

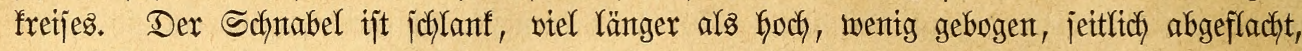
breitrücfig, in eine lange verjaffntälerte, fajt wagerecht vorragente Spitze ausgezogen, vor

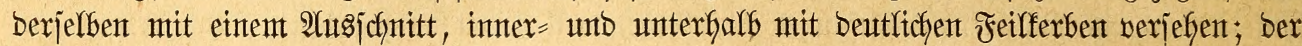
Unterjantabel ijt ebenjo hoch wie ber obere, jeitfich abgeflacht, bie Diffenfante abgerunbet, ber Sdfneiberant janft aufwärts gebogen. Waachaghaut unt Majenlöbcher fint mit furzent

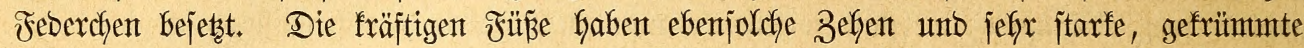

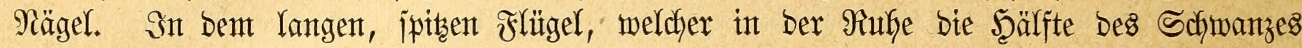
becft, iłt bie Flügelfpitze nidyt ganz jo lang wie ber halbe Sberflügel, bie zweite Sdywinge bie längjte, bie zweite bis vierte ansen, bie eríte unt zweite innten etwas ausgejchnitten,

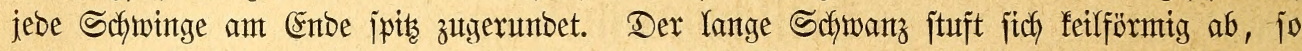

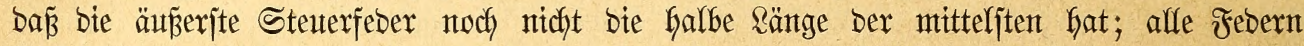

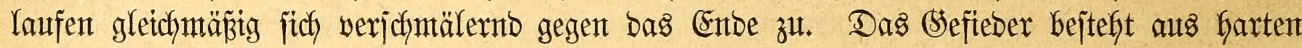
Febern.

108. Der \&angidnuthelittidi, Ehoron Der EGilejen, Henicognathus (Ps., A., S., C., Leptorrhynchus, Psittacara) leptorrhynchus, King, (erythrofrons, rectirostris, ruficaudus). (Erö̈ß̈e imferer

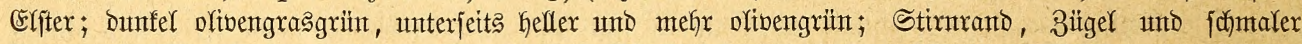

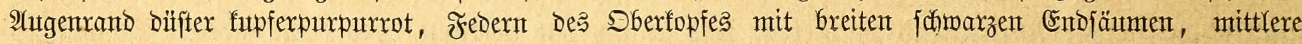

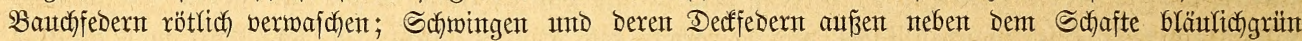

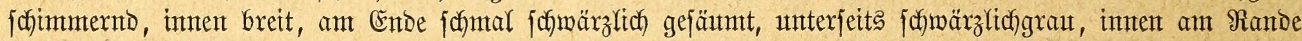

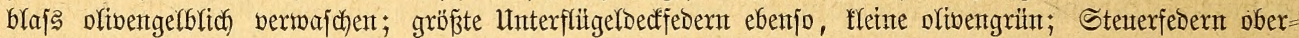

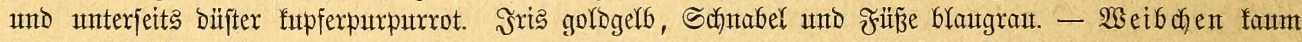

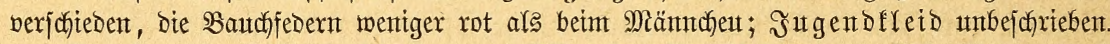

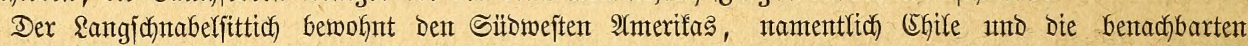

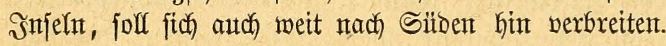

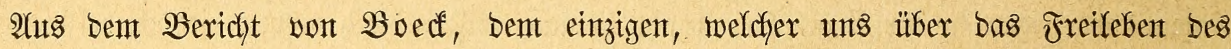

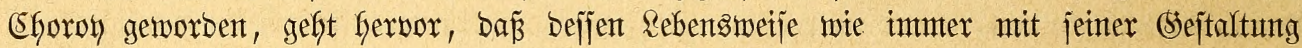

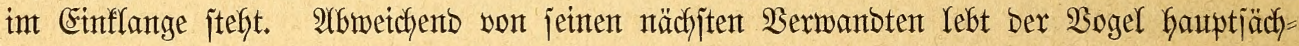

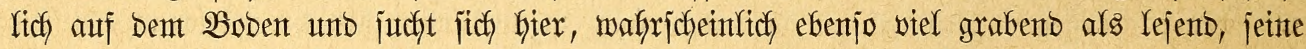

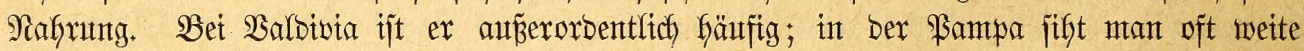

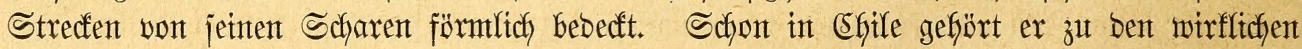

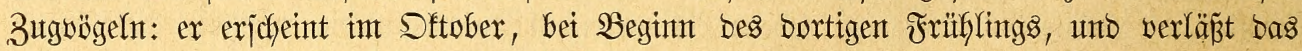
Ranto int 2 (prit, bei Eintritt bes Şerbites, wieber. Seine Büge folgen, wafhricheinlidy burth

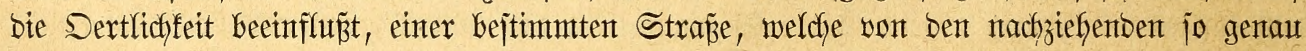

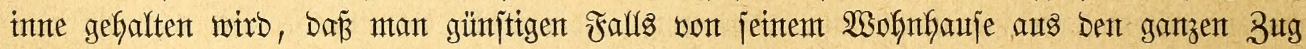

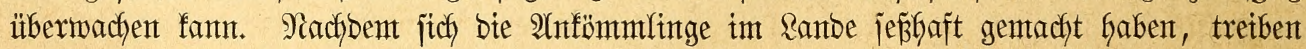

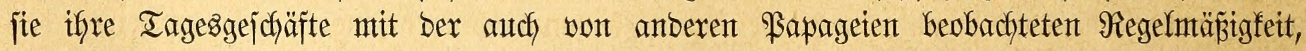

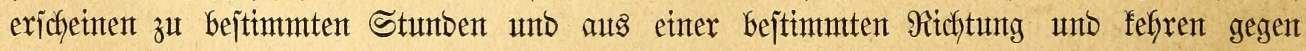

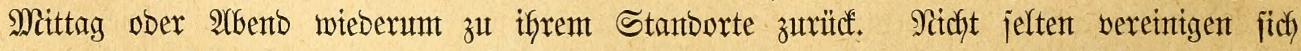

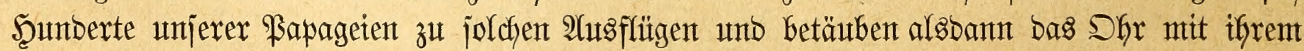

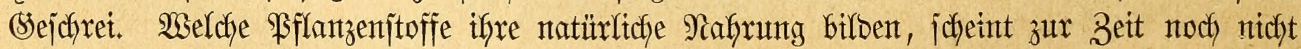

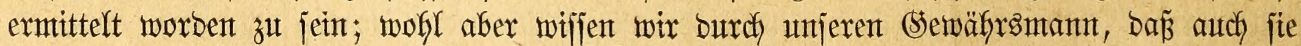

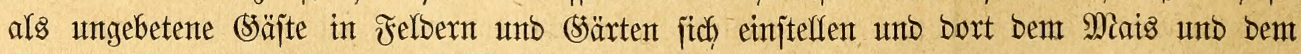

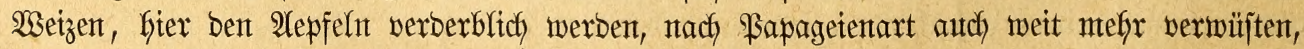

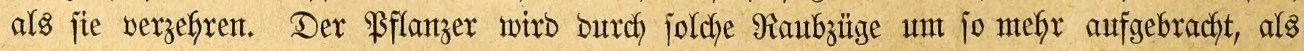

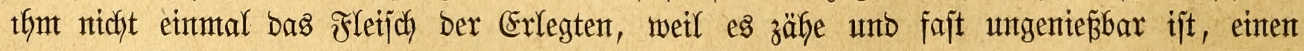
geringent Exjä für ben ifgnt angetanten Sctjabent bietet. 
Ess läßjt jich annefmen, bas unjer \$apaget in Feljen brütet uno bie von ifm be=

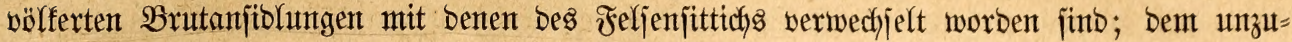

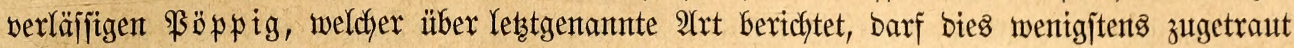

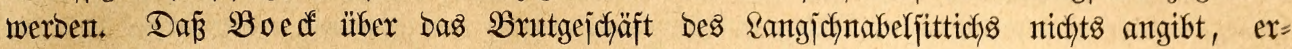

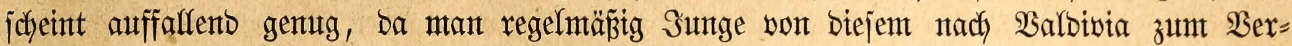
faufe bringt unto fie gern in (Sefangenjchaft Gält, weil jie zafgm werben. Snwiefern fie fids) jonjt auszeichnen, ftefyt bafin; int Borjtebenben Gabe ich alles mitgeteilt, was uns befannt gemorben ift. Das Betragen ber Sefangenten, bie ifnen gereidfte Nahrung zc. bejdfretben nicht einmal Diejentgen, weldye Den teilnafmtsmerten $\mathfrak{B}$ ogel in Europa pflegen fonnten.

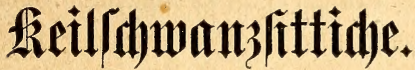

Heber ben gröpten Teil âmerifas berbreitet fich eine reichbaltige Sippe ber Familie,

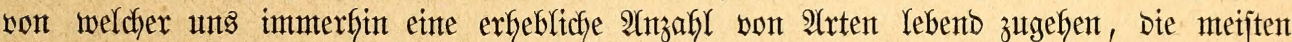
won thnen als balb ober volfjtänbig gezäfmte Bögel, ba gerabe fie zut ben Rieblingen ber Sntotanex gefjörent und beren Şütten in Menge beleben und jdymülfen.

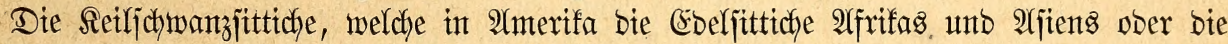

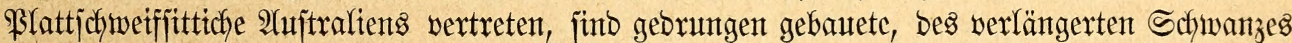

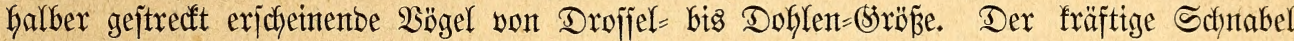
ijt jtarf gefrümmt, ebenjo lang als hoch, auf ber Sirjte jtumtpf abgejetst unto eine jdymale

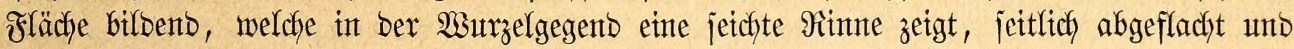
zujammengebrüct, vor ber jtarf gebogenten, überbängenben Spize, Deren Unterjeite Feifferben

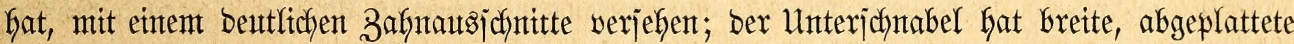
Diflenfante, abgejtubte Spize uno janft auggebudftete Seitentänber. Die fleinen, rumben

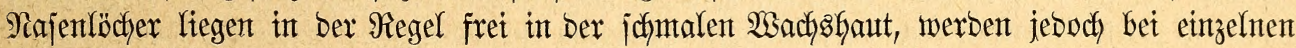
2(rten nebjt biejer von Febern überbecft. Der \&auf Des fräftigen Fußzes ijt ziemlich furz,

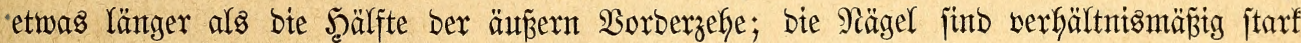
unto wentg gebogen. Dex Flïgel ijt lang, jpits, jtets länger als ber Schrwanz, Deffen

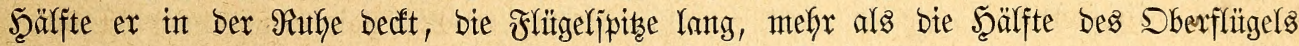
erretcyend; unter ben ant Enbe ipis zugerunbeten Schwingen fint bie zweite unt britte bie längiten, bie zweite bis vierte ober zweite bis britte auren johwadh, bie erjte bis britte inten merflich, zuweilen auch bie vierte am Enbe auffaffend ausgejchnitten ober verjchmälert. Sn Dem langen, feifförmig abgejtumpften Schmanze jüb bie Febern gegen bas Enbe zut gleid)=

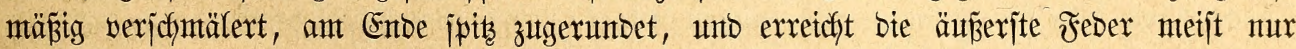
die Şälfte ber längiten mitteliten. Das harte (sefieber, in weldhem bie grüne Färbung zwar vorkerjat, aber burdy mandfyadhe bunte Zeidynung nodh bejonders gefoben wirb, be= fleibet bie Bügel, läß̈st jeboch jtets einen beutlichen Sreis um bas âtge fret. Betbe (Se= ichlechter unterjchetben jich) wentg ober nicht in ber Färbuntg, unb bie Sungen ähneln ben Iflten.

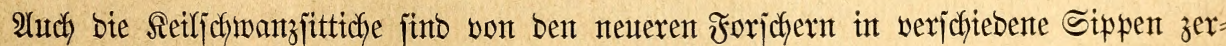

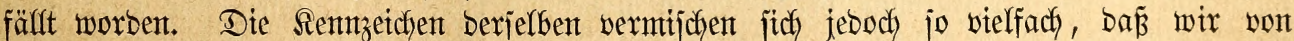
ifyen abjeken bürfen uno uns zur retdytern lleberjicht ber bon Fin $j$ d aufgejtelften, auf Dex Farbengruppirung berubenden Einteilung bebienten wolfen.

Eine joldye Unterabteilung bilben biejentigen 2 trten, bet benen bie Schwanzfebern nidft

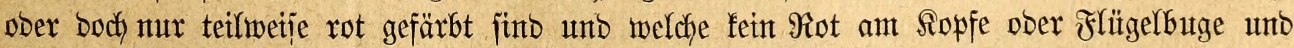

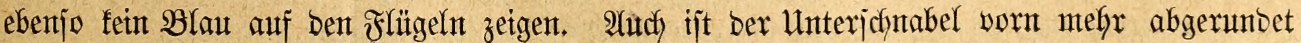




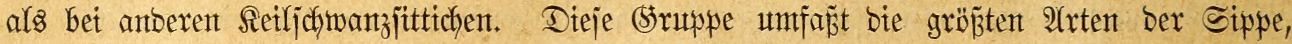
yon benten einzelne fleinen $\mathfrak{A}$ raras an (strößze gleich)fommen.

109. Der Felfenittid, Eoro unto Cateita der Sïbanterifanter, Conurus (Ps., Sitt., Ar., Psittacara, Cyanolyseus) patagonus, Viell., (patagonicus, cyanolyseus, Byroni). Sef̧r grof́; Sberjeite

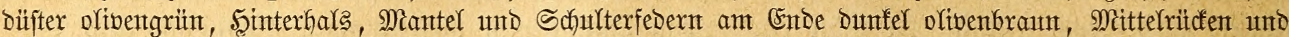

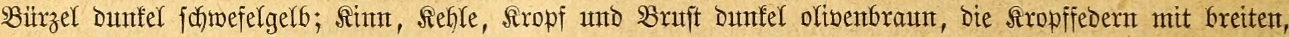

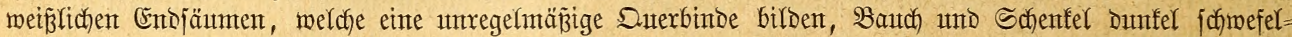

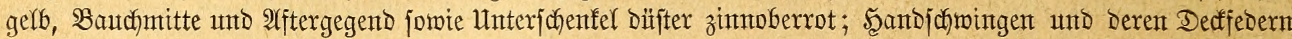

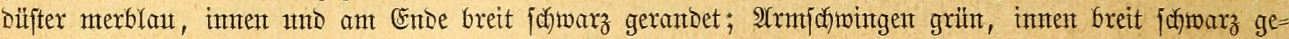

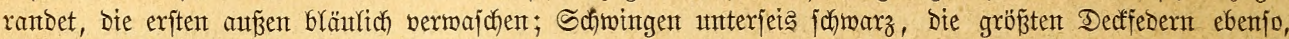

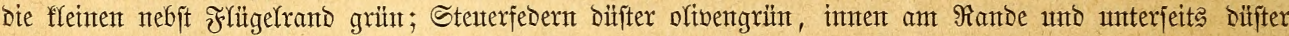

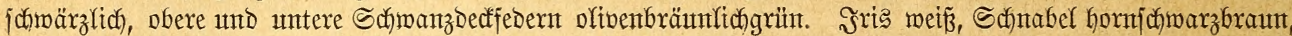

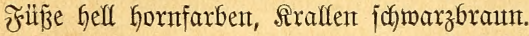

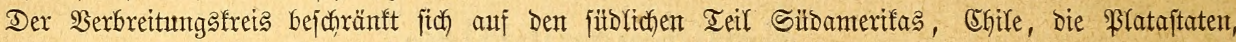
Paragay und bas tiobroliche Patagonient.

110. Der Spitzidınnzzittid, C. (Ps., Psittacara, Evopsitta)acuticaudatus, Viell., (cyanops, fugax).

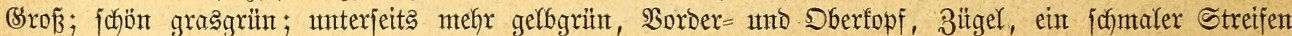

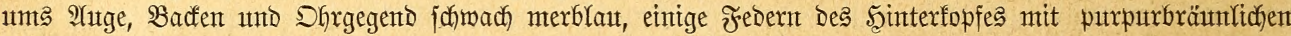

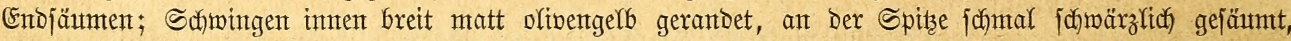

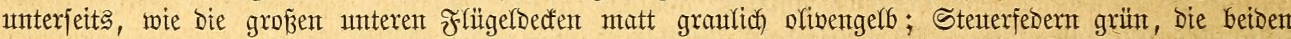
mitteffen einfarbigen ausgenonmen, innen bis gegen die Spiz̧e blutrot, unterjeits ebenfo gefärbt, das̉

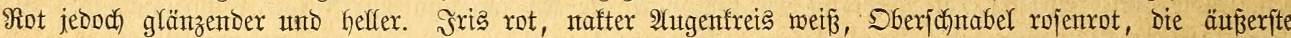

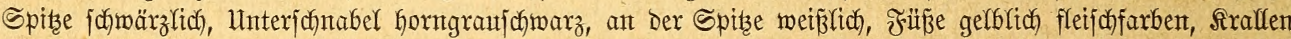

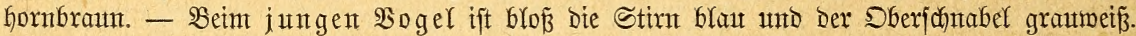

Bolivia und bie Firataftaten find die Seimat des in umferen Sammlungen feltenen, objojon in feinem $\mathfrak{B a t e r l a n b e ~ f e h r ~ h a ̈ r f f i g e n ~} \mathfrak{B}$ ogels.

111. Der $\mathfrak{B l m u}$ itimituttid, C. (Aratinga, Ps., Psittacara) haemorrhous, Spix, (coeruleo-

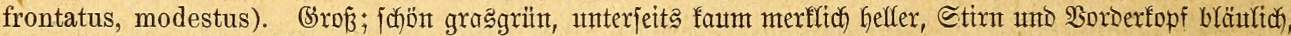

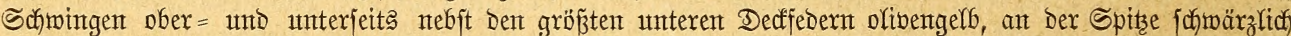

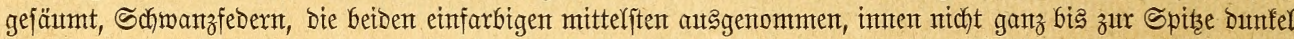

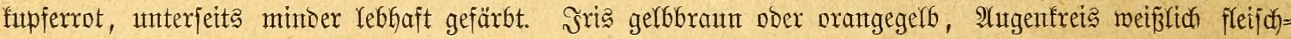

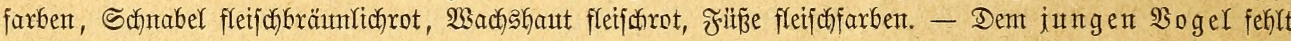
Das $\mathfrak{B l a u t}$ ant Borderfopfe.

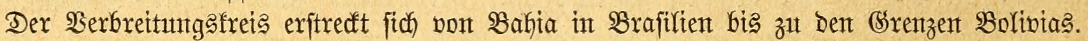

112. Die (5naruba, C. (Ps., S., Arat., Guaruba, Heliopsitta) luteus, Bodd., (maculatus, chloro-

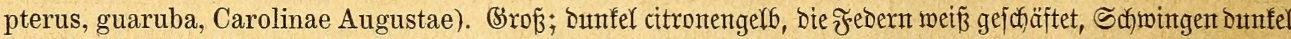

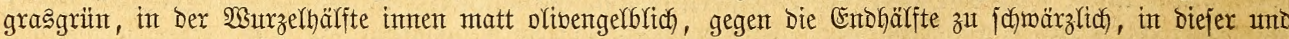

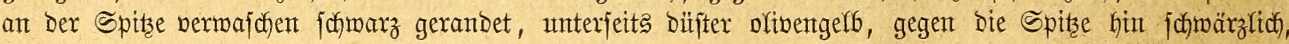

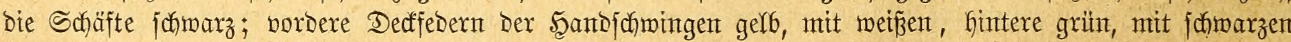

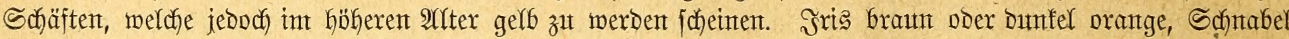

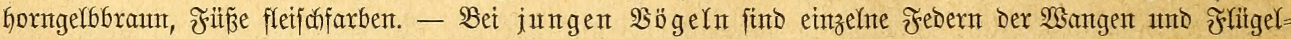
Dectent grünlich).

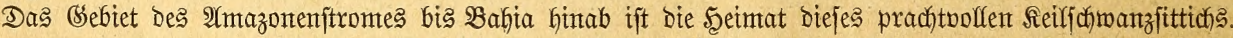

Eine zweite Unterabtetlung bejteft aus Denjentigen Arten, Deren Shmanz fein Rot unt beren Flügel fein $\mathfrak{B l a u}$ zetgen, währent fiop uto Flïgelbutg mefr ober wentger rot zu jein pflegen. Ess enthält dieje Unterabteilung ebenfalls jefr grobe 2̂rten, welche fids burch einen fräftigen, Gell gefärbten Sdynabel, Deffen unterer Ieil vorn jtets abgerunbet ijt, aużzetchnen. Sn ber Färbung Gerjcht Sriün unbebingt vor; Die unterjeite ber Sdywingen unto bes Schwanzes ift vlivengelf, während bie unteren Flügelbecfen ober ber Bug ganz ober teillweife rot ausjeken.

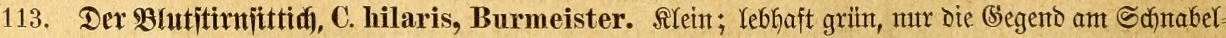

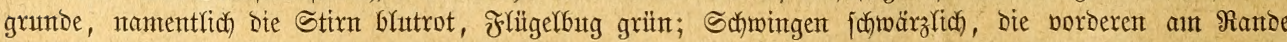

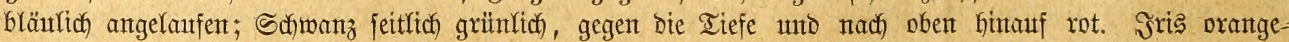

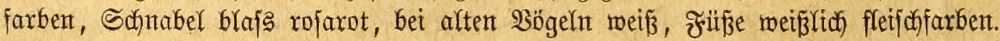




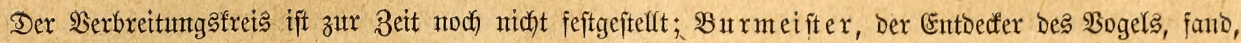
Daß̉ Derfelbe bei Infuman in Den Wilataftaten namentflid) im $2 s i n t e r$ fehr gemein war.

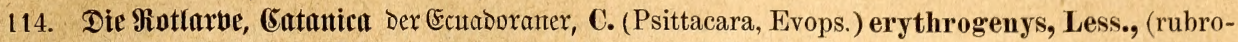

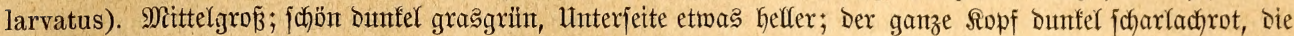

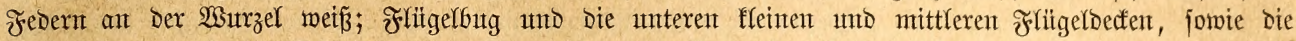

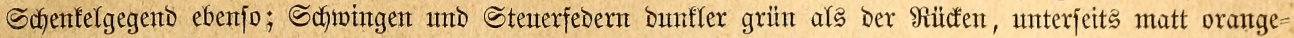

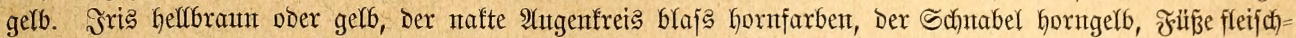

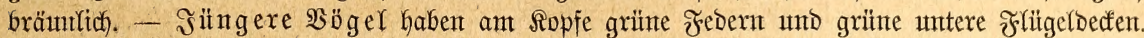

23 urbe bis jetzt mur auts (Ecutabor nach)gewiejent.

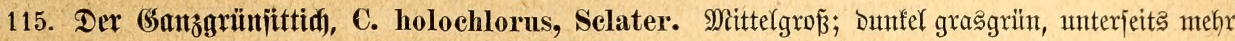

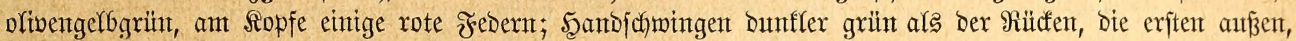

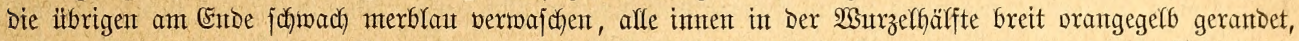

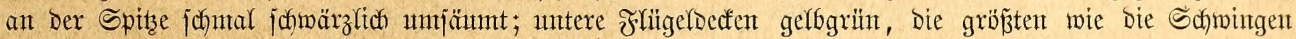

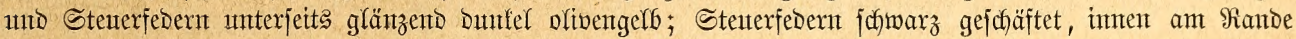

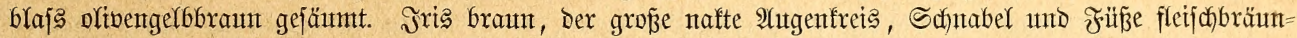

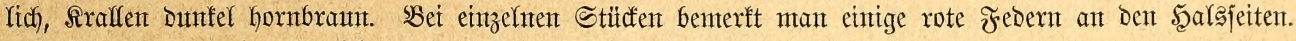

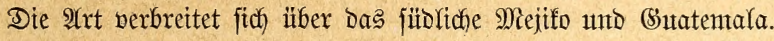

116. Der (Gofonugenittidi, C. (Ps., Arat., S., Psittacara, Ar., Evops., Maracana) pavua, Bodd., (guianensis, leucophthalmus, notatus, nobilis, cayana, Maugei, propinquus). (6roß $\tilde{\beta}$; gra $3=$ grïn, unterfeits faum helfer, Echmingen unt Stenterfedern etwas Dunffer; am Ropfe und Scalfe, fowie um

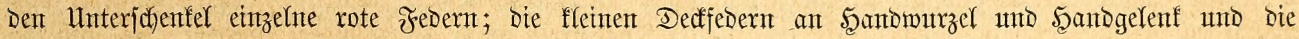

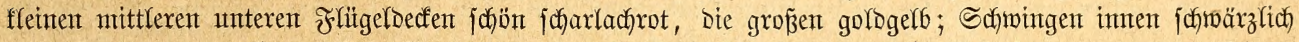

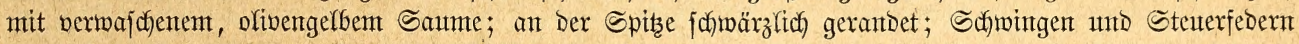

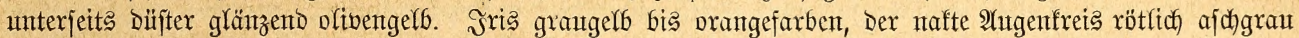

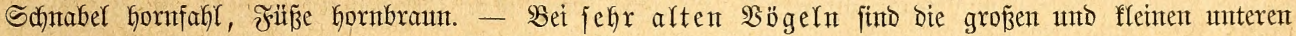

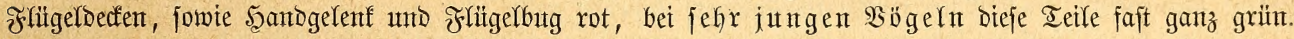
Einzelne Stïlefe zeigen rote Federn am Stirnrante. Rad, Den Beobachtumgen Des Frinzen von Reumied befommt ber 2 ogel am jo mefr rote Febern, je älter er wirb.

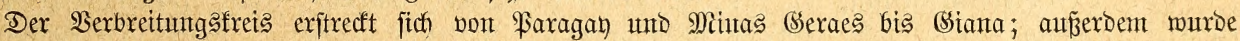

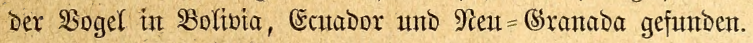

117. Der 5mumnaittin, C. (Ps., S., Evops., Psittacara) euops, Wagler, (evops, guianen-

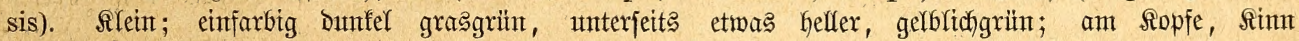

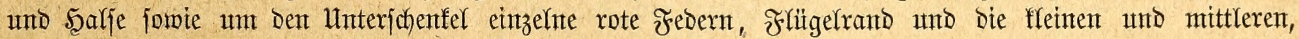

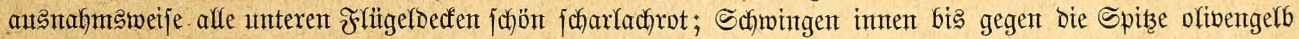

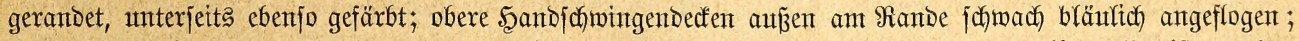

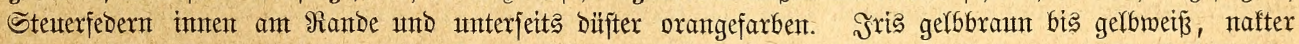

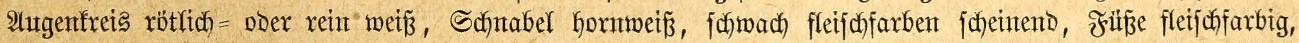
গiägel fałmarz.

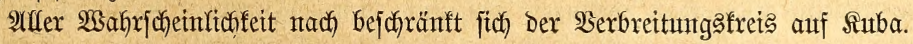

118. Der Rarulinajittid , C. (Ps., Ar., Arat., P., Centurus) earolinensis, L., (ludovicianus,

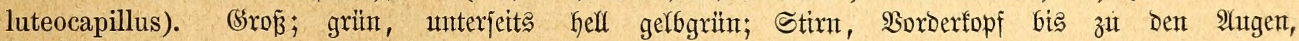

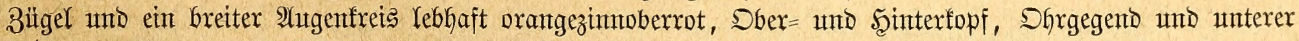

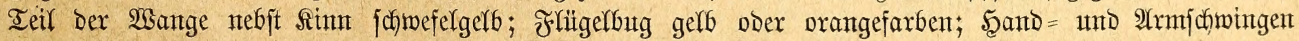

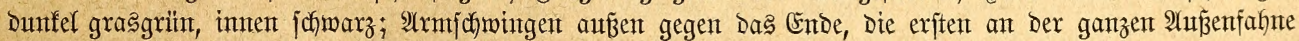

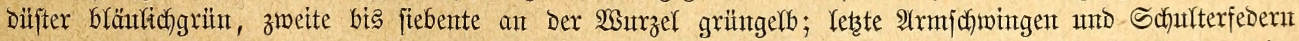

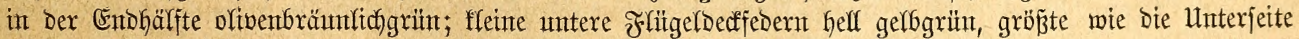

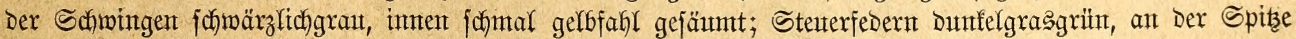

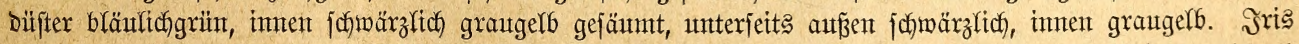

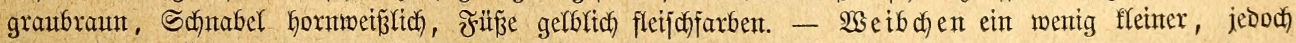
ebenjo gefärbt; Dả Jugen Dfleid einfarbig grït.

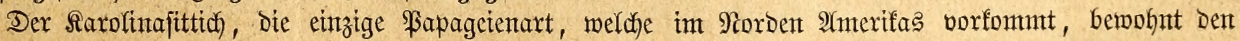

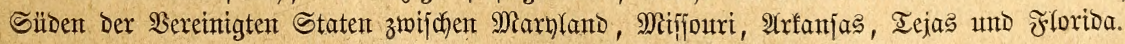

Sn einer fernern Unterabteilung fant man biejentgen 2 (rten vereinigen, welche ebent=

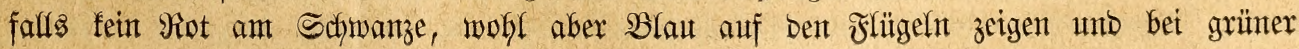




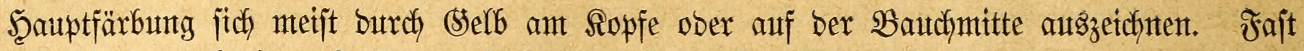
alfe Gierger geförigen Reiffchmanzjittiche haben bunflen Sdjnabel.

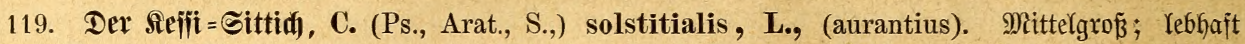

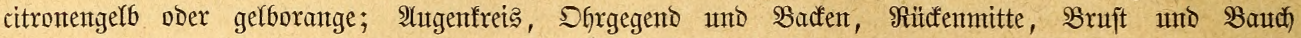

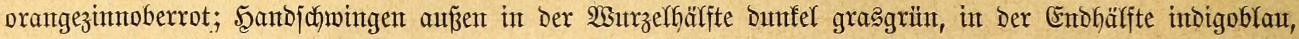

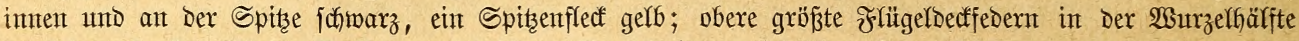

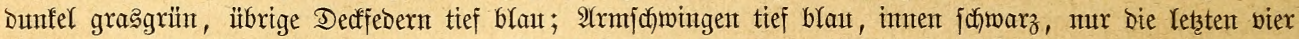

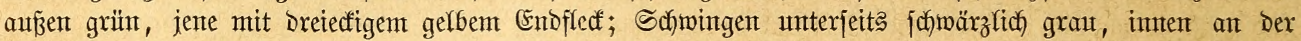
Wurzel gelbliç), Steuterfebern oliwengrün, im (Enborittel tief indigo, vorfer lebhaft bunfelgrïn, ebenfo

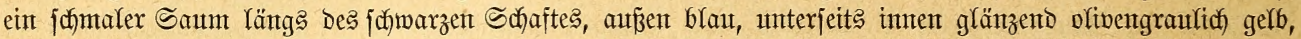

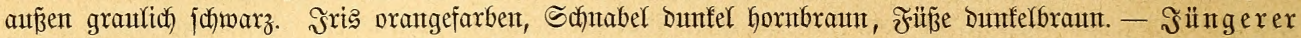

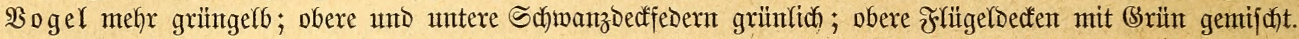

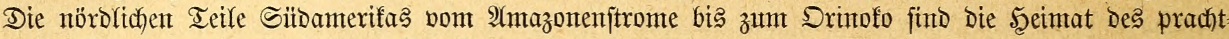

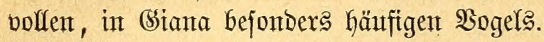

120. Die Ientana ber Brafiftaner, C. (Ps., Psittacara, Arat., Arara, S.) jendaya, Gml., (chryso-

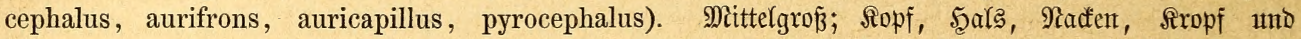

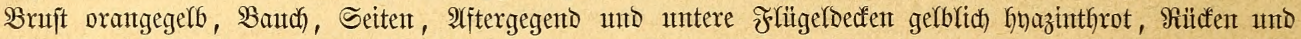

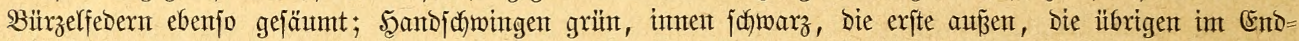

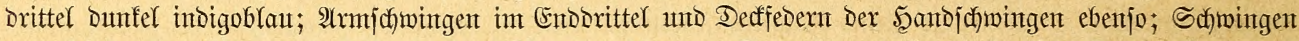

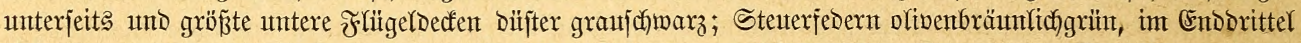

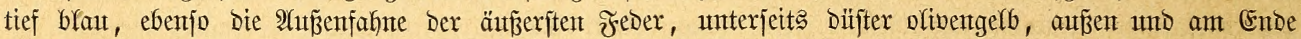

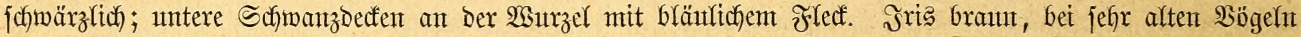

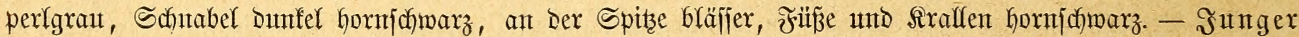

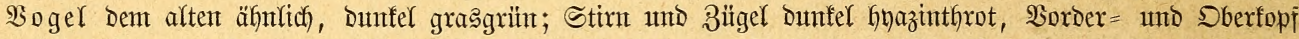

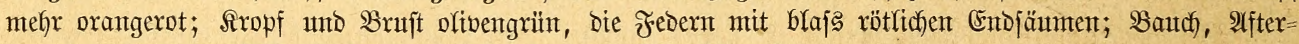
gegend und untere Flügeldecten Dunfel hyazinthrot; Schenfel grün.

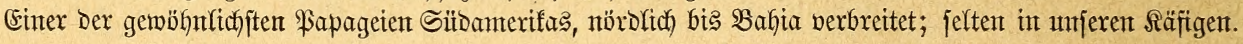

121. Der (ŚlDitimitittid, C. (Ps., S., Arat., Eupsittula) aureus, Gml., (brasiliensis, cani-

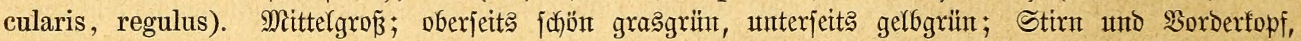

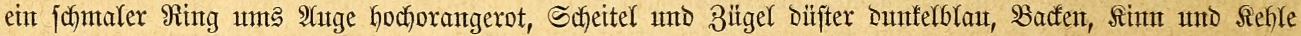

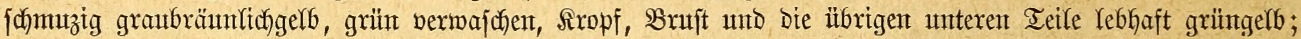

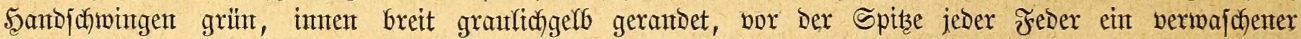

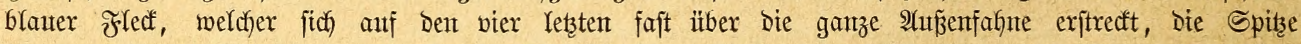

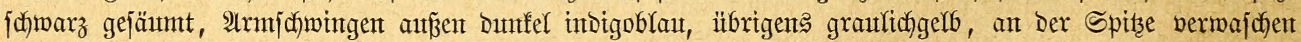

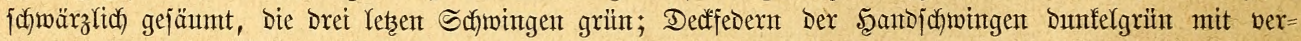

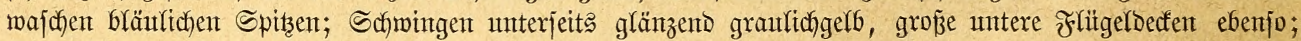

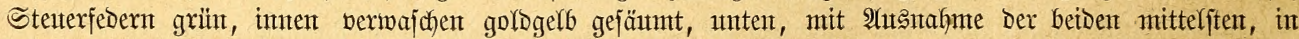

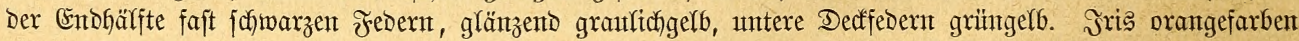

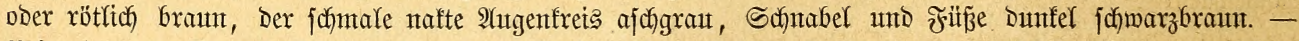
Beim jungen Dogel Stirn matt orange, Bacfen, Rim, Rehle und Rropf mefh gelblich, oliven verwajd)en.

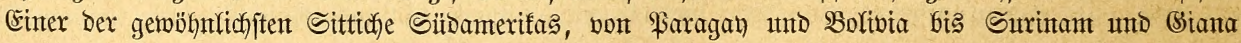
verbreitet.

122. Der (śfenbeinitttid), C. (Ps., S., Eups., Eupsittaca) Petzi, L., (eburnirostris).

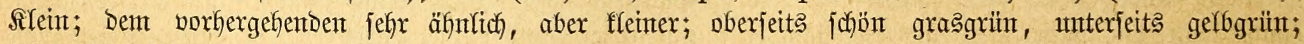
Sorberfopf bis zu Den $\mathfrak{A}$ tgen Yebhaft orange= ober morgentot, Sberfopf Dunfelblat, Bacfen und. Shrgegent,

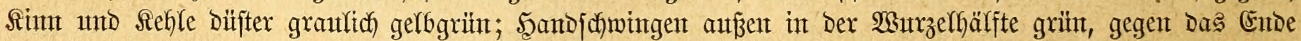

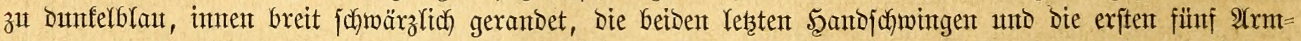

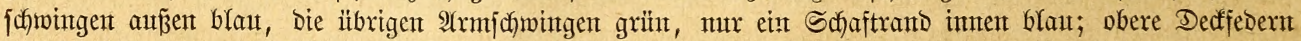

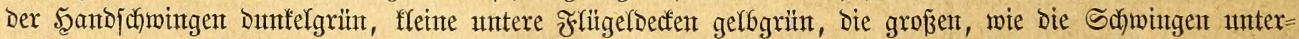
feits fdumärzlich; Schwanzfebern innen mo anterjeits olivengelb mit grantem Scheine, gegen bie Spize zu

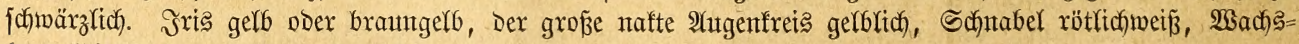

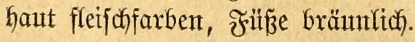

Sertritt Den borigen in Mejifo und Mittelamerifa, wofelbjt ex fefr gemein ift.

123. Der (Gofomagfenittidif), C. (P.s., Psittaca, Arat., S.) pertinax, L., (illiniaca, tui, chrysogenys, chrysophrys, martinicanus, xantholaemus, aeruginosus, ocularis, inornatus, xantho- 


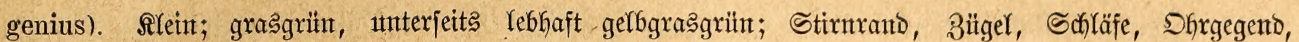

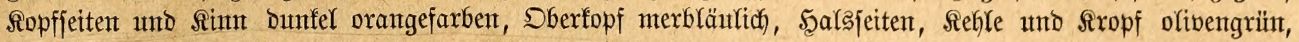

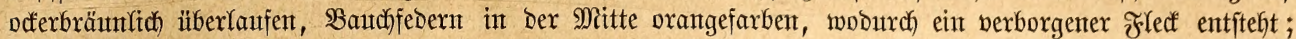

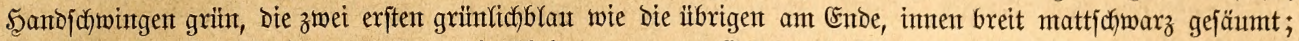

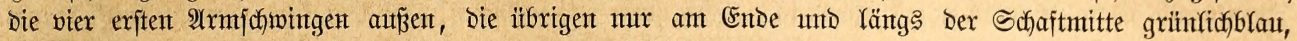

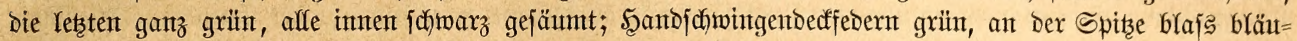

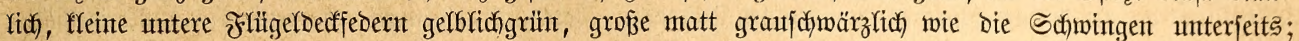

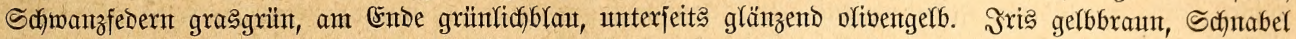

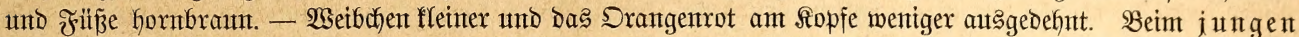

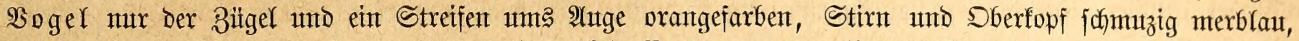

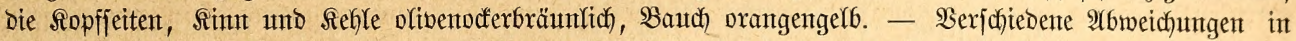

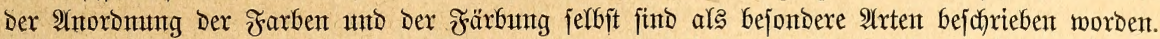

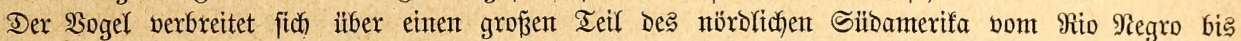

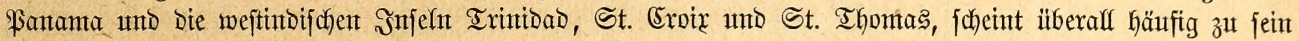
uno gefangt regefmäß̈ig auf Den europäifchen Marft.

124. Der Iaftusitttid, C. (Ps., Arat. S.) eactorum, Neuw., (lepidus, caixana). Ritein;

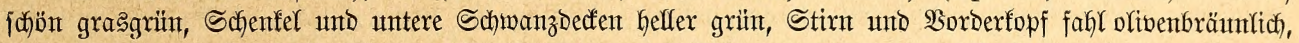
Sint, Refle uno Sropf oliwenbraum, Bruft, Bautd und Ifftergegento tief orangefarben; Sdywingen Dunffer

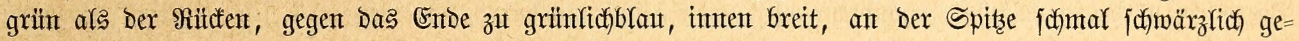

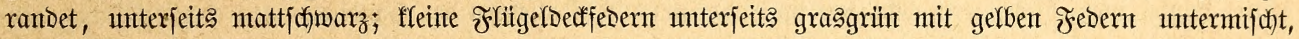

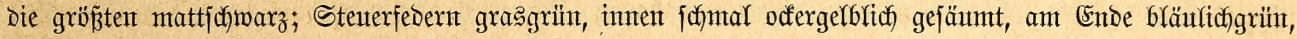

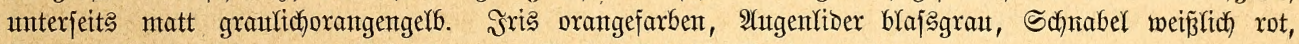
Beine rötliç) Dunfelgrau. - Seim jungen $\mathfrak{B}$ ogel fint bie Farben matter.

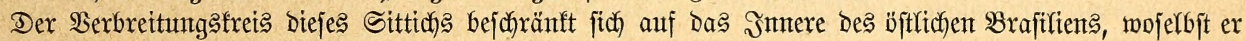

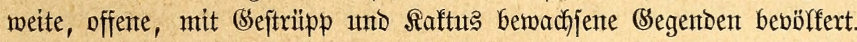

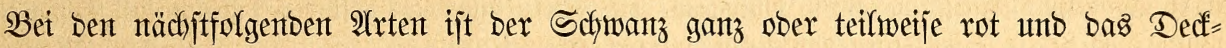
gefieber ber J̧anbjchmingen blau ober grün, bie Färbung überfaupt eine fefr bunte. Sie finto grö̈̈tenteils flein unt Gaben bunfle Sdynäbel.

125. Der Smaragdittid, C. (Ps., Microsittace) smaragdinus, Gml., (ferrugineus, phoenicurus,

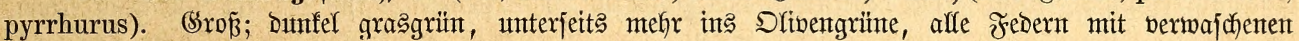

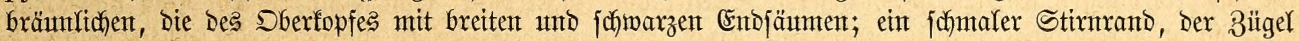

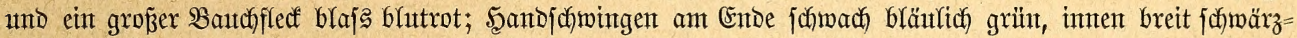

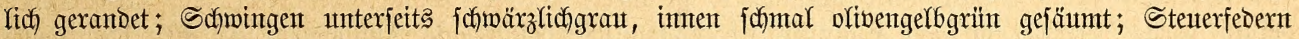

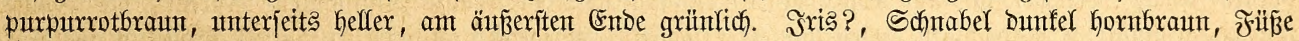

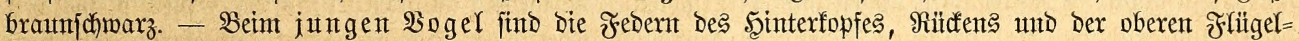

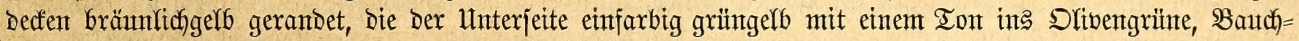
flect blafarrot.

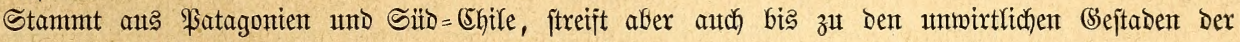
Magethaentaftraß̧e hinauf:

126. Der Blaulabjittid, Tirifa Der Braffliater, C. (Ps., S., Arat., Psittacara, Pyrrhura) cruentatus, Neuw., (erythrogaster, squamosus, cyanogularis, Lichtensteinii, Vigorsii, tiriba). $\mathfrak{T}$ Tein;

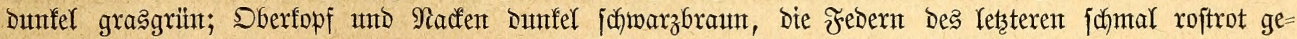

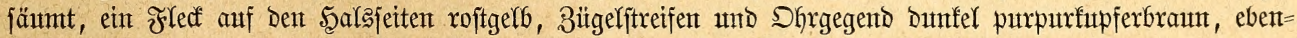

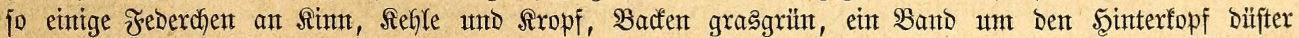

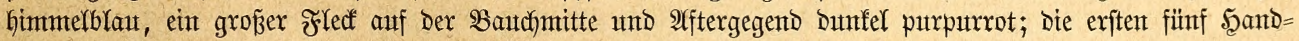

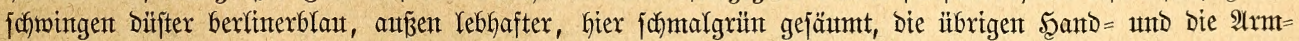

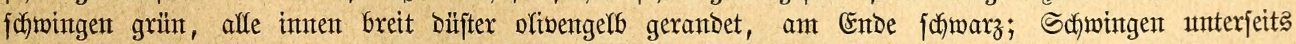

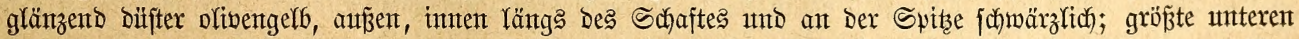

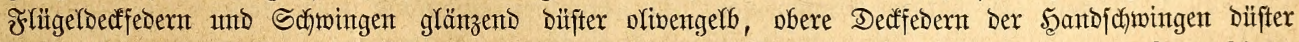

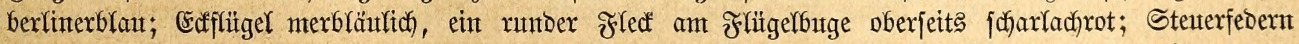

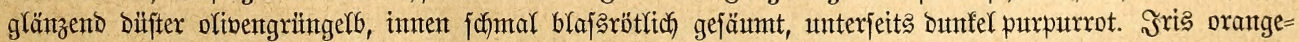

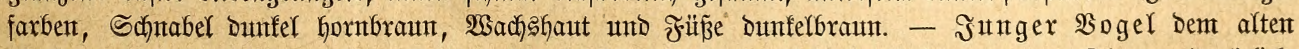

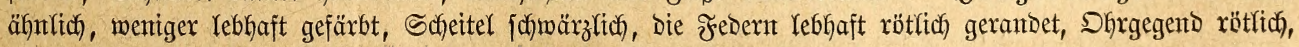

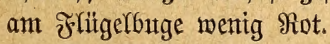

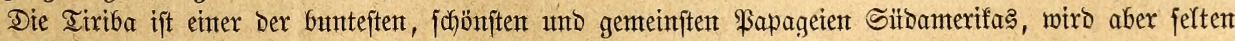

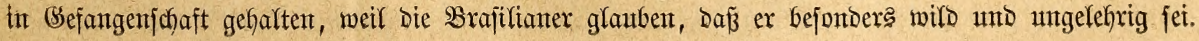


127. Der Brautufritttid, C. (Ps., S., Arat., Micr., Pyrrh., Psittacara) vittatus, Shaw.,

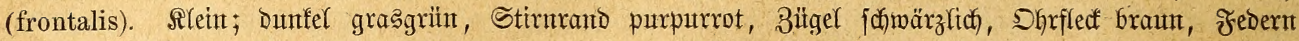

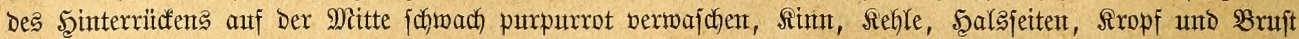

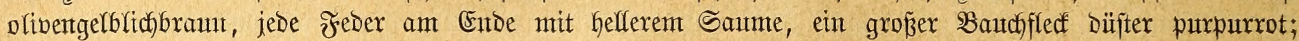

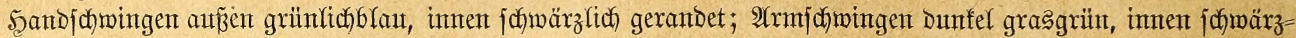

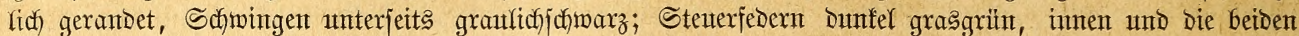

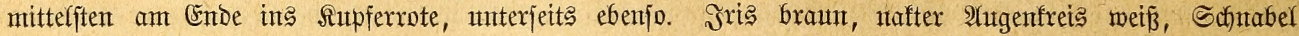

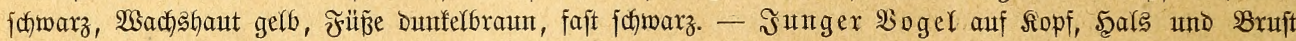

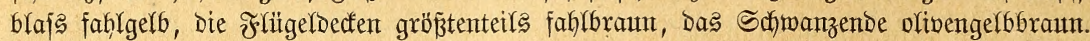

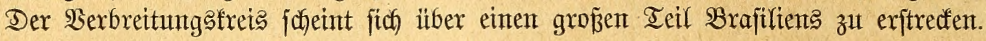

128. Der $\mathfrak{B e i p o h r j i t t i d , ~ C . ~ ( P s . , ~ S . , ~ A r a t . , ~ P s i t t a c a r a , ~ M i c r . , ~ P y r r h . ) ~ l e u e o t i s , ~ L i c h t e n - ~}$ stein, (ninus). Rlein; Dunfel grasgrïn; Stirnrant, Bïgel, Badfen fupferrot, Stimfedern blauffed

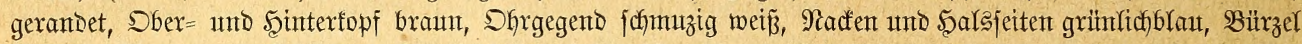

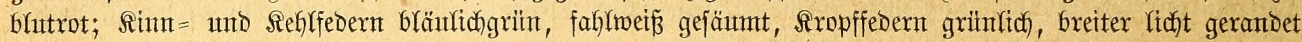

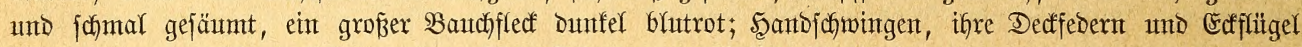

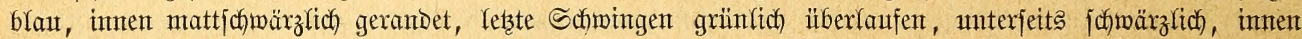

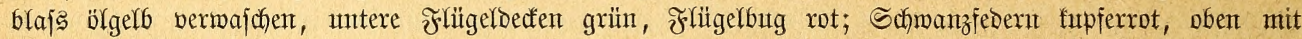

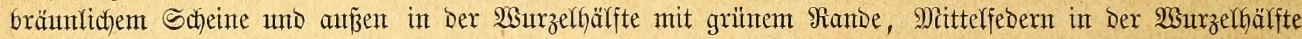

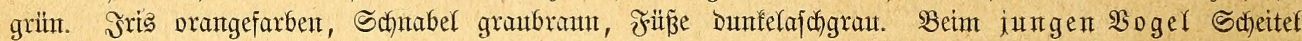

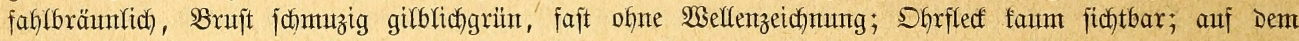

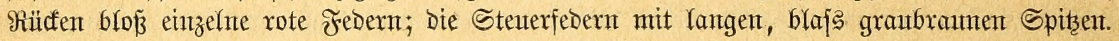

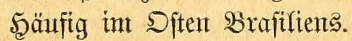

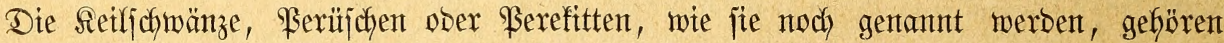

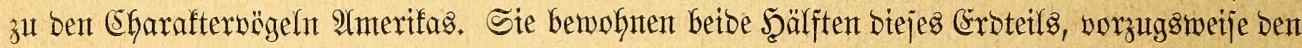

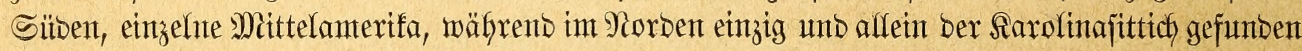

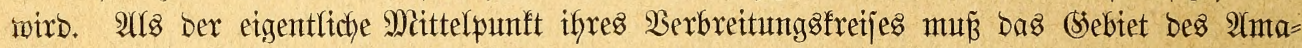
zonenjtromes und jeiner Buflïfje betrachtet merben; jebenfalls treten fite fier in ben meiften Ârten auf. Das meitliche Sïbamerifa beherbergt iffer meit mentigere, und bie bort vorfommen=

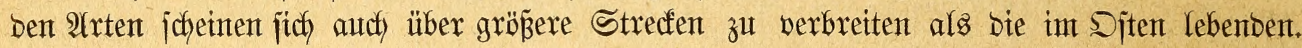
Einzelne $\mathfrak{A}$ rten ber nörblidjen Ieile Sitbamerifas werben weiter jüblich burch anbere, jenen

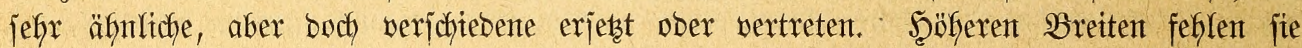
übrigens feinesiwegs, wie ber Sarolinajittich im Norben ober ber Smaragojittich im Süben zur

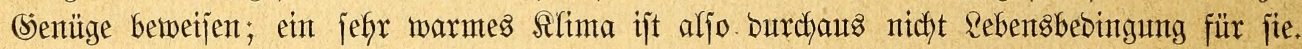
W3iljon jafy zu jeiner nidyt geringen Bermumberung Den farolinajittich im Februar währento

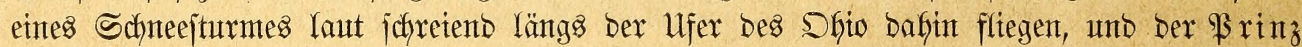

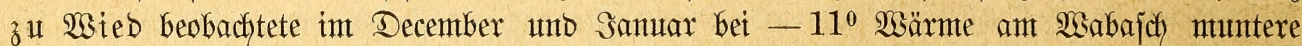

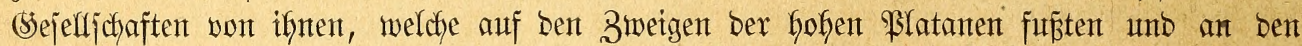

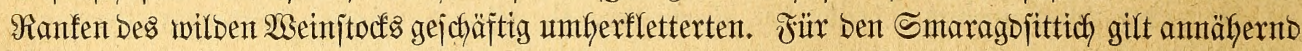
basjelbe, ba ex noch in bem jüblichjten SGite gefunben wiro, ja jogar bis zux Magelfaenz= jtraje nach Sïben fintaufgeft.

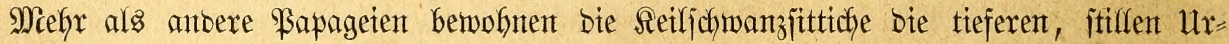

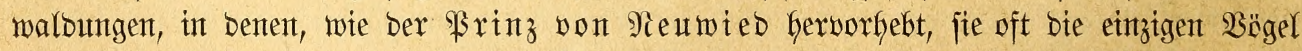

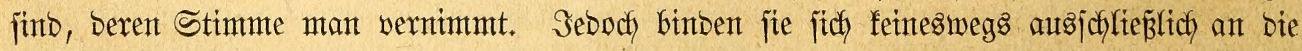
Walbungen; mebrere $\mathfrak{A}$ rten finben fich mur in ben jteppenartigen Iriften bes intern $\mathfrak{B r a}=$ filiens, in benen bie Bäume bloź dajenartig zeritreut auftreten und anjtatt if̧rex willoes (S)ejtrüpp, aus Sträuchern und Raftuspflanzen gebilbet, Den von Menjichen noch nicht in Bejits genommenten Boben bebedf; einzelne Ârtent, wie ber Feljenjittich, wurben in noch

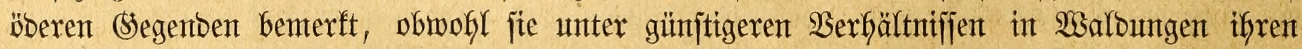

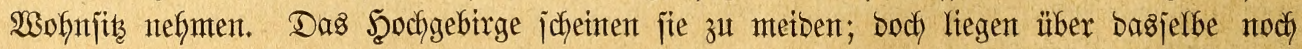

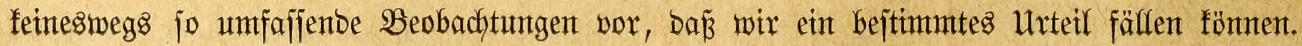




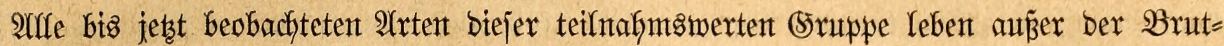
zeit, einzelnte auch mäfrento berjelben, int Bejelljchaften von größ̈erex voer geringerer 2 (nt=

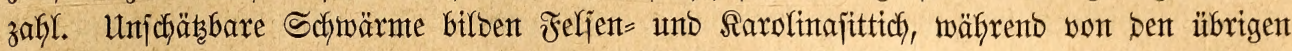

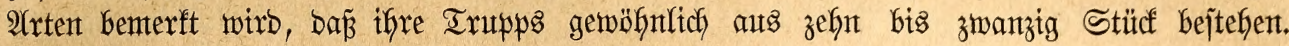

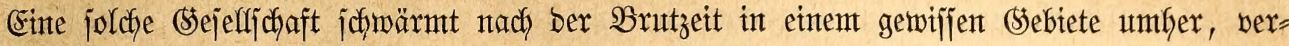

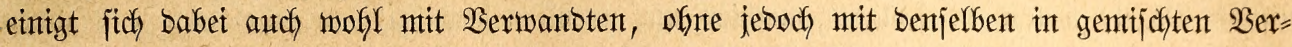
banto zu treten; jeber Irupp bält jich int (segenteile für fich unb bilbet greicfjamt eine ge=

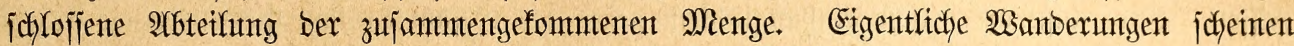

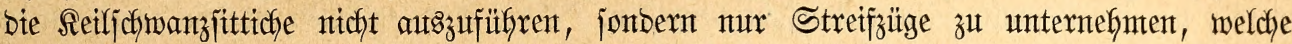

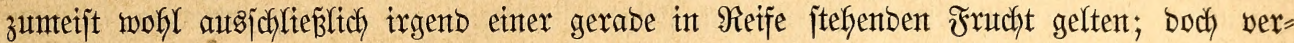

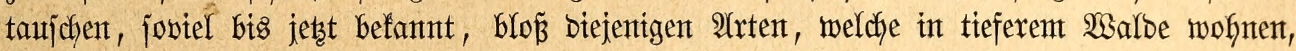
biejen zeitweifig mit ben \$Fflanzungen an ber Süfte, während bie mefr ben öberent

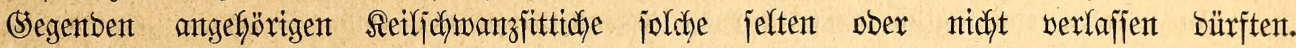

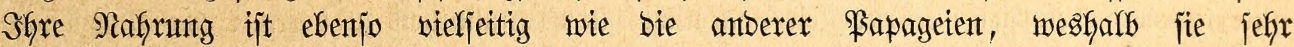

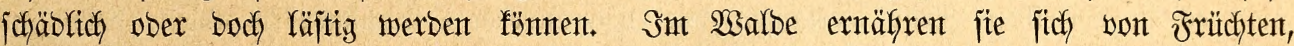

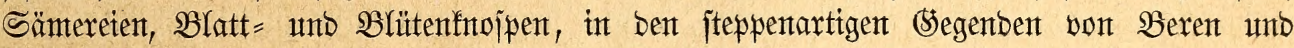

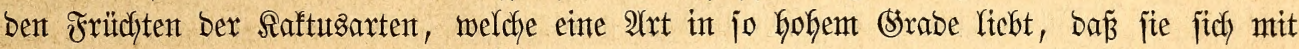

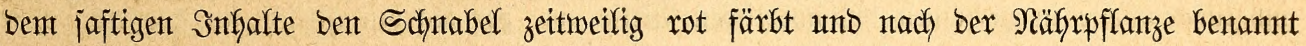

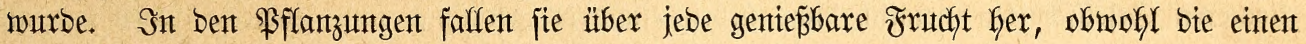

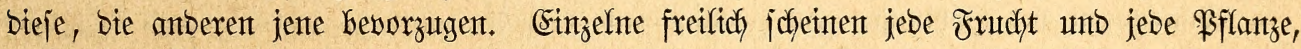

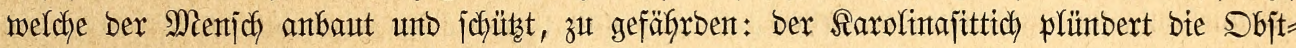
pflanzungen, fäflt auf Den Felbern eint, jobalb bie Sat zu feinten beginnt, unto ziefyt mit bem

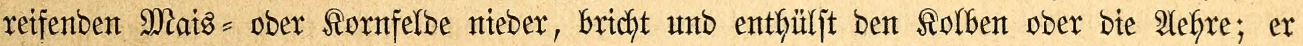
erjoheint noch int Spätherbjte unto Winter auf ben int Felbe ftehenten Feimen, Gängt fich

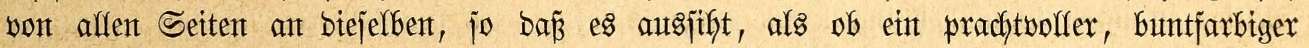

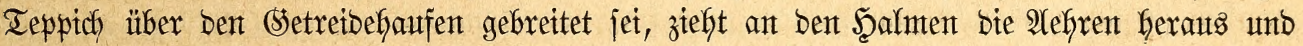

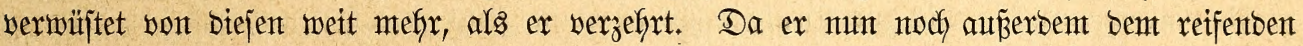

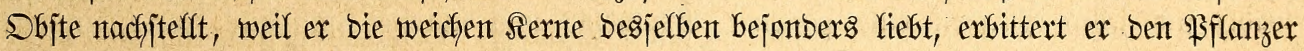

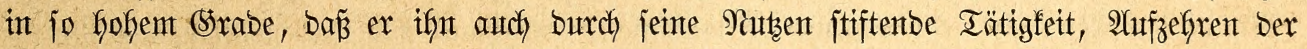

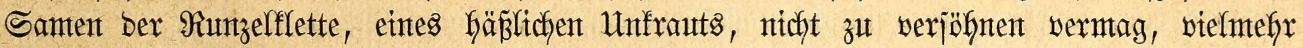

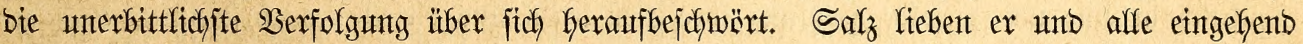

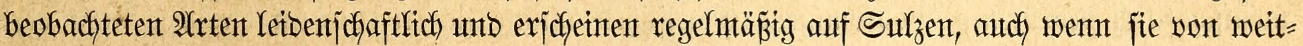
Ger zu benjelben fliegen müfjen. Saum befier als bie Sarolinajittiche treiben es bie übrigen

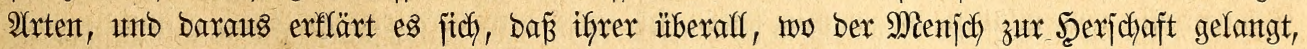
immer wentiger werben. Zut biejer Berminbenung trägt freilich auth bie mehr unt mefyr

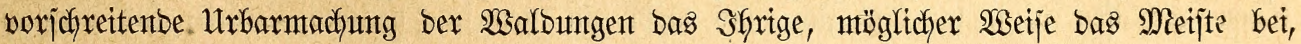

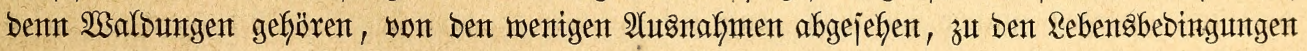
unjerer $\mathfrak{i b ̈ g e l . ~}$

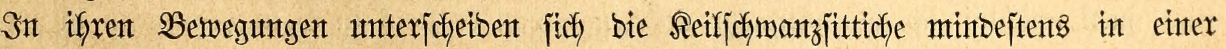
Sinficht von ben biaher erwähynten ßapageien unt Sittichen. Sie jint ziemlich jofwerfäflige (Sänger - Räufer fant man nicht jagen - aber äuß̌erjt gejchicfte Sletterer unto ganz vorzügliche Flieger, wie ber Baat ihrer Sdywingen unb ifyrez Schwanzes von vornfyerein

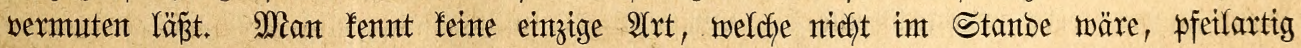

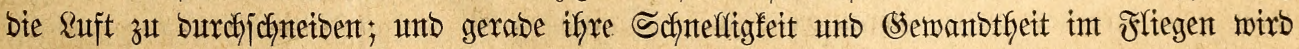

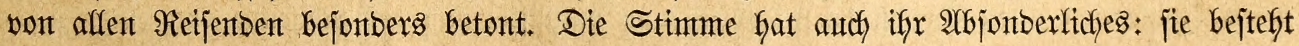

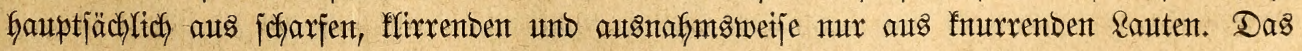
miberwärtige Sretjchen ber Rafabus unb anberer größ̈erer ßapageten vernimmt man von 
ifynen ntidyt; in ifyremt Sejdyret liegt sielmebr trots aller Schärfe ber einzelnen Raute, einte gemiffe Mafiff, meldye namtentlich zut Beltung fommt, went bie $\mathfrak{B o ̈ g e l , ~ m i e ~ f i e ~ z u t ~ t u m ~}$ pflegen, juretent in hoher suft bafinjagen. Die geiftige SBegabung unt Eigenjalaften fommen mit benen anberer Fapageien wentgitents antähernd überein. Alfe Seifjchwanz= jittiche, bie fleinern $\mathfrak{A}$ rten faum autggenommen, jund fluge, verjtänbige, vorjichtige, icheue unt

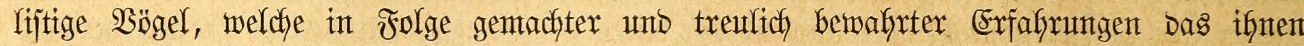

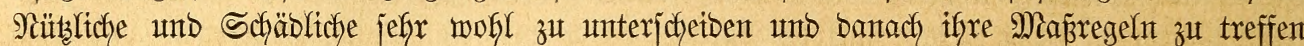

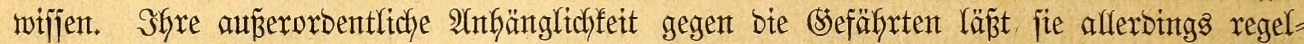

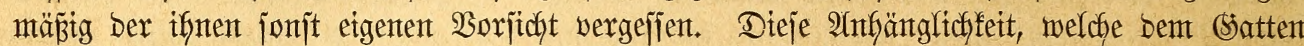

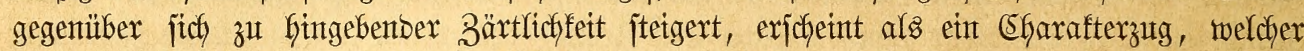
umjer Urteil über bie bejonbere Begabung ber Bögel mur bejtätigen fant. GGre leidjte 3ähmbarfeit unb (Selebrigfeit jteft hiermit ebenfalls volffomment im Einflange.

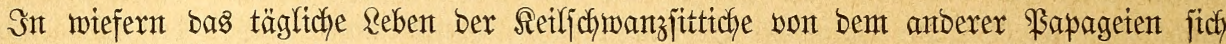

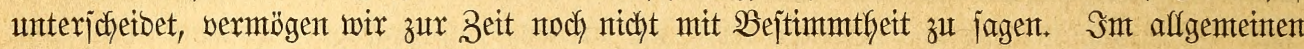
mag es in berjelben Weije verlaufen wie bas anberex Srbnungsverwantent; Dod find immerfin einzelne Büge vermerft morben, weldye ifnen eigentümlich zu jein jcheinten. So

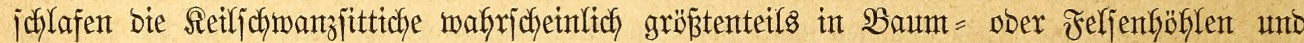

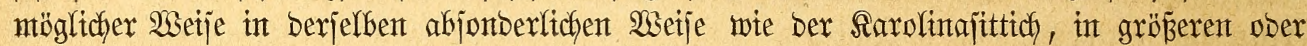
flemeren (Sejellfchaften nemlich Didft neben einander gebrängt und jenfrecht angefängt an

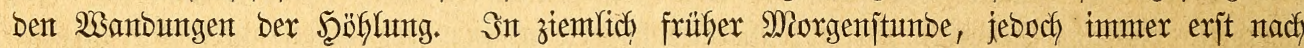
Sontenaufgang, jammeln unt erheben fie jich und fliegen mut unter lautemt (sejchrei nach

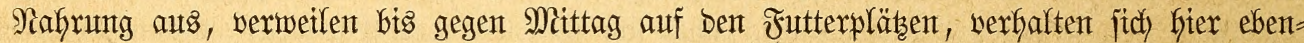

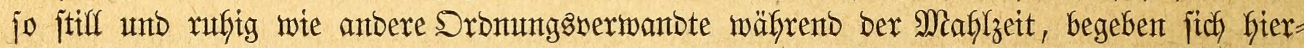
auf zu Sulzen und zum Wajfer und fefren, went bie Iageshize empfintlich wirb, zum

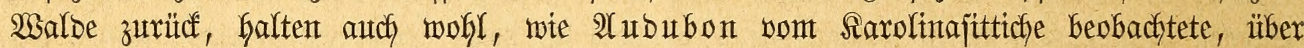

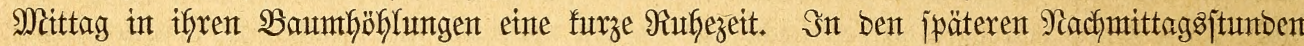
begeben jie jich nodymals zum Jutter, und furz vor Sontenuntergantg febren fie zut ifrent Schlafpläben zurücf. Bis zur Brutzeit fint leben fie jtets gejellig; wäbrent ber Brutzeit mählt jich jebes ßärchen einte pajfente Bruthëhle unb jchreitet nut zur Jortpflanzung; boch fintb auch fiterbei eintige Züge bejonberer Ermäfnuth wert. So liegen gentügenbe

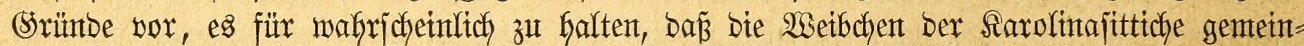

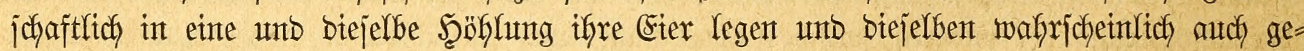

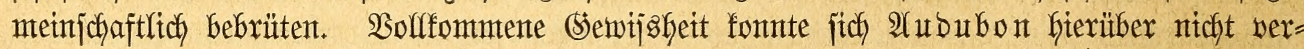

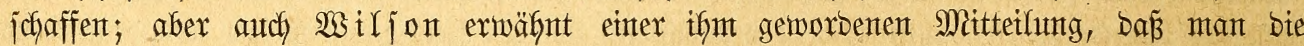
Sifalenteite von mintoptents zmanzig Eient in einer und berjelben Scöblung gefunben Gabe. Bei bem innigen Berbantbe eines Irupps ober Schmarms biejer Sittiche, bent genteinjechaft=

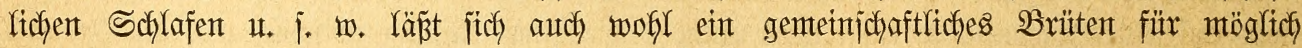

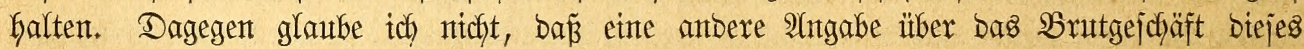

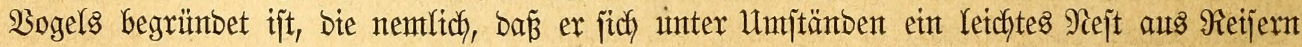

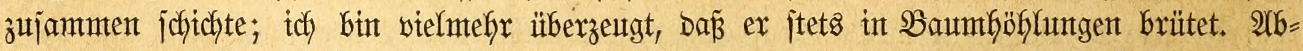
metchent von affen übrigen bis jebst genauter befannten 2 (rten nijtet ber Feljenjittich. "Dft,

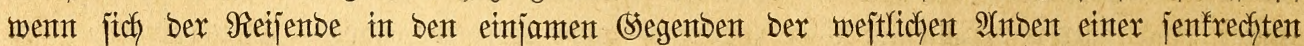

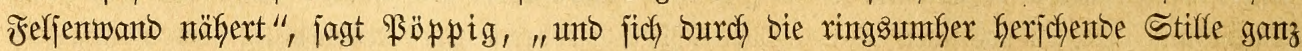

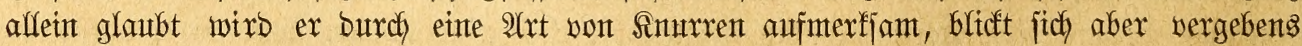

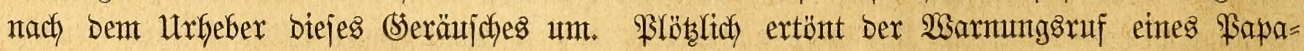
geien, wirb won alfen Seiten beantwortet, und bald fift fich ber Reijenbe von einer zafyl=

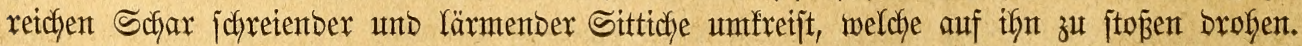

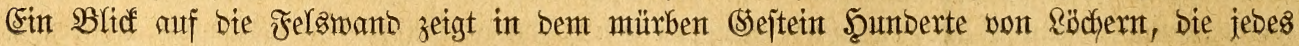




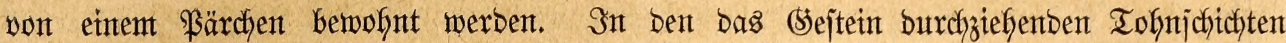

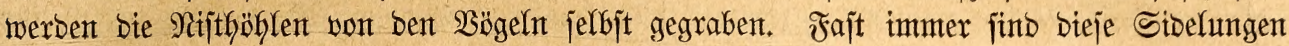
jo flug angelegt, baß̉ ifnent weber Raubtiere noch Menjchen beifommen fönnen; Da aber

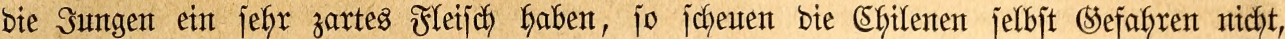
unt ifjrex jich) zu bemtächtigen, laffen fich) an lantgen safjos an ben Feljentwänben herab unb

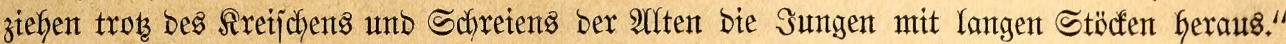
Aluch Darmin beobachtete benjelben Papaget bet Bafta blanca als Brutvogel, und zwar nijtete er fier in sejelfichaft einer Schwalbe ebenfallz in Feljen = und Erolöchern. Satn=

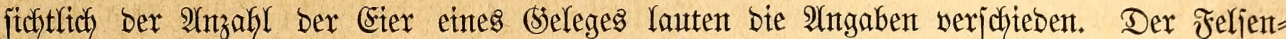
fittich foll nach $\mathfrak{B}$ ribges brei bis jects (Eier Yegen, won Denen Darinin noch bemerft,

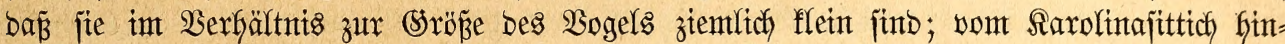

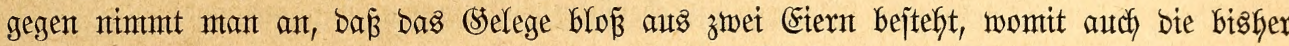

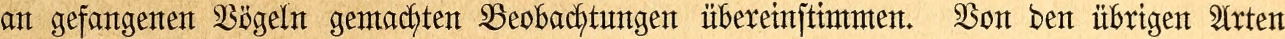
wito bie $2(n z a h l$, meift nach Bericht ber Eingeborenen, auf zwet bis vier angegeben, uno

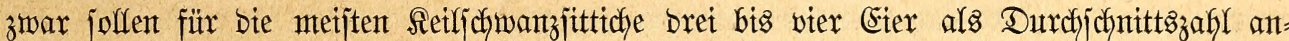
gentonmen merben fönten. Ueber bie Sflege ber Sungen mifjen wir mentg, wohl aber fo

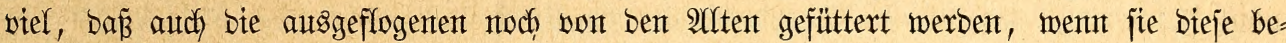
reits auf ithren $\mathfrak{B e u t e z u ̈ g e n ~ b e g l e i t e n . ~}$

Wie jchon bemerft, erletben bie Retljchmanzjittiche ba, wo jie ben Menjchen läjtig

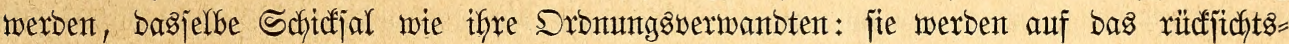

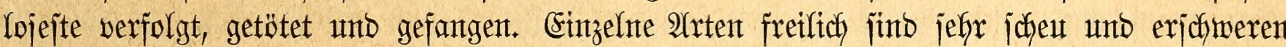
Die Sago; fein einziger Seilfchwanzjittich aber jcheint, wie andere Fapageien es tun, Wachen

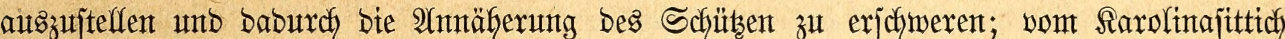
mird jogar erzählt, baj er mit einer faum glaublidhen seidftfertigfeit mieberholt biejelben Stellen bejuche, auf Denen wentge Minuten zuvor Dubende jeiner Sienofjen erlegt wurben. Mit Şilfe eintes Rodf́ogels ijt es leidft, jie in ben verjediebenjten Falfen zu berüdfen; Denn fie achten bant weber bas ifnen gejtellte Rets noch bie Reimmute. Went man unter einen

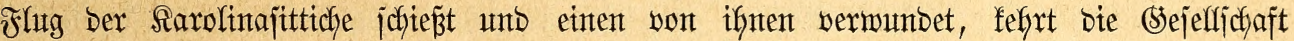

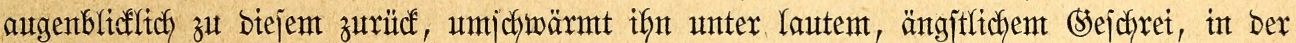

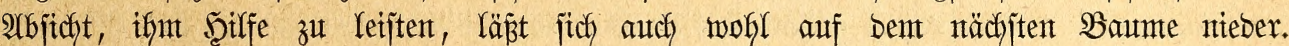

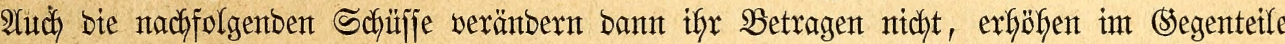

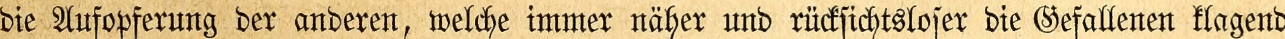

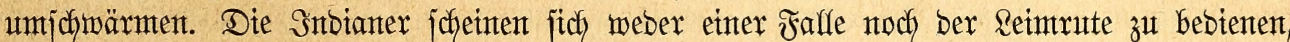

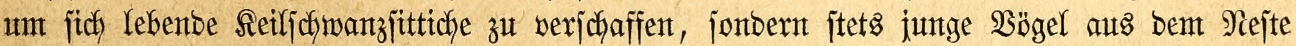

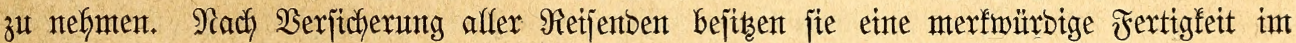

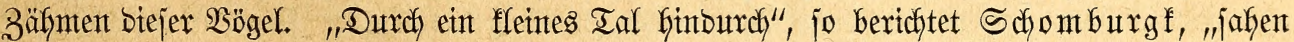

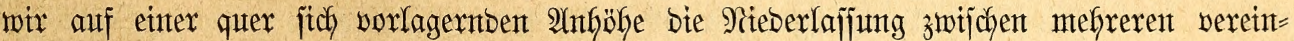

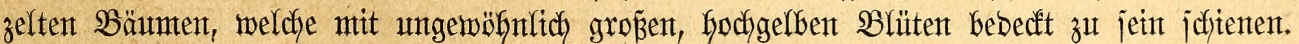

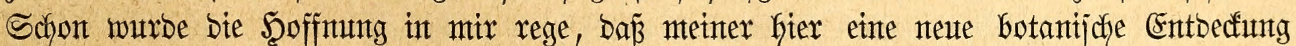

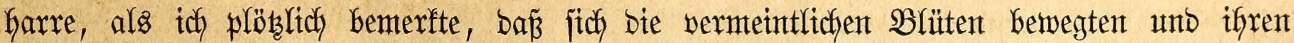

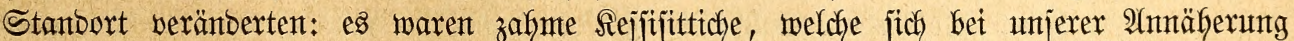
unter einem wahren Së̈lfenlärm erfoben unb nach einer ber nahen Së̈tten flogen. Die

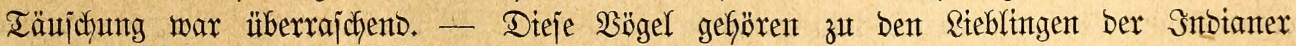

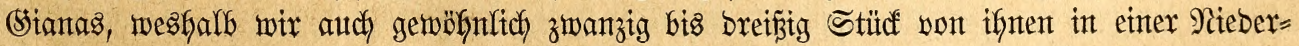

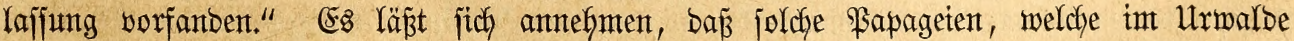
an frees $\mathfrak{A}$ (1ts = unb (sinfliegen gemölynt waren, nur jung aufgezogente jein fonnten; affein

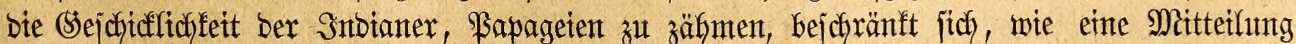
bes glaubwürbigen $\mathfrak{B}$ ates beweijt, fentesmegs auf Sunge. 


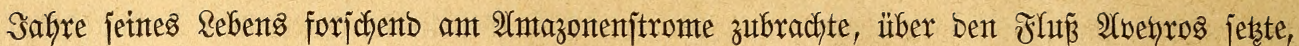

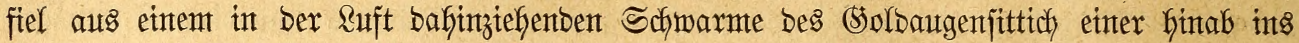

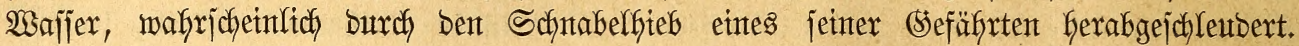

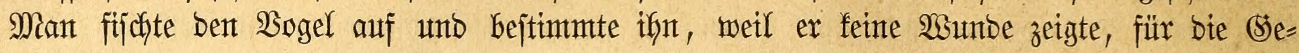

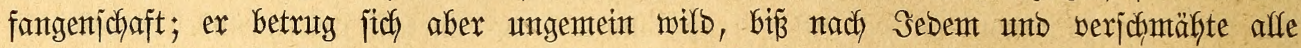

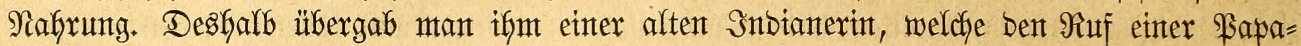

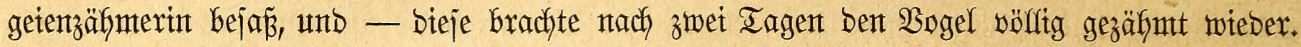

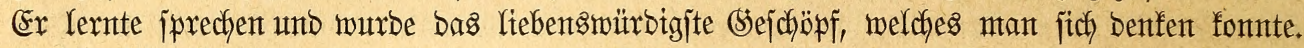

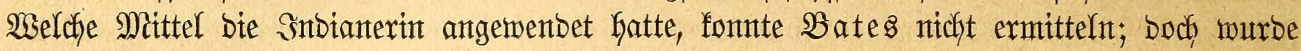

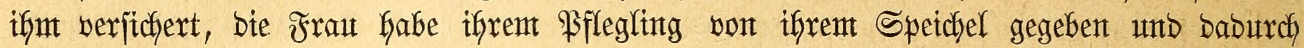
bieje mutnberbare Wirtung erzielt. Wä̈re $\mathfrak{B}$ ates einer jenter unfunbigen unt leidftgläubigen

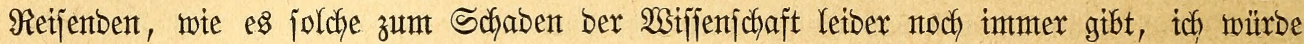

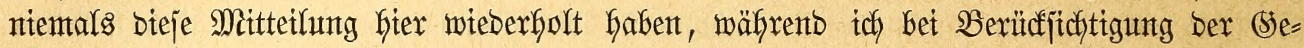

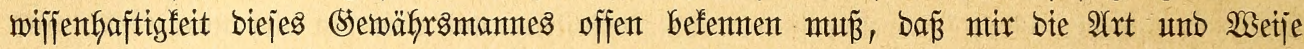

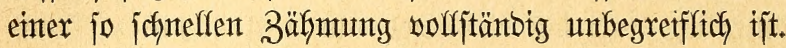

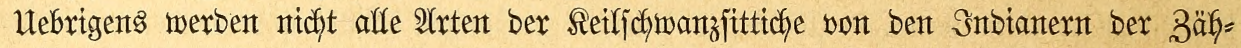

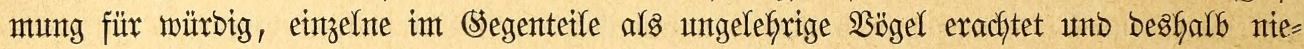

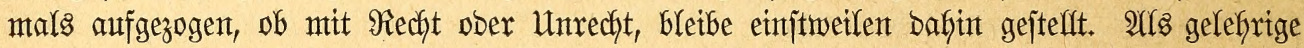

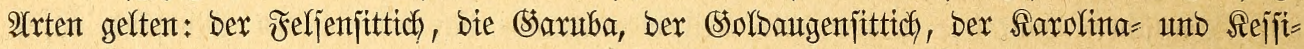
fittidy, als ungelefrige bezeddyntet man bie übrigen oben aufgefüffrten 2 trten. Mian fiht

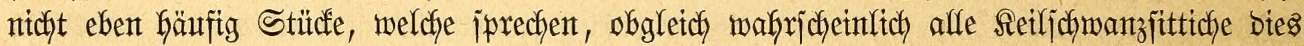
lenten; effer noch fintbet ntant einen unto ben anberen, welcher eine Singweije pfeift, was

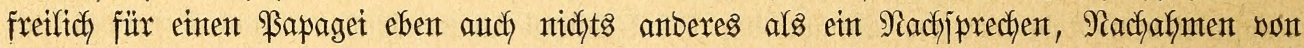
ifgm uriprünglidy fremben Rauten ober Tönten ift; Dent fein einziger biejer Sittiche bejitzt

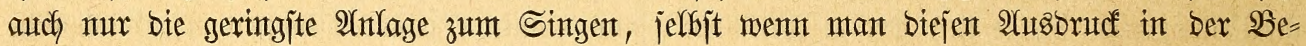

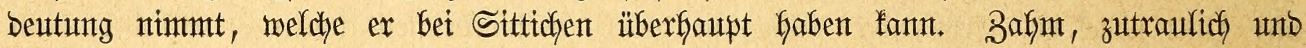

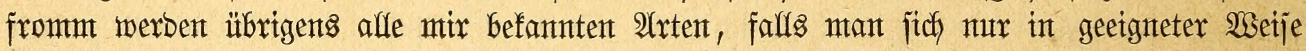

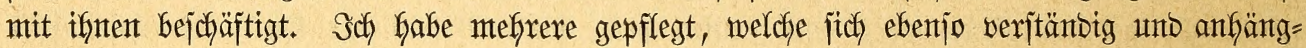

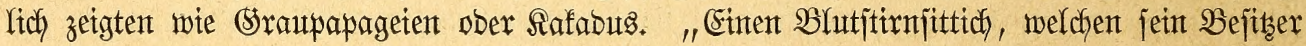

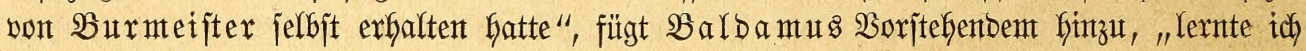
als ben liebenswürbigiten unt zutraulfichjten alfer \$rapageien fenten, welche nir jemals

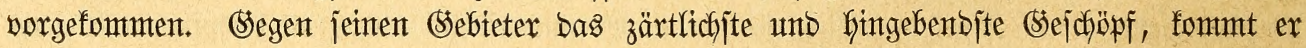

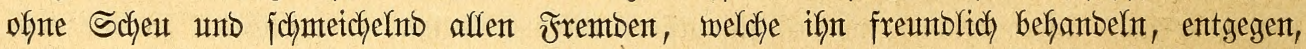

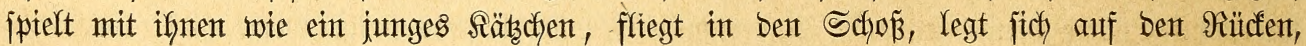

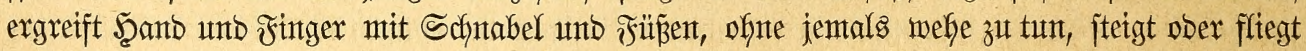
auf bie Schultern, jpielt mit bemt Shre, bent Şargfragen 2 ., aber jtets in bejcheidenjter

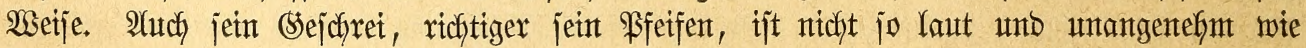

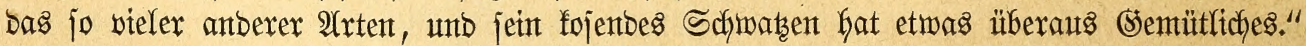

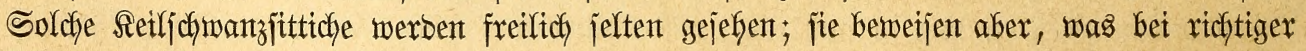
Fiflege auts ithrent Sejchlecthte werbent fantr.

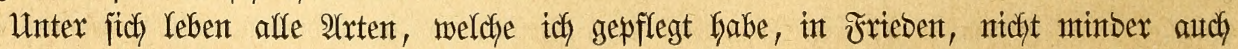

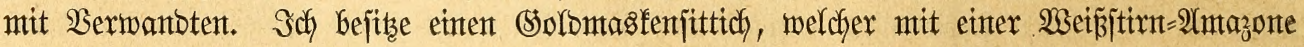

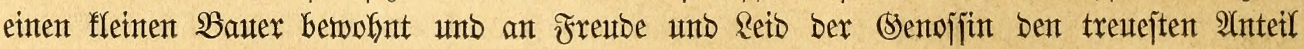

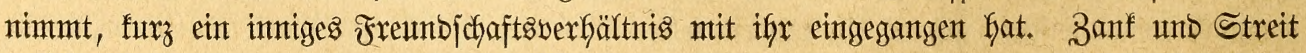

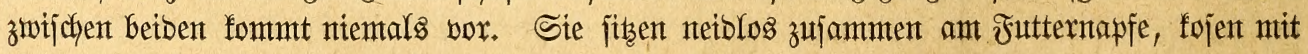
einanber und wefyren gemteinjant jebe Störung ab.

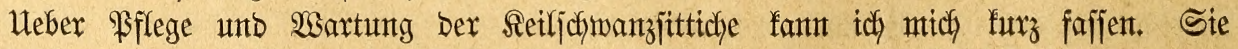

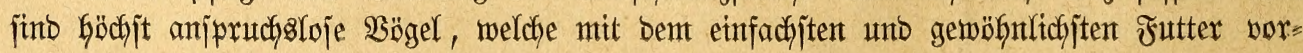




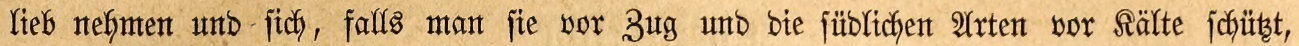

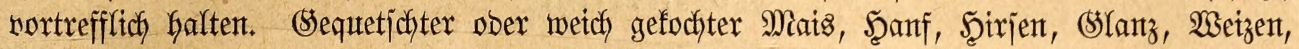

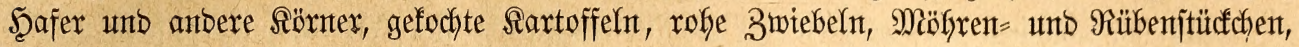

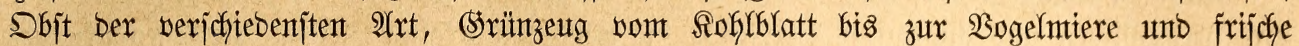

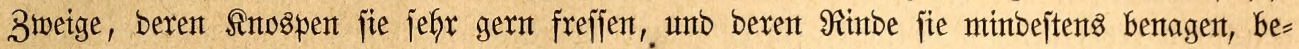

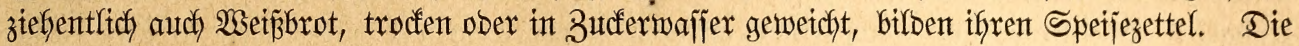

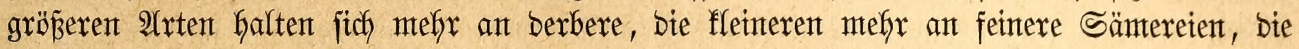

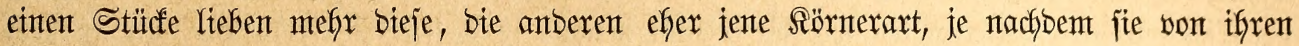
Fängern und erften Zäfntern gewöhnt mutrbent. Einzelne $\mathfrak{A}$ rtent, namtentlich ber Rarolina=

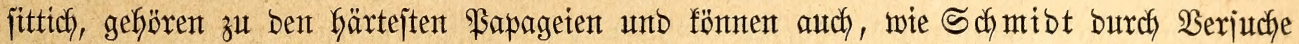

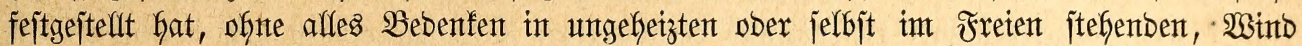
untb 2 Setter zutgäntglidchen Fluggebauternt ïberwintert merben.

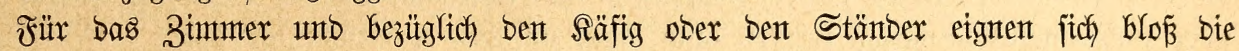

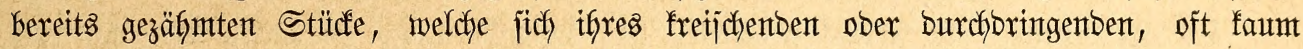

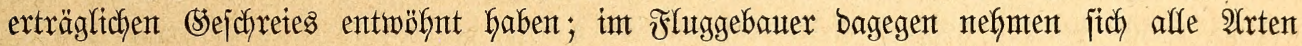

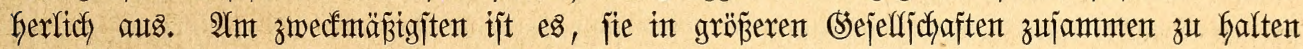

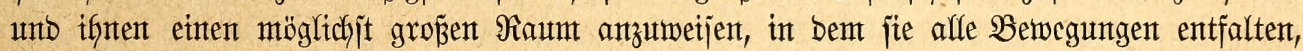

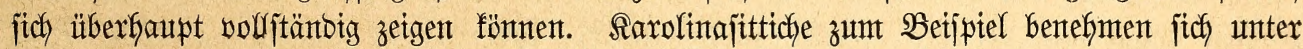

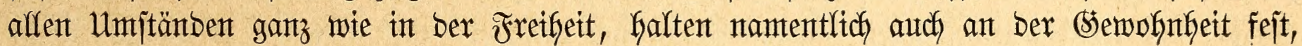

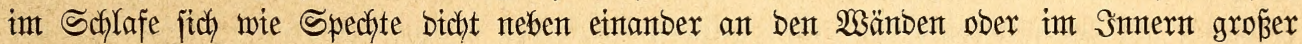

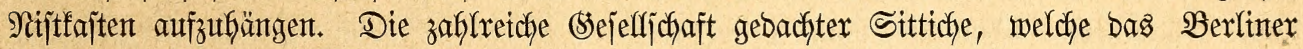

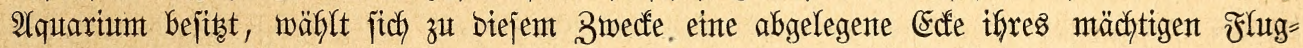
gebauters und flebt fier von Begint ber Dunferffeit bis zunt früfen Morgen in ber an=

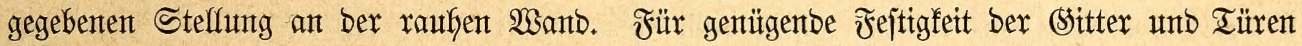

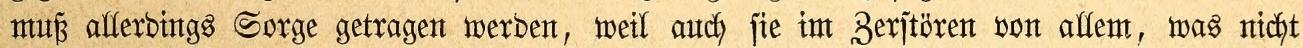

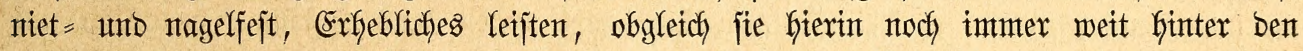

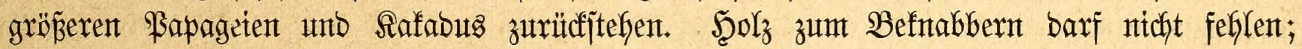

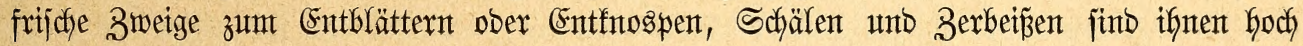
mitffommen.

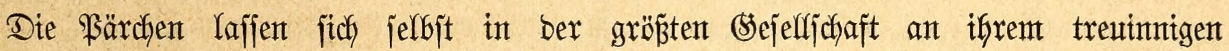
Zujammenthałten unb ber Zürtlidsfeeit, meldye fie gegen einanber betätigen, Yeicht erfentent.

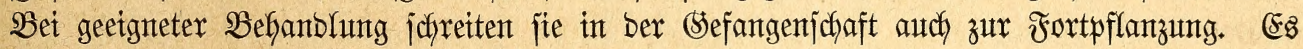

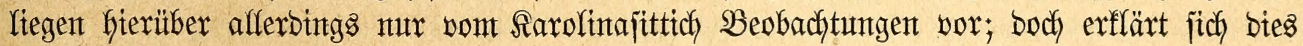

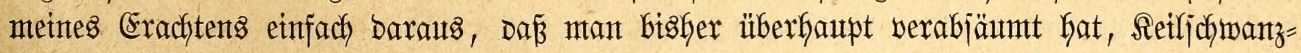

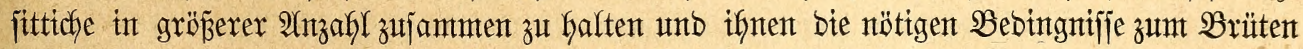
zu gewwäfren. Woollte ntan auf jie ebent biejelbe Sorgfalt werwenten wie auf bie flenteren

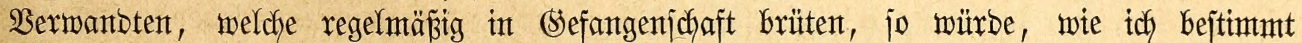
antefymen barf, Das Ergebnis ficherlich antäherno basjelbe feit.

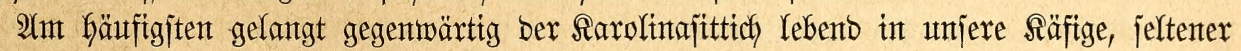

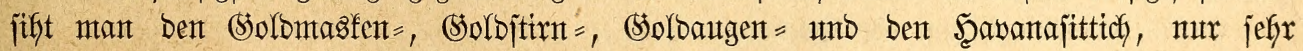

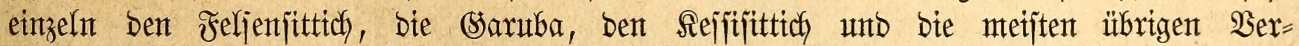

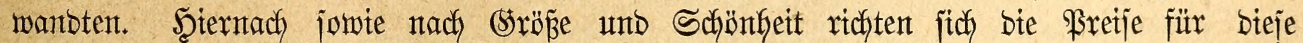

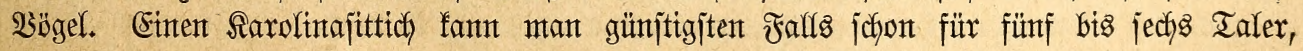

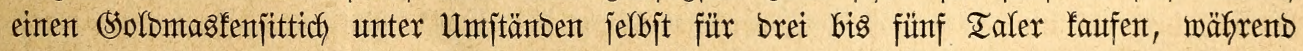

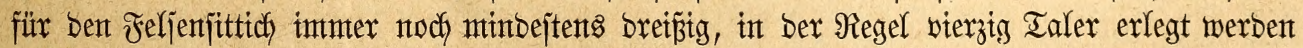

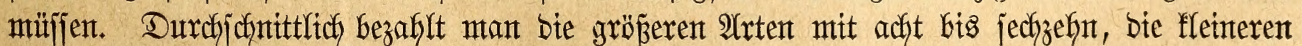
mit fünf bis zefgn Ialern ifyremt 2 serte entjprechento. 


\section{(E)delfittidide.}

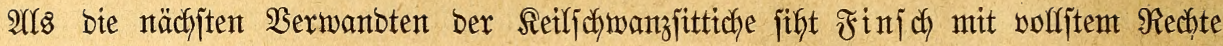

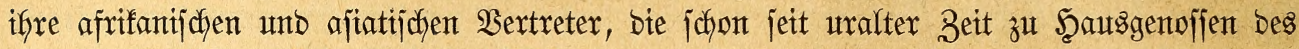
Menjchen erfobenten, in Sejtalt, Färbung unto herworragenden Eigenjchaften gleich ausge=

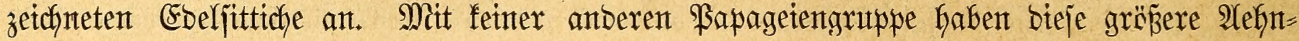
lichfeit als mit jenter, und zwar zeigt jich bies nicht blo ber \&ebensmeije. "Betrachten wir bie Sejtalt genau, fo bieten bie Eseljittiche mur in bem feilförmigen Sdywanze mit ben verlängerten zwei mittelften Febern, in bem Feflen eines Deutlichen naften Afugenfretjes und bem weniger zujammengebrücften Schnabel auffaflende

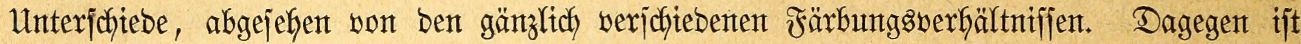

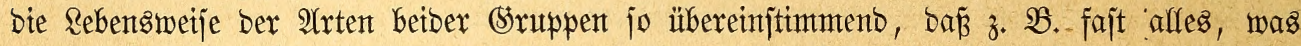
vom Şalgbandjittiche gejagt werben fant, auch auf ben Siarolinajittich pañt."

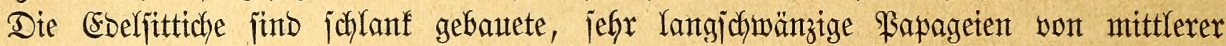

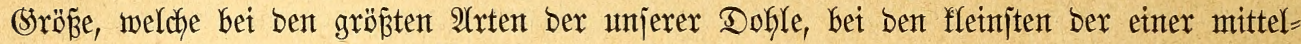
groß̈en Drojfel annäherno gletchfommt. Der jefrx fräftige Sdynabel ijt ebenjo lang ober länger als hody, ber Dberjanabel in Der Wurzelfälfte lantig abgejebst unb fier mit einer jeidhten Rängertnne verjeben, jeitlich janjt gewölbt, baher etwas zujammengebrïctet, jeine Spibe, vor welcher ein Yeidjter Zafnausjednttt jich befintot, jtarf abwärts gefrümmt, über= Gängent, auf ber unteren Seite mit beutlichen Feilferben bejetst; Der Unterjchntabel Gat eine breite abgerundete Diflenffante, längs melcher meijt ein jchwacher Reijtenvorjprung verläuft. Die fleinen Najenlëcher liegen frei in einer fdhmalen Wachshaut. Der furze fräftige Fuz hat itarfe Räufe. Der Flügel ijt lantg unb ipits, meijt etwas fürzer als ber Schmanz, weldher

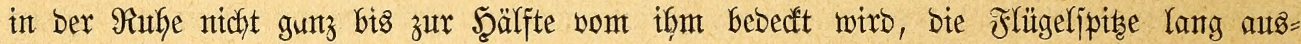

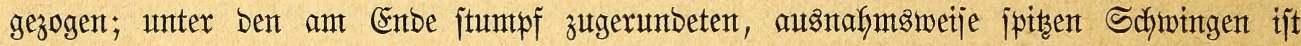
Die zweite ant längiten, bie zweite unt britte außen etwas, bie exjte und zweite jef̧r un= bebeutent auggeidhnitten. In bem feilförmigen abgejtuften Sdywanze ragen bie beiben mitteliten Federn meijt anjegnlich über bie anberen vor, berjchmälern jich gegen bas Enbe fin, zeigen aber wie bie übrigen eine abgeruntete Sptze. Das Befieber, meldhes audh Den Bügel und ben Arets unts âtge befletbet, bejteht aus Garten Febern; jeine vorher=

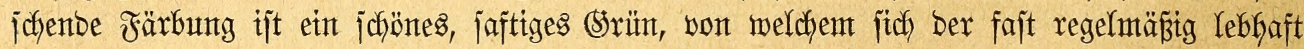

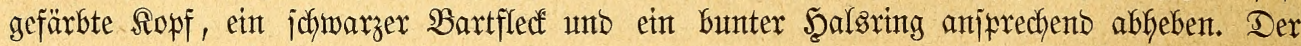
Schnabel hat meijtens rote, jelten jubwarze Färbung, fann aber auth zmeifarbig jetn. SBeide

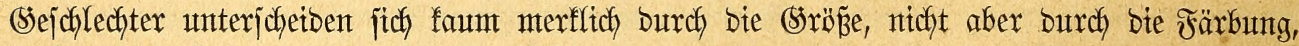

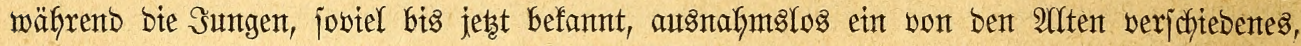

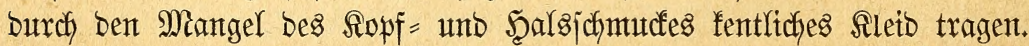

Bei ber auß̈erorbentlichen Uebereinjtimmung alfer Ebeljittiche läß̈t jich bie (sejant= Geit Gloß nach ber Färbung in zwei Sruppen zerlegen, je nachbem bie Seandidymingen unto thre Dedfebern grün ober blau finto.

(5)rüne Şandidymingen unt Dedfebern Gaben:

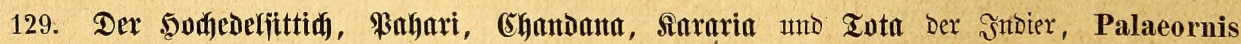
(Ps., Psittaca,) eupatrius, L., (ginginiana, nipalensis, neglectus, cucullatus, Sonnerati). Sefr grofß ; graggrün, auf Sbergars unt Şinterbruft fdiwach graugrün angeflogen; im Ractent ein breites rofafarbentes

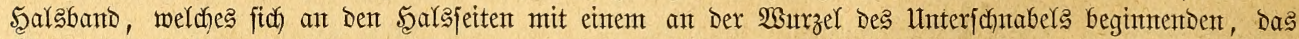
Finn mit bebectenden, fdhmarzen Bande vereinigt; Die ffeinftent Decffedent oberfeits am Unterarm birben

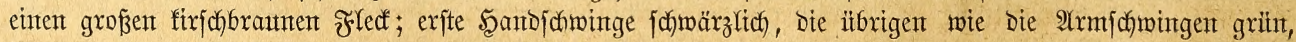

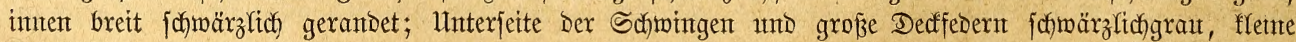

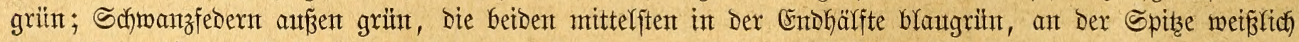

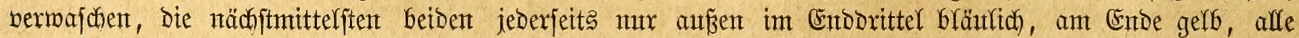




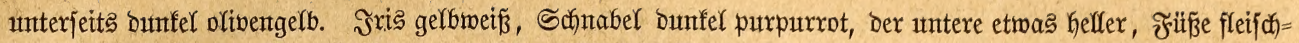

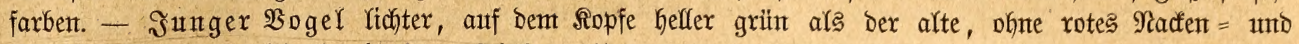

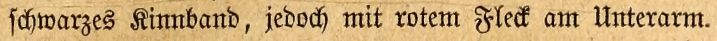

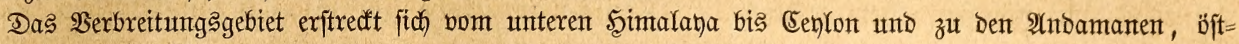
lič bis ßegu unt Siam.

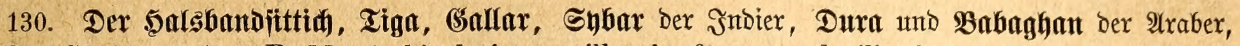
P. (Ps., C.) torquatus, Bodd., (cubicularis, manillensis, frenatus, docilis, inornatus, streptophorus,

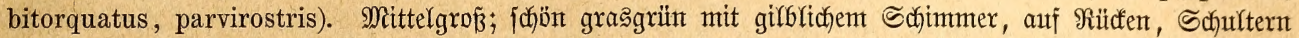

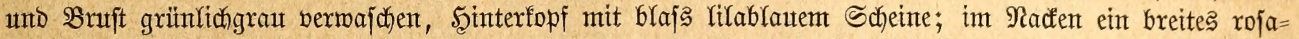

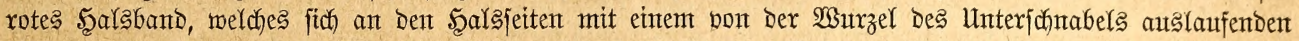

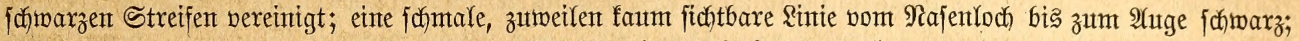

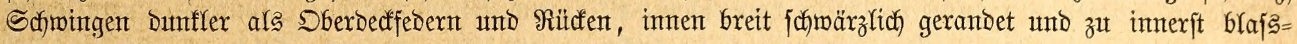

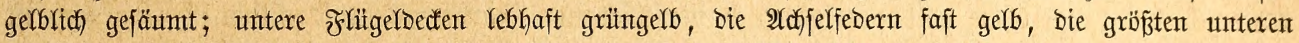
Dedfedern wie bie Schmingen unterfeits büfter graufdiwarz; Steuerfedern oberfeits grasgrün, inten reb=

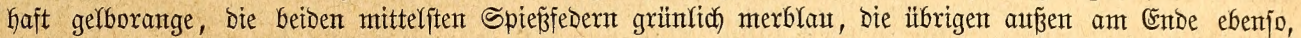

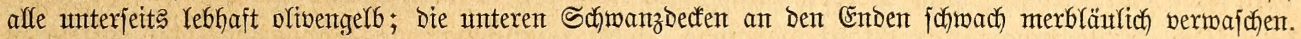

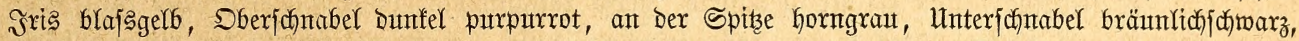

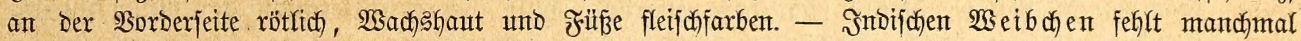

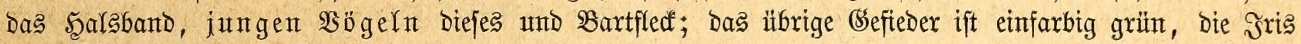

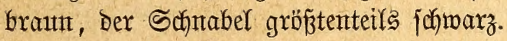

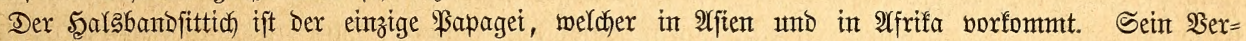

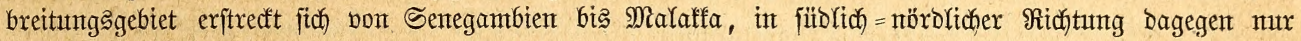

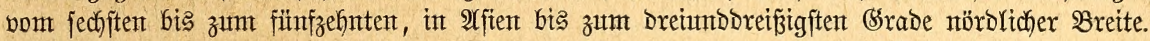

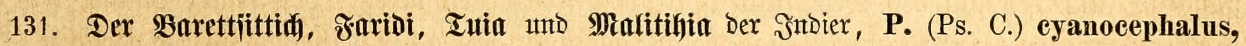
L., (erythrocephalus, annulatus, flavitorques, xanthosomus, flavicollaris, rosa, bengalensis, rhodo-

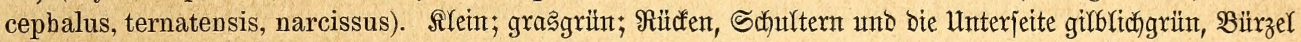

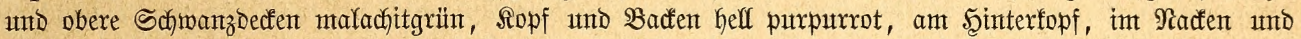

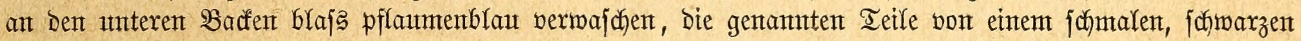

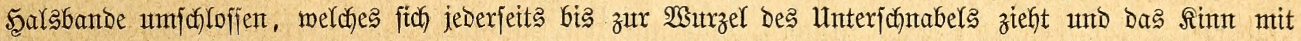

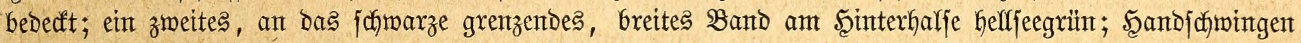

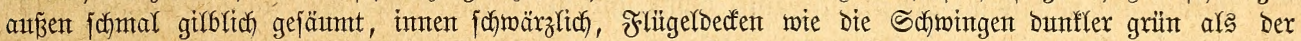

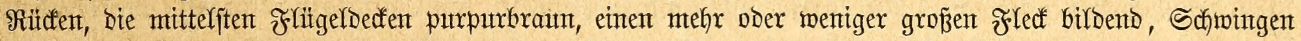

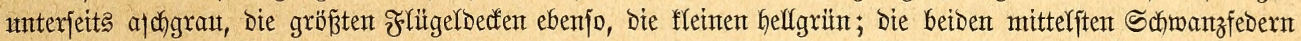

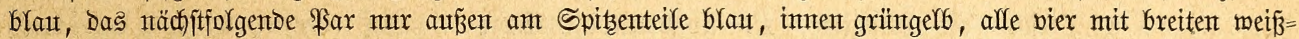

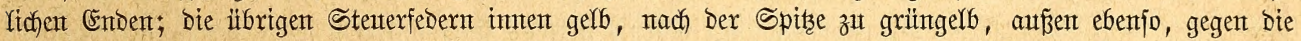

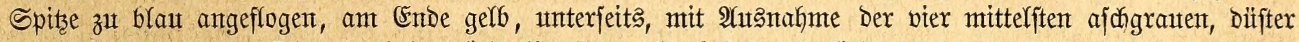

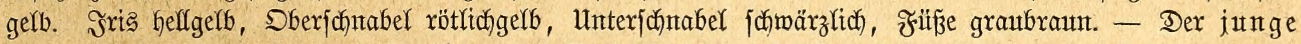

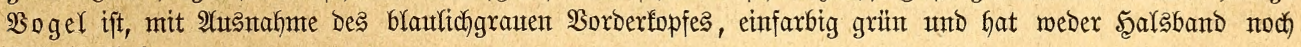
Sofulterflect.

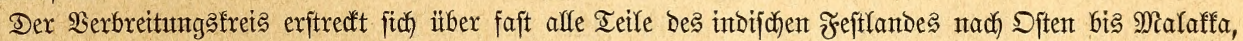

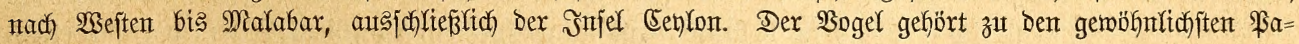
pageien Эntient.

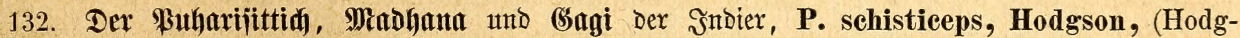

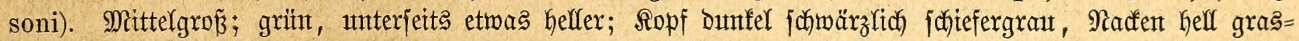

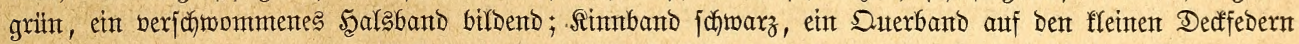

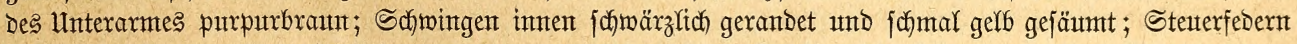
hell grasgrün, im Enborittel innen umb unterjeits fäb̈n gorlogelf, bie beiden mittelften Sdymanffedern

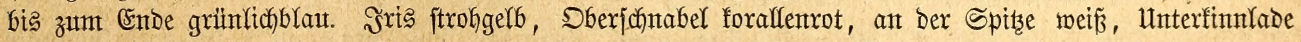

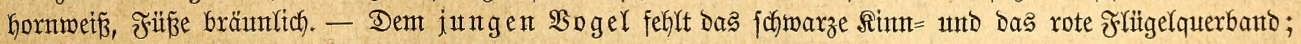

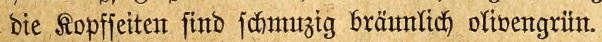

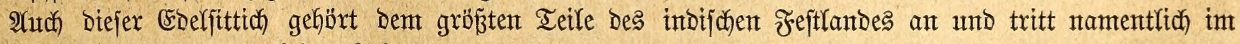
unteren Şimalaya in zahfreich)en Schiwärment auf.

133. Der Bartijttid), P. (Belurus) Luciani, Verreaux, (barbatus, Fraseri). (Broṕ; grün,

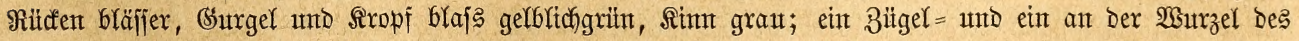

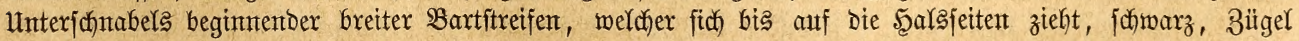

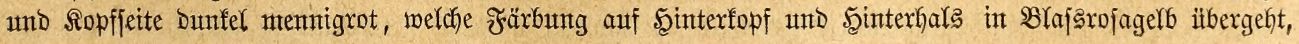




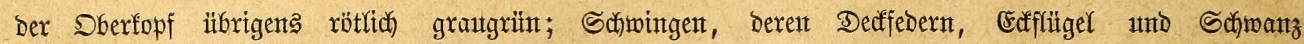
Dunfelgrün; Scantofdiwingen innent uno unterjeits faft fajwarz; bie ffeinen Dedfedern unterjeits grïn, bie

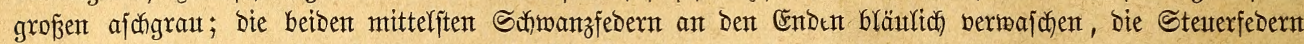

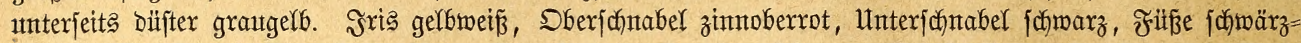

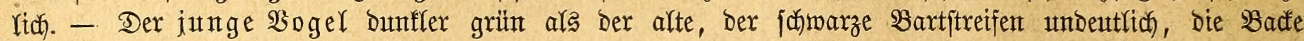
fadmetzig rot, Der Schnabel fofiwarz.

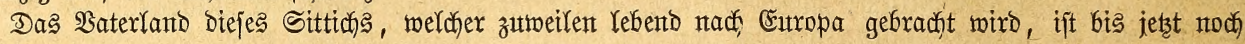
unbefannt.

134. Der Afexatderjittid, P. (Ps., C., Bel., Belocercus) Alexandri, L., (fasciatus, javanicus, pondicerianus, Osbeckii, mystaceus, bimaculatus, trimaculatus). RYein; grïn, unterfeit’ gelfgriin; ein fddmałer Stirntranto, Der Bügelftreif unt ein breiter Bartftreifen, welder bie Baden unterfeits begrenzt,

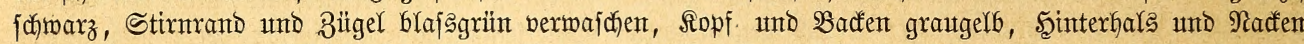

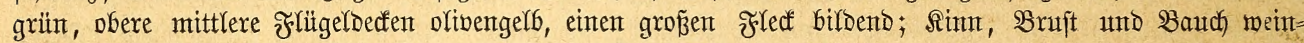

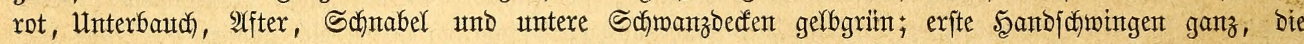

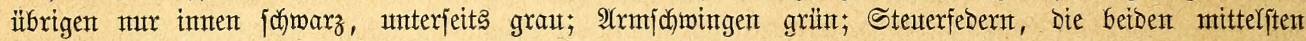

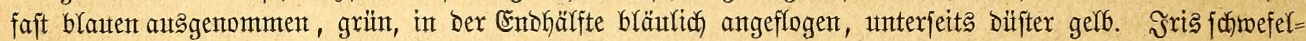

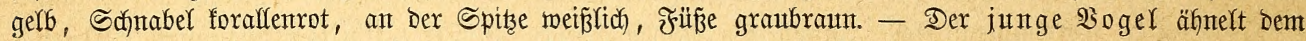

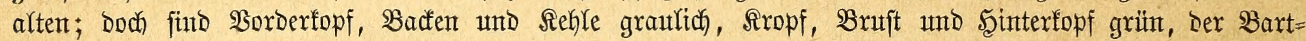

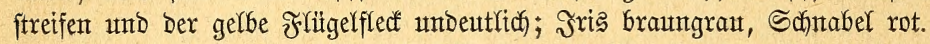

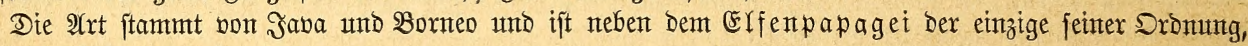
weldeer auf Saba borformmt.

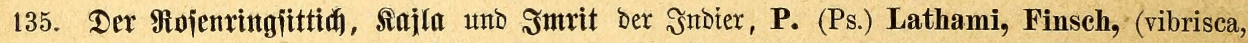
borneus). Dem vorhergehenden ähntich), aber etwas gröfer; grïn; Dberfopf unt Badfen helfgrau,

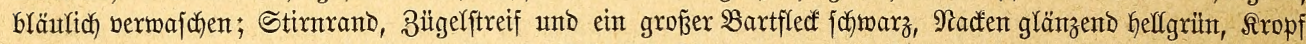

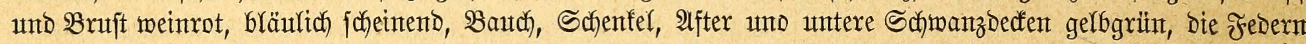

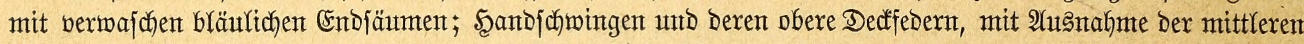

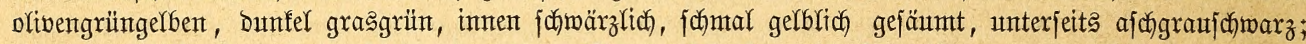

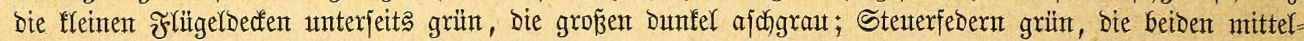

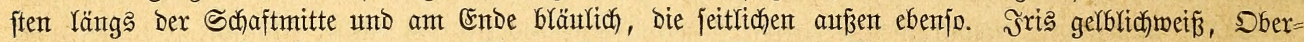

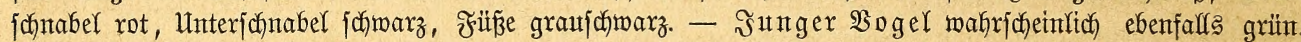

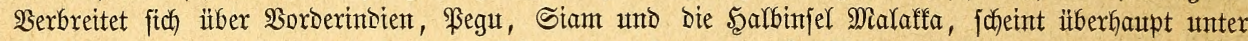

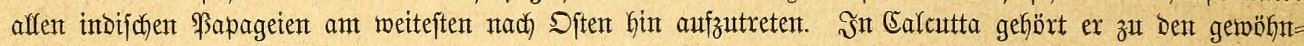
richen Erfacheimungen bes $\mathfrak{s o g e f m a r f t e s . ~}$

136. Der Sdiwarzidatabelitttid, P. melanorrhynchus, Wagl., (nigrirostris, Derbyanus).

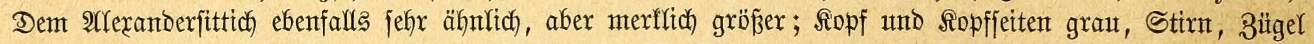

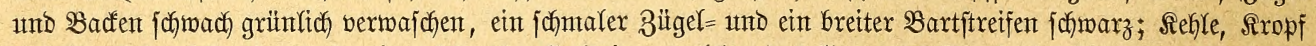

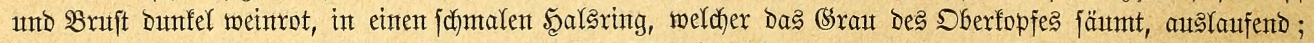

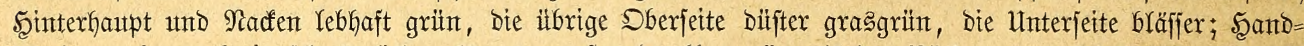

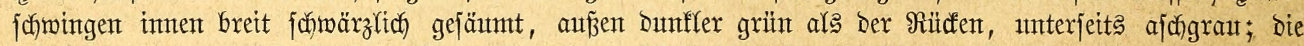

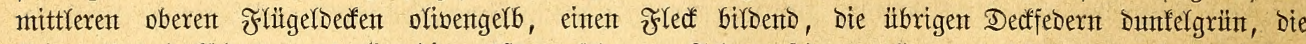
fleinent Unterbedfedern graggrïn, bie gröptent afdgrau; Schwanzfedern grün, unterfeits graugelb, bie beiDent

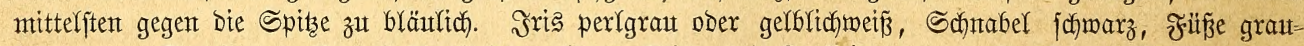

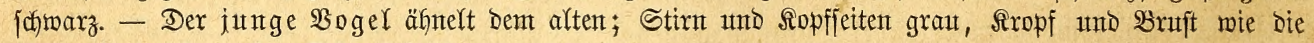
ïbrige Unterfeite grün; Sdynaber fdimarz.

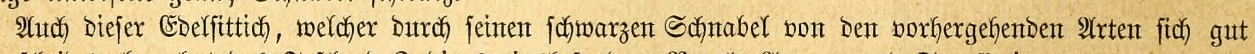

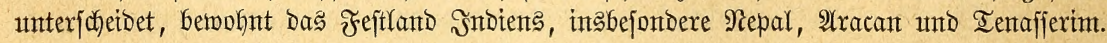

137. Der Taubenittid, P. columboides, Vig., (himalayanus, peristerodes). Rileit; fiopf,

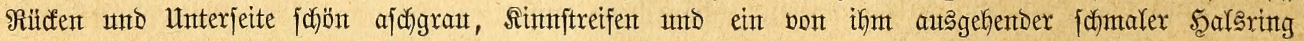

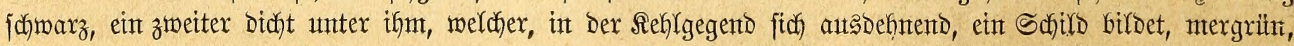

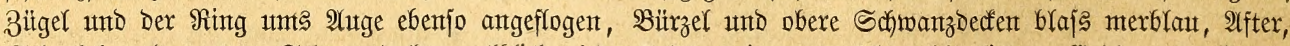

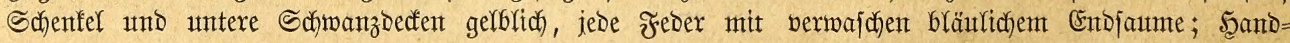

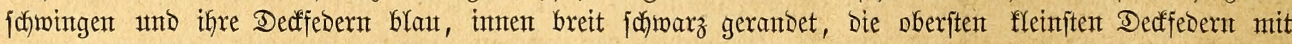

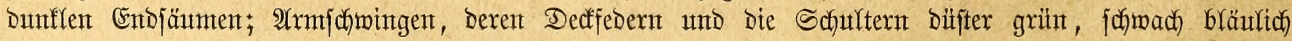

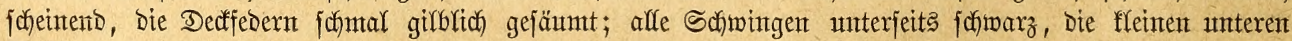

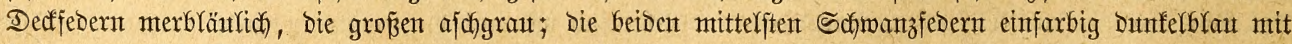

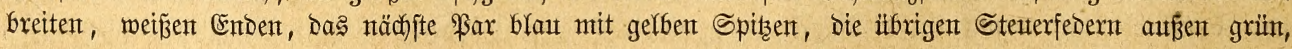




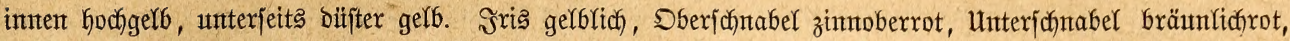

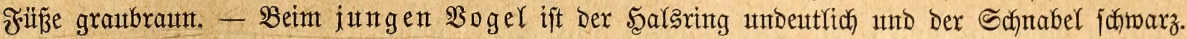

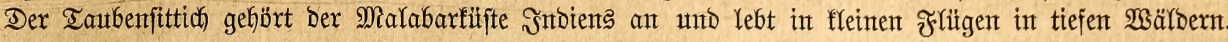

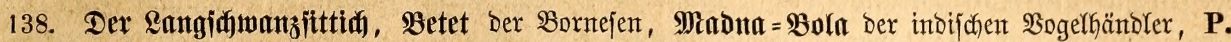
(Ps., B.) Iongicaudatus, Bodd., (barbatulatus, erubescens, malaccensis, affinis, viridimystax).

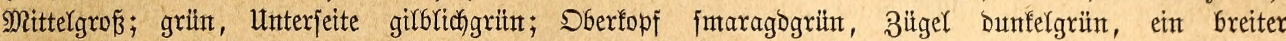

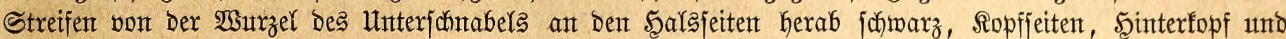

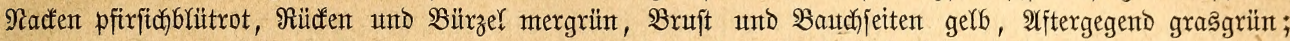

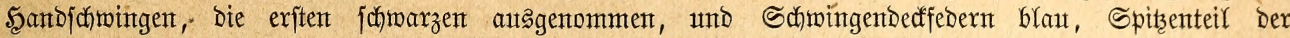

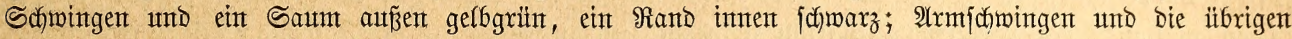

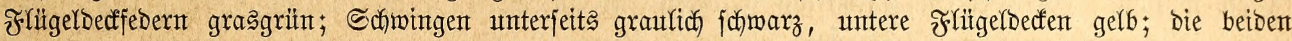

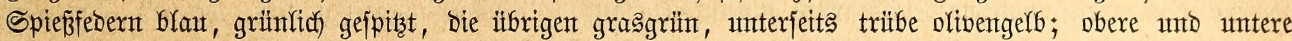

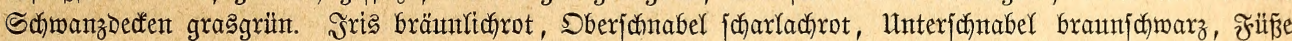

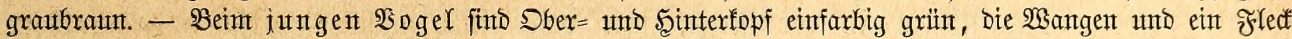
über bent 2atge fdomuzig weinrot; Der Bartiftreif fint grün, Der Schnabel bräunlich aus.

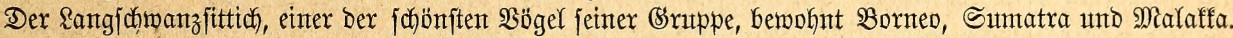

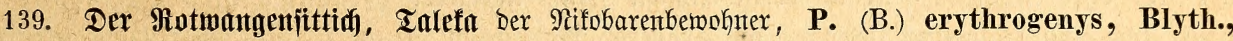

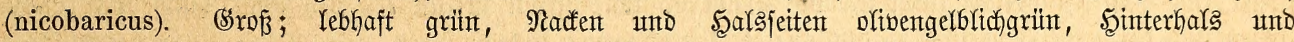

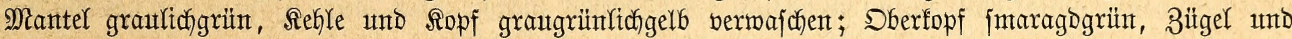

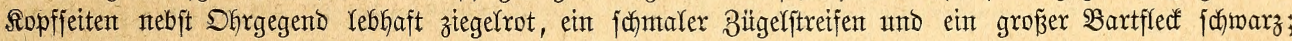

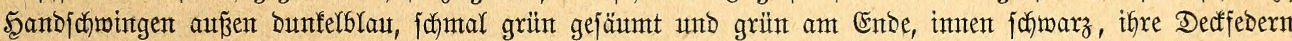
Dunfelblau; $\mathfrak{A}(\mathrm{m}$ ij

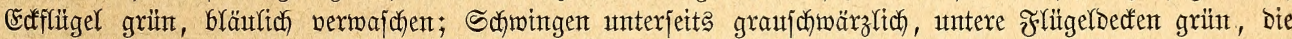

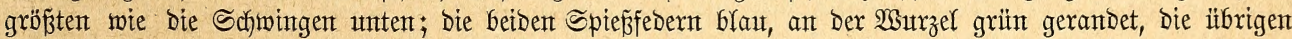

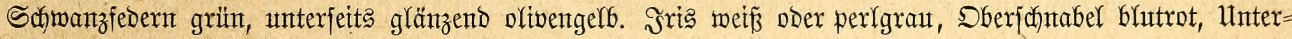

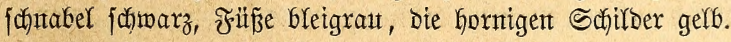

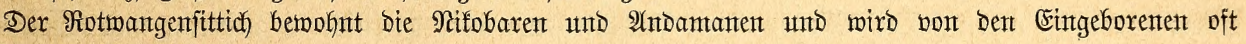
in (Befangenjobaft gehalten.

Die EDelfuttiche gebören ber alten Welt ausichließslich an und verbreiten fich über Mittelafrifa unt Silbajten, yom Sïbrante des Simalaya bis Seylon unt ben Sumba=

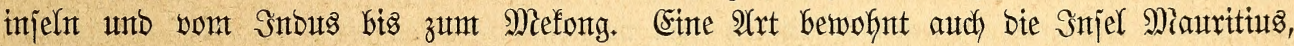
einte antbere jelbjtänbige bie Sejchelfen. Mefrere Arten babent einen jefr auggebefntent,

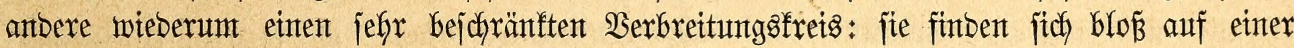
Injelgruppe.

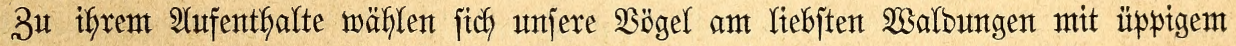
Baumtwudfje; boch fommt es ifnen auf bie (stöbe berjelben nicft eben an. Nitcht jelten bemerft

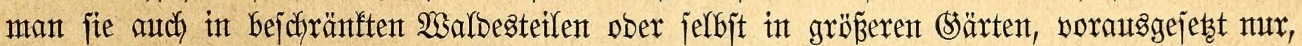

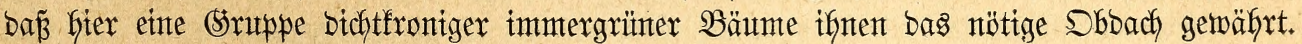
Der Şalsbandjittich fonmmt in Intien unbedenflidy bis in bas Snnere ber Dörfer und

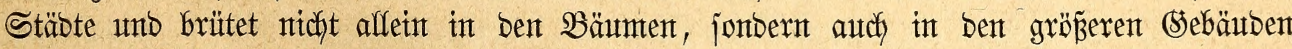

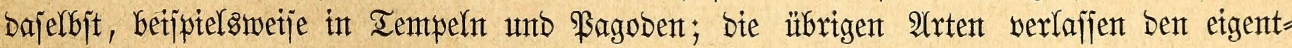

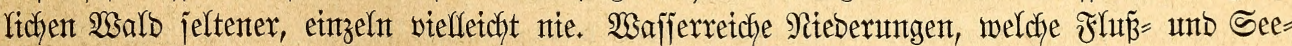
ufer umiäumenton $\mathfrak{B a ̈ u n t e n ~ b i e ~ n o ̈ t i g e ~ F e u d j t i g f e i t ~ j p e n t o n ~ u n t ~ e i n e ~ b e j o n b e r e ~ l l e p p i g f e i t ~ b e s ~}$

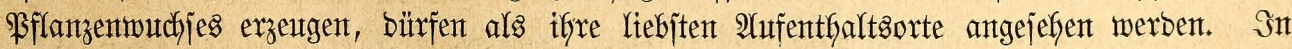

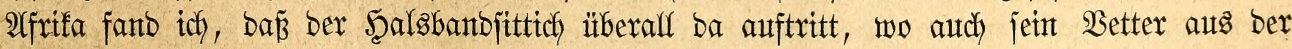

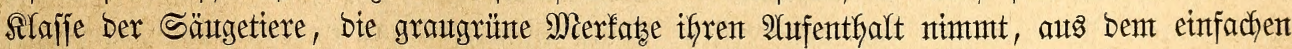
(Strumbe, weil bie Rebensbebingungen betber Itere wohl jo ziemlich biejelbent finto; in arfient

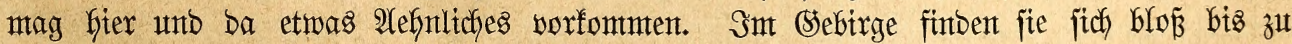

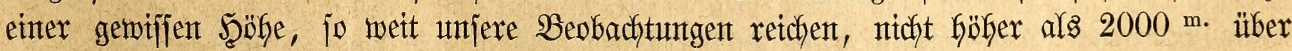
Dent Miere.

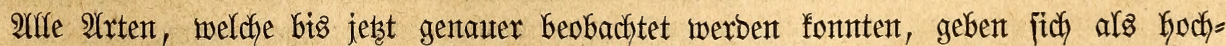
begabte $\mathfrak{B}$ ögel funtb. Es finbet fjerin wie audh in ber Rebensmeije unter ben berjefjebenen 
Arten faum ein merfficher Unterjefied ftatt; fie affe fint wie aus einem (Sufje gejtaltet, unt

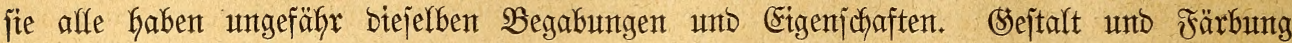
weifen fie auf bas Belaube ber Bäunte ant. Sie gefent, went fie einntal zunt Boben

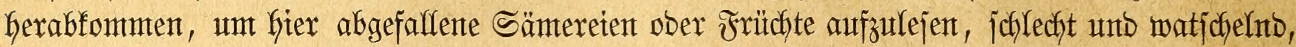

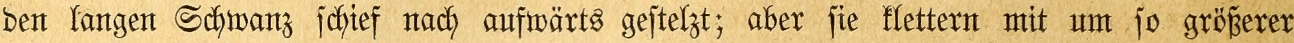

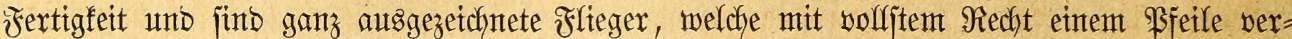

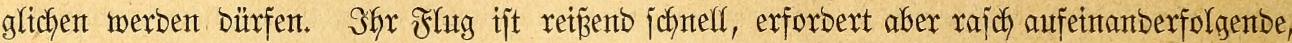

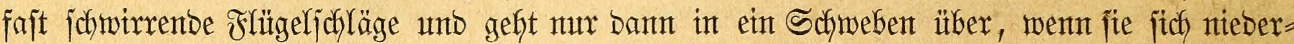

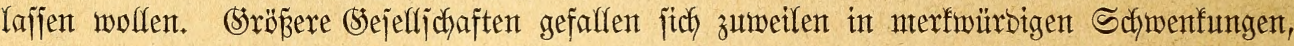

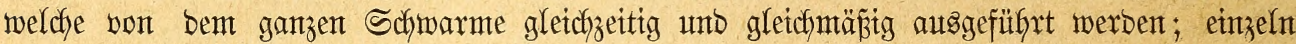
ober in Trupps bafinfliegente Eberfittidche bagegen ftreben jtets io eiffertig als möglid

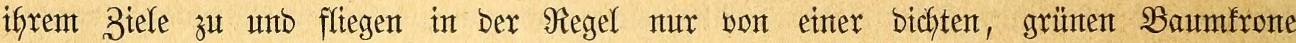
zur anberen. Die Stimme betwegt fitw in Gohen, burchboringentben, auf weitfin Gärbaren

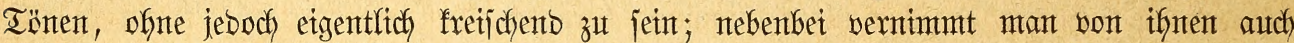

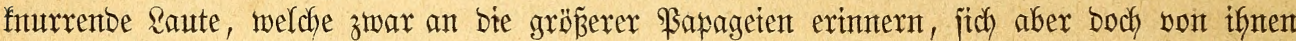

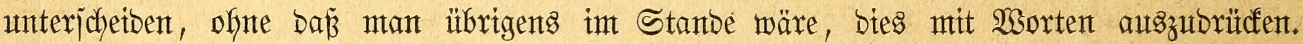
Die geiftigen Eigenjadaften jtelfen bie Eeberitttiche jefre hodh; jie zählent unbedingt zu bent be=

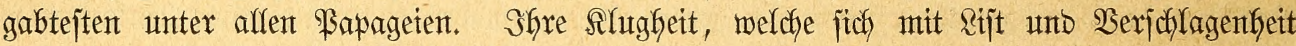

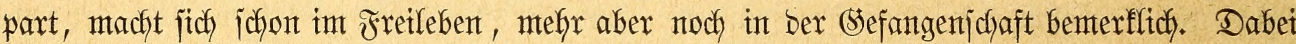

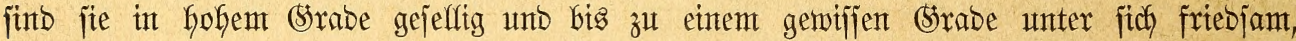

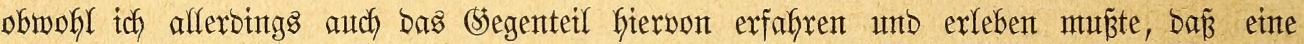

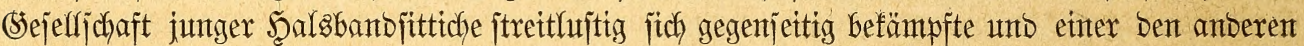

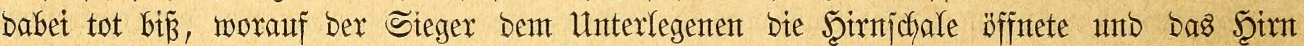

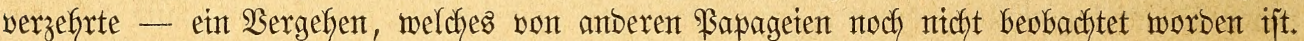

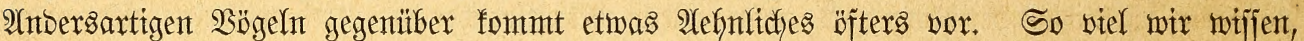

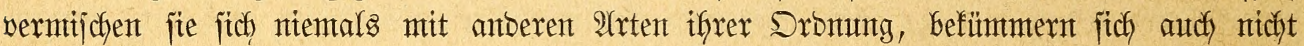

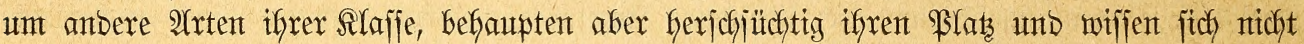

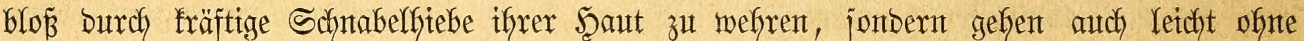

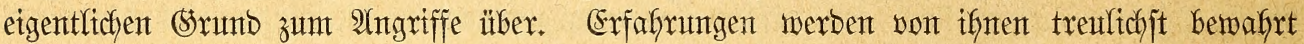

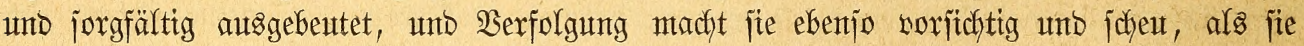

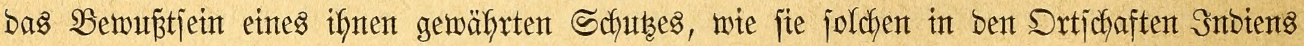

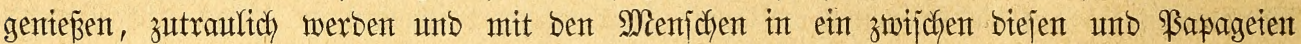

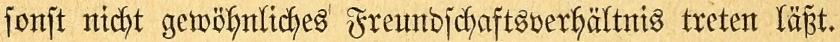

2luß̧er Der Brutzeit verläuf́t baz. tägliche Reben ber Evelfittiche antäherno in berjelben

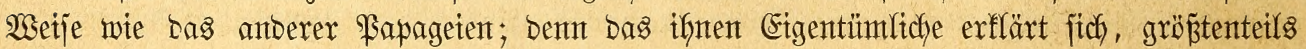
wentigitens, aus bem guten Einvernefynten, weldhes zwijden iffnen unb ben Menjchen ifyes Serbreitungsgebietes obwaltet. Bald nach ber Brutzeit jadfagen fich alte und Sunge in

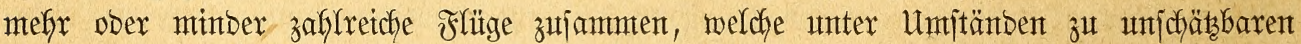

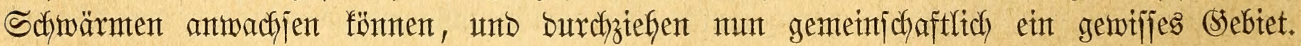

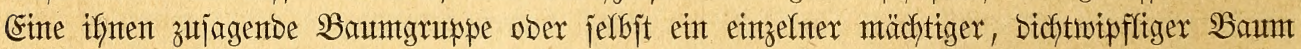

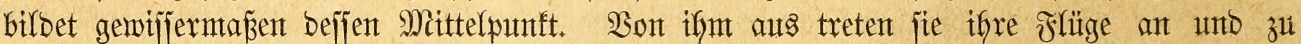
ifym fefren fie zurüd. Sn ber exften Morgenjtunbe benterft man fie wenig; fie jecheinen Dann nodh mit bem \$sutsen und Sronen ifres befiebers bejchäftigt zu jein. Sobarb

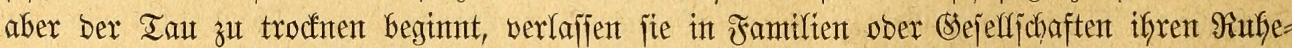

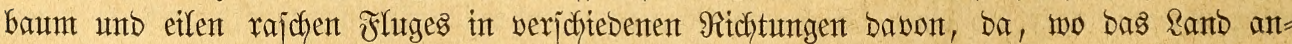

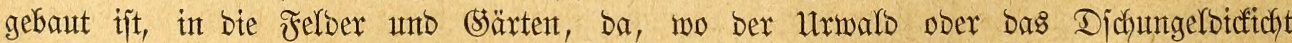
meilentweit ben Boben bebecét, zut einent mit Fritchten belabenten Bautnte ober auf eine

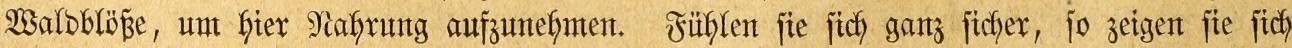




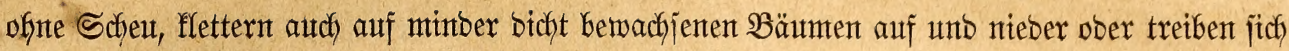

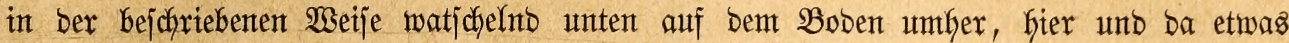

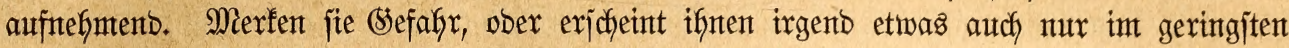

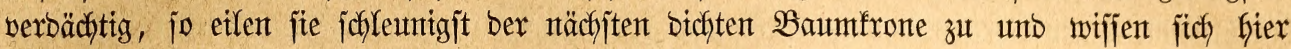

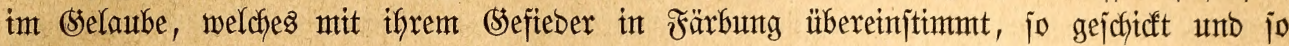

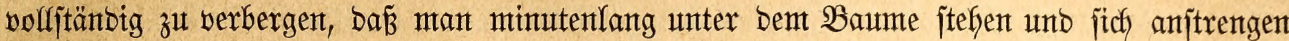
fant, ohne einten eitzigent von ifgnen zu jefen; unt währent mant ifgnen noch nachipäht,

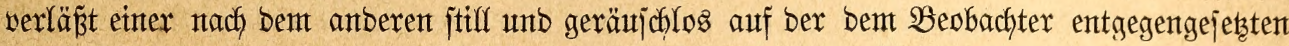

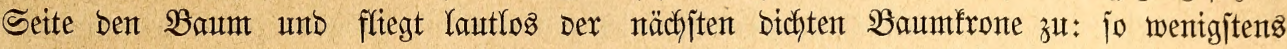

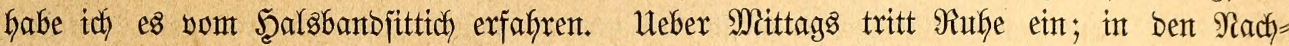

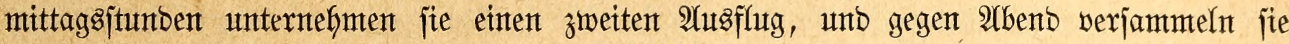

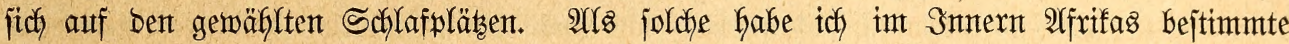

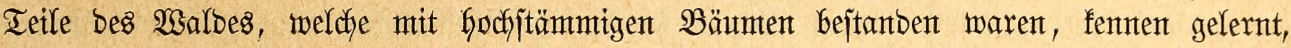

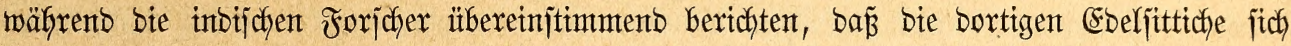

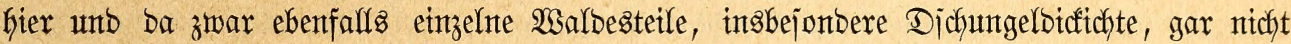

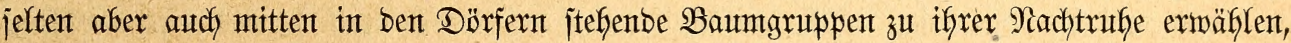
Durchauts unbefümmtert umt bas lebentige und geidfäfftige Treiben unter ifnen. So erzählt

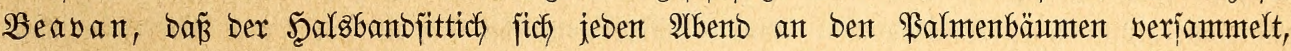

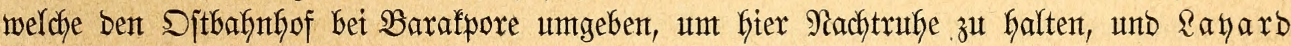

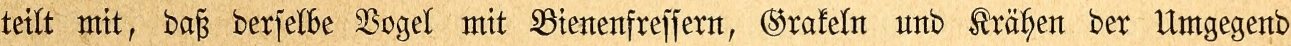

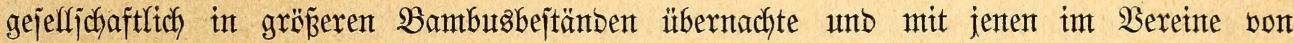

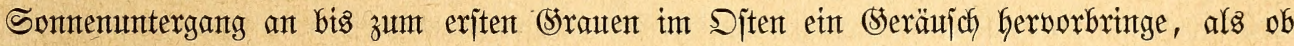

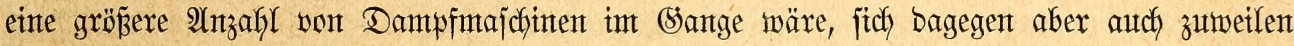

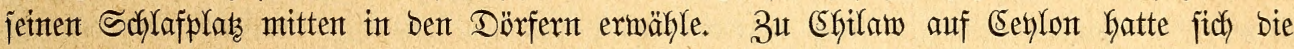

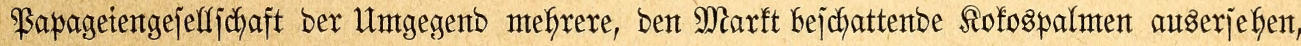

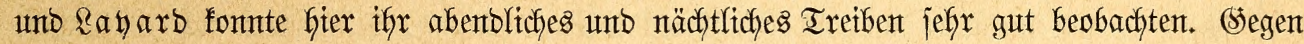

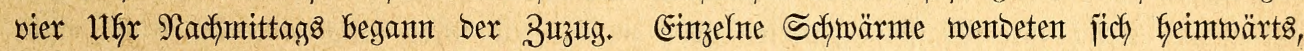

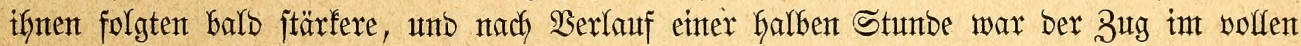

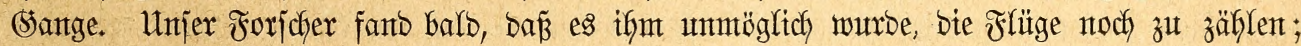

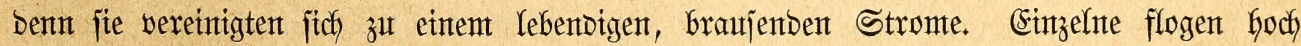

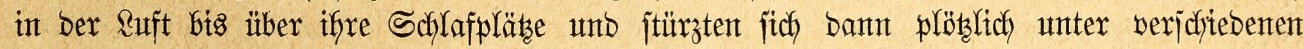

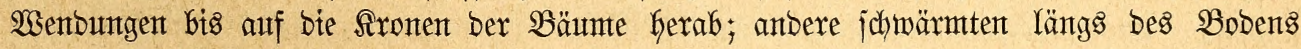

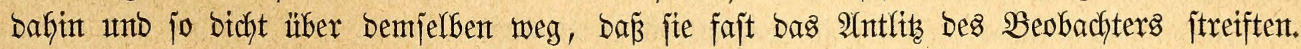

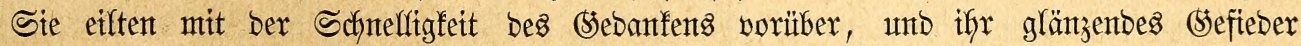

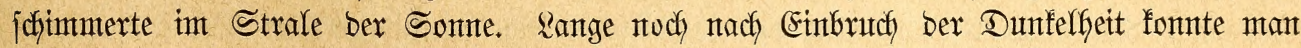

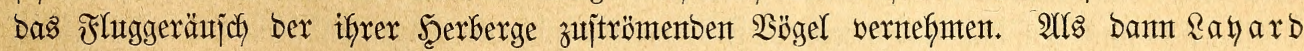

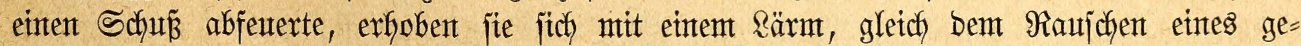

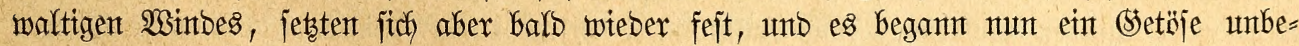

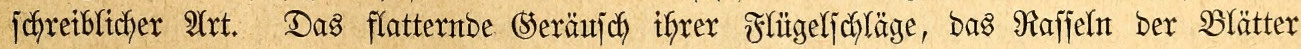

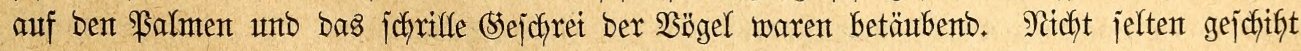

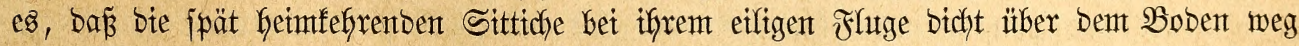

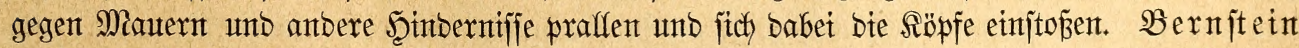

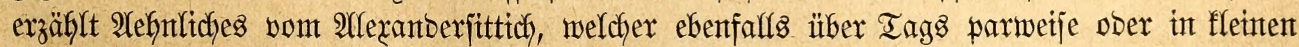

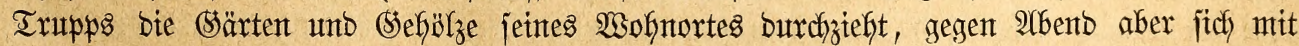

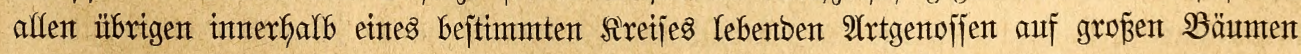

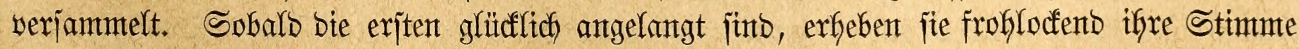

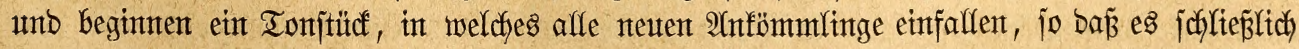

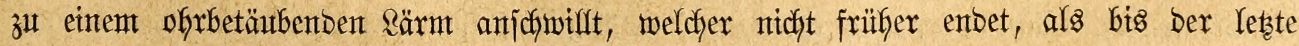




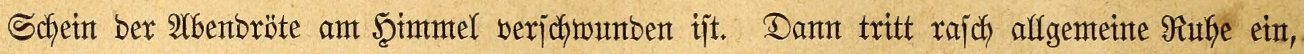

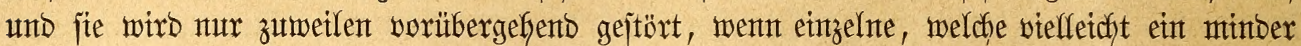

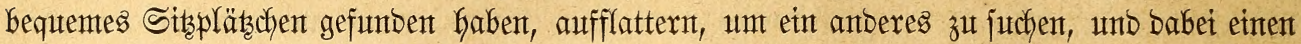

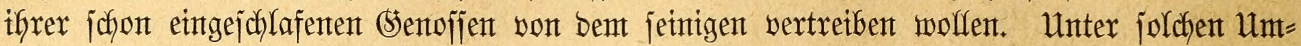

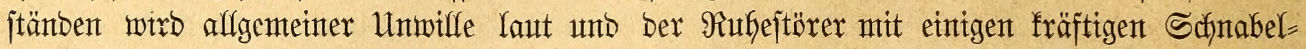

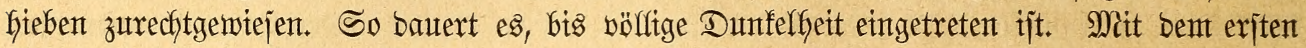
Scheine bes anbrechentoen Iages zerteilt jidf ber Sdywarm.

Wä̈hrent Der Brutzeit fintoen bie abenblichen Bujammenfünfte niddyt jtatt; bent bie Eberfittiche leben, bie noch nicht ausgefieberten Sungen vielfeicht ausgenommen, jetzt partweife

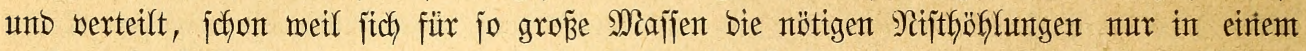

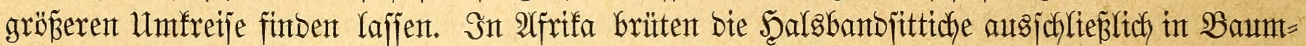

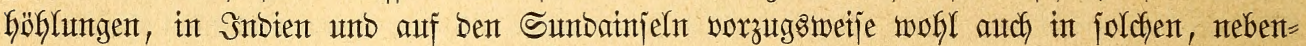

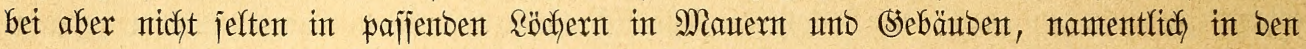

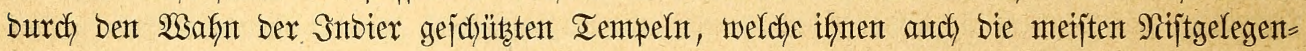

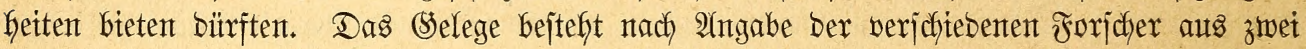
ober auz bret biz vier Etern. Beavan gibt an, bá̉ bie Sungent bereits vierzefhn Iage

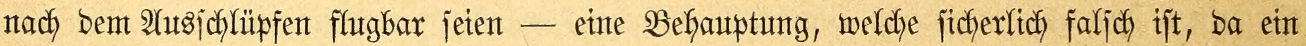

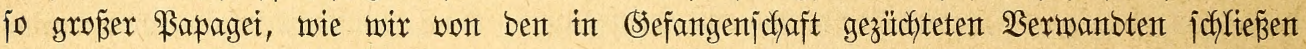

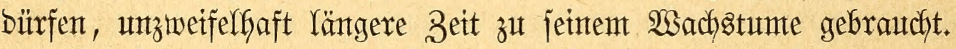

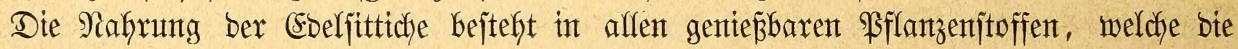

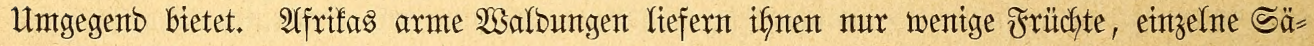
mereien, $\mathfrak{B}$ hatt=und $\mathfrak{B}$ (ütenffnospen, benachbarte Ferber bant unt wann Durra unb Dofigen=

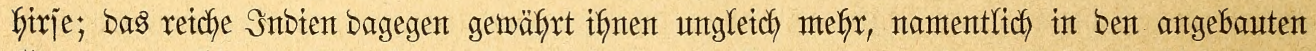

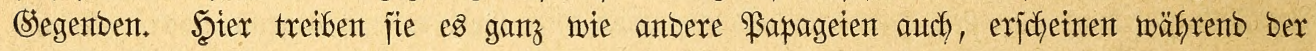

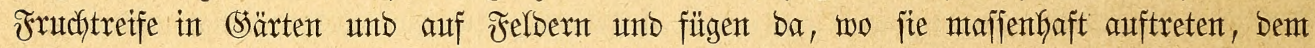
Menjofent erfeblidhen Echaben zu. Bejonbers geflagt wirb über bie vielent Berferungen,

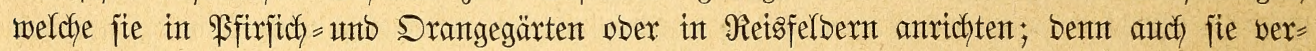

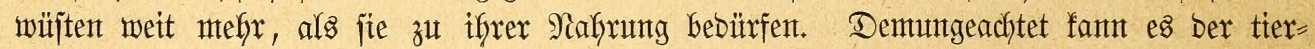

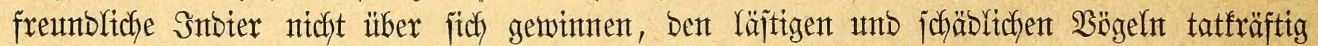
entgegenzuttreten, wie ber Europäer es unter alfen $\mathfrak{H}$ mịtänben tut. Utno baher bent aud bie zubringliche Dreijtigfeit umferer Sittiche.

Sogleich unz bejtintmte Suttbe mangelt, bürfen wir body ntit zientlicher Bejtimmtheit

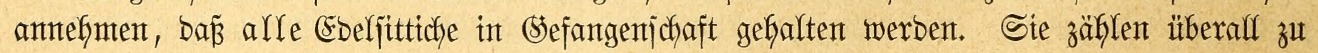
Den beltebtejten Stubentögeln unt werben, jung Den Nejtern entfobent ober alt gefangen,

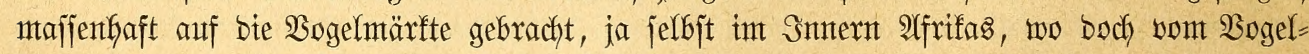
fange fautnt zu rebent ift, bent reijentoen Foricher vber jebent anberen Bejtefler geliefert. Die

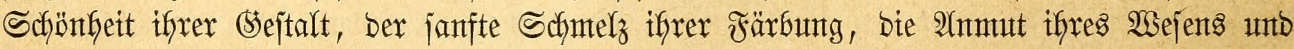

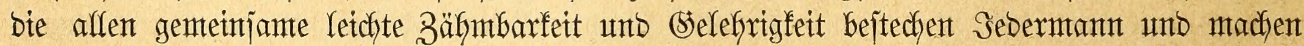

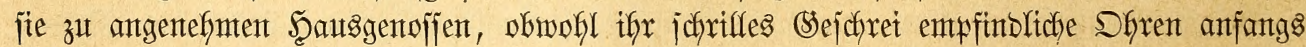

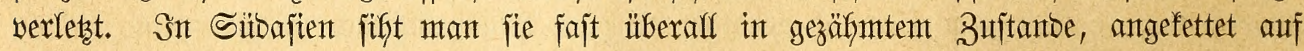

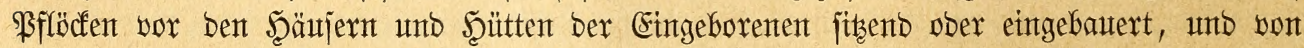

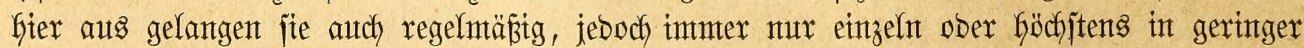

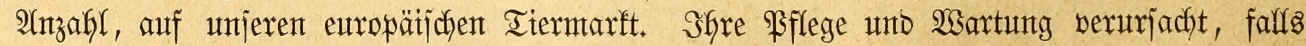

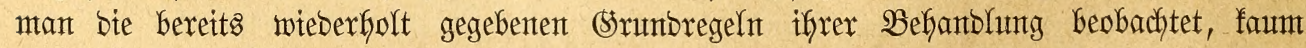

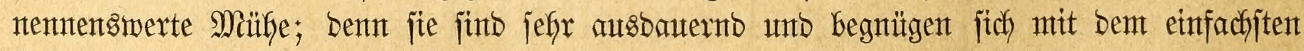

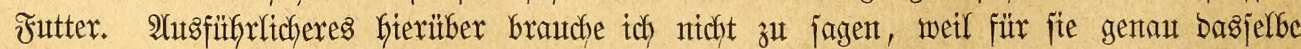

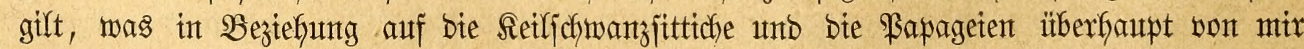

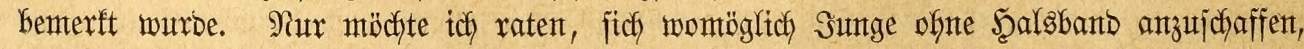




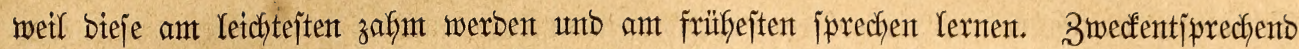

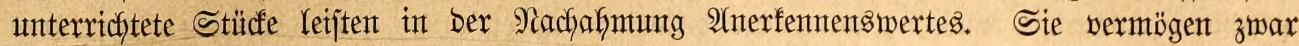

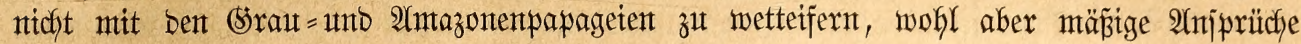
volffontment 孔 befriebigen.

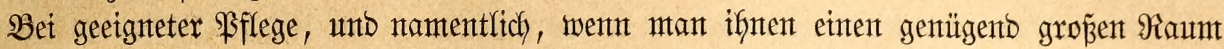

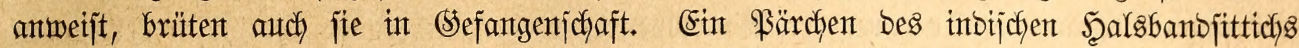

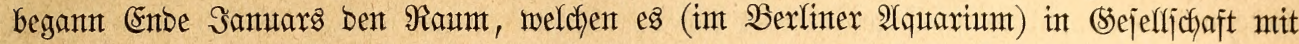

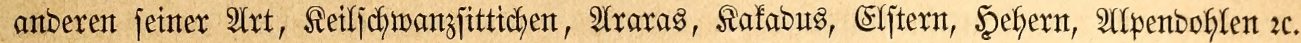

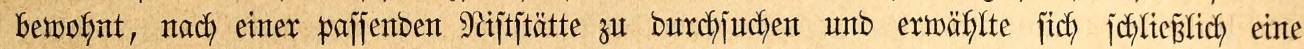

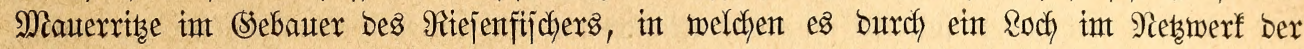

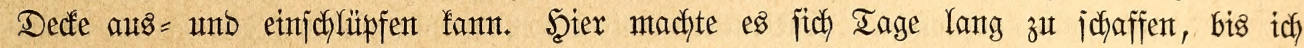

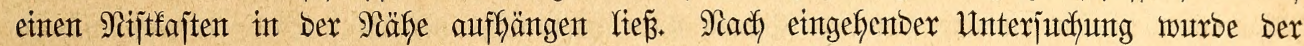

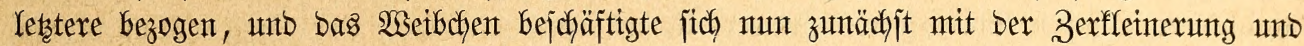

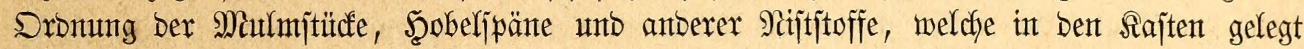

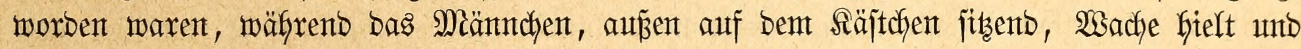

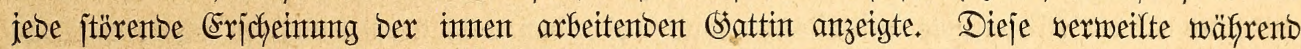

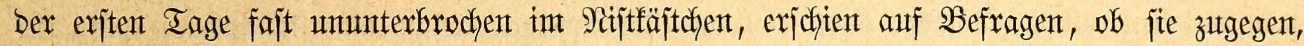

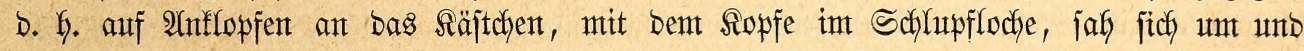

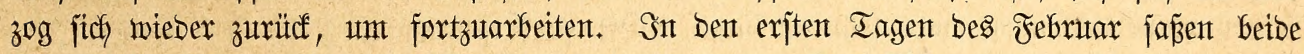

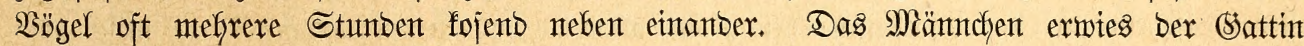

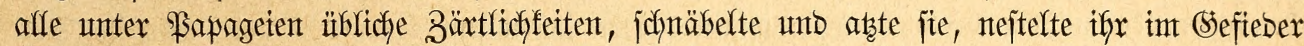

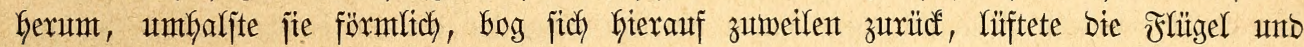

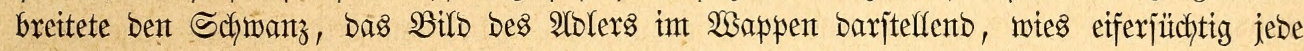

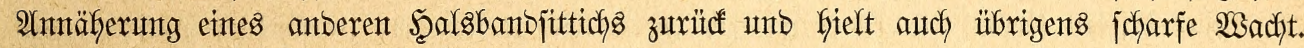
2(m zefrnten Februax beobachtete idh bie erjte begattung; fie war ebenjo innig wie bie ber

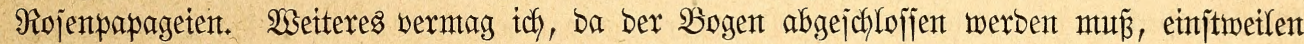

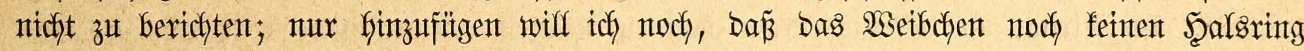

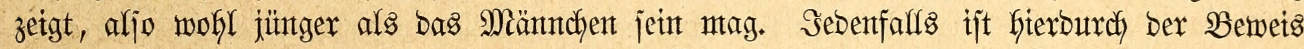

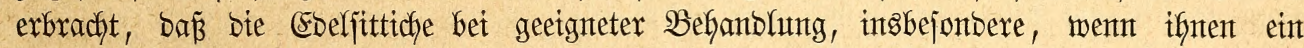

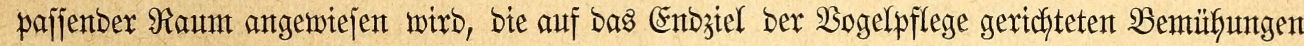
mit Exfolg frönent werbent.

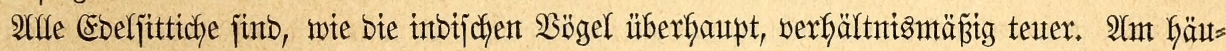

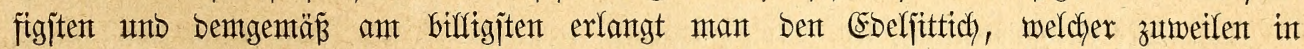

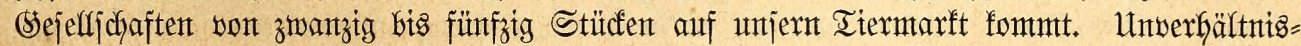

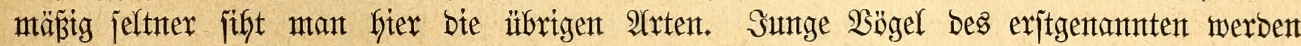
burdejidnittlich mit 5 bis 7 Talern, bie übrigen Ebelfittiche nidght unter 12 Ialent verfauft,

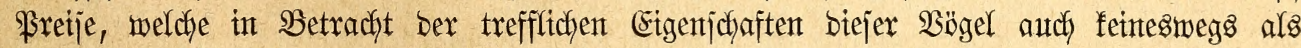
zu hobe bezeidghtet werbent bürfen. (Sinten bejtimmten Marft Gaben fie nicfft; fie fontnten

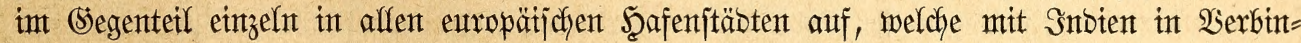

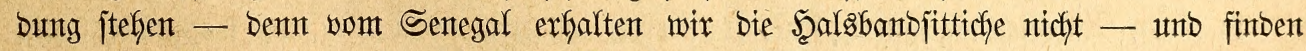

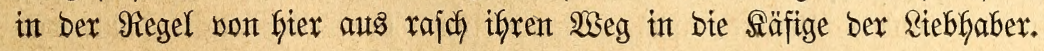

\section{Sidjulalfdunabelittide.}

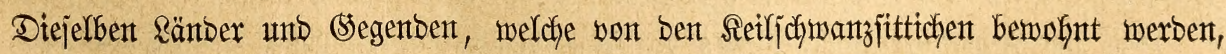
bereidyern unjere (sebauter mit fleinten, zierfictent unb in ber (sefangenjchaft trefffidy auBbauternben 
Sittichen, welche won Einzelnen Den worker genannten, teilweije auth wohl ben 3merg=

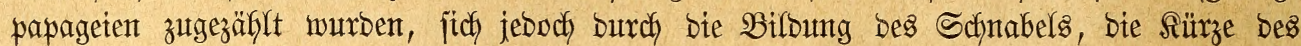

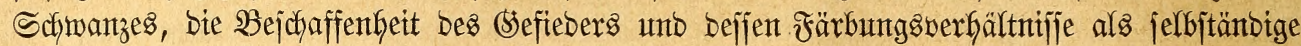
(Sruppe fentzeidynent.

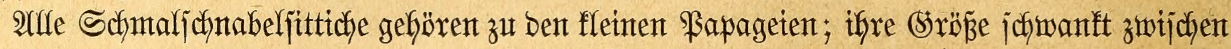

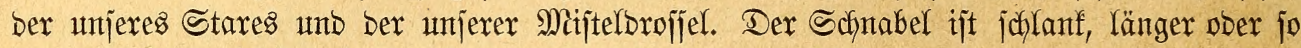
lantg als hoch, jeitlich jtarf zujanmengebrïuft, auf Dex Firjte fantig, an ber Spibe lang

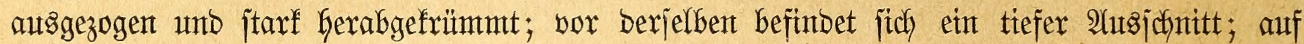
ber Unter = und Snnenjeite find jajwache, aber body Deutlidy jidftbare Jeilferben vorhanben; ber Unterjahnabel ijt ebenfalls jeitlich zujammengebrürdt, bie Diflenfante breit unto abgerumbet;

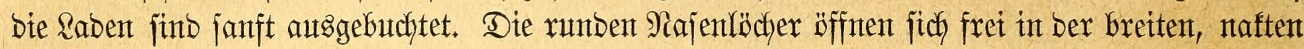

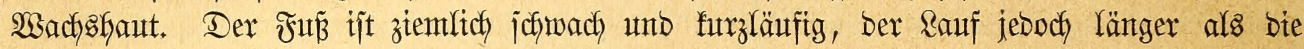

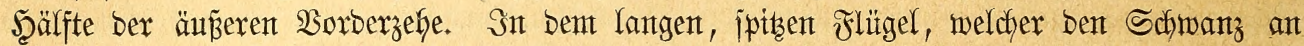

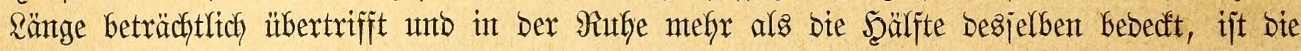
zmeite Schininge ant längiten, bie exjte bis britte innen jtarf, außen faum merffich aus = gejdyntten, bie Flügelipitse mittellang, bas Ende ber Sdywingen runblidy zagejpizt. In

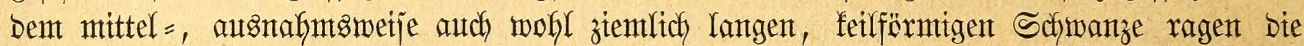
mitteljten, ein wentig berjchmälerten Febern etwas vor, und fint bie äurerjten Sdywanz=

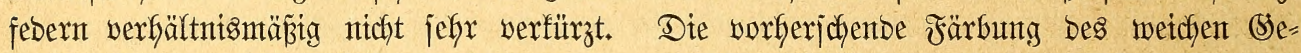

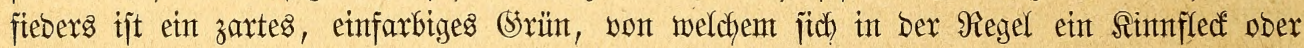
bie mefr ober minber brennento gelb gef̈̈rbten Şandjumingendedfebern lebhaft abheben. Die

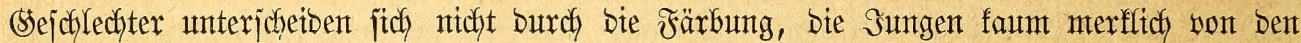
2lltert.

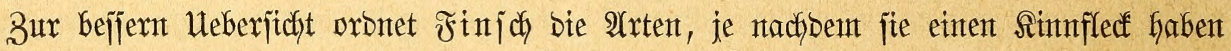
ober biejer ifnen feblt, in zwei Unterabteiluntgen. Den nachjtebento erwähnten 2lrten feblt Der Rimnflect.

140. Die Iixifa, Brotogerys (Ps., Aratinga, Conurus, Tirica, Sittace, Psittacula) tirica, Gml., (tiriacula, acutirostris, rufirostris, brasiliensis, viridissima). (Grofß; fujön graఏgrün, obent

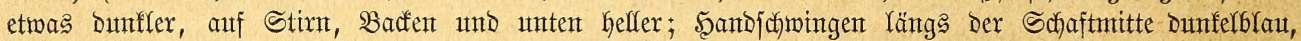

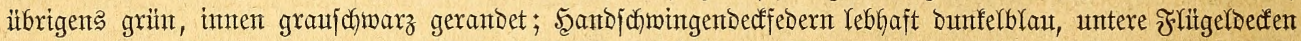

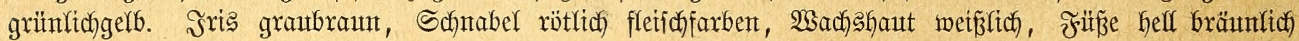

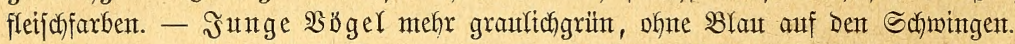

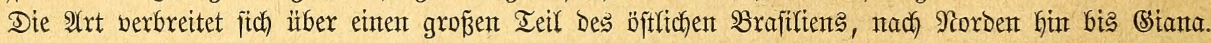

141. Der (Selbflügelifttid, Br. (Psa., Psittacara, Psla., Art., C., S., T.) xanthoptera, Spix,

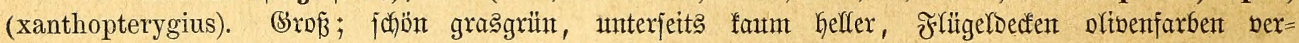

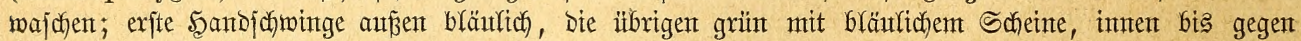

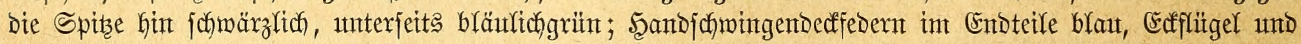

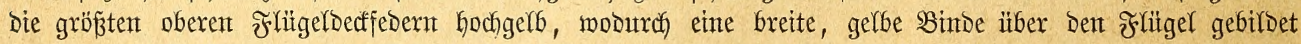

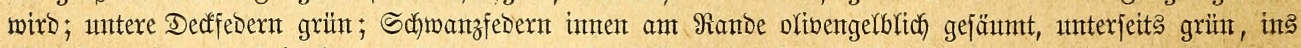

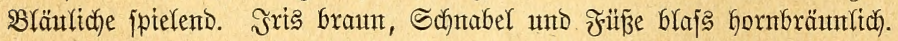

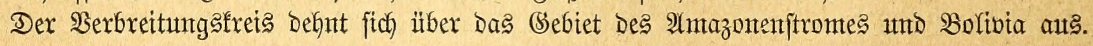

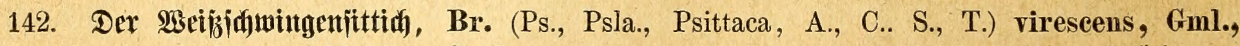

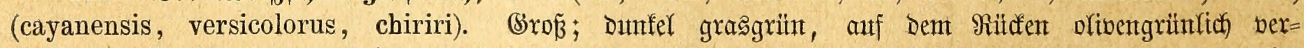

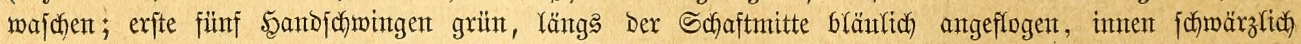

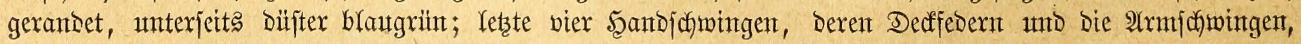

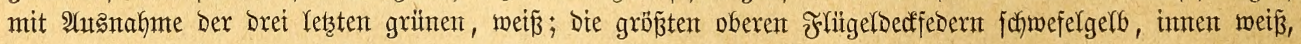

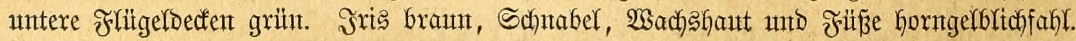

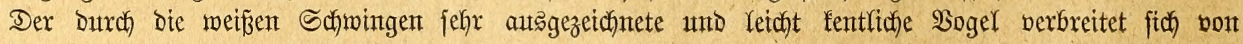

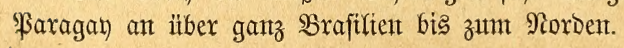

143. Der Fetuefflügelitttid), Berico Der (Ecutadorianter, Br. (Ps., Psa., C., Trichoglossus) pyr= rhoptera, Lath., (griseocephalus, griseifrons). (Sroß̋; Dutfel grasgrïn, auf Den oberen fGlitgel= 
Decten oliwengelbbrautn verwafdhen, Unterjette hell grasgrün; Stim, Bügel, Bacfent unt Shrgegento graut,

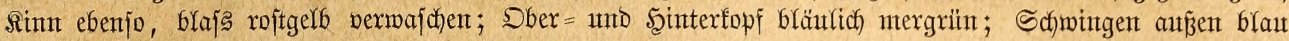

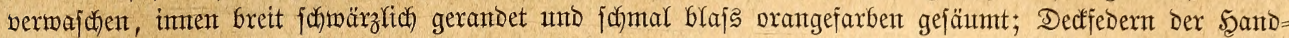

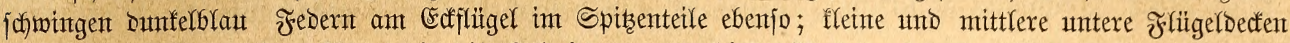

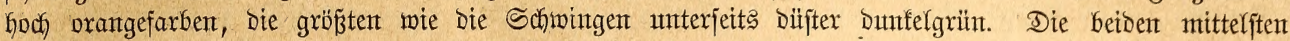

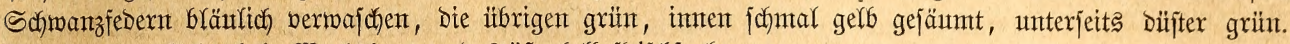

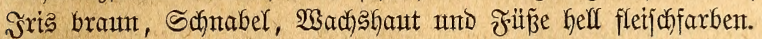

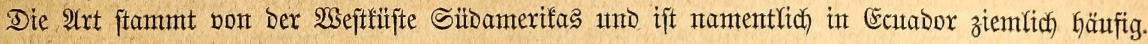

Die übrigen 2lrten Gaben orangefarbenten Simnfledf ober (Selb am Sopfe.

144. Der (Solotimuittidh, Br. (Ps., Psa., Psla., C., Psittovius,) tovi, Gml., (chrysopogon, gutture-

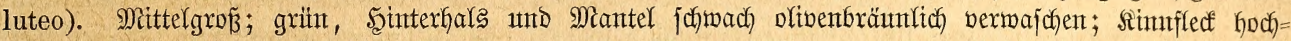

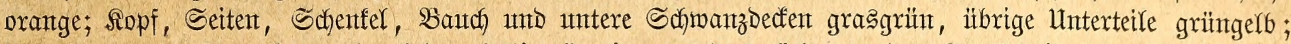

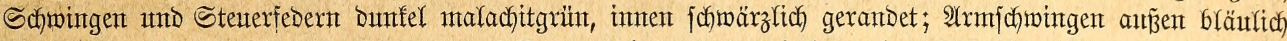

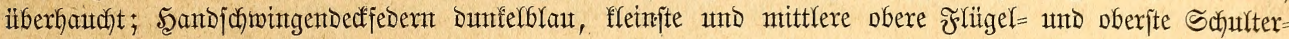

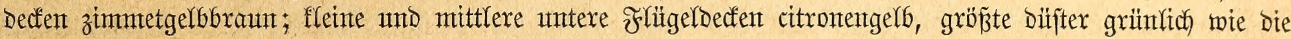

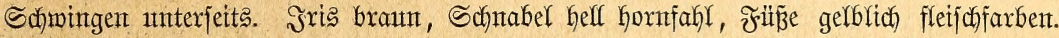

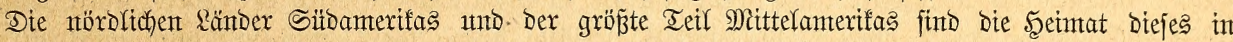

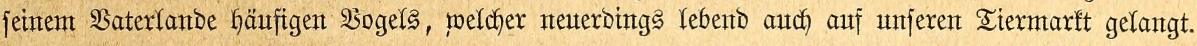

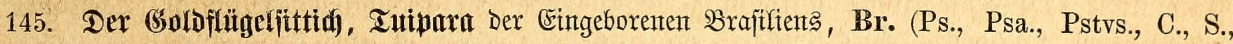

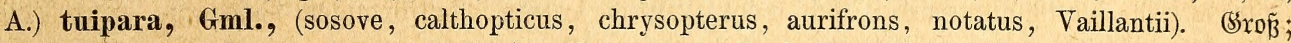

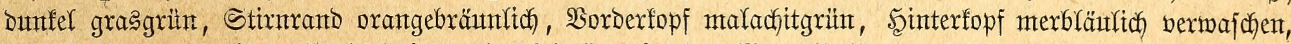

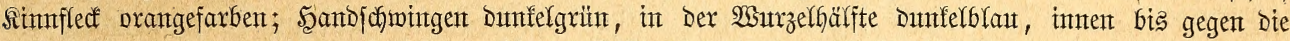

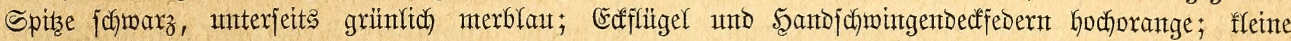

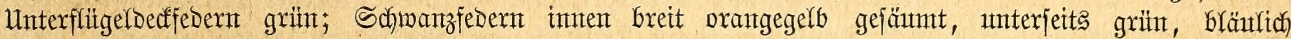

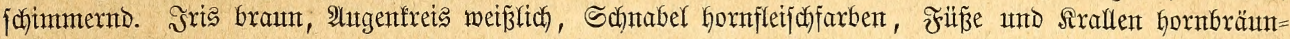

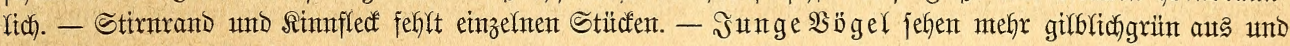
haben grïne Şandodumingendectfedern.

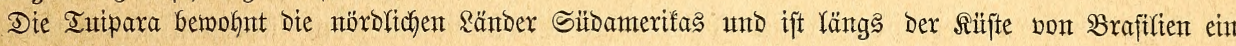
Gäuffiger গ̊ogel.

146. Der (Enldofopfitttidh, Ini ber Braftlianer, Br. (Ps., Psa., Psta., Pstvs., C., S.) tui, Gml.,

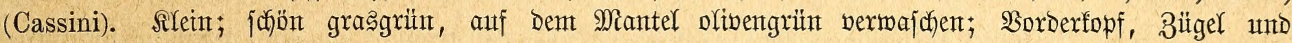
ein fafmaler Strich in Der Dhrgegent citronengelb, Bürzel und obere Schmanzoceffedern Yebhaft gelfgrrïn,

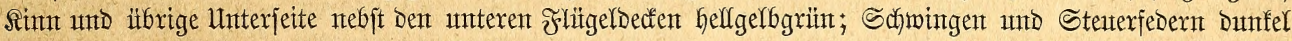

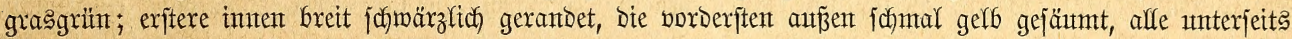

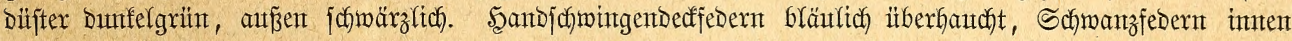

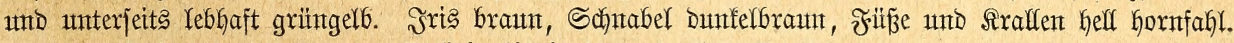

Dex Itit verbreitet fich von Bolivia bis in bas nörolide Brafiltent.

Rebensmeije unt Betragen ber Sdymaljdyaberfittidye eximtern ebenjo jefr an bas

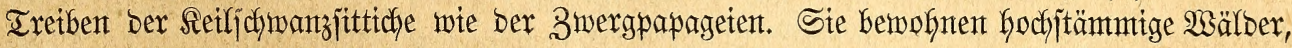

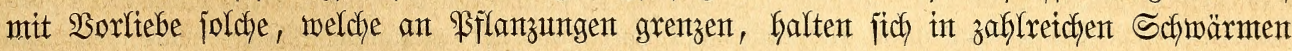
zujammen and Durchjtreifen won ifyen Stanborten aus, pfeiljedneff bafinfliegend, unter

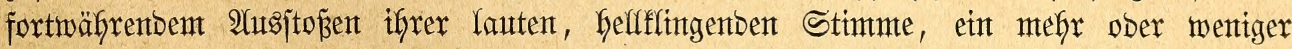
auggebefyntes (s)biet. Nitdyt jelten bereinigen fie fich mit ben bie Felber plünbernben

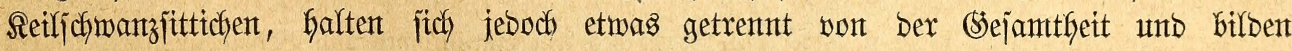

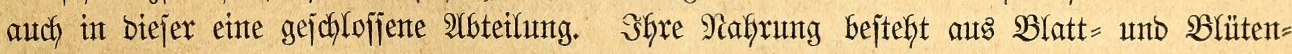

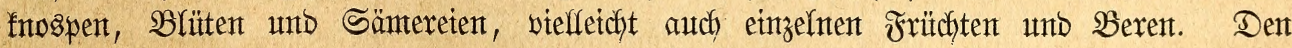

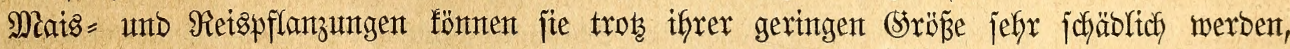

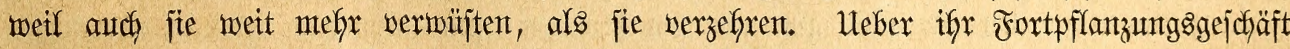
haben wix nur bürftige Bertchte. Sie brüten in Goblen Baumäpten ober Baumböhluntgen überhaupt unb regen brei bis vier (5ier - ob ein ober mefrere Male im Jahre, ijt zur 3eit noch nicht feitgeitellt worbent.

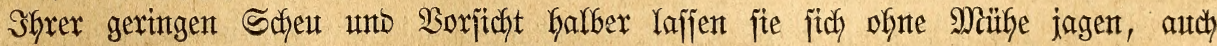

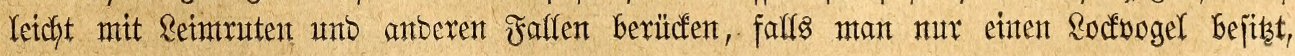


welcher bie vorüberziefentben Gerbeiruft. Die Brafiltianer lieben fie fehr unto falten fie

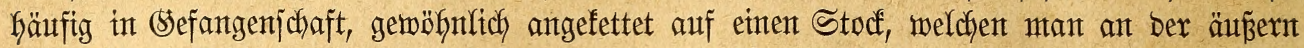
Seite iffrer 2 soffnuth anbringt, inbent mant Das einte Entbe Desfelben in Der Rettentwanto befejtigt. Sie lerten zwax, wie man aflgentein annintmt, nidft jprechen, werbent aber un= gemein zafm unt zutraulich und fint wegen ifres janften Wejens bejontbers beliebt. AYuf

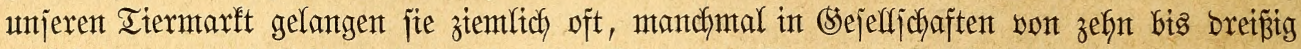

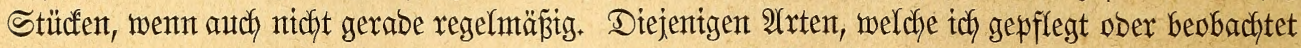

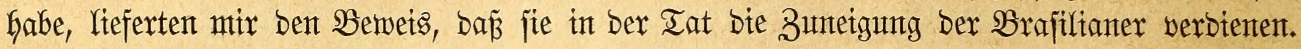
Sadf Darf fie als numtere, regjante, fluge unb antutige Räfiguögel warm empfefflent. Sie fint vont frühfen Morgen bis zunt 2lbent in Tätigfeit, machen jich uthabläjfig mit biejent

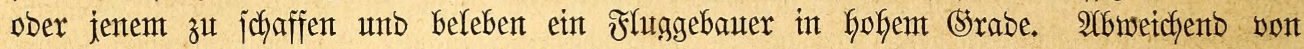
jo viełen anberen \$apageent Yaufen fie, mit fleinen, trippelnben Sedyritten zwar, aber body

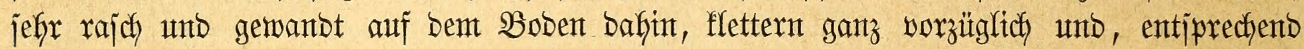

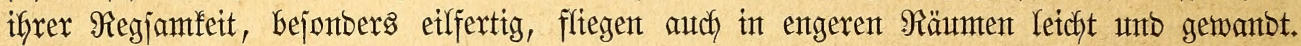

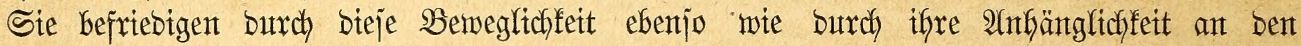

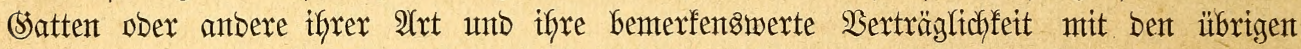

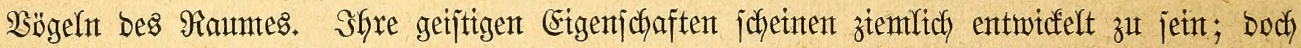

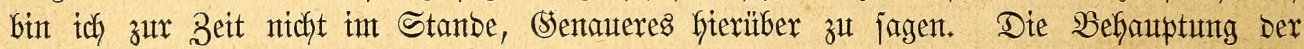

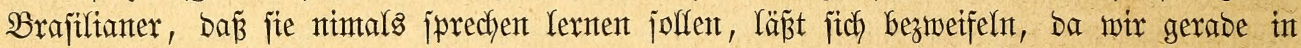

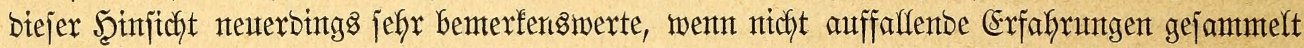

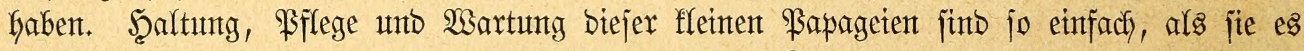

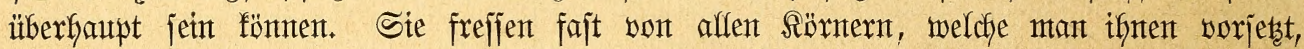

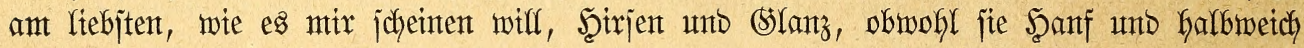

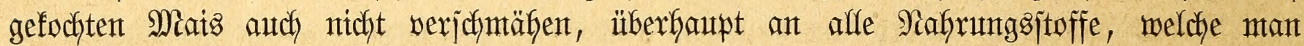
Fapageient reidgt, gemöfhnt werbent füntrent. Srü̈rzeng, Baumfnospen unto Baumblätter erachte idy als Futteritoffe, weldhe jie besürfen, mintbejtents entbefrent, went jie biejelbent

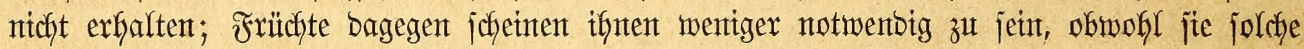

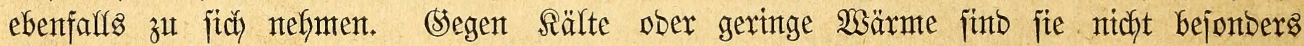

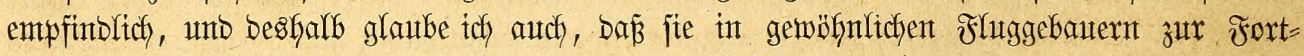

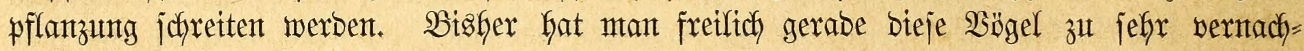

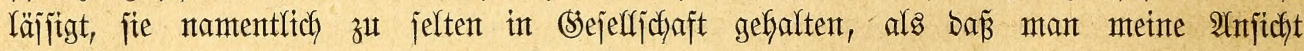
beítätigento beobachtuntgen hätte machen fömtnen.

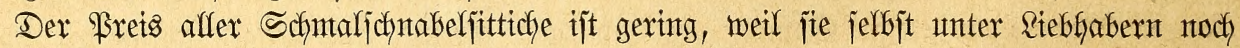

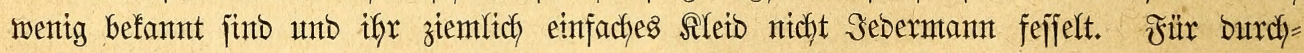

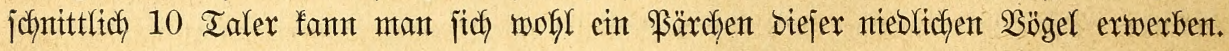

\section{Didk/dintabelifttidje.}

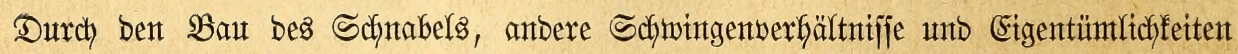
in ber Färtbuntg unterjcheibet jïh eine Sippe jübamterifanijcher Fapageien vont ben Reil=

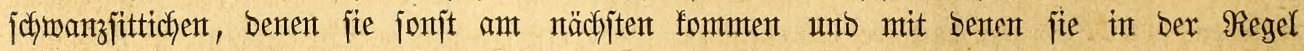

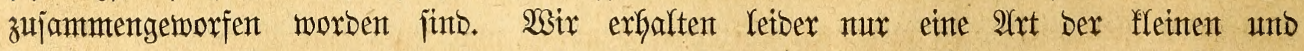

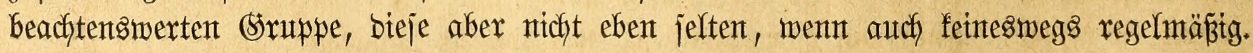

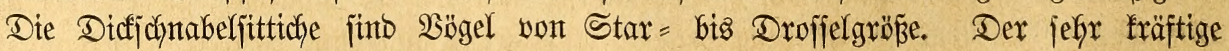

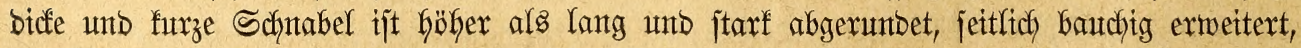

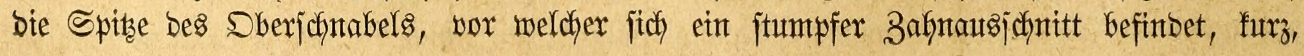


Greit und ftumpf, inten mit beutlichen Feifferben verjeken; ber Unterjdynabel God, bie Diffenfante breit abgeruntoet unt vor ber abgejtutsten Spize janft augigebutftet. Die fleinen

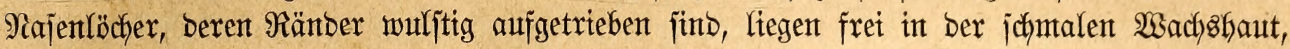

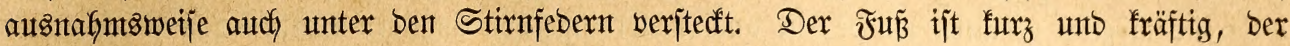
Flügel fajt ganz wie bei ben EDelfitticlen gebaut, lang unto an ber Flügeljpizze vorgezogen, bie Schmingen, unter benten bie exften brei fajt gleidh lang und mur bie zmeite unt britte außen etwas ausigejchnitten jütb, jpitzen jich ant Entbe zu. Der Schmanz ijt feifförmig

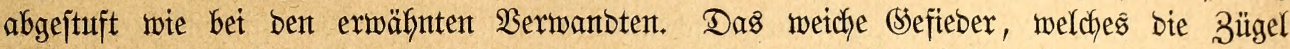

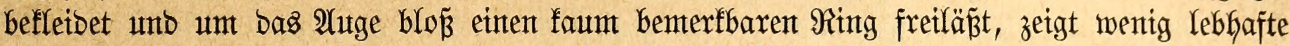

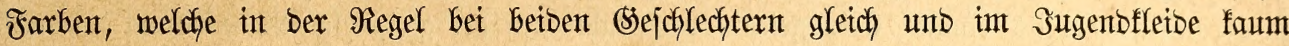
abtwetchento jitto.

147. Der Mänd́jittid, Die Cotorra oder Canlita Der Sil̈bamerifaner, Bolborrhynchus (Ps., C., S., Psittaca, Myiopsitta) monachus, Bodd., (murinus, cinereicollis, canicollis, griseicollis, calita).

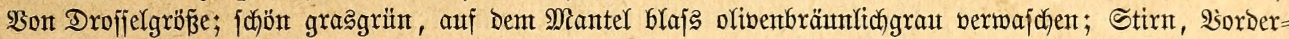

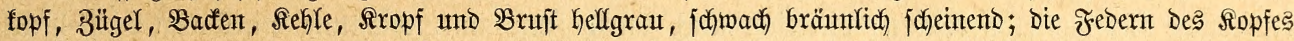

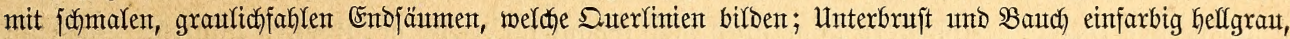

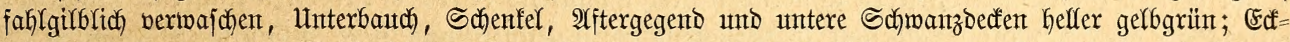

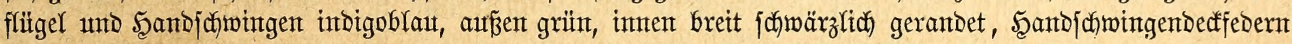

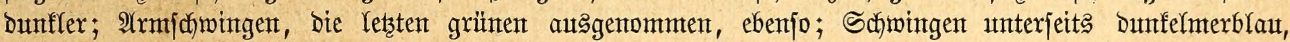

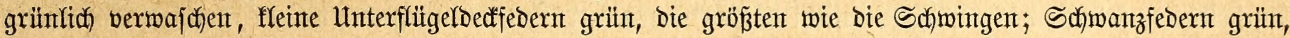

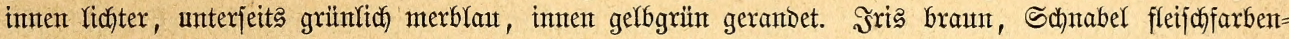

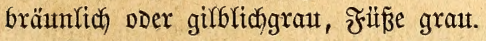

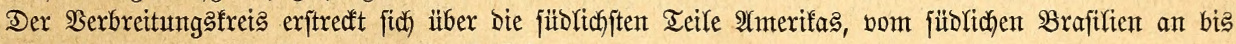
ïber bie Prataftaten, nady 2 Beften hin bis Bolivia.

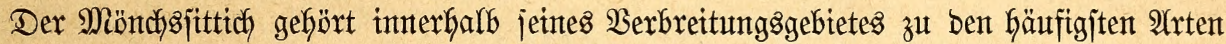

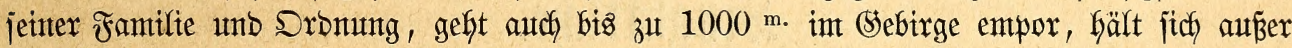
Dex $\mathfrak{B r u t z e i t}$ in Flügen von fünfzig bis zweifyumbert Stüd zujammen, ftreift gemeinjdyaftlid,

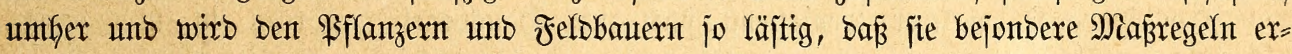
greifen, um ifjn möglichjit unjchäblich zu machen. Irotz affer biejer Sittidje halber eigens

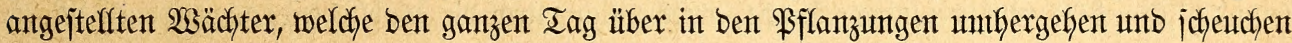

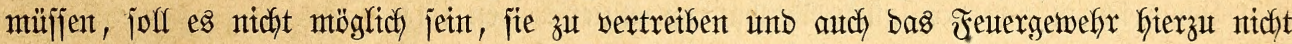
ausreichen. Ranbeseingeborene berjicherten Darwin, baź in einter Sibelung ber Blatajtaten im

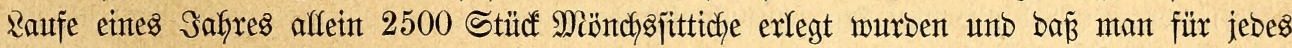
Dutzeno Sïpfe ente gemiffe Summe als Sdyufgeld zaflte. Sm übrigen idjeint bie Rebents=

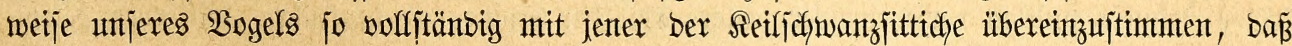
bie berjefjebenten Forjcher, weldye über ifhn beridyten, in biejer Seinjicht etwas zu jagen nicht für nötig eradjten. Dagegen unterjcheibet jich Der Mënddjittich von jeinen Bermanoten uno,

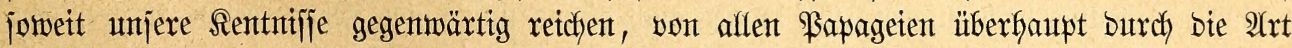
uno $\mathfrak{B e i j e ~ j e i n t e s ~ \Re e j t b a u e s . ~ E r ~ b r u ̈ t e t ~ n a ̈ m l i c h ~ n t c h t ~ i n ~ B a a u m b o ̈ f l u n g e n , ~ j o n b e r n ~ e r b a u t ~}$

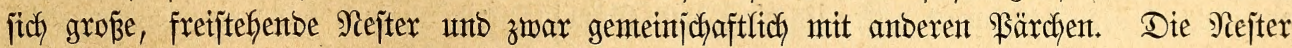

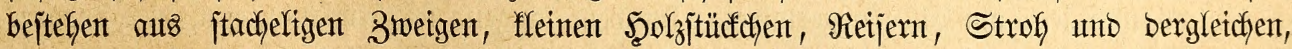

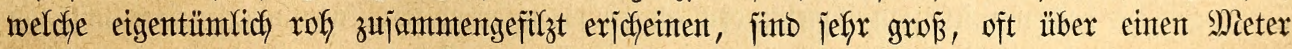
im Durchmefijer, oben vollftändig bebecft unt jettlidh mit einem ober mefreren Fluglöchern werjeben, weldye in bas mit wetchen (Sräjern ausgepoljterte innere গejt fübren. Ein joldjer

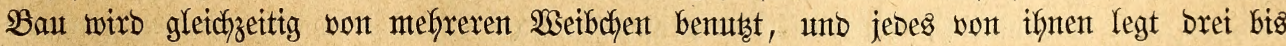
vier (Eier, ob gemteinjechaftlich auf einten Şaufen, ober wie idy antebme, in ein bejonberes

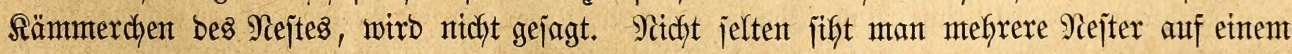

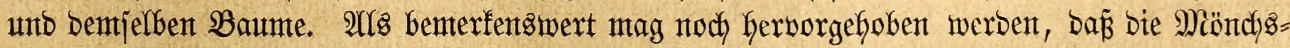
papageten fich nicht eimmal immter belaubte Bäıme zur $\mathfrak{A}$ ntage ifyer gemaltigen $\mathfrak{B}$ auten 


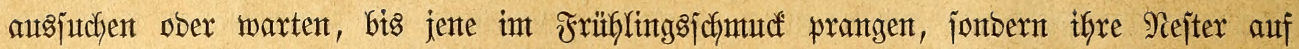
blattlojen $\mathfrak{B a ̈ u m e n ~ a n l e g e n , ~ b e z i e h e n t l i c h ~ w a ̈ h r e n t o ~ b e r ~ W i n t e r z e i t ~ b r u ̈ t e n . ~ D i e j e r ~ e i g e n t u ̈ m l i c h e ~}$

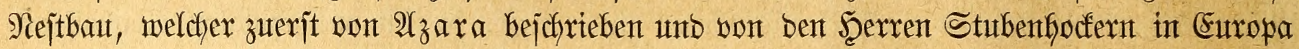

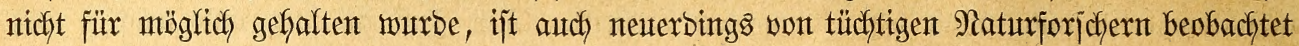
und jomit $\mathfrak{A} z a r a$ gered $f$ tfertigt worbert.

In umjere Räfige gelangt Der Miönctigjittich, wie alle Bögel ber \$latajtaten, wer=

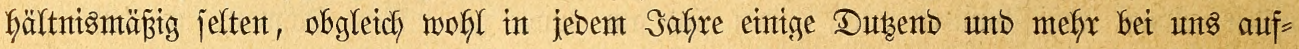
fonmen mögen. Er gebört trok jeines unjcheinbaren Sefiebers zu ben anziehenben Sitticfent, welche 2(merifa uns liefert, ijt munter, rege, genïgjam, ausobaterno, hat audb im Iiergarten zu Franffurt bereits einmal Eier gelegt, weripricht aljo bei geeigneter Behantolung bei uns

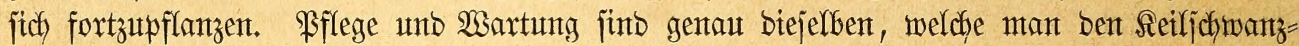
jitticten zu Teil merben lajjen muz; bezüglich ber Fortpflanzung aber wirb man jelbjtwer=

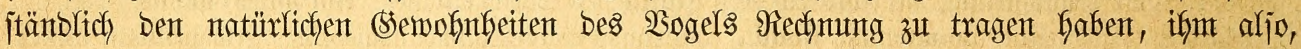

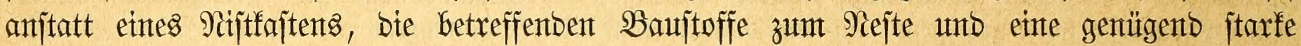

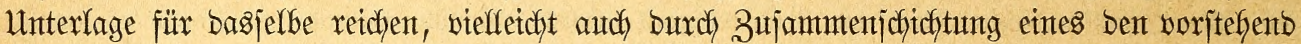

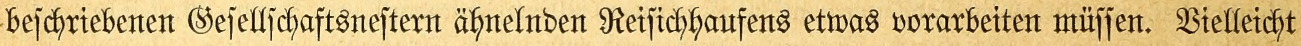

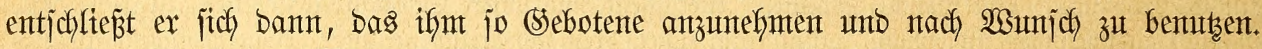

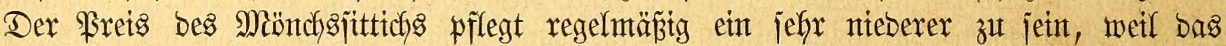
bejchetbene Sileto Des $\mathfrak{B}$ ogels nicht Sebermant für ifgn einnimmt unt er bem entjprechento

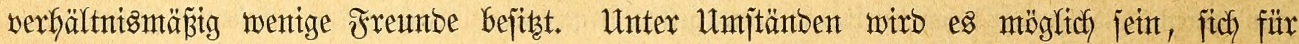

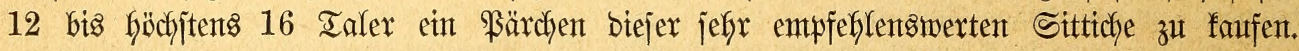

\section{Sinteglittidge.}

Der Fapagei, weldyer wentgiftens fajt zum Şausvogel gemorben ijt utb gegen= wärtig in Europa zu Şumberten und Iaujentoen gezühftet wirb, bertritt als ber einzige

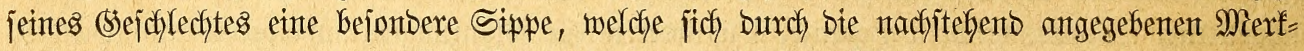

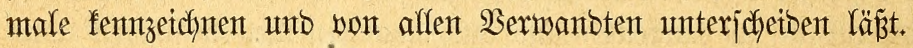

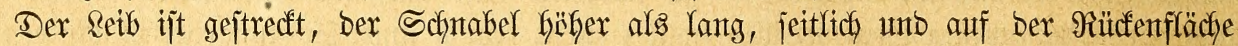
abgerunbet, ber Sberjednabel fajt jenfrecht herabgebogen, jein Spibenteil weit itberfängeno, bie Rabe vor bemjelben tief auggeranbet unb in ber Butcht mit zmei, zumeilen aud brei

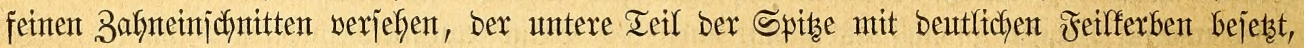
ber Unterichnabel ebenjo God afz ber obere unt an jeiner Diffenfante abgerunbet. Die

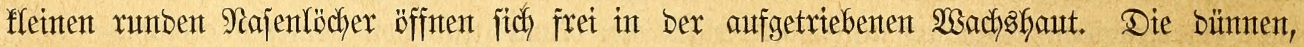

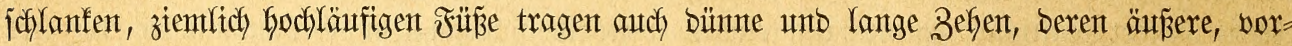

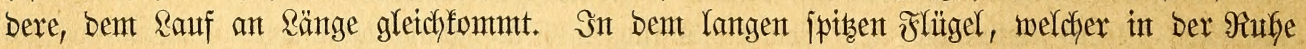

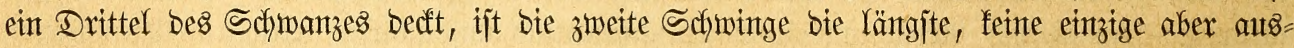
gejchnitten und jebe ant Enbe abgerunbet. Sn bem langen, feilförmig abgejtuften Schwanze

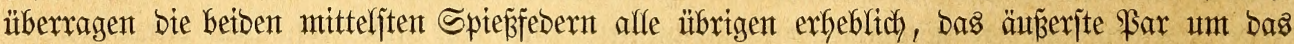
Dreifache; aber audf jie, wie affe übrigen Steuerfebern, finto am Enbe breit abgerumbet. Das weiche Siefieber zeigh lebhafte Farben und eine eigentümlich weflentartige Beichnung.

148. Der $\mathfrak{S e l l e n j i t t i d ) , ~ S a n a r i e n ~ = ~ D D e x ~ M u i d j e l j i t t i d ~ ( C a n a r y ~ a n d ~ S h e l l ~ p a r r o t ) ~ D e r ~ E u t r o p a ̈ e r ~}$

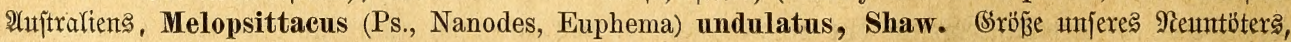

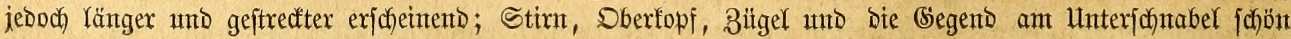
(d) wefelgelb, auf Dex Mitte Dex Bacte einige verlängexte Feberchen mit ftarfen, hornartigen (Endfabment von

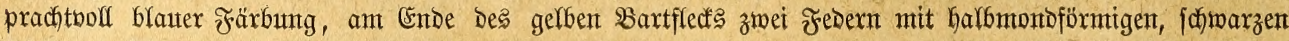

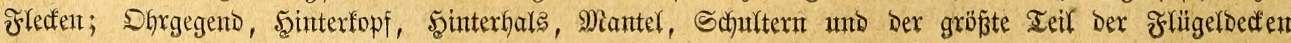




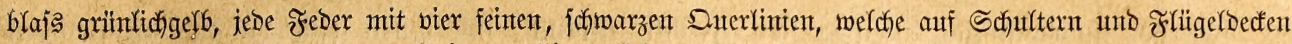

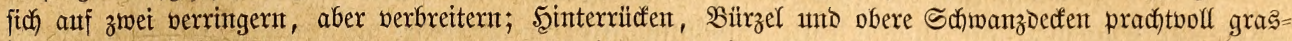

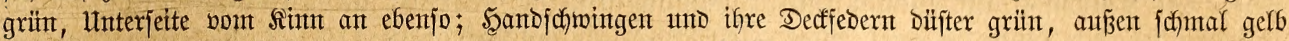

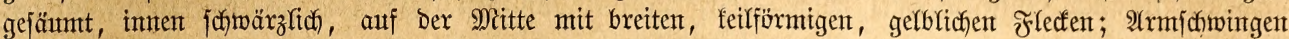

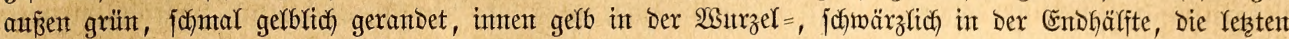

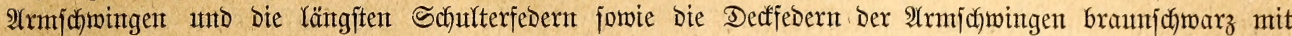

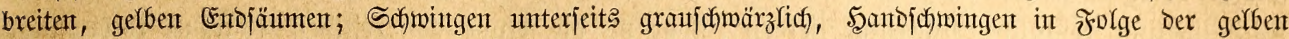

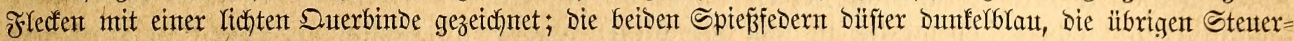

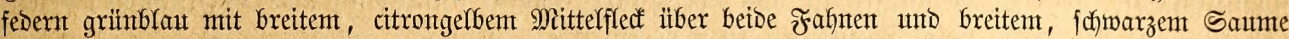

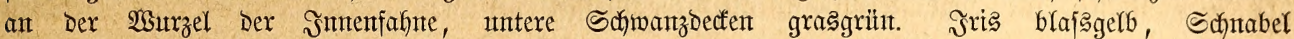

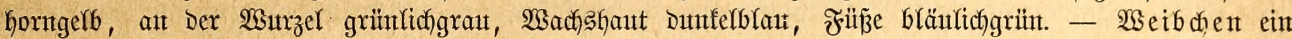

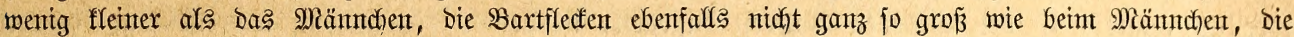

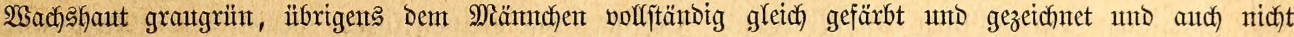

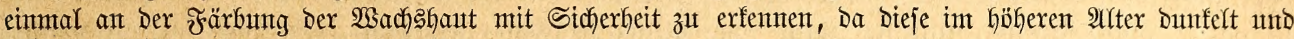

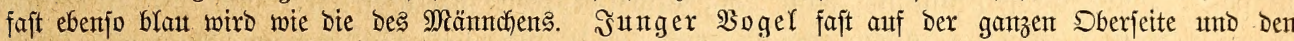

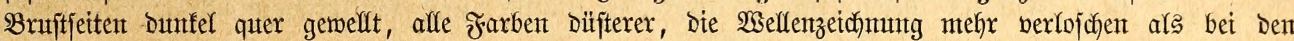
alten $\mathfrak{B o ̈ g e f t r . ~}$

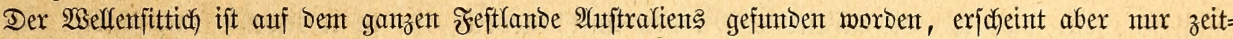

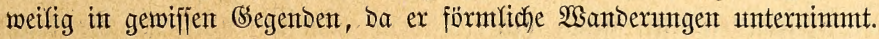

(5) ould war ber èrje Naturforjcher, weldyer uns über baz Freileben bes Wellenjittichs

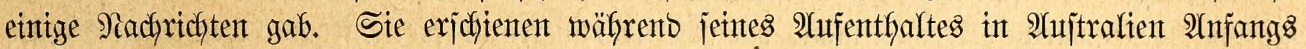
December auf ben Ebenen bes Inneren unb belebten bieje balb zu Taujenden. Wäartend

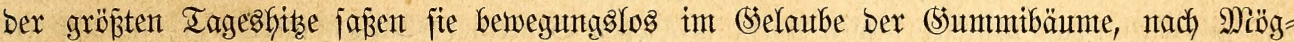
lichfeit veritedft; Morgens und Afbents aber zeigten jie ficty auf Den Spizen ber Bäume unt begaben jich bald barauf in Flügen von zwanzig bis fumtert Stücfent zut Iränfe, von wo aus fie ant Morgen nach ben (Sragfeldern ber Ebene auszogen, um fich ifre Safrung zu juthent. Sm December brüteten jie gemeinjchaftlich in Euffalypten.

Danf ber Mitteilungen, weldye mir Engelhart gemadyt Gat, bint idy im Stanbe, bas won Sould unt alnberen entworfene Bitb bes Freilebents unjerer Bögel wejentlich zu er= weitern. "3u ben unitäten (Säjten Sübaujtraltens gefört auch ber fier wie überalf io

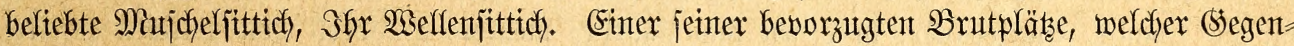
jtanto meiner unmittelbaren Beobachtungen murbe, ijt jebenfafls ber Mallee-shrub, ein föjt = licher Euffalyptentwald, welcher fich gleichlaufend mit bem Maurray, bon befjen Meündung

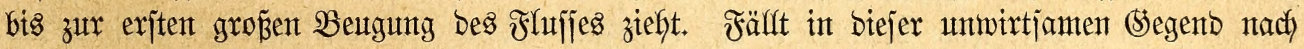
einem nafjen Winter auth nodh int Jrüblinge, D. h. Enbe Septembers und in Sftober

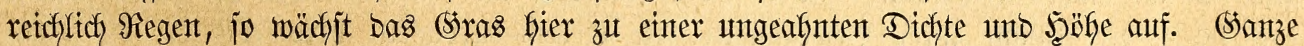
Steviertmeilen, weldhe jonjt bas unverfennbare (Sepräge einer trojtlojen Sanbmüjte an jich

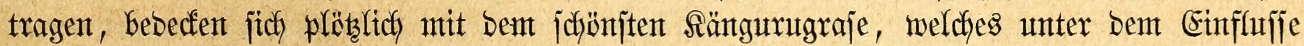

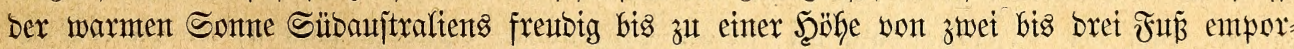

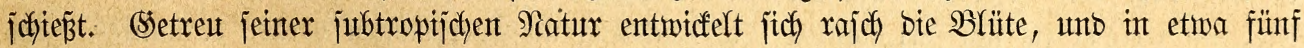

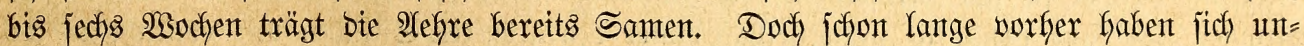
gezähllte Scharen bes nieblichen Sittichs eingefunben unt beginnen eifrig bas Brutgejchäft.

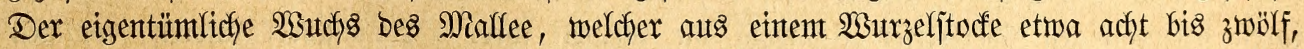
$6 \mathrm{~m}$. Gohe, meiß̧rindige Stänme mit bürftigen Saubfronen emportretbt, in benen fich un= zählige afjtlöcher funben, begünjtigt biejes (Sejchäft in Gohem (Srabe. Geber hoble Stamm,

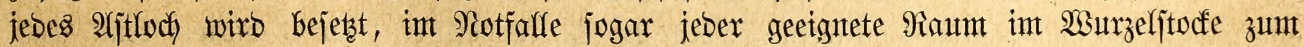

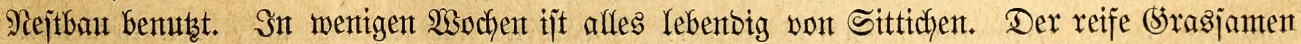

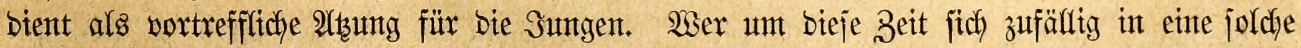
(Segent berirren jollte, fönnte Yeidjt Şunberte biejer Yeţteren mit ber Şand fangen. In zahlreidfen Scharen fliegen fie vor jeintem Fustritte aus bem (Sraje auf, jetzen jich in langen Reiken auf bie naften Ziweige, mit zmiticherntomt (Sejange jich unterhaltent, unt jeken harmlog 


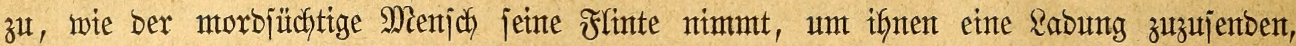

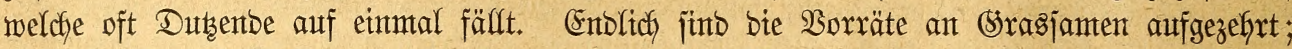
vielfetcht ijt auch) Waffermangel eingetreten, und ber Wantertrieb regt jich in ben präd)tigen

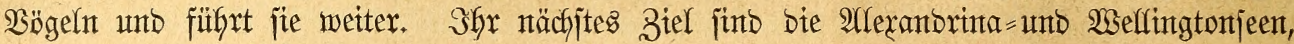
welche betoe vom Marray burchitrömt werben, ehe ex in bas Mer münbet. Db fier bie

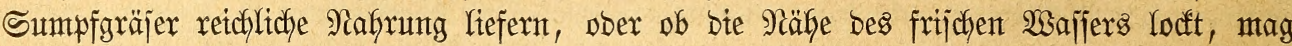

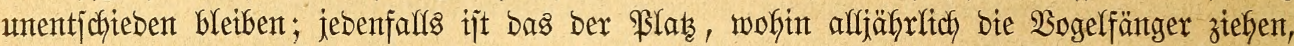
ifre Netze itellent und viele Taujende unjerer Sittiche erbeuten.

Dieje Schilberung gilt, wie nodymals zu benterfen, mux für bie Sahre, in benten es

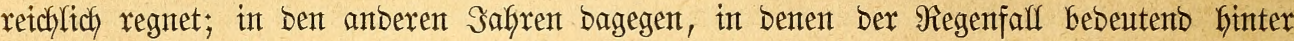

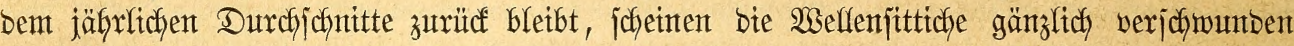

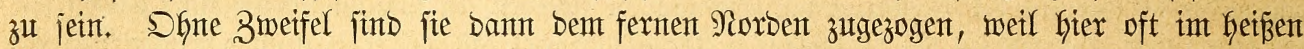
Sommer heftige Semitter fallen und in furzer Zett aus einer vollytäntigen Santoüpte eine grasretche Steppe zaubern. Es ijt, als ob alle wantbernbent \$apageien bies im Boraus

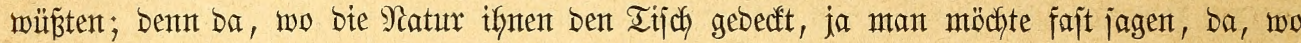
fie iffnen Den Iijch becfent wirb, jtellen jie jich jitcher ein."

Anfangs ber fünfziger Эafre gelangte bas exjte Färchen Yebenber Welfenjittiche nach Europa: gegentwärtig befrachtet man, wie (ธ. 130) bereitz bemerft, jo zu jagen ganze Sdjiffe mit biejen $\mathfrak{B o ̈ g e l n . ~ N a c h ~ M e l b o u n t e ~ b r i n g t ~ m a n ~ f i e ~ i n ~ u n g l a u b l i c h e r ~ M i e n g e . ~ S i e ~ w e r b e n , ~}$

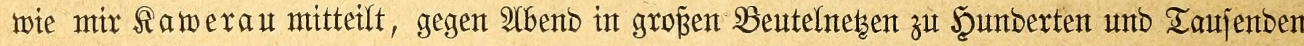
gefangen, in rohe Sijtenfäfige gejperrt unt jo Den Şänblern ̈̈bermittelt. Went ifgrer viele am Marfte find, fauft man jie int einzelnen für etwa 25 Sgr. (Das $\mathfrak{S a r}$ ), mährent bei

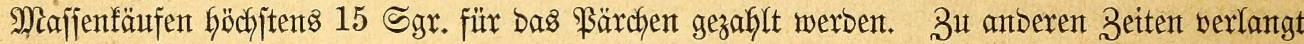
man auch in Melbourne zwei bis brei Ialer für bas ßar. Unterwegg fterben viele, nicht twentger geraume 3eit nach ifyer 2 nfumft in Europa. Sn Folge ber Majfeneinfufyr find

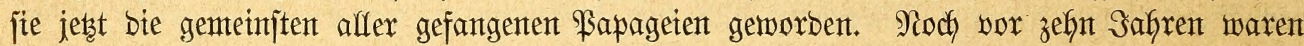
fie jeltene Exjchetnungen in unjeren Räfigen; gegentuärtig bevölfern fie fiter uno ba eigens für jie erbaute Fluggebauter, in Denten man jäfrlich mefrere Scunberte von \$ärchen züdhtet,

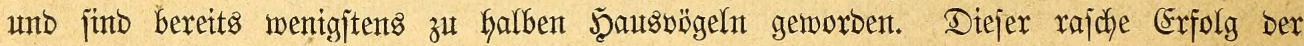

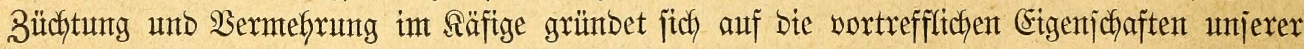

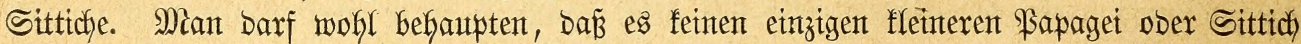

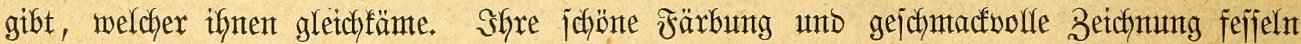

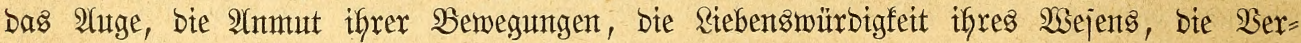

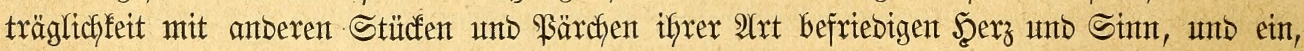
menn auth nicht gerabe retdhbaltiger und volrtönenter, jo boch gemütlicher unb anjprechenter Stejang trägt noch wejentlich Dazu bet, jie als Stubentö̈gel beliebt zu machen, wie bie Reichtig=

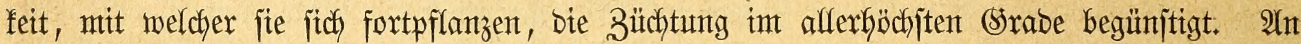

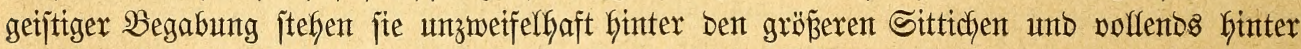

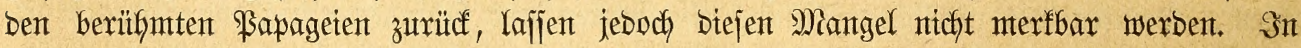
thren Sewegungen übertreffen fie wohl bie meiften ifyrer Sromungserwanten, fommen wenigjtens ben in biejer Beziefunt ant volffommenjten auggerüjteten volljtändig gleich.

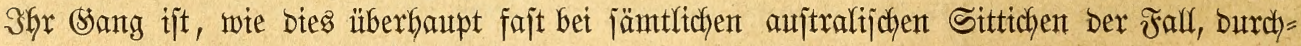

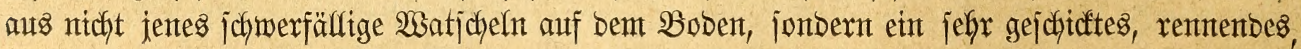
trots ber fleinen, trippelnben Sdyritte förbernbes Raufen; int Sllettern unb affen turnenten Benegungen im Sezmeige juchen fie unter ifren Sronungguerwandten iffren Mieijter; im Fliegen übertreffen fie, wie midy freigefonmene belebrten, affe übrigen mir audf in biejer Şinjicht befannten Sittiche: jie jagen mit einem Falfen um bie WSette, füfyren bie zierlichjten

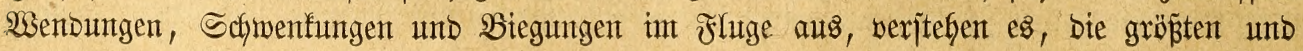


geringiten Entfernungen, io zu jagen, bis auf Bolfweite abzumejien, furz lafien jich ben volfenbetiten Fltegern an bie Seite ftellen. Shr gewähnlicher Rocfton ijt ein zmar nicht gerabe wohflautenter aber boch audh nicht abjtofienter Sdyret, weldyer mit bem befannten

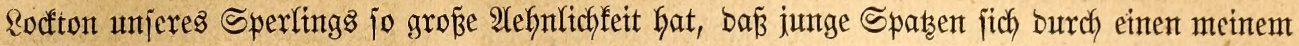

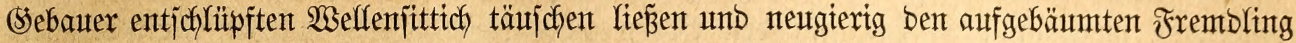

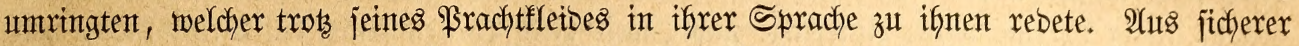

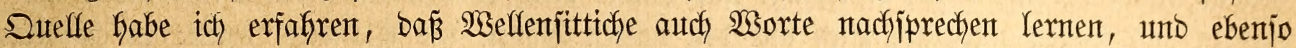

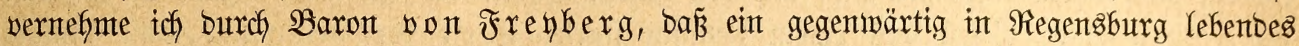

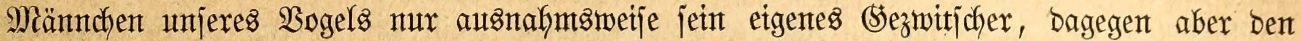
(sejang bes Silberichnabels flar, rein und jefr getreu, nur etwas jtärfer vorträgt. (5z mögen bieje Iatjachen als jeltene 2 (tisnafmen betrachtet werben; fie betweijen aber nichts bejto

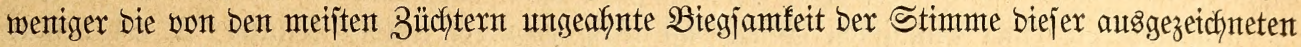

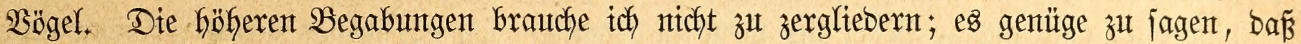

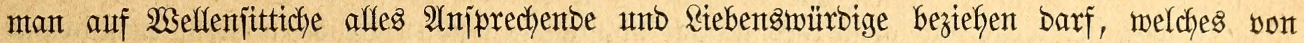
anberen fleinen Fapageien unb Sittichen überhaupt befannt gemorben ijt. Sch. Galte fie un= bebingt für bie Danfbarjten Räfigoögel, welche ifre Familie, um nicht zu jagen, ifyre Sro= mung, uns bieten fann, und laffe mich auth Keutigen Tages noch nicft beirren burch bie Robpreijungen, welche von einzelnen Bielichreibern anberen fleinen Fapageten gejpendet worben

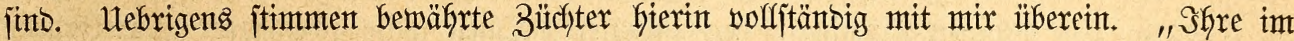

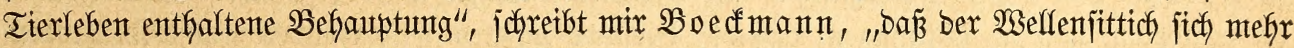

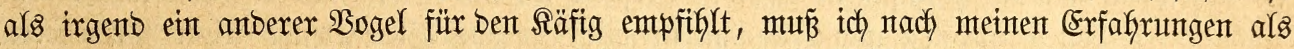
unbebingt ridftig bejtätigen, unb glaube ich nicht, baj ein Riebfaber bieje 3udft zu (sunjten einex anberen aufgeben wirb, jobald ex biejelbe nutr einmal verjtändig betrieben und bem entiprecheno Erfolg ergielt hat. Snzbejonbere begreife idy nidyt, wie ein Sdyriftiteller ben Sperlingspapagei jo ungebürlich herausjtreichen und babei ben Welfenjittich jo gänzlich ver= nachläjifigen fant. Die Sperlingspapageien fint nidht nur langweilig, jonbern aud unver= träglich), fönnen fich jeoenfalls mit ben $\mathfrak{W e l f e n f i t t i c h e n ~ a u d h ~ n i c h t ~ i m ~ e n t f e r n t e j t e n ~ v e r g l e i d f e n ~}$ lajfen." Bon biejen lebzteren mieberhole ich ben bereits im Tierleben gegebenen 2Yusjpruch eines Büchters: "Se länger man jie fennt, je lieber geminnt man jie."

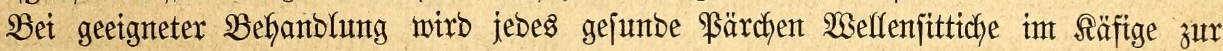

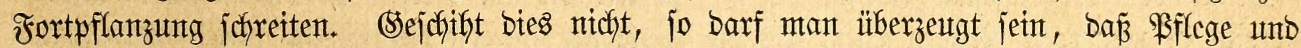
Wartung nidfyt bie ridftigen waren. Nar zu oft vernimmt man eine Alfage itber bieje Bögel; geft man berjelben auf ben (Srunto, jo fintoet man, bas fie unabänberlich auf Den Riebfaber

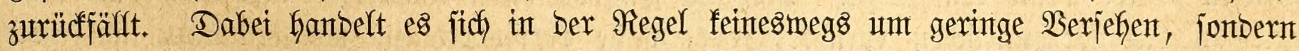
in ben meijten Fällen um unwerantwortlich grobe Fefhler, welche bie Unerfahrentheit, Reichtst=

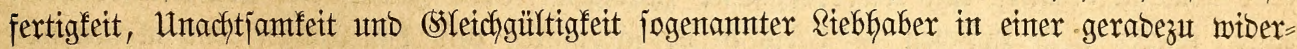

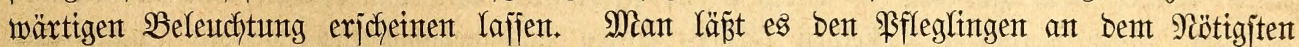
fehlen und ift bann töricht genug, ifnen aufzubürben, was man jelbjt serjchulbet. AYus

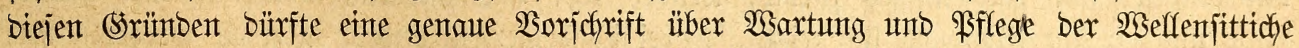

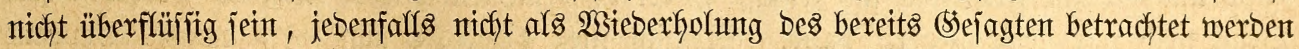
fännen, umjomehr als jie zugletch für bie meijten anderen Sitticharten gilt.

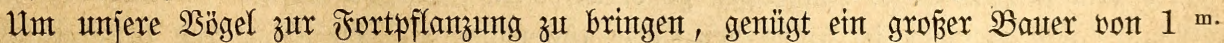
Ränge, $50 \mathrm{~cm}$. Breite unt $60-80 \mathrm{~cm}$. Ş̈̈he, in weldhem ein fleintes einfaches Räjtchent von $15-20 \mathrm{~cm}$. Ränge, Breite unb Ş̈̈he int \&idytent mit eintem $3,5-4 \mathrm{~cm}$. im Durdfmeffer Galtenbent

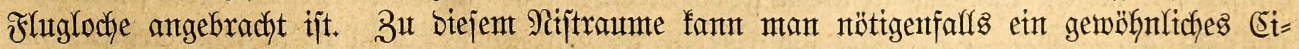
garrenifäjtchen berwenben, boch ijt es befjer, anjtatt befien ein oben unb unten mit feiten,

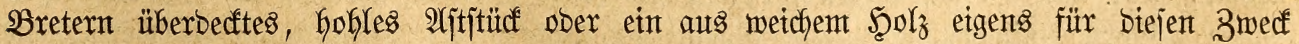

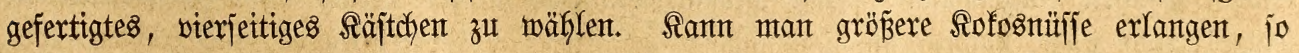


Göble mant einige won biejen aus, erweitere bas Flugloch auf ben angegebenten Durdhmejer

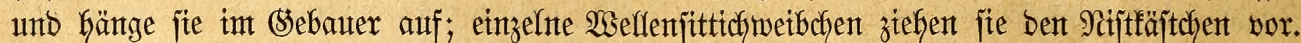

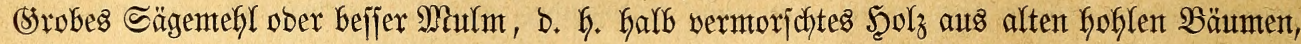
weldyes vorfher in ober auf bem Dfen gebörrt wurbe, bient fur Unterlage ber Eier und fant

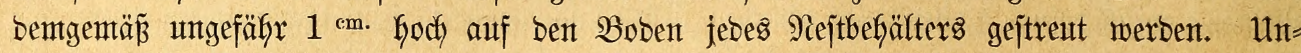
bebingt nötig ijt eine joldye Unterlage nicht, weil niele wellenjittiche bie Brutfäjtchen volf=

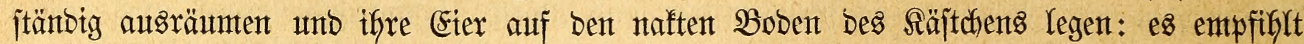
jich Deshalb audh, Diejen aus einem ziemlidy ftarfen Brete Gerzujtellen unt janft mulbig

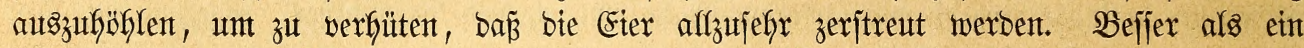
Säfig ift ein nach Mittag hin gelegentes Bimmer, weldhes einzig und afrein biejen $\mathfrak{B}$ ögeln angemiejen werben fant. Retsteres erjcheint jchon aus bent Srunbe notwendig, weil bie

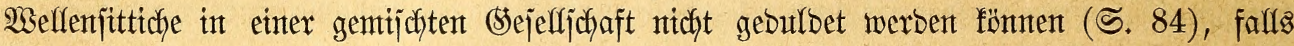

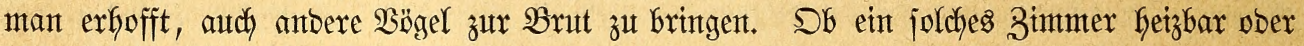
nicht Keizbar ijt, bleibt jich gleidf; es genügt volfjtänbig, went bie Rälte nicht unmittelbar einwirfen fann, beżehentlidy, wenn man bafür jorgt, baß̉ bie 2 b̈gel gegen harten Frojt uno

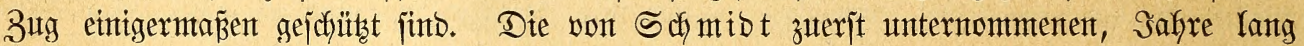

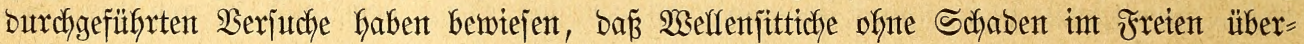

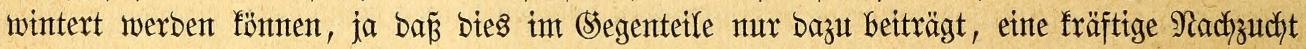
zu erzielen. Itm gewifjen \&lüglingen Den unlauteren Duell weije fcheintenber Bemerfungen

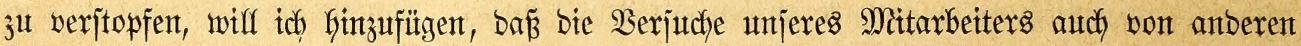
Büdftern, jo von Freyberg uno $\mathfrak{B}$ oed mann mit bem günjtigften Erfolge wieberfolt worben

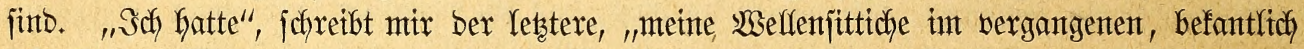
jefr harten $\mathfrak{B i n t e r}$ in eine geräumige Bogeljtube geję̧t, beren Fenjter zum Ieil wäfreno Des ganzen $\mathfrak{B}$ inters nidft gejchlofien wurben. Die $\mathfrak{B}$ ögel waren niemals nunterer unb gejünber als währent biejer Zeit, obgleich bie Rälte mantłumal bis auf -8 , ja $10^{\circ} \mathrm{R}$. jtieg. Sämtliche Sniafien ber Bogelfutube waren in Europa gezüdhtet, unb beshalb vielleidjt brütete fein einziges Bärchen von ifnten; imt Sommer aber fyolten fie baz $\mathfrak{B}$ erjäumte retchlidy nach, unb erfjelt idh), um ein Beijpiel anzugeben, won einem $\mathfrak{B a r e}$ meiner Sittiche in zmeiter $\mathfrak{B}$ rut aflein adjt fräftige Sunge." Schmibt hat Borjtehenbem jeine neuejten Erfahrungen angefügt. "Im Jebruar Des vergangenen Safhres (1870) hatten bie int Freien gefaltenten Wellenfittiche

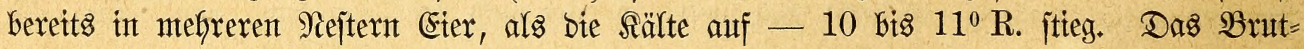

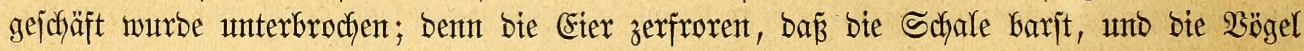

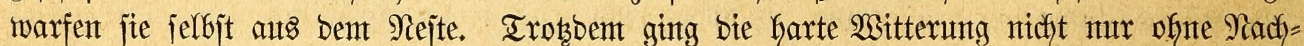

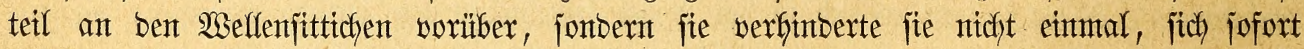
auf's neue zu begatten' unb mieberum (Eter zu legen. Atud gelantg bie Brut, obwohl bie

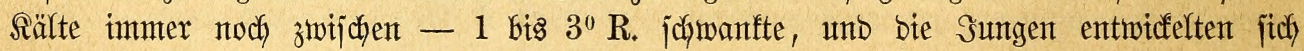

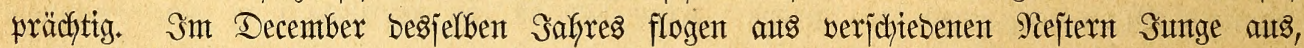

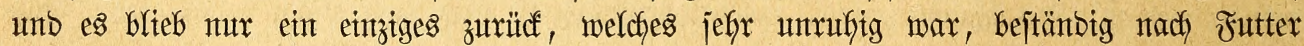

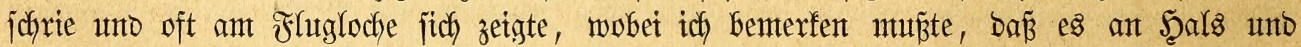
Brujt nod) gax feine Febern hatte. Plöbzlich jtieg die fälte auf -5 bis $8^{0} \mathrm{R}$, whne jeboch bem jungen $\mathfrak{B g g e l}$ Untbefagen zu berurjachen. Erjt bei $-12^{\circ} \mathrm{R}$. jtarb er, wie idf

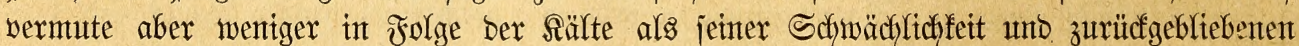

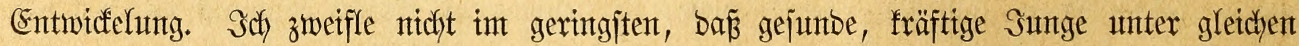
unmitänoen ungefähroet aufgefommen jein mürbent. Die faum ausggeflogenten Sungen bliebent

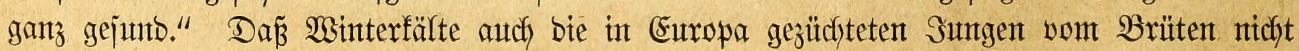

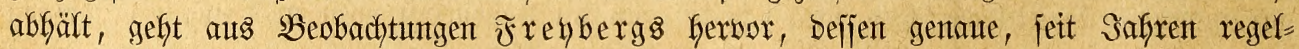

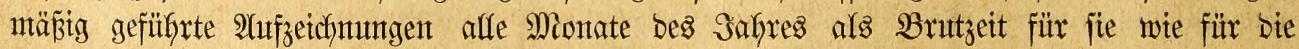
eingejührten $\mathfrak{B a ̈ g e l ~ n a d j w e i j e n t . ~}$ 
Wer über einte paffente Sertlichfeit unto bas nötige (selb bexfügt, wiro aud̦ ein

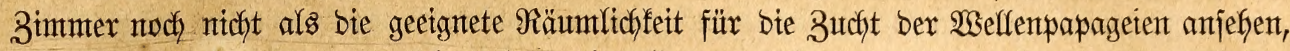
fich vielmefy ein bejonberes Fluggebauter im (Sarten anlegen. Seterzu eignet finch am bejtent

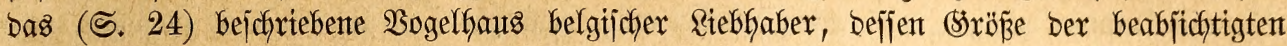

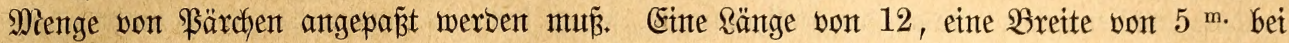

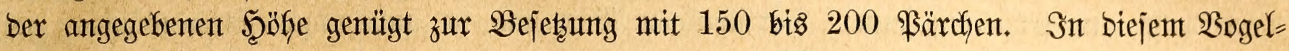

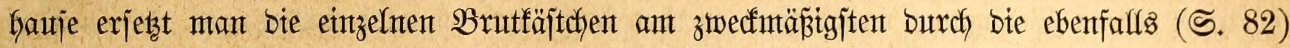
gejchilberten $\mathfrak{B e i b e n j t a ̈ n t m e ~ o b e r ~ a n d e r e ~ a b g e t e i l t e ~ h o h l e ~ B a ̈ u m t e . ~ S o l d y e ~ B a ̈ u m e ~ f i n t o ~ z w a r ~}$ ebenfafls nicht als unbebingtes Exforbernis anzueben, haben aber vor gemöfnlichen গijt=

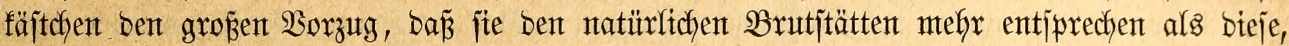

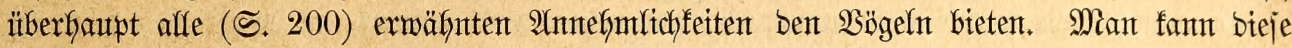

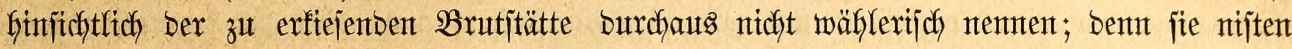

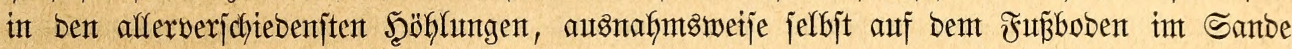
ober, was noch auffallenber, in ben mit Febern autgepolfterten Nejtern fletner Finfen; Dem= ungeadjtet werben fie fich, wenn fie fönnen, ftets ber iffren natürlidfen am meijten ähnelnoen Brutitätten bedienent.

Die erjte $\mathfrak{B}$ edingung mut für günjtige Buthtergebnifje ijt geetgnete Fütterung umjerer

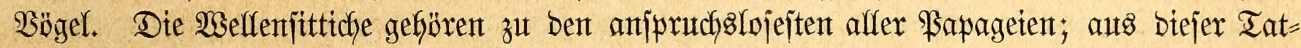
jache folgt jebody feintesmegs, baz man ifnen mux ein unb basjelbe Futter reichen joll, wie es aus reitrex Bequemlidjfeit in ben meiften Fällen gejdjift. Freybergs eingehente $\mathfrak{B e r}=$

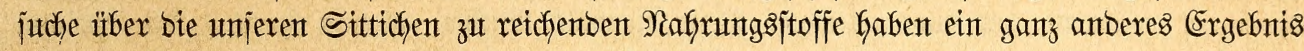
gehabt, als erwartet worben jein mag. "Sch füfre fier", jo beridytet biejer aubgezeidfnete

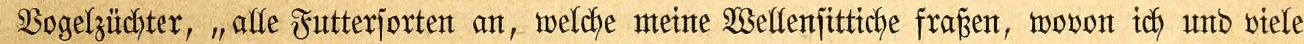

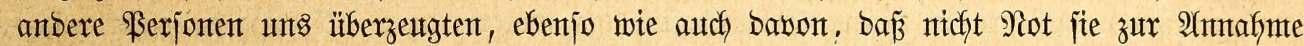

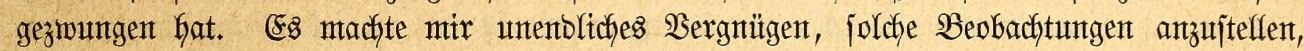

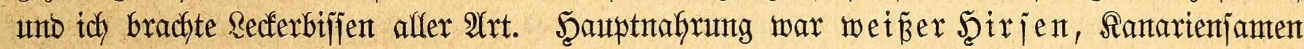

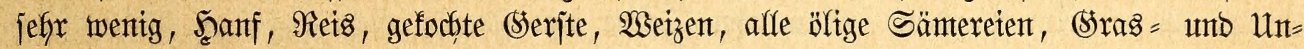
frautjamen mancher 2̂rt, Sonnenblumenferne, getrodfnete 2 tepfel, Birnen, Zwetichen,

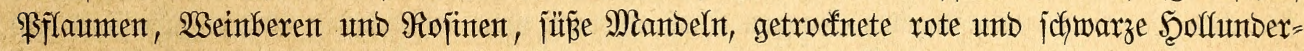

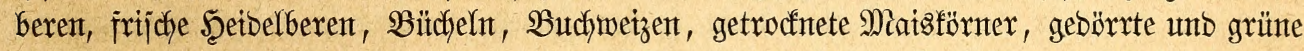

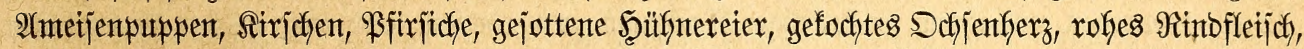

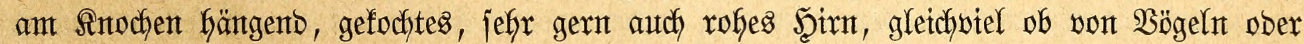

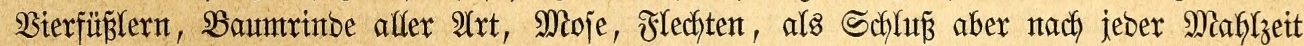

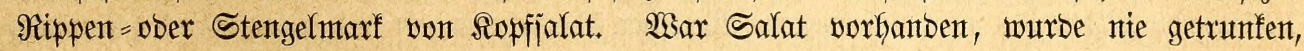

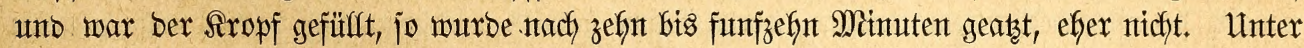

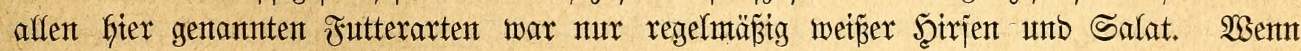
fie jich audf an bem einen ober anbern jatt frazen, jo war boch nicht zu erwarten, baj bei

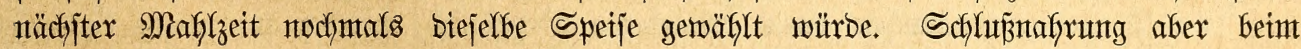

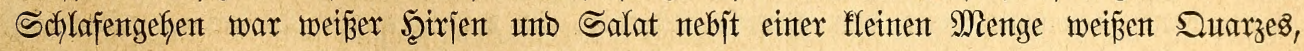

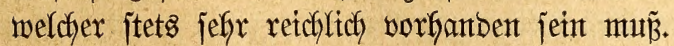

Dies lautet mut ganz anbers, als bereits ïber bie Tiere berichtet wurbe, unto es ijt

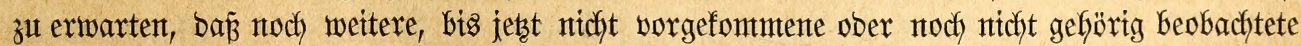

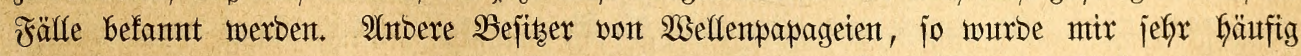
bemertt, Gaben zu Şauje noch nichts berartiges gejefen. Dies ijt ganz ridftig; benn bet

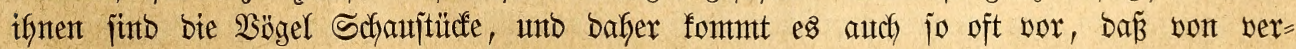
fdyiebenen Bejutiern gar feine Brut exzielt ober jonjt Bemterfentwertes beobachtet wurbe."

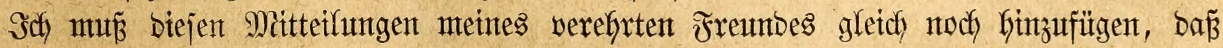

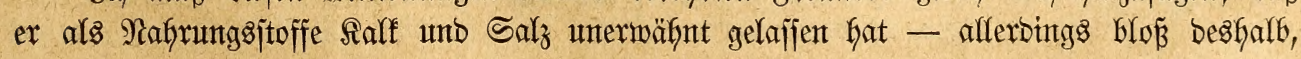


wetl erjterer Stoff int Fluggebauter burch alte Mauterbroden umb lebterer burdy - Sdjinfent= jchwarten, "moran fie jich jefyr gütlich taten", ziemlich wollitänbig exjetzt wurbent. Salz lieben,

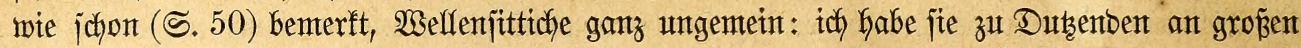
Steinjalzflumpen bängen, bieje eifrig belecfen unb, wenn ein Ieil jich gejättigt, fie jofort burch anbere ablëjen jehen. Was ben falf anlangt, jo ijt berjelbe, nodjmals jei es einbringlidyjt

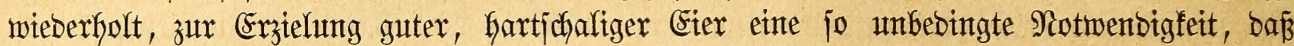
ex unter Ketner Bebingung weggelafjen werben barf, unb ob auch falffaltiges Stemäuer int Säfige vorhanten unt Den $\mathfrak{B} \not ̈ g e l n$ zugänglich wäre. Nieiner fejten Heberzeugung nach finto

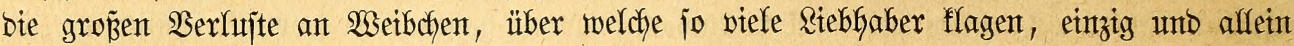

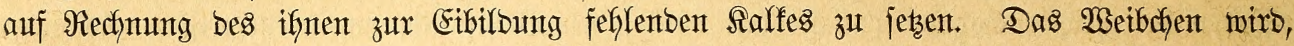
wenn man jeinem Şlute nicht ununterbrochen neuen Salf zuführt, in furzer Beit burch bie Erzeugung von Eiern entfräftet unb geft in Folge Deffen, nicht aber an eigentlicher sege= not zu (Srumbe. Dafyer verjäume man mährend der SBrutzeit num und nimmermefrx, ungelöjchten Salf, Sretbe und Schulpe Des Tintenfijches (os sepiae) in Siäfige aufzufjängen,

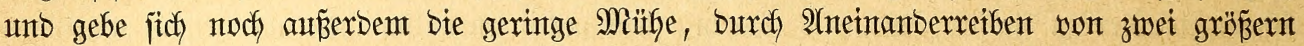
Sreibejtücfen über Dem Futternapfe Die Nafhung mit einer geeigneten Menge von Salf zu verjetzen. Weit minber nötig al\& bie genannten Stoffe jcheint ben Weflenjittictjen Wajfer zu jein. Sie trinfen auffalfend wentg und baben fajt nie, wenigjtens in flachen Befä̈̈en

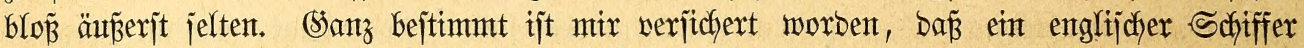
vor furzem über breifunbert $\mathfrak{B a r e}$ Welfenjittiche, prachtwolle Bögel, nach Europa bradhte,

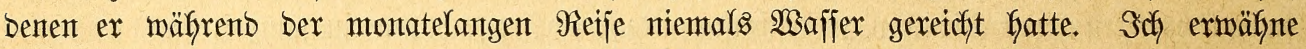

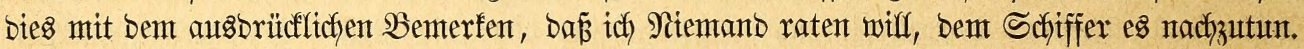

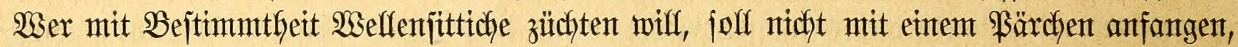
jonbern ifyer mefrere in einem Bejelfichaftsbauer unterbringen. Damit ijt nicht gejagt,

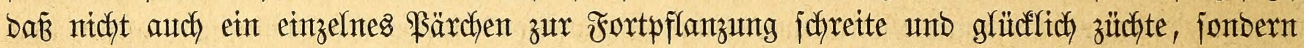

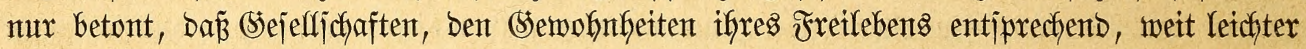
brüten als einzelne $\mathfrak{B a ̈ r c h e n . ~ ( S a n z ~ o f n e ~ S t r e i t ~ u n d ~ \Re a m p f ~ p f l e g t ~ e s ~ u n t e r ~ j o l c h e n ~} \mathfrak{B e r}=$ einigungen nidft abzugeben: es fommt, wie ich jelbjt beobadytet habe, jogar vor, dañ ein

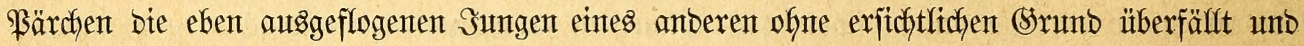

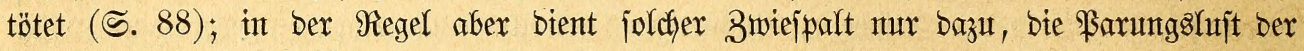

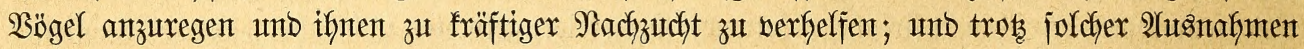

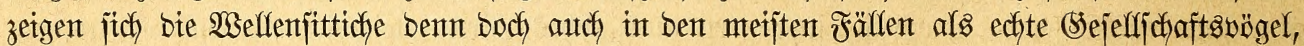
melche ecto und Freut mit einanber teilen und jich nötigenfalls gegenjeitig unterjtüzent. Unbemeibte Männtchen ober unbemannte 2 eibchen übernebmen oft aus freten Stücfen 2 (mment=

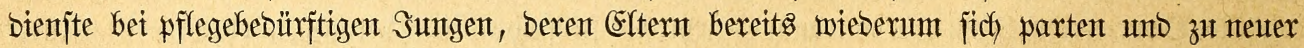

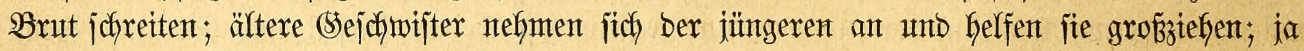
bie trefflidjen $\mathfrak{B}$ g̈gel erbarmen jidy jogar über anbersartige Sittiche: Schmibt beobachtete,

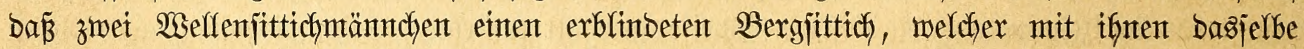
Fluggebauter bewohnte, aus bem Iropfe fütterten, als wäre er ifr Weibchen. Der viel

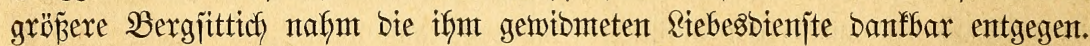

Bezüglich ber Zeit, in welcher man Die Färchen zujammenbringt, ijt man noch wer=

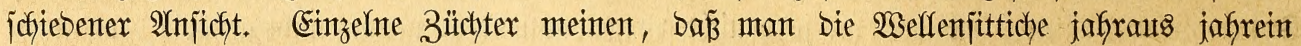
zujammen laffen jolle, anbere unto namentlich bie $\mathfrak{B e l g i e r}$ trennen mintoeitents eintige Monate

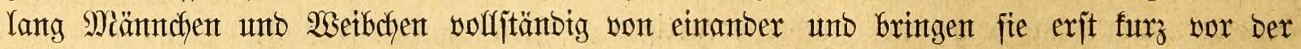
Farunggzeit in ben gemeinjchaftlitfen Räfig. Natürlicher, D. h. Den (Semofnheiten frei

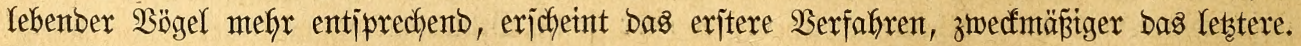
Maan hat wieberfolt bie Beobachtung gemadjt, baß̃ ein \$ärchen Welfenjittiche währento eines

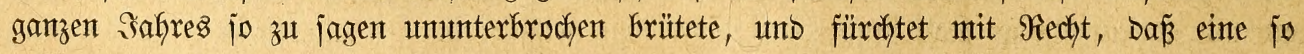




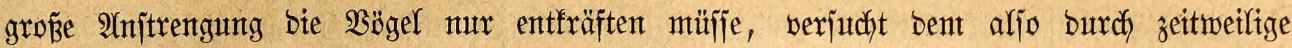

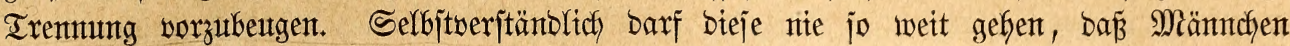
unb Weibchen fich während ber ganzen Beit gar nicht mehr zu jehen befommen; es genügt int Begenteile, went man bie einen in bieje, bie anberen in jene 2lbteilung eines Fluggebauters

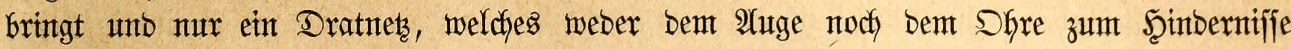
miro, als Schetbemant ziwijdyen betbe ziefjt.

Ein Derartiges Fluggebauter, welches mit fünffunbert bis taujent pärchenmeije zujanmen=

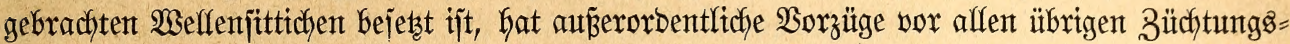

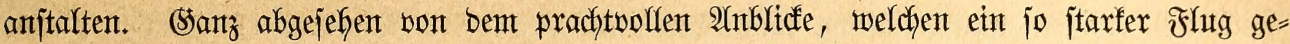

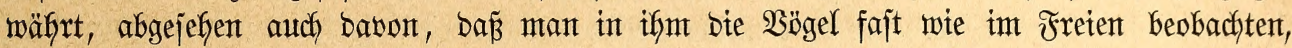

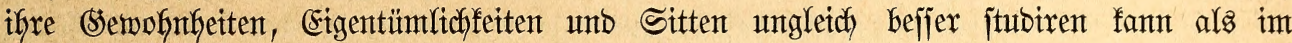

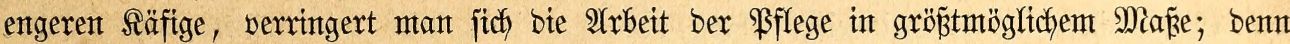
es genügt ein halbes Stündchen, um Das Fluggebauter in Dromung zu bringen, Futter=

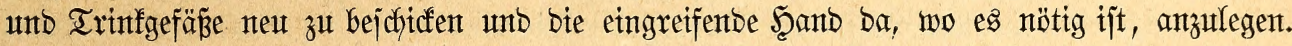

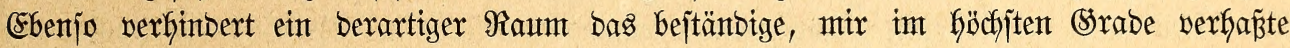

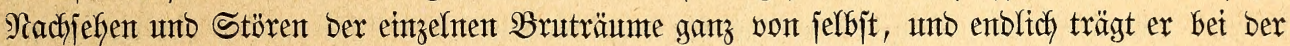

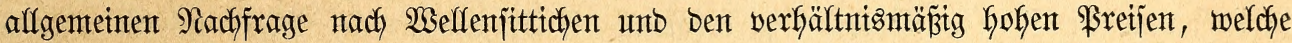
für fie gezahlt werben, nicht allein reidbliche Sinjen, jonbern winft audf einen feineswegs unerheblichen Seminn ab. Dies affes fann man weber in ber Brutfammer, noch im Sebauter

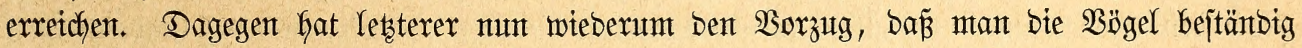
um jiłf hat unb, wenn man bas $\mathfrak{B}$ rutfäjtchen auren am Bauer anbringt, es nur burch ein Sallupfloch mit bemjelben werbintoent, baj man jich über bie Rege=und Brutzeit genauter unterrichten fann, als joldhes int Flutggebauter möglich. Der einfache Brutfäfig wiro aus biejen (srünben, troks aller jetner Miängel unt afler (Sefahren, weldye ber Brut bejonbers

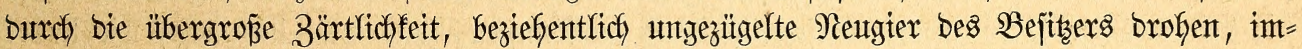
merfint jeine Riebbaber behalten, weil man es namentlich bem angebenten Büdbter nidyt

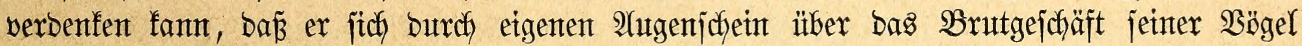
unterridften unb burdh eigenen Sidaben flug werben will.

Eingefübrte $\mathfrak{B e l f e n j i t t i c h e ~ b r u ̈ t e n ~ i n ~ u n j e r e n ~} \mathfrak{B}$ intermonaten, in Europa geborente oft, feinesmegs, immer in ben Sommermonaten. Erjteres hat, wie leidyt erflärlich), feine Nach)=

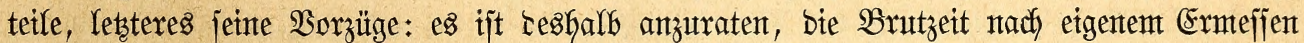

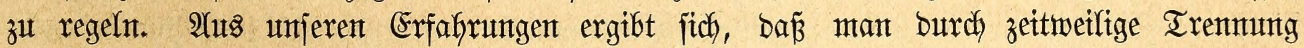
unt Wiebervereintgung Der Miännchen unt Weibchen bie Brutzeit nach $B e l i e b e n$ abänbern, beziebentlich bejtimmen fann, falfs man mur jelbjt einen gemiffen (Srab von Beobachtungaggabe bejitst. Dem entiprechento erreidyt man burch bas Berfahren ber belgijchen Büchter Borteile, auf beren weitere $2(1$ setnanberjebung idh, benfenben Rejern gegenüber, berzidyten barf, weil

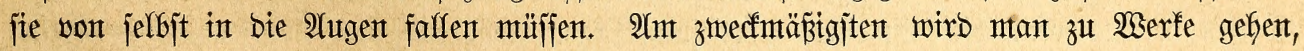

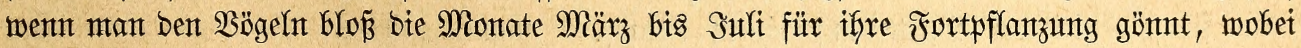

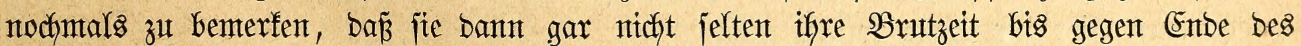
Sommers ausbefnen. Es ift wieberfolt beobachtet worben, baß́s winterliche Bunten einzig unb affein aus bem (Srumbe verfamen, weil bie Eltern nach Einbrudch ber Nadft nicht im Stanbe maren, ihre Sungen zu aben, bieje aber ein jo langes Fajtent nidyt ausfaltent fonten unb itarben. Afnbererjeits wiffen wir burch Freybergs unb meine eigenen

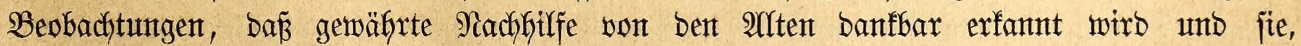

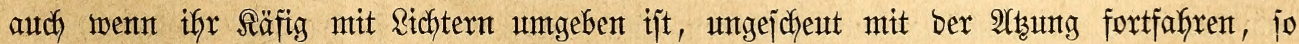

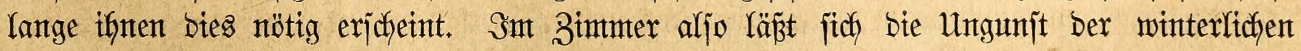

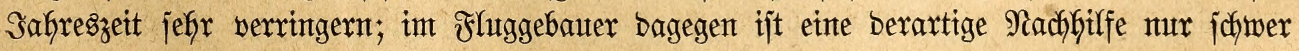
und mit groß̈en Siojten auşfüfhrbar. 


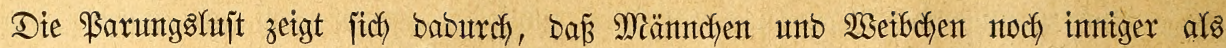

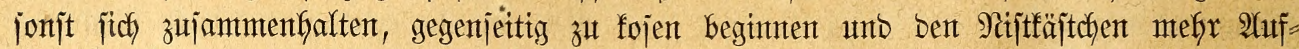
merfjamfeit zumenden, als jie es früber taten. (Einer ber (satten nach bem anderen fallüpit in Das Snnere Des Raumes unt madht fich hier fürzere ober längere Beit zu jchaffen, benagt bie Wanbungen, zerfleinert Den Matlm, wirft Sägejpäne keraus. Schon wäfrent biejer Worbereitungen exfolgt bie Begattung, meift wieberfolt int Raufe eines Iages und minbejtens

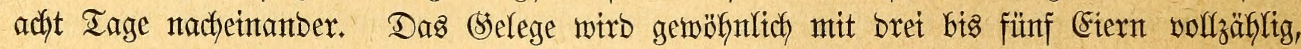
fant aber audy bis zu jedbs bis adyt Stüdfen anwadhjen. Die Brutzeit wirb von ber

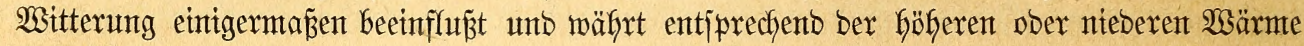
jectzefn bis actyzefn Iage. So weit meine Beobachtungen reidjen, brütet nur bas weibchen;

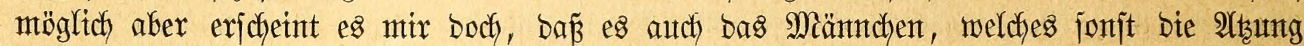
ber (Sattin ïbernimmt, zettweilig ablöft ober gemteinjchaftlich mit brïten bilft. "Mcit Şilfe eines an einem Stode befeftigten Spiegels", jujreibt Freyberg, "Kaben Freunbe von mix und idy bie brütenben allten oft beobadftet. Die Eiter lagen int Mulm ober Sanbe, bie Arlten mit gefdloffenen Schmingen anteinanbergebrïcft in gefreuzter Stelfung auf jenen. Der Şals war eingebrüdft, bas âtuge sejdloffen, ber Flügel aufent ein wentg ge= breitet, um Den Eitern alle Wärme zu erhalten. Dabei atmeten bie Bögel auffallento rajch

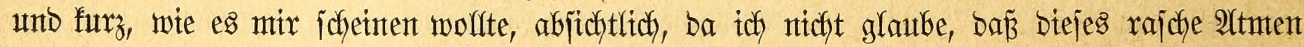

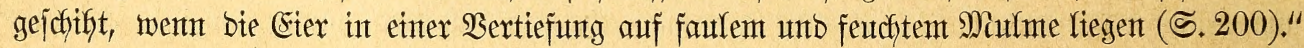

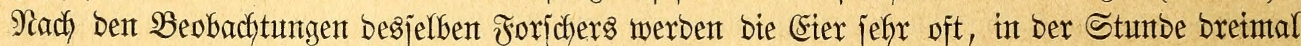

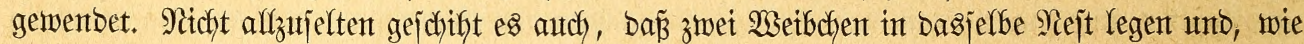
es icheint, bie Matterpflidften gemeinjchaftlich ausüben. Die Sungen fommen nach eintanber zum Borjchein, ba bas Weibchen regelmäp̈ig vom zmeiten, zuweilen fchon wom exf́ten (Ei an zu brüten beginnt untb bie exiten (Fier früber zeitigt als bie lebteren. Diejen fommt entichieden

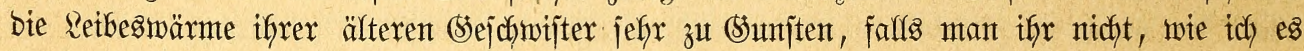

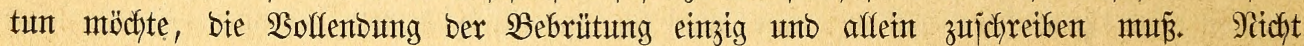
jelten madft man gerabe in biejer Scinjicht Göchjt merfwürbige Beobadfutungen. "Sch unter=

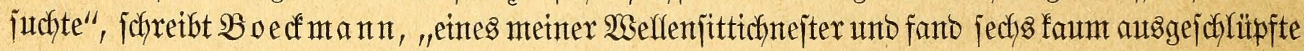
Sunge in ifm, nicht aber auch noch (Eier. Dret Wodben jpäter bemterfte idy zu meinent

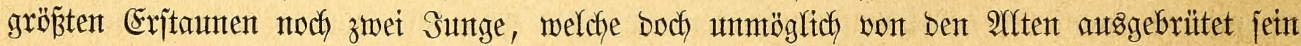

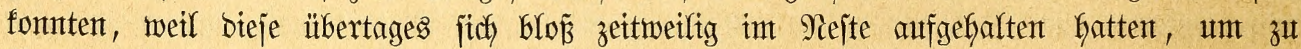

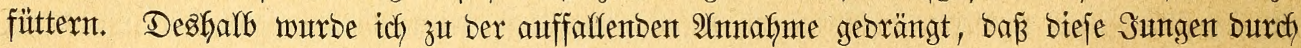

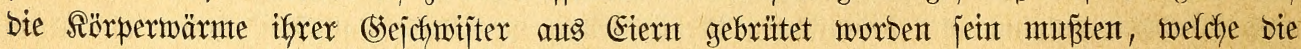
Mitter erjt gelegt haben fonnte, nachoent jente jechs Sungen bereits ausgejchlïpft maren." Neubert hat vor $\mathfrak{B}$ oed $m$ ann biejelben Beobadytungen gemadyt unb ebenjo gebeutet; Frey =

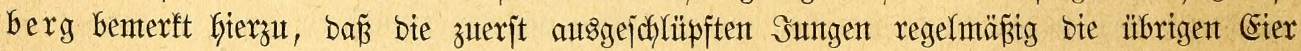
zeitigen Gelfen, went bieje in einer Bertiefung liegen, während fie, entgegengejetzten Falls, weil fie jtets in ber Mitte auf einem Silumpen zujammenliegen, bie noch nidht aus= gefommenten Eier zur Seite rollen.

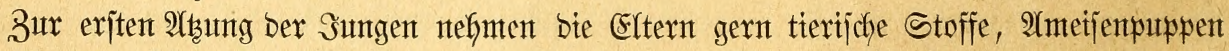
zeitweilig Dem Rönterfutter gegenẗber in überwiegender Menge. Ebenjo verwenden fie mit Borliebe feingejtopente Semmtel. Affle Rörner, welche fie ben Sungen reichen, quelfen fie worber in ifrem Iropfe auf; $e$ s ift aljo burchaus nicht nötig, ifnen aufgemeethte Säntereten

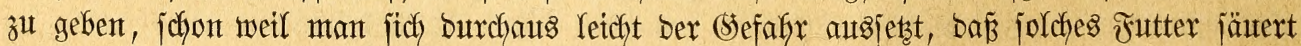

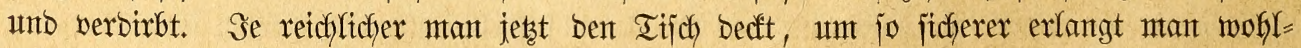

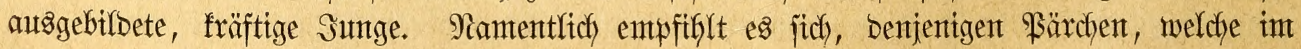

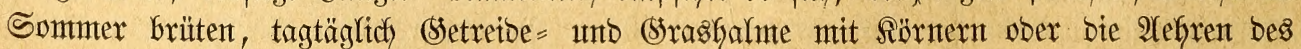
Bogel = unt gemetnen ફ̧irjen zu reidjen. Retzterex wirb in Belgien ganz affgentein verbraudft; 


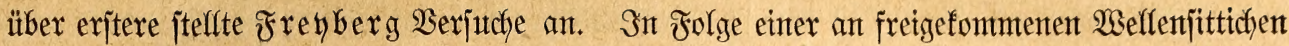

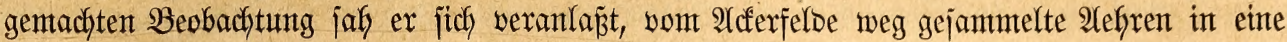
fleine Sarbe zu binton und biejelbe im Fluggebauer, bie AYefren nach unten, jajwebend auf =

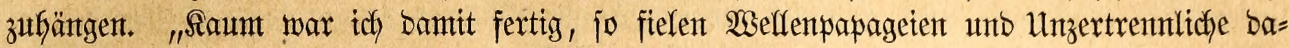
rïber her. Es ijt jefr anziehent, wie jie fich an einzelnen Scalnten anflammern, unter ununterbrochenem (seplauber necten, jagen und zanfen. Arlten Garten Şafer in Barben lieben jie ntidft jebr, fajt reifer mit nody weidfen Sörnern bagegen ijt ein wahrer Recferbijfen für fie, ja jelbjt noch ganz grüner wirb bem harten vorgezogen." Sch habe ben bet mix brïtenben Welfenpapageien ftets Betreibe = unb Srasäbren reichen lajjen und in Ermangelung

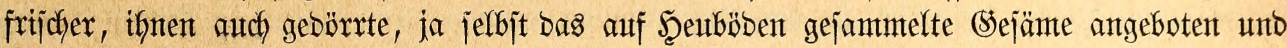
inmer gefunden, baß̉ ifnen eine berartige Nahrung beffer als jebe andere behagte.

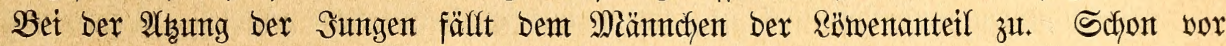

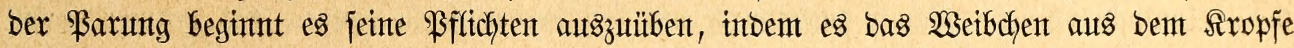

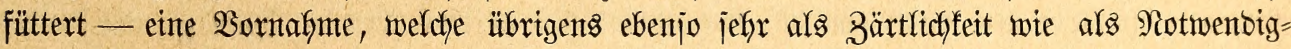
feit erjcheint. Wäfrent ber ganzen Brutbauter ernährt es bas Weibchen volfitändig, und ebenjo jorgt es in ben exjten Tagen nach bem 2 Utäjchlüpfen ber Sungen für bieje, intom ez ber Mutter bie im Sropfe aufgeweichten Sämereten und andere Nahrunggitoffe füttert

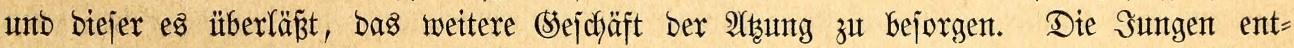

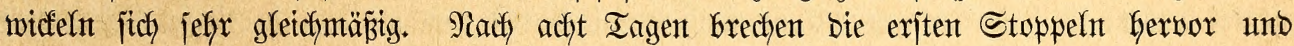

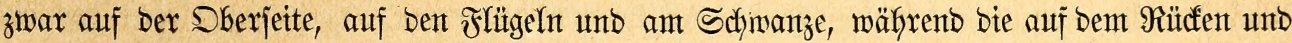

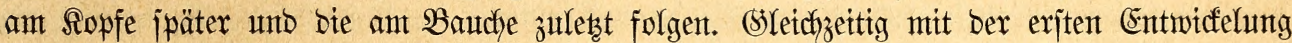

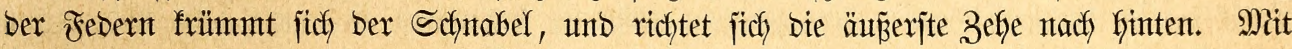

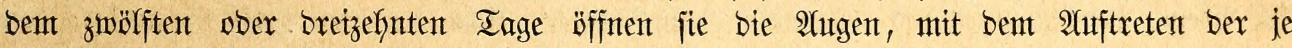

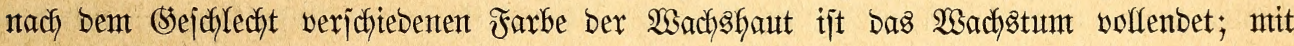

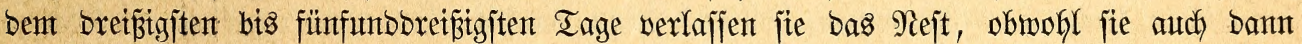

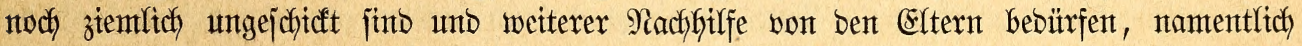
gefüttert werben müfjen. Doch beginnen fie johon früfyzeitig nebenbei jelbjtändoig etwas

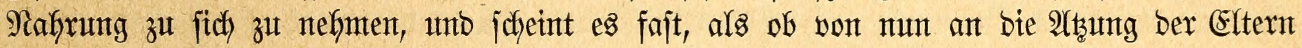
audh mur aus Bärtlidffeit gejchefye. Sunge, weldhe in ben Wintermonaten in einem falten

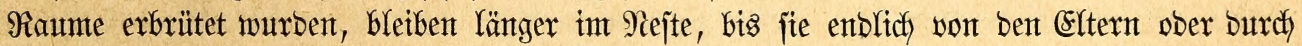
ben Şunger ausgetrieben werben. Bei fortgeiebter Snzudft Geobadhtet man, laut Freyberg, auch int Sommer basjelbe, weil bie betreffentent Sungen jobwädyer, furchtjamer uno feiger fint als bie von nidyt blutşerwanbten Exltern erzengten. AYm bäuffigiten füttern bie âlten,

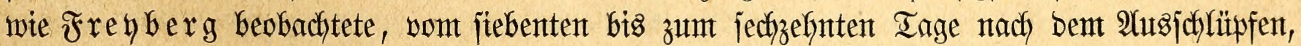
nentlich vier bis fünf Mal in ber Stunbe; vom jedyzefnten. Tage ab nimmt nach ben

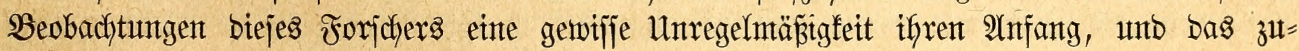

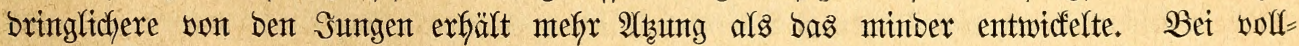

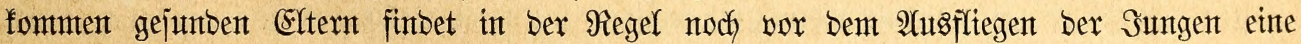
neue Farung ftatt, unb es fommt bann, wie erwähnt, nicht jelten vor, bas wentger bas Weibchen, als bie Sungen ber vorkergehenben $\mathfrak{B}$ rut bie Eier ber zweiten zeitigen, mintoejtens

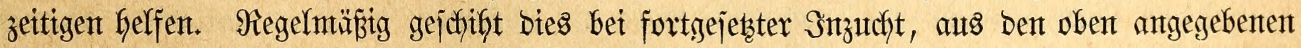
(s)ünben.

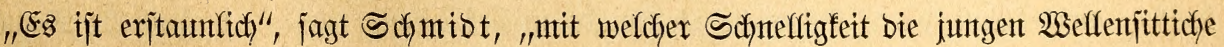

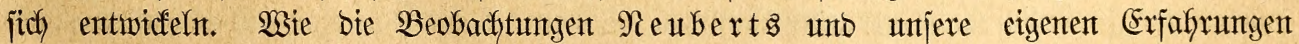
gelefyrt haben, fönnen biejelben mit brei Monaten fortpflanzungäähig jeint: eine Iatjache,

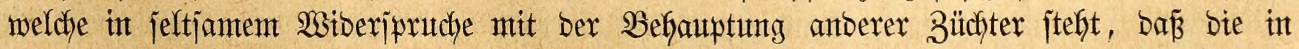

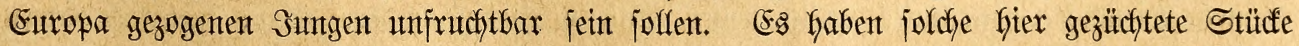
gröptenteils ifye 2 rutzeit im Sommer, unt zwar war biejelbe bei umjeren Welfenjittichen 


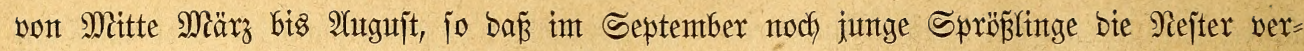

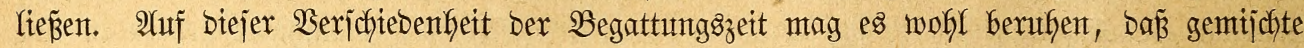
Fare, weldje aus eintem eingefüfyrten unto eintent fier gezogenten Stüdfe bejtehen, bisweilen

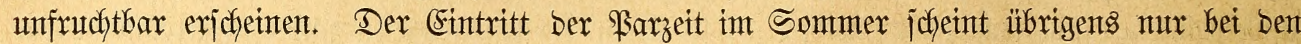

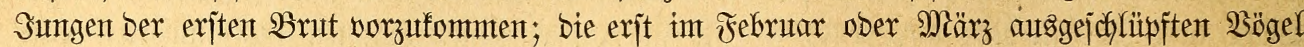
brüten nach umjeren Beobachtungen nicht vor bem nächjten Winter." (Sar nicht jelten ijt es,

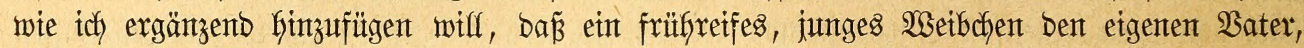
während bie Mutter mieber brïtet, mit Zärtlicbletten überfäuft, bis diejer es begattet und ex jo gleidfzettig Sintoer und Enfel erzeugt. Freyberg hat bies fünfmal erlebt unto

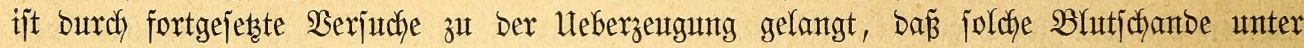

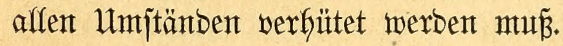

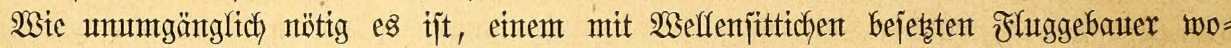
möglich alfjägrlich neute Stücfe zuzufügen, um ben verberblichen Folgen ber Inzudst vorzu= beugen, mag aus bent nachfolgenden, wie immer mit gröpter (Stewifienfhaftigfeit angejtellten

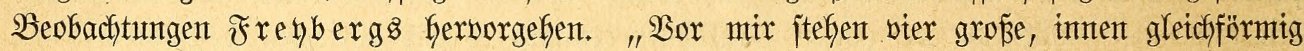
eingeridjtete Räfige. In benjelben befinden fich, jebes ßar für jith abgejdylofjen, ein ein= gefüfrtes Erternpar, ein $\mathfrak{B a r}$ Der Sintoer, aljo Sejdjwijter, ein \$ar Enfel, Sejdyijter, unto ein $\mathfrak{B a r}$ Urenfer, ebenfalls Bejchmijter. Das Benefmen ber eingefüfytent Esttern zeigte

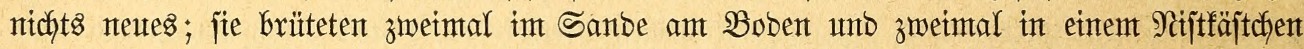

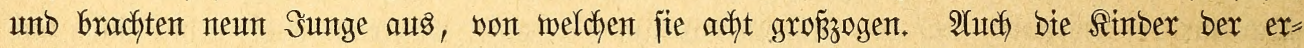
mähnten (EItern brüteten zweimal int Sanbe unb einmal in Nijtfäjtchen; fie wurben ein Jahr vorker im freijtehenden Fluggebauter geboren, begatteten fich jebr balb und zeigten in ifrem Bentefmen nichts bejonders bemerfbares. Afus breizebn Eitern zogen jie adyt

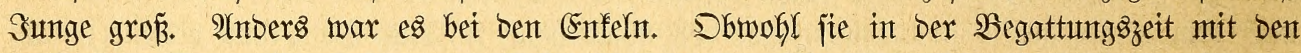

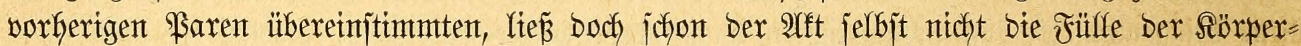
fraft, wie bei jenten, erfenten. Nach bemjelben trat Erjchäpfung merffich Gerwor, unto bei

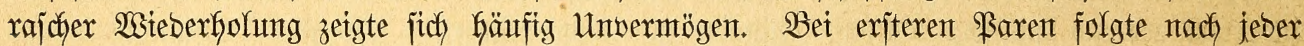
Sereinigung rajche Bemegung; es wurben bie Febern georbnet, geputht, geplaubert, gelteb=

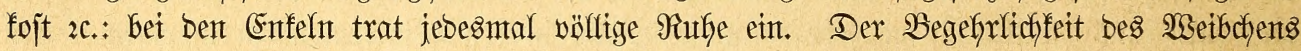

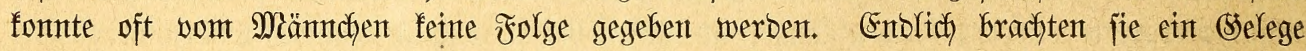

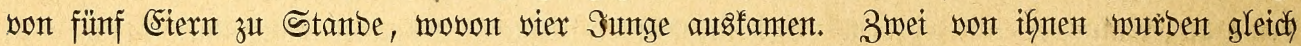

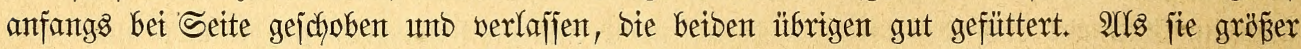
mutben, biż ber $\mathfrak{B a t e r}$ bas eine in ben Scals, woran es jtarb. Cintige Iage Darauf übte fich bas nodh übrige, neben ber Matter im Sande fitzend, in Bewegung feinter Fflïgel.

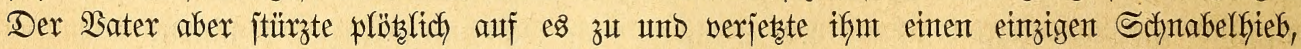

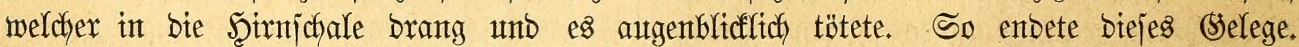
Das 2 seibchen hatte nach furzer 3eit wieber gelegt unb zwar fünf Eier, welche alfe aus= gingen. Zwei Sunge wurben abermalz verlafjen und brei Stücf grö̈gezogen. Die britte

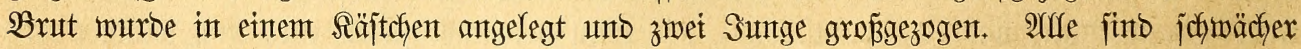
afs bie ber früferen $\mathfrak{B r u t}$, unt ifyr $\mathfrak{B a c h s t u m t ~ i j t ~ e i n ~ l a n g j a m e r e s . ~}$

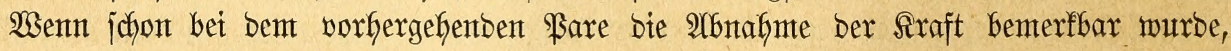
jo war fie bei ben Urenfeln noch viel auffallender. Nach jeber Begattung folgte gänzliche Erjchöpfung. Eine burch Schwäche mefrmals unterbrodjente, genau beobachtete Begattung bauterte bis zu ifyremt Ende breizefnt Mituten. Miefr als bie Şälfte ber gemtadten Berjuche

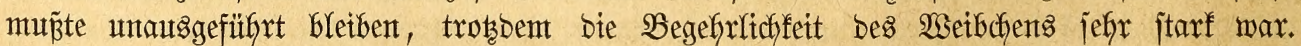

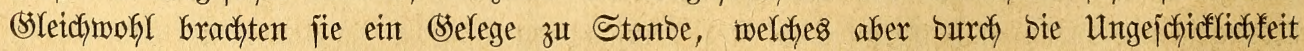
meines Dieners berunglücfte. Ein neuter Sats von fünf in ben Sand gelegten Eiern fam glüdflich auts. Die betben exjten Sungen nurben jogleidy bet Seite gejchoben und ver= 
lajfen, bie übrigen gut gepflegt unb gewartet. Die Aleinen gaben aber jänmterltche Töne, eigentlich ein ununterbrodhenes Seädhze, von jich, weldyes jich mit jedem Iage mefjrte. Da bie Allten jie fefor gut bebedften, wurbe es mix exjt am neutten Tage möglidy, jie näher

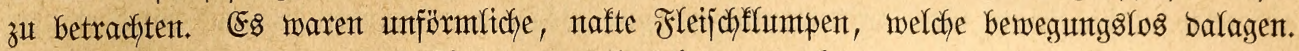
Wenn auth bie Wärme bes Zimmters nodh jefr angentefm war, jo froren jie bod jefr jtarf; bie Rörper waren jtatt rötlich weisgelblich, unto idd vermutete Deshall SBhutarmut Nach abermaligen neun Iagen, aljo am neutzefinten jeit ifrer (Seburt, bejah idh jie wieder. Die bereits zu Iage getretenten Feberfeimte waren jtruppig; bie fiörper lagen betwegungalos auf ber Brujt jtatt auf Dem Bautfe; bie Flügel waren verfümmert, bie Fü̈ße Antorpel=

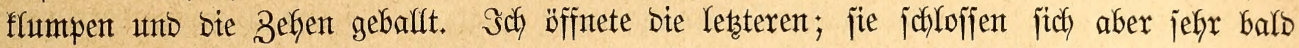

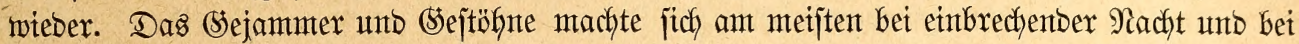

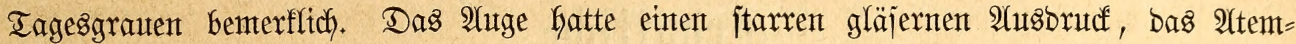

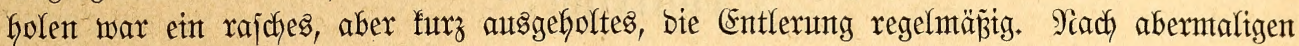
neun Tagen, aljo am achtumbzmanzigjten ifyres Rebents, jah idh wieber nach. Sch fand beibe

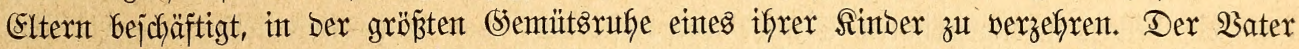

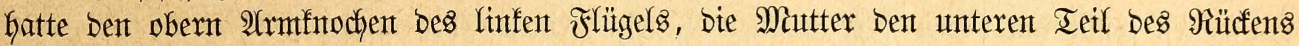

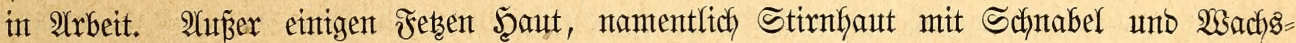
haut nebjt einigen abgebijfenten Febern blteb von bent aufgezefrten Sungen nidfts übrig.

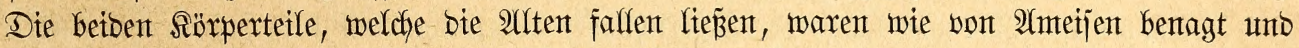
alles Fleijches beraubt. Die nodh lebenben Sungen lagen wentig gemadjjen nur auf ber Brujt und fonnten außer Siopf unb Şals nichts bewegen. Shre Federn waren jtruppig unb fajt ganz idhnuzigmeins, bejonbers bie Schmung = unb mittleren Sdymanzfebern. Das (Srün exjchien fajt grau und jobnuzig in einanber verfloffen. Afm vierzigjten Iage fonnte nody fein Sunges gehen ober ftehen; fie waren eben auperorbentlich zurïcf. Die betoen arten begatteten fich noteber, unt beshalb nafyn ich jene am fünfzigiten Iage weg.

Bon (seken und Seüpfen mar bet Diejen Sungen nodh feine Spux zu bemerfen; nux eines fing an zh flettern, fonnte fich aber mit ben Jü̈ren nicht halten, fiel rüfftwärts ab einen 3oll tief nieber und mar tot. Bet Der Eröffnung fand fich in Der Bruftgöble eine gelblichyötliche Flüjijgfeit, welche vielleidyt Urjache bes Iobez gemejen jein mag. Die Ferjen maren nicht beweglidh, bie Behen bis zur halbent Faujt gejchlofien, zwei nady worn, zwei nach finten gerichtet. Das nody lebende Sunge kewegte jich auf ben Ferjen; bie Flügel entwicfelten fitch regelmtäß̄itg, fonnten auch auggeipannt werben, aber Flügelichlag

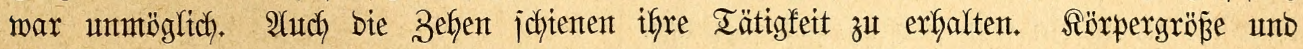
Färbung maren burchaus ungemöhnlich. Das sejtöbne unb sejammer bauerte fort, jobjen

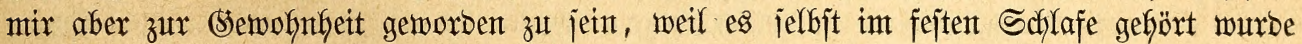

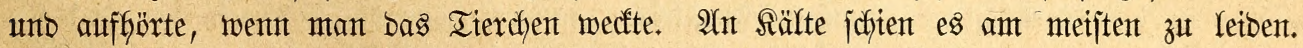

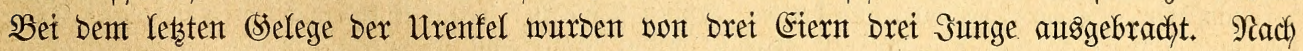

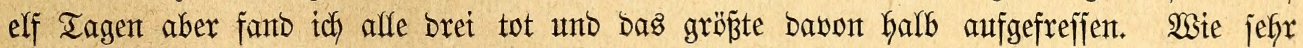

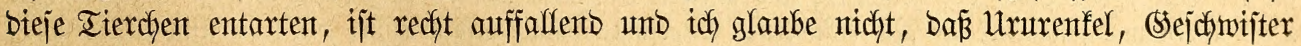
won gleichem (selege, zeugungsfä̈hig bleiben."

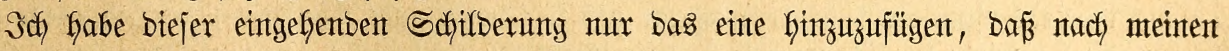
Erfahrungent in gejchlofienten Fajanterien nady geraumer Beit. unter ben fier gezüdyteten

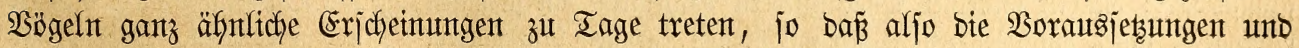

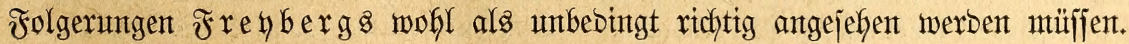

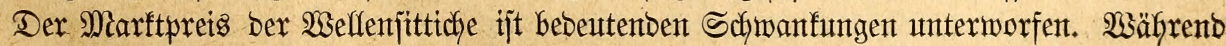
man vor einigen Safhen, zur Zeit, als bie Şögel in ber (ऽ. 130) erwähnten Mienge ein=

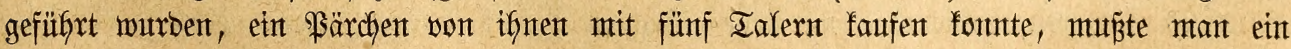

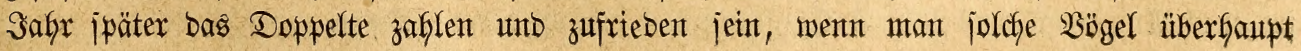


erfielt. 2Yus ben belgifchen Züchtereien befam man fie alferbings für cine geringere Summe,

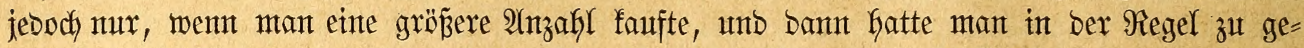

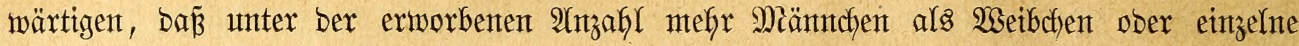
abgelebte, unfruddtbare und jonjtwie unbrautchbare $\mathfrak{B}$ ögel fich befanden, welche bie $\mathfrak{B e r f a ̈ u f e r ~}$ eben los werben wollten und zu biejem Zmeaf jobon vorker abgejchieben hatten. In biejem

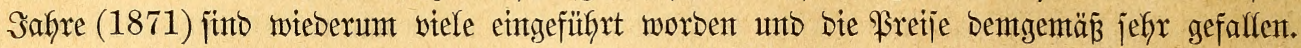

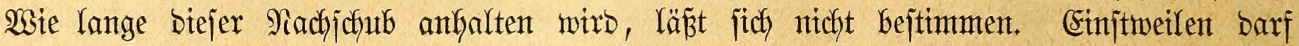

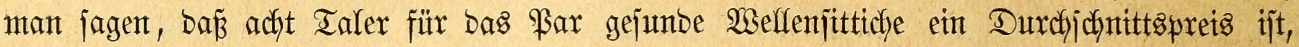

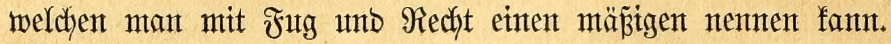

\section{(Ev)littide.}

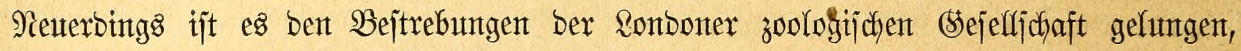

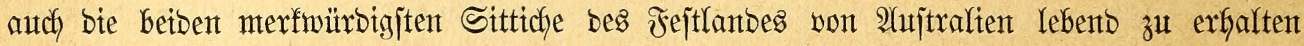

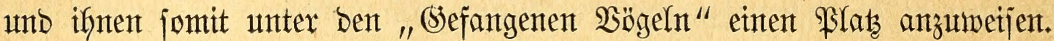

Die Erojittiche, weldye interfalb ifrer Familie afB bie Sertreter ber Eutentpapageien angejehen werben bürfen, fint johlanf gebautete Bögel von Drofjelgrößze. Der furze unt bidfe Schnabel ijt höher alz lang, ber Sberidynabel abgenunbet mit furzer, überfängender, etwas abgeitumpfter Spibe, welche unterjeits beutliche Feilferben zeigt, ber biffe Unter= jchnabel höher als ber obere, mit breiter abgerumbeter Diffenfante. Die rumben, an ben

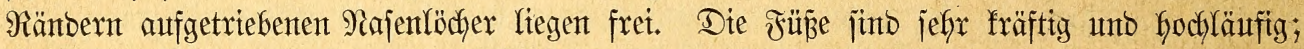

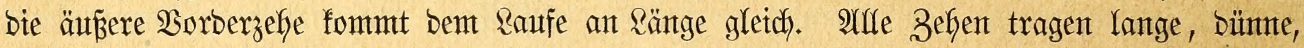
wentig gefrümmte Nägel, wie joldhe unter Sittichen jonjt nitht wieber borfommen. Der Flügel ijt fürzer alz ber Schmanz, lantg unt ipits, was namentlich audf für bie Flügel= fpitze gilt. Unter ben Schwingen überragen bie zweite und bie britte bie übrigen unto

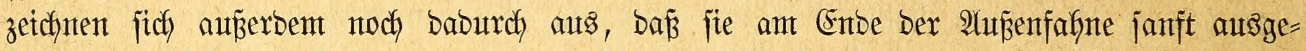
jechntten exicheinen. Zujammengelegt erreidyt ber Flügel etwas mtefy als ein Jünftel ber

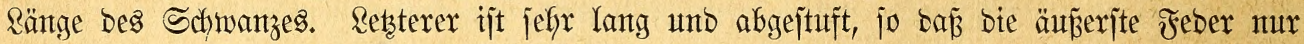
ben britten Ieil ber Ränge Der mittelften hat. Die Febern laufen gleichmäp̈ig in eine

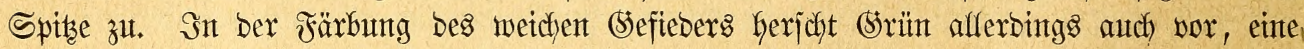
eigentümliche Fledfenzeidfunty auf Der Sberjette und Duerzetchnung auf ber Unterjeite ver= leifgt ifgr jebody eint jefr jelbjtänotges sepräge.

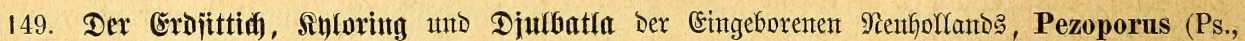
Euph.) formosus, Lath., (terrestris). Slivengraggrün; Jebern Des Sberfopfes mit fofwarzem Schaft=

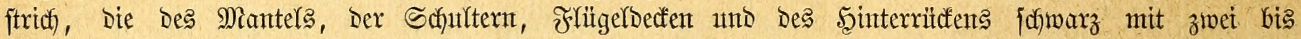

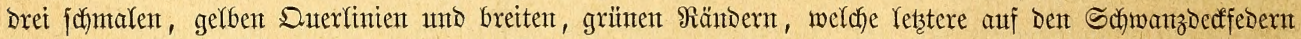

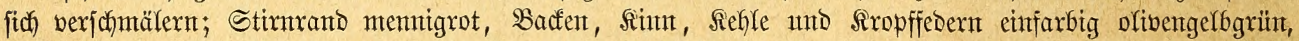

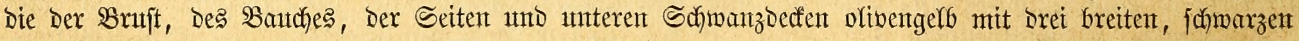

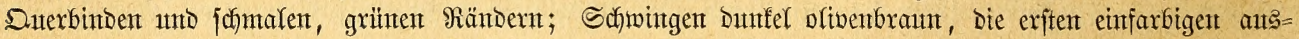

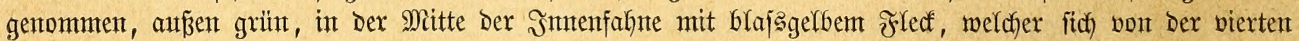

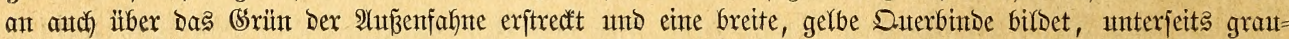

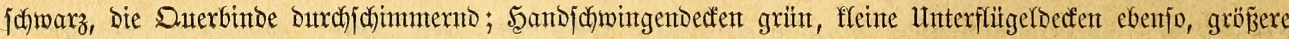

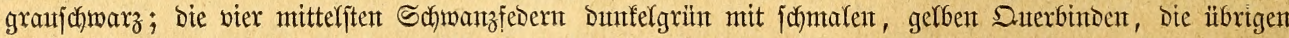

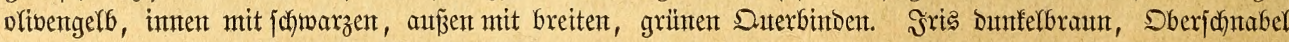

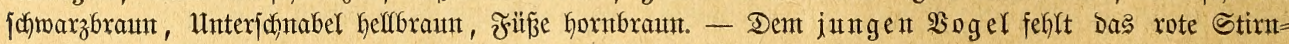

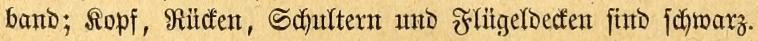

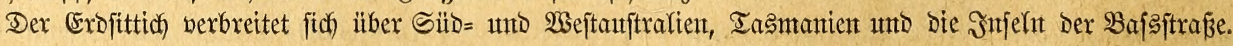

Des fürzeren Sdywanzes unto ber fürzeren sägel falber bildete (sould für bie

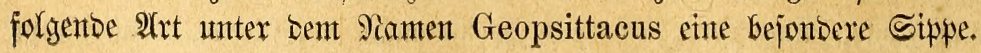




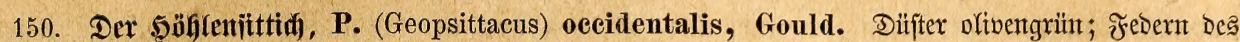

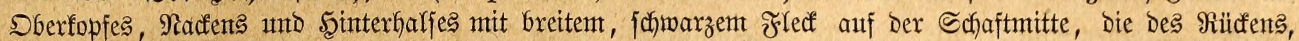

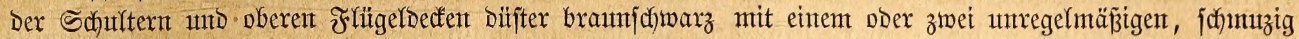

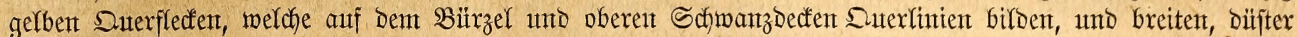

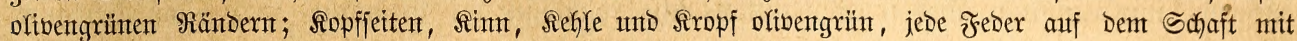

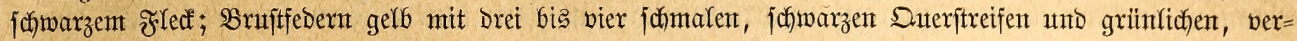

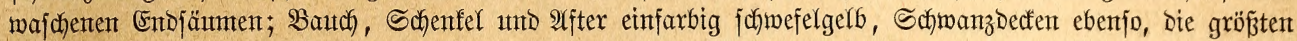

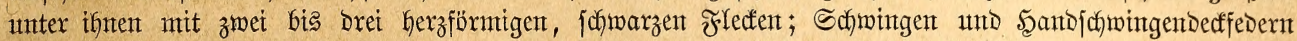
Düfter olibenbraun; $2(x m$;

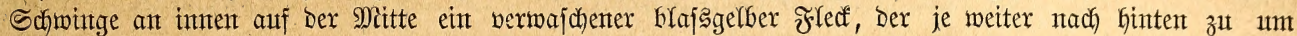

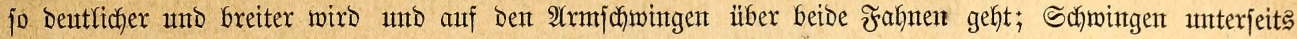

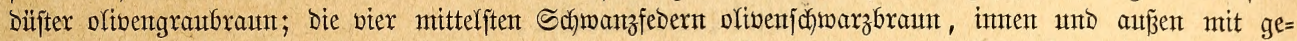

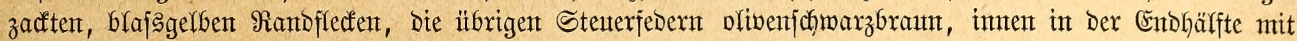

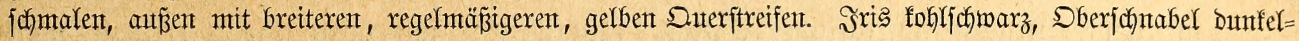

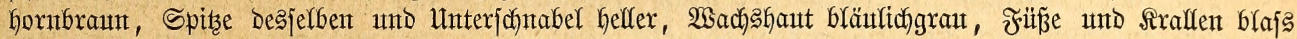
fleịchbräuntlič̀).

Dex $\mathfrak{S o g e l}$ bewohnt $\mathfrak{B e j t}=$ und Sildauftralien.

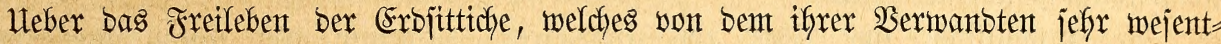
lich abrweidst, liegen Beobachtungen won Bould und Mürler vor. "So weit, als ich in Erfafinnt bringent fonnte", jagt (S) oulb, "ijt Der Erojittich affer Drten ein Stand =

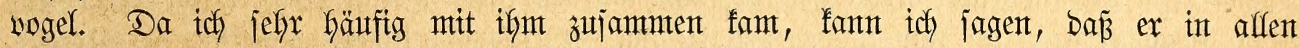

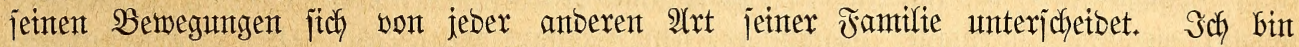

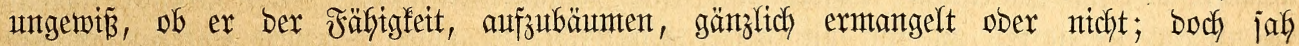

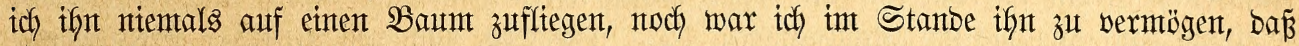

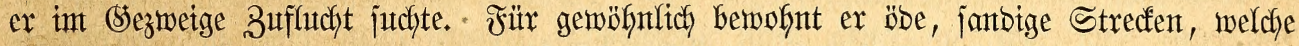
mit nieberen (Sräjern unt anberen äfnltidfen SFflanzen bebecft jind, fommt aber auch eben= jomofil auf jumpfigem Boben bor, weldher mit Binjen unb anberen biejen Sorten eigentüm=

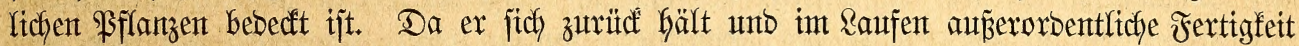

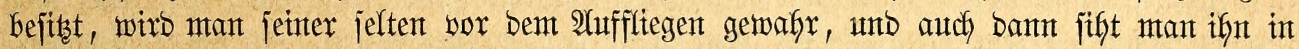

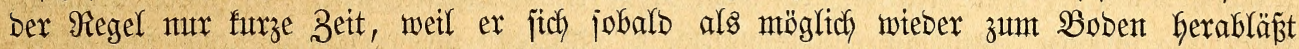

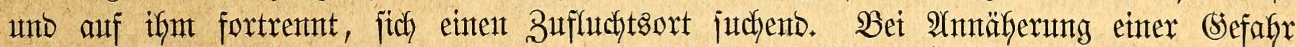
bufft ex fich) auf bem $\mathfrak{B}$ boen nteber ober läuft ummerfbar burch bas (stas, und ba er mun

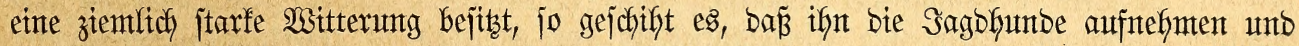

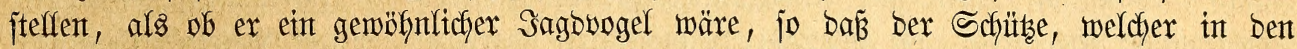
aujtralijachen Sümpfen jagt unb jeinen Scumb vor jidy jteben jifht, niemals jicher ijt, ob ein Erbjittich, einte Wadjtel ooer cine Sdynepfe jich erkebent werbe. Er fltegt mit ber gröp̈tent Sdynelligfeit unb fübrt häufig werjediebente Sdhwenfungen im Bidfzad aus, geft aber jelten

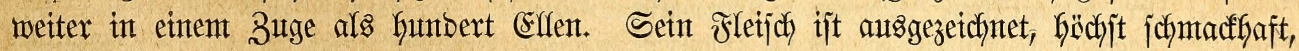
minbejtens bem Willopret einer Wadjtel ober Sdynepfe gleidy, went es basjelbe nicht noch übertrifit. Die fünf ober jechs Eier werben auf Den naften Boben gelegt."

Diejen Beobadtungen Gat Mïllex, Borjteher bes \$flanzengartens in Melbourne,

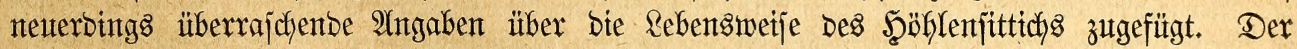

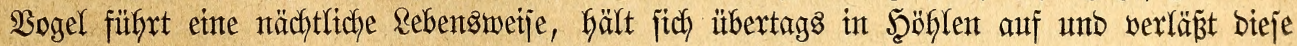

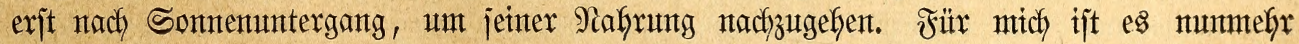

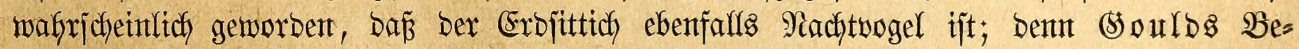

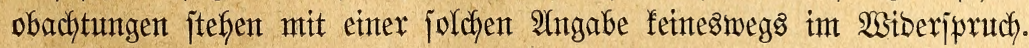

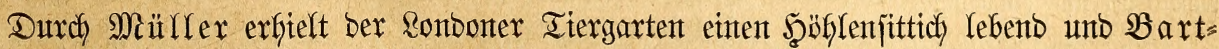

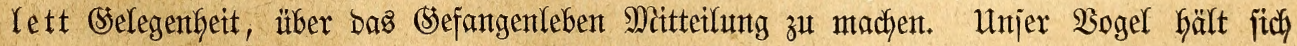

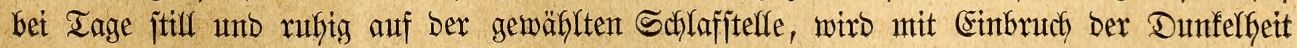

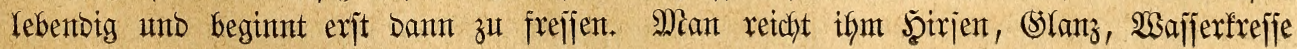




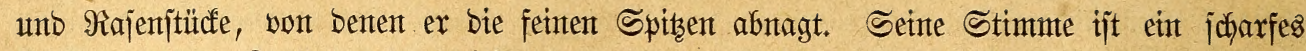
Bfeifen; anbere \&aute murben nidft verntommen. Aluch or ijt ein Erovogel, jest fich nie auf bie Sibjtange jentes Säfigs, jonbern betwegt jith, zumeilen nach $\mathfrak{A}$ rt bes Sperlings

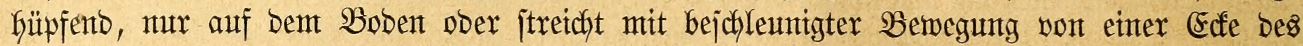

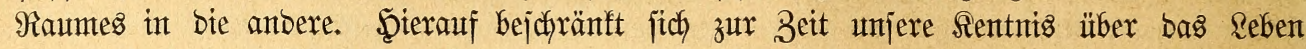
ber merftmürotgen $\mathfrak{B}$ ögel.

\section{(biastittide.}

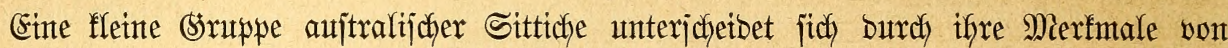

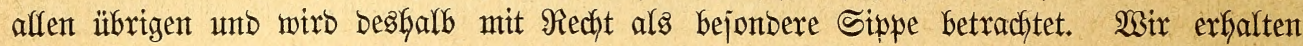
mebrere 2 (rten berjelben lebento und Gaben einzelne in unjeren Säfigen auch bereits zur Jortpflanzung jadretten jehen.

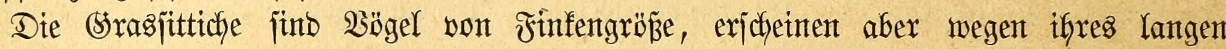
Schwanzes unb żemlich locteren (Sefiebers anjehntich größ̈er als unjere Eselfinfen. Der Sdynabel ijt furz, ungefäbr ebenjo hoch als lang, auf Der Firjte jtarf abgerunbet, an ber Spize jatarf herabgebogen, int Innern ber Yebteren mit beutfichen Feifferben verjehen, ber Unter = jafnabel an Der Diffenfante abgerundet; ein Zafhnausjednttt fefilt. Die gropen runtoen

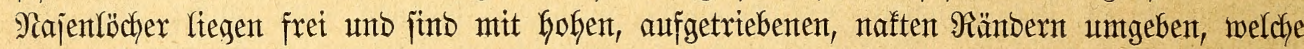

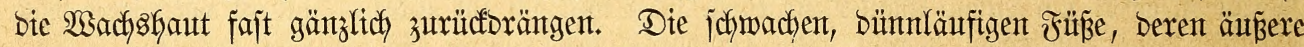
Borberzehe Dem Raufe an Ränge meijt gletchfonmt, tragen lange ipize unto gefrümmte

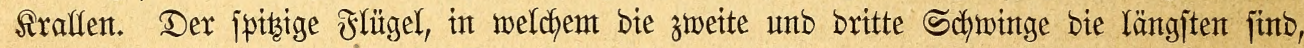
bectt zujammengelegt über ein Drittel bes ifym an Ränge antäherno gletchen Schmanzes; jeine Flügeliptze ijt lang; unter ben Schwingen fint bie zweite unt britte am Ende ber

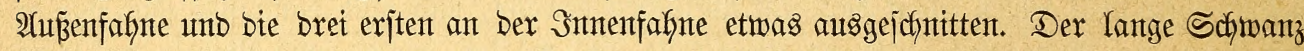
bejtegt aus breiten, gegen bas jtumpfe Enbe zu affmählich jich verjchmälernben und ftufig abgefürzten Febern, Deren äuß̌erite fajt ebenjo lang als bie Scälfte ber mitteljten ijt. Die Färbung hat ein eigentümlicfes Stepräge. Bon Der olivengrünten Sberjeite hebt fïch ein lebhaftes $\mathfrak{B l a u}$ auf Stirn unt Flügeldecfen $a \mathfrak{b}$; ber Schmanz ijt regelmäp̈ig, bie äußere

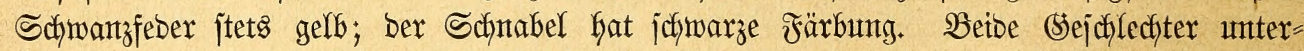

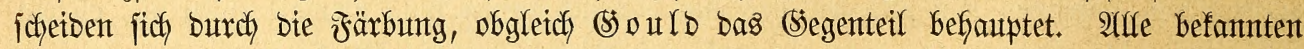
2łrten haben annäherno biejelbe Sröß̉e.

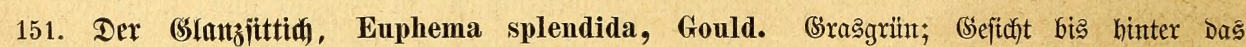

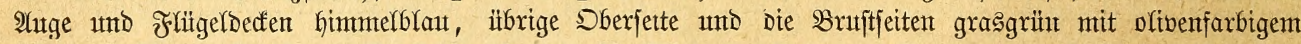

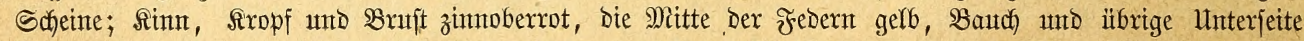

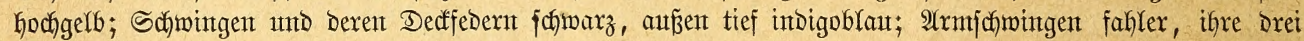

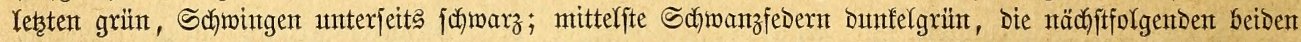

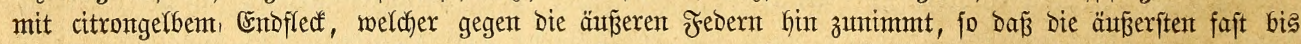

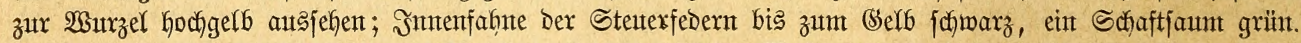

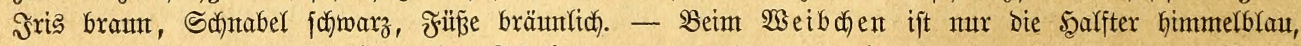

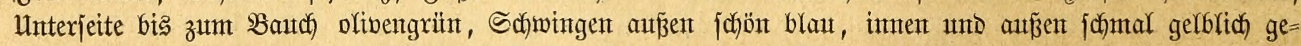

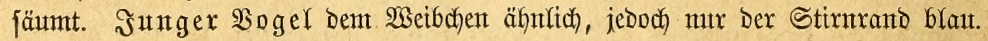

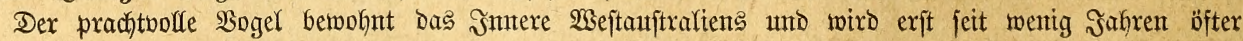
Yebent bei unts eingejühtht.

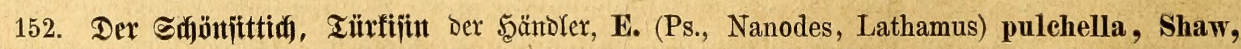

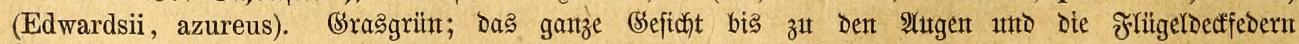

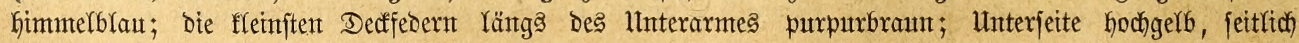

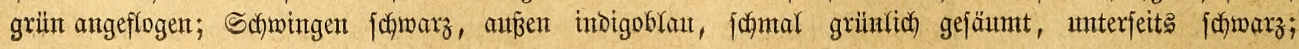




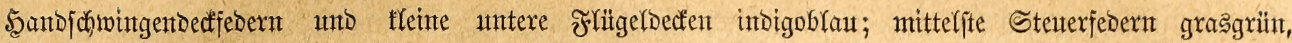

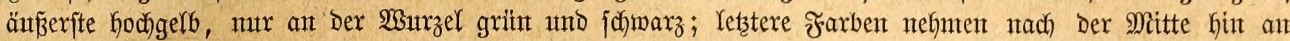

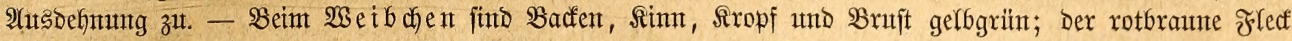
auf bem $\mathfrak{u}$ nterarm ift wenig bemerflich.

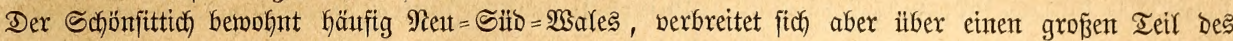

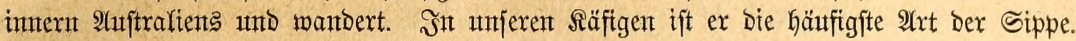

153. Der Feinitittid, E. (Ps., N., Conurus) venusta Tem., (chrysostoma). Slivengrïn;

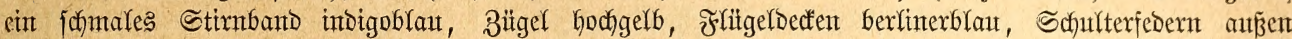

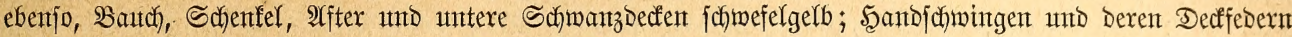

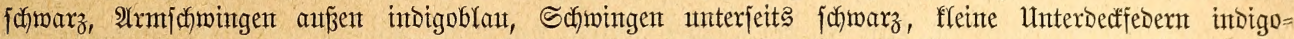

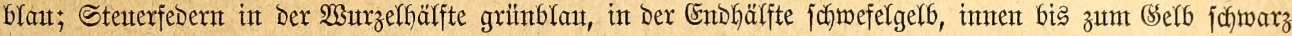

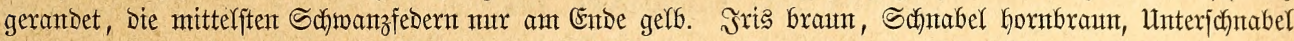

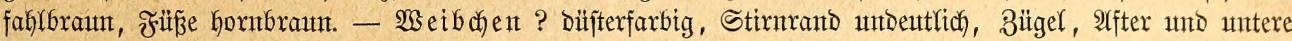

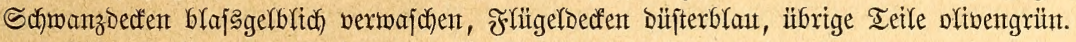

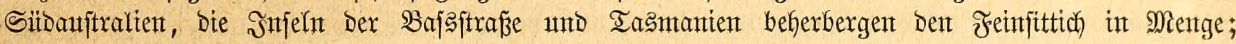

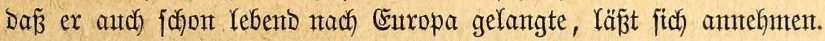

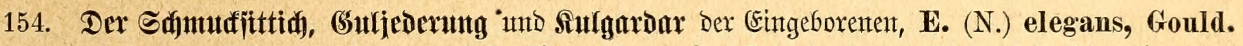

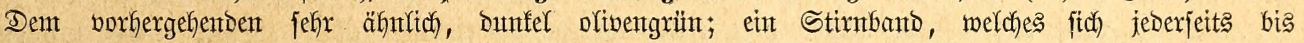

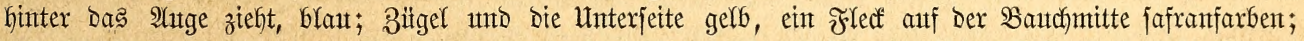

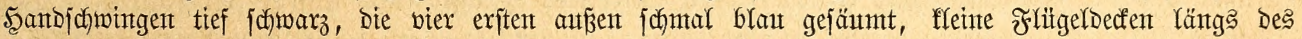

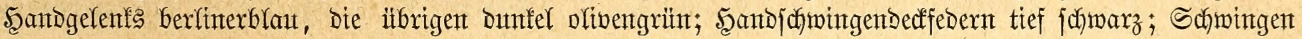

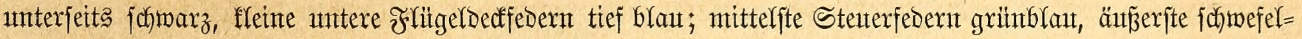

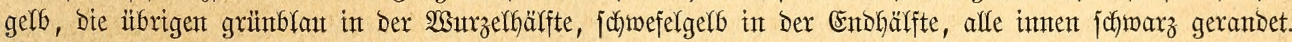

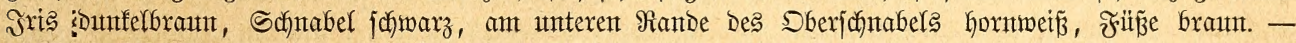

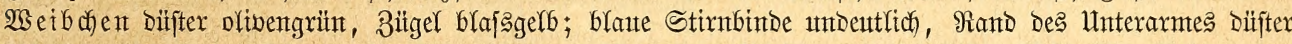

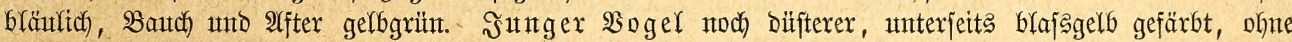
Dunffen Frede auf Der Bautchnttte.

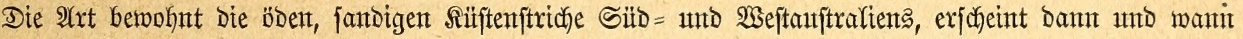
atch in $\Re_{\text {eat }}=$ SüD $=$ Wares.

155. Der Rippenittid, E. petrophila, Gould. Slivengrün; Stimbinde dutnfel intigo,

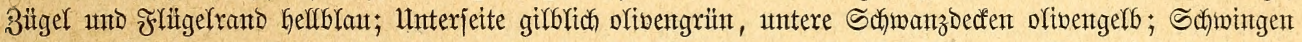

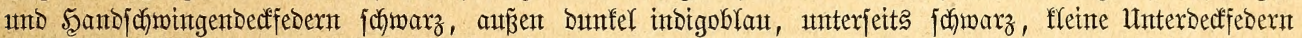

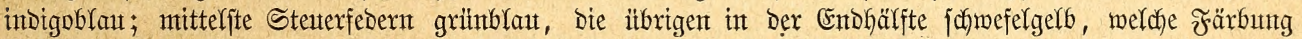

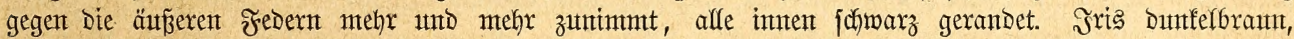

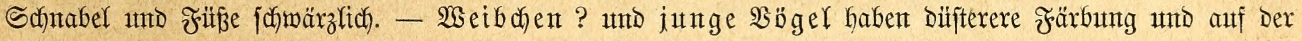
Mitte ber interent Sdimingenfahne eine meisffahle Suterbinto:

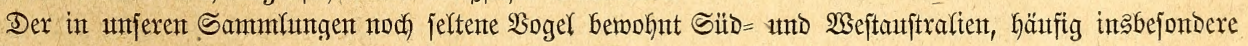

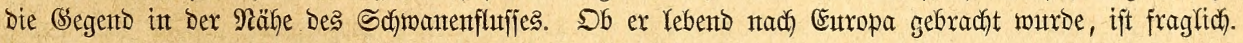

Heber bas Freileben ber ungentein zierlichen (Srasjittiche haben wir bis jebt fajt einzig

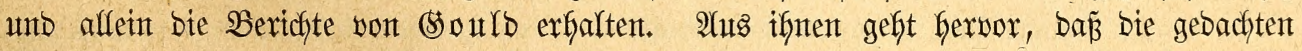

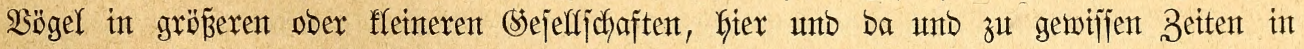
Mariaben, Die öberen Süjtenjtridhe Der erwähnten Ränber beleben, mit Beginn Des Früflings, aljo in Septentber ober Sftober, Gier erjofeinen, brïten utto nach ber Fortpflanzungszeit

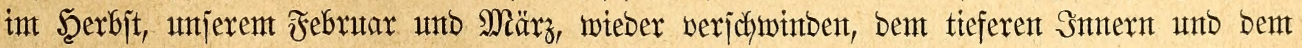

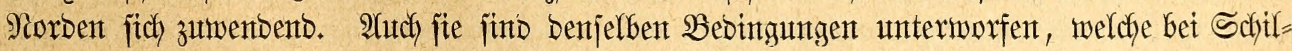
berung ber Eorelfa und bes : aujtralijchen Fremto bejonbere Nadyrichten itber jie nicht gegeben. (5ould benterft aus =

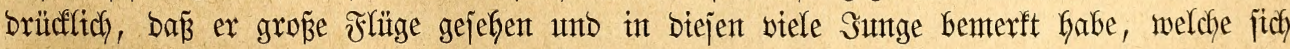

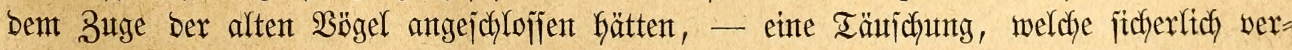

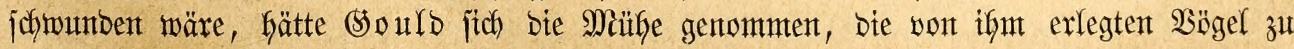

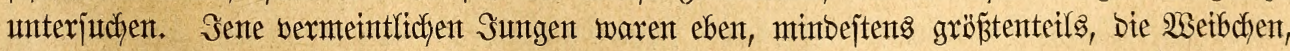

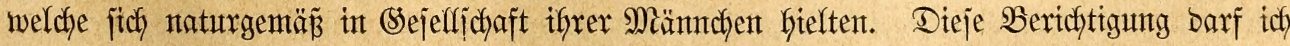

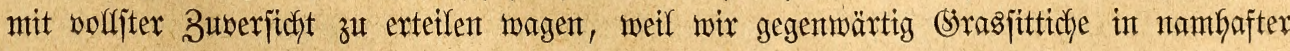




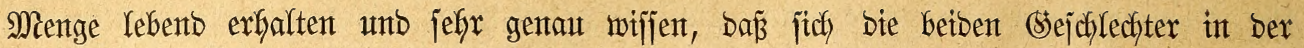
Färbuntg untericheibent.

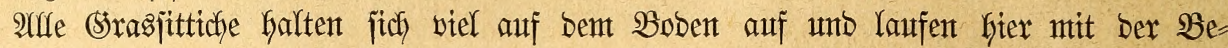

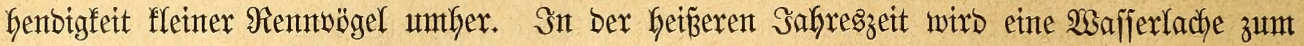

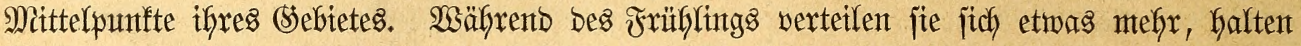

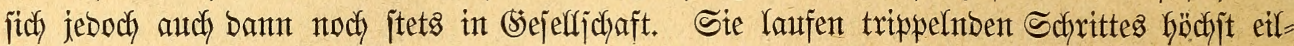

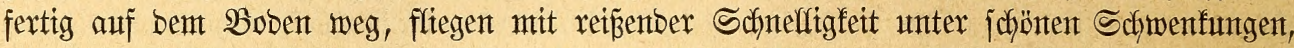
bie einen Goch butrch bie Rüfte, bie anberen ntebrig über bem $\mathfrak{B}$ oben fin, flettern audf

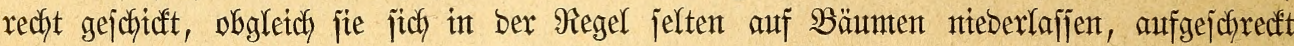

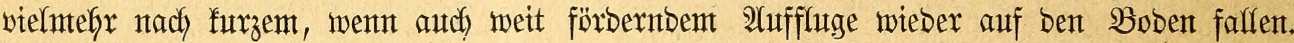

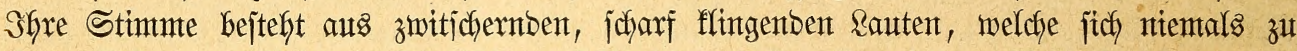

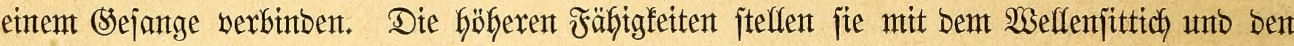
fleinen $\mathfrak{B l a t t i j c h w e i f i i t t i c h e n ~ a n t a ̈ h e r n o ~ a u f ~ b i e j e l b e ~ S t u f e . ~}$

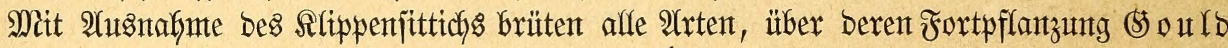

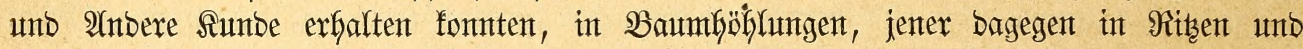

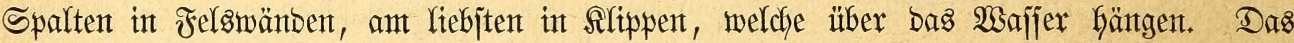

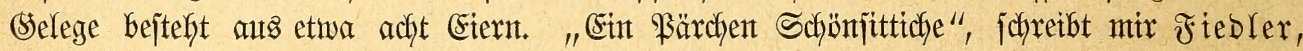

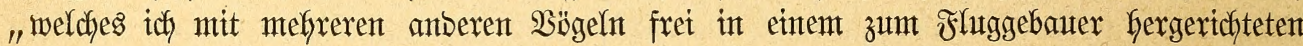

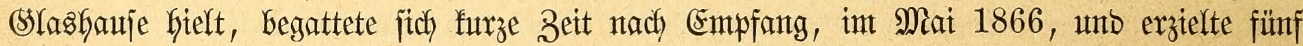

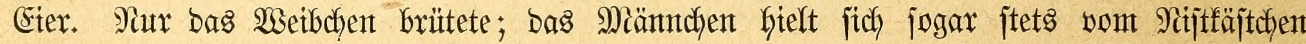
entfernt. Reiber ging bas Weibchen ein, nacthoent es zmanzig Tage auf bent Eitern gejefien

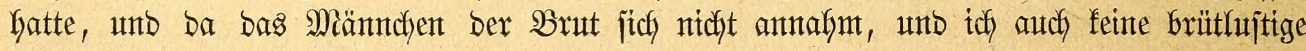

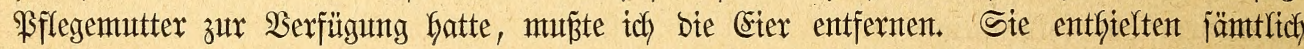

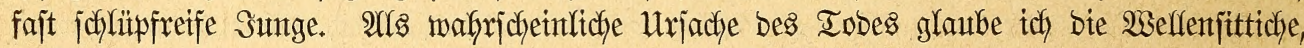

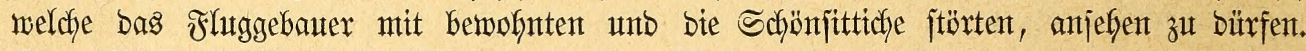

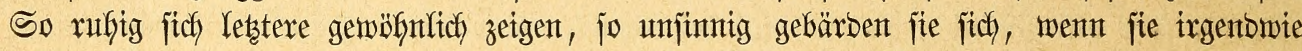
exjafrecft werben ober in 2 (ngjt geraten, zunal währent ber SBrutzeit."

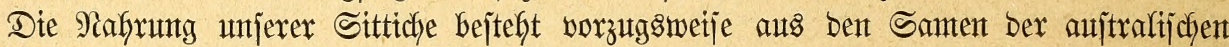

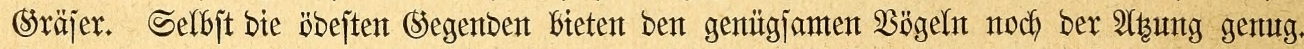

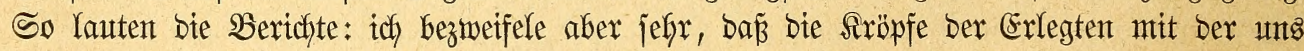

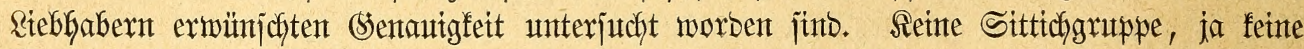

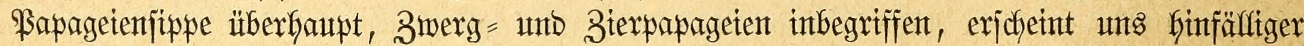

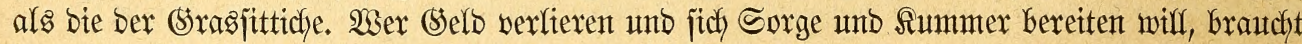

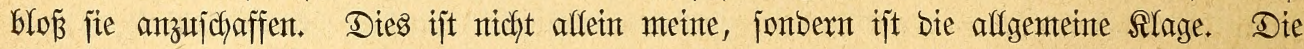

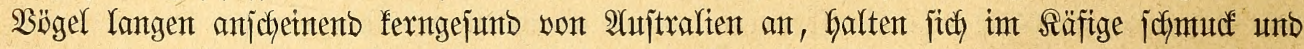

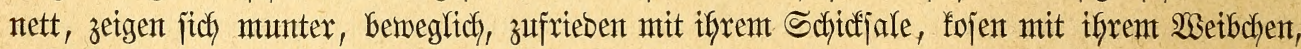

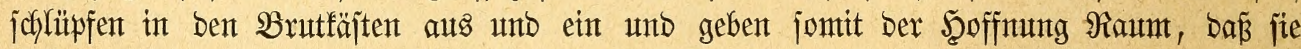
brüten weroen; jie brüten audch wirflich: aber fie treiben es nie lange; benn audch

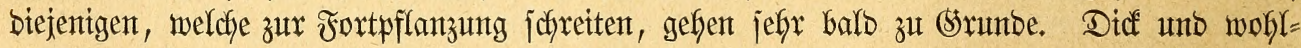

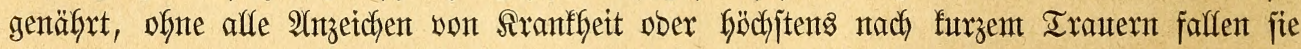

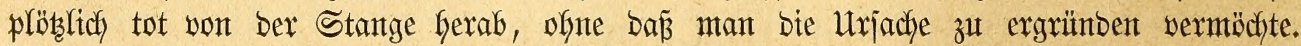

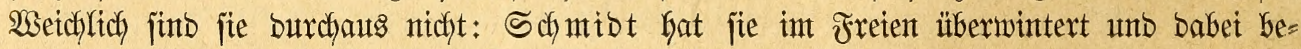

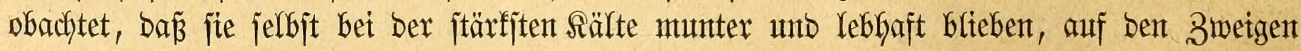
umberffetterten, einanber nadjflogen unb niemals mit gejträubtem sefieber zujammengefauert

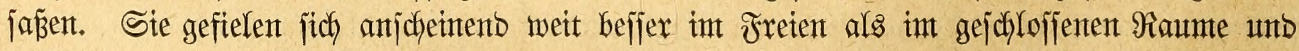

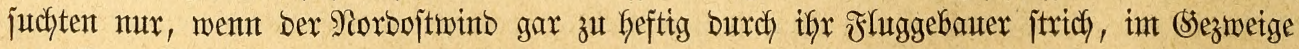

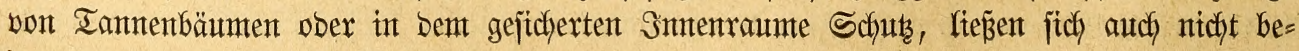

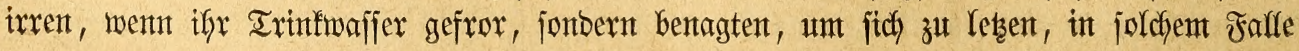




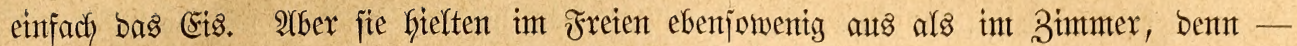
auffalfent gentg - währent ber itrengiten Sälte trat bie Maujer ein, uno wentgitens ein

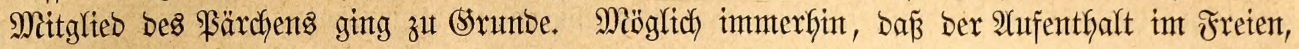
Der Bsemus frifher, reiner \&uft ifnen bejonbers zujagt, möglich, baj fie bet etwas mefix Schuts int Winter, als Schmibt ifnten gewährte, brauken beffer unt länger ausbautern

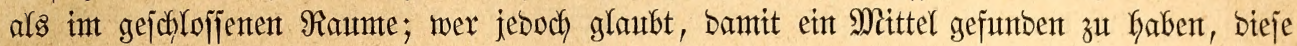

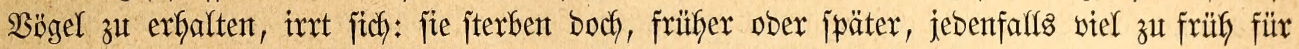

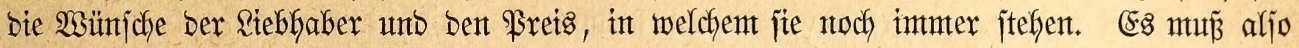

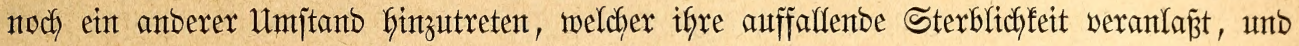
es exjcheint wohl gerechtfertigt, Gierbet zunächjt ant bie Nabrung zu benfen, welche fie int Säfige erfaltent. Den aujtralijchen (Srasjäntereien entiprechen Şirje und (\$) lanz, Das gemöfnt=

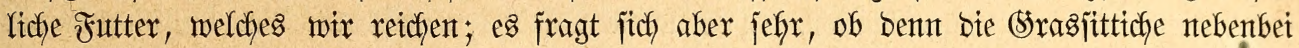
nicht nodh ganz antore Stoffe verzebren. Diejenigen, weldye ich pflegte, nafment aujer biejent beiben Sämereien noch etwas Şanf, bann unt want aud ein Salat = ober Sobjlblättchen,

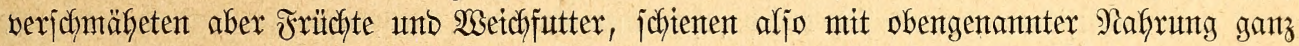
zufrieben zu jeint: - unt jie jtarben body; jie fielen bet berjelben retch bejdyidften Iafel,

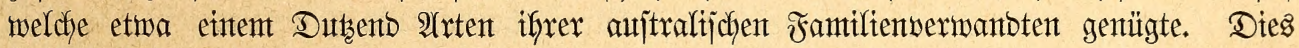

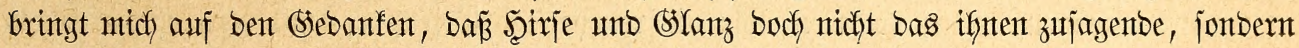

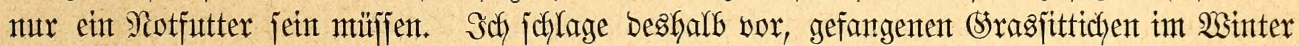

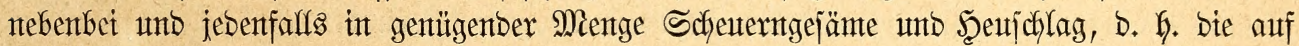
bem Sceuboben zurütfbleibende Spreu, unjere Strasarten jamt 2Aefren und Sürnern ber (Sräjer anzubieten, ein Jutter, über welches afle flement Sittiche giertg herfallen. Dodh

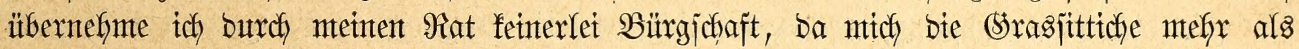

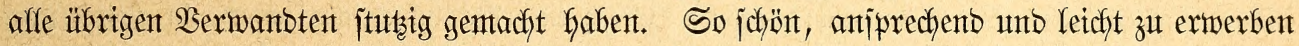

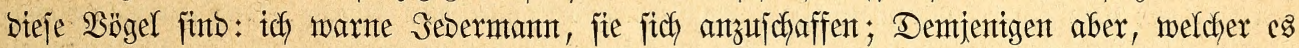

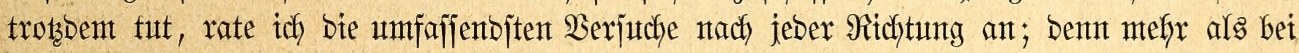

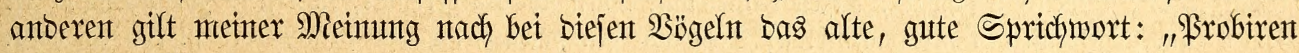
geht über Stubiren."

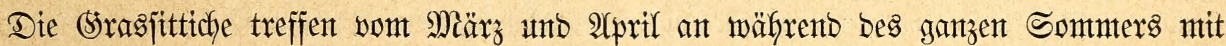

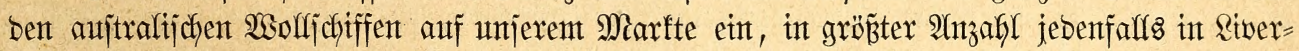

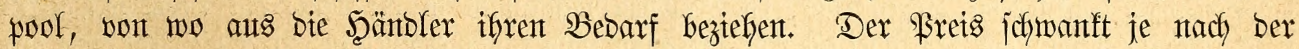

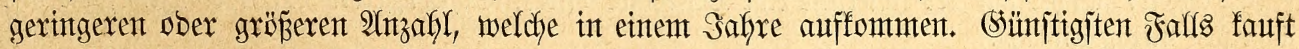

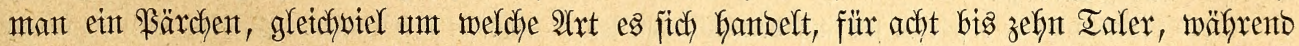
bafür in anberen Gafren bas Doppelte geforbert mirb. Entiprädbe igrer Sdjönheit autd)

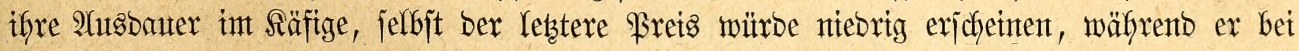
Berïdfitchtigung bex üblen Erfafringen, weldhe wir affejamt gemadht haben, als ein un=

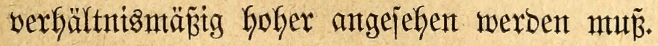

\section{Dlattrdhweiffittidide.}

Die Scauptntenge alfer aujtralijchen Sittiche fommt in Sejtaltung, Eigenjchaftent unto

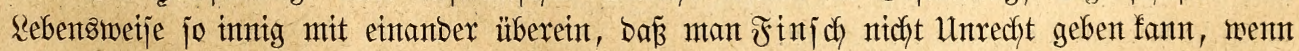
er fie in eine einzige Sippe wereinigt, anjtatt fie nach Dent Borgange anberer Naturforjcher in mebrere Sruppen zu zeriplittern. Sein uno Ssebahren alfer fierher gehörigen $\mathfrak{B}$ ögel jutb in ber Iat wejentlide biejelben. 


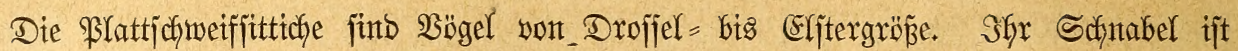

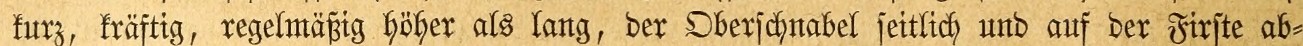
gerunbet, an ber meift furzen Spibe ftarf übergebogen, wor Derjelbent mit eintent itumtpfen

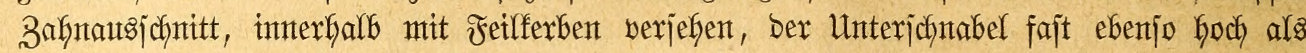

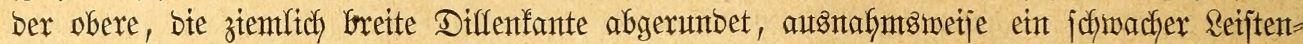

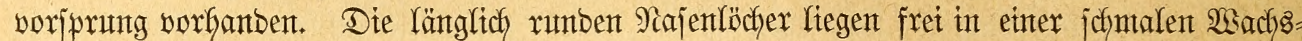

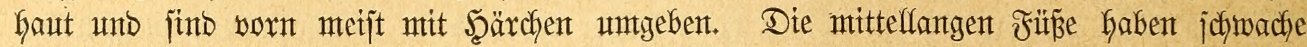
Räufe, welche ungefähr ebenjo lang ober etwas länger als bie äunere Borberzehe füto. In Demt ipitzen unt langen Flügel, welcher zujantntengelegt ein Drittel Des Sdjwanzes ober etwas mefr bebectit, unto Defjen Flïgelipitze lang ausgezogen ijt, überragen bie zweite bis

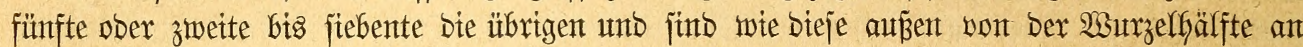

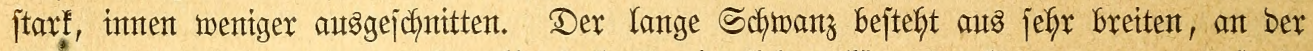

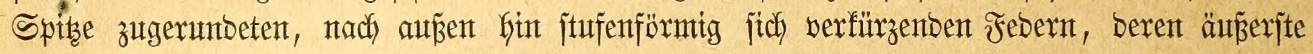
meijt halb jo lang als bie mittelifte ift; ausnabmsmeije überragen lebtere bie übrigen. Das weiche (stefieber zetchntet jich burch jefy bunte Färbung auts; über bie Farbenberteilung

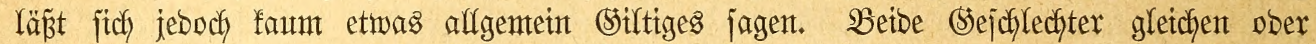
unterjcheibent jich, unto bie Suntgen weichent oft beträchtlich von ben Iflten ab.

Bur leidfteren Ueberjidyt teilen wix bie reichgaltige Sejelfichaft mit Finj in in Unter= abteilungen ein, von benten einzelne nit früber aufgejtellten Sippen zujammenfalfen. Şterzu gibt insbejonbere bie Färbung ber Sdjwanzunterjeite gute Mierfmale.

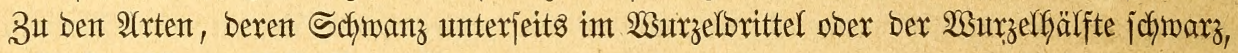
übrigents aber blau gefärbt ijt, gefören:

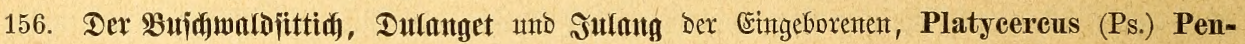

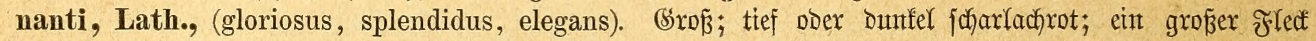

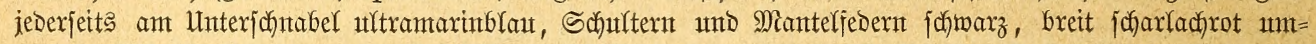
ranbet, Frïgeldedfedern pradftwoll helfblant, ints silafarbene ziehent, Die fleinften Dedfedern am Unterarme

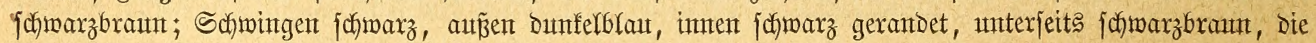

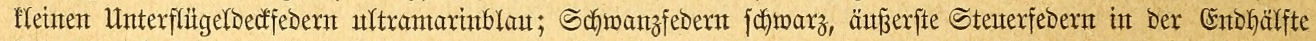

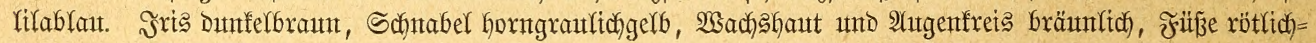

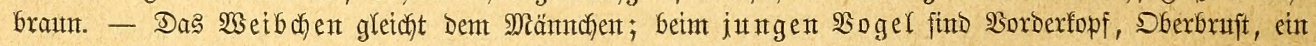

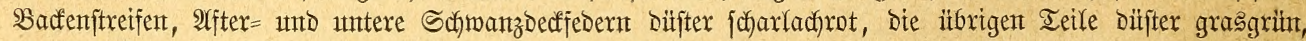

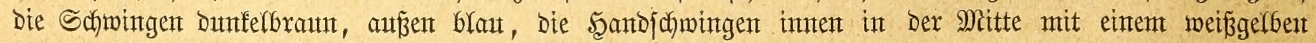

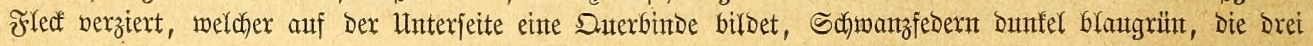
äußserîten ultramarinblaut.

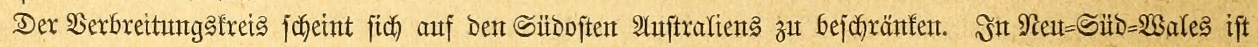

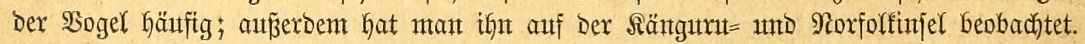

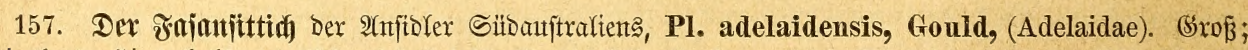

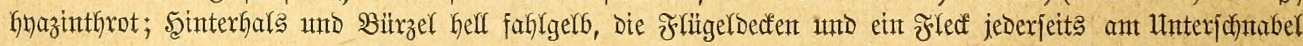

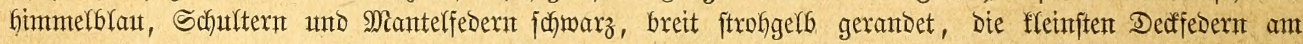

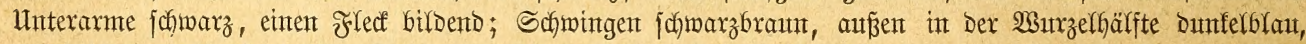

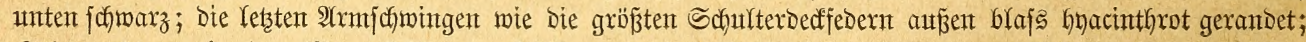

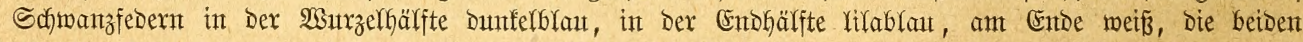

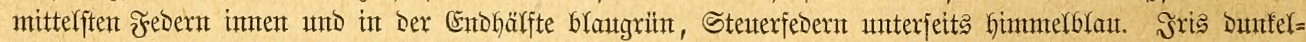

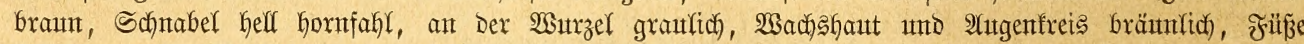

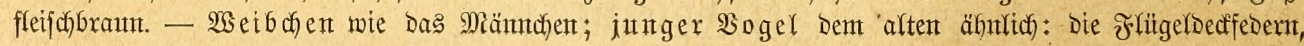

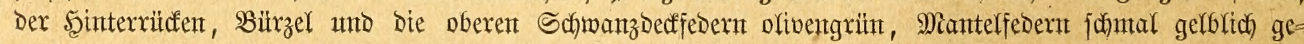

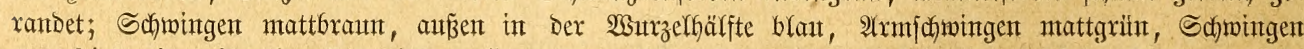

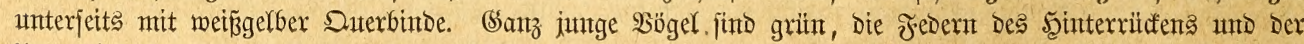
Untexjeite Gier unt ba hyacintfyrot gejäınt.

Die $\mathfrak{2}$ xt gehört Dem Siliden 2 huftrafient an.

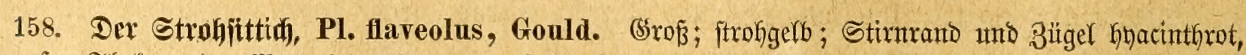

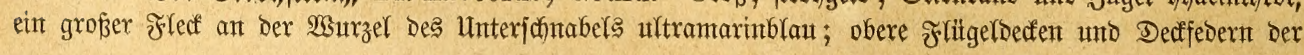




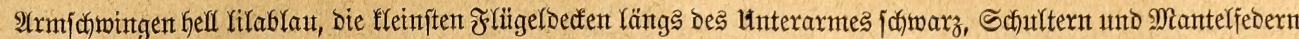

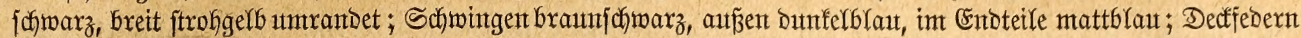

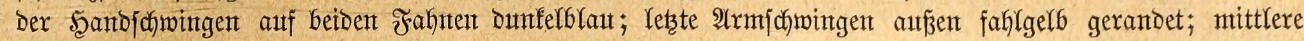

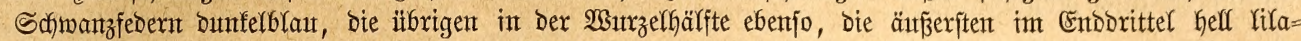

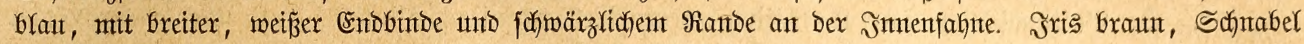

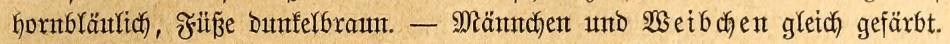

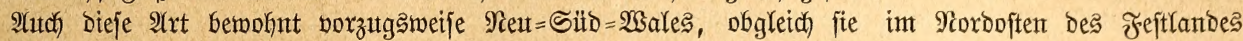
ebenfalls vorfonmt.

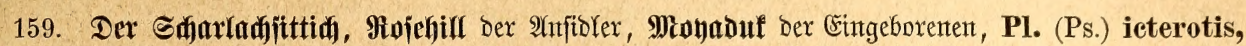

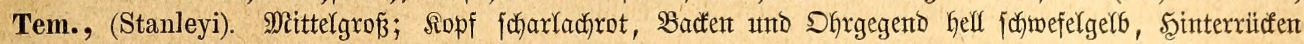

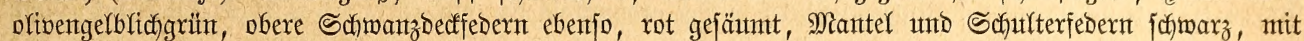

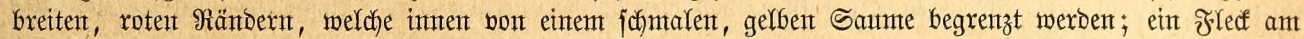

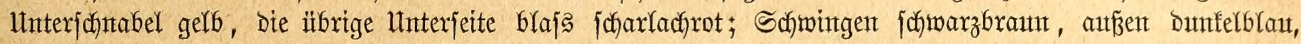

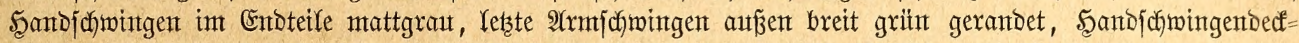

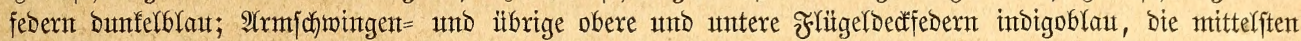

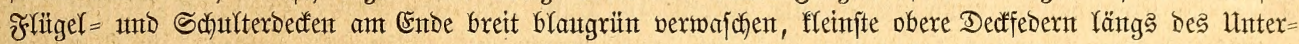

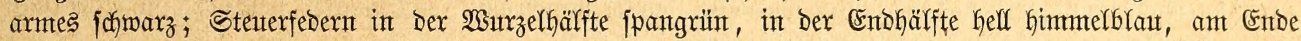

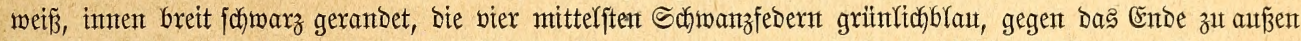

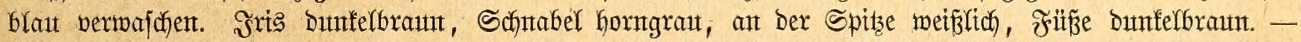

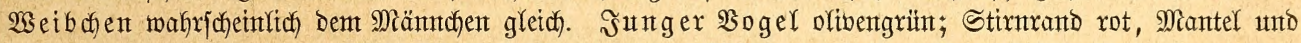

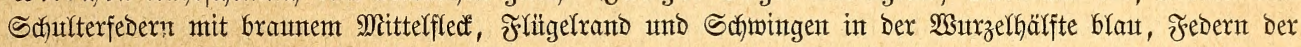

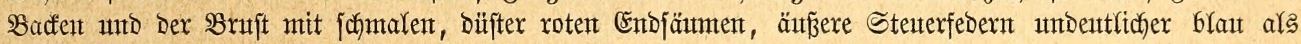
beim altent 20 gel.

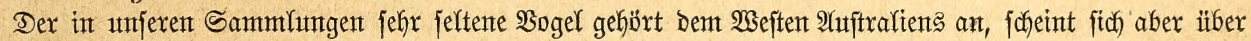

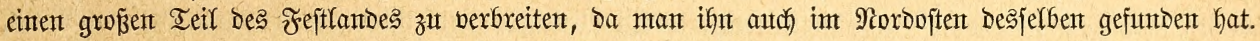

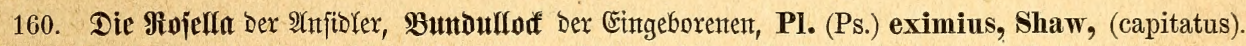

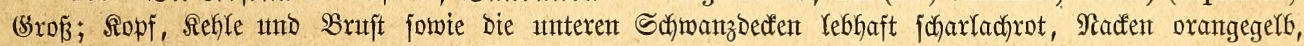

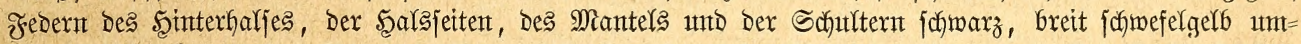

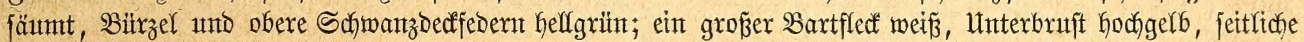

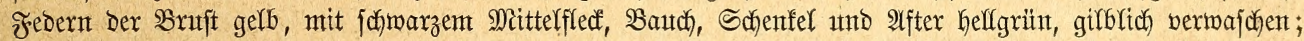

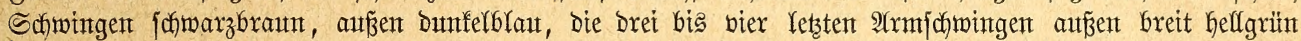

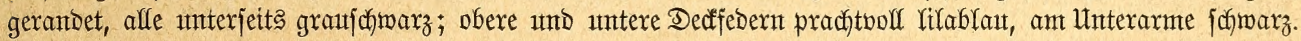

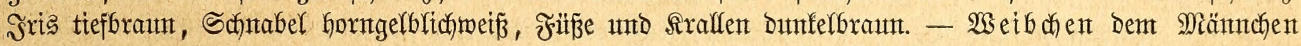

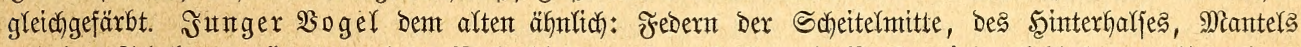

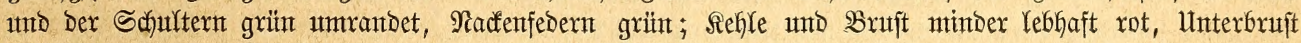

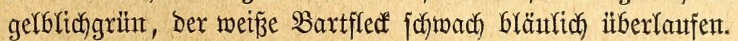

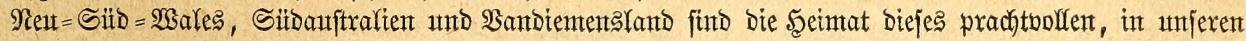

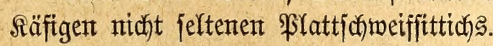

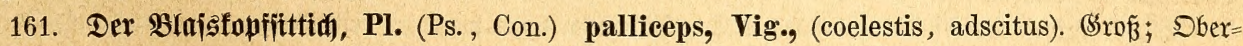

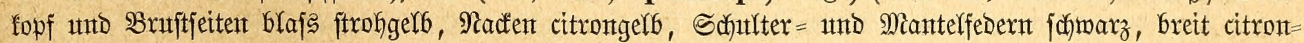

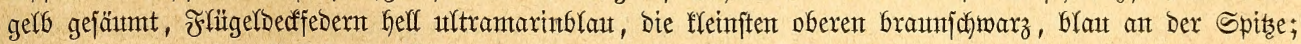

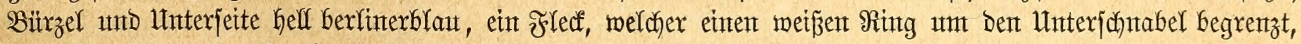
ultramarinblaut; $\mathfrak{A}(\mathfrak{m}$;

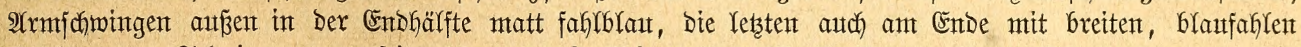

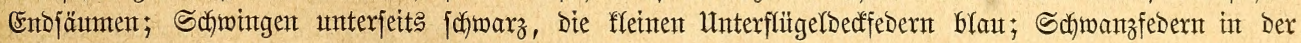

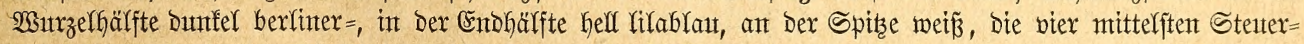

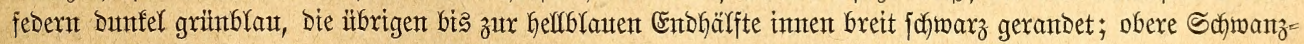
Decffebern hell berfinerbfaut, intere Schwanzbecfedern rot. Sris fafmarzbraun, Sdhnabel horngraut, ant ber

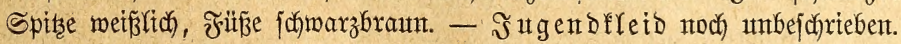

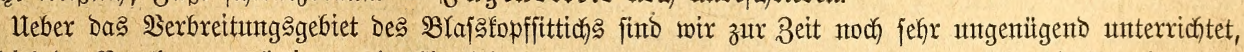

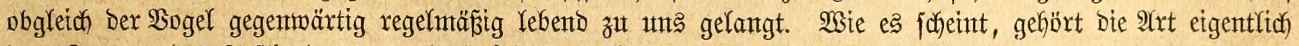

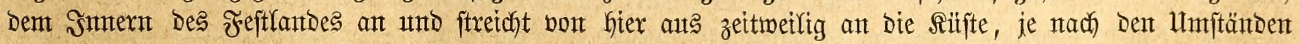

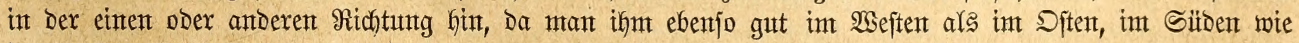
in Rorben Reutholfands gefundent hat.

Sn einer zweiten 2Ubteilung vereintgt Finj vont ben bis jebst genannten baburdh unterichetben, baj ifyren Mantelfebern bie farbigen 


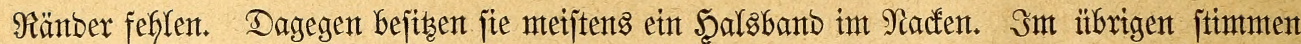

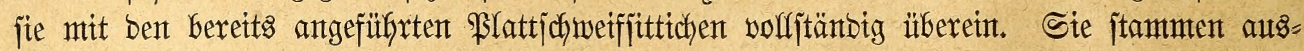
nafymblos aus Neutfollanto.

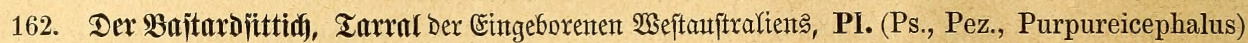
spurius, Kuhl, (pileatus, purpureocephalus, rufifrons). Broß̋; grün; Sberfopf Dunfel blutrot,

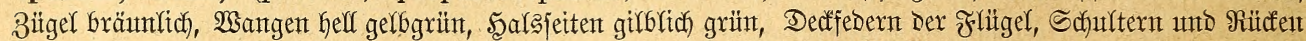

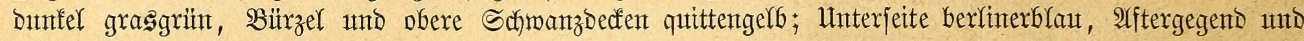

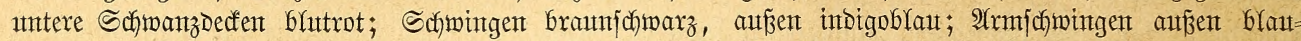

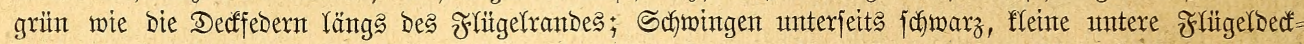

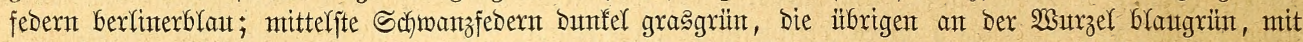

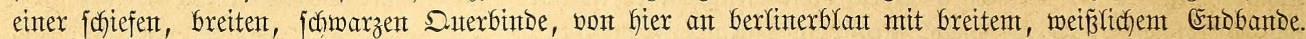

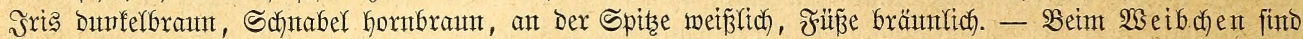

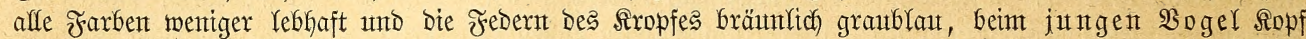

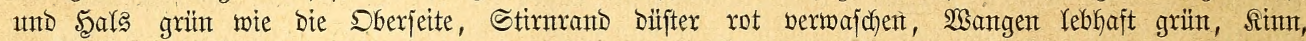

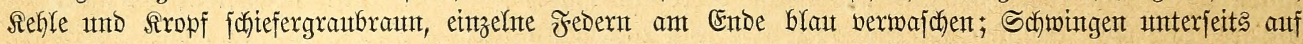

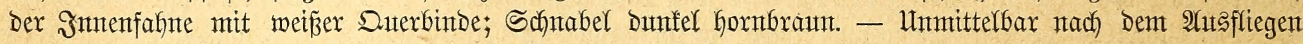

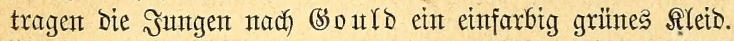

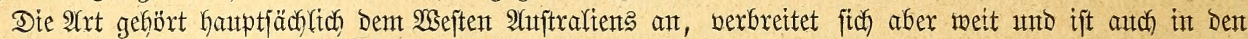
antoerent Gegendent Des Feftlandes beobachtet wordent.

163. Der (Seffobaddjittid), PI. (Ps.) flaviventris, Tem., (flavigaster, xanthogaster, caledonicus,

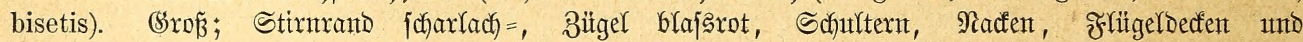

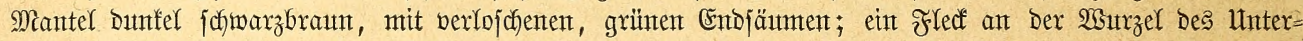

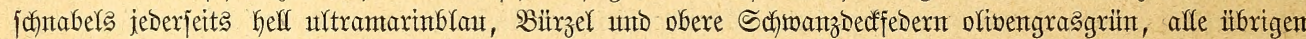

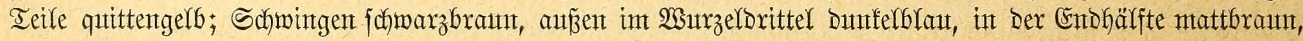

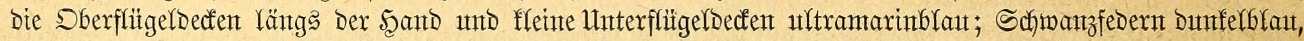

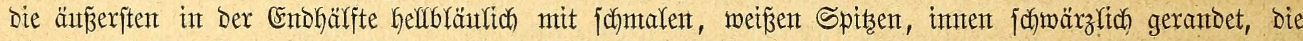

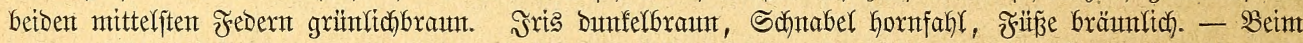

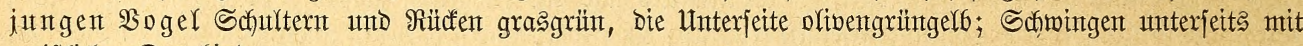
weipiricher Duterbinte.

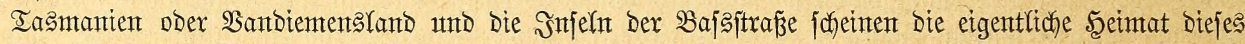

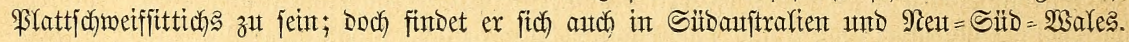

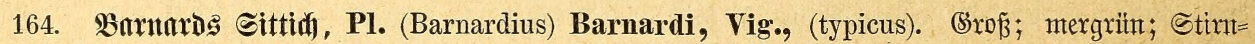

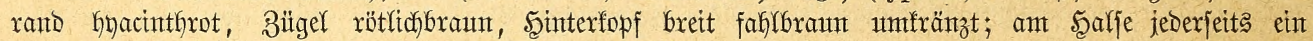

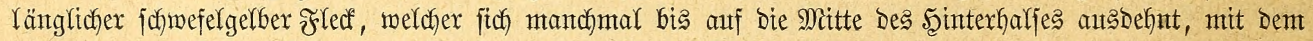

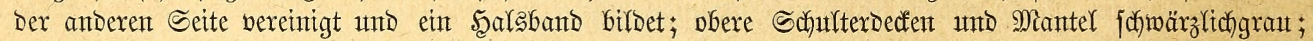

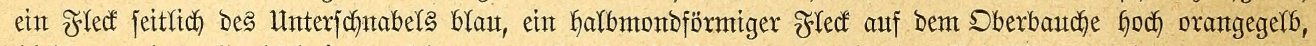

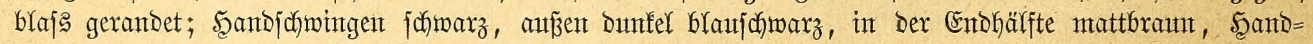

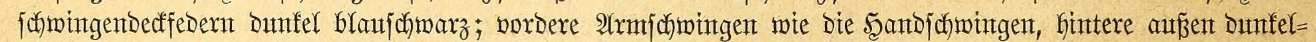
grïn; Dedfedern finmelblant, Die übrigen DberflïgelDedfedern grünt unt Die oberften, fleinftent am Unterarme

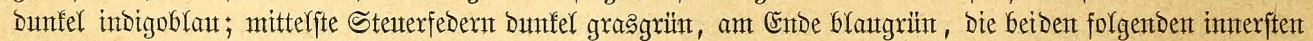

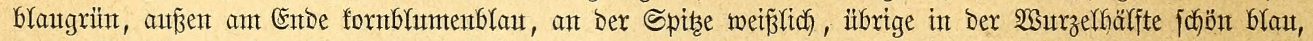

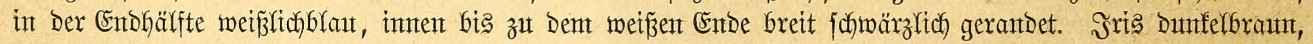

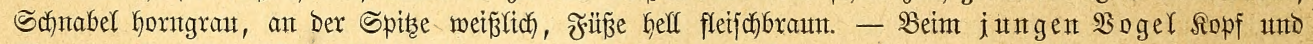

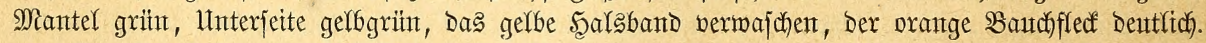

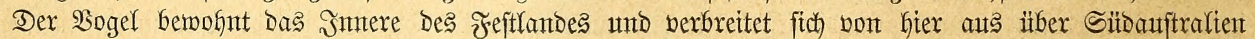
utto Rett $=$ SïD $=$ Sartes.

165. Dex Siragenittid, Dumuluf und Domann bex Eingeborente, Pl. (Ps., Con., Barn.)

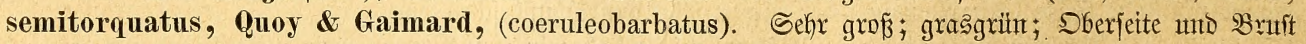

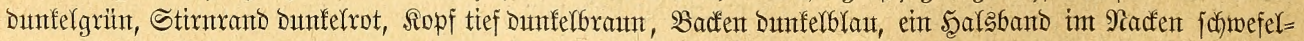

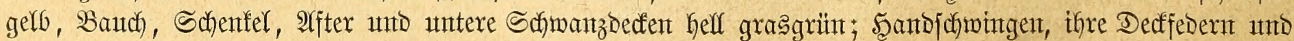

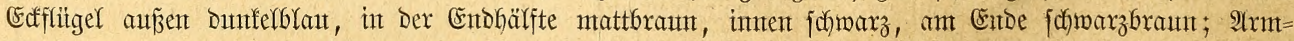

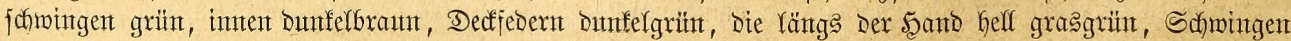

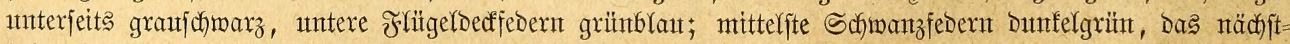

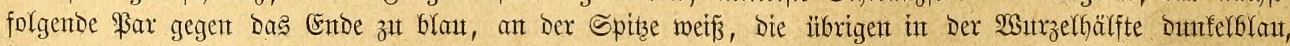

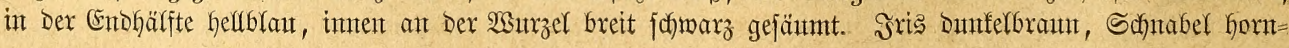




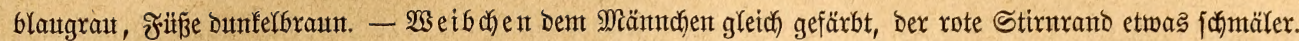
Ingend fle io unbejdriebent.

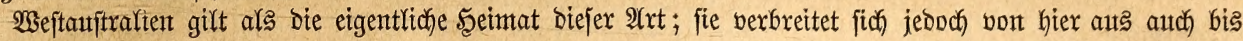
Sïbauftrafiett.

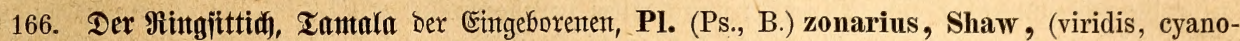

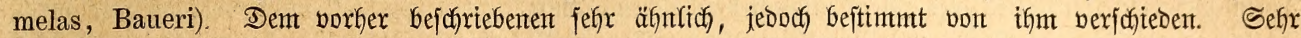

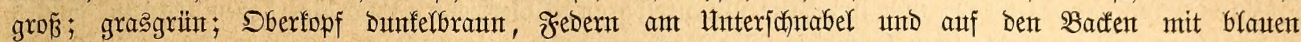

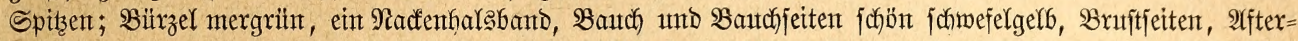

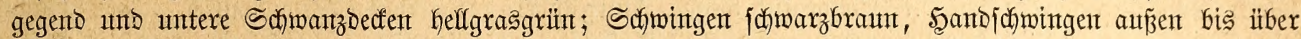

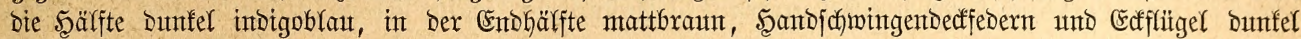

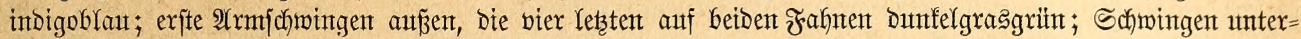

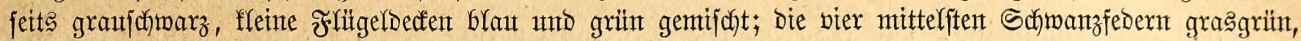

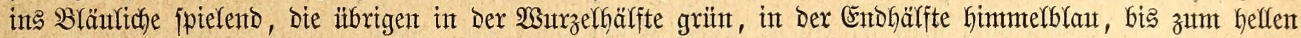

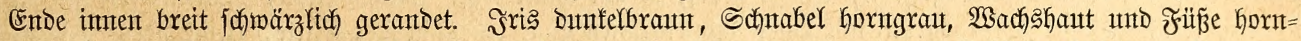

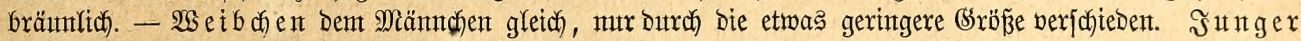
Bogel Dem alten ähnlich, alfe Farbent matter, Der rote Stirnxanto fehlento.

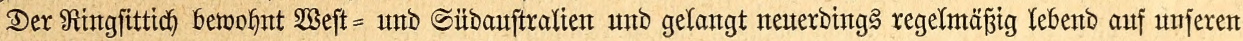
Tiermartt.

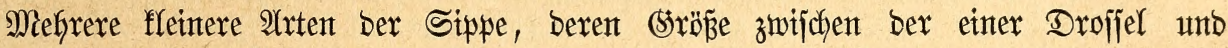
unjeres Neuntöters ichwanft, in ifrem Sejantetnbrud an bie Srasjittiche erinterno, jeboch ädyte Plattjchmeiffittiche, fint von (5ould in eine bejonbere Sippe (Psephotus) ver=

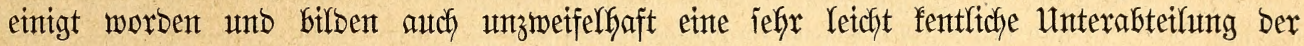

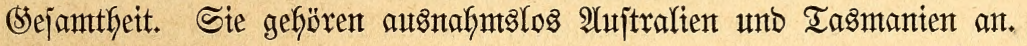

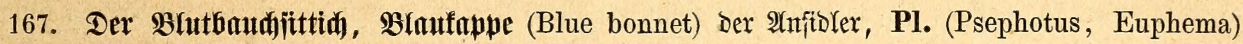
haematogaster, Gould, (haematorrhous). Rlein; Befidft Ittramtarinblaut, Sberfopf, Schultern

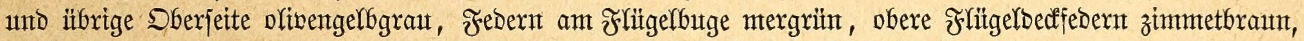

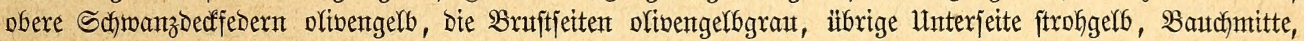

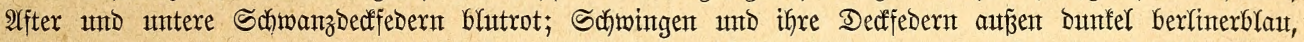

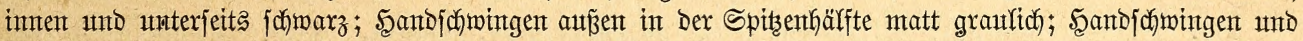

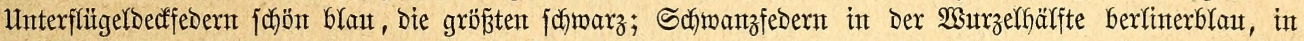

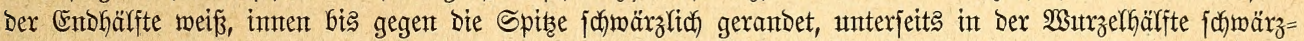

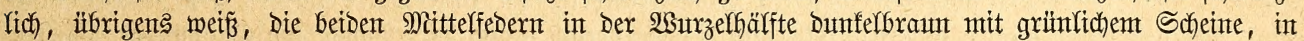

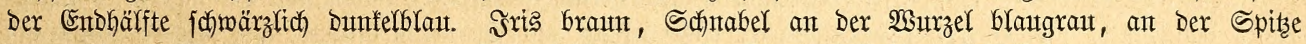

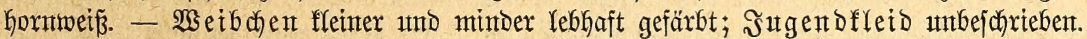

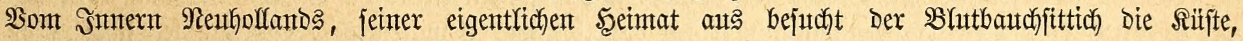
namentfich Seftauftralien.

168. Der (Gelbiteipjittid,, PI. (Pseph.) xanthorrhous, Gould. Siein; Dem vorferbejchriebenent

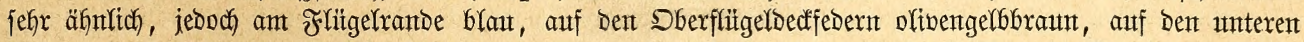

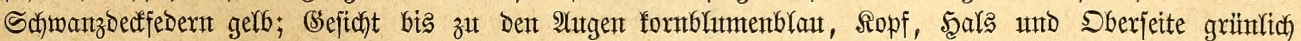

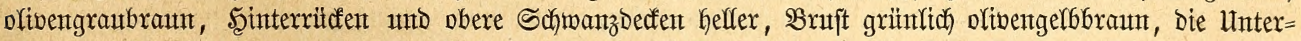

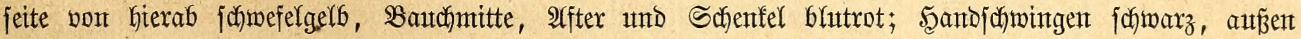

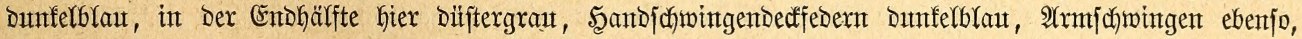

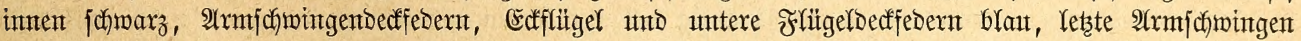

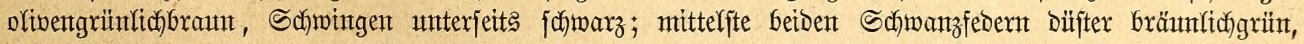

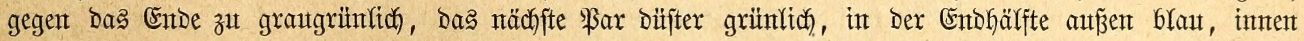

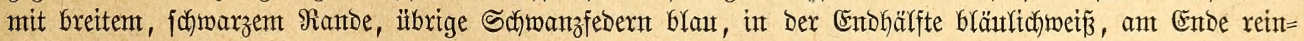

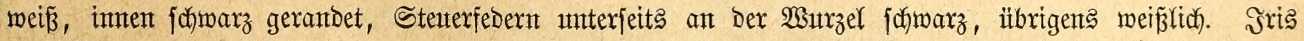

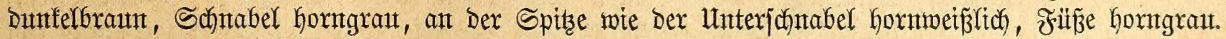

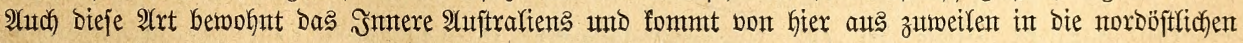
Ritiftengegendent.

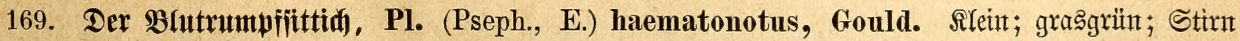

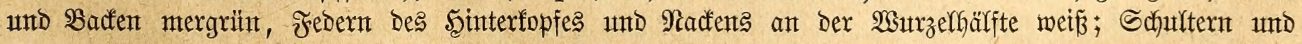

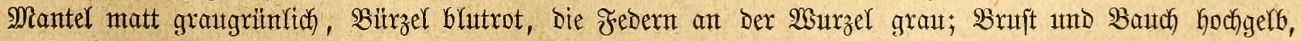

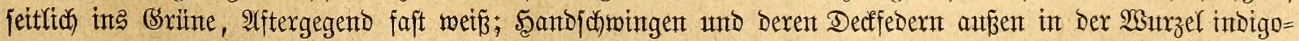

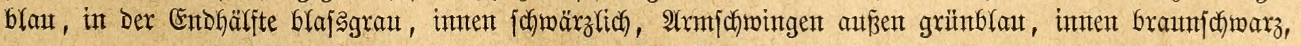




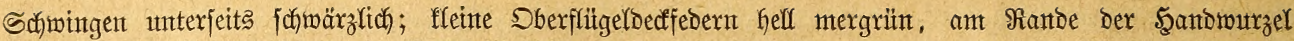

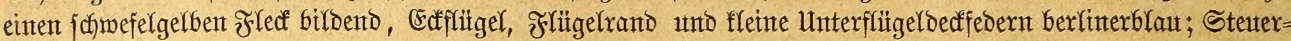

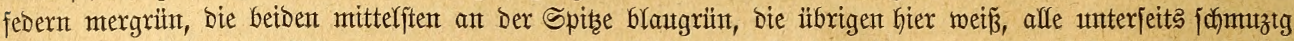

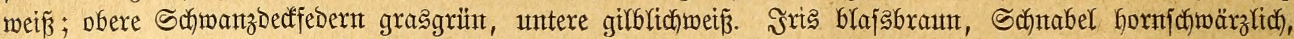

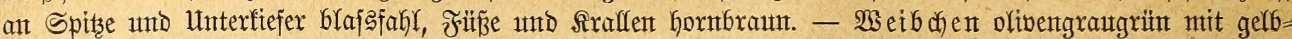

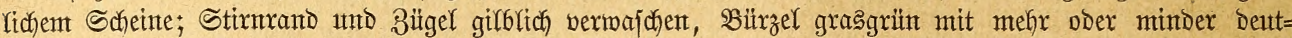

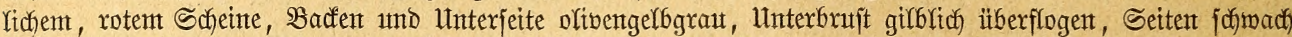

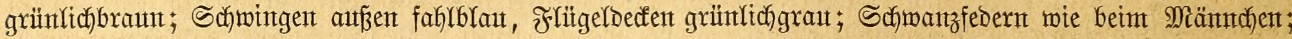

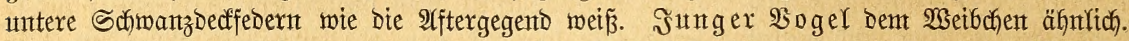

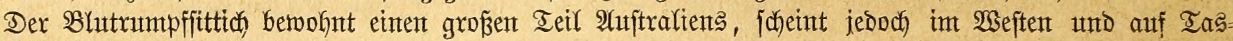
mantent zat feflett.

170. Dex Buntrittid, Pl. (Ps., Pseph., E.) multicolor, Tem. RYein; mergrïtı; Stirn

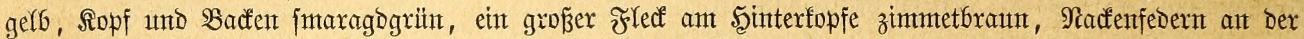

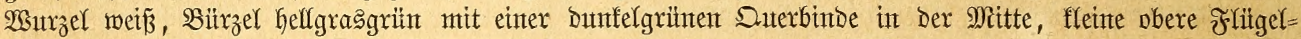

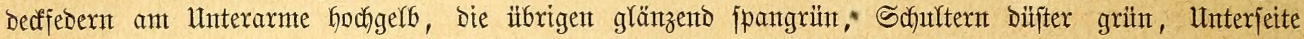

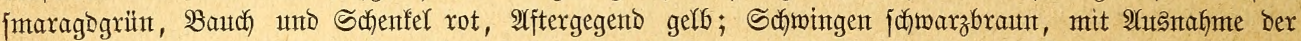
brei ober vier Yetztent grünen $\mathfrak{A}$ rmidomingen außen tiefblau, unterfeits graufdwarz; Dedfedern ber Şanto=

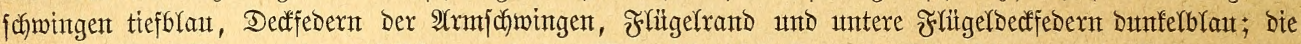

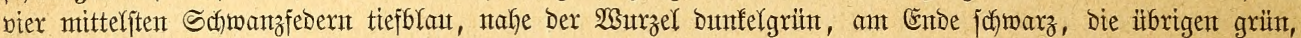

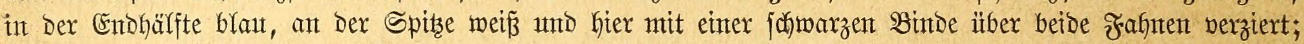

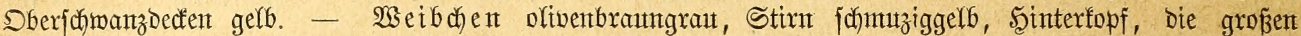

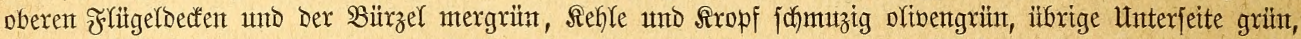

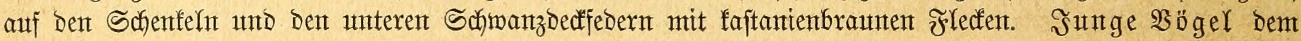

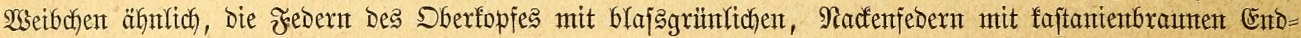

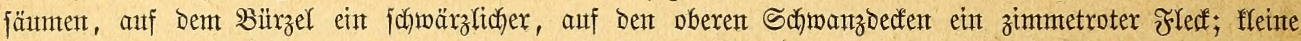

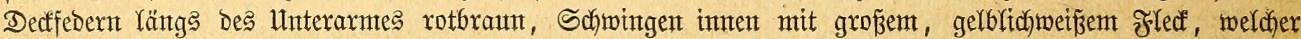
mit anderen eine Duterfinte erzengt.

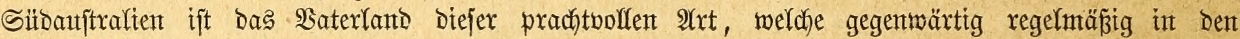
Scantel fonmt.

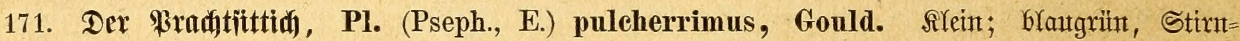

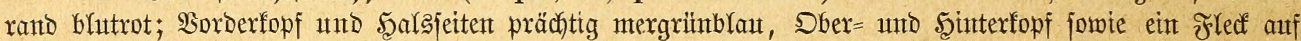

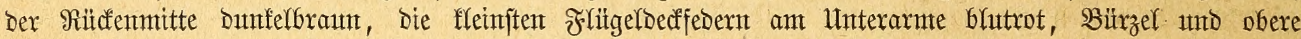

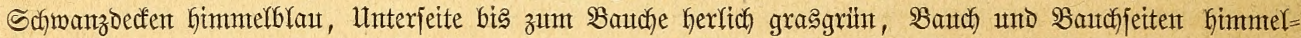

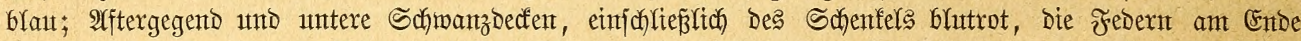

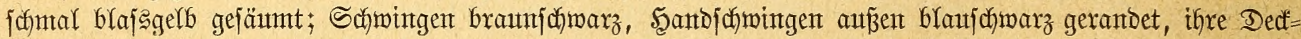

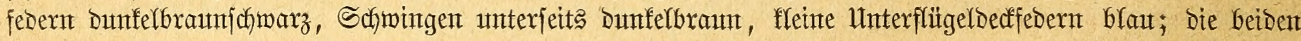

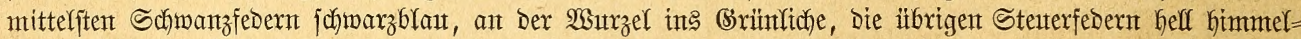

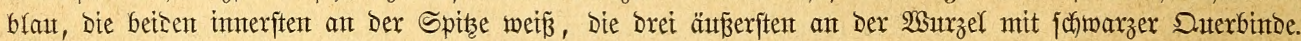

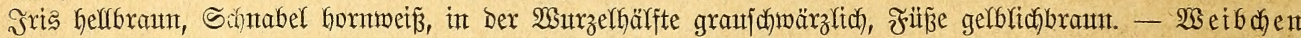
weit wentger rebhaft ars Das Mlännchen, Stirntanto unt SBrautenbogent blajsrot, Ropffeiten grautgrünt,

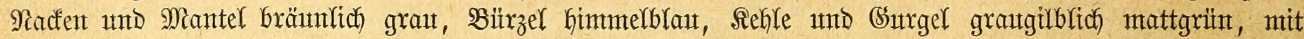

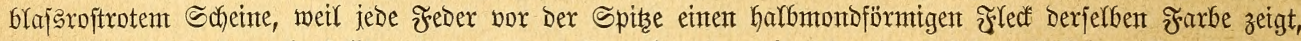

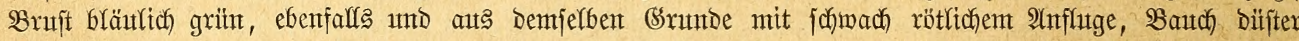

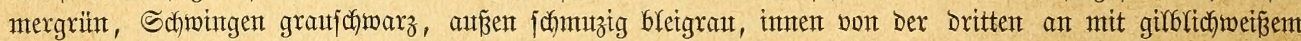

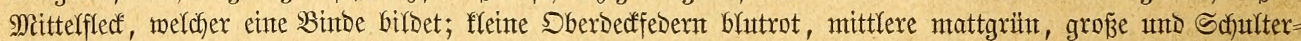

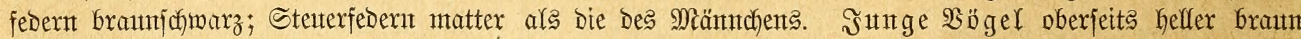
als bie alten, unterfeits hell blautgrïntich), mutr auf ber Sautd) feits anf Der Îmenfahte mit blafsgerbent Flecten, weldhe einte Suterbintoe birbent.

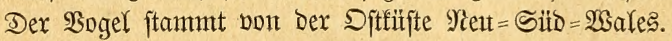

172. Bunteg Sittid), Pl. (E., Nanodes) Bourki, Gould. Seff fleit; olivenfahlfraut, obere

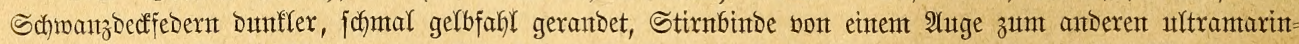

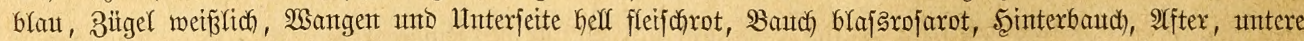

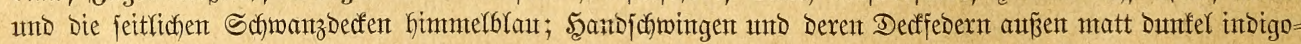

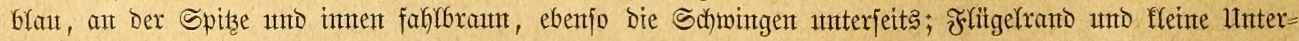

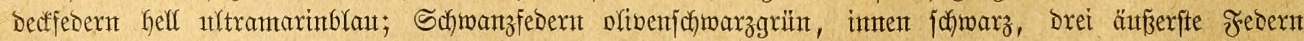

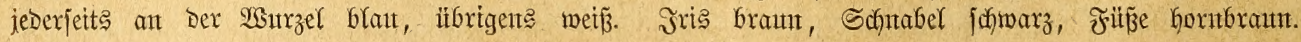




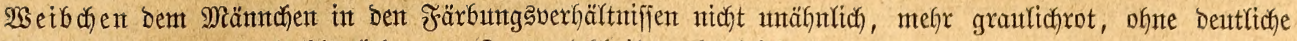

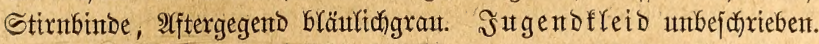

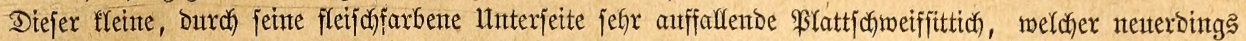

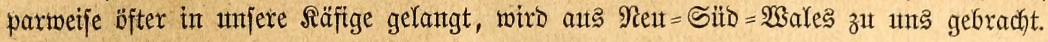

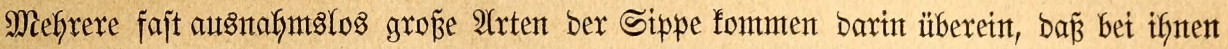

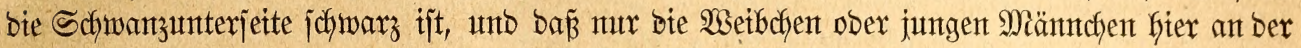
Sintenfafyne breite, rote Ränber zeigen. Der Schnabel ijt gemöbnltch rot, feltener bunfel= farbig. Bei eintgen, weldye ein hartes Sefieber haben, Iaufen bie Sdywanzfebern ipitziger

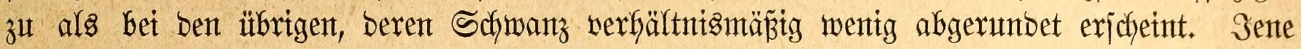

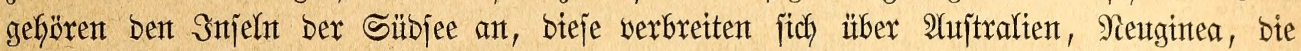
Moluffen bis çeram, Buru unt Timor.

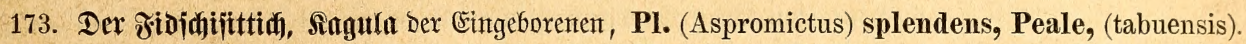

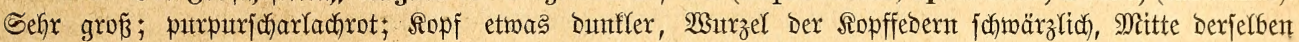

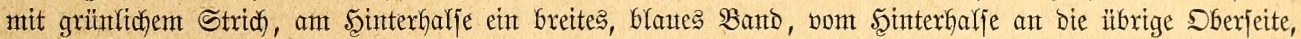

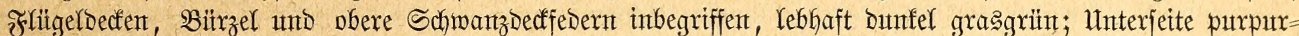

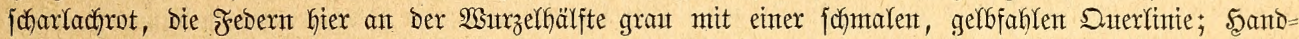

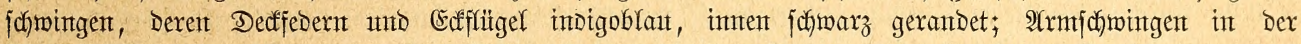

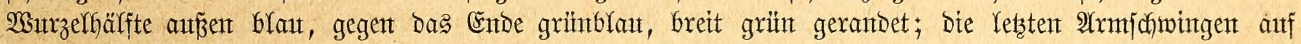

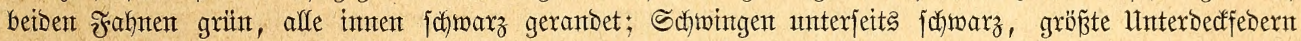

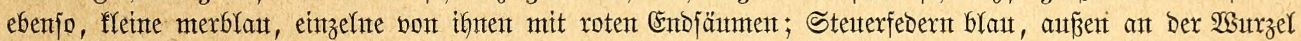

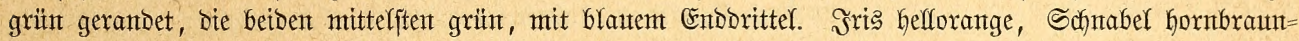

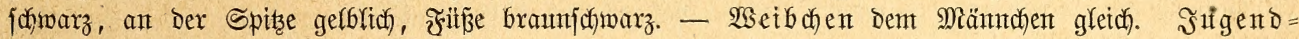
freid intefdriebent.

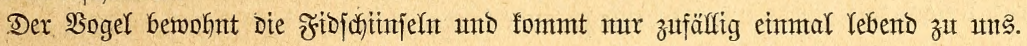

174. Der Miastenittiă, Siafa Der Eingeborenten, PI. (Ap., Coracopsis, Pyrrhulopsis, Prosopaea)

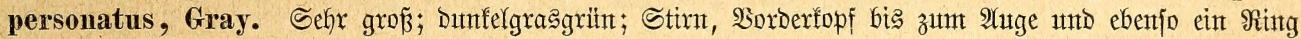

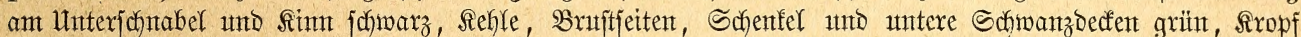

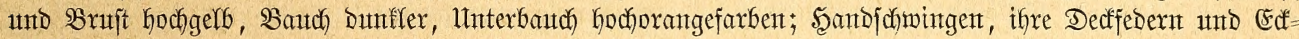

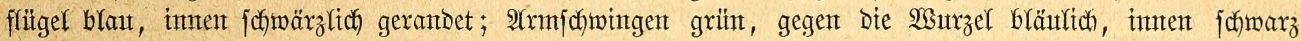

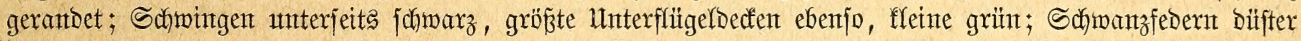

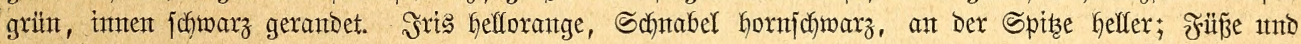
Sirallent fojwarz.

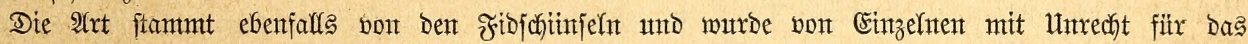
2̧seibchen des vorhergehenton erflärt.

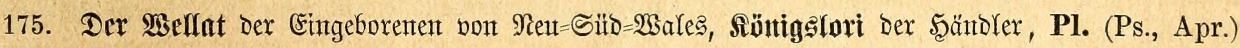

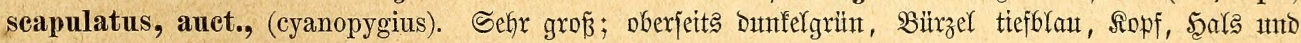

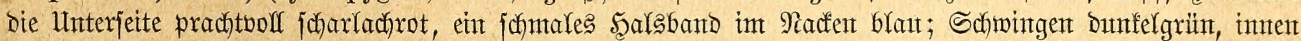

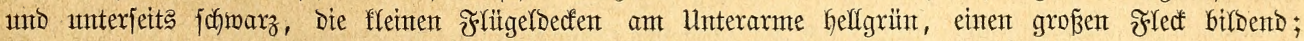

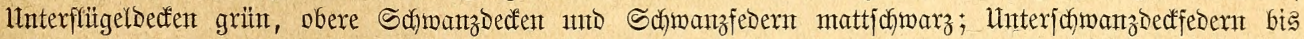
auf einten Greiten, roten Ëndrant tiefblant. Jriłs fafmefelgelb, Sberidntabel foraflentrot, an Der Spize

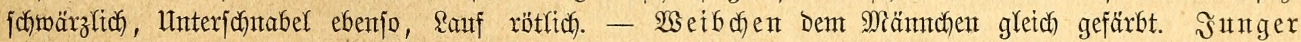

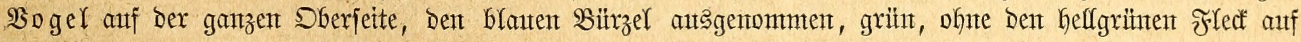

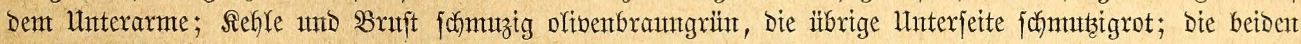

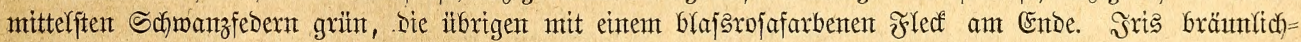
gellb, Sdantabel gelfbrautut.

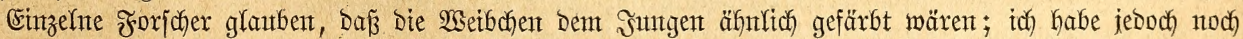

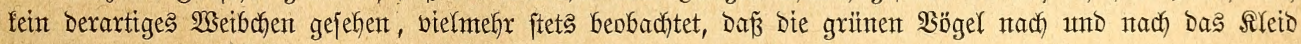

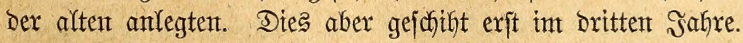

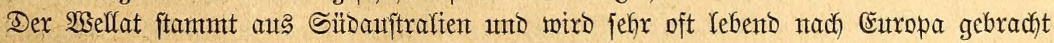

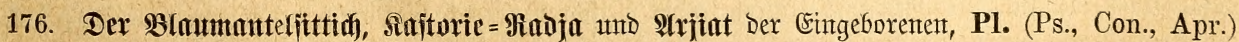

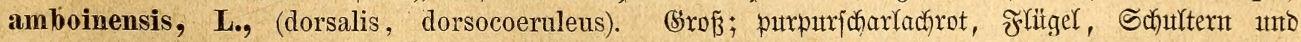

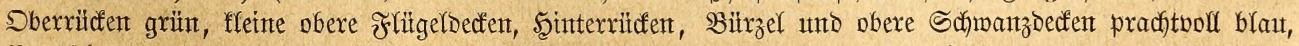

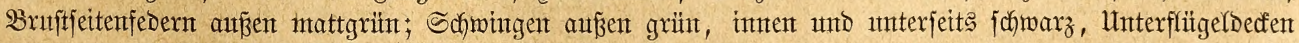

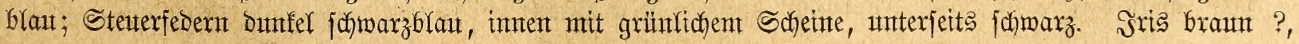




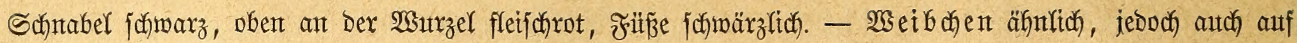

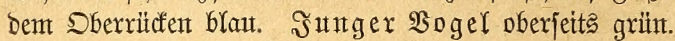

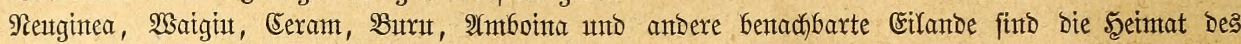

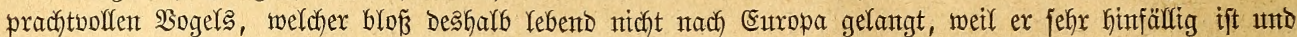

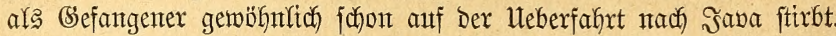

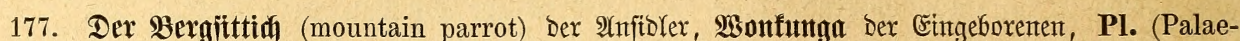
ornis, Polytelis, Barrabandius) melanurus, Vig., (anthopeplus). (Brofs; ofinengelf; Sedulter=

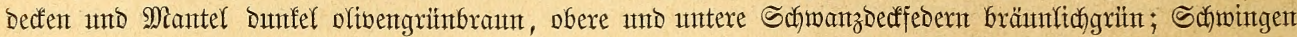

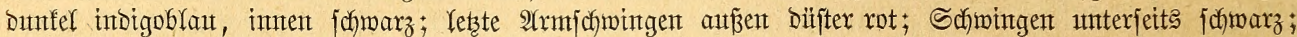

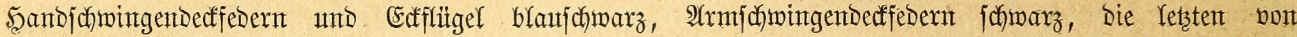
ifnen mit breitem, rotem Ende; Steuterfebern Dunfel intigoblaut, interjeits fotwarz. Sris blutrot,

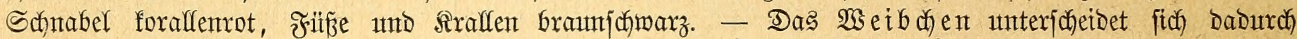

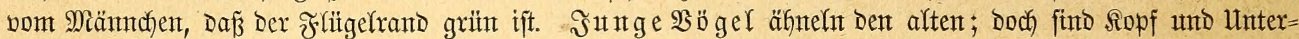

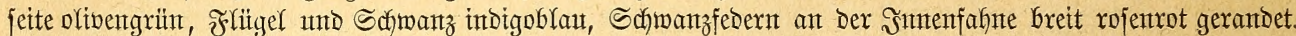

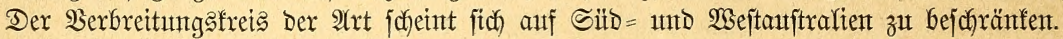

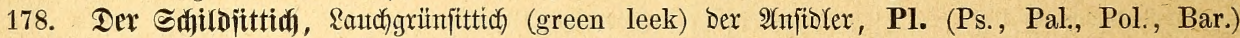

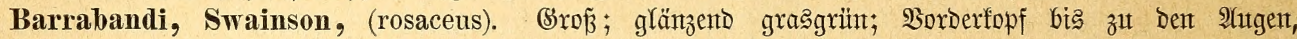

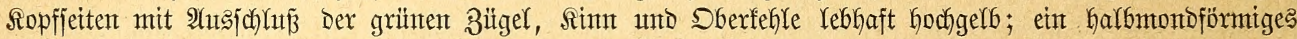

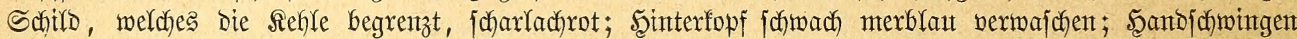

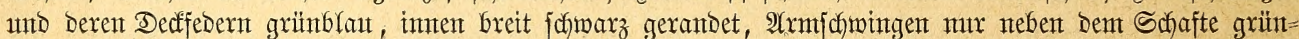

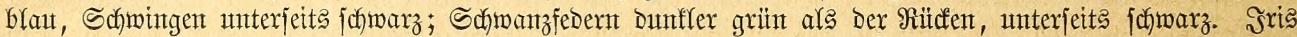

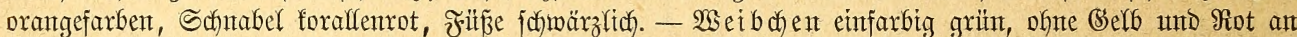

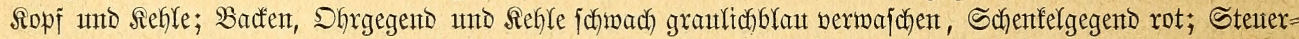

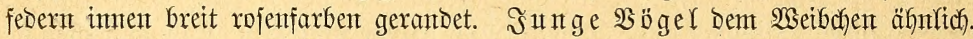

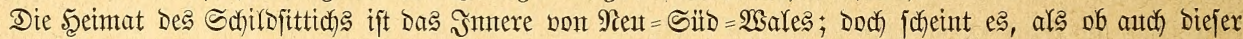
Sogel zumeilen an bie Rïfte gelangt, Da er neterbings nidht felten zat unt gebracht wirb.

179. Der Sdfarladflitgelfittid), Pl. (Ps., Apr., Ptistes) erythropterus, Gml., (melanotus, coc-

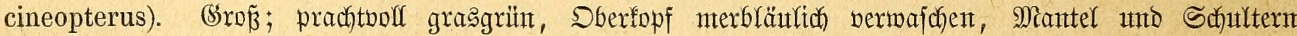

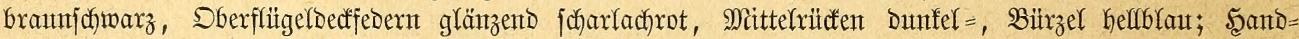

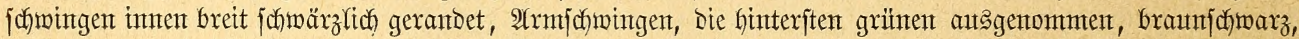

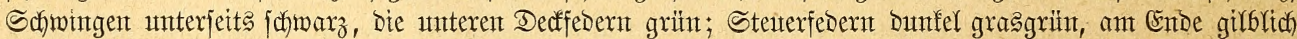

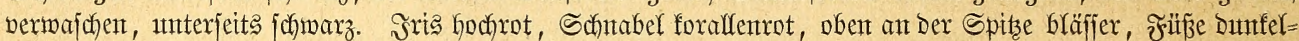

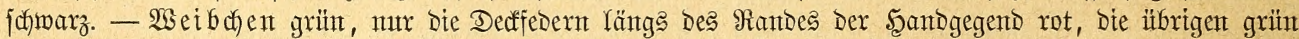

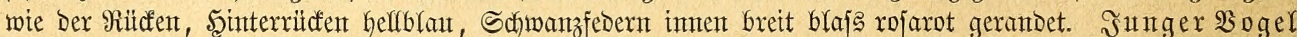

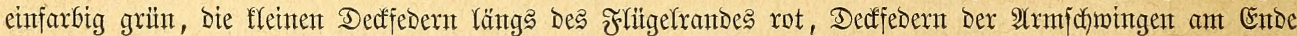
rot gejäıtmt.

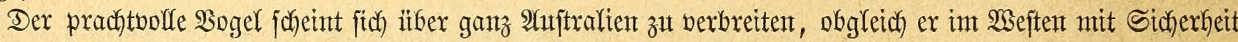
bis jetzt noch nicht aufgefunden woroent ift.

Bei ben nod) zu erwähntenden 2(rten, weldhe von Bonaparte in eine bejonbere Sippe, bie Blaujdyäbel (Cyanorhamphus), wereintigt morben finto, ijt ber Sdynabel ganz ober an ber WGurzelfälfte blangrau, bie Dberjeite eimfarbig, bie Unterjette Les Sdywanzes oliwen=

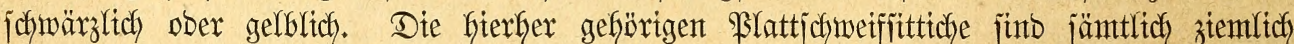
flein, faum jo groz ober boch nidft grö̈er als umjere Singoroffel, ähneln im Sdynabelbaut Den Sragjitticfen, Gaben jebr übereinjtimmento einte eintöntg grüne Färbung, rote Stirn=

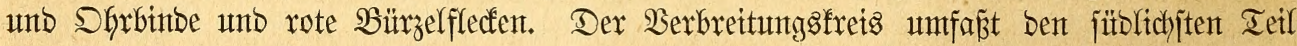

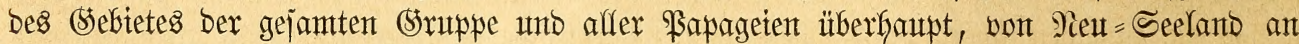
Gis zu Den Macquariemjeln, öjtlich bis Iafiti, wejtlich bis Reufalebonten.

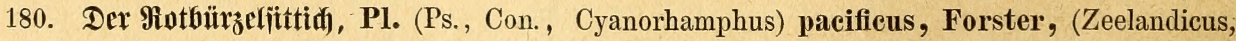

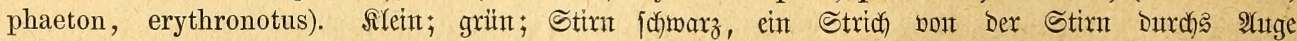

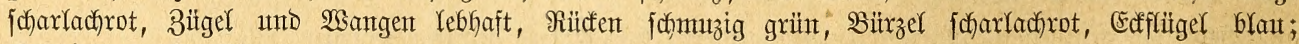

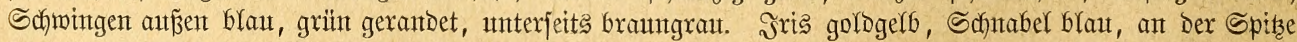

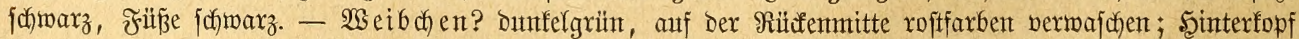

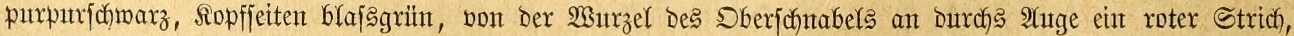

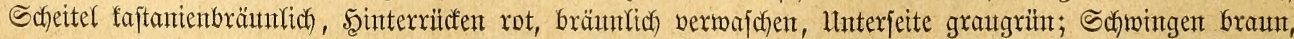




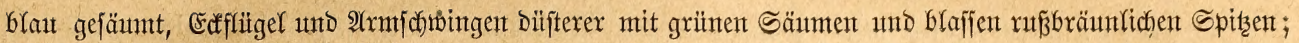

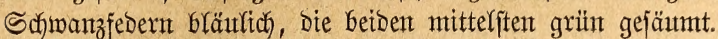

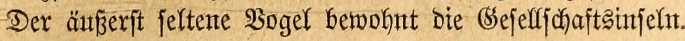

181. Der \&nufittid, Sinfitifi Der Moarį, Pl. (Ps., Cy., E., Coriphilus, Lathamus) NovaeZeelandiae, Sparrm., (erythrotis, Novae-Güineae, Rayneri, Cooki, aucklandicus, Saisseti). Mittelgrổ;

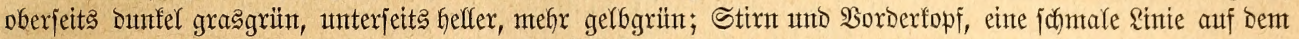

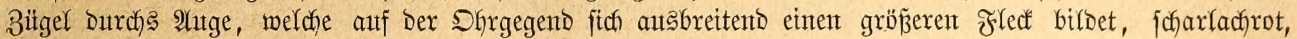

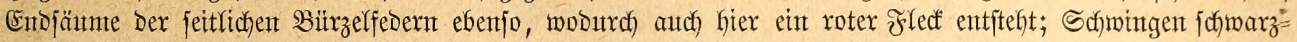

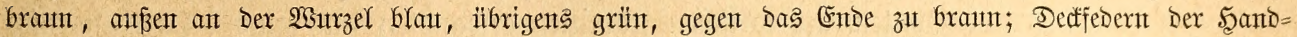

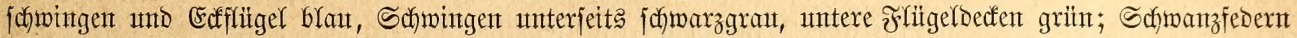

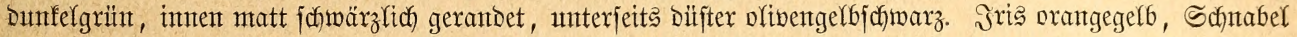

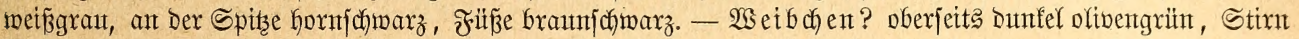

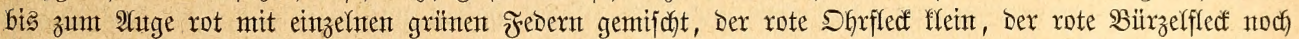

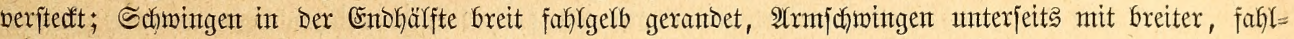

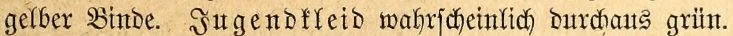

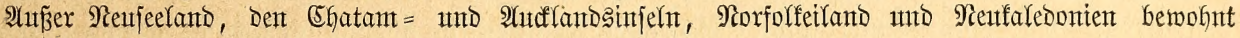
Dieje $\mathfrak{A r t}$ autch Die Macquarieinfelnt.

182. Der Springittid, PI. (Ps., E., Cor., Cy.) auriceps, Kuhl, (Malherbi). Rlein;

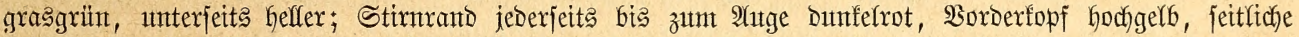

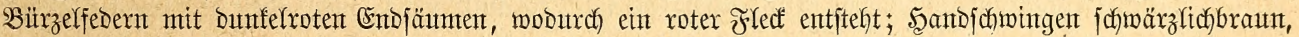

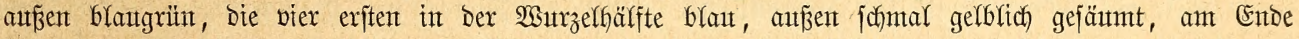

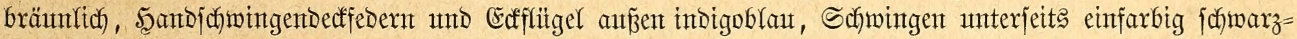

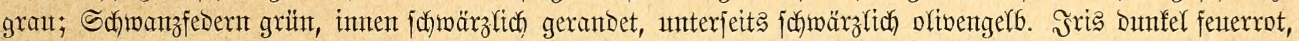

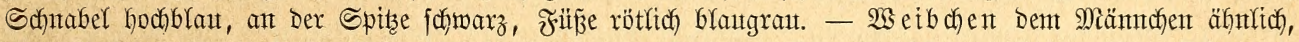

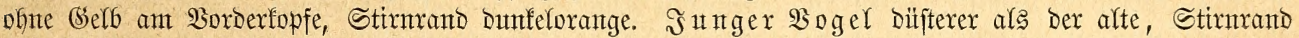

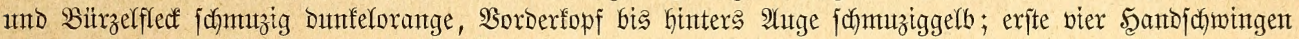

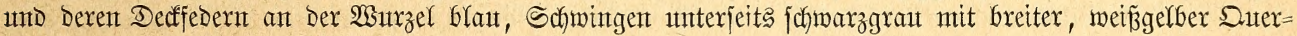
binde.

Der Springfittid, wie einex anjerex Seäntlex fehr bezeidynend den Sogel gentant hat, bemohnt

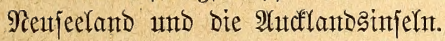

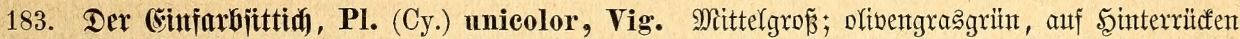

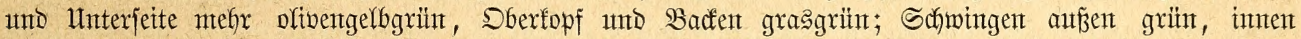

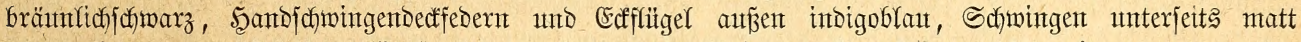

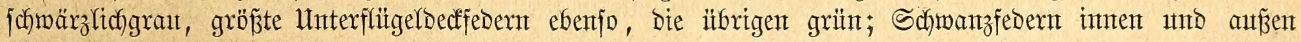

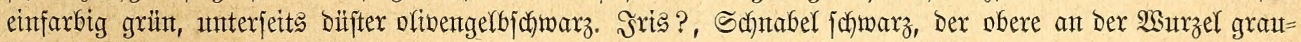

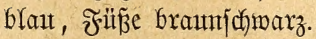

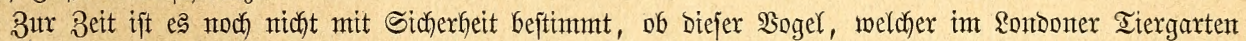

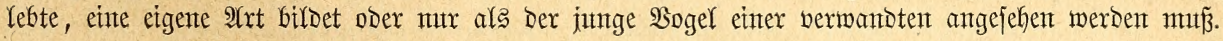

Es mag als bedenflich exachtet werben, ein (Sejamtbild des Rebens ber retchbaltigen unb weit verbreiteten Sippe ber \$lattichmeiffittiche zu entwerfen, weil Das Treiben und Stebafyren

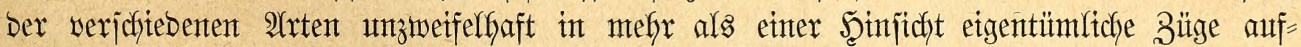
weift; Demungeadjtet glaube ich auch in biejem Faffe bie bißgher befolgte alrt und Weije ber Schilberung betbefalten zu Ditrfen. Unjere Sentnis bes Freilebens ber prädytigen $\mathfrak{B}$ ëgel

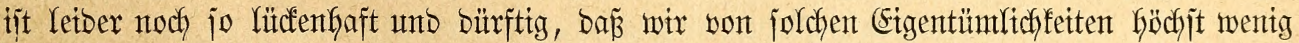

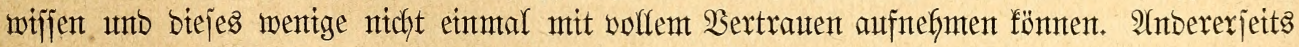
lauten bie 2 Angaben über Das Fretleben unjerer Sittiche jo übereinjtimment, Dá̉ wir das von eintem Exforjate, ofne bent heutigen Stande ber Wijfenjchaft zu nake zu treten, immerfint auf mebrere anbere bezteben mögen.

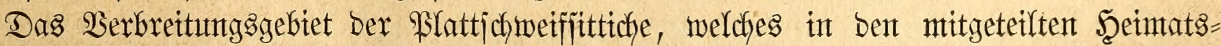
antgaben bex einzelnen Ifrten teilfweije feitgeitelft werben fonnte, beginnt, wie Finj ch Gervor=

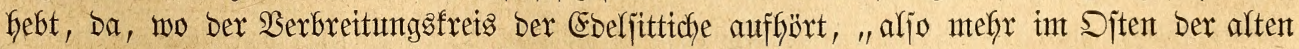
Welt, unt retcht nörolidy mentg über Den (Sletcher finaus. Iintor, Buru, Ceram, bie

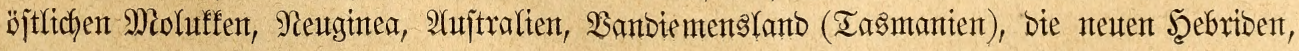




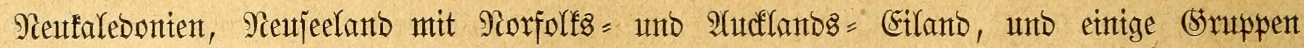

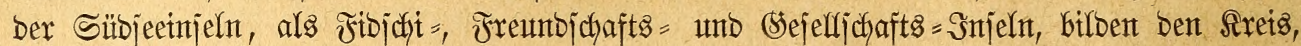

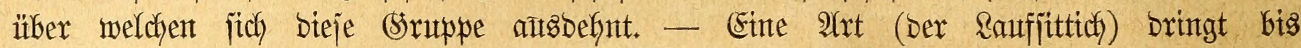

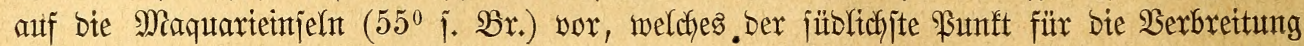

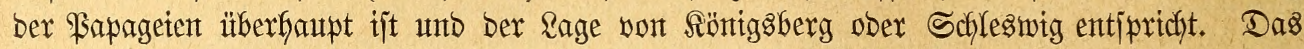

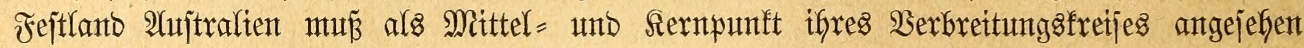
werbent.

Wite bie bisher erwähnten aujtralijchen Familitenwermanbten fint auch Die Reilichwanz=

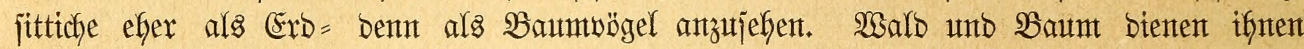

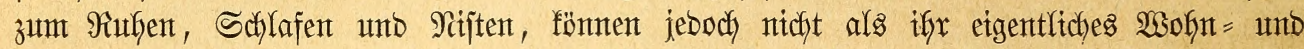

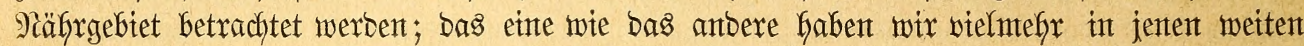
parfartigen esbenten zu juchen, weldye zettweilig int Sahre mit retchent strasmuthje bededt

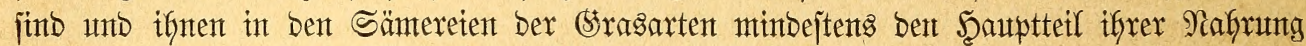

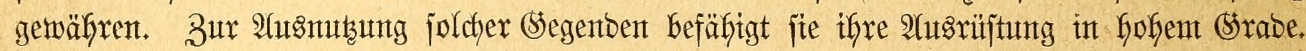

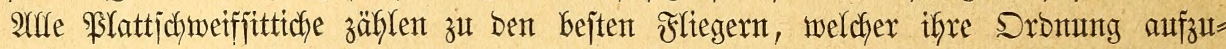

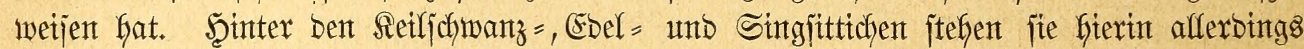

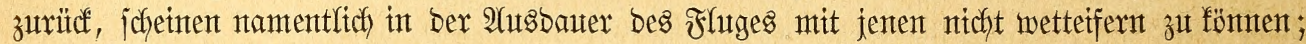

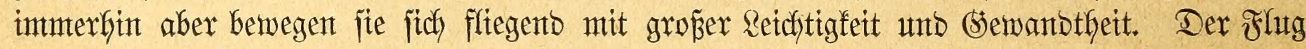
ber grö̈eren $\mathfrak{A}$ rten ijt welfenförmig unt wentg anbaltento, ber vieler fleinten 2 (rten zwar audd bogenförmig, aber jefr rajch unto hödyjt gemands, wie mix sefangene, weldye fich in

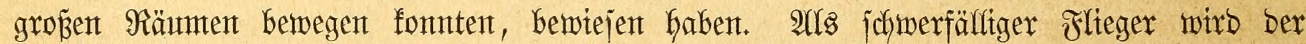
Wellat gejchilbert, und ftmment bamit meine Beobadytungen an (sefangenen Durchaus überein;

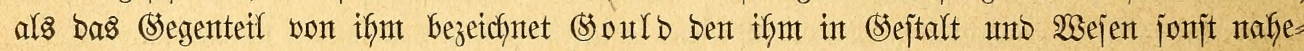
jtehenben Scharladyflïgeljittich, weldher int Fluge überhaupt von anberen \$apageien abmeichen unb an unjeren Riebth erinnern joff. Mangelfaftes Flugwerntögen befunbet fein einziger

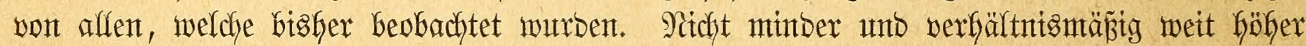

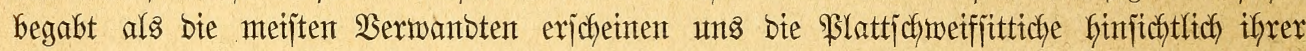

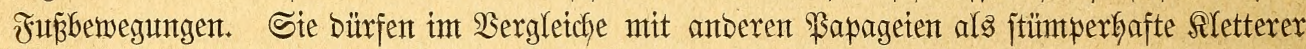
bezeidyntet werben, obgleidh jie in biejer Beziefung intmerhin nodh Erfflectliches leijten; aber fie finto ganz vortreffliche Räufer: einzelne von ifnen fönten im Raufen gerabezu mit volfendeten Erboögelnt wetteifern. Die meiften âten renten, trippelntben Sanges zwar, jebody jefyr eilfertig, mit anmutiger Befsendigfeit über ben $\mathfrak{B}$ oben bafin; einige finto jogar int Stantoe, Sprïnge von beträchtlicher Wiete auszufüfren: jo unter anberen ber Springitttich, bon welchem ich ein Bärdhen gepflegt und geraume Beit beobachtet babe. Furz, ifre Bemegungs =

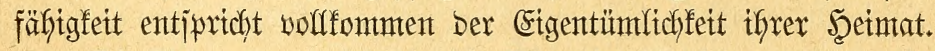

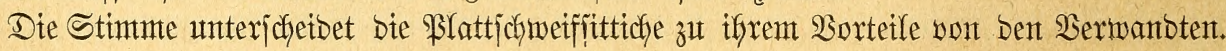
So miberwärtig freijdyenbe ober fnarrenbe Raute, wie mant fie von \$apageten, fafabuts unt $\mathfrak{A}$ raras Gört, wernimmt mant won ifnen ntidyt, ebenjo wentig bas eigentïmltch flirrende

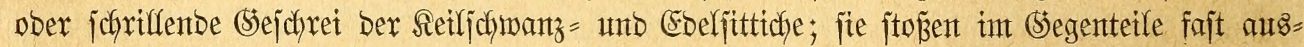

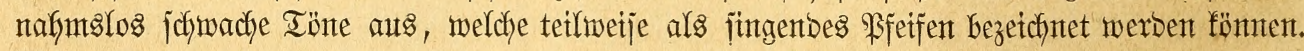
Went ifrer viele vereintigt jün, mögen audf bieje Töne untangentefm ins Shr flungen, jicherltch aber niemals io nerventerregent wie bas (Sefreijch einer nambaften $2(n z a b)$ non

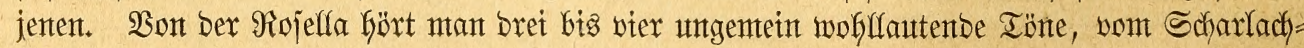

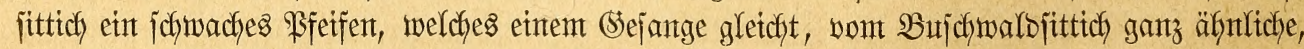

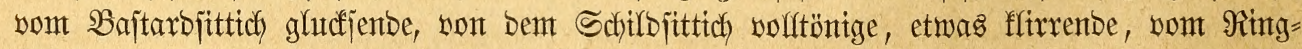

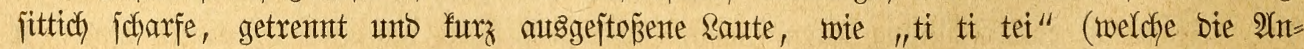

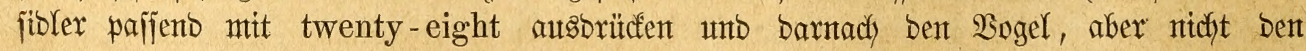

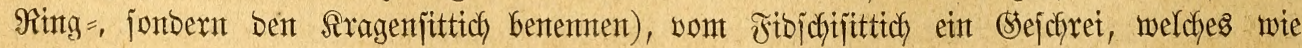




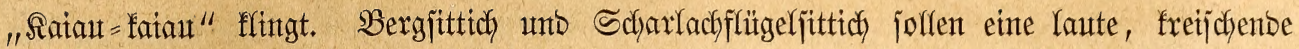
Stimme haben; Der B̉htrumpfifttich bagegen gibt einen ganz hübjchen (Sejang, richtiger ein

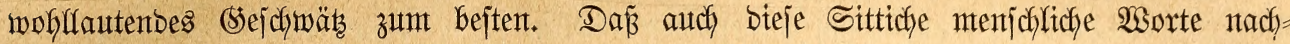

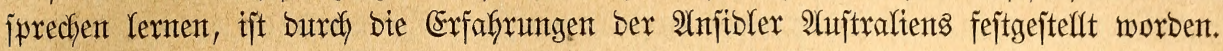

Ueber bie fÿ̈heren $\mathfrak{B}$ egabuntgen glaube ich ein günjtiges Urteil fällen zu Dürfen. SGre Sinne find ausnafntslos wohl entwidfelt, ifre Steiftesantagen zwar geringer als bie ber

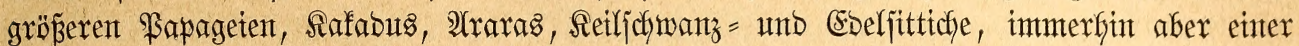

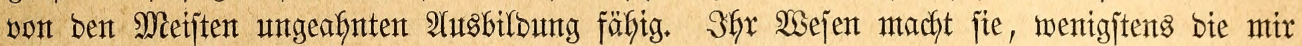

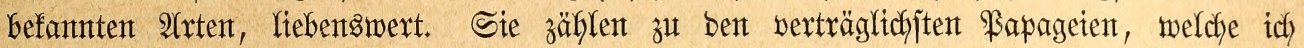
fente. Zanf unt Streit fommen unter gleidjartigen ober ungleidyartigen Blattjchweif =

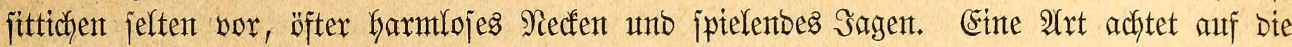
anbere und tut mit ifyr gemeinjchaftlich zu gleidher Beit basjelbe. Waie es int Freileben ge= icheben mag, io auth in ber Stefangenjichaft: Der Rodf = ober Warmungeruf bes einen wirb

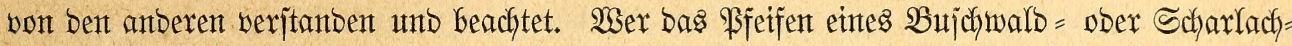

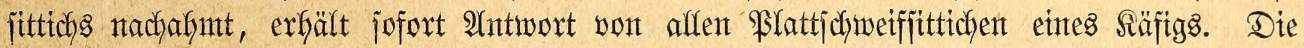

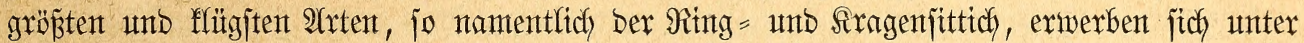

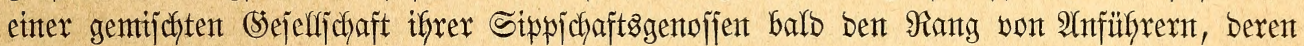
Ratichläge augenblicflich befolgt werben. So wentgitents gejdyift es int Fluggebauer bes

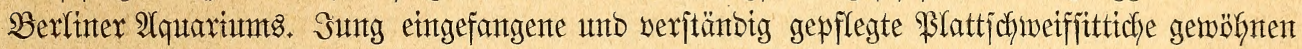

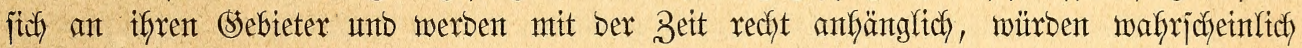

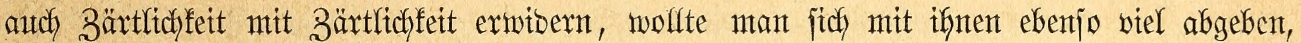
als man bies mit anberen 2 (rten ifrer Srbmung tut. Mëglicherweije mürbe jelbjt ber als

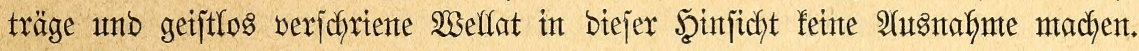

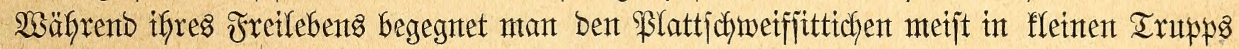

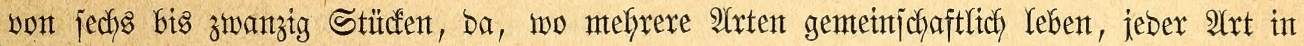
gejonberten Flïgen, objchon jich bieje zeitweiftg wohl auth mit anbersartigent vereintigen mögent.

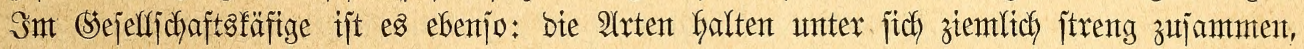
aber gute Semeinjdyaft mit anberent ber Sippe. Nach ber Brutzeit joharen fich ftärfere

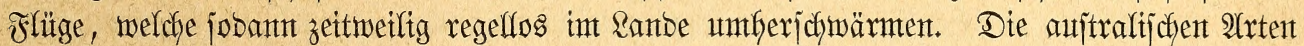

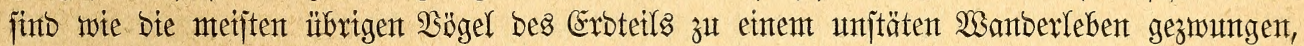

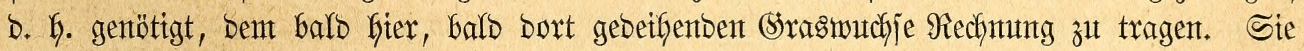
tretent Dententiprechent in einent Safre mafjentbaft in ben Sïftengegenben auf unt fehlen in einent anberen gänzlich bajelbjt. Mit bem 3uge umjerer ntorbijchen Bögel barf ntan bieje

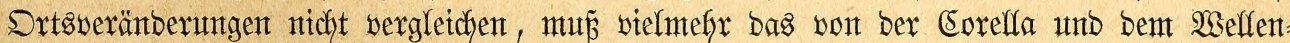

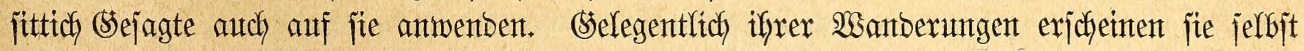

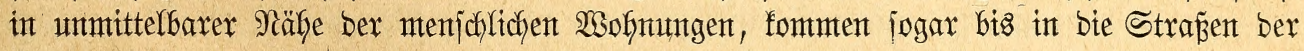

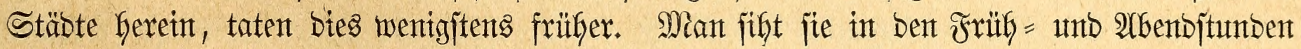

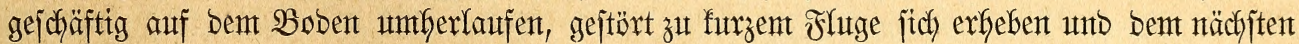
Baume ober Bufche zufftegen ober ant eiter anberen pafjentent Steffe wieber auf ben Bobent

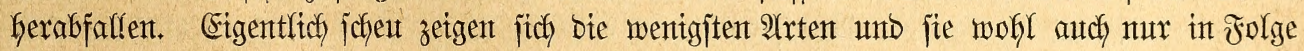

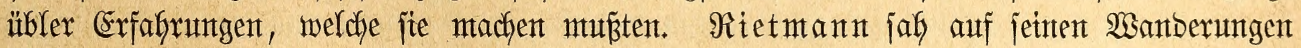

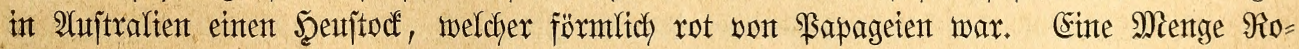

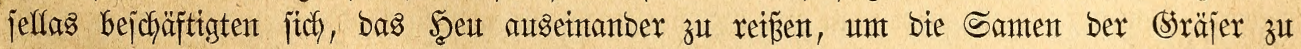

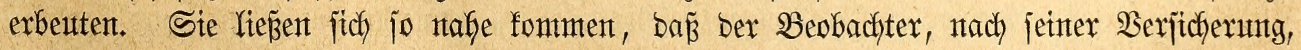

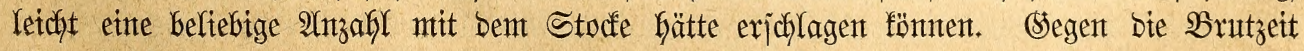

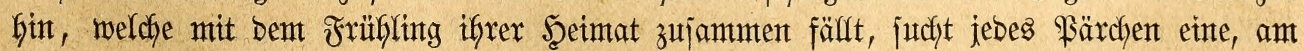

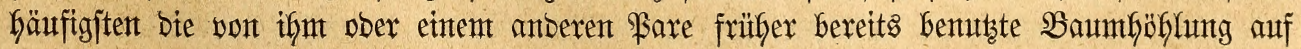

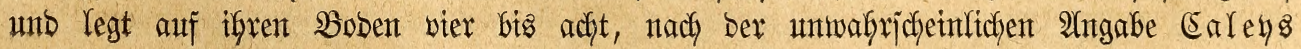




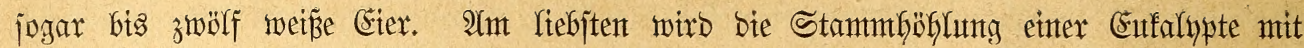

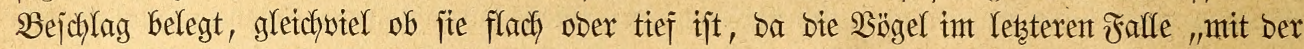
(Semanbtheit einte Spoffunts" auf unto nieber flettern. Whie lantge bie Brutzeit nährt, ob

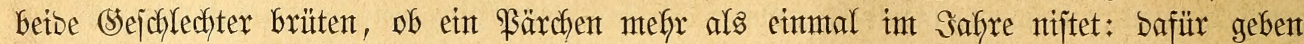
weber bie an freilebenten noch an gefangenen Mitgliebern mierex (stuppe gemadten Beobachtungen verläß̈lichen 2 tnthalt.

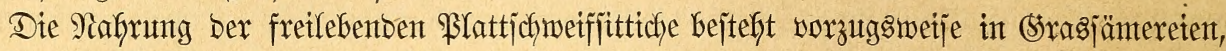

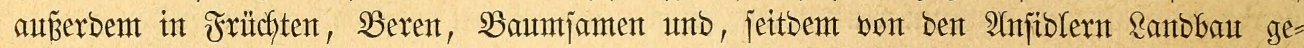

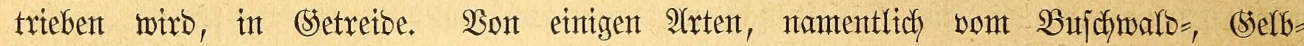

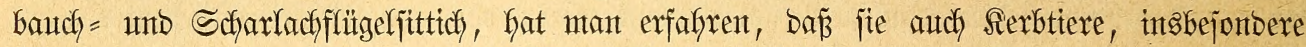

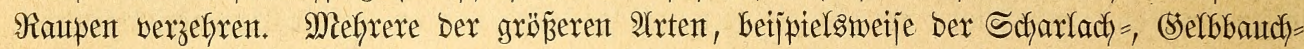

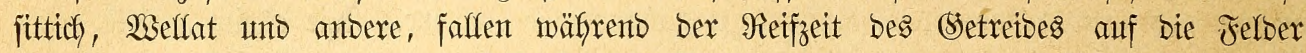
ein ober bejutten zur Zeit ber Skjtreife bie Särtent unb rithtent bant fiter wie bort jo

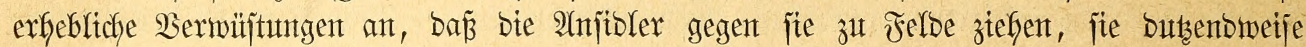

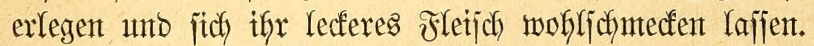

Erjt jeit ungefähx acht bis zefnn Safren gelangen shattichweiffittiche in nambafter

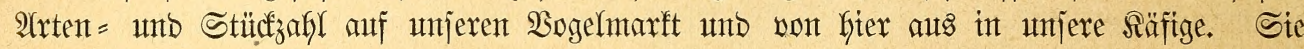

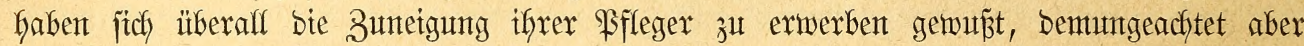

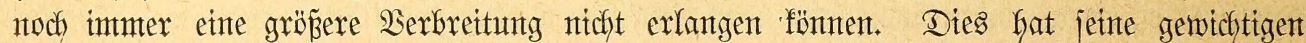

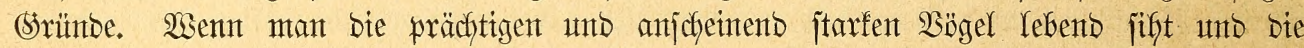

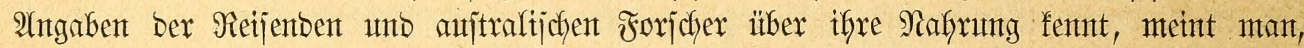

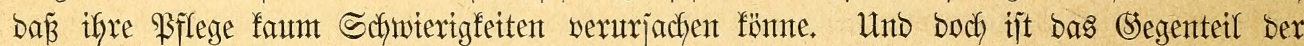
Fall. WGer viele \$lattichmeiffittiche gefangen gebalten hat, ijt viel stelb los gemorben,

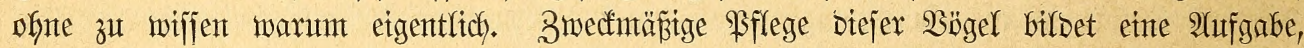

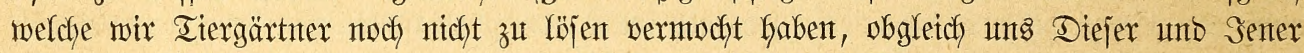
mit Der alfen Scalbmifjern eigenen Dreijtigfeit Das Segenteil verjichert. Das natürfidjpte

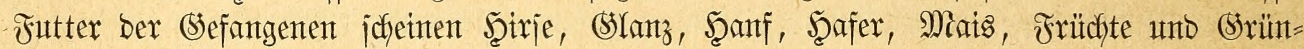

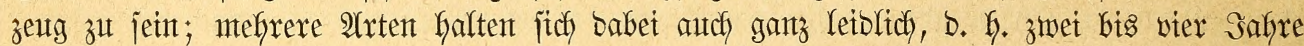
lang, für jo grofere, anjchetnento anjprudbsloje Bögel aber body biel zu futze Zeit. Mant

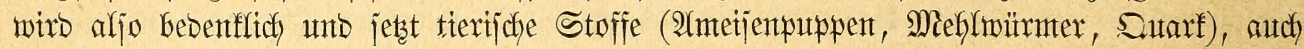

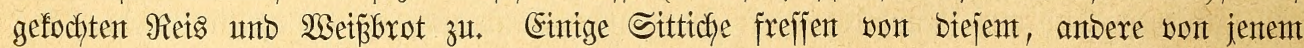

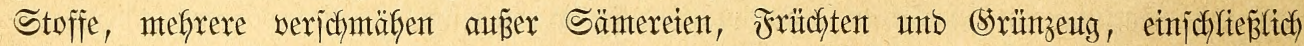

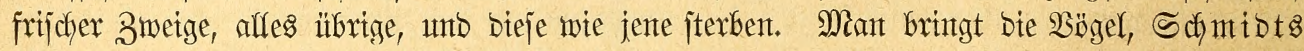
Sorgange folgent, io viel als möglich ins Freie, ïberwintert fie fier jogar: ite focheinen

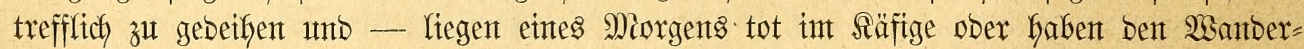

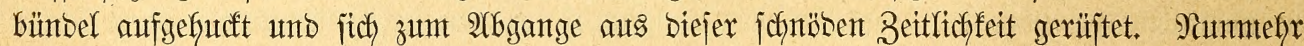
befolgt man bas gerabe (segenteil umb bringt fie in jafraus, jabrein gleintäp̆ig warmen Räumen unter. Mit befferem Erfolge? Sa, nein! Soldhe Berjuthe Gaben wir Alfre, welche

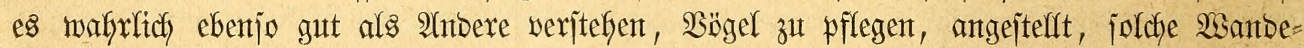

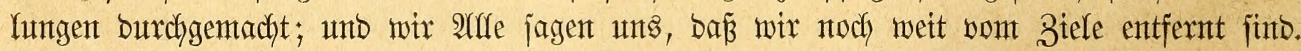
Seien mix aljo effrlich, und betrügen wir mentgitens nidyt alnfänger, weldye bas Untichtige

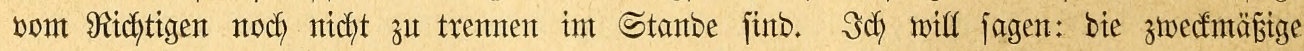

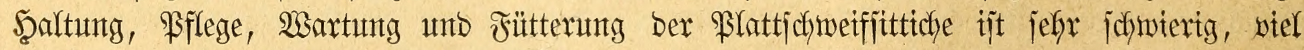

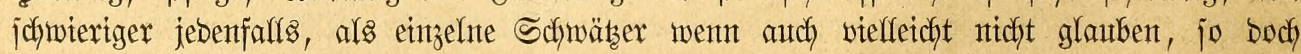

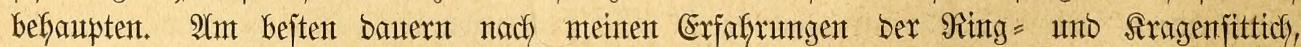

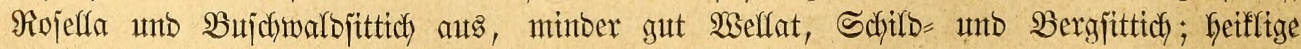
2ögel fint unto bleiben alle fleinteren 2(rten, aljo inabejonbere biejentigen, welche bie Unter: abteilung Psephotus bilben, obgleich gerabe fie am exiten in Sefantgentichaft nijtent. 


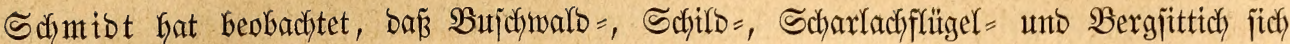
währent eines ntcht alfzuftrengen Winters in einent freiftebenben Fluggebauter treffich hitelten

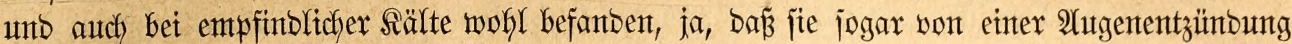
genajen, nachoent jie ins Frete gebracht worben waren; $\mathfrak{B}$ obint

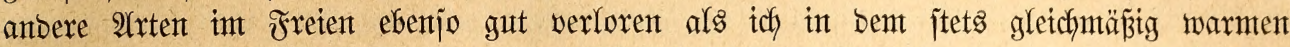

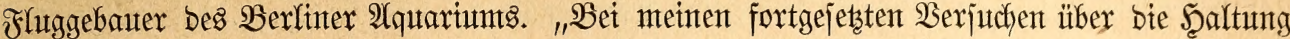

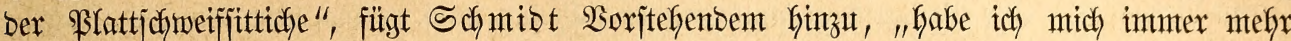
überzeugt, Dá̧ biejelben unbebenflich int Freten überwintert werben bürfent. Der gegen=

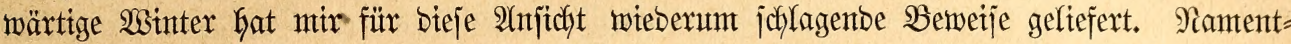

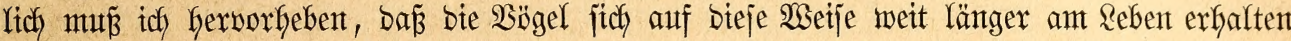
lajfen, als bies mix früfer jentals gelingent wollte. Die meijten Tobesfällfe Gabe idy immer

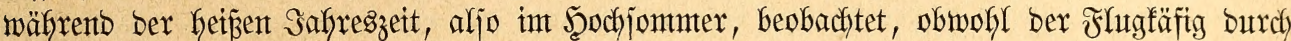

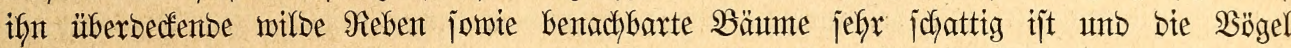

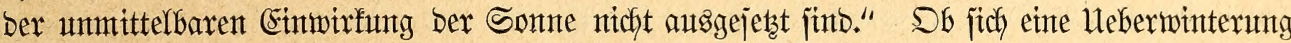

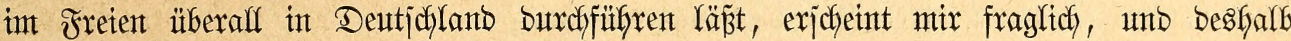

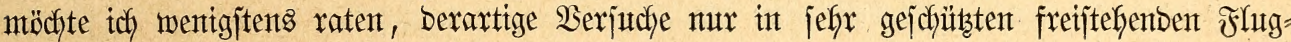
gebautern arzultelfen.

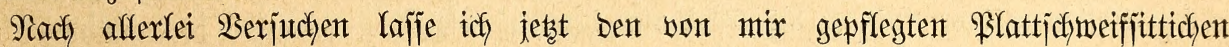

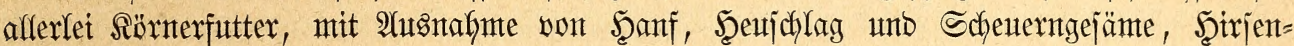

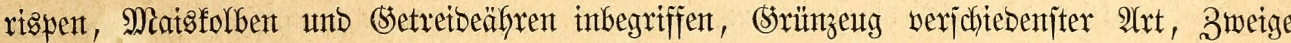

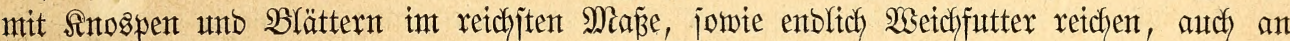
Raff unt Salz es nicht mangeln, unt bint, jeitbem ich jo berfahre, mintojtens einiger =

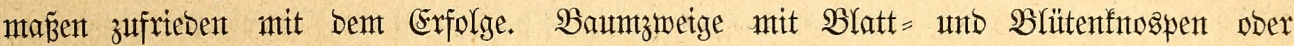
Brä̈ttern erachte ich als ein unumbänglich nötiges Nafrungsmittel unjerer Sittiche. Man

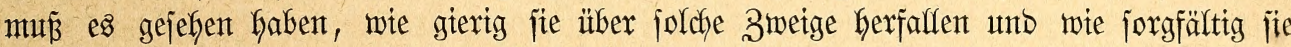

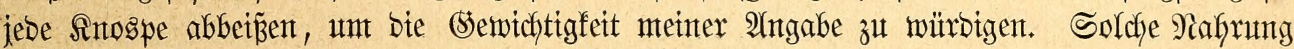

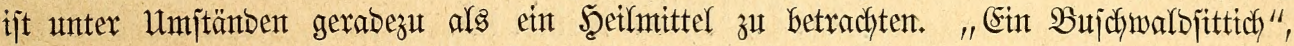

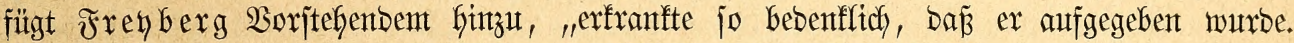

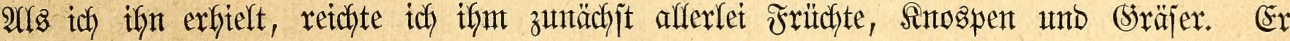

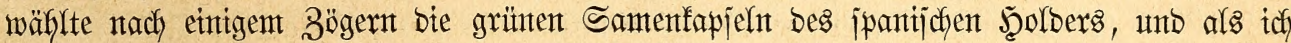

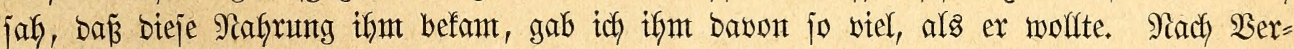
lauf von zmeiunbzmanzig Iagen war ex volfjtänbig gentejen. Esbenjo günjtige Exfolge

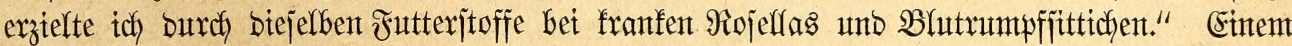

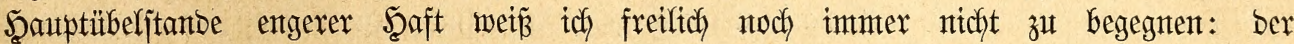
Berfettung, zu weldyer bieje Sittiche, wie alfe Bögel, weldje fich int Freten viel bemegen, in bejonberent Srabe finteigen. Ânbere Fapageien werbrenten wegen ifrer

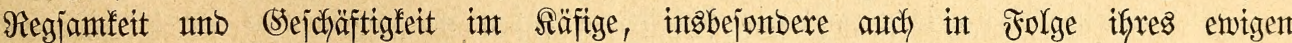

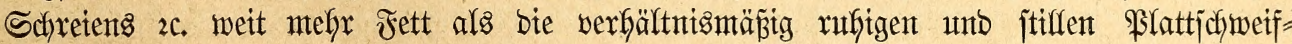
jittiche, weldye jith ungletdh weniger bemegen als jente, fich jelten mit Bentagen unb Sernichtent ber Sprofien, Sitzitangen und (sterätjchaften ifres Sïfigs befaffen, fich wentg ober nidht über anbere 2 b̈gel ärgern, nidyt ımunterbrodjen jchreien, furz ein weit

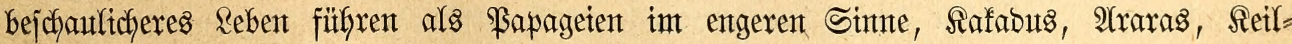
jdywanz = und Ebeljittiche. Dieje Ruhe und Schwetgjamfeit empfiglt jie jefr für das

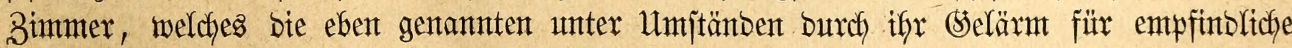
Mienjiden gerabezu unbewofhtbar machen; fie ijt anbererjetts aber, wie tch antefme, eine

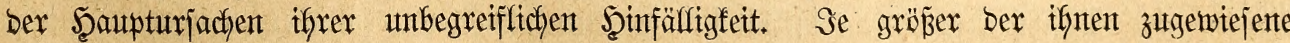
Raum, unt jo. bejier Galten jie jich: aus biejent einten Sebrjatze fant man entnefymen, was

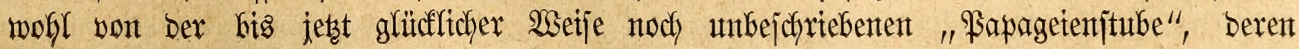




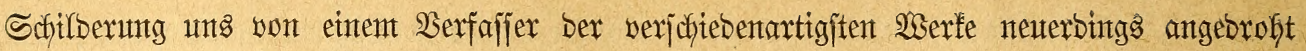
worben ijt, zu halten jein bürfte.

Borjtełendes erflärt zux (sentige, weshalb jich bisher auffallend wentge Blattichweif=

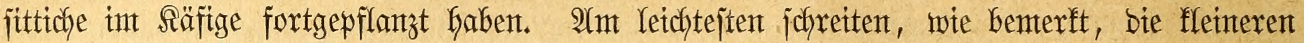

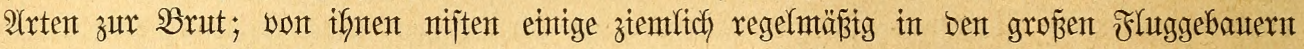
ber belgijchen siebfaber, einzelne bant unt want auth in engerer Scaft, bei biejemt unt jentent Riebfaber. Shr B̈ntgejdjät unterjchetbet fich mut injofern von bem anberer fleinerer. Sittiche, als fie autch Retjerchen, Scälntchen und Febern eintragen, berartige Stoffe ifnen aljo zugänglicty jein müriffen. Dies tun namentlich SBlutrumpf $\Rightarrow$, Sunt $=$, Fracht $=$ untD

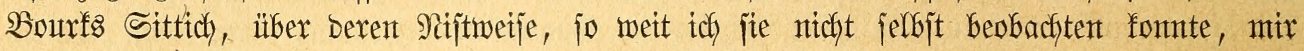
glaubmürbige Mitteilungen wurbent. Beibe Bejchledter jcheinten fich ant Brüten zu be=

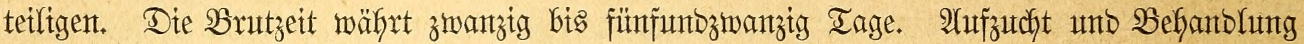

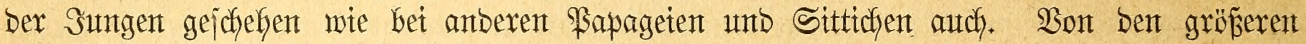

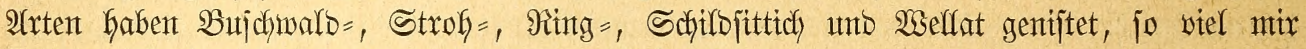
befannt, bis jetzt jebod ntrgentos Sunge aufgebradyt.

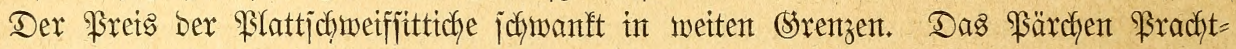

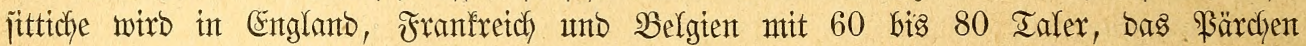
Scharladfflügelfittiche mit 40 bis 50 Ialer bezahlt; Die üfbrigen ârten find biffiger. Etne

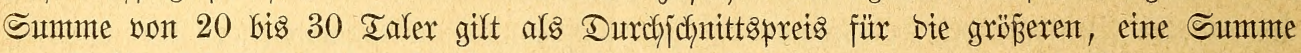

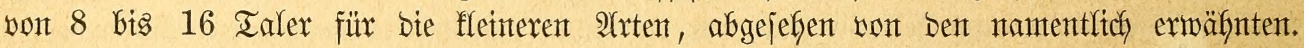

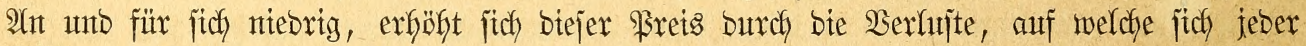

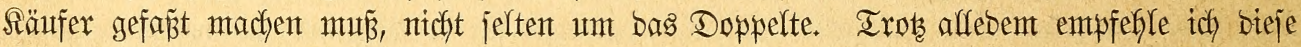
Bögel arfen, welche ber Riebhaberei unwermetbliche Spfer zu bringen im Stantbe fint.

\section{Rereitldumatslorts.}

Dent reichen (Sebiete \$olyntejtens unb Der \$apulänber entitammt einte \$apagetengejellichaft,

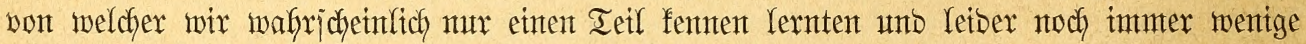

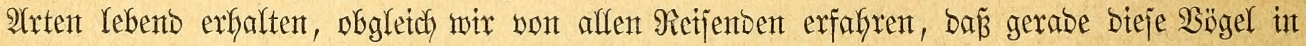
ifrer Sceintat Durdigebentos gefangen, im Räfïge gebalten unt als Scantels = ober Iaujals=

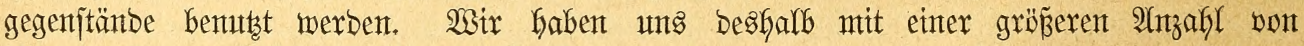
ifnen, als ertweiglich bis jebt nach Europa gefonment fint, zu bejdäftigen, weil jedes

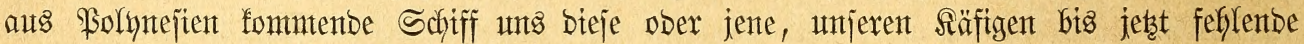
2)rt bringent fant.

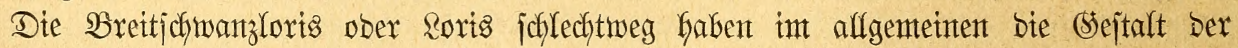
Papageien in engeren Sinne bes Wortes, find jeboch jchlanfer gebaut und etwas fleinföpfiger

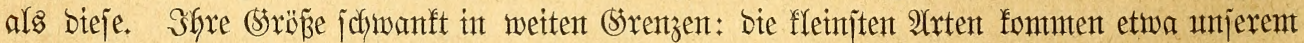
Sperling, bie gröperent unjerer Dofle gleidy. Der Sdynabel ijt meijt fräftig, ebenjo hods als lang, jeitlich zujantmengebrücft, Der Dberjednabel auf ber Jinjte abgerumbet, worn ftarf

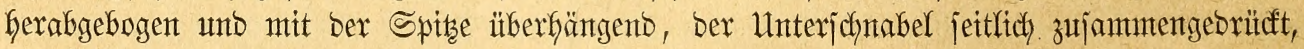
Die Diffenfante in geraber sinte aufjeigento; in ben oberen saben bemerft man eine janfte

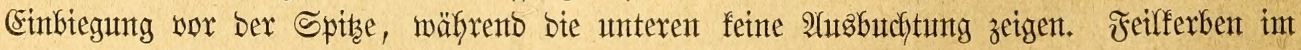
Schnabel feflen immer, unt gilt bies als ein Kezeidynentes Merfmal ber Gierfer geförigen

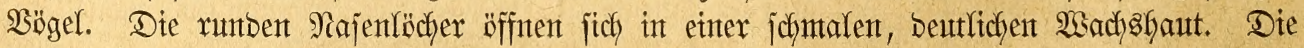

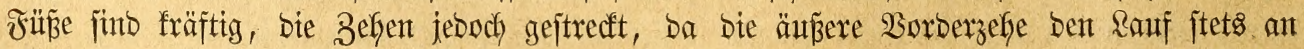

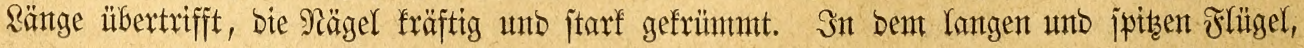


melcher zujammtengelegt über bas Enbe ber oberent Schwanzbeffen reidyt und ungefähr bie Şälffte ber Steuterfebern bebecft, tritt bie lange Flügeljpibe jehr herbor; unter bent ant Ende meifit breit abgerunbeten Schwingen, beren ztweite ober britte bie längíten jüto, pflegen bie exjten brei inten ausgejchnttten ober boppelt eingeengt zu jein, woburch fie amt Enbe ipizer

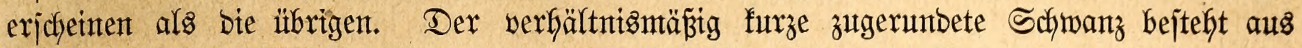

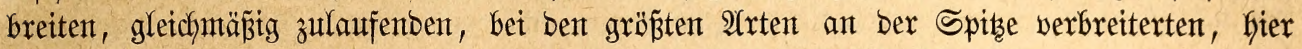
jtumpf zugerumbeten Febern, welche nach auken fin gleidymäz̈ig fich abjtumpfen unt in ber Mitte bie übrigen nicht überragen. Das berbe Sefieber wirb gebilbet aus ziemlich harten Febern, welche auf Şals und Dberjeite lang und Garig zerjchlifjen, auf Dberfopf unt Seinterhals zumeilen verlängert unt in ber Schaftmitte getwöhnlich ftarx jint. (5s be=

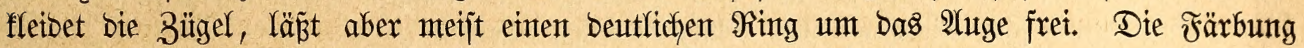

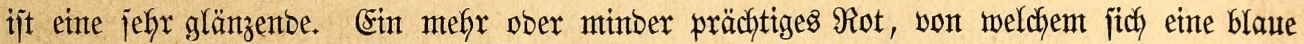

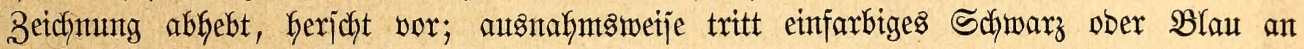

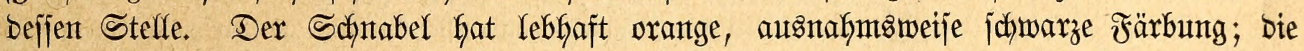

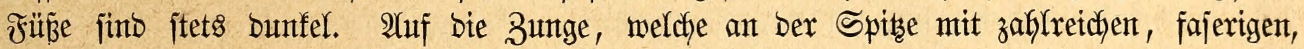
aufridftbaren, bei ben fleineren 2 rrten jternförmig auggebreiteten $\mathfrak{B a ̈ r z c h e n ~ b e b e f f t ~ i j t ~ u n d ~}$ geniffermaß̄en einte SBürjte bilbet, murbe (ऽ. 144) bereitz bingemiejen.

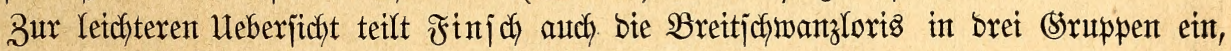

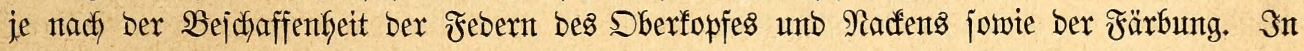
ber exjten Sruppe berentigen wix mit ifm bie blauen, grünen ober jedwarzen $\mathfrak{A}$ rten, beren

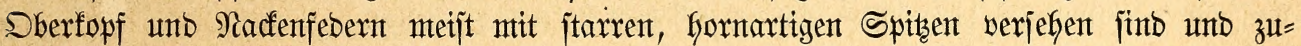
meilen einte 2(rt von Sdjopf bilben. Die Sruppe murbe von $\mathfrak{B a g l e r}$ als beịonbere Sippe aufgejtellt uno Maibloris (Coriphilus) genannt.

184. Der Saphirfori, Irrimanu und $\mathfrak{B i n i}$ Der Eingeborenen, Domicella (Ps., Cor., Brotogeris, Nanodes, Trichoglossus, Lorius) taitiana, Gml., (sapphirinus, porphyrio, cyaneus, notatus, vini,

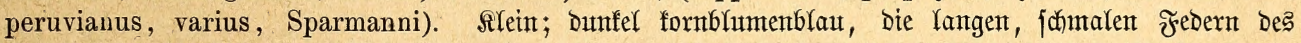

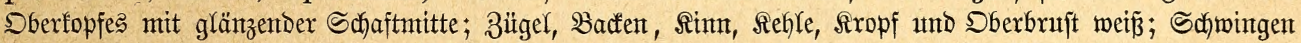
inmen breit fajwarz gerandet, am Ende fajwärzlich), Stenterfebern am Ende ebenfo, Sdjwingen unto Steuer=

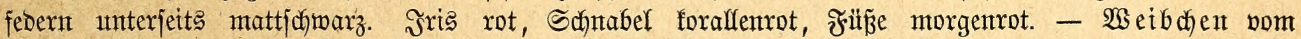

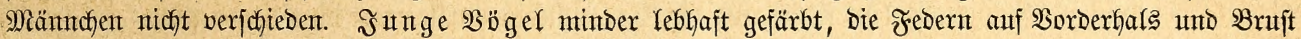

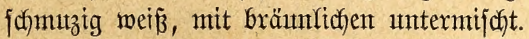

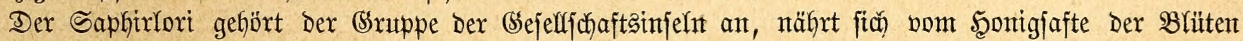

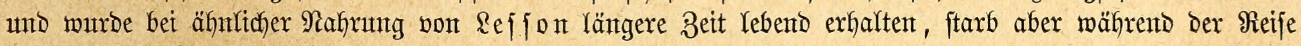
beim Eintritt in fä́ltere Sreiten unto gelangte (ebento nidatt nach) Ėtropa.

185. Der Rubiutrori, D. (Ps., Psa., Lor., Cor., Brot., Vini) Kuhli, Vig., (coccineus, inter-

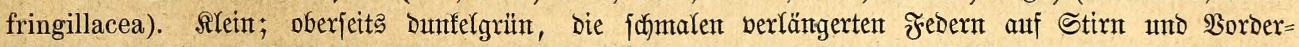
fopf ebenfo, Die auf Scheitel unb Şinterfopf Dunfel violett, Mantel oliventrün, Şinterriütẹt uno Bürzel

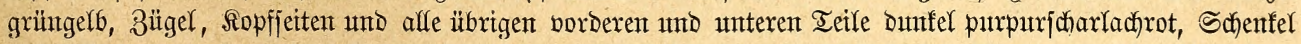
uno 2fftergegent Duntel violett, mit purpurnem Sdjinmer; Şandjojwingen fafwarz, zweite bis vierte

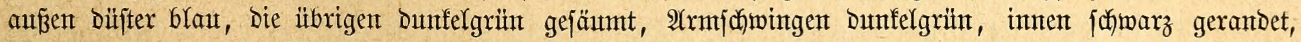
Dedfebern beider grün, Schwingen unterjeits jobwarz; Stenterfedern purpurrot, am Entoe, bie beiden mittelfiten

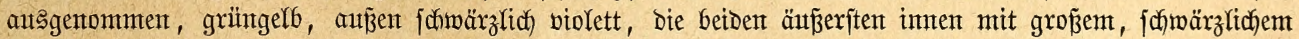

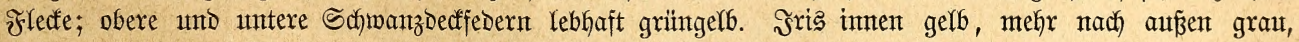

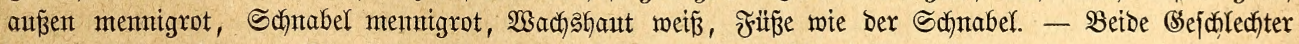

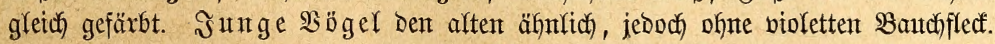

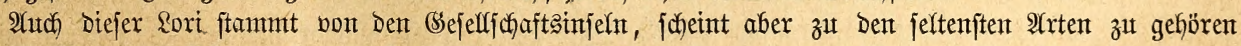

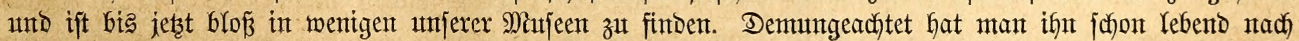
Eirropa gebradi)t.

186. Der Srjimmerlori, Imranfra bex 2 truaner, D. (Ps., L., Cor., Chalcopsitta) scintillata,

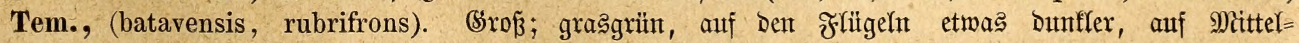

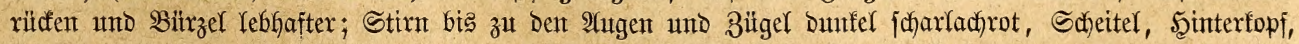

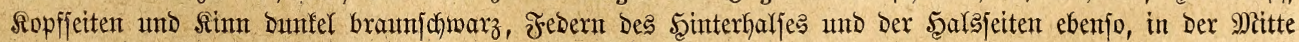




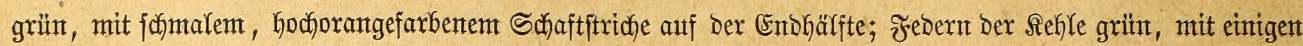

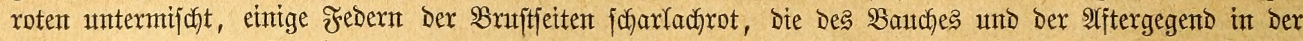

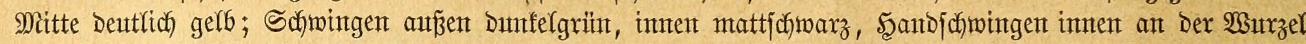

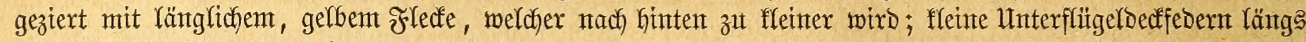

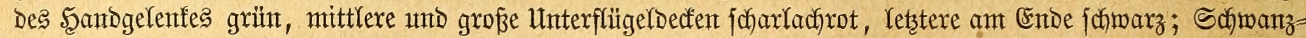

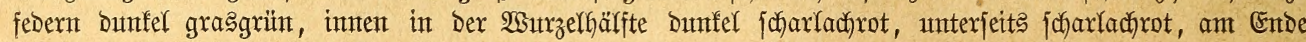

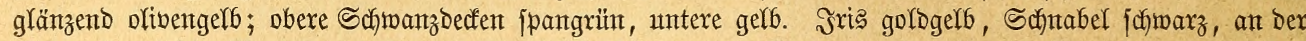

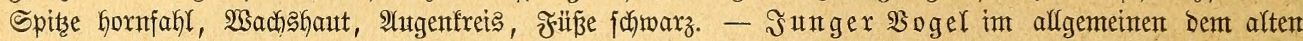

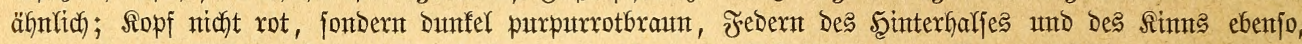
retztere in Der Mitte grünlich) and mit feurigorangefarbenten Schaftflectent am Ende, welche auf Iropf unt Bruft bläfiex merdent.

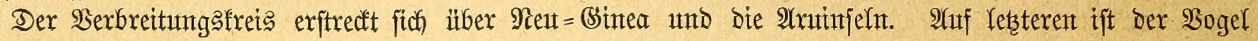
bet Den Eingeborenten fehx beftebt unD wiro häufig im Räfige gehartent.

187. Dex Sammetfori, D. (Ps., E., L., Ch., Platyc.) atra, Scop., (Novae-Guineae, Bern-

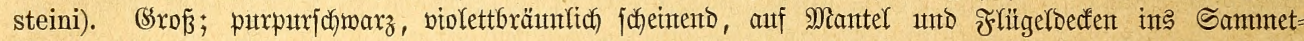

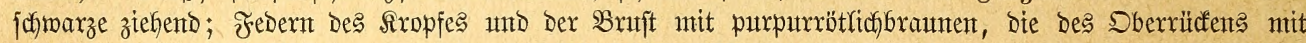

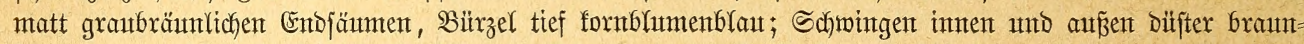

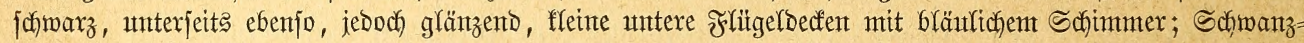

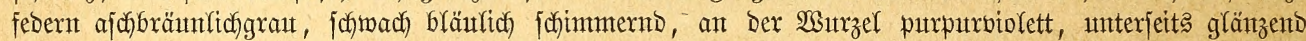

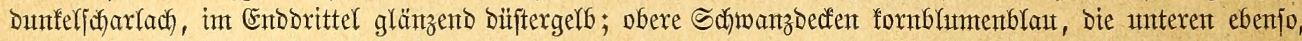

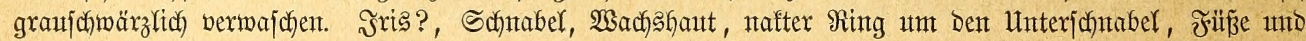

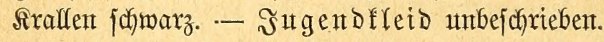

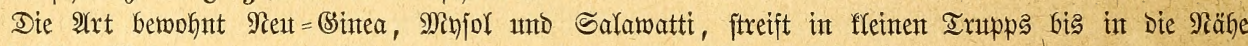

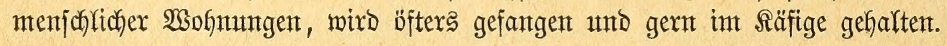

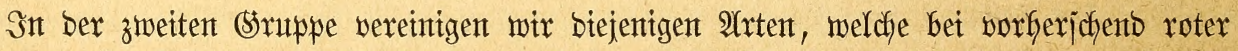
Färbung grünte Flügel unt Flügelbedfebern baben. Sie bilben nach A(njicht einzelner Natur= forjcher ben Sern ber SBreitjchnanzloris (Lorius und Domicella) überfaupt unto gefören

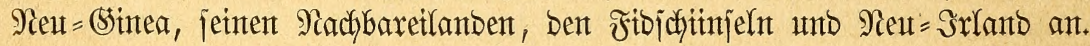

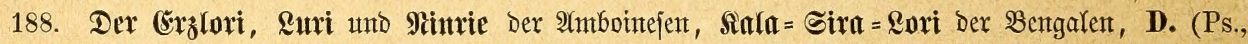
L.) atricapilla, Wagl., (domicelIa, raja, radhea, rex). (Brof́; farmintrot; Stirn umo Sdjeiter

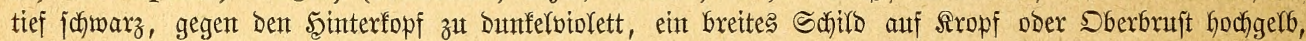

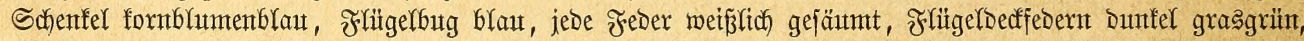

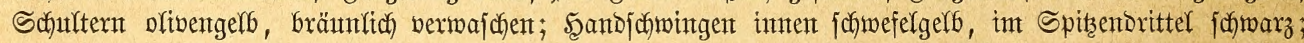
Armidgingen, Die beiden Yetzten grünen ausgenommen, inten gelb, untere Dedfedern fornblumenblan;

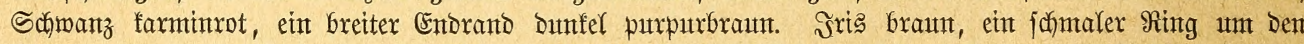

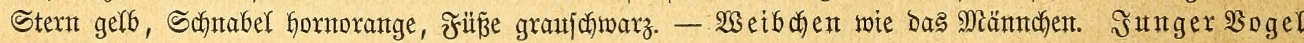
bilfterer rot, ofnte gelfes Bruftichitro.

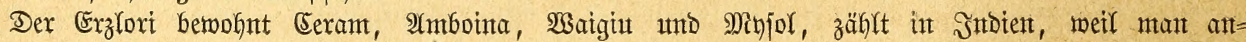

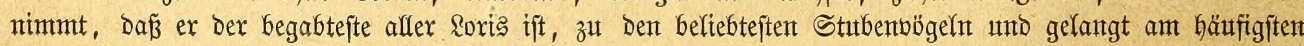
rebend in umpere Räfige.

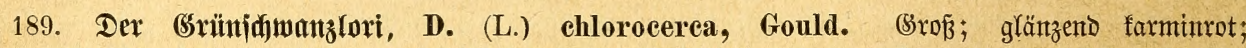

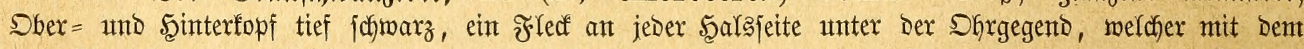

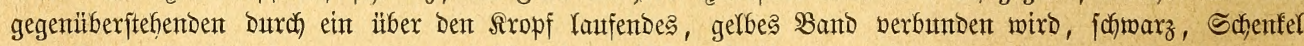

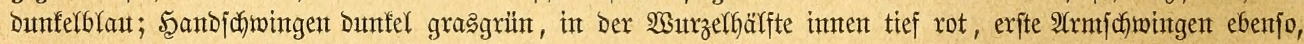

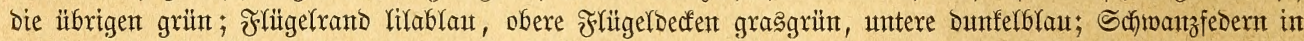

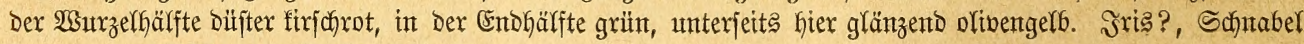

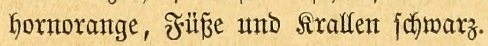

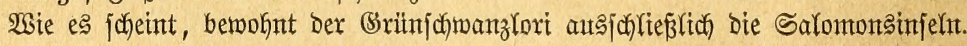

190. Der Frauentori, \$aputafori Der Bengalen, Manjaux Der Bemofner Doreł̧, D. (Ps., L.) lori, L., (lory, philippensis, tricolor, Sebanus). (Šroß̉; glänzento farmintrot; Dber = umb Seinterfopí

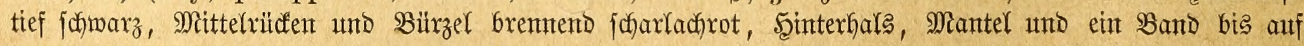

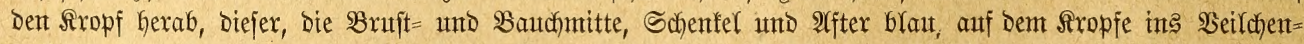

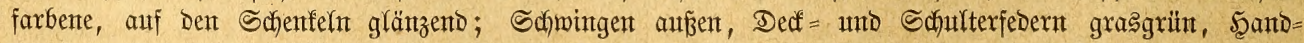

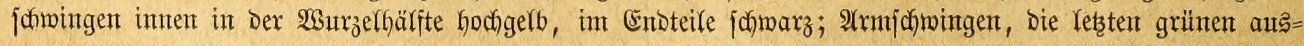




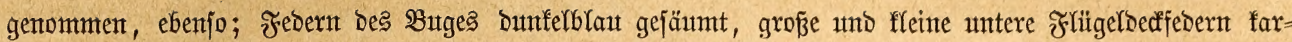

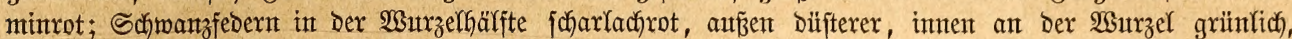

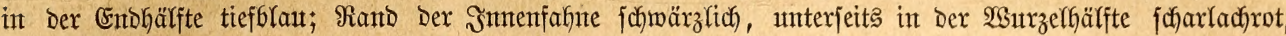

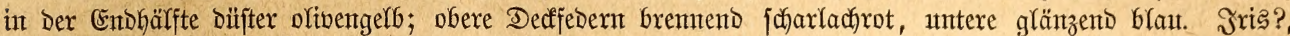

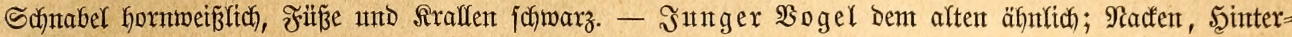

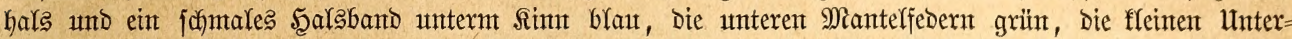

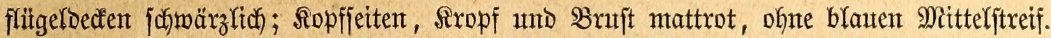

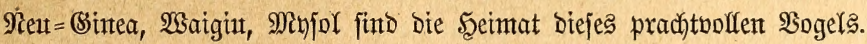

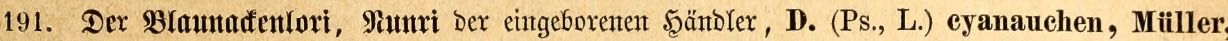

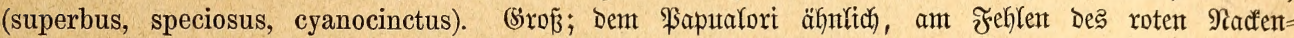

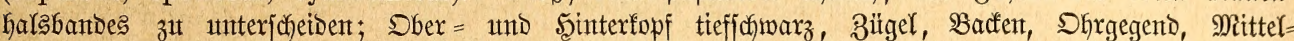

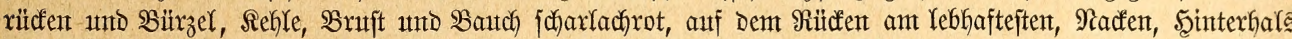

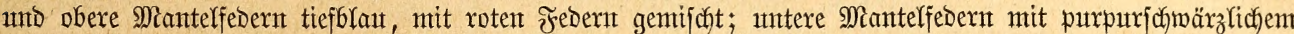

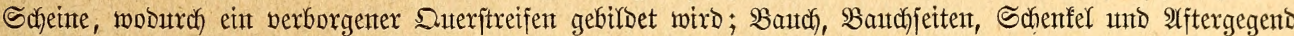

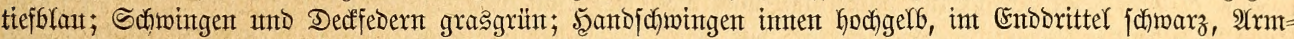

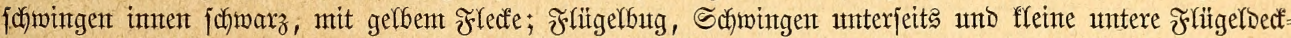

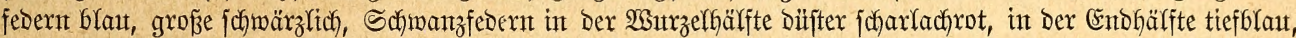

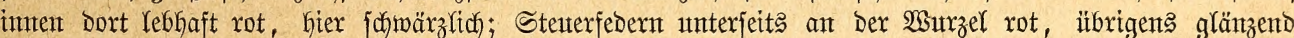

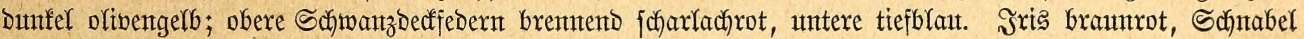

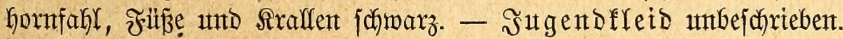

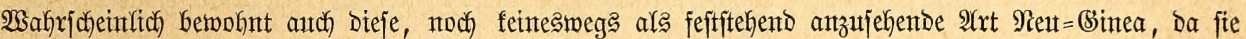

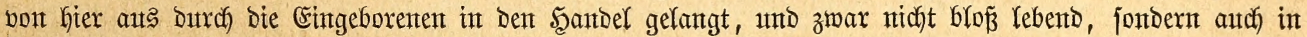
getrodtuteten $\mathfrak{B a ̈ l g e n t . ~}$

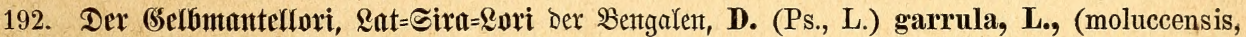

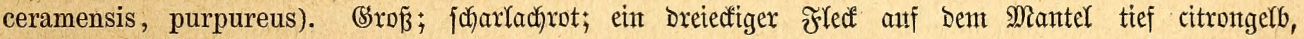

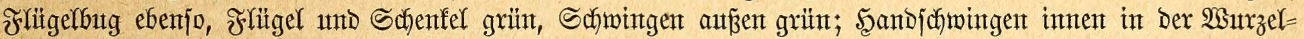

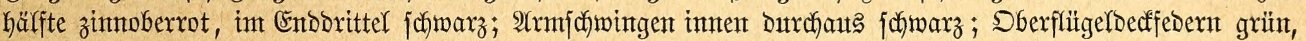

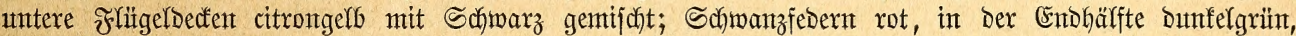

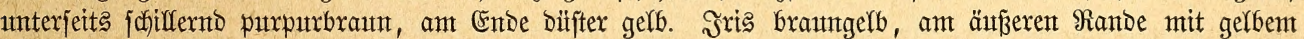

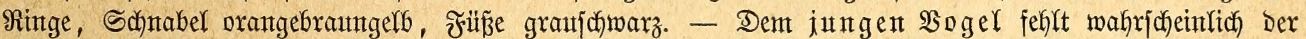
gelbe Miantelflect.

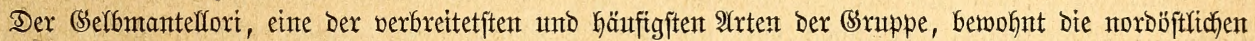

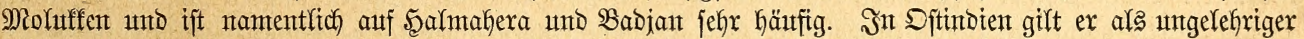
Sogel, wiro jebod) trotzoem oft in (Befantgemjedaft gebalten.

Die nodh übrigen $\mathfrak{A}$ rtent ber Sippe, weldye $\mathfrak{W a g l e r}$ unter bem Ramen Eos von ben genannten getrennt hat, fund ebenfalfs rot, ifre Flügel unt Flügelbedfebern aber nidgt grün.

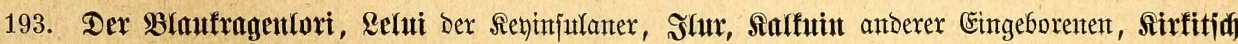
ber Bentgafen, D. (Ps., E., L.) rubra, Gml., (chinensis, coeruleatus, cyanotus, cyanurus, guebiensis,

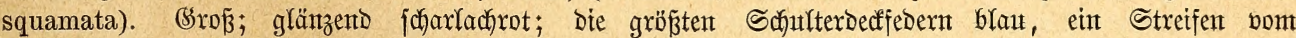

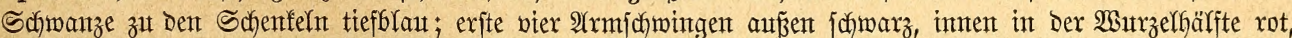

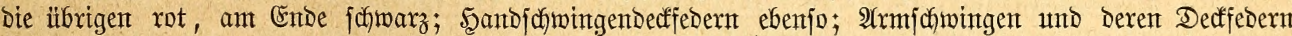

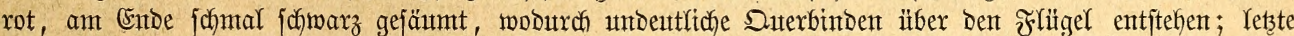

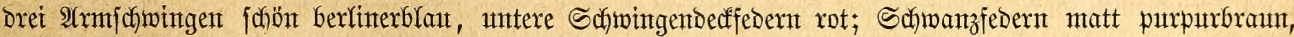

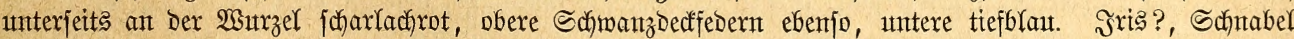

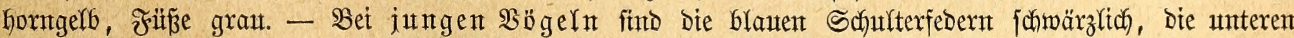

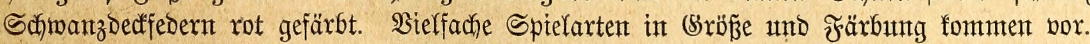

গmbointa, Butru, Banda, Ceram und andere Eifande biefer Begend find bie Secimat biefes häufigen Sogels, welejer ebenfalls in (sefangenja)aft gehalten wiro.

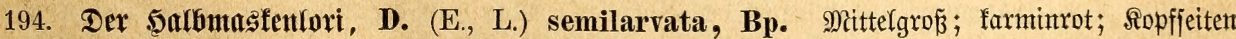

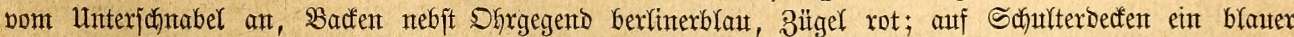

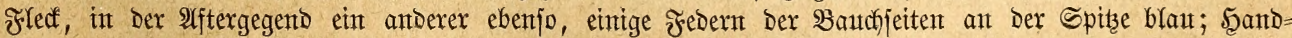

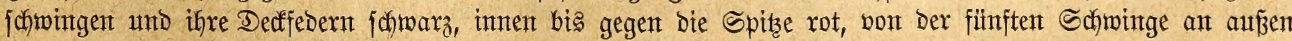

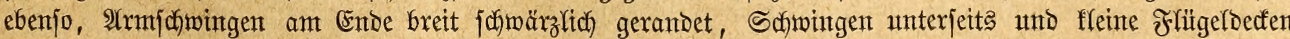
fharfachrot; Schmanz oberjeits matt Dumfer purpurbraun, imnen bis gegen bie Spibe fdarfach, unterfeits 


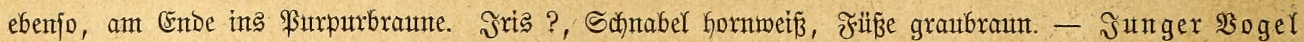

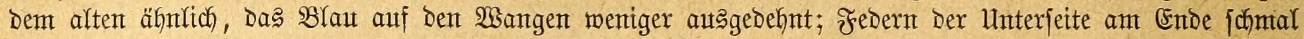

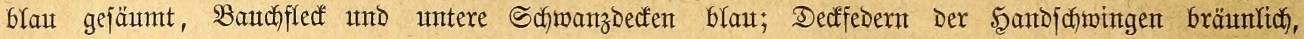
aนก̃

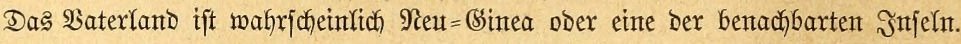

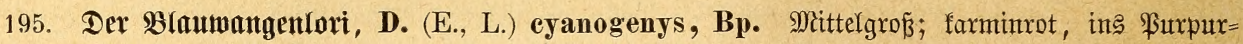

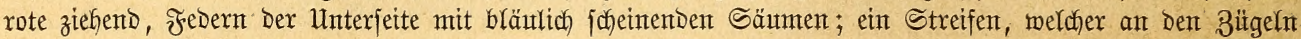

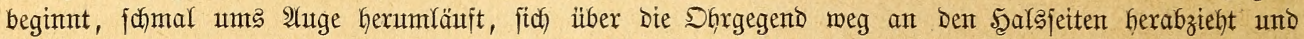

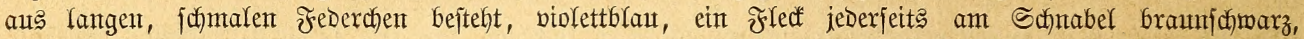

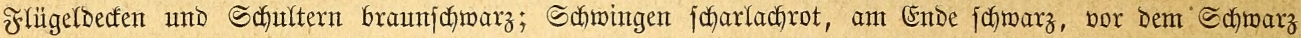

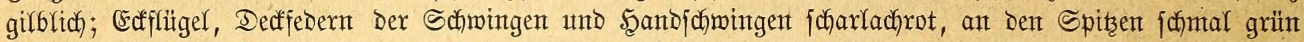

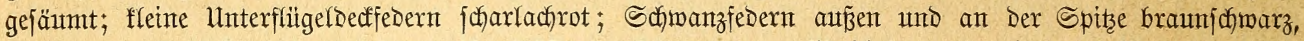

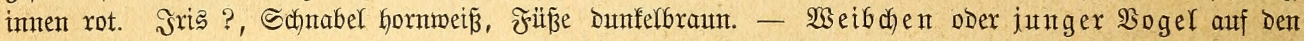

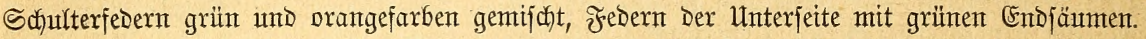

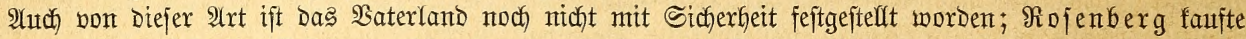

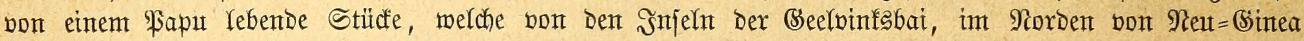
herftammen follten. Waflace erbielt andere angeblich eben baher.

196. Der Stridfllori, Iata= $=\mathfrak{B a} \mathfrak{a}=$ Sitrfitid Der Bengałen, D. (Ps., E., L.) reticulata, Müller, (cyanostriata, cyaonstictus, guttatus, borneus). Mittelgroß́; farminrot; bie auts zugefpitżten, ranzett= förmigen Federn gebilbeten Shrbecten Dunfel violettblau, Sberriüfen fatwach violett angeflogen, Die End=

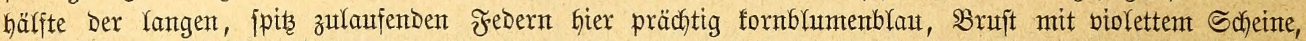

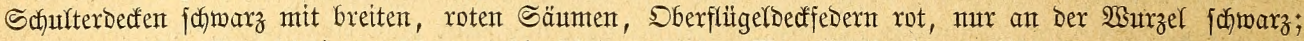

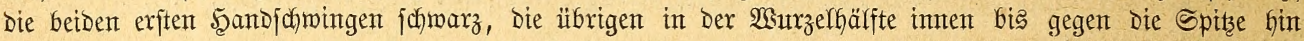

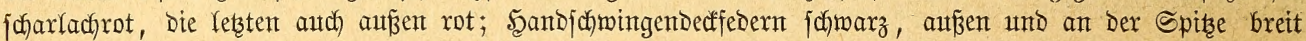

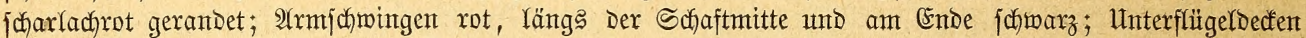

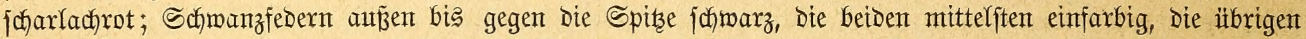
innen und unterfeits rot, am Ende in fejiffembes Bselb ïbergefend. Jris brautn, Santabel orangerot,

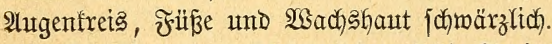

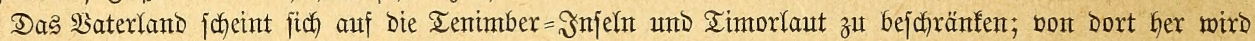
Dex 2 ogel bifters lebent nach Mafaffar gebradgt und gelangt bann auch nach) Eitropa.

197. Der Diademlori, D. (Ps., E., L.) coceinea, Lath., (histrio, indicus). (Broß̋; farmint= rot; ein breiter, blauer Duterftreifen bon einem 2luge zum anderen über bie Scheitelmitte weg und ein

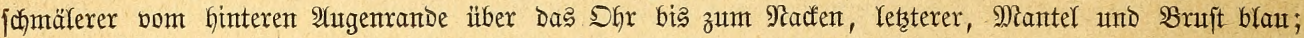

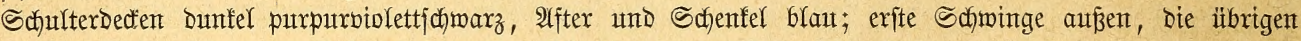

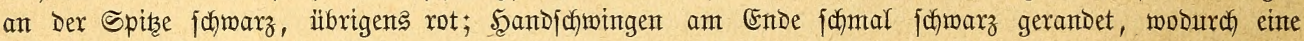

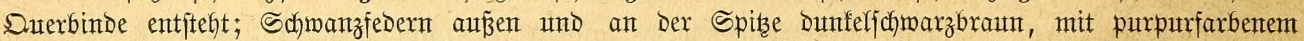

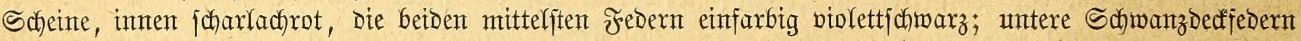

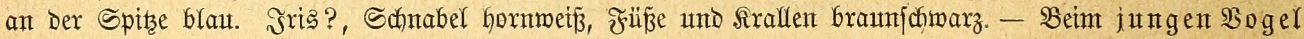
ift DaS blaue Suterband über Den Sdjeitel nur angedeutet und bie blaute Suerbinde über bie Burt mit roten Federn gemijatt.

Rebt auf Den Schangir = Injefn im 9lorden won Eelebes.

198. Der ภapuzenfori, D. (Ps., E., L.) riciniata, Bechst., (cucullatus, Isidori, cochinchinensis,

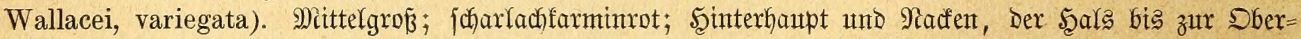

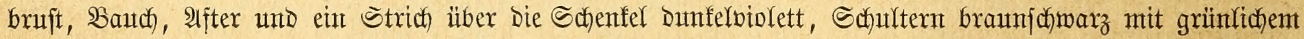

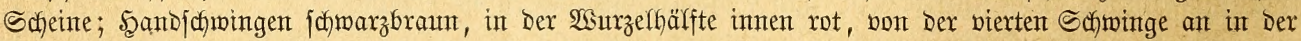

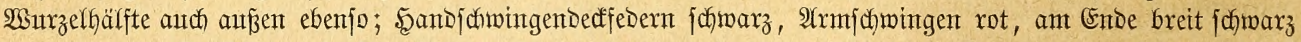
gerandet; Die Decffebern ebenfo gefärbt unt gezeidynet, wodurch zmei fafwarze Duterbindent auf Dem Flügel entiftehen; obere und untere Frlügeldeden rot; Sdjwanzfedern purpurboraun, unterfeits am Endoe ins Belbe

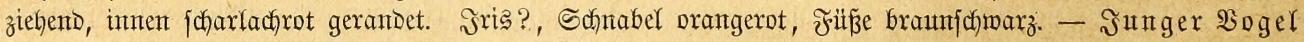
Dem alten ähnlich), žedern Der Unterjeite am (Ende büjter violett gefäimnt.

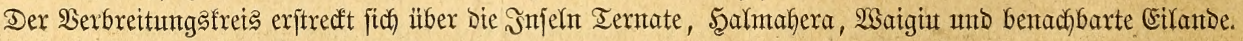

Die Sbettichnanzloris teilen mit ben meijten interbalb ifres Berbreitungsgebtetes vor= fommenten Bögeln basjelbe Scficfjal: ityre Rebensmeije ijt fo gut als umbefannt. Wix

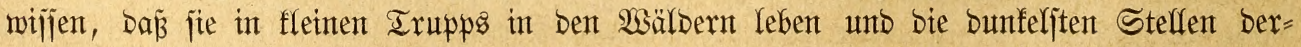

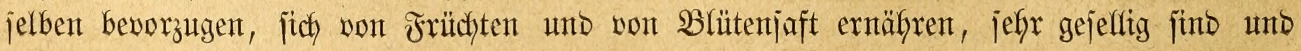




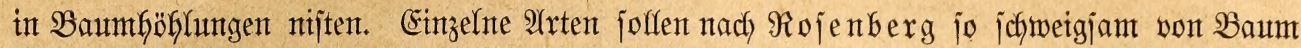

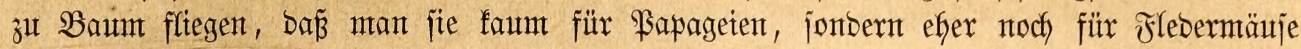

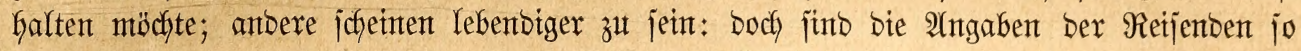

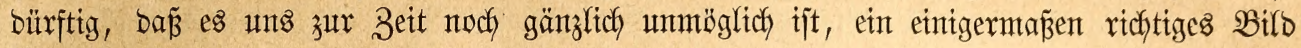
iffes Jreilebents zu geminnent.

Shrer Sdjöntheit halber werben bie Breitjchwanzloris von ben Eingeborenen regelmäp̈ig in (sefangenjchaft gehalten, als Iaujchgegenitänbe von einer Snjel zut anderen gefüfyrt und Den Reijenben angeboten. Heber ben Fang gibt ein ungenannter Beobachter eine furze Mitteilung. Die freijtefenten 3weige eines Baumes, weldye gerabe ben heiren Sonnent=

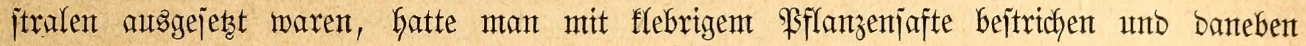
einen zafmen, mittels eines Siettchens befejtigten sort als soctwogel aufgeitellt. Durch jein

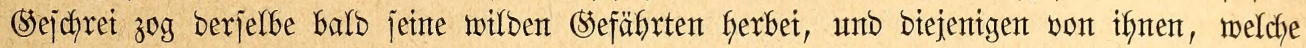

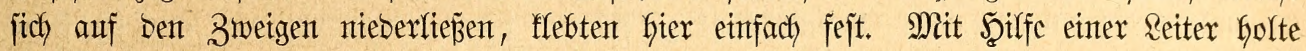
bie Bogeljtelferin ifre Sefangenen herab, nadybem jie jich vorher bie Şände mit Tüchern ummidfelt hatte, um jie vor ben empfintlicfen $\mathfrak{B}$ ifjen Der $\mathfrak{B}$ ögel zu jichern.

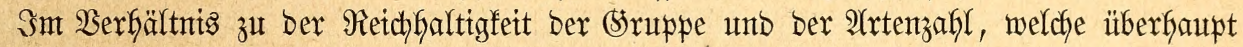
in Befangenjdhaft gehalten wirb, gelangen mur jefrx wentge biejer herlichen Bögel rebento

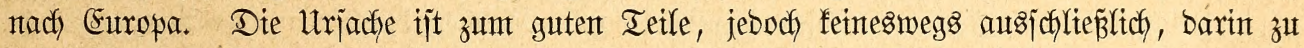

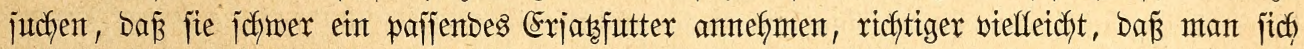
in iffrem Baterlande nidgt bie Miübe gibt, jie an eine Yeidyt zut bejdyaffente unt ifnen zu=

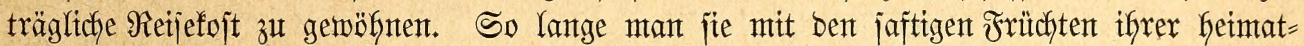

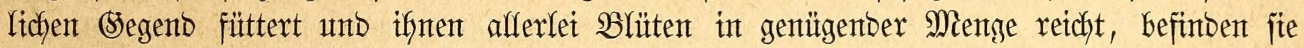

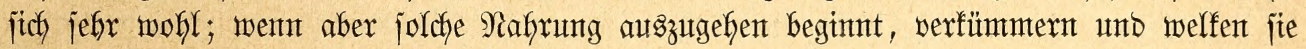
Dafin. Nitcht jo ijt es mit benen, weldye als bereits eingemofnte Räfigbögel in bie Şänbe Des europäij fyen Sdjiffers gelangen. Sie werben untermegs Gauptï̈chlich mit hart gcfochtem

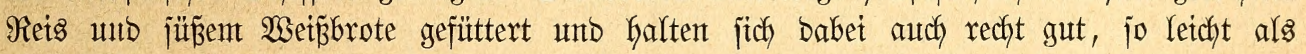

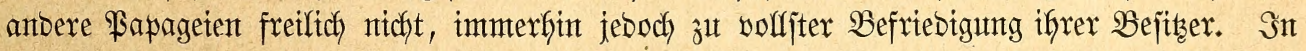

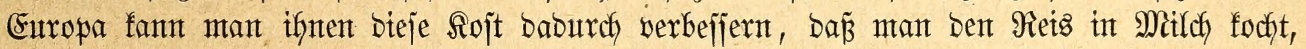

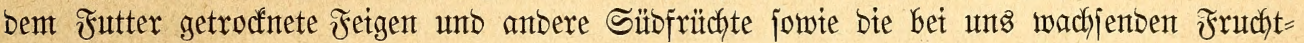
arten uno nach unb nach Dem (sanzen etwas Šanj beimijacht, beztehentlich biejes treffliche

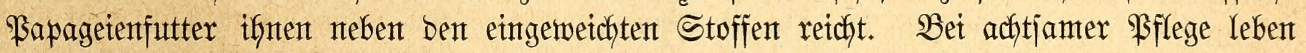
fie viele Sabre lang in bejten Wobljein; jie verlangen aber, wie Giermit nachorüdflich betont jein joll, eine in jeber Şinjidyt jorgfältige Albwartung unt namentlich gute, b. h. gleidy=

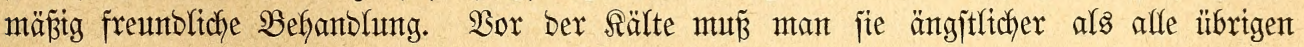

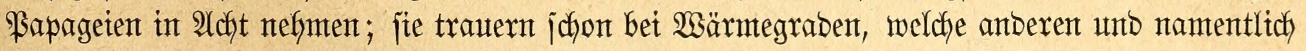
aujtralijchen $\mathfrak{A}$ rten nidft im geringiten bejchwerlich merben. AYts biejem Srumbe barf man fie autch mur bet bent jchönjten, wärmiten Wetter in bas Frete bringen, fier aber unmittel= barer Bejontung nidyt ausjeben. Ein milber Sommerregen johabet aud ifnen nidfot, wenn man bie nötige Slahtjamfeit bejitzt und fie unmittelbar nach Demjelben in einen wohl Durds=

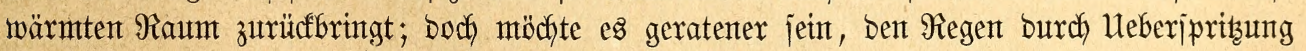
mit laumarmem $\mathfrak{B a j j e r ~ z u ~ e r j e b e n . ~ S i e ~ b a b e n ~ g e r n ~ u n d ~ b e d u ̈ r f e n ~ b a f e r ~ e i n e r ~ j o l d j e n ~ ( s i n = ~}$ näjĭung ebenjo nöttg als irgento ein anberer ifrer Dronung.

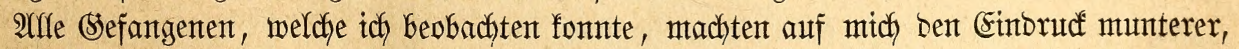
lebhafter, gewedter und fluger $\mathfrak{B}$ öger. Sie fint währent bes ganzent Tages in Bemegung unt adhten auf alles, was fich in ifrem Beretche zuträgt, bejwäftigen jich bald mit biejem

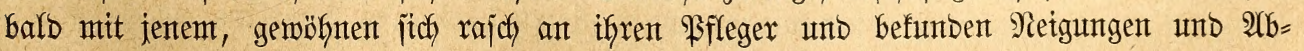

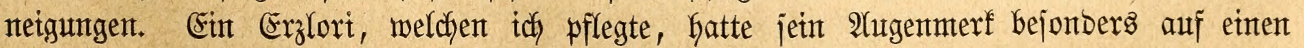

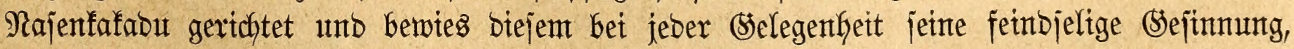




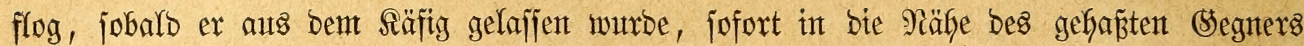

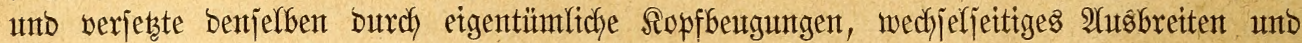

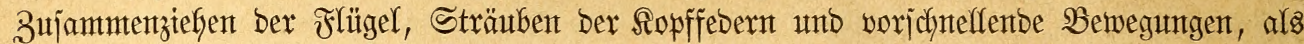

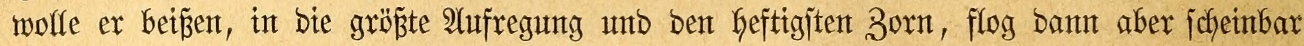

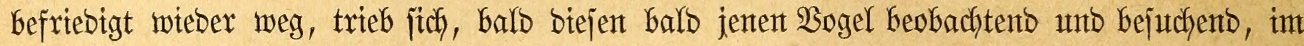
Bimmer umber und fefrte jobant von neuemt zu bent inzmichent etwas rufiger gemorbenten Wiberjacher zurücf, unt ifnt nodynals Gerauszuforbern. Berträglich fonnte mant meinten sori nicht nenten; wentgitens lebte ex bló̉ mit fleineren $\mathfrak{B}$ ögeln in Frieben, währent ex anderen Bapageien gegentïber ftets eine gewiffe Erregung und untwerfentmbares Hebelwolfen an Den Tag legte. Scierunter Gatte jelbjt bie int ganzen jefr Garmloje Maatafa zu Yetben, obgletch

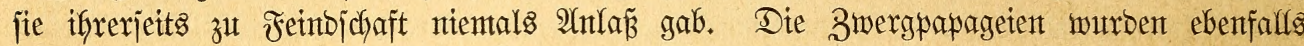
bejucht, fanben aber balb feine Beadhtung mefrx, weil fie fich beint Erjoheinen bes Roxi

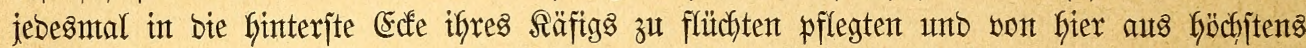

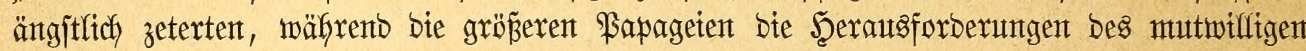

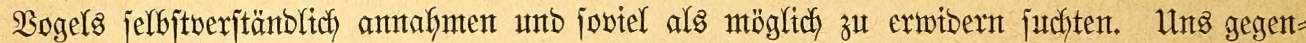

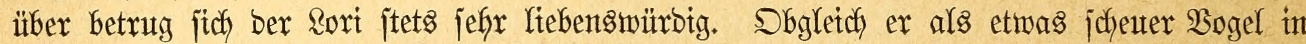

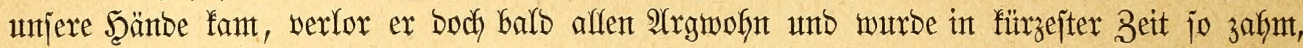

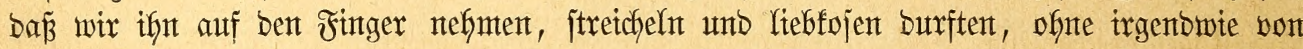

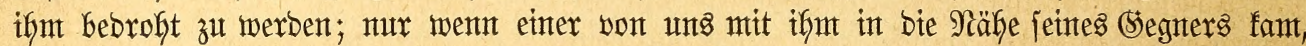
ïberwog bie Feintojchaft gegen biejen bie 2Antjänglichfeit an uns, und ex pflegte bant in gemofnter Weije jeinte Rampflujt an ben Iag zu legent. Bei einer Derartigen Belegenfeit

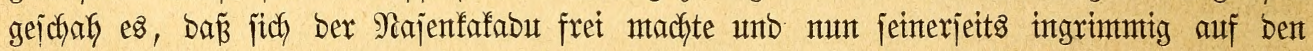
Rort zujtürzte. Wix retteten biejen, nodh efge ex won bent wütenden fiafabu erreidyt werben fonnte, bradfent ifyn in ein anberes 3immer unb verjudten jeinte Alufregung foviel als

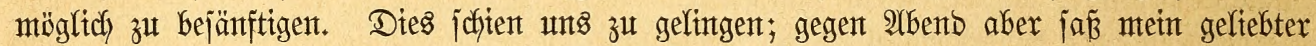

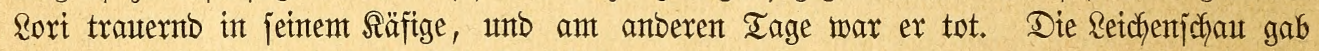

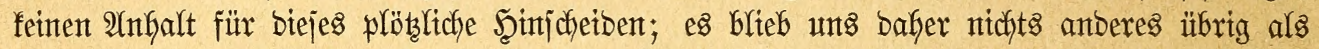

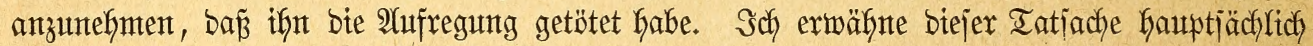

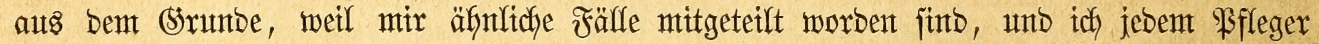
raten möchte, gefangene Roris oor Bemütserjedütterungen jorgfältig zu Kemafyren.

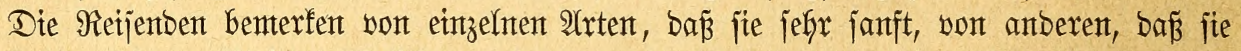
jefr heftig jetent. Meiner ÂAjicht nach tut mtan Untrecht, berartige Bemterfungen auf

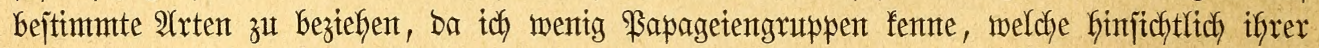
Begabung fo viel Heberemitimmung befunben als gerabe bie Roris. Dagegen ijt es gewís

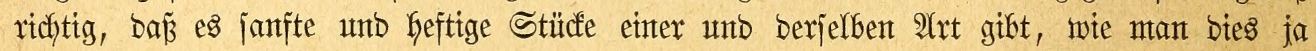
auch won allen übrigen Papageien beobadjten fant, unt wohl auf Die Sergangentheit bes

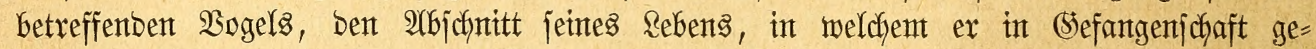

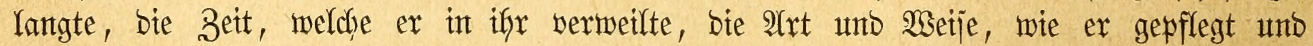

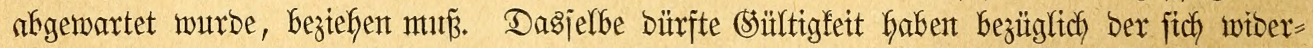

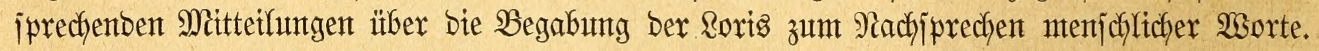

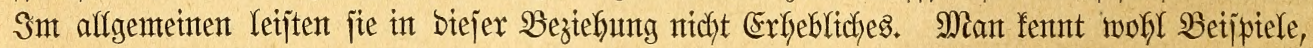

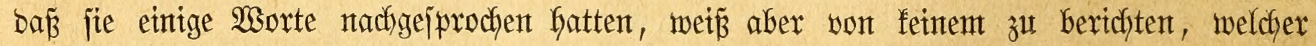

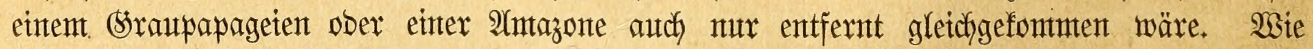

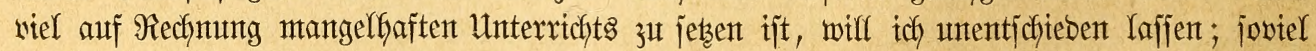

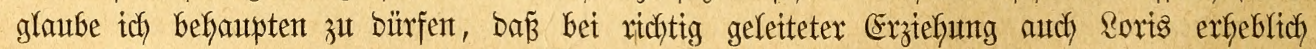

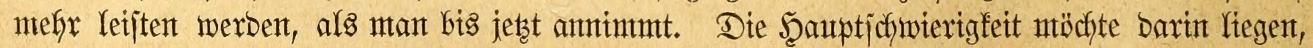
junge $\mathfrak{B o ̈ g e l ~ z u ~ e r h a l t e n . ~ S r a u p a p a g e t e n ~ g e l a n g e n , ~ w i e ~ b e m e r f t , ~ r e g e l m a ̈ ß ̄ i g , ~ 2 A m a z o n e n ~}$ minbejtens jefr oft in ifrem exiten Rebensjabre in unjere Scänbe; bei ben Roris ijt bas 


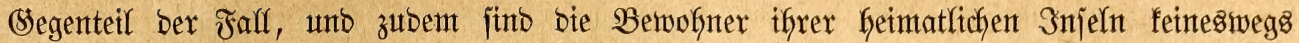

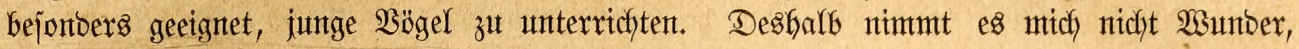

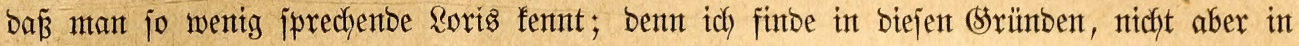
mangelnber $\mathfrak{B}$ egabutng unjerer $\mathfrak{B}$ g̈gel bie einfache unt genügente Crrffärung bafür.

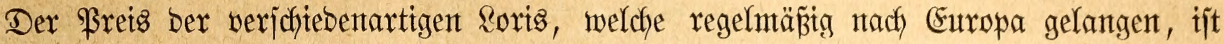

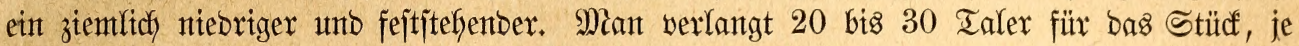

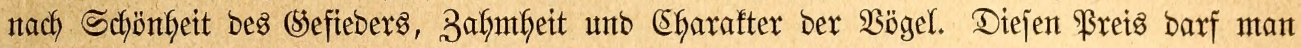
gering nenten, wenn es fich, um einen gut eingewofgnten 2 Bogel Ganbelt, ba mant bebenfent mut

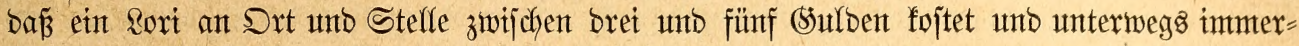

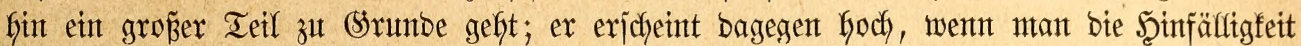

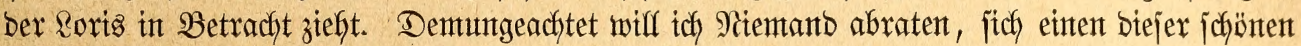

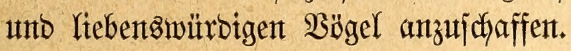

\section{feillidhwamlorts.}

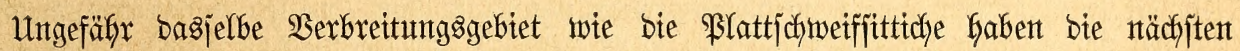

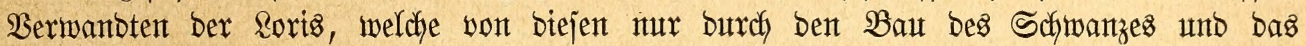

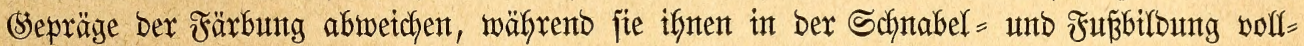
fommten ähnteln.

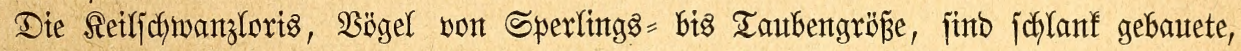

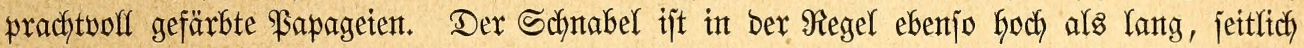
zujammengebrïlatt, auf ber Firrjte fantig, jeine Spitze verjchmälert, jtarf herabgebogent unt

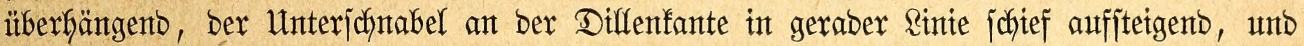

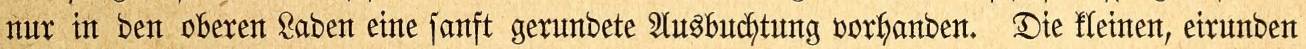

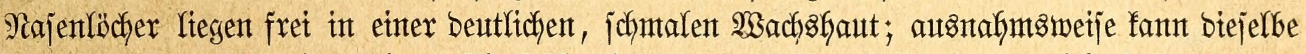

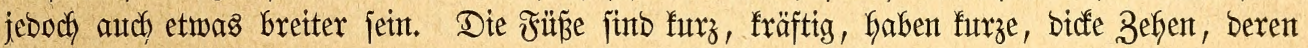
äuß̌ere vorbere bent Rauf an Ränge übertriffft, unto tragen berbe, gefrüntntte शä̈gel. Der lange, ipitze Flïgel, welcher zujanntengelegt bis an bas Enbe ber oberen Sdywanzbectent

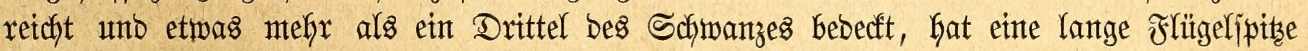

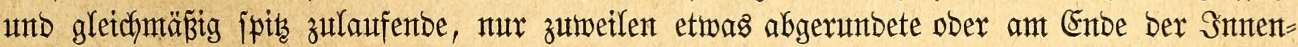

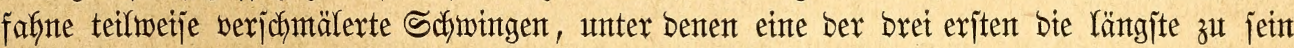

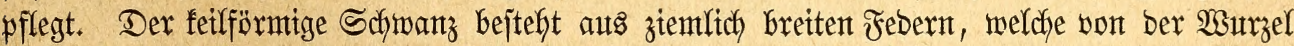

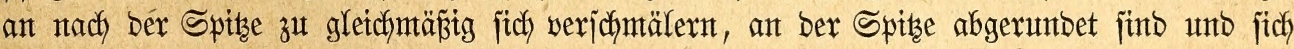

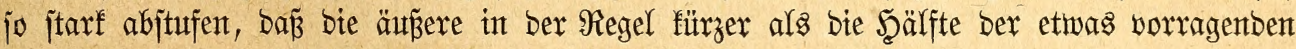

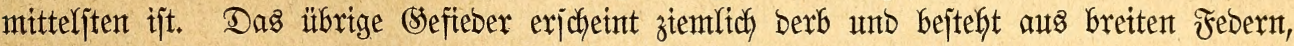

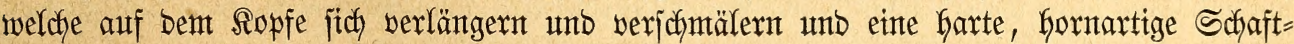
mitte zeigen. Uleber bie Farbengebunt lä̈st jich int affgenteintent faumt etrwas jagett. Die

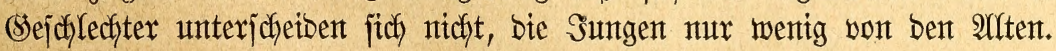

199. Der Allfarblori, Pflaumenfopf ber Şändlex, Trichoglossus (Ps., Australasia) NovaeHollandiae, Gml., (haematodes, haematopus, cyanogaster, multicolor, Swainsonii, semicollaris).

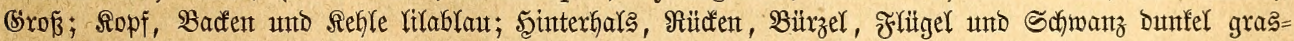

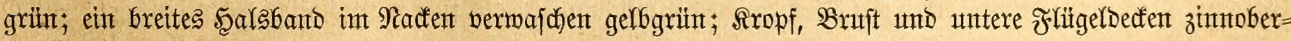

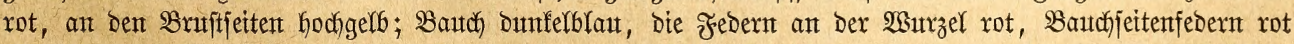

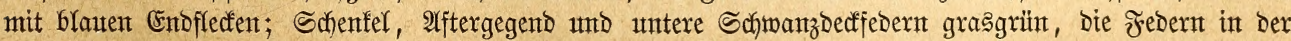
Mitte gefb unt an Der Watrzel rot; Schiningen imten fdywarz, int Der Mitte mit breitem, gelbem Fłlede;

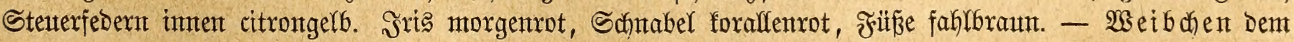

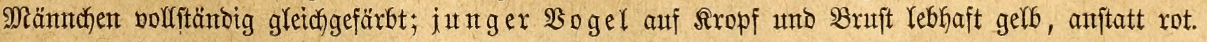




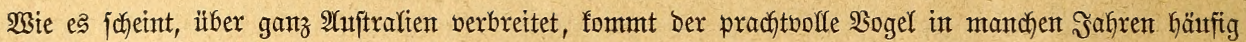

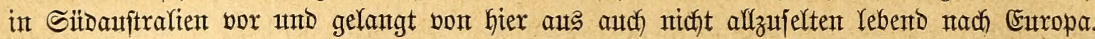

200. Der Rotbruitlori, Tr. (Ps.) haematodes, L., (capistratus, haemadotus). Broß̋̃; פ̧order= fopf, Bacent unt Simm Dunfer violettblaut mit fadmärzlichem Scheine, Şinterfopf Dunfelgrün, ein

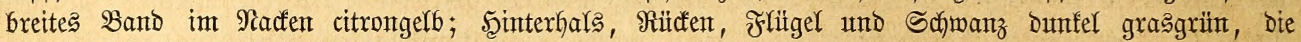

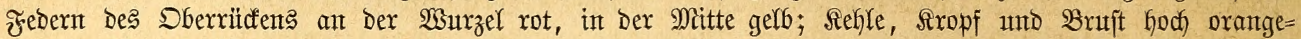

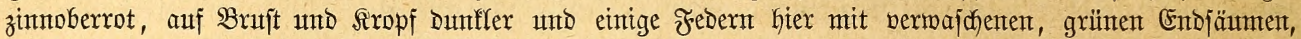

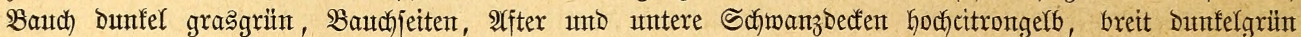

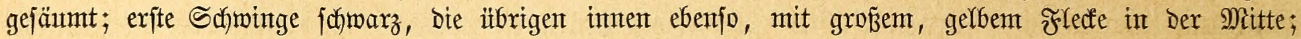

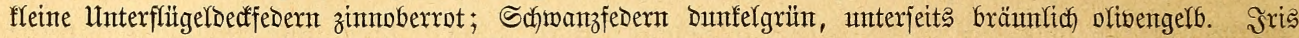

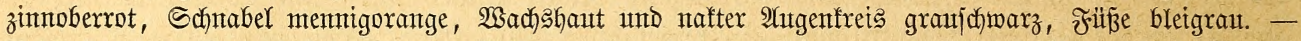

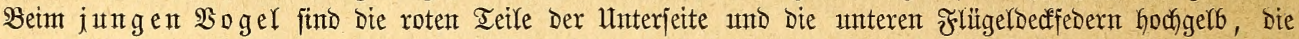

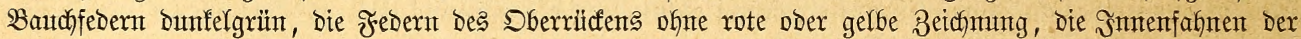
Stenterfedern gelb gerantoet; Das Ractentbanto grünlich verwajchetr.

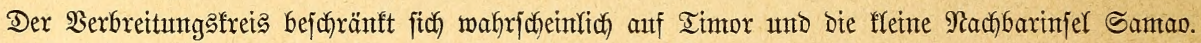

201. Der Blaumangentori, Sitifi, Farian und Sirtein Dex Eingeborenen, Tr. eyanogrammus,

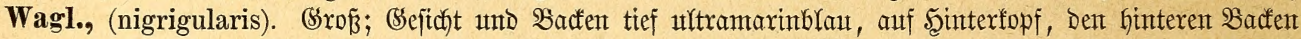

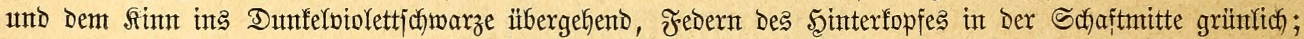

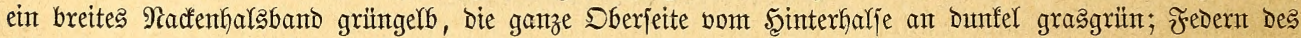

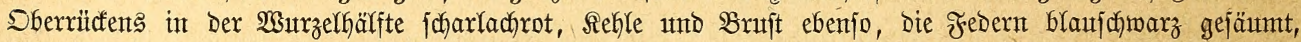

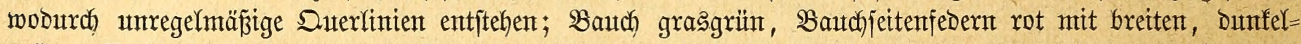

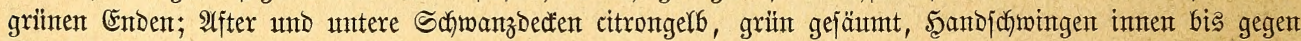

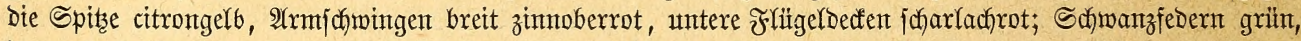

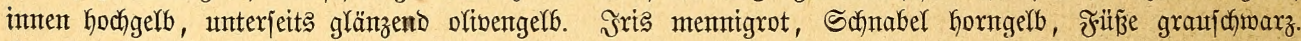
Эugendfleid umbejdrieben.

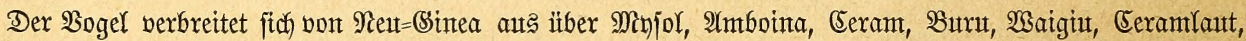

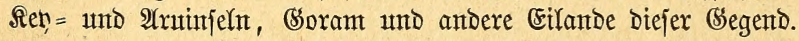

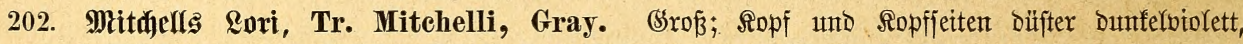

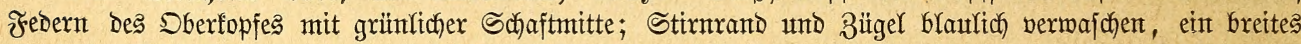

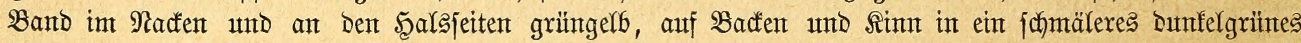

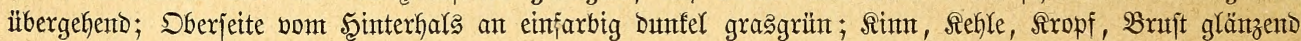

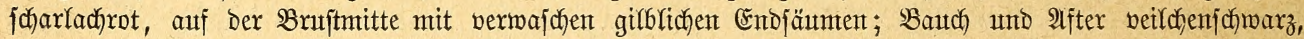

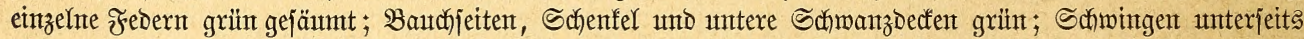

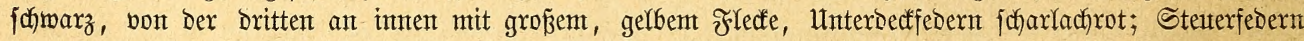

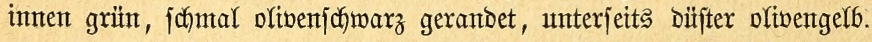

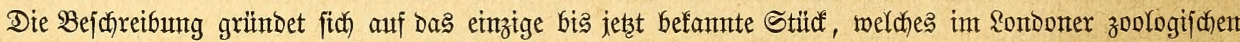
(Barten gelebt hat.

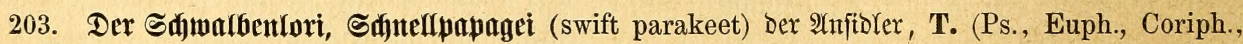
Nan., Lath.) discolor, Shaw, (humeralis, australis, Lathami, Banksianus). Mittelgrooß; oliven=

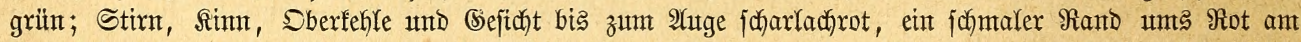

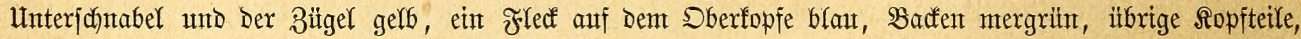

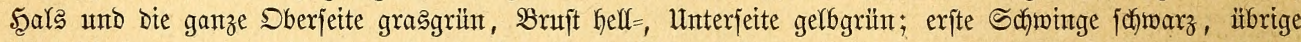

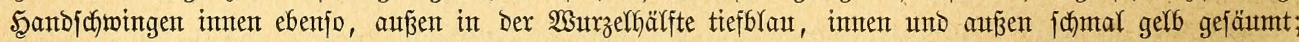

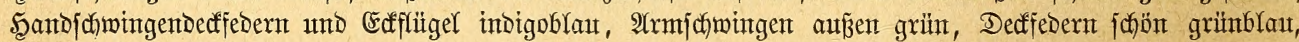

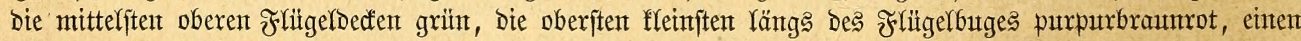

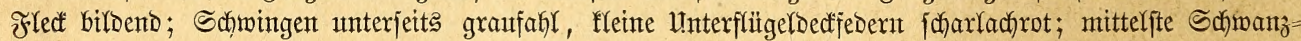

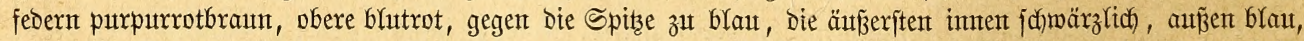

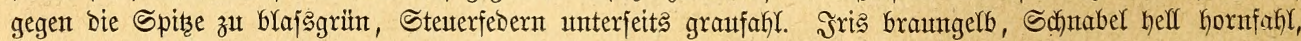

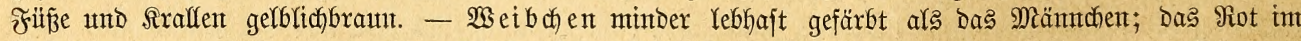

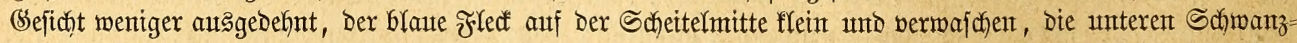

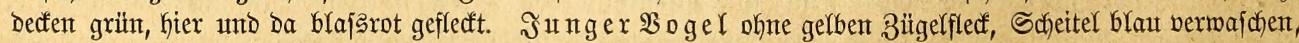
Sdjwingen grün, Untterflügeldecten gelbgrün; Schwanz oberjeits grün, unterjeits brau, bie feitfichen Sdymanzfedern gegent bie Wurzel zit rot verwajden.

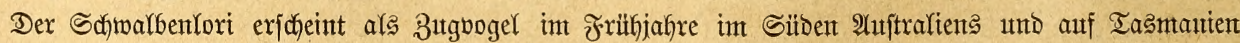
unto zieft mit Beginn bes Seerbjtes wieber nörolidy. 


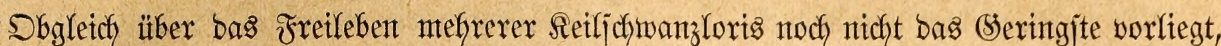
bürfen wir boch antmefymen, bie Rebensweije biejer $\mathfrak{B a ̈ g e l}$ ziemficty gut zu fenten. Dies

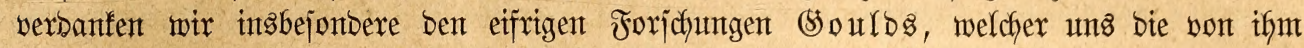

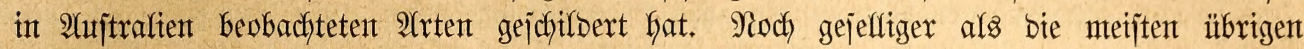

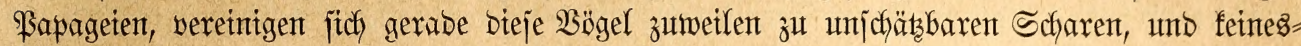

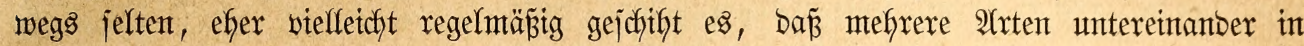

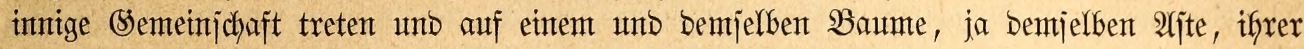

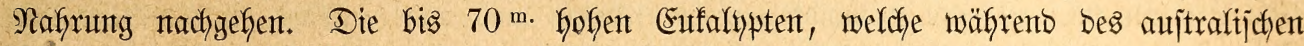

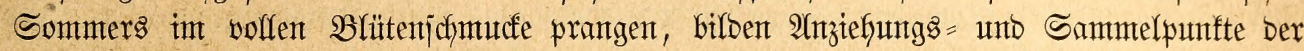

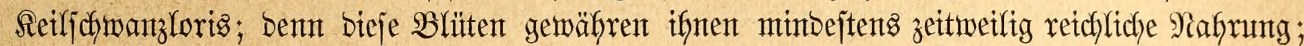

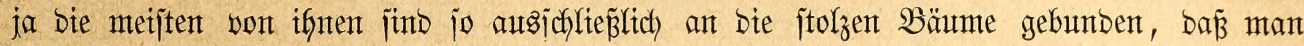
fie faum ingent anberswo wafhrninmt. Sieine bejdyreibung, meint (5ould, bürfte im

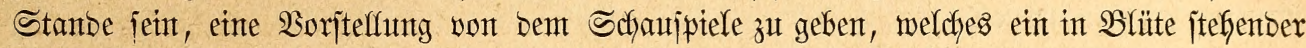

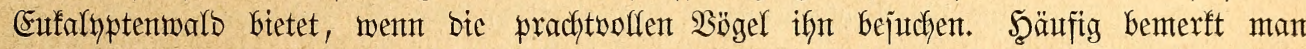

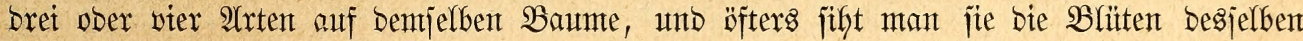

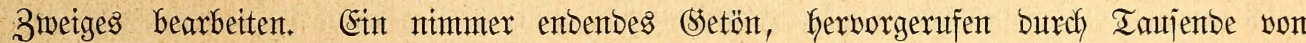

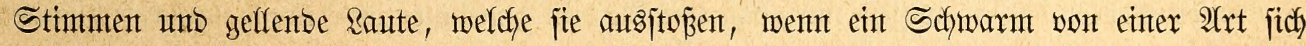

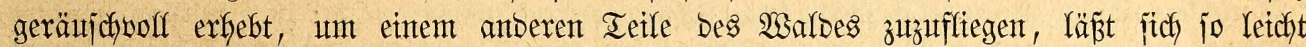

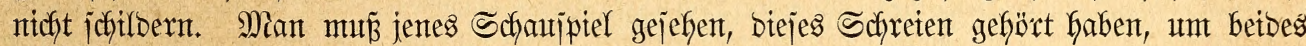
mirflide volfftäntig begreifen zu fönten. So eifrrig fint fie in ben Stunben nadh Sonnten=

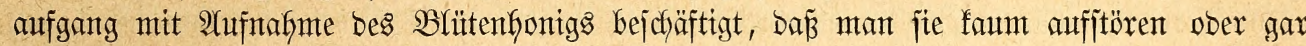
von einem Baume, auf weldhem fie gerabe frefjen, vertreiben fant. Ein unter jie gefenerter

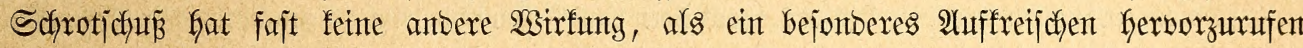
ober fie zu betwegen, jich auf ben benachbartent 3weig zut begeben, auf weldhem fie augen=

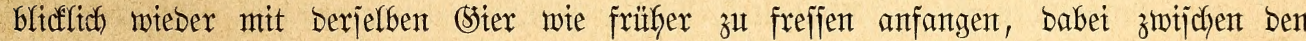
Biättern burcdffriechento uno ant bie 3rweige fich Gängento in jeber benfbaren Steflung.

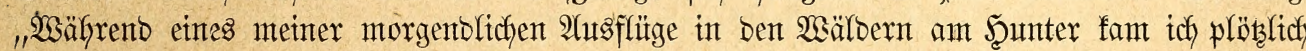

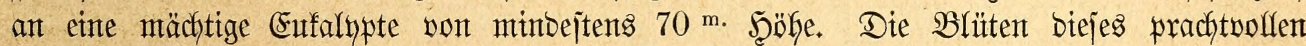

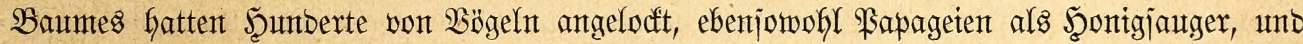
von einem einzigen 3 weige erlegte idf vier verjofiebene $\mathfrak{A}$ trten ber eriteren, was ich erwäfhnen

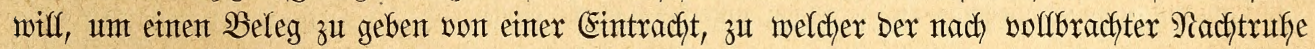
lebhafte Şunger mofil Das Seinige beitragen $\mathfrak{m a g}$, ba idh zu anberen Tagezzeiten beobadjtete,

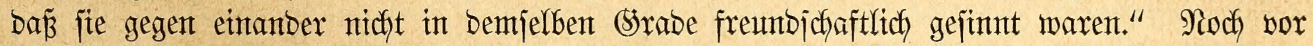

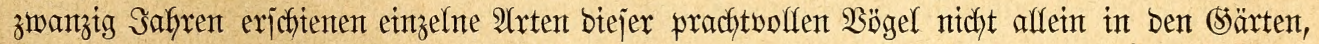
jonbern jogar in bent volfreichent Strap̃en aujtralijcher Stäbte unt bewegten jich ofhe alfe Scheu vor bem Menjichengemoge in Demjelben. Şeut zu Tage ntag bies woffl anbers gemorben jein, obgleidh bie Seiffichwanzloris unzmeifelfaft noch überall ba fich finbent werben, wo Euffa= Iypten Der vernichtenten 2 (xt Des 2 Anjiblers entgangen finto.

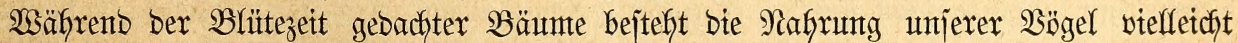

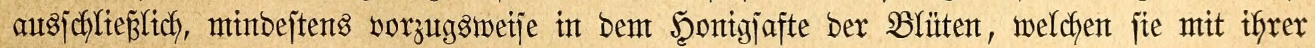

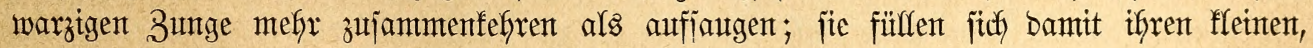

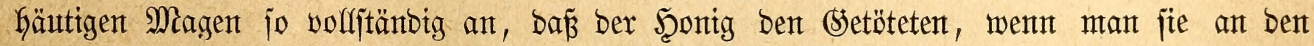
Beinen emporkebt, als ein Stront zun - Sdynabel heraußläuft. Sb fie nebenbet audd Rerb=

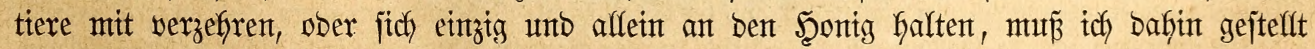

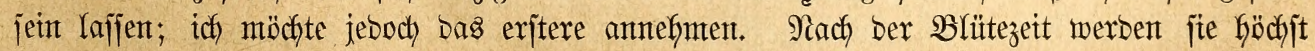

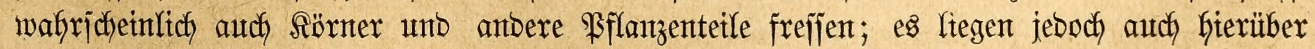

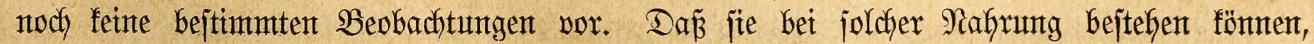
unterfiegt feinem Zlweifer: unjere Stefangenen beweijent bies zur Stenẗge. 
Sn iffen Bemegungen wetteifern bie Seilichwanzloris mit Den jdynelfiten Papageien und Sittidjen: Der Sdjwalbenlort trägt jeinen Namen nicht aus bem (Srunbe, weil ex einter Sdimalbe ähnlich figt, jonbern beshalb, weil ex eine ber ifrigen ähnelnbe Stimme und

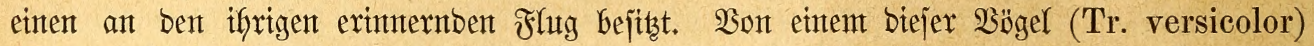

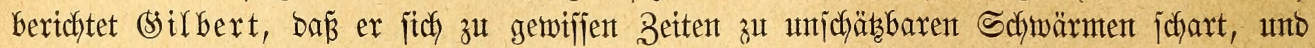

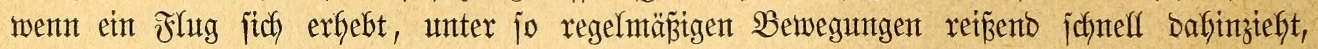
Daßj man zu ber Meinung verlettet werben möchte, eine $\mathfrak{B o l f e}$ zu jehen, welche mit rajenber

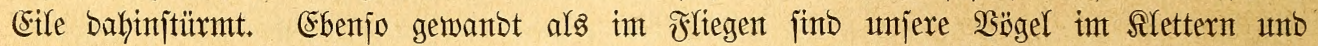
Iurnen in Sezweige; fremb bagegen exjdyeinen fie auf bem Sboben, welchen fie autch

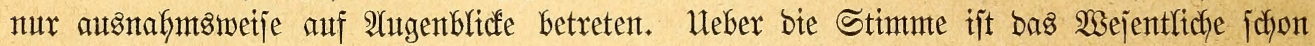
in ben Mitteilungen (\$oulds entfyalten; fie bejteft Gauptjächlich aus jofjarfen, geflenben

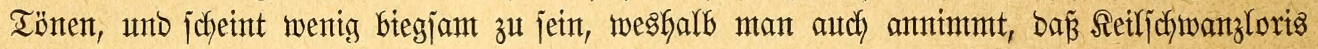
nientals iprectyen Yernent.

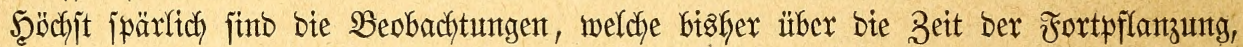

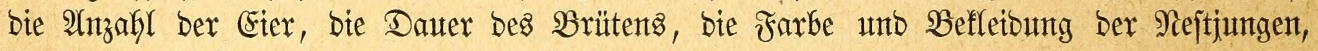
beren Entmidfelung und bas engere Familienleben unjerer $\mathfrak{B o ̈ g e l}$ angeitellt, ober boch ver=

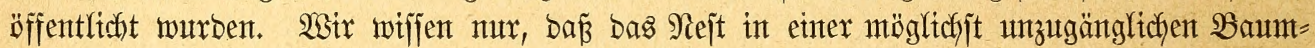
föblung antgelegt wirb und zwei bis nier weipe Eier enthält. Sb einte ober mefrere Bruten int Safyre gemadht werben, ijt zur Zeit nodh unbefautnt.

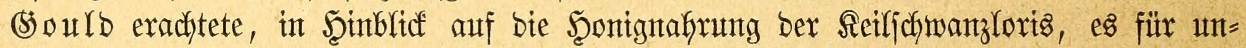

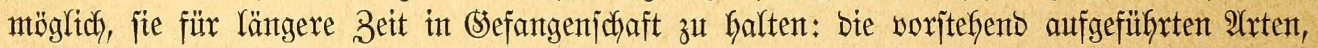
weldye jämtlich lebento nach Europa gelangten uno in ber Folgezeit unzmeifelgaft burch andere nody vermefyrt werben bürften, bemeijen bas Begenteil jenter ântabme. Mit Şonig=

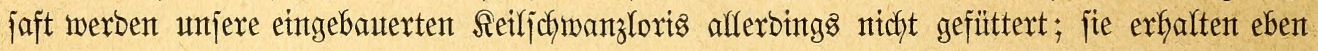

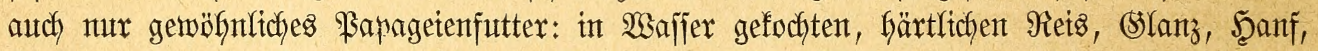

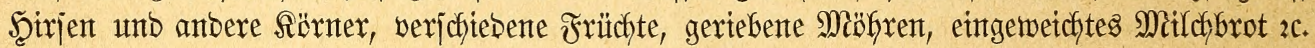
und befinben fich babet anjcheinent nohl und munter, balten audh immerfin geraume Bèt

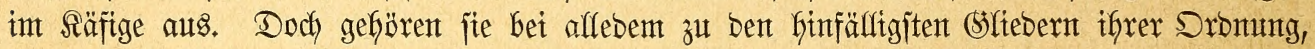

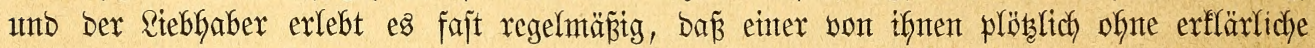
Urjactje tot von ber Stange Gerabjällt, fo munter ex furz vorfer auds zu jein joften und

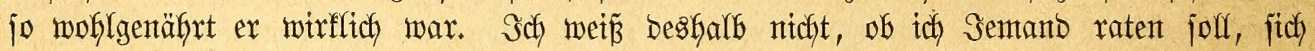

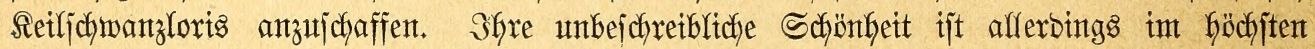
(Srabe bejtectjent; aber bieje Schöntjeit ijt vergängltcher als irgento einte antore, und ber

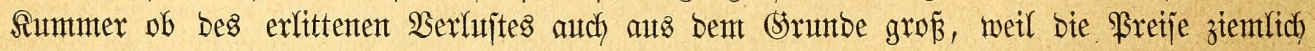
hoch zu jein wffegen. Unter 50 Talern erbält man ein \$ärchen Sieiljobmanzloris nitht, in Der Regel fommen jie jogar nody etwas bäher zu jteben. Einte joldye Summte aber unter

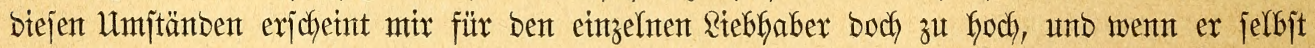
ein fletner Eröjus märe; unb jomit möchte id bem gröpizten Ieile meiner sejer anxaten,

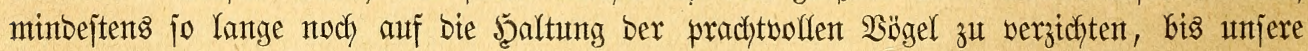

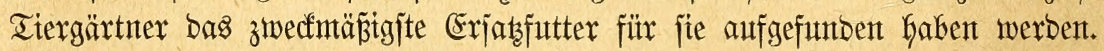

\section{Stumteffidmontilorts.}

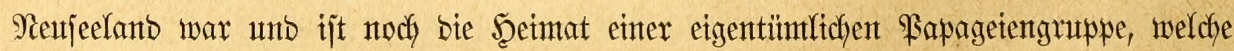
von eintgen Raturforjchern zu ben Safabus, won anberen zu ben Roris gezählt, bon anberen als bejonbere Unterfantilie betradjtet wirb, unt in ber Tat ein jo eigentümlidfes (sepräge

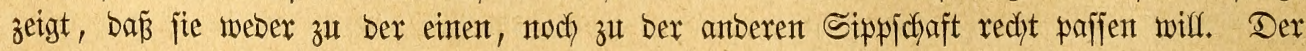




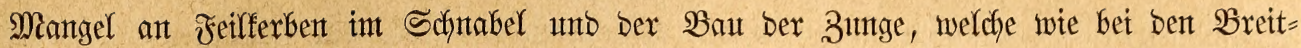

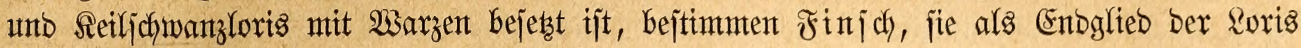
anzuljegent.

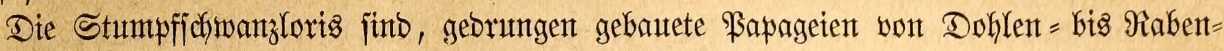

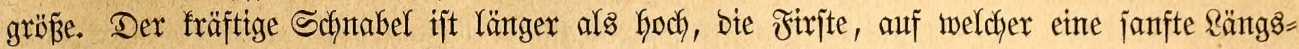

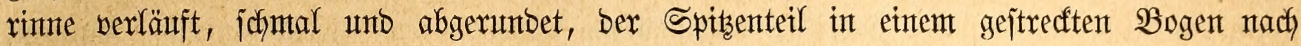

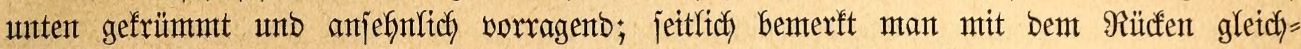

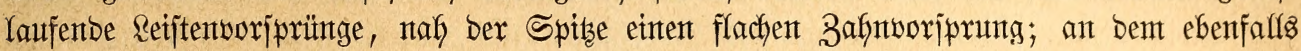

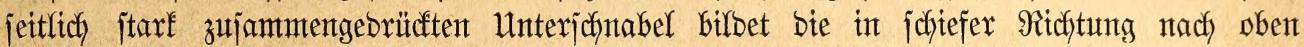

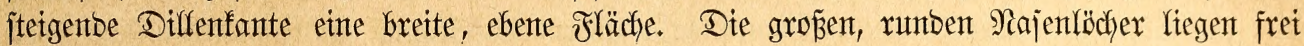

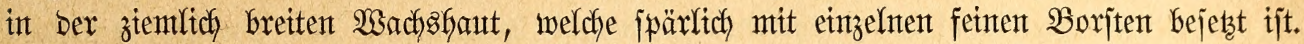

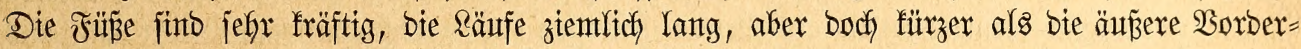

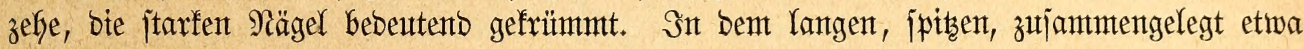
zwei Drittel bes Schlyanzes bebecfenton Flügel ift bie Spizze mittelfantg, unter ben ant Entbe breit afgeruntoetent Schmingen bie britte ober vierte bie längjte, bie erjte bis britte innen, bie zweite bis fünfte aurent eingeengt. Der Sodfwanz beitefft alts breitent, ant ber Spibze,

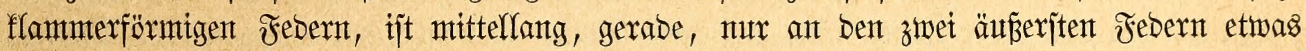

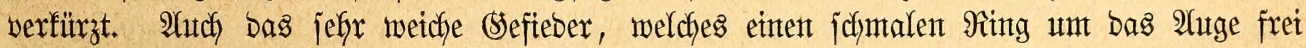
räßst, wirb aus Greitent, amt Enbe jtumpf zugerumbeten Febern gebitbet. Die (sejd)lectiter finto nidgt verjefjebent.

Streng genomment hätten wir es mit zwei $\mathfrak{T}$ rten ber Strappe zut tut, weil bieje bis

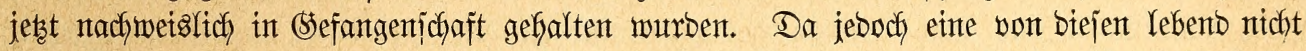

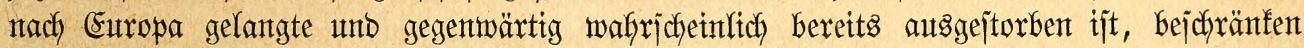

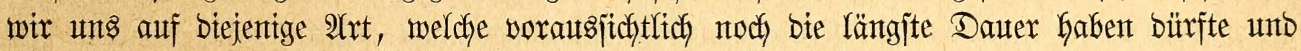
gegenwärtig im Rontonter Tiergarten lebt.

204. Der Siffa Dex Mparis, Nestor (Ps., Centrourus) meridionalis, Gml., (Nestor, hypo-

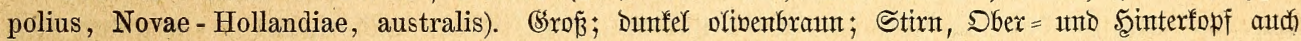

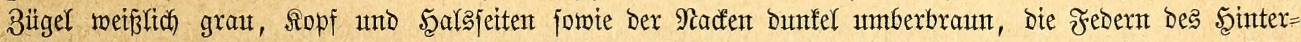
harjes an Ende fanmal orangebräunlich, die unteren Bactenfedern büftex purpurrotbraun gejäumt, Shr=

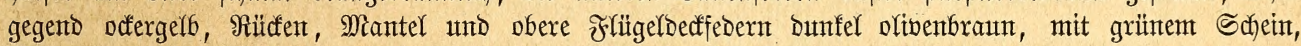
am Ende fabmarz=, bie mittelften Flïgeldedfedern purpurbraun gejäunt; ein breites Duterbant über Dent

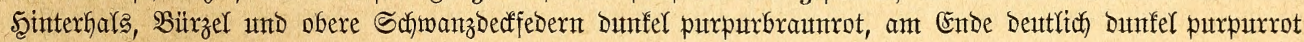
gefäumt; Rinn, Reble, Rropf und Dberbruft Dunfel umberbraun, einzelne Febern bïfter purpurbraun ge=

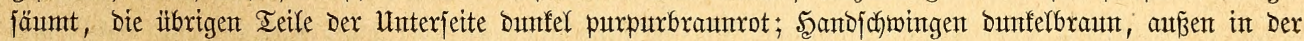

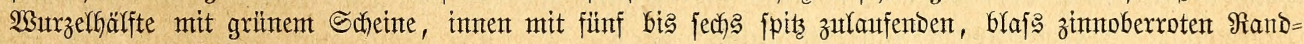

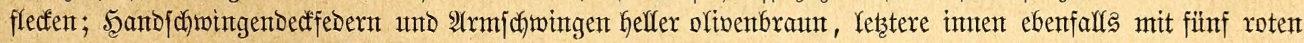

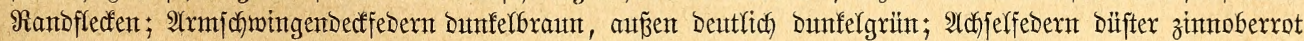
mit vermafchen braunent Snexitreifen; Schningent unterjeits wie oben, fleine Interflitgeldectent wie die

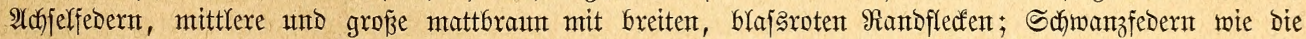

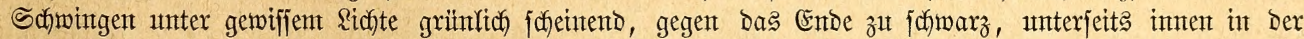

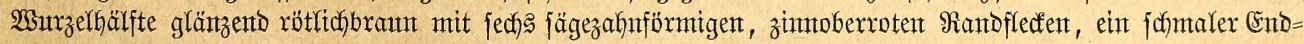

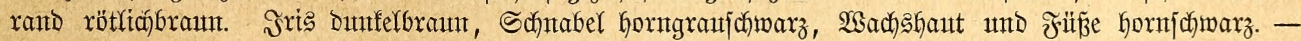

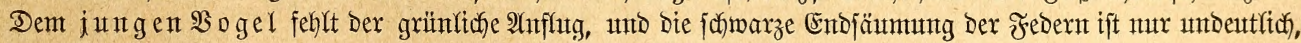

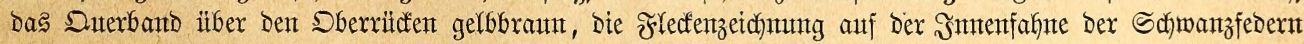
flein und unbedentent.

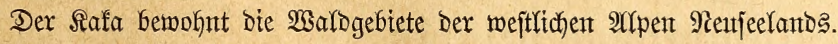

Die Berichte über bas freileben alfer Stumpfichwanzloris jütb fegr bürftig. Nach

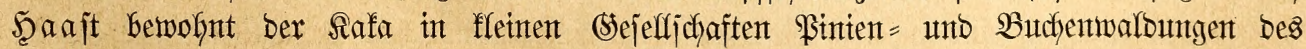

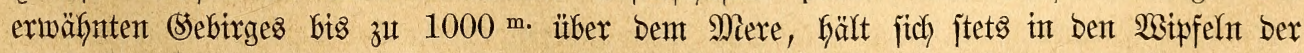

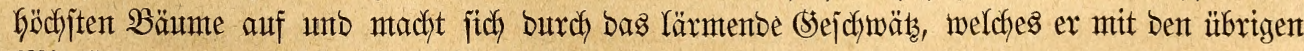

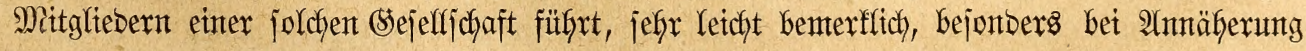


Roris.

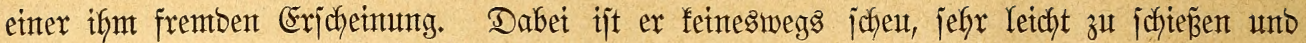
wenn auch nicht jo bummbreijt wie ein auggerotteter Serwanter von iffm, welcher fich

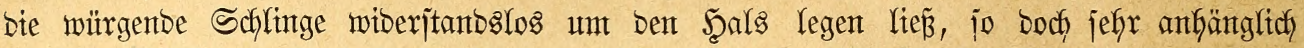

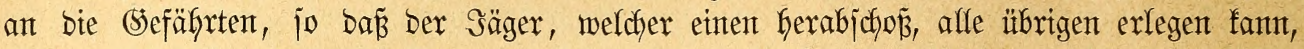

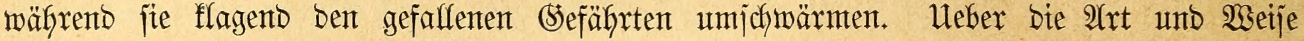

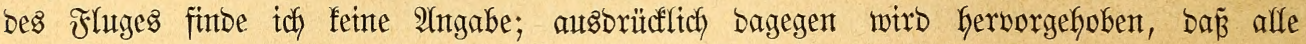
beobachteten Stumpfichnanzloris treffliche Räufer fund unt in biejer Betwegung weit mefr an einen gebenben Raben als an anbere Bagageten exinnern. Finjch teilt won bem im Ronboner Tiergarten Yebenben fiafa mit, baj er jith in jeinem Betragen fajt bon alfen

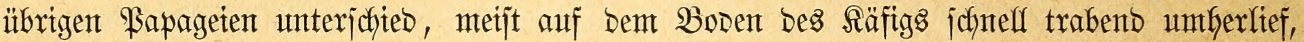

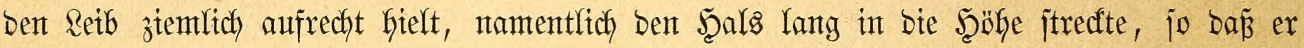

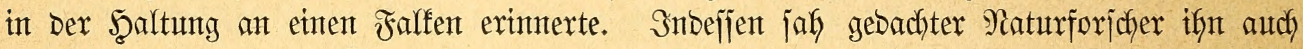

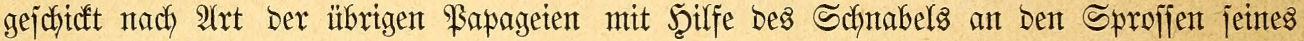
Räfigs emporflettern. Die Stimme ber ausggejtorbenten $\mathfrak{A}$ rt joll eigentümlich rauly unt quafent gemejen jein unt an bas beflen des Scunbes erintert haben, wälyrent ein noch rebenter, bis jebt nicht in Sefangenjchaft gebaltener Berwandter nach Şa ajt flagende, bem Miauten einer Sazze ober Dem Stejdyret fleiner Sinter ähnelnde Raute unt bet Erjcheinung

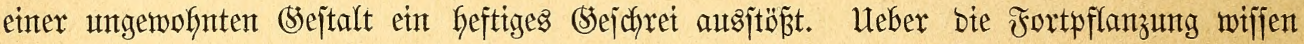
wir mux jo viel, baj bie $\mathfrak{B}$ rutzeit in bie Monate Februar und Miärz fällt.

Die Rahrung unjerer Bögel bejteht noch Forjter aus Früchten und Näffen, nach

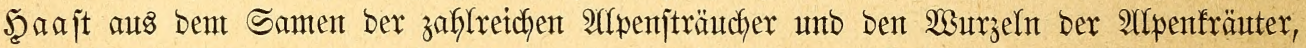

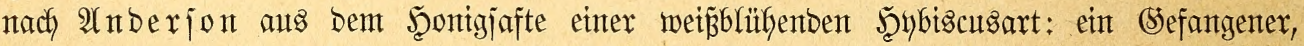
welchen \$ould beobachtete, liebte bejonders jaftige Nahrung, frijche Bä̈tter verjeftedenter

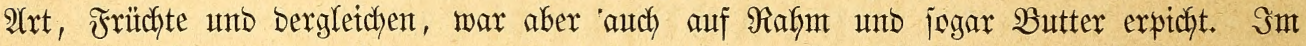
Ronboner Tiergarten reicht mant Den Dortigen Nejtoren gewöhnliches $\mathfrak{B a p a g e t e n f u t t e r , ~ g e = ~}$ jtattet iłnen aber $\mathfrak{A}$ uswahl zwijchen Sïrnern, Mitldyreis, Früdhten unto Srünzeug. Eigent=

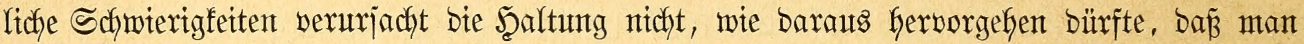

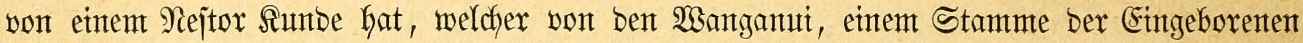
ఇeujeelands, jeit zmanzig Jahren gefangen gehalten wurbe.

Die Stumpfichwanzlorts werben inmer nur Sefangene ber Iiergärten und äfnlficher

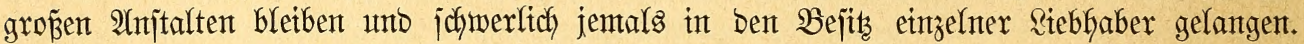
Bis jebst ijt mux ber Ronboner Tiergarten, Danf jeinen auggezeidfneten Berbintungen, io glütflich gewejen, überfautpt einige Stüdfe ber bejdyrtebenen $\mathfrak{A}$ rt zu erfalten. Einen Prets Gaben joldhe $\mathfrak{B}$ g̈gel jelbjtwerjtändlich nicht. 
Dritter $\mathfrak{A}$ bidunitt.

Röruerfefífr. 



\section{But Heloetlidht Der (Gelianthett.}

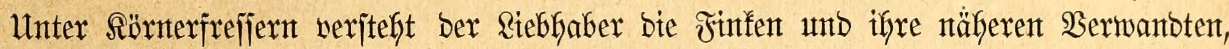

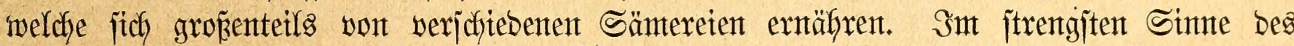

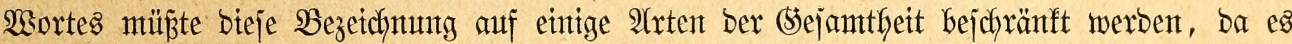
in ber Iat nur äuß̌erjt wentge jogenannte Sïrnerfrejfer gibt, weldhe nicht nebenbet, mintojtens zeitweilig, ferbtiere verzefren; ber Begriff hat fich jeboch alfgemein eingebürgert unt, bei Berücffichtigung bes ebent (Sejagten, volfjte Berechtigung.

Die Sönterfreffer bilben einen wejentlichen Ieil ber Stubenvögel, weil ityre Erfyaltung

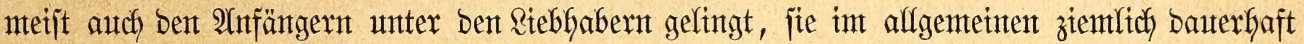
finto, fich oft burch anjprectjentbe Färbung auszzeichnen, zum Teil gut ober boch leiblich unto,

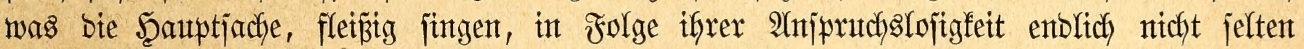

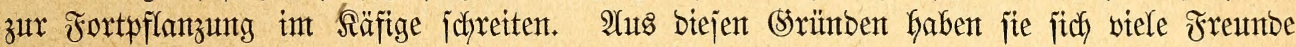

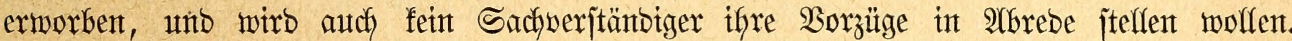

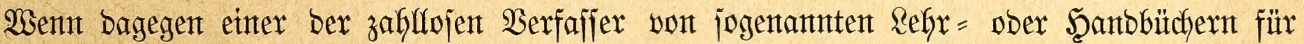

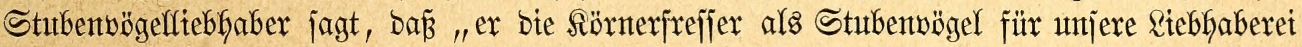
alfein geetgnet und auth burdjaus ausretchend erachte", jo ijt bas als ungereintes sejchwäts anzujehen, welches allein in grober Unfentnis bes Begenjtantoes jeine Errfärung fintont

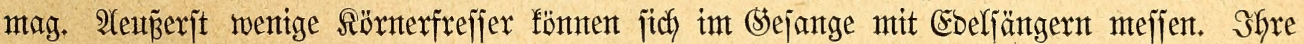
Scaltung berurjacht geringere Müfhe als bie ber Wetdffeffer, und jie pflanzent fich int Räfige Yeidjter fort als bieje, bejtzent aber feine einzige Eigenjchaft, weldye fie ïber letztere erfyeben fönte.

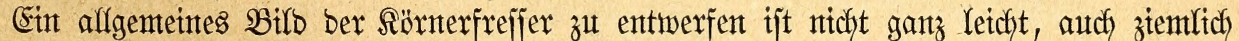

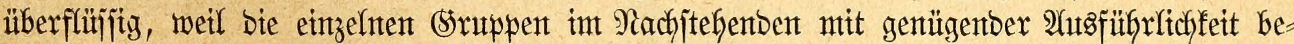

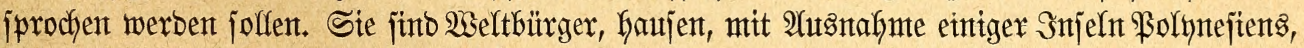

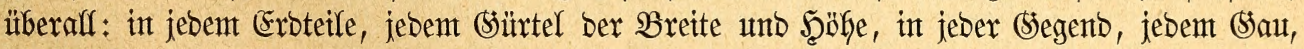
int Balbe wie auf Dem Felbe ober Der jteinigen Şalbe bes Şortgebirges, int Dorfe, in ber

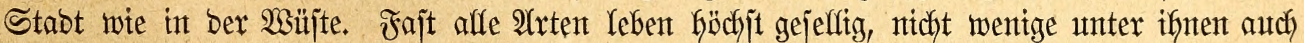

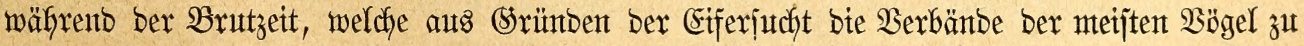
löjen pflegt: es gibt edfte Sibelyögel unter ifnen, einzelne, weldje jogar in stejelljwaftantejtern

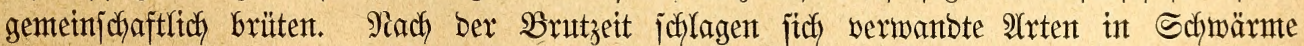

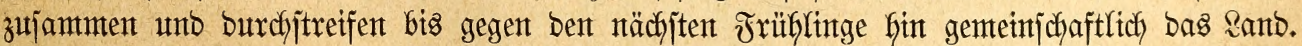
Einige żehen, bie meijten wanbern, mantche jtreifen nur, einzelne fint Standögel int volrjtent

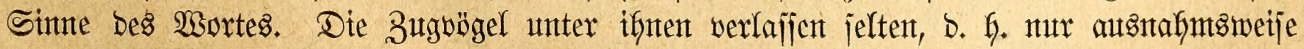

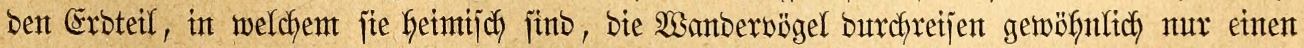
Ieil besjelben, bie Strichbögel faum ben Stau, in weldyem ifre Witege jtanb. Unjere

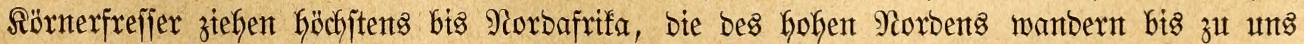

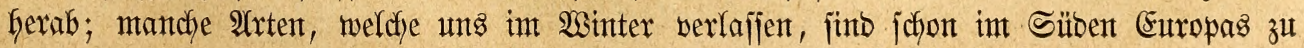


Stridfoögeln getworben und vertaujchen iffren Stanbort blö mit cintem anberen, weldber

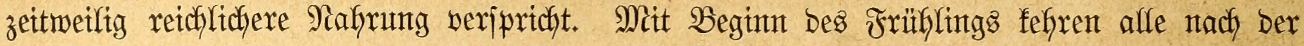

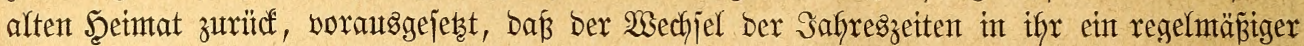

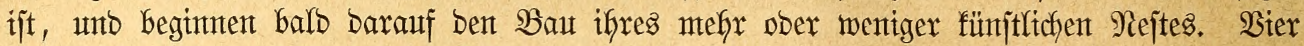
bis jechs, felten blós brei, noch jeltenter bis adyt einfarbige ober bunte Eier bilben bas (S)lege und werben entweber bom Weibchen aflein ober won betben Eertern mit vergeffender

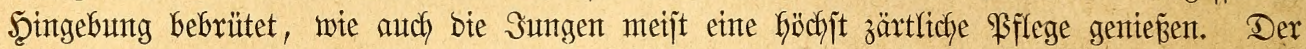

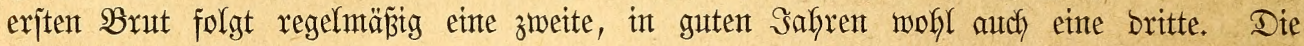
Sermefrung ijt bem entiprechent eine jehr jtarfe, jebenfalls eine volffommen aubreidjente,

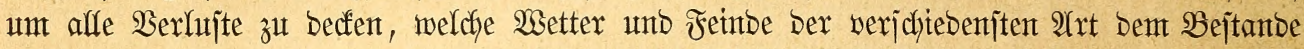
zufügen; jie fant aber auch unter Umitänben einen Ueberichun ergeben, welcher bem adferbau=

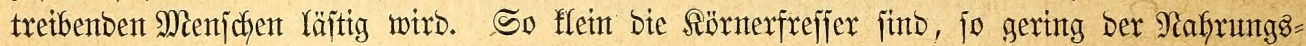

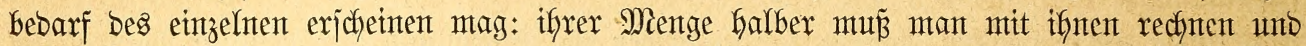

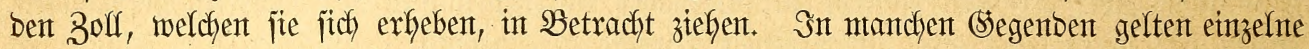

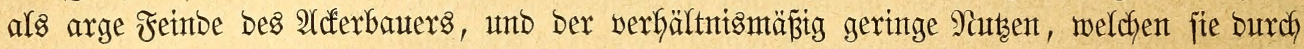
Derzefyren jobäolicher Sierbtiere und Sämereien mandferlet Unfrauts, Durch ifyren Sejang,

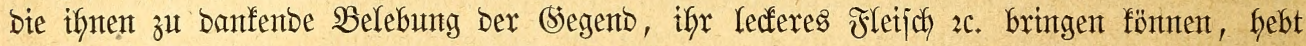
ben Schaben, weldhen jie antridjten, nidfht auf.

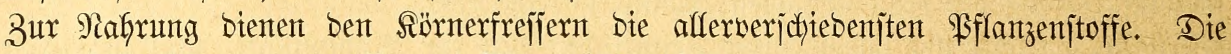

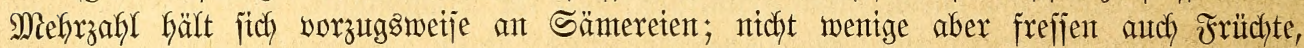
anbere berwijiten biejelben mentgitens, um zu Den Siernen zu gelangen; andere füflen fich Sropị uno Magen mit $\mathfrak{B l a t t}=$ und $\mathfrak{B}$ lütentfnospen, Den $\mathfrak{B l a ̈ t t e r n ~ z a r t e r ~ f r a ̈ u t e r ~} 2 c$; fajt afle freffen nebentbei Rerfe unt Särmer, namentlich während ber Brutzeit, wie jefr viele

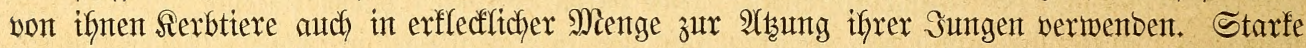

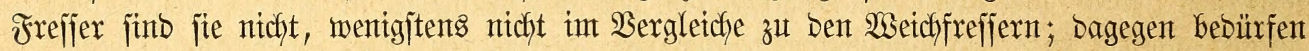

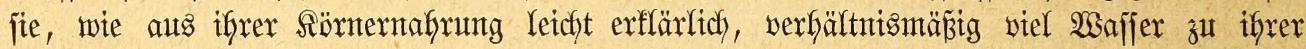
Sättiguntg.

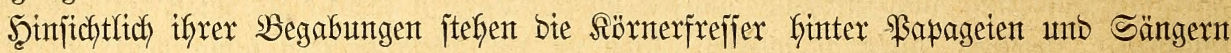

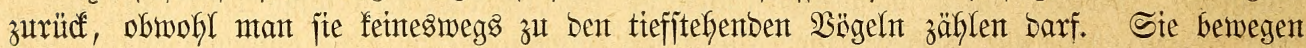

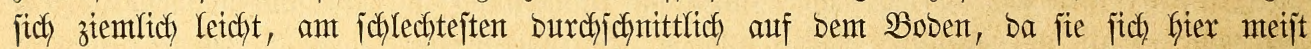
Güpfent förbern, befifer auf Bäumen, objchon mur wentge von ifnen zu ben Iurn = ober

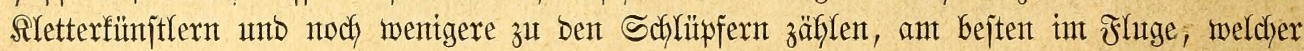
bei einzelnen zwar etwas jobwerfällig, bet ben meijten aber bodh rajch und ofne 2Anjtrengung

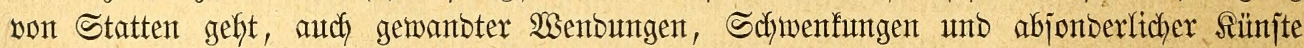
nicht ermangelt. Die Sinne icheinten burdjgehenos wohl unto gletchmäp̈ig entrvidfelt zu jein;

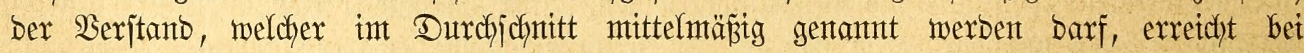

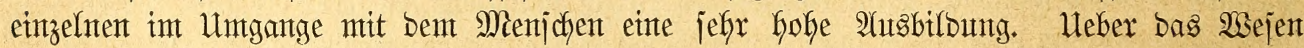
läß̈t jich int affgemteinen wenig fagen, weil es allzu verjefieden ijt.

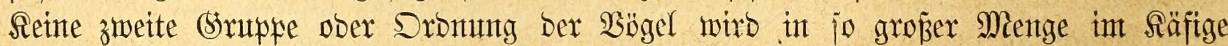

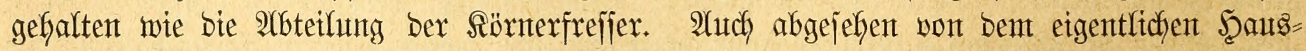

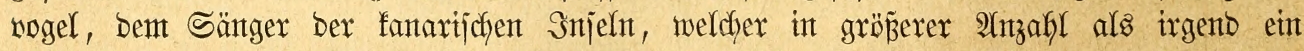

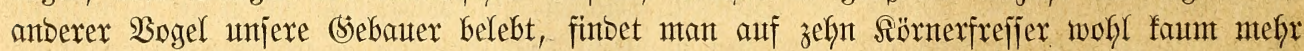
als einen anberen Stubenwogel in (Sefangenjchaft. Ein erheblicher Teil bes Bogelfantbels

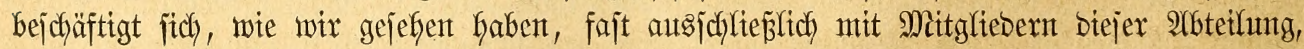

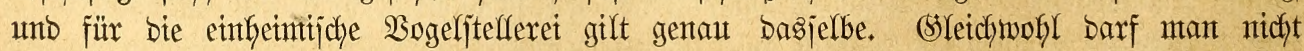

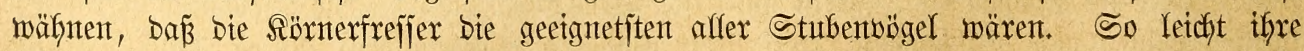

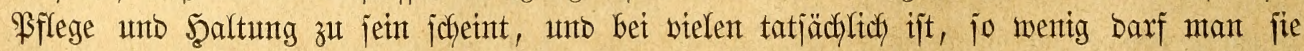

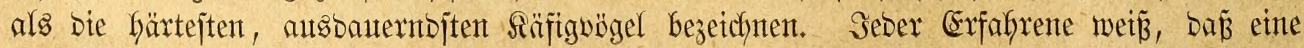




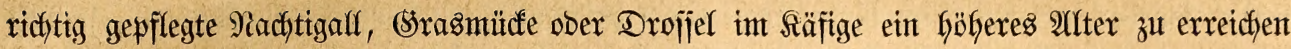
pflegt, als bies bei ben meijten Sörnerfrefjern, Den jeit (Sejchlechtern im (sebauer ein= gebürgerten Ranarienvogel viefleidjt autgentommen, Der Fall ijt. Schon bie außserorbentlidye

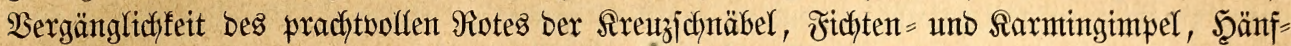

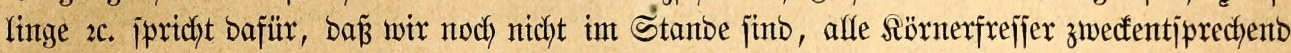
zu pflegen. (5:s madjt jich jebod) nidjt allein Wergänglidjfeit ber Farben, jonbern auth

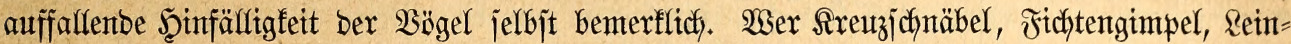

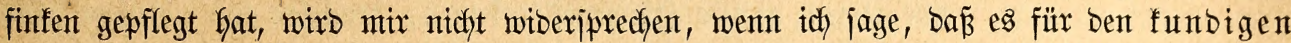
Bogelwirt - jene Scalbwiffer und Stümper, welche Unerfafrentes ober Unverbautes frijchweg

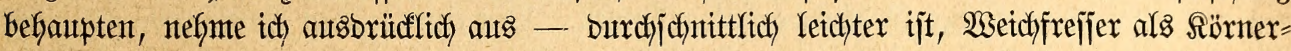

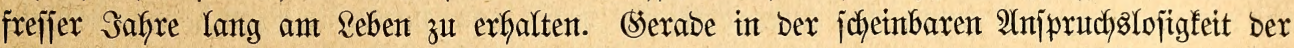
lez̧tgenannten liegt für Den $\mathfrak{B f l e g e r}$ bie Sefahr, einjeitig zu hanbeln, auf Wartung und

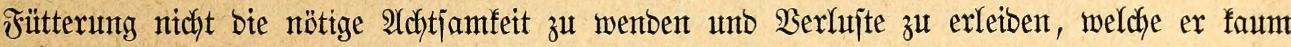

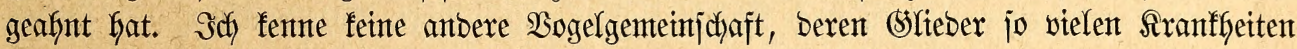

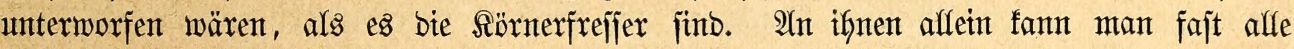
Sranfheiten itubiren, weldhe man bisher an $\mathfrak{B}$ g̈geln überfant beobachtet hat: Der eine leibet

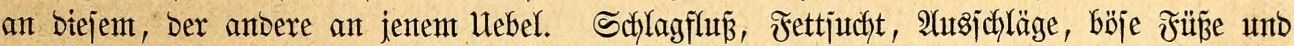
jonjtige Reiben juchen gerabe bie Sönterfrefjer bejonbers häufig heim, anbere Aranflyeiten treten unter ifyen nicht weniger jelten auf als unter ben WSeidffreffern, unb nur bie Sungen=

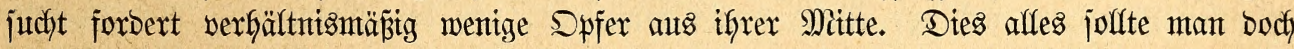

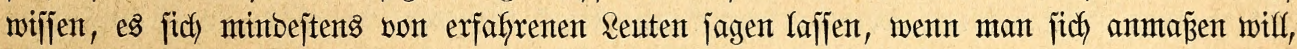
über Stubenvögel zu jatreiben, und Dabei verjudyt, bie Riörnerfrefjer als bie "für unjere Riebhaberei allein geeigneten" Ginzujtellen. Einem erfabrenen Siebsaber jchabet man freilich

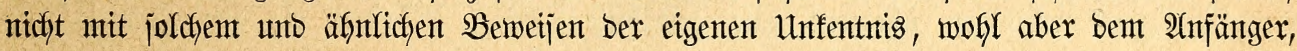

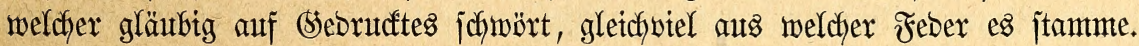

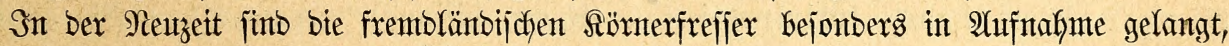

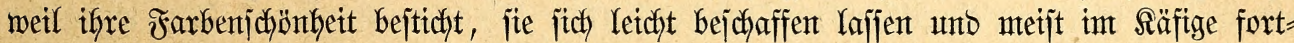

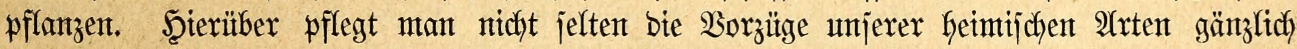
zu vergeffen, unto mur alte bewährte Siebhaber jchenfen biejen bie gebürenbe Würroigung.

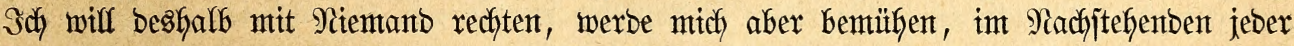

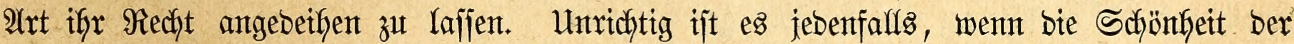

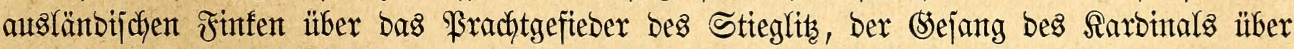

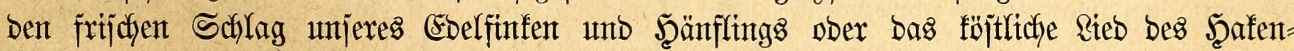

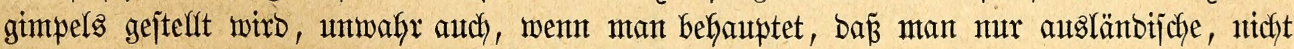

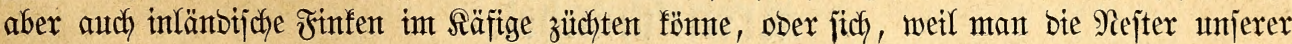
Geimijchen 2 rten nicht fennt, begeiftert über bie Sumjtbauten ber irremblänbijchen augijpriçt.

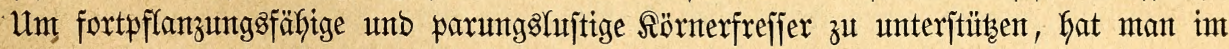

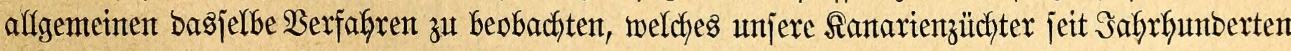
geübt haben. Wer Sanartenbögel zu zübten verjteft, wirb aflen Rörnerfreffern währent iffrex Fortpflanzung bie exforberlicbe Şilfe zu leiften im Stande. jein. Uleber bie 3utht in

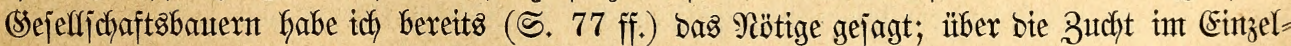
fäfige föntmen einjtweilen eintge 23 orte genügen, ba ich bei Bejpredyung ber einzelnen (Sruppen in eingehentoer Seije auf benjelben Segenjtanto zurüdfuffommen habe. Ein Bauer von $0,70 \mathrm{~m}$. Ränge, $0,40 \mathrm{~m}$. Tiefe und $0,55 \mathrm{~m}$. Sähe nach SBauart bes Jinfenfäfigs mit nodh zwei Türchen von etwa $10 \mathrm{~cm}$. Weite in ben oberen und Ginteren betben Ecfen fann für bie meijten Finfen als şedfbauter bienen, einte gemöhnliche Sanarienfecfe tut es ebenfalls. Im Snneren bringt man vor ber einen Iüre ein aus Drat gebilbetes würfeliges Säjtchen an, weldjes an ber Tïrjeite feine Wand, an ber entgegengejebten oben ein Sdjlupfloch hat; 


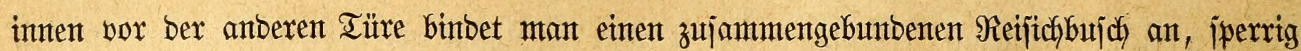

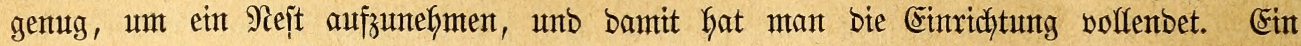
Bogel Gaut in bas Dratfäjtcten, ein anberer in bent $\mathfrak{B}$ ujich, unb Gier wie bort fant man

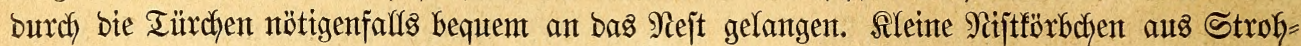

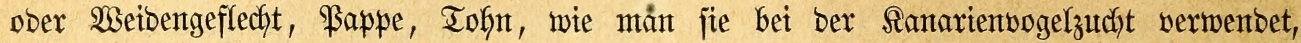

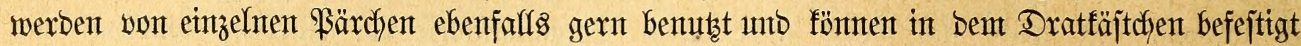

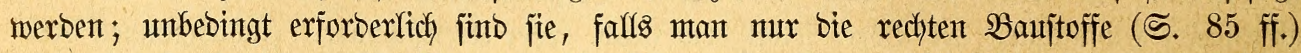

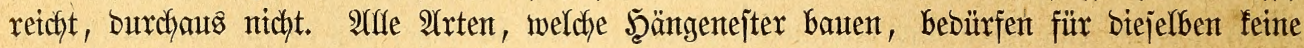

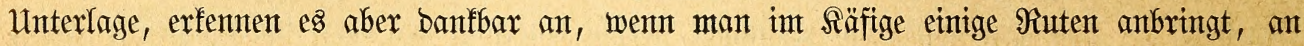

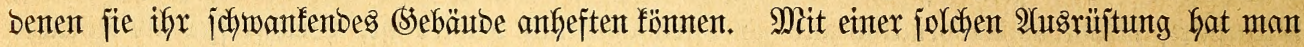

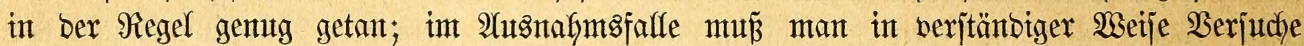

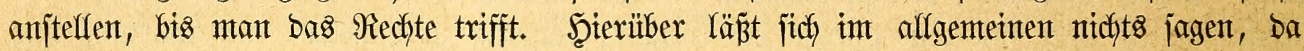

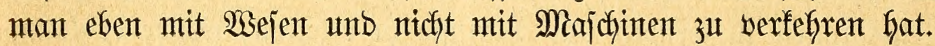

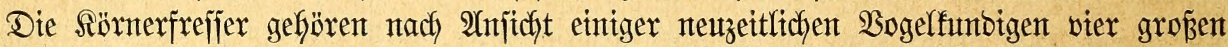
Familien (ben Finfen, WSebern, Tangaren unt Rerdyen) voer vierzefyn Unterfamilien an,

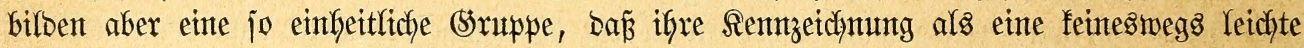

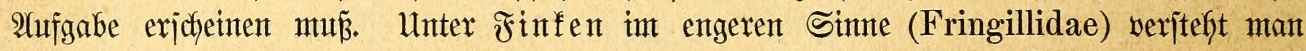

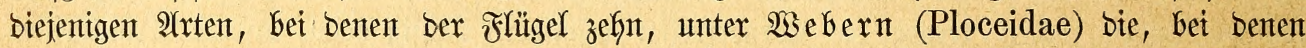

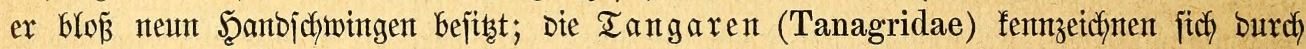

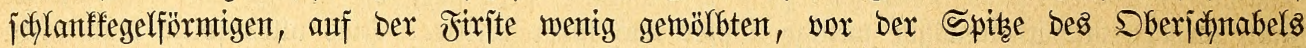
auzgeferbten Siffnabel unt Derbes, jefri buntfarbiges Befieber, bie Rerchen (Alaudidae)

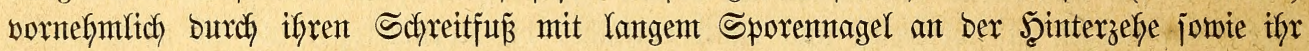
reiches, erbfarbiges (Sefieber. Mitdyt wenige uno feinesmegs bie ant ntinbejtent tüchtigen Sogeffunbigen vereinigen übrigens affe erwähnten $\mathfrak{B}$ g̈gel in einer einzigen Famillie uno

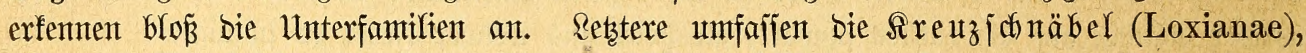
(Simpel (Pyrrhulinae), (simpelfinfen (Sporophilinae), Rernbeiner (Coccothrau-

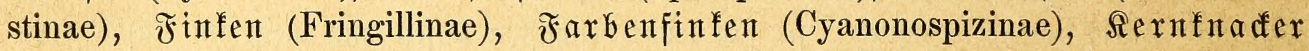
(Pytilinae), Iangaren (Tanagrinae), $\mathfrak{B r a} \mathfrak{d}$ tfinfent (Spermestinae), $\mathfrak{B} e \mathfrak{b} \mathfrak{e r}$ (Plo-

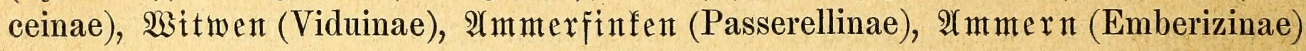
uno Rerctyen (Alaudinae). In biejer Reifgenfolge werben wir bie zafhlreidyen Sippen uno 2rten ber (sejantheit an unz vorüber gef̧en rajfen.

\section{farentidhüübel.}

Den Bigeutern gleid ftreift eine Finfengruppe burch bie Nabelwalbungen ber alten

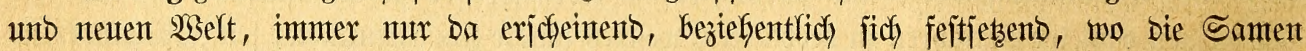

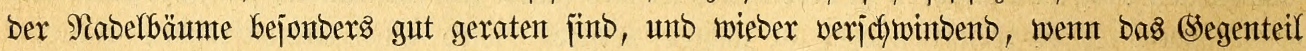

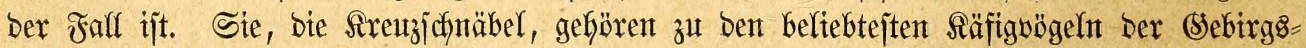
bewoffner unb verbienen bie ifynen entgegengebradte Buneigung voulfommen.

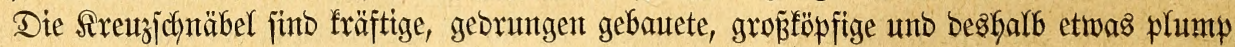

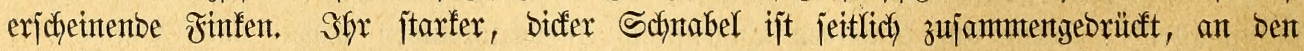
Sifhneiben eingezogen, Der obere auf ber idymalen Firifte zugerunbet, in eine lange Spize außlaufent unb janft hafenförmiz herabgebogen; Der untere, welcher an ber 23 urzel jtärfer

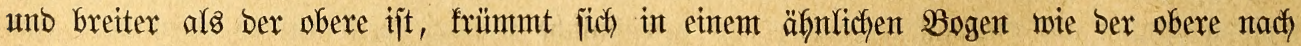

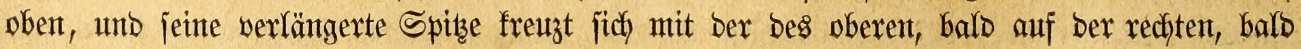
auf ber linfen Seite. Die jeffr fleinen, freizrumben, bidft an ber Sdynabelwurzel liegenten 


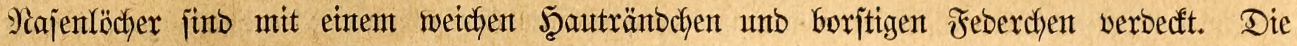

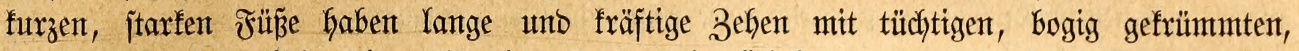

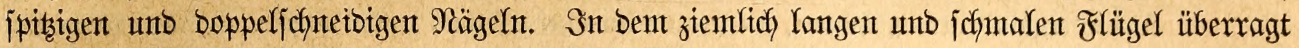
Die erjte Schyinge alfe übrigen, uno jint bie vorberen fadmal unt lang zugertmbet, bie mittleren gerabe abgejdynitten, bie Ginteren gerutbet. Die Febern bes funzzen, gabeffürmigen

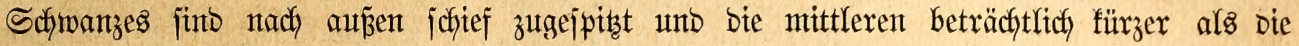

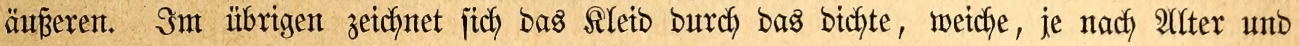
(5ejdylecht hödjjt verjodjeben gefürbte Aleingefiteber auß.

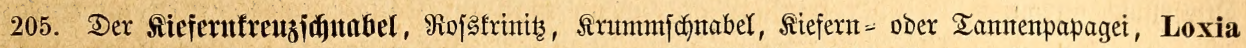

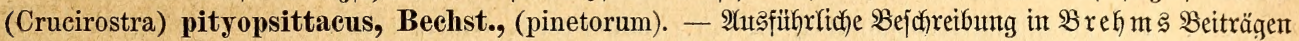

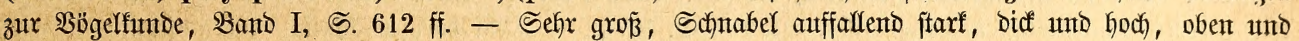
Inten in einem faft vollftänoigent Scalblreife gefrïmmt, Spizen mux menig fich frenzent; Ropf, Rehle, (Surgel, Bruft uno Baatch butfel = ober helfmennigrot, ziunober $=$, rötel $=$, ziegel $=$ ober bunfel johannisberrot,

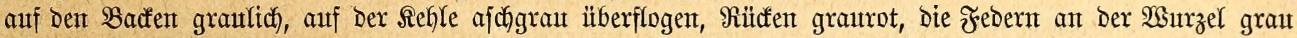
unt mur an Den Spizen rot gejäımt, Bürzel lebhafter rot als das übrige Âleingefieder; Unterbauch uno

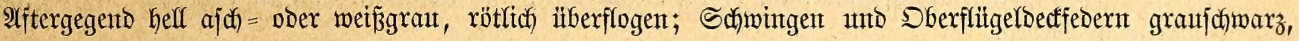

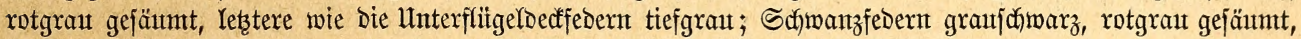

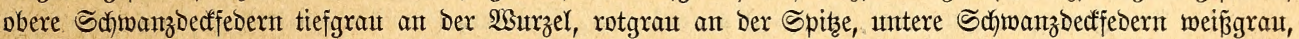

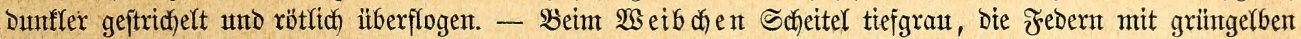

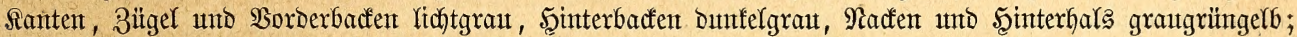

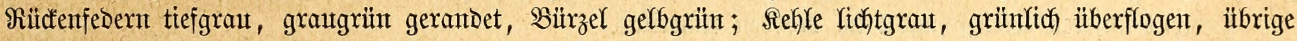

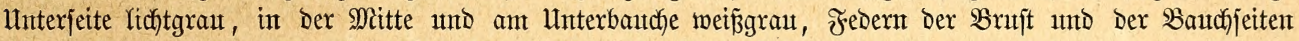

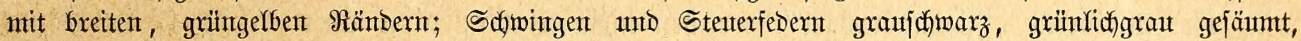

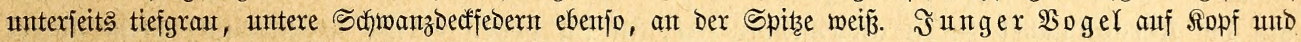

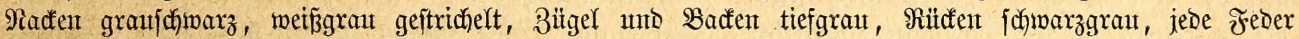

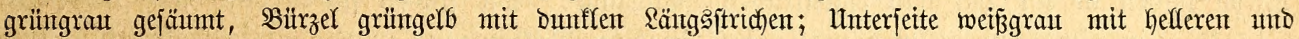

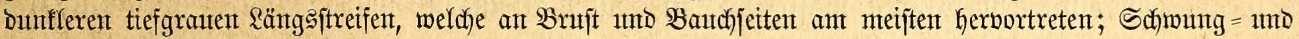

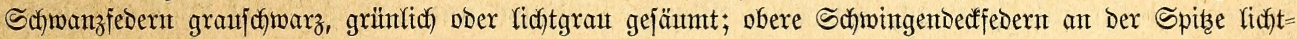

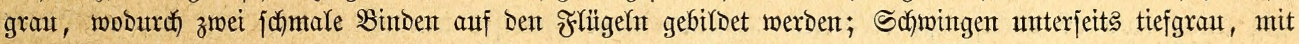

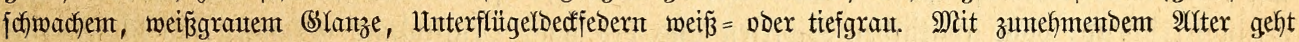
Diejes Jugendfleto allmählid) in Das ber altent ïber.

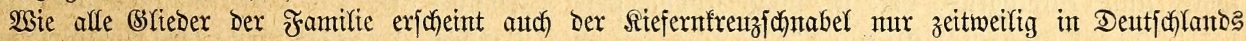
Waldungen uno zwar gegentwärtig weit jeltenter als früher.

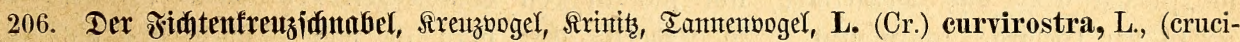

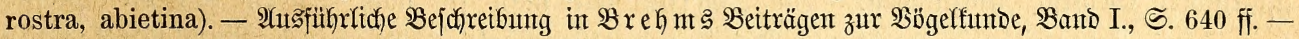

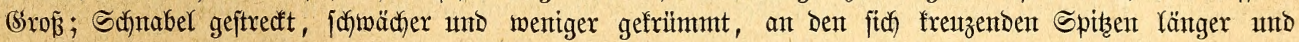

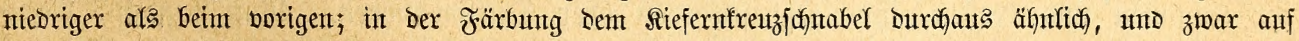
Ropf, Nacten und Unterförper entweder zinnober $=$ ober rötel $=$ ober mentig $=$ ober ziegel $=$ ober jobannisberrot,

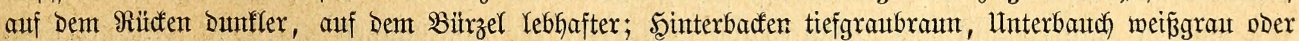

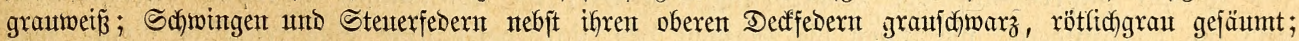

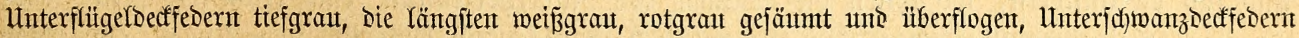

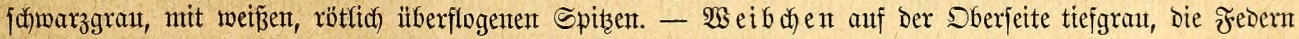

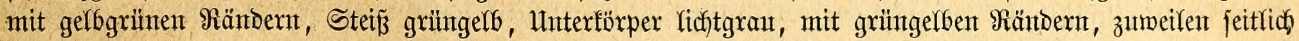

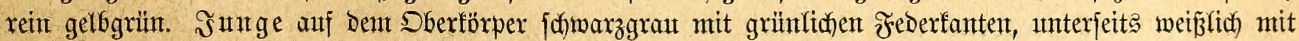

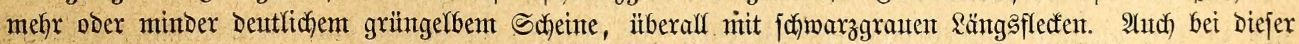
Art geht Diejes Rleí exjt Durch mehrfache Maujer in bas bex alten Sögel über.

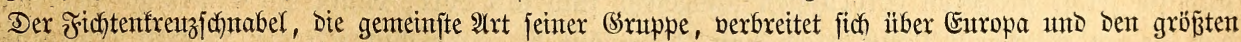
Teil Norbafients.

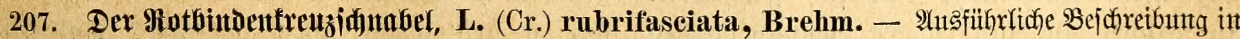

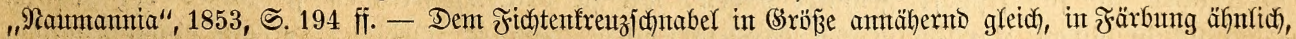

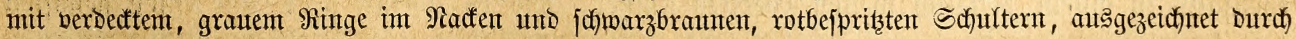

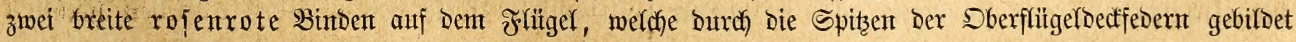

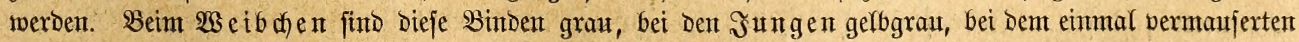
Mätutchen ebenjo oder gelbgrïnt. 


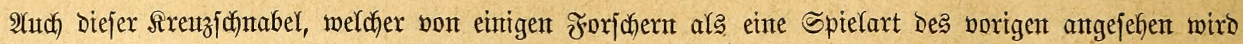

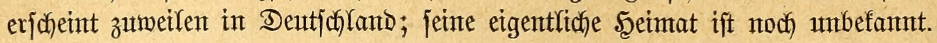

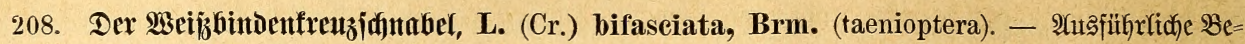

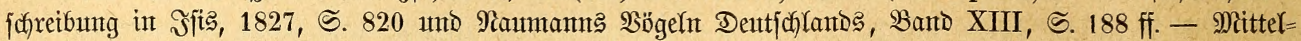

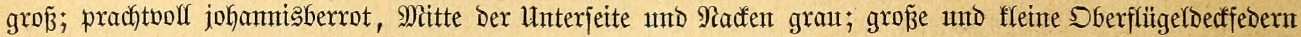

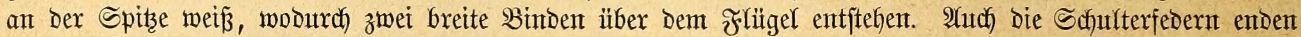

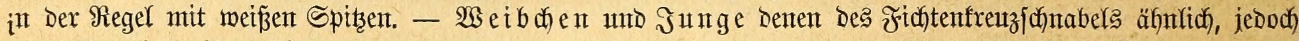
ebenfalls mit weiß̌nen SBinden.

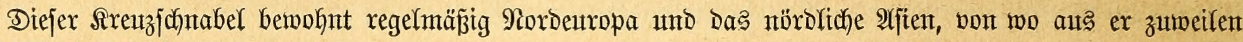
Deutjulfand bejucht.

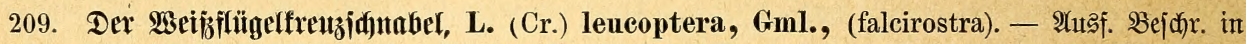

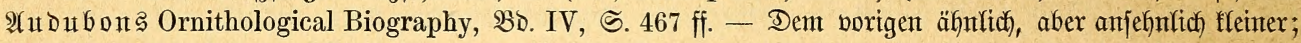

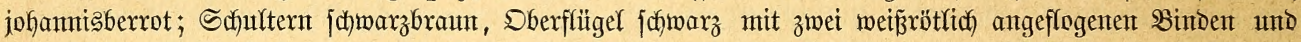

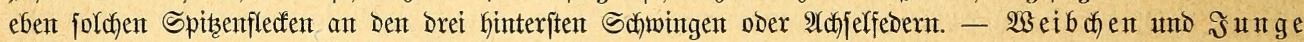
Denen des vorkergehenden ähnliç).

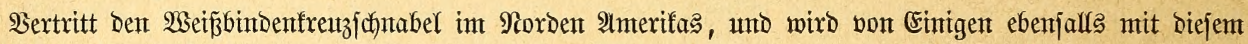
als gleichartig angefehen.

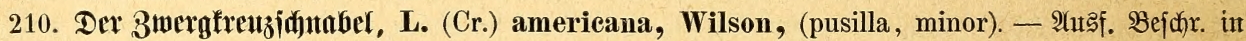

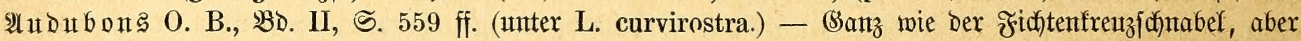
anfeghntich ffeiner.

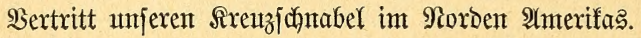

Der 2 (t) auf bie Sreuzjdynäber zuerjt angementet hat, ijt im Goken Srabe bezeidfnentb; Denn umjere Sö̈gel haben in ber Iat fein eigentliches 2 aterlanb. Sie fimben jich überalf unb nirgends,

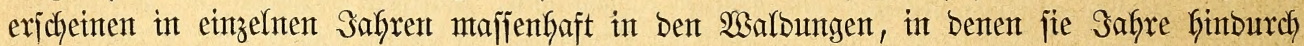

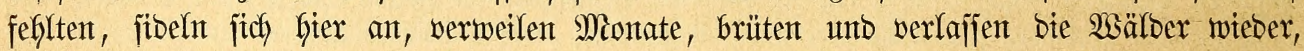
um anderşwo es ebenjo zu treiben. Saum einem Zmeifel unterliegt es, baí fie, in biejer

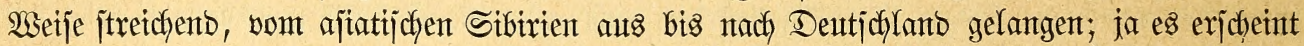

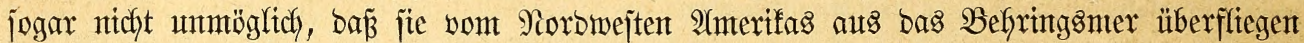

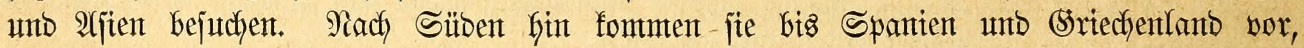

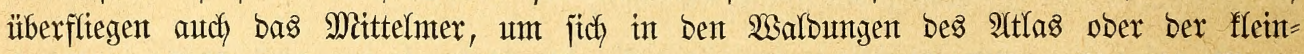

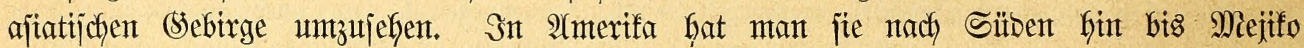

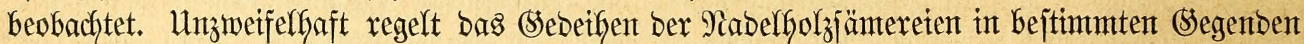

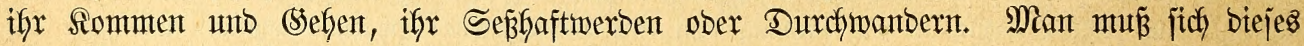

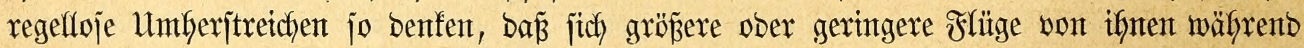
bes ganzen Safres auf ber Wanberung befinden, bie Waaldungen Europas burdjitreichen

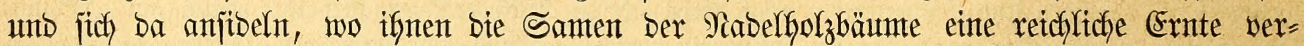
iprechen, biejentigen Stegenben aber, in benen bies nicht ber Faff ijt, überfliegen, obne fier

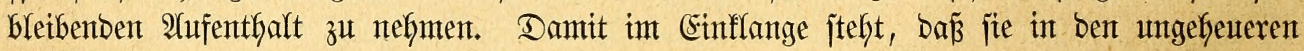

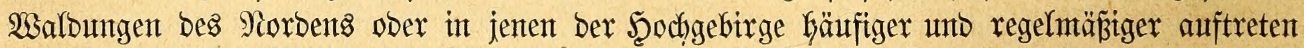
als in ben vielfach unterbrochenen Wälbern ber Ebene, in benten gute Samenjahre jeltenter unb fie jelbjt größeren Störungen auşgejeţt fint als bort; Damit im Einflange jteht ferner,

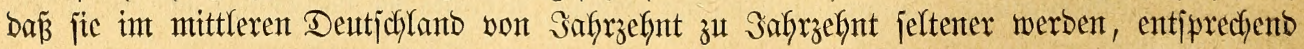

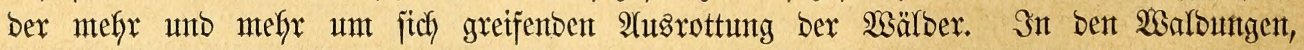

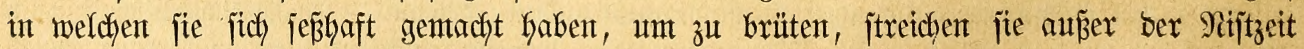
ebenfarls in einem ziemlich weiten Sebiete umther, wie es jobeint aber mit einer gemififent Regelmäpigfeit, wie fie benn auch in einem beftimmten Ieile bes $23 a l b e s$ auf ben bödyjtent

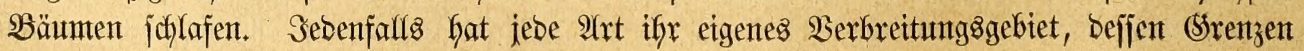

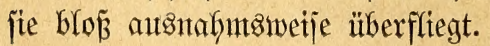




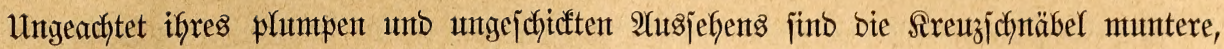
flinfe, rajche unt benegliche Bägel, weldhe nur währent bes viel Beit erforbernben Jreffens anjcheinento träge auf einem und bentelben Baume ober boith in einem fleinen Bezirffe fitzen,

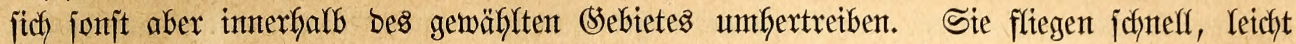
uno in janften Bogenlinten, vor bent Nieberjizen jawwebend, währent ber Brutzeit eigen= tümlich) flatterno, wie bas audf unter anberen Finfentoögeln Sitte, geken auf bem Soben

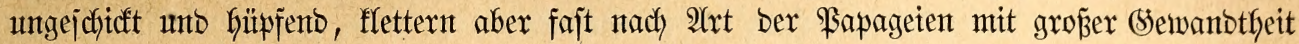

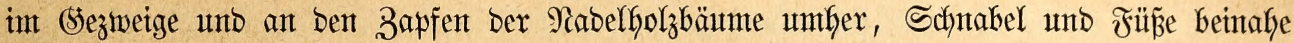

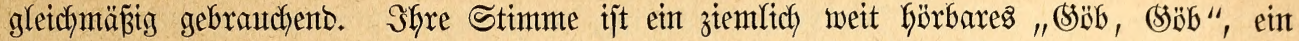
leijeres "\$ib, \$sib" und ein janftes "Zodf, Zod", ausnahmsmeije aud ein gezogenes "Drit, Drit", und zrwar rufen in biejer 2 Beije alle Sreuzjdynäbel, bie größ̈eren mit tieferent, bie fleineren mit Göherem Ionfalle, jo baz es eines geübten Shres bebarf, um bie be= treffenden 2lrten burch Dasjelbe zu unterjchetben. Der (Sejantg ber Miännthen fant fich mit

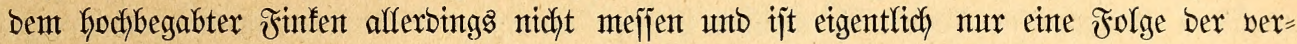

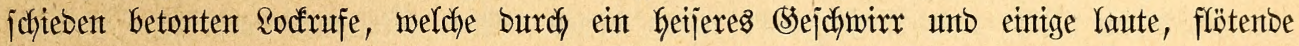
Töne verbunben werben; wie unter alfen Singvögel aber gibt es unter ben Sireuzjdyäbeln

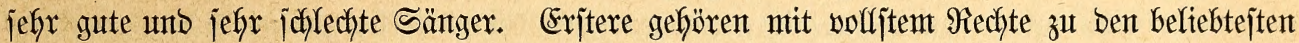

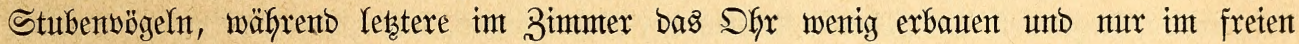

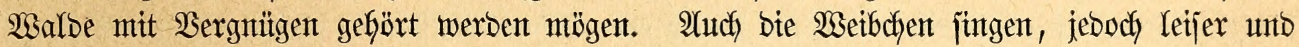
minber anfaltend als bie Miäntutjen.

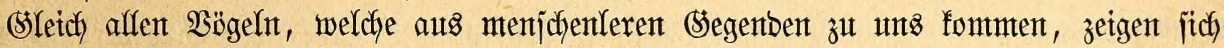
bie Areuzidnäber in ber erjten Beit nady ifrem Eintreffen in Gohemt Srabe vertrautengjelig, weshalb ifnen Einzelne ben unverbienten Bormurf ber Seiftesarmut und Dummbeit gemadft

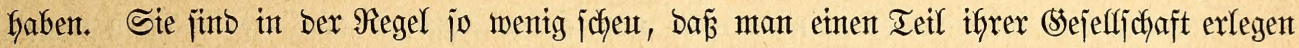

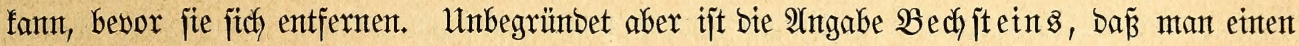

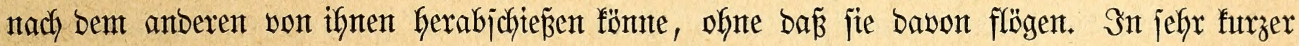
Zeit änbert jich biejes Wejen; jie Yernen ben Erzfeind aller Titere fennen unt werben bant mitunter jefr vorjichtig. Unter jidy leben jie in ber Freifeit im tiefjten Frieben, nidfft jelten audf) berjofiebene 2(rten unter einanber, und mux gegen bie $\mathfrak{B}$ rutzeit fin jonbern jich bie Bare von Den Trupps, und jebes von ifnen erwählt fidf wenigitens ein fleines Bebiet.

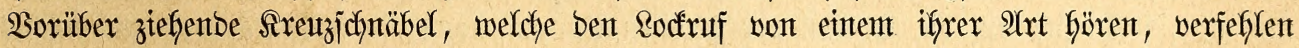

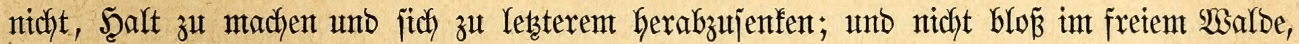

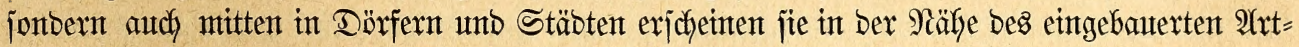

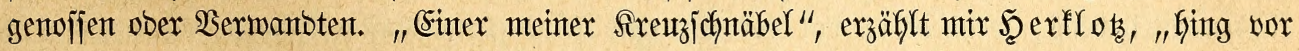

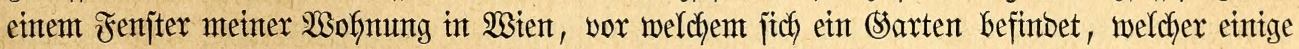

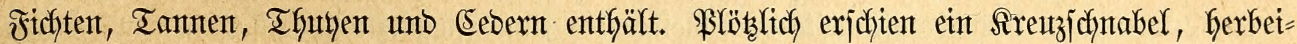
gelocft burch ben eingebauterten, auf bem Räfige besjelben. Der Bauer wurbe aljo in bas Zimmer gebradyt und an bem Fenjter ein Binbfaben zum Zuzieben angebradyt. Saum fünf Minuten fpäter fam ber burch unjer Beginnen verjcheuthte Bogel wieber, ber $\mathfrak{B}$ into=

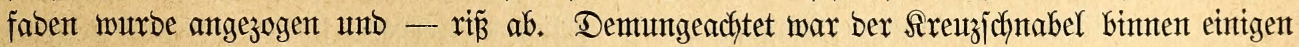
Minuten nodymals im Simmer unb wurbe mumefrx, ba ber Faben jeinte Schulbigfeit tat, wirflich gefangen."

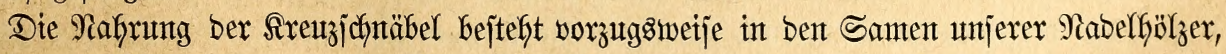

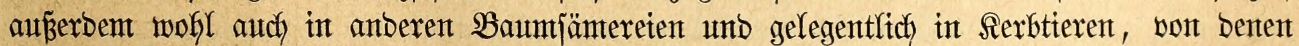
fie vielleidft größ̈ere Miengen vertilgen, als man anzunefynten pflegt. Wermöge ber eigen=

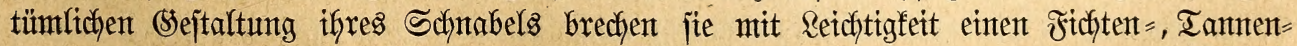
ober jelbjt einen Riefernzapfen auf. Sie jdynetben ben Zapfen ab, tragen ifn mit bem

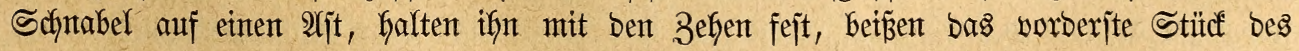


Decteldyens ab, jujteben ben etwas geöffneten Sannabel unter basjelbe unb heben es burdy

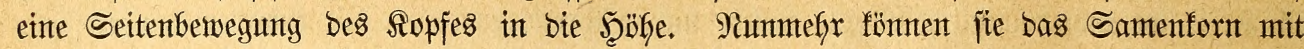
ber 3unge letdyt in ben Schnabel jujteben, von bem Flugblättchen unb ber Schale befreien

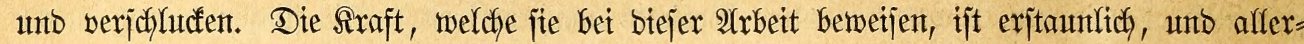
liebjt jift es aus, went ein jo fleiner $\mathfrak{B}$ ogel, mit bem jefweren Bapfen belajtet, einte Ent= fermung von 6 bis $10 \mathrm{~m}$. Durdffftegt, um jeine Beute auf einen geeigneten $\mathfrak{B l a t z}$ zu tragen.

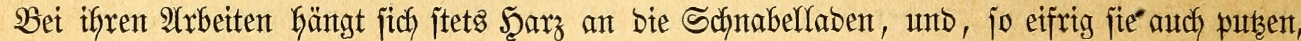

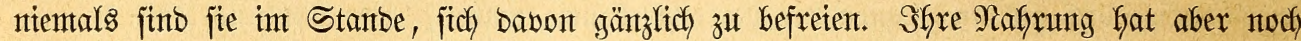
etwas anberes zur Folge. Das Şarz burdboringt jo zu jagen ityren ganzen Reib und ver=

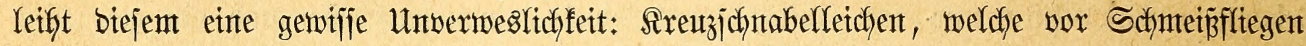
bewahrt wurben, trodnen zujammen und werben zu Mamien.

Wite jo sieles im Reben biejer anziebenten (Sejchöpfe, hat audd Das SBrutgejdyät jein

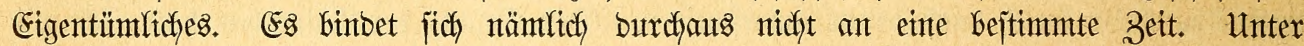

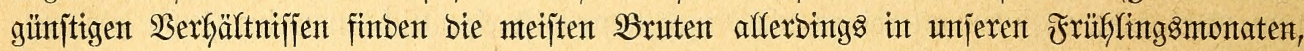
namentlich in März und 2 (prif jtatt; neben biejen beiben Monaten aber gibt es nicht einen einzigen im ganzen Sahre, in weldyem man nicht Nejter biejer Bëgel gefumben bätte:

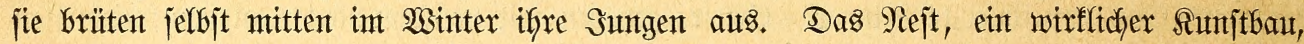

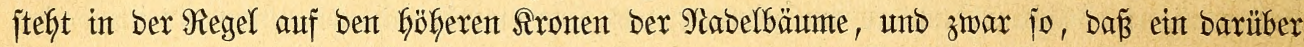

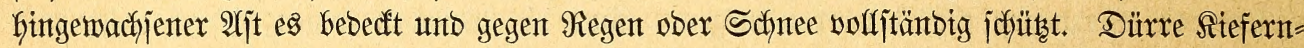
reijer, namentlich mit Flechten bewachjente, bilben jeine Srumblage, Fidftenbartflectenten und

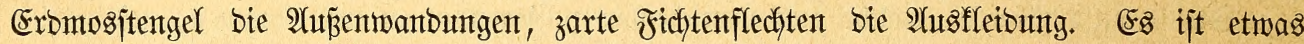
tiefer als einte Şarbfigel und ungemöhnlich bicht unt fejt gebaut, jo baz

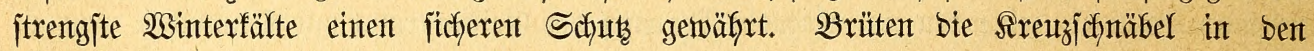

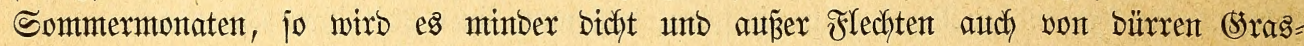
balmen, (Sragblättern, aud) wohl einigen Febern und bergleithen gebaut. Das (Selege bejteft

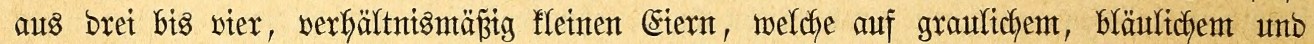
weip̈lichem Srumbe mefyr ober minber bidft mit verwajchenen, blutbraumen, blutroten, helf=

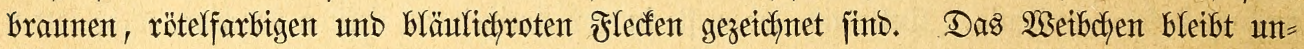
mittelbar nadjoem bas erjte Ei gelegt ijt, im Nejte fitzen unb wirb mährent ber ganzen Brutzeit vom Miänntyen ernährt. Worker war biejes in Gohem Srabe unrufig, flog fint

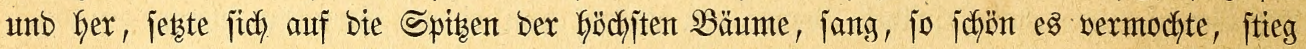
auch wohl wäfrento bes Singents mit zitternber Flügelbemegung in bie Şöhe, um jich von fier aus wieberum johmebent Gerabzujenfen - alles zur Freute unb Erbeiterung Des ge=

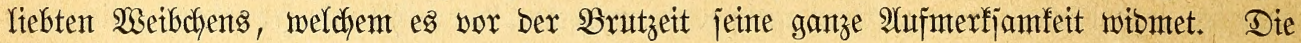
Sungen werben von betben Eltern jefr geliebt, anfangs mit erweidhtem, jpäterfin mit bär=

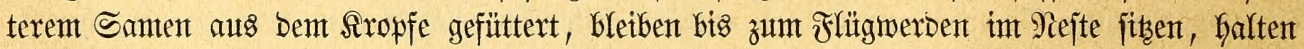

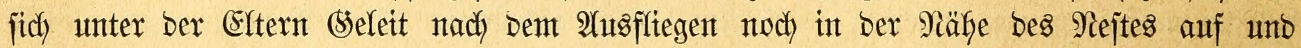

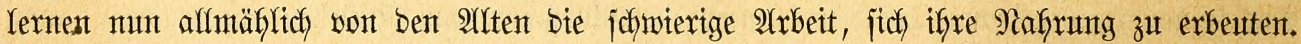

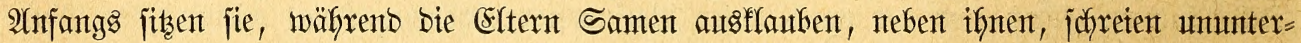
brodjen und fönnen es faum erwarten, bis jie gefüttert werben, fliegen ifyren Erzeugern auf Schritt und Iritt nadh ober lodfen jo ängjtltidy, Gis bieje wieber zurücffommen. Die 2llten unterrichten fie ganz alfmählich, bringen ifnen erjt balbgeöffnete Zapfent, um fie int

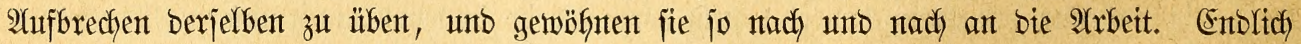
jelbitänbig geworben, jchlagen jich bie Sungen mit anberen in Flüge zujammen.

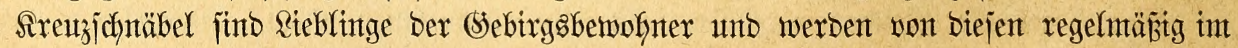

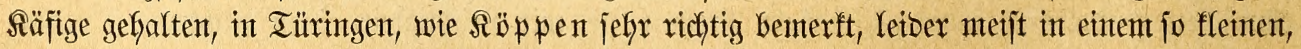

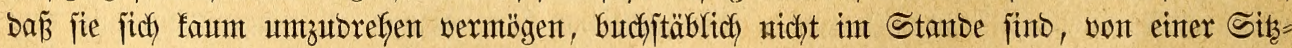
ftange zur anberen zu hüpfen, gejdhweige benn ifgre Sletterfïnjte entfalten fönten. Berjchiebene 
Sagen, abgejdymadte wie anmutige, Yaufen int $\mathfrak{B o l f s m u m b e}$ um, und ber alberglaube Gat

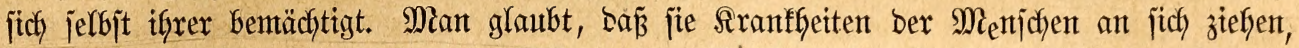
unt zwar bie Männthen joldbe ber Mänter und Sinaben, bie Weibchen joldhe ber Frautent unt Meäbchen, hält jie beşalb in Sranfenzimmern, trinft jogar bas Wafjer, in weldyent

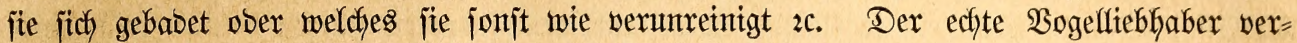

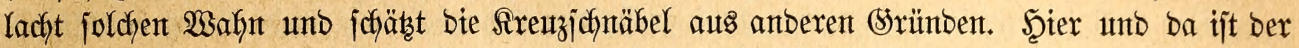

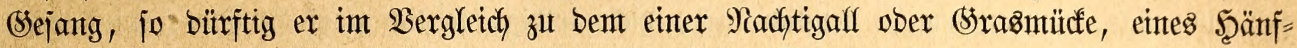
lings ober Stieglizes auch exjcheinen mag, in hohen Srabe beliebt, unt ïberall erwerben

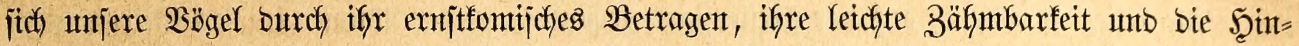
gebung an itgren Pfleger, welche fie in furzer Zeit befunton, Riebfaber und Freutbe. In Der Regel vertiagen fich mehrere Männchen, weldhe in einem Bauter gefalten werben, recht

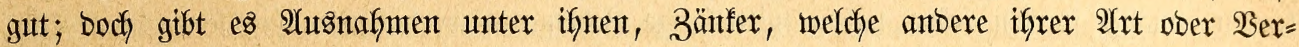

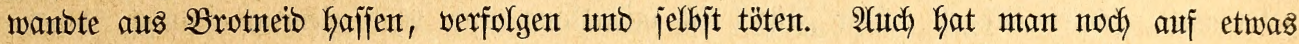
anberes Bebacht zu nefment: fie nagen fajt mit ber Fertigfeit eines Fapageten und zeritören fölzerne Säfige in furzer Bett, müffen aljo in Dratbautern gebalten werben. Uno jelbjt fier

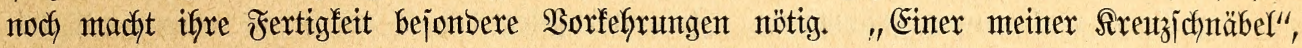

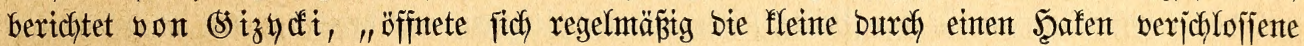

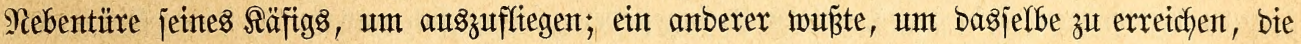

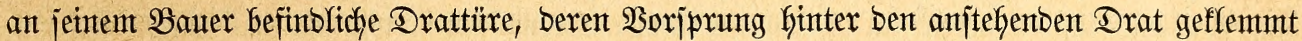

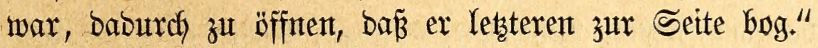

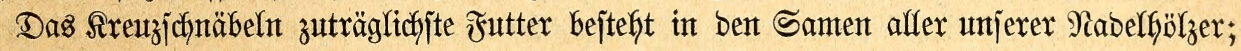

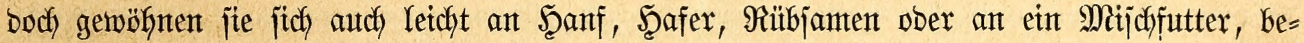
jteheno aus einem (Semenge verjefiebenter öl = und meblfaltiger Säntereien, freilich nicht zut

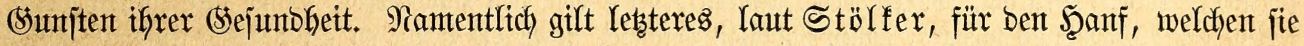

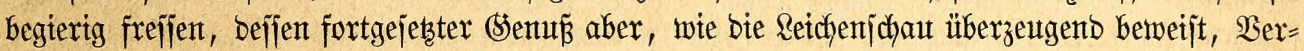

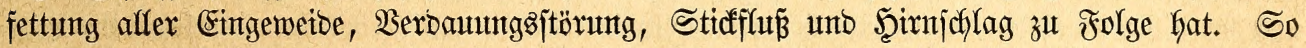

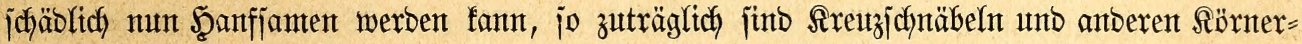

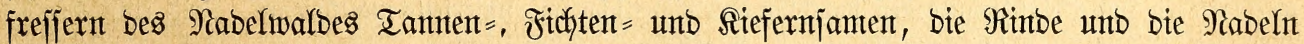
junger Sdjößlinge. Man gebe aljo mintoejtenz bie leb̧teren, weldye von Sreuzichnäbeln leiben=

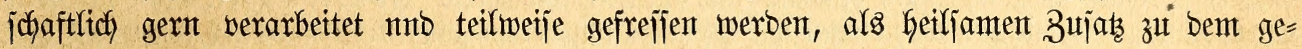

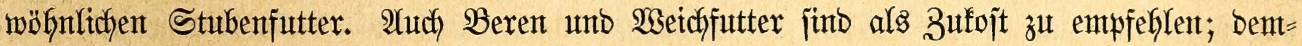

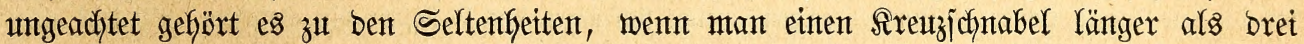

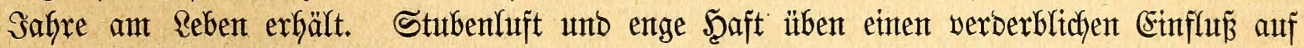

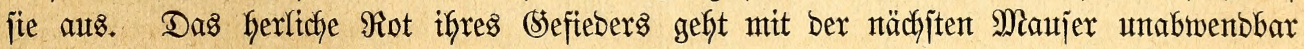
in ein büfteres, jaymuziges (Sraut ober Srünlichgelb über, ober aber bas Befieber bes jung eingefangenen Bogels erfält niemals jeine volle Schönbett. Şiergegen fitfft, jo weit unjere bisherigen Erfahrungen reidjen, fein Mittel, obgleidh wir uns jagen müfjen, bá̃ diejes

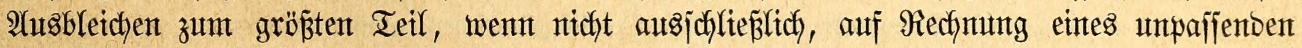
Stubenfutters gejebt werben mußs. 2(n frijchent Wafjer barf es ifnen niemals fehlen; benn

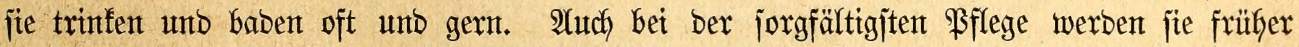

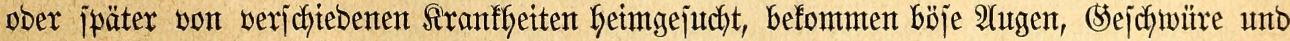

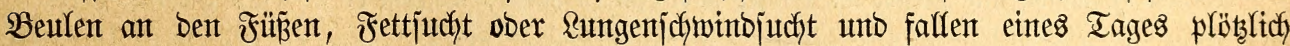
tot von ifyrer Stange herab. Dieje Şinfälligffeit bes prachtwollen Sefieders und bes Rebents gefangener Areuzidnäbel werletbet gar ntandyem warmen \&iebhaber, fie zu halten.

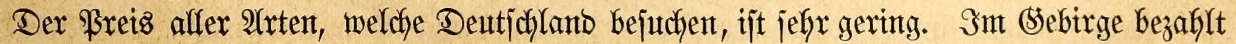
man jelten mebr als zefnn Silbergrojchen für ein frifdgefantgenes Miäntuchen, in ben Stäbten bes Flachlandes bas Doppelte, Göchjtens bas Dreifache - wentg für einen jo an= mutigen, genty für einen jo vergänglicłen $\mathfrak{B}$ ogel. 


\section{(bimpel.}

Unter unjeren Geintatlichen Finfentügeln zeichnet fich ber Simpel jo entjchieben aus,

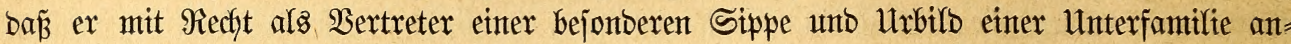
gejeben wirb.

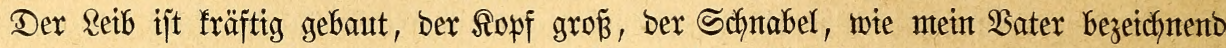
fidf ausbrüaft, bombenförmig, nemlidy furz, bidf, folbig, jeitlich jtarf gewölbt, mur gegen

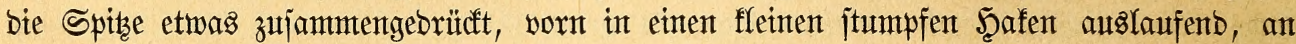
ber Difle effig vortretent, auf Der Firjte jtarf gerumbet, an ber Wurzel in bas Stirngefieber eingreifent. Die an ber Schnabelwurzel liegenben runben Najenlöcher jinto jefre flein unto werben von bem Stirngefieber und nadh vorn gerichteten Boriten fajt ganz bedectit. Die

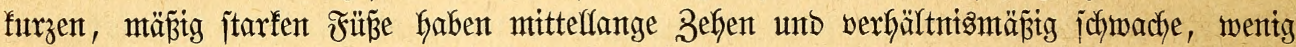

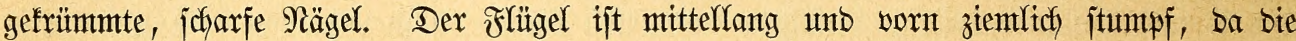
zweite, britte und vierte ber unter jidh gletch langen Sdjwingen bie anberen überragen; bie Sdywingen fint vorn und finten zugerunbet, in ber Mitte ausgejdyntten, bie erjten vor ber Spize auch auken verjałmälert. Zujammengelegt bebecft ber flügel etwa ein Dritt= teil bes ziemlich langen, in ber Mitte jeidjt ausgejchnittenen, aus breiten, worn abgerunbeten Febern bejtehenten Schwanzes. Das Aleingefieber zetchnet jith aus burch jeine Didhte und

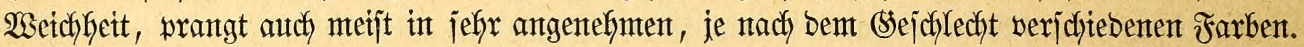

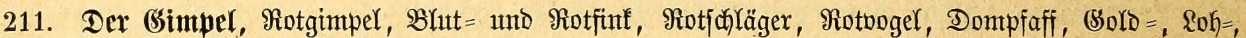

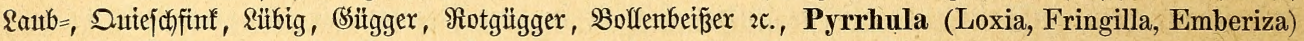

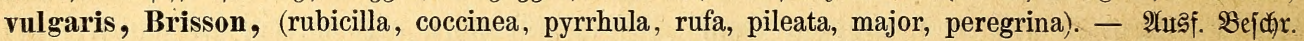

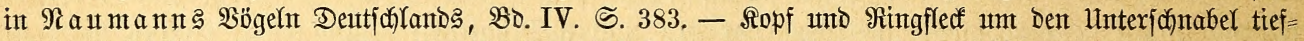

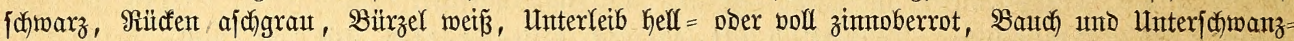

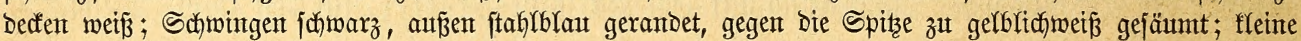

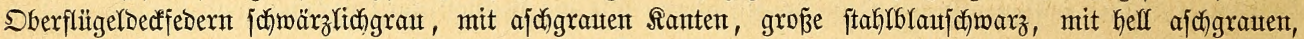

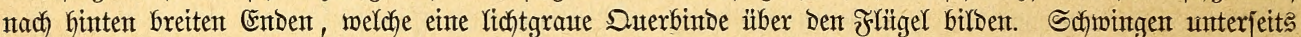

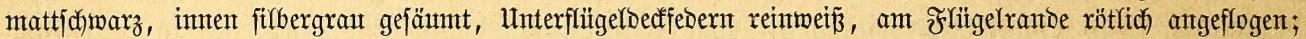

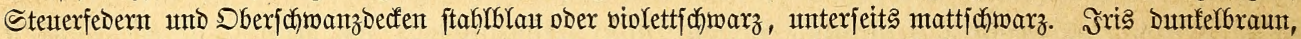

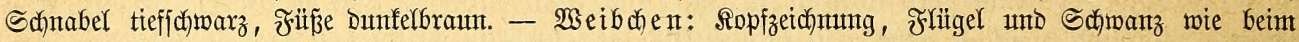

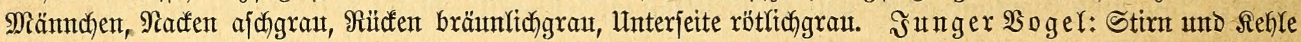

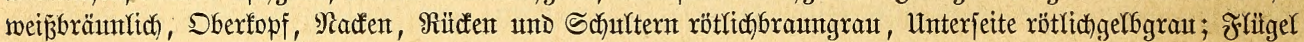

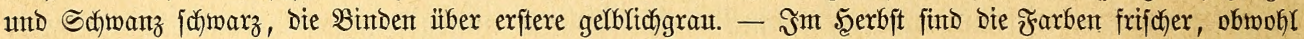

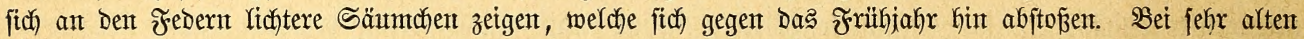

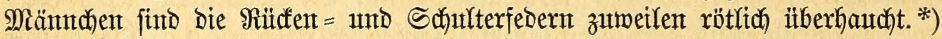

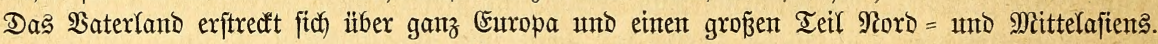

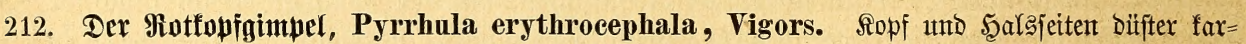

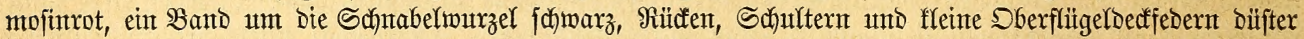

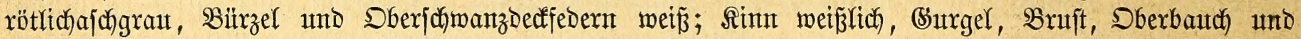

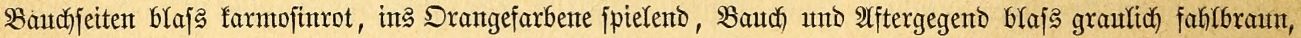

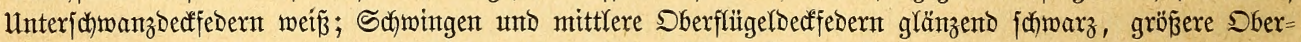

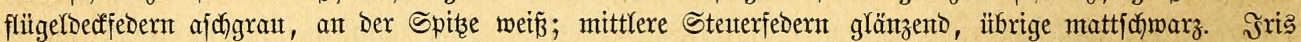

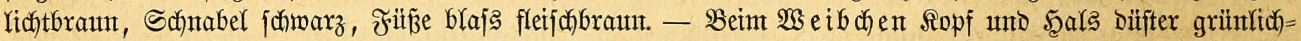

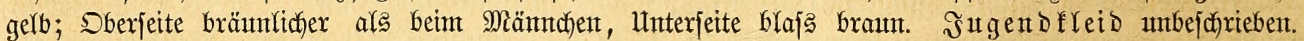

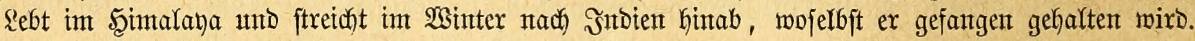

Das Serbreitungsgebiet ber (simpel im engeren Simne erjtrecft fich über Europa,

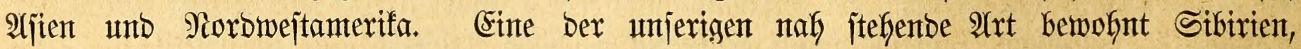

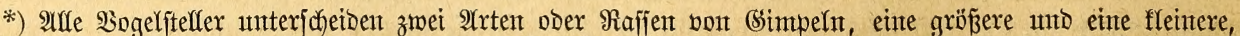

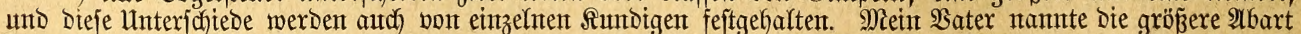

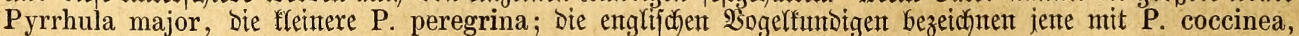
biefe ntit $P$. vulgaris. 


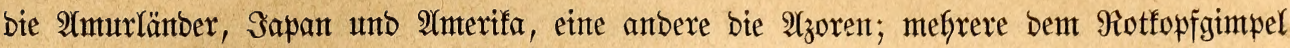

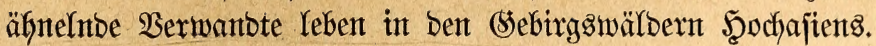

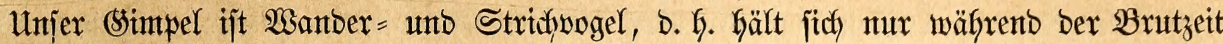
ftänbig an jeinem Sceimat8orte auf, verläß̈t biejen gegen ben Winter fin, ftreift im Ranbe

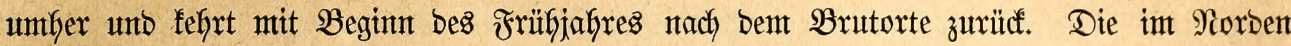

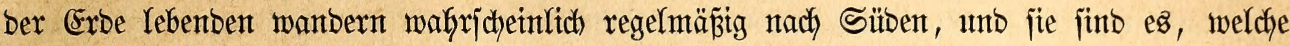

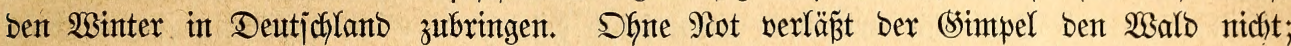

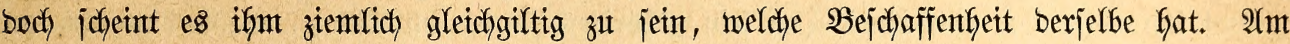

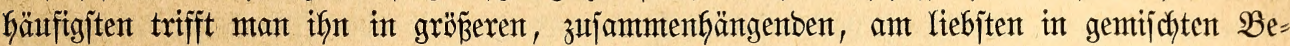
ftänben an. Sein $\mathfrak{B e j e n ~ m a d f t ~ i f g n ~ i n ~ h o h e m ~ S r a b e ~ l i e b e n s w e r t ~ u n d ~ r e c h t f e r t i g t ~ b i e ~} 3 \mathfrak{u}=$

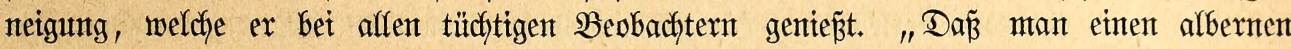

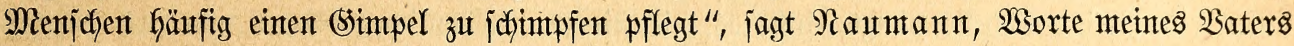
bem Sinne nach wiebergebent, "und bies von ber Dummbeit umjeres $\mathfrak{B}$ ogels ableiten will, fann mux aus einex jebr oberflächlichen Beurteilung jeines Betragens entjtanden jein." Sn ber Tat, ber Ssimpel ijt nidhts wentger als bumm; man barf ifn einen harmtlojen, janften, gutmütigen, nicht eben lebhaften unb vertrauensjeligen (sejellen nenten, nimmer = mebr aber jeinen Berjtanto unterjajäzen; Denn biejer befunbet jich jojlagento genutg burch bie

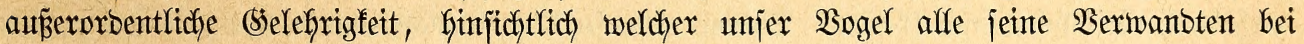

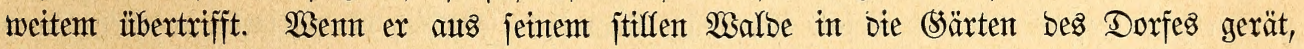

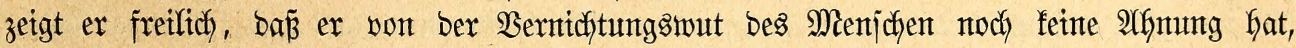

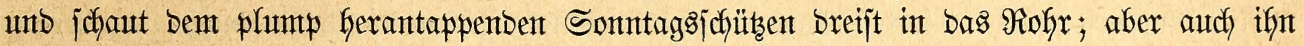

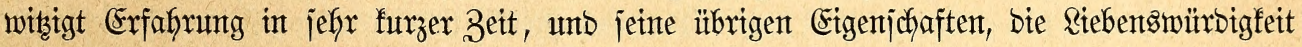

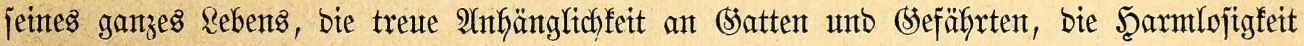

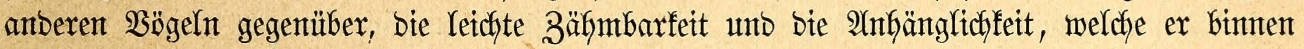

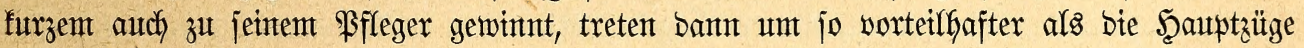

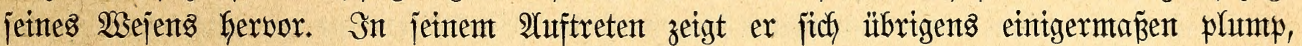

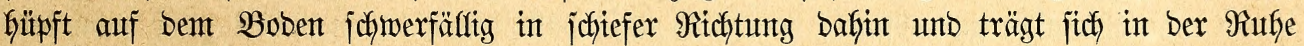

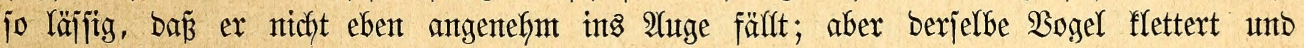

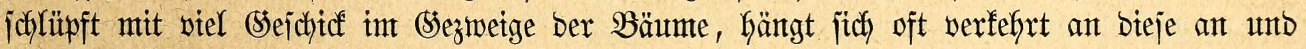
nimmt, wenn er jich auf bie Spizen jebst und jein (Sefieber glättet, eine jo nette Şaltung

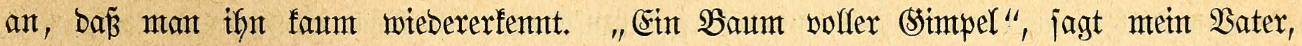

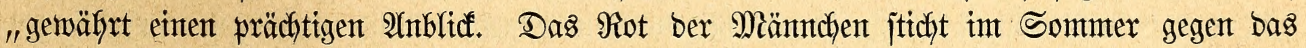

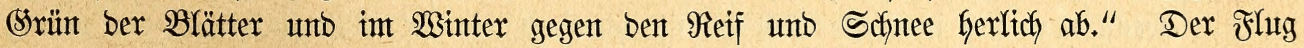
Gat mit bem unjeres Ebelfinfen einige 2 (ebnlichfeit, ijt letcht, aber etmas langjam, beim

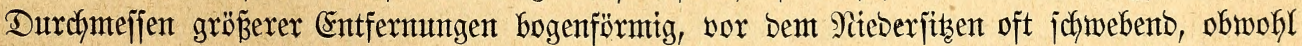
fich ber $\mathfrak{B o g e l}$ zuweilen audh mit jtarf eingezogenen Flügeln plözlich Gerabzuitürzen pflegt. Der Rocfton flingt janft flötend mie "Düh ", bie Einlabung wie "Biüt. Der (Sejang, weldyer von beiben (sejchlectstern, vom Männdyen aber weit bejjer unb lauter vorgetragen wirb, bejteft aus furz abgebrochenen, mit länger gezogenen verbutnoenen gebämpften Tönen, welche Bechitein nicht umpaffend miebergibt burch bie saute: Si üt üt üt ji re üt üt

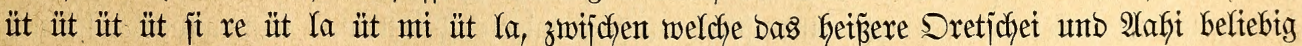

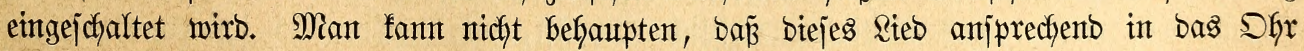
falle, und es erwirbt jith ber (simmel aus bem (strutbe auth nur wenige Siebbaber, obmohl es immerfin Einzelne gibt, wefdye jeinen natïrlidfen sejang jefön finden. Um jo mefrx nimmt bex Bogel. Durch jeine übrigen Eigenjidyaften für jidh ein. "Echon jein

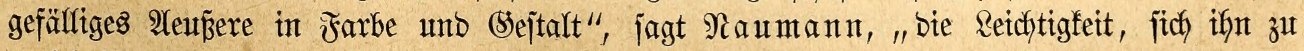
berjchaffen und ifn zu exhalten, jein zutraulidjes, janftes 2 sejen, vorzüglich aber jeine be=

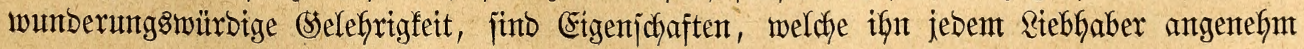


Into jeintem Befizer wert machen. Seine Zahmbeit, Das Sdynäbeln und zärtfiche Spiel, wenn Miänndyen unb $\mathfrak{B e i b c h e n ~ i n ~ e i n e n t ~ B a u t e r ~ b e i j a m m e n ~ j t e d f e n , ~ g e w a ̈ f r e n ~ m a n t h e ~ a n g e = ~}$

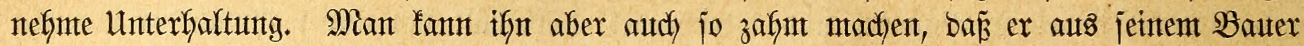
Gerausgeflogen fommt, jobals man ifn loutt, jich auf bie Seanto jetst, bas vorgehaltente Jutter auf berjelben ober aus bem Mambe nimmt, ben Speidfel bon ben Rippen trinft, ober aufgeforbert Berbengungen madht, Den Schnabel auf Befehl offnet 2 ." Bechjtein

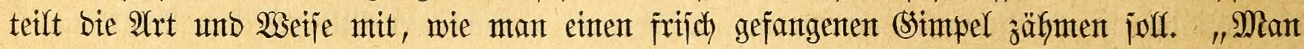
nimmt ifn, gibt ifm mux einten Iag jein geböriges Futter im Säfige, macht ifm alsoant einten Siflen, wie bie Bogelftelfer auj bem Scerbe um ben Reib ober Flügel bez Räufers zu tun pflegen, unb binbet iffn mit einem $0,33 \mathrm{~m}$. langen Faben irgentwo fo an, baj ex nicht Gerabfallen unt fidch totflattern fann. Şierauf nimmt man ein Yeres Beuteldyen, an weldyem

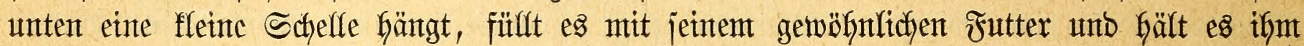

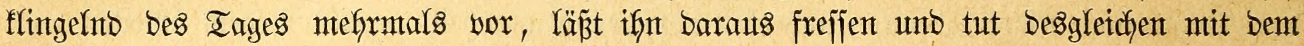
Trinfgejefirr. Âtnfangs wirb ber gefeffelte $\mathfrak{B o g e l}$ weber effen nody trinfen wolfen. Man entf̣ernt fich baher bie erjten zwei Tage etliche Male, wenn ex nicht zulangen witl, unt läp̈t ifyn aus bem beuteldyen freffen uno aus bem Trinfgejchirr jaufen, tritt aber, währento er

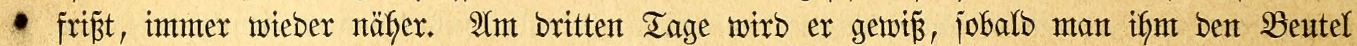
vorfält, Gerbeifüpfen und frefien. Tut ex bies, jo flingelt man immer und läp̈t ifhn weiter Güpren und freffen. WSenn er jatt ijt, trägt man ifgn, obgleced er flattert, auf ber Şand Gin uno ker, auf weldyer ex bann audh, ba ex nidft losfommen fanm, zu frefjen anfangen wirb. $2(m$ britten ober vierten Tage, went ex von jelbjt auf bic Şanto Güpft, in welcher

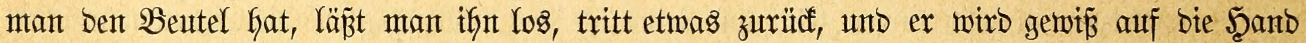
geflogen fontmen; jolfte ex wegfliegen, jo bintot man ifn wieber an unb läß̈̈t ifn nod)

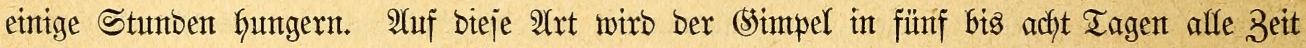
auf bie Şand und bafint fliegen, wo ex flingeln Gört. 3ur vollfommenten 3ähmung gefört

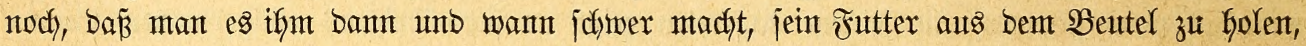

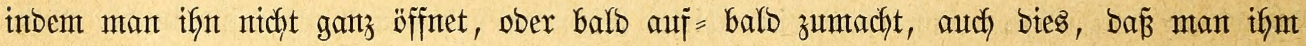

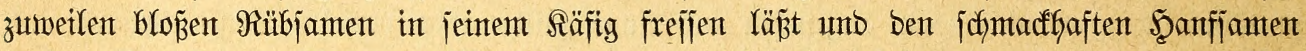

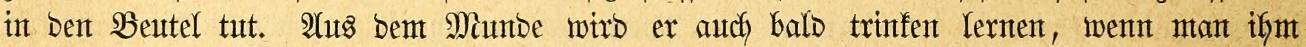

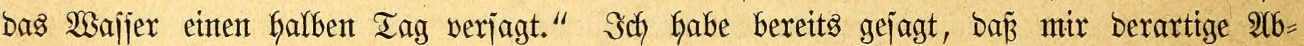
richtungamittel ein (Sreuel fint, und Darf finzufügen, Daj beim (Simpel eine Derartige

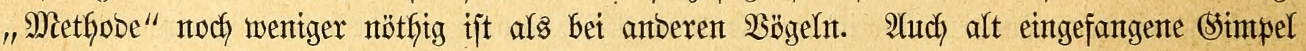
werben, wenn man jidh in redfter 2 seije mit ifnen abgibt, fie jelbjt füttert, ifren Bauter entiprechend fyängt (ङ. 55) 2c., in jefr furzer Zeit zafm, zutraultidy uno ifrem (sebieter ungemein zugetan; bent ebenjo treu, wie jie an ifrem Befährten Gängen, lieben jie ipäter

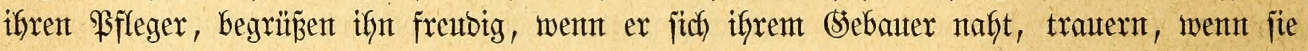
ifhn längere Beit nicht jeben, ja jie fünnen jogar, wie ich nach hinlänglich verbürgten 2 (nt=

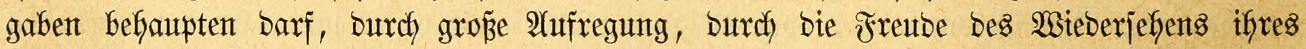

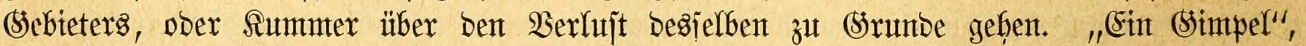

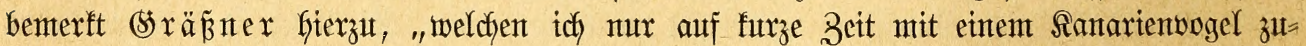
jammeniperrte, befam Arämpfe und jtarb nach wentgen Minuten. Ein anberer meiner

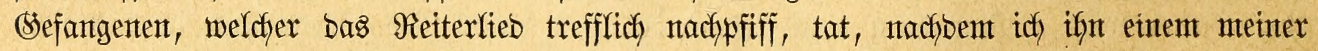
Freunbe gejchenft hatte, ben Schnabel nidbt auf, pfiff aber jofort wieber, als mix jener Den "ntchtsinutzigen Bogel" zuxücfgegeben Gatte."

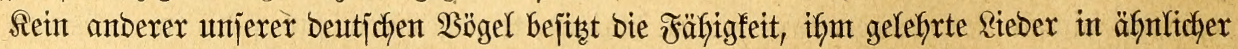

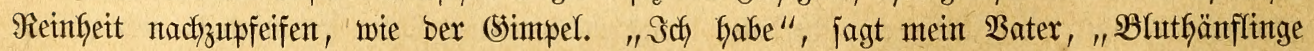

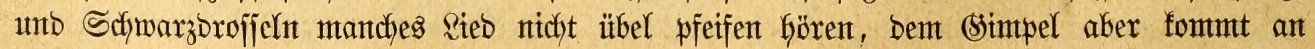

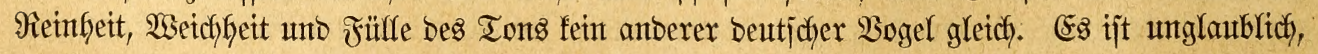


wie weit ex gebracht werben fann; ex lernt oft bie Weijen zweier Sieber unto trägt jie jo

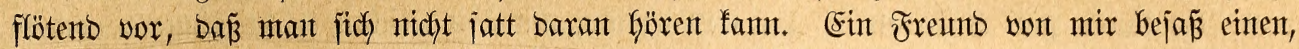
welchen er jelbjt aufgezogent unb gelehrt hatte. Derjelbe fing ganz tief, jo baj man nafye zut ifm treten unt jich mit ifm unterfalten fonnte; Dent ex jicheute fich aud wor fremben

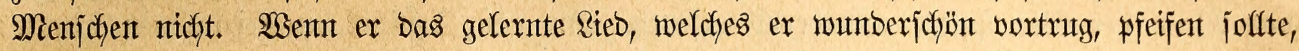

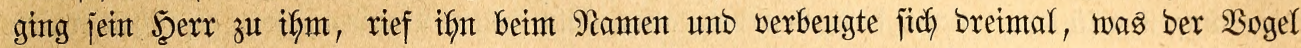
jebesintal mit groperer Freube unt 2 (nnmut ermiberte. Nach ber britten Werbeugung fing ex an bie herfiche $3 e i j e$ zu pfeifen, unb volfentote fie in einem 3uge, ofyne Den geringiten

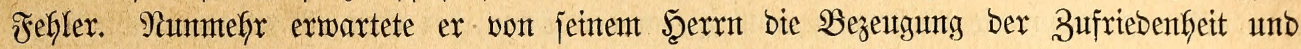

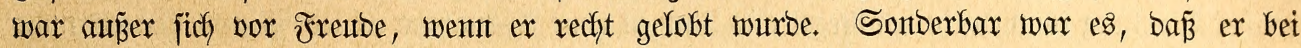
jebent Manne, welifer fich ifm näherte und ifn gebörig mit Berbeugungen begrü̈ste, ein (5) leidjes tat, aber nie einem Frautenzimmer (Seforjam Keijtete. Eine Bermandte Des Bejübers

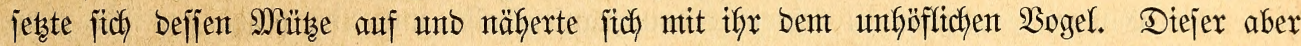

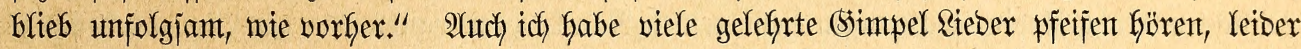

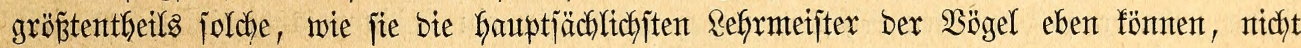

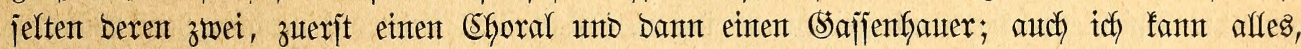

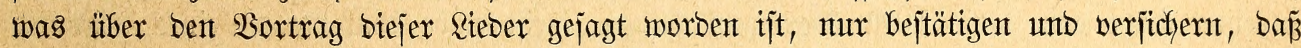
anfangs ein gelefrter (simipel bie größ̈te Freube macht, ja wirlich entzücfen fann. Dod geft es mie mit einer Spieldoje; man befommt bas ein unb bagijelbe in furzer Zeit berzlich jatt und fann jo abgejtumpft werben, baj man ben natürlichen Walogejang, jo

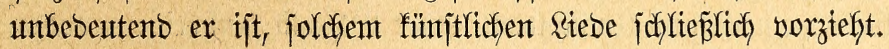

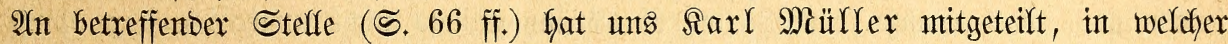

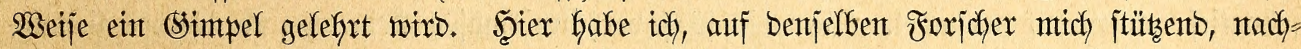

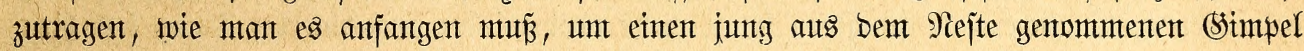

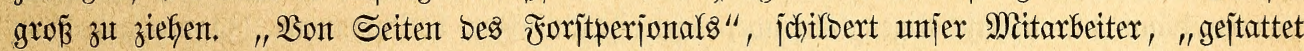

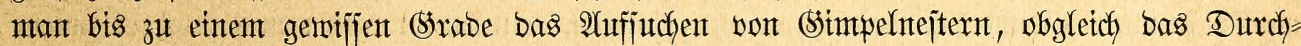
jtreifen ber jungen Şege nach 2 ogelnejtern jtreng verboten ijt. (Sewöhnlich wirb ber Sonntag

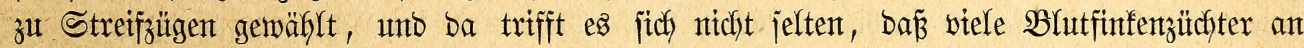

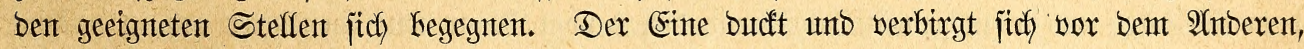

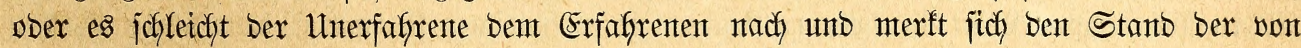

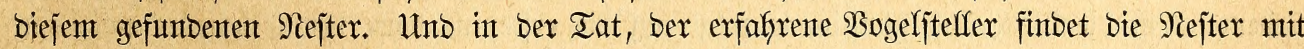
eritaunlicher Sidjerheit. Er verjofwentet feine Beit, inbent er jelbjt bie ifgm fremben (se=

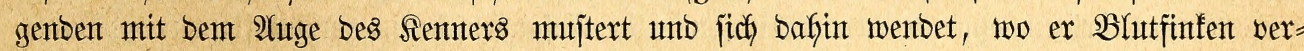
muten fant. Wite jein $\mathfrak{A}$ thge aufmerfjam umberjpäht, jo ijt jein Shr fortwähreno gejpannt;

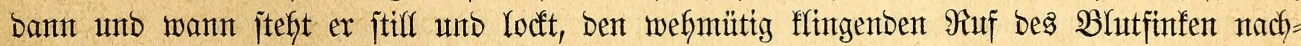
afmend. Erfä̈lt ex 2 (nntwort ober bringt von ungefähr biejer Ion zum Shx, bann beobadjtet

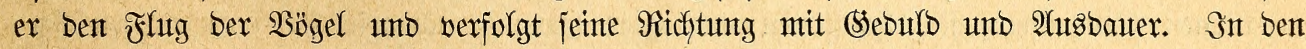

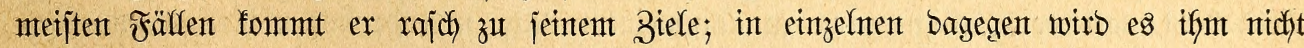

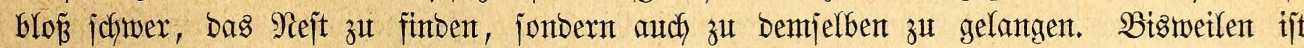

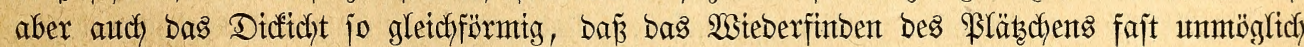

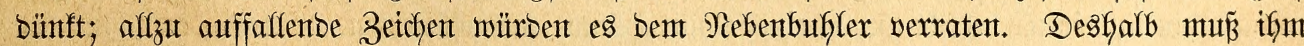

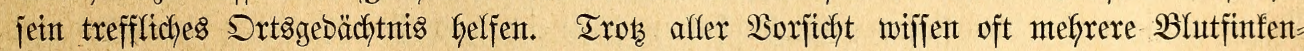
züdfter ein und basjelbe Rejt. Mandhe jodreiten in joldhent Fafle zu Dem Mittel, bie (Eter

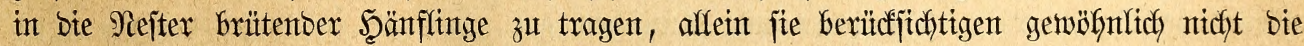
bereitz gefaltene Brütezeit Des (Simpels jomofyl wie des Scänflings; ober ber fluge Bauter wiro von einem nody flügeren ïberliftet, weldyer bie Bhlutfinfenter wieber aus biejem

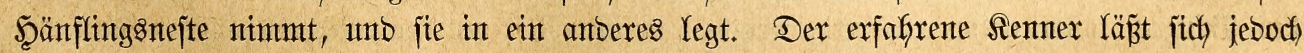

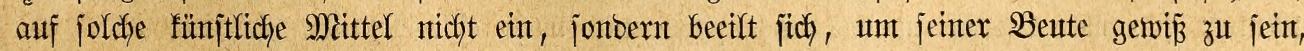


bie naften Sungen fo früf als möglidy aus Demt Rejte zu tefinten. Da hat ex bent jeine Not, Die faum zwei Tage alten, ber Ermärmung unto Des weidjen fierbtierfutters noch jo

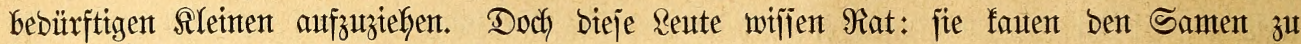
Bret, inbemt fie ifn bierbei mit ber nötigen Menge non Speidhel vermengen unt jo bie 2 rt und Weije ber Erternyflege annäherub erjezen. In ganz bejtimmten Beiträumten werben

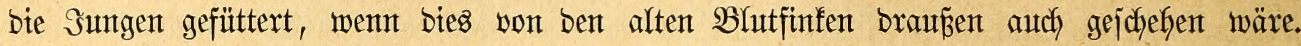
Demt Futter wirb in jehr mäpig geheiztem Dfen bie geeignete Wärme unmittelbar vor ber Fütterung ber Sungen beigebradyt. Dieje jelbjt merben nad ifyrer Sättiguntg jorgfältig

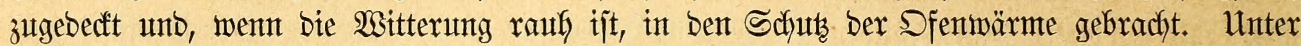

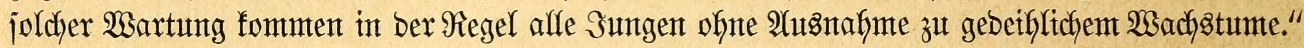

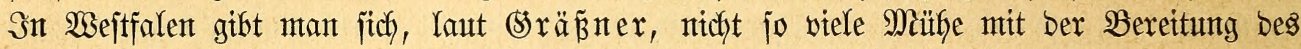
Futters, jonbern wendet hauptjächlich İmeijenpuppen an und erzielt bagijelbe.

Der Simpel bevorzugt zut jeinem Sommeraufenthalte unb SButplatze gemijate, an

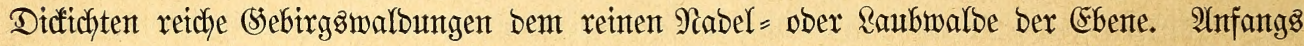

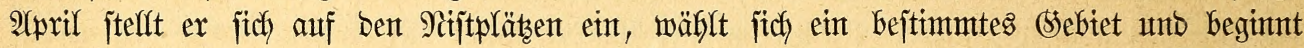

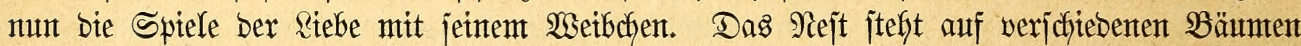

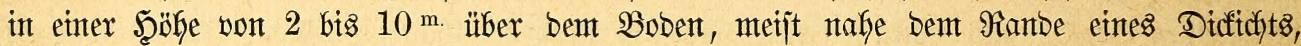
unweit eines $\mathfrak{W e g e s}$ ober einer freien Stelle, entweder bicht am Stamme ober in eintem

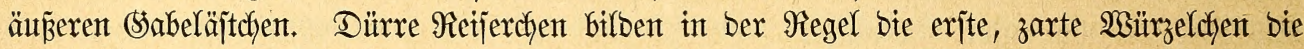

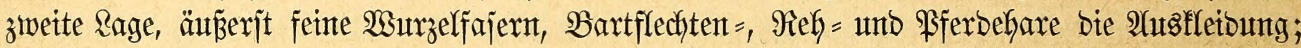

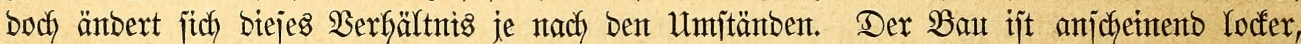

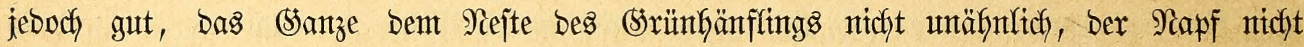

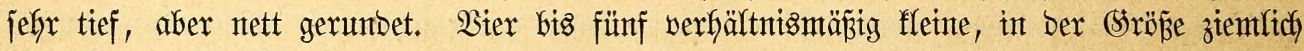
abrweichenbe, längliche, am jtumpfen Enbe mebr ober minber zugerunbete, jelten fajt birn=

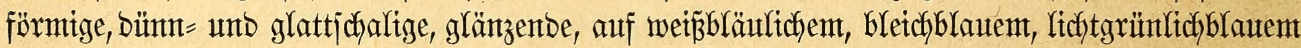
ober Gläulichem Sirumbe mit violettgrauen, violetten, Dunfelbraunroten unt purpurbraunen,

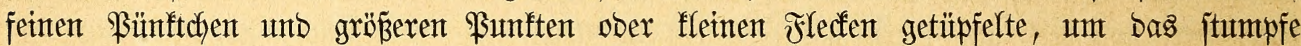
Enthe franzartig bejeste Eier bilben bas Belege unb werben im Raufe von vierzefn Iagen

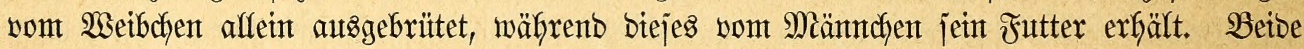

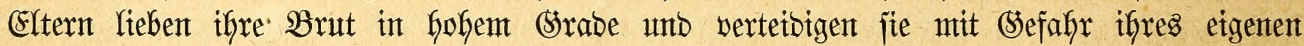
\&ebens. Sit bie Witterung günjtig, jo folgt auf bie erjte int Raufe bes Sommers nodh eine zweite $\mathfrak{B}$ rut.

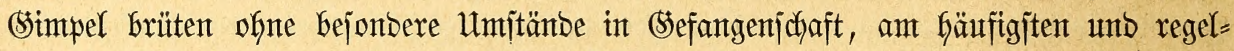
mäp̆igften im Fluggebauter, jeboch aud in Säfige. Frevberg erfielt, ofne fidh jeiner gefangenen (Simpel bejonbers anzunefmen, binnen brei Safren fünf Bruten, weldye jämt=

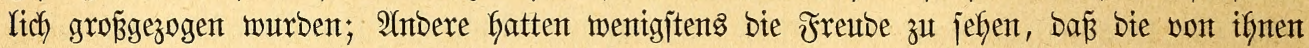
gefaltenen (Simpelpare jich begatteten unt Eier legtent. Sch wifl bie Erfafurungen eintes Riebhabers, weldyer glücflich war, zu allgemeinem Nuts und Frommen bier folgen lafjen.

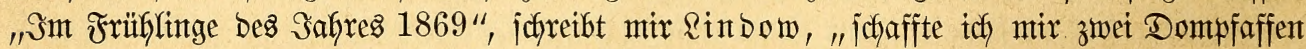

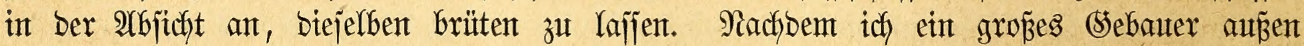
mit Tannenzweigen bebecft und einen mit Iuch ausgefütterten Nijtforb zwijchen Den Tamnenzweigen in ben Räfig gebracht hatte, jeţte idh bas $\mathfrak{B a r}$ Ginein. Ungefähr brei Wodjen ipäter begann bas Weibchen ein Mejt zu bauen, weldhes jeboch vom Meäntchen

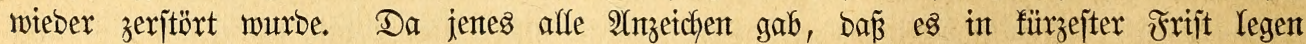
werbe, nafm idy Subhare unb flebte bieje mittels etwas seim in ben Nijtforb. Schon am anberen Tage legte bas Weibchen, aber nicht in bas গejt, jonbern auf ben Boben

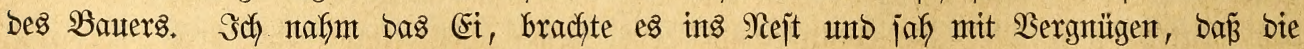

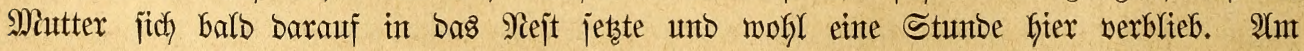




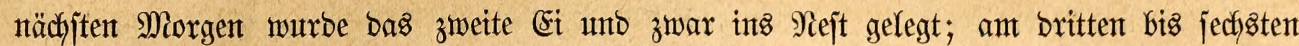
Morgen folgten bie übrigen (Eier nach, unt nachbem bas vierte gelegt worben war, begann bie $\mathfrak{B}$ rütung. Das Miännthen trat oft als Störenfried auf, wäfrento das

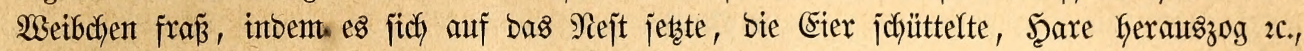

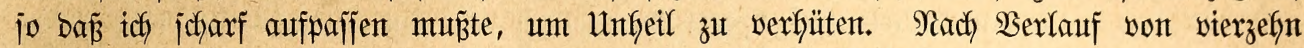

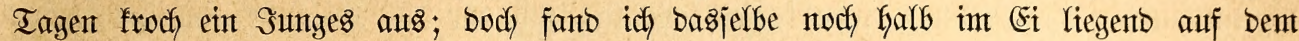

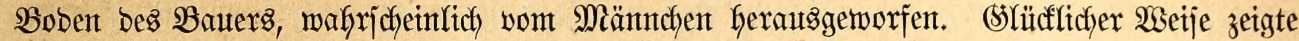

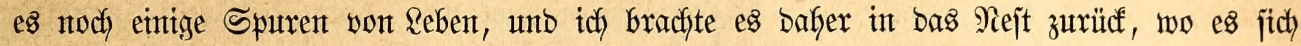

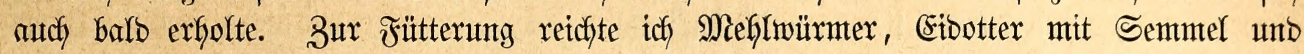
eingequelltem Rübjamen. Die Matter fütterte jefr eifrig bis zum vierten Iage, murbe

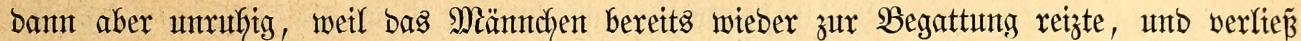

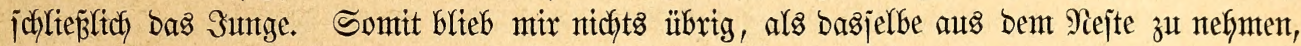

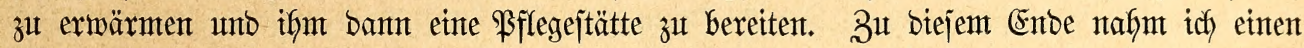
Iopf, fütterte ifn mit Rubharen aus, brïcfte in bieje eine Mutbe ein, jtellte ben Iopf

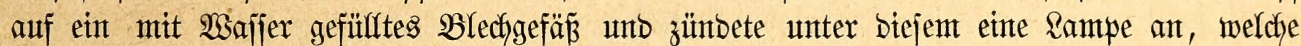

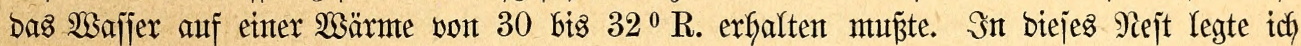
Den fleinen $B$ ogel, becfte einen jetbenen Rappen barüber und hatte bie Freube, ifn bald redjt

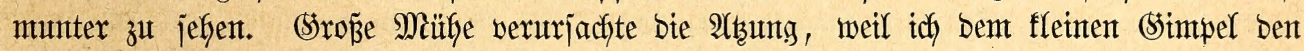

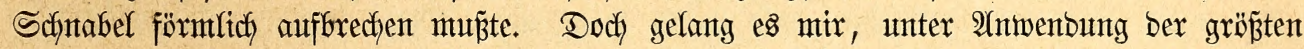
Borjicht, ifm Semmel ant Ei beizubringen, ex gemöfnte jich an bie fünjtlliche Fütterung

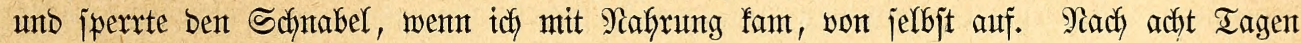

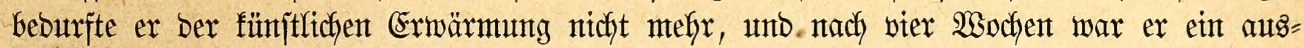

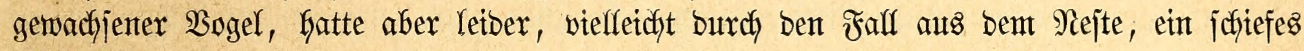
Bein befommen.

Eintige Tage nadjoem bie Matter gebadjtes Intge verlajfen hatte, begattete jich bas ßärchen von neutem, unb ę verging auch mur furze Zeit biłz zum Eierlegen. Nachbem bas britte von ben fünf Eiern bes (seleges int Mejte lag, iperrte ich bas Männdyen ab.

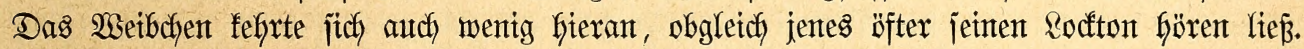

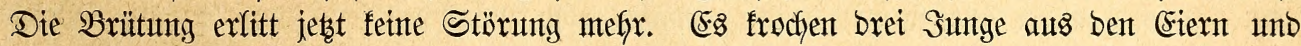
wurben bon bex 2rlten mit Mefllwürmern, Ei unb Semmel, und päter mit eingequelltem

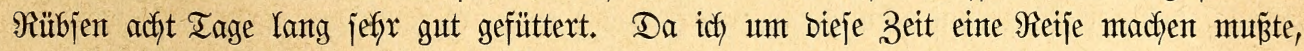

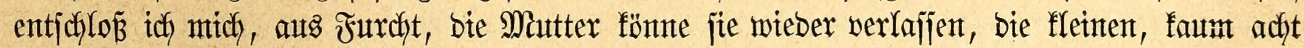
Iage alten (Simpel mitzunebmen, um jie jelbịt aufzufüttern. Sch madhte aljo einen fleinen Rajten zum Reijenejte zuredft, unt von ben brei Sungen überjtanden zwei audh recfyt gut

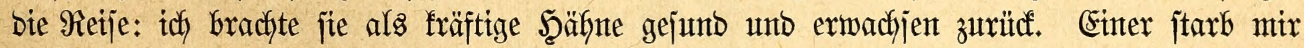

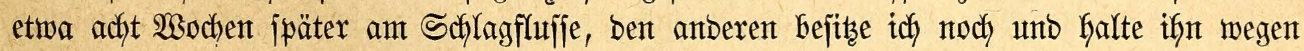

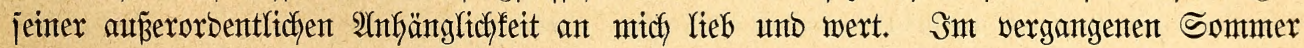
(1870) gejellte ich ifym ein $23 e i b d j e n$ zu. Sifon nach furzer Frijt parten fich bie $\mathfrak{B}$ g̈gel.

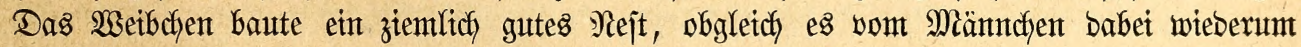

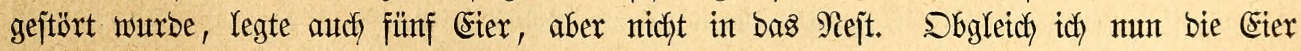

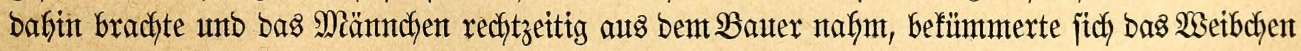
boch burchaus nicht um biejelben, und jo muste ich midh entichliesenen, bie fünf (Eier einem - Santarientweibchen unterzulegen, weldyes brei von ifnen ausbrütete unto grof fütterte. Esinige Tage jpäter parten jich. Die mieber zujammengebradjten (simpel zum zweiten Male, unto

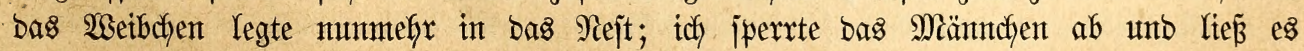
bló̉ jo lantge zu bem Weibchen, bis eine nette Begattung exfolgt war. Nach bem Regen Des britten Eies blieb die Matter auf bem Nejte jitzen, Yegte aber noch zwei (Fier

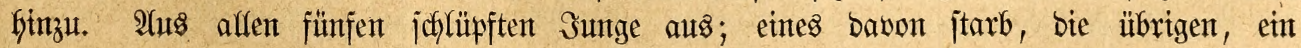


Männchen unt bret Wetbchen wurben von ber Matter mit ben angegebente Futterjtoffen glüdfich gró gefüttert.

2ldft Iage fpäter begann auch bas ältere \$ar mit jeiner Brut. Bier Eier murben

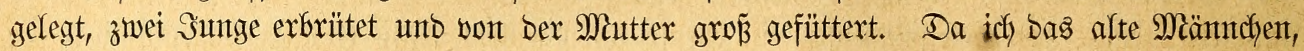
während bas Weibchen Grütete, abgeiperrt hatte, gab idh ifm berjuchasweije eine ztweite

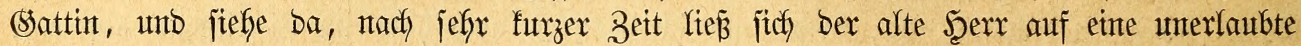

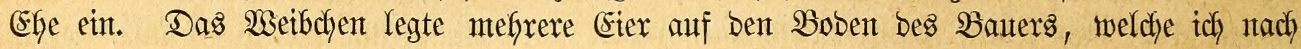

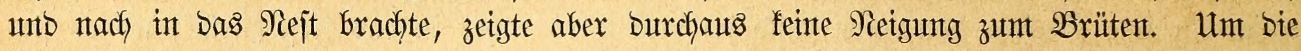
Eier zu verwerten, wurben fie einem Ranartentweibchen untergelegt unb zwei von ifynen ge=

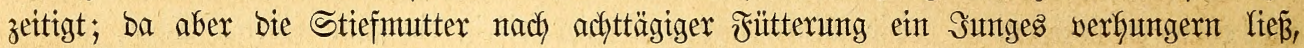
nahm ich bas andre zu mitr unb fütterte es jelbjt grof. - Nach meinen Erfafrungen ijt aljo

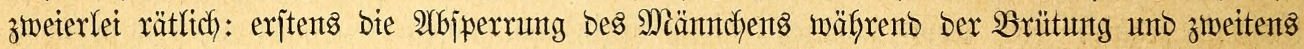

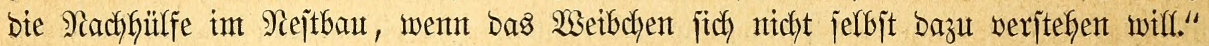

Wä̧rent jeines Jreilebens ernährt jich Der (sintpel von allerlet Bammjamen, anderen Sämereten, Berenfërnern unb fnospen, insbejonbere ben Samen ber Erfent und Birfen,

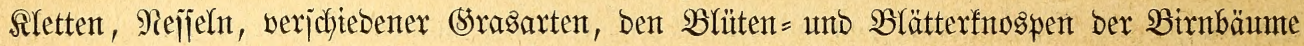
(meshalb ex in Sbitgärten jebr jchäblich werben fann), Butchen, Etchen, Eberejchen, Sireuz=

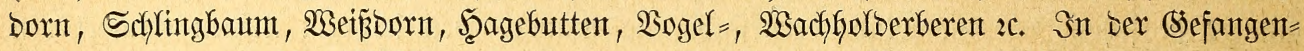

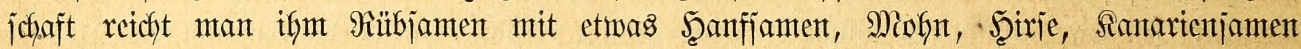

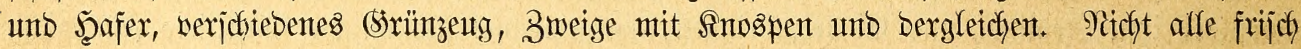

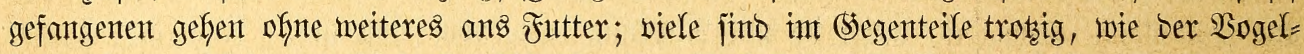

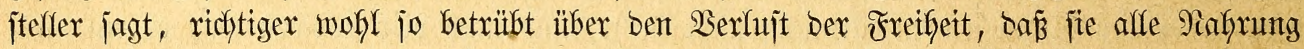

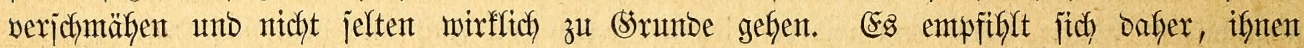

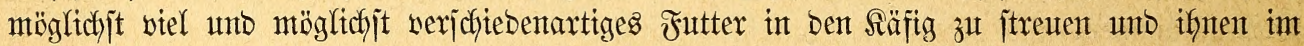
Winter, ber gemöhnlichen Fangzeit, werjeftebene Beren, namentlich bie verlocfenten Eber = ejchenberen zu retchen. Sit man im bejits eines gezähmten (Simpels, jo hat man mit der

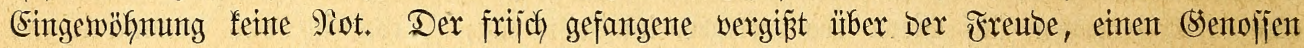
gefunben zu haben, Yeidyt ben Berfujt jeiner Freibeit unb tut, was er jenten ungejdyeut tun jifht. Aluch mefgrere Witbfänge, weldhe zujammen in einten Räfig geiperrt merben, gehen

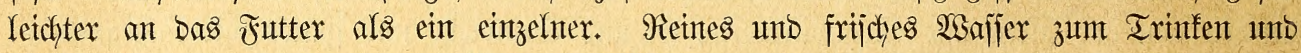

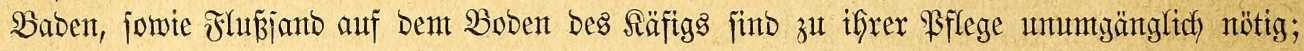
Sierbtiernafyrung unt tierijche Stoffe überfaupt bebürfen jie nicht, obgleidh jie fich leicht baran

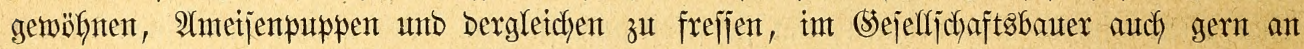

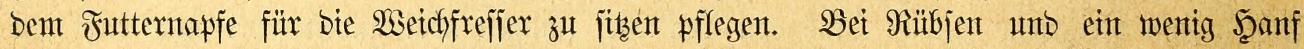
Galten fie jith ant bejten unb bauern, went man jonjt fie abwartet, Dabei biele Gafire im

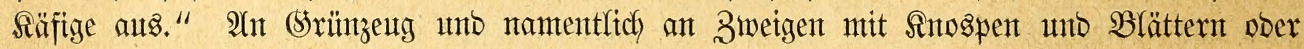

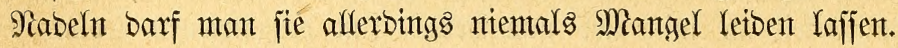

Sm (Sejelfichaftabauer gefören fie nicht gerabe zu ben friebfertigften Mitgliebern, uto

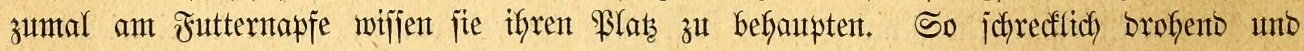

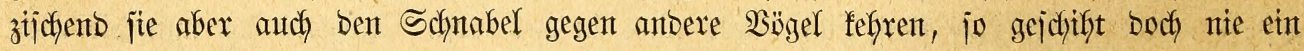
Untglüaf burch bie von ifnen aubgeteilten Şiebe. "Selbjt bie Fare", jagt ธtölfer, "fitreitent

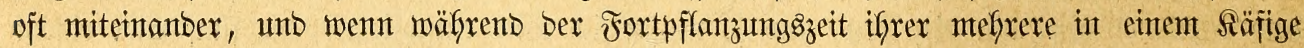
beijammen Keben, hat ber Scaber fein Ende; ja fie fönmen, weil fie fich oft heftig verfolgen, bie gejamte Bemohnerichaft bes Fluggebauers in Unruke verjeben."

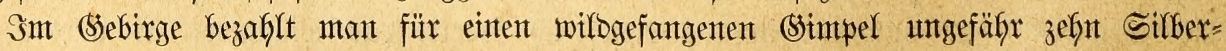

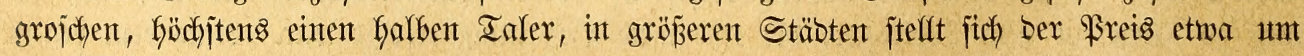

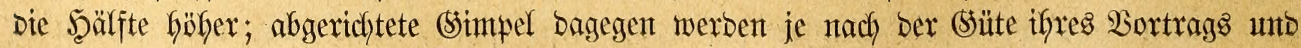

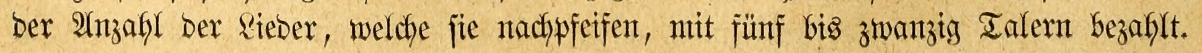




\section{finkengimpel.}

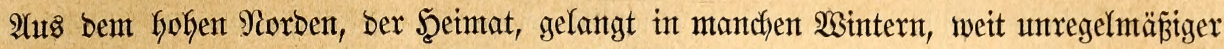

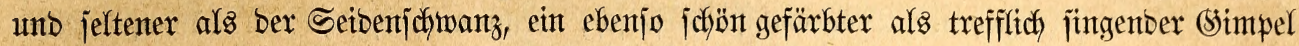
bis in bie Mitte Dentichlands, unt ebenjo jtreicht berjelbe won ben eifigen Ssefilben \&abrabors bis in ben mittleren Ieil ber vereinigten Staten herab. Şier wie Dort aber fefrt ex jobalo als möglid, nach jeinen ftiflen $\mathfrak{B a l b u n g e n ~ z u r u ̈ r f ~ u n d ~ g e l a n g t ~ a u s ~ b i e j e m ~ ( s x u m b e ~ v i e l ~ z u ~}$ jelten für jeinen $\mathfrak{S e r t}$ in unjere Räfige.

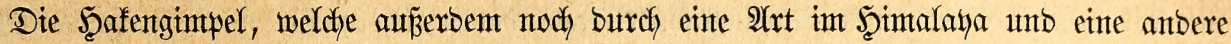
auf bem Cameruts in Wejtajrifa bertreten werben, gehören zu ben größ̧ten Sïrner=

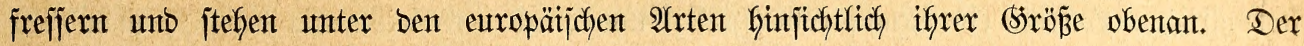

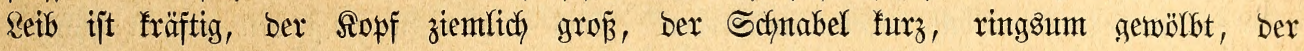
obere in eitte bafenförmige Spike aushaufent, an ben Seiten auggebautht, an ben

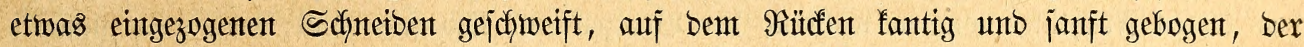

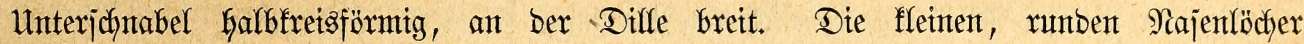
werben bon glatt aufliegenben Borjtenfeberchen bebecft. Die Füre find jtarf unb

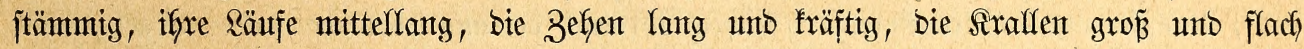
gebogen. Unter ben Sdymingen bes mittellangen Flügels finto bie zweite und britte bie längiten, bie vierte und fünfte außen leicht ausgejejnitten, bie übrigen im Enborittel ver=

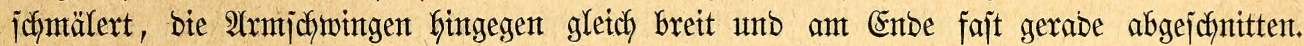
Der mittelfange Safwanz, weldher won ben zujammengelegten Flügeln biz zu einem Dritt=

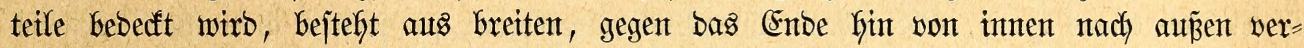

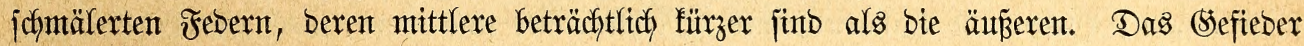
ijt ziemlich weich und prangt in prächtigen Farben.

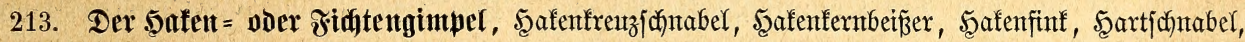
Farisonger, Ixappenfrefier 2c., Pinicola (Loxia, Fringilla, Strobilophaga, Corythus, Pyrrhula) enu-

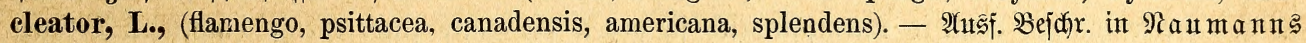

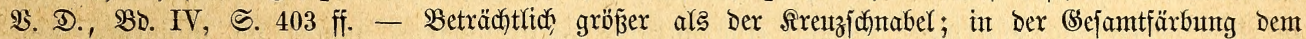

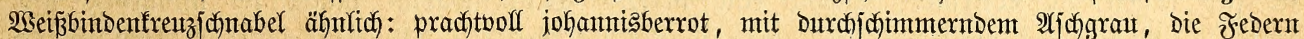

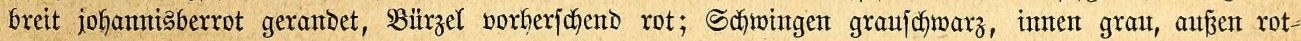

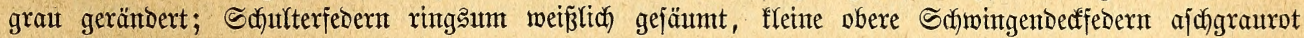

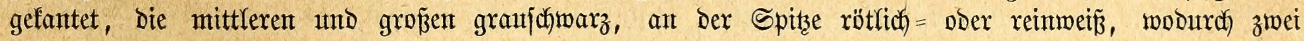

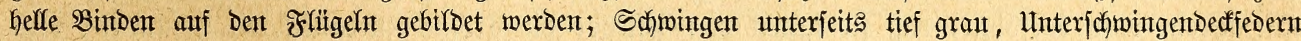
rötfich) grau; Stenterfesern graujd)warz, rot = ober grüngrau gejäumt, obere Sdjwanzbedfebern rot, untere

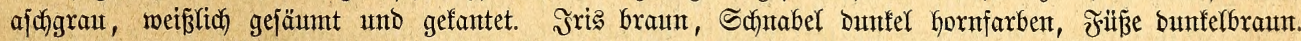

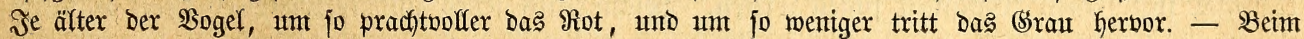

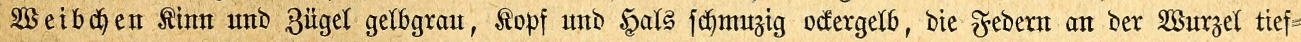

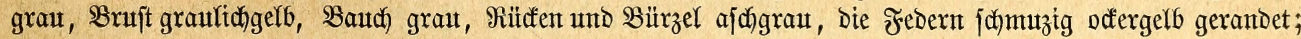

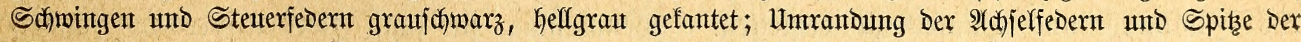

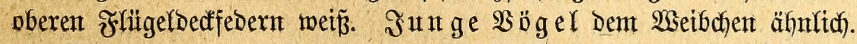

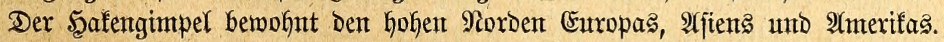

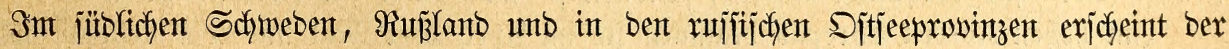
Saafengimpel fajt in jebem jeffneereidyen unb falten $\mathfrak{B i n t e r , ~ i n ~ M i t t e l b e u t j c h l a n o ~ b a g e g e n ~ n u r ~}$

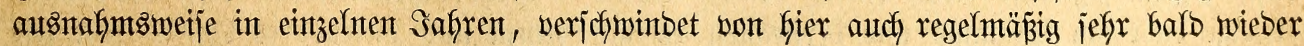

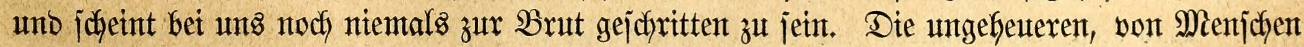

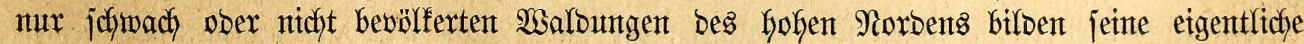

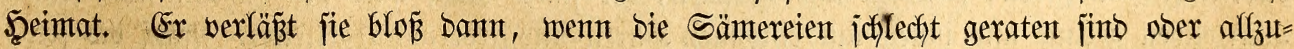

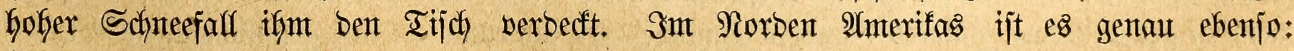

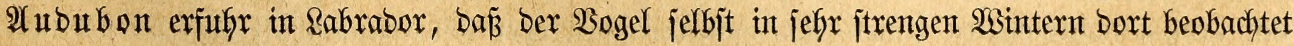
merbe. Entiprecheno joldyen 2Uufenthaltzorten zeigt jich ber Şafengimpel, went er in be= 
bölferte (segenben fommt, nod) vertrautengjeliger als bie bisher bejchriebenen Rörnerfinejer

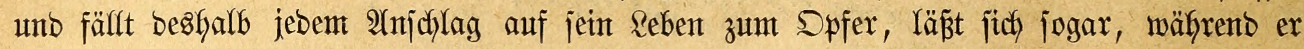
auf Dem Baume jitżt, mittels einter längeren Sierte eine Schlinge über ben Siopf werfen

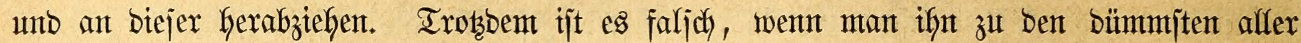

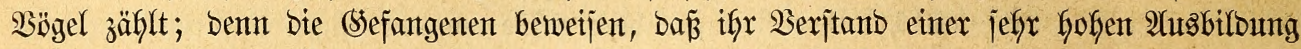

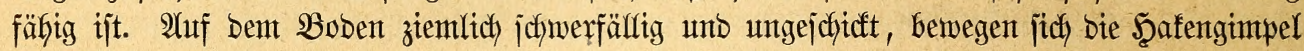
nach Mieijenart fletternd in Den Zweigen mit groéer (Semantbtheit, fliegen aud) ziemlich idfnell,

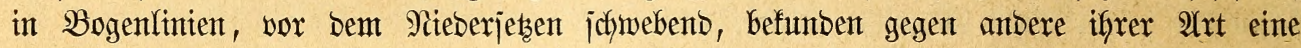

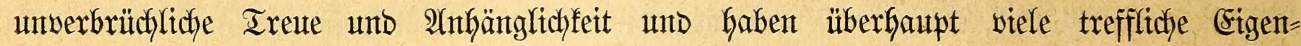
jdhaften. Unter aflen obenan jteft ifgr ganz vorzüglicher (sejang, in welchem bie weidjen,

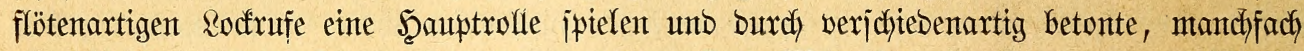
abwedjelnde, jante Iöne verbunben werben. Das Männdhen fingt ben ganzen Winter finturdh, obwohl um bieje Zeit noch leije, entfaltet jein volles Jeuer aber boch exjt in

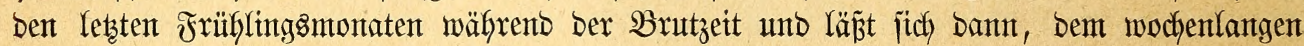

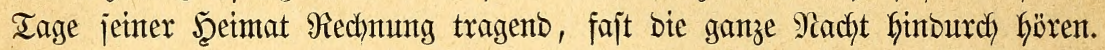

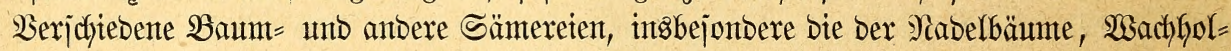

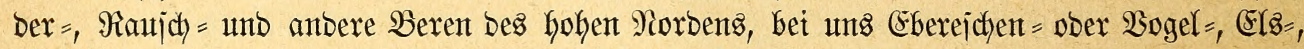
Schlingenbaumberen unb zwar vorzugsmeije bie förner berjelben, Baumfnospen u. bergl.

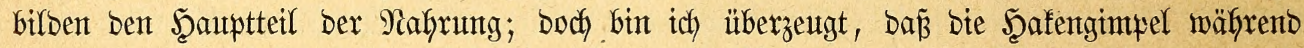
Des Sommers fajt ebenjo viele Rerbtiere als Pflanzenjtoffe zu jich nefmen unto mit

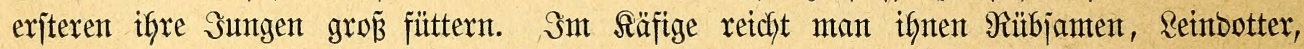

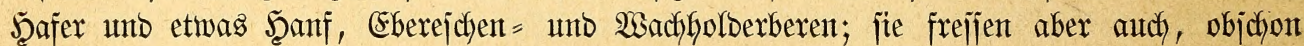
minber gern, Şirjen und Sanarienjamen. Meblyürmer jint ibnen, nach eigenen Beobach=

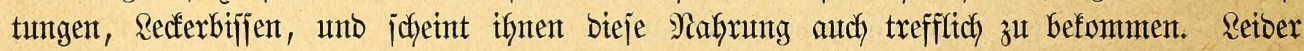

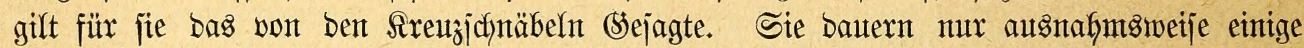
Safyre im Ssebauter aus, am längjten, went man diejen in ein ungebeiztes Bimmer ober in bas Freie hängt; Denn jo ınempfindlich jie gegen bie Sälte fint, ebenjo empfindlid zeigen

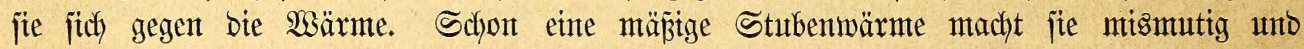
traurig. Wäre bies nicht ber Falf, man würbe fïf faum einen angenefmteren Stubenwogel benfen fönnen als fie. Sofort nach Dem Fange ridften fie fich im Räfige ein, ofne $\mathfrak{B C}=$ Denfen geben jie an Das vorgelegte Futter, und jidjon nach einigen Iagen haben jie fich jo

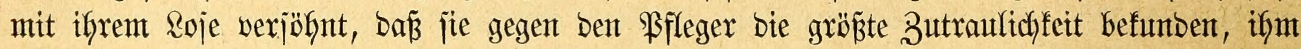

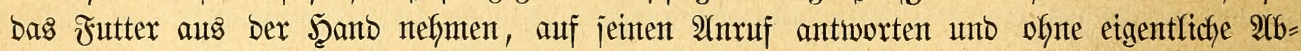
ridjtung jich jeinen $2 \mathfrak{B u ̈ n j}$ dyen fügen lernen. Reichter als jebes anbere Mitglieb ifyrer Familie gemöbnen fie fich, won bem geöffneten Räfige aus auj Den Finger ifyres (Sebieters zu fliegen

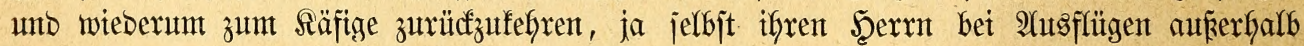
Des 3immers und Şaujes zu begleiten. Wenn man jie jonjt zwectentipredjent pflegt,

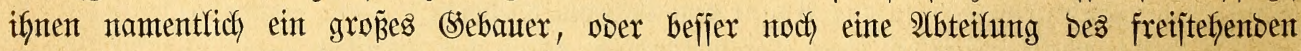
Fhtggebauers zur Wobnung anweift, jofreiten jie aud leidyt zur Fortpflanzung.

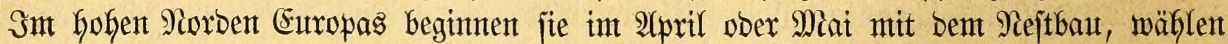

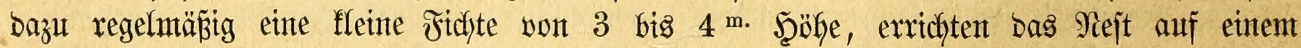
3roeige bicht am Stamme und verfifechten es mit jentem und biejem, jo baj es jefr fejt

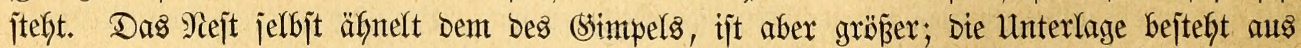

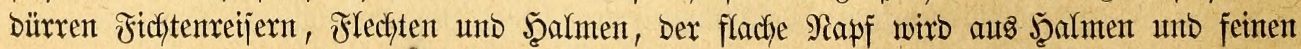
Wä̈rzeldben gebaut unt innent mit einzelnen Şaren und Febern ausgefleibet. Fัünf bis jechs

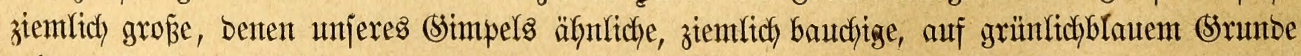
mit grożen mattvioletten Unter = unb Dunfelbraumen ober jdjwarzen, jidyarf begrenzten Sber=

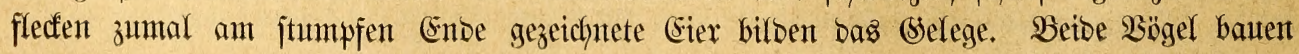




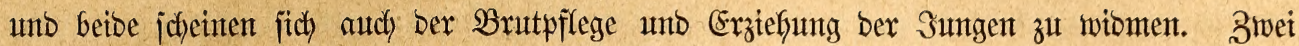

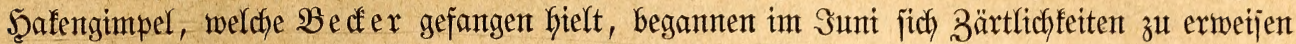

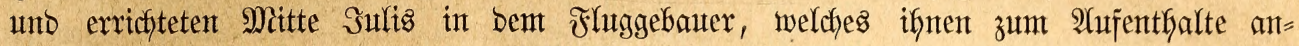

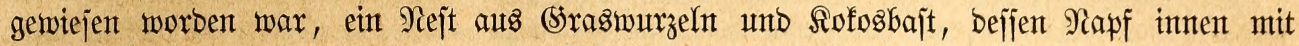
Bjerbeffaren ausgefüttert murbe. Dagjelfe war in einer ફ̧öhe von $1 \mathrm{~m}$. über bemt $\mathfrak{B}$ oben

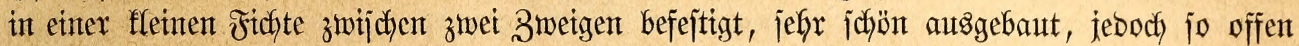

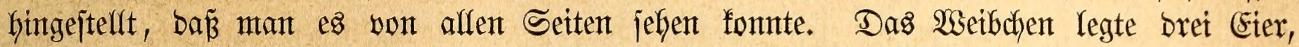
bebrütete bieje fünf Iage, verfię

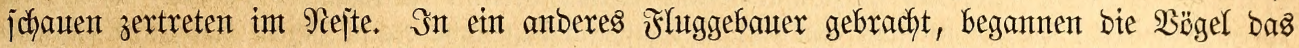

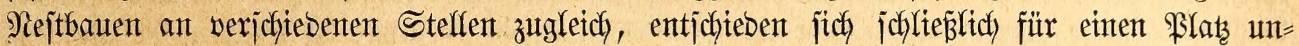
mittelbar vor bem fenjter, burch welches man vom Zintmer auts in bas Fluggebanter jeffent

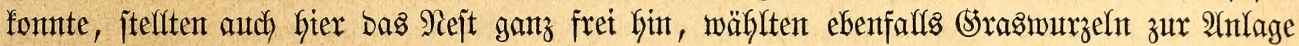

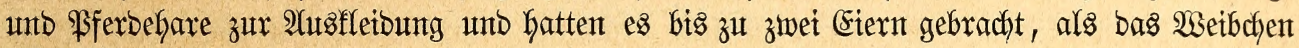
beim Regen Des britten ftarb.

Wì erfalten gegentwärtig bie Şafengimtpel regelmäß̈iger als früfer unb zwar hautpt=

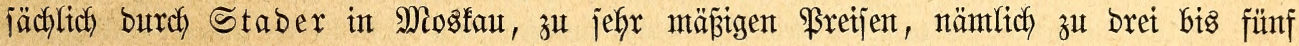
Ialer für bus Stüdf. Für siebgaber, welche ein freijtehenbes Fluggebauer bejitzen, emtpfiblt

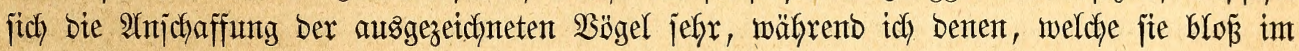
Simmer unterbringen fömen, entichieben abraten möchte, fie jich zu halten.

\section{farmitutumpel.}

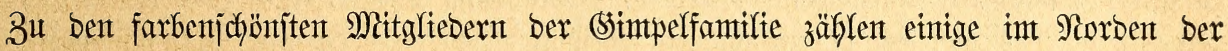

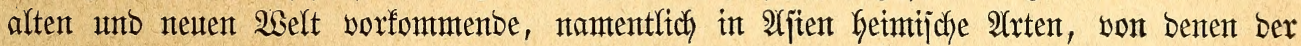
eine unto Der anbere auch in unjere アäfige gelangt.

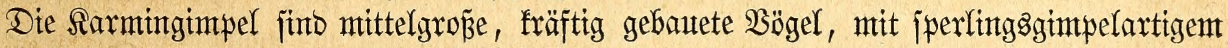

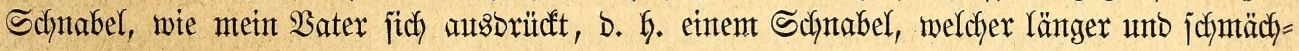
tiger als ber anberer (simmel, aber jtärfer unb gemölbter als ber ber Finffen ijt. Die Finjte

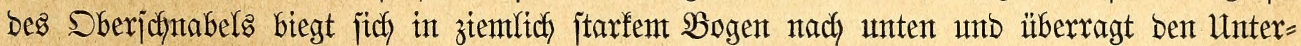

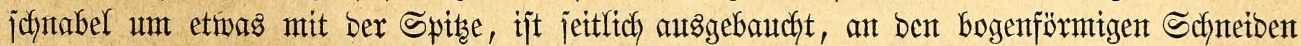
ein wentig eingezogen; ber Utnterjachnabel mölbt fich alfeettig gegen bie Spitze zu. Die mittel=

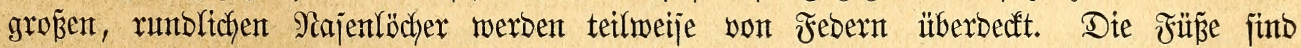

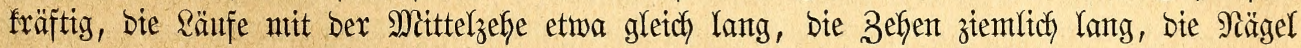

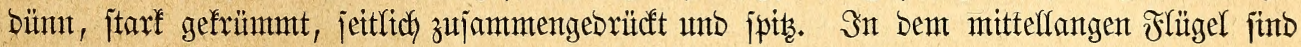

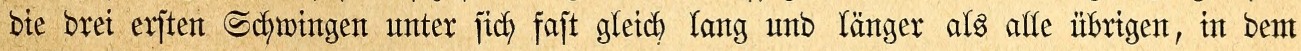

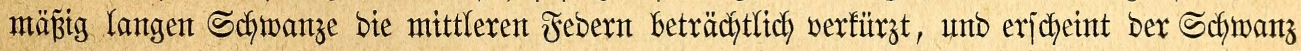
Desfalb in ber Mitte merflich auszeidnnitten. Das volfe, weidfe Slecingefieber prangt bei ben

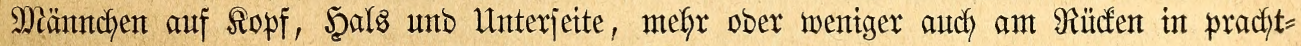

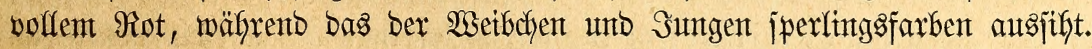

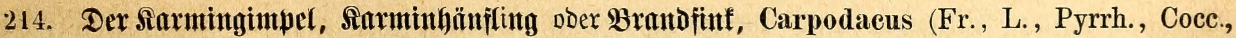
Erythrothorax, Erythrospiza, Pyrrhulinota, Propasser) erythrinus, Pallas, (flammea, cardinalis,

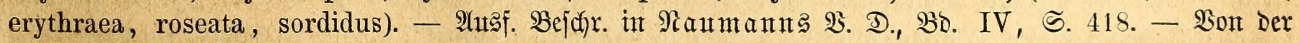

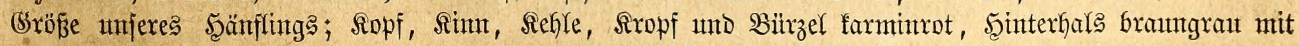

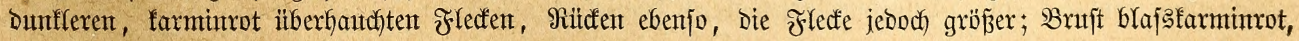

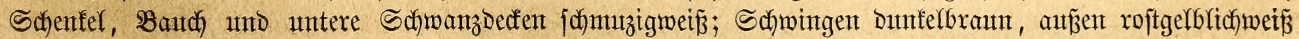

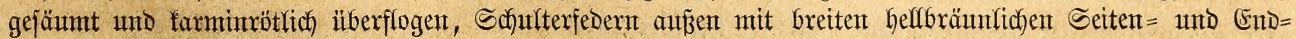

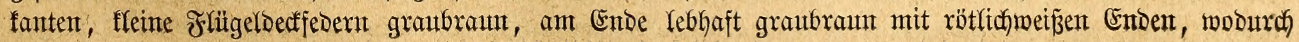
$\mathfrak{B r e b m}$, gefangene $\mathfrak{B o ̈ g e l . ~ I . ~}$ 


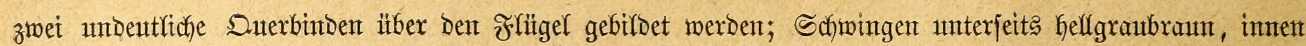

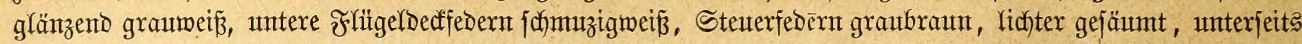

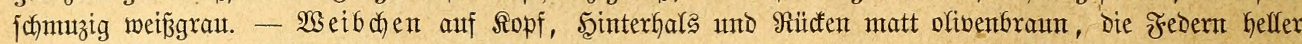

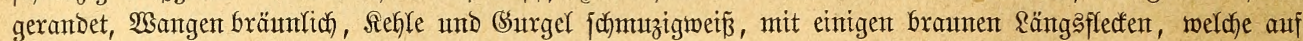

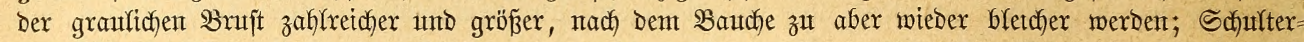

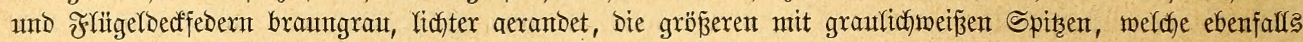

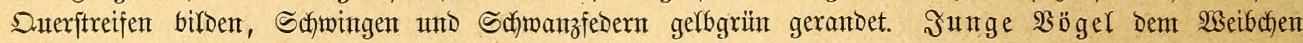
faft gleidy.

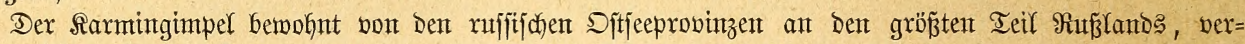

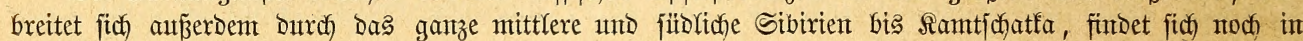

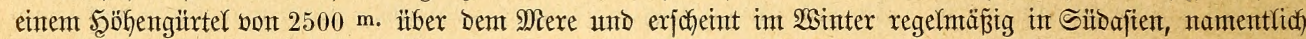

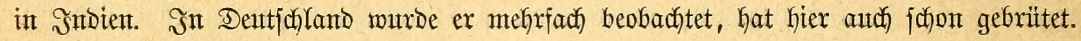

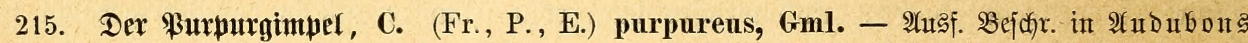

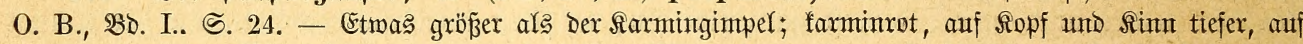

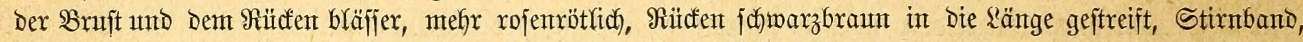

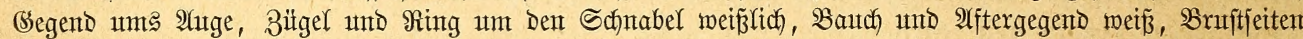

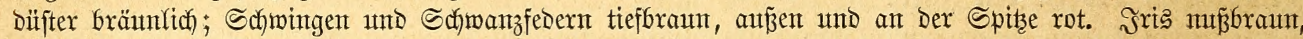

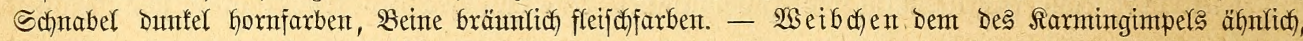

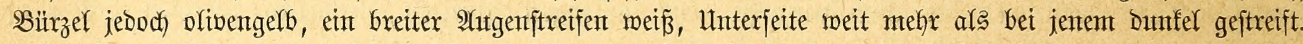
Sbei jungen Miänn chen alfe farminroten F̌ebern mit breiten rofenfarbenen Ranten.

Berbreitet fich von Rabrador bis nach Iejas und fonme wenigftens auf Dem 3 uge in affen $\mathfrak{B}$ ereinigten Staten vor.

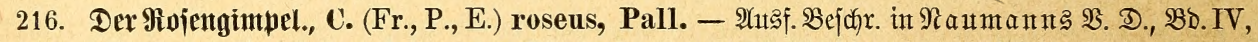

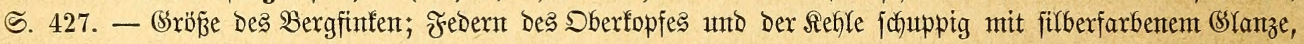

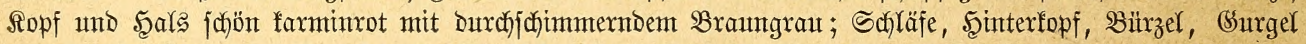
unb Bruft glänzeno hod) rofenrot, Brufffeiten mit Dunfelen Schafffleffen, Bauth und untere Sdiwanz=-

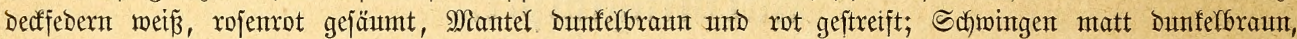

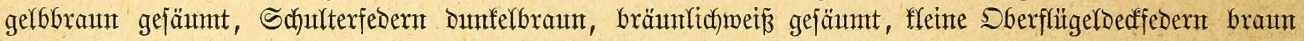

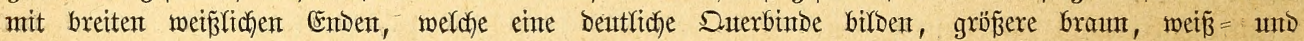

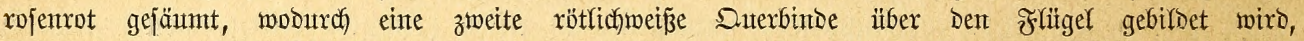

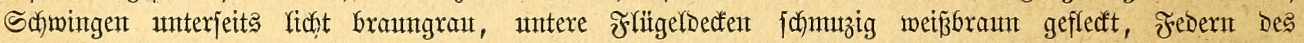
unteren Fłḧ̈gefrandes rofenrot überlaufen; Steuterfedern Dumferbraut, rofenrot gejäumt, obere Sdfwanz=

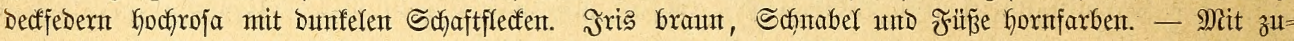

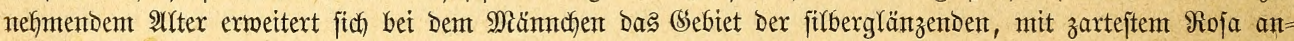

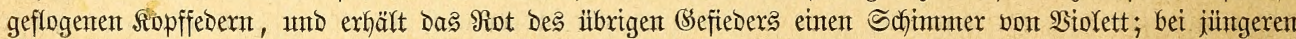

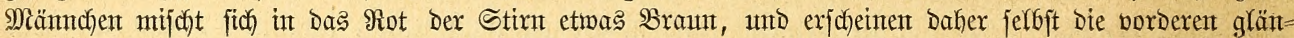

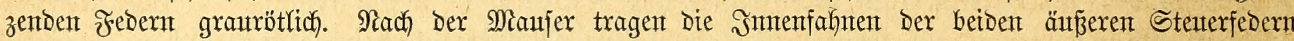

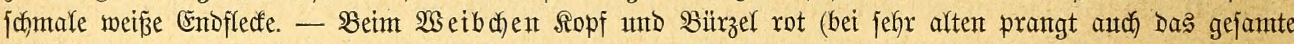

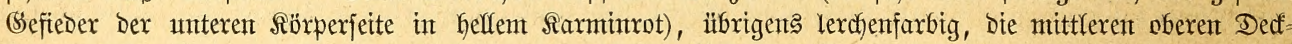

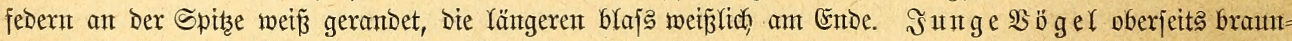

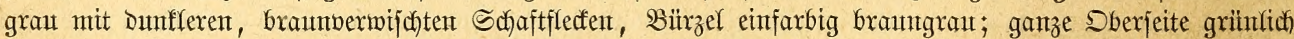

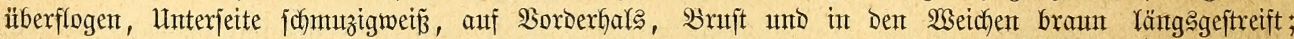

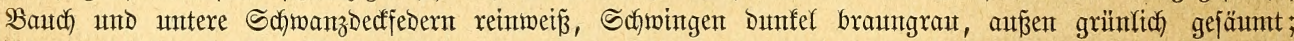

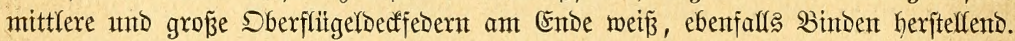

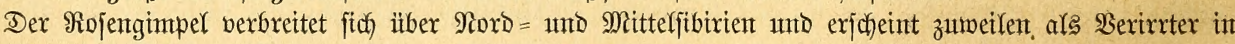

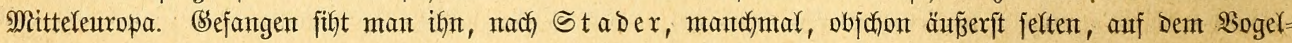
marfte in Miosfaut.

Die Sippe Dex \&angichnanzimpel (Uragus), weldhe wix ben Sirmingimpeln an= reifgen wolfen, fennzeidynet jich burch geitrectiten Baat, jchwachen, furzhafig übergebogenen Schnabel mit edfiger Difle und gerabe aufiteigender Diffenfante, fdywache Füne, itumpfe Flügel, unter beren Schiningen bie vierte bie Yängjte, förperlangen, ftufigen, in ber Mitte ausgejdynttenen Sdymanz und jeibenweidjes (sefieber.

217. Der Meijengimuel, C. (P., L., Uragus) sibirieus, Pall., (caudata, longicaudata, sanguino-

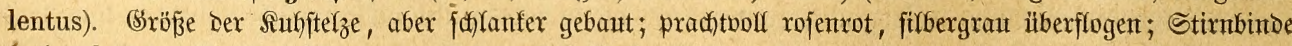

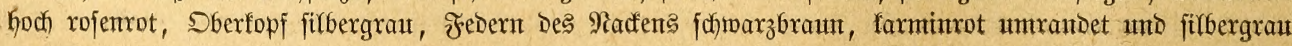




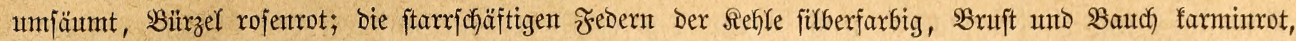

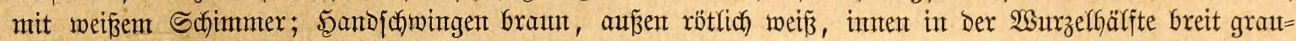

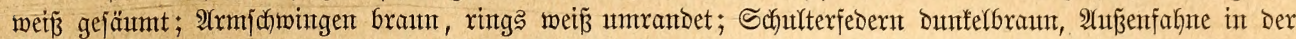

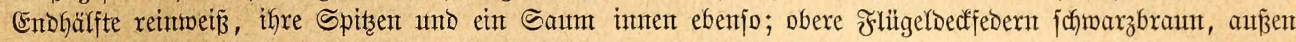

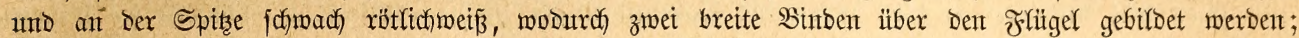

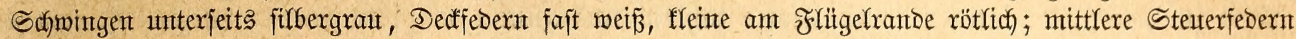

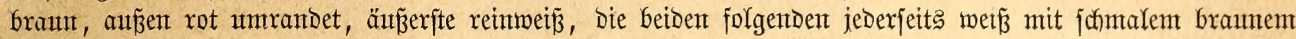

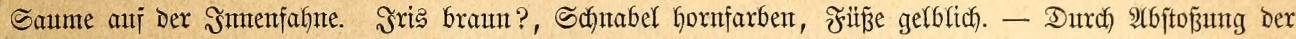

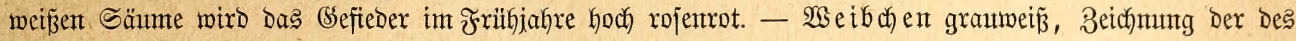

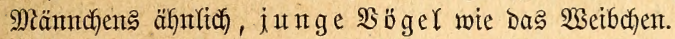

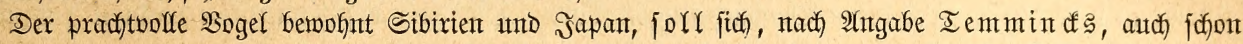

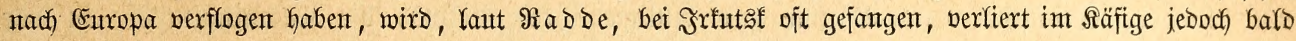
feine Rebentigfeit unto hält fïh) nidat lange in enger Scaft.

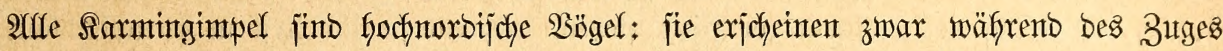

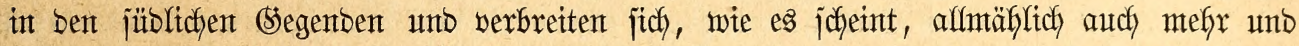
mefy nadh Sïben bin, brïten fier aber nidft. Sarmin = und \$urpurgimpel fenten wir am

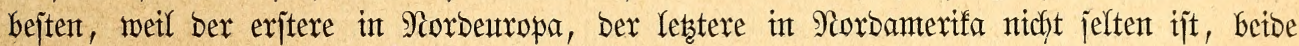

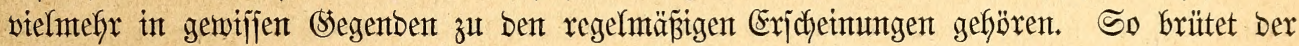

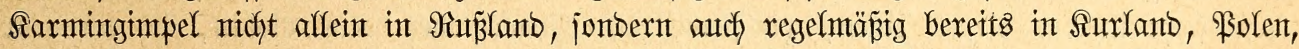

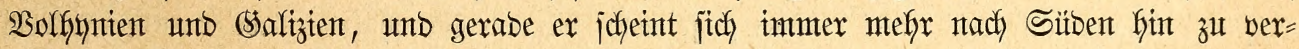

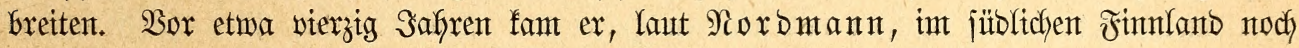

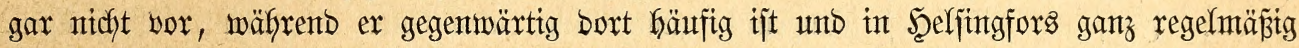
im botanijchen (Sarten brütet. Sn ber Untgegend von Miosfau erjejeint er, nady Stader,

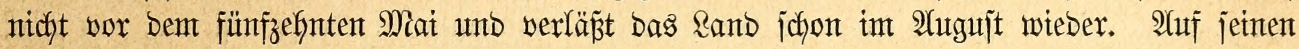

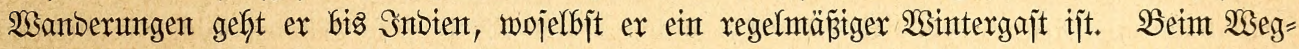

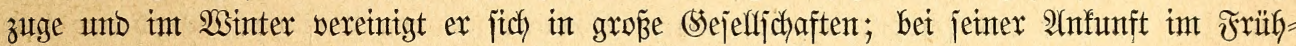

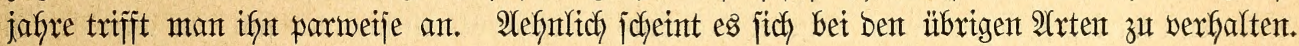

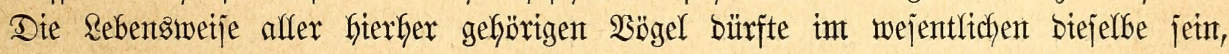

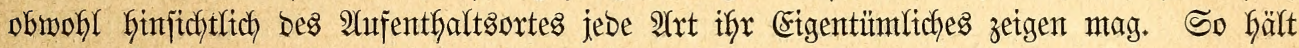
jich) Der Sarmingimpel, wie Baron Şü ne berichtet und Staber bejtätigt, vorzuggmeije in

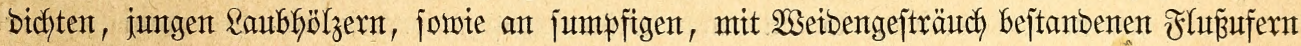

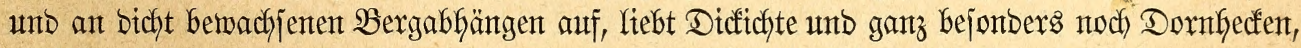

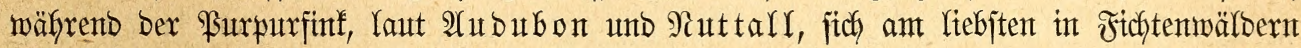

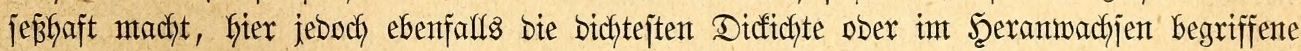

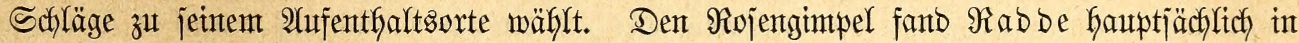
lichten Raubwalbungen Sibiriens, namentlich joldyen, welche aus Eichen und Schwarzbirfen beitehen, ebenjo aber aud in bidyt bebujchten Iälern, während er bagegen Den Meijengimmel roteberum mefix auf jumpfigen ober bruthartigen (sebteten antraf, wojelbjt ex eher nach atrt

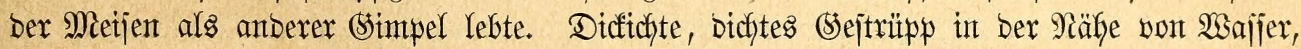
Bruch = und Sumpfgegenten aljo jocheinen bie eigentlichen Wobnjitze unjerer Bögel zu jein.

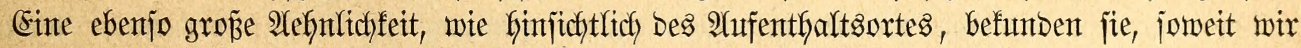
gegentwärtig Darüber urtełlen fönnen, in ifrem Wejen und Sebafrent. Sm Bergheich mit

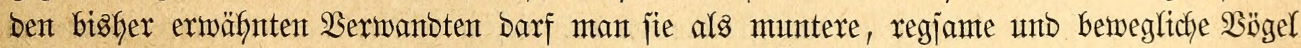

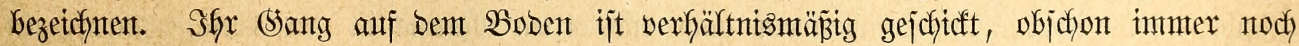
Güpfent; ber Flug gejfyift in flachen, geftrecften Bogen, beim Mieijengimpel unter Görbarem

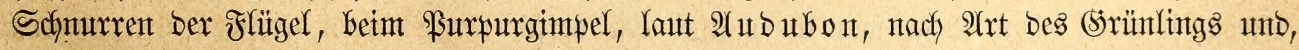
wenn bie $\mathfrak{B o ̈ g e l ~ j i c h ~ z u ~ I r u p p s ~ v e r e i n t i g t ~ G a b e n , ~ j t e t s ~ i n ~ g e j d ) l o f f e n e n ~ M a j f e n . ~ S e j o n d e r e ~}$ Beadtung verbient ber (sejang, namentlict) ber bes Sarmin= unb \$urpurgimpels wegen jeiner

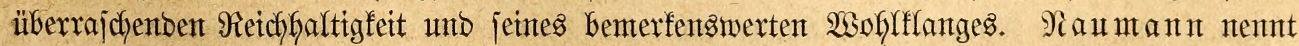
bas Ried bes Rarmingimpels nicht umpajfend eine Bujammenjetzutg aus ben (Sejängen bes 


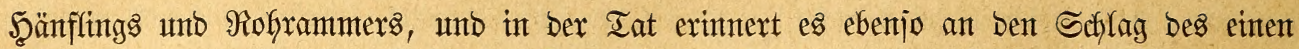
wie bes anberen 20 ogels. (Sefangene Sarmint= und Purpurgimtpel, weldye idf pflegte, Gaben

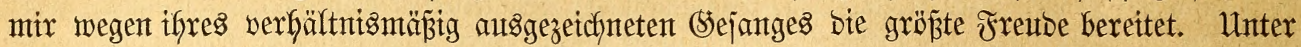

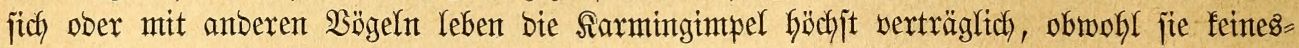

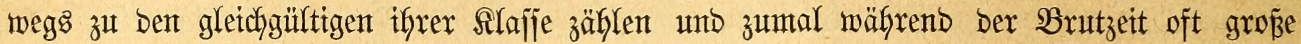
Erregung zeigett.

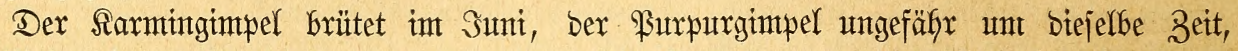
ber Meijengimpel int Suni ober Sulf; über bie Jortpflanzung bes Riojengimpels liegen, joweit mir befannt, nod feine Beobacthtungent wor. Die brei erjtgenanntent wäflent fich bichte

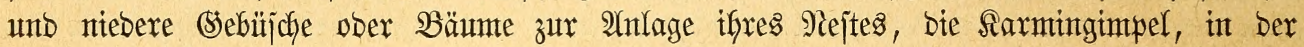

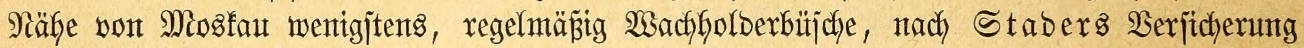

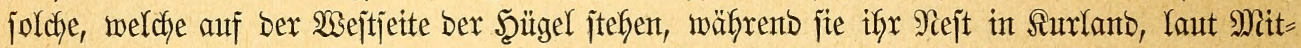
teitlungen wont $\mathfrak{B}$ üttnex an $\mathfrak{B}$ alda

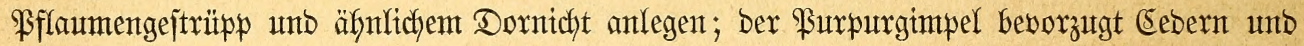

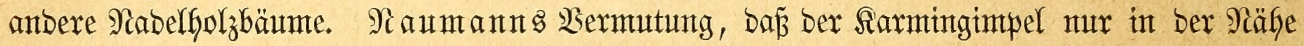

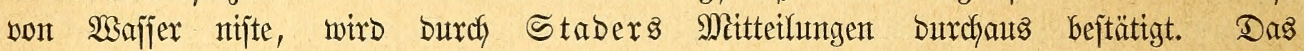

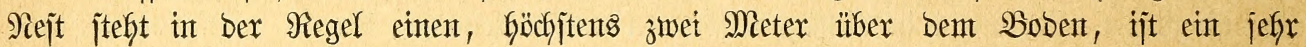

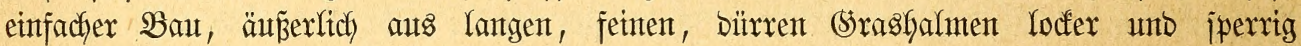

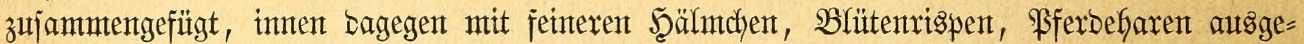
fleibet. Frünf bis jechs tief Glaugrüne, zumal am biffen Enbe mit fleinen blaugrünen,

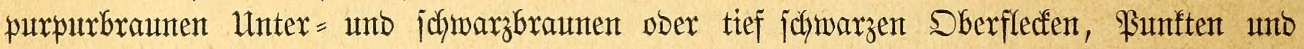
Stridyen gezeidynete Eter bitldent bas Btelege Des Sarmingimpels, ebenjo gefärbte, mur nach Bergältnis fleinere - von Debowsfy in ber Baifalgegend gefunben - bas bes Miejen=

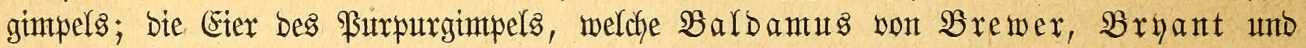

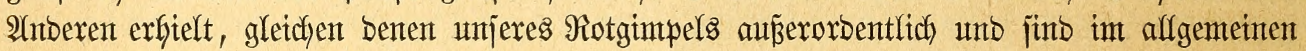
nur etwas jadranfer und gejtrecter. Bei erfterent pflegt bas Bselege, in ber Ungegend

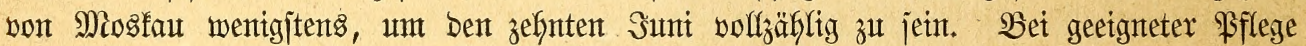
bürften aud bie Rarmingimpel in ber (sefangenichaft zur Brut jodreiten.

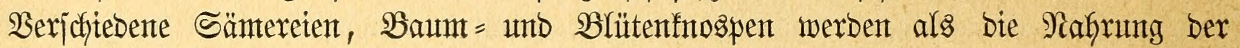

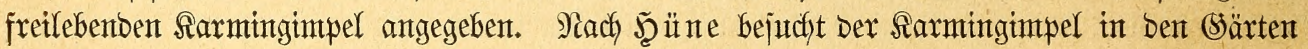

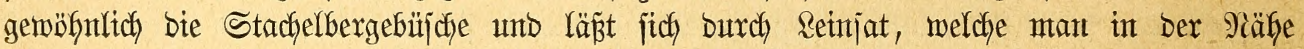

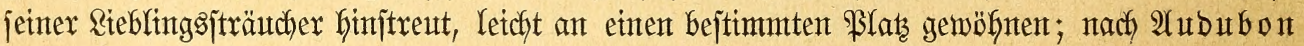

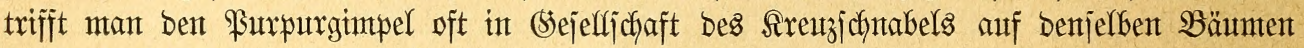

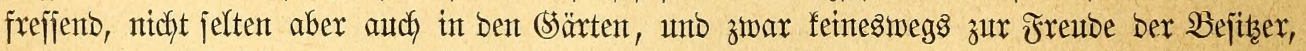

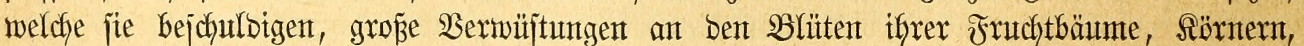
Beren unto $\mathfrak{B l a t t f n o s p e n}$ anzuridyten.

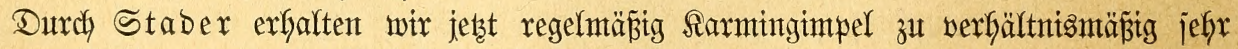

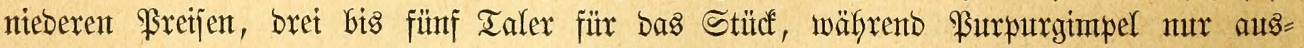
nafymsweije auf unjeren Marft gelangen. Shre Şaltung im Säfige verurjadgt feine

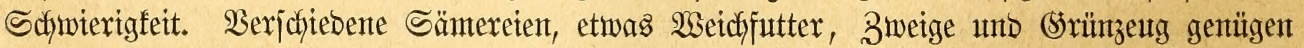

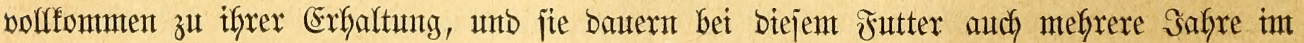

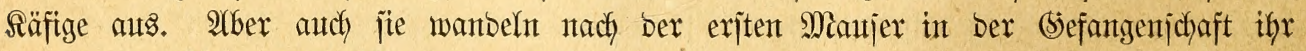

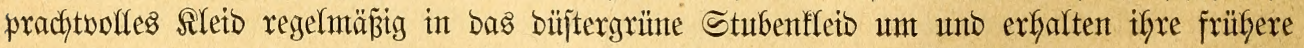

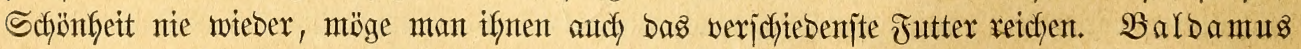

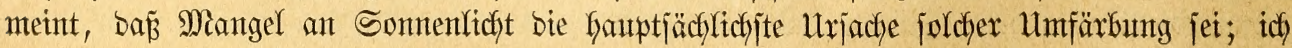

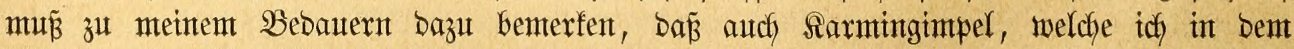

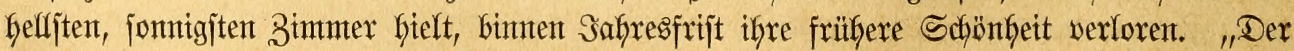
Sarmingintpel", ¡ajreibt mix Staber, "übertrifft meines Dafürfhaltens jeben anberen 


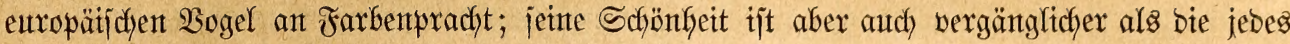
anberen. Saum hat bie Şand ifn eintge Male berïfyrt, jo werliert bie Farbe an (Slantz unt Tiefe, unt went ber Sogel erjt einige Wodjen in SBauer zugebradjt hat, ift er faum nod) nieberzuerfentent." Dasjelbe gilt für bie übrigent (b)lieber der Sippe. Dieje $\mathfrak{B e r}=$ gänglichfeit Des Gerlichen (sefiebers ijt meiner Ânjicht nach bas Einzige, was man an ifnen

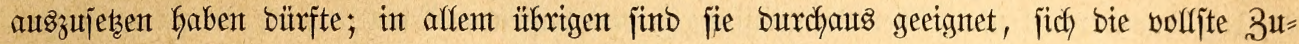
neigung ifres Pflegers zu erwerben.

\section{Miiftengimpel.}

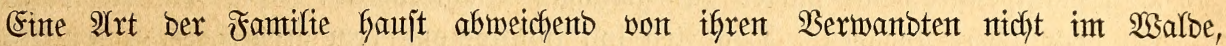
jonbern auf pflanzentojen Streffen, vornefymltch in ber Wüjte, beren Beiteinżmafjen fie in Der antutigiten Weije belebt.

Die Wüjtengimpel find fleine, georungen gebaute, grofiföpfige uno grofjidntäbelige (s)lieber

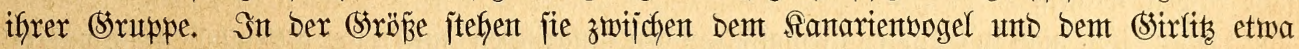

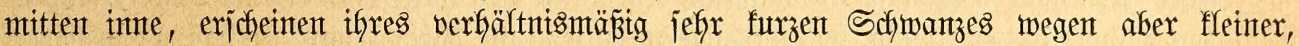

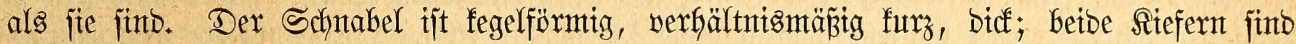
annäherno gleichboch, Die Rabentänber eingezogen. Die furzen Fitże haben mittellange Zeben.

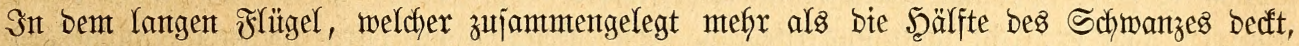
ijt bie erjte Schminge bie längite. Der furze Schwanz bejteht aus breiten, am Ento abge=

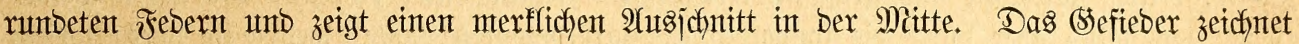

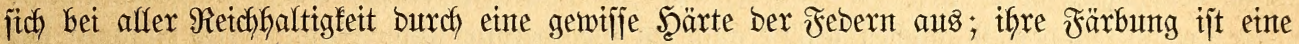
ungemein zarte. - Man fennt bis jeţt mur eine 2 rth biejer Sippe.

218. Der $\mathfrak{B}$ ïitentrompeter, $\mathfrak{B a p a g e i e n t}=$ ober $\mathfrak{B a u ̈ i t e n g i m p e r , ~} \mathfrak{B}$ ïitenfinf, Bucanetes $($ Fr., P.,

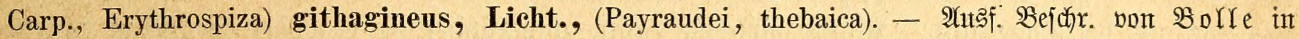

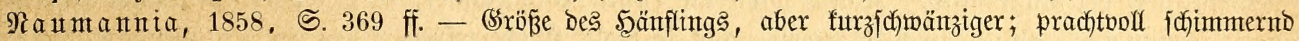

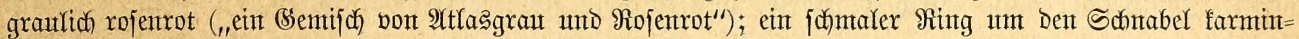

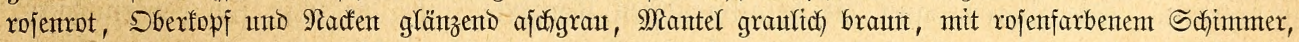

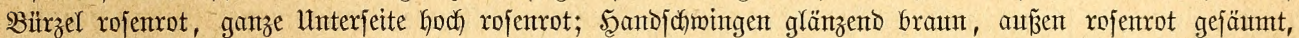

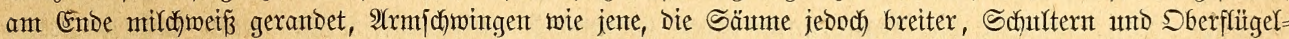

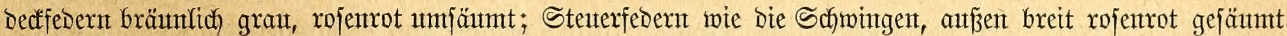

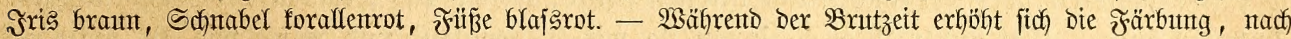

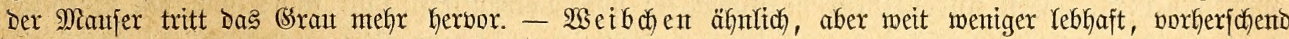

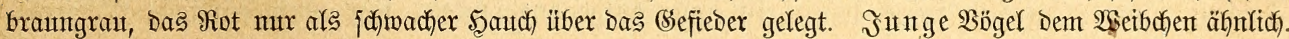

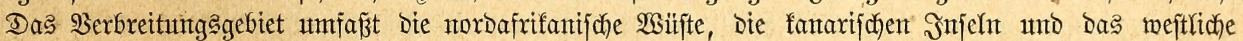

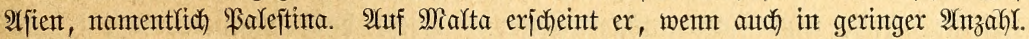

Wer Den Wüjtentrompeter, wie umjer Mitarbeiter $\mathfrak{B}$ olle ben $\mathfrak{B}$ ogel genannt hat, ben "Mioro" Der Santarier, Den Trumbettier ber Mialtejen, Den "Steinbogel" Der 2 traber fenten

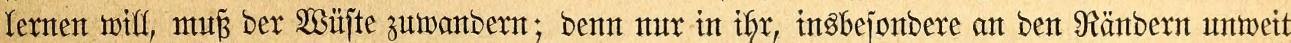
ber Yetzten Felber, finbet er fich häuftg, unt went ex antberşwo, wie auf ben fantarijchen Snjeln,

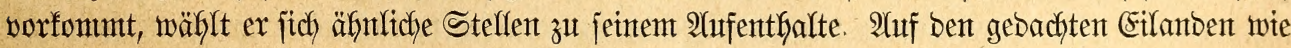
in Sbereghpten unto Mittelmubien ijt ex jefy häufig; nadd Dem jüblichent Europa hat ex jich mefrere Male verflogen. Sn jeiner eigentlichen Sgetmat trifft mant ifn jtets in (Sejelljchaften an,

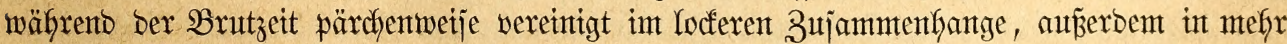
voer minber zafhlretchen Flügen. Sm Sireije jeiner Familiengenoffen ijt er ber eigentliche

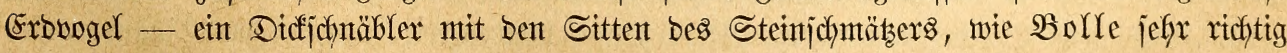
jagt. Familien $=$, trupp = ober flugmeije erjcheint ex auf abgeernteten Felbern ober an Steffen,

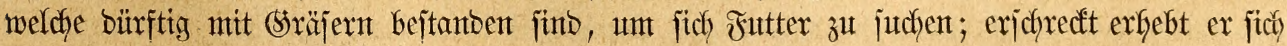




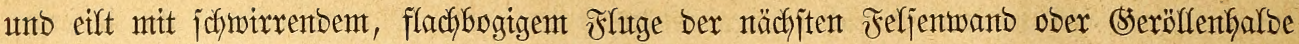

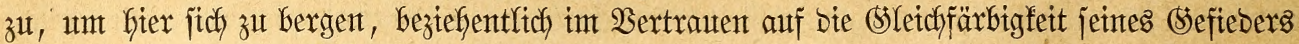

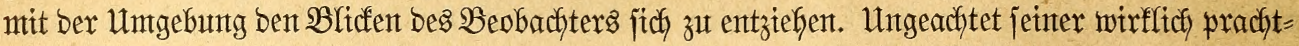

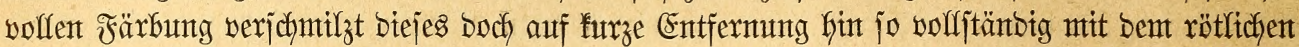

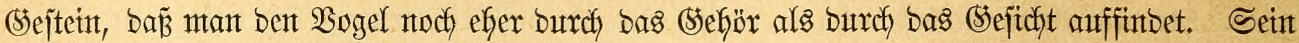

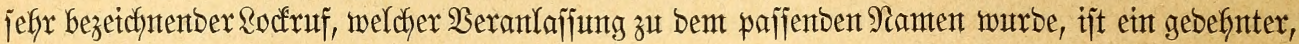
zitternber, Dem Silange einter flement Irompete äfnllidyer Ion. Dex Sejantg jebst fitch vor=

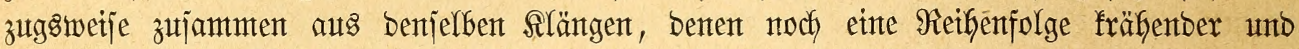

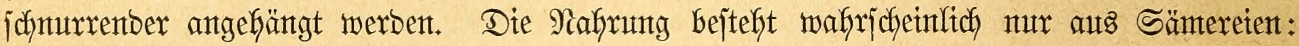
Serbtiere jhetnent verjchmäht zu werben; Wajfer bagegent ijt erflärlicher Weije Bebürfntis,

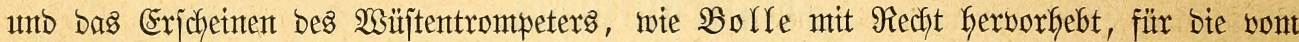
Durjte gequälte Saramante inmer ein günitiges Wafhrzeichen. Heber bie Fortpflanzung mangeln nodh jidfere 2lngaben. Das Nejt joll funjtlos aus bem groben Strof ber 2 Büjten=

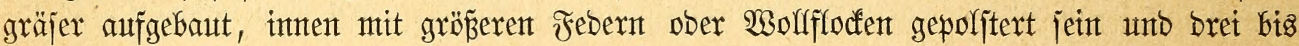
fünf (Fier enthalten; idf habe es, trots bes eifrigiten Sutchens, in Sberegypten unt Nubient nticht fintoent föntmen.

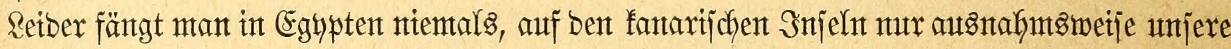

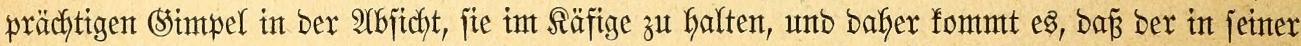

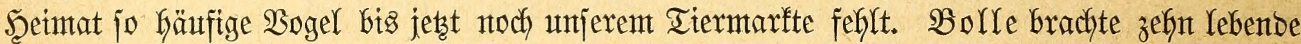
Wäritentrompeter mit nach Deutjchlantb unb ijt ifres Robes voll. "Das Bentefmen biejer

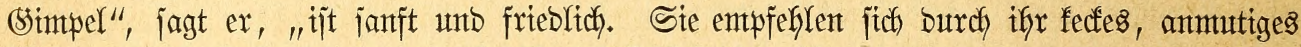
Wejen, burch Zafyntheit und grope Serträglidffeit jowohl unter eintanber als gegen anbere Bëgel, vorzüglid' aber burdy bie jontberbaren, jtarf betonten saute, weldye fie Gören laffen.

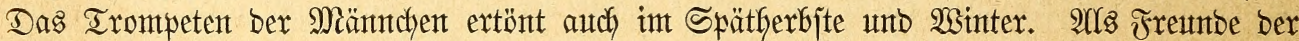

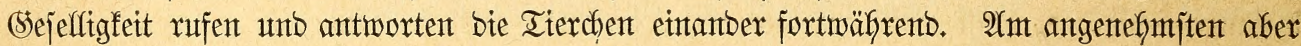

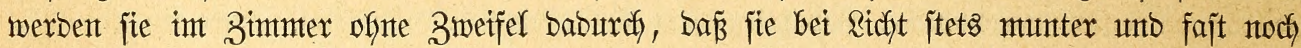
Yebfafter als bet Iage juth. Siaum wirb bie Rampe antgezüntbet, jo begrünen fie igren Seerrn burch Iromtpeten, ofyte burch Flattern, wie jo viele Rerbtierfrefjer, zu pä̈ter Stunbe läjtig zut werbent. Sie führen bann bie beluftigendjten Sonzerte auf, bie mant fich benfen fant. Bald funt es fchäne unto Gelle, aber furze Irompetenflänge, balo jenter langgedefynte,

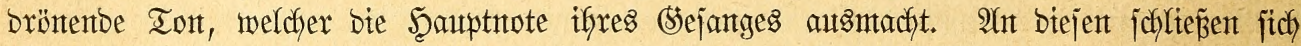

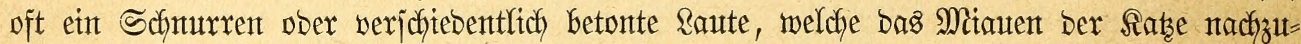
afmen jheinten. Ein anber Mial beginten fie mit Iönent Yeij' unt rein, wie ein Silber= glöctchen lä̈tet; Darauf folgt bann ein gantz entgegentgejetstes, fajt ammerartiges sejd ret.

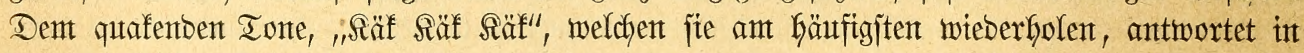

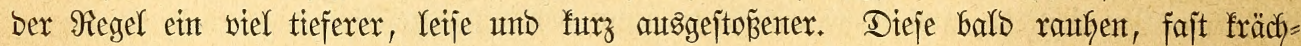

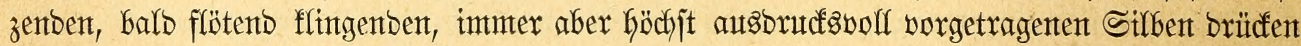

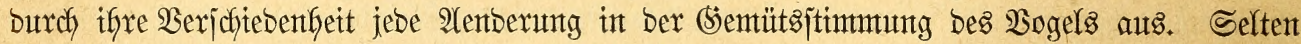
Gört mant eit zmar unzulammenfiängenbes, aber langes Steplauber, wie bas fletner Fapa=

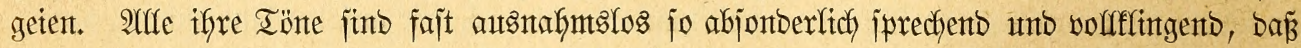

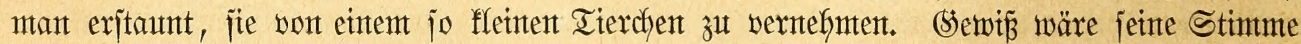

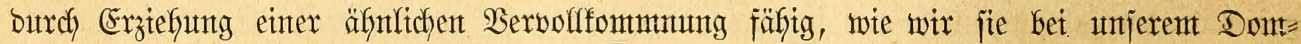

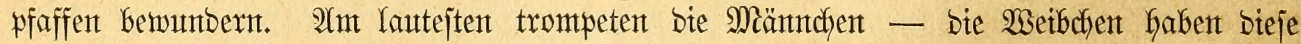

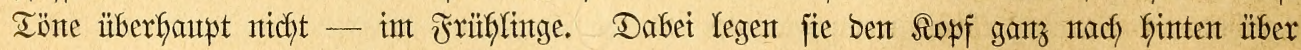
unt ridften ben weit geöffnteten Sdyntabel gerabe in bie Sëble; bie leijeren Töne werben mit gejchlofifentent Sdynabel herborgebracht. Heberhaupt machen bie Bögel beint Singen, auth

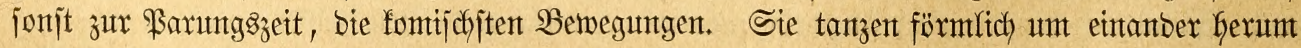
unt treiben jich joffarf, went jie in erregter Stimmunt fint. 


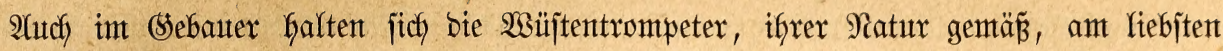
aut Boben auf, Yernent jeboch bald, fich auf Sprofjen unto Stangen zu jeben. Heber Den

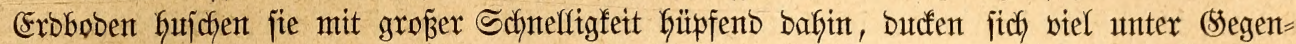
ftänbe, weldbe fie verbergen fönten, friedhen aber nte in Şöhlungen mit engemt Eingang.

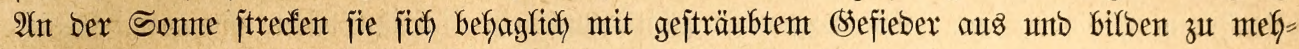
reren beijantmen jo bie reizentiten Sruppen.

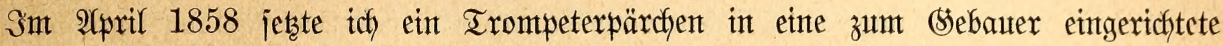
Sammer, Deren vergittertes Fenjtex Der Nadymittaggjonne freten 3utritt gejtattete, und bald

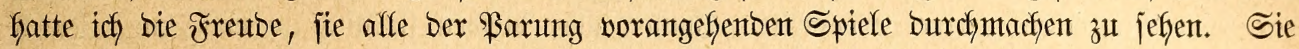

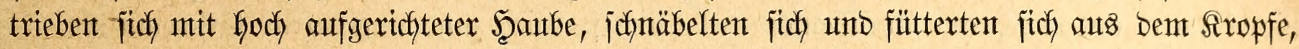
niddyt oft zwar, aber bafür bejto leibenichaftlidfer und ftets mit in höchjter Erregung ge= iträubten Scheitelfebern und herabGängenben, wie framtpfhaft zudfenben Flügeln. Bum গititen wählten fie ein hodhGängendes Şarzer Bauterchen. Sie zogen Stroh jedem anberen Bauftoffe vor und nafment babei auf einmal joviel Şalme in Den Schnabel, als biejer zu fafjen ver= modste. Snwentig legten fie bas Nejt mit Febern aus. Der Bau, jaylicht unt einfach wie ex war, ging langjant won ftatten unb warb, obwohl auch bas Mäntchen etwas zum Nejte

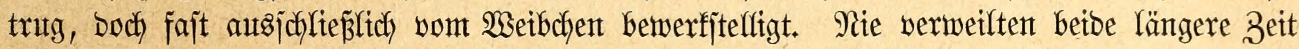

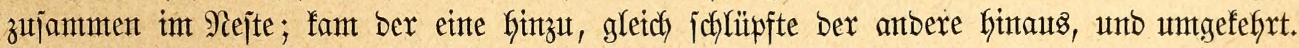
Ifm 24. Morgens fand idh bas exjte (si int Nejte. Die folgenten Tage warb täglich ein neutes Ginzugelegt, biz bie Zahl von vier beijamment war. Die Matter Gatte zwar bis bahin nicht fejtgejejen, würbe aber wahrjcheinlich gebrütet haben, wäre idh nicft entjchlojien ge= mejen, Die Şälfte biejes exjten (Seleges auf Dent 2rltare ber Eierfunbe zut opfern. Die übrig= gebliebenten zwet Eier legte idy eintem mix als vortrefflicher Brüter befantent Ranartenvogel

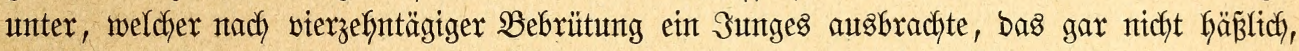
wie junge Singoögel jonjt wofhl, vielmebr ganz nieblidy auşah. Es war an ben naften

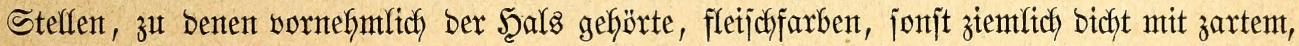

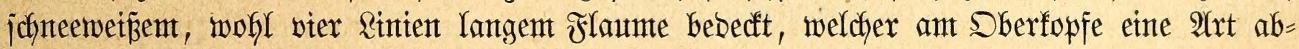

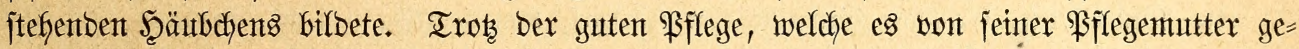

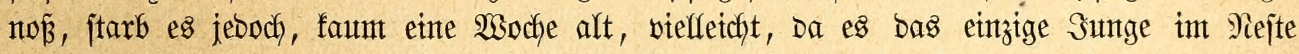

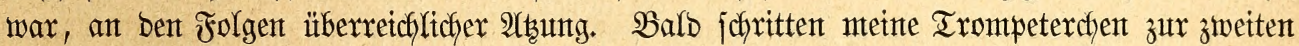

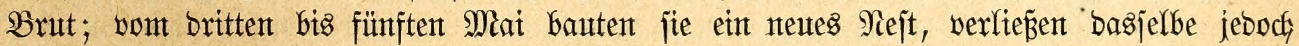

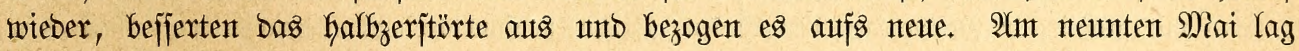

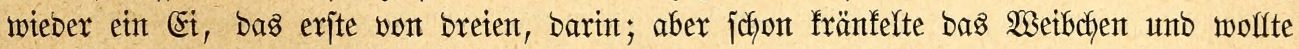

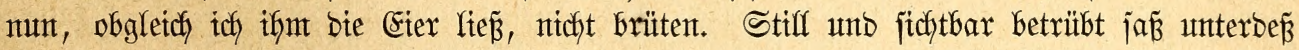

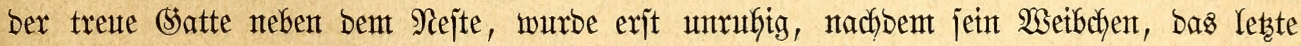

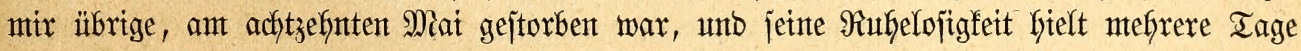
an. Die Eier fint für Den $\mathfrak{B}$ ogel ziemlich grof́; von Farbe matt blajsntergrünltich oder noch hefler, mit zeritreuteten rotbraunen \$ünftchen unb Fledfen, bie ant jpitzen Enbe jefy wer=

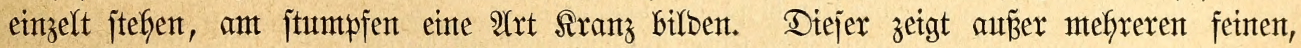

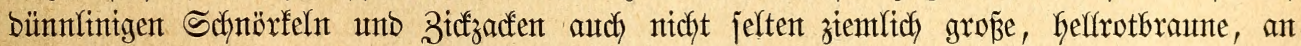

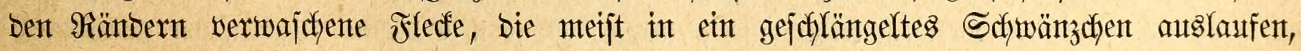

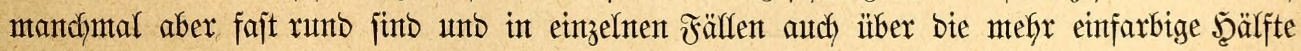
Des Eites zeritreut iteben.

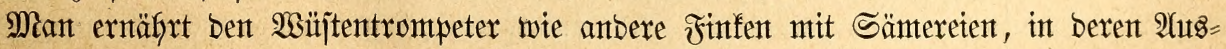

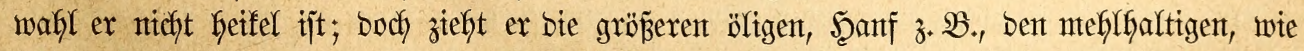

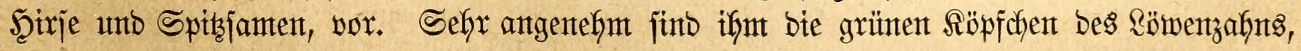

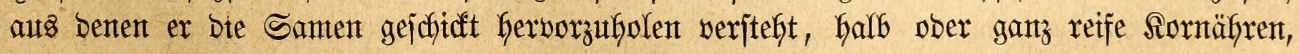

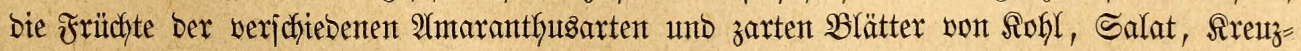




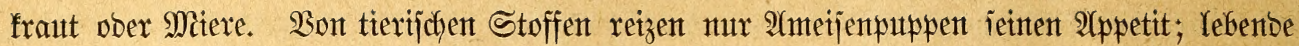
Serbtiere bleiben unberïfrt. Ein fojtuerächter ijt ex nicht, im Begenteile jebr rectht zu ex= Galten; ich jah ifn in jeiner Sceimat mit zerfletnertem Miais vorlieb nefmen. Weiches Futter, in Mildy ober $\mathfrak{W a f j e r}$ geweichte Semmel, Sbjt, ja jelbjt gefochte Rartoffeln verzefyrt er mit

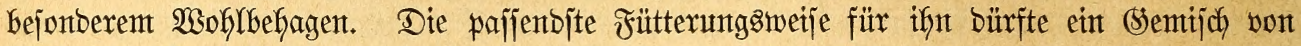
Seirje ober Ranartenjamen mit ein mentg Şanf, von Zeit zl Zeit banteben etwas (Srünes jein."

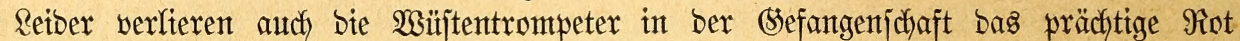

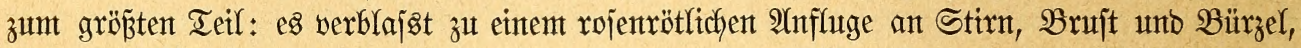
Der beint Männthen ftärfer herbortritt. Smmer aker bleiben fie auth jo noch, und burch nichts mefr als burch ben Soralfenichnabel, eine ftattliche und angenefyme Erjcheinung.

\section{(bitlitge.}

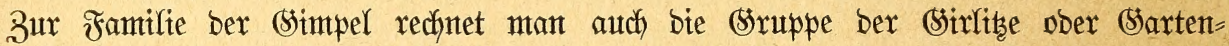

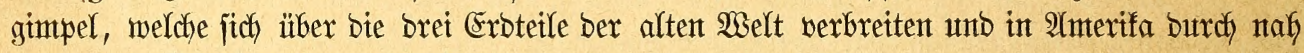
bermanbte $\mathfrak{B}$ g̈gel wertreten werben.

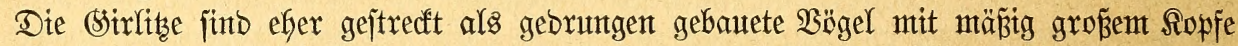
unt vorkerjchento grünlich gelbem Befieber. Der Schnabel ijt flein, furz, bidf und jtumpf= ipizzig, obent wentig gewölbt, an ben bogenförmigen Schntben eingezogen, vor ber Spize

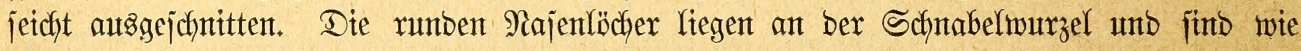
bieje von furzen Feberchen bebedt. Die Füß̄e Gaben furze ober mittellange Räufe, mäß̈ige

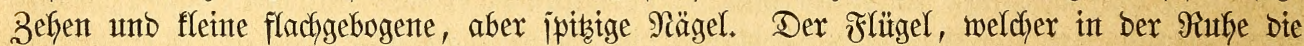

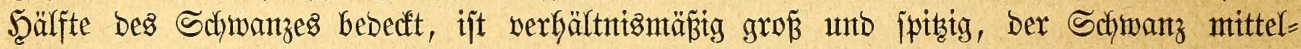
lang unb am Enbe tief eingeichnttten. In bem ziemlidy reidflidfen, weidyen Sefteber find (Srün unt Solbgelb Die hervorragenditen Farben.

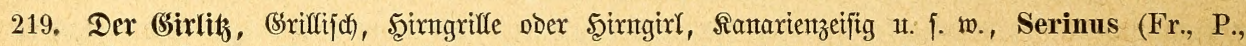
Dryospiza) hortulanis, Koch, (serinus, flavescens, meridionalis, islandicus). - $\mathfrak{A} 1 \mathfrak{3 f}$. Bejd $\mathfrak{x}$. in

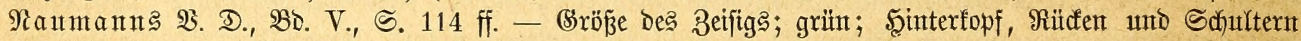

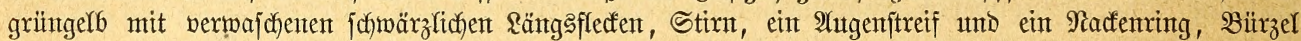

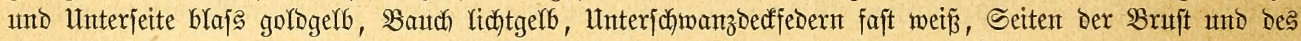

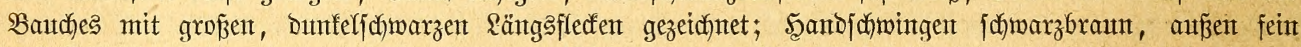

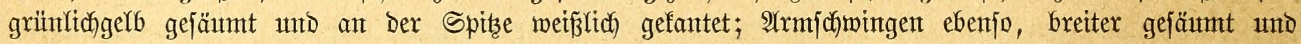

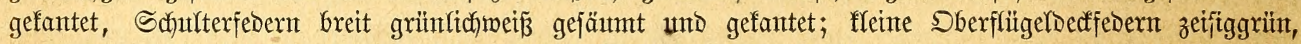

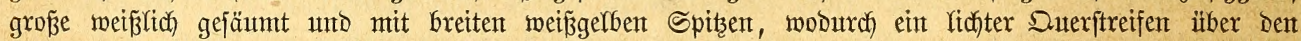

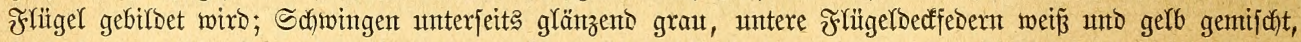

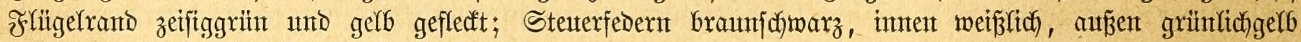

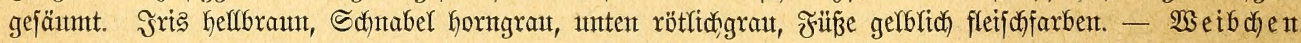

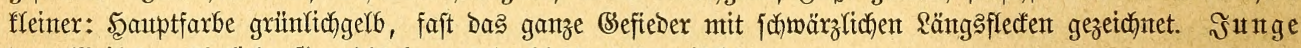

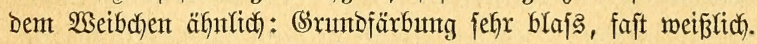

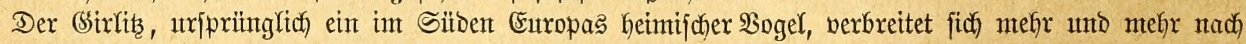

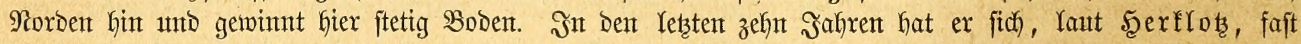

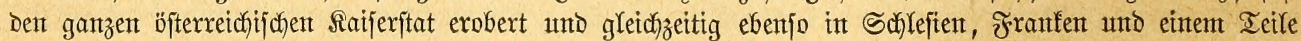
Iiningens feft angefibelt.

220. Der Santurietwogel, S. (Fr., Crithagra) canarius, L. - $\mathfrak{A}$

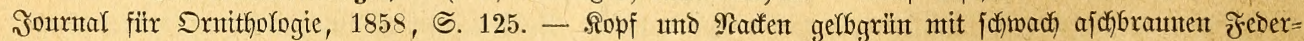

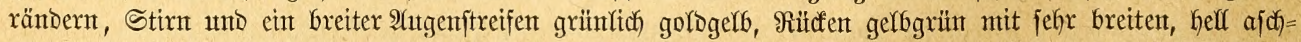

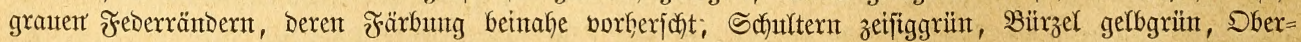

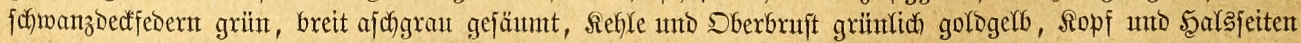

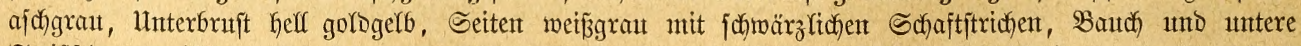

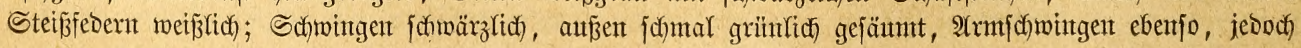




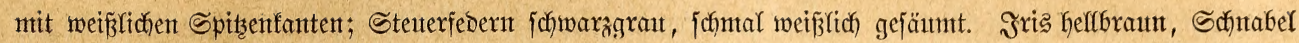

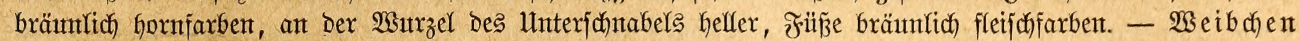

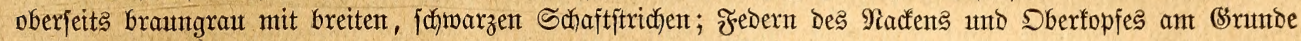

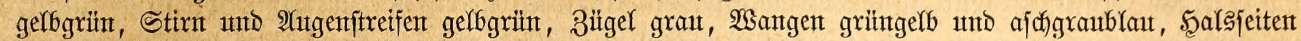

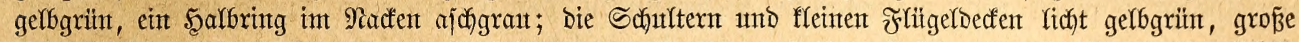

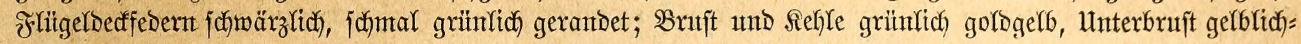

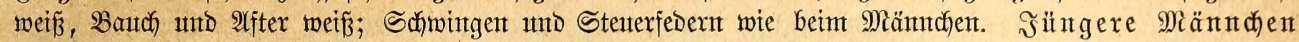

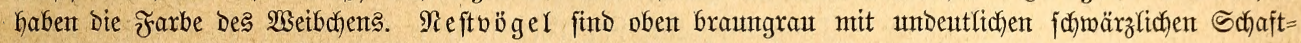

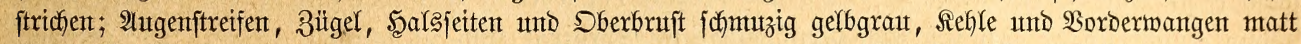

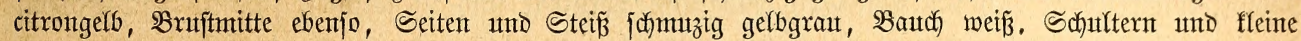

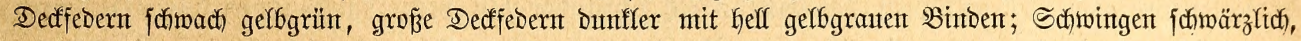

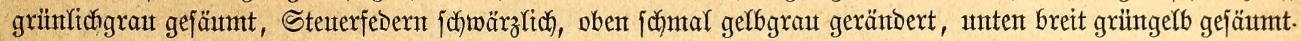

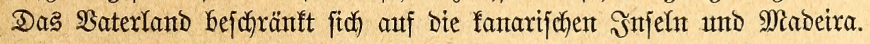

Alls ein Mittelglieb zwijchen Sirtits unb Reinzeifig betrachtet ntan einent (simtpel mit

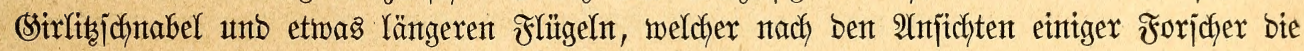
Sippe ber sirlizzeijtge, Oraegithus, vertritt.

221. Dex (Solditirntgirlity, S. (Passer, Pyrrh., Oraegithus, Emberiza) pusillus, Pall., (auriceps).

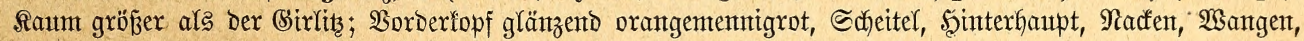

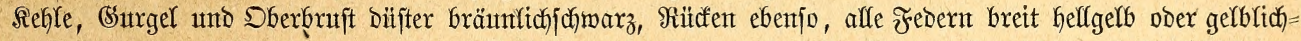

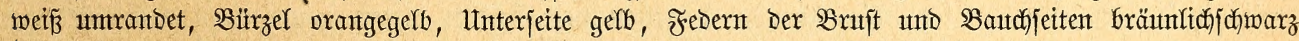

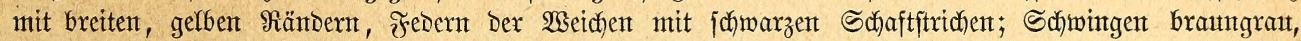

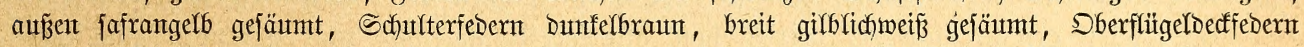

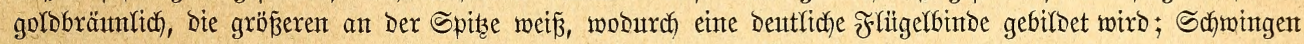

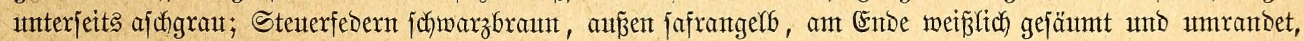

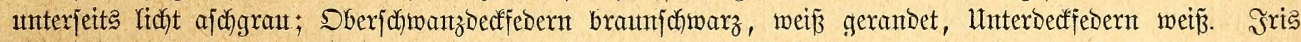

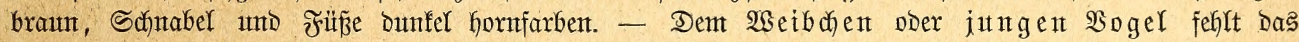

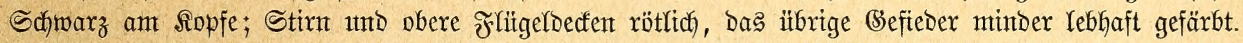

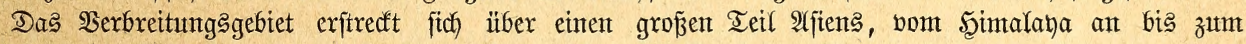
Rautafits uno Rleinafien, von wo aus ex fich zumeilen nach (Europa verfliegt.

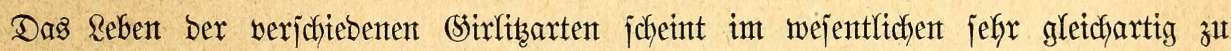

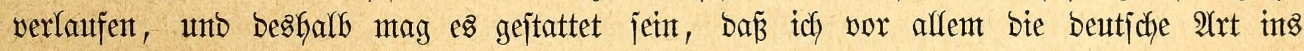

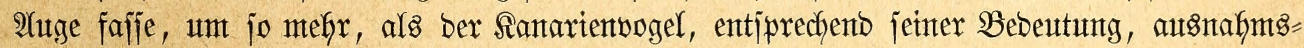
weije in einem bejonberen 2 bGjdynitte befhanbelt werben wirb. Heber bas Freitebent bez

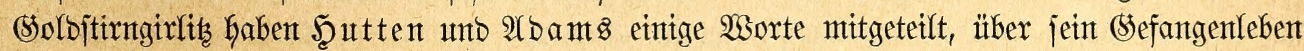

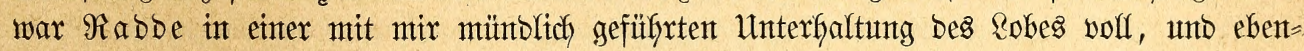
jo beridhtet Bètant, weldher ben $\mathfrak{B}$ ogel bei Smtynna erbentete, längere Beit in Bsefangen=

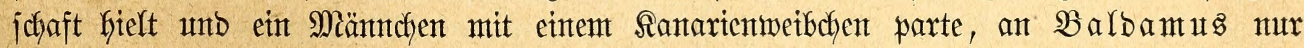
(Sutes von ifyt; aus ber einen wie aus ber anberen Mitteitung aber geft Gervor, bá meine

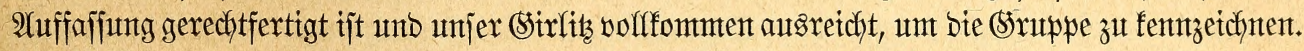

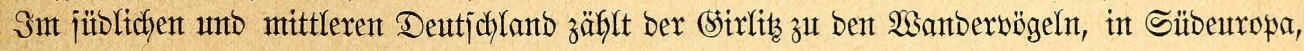

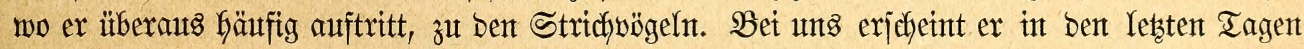

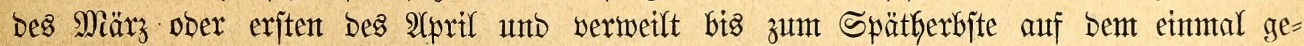

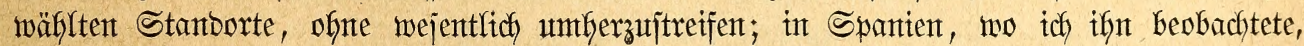

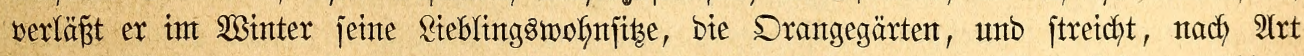

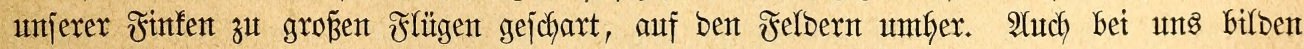

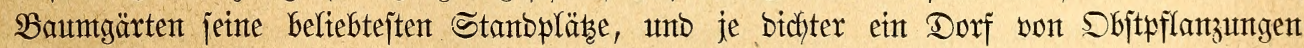

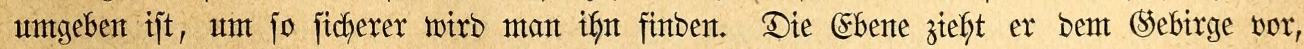

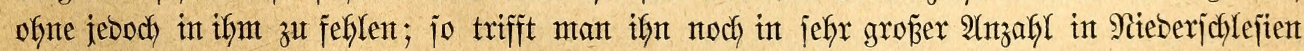

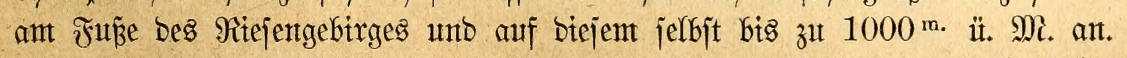

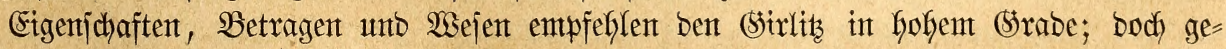

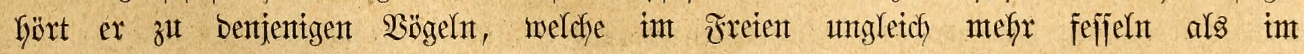




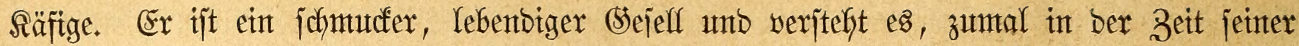
Siebe, ben Sarten, weldhen er zu jeinem 28 ofnjitze erforen, anmutig zu beleben. Unmittelbar

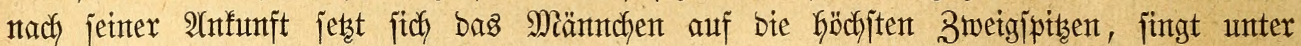

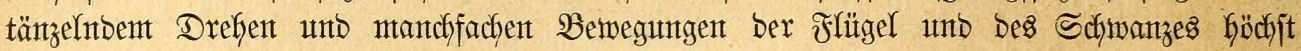
eifrig, erfebt jich, wenn bie Brutzeit näher Geranrüdt, aud wohl bon jeinem Sitze, jteigt

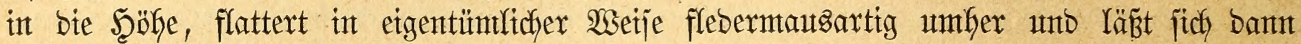

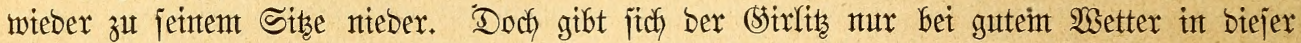

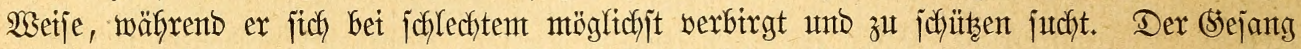

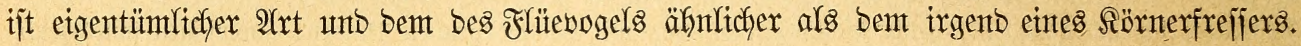

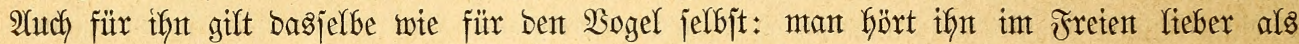
int Binmer, weil ex burch jeine Einföntigfeit und bie vielen jobwirrenben Raute, weldhe zwijhyen bie einzelnen, wolleren Töne gemijdst merben, bald ermübet. Das rejt äfnelt Demt unjeres Edelfinfent und wiro in bifften Stelfen ber Frone eintes Sartentbauntes an= gebracht, int Sïben auf Drangen, Eypreffen und bergl.; bet unt zu Ranbe auf 21 epfel = und

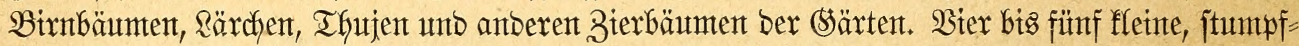

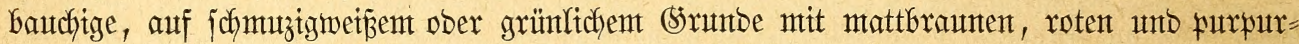

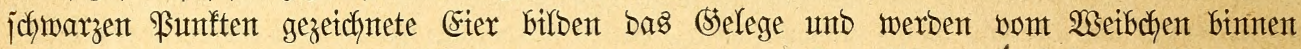
breizefnt Iagen ausgebrïtet, bie Sungen bagegen von betben arlten genteinfam aufgefüttert.

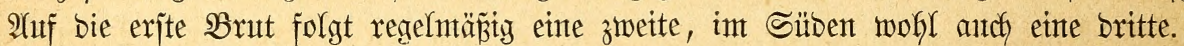

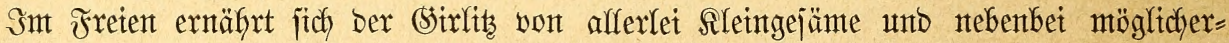
wetje auds von Serbtieren; in ber Sefangenjchaft retcht mant ifm ein Semenge von Miohn,

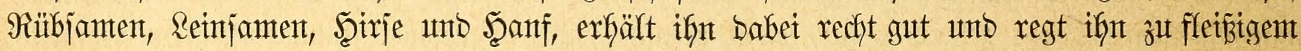

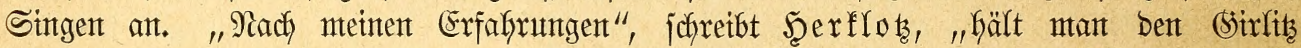

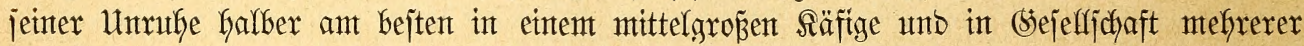
jeinter 2 rrt. Snt eintem größeren $\mathfrak{B}$ ogelfluge ober Fluggebauter gedeift er wentger gut uno

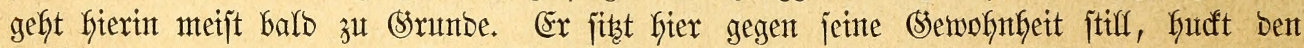
Wanterbünbel auf, ftecft ben Sopf unter ben Flügel unb verenbet. (S)leich) Dent Beifige neigt

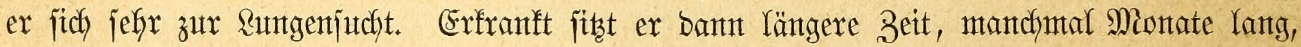

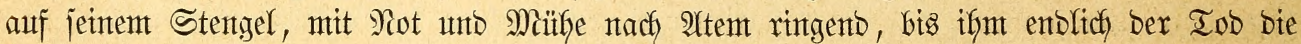

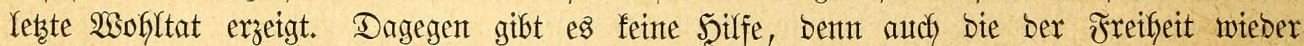

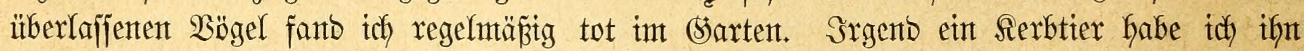

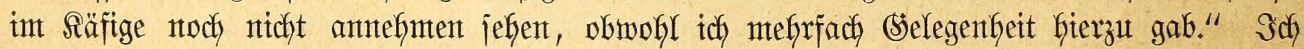

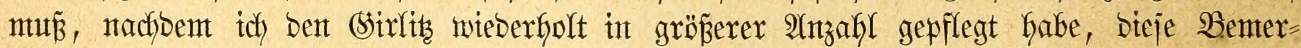

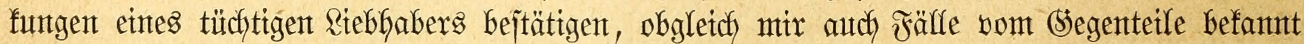

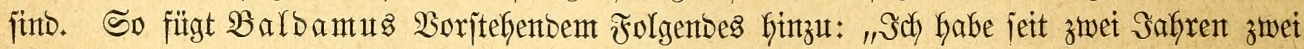

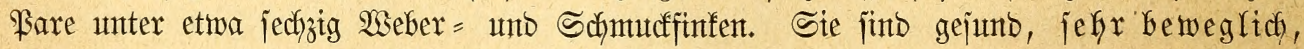

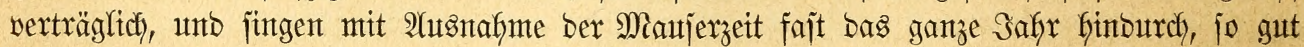
jie es föntent. Eben beginnt eines ber \$are in einter fleinten Ftchte zu bauten." 2(udd) Borle rüfmt ifn als ziemlich) ausbauterntoen Stubenoggel. "Er hat", jagt er, "bei mix

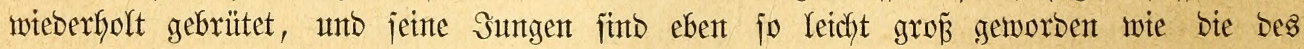
fintartentwogels, mit weldfem ex fich gern part unb Blentlinge exzengt. Beint Brüten

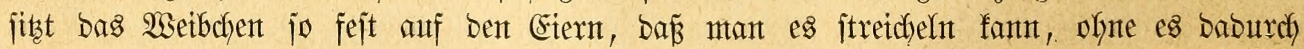
bout Rejte zu treiben."

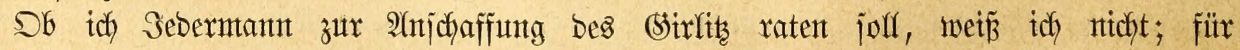

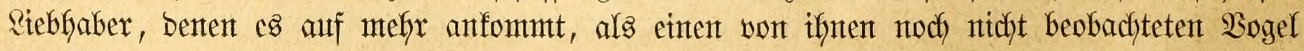
im Räfige zu haben, möchte idh ifhn ntidft empfeblen. Sein \$reis ijt freilich jehr gering,

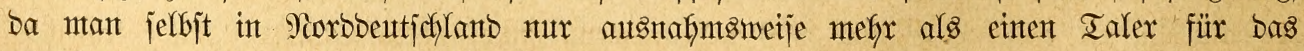

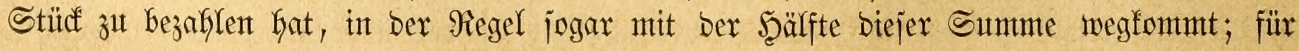




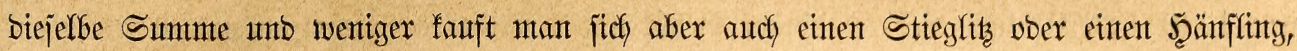
ant weldyent mtan bod) entjoffiebent melyr Freube hat als an ifm.

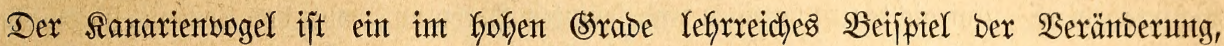

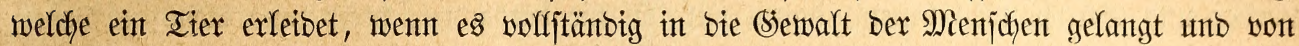

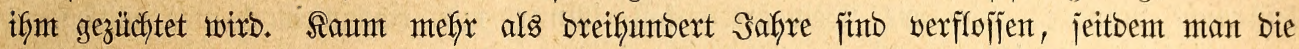

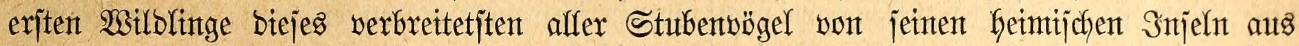
nach) Eurropa bradthe, unt in biejen breifyutbert Safhen hat mant aus bent Naadffonment

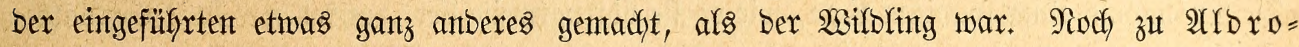

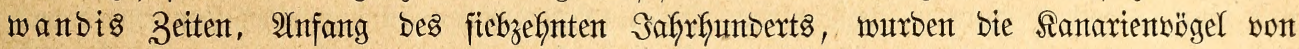

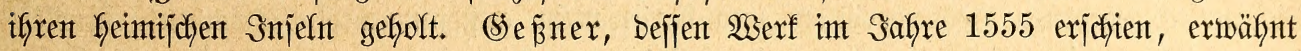

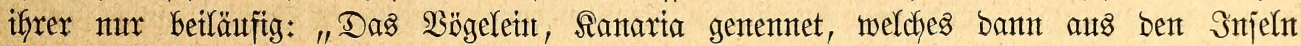

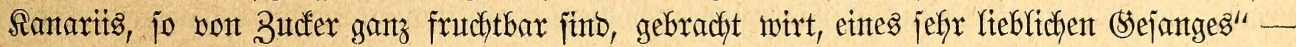
jo gibt jein Meberjetzer (1600) bie betreffento Stefle im Deutichen wieber. Erijt unt bie

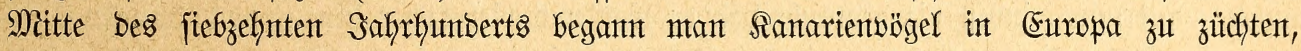

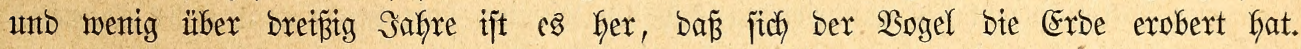

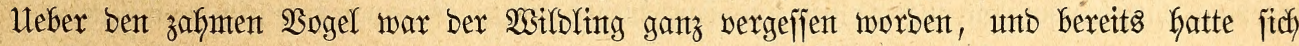
bie Sage jeiner bemä̈dtigt. Eint Schjiff, jo erzähflt fie, welches von Rantaria fant, fcheiterte

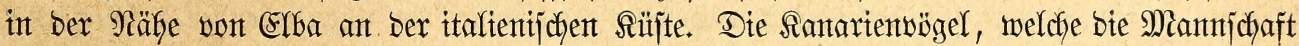

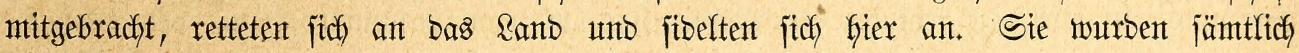

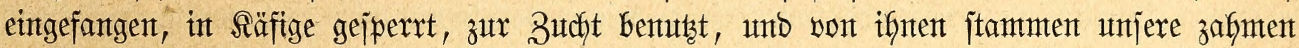
Santarientuoggel her.

Bis zu $\mathfrak{B}$ orles Erforidyung ber fanarijchen Injeltn hatten wir über bas Fretleben

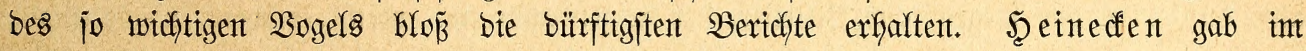

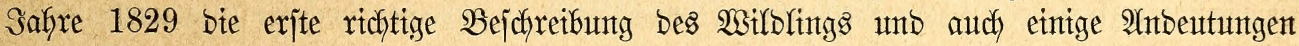

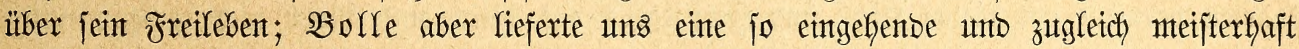

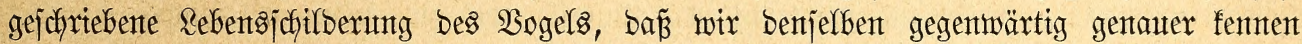

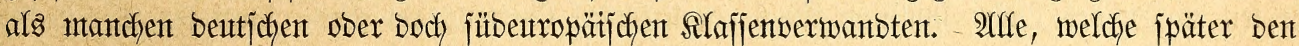

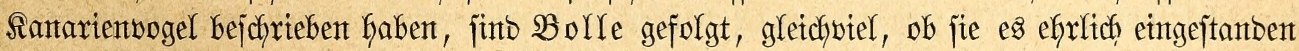

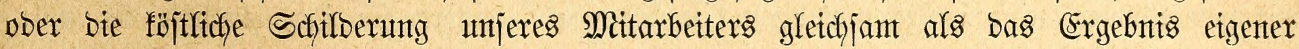

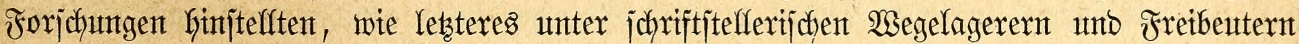

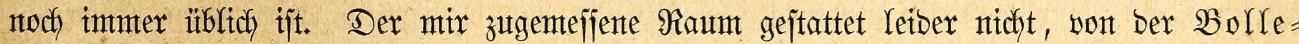

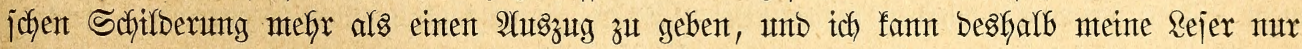
auf bie angegebente Stelfe jelbjt verweijent.

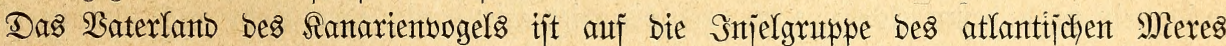

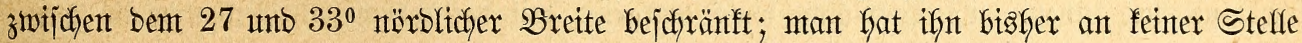
Des nahe liegentbent Fejtlanbes angetroffen. A2uf bent Eifantben, yon benten er bent Rament

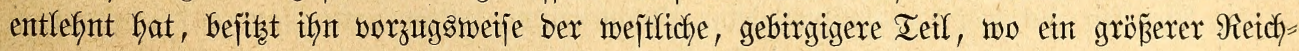

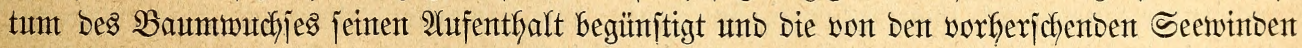

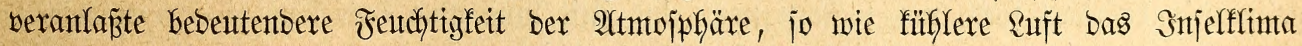

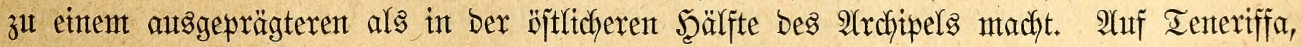

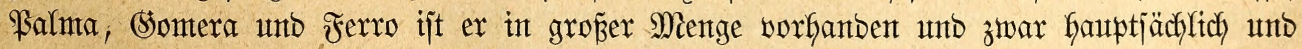

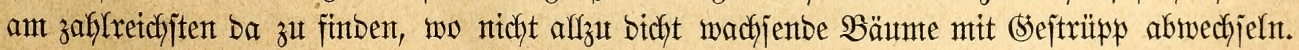

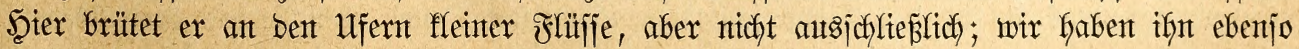

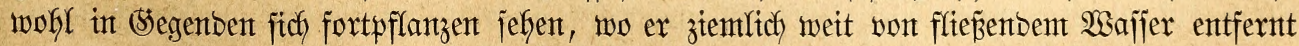

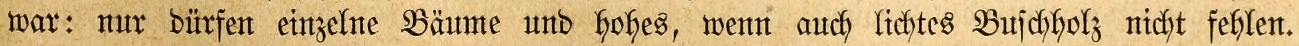

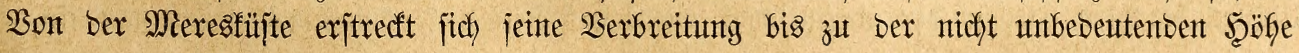




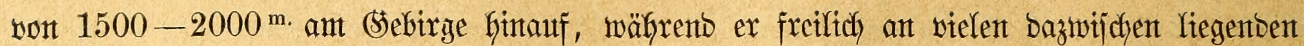

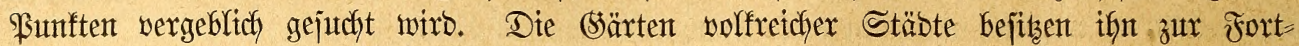

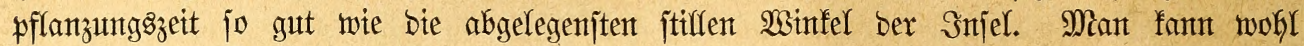

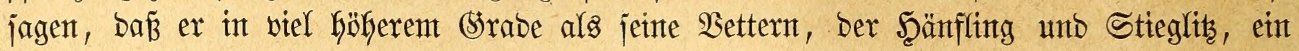

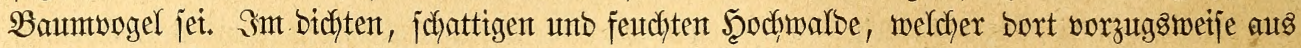

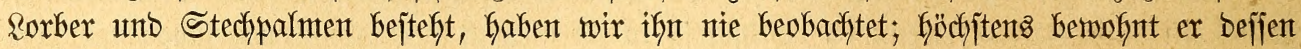

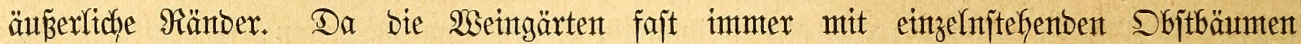

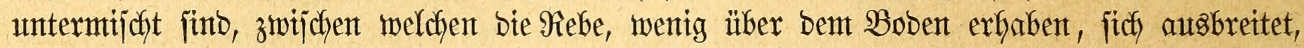

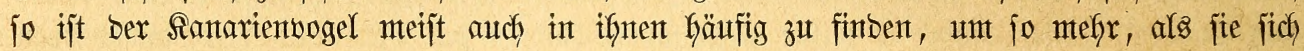

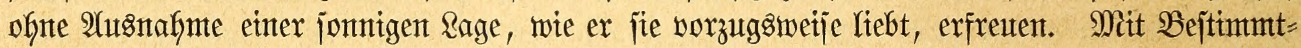

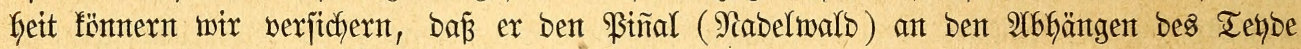

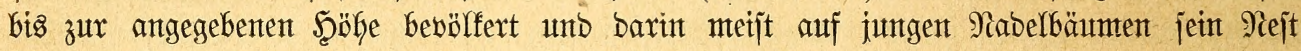

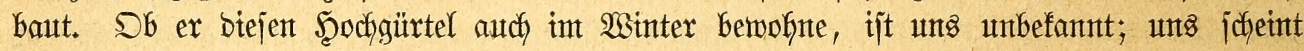

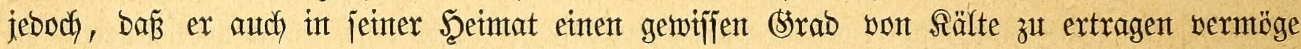

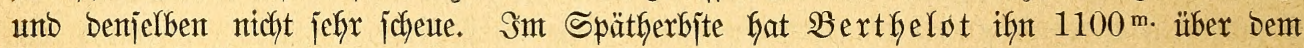

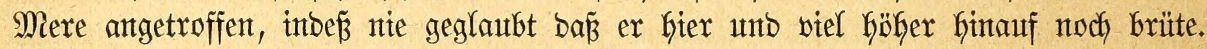

Der Fortpflanzzung bez Santarienwogelz Gabent wir int Tale wont Srotawa auf Tenteriffa

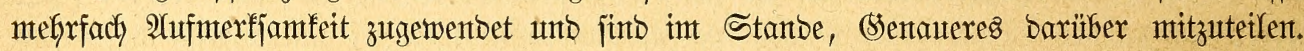

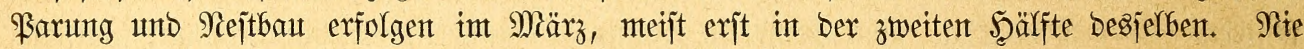
bautete ber $\mathfrak{B}$ ogel in ben uns zu Sejicht gefonmtenten Fällent niebriger als $2,5^{\mathrm{m}}$. über bent

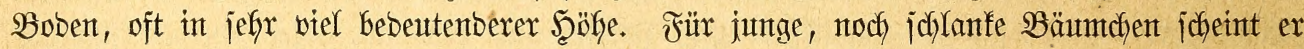

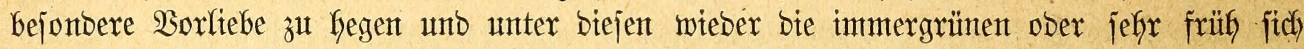
belaubenben vorz̈̈̈glide gern zu wäflent. Die Birne unt Der (Sranatbaumt werben iffrer vielfachen unb boch lichten Beräjtelung harber fefgr häufig, ber Srangenbaum jeiner immter

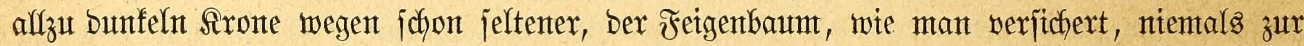

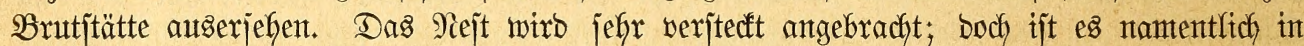

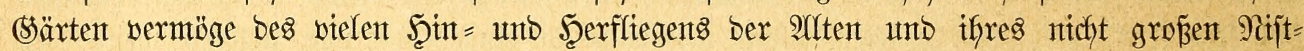
gebietes umjdywer zu entbeffen. WBir fanben bas erjite unz zu (Seficht gefommene in ben Yeţten Tagen Des Miärz inmitten eines verwilberten (Sartens Der Biflla Drotaba auf einem

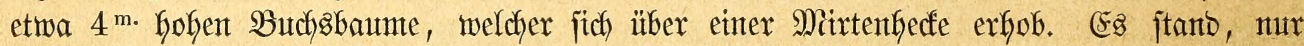
mit bent Bobent auf ben 2 ejten rubento, in ber Stabel einiger Zweige, unten breit, obent

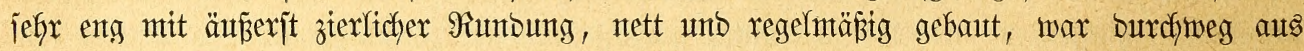

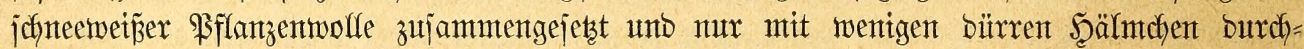

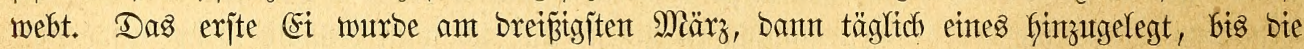

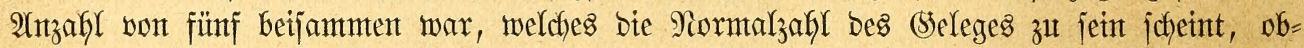
gleidy wir in anberen Fällen mur brei bis sier Ejer, nie aber mefgr als fünf in einem

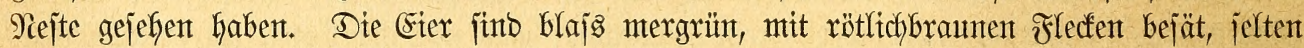
beinahe voer ganz einfarbig. Sie gleidyen benen bes zaffmen 2 bogels volffonnten; ebenjo Gat bie Brutzeit burch bie Bäfmunty feine Untänberunty erlitten: fie sautert beim wilben Santarienvogel ebenfalfs ungefähr breizefnn Iange. Die Sungen bleiben im Siefte, bis fie

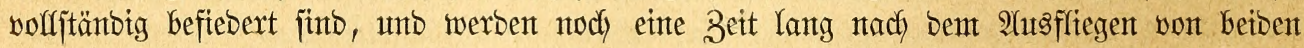
EItern, namentfich aber vont $\mathfrak{B a t e r}$ auf bas jorgfärttigjte aus bent Siropfe gefüttert. Die

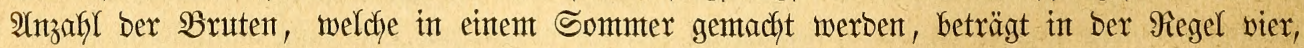
mitutter aber autch nur brei. Enbe Sulfis beginnt bie Mianjer, mit weldyer, wie natürfich,

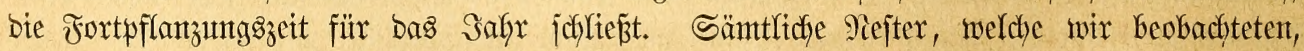

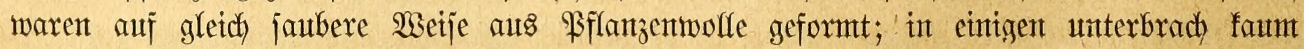

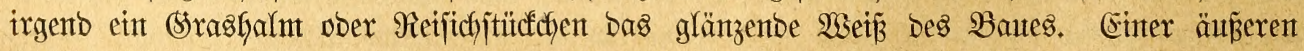

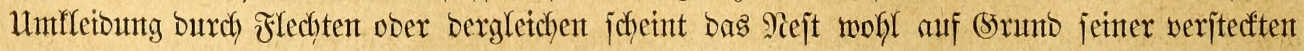




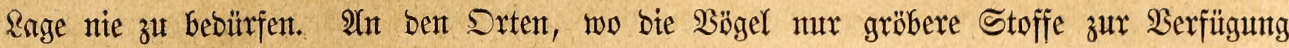
Gaben, joll man mefr aus Mos und Scalmen gebaute Neṕter finben.

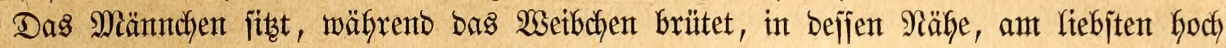

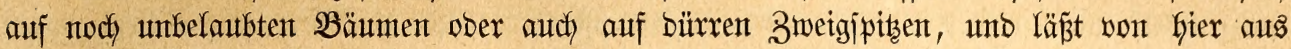

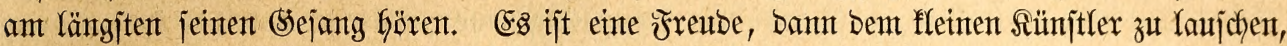
zumal wenn es vom Exfer eines Şaujes Gerab gejcheben fann, wo man jich oft in ber Şähe bes fingenten $\mathfrak{B}$ ogels befintoet, welcher in ganz geringer Entfernung vor uns firzt.

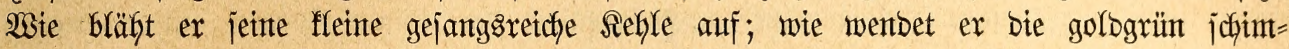
mernbe Brujt balb rechts balb linfs, fich int Strale jeiner heimatlichen Sonne babento,

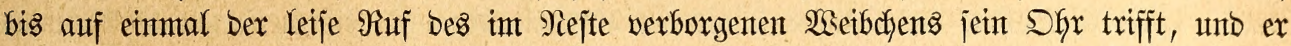

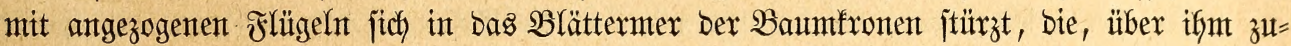

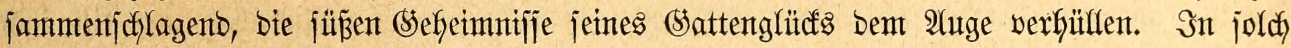

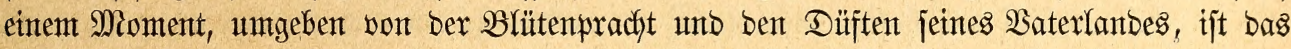

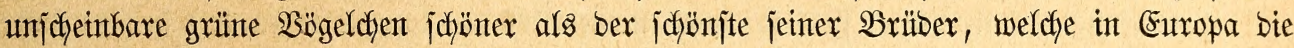
Snechtestracht Der Sflaverei tragen. Ex ijt an jeiner Stelfe, unt bie Melobie jeines Riedes

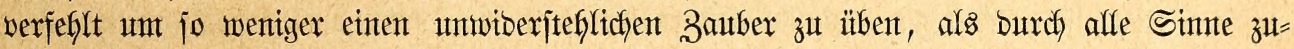

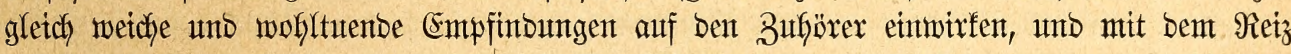
bes Jrembartigen jich gerabe burch bieje 2 ogelitimme träumerijche Erinnerungen ber Sintheit mijchen. Unzweifelfaft ijt nidfits mefr im Stambe gewejen, uns anzuheimeln und bas Se= füfll bes Jrembjeins auf Den Injeln zu verjcheutchen, als gerabe ber überall jo freundlich

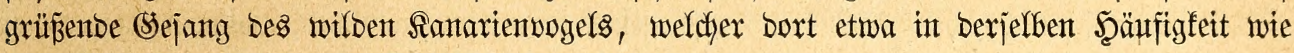
Der Sallag bes Finfen in Deutichlanto ertönt.

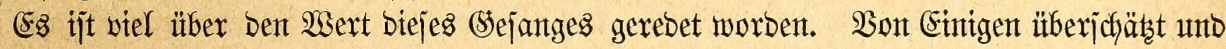
affzujefyx gepriejen, ijt ex von 2̂nberen einer jefy jtrengen fritif unterzogen worben. Man

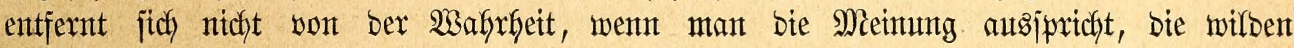
Sanatienwögel jängen wie in Earopa bie zafymen. Der Schlag biejer letzteren ijt burchaus

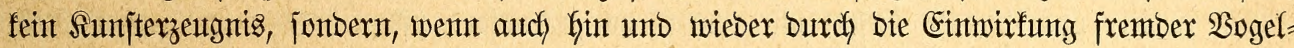
gejänge abgeänbert, boch int groß̄en \$anzen ınveränbert geblieben, was er uriprünglich war. Einzelne Teile hat bie Erziefung umgejtalten unt zu glänzenderer Entwidfelung bringen,

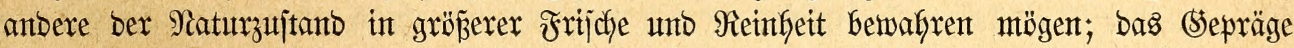
beiber (sejänge aber ijt noch jebst vollfomment ïbereinjtimmento. So wentig als alfe ફ̧änffinge

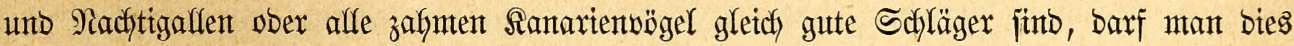
von ben wilben forbern. Atuch unter ifnen gibt es jtärfere unb jchwädhere; bas aber ijt

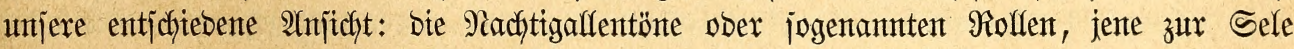

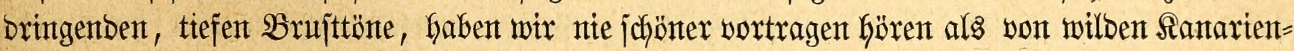

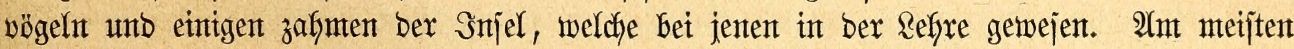

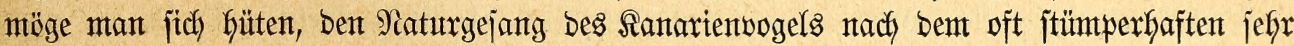
jung gefangenter Stïcfe, welche im Räfige obne guten Borjchläger auf̣wudjjent, zu beurteilen.

Der Flutg Des Santarienungels gletcht bemt bes Şänflings, ijt etwas wellenfürming

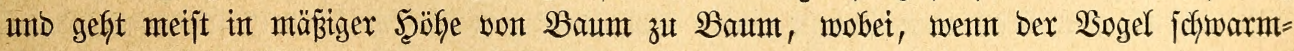
meije fliegt, bie (Slieber ber (Stejelfjchaft jich nidjt bicht antinanber brängen, jonbern jeber

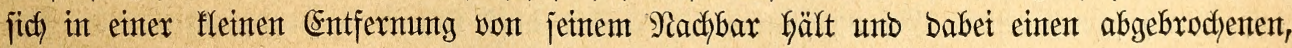

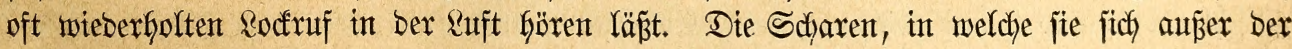
Jortpflanzung zujammentun, find zahlreidh, löjen jidy aber ben größ̈ten Teil bes Tages finburch in fleinere Flüge auf, weldye an Den geeigneten Drten ifyrer Nafyung nadfgeben unb jefx fräufig längere Beit auf ber (Erbe verweilen, vor Sonmenuntergang aber fich gern

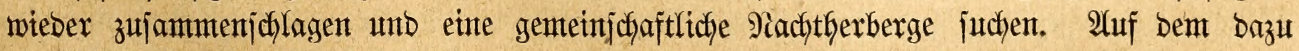
gemäblten Saame jtimmen jie bann ein lautes und verwirrtes Sonzert an. 


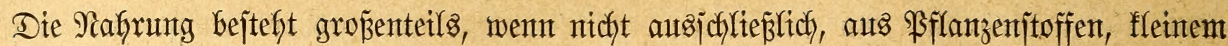

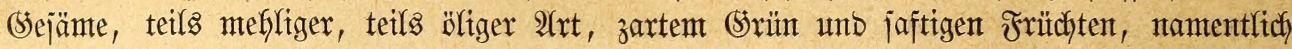
Feigen, welche letstere er wie fait alfe Singbögel ber fanarijchen Snjeln auch in ber (Se=

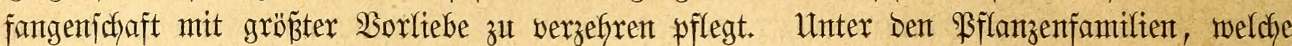
ifm jeinen Unterfalt liefern, jofeinen bie frewzblütigen vorzugsmeije von ifm aufgejudyt zu merben. Den Sropf bon ben in Frühlinge erlegten fant ich fajt ausjchließ̧lich mit grünen

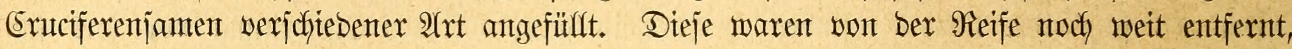
Daher um jo zarter und büriten Yeidyt Das Scauptfutter füx bie noch fleinen Sungen abgeben. Dem Sobl = und Salatjanten gehen fie Den Sommer hinturch auf Felbern und in Särten

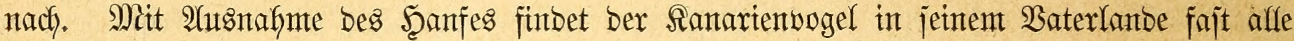

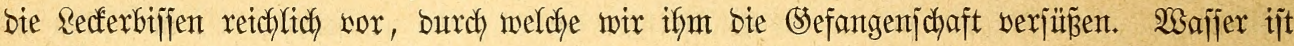
für ifnn ein gebteterijches Sebürrnis; ex fliegt oft, meijt gejelfig zux Iränfe uno liebt bas Baben, bei welctem er jich jehr najs madyt, im milben 3ujtanbe ebenjo jefr als im zafymen.

Der Fang umjerer $\mathfrak{B}$ ögel ijt jefr leidht; namentlich bie Sungen gehen fajt in jebe Falfe,

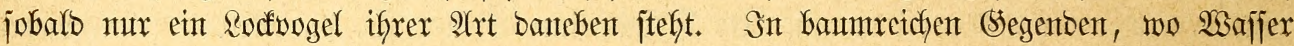

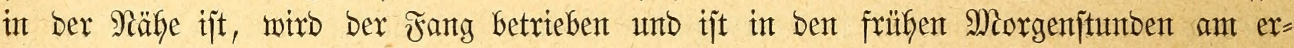
gibigjten: wix haben binnen wentgen Stumben jechzefn biz zmanzig Stüct eines nach bem anderen fangen jefen, auch mitunter beren ein bis anderthalb Dutsend auf eimal bejeffen. Der Preis junger, bereits ausgeflogener $\mathfrak{B}$ b̈gel pflegt in Santafruz ctwa $2 \frac{1}{2}$ Silbergrojchen unjeres Steldes für bas Stücf zu betragen; frijch gefangene Miänndhen werben mit ungefähx 10 Silbergrojchen bezahlt. Die frijh gefangenen fint untufige Bögel, weldfe längere Beit

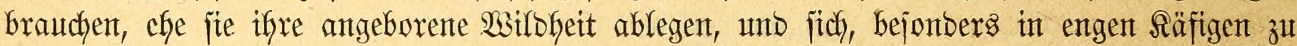

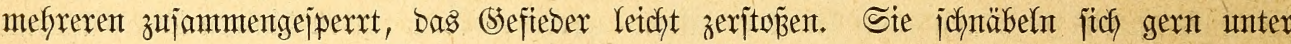
einanber, und bie jungen Meänndyen geben jidh binnen furzem Durch fortgejestes, lautes 3witjchern zu exfentmen.

Saum gibt es einen weicflicheren Sönnerfrefjer! Man verliert ifn meif́t an Srämpfen, beren zweiter ober britter 2 (nffall mit Dem Iobe zu entigen pflegt. Wer jie über See mit

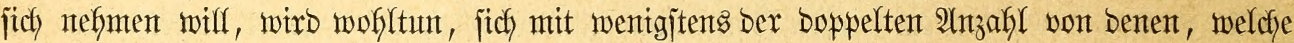

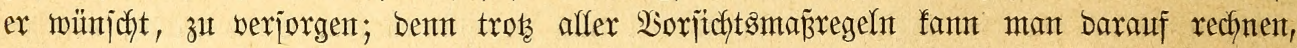

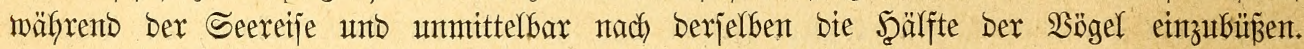
Wir haben von elf glüdfich hereingebradfen, bereits vermaujerten, wollfommen eingemofnten unto zum Teil jofon johlagenden fanarienbögeln in Raufe bes erjten winters noch mefrere ganz unerwartet an Srämpfen zu Srunbe gehen jehen. Das eine Weibchen, welches mir wäfreno

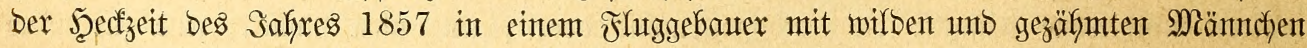

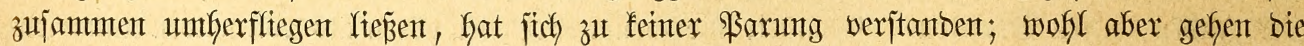

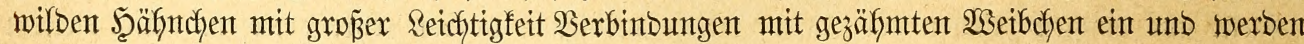

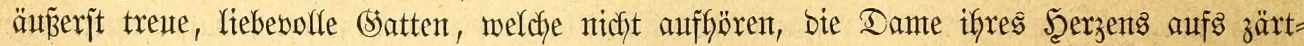

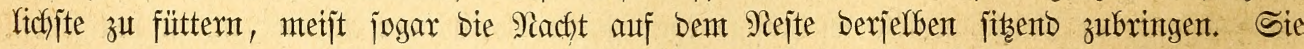
bieten jebem anderen Bogel, weldyex ifnen zu nafje fommt, bie Spibe; ja ein älteres

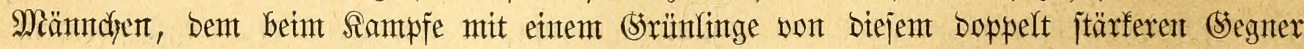

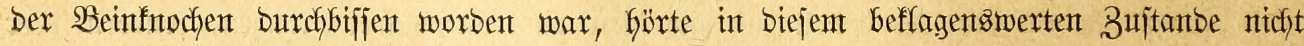

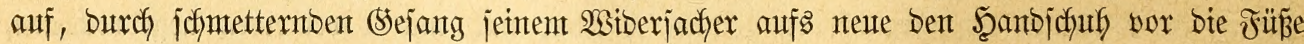

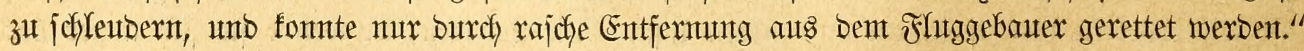

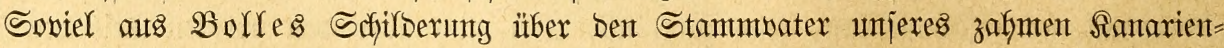

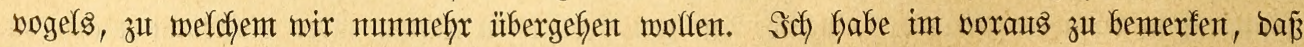

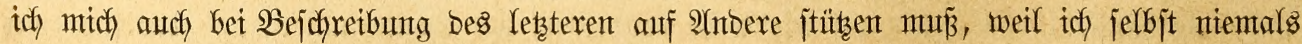

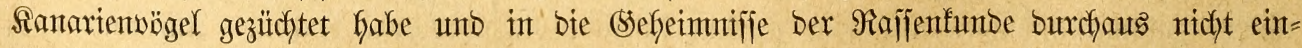
getweift bint. Doch liegen über ben Sogel von jo tüchtigen Büchtern Mitteifungen vor, 


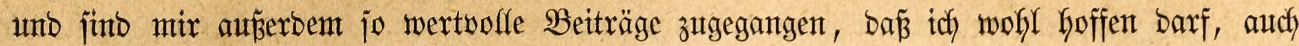
über ifn ein ziemlich richtiges Bild geben zu fömen.

Was zuerjt bie Rafjen anlangt, jo unterjcheibet man beren hauptjächlich zmei, bie

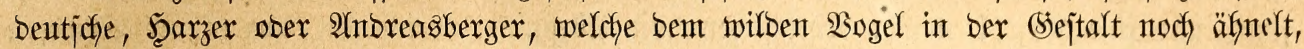

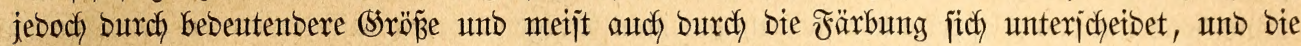

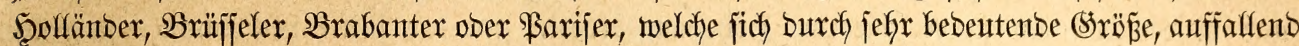
hohe Beine, Schlanfheit bes Reibes, hochgemölbten Rüdfen und verfraujte Brujtfebern fenn=

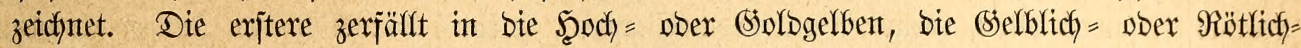

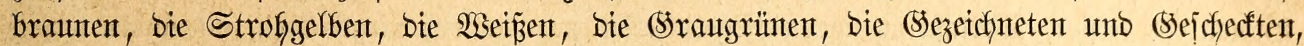

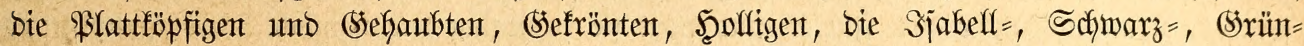
flügel und plattföpfigen Şalbjhyalben, Schwarzgrünen unt Sraugehaubten, Schwarz= und

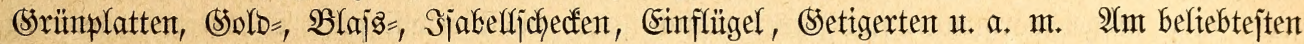

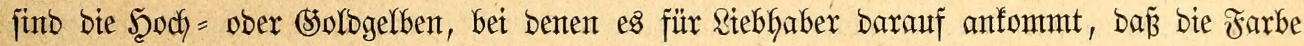

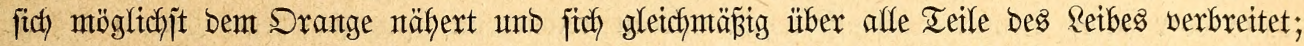
bei ben (Selblichbraunten ober Sjabellen kerjdyt oben bie betreffentbe Färbunt vor, währent fie unten golbgelb ausjefyen müjjen; bei ben Strofgelbent ijt bie Färbung eine burchaus

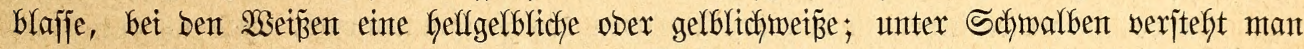
biejentgen $\mathfrak{B} \not ̈ g e l$, bei Denen mux bejtimmte Teile, insbejonbere Dberfopf und Frlïgel eine Dunflere Färbung haben als ber übrige Reib: bet Den Schwarzidymalben aljo jund Sberfopf

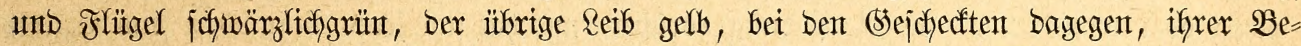

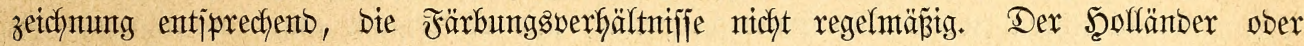

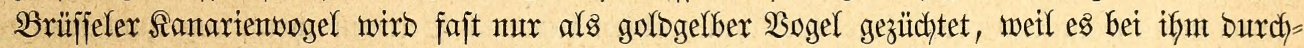
aus nicht auf bie Färbung, jonbern einzig uno affeth auf bie eigentümliche, man barf wohf

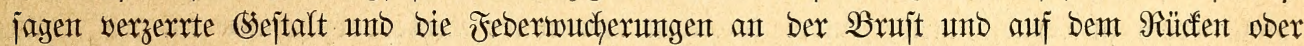
Sberflügel anfommt. Sch habe in Jranffurt a. M. eine berüfmte Züchterei biejer Bögel

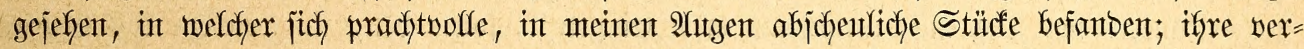
längerten unt aufgefrempelten Brujtfebern bilbeten won ber (Surgel biz zur Baudjmitte eine Srauje, und nidyt alfein bieje Ietle, jonbern audh bie Schultergegent und bie Schenfel waren mit joldfen berlängerten Febern bebectt. Die Şolländer zerfalfen mieberum in mefrere Unterrafjen. Sbenan ftellt mant bie größ̈ten, Barijer ober Irompeter, jo genannt wegen ifrer gefrauften Sdyulter = unb Bruftfedern; auf jie folgen bie eigentlichen Seollëntber ober Brabanter: etwas fleiter als jente, mit unvolffommenter Butjtfrauje (Ehapeau) und

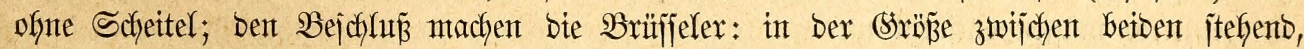

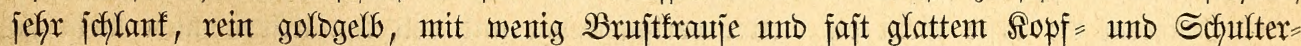

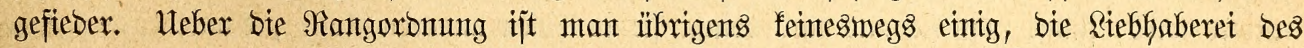
Einzelnen vielmefr majgebend. Nach Serjicherung alfex Siebhaber erfalten bie Scolfänber

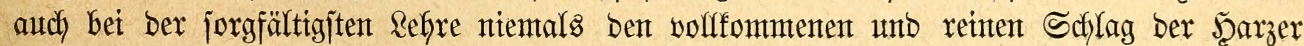
Bögel unt werben aus bem sruntbe unzweifelfaft ebenjo bejtimmt vergeken, wie Miopje

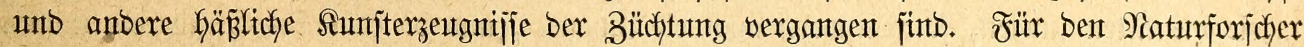

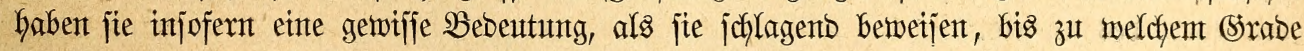
ein Titer in furzer Frijt burdh bie Büchtung veränbert werben fant.

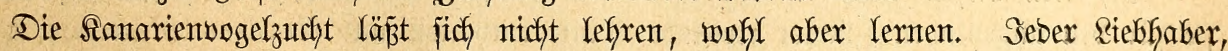

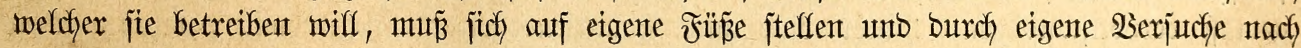

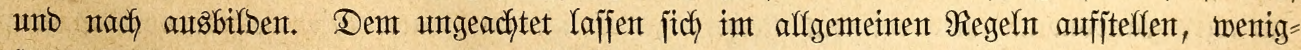
itens Sdfilberungen ber an meiften üblidfen Befyanblung geben. Ueber bas am Şarze ge=

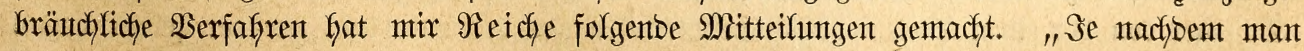

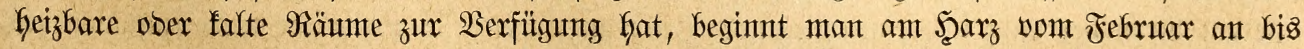

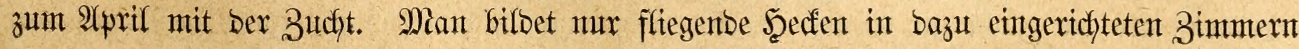




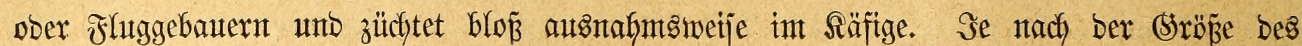

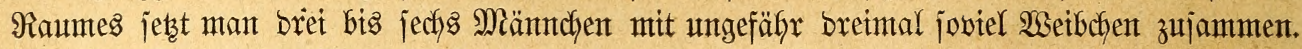
Für eine Mienge von Springitöcfen, von benen einzelne hodh, bie anberen niebrig angebradht

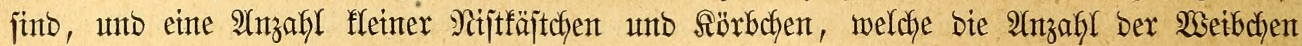
minbeftens um bas Doppelte überjteigen, hat man Sorge getragen und leţtere an ben 2 änden

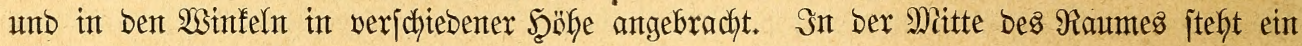

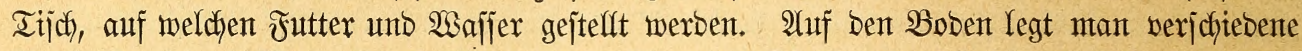
Baujtoffe, feines Mos, (Sras, Wumbfäben (Sharpie), Şirjol)= ober Suthhare, Feberm zc. zum

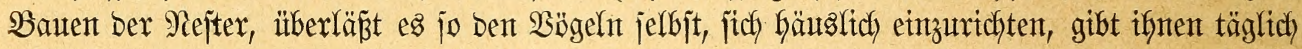
frijches, gejunbes und reintes Jutter und ftört jie jo wentig wie möglich. 2Als Scauptfutter

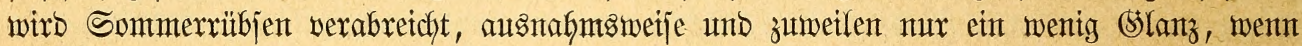
exjt junge Bögel vorfanden jimb, aber täglich zwei = bis viermal frijches hartgejottentes und bann geriebenes (Eit, weldhes man mit ber gleidfen Mienge angefendhteten gejtopenent 3wie=

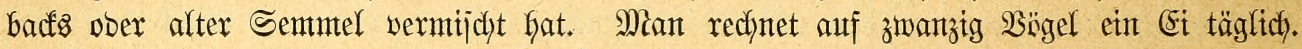

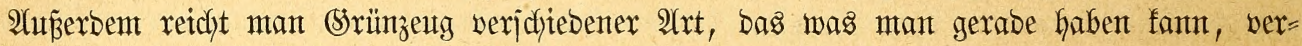

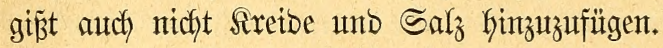

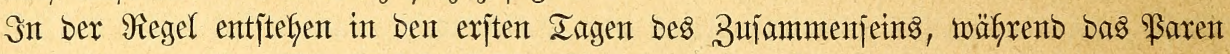
wor jich geht, unter ben Bägeln jefr heftige Sämpfe, wobet nicht jelten bas ente ober anbere

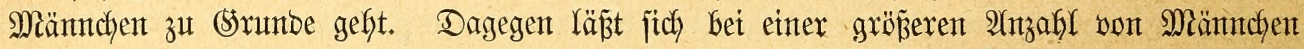
mentg ober nichts tun. Sit bie \$arung vorüber, unt hat jich jebes Meänndjen jeine Weiber crrungen, io fefren Friebe und Eintracht zurüct, unt es beginnt nun ein rüfhriges und

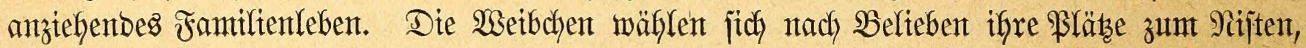

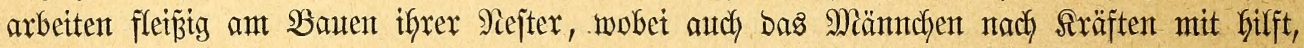
ofne jeboch zu verabjäımen, jeinem Weibdjen aus volfer Siefle vorzujcymettern.

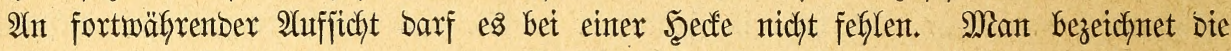
Nejter, merft ben Iag auf, wann bas exfte Ei gelegt, jowie ben, an welchem bas Selege vollzäflig wurbe, unt zu wiffen, want bie-zwölf Iage ber Bebrïtung vorüber fint und bie

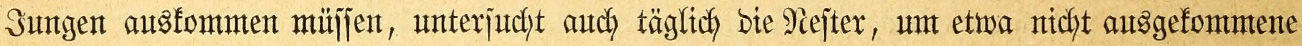

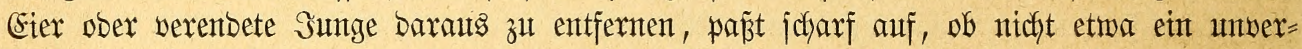
bejierlicher Sirafebler ober jonjtiger Iaugentdyts jich in ber Seecfe befinbet $2 c$. Es gibt nemlich

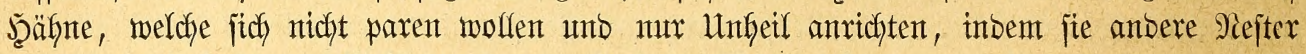
zeritören, Die brütenben Weibchen ärgern, ja jogar Eier vernichten und Sunge töten. Soldye Störenfriede müffien entfernt werben.

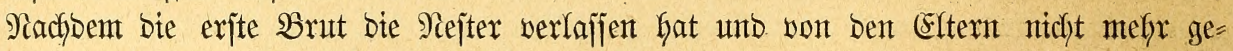
füttert wiro, fängt man fie aus unb bringt fie in einen anberen $\Re a u m$, Damit bie fotgende SBrut nidfyt burdy fie gejtört werbe. Mit ber zweiten verfährt man ebenjo, unto mit ber britten wirb bie Şecfe gejchlofijen.

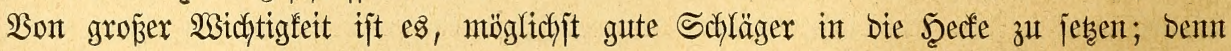

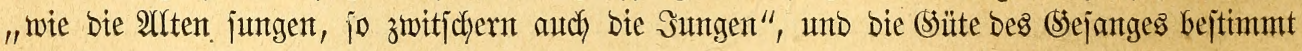
Den Wert bes $\mathfrak{B}$ ogels."

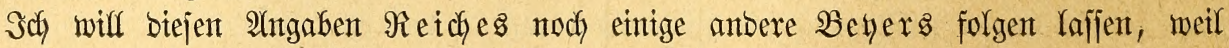

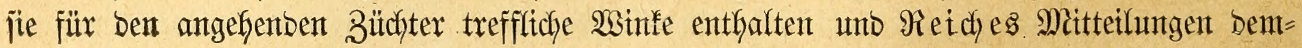

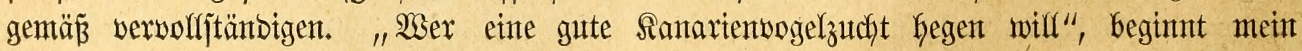
türinger \&anbsmann mit volfjtem Rechte, "Darf nie mit Sater unb Todjter ober Bruber

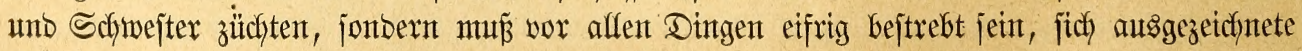

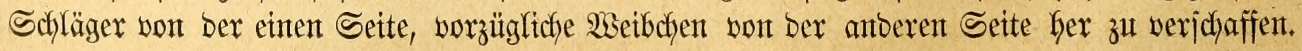

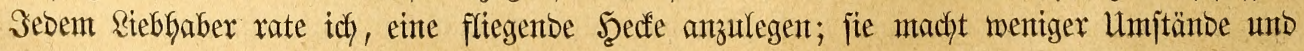

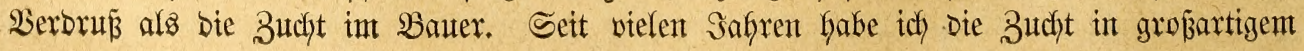




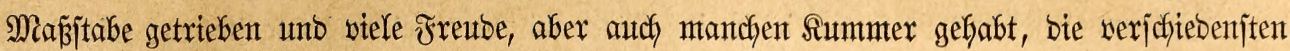

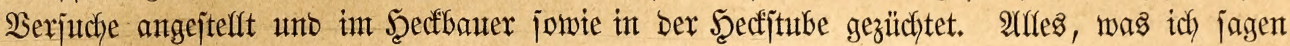
werbe, beruft afjo nur auf eigenen $\mathfrak{B}$ eobad,tungen unt Exfahrutngent.

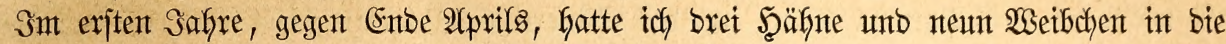

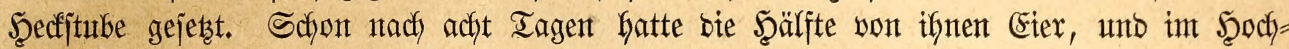

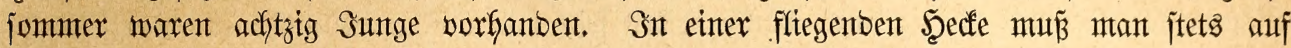

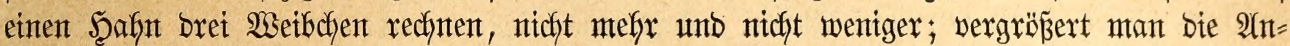

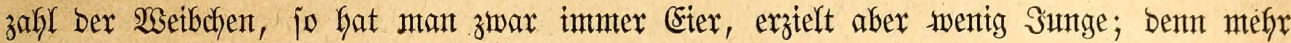
als brei Şenten fant ein Şafgn nicht verjorgen. Bein Zuja

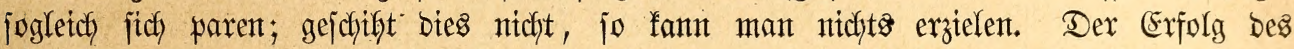

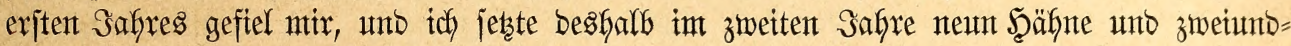
zwanzig $23 e t b c h e n$ zujammen. Das Ergebnis war aber ein anberes, als id erwartet hatte:

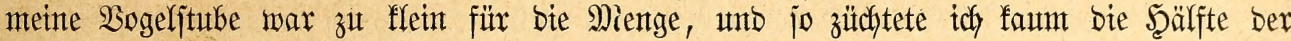
Sungen, welche idh int borigen Safre erzielt hatte. Sch wurbe aljo butrdy Schaben io ffug,

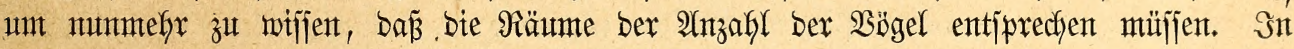

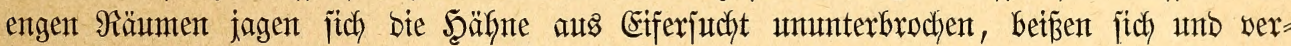

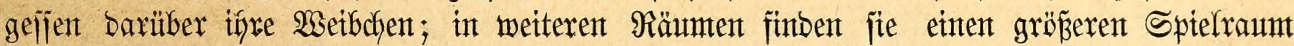

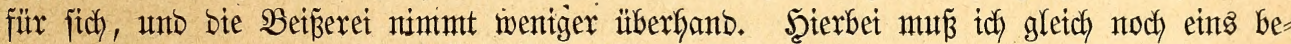

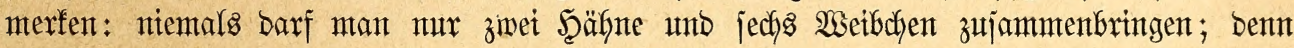

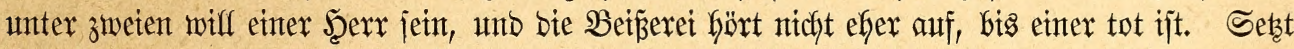

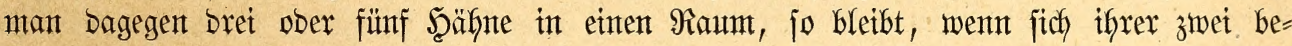

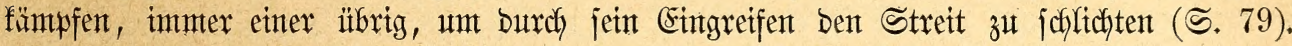

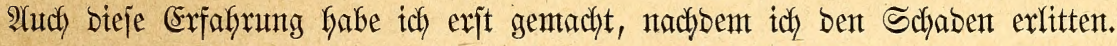

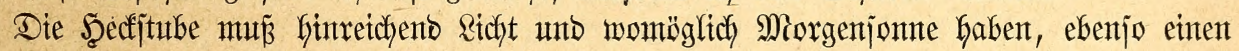

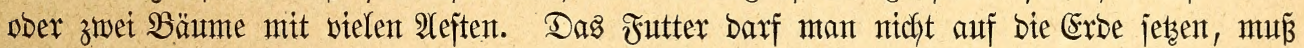

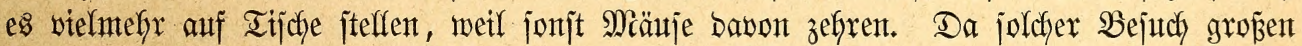

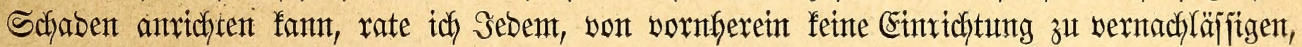

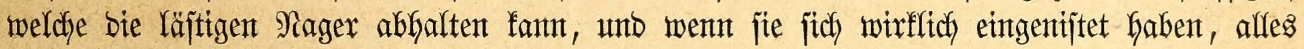

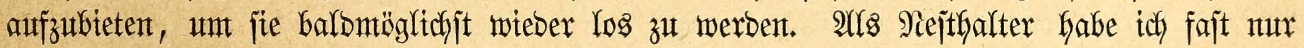

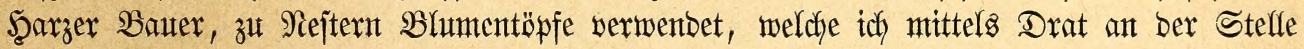

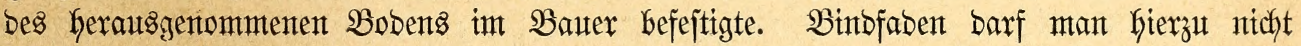

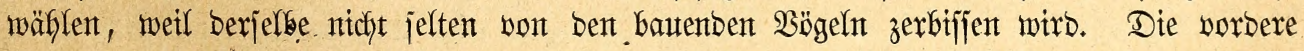

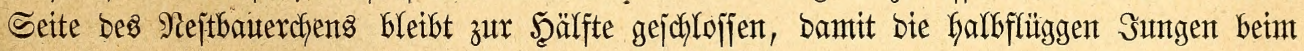

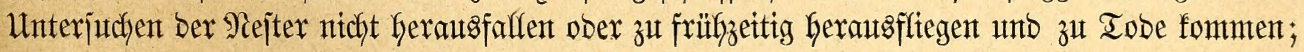

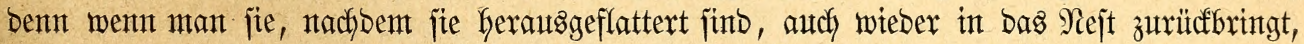

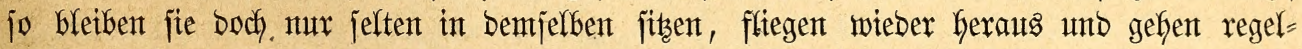

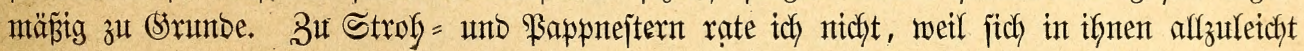

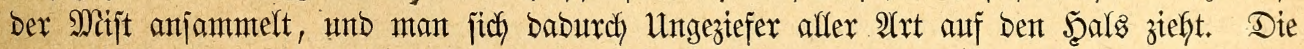

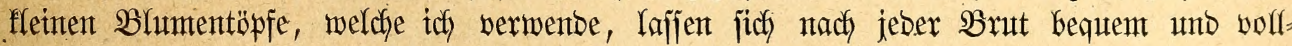

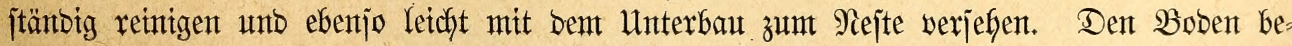

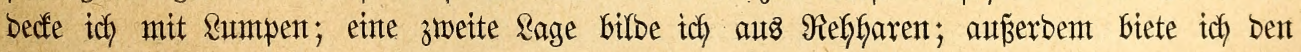

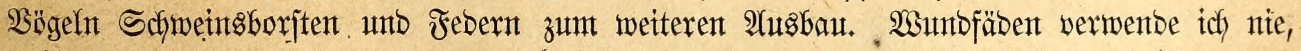
weil jich biejefben reidgt anfü̈ngen, vertwirrent unb ben Sungen bie Fü̈e ausbrehen ober

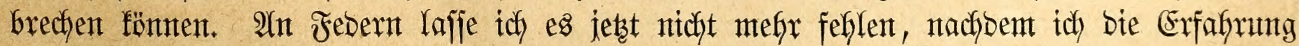

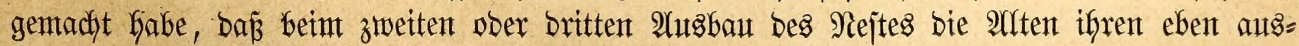
geflogenten Sungent bie Sdywänze ausbififen, unt nit ben jo gewonnenten Febern zut bauten.

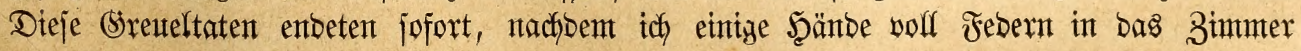
gemorfen hatte. 


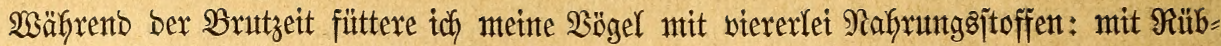

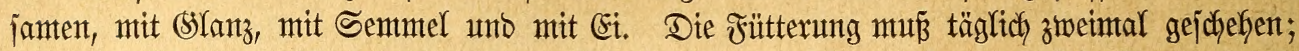

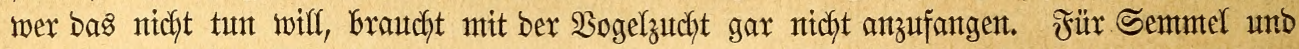

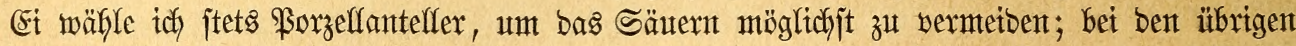

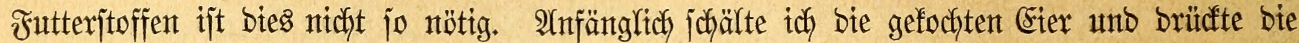
aufgeweichte Sentmel tüchtig aus, hacte beibes fein unto mijjote es unter einanber. Daz̧u

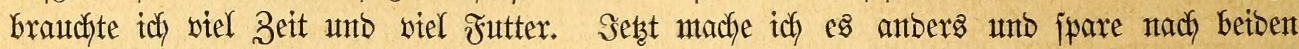

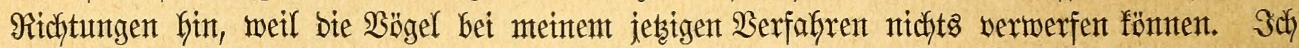

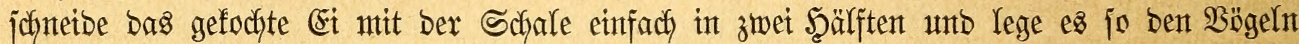

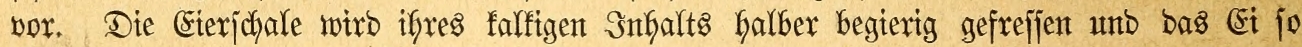

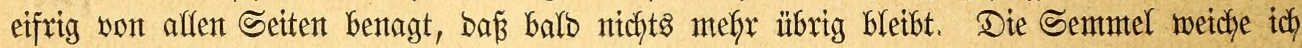

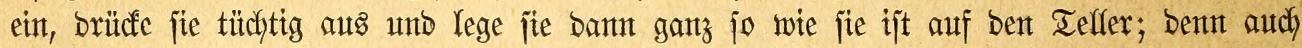

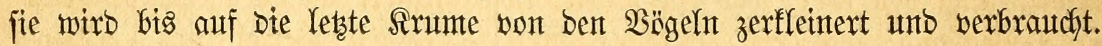

Die auzgeflogentent Sungen barf man noch nicht jogleidh wegfangen, weil jonjt viele

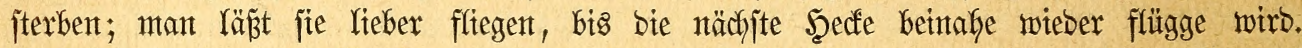
Pinmeffr fängt mant fie, füttert fie aber nodh eine Beit lantg mit eingemeidyter Sentmel

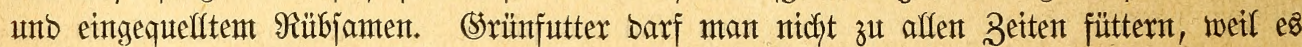

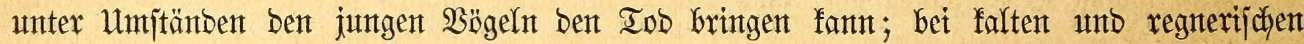

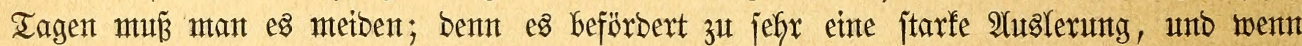

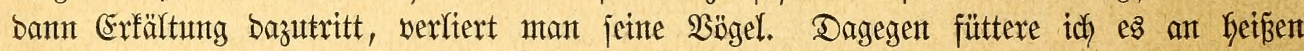

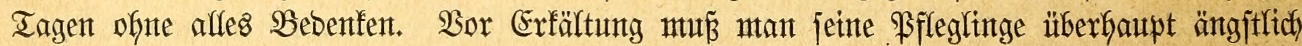

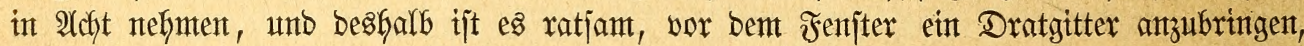

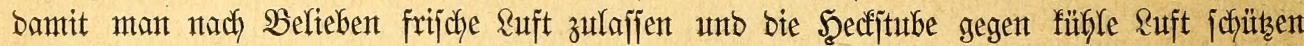

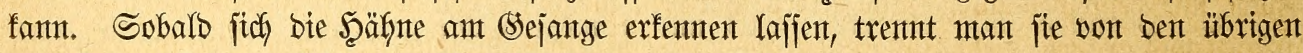

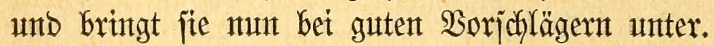

Eine Şauptiache bei ber Sanarienbogelzudd, ijt, nicht zu zeitig anzufangen, unb bie

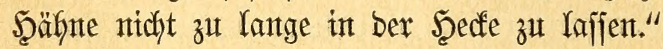

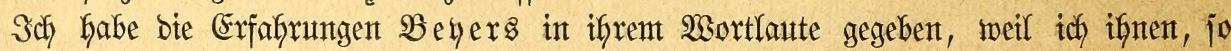
weit idy won anberer $\mathfrak{B}$ ogelzudofyt folgern barf, mur beipflidyten fann. Sie enthalten in ber

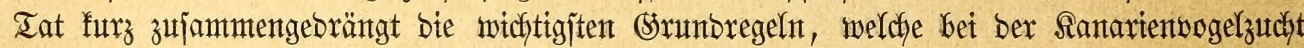

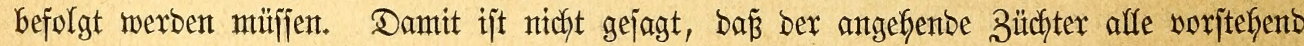

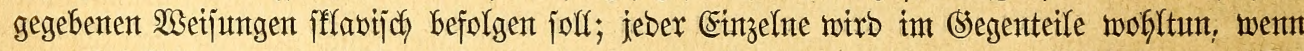

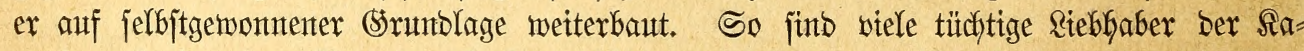

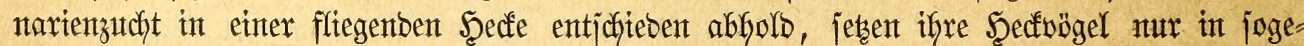
nante Eintwurtffäfige, entweber ein \$ar in einent einfachen ober ein Männthen unb zwei

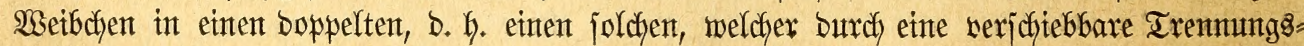

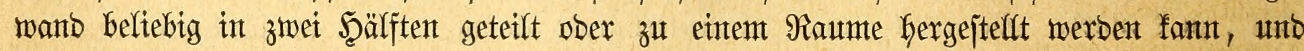

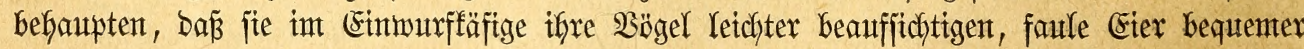

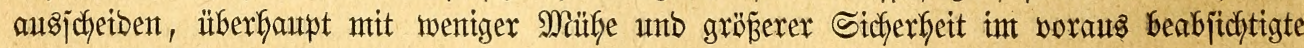

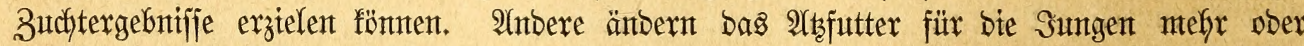

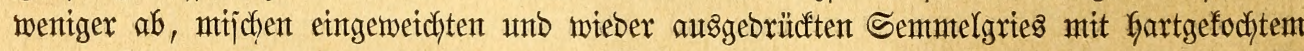

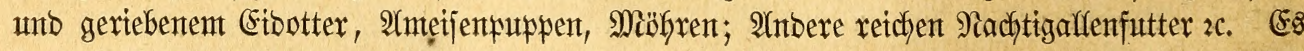

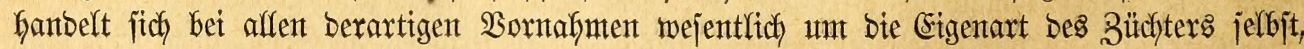

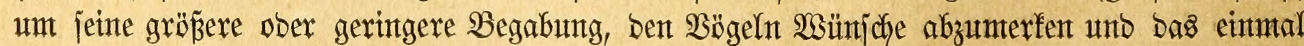

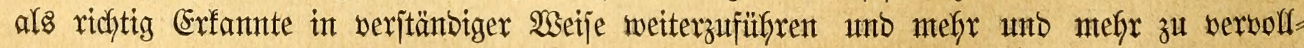

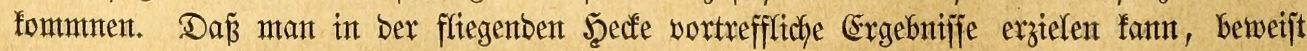

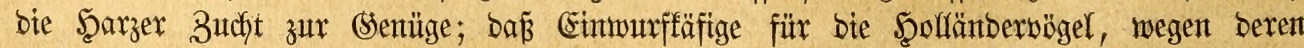

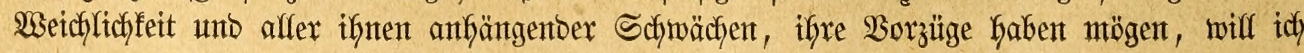




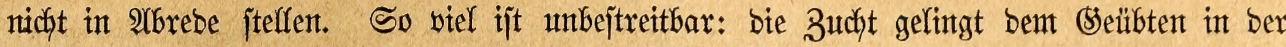
fliegenben Secte nicht minber gut als in bem Einmurnffäfige unb in biejent oft ebemio gut

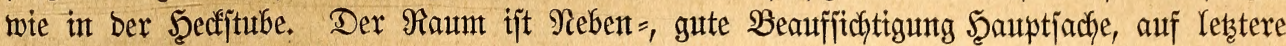
aljo jtets bas größjte (semicht zu regent.

Meenter 2(nficht nach Gantbelt es fich für Büchter wentger barum, bejonbers jchënfarbige Bögel zu erzieben, jonbern barunt, gute Schläger zu erzielen unt ifgren natürlichen (sejang

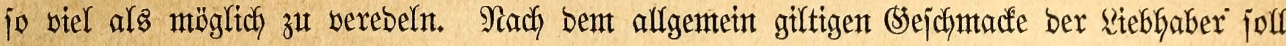
Der verebelte Bejang nur aus wohlffintgenten Iönen bejteben. Die beliebtejten fint bie

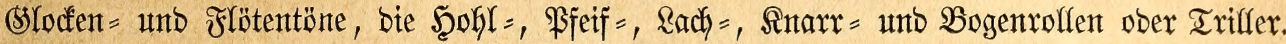
Se wedhjelreicher bieje verjofiebenten Raute vorgetragen werben, je angenthnter bie Hebergänge

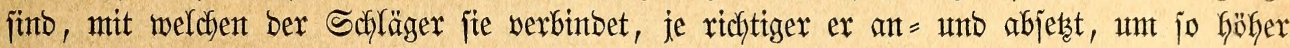

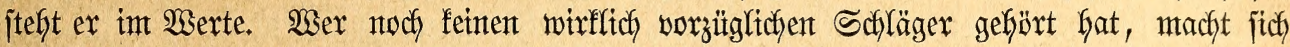

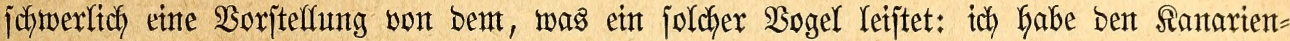

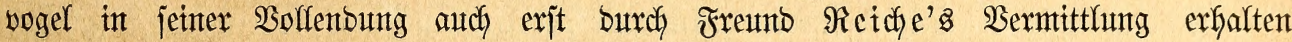
unto wïrbigen gelernt. Der oft mitffich ftautenerregentbe \$sejang eines ausgezeichneten

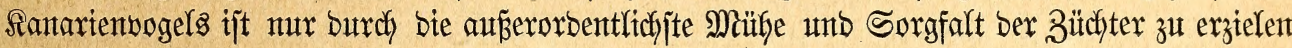
unto zu erfialten.

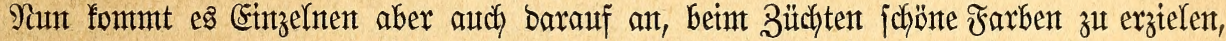

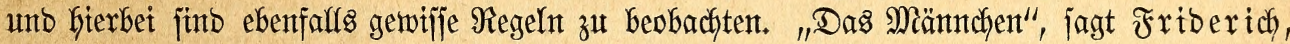

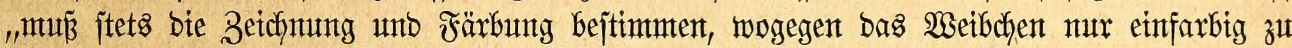

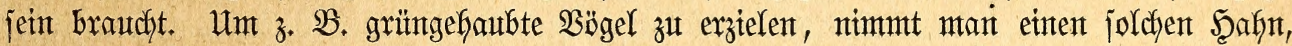
braudst aber mur eine mittelgelbe, glattföpfige Sente zu mäblent. Se reiner bie Bögel "ourch)= gezogen", b. h. auts je mefgr Bruten jie jtets rein herborgegangen junb, bejto reiner fälft bie

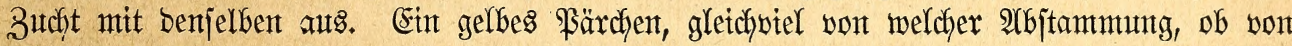
grünen unb grauen, ziefjt Sunge: barunter ijt eint gelbes Meäntchen; biejes ziteft im folgenden Safre int Cinzelfäfige mit einem gelben Weibchen mieber Sunge auf, unter benten fich ebenfalls ein gelber Sofnt befindet. Diejer rebzte gelbe $\mathfrak{B}$ ogel mut wirb, mit einemt gelbent Weibchen zujammengepart, weldhes ebenfalls burch zwei vorrftäntoige Bruten rein erzogen ijt, faum jemals anbere als rein gelbe Sungen erziehen. Şat man auf bieje Weije brei bis vier

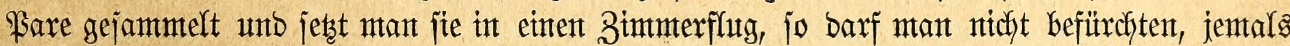
anbere Bögel zu befonmen; bie Stanmthalter müfjen aber ftets in Cinzelfäfigen auferzogen werben, Damit man jeiner Sache gemiz ijt. Dasjelbe gilt für bie einfarbigen, grüngrauten, weif̧en, ftrobgelben, hodhgelbent unb ijabelffarbigen, nitht aber audh für bie gezeidynetent. Dieje jutb weit mefr bem Bufalfe unterworfen, unb man barf froh jein, went man unter

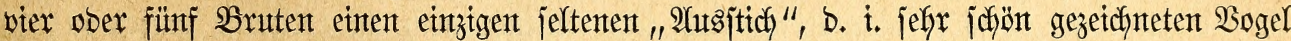

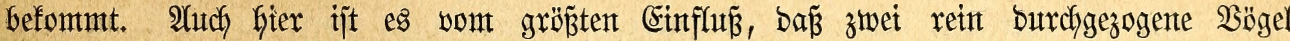

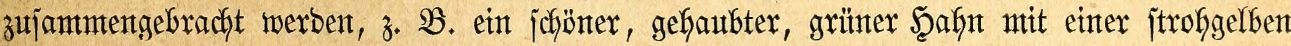
Sentte. Die meiffen ber von ifnen erzielten Sungen werben ben Eltern gleich, nämlidy grün ober gelb jein; fommt aber einmal eine Farbentbermijchung vor, jo gibt es aud ge=

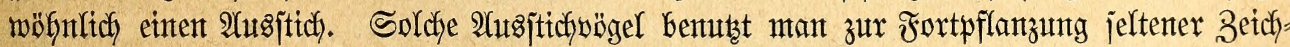

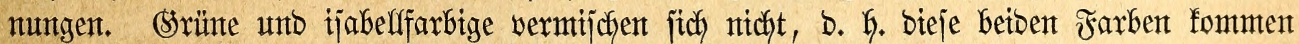

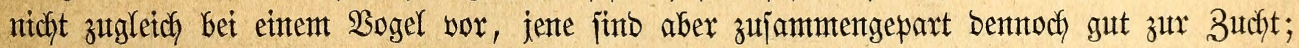

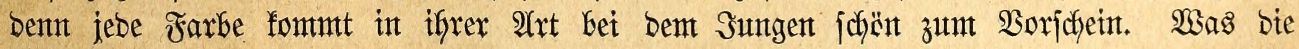

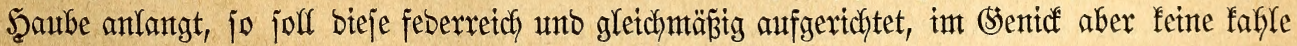
Stelle jidytbar jeir. Bei mtanthen Bögeln ijt ber halbe fopf jant bem (Senicfe fafjl. Dieje mur man aub bent Einwurfe entfernen, weil jich bie Misbilbung leidft auf bie Sungen

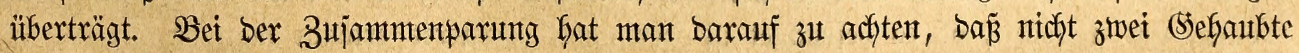

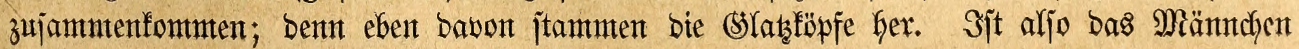




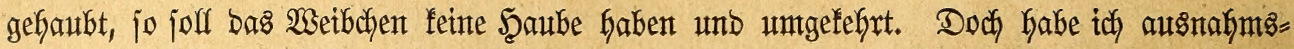

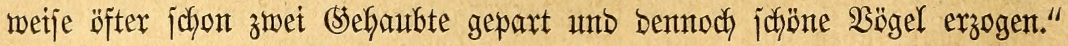

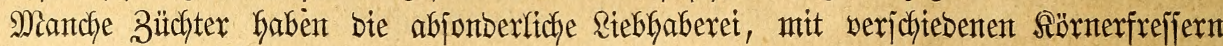

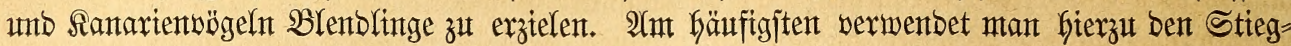

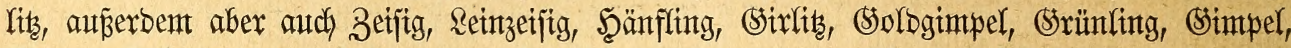
Sitronenfinfen und verjchiebene auslänbijche, jpäter zu erwähntenbe Jinfenarten; ia man

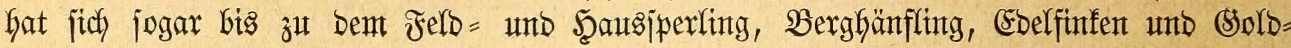
ammer verint. Sch meinestetls bin fein zreund joldher 2 Berjuche unt nodh wentiger jolcher

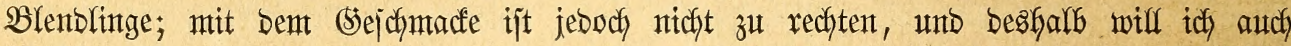

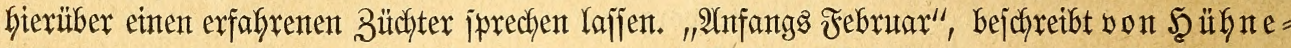

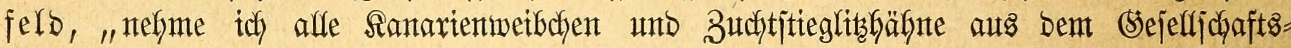

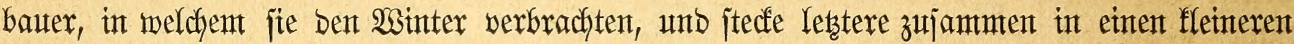

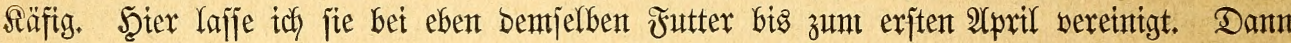
wirto jeber Stiegfits in einen bejonbern Iurntbauter gebracht, unb nun ber einzelne jo gebängt,

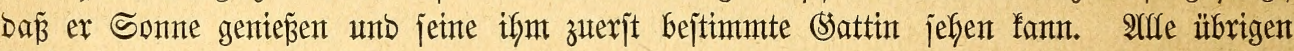

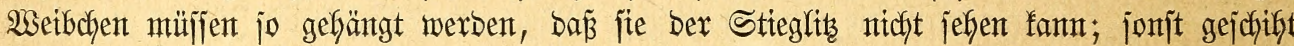

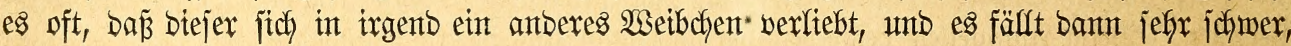

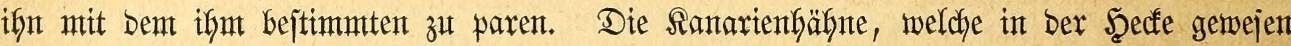
find, nu⿰

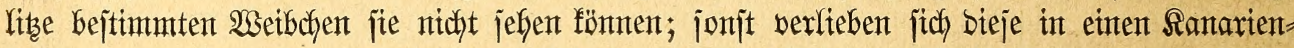

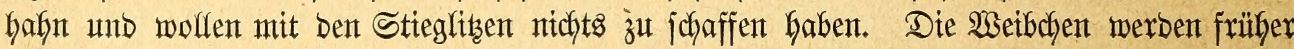

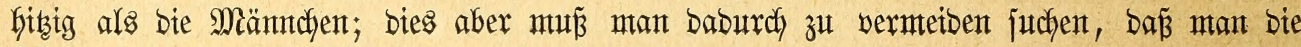
3imtmerwärme nicht häger als auf $13^{\circ}$ jteigert. Das Şiz̧igwerben fünbigt fich Durdf ichnelfes Flügelichlagen att.

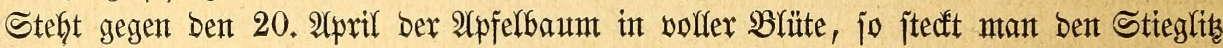
zum $\mathfrak{B}$ eibchen, und went es nidht etwa gerabe fartes $\mathfrak{W e t t e r}$ ijt, wiro ex biejes jofort

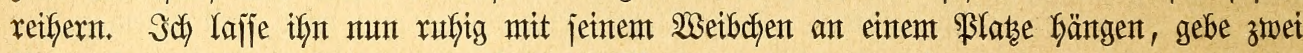
Neejter in ben $\mathfrak{B a u t e r}$ und werfe $\mathfrak{B}$ aujtoffe Ginein, mit benen betbe anfangs fptelen, fpäter

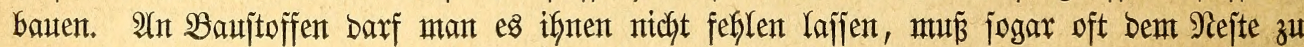

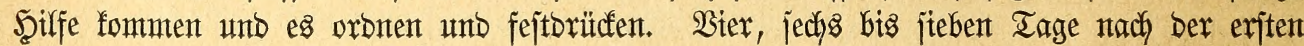

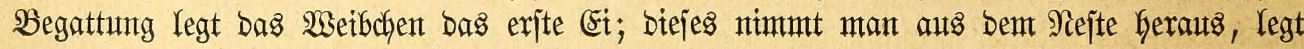

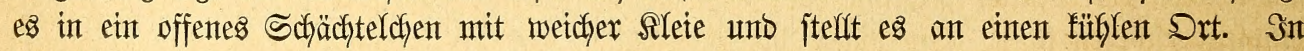

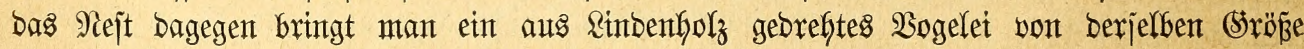

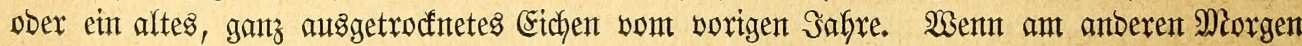

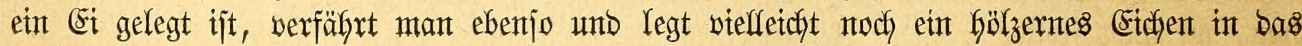

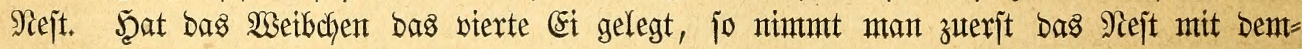
jelben Keraus, fängt bann ben Stieglits unb bringt mun bie übrigen Eter in bas Neẹt,

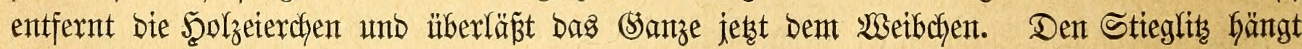

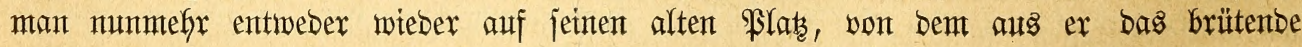

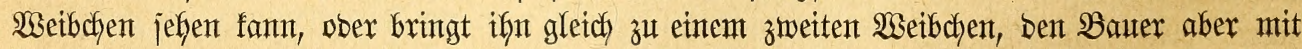

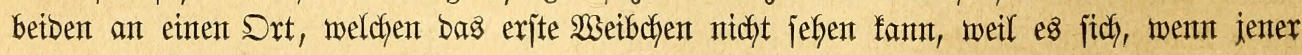

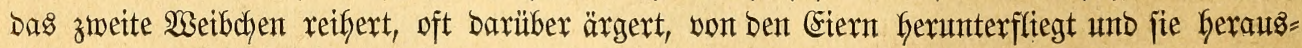

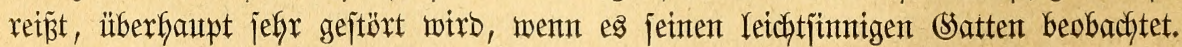

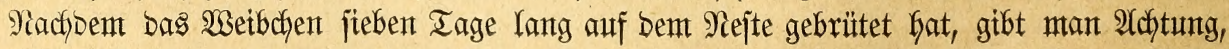

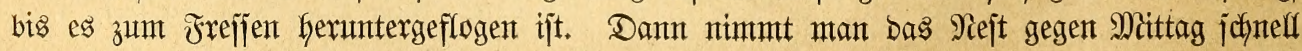

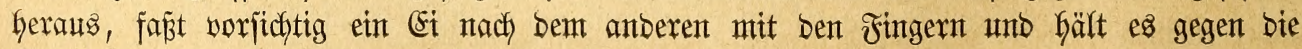
Somne, unt zu jefen, ob es befrucctet ijt ober niffjt. Erjteres erfennt mant baran, Dás es

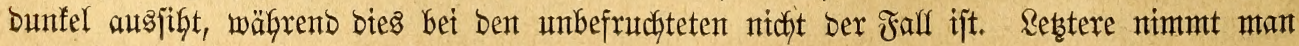




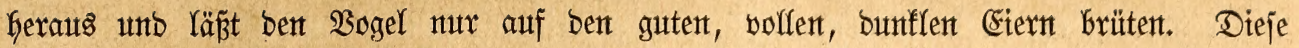

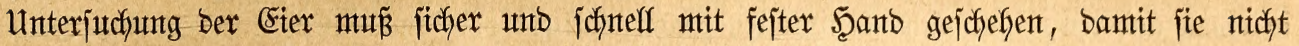

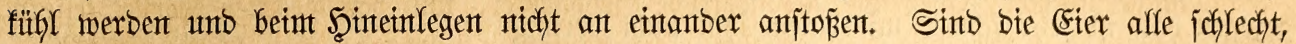

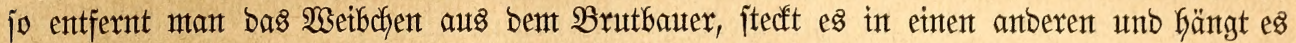

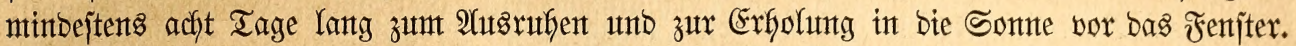

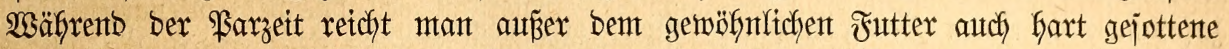
Eier unto intmter etwas Srünzeug, wäfrent ber Brutzeit nur fïnter; gegen ben brè= zefnten Iag ber Srütung hin aber jetzt mant fein gefacftes (Fibotter in ben Bauter unt

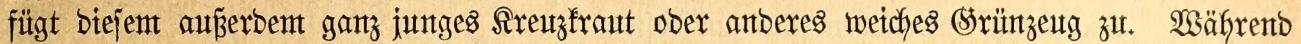

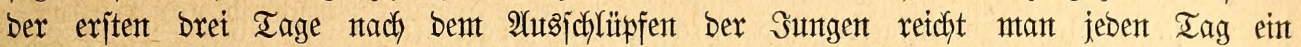

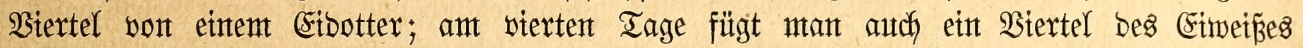

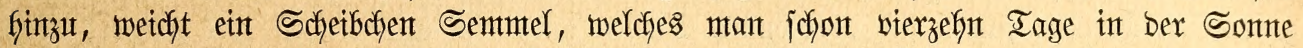
ober auf bemt Dfent getrodfnet Gat, 2Ubentos vorker in frijchent Wajfer auf, lä̈̈t es bie Nacht Gindurch barin liegen, brüdt' es ant Morgent früh tüdftig aus, nimmt bas Sntnere bavon unb mijd unto ganz jungen Salat, vont adjten Iage an gequellten Sonmtertübianten für bas alte

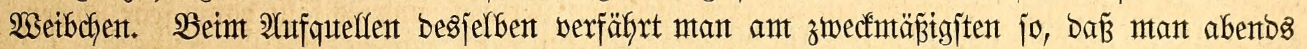

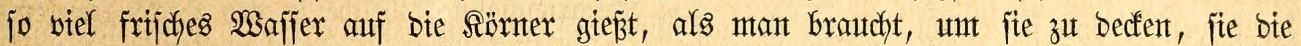

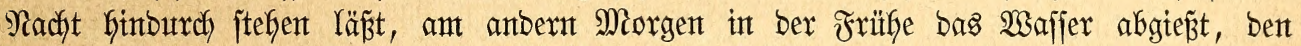

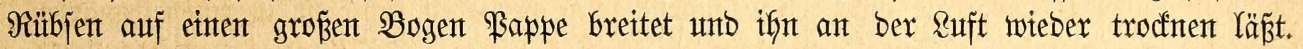

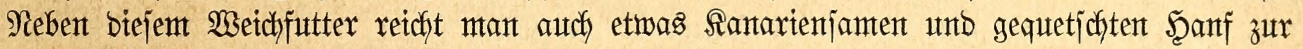
Nafrutg für bas alte Wetbchen, ebenjo freuffraut, jungent Salat, Şüfnterjcharre, Airetbe

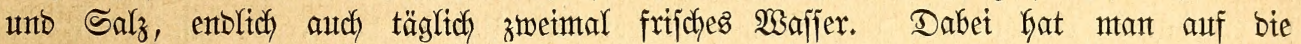

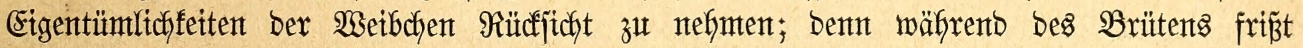

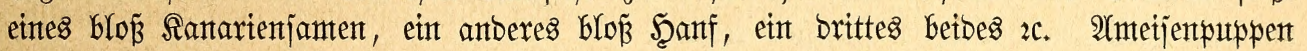
füttere ich jeltent unto wentg; frefjent bie jungent $\mathfrak{B}$ ögel erjt jelbjt alfeint, bant gebe idh gar

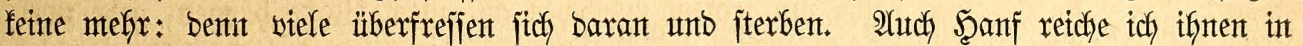

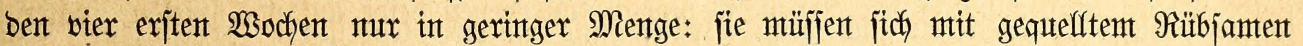
Galten, benn biejer unt Sreuzfraut finto ifnen ant gejünbejten."

Frijche Ruft und Sonne ijt Rebensbebingung für bie jungen $\mathfrak{B}$ g̈gel, namentlich nachbent

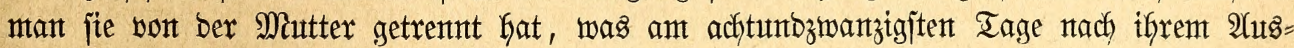

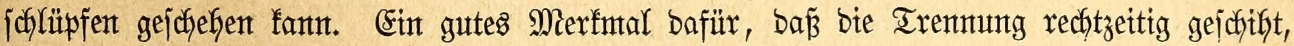
geben bie juntgen $\mathfrak{B}$ gel jelbjt, went jie zu frejfent anfantgen. Nach Der Trentunt barf mant fie mit ben Eltern nidgt in einemt Bimmer balten, weil fie jonjt, went jie bie âAten lodfent Gören, oft nidft freffen wollen, vielmefyr ben $23 e t b c h e n$ antworten, fdyreien unt wohl gar

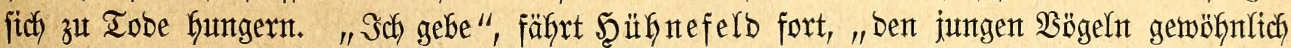
noch adjt Tage lang Eibotter unto Semmel, jpäter bloź nodh Semmel nebenbei unto entolich nux bas getwöhnliche Rörnterfutter nebjt (Srünzeug nach Beltebent. Şat jebe Brut vierzefnt

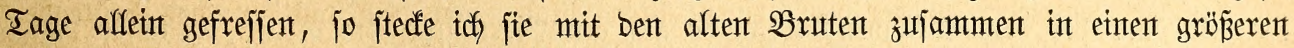

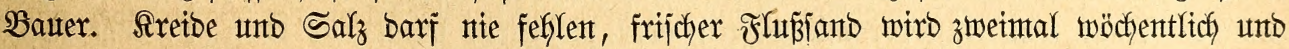
frijches $\mathfrak{B a j f e r ~ z u m t ~ I r i n f e n ~ u n o ~} \mathfrak{B a b e n t}$ zweimal tägltch gereidjt.

Den Stieglits habe idy in ber Regel gleich nach ber Irennung won jeintem erjtent Weibchen zu einemt ztweiten gejtecft, ifm jo finter einanber brei 2 seibchent gegebent und bant

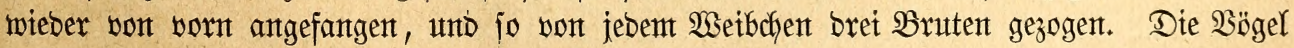

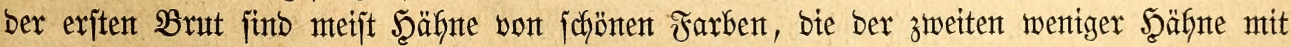
minber jäbnen Farben, unb bie ber britten $\mathfrak{B}$ rut meijt $\mathfrak{S e i b c h e n t ~ m i t ~ j c h l e c h t e r e r , ~ b u n f f e r e r ~}$

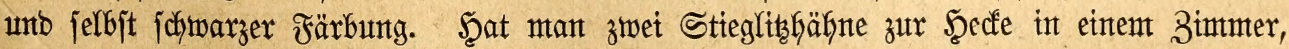

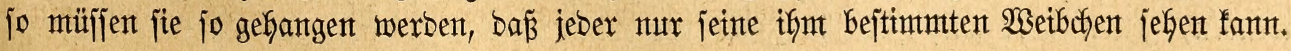




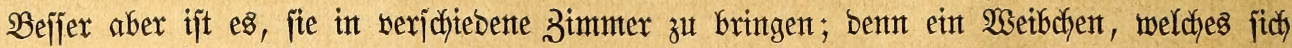

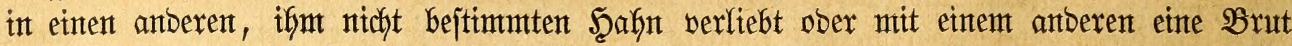

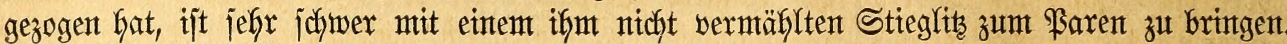

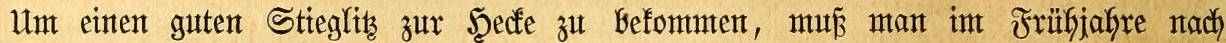

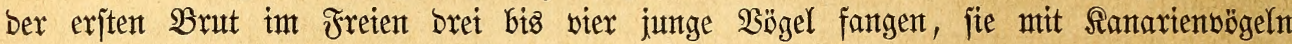

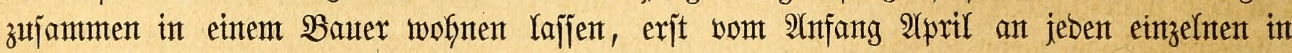

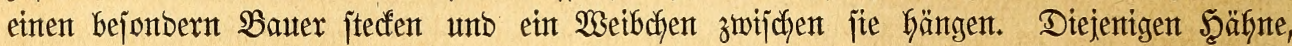

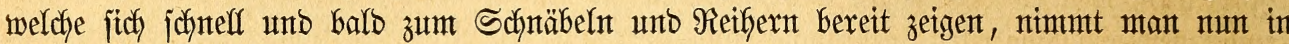

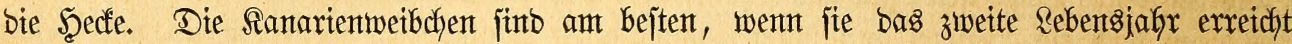

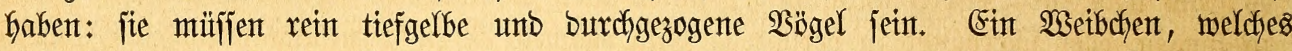

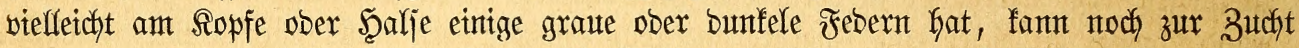
genonment werben; fintent fid aber bunffe Steffen an einem anbern Teile bes Rörpers vor,

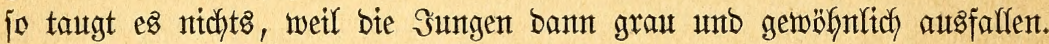

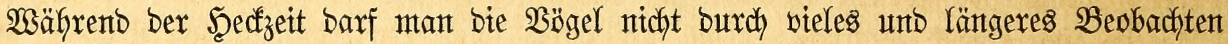

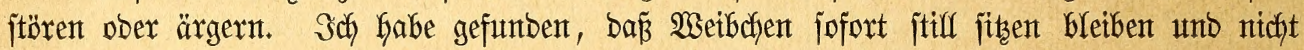

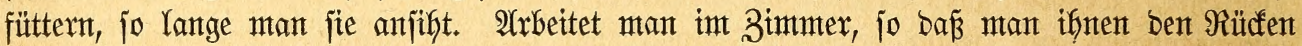
zugefefyrt hat, Dann reigern, füttern uno tun fie alfes unbefyelfigt; jowie mant aber ben Sopf wenbet unt fie amjitht, Gören fie auf ifgre (sejwäfte zut verrichtent ober jetzen jich auts

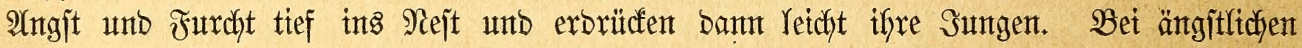

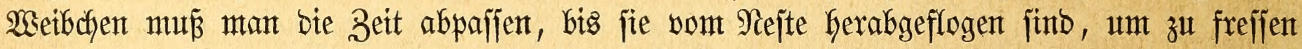

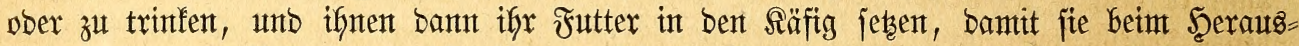

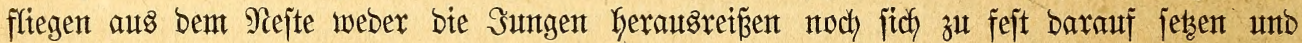

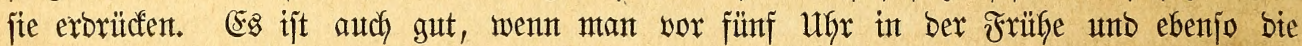
beiben Yeţten Stunben vor bent Dunfelwerben baß Zimmer nidyt betritt, weil bie $\mathfrak{B}$ ägel

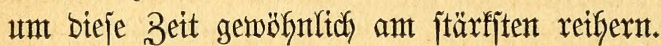

Şat mant ein gutes 2 Seibchen, weldhes orbentlich baut, brïtet unb füttert, jo verbient

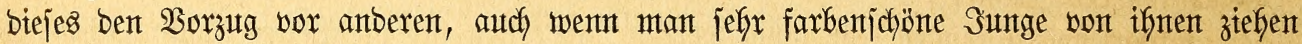

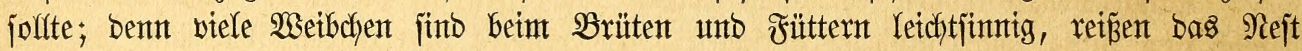

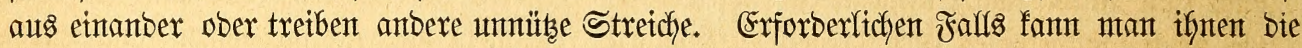

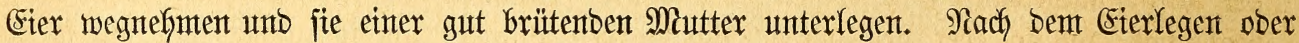
nadh vollenbeter Brut Gä̈nge ich bas WBeibchen vierzefrn Tage vor bas Fenfter in bie Sonne,

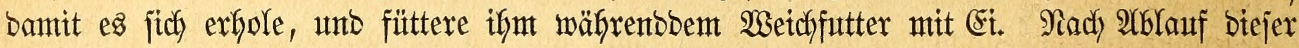

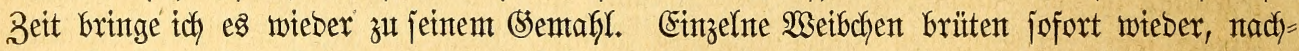
bent jie bie erjtent Suntent erzogent haben; bies aber ftrengt jie an unb ift auts biejem

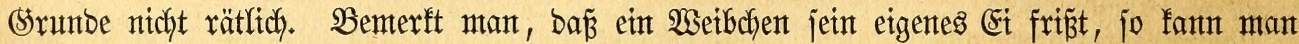

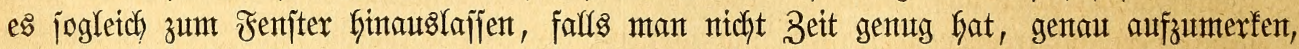

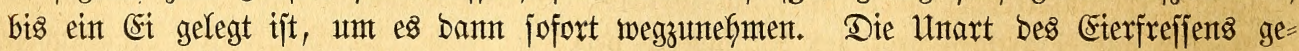

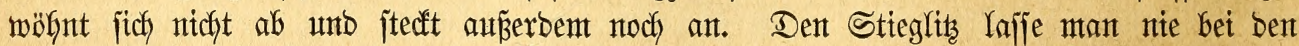

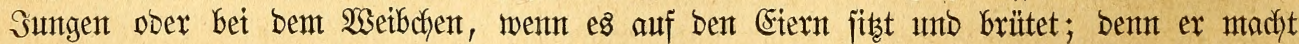

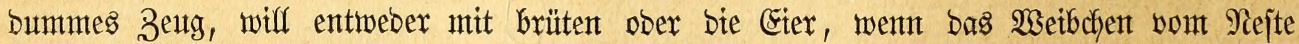

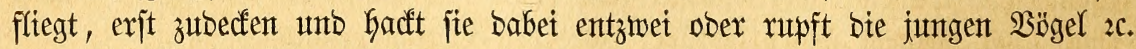

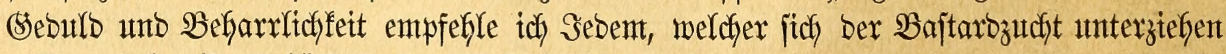

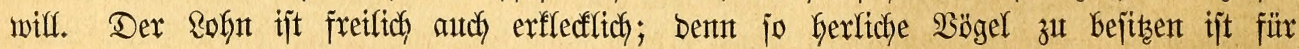

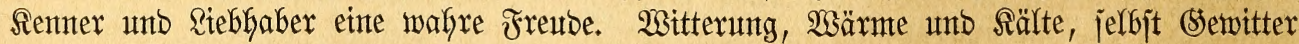

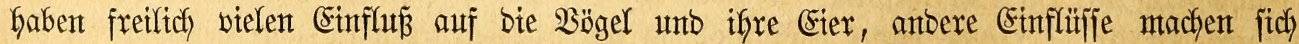
ebenfalfs geltent, unto es gelingt feintesmegs inmer, bas zu erżelen, was man beabjictitigt."

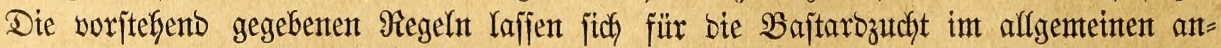
mentoen, geltent aber audd für bie Zutdht ber Santarienvëgel jelbjt. Sidj bin weit entfernt, 


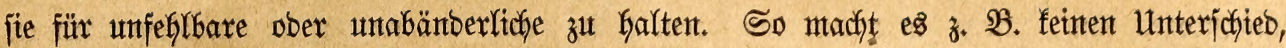
ob man bie Stieglibe unb anbere ŞäGne mit ben Sanarientweibchen zujantmen überwintert voer bie (sejchlechter währento bes Winters getrennt bält; jo ijt es burdjaus nidft immer

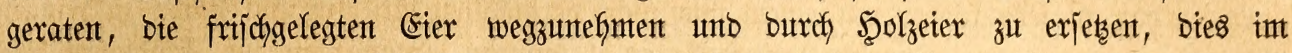
(segenteil nicht jelten von jchäblichen Folgen wie teber anbere nicht unbebingt nötige Eintgriff

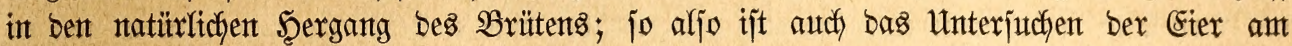

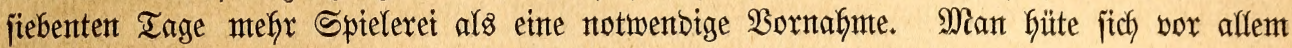

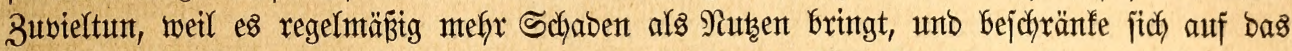
unbermeibliche Eingreifen, gebrauthe bann aber affe erbenffiche Borjicht. So vermeibe man

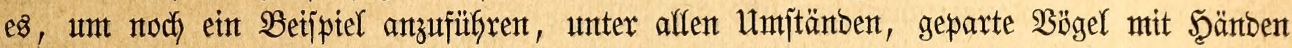
zu fangent ober überhaupt zu berüfren, teife vielmefr jeden Brutfäfig burch eine Sadjeibe= want, bringe an biejer eine Zugtüre an, lodfe exforberlichen Falls mittels einer Rieblings: =

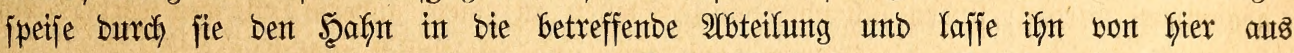

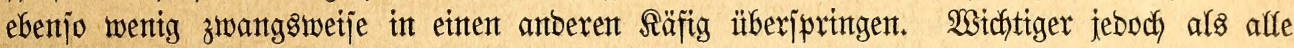
Regeln find eigente Serjuche; Denn mux burch joldhe ermirbt mant jich Sentnis und bas

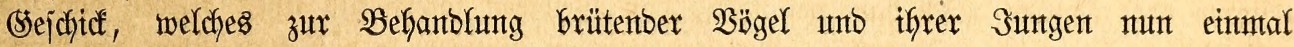
umumgänglich) ijt. Sanz bejonbere Sorgfalt hat man bet reinten Santarienbögeln immter

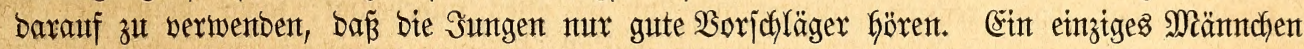

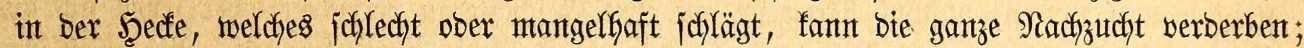

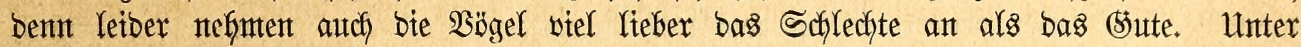
Gunbert jungen Rantarienvogelfähnen, weldhe mit aflex Sorgfalt befantbelt unto von bent

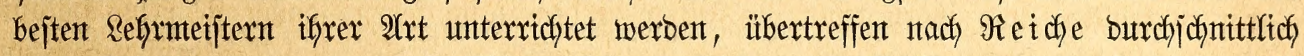
nux zefnn ifre Refrer; zmanzig bilben fich zu gleich gutent Schlägern auts mie bieje, unb fiebenzig bleiben mefr ober wentiger Stïmper. Dies jüt $\mathfrak{A}$ ngaben eines Manntes, burth

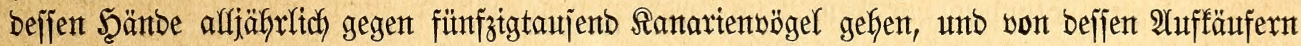
minbejtens bie boppelte $\mathfrak{A}$ nzahl junger Şähnte verfört werben. Sie verbienten aljo bie vollfte Beachtung bes Büfjterş.

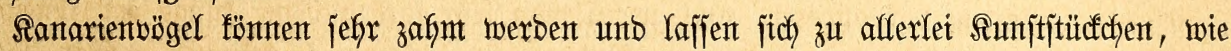
aud) zum $\mathfrak{A}$ us = unb Einfliegen abridjten. Unt erfteres zu erreidjen, hat mant bie bereitz ( 5.56 ff.) mitgeteilten Srumbregeln zu befolgen. Se. mefr mant fich mit eintent Santarienbogel

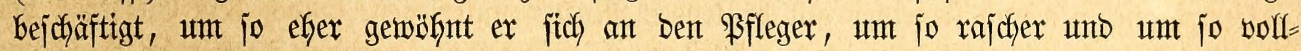

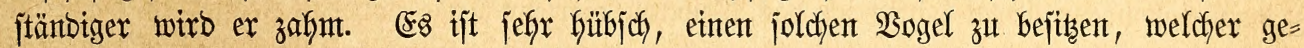

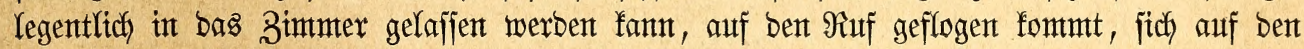
Finger jetst, ein Stüdfdyen Zutfer aus bem Mantbe nimmt 2 .; bas Enbe aber von alfebent

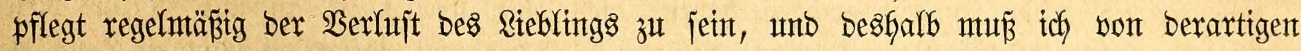

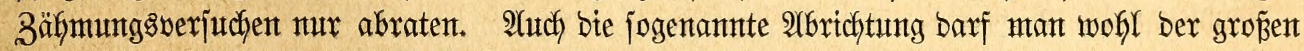
3unft ber Ranbitreicher überfaffen, umt jo mefir als es wafhrfaftig ntidyt Sebermanns Sache ijt, fich mit berartigen brotlojen Rünjten zu befajfen. Heber bie Selebrigfeit ber Sanarien= bögel gemoinnt man ein Utreif, audd went man jie tricht abrichtet Santonen abzufeutern, fich

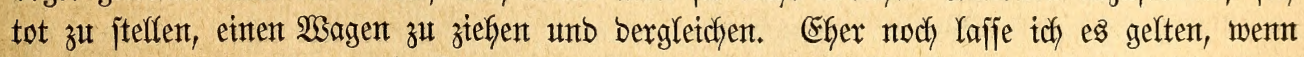
man an paffenben Drten bie Sanarienvögel zum 2 (4ts = unb Einfliegen gemöfnt. Ein Rieb= habex, (5) ritnz, Gat meinem $\mathfrak{B a t e r}$ hiexüber folgemben $\mathfrak{B}$ eridft exitattet.

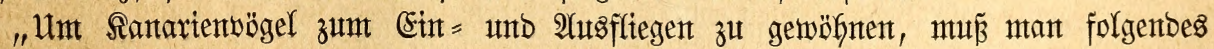
Berfahren anwenben. Dan jtellt einen groß̉en Ranarienvogelfäfig mit eintem $\mathfrak{B a r}$ Scecf́ögelnt inwentig bor ein Bobenfenjter unb zwar vor ein joldjes, weldies mit einem Schiebefeniter werjefent ijt. Rebsteres öffnet man anfangs an wärmeren Iagen unto gewöhnt bie $\mathfrak{\text { Bägel }}$

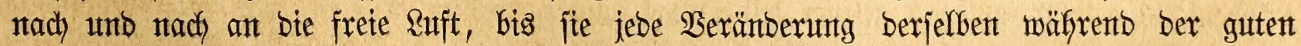
Safreszeit extragen fönnen. Went jie nun Sunge haben, weldhe jeit brei ober vier Tagen 


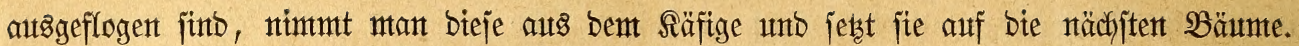

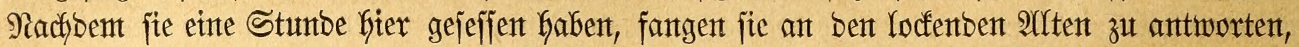

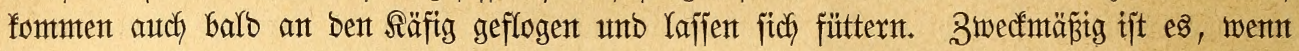
vor bem Säfige ein Steg angebracht wirb, auf weldhent jie jich bequem nteberlafjent fönnen,

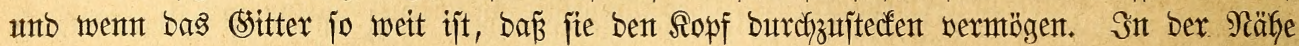
Des Brutfäfigs ftellt man einen zweiten auf, weldher einte Falltüre hat unt zum Einfangen eintgerichtet wurbe. Sn biejen Siäfig jebst man gutes und reichliches Futter und gemöfht bie

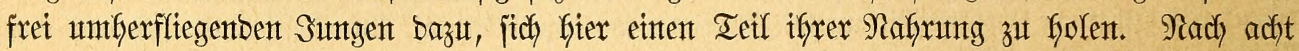

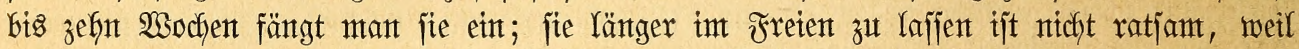
fie jich jomjt leidft ganz entfernten. Die lebte Sedfe fängt mant jogar frïfer, gleich nach

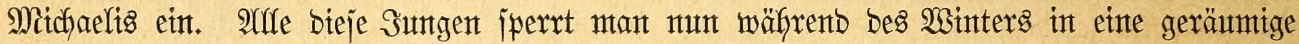
fantmer ober ein Fluggebauter, in welchem fie fich bequent betwegen fönten unb bie (s)e= wantbtheit ifyres Fluges nicht werlernent. Imt nächjten Früfjahre jtedt mant fie parmeije in

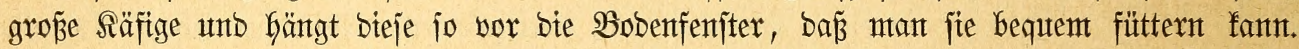
Sobald bas Weibchen fejt brütet, effintet mant bie Iïre, füttert aber nach wie vor im

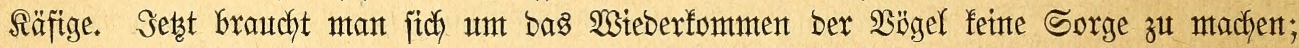
fie fint wom borigen Sommter her nodh an ben Flug gewöhnt unt burdh ben langen

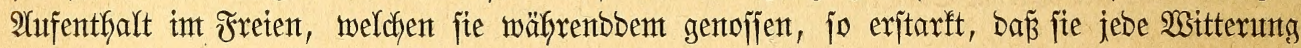
ertragen fönten. Die zweite und britte $\mathfrak{B}$ rut machen fie gemöhnlich auf ben nächjten

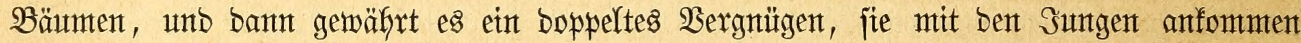

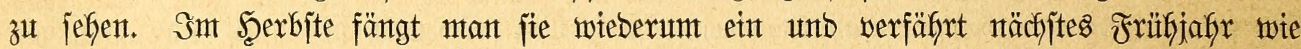
vorker. Reiber ijt biejes Serfahren nur ba anwentbar, wo man bas Raubzeng, insbejonbere Die Raubuögel unt Elftern, geförig int Zaume balten fant, Dent jonjt werltert man bie

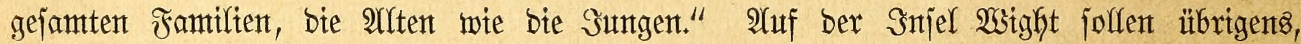
wie idf won glaubmïrbiger Seite verjichert worben bin, in ben föntglichen Särten Santartenvögel bolffommen eingebürgert fein, jafraus jafyrein int Freien verweilen, fier

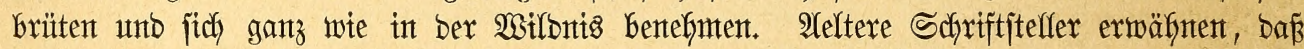

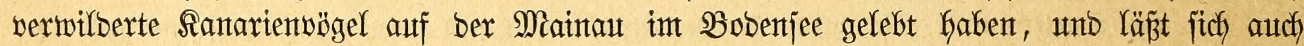

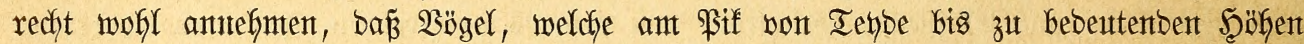

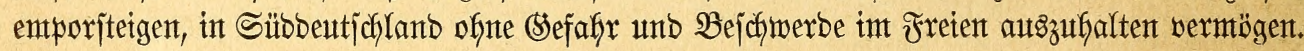

\section{freliguimpel.}

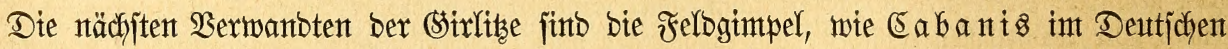

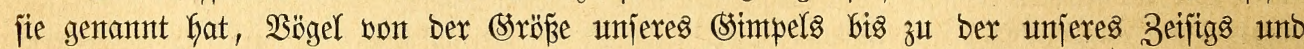
entweber vorfherjchent golbgelber ober grauter Färbuntg. Eintge Forjcher vereintgen fie unt bie (Sirlitise in einte Sippe, weil beiber Merfmale tatjächlich wejentlich biejelben finto. WBill man bie Felogimpel bejonbers fennzeidynen, jo hat man folgente Merfmale zu beacften:

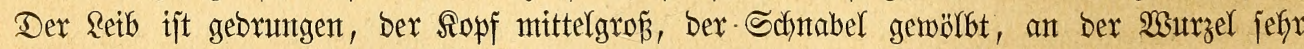

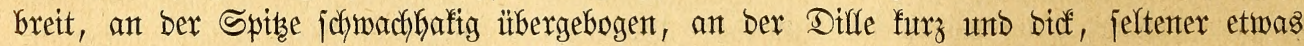

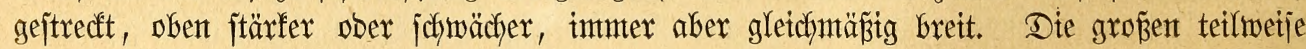

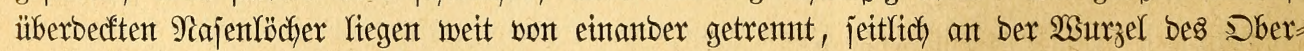

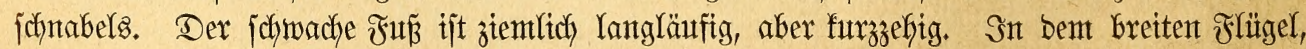
weldher zujammengelegt faum ein Drittel bes Schwanzes bedft, verlängert fich bie britte Sdjwinge über bie übrigen, und fint bie Şanbjdyingen aupen verengt unt gegen bie Spizen zu augigeidnitten. Die breiten Febern bes mittelfangen Sdywanzes rumben fich an 


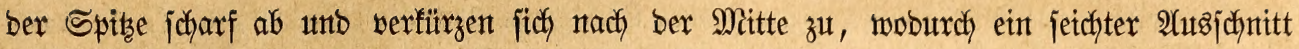
gebilloet nirb.

\section{(Stelbe $\mathfrak{A}$ rtent fint:}

222. Die Gnoffehle, Crithagra (L., Coccothraustes, Buserinus) sulfurata, L. $-\mathfrak{B}$. $\mathfrak{A}$.

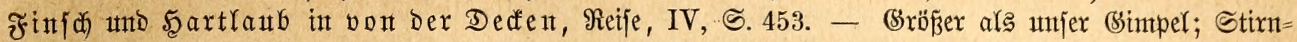

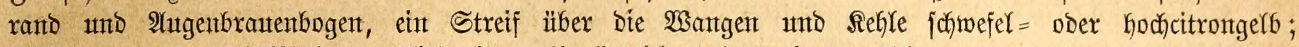

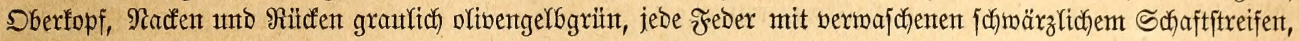

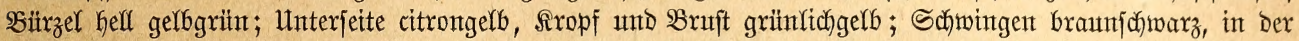

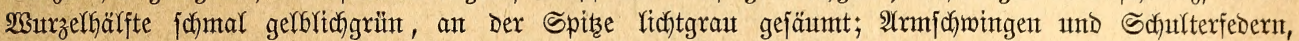

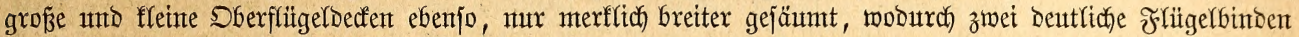

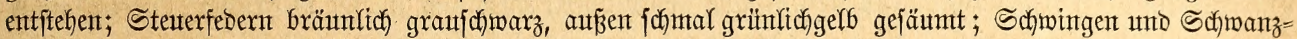

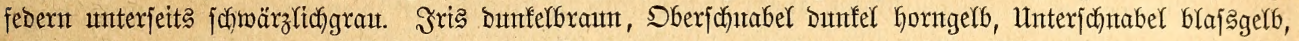

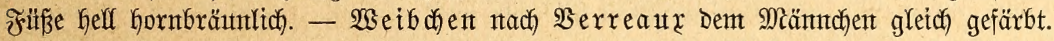

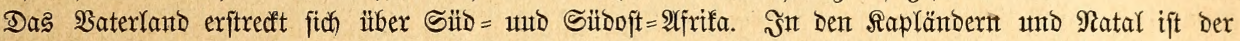
Sogel feitresmegs felter.

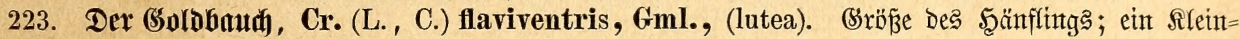

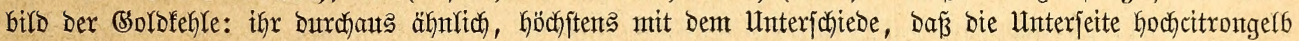
ift uto ber grünfidje $\mathfrak{A}$ nflutg auf Siropf uno Bruft feglt.

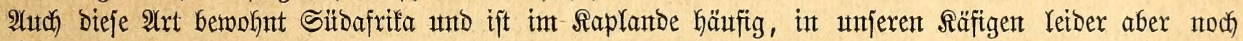
jebr feltert.

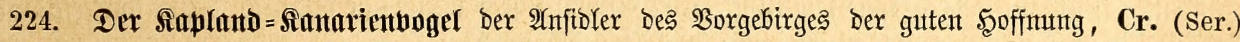

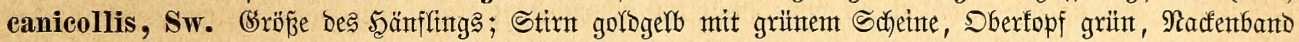

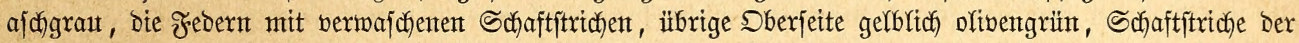

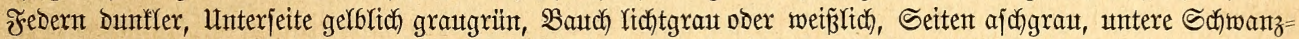

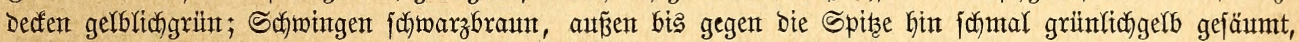

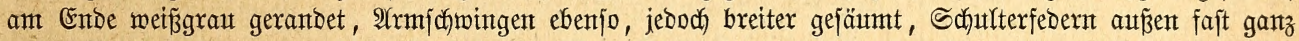

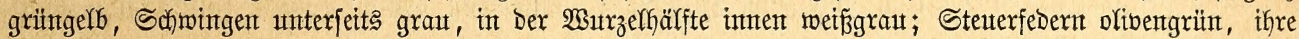

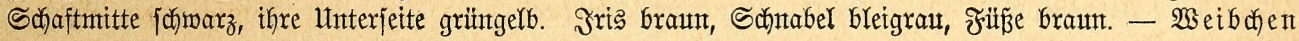
wahricteintlid gleid) gefärbt.

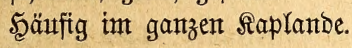

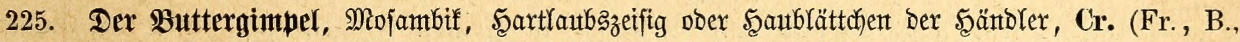
Ser.) butyracea, L., (chrysopyga, ictera, Hartlaubii, mosambica, barbata.) - Finf

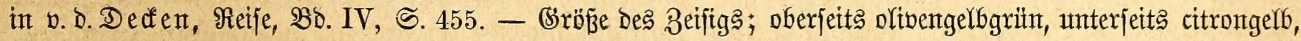

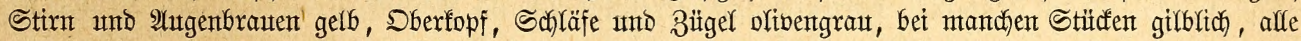

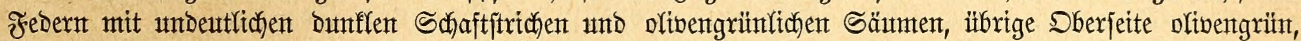

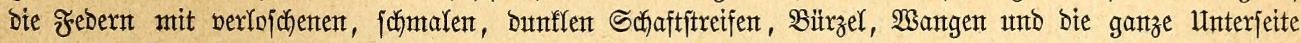

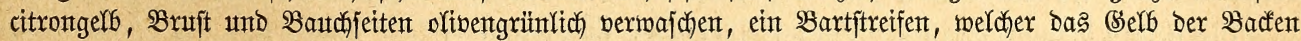

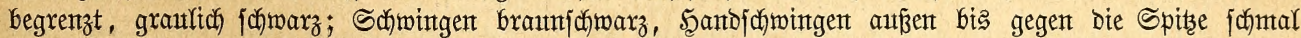

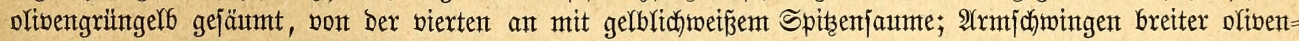

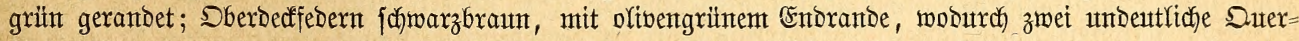

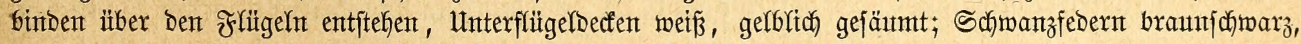

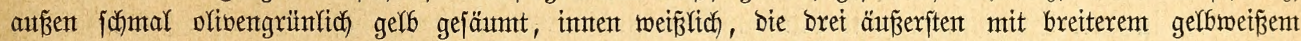

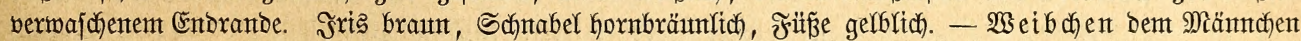

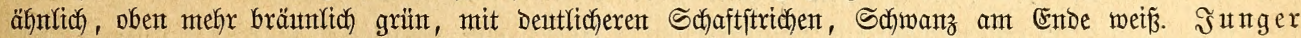

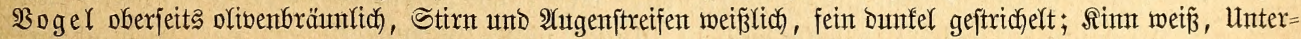
feite blafsgelb, Siropffedent mit bräıntlichent Schaftftrident.

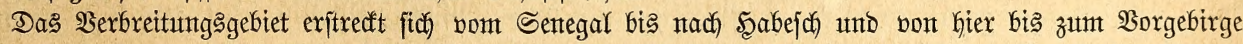

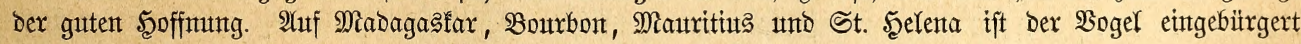
worbent.

\section{3u bett grauen 2 rrten gehörent:}

226. Die $\mathfrak{B e i f f f e h l e , ~ C r . ~ ( B u s . ) ~ S e l b y i , ~ S m i t h ~ ( c i n e r e a , ~ c r o c c o p y g i a ) . ~ - ~ J a r b i t t e ~ u t b ~ S e l b y , ~ I l l . ~}$

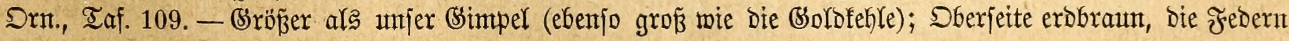

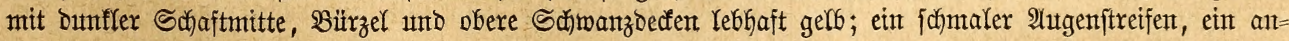

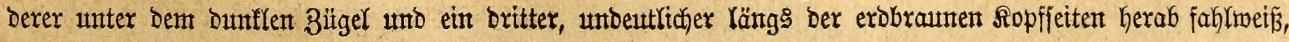




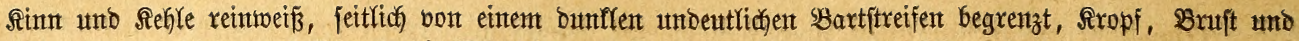

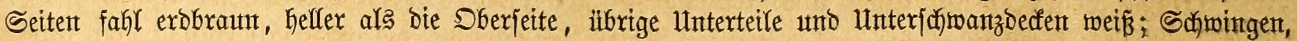

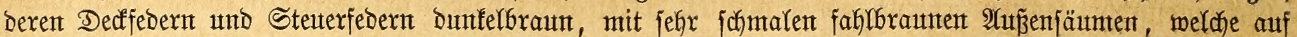

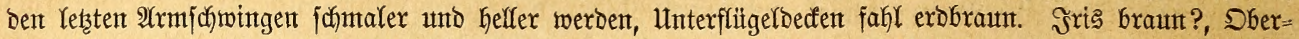

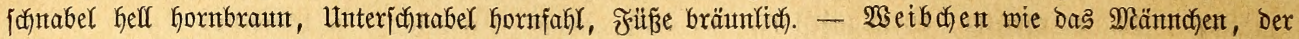
Bürzel aber trüber gefärbt ober ganz ohne Berb.

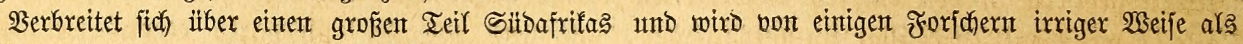

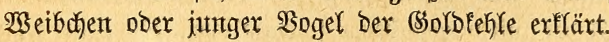

227. Der $\mathfrak{A}$ tgulagimpel ober $\mathfrak{A n g u l a h a ̈ n f l i n g , ~ C r . ~ ( F r . , ~ L i n a r i a , ~ P o l i o s p i z a ) ~ a n g o l e n s i s , ~ G m e l . , ~}$

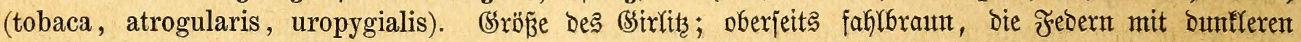

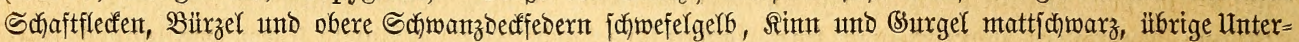

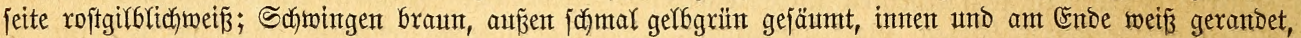

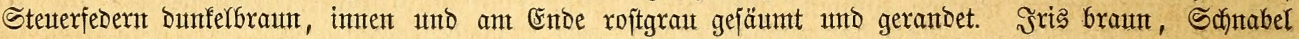

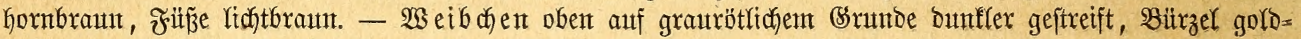

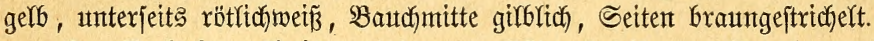

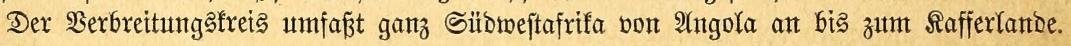

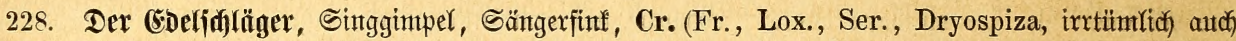
Estrelda, Pholicodoma, Hypochera) musiea, Viell., (leucopygia). Rleiner afs ber 3eiftg; Ropf blafs

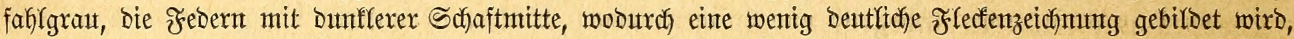

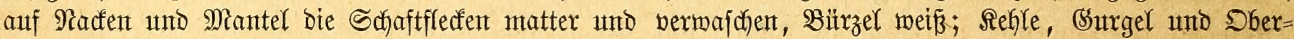

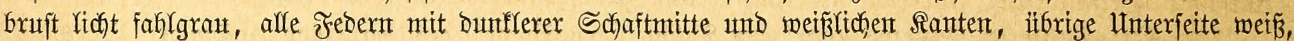

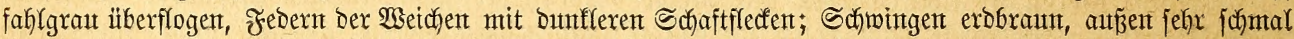

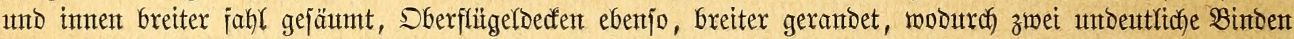

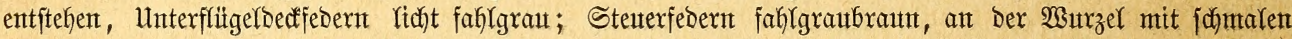

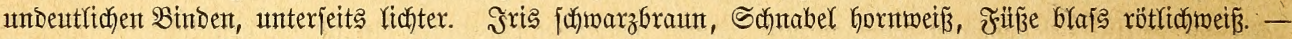

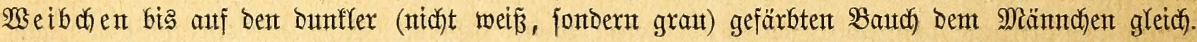

Der $\mathfrak{B o g e l}$ verbreitet fich) vom $\mathfrak{B}$ eftent ant burch) ganz Mittelafrifa bis zur Dittiifte uno gelangt regel= mäß̋ig atf umferent Marft.

Ueber bas Freileben ber Felogimpel Gaben wir bis jebt mux bürftige Berichte erfalten.

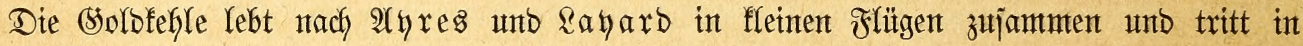
einzelten (stegenben jefr häufig auf; Der (Solbbautch gehört zu ben gemeinjten Bögeln bes Saplandes, lebt im Sommer parweije unt vereinigt jich int Şerbjte zu grokent Flügen, weldhe

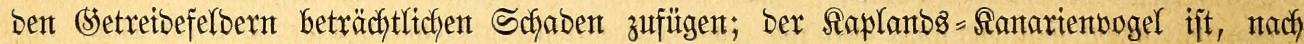

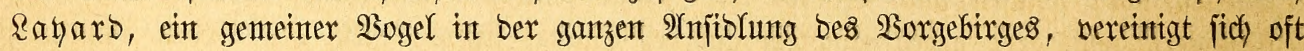
zu Flïgent unt bejucht bant gepflügte Felber ober überfaupt offentes Rand, unt Gier Sämereien

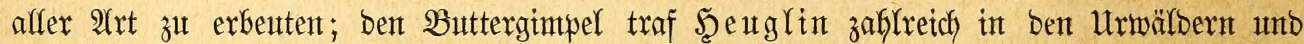
auf einigen Wilbjeigenbäıment neben ?egenbädben bes oberen Nitlanbes, meijt in Paren

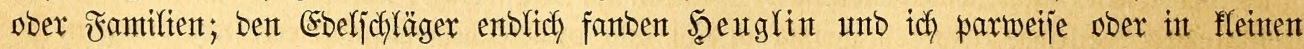
Familten in ben Waldungen am blauen Mile unb zwar in ber Nähe bes Fluffes bäuffiger als in ber Steppe. Sm

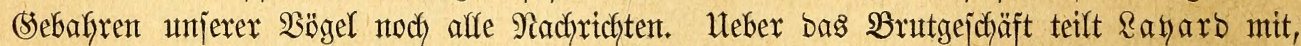

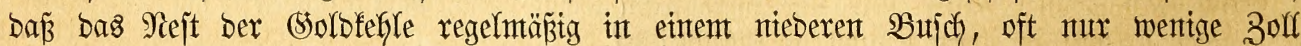

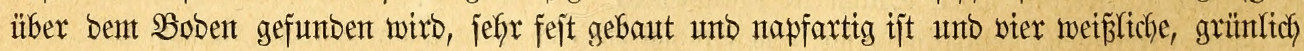

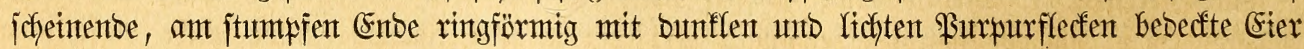

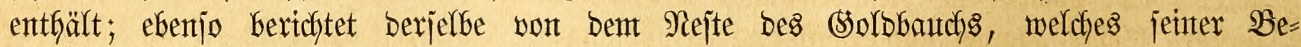

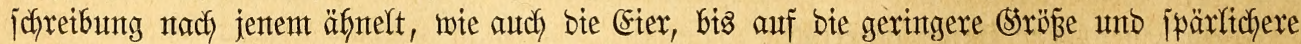

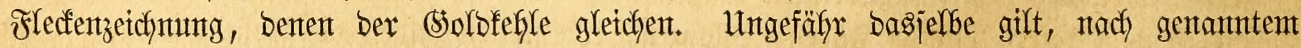

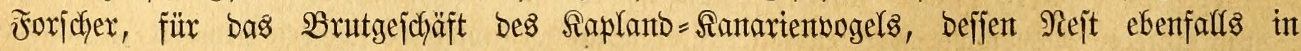

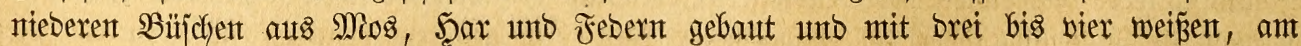
biffen Enbe purpurbraun gejtrichelten uno gepunfteten Eiern belegt wiro. 


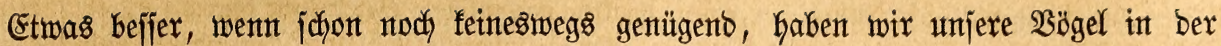
(s)efangenjachaft fenten gelernt. Die meijten $\mathfrak{A}$ rten ber Sruppe gelangen allerbings nod) immer jeltent nach Europa, Buttergimpel unto Edoljchläger bagegen, went audf nicht ebenjo regel=

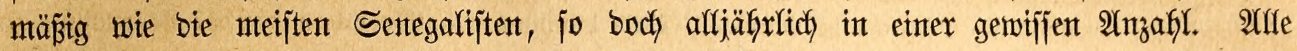

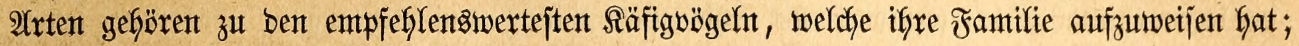
alfe werben mit ber 3eit immer jeföner, unto afle zeidynen jich burch einen überrajchento

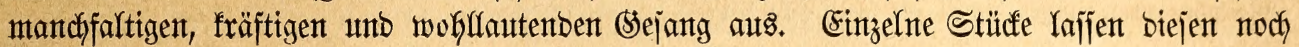

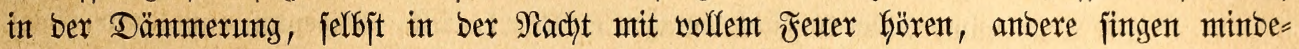

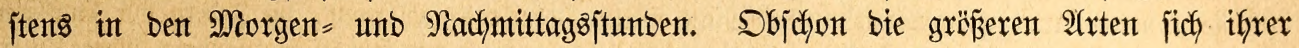

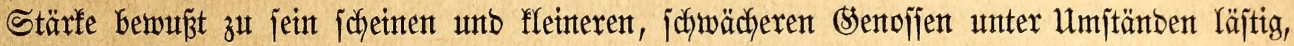

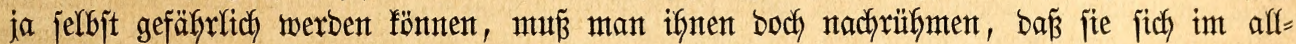
gemeinen mit anberen $\mathfrak{B a ̈ g e l n}$ gut vertragen unb bem entjprechent in jebem Sejelfichaftabauter gefalten werben funtent. Fflege unb Wartung verurjachen feine Sdjwierigfeit; bent alle

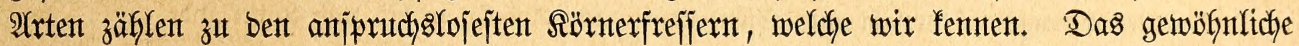
Futter fleinerer Finfen, ein (semijich von verjediebentartigent Sämereien, inţbejonbere von

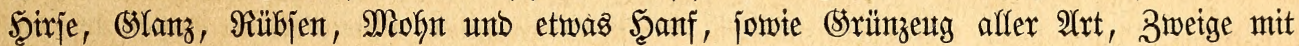

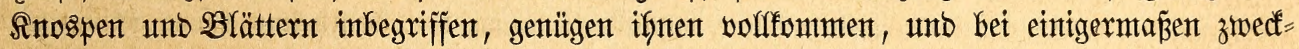

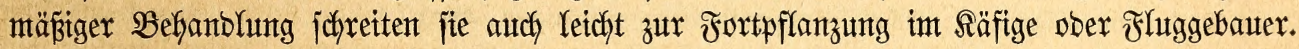

Für rebteren ijt, wie Bolle mit Recht herworkebt, ber häufiger als jeber Berwantste

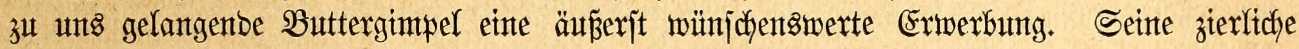
(Sejtalt und wafhrbaft anmutige Färbung werben burd) ruffiges unb gemanbtes, obwohl nidft gerabe auffalfent zutraulidjes Sejen noch mebr herworgeboben. Der sodfruf ijt aus brei

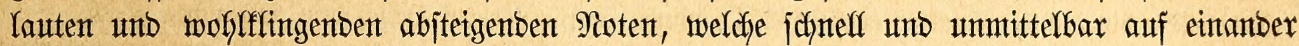
folgent, zujammengejebt, ber (sejang ein Gelfer frijcher Schlag, weldyer in mandber Şinficht

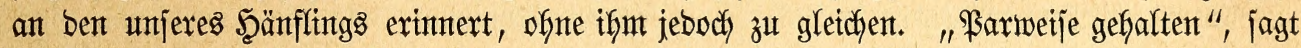

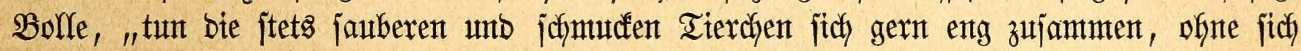

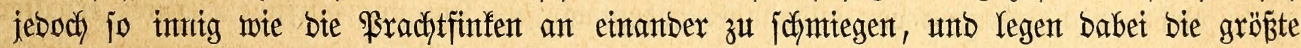
3ärtlichfett an ben Tag. Sie jüto ftarfe Freffer; fortwäfrent jantäbeln unt füttern fie fich

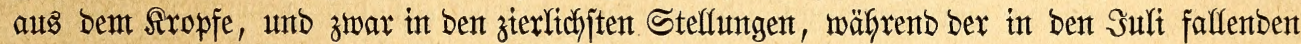

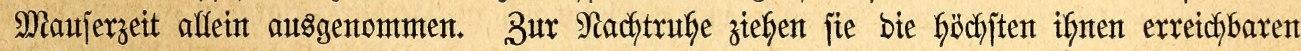
Stellen vor, ichlafen audy oft wie bie Beifige feitwärts am (sitter ifyres Bauters antge= flammert, jomit gern neben einamber auf ber Stange jizkent. AYuf ben Boben fommten fie

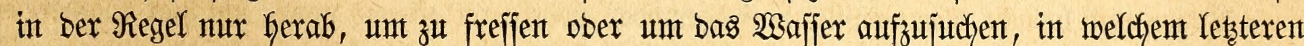
beim $\mathfrak{B a b e n}$ jie jich jehr burdynäjjen. Einte bejonbere (Empfindlidbfeit gegen füblere suft habe

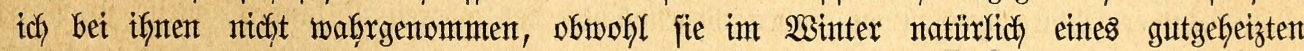

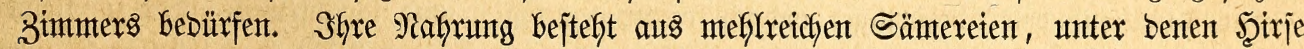
unb Sanarienjamen ifnen bejonbers zuzujagen jdyeinen; bod verjdymähen jie aud ölartiges

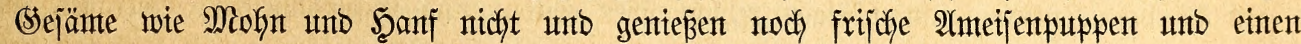

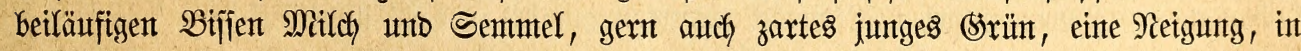
welcher fie wie in ifren Sitten überhaupt mit ben meijten anberen verwanbten $\mathfrak{B}$ g̈geln zu= janmentreffen." Meflwürmer freffen fie, wie idy noch fintzufügen wiff, mit bejon=

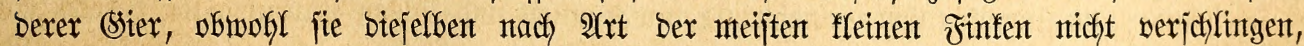

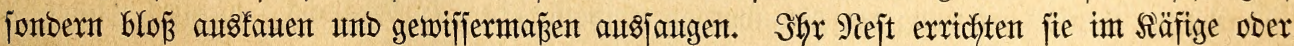
Jhggebauer aus ben verjofitebenjten Bauftoffen, beren fie habhaft werben fönnen. Siofos:

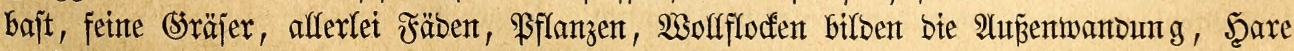

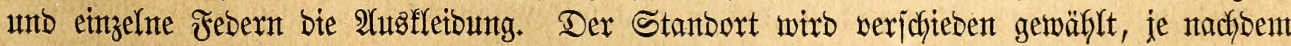

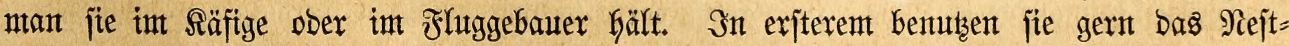
bauterchen zux Unterlage, int Fluggebauer wäblen jie bazu meift einen nieberen $\mathfrak{B} u j \mathfrak{c}$. 
Mindejtens biejelfe Beachtung verbient ber Edeljchläger, wohl ber bejte Sänger unter allen Finfentögeln, welcher beshalb von $\mathfrak{B a l b a m u s ~ S a ̈ n g e r f i n f ~ g e n t a n t ~ w u t b e . ~ S c h o n ~}$

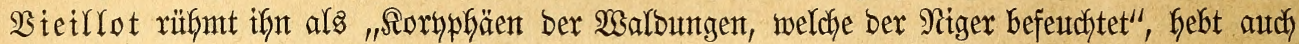

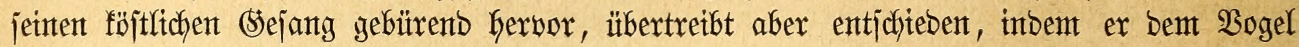

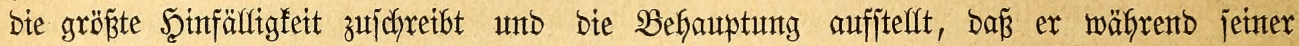
Brutzeit mintbejtens $25^{\circ}$ R. Wärnte Gaben müfife. Barter als bie Werwantent ift ber Eoel=

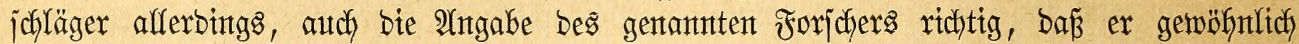
in jefr jalechtemt 3ujtantbe, mefr ober wentger entfebert, jelbjt halb naft unb inmer be=

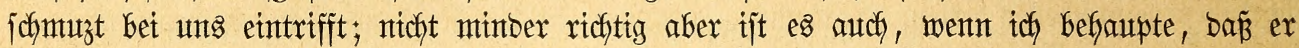
bei ber oben ( 5.47 ) angegebenten mittleren 2 ärmte bes Raumes recht gut ausobautert und

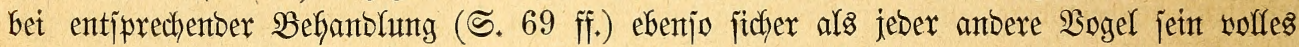
(sefieber wieber erfä̆lt. Sch will utjeren Mitarbeiter Barbamus, zu befjen exflärten

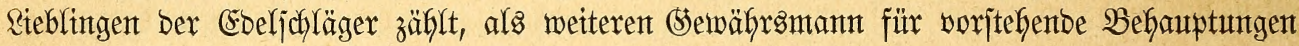
eintreten unto anjtatt meinter reben lajjen.

"Der Sängerfinf", jo jajreibt mix mein geefrter Freunt, "ift ofyne 3weifel ber bejte Sänger unter alfen mir befannten Finfen int weiteren Sinne unb nimmt überhaupt eine

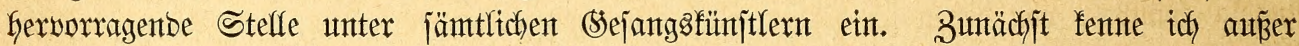
ber mefy als boppelt jo grofent Felblerche feinen Sogel, Deffen Strophe ofnte Unterbrechung brei Mitnutent bautert; jobann hat unter ben Bögelnt gletcher (srö̈pe wohl mur ber Zautfönig

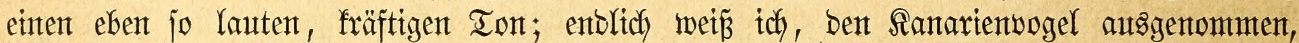

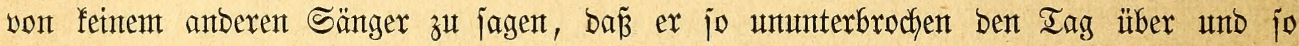

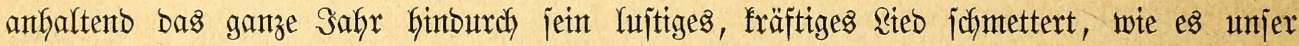
fleiner $\mathfrak{A}$ frifanter tut, weldher bei $4^{0} \mathrm{R}$. Wärnte ebenjo eifrig fingt als bei $20^{\circ}$ und höchjtens

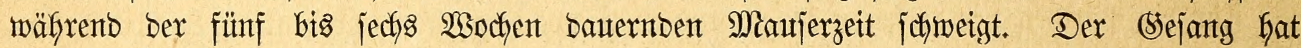

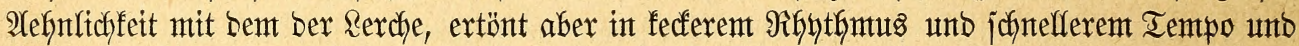

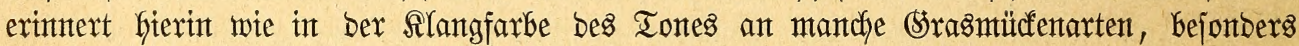
an bie (Sarten = unt noch mefr an bie Sperbergrasmülfe, beren Ton aber tiefer und volfer ijt. Sch war freubig ïberrajdyt, als idy Den wumberwollent (sejang - Schlag Darf man nicht jagen, weil bie Strophen zu langatmig finto - zunt erjten Male in meiner gropent

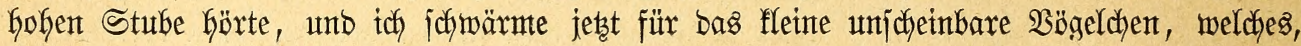
wenn ith in bie Stube trete, zugleidh mit einem Zeifig auf bie nächjten Zweige fonmt, um mix jein frijches Rted vorzuichntettern.

Aluch jonjt hat ber Sängerfinf biel Entpfeblentsmertes. Er ijt munter, untunterbrochen bei guter Saute, verträglich und friebfertig gegenüber allen (sentifien, mit benten ex itets int bejten Eintwernebmen jteft, ebenjo audh anjprudbslos unb bejchetben in jeinen Forberungen

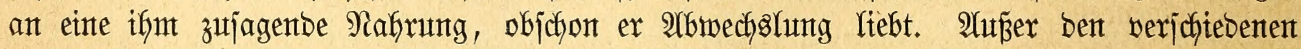

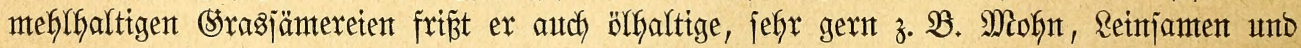

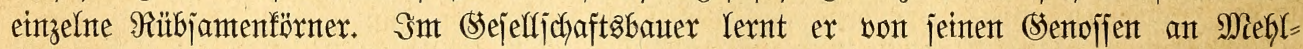

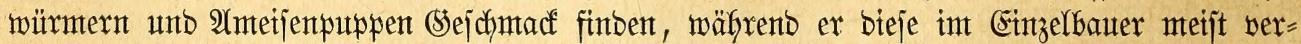

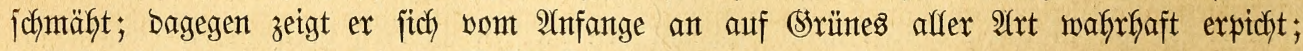
başelbe joheint auth zut jeintem Woblbefinten notwentoig zu jein.

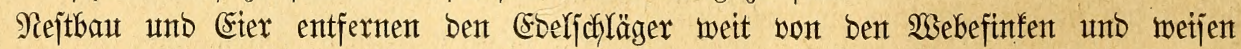
ifm ebenfalls jeine Stelfung bet bent übrigent Felbgintweln an. Das Nejt, weldyes idh affer=

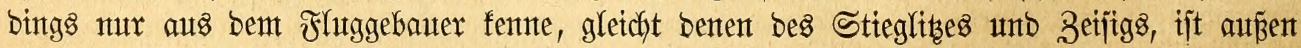

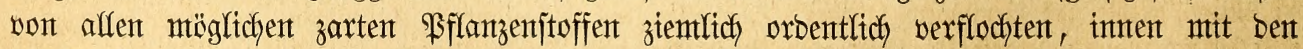
feinjten unt weichjten ber gebotenen Stoffe, als mit baumt = unb Samentwolle, Wunbfäben unto bergletchen autgelegt. Wite int Fretent mirb es int bichtejten (Selaube, ausnahmsweije auch am Stamme einer Sopfwetbe angebracht. Die vier bis fünf Eier Gaben bie größste 


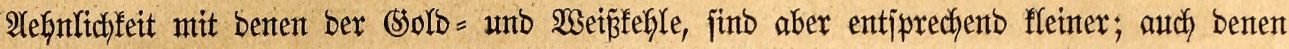
Des Saplant = Sanarientogels unt Buttergimpels itehent fie nake. Sie haben bie Brö̈e

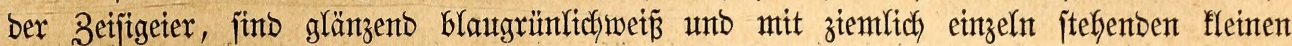

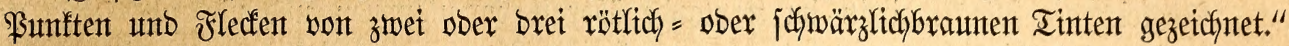
Dex $\mathfrak{B}$ ogel brütet Yeidyt in Sefangenjchaft, ijt überbaupt in feiner Scinjidyt jo beiffich, wie Bieirrot ifn gejdyildert hat.

Schon aus unjeren bisher gejammelten $\mathfrak{B}$ eobadjuntuen über bie anberen 2 rten ber

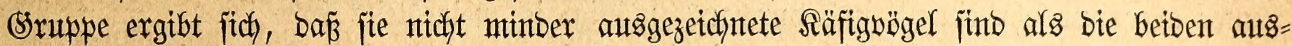

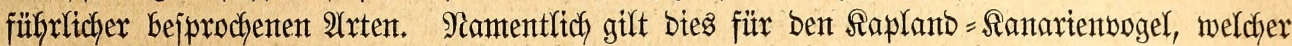

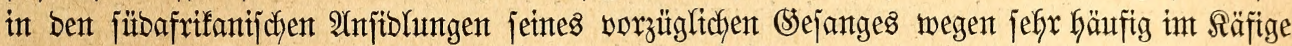

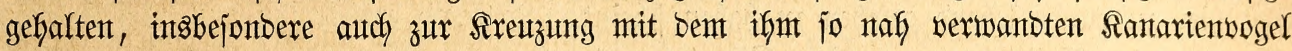

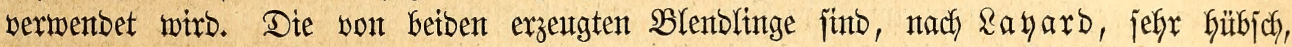
follen jich auch, wie man unjerem Forjcher werjichert hat, wieber fortpflanzen und zwar ebenjomohl mit ber einen wie mit ber anberen Stammart. Für untwahr ober unmtöglid

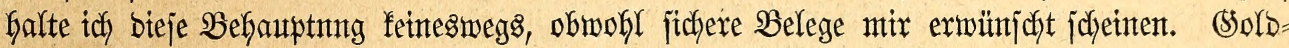
unb Weisfeble, weldye ich niemals gefalten habe, werben won Einzelnen, Soldbauth und

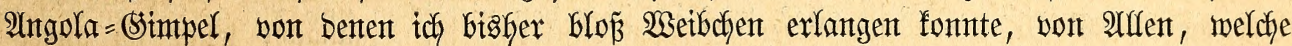

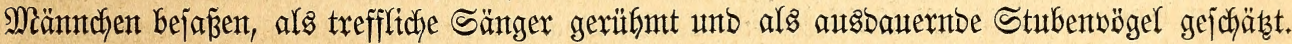

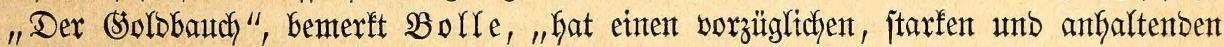
(Sejang, welcter flingt, al\& ob ex ein (Semijch von bent bes Şänflings unt ber Felblerche märe. Alußserbem brütet ex leidfyt im Säfige, part jich mit bem Ranarienwogel, mit bem

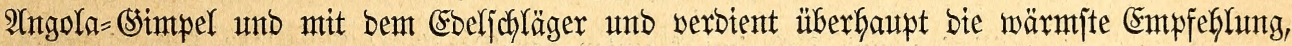

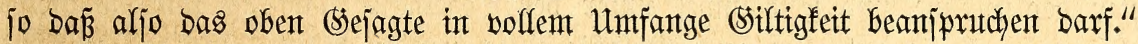

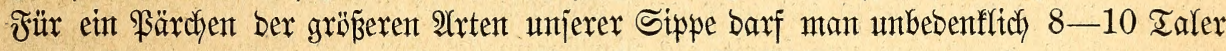

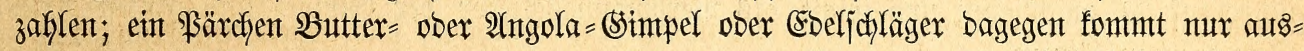

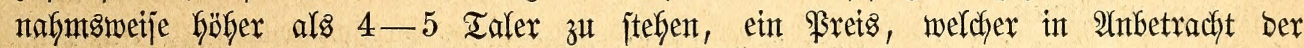

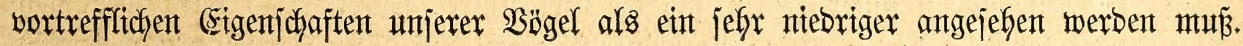

\section{hooftgimpel.}

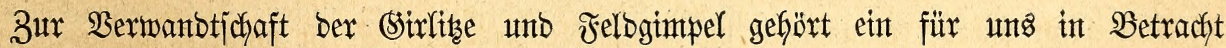
fommenter Sogel, weldyer son Den Forjchern vielfach fin unb her gemorfen worben ijt, won fajt alfen aber als Bertreter einer bejonberen Sippe angejeben mirb. Seine Merfmale fint bie folgentort.

Der \&eib ijt jaflanf, ber Schnabel furz, arfjettig gemölbt, auf ber Firjte janft gebogen,

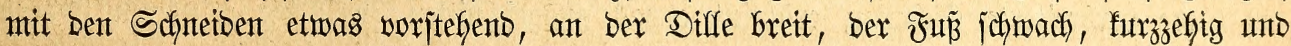

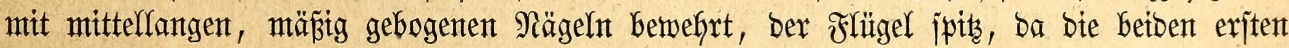
Sdjwingen afle übrigen an Ränge überragen, ber Sdywanz mittellang, jeidyt eingejunttten, bas (Sefieber żemlich retch, aber fejt. Miännchen unb Weibchen ober âlte unt Sintge unter= jcheiben jich in ber Färbunt eintgermaß̈en.

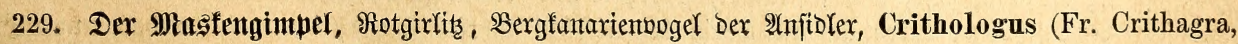

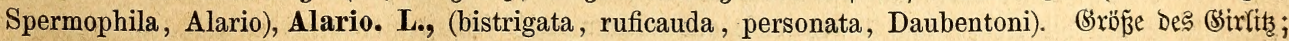

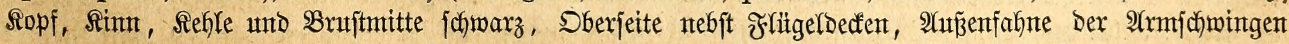

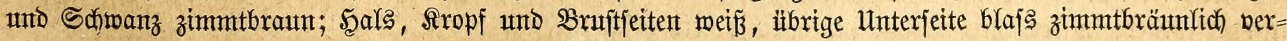

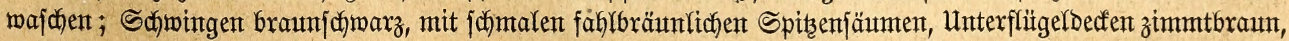

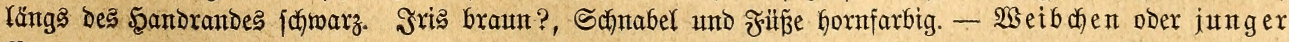
Boger obexjeits fahlgrau, mit Dunffent Sdaftjtreifen, Bürzel bräunlich), unterfeite gerblich) fahlgrau; 


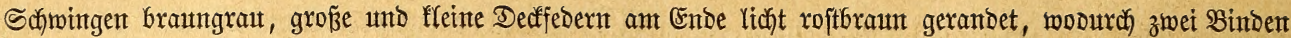

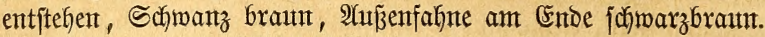

Stammt att Silibaftita.

Dbgleich ber Meagfenginlits im Saplanbe überall vorzuffommten unb nirgentos jelten zu jein jcheint, ben $2(n j i b l e x n$ unter bent angegebenen Namten wohl befannt ijt, bielfach im

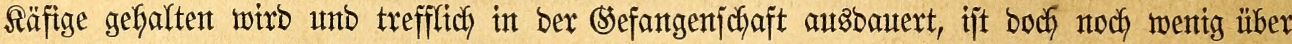

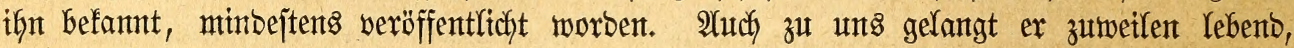
immer aber nur jefr eitzeln unb burchaus zufälfig: ich meinesteils habe ifn weber in einer

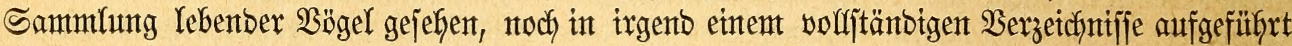

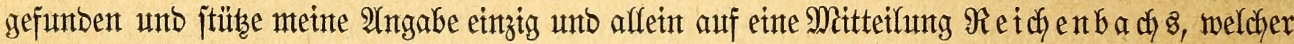

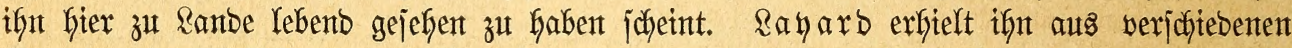

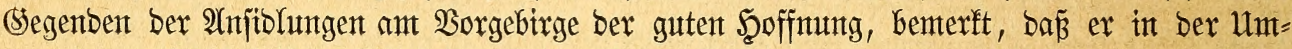

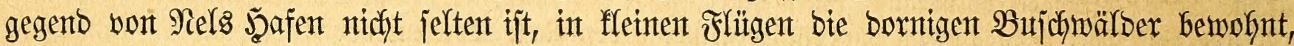

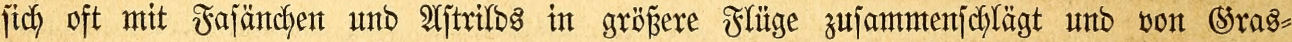
jäntereien ernäfrt. "Sein Siejang", jagt er, "ijt ungentein amjprechend (jür) und babei

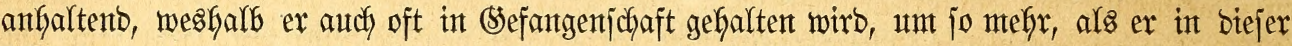
jefy gut ausbautert." Dies ijt affes; was ich über ben nieblichen und mit trefflichen Eigen= jchaften begabten Bogel za jagen weißß.

\section{(5olidgintuel.}

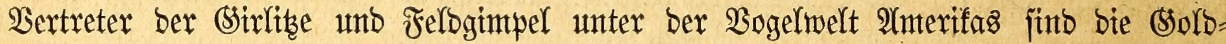
gimpel, weldye mant ebenjo gut aber audh Solbhänflinge nenten fönnte, weil jie an bieje

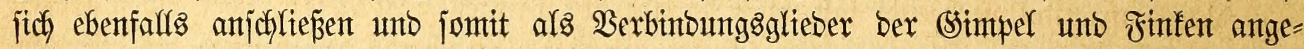
jeben werben fönten.

Bon ben Felbgimpeln unterjchetben fich bie (Solbgimpel hauptjächlich burch ben mefr gemölbten, iptbininfeliger in bie Stirn einjpringenben, an ben Schnetbenränbern mebr ein= gezogenen Sdynabel, bie hod)läufigeren, jchlanferen unb boch fräftigeren Beinte, bie fürzere

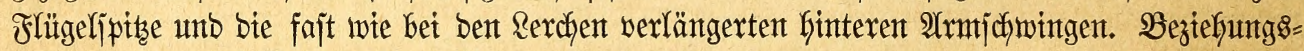
los zujammengejtellt jüb ifre Merfmale bie folgenton:

Der Schnabel ijt ziemlich bicf, furz, fegelförmitg, ant Srumbe breit, tach vorn ftarf berjdyntälert unb besfalb jpits, auf ber Finjte grablinig, ber untere Siefer etwas niebriger als ber obere. Die Gochläufigen Beine Gaben lange Beben unt auffäflig lange, icharfe,

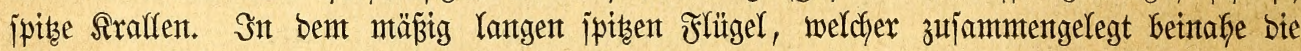
Mitte bes Sifwanzes bedt, ijt bite erjte Sifwinge wentg fürzer als bie zweite längite, unto

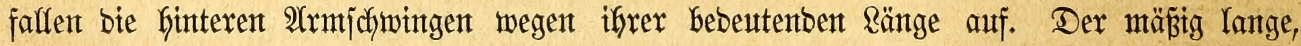
am Ende verbreiterte Schwanz erjecheint etwas ausgejdynitten, weil bie mittleren Febern einige Sinten fürzer fint als bie äußerent. Das Bsefieber prangt in rebhaften Farben.

230. Der Safrantinf, Canario Der Brafilianer, Boldfronenfanarienvogel Der Betwofner Samaifas, Syealis (Emberiza, Fr., Passerina, Linaria, Crithagra) brasiliensis, Gml., (flava, aurifrons). - $\mathfrak{B}$ ergr.

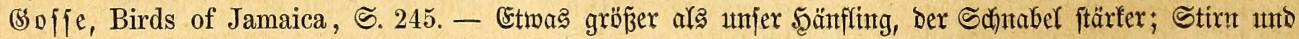

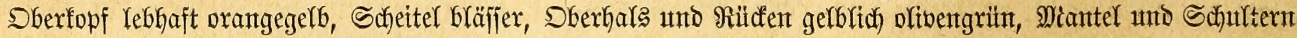

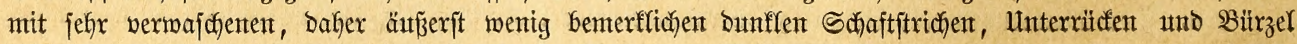

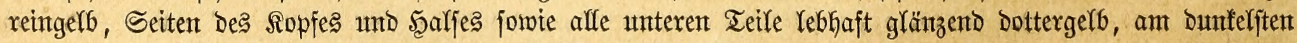

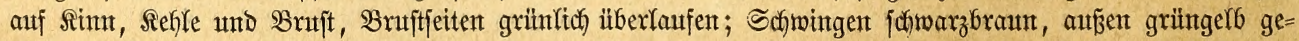

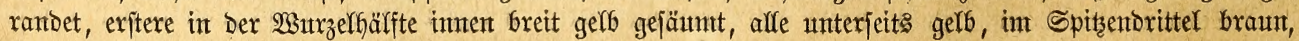

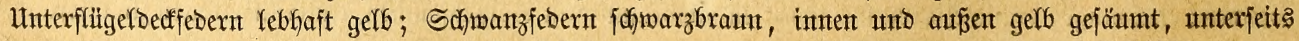

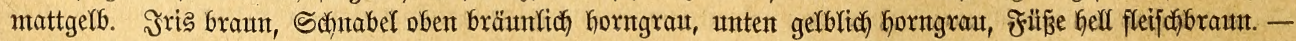

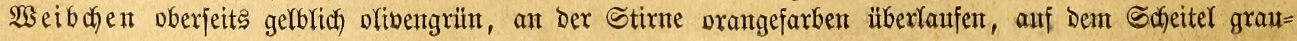




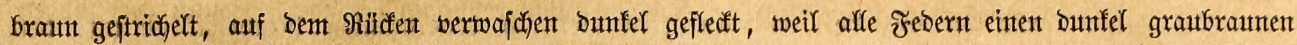

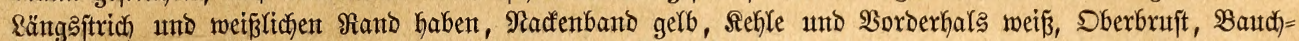

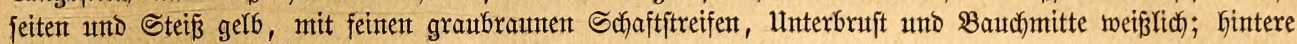

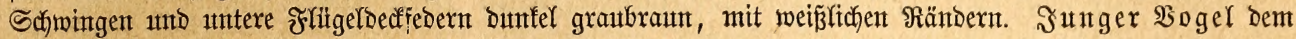
Weibchen ähnfich, Die Färbuntg jeboch trïber und matter.

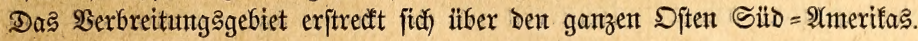

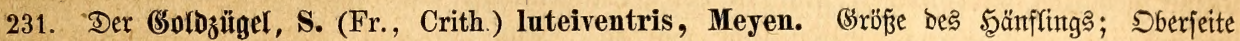

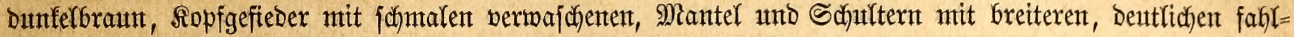

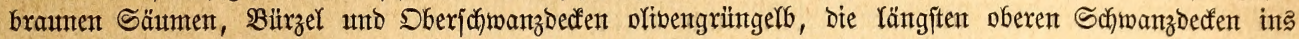

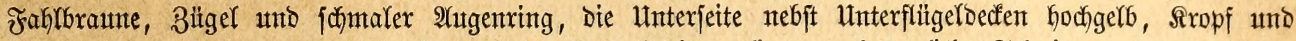

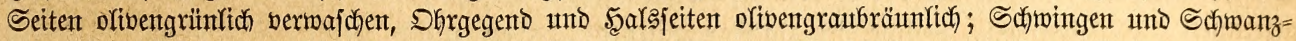

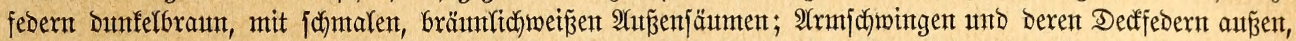

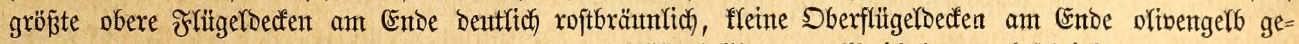

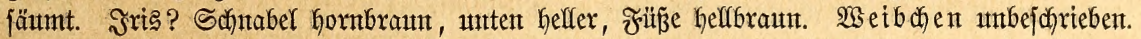

Der Bolbzïgel verbreitet fich) über Sïbmeftamerifa von \$eru bis Neugranada.

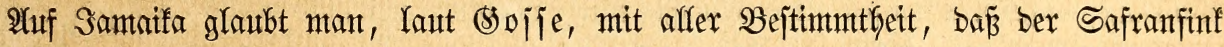
ein Rachfonmte Des Rantarientogels jei. "Ein Scerr, Namens Sheafjpeare", Genterft

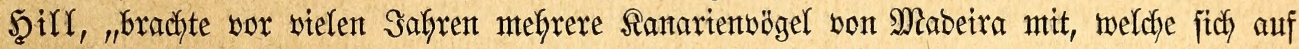

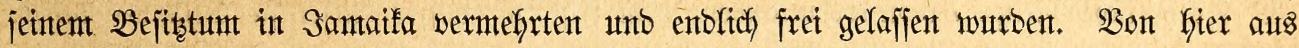

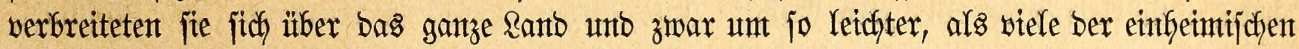

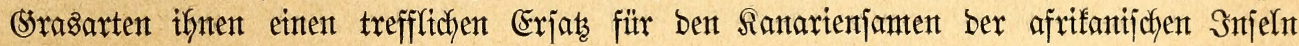

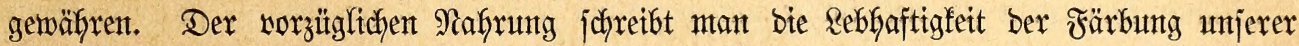

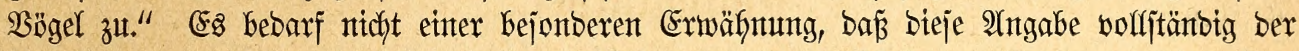

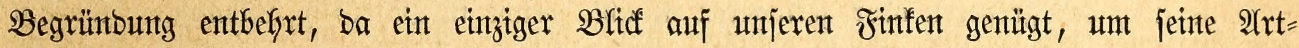
jefbjtänbigfeit aurerer alfen Bmeifel zu jteflen.

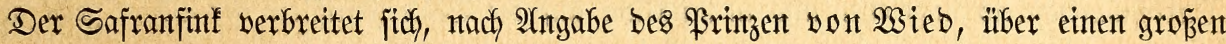

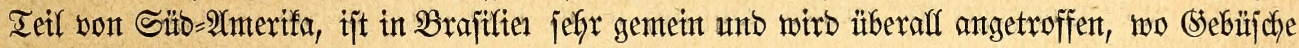

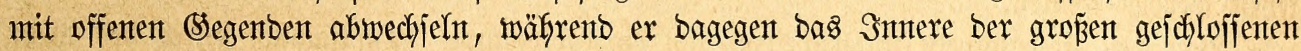

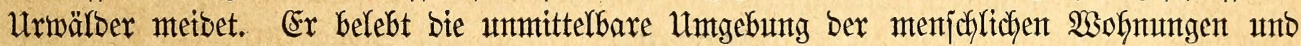

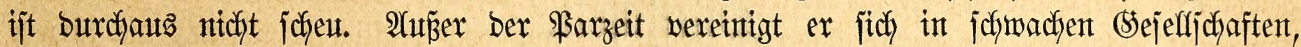

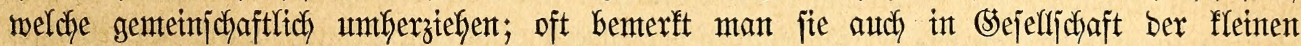

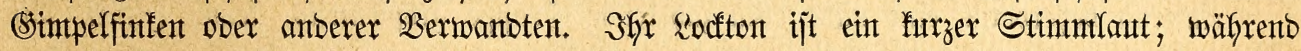

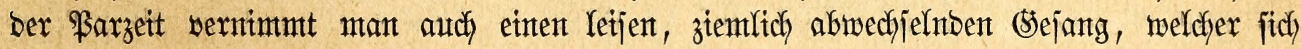

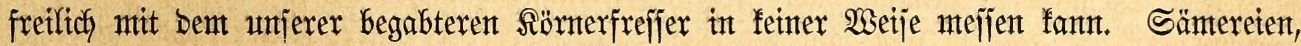

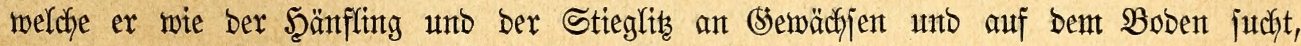

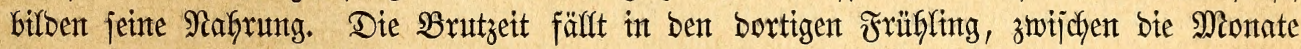

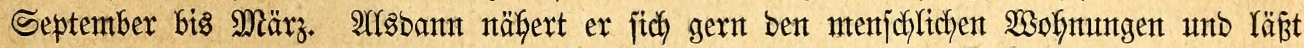

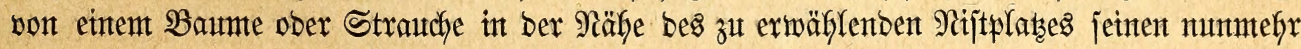

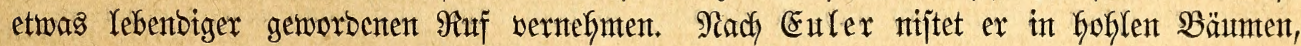

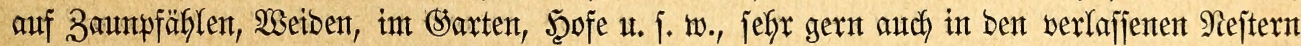

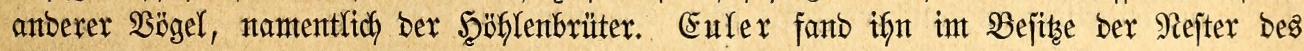
Jfhegenfängers unt eines Baumjjłlüpfers (Synallaxis mentalis), Defifent geräumigez, gut

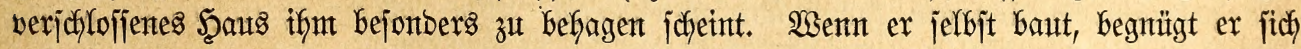

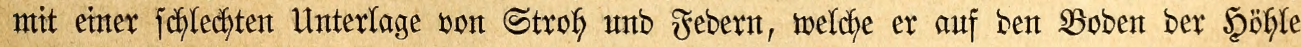

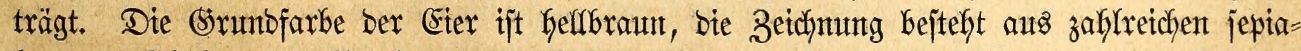

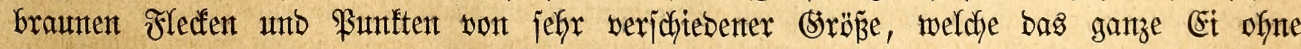

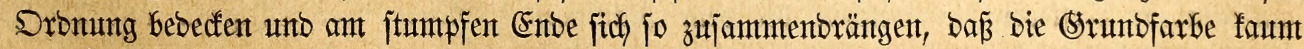

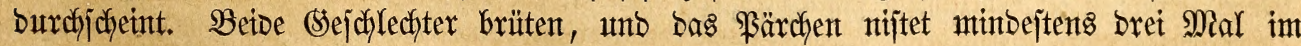

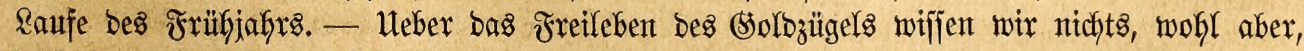
Dá̧ er zu ben bejten afler Sänger Sübamerifaz zähflt. 


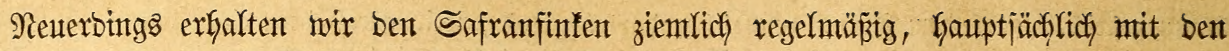

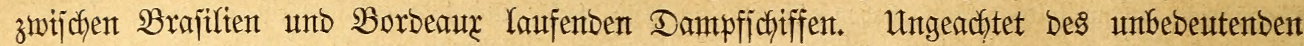

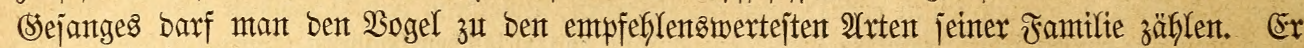

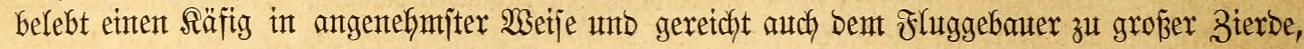
wirb aber burch jeine Rebhaftigkeit anberen fleineren Finfen oft läjtig. SBijitg ober unver= träglich fant ntant ifn übrigens nidyt nenten; mur gegen bie Farzeit fin fechten verjediebente

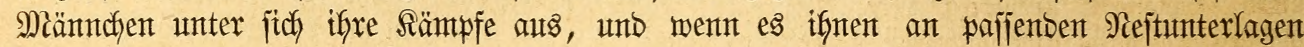
feblt, bentächtigen jie jich Dann wohl auch eines bereits fertig ober Galb fertig gebauteten

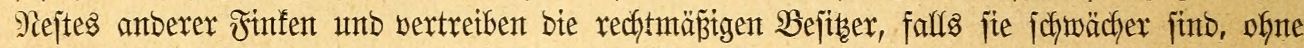
Rücfficht. Diejentgen, weldye ich bisher pflegte, Gaben ntcht geniftet, wäfrento dies int Jranlfurter Itergarten und bet einzelnen Riebgabern wieberholt Der Fall gemejen ijt.

Der Safranfinf und jein Serwandter gegören zu Den anjpruchslojejten und Dauerhaftejten

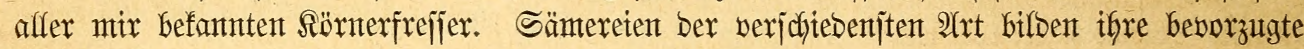

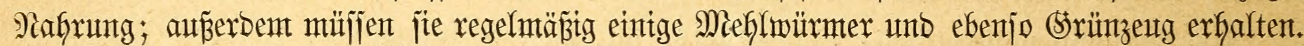

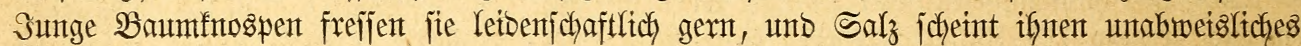

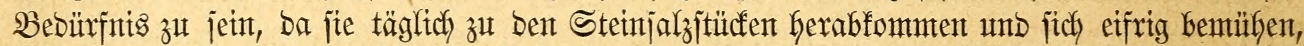

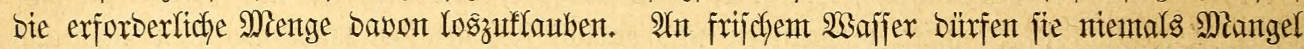

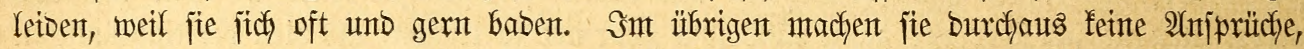

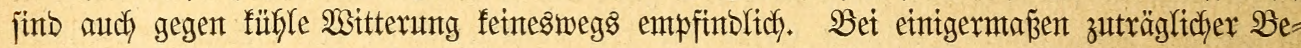

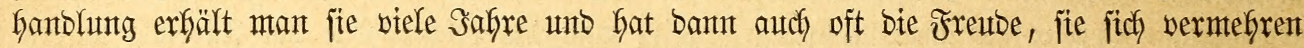
zh jebett.

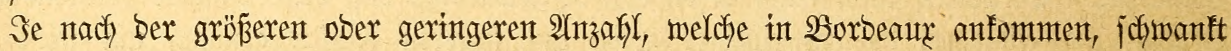

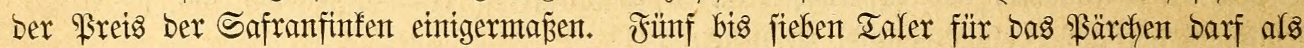

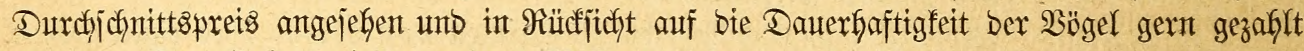
werben. Der Solbzügel ijt, meines 2 ifjens, rebend nod nicht zu uns gelangt.

\section{Wffifffichet.}

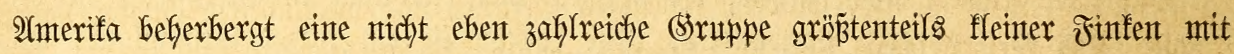

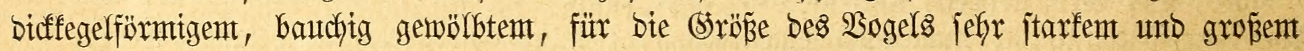
Sdynabel, żemlid langen Daumen, werfürzter erjter Sdjwinge unt int alfgenteinten nidft bejonbers buntfarbigemt, meijt aber boch redgt anjprechenbent Sefieber, bie (simpelfinfen (S porophilinae), weldje von (S) ray unb âtberen in eine bejondere Unterfamifie vereinigt

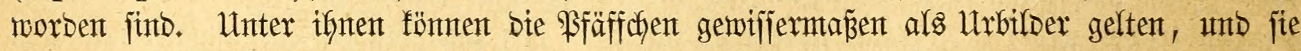
mögen beshalb obenan gejtellt merben, um jo mefy, als wir jeit einigen Safren mefjere

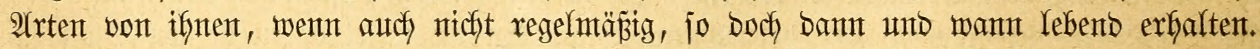

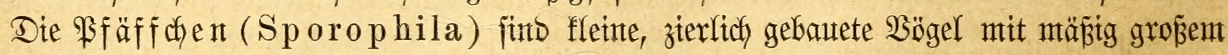
Sopf unb mittelftarfem, auf Der Finjte jefr gewölbtem, an ber Spibe haftig Gerabgebogenem ant Srumbe bes Unterftefers breitent, an Den Seiten bautfig vortretentem Schnabel, feinen

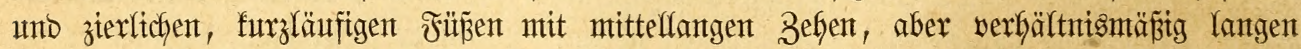
Daumen, langent, ipti̧emt Flügel, welcher zujammengelegt ungefähr ein Dritteil des Sifwanzes becft und unter befien Sdjwingen bie zweite unb britte bie Yängjte ijt, furzemt, idhmalfebrigem, in Folge ber werfïrzten Seitenfebern etwas abgerunbetem Sdywanze, glatt

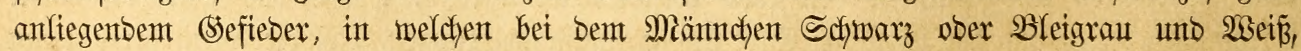
bei Dem $\mathfrak{B e i b c h e n ~ D l i v e n g r a u g e l b ~ v o r k e r j a t . ~}$

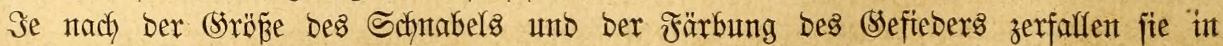
mebrere Unterjippen, weldye mir nebenbei vermerfen wolfen. Zu benen, weldhe verbältnis: 


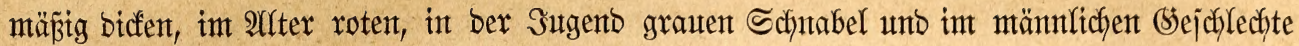
blet $=$ ober jofiefergrautes sefieber haben, gefören:

232. Das Sorallentidntäbeld)en, Sporophila (Fr., Pyrrh., Spermophila, Gyrinorhynchus) hy-

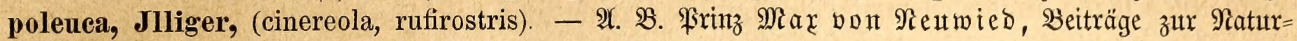

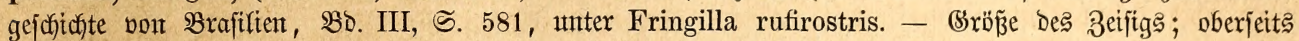

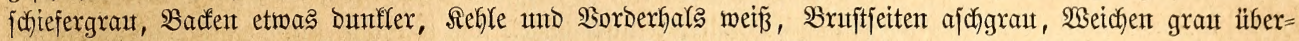

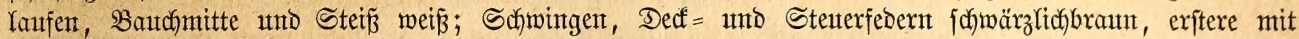

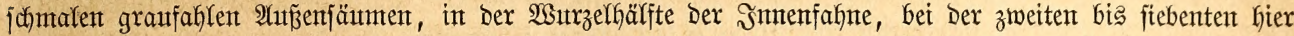

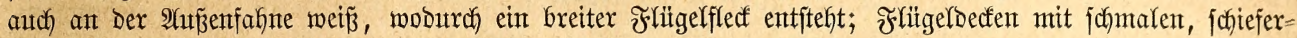

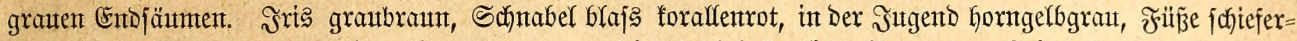

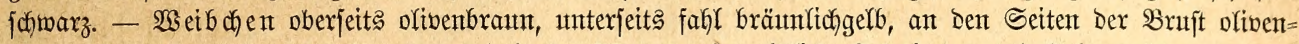

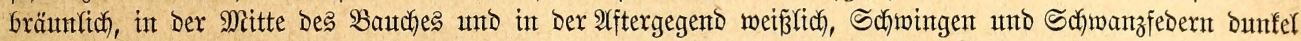

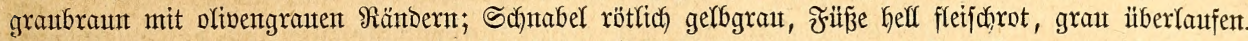

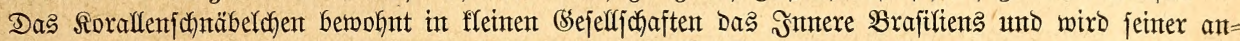
genehment Stimme harber bort biel im Räfige gehaltent.

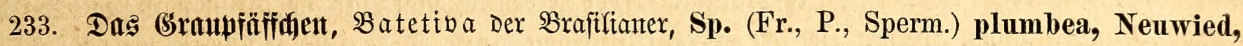

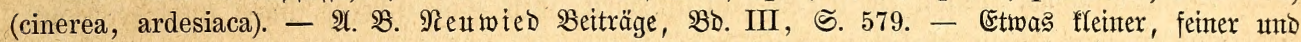

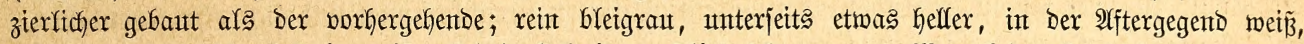

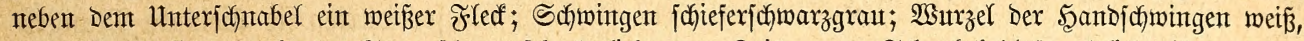

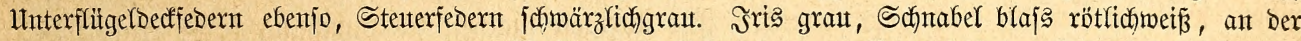

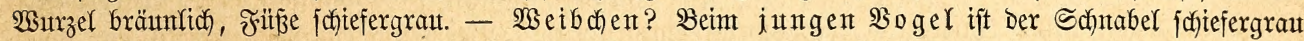
mit meißlicher Spitze.

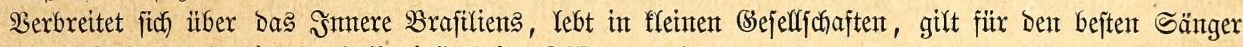

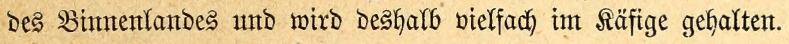

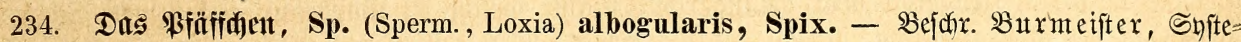

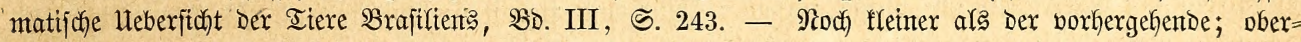

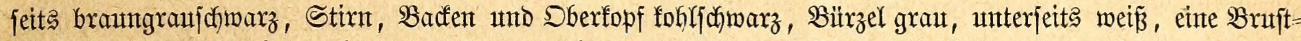

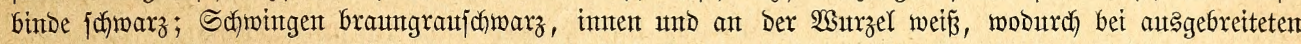

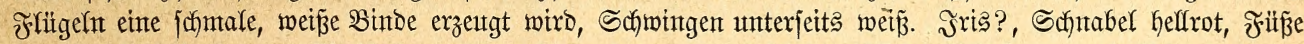

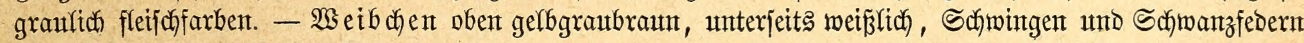
brautgrau, erftere ant ber $\mathfrak{B u t r z e l}_{\text {el }}$ weip.

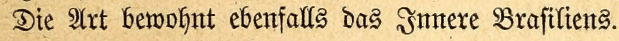

\section{Dunfelgelfgrautes, öfter teilweije jumarzes (Sefieber unt weifichen Sdyntabel haben:}

235. Das $\mathfrak{B c i f b a ̈ r t h e n , ~ S p . ~ ( F r . , ~ S p e r m . ) ~ o r n a t a , ~ L i e h t e n s t e i n , ~ ( l e u c o p o g o n ) . ~ - ~ B e j d x r . ~}$ Sieuwied, Beitr., III, 572, unter Fringilla leucopogon. - Größ̈e DeS vorhergehenden; Stirn, Bacfen,

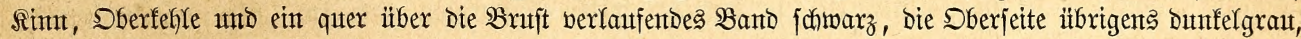

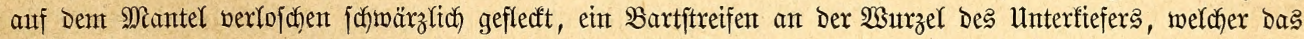

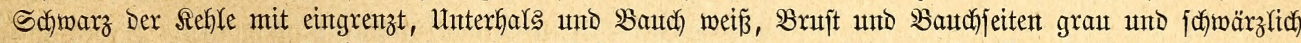

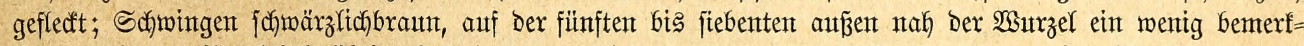

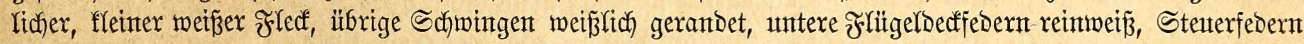

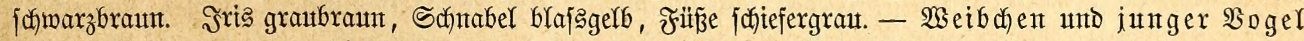

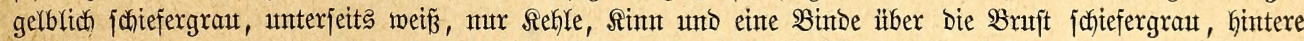

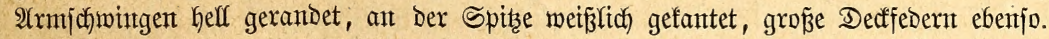

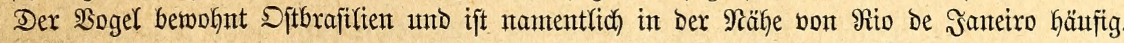

236. Das Gajunrzfüpuden, Sp. (Fr., L., Pyrrh., Sperm., Phonipara) gutturalis, Licht.,

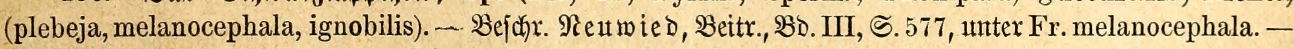

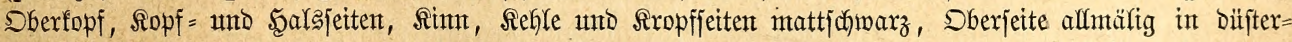

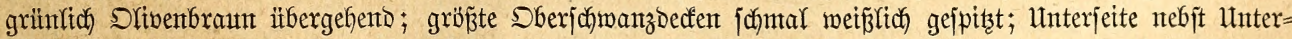

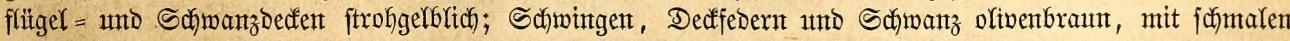

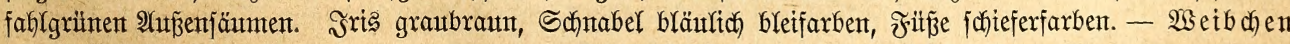

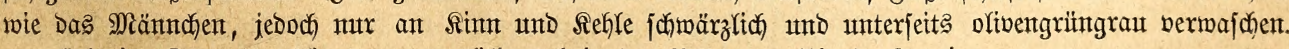

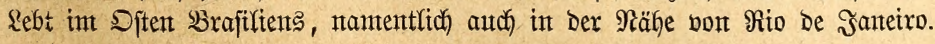

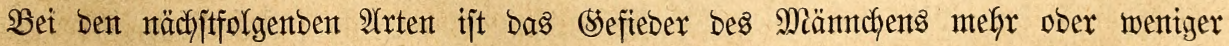
¡đ̆warz, weiß geflectet, ber Schnabel horngrau.

$\mathfrak{B}$ reh $m$, gefangene $\mathfrak{B o ̈ g e l . ~ I . ~}$ 


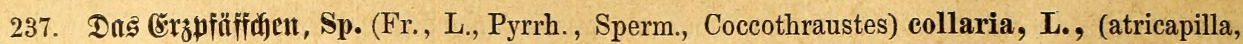

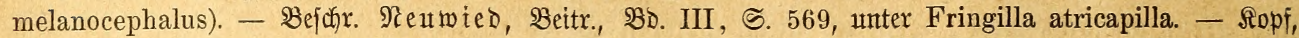

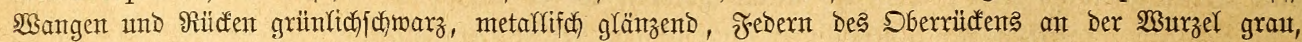

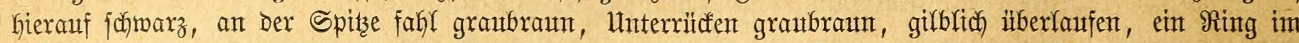

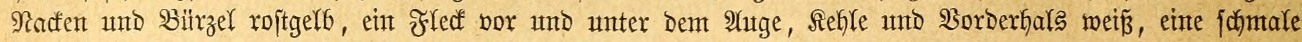

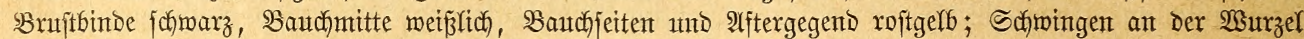

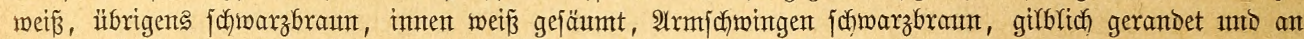

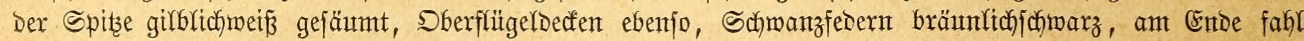

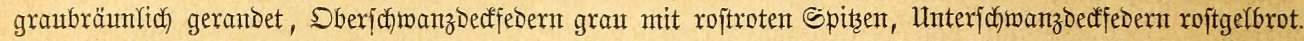

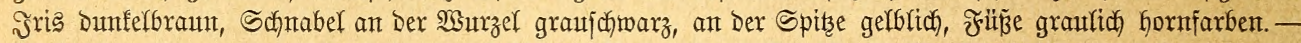

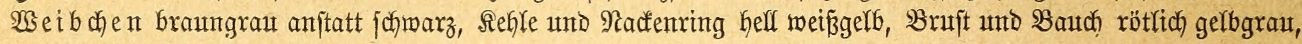

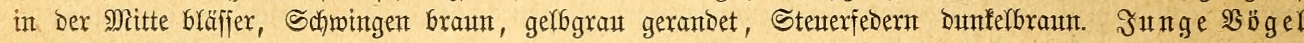
ähneln bem $\mathfrak{s e i b d j e n . ~}$

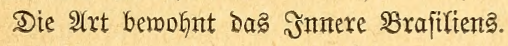

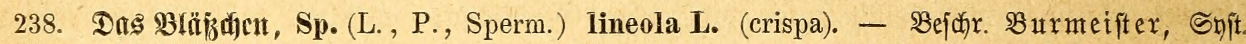

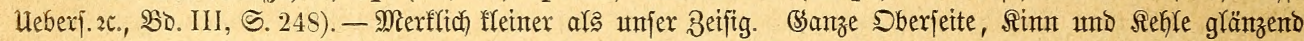

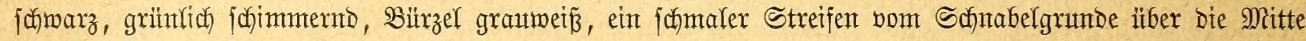

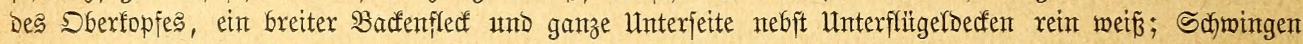

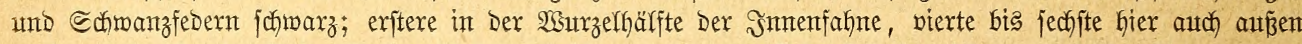

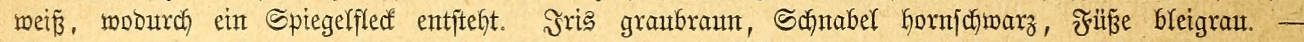

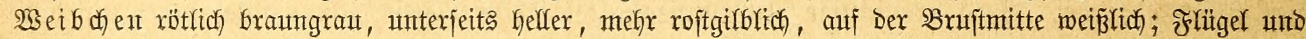
Steuterfedern Dumfelbraum, Geller gerandet, Yekztere namentfich an ber Spitze.

Die $\mathfrak{A}$ rt bemognt DaS nörolidje Brafilien, insbejondere bie Begent pon \$ara.

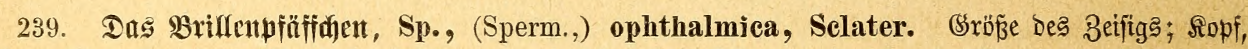

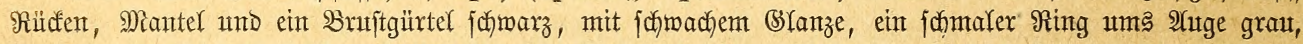

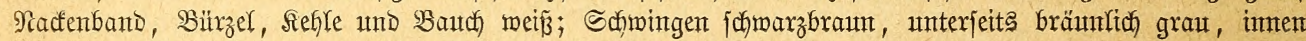

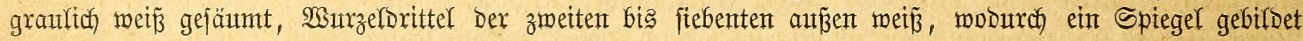

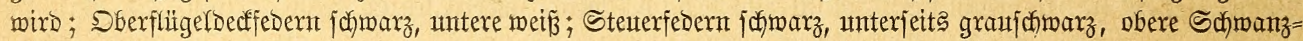

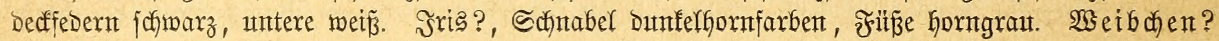

Das $\mathfrak{B}$ g̈glchent ftammt auts bogota.

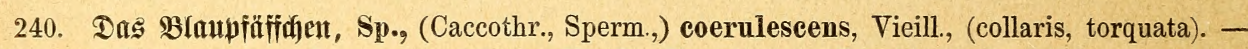

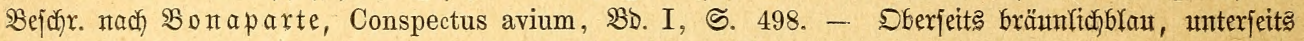

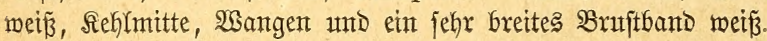

Das Satexfant ift Brafitien.

Ebenjo jelten wie bie in vielen 2(rten über ganz Sïbamterifa verbreiteten \$fäffchen lebento in umjere Säfige gelangen, ebenjo bürftig fino bie Berichte über ify Freileben, unb fajt mill

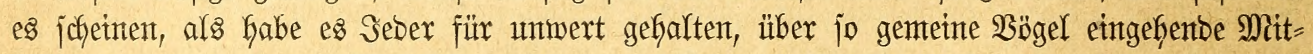

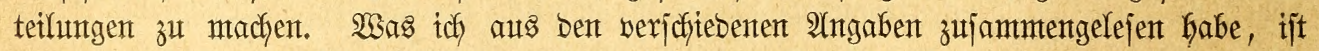

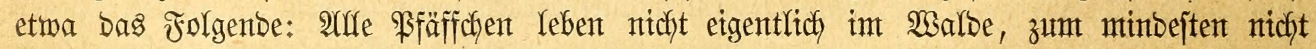
im Urmalde, jonbern am Ranbe Der Walbungen, in nieberen Siebiijchen unt Sträuchern,

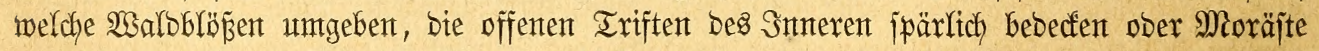

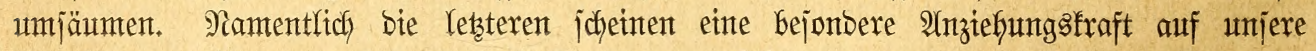

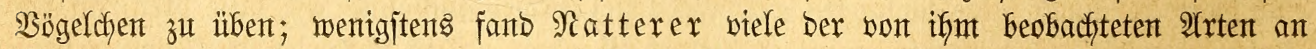
Sümpfen. Bon joldyen Stanborten aus fliegen fite nach ben mit Stras bejtandenten Ebenten,

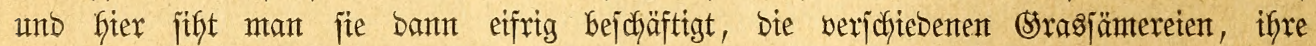
Gauptiächlichjte গahrung, auszufflauben. Bur Beit ber Betretbereife falfen fie auth auf Den Reis= ober ŞirjefelDern ein und fügen Denjelben zumeilen merffichen Schaben zu. (Segen

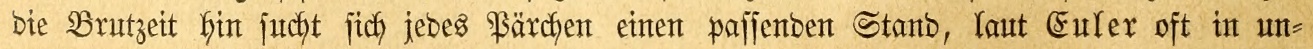

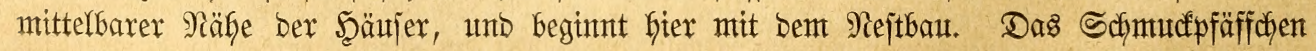
baut gern in bie Rojenjträucher in Sarten. Sein Nejt ijt flein, tiejnapfig, Yuftig, aber

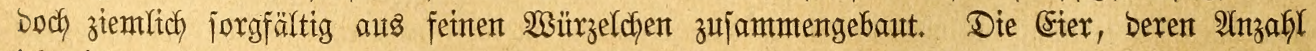
ich nicht angegeben finbe, haben auf meiz̄lich grüment (srunbe zahlreiche braune Rängsfflecten 


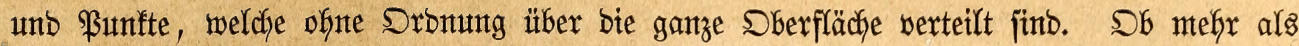

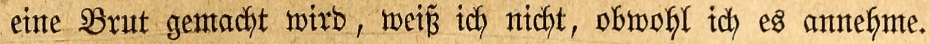

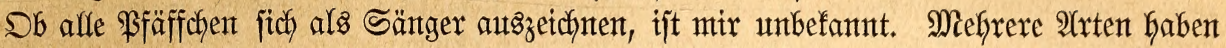
zrwar jchwache, aber flangwolfe Stimmen, einzelne jogar einen redjt lieblichen (sejang, melchen

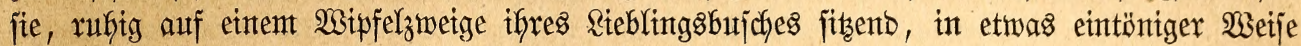
vorzutragent pflegent. Man hält jie beshalb überall in thrent Sceimtatglande int Säfige und

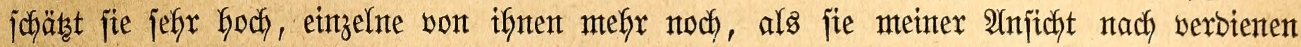

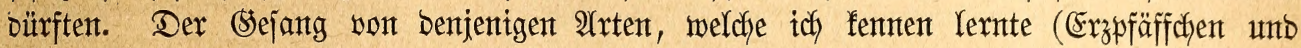

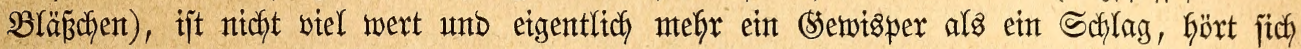

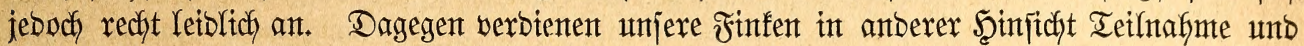
3uneigung bes Riebhabers. Sie gefören zu ben hübjchejten und munterjten (5)lebern ifrer

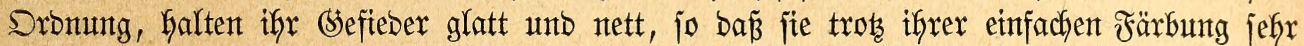

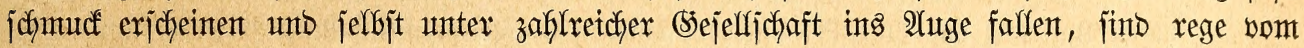
Morgen bis zum 216ent, vertragen jich vorzüglidy mit alfen übrigen Mitgliebern ifres Flug= gebauters unb fteflen an bas Jutter bie alferbejcheibenjten Intiprïche, ba jie in ungleidh Göherem Make als affe afrifantichen unt aftatijchen Finfen unb Weber Rörnerfreffer jüt. (Srïnzeug ijt aldch iffnen Bebürfnts; Serbtiere aber babe ich metne. Sefangenen ntemals zu jich nefmen jeben. Das treutmige Bujantmenthalten beiber (sejchlechter joheint barauf bin=

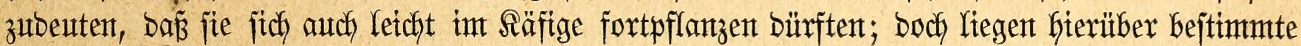
Beobachtungen noch nicht vor. Nach all biejem glaube idh gerabe bieje bisher jo mentg beachteten $\mathfrak{B o ̈ g e l ~ D e n ~ R i e b h a b e r n ~ b e j o n b e r s ~ e m p f e h l e n ~ z u ~ b u ̈ r f e n . ~}$

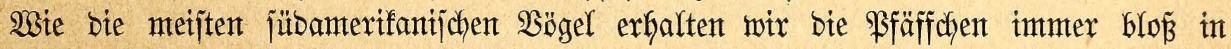

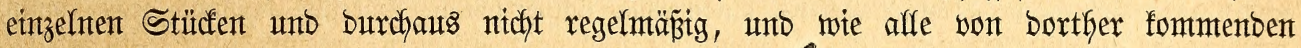
Sögel jtehen jie ziemlich hoch im

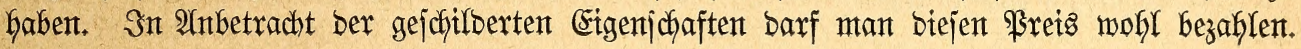

\section{(birasgimpel.}

Wejtinbien unb bie benachbarten Ränber Mittel= unb Sübamerifas beherbergen eine geringe

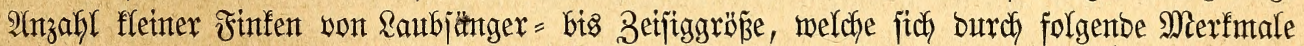
fennzeddhen: Der Sihnabel ijt furz, fräftig, jeitlich jtarf zujammengebrücft, baher viel Göher als breit, auf ber Firjte gerabe ober faum merflich gebogen, ber Unterjadnabel ebenjo foch als ber obere, bie Difle breit, bie Diflenfante gerabe. Die fleiten Najenlödfer liegen jeitlich an ber Sdynabelwurzel, unter Borjtenfebern verjtedf. Die fräftigen J̃üpe haben

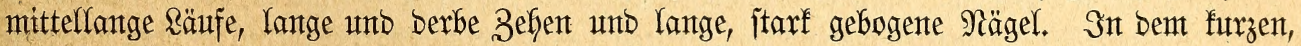
rimben Flügel, weldyer zujammengelegt bie Şälfte Des Schwanzes bedft, überragen bie britte unb vierte ber unter fich gleidflangen Sdfwingen bie übrigen und fint roie bieje breit, an ber Spitze gerumbet, bie borberen aupen auch jtarf eingeengt. Der furze, gerabe Sdywanz mirb von breiten, weichen Febern gebilbet. Das reiche weidfe siefteder ift vorberjcheno olinen=

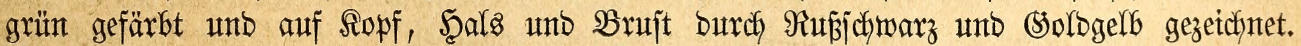
Die (Sejd)lechter unterjchetben jich Durch bie Färbuntg; bie Sungen ähneln Den Weibchen.

241. Die (SnlDfraute, Euethia (Fr., Emberiza, Passerina, Phonipara, Spermophila) lepida, L.,

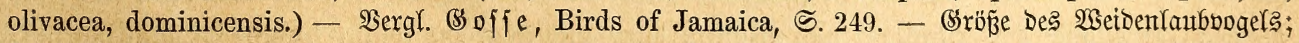

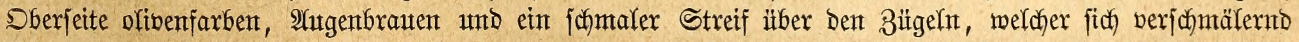

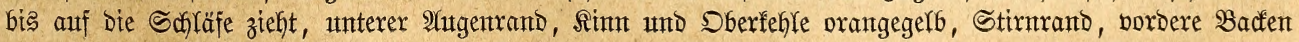

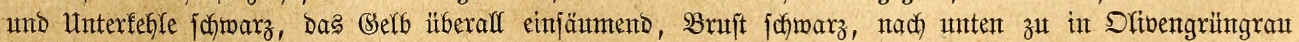

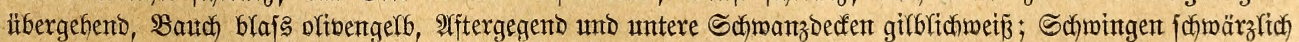




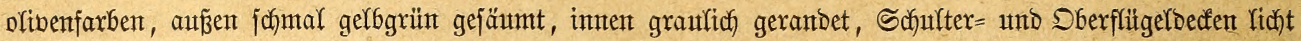

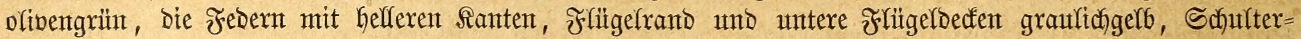

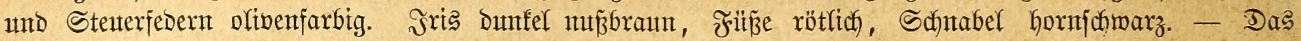

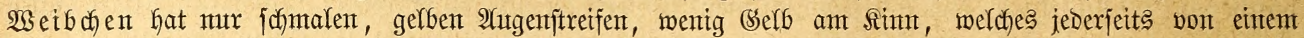

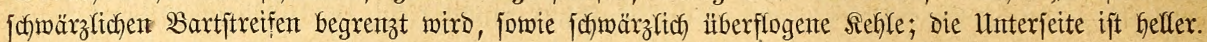

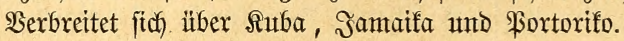

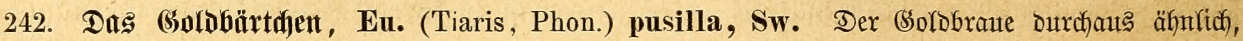

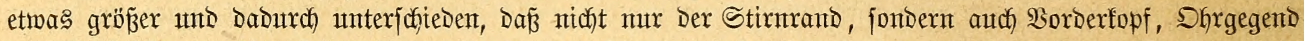

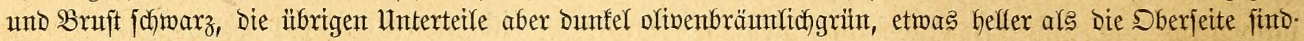

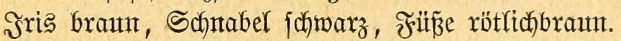

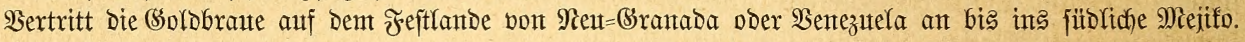

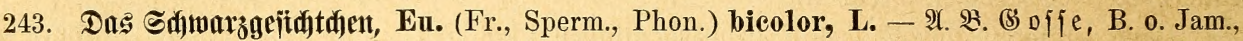

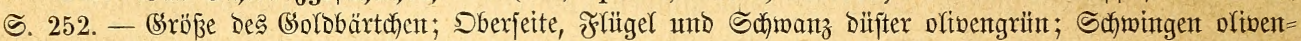

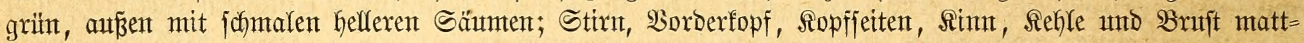

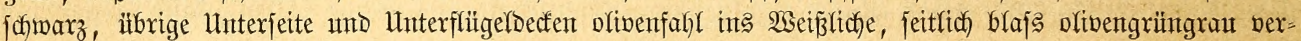

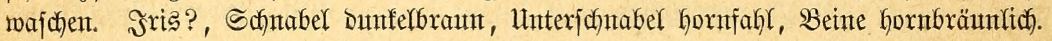

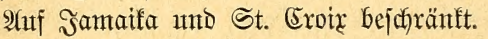

244. Der (sofofragen, Eu. (Fr., Lox., Pyrrh., Pass., Phon.) canora, Gml., (collaris). -

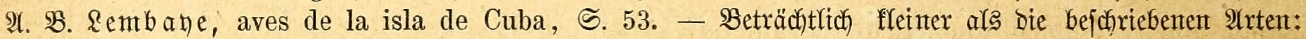

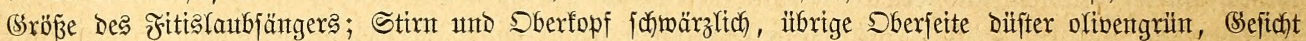

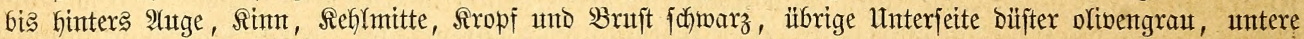

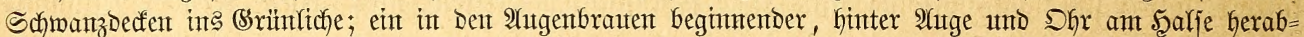

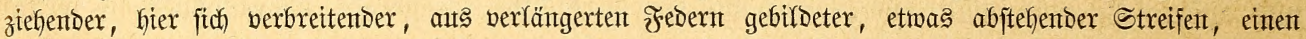

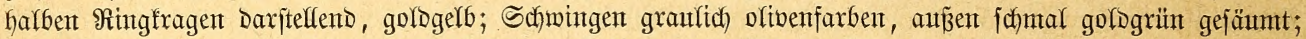

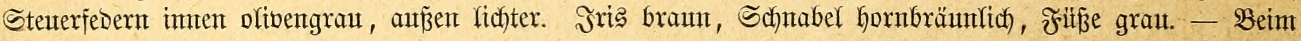

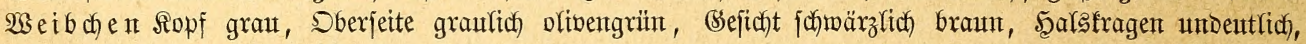
grünlicdggerb, Unterjeite fahigrau.

Der Goldragen bewognt Iuba.

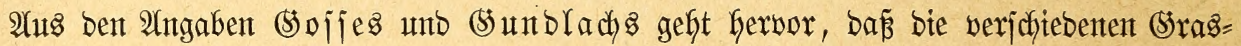
gimpel mebr ober wentger biejelbe Rebensmeije füfrent. "Shre Sitten und Ssemohnheiten", jagt

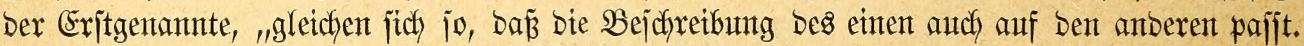

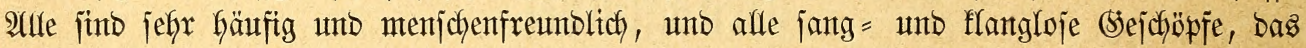

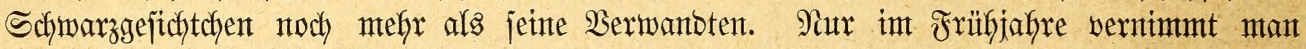

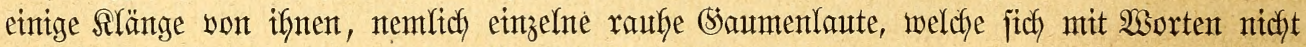

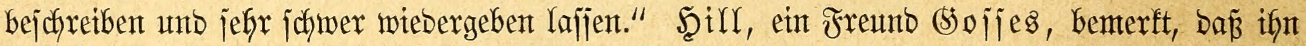
bie Soldbraute lebgaft an unjere europäichen Sperlinge erintert habe: "fie find", meint er,

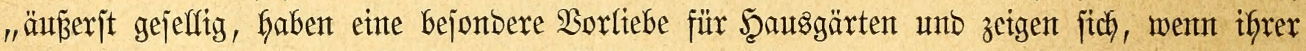
viele 孔ujammenfommen, als lärmente (Sejelfen, welche ununterbrochen ein eigentümliches, jayrifles Bixpen vernegmen lajjen. Währento ber Srasreife jift mant fie oft auf Den Spizen Des (Srajes erjcheinen und jich fjer nach Meijenart anthängen, um bie Samen auts ben Afefrent zu flauben." (\$oije fand Dant Den fropf und ben Magen, jo zu jagen, bis zum Berplaben mit gebachten Sämereien angefüflt. Der Selbfragen, welcher auf Suba gentein ijt, fyält

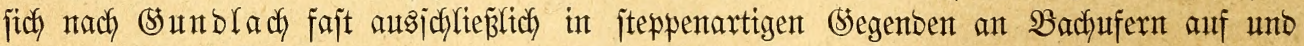
fommt nur zumeilen in bebaute Segenten. Went man bieje Rebensweije fennt, verjefht man, um mich jo auszubrïcten, erjt Bejtaltung unt Färbung biejer nieblichen (sejchöpfe. Sie vertreten gleichjam unter ben förnerfrefjern bie fleinen Sänger, welche wie fie bas (S)e

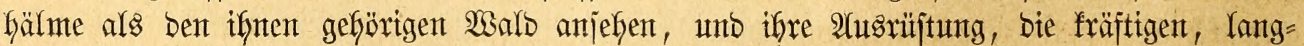

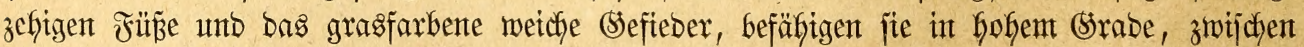
ben Şalmen ein behagliches reben zu füfyren.

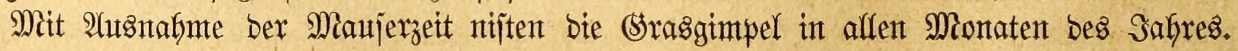

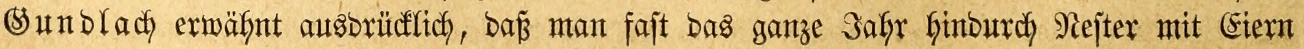




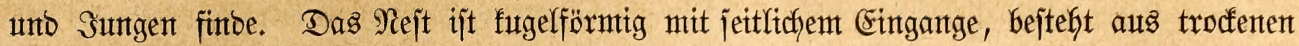

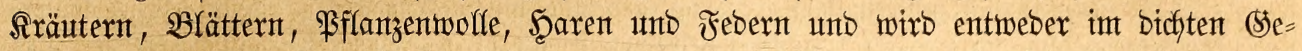

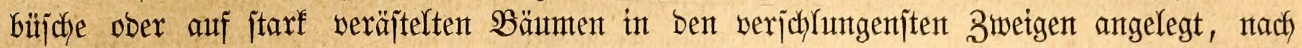

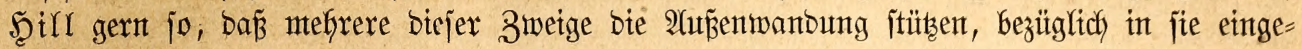

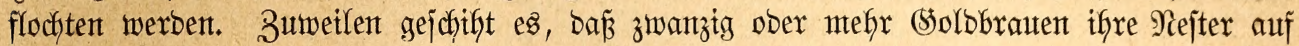

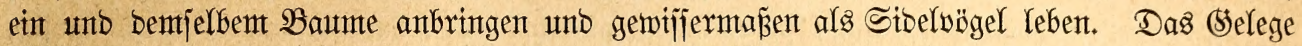

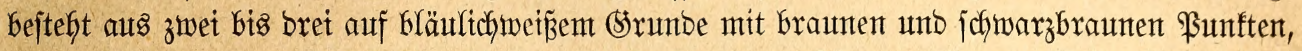

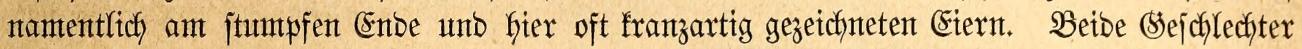

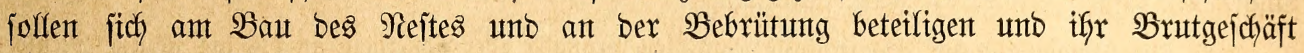
interfyalb vier 2 sodfent beentert.

Seit einigen Safhen gelangen (5raggimpel aud auf imjeren Tiermarft, inmmer aber

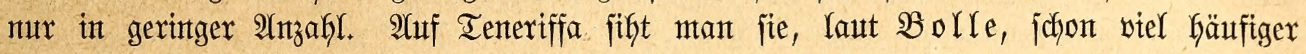

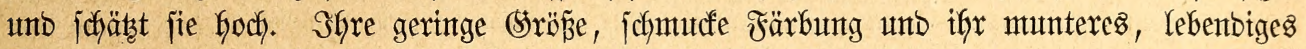
Wsejen, welches vielfach an bas unjeres allbeliebten Zaunföntgs erinnert, emtpfiffit fie

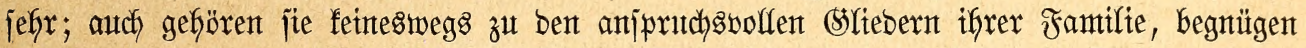

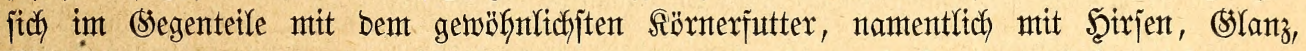

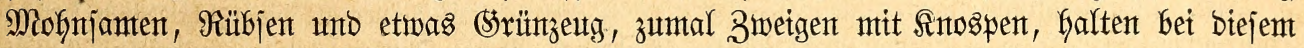

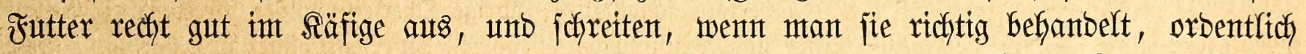

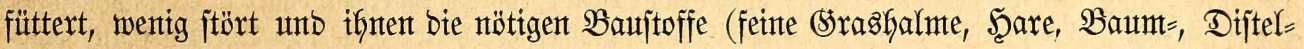
unt anbere \$ffanzenwoulfe jowie weidhe Febern) gibt, zur Fortpflanzung int (sebauter. Shr

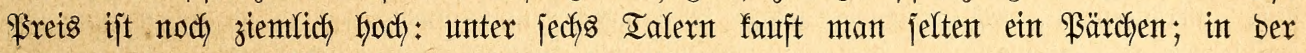
Regel mun mant woffl nodf etwas ntefir bezaflen.

\section{(Gimpelfintkent.}

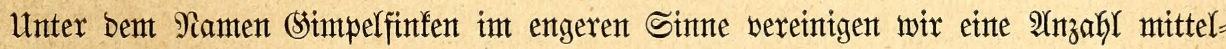

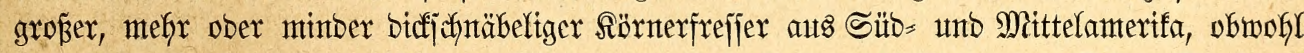
autch fie neterbings in verjchiebente Sippent unt Utnterfippent zerteilt worben fittb. Sie fent=

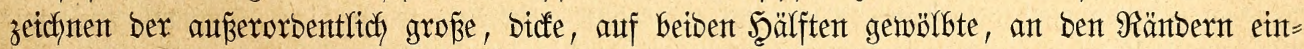
gebogene Sdynabel, Defifent oberer Teil mit ber Firite in bie Stirnt eintritt uno weber Şafent

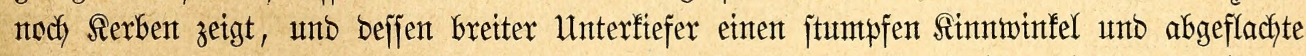

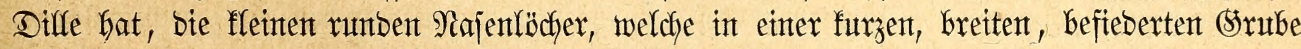

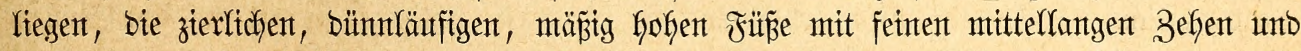

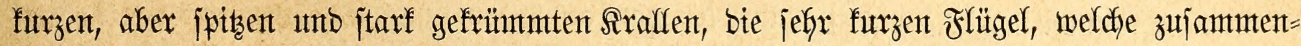
gelegt ungefäfrr ein Drittteil bes Sdywanzes bebedent unb unter beren Sdjwingen bie britte

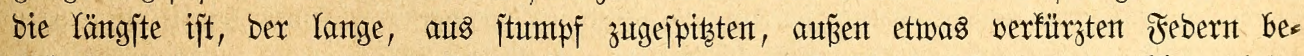
itefhenbe Sdywanz utto bas berbe, meift einfarbige, workerjchento jafmarz ober blaut, Geint Bseibchen bräınlich) ober graut gefärbte (Sefeteber.

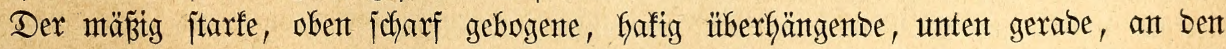
Schyteiben mit ber Finjte gleithlaufente, fhier wentig eingezogente, jeitfich etwas zufantmten=

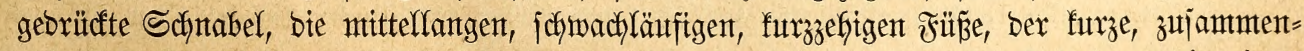

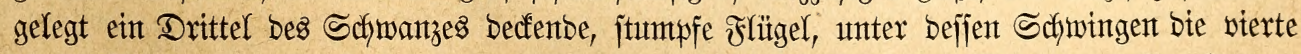
bie Yängite, ber żentlich lange, in ber Mitte ein wentig auzgejdynttente Schjwanz, befijen Febern gegen bie Spitze hin fidch verbreitern, und bas bunffe (sefieber fino bie Merfmale bes zum Bertreter einer bejonbern Sippe (Melopyrrha) erthobenten Schmarzgimpelfinfen. 
245. Dex Sdfwarzgintperfinf, Goniaphea (L., Pyrh., Spermoph., Melopyrrha) nigra, L.,

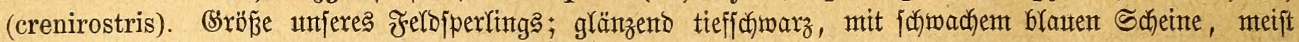

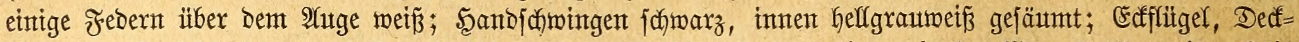

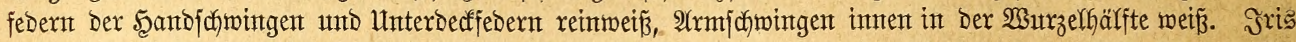

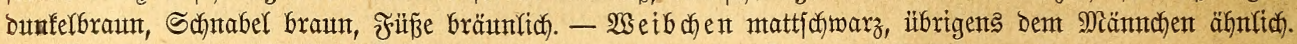

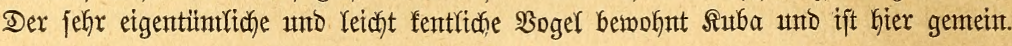

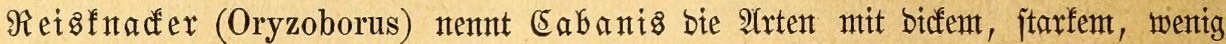

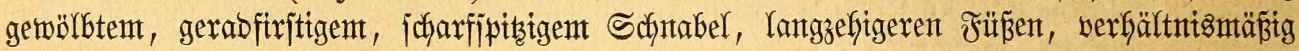
längeren Flügeln, aber fürzerent Schwanze.

246. Der Sdmarzftnder, Becuto Der Brafftianer, G. (Fr., L., Spor., Oryzob.) crassirostris, Gml.,

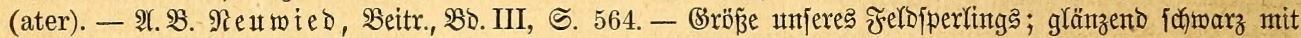

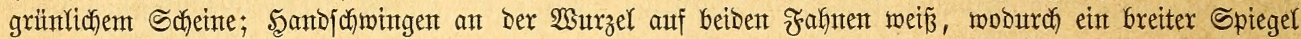

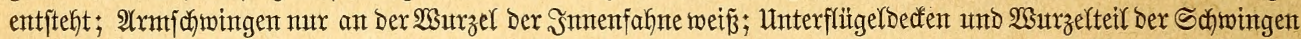

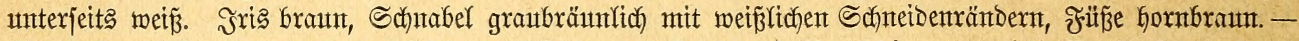

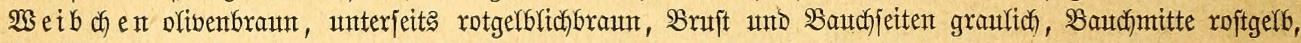

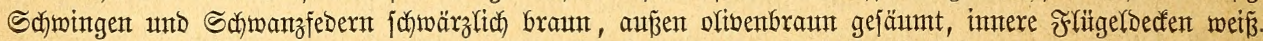

Die Art bemohnt Das 2 aldogebiet bes mittleren Brafilients und Bianas.

247. Der Reisfnudere, G., (L., Fr., Pyrrh., Coccothr., Coccoborus, Oryzob.) torrida, Gml.,

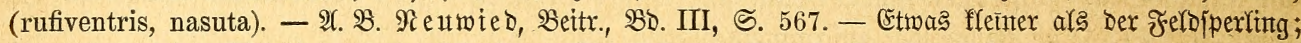

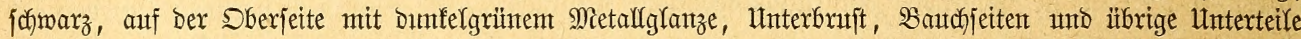

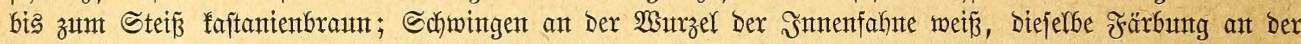

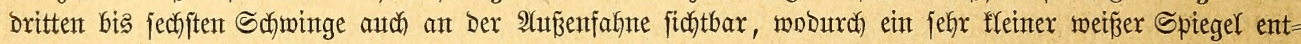

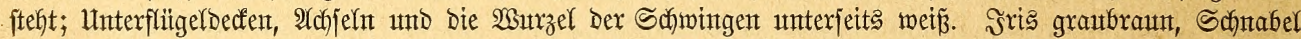

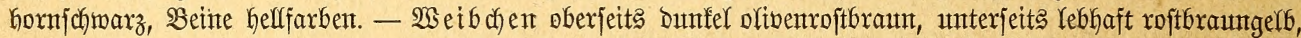

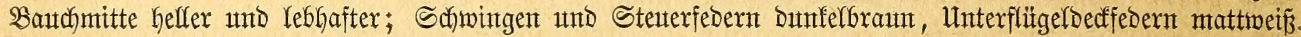

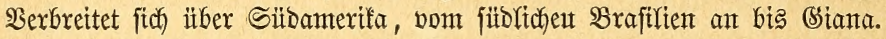

Die übrigen 2 rten entiprechen ben oben gegebenten Merfmalen ber Sippe.

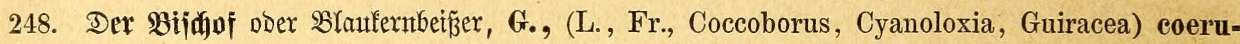

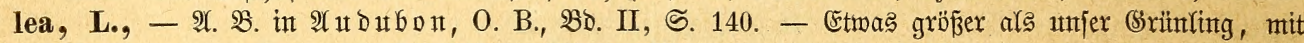

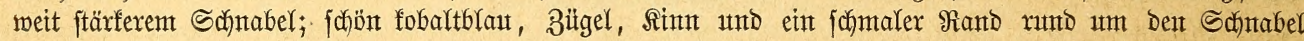

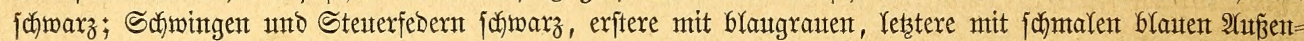

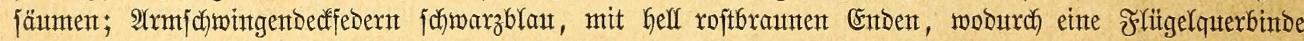
entfteft; obere Deleffedern Yebhaft faftanienbraun, bie fleinften Yängs des Ututerarntes und bie Utnterflïgel=

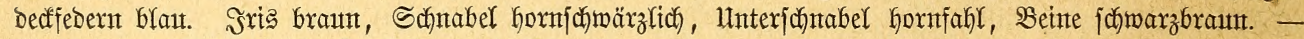
WSeibden roftbraumfahl, Sopffeiten unt Bürzel graublaut verwafchen, unterjeits lebhaft roftbräunlichgelb,

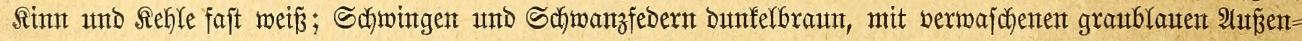

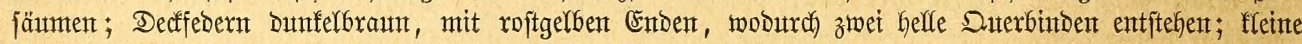
Dberflügeldeceffedern mattblatt.

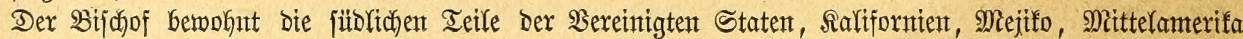
unto $\mathfrak{\text { Seftindient. }}$

249. Der Brangimpelfinf, G. (L., Fr., Coccothr., Coccob., Cyanol.) eyanea, L., (Brissoni). -

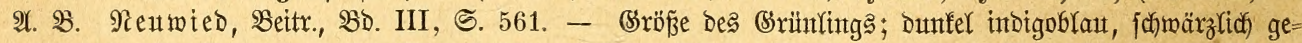

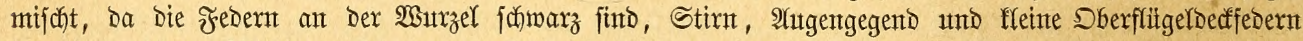

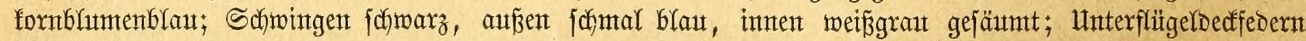

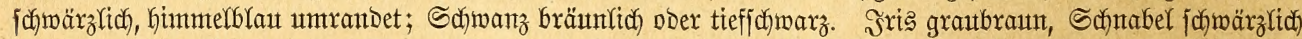

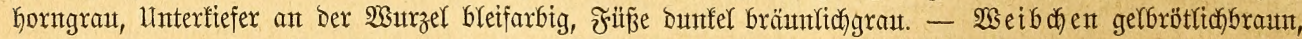

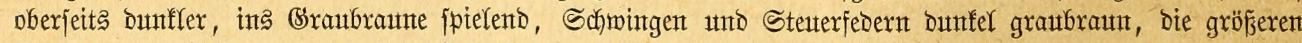

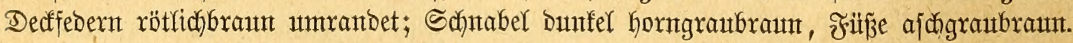

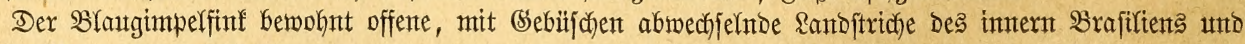
ebempo siana.

Won affen vorjtehento aufgefüfrten (Simpelfinfen fenten wir nut bie Rebensmetje bes

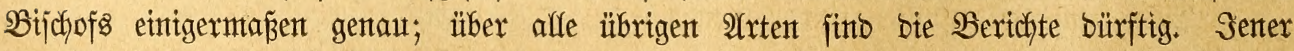
jowobl wie jein brajiltanijcher $\mathfrak{B}$ erwanoter wäblen jich zunt 2lufentbalte abgelegente, einjante, 


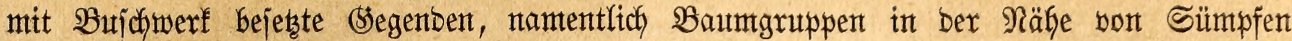

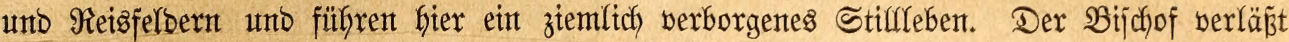
bas Rant jeiner Sceimat mit Beginn Des Winters, wanbert jüblich, bejucht babei bie

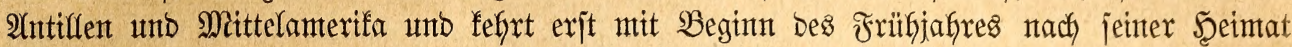
zurütć. Sn Routijanta ericheint ex ungefäbr in ber Mitte Des Miärz, und zwar wanbern

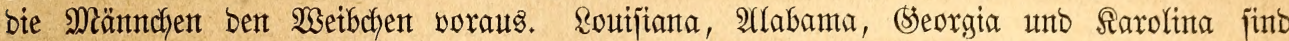
biejentgen Staten Norbamerifas, in benen ex am häuftgjten auftritt; nach Wepten fin ver= breitet er jich bis Sarifornten, und in Iejas ijt er bejonbers bäufig. Sint ober zwei

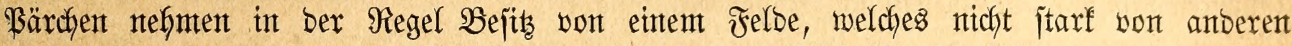
Bögelnt betwohnt wiro, juthen fich einten ber verborgenjten Büjche aus unt erbauten fict

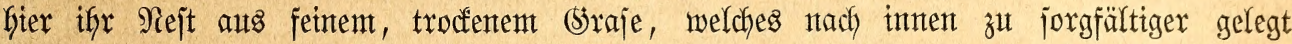
unto mit feinen Würzeldyen, trocfentem Mioje und \$Ferbefarent augigefletbet wirb. Das (selege enthält meijt vier Eiter, weldye bas weibchen allein ausbrütet, wäfrent das Männchen ficts bamit bejchäftigt, bie (Sattin zu füttern ober auf einem ber benachbartent

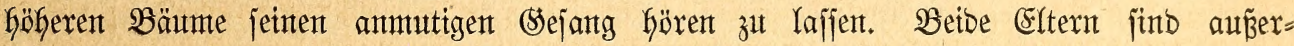

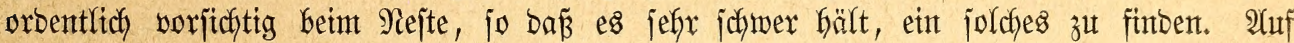
bie erjte Brut folgt genöhnlich eine zweite, währenboent fich bie Sungen mit anderen

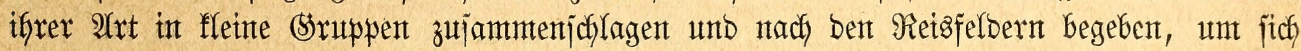
fier son bem forn zu näfren, nodh bevor es gereift ijt. AYuzerbem freffen fie bie ver= jufiebenjtent anderen Sämereien, insbejonbere bie ber (Srabarten, falfen autch mobl auf einem Maisfelde ein, ba bas farte Sorn biejes (stetreibes ifrem ftarfent Schntabel keinen

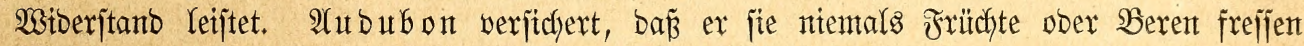

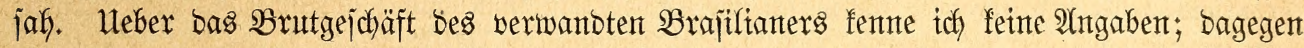
gibt (\$) nolach über Die Fortpflanzung Des Schwarzgimtels einen furzen Beridht. Das

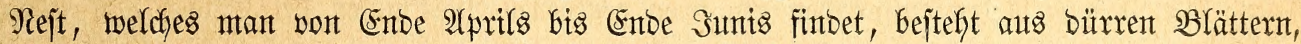
(Siras und Scaren, ijt grof́, oben ïberwölbt unb bat einen nach abwärts fich neigenbent jeitlichent Eingang. Die vier Eiter bes Beleges finto meiz mit rotbraunen und verlojchentent

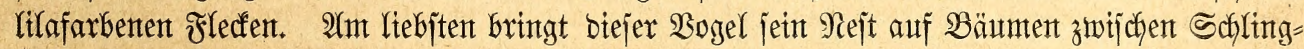
pflanzen ant.

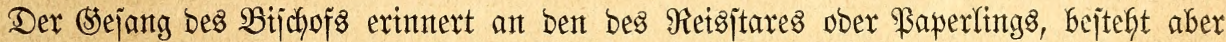
eigentfich nut aus einter ober zwei Strophen, weldye jefy häufig wieberfolt werbent. Bont

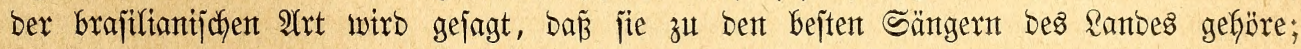

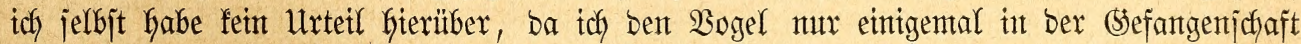
gejehen habe. Arffe Irten ber Srutppe Galten jich żemlich gut im Sä̈fige, verlantgen aber eine jorgfältige $\mathfrak{B f l e g e , ~ n a n t e n t l i c h ~ w a ̈ h r e n t o ~ b e r ~ M a u j e r . ~ M a n ~ e x t a ̈ b r t ~ f i e ~ m i t ~ v e r j c h i e b e n t e n t ~}$

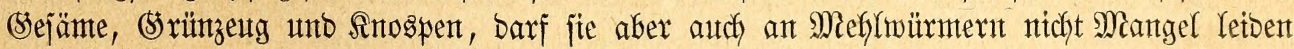
laffen, weil Yetztere zux Erfhaltung ifrex (Sejuntbeit unbebingt beitragen. Sung aufgezogente

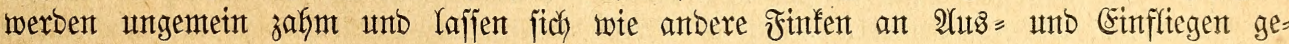

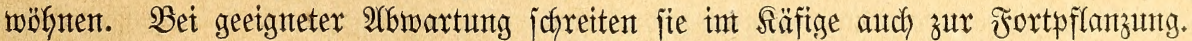

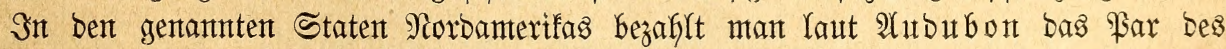

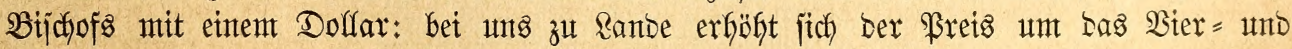
Fünffache. Zut bent regelmtäß̈tgen Ericheinungen bes Tiermarftes gefört ber 2 bogel nicht; noch viel jeltener aber fift man einntal einen jeinter $\mathfrak{B e r m a n b t e n t . ~}$

\section{faertituetier.}

Einer unjerer auffalfentiten Finfent gilt als bas Urbilo einter bejonberen, nicht ebent zaflreichen Unterfamilie, weldye in ber alten und neuen $2 \mathfrak{s e l t , ~ i n t s b e j o n b e r e ~ a b e r ~ i n ~ E u r o p a , ~}$ 


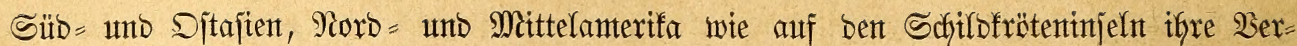
treter hat. Das Şauptmerkmal affer Gierher geförigen $20 ̈ g e l$ ijt ber ungemein bidfe unb fräftige Sdynabel.

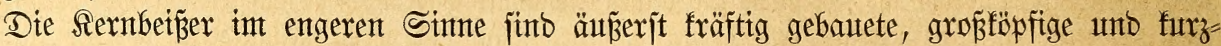

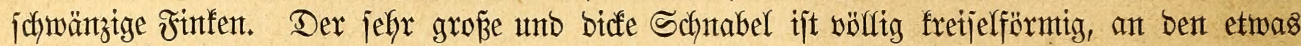
gebogenten, jharfen Sdynetben wentg eingezogen, nor ber Spike Des Sberjdynabels mit eintem

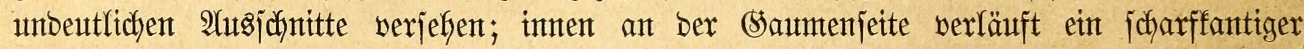

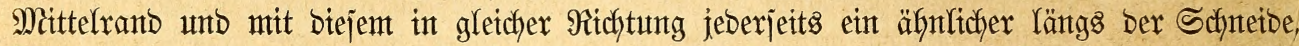

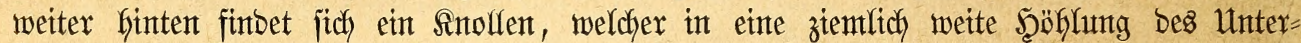

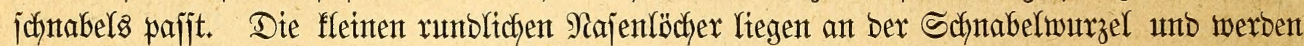

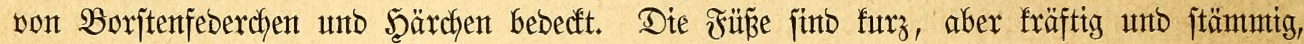

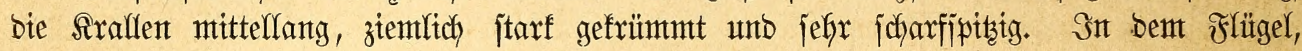
weldyer zujammengelegt ungefälyr bie Seälfte bes Sdywanzes bedft, verlängert fich bie britte Sdyminge über afle übrigen, unter benten eintige vor Der ftumtpjen Spitze eine eigentünltde

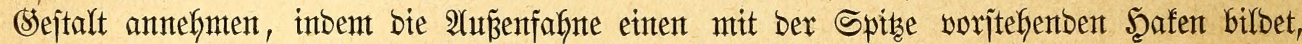

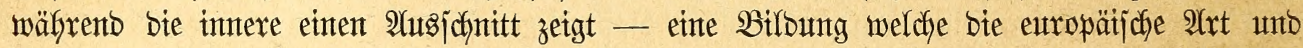

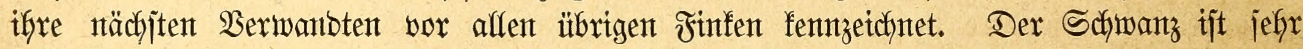
furz und in ber Mitte ziemlich beutlich ausgejdyntten; bas (Sefieber zetdyntet fich aus burch jeinte Dicfte und Weichlyeit.

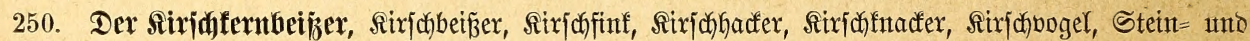

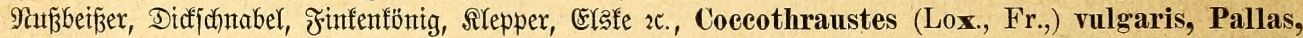
(coccothraustes, deformis, europaeus, atrigularis). - $\mathfrak{A} . \mathfrak{B}$. $\mathfrak{N a \Perp m a n n , ~} \mathfrak{B}$. D., $\mathfrak{B}$. IV, $\subseteq$. $435-$

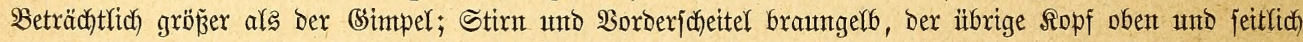

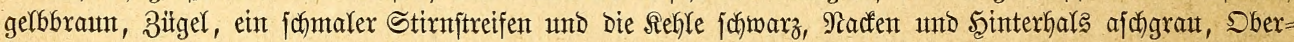

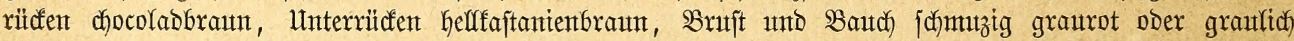

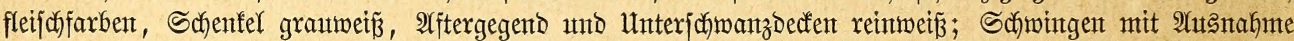

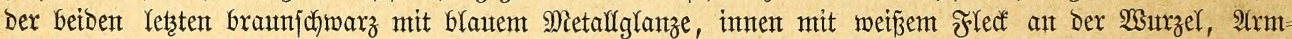

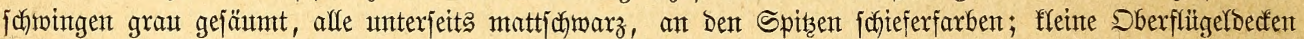

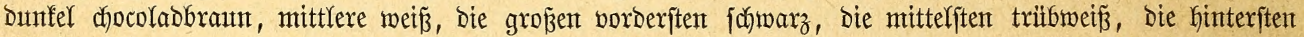

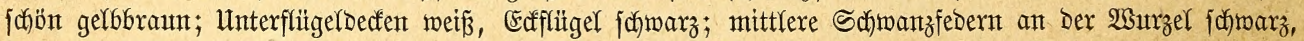

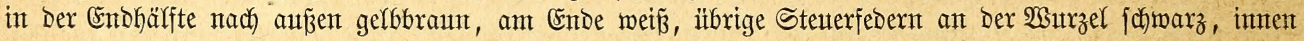

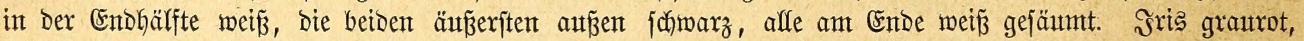

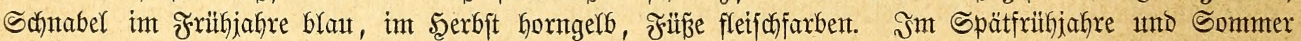

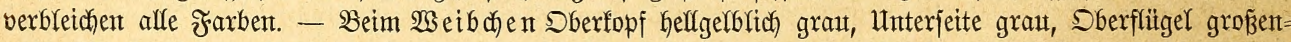

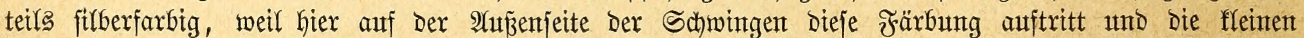

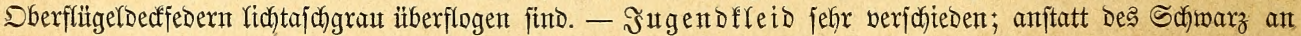

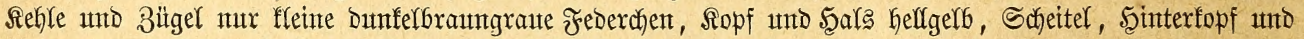

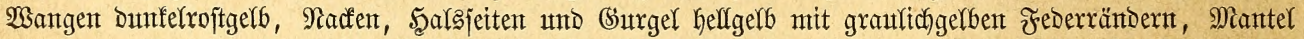

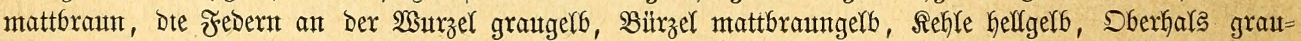

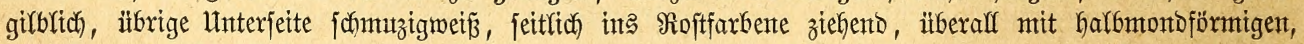
Duntelbrautnen Daterfledéten gezeid,ntet.

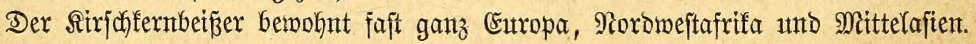

251. Der Magfenfernbeifzer, C. personatus, Temm. \& Schlegel. - A. $\mathfrak{B}$. Fauna japonica,

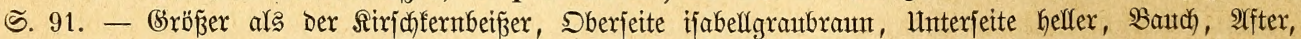

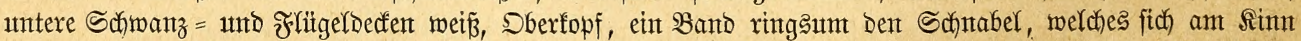

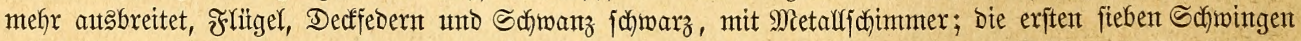

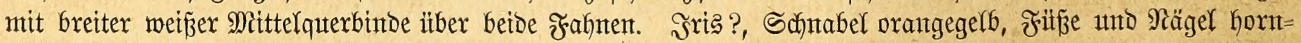

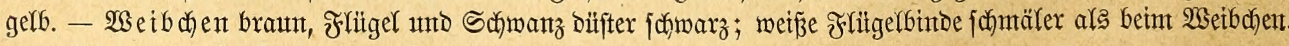

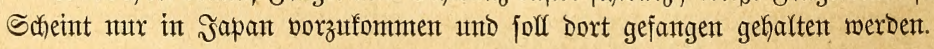

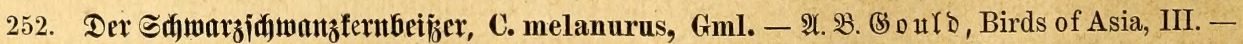

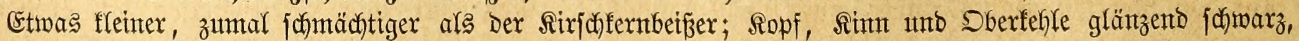

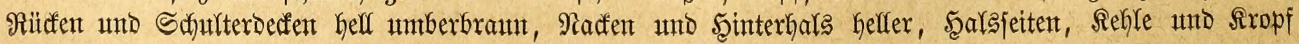


allntälig in Bräunlidugraut ïbergeheno, Bürzel ebenjo, obere Sdymanzodefen noch heller, fajt in Wein ber=

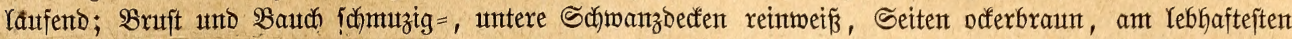

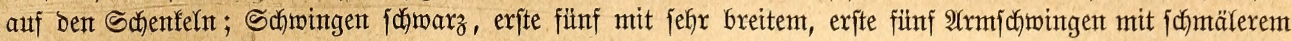

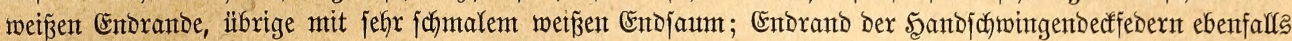

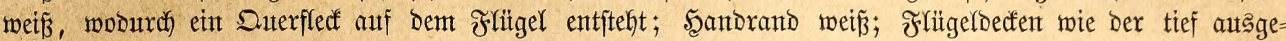

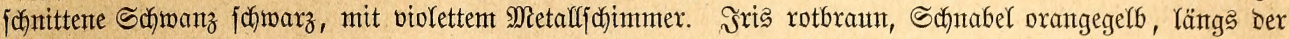

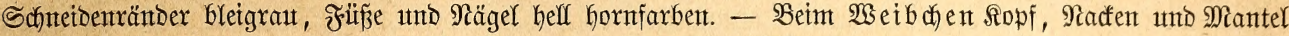

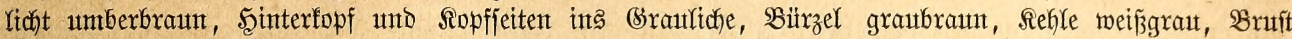

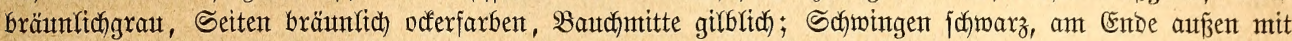

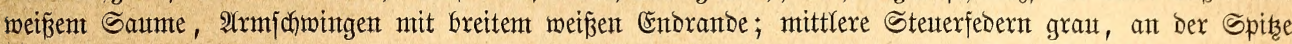

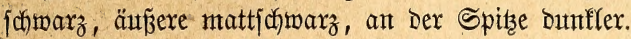

Das $\mathfrak{B a t e r t a n o ~ i f t ~ C h i n a . ~}$

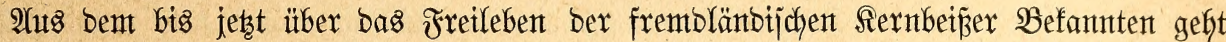

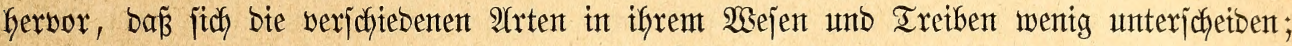

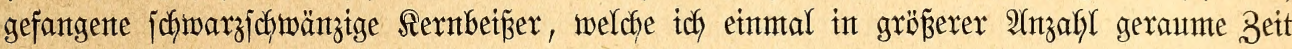
pflegte, bejtätigten vorjtebende 2 ngabe ebenfalls, jo baß wir ans einjtweilent auf einte ein= gebenbere Schjlberung ber Geimijchen 2 trt bejdyränfent bürfent.

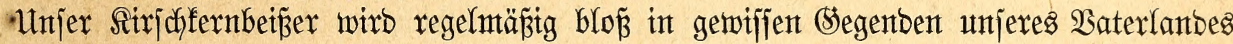
gefunben, insbejontbere in ebenten, an Baumpflanzungen retchen Stelänben, wo ex bann

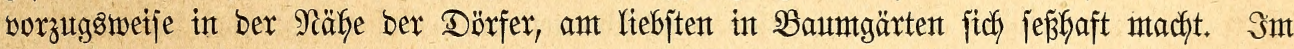

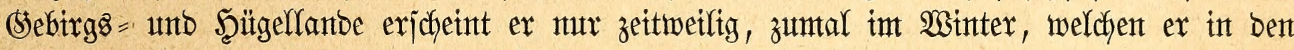
meijten Fällen int Baterlanbe verbringt. Sentau ebenjo ijt es int Norbent wie int Sïben

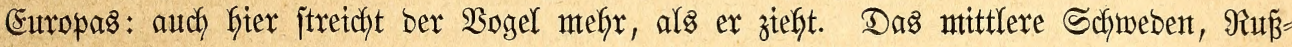

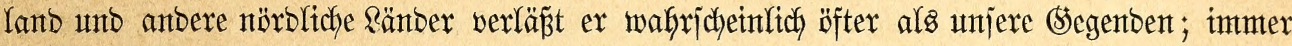

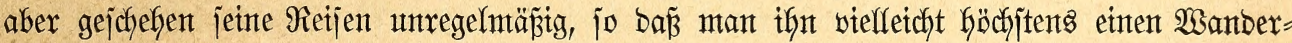

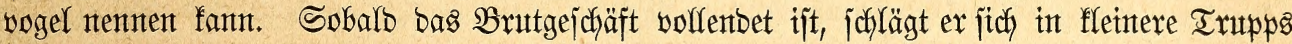
zujantmen und freift genteinjchaftlich int Ranbe umber, biejentigen Dertfichfeiten bevorzugent, weldye ifym bie meijte Niafrung beriprechen. Stelft fich raukeres Wetter ein, jo vereinigt

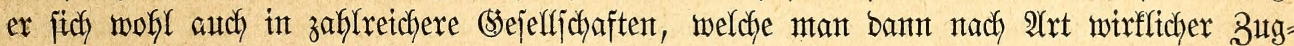

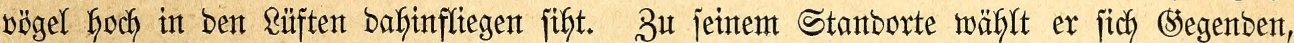
in benen bas Raubfolz workerjedt; int Nabelwalde wirb ex nicht ober body nur jefr jeltent

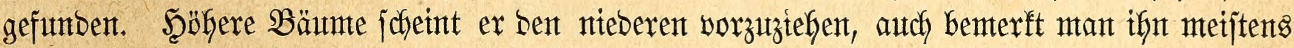

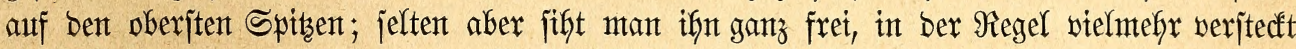
in Selaube: Denn er ijt unter alfen Umitänben vorjichtig unto traut ben Menjchen nie,

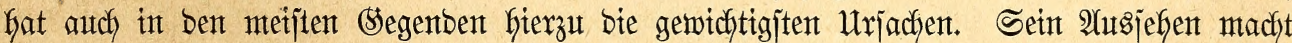

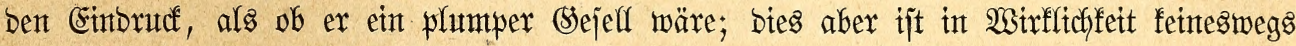

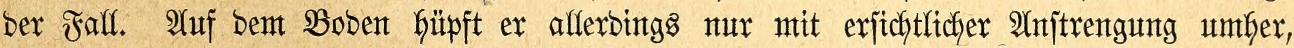

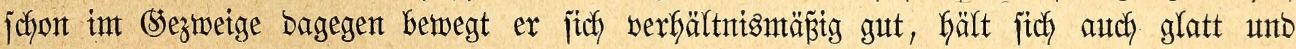

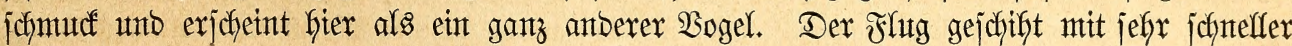
Flügelbetwegung, nutfweije in flachen $\mathfrak{B}$ ogenlinien, jcheint zu ermïben, wiro jeboch bentut = geadftet oft auf grope Strecfen in einemt Buge fortgejest. Der Rodfton ijt ein bohes,

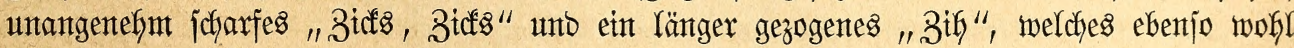
als Cintabung wie als Warnung bient. Won eintent (Sejange fant mant eigentlich nticht reben,

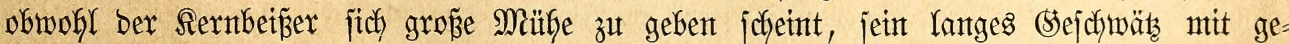

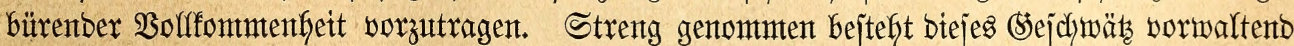

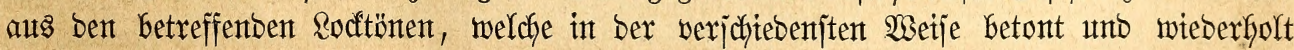

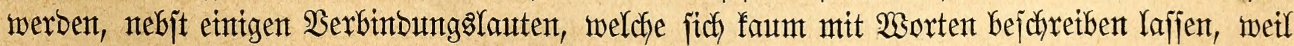

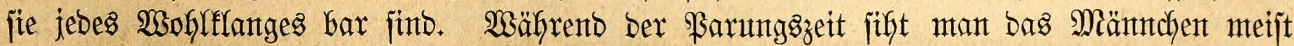

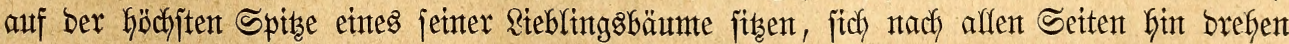

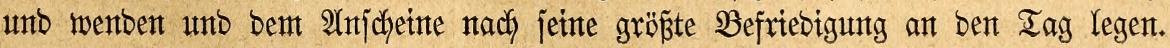




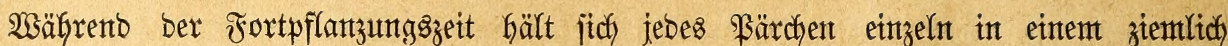
umfantgreidgent Ssebiete auf, befijen Mittelpunlt ein ober meffrere höbere Bä̈tme bitben, uñ bertreibt aus biejent jebes andere Pärchen, weldeses fich etwa eimniften müüte, mit größ̈ter

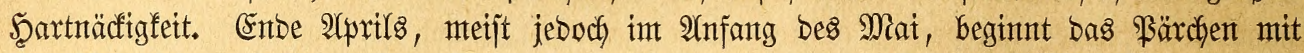

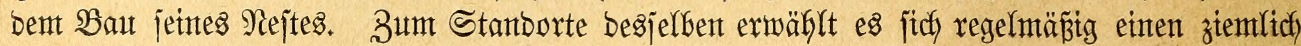

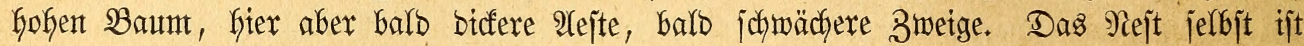

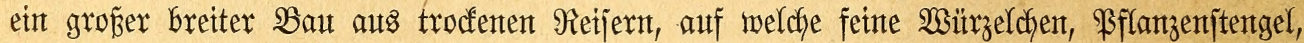

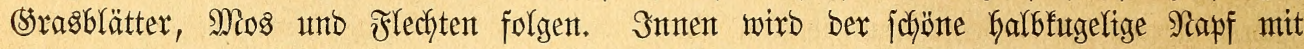

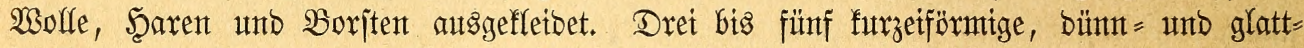

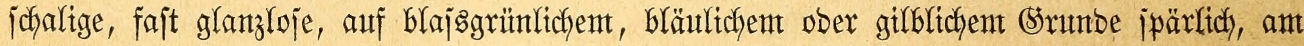

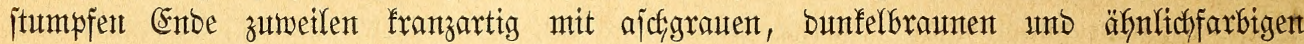

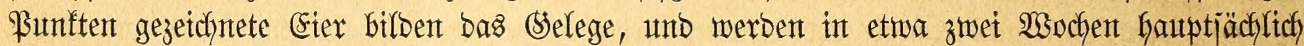

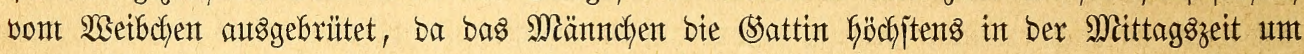

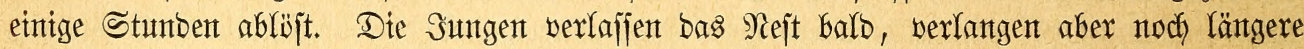

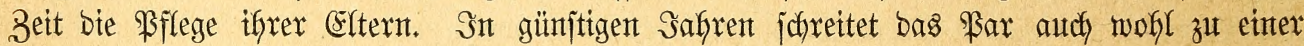

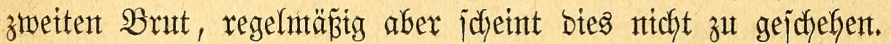

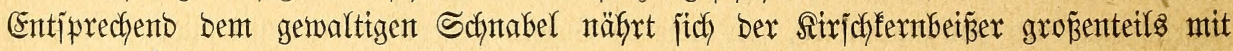

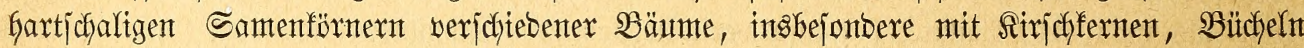
und bent Samen bes 5̧ornbaumes und. Felbaforns, autserbent mit Baumfnospen, einzeftnen

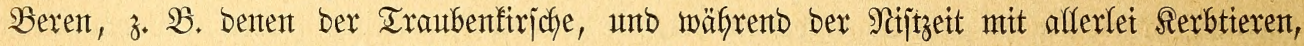

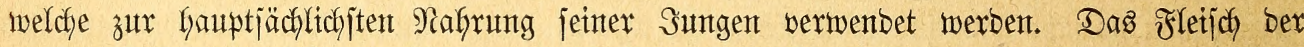

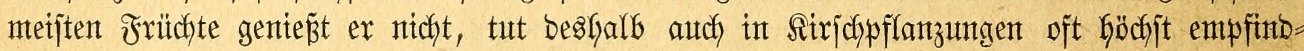

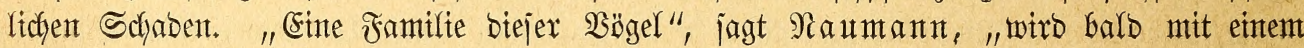

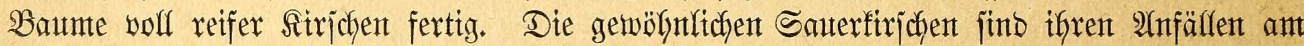

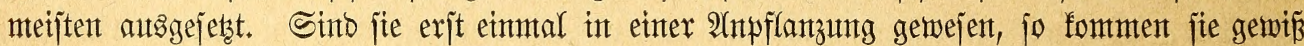
immter nteber, jo lange es nodh bajelbjt Sirrjchen gibt, unto alles Rärmen, STappern, Feitjchent=

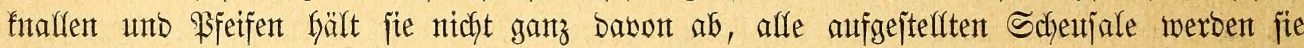

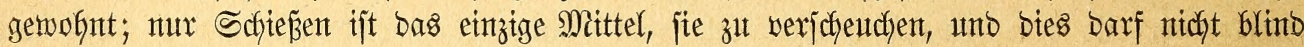

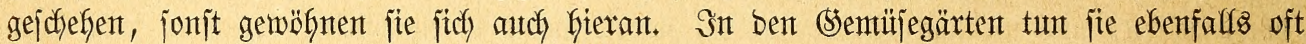

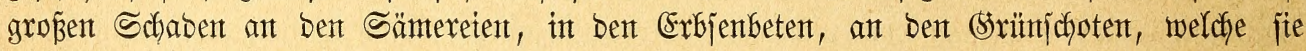
ungemein gernt frefifent unb von benen mant fie nur mit Stemalt abzuffaltent vermag. Sie zerjchrotent Dent Säger jeine Berent auf Dent EGberejđfbäıment, welche er für bent Winter=

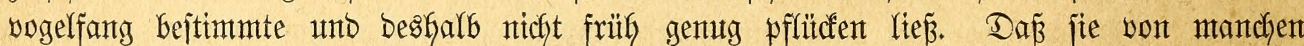

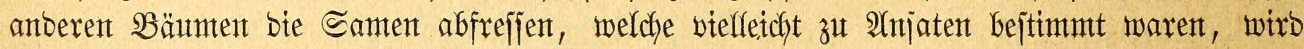

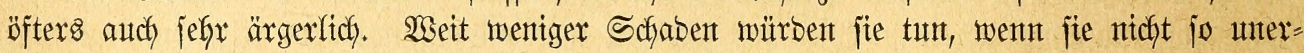

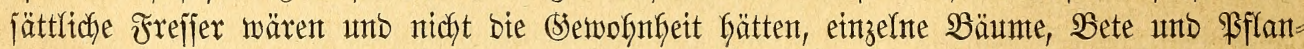

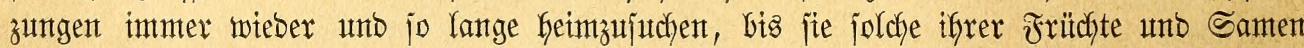

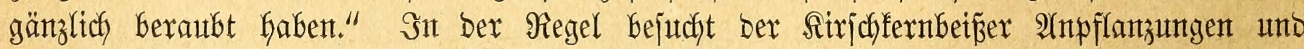
(särtent familientweije, jammelt jich Gier aber, went mant ifgnt nicht vericheutdot, manddyntal

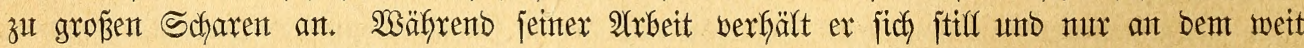

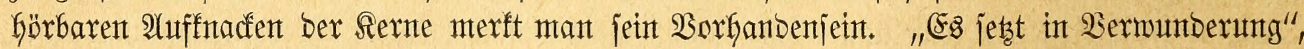

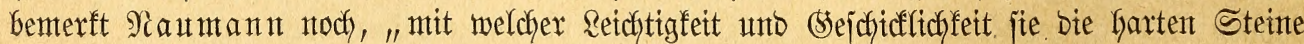

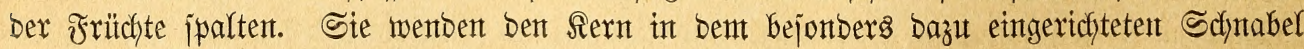

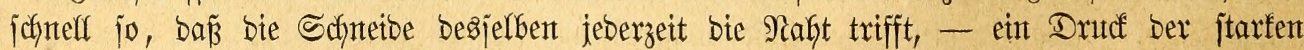

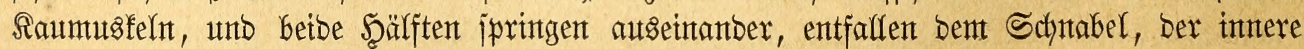

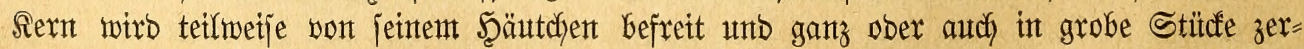

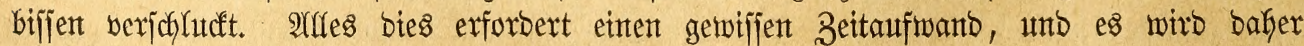

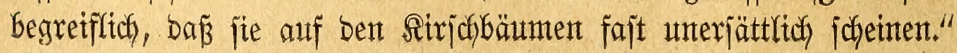




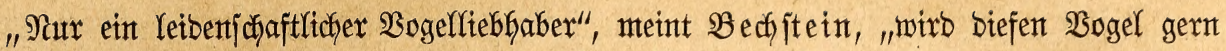
in ber Stube jehen. Sch für meine \$erjon fann igh nidft Yeiben, bejonbers wegent jeiner

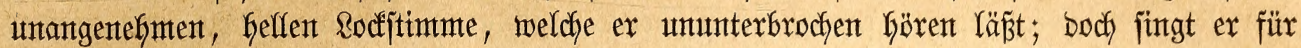

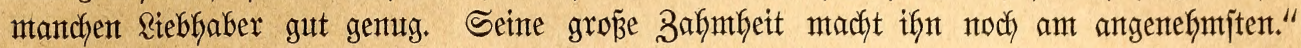

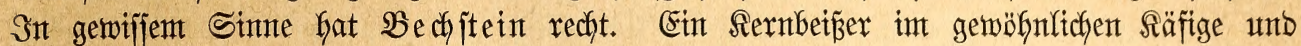

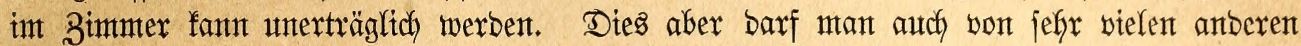

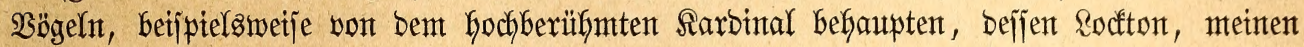

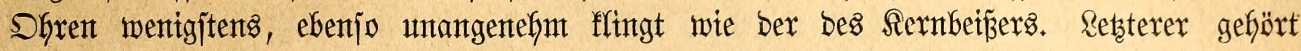

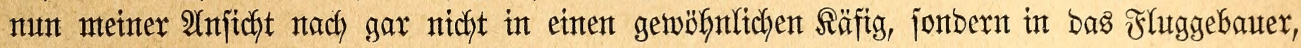

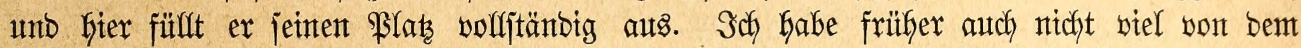

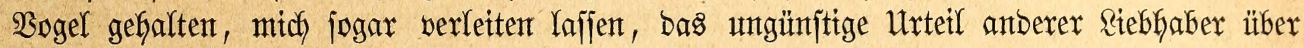
thn wieberzugeben, netterbings aber ununterbrochent mtefrere Rerntbeiß̌er in

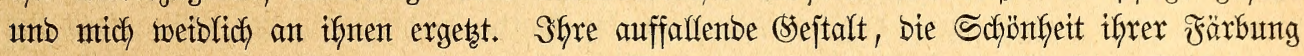
uno Zeichnung, bie Etgentüntlidffeit ifyrer Bewegungent unt ber unzerfẗ̈rbare Ernjt poer

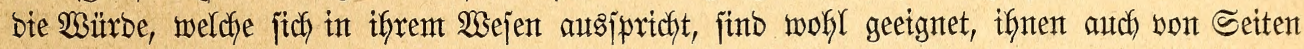

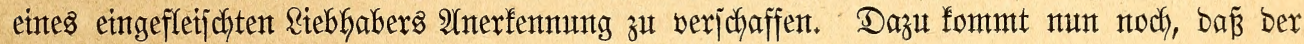

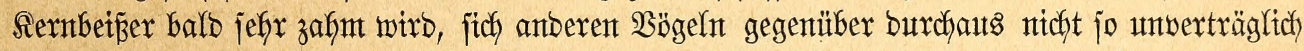

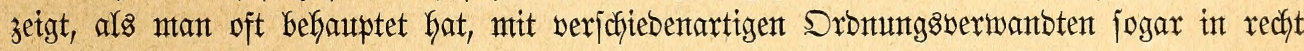

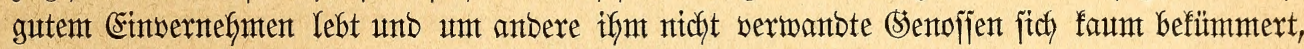

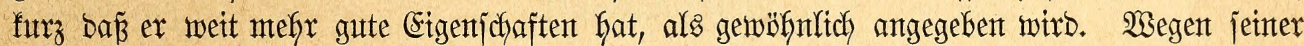

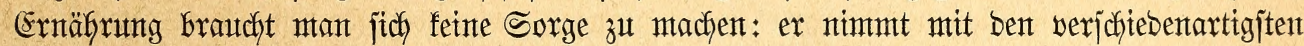
Sämtereien fürlieb, iłt burchaus fein ftarfer Frefijer, unto verfangt nidftę weiter als einen

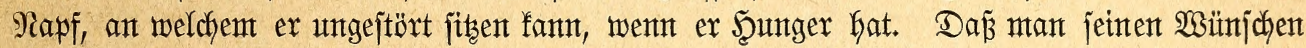
einigerntaßsen entgegentommen, ifgnt numentfich Zwweige mit Sinospen, int Sonmer reife

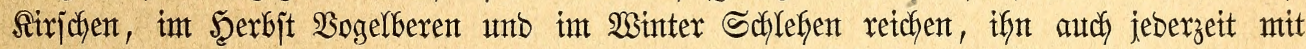

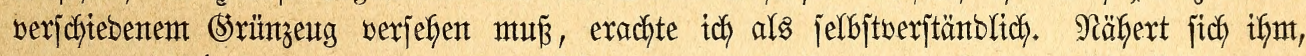
went ex frişt, eint anberer $\mathfrak{S}$ ogel bes ffhtggebauters, jo frauft er aflerbings bie Stirnfebern

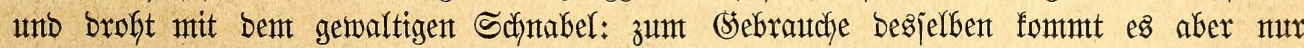

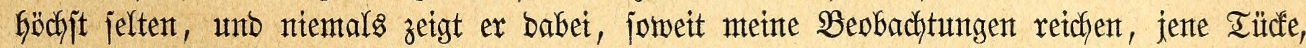

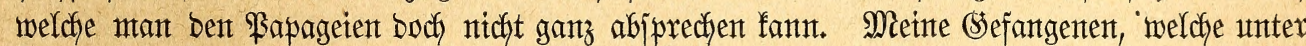

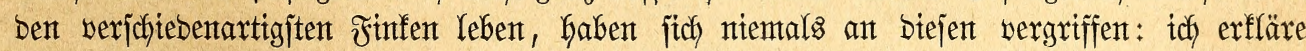

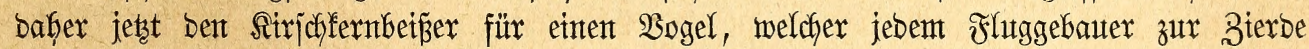

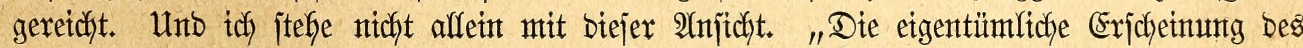

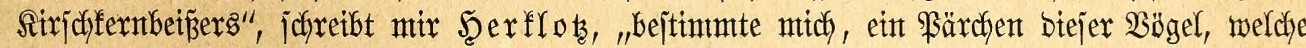

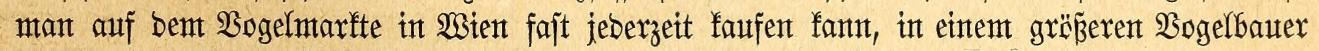

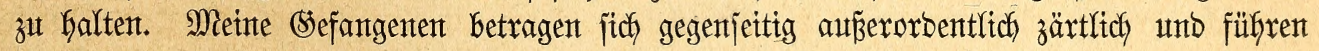
ein Reben wie juntge Egeleutte in ben Flitterwochent. Sebe ifyrer Stellungen, unt nicht zut

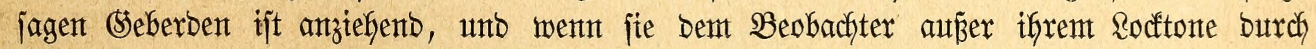
etwas läjtig werben, jo ift es ifyre Sieberfichfeit beint Frefifen, namentfich bas Untherwerfen ber ausgefreffenten Schalent ifres Futters, mit betten fie einen grofét Teil bes Bimmers

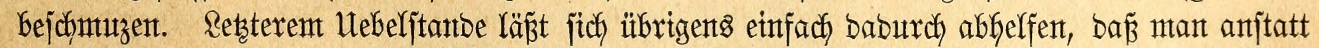

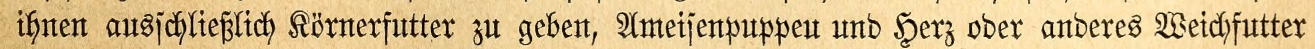

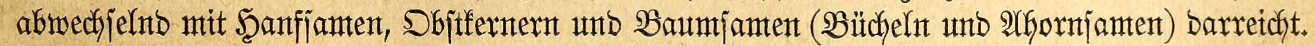

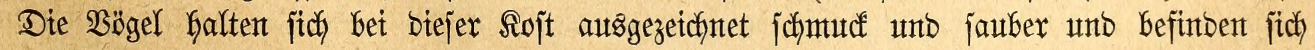

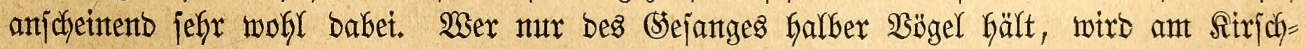

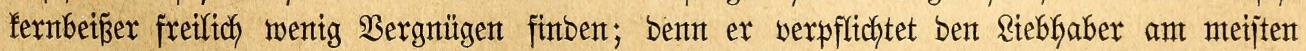
zumt Danfe, went er fodweigt, unto fant einen gegen fich auffringen, went er verjutcht,

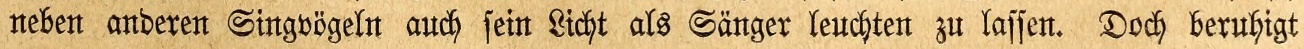


eint ïber ben Säfig getworfentes Tuth ja ntdyt blo marumt arjo ifyn jobelten?"

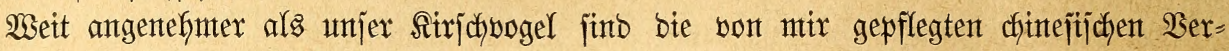
manbten. In ifyrer jchututen Sealtung, ifren Bemegungen exintern fie eintgermaß̧en an

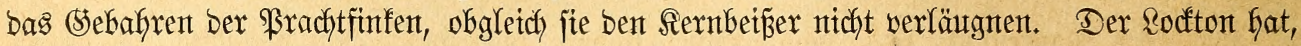
jo viel ich mich entfinte, nicht bie unangenthme Schärfe wie bet bent $\mathfrak{B}$ erwandten; einten eigentlichen (Sejantg aber habe ich von jentem ebenjo wentg gefönt wie von biejem. Metne

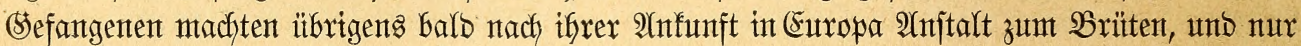

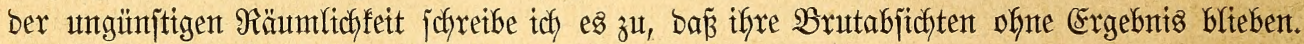

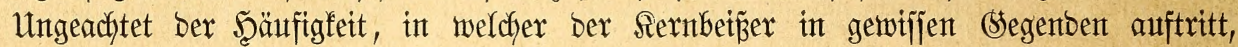

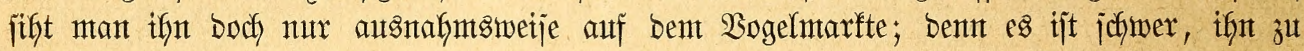
berütfen. Demgemän pflegt ber $\mathfrak{B r e t s}$ auch jtets ein ziemlich hoher zu jein: 20 Sgr. bis

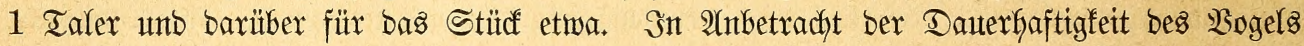
fant man eine joldye Simmte freilidy jefr gern ipenden. Die übrigen âtrten bürfen mit

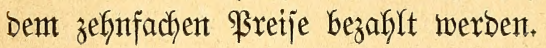

\section{(ridelfinkent.}

In Der Unterfamilte ber Finfen (Fringillinae) ftelfen wir bie Ebelfinfen (Fringilla) oben an. Sie fint gejtrecft gebaute, woblgejtaltete $\mathfrak{B o ̈ g e l , ~ m i t ~ m i t t e l = ~}$ jtarfem, rein fegel= ober freijelförmigem Sdynabel, beffen oberer Ieil an Der Spibe nur

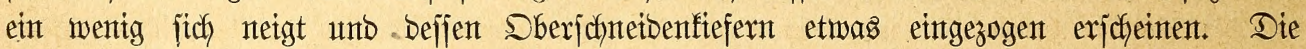

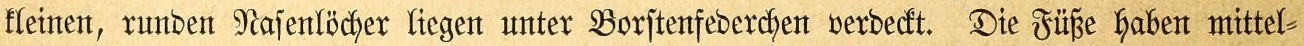

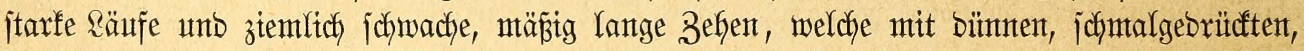
jetcht gefogenen, unten zweijdyneibigen, iptzigen Nägeln bewehrt werben. Sn bem ziemlich) langen Flügel, maldjer zujammengelegt ungefähr bie Şälfte bes Sdymanzes bedt, finto bie

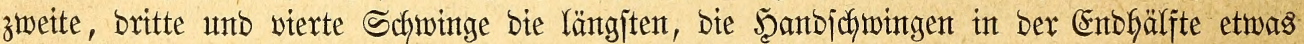
verjammälert und jałmal zugerunbet, bie $\mathfrak{A}$ rmjchningen breit, am Ende fajt gerabe und eit wentg ausgejchnitten. Der mittellange Schwanz bejteft aus breiten Febern, welche in ber Mitte jidy etwas werfitrzen. Das Sefieber ijt weber bejonbers retch, nody fnapp uno wirb

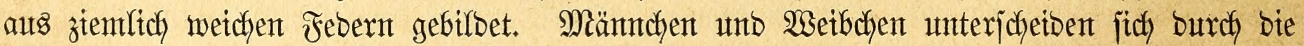
Färbuntg; bie Sungen ähneln Dem Weibchen.

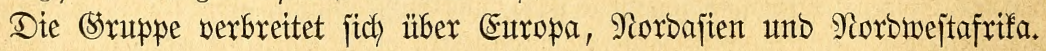

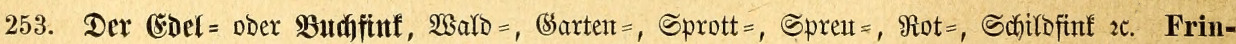
gilla (Passer, Struthus) coelebs, L., (sylvia, nobilis, Spiza). - A. B. Nautmann, $\mathfrak{B}$. D., $\mathfrak{B}$ D. V,

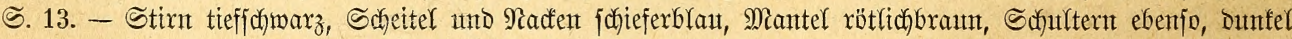

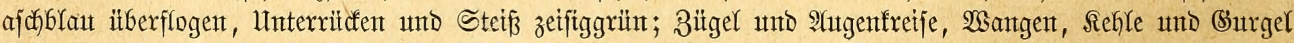

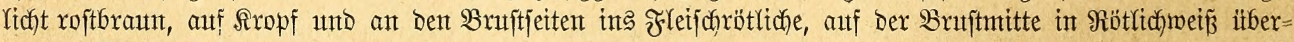

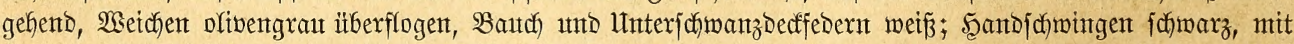

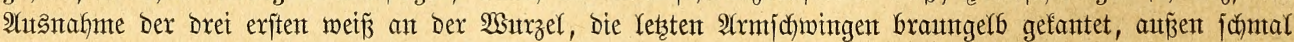

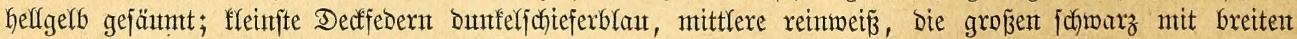

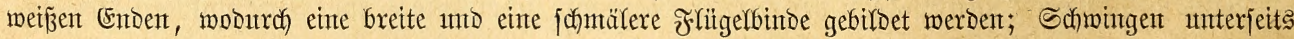

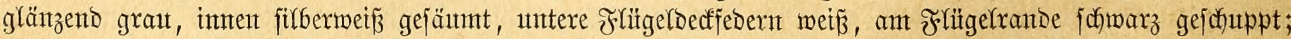

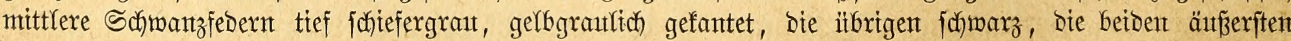

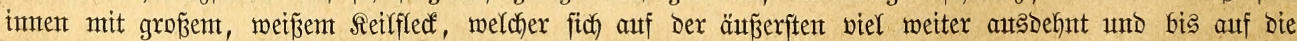

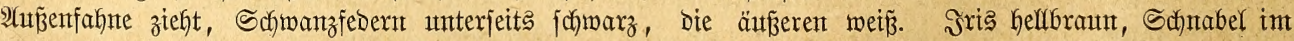

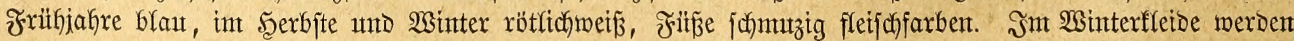

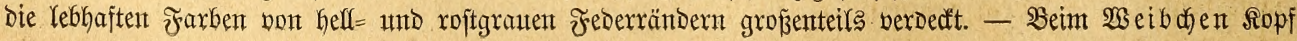




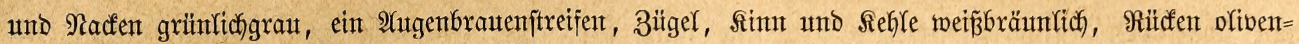

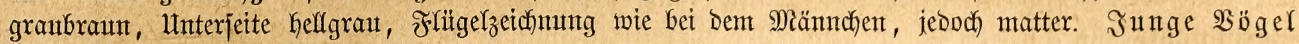
Dem $\mathfrak{S e i b c h e n ~ a ̈ h n l i c h ) . ~}$

Dex EDelfint verbreitet fich über ganz Europa bis zum 65. (Brabe Dex Breite, fommt autch in einzelnen

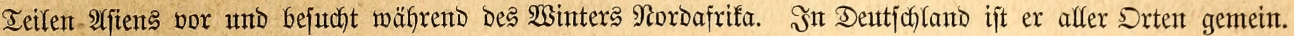

254. Dex Mautenfinf, Fr., spodiogenia, Bonap. (africana). Dem Eedelfinfen jefrx ähnlich,

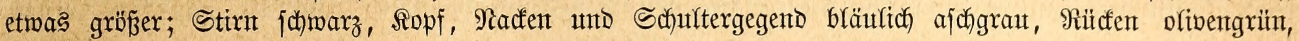

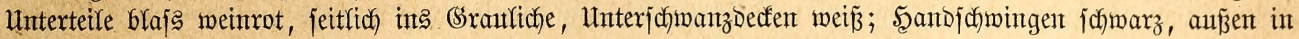

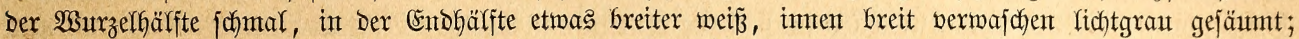

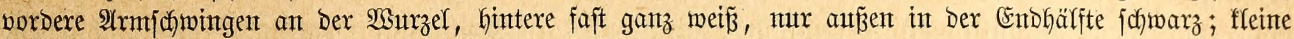

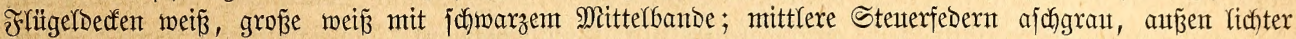

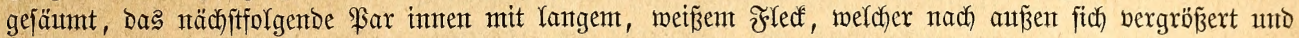

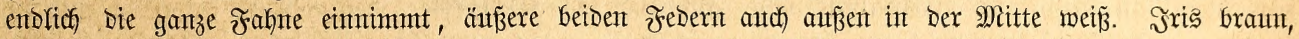

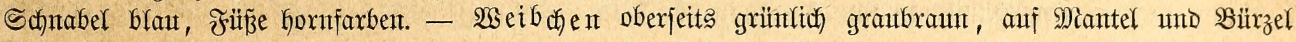

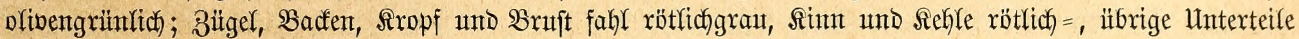

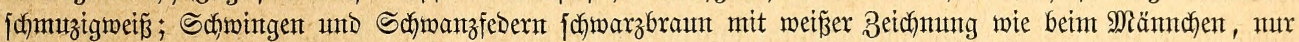

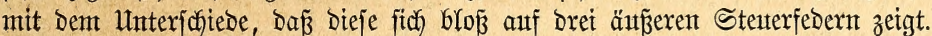

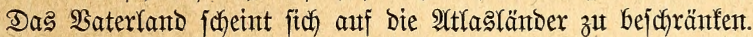

255. Der Rorberfinf, Tintifron Der Ranarier, Fr. canariensis, Vieill., (tintillon, Moreletti). -

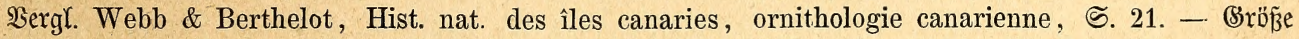

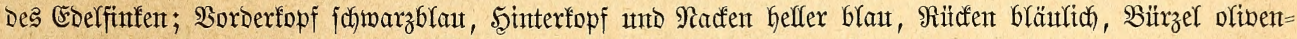

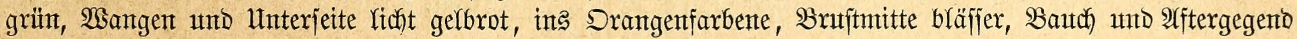

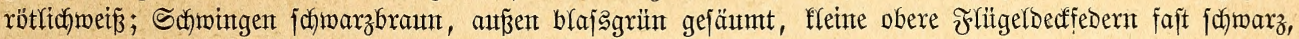

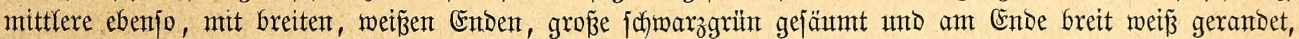

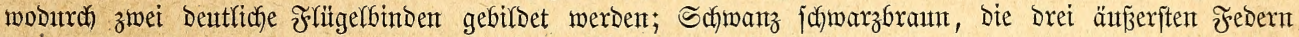

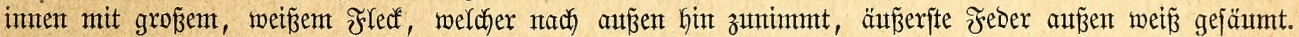

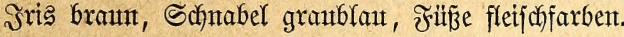

Dex Tintillon bemohnt in zaflreicher Menge bie Göheren Sorberwaldungen ber fanarifden Injeln, fommt im Winter biß in die Bärten ber tiefer Yiegenden Drtjchaften Kerab and wird dann, Yaut Borre, zumeilen gefangen und im Räfige gehalten.

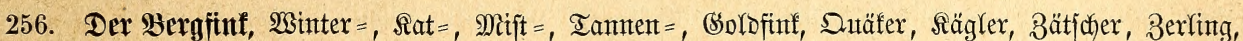

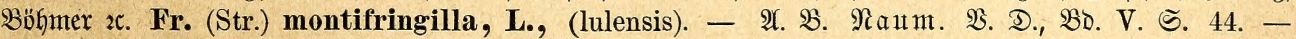

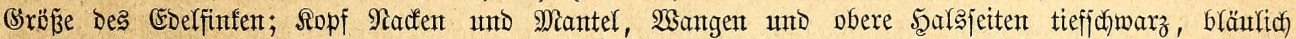

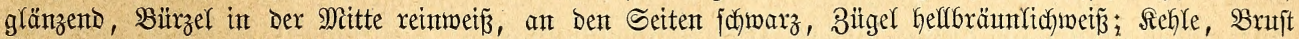

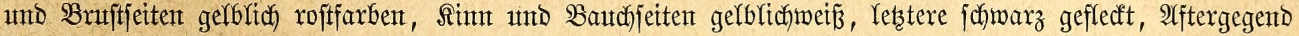

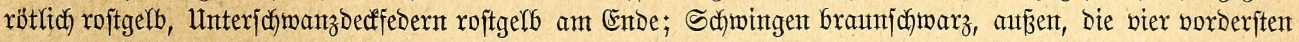

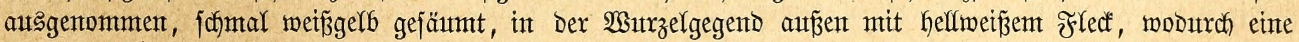
Binde gebilbet wird; Shullterfedern gelblich roftfarben, fleine Decffedern etwas lichter, Dunfelpomeranzen=

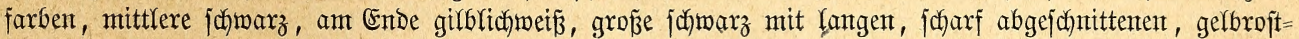

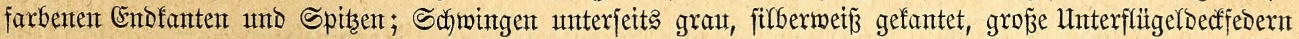

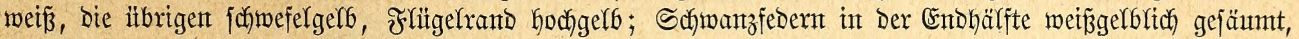

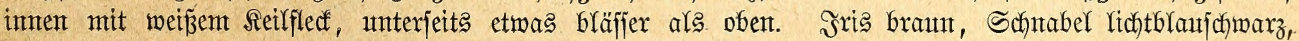

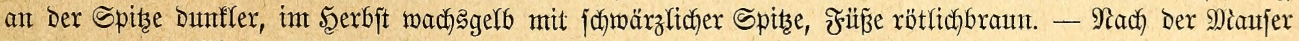

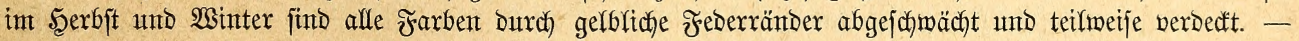

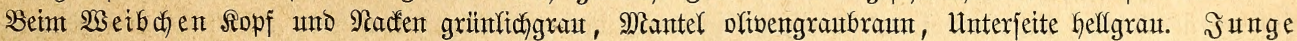
Böger dem Weibchen ähnlidó.

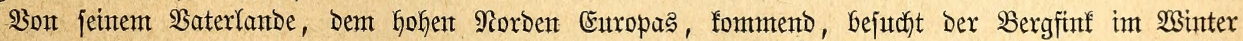
regelmäßjig Deutjăland und ftreift unter Itmptänden bis Sildeuropa Ginab.

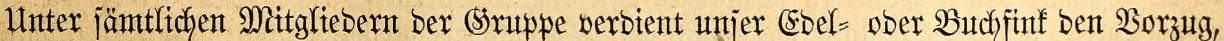

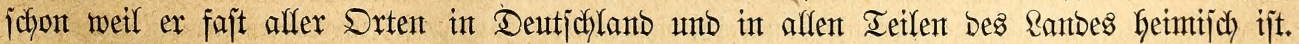

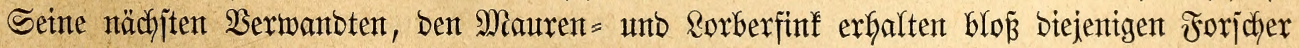

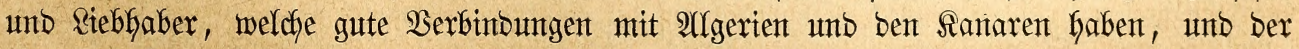
Bergfinf fant jich nur in ber Sdjönffeit jeines. Seffebers, feinesmegs aber in jeinen Eigenichaften mit jenem mefien. 


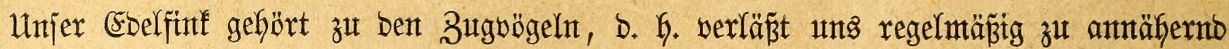

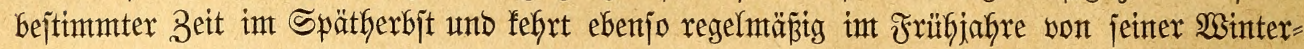

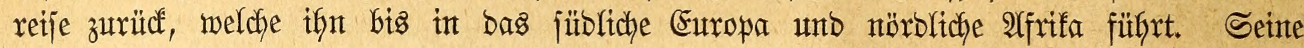
Bertreter in 2 flgerien unt auf bent fanaren jcheinen nicfst zu wanbern, jonbern mur Stridf)= vögel zu jein, weldye während bes Winters aus ben höheren Bebirgsmaldungen in bie Tatefe Gerabfonmen. Insbejonbere gilt bies für ben Iintiflon, welder, laut Borfe, bent Sürtel Der Şetben und Rorberen auf Den fantarijchen Snjeln bemofhnt, an manchen Srten jefy häufig auftritt unb fich mit $\mathfrak{B}$ eginn bes Winters in bie wärmeren Iäler herabbegibt, Dort

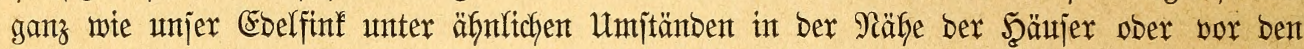

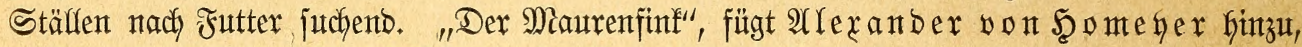

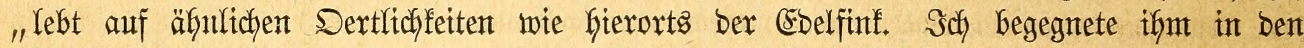

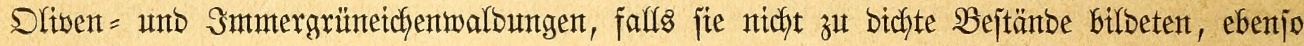

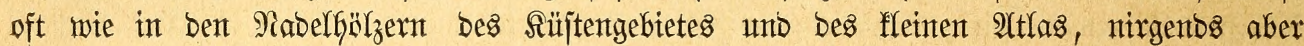
bejonbers Gäufig." Der norbijche Bergfinf, melcher erjt jenjeit bes 65 . Srabes jeine Seimat, D. h. jeine SBrutjätte Gat, rottet fich an ihx bereits im 24ugujt zujammen und wanbert mut gemächlich weiter unb weiter nach Silben finab, bet unts in ber Regel Enbe Septembers und im Dftober erjcheineno und in Sejelfichaft von Ebelfinfen, Seänflingen, Almmern, Felbjperlingen $2 c$. jo lange verweilend, bis die jtrengere Sälte eintritt uno er ge= nötigt wirb, in tieferen Sïben Europas, Sriechenlant, Stalien und Spanien, eine geeigntere Serberge zu juchen. Ebenjo langjam, ałs bie Şinreije gejchitht, fehnt ber Bergfinf vom

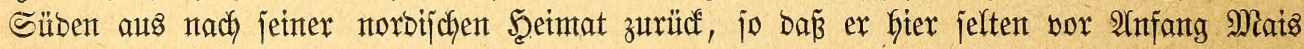

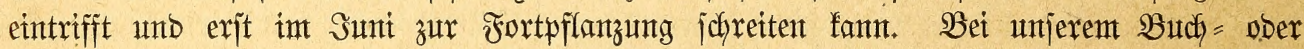
Ebelfinfen ift ber $3 \mathfrak{u g}$ meit regelmäpitger. Ânfangs September fammelt er fich mit anberen Seinesgleidyen zu Bejellichaften, jchweift mit biejen in ber Sceimatgegend umber, jutht bie Felber nach Unfrautjämereten ab und madft fich gegen Enbe bes genannten Monats lang= jam auf bie Reije. Sn Den Minnat Sftober fällt ber Şauptzug; gegen Enbe besjelben itht

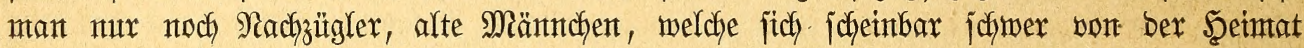
trenten fönnen und ben Weibchen und Эungen nachmantern, wie fie im Früfjahre auth etma umt viexzefyn Iage früher als ber Şauptzitg in bex Şeintat mieber exjdyetnen. In

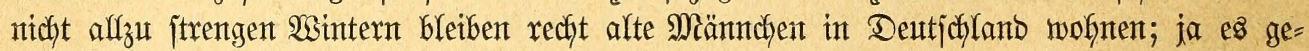

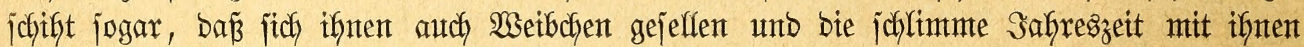
verleben. In $\mathfrak{B e r l i n}$ gibt $\mathrm{eB}^{\mathrm{B}}$, wie Freund $\mathfrak{B}$ orle beobadjtete, affminterlich männliche Jinfent,

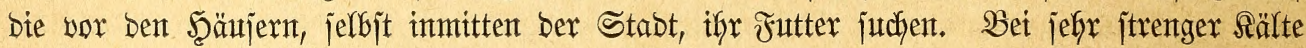
barben jie freifich jefy und entjcyliezen jich bann jogar (sberejchberen, welche jie jonjt Durdjaus nicht lieben, zu verzehren. AYu bem 3uge fiht man fie oft zu vielen Iaujenben vereinigt, in bent frïhejten Morgenjtunben hoch burch bie Rüfte fliegent, weber gebrängt noch zeritreut, einten zu= jammengefjörigen Sdymarm bilbent, in meldyem ber einzelne nodh nidft jeine volle Selbjtäntbig= feit aufgegeben hat; in ben Mittagsftunben jenfen fie fich auf bie Felber Gerab, um zu frefjen,

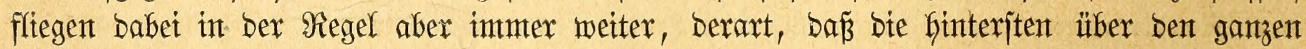
Schmarm megrüdfen und jich vor bemjelben wieber nieberlajjen und jo fort. Nar bei ftürmijicher Witterung und ungünjtigent Winte D. W. joldyem, weldjer ifnen von finten ints Sefieber bläjt,

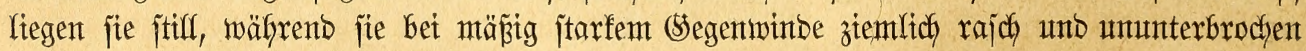

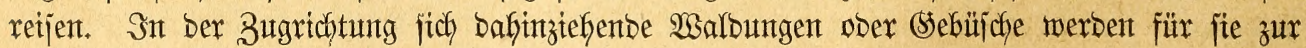

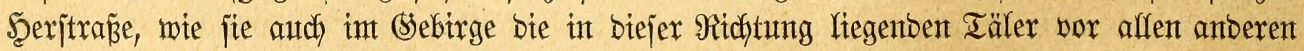

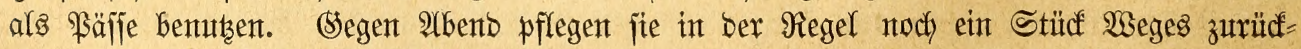

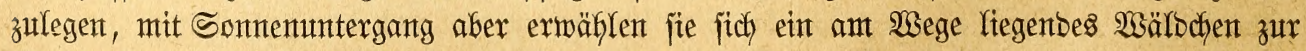
Nachtruke, oft int Semeinjchaft mit Şänflingen, Beifigen, Bergfinfen uno anberen Bögeln. Sobald das Jrühjafyr es gejtattet, ftelfen fitch bie Miänndjen nieber in ber J̧eimtat ein, 


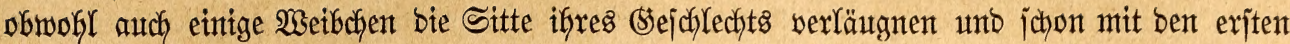

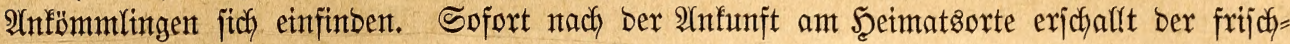
fröbliche Sdflag ber Ebelfinfen won ben $\mathfrak{B a ̈ u m e n ~ K e r a b , ~ u n t ~ j o b a r b ~ b i e ~ W S i t t e r u n g ~ e i n i g e r = ~}$

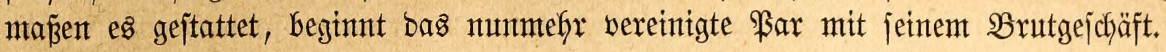

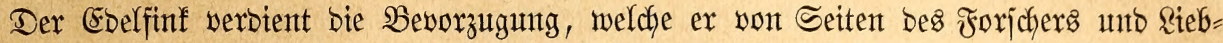

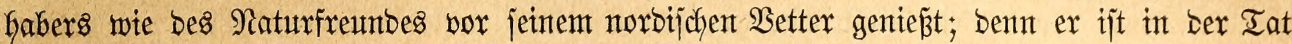

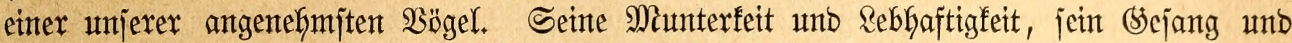

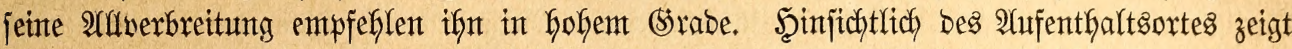
jich faum ein anberer $\mathfrak{B}$ ogel jo genügjant wie er: mant finbet ihgn Gutchjtäblich überafl, wo einige Bä̆me zujammenitefher, imt Sarten Des Dorfes oder jelbjt ber wolfreidjen Stabt

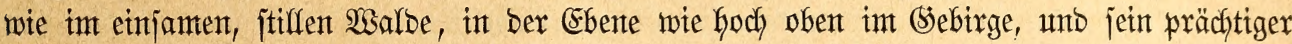

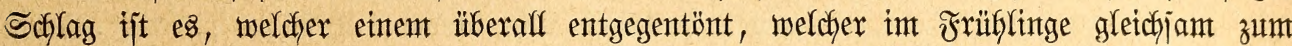

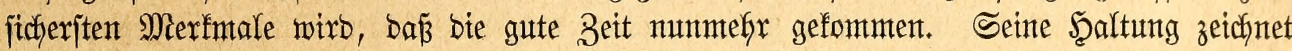

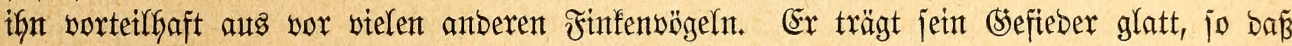

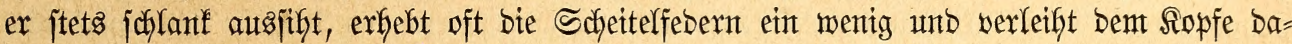

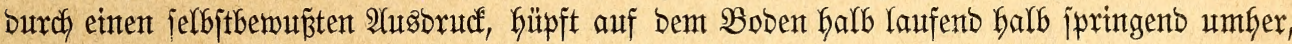

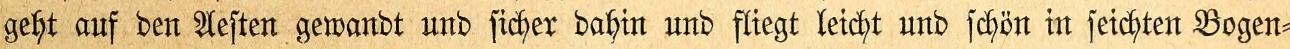

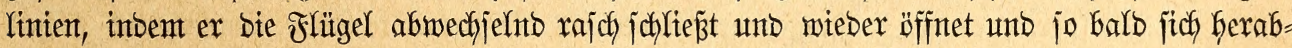

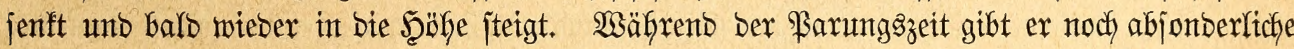

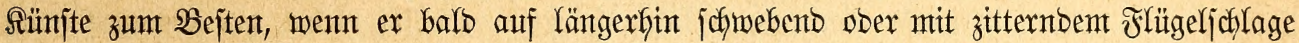

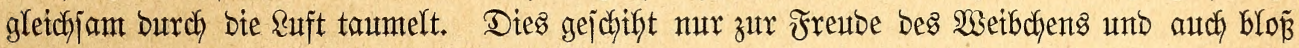

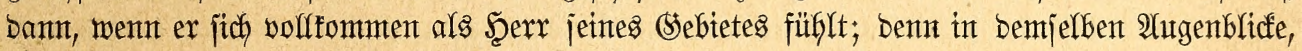

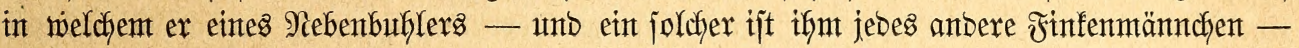

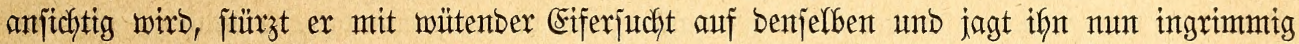

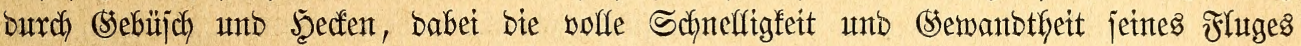

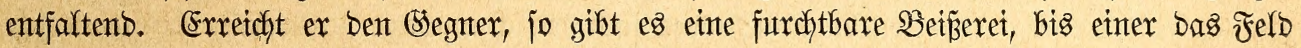

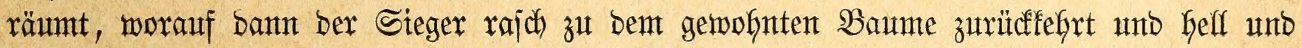
freubig einen Siegesejejang won wben Gerabjeyntettert. Der gewöbntliche Finfengejang iit jo

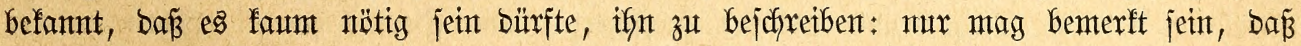

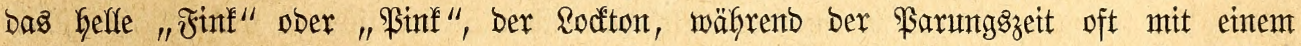

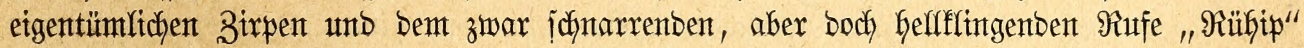

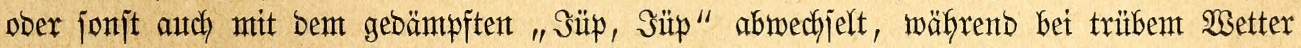

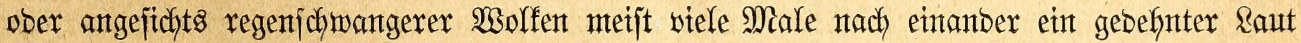

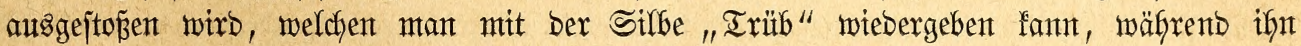

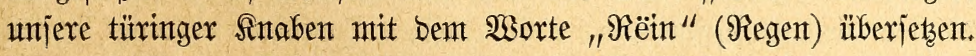

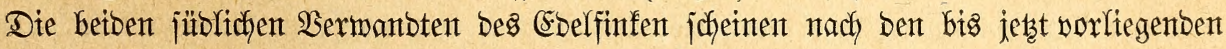

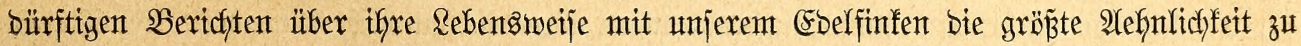
faben. Son bem Reben und Ireiben bes Rorberfinfen wififen twix alferbings nodh gax nichts;

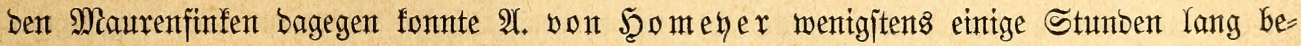
obachten. "Der $\mathfrak{B}$ ogel", jagt er, "î́t nicht affein größerer als unjer Ebeffinf, jonbern auch

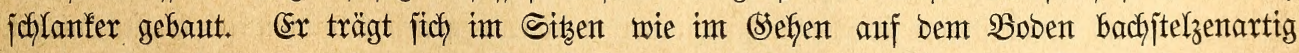

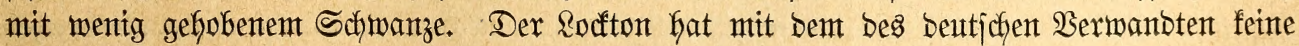

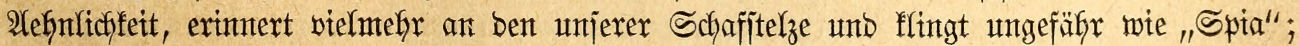

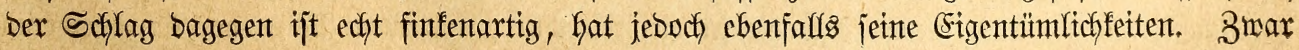
erfennt man in ifm fofort bas sied eines Ebelfinfen; bod merbent bie einzelnen Silfen

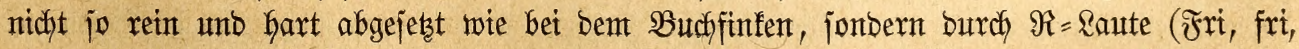

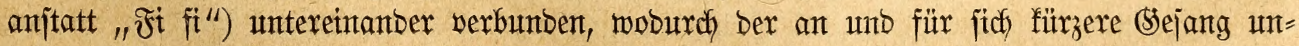

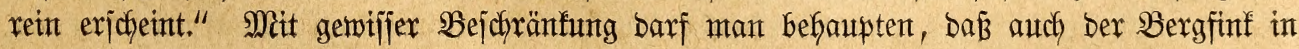


jeiner Rebensweije mit bem Ebelfinfen übereinftinnt. Snzbejonbere gilt bies für jeine

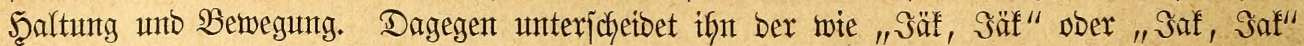

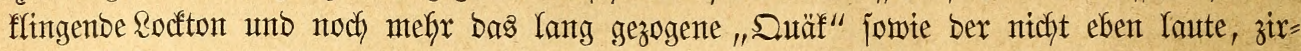

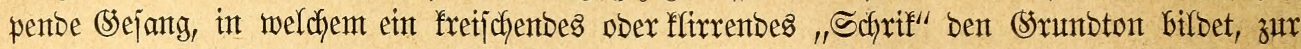

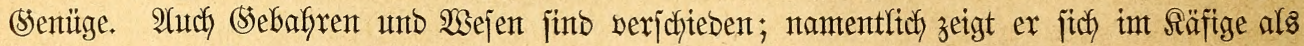

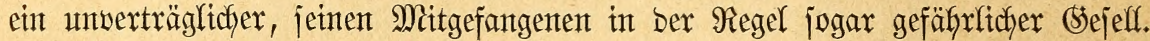

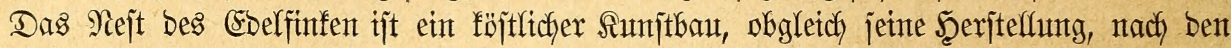

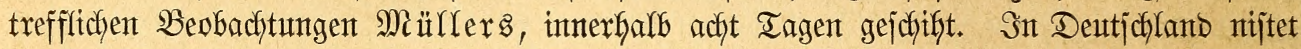

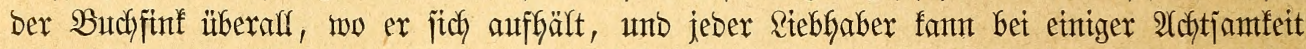

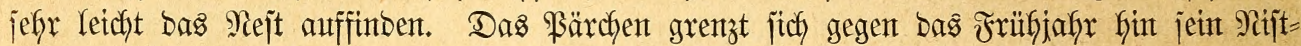

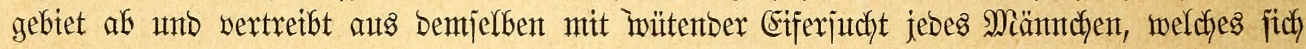

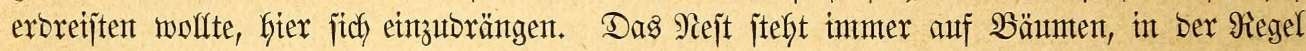

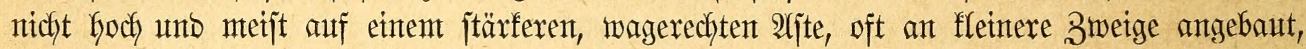

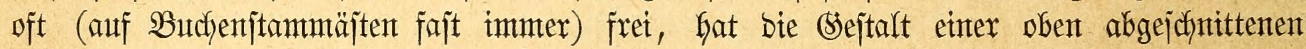

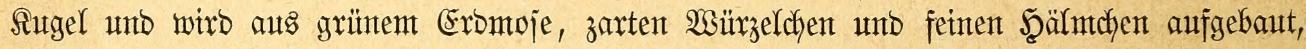

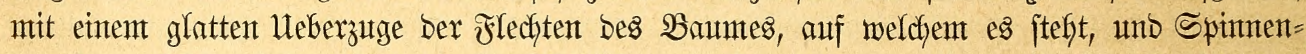

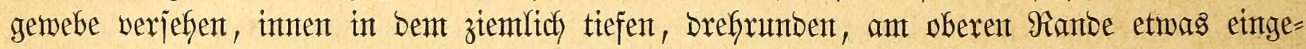

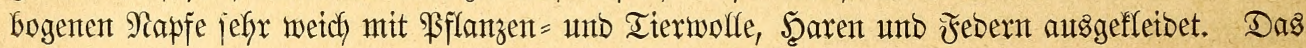

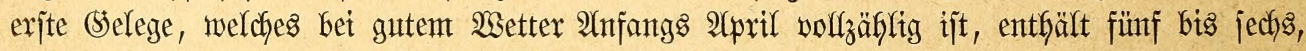

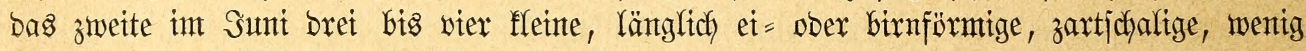

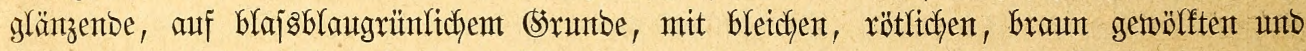

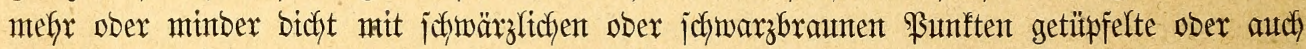

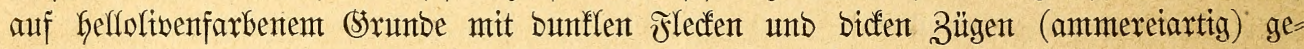

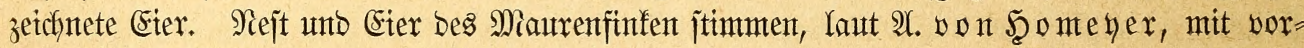

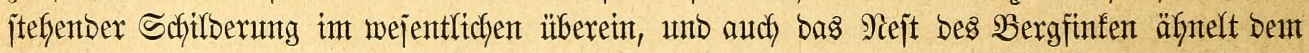

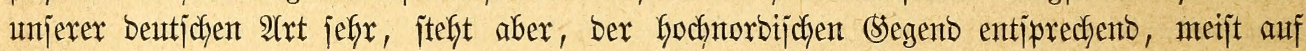

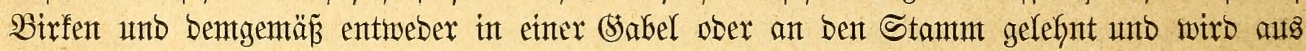

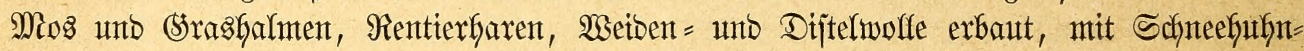
febern, Şaren unto Dijtelwolfe weidy ansgefüttert. Die Eier, jechs bis jieben an ber

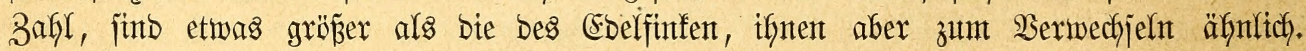

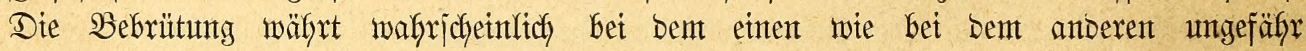

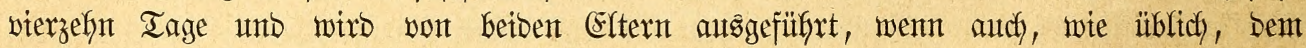

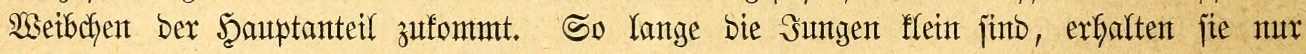

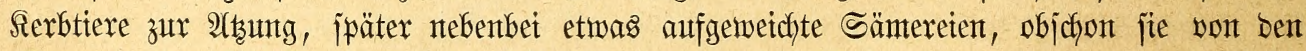

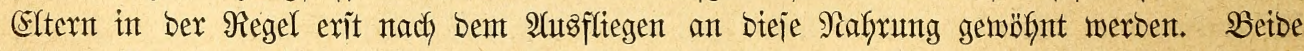

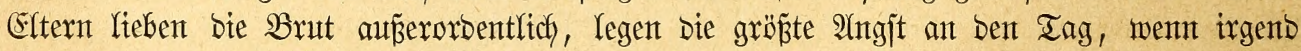

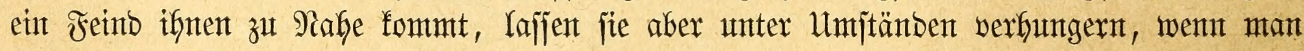

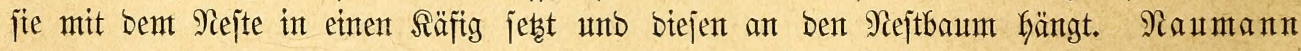

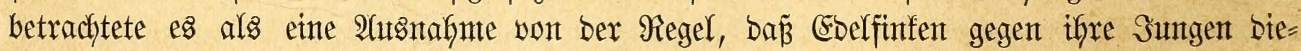

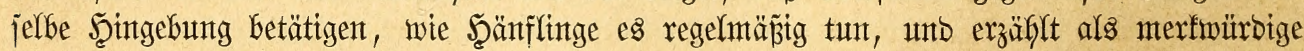

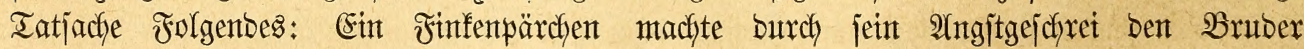
unjeres Forjders auf einen Eidgelfeeger aufmerfjam, welcher bejdä̈ftigt wax, bie jungen

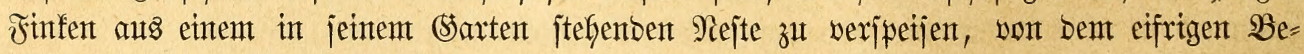

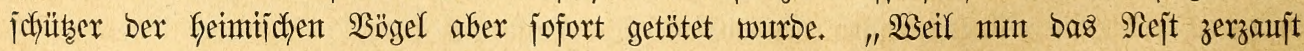
war unt bie brei übrigen 3ungen, weldye herauggepurzelt waren, meinen Bruber bauerten,

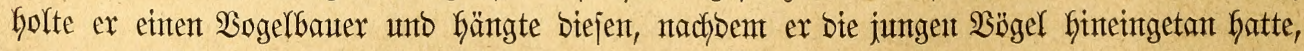

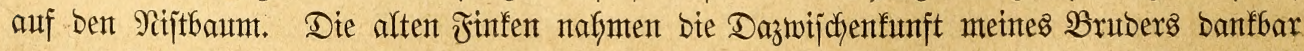

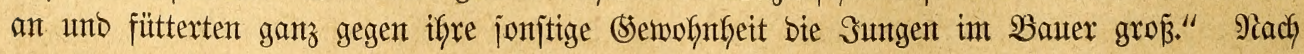




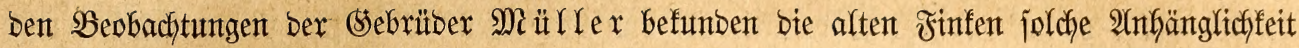

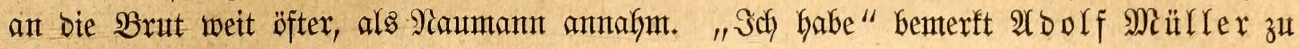

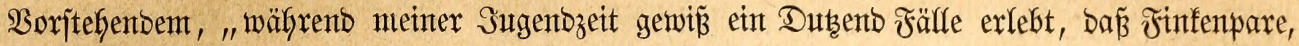
jelbjt etwas entfernt von ifyrem urjprünglichen Nijtplabe, bie in Räfige vor bas Jenjter ge=

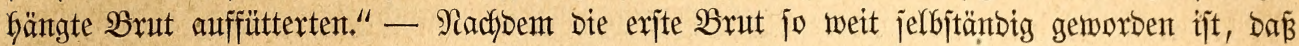

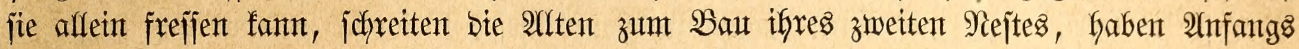

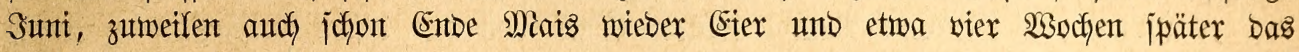
zweite Mal flügge Sungen.

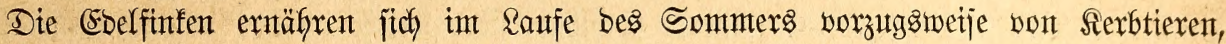

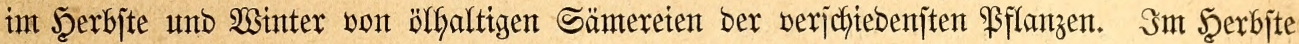
rejen jie auf ben Stoppelädfern ben Samen von milbem Miohn, Sceberich, Wegeridy, Şirje,

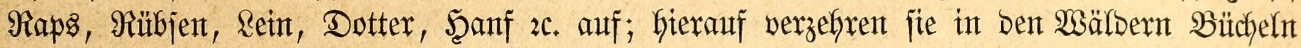
unb jammeln jich bei guter Ernte ber lekteren an ber reich bejchicften Iafel oft zu un=

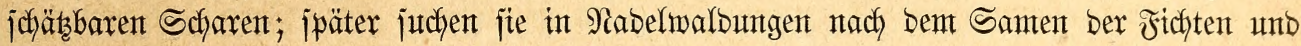
Ianten, in ben Raubwaloungen nach joldhen ber Erlen und Birfen; im Winter endlich

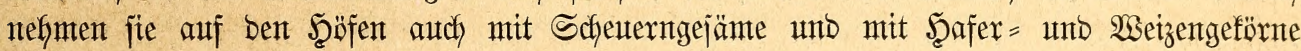

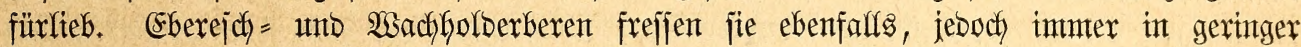
Mienge und wohl nux im গotfalle.

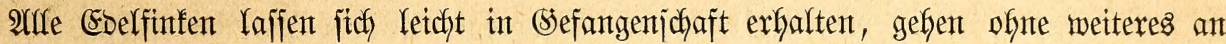

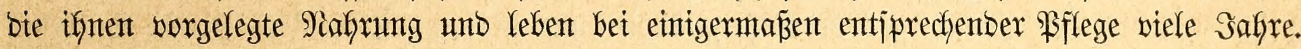

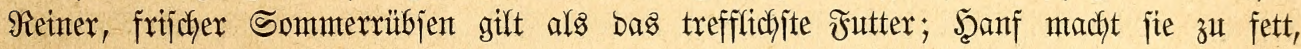
Şafer ober Şirje zu mager; Reinjamen joheint ifnen auf bie sänge nicht zuträglich zu jein. 2(ber alle Finfen, weldye man halten will, müjjen nebenbei Serbtiere erfalten, uns wenn

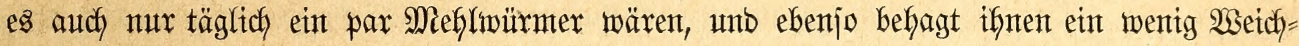

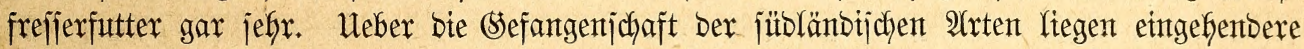

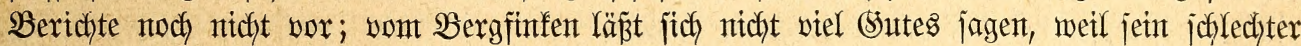

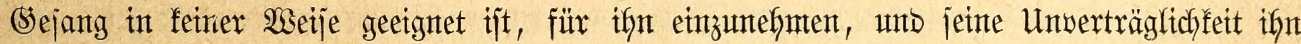

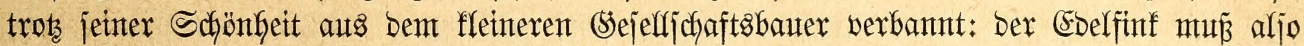
auch in biejer Scinjidyt als ber ausigezeidynetjte jeines (sejejlechts gelten. Unt ex ver= eintigt wirflich afle Borzïge in fich unt hat einte Riebhaberet ermedft wie faum ein anderer Sörnerfrefjer. Alfferbings ijt ber Ranarienbogel meiter verbreitet als ber coblfinf; biejer aber

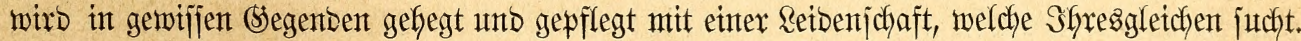
Sn ben Yetzten Safrzefnten Gat bie Finfenliebhaberet gegen früher bebeutend abgenommen,

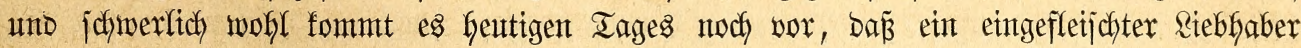
für einten guten Ebelfinfen noch hohe Simmen zahlt ober, wie meilant ein berüfmter Türinger Riebfaber, eine Suth in Taujdye neggibt; erjtorben aber ijt bie Riebgaberei feines=

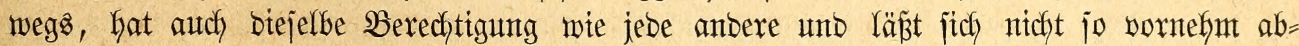

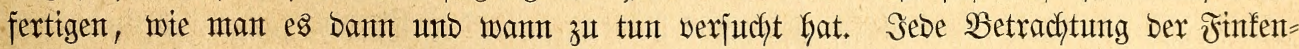
liebgaberei füfrt in eine finter uns liegende Beit zurüd, in weldher ber heimijche Bogel noch ntidht burch ben fremtbländijchen verbrängt worben war unt gefangen gefalten, beos

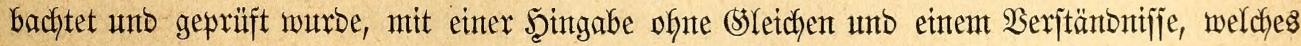

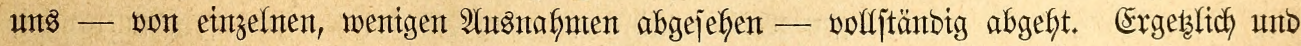
anmutento in gleichem (Srabe erjcheinen uns bie Stejchidchten und Erzählungen, weldye man

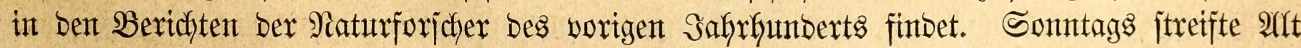

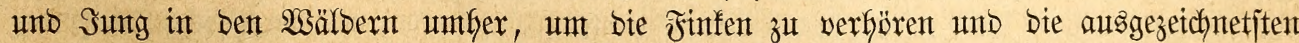
won ifhnen womöglich zu fangen; jelbjt aus fernten (Siegenden jobleppte man gute Finfen im (Sebauter auf bent Rïffen Gerbei, unbefümmert um alfe Rajt und Miühe, weldhe bies ver=

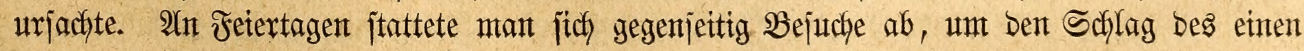




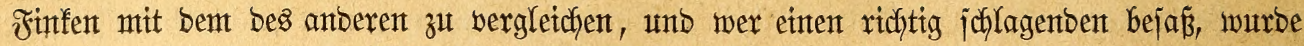

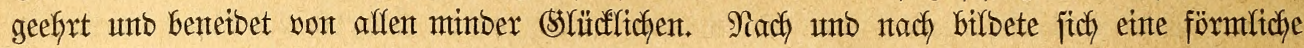
2Biffenjchaft ber Finfen aus: man unterjchteb eine $2(n z a h)$ von Sdylägen, benante fie unto

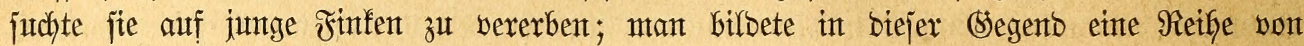
Schlagarten, in jener eine anbere Reibe berjelben aus. Snt Iüringen ichäbzte man, nach)

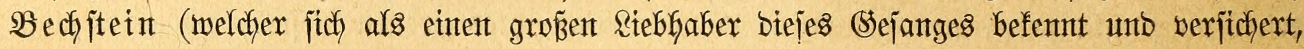

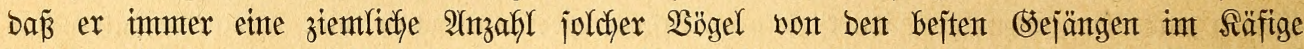

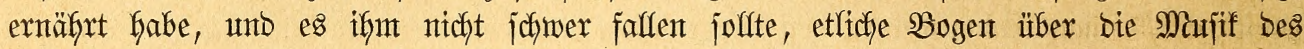

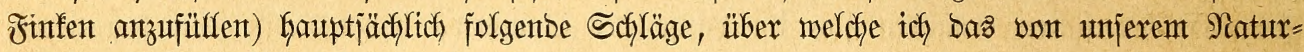
forjcher Sejagte fier folgen lajien mur.

"1. Der Şärzer Doppeljal lag. Er bejteht aus fünf langen Strophen, bon benten

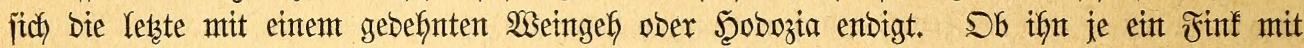

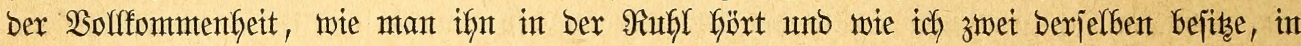
ber Freifeit am Şarze gejchlagen habe, Daran ztweifle ich. Es ijt ein in ber Stube mentgitents

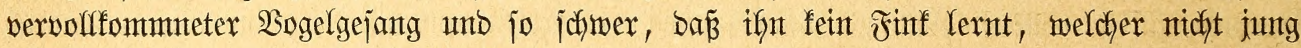
aufgezogen mutbe. Selten jingt ifn auch einer recht gut, ofne etwas auszulafien, berfernt ifn ebenjo letcht mieber, went mant anbere Doppeljobläger banteben hängen hat. Neben bemt

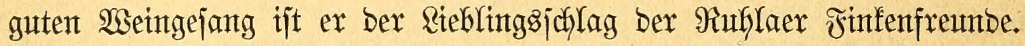

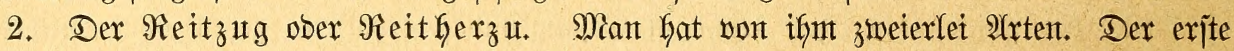

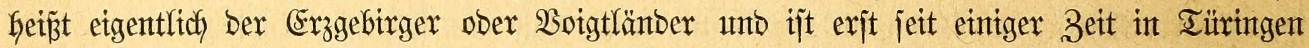

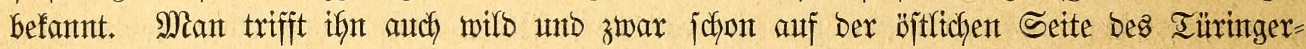
walbes an; alfein aufgezogene Bögel jingen ifn langjamter, gröber, länger und beffer. E⿺s ijt ein fräftiger, jchntetternber (sejang, welcher aus vier furzen Strophen bejteht, von benten bie erjte recht hodh herabflingeln unb vor ben Silben Reitzug einent 2Hbjab, D. h. einten Irifler

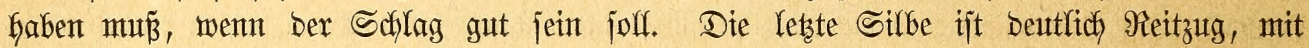
einem Schnapp, wie ber Jinfentiebhaber ipricht, ober mit Dem Tone 3ap. Der zweite, ber Dberlänber ober Breitenbacher, i jt länger unb flingt flötender, bie leb̧te Sillbe aber

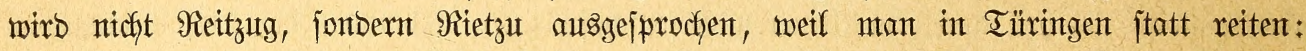
rieten jagt. Beibes jint vortrefffiche (Sejänge. Wer nod) feinten volffommtenen Şärzer Doppel=

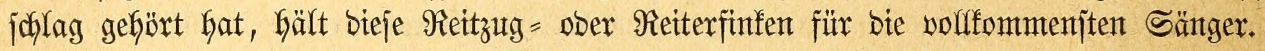

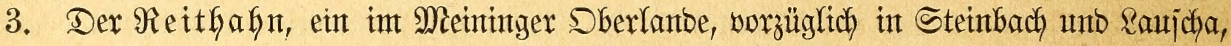
gemöhnlicher Stubengejang, weldyen man nidyt mit bent Reitzug verwechjeln barf, bejtefst aus einer langen, Goch Gerabjdymetternben unb etwas zijchentoen Strophe, welcher am Enbe

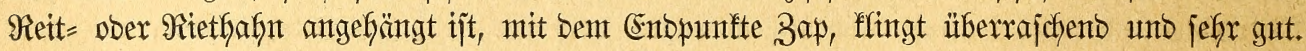

4. Dex $\mathfrak{B}$ eidmann zerfällt in ben Stubent = und Walbweibntant. Erjterer ift im

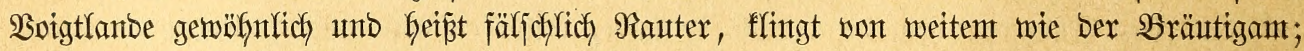
bie betben Borberjtrophen jint jeboch beutlicher abgejetzt, itart unb jcharf, unt ber Scaupt=

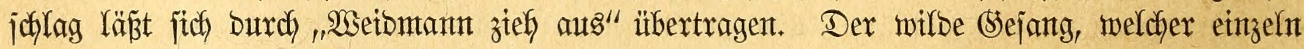
in Franfen in ben Raubmalbungent gefört wirb, ijt vornferein viel fürzer, auth nicht jo grob.

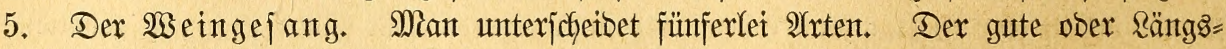
felber ijt ein ausnefgment jdyöner Bejang, hat bier furze Strophen, weldye aber mit einem Der Sboe ähnlichen Ione gejungen werben müfjen, went ber Bejang edft fein joff. Die retste Silbe flingt Weingeh ober Wiengieh. Diejer (Sejang ijt auch blof ein won un= gefäbx in ber Stube erlernter unb von ba weiter fortgepflanzter, ben man nie, wentigftens

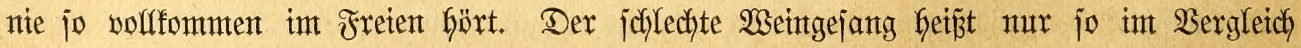

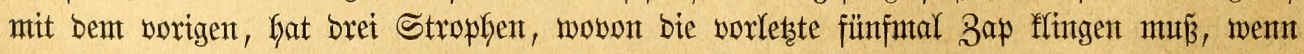
ex gut jein jolf. Weingeh ijt auch bie letzte Silbe. Man hört ifn im Jreien. Das gerabe $\mathfrak{B}_{\text {eingeh }}$ ijt ein aus bem jallechten und jojarfen Weingejang gleichjam zujantmen= 


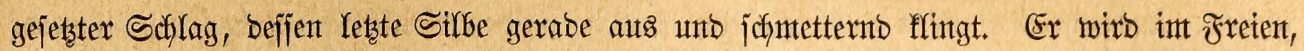
namentlich in Franfent gefört unto ijt nicht untangentefm. Der jajarfe 2 seingejantg ober

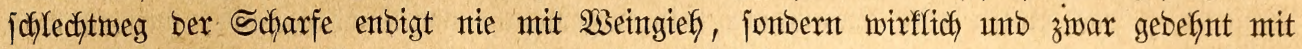
2Beingeh. Miant teilt iffn ein in bent genteinen, welchent man int Freien Gört unto weldcher,

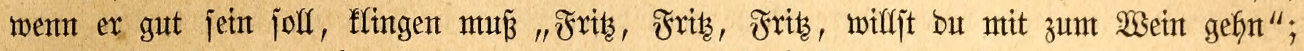

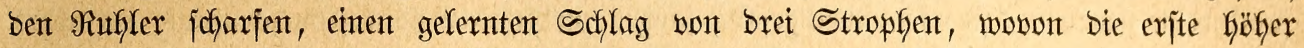

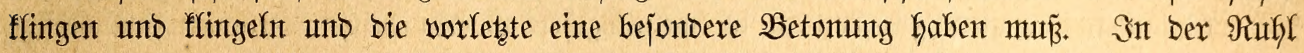

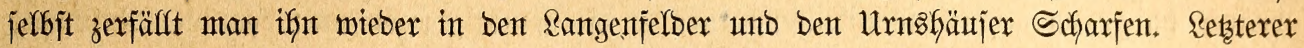

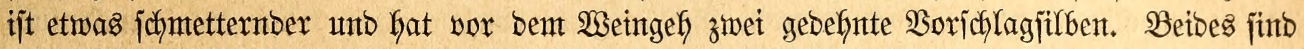

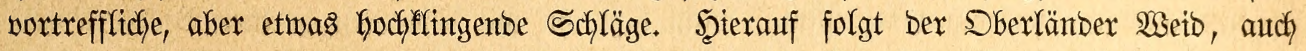

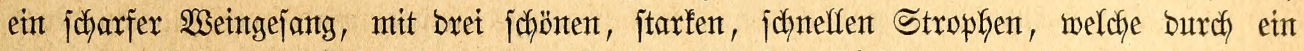

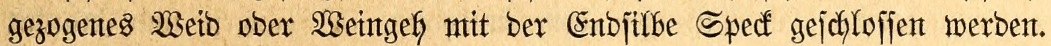

6. Der B̉räuttgam. Şiervon gibt ę Den guten, welcher nutr in ber Stube gelernt wirb unt zwei Strophent hat, wowon bie erite leije unb hodh unto bie zweite machjent,

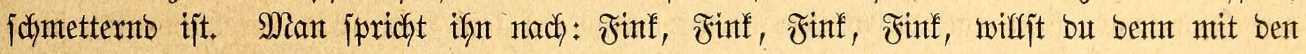

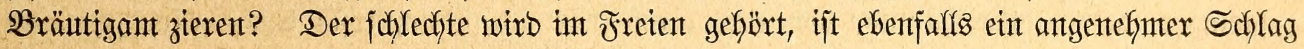

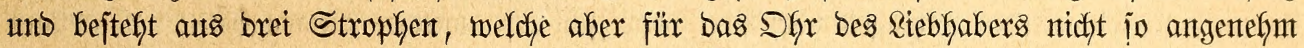
fint als bie wont jentemt.

7. Der Doppelidslag. Er bejtefyt aus zwet langen, in ber Mitte beutlich abge=

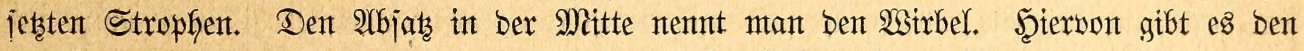

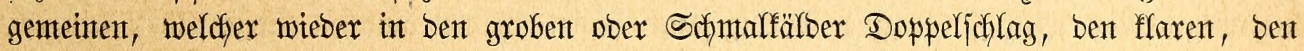
langen unt ben futrzen eitgeteilt wirb. Dieje (Sejänge Gört mant aud int Freeient. Int

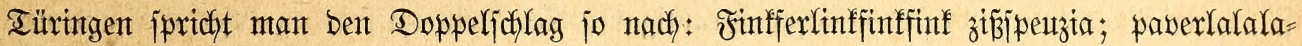

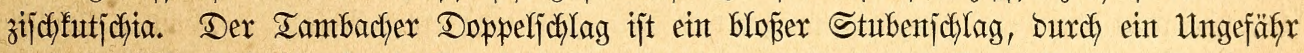
erzengt. Ein Edyufyntadjer in Iambach hatte bet einent ganz groben Doppeljefläger fünf junge

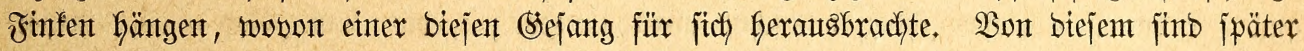

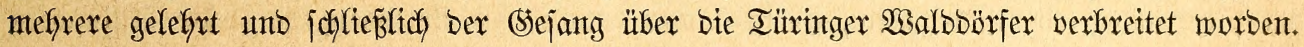

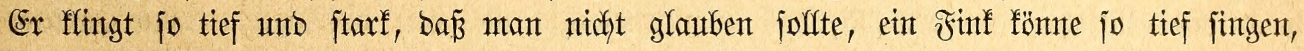

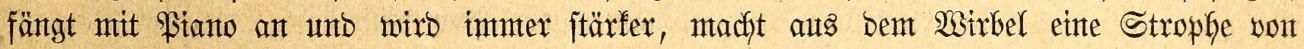

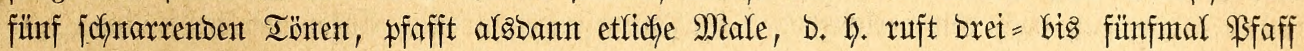

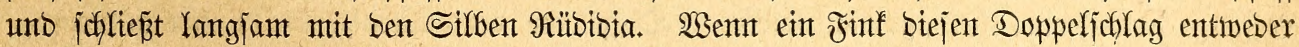

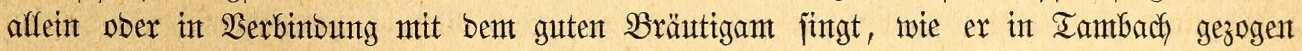

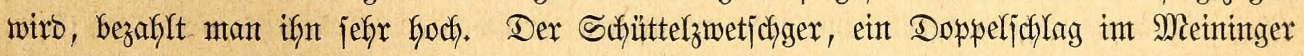
Oberfanbe, ift bent genteinent ähnlithy, aber ebenfalls ein geternter Stubengejang vont zwet langen, beutlidsen, grobent Strophen, welche am Enbe fich mit ber Sitlbe Speef enbigen.

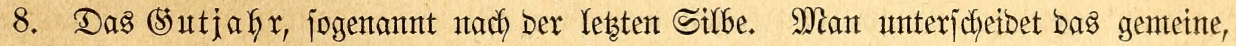

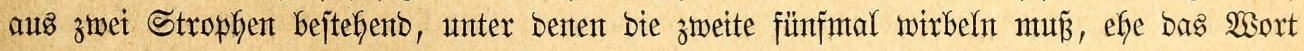

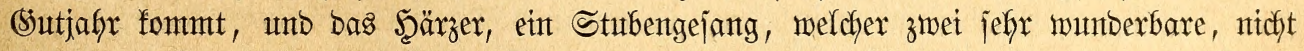

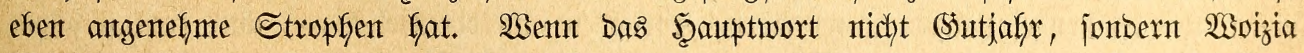

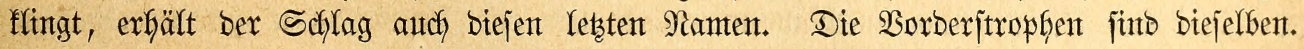

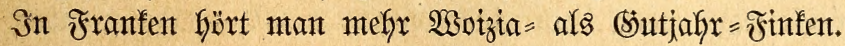

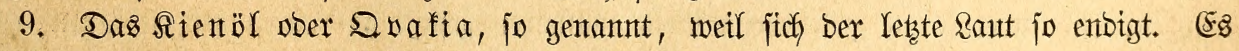
gibt ein boppeltes und eit einfaches; jenes bejteft aus zmei Strophen, Diejes auts einer.

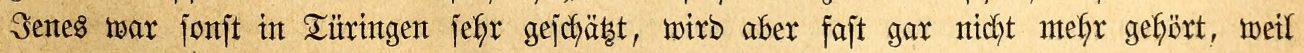
man int Wsalbe alfe Finfen, weldhe es jangen, weggefangent hat unto bent in ber Stube aufgezogenen lieber ben guten $\mathfrak{S}_{\text {Seingejang leffrt. }}$

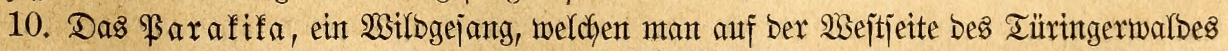

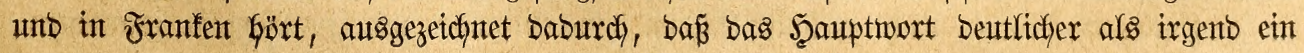


anberes ausgeiproctsen wirb. Sr Gat im Freient zwei und in ber Stube brei flingento Strophen unb Gängt finter bem Scauptworte 3ap ant.

11. Das \$itia ober Iremetia, ein ungemein angentehner Sejang, welchen man noch einzeln in Den tiefen (sebirgen bes Türingerwalbes hört. Won vorntherein mus ex eine

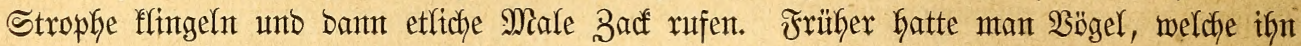

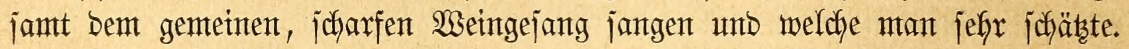

12. Das Schwarzgebïr, ein im meiningichen Sberlanbe gemöhnticher sinfenjchlag, melcher in Freien gefört, aber volffommenter in ber Stube gezogen wirb, hat brei Strophen, unter benen bie britte bejonters grob unb wogent flingt. Das letzte Wort brücti fich

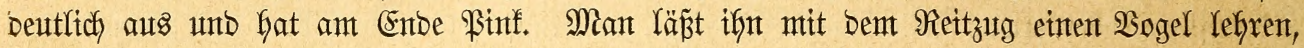
und ein Finf, welcher bieje zmei volffommtenten (sejänge vorträgt, wiro jefr gejchäbt.

Dies jinto bie vorzüglidyjten, in Türingen unto überhaupt in Sadjjen und Jranfen gejchäbten Finfenjchläge. Man hört, wie bemerft, manthe berjelben im Freien, aber ge= möhnlich nidyt jo bolffommen, D. h. jo lang und mit jo jtarfer und reiner Stimme. Waenn ein $\mathfrak{B o g e l}$ mux einen won biejen (Sejängen vorträgt, io jünt ex ifn auds gewöhnlich bejto

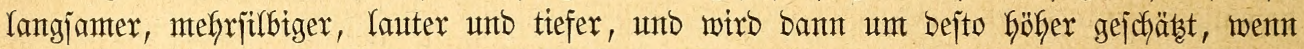

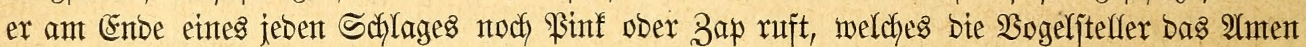
nenten. Sch bejize einumbzmanzig Finfen, und went idh bie guten Sdyläger, weldhe alfe in bejonberen Räfigen unt in adyt Bimmern berteilt bängen, nach meintem (Sejchmacf in eine

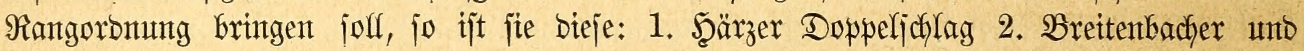

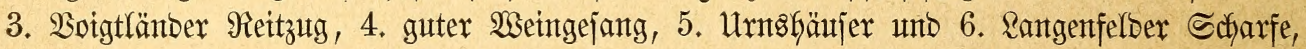
7. Weiogejang, 8. Iambacher unb 9. grober Doppeljwlag, 10. Schüttelzwetichger, 11. Boigt=

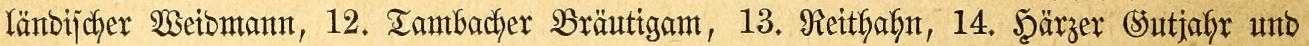
15. Barafifa.

Die übrigen $\mathfrak{B}$ ogelgejänge, weldye man aflentfyarben hört, aber nidyt jonberlich achtet,

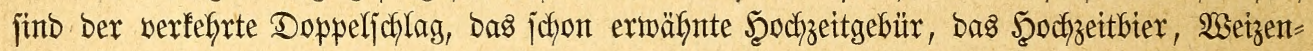
biex, Serichtggebür, Würzgebür, Steffgaf, ber gerabe, jcharfe Weingejang, bie Weinjchere, das tolfe Sutjafy, das Davida, Das 2 err, Slapzia und alfe diejentgen, deren Endiflbe

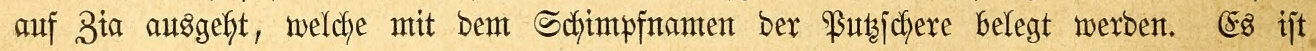

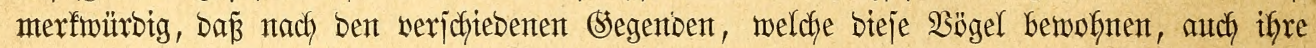
(sejänge abmechjeln, jo baj man anbere Bejänge auf bem Türingermalbe unto anbere auf

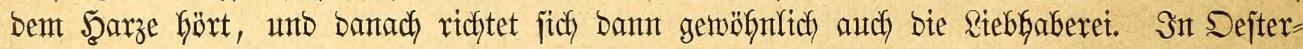

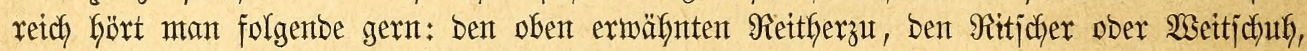

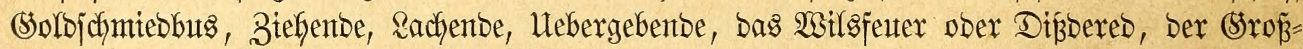
rollende, Aleintollende, Sibaufthül, Mitgetirer, Malvajter, Subdeb, Wey, Sparbarazier,

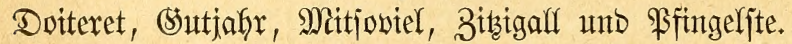

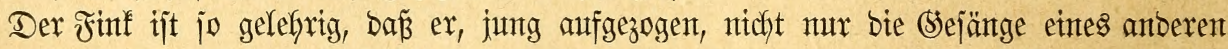
Finfen annimmt, fafls ex fie alfein Gört, jonbern audf, went ex bei einer Nadftigalf ober einem Santartentogel bängt, abgebrochente Strophen aus beren Rtebern, aber freilich nichts

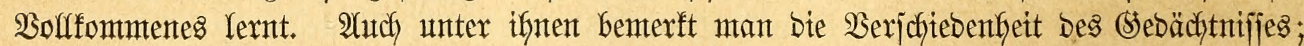
Denn einer hat zuweilen ein halbes Jahr nötig, umt einen einzelnen Sejantg zu fubiren, wäfrend ein anberex ifn gleich beim Erjtenmalkören gefajt hat unt abjügen fant. Einer

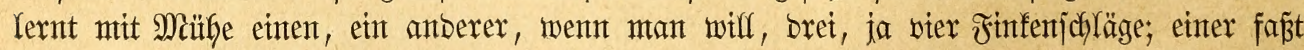
ifn untoolffommen, ein anberer vollfommen, jetzt aud wohl noch einige Silbent finzu und

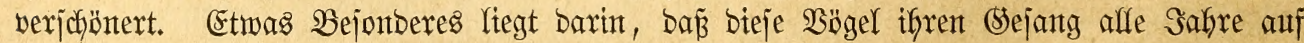
eine ganz eigente $\mathfrak{A}$ rt won neuent Yernen müfjen. Es gejefifft bies unter eintent jofmurrenbent

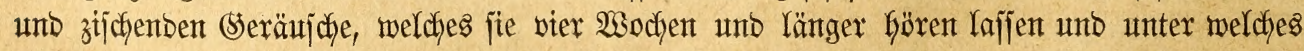
fie ganz leije exjt einige, bann ntebrere Silben ifres Sejanges mit einmijchen. Man nennt 


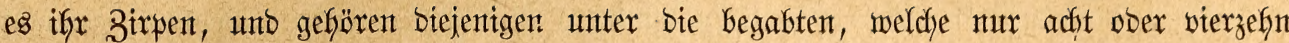

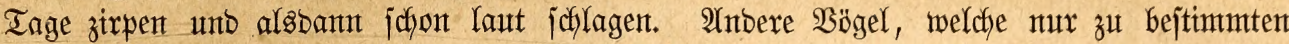

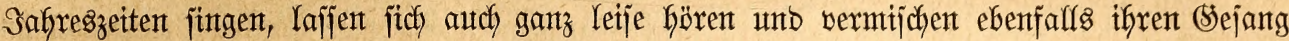
mit fremben unb unreinen Tänen; alfein feiner bringt io ganz eigene, mit bent eigentfidyen

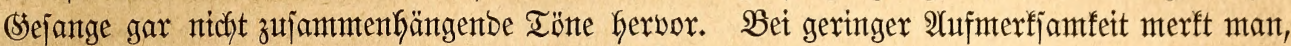

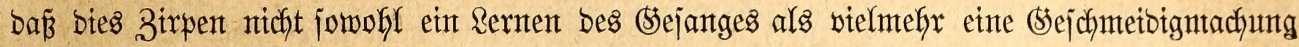

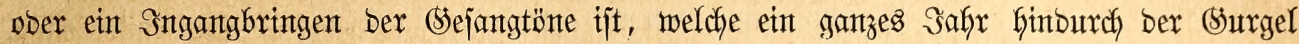

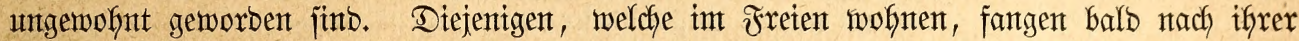

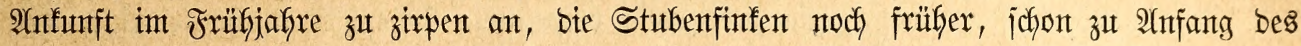
Februtar; fie probiren aber audch länger, zumeilen faft zwei Mionate lantg, efhe fie recht laut

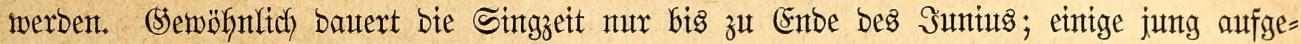
zogente Stubenfinfen aber fintgen audh woffl bis Mitchaelis unto Martint."

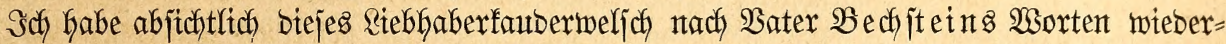
gegeben, unt benjenigen meiner Rejer, weldhe bas trefflithe, nteuterbings leiber ebenfalfs ver=

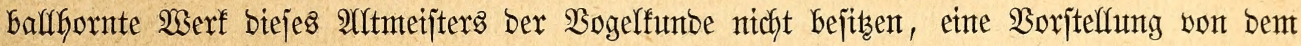

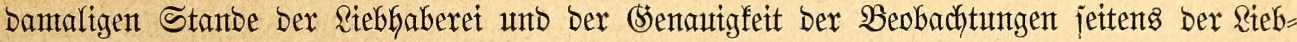

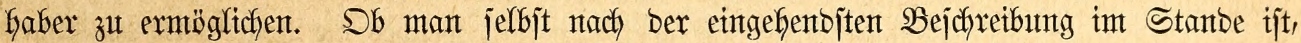

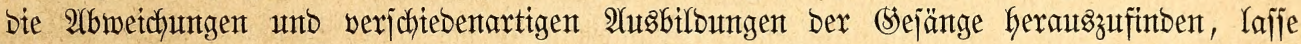

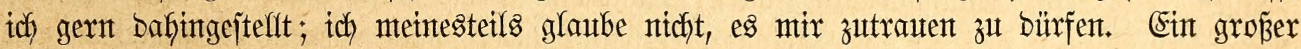

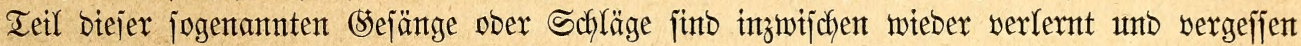

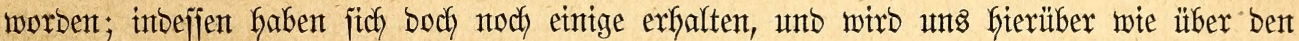
Geutigen Stano bex Finfentlebfaberei unjer Mitarbeiter Solz, ein Riebfaber int Sinne Bechjiteins, beleffren, "went autd nur in bejcheibener Sürze", wie er jeinen Mitteilungen

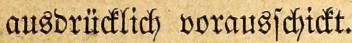

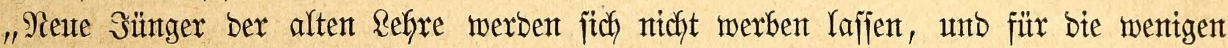

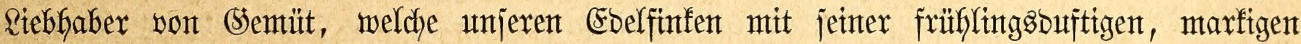

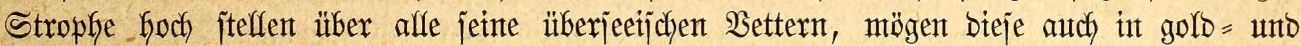
purpurfarbigem (befieber zwitjichern unb flöten: - für bieje ntehr zu jofreibent als zutver=

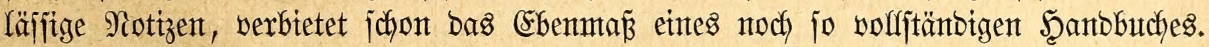

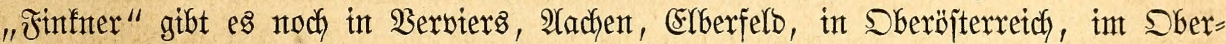

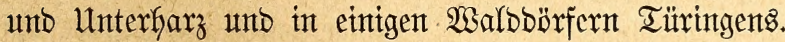

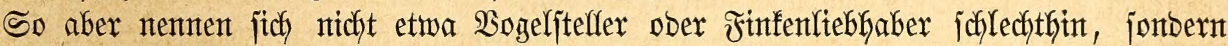
nur Reute, weldye jaffraus jafrein bemüfyt finto, bie bejten Schläge biejer Sogelart ant seben zu erhalten, inbem jie junge Wsitblinge aus bent Mejte nefymen, nit Mitch, Sentmel

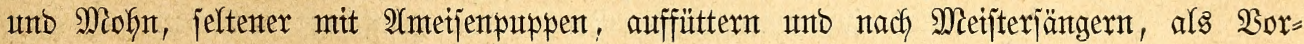
jđłyägern, herantbitben.

Die Sache jifht Yeidfter aus, als jie ijt. Mit ben Schulfregulativen biejer Finffner

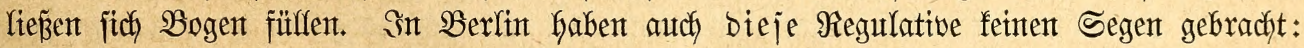

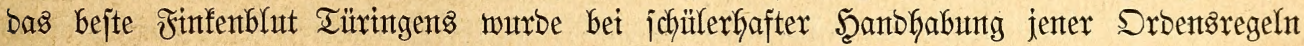

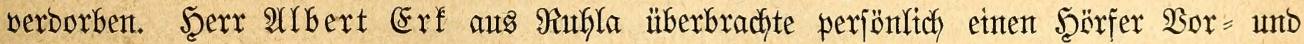
Doppefichläger, - junge Safobifinfen, weldhe bas naturwü̈chjige Sied ifgres Baters nody

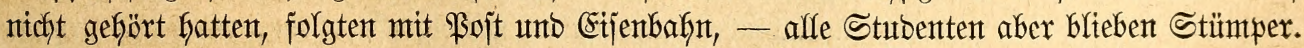

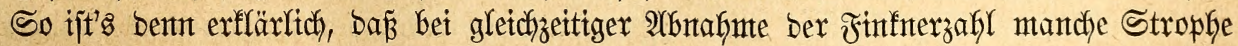

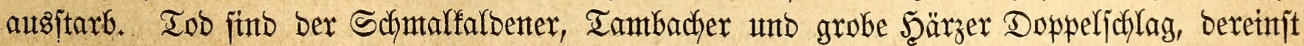

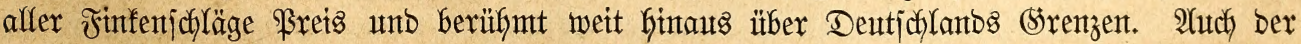

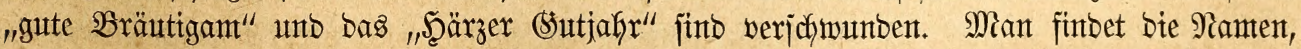
nicht ben (Segenjtano; eritere jitno in ben Yetzenten vierzig Saffren auf geringere, ähnliche

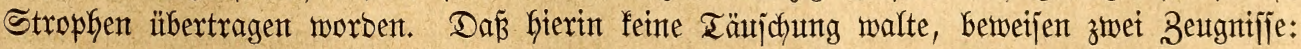


Finfen.

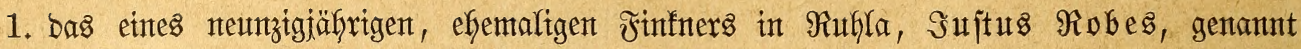
Roebin, unt 2. Der (Stlanz ntody lebender Runjtgejänge.

Rebentig finto noch ber gute alte Weingejang, jowohl mit bent 21uggantge "Wiengeh",

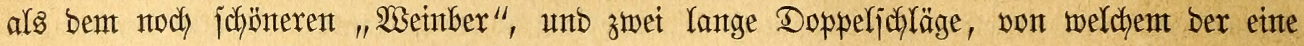
Sërjer, ber antore Brotteröber heif́t.

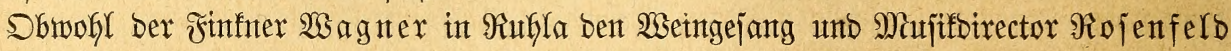

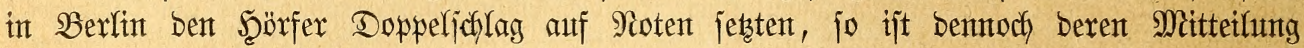

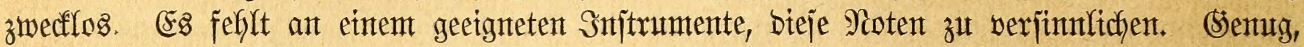
baj ber alte Weingejang wahrfaftig brei wolfe organijirte Strophen in jich wereint, won

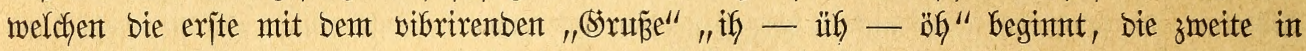
einem fünffachen, bogenförmig fteigenben und fallenten "Iacfen" befteft unb bie letste in

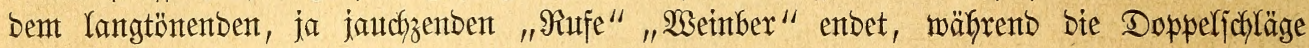
Goch Gerabflingeln, in ber Mitte wirbeln unt trommeln unb mit eintem bejonbers Garmonijoch

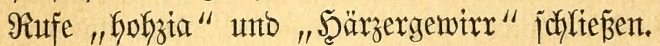

Parr in Brotterode unterm Snjelsberge, in Steinbach unterm âftenjtein und in ber

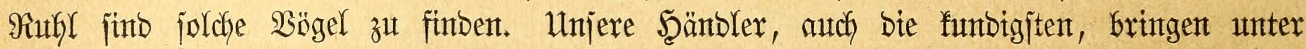

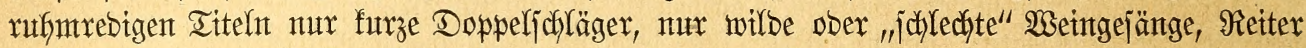
ofne $x$, mur "tolfe" (Sitjafyrs und grautenerregende "Putjicheren" auf Den Marft, zumeijt

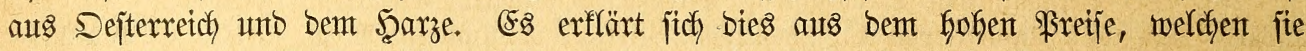
jdyont an Drt und Stelle zahlen müpten. Zwar feine Suth, aber zefnn Ialer und mefhr gilt

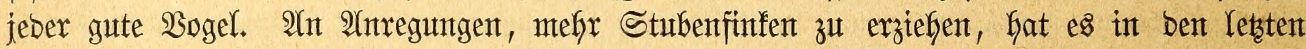
Safren nicht gefeblt. Und fo werben siebbaber fie exfangen fönten und foffentlich bieje (sejänge vorerjt gerettet bleibent.

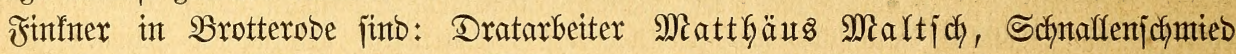

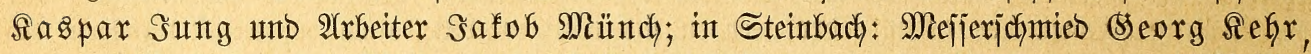

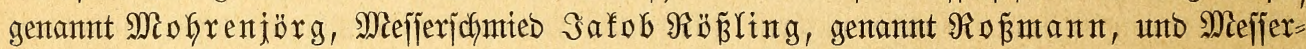

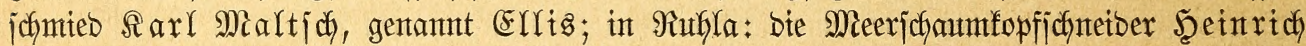

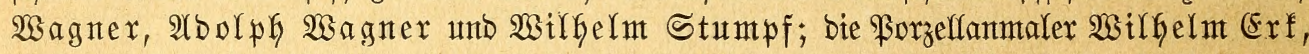
Urbert Erf und Ferbinand Sffert; entlich bie Fabrifanten Theobald Schinf unto Rarl Sreaburg.

\section{fä̈nflìntue.}

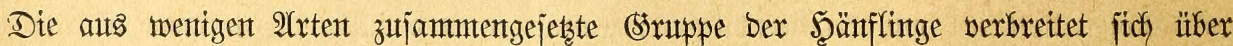

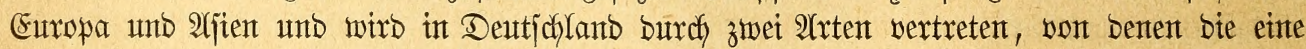

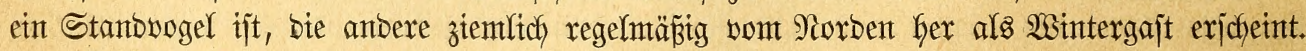

Die Scänflinge, für weldye anjere alfbefannte $\mathfrak{A}$ trt als $\mathfrak{B}$ orbilo gelten mag, finto mittel=

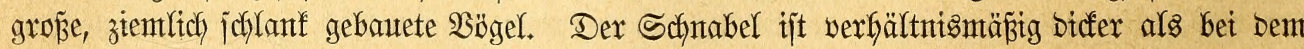
Ebelfinfen, freijelförmig, gerabe, jcharf zugejpizt, an ben Schneiben fintermärts ein wentg

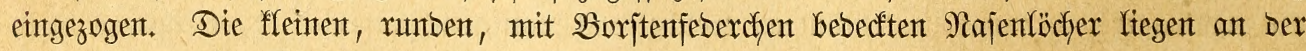

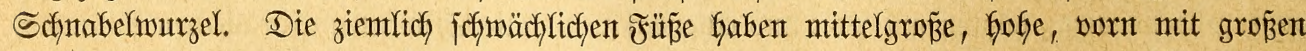

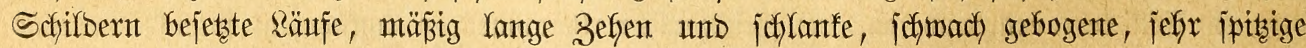
Siralfen. Sn Dem langen unt ppisen Flügel, weldfer zujammengelegt ungefähr bie Şälfte bes Sdymanzes bedft, ragt bie zweite, längite Schwungfeber ein wentg über bie betben folgentent vor, unb finto bie exiten brei beutlich serengt. Der mittelfange Sifwanz ijt jtarf ausgejchnttten. Das fnappe (Sefieder ijt nad) (Sejchlecht und nach Sabreszeit merflich verichtebent. 


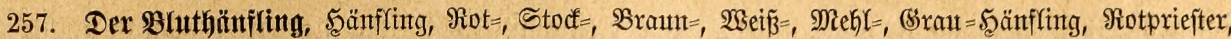
Semperfing, Cannabina (Fr., Passer, Ligurinus, Linota, Acanthis) linota, Gml., (cannabina,

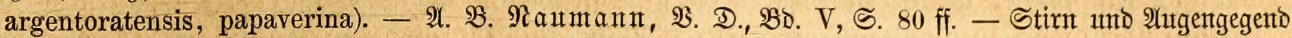

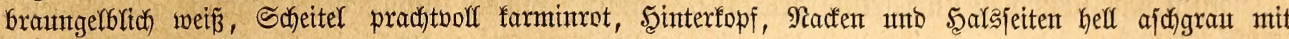

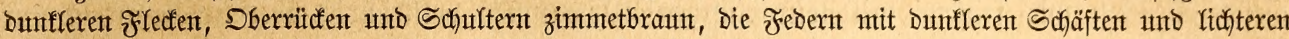

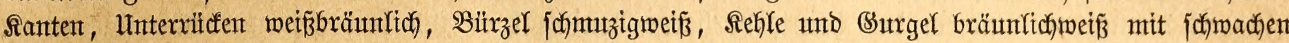

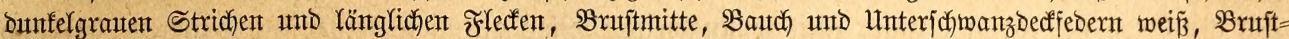

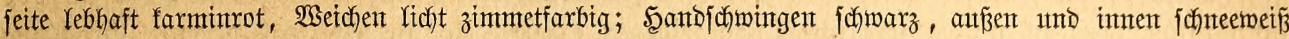

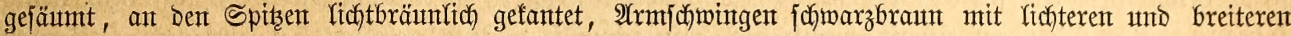

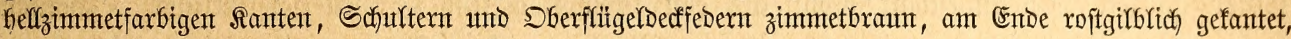

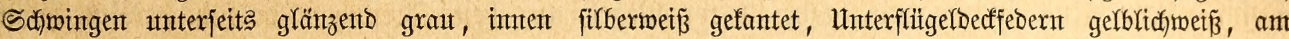

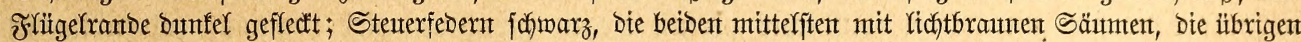

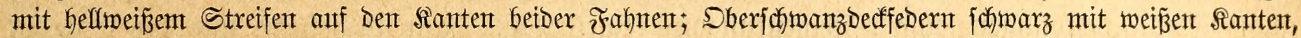

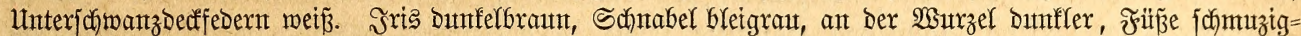

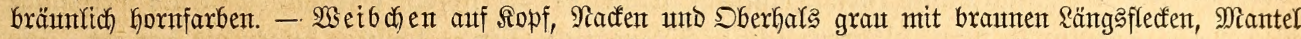

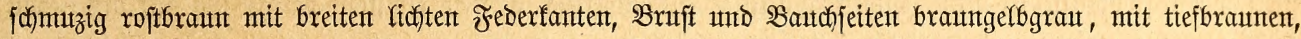

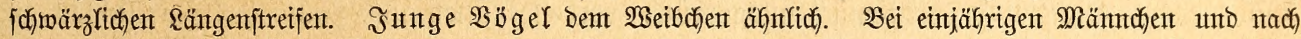

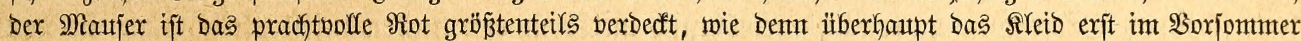
feine volle Sçjöntheit erfält.

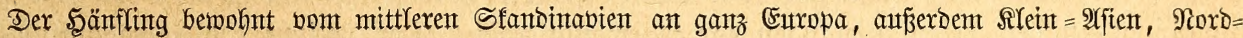

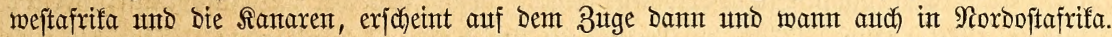

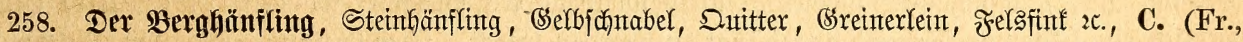

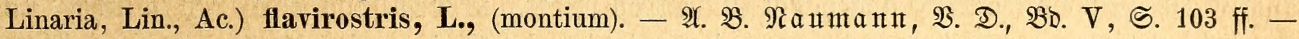

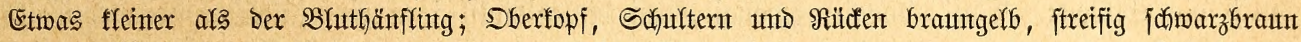

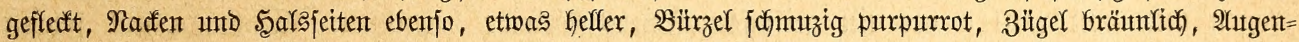

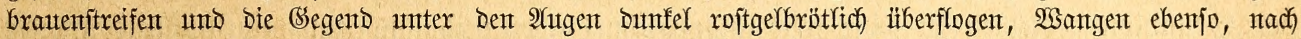

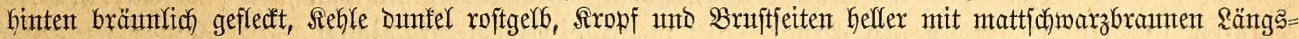

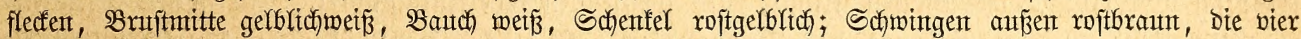

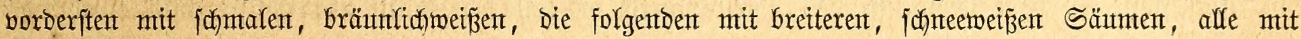

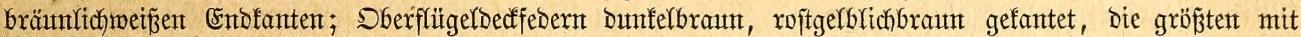

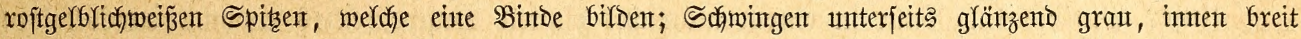

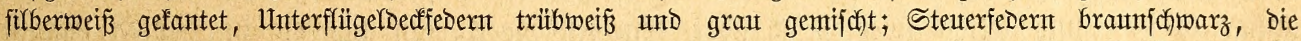

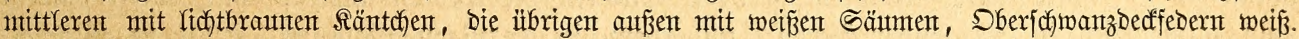

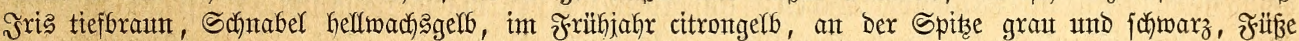

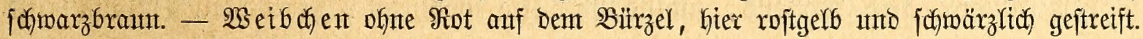

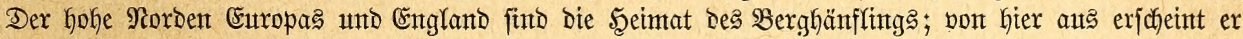

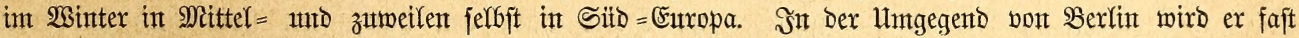
in jebent Winter gefangen.

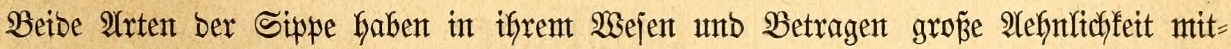

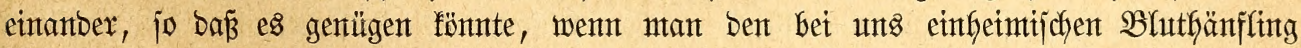

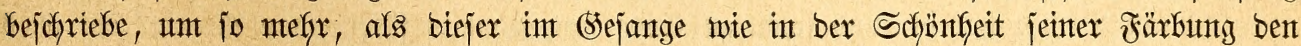

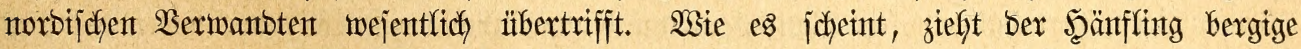

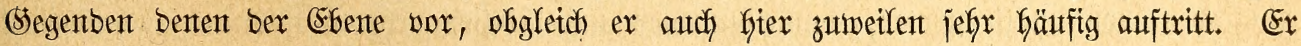

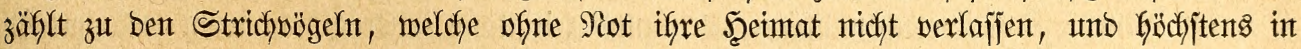

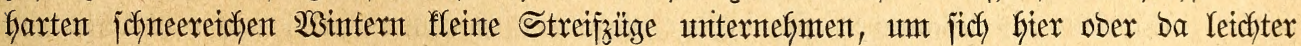

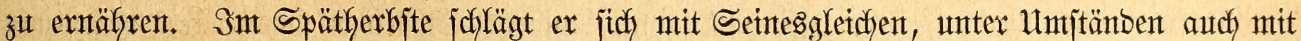
Den Bernanbten ober jelbjt anberen Finfentwögeln (B̈ergfinfen, Sperlingen, (Srünlingen) in

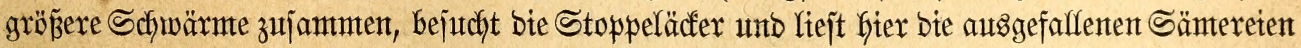

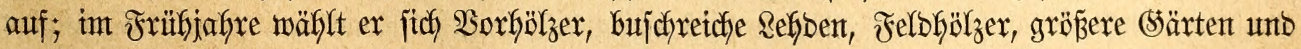

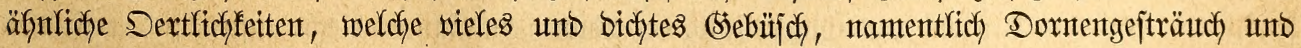
Wadjolberbüjche haben, ebenjo gern Wentherge unt jelbjt größ̈ere, mitten int freten Felbe

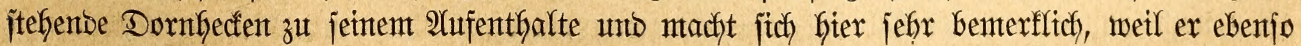
munter unt flüchtig als gejelfig, flutg unt vorjichtig ijt. Begen jeinen Satten bemeijt ex bie

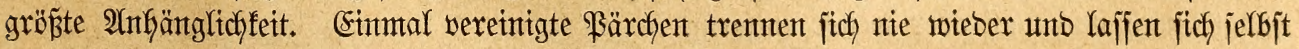


int größzten Sdywarnte nod) erfentten: wo ber einte finfliegt, folgt ber antere, untb audh, went

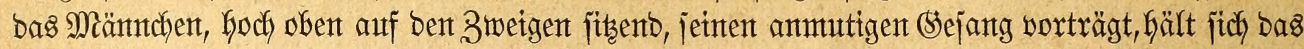

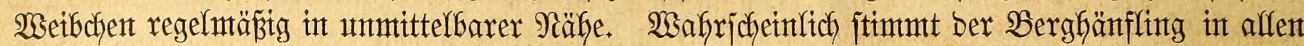
biejen Stürfen mit jeinem mitteleuropäifłch Serwanbten volljtänbig überein; mäfrento ber 3itgzeit wentgitents unt in ber 2 interferberge benimmt ex jich fajt genau ebenjo wie jenter.

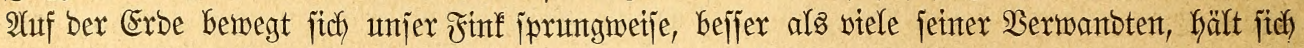

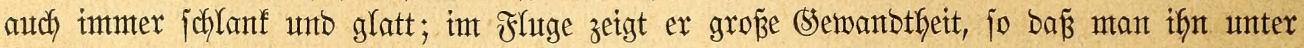

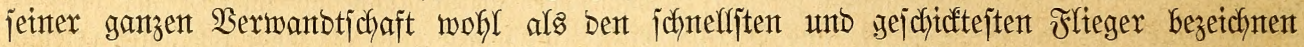

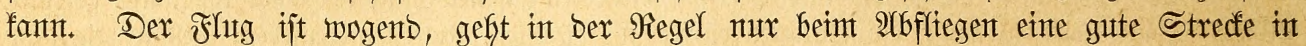
geraber sinie fort unt bilbet jonjt aus gropen $\mathfrak{B}$ ogen zujammengejetste Rinien, entbefort aber autch) jäher Wentoungen unt Schmentuntgen feintesmegs. Ein furzes hartes "(sef " oder "Secfer", ber Sodfton, Yäßjt Den Şänfling jelbjt in gemtichter (Sejelljchaft Yeidht erfennen. 2luperbem wernimmt mant mehrere janft flütenartige Iöne, weldhe burch bie Sillben "sï,

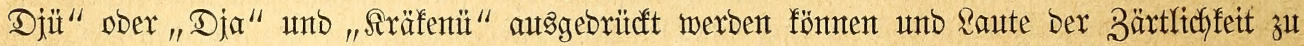
jein jcheinen. Dex sejang beginnt gewöhnlich mit bent exjten erwähnten Rodfton, an welchent

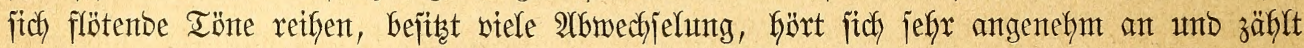
unbebingt zu Den bejten Sejängen ber Bermanbtichaft. Der Rodton Des Berghänflings ijt

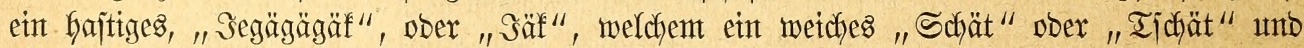

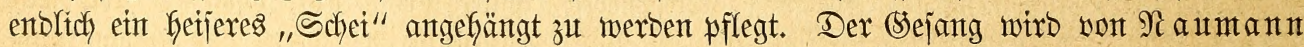
burch bie Silfen: "Dait, bobaii, jebobaii, beit biblbetbiblil $i$ arrrit, jäfjäfjäł beit 2 . über=

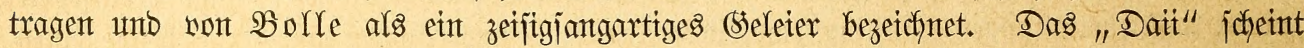
ber (Sruntoton besjelfen zu jein; jefr ausgezeidynet aber unto ifm ganz eigentüntlich ijt bie fitarrente Stropke, welche jo flingt, als went ein Ebelfinf bidftet. In jeinter Bejant= mirfung fteft ex bent (Sejange bes Serwandten meit nach, fann überfaupt nicht unter bie guten $\mathfrak{B o g e l g e j a ̈ n g e ~ g e z a ̈ f l i l t ~ w e r b e n t . ~}$

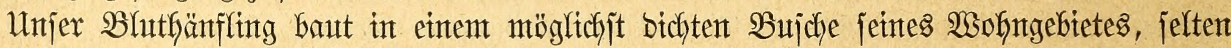

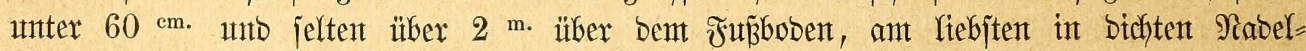

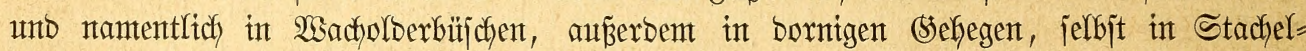

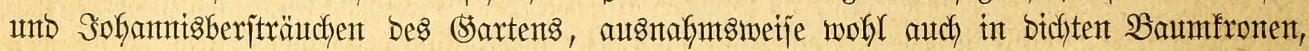

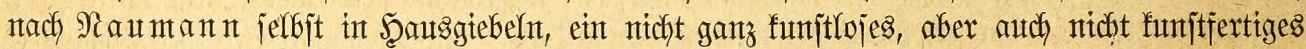
Nejt aus Stoffen, wie ex fie gerade zux Scand hat, ant häufigjten nody aus gröberen

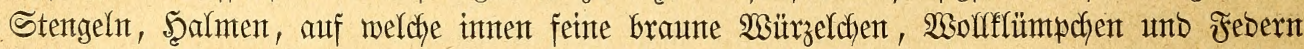
folgen, währent ber halbfugelförmige গapf mit Wolle, Würzeldyen, Scaren, Sorjten unb bergleidfen ausgepoljtert zu jein pflegt. Schon âtnfangs März jtellen jich bie einzelnen

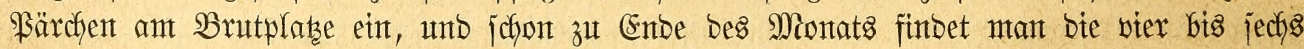
weitbaudfigen, zartjchaligen, fajt glanzlojen, auf blaugrünlidh weizent Sirunbe mit jefr feinent

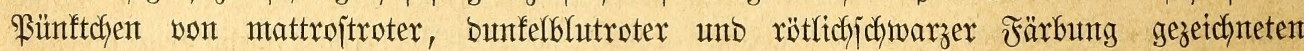

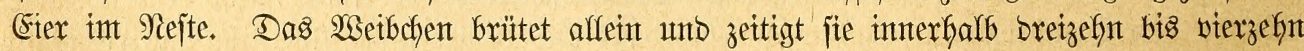

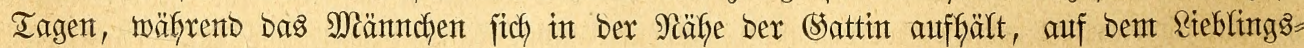

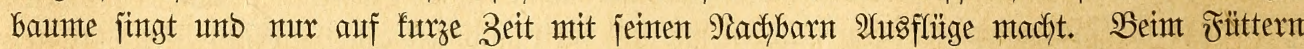
ber Suntgent beteiligt es fich jefr eifrig. Beibe Eltern lieben bie Brut in Gobem Srabe,

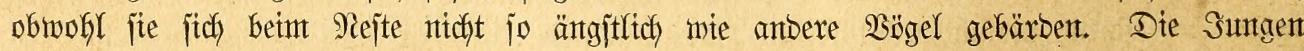

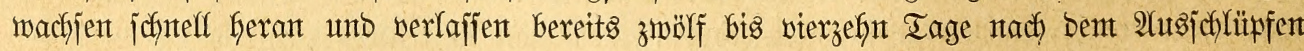

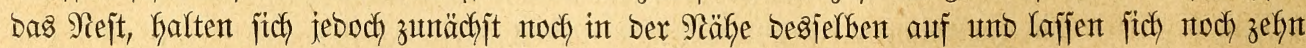

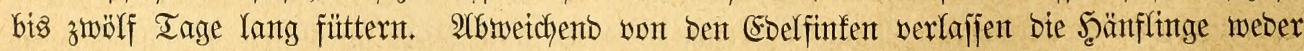
(Eter noch Sunge, uno beshalb ijt es nicht jchmer, Yeştere burch jie gropifüttern zu lajjen,

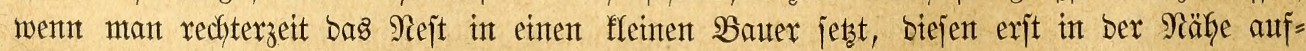
Gängt, nach) unto nach aber weiter entfernt. 


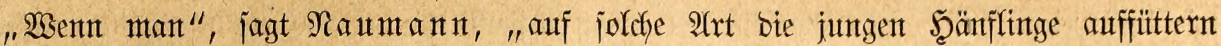
Yajfen milll, ber Srt aber unjidjer ijt, jo Gängt man ben SBauer mit ben Sungen am erjten

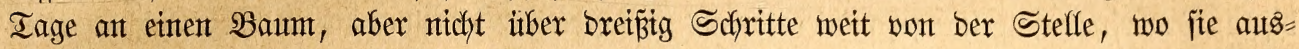
gebrütet twaren. Şaben bie Aflten Gier erjt einige Mare gefüttert, jo fantn man ben Bauer ntach und nach alfe Iage um jo viel weiter wegtragen und fie jo bis zu einer bequemten fichern Stelfe, jelbit biz zu eintem Fenjter finlodfent. So aufgezogente juntge B̧/utfänflinge fint aber aurerorbentlich wilb, unt es bauert lange, efje fie zahm werben; ja fie flattern

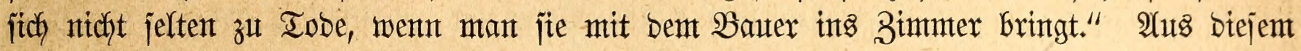

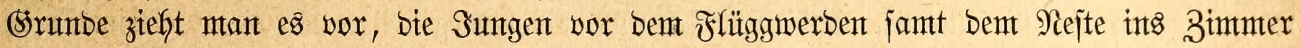

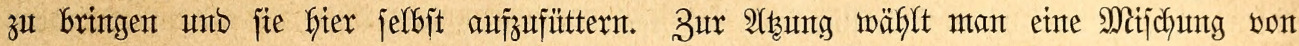

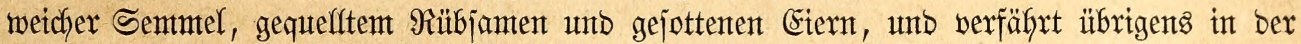
(ธ. 62 fi.) angegebenten Wetje. Derartig gepflegte Scänflinge werben erflärlicher Weije

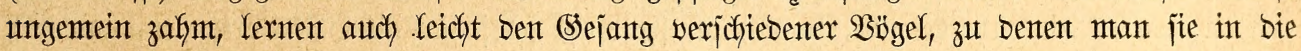

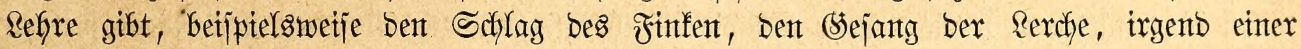

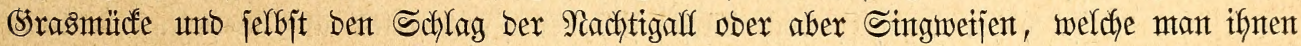

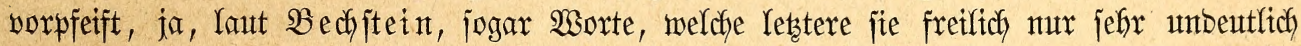

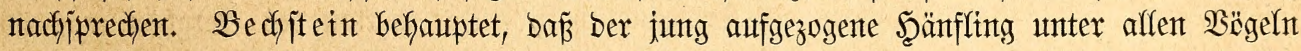
megen jeiner natürlichen Flötenjtinme bie Melobien am reinjten unb jobönjten nadypjeife

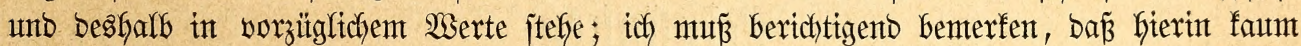

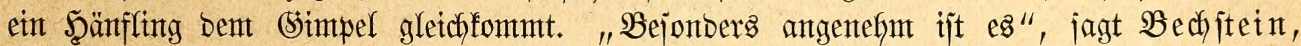

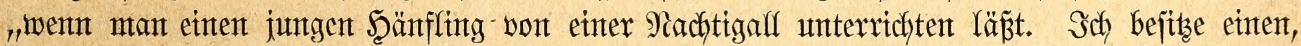

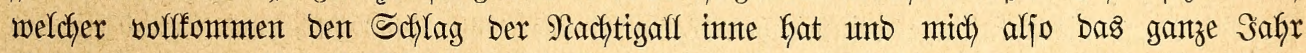
finturch, went meine Nachtigalfen jufweigen, mit biejem lieblichen (Sejange erfreut." Eintes

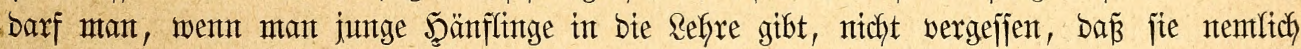
alfes nachzutpfeifen juchen, was jie bören, und beshalb jefr letcht zu abjcheulfichen Stümpern

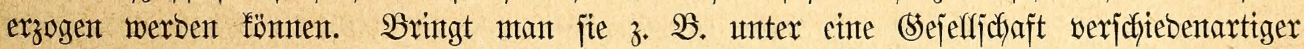
Sögel, jo nefynten jie ebenjo viel won biejemt als won jenem (sejange auf, mijchen alles Durchetnanber, eignen fich wofhl auth mandherlet Mistöne an und werben in Folge beffen

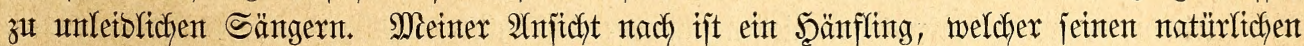
(Sejang vorträgt, einemt gelefrten bei weitem vorziziehen. Die Retchbaltigfeit bes Bejangez, ber Eiffer uno bie Âtıbauter, mit weldher ex ifgn vorträgt, ftellen ifgn ïber viele antoere

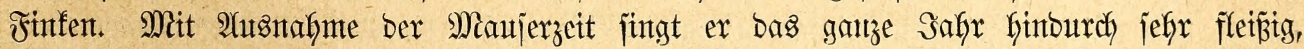

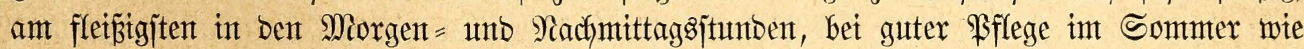

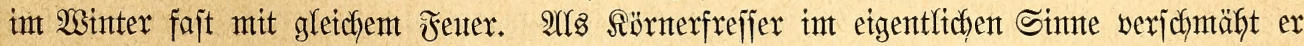

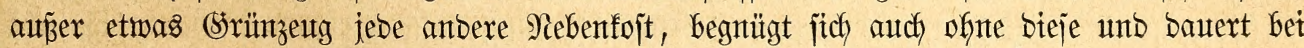

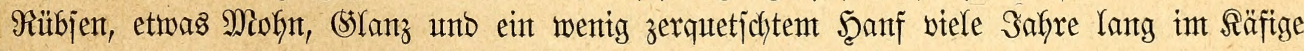

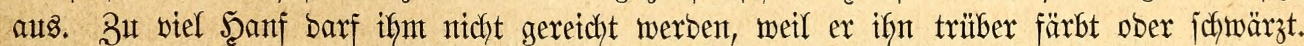
Mit ber Rörnernafrung im Einflange jteft, ba

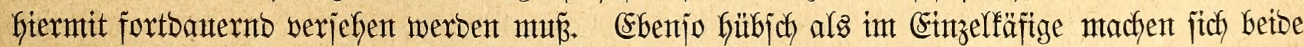
Şänflinge im Fluggebauter. Sie gefüren zu ben verträglichjten affer Rörnerfreffer, ftreitent

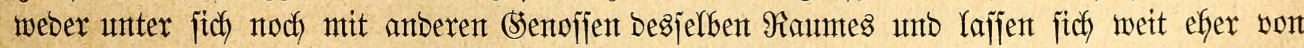
biejen beberjchen, als fie jelbjt Mine madjen jollten, bies zu tun. WSent man jich viel

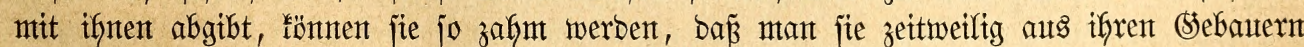
lajjen, ja jelbjt ins Frete ifnen einen 2Altsflug gejtatten barf, ba jie bodh immer wieder zu

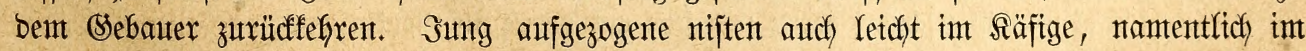
Jluggebauter, bauten fier, falls fie einen pafjenten Srt unb bie nötigen Baujtoffe haben,

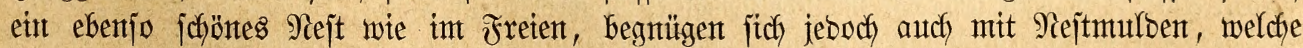
fie gejchicft auspolftern, brïten jefr fejt und pflegen iffre Sungen mit berjelben Şingebung 
wie int Freten. Mit bent Ranartentwogel erzengent fie Blenblinge, weldhe fich freilidh nicht eben burch fojöne Färbung auszeichnen. Allfe bieje Eitgenjchajten jtellen jie hoch über viele fremolän=

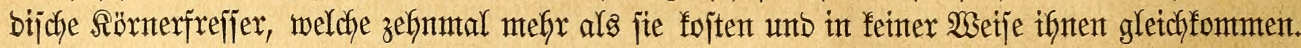

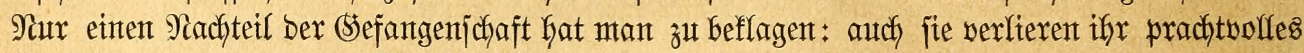

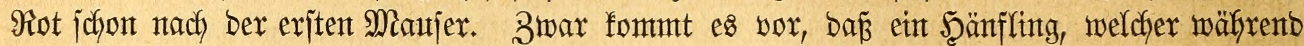
Des ganzen Safres genïgende suft und Sonte hat, wentgitens einen Teil jeiner Farben=

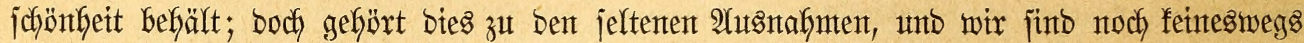

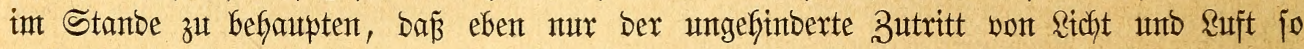

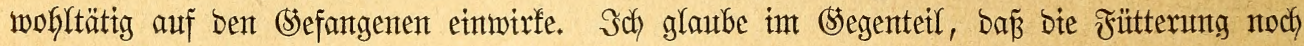

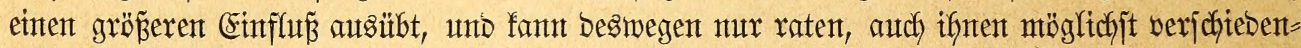
artiges (Sejänte, aber wentg Şanf, unto mancherlet Srünzeng zu reichent.

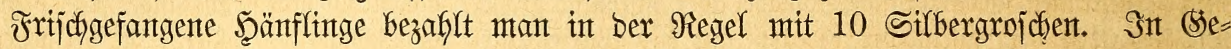

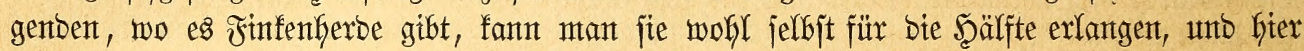
fojten bie Dutter audd ntidft mefyr als bie Bhlutfänflinge. Bejonbers gute Sdyläger werben

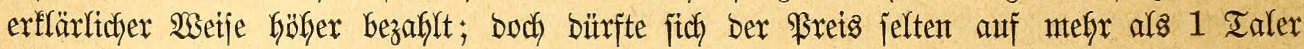
jteigern.

\section{Petufinkent.}

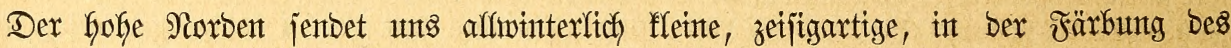

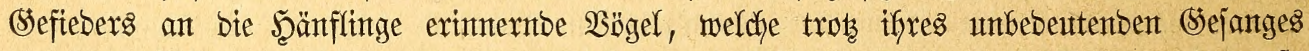

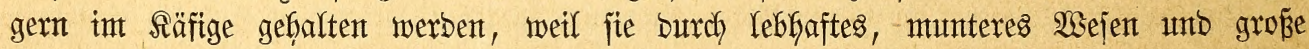
3utraultchfeit für jich eintulgnten.

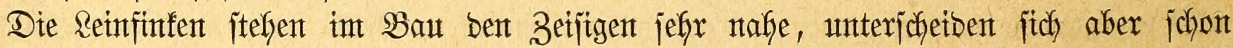

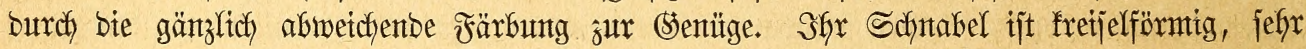

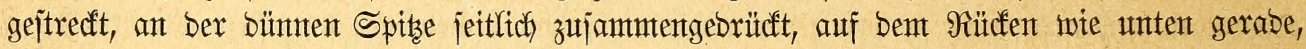
bie feine Spibe Des Sberjanatels etwas verlängert unt über bie antere vorragent.

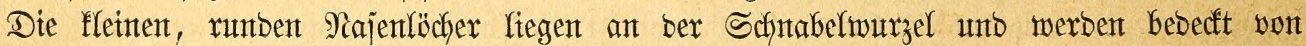
ziemlith langen, bidjten Borjtenfeberchen, weldye bie Sintabelmurzel rings umgeben. Die

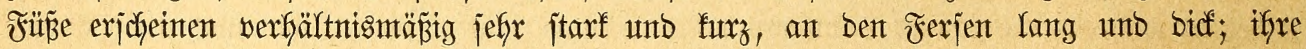

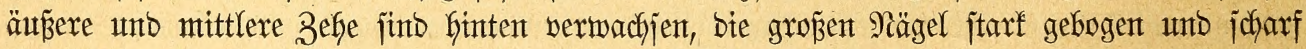
zugeipizt. Sn Dem mittellangen, jpitzigen Flïgel überragen bie brei exiten Şandjdywntgen

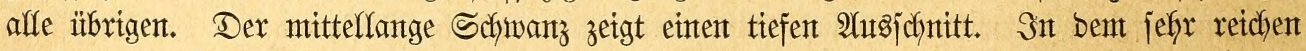
(Sefieber ijt ein mattes, fahles Braunt bie Sruntofärbung; alte Mänththen aber zeigen ein

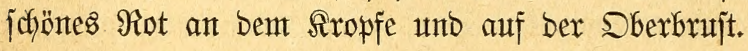

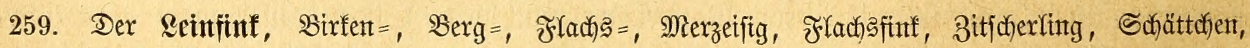
3ifferinctent 2c., Aegiothus (Fr., Spinus., Lin., Linaria, Ac.) linarius, L., (minor, borealis, rufescens). -

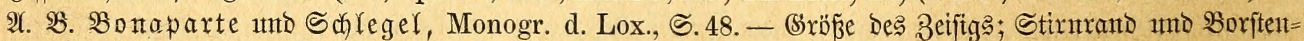

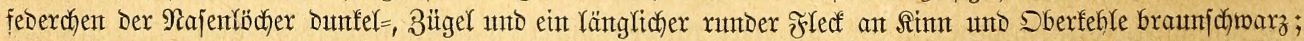

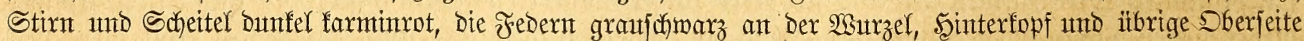

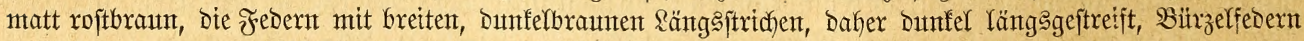

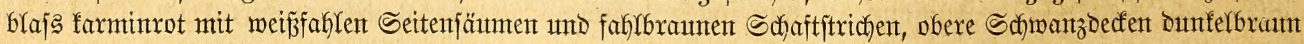

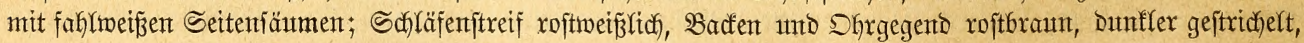

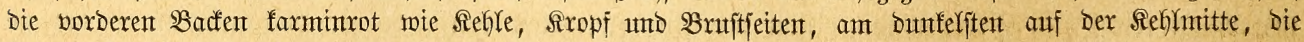

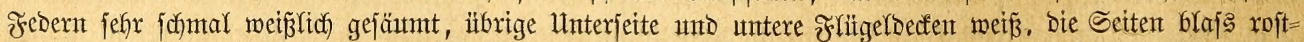

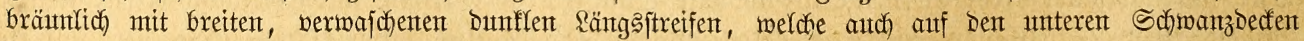

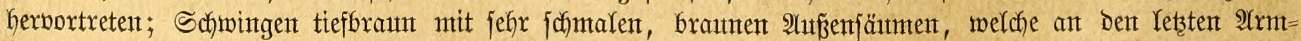

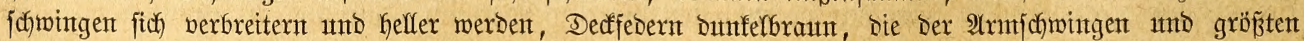

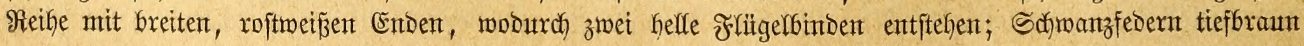




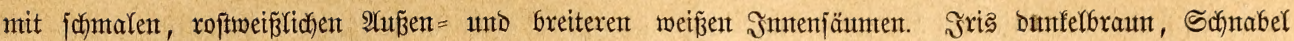

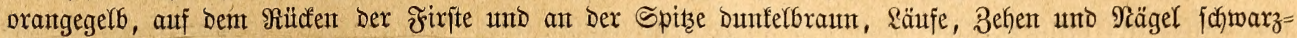

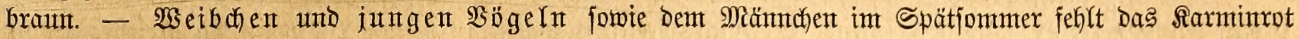

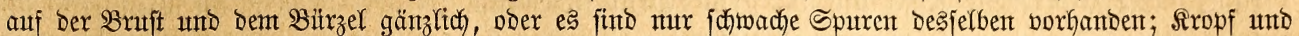
Bruft exicheinten Daher mie bie Bacten roftbräunlich, an bent Seiten mit Dunfelen Sdjafflecten, welche auf Dem graulichmeifien Bürzel zahlreich vorhanden fint; bie rote Ropfplatte ift matter und minder ausgebefnt;

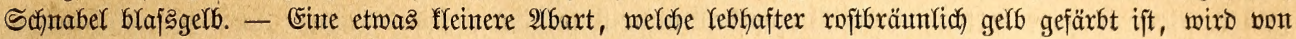
manchen $\mathfrak{B}$ ogelfundigen als bejondere $\mathfrak{A}$ rt (Ae. rufescens) betrachtet.

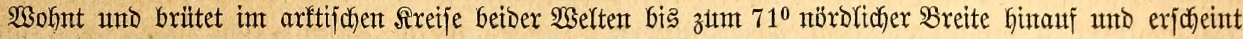

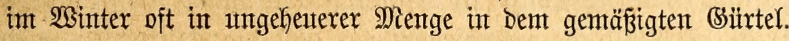

260. 5olbäl's \&cinfinf, Ae. (Linaria, Ac.) Holboelli, Brehm. - 2 . S. Şonaparte und

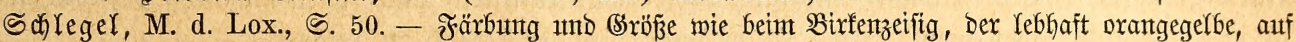

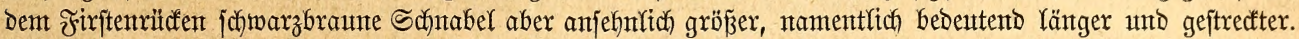

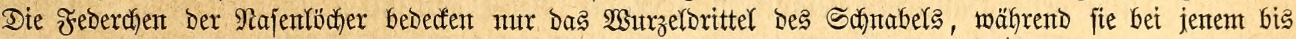
ơt Şälfte reichent.

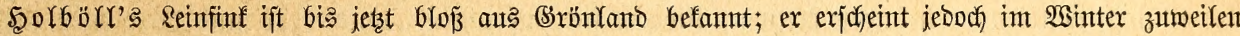
ebenfalls bei uns, obwohl ftets jeltenex ars dex SBirfenzeifig.

261. Der (Srmuleinfinf, Ae. (Fr., Linota, Linaria, Ac.) canescens, Gould, (borealis, Hornemanni). -

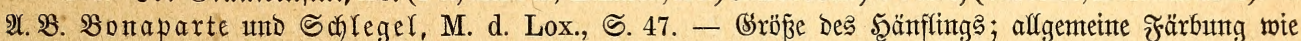

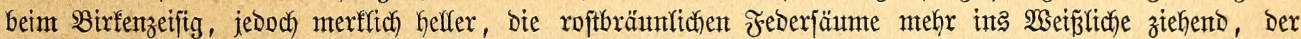
Bürzel wie die Unterjeite faft einfarbig meiź, an Den Seiten mux mit jefr wenigen, feinen, Dunfelent Schaft=

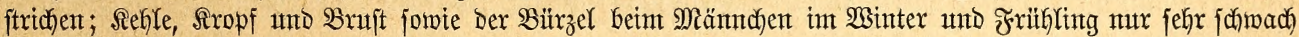
farminroja verwajden. Sris Dunfelbraun; Sberjanabel hormidwarz, Unterjanabel gelb, im Sommer ber

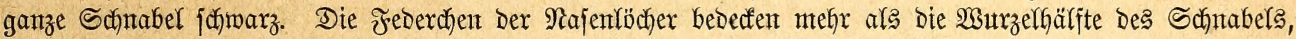
Yetzterex exjcheint Daher auffalfento furz und höher als lang.

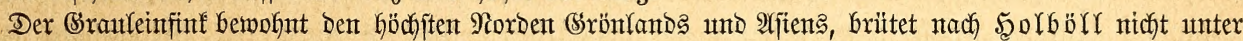

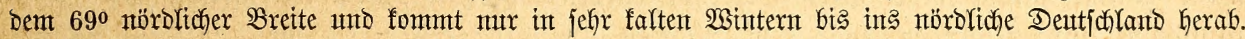

Rebentsmeije und Betragen ber genannten Reinfinfen, welche mant wohl als jelbjtänbige 2rten auffajfen barf, jheinten burchaus übereinjtimmtent zu jein; wenigjtens füto unjere

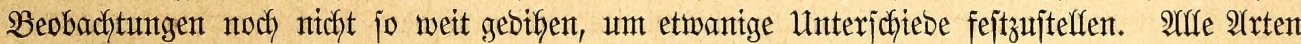
bewofnen in ifrer Gochnorbijchen Seimat bie Birfenwaldungen, welche freifich mit ben

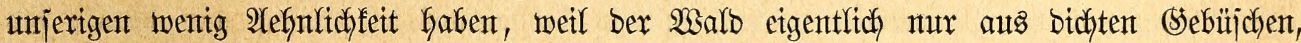

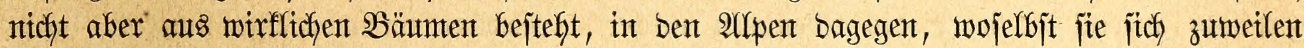

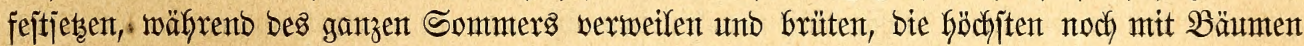

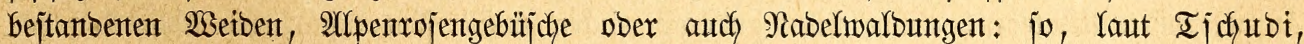

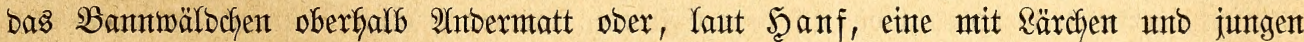

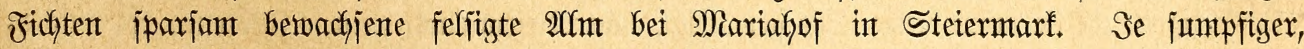
bichter und ftifler ber norbijche Wald, unt jo jicherer begegntet man ifinen fier, unto zwar regelmäp̧ig ebenfalls in (sejellichaften, welche, wie es icheint, ebenjo einträdbtig nake bei einanber niften, als jie auf ifrer Wanberung nach Dem Sitben zujammen Yeben. Waafy $=$

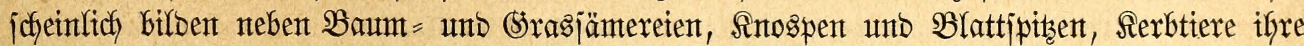

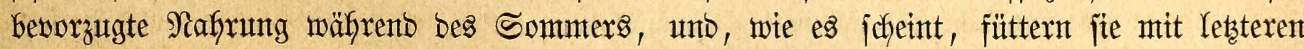

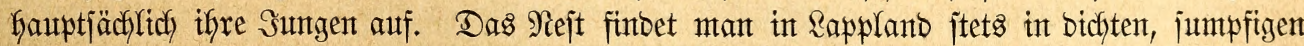

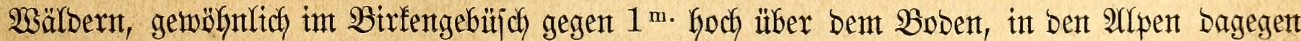

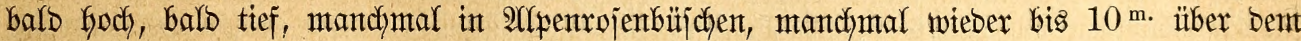

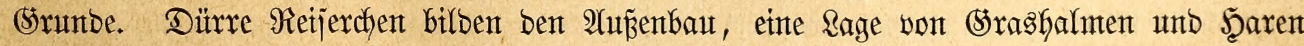

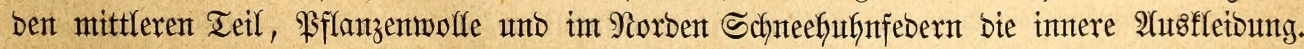

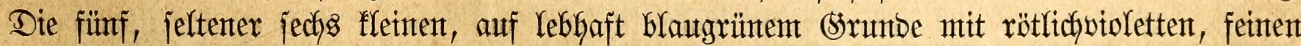
Sunften unto grö̈ßzeren, verwajchenen Unterflecfen ober rötfic) = unb fajtantenbraunen, oft in

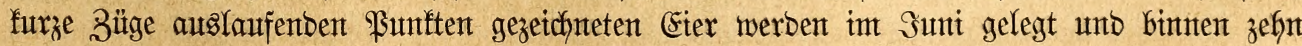

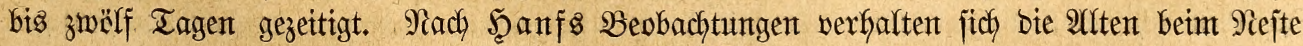




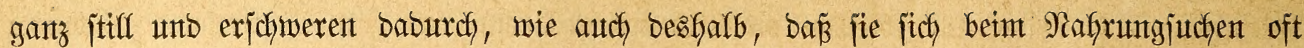

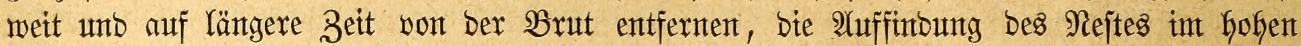

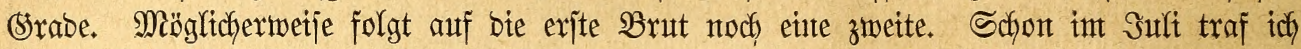
bie Reinfinfen familientweife in Den Walbungen Rapplantos an, bie Allten mit bem Fange von

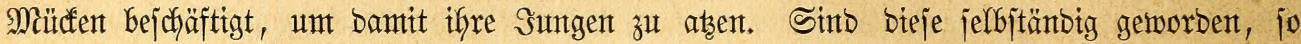

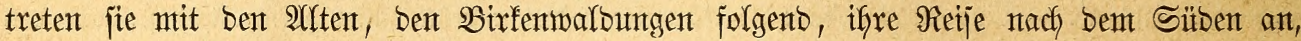
jtreifen anfänglich int (s)eburtslanbe umber, wantern weiter unb weiter und erjcheinen int Spätferbjte ober mit Begint Des Winters majfenfaft in unjeren Segenben, burdjreijen autif mobl Deutichlanto unt gefhen bis in bie jüblichjiten Ränber Europas finab. Sn mantchen Sahren jtellen fie fich in ungebeuterer $\mathfrak{A}$ trzafil bet uns ein, in anberen mux in flemeren Bejelf=

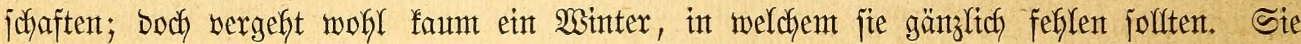

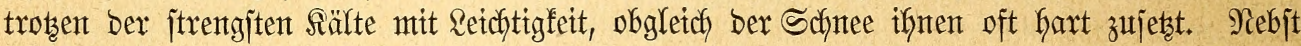
bem Birfenjanten, ifrer Rteblingsipeije, frefjent fie ben ber Erten, unt went fie weber bent einen noch ben anderen Gaben fönten, fliegen jie auf bie Stoppelfelber unb lejen fier alferlei fletne, ölige Sämereten ober im Walbe Sceiben = unb Fichtenjamen auf. Bei ruftgem,

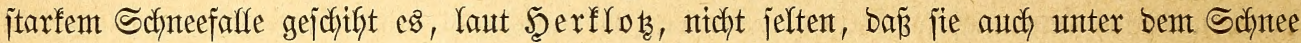

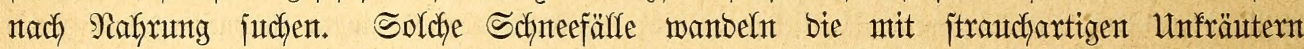
bebeclten, frudftbaren Ebenten Ungarns in lauter einzelne Sifneemehen um, unt bie Bögel werben jomit gezmungen, Durch fletne Deffnumgen, weldhe zwijchen Dem Sezweige ber firäuter jich finben, unter bie Schneebecfe zu jchlïpfen, um zu ben Samen zu gelangen. Seterbei

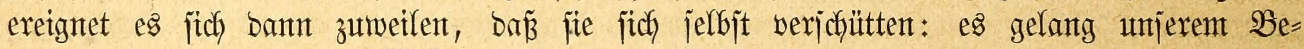

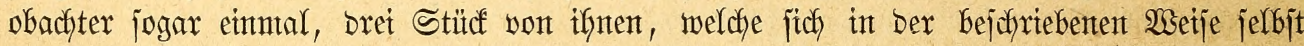
gefangen hatten, unter Demt Sdynee hervorzuziehen. Mit Beginn Des Jrüfjafyres treten

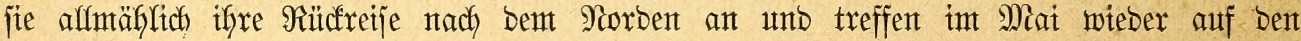
eigentlichen Srutpläken ein, fafls fie nicht, wie bie oben angejüffrten Fälle betweijen, fïch in Der Frentbe zeitweilig anjibelit.

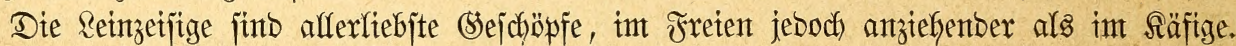

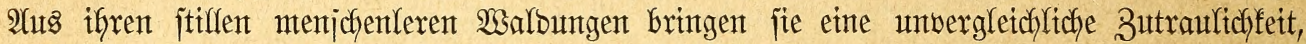
melche mant fajt Einfalt nennen möbjte, mit in bie gefäfrrliche Frembe unto treiben ficts

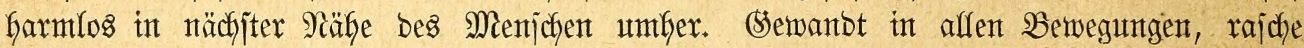

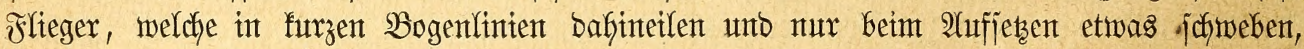
ausgezetdynete Aletterer, welche jeben anberen Finfen übertreffen und Gierin faum von ben Meifen überboten werben, bloz auf bemt Eroboben minber gejeficft, erfreuen jie burch jebe

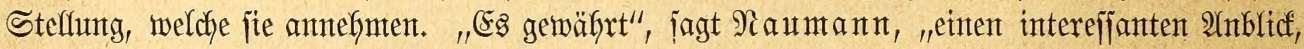

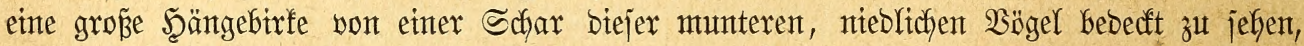
went viele auf einmal an ben (snben ber fabenäfntichen 3tweige angeflammert fich in ber Ruft wiegen"; es gewährt, füge ich Ginzu, Sergntügen, ifnent bei affen Sejchäften, weldye jie überbaupt treiben, zuzujehen, ja jelbjt jie im Räfige zu beobadyten, in weldhem je alle in

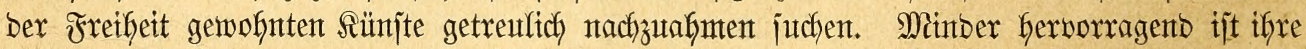

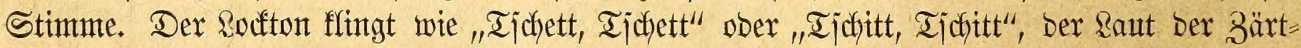

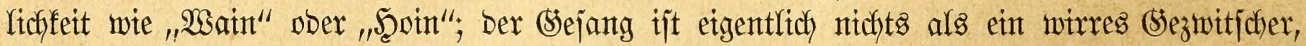
in welchent bie exjt erwähnten Rodftönte und ein langgedefnter etwas freijchender Raut bie Saauptrolle iptelent.

Snturbalb iffer Familie bürfen bie Reinfinfen wobl als bie gejelligiten angejehen werben. In ber Regel begegntet man ifyen in jefr zaflretchen Scharen, gar nicht jelten aber audh in Ssejelfichaft von Zeitigen unt nötigenfalls jelbjit in joldher von Şänflingen und Felbiperlingen, mit beren Rebensmeife bie ifrige wentg Aefultichfeit Gat. Einzelne Pärchen fift mant nie, flettere Irupps bann und want, mit ben werwanbten Zeifigen 
wereinigt. Wie es jaheint, bleiben bie Siharen mäfrend bes ganzen Winters zujammen

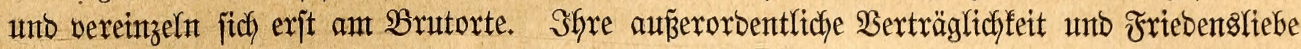

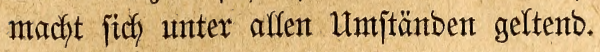

Die harmlojen seinfinfen fallen ber phmpejten Fafle zum Spfer und merben baher alfminterlich maffenthaft gefangen. Ein einziger Rodfoogel zieft ben ganzen Schwarm herbei,

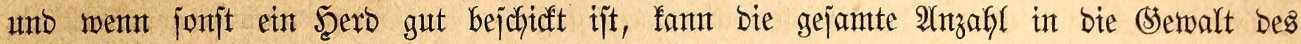
Fängers gebracht werben. Mit Der Eingemöhnung ber Sefangenen hat man nidft bie geringite Mïhfe. Sie gefen ofne meiteres an bas Futter, gletchotel, ob man jie alfein ober in Sejelfichaft in ben Säfig jperrt, Galten jich audh ziemlich gut, einzelne bis jechs Safre unto barüber in Säfige, obmohl bie exjten Keipen Sommermonate unter ben im Winter gefangenten regelmäp̈itg viele Spfer forbern. Mioknjamten und Scheuerngejäme ijt ifnen bas liebjte unb am meijten zujagende Futter; ein wentg gequetjchter Şanf jchabet

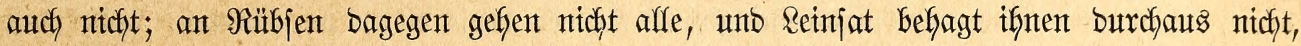
trobzbem fie ben Namen biejer Sämerei tragen. ATt Srünzeng bürfen fie ntcht Miangel

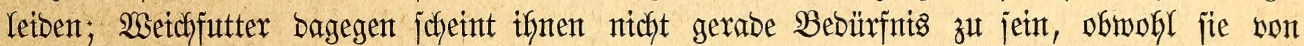

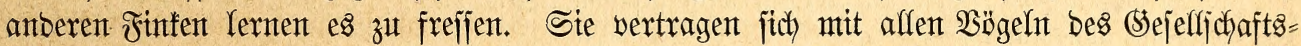
fäfigs, meicfen ben ftärferen ängjtlich aus und benfen ifrerjeits niemals baran, mit gleich)

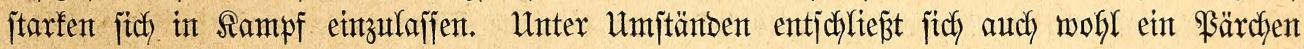
zux $\mathfrak{B}$ rut int Räfige; Doch fino Dergleidjen Fälle jelten.

Der Brets affer Reinfinfen ijt jefr gering, audy mur unbebeutenben Scywantungen untermorfen. Für einen Ialer mieres (Seldes fauft man wobl überall in Deutjalfand bret bis fünf ßärctjen.

\section{Stinlitibe.}

Der buntejte unjerer Finfen Gat nur noch in afjien einige Bermanbte, won benen wir leiber jefr ausinafmmineije bloź einten einzigen noch für unjere Räfige erhalten.

Die Stiglize fint fleine, jallanf unt zierlich gebauete, farbenjchöne Finfen. Der Sdynabel ijt freijelförmig, jefy gejtredft, bünn zugejpitzt, ein wentg abmärts gebogen, an ben Schnteiben etwas eingezogen. Die fleinen rutben Najenlöcher liegen an ber Wumzel umb werben von Borjtenfeberchen bebecft. Die futzen ftämmigen Fü̈ße Gaben żemlich lange

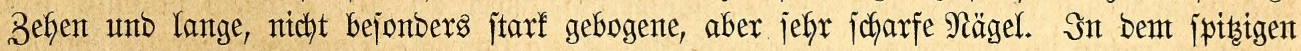
Jlïgel, welcher zujammengelegt etwa zwei Drittel des Schwanzes bebecft, überragen bie beiben ober bie brei erjten Schwingen bie ïbrigen und fint bie Armijhmingen verengt. Der

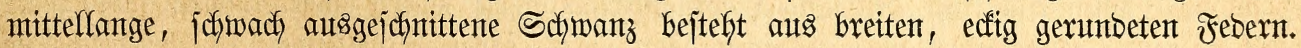

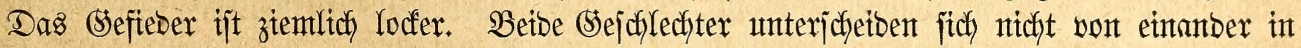

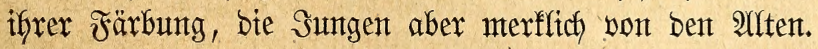

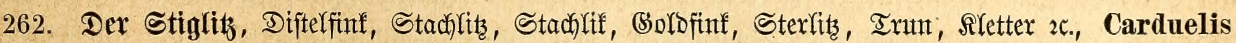
(Fr., Pass., Spin., Ac.) elegans, Stephens (carduelis, ochracea, auratus). $-\mathfrak{A} . \mathfrak{B}$. $\mathfrak{A} \mathfrak{a} \mathfrak{u}=$

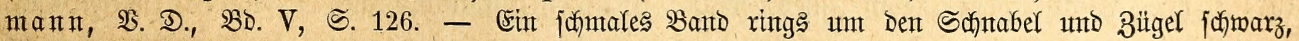

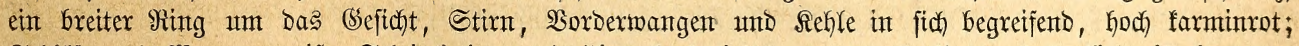

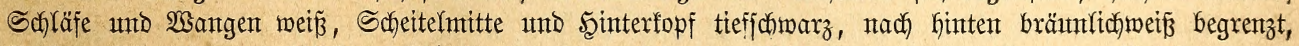

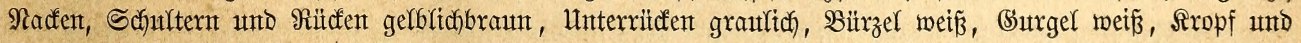

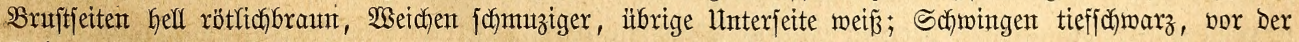

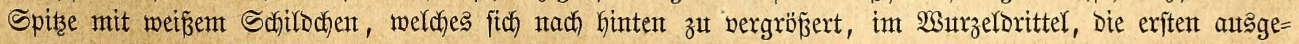

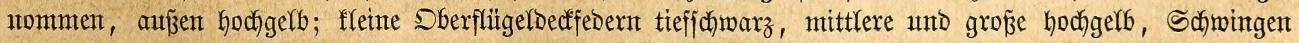

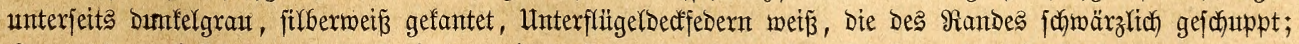

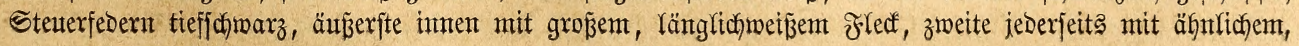




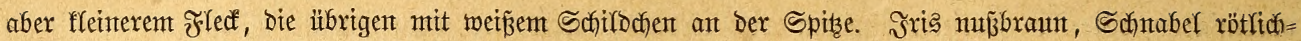

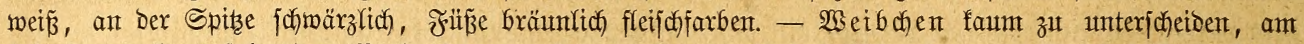

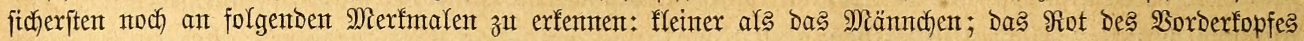

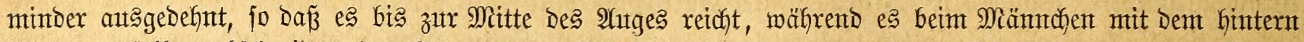

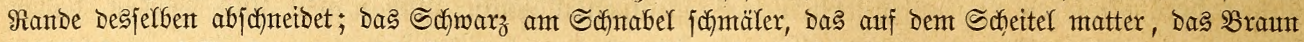

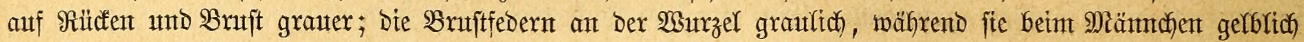

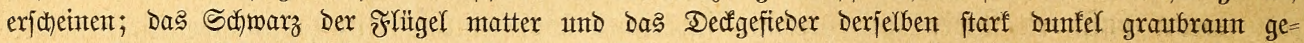

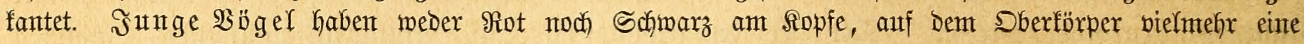

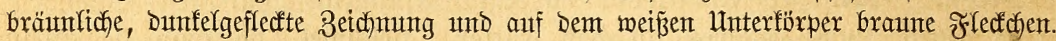

Som mittlexen Sdameden an bemofnt ber Stigritz gant Entropa, ftreift von Spanien nach Norbmeit =

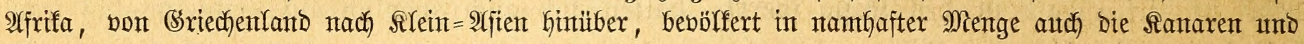
Miadeira utno ift auf Ruba eingebürgert worbent.

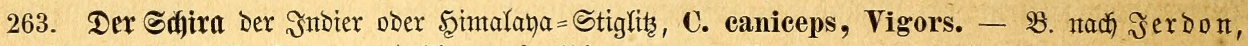

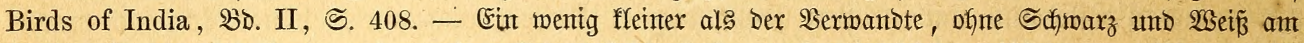

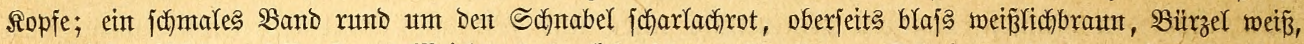

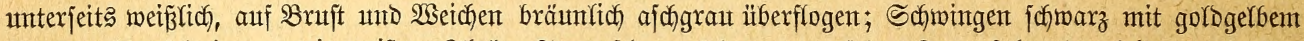

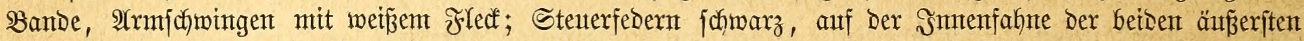

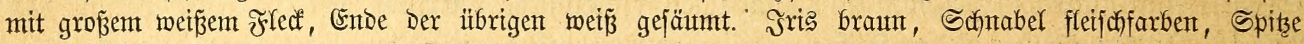

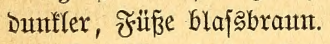

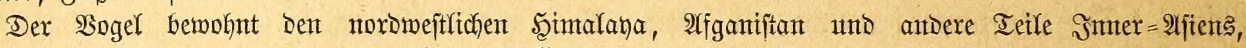

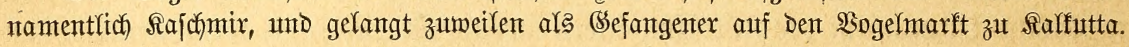

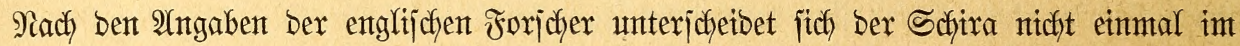

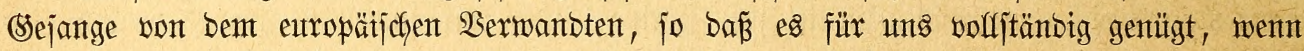

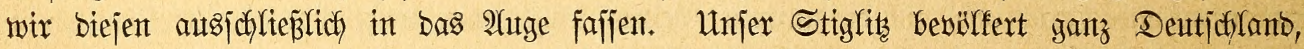

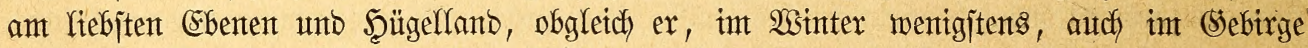
exjcheint. Ein eigentlicher Walbongel ijt ex nicht, liebt vielmebr Bujchbölzer und $\mathfrak{B a u m =}$ pflanzuntgen mefgr als bichtere Bejtänbe, und went er wirffich int 2 balbe fich anjibelt, bält ex fich meijt in Sorbölzern ober in mandhfach abwedjjelnbem Walbe jelbjt auf. Sefr

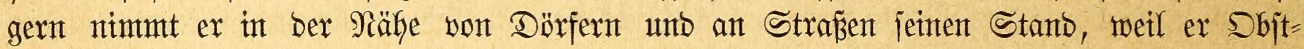
bäumte affent übrigen vorzuziefgen joheint. Mit Begint bes Şerbjtes fachlägt ex fich in mehr ober minber zahlretche Sejelfjchaften, int jüblichen Europa oft in ungefentere Schwärme zujammen unb ftreift num gemeinjchaftlich umber, von einem nafuntgweriprechenten \$laze zum

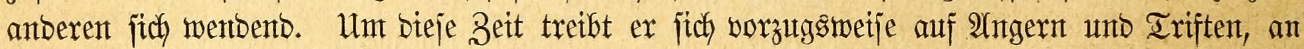
Felorninten, Dämmten unt Dergleidyen umber, jeinten Rieblingspflanzen, Den Dijteln und

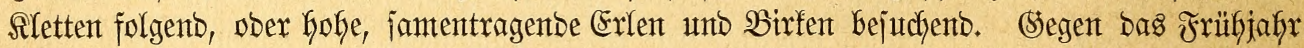
Gin vereinzelt ex jitch, und jebes \$ärchen nimmt mun jeinen Stand auf einter ber erwähnten

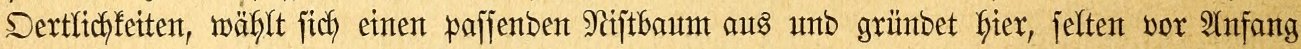
Mais, wenn bie Bä̈nte beretts int jungen Srüne prangent, in einer Sृöhe von $6-12 \mathrm{~m}$.

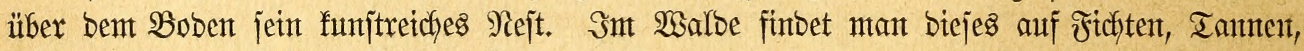

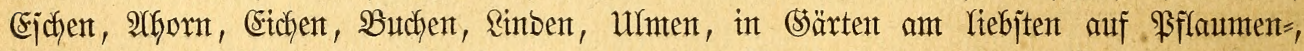

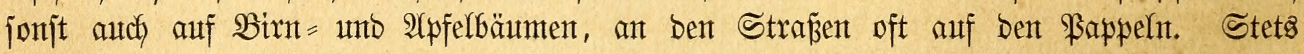

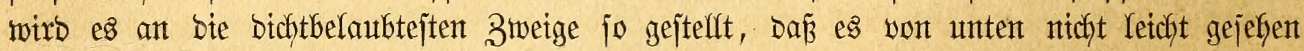
merbent fant. Es bejtefgt aus einem bichten Fitzmerf won grünem Baum = unt Erbmos,

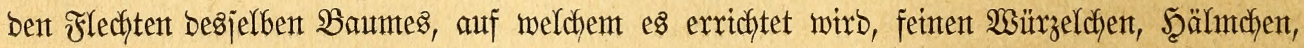

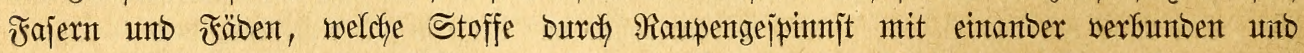
nach inten mit einer Sage Pflanzentwolle unto einigen bieje befejtigenben Pferbeharen unt

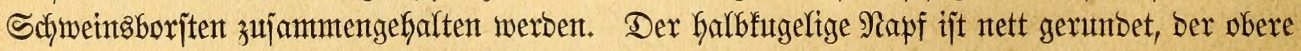
Rand etwas eingebogen. Das Selege bilben vier bis fünf, zuweilent jects furzeiförmige,

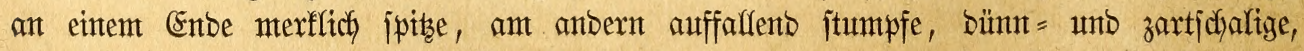

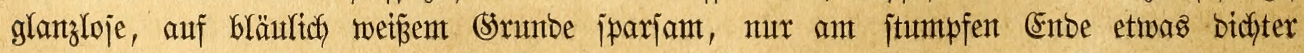
mit violettgrauen Punften, blajgeroten, bräunlichen unto rötlichjchwarzen Strichelchen ge= 
zeidhnete Eiter. Sie werben binnen breizefnt bis vierzefnn Iagen vom Weibchen alfein ausz= gebrütet, währent das Miännthen inzmijchent bie Ernährung ber Słattin übernimmt. Die

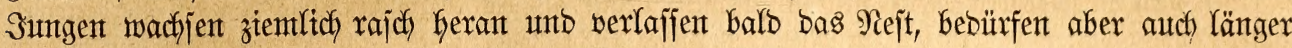
al\& anbere Fitnfentö̈gel ber elterlichen Pflege unb Füfyung: man fiht jie noch im Spät= jommter mit ifren Eltern bereintigt.

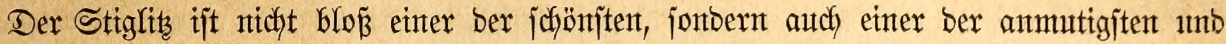

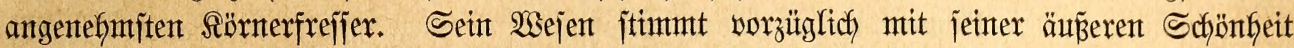

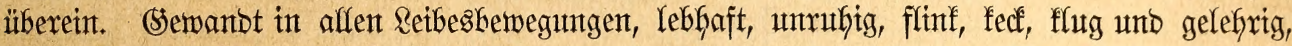
Dabei ein fleip̧igex und trefflicher Sänger, vereinigt er jo viele gute (Eigenjchaften in jitch,

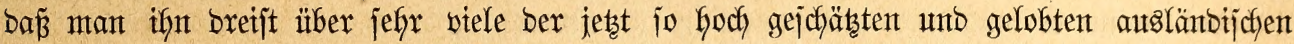

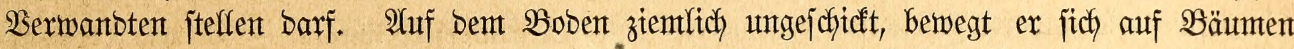

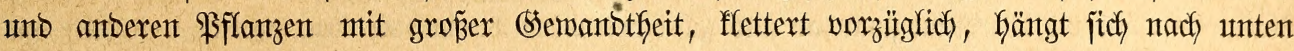
an bie 3roige, wiegt fich an ben bünnften Spizen und zeigt fich überfautpt im Sezmeige ber

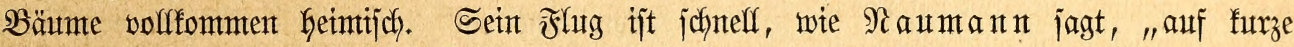
Stredfen fajt zudfend", gejdjifht in furzbogigen Rinien und entfaltet erft bie volfe Fracht bes

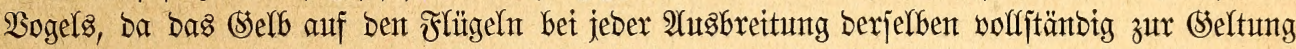
fommt. Die Rodfitimme, weldhe Der Siamte Stiglits als Slangbill miedergibt, ffingt wie

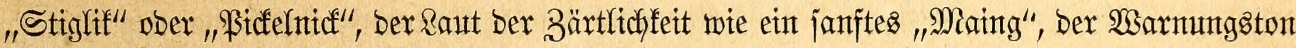

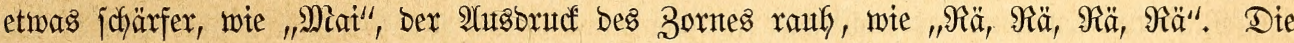
Sungen jdyreien unaufförlich) "Biffitt, Bizi, Bifflitt". Der (sejantg gebört, obglecth er bem bes

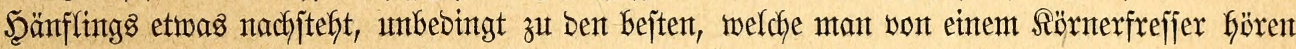

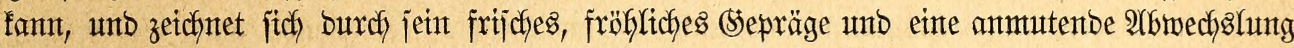

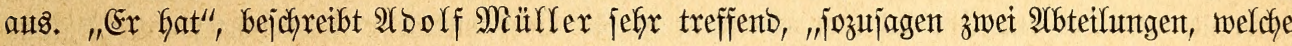
oft jebe für jich alfein auggefübrt werben, ebenjo oft aber auch in fleinen 3mijchentaujen

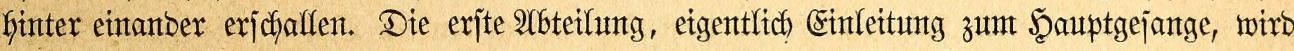
zujammengejebt aus bes $\mathfrak{B o g e l s}$ Rocftönen und benjelben ähnlichen, hüpfend pfeifenden Rauten

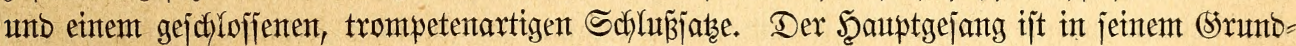

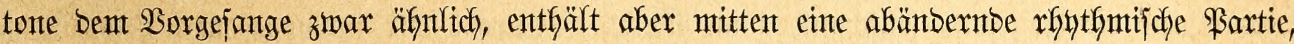

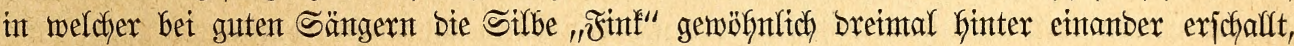
bant in etwas gefaltente, mit bent "Fint" gleichjam ben Sipfelpunft des Riebes bilbende

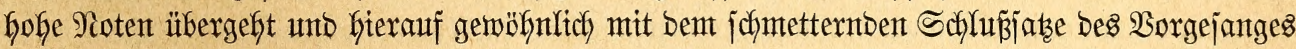
enbigt." WSie bet affen Singbögeln finbet man auth unter bent Stiglitzen mefyr ober wentger

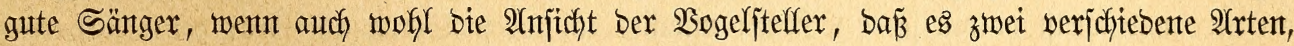

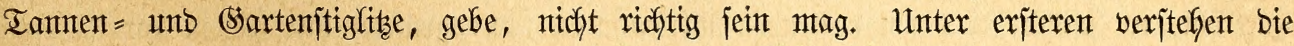
Türnnger Riebhaber bie größ̈eren, unter Yeşteren bie fleineren Stülfe. Jebenfalfs tut man

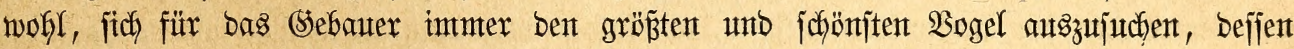
man Gabgaft werbent fant.

Jm Freien ernährt fich ber Stiglits bon $\mathfrak{B a u m}=$ und Straudyjämereien ber ver= jafiebenjten $\mathfrak{A}$ rt, nebenbei won Serbtieren, welche nebent aufgemeichtem Rleingejäme nantentlich

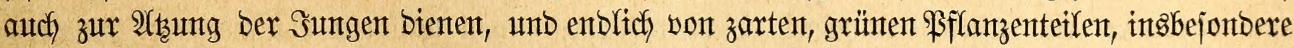
won verjchiebenen $\mathfrak{B l u ̈ t e n . ~ D e n ~ \Re a m e n ~ D i j t e l f i n f l ~ t r a ̈ g t ~ e x ~ m i t ~ v o l l j t e m ~ \Re e c h t e , ~ w e i l ~ e r ~ i n ~ b e r ~}$ Iat ben Samen ber Dijtel und anderer Pflanzen alfent übrigen borzieft, Miofnjament viefletdjt

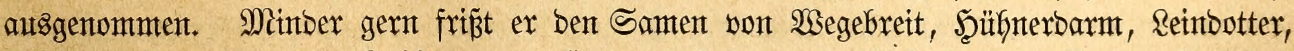

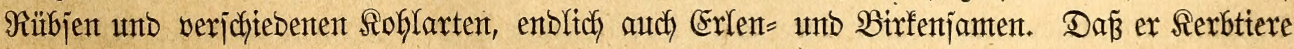

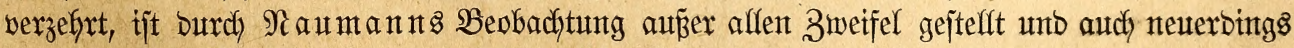

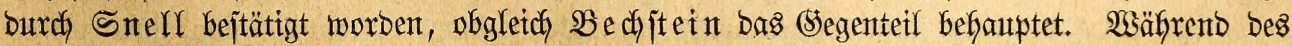

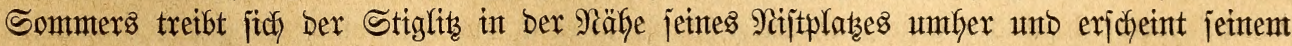
unrugigen 2 ejen entiprechent balo fier bald Da, um biejen ober jenten Samten auşzflauben; 


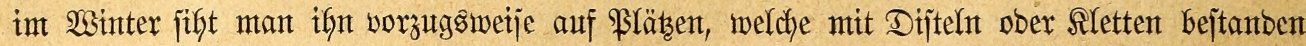
merben; ja jeine Vorltebe für bieje Sämereien geft jo tweit, baj man ifn burch zujammen= getragene Dijtelbüliche eigentlich bafin locfen fant, mofint man mill. Seine Iätigfeit im

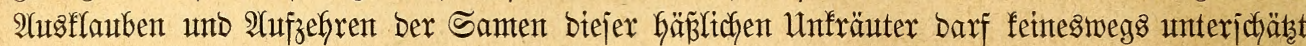
merben. Naumann beobachtete, bap einige von ifm geichonte Stiglitze binnen wentgen Sahren eine von Dijteln überwucherte Witeje volfitänbig jäuberten. Sn Der Befangenjichaft

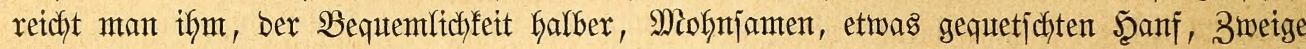
mit feinen Inospen unb anderes Srünzeng, namentlich Bogelmiere, feingehacte Salat= und Soblblättchen, barf ifym auch Wetchfutter vorjetzen, ba ex jich letcht an basjelbe

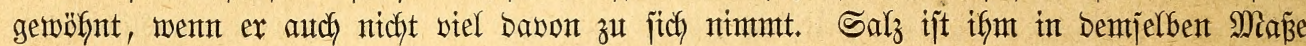
Bebürfnis wie anberen Rörnerfrejiern, weldye wentg Serbtiere frejien. Rebtere beachtet ex im Säfige fajt gar nidjt, nimmt zmar ab und zu einen Meblyurm unb faut ifgn aus, jofeint ben= jelben aber nidjt gerabe zu vermijjen, wenn er ifn nicht erfält. Dijtel = und slettenjamen

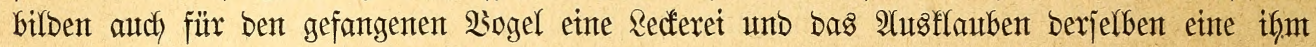
wie es jueint jebr angenefyme Unterhaltung.

Sn mandjen Stegenten zieft man Nejtftiglitze auf, um fie von anberen $\mathfrak{B}$ ögeln unter=

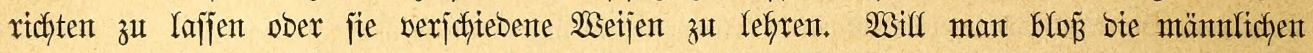

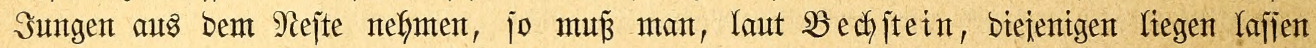

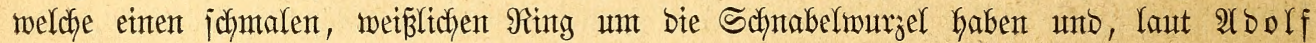

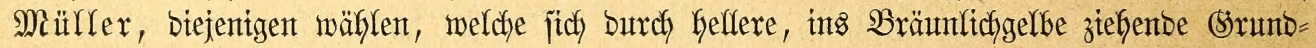

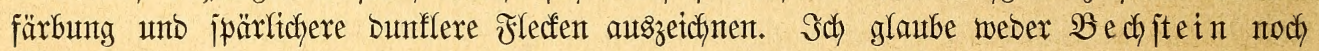

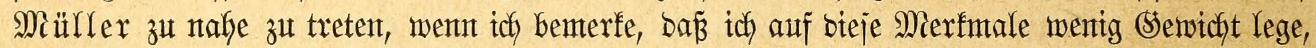

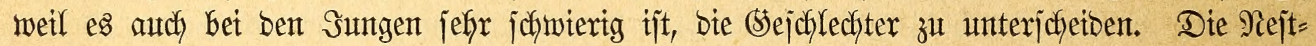
linge merben mit Miofnt und Mitldyemmel aufgezogen, gemöhnen jich bann jelbjtwerjtänolich)

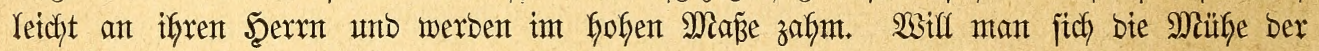

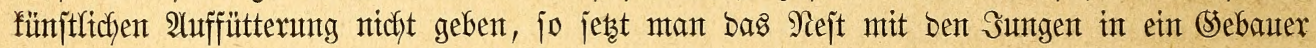

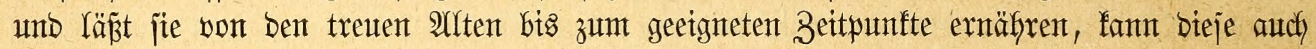

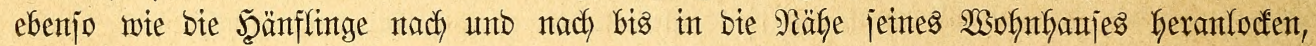

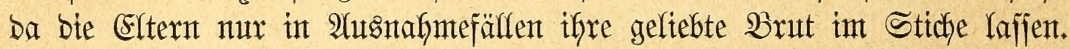

Ter Stiglibs eigntet jïh ebenjo jebr für ben Einzelfäfig wie für bas Fluggebauter. Int

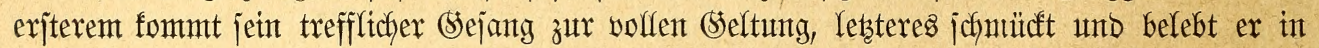

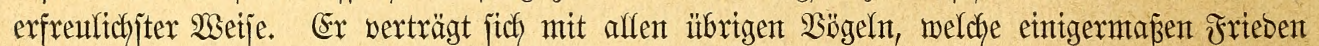

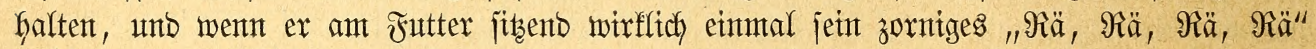

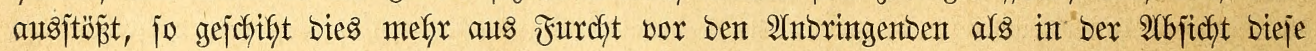
zu vertreiben. Bei Der Sleinfeit Des Meofnjamens, jeintes hauptjächlidjjten Futters, bedarf

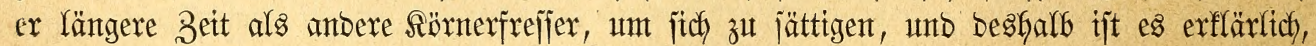

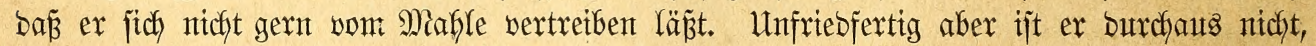
bentmmt jidh im (Siegenteile jtets liebensmürbig gegen jeine Mitgefangenen und macht jich) vft ein Bergnẗgen baraus, einige von biejen, namentlich Beijtge und Flachşinfen, zu ałen, als wären es jeine eigenten Sungen. Bärchenweije gef̧alten und mit ben nötigen Baujtoffen verjefgen, brütet er autch in Fluggebauter, am ehejten, wenn mant ifm ein gejtricftes Drat=

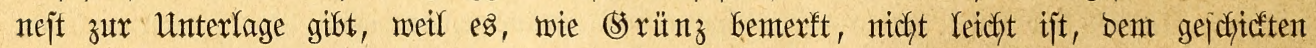
Baumeijter einen ifm bequemen Standort für bas Nejt unt bie ifgm rechten Baujtoffe zu liefern. In Dem Fluggebauer Dr. Schufters, eintes jefr eifrigen Züdbters, brütet ein ßärchen regelmtäß̈ig.

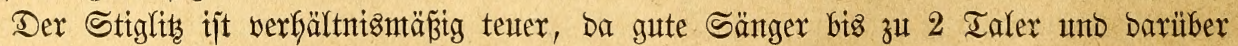

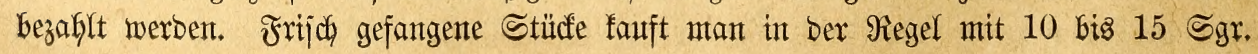




\section{Beilitige.}

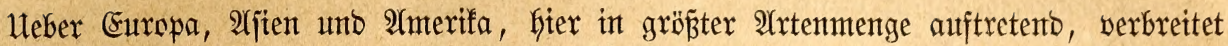
fich) bie Sippe ber Zeifige, Deren Mitglieber als vorzügliche fiäfigwögel gejchätzt werben.

Die Zeifige finto fleine, unter jich ziemlich gleich groß̉e sinfen won gejtrecttem Reibesbau.

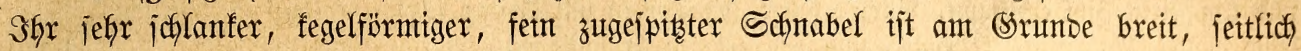
cintoärts gebogen, zujammengebrüdț, ber Munbrano janft gefrümmt. Die Najenlödjex liegen völlig unter ben Febern verjtecft. Die Beine jüt furz, Die Beben fräftig, bie Sirallen ftarf gebogen unt jocharf zugeiptżt. Sn bem langen, jpizen Flügel, welcher jtets über bie Mitte Des Sdjwanzes Ginabreicht, ijt bie zweite Sdjwinge bie längite, bie erite wenig fïrzer als bieje. Der furze Schwanz zeigt in Der Mitte einen Yeidften AYusjidnntt. Daz weiche (Sefteder prangt bet vielen $\mathfrak{A}$ rten in jefy lebfajten Farben. Srün, (Selb und Sdymarz find vorkerjachent.

264. Der 3eiftg, 3eifing, 3iefintg, 3ieschen, Engeldyen z., Chrysomitris (Fr., Spin., Linaria,

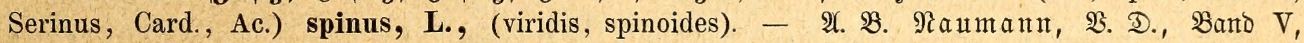

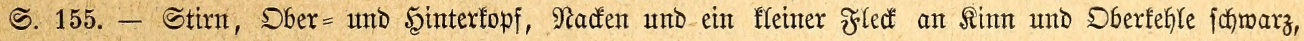
Shrgegend, Şinterhals, Mantel und Schultern olivengelbgrïn mit Dumfferen Schaftitrichen, Bürzel olivengelb,

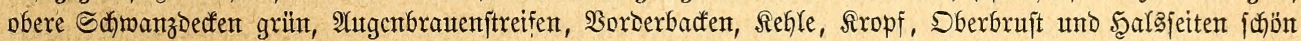

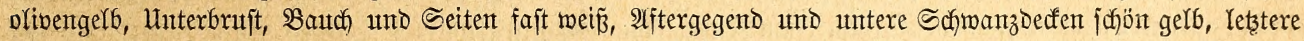

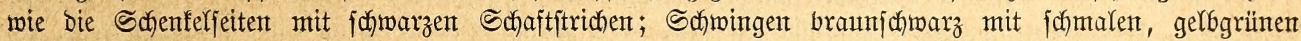

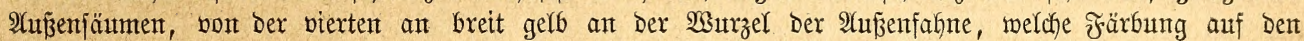

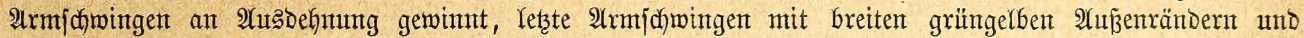

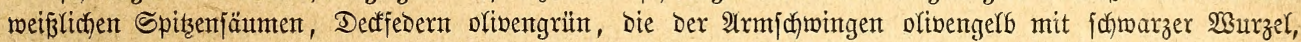

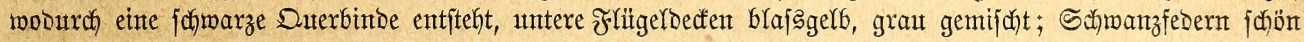

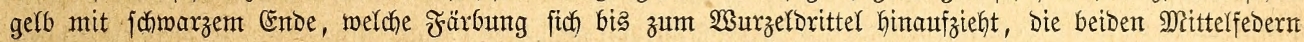

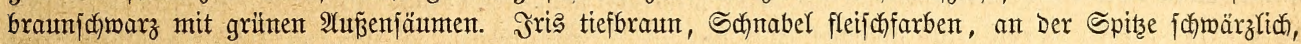

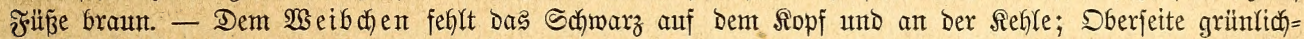

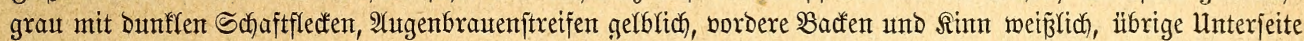

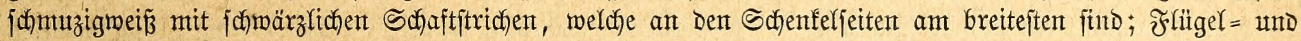

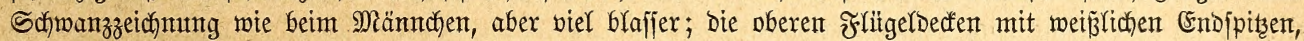
Daher zwei weip̧lidje Duerbittoen.

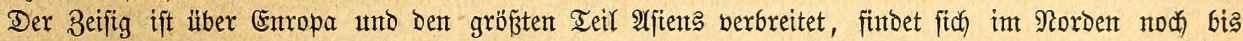

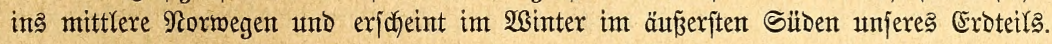

265. Der Sappenzeifig, Chr. (Fr., Card.) icterica, Vieill., (magellanica, campestris, capitalis). -

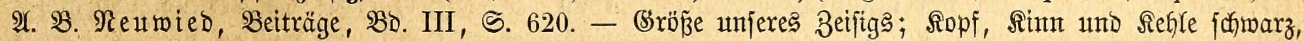

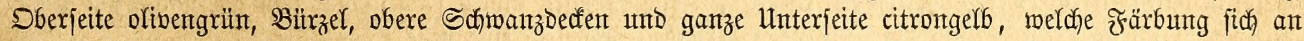

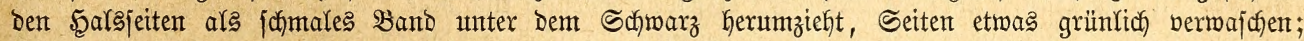
Sabwingen uno beren Dedfedern fdhwarz, exftere in ber $\mathfrak{B u t r z e l f a ̈ l f t e ~ i n n e n ~ g e l b , ~ b i e ~ b r i t t e ~ b i ß ~ f e c h j t e ~ u n o ~}$

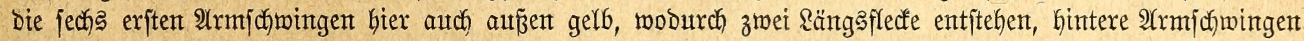

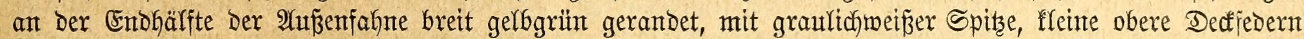

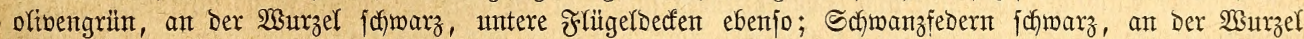

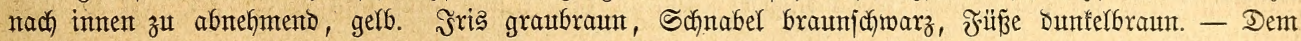

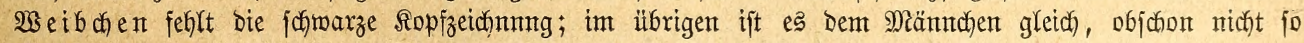
rebbaft gefärbt.

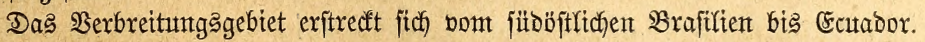

266. Stanlen's 3eititg, Chr. (Card, Hypacanthus) Stanleyi, Audubon. - 2 . B. $\mathfrak{A}$ to bubort,

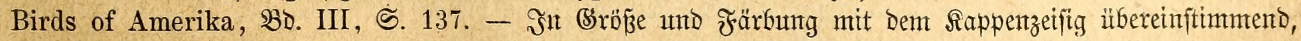

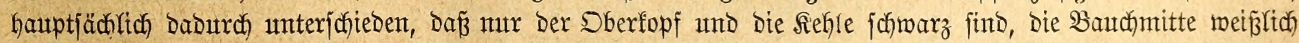

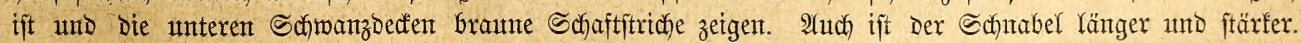

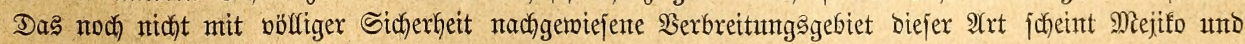
Rafifornien zu umfafien.

267. Der Mäıdjazcifitg, Chr. (Fr.) spinescens, Lichtenstein. - Sgl. Bonaparte, Con-

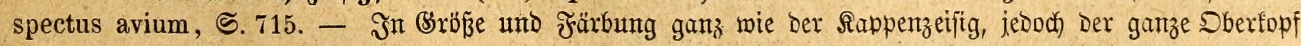

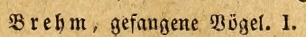




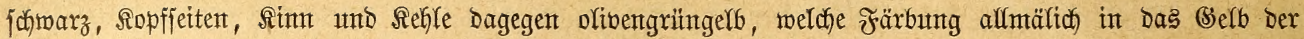
unterfeite verläuft.

Dab Saterfand ift Reut= (Sranaba.

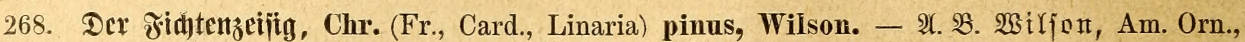

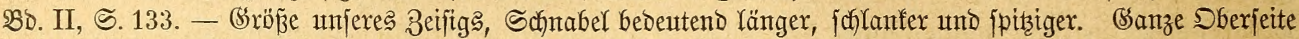

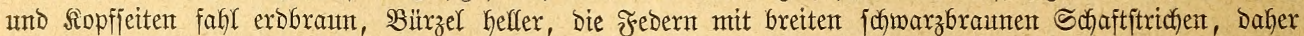

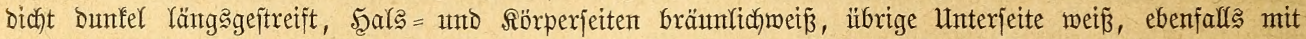

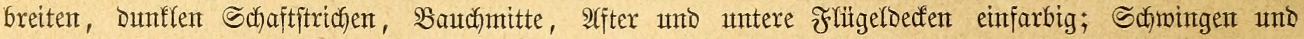

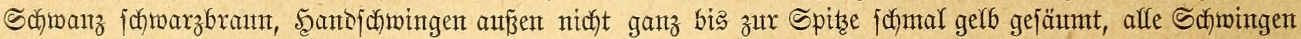

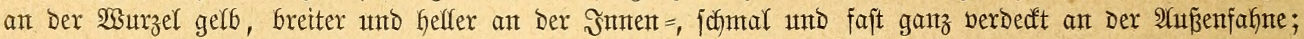

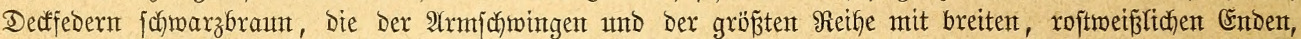

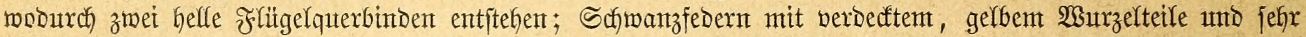

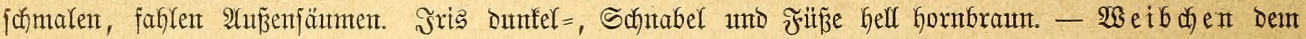

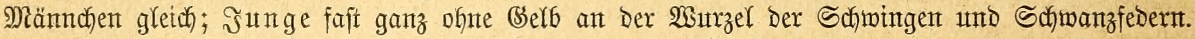

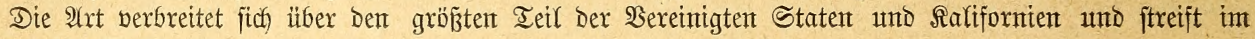
Şinter bis Mejiffo finab.

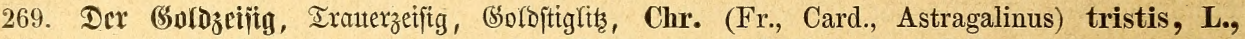

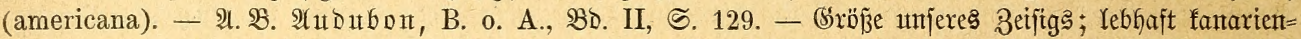

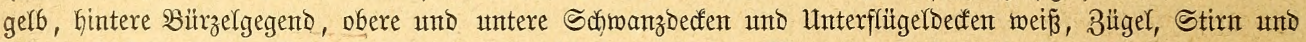

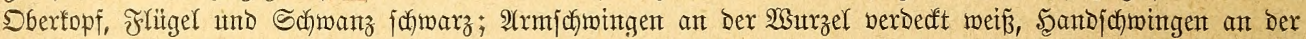

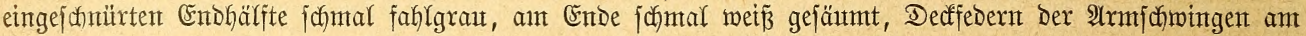

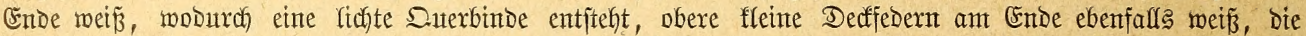

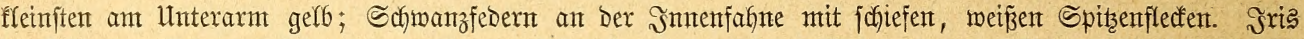

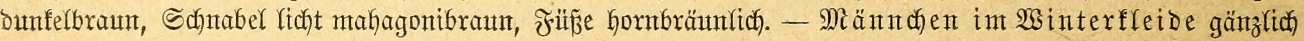

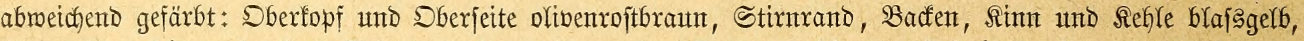

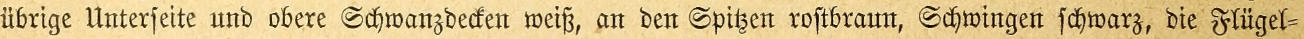

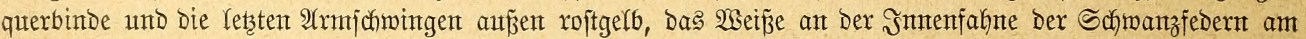

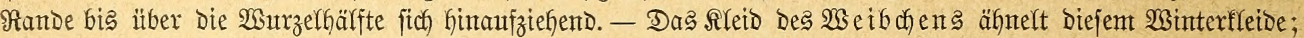

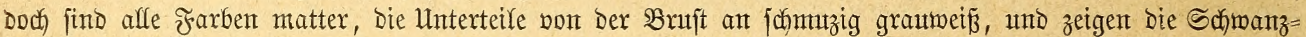

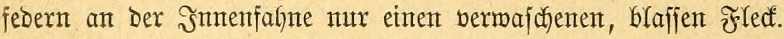

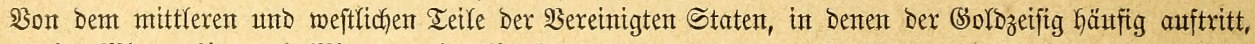
zieft er im Winter bis nach Mittelamerif́a finab.

270. Der Arfiniagzeifitg, Chr. (Fr., Card.) psaltria, Say. - 2. B. $\mathfrak{A} 1 \mathfrak{d} 601$, B. o. Am.,

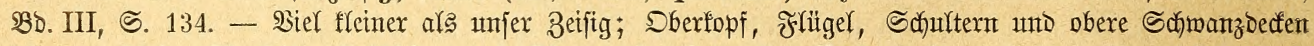

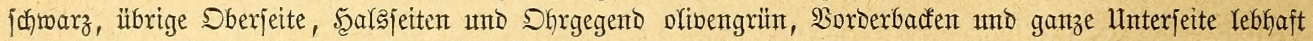

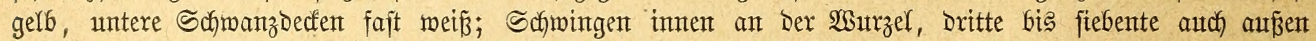

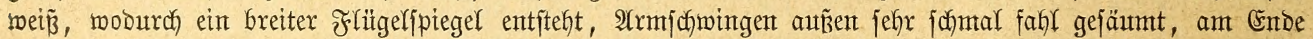

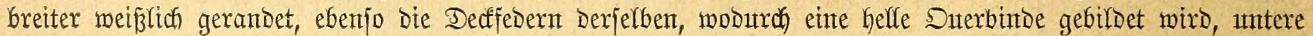

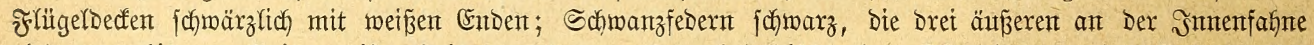

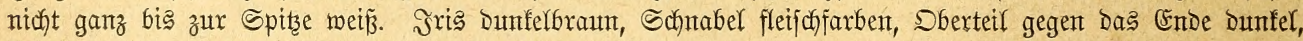

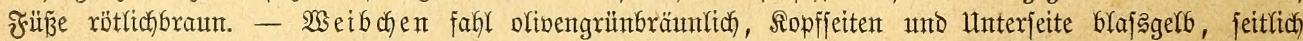

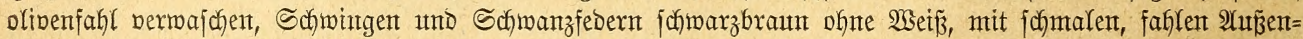

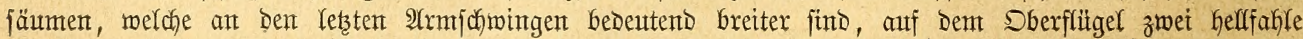
Duterbinden.

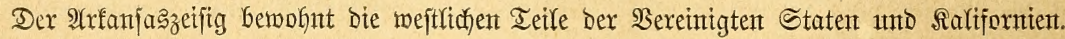

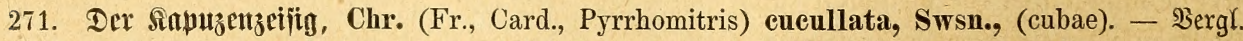
Smainfon, Zool. illustr., Iaf. 7. - Anjegnlich fleiner ars Der Beifig; Sberfopf, Ropffeiten, Rimt uno

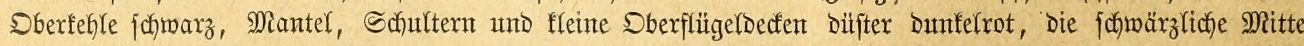

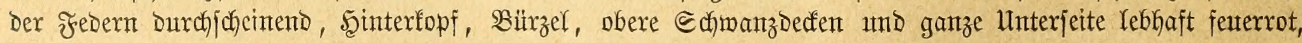

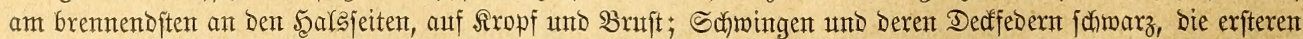

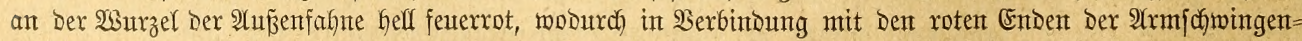

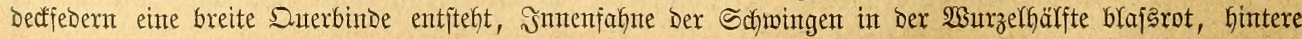

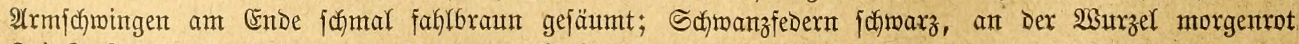

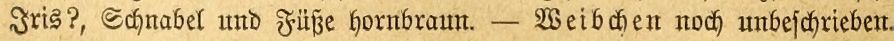

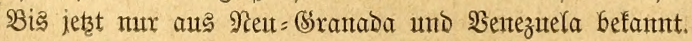


272. Der (Soldoürzelzeifi, Chr. uropygialis, Sclater, - $\mathfrak{A}$. $\mathfrak{B}$. Gelater, Catal. Am. B.,

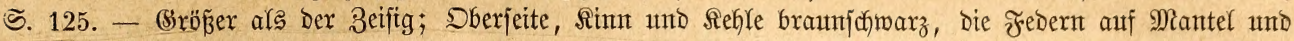

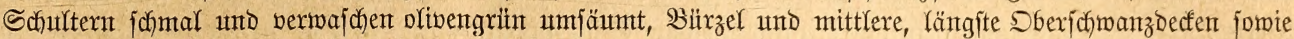

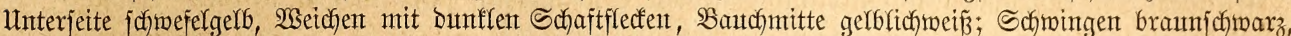

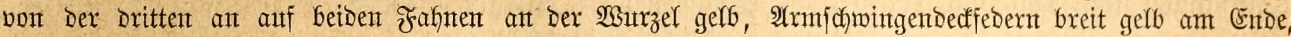

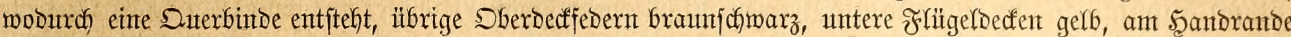

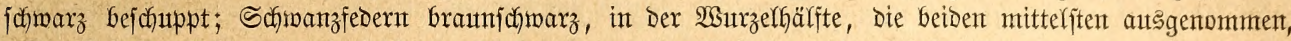

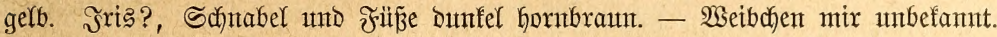

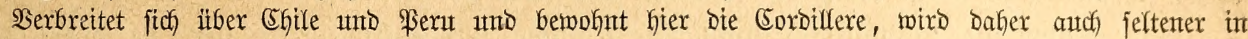
Befangenichaft gehalten als Dex Rappenzeifig.

273. Der Irmuerzeiitg, Chr. (Card.) atrata, Lafresnaye et d'Orbigny, - 2 . 3 . d'Orbigny,

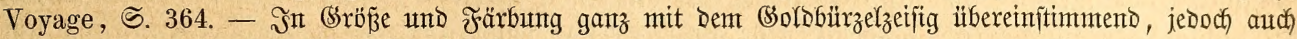

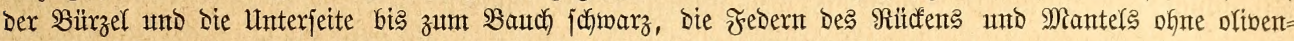
grünte Säıtme.

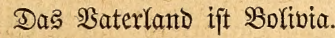

Heber bie Rebensmeife ber auzlänbijchen Zeifige haben wir biaher mux bürftige Berichte

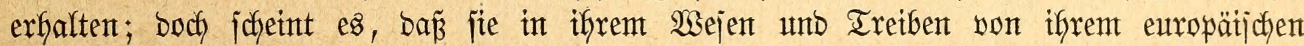
Berwantent wentig abmetchen. Diejer betwohnt gant Mitteleuropa und fefilt in Deutjchland

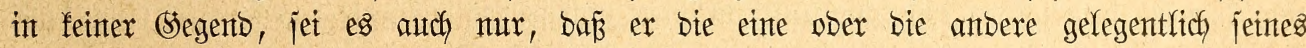

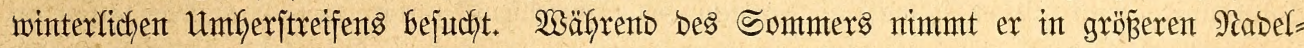
malbungen jeinten Stant, am liebjten in joldfen bergiger begenten, unb brütet fiter, beginnt

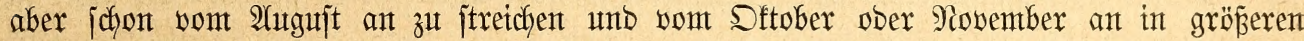
Scharen weiter umberzujdyweifen. Um bieje Beit begegnet man ifgm jtets in zafilreidjer

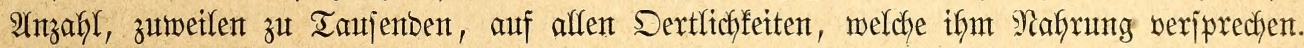
Das Sebeifyen ober Mitzraten gentifer Baumjämereten bebingt unzmeifelfaft ebenjo nohl

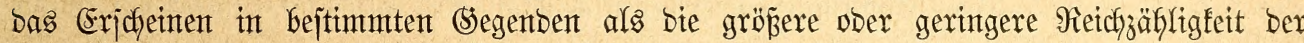
Schnärme. Went ber Erlen = ober $\mathfrak{B i r f e n j a m e n ~ g e r a t e n ~ i j t , ~ f i n b e n ~ j i ̈ h ~ b i e ~ B e i f i g e ~ a u f ~}$

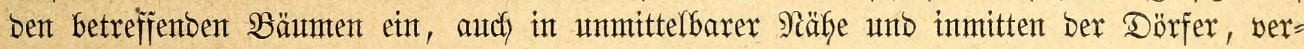
weilen fier währent bes ganzen Binters und zerteilen jich erit in Frühjafre wieberum in

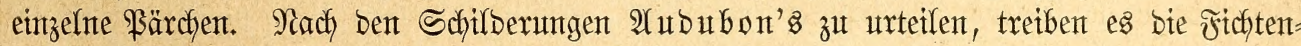

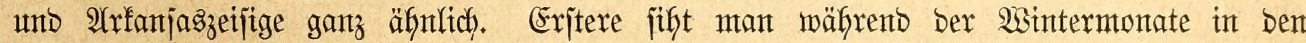
nörolichen Ieilen ber Sereintgten Staten ebenfalls in grö̈̈eren Schwärmen, zumeilen in

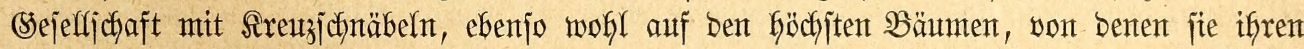
Namen tragen, wie in nieberen Didftchtent. Unjer Semäfrsmant traf fie an Den Sïjten

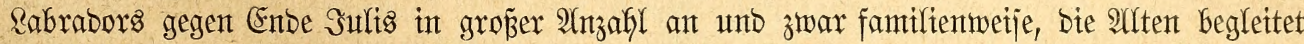
vont ifren Sungen unt Gödhjtens zwei ober brei Familien vereinigt. Der 2trfanjazzetjig wurbe in ben Feljengebirgen entbecft, ipäter aber aud in Rouijtana als unregelmä̈̈̈ger Wintergajt aufgefunben. AYububon jefilbert ifn als einen untubigen Bejellen, welcyer jelten längere Beit auf berjelbent Stefle verweilt, jonbern einte Dertlichleeit bann unb wann bejudft, in locferen Flügen bafinzieft, währent Des Fluges oft eigentümliche Sdjwentungen ausfühtyt, als ob ex fich won ber Befabrlofigfeit eintes beftimmten Srtes überzeugen wolle, jebe SBaumgruppe berücffictjtigt und fid bant fofort an bas Futter macft. Siappen = und (Solbzeifig idhetnen mefr umjerem Stiglits als Dem Zeifige zu ähnteln. Eriterer, weldyer porzugghweije Den jüblithen \&änbern ber Sereinigten Staten angebört und, wie bemerft, bis Iejas, Mejif́o ober jelbjt auf bie mejtinbijchen Injeln kerïberitreift, bält jich währeno bes 3uges fajt nur auf ben Spiben ber bödjiten Bäume nake am Wajfer auf, bilbet jelten

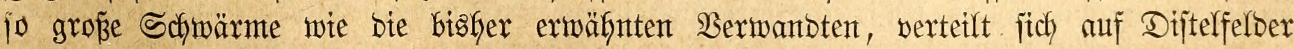

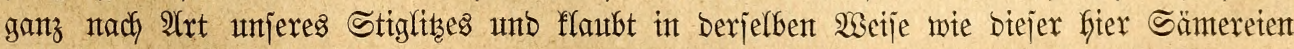
au8. Sn Den nörolichen Staten, namentlich in शiew = Yyorf exicheint er um bie Mitte Des April, verweilt fier währent bes ganzen Sommers und ijt bis zum ફ̧erbjte fint überall 


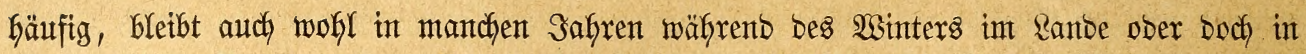
Den mittleren Staten wofnen, wenn icton ftets nur einzefrn. Der Rappenzeifig gef̧ört, Yaut Barmeiftex, bemt jogenannten Eamposzgebiete Sübamerifas an, metbet aljo bie gejejlofifenten Warbungen unb bevorzugt bagegen bie Steppent ober partäfuntichen Ieile bes Ranbes. Seinen

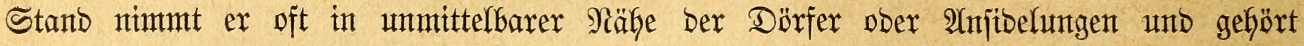

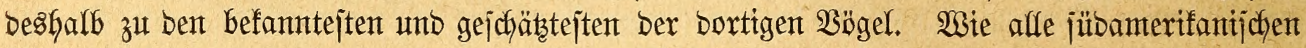

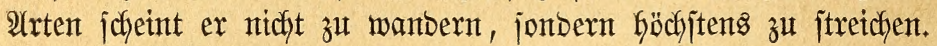

Alfe Zeifige jind anmutige, muntere, regjame und zutrauliche, bafker bei Sebermann

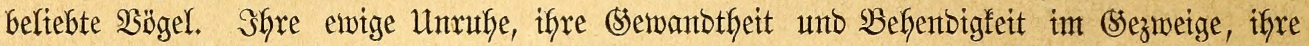

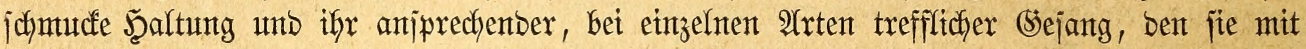

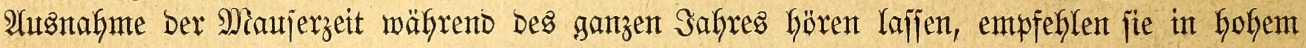

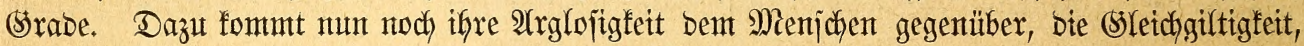

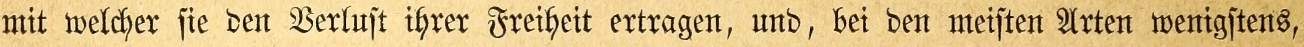

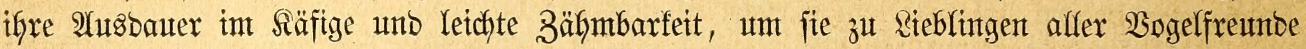

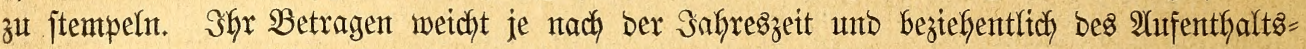

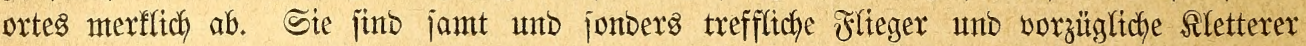
unt Iurner, wetteifenn hierin mit ben \&einfinfen uno ftefgen mie bieje ben Mieijen faum nady. Sollftänbig gleich) gilt $e 8$ ignen, ob jie fich oben auf einen 3weig jetzen ober won unten an Denjelben Gängen; Denn fie Güpfen, jteigen voer flettern mit Derjefben Jertigfeit uno wiffen

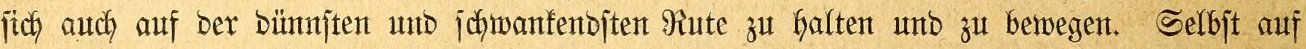

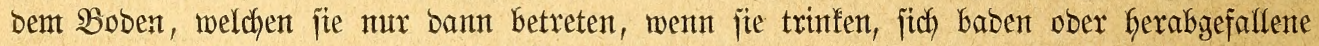

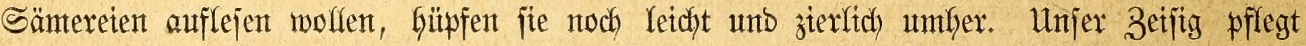

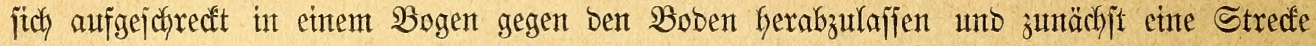

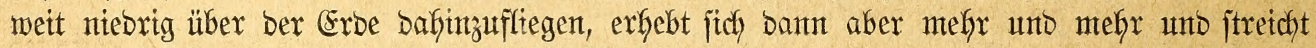

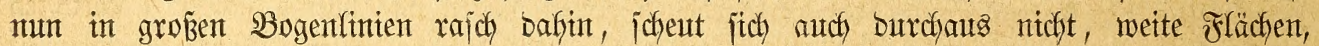

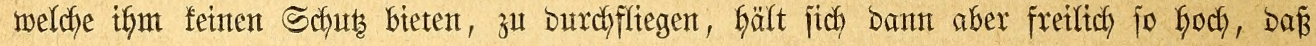

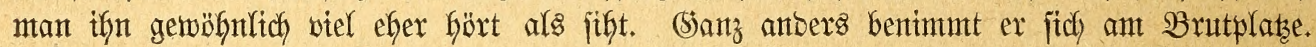

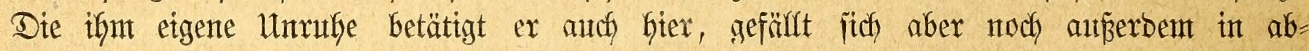

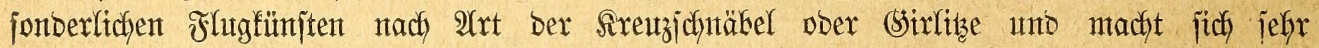

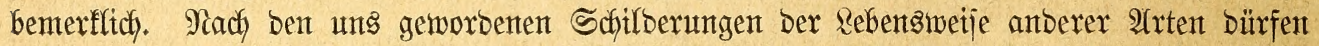

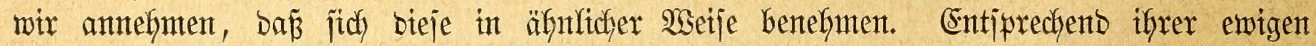

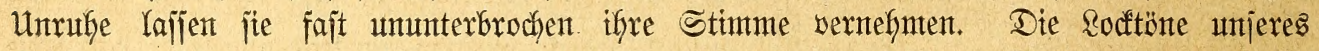
3eifigs, welche man an Gäuffigiten Gärt, fönten Durdh Die Eilben "Trettet, trettertettel," ober "bie, bir, bei," und "Dibel, biolei" ungefähr miebergegeben werben. Der (sejang bejteft

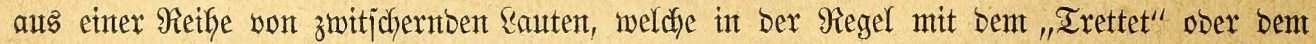
gebefynten "Diebelbibeflei" beginnen unt nit einer lang gezogenten, burdy bie Silben "bibel=

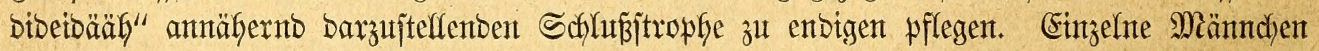

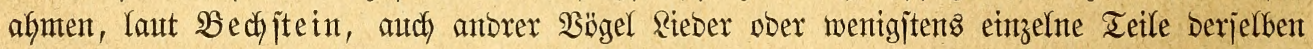
nach; Dodh jefjeinen joldhe Spötter redgt jelten borzufommen: idch wenigitens habe nie einen Beifig gehört, weldher bätte. Suntg aufgezogene Yernen, auch went mant fie zu Dent bejten Mieiftern in bie Refre

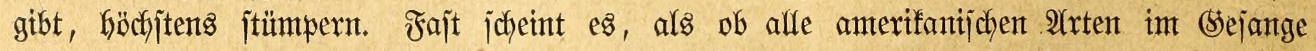

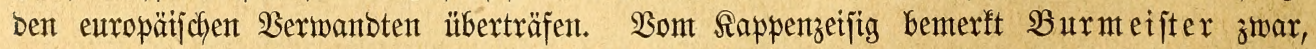

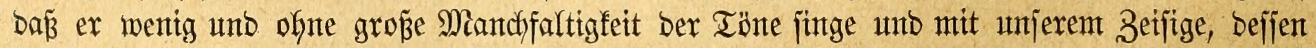

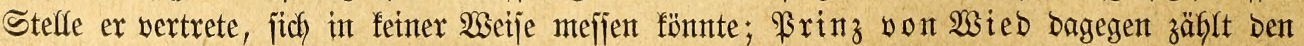

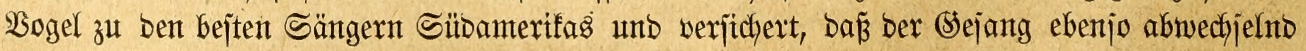

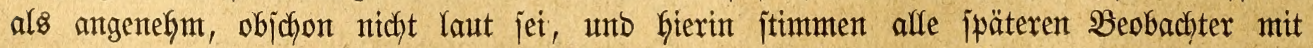

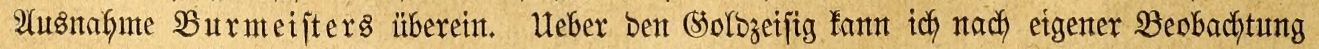


urteilen. Nidgt mit Untredft betrachtet man ifgn als ein Mittelgfied zwijchen Stiglits uno Beifig. Betragen unb (sebaren, $\mathfrak{B e j e n}$ unto Sigenichaften, Bemegung unt Bejang erintern

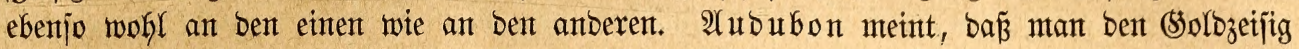

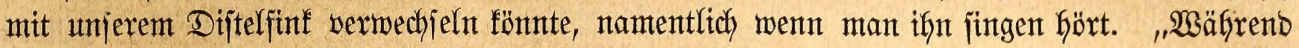

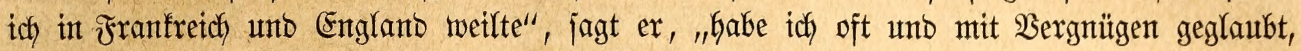

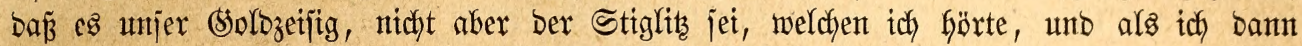

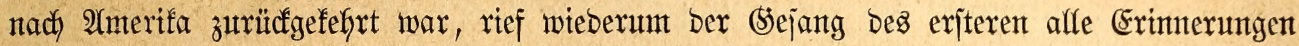

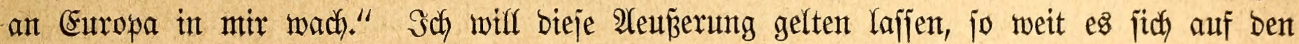

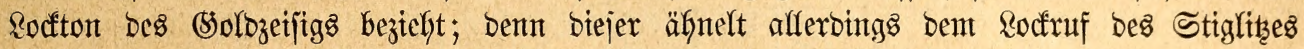

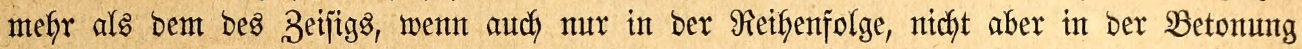

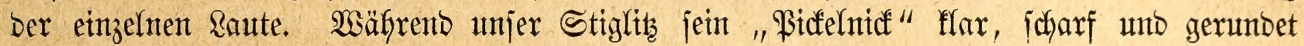

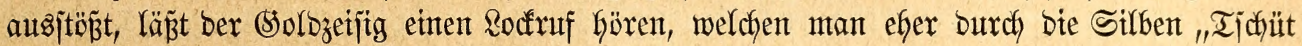

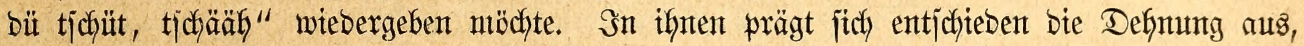
welde bent Roctruf umjeres Zeifigs eigen ift, um wie viel voffrautenter jie auth fint. Das

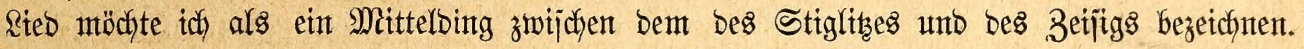
Mian frat Reedht, biejen \$sejang zu loben; benn er ift in ber Iat einer ber bejten, weldyen

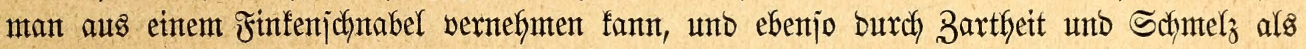

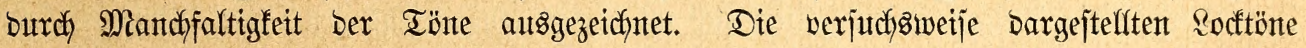
jpiefen eine Şauptroulfe in ifm, werbent aber burdj jefr anjpredtente Hebergänge verbunben

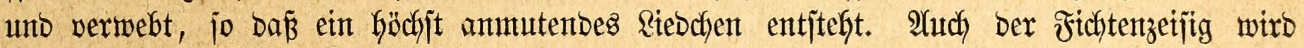

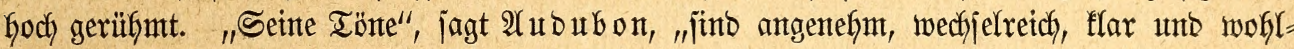

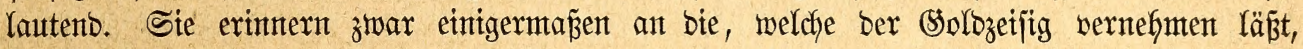

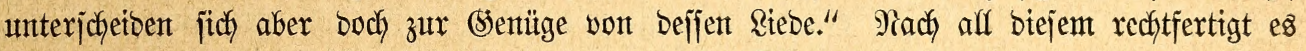
fidd, wern mant bie Beifige intsgejant $3 \mathfrak{u}$ ben guten Sängern zäflt.

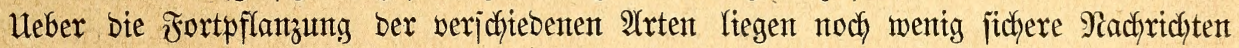
vor, und ez mag audd jeine Schwierigfeiten Gaben, Gierüber eingefende Beobacthtungen zut

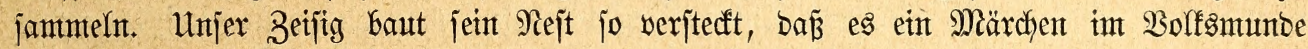

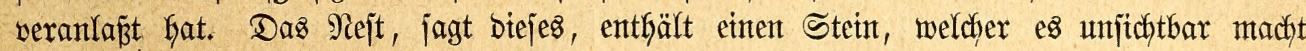

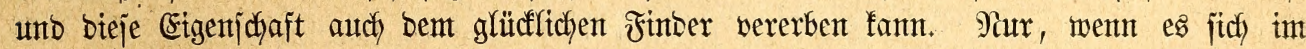

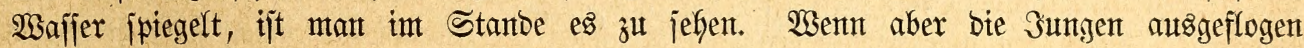

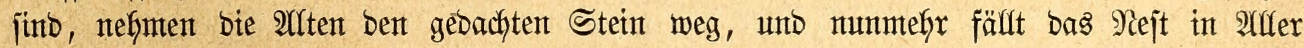

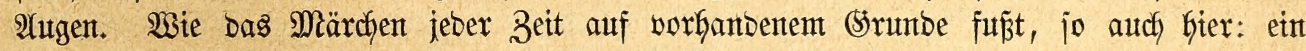

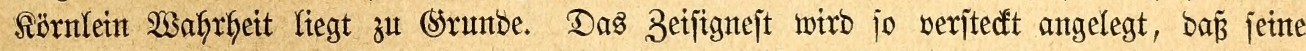

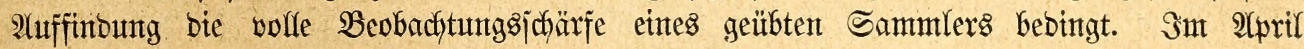

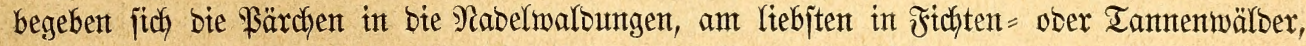

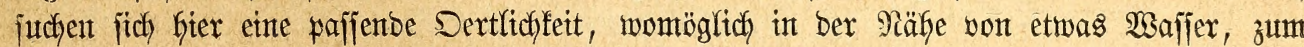

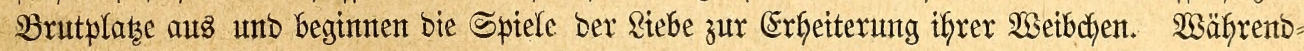

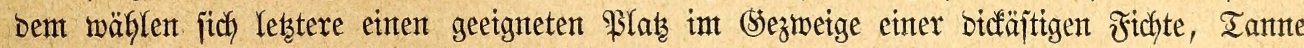

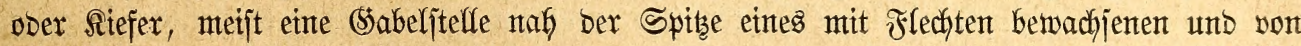

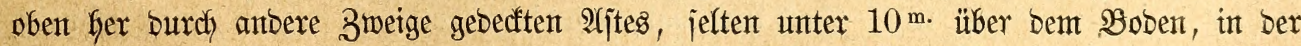

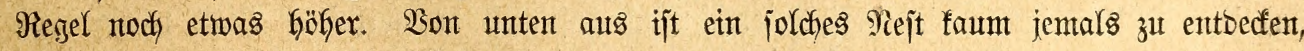
vont $\mathfrak{B S i p f e}_{\text {ald }}$ oft erit zu fittben, went man bie betreffentent 3 weige auseinanbergebogen

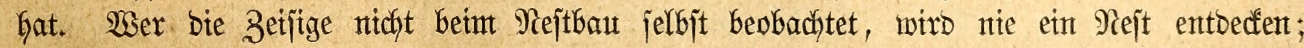

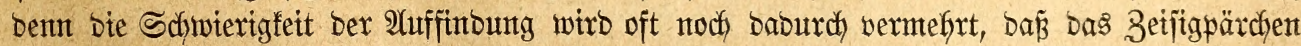

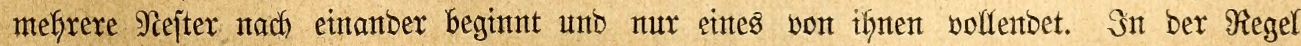

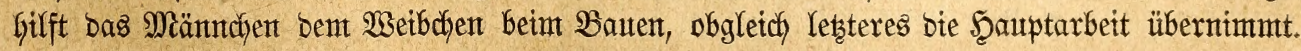

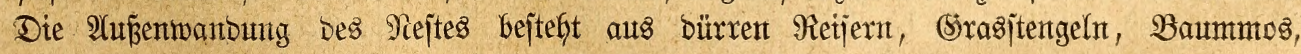

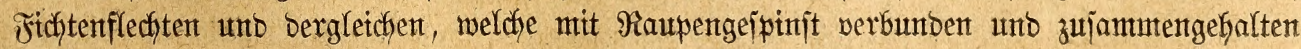




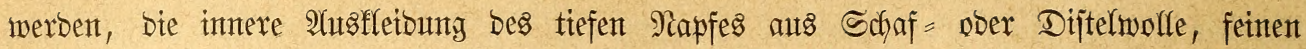
Fledjten, eintigent Febern unt äfntlichent Stoffen. Die fünf bis jechs fleiten, runblichen,

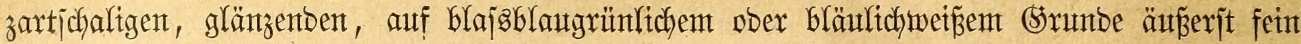
mit Glajgblutroten ober roftbraunen, am bicferen Enbe größeren und bichter jtehenden

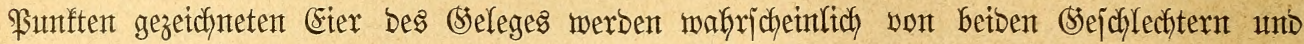
zwar binten 13 ober 14 Iagen ausgebrütet. Beibe Arften beteiligen fich an ber 2 (uffudft

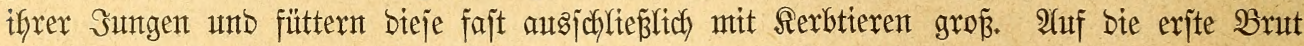

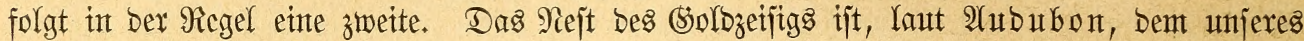

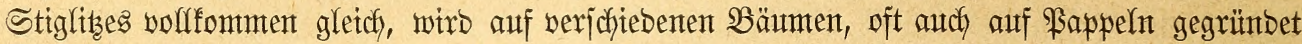
unto mit viex bis jechs meif̈bläulichen, rotbraun bepunfteten, nach anteren Forjchern mit

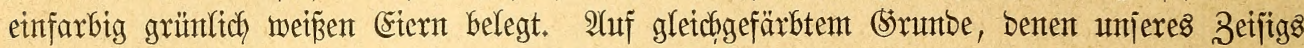
äfnllich gefledt, bejchreibt Baldamus bie Eier bes Sappen= und bes Fichtenzeifigs. Heber bie Fortpflanzung unt jelbjt über bie Eier ber übrigen 2 (rten feblt noch genautere Sunto.

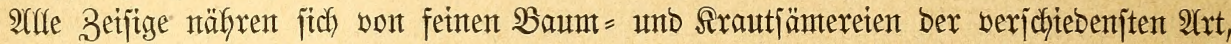
wäfrent Der Brutzeit aber zum größ̈ten Ieil son fierbtieren. Unjer Beifig frif̧t Erren=, Birfent=, Fitdtent=, Aitefernt=, Alettent=, Dijtel=, Salat= unt Miofnjamen, Der Bolbzeifig Sonnen= blument $=$, Salat $=$ unt Dijteljamen, Dann und twann, insbejonbere währent bes Winters

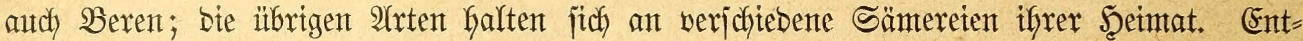

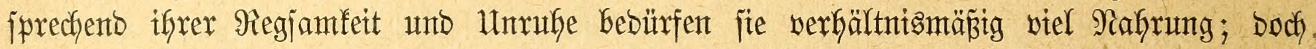
trägt bie Sileintheit ber beliebtejten Säntereien, weldhe jie genteß̈en, wejentlich bazu bei, fie

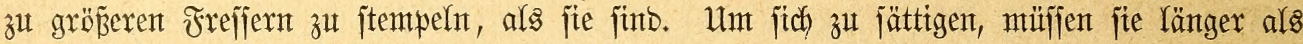
bie nteijtent übrigen Finfent ant Futternapfe jitzen und geben aus biejem (strunbe zu Mits= beutungen $\mathfrak{A}$ tha

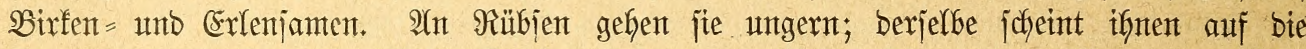

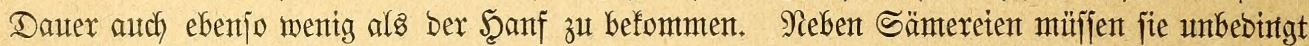

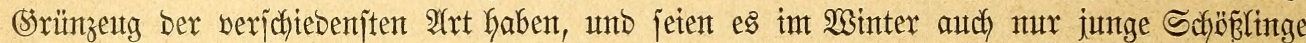

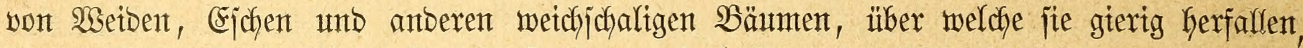

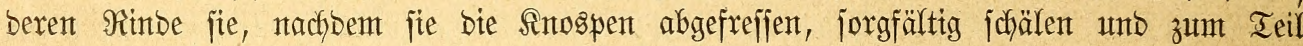
ebenfalls genteßzen. Meflmürmer ober 2(meijenpuppen nefmen fie nicht immer an, nicht ungern bagegen etwas Weichjutter, beijpielsmeije ein (Semijh von fein geriebenten, gebörrten

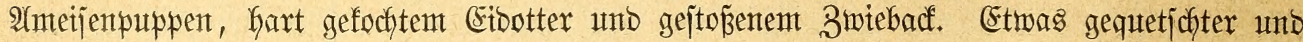

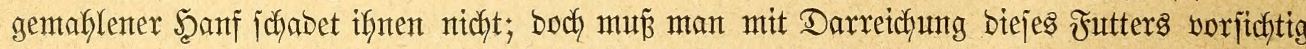
fein, weif es leidft zut fett madyt und Schlagflüfje begünftigt. Unbebingtes Exforbernis für jie ift feinfiefiger Sand, Salz, Sreibe mo täglich minbejtens zmeimal frijches Wafjer,

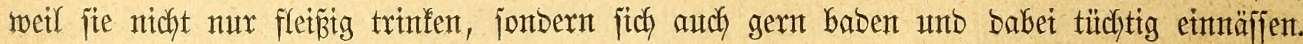

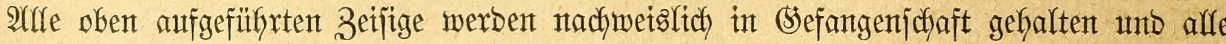
bautern in Räfige mehrere Sahre aus, unjer Beifig zefn bis zwölf, Der Solbzeifig, nach

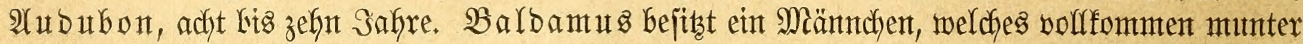
ift und noch eifrig jingt, jeit neun Safren und fennt ein joldhes, weldhes bereits feit zwölf Safrent in Sefangenjochaft lebt. Dody barf man, von biejen Iatjachen folgerno, nicht glauben, baj jeber Beifig eine fo viel werjprechende Dauterhaftigfeit bewahrkeite. Nitcht wenige von

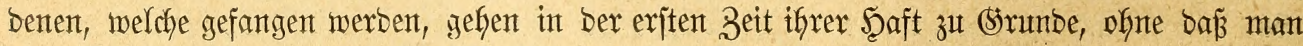
etgentlich jagen fann, weshalb. So hört man beijpielsweije über ben (Solbzeifig, unzmeifelfaft eitres. Der Gervorragentiten Mitglieber Der (sruppe, vielfache fllagen won Den Riebrabern,

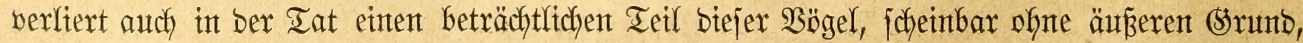

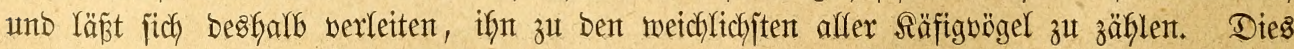

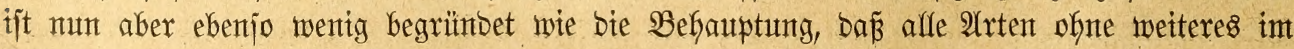

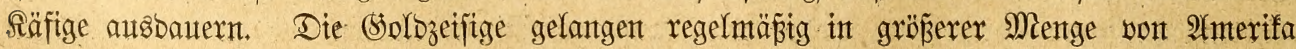




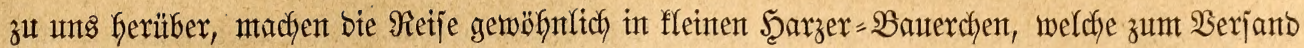

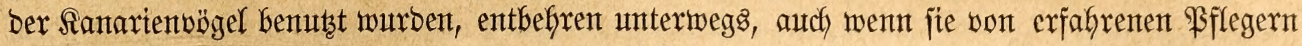
begleitet werben, einer genügent jorgjanten 2(bmartuntg unt falfen biejem Mangel geraume

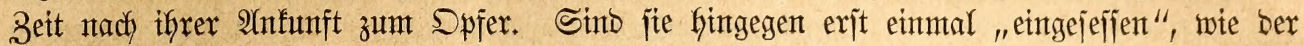

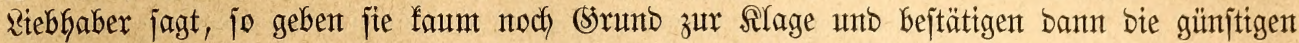

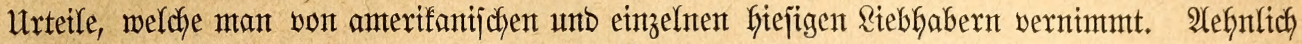

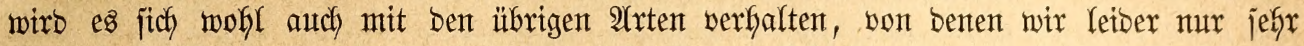
ausnafymsweije eine unb bie anbere lebent in Europa jefen.

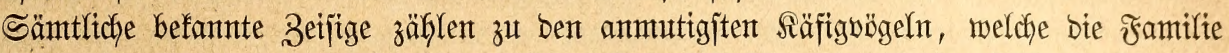

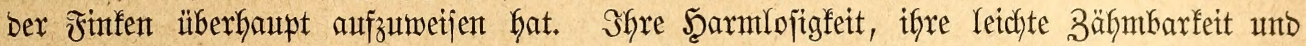

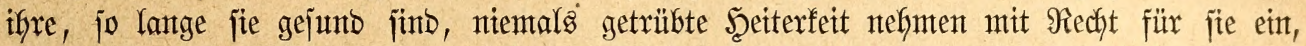

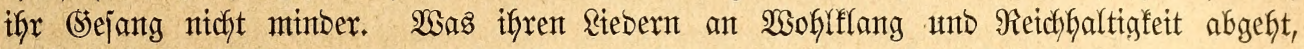

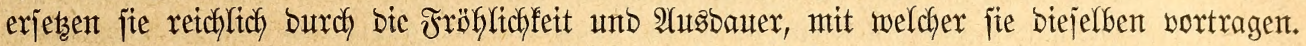

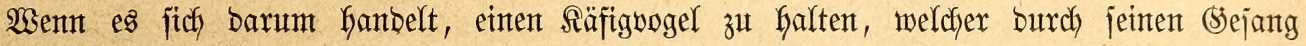

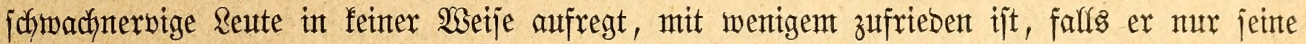

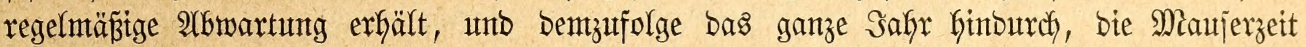

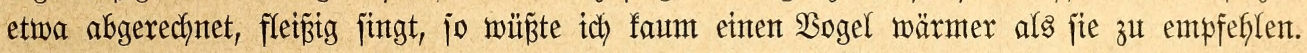

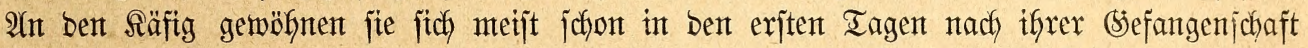

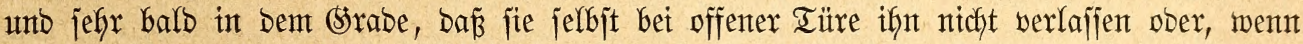

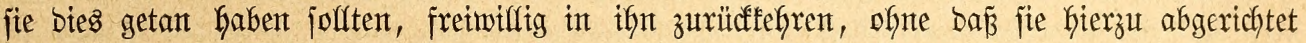
worben wären. Der Eine ober ber 2 tnbere finbet ein $\mathfrak{B}$ Bergnügent barin, fie nit finbijchen

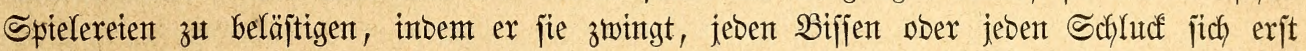
burch ein jogentantes Suntititüaf zu verbienen; Demt wafren \&iebfaber aber jind Derartige

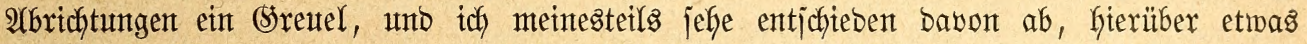

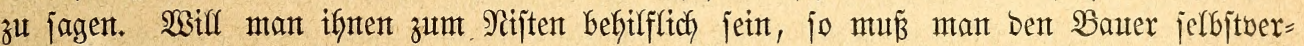

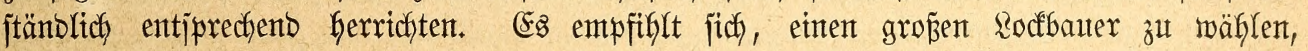

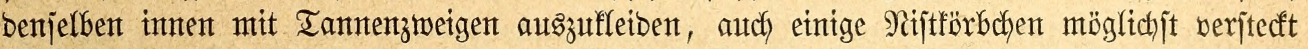
zwijchen ben 3weigen anzubringen. Dft freilich) Gleibt joldhe (sinlabunt exfolglos; bas eine

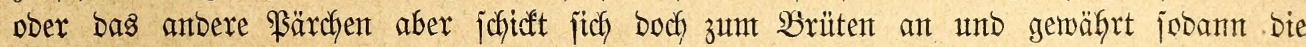

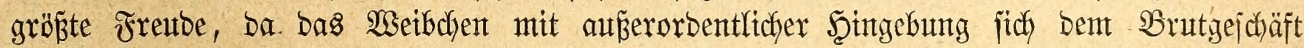

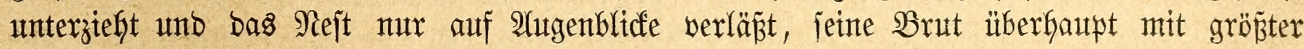

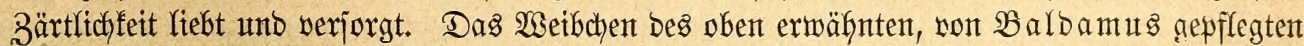
Më̈nndfents Yegte in einent Safre breintal je fünf Eier; anbere Pärchent zeigten ähnlichent

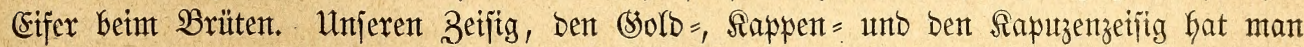

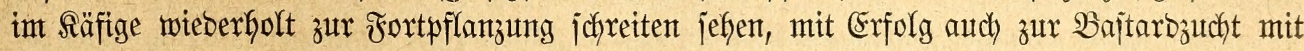

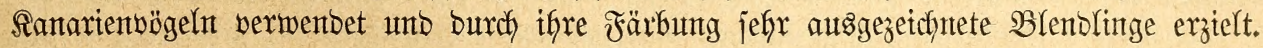

Der \$reis eines gefangenen, europä̈iften Zeifigs überjteigt jelten $71 / 2$ Sgr. umjercs

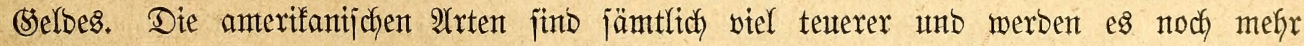

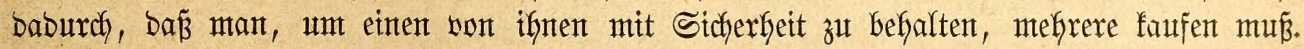

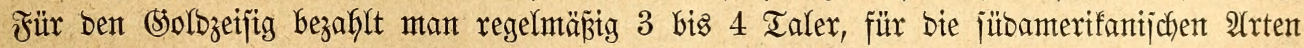

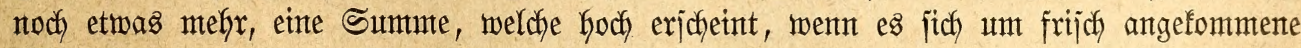
Sö̈gel hanbelt, währent für eingejeffene gern bas Doppelte bezafft werben barf.

\section{Cittronfitkent.}

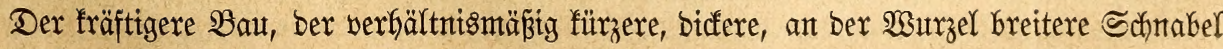
unterjachetbet eine ben Beifigen feffr nafe verwanbte (5ruppe von biejen. Hebrigens fimmen 
Getber Merfmale int wejentlithen überein. Die Sippe verbreitet fich über bic alte unb

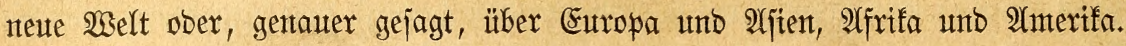

274. Der Citronzeiftg, Citronfint, Cittrinchen, Ciprinchen, itafienifaher Rantarienvogel 25. , Citrinella

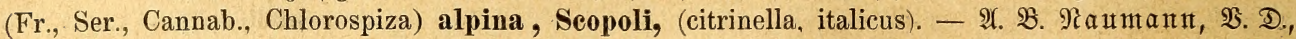

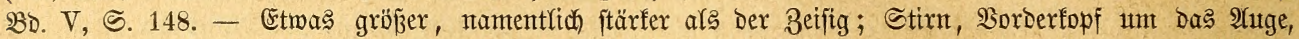

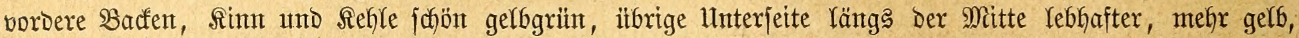

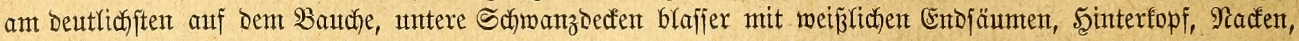

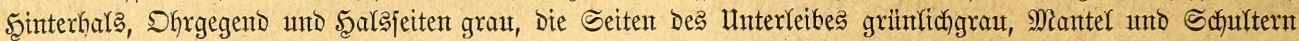

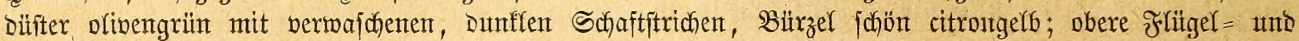

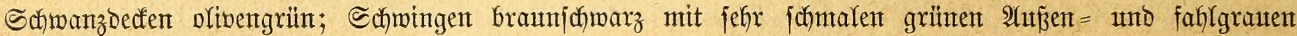

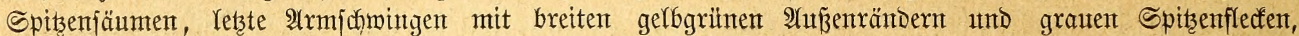

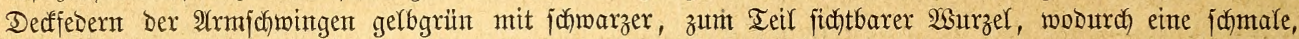

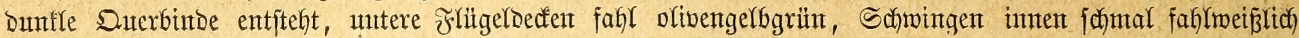

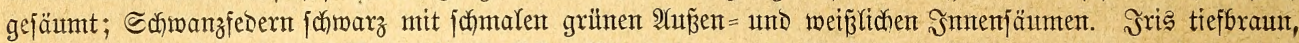

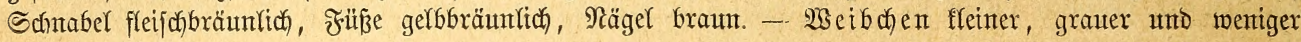
reshaft gefärbt.

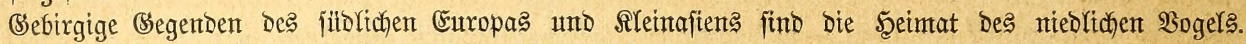

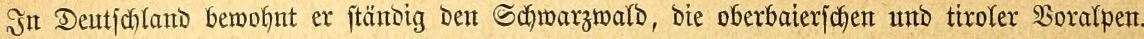

275. Die Citrintlfe, C. (Card., Chrysom.) Lawrenci, Cassin. - 2. B. Baird, Birds of N.

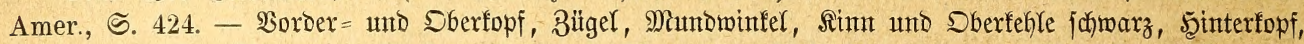

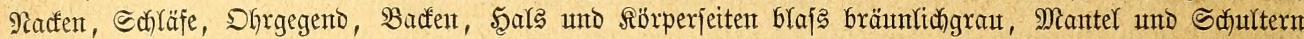

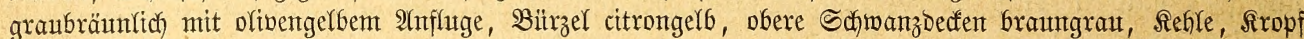

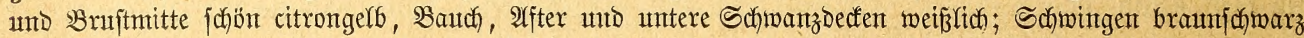

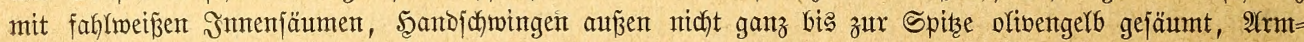

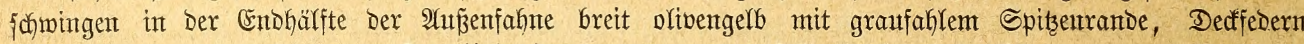

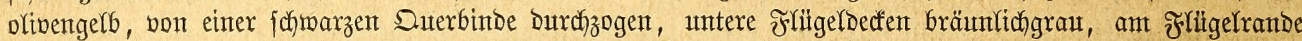

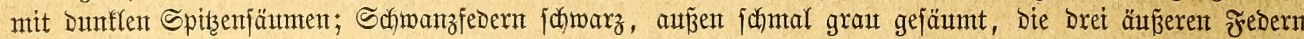

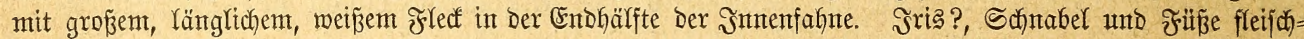

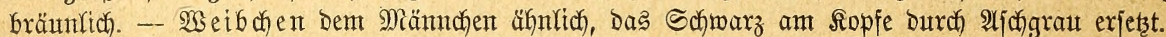

Şäufig in Ralifornien.

276. Der $\mathfrak{B u r t c i t r u n f i n t ,}$ C. (Fr., Chrys., Chrithagra) barbata, Molina (campestris, marginalis,

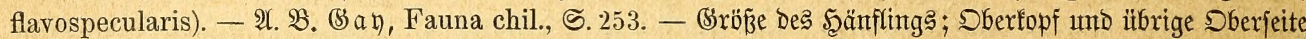

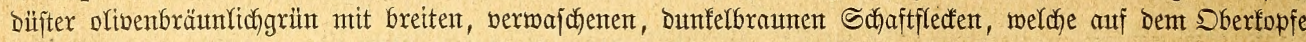
am Deutlichften herwortreten, Bïrzel helf olivengrïngelb, obere Schwanzocfen braungrün wie Badent unto

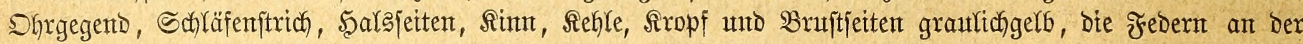

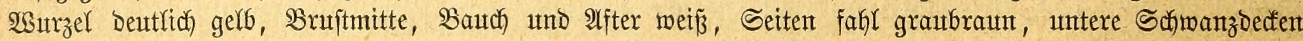

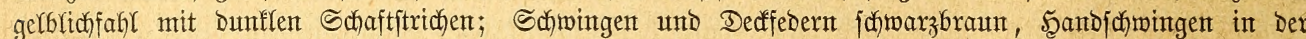

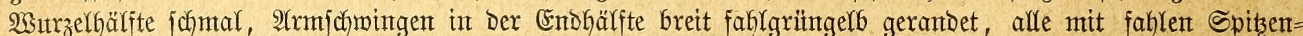

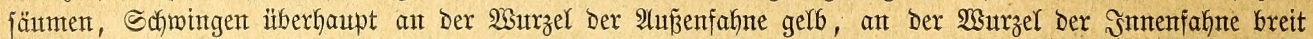

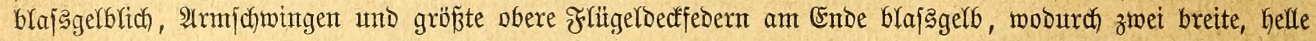

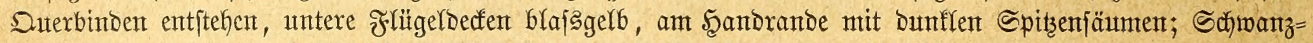

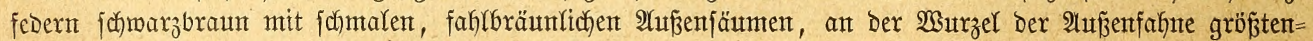

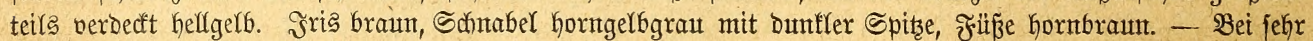

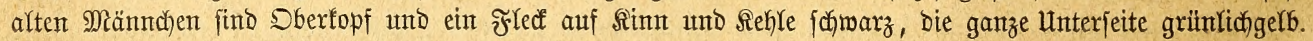

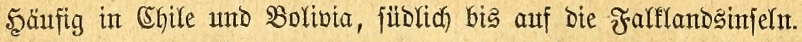

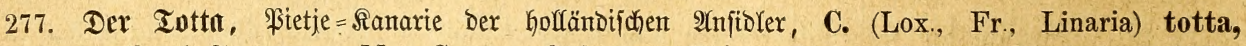
Sparman. - Vergl. Sparman, Mus. Carsan., Taf. 18. - STeiner ałs Der Şänfling; Sberfopf uno übrige

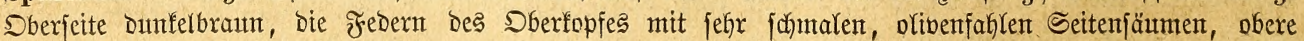

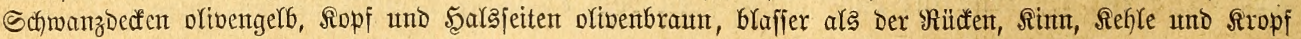

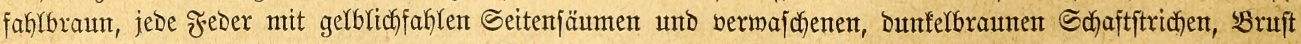

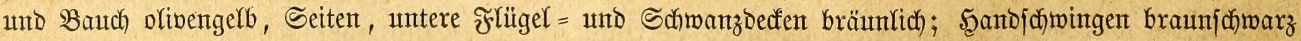

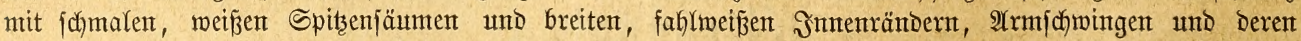

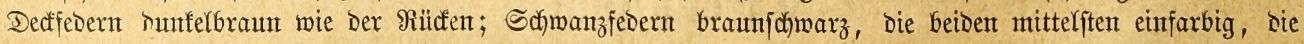

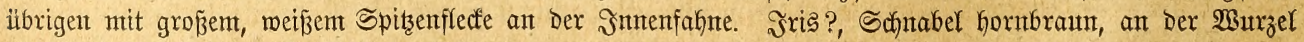

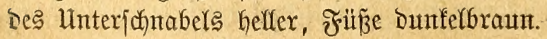

Die 2 trt bemolnt SïDafrifa uno tritt vorzuggmeife int Iaplande auf. 
Ueber Das Freileben ber frembläntbifchent Eittronfinten mififen wir nichts; ; ïber bas ber

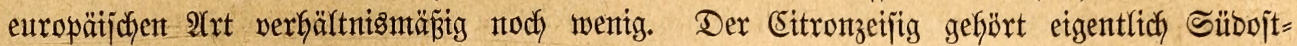
europa an, ift in Spanien jelten, in (Sriechenlanto uno Stalient häufig, hat fids won Gier

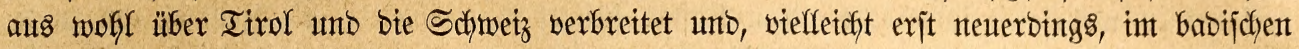

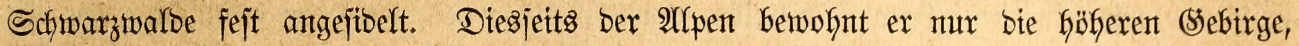

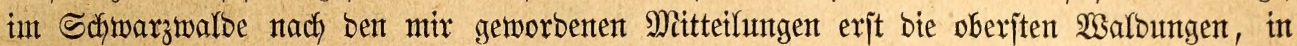

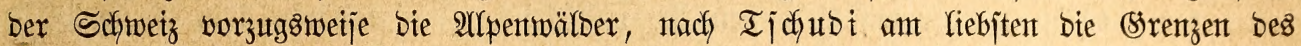

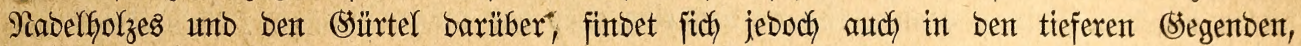

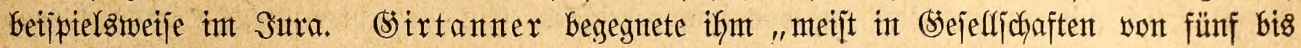

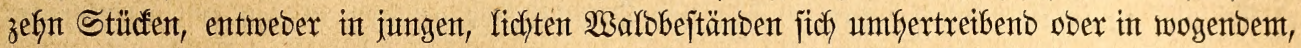

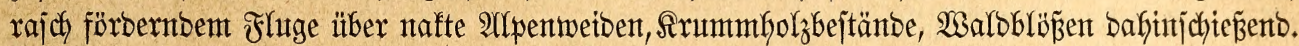

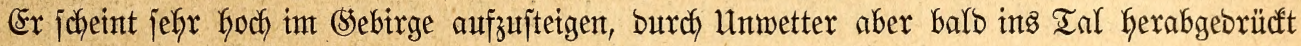

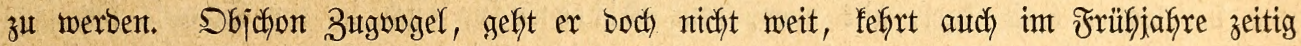

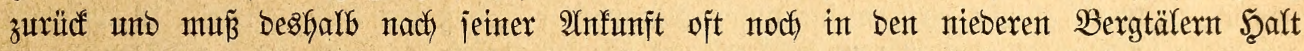

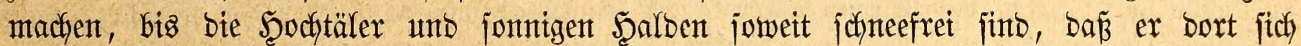

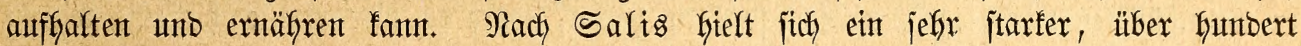

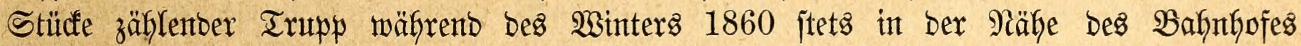

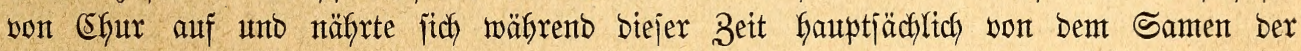

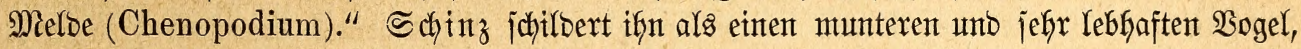

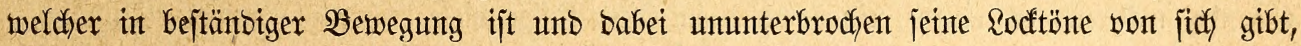

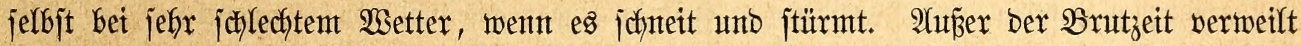

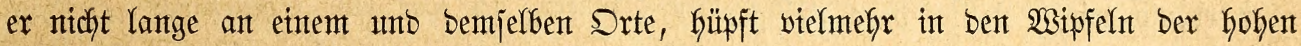
Tanten ebenjo unruffig hin unto her als auf bent Bobent. Snt ben bergtälern fitht mant

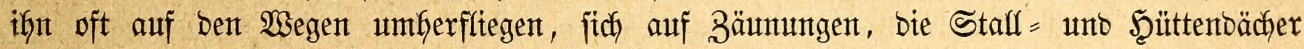

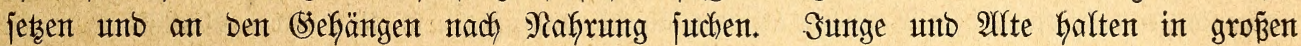
(Sejeflfchaften zujanmen unto zeigen, wie bie meijten Allpenvögel, faumt Socheu vor bent Menjaten. Die liebjten Brutorte in ber Schyeiz jind lichte Steflen an ben Srenzen ber

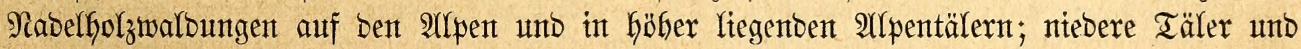

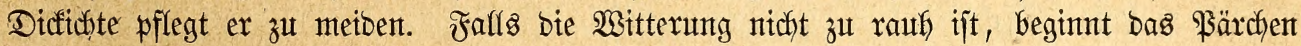

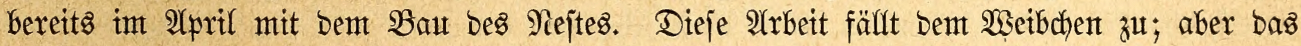

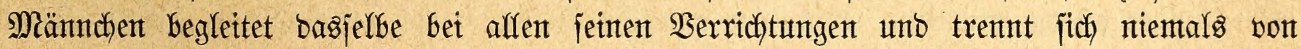

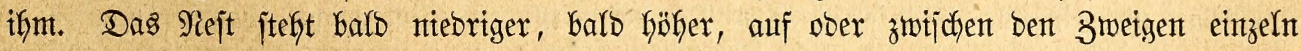

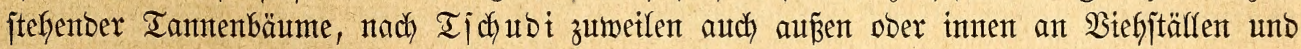
Sennfütten. Sm eriteren Fafle wiro es nicht Yeidgt gefunben, weil bie Unruhe bes fleinent

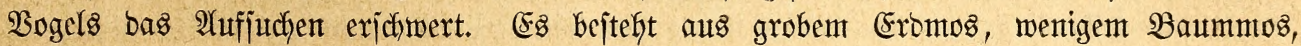

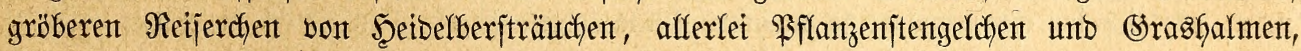
ift won aufeen ftruppig, platt uno wiro innen mit Samentwolfe verjefiebener \$fflanzent,

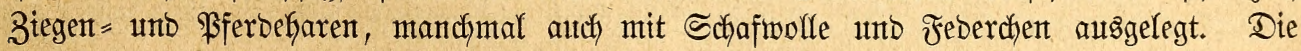

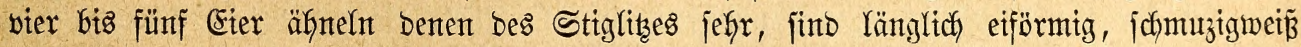
ober Gell grünlitchblaut unt mit fleinen, matten, Yeidgt vergänglichen, buntfarbigen Flecten

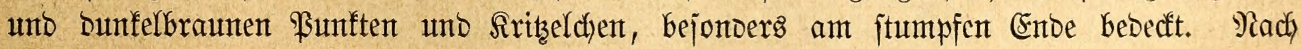
ben Beobactuturgen Courados brütet nut bas $\mathfrak{B}$ eibchen, wiro aber währentobent vom Männthen geaţt. Die ausgeflogenen Sungen werben von betbent Extern gefüfrt, blciben mit iffnen währeno bes ganzen Sontmers vereinigt, jodjlagen fich aber int Scerbjt mit anterent Familien in größ̈ere Sch)wärme zujamment.

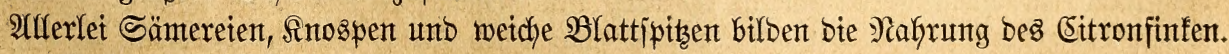
Sn ben Waalbungen liejt er Tanten = unb Fiddtenjamen auf, an bent (Sefhängen bejudht er

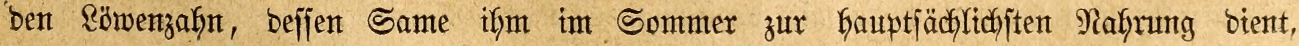


gleidfuiel ob ex bereits gereift ober nodh weidh ijt. Schon bevor bie Bhlume abgeblüfgt hat, jetst ex fidh auf ben Stengel, finft mit bemjelben nieber und madyt mun unten an ber Seite ber Pflanze einte Deffung, unt ben Samen Gerautzztbringent. Mit ähnltchen Pflanzen verfäfgrt ex wafyrjacheinlich ebenjo. Sm Räfige füttert man ifgn wie bie Beifige, am zwect= mäß̈̈giten mit feinen mebligen Sämereien, benen man gequetichten Şanf beimijadt. 3u viel won lesterem madyt ifn bald jegr fett und zu Sallagflüffen geneigt, verfürzst überhaupt

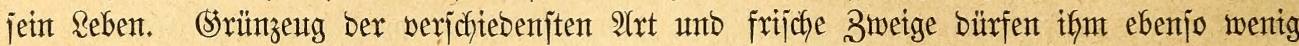
fehlen als bem Zeifig; Dent went ex bas eine ober bas anbere längere Zeit entbefrt hat,

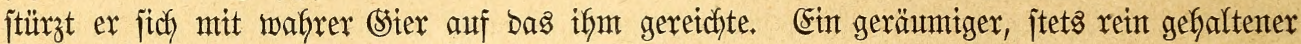

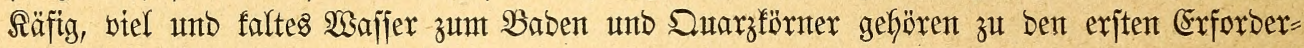
nififen Des gefangenen $\mathfrak{B o g e l}$.

Der Eitronzeifig ijt im Stebirge, beippielsmeije in Srraubümbten, einter ber Gärfigiten utto beliebtejten Säfiguögel, gilt aber, laut (sirtanner, aud in ber Schmeiz für jebr

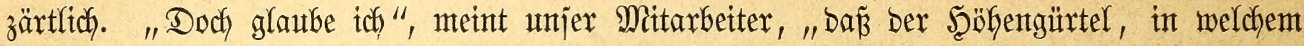
man ifn gefangen bält, Gierbet in Betracht gezogen werben muź; benn offenbar mürbe man

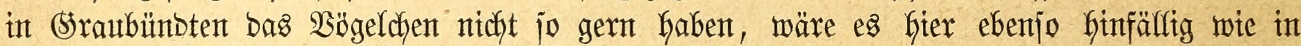

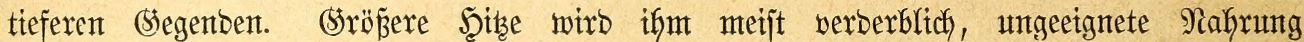
wohl nidjt mintoer. Ex gemöhnt jidf nicht jo retdyt an bas Stubenfutter wie Beifige und

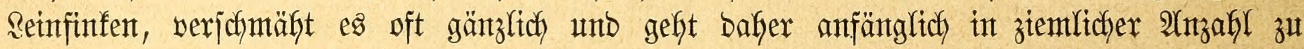
(srumbe, währent er, einmal eingewöhnt, im Einzelfäfige viele Эafre ausbautert. 2(nfänglich etwas wilb und jefeu, wirb er mit ber Beit in einem gemiffen (Srabe zutraultich, niemals aber ebenjo wie Stiglite oeer Beifige. Der Roctton ijt bas gerabe Siegenteil bon bem Des Beiftgs, Da ex nicht wie "Tit- $\mathfrak{i} "$, jonbern wie "T̈̈- $\mathfrak{i}$ "flingt. Er wirb

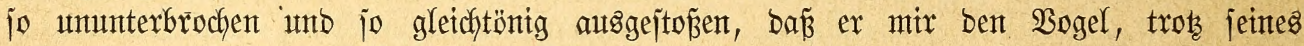
amiprechenten Wejens, bald unterträglich gemtadht Gat, weil er mich jtets ant eine betwegte, ungeidhmierte Schaufel erinnerte." Der eigentliche Sejang bagegen witb als wohllautent und

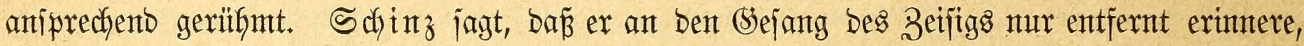

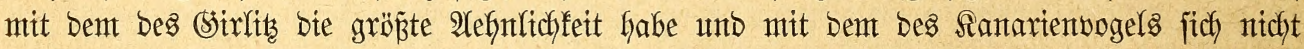

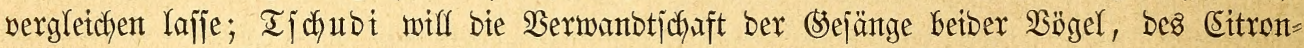
zeifigs unb des fantartentogels, gefunten haben, nur baj̃ bas Rted bes erjteren viel leijer und wentger ausbauernd ijt. In bejonberem (Strabe jofl ex jitch burch einen eigentümlichen Woffllaut und einzelne; fräftig flötende Metalltüne unt Gänflingartiges (Sirrent auszetchnen.

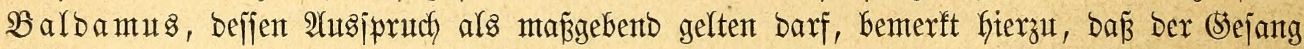

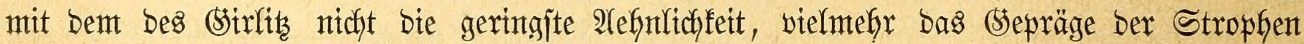
Des Beiffigs hat, aber auth an einzelne Töne Des fanarientogeljohlages erintert. Sch jelbjt

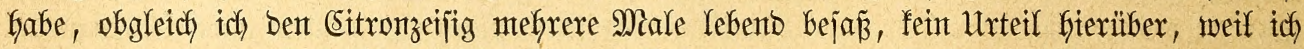

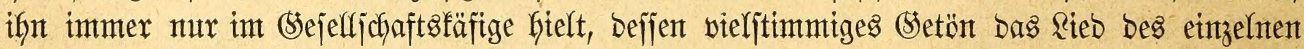
Sogels unfürbar madjte. Won anberen Riebfabern wirb gejagt, baj ber Eitronzeifig fich

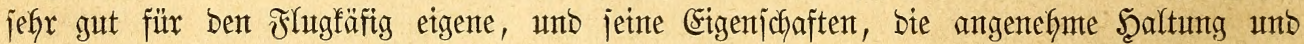

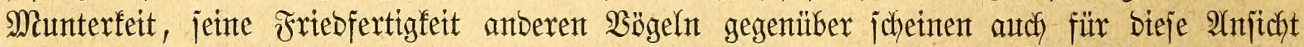
zu iprechen; idh aber habe bisher fein (s)hüd mit metnen (sefangenen gehabt, fie viel=

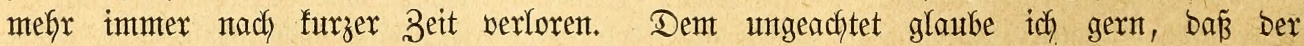

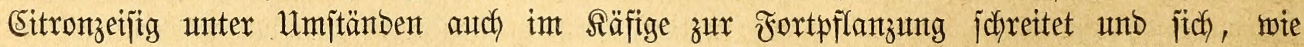
Friberich bemerft, zur Bajtarbzudyt mit Dem fanartenbogel eignet. Daßj Yetzteres auth bet

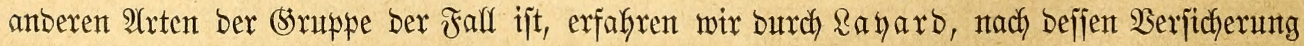
ber Iorta im faplande oft zur Bajtarbzudjt mit bent fanarienvogel verwentet wirb.

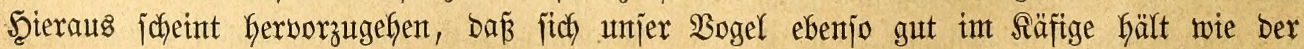
Bartcitronfinf, welcher in Ehjile mit $\mathfrak{B o g e l l e i m}$ gefangen, auf bem Marfte verfauft und bes 
(Sejanges halber gext in Räfige gefalten wirb, ba biejer, laut $\mathfrak{B}$ rioges, fajt jo angenehm wie bas Rieb bes Sanarienvogels ijt.

Db Die fremblänbijchen Eitronfintent lebento nady Eutropa gelangt jind, vermag ich nicht

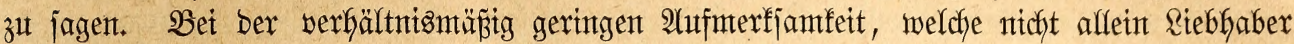

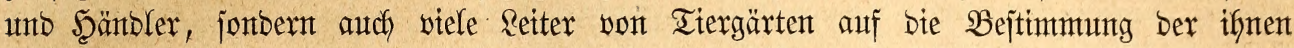

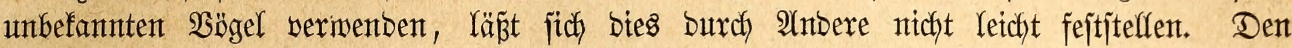

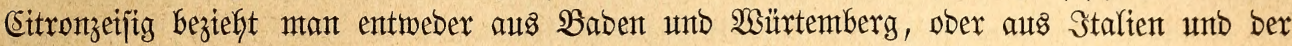

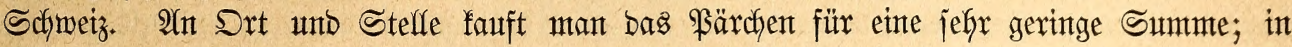
Mittelbentichland hat es einen $\mathfrak{W e r t}$ von etwa zwet bis brei Ialern.

\section{(Griintfinken.}

Aräftige, gebrungente Ssejtalt, Der futze, fegelfürntige, an ben eingezogenen Raben icharfichneibige Schnabel, bie ftarfen, etwas furzzefigen Fürße, weldye mit mittelfangen, wentig gefrümmten Sirallen bemehrt find, Die mittellangen, zujantmen gelegt bis zut Şälfte bes Schwanzes Kerabreichenton Flügel, unter beren Schmingen bie brei vorberften bie übrigen überragen, ber mittellange, in ber Mitte jeidjt ausgejdyntttene Sdywanz unt bas ziemlich fntappe, vorkerjchento grün ober grüngelb gefärbte (S)efieber fennzeidfnen einte fleine Jinfen= gruppe, weldye nach bem beutichen Mitgliebe Genant nutrbe.

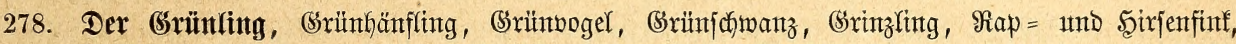

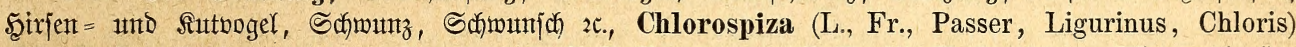

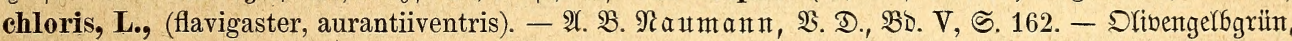

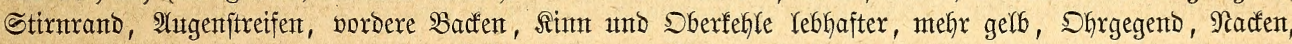

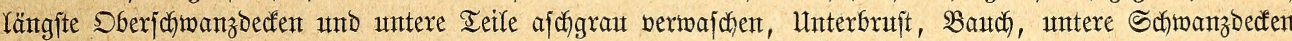

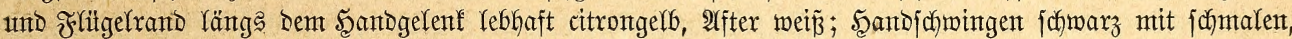

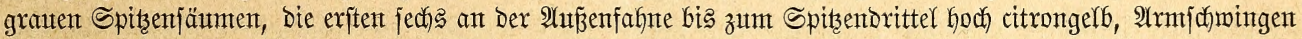

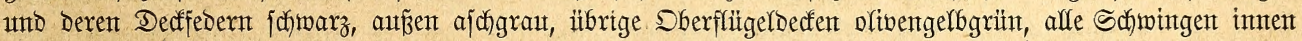

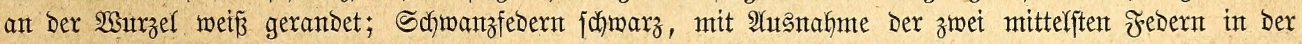

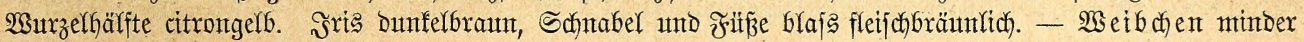

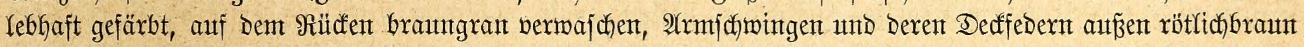

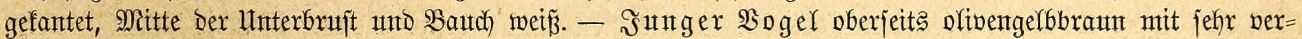

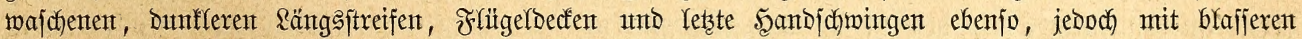

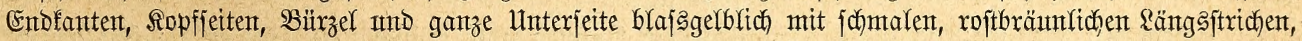
Bautch) und $\mathfrak{A f t e r}$ einfarbig.

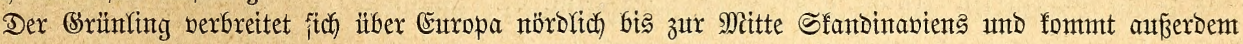

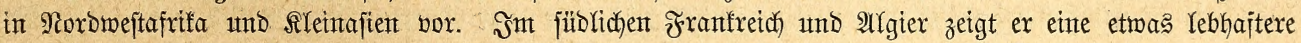

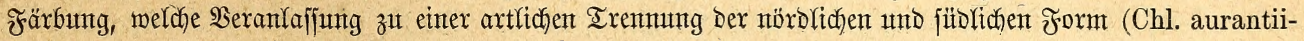
ventris) gegebent hat.

279. Der Samarahiba der Japanejen, Chl. (L., Fr., Ligur., Chl.) siniea, L. (sinensis, chlorion, sinicus, Kawarahiba minor). - $\mathfrak{A}$. $\mathfrak{B}$. Temm., und Schleg., Fauna japon., S. 88. - Viel fleiner ałs

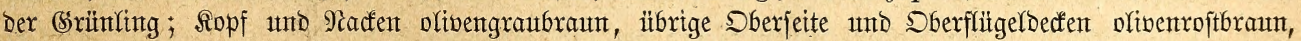
Átgenftreif, Ropffeiten, Rinn umb Refle olivengefbgrün mit eintem verwajchenen Dunfferen Streifen vom

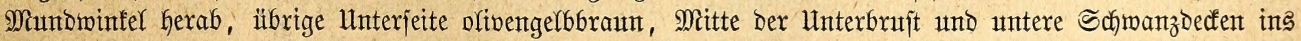

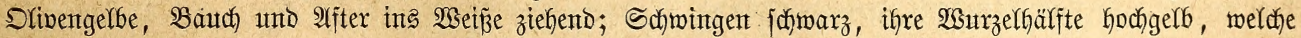

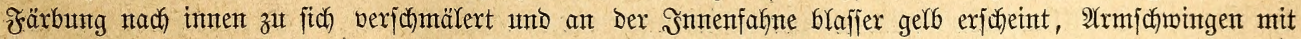

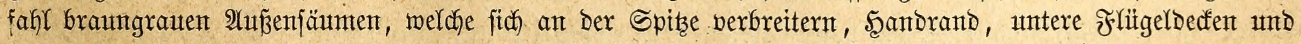

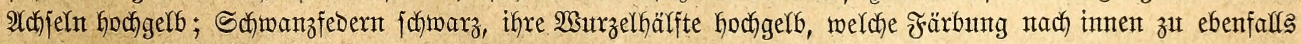

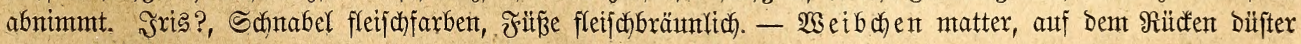
grautgrün, auf ber Unterjeite mefir grautbraut.

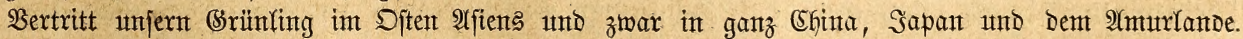

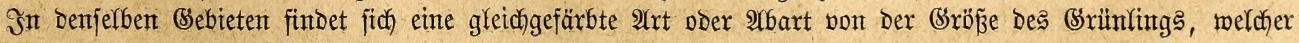




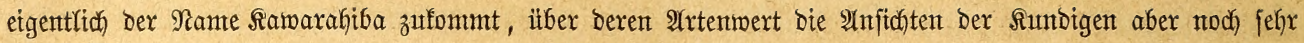
geteilt fints.

280. Der 3eifiggrünting, Chl. (Fr., Card., Chrysom., Hypacanthis) spinoides, Vigors. Bergl. Giould , Century of Himalaya Birds, Tafel 33. - Rleiner ats ber Errïnting, aber größer als ber Stiglitz; Sberfopf, Badfen unt Shrgegeno jowie ein abgejetzter Bartittreif olivengrïnidjwarz, übrige Sberjeite

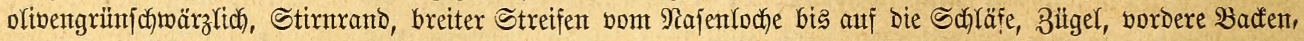

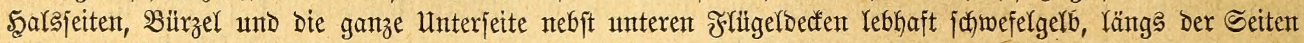

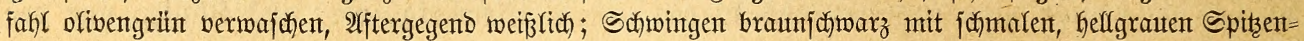

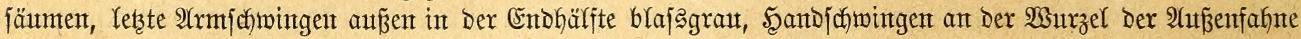

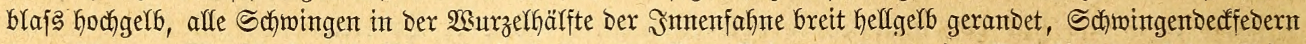

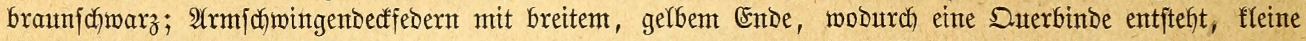

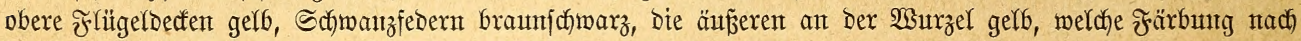

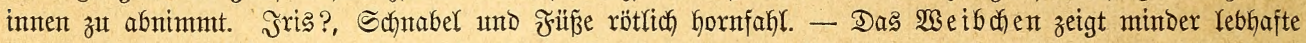

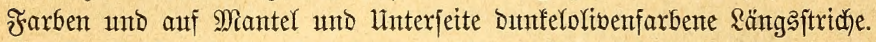

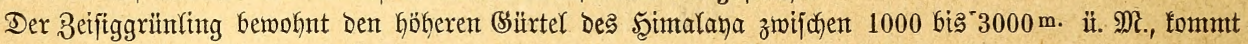

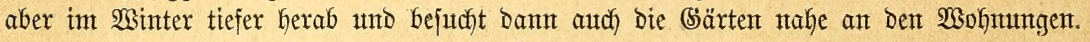

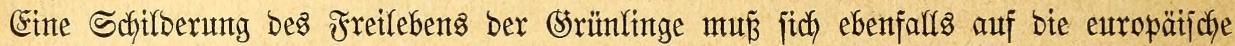

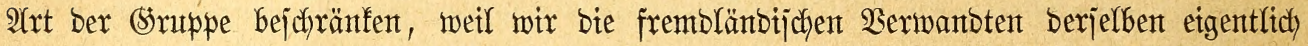
nutr als Bälge fenten. Bon ben (Sefangenten, weldhe man an Drt unto Stelle bält, ijt meines $\mathfrak{B}$ iffens nod feiner lebeno nach Europa gelangt, und ba aud über ifyr Betragen

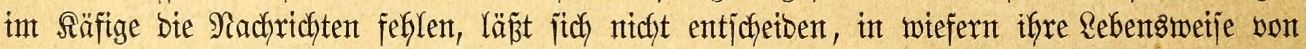
bex unjeres (Srünlings abweidyt. Diejer zählt in Deutjchland zu Den allbefannten $\mathfrak{B}$ b̈geln, bewofnt jedes \&and und jeden (sau, jede Ssergento und exjcheint da, wo er mur einzeln auftritt, wentgjtens währeno jeines Umberjtreifens int Şerbjte oft in größerer $2(n z a h l$. In milben \$segenden zäflen die Strünlinge zu ben Standwögeln, raukere verlaffen fie bei

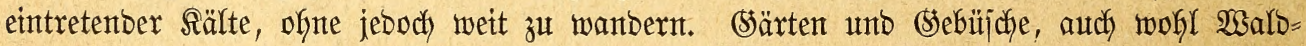

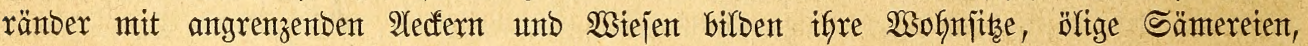

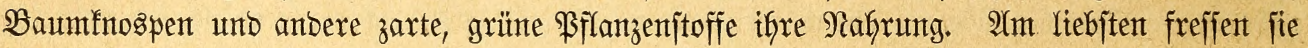

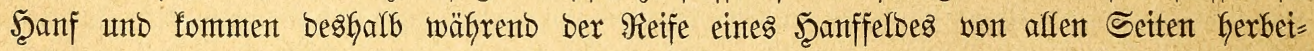

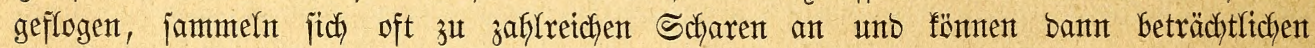

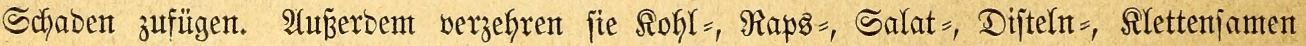
und Dergletchen, audy Baumjamen, meldjen jie mit ifrem Garten Sdynabel leicht auffnaden fönnen, meiben aber alfe mehlfaltigen Sämereten uno jomit unjere (setretbearten. 2(ud) ifre Sungen füttern fie mit biejen Storfen auf.

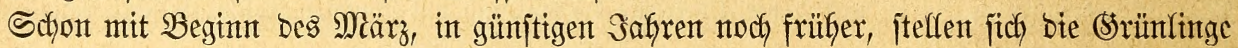
auf ifren Brutorten ein, unb bie Männchen ftimmen nun bereits ifren Sejang an. Sebes

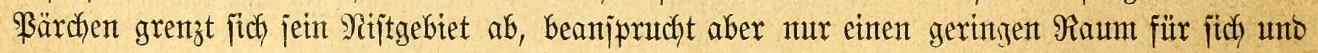

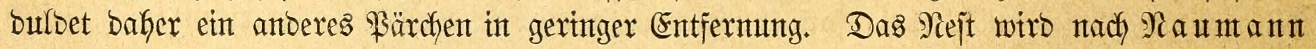
am liebiten auf Sopfwetben, nach unjeren Beobachtungen in Türingen in ફecten unt Büjchen ober niebrigen $\mathfrak{B a ̈ u m e n t ~ b e r ~ S a ̈ r t e n ~ e r r i c h t e t , ~ a m ~ G a ̈ u f i g j t e n ~ i n ~ e i n t e r ~ ફ ̧ a ̈ h e ~ v o n ~} 2$ biş $3^{\mathrm{m}}$. über bem Boben, jeltenter Dofpelt jo hoch, je nach ber $\mathfrak{A}(r t$ bes $\mathfrak{B a u m e s}$ verjchieben, balo näher bald weiter vom Stammte ober, wenn biejer geföpft, auf ifm felbjt, ijt meijt groż, ziemlich) bidft und nett zujammengebaut. Würzeldjen, Reijerchent unb anbere Pflanzenjtengel bilben bie 2 Uน

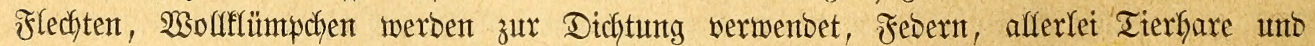

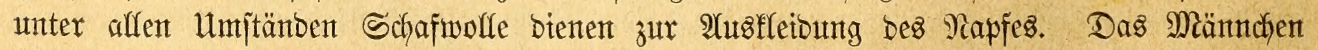
Giffft Dann unb wann beim Bauen, obgleich bie Şauptarbeit bem 2 seibchen zufällt. Wier bis jechs zarte und glattichalige, längliche ober echt eiförmige, auf meipem, blaugrünlich fcheinenbem siruttoe mit menigen, fleinen, bleich blut = ober grautroten, blutbraunen uno

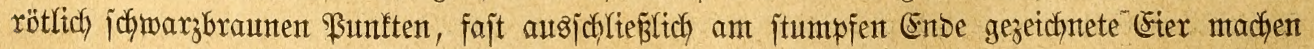




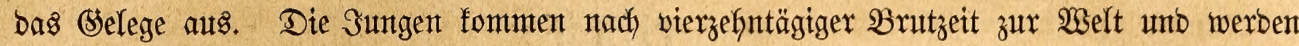
wie bie Brut von iffen Ertern aukerorbentlich geliebt, audh jefr jorgjam mit im Rropf

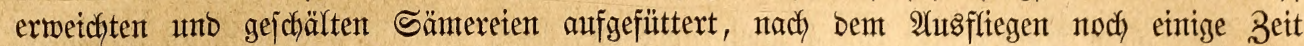

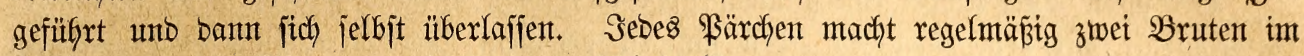
Sahre, falls bie Witterung nicht gar zut joblecht ijt.

Unter unjeren Finfen zäfilt Der (Srünling zu Den plumpejten und zeigt audy in jeinem Betragen bet verfhältnismäp̈tger (Semandtheit etwas Schwerfälliges. Doch hüpft er auf bem Boben in ziemlich rajchen Sprüngen umber unt hat einen jefr fräftigen, ziemlich raichen Flug, weldjer fich in einer gropen Bogenlinie betwegt, went weitere Strecfen bur(f)=

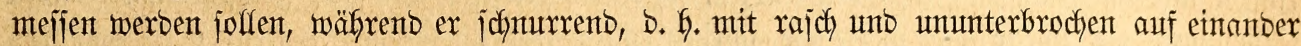

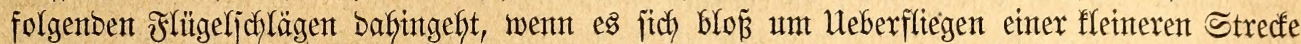

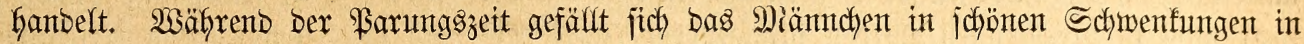

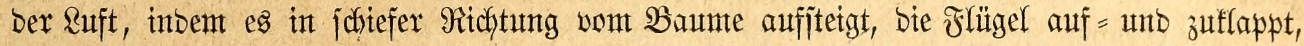

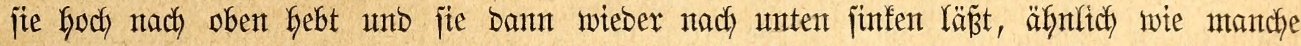
Tauben ober bie Sirrlize und anbere Singoögel ebenfalls tum. Der Rocfton löß̈t fïch burch bie Silbe "Ifdyif", weldye mefyr ober mentger oft hinteremander wieberfolt wirb, am

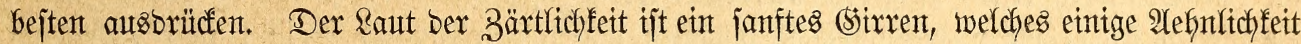

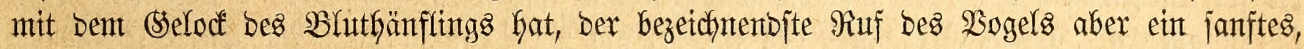

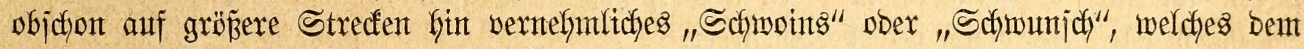

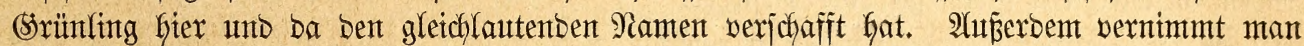

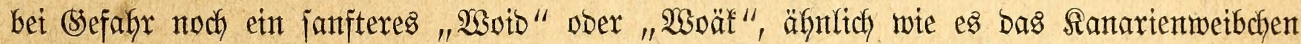
Gören läßjt. Der Sejang hat Deşalb bejonberen Wert, weil er jojon jo früf im Sabre

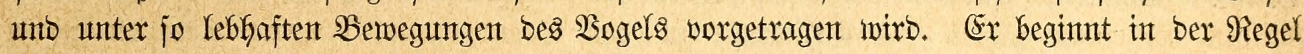
mit berjofiebenten Rocttönen, auf weldje als Şauptitrophe bie Raute: "Ijoi, Ijot, Ijot, Ijoi,

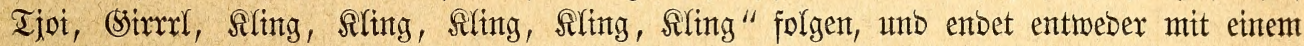

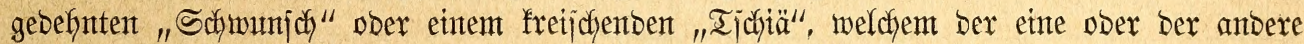
Rodfton rotederum angefängt wiro.

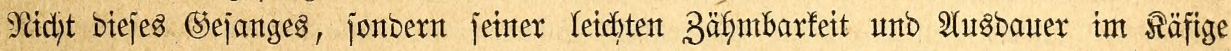
Galber fält man ben (Srünling gern in Sefangenjchaft, umb zwar im Einzelfäfige ebenjo wohl

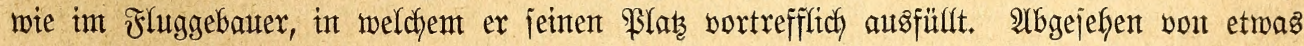
Futterneto, in Folge bejjen er fleineren, idwächeren $\mathfrak{B}$ b̈gefn jogar gefähritidy werben fann, zeigt ex fich friebfertig unb befümmert fich cigentlich mur um fich jelbjt, lodft, fingt, fliegt munter hin unb her uno trägt jomit zur Belebung uno zum Schmud Des \$sebauters nicht unmejentlidh bei. Unter unjeren einficimijchen Jinfen jabreitet er am leidjtejten zur fort=

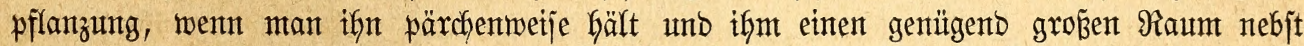

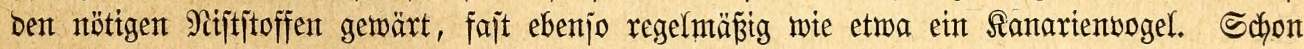
in ben exjen Iagen Der Sefangenichaft volffommen zutraulidy geworben, berrichtet er

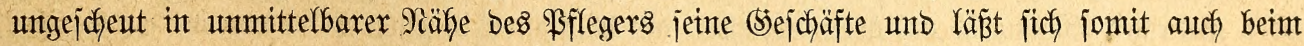

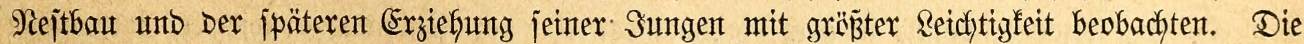

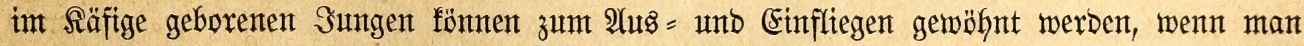

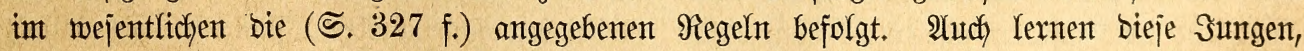
wenn man fie von Şänflingen, Santarienvögeln unb anberen guten Sängern unterrichten

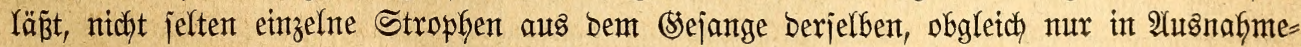

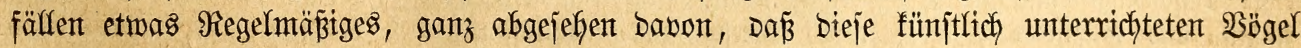

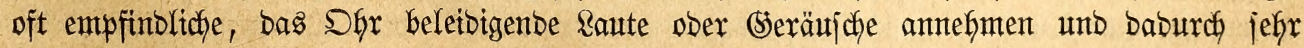
unangenefim werben fönnen.

(Einen fejten Marftpreis hat ber Srünling nicht; man fauft ifn aller Drten in Deutichlanto für renige (strojchen ober fireuzer. 


\section{Sperlintae.}

Der alten $\mathfrak{B e l t}$ gefört ente Finfentgruppe an, beren Mittglieber gropenteils in intiger

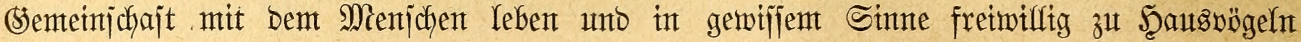
gemorben jint, fich aber wentg für bie Befangenjchaft eigenen, weil mur einzelne unter ifnen einen einigermap̃en befriebigenden (sejang Gaben, bie ïbrigen aber unjer Shr burch ifre Stimmtlaute gerabezu beleisigen: bie Sperfinge. Sie fint fräftig gebaute, furzleibige, etmas bidfëppitge Finfen mit mitterlangem, żemlidy ftarfem, folbigem Schnabel, ftämmigen

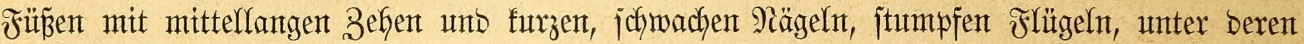
Sdywingen bie zweite bis vierte bie übrigen an Ränge überragen, furzem ober fö̈hjtens mittelfangem, am Enbe gerabe abgejdhittenem ober etwas eingeferbtemt Schwanze und reichem,

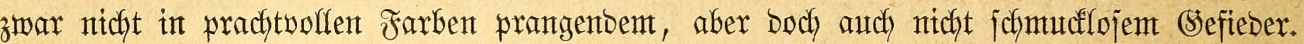

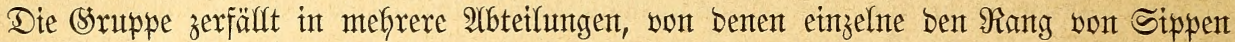
beanjprutchen fünnen. Eine jolche Sippe bilben bie Feljeniperlinge, Die am georungeniten gebaueten Mitglieber ber (Sejamtfeit, auggezeidfnet Durch ifgren jefr fräftigen, freijelförmigen, an Den Schneiben etwas eingebrücften, born folbig zugemölbten, aber body ipiben Schnabel,

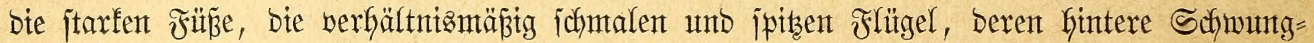
federn am Enbe auggerantet jint, ben furzen, am Entbe fajt geraben Sdywanz und bas bei Eciben (sejchledhtern gleich gefärbte (Sefieber.

281. Der Steit = Dder Bergiperfing, Steinfinf 2 2. Pyrgita (Fr., Passer, Petronia) petronia, L., (silvestris, torquatus, stultus, bononiensis, maculatus, rupestris). - $\mathfrak{A} . \mathfrak{B} . \mathfrak{B} \mathfrak{x} \mathfrak{f} \mathfrak{m}$, $\mathfrak{B}$ eiträge, $\mathfrak{B} \delta$. I,

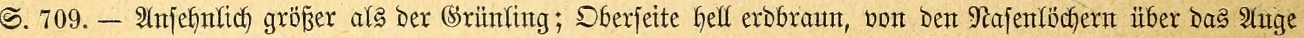

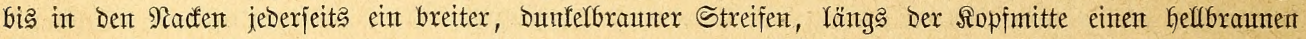

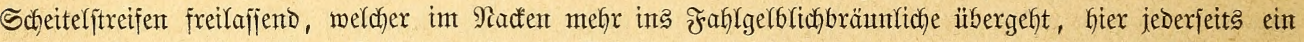

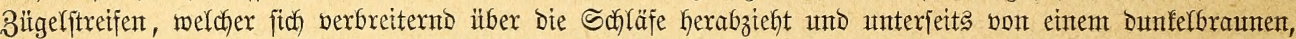

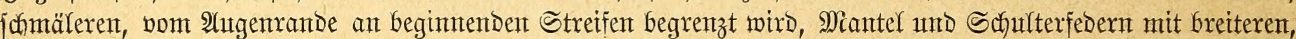

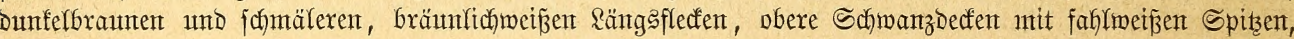

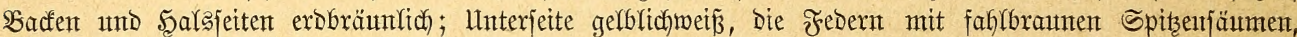

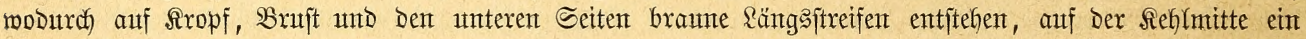

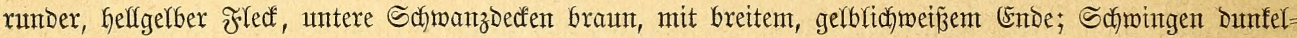

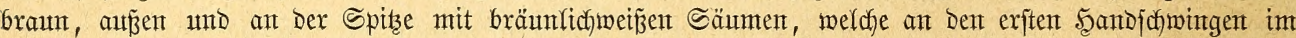

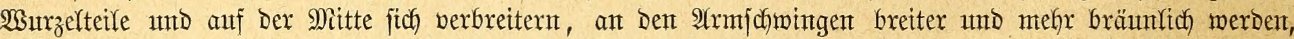

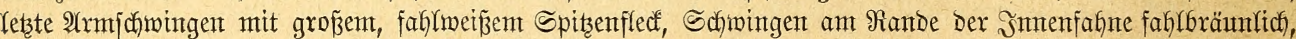

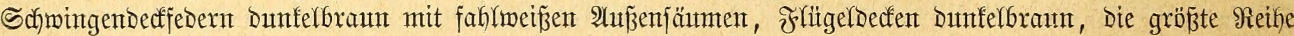

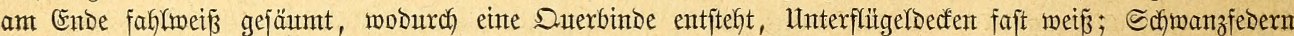

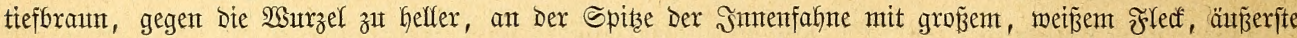

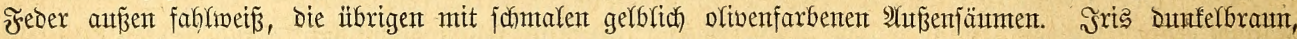

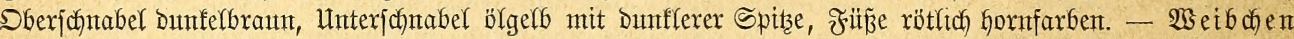
Dem Miänndent bis auf ben fleiteren, gelbent Reflffedf gleid) gefärbt.

Der in Dentichland überall feltene uno mur einzeln auftretende Sogel bewohnt häufig und gejelfichaftsmeife

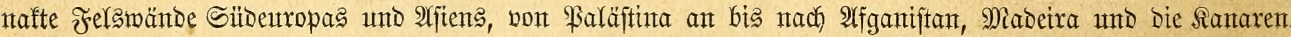

282. Der $\mathfrak{B u ̈ p t e n j p e r ( i n t g , ~ P . ~ ( F r . , ~ P e t , ~ P y r e n e s t e s , ~ C a r p o s p i z a ) ~ b r a c h y d a c t y l a , ~ H e m p r i c h , ~}$

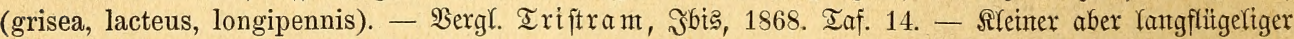

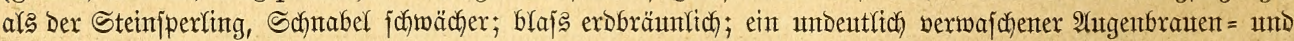

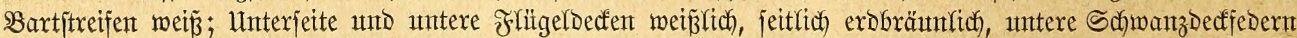

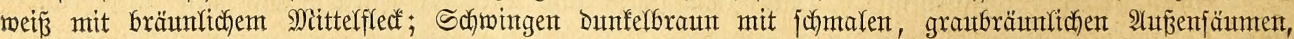

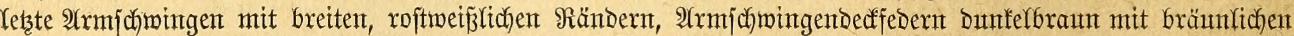

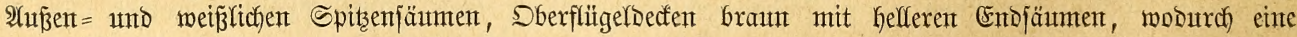

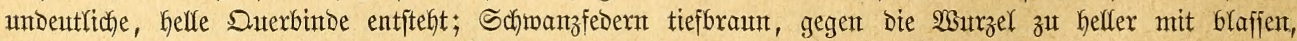

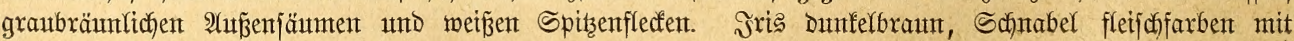

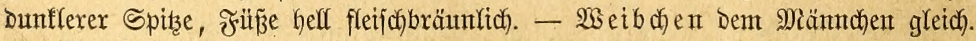

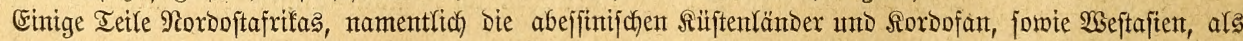

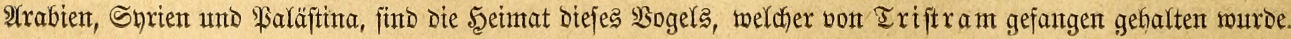


283. Der ßnitiperling, P. (Ligurnus, Buserinus, Crithagra) rufobrunnea, Gray, (rufilatus). 2. 3. Şartlaub, Proc. zool. soc. 1866. - Brö̈ß̈e Des (Srünlings; Sberjeite büfter roftbraun mit

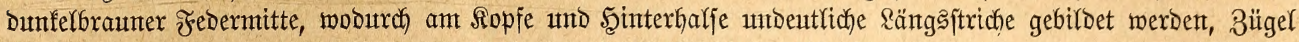

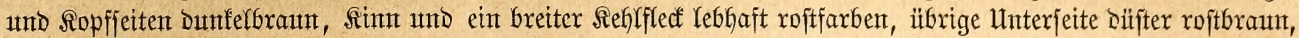

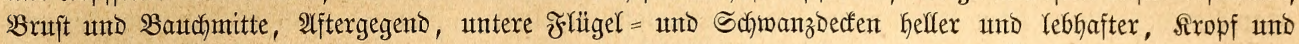

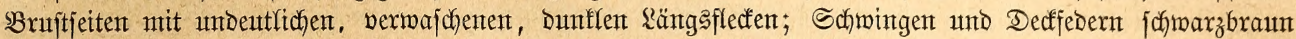

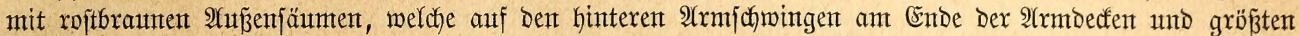

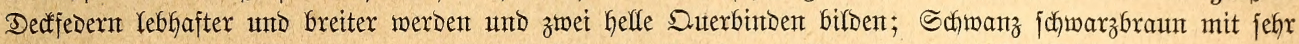

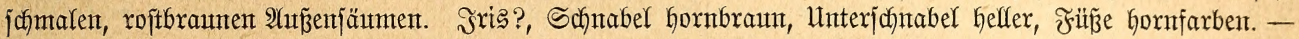
Beibc)en Dem Mä̈ntchen gleid) gefärbt.

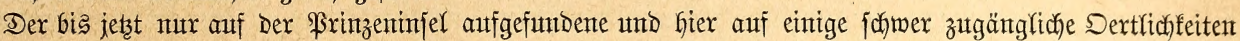
bejdxräntte $\mathfrak{B}$ ogel, ein jef̧ angentehmer Sänger, wiro in feiner Şeimat gefangent geharten.

\section{Die Sperfinge in engeren Sinne entiprechen ben oben gegebenten Merfmalen ber Struppe.}

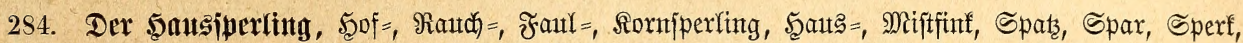

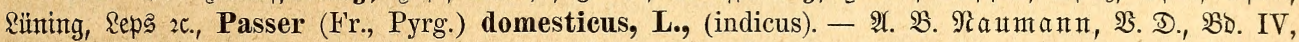

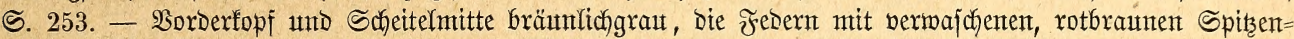

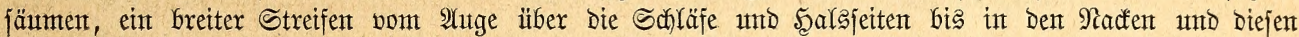

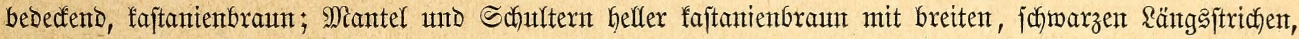

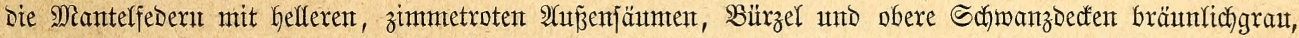

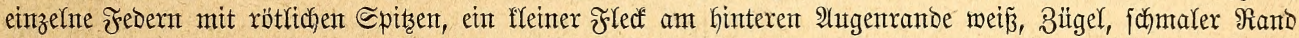

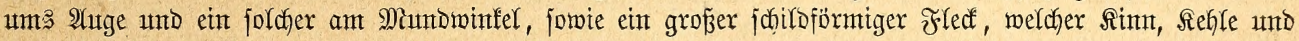

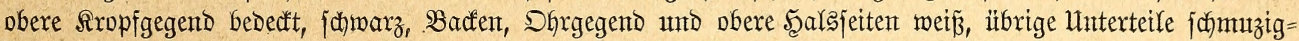

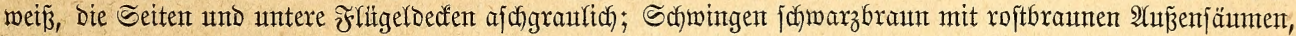

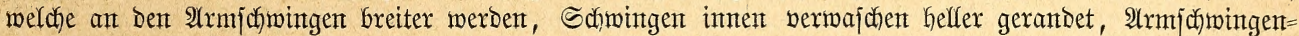

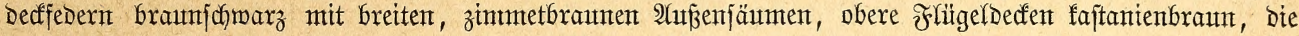

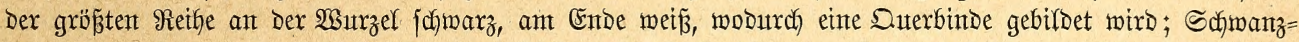

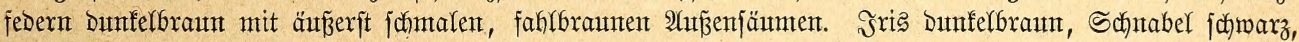

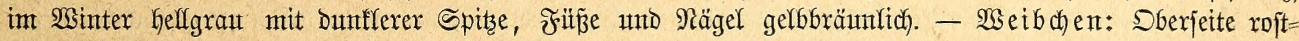

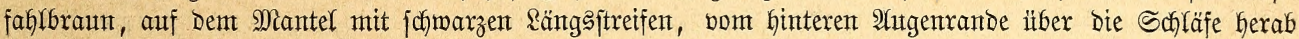

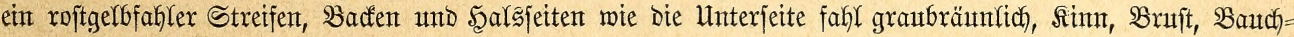

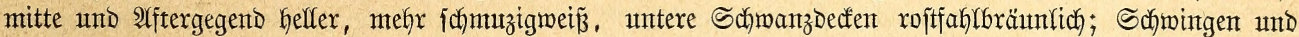

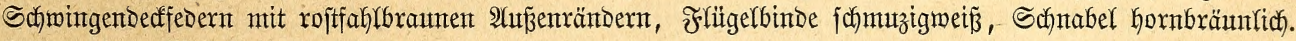
Jutnge Dem $\mathfrak{W e i b c h e n t ~ a ̈ h n e l n t . ~}$

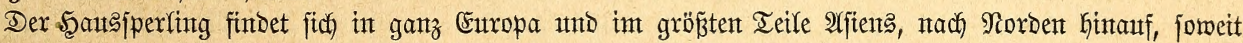

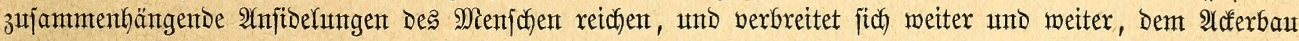

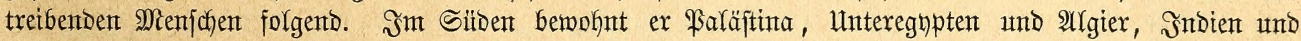

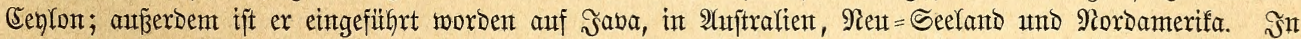

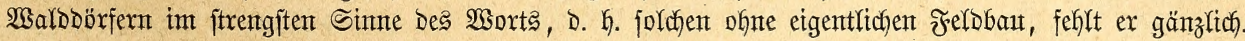

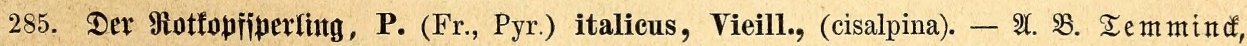

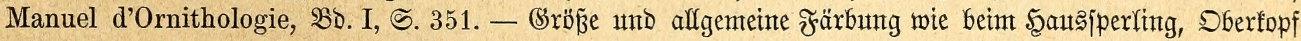

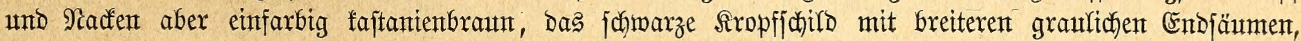

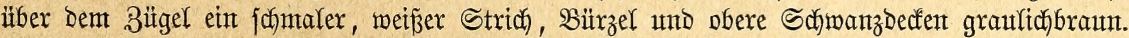

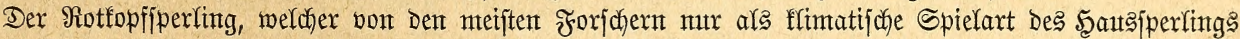

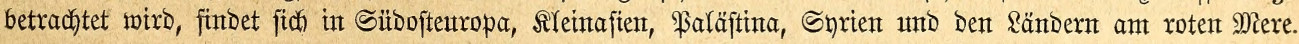

286. Der Bammiperling, P. arboreus, Licht. (rufidorsalis?). - 2 . $\mathfrak{B}$. Seeuglin, Drnitfologie

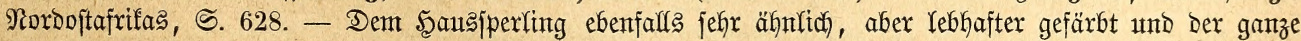
Sber = nnd Şintertopf fowie Der Nadfen einfarbig matt graubraum, Daher vom Ginteren Fltgenrande an mur

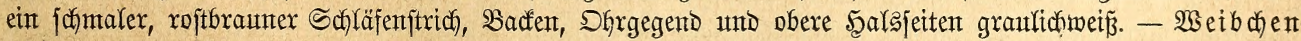
blaffer gefärbt als dą des $\mathfrak{B}$ ermantent.

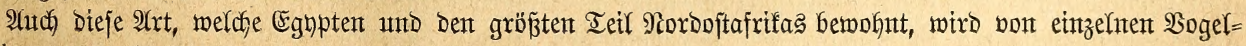
fundigen mur afs 2lbart injeres Sperlings angejefent.

287. Der Stmtpi $=$ doer Bseideniperling, P. (Fr., Pyr.) salicarius, Vieill., (hispaniolensis

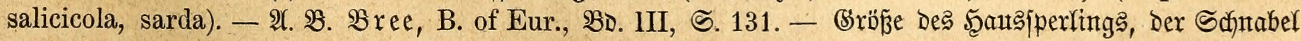

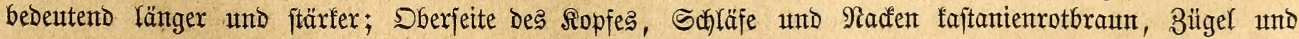

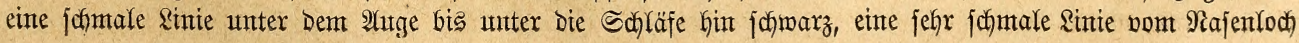




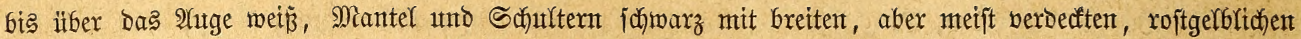

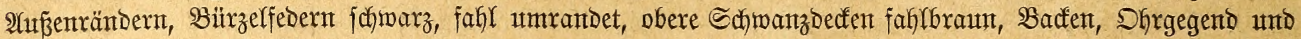

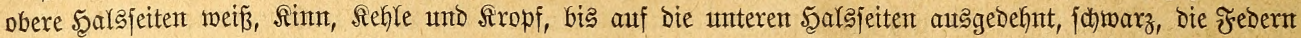

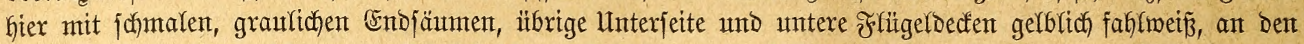

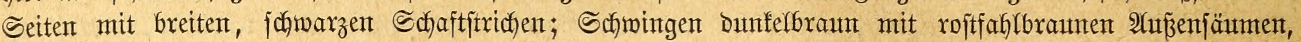

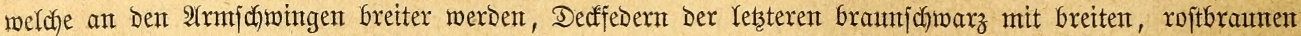

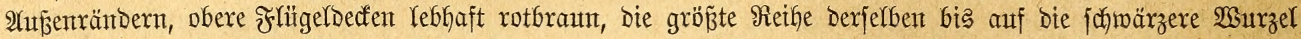

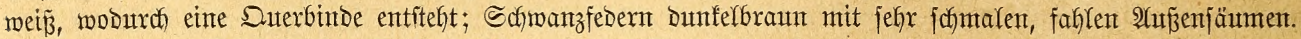

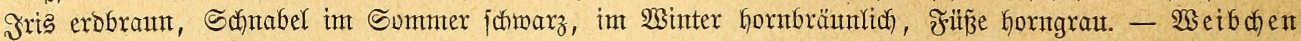

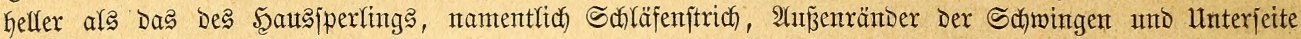

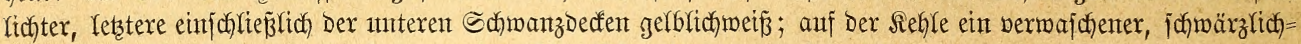

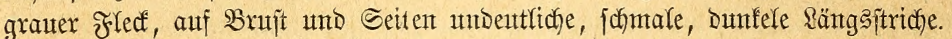

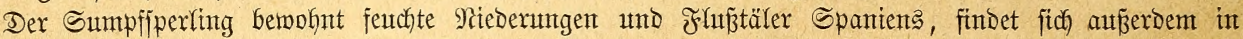

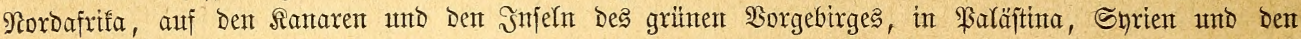

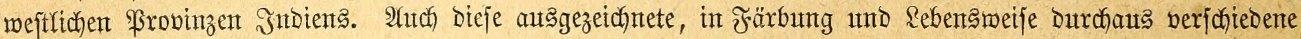

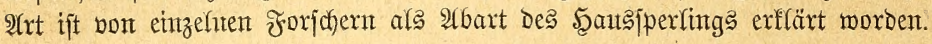

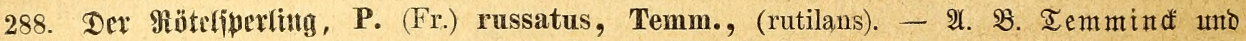

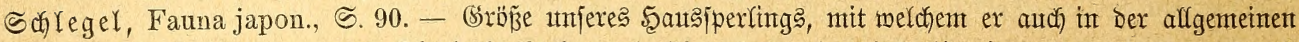

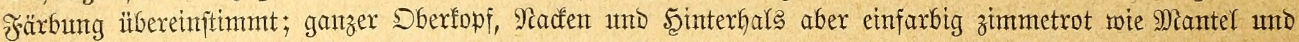

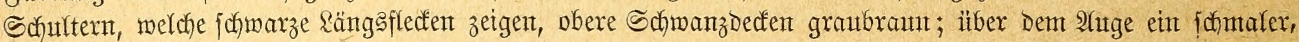

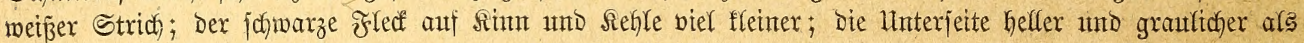

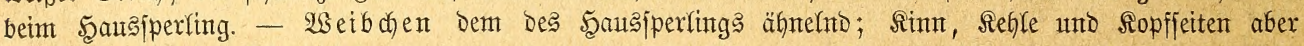
Deutlicac) fagl rofitgelbliç) gefärbt.

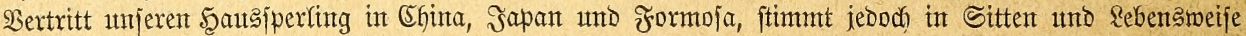
mit Dem Ferbjperfing ïbereint.

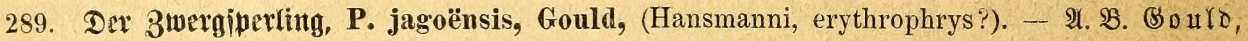

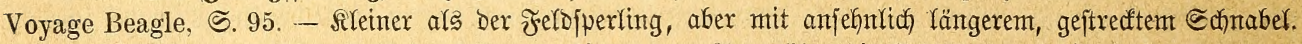

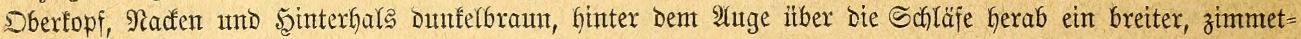

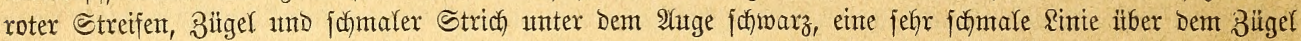

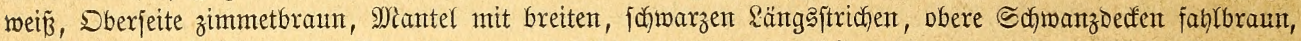

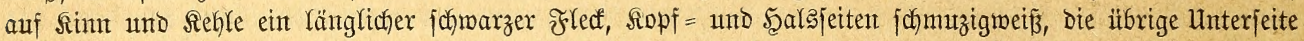

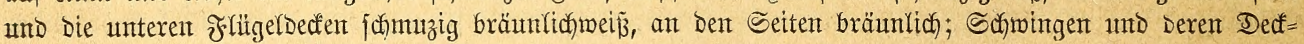

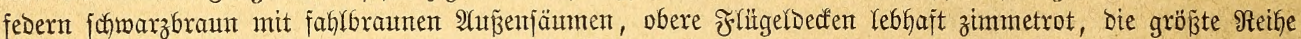

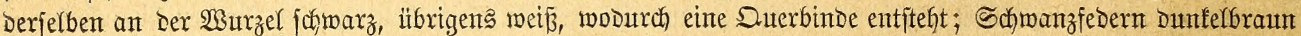

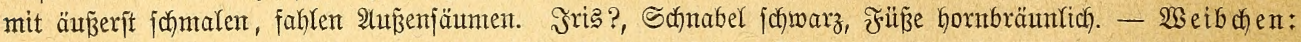

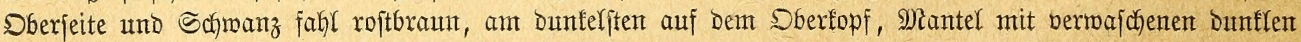

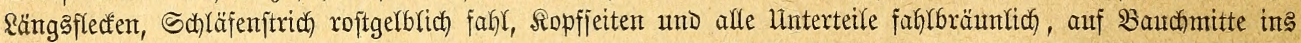

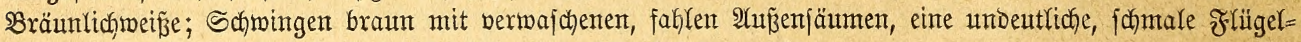
querbinde rojtfahl; Sberidhnabel bräunlid, lunterjagnabel horngelb.

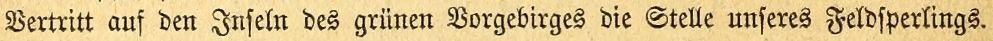

290. Der Rapjperling, P. (Fr.) arcuatus, Gml. - Vergl. \&ayarb, Birds of South-Africa,

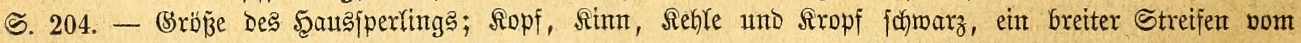
finteren 2Agenrande an über bie હafläfe herab, welcher fich hinter Der Shrgegend hufeifenförmig bis zu Den

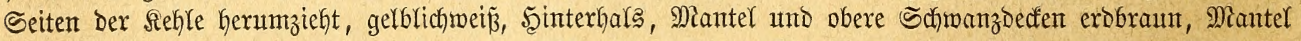

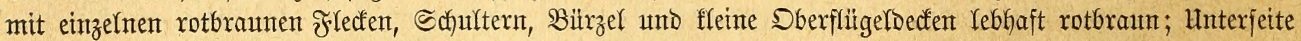

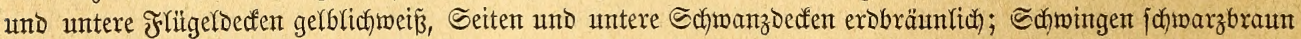

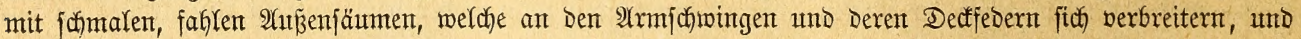

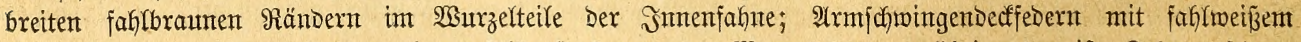

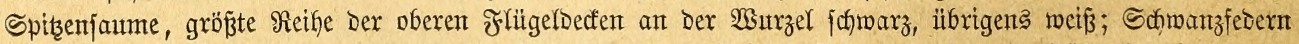

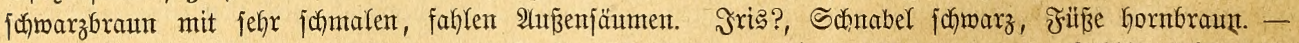

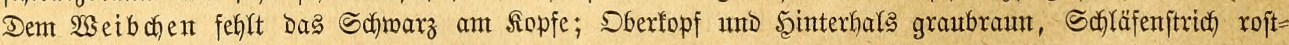

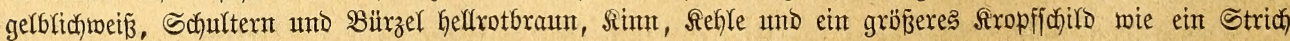

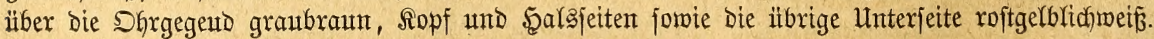

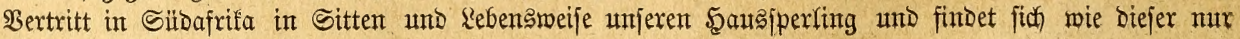

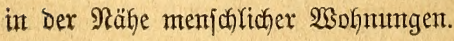




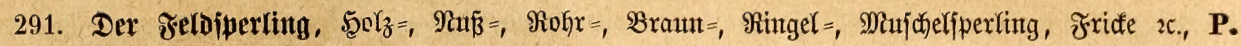

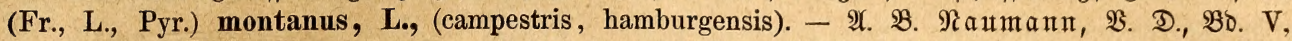

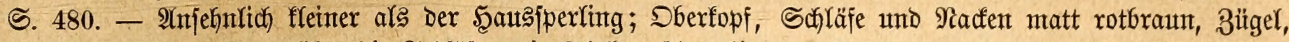

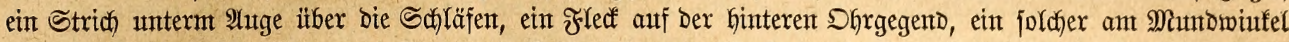

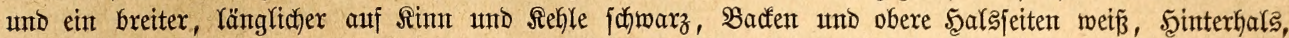

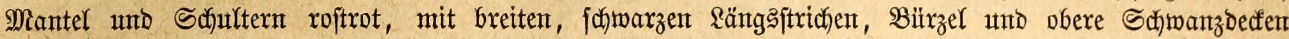

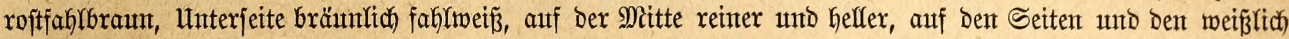

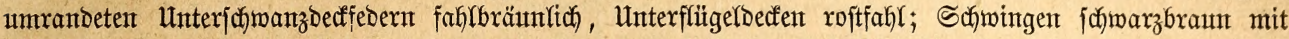

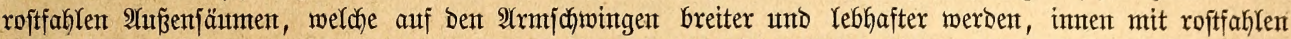

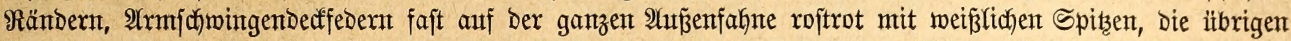

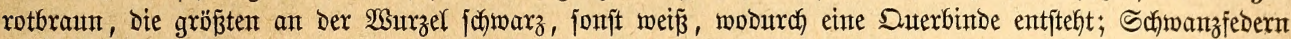

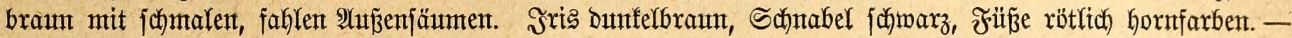

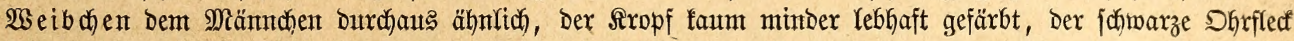
ffeiner.

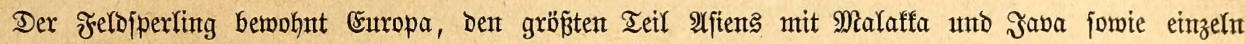

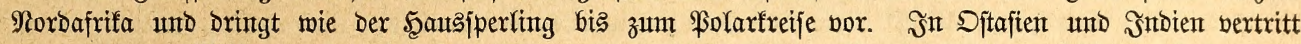

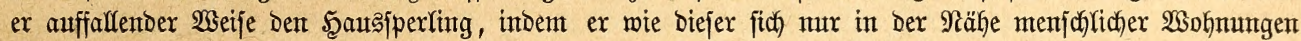

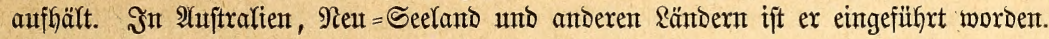

Die nächjtfolgento 2Art wirb won einzelnen Forjchern alz $\mathfrak{B e r t r e t e x ~ e i n e x ~ b e j o n b e r e n ~}$ Sippe betrachtet, unterjcheibet jich aber nur burch etwas gejtrectteren $\mathfrak{B a u}$ und bie Eigen= tümlichfeit ber Färbung von ben echten Sperlingen.

292. Der $\mathfrak{B a f d h u ̈ t t e n j p e r l i n g , ~ P . ~ ( F r . , ~ P y r . , ~ P y r g i t o p s i s ) ~ S w a i n s o n i i , ~ R u e p p e l l , ~ ( d i f f u s a , ~}$

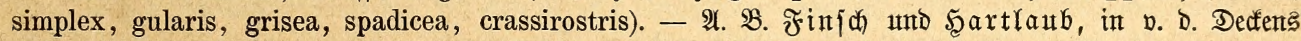

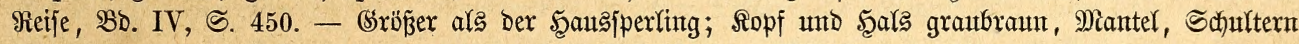

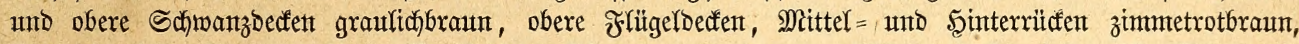

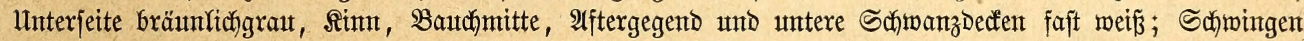

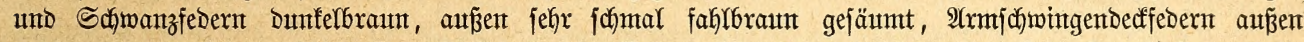

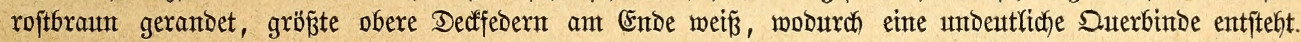

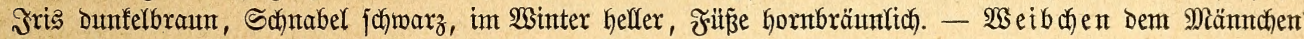

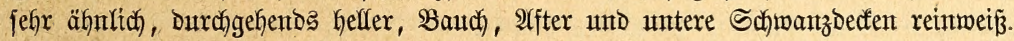

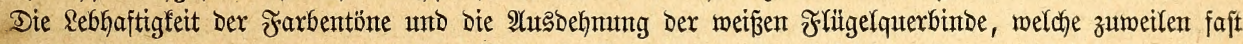

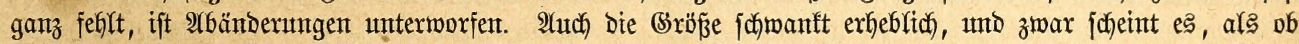

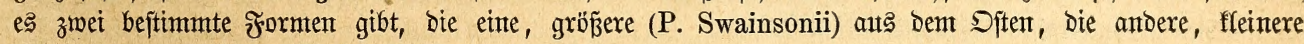
(P. simplex) aut bem $\mathfrak{B}$ eften $\mathfrak{A}$ frifas.

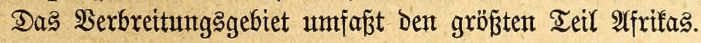

Der fürzere Sdynabel unb bie auşgezeidynet jchöne unb lebhafte Färbung unterjchetben

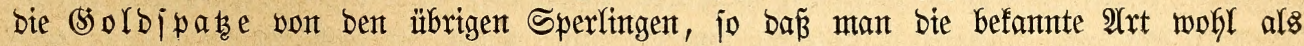
Bertreter einex bejonberen Sippe betrachten barf.

293. Der (SnlDiperling, Chrysospiza (Fr., Ser., P., Pyr., Auripasser) lutea, Lichtenstein. -

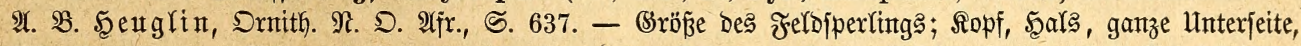

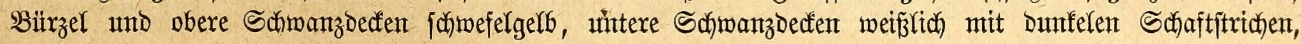

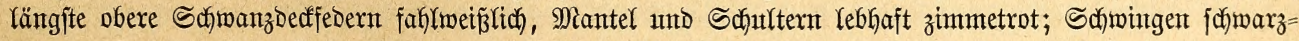

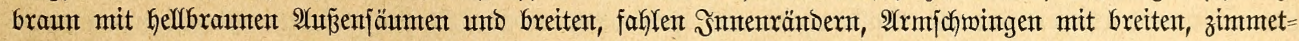

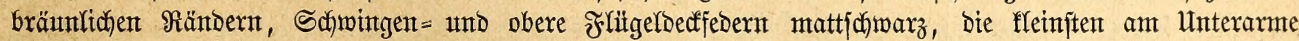

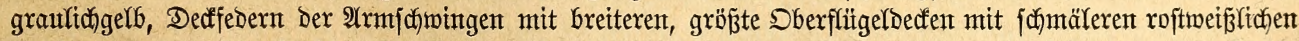

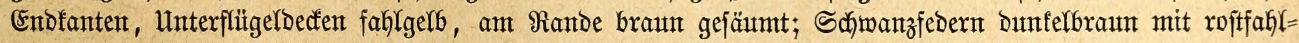

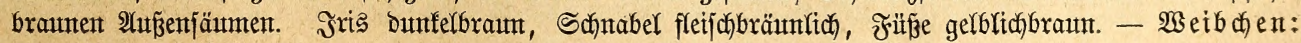

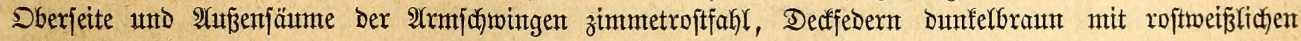

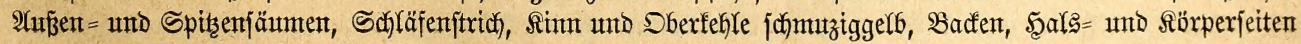

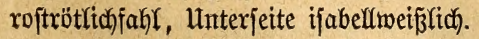

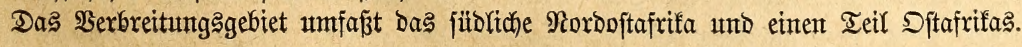

Durd ben geitredten Sdjnabel, meldfer in jeinem $\mathfrak{B a u}$ bem ber Ebelfinfen gleicfit,

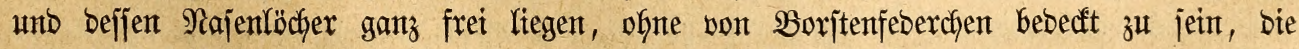

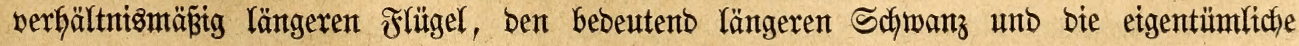




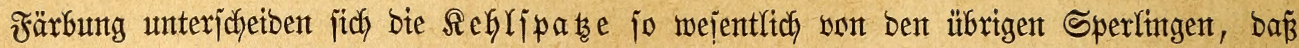
mant iie in eine Gejontbere Sippe vereinigt hat.

294. Der Bintenfehlipatz, Gymnoris (Fr., P., Xanthodina) flavicollis, Franklin, (jugularis). -

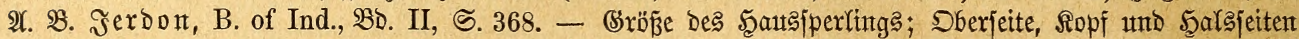

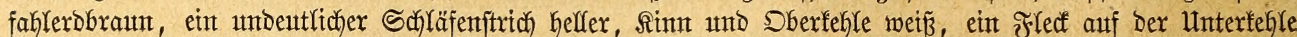

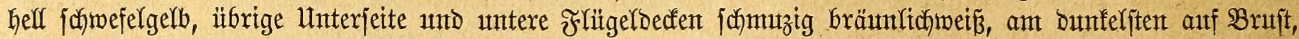
helfer und mehr weiźs auf Bauthmitte und Den unteren Schwanzbecten; Sdhwingen und Dedfebern Dunfelbraut

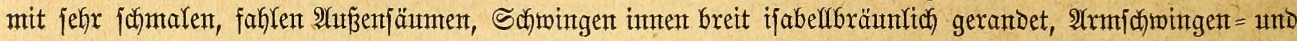

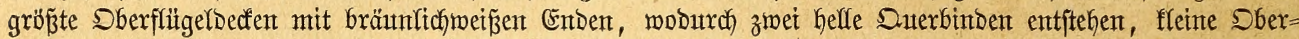
Dedfedern am Unterarme Yebhaft zimmetbraum, Sdhwanzfebern Dunfelbraun mit äunerit fámalen, fahlen

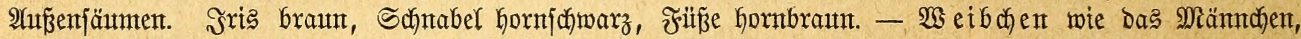
Der gelbe Reblflect fleinex ind blaffer.

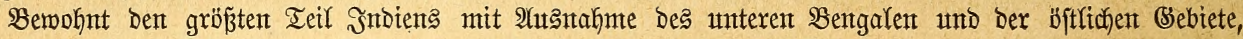

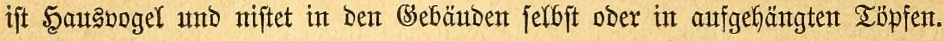

295. Der fiehlipaty, G. (P. Pyr., X., Petr.) dentata, Sundevall, (albigularis, lunatus, cani-

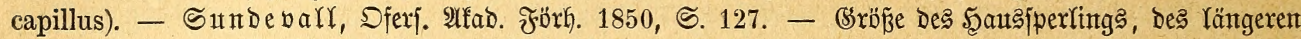

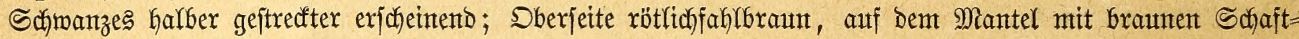

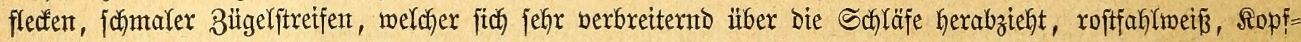

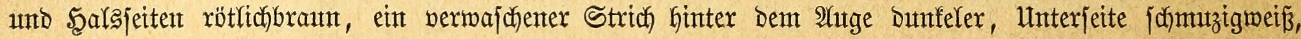
Rropf, Bruft and Geitent blafs bräunlichgraut bermajchen; ein runber Fleat auf ber Rehlmitte helfgelb, ein

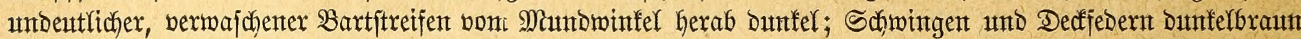

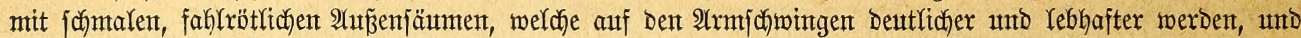

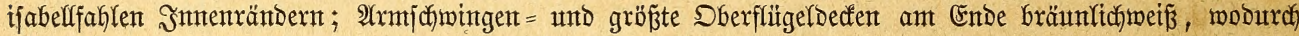

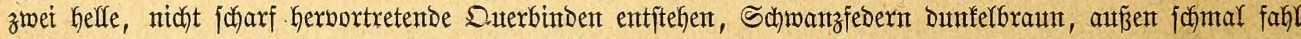

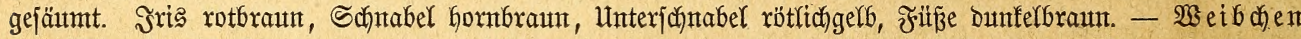

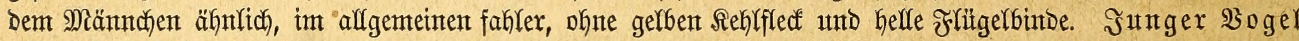
mit weißßer Reblmitte.

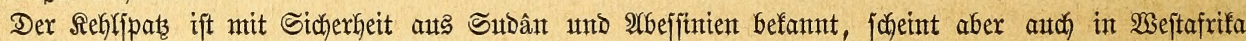
porzufommen, weil ex nidft felten in ben Scandel gebracht wird.

296. Der (Srofjfehlipaz, G. (P., Pet., X.) flavigula, Sund., (petronella). - $\mathfrak{A}$. $\mathfrak{B}$. Sundedaff,

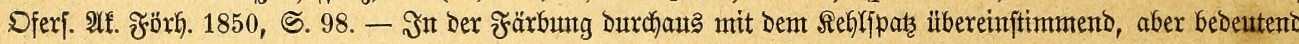
größ̄er.

Bertritt Den Yestgenannten in Sildafrifa.

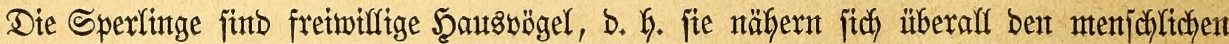
Woofnungen, unt hier als Schntarotger won ben abfallenben Brofanten zu leben. Selbjt biejenigen $2(x t e n$, welche in einzelnten (segenben wentg ober nithyt umt bent Mienjichen fich zu

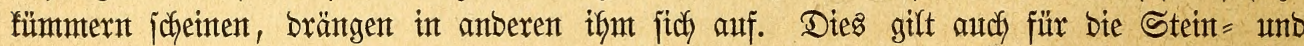

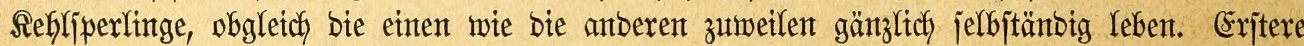

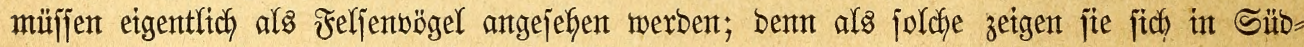
europa, wo fie in ungleidy zafhlreidjerer Mienge auftretent als bee uns. atber aud fie haben

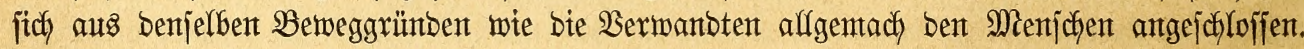

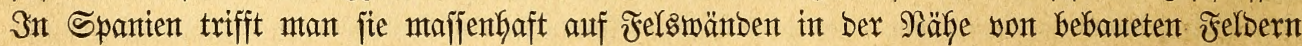

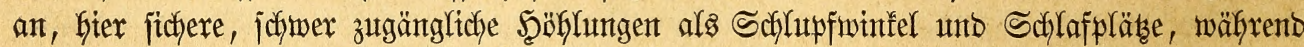

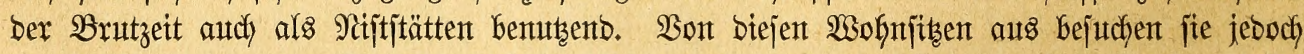

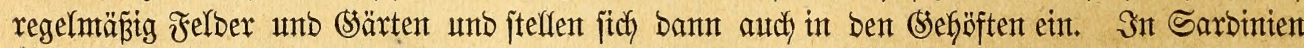

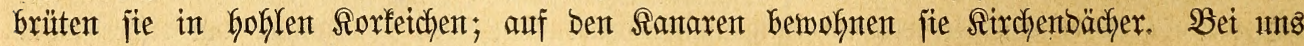

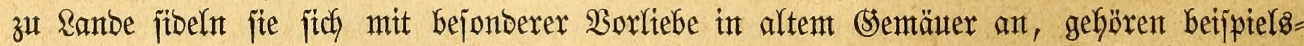

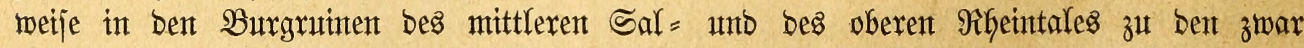

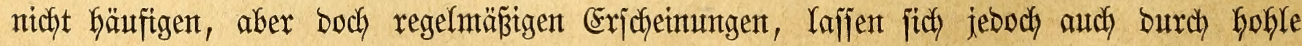

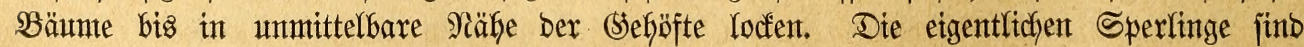

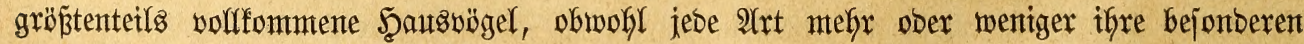

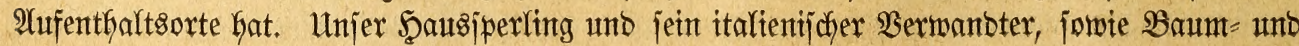




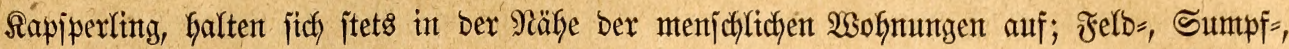

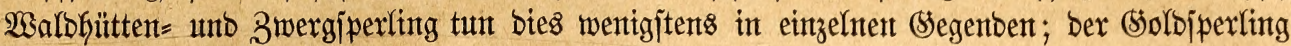

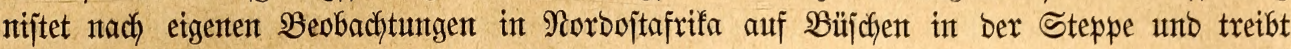

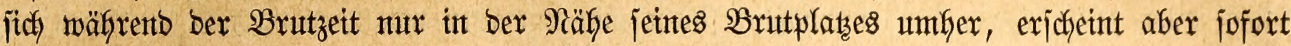

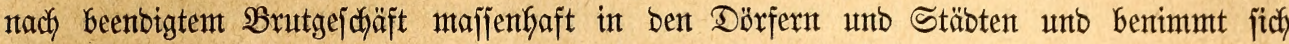

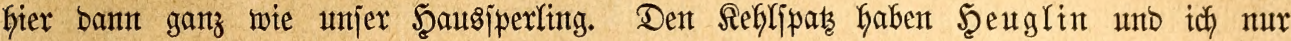

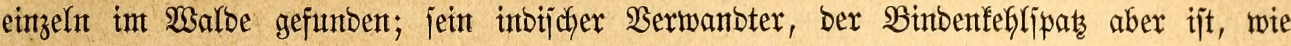
bemerft, ebenfalls zum 5̧autsoggel geworben. Rurz, alfe Sperfinge treten unter $\mathfrak{u m}$ itänben

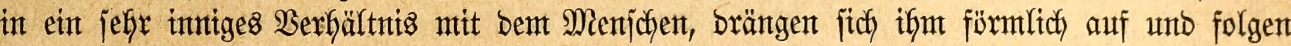
ify jogar freimitlig in \$segenben, in benten fie uriprürtglich nicfft vorbanbent waren, jobarb jener fejte Sibelungen grüntoet unto, was vor affent für fie Bebintgung, regefmä̈ß̈igen JelbGaut treibt.

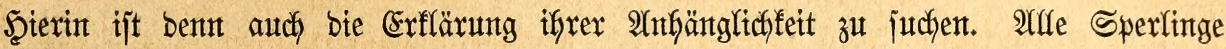

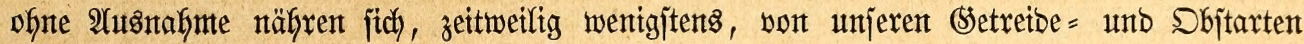

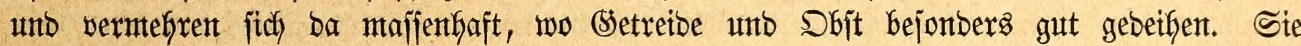

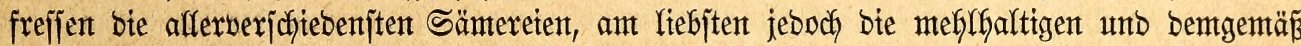

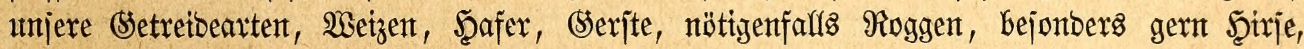

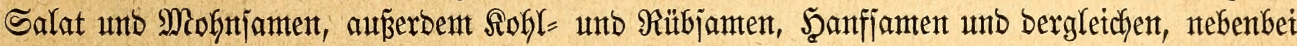

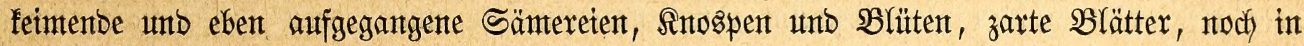

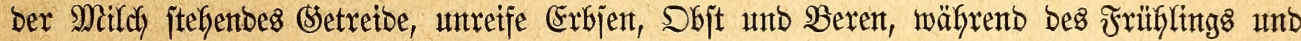

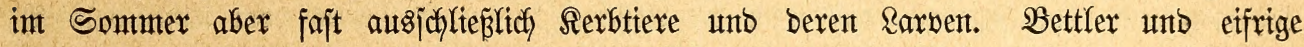

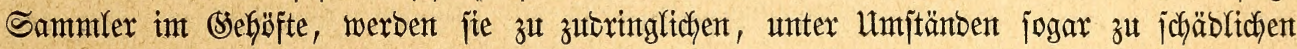

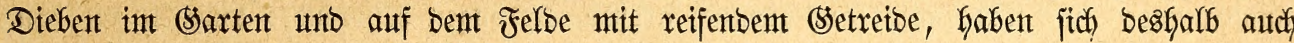

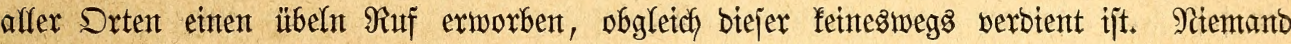

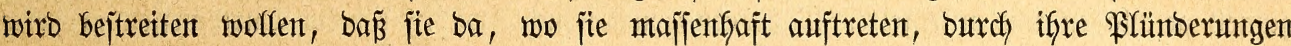

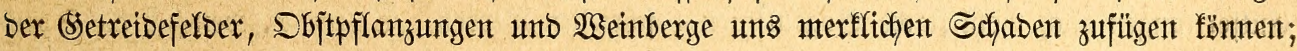

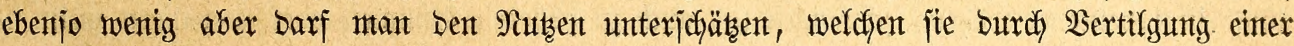

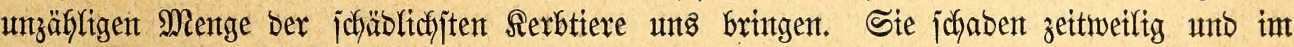

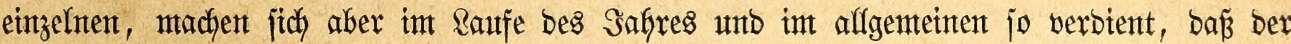
burdh fie geitiftete Putsent bent won ifftent verurjachten Schaben unbebingt auffebt. Man

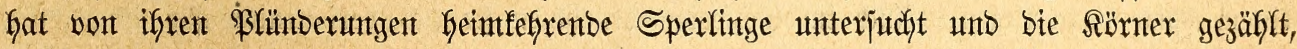

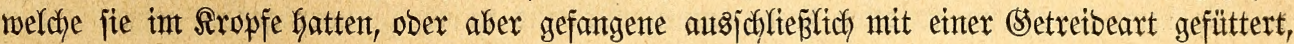
um zu erfafren, wie viel Sörnter jie zu ifrer Naafrung bebürfen; ntan hat auf bieje

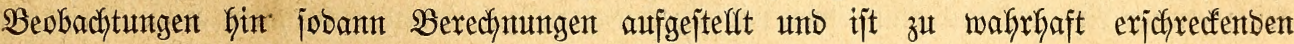
Ergebniffen gelangt: aber ntan hat babei vergeffen, baß̄ ber Sperling wirflidy nutr währento

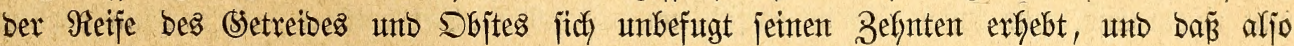

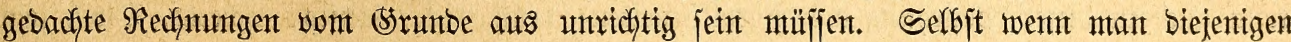

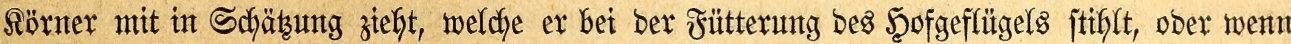

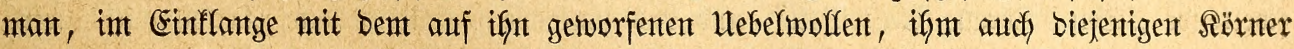

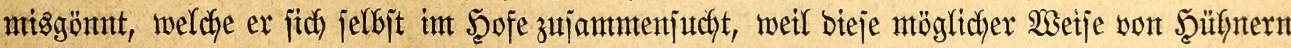

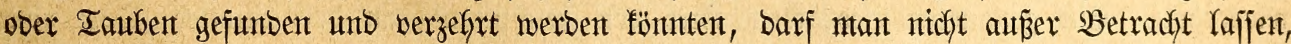

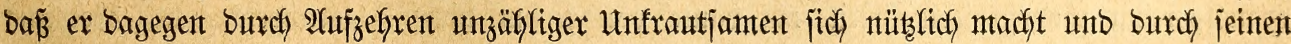

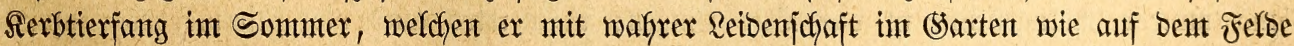
betreibt, fich wafurgaftig ben geringen Rofin bereits verbient hat, ben er int 2 Sinter ober

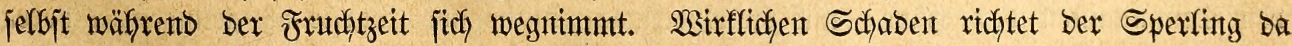

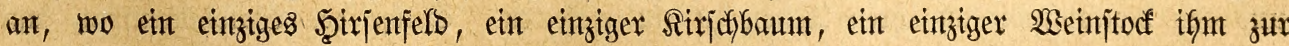

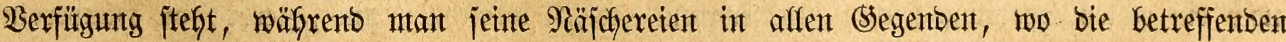
(Setreibe = unb Dbjtarten in größ̈erer 2ubbefhnutg gebaut werben, faum merft. Dies bei= 


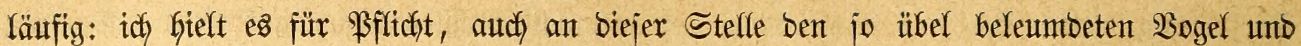
jeine $\mathfrak{B e r w a n b t e n}$ in Schuts zu nefymen.

"In Dem Iun unt Ireiben unjeres Sperlings, ben man balb einen Sdyelm, bald

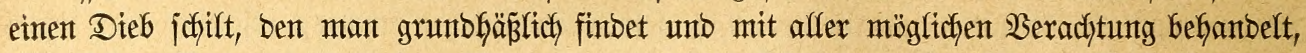

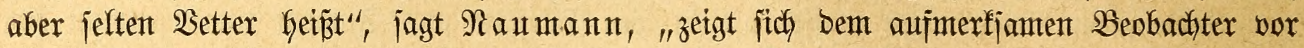

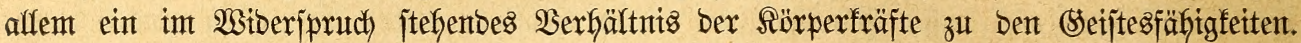
Denn jeine förperlichen Bewegungen jint in ber Iat etwas plump ober zienlich ungejchicft,

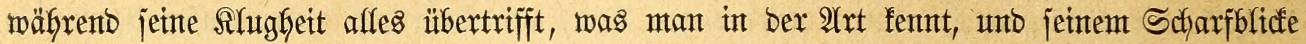
nicjts entgeft, was ifgm nützen ober jeine Sicherheit irgend gefähroen fönnte." Dieje Bemerfung ijt volffommen richtig und gilt für afle 2Yrten, weldfe längere Beit in Sejellichajt

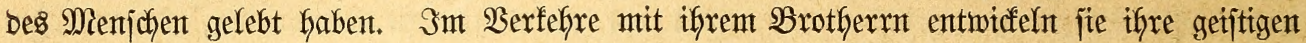
FäGigfeiten zu einer unglaublichen Şöhe: jie jtubiren ben Mienjchen uno richten banach ihr

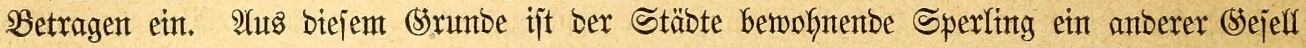
als ber Dorfipats, ber in ben einjamen Walboürfern Snterafrifas haujente Wald hüttenjpats jahembar wejentlich verjuteben von bem Steinjperfing, ber Sumpfiperling bon bem Refl=

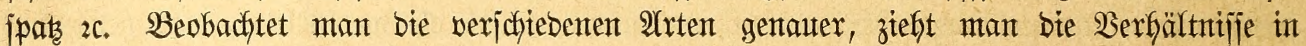

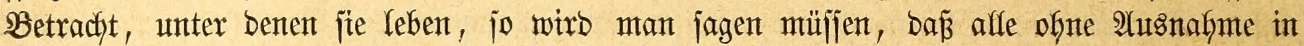
ifrem $\mathfrak{B e j e n}$ und Sein einanber jebr nahe fommen. (Etwas eigentümliches zeigt freilich

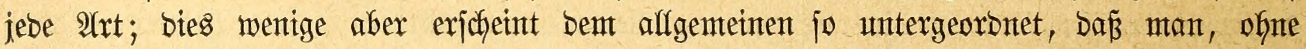
mejentlich fehlzugreifen, eine an ber einen 2 rat gemadjte Beobachtung auch auf bie anbere

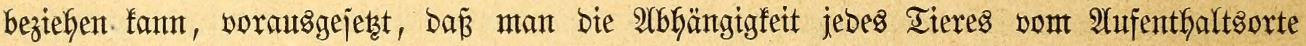

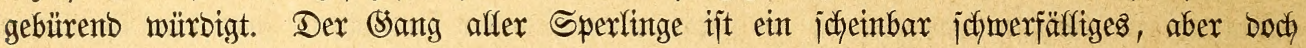

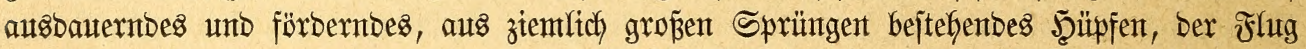

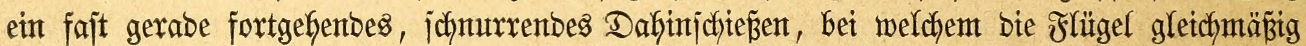

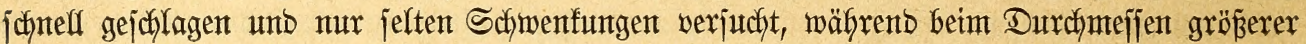
Entfernungen aud wobl flache Bogenlinien bejdyrieben werben. Selten exfeben fich bie Sper=

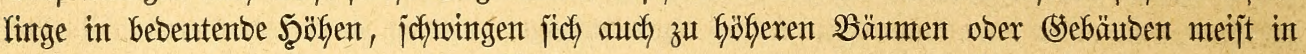
Ibjäzen auf, inbem jie von einem Ieile zum anderen fliegen; wobl abex zieben fie ba, wo fie

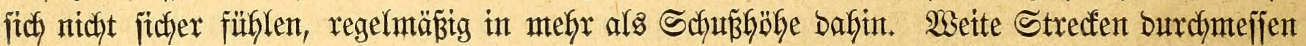
fie jelten: Entfermungen von einer Biertelmeile fint beinabe bas Gödjite, welches jie in

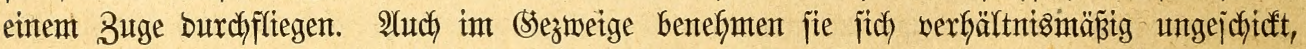
wie jie benn überfaupt in aflen Bewegungen burchaus nichts Gervorragentes zeigen. Das

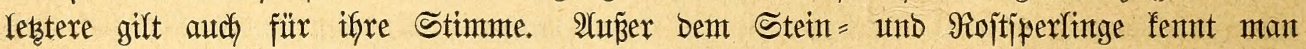

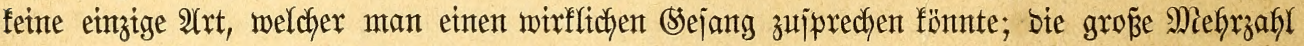
zeidhnet jich im (segenteile burch gerabezu unangenthme Stimmlaute aus, gibt biejelben aber

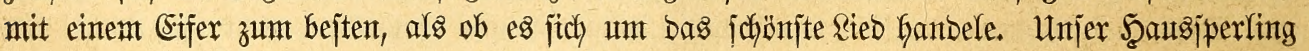

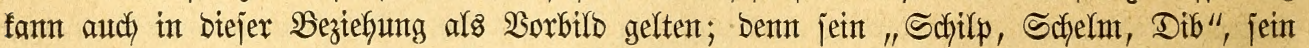
janfteres "Dürr, Dih, Dih, Dih", Das heftig junarrende untb warnente "Ierr" ober bas

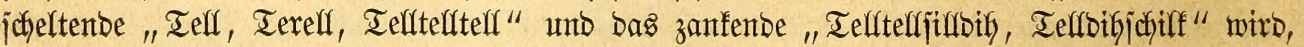
verjachieben betont zwar, aber boch im wejentlicten gleichlautend, auch von ben anberen Arten mieberfolt. Ein genauerer Beobachter witro ben Felbjperling an ber Stimme jofort vom Şausjperling unterjchetben, weil bie \&aute von jentem fürzer, gerunbeter, abgebrochener unb minber unangentefm in bas $D \mathrm{fr}$ ffingen; man wirb aud bie Stimmte bes Sumpf= jperfings jofort erfenmen, obgleich Gier bie Unterjefiede noch viel geringer jinto als zwijden Den Stimmlauten bes Scaus = unt Feldjperlings: faum aber bürfte es gelingen, umjeren unb Den Rotfopfipats an ifren Iönen zu unterjchetben. Selbjt ber Warbhüttenjpats läß̈t

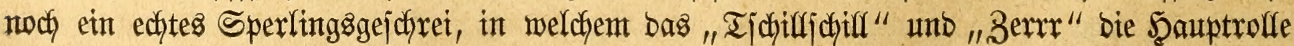
iptelen, bernthmen; ja jogar bie Stemiperlinge, unzmeifelfaft biejenigen 2 (rten ber Bejamt= 


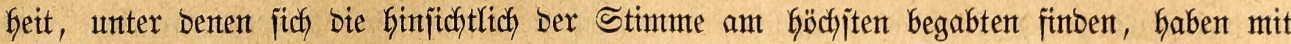

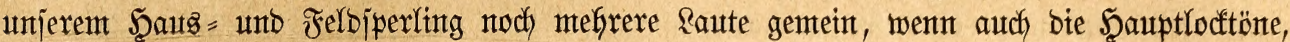

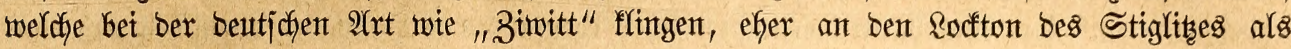
an bett umeres Spazes exintern.

Reine Sperlingsart hat jich bent Mienjiden bebingungelos unterworfen, jebe, welche

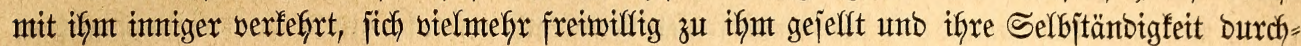

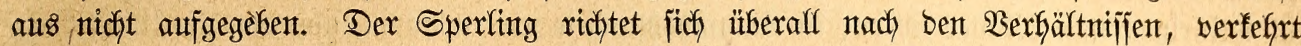
beşalb mit bem Stäbter anbers als mit bem Dorfbeewogner, mit unjerem Bauter nicht in berjelben 2 seije wie mit bent Egypter unb Snbier, mit bem Snnterafrifanter anbers als mit Den Yekgenannten beiden. Ex merft jefhr balb, in wie weit ex jeinem $\mathfrak{B r o t h e r r n}$ trautent

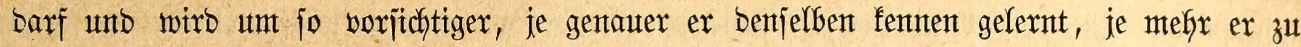

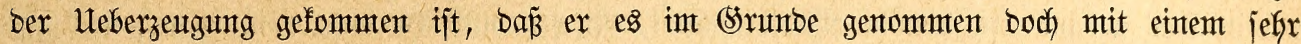

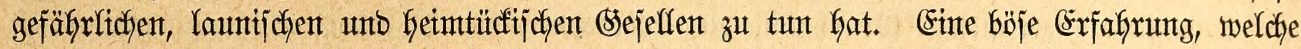
von Sperlingen einer Begento gentadgt murbe, wiro binten furzent von ber Bejanttheit auf8

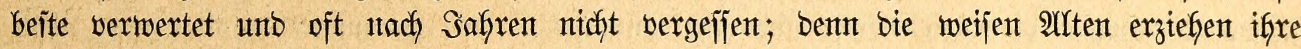
unterfagrenten Sungen regetrecht utto weihent jie bald in alle Bsefahren bes Zujammentebens

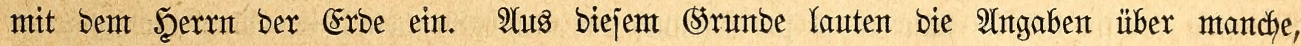

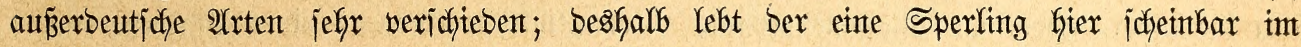

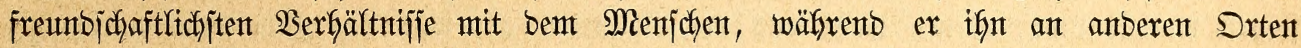

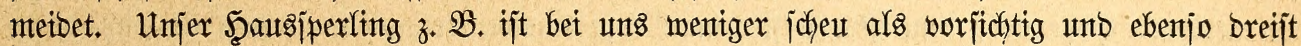

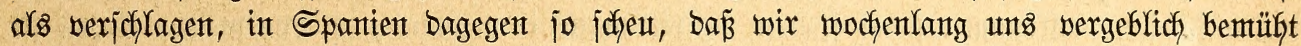

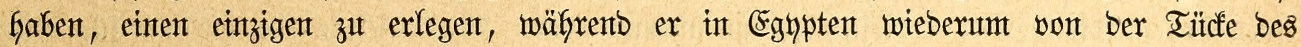

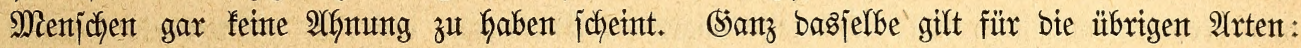

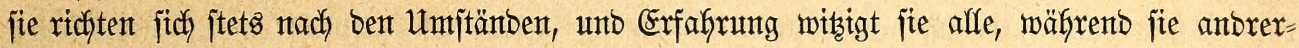
jeits jich gehen lafjen unb bis auf weiteres ein gewififes $\mathfrak{B}$ ertrauten funt geben. Unter

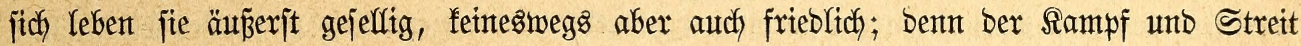

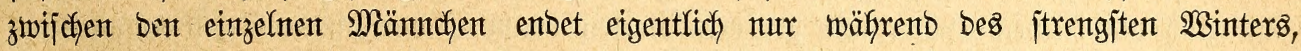

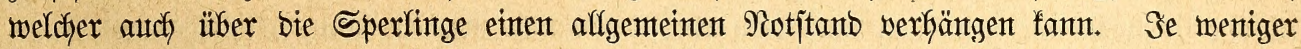

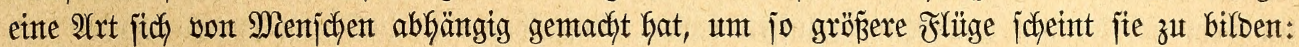
io rottet fich ber Sumpfiperfing ba, wo er häuffig auftritt, oft in unzählbare Schjwärmte

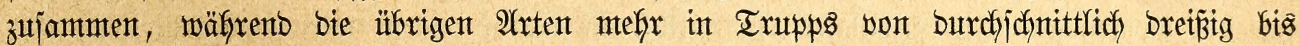

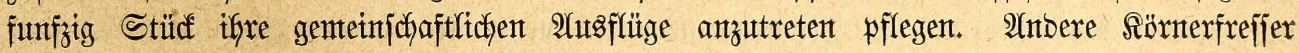

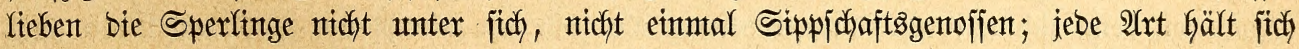

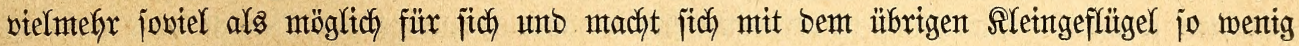
3u idłaffen als ntöglich.

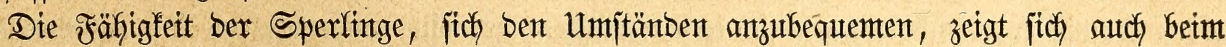
Mejitbau. Der Stanbort besjelbent wiro jo verjdjeben gewählt alz bentfbar, weil jebe paffente Dertlidffeit won bent einten ober bent antberen entipredjent bentht. So jteft bas Neejt

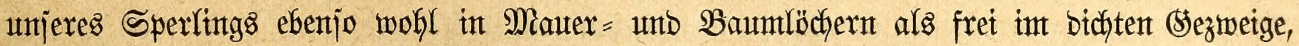

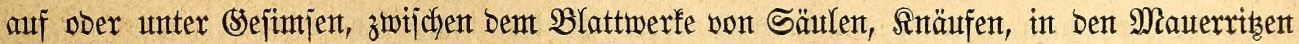
offener Brumnen wie int Unterbau eines Storchnejtes, ober es wirb ber für bie Stare auf́=

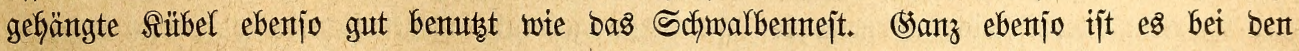
übrigen 2 rten, went bies autd nody nicht won alfen beobachtet worben jein jollte. Der Feld=

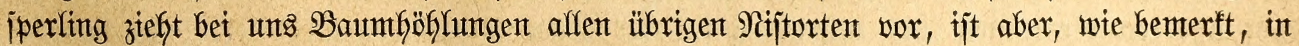

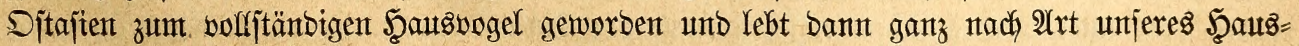

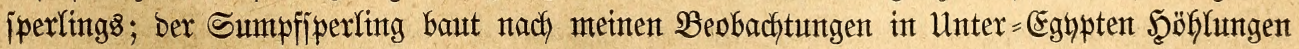
in ben Stämmten ber Fadnten aus, an anberen Steflen Desjelben Ranbes bagegen, laut

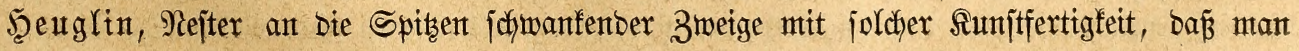


fie mit benten ber Weberwögel vergletchen fann, ba fie nidfyt blof einte Decfe, jonbern auth einen (jeitlichent) ntefr ober wentger röfrenförmigent Eingang habent. So ift es auth bet

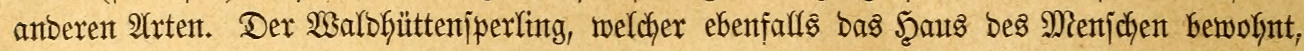

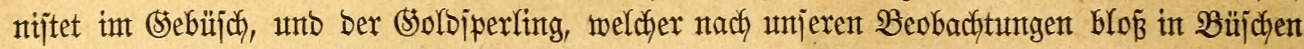

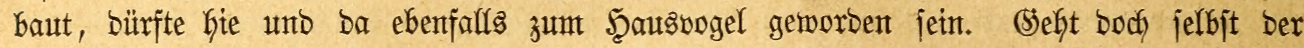

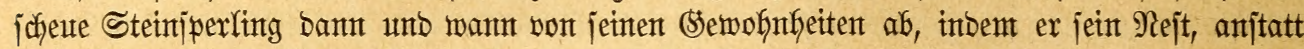

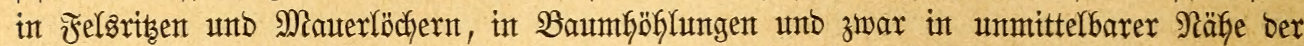

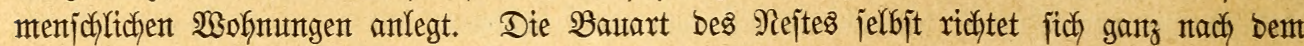

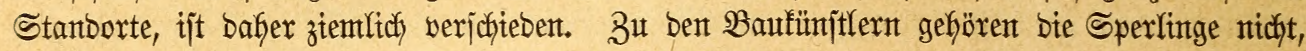

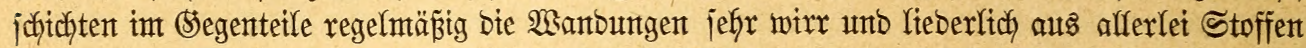
zujammtent. Die auf Baumzmeigen ftehenbent Rejter werben jelbjtwerjtänblich fejter unto orbentlidjer gebaut als bie in Mautrlöchern, Nijchen und Sejimjen, überfautpt in uno

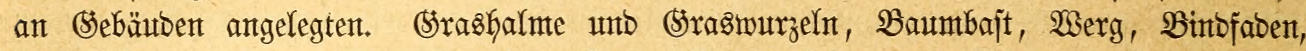

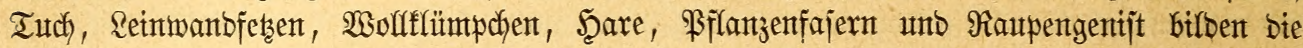

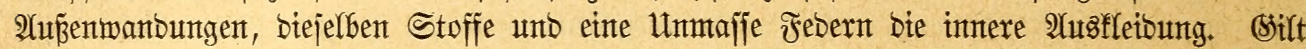

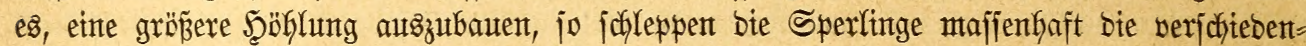
artigftent Stoffe Gerbei; Ganbelt es fidh barum, ein Sdymalbentejt Gerzurichten, jo wiro oft nur bie intere Feberlage zujamntengebaut. Der glüdfliche (sebanfe eines Pärchens fintet

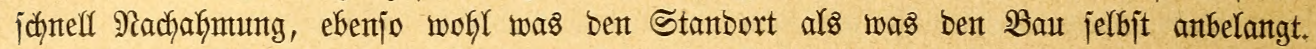

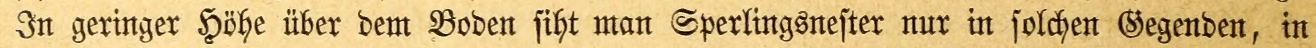
benten fie jich volffommen jicher fühlen, beijpielsweije in Egypten; int alfgenteinen zieben fie einen hohent Standort bes Rejtes jebem anderen vor. Das Stelege bejteht aus fünf bis

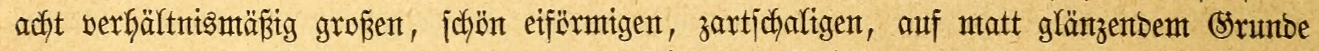
yon verffhtebenter Färbung braun ober bunfelgrau geflecften, geipristen into gepunfteten

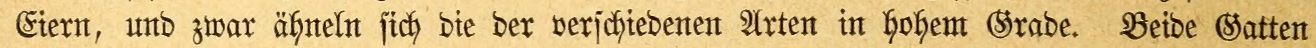
bebrüten fie wechjelsmeije, zettigen jie bintnen breizehn bis vierzehn Tagen, füttern bie Iutgen

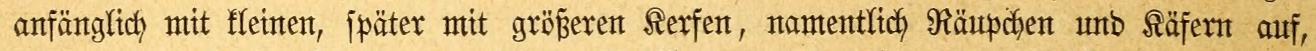

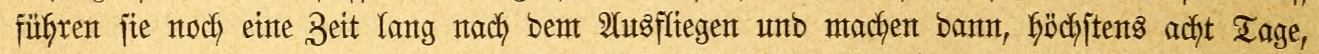

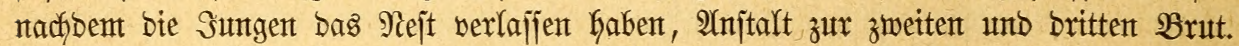

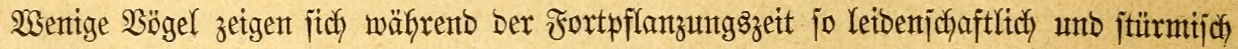
wie bie Sperlinge. Die (sejelligfeit, in weldher jie bisher lebtent, wiro aud jebst nodh nidjt aufgeboben; Des Şaberns und Streitents aber ijt fortan fein Enbe; Denn jebes verliebte

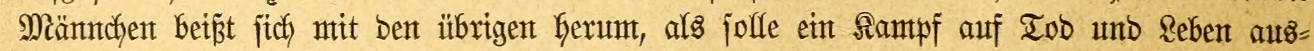

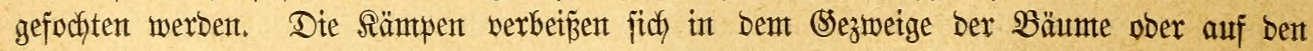
Dädjern, wirbeln won ba Galb taumelnt, Galb flatternd zum Boben Gerab, jeben untent thren Rampf fort und trenten fich exft, nadjoent ber einte augenbficflich fid entichteben für bejiegt erffärt und bas Weite gejudft hat, unt furze Zeit ipäter ben Rämp von neutem zu beginten. Begefrltch in bödhiten (Srabe verfolgt bas Meänndjen mit halb gebreiteten, zitterno bewegten Flïgeln, erhobentem Sdjwanze, niebergebeugtem Sopfe unb geiträubtem Sefieber bas

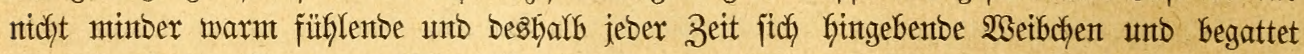
es währento des Tages unzäflige Male nach einanber, weshalb bent auch bie Brünjtigfeit

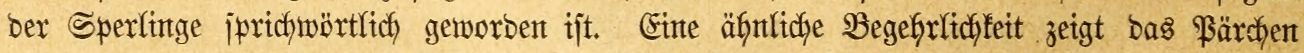

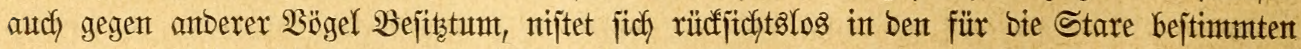

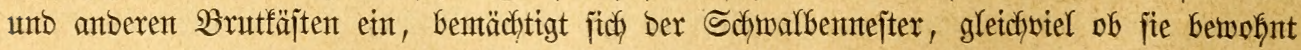
waren ober nicft, verbrängt int erjteren Falfe bas Sdymalbentar ober wirft jelbit bie burch

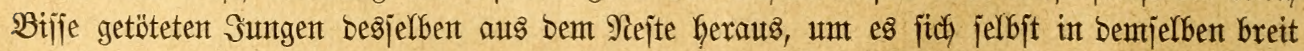

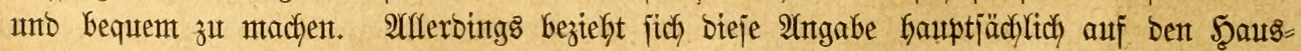

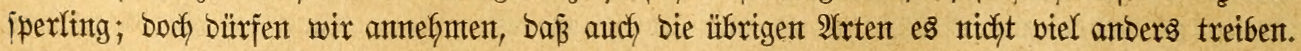


Selten mux fiht man Sperlinge als (sefangene in mieren Räfigen ober Fluggebauern. Manche 2 rten haben aflerbings menig Empfeflenswertes, thre Dauerhaftigfeit etwa aus: gentommen; Die Mitsachtung aber, in welcher fie int aflgemeinen jtehen, verbienten fie nidft. Selbjt unjere Şaus = unb Felbjperlinge füflen ifren \$lats int Fluggebauter aus unb bürfen

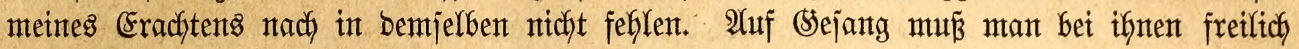
won vornherein verzichten; ifyre Raute werben im affgemeinten Stimmengeminx aber auth nicht läjtig, ifre Sitten unb Ssemofnhlyeiten, weldye fie, einmal eingemöhnt, bald wie int Freien

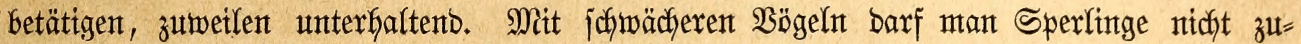
jammenjperren, weil fie biejen burch ifyre Biffitgfeit läjtig fallen, obmohl fie in ber Regel ifyre

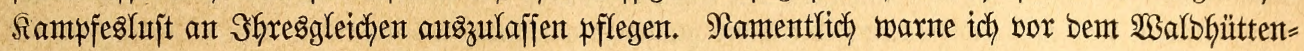
iperling, einem jonjt gar nicht unangenefomen, went auth gejangslojen Räftgoogel: er iji nach meinen Erfafrungen bas bijfigite unb bändeljüchtigite affer Mitglieber jeiner Sruppe.

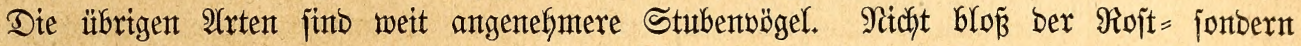
audy unjer Steinjperlintg zählt zu ben Singoögeln, lernt, went ex jung eingefangen wurbe, von jeinten Mitgefangenen aflerlet Raute unt Töne nachafynten unt trägt zuletst einen

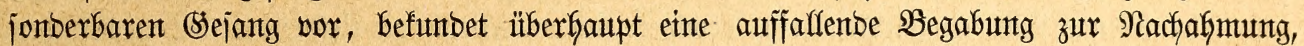

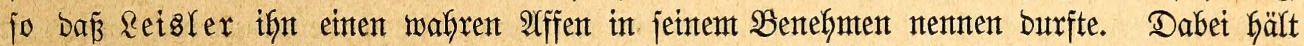

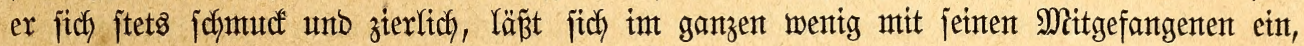

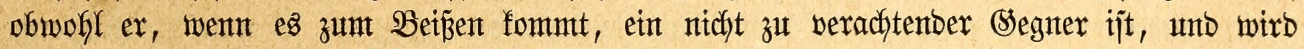
in fürzerer Zeit als bie übrigen zafym wie nur irgent ein anberer jeines (Bejc)lechts. Der

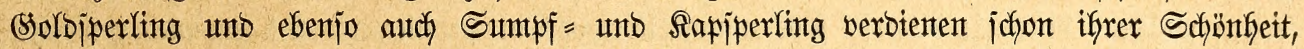
ber exjtere auch jeines janjten unto anmutenden Wejens halber bie Seachtung bes Riebhabers;

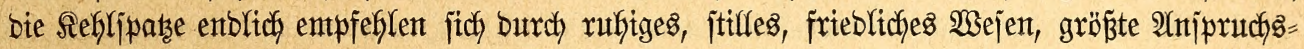

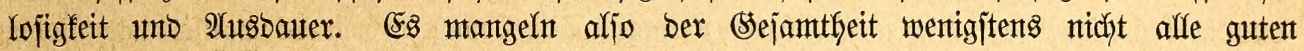
Eigenjichaften.

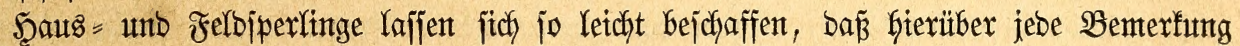
unnötig exjdjeint. Den Steinjperling exhalten wix zuweilen aus ber Schweiz, Arain unb

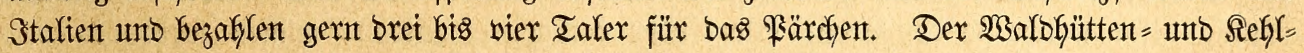
ipatz fommen einzeln in (semeinjchaft ber wejtafrifantichen Sögel auf unjeren Titermarft unb fojten etwa brei Taler bas \$ärchen. Bolbiperlinge werben auf bemjelben Wege, immer aber nux jebr jelten geliefert; bie übrigen $\mathfrak{A}$ rten babe ich bei unts zu Rambe noch nidjt

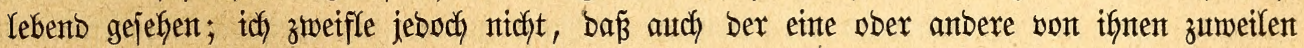
mit herüber gebracht wirb.

\section{Alpenfinkent.}

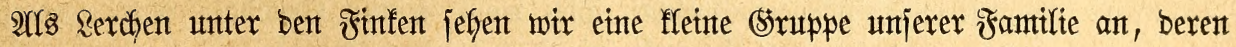
Mitglieber auf ben hödjiten Sebirgen an ber Sdyneegrenze lebent unt nur jelten in bie Tiefe

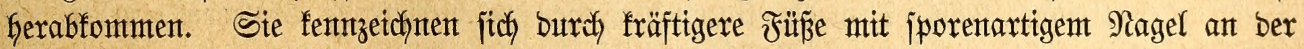
Daumenzehe, lange Flügel, welche zujammengelegt fajt bas Enbe bes Schwanzes erretchent, unb unter beren Sdywingen bie erjte unb zweite bie anberen überragen, ntittelfangen, jeidyt gegabelten Sdywantz uno ein jebr reiches, weidjes, bei beiben (sejchlechtern gleidhgefärbtes Sefieber.

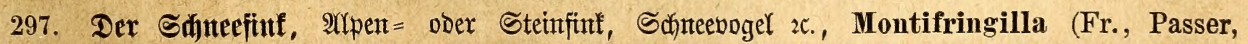

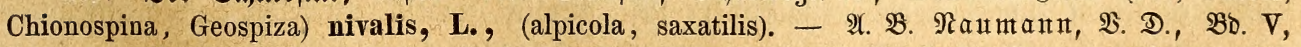

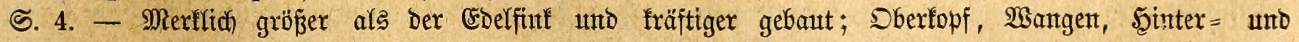

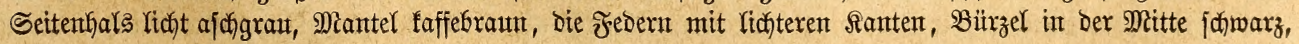




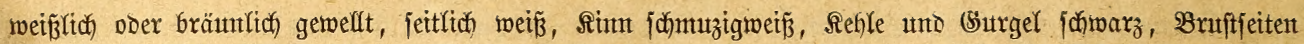

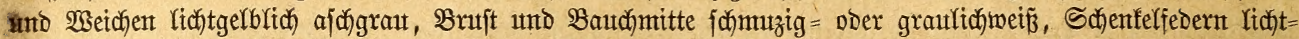

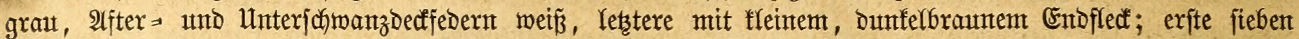

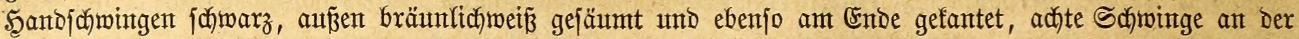

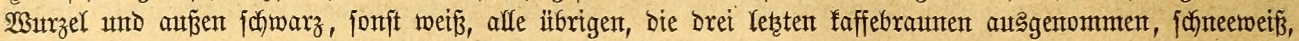

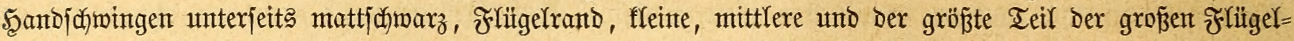

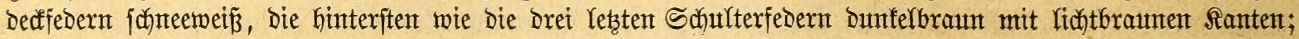

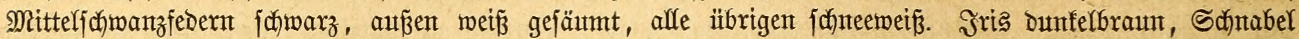

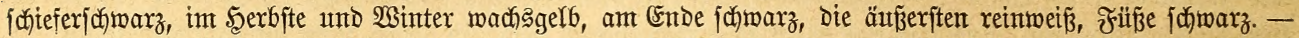

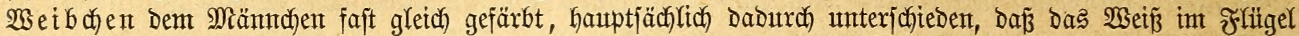

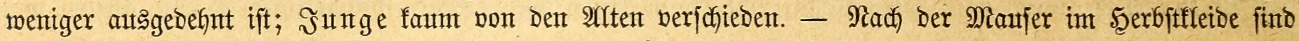

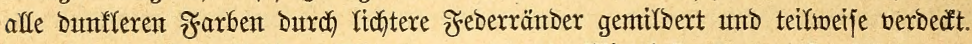

Die Gödfftent Bebirge Mitteleuropas unto Mittelafiens, ber Sautfajus unt ber Şimalaya bifden den

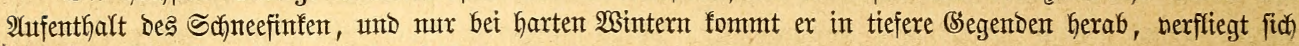
Dant zumeilent aud bis nach Deutichlanto.

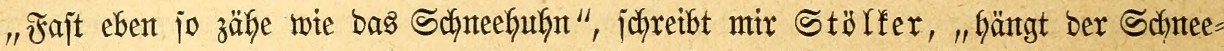

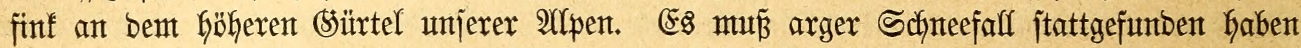

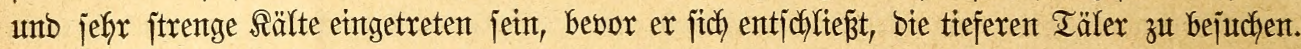

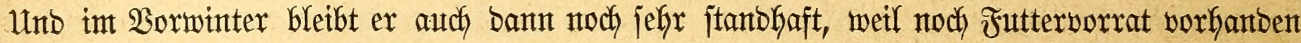

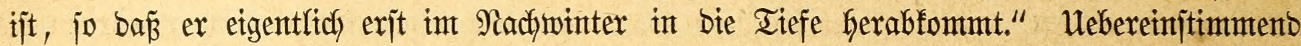

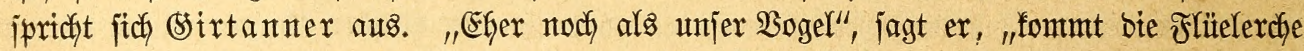

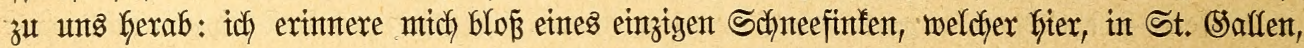

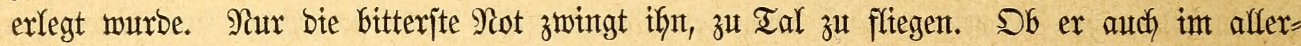

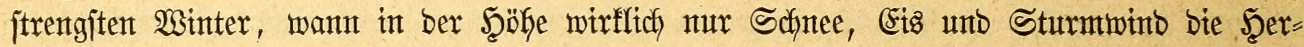

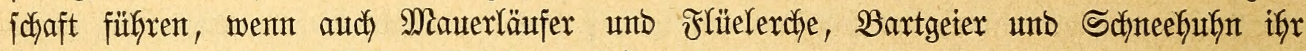

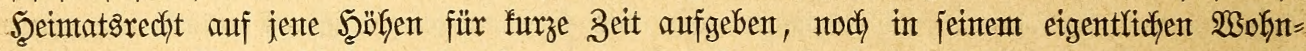

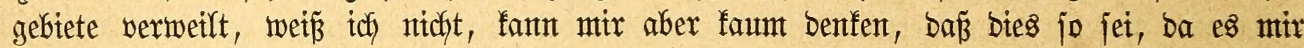
nidyt müglidu ift, fejtzufteflen, was er bann bort aber zu frefien finben jollte. Waie bem

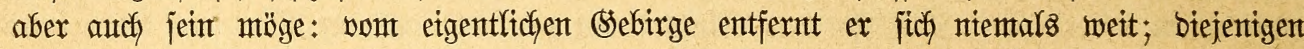

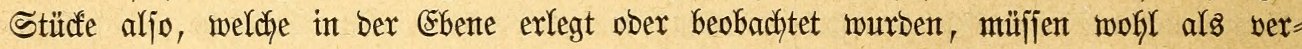
ichlagente angejefyen merben."

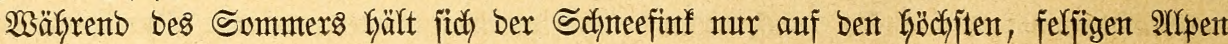

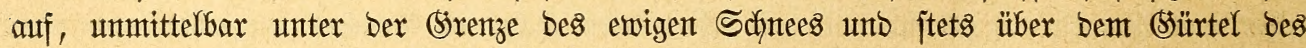

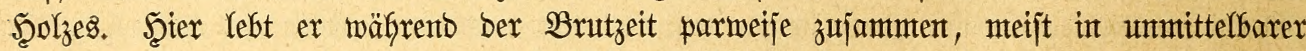

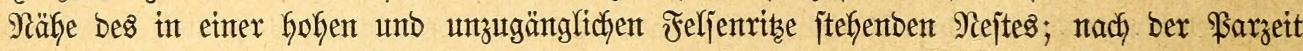

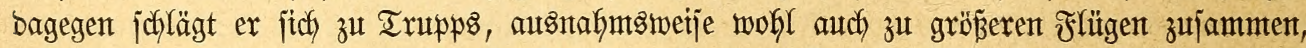

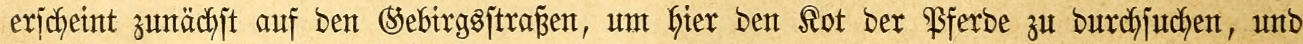

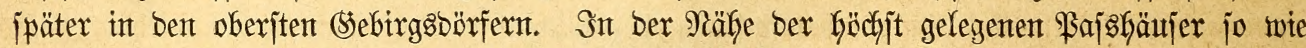

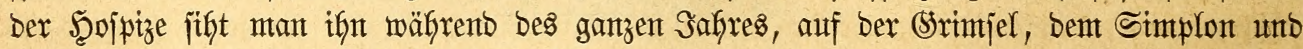

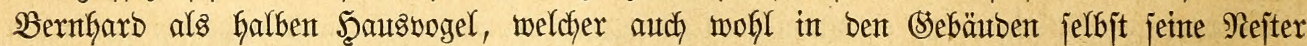

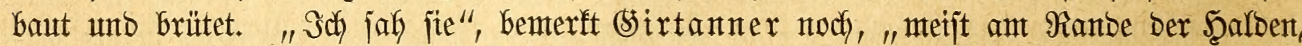
truppweije vereintgt, rajch über bie einzelnen Feljent bafintrippelnto. Beitweije erhebt fich

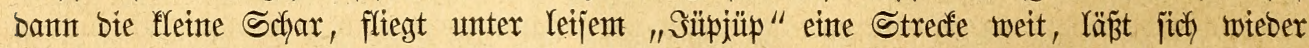
nieber unt begint ifgr Suchen nach) Naffrung mit berjelben Emfigfeit wie vorher."

Wite affe Bögel, weldye mit bent Mentichen mentg in Berüfrumg fommen, zeigt

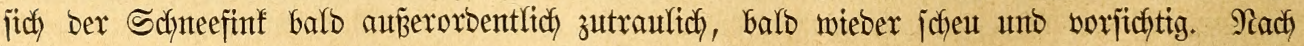

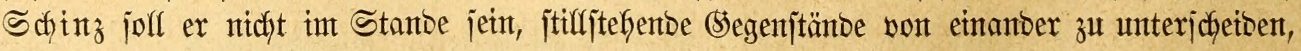

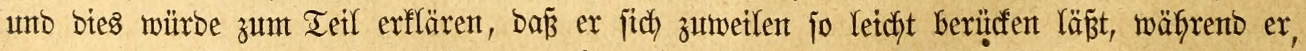

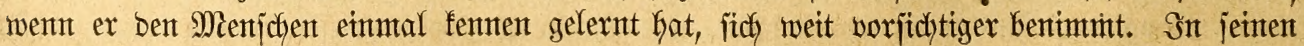

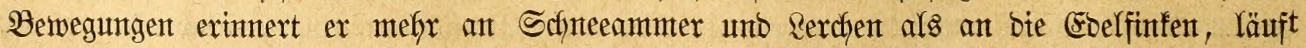


trippeltrben Sdyrittes, aljo nidyt hüpfento wie biejer, gefht niemals auf Bäımte unto fliegt im

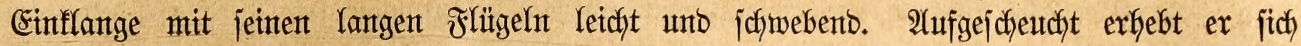

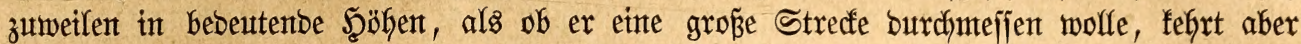

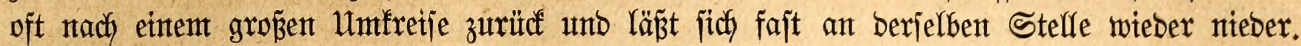

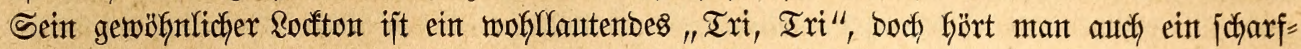

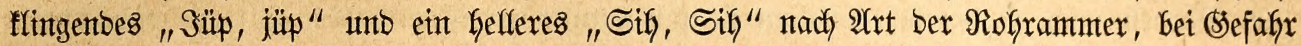
ein jchmetternbes "Srö̈̈. Der Bejantg gefört fetneswegs zu ben vorzüglichen, ijt int

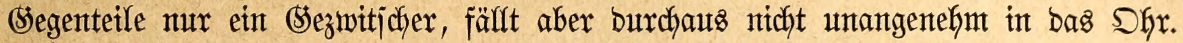

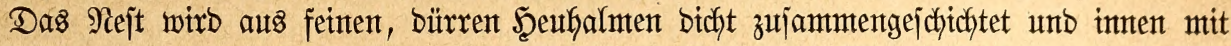

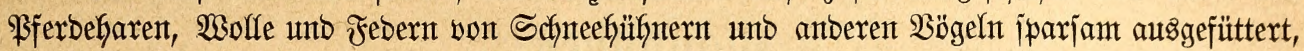
ijt aber je nadh bem Stanborte jefr verjedteben, balo größerer, balo fleiner. Fajt immer jteht

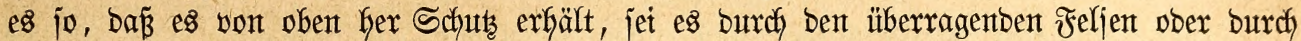
bas Dach eines Sebäubes; unt bies ijt, wie Schinz bemerft, auch jefhr nötig, ba wohl

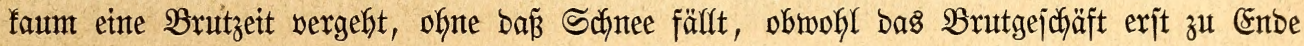

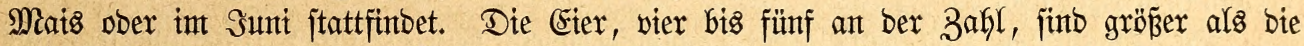

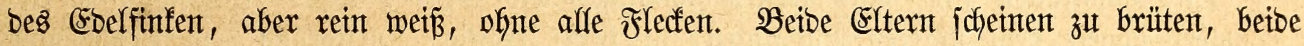

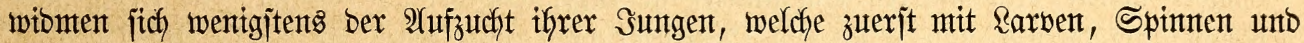
Würmthen genährt, fpäter an veridfiebene Sämereien ber Âlpenpflanzen unt zulleţt an bie vom Menjiden veridfütteten Sietretbearten gewöhnt unb int hödjiten Srabe geliebt werben.

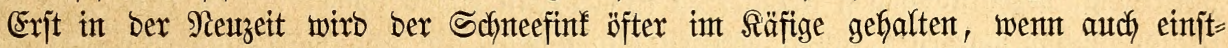
weilen nux von Sdyweizern und beren Freunben. "So herbe ber Sogel int Freien jein

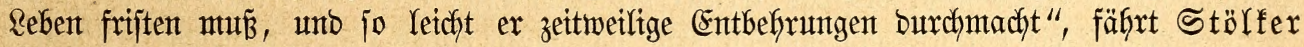

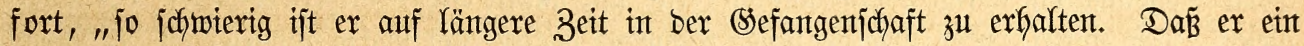
hartlebiger Sogel ijt, exfufyr ich mieberfolt, indem er mir vom St. Sottharb Ger, frijich gefangen, in jefjr abgemagertem 3ujtanbe unb mit bem bürftigjten Futter verjeken, zugejantot

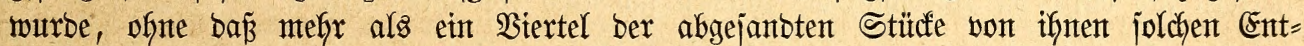
bebrungen unterlagen. 2Auch an bas Stubenfutter gehen bie Sdyneefinfen jebr leidyt; ifyre

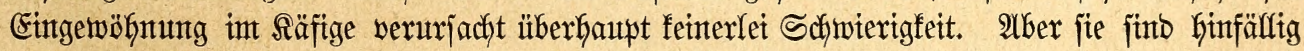
uno Galten auf bie Dauer nicht im Räfige aus." Sdh vermag nidft, meinem verefrtent

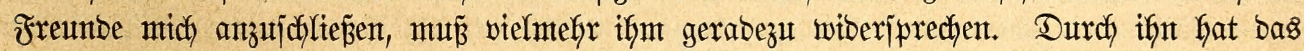

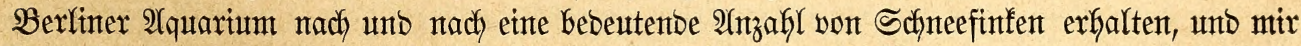
ijt baburch) (selegentheit geworben, fie näher zu beobachtent. In meinten 2 ugen zählen fie zut ben

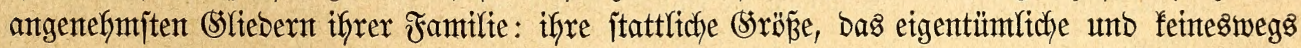

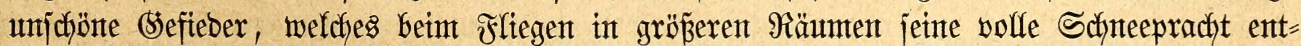

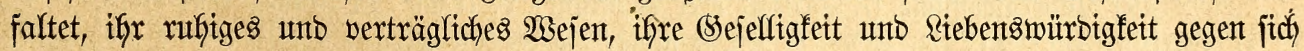

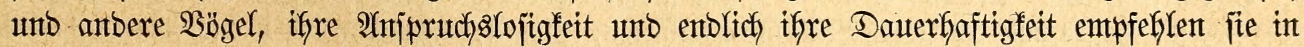
hohem Srabe, vielfeidft mentger für ben engen Räfig, ficherlich aber für jebes Fluggebauer.

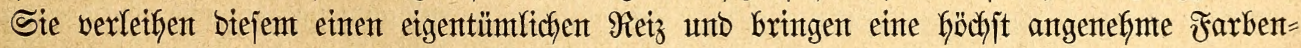
abwechjelung unter bas semimmel ifyrer Mitgefangenen. Afnfänglich Galten fie fich fajt nur auf bem Boben und Den Felsanntpen bes Fluggebauters auf, mit ber Zeit aber gewöhnett fie fich jehr wohl an bie höheren Sitjitangen ober Baumzmeige und machen bie Befauptung

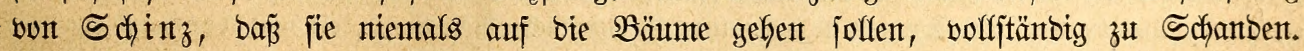

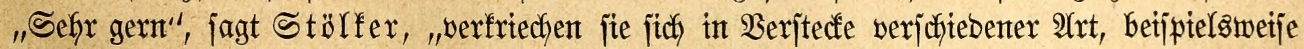
in Nijtfäitchen mit engem Eingange, namentlich, went jie bes Nadjts eintge Male geitört wurben. Ein bequemer Schlupjwinfer fann jogar Urjache merben, fie, bie Berträglichen, zu

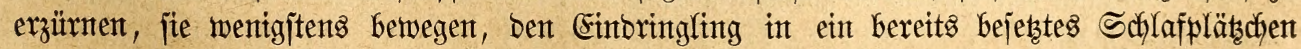
mit $\mathfrak{B t p e n t}$ unb Bijchen zu empfangen, eine Drofyung, welche biejen freilich jelten abfält,

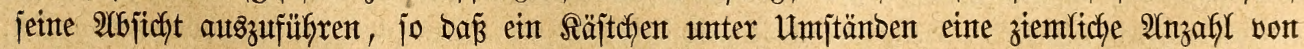




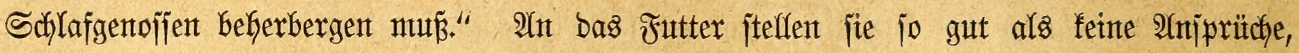
D. 5. finto mit aflem zufrieben, und went man, wie cs bie Bebölferung eittes Fluggebauters

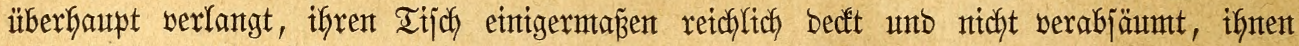
Weichfutter unb täglich eintige Mefhlmürmer ober int Sommer 2(meijenpuppen zut geben, es

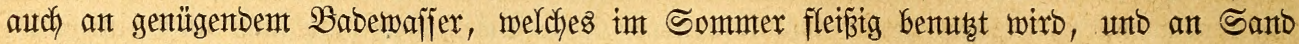
zum Babbeln nicht fehlen läßjt, Galten fie fich ganz vortrefflich. Man barf fie baher alfen wabren Riebhabern, weldye nidyt allein auf bas Slleto jehen, warm empfehlen.

\section{Bilanfintken.}

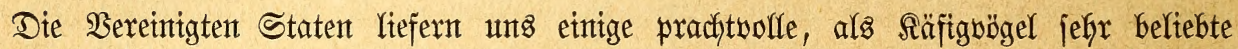
Finfen, weldye wir ifyer Şäufigfeit und 2urbefanntichaft balber unter ben Farbenfinfen obenant jtellen mollent.

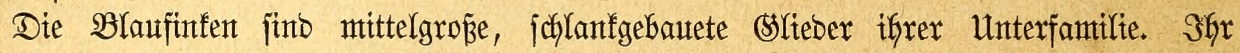
Schnabel ähnelt bem unjeres Butchfinfen, ijt furz, fräftig, fegelförmig, ein mentig ause = gebaudht, gerabfirftig und ipib, jein Dberfiefer breit und gegen bie Spitze etwas genteigt.

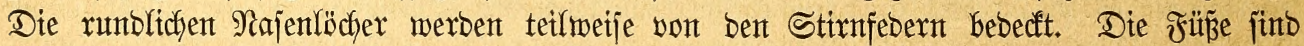

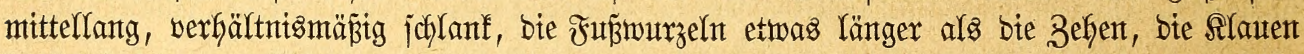

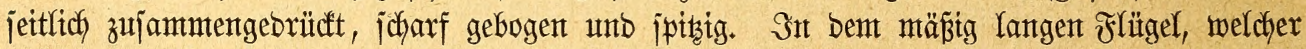
zujammengelegt etwas mefr als Das Drittel Des Schwanzes becft, überragent bie zweite bis vierte Schwinge bie übrigen, und fint bie erjte und fünfte etwas fürzere Schningen einander gleich. Der mittel = ober ziemlich lange Schwantz bejtefht aus mäß̈̈g breiten, an ber Spize

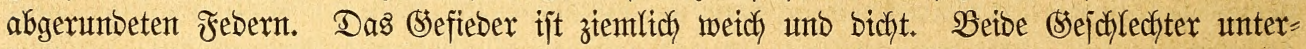
fcheiden fich Durch bie Färbung, Die Sungen fich aud von ifren E.ttern.

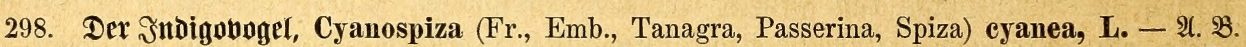

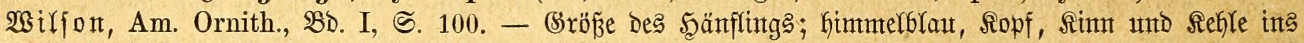

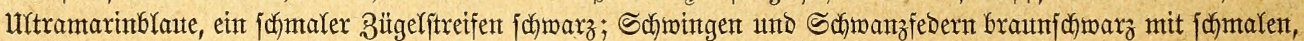

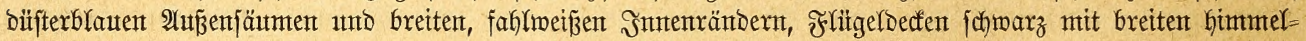

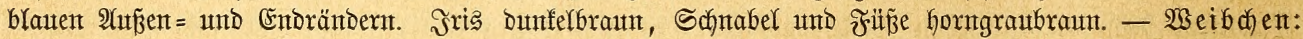

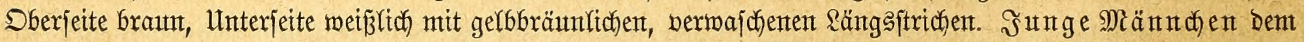

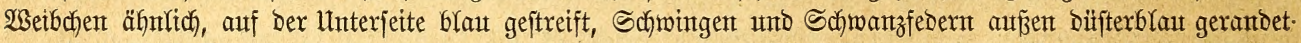

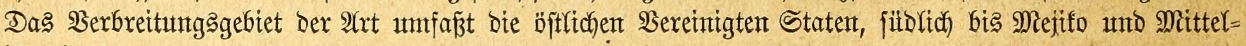
amerifia Ginab.

299. Der Utuvergleidflide (Nonpareil) ober \$apitfinf, C. (Emb., Fr., Pass., Sp.) eiris, L. -

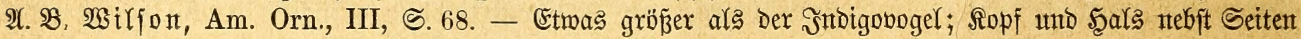

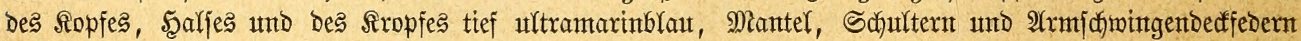

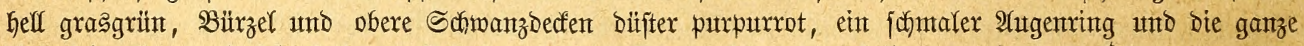

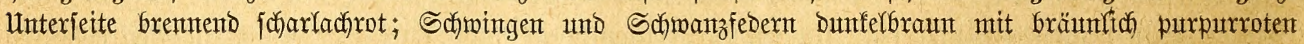

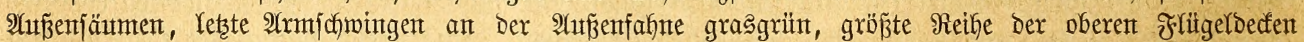

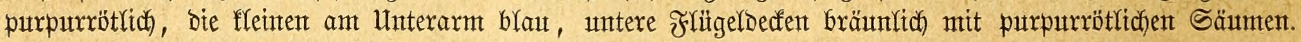

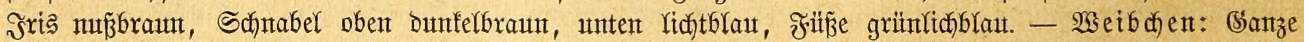

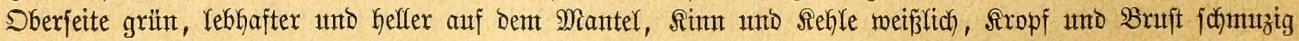

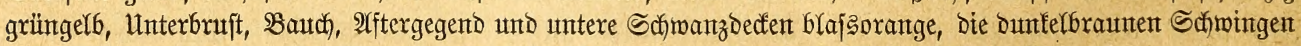

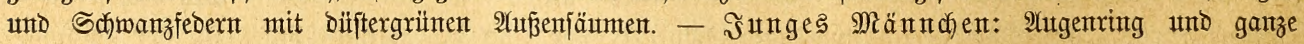

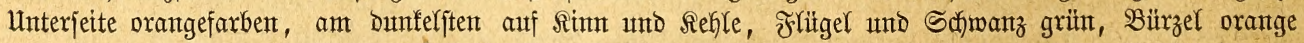

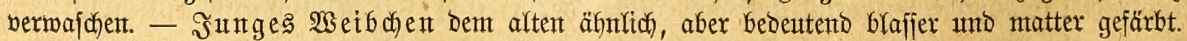

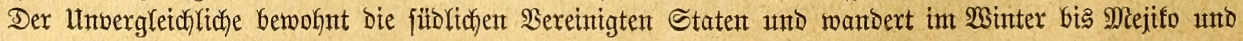
Mittełamerif́a Ginab.

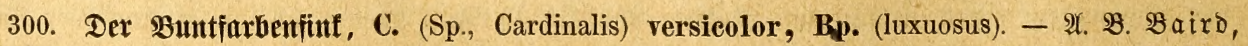

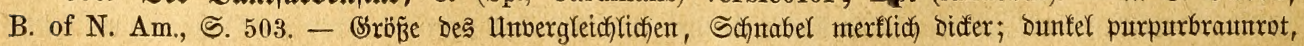




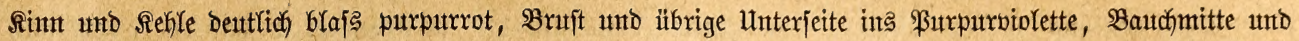
Aftergegent ins Dijftergraute ziehend, untere Sdjwanzbecfen blajs roja umranbet; Stirnrand, 3ügel unt

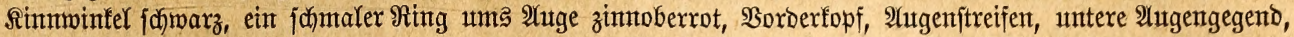
fleite Sberflïgeldeden am Interarme wie ber Bürzel Yilablau, obere Sdyanzoeffen tiefblau, Mantelfedern mit

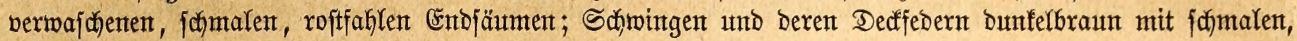

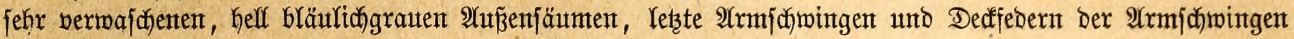

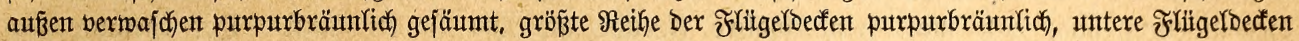

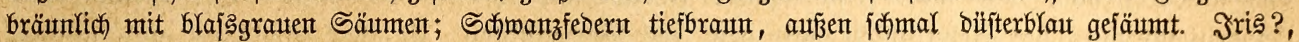

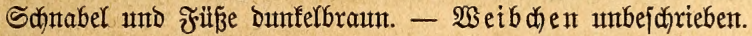

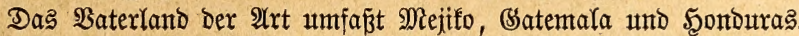

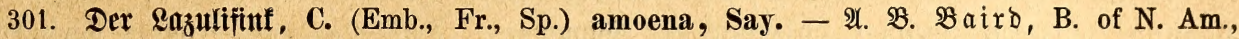

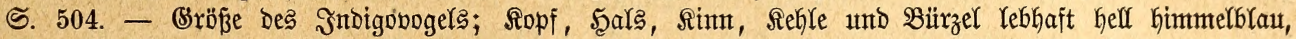
Mantel, Sdjultern unt obere Sdjwanzbectent braun mit blauten Säumen, weshalb bieje Teile büfterblaut

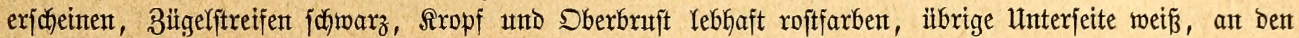

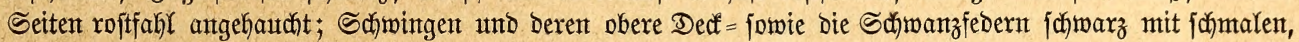

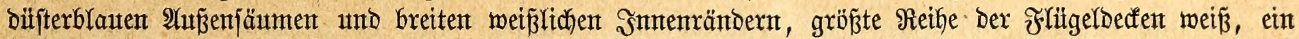

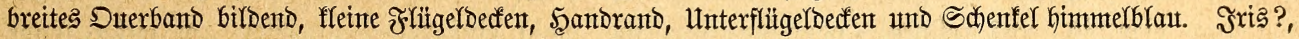

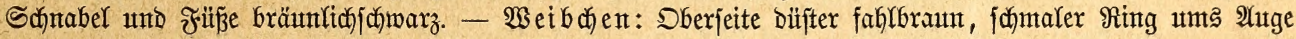
uno Interjeite Kell roftbräunfid, auf bem Sropfe biel bunfler, gegent ben Bauch zut und auf ben unteren

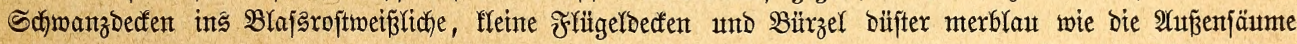

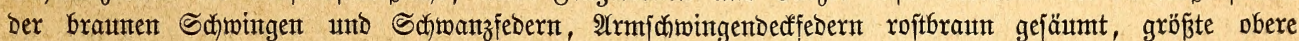

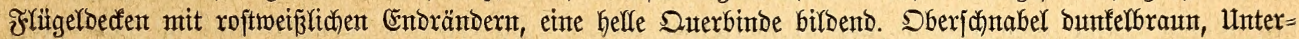
jantabel kellbraun.

Dex pradtwolle 20 ogel bemohnt bie Sedhebenen ber weftlichen Sereinigten Staten und Ralifornient.

Unter ben genannten $\mathfrak{B}$ laufinfen haben wir es zunädhjt mit bent Sntigovogel unto bent Unvergleichlichen zu tun, weil beibe in jebem Jrüfjahye zu unz gebracht werben unt bent=

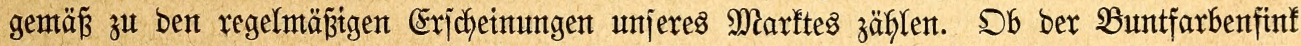

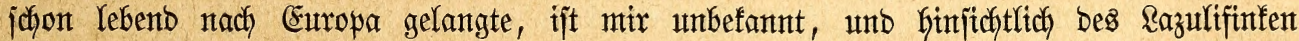

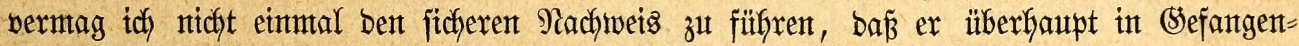
jujaft gebalten twurbe. Bapiffinf unto Snbignoggel verfafjen bie Bereinigten Staten int Dftober, unt ben Winter weiter jüblich, namentfich in Mejifo unt Mittelamerifa zu ber=

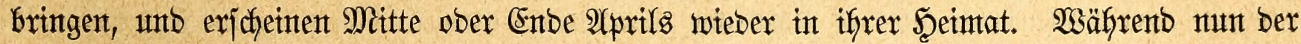
Bapitfinf bloḱ bie jüblichen Ieile bevolfert, berbreitet jidch ber Inbigovogel über alle Staten

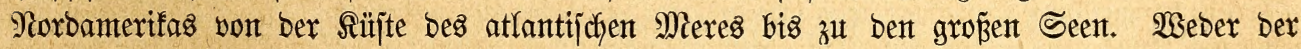
eitte ntodh ber antere barf zu ben Walbvögeln gezählt werben. Der Snbigovogel wählt fich zu jeinem 2lufentfhalte bie Säume Der Walbungen, fletne Felbgehölze, Wiejen mit etwas Bujchwerf, SSärten unb Dbjtpflanzungen, ber ßapjtfinf vorzugäweije bie Yetzteren. Das अärchen grengt fich fier ein fleines (sebiet ab unb vertreibt eiferjüthtig aus biejem jedes

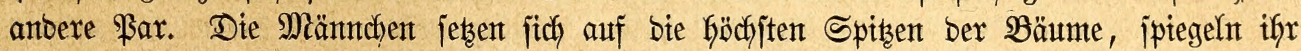

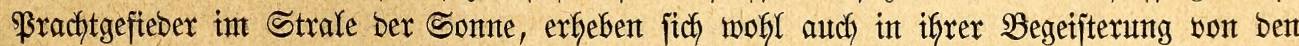
3weigipizen jingent in bie \&uft, fliegen halb fdywebent, Galb flatternb eintent zweiten erföften Stanbpunfte zu unb falfen, über bemjelben angefommen, plöblich lautlos auf einten äfnllichen Sibpunft Gerab, unt basjelbe Spiel nach geraumer Zeit von neuem zu beginnen. Die Weibchen Galtent jich weit mebr, meijt in bidjteren Büjchen ober jelbjt int Sraje verborgen,

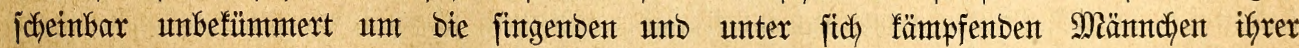

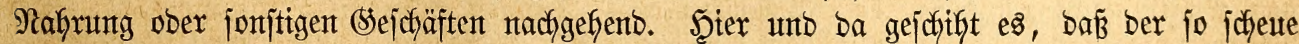

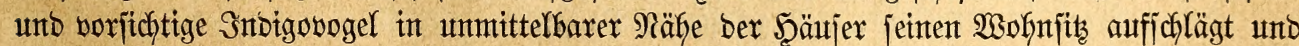

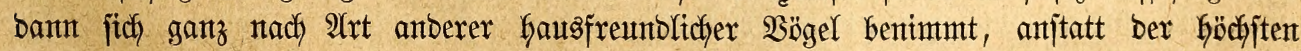
3 weigfpizen fich auj bie Dadffirite ober ben Sdfornjtein jetzt und von bort Gerab zur Freube

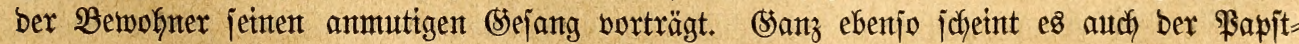

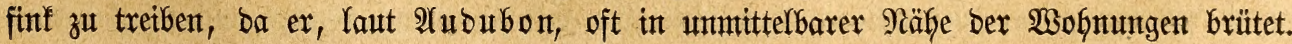


Der Stejang betber Bögel jteft Ginter bem umjerer meiftbegabten Finfen alferoings żemlich weit zurüde, fällt jeboch feineşwegs unangentehm in Das Shr. Der Sntoigowogel jebt jein Rieb aus wentgen Tönen zujammen, unter benen cintige volfe, wohlflingenbe Raute,

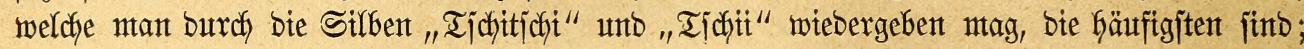

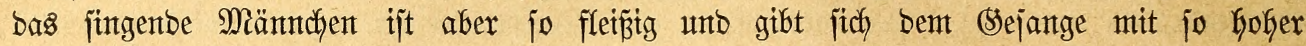

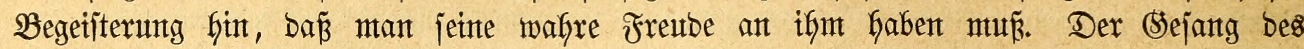
Unvergleichlichen hat 2 (effnlichleit mit bem bes

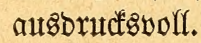

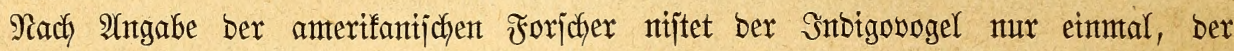

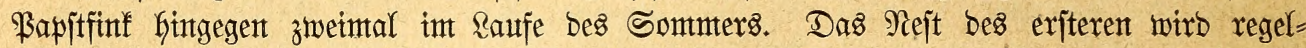

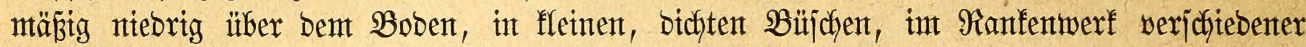
Siblingpflanzen ober jelbit int (Siraje angelegt, int lebzteren Falfe förmlich angehängt, nemlich mit mefreren Stengeln fejt berbunden. Sröbere Srasblätter bilben ben 2̂tukenbau, feinere

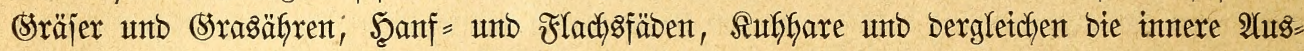

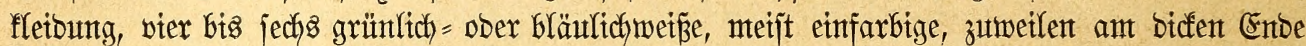

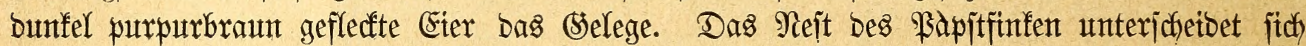

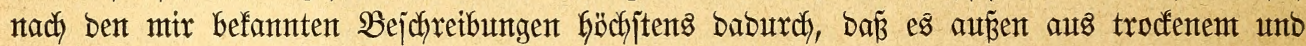

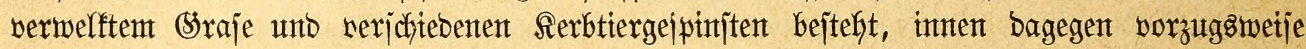

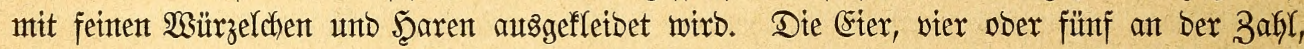
finto auf perlweipent Srumbe mit bunfel purpurbraumen Fledfen gezetdnnet. Bei betben 2̂trten brüten vorzugstweije bie Weibchen, zeitigen die Brut inmerbalb 13 bis 14 Iagen, werben

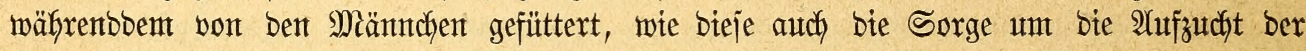
Sungent übernefgnten. Nachbem bie eine ober bie letzte Brut volffommen flügge geworben ijt, treten bie 2 (rlten mit ben Sungen langjam ifre Reije nach bem Siben an.

Arfe B̉laufinfent näbren fich in ber Freifgeit ebento viel von Serbtieren wie von Sörnern unb anberen Pflanzenjtoffen, wäfrend bes Sommers vorzugsmeije von jenten, in Scerbjt unto vielleidyt audf int $\mathfrak{B}$ inter mefyx von biejent. Währento ber Brutzeit fitht man fie ber Serbtierjago mit Eifer obliegen, unb zwar verfolgen fie auth fltegenbe Sierfe nach 2 (rt ber Fltegenfänger ober ebenjo unjerer Sperlinge. Später halten fie fich an Früthte. "Sobalo

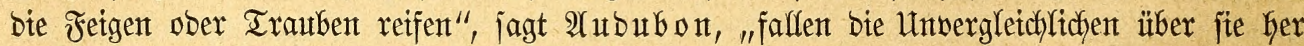

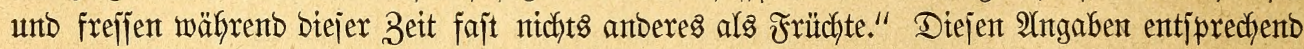
hat man bie Nafhung Der \$ejangenten zu regeln. Bei einfachem Sörnerfutter unb etwas (Srün= zetg bautern zwar auch fie längere Zeit im Räfige aus, werlieren aber bet ber nächjten Maujer ben größ̈ten Ieil threr Schüntheit ober gefen mährent berjelben zu Brumbe. Dies gilt insbejonbere von Dem $\mathfrak{B a p i t f i n f e n , ~ w e l c h e r ~ b e t ~ u n g e e i g n e t e r ~ F u ̈ t t e r u n g ~ f a j t ~ a l f e ~ l e b b a f t e r e n ~}$

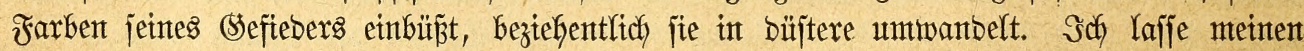

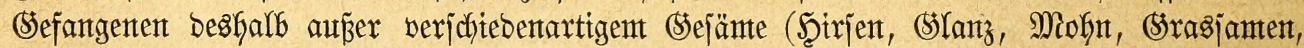

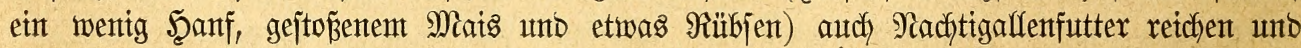

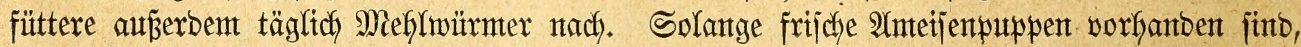

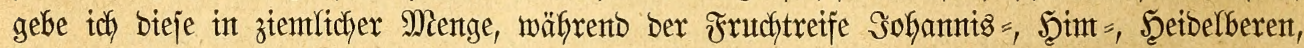

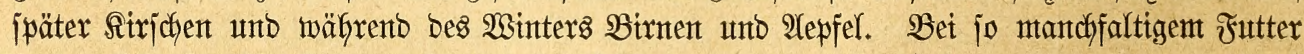
Galten jich bie Blaufinfen redjt gut int Säfige, verlieren jebody immterfin viel von iffer urjprïnglicken Schöntgeit.

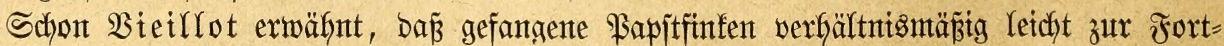

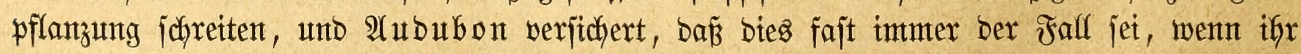
Räftg bie nötige Bequemtlidfleit biete. Sch bin noch nicht jo glïdflich gemejen, Sunge zu erzielen, währent verjofiebente 3ütchter audy in Europa günjtige Ergebnifje erlangt Gaben.

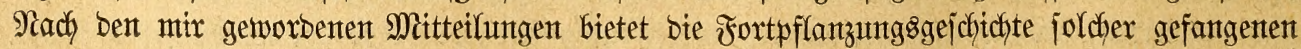




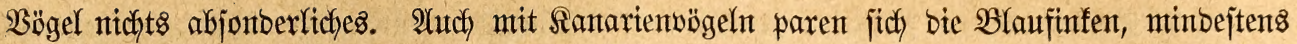
ber Snbigobogel zuweilen, wie mix bies erjit neuerbings von glaubwüroiger Seite verjictert worben ijt.

Die Slaufuten verbienen bie Beachtung bes siebhabers. Shre Shbönheit, ify an=

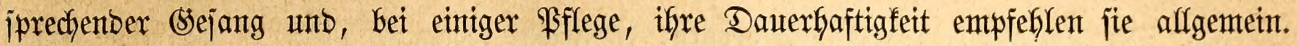
Durch ifre Banfjucht werben jie freilich aud oft unangentefm; bod bejdyränft jich ber Şaber

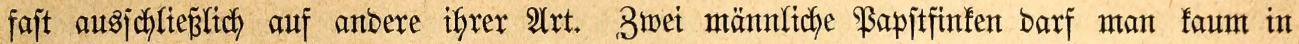

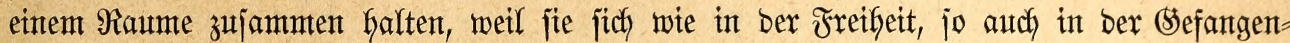

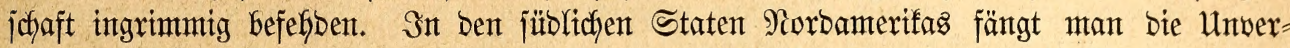
gleichlichen, intoem man in eine Schlagfalfe ein in Sampfiteflung augigejtopftes Männchen jekzt, auf welches fich jeber vorïberflitegende, liebegbegeijterte \$apjtfinf mit größjter Wut herabjtürzt, Durch bie Berührung bie Falfe zum 3ujchlagen und jich jelbjt um bie Freifeit

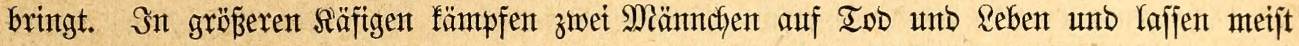
nicft eber vom (segner ab, als bis berjelbe vollftänbig fampfunfäfitg gemorben ober getötet

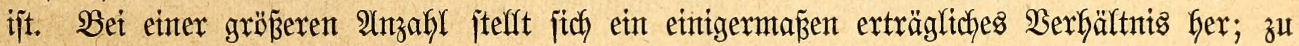
eigentlichem Frieden fonmt es aber audh Gier jelten, unt namentlich neu eingejebte werben

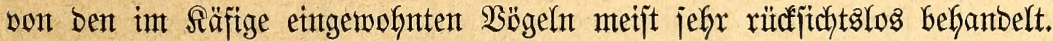

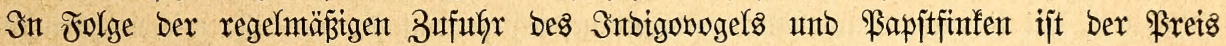

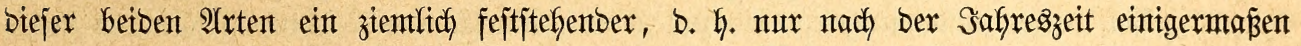

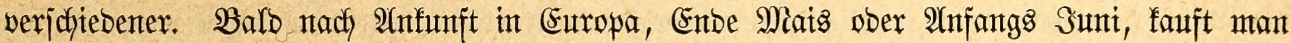

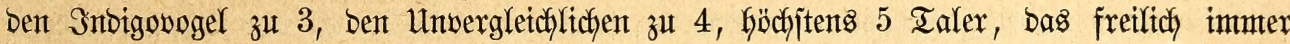

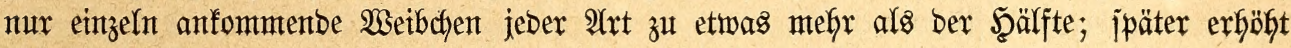
fich) ber $\mathfrak{B r e t s}$ um etwa ein Fünftel ber genannten Summe.

\section{faronfintkent.}

Wir vereinigen fier in einem 2 bjojnitte mefrere Sippen, weil bie Rebenżweije ber betreffenden Mitglieber noch wenig befannt ijt und jie jelbjt ber Riebbaberei in geringem (Srabe zugänglich jinto.

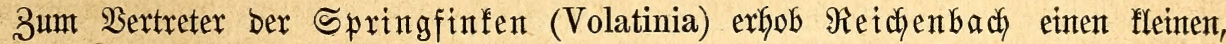

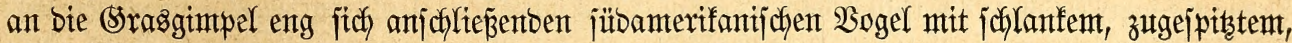

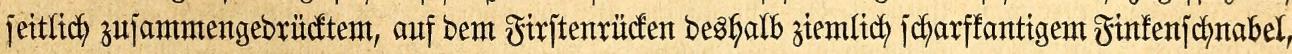

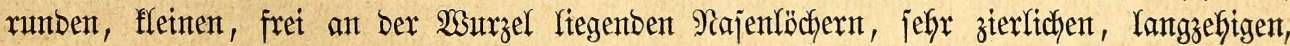

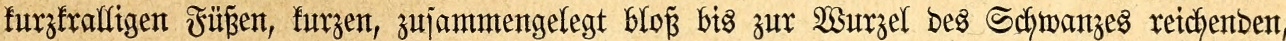
abgerunbeten Flïgeln, in benen bie exjte Schwinge beträdhtlich, bie zweite faum verfürzt ijt,

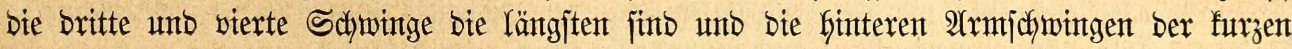
Şantjofjwingen Galber ziemtich lang erjoheinen, merffich langem, objchon bie Flügellänge nicht erreichendem, janft abgerumbetem, jumalfeberigem Schwanze und ziemlich berbem (Sefiteber.

302. Dex Springfinf, Эacarint Dex Brafifianex, Volatinia (Fr., Tanagra, Passerina, Spiza)

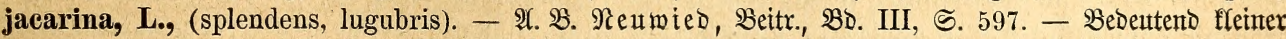

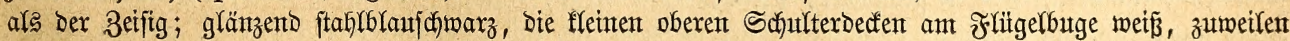

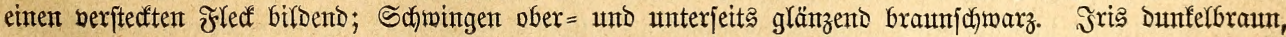

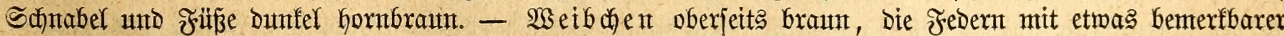
bunflexex Mitte, untexjetts roftbräunlich, auf Rxopf, SBruft und Seiten mit vermajdenten, Dunfelbraumen

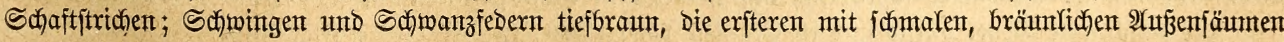

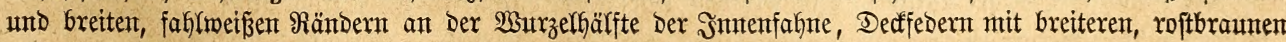

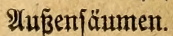

Berbreitet fich über Den größ̧ten Teil Sübamerifas vom jüblichen Dftbrafflien an bis Mejifo. 
Die Schopffinfen (Tiaris) ähneln bent Springfinfent nod jefr, fitto aber gehaubt.

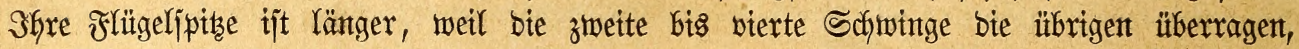
ber Schyanz breiter als bei jenten, janft gerunbet unt in ber Mitte auzgejchnitten, bas (seffieber weict.

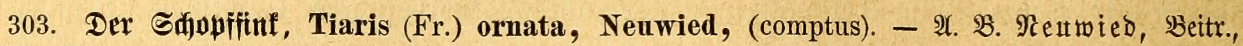

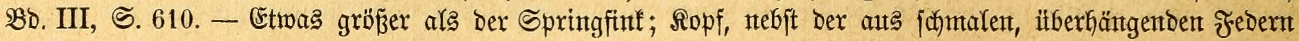

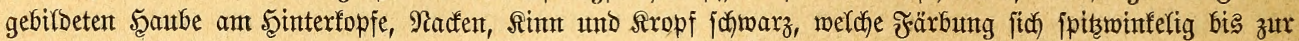

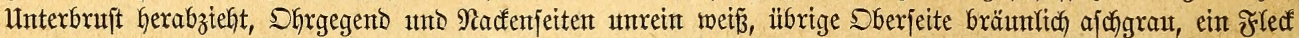

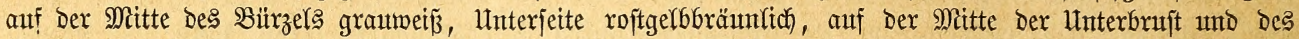

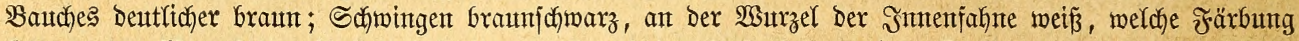

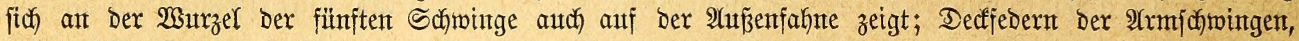

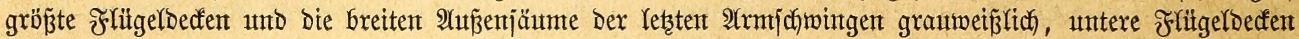

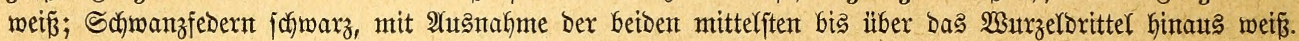

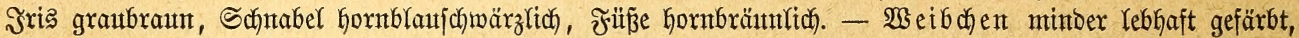
Dberfopf ofibenbräıtultid̆, Utnterjeite biajsgelfrot.

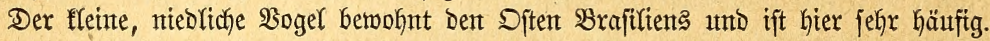

Die Scheitelfinfen (Coryphospingus) haben jadlanfen, fegelfürmigen, jeitlidy etwas zujammentgebrüuften, ant Mutubranbe eingebogenen, auf ber Firite fajt ganz geraben

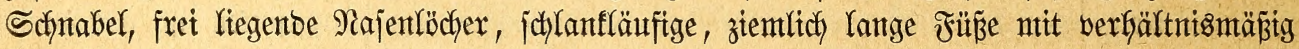
furzen Befen, furzze, zujanmengelegt biz zur Schwanzmurzel hinabreithenbe Flügel, in benen

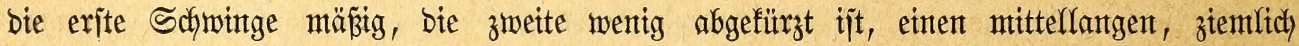

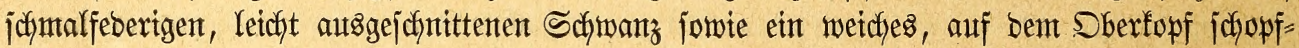
artig verlängertes (Sefteber.

304. Der 5autbenfinf, Coryphospingus (Fr., Emberiza, Lophospiza) cristatus, Gml., (ara-

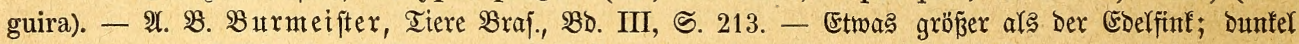

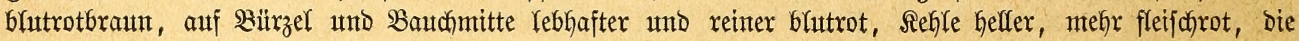

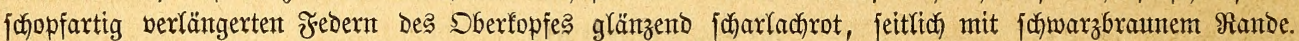

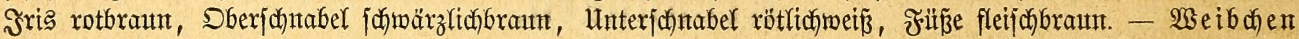

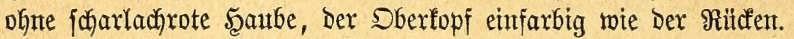

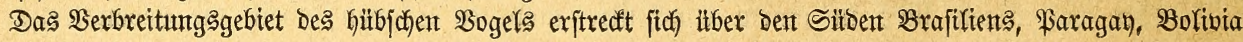
bis Ectuabor.

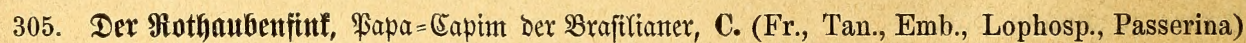

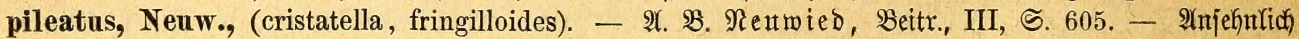

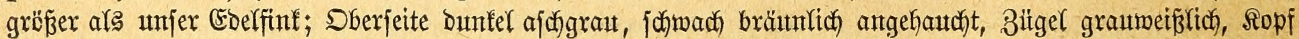

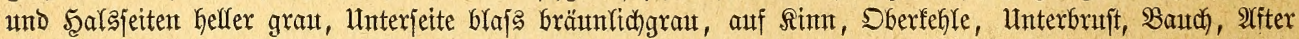

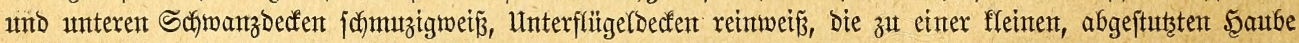

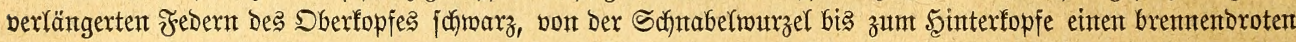

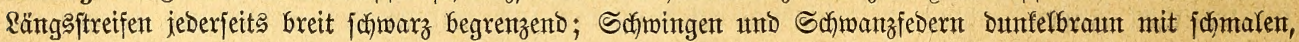

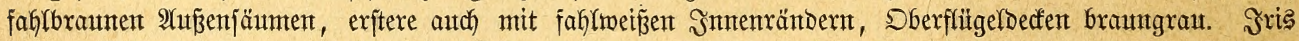

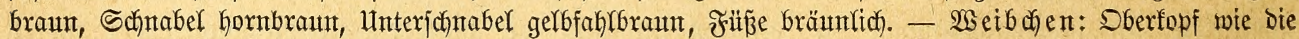
übrige Sberjeite einfarbig graubraut, jonft bemt Miännchent gleich).

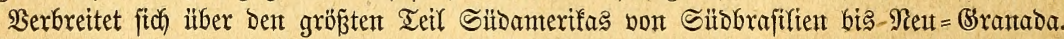

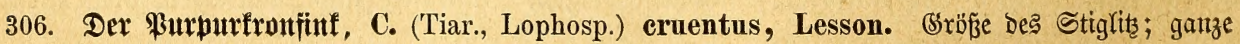

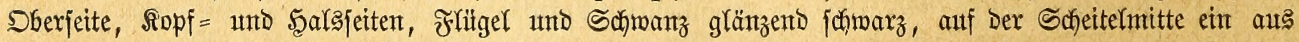

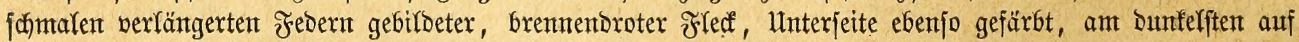

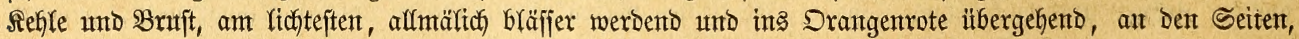

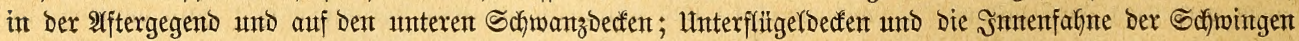

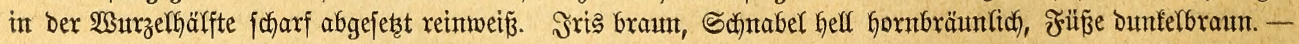

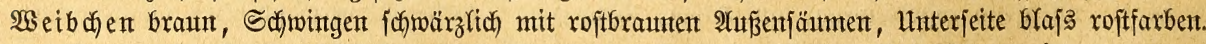

Der pradttoolfe Bogel bürfte mux in Entador vorfommen, ift biex aber jefr gemein.

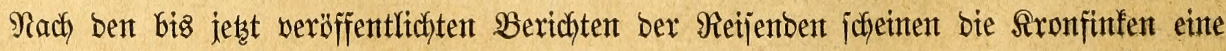
jehr gletdfartige Rebensweije zu fübren. Sie benofnen vorzugsweije bie Godygelegenen, 
offenten, mit (šras betwadjjenen, jpärlich mit (sebüich bejeşten Iriften bes jogenannten Eamposgebtetes, leben währento ber Brutzeit parweije, nach berjelben in fleineren Bejefl=

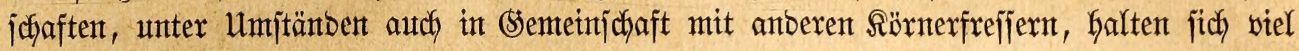
am Boben auf, unt Giter Sämtereten aufzulejen, ober flettern an ben Stragjtengeln auf und nieber, um beren Santen auszuflauben, finto wentg jcheu und fommen nicht jelten bis in bie (särten ber 2lnjitbelungen herein, gehören beshalb audh zu ben wentgen $\mathfrak{B}$ g̈geln, weldye

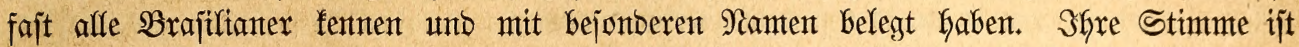
unbebeutent, bet ben meijten $\mathfrak{A}$ rten nur ein furzer Rodton, weldyer bei einzelren, insbejonbere

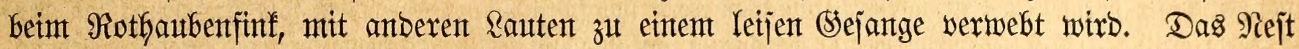
bes Springfinfen fand $\mathfrak{B}$ urmeifter in einem Sarten und zwar in einem Saffebujche,

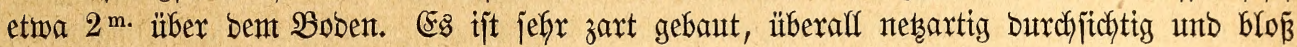

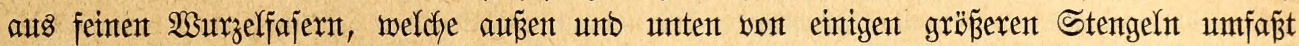

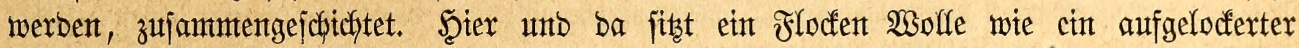

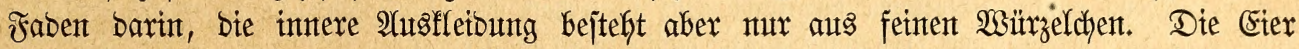

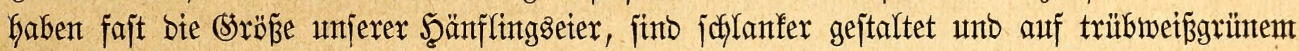

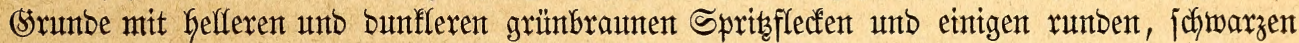
Iropfen gezeidyntet. Dex Scaubenfinf nijtet nach bemjelben Forjcher int bichten (Sebüjch, meijt in ziemficher Söhe und legt brei bis vier weike, vom ftumpfen nach bem fpizen Enbe abnefmentb graubraun getïpfelte Eier.

Untgeadftet ber geringen Begabung alfer Aronfinfen bält man fie an Drt unb Stelle

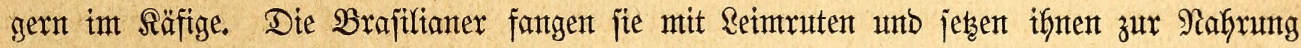

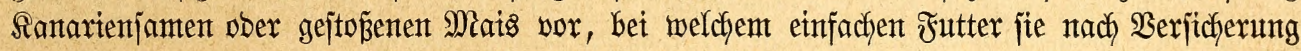

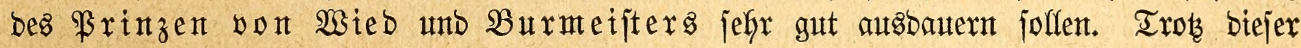
Anjpruchslojigfeit gelangent fie jelten lebent nach Europa: ermeislich hat mur ber Spring= finf in unjeren Räfigen unb zwar int zoologijchen (Sarten zu Ronbon gelebt. Heber bie

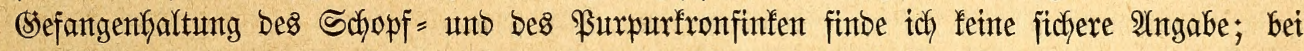

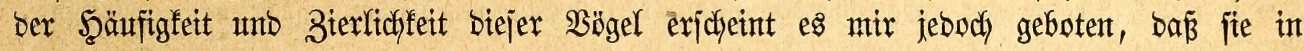
unjerem $\mathfrak{B u c h e ~} 2 \mathfrak{u}$ juafme verbienen.

\section{(branfinken.}

3u ben häuftgiten Räfigbögeln Sübamerifas zählen bie Braufinfen, von benen all=

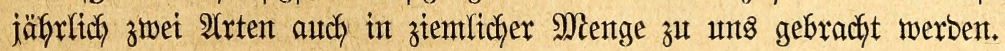

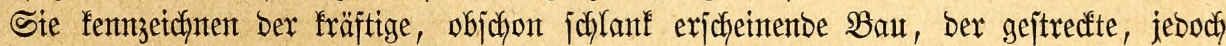
ziemlich biffe, am Mintoranbe etwas eingebogente Schnabel mit gerablinigen Schnetbentänbern,

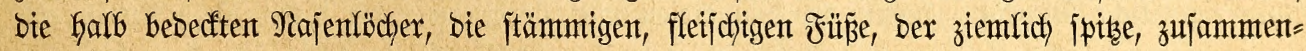
gelegt fajt bis zur Sdywanzmitte reidjenbe Flïgel, unter befjen Sdywingen bie britte unb vierte bie längiten fint, wälyrento bie erjte jtarf verfürzt ijt, ber janft gerunbete, in ber Mitte etwas eingeengte Schmanz unb bas weiche, bleigraue, ant Ropfe rote unb fier zumeifen jchopfig verlängerte Siefteber.

307. Der (Sraufaroinal, Paroaria (L., Fr., Calyptrophorus) cucullata, Latham. $-\mathfrak{A} . \mathfrak{B}$.

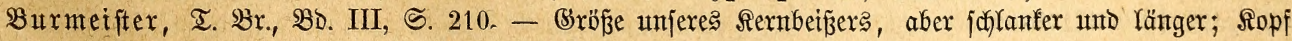

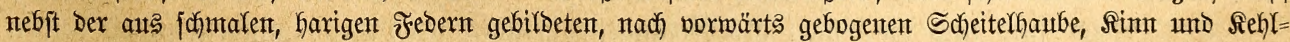

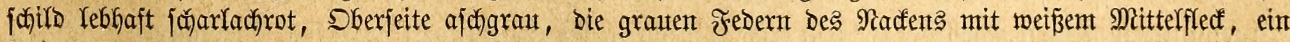

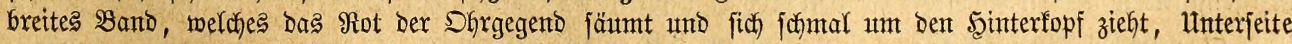

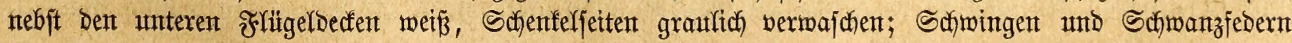

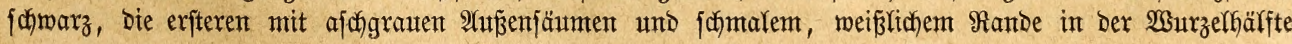




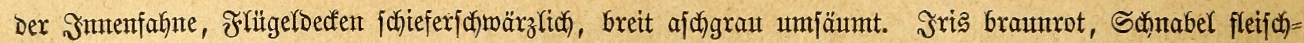

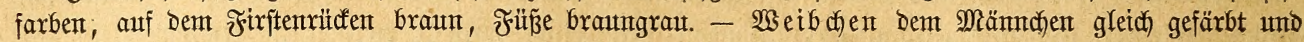

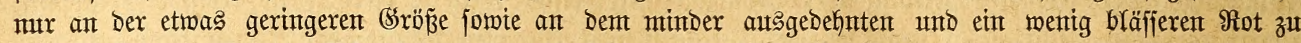

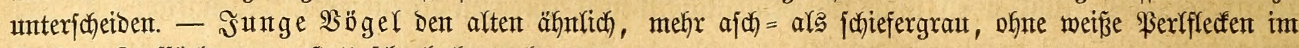

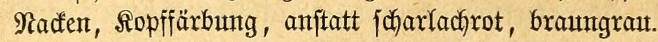

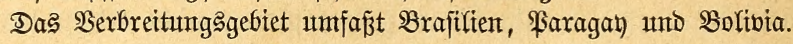

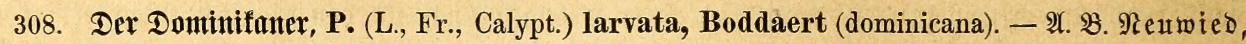

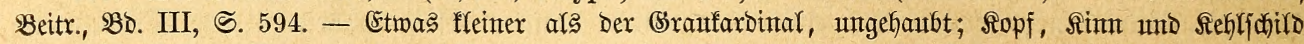

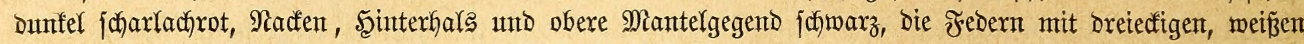

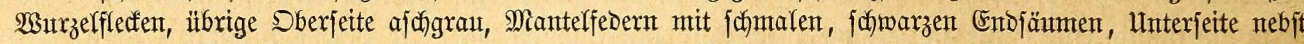

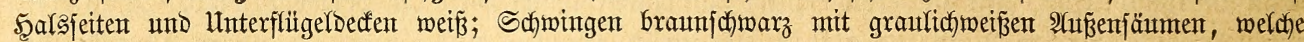

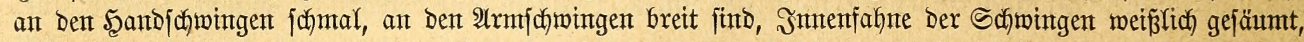

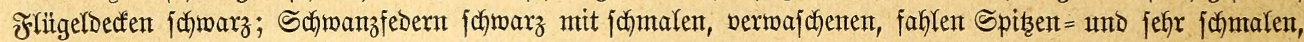
grauten $\mathfrak{A}$ ur

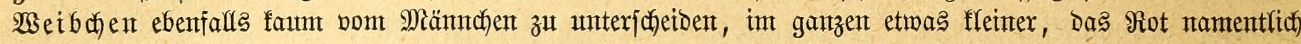

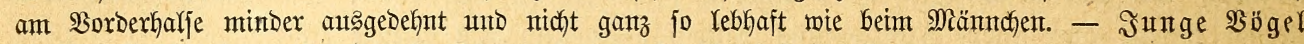

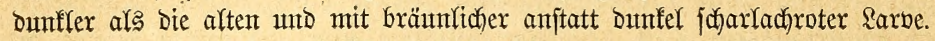

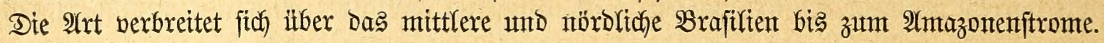

309. Der Manteffardinar, P. (Tachyphonus, Coccopsis) capitata, Lafresnaye. $-\mathfrak{A}$. $\mathfrak{B}$. Lafr.

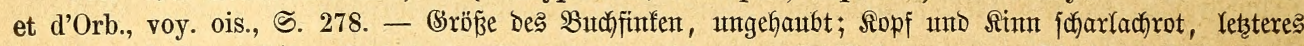

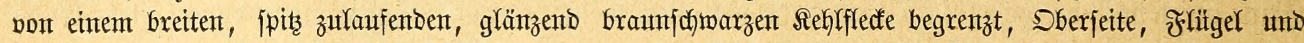

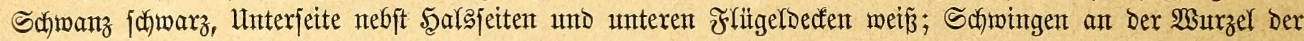

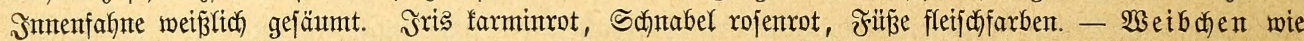

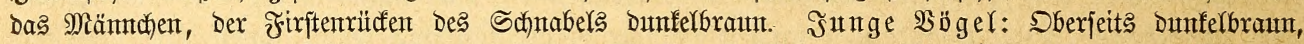

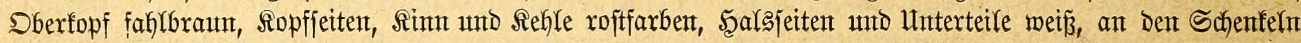

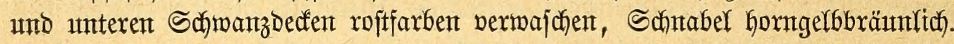

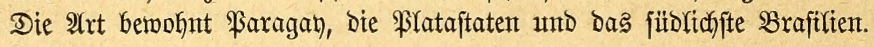

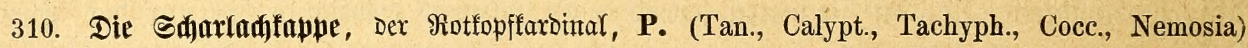
gularis, L. - 2 . B. $\mathfrak{B}$ urmeifter, $\mathfrak{I}$. Br., III, S. 211. - Banz wie Der Mantelfarbinal, aber etwas

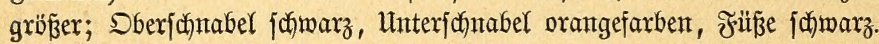

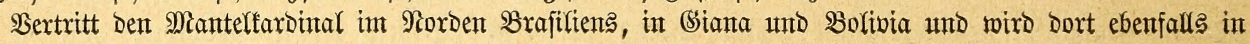
Befangemidaft gehalten.

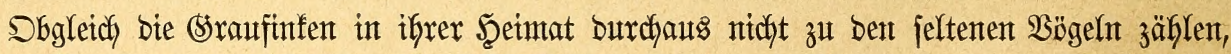
bei ben Eingeborenen auch allgemein befannt jind, haben wix bis jebt body mur jefr bürftige

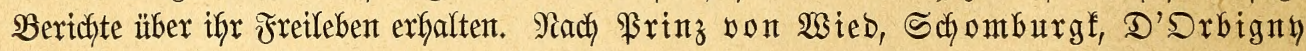

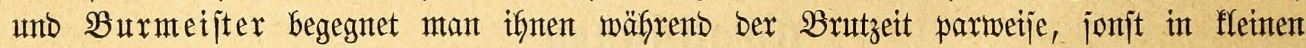

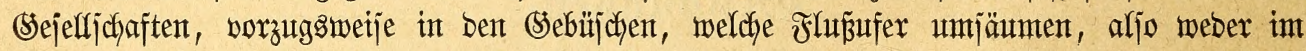

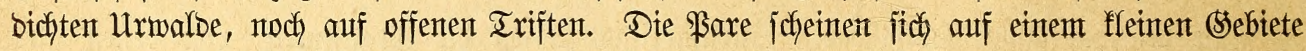
aufzubalten; bie siejellichaften jtreifen im Rantbe umber und fomment bann auth öfters in

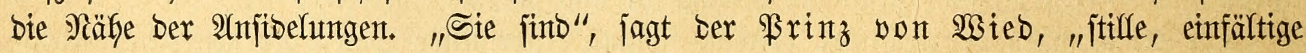
Tiere, Gaben einen Gelfen Rodfton und einen fleinen (unbebentenden) zmitjefjernden Bejang."

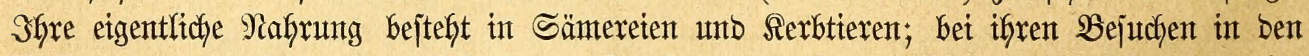

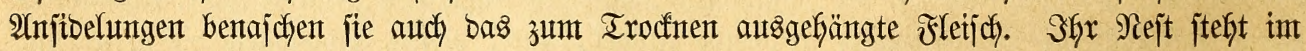

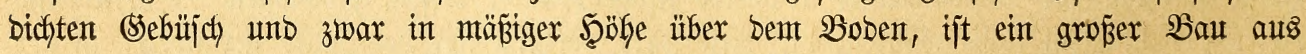

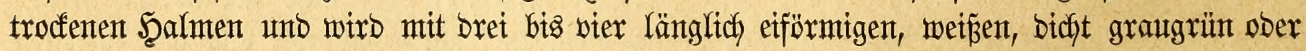
grünbraun bejprengten und gepuntfteten Etern belegt. Man bält jie überafl int Räfige,

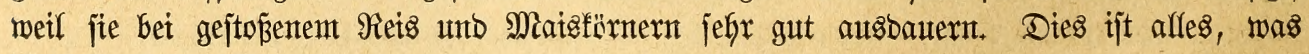
id) Gabe finben fönnen.

Weit beffer jint uns bie $\mathfrak{B g ̈ g e l ~ a l s ~ B r e f a n g e n e ~ b e f a n n t ~ g e m o r b e n , ~ m i n b e j t e n s ~ b i e ~ b e t b e n ~}$

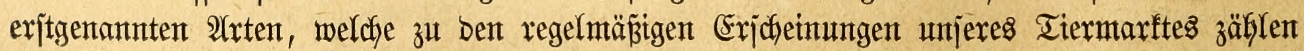

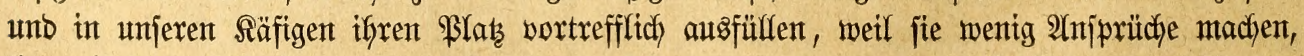

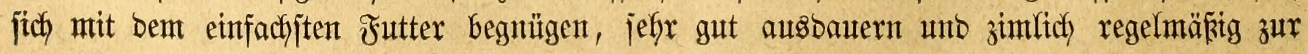




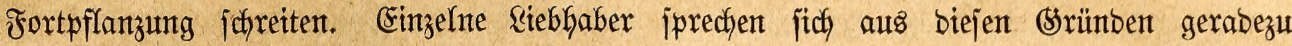

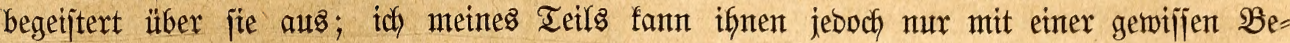

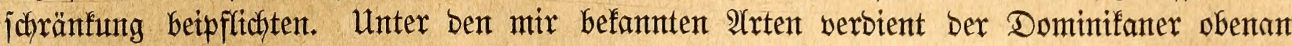
geitelft zu werben, nicfft alleein weil er ber jefönjte, jonbern audd, weil er ber munterite ijt

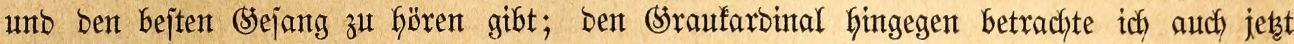
nod), nadjoent mir von beachtenswerter Seite wiberiprodhen worben ijt, als einen vergältnis=

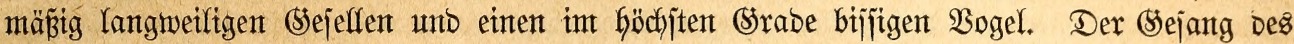

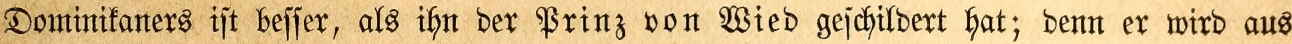

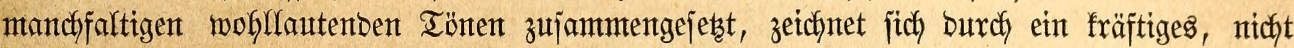

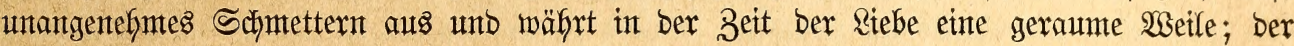

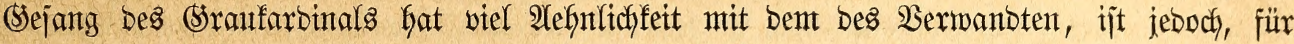
mein Dfy menigjtens, bei weitem meniger anjprectjent und, jowiel id bis jebzt beobadjten

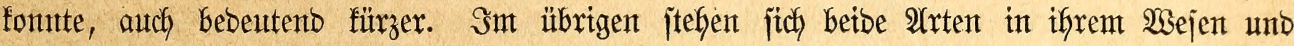
(Sebaren jeffr nahe; insbejontbere zeicfynet jich bie eine wie bie anbere burch eine untwertifgliche

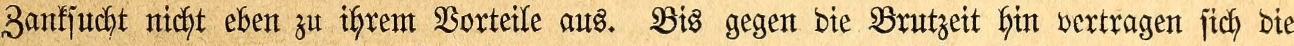

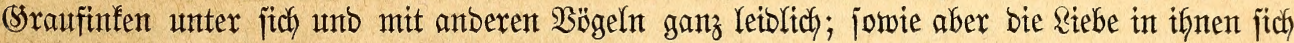

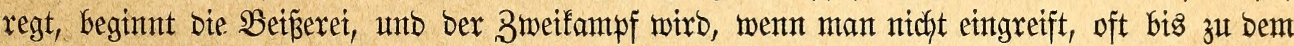

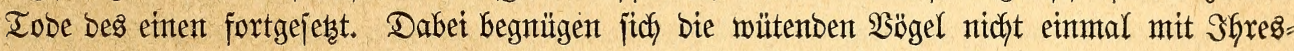

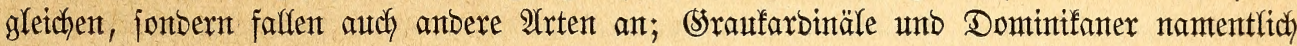

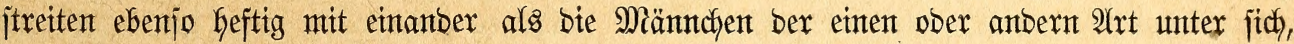

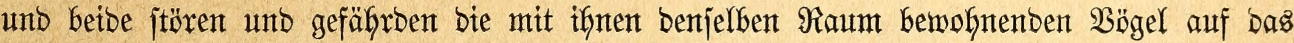

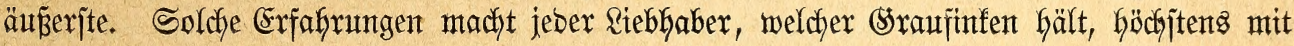

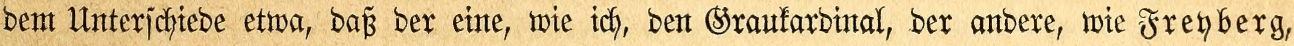
ben Dominifaner für ben umberträglidłeren won beiben erflärt. "Seit zefin bis zmölf

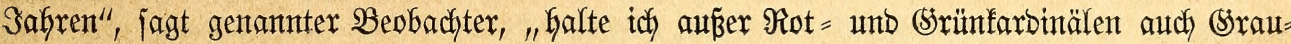

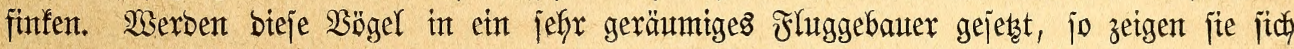

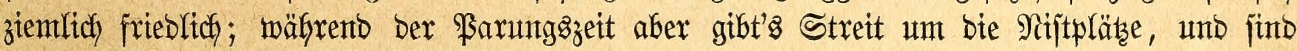
erit eimmal Sunge auzgefrochen, ober ift Futtermangel vorfyanben, ober werben Recterbififen,

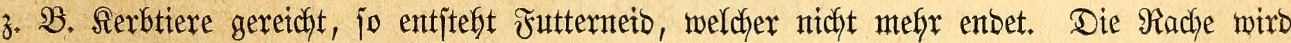
bann an bes Feintbes junger Brut gettontnten unb biejer ber Flügel, vorzuggiveife aber ein

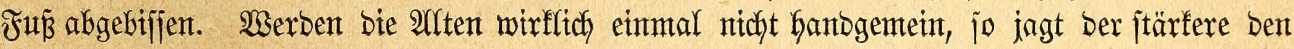

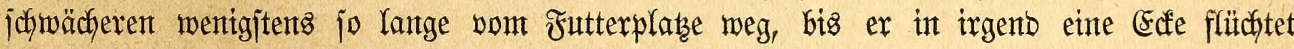
unb entfräftet Şungers ftirbt." Somit bleibt faum etmas anberes übrig, als bie Straufinfen

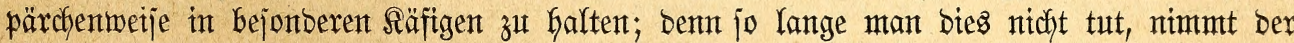

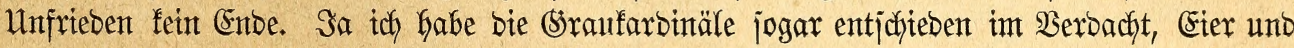

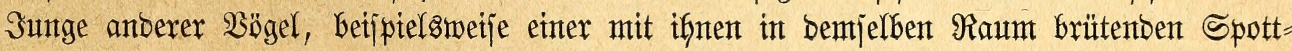
Droffer, werzefrit zu haben, obgleidh es ifgnen an nidyts mangelte. Diejent unangenefymen

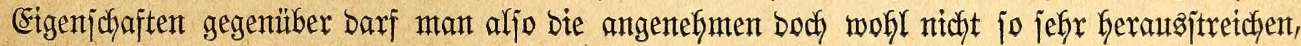
als bies won Einzelnen gejchefen ift.

Wentge Sörnerfrefier nijten jo leidgt in Befangenjdaft wie bie Braufinfen, unb wenn

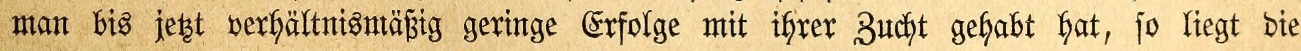

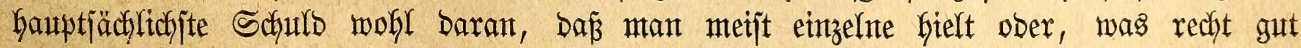

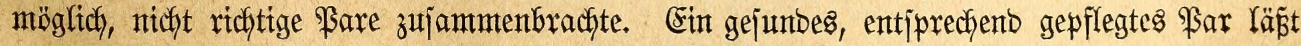

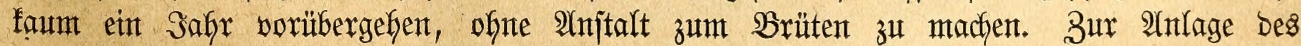

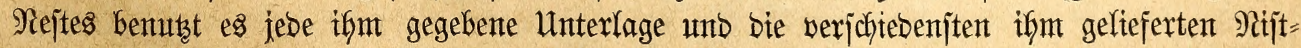

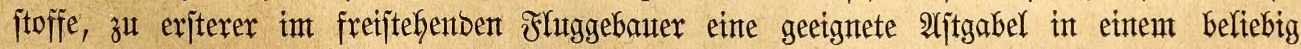

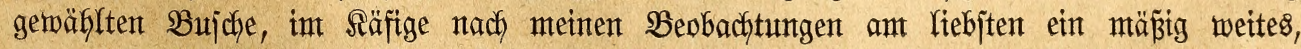

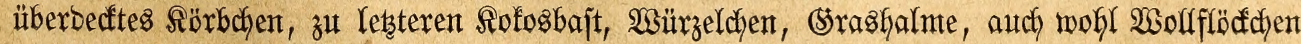




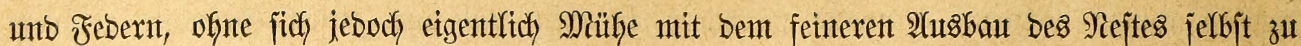
geben. Ein Şarzer Bauterffen ober eine jonjtige Unterlage wiro übrigenz aud nidjt ver= jchmäft, uno verjefiebene anbere Baujtoffe, beijpielsmeije Seegras, bienen ebenjo gut als

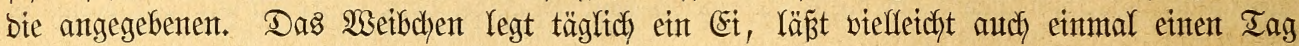
bazmijchen ausfallen, bis bas Belege voll ijt, bleibt auf ben leţten Citern bereits jitzen, brütet 13 bis 14 Iage und wiro wäGrenboem vom Meännchen gefüttert, auth wohl mand = mal auf furze Beit abgelöft. Die Sungen futo nach 14 bis 18 Iagen flügge unto nach weiteren jechs Iagen ber Pflege ifyer EItern nicht mefr bebürftig, berfajfen jebodh meift

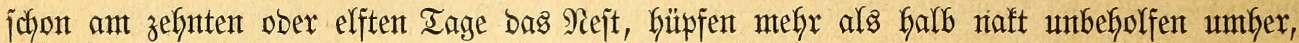

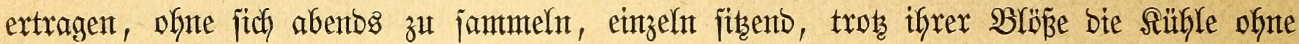

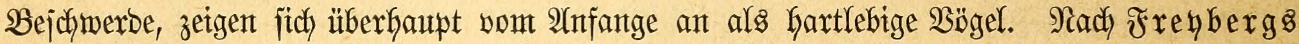
Beobactutungen fint fie nie bie eigentlidfen unt bie Srrünfarbinäle äunerjt empfänglich für

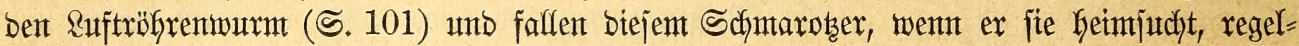
mäß̈̈ zunt Dpfer.

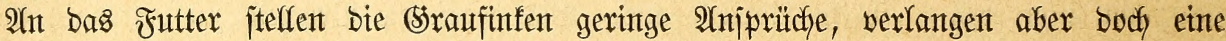

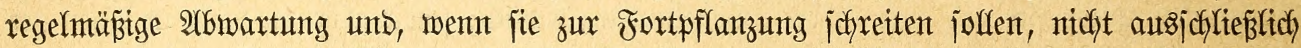

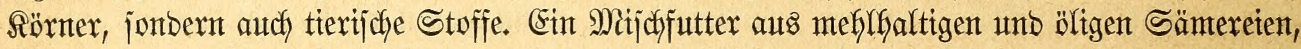

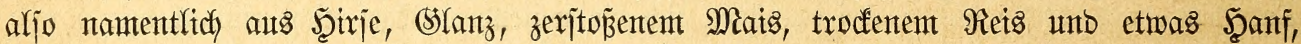

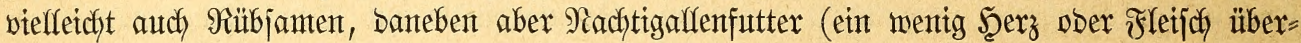
Gaupt, 2(meijenpuppen, Nebltwürmer), allerlet Serbtiere, (Srünzeng uno fein geriebene

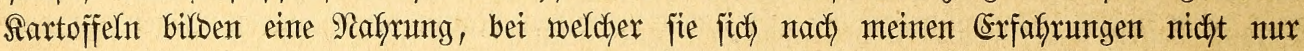
bortrefflich halten, jonbern audh nidhts von ifyrer Schönheit verlieren. Sreibe unto Salz bürfen ibnen ebenjo wentg feflen wie anberen Sönterfrefjern.

Der Preis affer (Sraufinfen ijt ein ziemlich regelmäß̈tger und feitjtebender. Er beträgt im Einzelverfauf zwijchen 12 und 14 Taler für bas $\mathfrak{\text { Bar. }}$

\section{Ammerkardintäle.}

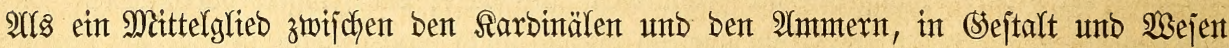

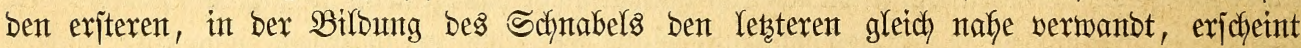

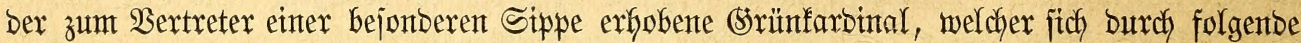
Merfmale fennzeidynet. Der seib ijt gebrungen, ber Sopf mä̈̈ig groß, ber Schnabel fräftig, jtarf gewölbt, an ben Sdyneibenränbern eingezogen, nach bent Mumbminfel zu ftumtpfwinfelig

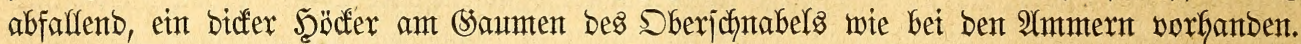

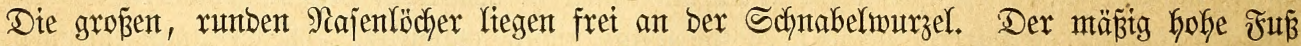
hat fleine Zehen; bie Şinterzehe trägt, amitatt eintes Sporens wie bet ben 2 (mment, eine

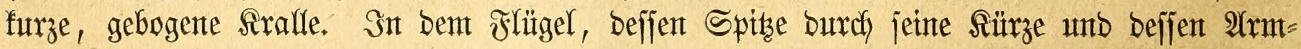
johningenteil burch feinte sänge auffällt, fint bie zmeite bis fünfte Schminge bie längjten, bie erjte und jechjte etwas fürzer und einanber gletch, bie zweite bis jechjite ausen jtarf eingeengt. Der mittellange, verfältnismä̈̈ig lang erjcheintembe, vom zujammengelegten Flügel bis etwas mefy als ein Drittel bebectte Schwanz ijt an ber Spize gleidymäp̈tg zugerumbet. Das berbe (Befieber hat ammeräfnltiche Beichnutg.

311. Dex (Grünfaroinaf, Gubernatrix (Emberiza, Lophocoryphus) eristatella, Vieill., (guber-

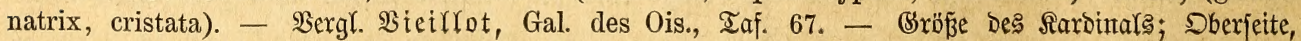

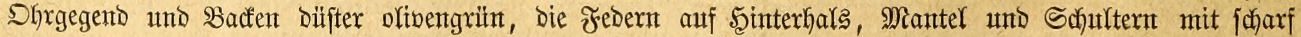

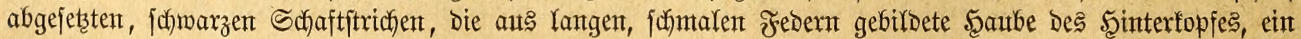

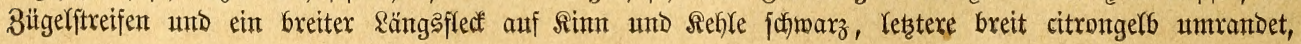




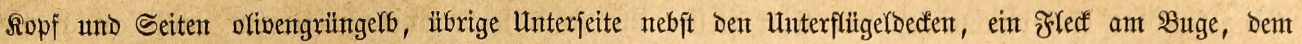

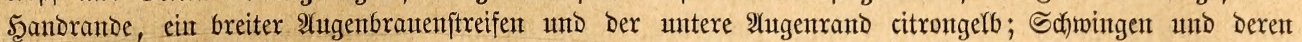

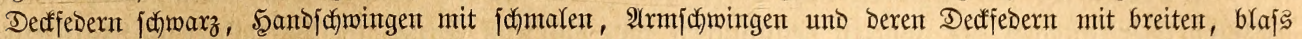

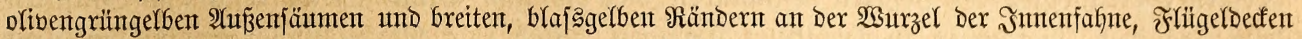

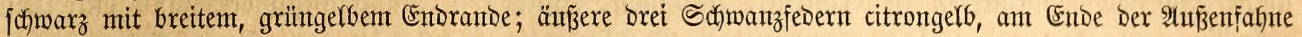

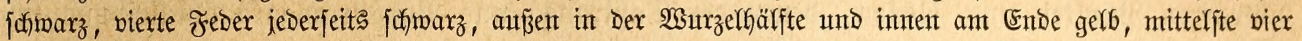

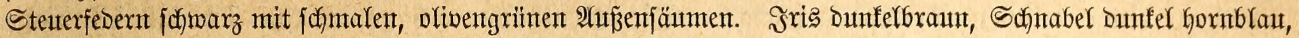

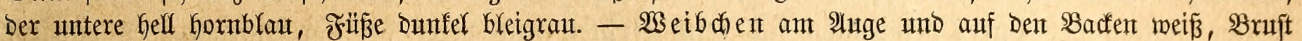

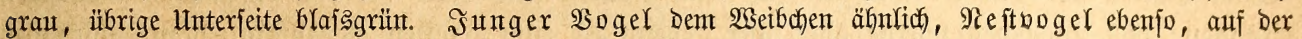
Unterjeite, zumal Der Brutt, mit breiten, Dunfelgrauten Schaftitrichen gezeidnet.

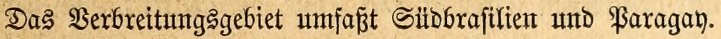

Heber bas Jretleben bes Srünfarbinals, einer ber Gerborragentojten Zierben unjerer Räfige und Fluggebauter, wiffen mix immer noch nidjt viel mefrx, als $\mathfrak{A} z a r a$ mitgeteilt hat. Der $\mathfrak{B}$ ogel rebt nach jeinent Aftgaben wäbrend ber Brutzeit parmeije, jonjt in flement (Sejelfichaften nach 2fmmerart zmijchen lichtemt (sebüjch, viel auf bem Boben, ijt ziemtich) träge unb fliegt ungern weit, nägrt jich von Rerbtieren unb Rönnern unb wirb in Falfen verjchiebemiter 2 (rt leidyt gefangen. Sm Säfige haben wir weiteres über ifgn beobachtet.

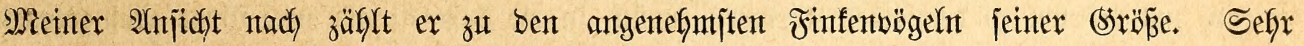
munter unt fajt unabläjijg in Benegung, zeidynet ex jich ebenjo jefr burch jein anjpredjendes Befieber wie burch idnmucfe Şaltung aus. Sein Flug ijt etwas jobwerfällig und mit

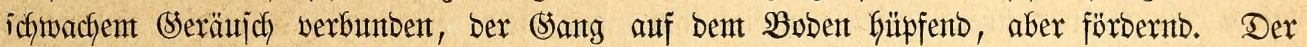
(Sejang bejteft aus mefreren Gellflingenten unt ziemlich fräftigen Rauten; als reichbaltig

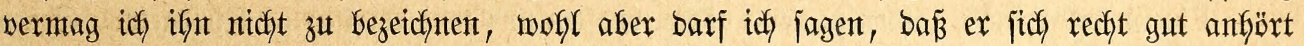

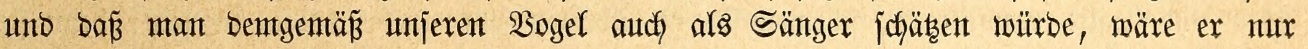
fleipitger, als ex zu jein pflegt.

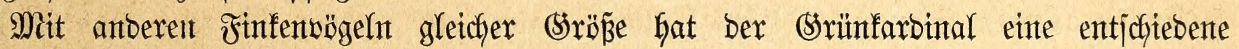

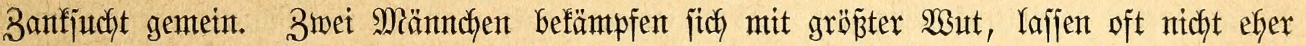
von einander $a b$, als bis ber eine erliegt, und verfahren bei ifrem Streiten jo rünfichtzloz

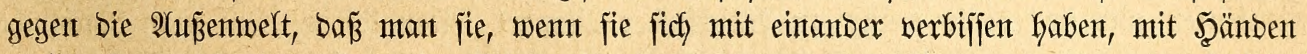
greifen fant, überhaupt faum in Stande ijt, fie zu trenten, es aljo von vornfyerein unbebingt

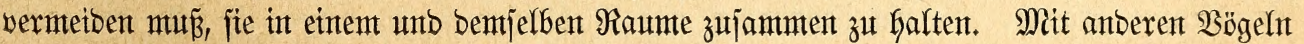
werträgt jich unjer Rarbinal in ber. Regel recht gut ober ridftiger, befümmtert jich gar nicht

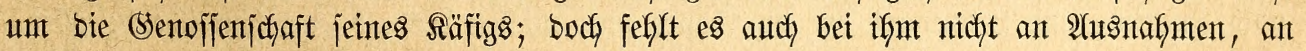

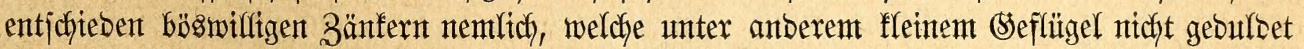
werden föntnen. So überfiel einter meiner Strünfarbinäle einen alten Pirol und jebste ifm

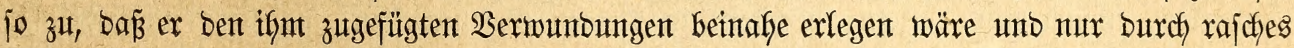
(Eingreifen übergaupt gerettet werben fonnte. Freilich war biejer Sogel ein siänthen,

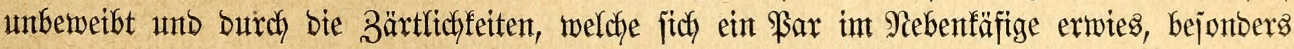
aufgeregt.

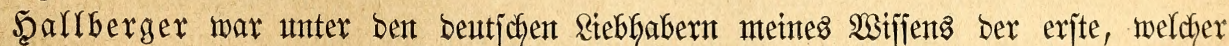
von ifgm gepflegte Brünfarbinäle zur Fortpflanzung idfreiten jah und son einem $B a ̈ r d j e n$ mefyrmals finter einanber. Sunge erfielt. Später Gaben bie $\mathfrak{B}$ g̈gel in ben Tiergärten zu Franffurt und Söln und in biejem Safye (1871) aud int Berfiner 3oologijdjen Sarten

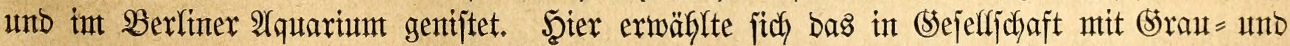
Dominifanterfarbinälen, Spottbrofjeln unb einigen 2 mmerfinfen Yebento \$ärchen ein flaches, aber geräumiges Sorbnejt, fletbete başelbe notbürftig mit einigen Sofosbajtfajern aus und belegte es mit brei auf graulichem (srunbe bunfler gejprenfelten Etern. Das (Selege twurbe erjt benterft, als baz 2 eibchen bereits brittete; bent ber $\mathfrak{B}$ au war in affer Stifle vor fich gegangen unb eine bejonbere Erregung am Männdfen nicht jichtbar geworben. 


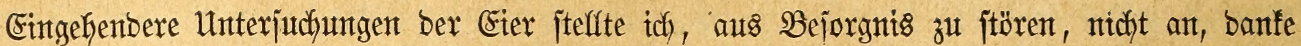
aber $\mathfrak{B a l b a m u s}$ bie Beichreibung berjelben. Die in ber bebeutenben Sammlung biejes

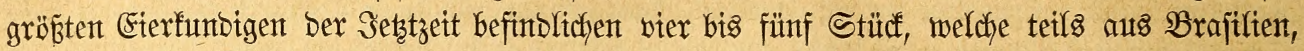

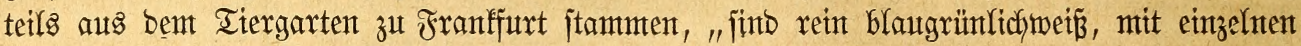
jefwarzen $\mathfrak{B u n f t e n}$ und Flecten, Denen ber Iapiranga und \$urpurtangara äfnllich und mit ifnen zu einer eifichen (Sruppe geförig." Die SBrutbauter jobäze ich auf 12 biz 13 Iage. Beibe (Satten bes Fares beteiligten jich beim Brüten unt beibe bei ber 2 urfutyt bes einzigen Sungen; bas Weibdjen wurbe aber nur, wenn es zum Frefjen herabfant, von Mäntheten

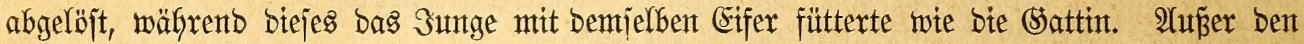

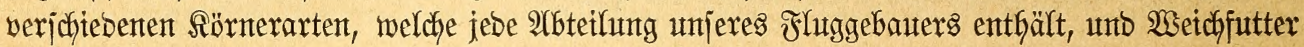

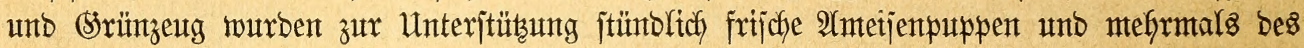

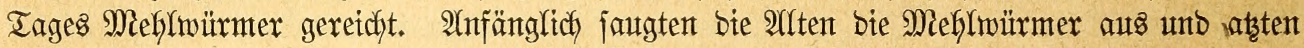
ben Saft; jpäter töteten jie zunächjt bie Rarven, verjollangen eintige unt jofleppten antbere

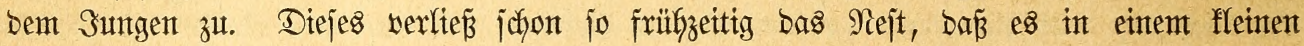

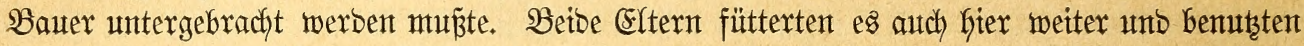

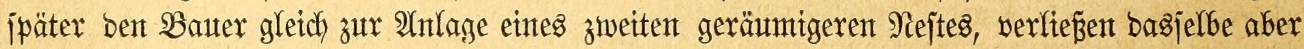

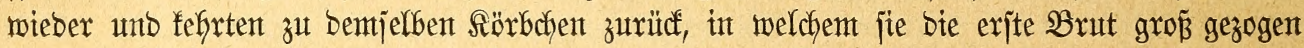
Gatten. Während Das Weibchen bereits zun zmeiten Male brütete, flog bas Sunge der exjten Brut offers mit in bas Nejt unb verweilte fiter ftunbentang, ftifl unt betwegungalos neben ber Mutter fitzent. Dieje erwies ifm zwar nidft bejondere Zärtfidjfeit, bulbete es

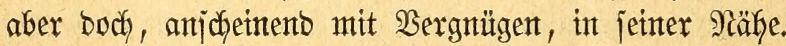

Die (Srünffarbinäle zählen zu ben auşbauernbjten unto langlebigjten Finfentögeln. Begen

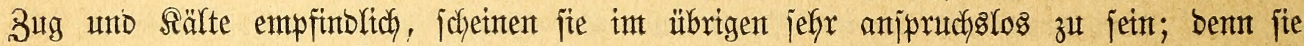

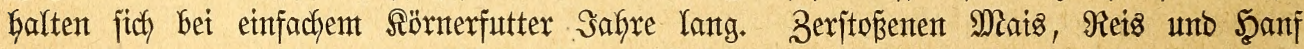
ziehen fie anberen Sämtereten (Şirje, (SIanz, Scafer) vor, Galten jith aber audy bei biejen

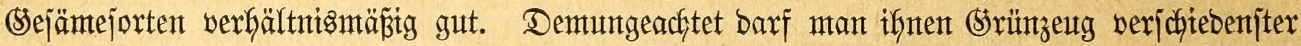
Art (Salat, Bogelmiere, Rohlblättchen, Zwetgfnospen unb frifche Baumblätter) nicht vor=

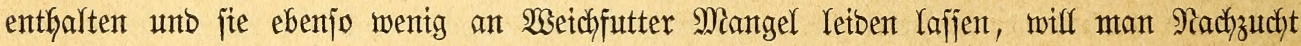
von iffren erfoffen. Einzelne Stücfe freffen gern gefodte und geriebente Sartoffeln, anbere

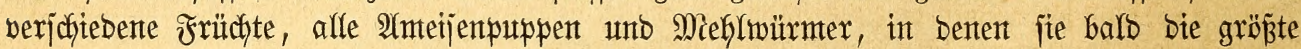
Secferet exfenten. Sie trinfen viel, baben fich verbältuismäpäg jelten, pabbeln jïch aber nach Ammer = und Serchenart oft im Sanbe und müffen beshalb eine finxeidyende Mienge bes lebteren zu ifyer $\mathfrak{B e r f i u ̈ g u n g ~ h a b e n . ~ I n ~ j o l d j e r ~} 2$ seije gepflegt, fint fie fajt umberwüjtlidy.

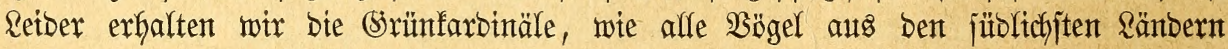

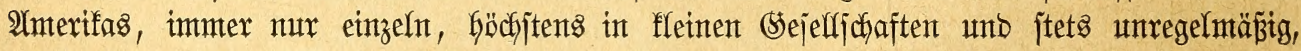

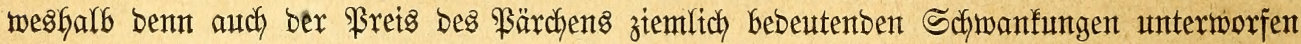

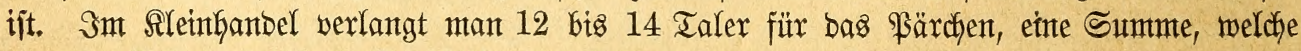

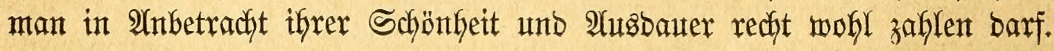

\section{fạ⿰氵丶⿱亠䒑十äle.}

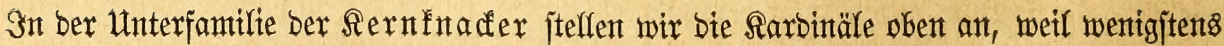

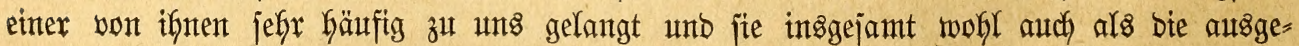
zeidjnetjten ber Siruppe betrachtet merben fönnen. Sie fint fräftige, Des langen Sdymanzes Galber gejtrectt exjcheinente Bögel. Der furze, fegelförmige Schnabel ijt an ber Wurzel böher als breit, auf ber Firite gemölbt, an ber Spitze Gaftig herabgebogen, an ber Rabe 
etwas nach unten ausgejdyweift, jeine untere Sinnlabe breiter als bie obere, ifre Diflenfante

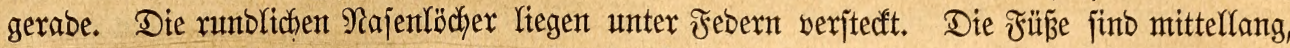
aber jtarf, bie Behen wie bei alfen Siernfnactern lang, bünt und mit jchlanfen, ipizen, wentg gebogenen Sllauen bemefyrt. Sn bem furzen, ftarf gexunbeten Flügel, welcher zu= jammengelegt faum ein Drittel bes Schwanzes bedectt, überragt bie vierte Schninge bie

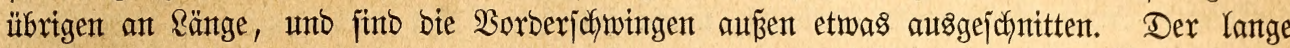
Schwanz ijt abgerumbet. Das auf Demt Sopfe zu einer Şaube verlängerte Ssefieber zeigt

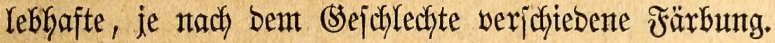

312. Der Sinvitur, Cardinalis (Lox., Fr., Coccothr., Pitylus) virginianus, Briss. (cardinalis) -

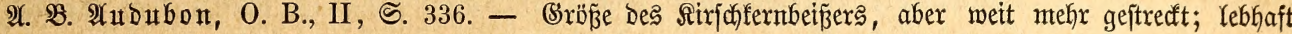

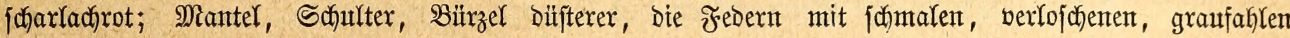

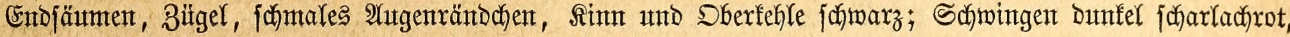

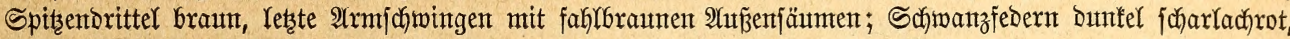

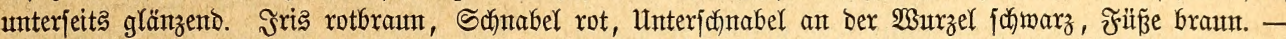

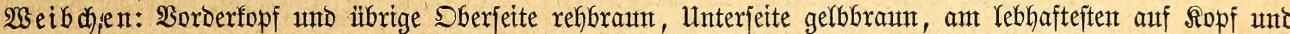

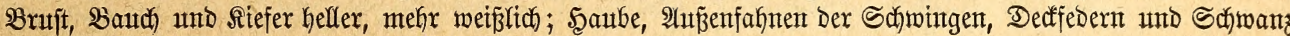
büfter fadarfachrot, Simm umb Soberfefle graufdimärzlich.

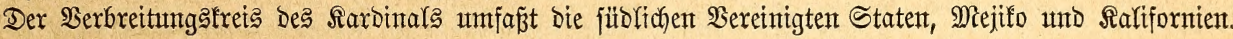

313. Dex \$urpurfardinaf, C. phoeniceus, Gould. - $\mathfrak{A}$. B. Proc. Z. S. 1837, S. 111. -

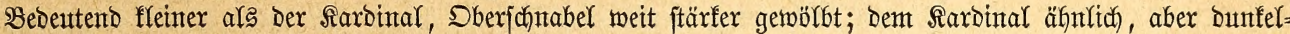

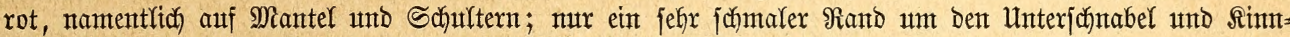

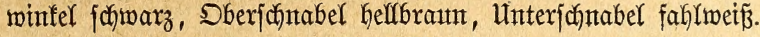

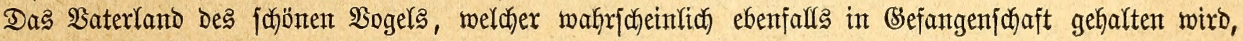
ift Mittelamerifa, Senezutela and Irintibab.

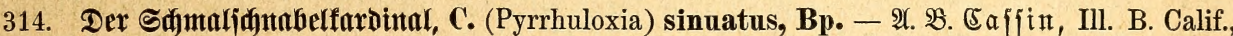

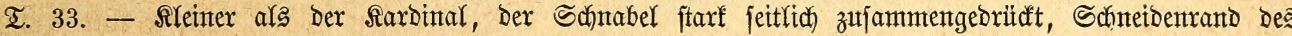
Sberjantabels an ber Wrutzel wintelig abfallent ; Dberjeite fahl graubraut, ebento bie Scheitelfedern, weldae

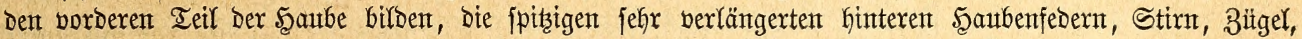

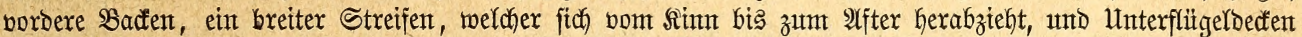

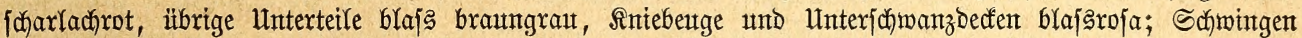

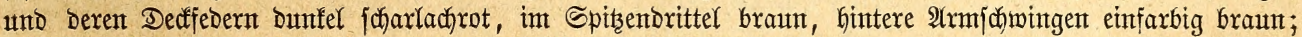

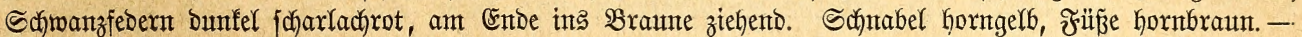

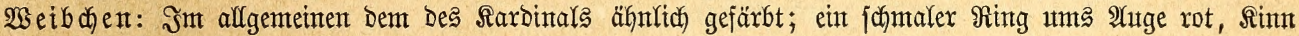

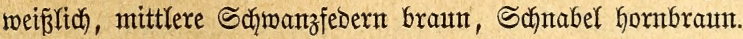

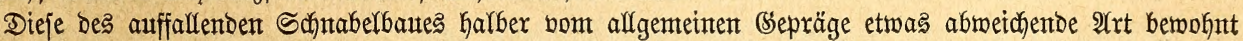
Mejito und Tejas.

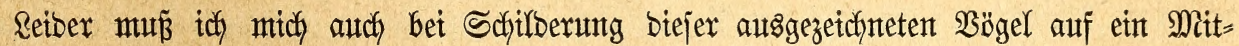
glied ber Srappe, das Urbilb ber Sippe jelbjt, bejdyränfen. Heber bie beiben übrigen Ârten mangelt uns genügenbe Aunbe, ebenjo wohl was ify Freileben, afs was ifgre Ssefangen= baltung betrifft.

Der Rarbinal, einer ber befanntejten $\mathfrak{B g ̈ g e l ~ D e r ~ B e r e i n i g t e n ~ S t a t e n , ~ b e b o ̈ l f e r t ~ v o r z u g s : ~}$ weije bie jübwejtlichen Teile berjelben, Tejas und Mittelamerifa, bejucht int Sommer aber

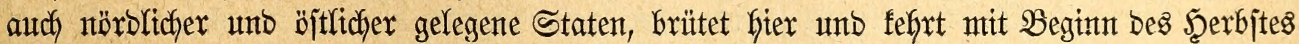

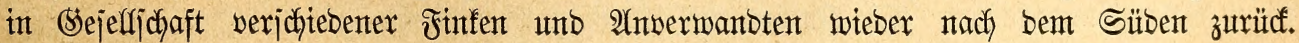
Seier jifht man ifn überall, im tiefiten Difftcht ber Walbungen ebenjo gut wie in unmittel=

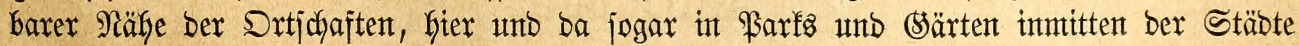

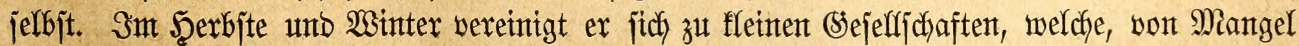
getrieben, auch wohl bis auf bas (Sefjoft bes Rantontantes Kereinfomment und im Bereine mit Şehern, Spottorofjeln, beridjtebenen Rörnerfreffern und Iurteltauben vor ben Scheuern

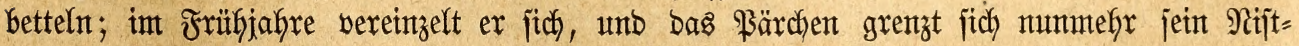
gebiet $a \mathfrak{b}$, aus bemjelben jebes andere Mënndjen mit wütenter Eiferjudjt vertreibent und 
unter Untitänben auf Iob unb \&eben mit ifm fämtpfeno. Mebr als alfe übrigen Sïrner= freffer trägt er zur Belebung ber (Segento bei. Das prachtuolle Rot bes Männthent, meldjes jich beint Singen gern auf bie födjiten Zweigipitzen jetst uno mur bei Befahr int

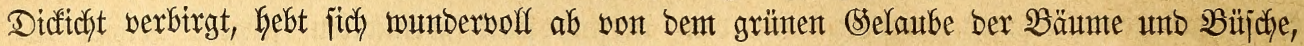

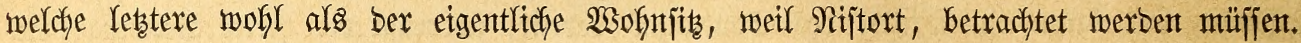

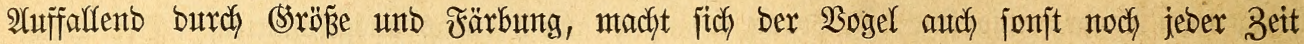
bemerffich, jet es burch jeinte enige Unrube ober jei es burch jeinen lauten, jaymetternben

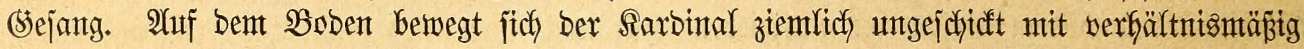
meiten, etwas plumpen Sprüngen, int Stezmeige bagegen mit wafrer Meifterichaft, ba er

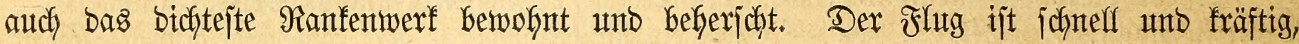

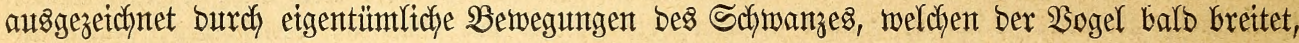

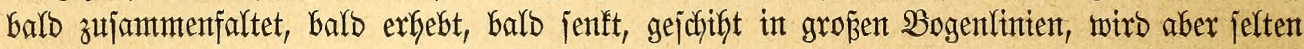

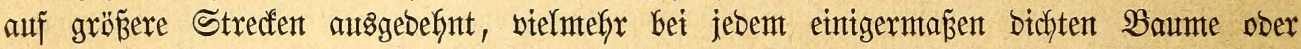
Bujche unterbrodjent unb Dant von neuem fortgejest. Der Sejang, melcher bem Sarbinal

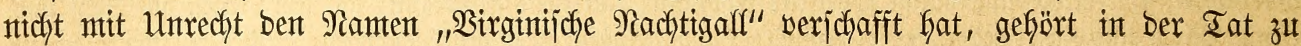

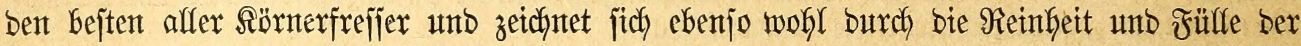
Töne wie burch bie Berjefjebenfeit unb Mandhfaltigfeit ber Strophen aus. Währento ber Brutzeit trägt ber $\mathfrak{B}$ gel jein Rieb mit erföfter Rebhaftigfeit vor, fträubt babei oft bas

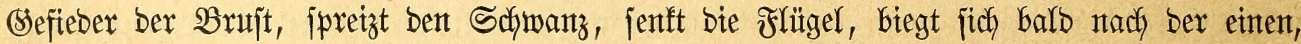

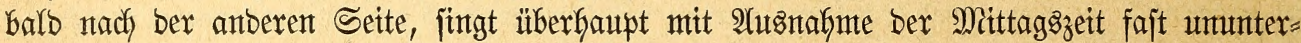
brochen. Noch bevor bie Sonne ant Morgen jich erfebt, wernimmt man bereits bas

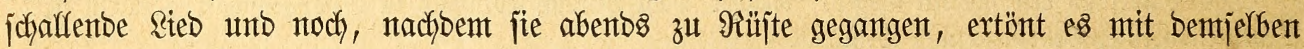

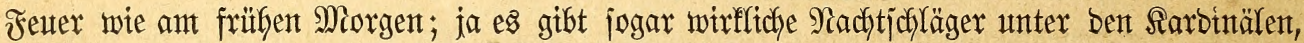
Bögel, welche fich zu jeber Stunbe ber Nadft fören laffen. Sb fie, wie Fiebler meint, erjt burch längere Befangenjabaft zu foldyen gemorben finto ober wie bie rojenbrüjtigen Sernffnader audy in ber Freikeit bes Nachts ifre steber vortragen, lajje idh Dafingejtelft; jebenfalls trägt joldjer Eifer int Singen nur bazu bet, ifren Wert zu erföben. Wer Ien

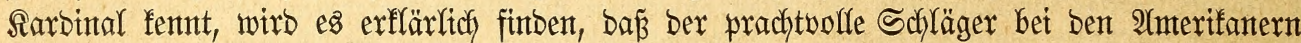

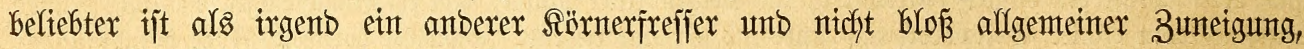
jonbern förmlticter Bemuldorung fich erfreut.

Sn Dent nörblictyen Staten brütet ber Sarbinal, laut $\mathfrak{A} u b u b o n$, nur einmal int Raufe bes Sommers, in ben jüblichen bagegen minbejtens zwei=, in günjtigen Sonmtern jogar

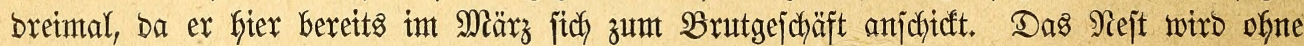
bejonbere 2 orjicht auf ingent einem Baume ober in einem bidften, niebrigen Bujche, Dornen=

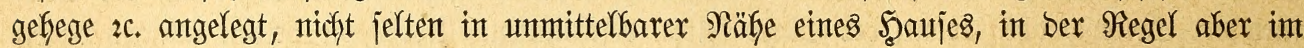

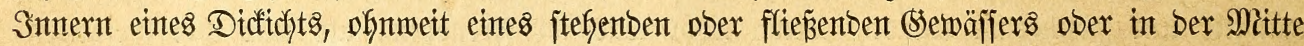

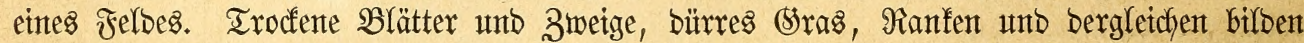

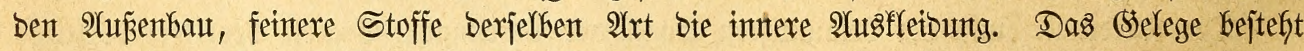

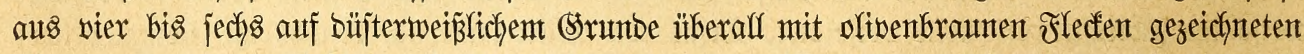
Eiern. গur bas Weibchen brütet, wirb aber vom Meäntdchen mäfrenboem gefüttert uno burch (sejantg unterbalten. Die Sungen entjdylüpfen nad) breizefyn= bis vierzebntägiger $\mathfrak{B}$ rut=

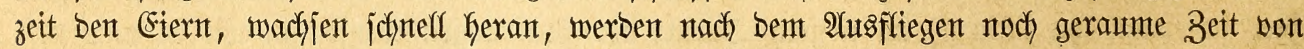

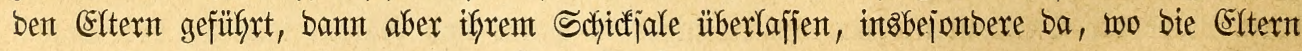
zur zweiten ober zut einter ferneren $\mathfrak{B}$ rut jodreiten.

Sämereten Der verjcytedenjten $\mathfrak{A}$ rt, Baumfnozpen, zarte Baumblätter und im Spät=

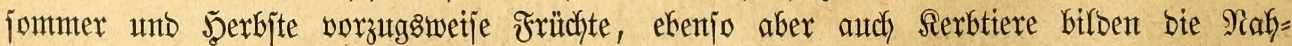
rung ber Sarbintäle. Smt Säfige reidft man ifnen ein (semtijch von öfigen unto megligen

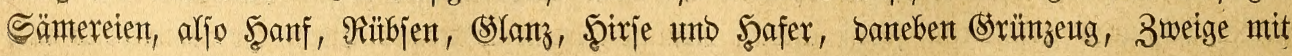




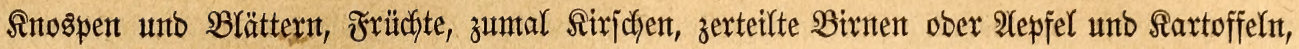
außerbem aber Weidjfutter und täglich einige Mefjlwürnter, weldye jie balb leibenjidyaftlich

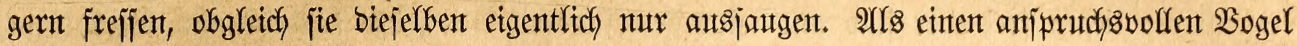
fann man ben Sarbinal nicjt bezetdynen: er nimmt mit bem einfactjiten Futter vorlieb und

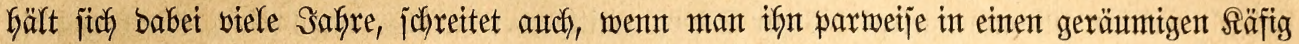
jetst, ziemlidy leidfyt zur Fortpflanzung. Um ifyn hierin zu unterftütsen, befejtigt man ein

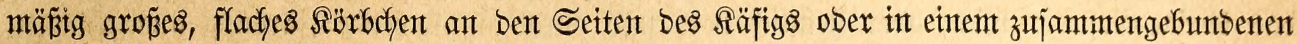
Reifichbünbel, bilbet in ifmt aus gröberem Sraje und Dattelbajt ein robes Rejt und über= läpt es ify mun, biejes nach Befintben mit verjchiebenten pajfenden Stoffen, weldye man

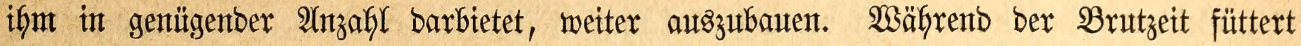

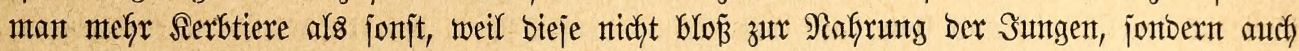
zur Ânreizung ber Allten bienen jollen. Da bie Brutzeit in unjere Früfylings = ober Sommter=

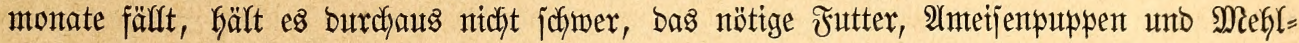
mürmer, zu bejdyaffen; nötigenfalfs bietet Gart gefocftes unb fein geriebentes citootter ober

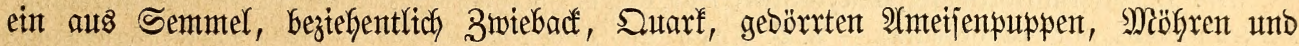

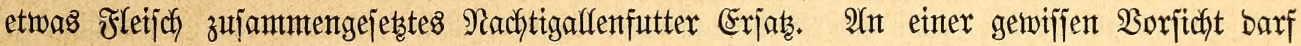
man es übrigens nidft feflen lajjen. "Went jungen Sarbinälen lebende ober getötete Mehlwürmer unzerjtütfelt gegebent werben", bemerft Freyberg, "gehen bieje meijt unwerbaut

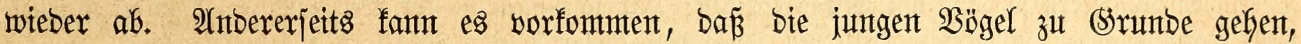
wenn fie zu viele Mebliwürmer erbalten: bet eintgen Stüdfen, weldye tidy nady ifyrem Iobe

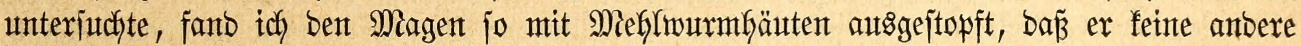

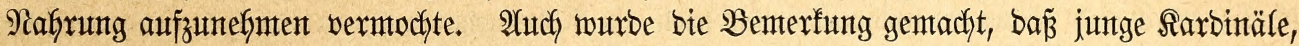
weldye viele Mieflwürmer erfielten, am \&uftröfrenwurme zu Strunbe gingen, währento anbere, benten man Suarf, Jleijch, Sceujchrecfent unb anbere Serbtiere reichte, trefflidh gebtehen und

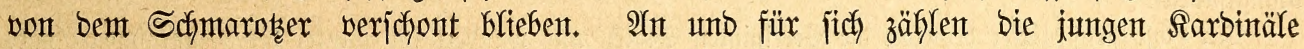

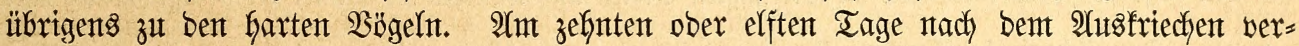

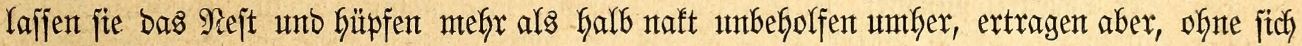

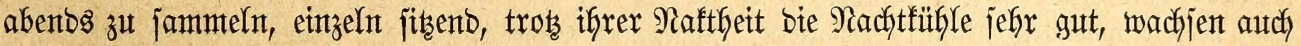
in ber Regel rajch heran unt werben zu ebenjo fräftigen Bögeln wie bie wilbgefangenten. Sobarb

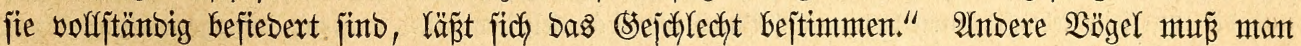

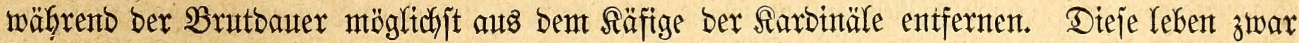

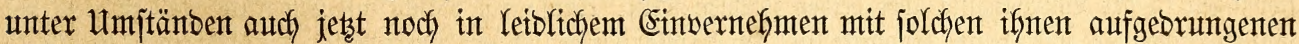

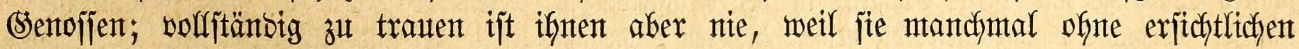
(S)rund über jchwädsere Bögel Gerfalfen unb bieje, went ntcht umbringen, jo boch gefägrlich verlebent. Mit gleich jtarfen, beijpielsmeije mit Strauffarbintälen, reben jie in emigem Saber,

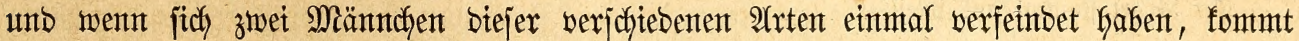
es jelten zum guten Ende.

Die Rarbinäle treffen in ben erjten Früfjafhrsmonaten auf umjerem Marfte ein, jelten

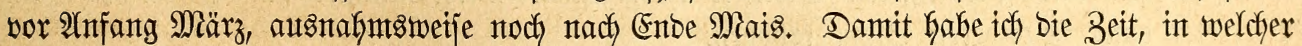

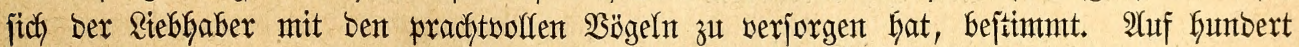

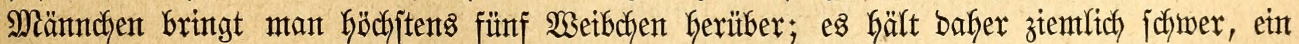

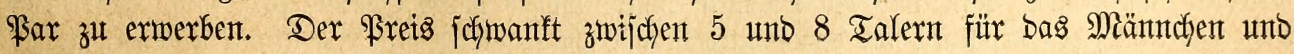
zroijdyen 3 und 5 Ialern für bas Weibchent.

\section{Eernbeikerfinkett.}

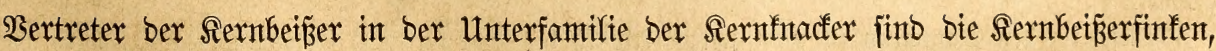

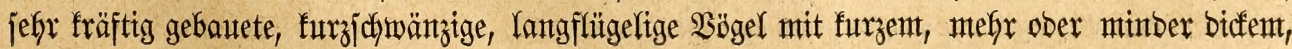




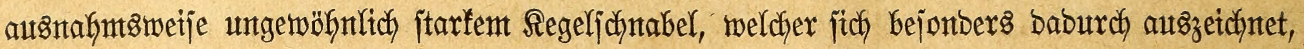

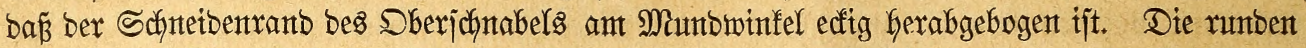

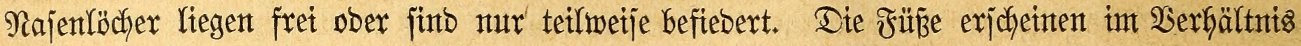

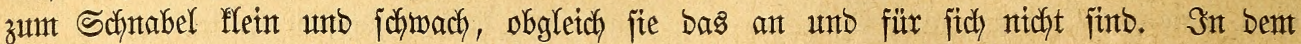
Flügel, welcher zujamtmengelegt bis zur Sdywanzmitte ober barüber Kerabretcht, überragen bie zweite, britte unt vierte Schwinge bie ïbrigen. Der Schwanz ijt furz, gerabe abgeidynitten, bas übrige (sefteber reich, aber ziemlitch berb unb butch anjprechenbe Färbung auszgezeichnet.

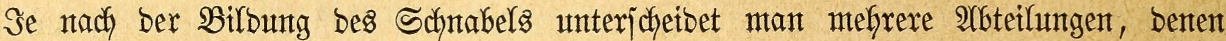
ber Rang bon Sippent zugeiprochen werben barf.

Bei ben Singfnadern ijt ber Schnabel furz, fräftig, an ber Wurzel etwas autgetwölbt, übrigens fegelförmig unb ipis, auf ber Firjte, bem Sber = unb Unterfiefer jeicht gebogen,

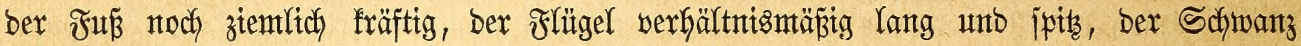
mittelfantg.

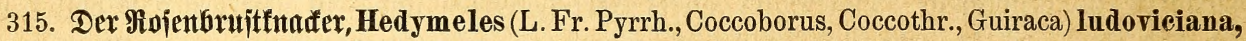

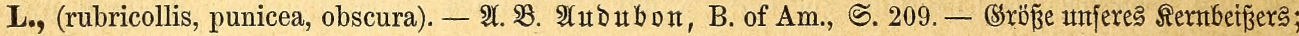

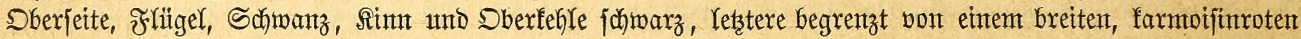

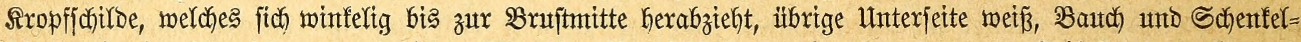

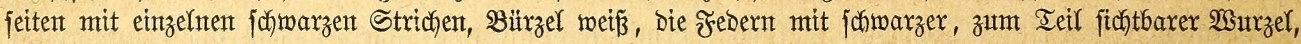

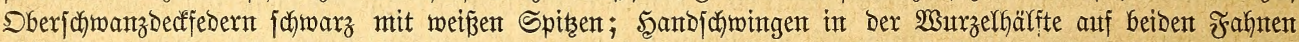

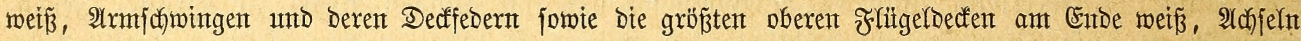

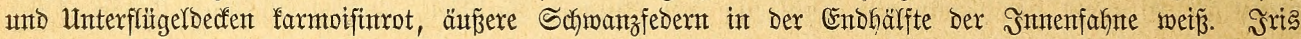

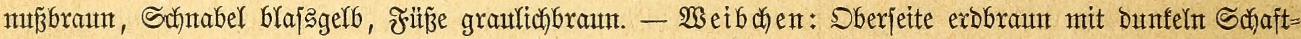

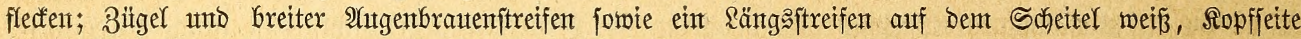

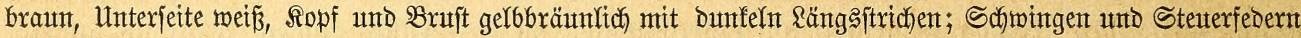

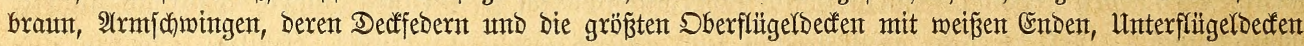
orangefarben.

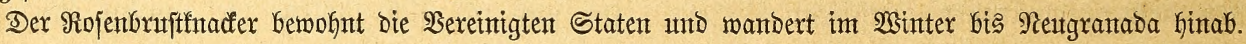

316. Der Sdymarzfopffitufer, H. (Fr., Guir., Coccob., Pit.) melanocephala, Swsn., (xantho-

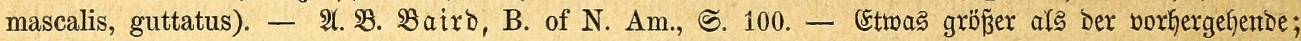

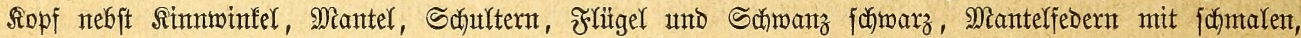
zimmetbraunten Seitenjäımen, obere Bürzelfebern mit fadwarzen Spitzenflectent, ein Greites Nactentbanto, Bürzel

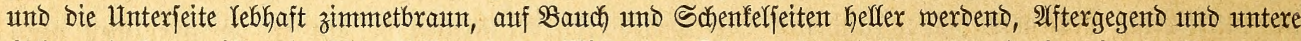
Sabwanżecfen weir

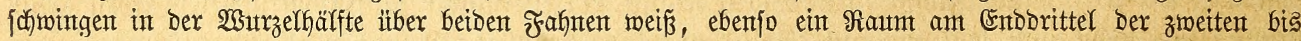

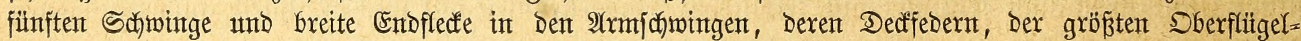

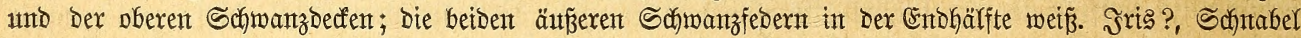

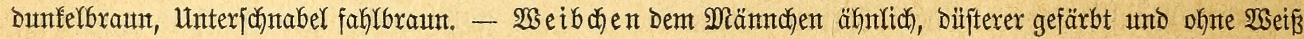
am Sanwanze.

Der Sogel ftammt auts Mejiffo.

Einen burdy jeinen riejigen, im wejentlichen bem ber Singfnader gleidh gebilbeten, aber biel ftärferen unt gemaltigeren Schenfel ausgezeddneten Siernftnacfer hat çabanis zum Bertreter einer bejonderen Sippe erfoben.

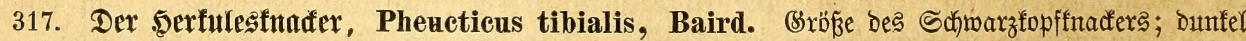

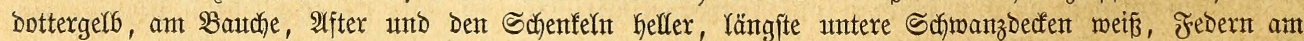

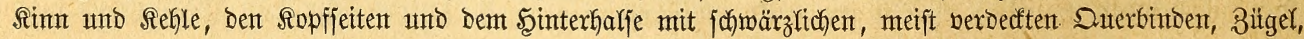

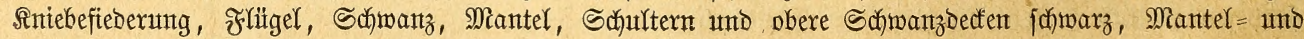

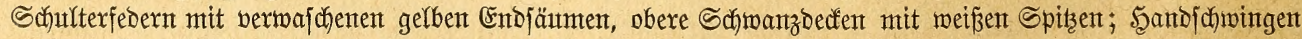

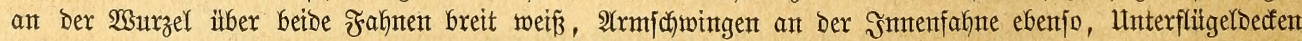

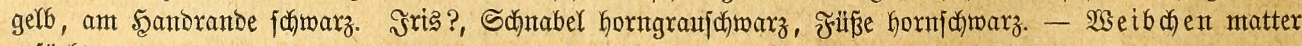
gefärbt.

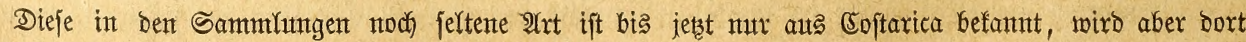

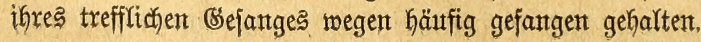


Der ganz wie bei ben Singlnadfern gebilbete, aber mit bentlidyem Sierbzahne verjebente

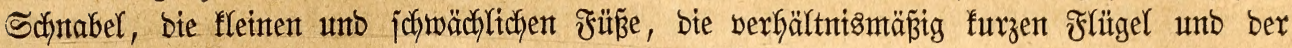
auffallento furze Sdywanz fentzeidnten bie $\Re$ unftnacferfinfen.

318. Der Mtąfenfernfutafer, Caryothraustes (L., Fr., Pit., Coccoth.) viridis, Vieill., (cana-

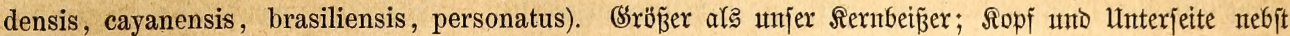

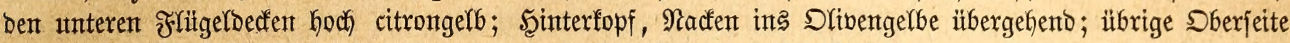

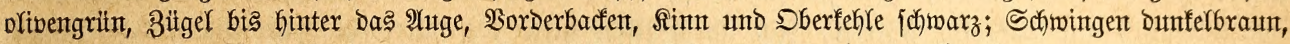

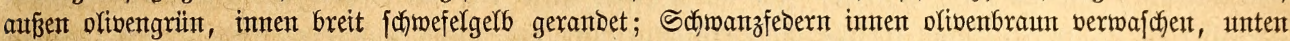

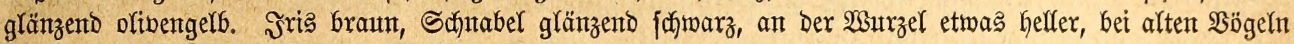

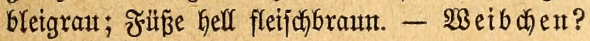

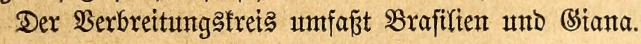

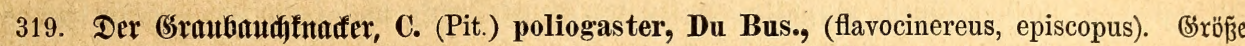

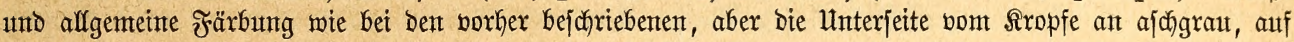

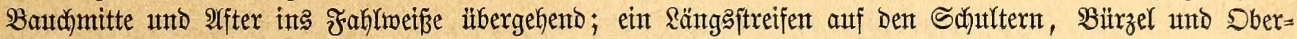

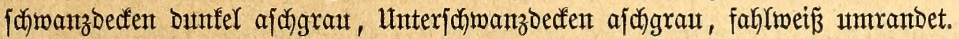

Der Soger bemohnt Sïbmejif́o umb Mittelamerifa.

Unter Den genaunten $\mathfrak{B o ̈ g e l n ~ i j t ~ b e r ~ \Re o j e n b r u f f t h a c f e r ~ b e r ~ b e f a n n t e j t e ; ~ u ̈ b e r ~ b i e ~ R e b e n t s = ~}$

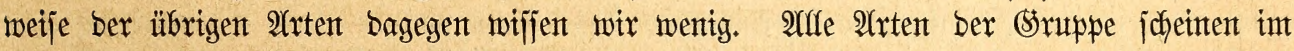
eigentlichen Sinne bes Wortes Walobögel zu jein und fich mur gelegentlich iłres 3ugs

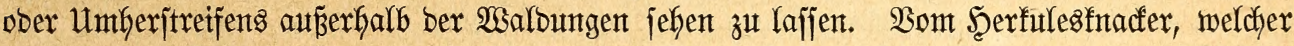

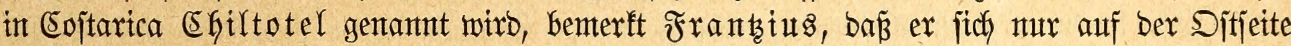
bes \&antbes finde, bort bie Maisfelber bejuche und int Räfige auth mit Mais ertährt werbe, ba ex biejen mit Reidytigfeit zerjdyrote.

Das Reben bes rojenbrüjtigen Rernfnaders bejchreibt $\mathfrak{A}$ ububon mit gewohnter

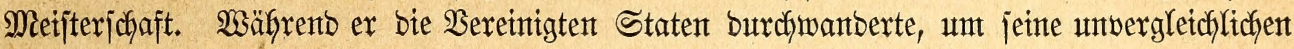
Beobadjtungen über bie bortigen $\mathfrak{B e ̈ g e l}$ zu jammeln, fant ex unjeren fernftnader in ben

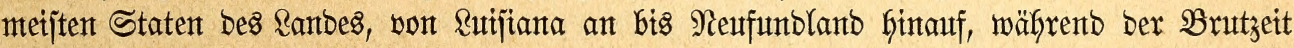
ftets in zujammenfängenden Wälbern, währent bes 3ugs hoch über bie Walbungen bahin itretchent. Sein flutg ijt hart und geft gerabe aus, entbefyet aber boch anjprechenter Benbungen nicht; im Siben bagegen nimmt ber Sogel eine zientich iteife Scaltung an,

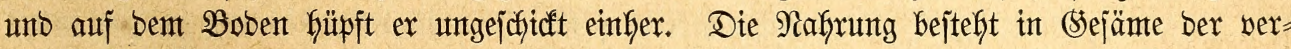

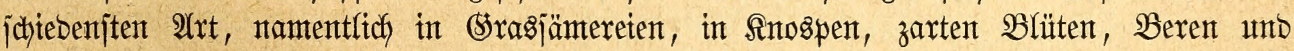

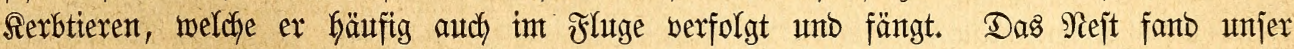
Forjcher in ben lebten Früflings = und exjten Sommermonaten in Den oberjten Zweiggabeln

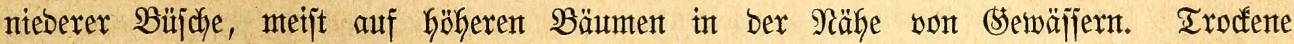

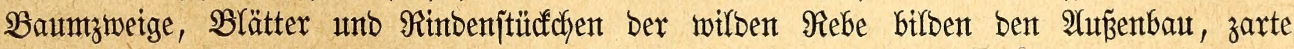

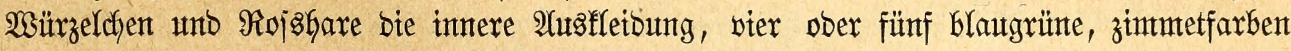
unb gelbbraun gejtrichelte und geflecte Eiter bas (selege. Beibe Bejchlechter brüten, unt betbe wibuten fich mit Scingebung ber Errziefung ifyrer Sungen, melche anfänglich fajt aus=

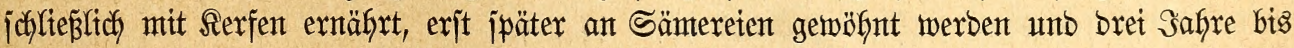

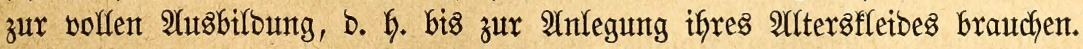

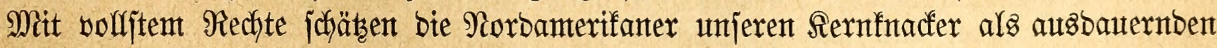
Säfigwogel und trefflichen Sänger. Die gefangenen gehen ofyne meiteres an bas Jutter, werben in furzer Zeit jefyr zahm unt halten bet eintigermazen entiprechentoer

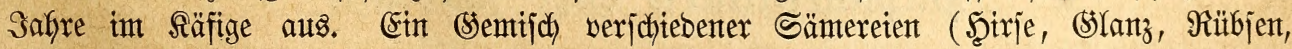
Mais, Şajer und etmas \$ุanf) bilbet bas Futter, weldyes ifnen gemöhnlfich gereidyt wirb;

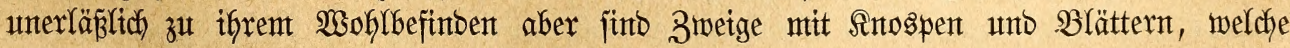
gierig benagt twerben, Sofll, Salatblätter, Bogelmiere unt anderes Srünzeng. Beren,

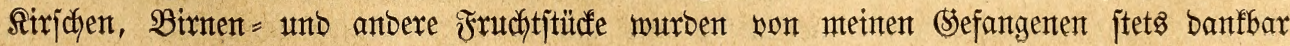




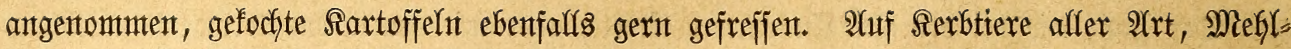

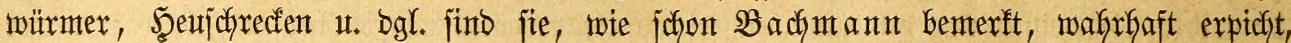
jiţent ftuntoentang auf ber Rauer nach Fltegen unb ftürzent fich auf jebent Miaifäfer, jebe

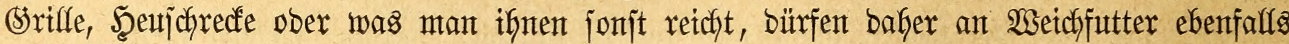

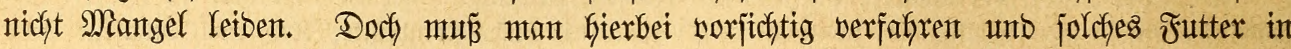

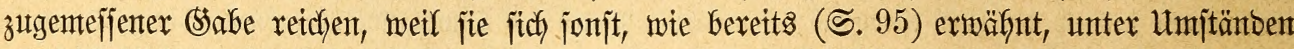

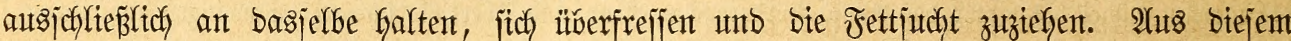

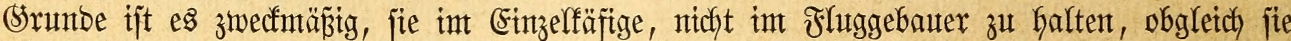

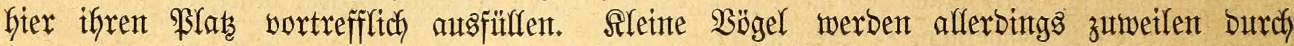

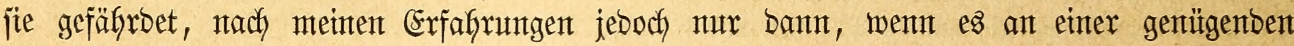

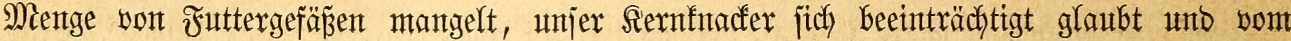

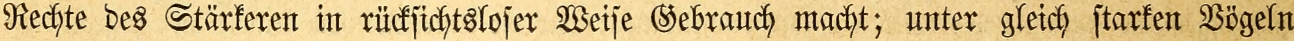

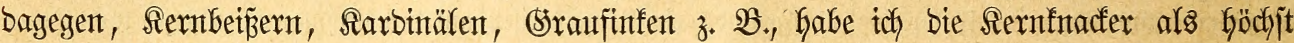
verträgliche $\mathfrak{B o ̈ g e l ~ f e n n e n t ~ g e l e r n t . ~ D e r ~ E i n z e l f a ̈ f i f g ~ e m t p f i f f l t ~ f i d f ~ f u ̈ r ~ u n j e r e n ~} \mathfrak{B}$ ogel übrigens

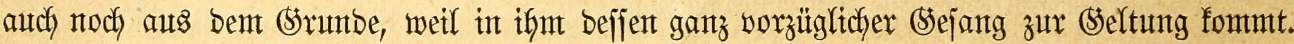
Diejer ifj jeffr wedfjelreich und Gächjt wofhlfautent, jeber Ton volf unb flax, ber Sänger

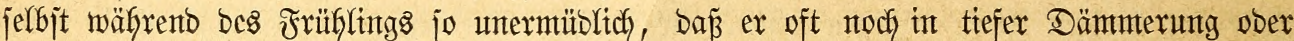

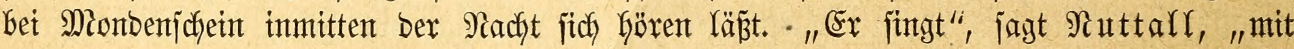

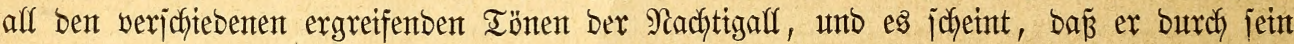

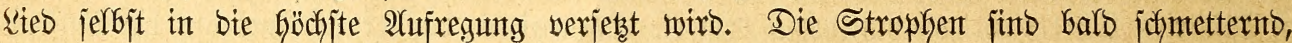

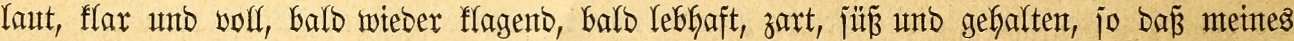

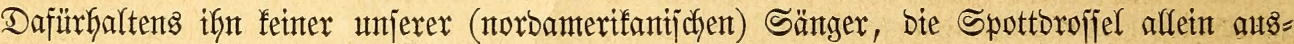
gettommen, zut übertreffent berntag."

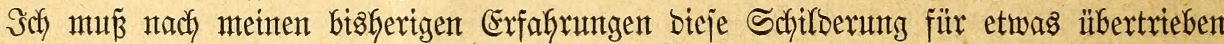

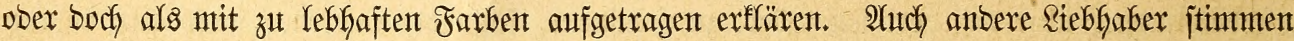
mir bei. "Das (seprïge bes (sejanges", jagt Fiebler, "fann id nidht anbers als bas ber

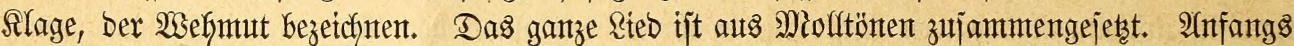

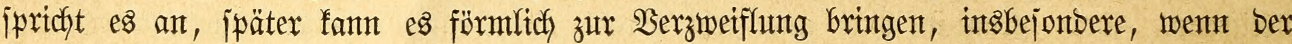

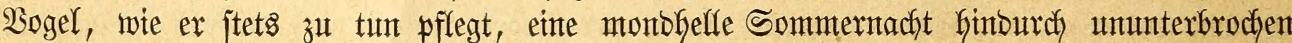

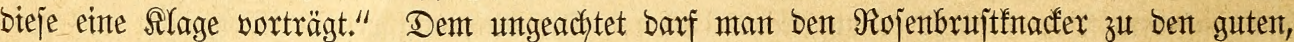

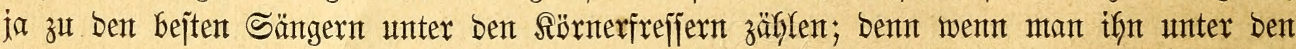

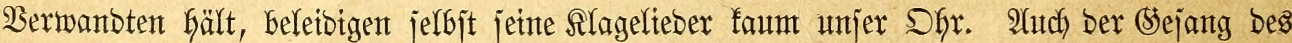

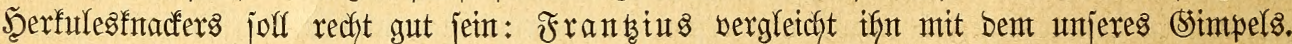

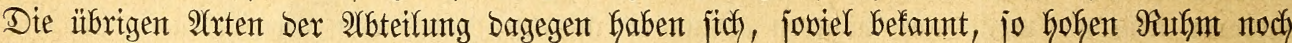
nidft erworben.

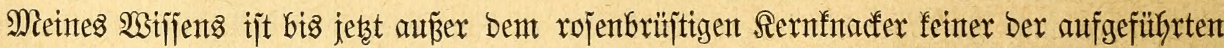

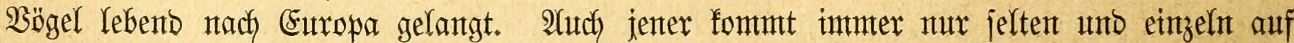

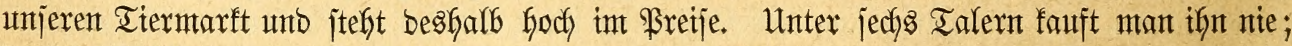

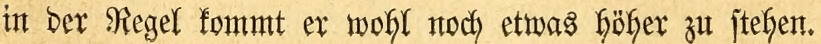

\section{Wapanetfinken oder fjabias.}

Eine vorzugsweife in Sübamterifa heintijafe unt bort zaffreich vertretene, in mefrere Sippen zerfalfente (Stuppe bon Rernfnadfert wolfen wir unter bem Namen \$apageifinfen

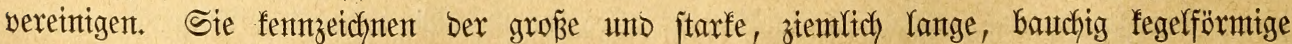
Schnabel mit beutlicher Rerbe unt mefyr voer minber vortretenbent Enofgafen, bie jtarf 


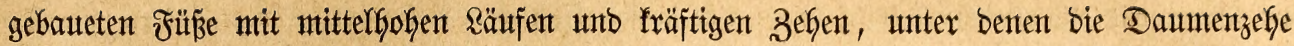

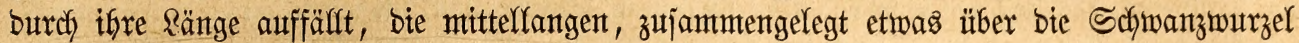

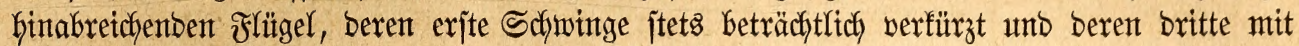

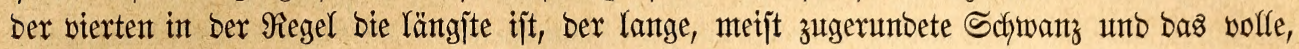
zientlich weiche Seffieber, in weldyent ein grünlliches SOlivengrau voer einfarbiges (s)rau vorferidgt.

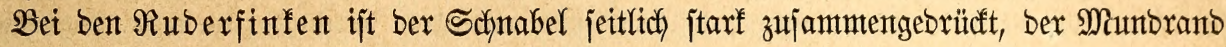

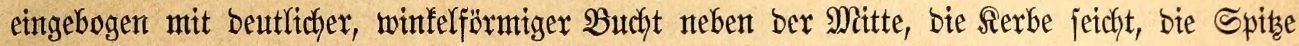

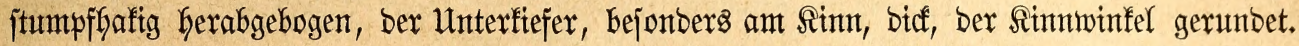

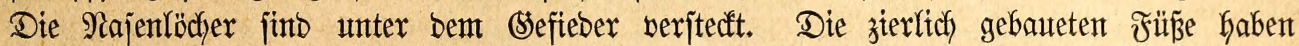

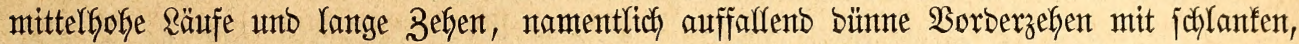

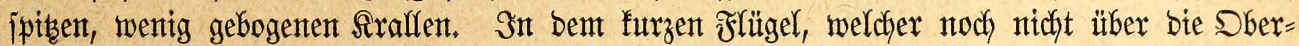
jdhwanzbeden Kerabreidht, ijt bie fünfte Sdywinge bie längfte; in bemt Yangen Schjwanze jitho bie bree äunerjten Febern jtarf verfürzt, bie jechg mittferent aber gleich lang.

320. Der Rutoerfinf, Pitylus (Fr., Coccothr., Tanagra, Saltator) fuliginosus, Daudin, (coerulescens, gnatho, atrochalybeus, psittacina, erythrorbyncha). - $\mathfrak{A}$. $\mathfrak{B}$. Reutwied, Beitr., III, 552. -

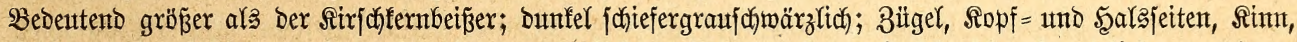

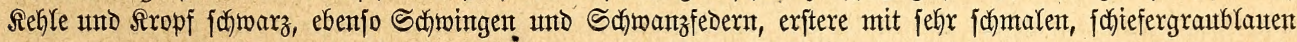

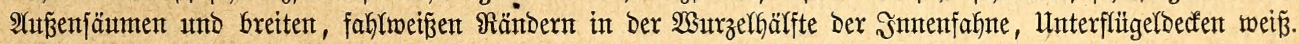

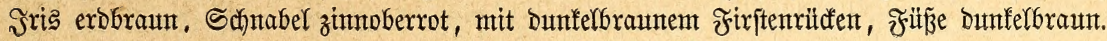

Die $\mathfrak{A}$ rt verbreitet fich über ben gröpten $\mathfrak{T}$ eil $\mathfrak{B}$ rafilients.

321. Der \&agruberfinf, P. (L.) grossus, L. RTeiner afs ber vorhergehente, ifm aber im ganzent

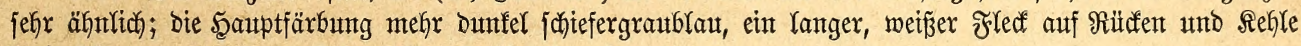
breit fdywarz umranbet; Sdynabel einfarbig zinnoberrot.

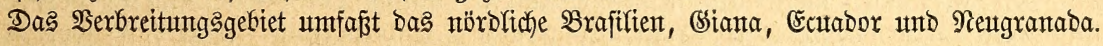

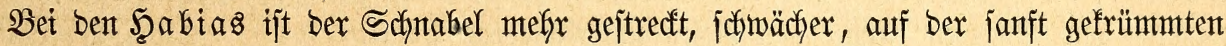
Firjte fantiger, ber Unterjchnabel niebriger als ber obere, ber Manbrand ftarf eingebogen, ber Fun fräftig, ber Flügel furz, bie britte Sdywungfeber bie längjte, Der Sdywantz lang, breitfeberig, janjt gerunbet.

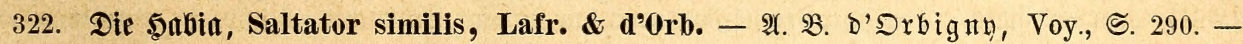

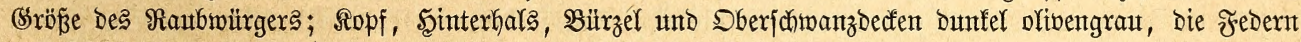
Des Sherfopfes mit verwafdenen olivengrünen Spikeenfäumen, Mantel, Sdhultern unt F̧lïgel olivengrün,

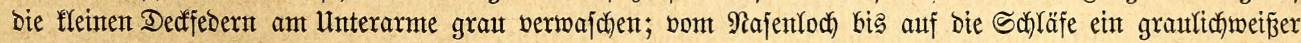

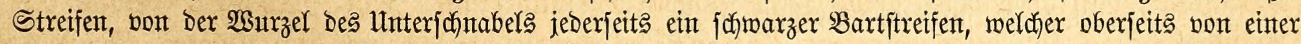

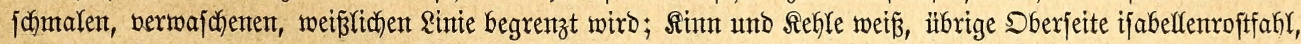

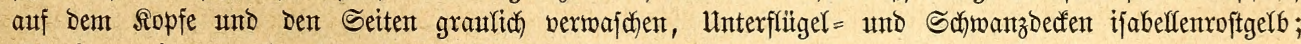

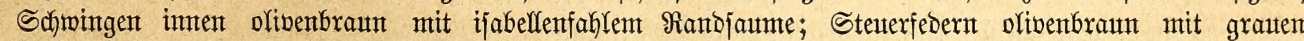

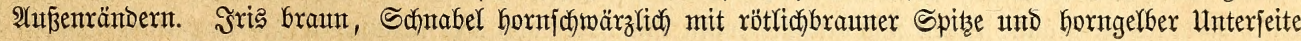

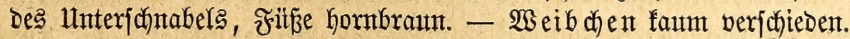

Die Şabia bewognt bas jüböftliche Srafilien, bie Blataftaten, Solivia unt Peru.

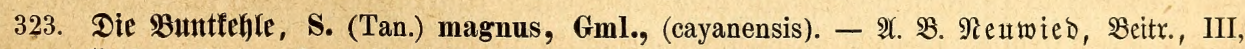

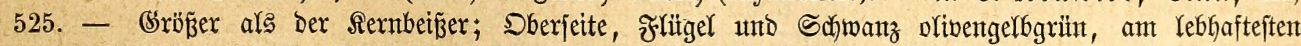

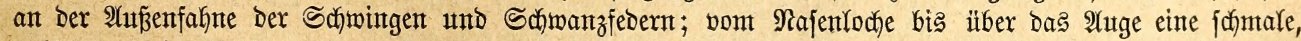

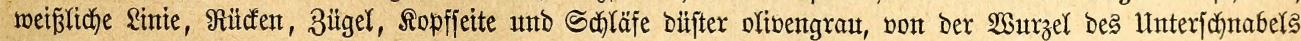

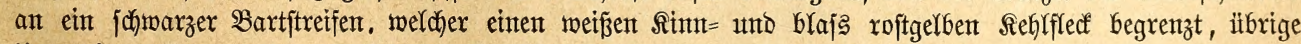

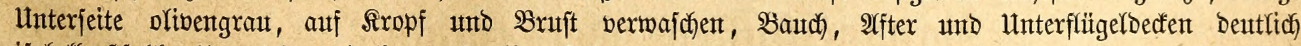

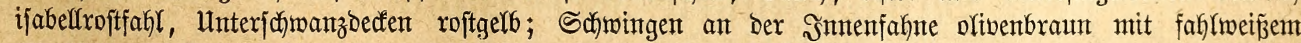

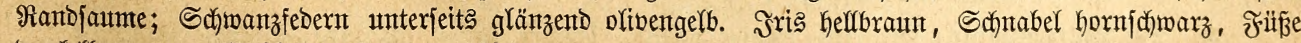
duntelbraum. - $\mathfrak{B}$ eib den faum verjofieden.

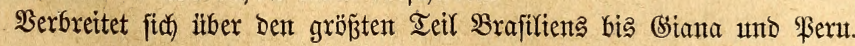

324. Die (ङrünthabia, S. olivascens, Cab., (plumbeus, icterophrys). - 2 . $\mathfrak{B}$. \&eotant , Ois.

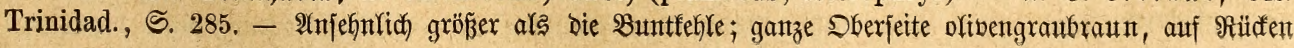




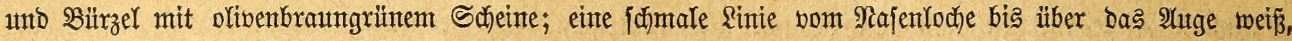

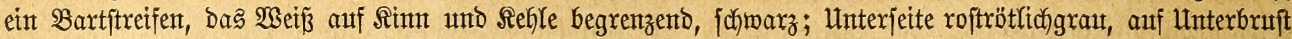

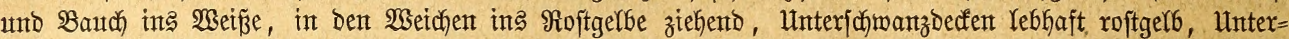

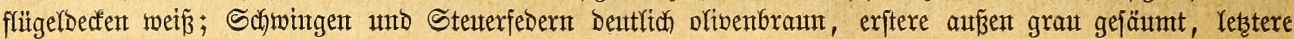

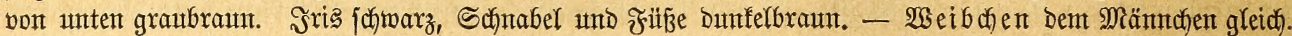

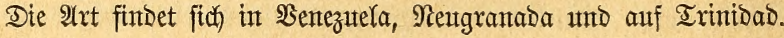

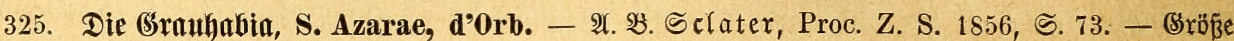

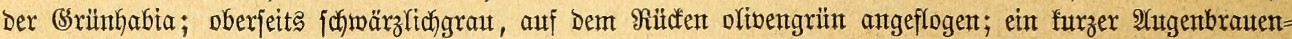

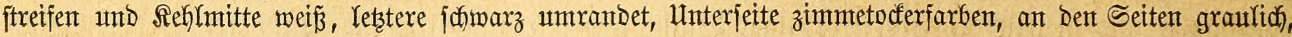

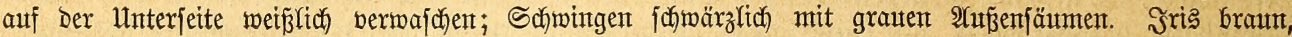

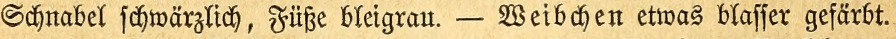

Serbreitet fich) über $\mathfrak{B}$ olitia und bie weftlicten Provinzen Brafitients.

326. Der Canpi, S. coerulescens, Vieill. - 2 . $\mathfrak{B}$. $\mathfrak{B}$ ieir rot, Nouv. dict., XIV, 105. - Sefr

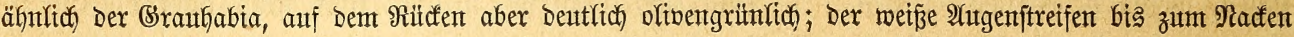
herabziefento; Sdiningen olivengrün.

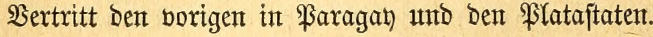

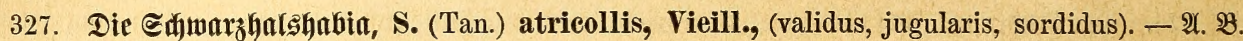

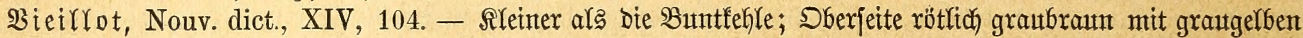

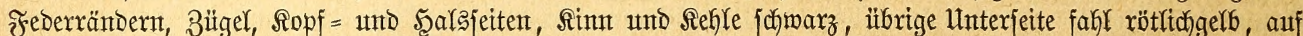

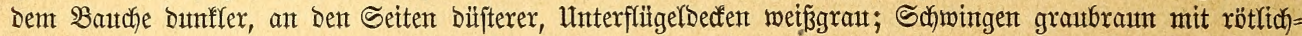

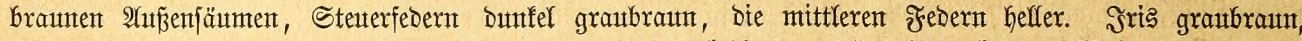

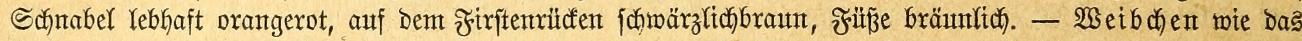

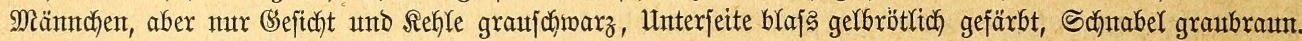

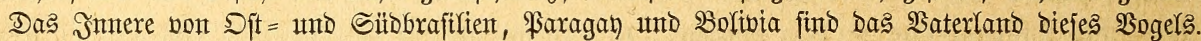

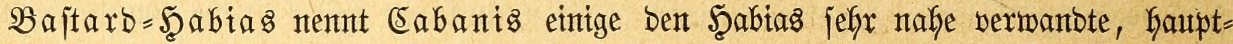
jächlichy burch ben fürzeren, mebr zujammengebrücften, längs ber Firjte ftärfer gebogenen Schnabel, bie zierlicheren, Durch bie ichlanferen Behen ausgezeidyneten Fübe unt ben etwas ipizeren und längeren Flügel von biejen unterjafiebene* $\mathfrak{B}$ ögel.

328. Der (Jraummatel, Orchestieus (S., Tan., Pit., Schistochlamys) eapistratus, Neuwied,

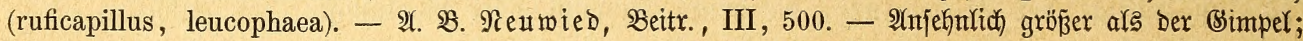

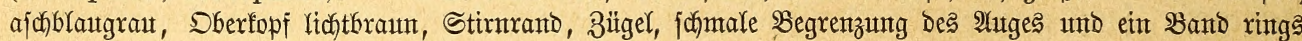

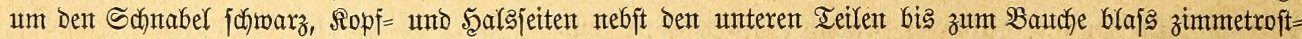

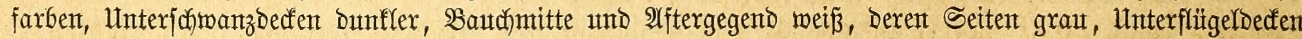

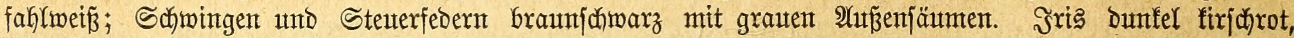

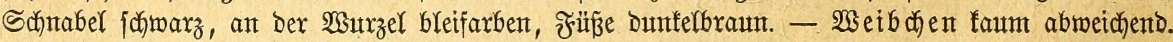

Die 2 rat bemognt bą fïböftliche Brafitten.

329. Die Saleierhatia, 0. (S., T., Schist., Nemosia, Diucopis) ater, Gml., (melanopis). -

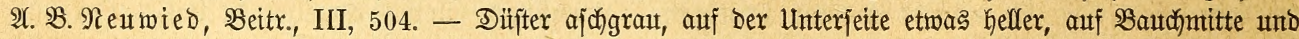

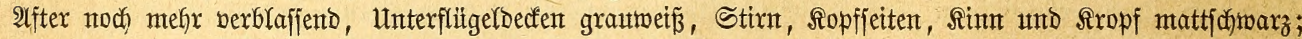

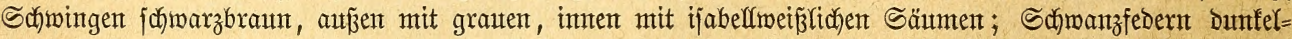

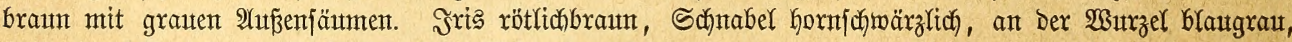

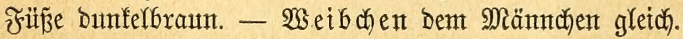

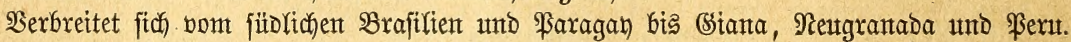

Der noch fürzere, jeitlicł ftärfer zujammengebrücfte, fajt gerabe Schnabel, bie jtarfen

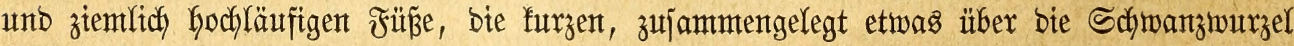

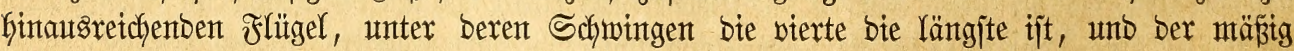
lange, jobmale, nur wentg abgeruntbete Schwant fint bie Mierfmale einter ber vorfergehenden ebenfalls jefy nabe jtebenden Sippe.

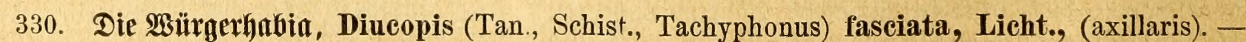

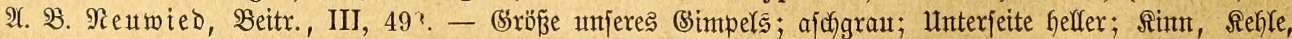

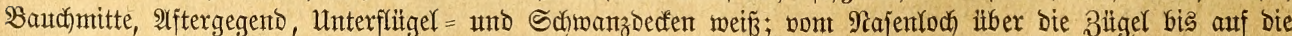

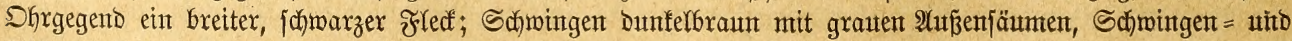

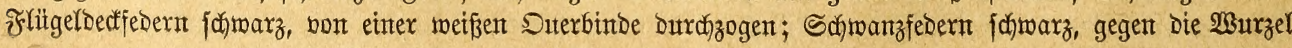




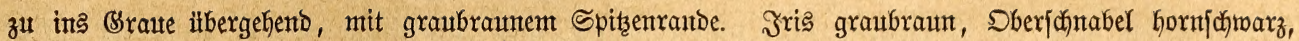

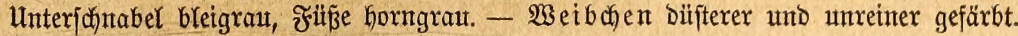

Der $\mathfrak{B o g e l}$ bewohnt bas füböftlidje $\mathfrak{B}$ rafiften.

Die Mitteilungen über bie $\Re a p a g e i f i n f e n$, weldhe wir ben reijenben Forjchenn verbanfen,

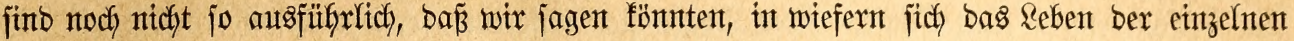

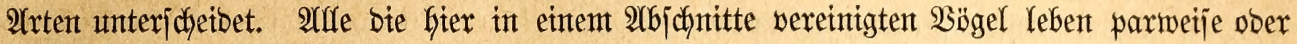

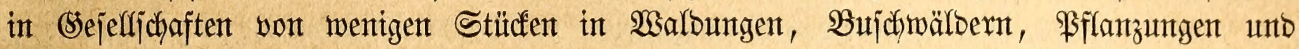

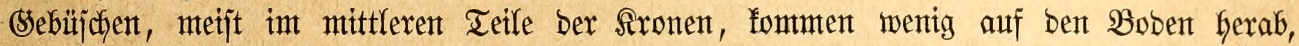

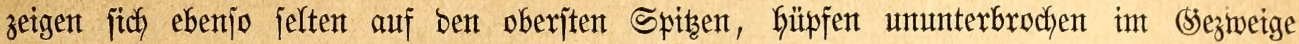

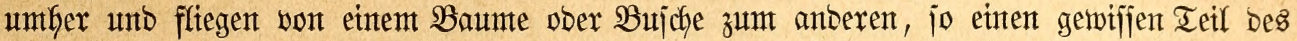

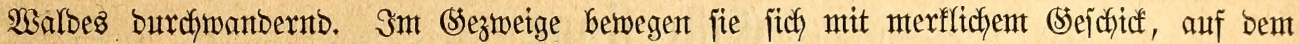

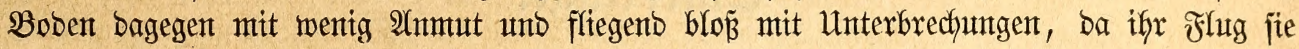

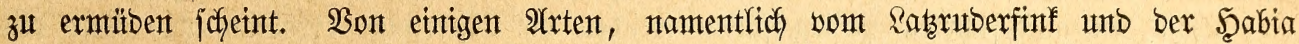
(S. similis), ber (Srautabia, Dent Capi, ber Sedfwarzhalahabia, wirb ber (sejantg gerü̈fmt; bie übrigen jollen Gächjtens einzelne woffllautenbe Iöne zunt Bejten geben, einige aber

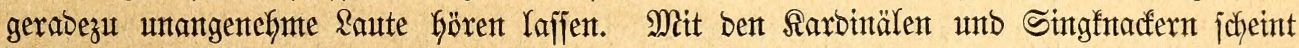

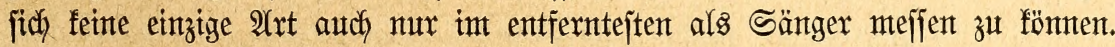

Ueber bie fortpflanzung wiffen wir wentg, bas meifte noch über Mejtbau unb Eier

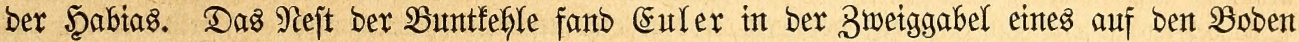

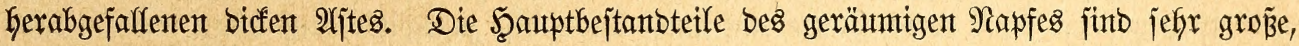

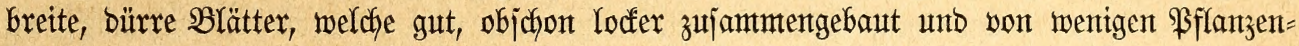

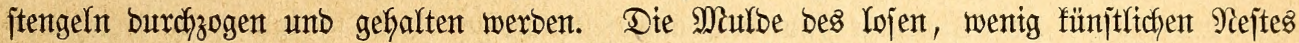

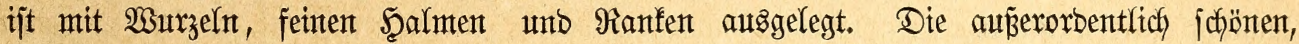

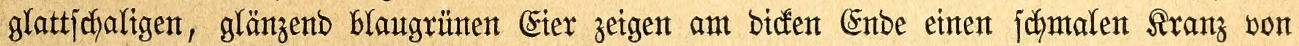

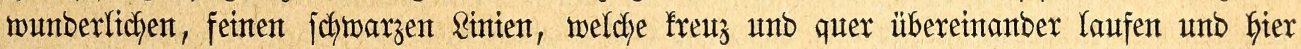

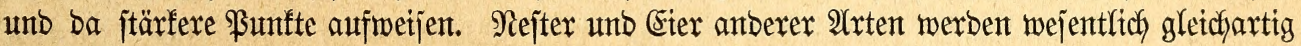
bejchrieber.

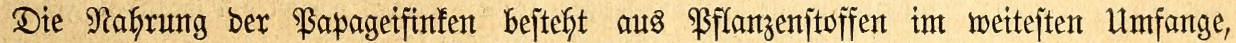
ebenfo auch aus Rerbtieren. Son eriterent verzefrent fie verjafiebente Sämereien, Berent,

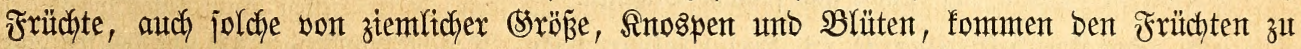

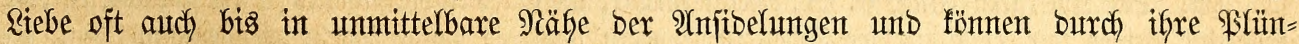

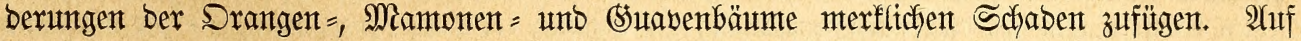

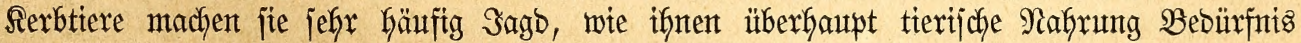

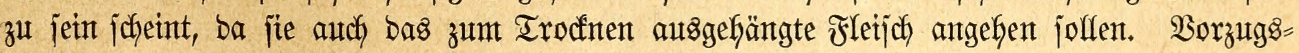

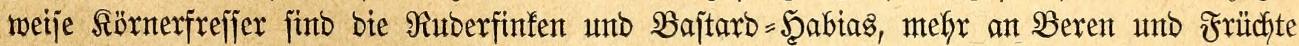
Galten fidd bie eigentlidfen Şabias; Rerbtiere freffen alfe nebenbei, ant gierigiten vielfeicht (Srau = unt Eatharzhalshabia jowie ber Eapi.

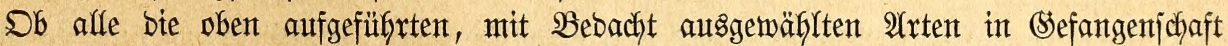
geffaltent worben finto, ftefft bafin; nach Europa fint jebenfalfs wentge von ifgnen rebent

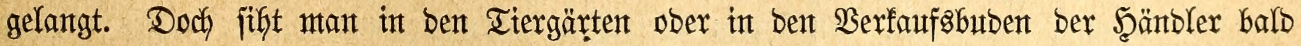

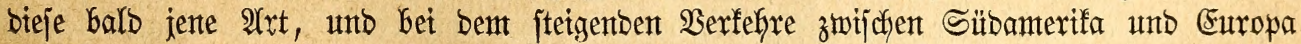

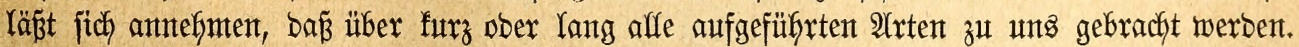
Die $\mathfrak{B} e$ gand hung ber gefangenten $\mathfrak{s} a p a g e f f i n f e n t$ ift einfact. Son mir unb Befannten gepflegte

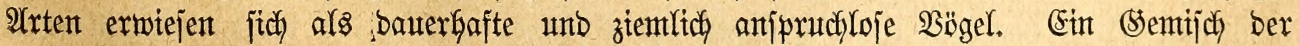

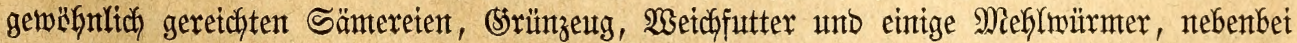
aber Dbjt, fint bie Futteritoffe, weldje mtan zu reichent hat. Früdfte fraß̧en bie von mix

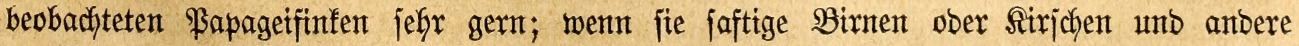

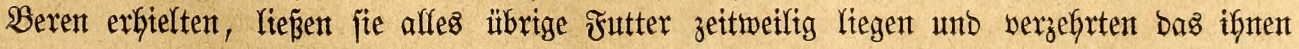




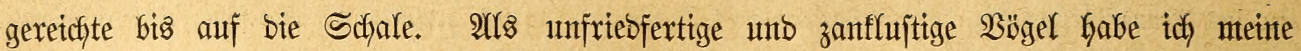
Sefangenen nicft fenten gelernt; fie befümmtern jich überfaupt wenig um bie Mitgenofjen= jehaft bes Fluggebauters unb Galten jich mefy ober minber für jich. Sin Eapi, welchen

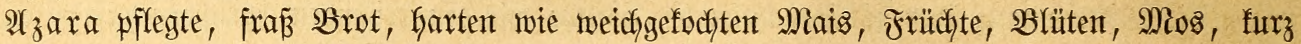
bie berjchiedenjtent Futteritoffe. Der Bogel fiel umjerem Forjcher bejonbers beshalb auf, weil er grö̈ßzere $\mathfrak{B}$ ifjen förmlich zerfautet.

Dies ijt alles, was idh über bas Sefangenleben ber beadhtenswerten Bögel zu jagen weiß̄.

\section{(El|terlintug.}

Bon ben aufgefüfrten ßapageifinfent weichen bie Eljterlinge erheblich ab. Der mit

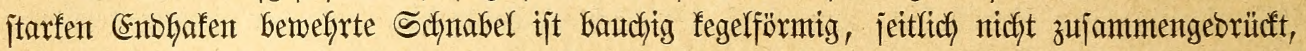
auf ber Firjte jtarf gefrümmt, ant Manbranbe etwas eingezogen, bie Najengrube bicht

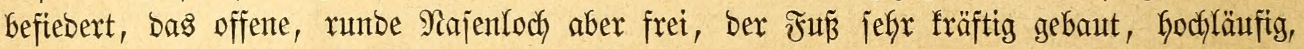
mit bünten, mittellangen Zef̧en unt großéer, ftarffralfiger Daumenzetye, ber Flügel furz,

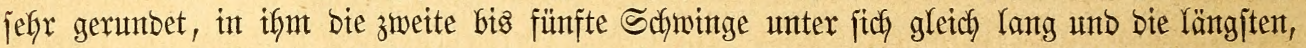

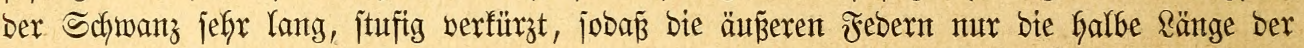
mitteljten Gaben. Das berbe, glatte, ant Sopfe unt Şarje zugejpizte, auf Stirn unb am Siunt abjtehente, jchwarz unb weís gefärbte (Sefieber verbient noch bejonberer Errwähnung, wie

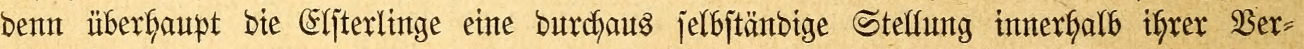
wanstichaft einmehmen.

331. Der Erfterling, Cissopis (Lanius, Corvus, Bethylus) Leverianus, Gml., (picatus, collurio).

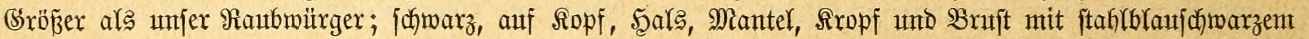

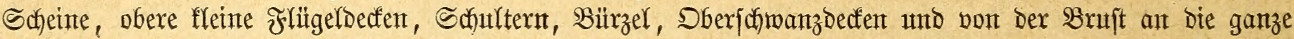

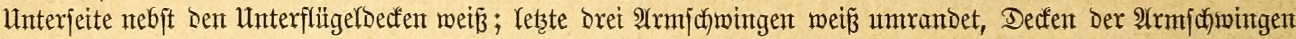

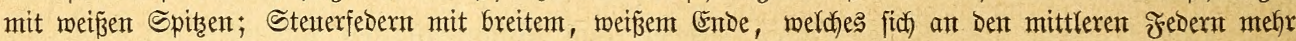

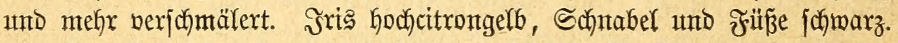

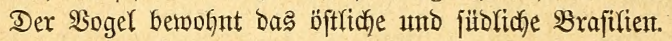

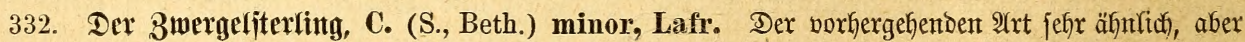
bedeutent fleinter und nicht mur bie Schultern, fondern auth) Die ganze fintere Mantelgegend weiß̄, bie

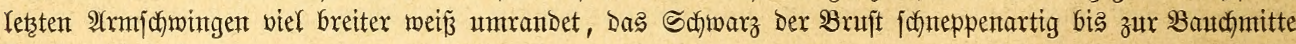
fich) herabziefento.

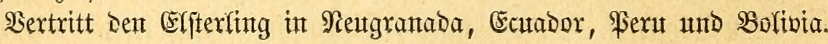

Prinz von Wied, Schomburgf und $\mathfrak{B}$ urmeijter geben uns furze Seridyte über bas Freileben ber in hohem Srabe auffaffemben Bögel. Man begegntet ifnen in ben Rïjten= malbungen, bejonbers in ben licften Borwälbern, ausnahmsmeije audh wohl in Felbern unto Pflanzungen, parweije ober in fleinen Sejerfjchaften. Sie treiben jich regelmäp̈ig in ber Mitte ber Baumfronen umber; auf bem Booen hat jie Sdyomburgf, wie ex ausbrüdflidy bemerft, niemals beobadjtet. Sn ifremt Betragen haben fie mit unjerer Erljter größere

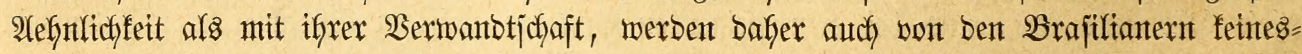
wegg zu Den Rernffnacfern, fonbern zu Den Blauraben gezäblt. Nach SBurmeijter Iafjen fie eine laute Stinme hören, welche einte furze, nicft unangentefme Melobte Gat. Shre

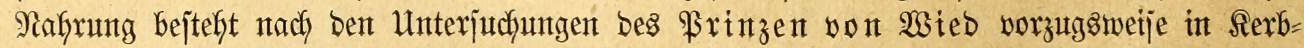

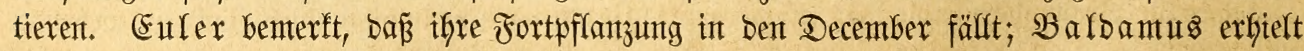

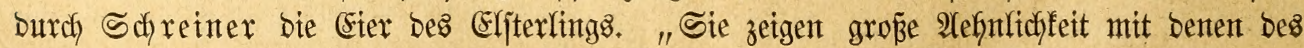

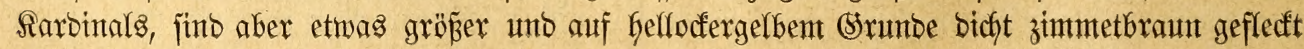
unto gejđ)nithet." 
1. Sefangene Elfterlinge babe idy im Tiergarten zu 2 (ntwerpen gejehen. Sie fallen ebenjo jefy burch ifre fdymudfe Şaltung wie burch bie eigentümliche Färbunt auf, Gaben aber jonjt

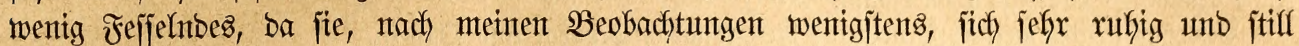

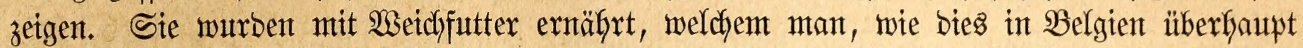
üblich, biel gefochte und geriebene fartoffeln beigemijaft hatte. Sb jie zu ben bauterbaften Räfigbögeln gehören, wermag ich nicht anzugeben, ba Jeerr Befemanz, ber Reiter bes genannten (Sartens, fich) über berartige Dinge nicht näher auszulajfen pflegt; bod) glaube

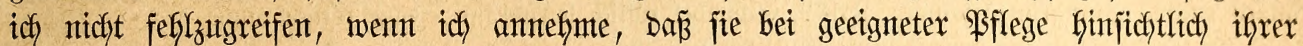
Dauerhaftigfeit feinesmegs finter ben Berwandten zurüdfitefen werben. Eine grope Zierbe

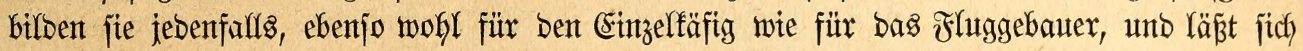

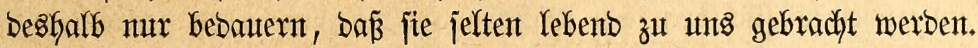

\section{Ammethabias.}

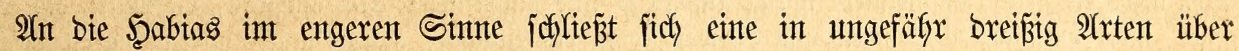
Sïbameriffa verbreitete (Sruppe von Sernfnadern an, von benten wentigjtens bie am Käufigjten vorfommenden 2 rten in unjerem Butbe einen Plats verbienen, weil jie jamt und jonders

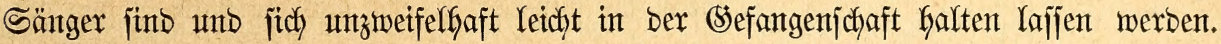

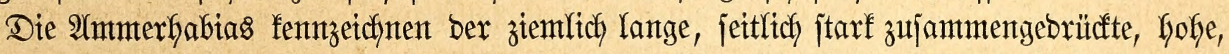
fein zugejpizzte, an ber Spibe leidyt gebogene Sdynabel ofne Rerbe, aber mit beutlich ein= gebogenem Mantoranbe, bie hodjläuftgen Füß̈e mit langen Behen, unter benen fich ber Daumen burch jeine Ränge unt bie fanft gebogene Sraffe augzeichnet, bie furzen Flügel,

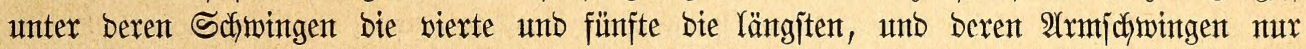
menig fürzer als bie Scanbjaymingen finb, ber lange, merflich zugerunbete Sdywanz unb bas reiche unt weiche Sefieber, Deffen Färbung auf Der Dberjeite vorberjchent grün, auf ber

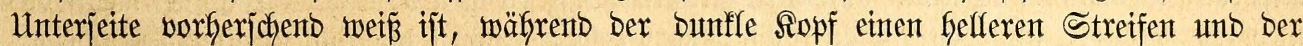

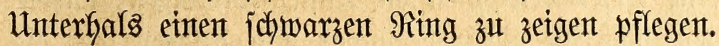

333. Die $\mathfrak{2}$ mmerhabia, Arremon (Tan.) silens, Bodd., (torquatus). - $\mathfrak{A}$. $\mathfrak{B}$. Bi cifrot, Gall.

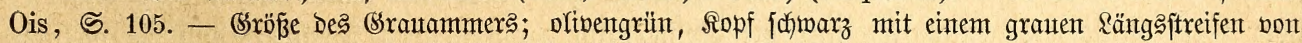

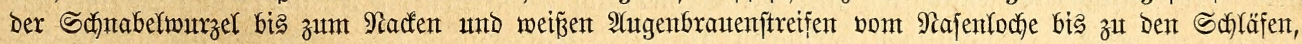

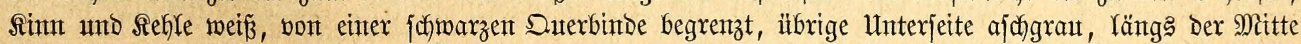

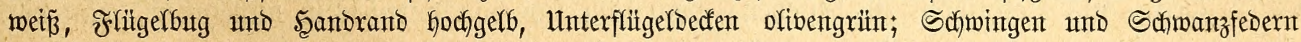

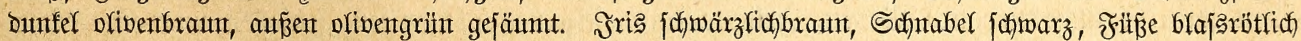
bleifarbent. - 2 seibden ofne Dentfiche Sropfquerbinde, auf Der Unterjeite roftifabelf verwajchen.

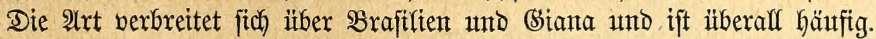

334. Die Buntfopfhabia, A. semitorquatus, Swsn. - $\mathfrak{A}$. $\mathfrak{B}$. Swainjon, Anim. in menag.,

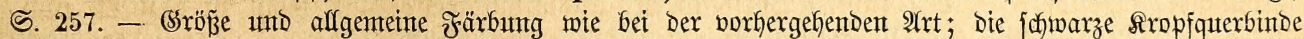

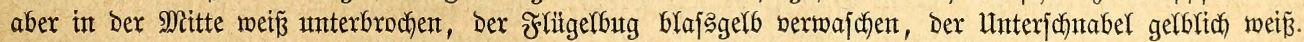

Bemohnt Das jüblidese Sraftitient.

335. Die (Gelbidnaberhabia, A. flavirostris, Swsn. - $\mathfrak{A} . \mathfrak{B}$. Swainfon, Anim. in menag.,

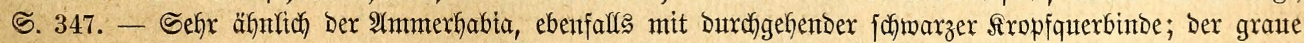

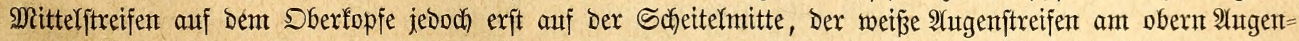

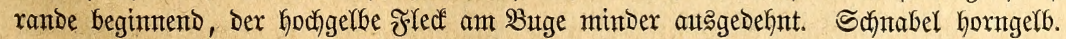

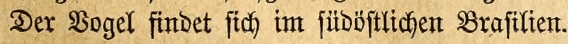

336. Die Braumuafenhabia, A. (Embernagra, Buarremon) brunneinuchus, Lafr., (frontalis,

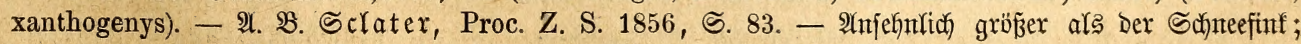

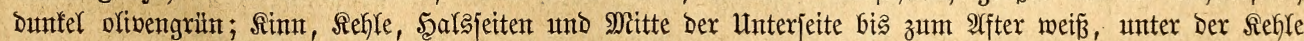

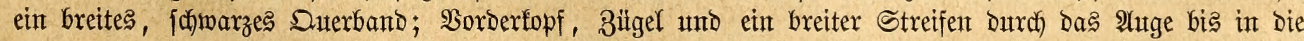

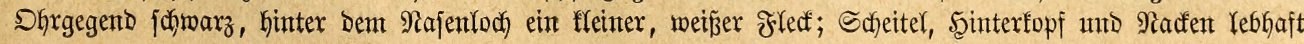




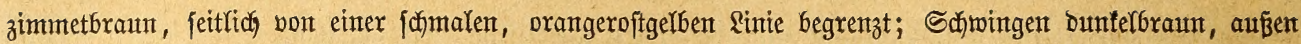

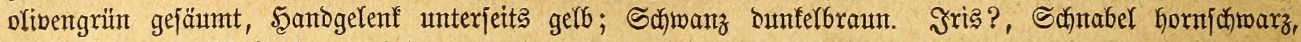
Fü̈ß̉e braun. - Weibctent unbefant.

Bemofnt Mittelamerifa, Senezuela, Mengranada, Ecuador uno Dftperu.

337. Die Rötelfabia, A. (Tan., Buarr., Pipilopsis) semirufus, Boiss. - $\mathfrak{A} . \mathfrak{B}$. Sclater,

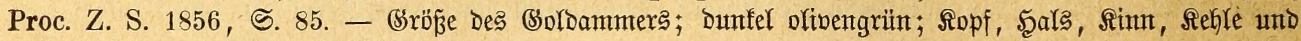

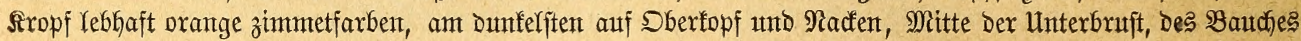

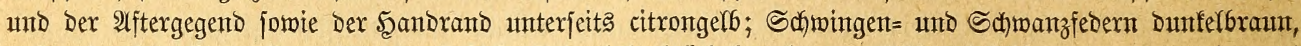

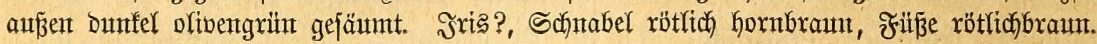

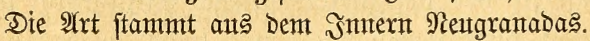

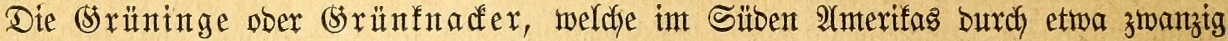

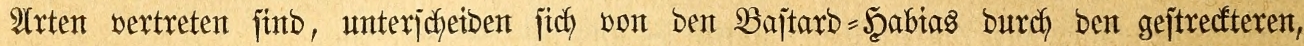
idhlanferen Sdynabel, bie längeren Flügel, unter beren Schmingen bie britte bis fünfte bie längiten fintb, unb ben weniger gerunbeten ऽcywanz.

338. Der (Snd Dferlgrüning, Chlorospingus (Pipil.) flavigularis, Sclat. $-\mathfrak{A}$. $\mathfrak{B}$. Contrib. to

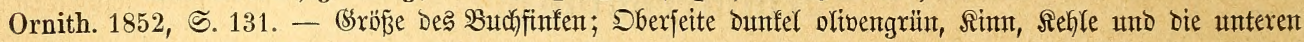

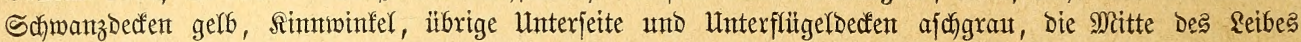

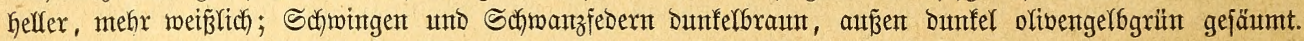

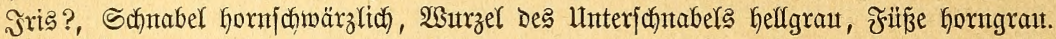

Die $\mathfrak{A}$ rt bewofnt Mengranada.

339. Der $\mathfrak{B r a t e n g r u ̈ n}$ th, Chl. (Arr., Pipil.,T., Nemosia, Hemispingus, Hylophilus) superciliaris,

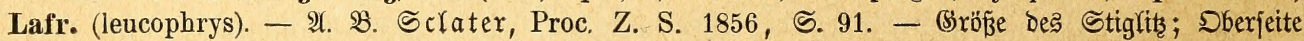
ofibengrün, Borberfopf uno Scheitel grau, jeberjeits von einem meißen 2 ugenbrautenftreifen begrenzt, 3ügel

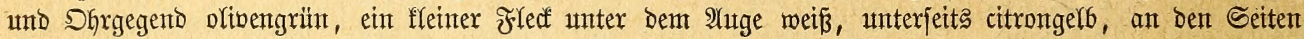

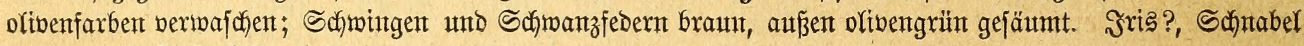

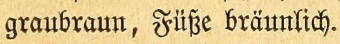

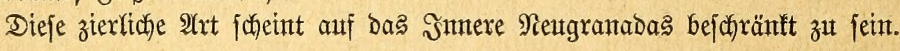

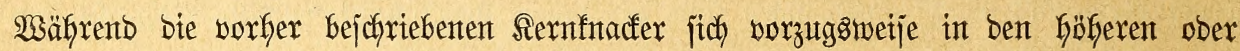

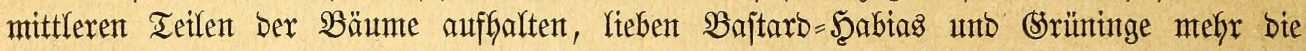
nieberen (Sebüjche und Den Boben. Einzelne Âten berwoknen bie Süjtentwaldungen, andere

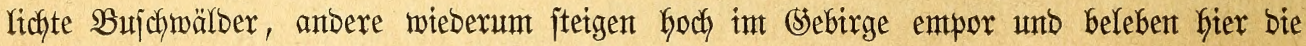
frijchen, feuchten Beftänbe. Heber ihre Bemegungen finbe ich feine aubfüfyrliche Ifngabe,

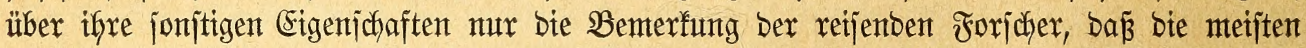

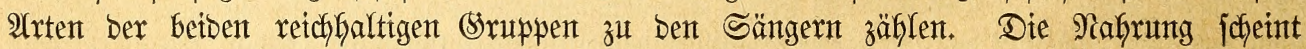

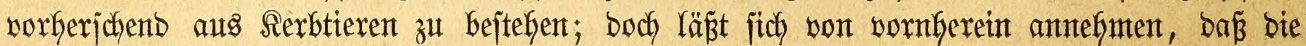
einen wie bie anberen audh Beren, Früchte und einzelne Sämereten gentepen merben. Den

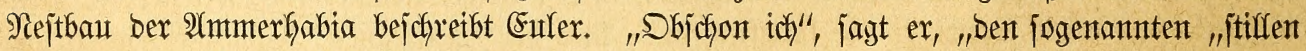

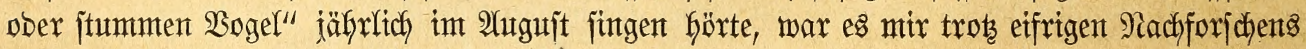

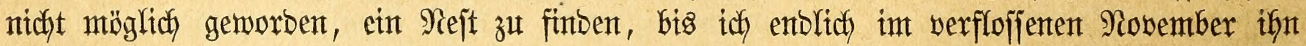
auf ben Eient ertappte. Sein Baut iteft ant Boben im Difficht, entweber in einem (Sras= büjchel ober in einem Şaufen $\mathfrak{B}$ lättex verjtedft, uno bejteft aus einem geräumtigen, üferbachten Napfe, beffen meite Seffmung etwas nach obent gefebrt ijt. Das Nejt ijt imt Berhältnis zum $\mathfrak{B}$ ogel überrajchento grof̉, einte raumbaltige $\mathfrak{A}$ njammlung bürrer $\mathfrak{B f l a n z e n j t o f f e . ~ D i e ~}$

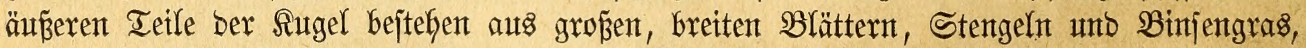

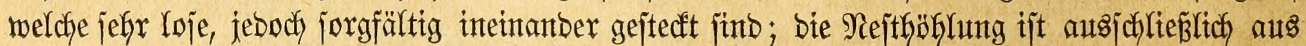
jehr feinen $\mathfrak{B u r z e l f a j e r n ~ w e r f e r t i g t ~ u n b ~ j i t z t ~ w i e ~ e i n ~ R e r n ~ i n ~ b e m ~ a ̈ u ß ̈ e r e n ~ S t o f f e ; ~ i f r e ~}$ Wänbe jinto vorzüglich bicht geflochten unb jchön glatt gebrüdft. Das (s)anze ruft auf einer

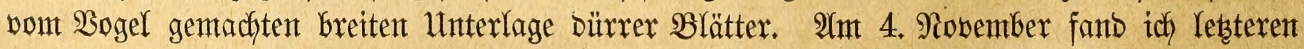

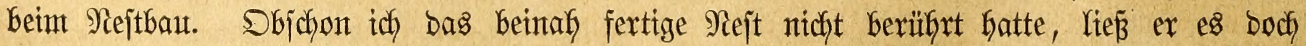

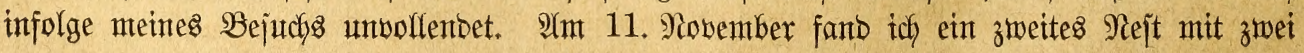




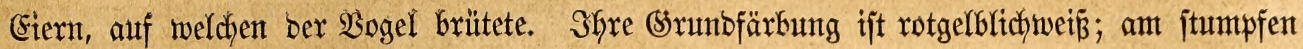

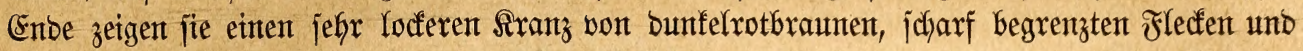

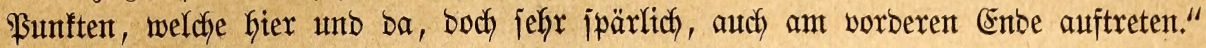

Ueber bie Befangenfaltung ber gebadten $\mathfrak{B o ̈ g e l}$ vermag ich feine 2 (ngaben zu machen.

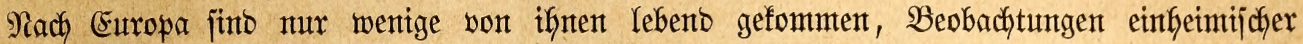
Siebhaber ober ber reijenbent Forjher über ifhr Bsefangenteben meinez wsiffenz nicht

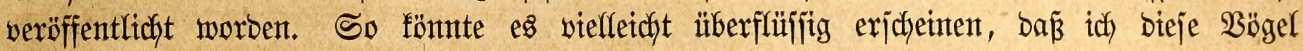
überfgaupt in unjerem Butche aufgenommen Gabe, iprächen nidgt umjere Exfahrungen über bie von Safr zu Safr fidf fteigernbe Zufuffi bagegen. Mir lag ez vorzugameije baran, auf bie amjechentent viel veriprechenben Sänger aufmerfjam gemadjt zu haber.

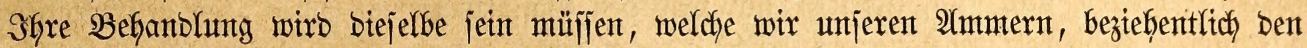

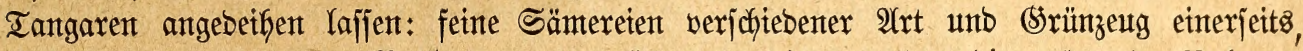

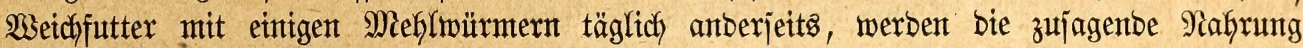

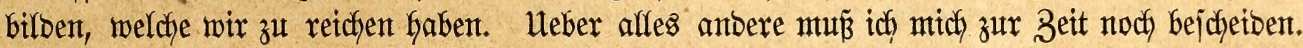

\section{Tantament.}

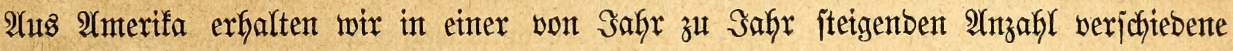
Mitglieber ber reidjhaltigen Familie ber Tangaren. Sie fint aus̆nafmbloz anjprectent

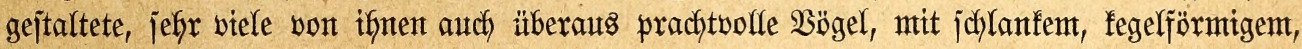

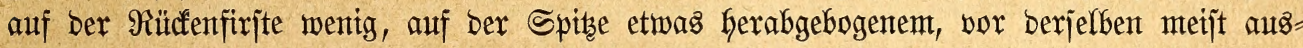

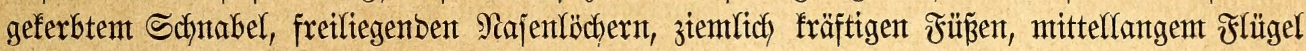

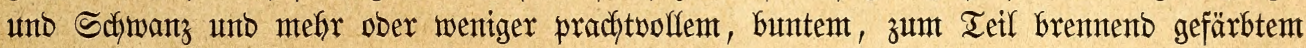

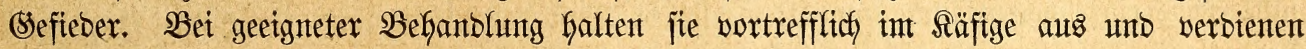
baher bie Beachtung ber Riebfaber in Gohem Maáe.

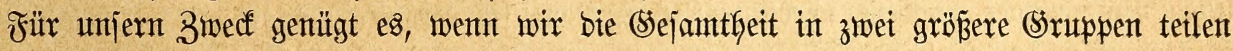

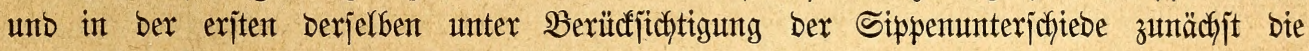
cigentlictjen Tangaren zujammenfajient.

Der jefr gejtrecte, nach vorn zujammengebrüctte, am Entoe etwas herabgebogene

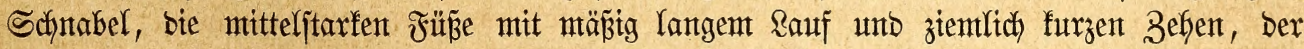

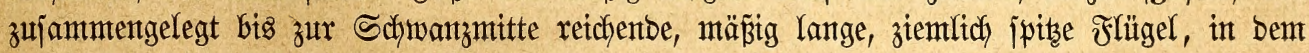

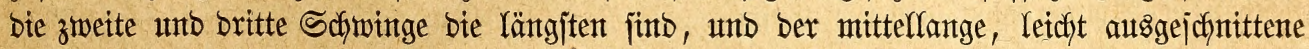
Sajwanz fentzeirfhnen bie Sippe ber şarbtangaren, won benten man gegentuärtig etwa zmölf $\mathfrak{A}$ trtent fentt.

340. Die Mionta)tantgara, Nemosia (Tanagra, Hylophilus) pileata, Boddaert, (cyanoleucus,

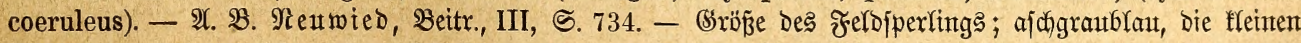
Dberflügeldeden Deutlicher blau, Sberfopf, Schläfe, Shrgegend und ein breiter Streifen an Den Scalsjeiten

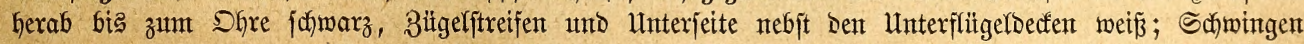

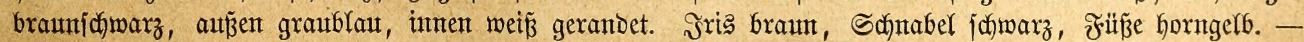

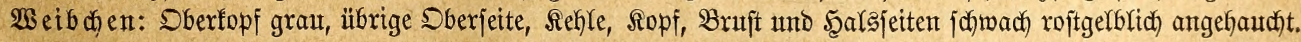

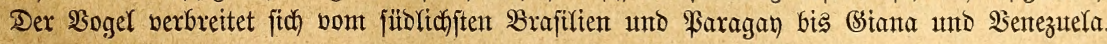

341. Die Barttangara, N. (Sylvia, Motacilla, Tan, Hyloph., Hemithraupis) guira, L., (nigrigula,

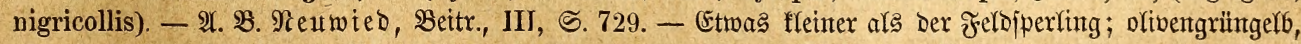

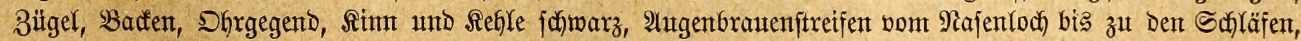
breite Einfafjung Der Badfen uno Unterjdwanzbedfen citrongelb; Sropf, Brujt und Bärzel zimmetorangefarben,

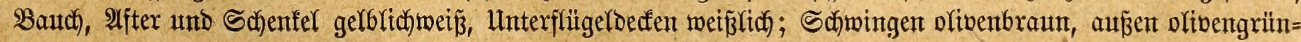

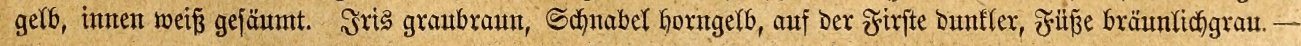




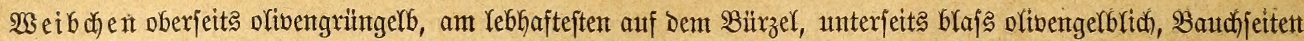
mefrix grau, Unterichmanzoeffen gelf.

Das jüböftliche Brafilien und Faragay ift bie Seemat biejer $\mathfrak{2}$ (rt.

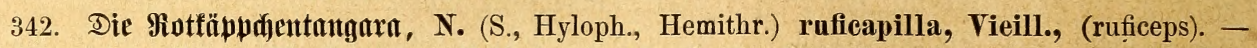

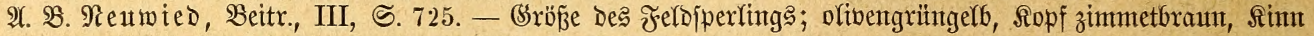

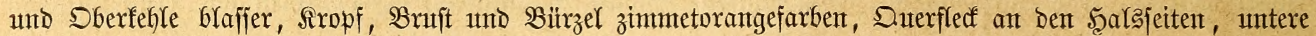

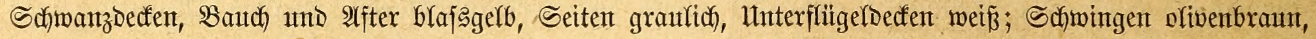

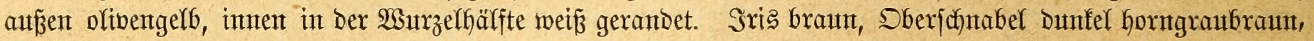

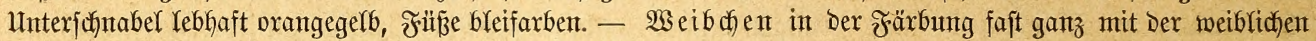
Barttangara übereimftimment.

Bemohnt Da: 2 Garbgebiet des z̈ftlichen Brafitien?.

Der etwas gejtrecttere, längs Der Firjte jtärfer gebogene Schnabel, Dejien oberer Ieth

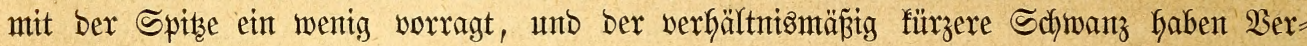
anlajjung gegeben, bie nachfolgenbe 2 rt unter bem Namen (5) Yanztangaren zur $\mathfrak{B e r}=$ treterin einer Sippe zu erkebent.

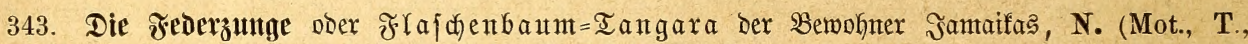
Tanagrella, Tachyphonus, Pyrrhulagra, Neornis, Glossiptila) rufieollis, Gml. - $\mathfrak{A}$ : $\mathfrak{B}$. (Soffe, B.

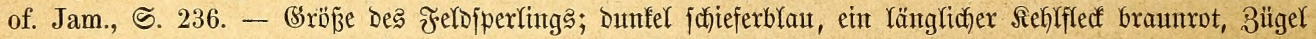

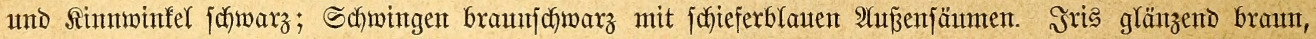

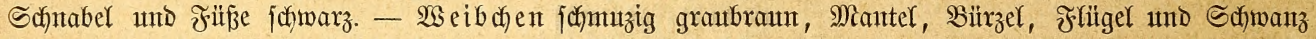

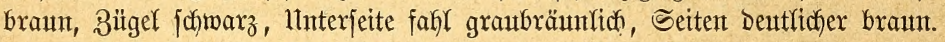

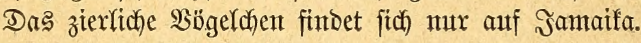

Die Arontangaren haben emen etwas bidferen und baudfigeren Schnabel als bie (5)lieber ber vorkergehenten Sippe, beffen Sherfieferranto eingebogen, Der Firjtenrühfen janft gefrümmt, Die Spizze Gerabgefrümmt ijt and vor ber Yetzteren eine fchmache Sierbe zeigt, zierliche

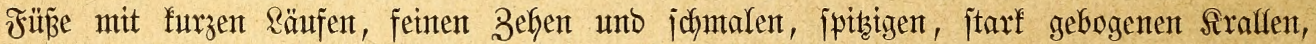

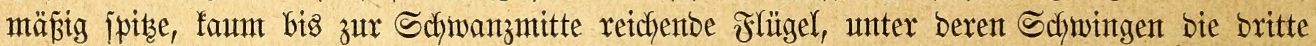
und vierte bie längiten jint, langen, reidjt abgerunbeten, jeitlich etwas verfürzten, ftumpf zugejpibsten Schwanz und volles, Derbes, auf Dem Sberfopfe beim Miänndyen meift hauben= artig verlängertes unb fier brennenbrot ober gelb gefärbtes (sefieber.

344. Dir Sajmarztangara, Tachyphonus (Oriolus, T., Pyrrota) melalencus, Sparm., (nigerrima,

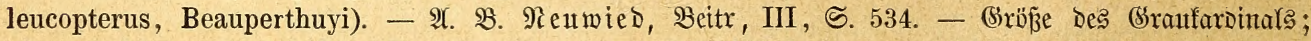

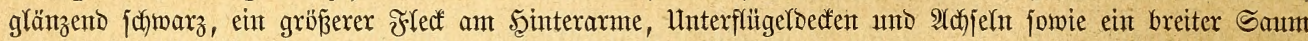

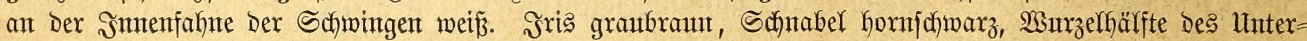

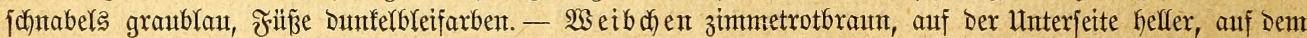
Schmanze am rebhafteftert.

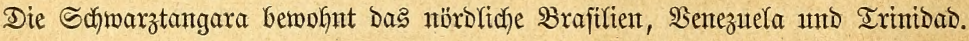

345. Die Trmuertatgara, T. (Pyranga, Lanio) luctuosus, d'Orb., (tenuirostris, albispecularis). -

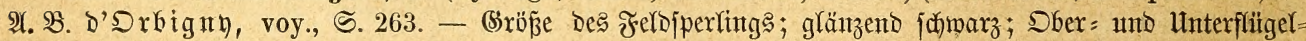

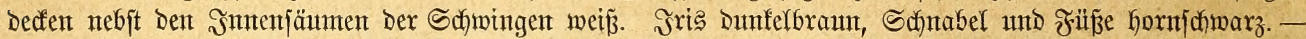

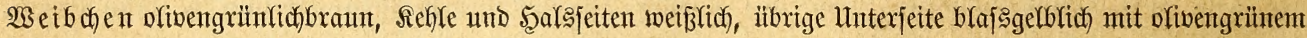
Anfluge.

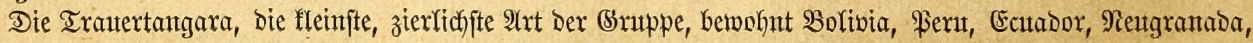
Irinidad and Tabago.

346. Dic Rrontantgana, T. (T., Pyrr., Agelaius) coronatus, Vieill., (coryphaeus, Vigorsii). -

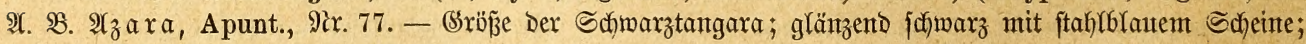

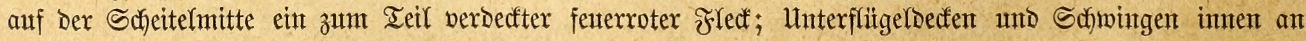

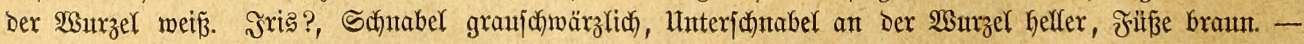
פseibchen roftbraum, unterjeits roítgerb, Dberfopf graubraum, Shroecten grau.

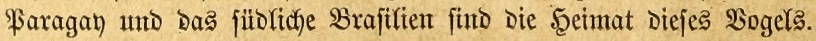

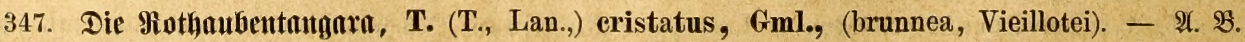

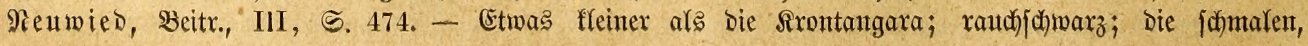




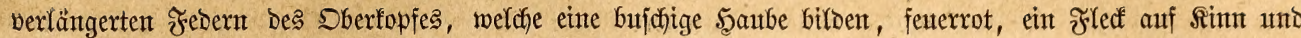

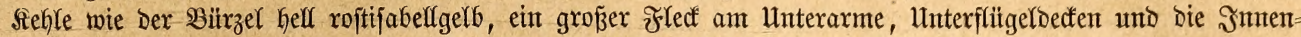

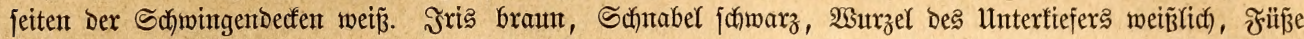
bleigraut. - Weibchen ungebaubt, Yicht roftbraut, am Yebhafteften auf Dem Bärzel, llnterjeite rebhait zimmetroftgelb, S(h)tabel rötfich)braun.

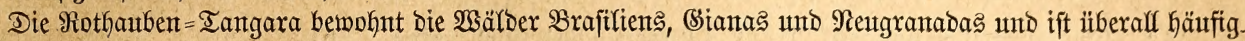

348. Die Gtafltatgaxa, T. (Merula, Turdus, T., L.) surinamus, Briss., (surinamensis, martialis,

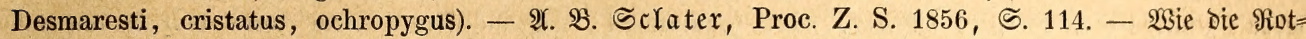

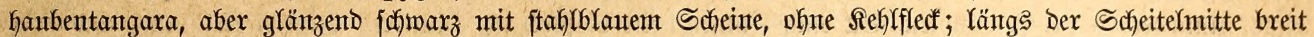

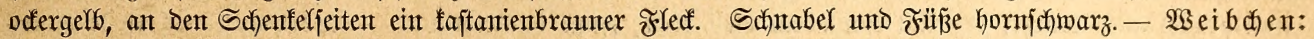
oberjeits oliwenfarben, fopf grau mit oliwenfarben verwajchener Sdyeitelmitte, Angenring uno Dhrgegeno gelb, Unterjeite hell rojtgelb, alftergegend mehr gelblich.

Die Seimat ift das nöroliche Srafflien, Siana mo Surinam.

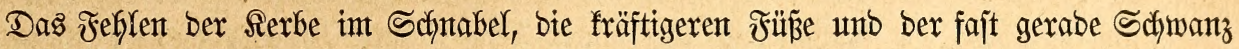
bilbent bie Mierfintale einter bejonberen Unterjippe.

349. Die Sf)malbentungaxa, T. (T., Leucopygia, Cypsnagra) ruficollis, Licht., (hirundinacea,

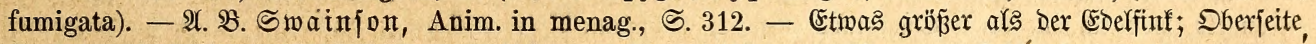

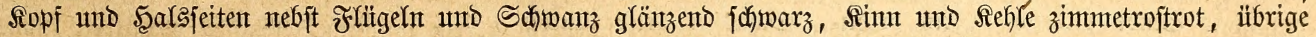

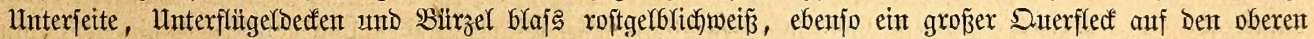

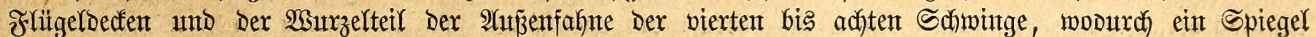

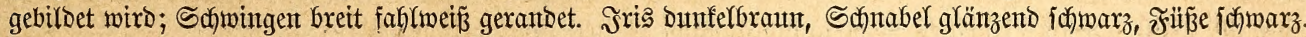

Brafilten uno Bolivia finto die Secimat biejer $\mathscr{A}$ rt.

Der etwas fürzere, gebrungenere Schnabel unb bie eigentümlich gebilbeten Nacfenfebern, weldye Gier in harähnlliche Schäfte außlaufen, gelten als Mierfmale ber Borjtentangaren.

350. Die 5axtatgaxa, T. (T., Muscicapa, Trichothraupis) quadricolor, Vieill., (melanopus,

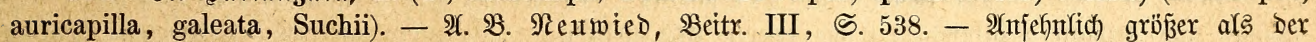

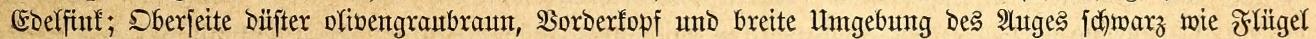

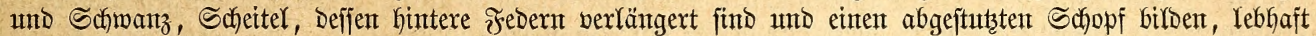
gologelb; Unterjeite zart ijabellzimmetfahl, Interjabmanzbecten Dunflex, an Den Seiten olivengraubraunt

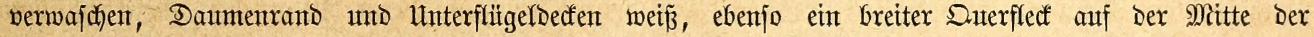

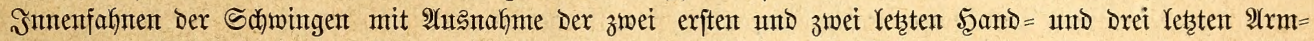

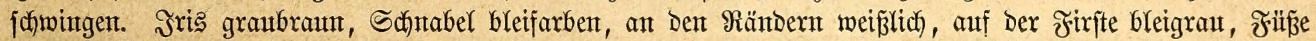
bleigrau. - $\mathfrak{B} e \mathrm{ib}$ d)en mit einfarbig oliventgraubrautem Dberfopfe.

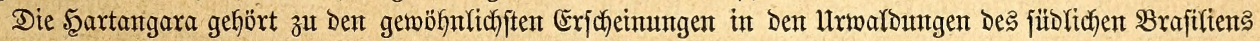
und Faragay.

Bei ben Feuertangaren ijt ber Sdynabel bidf fegelförmig, unt zwar jeber Riefer

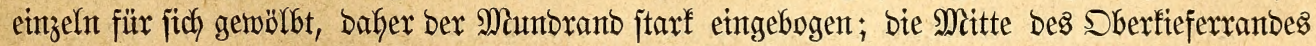

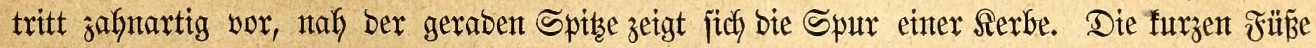

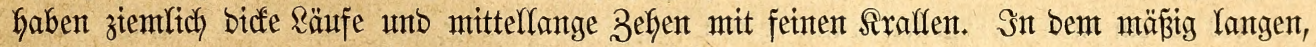
zujammengelegt bis zux Schwanzmitte reichenten Flügel ijt bie zmeite Schninge bie längjte;

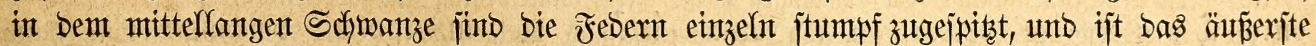

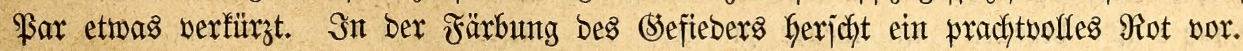

351. Die Sdjaxladjtautgara, Pyranga (T., Phoenicosoma) rubra, L., (erythromelas). - $\mathfrak{A} . \mathfrak{B}$.

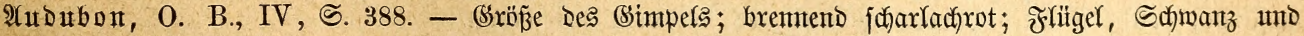

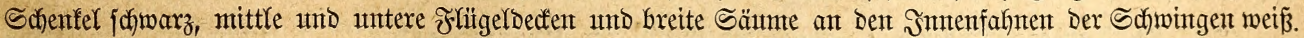

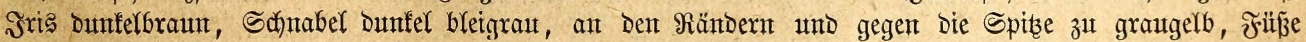
braut. - Weibc)en olivengrün, unterjeits olivengelb, Baud) uno unterjabanzbecfen lebhafter gelb, Jlügel

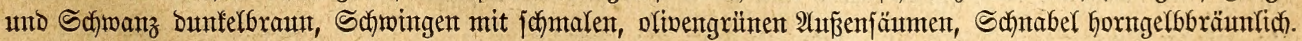

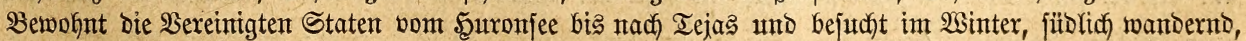

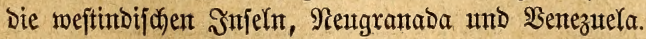

352. Dex Gommerrotuogel Der 2 merifaner, P. (T., Lox., Muscic., Phoen.,) aestiva, Gml., (rubra,

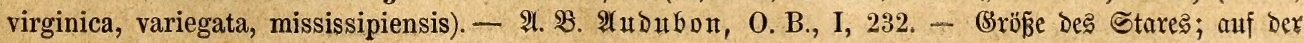


Iangarett.

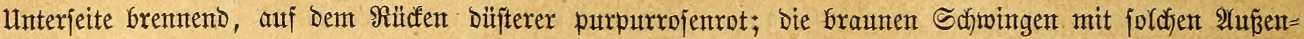

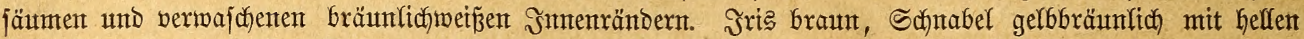

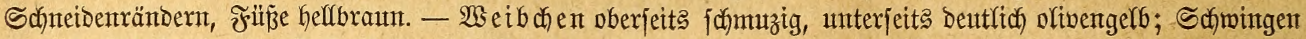

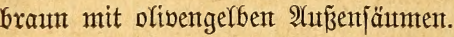

Dả Serbreitungaggebiet ift basfelfe wie bei ber Scharfachtangara.

353. Die 3imnbertmenara, T. (T., Phoen., Saltator) saira, Spix, (ruber, flavus, Azarae,

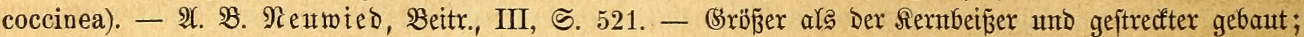

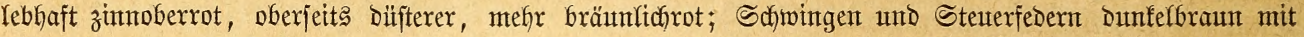

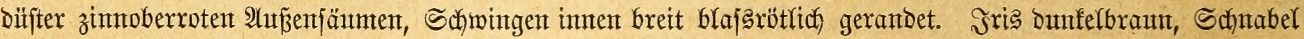

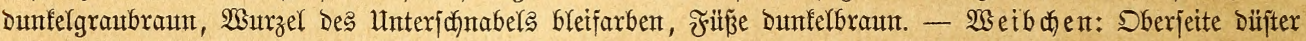
ofivengelbgrün, 3ügef und Unterfeite rebhaft gelb, an Den Seiten olivengrünfich verwajdjen; Safwingen

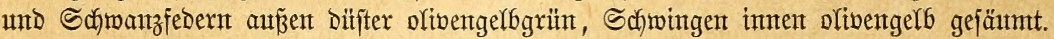

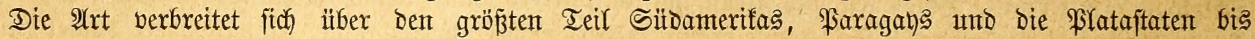
britijac) (Biana.

354. Die Groldotatgara, P. (T.) ludoviciana, Wilson, (columbiana, erythropis). - Wergl. $\mathfrak{B}$ irf

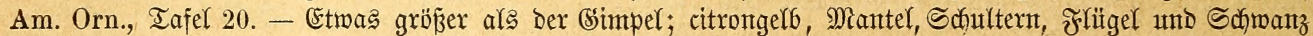

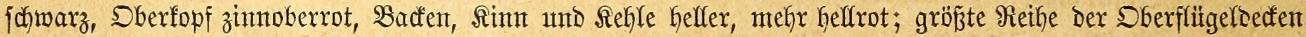

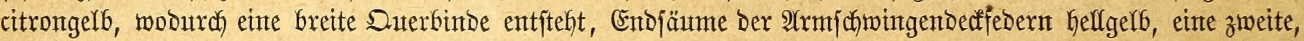

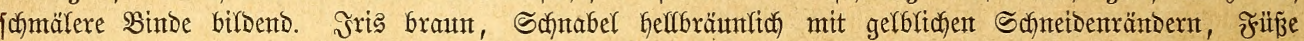

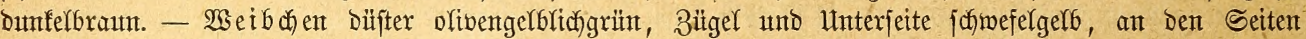

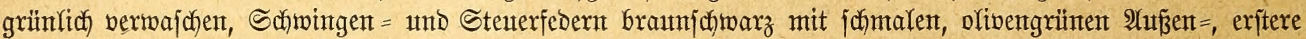

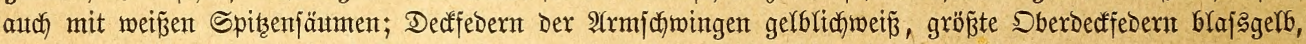
am Ende wein, wodurch zwei Suterbindent entitefen; Sdjnabel heller, Der untere Gorngerb.

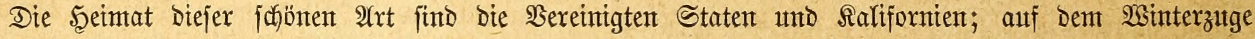
berïfrt jie Mittelanterifa und $\mathfrak{G e f t i n d i e n . ~}$

355. Die Rotfopitangaxa, P. rubriceps, Gray, (erythrocephala). - 2 . $\mathfrak{B}$. Sclater, Proc. Z. S. 1856 , S. 125 . - Der Goldtangara fehr ähnlid, aber Der ganze Sopf und Şałs büiter zimtoberrot,

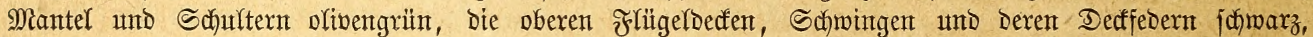

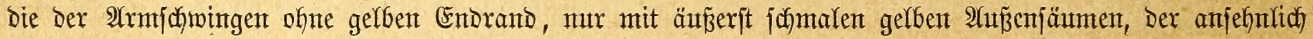

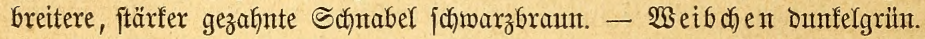

Das Saterfand ift Neutgranaba.

356. Die Bintoentangana, P. (Phoen,) ardens, Tschudi, (bivittatum, erythromeles). - $\mathfrak{A} . \mathfrak{B}$.

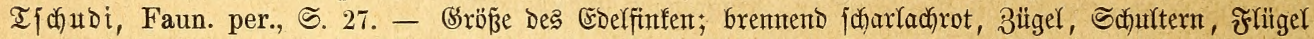

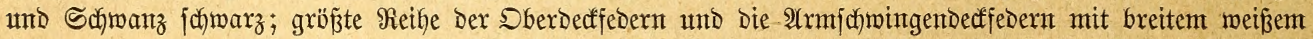

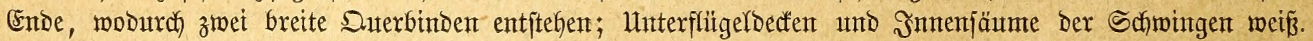

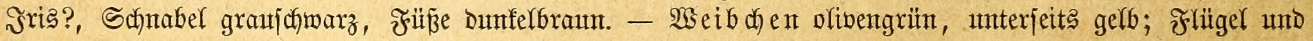

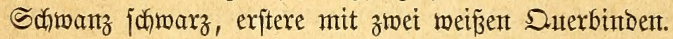

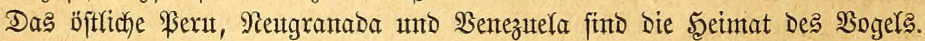

Die Schwielentangaren fentzeidynen fid vornefmlich burch ben biden, Gohen, an ber $\mathfrak{W u r z e l}$ baudfig angejdymolfenten und fier anbers gefärbten Unterfiefer, außerbem burdy ben etroas einmärts gebogenten Rand bes Sberfiefers ofne Bafn. Die fleinen Jübe haben

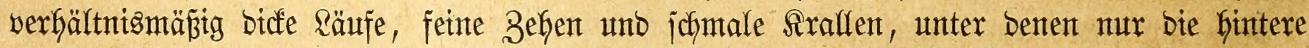

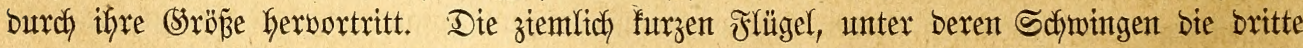
bie längjte ijt, bebecfen zujantmengelegt etma bie Şälfte bes beträchtlich langen, jettlich merffich verfürztent Schwanzes. Das (Sefieder ijt bei Dem Miännchen nicht blos prachtwolfer gefärbt, jonbern auch) Derber gebaut alz bei bem 2 seibchen.

357. Die Tapiranga ober Tije piranga bex $\mathfrak{B}$ rafitianter, Rhamphocelus (T., Rhamphopis) brasilien-

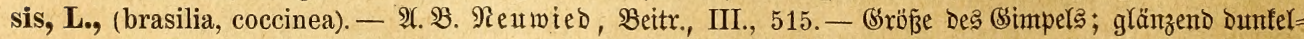

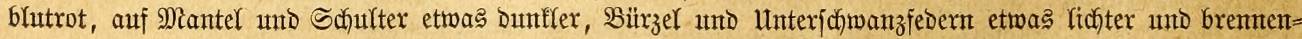

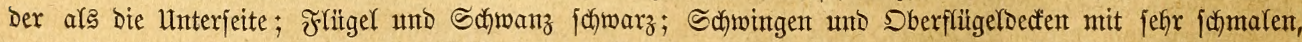

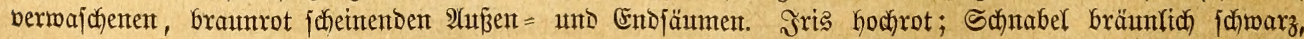

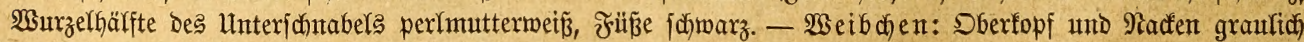

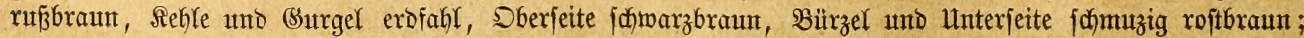

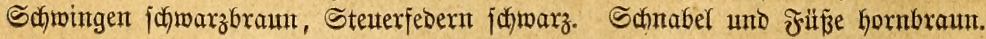




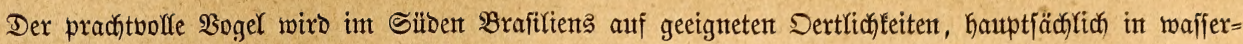

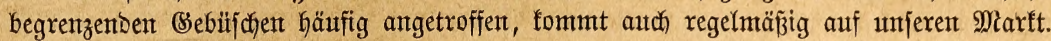

358. Die Sammettangara, R. (T., Rhamph.) nigrigularis, Spix, (ignescens). - 1 . $\mathfrak{B}$. Spix

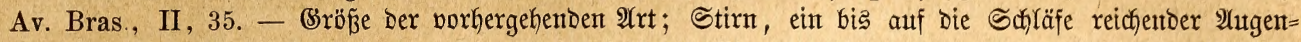

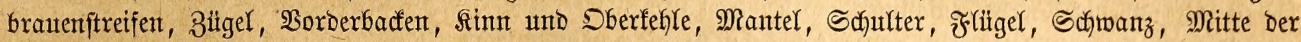

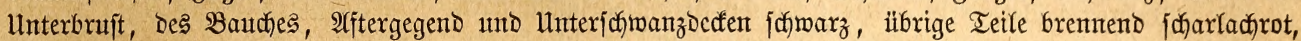

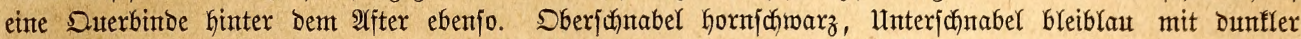

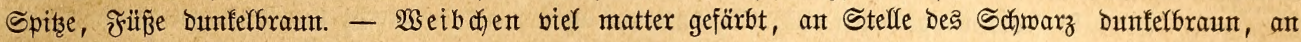

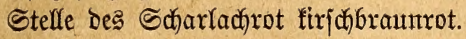

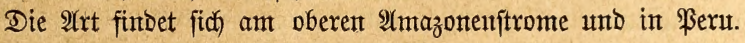

359. Die \$urpurtangara, R. (T., R.) jacapa, L., (albirostris, purpureus, atrococcineus). -

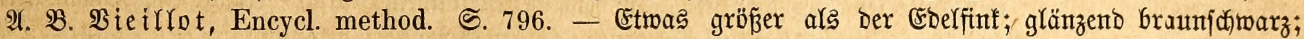

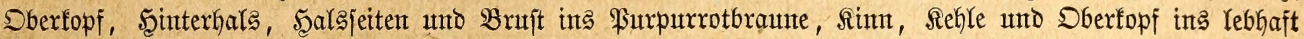

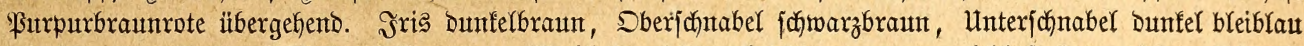

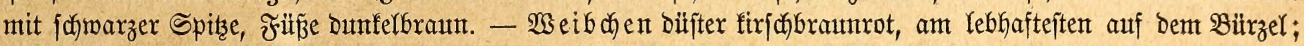
Sdiwingen = 1tmo Sdjwanzfebern fojwarzbraut.

Die \$urpurtangara ift eine ber häufigften $\mathfrak{A}$ rtent bes nörolichent Braftliens utto Biantas.

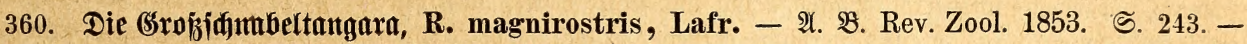

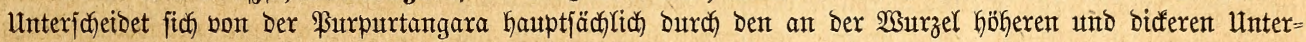

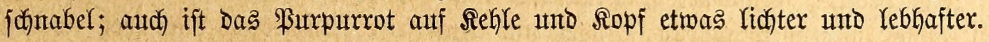

Die Secintat fackeint fich) auf bie Injel Trinidad zu bejdränfen.

361. Die Bluttangara, R. (T.) sanguinolentus, Less. - 2 . B. Cent. Zool. S. 107. - Faft fo

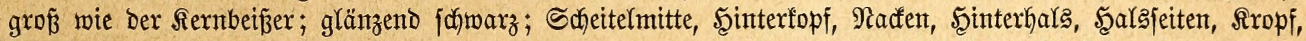

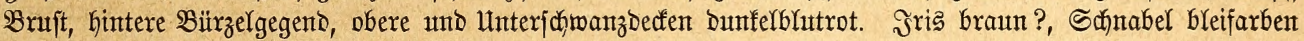

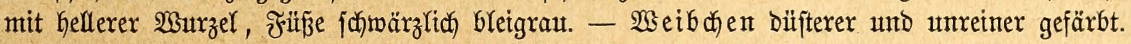

Das $\mathfrak{B}$ erbreitungsgebiet umfaß̧t Den SïDen Mejifos und Den größ̄ten Teil Mittelamerifas.

362. Die (Snldhürzeltangara, R. (Rhamph.) icteronotus, Bp., (varians). - 2 . B. Sclater,

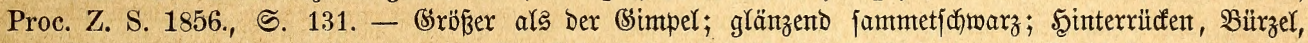

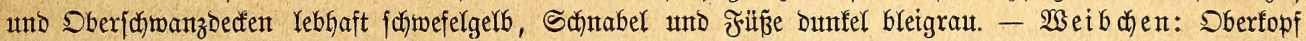

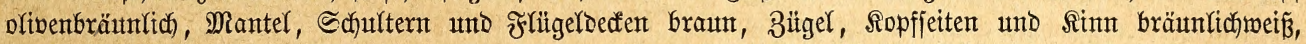

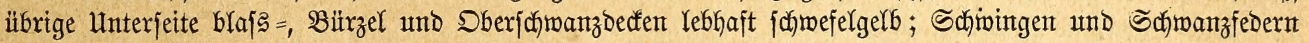

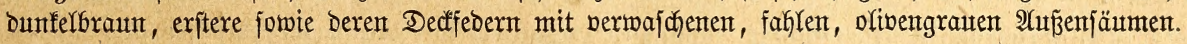

Die pradtollfe 2 rt bemofnt Ecuabor, Neugranada und \$anama.

363. Die Rotbürzeltangara, R. (R.) Passerinii, Bp., (flammigerus). - 2 . B. Sclater,

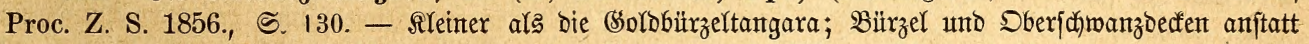

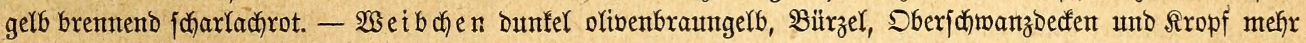

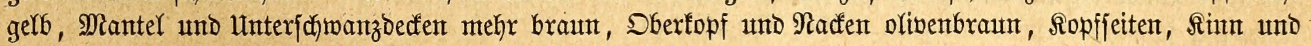

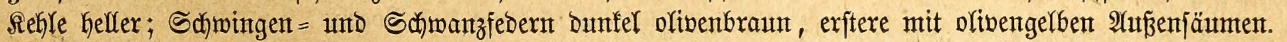

Stanmt aus Miejif́o uno Mittelamerifa.

Ebeltangaren nemten wir bie ârten mit mäp̈ig langent und ftarfem, feitlich zu= jammengebrüdtem, jharffiritigem, an ber Spize fajt gerabem Sdynabel, johwach ausgeferbtent Sber = unt niebrigem Unterjchnabel ofne Schwtele, ziemlich fräftigen Fü̈ßen, mittellangen 3ehen umb jtarf gebogenen, iptzen Rrallen, mäp̈ig langem, zujammengelegt bis zur Schwanz= mitte reichentom Flïgel, unter befien Sdjwingen bie zweite bie längite, mittellangem, nad) bemt Enbe zu verbreitertem, leidjt ausigeidynittenem Sdjwanze und wenig lebhaftem, vorherjchent

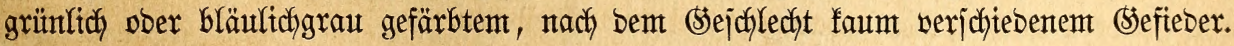

364. Die (Grautangara, Tanagra (Thraupis) cana, Swsn., (Swainsoni, episcopus, glauca). -

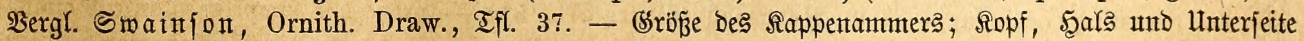

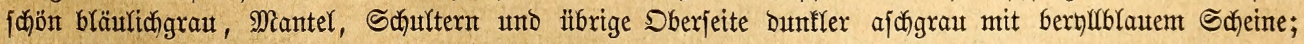

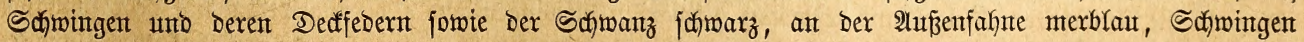

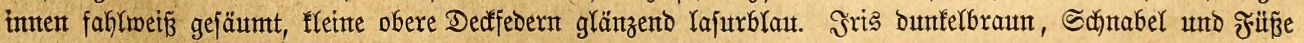

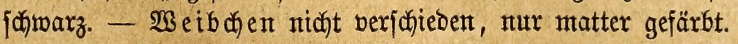

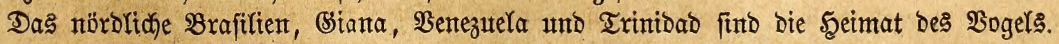


365. Der Sangajiu Der Brafifianer, T. (Thr.) sayaca, L. - 2. B. Teutwied, Beitr. III,

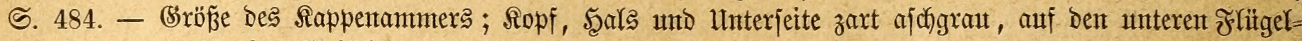

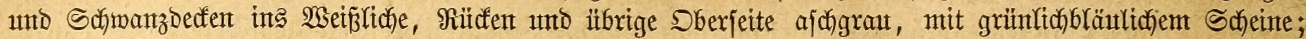

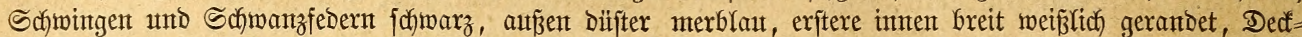

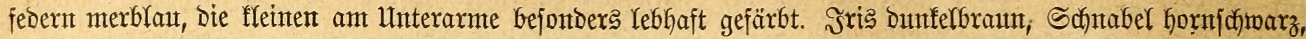

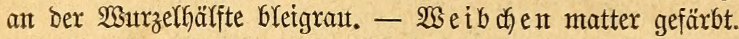

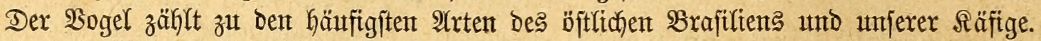

366. Die $\mathfrak{B} \mathfrak{n} \mathfrak{n}$ flügeltangana, T. (Loxia, Saltator, Thr.) cyanoptera, Vieill., (virens, inornata,

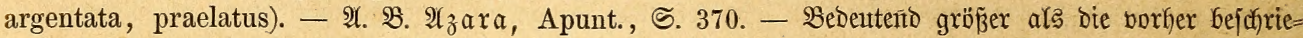

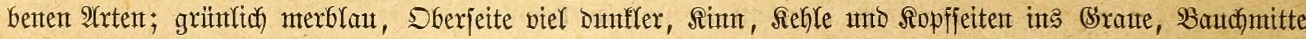

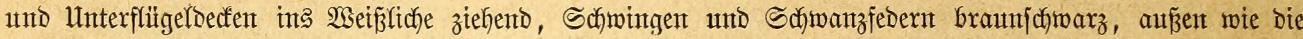

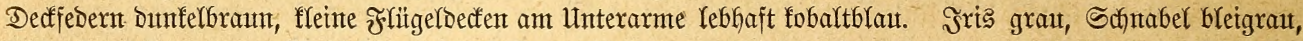

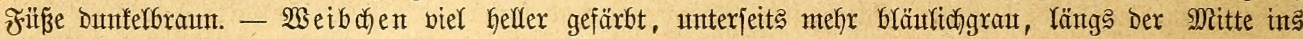

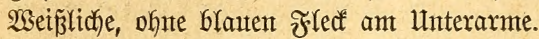

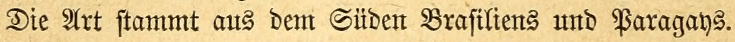

367. Die 3iertatgara, T. (Thr.) ornata, Sparrm., (archiepiscopus). - פergl. Swainfon,

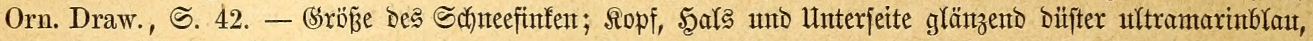
Sberfopf befonders lebhaft, Bügelftridi) fabmarz, Stirnrand und Sinn grautfidblau, Miantel unt Safultern

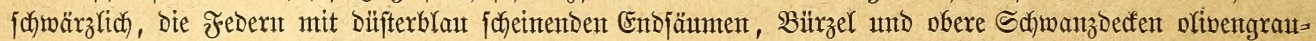

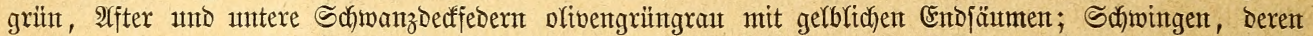
Dedfedern fowie bie Steuterfedern braumfdyarz, außen Dunfel olibengrün gefäınt, Die Schmingen in Der

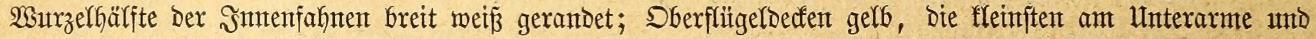

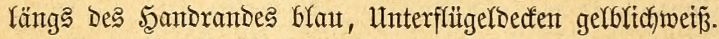

Berbreitet fich) über Brafilien und Ssiana.

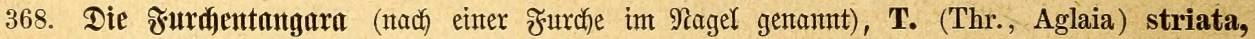

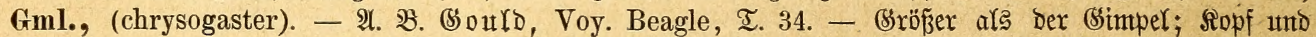

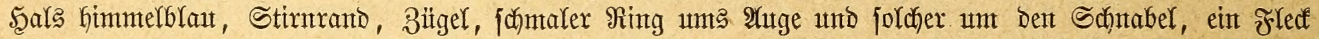
an Den Sopffeiten, Mantel unt Sdyultern fdjwarz, Bürzel und Sropf brentento orangefarben, übrige Unter=

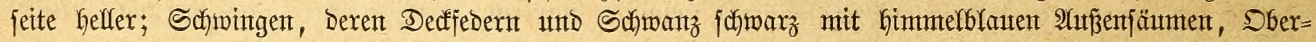

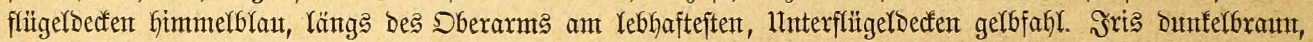

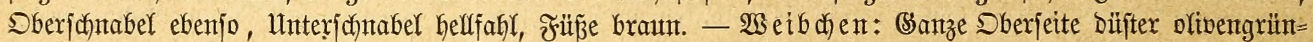

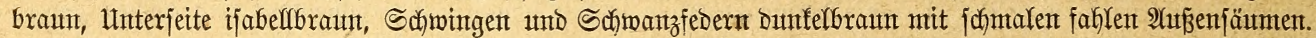

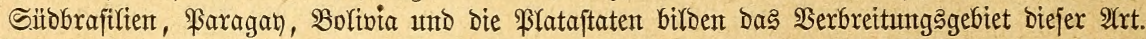

369. Die Frudttangaxa, T. (Calliste, Chrysothraupis) Darwinii, Bp., (frugilegus). - $\mathfrak{A} . \mathfrak{B}$.

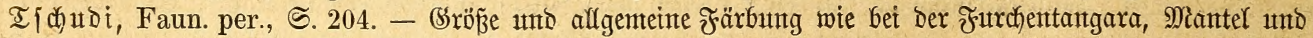

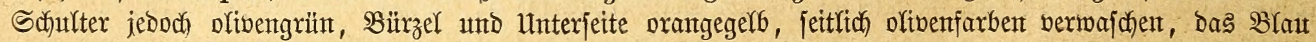

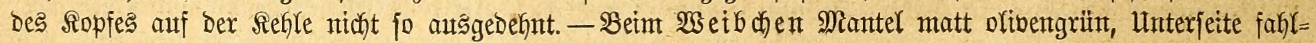
bräıtulič̆.

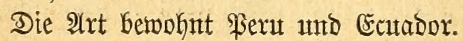

370. Die Drangentangara, Drangenvogel ber Betwofner Samailas, T. (Spindalis) nigricephala,

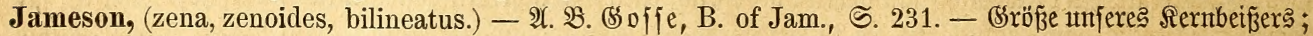

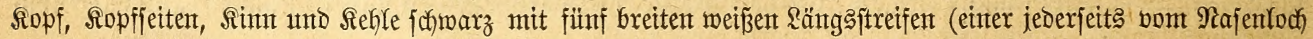

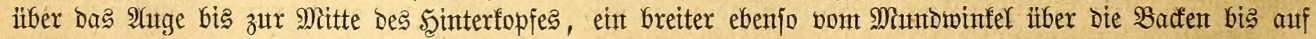

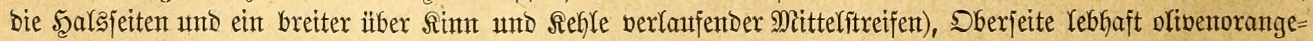

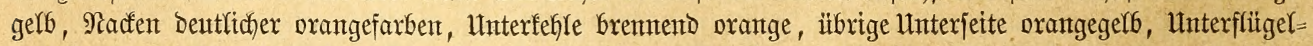

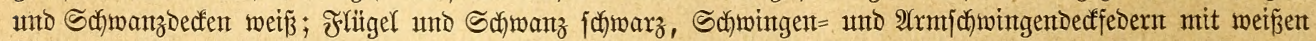

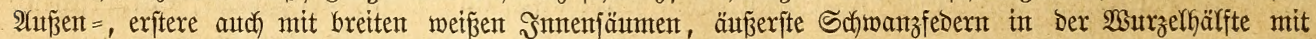

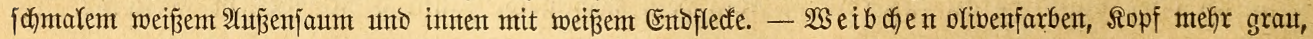

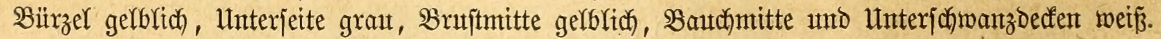

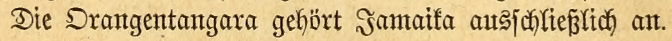

Einte zablretche (sruppe ber Fantilie wirb gebtlbet burdf bie Schntudtangaren ober Earrijten, żemlich fleine, gebrungen gebautete, pradjtooll gefärbte $\mathfrak{B o ̈ g e l ~ m i t ~ f u r z e m , ~ h o h e m , ~}$ jeitlich) zujammengebrücftem, auf Der Firjte jobarffantigem, bor ber Spitze jchwadh ausge=

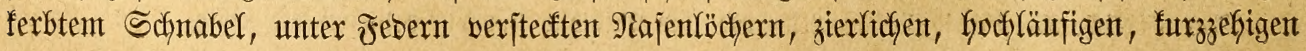




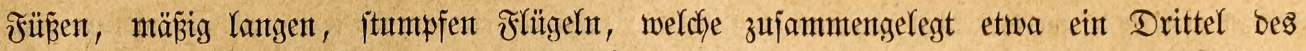
Ecfjwanzes erreidjen, unb unter beren Schwingen bie britte unt vierte bie anberen an \&änge überragen, mittellangem, etwas auşgejdynttenem, aus jdymalen Febern gebilbetem Sdywanze

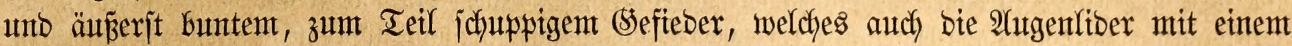
jchönfarbigen Iranze fleiner, platter Febern ungibt.

371. Der Siebenfarb, Calliste (T., Aglaia, Tatao, Callispiza) Tatao, L., (paradisea, septicolor). -

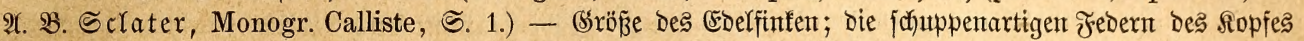

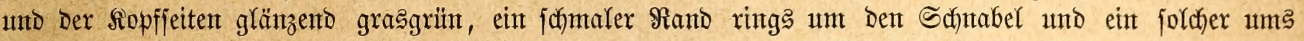

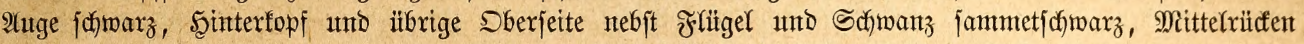

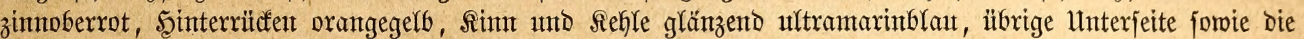

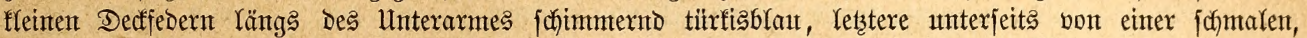

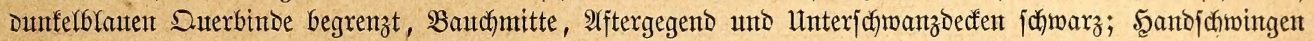

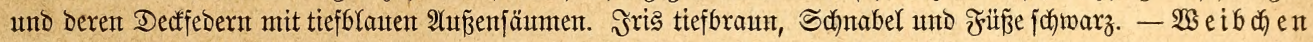

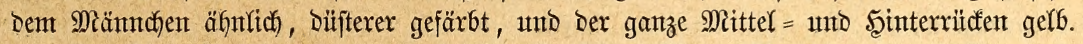

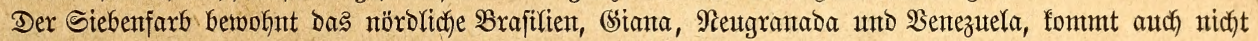
felten Yebeno nach) Eruropa.

372. Die \$arndistangana, C. (Agl., Callisp.), yeni, Lafr., (chilensis,) - $\mathfrak{A}$. $\mathfrak{B}$. Schater,

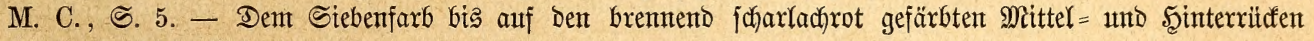
Durdfauts greidiggefärbt.

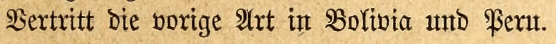

373. Die Dreifarbentangara, C. (T., Tat., Callisp.) tricolor, Gml. - A. $\mathfrak{B}$. Sclater, M.

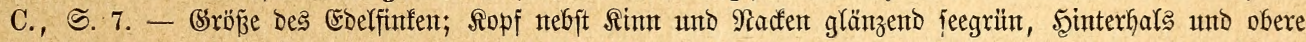

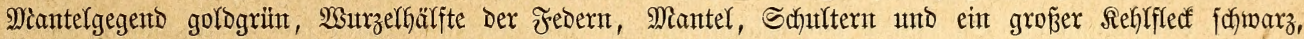

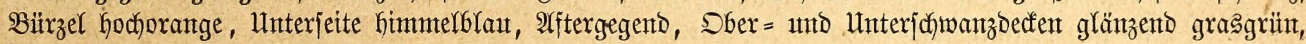

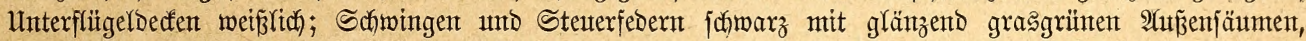

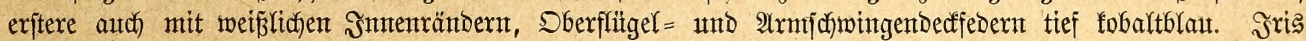

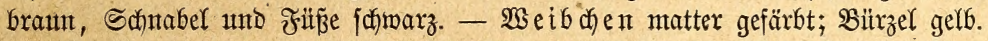

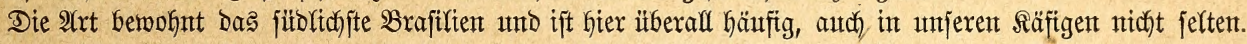

374. Die $\mathfrak{B r a d j t t u n g a r a , ~ C . ~ ( T . , ~ T a t . ) ~ f a s t u o s a , ~ L e s s . ~ - ~} 2$. B. Selater, M. C., S. 9. -

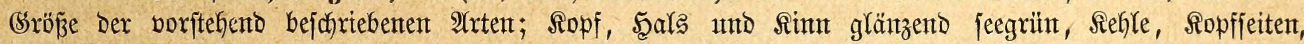

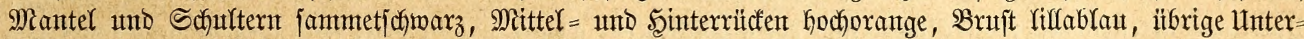

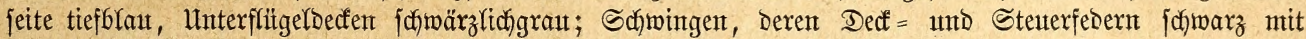

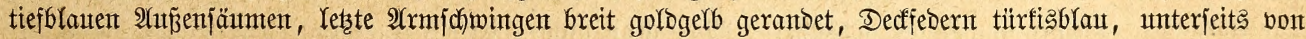

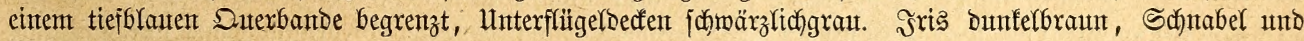

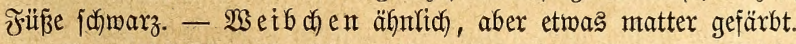

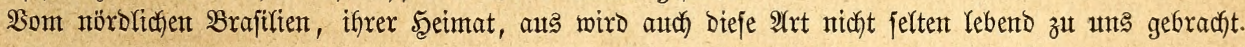

375. Die (ङnüntangara, C. (T., Agl., Gyrola) Desmaresti, Gray (gyrola, viridissima). -

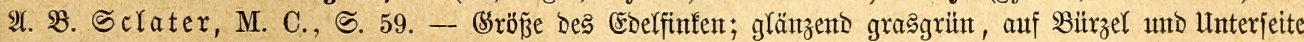

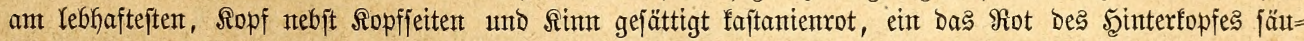

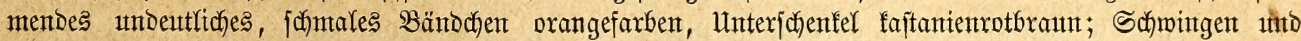

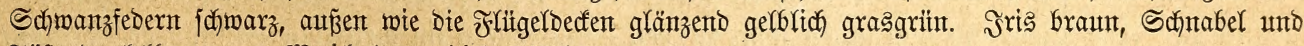

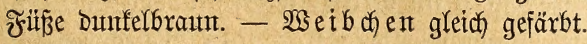

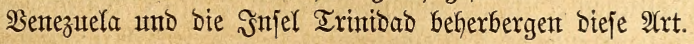

376. Die Türtistangara, C. (T., Callisp.) brasiliensis, L., (barbadensis). - 2 . $\mathfrak{B}$. Sclater,

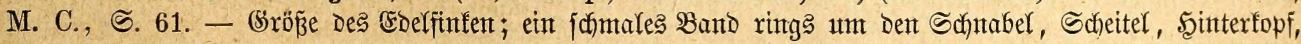

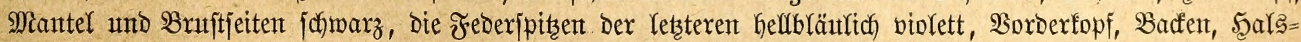

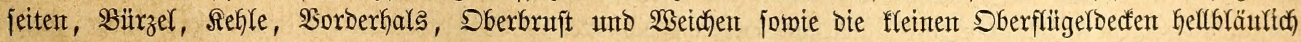

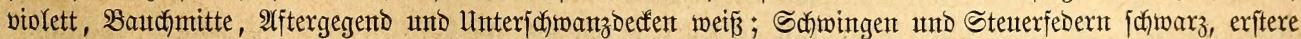

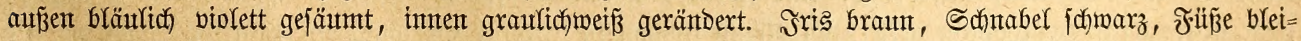

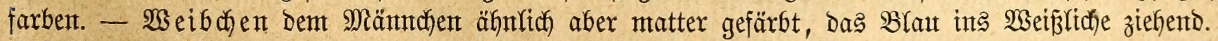

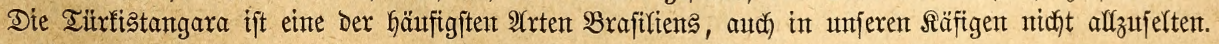

377. Die \$erlfalstangara, C. (T., Callisp.) Vieilloti, Selat., (flaviventris, mexicana). -

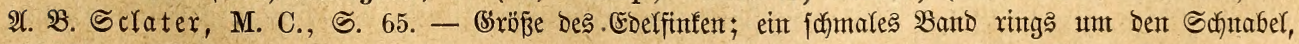

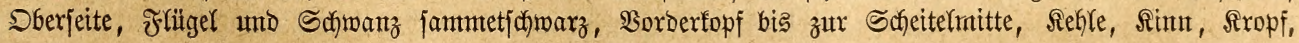




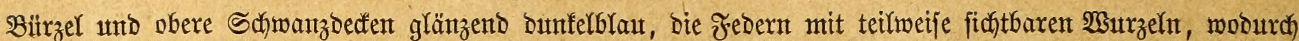

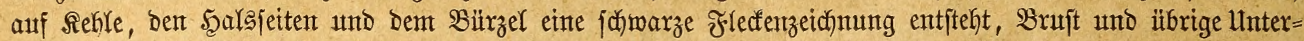
feite nebjt Unterflïgeldedten ftrohgelb, die Seiten mit einem breiten aus fanmarzblaut gerantoten frebern ge=

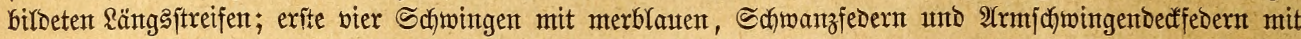

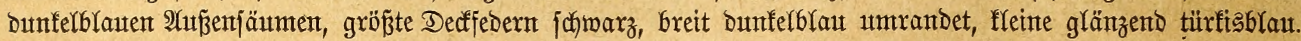

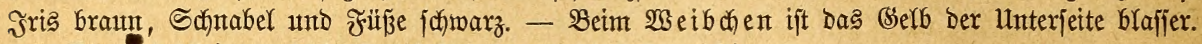

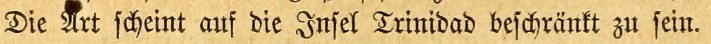

378. Die (Solorü̈fentangara, C. (T., Fringilla, Callisp.) eayana, L., (autumnalis, chrysonota). -

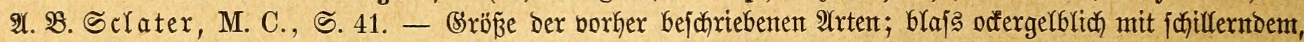

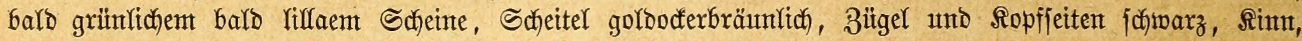

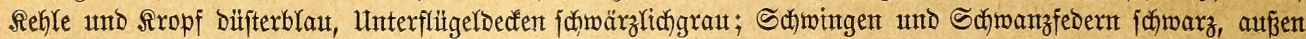

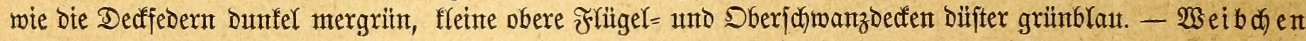
gleich) aber matter gefärbt.

Die 2 (xt ftammt aus Bsiana uto Cayente.

379. Die Siabelltungara, C. (T., Agl., Callisp.) flava, Gml., (formosa, chloroptera). - $\mathfrak{A} . \mathfrak{B}$. Scratex, M. C., S. 47. - Etwas fleiner als der Edelfunf; rötlich ifabellgelb, 3ügel, bis hinter bas Dhr,

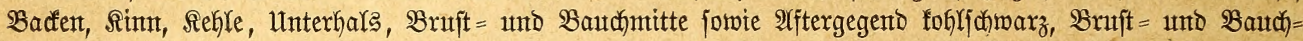

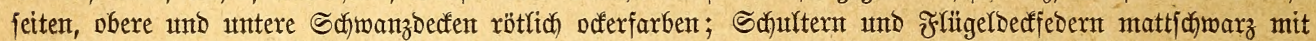

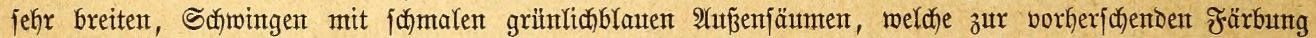

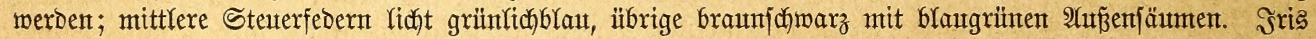

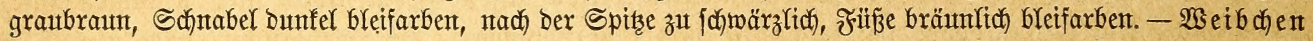

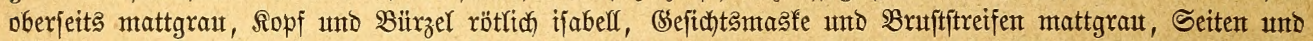

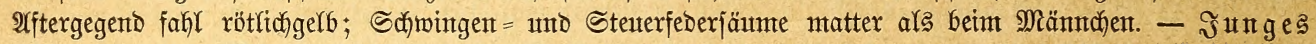
Männd chen ber Mitter gleich, junges Weibchen bem alten ähnlich, aber matter gefärbt.

Die 2 rt ftammt aus Ditbrafilien und gelangt zumeilen mit anberen Calliften und Iapixangas in unfere Säfige. Sebend int Berfiner 2 quarium.

380. Die Iropientangara, C. (Callisp., Ixothraupis) guttata, Cabanis, (punctata, guttulata,

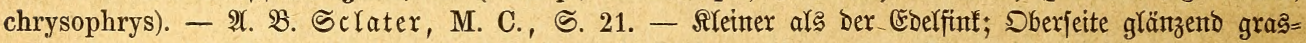
grïn, Jedern Des Mantels und Der Sdunltern mit breiten, Jebern Des Sberfopfes mit fanmäleren uno

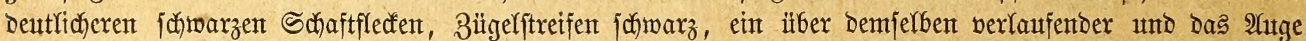

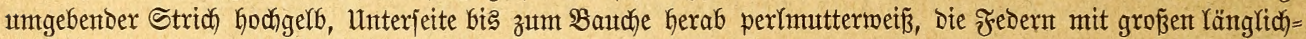
runben, am Enbe grünlich umrandeten Schaftfleden, Seiten grasgrün, Unterflïgeldectent uno sauth) meif̧lich),

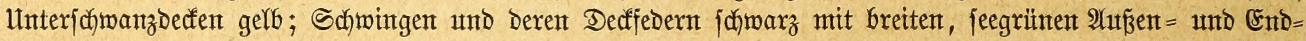

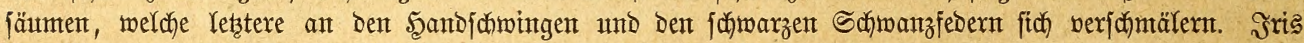

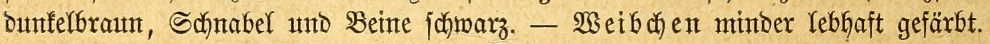

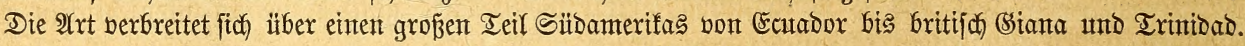

Sbgleich bie Iangaren, entiprectento ber Berjchiebentheit ifrer Sejtaltung unt Färbung, eine unter jidh abmeidjente Rebensmeije füfyren, läjt fich bod ein alfgenteines SBilo ber lebeteren entwerfen, um jo mefr als bie Berichte über biejelbe gegenmärtig noch bebeutente \&ücfen aufweifen. Die Iangaren berbreiten fich über ben grö̈bten Teil von 2Imerifa; Dent jie werben von ßaragay an bis Ranaba unb ebenjo int Diten wie im Wejten bes Erbteilz gefumben. Die Miefrzahl von ifnen zählt zu Den Walbö̈geln im meitejtent Sinne bes Wortes,

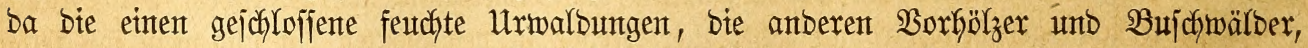

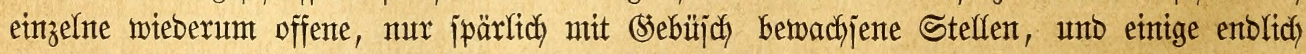
Brü̈che ober Sümpfe bewohnen. Demgemäß beborzugen eintge bie Göheren Raubfronen, anbere niebere (sebüjche, bieje bas lodfere (selaube, jente bas verjafluntgenjte Didficft. Biele von ifnen berlaffen bie Saubfronen jelten; einige treiben jich zeitweilig auf Dem Boben umber. Wo jie audh auftreten, fajt inberall gereidhen jie ber (segento zu hohem Schntud, und namentlich bie lebhaft gefärbten 2 (rten jtechen prachtooll ab von bem bunflen Selaube, in welchent fie jich bewegen. Die im Norben 2 merifas rebenben Iangaren Galten fich bier nux währent ber Sonmermonate auf, erjcheinen ziemlich ipät int Früfjabre, brüten unb ver:

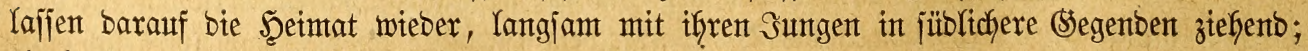

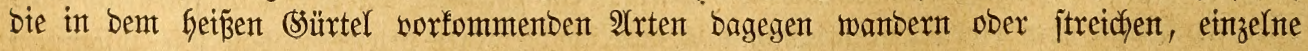




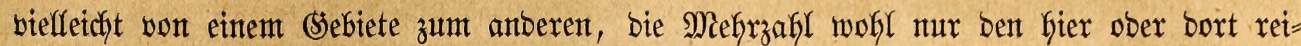

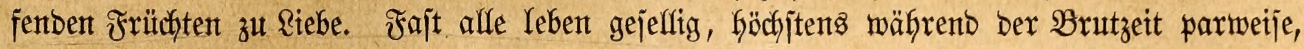

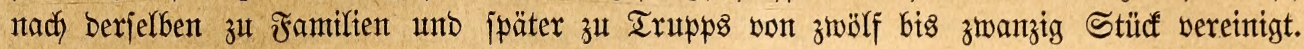

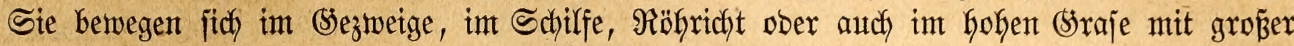

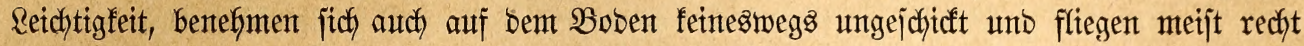
gut, je nady ber Bilbung ber Flügel rajcher ober langjamer, bie meijten 2 trten, wie es

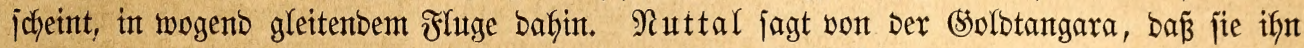

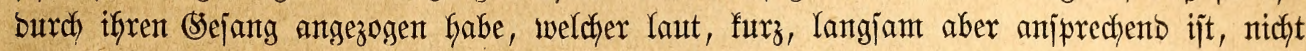

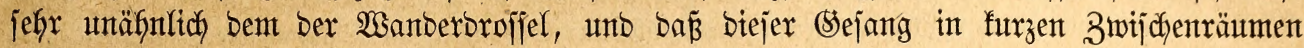
währenb bes ganzen $\mathfrak{B}$ ormittags vont ben $\mathfrak{B a ̈ ̈ m t e n ~ K e r a b ~ v o r g e t r a g e n ~ w e r b e , ~ u n b ~ E o o p e r ~}$

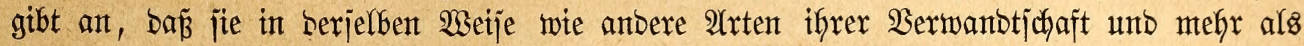

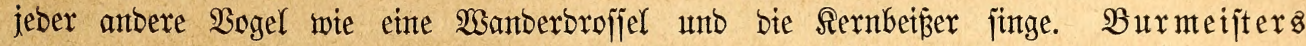

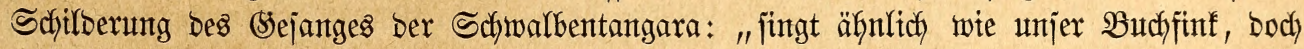

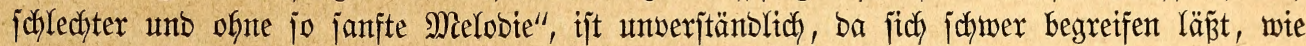

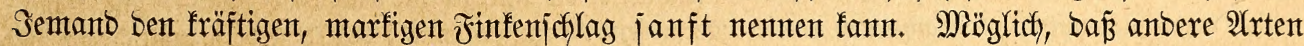

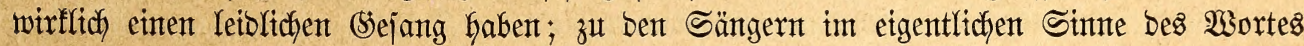

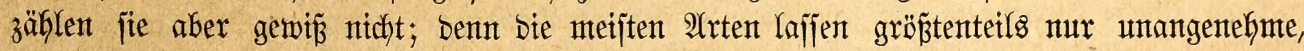

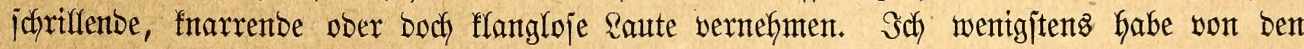
Tangarab, welche ich pflegte ober anberşwo in (sefangenjichaft beobachtete, namentlich won ber

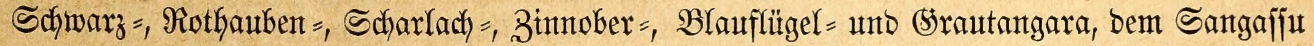
unb Siebenfarb, Der Dreifarben=, \$radyt=, Türffis = und Siakelltangara niemals Raute gefört, welche zu einer längeren Strophe verjđdynolzen ober audo mur flangwóll gewejent wären. Die Tapiranga vereinigt eintge Raute zu eintem furzen Satze; boch aud biejer Darf faum Strophe gentant werbett.

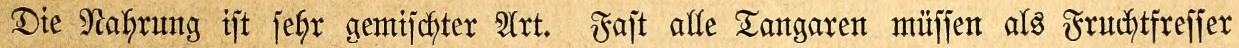

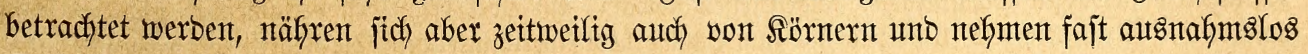

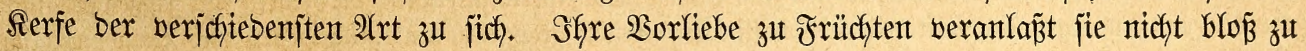
WBanberungen ober Streifzügen, jonbern audd zu Einfü̈lfen in bie Frudftgärten, in Denen fie

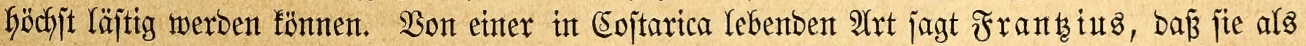

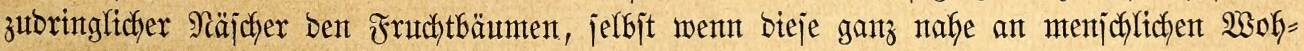

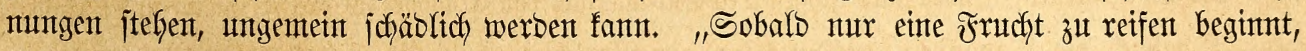

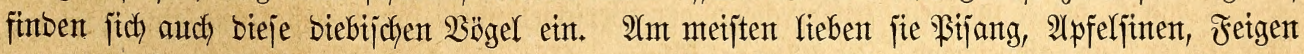

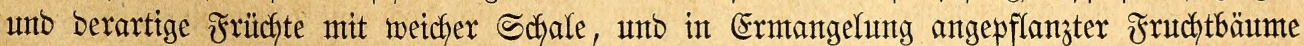

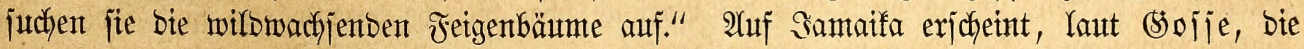

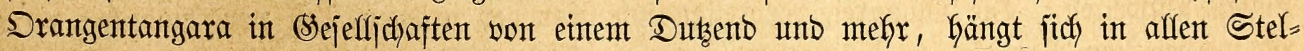
lutngen an berentragenbe Bäume an, umt Gier ifgre Ernte zu halten, Dber bie Feberzunge ftellt fich gegen bas Ennbe bes Safres, went bas bunffelgläntzentbe Blattwerf ber Srange

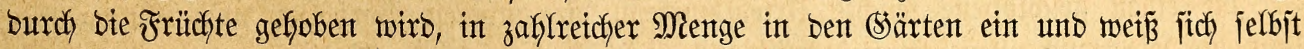

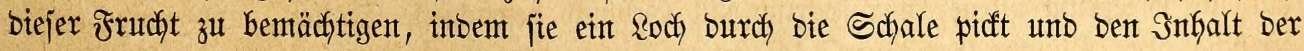

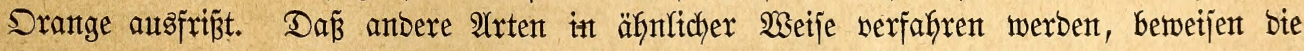
(Sefangenten zur Stenüge: affe Irten, weldhe idh gefangen Gielt ober beobad,tent fonnte,

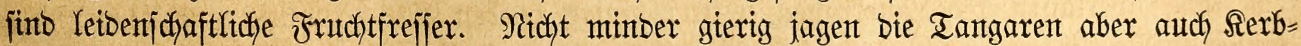
tierent nady.

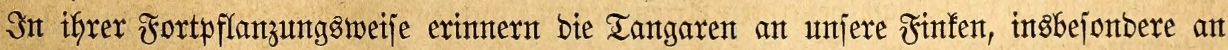

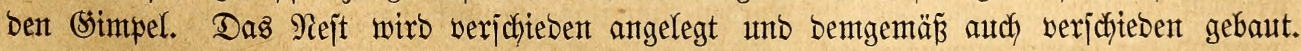

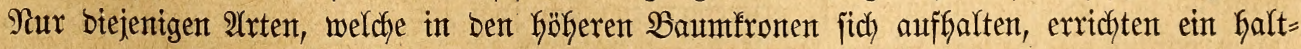

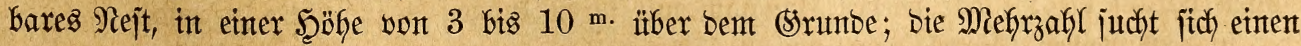

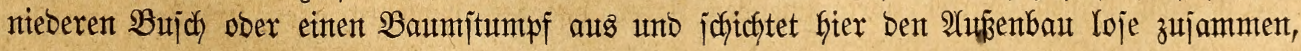




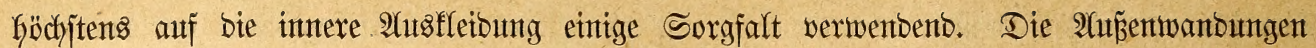

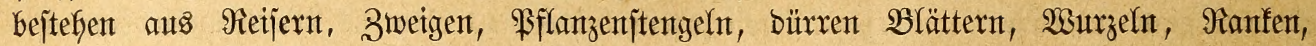
Sdhlingpflanzen, $\mathfrak{B l u ̈ t e n j t e n g e l n , ~ w e l d h e ~ a n ~ D e r ~ \Re e j t w a n t ~ n a c h ~ a u k e n ~ g e f e h r t ~ j i n t o , ~ u n d ~}$

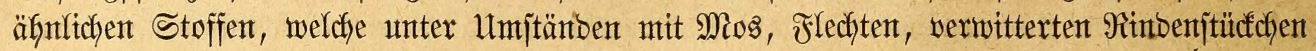
unto gropen, ausetnanber gezerrten, mefr ober minber jorgfältig in bie গejtwanto ein = gejpontenten $\mathfrak{B a u m w o l f e n f l o c f e n t ~ g e j d y m u ̈ d f t ~ u n t ~ z u j a m m m e n g e b a l t e n ~ w e r b e n . ~ D i e ~ \Re e j t m u l b e ~}$ ijt mit breiten Binjenblättern, feinen (Sraß̧almen, langen Walbfledjten, WHuzelfajern, Searen

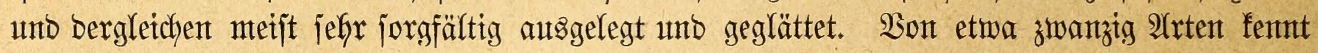
man bie brei bis fünf Eier, weldye daz Belege bilden." Sie zerfalfen, laut Balbamus,

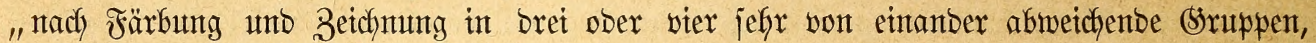

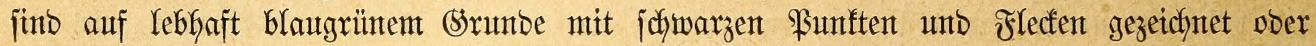
Gaben auf gletchfarbigem (soruntbe roftrötlictye Strichelzetchnung ober zeigen bei grünlich,

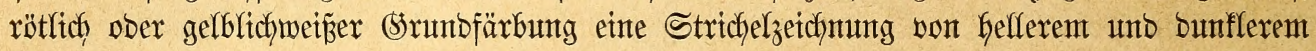
Braum, voer endlich, fie fint helfer ober bunfler braungelblich wein unt mit Şarzïgen, Sdynörfeln und Fledfen von Rotbraun bis Schwarz bebedft, wie joldhe ben Eiern mjerer

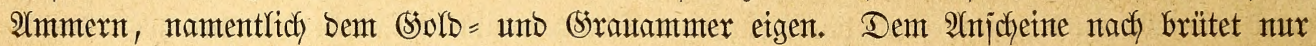

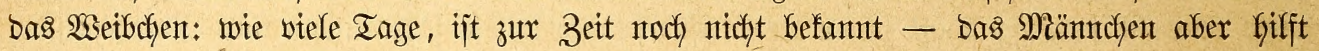

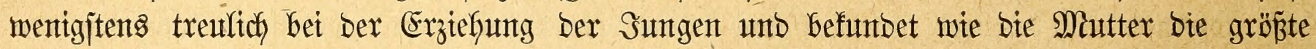

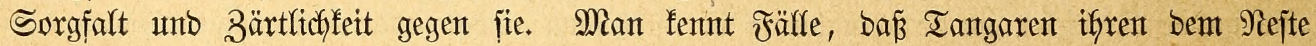
enthobenten unb eingebauterten Sungen halbe (englijache) Mieilen weit nachflogen unt fie unt=

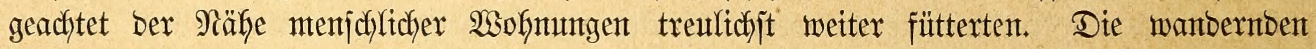

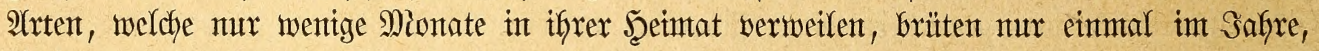
bie int warmen (sürtel lebenden bagegen ergieben wafricheinlidy mefrere Bruten im Raufe ber günitigen Эafreszett.

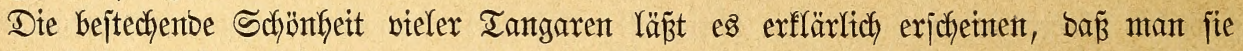
gern im Säfige bält, obgleich ben meijten von ifnen bie (Sabe Des (Sejanges verjagt blieb. Sie erforbern eine jorgfältige $\mathfrak{P f l e g e , ~ G a l t e n ~ j i c h ~ b e t ~ j o l d j e r ~ a b e r ~ w e i t ~ b e f f e r , ~ a l s ~ m a n ~ g e = ~}$

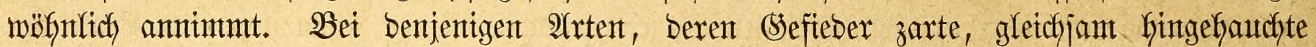
Farben zeigt, hat man finnen furzer Sefangenjchaft ein Serblafien Der Schönfeit zu beflagen: jo nach meinen Erfafrungen namentlich bet ber Scharlachtangara, währento dies bet allen Itrten, Deren (Sefieber berber ijt und beren Farben frättiger aufgetragen jind, nicht ber Fall

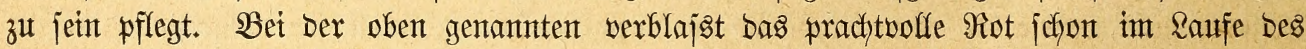
erjten Sahres, gefht bet ber nädjiten Maujer und beziebentlich Berfärbung in ein blaffes

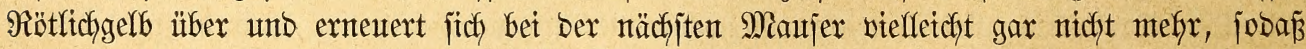

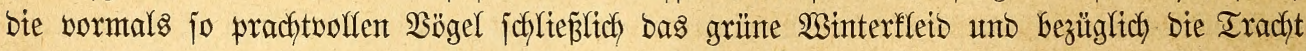
Des Weibdjens erhalten. Afnbers ijt es bet ben firon=, Ebel= und Schmucftangaren,

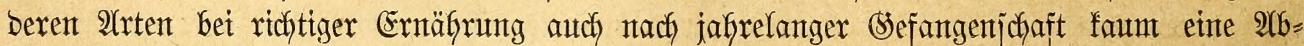

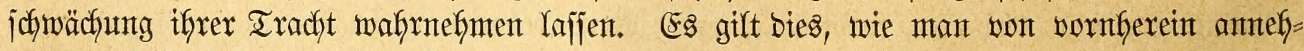
men barf, insbejonbere für afle vorferjchend johnarz, grau, blau, braun, mit einem Worte

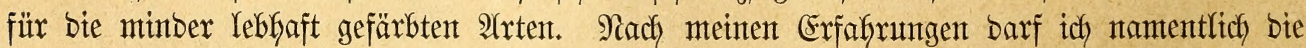
Sdywarz $=$, Irauer $=$, Sraut $=$, Blauflïgel =, Dreifarben = unt Prachttangara, Sangajiu unt Sitebenfarb als ebenjo Dauerhafte wie in ifrer Sijötheit fich gleich bleibente Befangene empfeblen; aber audh bie Schmielentangaren erfalten fich, objofon fie im Raufe ber (ses= fangenichaft bie Tiefe und ben Sdymelz ber \$urpurfarben berlieren, ifr \$rachtgefieber wentgitents in jeinen (sinutotönen.

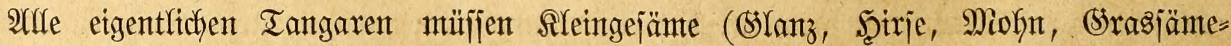
reien, Scheuerngejäme unt bergletchen), alfe audh mefgr voer wentger Şanf unto anbere

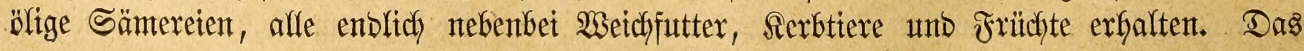




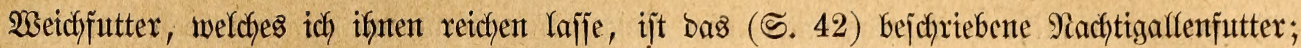
es wirb gern genommen und focheint aud gut zu befonmen. Unt bie Mittagšzeit pflege ich

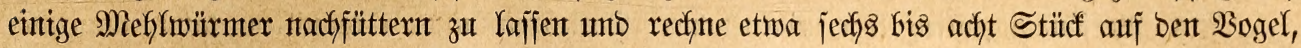

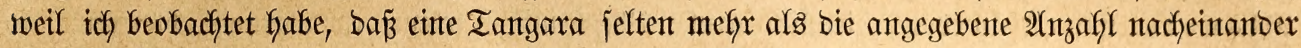

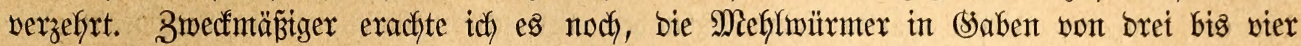
Stütef mebrmals im Raufe bes Tages anzubieten unb joviel zu reichen, als ber Sogel frefien wifl, ba jie, wie ich bejtimmt befjaupte, ifgn burdjaus nichts jchaben. Afls unerläp̈lichen, ja als

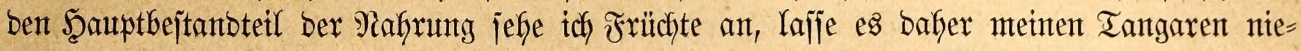
mals an jolchen feflen. Währento bes Sommers erfalten fie alfe Baum= untb Berenfrüchte,

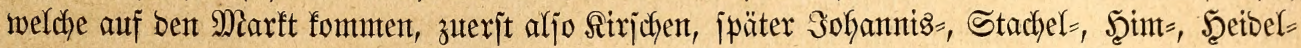
unt Preijelberen, in 2 inter $\mathfrak{B}$ ogel= ober Eberejchberen ant, jo lange jie vorfantoen, Birnen

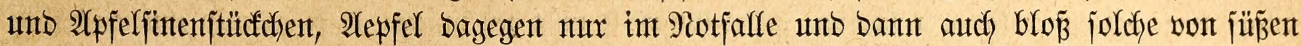

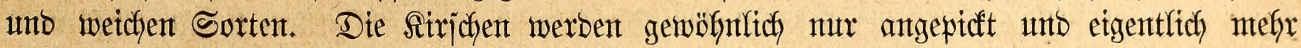

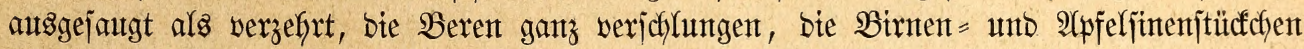

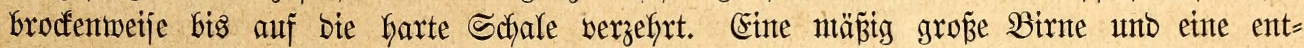
jprecfjente Mienge anberer Frïchte ijt für einte Iangara nidfyt zu viel, ant wentigjten bann,

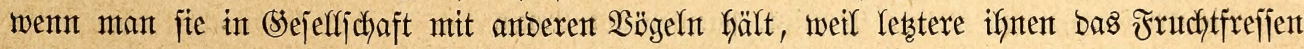

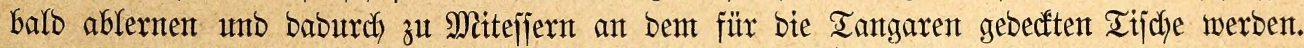
Wie notwenbig biejen bie Fructutnafurung ijt, fift man, jobalb man ifnen irgent einen ber erwähnten Jutterjtoffe reicht: jie lafjen bann jofort alles übrige jteben unb liegen und be= jojäftigen jich auf bas eifrigite mit bem 2lufpicfen unt Berzebren ber Fruchtteile.

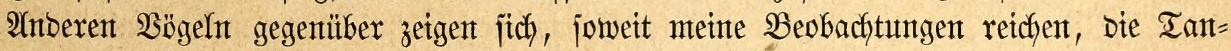
garen inzgejamt als vortrefflicfe (senvifen. Zanf und Streit fommt unter ifnen faum

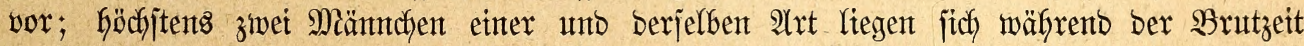

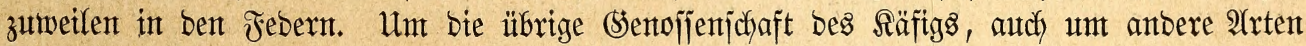
ifrer Familie befümmern fich bie Tangaren nidft, Yeben wenigitents mit ifnen in tiefitemt

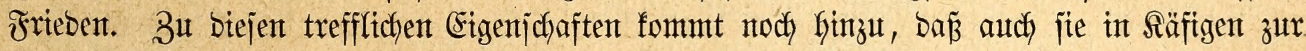
Jortpflanzung jofreiten: exjt vor wentgen Iagen ijt im Berliner Aquarium eine Brut Der

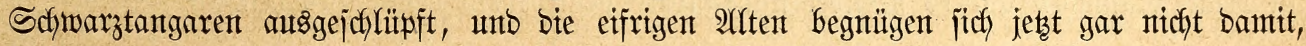
ifre Jungen zu füttern, jonbern bieten Den ifnen gereidyten Meflwurm barmberzig jebent anberen Bogel, weldyer barum bettelt. Wafychcheinlich brüten afle biejenigen $\mathfrak{A}$ rten, beren

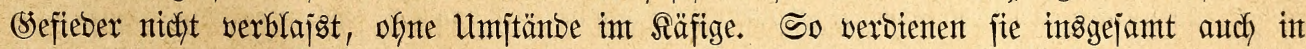
biejer Beztefung bie vollyte Beachtunty unto $\mathfrak{B u ̈ r}$ igung bes Riebfabers.

Der Marftpreis aller Iangaren ijt noch immer ein ziemlich boher. Fïr bie norbameri= fanijchen 2 rten, minbejtens für ben Sommerrotoogel zahlt man in ber Regel fünf bis jechs Taler für bas Stüct; alle übrigen Artent jind teurer, Pradyttangara unb Siebenfarb $\mathfrak{z}$. $\mathfrak{B}$. jelten unter zebn, bie Schntelentangaren nux auznahmsnetje unter zwölf bis vierzefn Ialern

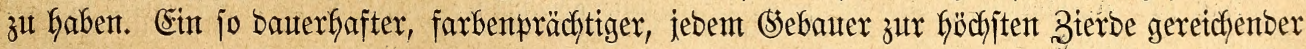
Bogel ijt joldyen $\mathfrak{B r e t 3}$ aber aud wert.

\section{(1)ranutiftent.}

Die Drganiften unterjcheiben jich von ben bisher aufgefüfrten Tangaren butrch ben gebrungenten Reibesbaut, Den bidfen Sopf, Den jtarfen, breiten, Dabei furzen Schnabel, welcher

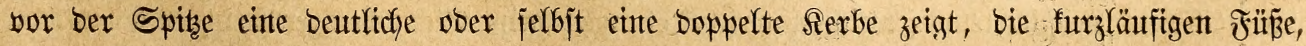
furzen Flügel und ben furzen Sdhwanz, ebenjo aud) burdy bie Eigentümlidffeit ber Färbung. 
Sie zerfallen in mef̧rere Sippen, unter benen einige von bem allgemeinen (Sepräge ber Srruppe mereffich abweitfien.

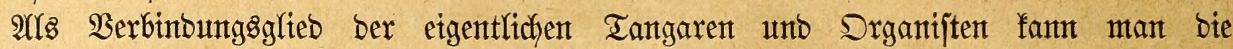

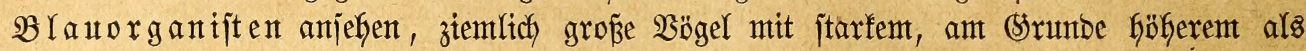

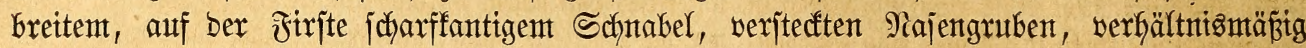

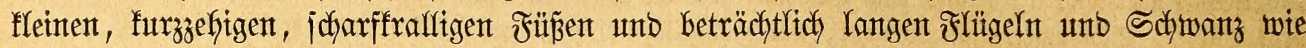
überfautpt aus langen Febern beitefentbent Bsefieber.

381. Der Blaunrganijt, Pipridea (T., Agl., C., Pipracidea, Procnopis) melanonota, Viéill.,

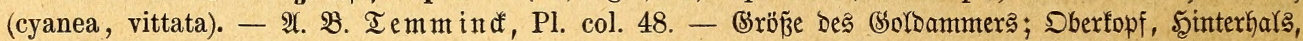

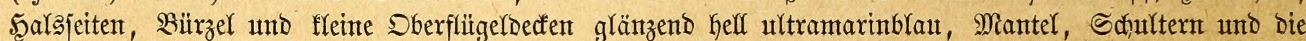

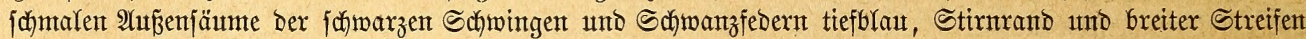

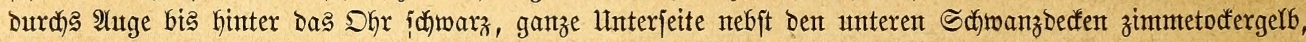

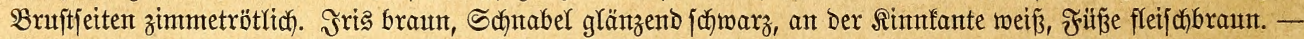

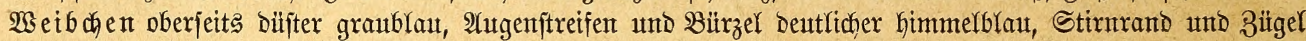

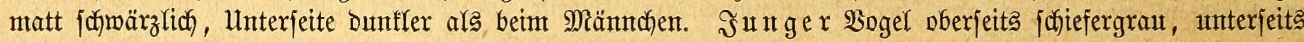

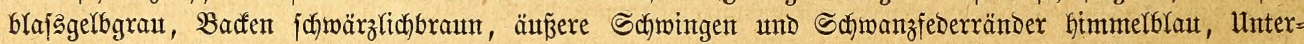
fiefer weí̄.

Die $\mathfrak{A}$ rt bemohnt bas fübliche $\mathfrak{B}$ rafilien, $\mathfrak{B a r a g a t}$ uno Urugay.

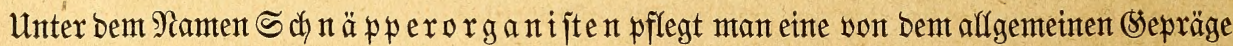

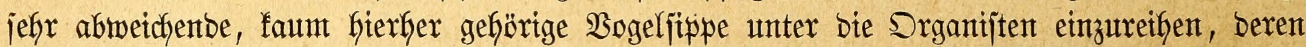

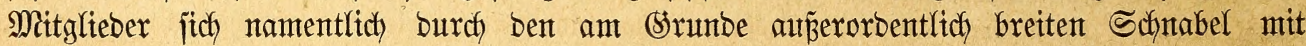

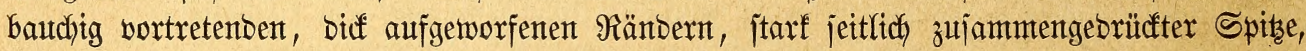
vor weldyer eine feine Serbe befinblidd, unt wenig gebogener, jtumpffantiger firite vor alfen übrigen Tangaren auszeidfnet. Die Najengrube wiro von feinen Febern bejchattet; Das

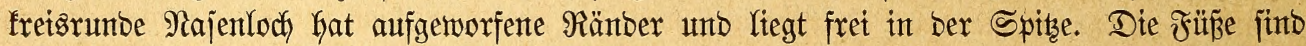

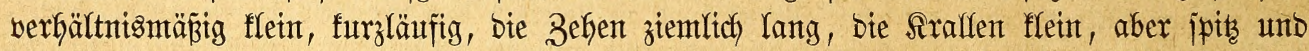

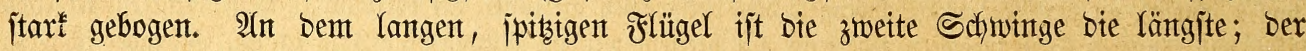

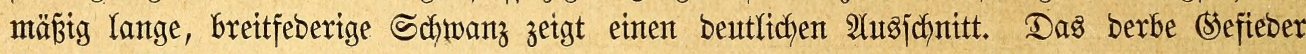
ijt beim Meännthen anbers gebilbet uno anbers gefärbt als beim 230 cibchent.

382. Der Santüppernorganijt, Proenias (Ampelis, Hirundo, Tersine) tersa, L., (viridis, ven-

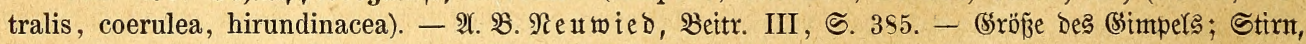

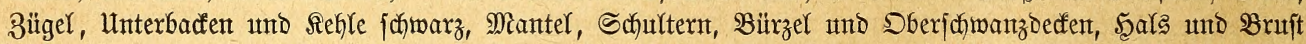

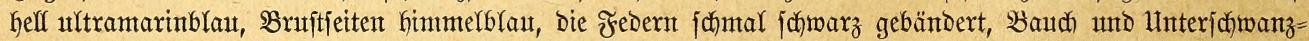

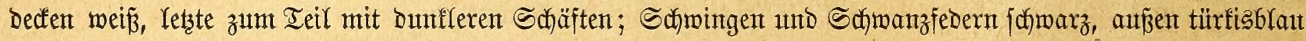

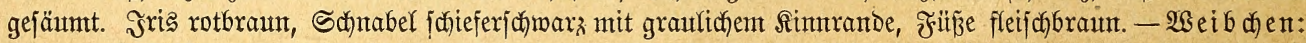

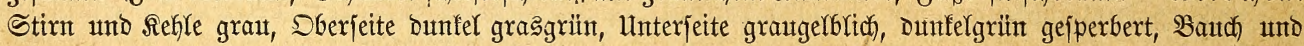

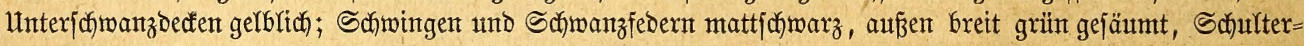
federn am Ende aud graugrün geranbet.

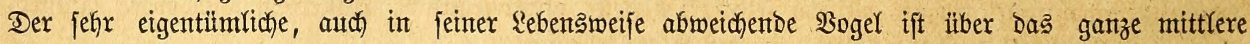
Brafifien verbreitet.

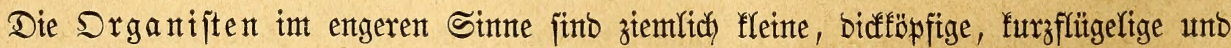
furzichwänzige $\mathfrak{B o ̈ g e l ~ m i t ~ j t a r f e n t ~ S c h n a b e l , ~ w e l c h e r ~ a n t ~ ( S r u m b e ~ b r e i t ~ u n d ~ h o c h , ~ n a c h ~ b o r n ~}$ jeitlich zujammengebrüdt und an ber einfach ober boppelt geferbten Spize herabgebogen ijt;

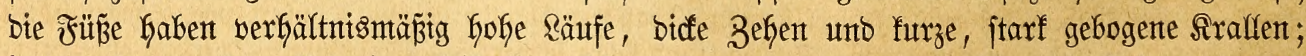
in bem furzen, idymalfeberigen Flügel, weldher zujammengelegt wentg über bie Sdymanzmurzel Ginabreicht, finto Die erjtent brei Schwingen gleidh lang, in bem ftummelfaften, aus furzent Febern bejtefjendem Sdhwanze bie einzelnen Febern abgerumbet. Das berbe Befteder, meldjes jich nach bem (Sejchlechte wejentlich unterjchetbet, zeight beint Meänndyen vorkerjchento Stahlblaut ober (s)rün, unterjeits ein Yebfaftes (selb ober Blajggrün. 
383. Dex $\mathfrak{B r a d j t o r g a n i j t , ~ E u p h o n i a ~ ( T r i g l y p h i d i a , ~ C l o r o p h o n i a , ~ A c r o c o m p s a ) ~ c a l l o p h r y s , ~ C a b . - ~}$

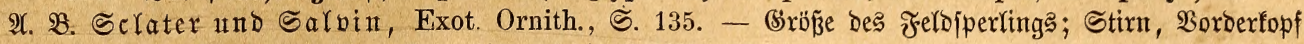

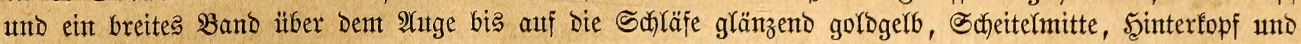

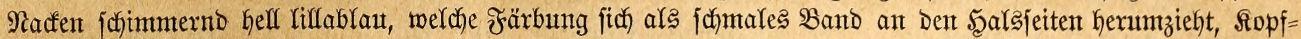

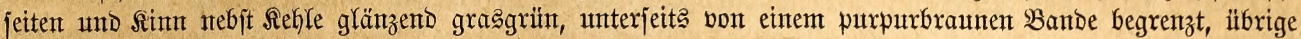

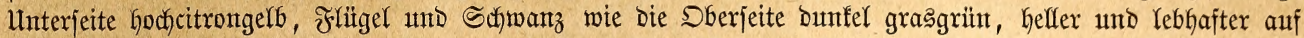

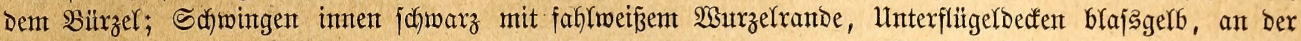

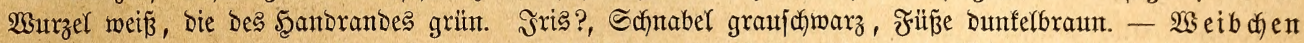

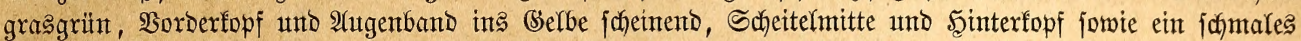

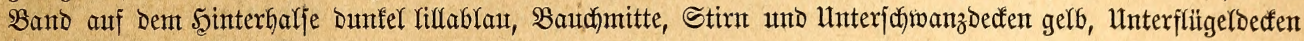
meiß̄ mit bláşgelben Säımen.

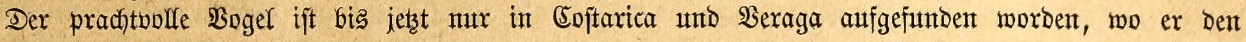
höheren berggürter betwohnt.

384. Der Samarzhalenrganiit, E. (Pipra, Tan.) nigricollis, Vieill., (cyanocephala, chryso-

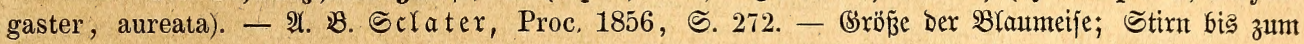

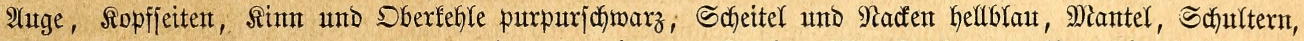

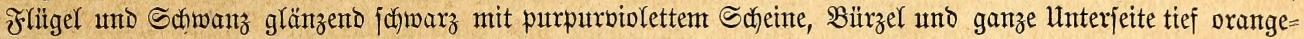

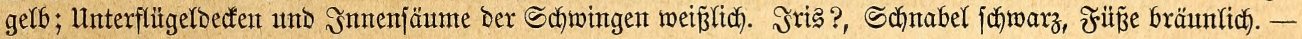

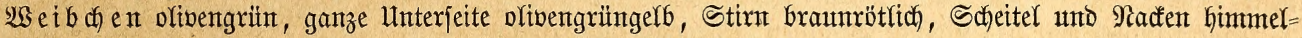

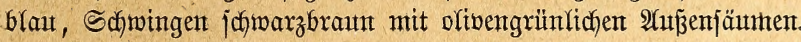

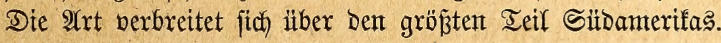

385. Der Rotitinturganit, E. (Pip.) elegantissima, Bp., (coelestis, galericulata, tibicen). -

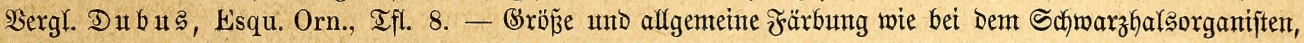

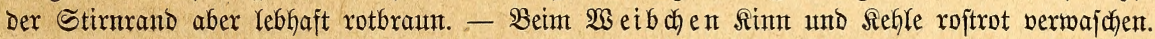

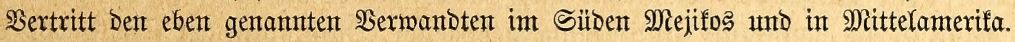

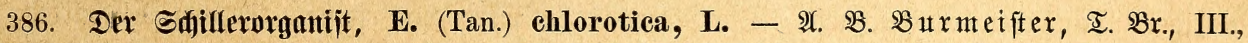

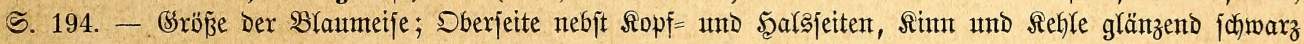
mit purpurbiofettent Edjeine, Der ganze Sberfopf und Die Unterfeite hod) Dottergelb, Die Federn bes Şinter=

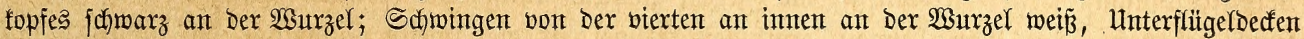

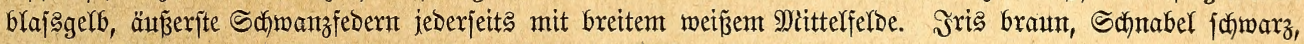

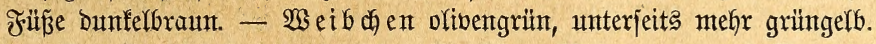

Der $\mathfrak{B o g e l}$ rebt im nörblichen Brafitien, Neugranada uno Bentezutela.

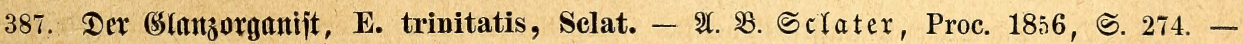

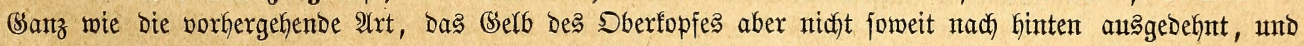

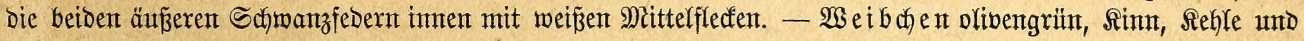
Seiten gelb, am Dunfelften auf Dent Unterichwanzoeffen; SBruftmitte unt Bauth helfgran.

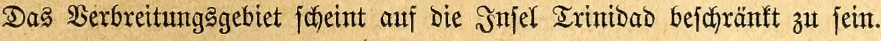

388. Der (SnfDititnorganift, E. (Tan.) affinis, Less. - 2. $\mathfrak{B}$. Sclater, Proc. 1856, S. 274. -

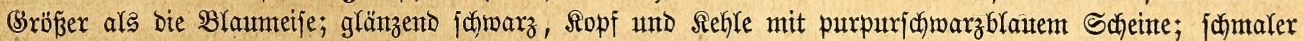

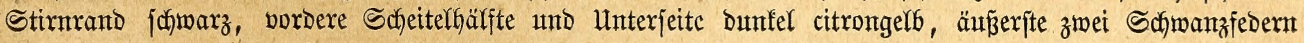

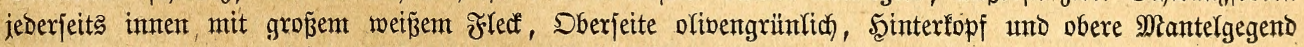
grau angeflogen, Unterfeite gelbrich, auf Der Mitte Yebhafter.

Die $\mathfrak{2}$ (rt verbreitet fich von Silomejifo an über ganz Mittefamerifa.

389. Der Rotidjeitetorganiit, E. Annae, Cassin., (rufivertex). - A. B. Proc. Ac. Phil. 1865,

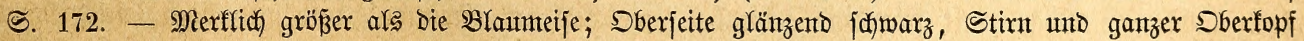

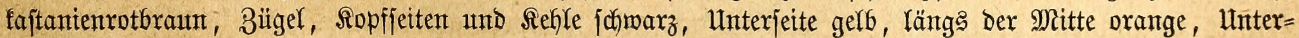

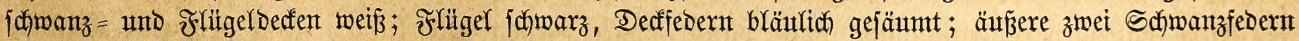

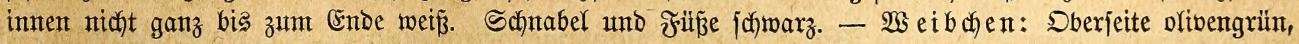

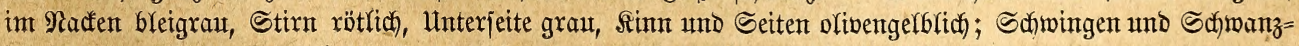

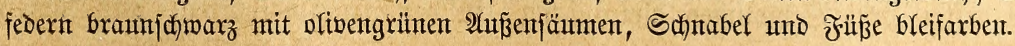

Die $\mathfrak{A}$ rt bemohnt Coftarica und einen großsen Ieil Mittelamerifas.

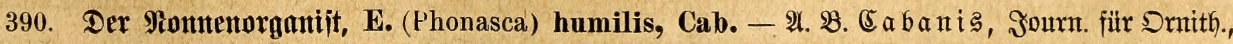

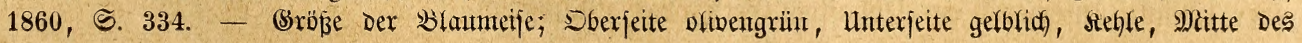




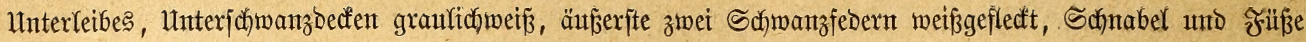
\{c(f)wärzlich *).

Die 2 rt ftanmt aus Coptarica.

391. Der 3ierorganiit, E. (Phon.) gracilis, Cab. - 2. $\mathfrak{B}$. Salvin, Proc. 1870, S. 186. -

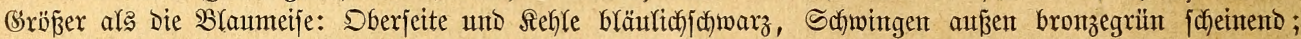

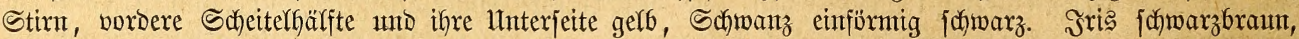

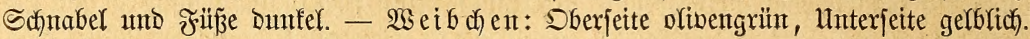

Die 2 rt ftammt aus Coftarica umo 2 seraga.

392. Der (Gelbideitelorganiit, E. (Phon.) luteicapilla, Cab. - 2 . $\mathfrak{B}$. Eabanis, รournal

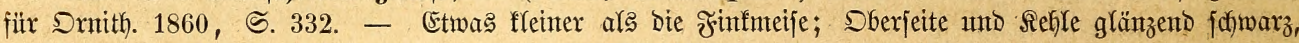

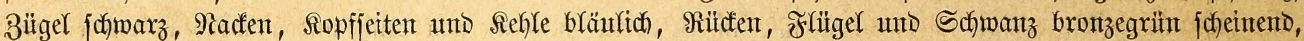

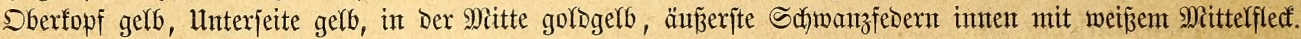

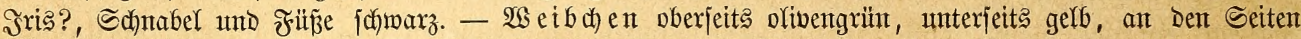

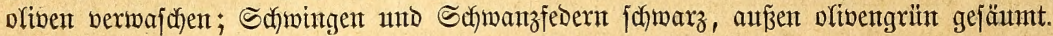

Son Coptarica bis Panama.

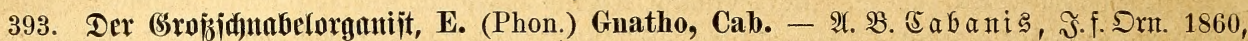

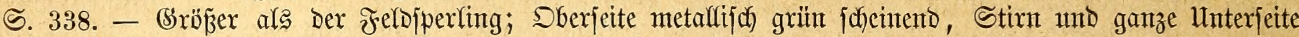

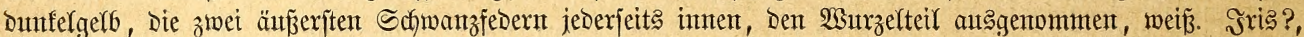

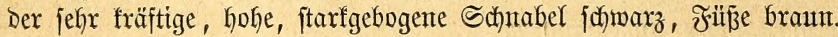

2(uct) bieje $\mathfrak{A}$ rt left in Coptarica.

394. Die (Sitturama Der Brafilianer, E. (Tan., Phon.) violacea, L. - 1 . B. Reuried, Beitr.

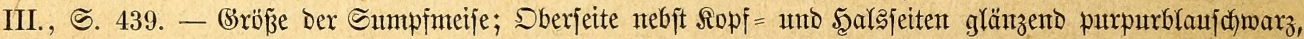

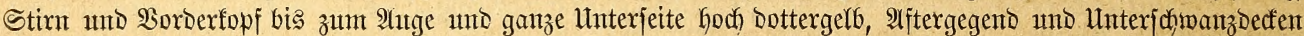

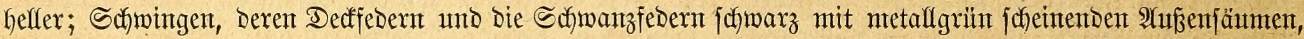

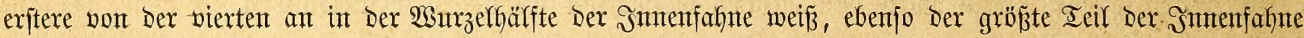

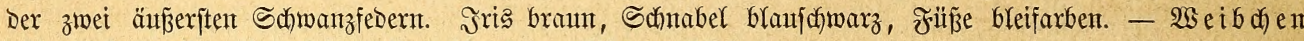

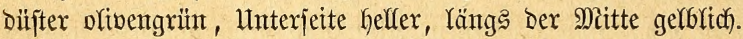

Die 2 (rt verbreitet fich vom jüblichen 8 rafilien an bis nach (Biana finauf.

395. Der Sfjwalbenurganiit, E. hirundinacea, Bp. - 2. $\mathfrak{~ B . ~ S c l a t e r , ~ P r o c . ~ 1 8 5 6 , ~ S . ~ 2 7 8 . ~ - ~}$

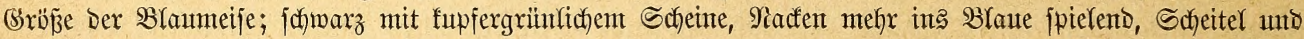

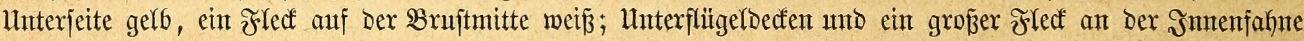

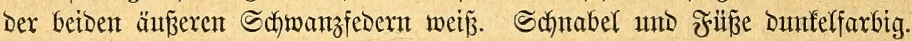

Die $\mathfrak{2}$ at bemohnt Silomejiffo uno Satemala.

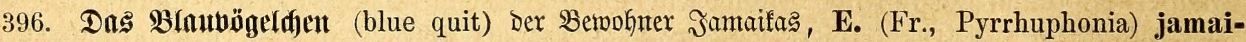

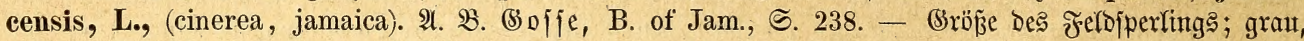

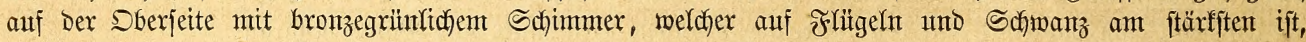

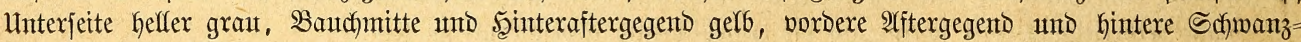

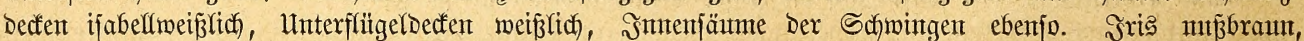

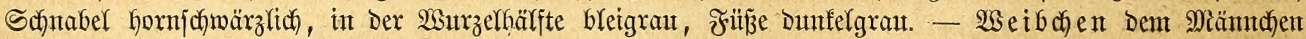

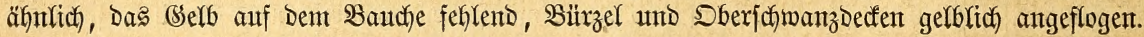

Die $\mathfrak{A}$ (xt findet fich mux auf Iamaifa.

Die Drganiften, won benen man gegen vierzig Arten unterjchieben hat, bemofnen partweije ober in fleinen Seịellichaften bie fruthtreichen Walbungen Silbamerifas unb

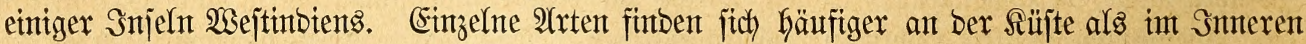
Dex Walbungen, anbere namentlich' auf lichteren Stellen berjelben, anbere mebr im (Siebirge als in bex Ebente. 3ux 3eit ber Frudjtreife jcheinten fie Wanberungen von größzerer ober

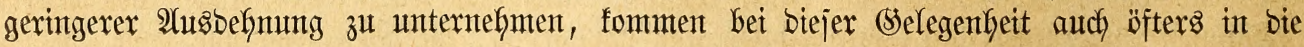

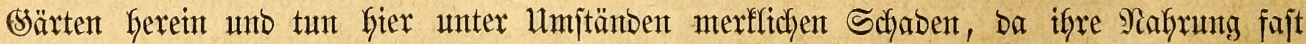

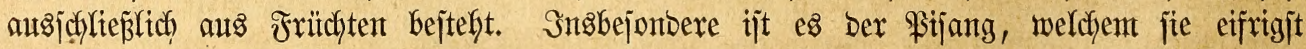

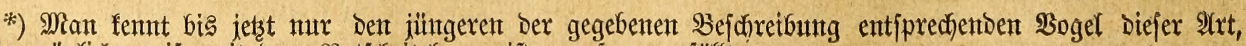

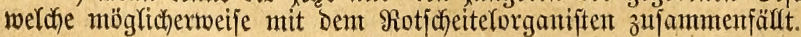




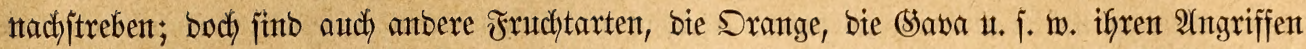

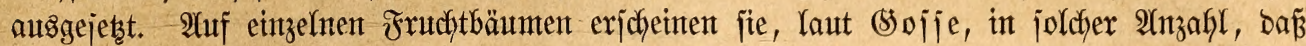
ber Baum won ifnen bebecft zu jein jcheint. Sie jüb jehr lebhaft unb beweglich, hüpfen

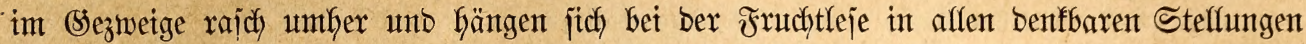

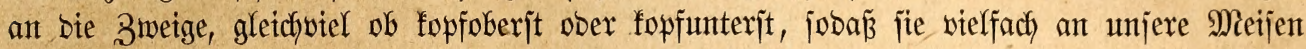
erinnern itögen. Stuch auf bem $\mathfrak{B}$ oben bemegen fie jich, wie ich von (sefangenen wahrgenommen

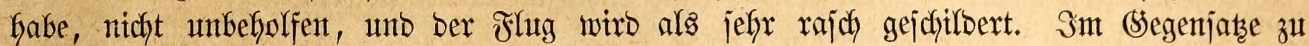
ben eigentlicken Iangaren jobeinen menigitens einige von ifnen mit einem Gübjüben (sejange

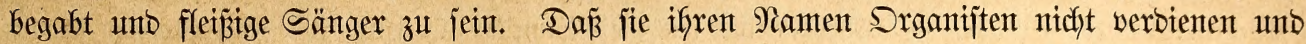
bie überrajchent volfen und anjprechenden saute, weldhe man ibnen zugejdyrieben hat, nidjt vernefgmen laffen, ift neuerbings zur (Senüge nadfgemiejen worben. So unterliegt es

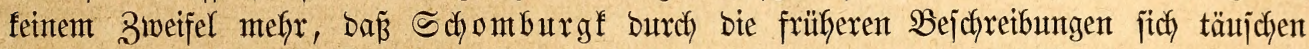

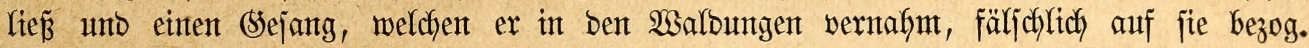
"fiein Sejang", jagt er, "feine Stimme irgent eines befieberten Bewofners ber Wälber, jelbjt nicht bie jo beutlich ausigejprochenen Worte ber Biegenmelfer haben in mix gletches Erjtaunen erregt wie bie (Stlodentöne bes Drganijten. Man bleibt laujchend unt gleichjam fejtgebannt jtehen, wenn jeine Sllänge, bie mur mit Dem Shylage flemer (stagglodfen zu vergleichen finto, vielfach mobulixt in einer regelmäp̈igen Melobie vereint, aus ben Baumwipfeln leije und langjam herabtönen. Es liegt etwas unbejdyreiblidy Sanftes, man

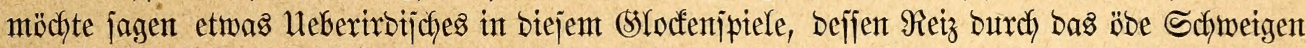
bes weiten Walbes uno bie Unjichtbarfeit bes überaus fleinen Sängers vermehrt mirb. Un feinen જreis möchte man ben enblich) bemerften töten." Sebenfalfs ijt es biejer (sejang,

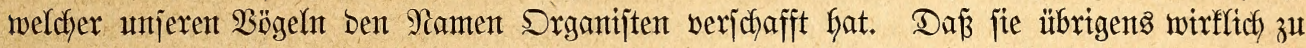
ben jangfähigen Bögeln zählen, Dürfte faum bejtritten werben fönnen: Gierüber jtimmen fajt

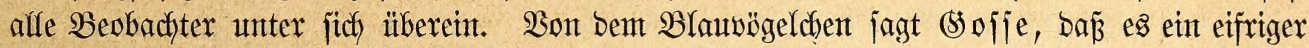
Singoogel jei, werjchiebente \&aute habe, oft burchbringenbe, Dann mieber langgezogene, tiefflingente Tönte bernefyment lajfe, weldye an bas flagende Bejdyrei eintes Falfent erinnern, abgejeben von affen biejen Tönen unb Rauten aber nody einen wirflidy angenefmen unb flangwolfen (Sejang zum bejten gäbe. Einmal Görte gedachter Raturforjcher zmei unmittelbar vor jeinem

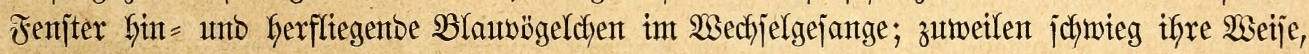

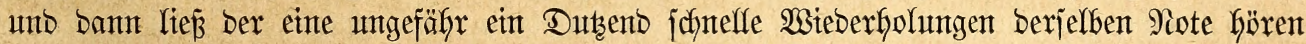
unt enbete bieje eigentümliche Mujif mit einem etwas bäheren Ione, welcher ben eigentüm=

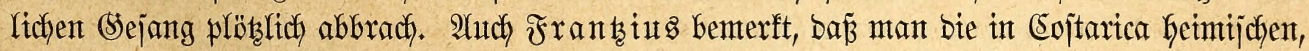
oben aufgefüfrten 2 rten ifyres (sejanges wegen im Säfige halte und beshalb oft mafjenweije fange. Rez̧teres gejuifht in Den meijten Fällen auf einfache Weije mittels bes flebrigen Saftes ingeno einer mildyigen $\mathfrak{F f l a n z e , ~ w e l d y e r ~ a l s ~ S o g e l f e i m ~ b e n u t b t ~ w i r b . ~}$

Uleber bie Fortpflanzung fino bie Beridfte noch bürftig. Ein \$ar Drganijten, meldye

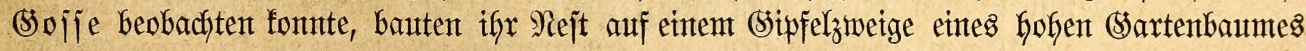

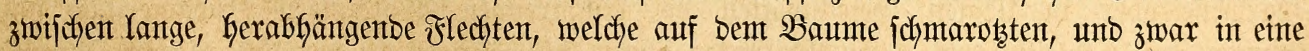

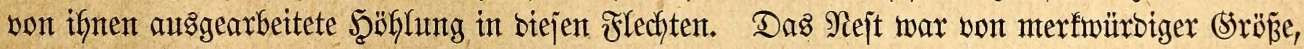

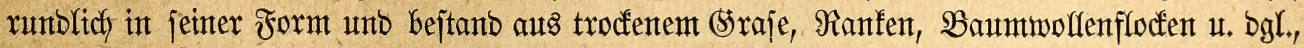

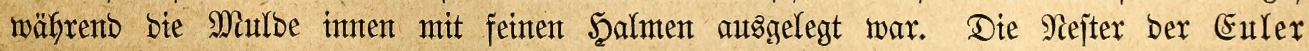

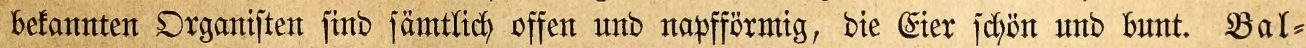

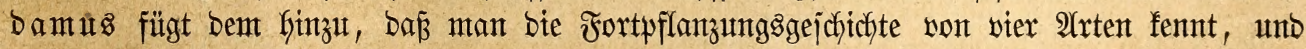

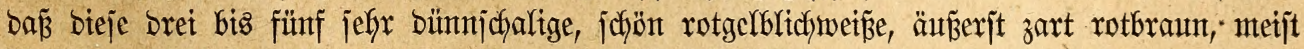

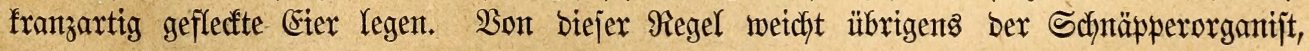
weldser ïberfyaupt in eine zweifelfafte Stelfung gebradjt zu jein jofjeint, wejentlich ab, ba

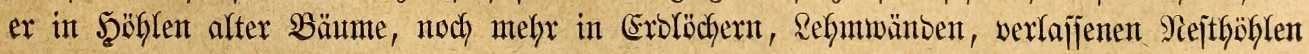




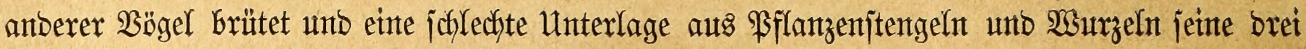
biş vier länglichen, glanzlojen, weiß̄en Eier legt.

In unjere Säfige gelangt vorgugģweije bie in Brajilten bäufige unt bort vielfach in (Sejangenjijaft gebaltene (Satturama, nidht eigentlich) regelmäpitg, aber bod) wohl fajt in jebem

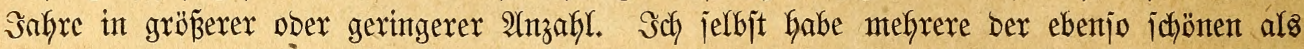
munteren unt lebhaften $\mathfrak{B}$ ögeldhen gepflegt unto begreife vollfommen bie $\mathfrak{B}$ orliebe ber Sïb=

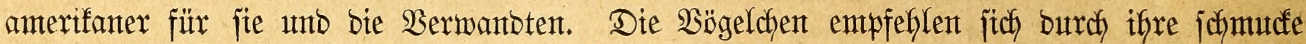

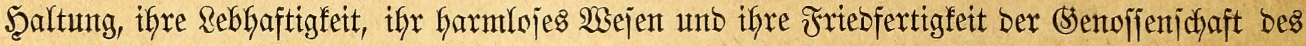

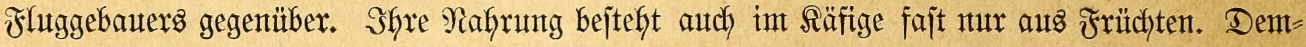
ungeachtet ijt es nidyt jobnterig, jie zu erfalten, weil jie jich nticht allein an unjere Dbjtarten, jonbern audh an gefodte Sartoffeln und geriebene Mëhren gemöhnen lajfen. Sie verbrauchen

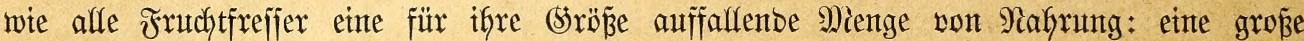
Birnte ift für eine (Satturama burchaus nicht zuviel, obgletch ber räumliche Snfhalt ber Frudht Die Reibesmaffe bes fleinen (sejelfen merflich) übertrifft. Sch lafje Die Frütste ganz wie bei ben Tangaren meijt in gropent Stüdfen retchen, eine Birne aljo in zwei, hödjitents vier Schnttte

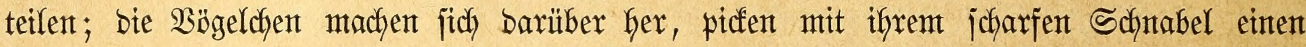

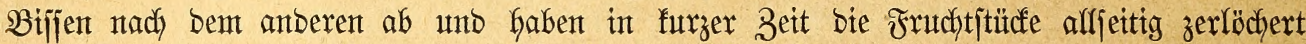

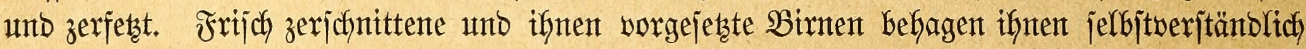
mebr als joldhe, welche bereits länger an ber \&uft lagen, unb es ijt beshalb zu raten, ifnen

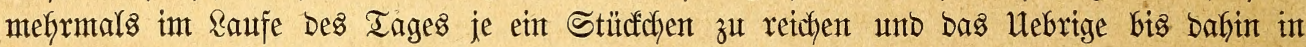

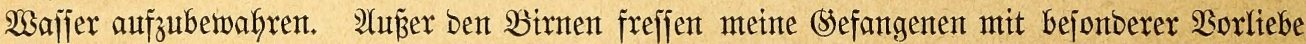
Srangen, minber gern 2Hepfel, wahricheinlich weil bie Şärte bez Fleijches ifynen Schwierig=

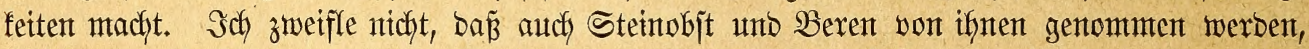
habe aber Gierüber noch feinte Derjuche anjtellen fönten. Şanfförner jedeinen von ifnen recht gern gefrejien z̆ werben; jie nefymen ein fiorn nach bem amberen auf, jojälen es,

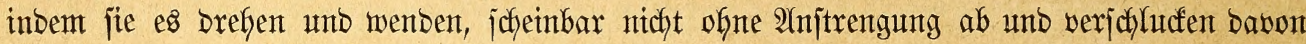

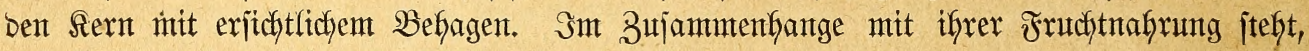

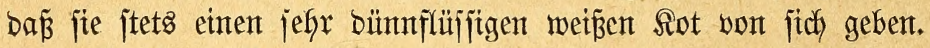

Arfe Srganijten jteben bet uns zu Ranbe noch ziemlidh hoch im \$reije. Unter acht

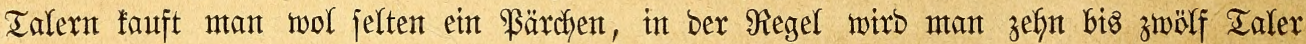
erlegen müfjen. Dies ijt viel für einten bod, immerfin jefy finfälfigen, weil ungemein

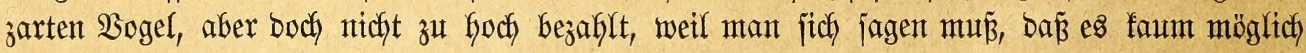
ijt, fich benjelben billiger zu verjodaffen.

\section{Ketisuönel.}

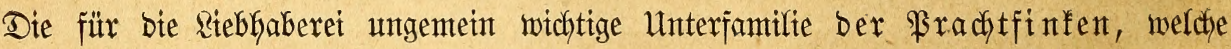
uns gegenmärtig mefr als jede anbere (Sruppe ber Sïnnerfrefjer bie Säfige füllt, hat auth

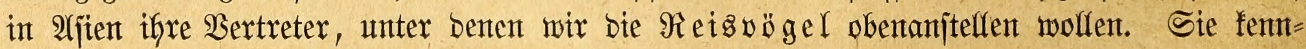
zeidynen ber groje und jtarfe, auf ber Firite alfjettig gemölbte, an ben Sdynetbentänbern eingezogene, bor ber Spize berjelben herabgebogene, im finteren Drittel ber unteren Schne: benränber jummpfwinfeltge Sdynabel, bie fräftigen, langzefigen Füß̈e, ber mittellange, zujammen= gelegt ein Drittel Des Schwanzes Decfente Flügel, unter beren Schwingen bie zweite bie anberen überragt, Dex mittelfange, aus breiten, furz zugejpizten Febern bejtełente Schmanz uno bas reiche, jeibige, in beiben (sejchledytern wollfonmtent gleich gefärbte (Sefieber. 


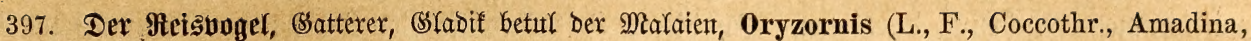

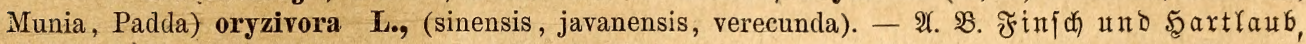

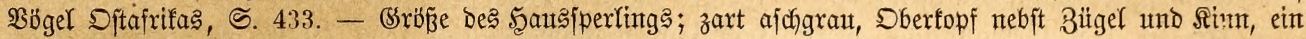

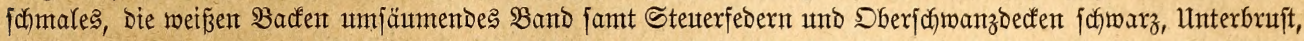

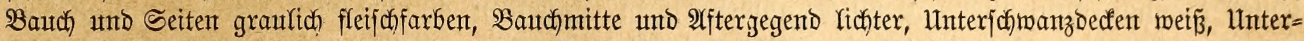

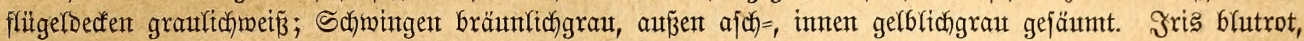

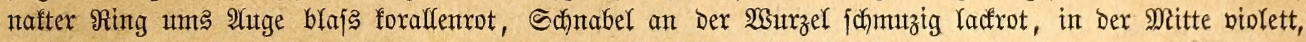

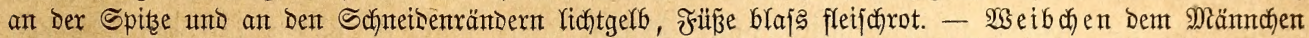

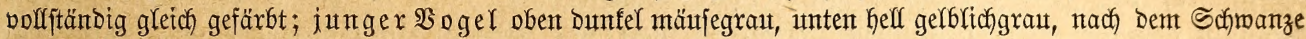

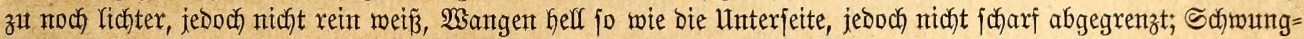

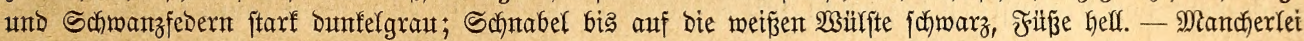

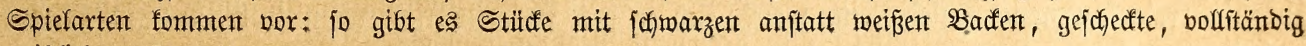
weiplicte it. f. w.

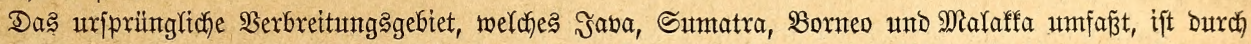

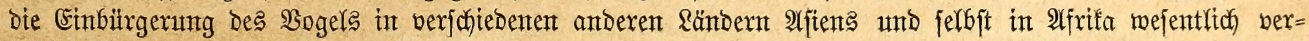
größerert wordent.

398. Der 3immetreisungel, O. (L., P.) fuscata, Vieill. - A. B. $\mathfrak{B}$ ieiffot, Oiss. chant., S. 95,

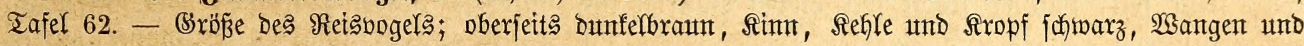

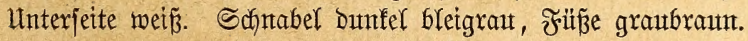

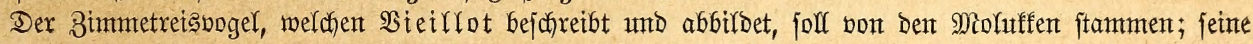

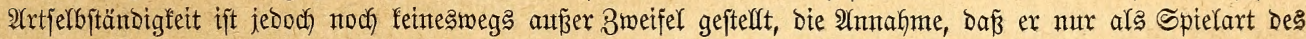

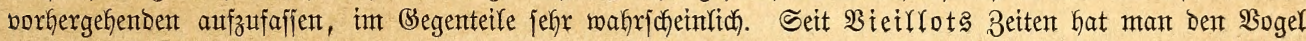

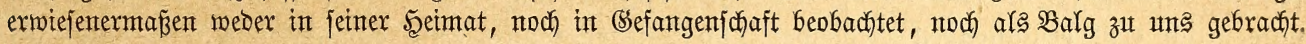

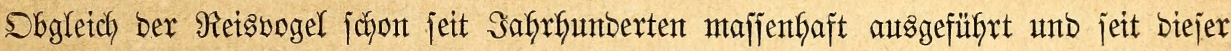
3eit auch überafl in Räfige gebalten worben ijt, haben wir boch erit in Der Neuzeit burch Bernjtein eine eingehendere Schillberung jeines Rebents erfalten. "(s)leich unjerem euro= päijchen Felbiperlinge", jagt biejer treffliche, für bie Wifjenjchaft leiber viel zu früh gejtorbene

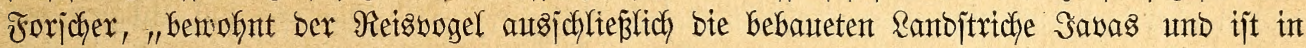

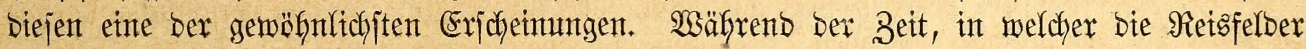

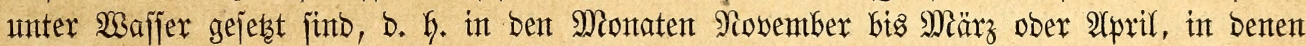
Dex Reis heranmächjt unt Der Ernte entgegenteift, Galten jich bie Bögel parmeije ober in

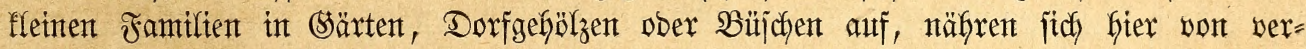

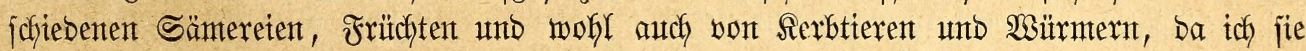

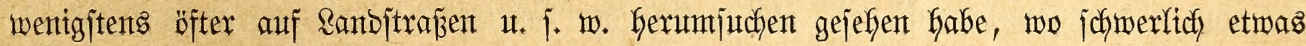
anberes zu funben fein bürfte, und auch in Den Magen mefrerer Stüdfe Rejter berjelben gefunben za haben glaube. Sobald aber bie Retsfelber fich gelb zu färben beginnen und Durch Arblafjen Des Mafjers trodfen gelegt werben, begeben fie fich oft in Scharen borthin

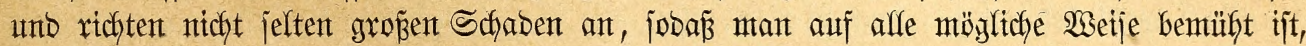
fie zu vertreiben. Sn ben Segenden, meldye bejonders von biejen gefieberten Dieben zu leiben haben, errichtet ntan zu biejent Bwecfe in ber Mitte bez Felbes ein - ober wenn

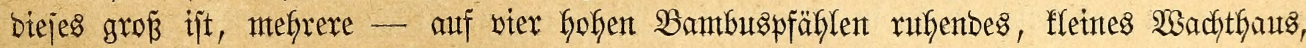

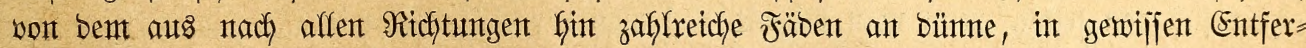

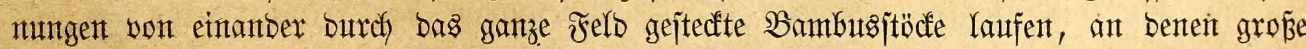
bürre Blättex, bunte Rappen, ßuppen, bölzerne Slappern u. bergl. Gängen. Wenn mun

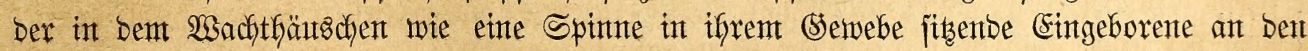

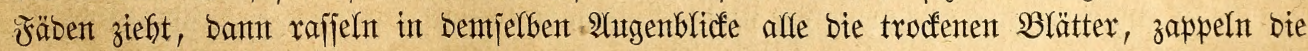

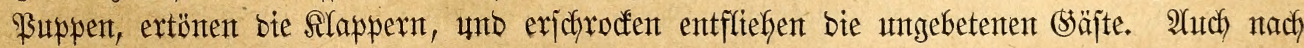
ber Ente fintoen bie Bögel auf Den alsbann nodh Kis zum Eintritt ber Regenzeit, D. h. bis

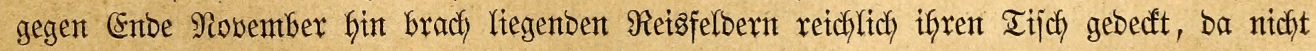
nur zahlreiche 2lebren liegen bleiben, jombern audh zwijchen ben Stoppeln in unglaublich) furzer 3eit mandffaltige Unfräuter emporjchiejen, beren bald reifende Samen ifnen einte 


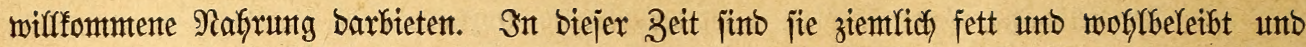
liefern, bejonbers bie Sungen, ein beliebtes (sericht, weshalb ifynen eifrig nadjgejtellt mirb."

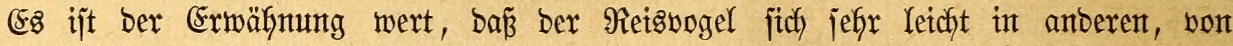

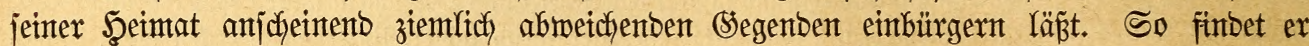

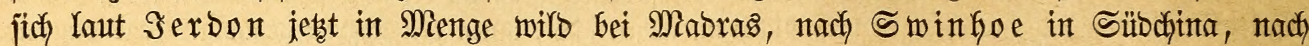
Re wton auf Bourbon unb Mauritus, nad) $\Omega$ irf unb yon ber Ded en auf ber Snjel

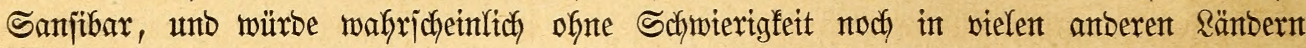

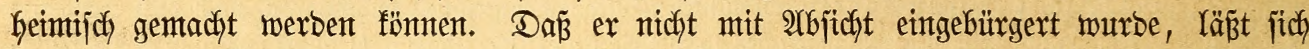

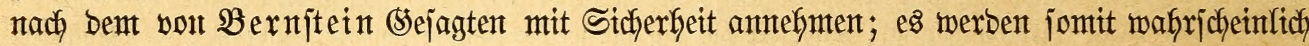
zufälfig freigefommene Stüdfe jein, welche fich) in ben uriprünglidy ifynen fremben Ranbjochaften angejibelt haben.

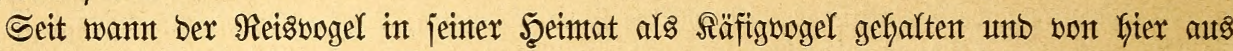

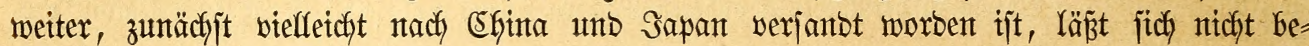
fitimmen, ja nicht einmal nadymeijen, wann er zuerjt in unjere Säfige gelangte. Sovbiel

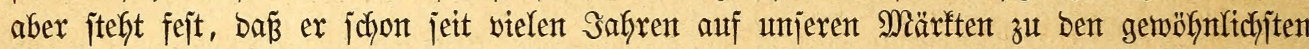

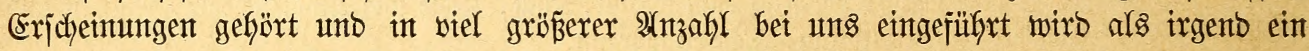

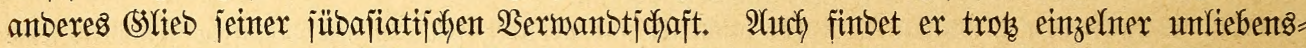

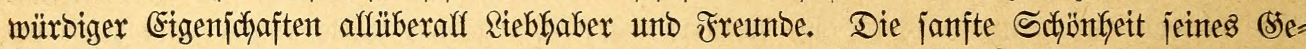

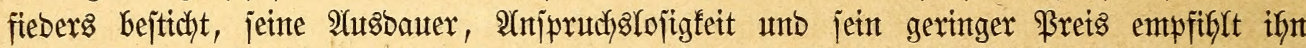
namentlich bent beginnenben RiebGaber uno Pfleger. Mit bem einfactjiten Räfige zufrieben

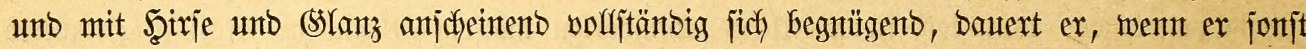

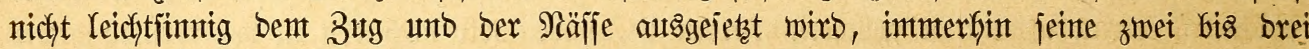

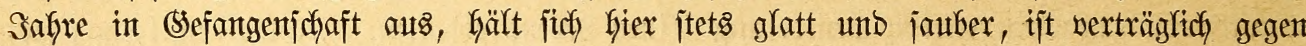

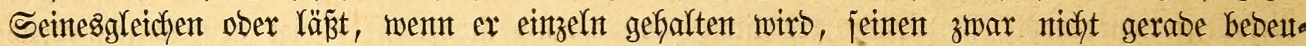

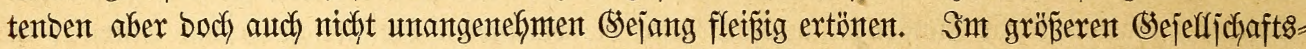

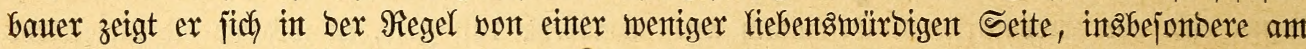
Futternapfe fleinen Bögefn gegenüber, hat fid) autd) aus biejemt (5runbe bei alfen funtigen Riebhabern eine gemifife Mizachtung zugezogen, weldhe idh nach meinen Exrafirungen als zu

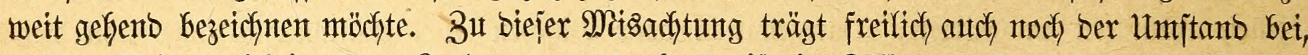

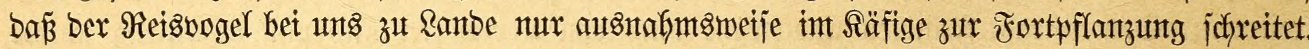

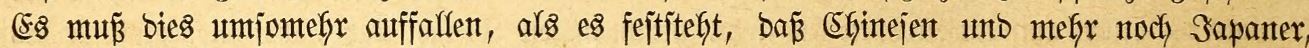

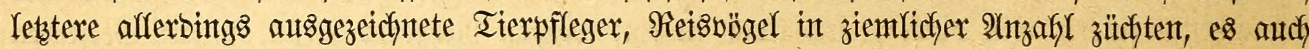

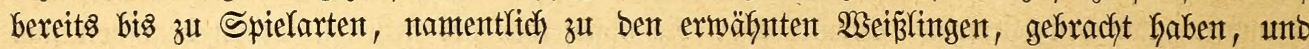

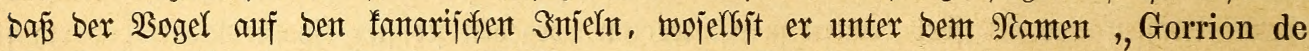

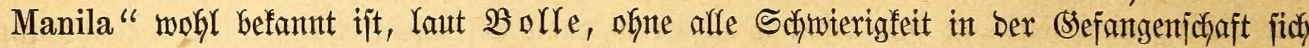
fortpflanzt.

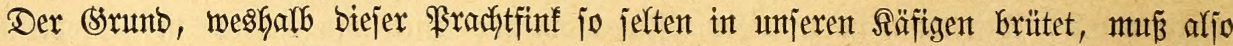

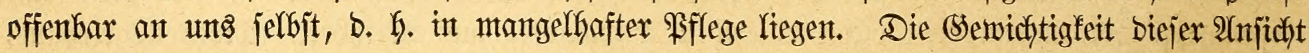

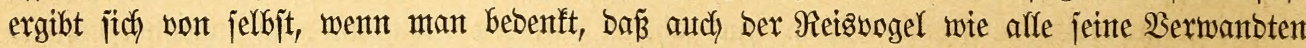

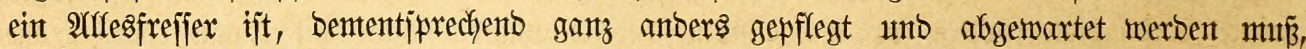

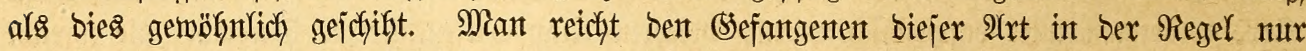

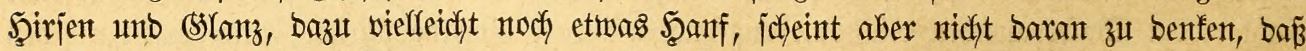

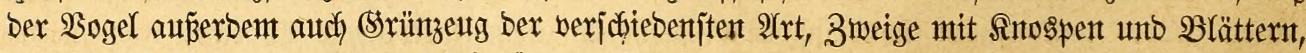

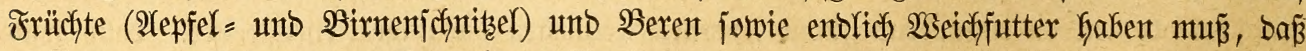

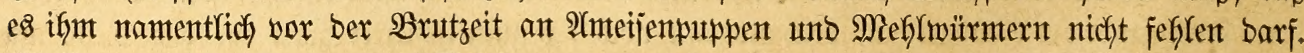

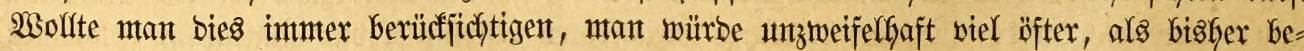

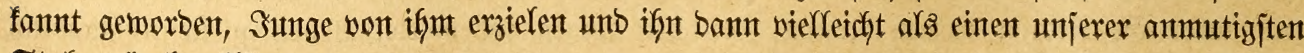
Stubenvëgel erflären. 


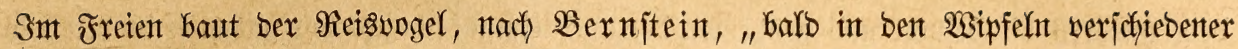

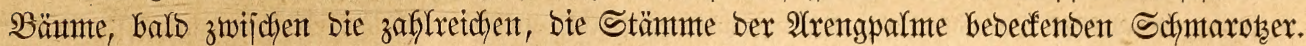

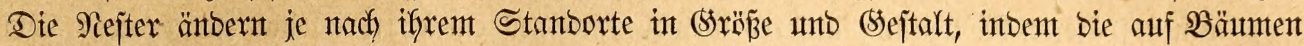

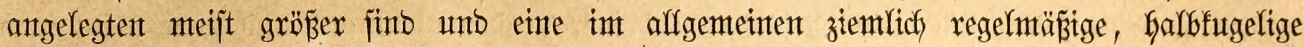
(Sejtalt zeigen, bie zwijichent ben Schmaroţern ber 2 (rengpafmenjtämme angebrachten bagegen fleitter fint unt eine wentg befitimnte, unregelmä̈̈ige, in ber Mitte nur unbebeutent ver=

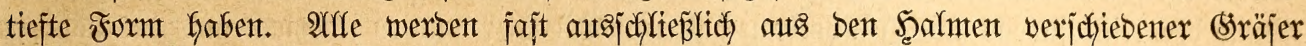
werfertigt, bie Şarnte untereintantber aber ebent nidht jeffr fejt verflodften, jo baßj ber ganze

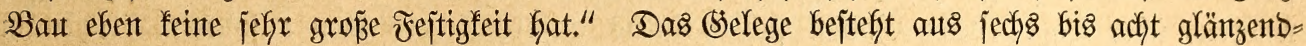

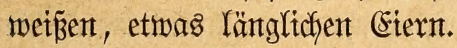

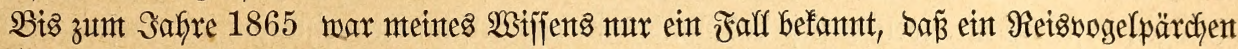

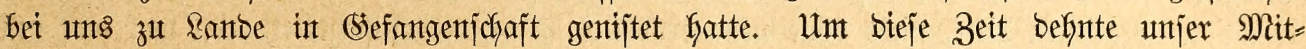

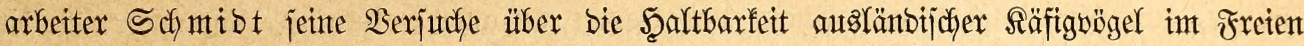

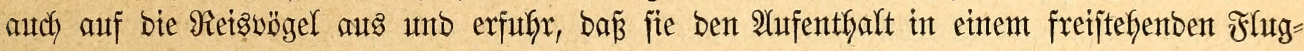
gebauter vortrefflich vertragen. Sie waren ntunter, babeten fleip̧ig unb lię̧en fajt bent ganzen

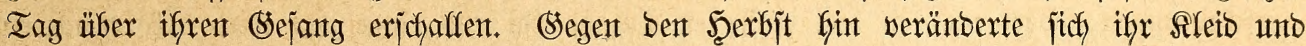

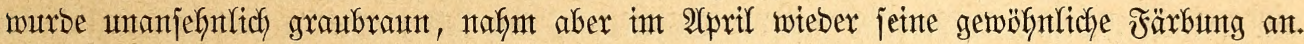

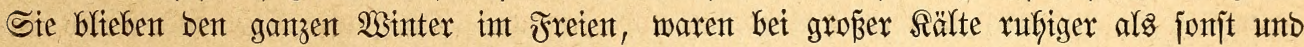
faß̉ent bant zuweiten ftunbentantg unbeweglide auf ben Stangent ober Zweigen, fofjenten aber

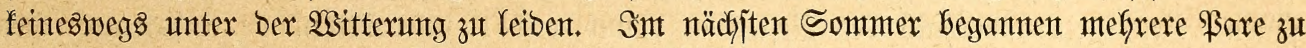

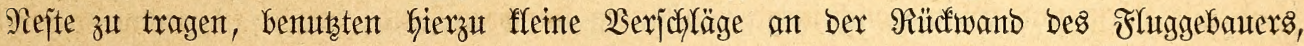

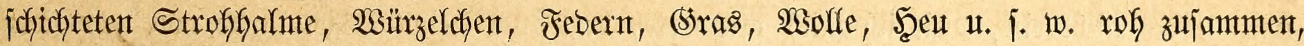

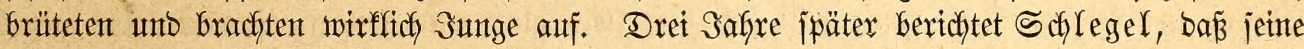

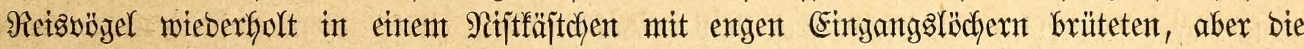
Untugent Gatten, ifgre Suntgen, nactyoemt fie zwei bis brei Tage aft getworbent waren, aus

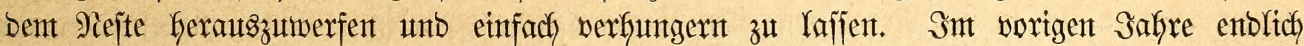

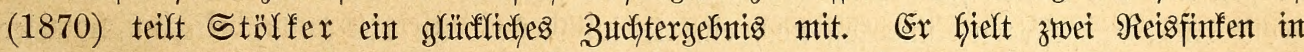
eintent ber oben (ङ. 13) gejdfitberten Siftenfüfige von $80 \mathrm{~cm}$. Säntge, $50 \mathrm{~cm}$. Tiefe unt $37 \mathrm{~cm}$.

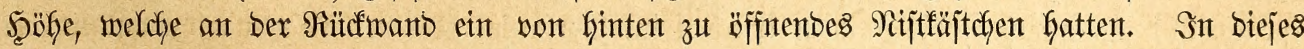

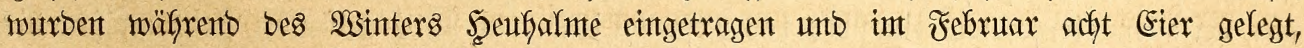

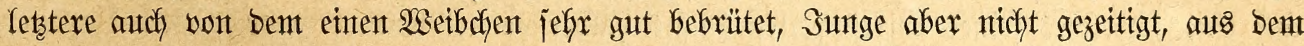

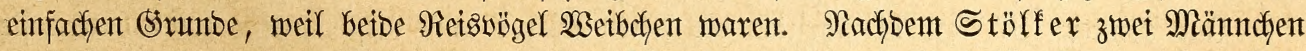

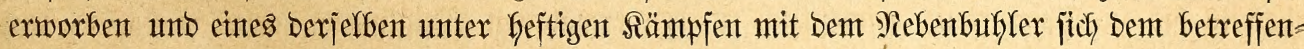

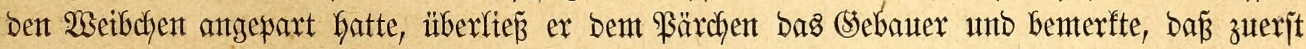

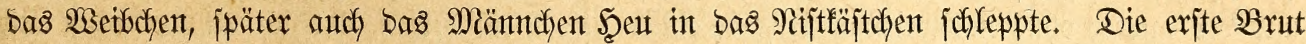

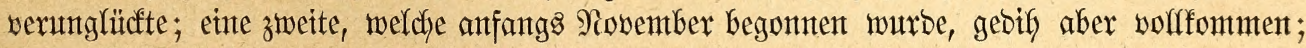

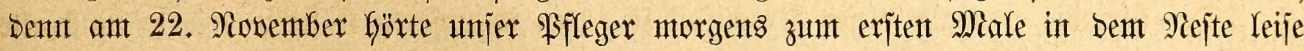

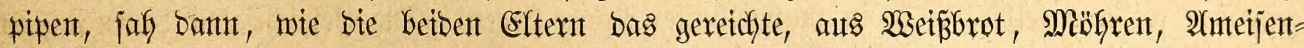

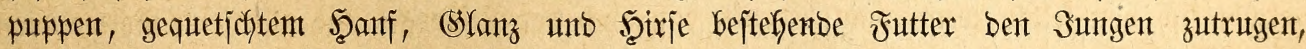

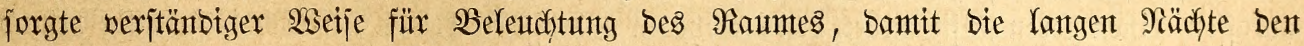

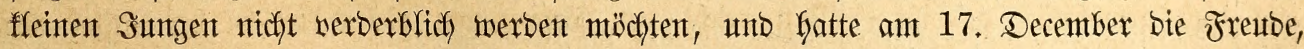

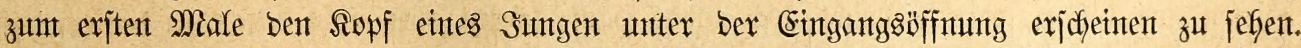
Tags barauf jtand eines füffr auf Demt Stabe bor bent Mejte, zog fith bant bald wieber zurǚd, fant wieber heraus unb froch aberntals einwärtz, währento ein zweitez, went jentes

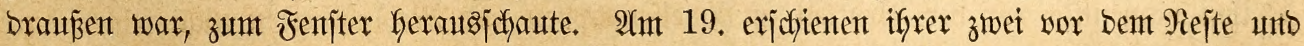
ein brittes noch in ber Seffintng; wentige Iage ipäter waren alfe vier glüuffich ausgefomment. Ob beibe (sejdflectiter brüten, fonnte St örfer wegen ber wolffommenen SIfeidffarbigfeit bes

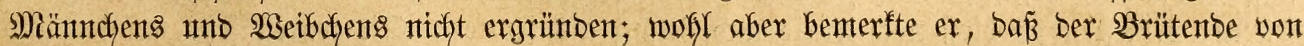


bemt anberen oft bejucht und geatzt wurbe, auch einutal täglich, vorziggineije in ben Miorgent=

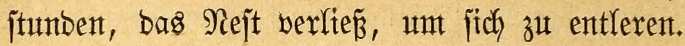

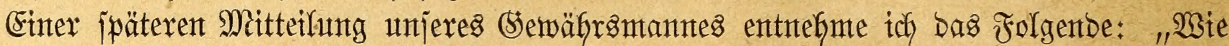

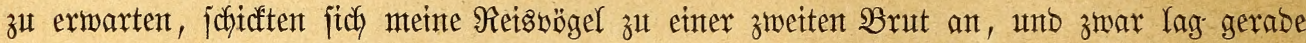

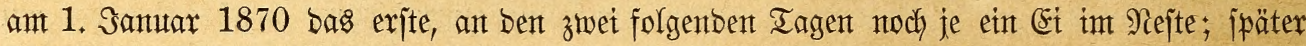

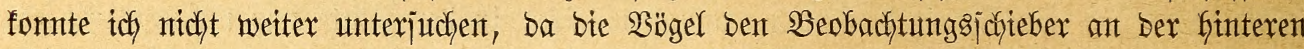

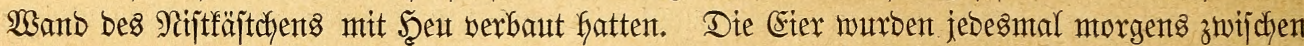
fieben und acht Uhr gelegt; wentigitens blieb bas Weibchen um dieje Beit länger int গejte, währent über Tages betbe (Satten jich meijtens außzerbalb besjelben auffielten. Erjt am 5. Эamuar begann bas Brüten, murbe jeboch noch oft unterbrochen, anfangs auth burdy bie Sungen erjter $\mathfrak{B r u t}$, welche jich bes Nachts in bas Nifitfäftchen einbrängten, wejentlich beein=

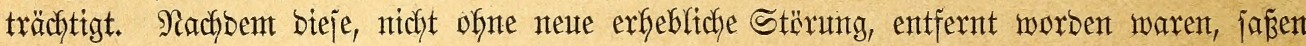
bie âften ganz fejt, brüteten aljo eigentlich) mux während ber zweiten Şälfte ber Sizzzeit

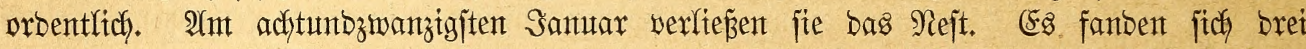
Eiex vor; zwei von ifnen waren taub, in bem britten lag ein vollitändig entwidfeltes Sunges

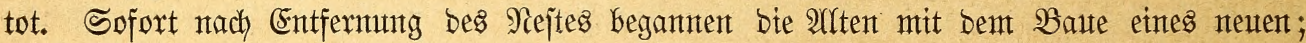
am britten Februar beobachtete ich bie Seegattung, und jofon tags barauf lag ein (5i im

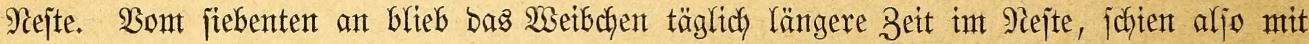
Brüten begonten zu haben; Doch fitelten fich beibe (Satten noch länger als acht Iage auf=

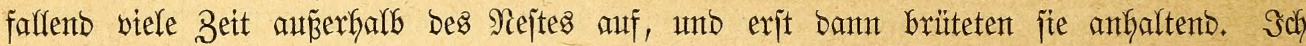
gab die Brut verloren, umjomehr als ich lange über bie berechnete Beit nichts pipen hörte,

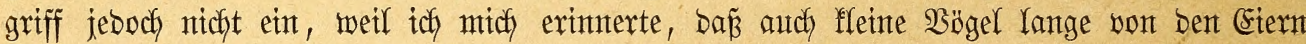

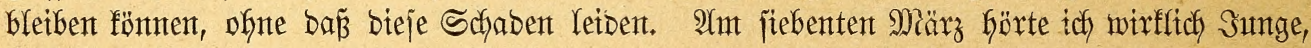

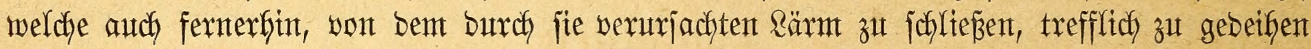

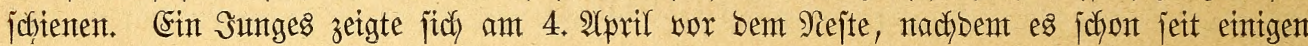
Tagen mit ben (Sejdywiftern zum Schlupfloche herauggejchaut hatte; bis zum 9. 2April waren

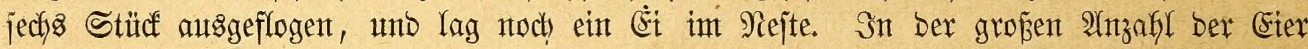

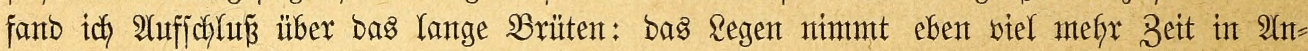
ipruch, als ich antafyn; bie Sungen friectjen im Serfaufe mefrerer Iage nach eintanber aus

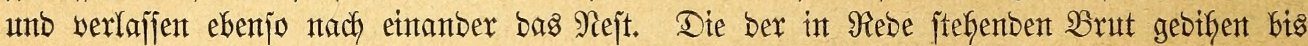
auf eines, weldjes jeines verfnüppelten Fukes Galber getötet wurbe, wortrefflich.

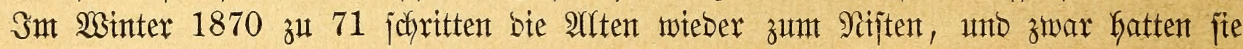
zwei Sielege, bet benten je ein Ei einen gut entwidfelten Sieimling enthielt, weldyer jeboch

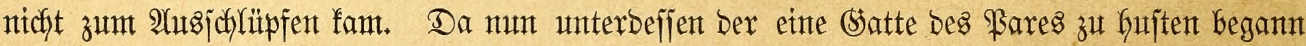

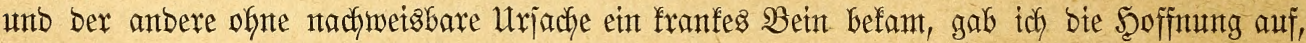

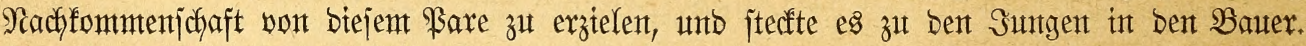

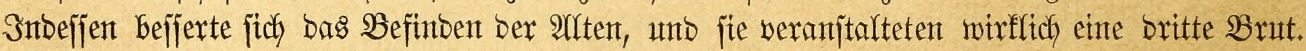

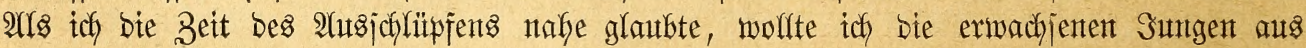
bem Säfige entfernent, ftellte, un nach meiner Meinung möglichjt mentg Störung zı ver=

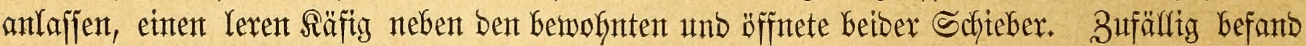

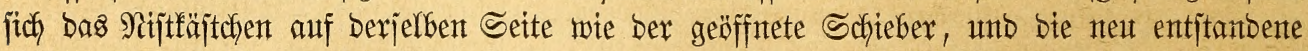

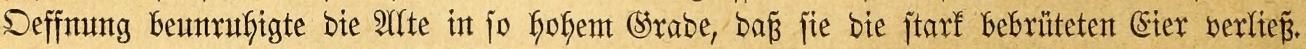

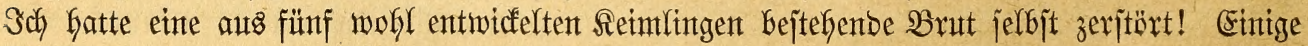

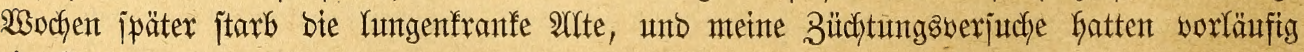
ein Enbe.

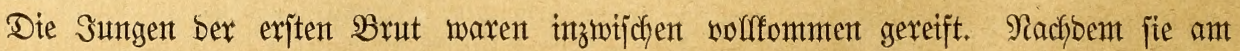

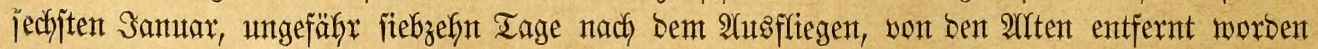
waren, exhielten jie blö noch Şirje und (5) lanz alz Futter. Sie maren jefr munter und 


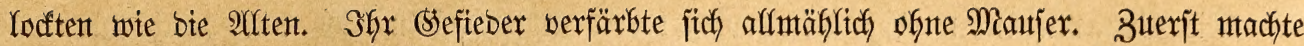

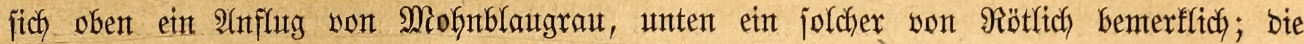

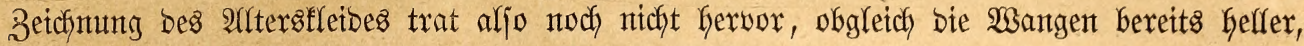
bie Sdyultern bunfler als bie itbrigen Ieile gefärbt waren. Âm zmanzigjten Samuar jafent

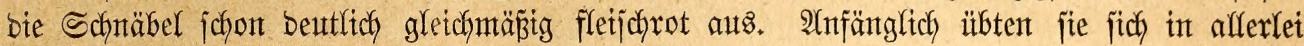

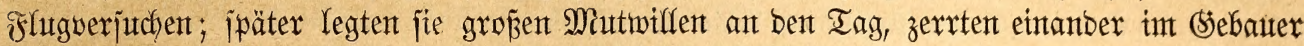
umber, rupften fich an bent Sdywänzent, biffen fich mantdymal auth gantz ernjtlich. SGx (Sejang erimterte mefr an Dent ber Welfenfittiche, won benen mebrere int Bimmer waren,

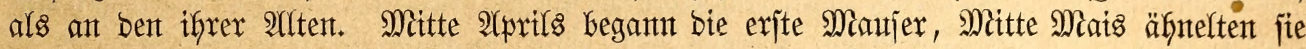

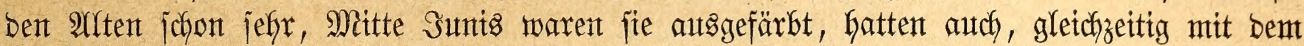
Feberwedjjel, einten (sejang erlernt, weldjer zwar nidyt ganz jo tönt wie ber ifyrer Eltern,

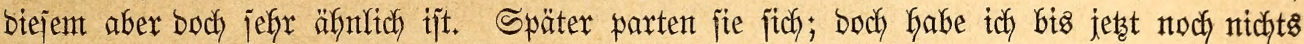
wont ifyten erzielt als zwei (Fier, weldye ith auf Dent Bobent bes Säfigs fanto."

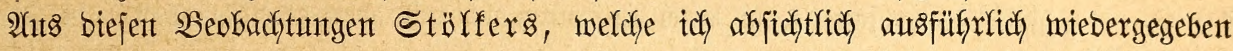

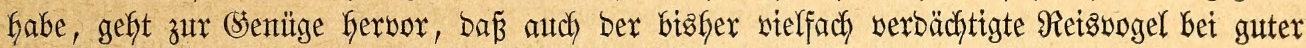
\$̧Flfege int Räfige zutr Fortpflanzung idreitet.

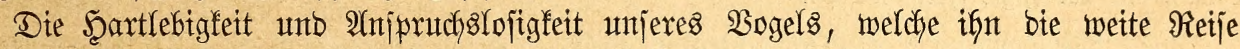

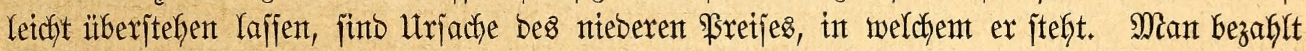

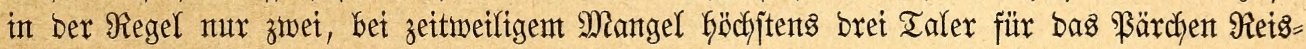
vögel. Für ben 3inmtetretsvogel mürbe ntan gern bas $\mathfrak{B i e r}=$ bis Fünffache aufwenben, fämte ex nux Yebento auf unjeren Marft.

\section{Ammòitren.}

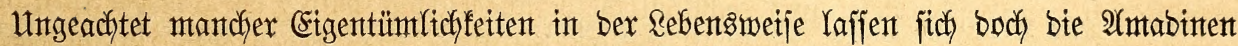
ober bicfichnäbeligen Fractjtfinfen (Spermestes) genteinjchaftlich bejpredhen, zumal man ben 2(bjonberlichfeiten, welche bie einen unt bie anberen in Sittent and Betragen zeigen, Yeidft Rechnung tragen fann. Wix verítehen unter $\mathfrak{A}$ mabinen bie nächjten $\mathfrak{B}$ erwandten ber Reis= bögel, D. G. alle bie fräftigen, gebrungen gebauten, mtebr vber wentger futzicdwänżgen unto

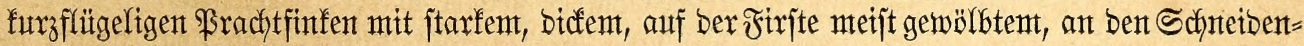

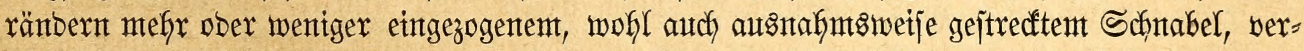

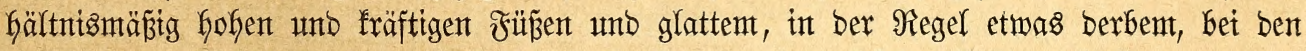

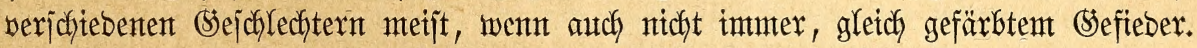

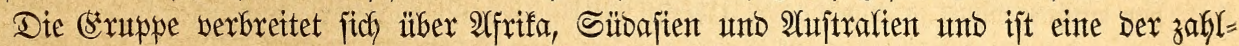
reicheren ifyer Unterfamilie.

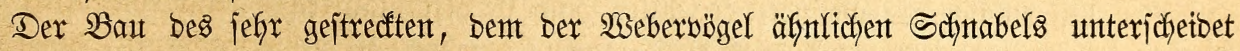

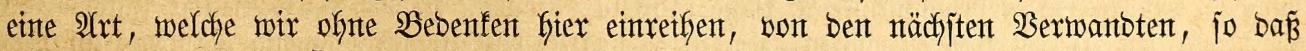
mant fie zum Sertreter einer bejonberent Sippe, ber Webereljterdyen, erhoben Gat.

399. Das ̊nttenterterdjen, Amauresthes (Ploceus, Amadina, Munia) fringilloides, Lafr. -

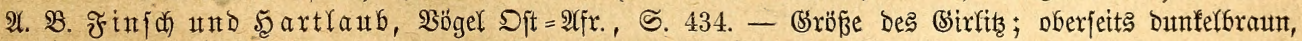

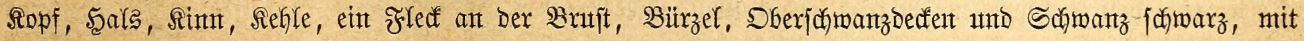

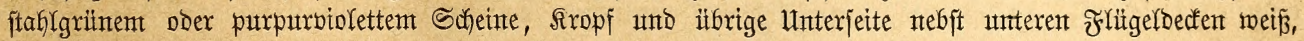

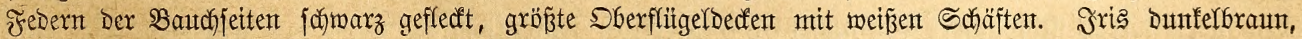

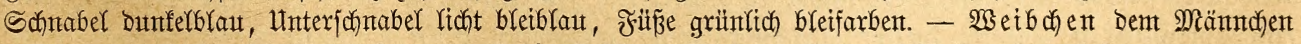

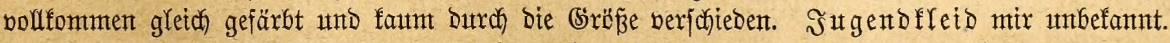

Der anmutige Sogel, weldher exft feit wenigen Jahren einzeln auf unjeren Tiermarft gelangt, bemofnt

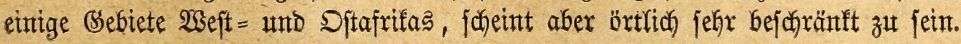


Die Erzamabinen ober Eljterbögeldyen unterichetoen fich mur burd fürzeten

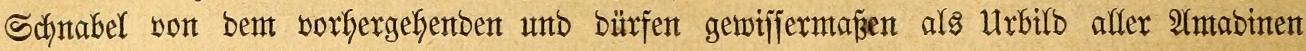
angejeben werbent.

400. Dả Eritervügeldhet, Spermestes (L., Am., Coccothr.) eucullata, Swsn., (prasipteron,

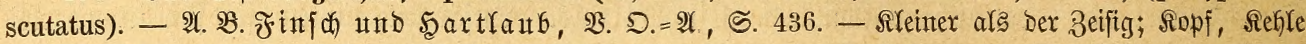

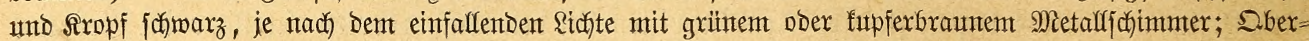

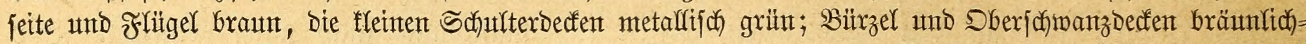

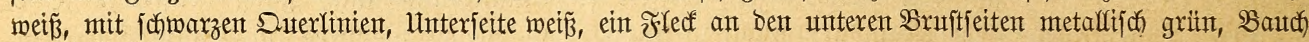
und Schentelfeiten braun mit weißen, Unterfatwanzoeden mit einigen fdhmarzen Duterfinten; Unterflügeldeden

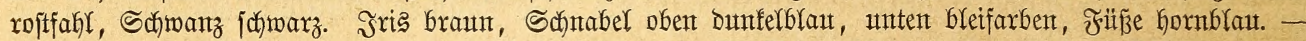

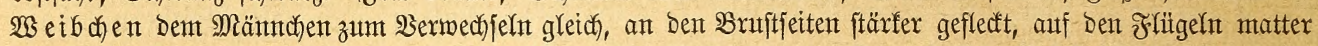

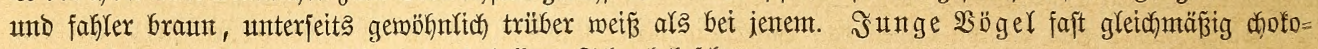
Kabenfarben, auf ber Unterfeite etwas helfer; Sctunabel fodmarz.

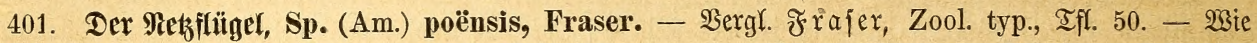

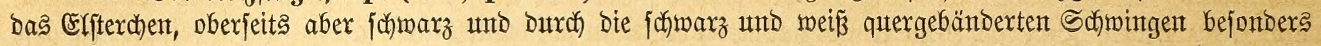
autģgezeiduntet.

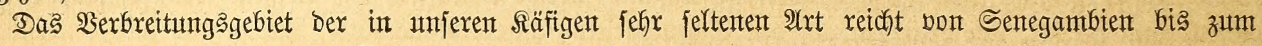

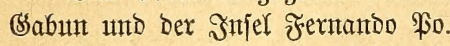

402. Der Doppelfarf, Sp. (Am.) bicolor, Fras. - Vergl. Frafer, Zool. typ., Ifl. 50. - Mierffich)

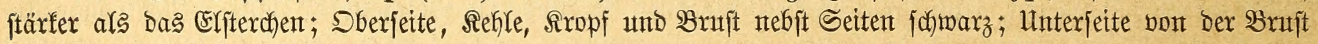

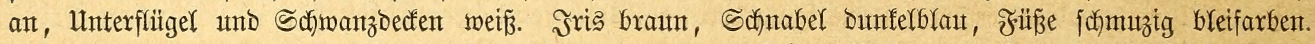

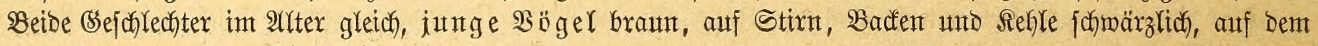

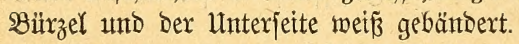

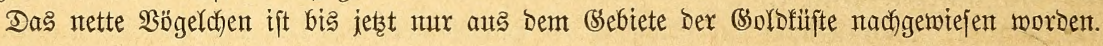

Die jübajiatijcten Bertreter ber Elfterbögeldjen, won ben Seinbojtanern "Miunte" ge=

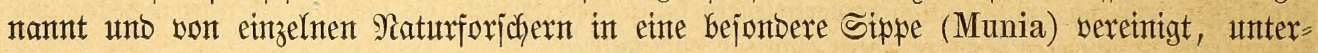
fchetben jich mux burch jebr untwejentliche Merfmale, namentlich burch Den etwas längeren Schwanz von ben vorkergebenden.

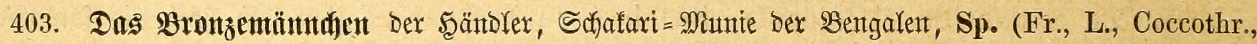

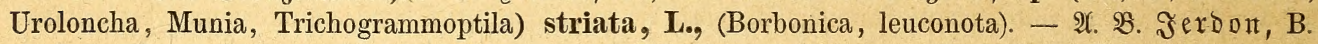

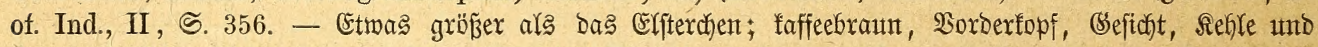

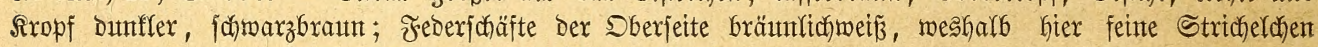

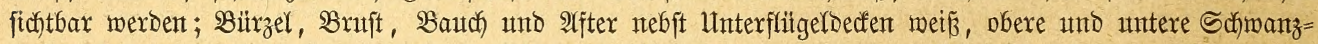
Deffent tiefbraun mit rötfidgbraunen Entofäımen; Schmingen inmen roftgerbfich fahl gefäumt; Stenterfedern

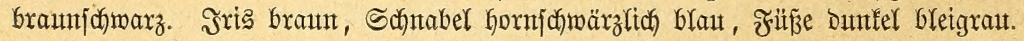

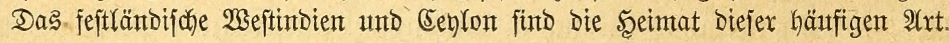

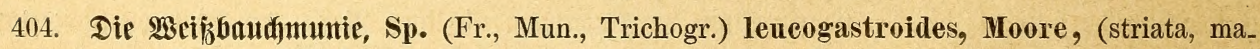

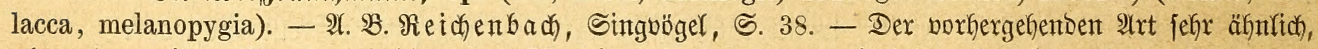

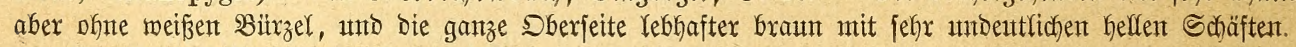

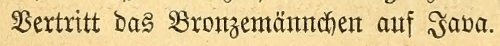

405. Die Spitjiđ̆manzmuntie, Sp. (Coccothr., Mun.) acuticauda, Hodgs., (molucca, muscadina,

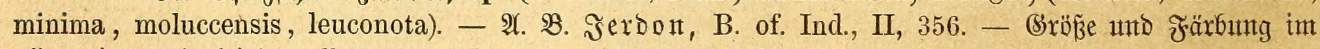

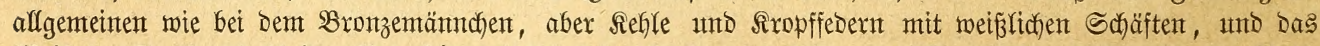

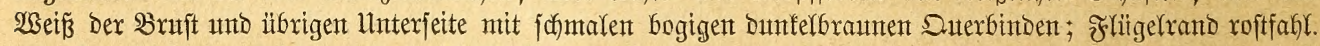

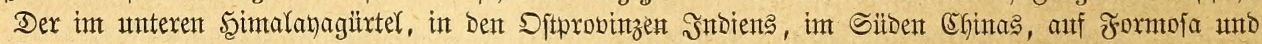

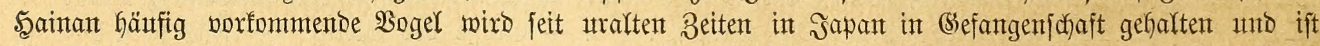

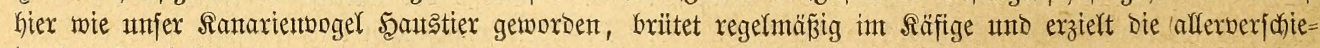
Denften Spielarten.

Der etwas jumä̈here Sdynabel unb merflich itufenförmige Sdymanz gilt als Merfmal einer bejonberen Sippe, weldhe Cabanis Ranzenjdhwänzchen genannt hat.

406. Der Silberidnaber, Zilverbek Dex Şänorer, Sp. (L., Cocc., Estrelda, Am., Uroloncha,

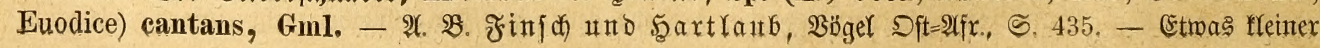




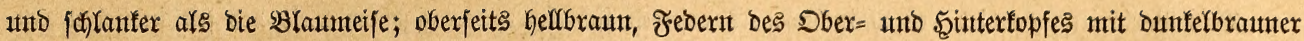

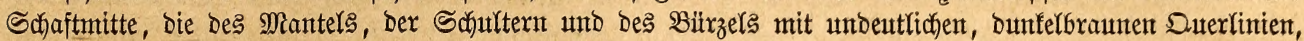

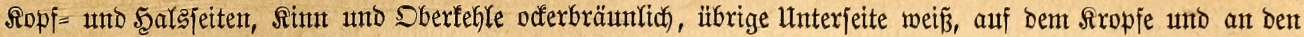

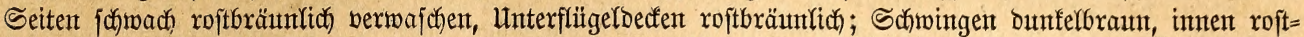

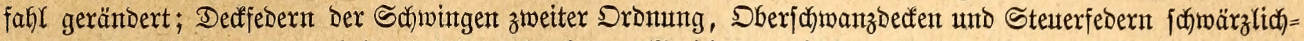

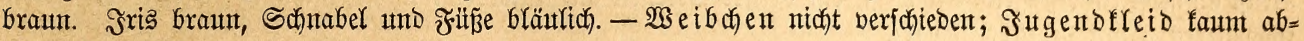

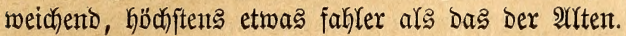

Dex $\mathfrak{B o g e l}$ verbreitet fich über ben größ̈ten Teil Mittelafrifas.

407. Das Silber = oder Malabarfátünden, Sp. (L., Euod., Ur., Lonchura) malabarica, L.,

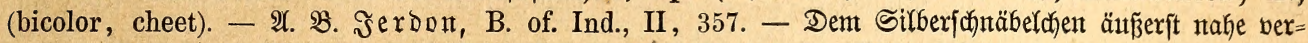

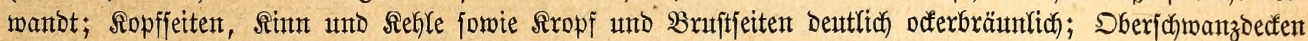

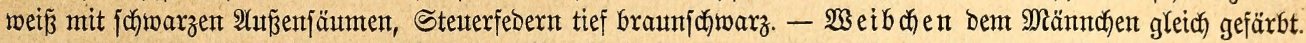

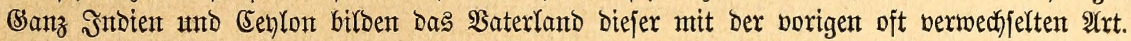

408. Der Mutufatwogel, Sp. (L., Fr., Mun., Ur.,) punctularia, L., (nisoria). - $\mathfrak{e x g l .}$

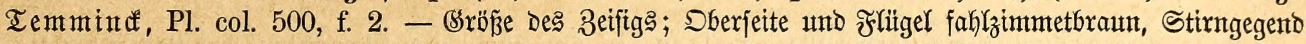

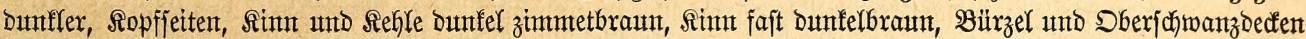

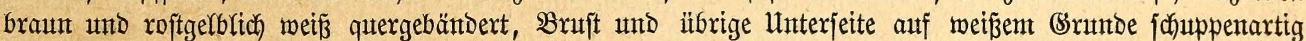

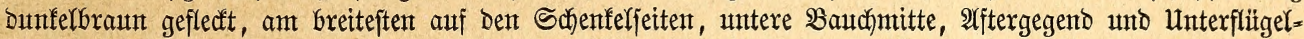

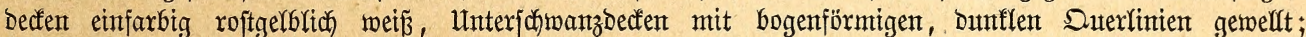

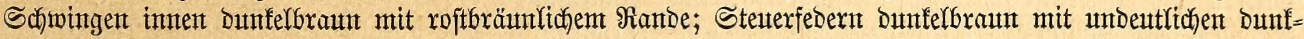
Yeren Duterlinien, die beiden mittelften mehx graubraun. Iris braun, Schnabel blauld) wärzlich, Wurzel=

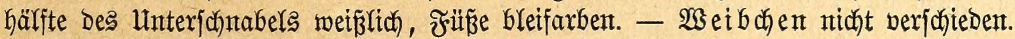

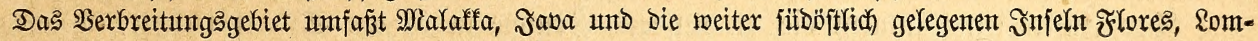
bod und Iimor; auf Maurituts ift Dex $\mathfrak{B}$ ogel eingebürgert worbent.

409. Dex Domino, Telia = Munta und Singbas Dex Scindoftaner, Sp. (L., M., Lonch.) undulata,

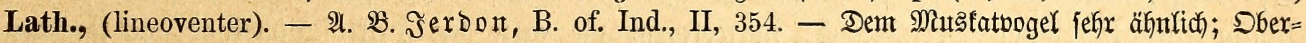

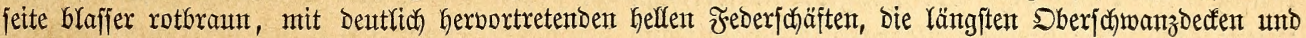

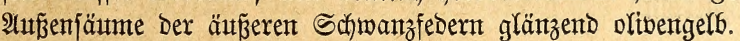

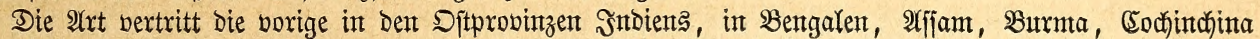
unto auf (Seblon.

410. Die Topela, Sp. (M.) topela, Swinhoe. - A. $\mathfrak{B}$. Ibis, 1863, S. 380 - Unterjdjeibet

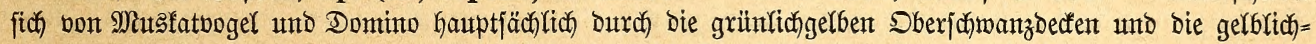
grïn berwajhenen Schwanzfebern; Dberjeite mie beim Dominto büfter braun, bie Febern mit weip̧lichen

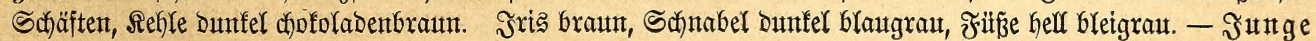
Den artent jaft gleid) gefärbt, Schnabel braunt.

Die Art ift häuftg im Sibden Shinas, anf Scainan unb Formoja, fiex überall ein feintes (Sejanges wegen beliebter $\mathfrak{R a ̈ f i g w o g e l . ~}$

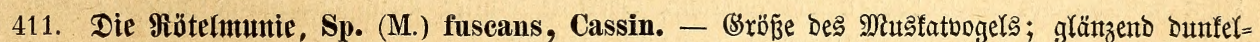

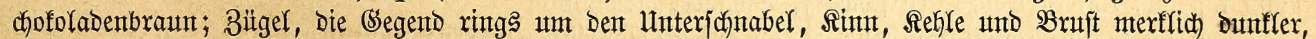
mebr faymarzbraun, Sberjamanzbecfen und Stenterfedern ebenjo, Febern des Sberfopfes mit etwas helferen

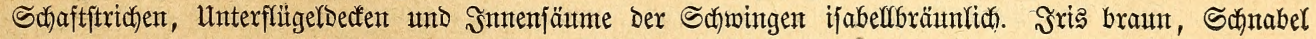

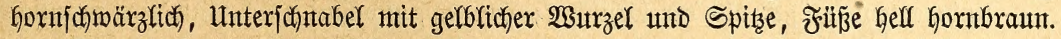

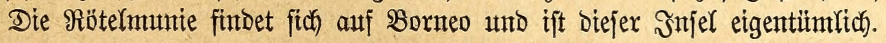

Nonnenvögel nennen bie Şänblex, Dermophrys einige Forjcher, mefrere aus Djtinbien und ben Sumbainjeln jtammenbe, gebrungen gebauete, bejonbers jtarfjchnäbelige Amabinen mit furzen, jefr gerunbeten Flügeln, mittellangent, gerabe abgejdynittentem Scymanze und weichen, feibigem (sefieber, weldyes fich burdy grope Jarbenfelber auzzeidnnet.

412. Dex Miöndigungel, Mongole ober CGinefe Dex Şänthlex, Sp. (L., M., Lonch.,) rubronigra,

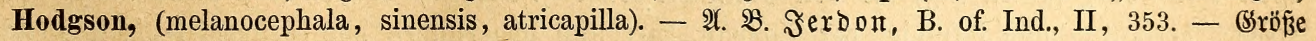

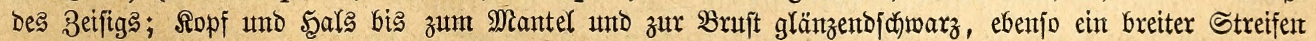

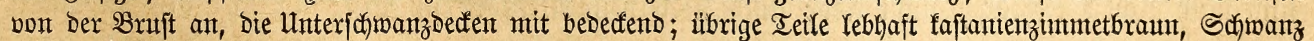

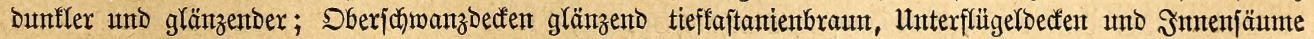

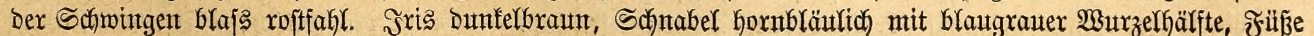
bunfel bleigrau. - Weibden nidft verfdjieden, nur etwas heller uno ber Schnabel mefr einfarbig bleigrau, 


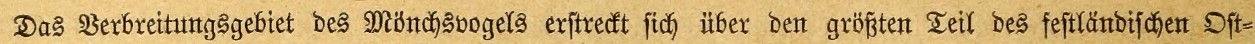

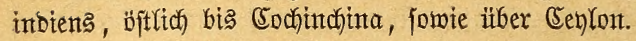

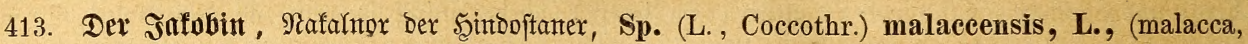

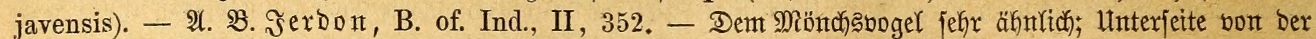
Bruft an nebft Unterflügeldoecfen weiß̄, ein breiter Streifent auf Unterbruft unto Bauchimitte, welcher bie Unter= fafmanzbecten mit bebeatt, fojmarz.

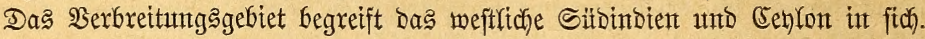

414. Der Montumuger, Sp. (L., Mun., Maja, Dermophrys,) maja, L., (leucocephala, sinen-

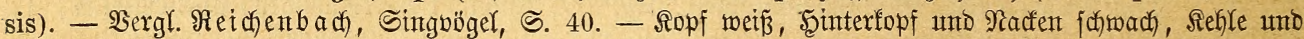

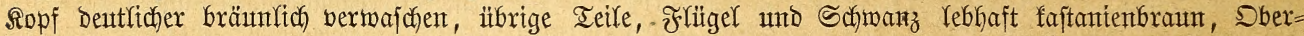

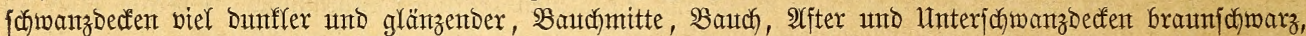

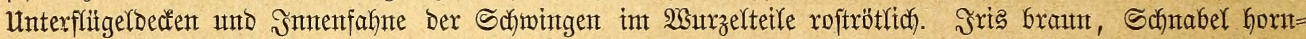

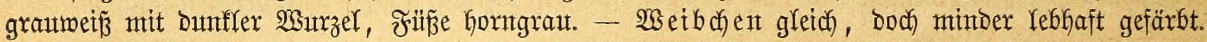

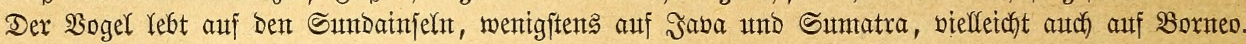

415. Der Bontonl ber Sunbanefert, Sp. (Fr., M.) ferruginosa, Sparrm., (majanoides, ferru-

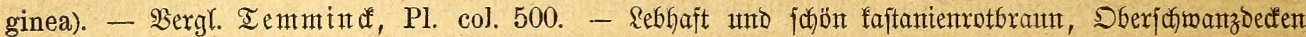

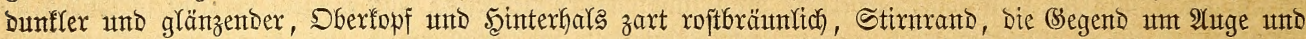

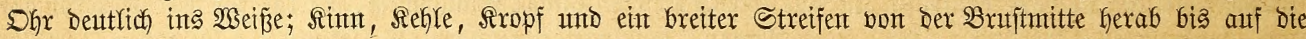

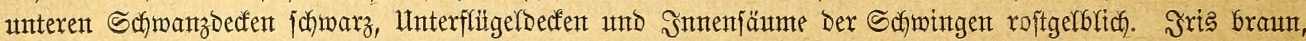

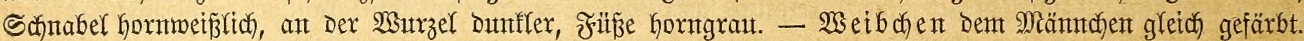

Der Bondol bewohnt Saba und Das benadibarte Flores.

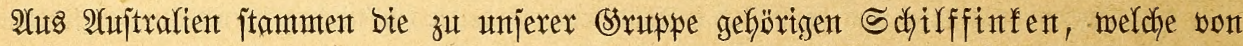
bemt alfgemteinen (Sepräge Gauptiächlich Durch bie ifnen eigentümliche Färbung abmeichent.

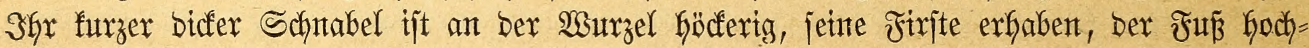
läufig untb langzefig, ber Flügel, in meldhem bie erfte bis britte Sdfwinge bie längiten, mäß̈ig ipts, ber Sdywantz gerabe abgejdyntten.

416. Der Srjilffinf, Sp. (Am., Donacola, Dermoph., Mun.) castaneothorax, Gould, (bivittata, flavipryma). - A. $\mathfrak{B}$. (S)

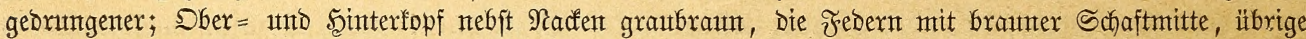

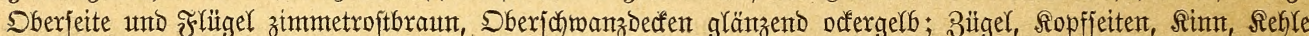

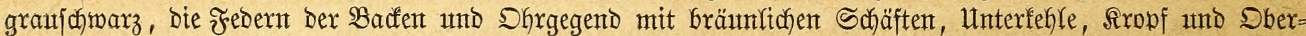

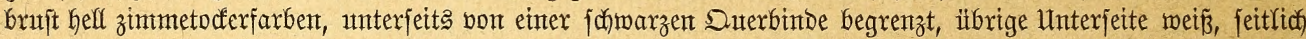

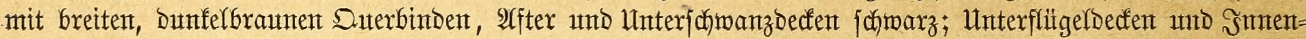

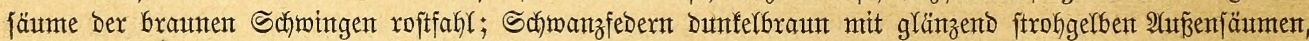

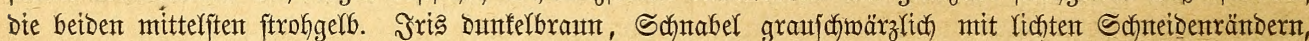

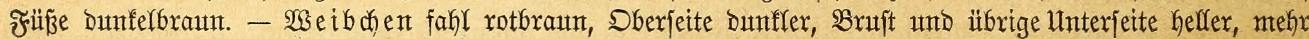

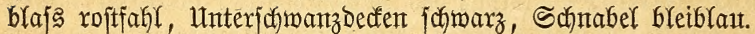

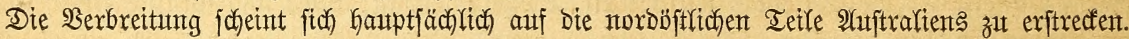

417. Dus Sduuppenbrüitthen, Sp. (Am., Don.,) pectoralis, Gould. - 2 . $\mathfrak{B}$. (B) ould, Handb.

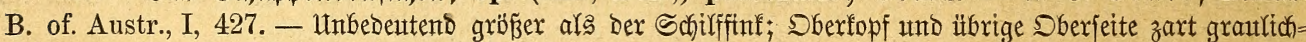

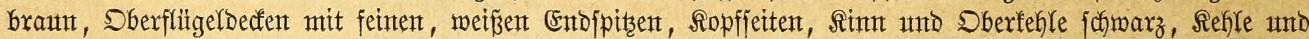

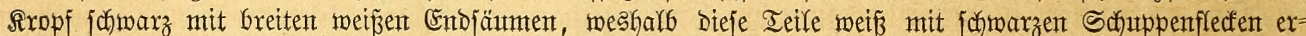

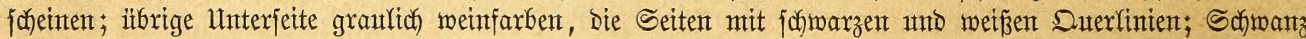

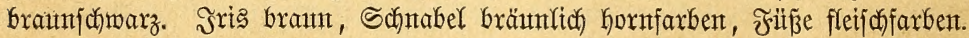

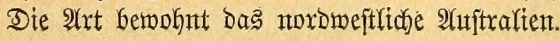

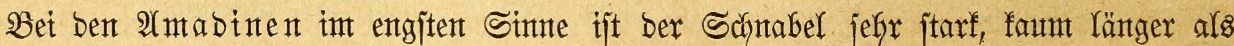
breit und hody, glattfiritig, an Den Ränbern Yeidjt gejdyweift, ber Rauf zientlich lang, ber

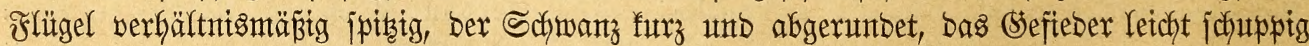
unto nach bent (sejchlecht, nidyt aber audf nach bem âlter verjchieben.

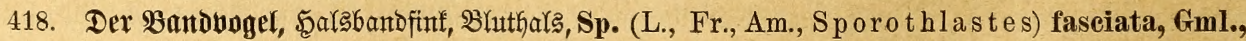
(jugularis, detruncata). - 2. B. Sart

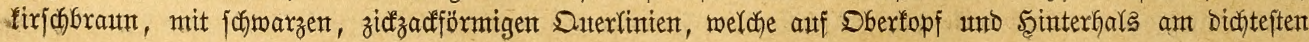




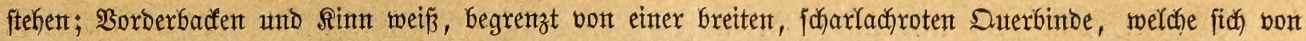

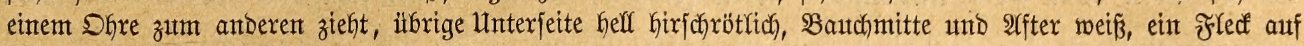

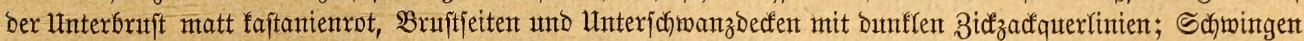

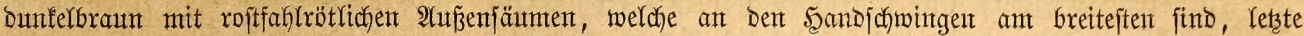
Sandfaningen, Deren Dedfedern und die rängften Schultexfebern mit roftgelbrötfichent Endrande, weldjex

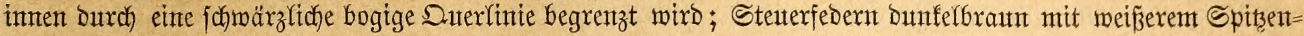

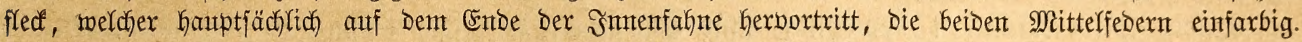

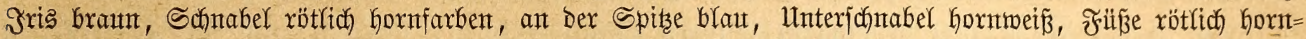

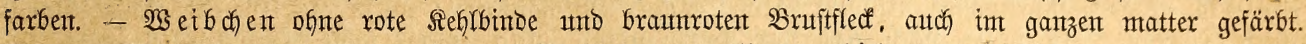

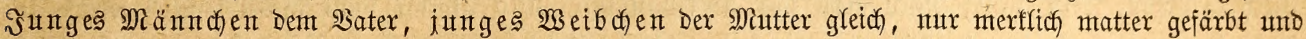

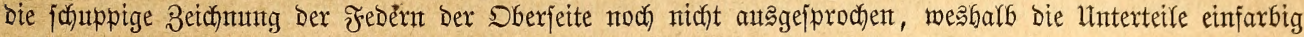
fablgelblich graut exjcheinen. Schnabel bräınlich grat.

Dex Banboogel bewohnt Mittelafrifia von Dex Weft = bis zux Dftfüfte und ift einte ber ant Gäıfigften vor= tommenden 2 rten feinex (Bxuppe.

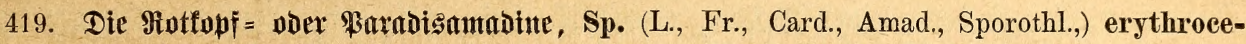
phala, L., (angolensis, brasiliana, reticulata, maculosa). - פergl. Smith, II. S. Afr. Zool., Tfl. 69. -

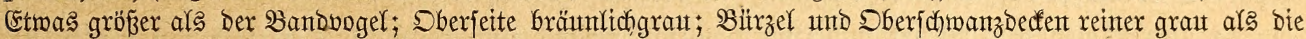

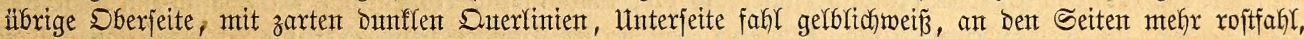

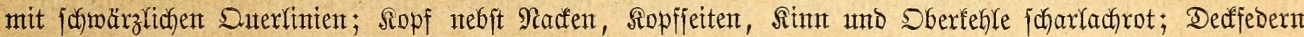

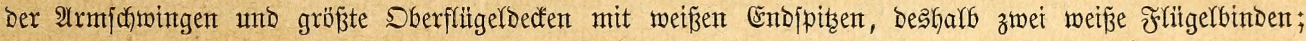

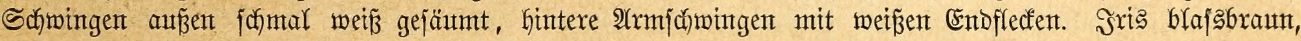

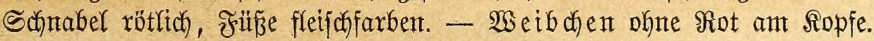

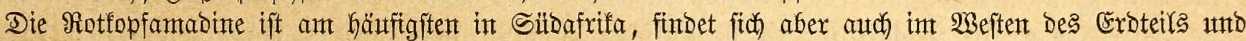
angeblich in Şabefat).

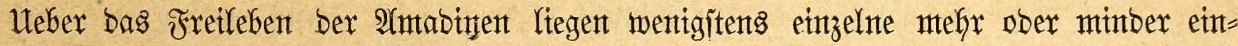

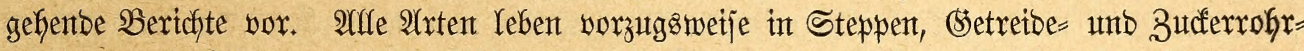

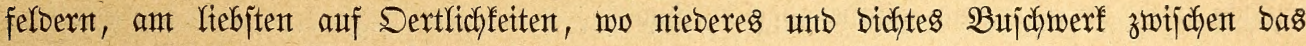

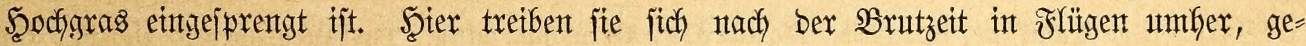

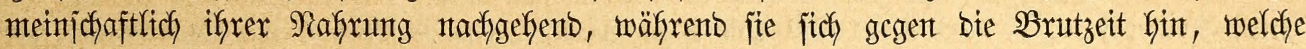

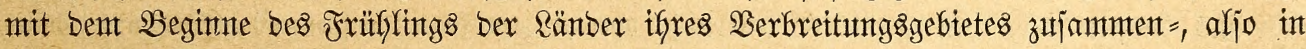
berjdjebene Mionate bes Safres fällt, int Bare auflöjent unto mut entweber einzelt ober audch

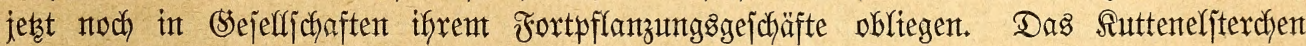

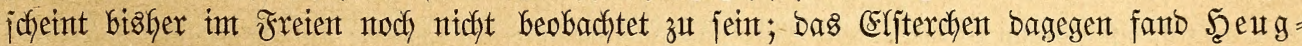

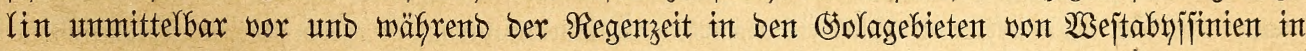
Bambusgebüfactent utno in Mittelafrifa im 5eddgraje ober auf niebrigen $\mathfrak{B a ̈ u m t e n t ~ i n ~ b e r ~}$

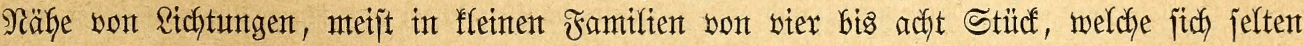

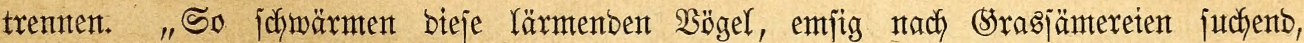
beitänbig umber. Snt rajdent Fluge unto intmer bicht zulantuntenfaltent, unter pfeil=

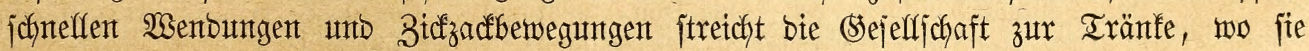

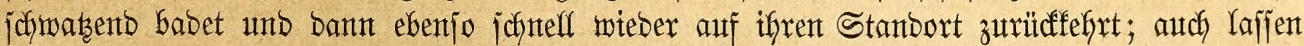

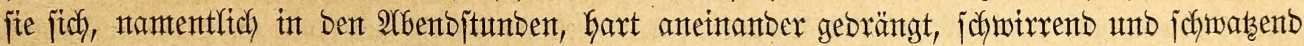

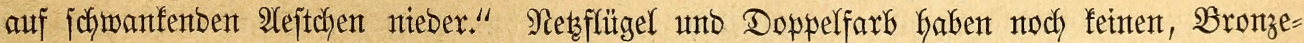
männdhen unto Spitgidywanzmunte in Seroon iffen Beobachter gefunton. Das Bronze=

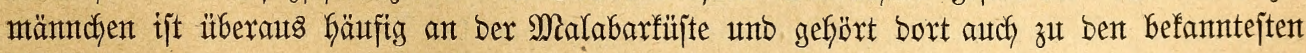

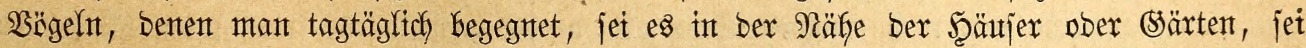

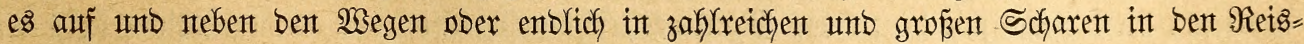
felbernt. Die Spitzidhwantzntunie bagegen finbet fïh mur int Şintaraya etwa bis $2000 \mathrm{~m}$.

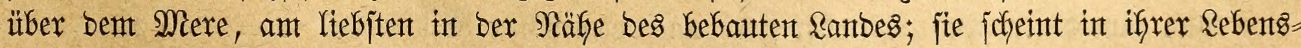

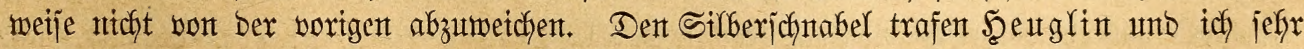

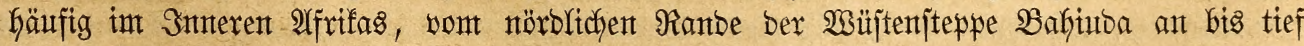

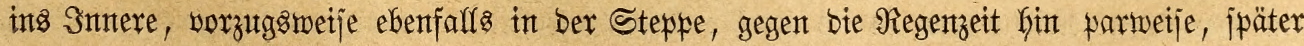




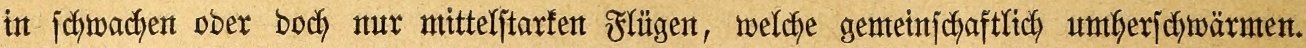

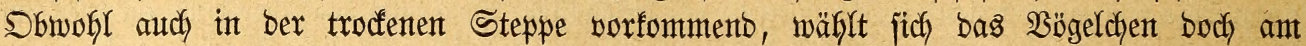

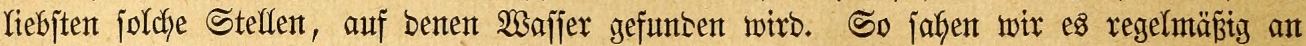

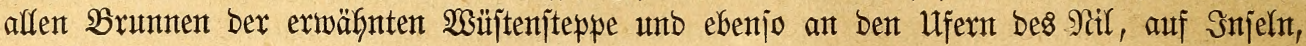

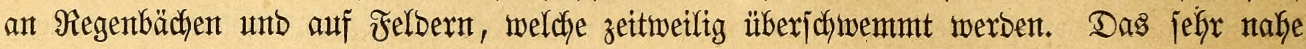

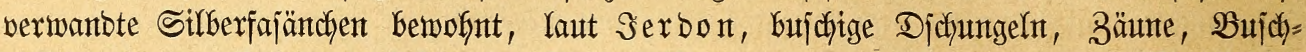

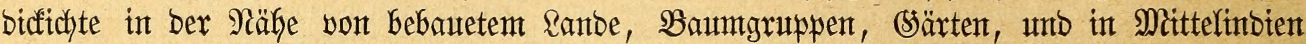

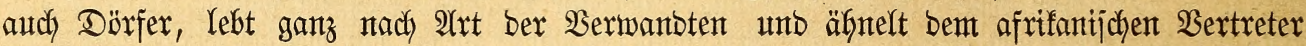

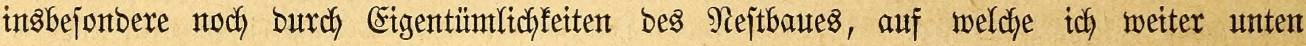
zu iprechent fommen werbe. Som Domino berichtet Gerbon, bas ex zwar in ganz Inbien

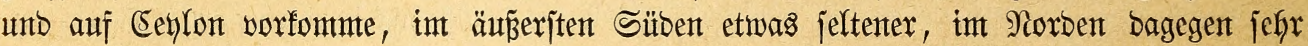

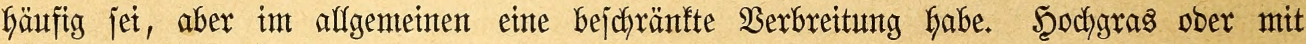

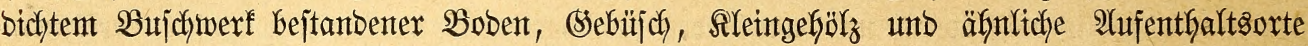
beferbergen ifg; bod fonment er auch in ben Dorrfern ferbjt vor unb baut-jogar zumeilen

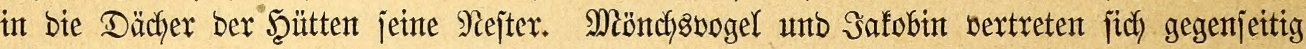

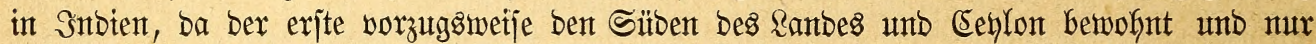
ausnafymatweije in Mittelinbien ober Bengalen vorfonmt, Der Yekstgentannte fingegen ben Norbent bes Ranbes längs bes Şimalaya bevölfert. Sener gef̧ärt in einzelnen Begenden

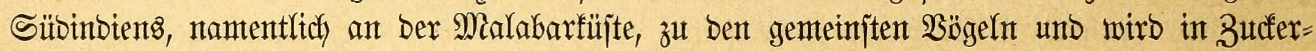

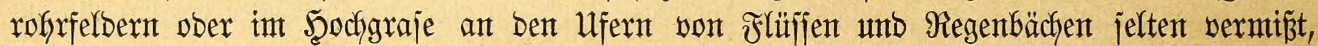

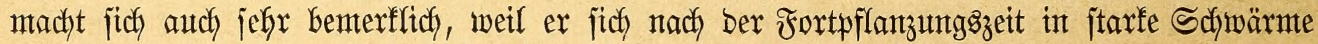
zujammenjallägt. Den Nonnenvogel erwähnt ber ie ficharf beobachtente Bernjtein auf=

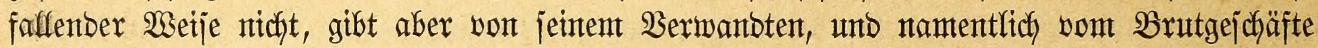

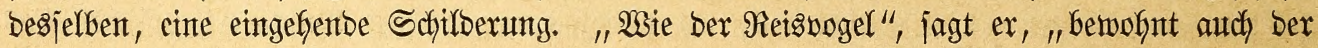

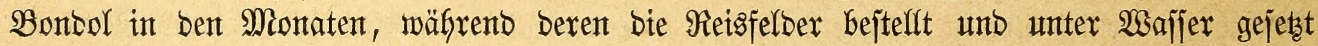

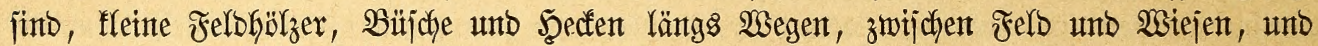

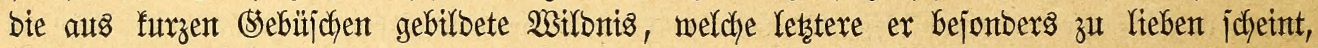

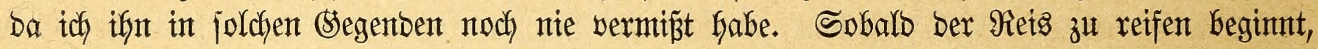
begibt er jidh auf bie Felber unb ridftet Gier burch jeine Mienge nidft jelten grojen Schaben

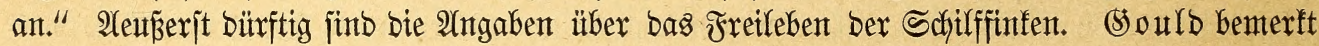

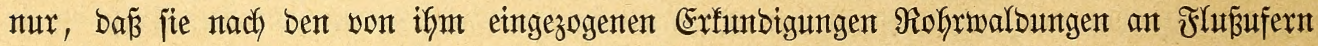

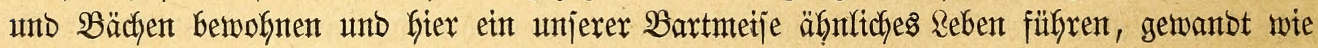
bieje an ben Stengeln Des Rëfrichts auf = unb nieberflettern, überfyaupt igre hodyläuffigen

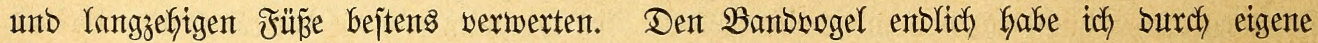
Beobachtung fenten gelernt, ba ex in Den won mir bereiften (Sebieten bes oberen Mit burct)=

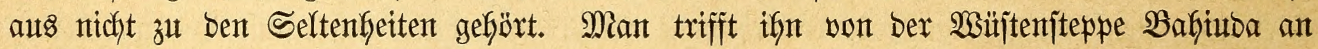
jüblich einzeln ober parmeije in ber Steppe, zumeilen audy imt lichteren $\mathfrak{B a l b e}$ an, meijt in

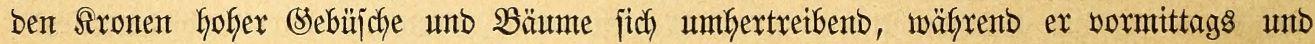

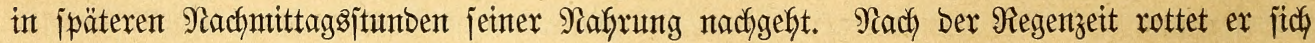
in Flüge zulanmten, welche je nach ber Stegent ftärfer ober idjwächer find und gemein= idhaftlich bie Steppe Durchjtreifen, unt bie Mittaggzeit an ber Iränfe fich einfinben, trinfen,

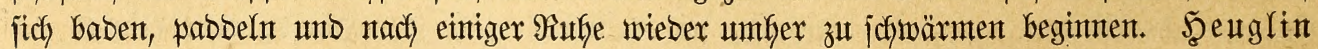

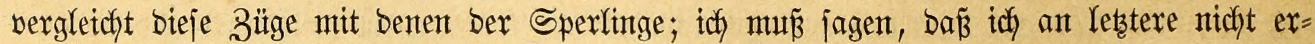
innert worben bin.

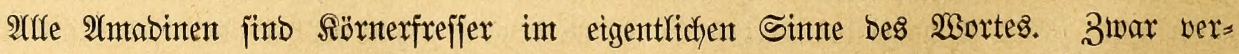
jagmähfent audh jie Rerbtiere nidgt, fünten bieje jebodh ofgne Sdjaben Yängere Zeit entbefren,

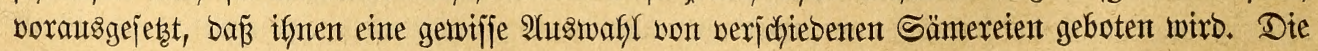

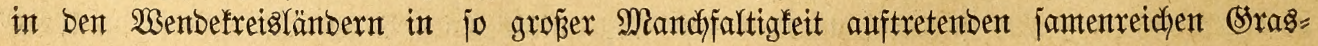




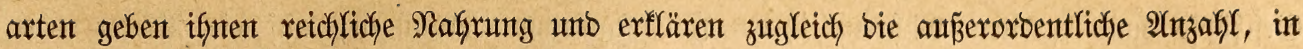
weldher bieje Finfenartent auftreten. Nafrungsmangel tritt niemals für jie ein, und went wirfflidh eine (segento veröbent jollte, finbent fie in ben Genadibarten (Sauen alles, was fie

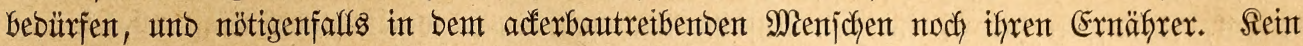

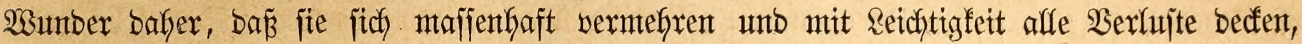
welche ifgre jänttlichent Feinoe ifnen zufitgent.

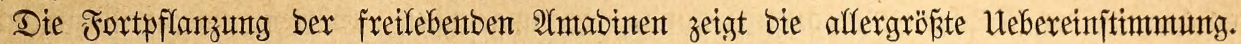

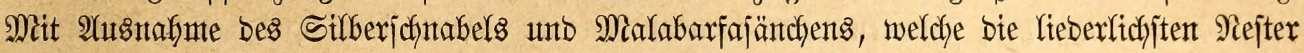

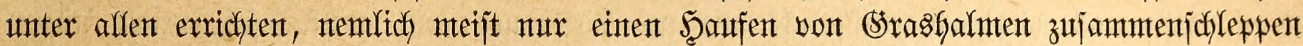

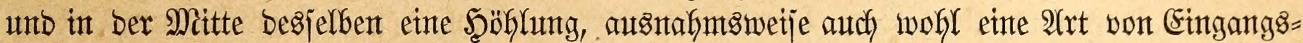

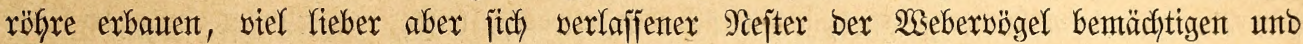

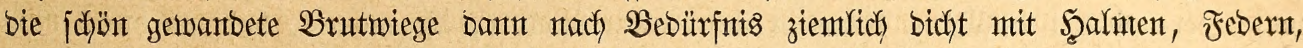

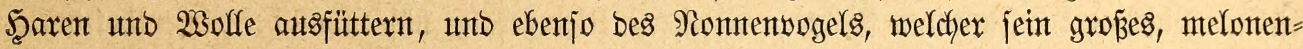

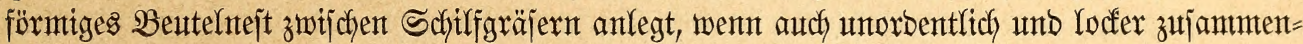

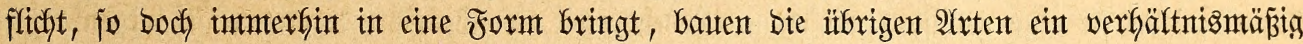

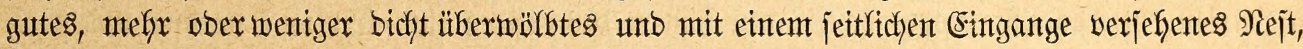

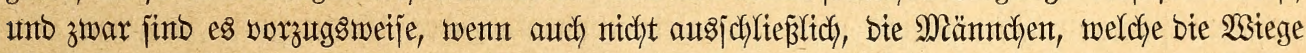

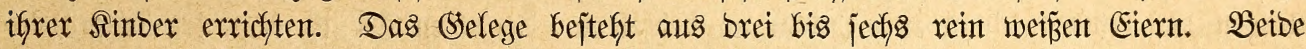

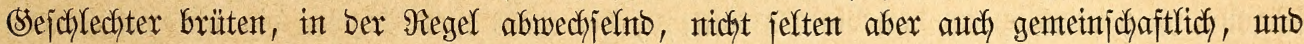

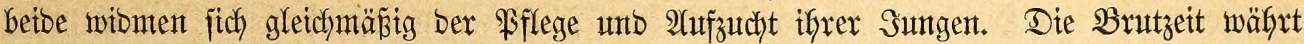

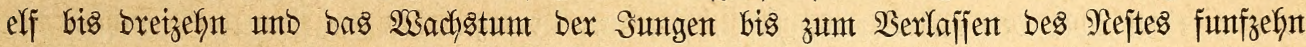

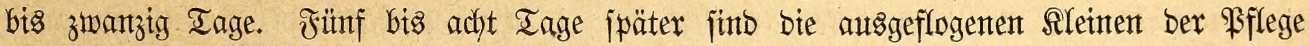

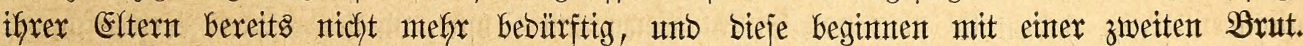

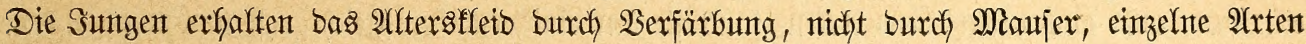

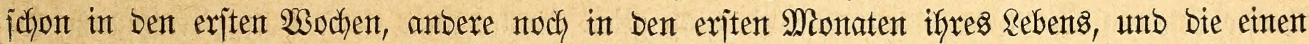

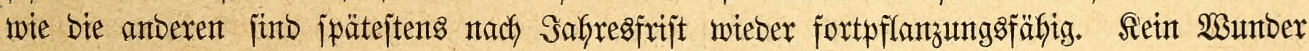

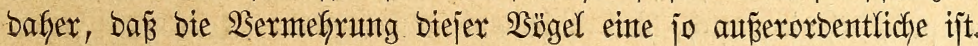

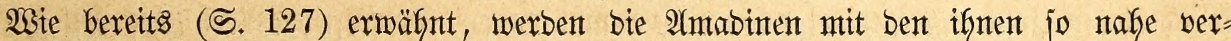

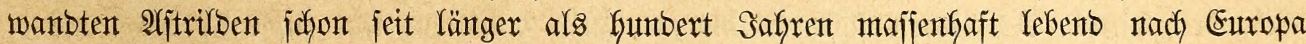

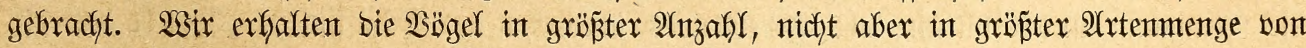

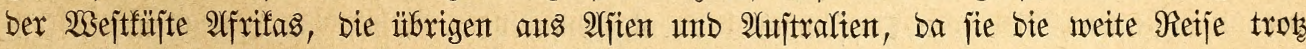

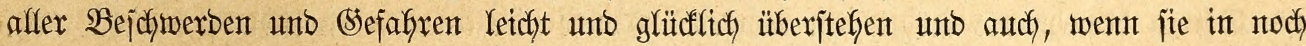

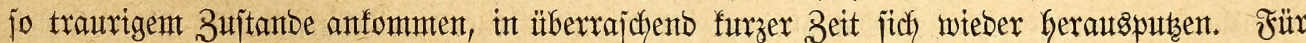
fie insbejonbere gilt bas won mir oben (ธ. 69 ff.) Mitgeteilte. IAn ber $23 e j t$ tiijte 2 ffrifas

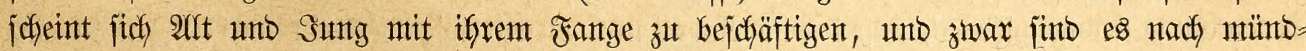

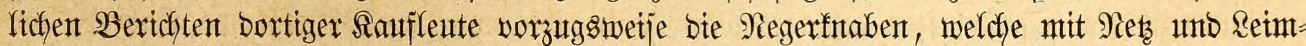

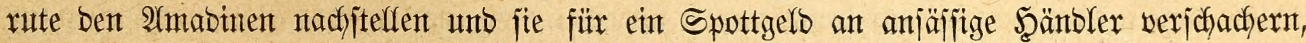

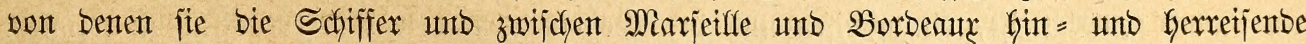

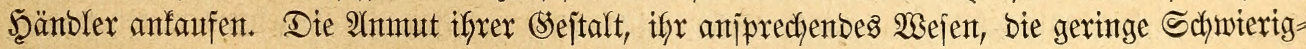

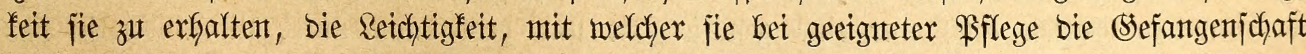

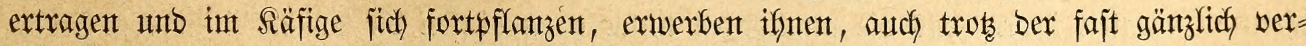

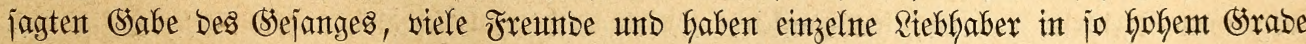

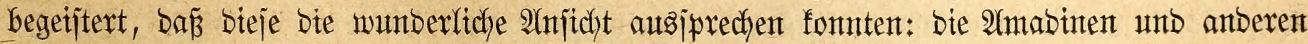

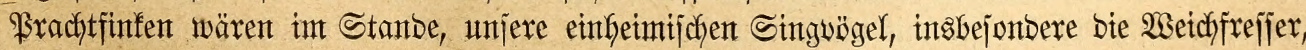

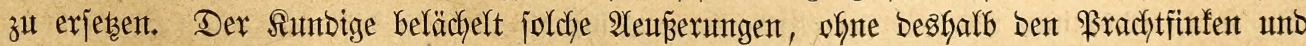

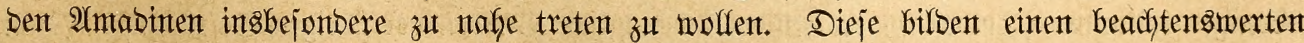

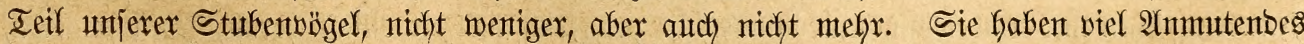

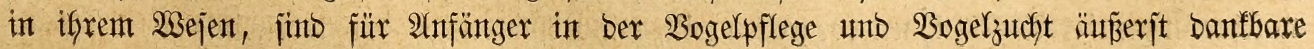


Stejchöpfe unto bereiten mährent ifrex Fortpflanzung Bergntigen; auf Die Dauter aber fönnen fie unmöglich befriebigen, weil ifyr Stezmiticher ober Befnarre, welches man unge=

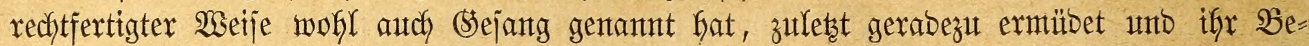
tragen, jo anjprectsent es für ben Anfang auth jein mag, wegen jeiner Einförmigfeit nux eine gemifje Beit zut fefjelth int Stanbe ijt.

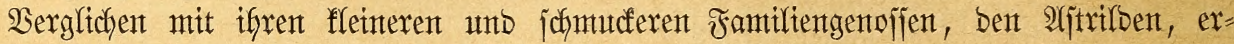

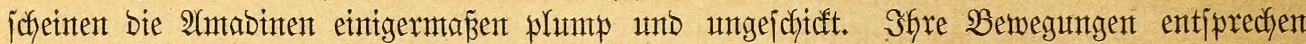

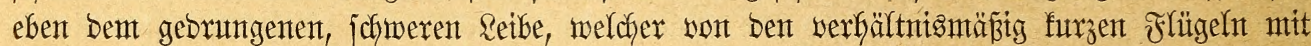

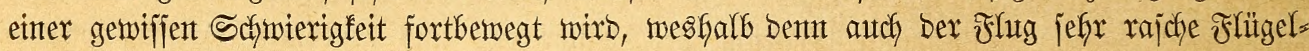

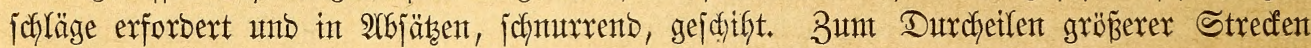
fint bie Atmabinen nidht geeigntet, Denn fie ermüben jefr bald, währento jie bagegen ifyre volfe Betweglichleet entfalten, wenn es fich barum hanbelt, fliegento unt bü̈pfent burch (Se)= büjch, Sejtrüpp, Röhridst und (Sras zu jd)lüpfen. Sebenfalls Güpfen und flettern fie reichter, als fie fliegen, wie bies audh jchon bie fräftigen, meijt langzehtgen Füre verntuten lafien.

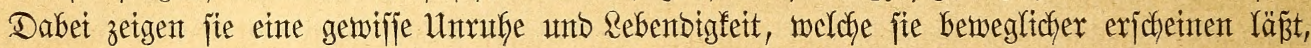

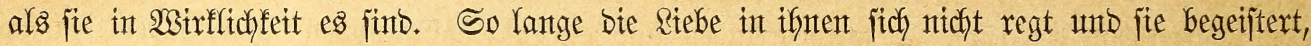

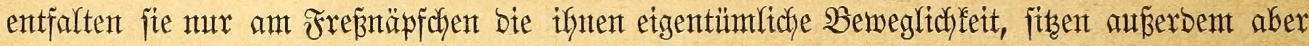
jtunbentang, bidyt antinanber gebrängt, auf einer uno berjelben Stelle, twent irgento möglich

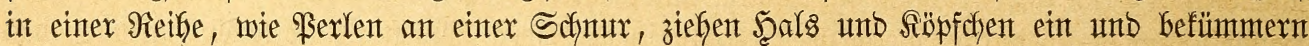
fich um nidfts anberes als un ifye Serbantng, bis bant entididy nieber seben in fie

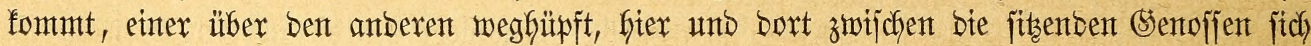

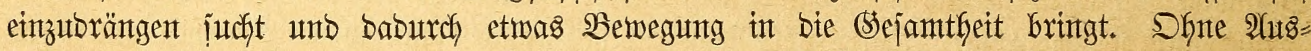
nafme gejeflig, balten jie jtets treufich zujammen, am liebjten bie Stentofien einter âtrt unter=

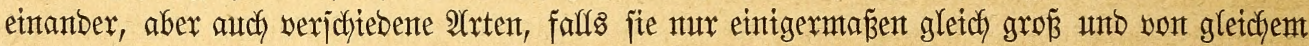

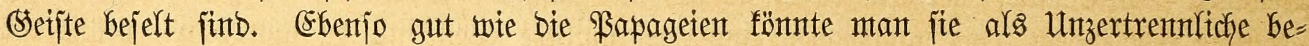
zeidfnen. Das Bärchen tut alles gemeinjchaftlich, fliegt gleidfzeitig zum Futternapfe unto

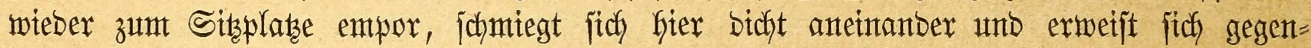
jeitig Riebesbienjte baburch, Daß̃ Der eine bem anderen im Sefieber Gerumnejtelt, mit bem Sdynabel zwijchen bie Febern fafrend und an ifnen fnapperno und zupfent, als molfe ex

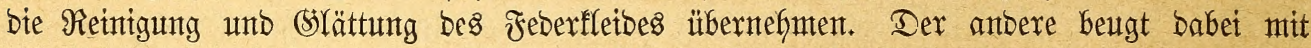
ber behaglidjiten Mine ben Sopf nach ber entgegengejekten Seite, un bem Senofjen jein (sejchäft jo bequem als möglich zu machen. Soldye sitebesbienjte ermeijen jich nicht aflein

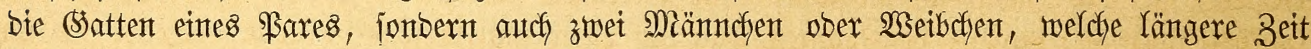

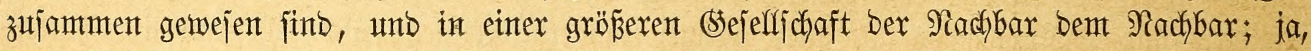

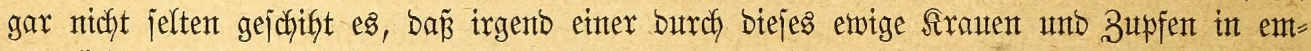
pfinolicher Weije gejchäbigt, nemlidy jtelfentweije ober bis auf bie Sdyntngen unb Schwanz=

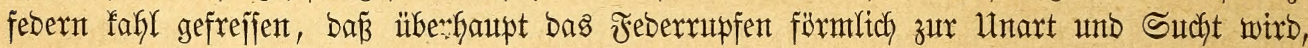
unt man genötigt ijt, einzugreifen und ben (sejchäbigten bon bem Senoffen zu trenten.

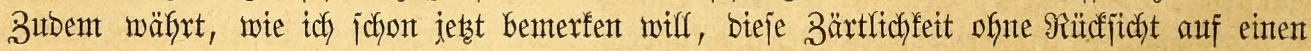

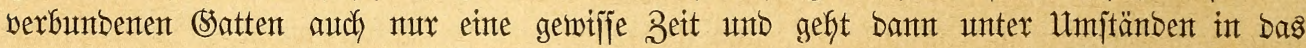
gerabe Segenteil über. $2(r s$ bie nunterjten unter alfen bürfen bie Erzamabinten ober Eljter= bögeldyen bezeidynet werben, inţbejonbere bie eigentlichen Eljterchen, Deren Ireiben in (se= fangenjchaft suchs in ebenjo treffenber als gefälliger Weije jojilbert wie folgt: "Int \$se=

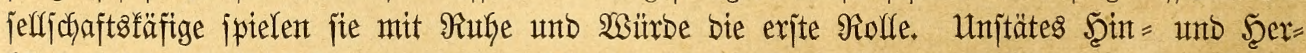

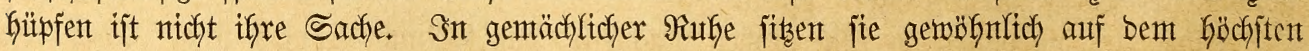
Stengel beijamment, unberünmtert um Das betweglidfe Ireiben Der übrigen Sejelljchaft. 3umt

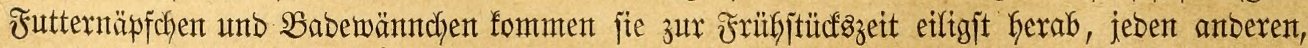

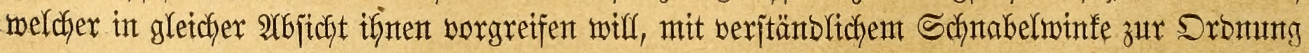


meijent. Namentlich lafjen fie fich ben Borrang beint Baben burchauts nidft jtreitig machent. Neutantgefommenten begegnten fie einige Iage ziemlidh unfreumblich, jagen jie wohl hin und her, bis fie fich an ben 2(nblid gemöbnt haben. Bur Nachtruke find fie bie eriten, weldye ifyr ermähltes ßräbchen, bicht an einander gebrücft, inne halten und es gern bulben, wenn anbere fleine Schlafgäite an ihrex Seite, nux nidht zmijchen ifnen, eine Stefle juchent. In

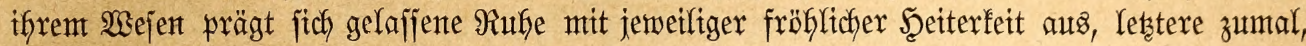
wenn bas Männchen, mit tänzelnber Bewegung auf bent Stengel fint = unt Gerhüpfend,

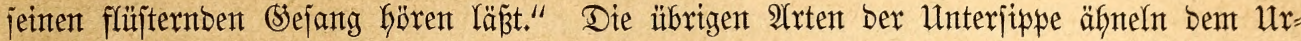

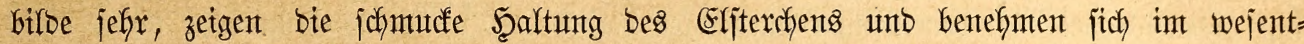
lichen gantz io wie biejes. Das berwanbte Sutteneljterchen hat ähnliche Sitten und (se= wohnkeiten, ijt mix aber als ein ernjterer unb, was bamit int cinflange jteft, als ein ruffigerer, wentiger betweglidjer Sogel vorgefonmen, weldyer vont bem (Sefüf) jeiner Würbe Durdforungen zat jein jcheint, jith beshalb audf meijt gejonbert Gält unt unt bas übrige $\mathfrak{B o l f}$ fich wenig fümmert. 2(tuch bie Manten unterjcheiben fich int threm Betragen wentg von bem

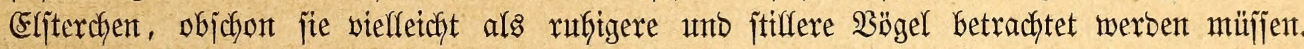

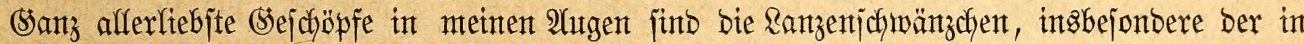

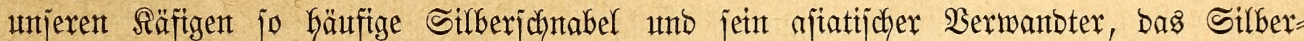
fajänthen. Beibe möchte man bie Mäuje unter ifyen Senofjen nenten, jo bef̧ento und ge=

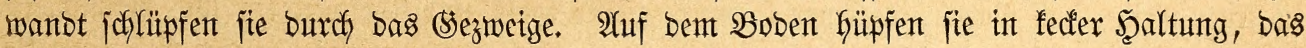

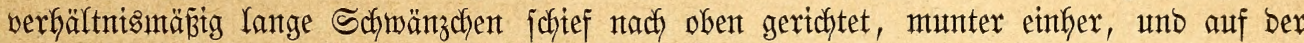
Sibjtange johmtegen fie fich two möglich noch bidfter anteinanber als bie übrigen Wermantoten. "Nitcht mur bie geparten", jagt Boolle jefyr richtig, "auth eintanber ganz frembe umb jogar

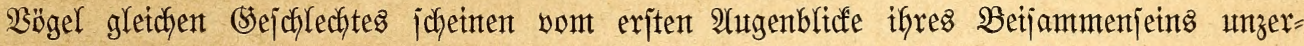

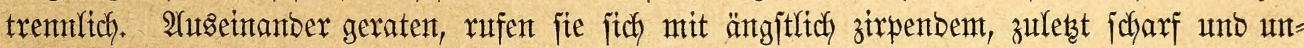
gebulbig flingentem Tone und haben eine eigentümliche Weije jich zu johnäbeln, welche ber "mierer Iauben gleicht." Wie mit Shreggletchen, leben fie audh mit Den Berwanbten itets in tiefitem Frieben, unt bie ajtatijche 2rrt part jich ofyne weiteres mit ber afrifanijchen,

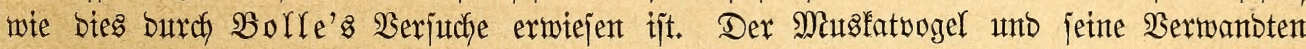
jteben weit finter ifnen zurücf und find nicht mur ftiffe, jonbern audh recht langmeifige

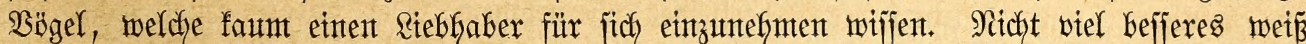
idf über bie Nonnensögel zu jagen, obgleich idy je jafrelantg gepflegt habe. Shr jaymucfes

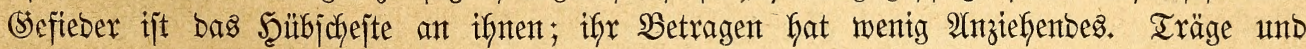
fautlos jitzen fie beinahe ben ganzen Iag auf einer und berjelben Stelfe, obwohl fie im

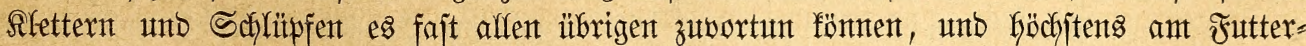
napfe betätigen fie eine gemifje Regjamfeit, gleidyzeitig aber fleineren $\mathfrak{B}$ ögeln gegenüber einte

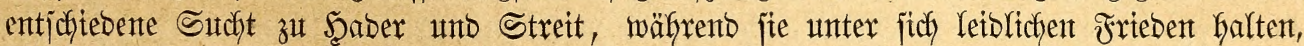
und zwar, joweit ich fie fente, alfe Âtrten überbautpt. Heber bie Schilffinfen urteife idy

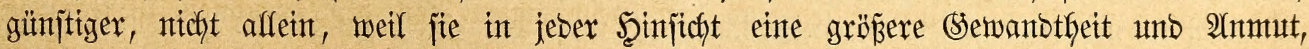

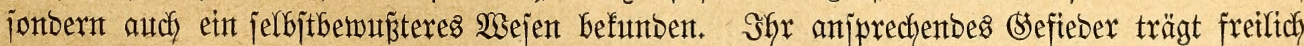

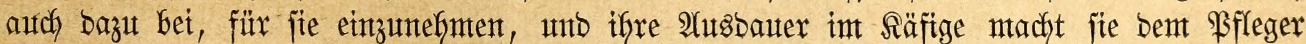
lieb unb wert. Biele won biejen (Eigenjelaften vereinigt ber Banowogel in fich; boch ijt ex etwas plump und berb, autch burchauts nicht bex frieblichjte unb beshalb unter fleineren Berwandten oft nidbt zu bulben, weil ex, einmal exzürnt, feinen fräftigen Schnabel in rück= fichtzlojejter $\mathfrak{B e i j e}$ zu gebraudjen pflegt.

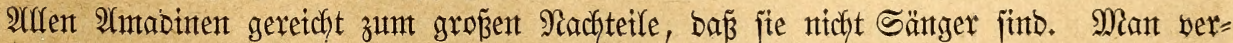
langt wenig won ifnen; aber auth biejes Wentge wirb nicht exfüllt, und wenn wirflids eint

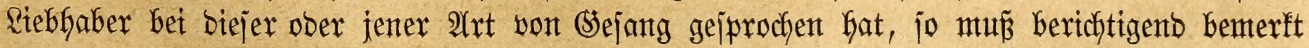

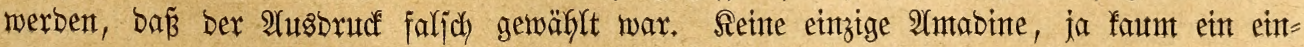




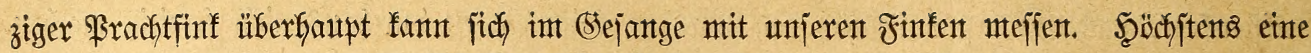

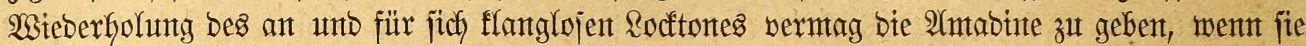

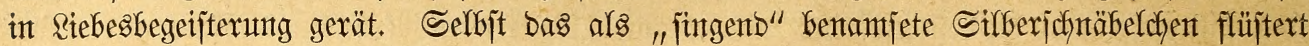

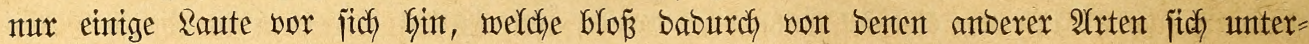

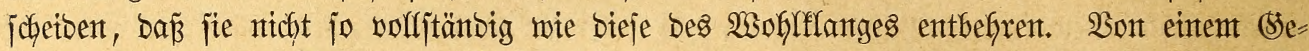

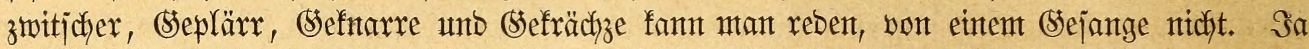

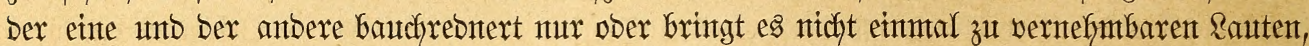

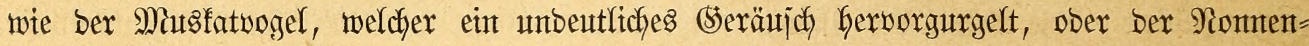

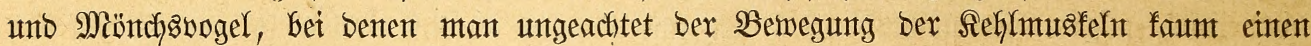
Raut vernimmet.

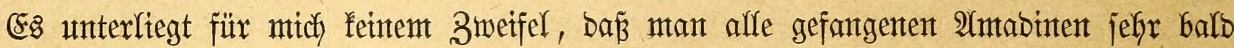

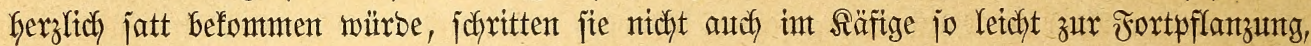

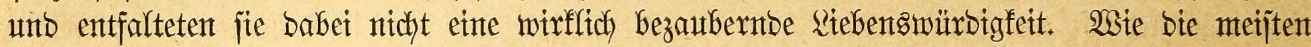
übrigen \$rachtfinten Yeiten aud fie bie \$arung burch ebenjo eigentüntliche als anmutige

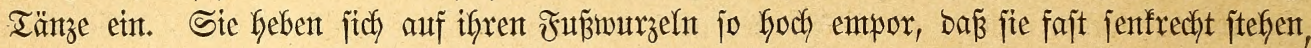

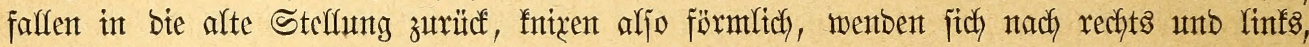

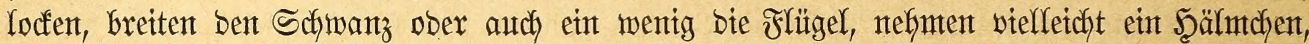

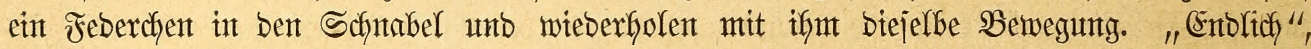

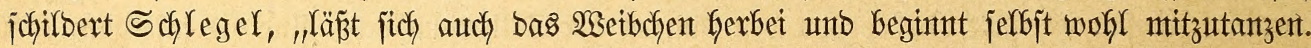

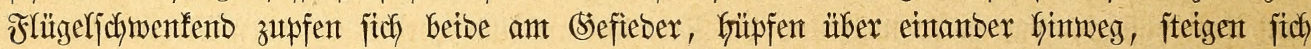

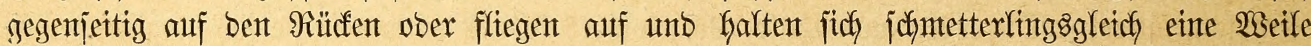

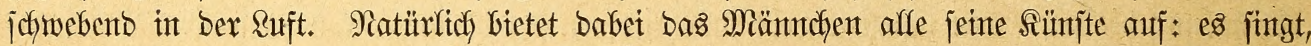

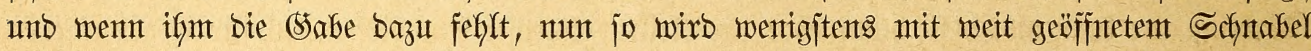

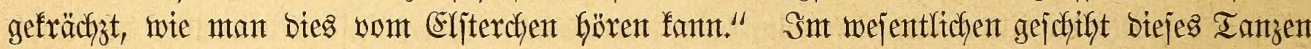

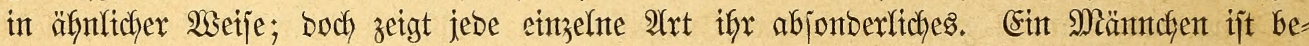
geffrficher, ein 2 seibchen hintgebenber. So zant bas Sifberjdynäbeldfen jeiner (Sattin ben

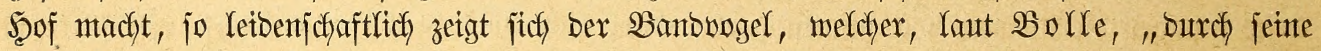

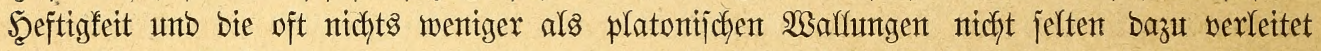

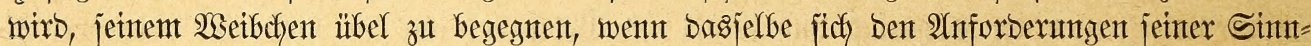

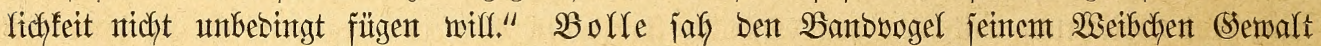

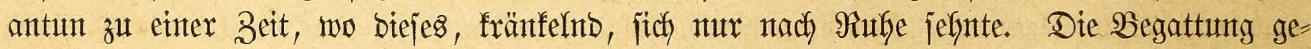

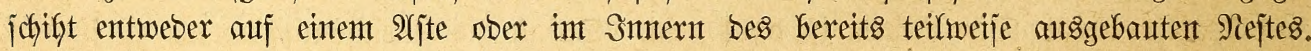

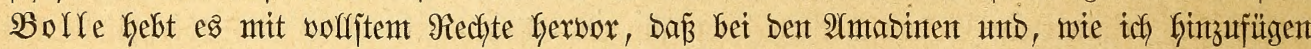

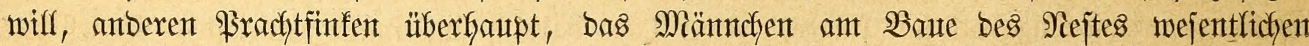

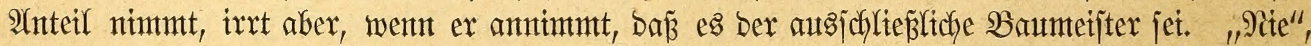

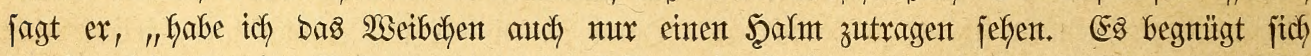

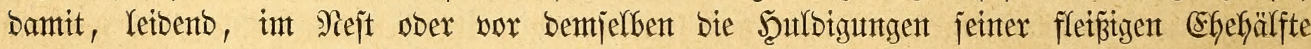

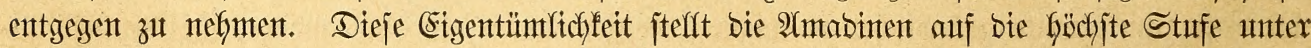

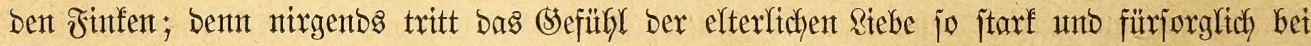

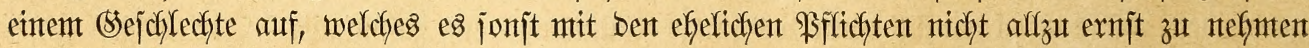

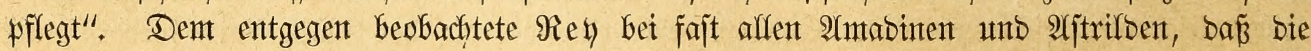

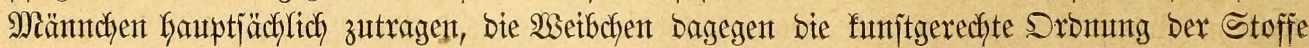
bejorgen, aljo bie eigentlicbent Baumteijter finto.

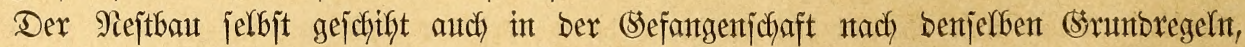

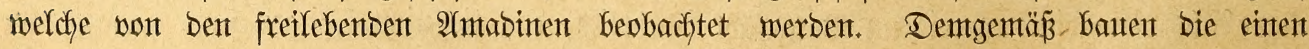
lieberficfjer, bie anberen jauberer, bieje ein ziemlich fünflfiches, oben übermölbtes, mit jeit=

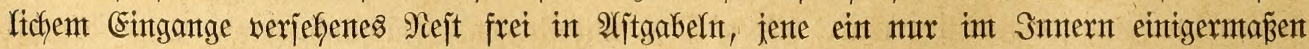

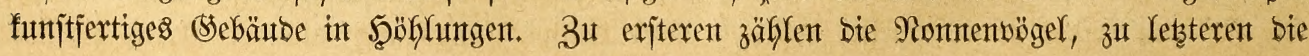




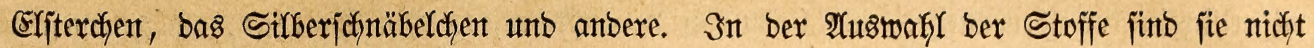

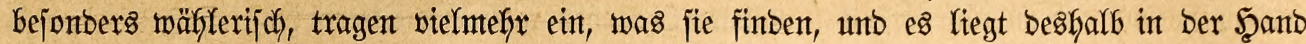

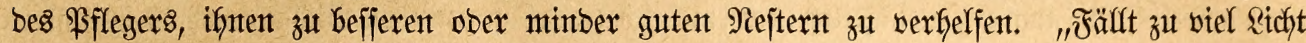
finein", jagt Borle vont Silferjdntäbeldyen, "ober waro bas Mejt in einem mur burch (5itter=

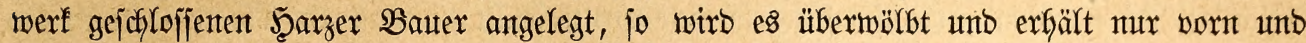

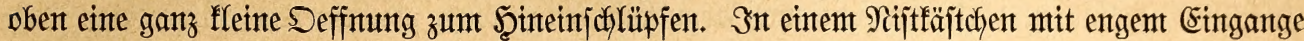

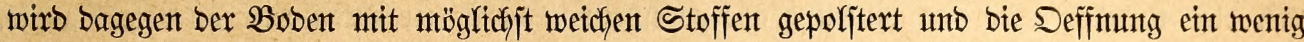
enger gebaut. Die 21 rbeit bes $\mathfrak{B a u t e n z}$ begleitet ber $\mathfrak{B}$ ogel mit einent ganz eigentüntlichent

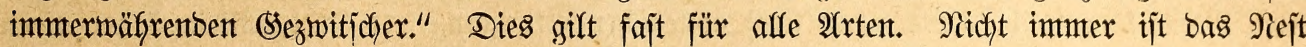
jofon wolfenbet, wenn bas Eierlegen beginnt; bas Miänntchen arbeitet int Begenteile oft noch

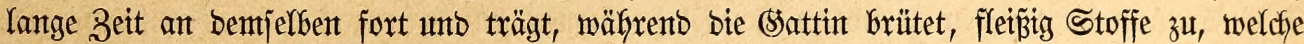

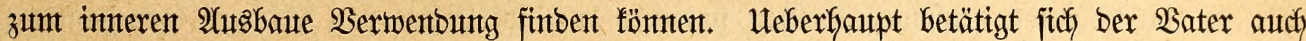

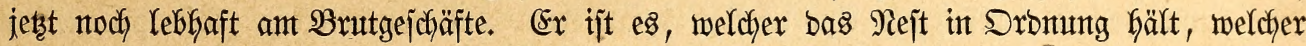

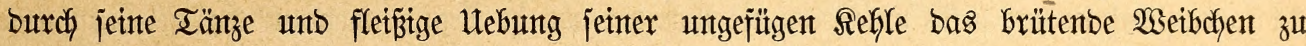

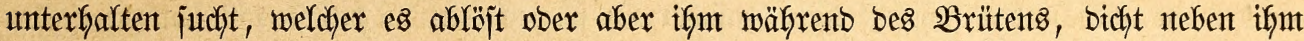

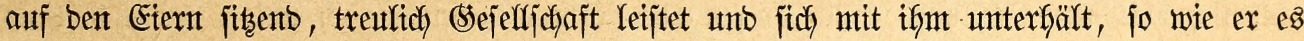

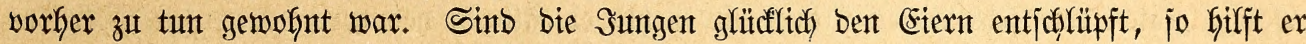

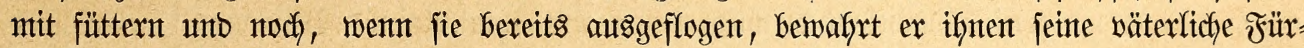

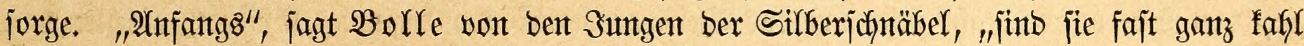

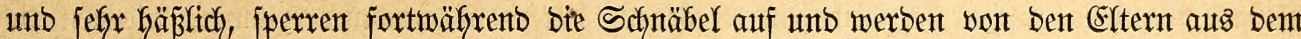

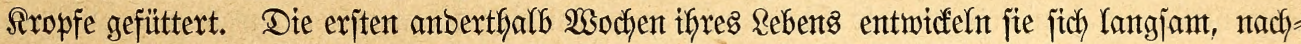

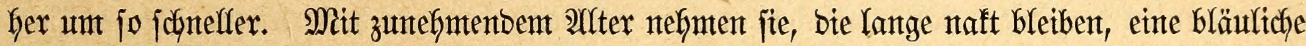

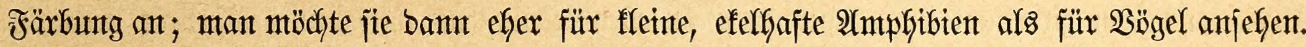

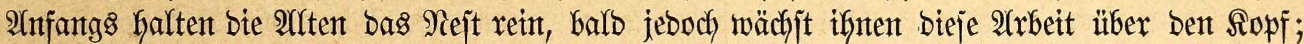

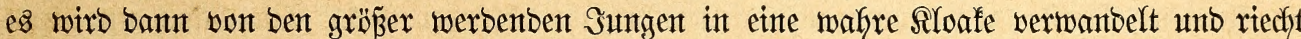

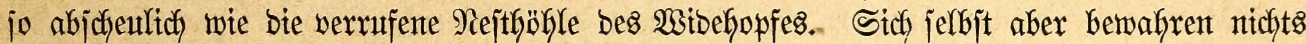
Dejto weniger bie Sleintent volffonment jauber; um bies zu bewirfen, jitzen bieje mit jenfreedft nach ober gefefrtemt Reibe unb ebenjo geftelltem ober etwas vorn übergebogentem Sodywänzthen in ber alferjeltjamiten Stellung, auf Brujt unb Refile ruthent, int Rejte unb vermetben jo

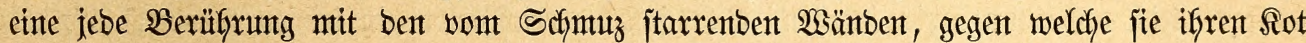

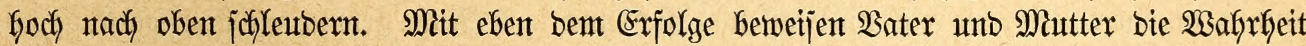
Dez Waakfijprutches: Dent Reinten ift alfes rein. Sobalo fie Gineinjoflüpfen, unt zu füttern,

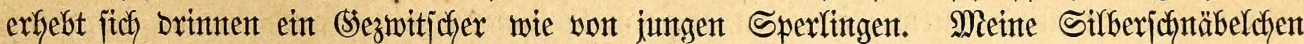

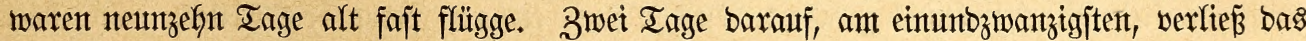

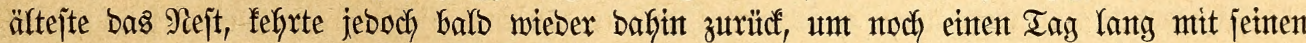

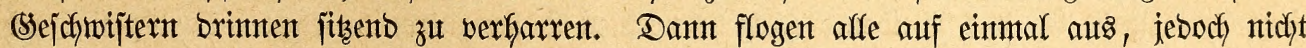

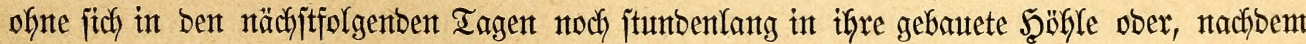

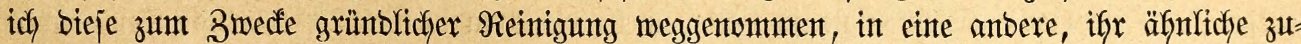

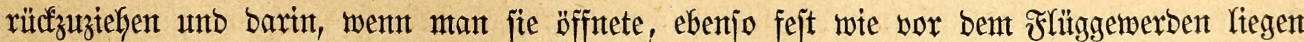
zu bleiben. Site neítelten fich bann wie juntge Zaunfönige eng zujammten. Die ausgeflogenten fizzen gleich aufmarajicfirten fleinen Solbaten neben einanber auf ber Stantge utnb forbern unter

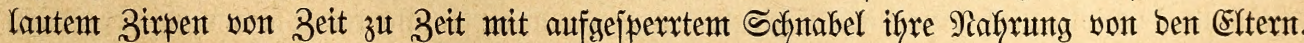
Sebes jutcht ben Mittelplats zu geminnen unt jpringt besfafb mitunter bent anberen auf ben

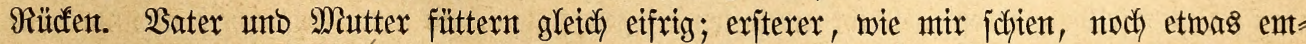

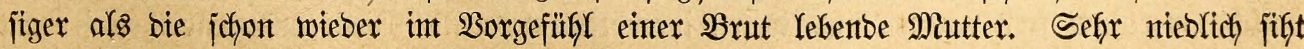

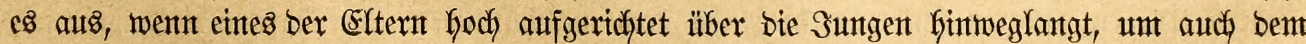

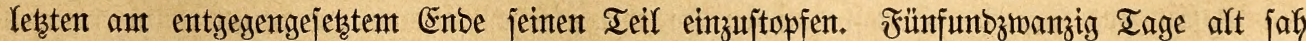
id) fie zunt erften Male affein freffen." Der Entmidfeluntgagang anberer Âtten berläuft 
mejentlich in berjelbent Weije. So brüten beim (Erjterchen, weldyes Schlegel ant genautejten beobachtet unt an ausfüfrrlichiten gejchildert hat, ebenfalfs beibe erltern jefr eifrig und zwar

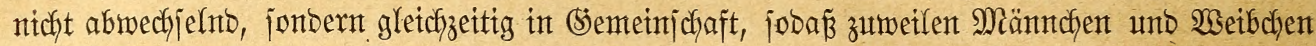

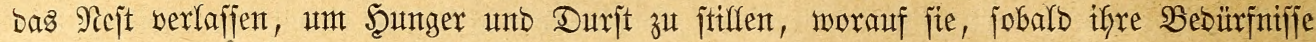
befriebigt, betbe nteber gemetnichaftlidy an Das Brutgeichäft gehen. Utno ebenjo fommen bie

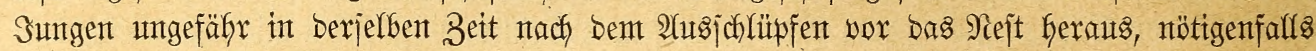
won Den 2 (Yten förmlich yon finten gejdyoben und son vom burch Rodejpetje geföbert. "Die Sungen", fagt Sdylegel, "find volfitändig befiebert, haben fajt bie (Srößze ber Eltern und

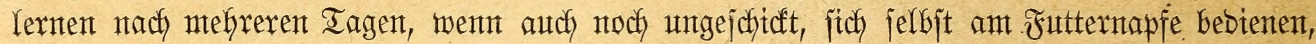
objcton jie, wite affe jungen Bögel, noch jefr gern fich füttern lajfent. Bumeilen fautern fie

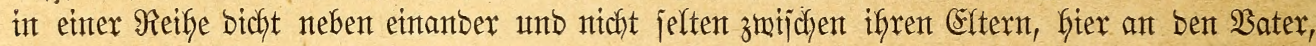
Dort an bie Matter gejdymiegt. (Semöhnlidy aber änbert fich bas reizente Jamitlienbil'

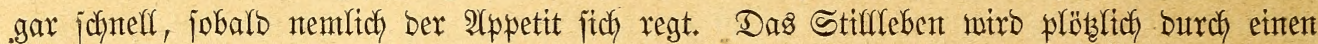

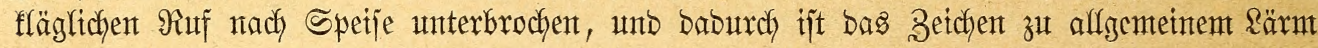
gegeben, weldyer nux wächjt, je unbemeglicher bie Estern bem ungejtümen Berlangen gegen=

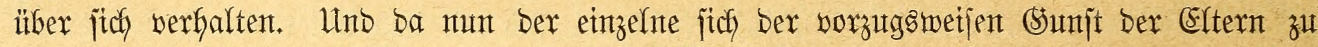
exfreuten glaubt und jein Bitten für untwiberjteflicher hält als bas ber anderen, eben meil es nichts zu frudften jofjeint, jo ftürzt ex über bie anderen finnweg, biejer auf Den Bater, jener auf bie Mintter ein, und ein britter läp̈t wohl gar, von bem Sezmeige herabhängend,

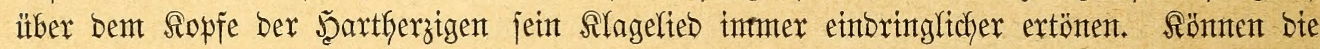

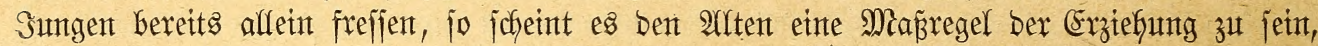

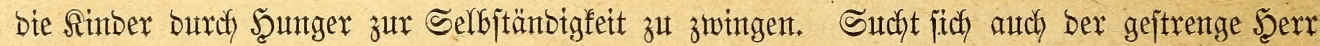
Fapa ber inmer zubringlither merbenden $\mathfrak{B} e t t l e r$ burch eine Burechtmeijung mit Dem Schnabel zu erwefren, ober fliegt er unwiffig Dawon: Das Serz ber Matter ift nicht int Stanbe, Den ungeftïmen Slagent ifrer Sinber auf bie Dauter zu miberjtefen. Hnd ment auch nux, um

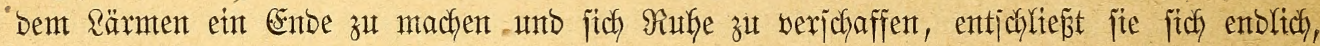

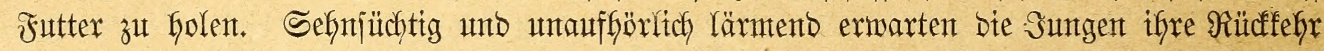
unt umringen bie 3urïffgefehrte oft nach affen Setten, rechts und lints, von oben herab

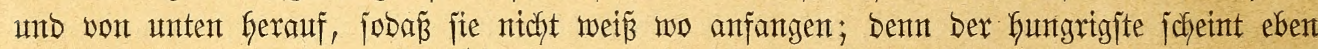
jeber. zu jein. So lange bie Sungen . nod) nicht ausretchend aflein freffen fönten, fund bie

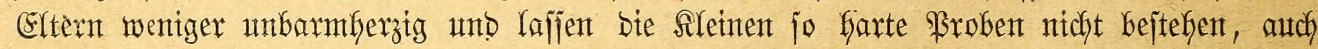

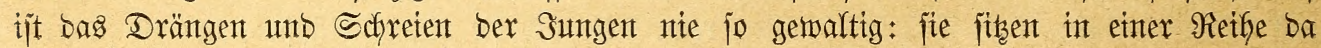

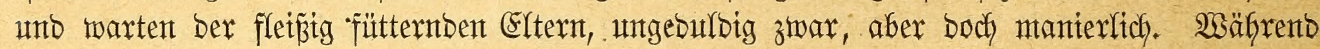
bie Nutter ein Sinto, welches gerabe neben ify fibt, füttert, iperren bie übrigen wohl auth

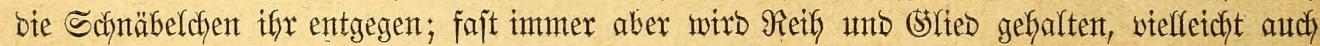

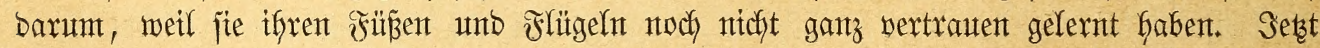

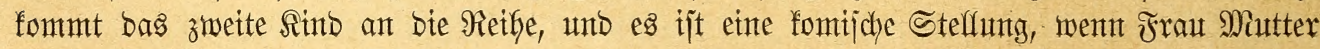

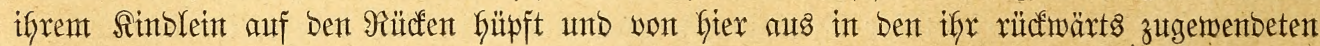

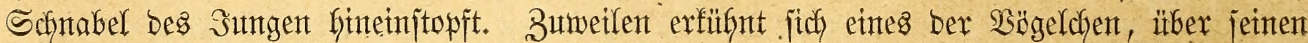

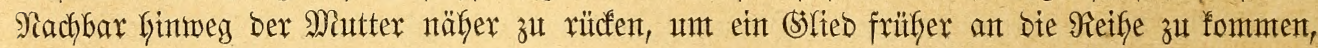

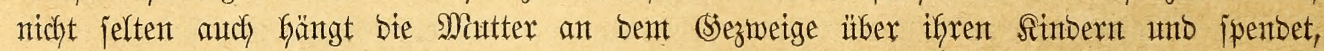

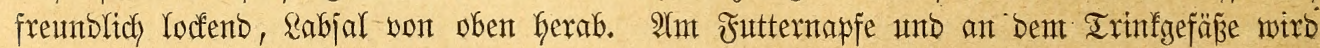

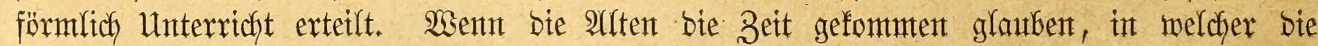
Sungen jich jelbjt zu bebienen rernen jolfen, jesent jie jich an bent Futternapf mto najden,

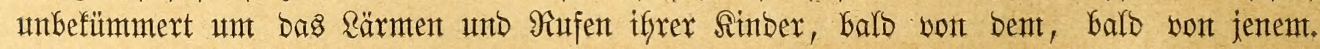

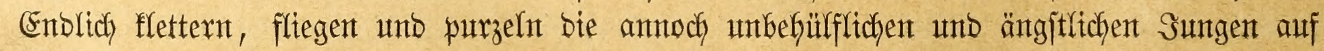

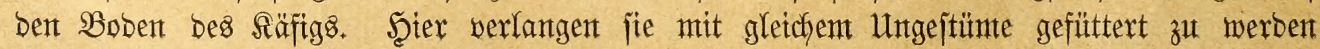

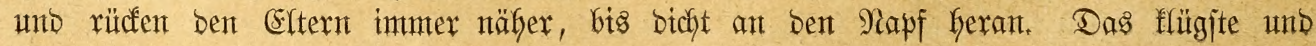




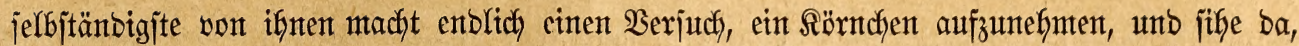

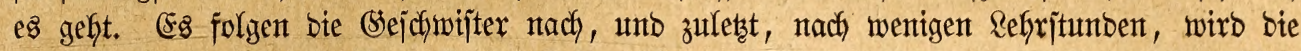

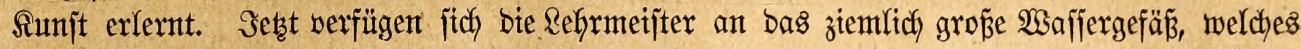

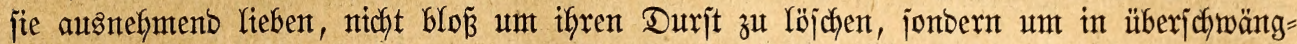

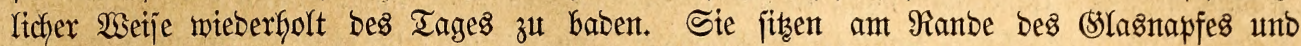

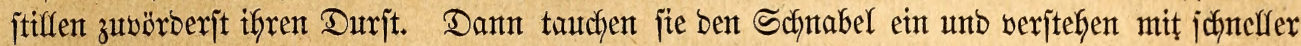

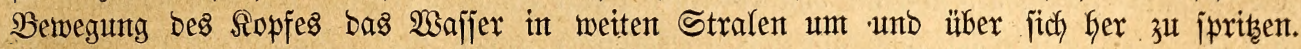

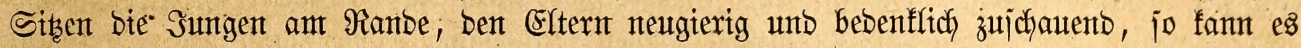

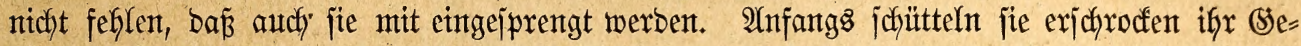

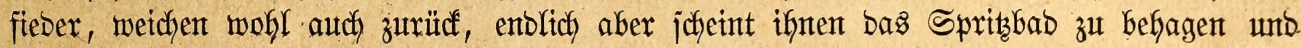

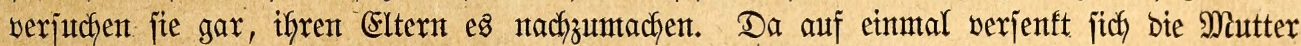

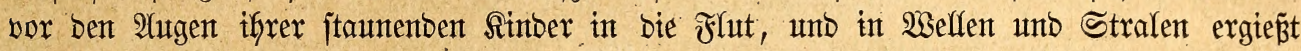

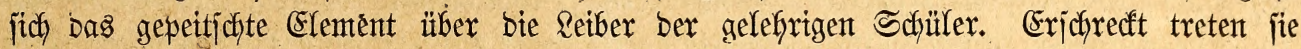

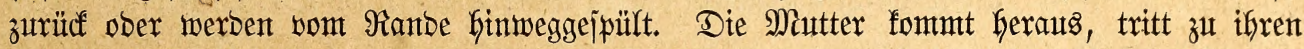

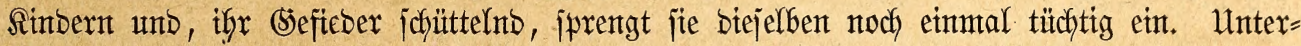

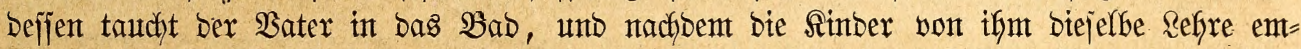

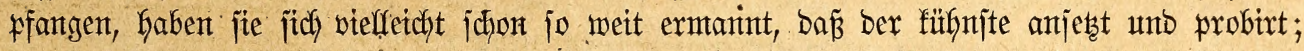

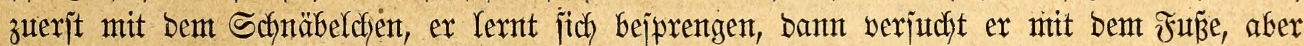

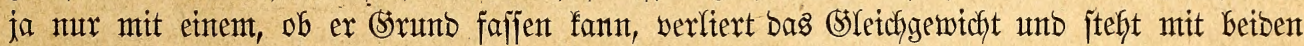

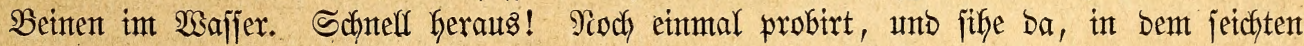

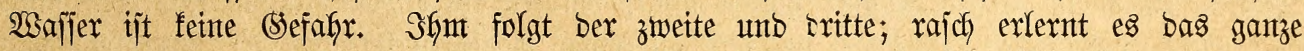

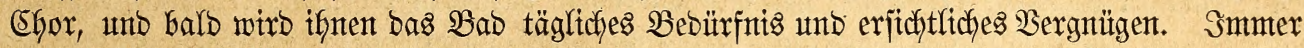

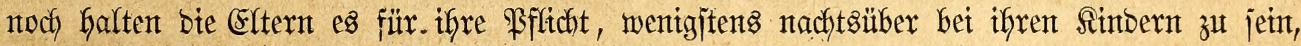

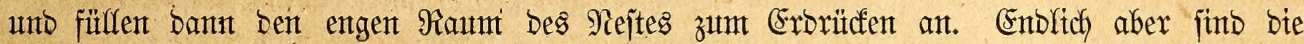

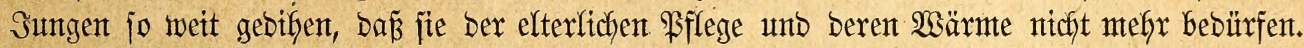

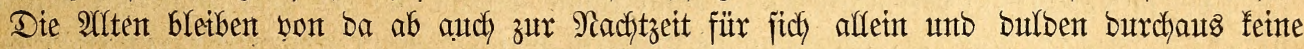
3ubringlichfeit iffrer Sungen mefry. Sie tragen (Stenijt ein, wenben jith ber Buffunft zut, für tyre Sinber jodeenten fie feinen Sinn integr zu haben."

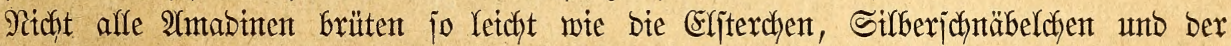

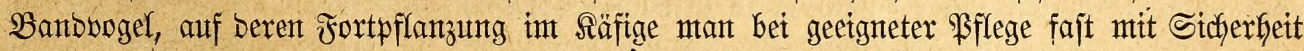

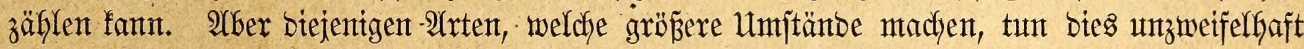

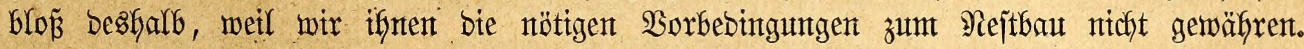

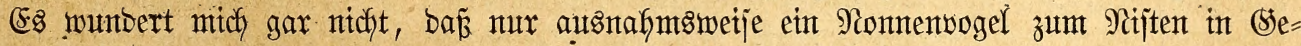

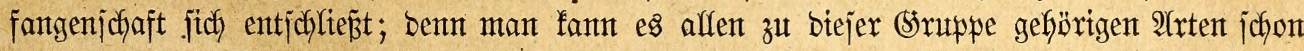

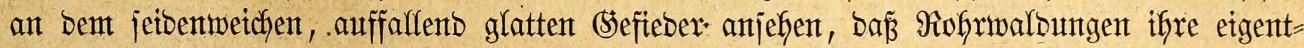

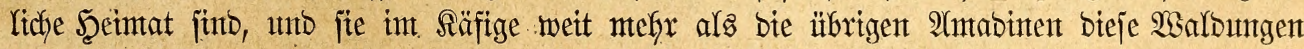

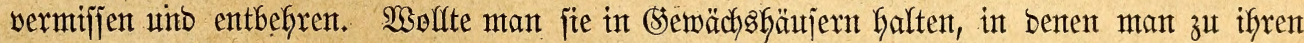

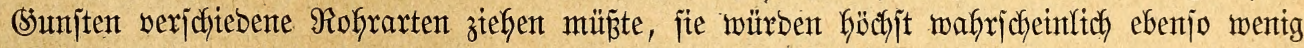

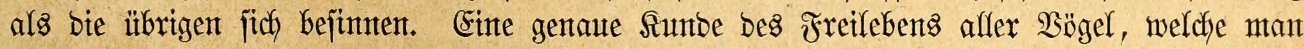

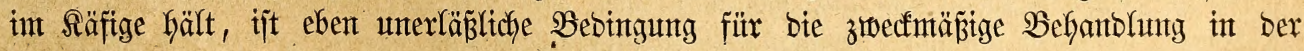
(Sefangenichaft.

Bieiflot, Der erjte Stebfaber, weldher über bie Fradyffinfent unto jomit aud unjere

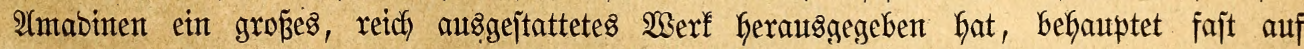

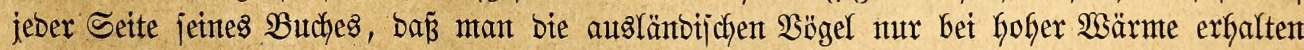

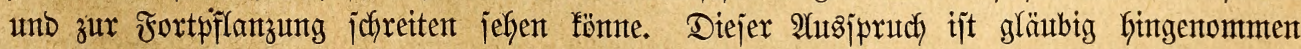

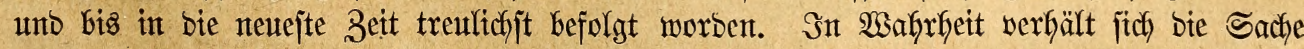

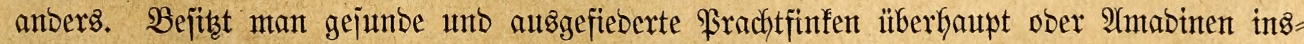

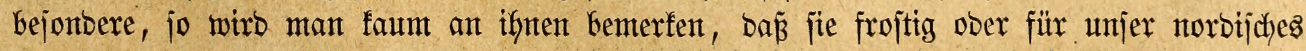




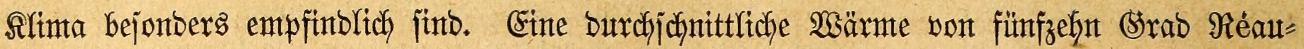
mux, aljo unjere Stubenwärme, genügt ifynen vollftäntbig; Dabei gebeiken fie, haltent fich

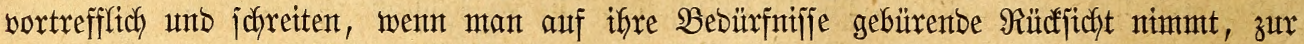

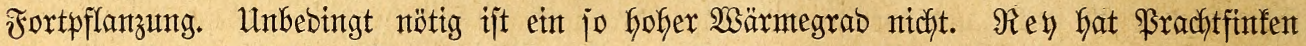
niddst nur in ungeffeizten Zimmern überwintert, jonbern aud bei einter bauterno unter ben

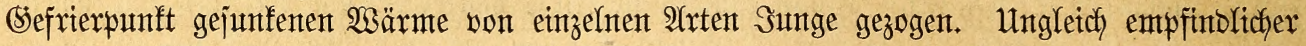

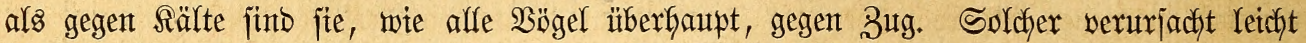

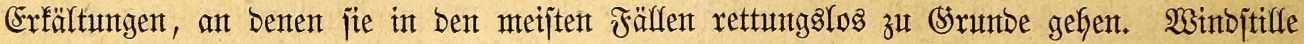

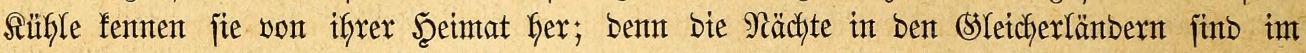

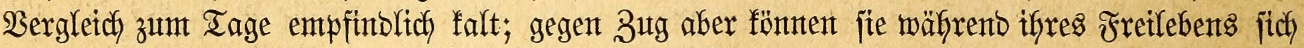

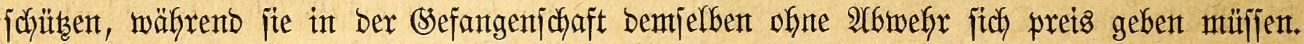

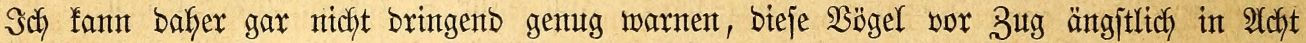

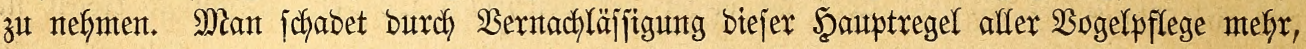
als man glaubt.

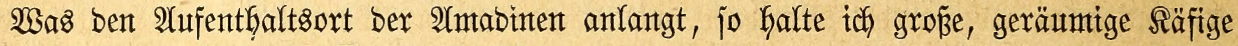

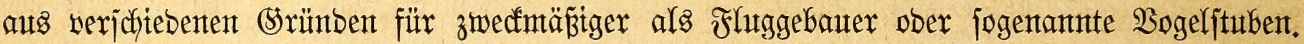

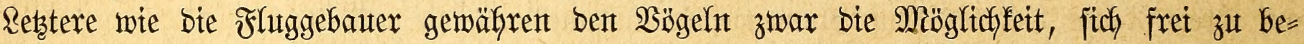

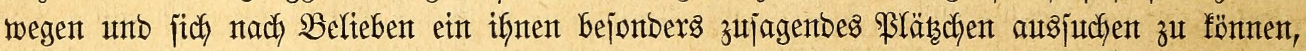

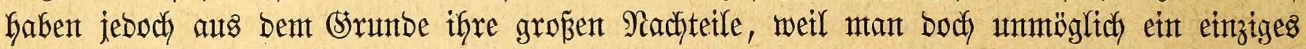

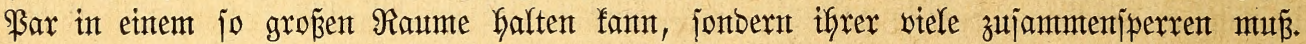

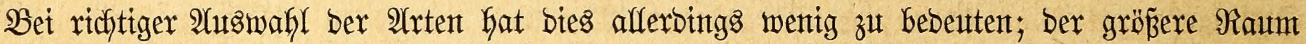
Des Fluggebauters ober ber $\mathfrak{B}$ ogelftube übt bann autch unverfentubar günftigen Einflús auf

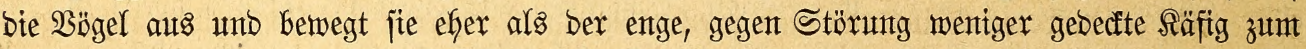
Brütent: unter einer gemijidtent Sejelfichaft aber gibt es inmter Zanf und Streit. Dies hat

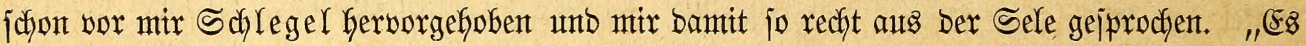

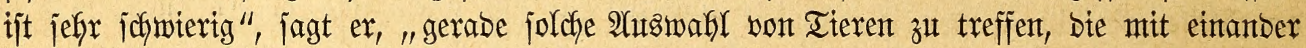

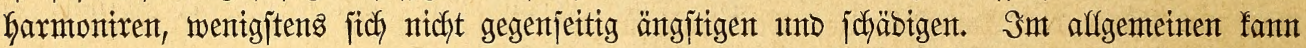

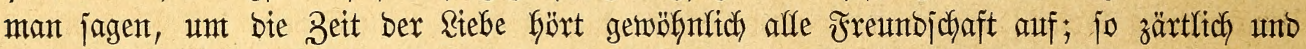
Gerzimntg bie (Satten unter einanber, jo neibija, mizgänjitig unt unteiblidy fint jie alabbant

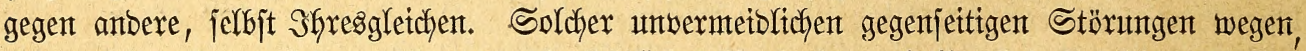

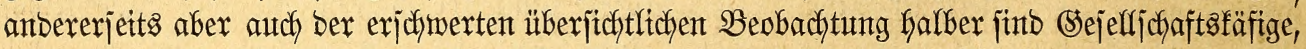

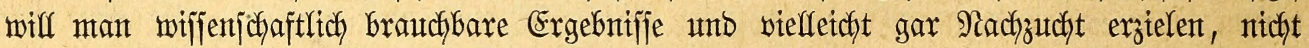

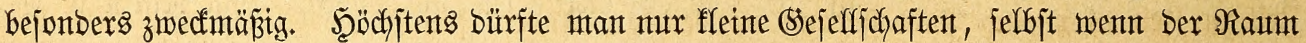

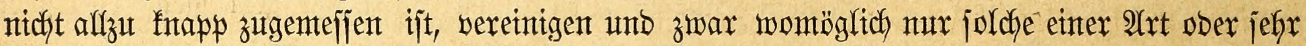

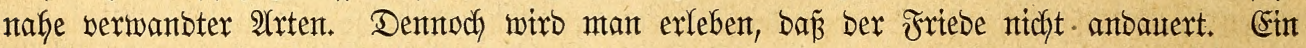

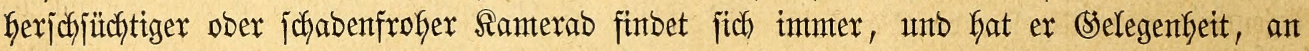
Feiglingen, Siechen unb Srüppefn fich eitzuftubiren, jo wirb er, zum Inrannen gereift, bie

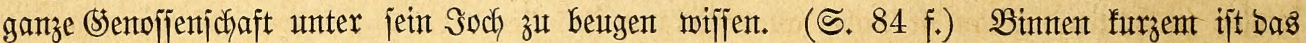

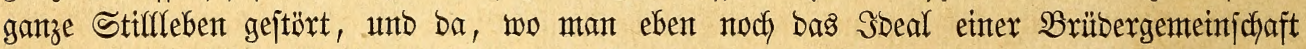

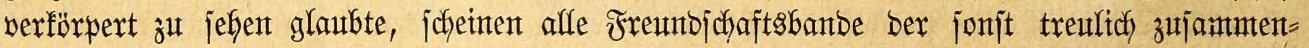
haltenbent Bejelfjchaft gelöjt, unb jeber einzelne ober wenigites jebes \$ärchent hulbight bent

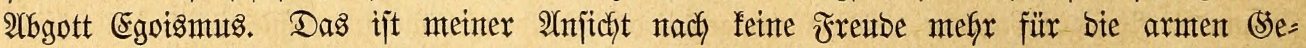
fangenten. 2Ulfe anberweit babei beabjichtigten Erquidungen reichen nidgt aus, fie für bie

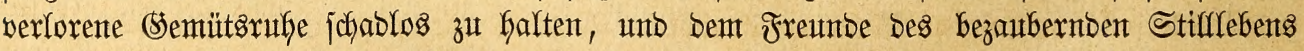

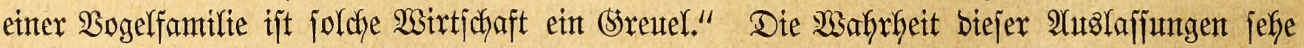

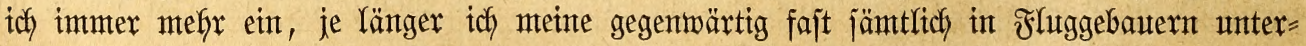

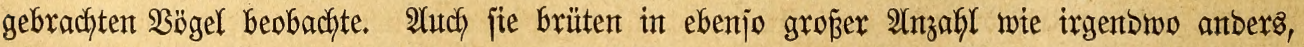
feineşwegs aber ungejtört, jonbern unter vielfachen Şinbernififen, gleichjant verftofflen; unb. 


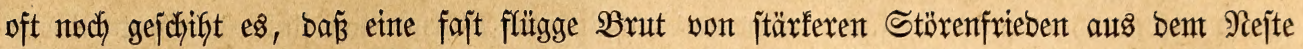
genorfen wirb unt zut Sintuto geft.

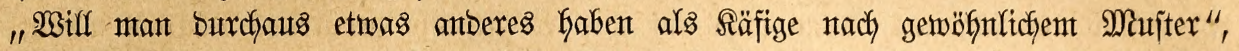

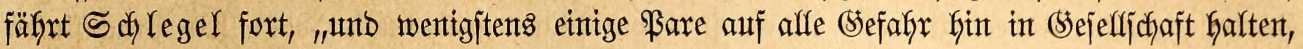

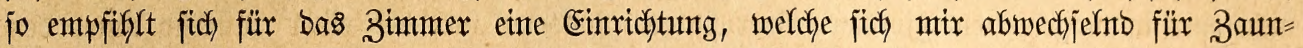

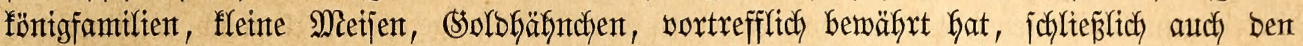
wont mir gezogenen Elfterbögeldyen alz Iummelplats biente, ein herliches Bifl gibt unb oen Titeren gax jefr befagt. $2 \mathfrak{n}$ ein womöglich ber früffen Miorgenjonne zugängliches Fenjter

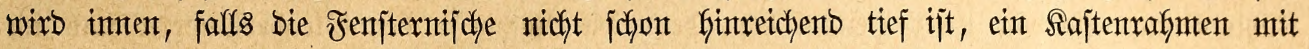

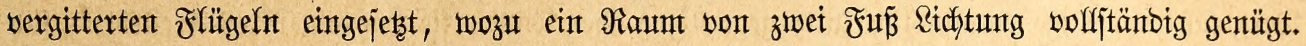
Die Wänbe nebjt Decfe werben mit Mlos tapezint, was am bejten in folgenber $23 e i j e$ ge=

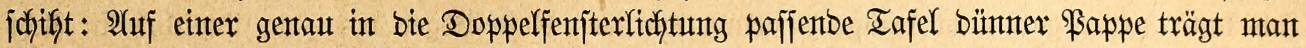

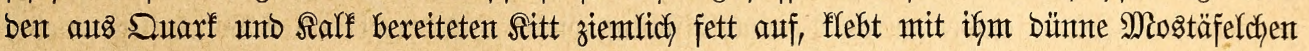

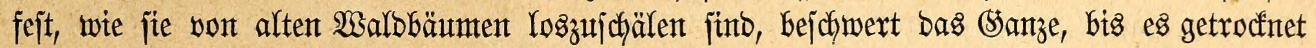

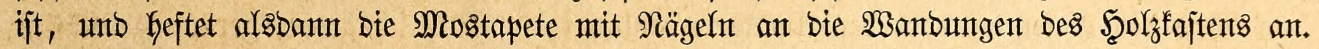

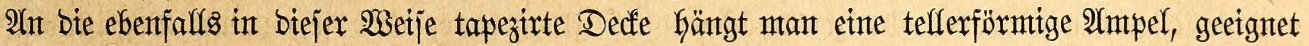

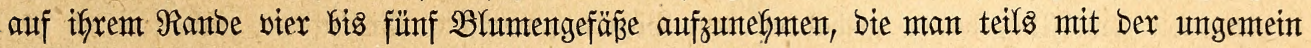
rajch wachjentent Cobaea scandens teifs mit Epheu bepflanzt. Die Eobäa wutchert fajt

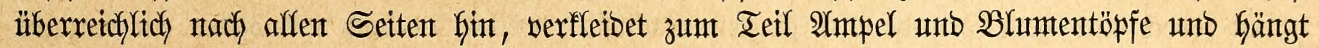
in langen Serwinbent bent Bobent zu. Ebento fönten, wentgjtents an einer Seitentwant,

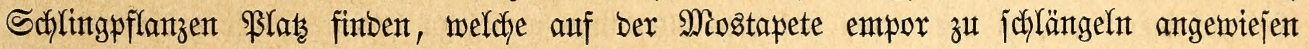
werben unb beren Raubwerf, zumal in Srün won abjtedfentem Ion, einen reizenben Sdymud

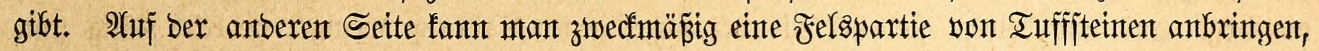

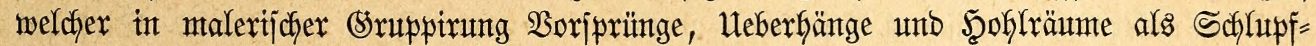

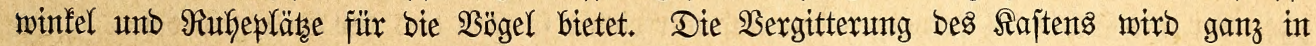
Der $\mathfrak{W e i j e}$ wie ein Fenjter mit Dker = unb Unterflïgefn zunt Deffnent eingeridytet, Damit

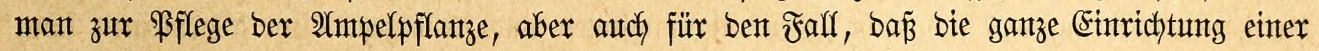
Untarbeitung bebarf, bequem yon allent Seiten Zugang hat. Eine Scheibe bes Bifasfenjters

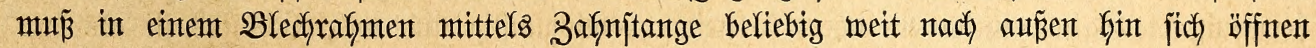

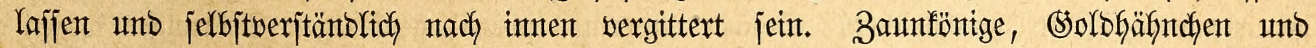
Meijen fügent bent Raubpflanzentwerf wentg Schabent zu, mur ant bem Mioje zaujent fie weiblich

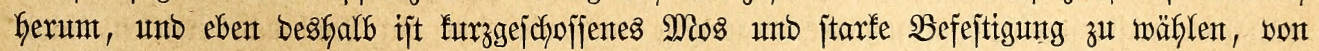

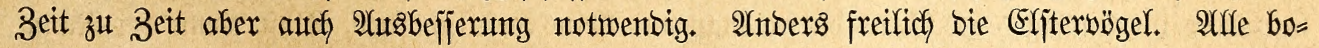

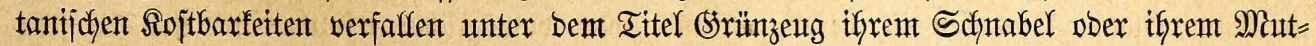

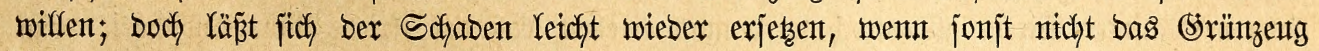
irgentobie nachtellig für bie $\mathfrak{B} \ddot{g} g e l$ iłt.

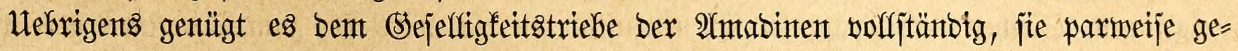
fangen zu Galten. Man ift babet alles 2(ergerniffes übergoben, gleidfwie bas \$ärchen un=

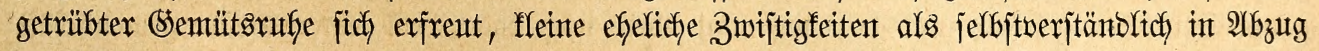

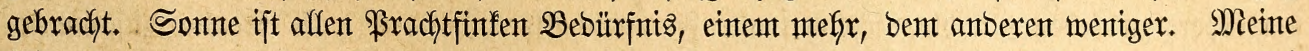

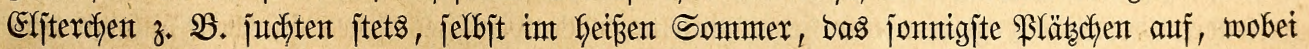

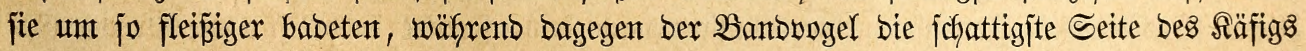

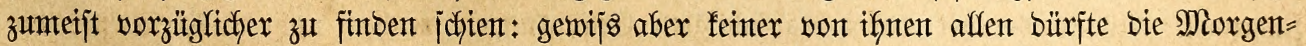

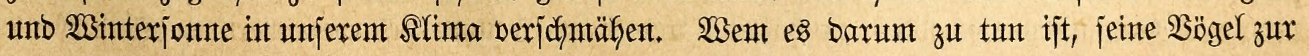
Fortpflanzung zu bringen, bem ift zut raten, auf ibyllijdhe Einridchtungen, ganz bejonbers aber auf

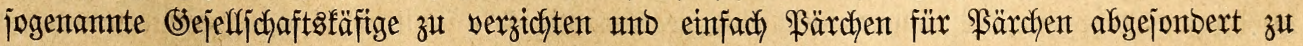

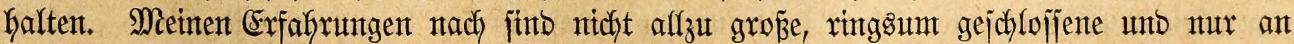
Der einen, bent Ridfte zugefefrten Seite verbratete @äfige Das bejte. Das Pärchen, mux auf fidd 


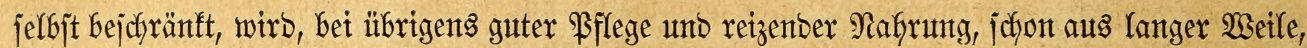

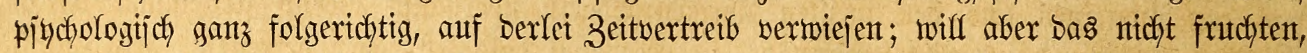
jo gilt es, Die Reibenjchaft burdy Eiferjudst zu jtacheln. Man gejelle bem \$ärdjen, zumal

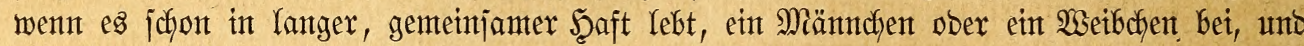

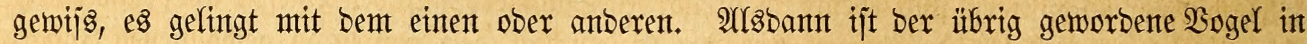
Der Regel mieber zu entfernen."

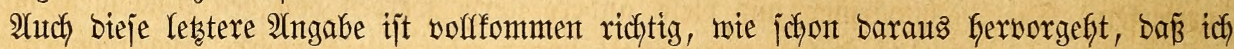
unabjängig non ธchlegel weiter oben (ङ. 79) basjelbe gejagt habe. Sch vermende zu

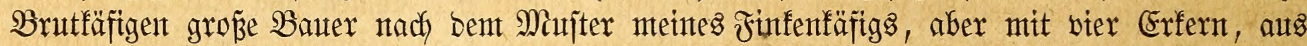

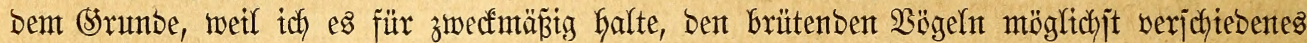
Futter zu reichen. Ebenjo gut, wenn nidft noch bejier, jind Sijtenfäfige, weil fie bent brüte=

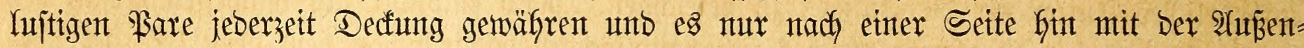

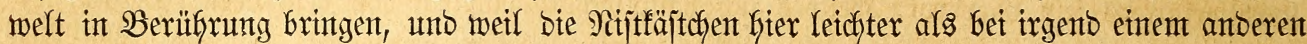
Räfige beaufjichtigt und unterjud werbent fönnen. Se grö̈ß̈er bieje ober bie Brutfäfige

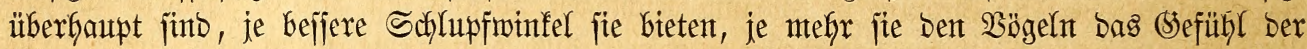

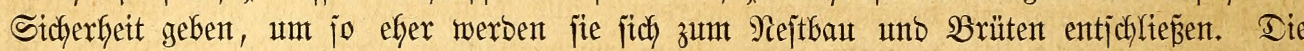
günjtigen Ergebniffe, weldye funbige Zütyter, wie $\Re$ ey, aud in Bogelituben erzielt Gaben, finto

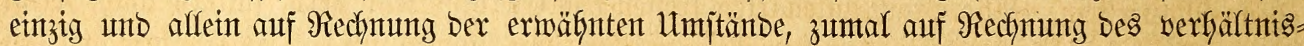

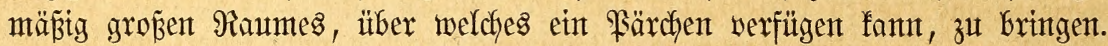

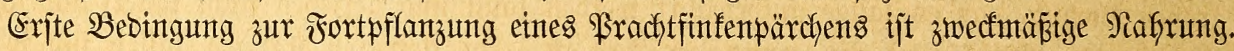

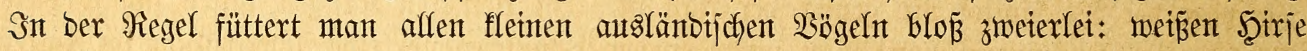

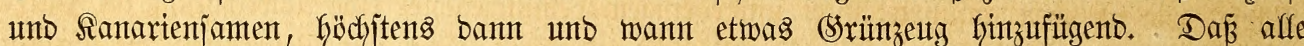

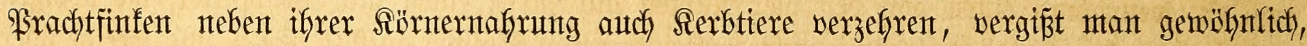

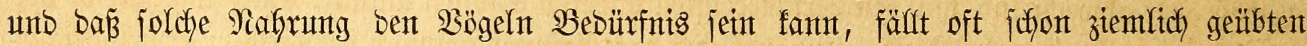

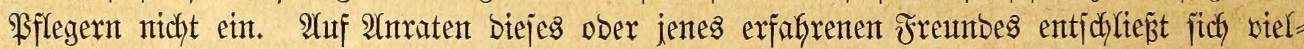
leidft ber Eine ober ber 2Anbere, went jeine \$rachtfinfen trots allebemt zur Brut jadreiten,

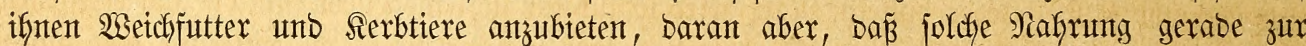

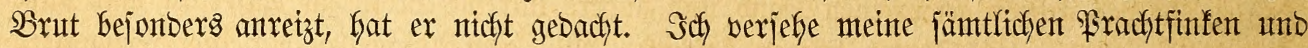
Weber, überfaupt alle meine förnerfreffer, ftets mit verjofiebentem Jutter und reicfe biejes

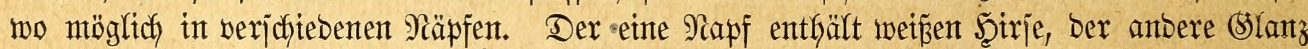
ober Sanartenjamen, ein britter Siheuterngejäme, ein vierter Sceujchlag, in einent fünften, werben geriebene Sartoffeln, mit etwas Gart gefodjtem unb geriebenem Eibotter vermijcht, vorgejest, ein jechster, reçt flacher wirb täglich minbejtens zmeimal mit jorgfältig bereitetem

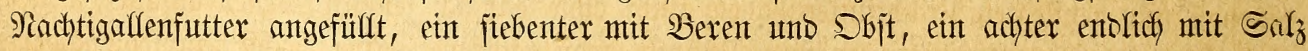

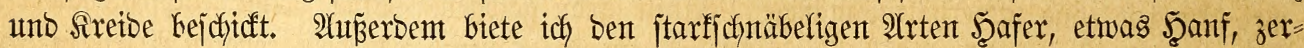

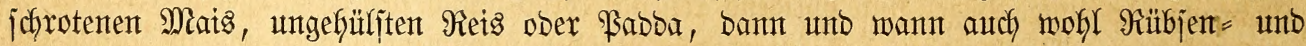

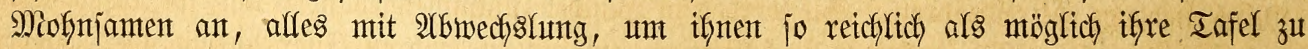

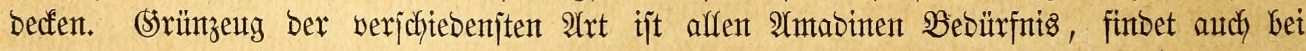
2Hffütterung ber Sungen $\mathfrak{B e r w e n d u n g . ~ S n ~ b e r ~} 2$ (uşwahl ber gebotenen Stoffe finto fie nidyt

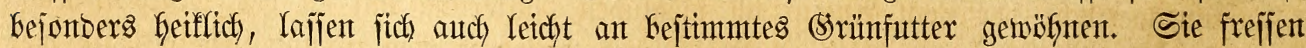
Salat= und Roblblätter, Bogelmiere, Rejeba, Mëhrenfraut, Rabinschen, Rörbel, junge Sat=

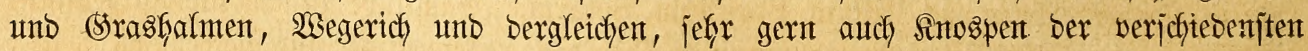

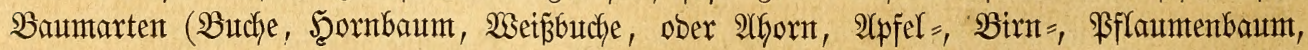

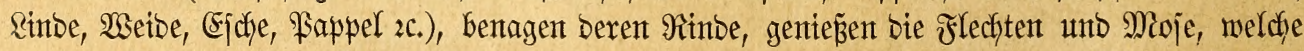

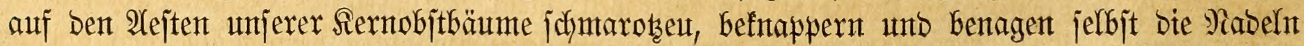
nnjerer Eoniferen, gefgen überbaupt nur wentge Pflanzenarten nicht an. 3umt Erjats ber

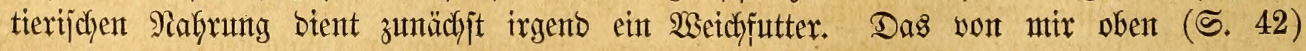

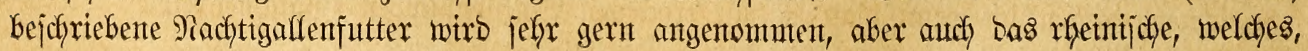


wie oben bemerft, nicht nachjäuert, aljo auds täglich mur einmal gereicht zu werben brautcht, von ben 21mabinen unt ben meijten ïbrigen $\mathfrak{B}$ g̈geln ïberhaupt, went fie einmal baran

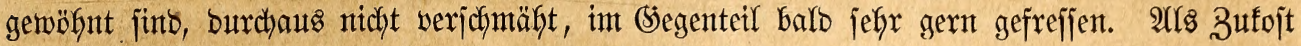
lafje ich täglich minbejtens einmal, wenn bie Bögel Sunge haben, auch fünf = bis jectşmal Miefliwürmer nadffüttern und ebenjo während bes Sommers auf Den Wiejen aflerbanto Sierb= tiere mittels bes Sijöpfers fangen unto ber (sejellidyaft ben ganzen jo gewonnenen Sntjalt vorwerfen. Die Mebliwirmer unto viele anbere Rerfe werben bon ben atmabinen oft mur aubgefaut unb ber weiche Inthalt aufgejaugt, immer aber mit Begierbe angenommen; und went erjt einer bie beliebte Recterei wirflich freffen gelernt bat, afmen ifm balo bie übrigen

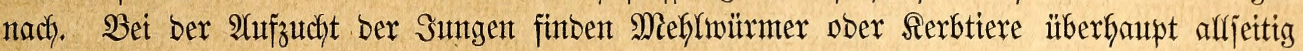
Berwentung, werben auch alfen Erjatzitoffen entjchieben vorgezogen und fint jomit als un=

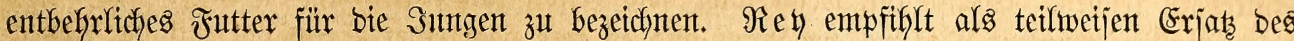
Serbtierfutters jein Eterbrot, weldjes fich hauptjächlich baburch von bem oben (ङ. 44) be-

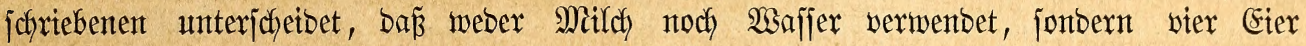
im Servidhte von 185 Sramm zu Schaum gejhlagen, jobant mit 280 (5r. feinem Weizen= mefhl verntengt unt gut burchgearbeitet werben. AYus bent Ieige formt man fleine breite Brötcten unt bädft fie in einem nicht affzumarmen Bacfofen ober in ber Bratrögre auf einem Miaueritein. Aaffe \$rachtfinfenarten freffen bas (Eterbrot jefr gern, füttern audh, went man es ifnen gerieben unb troffen vorjebt, mit ifm ifre Sungen auf. Das Eierbrot hat ben

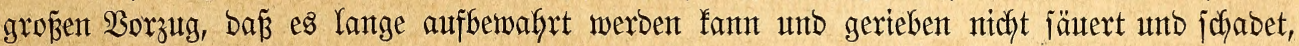
wie bies bei Weidffutter vft genug ber Fafl ijt. In fleineren Räfigen lajfen fich jo viele

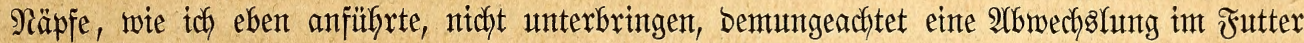

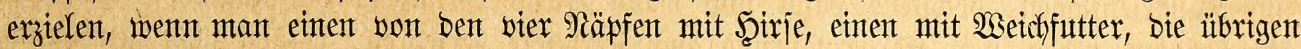
betben aber abwedfjefno mit Den verjojtebenjten anberen Stoffen anfüflt, Salz unb Siretbe über bie Särner reibt ober in Säfige auffängt unt bas (srünzeng einfach vorwirft. Servielfältigung

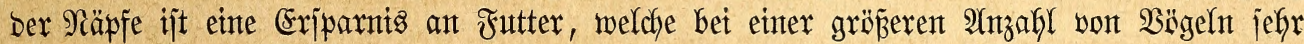

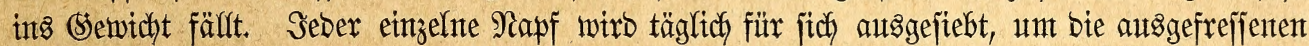
Şüljen, in bas Futter gemorfenten Sand unb anbere unreine Stoffe zu entfernen, und auker

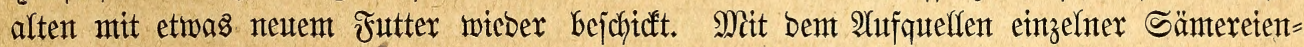
wie mandhe Siebhaber es angeraten haben, bin idh mur bebingungsiweije einverjtanden, nur

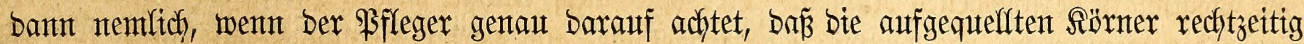
weggenommen unb neute gereicht werben, bebor jente jäuern. Bur Erziefung junger $\mathfrak{B}$ ögel fint

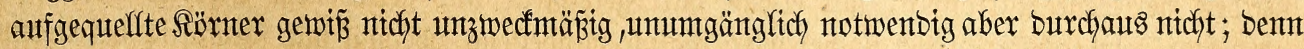

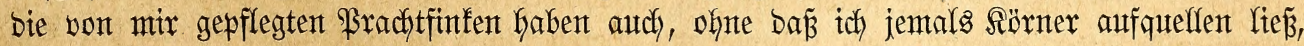

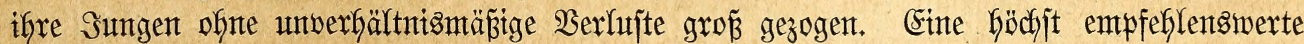

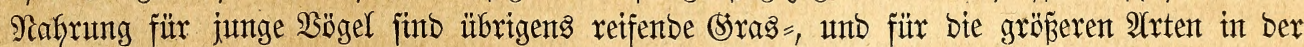
Metldy ftebenbe Setreibeähyen. Sie werben in Büjchel zujammentgebunben unt int Räfige auf=

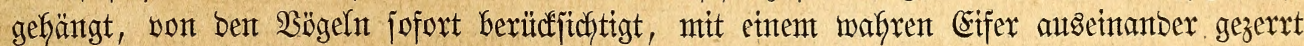

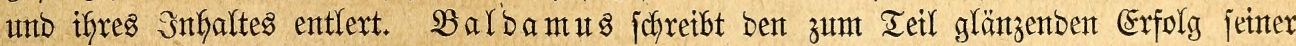

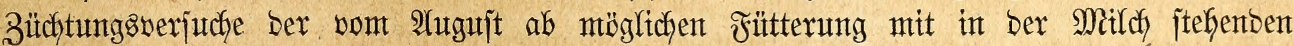

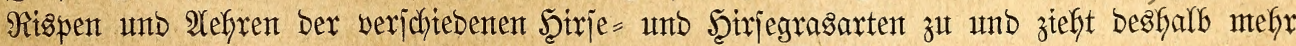

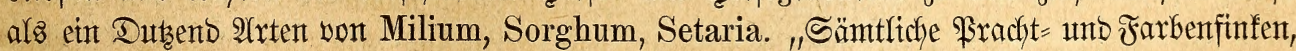

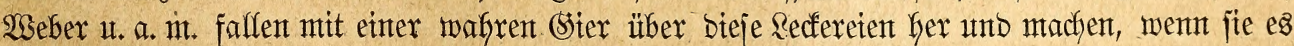

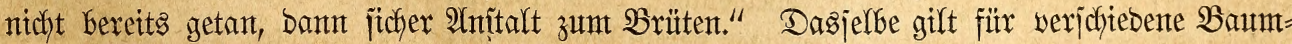

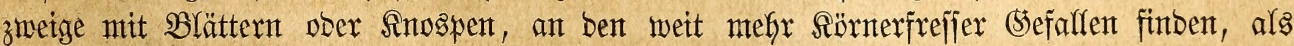
man glaubt. Şartgejottentes sibotter mirb von einzelnen 2 mabinen verjchmäht, von anberent begierig gefreffen und zux 2Ufffütterung ber Sungen verwendet, befommt biejen auds aus: = gezeidynet, namentlidy wenn man es mit trodfenen 2 mteijenpuppen zujammenreibt. Titerijaje 


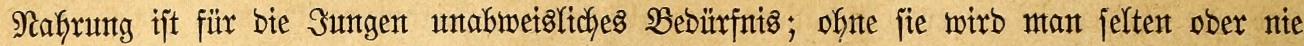

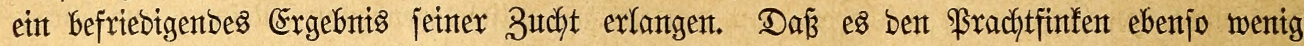

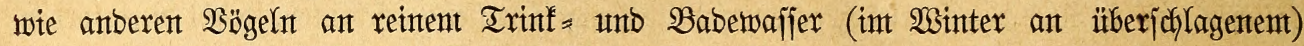

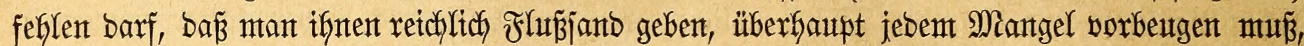

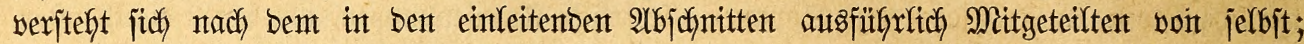

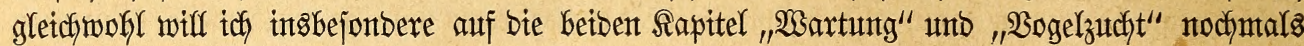
attobrüdflich verwiejen habent.

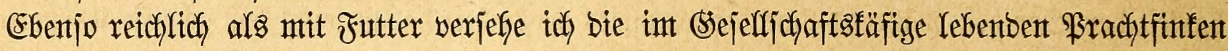
audf) mit Baujtoffent. Sch befolge bei Darretdyung berjelben bie gletchen (Srumbjätze wie bei ber Fütterung. Seber Bauftoff witro möglichjt gejonbert in fleinen Rörbchen geboten, jobar

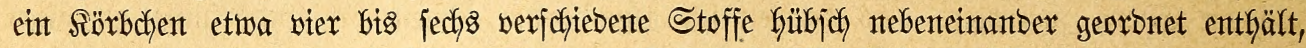

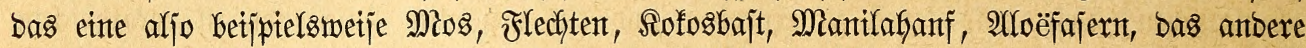

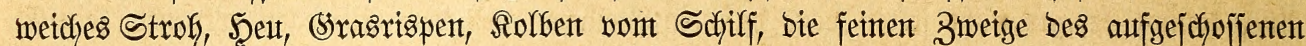

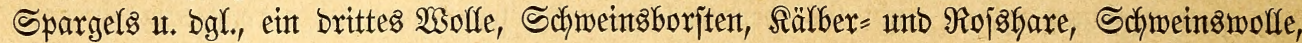

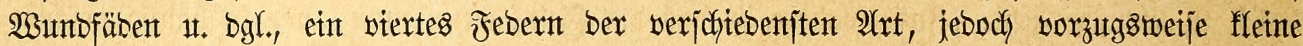

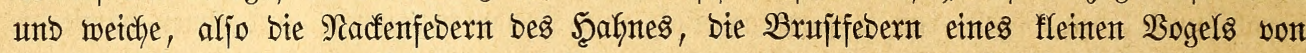
ber Droffel an abwärts, (Sänje = unto Entenbunten, ober ment man joldje nidyt bejizst, zer=

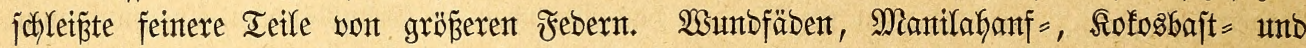

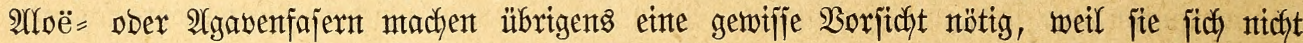

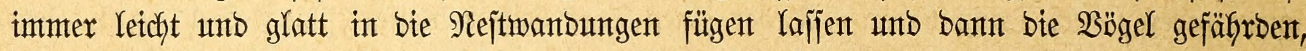
inbent jîch bieje in ben Fäben leicht verwicfelnt unb erfängen, wie ich jelbjt bies mefy als

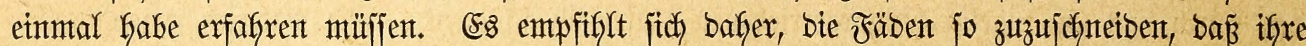
Ränge $15-18 \mathrm{~cm}$. nicht überjteigt. Den $\mathfrak{B o ̈ g e l n , ~ w e l d h e ~ i n ~ B r u t f o ̈ f i g e n ~ n i f ̈ t e n , ~ Y e g e ~ i c h ~}$ einen Teil ber Stoffe in ben Bauer, einen anderen auf bas (sitter, jobar fie, went audch nidyt ganz ofne Mühe, bie betreffentben Baujtoffe exjt burch basfelbe hereinzieben müfjen.

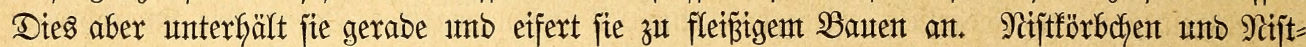

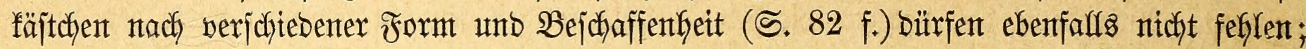

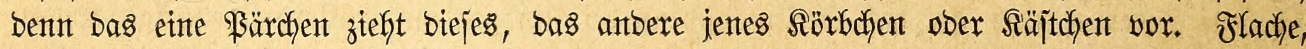
oben offente Sïrbchen, wie jie bet ber Ranartentudft Serwentung fintoen, werben von Den

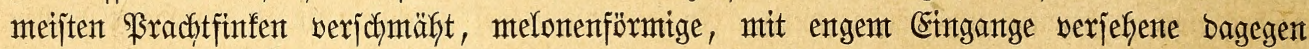
recht gern bentbst, ebenjo gern aber auch eit auş Draft zujammengebunbenes, eiförmiges Brut=

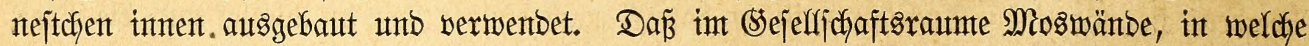

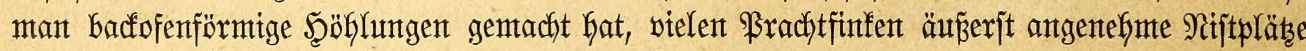

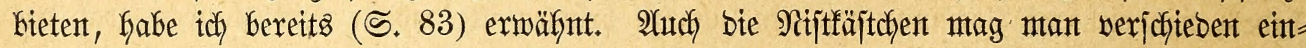
ridhten unt bie einen Göfer, bie anberen niebriger anbringen, bieje weiter, jente enger, einzeltte mit geräumigent, anbere mit engent Eingantge wählent. Dagjelbe ßärchen von 2Ymabinen,

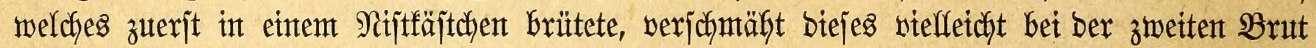
Int fchichtet fich in eintem $\mathfrak{B r u t n t e j t e ~ b i e ~ n o ̈ t i g e n ~} \mathfrak{B a u j t o f f e}$ zujanment, ober aber füfllt ein Scarzer Bauterchen von oben bis unten aus, baut jich einte längere, Durch Den 2(urentwujt in

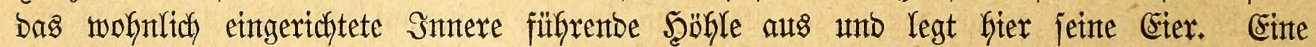

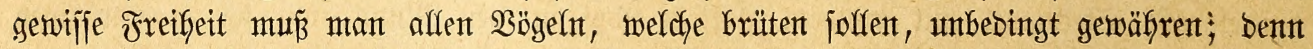
mant barf, wie Schlegel jefr ridhtig benterft, "ifnen nidyt zuntuten, in ber Sefangenjichajt ifyre Baufünjte zu üben, wie jie es in ber Freibeit gemöhnt find, weil man nidft int Strntbe ift, ifnten bie bazıt gehörigent Stoffe zu reidfen."

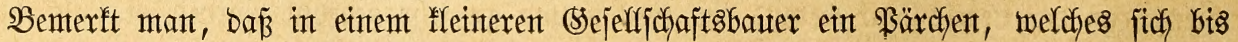
bahin frieblich zetgte, mit jeinen (Senofjen Scaber und Streit anfängt, jo ijt bies ein Beidjent,

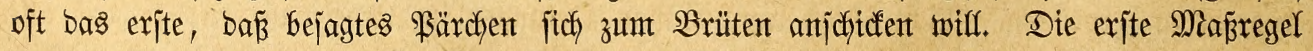

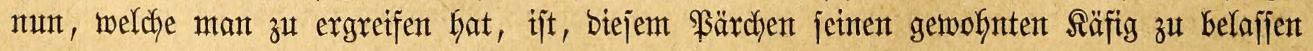




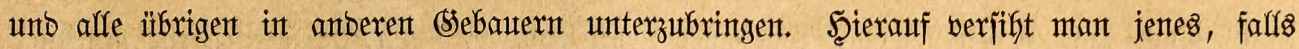

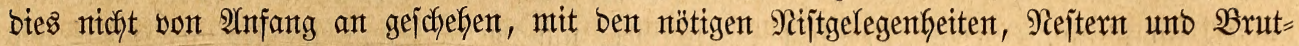
fäjtchen, wie jie nach bent bereits gegebenten Mitteilungen pafjent erjdyeinen, reidyt bie erforber=

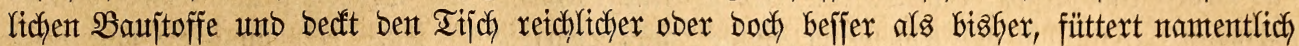
tierijche Stoffe, int Jrïhjabre und Sommter aljo frijche Âmeijenpuppen, ant bejten bie fleinjten, weldje mant befommen fant, aljo beijpielsmeije bie ber rotent unt gelben $\mathfrak{A}$ meije (Formica rubra und F. flava). (Einte joldfe Nafruttg reizt łur Begattung an unb trägt zur Frucht= barfeit ber (Fier bet, während mant antererjeits beobadjtet Gaben will, Daj gemiffe Sïnnerjorten, namentlich Şanf, bie Eier ebenjo wie bie $\mathfrak{B o ̈ g e l ~ z w a r ~ f e t t ~ m a c h e n , ~ b e r ~ F r u t c h t b a r f e i t ~ b e r j e l b e n t ~}$ aber Ginberlid jein jolfen. Sift exjt eine Begattung exfolgt, fo hat man mebr als jonjt

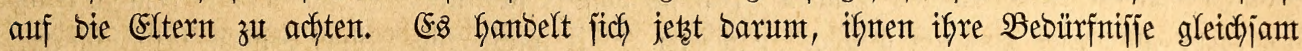
abzulaujchen, biejes und jenes zu exproben und bas erjichtlich Bujagenbe zu verabreidjen.

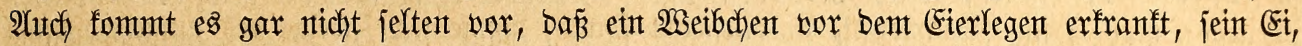
wie mant zu jagent pflegt, nicht los werbent fann unt, went mant nicht rechtzeitig eingreift, babei zu Srumbe geft. Sngbejonbere ijt bas ber Falf, went man, wie fo fäufig gejchifgt,

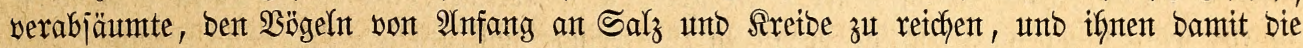

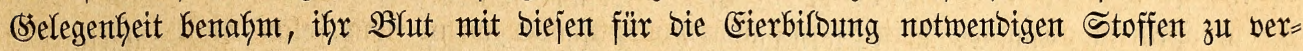

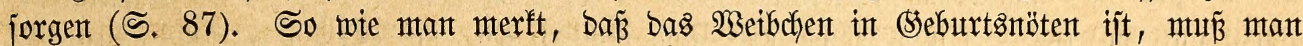

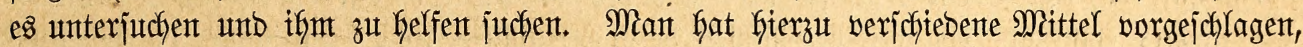

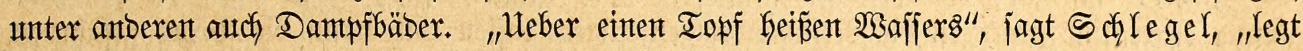

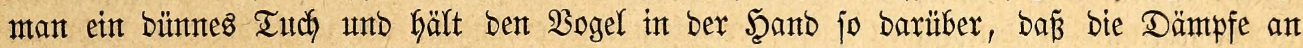
ben burch bas Ei fugelig herborgetriebenen Unterleib jallagen. Die baburdy erzengte (Ex=

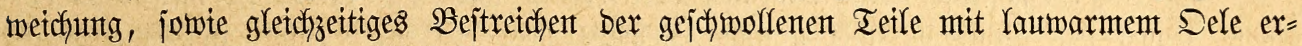

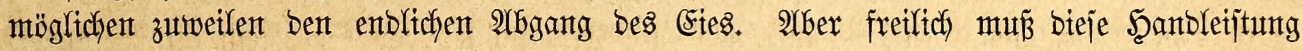
g̈fter vorgenommtent werbent. Einte weitere nicht unbebeutenbe Sciffaleiftung bejteft barit, mittels eines feinen Feberftels wieberholt einige Tropfen warmes Del in bie Regeröhre zit

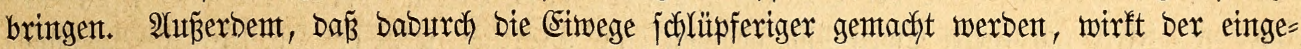
jchobente Feberfiel nach 2 (rt bes Seifenzäpfchents bet Sinbern auf Entlerung etwaiger Sotan=

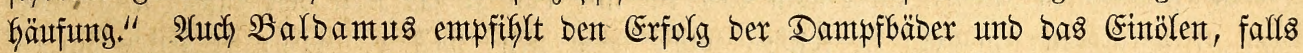

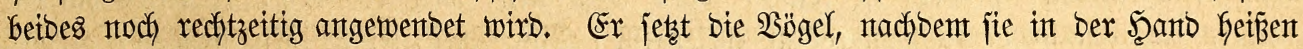
Däntpfen ausgejebst unt geölt wurben, auf ein locfer über ben Wajfertopf gejpantes Nets,

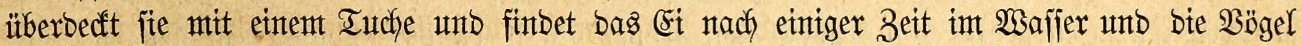

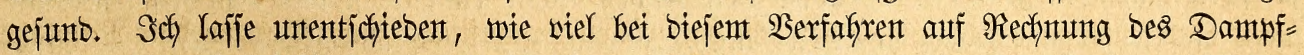

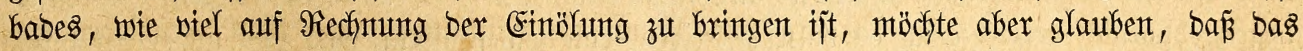

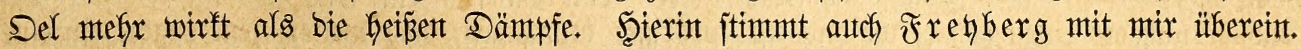
"Unter bent mantherlei Behandhungsartent, weldye zur Şilfe bei Regebejdywerben ber $\mathfrak{B}$ g̈gel

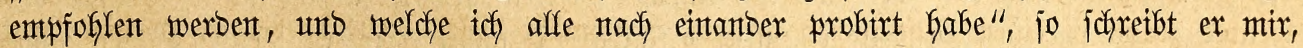

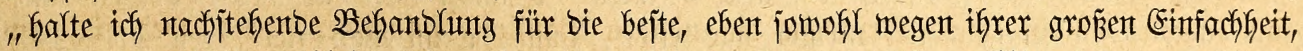

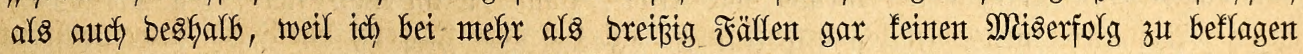

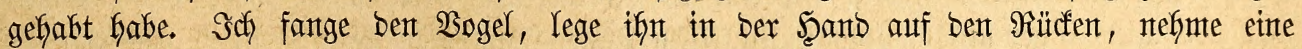

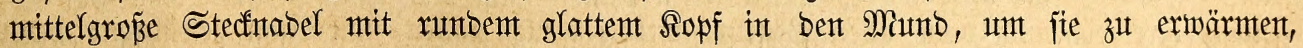
tauthe ben Sopf alsbant in feintes Sel, füfre ifgn in bie Slloafe ein unto wieberfiole bies bret = biz viermal. War bas (Ei noch ntcht fichtbar, fo wirb es nadf biejer Şilfäleijtung ficher abgehen; ijt es bereits jithtbar geworben, ofyne bá es gelegt werbent fant, jo betweijt

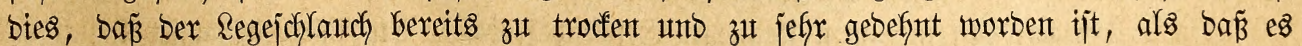
bon Exfolg jein föntnte, Fettförper einzufübrent. Snt leberent Falfe bletbt es bas Einfachjte,

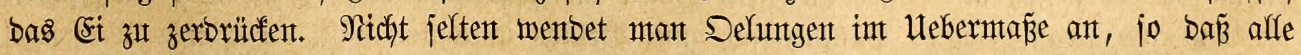
Baudfffebern mit ber fettigen Majfe geidfwängert werben. Wiro baburch bas (Ei auth wirflich 
zu Tage geförbert, jo erzeugt man boch einen Uebeljtant, welcher unter Umitänben bebenfficke Folgen Kaben fann. Das Del flebt bie Febern zujammen, Sand und Siot jetzen jicts fejt unb bilbent eine Srujte, Dem Sïrper wirb $\mathfrak{B a ̈ r m e ~ e n t z o g e n , ~ u n d ~ D u r c h f a l l ~ u n t ~ a n b e r e ~ U n t e r ~ = ~}$

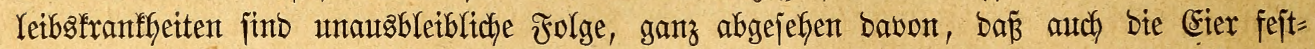
fleben und int günjtigjten Fafle aus ifgrer sage gebradjt werben. Es fann aljo mit bent

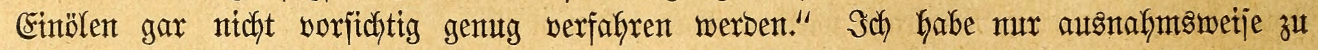

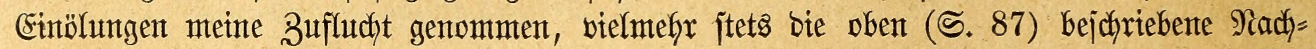
Gilfe geleijtet, regelmäp̈ig mit Dem bejten Exfolge. Dẩ bie Splitter bes zerorürdten Eies bie Wände bes Regejchlaudfes in bebenflicher Weije verleşt hätten, wurbe von mix nicht be=

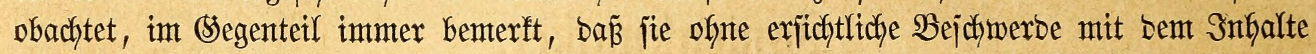

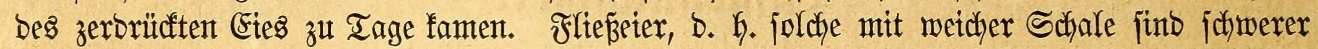
zit entfernen als harte, treten bei vorjichtigem Streichen entich aber boch aud herbor. Sümitlidje Entfermung Der Eijdyale ijt burchaus nicht ratjam, weil jie in ben meijten Fällen Entzümoung bes Regejchlauches verurjacht uno ben $\mathfrak{B}$ ogel baburch auf bas äußerjte gefäbroct.

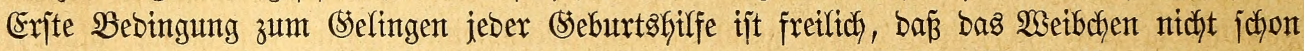
zu jefy gelitten hat unt fraftlos gemorben ijt, befjer noch als jebe Şilfe: Sermeibung bes

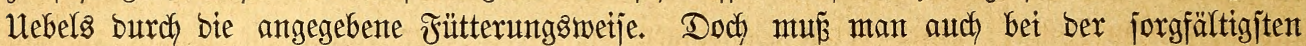
Pflege auf Derartige Berlujte gefäst jein, und besfalb hat Schlegel ganz redht, wenn ex

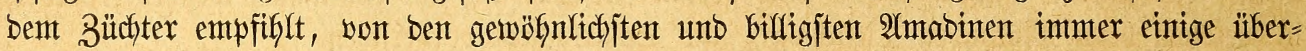
zählige Weibchen zu halten, von benen eines nady bem Tobe bes exjten bem Meänndien jo= fort beigegeben werben fann.

(S) fht bas Regegejdä̈ft ofne Störung vorüber, jo unterlafie man, wenigitens in ben

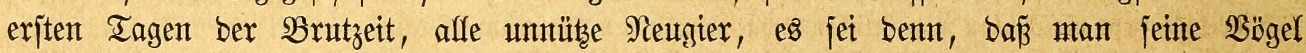

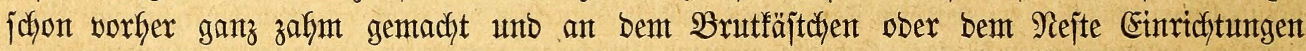
getroffen habe, weldye es ermöglidyen, bie brütenben $\mathfrak{B} \not ̈ g e l$ ofgne wirfliche Stönung zu be=

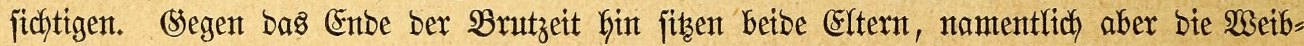

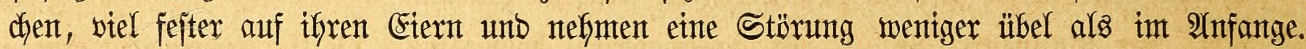
Die ausigejwlüpften Sungen fann man efer ein und bas anbere Mal bejichtigen, und wenn man im Brutbauter züchtet, ijt joldyes jogar anzuraten, weil es fich nicht jelten barum Ganbelt, ein abgejtorbenes Sunges zu entfernen. Sind bie Sleinen erjt jomeit ferange=

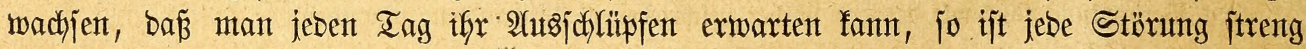

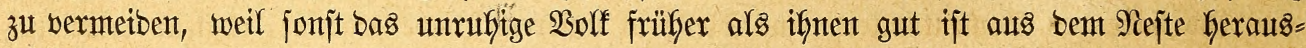

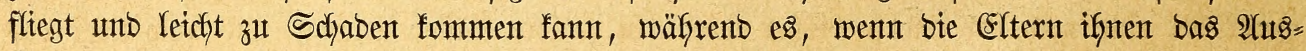
fliegen gejtatten, beziebentlich) es bazu antreiben, von jeinen natürlichen unb ungemein jorg=

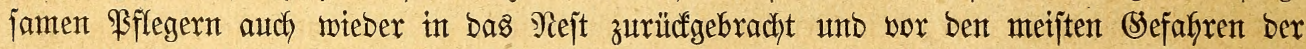

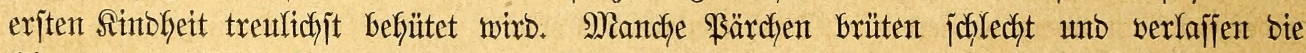
(Eter voer auds) bie Sungent ofne eigentlid) erflärliche Urjache. Sn ben meijten Fällen fant

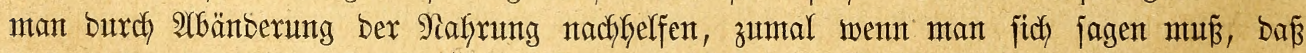
biejer voer jener zux Erziefung ber Sungen erforberliche Stoff feglte ober nicht in ge=

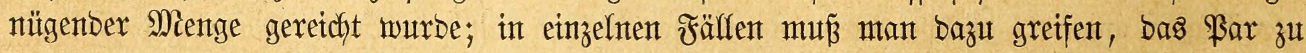
trenten und bem 2 eibctien ein anberes Miännthen zu geben. Dft freilidy bleibt betbes erfolglos und nichts anderes übrig, als bas vielfetcft zu liebeseifrige aber brutfaule अärchen wegzugeben. Im übrigen gelten für ben \$fleger afle bie Regeln, welche idy in beut

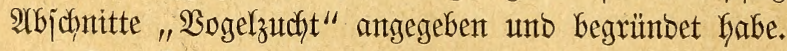

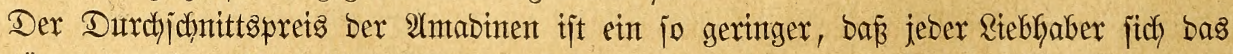

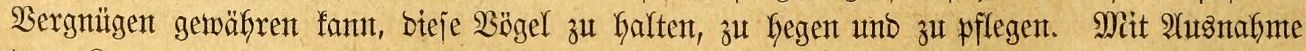
bes Suttenelfterchens, Des গetzflügels, Doppelfarbs, Schilf= und Schilbfinten, powie

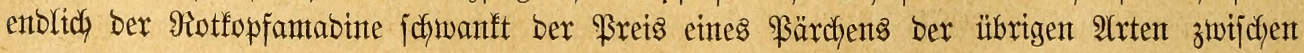


zwei unb cinhalb bis vier, hödhjtents fünf Talern. Erjtere fommen Gäher, unter Umitänben auf bas Doppelte zu jtehen, unb Darf man froh jein, wenn man jie zu joldjen Freijen über= fraupt erfält. Ifm billigiten jinto gerabe biejentigen 9 rten, weldhe am leidjtejten zur Fort=

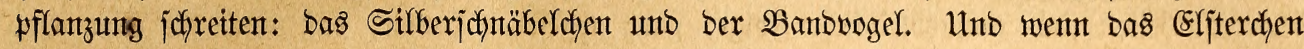

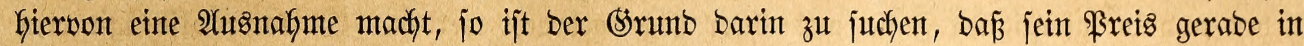
Folge ber vermefrten Rachfrage wieber etwas geftiegen ijt.

\section{Sumentuntadker.}

Die (3) leicherlänber $\mathfrak{W}$ ejtafrifas beberbergen einige in ber Färbung jebr ïbereinjtimmende,

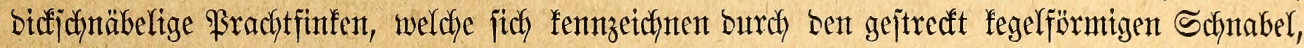
Deffen obere Şälfte bicfer als bie untere, auf Der Firjte runb gemölbt uno an ben Seiten zujammengebrücft ijt, unb befien gerabe, vom Mambrwinfel wentg abjteigenbe Ränder

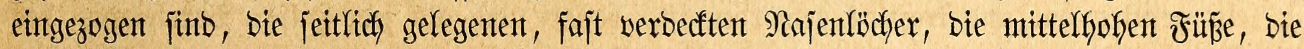
furzen, jtarfen Flügel, unter beren Sdywingen bie vierte ober fünfte bie Yängite zu jein pflegt, ben ziemlich langen, außen jtark gerunbeten Schwanz unb ein mäp̈ig weiches Sefiteder, in welchem beim Männdhen Tiefichwarz uno Scharladyrot vorberjchen.

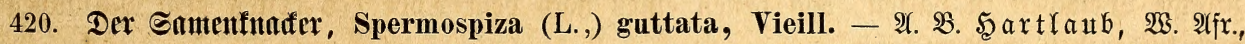

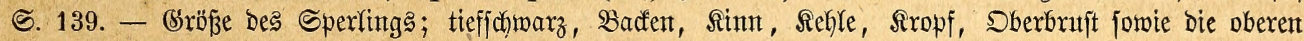

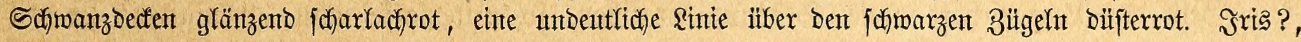

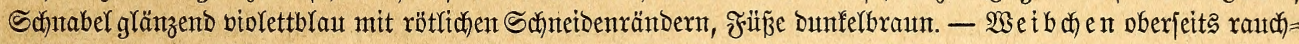

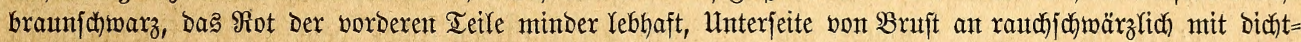

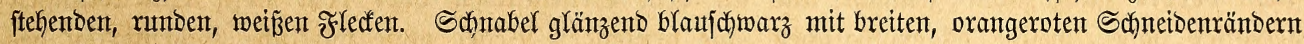
und ebenjo gefärbter Spiz̧e.

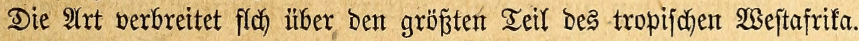

421. Der $\mathfrak{B l u t f u n f e r}$. Sp. (L., Fr., Spermophaga) haematina, Vieill., (punctulata, cyano-

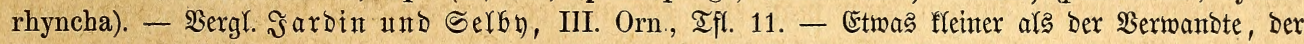

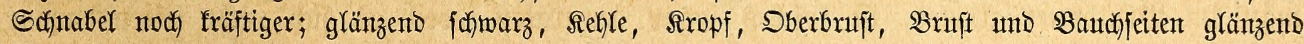

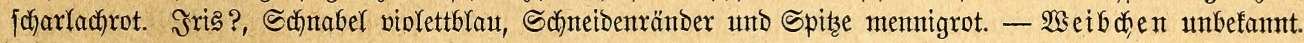

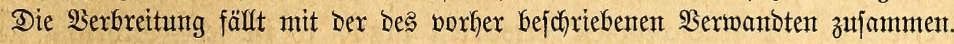

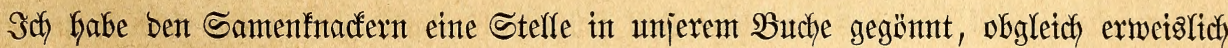
weber ber eine nody ber anbere biaker lebent in unjere Räfige gelangt unb auch über bas

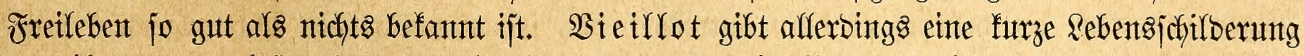

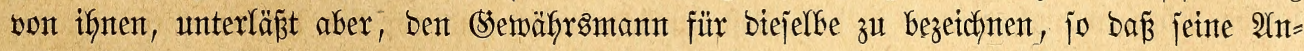
gaben jefr an $\mathfrak{B e r t}$ verlieren. "Das Sönigreich Songo", jagt er vom Samenfnadfer, "ijt

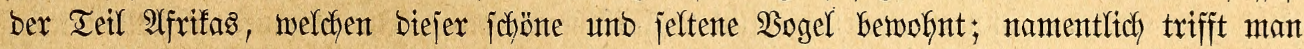

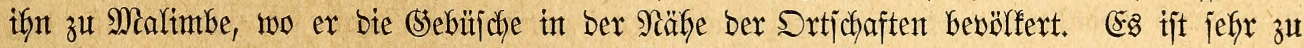

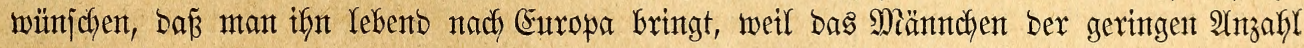
won $\mathfrak{B o ̈ g e l n t ~ a n g e f o ̈ r t , ~ w e l c h e ~ e i n e n ~ a n g e n t h m e n t ~ ( s e j a n g ~ m i t ~ p r a d h t w o f f e r ~ F a ̈ r b u n g . ~ w e r e i n i g e n t . ~}$ Shn an Srt unb Stelle zu erlangen, würbe nidft jobwer jein, oa er jein halbfugeliges,

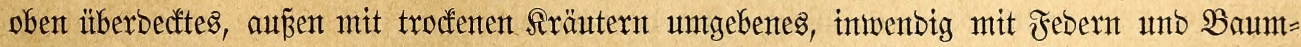

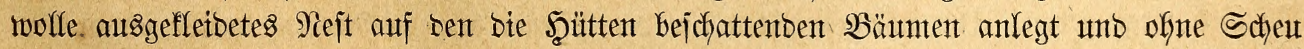

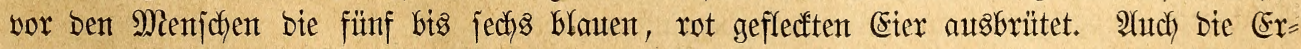
näbrung würbe feine Schwierigfeiten Gaben, weil jich bieje Didfjchnäbler leidyt an verichiebene Sämereten getwöfnen lajfen unb Göchjtents als $\mathfrak{B}$ g̈gel bes heipent (siürtels eine Wärme von

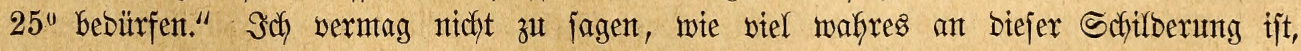

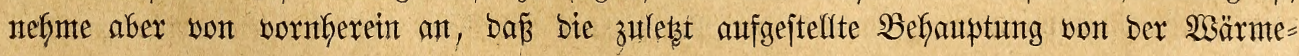




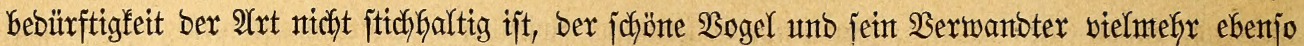
gut als anbere auts (S) Feicherfänbern jtammende Samenfreffier bei einter geringeren $\mathfrak{B a ̈ r m t e}$

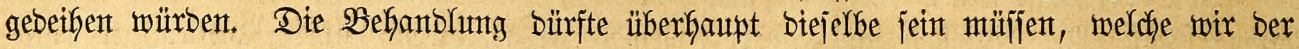

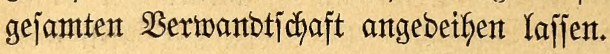

\section{Sittidffintket.}

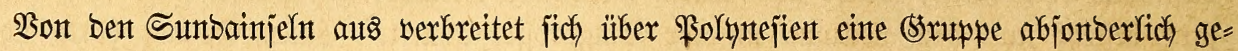

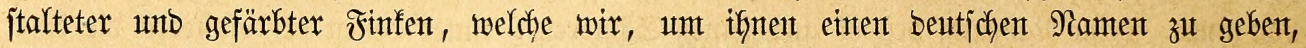

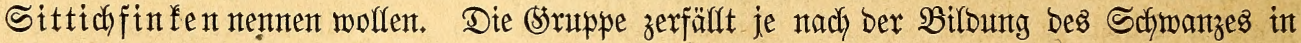
zwet Sippen.

Die Sittichfinfent int engerent Sinne haben jtarfen, aber body gejtrectent Sdynabel

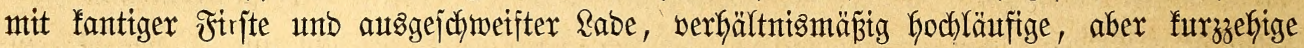

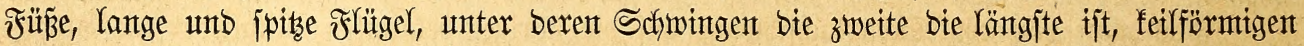
Schwanz mit weit vorragenben unt verjdfmälerten Mittelfebern und eit berbes, glattes (5e)= fieber, in weldyent Slivengrazgrün unb Pot vorgerjchen.

422. Der @đjaxfadjidjanz, Erythrura (L., Fr., Emb., Am.) prasina, Sparrm., (quadricolor,

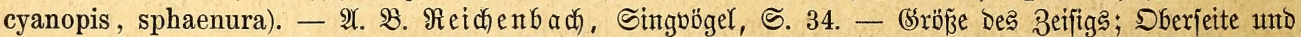

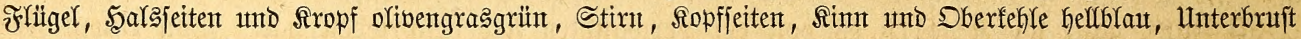

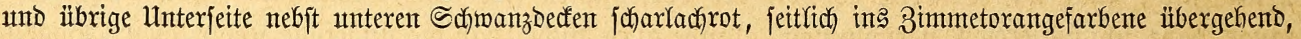

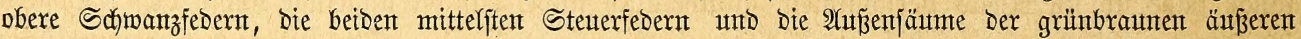

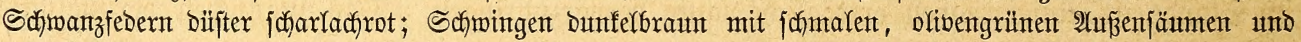

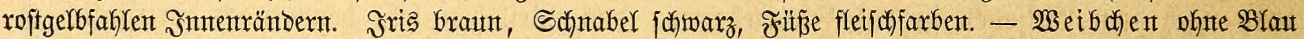

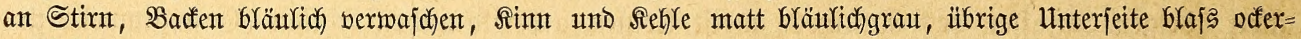
gelbfahl.

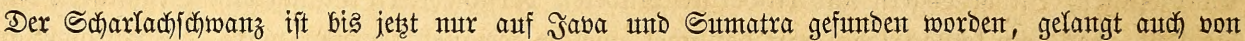
fier aut neutexing nicht gerade jelten in unjere Räfige.

423. Der Sittiøfinf, Ienii ber Eingeborenen, E. (Fr., Estr., Acalanthe, Poëphila) psittacea,

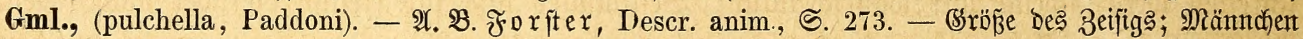

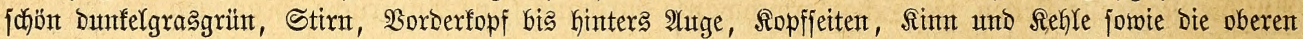

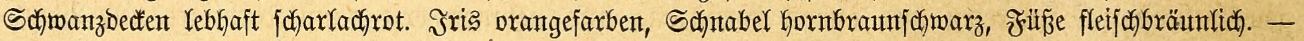
$\mathfrak{B}$ eib chen unbejodriebent.

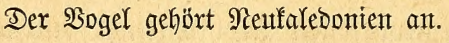

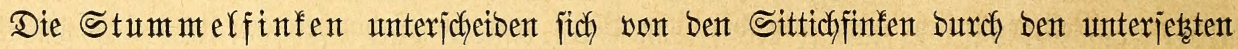

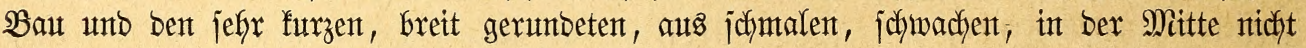
werfängerten Febern gefilbetent Schwanz.

424. Der Stummelidumuz, Amblynura (Geospiza, Erythr., Am.) cyanovirens, Peale, $(\mathrm{Pu}-$

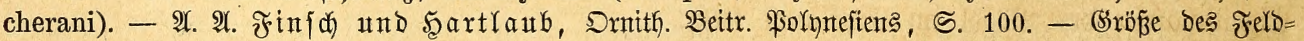

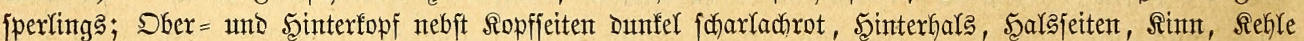

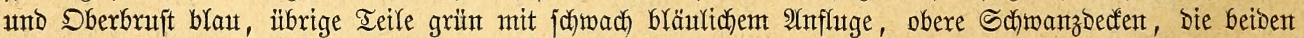

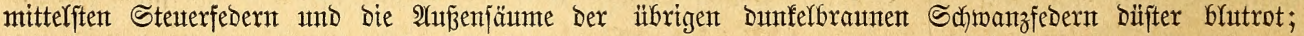

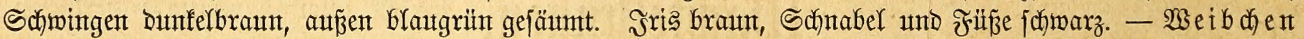

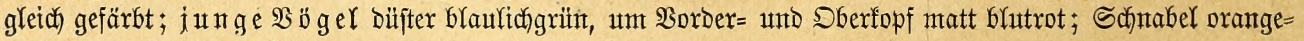
gelb mit mehr ober minber ausgedefntem, Dunflem Spitzenteile.

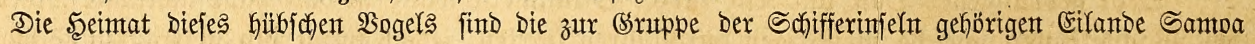
und Upolut.

Die Sittidffinfen, auth injofern beachtensmert, als fie bie einzigen Mitglieber iffrer Familie fint, weldye in \$olynefient worfonmten, bemofnnen partweije ober int fleinen Flügen bie trodenen, offenen, mit Eajuarinenbäument bejtanbenten Teile ber Snjeln, Galten fich fajt

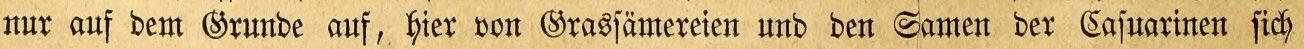




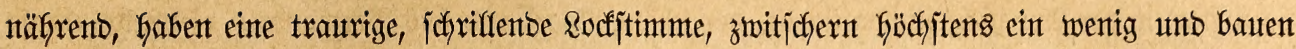

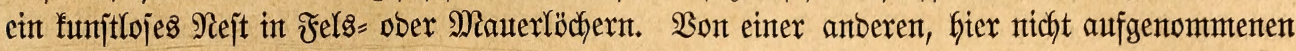
2trt ber Gruppe benterft $\Re$ ittlits bas Folgentbe: "Dex jchöne, fleine $\mathfrak{B}$ ogel ift in jeiner

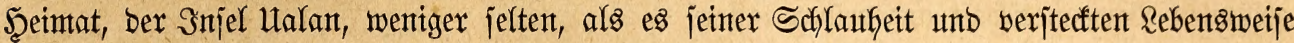
wegen erjedeint. Er lebt einzeln fajt überafl, wo es \$fflanzungen vont Bananen unt bergleidyent gibt, Gä̆t ficth hier gern niebrig auf ber Eroe unto liebt bie Werborgenfeit. Went er auf=

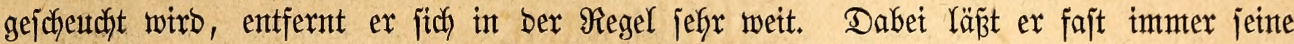

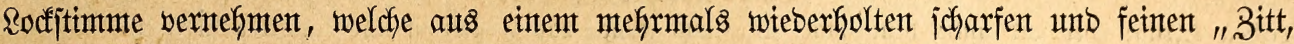

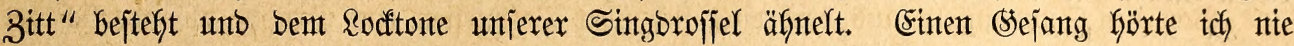

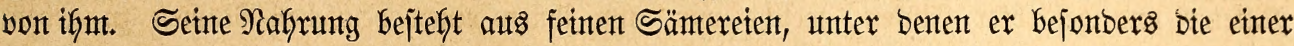

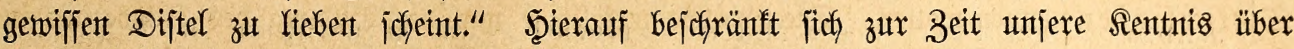

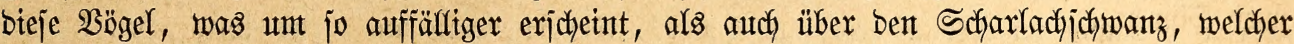

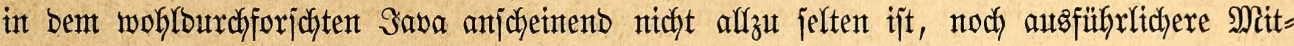
teilungen feflen.

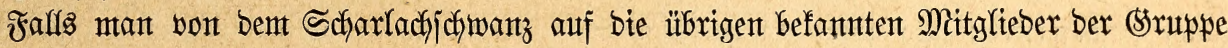

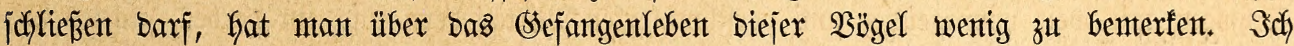

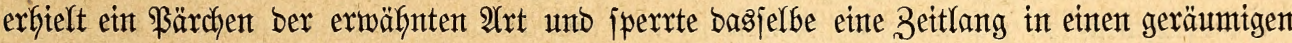

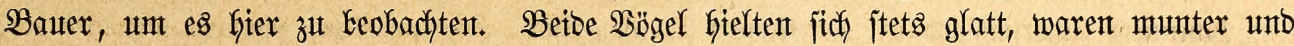

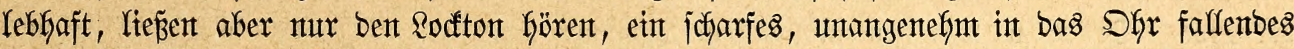

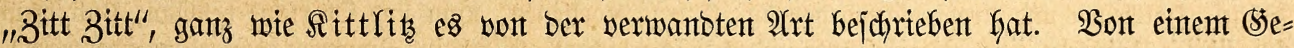

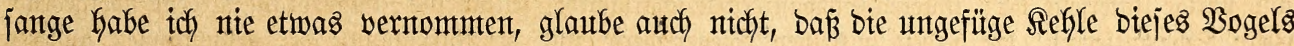

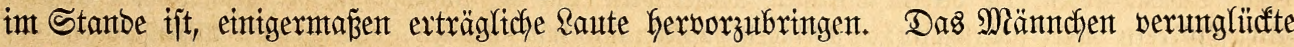

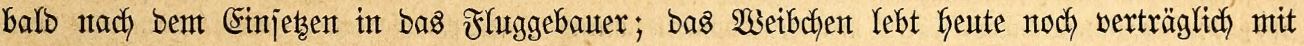

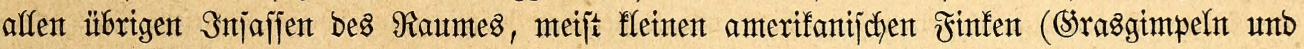

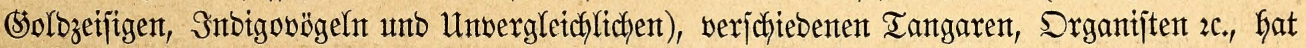

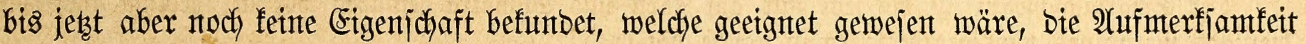

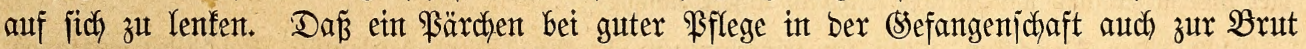

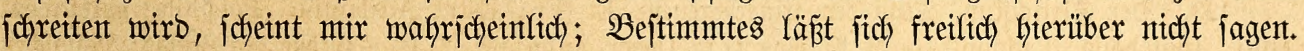

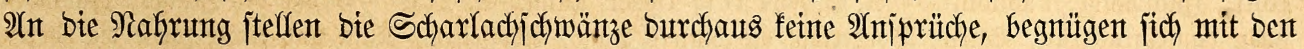

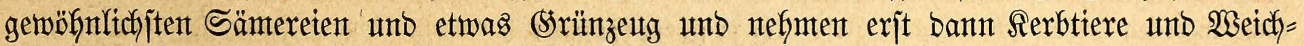
futter zu fidy, went fie biez ben Mittbetwofnern ihres Fluggebauters abgejefent haben; jo lantge

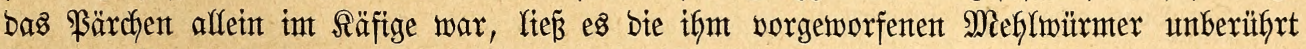

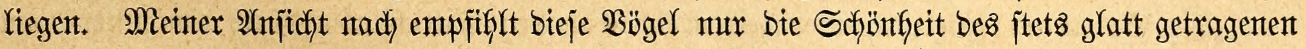
SEefiebers, nichts weiter.

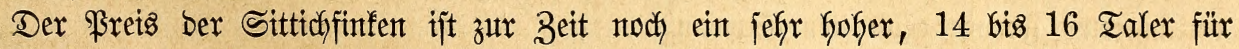
bas \$ärchen, eine Suntute, iweldhe ebent mur mit ber Seltenfeit, feitnešwegs aber mit bent Eigenffhlaftent ber $\mathfrak{B} \ddot{g} g e l$ int Einflange ftefft.

\section{Waddelfinken.}

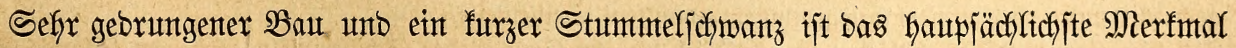

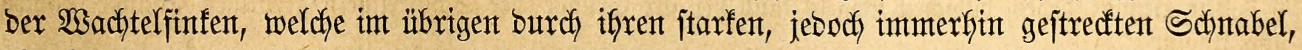

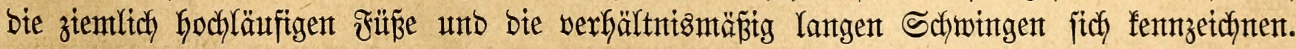

425. Der $\mathfrak{B a d y t e f f i n f}$, Ortygospiza, (Fr., Estr., Am.) polyzona, Temm., (multizona, fusco-

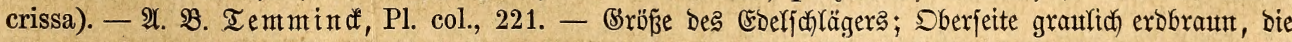

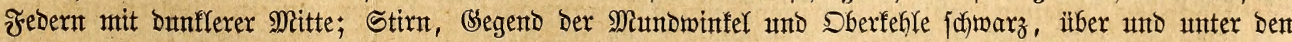

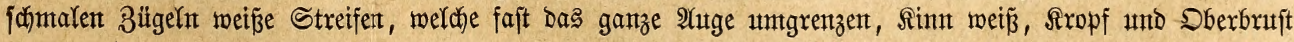




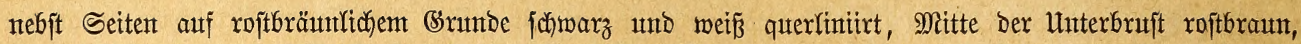

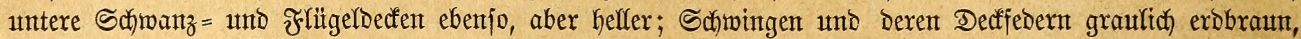

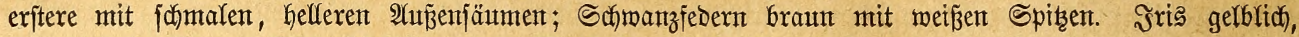

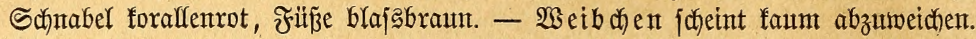

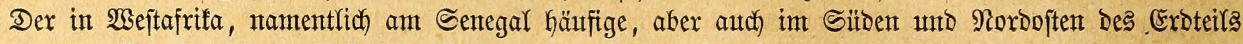
vorfommende $\mathfrak{B o g e l}$ gehört auffallender $\mathfrak{W e i f e}$ zu Den Seltenheiten in umferen Räfigen.

426. Der Miohrwadtelfinf, 0. (Fr., Am.,) atricollis, Vieill., (lunulata). - $\mathfrak{A}$. $\mathfrak{B}$. $\mathfrak{B}$ ieirrot,

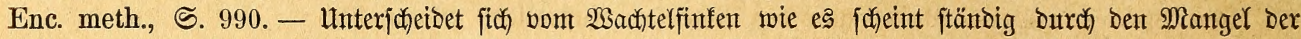

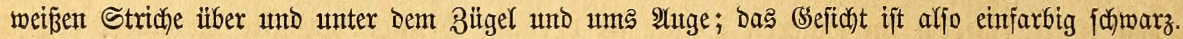

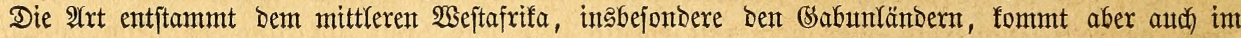

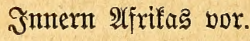

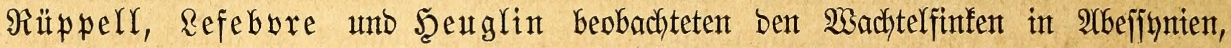

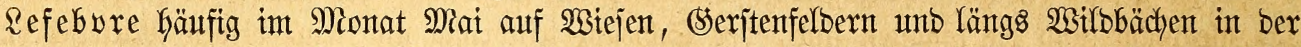

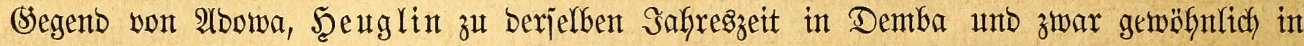

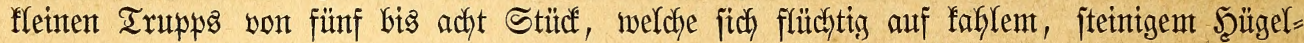
lande umbertrieben unb unter unangenefymem, fnarrenbem, Seeuglin jchreibt "rätjchenbem"

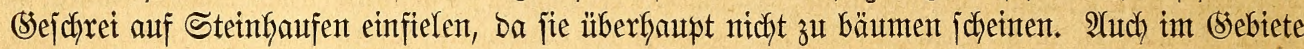

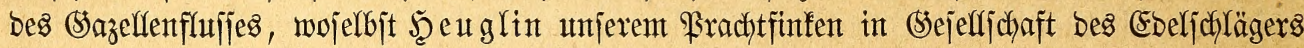

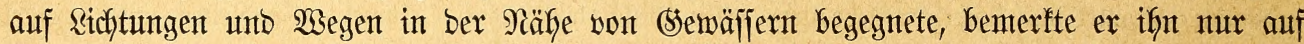
ber Eroce. Der Bogel war gemeiniglidy jefy jchüchtern und flog niebrig und jejwirrent ab unt

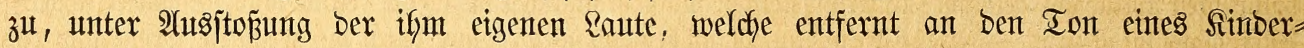
trompetchents exintern. Dies ijt afles, was ich itber bas Freileben habe finden fömen;

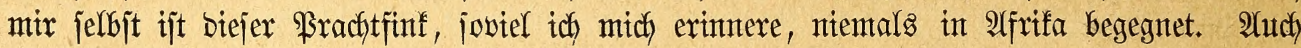
gefangen habe idy ifn mur bann unb wann einmal gejefen, einzeln unter anberen vom Senegal her gefommenen Finfenarten. Einen bejonberen (Einbrud madfte ex nicht auf mich, freifich habe ich ifn auds nie gepflegt ober längere Beit beobadytet unb verntag beshalb nidfyt anzugeben, ob ex fich in irgend einex Seinjicht auszetdynen wirb.

\section{(brasfinken.}

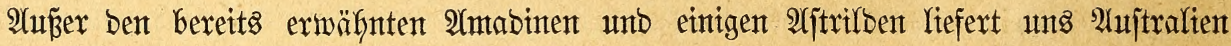

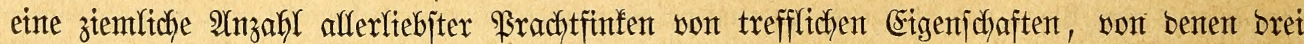

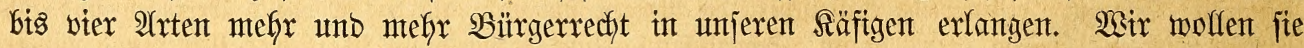

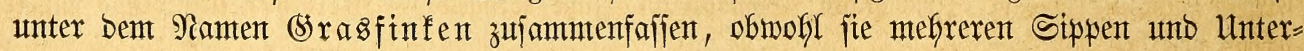
fippen angebören.

(S) itterflügel nannte Reichenbach Die Mitglieber einer fleinen (stuppe mit jtarfem, gleich langem, Gohem und breitem, an Den Sdhnetben etwas eingezogenem, faft gerabem Sdhnabel, mäß̈̈g langen Räufen und zarten Bełen, mittelfangen, afgerumbeten Sdjwingen, unter benen bie britte etwas über bie erjten fünf Geroorragt, Greiten, weichen, gegen bie Spitze fith etwas verjdymälerten, an Der Spitze gerumbeten Sdywanjfebern, weldye jidh nach ber Mitte zu auch) ein mentig verlängern, unb glatt anltegenbent Sefteber, welches auf ben Schwingen einte feine, gitterartige Beidynutg bat.

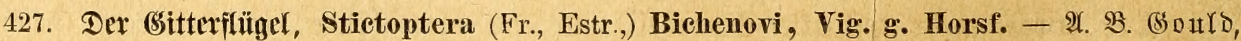

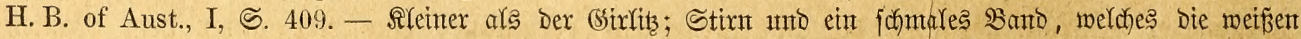

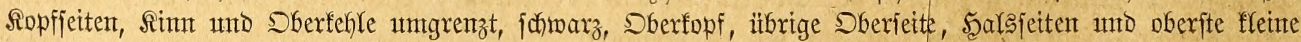

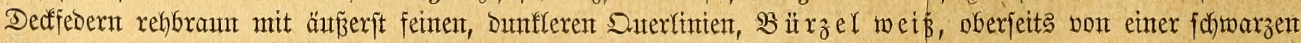

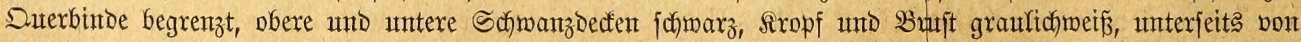

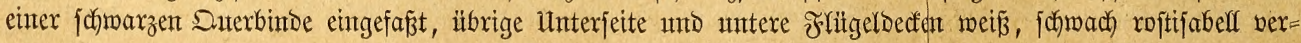




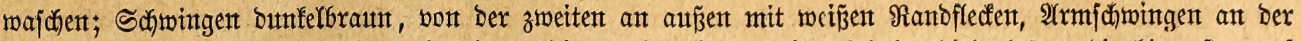

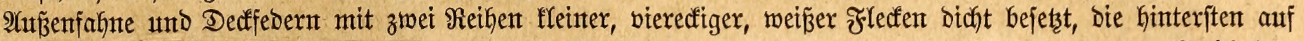

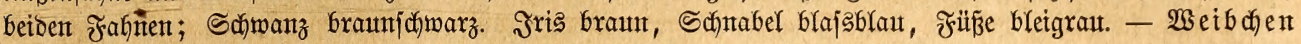
bis auf bas fámälere, fámarze SBruftquerbanto bem Mäntchent gleich) gefärbt.

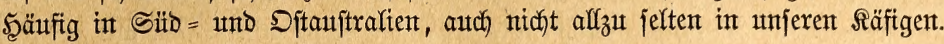

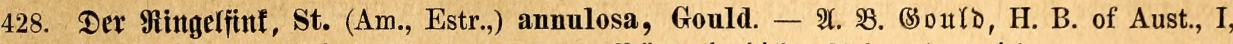

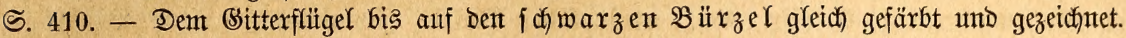

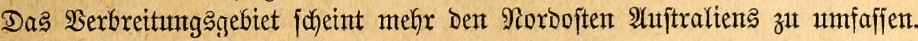

Bei ben (S) rasfinfen im engeren Sinne ijt ber ant (Srunbe verbidte Sintabel etwas mefyr gejtrecft, inmterfint aber nody fajt ebenjo hod unb breit als lang, ber Fur mittelfoch)=

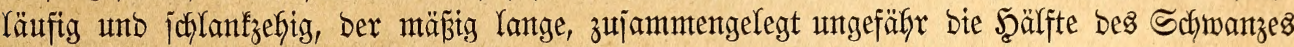
bebecfente Flüger etwas mefr zugeipibt, ba unter ben Sdywingen bie zweite bis fünfte unter fïh) gleichlang unt bie längftent füto, ber Schnanz feilförmig und jeine betben Mittelfebern meijt auth noch beträchtfich) über bie anberen verlängert, bas (sefieber jeibentweich und nach) Den (Siejchlechtern faum verjofieden.

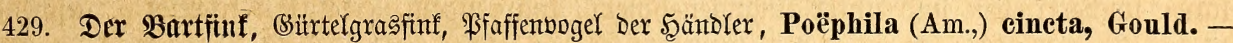

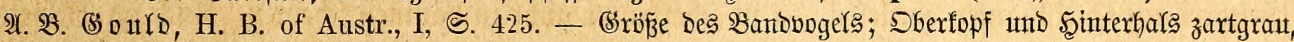

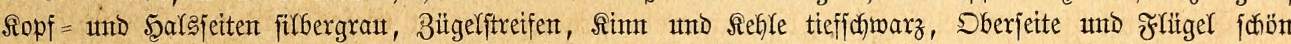

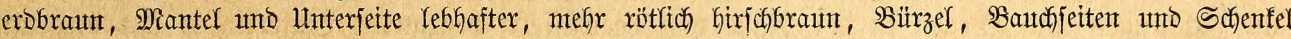

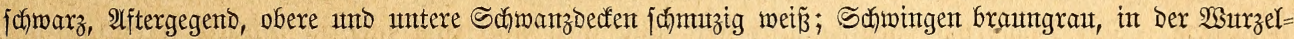

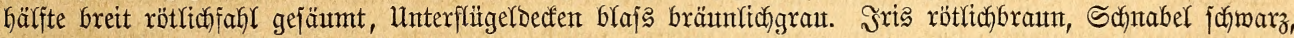

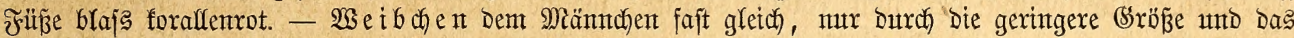

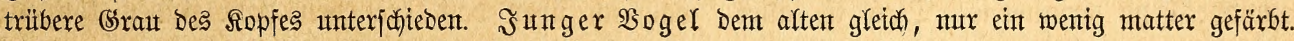

Dftauftrafien.

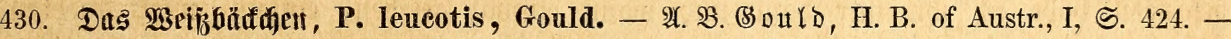

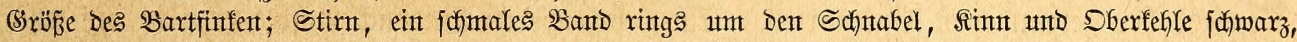

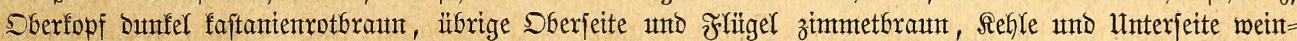

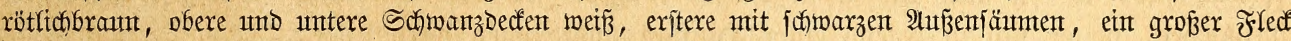
an Den Sd)

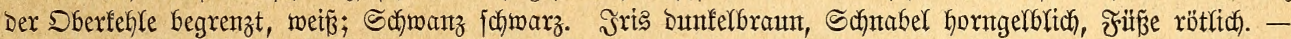

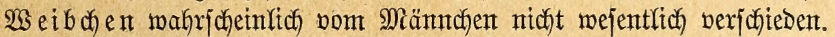

Norbauftraftert.

431. Der Spitzidumanzfinf, P. (Am.) acuticauda, Gould. - A. B. BS Durb, H. B. of. Aust.,

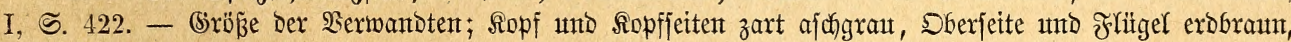

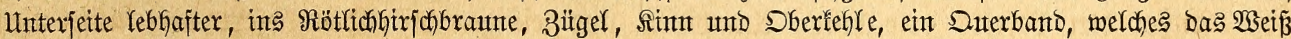

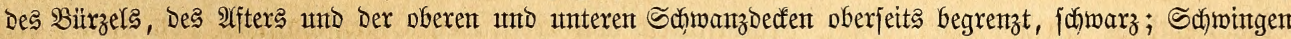

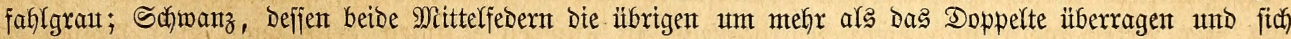

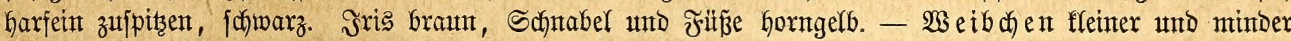
rebłaft gefärbt.

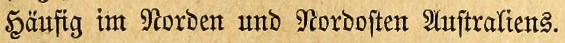

432. Der Masfengrasfint, P. personata, Gould. - $\mathfrak{A}$. B. (S) o uld , H. B. of. Austr., I, S. 423. -

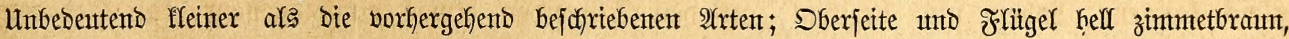

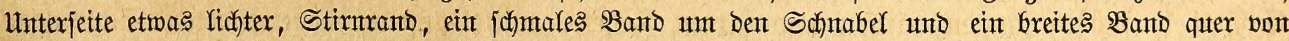

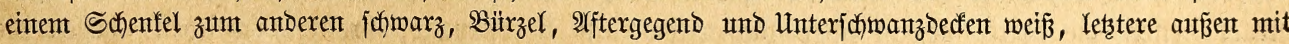

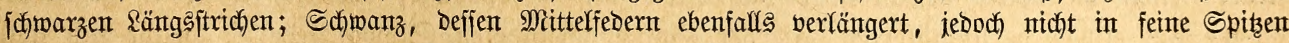

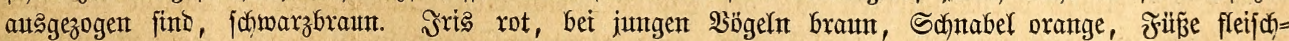
farbent. - 2 seib de en taum abweidfent.

Norbmeftauftralien.

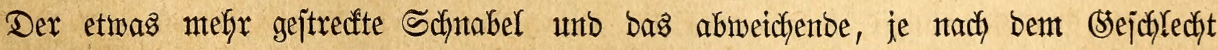

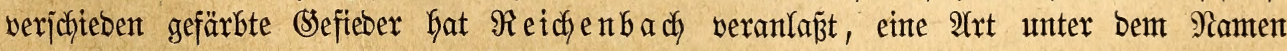
Sungfra uenfinfen von ben voriget zu trentent.

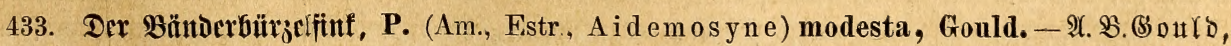

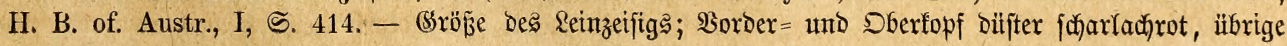




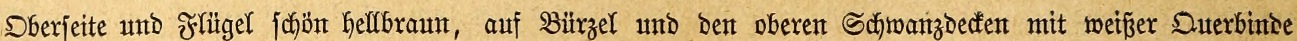

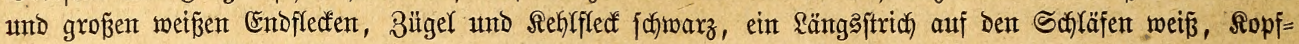

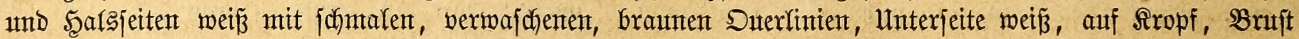
und an Den Seiten mit braunen Duerbinden, weldhe auf Den Schenfelfeiten am breiteiten find; Dedfedern

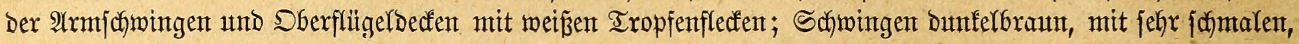

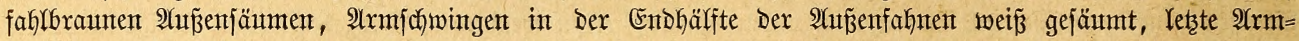

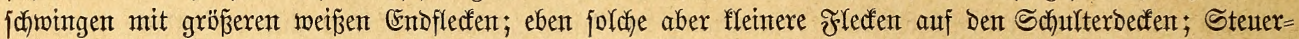

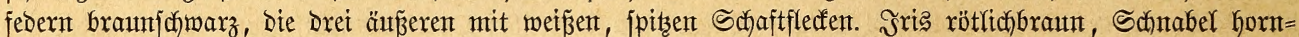

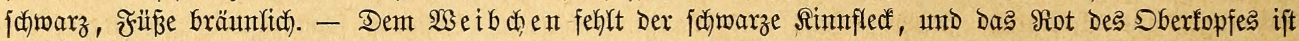
minder Yebhaft.

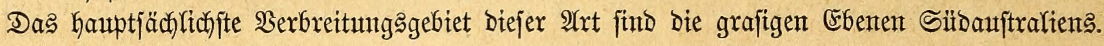

Mit grö̈erem Rechte hat man bie (sïrtelaftrilben bon ben ïbrigen Srasfinfen ge=

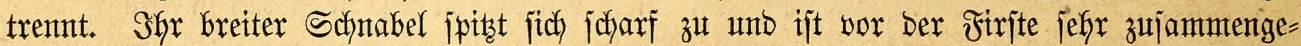

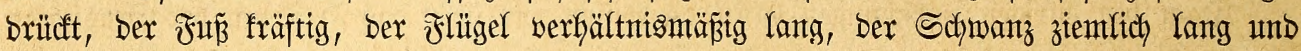
abgerumbet, bas (sefieber weich und locfer.

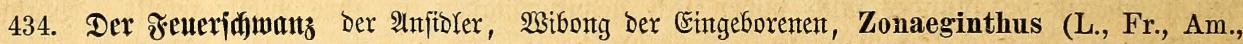
Estr.) nitidus, Lath. (bella). - 2 . $\mathfrak{B}$. (5)

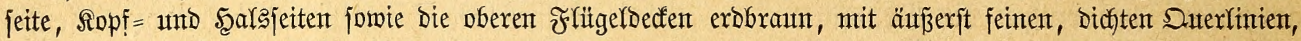

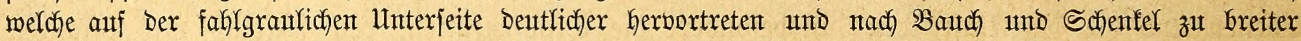

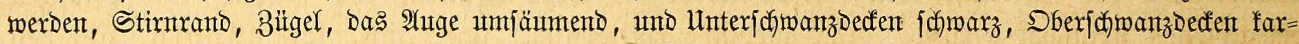

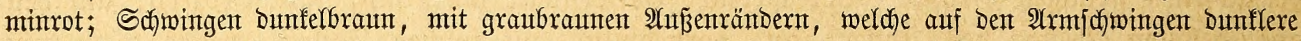

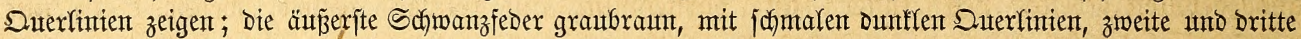

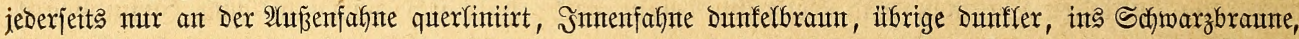

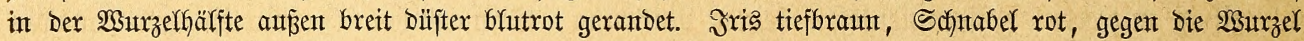

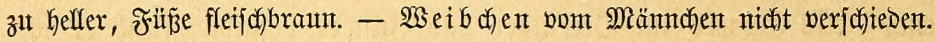

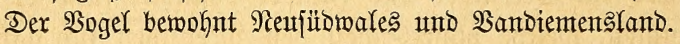

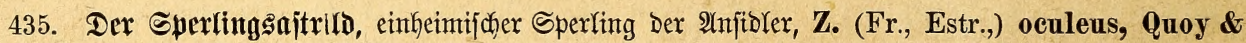

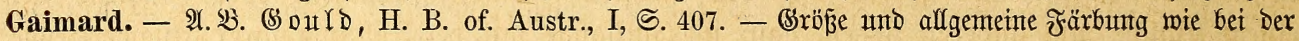

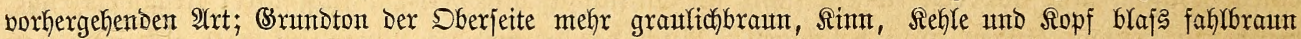

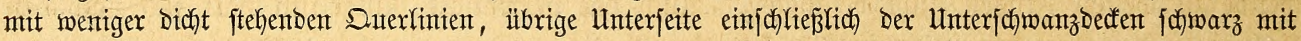

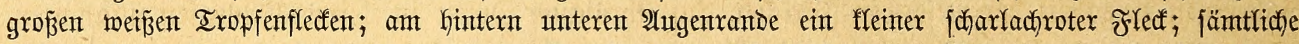

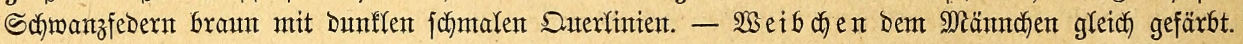

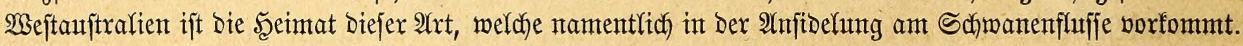

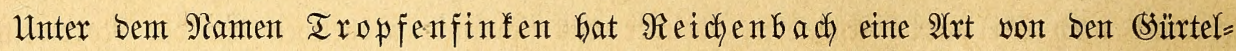
ajtrilben getrennt unto gibt folgente Sippenmerfmale: Schnabel fajt ebenjo hody unt breit als lang, auf bex Finjte platt, Rauf länger alz bie Mittelzefle ofne Nagel, zweite, britte unb vierte gletch lang unb bie längiten, Schwanz fürzer als bie Flïgel, gejtutzt abgerundet unto breitfederig; betoe (sejchledyter gleté gefärbt.

436. Der Dinumantuger, Z. (L., Fr., Am., Stag o nopleura) guttatus, Shaw., (leucoce-

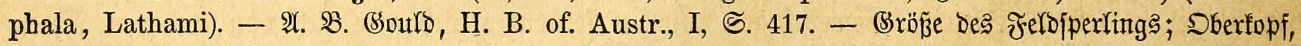

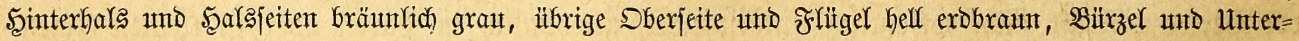

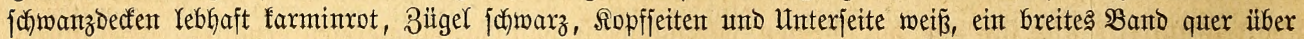

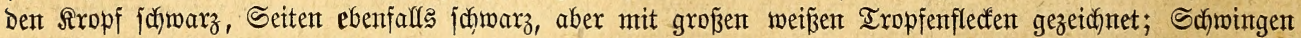

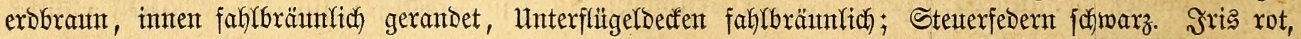

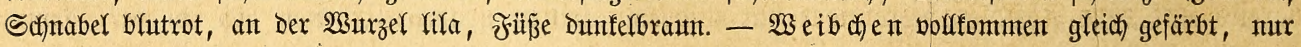
etroas fleiner.

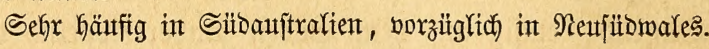

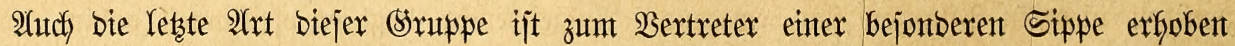

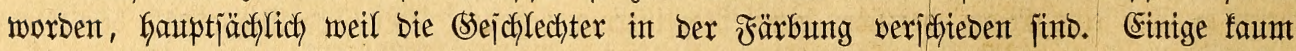
mejentfiche Unterjcfiede im Schnabel und im Serbältnis ber Sdywingen machen jich freilich aud bemerffict).

437. Der 3ebrafinf, Z. (Am., Stagon., Taeniopygia) castanotis, Gould. - $\mathfrak{A}$. B. (SD DHID,

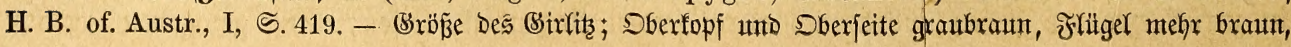




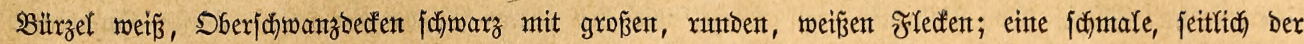

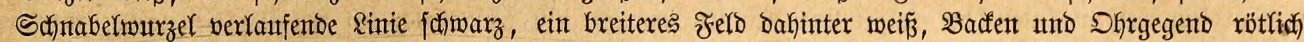

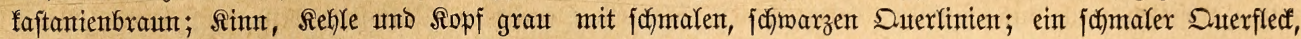

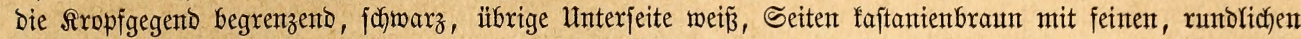

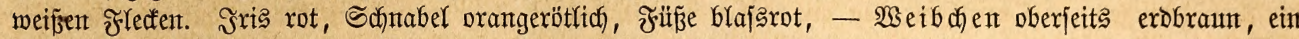

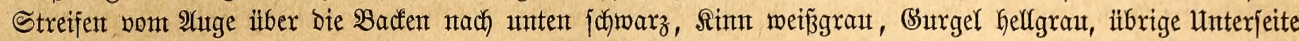

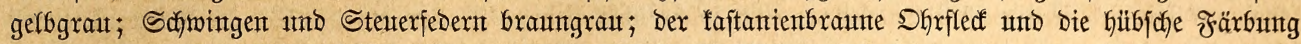

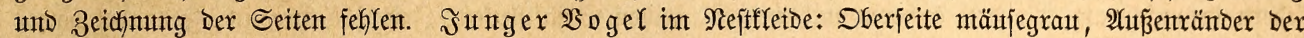

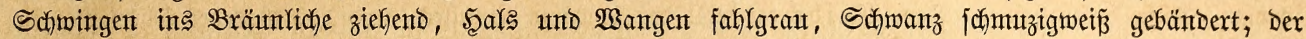

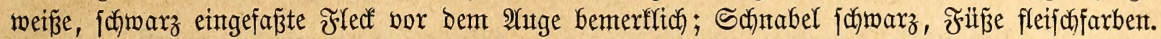

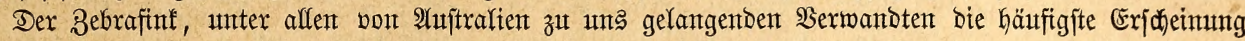

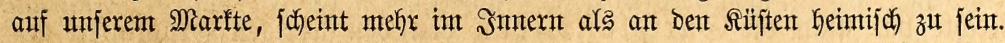

Danf ben eifrigen Forjchungen \$oulds miffen wix über bas greileben ber (sraşfinfen

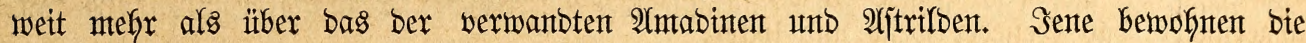
weiten Ebenen bes Randes unto haben jich gemiffermajen in ifre Welt geteilt. Währento bie (Sittexflügel hauptjächlich auf grajtgen $\mathfrak{B}$ löß̧en im Walbe und an ben Regenjtrömen jich aufhalten, bevorzugen bie Srasfinfen im engern Sinte bie Scalmentwaldungen ber offenten

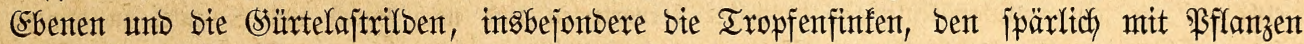
betwachjenten jteinigen (stund. Der niebliche (sitterflügel jibelt fich, laut (5) ould, auf ben

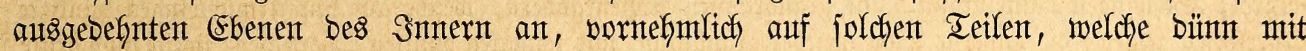

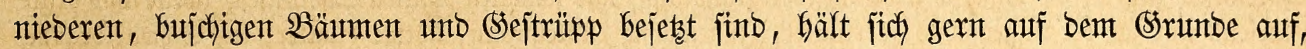
fich eifrig mit bem 3ulammenlejen jeiner Nafrung, Sament von Straşarten unt anderen

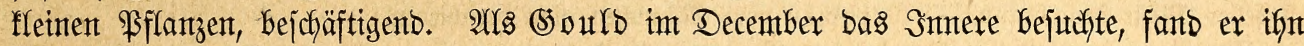
in fleinten Flügen von vier bis adft zujammen, weldhe ofne Scheu Den Mienjchen jidy nähern

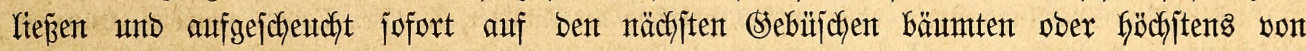
einem $\mathfrak{B}$ ujche zum anberen flogen, ganz int Einflange mit ber Bitlung ifyrer Flugwerfzeuge,

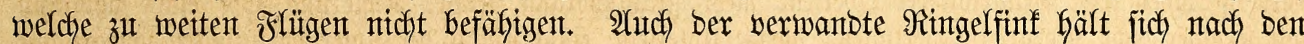
bisherigen 2Uthaben ber reijenten Forjcher auf ähnlichen Drten in fleinen Familien zujammen, jcheint überbaupt in wejentfichen biejelbe Rebensmeije zu füfren wie jener. Heber bie (Sragfinfen berichtet Sould auffaffender $\mathfrak{B e i j e ~ m u r ~ w e n t g , ~ b a s ~ m e i j t e ~ n o c h ~ u ̈ b e r ~ b e n ~ M a s ł e n = ~}$

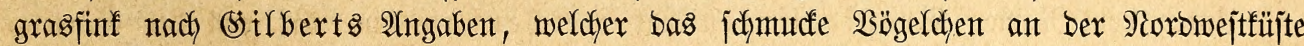

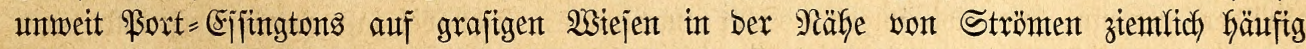
und zwar in Flügen von brcisitg bis vierzig Stüd vereintigt fant, fiter ganz nach âtrt

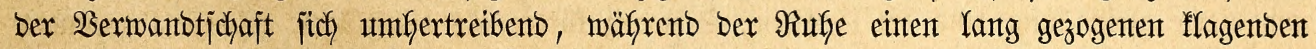

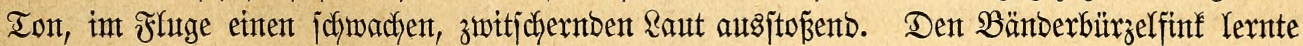

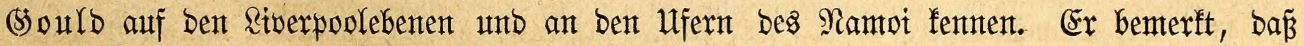

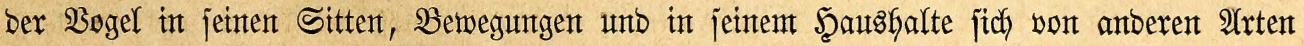

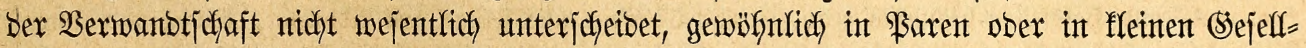

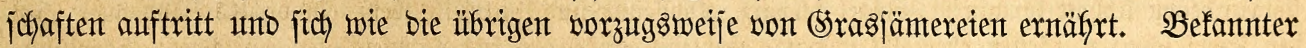
als bie bisher genannten jcheint ber Feuerjhwantz zu jein, weil ex fich in gemiffiem Sinne bereits mit bent 2 njibler befreunbet hat und von jeinen grajigen Ebenen bis in bie Särten und 2 (ntpflanzungen herein gefommen ift. Şier wie Dort fitht man ifyt ebenfalfs in fleinen (sejelljchaften won jechs bis zu einem Dutzend, emitg auf bemt Boben umbertrippelno ober

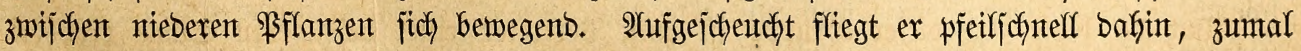

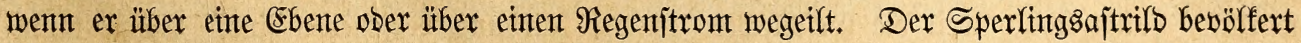

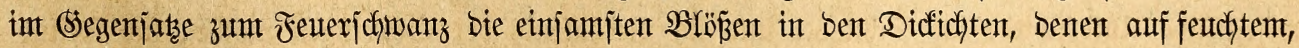

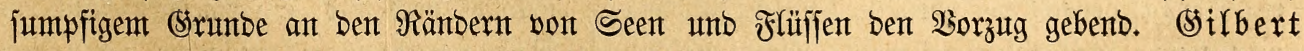
nennt ihn einen einjamen Bogel, weldher auf ben verjtecttejten $\mathfrak{B l a ̈ z z e n ~ i n ~ b e n ~ D i d f i c h t e n ~}$

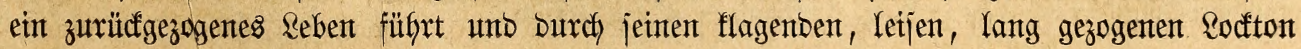


nur noch beiträgt, bie Einjamfeit jeiner Wohnjtätte füfl(barer zu machen. Seine Flugwert: zeuge icheinen nicht bejonbers entwicfelt zu jein, ba ber Flug ein langjanter ijt unb bloź von einem Baume zum anderent fich ricjtet. Unter ben Eingeborenten, weldye ifgn recht gut fenten,

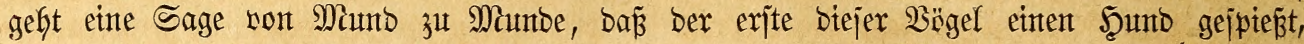

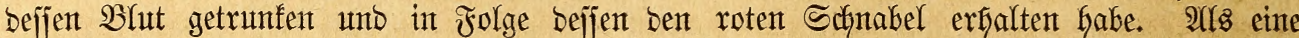

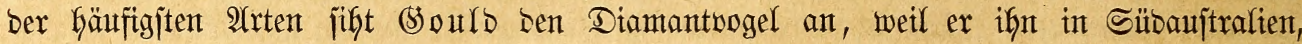

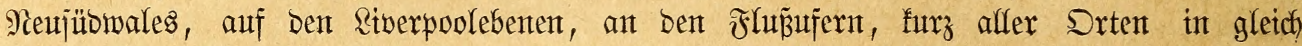
groperer Mienge bemerfte unt zwar, wie johon angegeben, Gauptjächlich auf bïnn berwadjjenem,

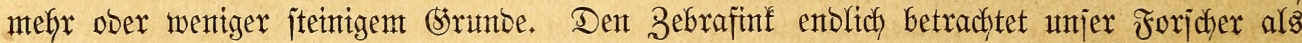

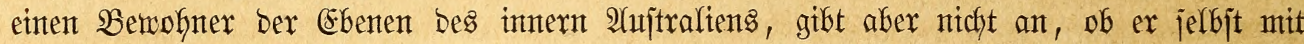
ifym jujammen gefommen ijt.

Das Brutgejwäjt Der verjofiedenen (Srasfinfen jcheint, nach ben bis jebt exfyaltenen

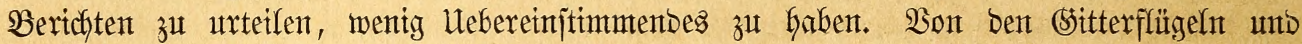
Sragsfinfent int engeren Sinnte weiz (5) ould nichts anzugeben, som Bänberbürzelfint nux

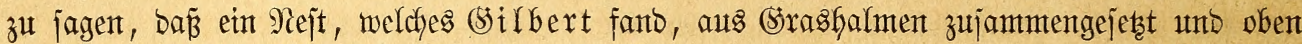

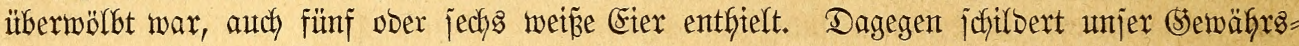

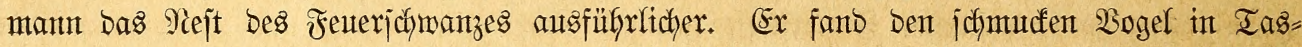

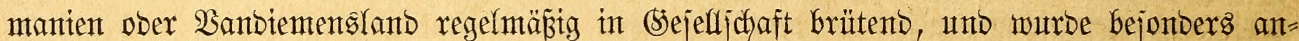

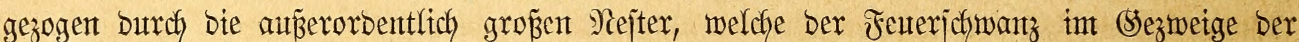

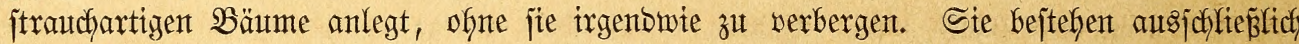
aus (s)ras = und Ffflanzenjtengeln, find übermölbt und baben im oberen Ietle ein Schlupf=

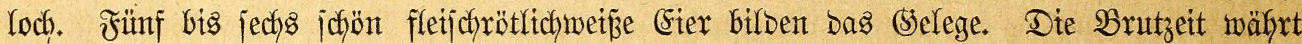
vont September bis zum Samuar, und zwar jcheint jebes \$ärchen in biejer 3eit zwei ober Drei $\mathfrak{B r u t e n t}$ aufzubringen. Sitcht minber eigentümlicty verfäfrt ber Diamantwogel. Ex nem=

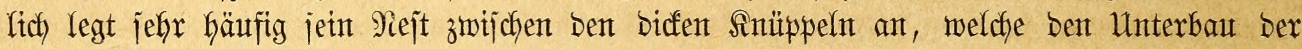
2lolerborite bilben und brütet zu gleicher Beit mit bent gewaltigen Raubvogel int bejten Cin= weritänonis. "Dies", jagt (5) ould, "fabe idy verjafiebene Miale erfafren und bie Eier bes 2lolers und bes finfen zu gletcher Beit, jo zu jagen aus eintem Rejte erfyalten. So fand icf) am 23. Sftober bas Nejt bes Diamantwogels in bem Scorjte eines Ffeifablers, auf welchem Der alte $\mathfrak{B}$ ogel brütete. Mein jdymarzer Sefährte Natty erjtieg Den Baum, einte Gohe Sajuarine, unb brachte mix bie Eier von beiben Bügeln. Die fleinen Jinfen jazen

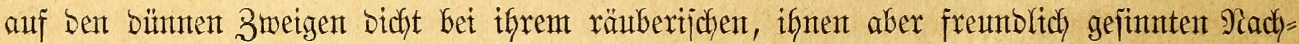

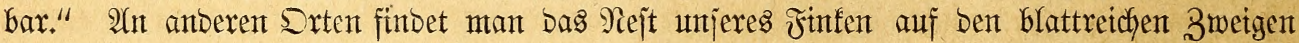

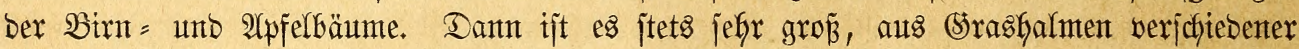

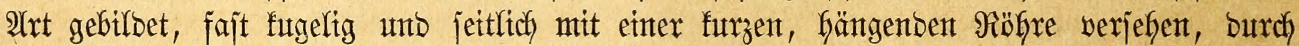

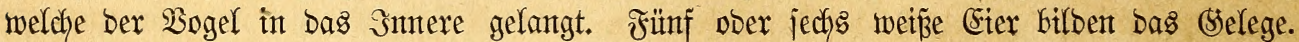

Durch neute Beobachtungen ijt feitgejtellt worben, Dá̉ bie von (5) ould gezogenen Berbreitungagrenzen ber verjutebenen $\mathfrak{A}$ rten unjerer Finfen noch wejentlidh erweitert und berichtigt werben müfjen. Wite alle an (Sragjämereten gebunbene Bögel Aujtraltens, ins: = bejonbere bie von mix worker gejdhilderten fleinen ßapageten, finb bie Srasfinfen volffommen

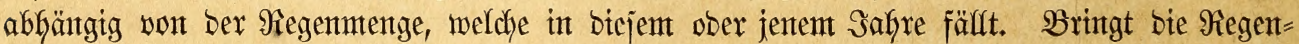

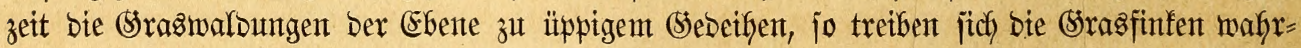

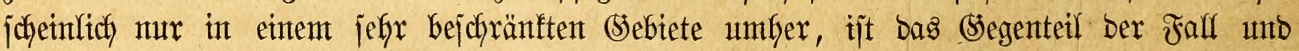

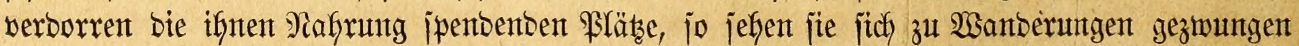

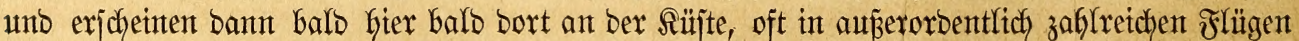

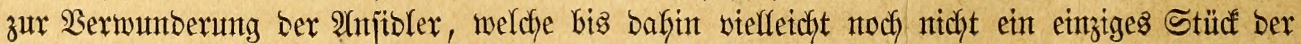

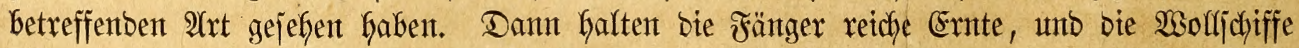
bringen eine 2rat, welche bisher mur einzeln auf unjeren Tiermarft gelangte, zu Şumberten 


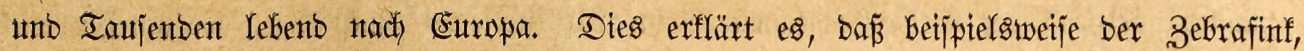

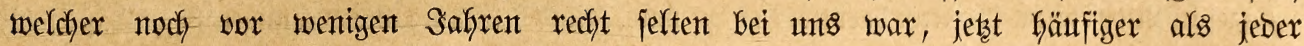

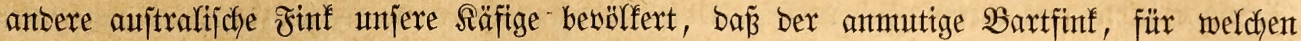

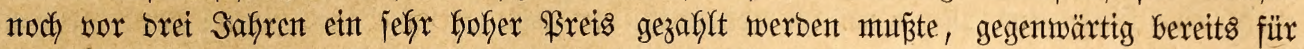

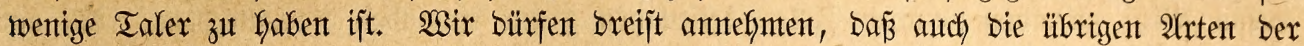

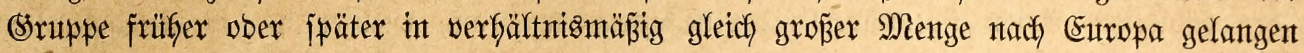
werben.

Seine einzige (Sintppe ber Fradtffinfen verbient wärmer empfofflen zu werben als bie (5rasfinfent intgejant, namentlich) bie (5rasfinfent im engeren Sinte unt bie Tropfenfinfen, wont benen gegentwärtig wenigitents einige (S)feber unter umjeren Riebfabern affgemeine $\mathfrak{B} e x=$ breitung finben fonnten. Die (Sitterflügel haben auf midch einent nidfyt ebenjo günjtigen (Ein=

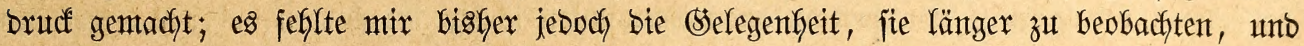

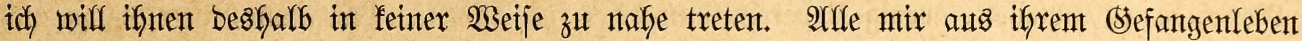

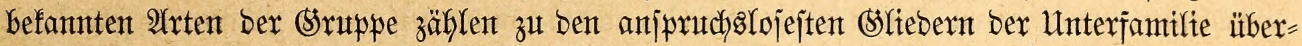

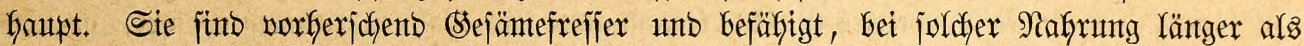

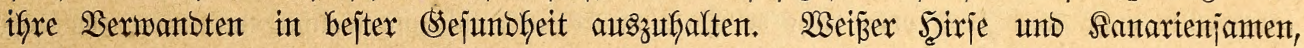

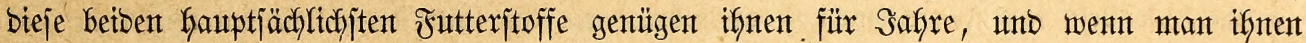
jonjt noch Şengejäme, während bes Sommers bie reifenten (5raşrispen, währento Des

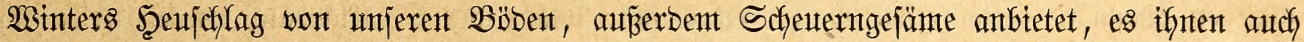

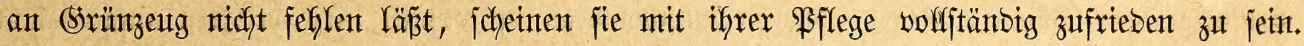

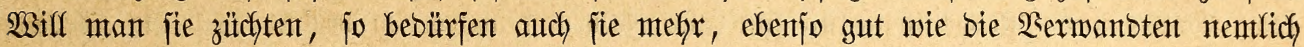

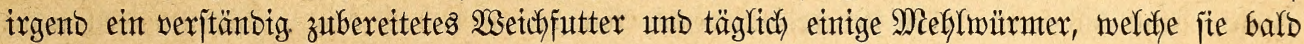

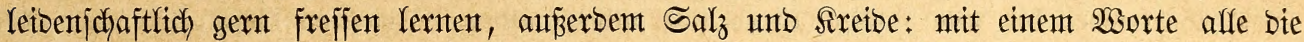

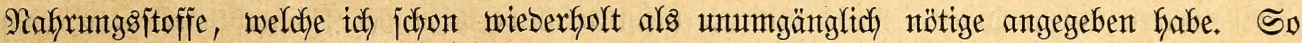
gepflegt Galten fie fict) ganz worzüglich, jebenfalls weit befjer als bie meijten ifgrer $\mathfrak{B}$ erwanbten

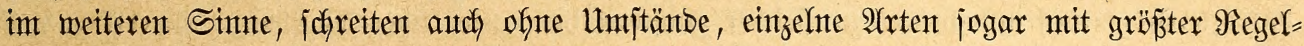

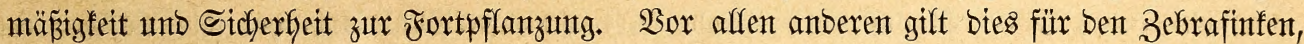

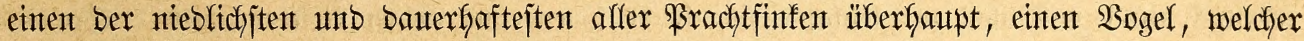

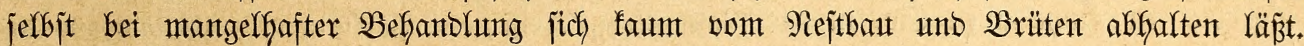

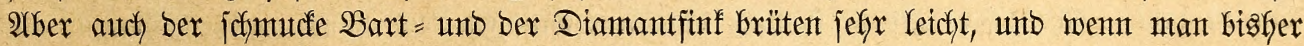
won ifynen nodh nidyt alfgentein günjtige Exfolge erzielt hat, jo liegt bies einzig unto alfein

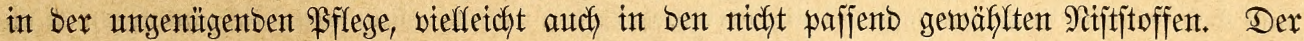

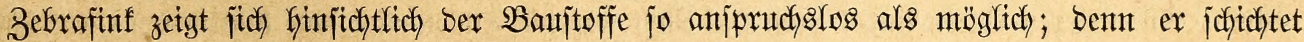

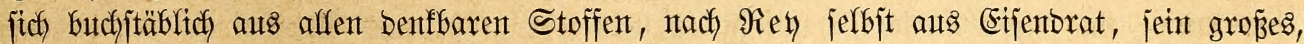

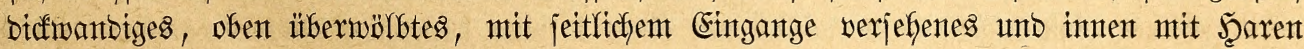

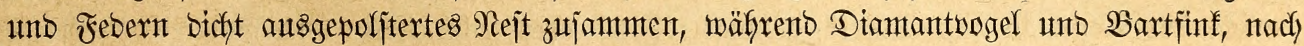
meinen Beobadftungent wenigitens, wählerifcher zu jein unb bejtinnte Stoffe, weiche (braz=

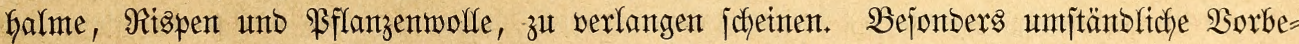

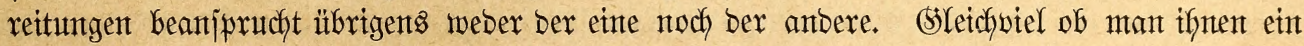

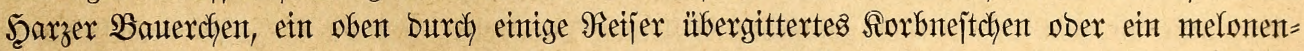
förmig gejtaltetes Dratnejt zur Unterlage gibt: wenn bie $\mathfrak{B}$ rutzeit herantrüctt, Gaut es biejer wie jener eifrigit aus unt beginnt audd in ber Regel balb zut brüten, und went er es

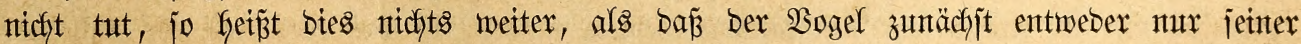

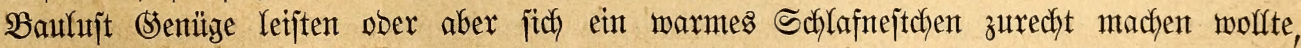

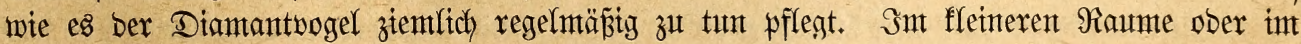

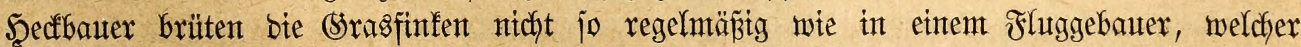

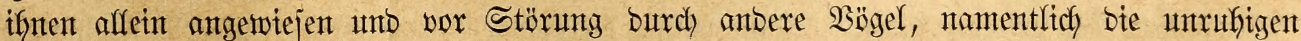

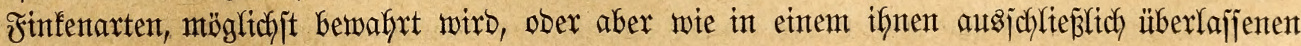




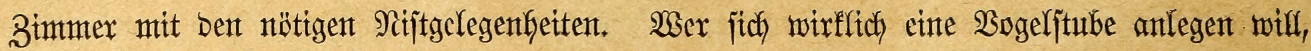

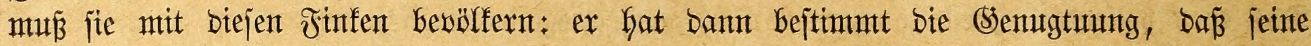
Wünjche gefrönt werben und ber Bejtand jeiner Sammlung jith in überrajchent furzer Zeit auperorbentlich vermefrt. Die Bebrafinfen brüten eigentlich ofne alfes Butun Des Menjechen,

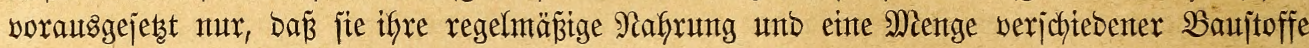
Gaben. Man füfllt eintige Sïrbchen mit Nijtjtoffen, Der Dromung megen, wie bereits angegeben, jebes mit einer bejonberen Sorte, und mirb bant entweber fofort ober bods einige Tage

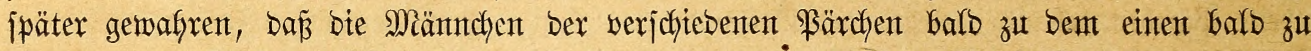
Dem anderen fïrbchen fich wenben, bie ifnen gerabe ermünjchten Baujtoffe fich ausinählen, zu ber erforenen Stefle tragen und num in Semeinjchaft Dex $23 e i b c h e n$ jo eifrig arbeiten,

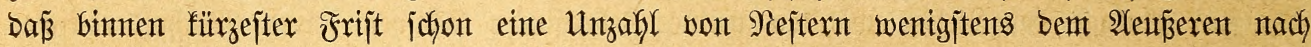

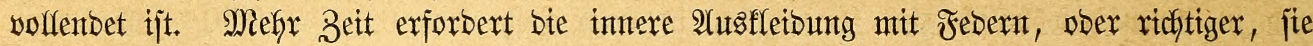

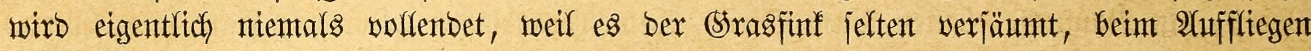

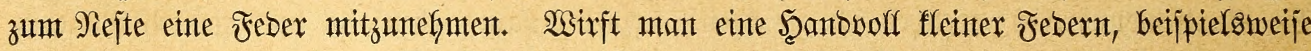
bas Aleingefieder unjerer Droffelarten (Aranmetsvögel), Enten = ober (S)änjeounten, Die

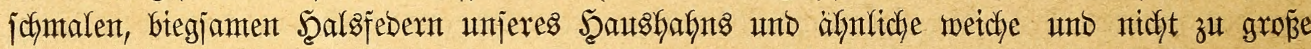
Febern, in Den Raum, jo ftürzen Die Zebra = und andere Srasfinfen eilfertig won allen Seiten Gerbei, und jebes Miännchen verjucht einte jo groß̉e Menge Davon zu Mejte zu tragen, als ber Schntabel eben fajfen will. Dies fant man täglidy mehrmals mieberholen: Der

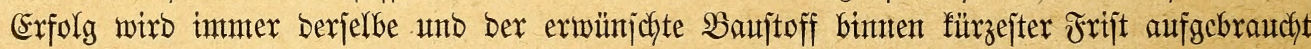
jein, gletchotel ob man mur in biejer Weije Jebern reicht ober ob audh bas eine Siorbdyen Damit bejtänbig gefülllt erkalten wirb; Denn, wie es jefjeint, lejen alfe \$rachtfinfen lieber

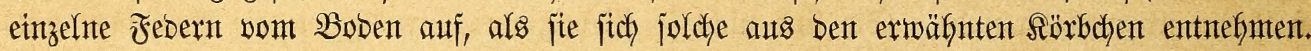
গody befiex als Febern jcheinen Den Bebrafinfen Scare zuzlagen; wenigitens beobachtete

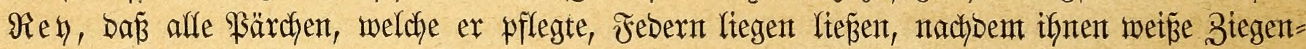

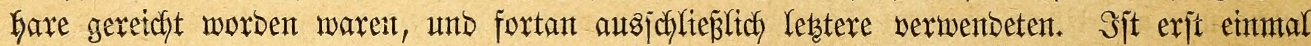

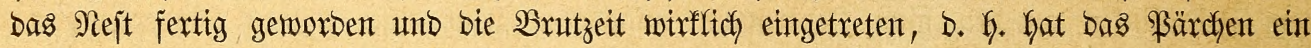

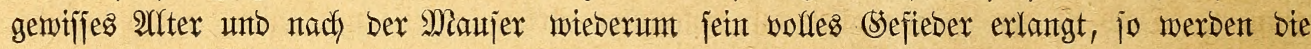

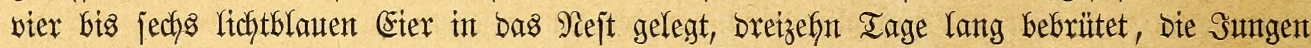

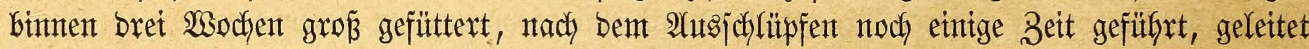
und erhalten; bann geft es rajch wieber zum $\mathfrak{B a u e}$ eines zweiten Nejtes und jofort Das

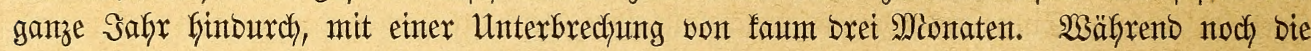

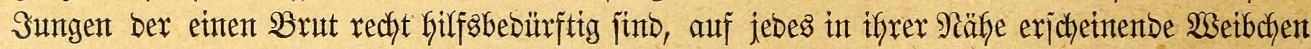
zuxennen, ben jeitlich gemendeten fopf tief gegen Den Boben Gerab brücfen uno mit auf= gejpertem Sdynabel betteln, bis endich bie Matter jich erbarmt, haben beide Ertern bereits wieber alfe 2 (njtalten zu einer ferneren Şrut getroffen und ïben gleichjam mux noch ge=

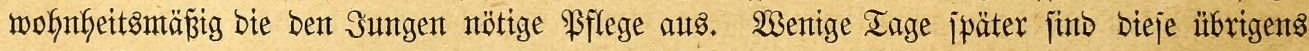
jajon jehr jelbjtändig gemorben, frejfen bereits allein, betteln jeltener unt unterlajjen bies entich gant. Sn ber Dritten ober vierten 20 oche ifres Rebens beginnt bie Serfärbung, und went jie das Sleid ber Allten angelegt, treiben jie es gantz wie bieje, bauten ebenfalls ifre

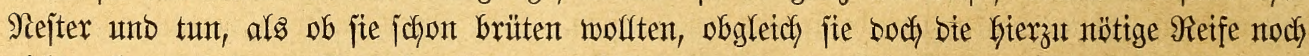

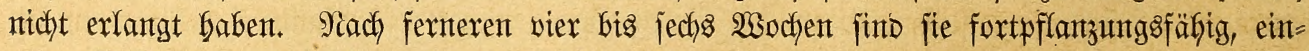

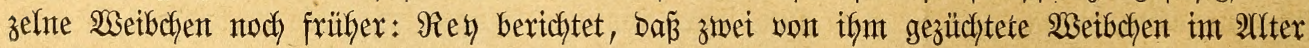

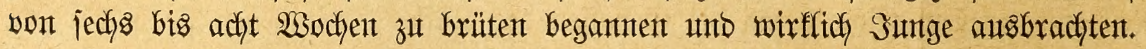

Whe Danfbar bie Zud jt ber Bebrafinfen ift, mag aus Folgenden hervorgehen. Unjer Mitarbeiter Fiebler erfielt int Früblinge zwei vor geraumer 3eit aus 21uftralien einge=

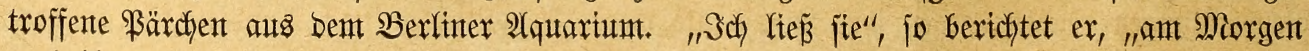
nach iffrer 2(nfunft in Den für fie unto andere 2 g̈gel bejtimmten Brutraum fliegen unto be= 


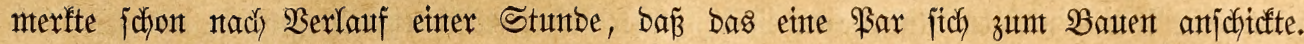
Das eben wolfenbete, went audh noch nicht gantz ausgefletbete Nejt murbe ant zweiten Tage

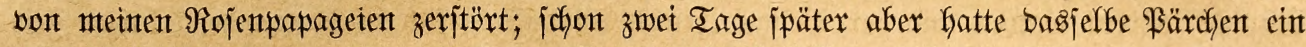
anberes Nejt fertig und es nach eintgen Tagen mit fünf Etern belegt. Die nach ber üblichen Brutzeit auggejchlïpften Sungen fanben ifren Tob Durch biejelben Fapageien; aber auth biejer Unfalf Gintberte bie AYten nicht. Sie bauten jofort ein newes Nejt unt brachten, nachbent bie Störenfriede entfernt worben waren, fünf Sunge auf. Wäfrendoben hatte aud bas zweite \$ärdjen gebaut, gelegt, gebrütet unb vier Sunge groß̉ gezpgent. Sofort nach bent Selbjtändigwerben Der Bruten nijteten bie Allten wieber, und ant Enbe bez Sommers betrug bie Ropfzafl ber gejunben Sungen bereits breiunbzwanzig.

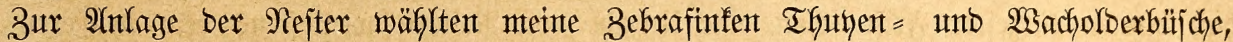

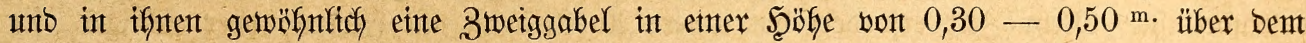
Boben; als Baujtoffe bienten ifnen Stroh, Şeu, (Srazrispen, Borjten, Scare unt Febern. Cin Bartfinfentpärchen, welches ich gleichzeitig erfielt, baute ebenfalfs in einem Wadyolber= ftrauche, jeboch 1,15 m. Goch über bem Boben. Es Gentbte biejelben Nijtftoffe, baute aber nur ben unteren Ieil, bie eigentliche शejtmulbe orbentlich aus, währent ber obere Ieth,

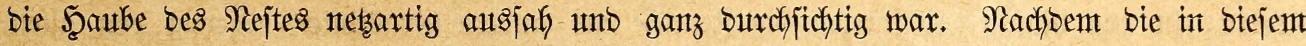
Nejte ausgefonmtenen, bereits faft flüggen Sungen ebenfalls burdh bie Rojentpapageten ge=

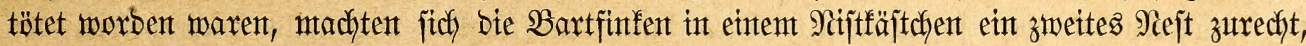
belegten es auch mit jechs Etern, brüteten aber nidfyt."

Währento ber Brutzeit finto bie Srasfinfent wie alfe Verwanden am anziefenbjten;

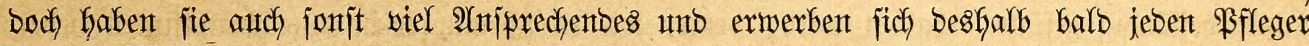
zu ifyrem warmen Freunbe. Sie fint nicht fo flüdftig unt untufig wie bie afmabinten unto

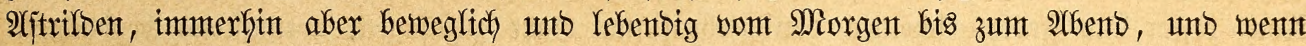

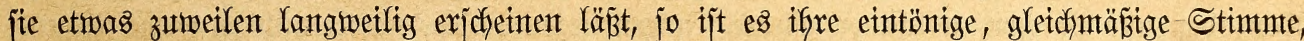
welche mir auts eintem einzigen Ione bejteft, ber antuterbrochen wieberfyolt wirb and bei bent 3ebrafinfent an ben nidyt Sebermant zujagentent \&aut einter fletnen Sinbertrompete

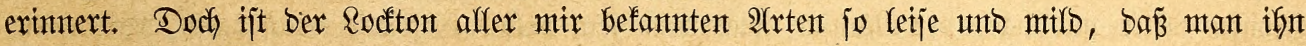

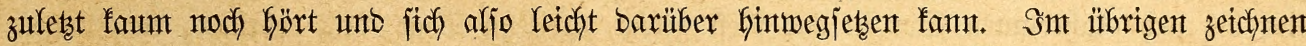

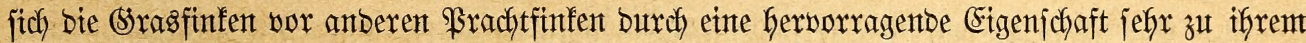

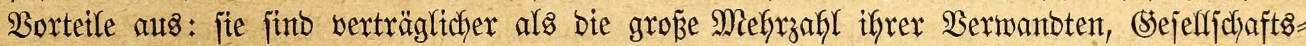
bögel int wafhren Sinte bes $230 r t e s$, weldye affe ifyre Sejchäfte gemeinjam zut tun lieben und ify einiges 3ujammenlebent faum burdy eiferjüdstigen Scaber ftören lafjen. Soldfer bleibt freilich audh bei ifnent nicht gänzlidh aus: zwei Männthen exbojen jich gegenjeitig, rüdfent auf

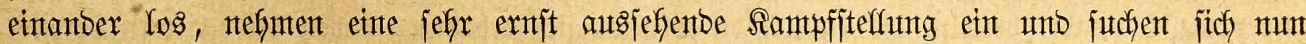
gegenfeitig einige Sifnabelfiebe betzubringen; aber es geft Gier fajt wie bet Den fampfläufern: zum erniflichen ober gar gefährlichen Streite fonmt es nicht, unt niemals wirb einer ber

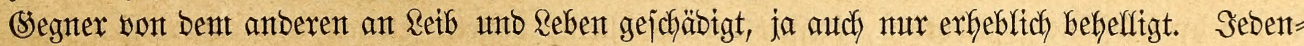

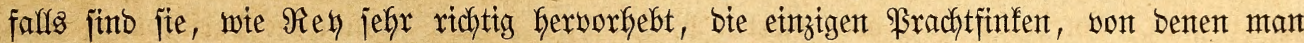

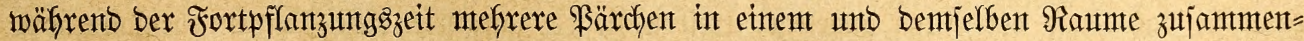
Galten fann, ofne Störungen befürchten zu mülfen. Mit ifren aujtralijchen Berwanbtent bertragen fie fich vortrefflich, unto um bie übrige (Sentoffenichaft bes Raumes befiummern fie fich mur bann, went bieje fie ftört unt ifnen jonjtwie läjtig wirb. So verteibigen fie bas

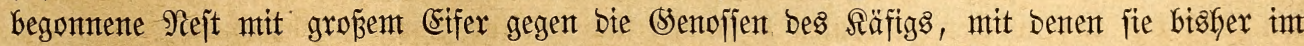

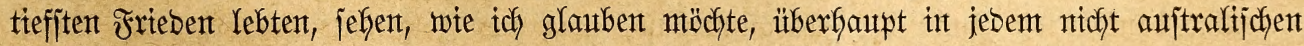
Bogel zur Beit ifyres Brütens einten Störenfrted unb Ssegner, währent jie, joweit meine

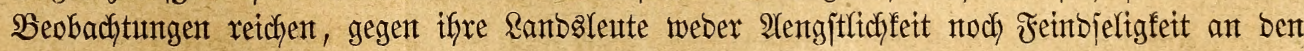
Iag zu legen pflegen. 


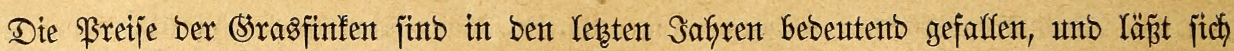
erwarten, baj fie binnen furzent auf Den niebrigiten ïberhaupt möglichen Stant herabgehen

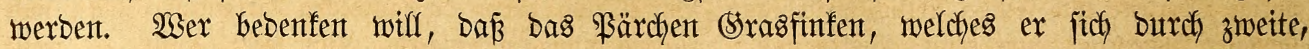

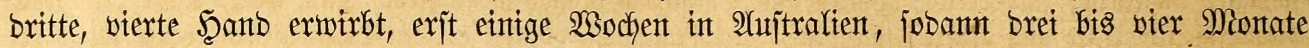
auf ber See unb fierauf wieberum einige Monate in Europa gepflegt werben musite, wirb 7 bis 9 Talex für ben $\mathfrak{B a r t f i n f e n}$ ober Diantantongel, 6 bis 8 Taler für Den Zebrafinfen

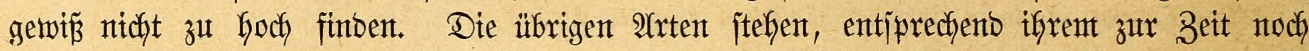
jeltenen Borfommen auf umjerem Marfte, etwas göber im Preije; boch bürfte faum mefy als 10 Taler für bas $\mathfrak{B a ̈ r c h e n ~ i r g e n t ~ e i n e s ~ b e r ~ v o n ~ m i x ~ i n ~ u n j e r e m ~ B u t b e ~ a u f g e n o m m e n t e n ~}$ (Sragfinfen verlangt werben.

\section{Aftrildent.}

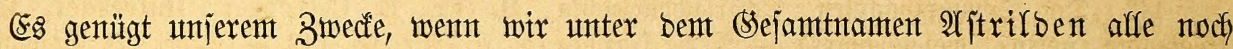

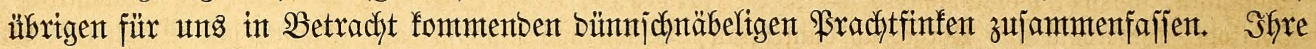
Gauptiädjlichjten Merfmale fint ber mebx ober minber gejtredfte Schnabel und ber längere ober fürzere, bald gerabe abgejdynittente, bald janft gerunbete, bald jtarf gejteigerte Sdywant. Man hat audh bieje (sruppe neuerbings in viele 2lbteilungen zerlegt; Dodt verbienten mur bie wentgiten von biejen zum Range einer Sippe erfoben zu werben, und bürfte bie fier befolgte (sinteilung zur Albgrenzung ber wirffichen Sippen ausreichent jeit.

Aljtrilben im engjten Sinne (Habropyga) nennt mant biejentigen 2 (rten, weldye fich fentnzeidynen burch gejtredften Bau, ichwachen, ungefäkr gleich bohen und langen, an ben Sdhnetben geraben, glatten, glänzenben und lebhaft gefärbten Sdynabel, ziemlich hohe, fallanfe,

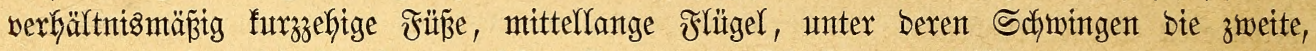
britte unt bierte bie längjten zł jein pflegen, ziemliț langen, feilförmigen, auts breiten

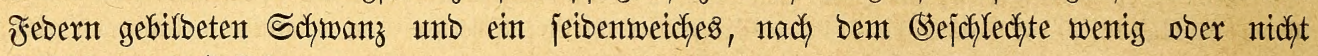
verjactiebentes stefieber.

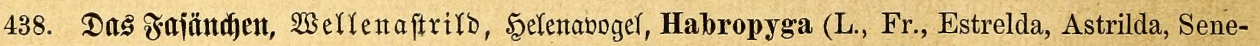

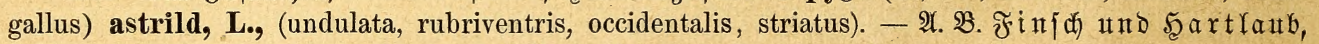

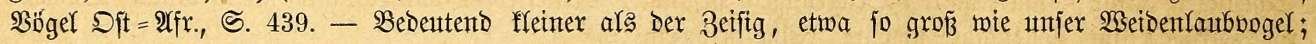

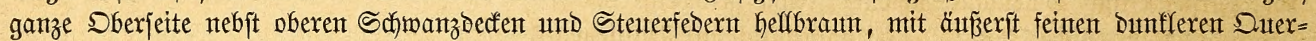

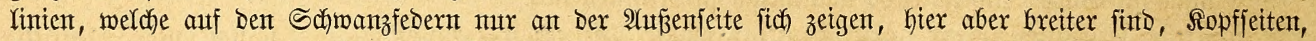

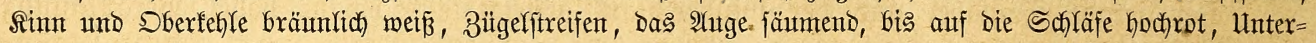
feite Glafsbraun, zart roja verwajd)en mit Dunfferen Duterfinien, Refle uno Ropf Dentficher rofenrot, Mitte

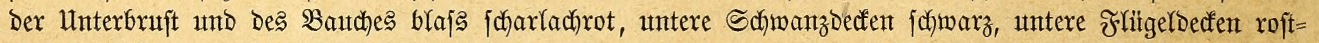

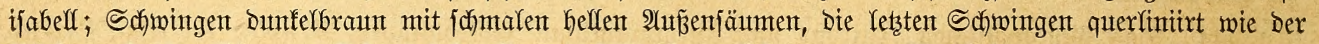

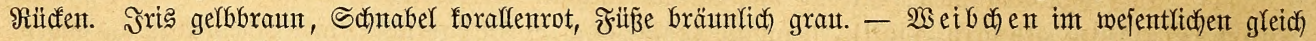

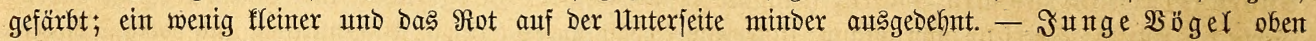

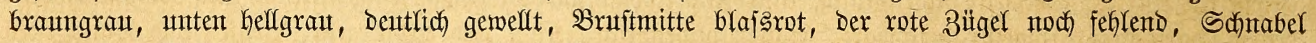

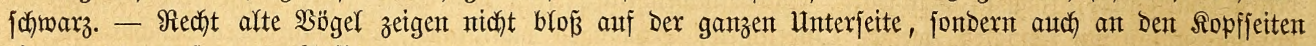
einet zarten rofenroten 2 nffltg.

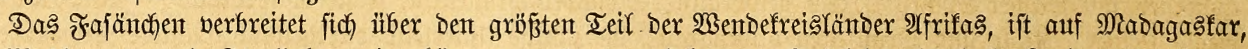

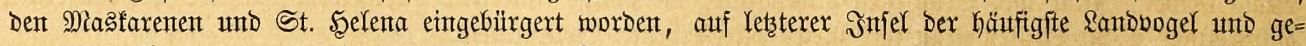
langt wout hiex auts zut şumbertent auf umferen Tiermartt.

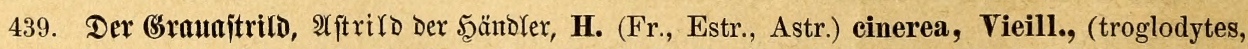

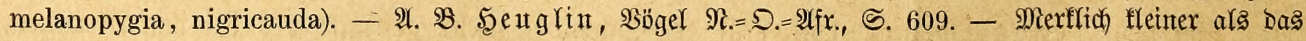

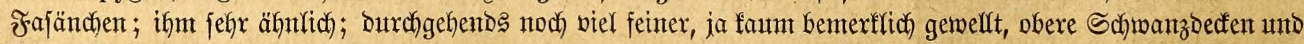

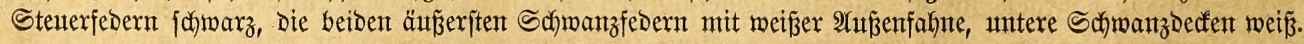

Das 2 berbreitungsgebiet erftrectt fich quer Durch) ganz Mittelafrifa. 
440. Das Drangebïlfden, Drangewange, H. (Fr., Melpoda) melpoda, Vieill., (lippa).- $\mathfrak{A} . \mathfrak{B}$.

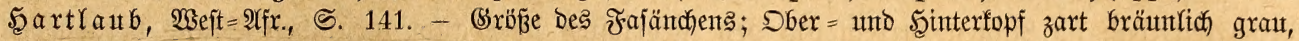

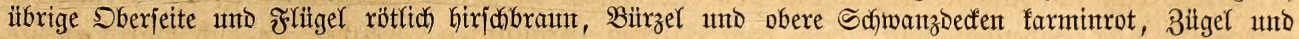

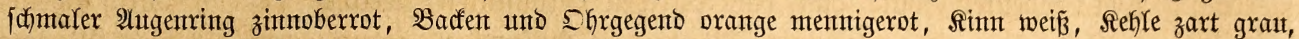

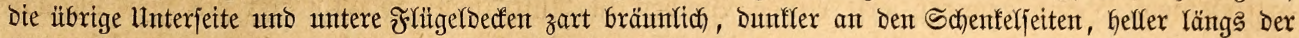

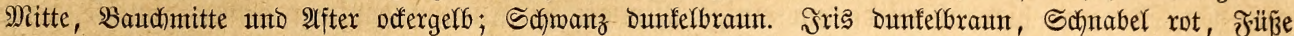
graubraun. - $\mathfrak{B e i b c h e ~ n ~ D e m ~ M i a ̈ n n t c h e n ~ v o l f f o m m e n ~ g l e i c h ) ~ g e f a ̈ r b t , ~ f a u m ~ m e r f f i c h ) ~ f l e i n e r . ~}$

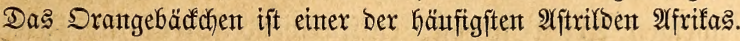

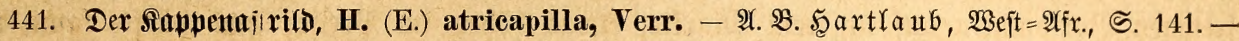

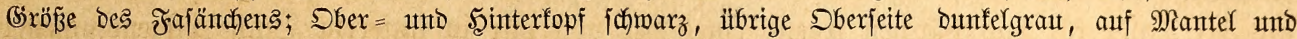

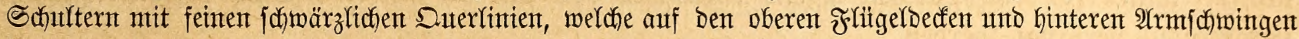

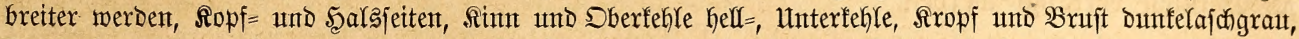

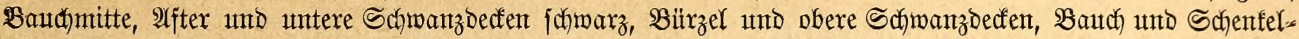

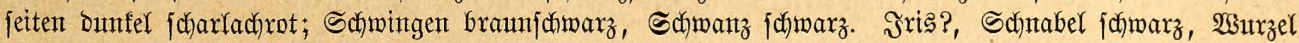
Des Unteridnabets gerb, Fünße Dunferbrautn.

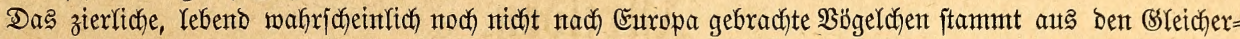
Yätoen Weftafrifas, namentfich) auts Dem (Sebiete bes Baabunt.

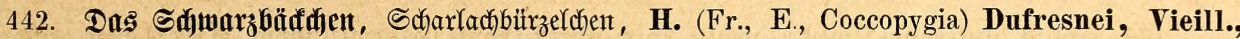

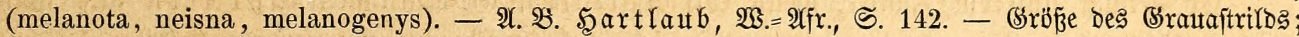

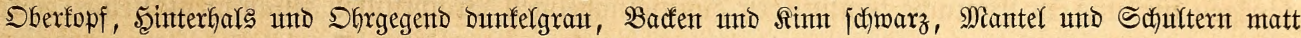

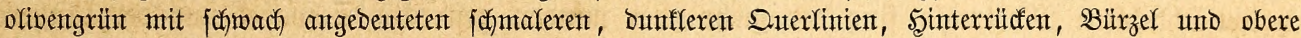

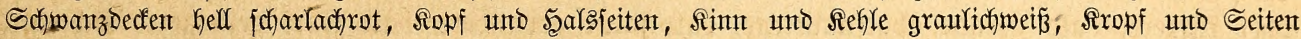

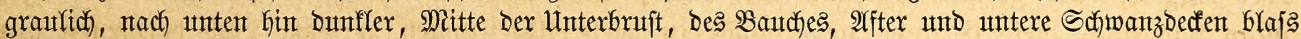

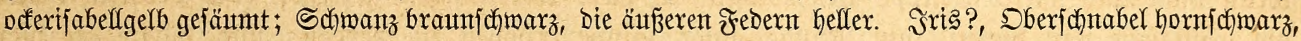
unteridgnabel rötlich), ช̌̈üße brautr.

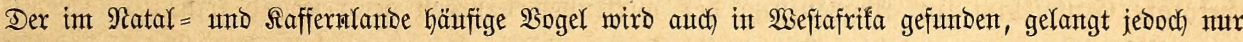
ausnafmtsmeife in untere Siäfige.

Des ipizeren Sdynabels, wentger abgerunbeten Flügels und fürzeren Sdymanzes halber

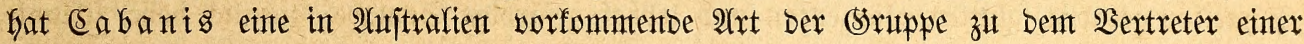
bejonberen Sippe erfobent.

443. Der DornatritD, H. (Fr., Es., A e ginth a) temporalis, Lath., (quinticolor). - $\mathfrak{A} . \mathfrak{B}$.

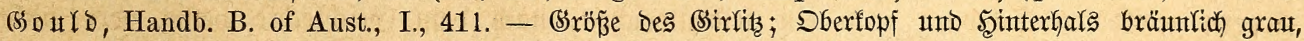

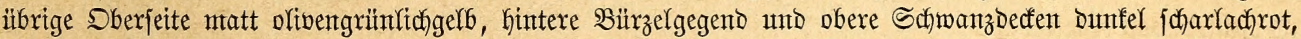

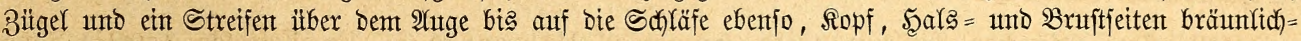

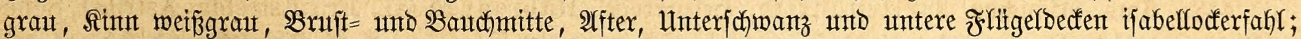

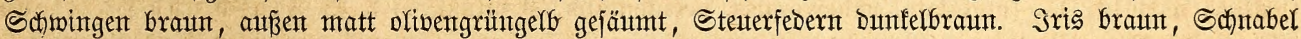

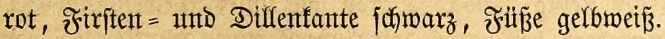

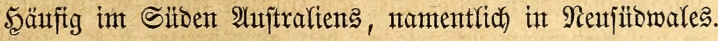

Der gerabe Sdynabel und ber nituber jtarf gejtetgerte Schwantz haben Beranlajjung

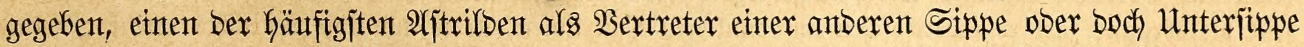
zu betrachten.

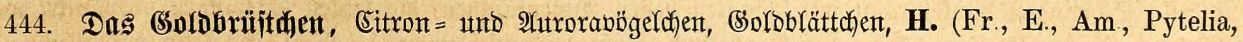

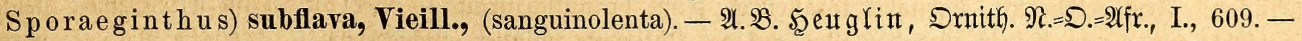

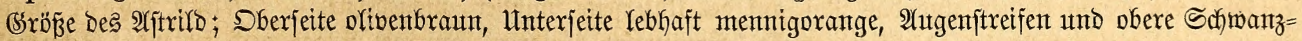

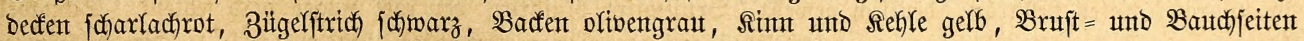

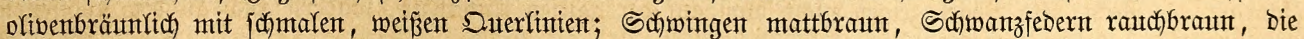

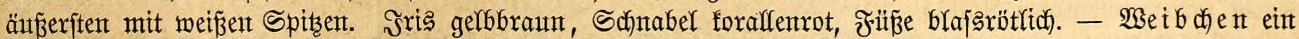

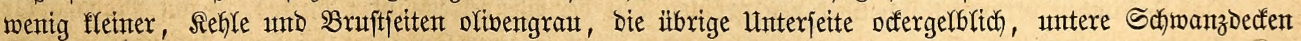

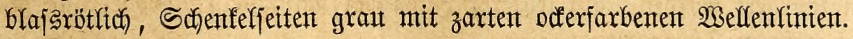

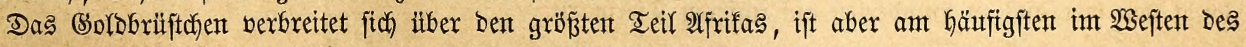
Eroteila.

Bet ben $\mathfrak{B} e n g e l$ iften (Pytelia) ijt ber Sdynabel mebr geitredt als bet bent 2rjtrilbent, ber Schwanz bagegen fürzer, gerabe abgejdynitten ober nur janft gerunbet. 2Yuzerbem gilt

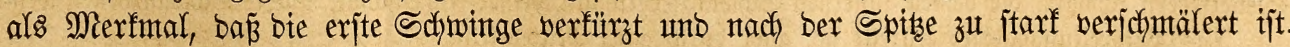


445. Der 3ierfinf, Pytelia (Fr., Estr., Loxigilla, Zonogastris, Marquetia) melba, L., (spe-

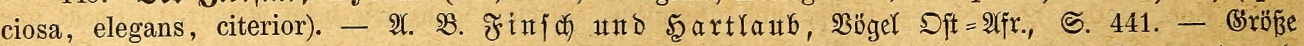

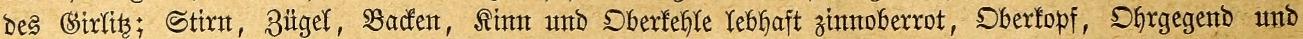

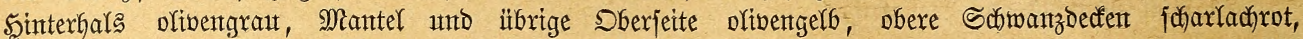

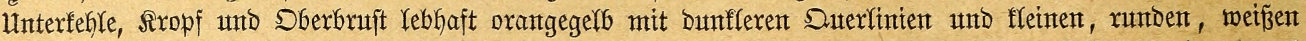

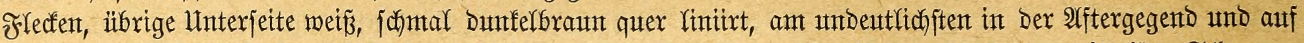

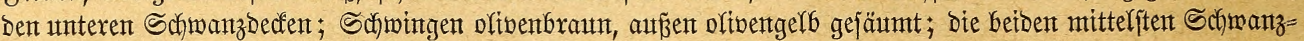

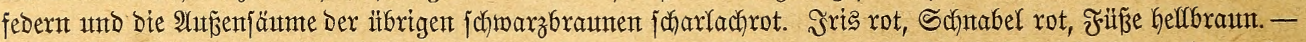

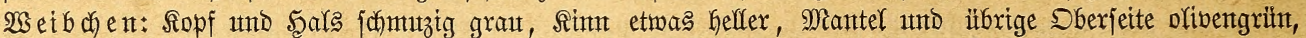
Unterjeite weins, Dunfel quex gemellt, obere Sdimanzocient biufterrot.

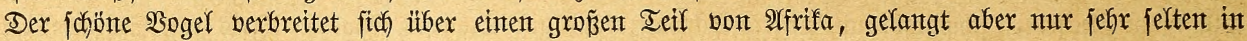
imijere ̊ǻfige.

Blataftrilben nent Cabants bie Mitglieber einter fleinen (Sruppe, weldye fich bon

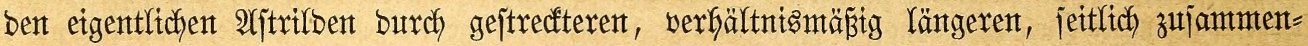

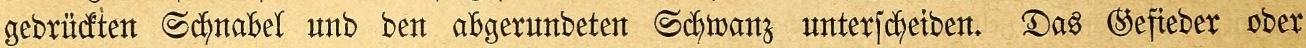

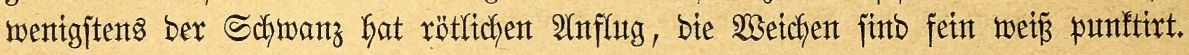

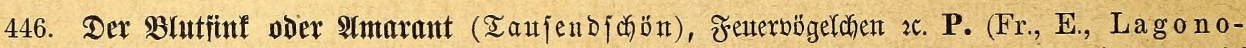

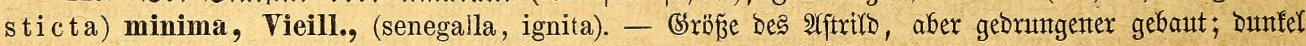

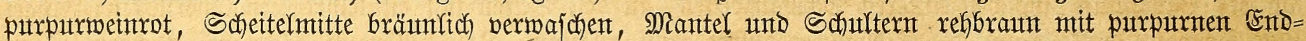

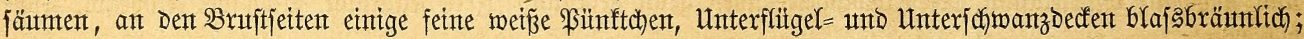

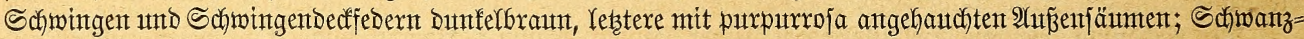

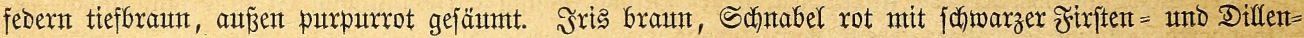

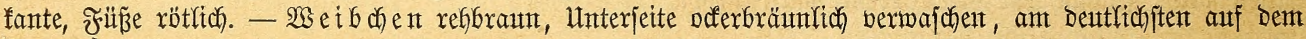

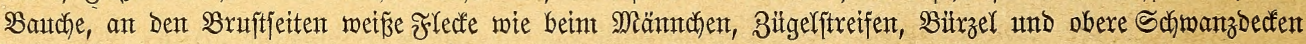
putrpitrrot, untere Sdfwanzoedent weîß.

Der reizente $\mathfrak{S}$ oger, ein mixfltcher Taufendjchön, bewohnt ganz Mittelafrifa.

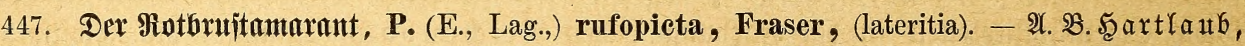

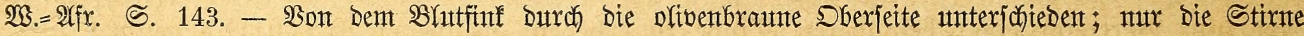
meintrot wie bie Itnterfeite.

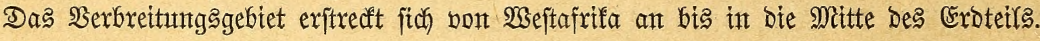

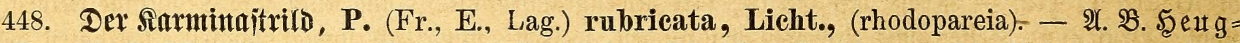

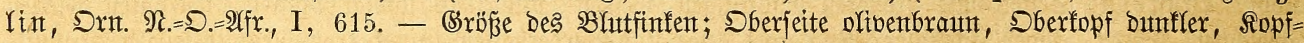

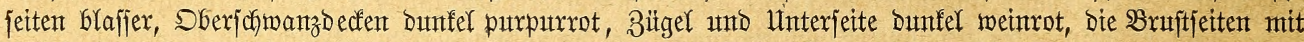

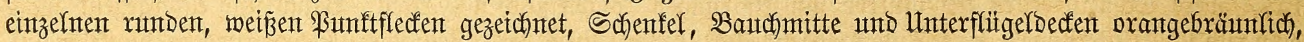

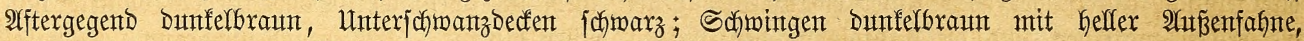

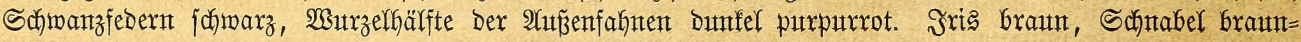

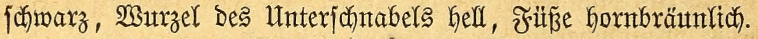

Der $\mathfrak{B}$ gel vertritt bie Serwantoten in Sübafrifa unto Den Rïftentüntbern Des rotent Meres.

449. Der \&arvenantarant, P. (Am., E., Lag., Habr.,) larvata, Ruepp., (vinacea). $-\mathfrak{A} . \mathfrak{B}$.

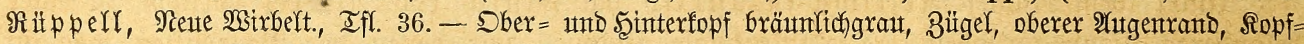

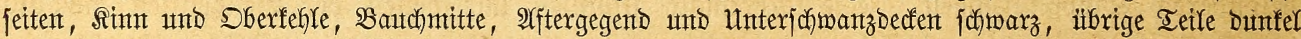

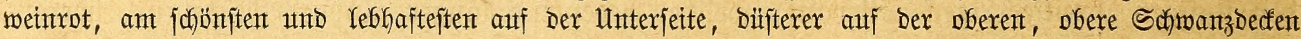

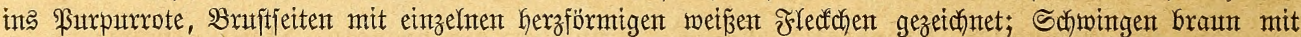
weinrötflichen $\mathfrak{A}$ (1)

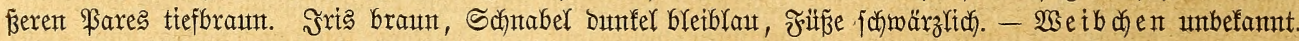

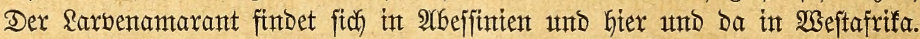

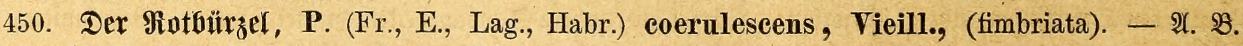

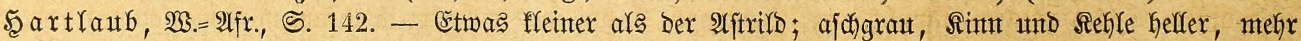

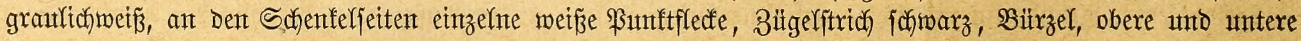

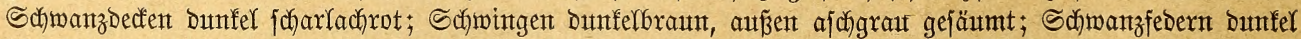

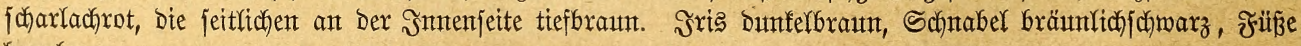
hornbrautt.

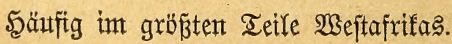


451. Der Sđünbürzel, P. (Fr., E., Habr.) Perreini, Vieill., (melanogastra). - $\mathfrak{A} . \mathfrak{B} . \mathfrak{B}^{\mathrm{i}} \mathrm{e} i \mathrm{Y}=$

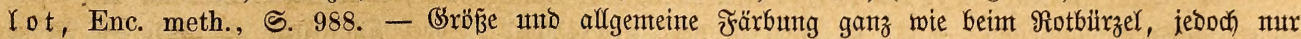
Bürzel und obere Sdymanzbeden rot, Bauthmitte, Afftergegent, untere Schmanzbeden und Sdhwanz fdumarz.

Stammt ebenfalls aus Beitafrifia.

452. Der Iigerfinf, P. (Fr., Es., Amandava Sporaeginthus), amandava, L., (punctulata, pu-

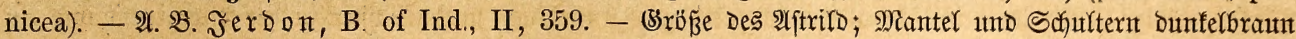

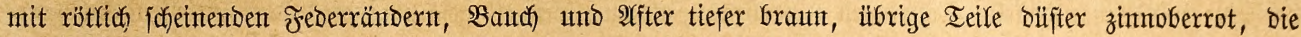

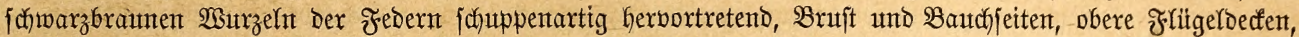

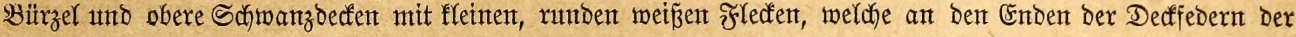

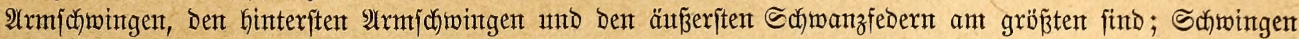

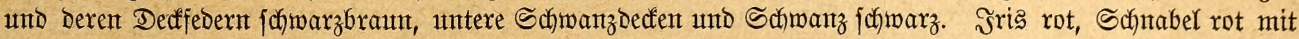

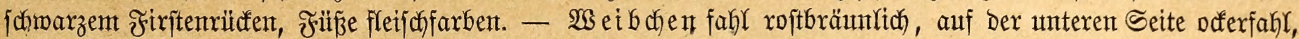

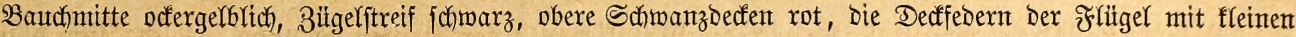

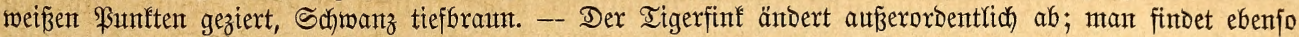

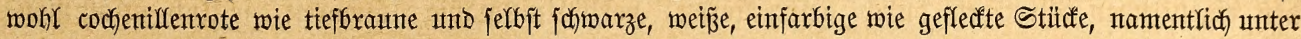
poldchen, welche rängere 3eit in (Befangenfduaft gelebt haben.

Das Saterland exftredt fich Ḧber Sildindien und bie Sintoainfeln.

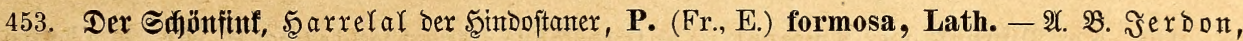

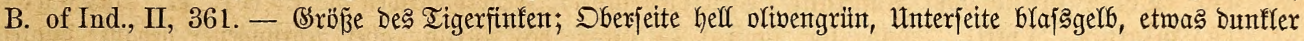

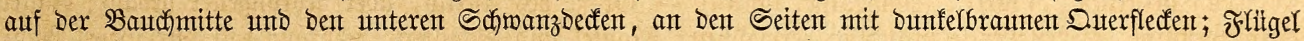

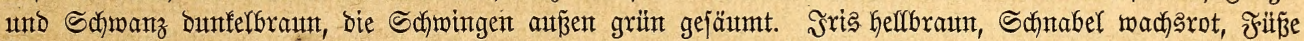
bleigraut.

Der Schönfinf, weldher in Mittelinbien, feiner Seeimat, häuftg vorfonmt anb oft in (Befangenjadaft ge= halten wiro, gelangt jehr felten rebento nach (Europa.

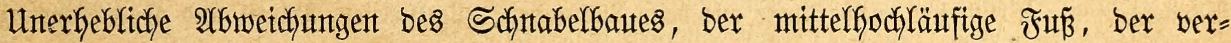

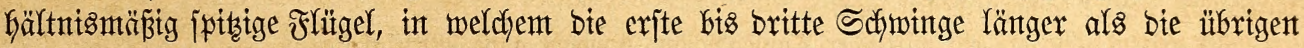
finb, umb ber janft geiteigerte Schwant, befijent beibe Mittelfebern bie anberent etwas überragen,

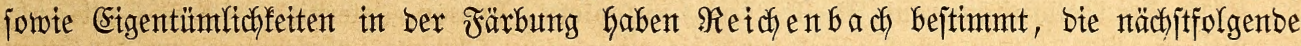

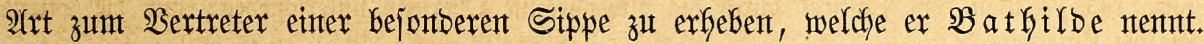

454. Der Sfotiterzfitf, P. (Am., Bathilda) ruficauda, Gould. - 9 . $\mathfrak{B}$. (S) D 1 lb, Handb. B.

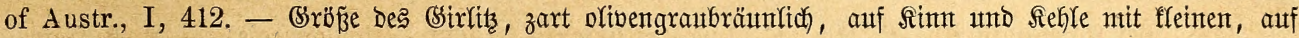

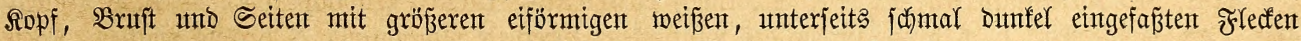

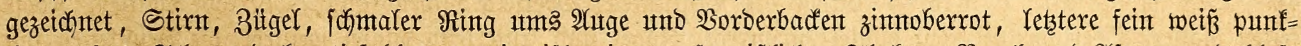

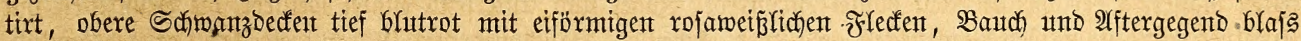

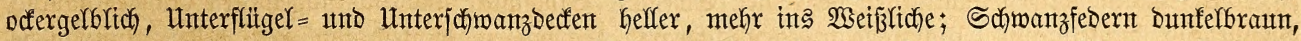

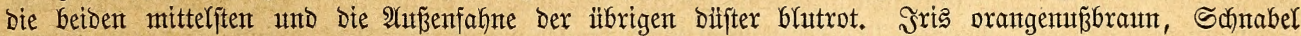

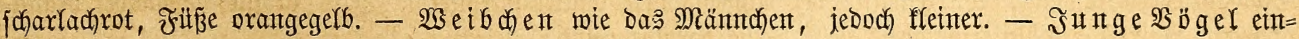

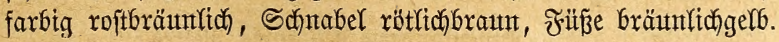

Silbautitralten und Rearitomales.

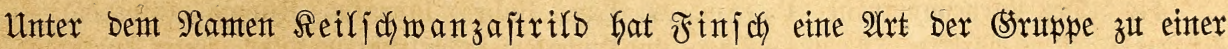
bejonterent Sippe erffobent. Die Merfintale ftintment mit benten ber Bengeliftent bis auf ben ftufigen, breitfeberigent Schwanz, welderer bebentent länger afs ber Flügel ift, übereint.

455. Die Bruthithe, Uropytelia (Fr., E., Brunhilda) erythronota, Vieill., (lipiniana). -

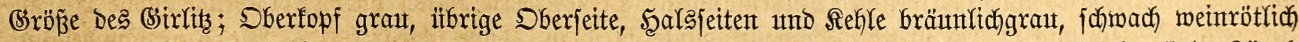

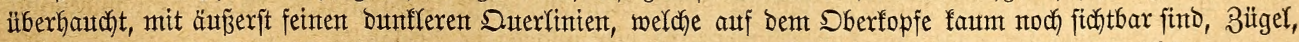

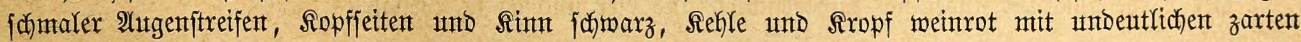

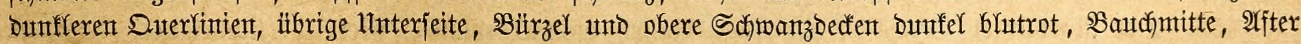

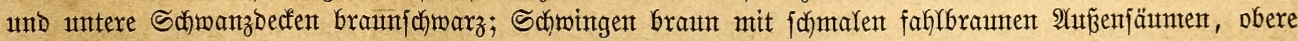

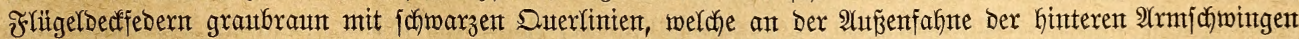

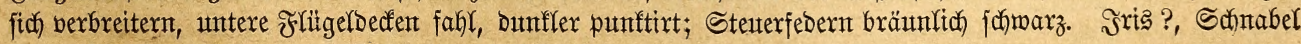

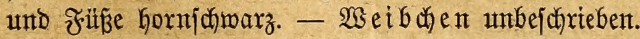

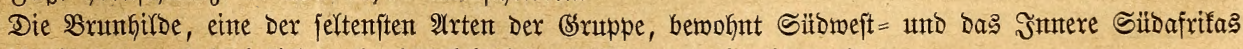

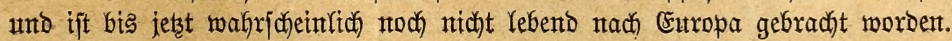




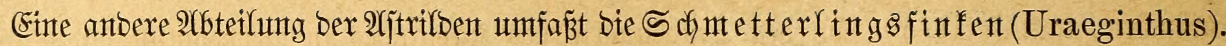

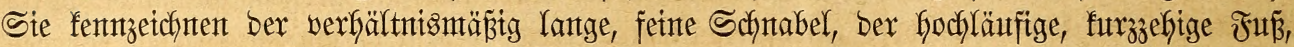
ber furze, jtarf gerumbete, zujammengelegt ein Sechjtel Des Schwanzes bectento Flügel, unter

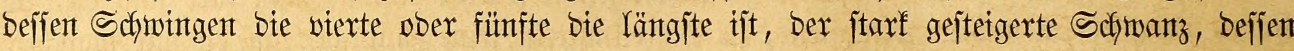
breite Febern fich feilförmig zujpizen, jowie bas retche, aus jetbenweichen aber glantzlojen Febern gebilbete flletb.

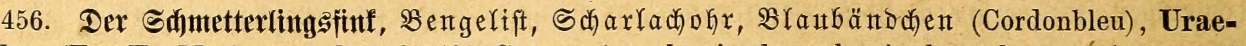
ginthus (Fr., E., Mariposa) phoenicotis, Swns., (angolensis, bengalensis, bengalus, máriposa). -

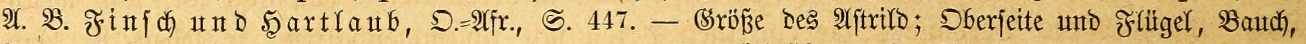

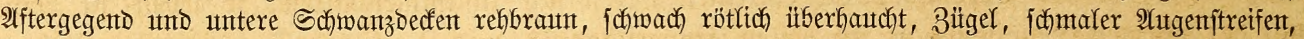

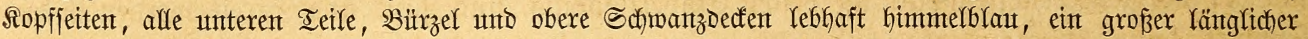

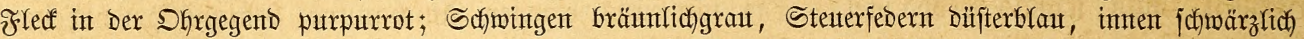

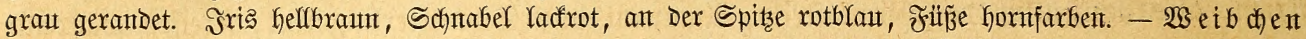

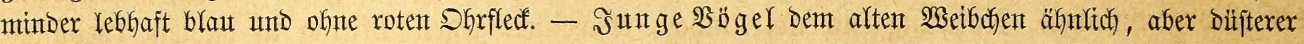
gefärbt.

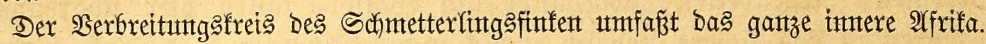

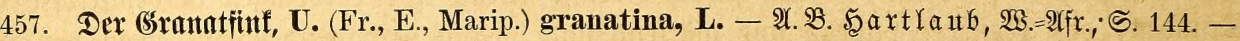

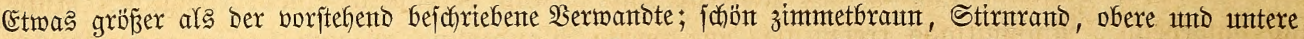

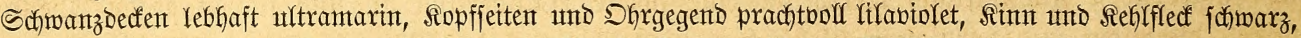

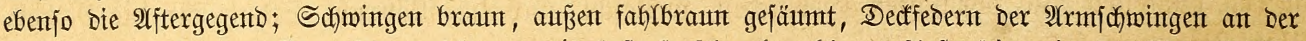

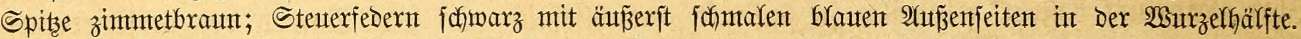

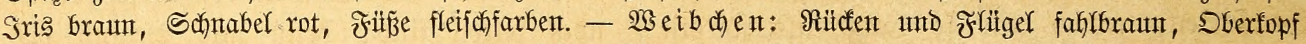

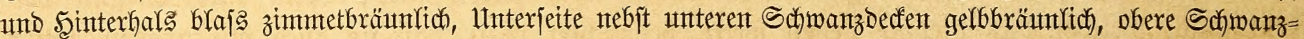
Dectert Kellflaut, ebenjo das Rila der Ropffeitent.

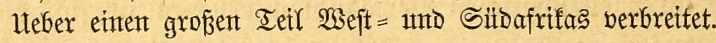

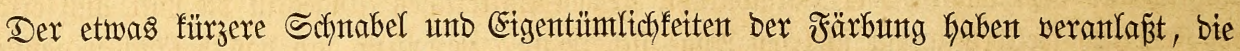

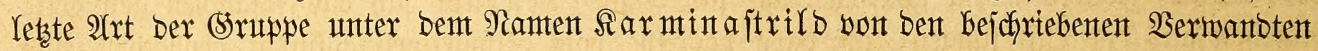
zut trentent.

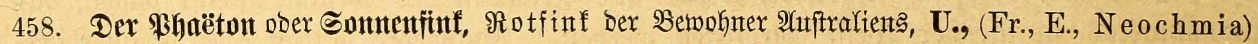

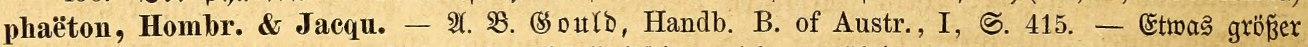

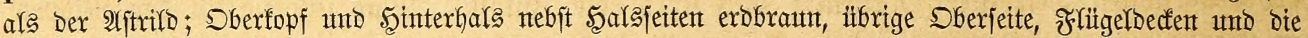

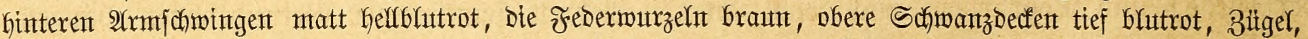

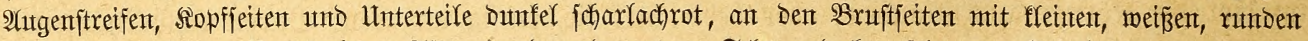

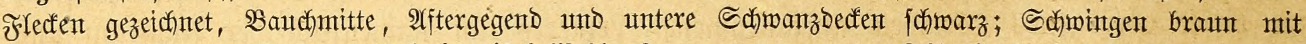

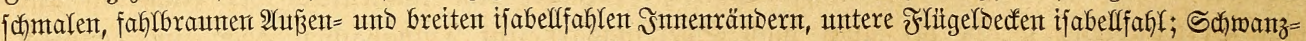

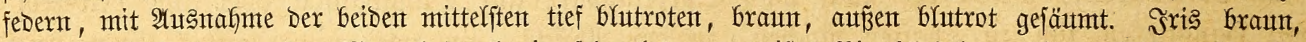

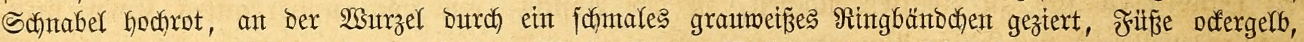

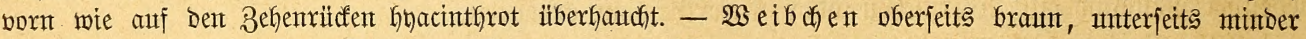

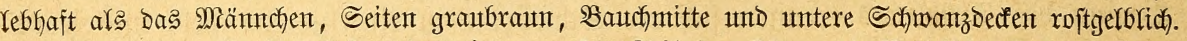

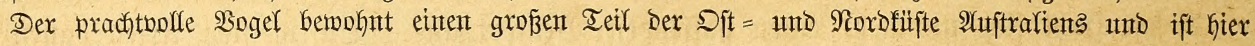
ïberall häıfig.

Die alftrifben füfren eine jefr überemitinntende Rebentsmeije. Sie bemofnten bie mit

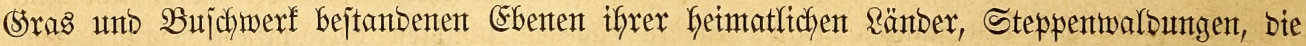

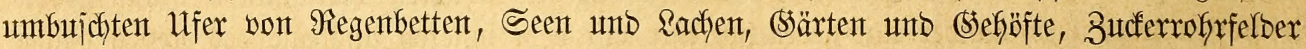

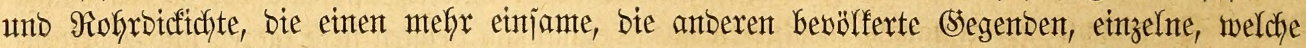

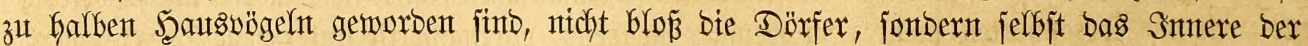
Stäbte. Die meijten gefören ber Nieberung an; boch twurben einzelne, wie bas Jajänchen

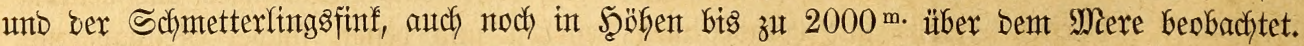

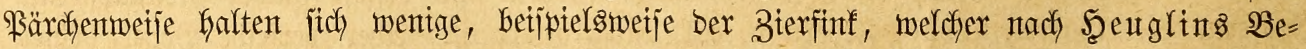
obachtungen nur einzeln und parweije gefunben wiro; bie übrigen leben in mebr ober

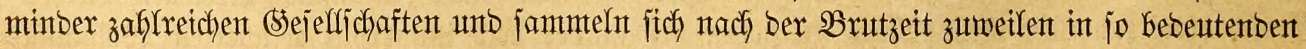
Schmärmten, Daj bie Ranbbater fich genötigt jefen, 2(bwefy zu treffen. So wirb bas reizento 


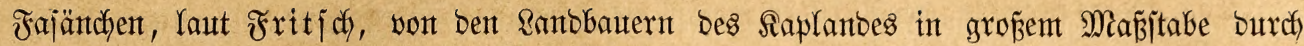

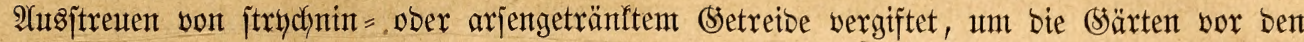
Nä̈jchereien bes zubringlicken (sejeflen zu ficfern, unto ebenjo nimmt ntan hier unb ba, in

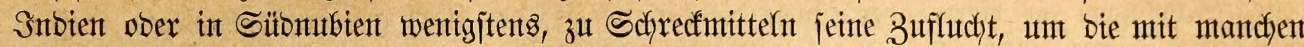

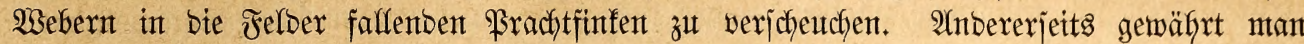

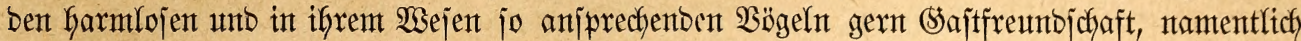
Denjentigen, weldhe int Befgöfte jelbjt fich anjibeln unt unter bem Sparrenwerf ber einfachen

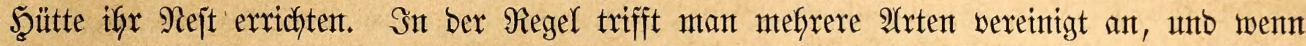

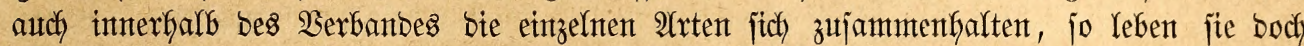
mit ber übrigen Bentoffenjfhaft int bejten Einverftänbnis, unb Zanf unt Streit werbent in ber Freitgeit faum jemtals beobachtet. Die mir aus eigenter Afnjchautung befannt gemorbenen

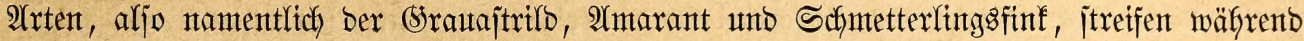

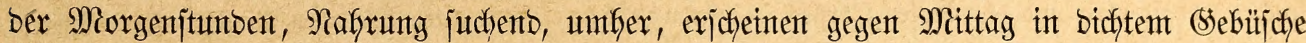

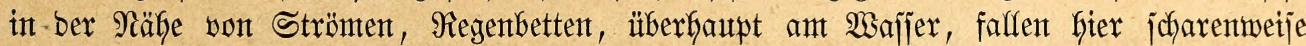

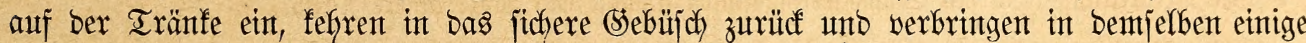

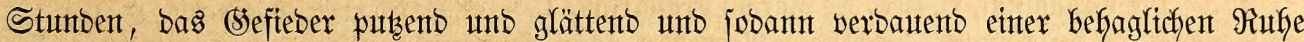

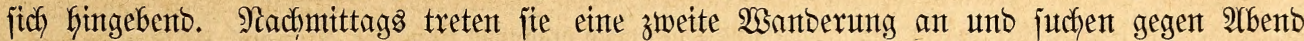

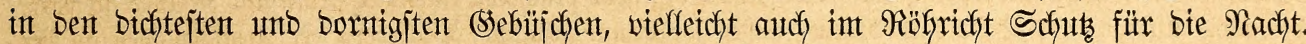

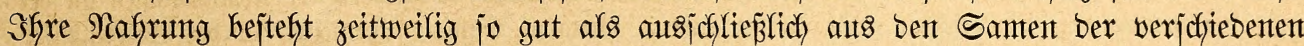
(5razarten, jebodh nut jo lange ars Serbtiere noch jelten finto; beent mit Beginn bes

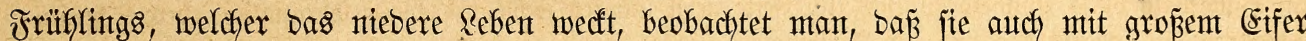

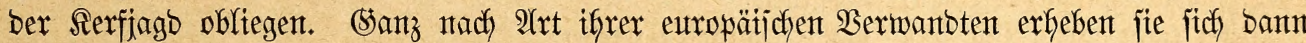

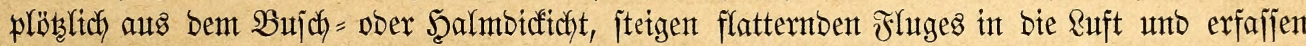

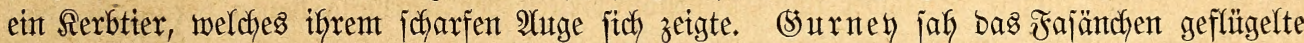
Imeifen aus ber \&uft fangen, idy habe basferbe vom Sdymetterlingsfintent beobachtet unt

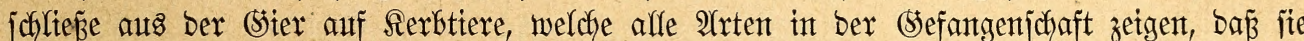

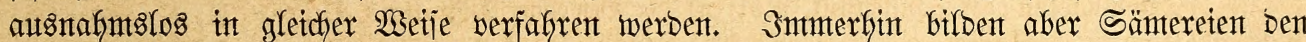

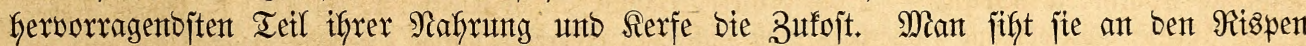

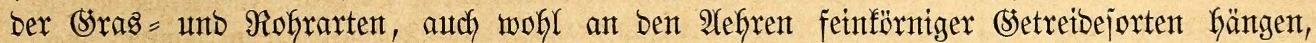

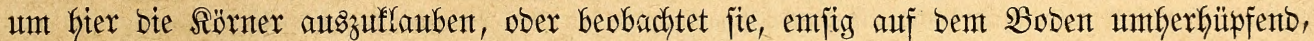

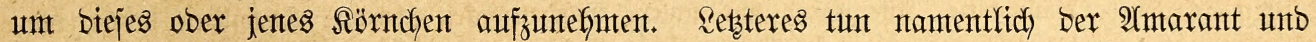
feine Berwantsten, weldhe oft audh nadh Sperlingsart auf Dunghaufent ober unt ben Sot

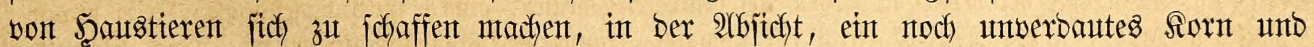

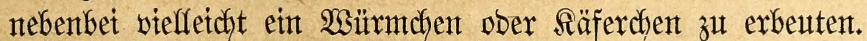

Mit Beginn bes Früflings trennen fich bie Schwärme in einzelne \$ärchent, unto jebes von biejen futht fich nummefr einen paffenton $\mathfrak{B r u t o r t}$ aus. Die meiften $\mathfrak{A}$ rten bautent in

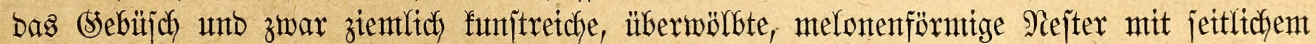
Eingange, fleiben bieje inten mit Searen unb Febern zierfich aus, verwenben überhaupt eine

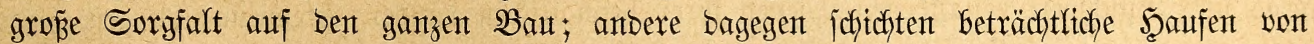

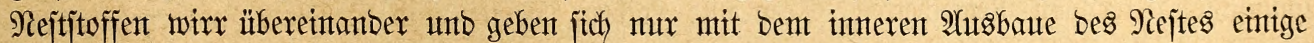

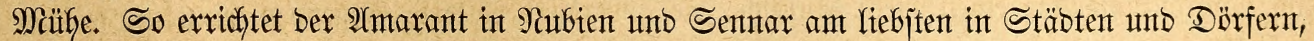
unb zwar bie Strofghütten mefir ober wentger meioenb, vorzuggweije unter bem Sparrentwerf,

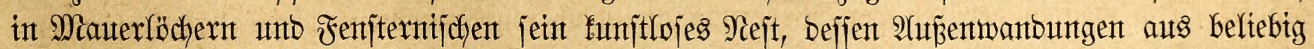
aufeinanber gefäuften Strof = unto (Srashalmen bejtefen unb befijen flacher Siejtnapf mit

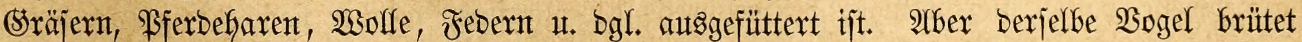
trach eigenen Erfaffungen auch auf ber (Erbe im noch nidfft zujammentgetretenen bürren

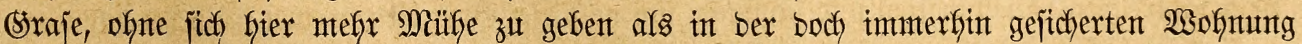
bes gaitfreien Eingeborenen. Der Sadymetterfingsfint jojichtet nach meinen unb Şenglins 
Beobadftungen in bidften Büjchent ein Göchjt eigentüntliches Rejt zujantmen, einen Bau, weldher, wie Şe

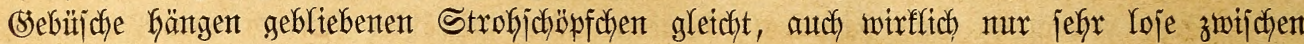

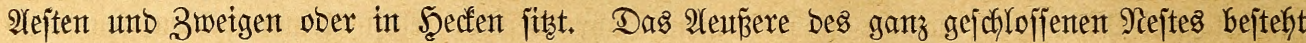

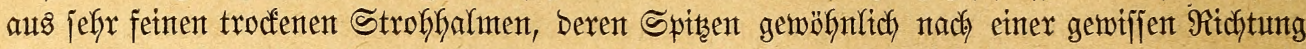

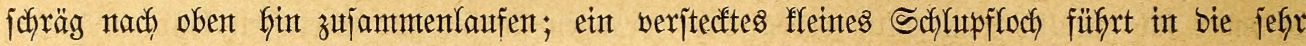

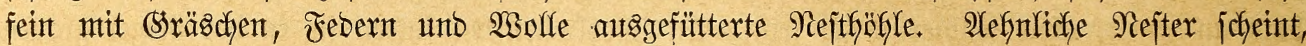

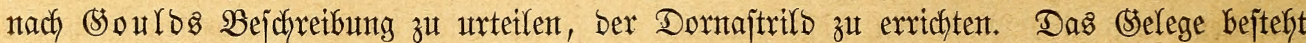
aus vier bis fieben fleinen weižen Eiern, weldfe won beiben EEttern abwedfjelno bebrïtet

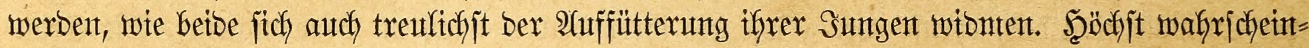

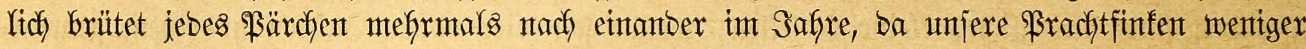

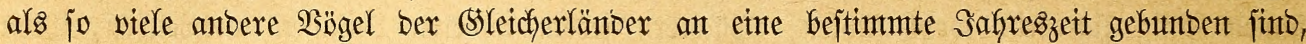
objchon autd) fïr fie bie Regenzeit ber Frïffling ijt.

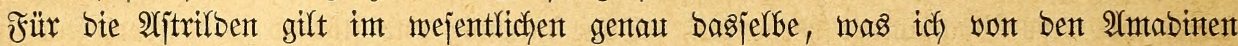
gejagt kabe. Snt begemjats zu biejen erfalten wir weitaus bie meiften 2 (rten von ber

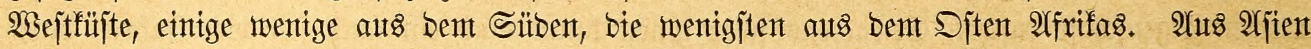

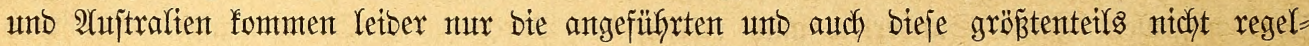

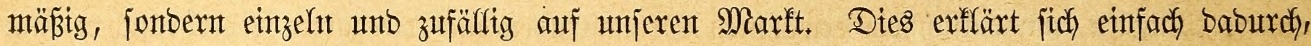

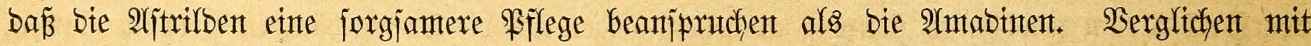

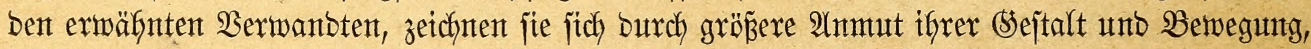
Gäferen Riebreiz ifres 2 Sejenz vorteitfaft aus, fint bei guter Pflege faum wentiger bauterfaft

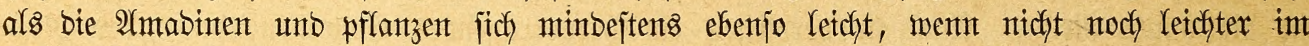

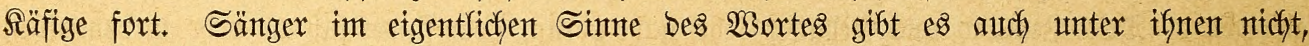

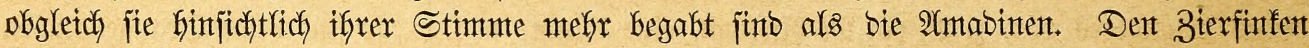

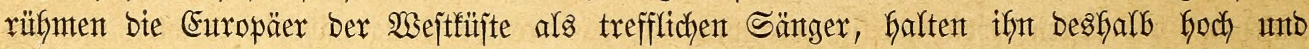

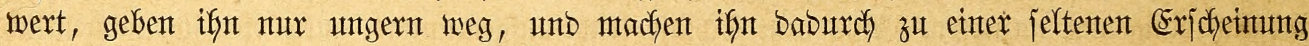

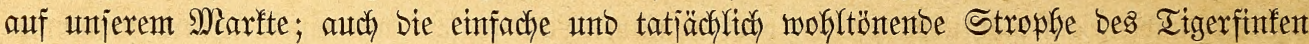
mirb oft alz Bejang bezeidfnet: ichon unjer Beifig aber ïbertriffit als Sänger bent einten wie

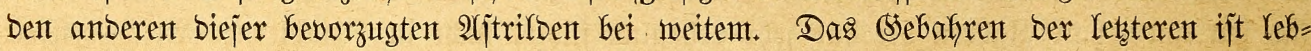
hafter als bas ber Afmabinen, unb beshalb feffeln jie mefyr als bieje. Shre geringe (5rö̈ß̈e

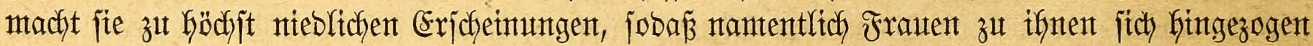

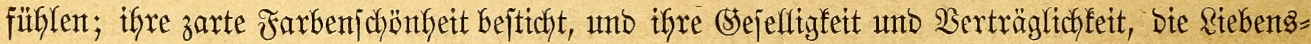
mürbigfeit, welche fie gegent ben (Sattent unt gegen bie Sirtber an ben $\mathfrak{I} a g$ legen, müffient

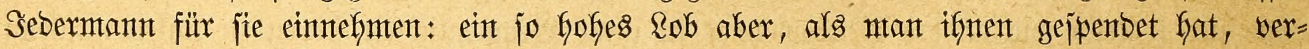

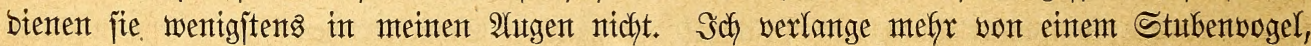
welcher mir genefynt jein jolf: idd verfange vor affent, ba

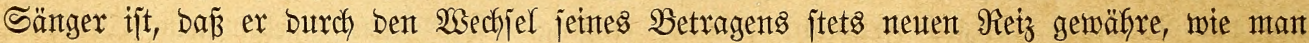

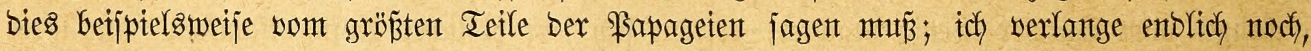

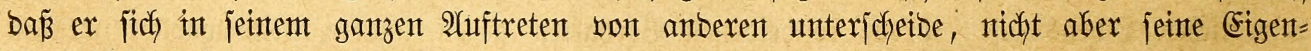

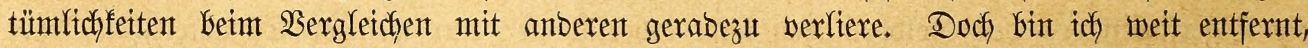

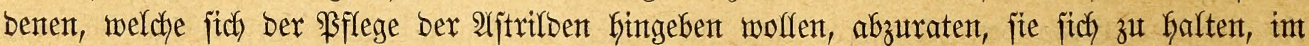

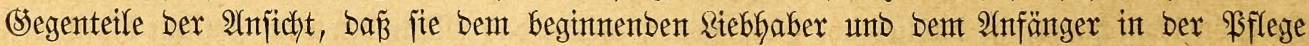

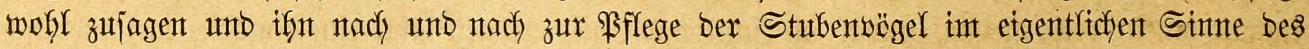

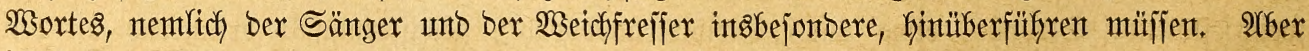

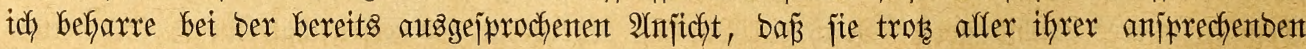
Eigenichaften auf bie Dauer ebenjo rentig befriebigen fönnten wie bie 2(mtabinen unt anbere

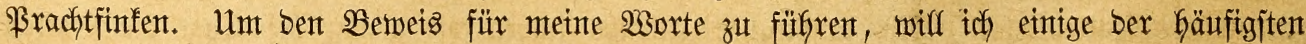

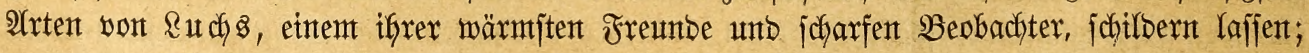


es wirb baraus herborgehen, wie wentg biejen $\mathfrak{B} \not ̈ g e l n$ jich abjef̧en läß̆t, forweit es jich unt ifr Betragen handelt.

"Sefyx verträglich unt harmlog", bemerft mein geichäbster Freunt vont Fajänthen,

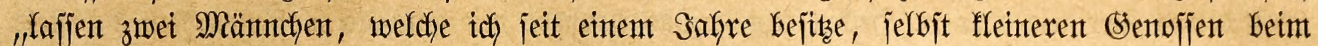

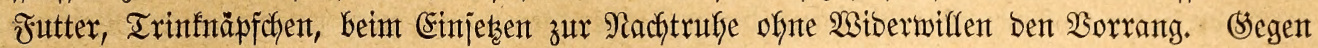
einanber jich ziemlidch gleidfgültig verbaltent, brängen jie fich zutr Schlafzeit bald an biejen,

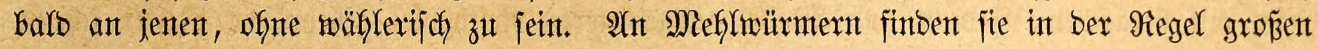

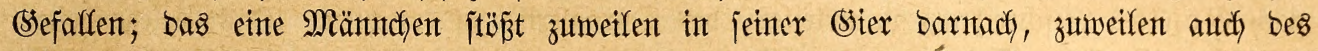

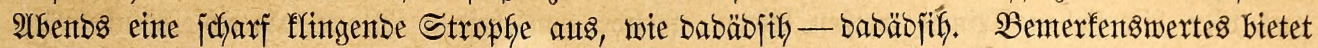

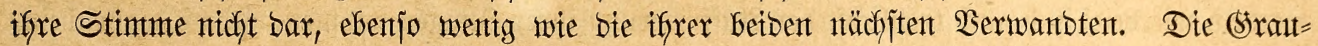
ajtrilbent fints bemeglidhe, fleine Sejellen, weldye jeit vier vollent Gafyen in einem gemeint=

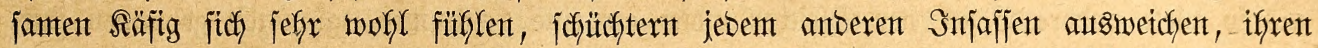

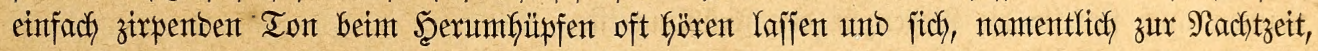

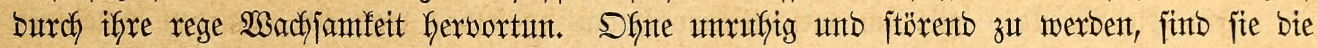

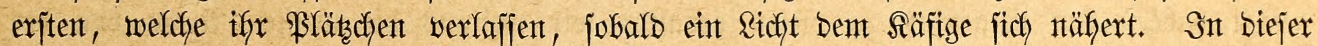

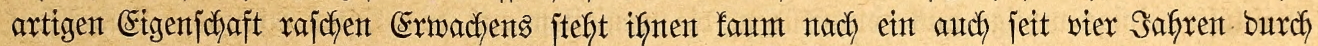
jeinte ungemein glatte Sauberfeit mich exfreutentes ßärchent Der Drangemantge. Währento

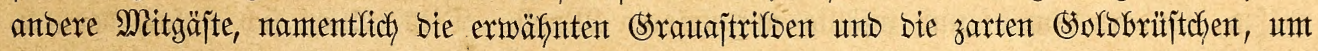

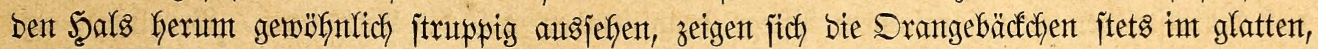

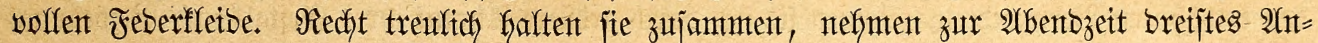

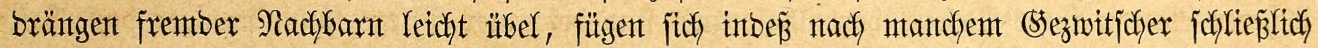

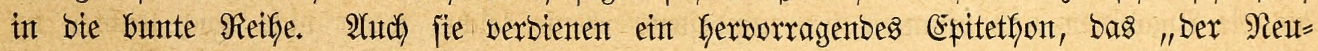
gierigen". Tritt Semant ans (sebauter fefr nabe kerant, ober finbet fich ant ober in bemjelben

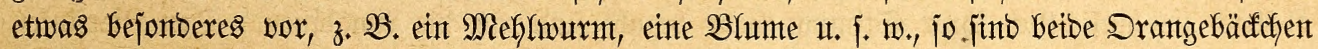
unfeglbar bie erjtent, weldhe, eilig Geranthüpfent, bas frembe Ding näher betrachten und wo

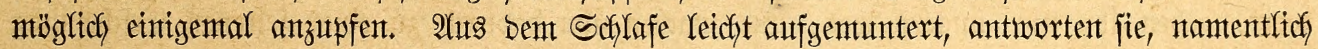

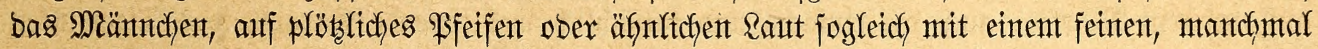

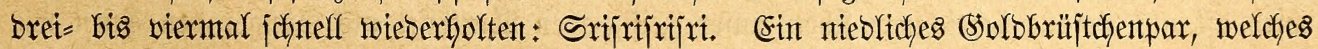

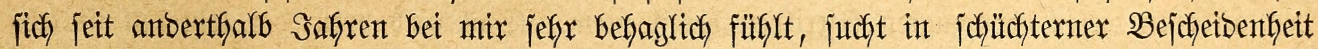
und treuer Sattenltebe Seinesgleicfen. Heber Iag in fortwährenber Bemegunt mit feinent ${ }_{11} \mathfrak{B t e b}$ - wieb - mieb" von Stengel zu Stengel Gühpfent, fautern fich betbe (Satten bes arbenbs in eines ber in Räfige eingelegtent Bappnejtchent traulity zujammen und lugen mit ifyren

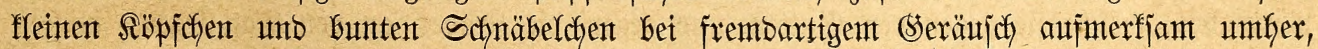

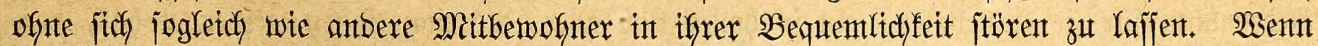

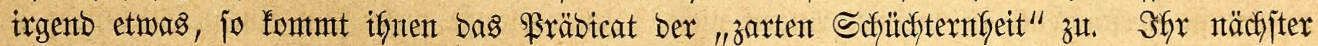
Serwantoter, ber Iigerfint, war in einem munteren \$ärchen ein Gafy lang bei mix vereinigt, als bas Weibdjen voriges Frühjafr plöthlich einging. Das neat zugefommente Weibdjen,

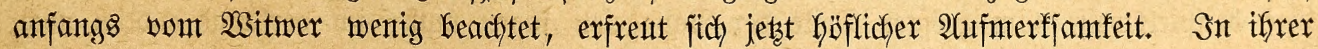
beweglichen Sebensmeije, ifrem bejcheibenen Serhalten gegen andere Mitbemofner weichen

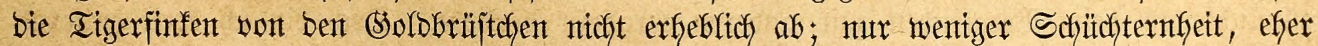

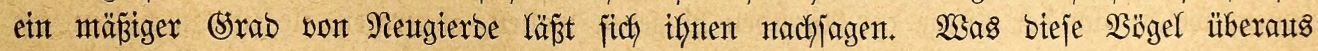

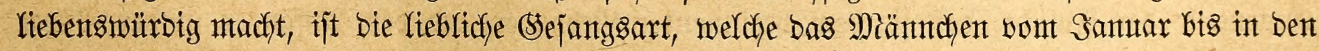

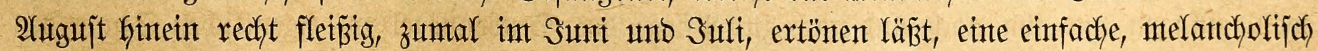
weich flötenbe Strophe, etwa wie "Dibibibibaboboboh", gemiffermaken exinternto an ben (Sejang unjeres Raubjängers. Noch ein \$ärchen beherbergt ber (Sejelljchaftafäfig: Schmetter=

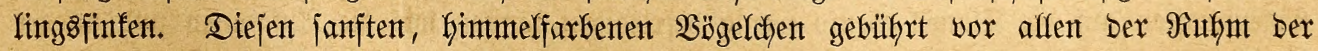

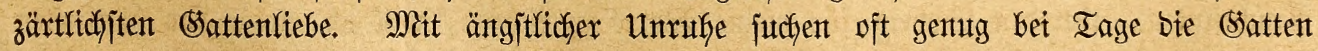
eintanber auf; namentlidy \{päht bas leidjt fröjtelnbe Miänndjent nach ber ermärmenten Seite 


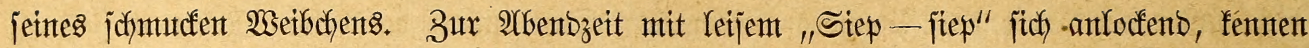

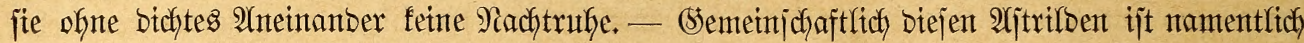

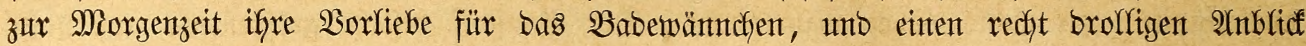

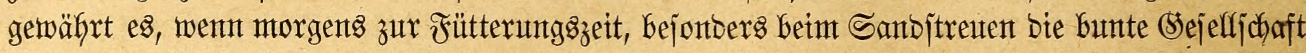

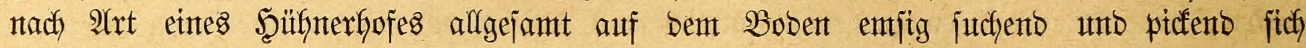
einfintbet."

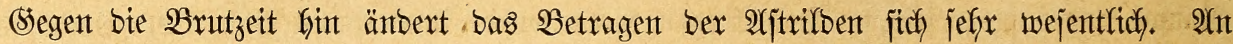

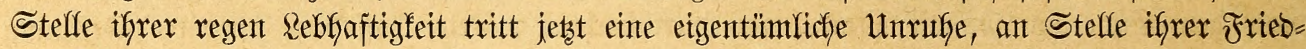

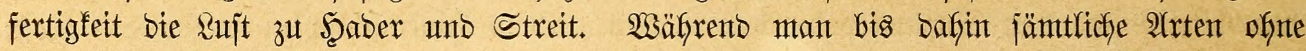

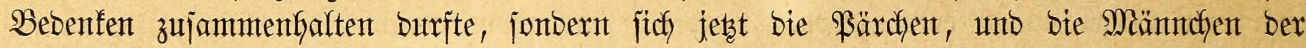

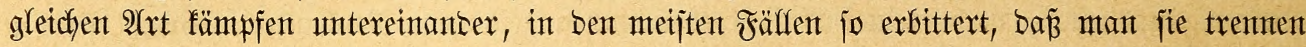

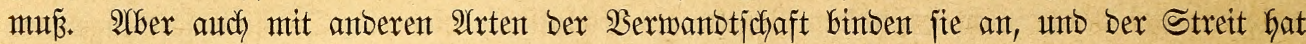

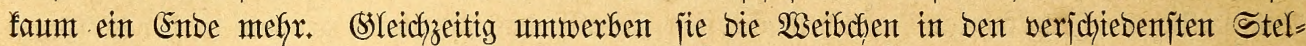

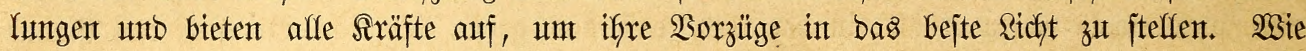

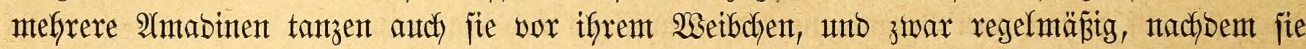

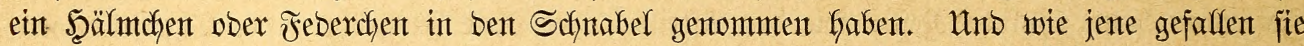

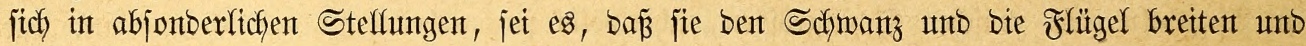

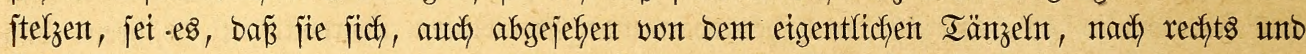

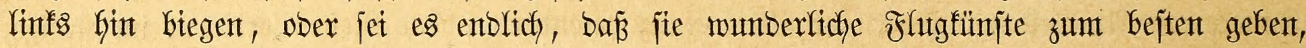

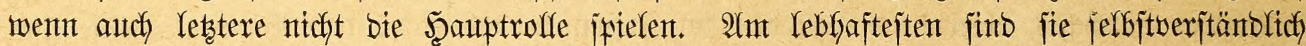
furz vor ber Begattung jelbjt, weil bant ifgre Erregung Den Göchjten (5rab erreidst

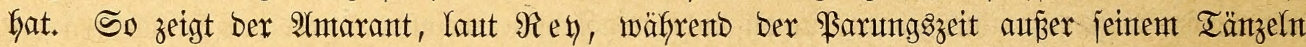
noch ein eigentünllicfes Benefgmen, "inbent er mit auzgejtrecttem ફ̧alje unt aufwärts ge=

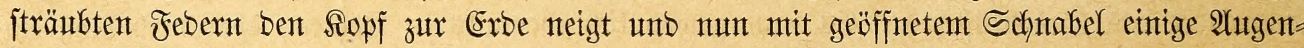

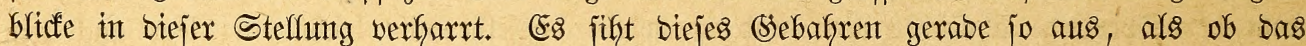

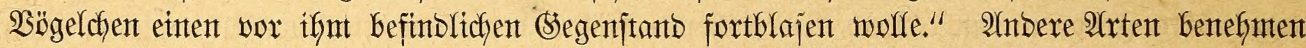

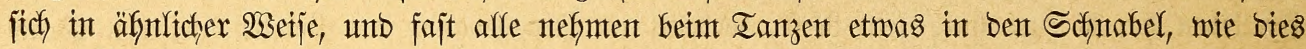

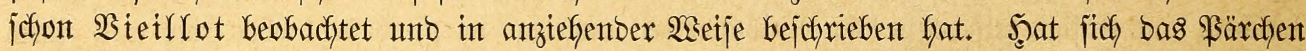
einmal geeinigt, jo Gängt es mit untvergleetchlicher Treute aneinanber, trent fich faumt cine

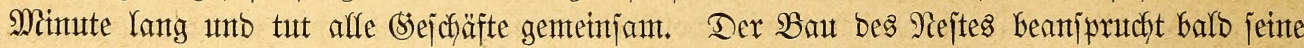

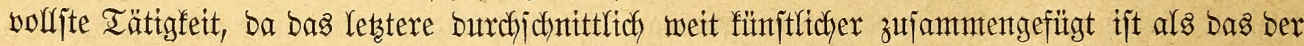

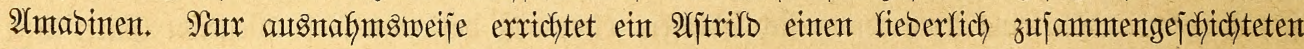

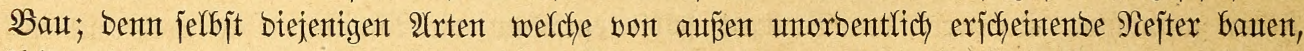

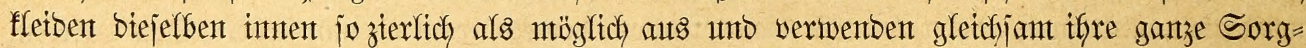

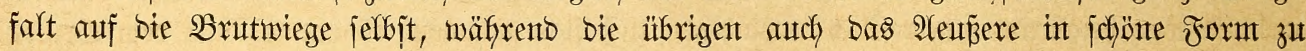

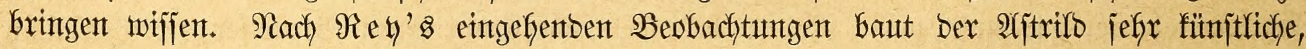

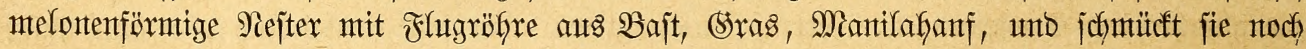

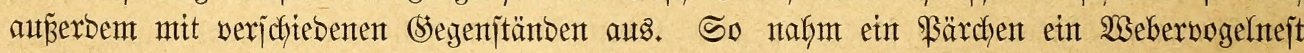

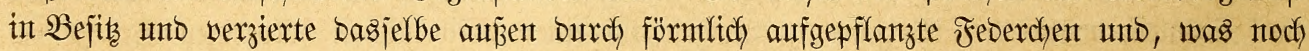

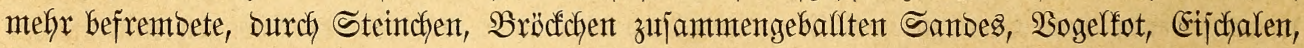

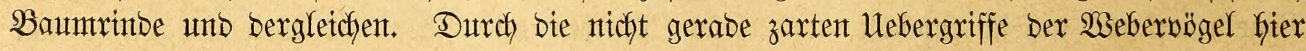

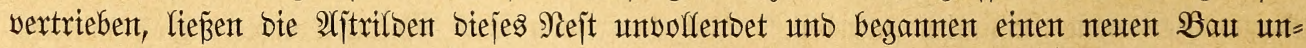
mittelbar an ber Erbe zwijhen einem Wsetbenbaume uno einem Epheutopfe. "Şier", jagt

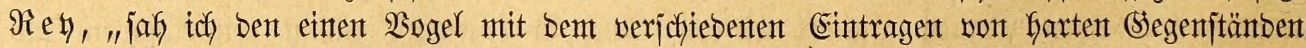

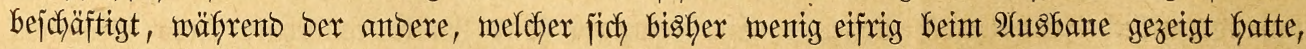

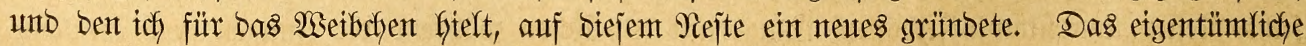
Doppefnejt murbe balb verfafien, unto nactbemt noch einige anbere mefy ober meniger weit wollenbet waren, fing ber $\mathfrak{B}$ ogel aberntals ein Doppelnejt an, unto zwar wurbe basjelbe 
bicht unter ber Dedfe bes Binmers angebradjt. Das untere ber beiben Nejter ijt fajt ei= rund und hat ein jo fleines Flugloch, baj man, went bie $\mathfrak{B}$ b̈gel nicht gerabe ein = ober

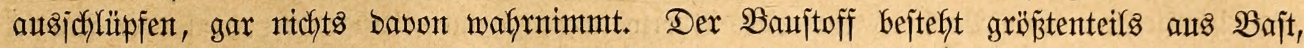

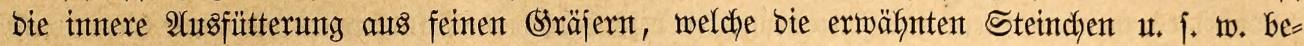
becfen, bas obere Nejt bagegen Kauptjächlich aus Febern unt jcheint in Bezug auf jeinte Form weniger nach einemt bejonberen $\mathfrak{B l a n e}$ gebaut, als vielmebr bem gerabe vorbanbenten Raume angepajt zu jeint." Das Eingangarofor wurbe immer aus Bajtfäben gemebt, weldye

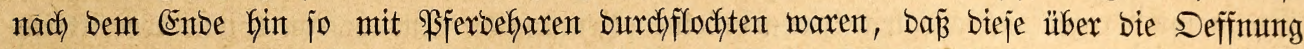

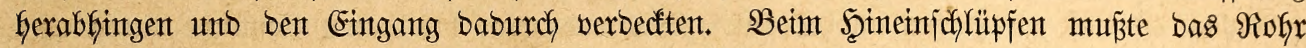

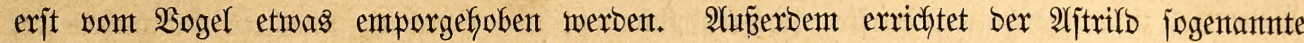

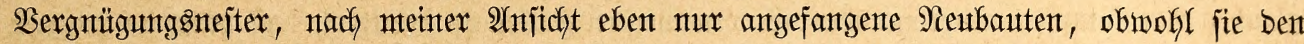

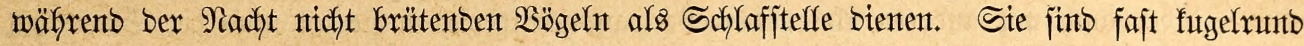
mit jeitlichem Flugloch aus gleichen Stoffen fo auf bas Bruttejt gebaut, baj bas (sanze

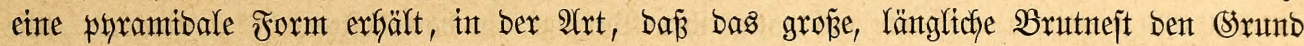

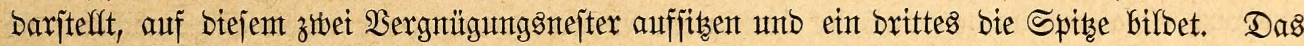

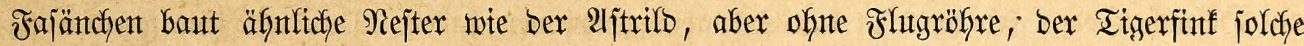
an 2ljtgabeln ober zrotjchen Schilfgräjern, überwölbt jie, arbeitet fie zierlich aus unt legt

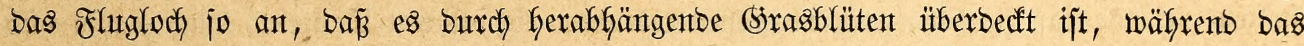

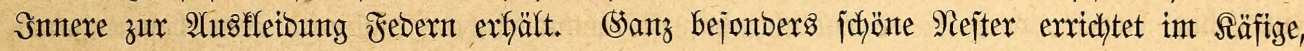
Int zwar burchaus abweichent von ben im Freten beobachteten, ber Itmarant. Sie fint,

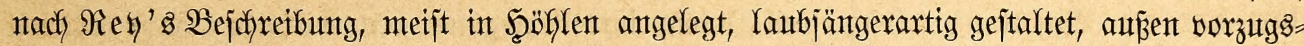
weije von Bajt zujammengebaut, innent bidft mit Febern, bejonbers mit ben Şalsfedern Des Şaushahnes ausgepoljtert, jobaß eine Seffnutg gar nicht fichtbar ijt. Seringere Sorgfalt

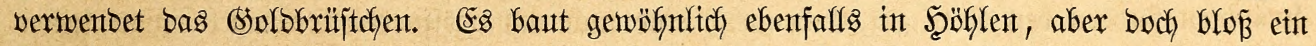

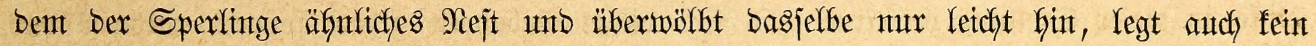
eigentliches Flugrofr an. Noch lieberlicher werfährt ber Sdymetterlingsfint, wie ex vom Freileben her ez gewohnt: jein 9ejt, welches im Fluggebauter am liebjten zmijchent Sras=

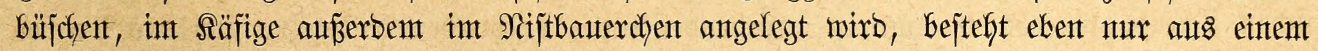
wirx zujammten getragenen ફ̧aufen mit ausgefleibetex Mitte.

Nitdyt immer jint bie Nejter bereits vollentot, went bas Weibchen mit bem Eierlegen

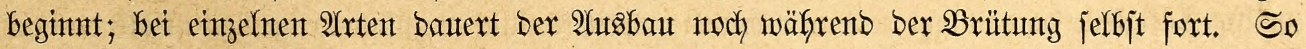

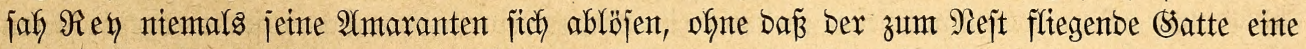

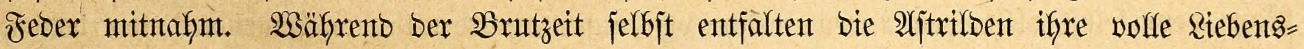

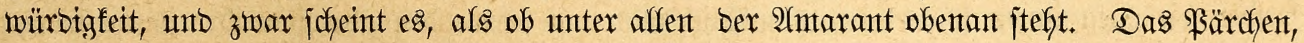

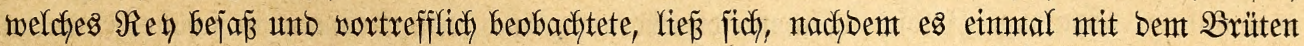
begonten batte, gar nidfyt mebr ftören, befumbete überfaupt einen Bruteifer, weldyer auds bie alferbïchjten Erwartungen übertraf. "Siltugt es nicht fajt untglaublich", erzählt unjer

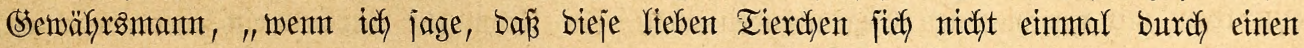

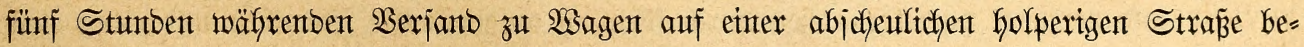

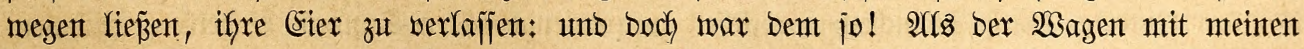
Sögefn anfam, jah tch zunächjt nach biejem Pärchen unt fihe, bas Weibchen mutbe nach

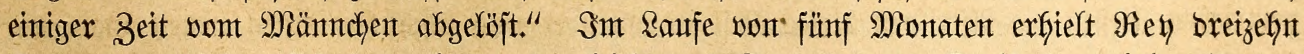
Sunge von biejent $\mathfrak{B a ̈ r c h e n t , ~ G a ̈ t t e ~ a b e r ~ l e i d y t ~ D a s ~ D o p p e l t e ~ u n t o ~ D r e i f a c h e ~ e r z i e l e n ~ f o ̈ n n e n , ~}$

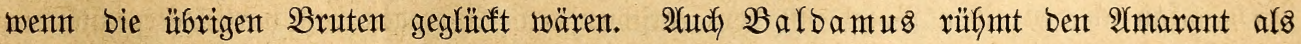

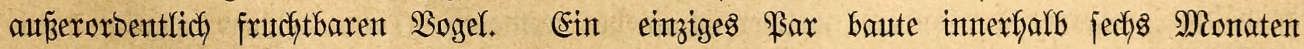

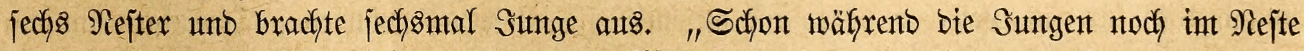
faß̧en", fagt unjer Mitarbeiter, "baute bas Miäntchen ein neutes Nejt, unto faum waren fie

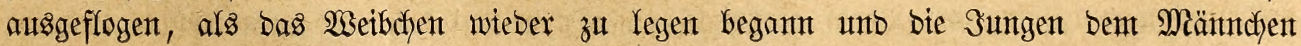




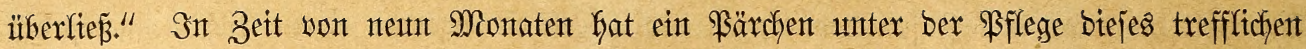

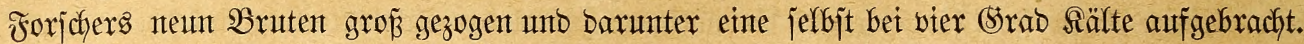

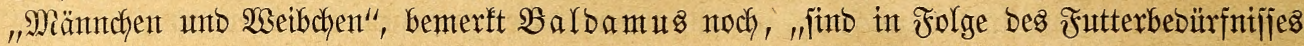
für thre Sungen fo zutraulich geworben, baj fie, jobald idy in bie Stube trete, mir ent=

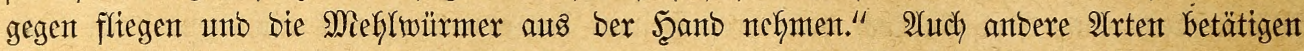

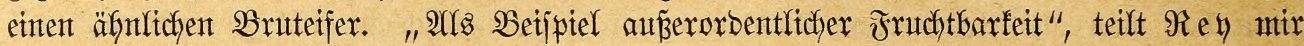

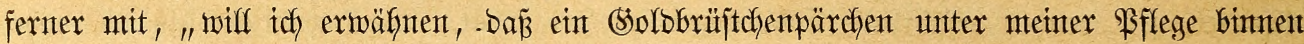

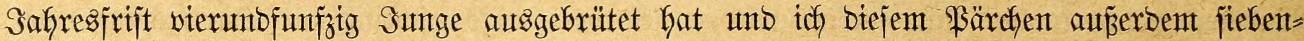

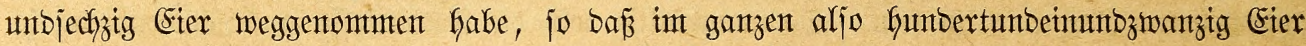
exzielt wurben. Ulm joldhe Evzengungsfäfigfeit anjchauticher zu machen, habe ich bas Weibchen und bie (ster gewogen und als (semidyt bes erjteren 5,86 (5rm., als burchjidnttliches Serwidyt bes Etes aber 0,788 Srm. gefunden. Es hat biejes ente Weibchen in einem Safre aljo bas Sechzefnffache jeines Sörpergemidhtes an Eitern Kerworgebradht. Bergleicht man mit

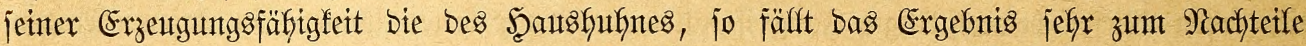
Des lesteren aus; benn einte genöbnliche Ranbhente, weldye etwa 1540 (5rm. wiegt unt

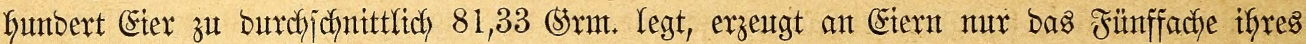

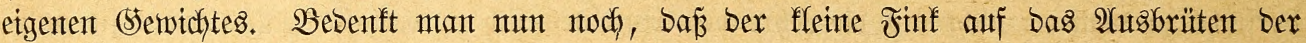

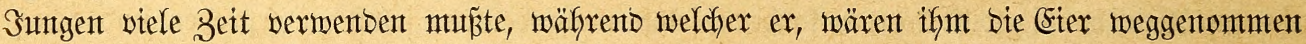

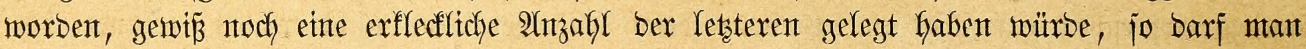
jeine Exzeugungsfähigfeit breijt viermal jo hoch annehmen als bie bes Şaushuthnes." Dieje

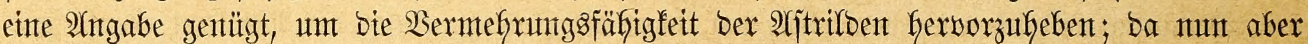
bie Sungen fich fchon in ben erften Monaten ifyres Rebents ebenfaffs zur Srut anjchidfen,

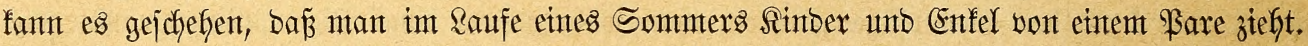

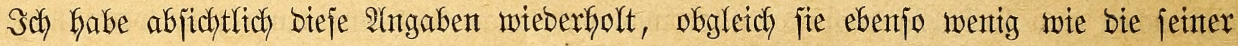

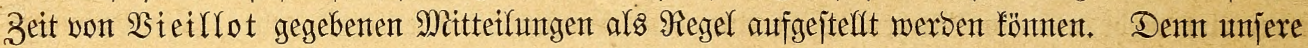

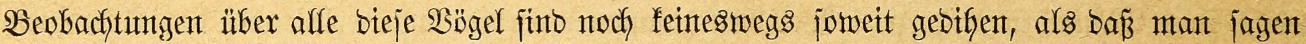

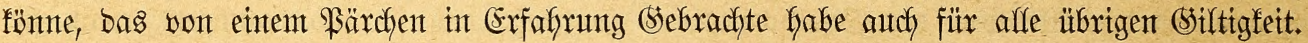

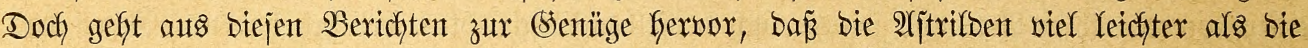
meijten Säftguögel, leidhter nody als bie 21mabinen, in Sefangenichaft zur Fortpflanzung jefreiten, jidy aljo in biejer Şinjicht auperorbentlidy empfeblent. Sb man mirffich recht hat, zu jagent, baj bieje leichter, bie anberen jchnieriger an bas sijtent gehen, bezweifle idf;

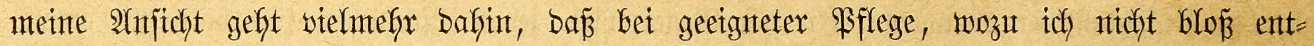

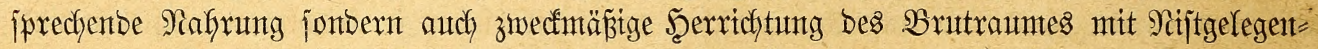

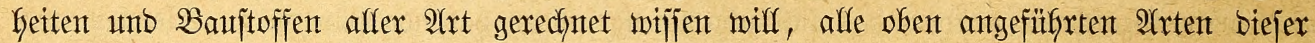
(Struppe in (Stefangenjchaft fich vermefyren werben. Alber freilich jimb wir noch feinesinegs

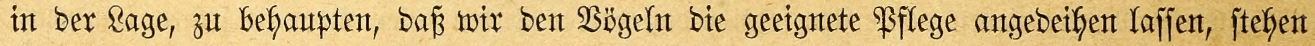

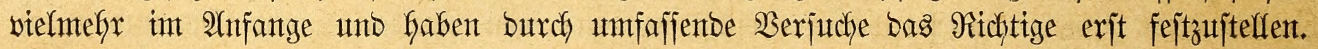

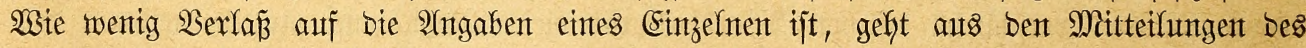
trefflich beobachtenden Bisillot hervor, welcher als erjte Bebinzung zur Büchtung ber

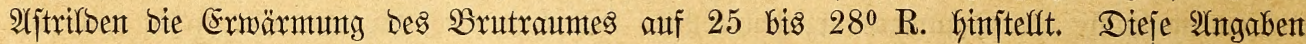
fint non jpäteren Büchtern, welche fajt auf jeder Seite ifyer Schriften befautpten, nux eigente

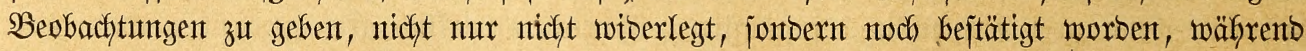

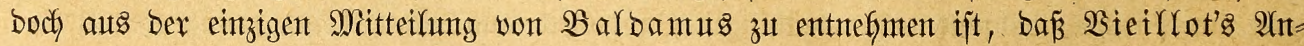

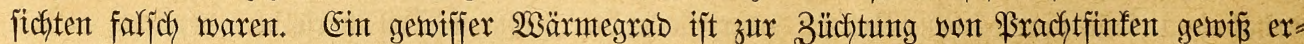
forberlich, nimmermefyr aber ein jo hober, fünjtlich emporgejchraubter, fonbern fyödjtens ein

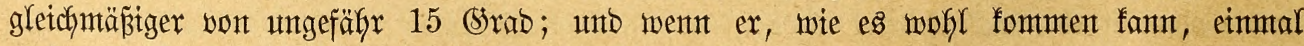
geringer wirb, ja jelbjt auf unto unter Naffgrab Gerabjinft, jo macht bas eben auds nidft

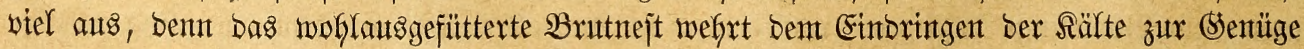




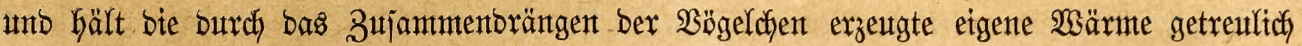

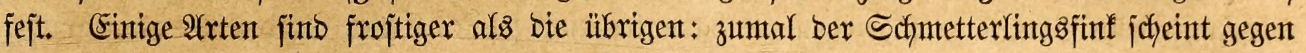

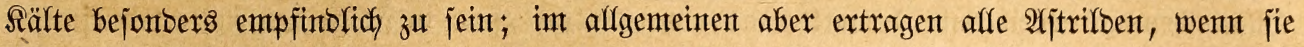

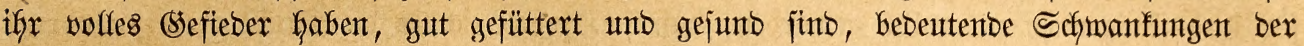
Wärnte recht gut: finb jie bod won ifgrer Şeimat her etwas anberes nidyt gewoofnt. Da=

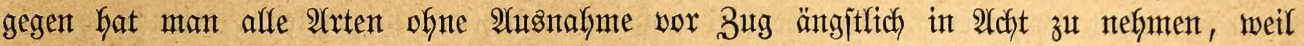

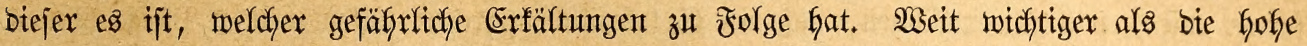
Wärme, welche inmer uno immer wieber geforbert wirb, fdjeint mir Darreicffunt einer

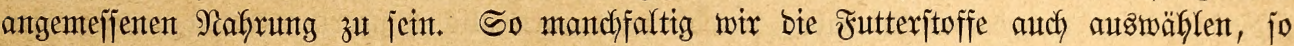
bitben fie boch immer mur einen Notbefelf für bas, was ber 20 ogel in ber Freigeit finbet, unto

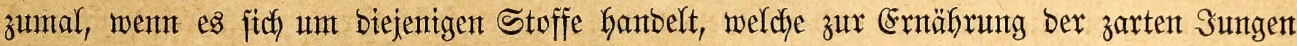

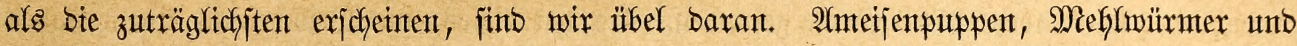

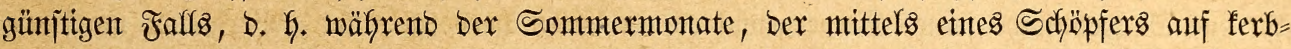

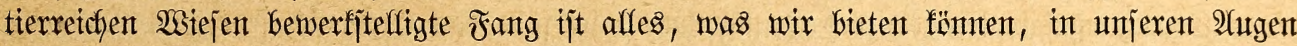

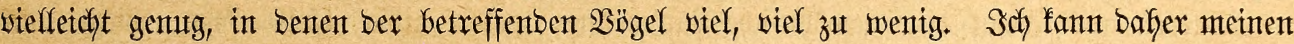

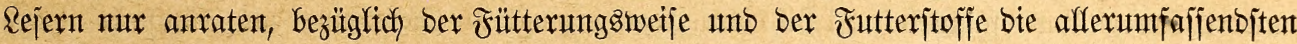

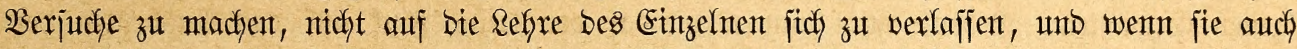

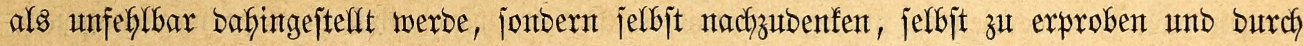
eigentes Erforjchen vorwärts zu jahreiten; Denn was ber Eine nidfyt exfährt, exfunbet ber

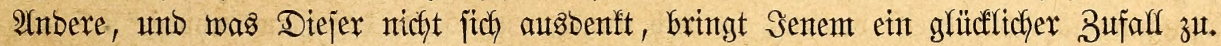

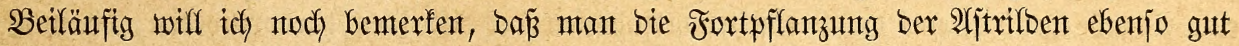
bis zu eintem gewiffien (Srabe regeln fant wie bie Brutzeit ber Welfenfitttche, unto zwar genau nach benjelben (Srunbjäbent, intbent man wäfrento ber ungünjtigen Wintermonate bie

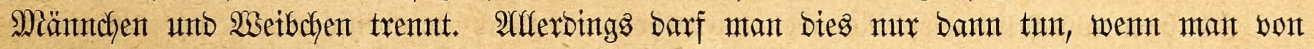

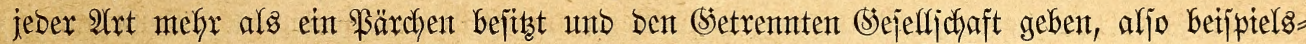
weije zwei Miämnchen und zwei 2 Seibchen zufammentperren fant. WBie bei ben 2 (mabinen

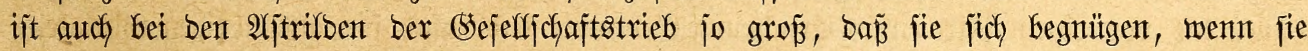

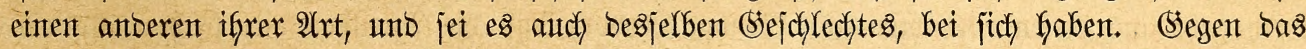

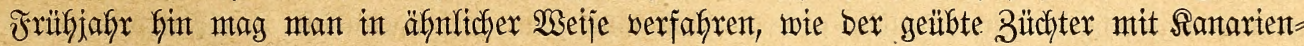

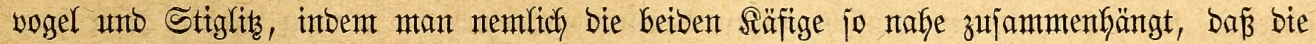

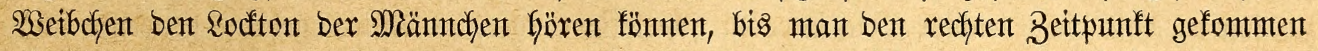
glaubt, fie zujammenzubringent. Sn ber Regel wirb jebes Miämnchent fitch Gald mit einemt WBeibchent paren, Zanf unt Unfrieben zwijchen ben jonjt bisher fo frieblidgen entjtehen und

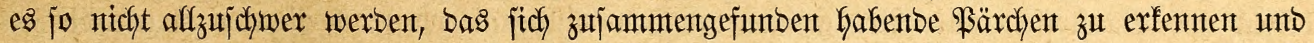

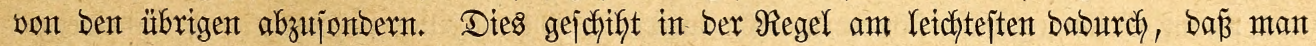

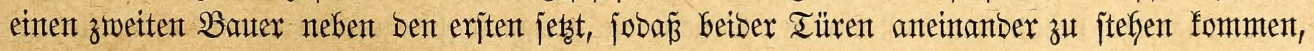

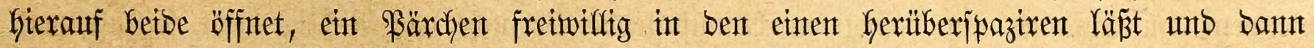

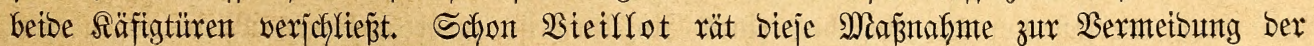

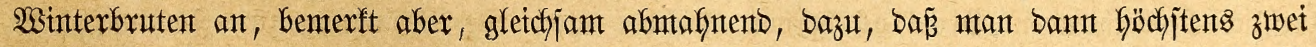

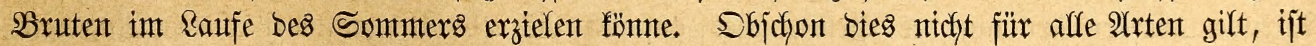

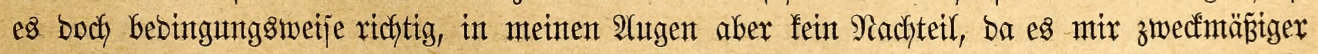

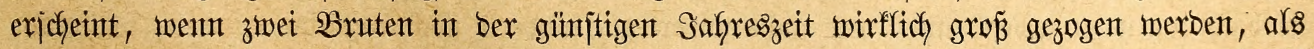

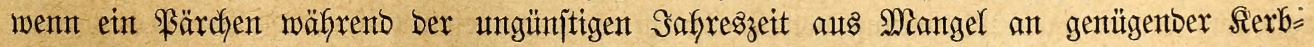

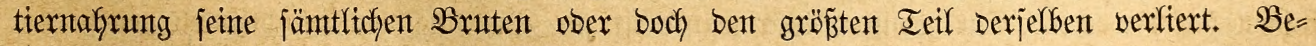

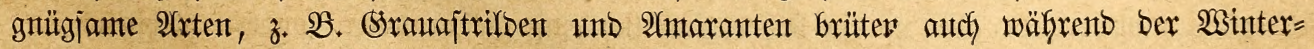
monate ofne exthebliche Nactyteile.

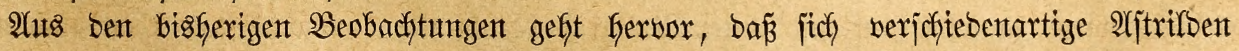

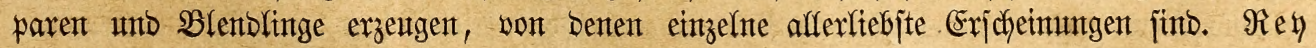




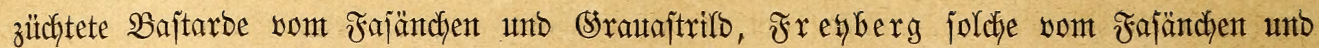

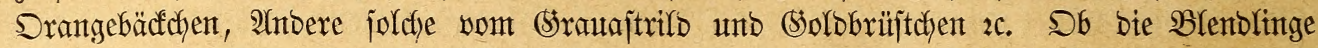

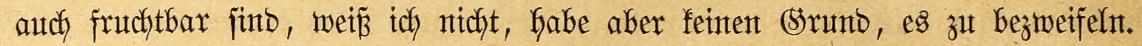

Int alfgemeinten reicken wir unjeren gefangenen ajptrilben biejelben Futterjtoffe,

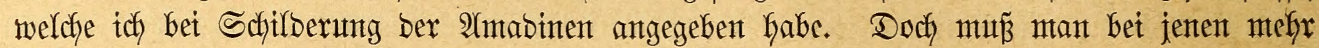

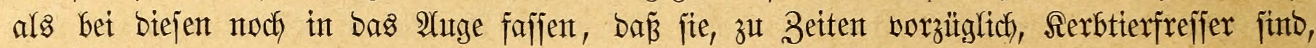

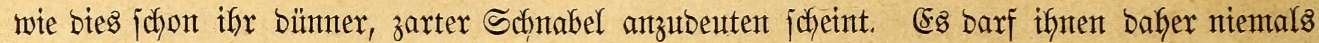

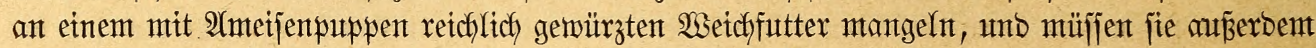
noch) jo viele Mefliwümer befonmen, als fie freffen wollen. Währenb bes Sonmers verjorgt mant fie mit anberen Sierbtieren, wie man fie gerabe bejchaffen fann, je mefr fie bavon wer=

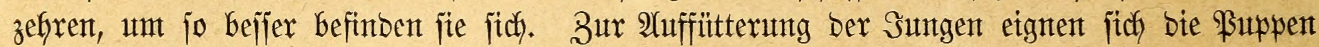
ber weiter oben ermähnten flemen roten unb gelben Almeifen, weldye befanntlidh nirgenos jelten jutb und fajt unter jebem Steine gefunten werben, ganz bejonbers, und nur in ers=

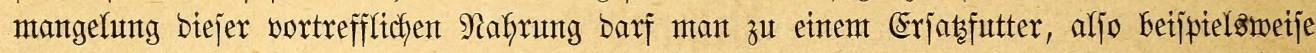

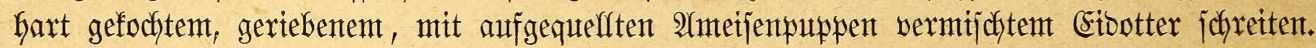

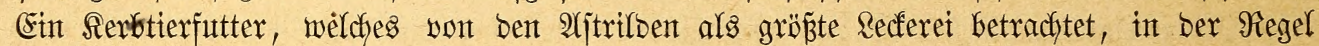

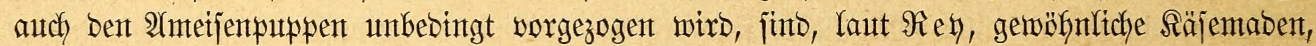
weldye man fajt jeberzeit leidht unb in ziemlicher Mienge bejdhaffen fant. (Srünzeug freffen bie afjtriben ebenjo gern mie bie meiften Finfen überhaupt; auf weidhe Antospen find fie förmtlich gierig, namentlich wenn mant ifnen biejelben abbridft und zerjofnetbet. (Se= quetjdyter Şanf barf immer mux in geringer Menge gereidft werben, weil er bas (s)efieber

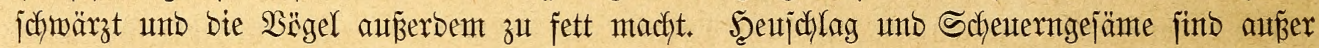

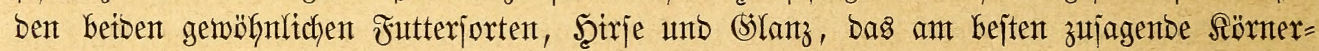
futter für alfe 2 litrilben.

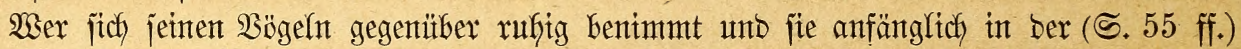

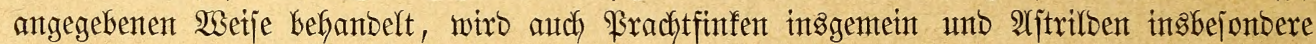
an fich gewöfnen. Sie werben, namentlich unter ber \$flege von Jrauten, balb auper=

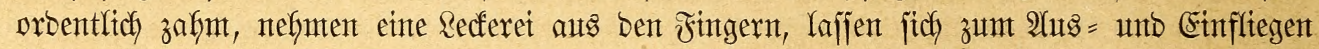

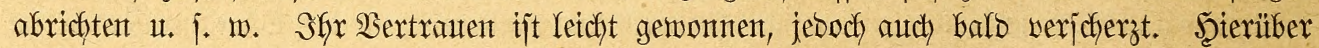

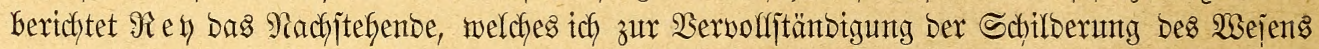
unferer $\mathfrak{B}$ ögel noch anfï̈fren wifl. "In meinem Sogelzimmer hatte idy zum bequemeren

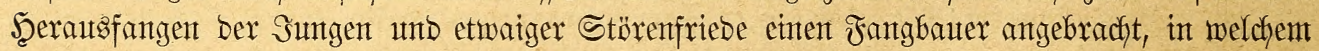
Das Sïrnerfutter ftand, unb Deffen Tïre won meinem Zimmer aus Durch eine Sdyntr ge=

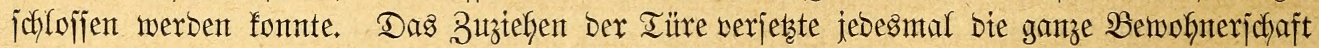

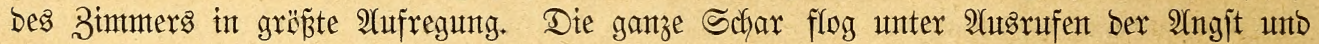
bes Sdyecfents wilb Durch eintanber, unt erjt nadh geraumer Beit legte fich ber Afufrufyr ein wentg. Dann waren es immer bie aljtritben, weldhe zuerjt ifje Neugier befriebigen

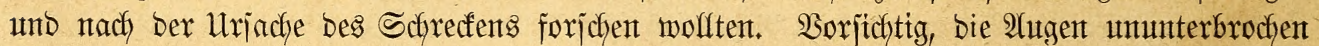
auf ben gefäfrlicken $\mathfrak{B a u t e r}$ geridytet, Den Şals lang gejtrectt unt bas (sefieber bicht an=

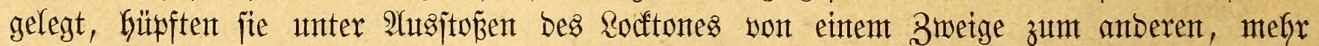
und mefy fidf nähernt, aber immer bereit, bie Fludft zu ergreifen, fobald bie Türe fidh

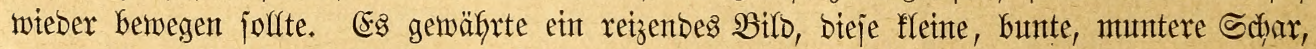

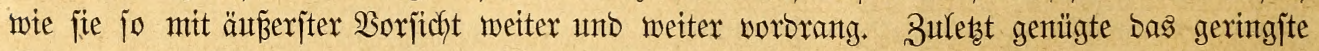

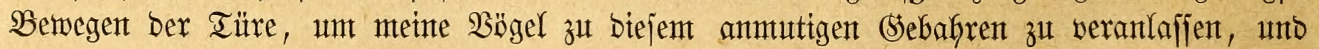
fonte idh jebent Bejucher bie brollige Scene vorführen."

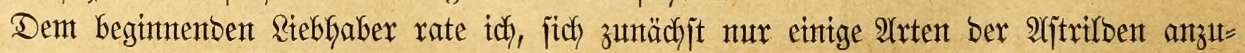

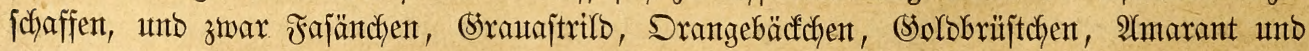
Rotbürzel, weil bieje zu Den genügjamjten (Stlebern ifrer (Struppe zählent und bem entjprectjento 


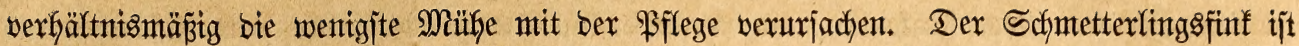

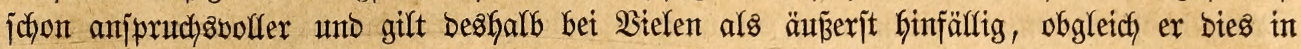

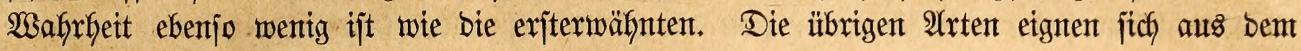
(Srumbe nidyt für Sebermann, als fie nur jelten auf umjeren Marft fommen unb beshalb noch ziemlicty hody int Preife ftehen.

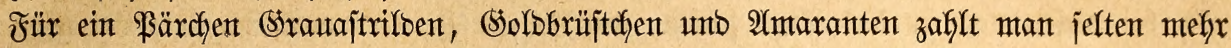

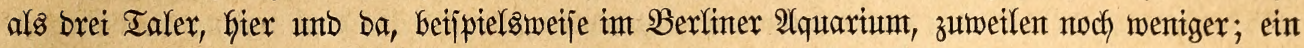

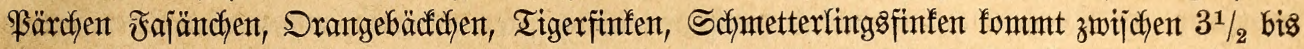

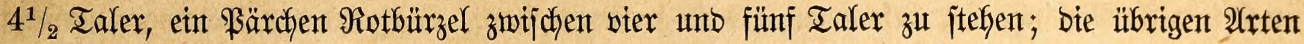

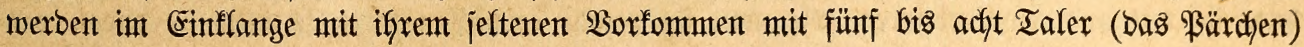
bezahlt.

\section{Dihweler.}

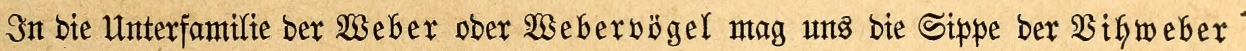
(Textor) einfüfren. SGre Mitglieber find fräftige, gebrungen gebaute $\mathfrak{B} \not ̈ g e t$ von Staren=

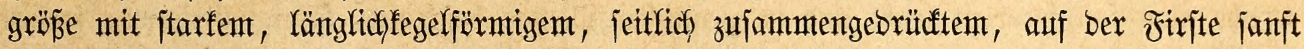

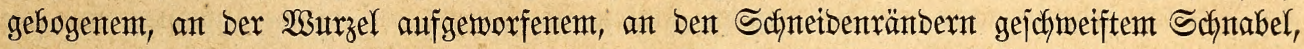

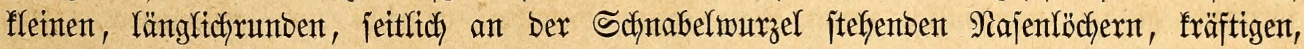

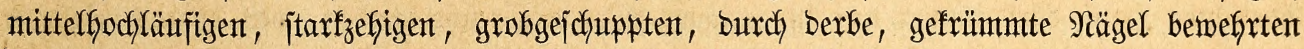

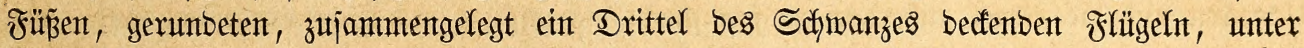
berent Schjwingen bie vierte ober jünfte bie längjte zu jein pflegt, mittelfangent, ftarf ge=

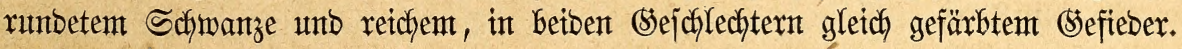

459. Der 9leftunogel, Whojderef Dex 2rbeffinier, Textor (Dertroides, Alecto, Alectornis) alecto

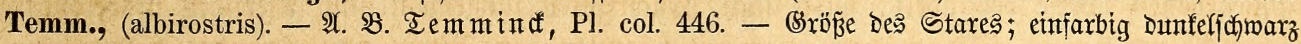

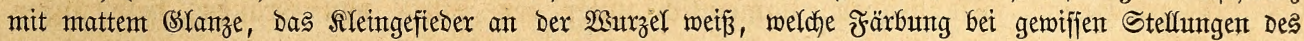

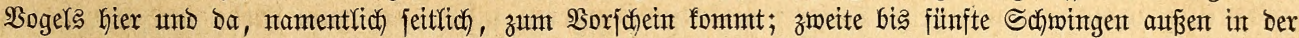

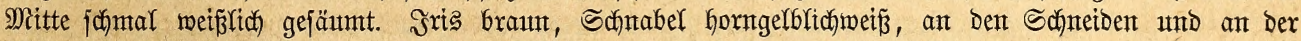

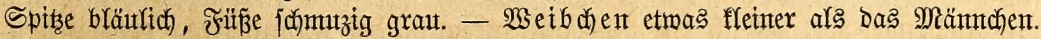

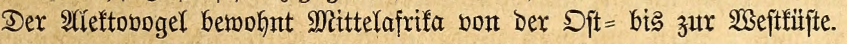

460. Der $\mathfrak{B u ̈ f f e f w e b e r , ~ T . ~ ( B u b a l o r n i s , ~ A l . ) ~ e r y t h r o r h y n c h u s , ~ S m i t h , ~ ( n i g e r ) . ~ - ~} \mathfrak{A} . \mathfrak{B}$. Sm $\boldsymbol{S}_{\text {th }}$,

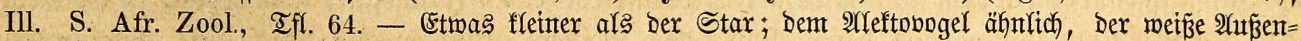

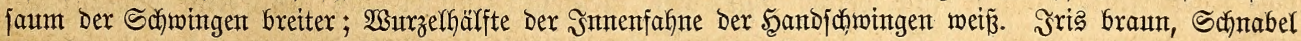

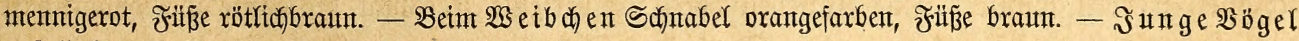

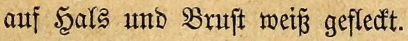

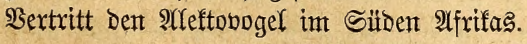

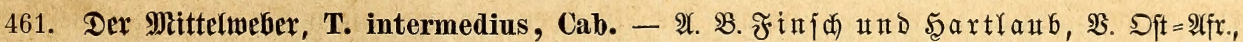

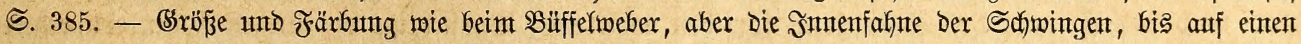

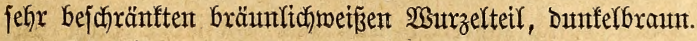

Ditairifa.

462. Der Bihmeber, T. (Al, Dinemellia) Dinemelli, Horsf. (leucocephala) - $\mathfrak{A}$. $\mathfrak{B}$. $\mathfrak{F}$ in $\{$ क

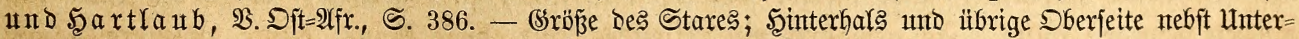

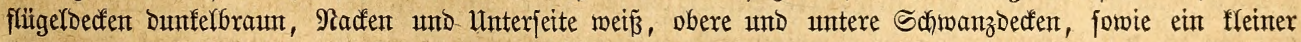

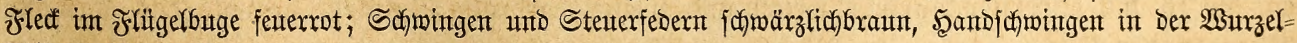
hälfte weî́.

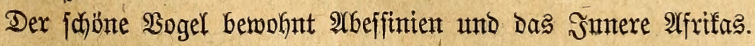

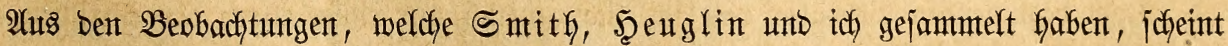

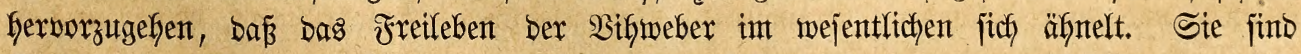

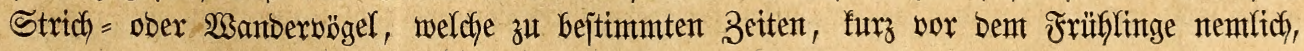




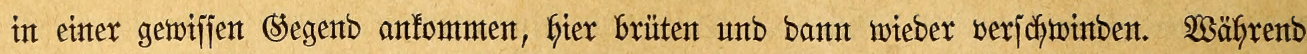

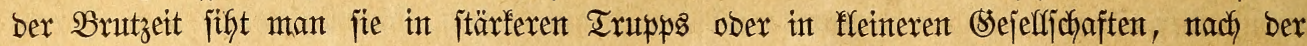

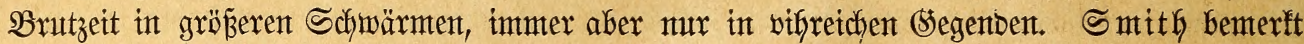

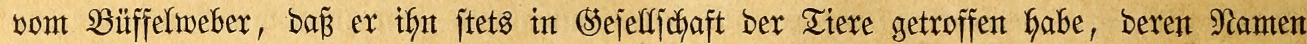

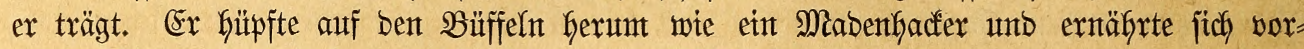

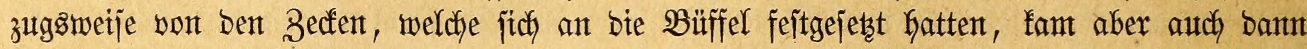

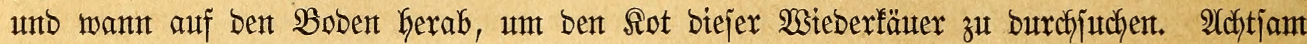

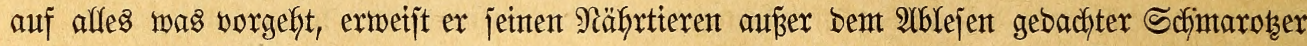

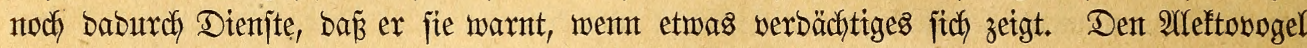

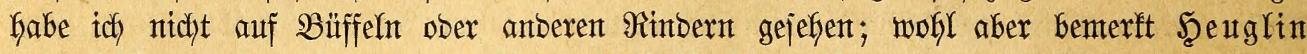

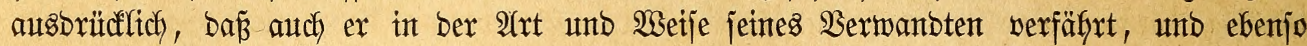

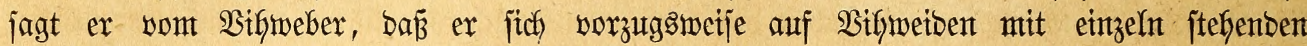
Bä̈uten unt (5ebüijchen aufgalte.

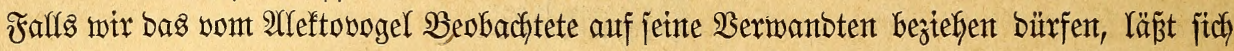

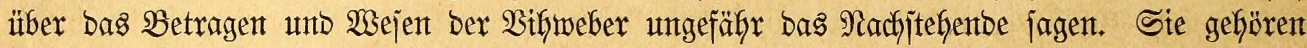

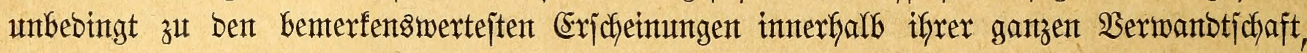

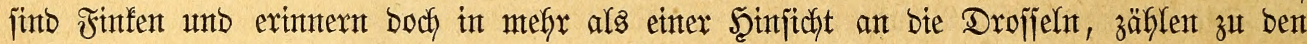

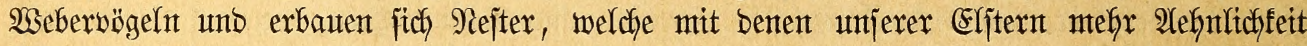

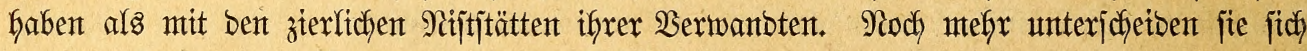
von ben Yetzerterent int Betragent unto int (Sejedret.

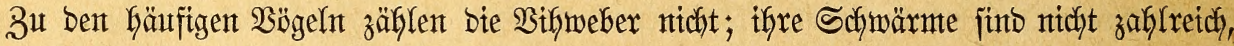
weil jeber einzelne eine abgejonberte Nifitanfibelung bifbet und an bieje fich binbet. Won

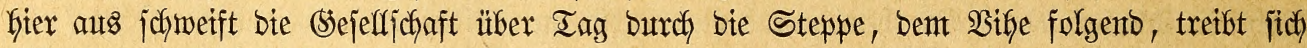

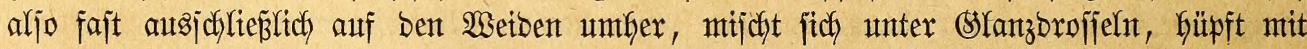
biejent nach Starentart unther, bejucht einen ober ben anberen iffrer geförntent orreunbe, reinigt ifgn von ben Schmarotern, jammelt jich wieberum auf einem paffentoen Baume, lärnt unt

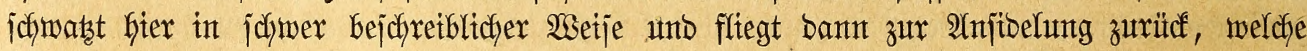

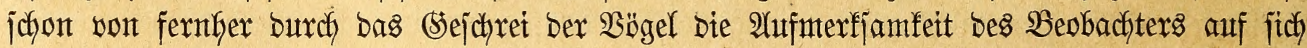

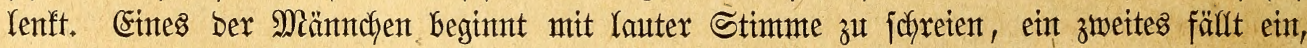
ein brittes gibt jeine Täne bazu, unb balb lärnt bie ganze Bejelfichaft wirr burcheintanber,

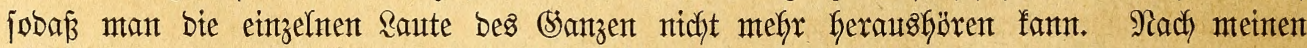
Beobadytungent lafjent fich bie jonberbarent Iöne burch bie Silfent $t i$, ti, terr, terr, terr, zerr, zäh unb gai, gai, zäh; guif, guif, guff, guf uttb gü, gü, gü, gü, gäh eintgerntaß̃ent

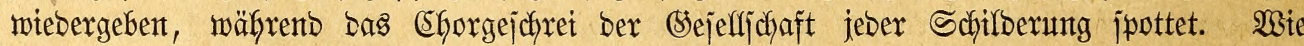

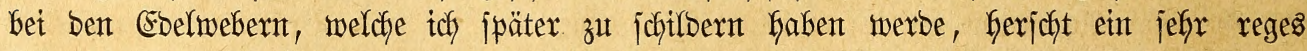
Reben in ber Sibeluntg. Utmuterbrochen fonmen, umunterbrochent gehent eintge von ben

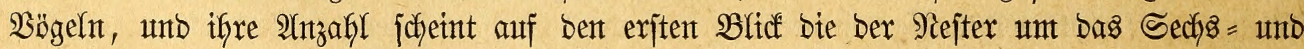

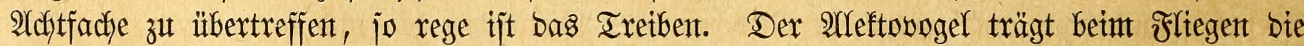

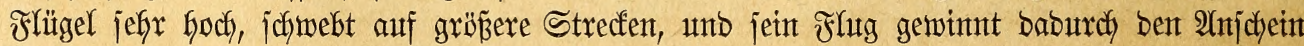

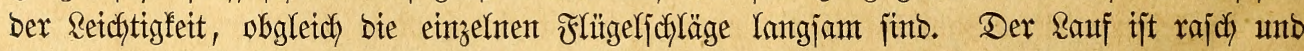

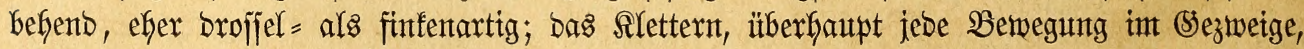
erintert an bie Bewantbtheit ber $\mathfrak{B}$ erwantent.

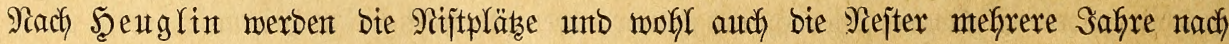

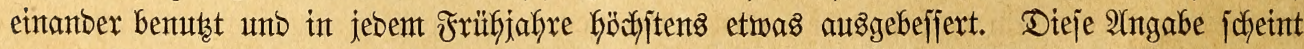

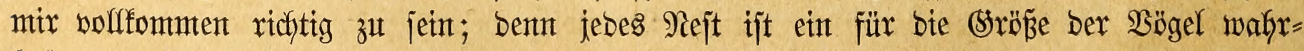

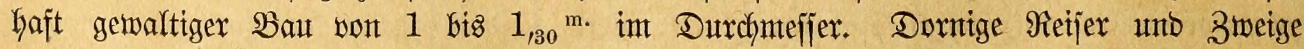

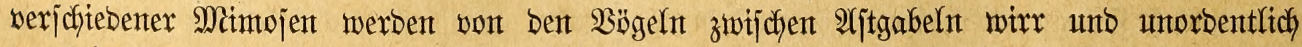

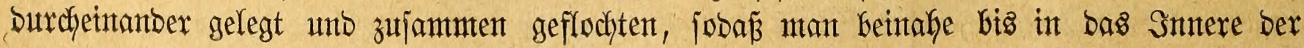




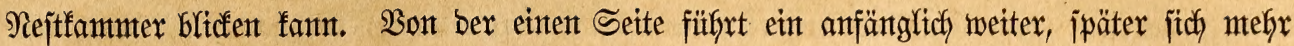
verengentber Eingantg in bas Sntere, welches nicfft nur einent, fonbern brei bis actit \$arent

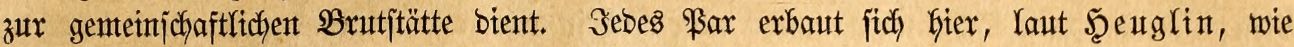

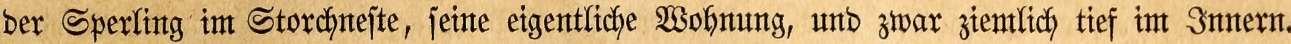

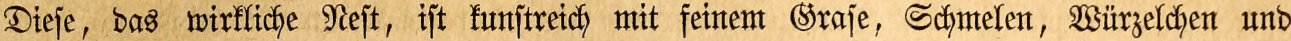

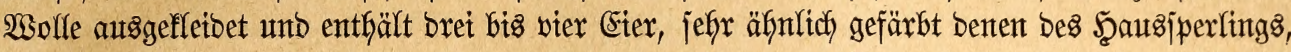

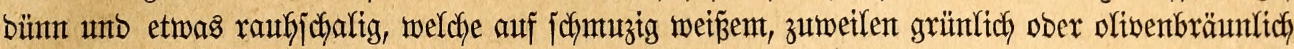

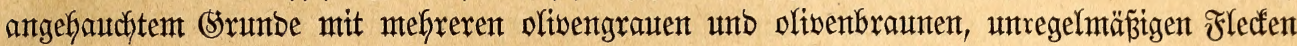

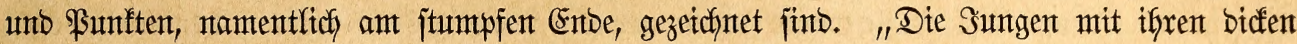

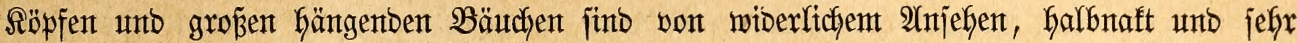

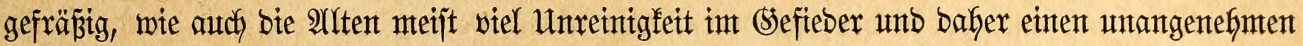

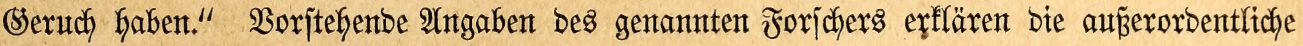

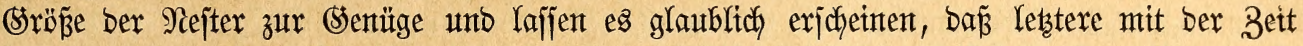

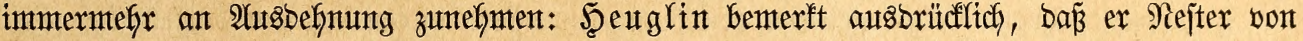

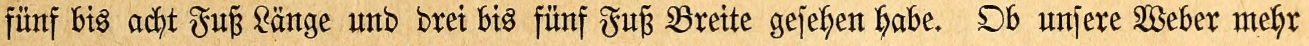
als eite Brut int Saffre erziefent, vermag idh nidht zut jagen.

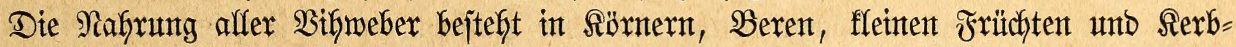

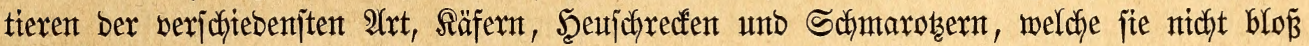

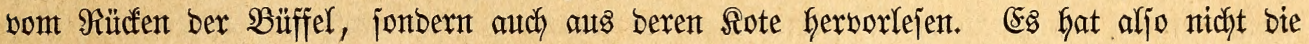

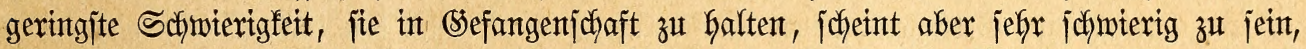

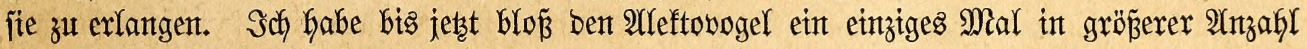
auf unjerent Marfte gefutbent unb bavon vier Stülde ermorben, weldye noch heute int bejten

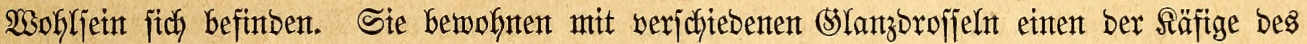

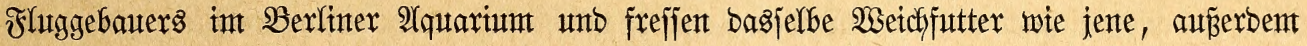

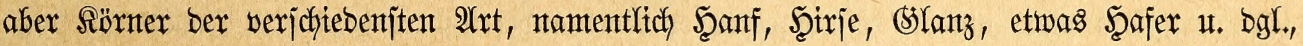

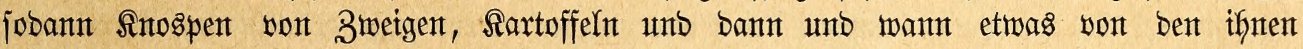

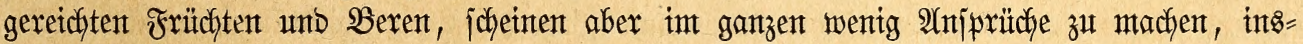

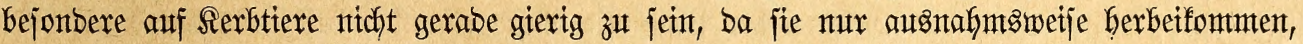

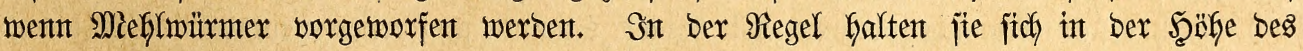

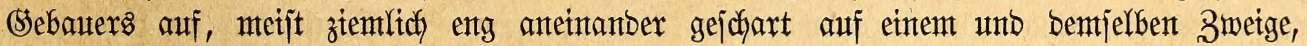
ofyte fidy bejonders bemerflid zit mactjen.

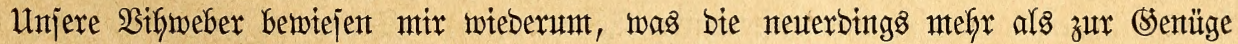

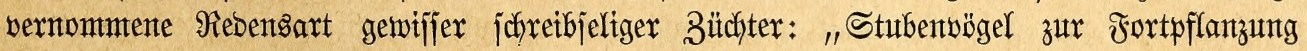

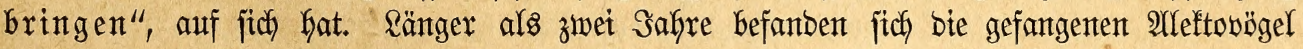

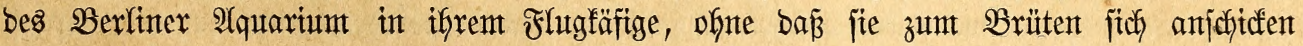

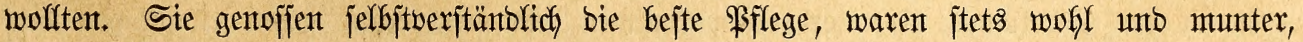

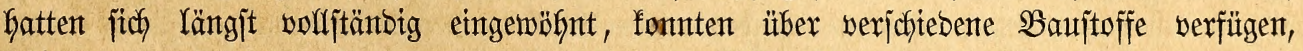

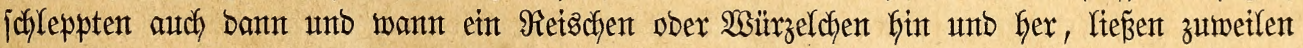

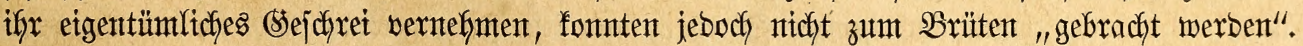

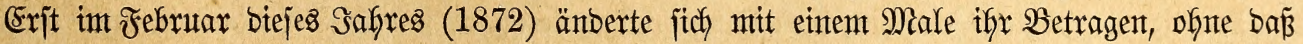

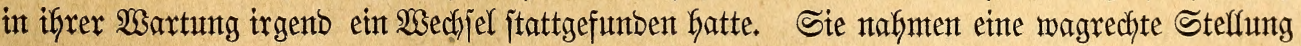
an, Gogen ben Ropf herab unb betwegten Flïgel unb Schwantz in äfntlicfjer WSeije wie bie

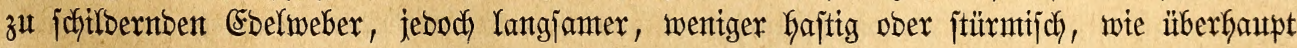

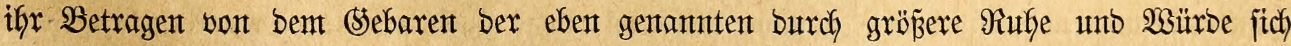
unterichetbet. Seşt wurbe ifynen ber nötigite Bauftoff, Bejenreifich, in gentügenber Menge worgeworfen, unt augenblicflids gingen fie ans $23 e r f$. Einer begann, ber zweite folgte, ber

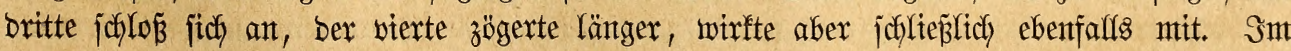

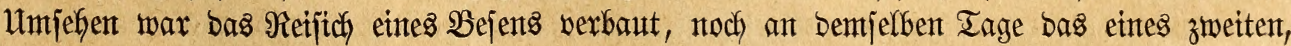


britten, bierten; nach brei Iagen Gatten jie bereits zefn şejen verbraudft, anderes, itär=

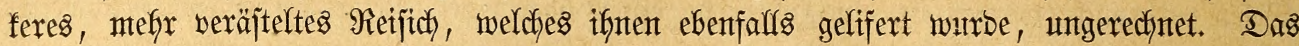

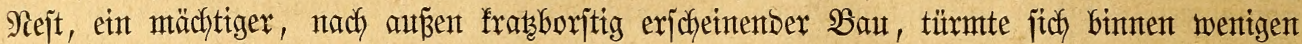

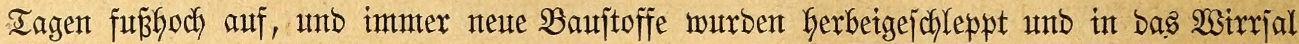
eingefügt. Dies gejdyaf feinteswegs ofne Heberlegung, im (Segenteile nady einem vorher fejtgejtellten \$lane und mit enticjiebenem Sejchidf. Uluf einem Unterbaute von etwa $9 \mathrm{~cm}$.

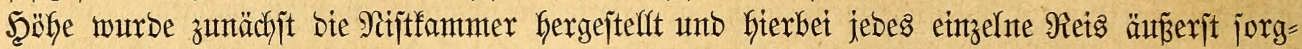
jam in bie rechte Rage gebradyt. Ein $\mathfrak{B}$ ogel baute, ber zweite und oft autch ein britter

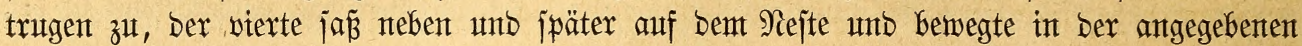

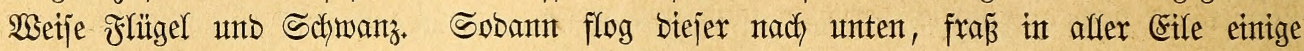
Broden, meijt vom $\mathfrak{B e i d j f u t t e r , ~ p a d t e ~ e i n ~ \Re e i s ~ m i t ~ b e m ~ S c h n a b e l , ~ w a r f ~ e s ~ m i e b e r ~ w e g , ~}$

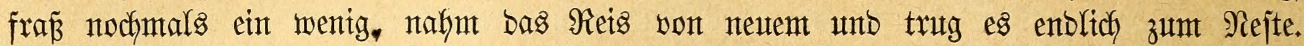

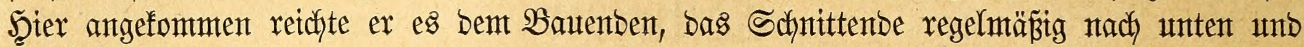

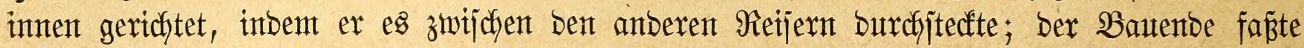
es mit bem Sdynabel, zog es jo weit Gereint, als ifym erforberlid fdjen, unb oronete es in zujagender 2 seije. In ïberrajchend furzer Beit entjtant jo ein laubentartiges Seripp der

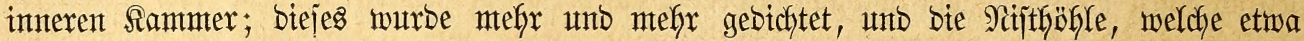
$18 \mathrm{~cm}$. int Durdhmeffer bält, war bis auf bie 2 ltsłfletbung mit weicheren Stoffen fertig.

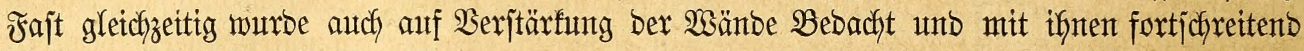
bie lange Flugrökre in 2 ngriff genommen, berart, baj bieje mit ben immer bidfer werbenton Wanbungen fich mebr unt mefyr berlängerte.

Welches won betben (Sejchlechtern eigentlich baute, fonnte mit Sicherfyeit nicht fejtgejtellt

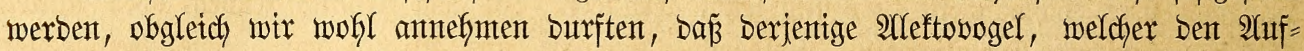
bau bes ঐejtes mit io Yebhaften (Seberben, Flügeljolägen und Sdywanzbreiten, beglettete,

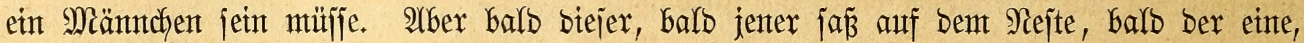

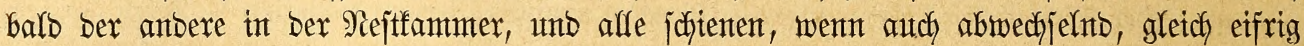

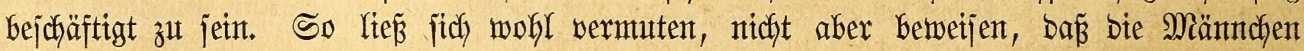
3uträger, bie Weibchen $\mathfrak{B e r a r b e t t e r ~ D e r ~ B a u j t o f f e ~ j e i e n . ~}$

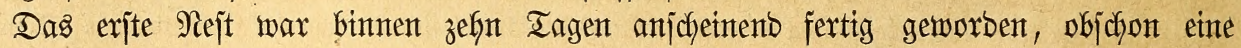
innere 2 (1tafletbung mit weidferen Stoffen nicht jtattfand. Es entiprach im alfgemeinen

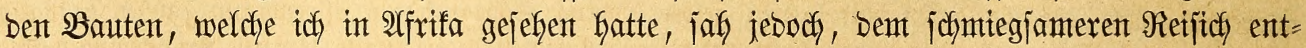

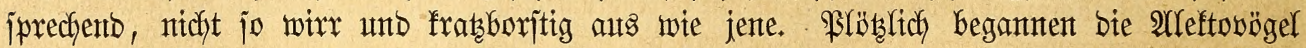

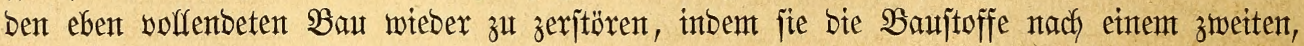

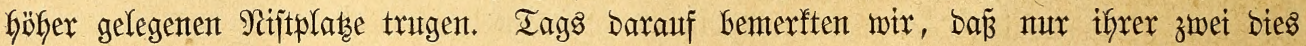
ausfüfrten, während bie betben anderen bas untere ঐejt fortwährent burch frijche Baujtoffe wieber ergänzten. Einer von ben oben Bautenten nafmt aud wohl bent zumt unteren Nejte Tragenden bas Reijidy, nidht ohne Geftigen 2 siberjtant aus bem Sdynabel weg, plärrte ifn wentgitents an, went ex mit einer neten Rabung exjchten. Âm vierten 2 (pril begant bas (Segenjpiel: Die eigenjuntigen Bögel fingen an bie Bauftoffe wieber nach unten zu tragen, anfänglich mefr iptelento als Den Baut wirflich förberno, ifn burch fleipiziges 2 frbeiten am

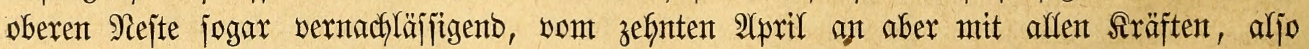
gemeinjam weiterfüfrent. Arfe vier trugen von obent ab, und nux, went ber eine ober anbere zum Futternapfe herabflog, nahm er von bier ein Reisdjen mit auf und trug es

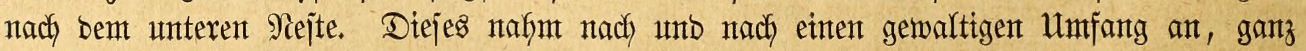

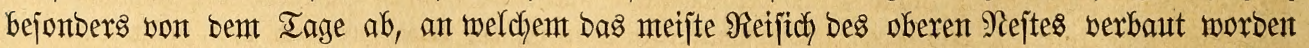
war. Sechs bentlich jichtbare Röfren füfyrtent in bas Intere, an anberen jojten gearbeitet

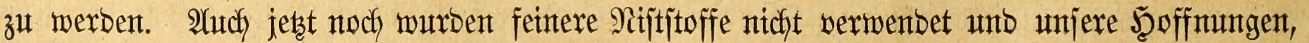
bie Bägel enolich zum Eiterlegen jayreiten zu jeben, minbejtens in weitere Ferne gerïcft. 


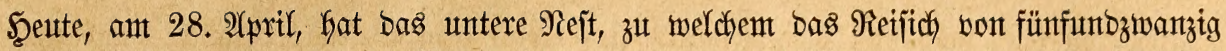
Bejen verbrautfft worben ijt, eine Säbe von etwas über einen Mieter, bet einem Durdjmefjer

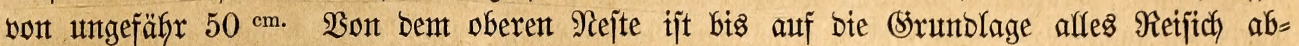
gefolt werben, unt nod bemüft fich biejer ober jenter, ein unto bas andere Rets von hier ab= zutragen, unbefümmert um bie Walbhüttenjperlinge, weldye ifyx 2ejt bereits in ben unteren

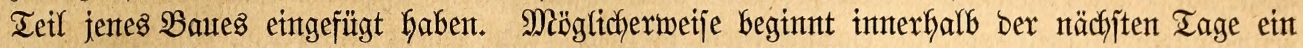

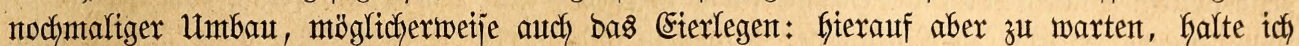

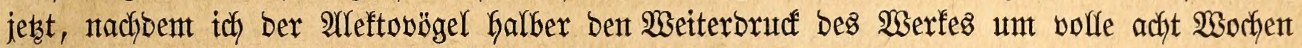
verzögert habe, für burchaus unratjan, umjomefrx, als idh über bas Enbergebniz in ben

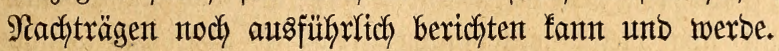

\section{Einelweber.}

Den Siern ber Unterfamilie bilbet bie Sippe ber Ebelweber, beren Merfmtale folgento finto: Der Schnabel ijt ebenjo lang ober etwas fürzer als ber Siopf, breit an ber Wurzel, jeitlich gegen bie Spitse fin zujammengebrüdft, auf ber an ber $\mathfrak{W}$ urzel breiten, flach gerumbeten

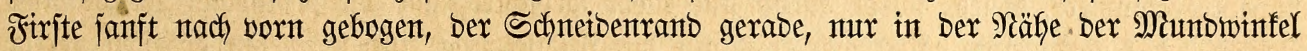

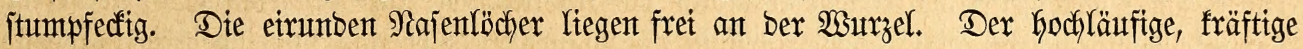

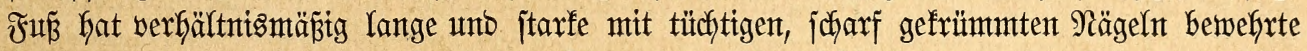
Behen, beren mittlere bem \&aufe an Ränge ungefähr gleich fommt. Int Flügel, welcher zujammengelegt etwa ein Drittel Des Shmanzes bedft, pflegt bie vierte Sdyninge bie längjte zut jeint. Der Sifmanz ijt furz unt jeidst geruntoet. Sin bent jiemlidy reichen, aber glattent

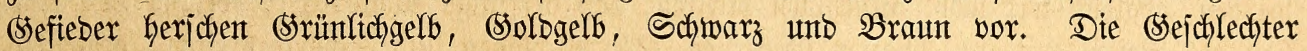

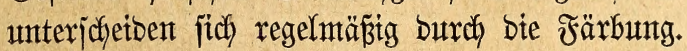

463. Der Riejenweber, Hyphantornis (Ploceus) grandis, Gray, (collaris). - Wergr. Fra fer,

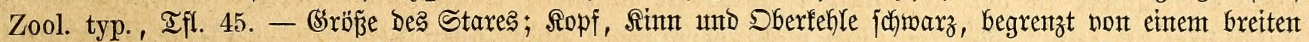
taftanienbraunen Bande, meldees oberjeits bis an ben Mantel reidft, unterjeits biz zur Bruft fich herab=

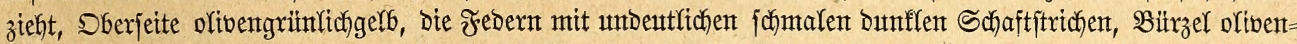

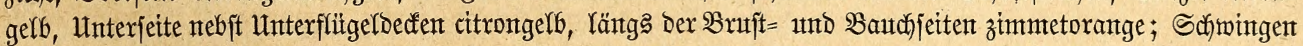

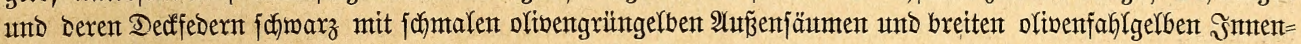

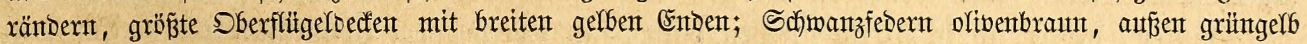

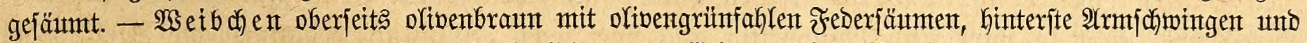

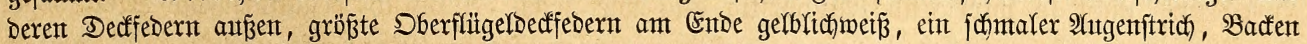

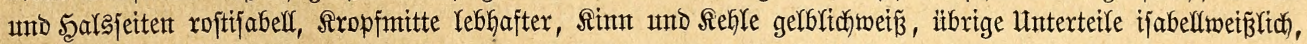

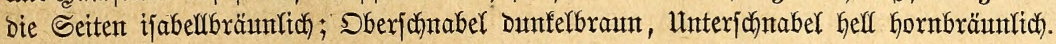

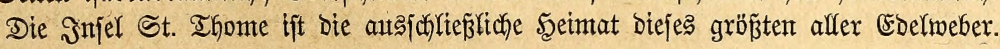

464. Der (Snlomeber, H. (L., Coccothr., Oriolus, Fr., Ploc., Text.) melanocephalus, Gml., (gambiensis, textor, longirostris, senegalensis, modestus, magnirostris). - $\mathfrak{A}$. $\mathfrak{B}$. $\mathfrak{F}$ artfaut $\mathfrak{6}, \mathfrak{W}$. $\mathfrak{A f r}$.,

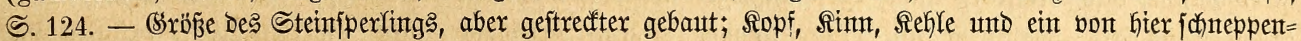

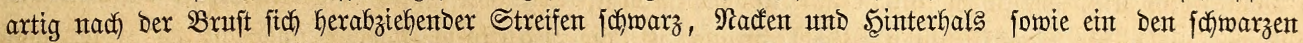

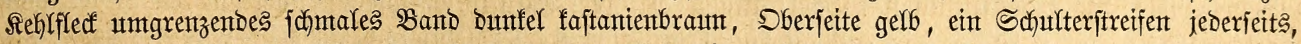

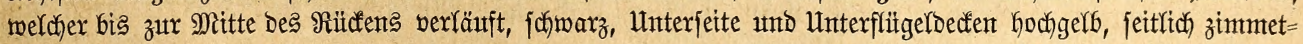

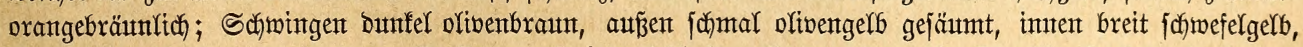
Gintere Armidjwingen unt Deren Dedffedern breiter Kebhaft gelb gerantet, bie Dberflügeldectent ebenjo am

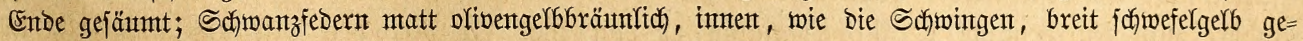

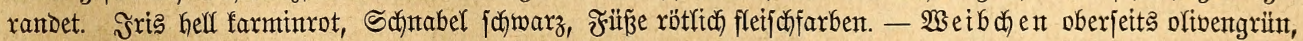

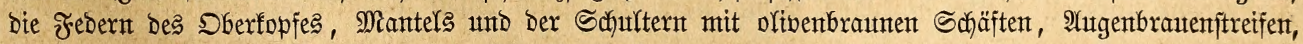

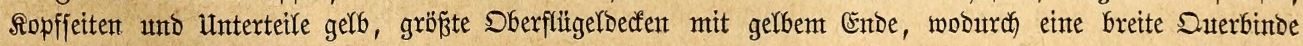

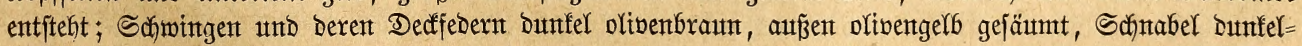

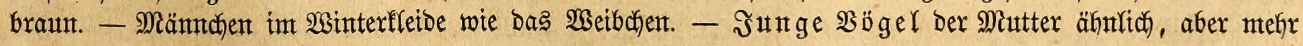
gratgrït. 


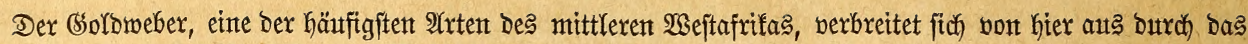

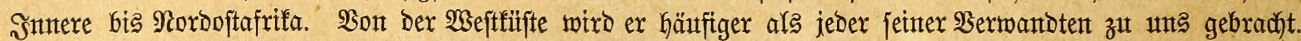

465. Der Mtafenweber, H. (L., Pl., T.) abyssinicus, Gml., (larvatus, flavoviridis). - $\mathfrak{A} . \mathfrak{B}$.

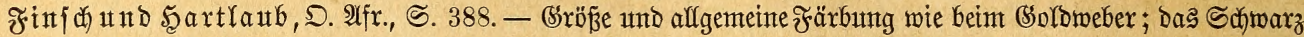

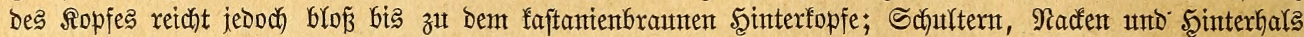

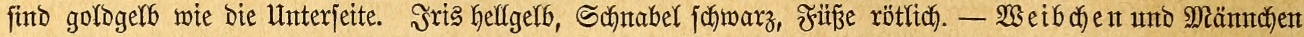

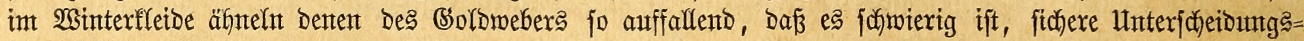
fentrzecthent anzugebent.

Vertritt bent vorhergehentent in Norboft = unto Sftafrifa.

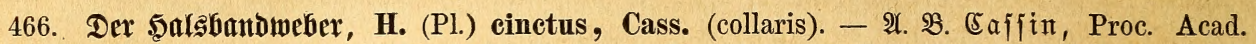

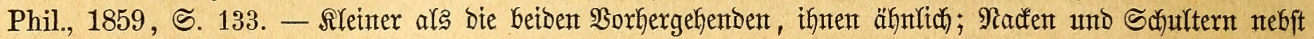

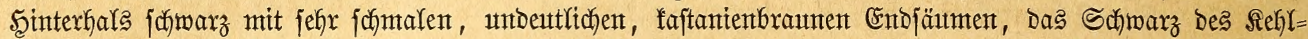
ftreifens, weldyer Die Breite Des ganzen Sropfes eimnimmt, Dunfer faftanienbraun begrenzt, Federn Des Miantels

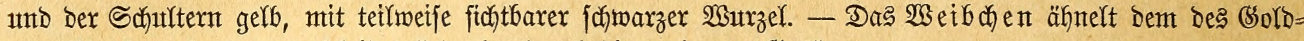

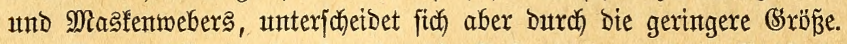

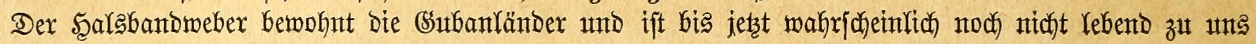
gebracht worbett.

467. Der Sdfleierweber, H. (Pl., Ploceolus) velatus, Vieill., (aureicapillus, nigrifrons, aethiops). -

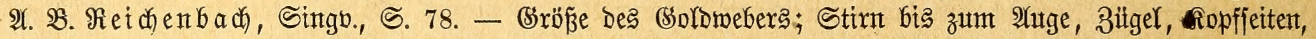

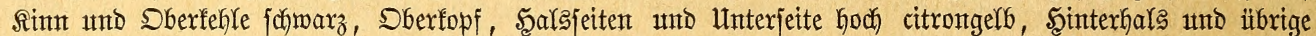

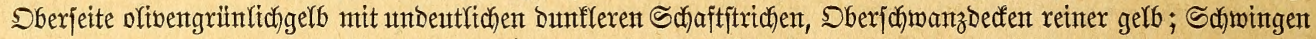

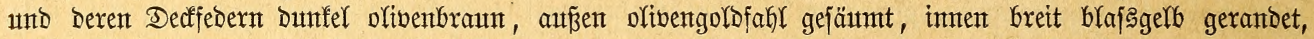

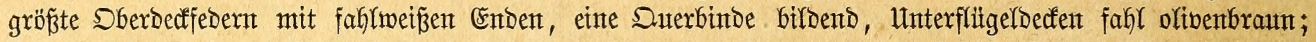

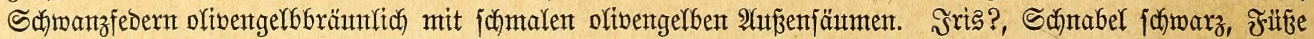

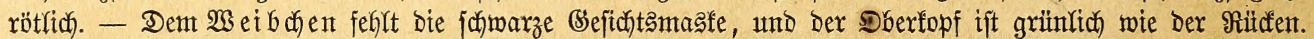

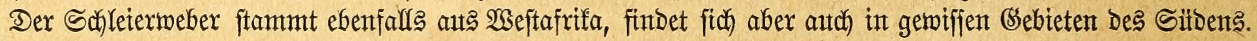

468. Der Sniranwelier, H. (Fr., Pl., Ploceol. Hyphanturgus, Sitagra) luteolus, Licht., (perso-

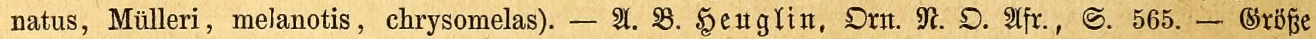

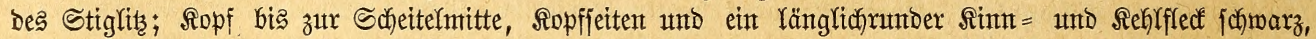

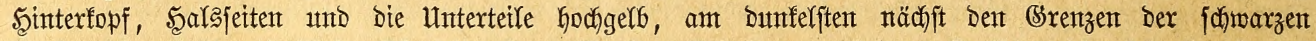

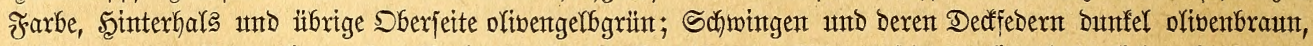

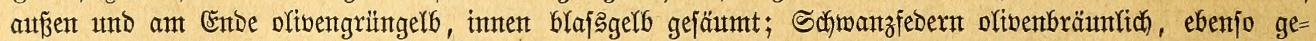

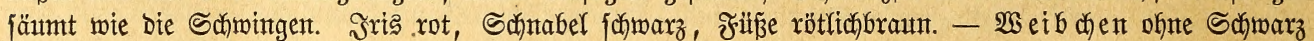
am Iopfe.

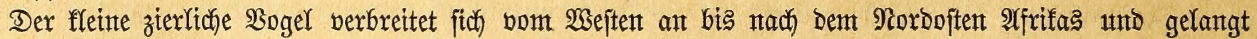

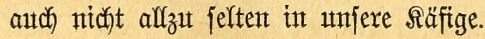

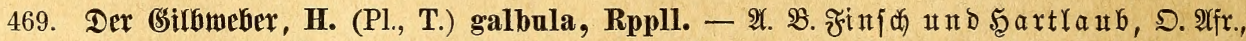

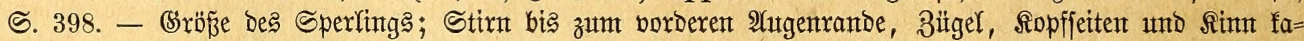

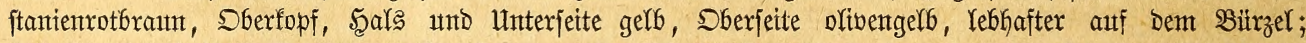

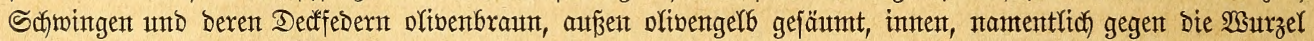

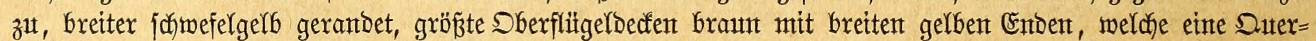

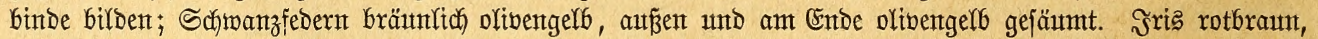

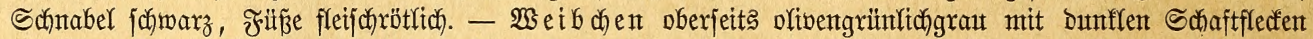

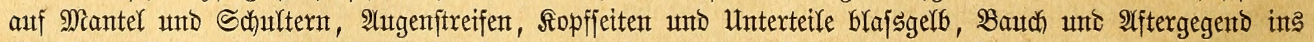

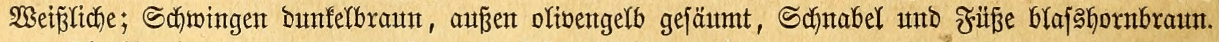

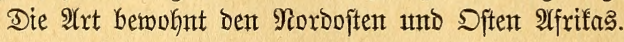

470. Der Feintmeber, H. (Fr., Pl., T., Ploceol., Xanthophilus) vitellinus, Licht., (ruficeps, sublarvatus, auranticeps, chrysopygos, flavomarginatus, sulfureus). -

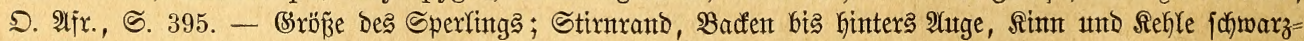

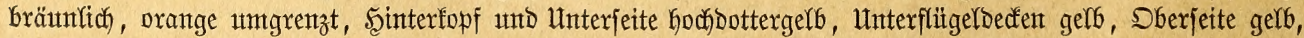

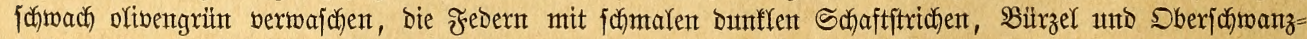

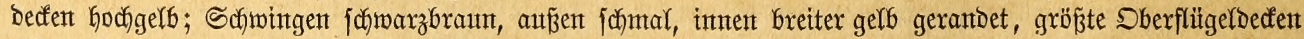

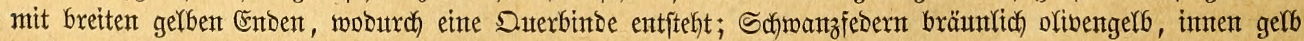

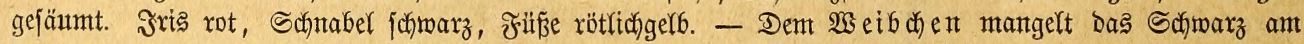




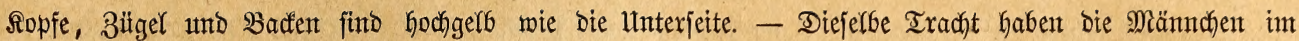
2Binterffeide.

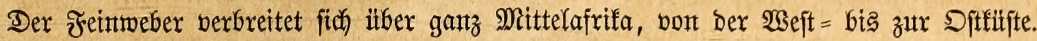

471. Der (SnlDiditeitefweber, H. (P1.) spilonotus, Vig., (stictonotus, flaviceps, cyclospilus). -

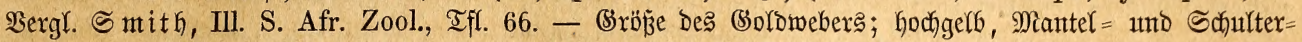

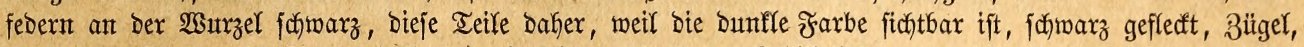

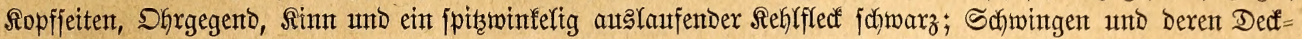

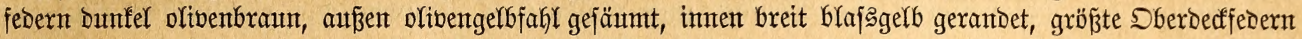

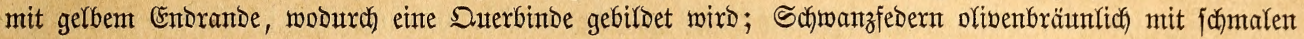

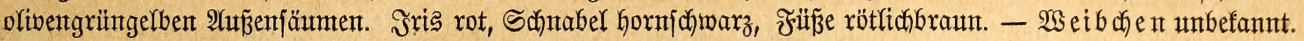

Der Sildoften Iffrifas ift bie Secimat biejes $\mathfrak{B}$ ogels.

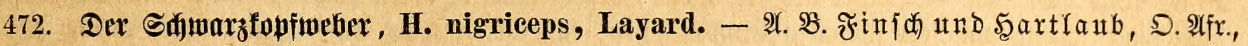

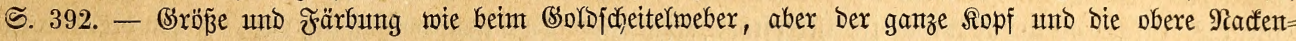

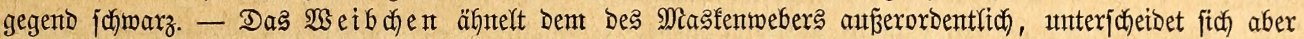

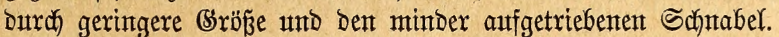

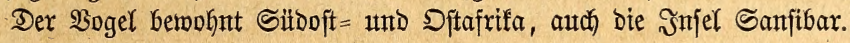

473. Dex $\mathfrak{B r i f l e t w e b e r , ~ H . ~ ( P I . , ~ H y p h a n t u r g u s ) ~ o c u l a r i u s , ~ S m i t h , ~ ( b r a c h y p t e r u s , ~ f l a v i g u l a ) . ~ - ~}$

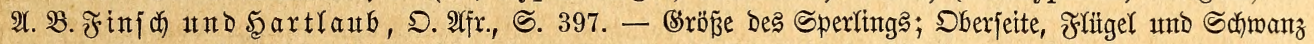

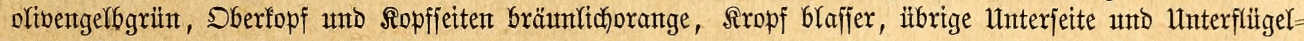

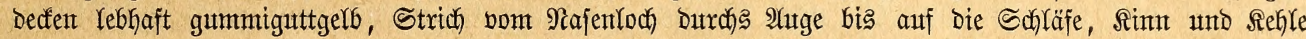

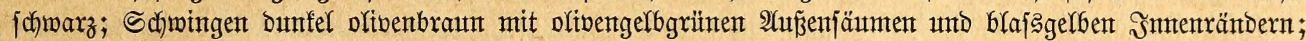

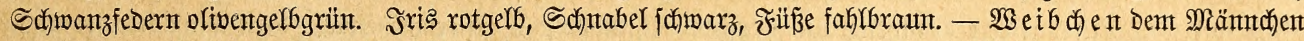

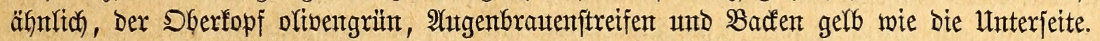

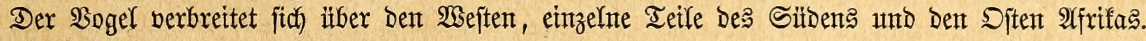

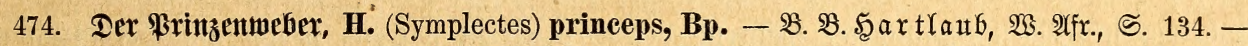

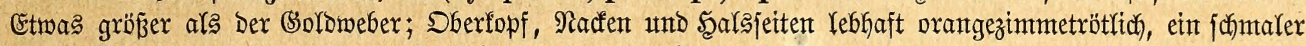
Strich) ïber Den Dunffen 3ügel, Ropffeiten und Unterteile nebit Unterflügeldecten Kod citrongelb, Sberjeite

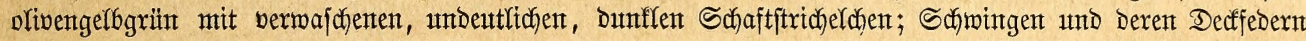

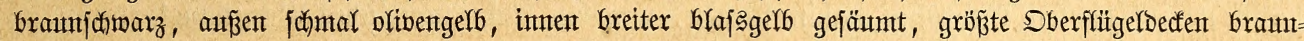

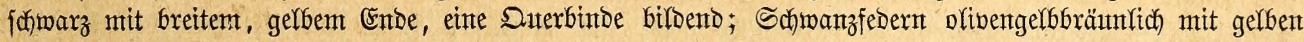

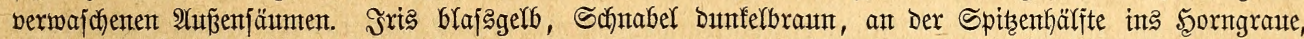

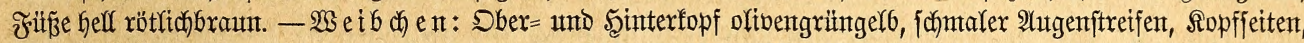

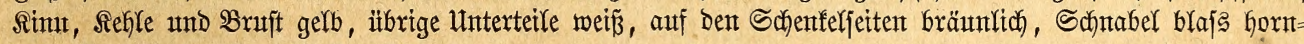

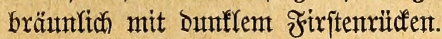

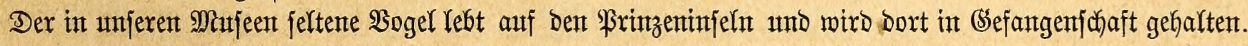

475. Der Sipmeter, H. (Pl., Or., Icterus, Oriolinus) olivaceus, Hahn, (capensis, cafer, auri-

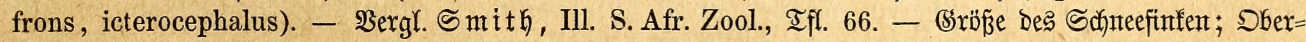

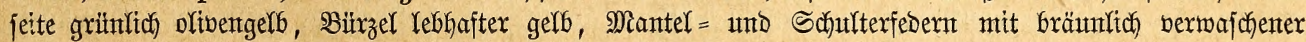

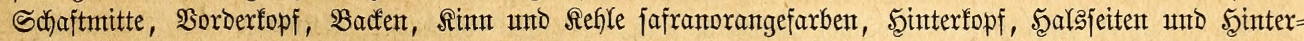

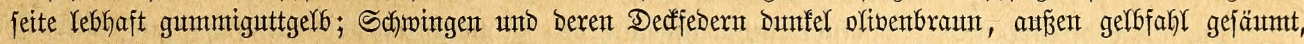

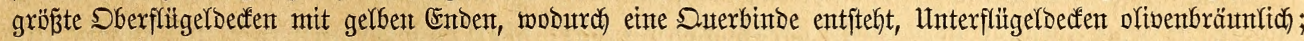

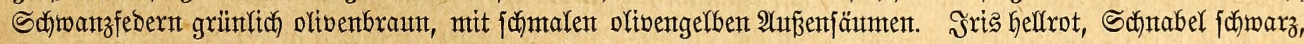

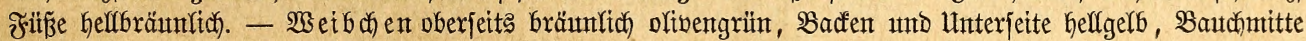

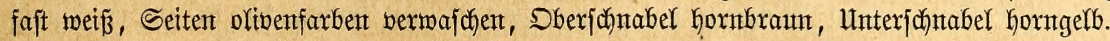

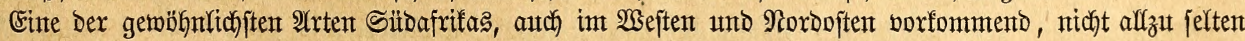
in utmexent Räfigett.

476. Der (Snlogilbweber, H. (Pl., T.) aureoflavus, Smith, (aurea, concolor, subaureus, au-

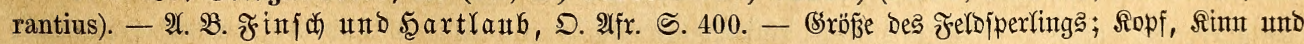
Refle bottergelf, ïbrige Unterjeite gunmmiguttgelb, Dberjeite olivengelb, zumal auf Demt Mianter; Sdimingen

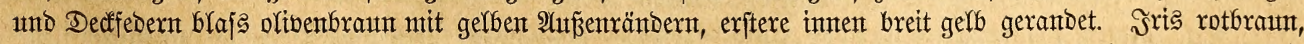

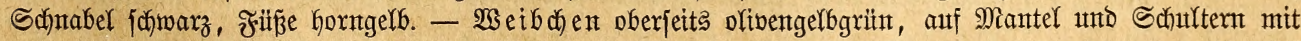

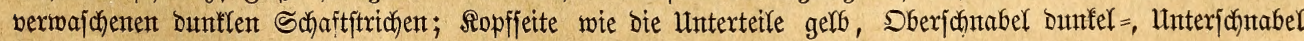
hellbraum.

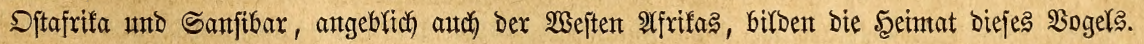




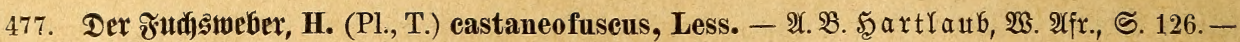

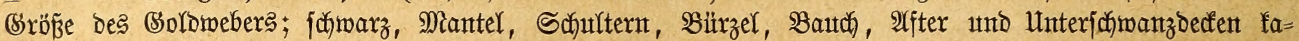

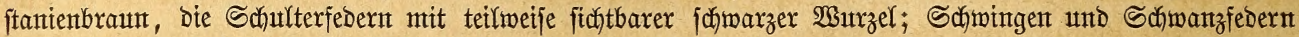

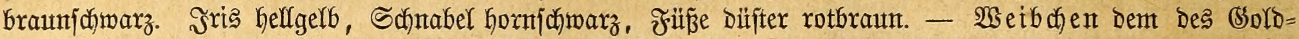

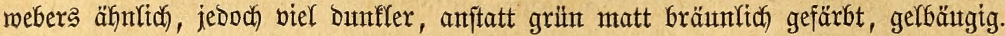

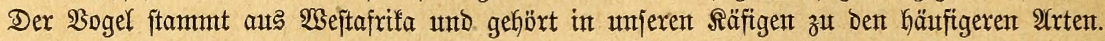

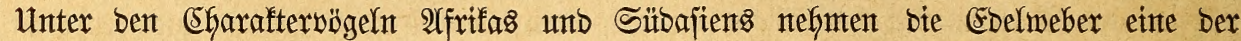

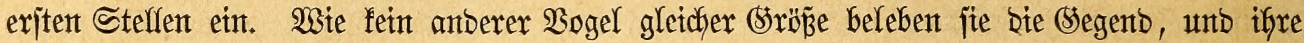

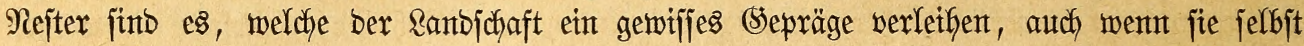
nicht vorkanben, jonbern eintem anberen Staue zugezogen jein jollten. Sebem Reijenden,

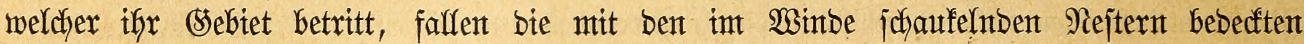

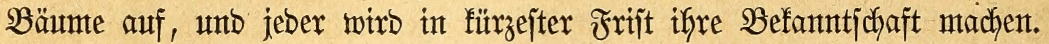

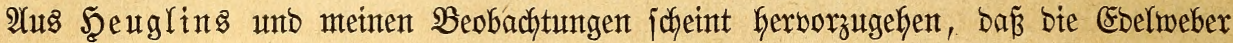

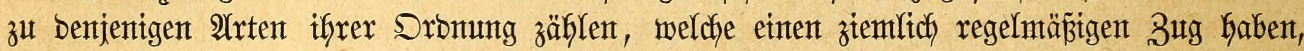
aljo aus gemifjen (Segenten zu bejtimmen Zeiten werjojwinden und zu bejtimmten Beiten

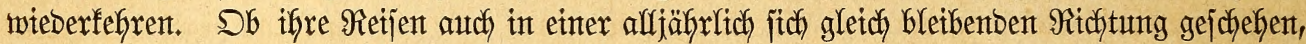

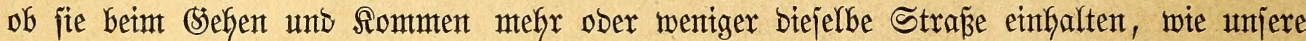
Bugügel bies tum, ijt zur Beit noch fraglich. SMeines Eradtens nach witro mant fie zut ben Wanter = unb Stridjögeln zu zäflent Gaken, welche, vom Nafrungsmangel getriebent unt von ber \&ujt, ifren Wofnjü zu veränbern, bewogen, nux währent ber Brutzeit an einer bejtimmten Dertlidbleit jich aufhalten, übrigens aber int santo umberjdyweifent. Fajt alfe

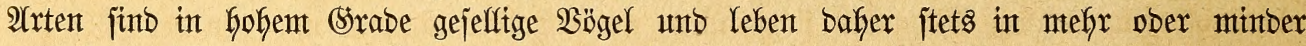

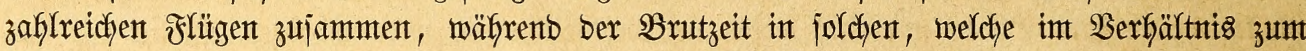

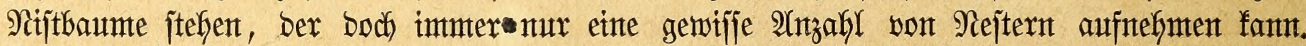

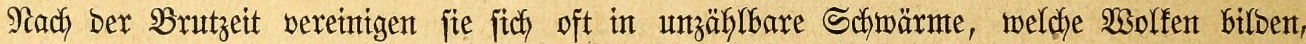
went fie in bichten sebränge bafint fliegen, unt ein unbejchreibliches Stemintmel, went fie

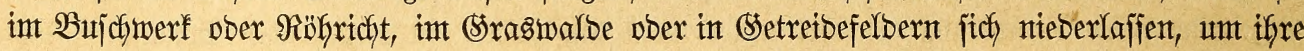
Nafrung zu juchen. Wie leidyt erffärlich), ridhtent jie ifre Wantorungen ober Streifereien nach Den Safreszeiten ber betreffenten Ränder unt Segenden, in Denen fie leben: fie erjcheinen

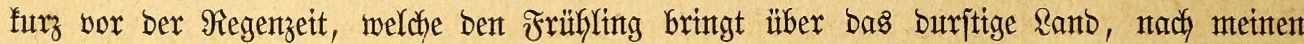
Beobachtungen ebenjo wie unjere 3itgö̈gel, nicht in grokent Flügen nemlich, jonbern eher parmeife ober boch mur in fleinen Sejelljchaften, jammeln fich aber auf bemt bereits benubten Sitftbaume ober einent anberen, weldyer ifyren 2 (nfforberungen entipridft, zut einer ntefr ober

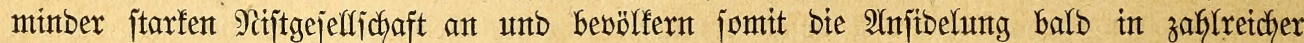

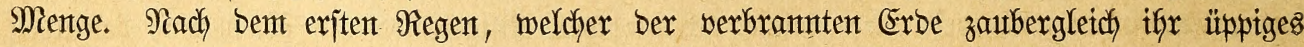

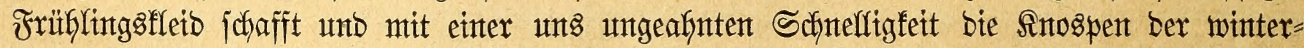
bürren Bäume iprengt ober einen (Srasteppich breitet über bas verburitete \&ant, ifnent arjo

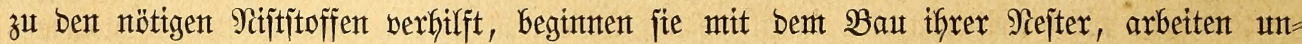
unterbrochen Iag für Iag, wont Morgen bis zum 2 (bento, uno baben jo in überrajchento furzer Beit bie Brutwiege volfentoet, nijten, füttern bie erite, bie zmeite Brut groß̧, nody

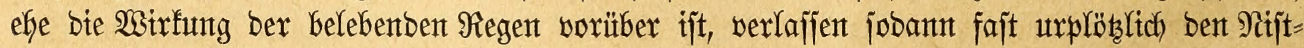
baum, begebent fich auf bie Wantberuntg, regen währent berjelben ifar Winterfletb, in ber

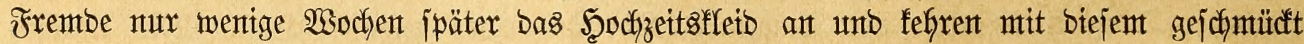
int näcbjiten Früblinge zur altgewohnten Stelle zurühf́.

alfe mir befannten Goelweber jün fräftige, gemantste, bemegungshujtige, numtere unto

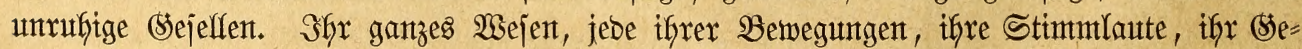
baren unter fich und anberen $\mathfrak{B o ̈ g e l n}$ gegenüber befutbet in untverfentibarer Weije Gajtige Iatfraft ober tatfräftige Şajt. Nur jo lange fie follafen, fitsen fie rufhig auf einter uno bex= 
jelben Stefle, währento ber übrigen Zeit finto jie untunterbrochent in Bemegutt utto jelbjt went fie raften, noch feines̉megs ruffig, ja jogar währent fie arbeiten, bewegent fie in unts

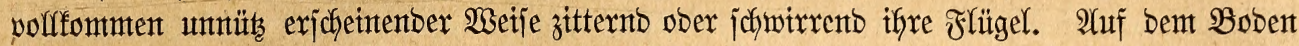

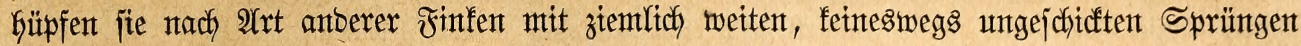
unther; int Seztweige bewegent fie fich mit einer Fertigfeit, weldye mant bent gebrumgen ge=

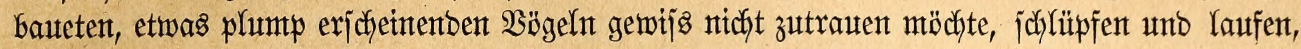

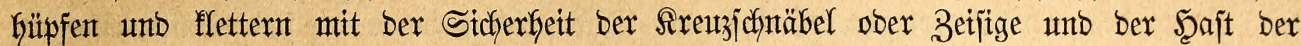

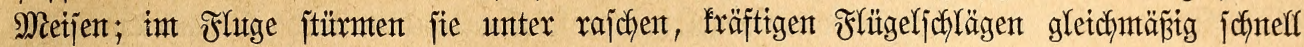

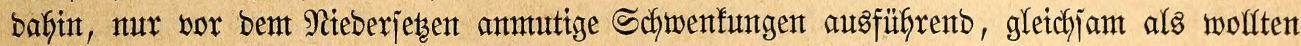

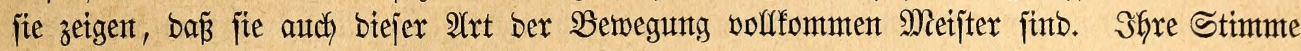

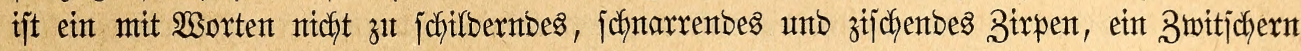

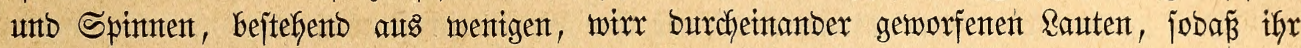

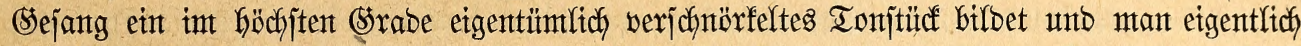
mur bas gebefnte Edfunarrent ber Endiftrophe beutflich Gerauts Görent fantr. Dabet wirb biejes abjonberliche Rieb mit ben Yebfafteítent Flügeljichlägent begleetet unt jo eifrig vorgetragen, als

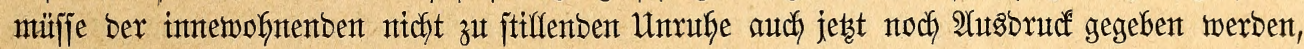
alB gelte $\mathrm{eB}^{3}$, mit Der Nachtigall zit wetteifernt.

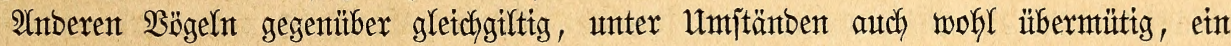

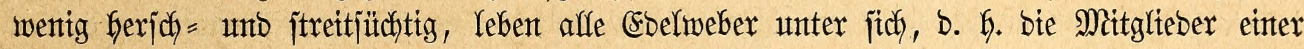

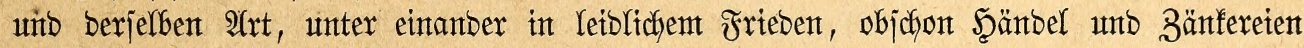

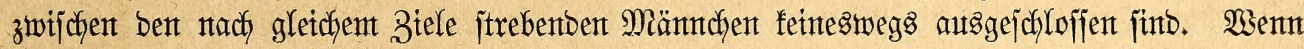

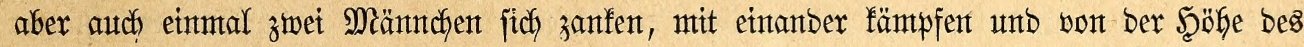

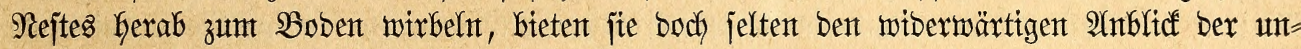

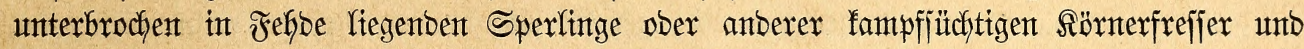

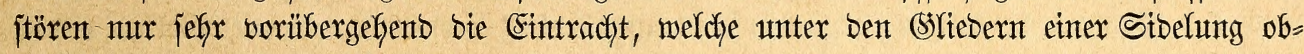
waltet unto obwalten mutur.

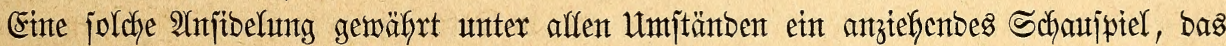

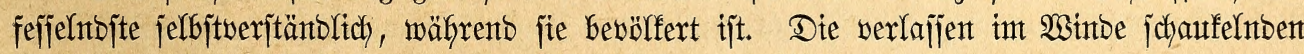

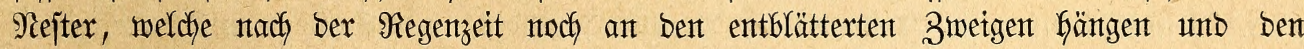

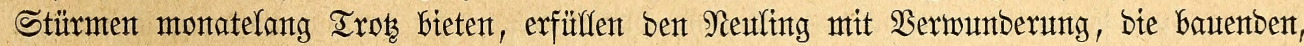

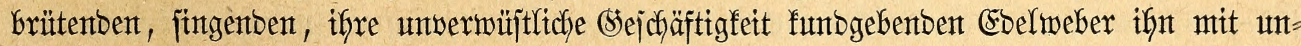

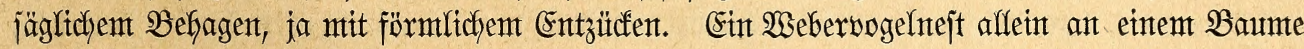

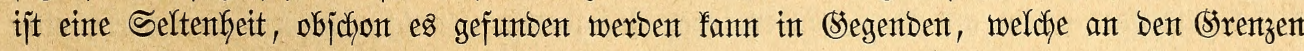

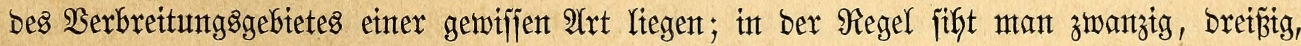

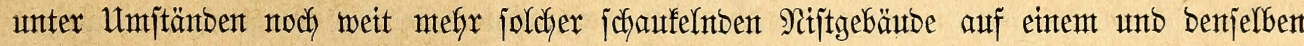

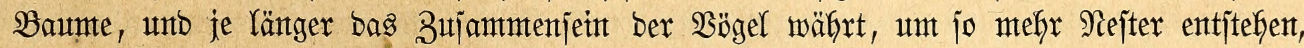

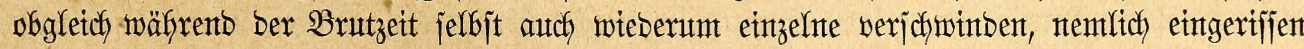

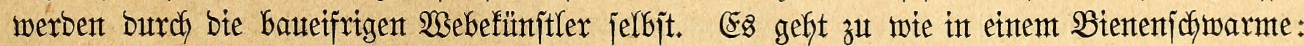

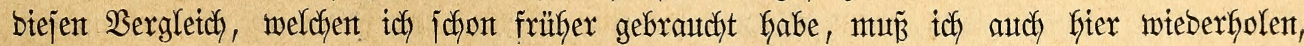
meil idy feinent treffentoeren zu finbent weip. Dieje fonmten, jene gehen, bie einten fitzent auf

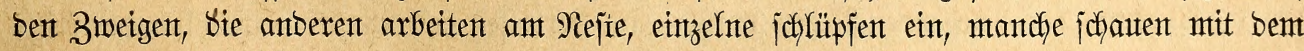

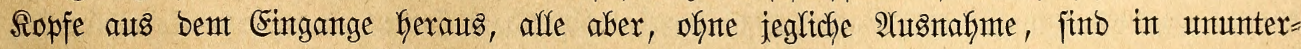

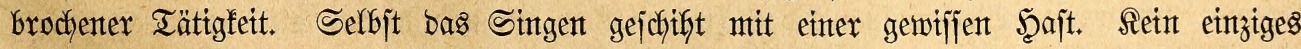

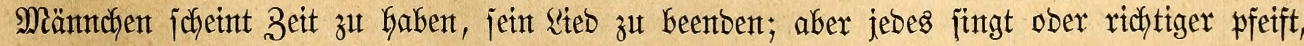

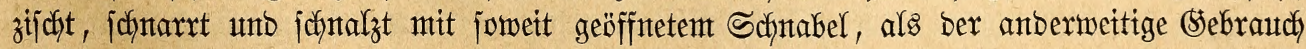

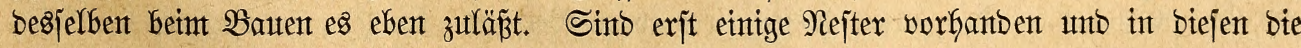
Suntgent aus ben Eiern gejeflïpft, jo gebent autd fie thre Stinntuten zum bejten, unto ber

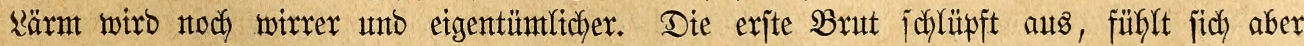


burchyaus nicht jelbitänbig genug, bie Sibelung enbgilttig zut verlafjert, treibt fich in einem

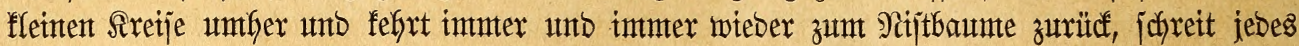

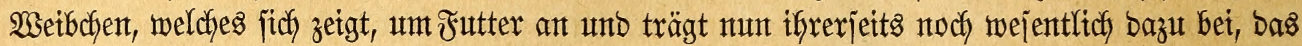

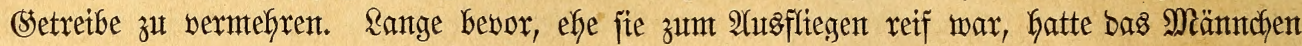

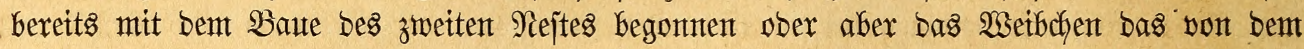

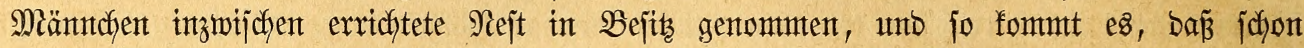
wentige Tage nadh Dent Selbjtänbigiwerbent ber erjten bie zweite Brut forgt. Sift nut autch

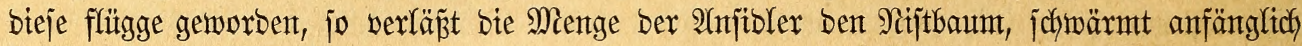

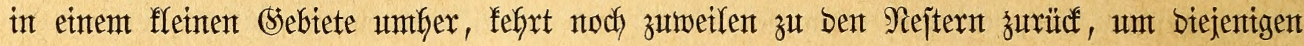

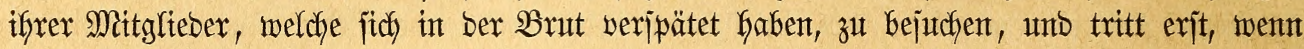
audd bieje reijefertig getworben finto, ben Stridy unto entlid bie 2 sanberung an.

Bet alfen Eberfwebern, Derent Rebent unt Treiben idh in ber Freiffeit ober (Sefangen=

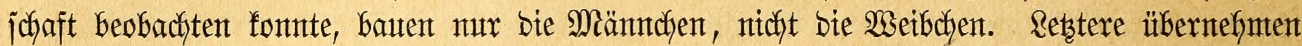

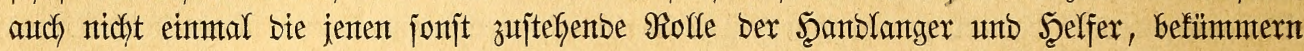

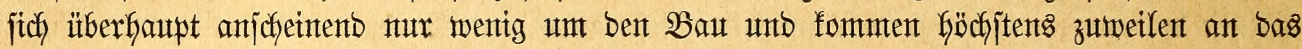

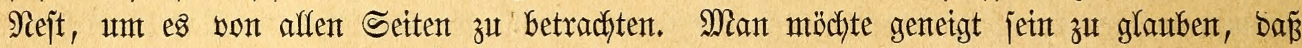

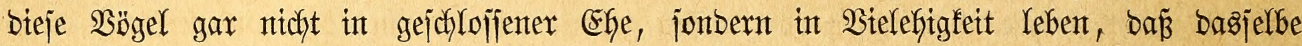

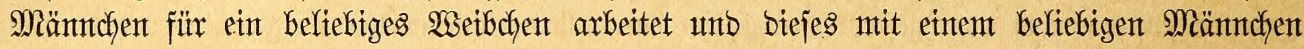

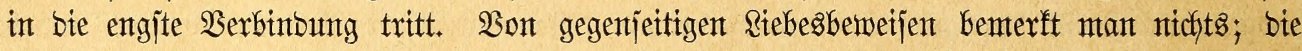

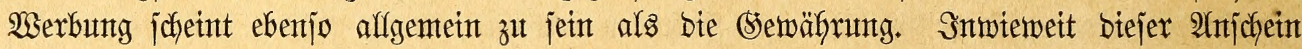

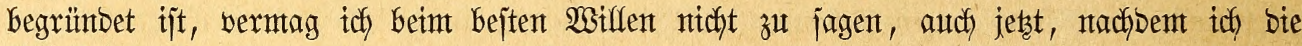

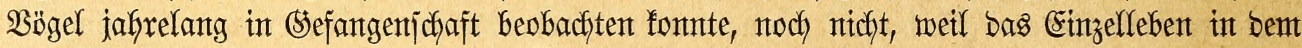

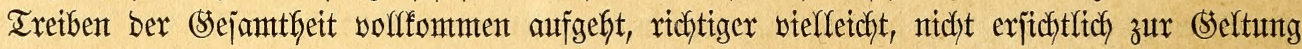

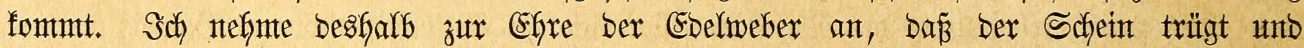

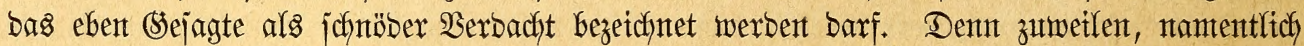

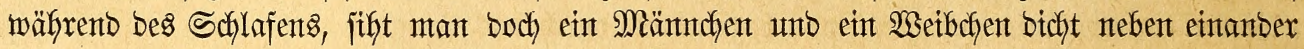
fitzen unb barf int ben betben ein treutwerbunbenes par vermuten.

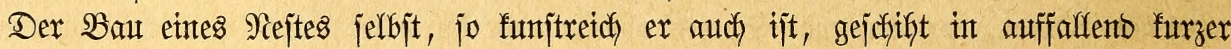

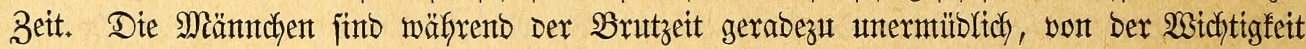

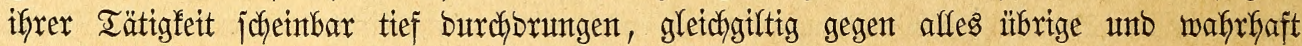

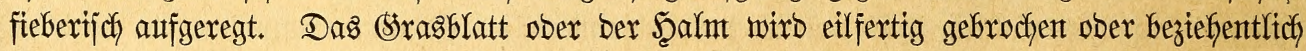

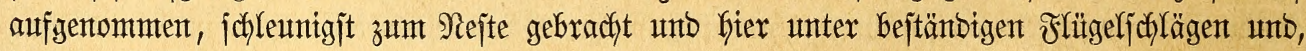

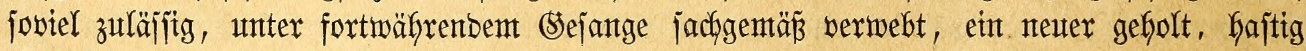
werarbeitet, cin britter herbet getragen 2 . So geft es umunterbrochen fort vom erfiten Morgenlicbte bis gegen bie Mittaggzeit uno von ben mittleren Nadymittagsitumben an bis

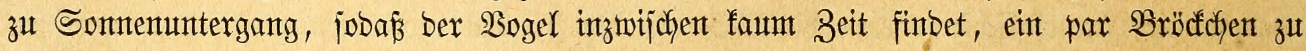

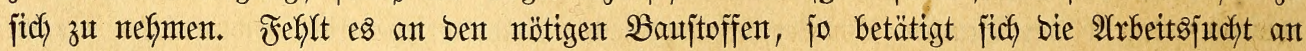

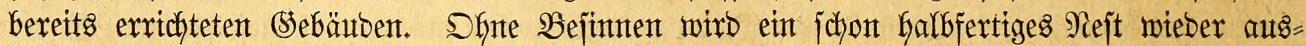
einanter gezerrt unb zeritört, weshalb mant bent autd, unter bem Saume ebenjo wohl wie

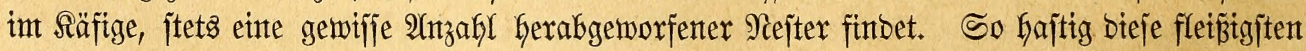
aller Baumeifter aber auch arbeiten, jo verfieren fie body äußerfi jelten bie Sidderfeit bes

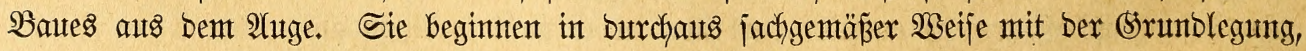

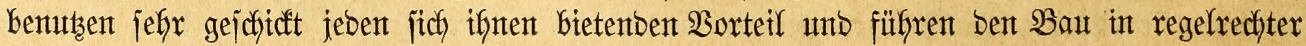

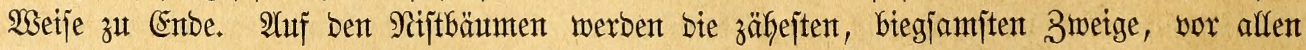
biejenigen, weldye einzeln, D. K. zientlich weit won ben anberen entfernt ftefhen und wo $=$

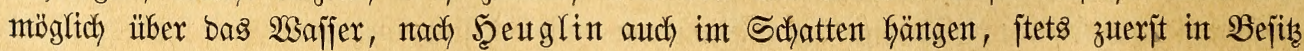

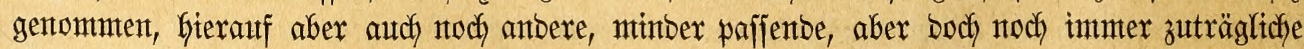

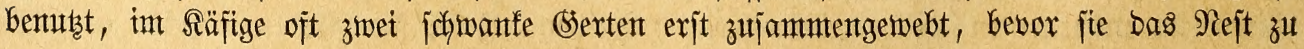


tragen befonment, unzmeifelfaft beşarb, weil fie bem $\mathfrak{B}$ auffünjtler noch nicht genügento

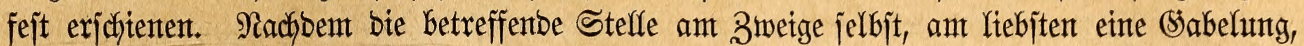

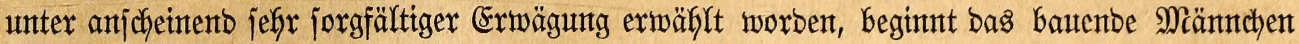

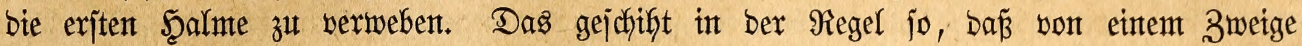

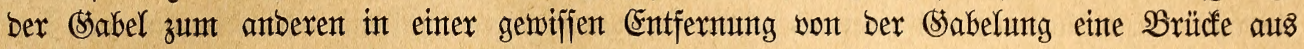

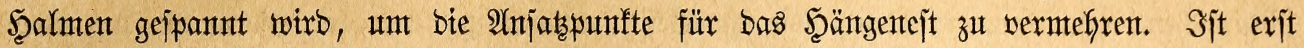

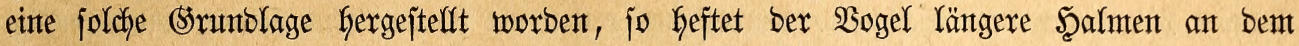

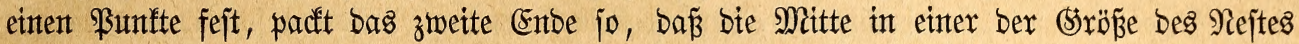

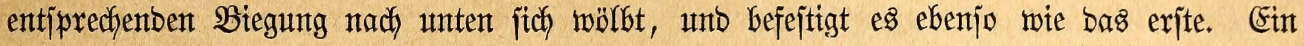

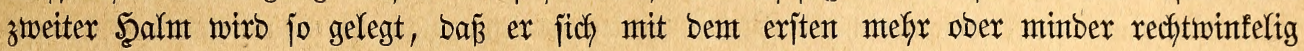

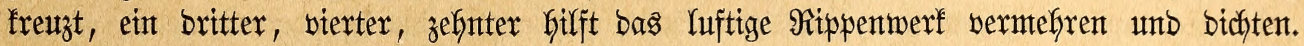

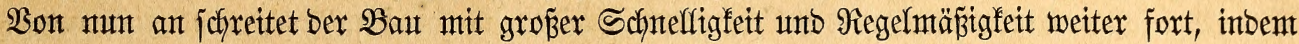

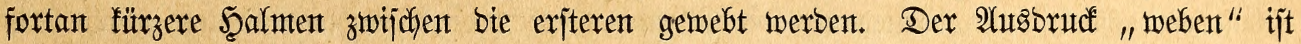
ïbrigent, wie id bemerfent will, nutr teif'weije riddtig; ebenjo gut fönte mant bie 2Trbeit ein

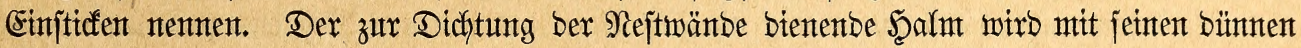

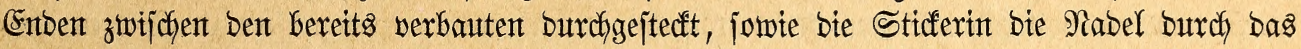

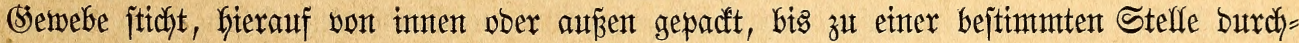

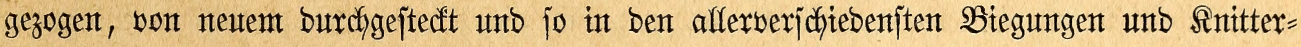

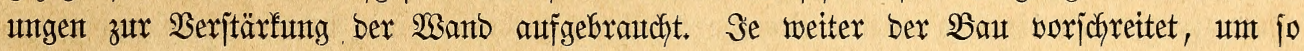

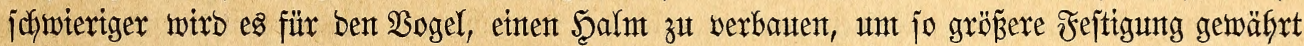

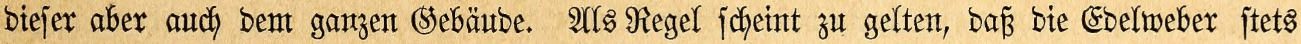

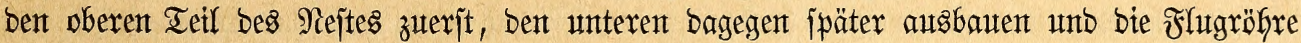

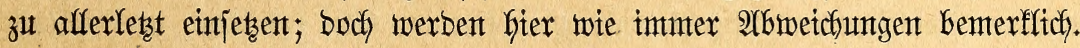

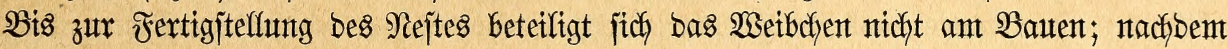

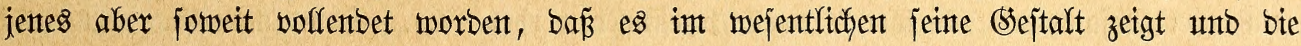

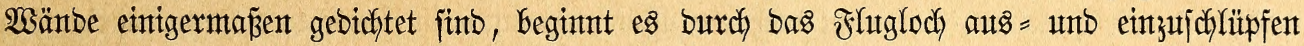

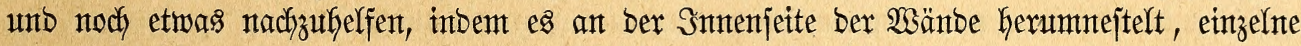

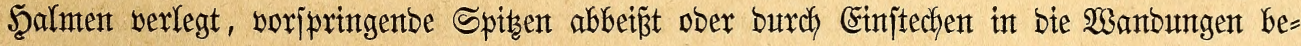

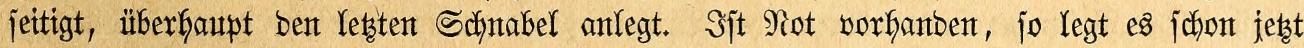

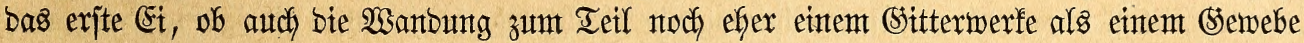

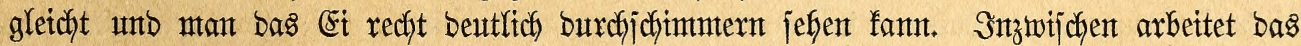

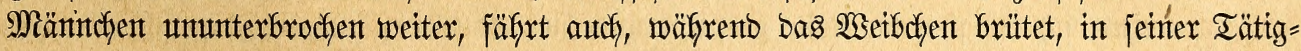

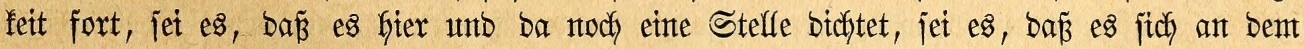

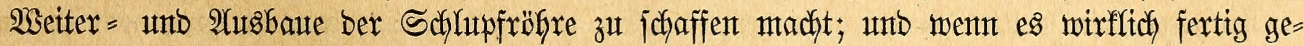

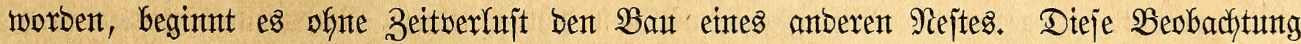

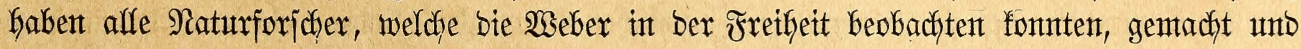

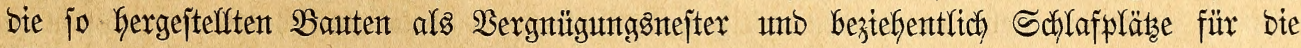

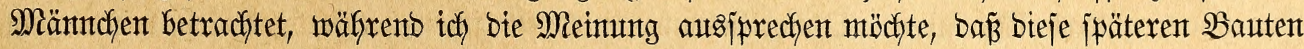

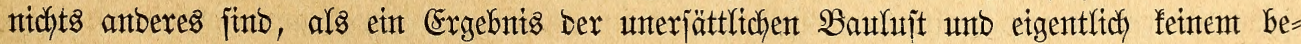

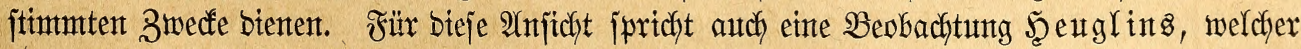

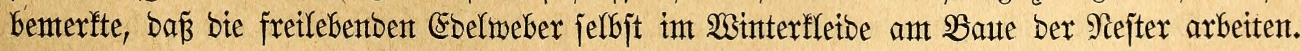
Sn Befangenjchaft tum fie basjelbe, arbeiten jeboch nicht jo eifrig als wäfrent ber Zeit, int welcher fie bas Şodyzeitsfletio tragett.

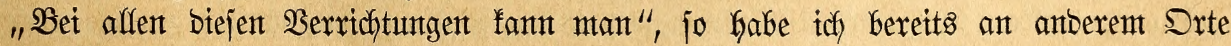

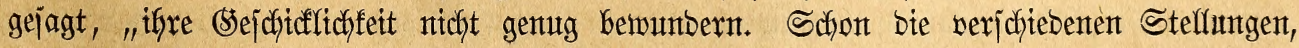

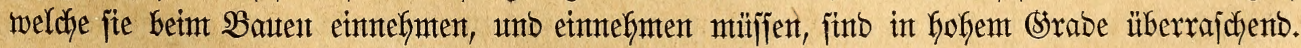

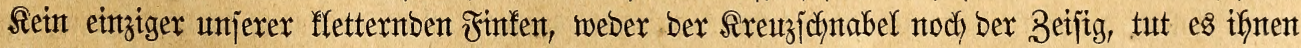

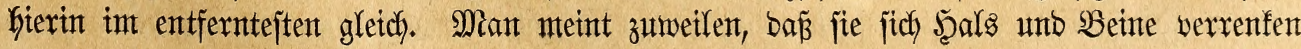




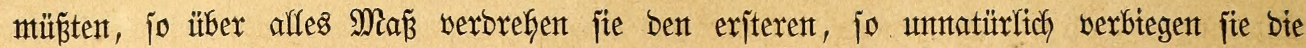

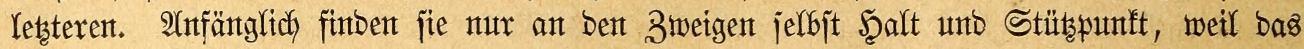

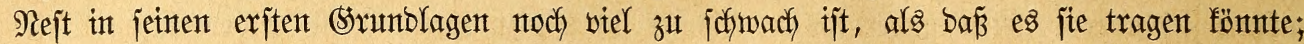
ipäter bängent jie jich an befien Wantuntgen an, gletdhoiel ob fopfoberjt ober fopfunterit, ob fie nack vorn fin ober zmijchen ben Beinten burdy arbeiten mitifien. Da jie mun autd jebzt

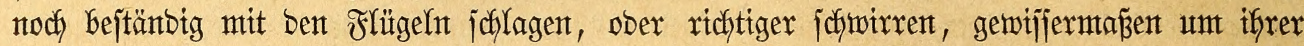

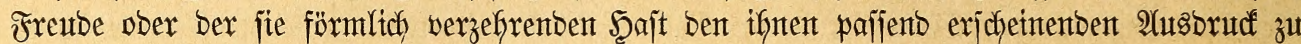

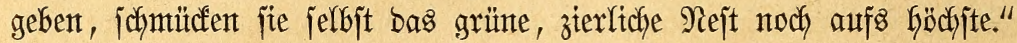

Die Bauzeit eines Rejtes ijt nach ben Umitänden, insbejonbere nach ben zum Baute vorkanbentent Stoffen jefr verjofieben. Sm Freten, bet ungefintberter Altsimafil ber Stoffe,

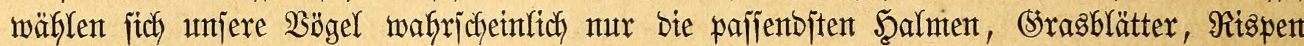
und Fajern aus, in Säfige nefmen jie erffärlicher Weije, was fie vorfinben, unb beruft

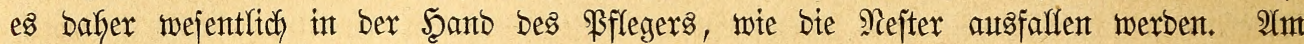

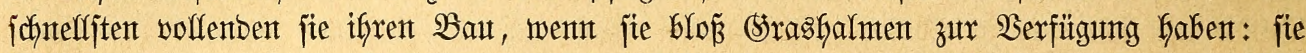

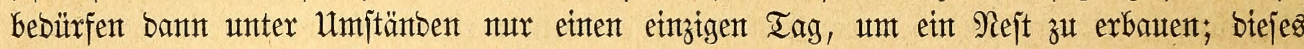
aber ift bant freilich audch jefr lieberlich zujammtengejebst unto fäflt nticht jelten bald nach

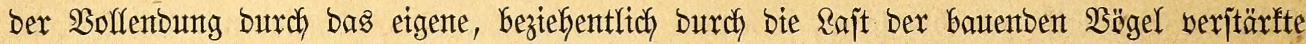
(Sientdit won jelbit ab.

2Y1s meinen int Freien begontenten unto vor ben fäfigent iafrelantg fortgejetzten $\mathfrak{B} e o b=$

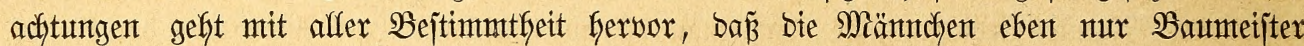
junb, übrigens aber alle Elternjorgen Den Weibdjen überlaffen. Dieje legen, wie bemerft,

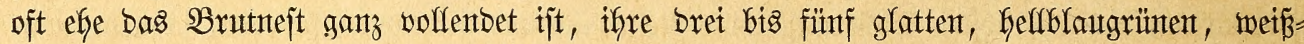

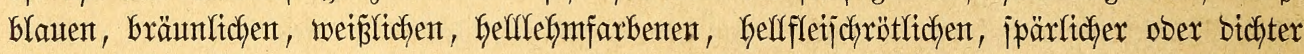
mit bunfelgraublauten, roftbraunten, graultchen, violettbräunlichen unt anberen Flecten ge= zeidfnteten, mandfyntal wie bejprizten und gegen bas bickere Ento hin umgrenzten Eier, be= brüten fie mit gropem Eifer vierzefn ober funfzegn Iage lang, erwärmen, füttern bie Sungent, reintgen beren $\mathfrak{W}$ tege und bejorgen ïberfautpt alfe nötigen Erzitefungggejchäfte, ofne von ben

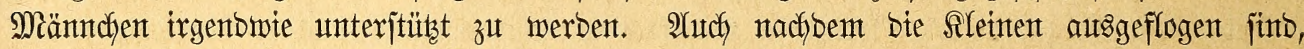
befïmmtert fich Der $\mathfrak{B a t e r}$ nicht unt jie, wäfremb bie Matter nach wie vor ifyer Pfflege fich

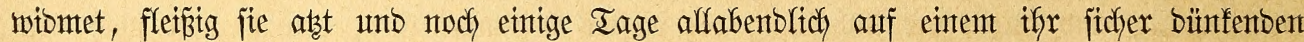

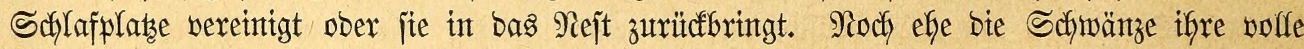

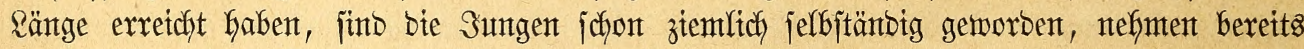

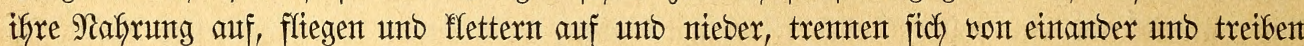

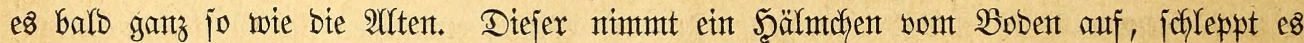

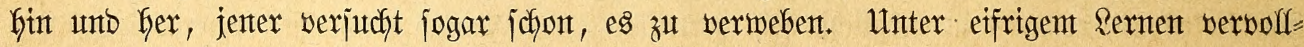

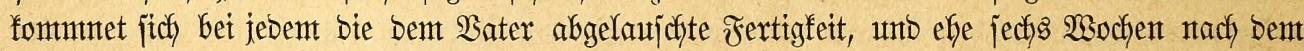

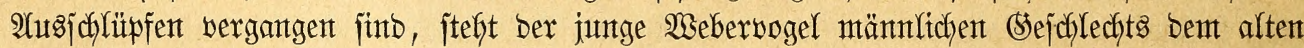

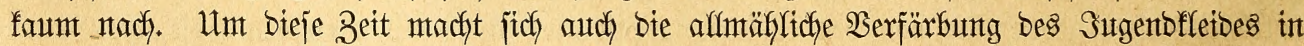

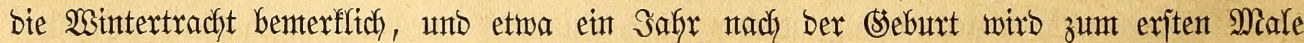
Das Şodyzettalleto angelegt.

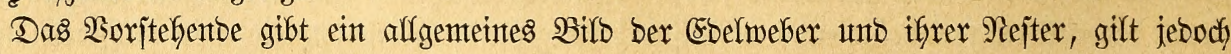
nicht für alle genauter befantnte 2lrtent. So lebt ber Safranmeber, laut 5eugli it, inmer

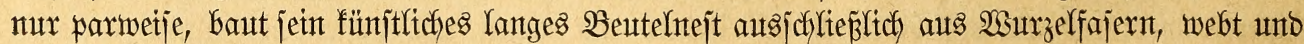

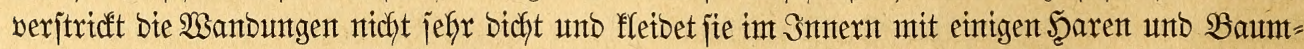

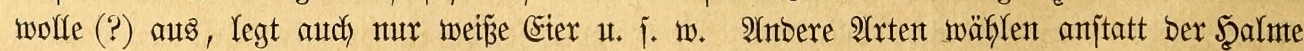
(Srasblätter, anbere \$almtenbajt, antere mieberum Fajern verjajtebenter \$flanzenblätter $2 c$. gleidgotel ob beren Bejdyaffung ifnten Mäfye verurjacht ober nicht. So zeritört ein Ebelweber Sitbafrifas fajt alfe B̧ätter cinter Sanseviera (agabenäfntlictent $\mathfrak{B f l a n z e ) ~ i n ~ b e r ~ \Re a ̈ h e ~ j e i n e x ~}$ 
Sibelungen, weil jente int Snnern biegjante unt bauthafte, zun Baute jeines ঐejtes paffente Fajern enthalten, obgleidy ifym bie serwinumg bes Bauftoffes feineswegs Yeidyt wirb; io

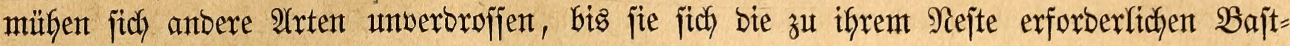

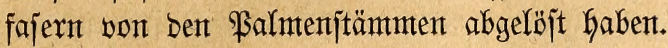

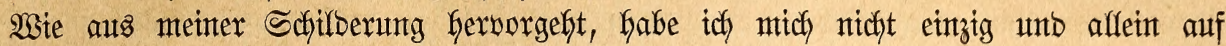

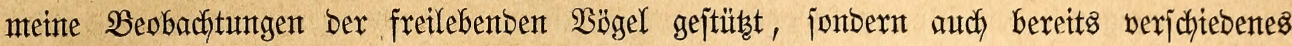

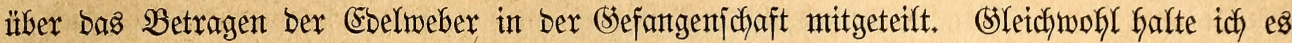

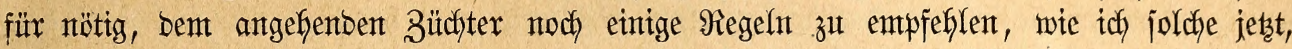

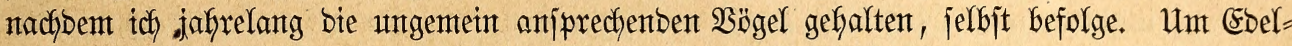

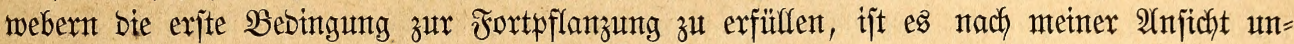

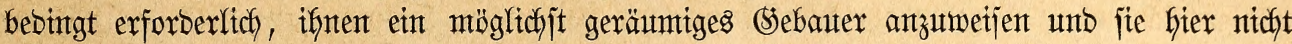

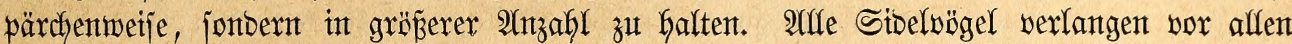

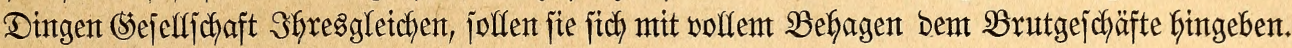

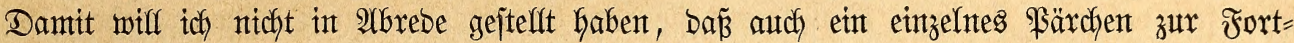

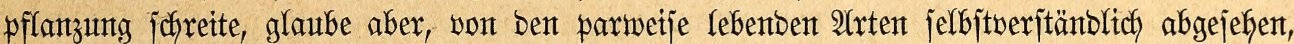

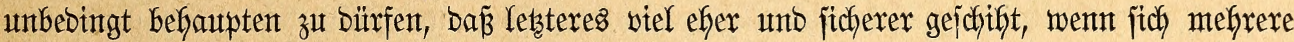

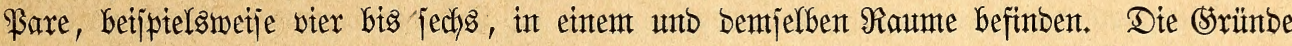
Gierfür Gabe idh bereits (Seite 79) angegebent: ein Meäntchen erregt burdh jein (Sebaren

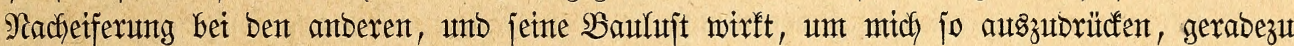

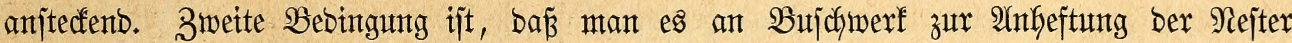

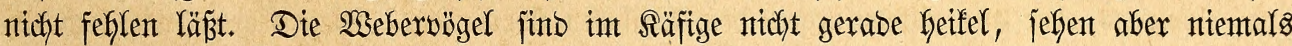

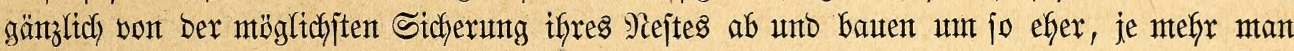

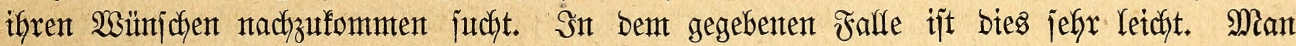
befejtigt in ben Eedent bes (Sebauers lange, febernbe (Serten unb biegt biejelben jo Kerab,

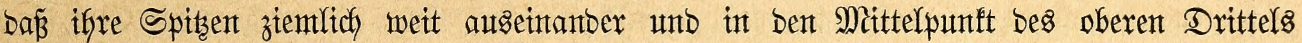

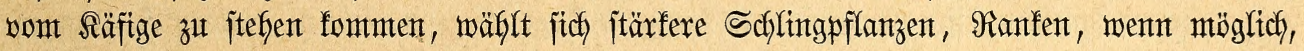
joldhe von Yeberben \$rlanzen, wenn nidht, joldhe von abgejtorbenen, Gefejtigt fie ntit Dräten

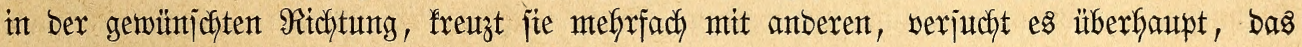

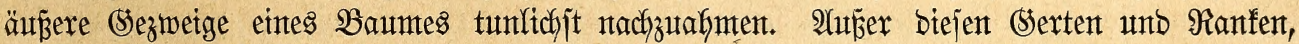

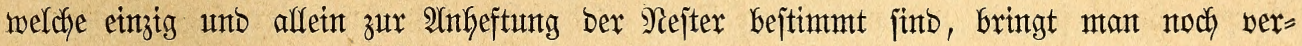

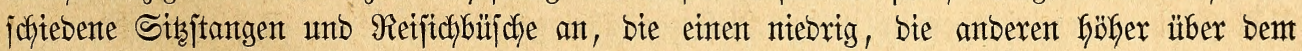

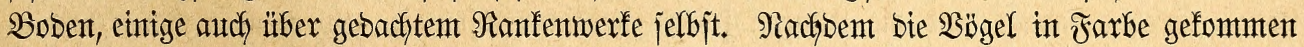

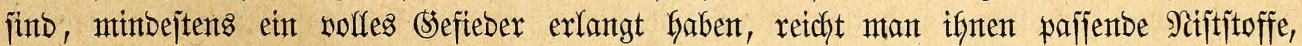

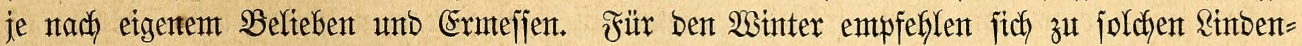

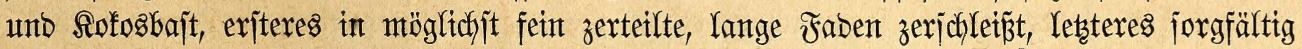

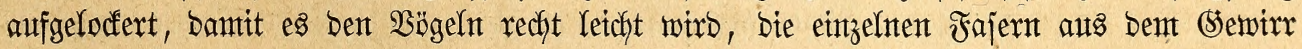

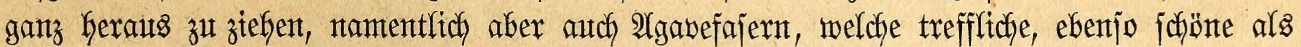

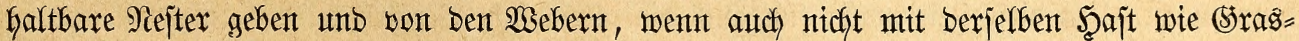
fafme io boch nicht ungern benutzet werben, autch ein iffnent burchauts antgemeifenter bauftoff

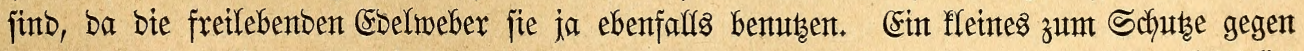

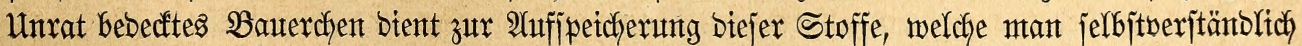

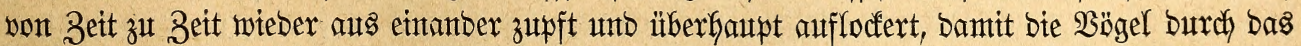

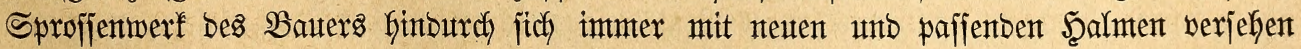

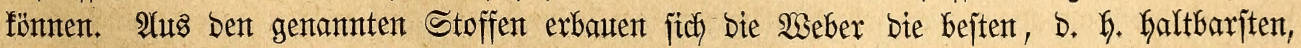

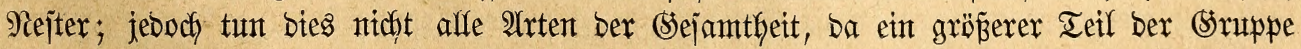

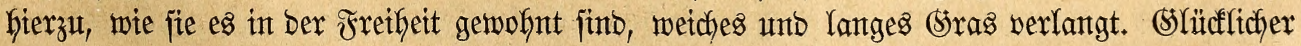

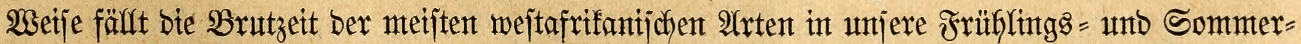
monate, unb es hält bafer nidgt jefwer, fie tagtäglich mit ben nötigen Stoffent zu verjorgen. 
Se frifheres Sras mant ifnen bietet, unt jo befier: fie benutben zwar audf bürre, eintige 3eit lang im Wajjer aufgetwetchte und biegjant gemtadje Scalmen unt Srasblätter, nientals

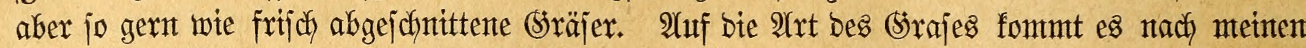

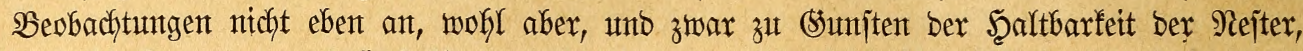

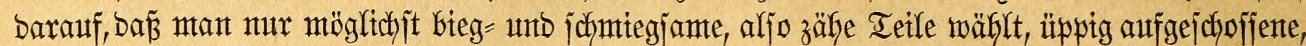

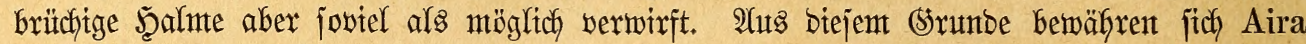
cespitosa unt A. flexuosa int bejonberent (5rabe als trefflicher Bauftoff; bie bamit her=

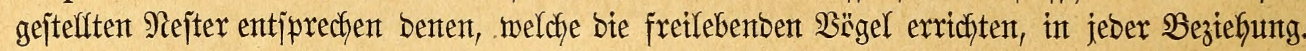

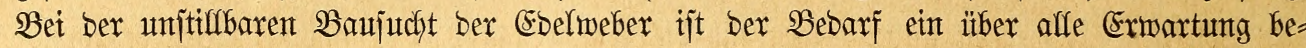
Deutender, unb Gat mant jorgfältig barauf zu achten, Daß̧ es ifnen nie, auch nicht ein par Stumben lang an bem Nötigen mangele, weil jie, mie bemerft, jonjt über bie fertigen Nejter berfallen, fie zerbeip̈en und zerzerren, unt jo zu neutem Stoffe zu gelangent. Şierbei verfahren

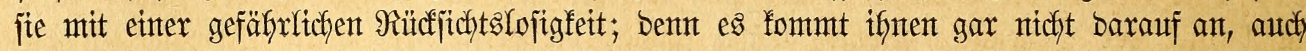
ein bereits belegtes, ja jelbjt ein mit ausgejchlüpfter Brut bejebstes গejt zu zerjtören. Şaben

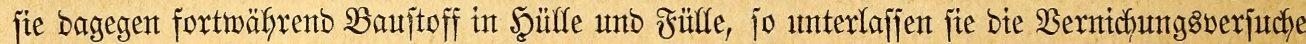
unt haltent jich lieber an bas letchter 3ugänglicke. Solange fie feit Sras zum SBatten haben, bebienten jie jity bes $\mathfrak{B}$ ajtes ober ber Fajern; jobalo man ifynen aber bas exjte frijche (Stras gereicht hat, nebmen fie mur, minbeitens vorzugsmeije biejes und lajjen jente meijt gänzlich

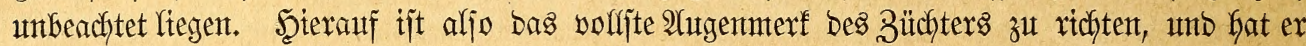

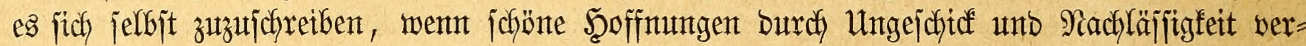
nichtet werbent.

Die Ernäfrung Diejer gentigjamen $\mathfrak{B o ̈ g e l ~ h a t ~ n i d f t ~ b i e ~ g e r i n g i t e ~ E c h w i e r i g f e i t , ~ f a l f s ~}$

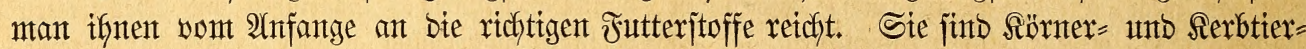
frefier, bas eine fo gut wie bas andere, ertragen zwar bei einfachent Sïnterfutter geraume

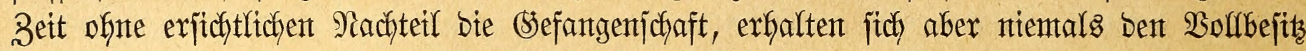

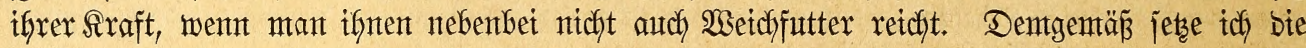

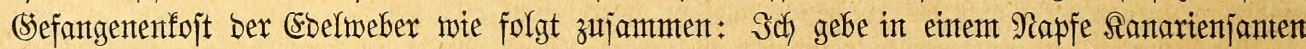
ober (S)lanz, in bent anberent Şixje, in bent britten mein (ธ. 41 fi.) Nachtigaflenfutter,

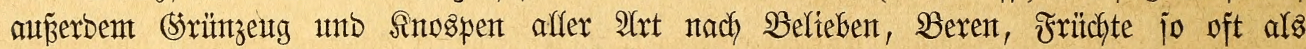
möglich, bazu als secferet täglich jebent $\mathfrak{B o g e l}$ mintbejtens vier, fallz ber Borrat vorkanben,

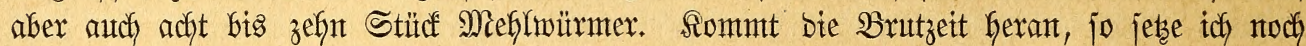
geriebene Sartoffeln, hartgefochtes und zerfleinertes Eigelb hinzu. Solange idy über frijche

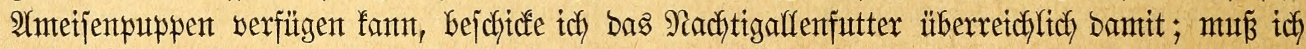
mich) an getrodfnete halten, jo gebe ich hierwon joviel, als bie Bögel eben freffen molfen. Salz und Areibe gefören jelbjtweritänblich auch für bie coblweber" zu ben unentbebrlichjten

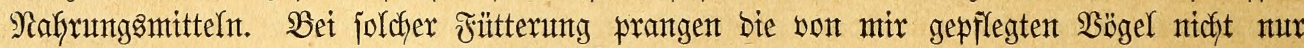
in ifrem jefönten Befieber, jonbern befunben audh affe Rebenshujt und vorfjten Eifer zum Bauten und zum Britten.

Wer jo viele Ebelweber gepflegt unto gezücftet hat wie idy, wirb mir beiftimmten, went

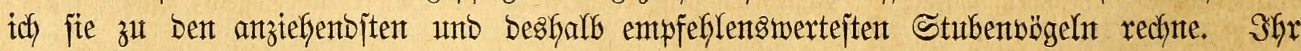

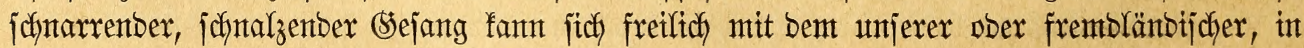
biejer Şinficht jich auszeidfntender Rörnerfreffer ntidyt mejfen, hat aber etwas jo Semüttliches,

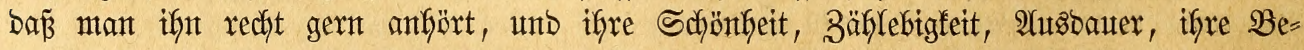

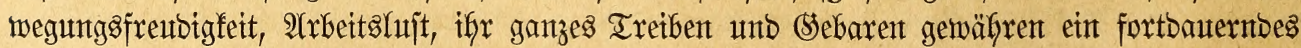
Sergnügen. Sch ziehe beshalb bie ebenjo jajönen als jelbjtbemunten, ebenjo eifrigen, fleiżigen, arbeitjamen als gejelligen, unter jich verträglidyen unb fortpflanzungshuitigen Edelweber ben meiften $\mathfrak{B r a d f f f i n f e n t}$ unbebingt vor und empfehle fie jebem Büdyter, weldyer in berjelben Weije wie idy berfafyren will ober fann, auf bas angelegentlidjite unb wärmite. 
Der Breis bes solbmebers unto jeiner Serwanten fteflt fich in ber Regel auf jecks

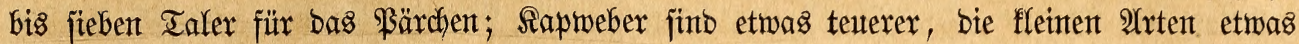

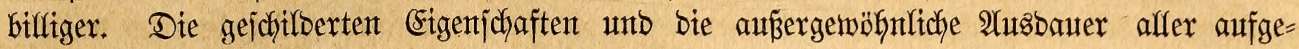

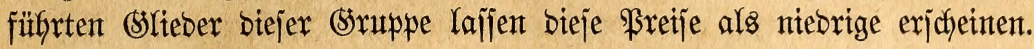

\section{Anmerweber.}

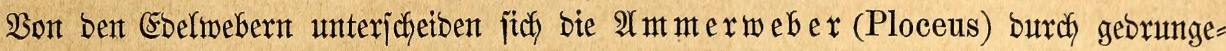
nere Sejtalt unb ftärferen, fürzeren Schnabel. Diejer ijt fräftig, fajt vierjeitig, glectymänjig zugeipitst, auf ber breiten Sirfite fanft getwölfbt, an ben Sdynetben Ginten mit jumpferem

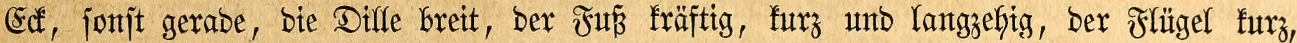
ein Drittel bes Schwanzes becfento, mäpitg fpitsig; bie zweite ober britte Schninge ijt bie längite, bie exjte bis fünfte in ber Wurzelfälfte eingezogen; ber furze Schnanz bejteht aus

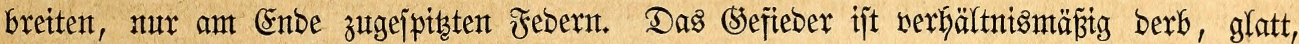

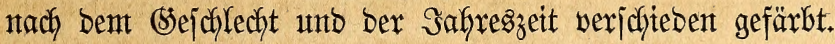

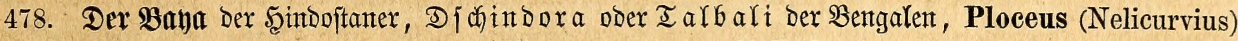

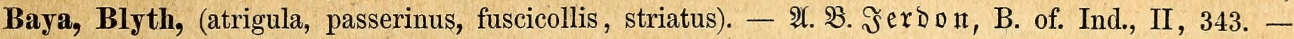

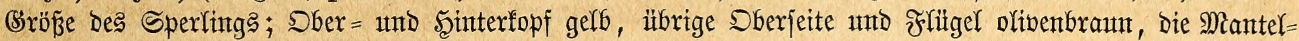

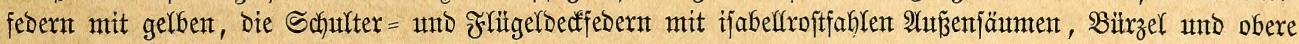

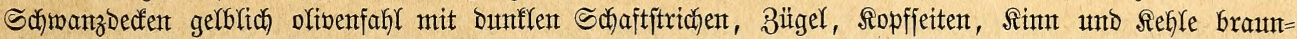

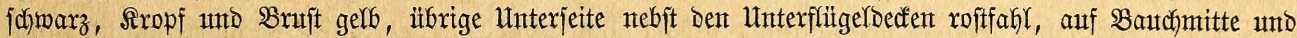

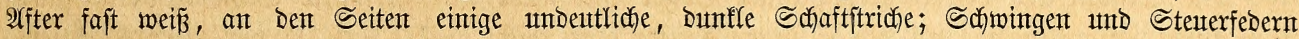

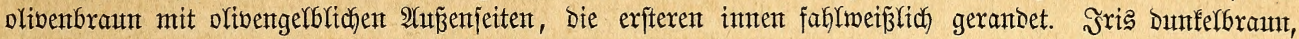

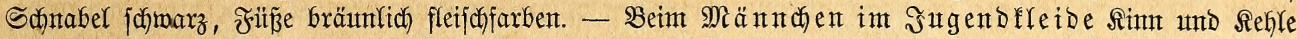

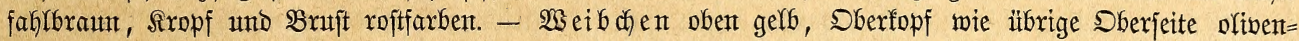

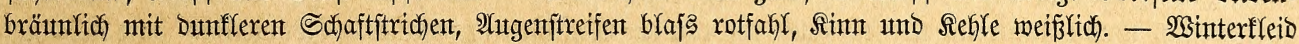
Der Miäntchen von Der Iracht Des Wseibchent nicht zut unterfacheident.

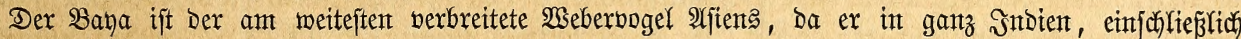
(Eeylon, Malaffa unt auf Sawa vorfonmt.

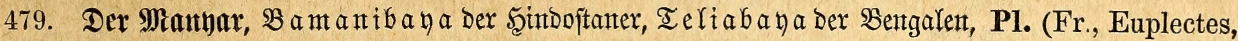

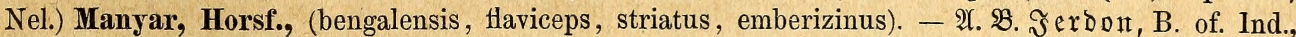

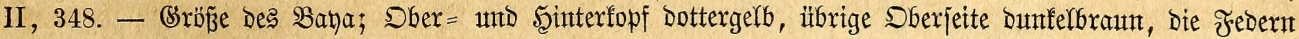

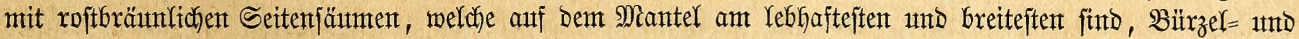

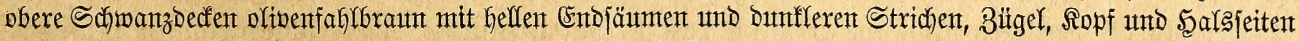

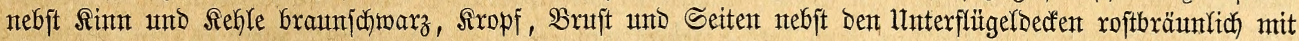

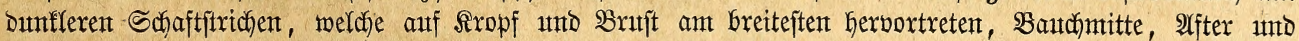

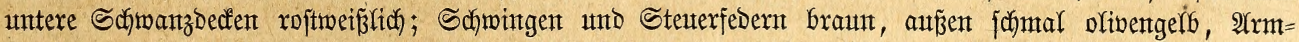

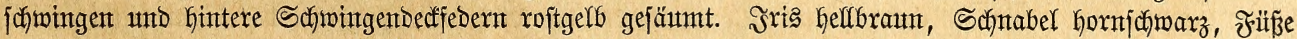

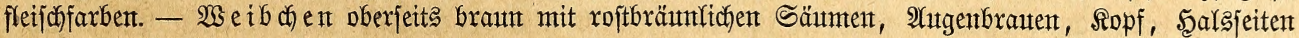

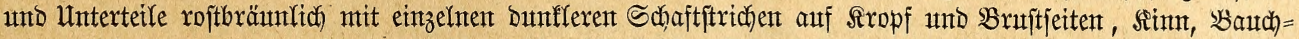

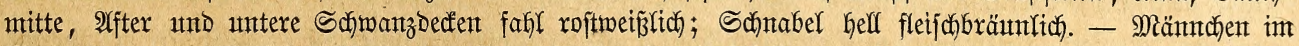

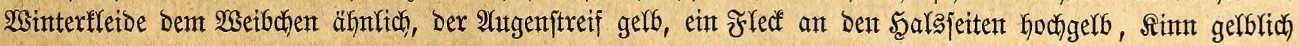
verwajchent.

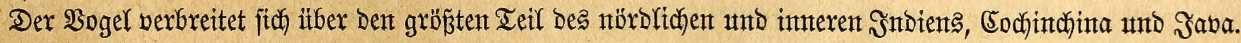

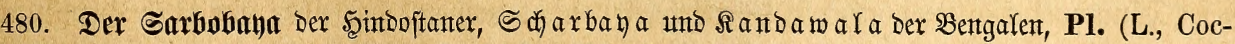
cothr., Eupl., Nel.) bengalensis, L., (flavigula, albirostris, aureus, regina, chrysocephalus). $-\mathfrak{A}$. $\mathfrak{B}$.

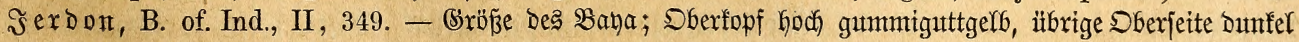

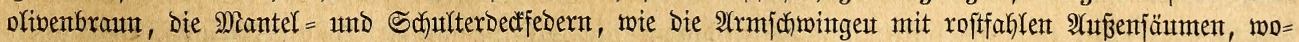

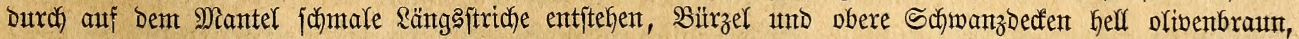

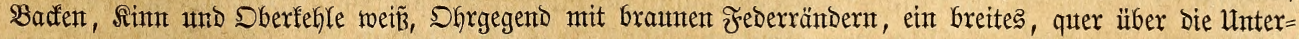
fehle und Den Iropf verfaufendes Band tiefGraut, itbrige Unterjeite weiß́s, rofffaht überflogen, bie Jebern

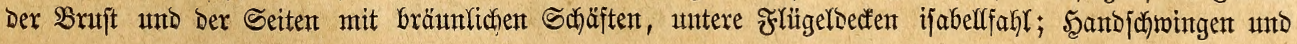




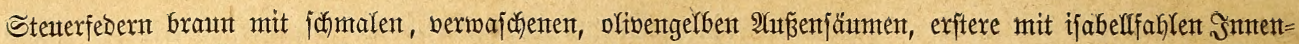

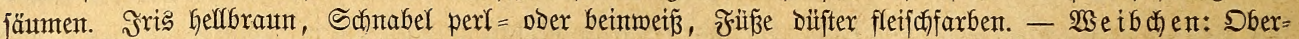

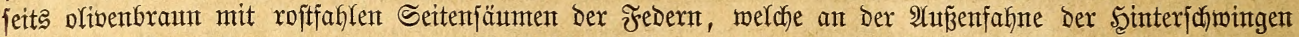

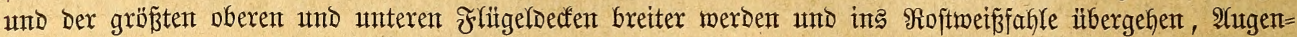

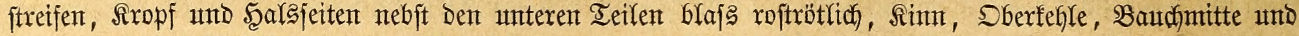

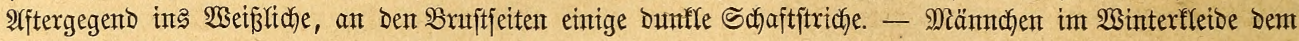
WSeibchen ähnlfudy.

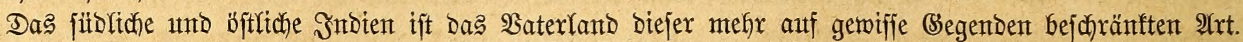

481. Der Mamuf-Mtantyar der Malaien, Pl., (L., Fr., Ploceolus) hypoxanthus, Daud., (philip-

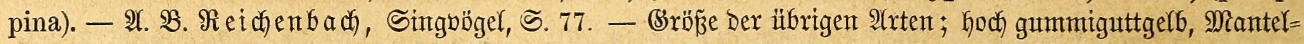

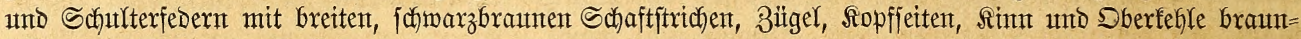
¡dfwarz, Fłlügel unt Sdjwanz Dunfel ofivenbraut; Sdjwingen und Deren Dedfedern mit faff olivengelben

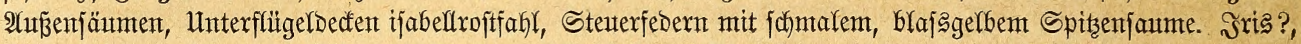

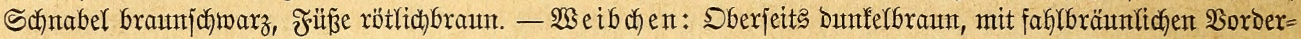

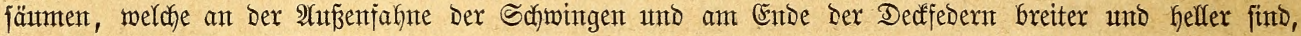

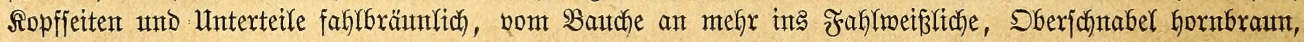
Unterja)nabel fahlmeiß̧.

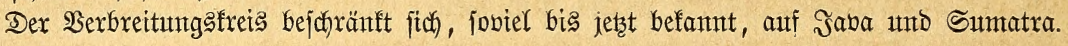

Der etmas fräftigere Schnabel hat $\mathfrak{B e r a n t a j j u n g ~ g e g e b e n , ~ D i e ~ f o l g e n b e n ~} 2$ (rten unter Dent গamten Didfwebex von Den vorkergehenden zut trentent.

482. Der ßotfopfmeber, Pl. (Eupl., Quelea, Foudia, Hyphantica) erythrops, Hartl., (capitata,

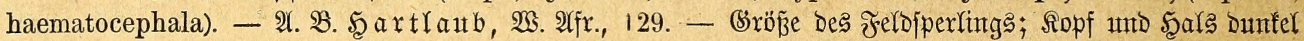

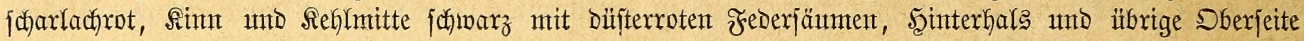

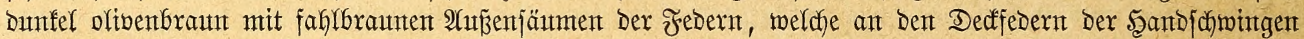

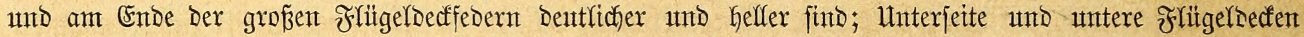

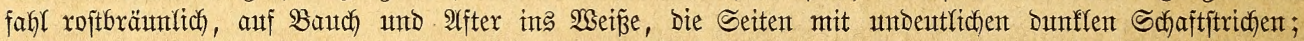

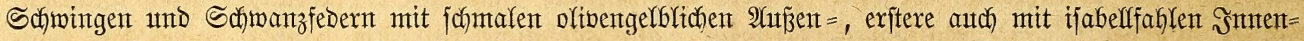

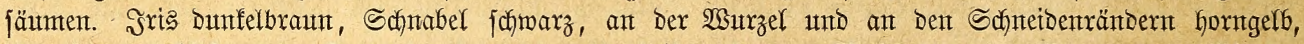

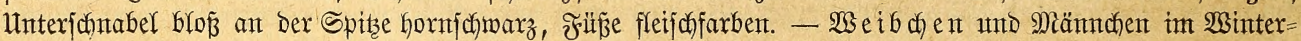

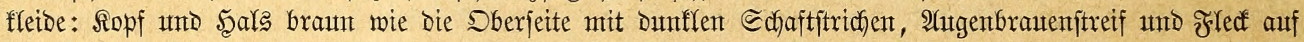

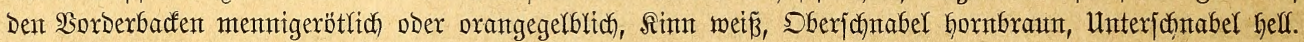

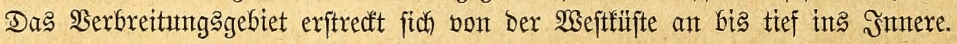

483. Der Dividy doex Bhttidntablmebrr, PI. (L., Fr., Eupl., Passer, Emberiza, Quelea, Hy-

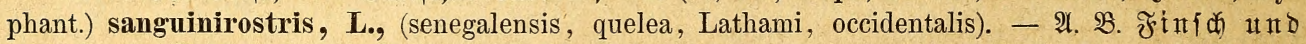

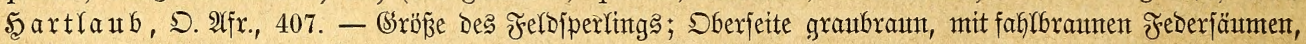

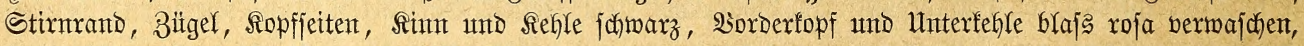

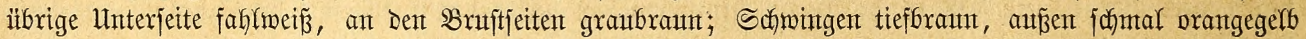

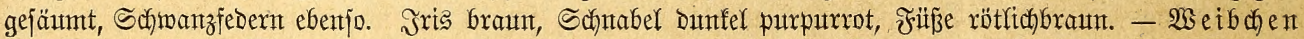

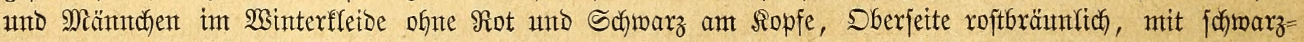

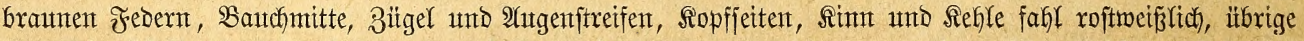

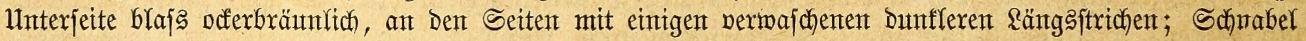

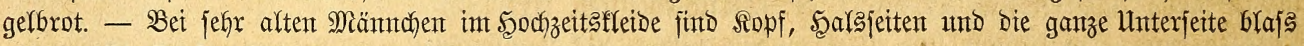
rofarot (Pl. Lathami).

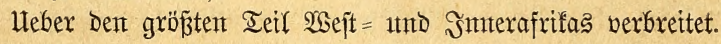

484. Der Iruppmeber, PI. (Quel., Eupl., Hyphant.) aethiopicus, Sundev., (orientalis,

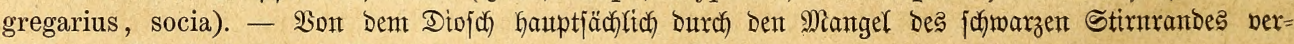
fchiebent. Sb als beftimmte $\mathfrak{A}$ rt zt betrachtent, noch fraglich).

Scheint ben Diofd im Siten $\mathfrak{A}$ frifas zut vertretent.

Nach bent ausfüfrltchen Rebenzbilbe, weldyes idy von ben Ebelwebern zu entwerfen

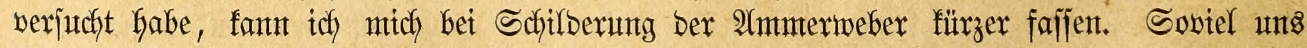
bis jebt befannt, unterjcheibet bie Rebensweije bie ajtatijchen 2Urten afferbings in manchen

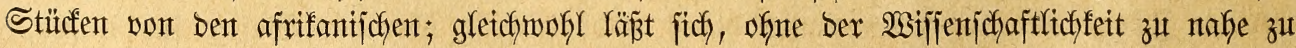

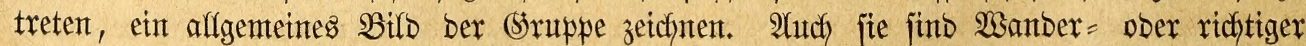

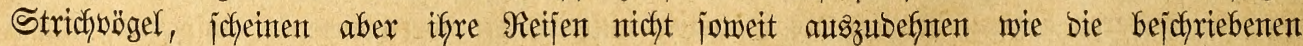




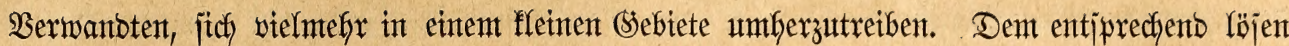

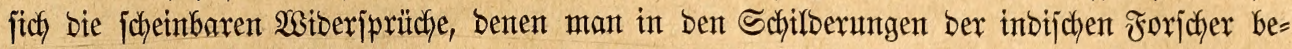
gegnet, won jelbjt. Diejentigen, welche bie $2(m m$ merweber als Stanbwögel betracthten, meinen,

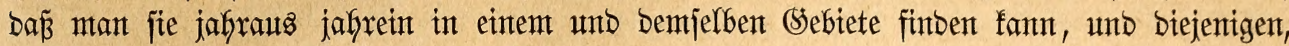

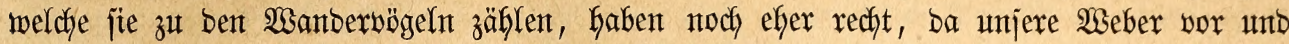

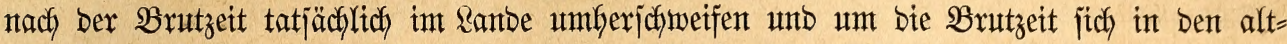

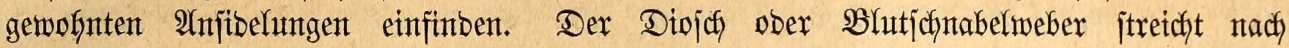

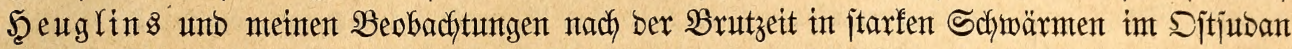

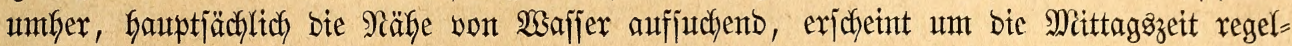

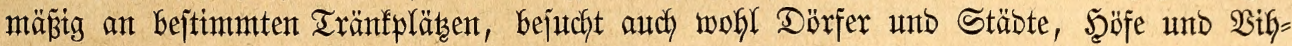

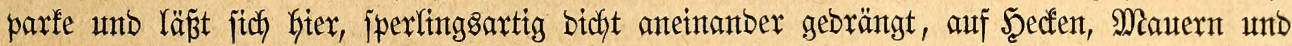

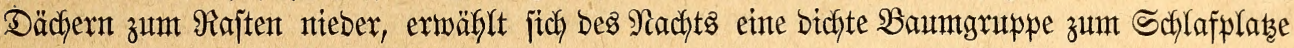

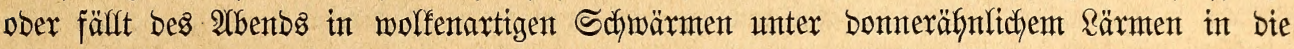

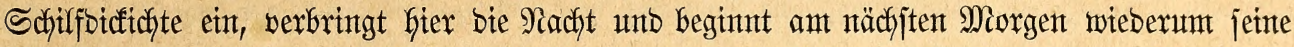
Streifzulge, mit ber vorrüudenton Dürre weiter unb weiter nach Silben fid menbent, mit

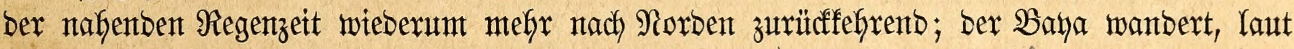

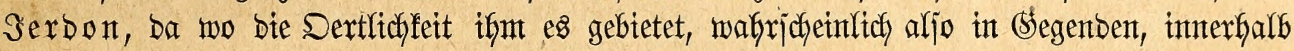

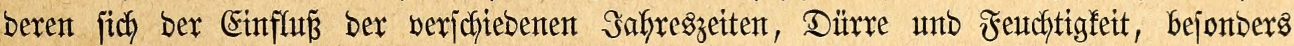
füfflbar macht, ebenfaffz unther, währento er auf günjtigeren Sertlichfeettent möglicher WSeije

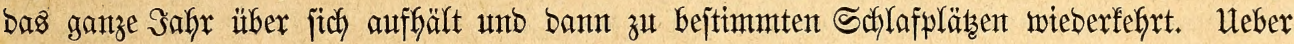

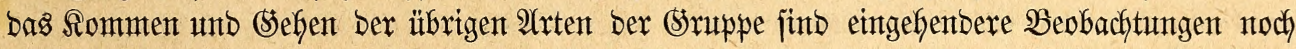

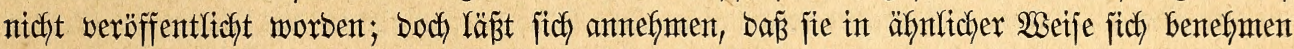

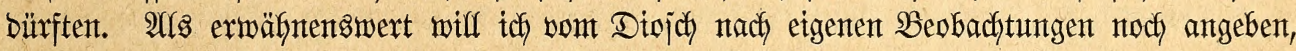

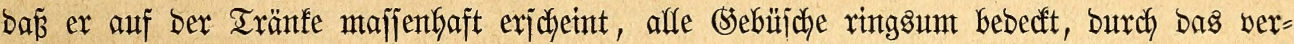

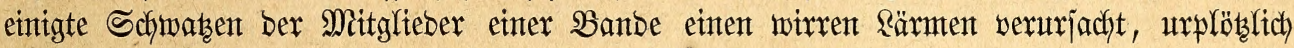

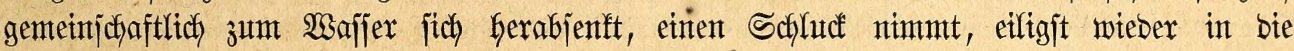

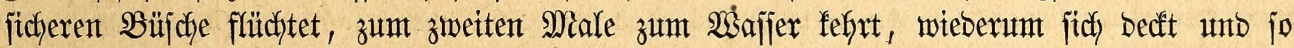

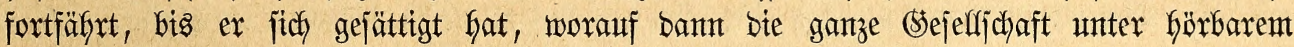

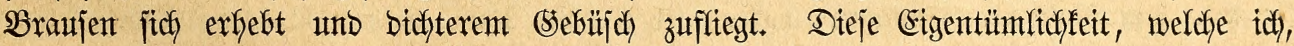

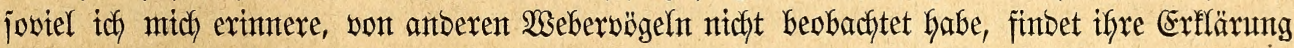

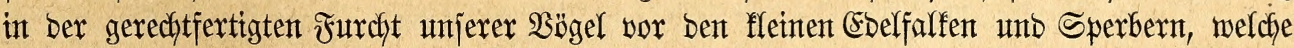

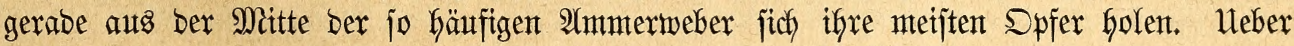

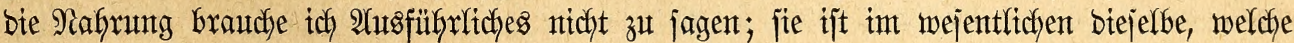

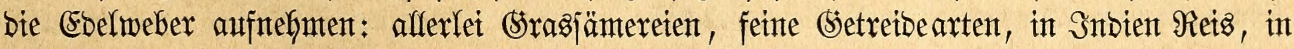

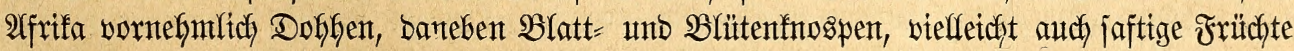
und Beren, unt entlid Serbtiere ber verjodiebenjten $\mathfrak{A}$ rt.

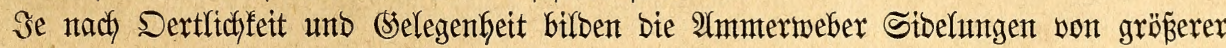

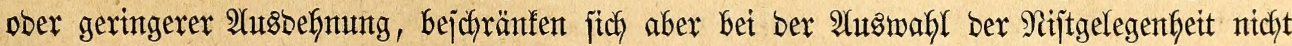

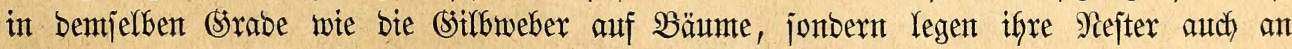

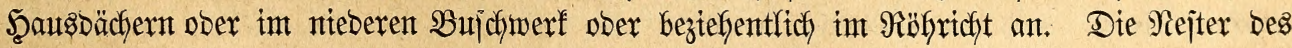

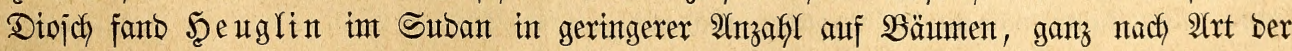

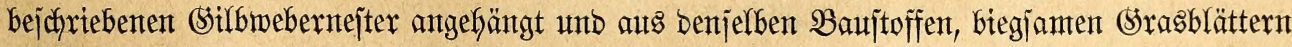

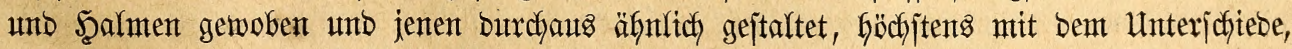

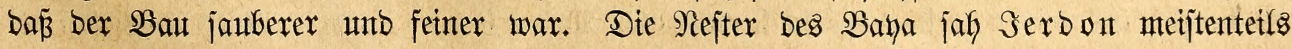

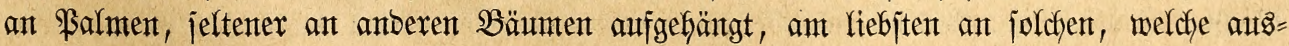

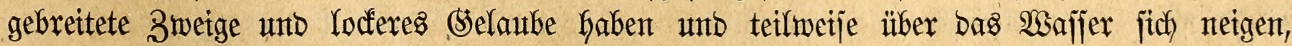

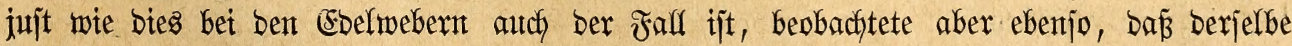
Bogel an anberen Drten förmlich als Şaustier auftritt, bie-bortretentent Dachjparren zum 


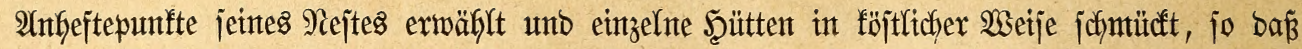

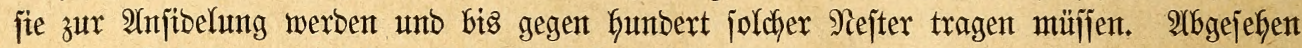

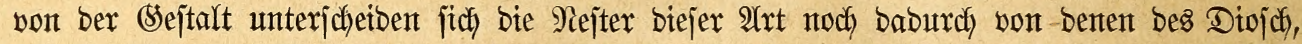

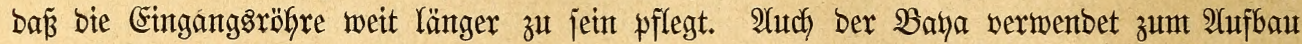

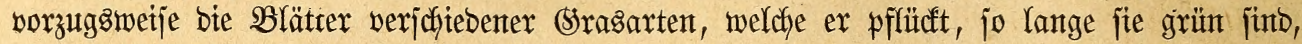
nimmt aber nidfyt jelten Streifen ber Salmenblätter ober fofogfajer unb gibt bann bent Nejte eine anbere Sejtalt, inbem ex es in volljter Würbigung bes fejteren, haltbareren Stoffes fletner unb jierlidfer anlegt. Das Nejt bes Manut=-Miantyar hat, laut $\mathfrak{B}$ ernjte in, eine binnförmige (Sejtalt und ijt mit jeinem jodmalen, faum $25 \mathrm{~cm}$. bidfen, ftielförmigen

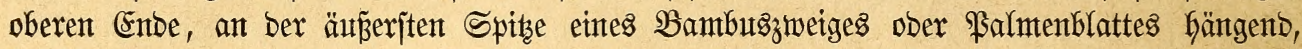
befejtigt und zwax jo jicher, baj jelbjt ein jtarfer 2 into mux jelten int Stanbe ijt, es ber: unter zu werfen. Etwa $16 \mathrm{~cm}$. unterbalb ber 9 Trbeftepunftjtelle wirb bas Nejt breiter und erreidjt jeinen größ̈ten Umfjang am unteren, gleidjjam von zwei Seiten etwas zujanmen= gebrücften Enbe, wo jein Durdymefjer $10 \mathrm{bez} .11 \mathrm{~cm}$. beträgt. Şier befintot jich ber für

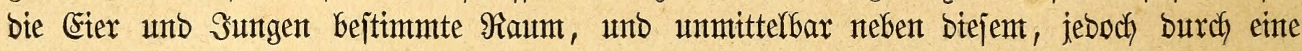
etwa zollfokge Duterwant getrennt, Der Eingang, welcher fich in einte 5 bis $11 \mathrm{~cm}$. lange,

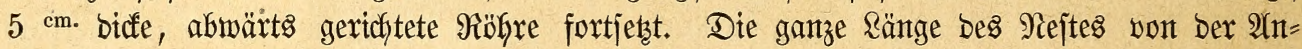
Geftungsiftelle bis zum 2fnfange bes joeben erwähnten röfrenförmigen Cinganges, b. h. ofne

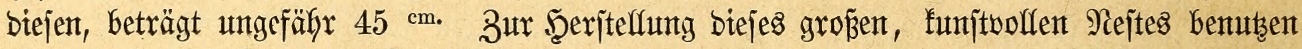

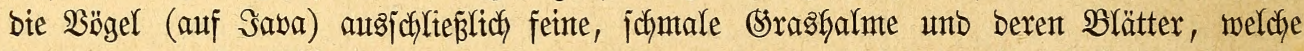
jo genau und jorgfältig untereinanber verflochten werben, baß̃ baburch bas (sonze ein jefyr

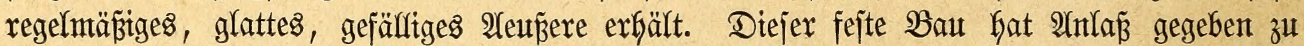

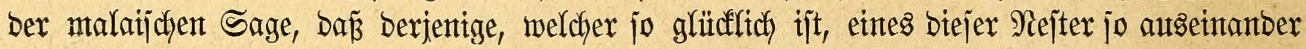

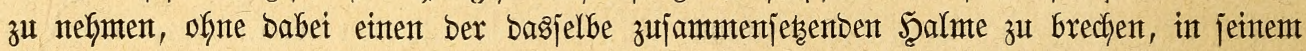

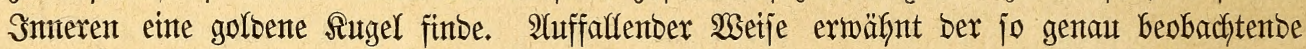

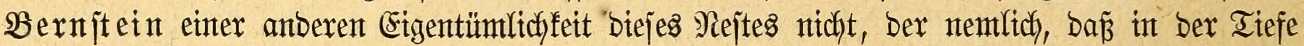

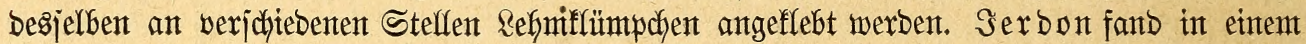

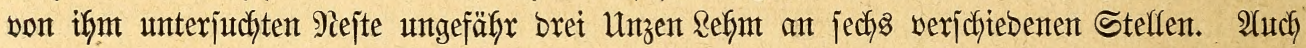
biejer in anberen $\mathfrak{B e b e r n e j t e r n ~ b i s ~ j e s t ~ n i c h t ~ b e o b a c j t e t e ~} \mathfrak{B a u j t o f f ~ G a t ~ v e r j c j i e b e n e ~ E r f f a ̈ r u n g e n ~}$ Gervorgerufen, unter benen eine, unzweifelfaft bon ben Eingeborenen Gerrïfyrento, went

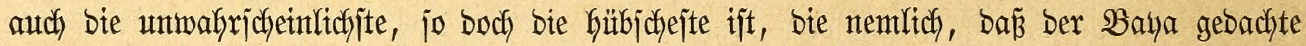

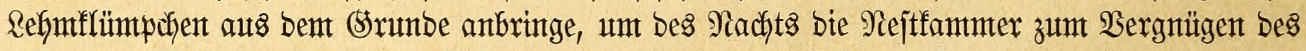

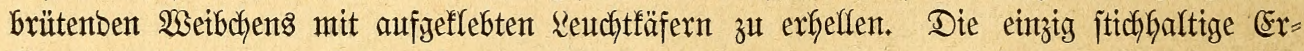

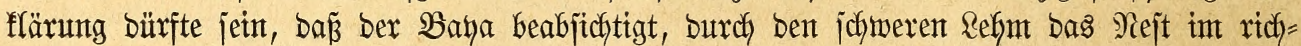

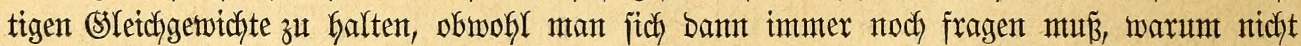
auch andere $\mathfrak{W}$ eber zu'bemjelben Mittel jedretten. Manyar unb Sarbobaya brüten nach ben

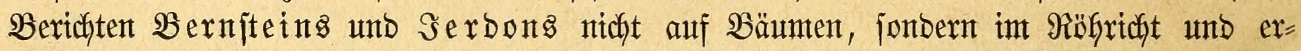

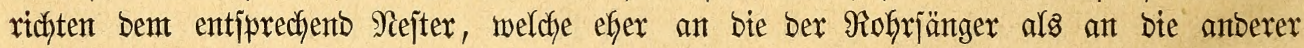
Weber erinnern. "Das $11 \mathrm{bis} 13 \mathrm{~cm}$. Gohe unt 6 bis $8 \mathrm{~cm}$. breite, mit jeitlichem (sin= gange verjebene Nejt bes Manyar", bejdyreibt $\mathfrak{B}$ ernjtein, "ijt viel fleinter als bas bes Baiza, audh nicht bängent wie biejes, jonbern zwijchen einigen Schilf = und Binjenjtengeln bez. Den 3weigen ingent einer Sumpfpflanze befejtigt"; bas Nejt bes Sarbobaya hat ganz

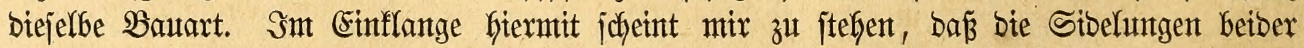

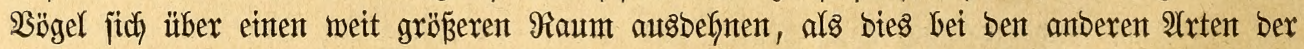

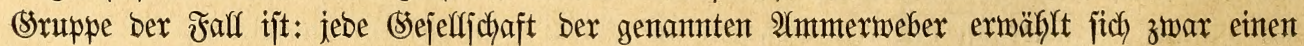

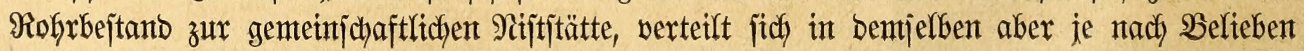
ber eimzelnen Färchen. 


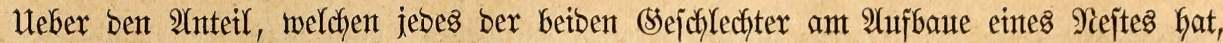
Iauten bie 2fngaben werjchieben. Nach meinen Beobadytungen an Sefangenen barf ich be=

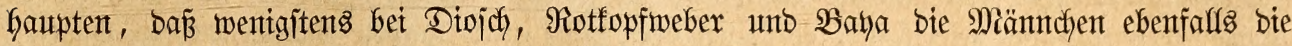

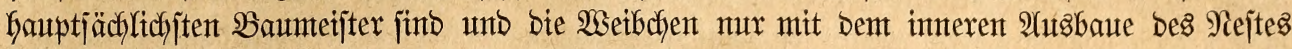

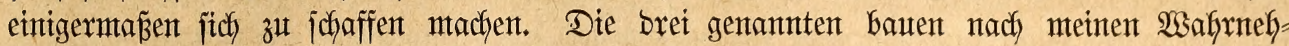
mungen zmar ebenfalfs mit (5ras, am liebjten aber mit Siofosbajt und richten ein biel feineres

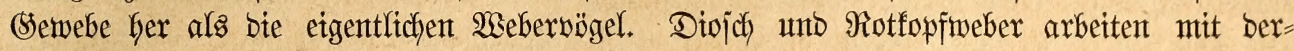

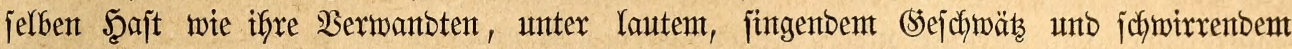

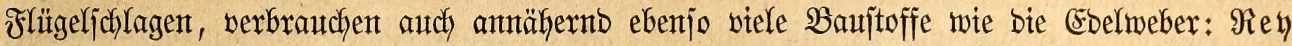

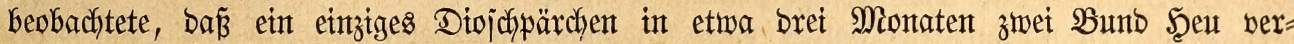
arbeitete.

Das (s)elege des Diojch entbält brei bis vier blaugrünliche, meijt unbepunftete, bas

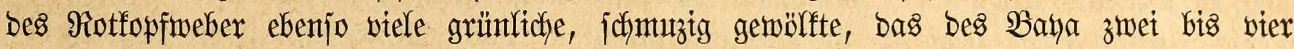

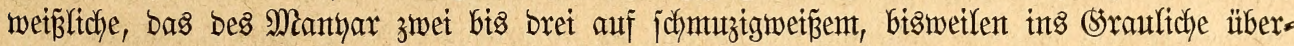

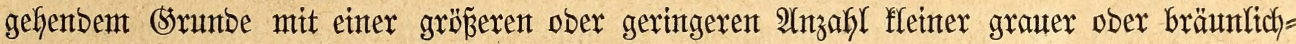

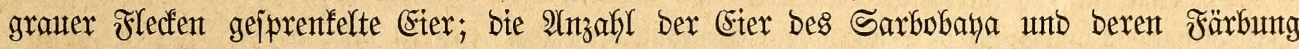

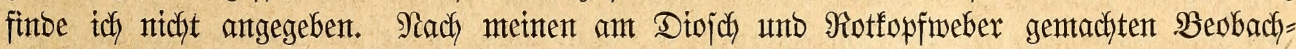

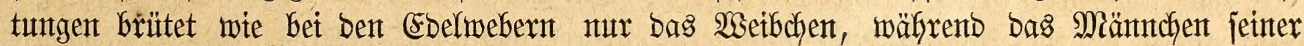

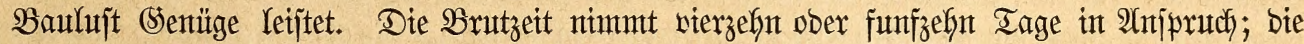
Sungen wadjjen binten zwei bis brei Wodjen zumt Flüggwerben Geran.

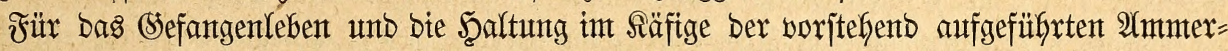
meber gilt mefr ober minber basjelbe, was idh bei Schilberung ber Ebelmeber angegeben

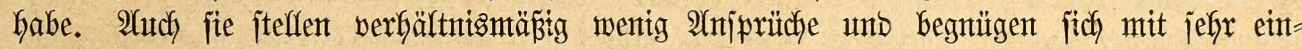
fachem Futter, verfangen aber neben ber Rönernabrung ebenjo gat wie bie Edelweber tierijche Stoffe. Snt Freien bilben bie Sämereten ber verjeftedenten Srasarten, in Inbien neben

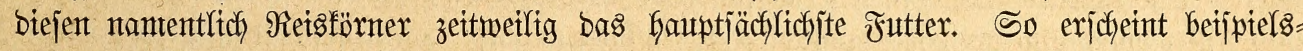
weije ber Diojh um bie Mittaggzeit mit won förnern ftrokentbem Sropfe auf Den Irinf =

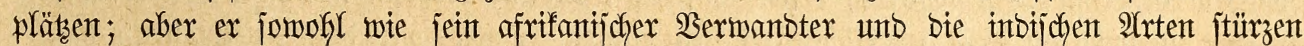

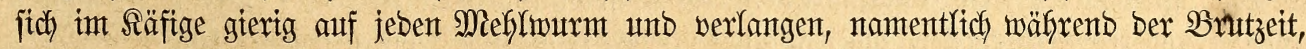
unbebingt tierijche Stoffe zur (Ernährung ber Sungen und eigener Sräftigung. Man wirb aljo wohl tum, auth ignen neben ben gemöhnlichen Sörnerjorten Wetchfutter zu retchen. Für einen möglithjt gropen, aber flachen Babenapf mit raubem $\mathfrak{B}$ oben nut tragen; Denn ber Diojdy treibt es in ber (Sefangenjadyaft ganz ebenjo wie in ber Freifeit. "Ex fonmt", jagt $\Re$ ey, "zu bejtimmten Beiten zux Iränfe, ftürat fich plump und un= gejchidft, id mödjte jagen fopjüber in bas Wajier, nimmt eifigft einige Schludfe ober be= ipritzt fich wohl auch ben förper in größjter Scajt unt fliegt eilig mieber von bannen."

Sint bie Ammerweber eingemöhnt, io gefören fie jamt und jonbers zu ben unver=

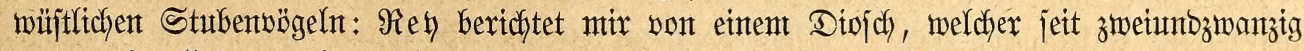

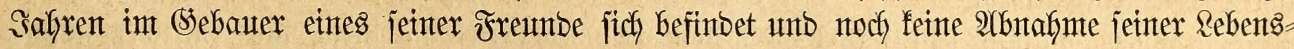
fraft veriphüren läß̈t. Şält man fie in fleinen (Sejelljchaften, richtet man ifynen ben Räfig

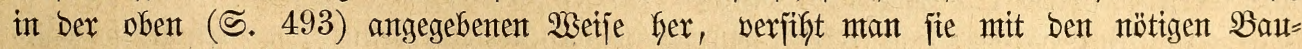

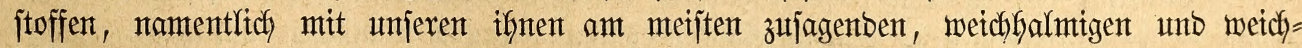
blätterigen Srasarten ober in Ermangelung berjelben mit Sofosbajt und Mantlafganf, unb reicht man ifhen wie ben (Ebelwebern neben ben bort erwäfnten \$flanzenftoffen ein Weich)=

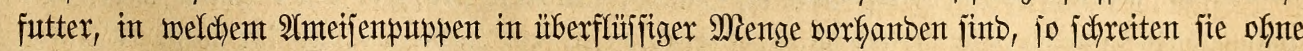

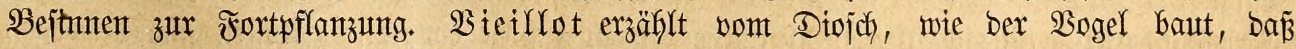

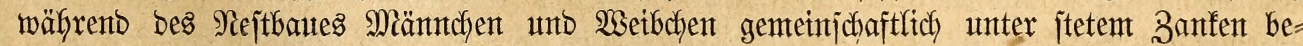

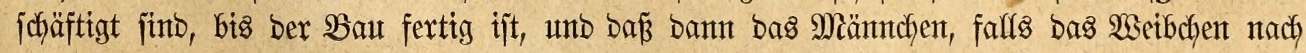




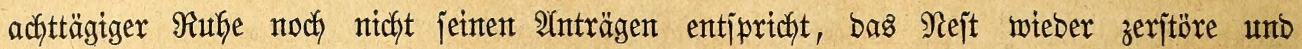

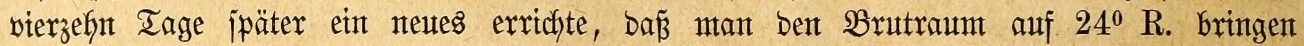

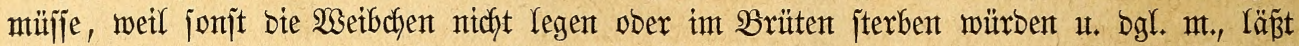

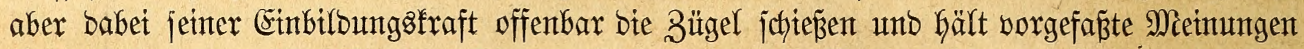

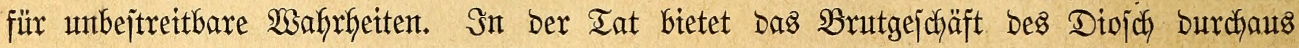
nichts, was als grumbjäblich abweidfent von bem anterer 2 Seber unb ber Cobelweber ins=

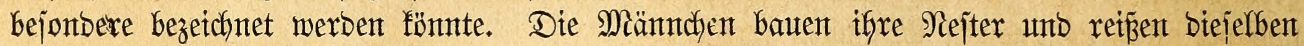
wieber eit, went es ifgnen an bent nöttgen Bauftoffen zur Errichtung anberer mangelt boer

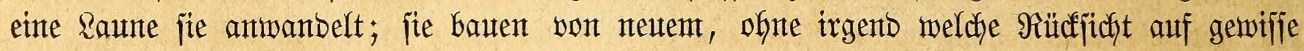

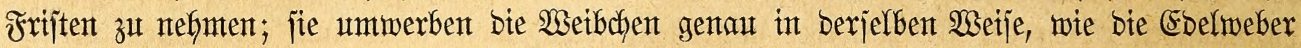
es tum, inbem fie mit exfictfltidfent Eifer als Mieijter in iffrer Sunjt fich zeigen, fortwährento

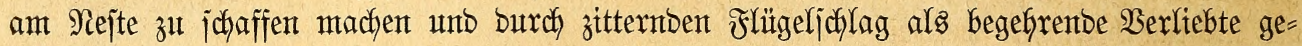

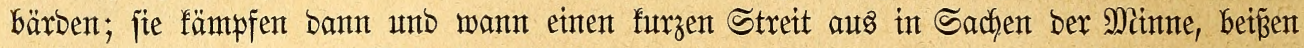

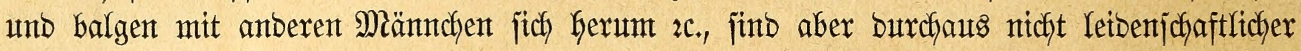

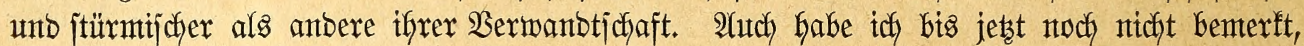

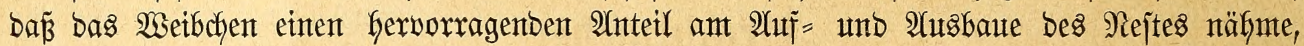

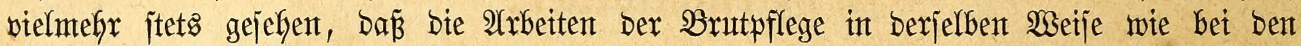

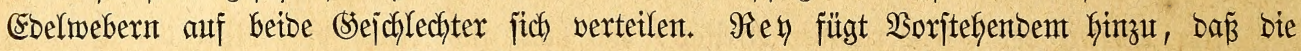

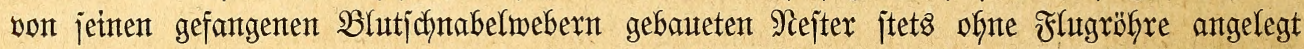

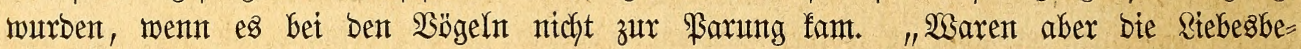

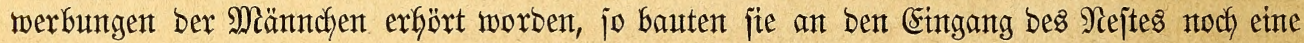

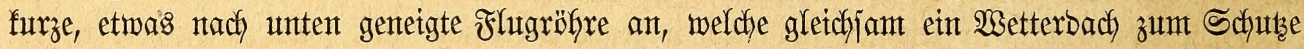

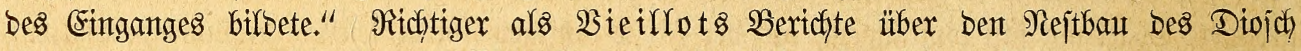

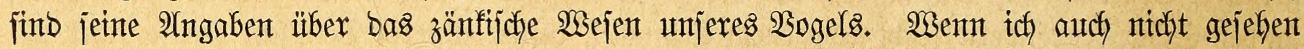

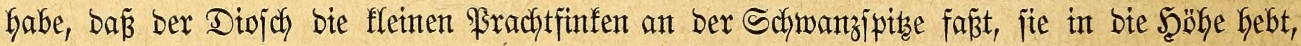

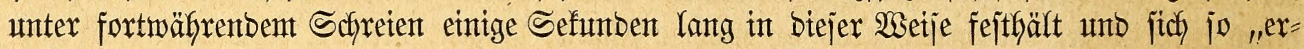
heitert," währenb bie armen Spfer jich tot jteflen, um mur logzufommen umb niddt geritpft zu

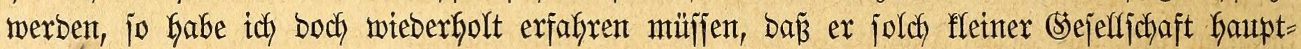

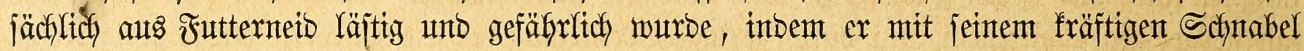
Bifife nach redyts unb linfs austeilte uno mantch einen babei arg bejchäbigte. Doch gilt bies mur

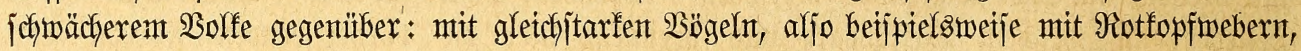

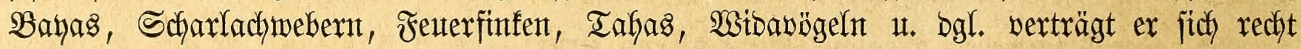
gut, went jofon bielfeidyt nutr aus bem (stumbe, weil jebem jeiner Ifngriffe bie gebürenbe

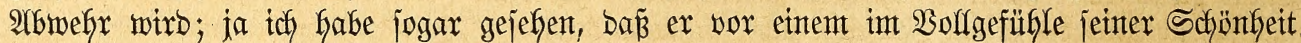

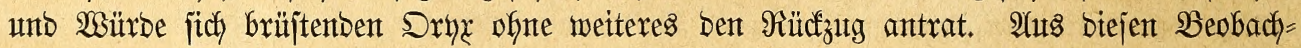

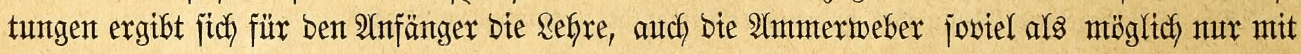

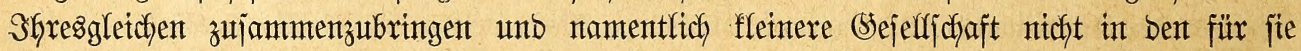
bejitimmten Räfig zu jperren. Se jtrenger mant Gierbet verfäfrt, b. K. je jorgfältiger man

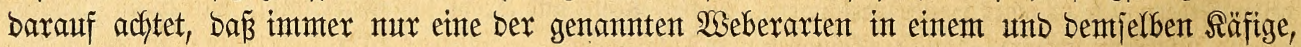

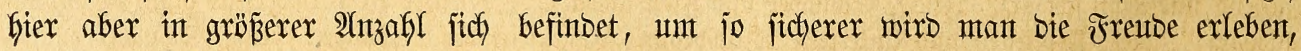

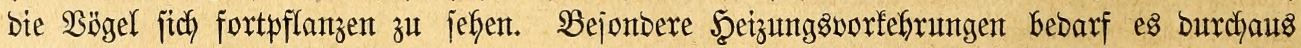

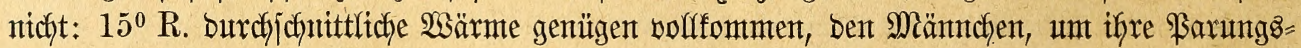

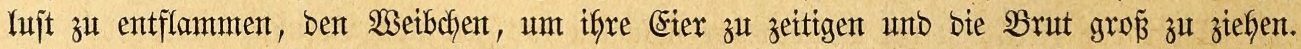

Nad) meinem Dafürffalten barf ich affen Riebfabern bie genannten 2(mmerweber und

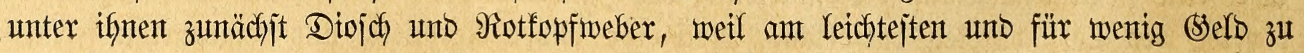

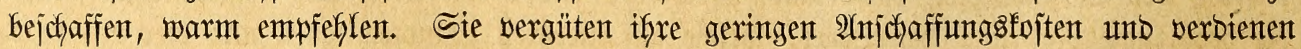

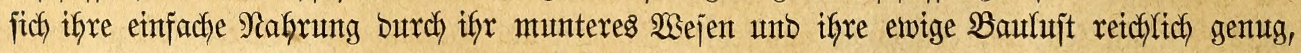
falfen nidft jebem 3ugriüftchent zum Spfer, beanjprutchen überfaupt burchaus nicfft bie jorg= 


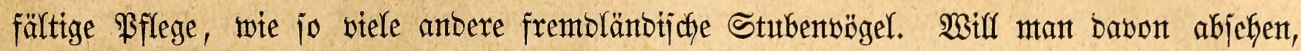
Dẩ fie fich fortpflanzen, io mag man ifynen wentgitens bunte Setben = ober Baumtwolfen=

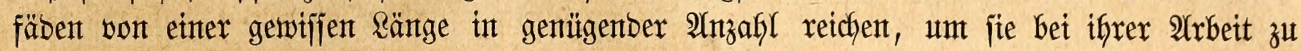

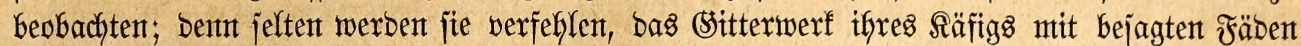

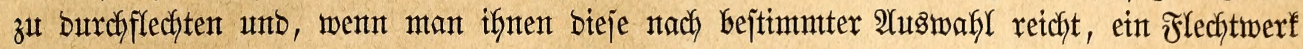
Gerzulteflen, welches eine teppichartige Buntheit erbält, bem $\mathfrak{B}$ ejitzer zum $\mathfrak{B}$ ergnügen gereicht unto bet aflen Unfunbigen Eritaunen erregt.

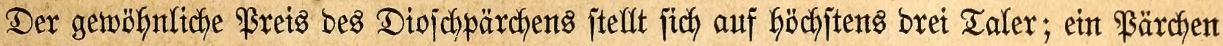

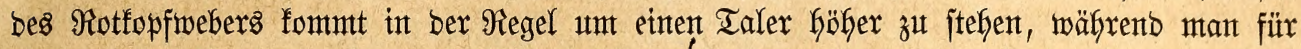

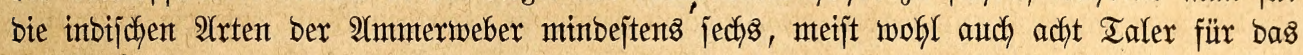

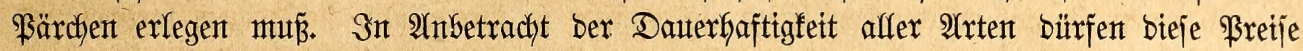
als niebrige bezetchntet werben.

\section{flradtweler.}

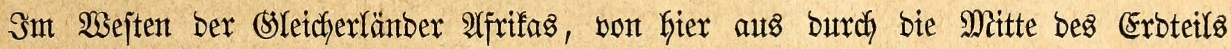

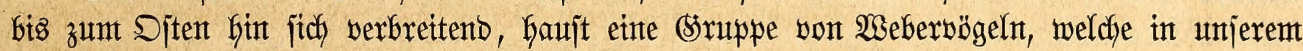

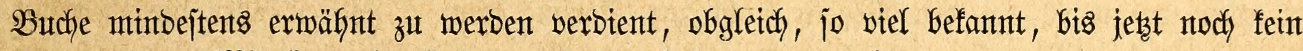
einziges iffrer Mitglieber int (sefangenjadaft gefaltent worben itt.

Die $\mathfrak{B r a d y}$ tweber zeidnten fich burch folgenbe Merfntale aus. Sie jüto groß̉e, fräftig

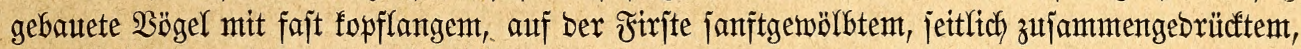
an ben Sdfneibenränbern jeicfft gebogenem Sdfnabel, befifen unterer Teil fajt ebenjo jtarf wie

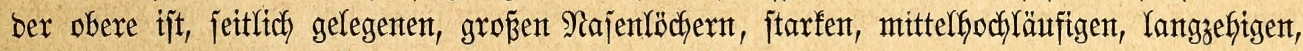

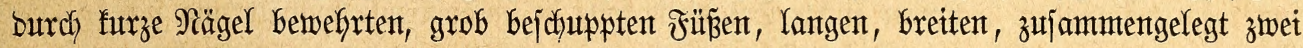
Drittel Dez Schiwanzes becfenten Flügetn, unter beren Sdjwingen bie vierte unb fünfte bie

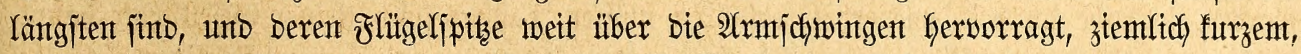

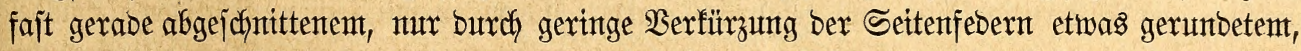
aus breiten, ant Enbe abgerunbeten Febern beftefenbent Sdfwanze unb reidfent, aber berbent

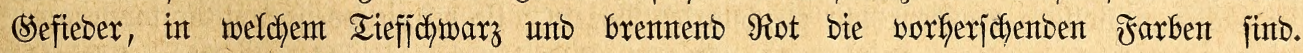

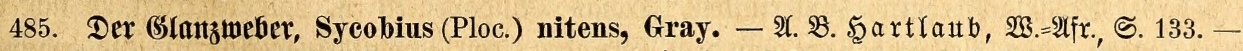

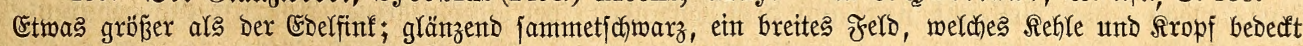

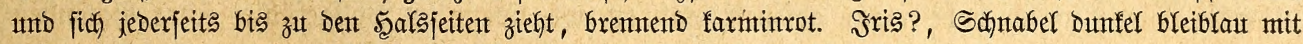

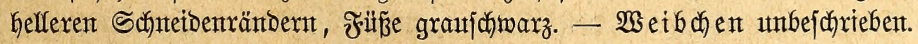

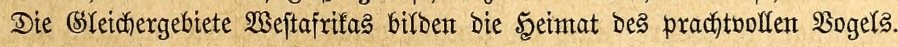

486. Der 5autbenteber, S. (Tanagra, Malimbus, Ploc.) eristatus, Vieill., (malimbica, nigri-

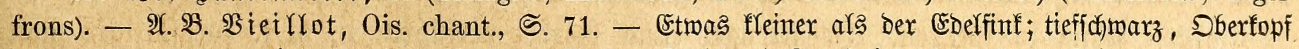

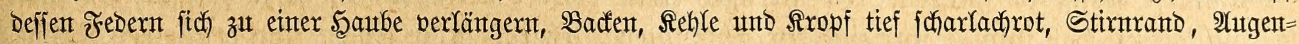

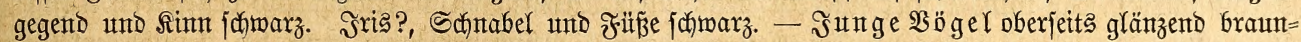

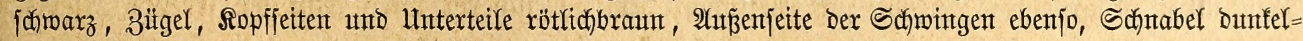

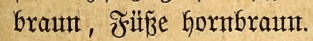

Die Secimat fällt mit der des (S)anzmebers zufanment.

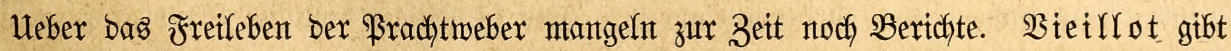

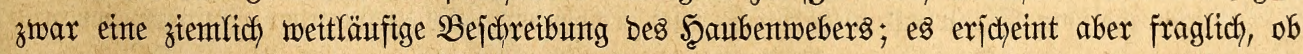

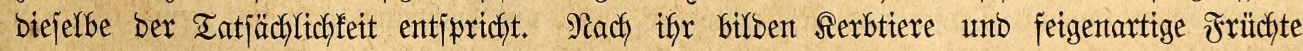

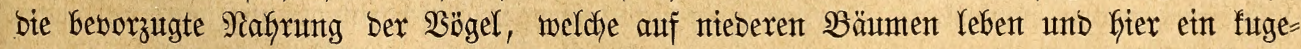

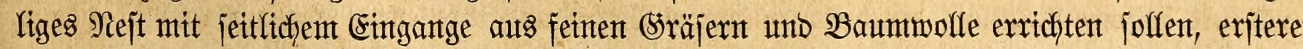

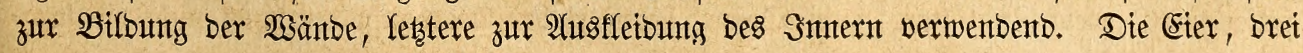




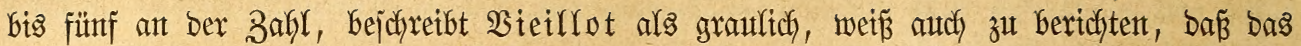

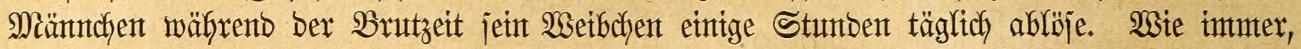

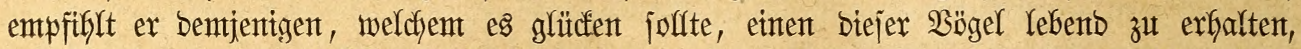

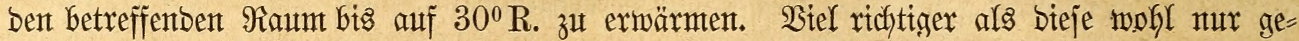

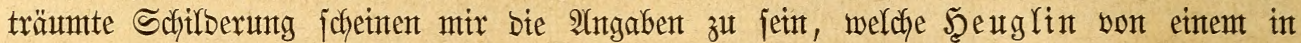

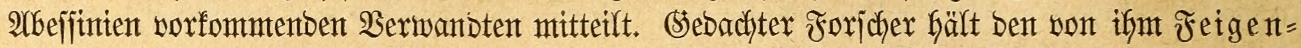
frejfer gentanten Sraddtweber (S. melanotis) für einen Stantboogel, weldher in unjeren

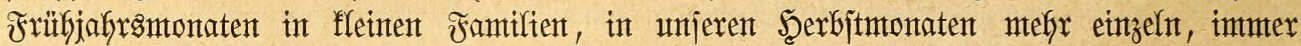

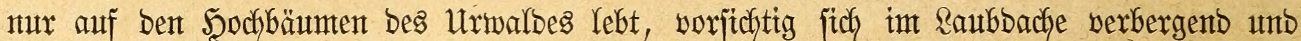

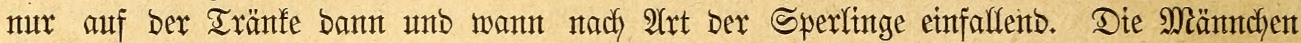

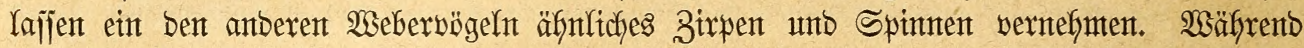

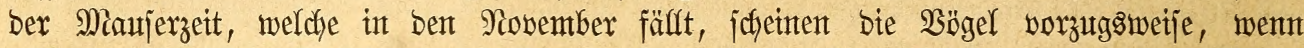

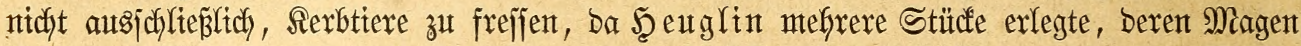

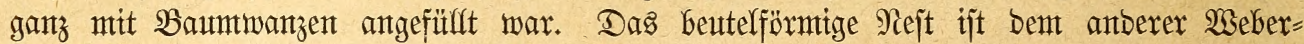

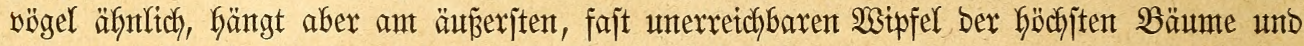
wiro ungefäfy in 2 ltgult belegt.

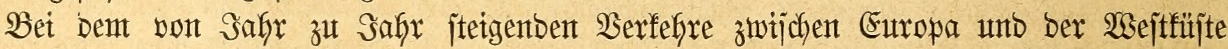

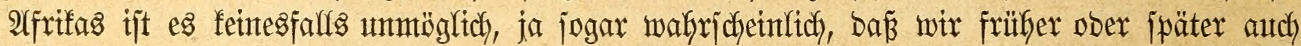

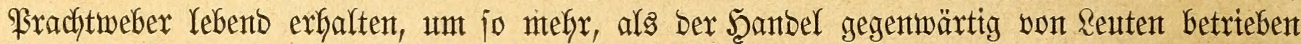

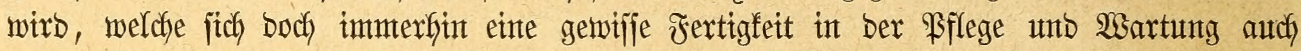

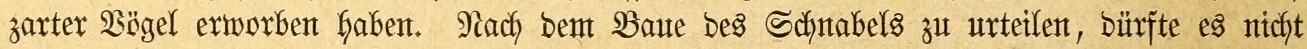

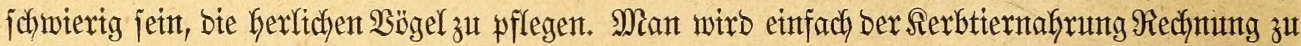

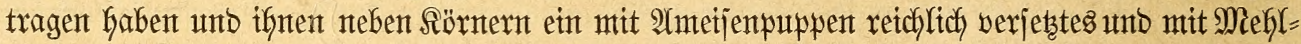

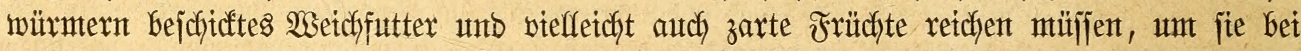

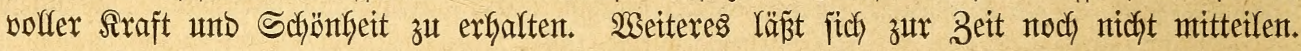

\section{Sidurtardhueber.}

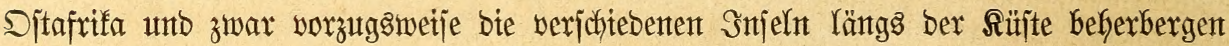

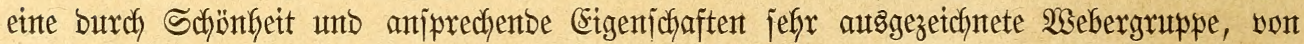

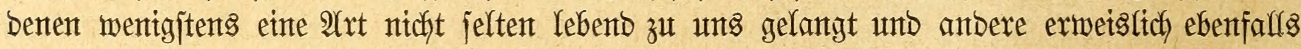
in Säfigen gefalten werben: bie Scharlach weber. Shre Mierfmale Yiegen in bent mittel= lantgen, fräftigen, auf ber Firite gewälbten, an ber $2 \mathfrak{B u r z e l}$ breiten, jeitlid ftarf zujammten=

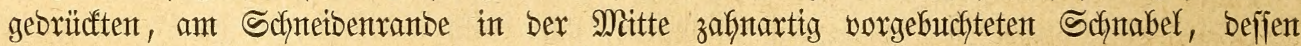
unterer Teil ebenjo hoch als ber wbere ift, ben Gochläufigen, furzzefigen, mit fleinen, aber

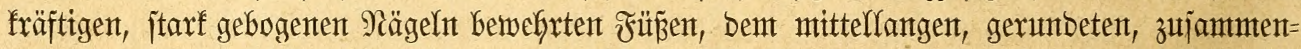

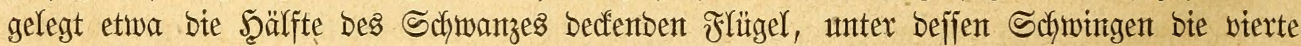
und fünfte bie längiten find und befien Spibenteil mentig vorragt, bem furzzen ober Gädjftens mittelfangen, aus zientlich breiten, ant Enbe jtuntpf zugeiptisten Febern bejtehenben Sdywanze

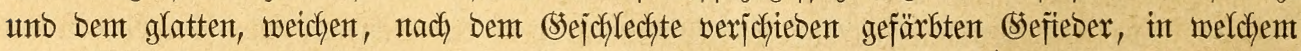

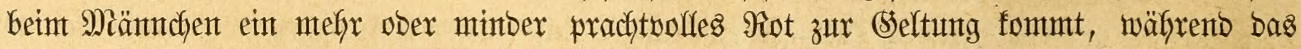

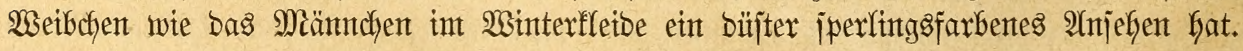

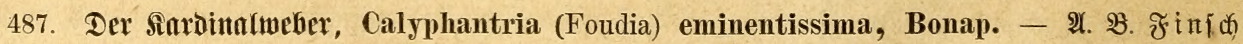

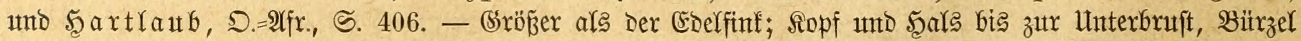

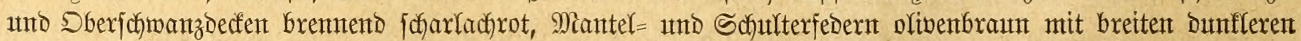

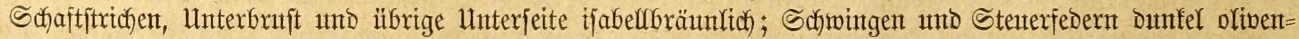

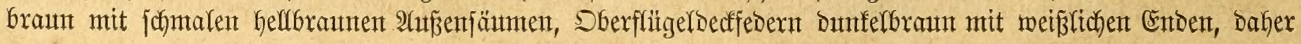




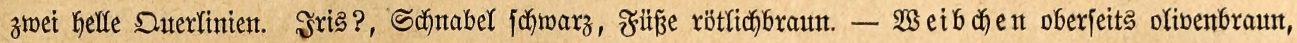
unterfeits fahfbräıturficy.

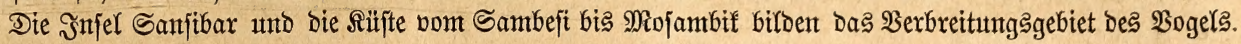

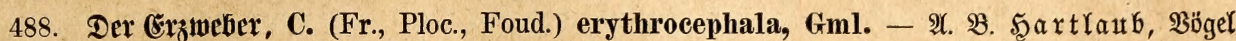

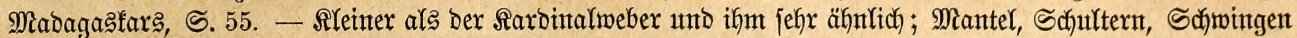

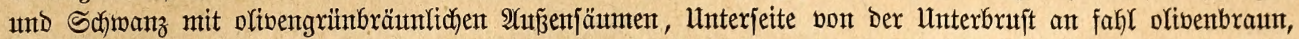

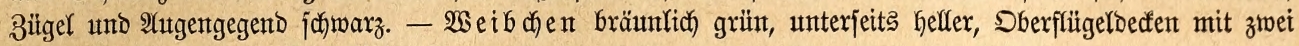
Geflent Duterbinbent wie beim Miänndyent.

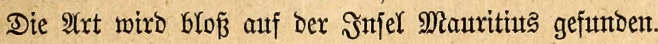

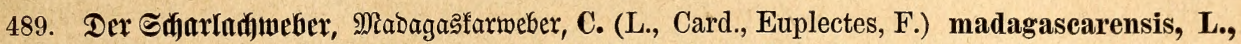

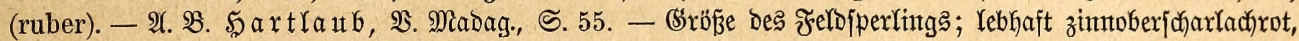

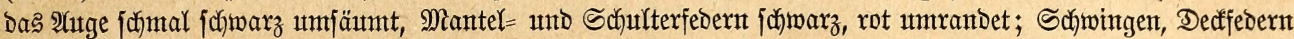

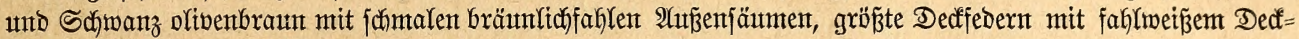

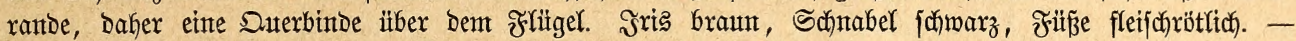

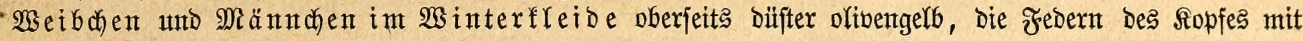

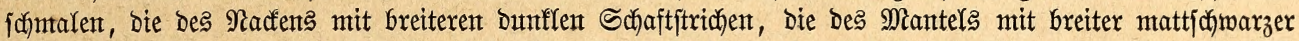

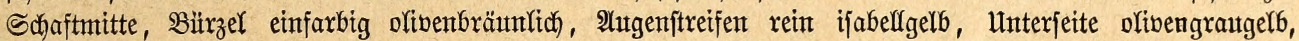

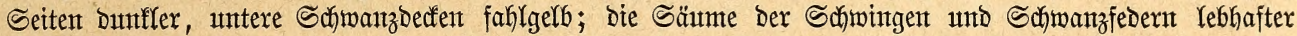

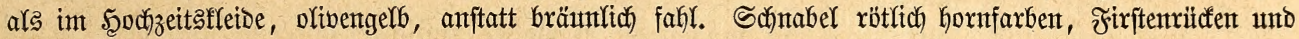

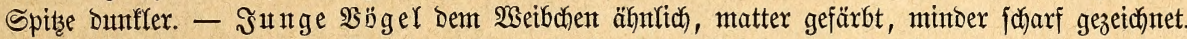

Bon Mabagasfar uno Retnion, Der urfprïnglidyen Şeimat, ift ber Scharfadfweber nadh St. Şelena

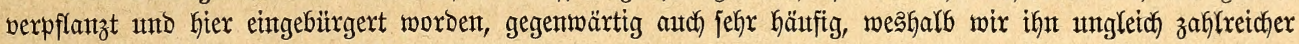
als bie übrigen $\mathfrak{S e r w a n t}$ tent Yebend erhalten.

490. Der Bijifofweber, C. (F.) flavicans, Newton. - A. B. Proc. Z. S., 1856., S. 47. -

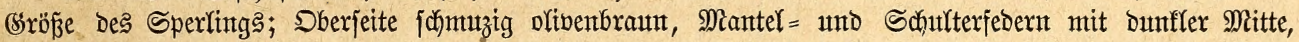

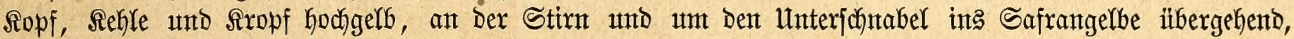

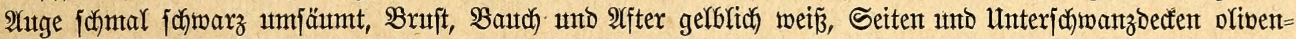

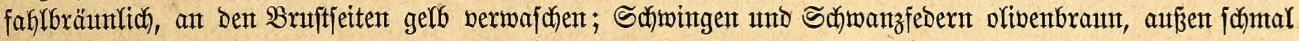

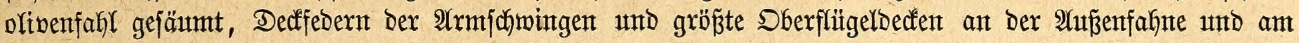

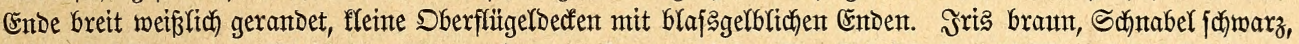

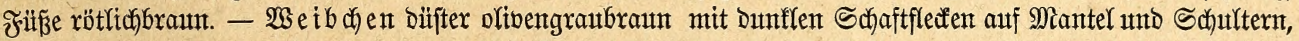

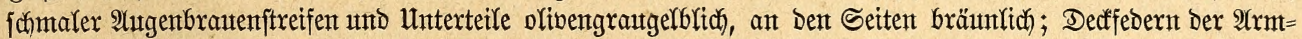

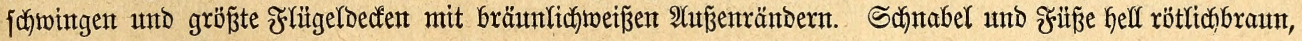
unteridntabel helfer.

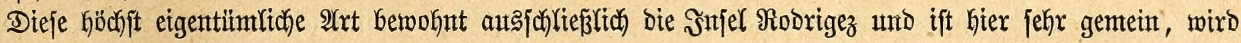
bort autch gefangent gefaltent.

Das Freileben ber Sdyarfachwebex hat bis jebzt nux in $\mathfrak{B}$ ollen einen Beobadyter gefunben. Die Mialgajdjen nenten ben Scharlad = ober Mabagazfarmeber Fubi, bie Alnjibler ber Snjel Sarbinal. Ex lebt in Irupps von jechs bis zwölf Stüdf, jachlägt fich aber ipäter zu viel beträchtlicheren Schwärnten zujammen, fälll bann plünbernb in bie Felber ein unt

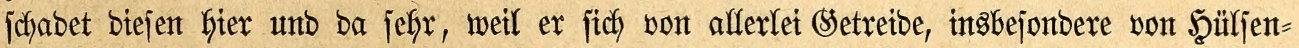

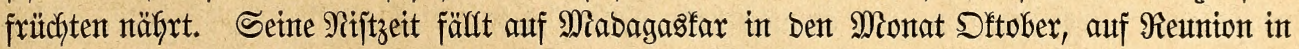

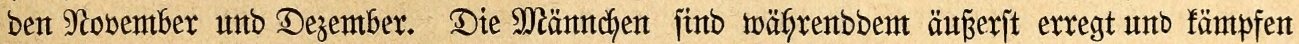

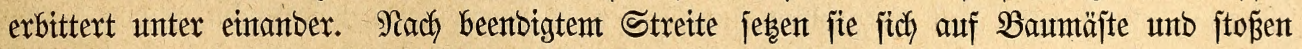
von Zeit zu Zeit ifren wie "Spit, Spit" flingenden Rocfton aus. Sobald eines von ifnten

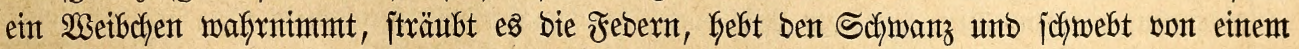

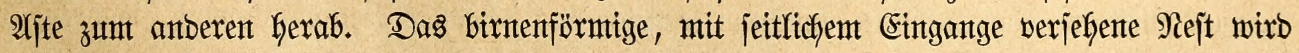
aus feinen (sräjern erbaut und zwijchen ztwei bis vier Stweigen von affazien, Mimojen,

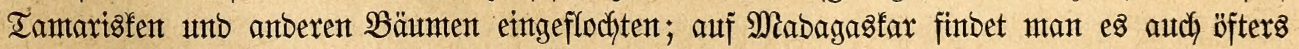

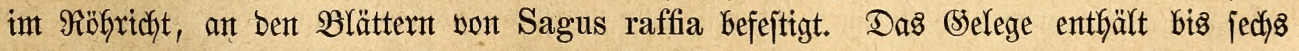

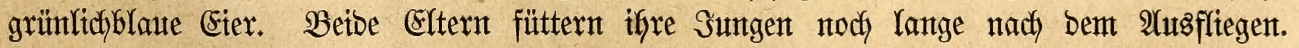

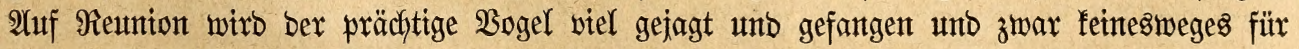




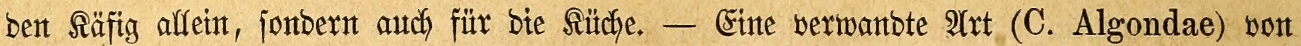

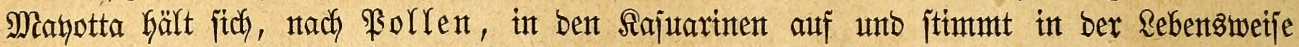
mit vorigent itbereint.

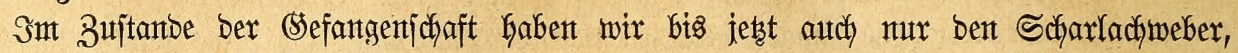

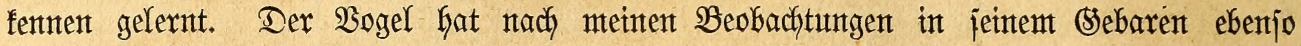

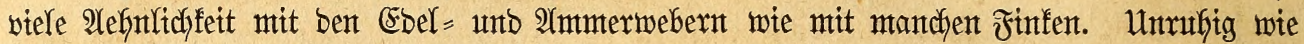

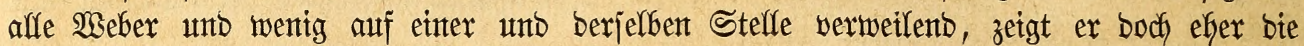
Bemeglideffeit gemififer Finfen als bie ber verwanten Ebelweber. Snzbejonbere exintern fein

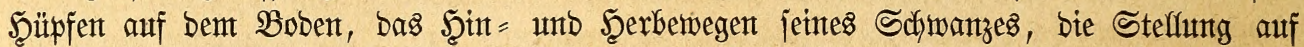

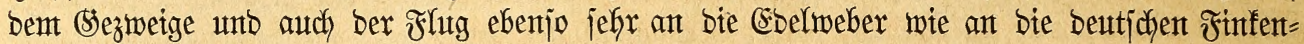

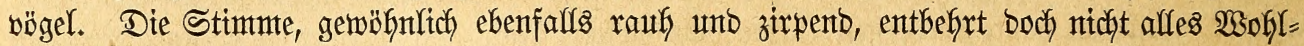

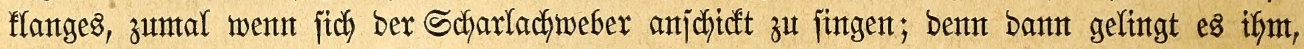

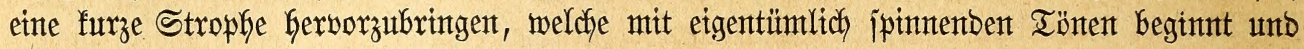
mit einemt ranggezogenten, wofflrautenten, zitternben Trifler enbigt. Sein Rodton ijt eint

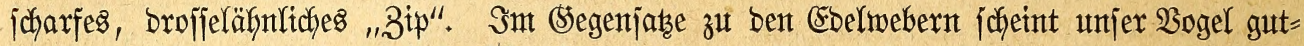
artig zu jein; minbejtens hake idh nie gejehen, baj ex mit anberen Streit ober Zant

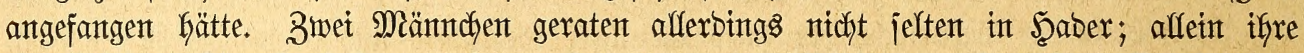

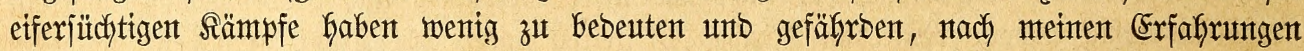

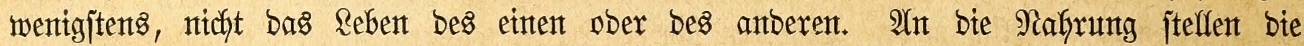

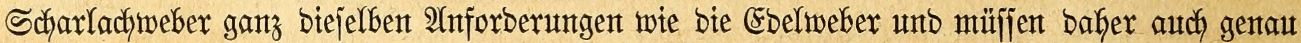
wie bieje gejüttert unb geefflegt merben. Bei guter 2(bmartung jofreiten jie ebenjo reicht

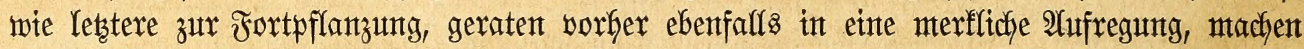

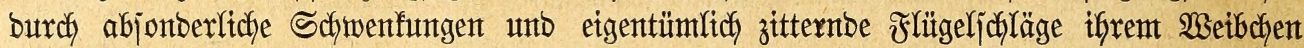
Dent Şof, offne fich jeboch jo antzultrengent wie bie Ebefweber, unt beginnent bann mit bent

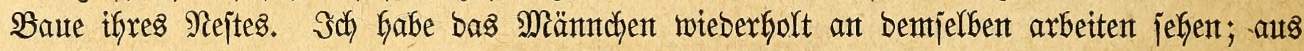

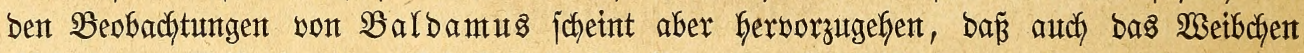

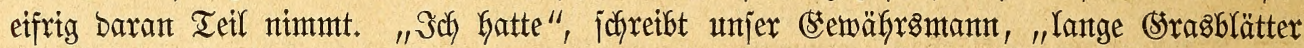

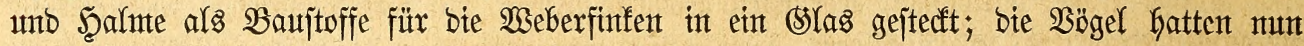

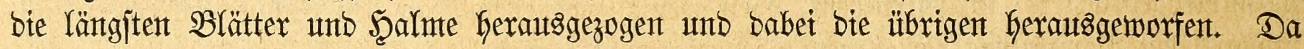

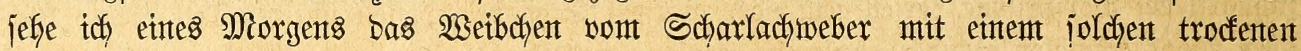

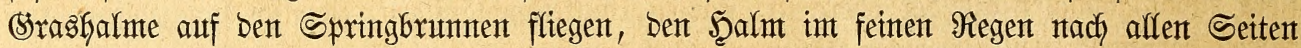

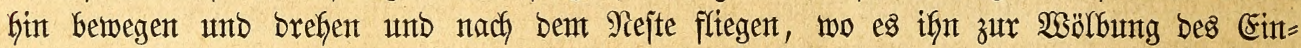

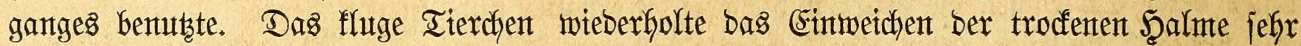

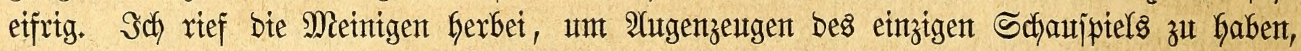

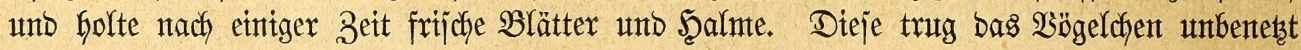

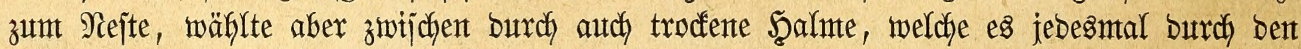

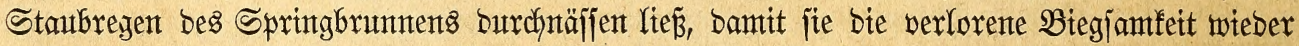

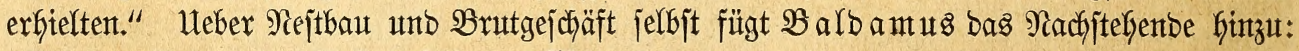

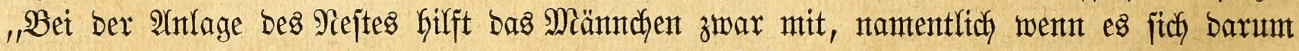

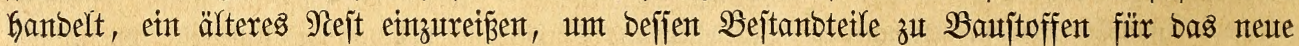

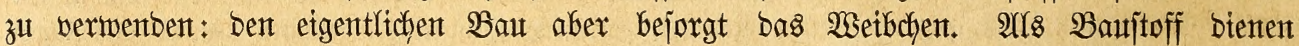

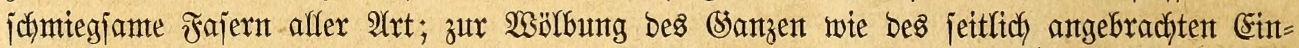
ganges werben $2(g a w e n f a j e r n$ anberent vorgezogen. Weidhere Stoffe, wie feine $5 r a b=$

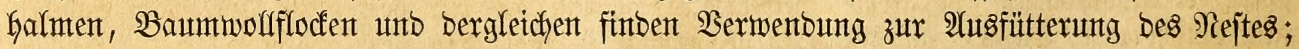

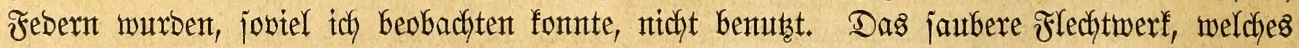

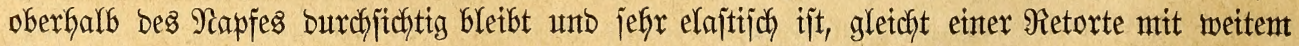

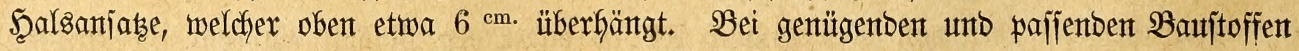

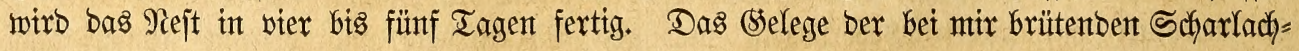




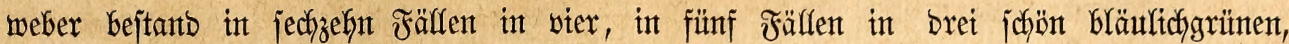
öligglänzenten, glattichaligen, rein eiförmigen Eiern, weldye bei entiprechenter Sommer=

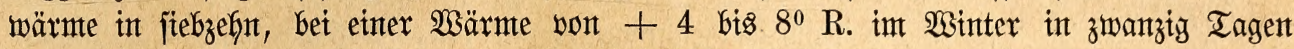
ausgebrütet wurbent. Die Sungen bedürfen tierijcher Nafrung, und beibe Ertern jimb eifrig bemüht, joldhe ifnent zu verjchaffen: meine Weibchen wurben, wenn fie Sunge hatten, jo

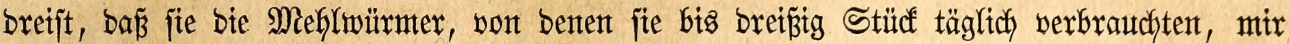
aus ber Şanb nafuten. Reiber wurben Eier unb jelbjt bis acht Tage alte Sunge vont

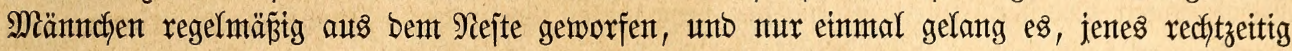
abzupperren unb jo brei Sunge aufzuziełen. Währenboem begant bas Männthen etn neues

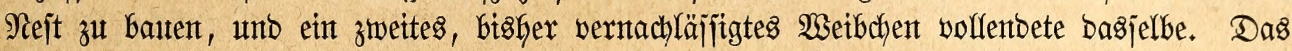

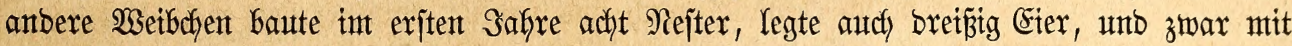

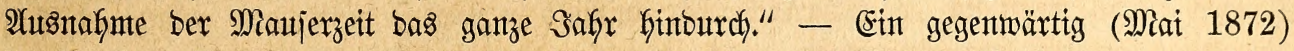
int Berlinter A(quarium bautendes Scharladyweberpärchen bejtätigt bie Beobachtungen unjeres gelefrtent unb erfahrenen Mitarbeiters volffommen. Nach jonjtigen Wabrnefmungen will ich

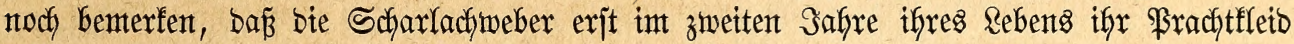

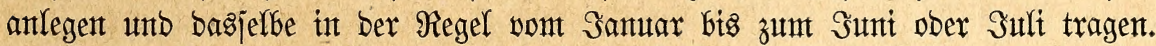

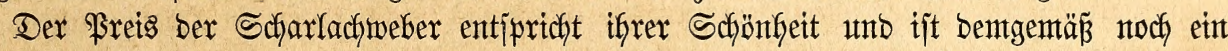

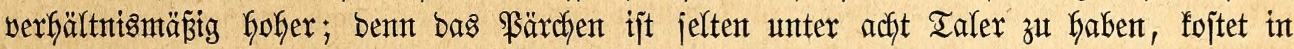

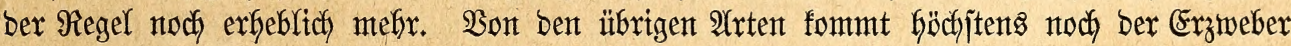
bann unt want einmal nady Eutopa herüber, hat afjo feinen beftimmten Breis. Falls

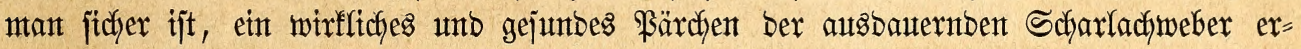
werben zu lönen, barf mant bie angegebente Summe ofne Bebenten zablent.

\section{Sperlintgsweber.}

Einige groß̉e, bidfföpfige, gebrungen gebautete $\mathfrak{S e b e r , ~ m i t ~ f a j t ~ f o p f l a n g e m , ~ j e i t l i c h ~ j t a r f ~}$ zujammengebrüdftem, fcharffirjtigem, oben wentg gebogenem, an ben Sdhnetbenränbenn mit zahnartigem $\mathfrak{B}$ orjprunge verjehenem ober glattem Schnabel, bejien unterer Teil ebenjo hoch aber etwas jchntäler als ber obere ijt, jtarfen, mittelhod)läufigen, ziemlich langzefigen, mit

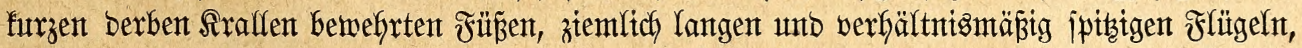
unter beren Schiningen bie britte unb vierte bie längjten jinto, furzent, gerabe abgejdynttentem, aus breiten, am Enbe gerumbeten Febern gebilbetem Schwanze unb zitemlich bichtem, büfter=

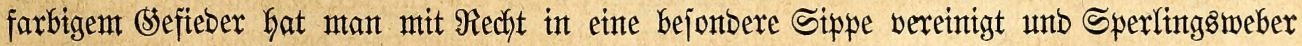
gettannt.

491. Der Mandali, Philagrus (P1., Plocepasser, Leucophrys, Agrophilos) mahali, Smith,

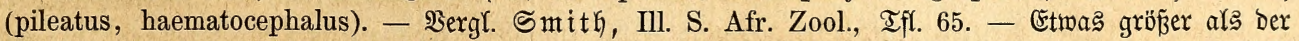

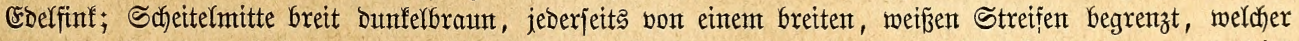
ïber Dent 3ügelnt entfpringt unt fidch bis hinter bie Sd)läfent żieft, Bügel unt Ropffeiten braut, unterfeits

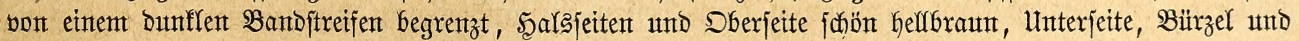

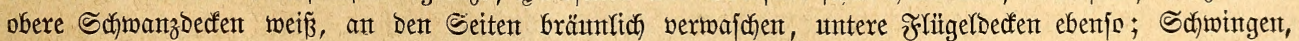

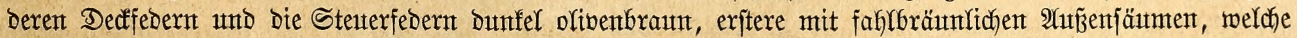

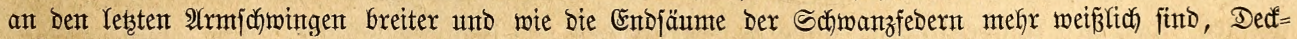

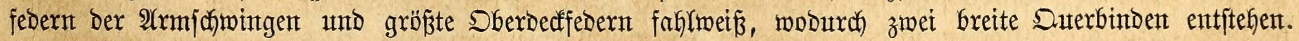

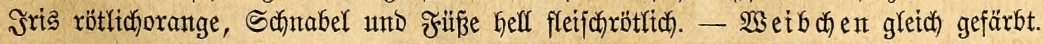

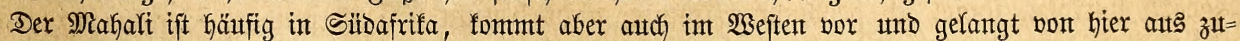
rweilen int utnjere Räfige.

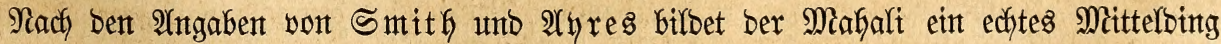
zwijchen ben eigentlichen 2 Beberwögeln uno ben Sperlingen, unt fiermit fimmt auth) 


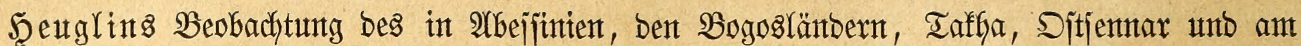

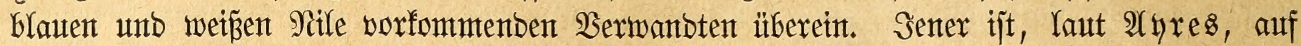

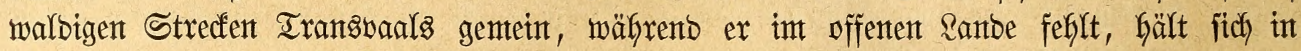

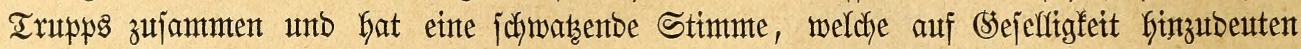

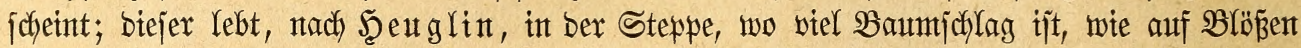
im eigentfichen Waarbgebiete woffl nicht über $2000 \mathrm{~m}$ über bent Miere, nteijt in Baren ober

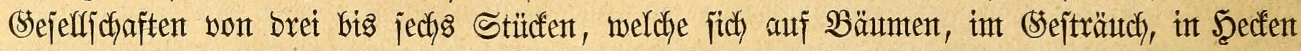
unt auf Stoppelfelbern auffalten. Der Roctton, ein joyarfes Birnen, äfintelt bemt ber. meiften

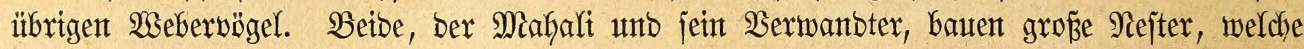

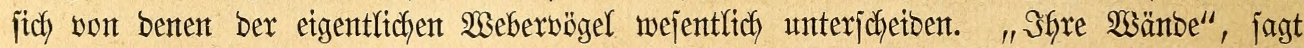

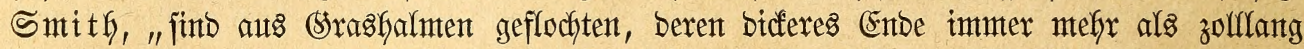

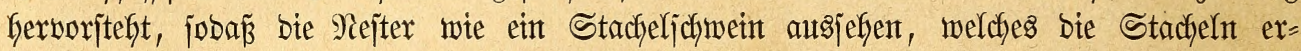

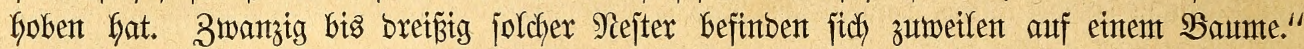

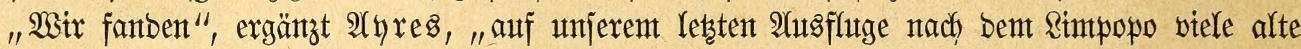

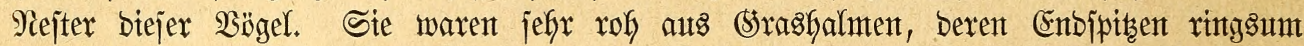

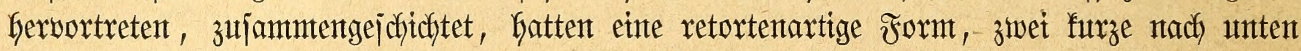

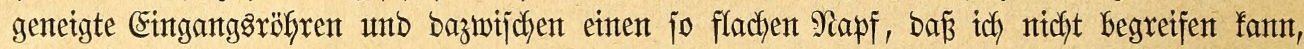

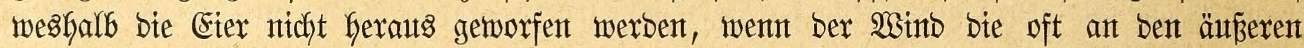

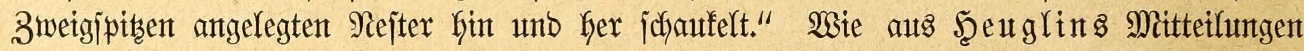

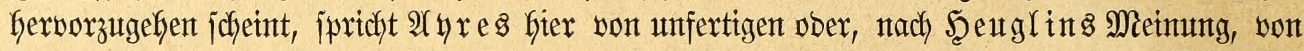

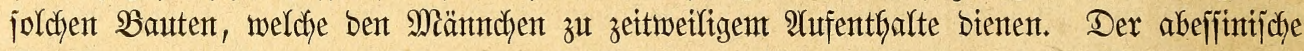

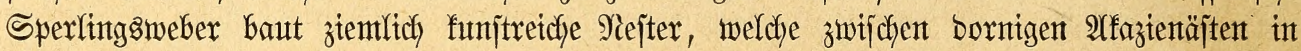

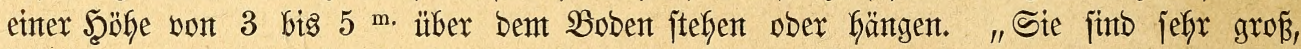

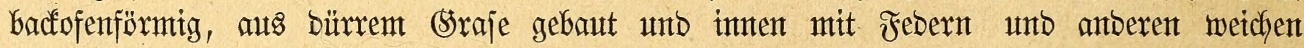

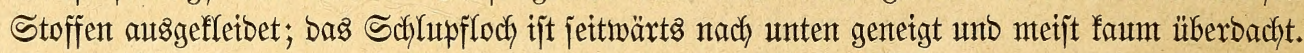

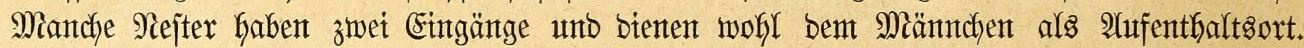

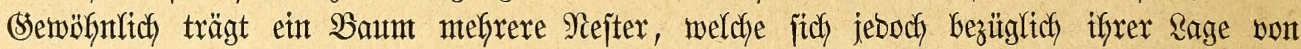
benen ber 2 Seberböget unteridyeiben, inbemt fie mefy int Sntmern ber Baumfronen ober nake bent 2 Bipfel, nicht aber an bent Entbe jofjwanter 3weige angebradjt fint. Mandje biejer

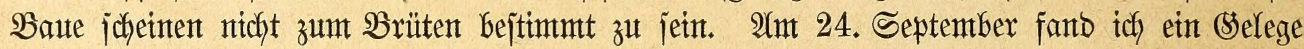

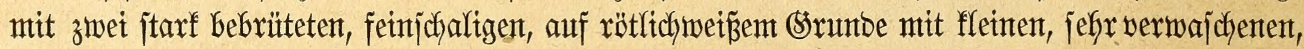

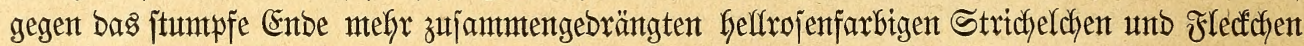
gezetdynete Eier."

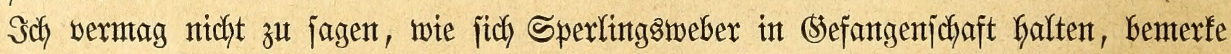

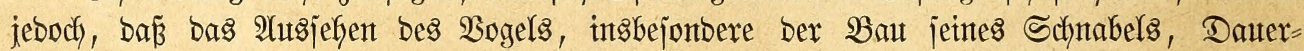

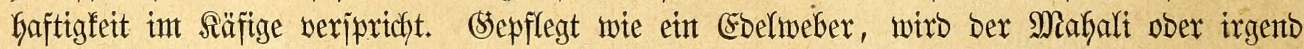

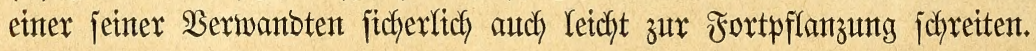

\section{(Jerellididaftsweder.}

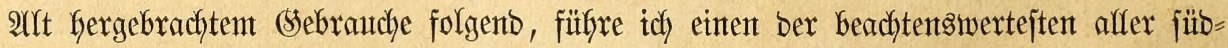

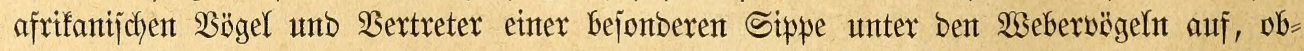

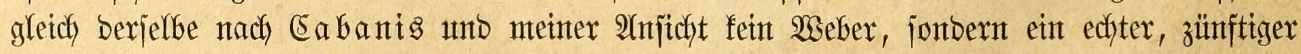
Sperfing ijt. SGgn fennzeidfynen ber gebrungene $\mathfrak{B a n}$, Der mittelfange, fräftige, jeitfich ebent= falfz jtarf zujanmtengebrüctte, auf ber Firifte janft gebogente, an bent oberen Schnteibentänbern

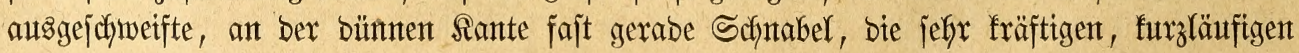




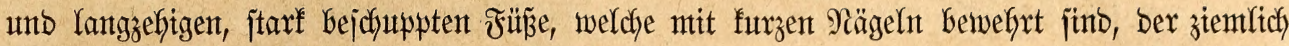
lange Flüget ofgne vertünmterte erjte Schyinge, in welchem bie zweite Sclywinge bie übrigen anberen überragt, unb ber futrze, Greite, gerabe, aus amt Endoe abgerunbeten Febern gebilbete Schwanz, jowie entlich bas bidfte ipertingsfarbene Befieber.

492. Der Sibelweber, Philetaerus (L., Euplectes) socius, Lath., (lepidus). - $\mathfrak{B e r g h . ~}$ S mith,

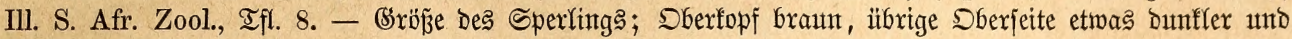

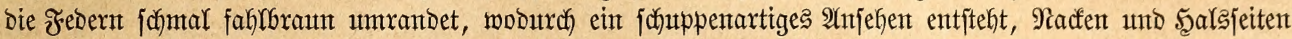

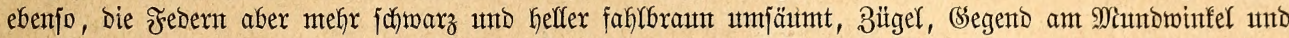

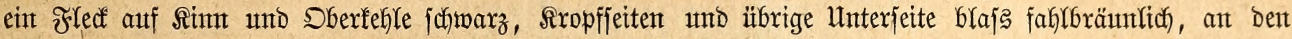

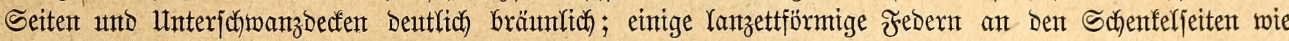

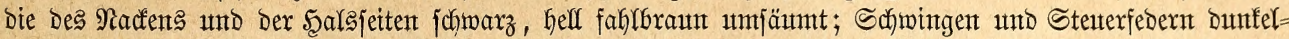

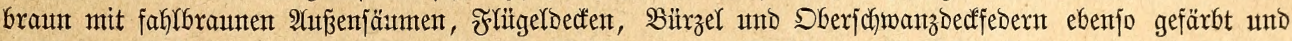

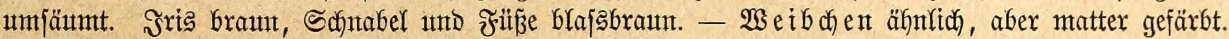

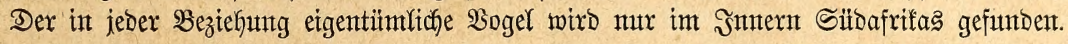

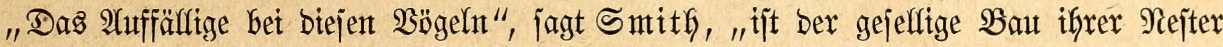

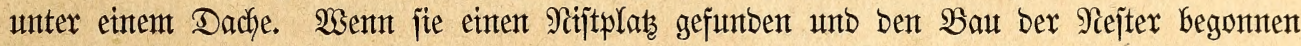
haben, madyen fie fidch zuerjt baran, genteinjchaftlidy ein affen bientenbes Dach zu errichtert.

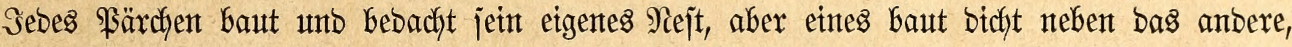

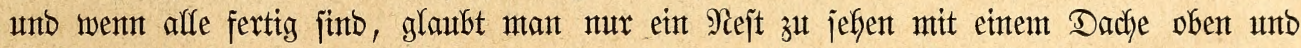
utzzähligen freisrunben \&ödhern auf ber Unterjeite. Bei einer zweitent $\mathfrak{B}$ rut werbent biejelben

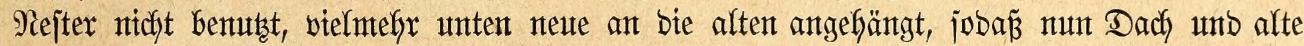

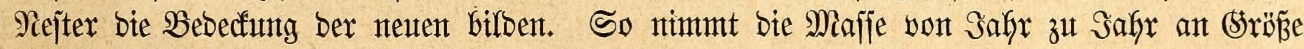

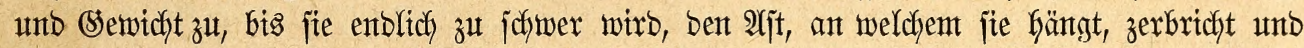

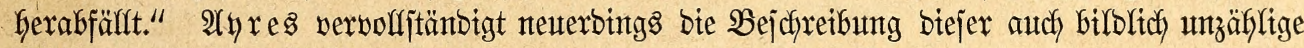

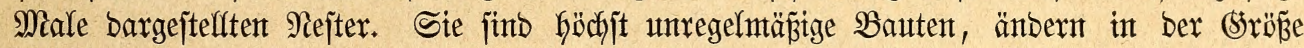

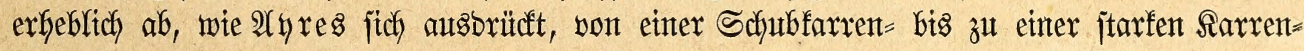

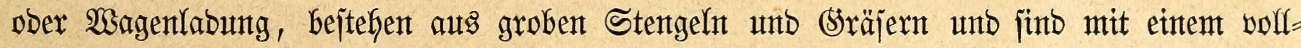

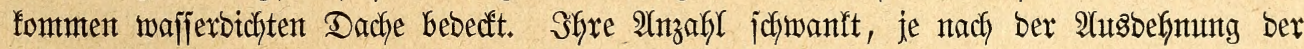

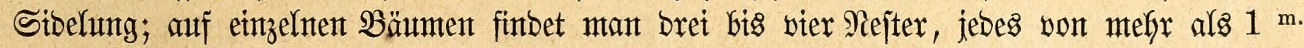

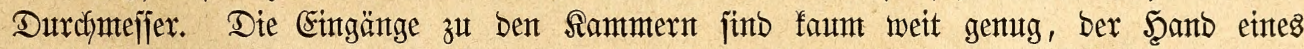

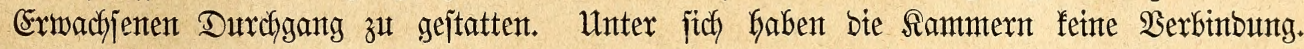

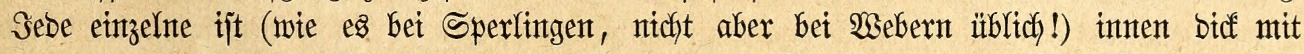

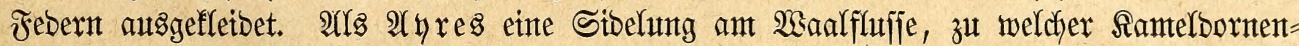

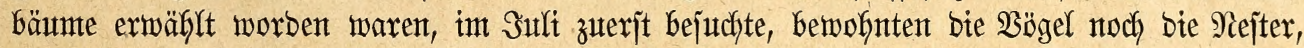

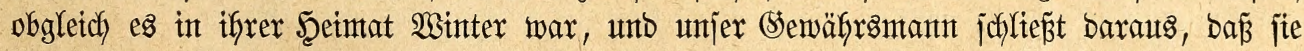

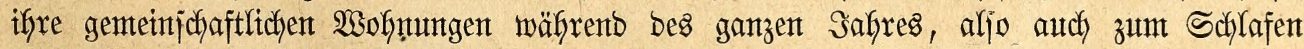

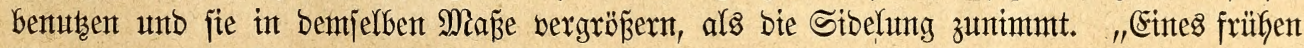

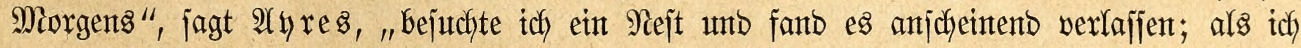

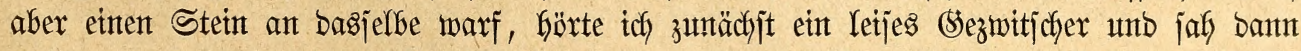
nach) unt nach eine ganze Familfe herausfliegen, eintes ifrer (5lieber nach bent anberent.

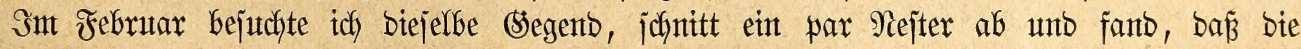

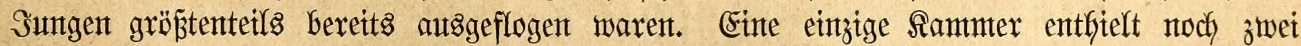

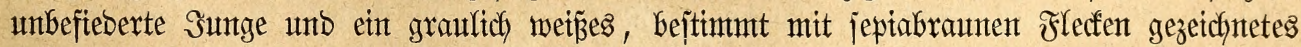

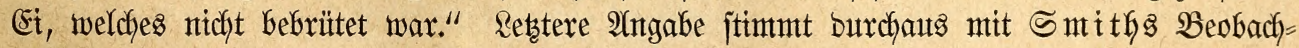

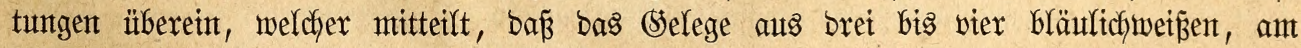

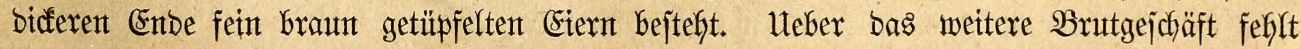

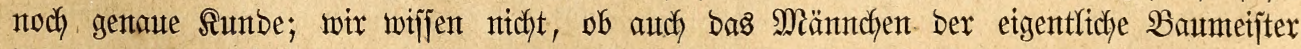
ift ober nicht. Serbtiere, welche ntamentficty auf bem Bobent gejucht werben, Gifben bie

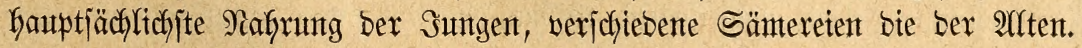


Seiber Yebt ber Sibelmeber zut tief int Sntern Iffrifas, namentlidy int Dantara = unt

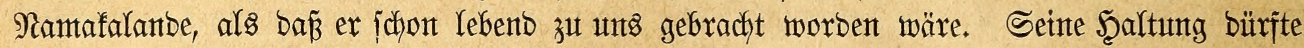
nidft bie geringiten Sdywerigfeitent verunjachen; bent man hat es jebenfalls mit eintent

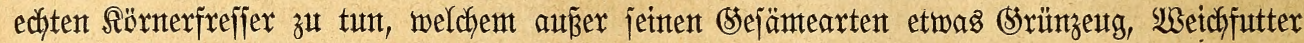
unto Mefliwürnter volrjtändig gentïgen werben.

\section{Siduppenueber.}

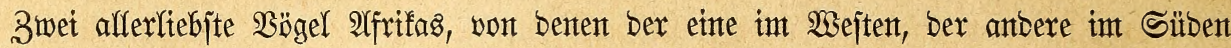
wohnt, vertretent bie Sippe ber Schuppenweber, beren Merfmale folgende jint: Der Schnabel ijt mittellang, folbig, auf ber Finjte janjt gemölbt, im Yesten Drittel jtarf zujammengebrüdt,

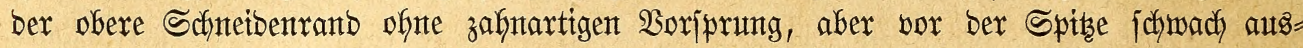

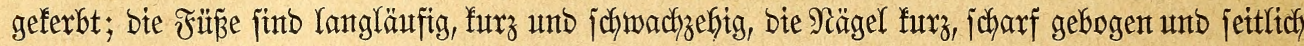
zujammengebrüdt, bie Flügel mittellang, gerunbet, in ifnten bie britte bis fünfte Sdywinge Die längiten, bie Sdyulterfedern jo lang, baż bie Flïgeljpitze faum vorragt, ber Sdywanz ijt mittellang, aus breiten an ber Spitze gerunbeten Febern gebilbet, bas weiche (Sefieber burch janfte Farben ausgezetchnt.

Eine eigentümltche, ichuppenartige Beichnung ber fopffebern unt ein breiter Streifen vom Schnabelwinfel abmärts mögen nody als bejonbere Siennzetchen gelten.

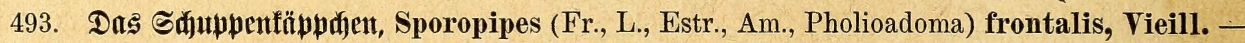

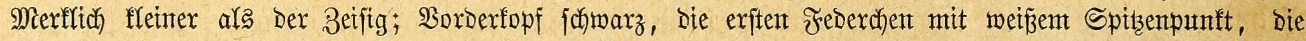

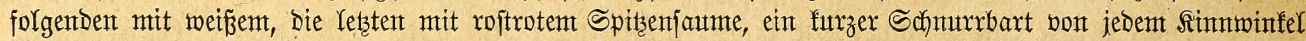

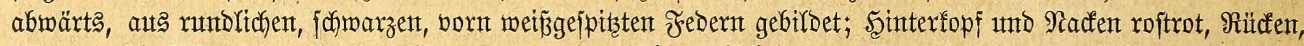

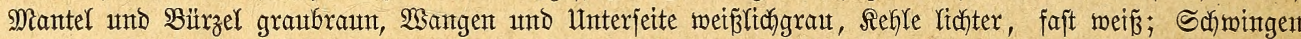

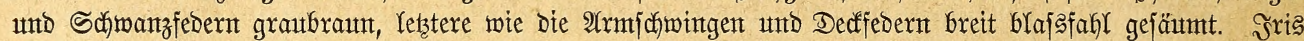

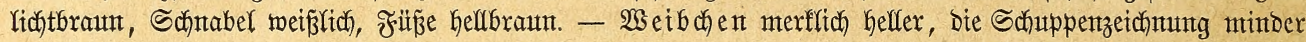
Deutlict).

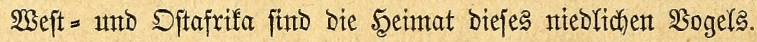

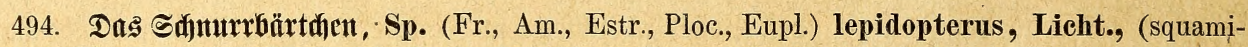

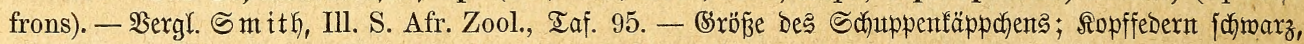

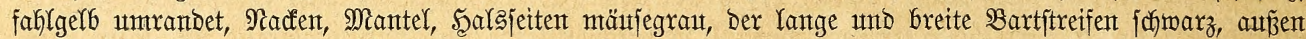

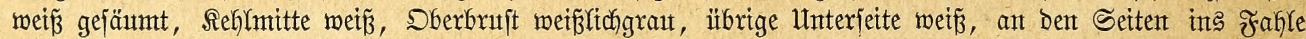

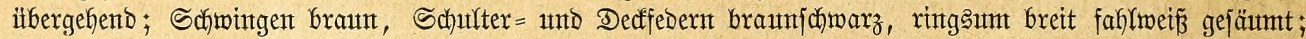

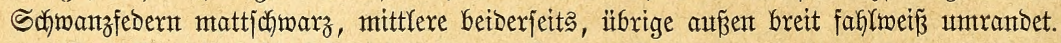

Das Saterfant ift Sild afrifa, nantentfich Das Damaralanto.

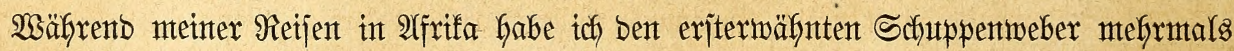
gefunton unt erlegt, niemals aber längere Beit beobadjtet, mur mich Daber auf Şeuglin

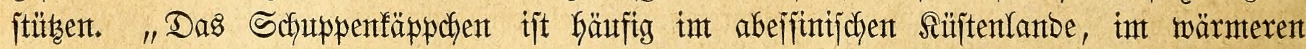
Şabeich, Sübnubien, Sentar uno forbofan, boch wie es jcheint, an gemiffe Sertlichfeiten

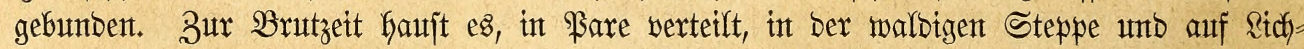
tungen in bent eigentfichen Walbgebiete, fonmt aber audd auf Seecfent und jelbit in bie

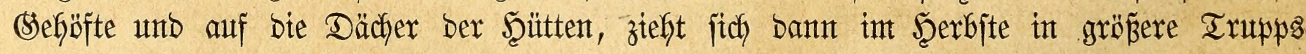

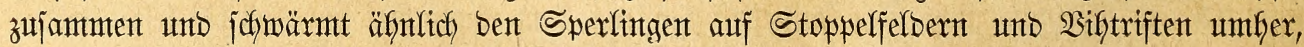

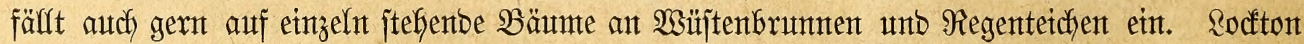

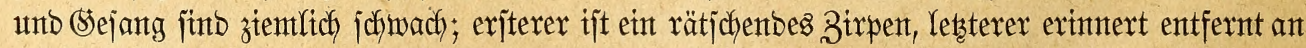

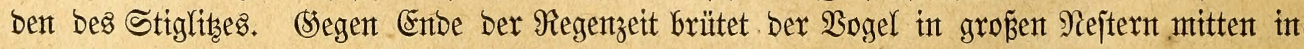

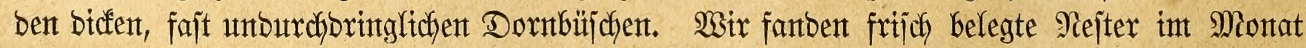
September int Sogoslantbe, ebent ausgeflogente Sunge int November in forbofant. Die 
Nejtex bejtehen aus trodfenen Sirashalmen, haben eine badfojenförmige Bejtalt, fint jehr bicht

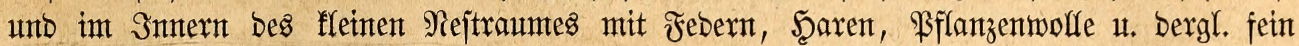
auggefleidet. Die Eier gleitjen Dunfelbraumen Şausjperlingseiern, fint aber viel fleiner, glänzenber, żemlich Gartichalig, von bräunlich) grauer (s)rumbjarbe mit bunfleren graubraunen Jlecten über unb über gleidfförntg bebedt." Freileben und Siejtbau bes Schnurrbärtchens jchilbert $\mathfrak{A}$ y res. "Dieje fletnen, abjonberlidjen gejelligen $\mathfrak{B o ̈ g e l}$, jagt ex, "leben am simpopo,

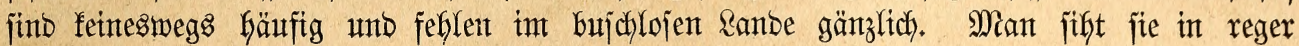
Tätigfeit, unter nieberen, Dornigen Büjchen untherhüpfent. Jm Miärz fanto ich jie am

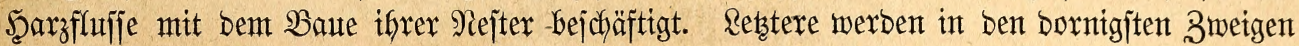
bes Sujches, faum ein Meter üfer bent Srrunbe angelegt, bejtehen äuzerlich aus bünnen (Sragitengelth, beren Enbjpitsent unorbentlich nady alfen Seiten vorragen, und find immen bidgt

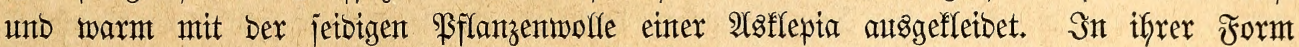

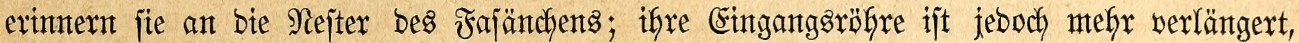

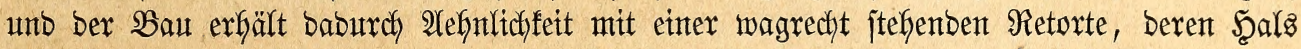
etwas nach unten fich neigt. Die fünf grünlich weisent Eier finto, zumal am bidferen Ende, bicht mit umberbrauten Flecten, einzelne auth mit braunen sinten gezeichnte."

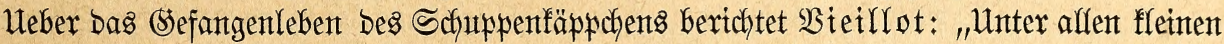
Bögeln, weldie man uns yom Sentegal zufüfyt", jagt er, "ift biejer ber zartejte, ber empfintolichjte

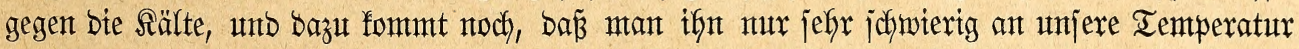
gewöhnen fant, weil er alfe unjere Sämereien, weldje ifym angeboten werben, verjanmäht unt ifym mux Şirje vom Sentegal behagt. Die Reijenten, weldhe ifn mit herüberbringen, müifen baker jtets eine bebententbe Mentge bes gebachten Şirje mitnefymen unt burch Betmijdyng von (S) lanz ifhn nach unto nach an bie neue Nafyung gemöhnen. Die Wärme, weldhe er in erjten Sabre unbebingt haben muś, barf nite unter $20^{\circ}$ faflen; wenn er fïh aber fortpflanzen joll, werlangt ex eine weit höfere Iemperatur. Er gefällt mur megent jeines janften unb gejelligen $\mathfrak{B e j e n s , ~ b e n n ~ e x ~ j i n g t ~ j e l t e n , ~ n t i n b e j t e n s ~ i n ~ B e f a n g e n j w h a f t , ~}$ unto jein Benefmen hat nidyts Bemerfenswertes." Sch habe midh über bie ânjichten

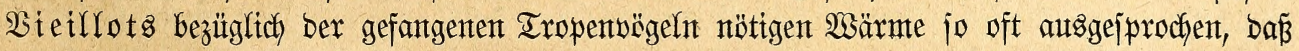
es unnötig erjejeint, nody Weiteres Gierüber zu jagen. Went man, wie bies beim Sctyppen=

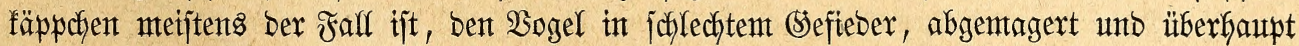

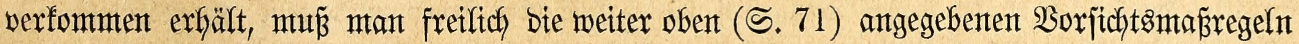

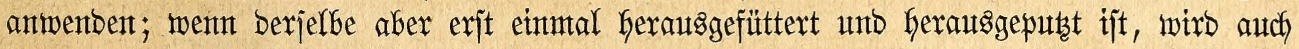
ex nicht meb̆r Umitäntbe machen als beijpielsmeije ein cobljchläger ober einter ber zarteren

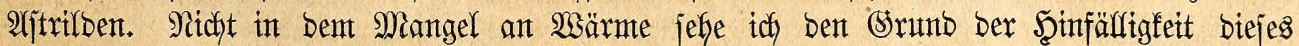
Bogels, jonbern in bem unpaffenten Futter. Der baat bes Sctyabels jpridyt beutlidy bajür,

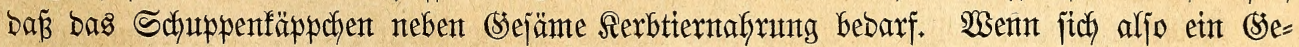

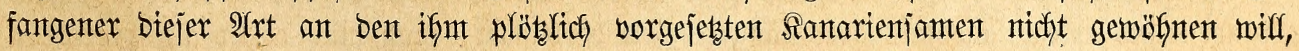

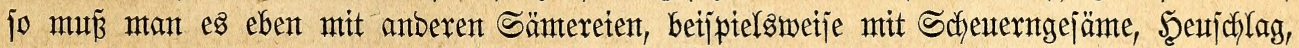
Mohn, Rübjenjamen verjuchen unb auberbem ein wohl zubereitetes Weidyfutter bieten, unb es mü̈̈te jonberbar zugehen, wenn jich Diejer Sogel babei nicht ebenjo gut Galten joulte wie mancher Djerwante. Beptimmtes fant id alferbings nicht befaupten, ba es mir zu= fälliger Weije niemals geglüdțt ijt, Das Schuppenfäppchen für mich zu erwerben, ich aljo unmittelbare Serjuche nicht habe amjtellen fönnen; Dem ungeadhtet habe ich bie fejte Heber=

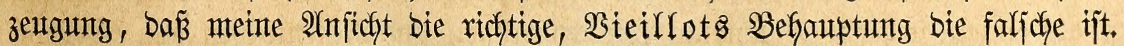




\section{Sidhwä̀}

Dex Borrytänbigfeit harber füfyre ich noch eine $\mathfrak{B}$ ogelgruppe an, welche gemöfnllich an bas Enbe ber Unterfamilie Der $\mathfrak{B e b e r}$ geitellt wirb, ebenjo gut aber auth als ein Binbeglied zwijchen ben 2 (mabinen und Webern betradjtet werben fant. Shre Merfmale jumb:- geringe (3röß̈e, żentlich jeflanfer, am Srumbe verbreiterter, gegen bie Spibe fin jeitlidy zujammen=

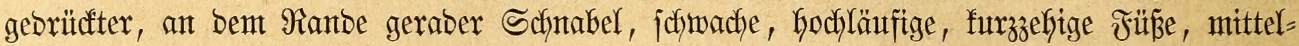

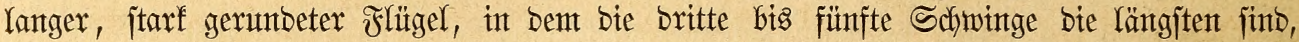
mittellanger, aus breiten, ant Enbe abgerumbeten Febern gebilbeter Safwanz, fowie entlich ein abjonberlich büjter gefärbtes fletb.

495. Der 3meifarbenidımär

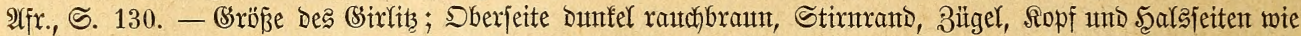

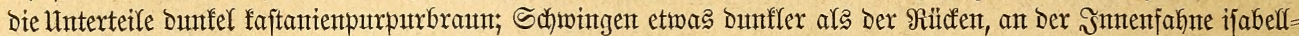

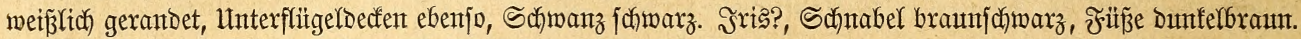

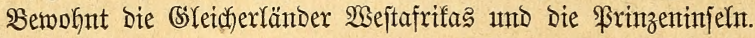

496. Der Mantelidmür

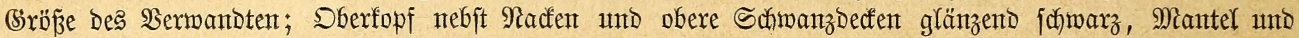

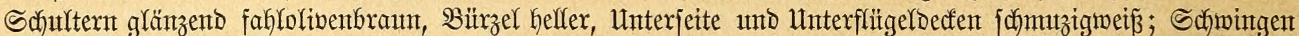

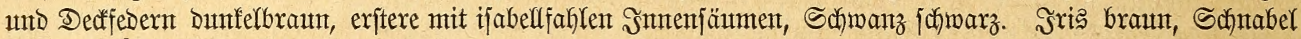

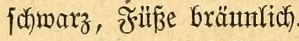

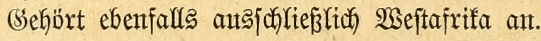

Das Freiteben ber aufgefüfrten 2 rten, welche erweislich bis jebst nody nidyt in unjere Säftge gelangt junb, aber für bie nächjte ßeit mit Bejtimmtbeit ermartet merben bürfen,

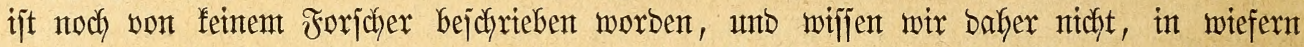

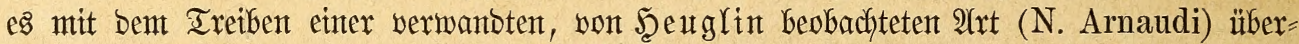

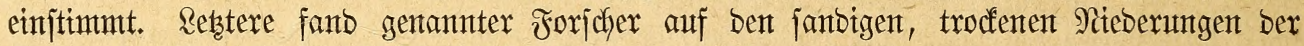

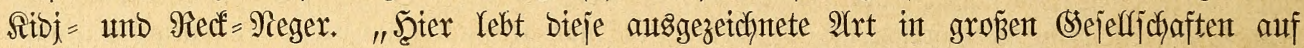

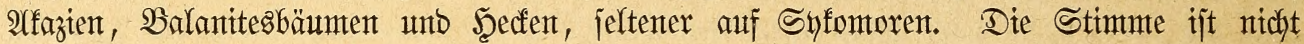
angentefm, zirpent und pfeifend, fperlingarartig. Snt Februar und Meärz baut fie grope Beutelnejter, beren oft Dubende auf einem Baunte hängen. Biele biejer Nejter haben zwei Eingänge von unten, weldye mux burdy einen jofynalen Damm getrennt fint. Dieje

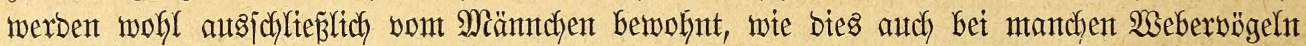
vorfommt. (?) Es ijt mir nidht gelungen, bie Eier jelbjt zu finben; bods erfielt idh joldye, melche biejer âtrt zugeidyrieben wurben. Sie junb jtuntpf eigejtaltig und reintweis

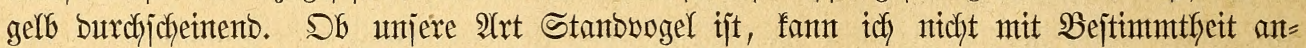

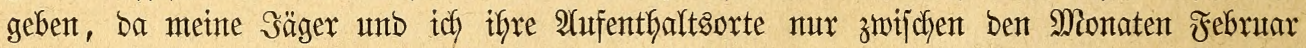
und 2 (pril bejuchen fonnten."

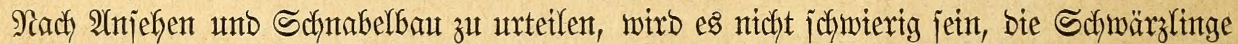
in Stefangenichaft zu balten; unt bei geeigneter $\mathfrak{P f l e g e}$ bürften jie ebenjo gut als antbere

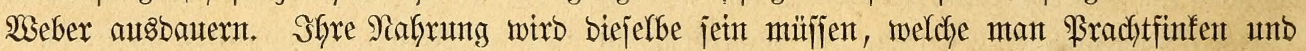
Webervögeln zu reichen hat: verjchiedenartige Sämereien, (Srünzeug, Weidyfutter uno fierb= tiere. Weiteres ijt zux Beit noch nicht zu jagen.

\section{EfHermeluer.}

2Y bie Spitze ber Wibavögel ftellen wir bie Feuerweber ober Feterfinfent, fräftige, gebrungen gebaute $\mathfrak{B}$ ögel mit mäß̈ig ober zientlich ftarfent, fegelförmigent, auf ber

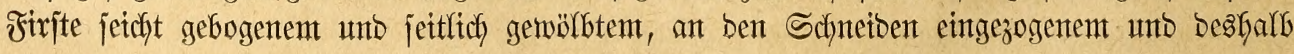




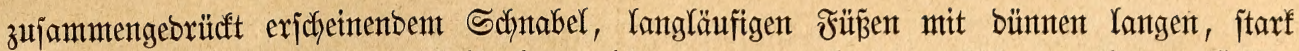
befrallten Zehen, mittellangen Flügeln, weldhe zujantmengelegt ben Sdhwanz bis zux Scälfte bebecfen unt unter beren Sifwingen bie britte unt vierte bie längiten jinto, furzent, aus gletchlangen abgerumbeten Febern gebilbetem Schwanze und reichent Feberfleibe, weldyes nach) (sejchlecht und Sahreszeit jich unterjchetbet. Währent bas Weibchen jafyraus jafyrein ein ziemlich fnapp anliegendes, aus berben Febern gebilbetes, iperlingsfarbenes @leib trägt, legt

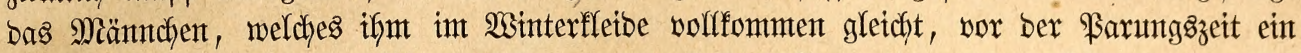
aus jammetigen Febern gebilbetes; brennend gejärbtes Stemant an, in welchem namentlich

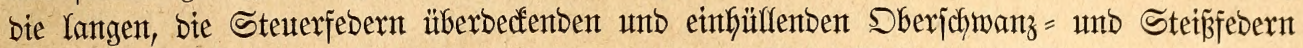

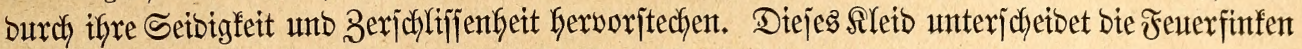

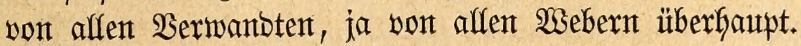

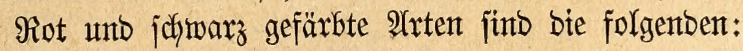

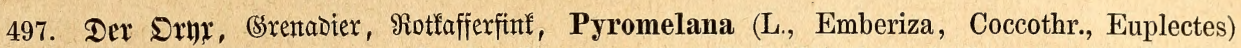

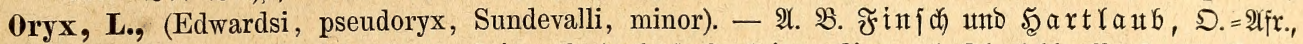

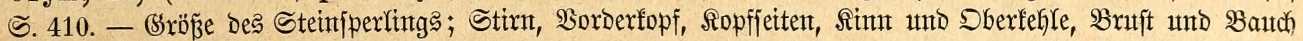

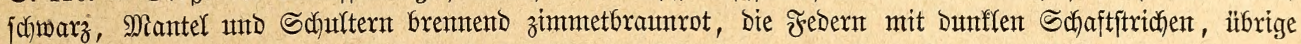

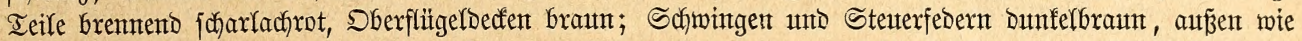

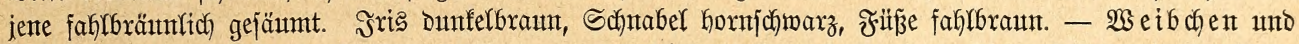

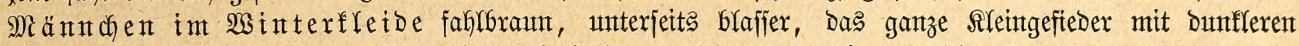

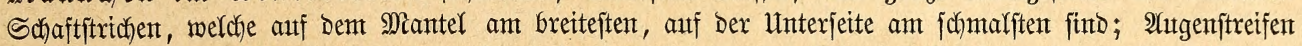

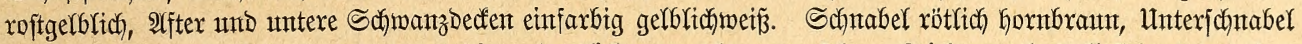

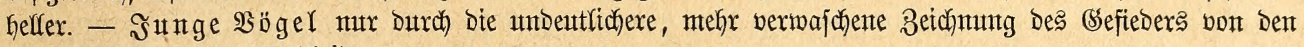

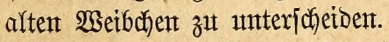

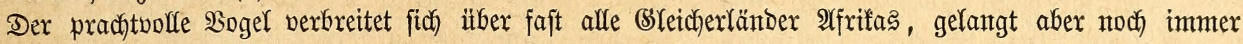
nutr einzeln int imfere ̊äfige.

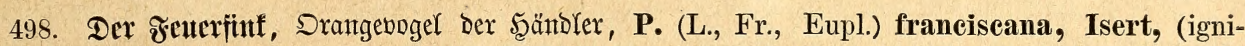

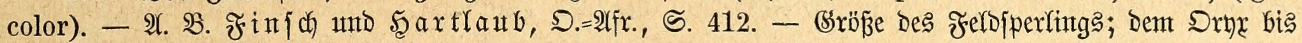

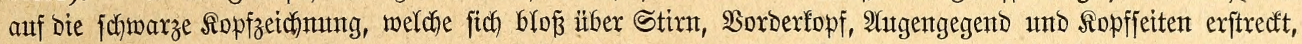

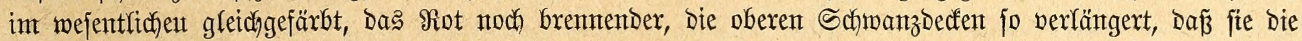

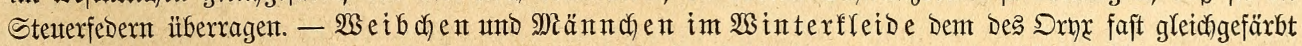

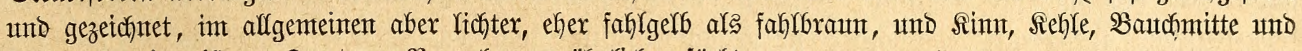

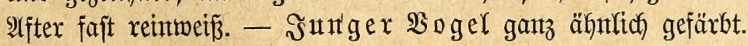

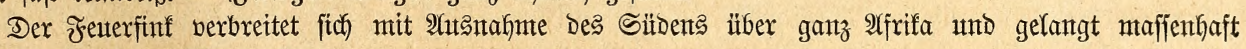
rebento auf umferen Tiermarft.

499. Der Flammenfint, P. (Eupl.) flammiceps, Swsn., (craspedopterus, pyrrhozona). - $\mathfrak{A} . \mathfrak{S}$.

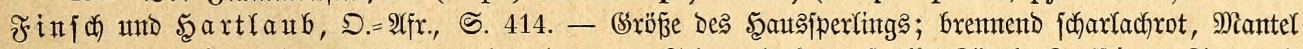

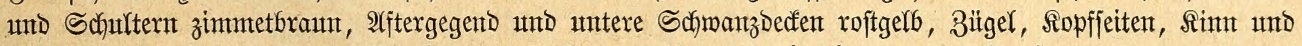

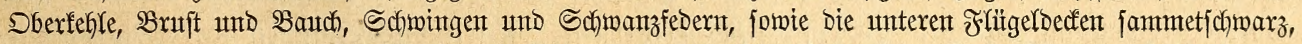

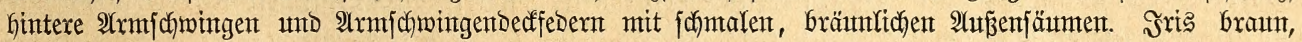

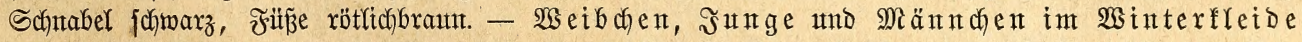

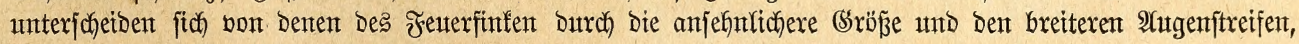
autch Dutufferent (Bintmbton des Befieders.

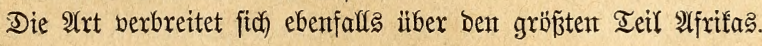

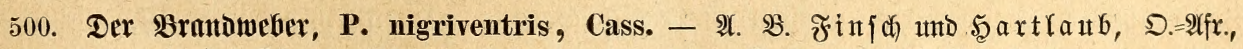

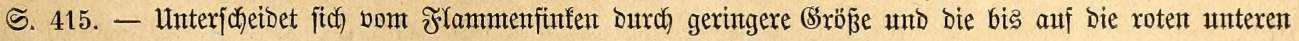
Sa)manzoeden einfarbig fanmetjojwarze Untter jeite.

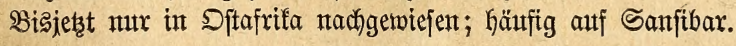

\section{(selb unt fichwarz gefärbte 2(rten fint:}

501. Der Sammetunger, P. (L., Coccothr., Eupl., Icterus, Orynx) eapensis, L., (flavescens,

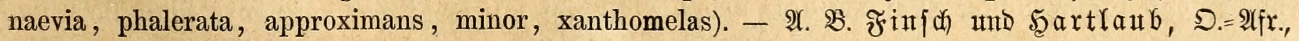

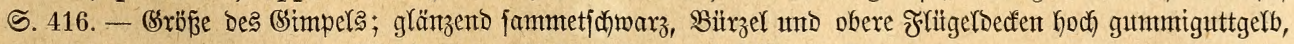

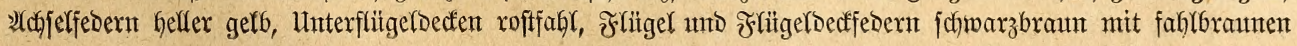


2Ңน

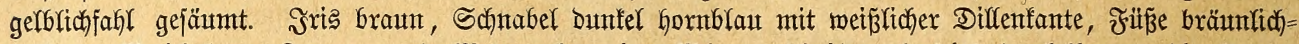

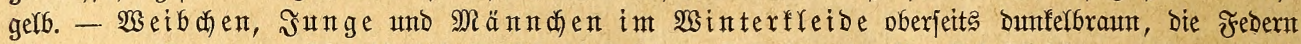

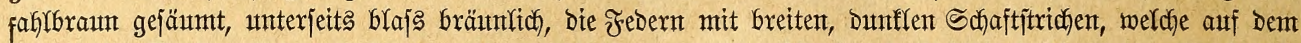

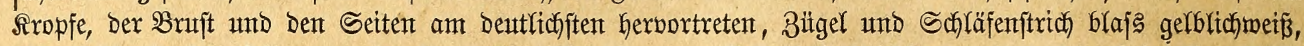

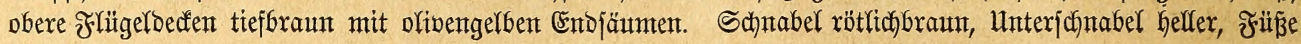
fortgell.

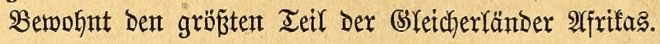

502. Der $\mathfrak{I n h a , ~ P . ~ ( F r . , ~ E u p l . , ~ T a h a ) ~ a b y s s i n i c a , ~ G m l . , ~ ( t a h a , ~ d u b i a ) . ~ - ~ B e r g l . ~ S m i t h , ~}$

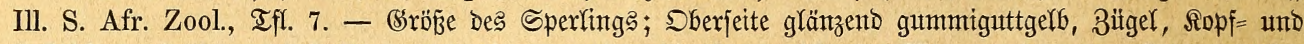

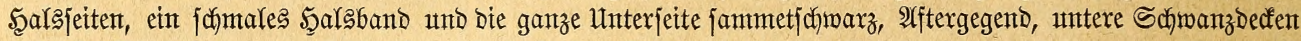

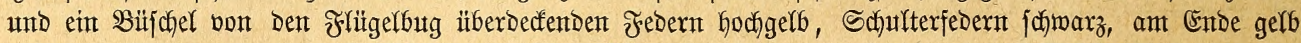

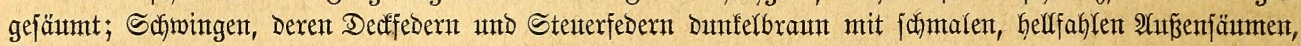

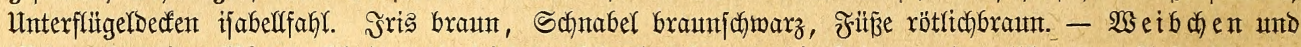
Männden im $\mathfrak{B}$ interfle

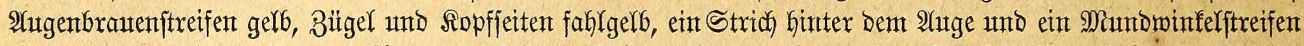

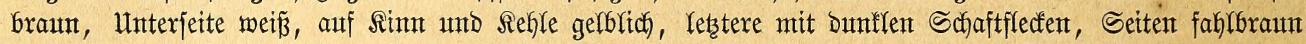

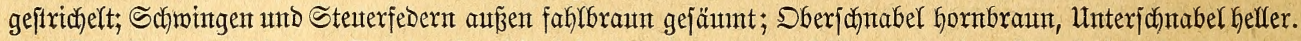

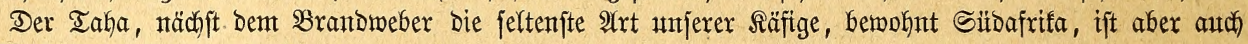
im Sorboften gefunden worden.

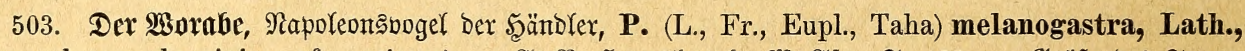

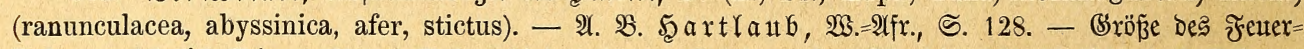

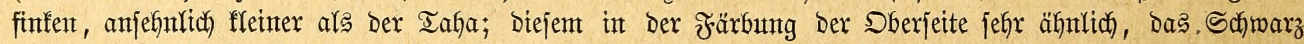

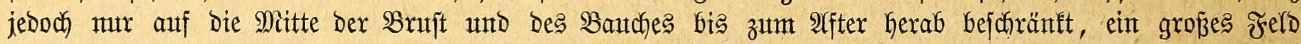
birdend, weldjes von Dem (Serb Des Sropfes, Der Seiten unto unterent Sdjwanzdeden umgeben iff; Das fdrwarze

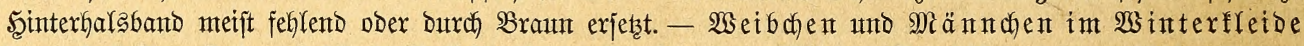
Denen Des Fenterfinfent täufcheno ähnlich) unt mur Durch) etwas girbfichere (Bnumbfärbung unterfafieden.

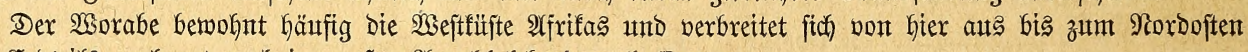

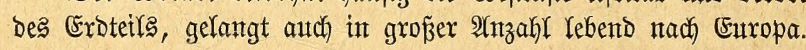

Alufentbalt und Betragen unterjcheiben bie Feutermeber auffaffent gemtg von ben bisher

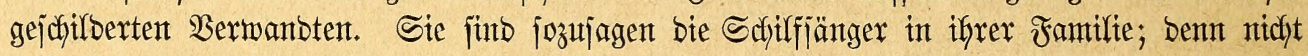

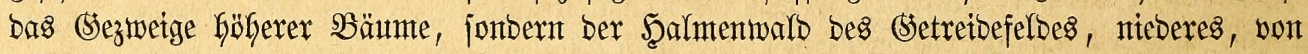

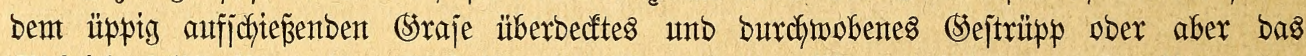

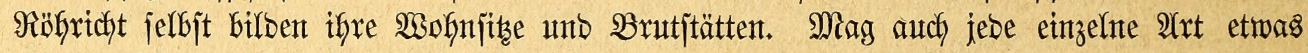

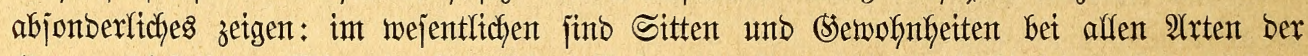
Sruppe Diejelben. Wie bie eigentlidfen Weber Wanber = ober body Stridjbögel, exjdyeinen

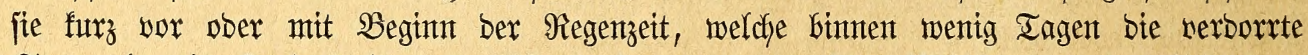

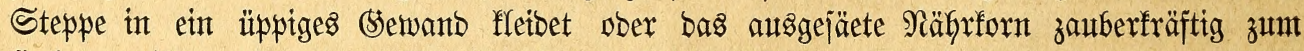

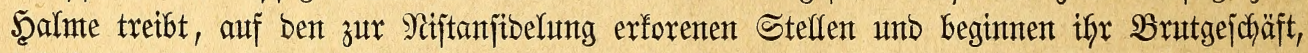

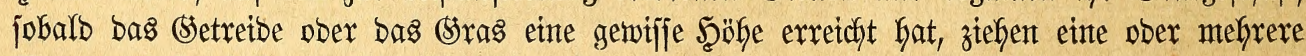
Bruten groź, jallagen fich mit biejen in ungefeutere Sdywärme zujammen unto treten num ifren Strich, vielletcht audy ifyre Wanberung an, vertaujchen ify \$rachtfleto mit bem

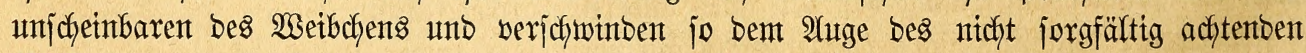
Beobachters, nody efge fie die segento berlaffen Gaben. Entiprechents bem fier früfer, Dort

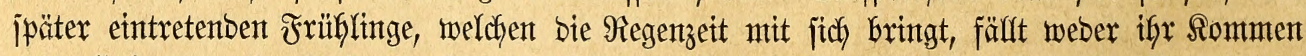

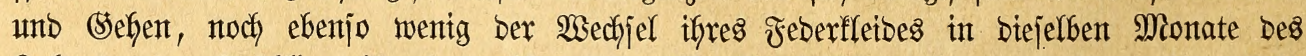

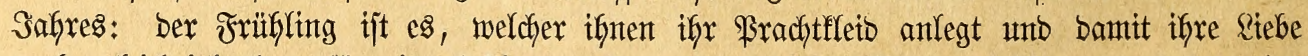
medft, gleidfoiel ob er für einte bejtimmte Ssegento um einige Mionate früfer ober fpäter ein= trete als in einer anberen. Went in Mittel= ober Sübnubien bie Durra ober ber Büjchel=

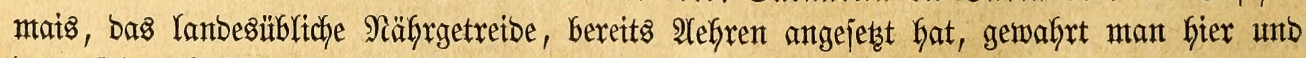

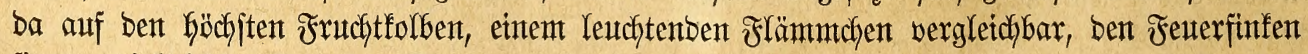
jigen, vielleicht exjt aufmerfjam gemacht burch jeinen böchjt unbebeutenben, zwitjchernben 


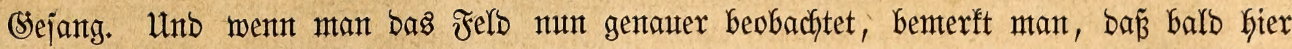

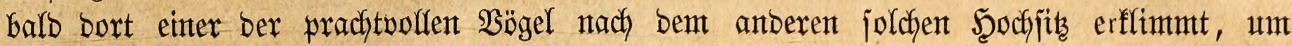

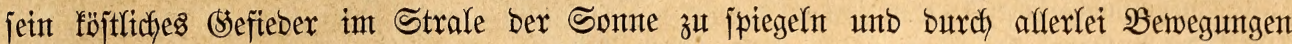

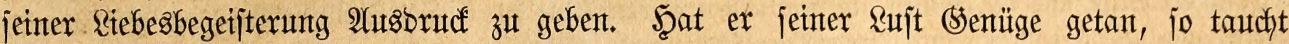

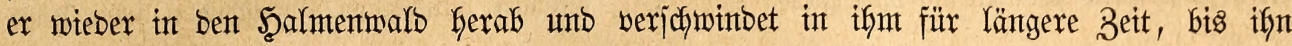
ber intnemohnende Drang aufs neute in bie Şb̈he füfrt. Sn biejer Weije treiben es nach eigenen Beobadhtungen unb 2fnberer Beridyten alfe befannten Feuerweber, gletdyoiel ob jie,

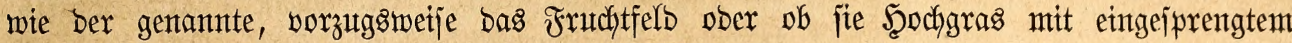

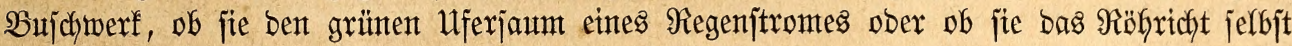
zur B̧rutjtätte jich erforen. So begegnet man, laut 2 yres, bent prachtoollen Sryx in

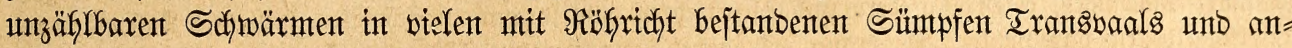
berer Teile Sübafrifas, welche ifhn zur Bruttiätte bienen, und fann wäfrento ber Brutzeit

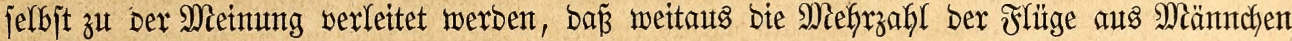

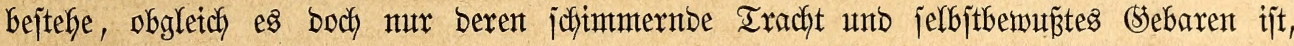
weldye fie Den verborgenter Kebenten unt bejchetbener fich betragenten Weibchen gegentiber

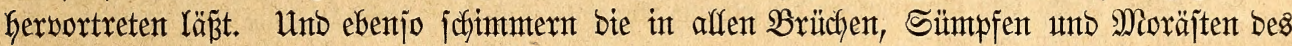
Raplantes Käufigen Sammetbögel, nach \&ayarb, in ber Zeit itgrex Riebe bem Forjcher

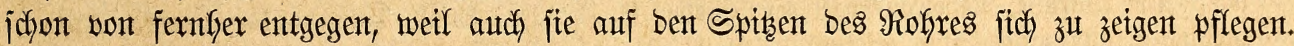

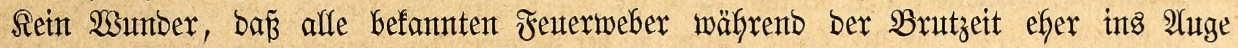
faflen als im Raufe bes übrigen Gafres. Nefyr noch als bie Beberwögel, in viel höherem

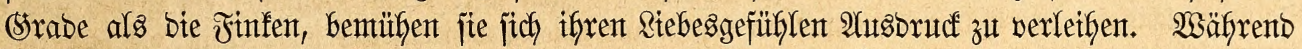

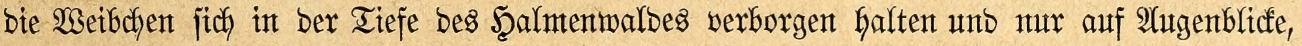

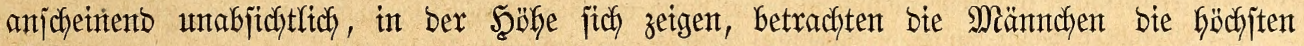
Spitzen als umumgänglich notwenbige Sike, um ifyre Riebesiwerbung auszubrütfen, ge=

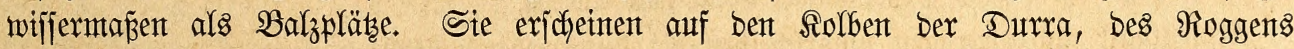

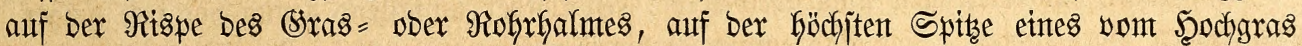

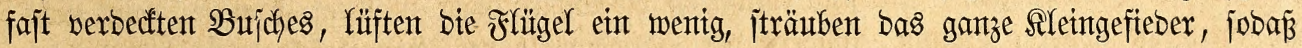
fie fajt noch einmal jo biof exjcheinen als jonjt, lafjen eintige zinpenbe saute vernefymen

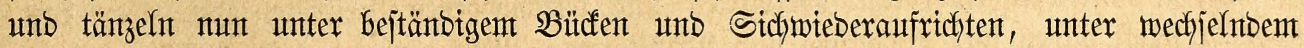

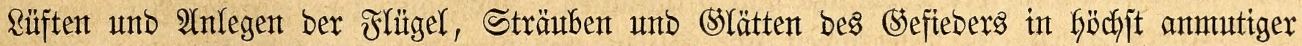

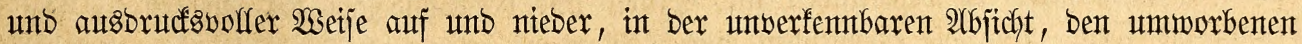
Weibchen ifyre volfe Schönheit zu zetgent. Shr Bejang, fo unbebentento er autch ijt, wedt bie (Eiferjucht ober boch bie Nackeiferung in bent Şerzen anberer Miäntchen; auth bieje er= Geben und brüjten jich in ber angegebenen Weije, unb ber Scalmentwald erfält bamit einen

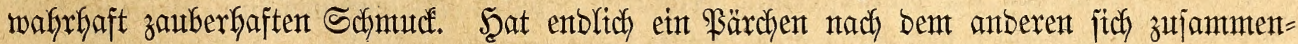
gefunten anto bamit bie erjte (s)lut ber Eiferjudft jich gelegt, jo beginnt ber befriebigte Werber mit bem $\mathfrak{B a u t e}$ jeintes einfachen Nejtes; unt zwar liebt auth ex ę, bie Wiege jeiner Sinber in geringer Entfermung von ber eines anteren \$ärchens aufzutichten. Die Sibelung

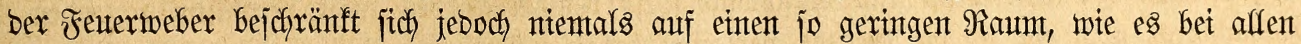
an $\mathfrak{B a ̈ u m t e n ~ b r u ̈ t e n t e n ~}$ Weberbögeln ber Fall ijt, jonbern erjtrecft jitch über einen Ieil bes

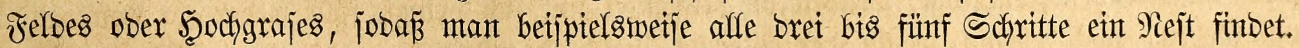

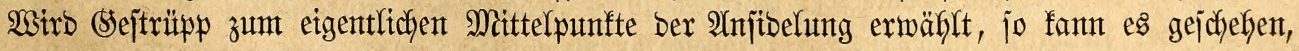

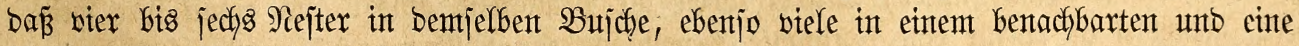
ähnliche 2 (nzafhl in einem britten unb vierten angebracht merben; immer aber bleibt auth

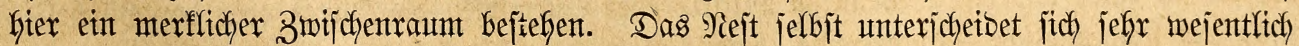

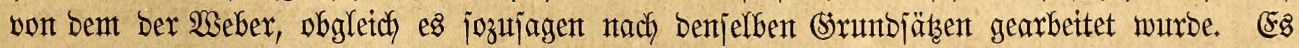

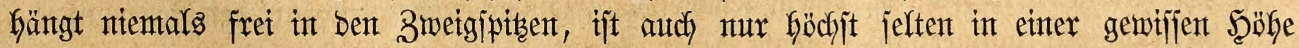

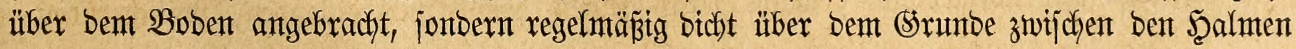




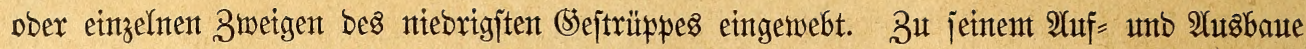

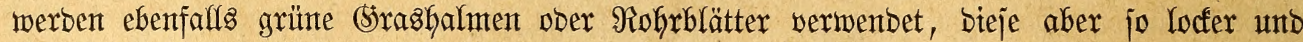
Yeidyt zujammengefügt, baß̃ man die brei biz jechs fimmelblauen ober jpangrünen, entweber eimfarbigen, ober am bicferen (Enbe mit äuß̈erít feinen, violetten Punften gezeichneten (Eier

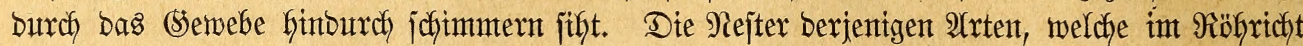
früten, wie Sryx unt Sammetwogel, find zwijchen zwei, brei ober vier Rofrifengeln funjt=

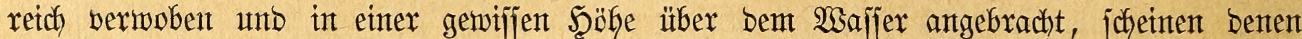
Des Feuerfinfen, weldye idh vorjtegent gejchilloert habe, jebods immerfin ähnlich zu jein, wie ïberkaupt bas Fortpflanzungsgejchäft alfer $\mathfrak{A}$ rtent int wejentlichen übereinftimment bürfte.

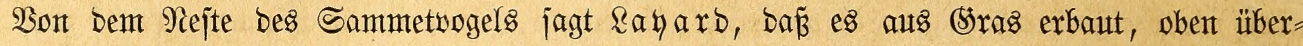

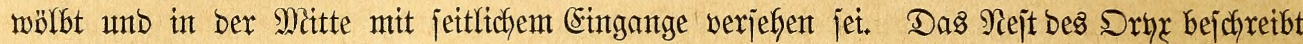

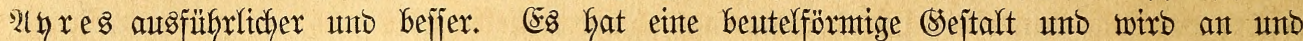

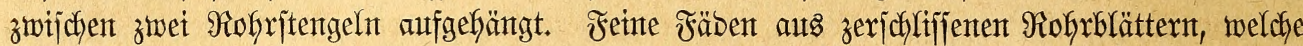
man leidht als (Srashalmen ober (Srasblätter anjeben fant, werben mit grö̈pter Sorg= falt und Nettigkeit verwoben, um es Gerzutelfen. Der Eingantg befintbet fich int oberen

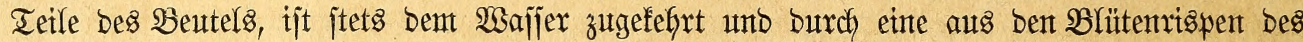
(Srajes hergejtellte Dorfhalle überbecft. Diejelben Sejtandteile bilben auth bie intere

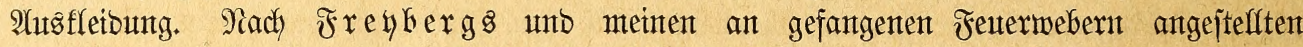
Beobachtungen bauen mur bie Miänndhen, nicht bie $\mathfrak{B}$ eibchen, welche bafür mit alfer (Empitg= feit fich bem eigentlichen $\mathfrak{B}$ nutgejchäfte Gingeben. Die Sungen entfchlüpfen nach breizebn=

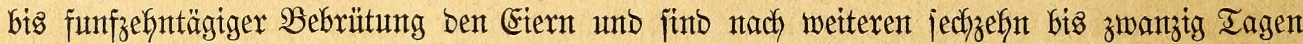

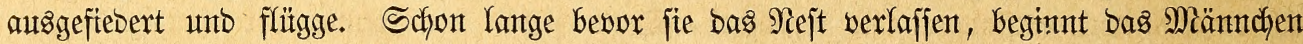

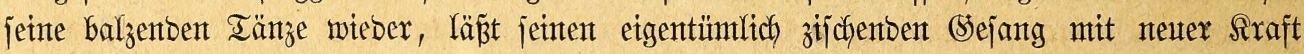

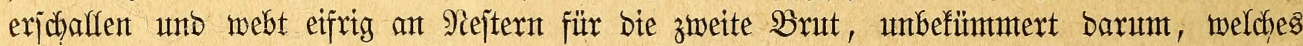
von benen, bie ex hergejtellt, von bem 2 seibchen gemählt werben mag. Sit auch bie zweite SBrut glüfflich ausigefommen, jo jammelt jich alt und jung in mefr und mefyr anmachjenden Sdjwärmen unt jtreidfen nun int Ranbe umber, feinesinegs zur Freube bes Ranbmantes, in

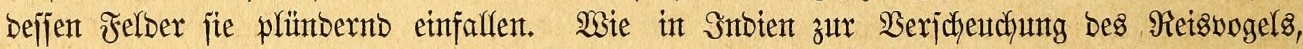

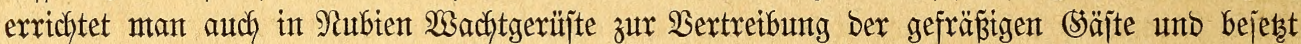
Diejelben vom Morgen bis zum 2tbend, umt Schabent zu verbüten.

(5) leicfzettig mit Begint Der Wantoenung ober boch nur wentig fpäter tritt bie Scaupt= maujer ein. Durd fie legen auth bie Männthen bas iperlingsffarbene Sleto ber Weibchen an. Die

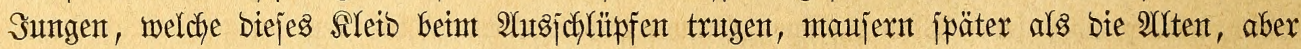

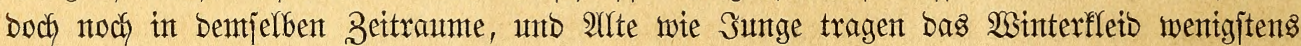
adjt Monate int Gafje. Sobann beginnt, minbejtens bet bem Mä̈nnchen, einte zmeite Maujer, meldhe anfänglich als Berfärbuntg fich zeigh, inbent bie alten Febern allmälich eine föbjere,

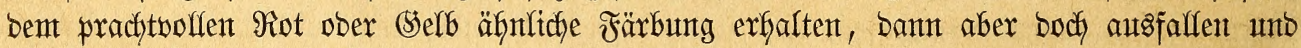
burch bie gänzlitch verjchieben gejtalteten Sammetfebern erjetst werben, welche unter bent

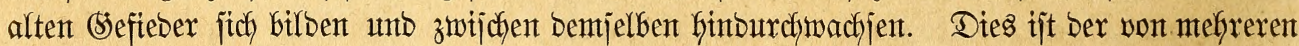

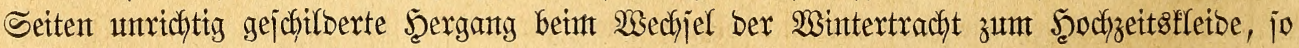

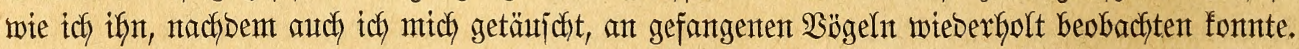

alfe Feuerweber find ebenfalls vorzugsmeije fïnterfreffer, fönten aber ofnte fierbtier= nafhung auf bie \&änge nicht bejtehen. Währento ber Brutzeit lejen jie nach Rofriängerart

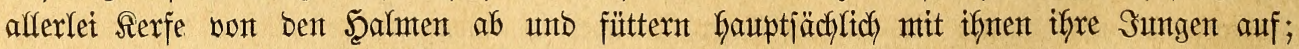

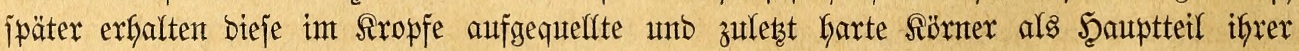
Mahlzeit: jtets aber werben Rerfe nebenbei mit verfüttert, unb jelbjt bann, wenn alt unb jung fidon bie Felber plüntoern, bilben tierijche Stoffe noch immer einten nichyt untwejentlichen Ieil Der Niafrung. 


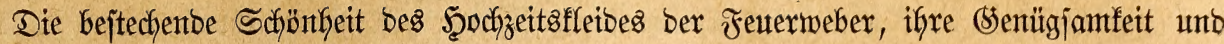

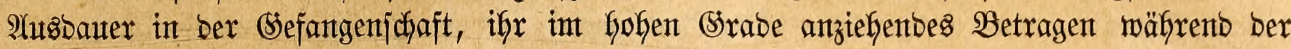

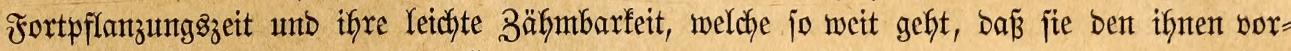

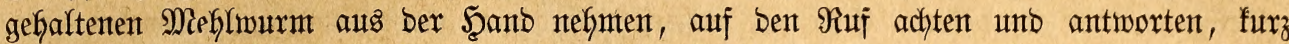

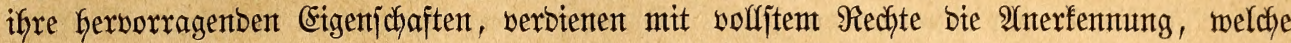
ifnen von ben Riebgabern gezolft wirb. Sie fint in ber Tat vortrefflidje Benofgner umerer

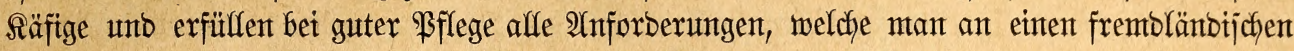

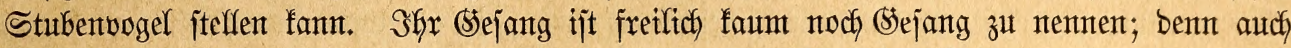
fie lafjen fein georbnetes, zujanmtenfä̈ngenbes unt mofiltönenbes Sieb vernefymen, jonbern

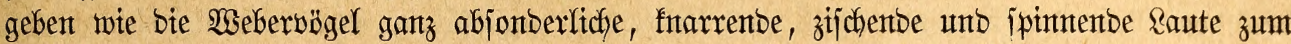

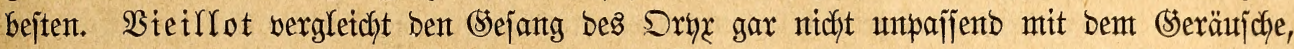

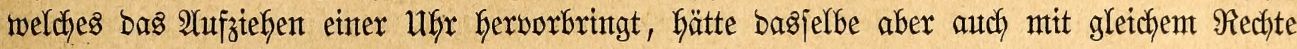

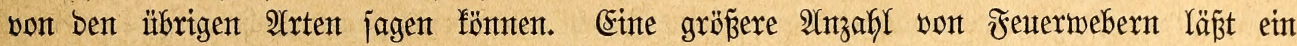

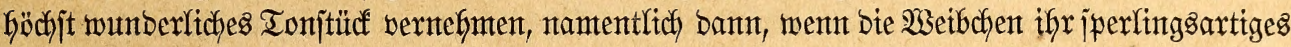

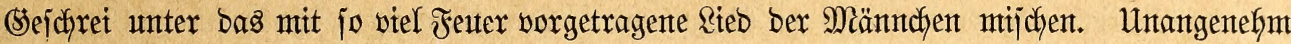
aber fant man weber biejes sieb nodf jentes sejechrei nentent: es flingt ebent nur jonberbar

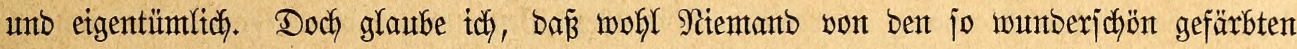

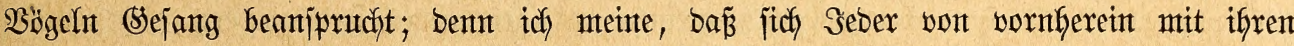

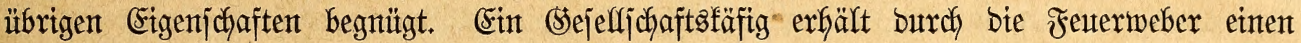

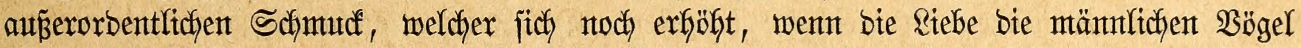

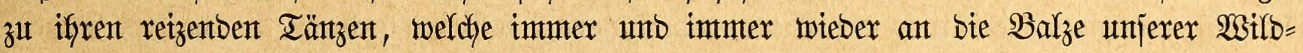
Gü̈Gner erintuern, entflannt unto begeiftert. Dann żeffen bie brententorot ober gelb unb

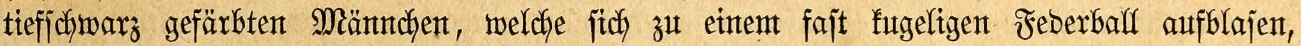

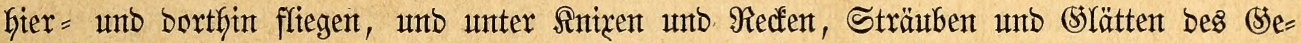

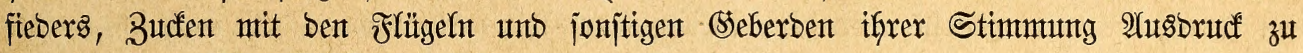
gebent jutchen, affrer B̧lidfe auf jich.

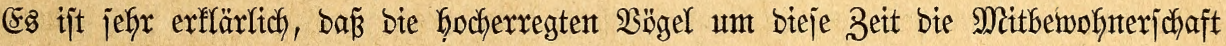
eines BefellfichaftsGauters in eine gemifife Unnuthe verjetsent. So frieblich jie jonjt mit

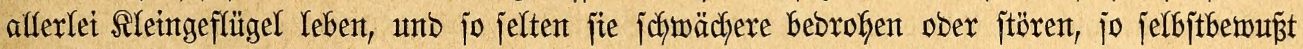

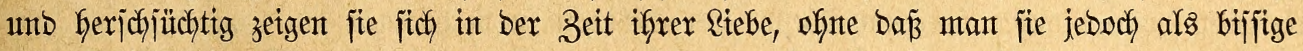

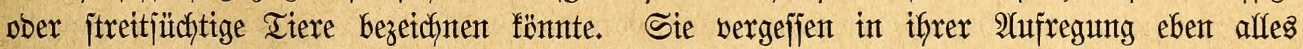

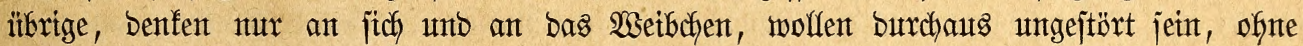

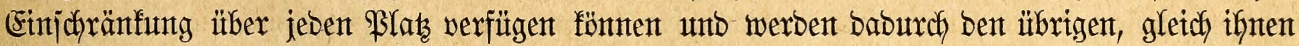

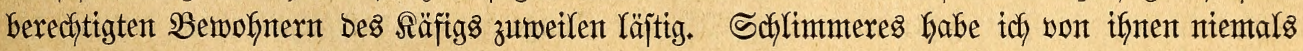
beobachtet; benn autdy, wenn fie ant Futternapfe fiben, zeigen jie nicht eigentlich Bijifigfeit,

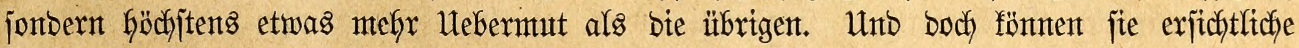

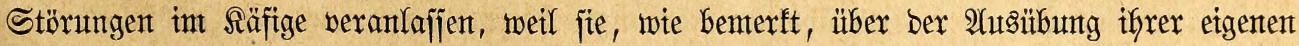

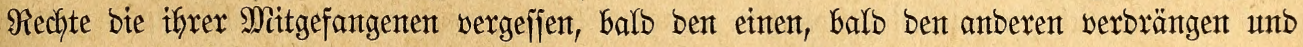

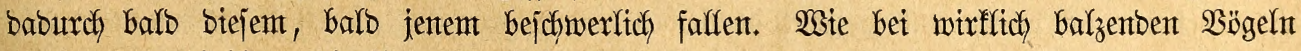

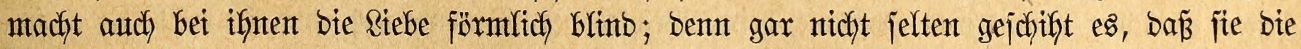

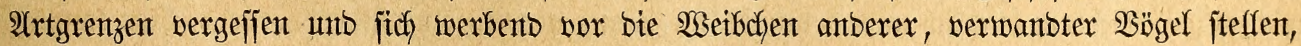

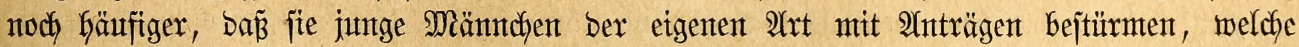

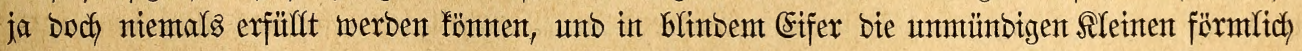
mishanbefrt. So wurbe ein junger Sryx, welcher in einem meiner Räfige bas Ritht ber

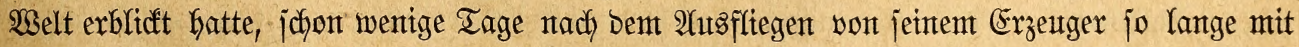

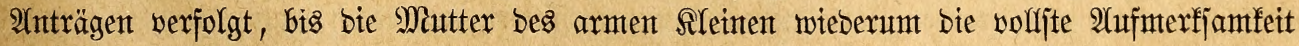

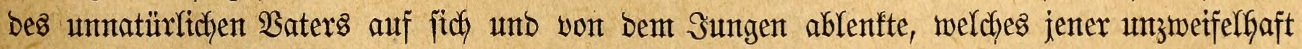

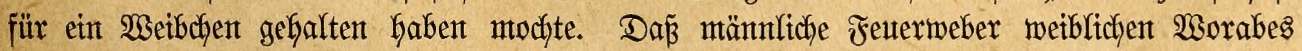




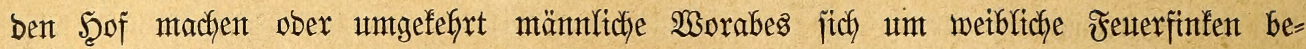

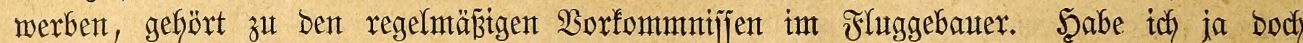

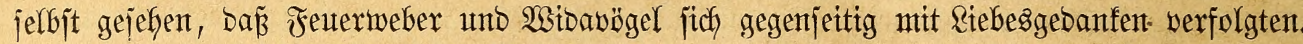

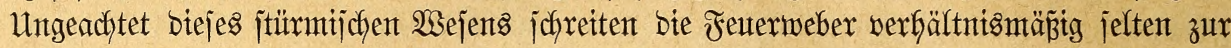

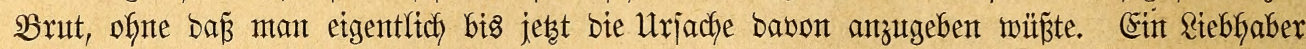

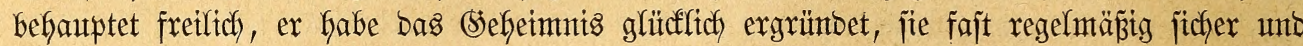

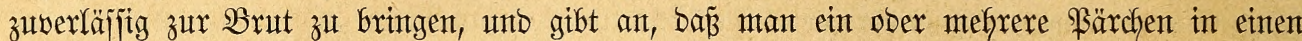

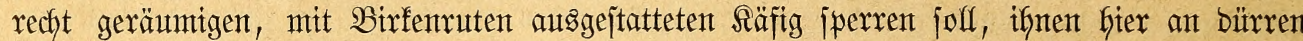

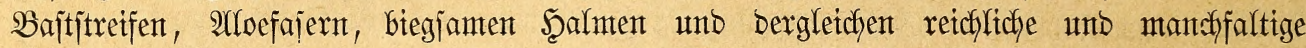

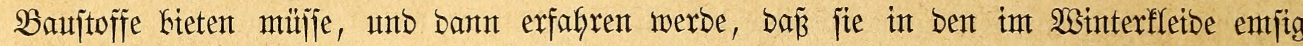

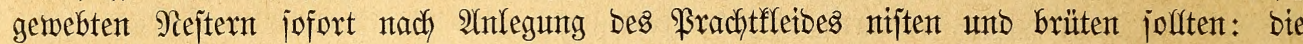

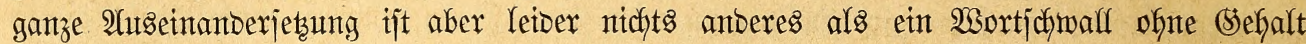

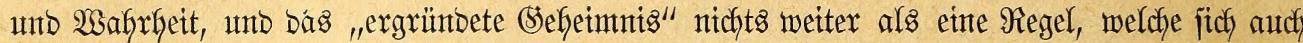

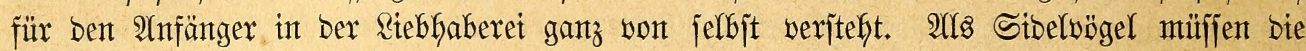
Feuerweber eben gejellichaftsweije gefalten werben, und Baujtoffe verichiebenjter ât bürfen

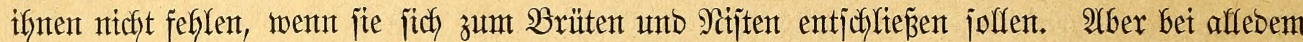

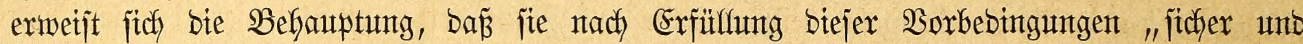

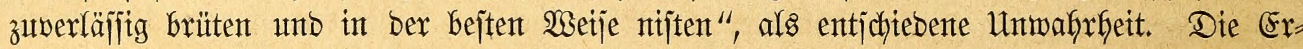

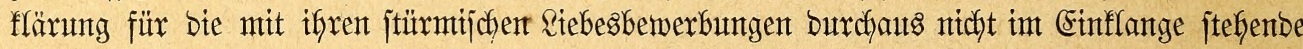
Enthaltjamfeit ift meines Erachtens nicht jefwer zu finden, wenn man fich an iffre Brut=

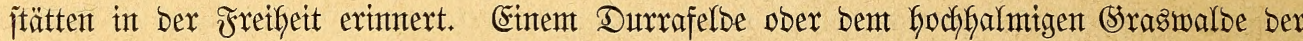
Steppe gegenüber exicheint jebes (5ebauter von bornferein afs ein trautriger Motbehelf, unto

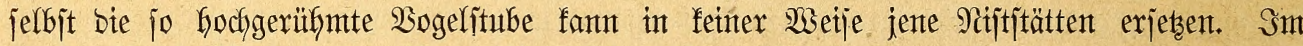

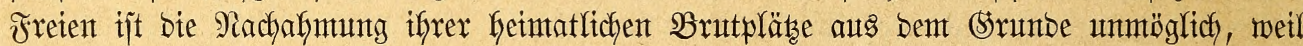

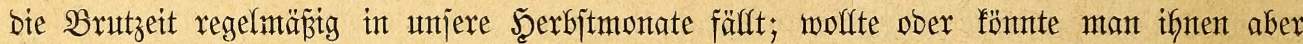

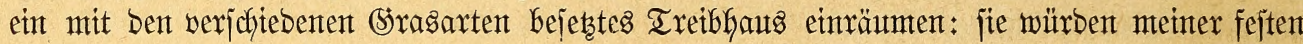

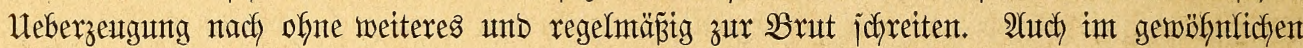

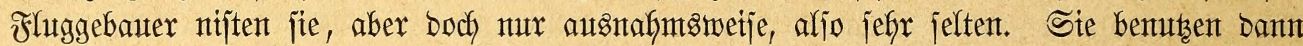

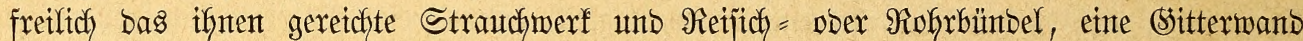

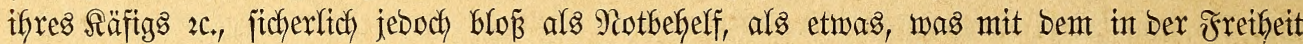

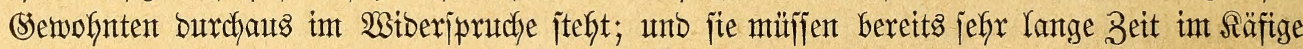

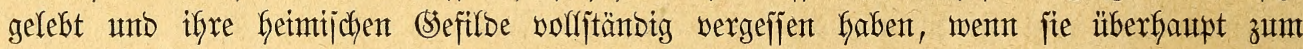

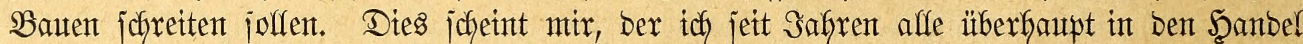
fonmentoen Fetterweber gefalten unt gepflegt, won mefhreren audd Sunge erfarten habe, bie geheimnizloje Erfflärunt bes jeltenen Brütens der Fetterweber zu jein.

Borftefente Wonte haben bie $\mathfrak{B i f f i g u n g}$ meiner Mitarbeiter erfalten, bürften aljo

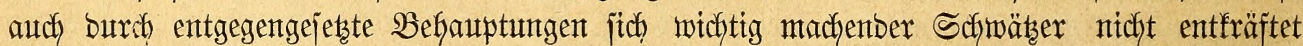
werben fönten. "Sechjjäfrige umutterbrodiene Berjutche", Gemerft Freyberg, nadjoem

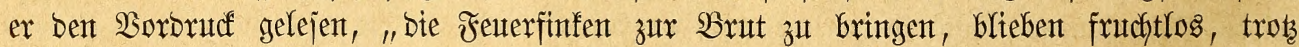

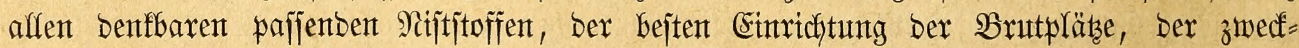

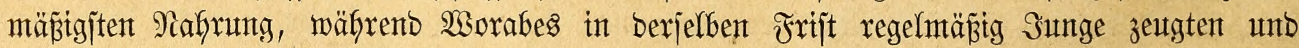

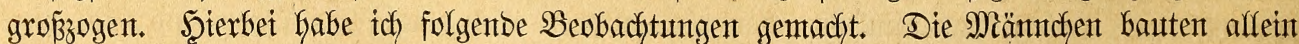

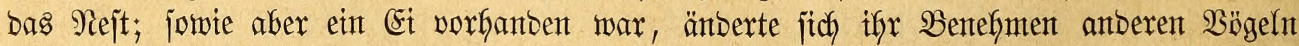
gegenüber volfitändig, unt alfe Dutbjamfeit gegen irgent weldhe Bentifien hatte ein Enbe.

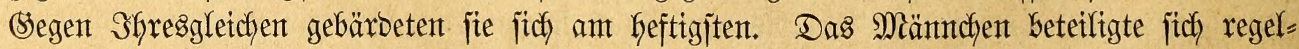

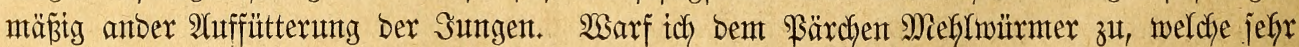

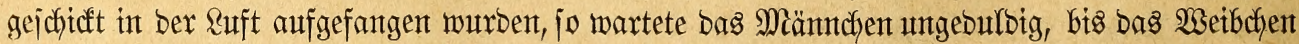
bie von ifgm erbenteten $233 u ̈ r m e r$ verfüttert hatte, um aud jeinerjeitz bie Sungen zu ałzen. 


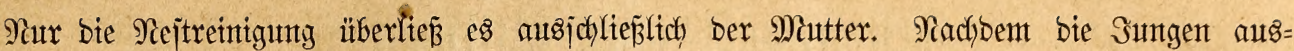
geflogen waren, übernafint es ben Sdyuth berjelben, befïmmerte jich jebody nidyt weiter um oie

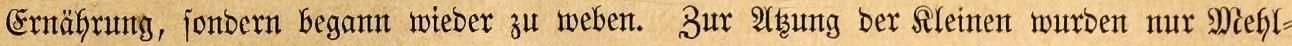
würmer neben bem gewöhntfichen Futter, (Şirje, Şlanz und in Wajfer geweichter Semmel) verwentoet, und bie Sungen gebifgen volffomment babei. Ungeadfet alfer Seidytigfeit, fich

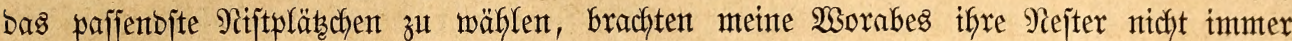
Gängento ober jefwebento an, errichteten jie vielmefyr mefrere Male audch in ber (Sabel eines nur $1 \frac{1}{2}$ m. Gohen Büjchchens." 2 (lud bie Feuerweber, weldye in ben Fluggebauern bes Berliner 2 quartum gentiftet Gaben, nemlich Drux, Flanmenfinf unt Sammetoogel, wäflten

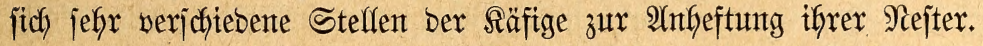

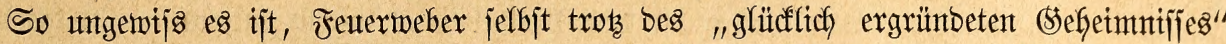

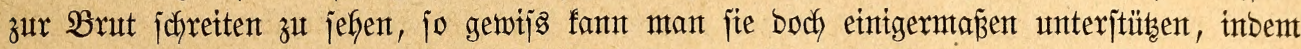

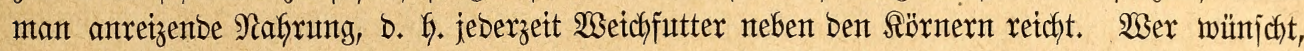

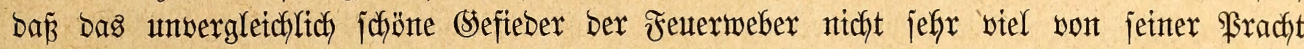
verltere, mur bies ofntefin und währent bes ganzen Safyres, ant meijten aber boch furz

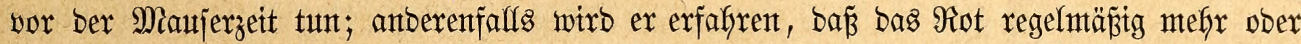
minber in bas (Selbliche übergeft, beijptelsmeije aus Zinnoberrot zur Mennigfarbe wirb, und

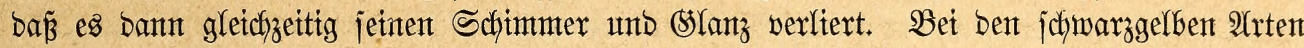

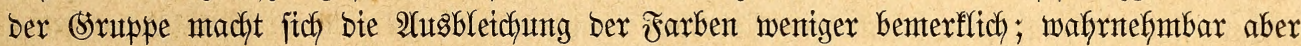
ijt jie auth Giter. Diejem Ulebeljtantbe tritt man mit zitemlich gutem Erfolge entgegen, went mant jeberzeit tierijche Stoffe, aljo fleingehacttes ober gemiegtes Fleijch, Ammeijenpuppen, Mefilwürnter unb andere Rerbtiere vorjetst. Wer exfafrent will, wie notwentig ober body

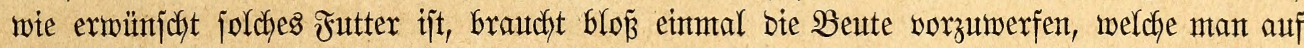

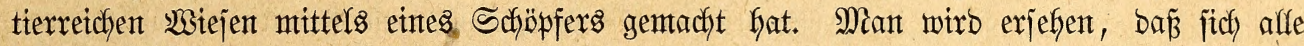
Feuterweber mit größ̈ter (Siter auf bie erjefnte Speije ftürzent und ganz vortrefflich mit bem Fange

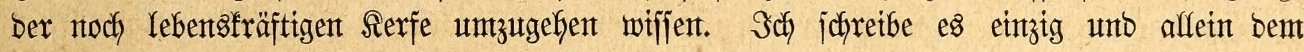

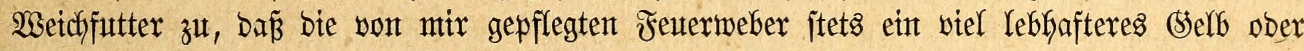

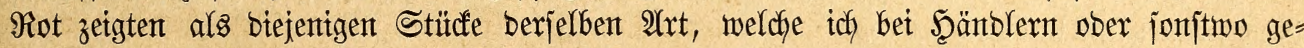

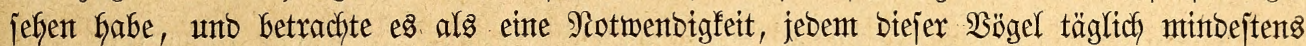
vier biz fünf Meflwürmer, int Sommter aber jo viele andere Rerbtiere ber verjediebenjtent 2(rt, als idy eben erlangen fann, zu reidfent. Sebenfalls fräftigt joldhes Futter unjere $\mathfrak{B}$ ögel

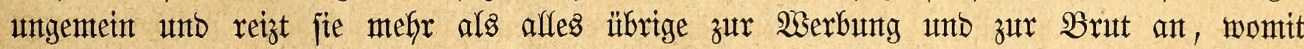

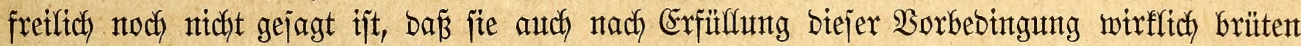
werben. Sch Gabe einzelne Bärchen gepflegt, weldye in bent einten Sahre brüteten unto fräf= tige Sunge erzogen, int bem anderen aber, trob volffommen gleicfer, womöglich noch etwas

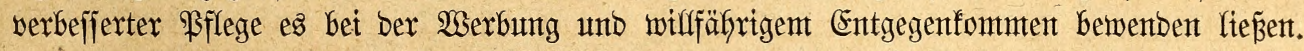

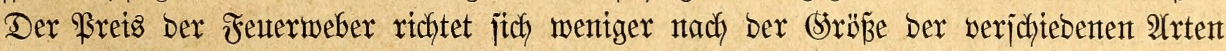

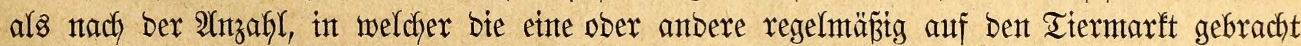
wiro. Feuterfinf und Worabe, weldye noch vor eintigen Safrzefntent nicht eben häufig zut uns famen, gelangen jest fait mit jeber Sentung weitajifianijcher Jinfentögel in bebeutender

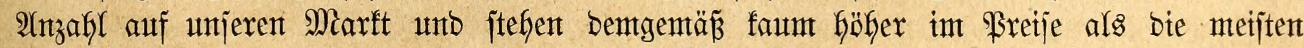

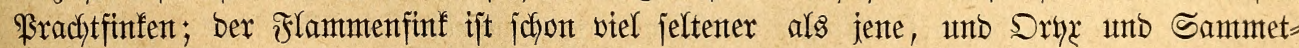
bogel fint auch bei autgebefnten Berbintungent feineswegs jebes Sahr zu haben. Dentent= iprechento muñ mant, währento man bas \$ärchen ber erjtgentannten im \$rachtfletbe mit viex bis fünf, int Winterfletbe mit brei bis vier Ialer faufen fann, für ein Bärchen Flammen= finfen jechs bis neunt Taler, für ein $\mathfrak{B a ̈ r c h e n ~ S a m m e t b o ̈ g e l ~ a d j t ~ b i s ~ z e f n t ~ u n t ~ f u ̈ r ~ e i n ~}$ Bärdjen Dryx zefn bis jectzefnt Ialer bezaflen. 


\section{Widnuögel oder Witweat.}

Dent Rern ber Famitle bifloen bie Wstbabögel int engeren Sinne, fo gentannt nach ber

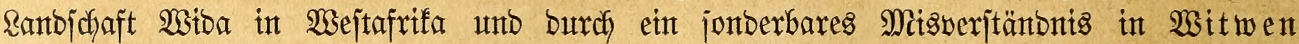

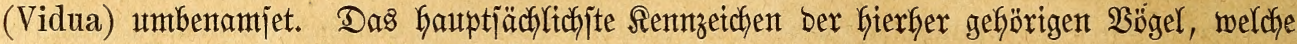
int zwee größ̈ere unt mefrere fleinere Strutppent zerfalfent, berufft in bent eigentüntlich gebirbeten

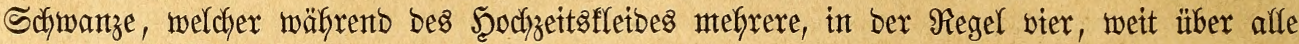
übrigen verlängerte, unter fïh verichieben gebilbete Febern hat. Der Schntabel ift bet bent

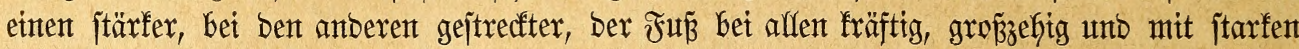

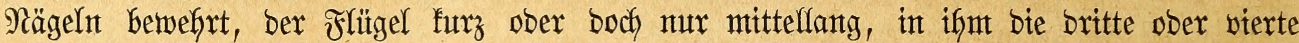

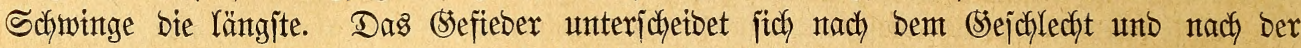
Sahreszett, ba bie Miänndhen im Winterfletbe bie Tracht bes 2 seibchents antegen.

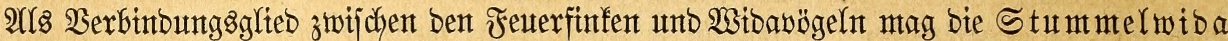

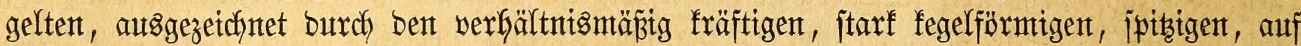

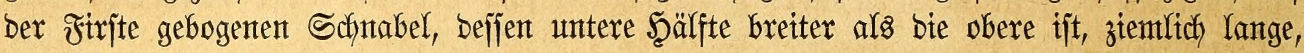
aber ftarf gerunbete Flïgel, unter beren Schiningent bie fünfte bie längite, jeffr furzent Schinanz unt wetches, jantmetnes sefieber.

504. Die Stummelmion oder Stummelmit we, Penthetria (Vidua, Urobrach ya, Coliuspasser)

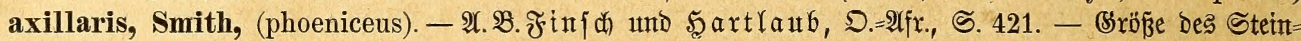

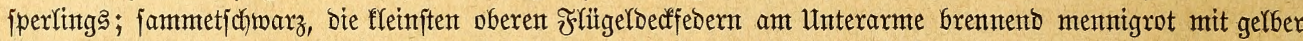

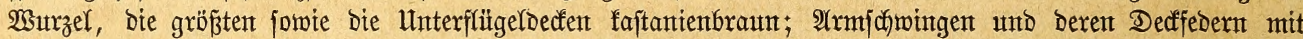

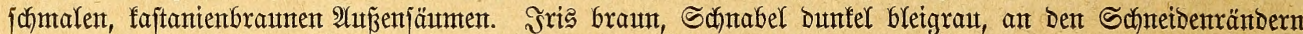

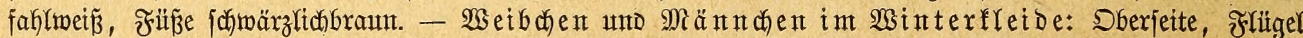

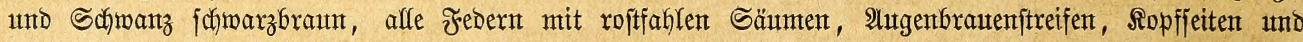

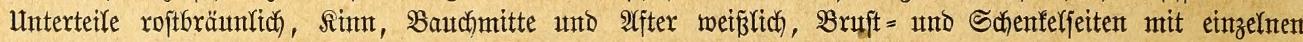

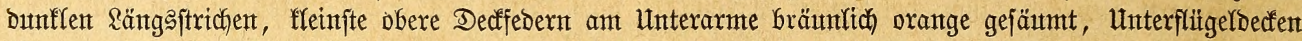

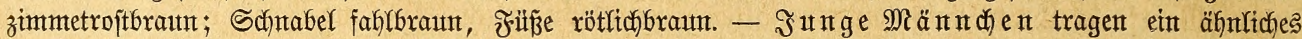
Rleid; aber bie fleinen Dedfedern oberjeits fint orangefarben.

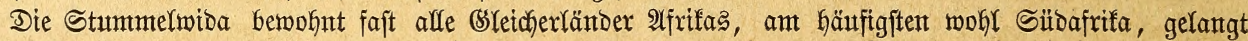
jeboch felten rebent in umjere Räfige.

Die nächitfolgentben Serwantoten, welche man Irauerwibas nennt, zetchnen fich aus burch ben jtarf gejtetgerten, aus breiten Febern gebilbeten Schwanz.

505. Die Trautermion, Irauterwitwe, P. (L., Fr., V.) macroura, Gml., (longicauda, chrysoptera,

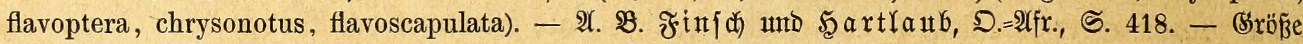
Des Sperfings, wegen bes langen Sdiwanzes aber viel geitredter exfdeinend; fanmet;d)warz, Mantel,

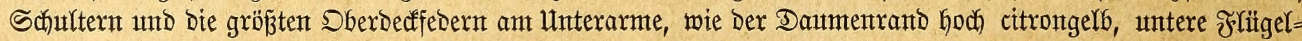

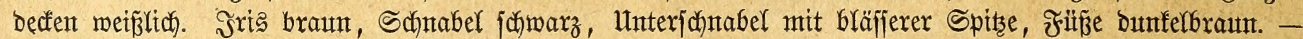

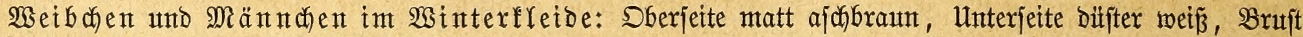

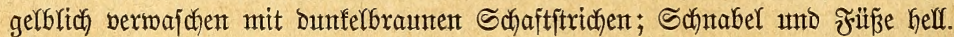

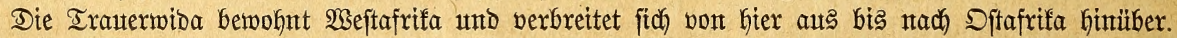

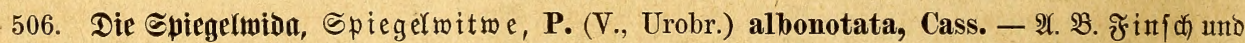

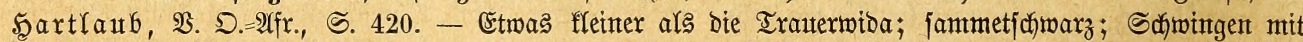

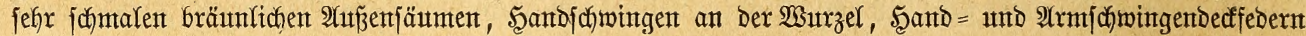

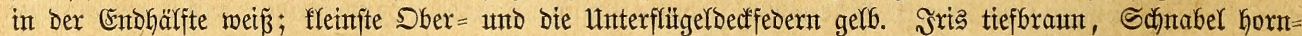

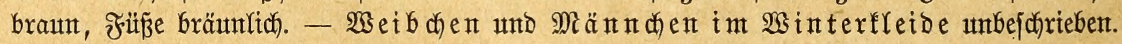

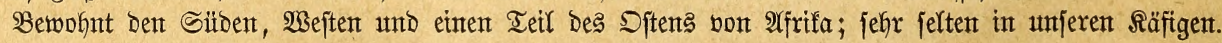

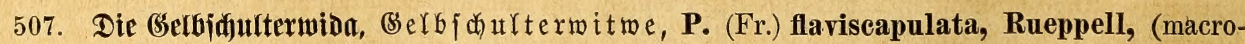

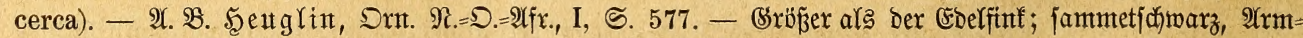

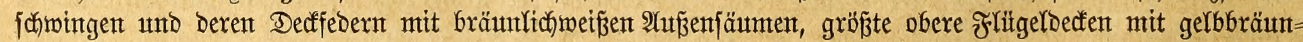

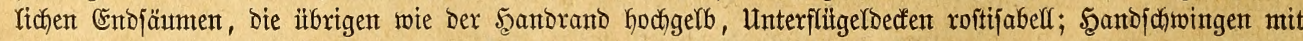

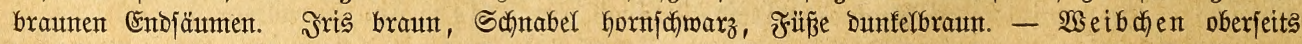

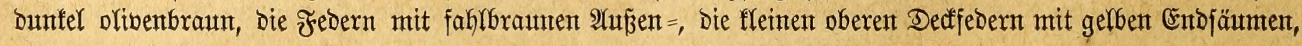




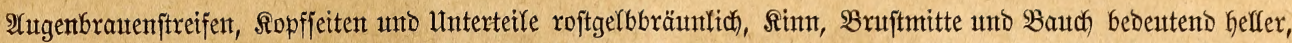

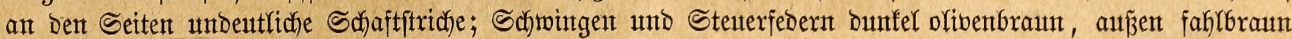

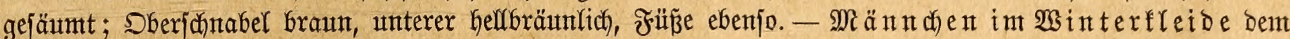
Wseibchen faft volffommen gleich, nur bie fleinen, oberent frlügeldedent lebbafter gefärbt.

Stammt ats 5̧abejó.

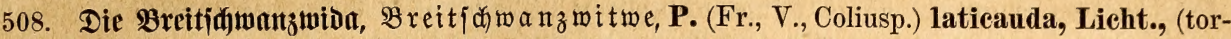

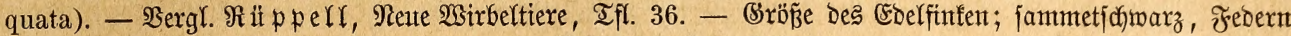

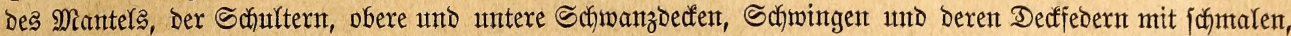

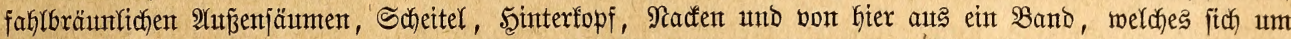

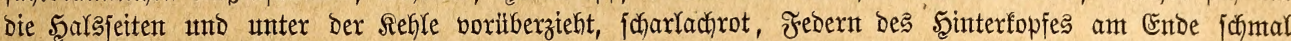

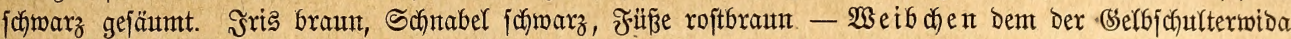

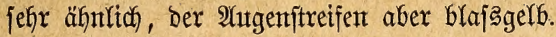

Diefe feltente $2(x t$ fojeint ebenfarfs mux in Şabejd) vorzufonment.

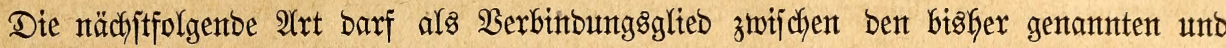

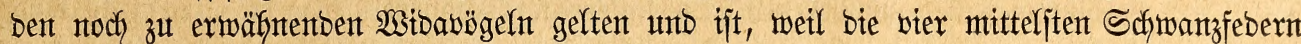

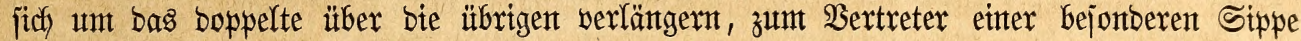
erboben worbett.

509. Die Sdjildmiton, Schilomitwe, P. (Emberiza, Fr., V., Niobe) ardens, Bodd., (signata,

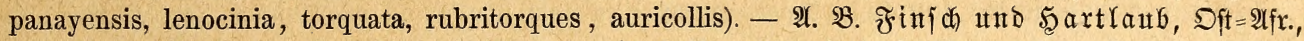

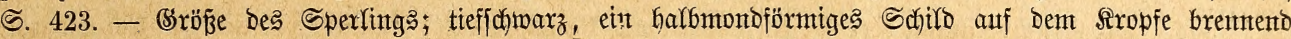

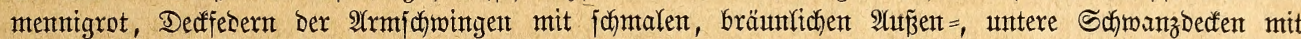

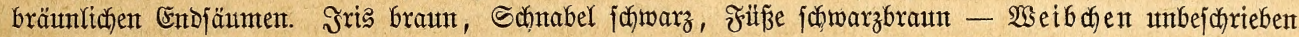

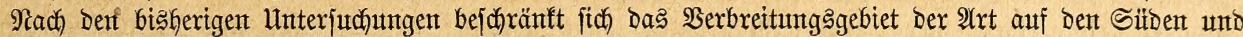
einen Teil Des Sftens von $\mathfrak{A}$ frifa.

Die Wibabögel int engeren Sinme unterjatjetben jich ebenfalfs hauptiächlich burch bie

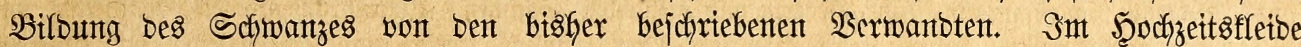
verlängern fich bei allen befannten Ârtent bie vier mittelíten Schwanzfebern um baz $\mathfrak{B t e r}=$

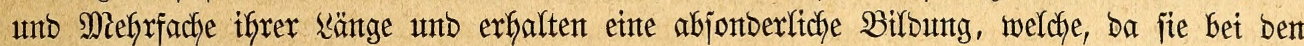

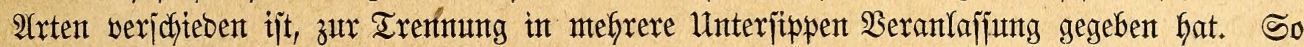

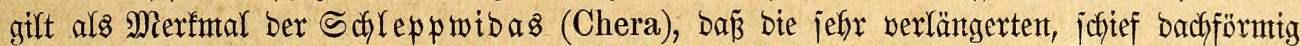

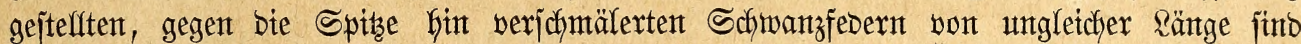
unto nidft blop bie mittleren, jontbern afle itberhaupt an biejer Wutcheruntg Teil nefment, als

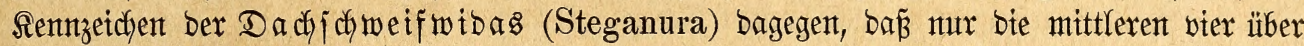
bie anberen Kerausmachjen, fich jenfredft fteflen unt zwei bon ifren mit Garigen Spizen, bie betben anberen, längiten verjđynälert entoigen, als Merfmal ber Wibavögel (Vidua) im

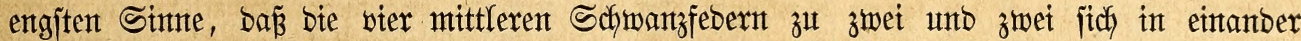

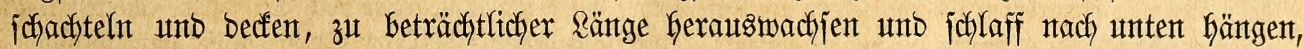

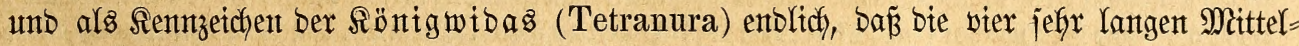

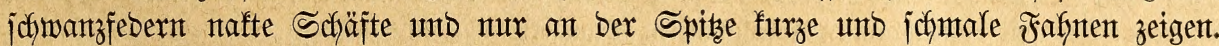

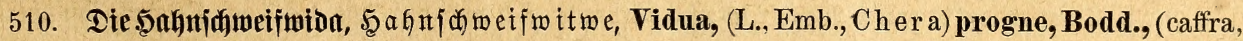

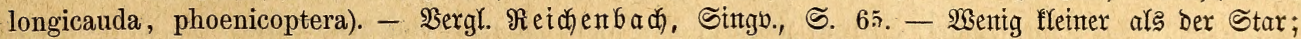

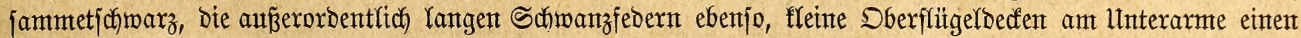

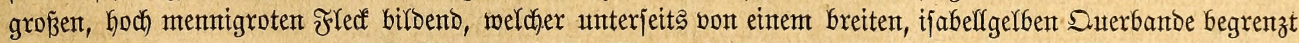

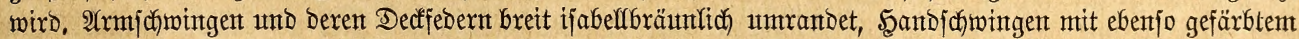

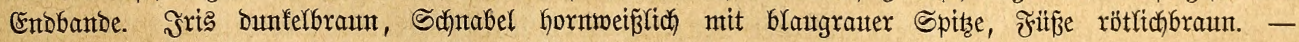

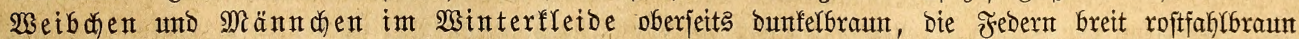

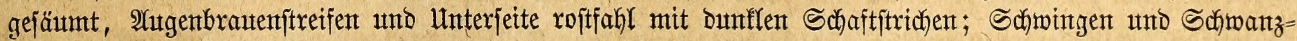
feberıt auţen roftfahl gefäumt.

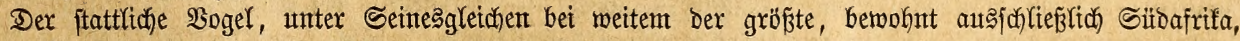
namentfich Rafferfand und Den öftlichen Ieil bes Saplandes.

511. Die ßarndismion, Farabiswitwe, V. (Emb., Fr., Stega nu ra) paradisea, L., (africana).-

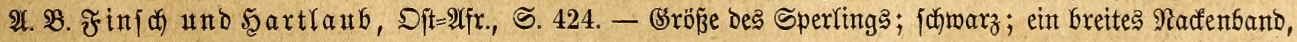




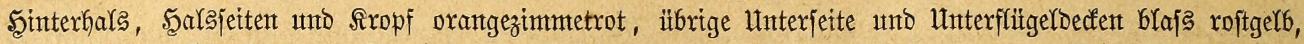

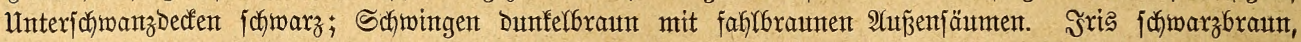

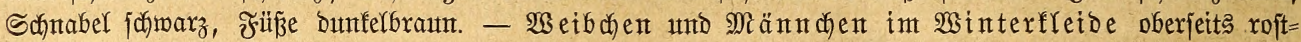

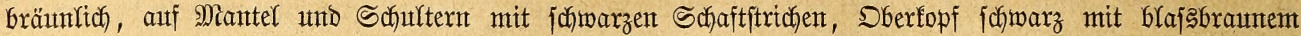

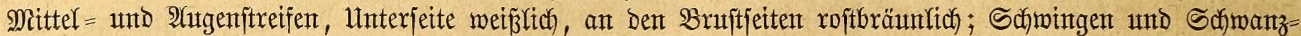

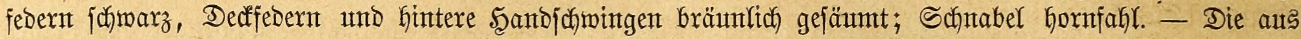

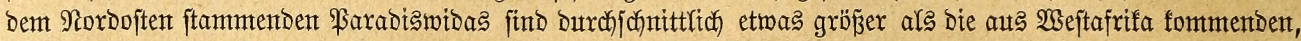

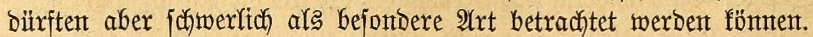

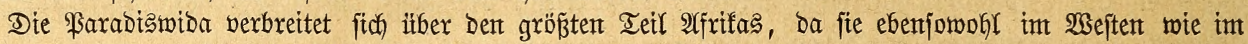

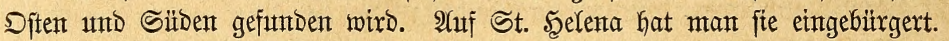

512. Die Dominifanermion, Domintfanterwitwe, V. (Emb., Fr.,) principalis, L., (angolensis,

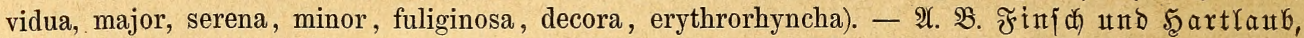

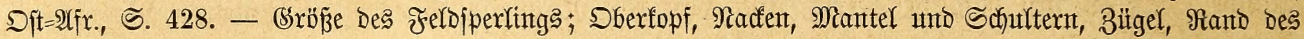

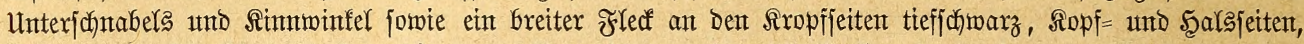

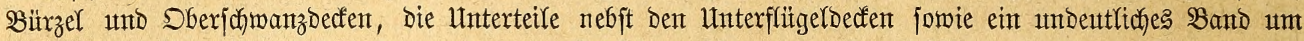

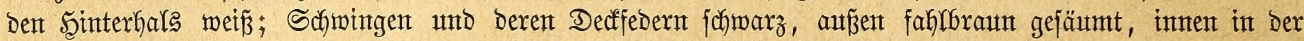

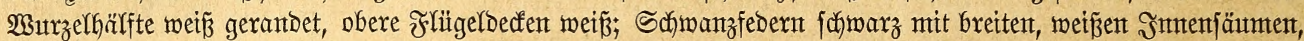

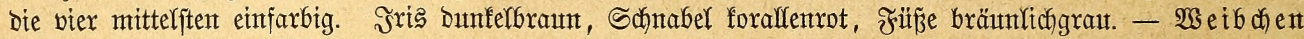
und Männden im 2 interfleide: Sberfopf facharz mit roftbrautem Meittelftreifen, inbrige Sberjeite

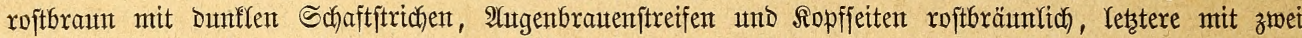

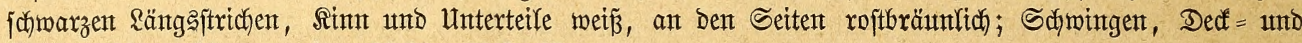

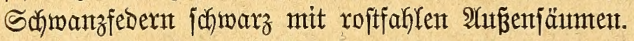

Die Dominifantermida hat biefelbe Serbreitung wie bie Parabismiba.

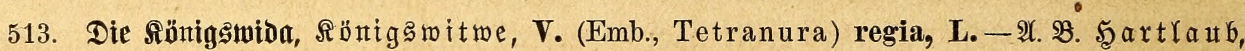

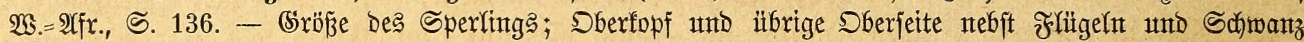

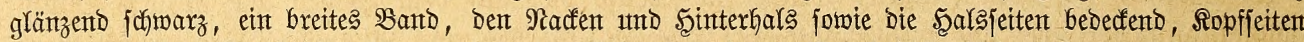

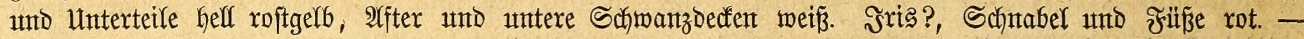

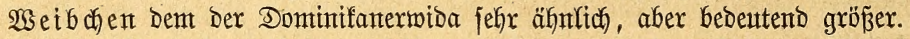

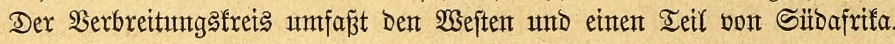

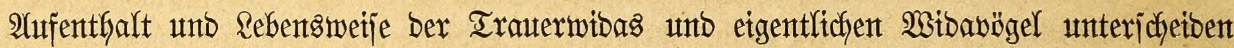

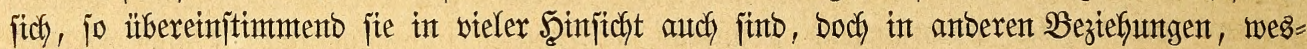
Galb es erjpriteşlich jein bürite, bas von ben einten und ben anderen Befannte gejonbert zu erwäfnent. Heber bas Jretleben ber Trautermibas hat uns Şeuglin Bericht erjtattet.

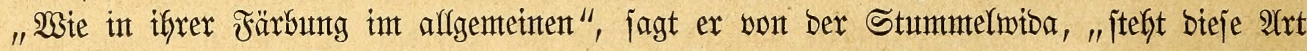

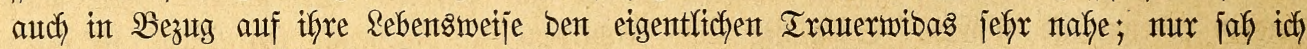
jie niemals in jo flemten (sejelfichaften wie einzelnte von biejen. (S)emöhnlich- trifft mant an

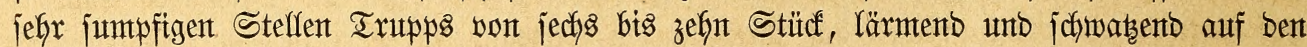

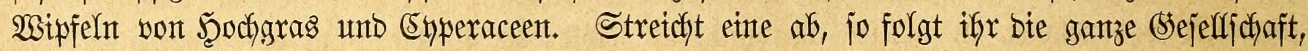
unt gletch wieber an einer anderen Stelfe im Seddgraje einzufalfen. Die Stintme ijt nidht unangenefyn, etwas flötent unto melandyolijch flagent. Serfärbung unt Maujer fallen in

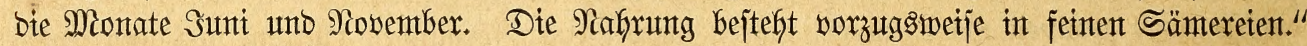

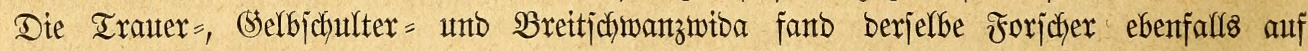

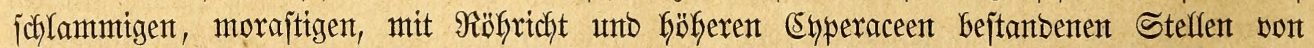

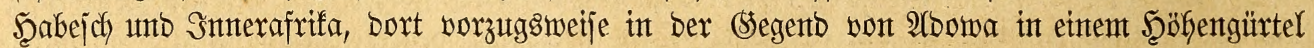
zmijchen $1000-2000 \mathrm{~m}$. über bem Mere, Gier in ben feuthten Neberungen Des (Sazellent=

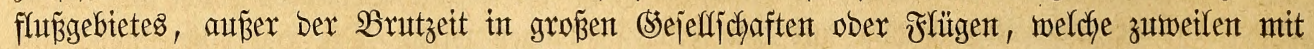

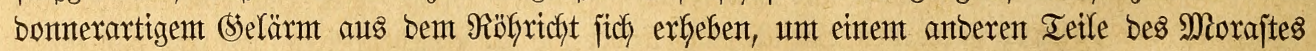

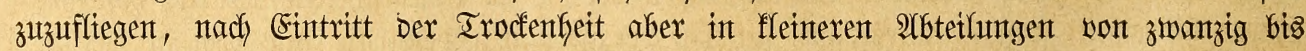

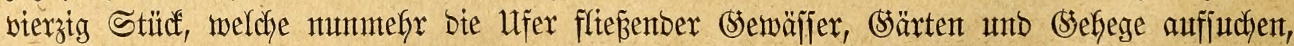

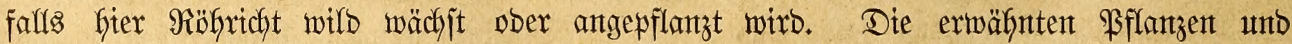
anbere Sumpfgräjer bebingen auts bem (Srumbe ifyren Afufentfalt, weil bie Sämereten ber= 


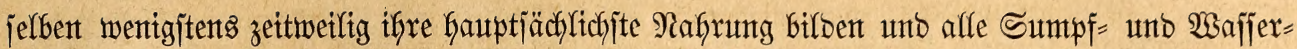

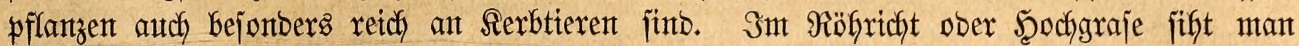

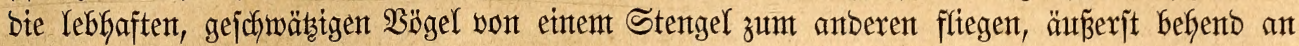

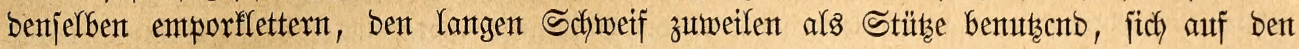

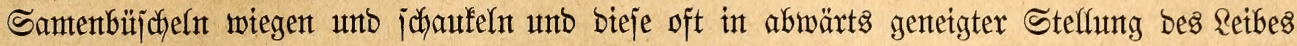

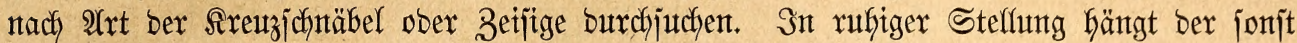

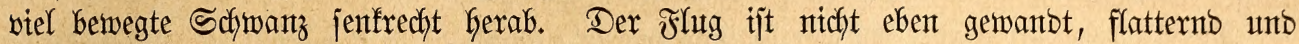

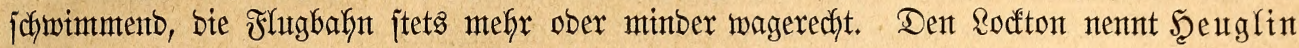

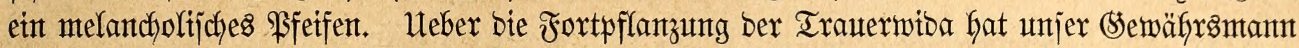

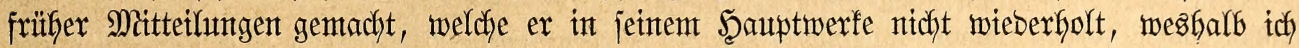

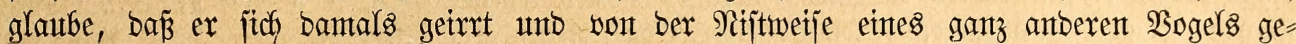

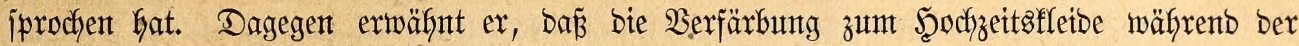

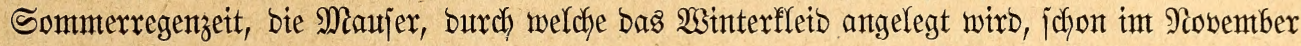

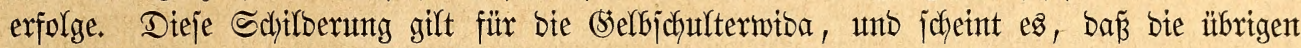
Ifrtent int wejentlidsent eine gleidchartige Rebenzweije fübtrent.

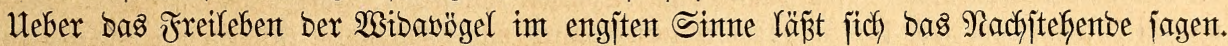

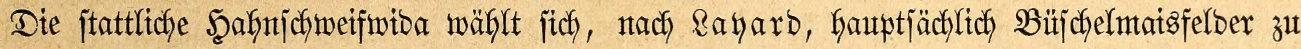

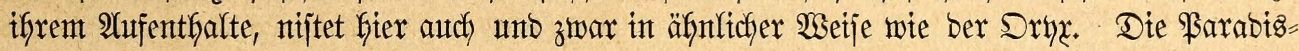

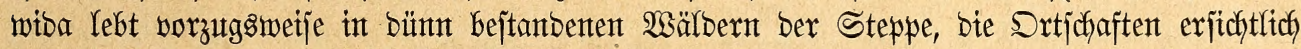

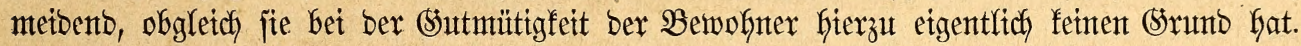

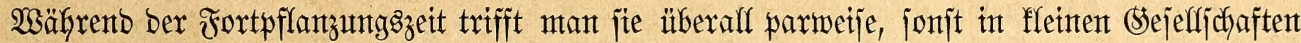

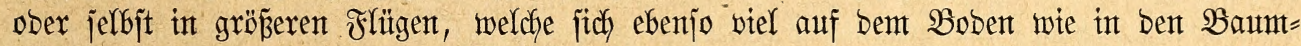

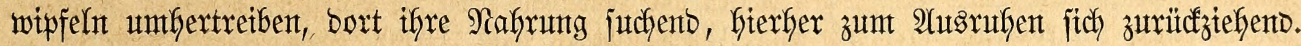

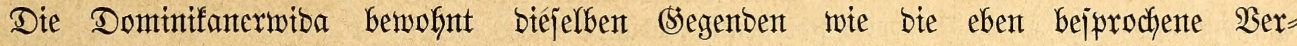

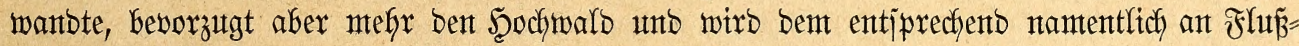

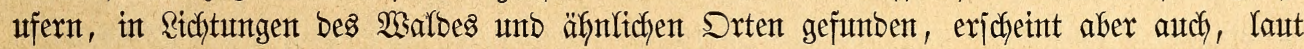

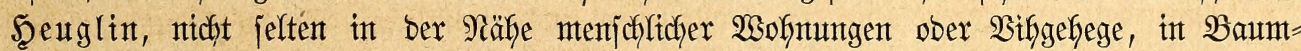

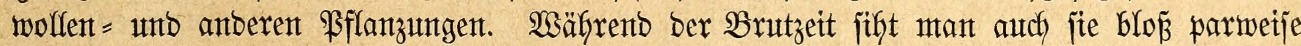

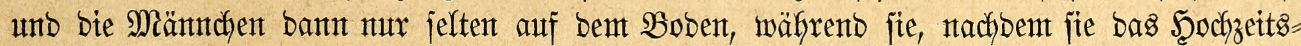

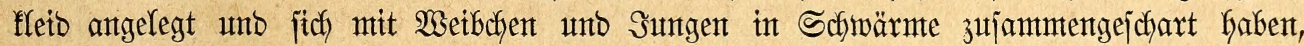
Gjer nach 2 mmmerart umbertrippeln unb int Santbe jidh pabbeln, furz icheinbar eine ganz anbere Rebensweife füffren. So ruffig unb bejcheiben affe bie genannten 2 stoas in ifrer WSintertracht auftreten, jo prallifitig unb herausforbernto zeigen fich bie Mä̈nchen währento

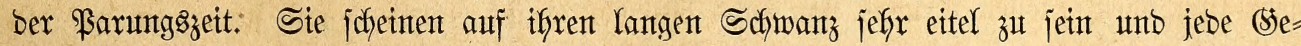

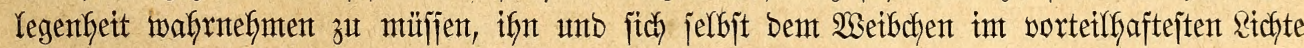

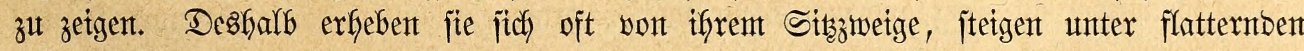

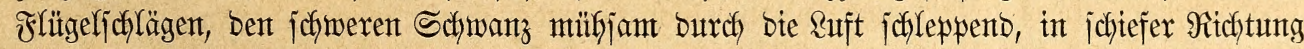

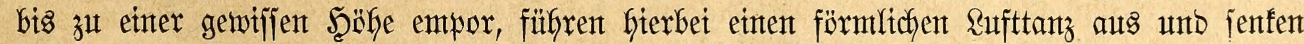
fich barauf langjant zut jelben Stelle wieber herab. Bet Geftigent 2 Sintbe ober ftarfent

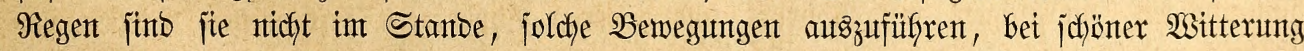

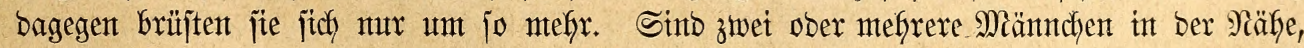

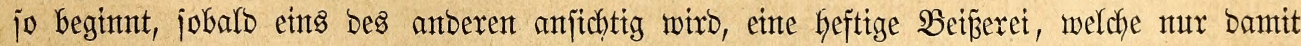

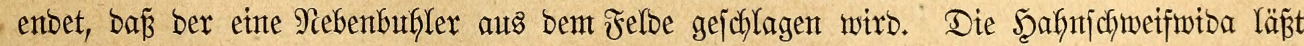

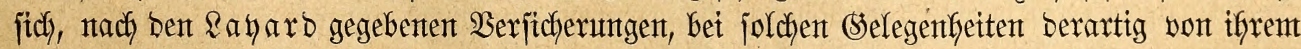

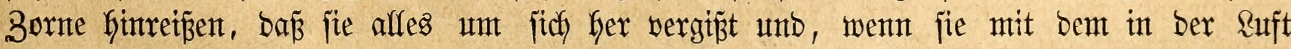

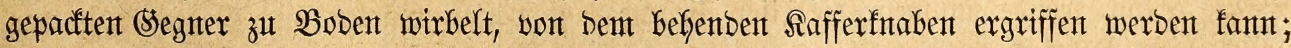
bie \$arabismiba jteft jenter faum nach, uno bie Dominifanterwiba, Derent Eiferjutcht unto Zanfluft nidht geringer ift, übertriffit beibe Berwantoten nur burch größere Beffentigfeit, 


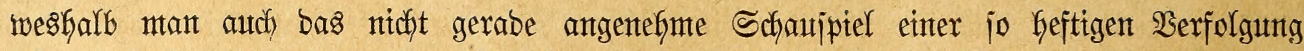

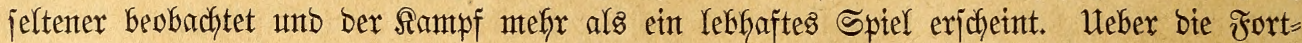

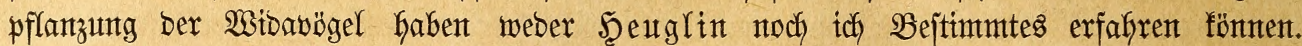

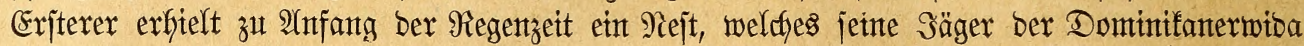

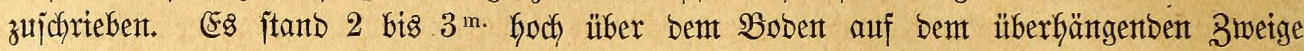

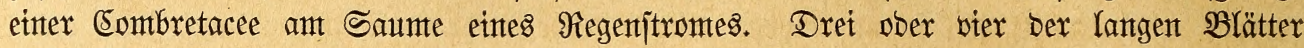

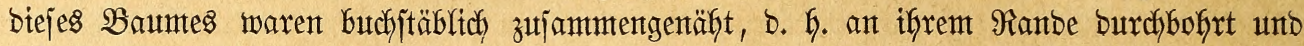

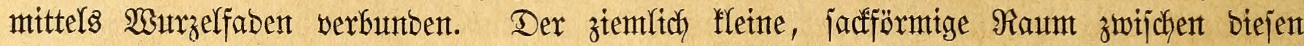

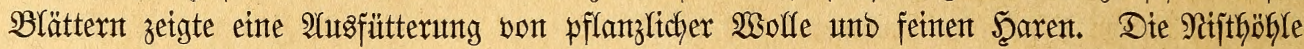

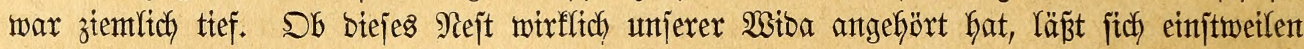
ntody nicht gentat bejtinment.

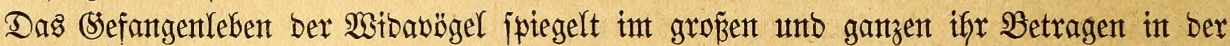

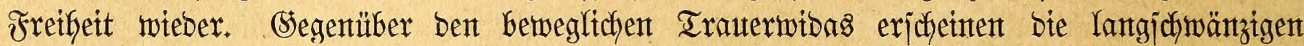

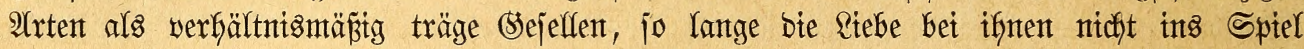
fommt. Die Stummelwiba gibt jith autd in ifremt 2 Bejent unt Sein als ein Mittelglied

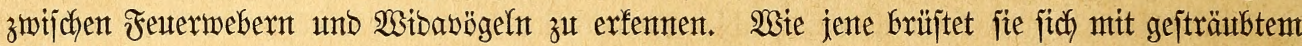

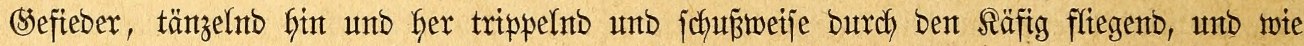

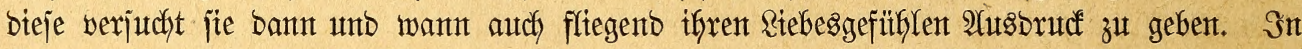

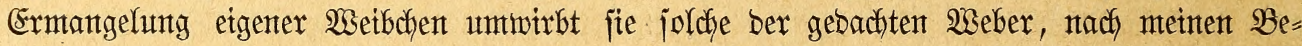
obachtungent intsbejonbere Sorne = unb Sammetwogefweibchen, nimmt mit ben Miäntchen ber

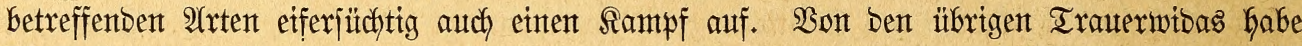

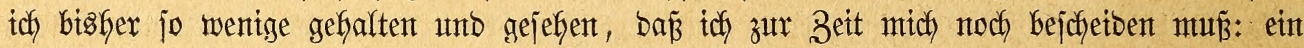

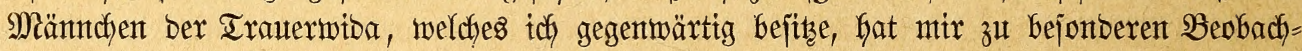
tungen feine Bselegentyeit gegeben. Dasjelbe gilt leiber ebenjo für bie Schjitomito, von welcher idh jeit einigen Safreen ein Miännctent pflege. Es entfaltet in jeiner Berein=

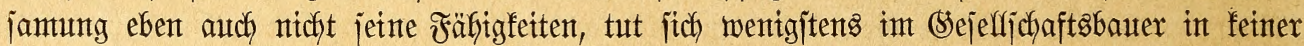

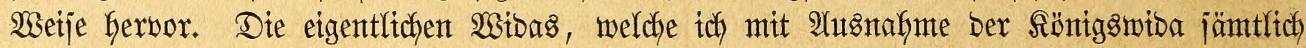

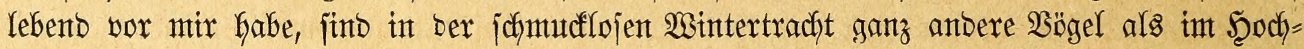

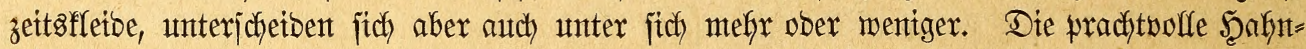

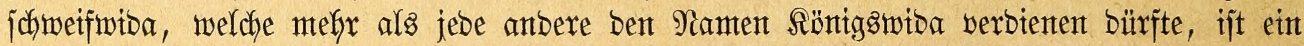

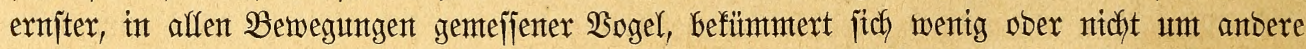

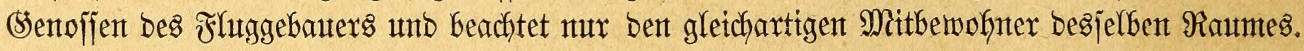

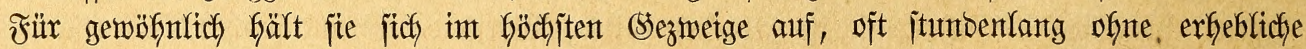
Bemegung auf einter uno berjelben Stelle verweilent, unto mur went bie Rieblingałojt uno

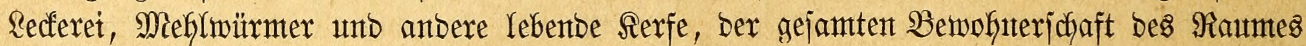

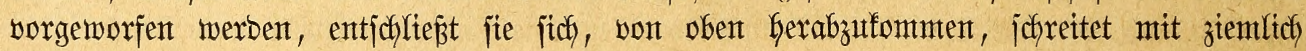

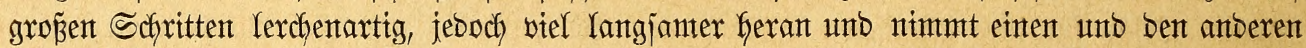

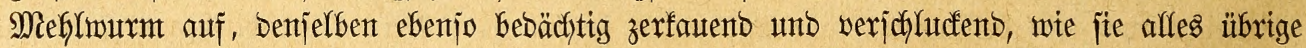

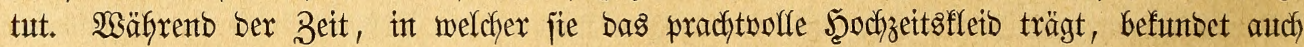

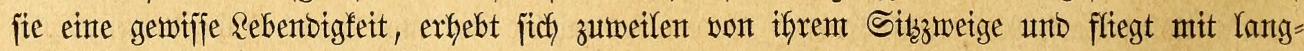

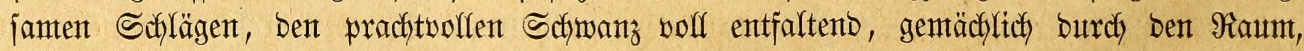
Gerausforbernb bem zweiten Miänndfen ober einent gerabe fich Grïjtenben Sryz ober Sammet=

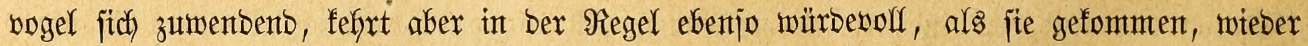

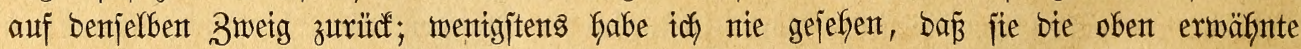

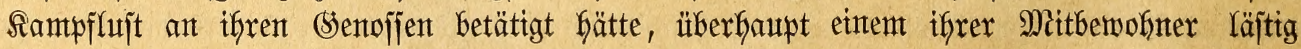

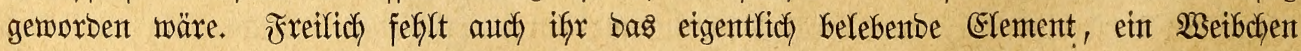
nemlidch; eit Santpf mit bent Rebenbufgler ober eintent anberen Sogel mürbe aljo gegen=

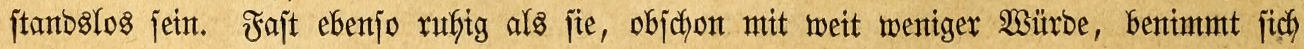




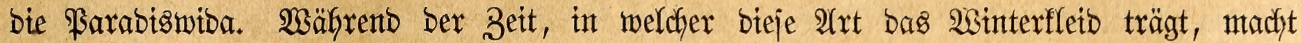

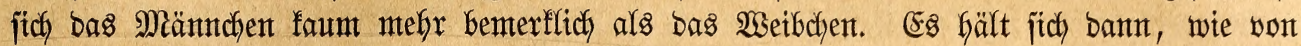
ber Freifeett her gemofint, viel auf bem Boben auf, Gier ammerartig umbertaufent uno in

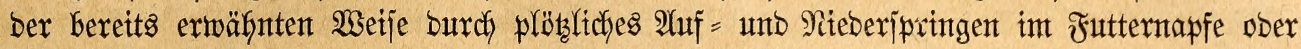

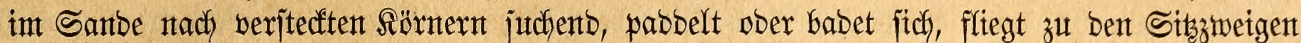

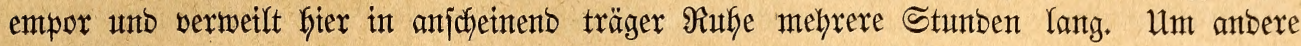

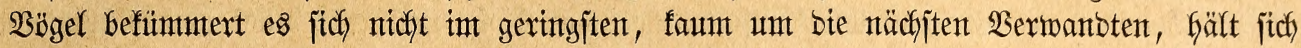

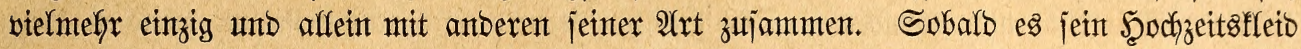

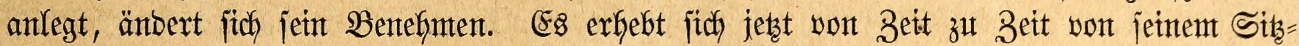

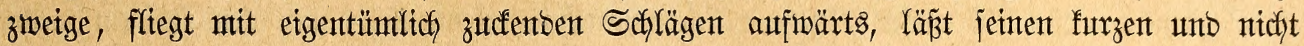

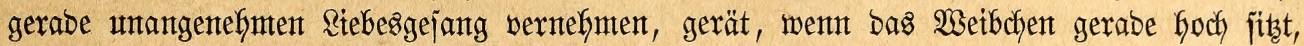
bei biejem sufttanz in förmfliche Begeifterung, wirb lauter unt ftürmiffcher, begefrender,

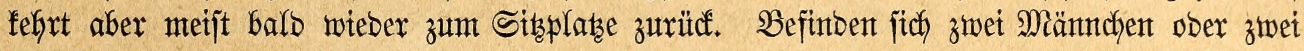

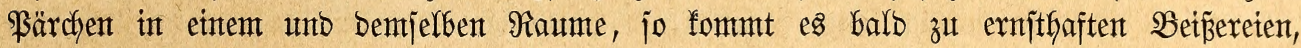

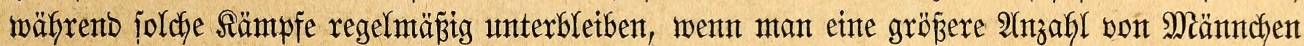

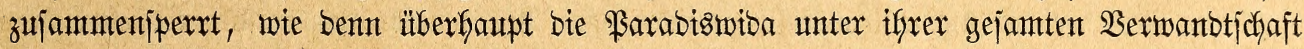

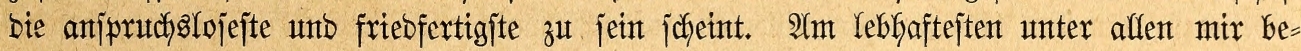
fannten $92 r t e n$ benintmt fich bie Domminifanerwiba währento ber Beit iffrex \&iebe. So lantge

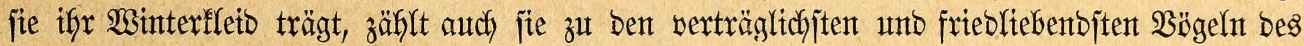

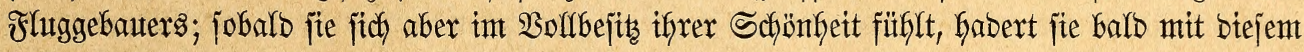
balo mit jenemt unto fämpft wolf Errbitterung mit jebent anberen Miännchent, weldhes Stant fä̈lt.

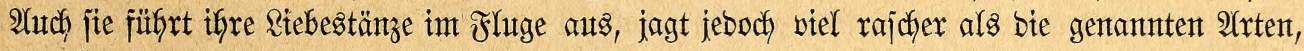

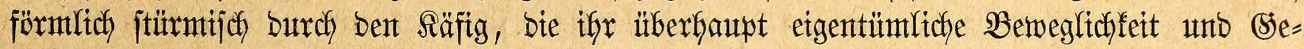

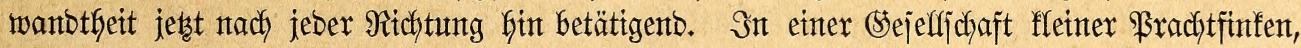

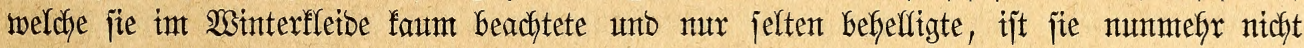

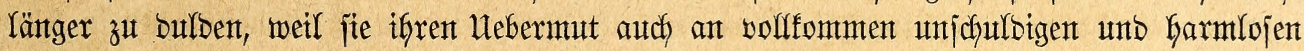

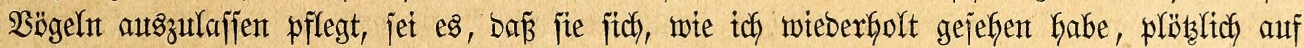

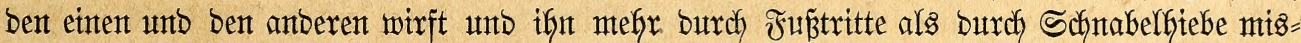

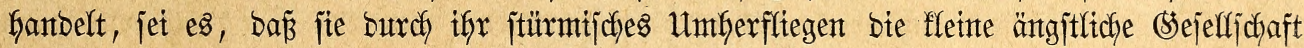
in Sdyredfen jeţt.

Bon alfen Witbavögeln, welche ich gepflegt Gabe, hat jich bis jeste feine zum 9iiften

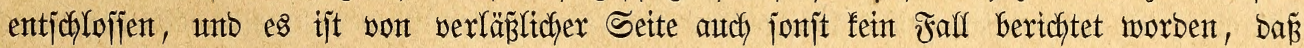

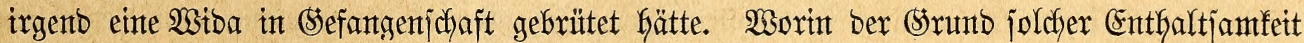

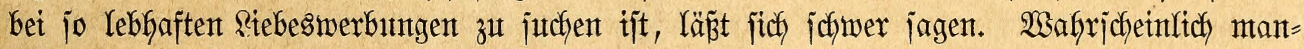

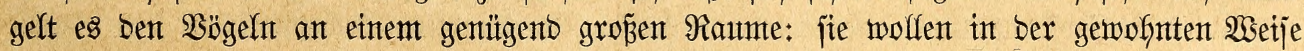

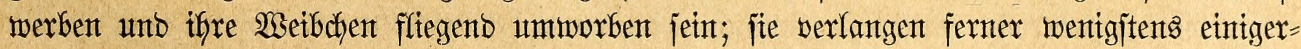

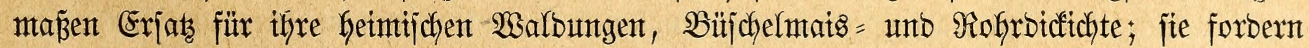

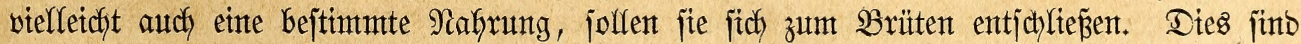
Bermutungen, weldye idh aber bod ausjpredfent möchte, um biejen ober jenen Riebfaber zut

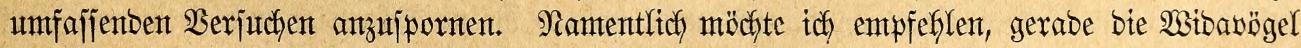

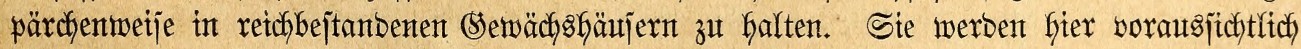

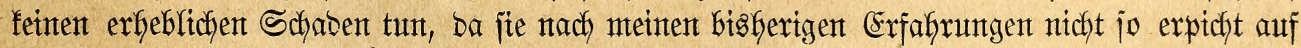

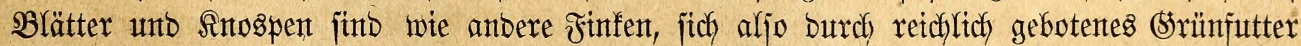

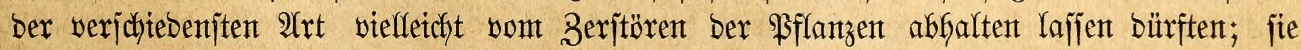

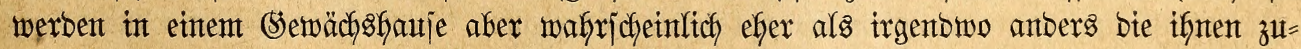

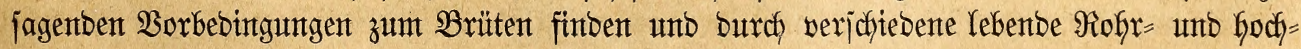
ftämmige (Srasarten noch bejonbers eingelaben werben fönnen, aus ben ifgnen jonjt reicflidy

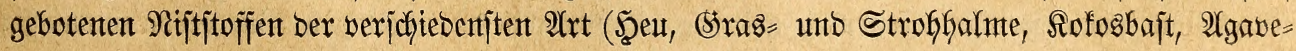




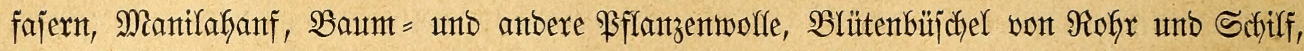

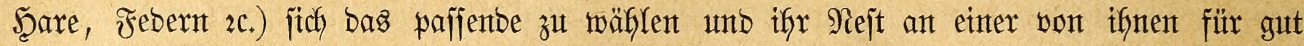
befunbentent Steffe zut errichtent. $S_{b}$ joldche Beiftrebungent mit Exfolg gefrönt jein merben, itefgt freilich Dafint.

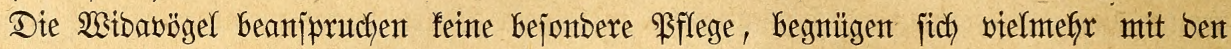

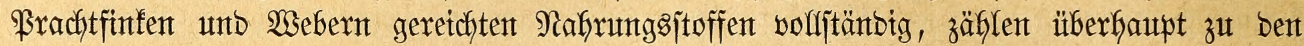

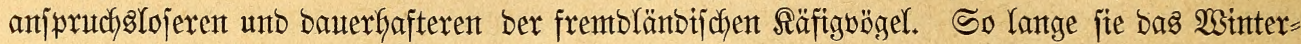

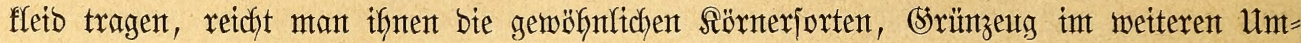

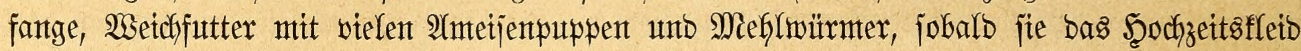

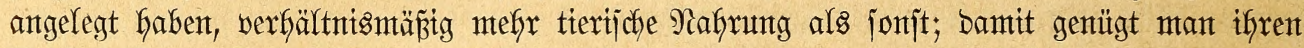
Bebürfnififent. Sollten fie zumt Brütent fidreiten, jo würbe mant ein bejonberes 2Atgenterf

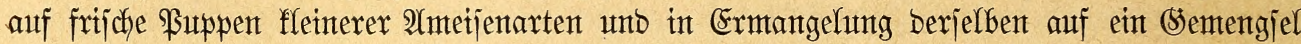

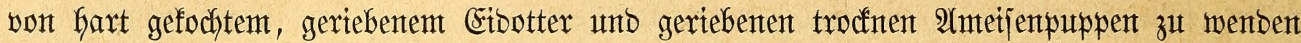
Gaben unt Mefflwürmer unt andere Rerbtiere in beliebiger Mentge bieten müffen, fie aud

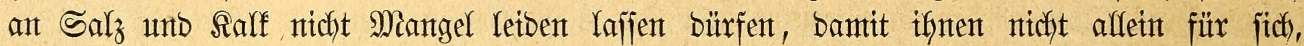

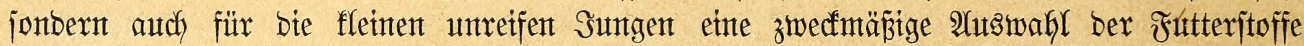
möglich märe. Meffr bürftent fie auch) bann nicht verlangen.

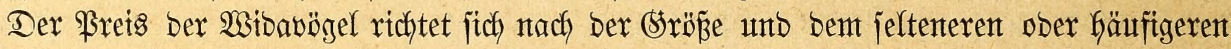

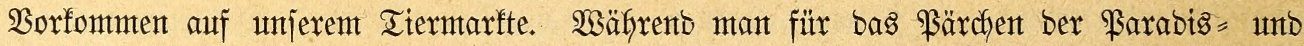

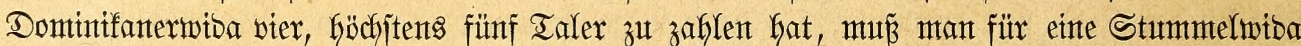

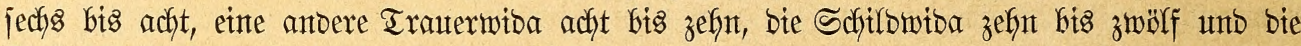

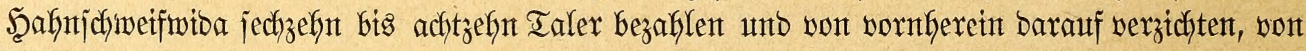

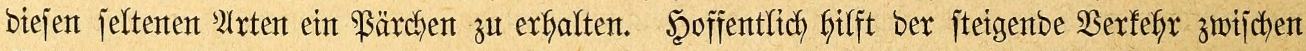

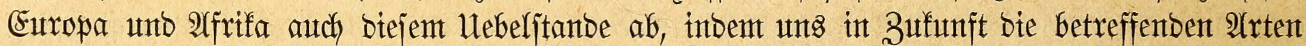

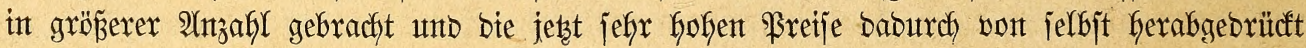
werbent.

\section{Stahlfinkent.}

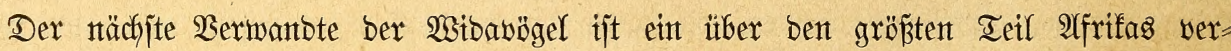
breiteter, in unjerent Säfigent Gäuffiger Finf ntit furzent, fegelförmigent, auf ber Firite ge=

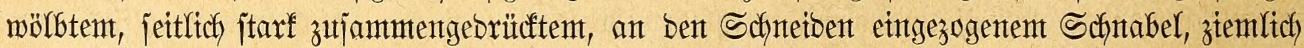
Goct)

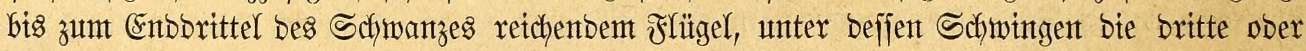
vierte bie längitent, unto furzem, gerabe abgejdnittenem, jeitlich) etwas gevunbetem Schlwanze

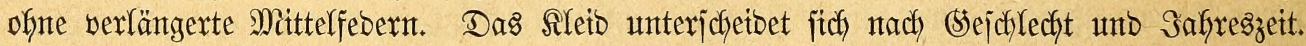

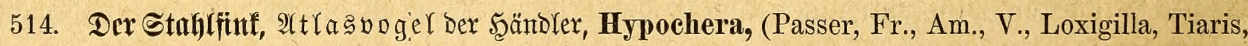

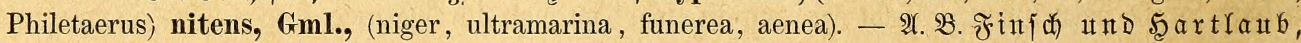

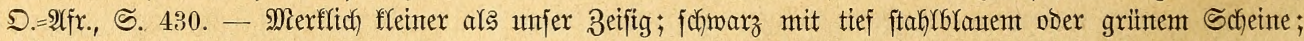

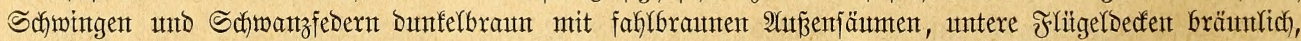

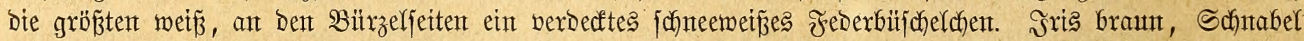

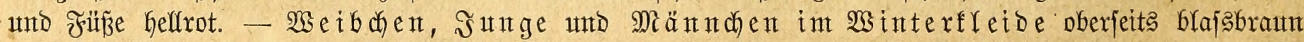

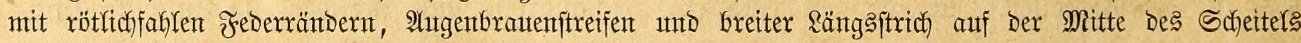

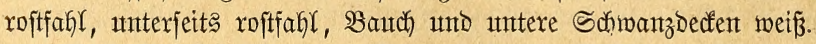

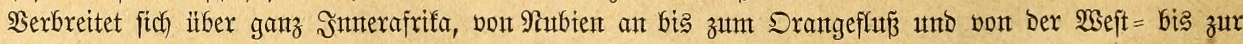
Ditfiutite, utto ift überall häufig.

Der Staflfintf ift einter ber erjten Iropentögel, benen man in Nutbien begegntet; man

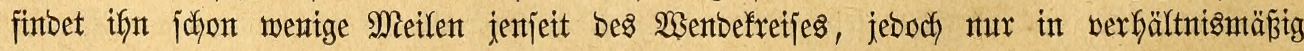


fruchtbaren (Segenben bes genannten Ranbes. Sion fier aus nach Süben zu mixb ex häuffiger,

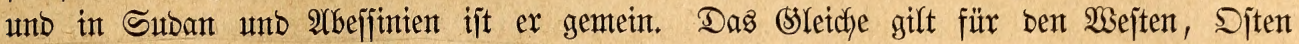

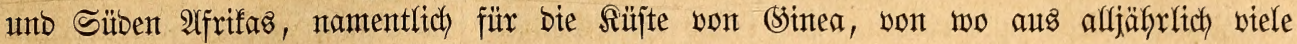

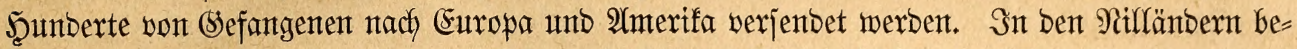

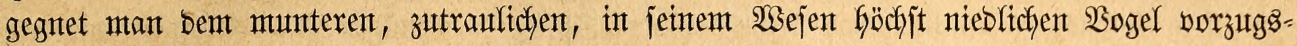

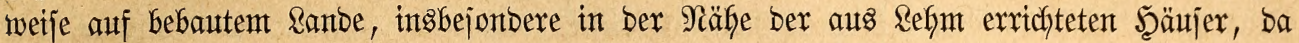

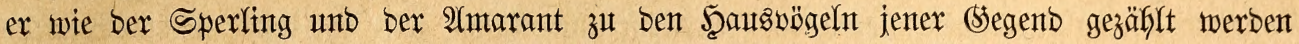

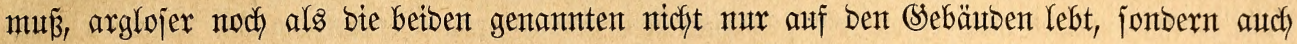
in bas Snnere berjefben Gereinfonmt, um Gier bie SBrojamen aufzultejen, welche von bes

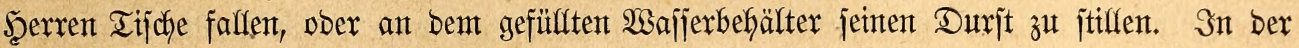

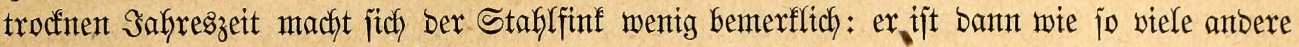
feiner engeren unb weiteren 2 erwantotichaft auf ber 23 anberutg, wereintigt fich ntit Fetter=

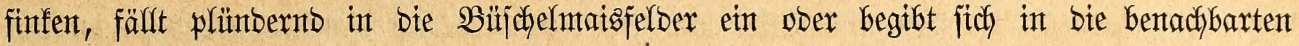

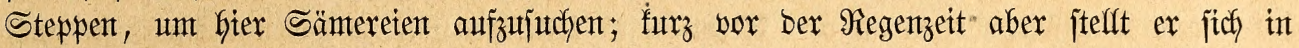

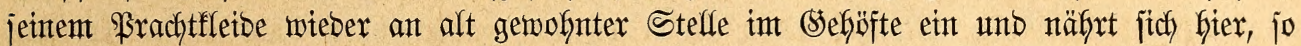
gut ex fant. Sein গiejt wiro ebenjo wofhl auf Bäunten als unter bent Sparrentwerf in

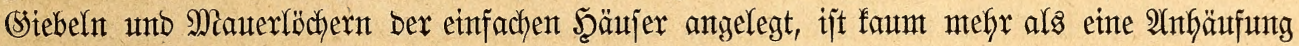
won Stroghafmen, WSolfflodfen, Febern unb bergleichen unto entfält in ber Mitte einen

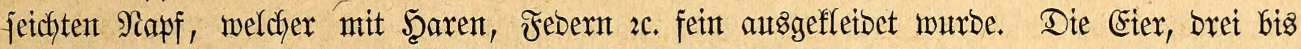

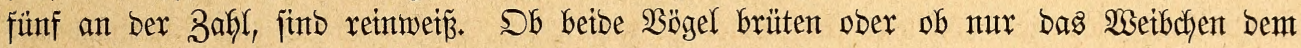

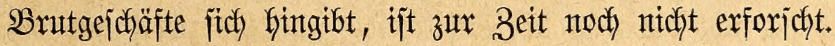

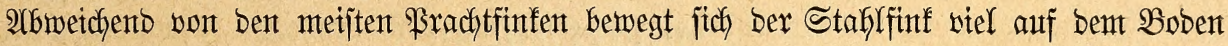

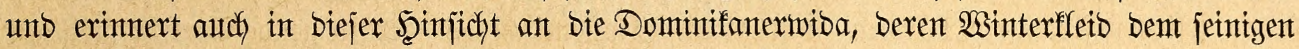

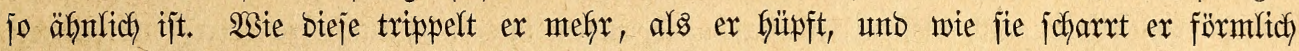

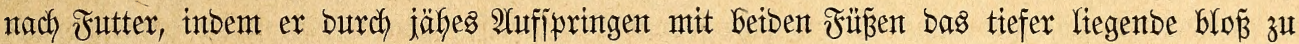

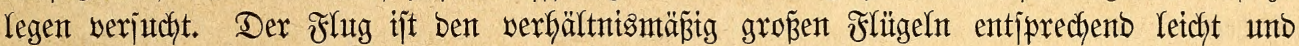

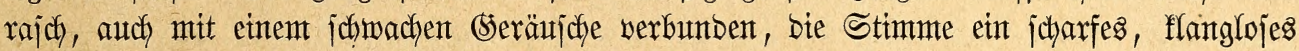
(Sezirp, ber Bejang ein mefhrfaches Witeberfyolen bes Rocttones.

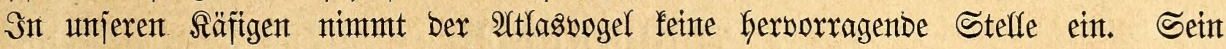
Bentefyten hat wentg anzitehenbes. Shjchon währent bes ganzen Tages beweglidh und un=

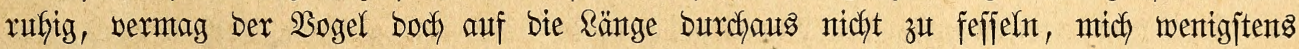

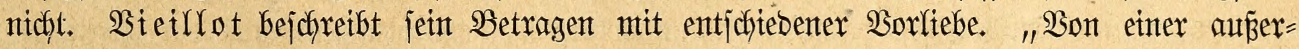

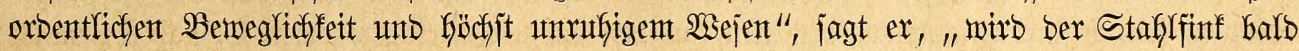
Der Suälgeif́t alfer Bengalijten, Senegalvögel unt anberer fleinter Räfiggenoifent. Selten

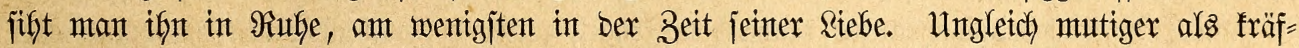

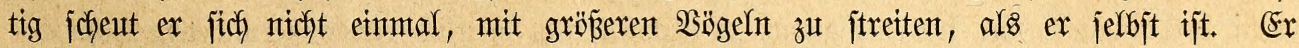

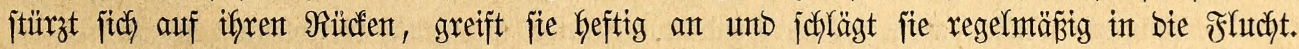

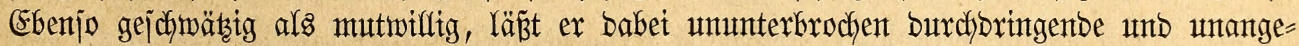

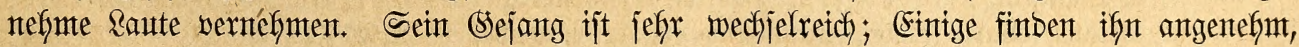

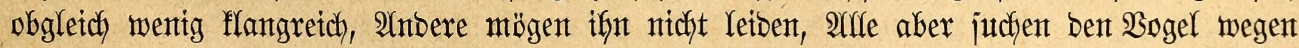
jeiner Rebfaftigfeit, 2Unmut und jeines jojönen Befiebers. Das 2 seibchen, nidyt wentiger

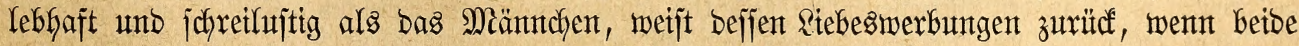

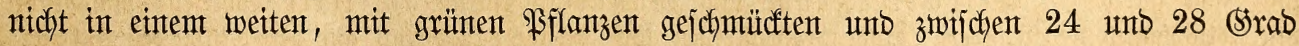

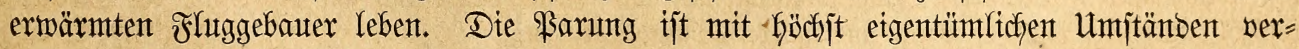

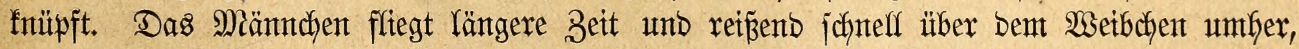

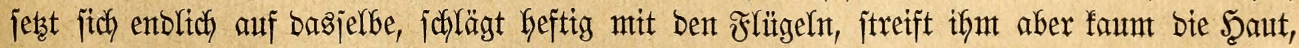

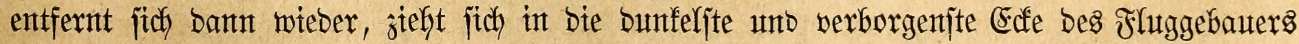

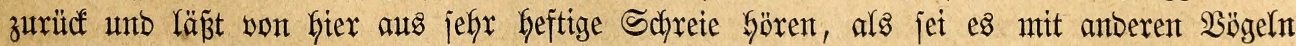




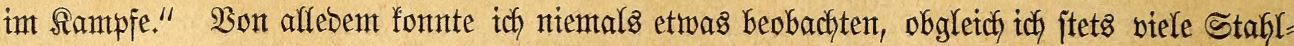

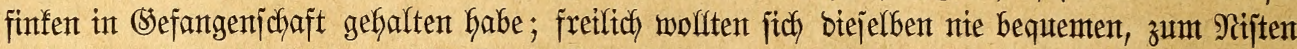

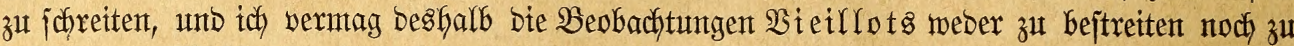

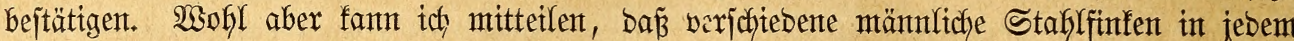

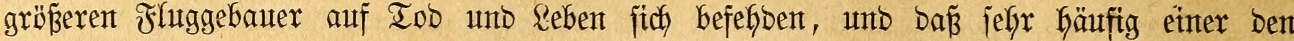

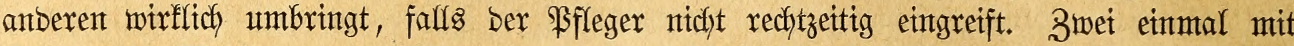
einanber in Streit geratene Männthen Diejer Keftigen $\mathfrak{B}$ gel Kafjen jelten von einanber ab, bevor ber eine erlegen ijt. Bon ben Riebestwerbungen Der Miäntchen, wie Bieirlot fie

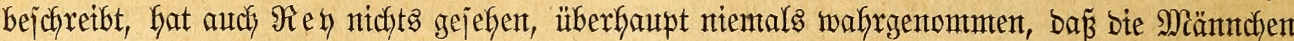

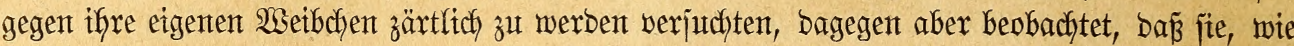

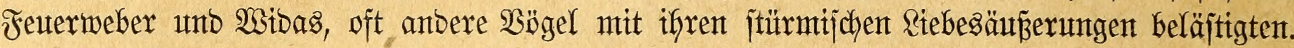

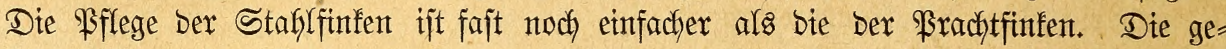

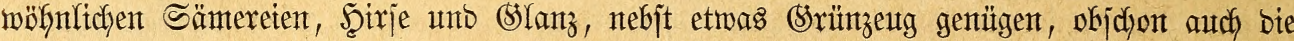
Stahlfinfen mit ber Beit jich getwöhnen, von Dem 2 Seidfutternapfe zu frefien und einten ober ben anberen Meflinurm aufzunefymen. Eines fo hohen Wärmtegrabes, als Bieillot an=

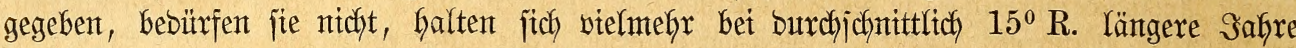

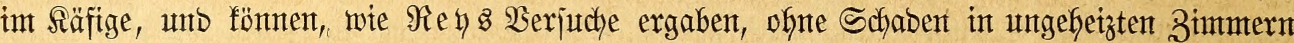

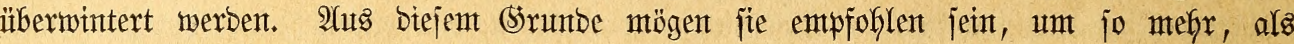

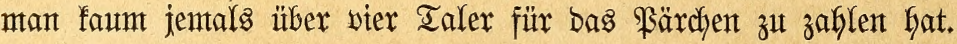

\section{Ammerfinkett.}

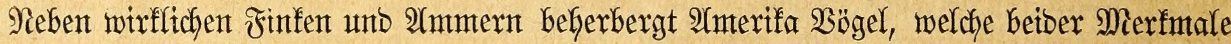
in fich vereinigen unb einen bies ausbrïffenton Namten erhalten Gaben. Die Mitglieber ber Unterfamilfe zerfalfen in viele Sippen und Unterjippen, Gaben aber ein jefr überein=

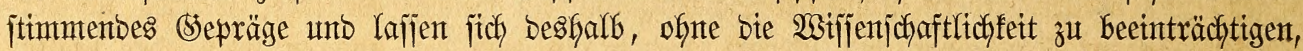

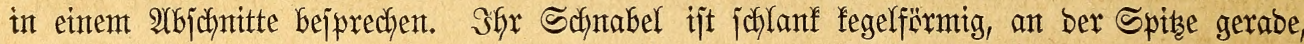
auf ber Firite wentg gekogen, an Muntoranbe eingezogen, ber Fủ hochläufig, langzefig unt

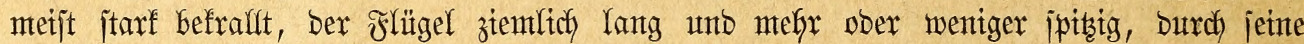

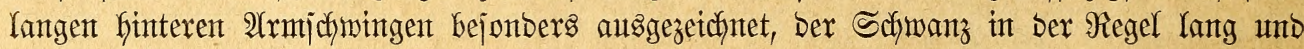
in ber Mitte altsgejdynttten, bas Befieber bunt unt im alfgemeinen ammer = ober lerdhenartig gezeichntet.

Die Sippe ber Sumpfammerfinfen mag zuerjt ermäfnt werben. Sie fennzeidntet

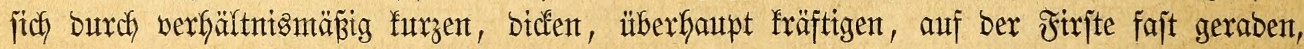
ant Manbranbe eingebogenen Scynabel, mit zafnartig vortretenber Edfe, jefyr fräftig gebaute,

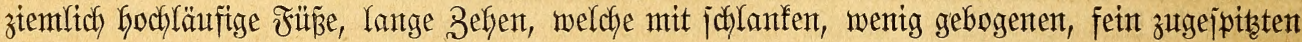
Sraflen betwehrt finto, furze Flügel, unter beren Schiningen bie britte, vierte unt fünte bie längiten zu jein pflfegen, mä̈̈tg langen, jtarf abgerunbeten Sithanz unb weiches, laxes Ssefieder.

515. Der Sumpfunterfiuf, Embernagra (Emberiza, Emberizoides, Limnospiza) platensis,

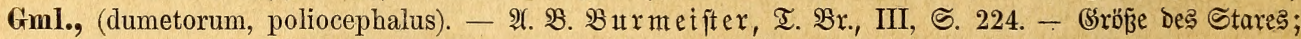

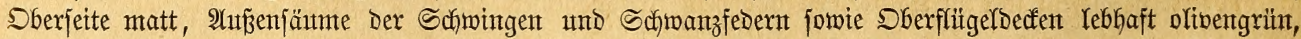

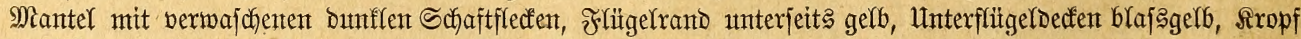

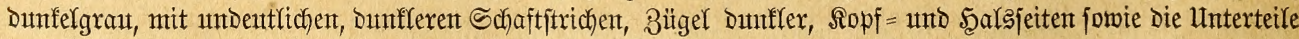

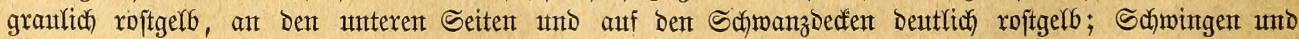

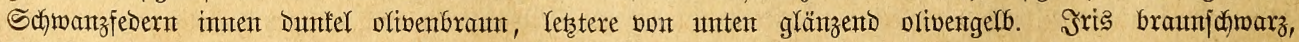

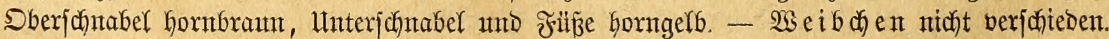

Serwofnt Dą jübliche Brafilien, Faragay, Die Platajtaten und Bolivia. 


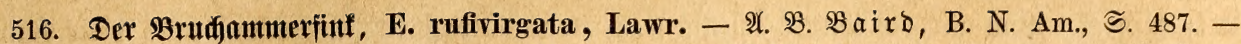

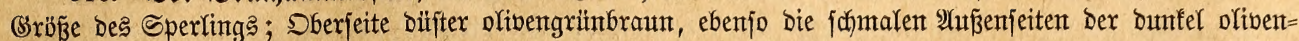

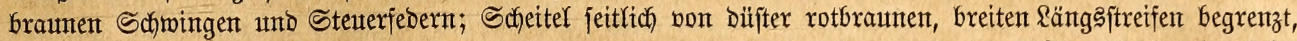

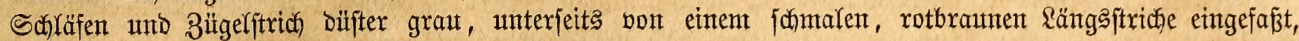

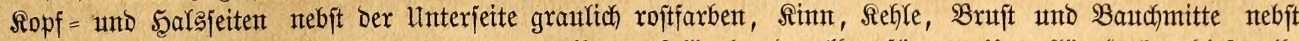

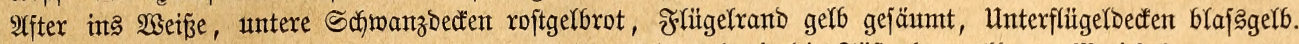

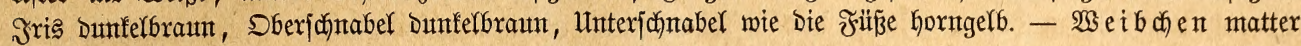
gefärbt.

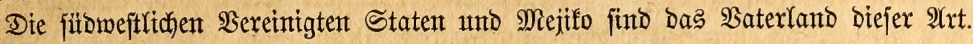

Die Dornammerfinfen haben im alfgemeinen bie Sientzeidyen bex Sumpfammerfinfen, namentlich aitch ben jtarfen Fuß̧bau unb ben langen Schwanz; ifyr Sdynabel aber ijt fräftiger unb häher, ber Flïgel ganz runb, Da bie britte, vierte unt fünfte Schninge bie längiten fint unt bie Flügelipitze faum vorragt.

517. Der Dornanuterfinf, Haemophila, (Emb., Aimophila) rufescens, Swsn., (pyrgitoides). -

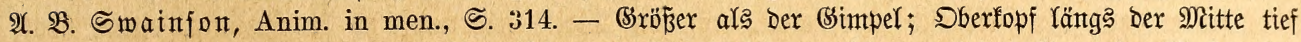

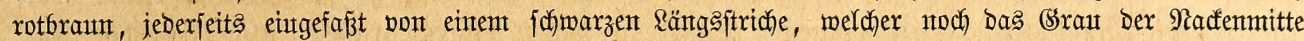

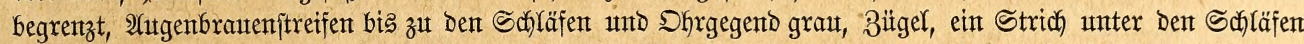

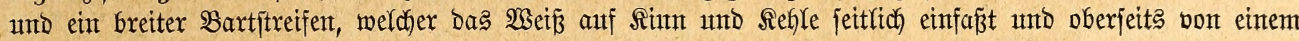

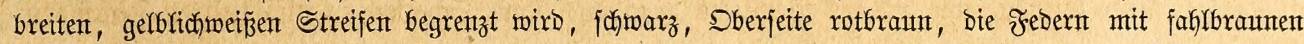

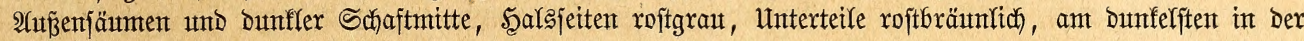

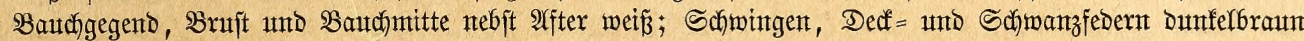

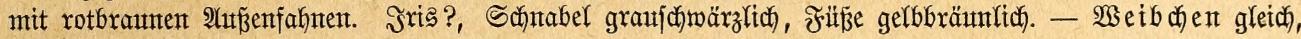

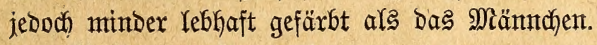

Miejifo und Gratemala.

Die (S) runbammerfinfen haben einen fräftigen, auf ber Firjte jeicht gebogenten, an ben Sdynetben faft geraben Sdynabel mit beutlidjer Aerbe vor bem Enbe, grop̉e, Yangläufige Füßß̨e mit langen fräftigen, jeicht gebogenen Zełen, furze, zujammentgelegt faum ein Drittel Des Sdjwanzes bebecfende, runbe Sdywingen, unter benten bie bierte bie längîte, merffich langen, aus breiten Febern gebilbeten Schwanz und ein metches (sefieber, welches auf ber

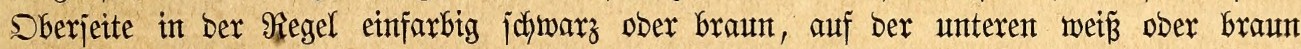
gefärbt î́t.

518. Der (Srumbrätel, G r o u nd ro b i n Der 9 tmerifaner, Pipilo (Fr., Emb.) erythrophthalmus, L.,

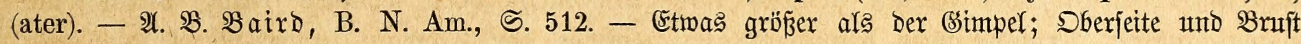

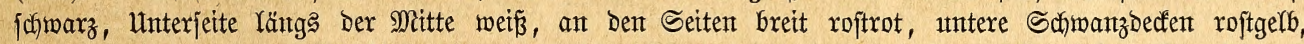

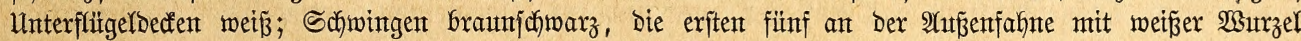

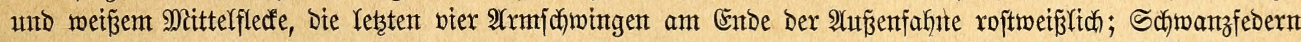

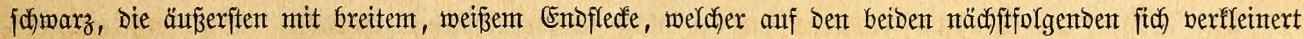

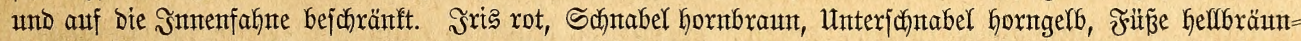

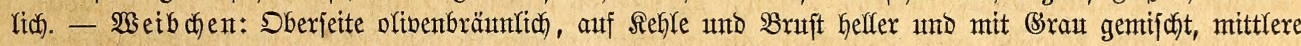
Sch)manzfedern Dunfel olivenrotbraut ; im übrigen wie bas Miänndhen.

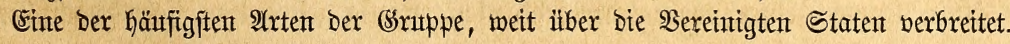

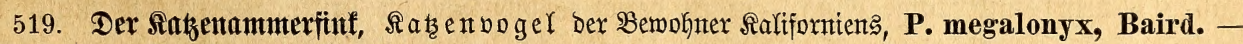

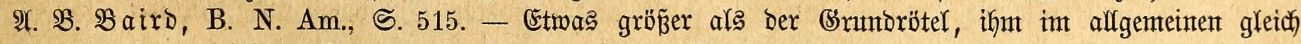

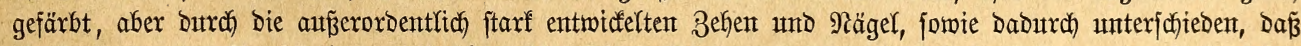

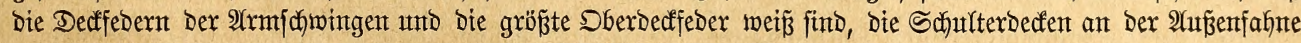

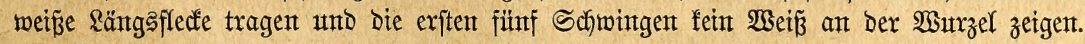

Die 2 (rt ift bisjestzt mux in Ralifornient unt bem $\mathfrak{A}$ rizonagebiete gefuntoen wordent.

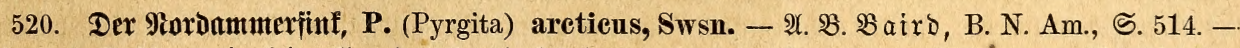

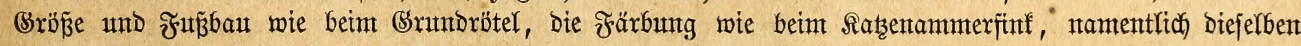

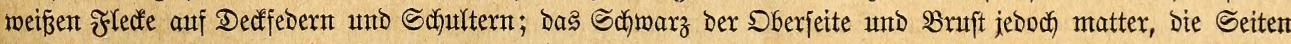

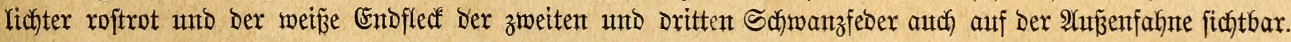

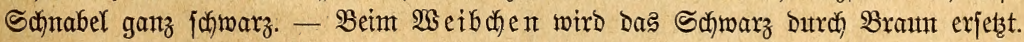

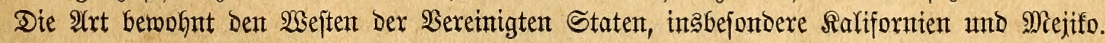


521. Dex $\mathfrak{B r a u t a m m e r f i n f , ~ P . ~ ( F r . , ~ K i e n e r i a ) ~ f u s c u s , ~ S w s n . , ~ ( c r i s s a l i s ) . ~ - ~} \mathfrak{A}$. $\mathfrak{B}$. $\mathfrak{B a i r}$,

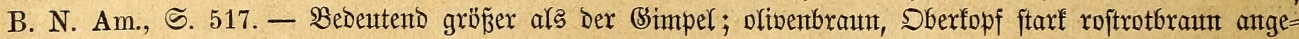

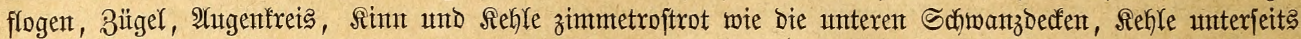

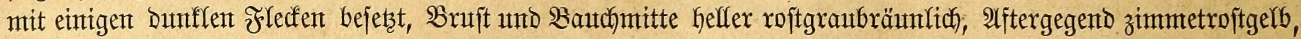

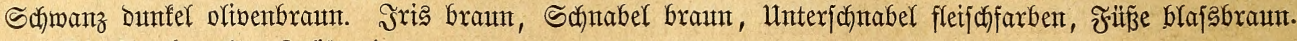

Die $\mathfrak{A}$ rt bemognt Ralifornient.

Die Sruppe ber Bindenammerfinfen, weldhe neterbings in veridfiebene Sippen

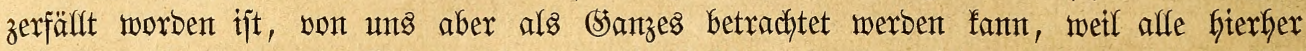

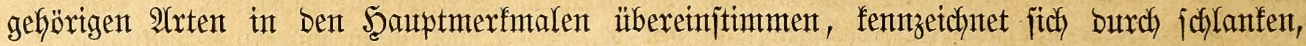
fegelförmigen, auf ber Firite geraben, iptzigen, ant Mautbrande bis zum Sirunbe eingebogenen, am Mantominfel etwas herabgezogenen Sdhnabel ofne fierbe, beffen unterer Teil fajt ebenjo hoch mie ber obere ijt, hochläuffige, langzehige mit gropen, wentg gebogenten, janft zugejpibtent

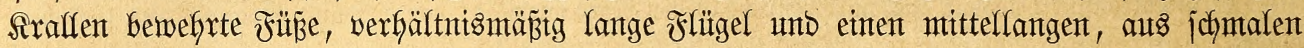
Febern bejtehenden, außzen etwas gerumbeten Sdywanz jomie ein ziemlich weiches, bolfes, ammerartiges sefieber.

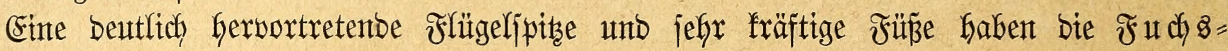
ammerfinten.

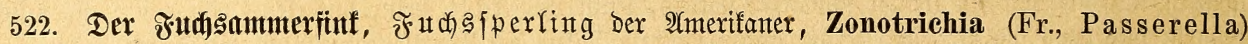

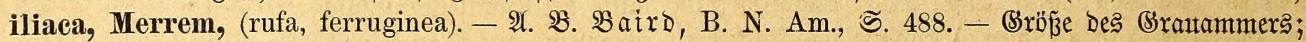

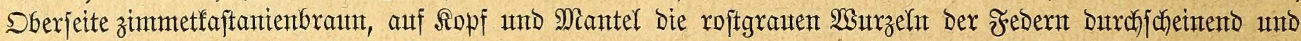

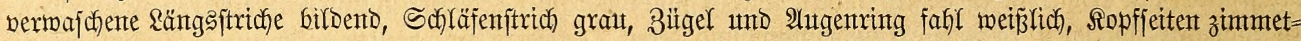

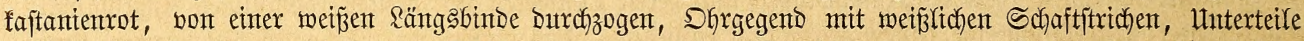

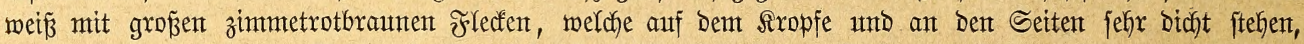

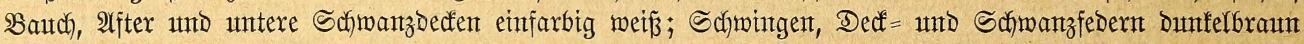
mit zimmetrotbrautnen $\mathfrak{A}$ ur

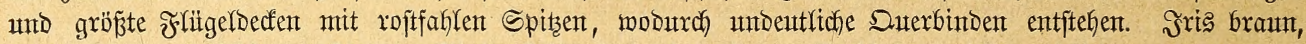

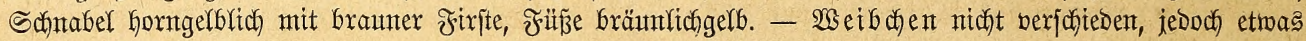
blafier gefärbt.

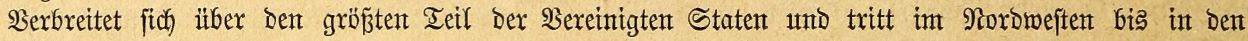
falten (Biintel eint.

523. Der $\mathfrak{A m i j e l a m m e r f i n f , ~ Z . ~ ( E m b . , ~ F r . , ~ P a s s . ) ~ u n a l a s c h c e n s i s , ~ G m l . , ~ ( T o w n s e n d i i , ~ r u f i n a , ~ m e r u - ~}$

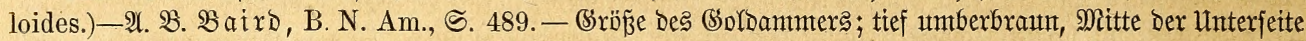

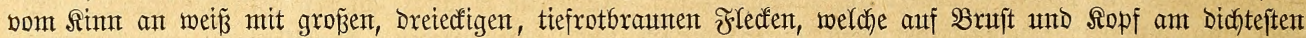

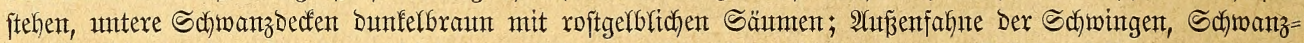

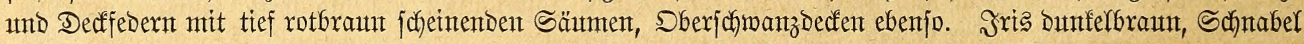

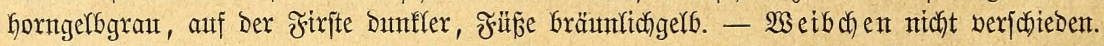

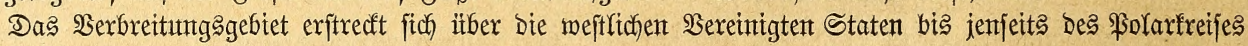
unto Ralifornient.

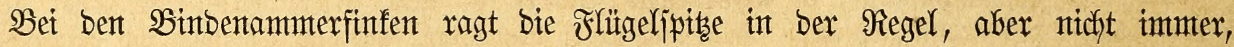
ebentalle vor.

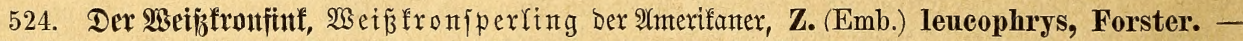

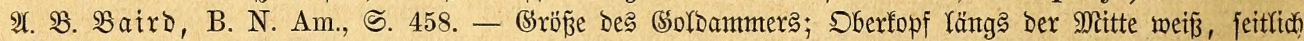
Durchzogent von zwei breiten fojwarzen Rä̈tggftreifen, welche vont Der Stirn bis zum Şinterfopfe laufent unto

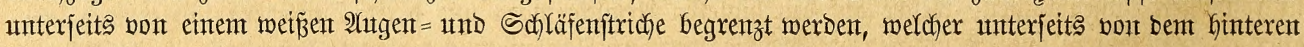

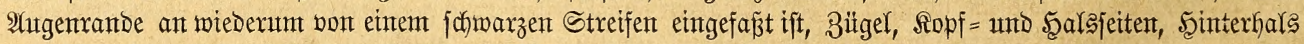

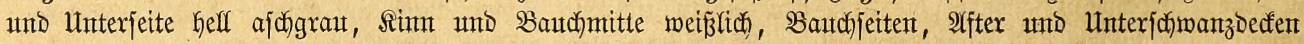

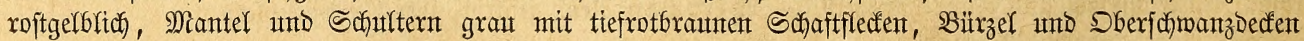

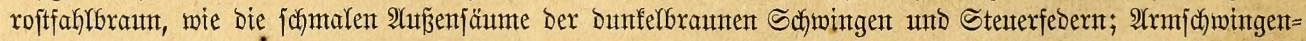

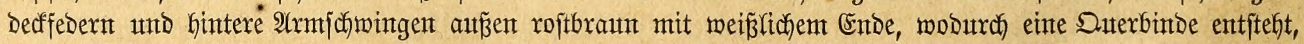

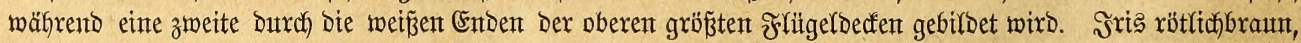

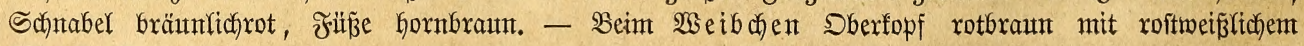
Mitterftreifen.

Ueber Den größ̈ten I 
525. Der Silberfronfinf, Z. (Fr.) Gambelli, Nuttall. - $\mathfrak{A}$. B. $\mathfrak{B}$ a $i x \supset$, B. N. Am., S. 460. -

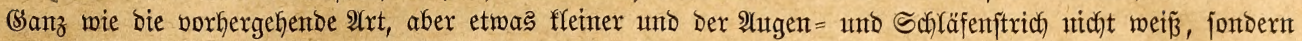

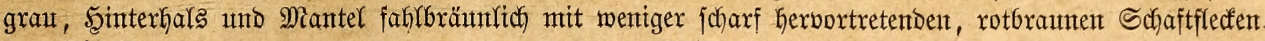

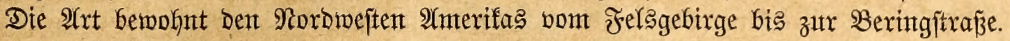

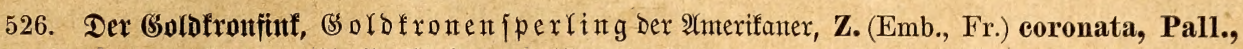

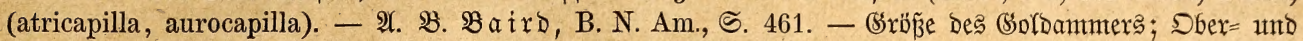

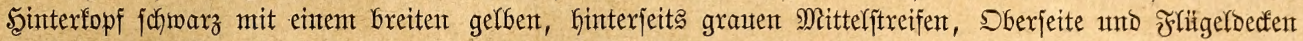

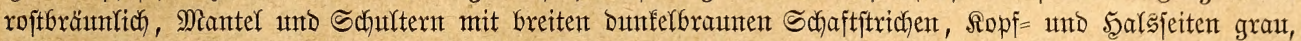

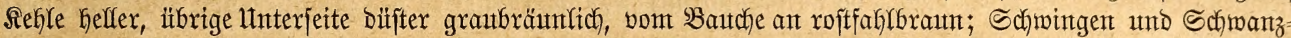

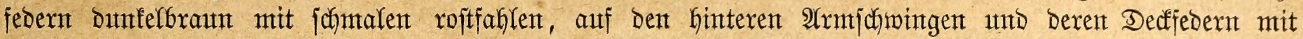

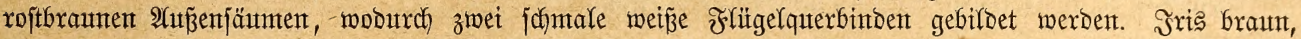

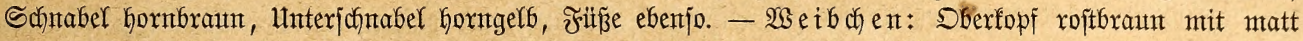
olivengelber Sckeitelplatte, Ropf = und Searsjeiten nebjt Butit Dentlicher rojtfahl.

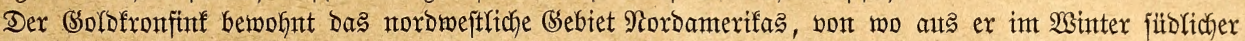
mantert.

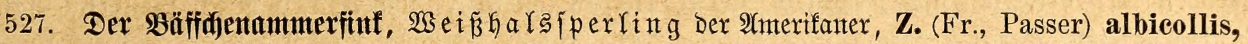

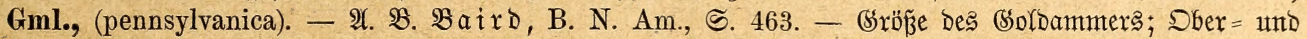

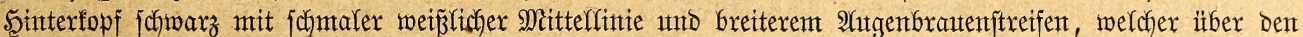

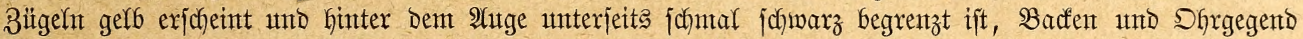

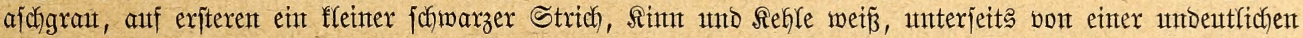

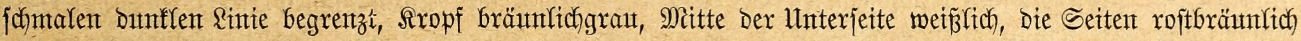

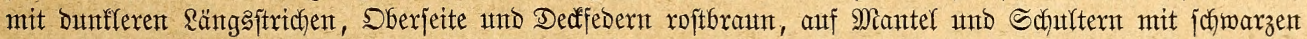

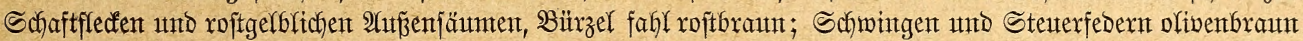

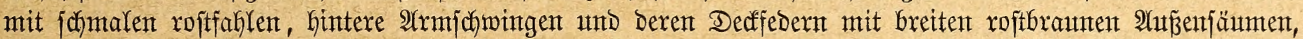

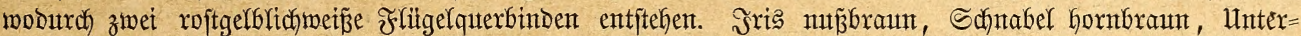

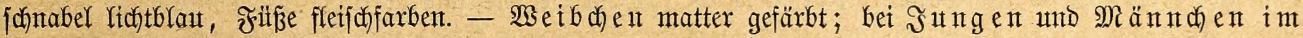

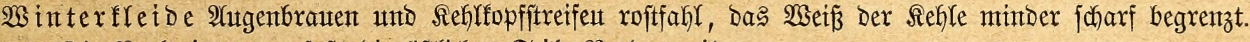

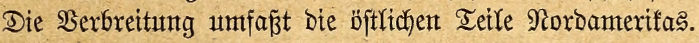

528. Dex Morgenfinf, Ehingolo und $\mathfrak{T}$ iå $=\mathfrak{T}$ ide der Sïbamerifaner, Z. (Emb., Fr., Tanagra)

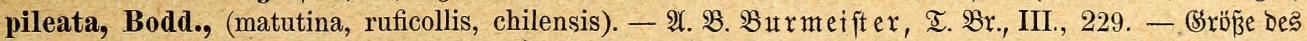
EDelfinfen; Sberfopf braungrau, feitlich begrenzt von zroei fohmarzen Rängsftreifen, weldhe fich bis in Den

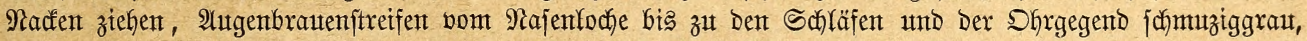

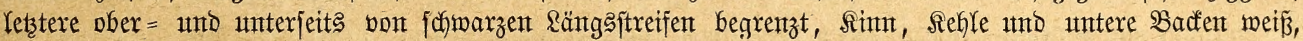

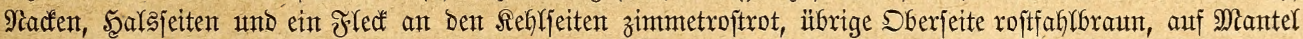

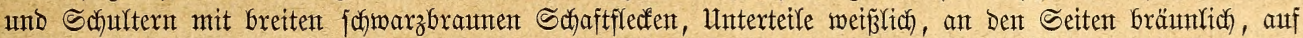

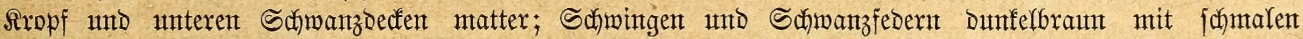

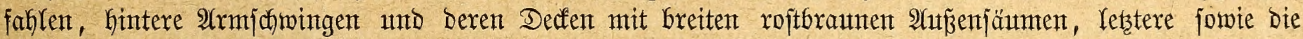

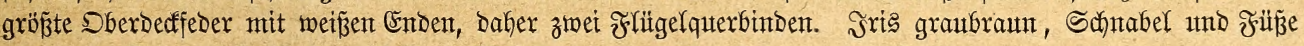
hornbräunlić). - $\mathfrak{W}$ eib d)en blafjer gefärbt.

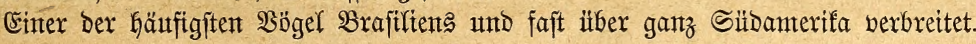

529. Der Bartammerfinf, Z. mystacalis, Hartl. - $\mathfrak{A}$. B. Scart $\mathfrak{a} \mathfrak{u} \mathfrak{b}$, Rev. Zool. 1852.,

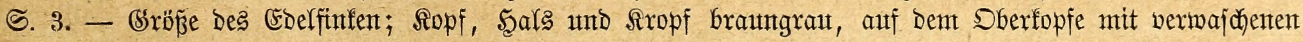

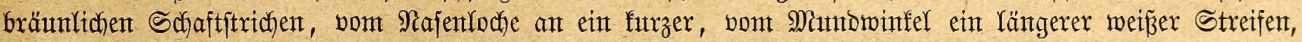

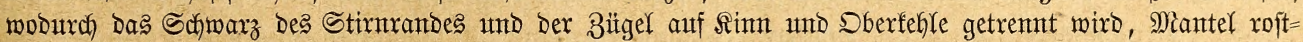

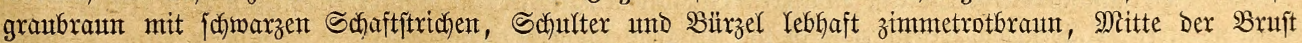

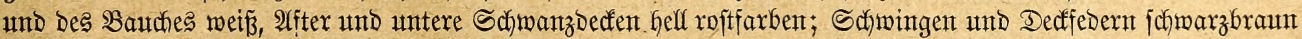

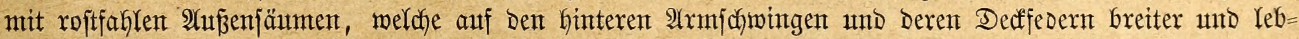

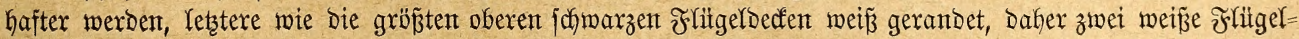

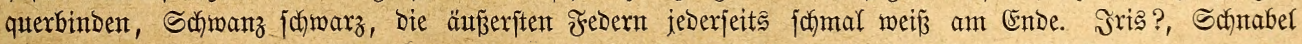

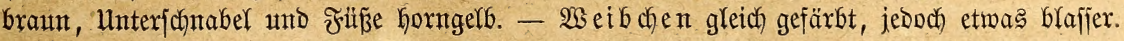

Dex 2 ogel beroognt Miejifo.

Die nächitfolgende 2 (nt ijt ber längeren Flïgelfpize Galber zum Bertreter einer be= jonberent Sippe erhoben worben.

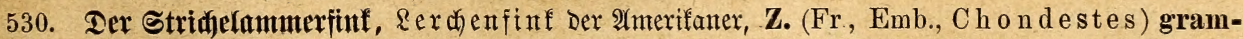

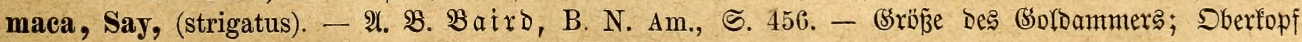
$\mathfrak{B}$ rehm, gefamgene $\mathfrak{B}$ öger. I. 


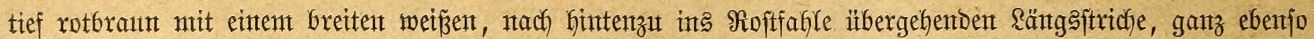

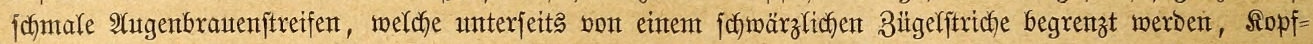

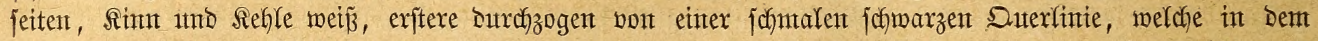

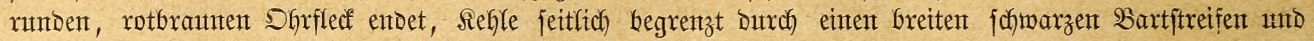
unterfeits gezeidntet Durch einige fofwarze Flede, Sberjeite roftfahlbrant mit Dunflen Schaftftridjen auf

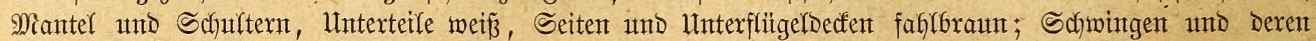

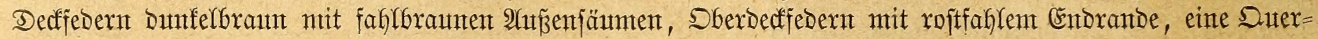

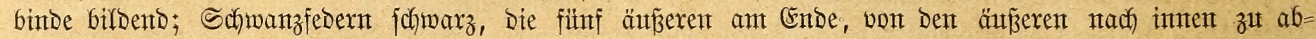

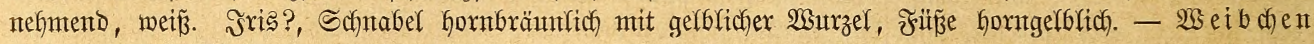
etwas matter gefärbt.

Bewohnt bie Sereinigten Staten, Iejas mo Mejifo.

Bei bex folgenben 2 rat ijt bie Flügeliptize jefr furz unb barauf mieberum ente Sippe be= grimbet worben.

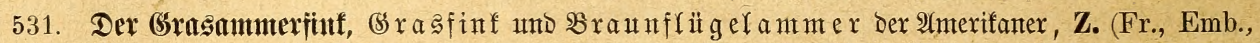

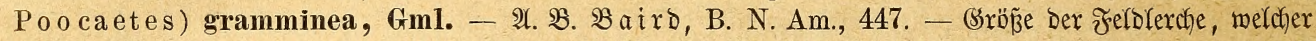

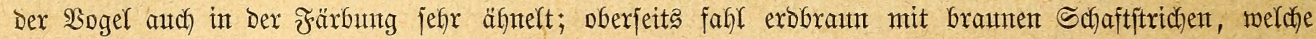

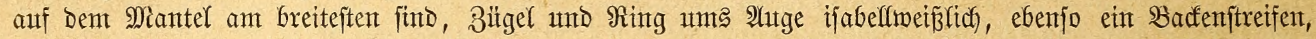

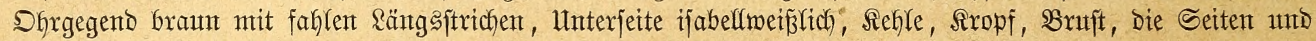

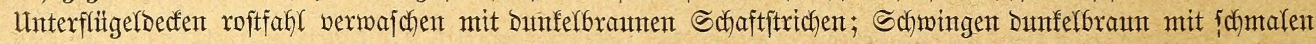

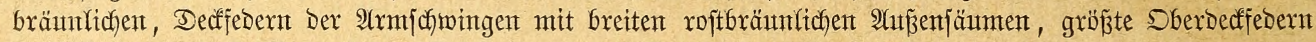

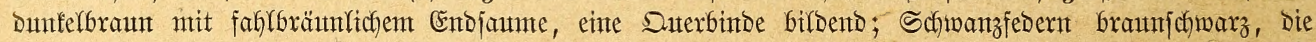

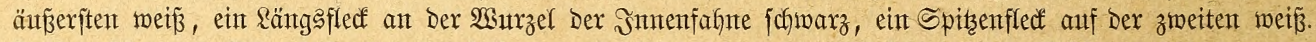

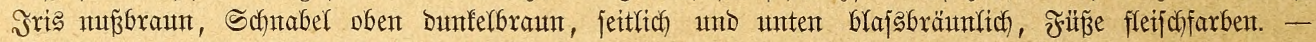
23 eibchent nidft veridgiedent.

Heber bie Sereinigten Staten bis Ranada unto jitblich bis Mejiffo verbreitet.

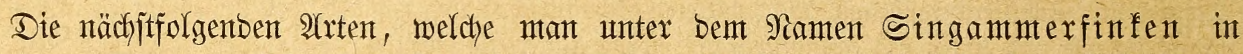
eine eigene Sippe vereinigt hat, fennzeidynen jich ebenfallz burch bie jefy furze Flügelipitze.

532. Der Cingammerfinf, Singiperling Der Amerifaner, Z. (Fr., Melospiza) melodia,

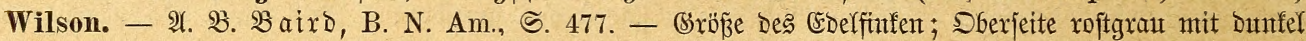

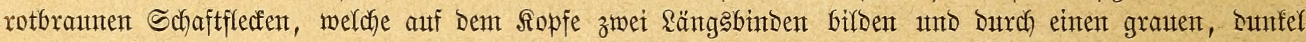
geftrichelten Mittelftreifent getrent fint, Bügel, Fugenbrautenftreifent unt Schläfe-afdograu, bont Ginterent

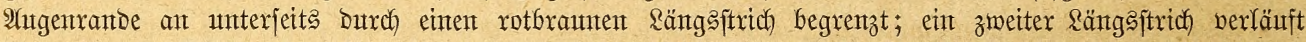

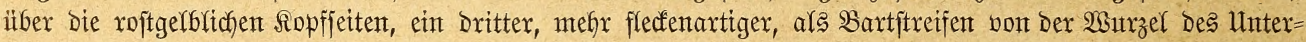

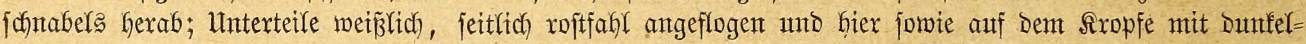

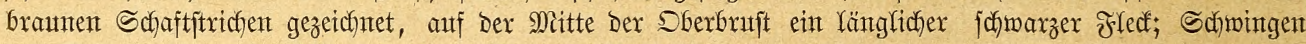

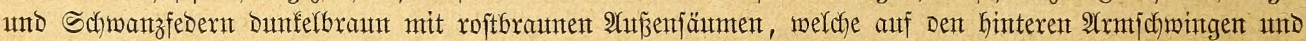

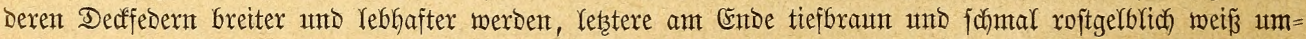

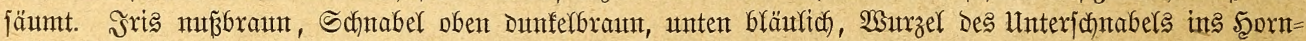

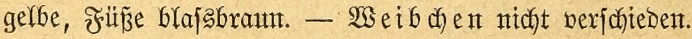

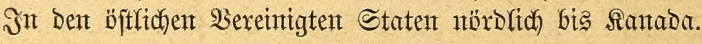

533. Der Sdjlagamumerfituf, Z. (Mel.) Heermanni, Baird. - 2 . 23. $\mathfrak{B}$ air D, B. N. Am., S. 476. Sefrx ähnflich Dem Singammerfinfen, aber ffeinex; oberjeits roftbrant mit fatmarzen Schaftflecten, Die Seiten

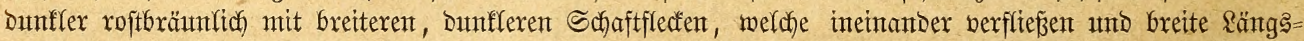

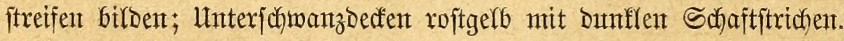

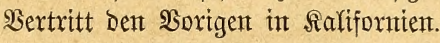

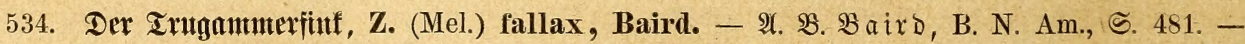

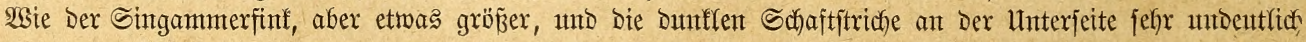
ober ganz fehlettid.

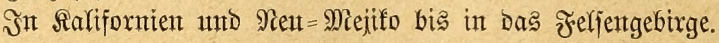

535. Der Smumammerfint, Z. (Fr., Mel., Passerculus, Peucaea) Lincolnii, Aud., (zonarius). -

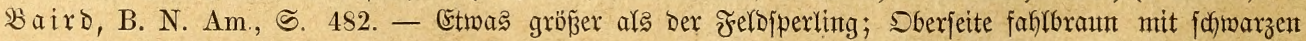

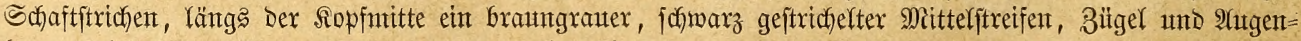

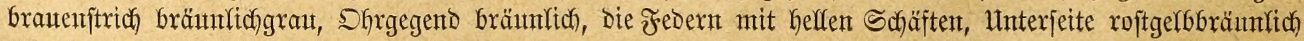

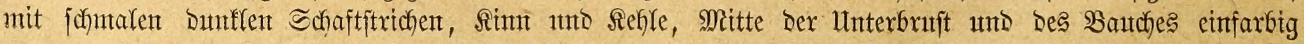




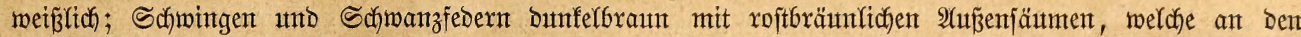

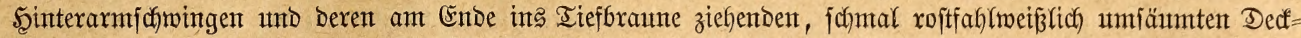

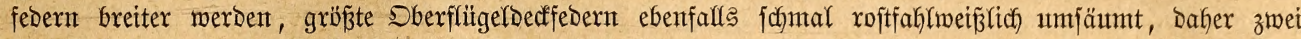

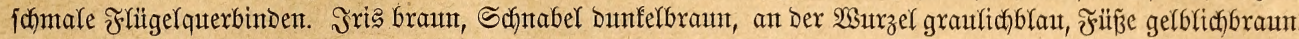

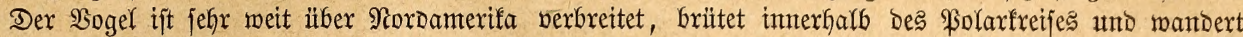

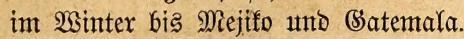

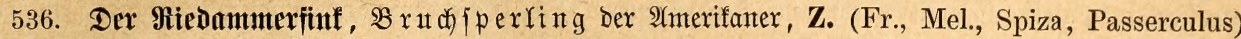

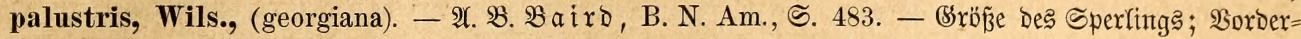
fopf fdrmarz, Scheitel und Scinterfopf Dunfel faftantentotbraun, breiter 2 atgenbrautenftreifen ajd)grau wie

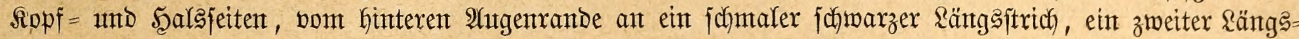

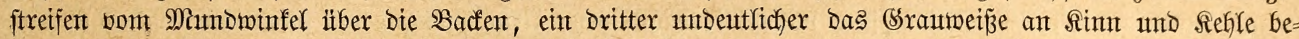

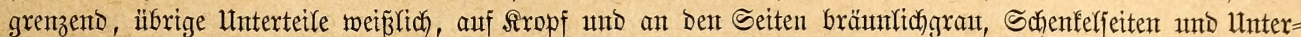

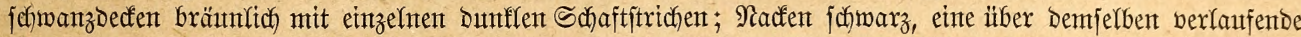
Mitterlinie, welche wie ber Şinterhals Dunfle Schaftitriche zeigt, braungrau, Mantel und Sdhultern roftbraun

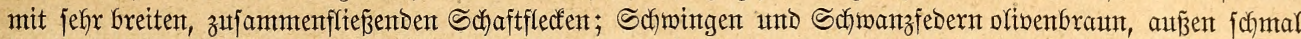

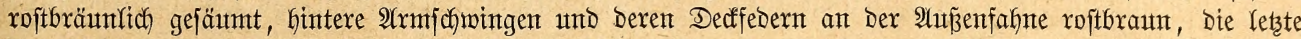

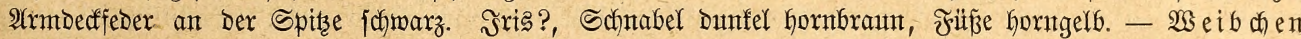
gleicf) gefärbt.

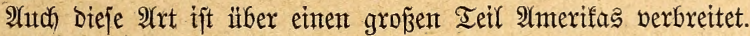

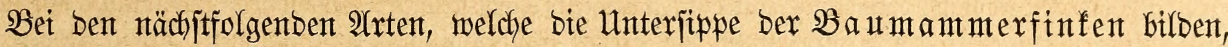
ift bie Flügeljpitze lang.

537. Der Bergammerfinf, $\mathfrak{B}$ a $\mathfrak{m}\{$ perliıg Der 2 merifanter, Z. (Fr., Emb., Spinites, Spiz.,

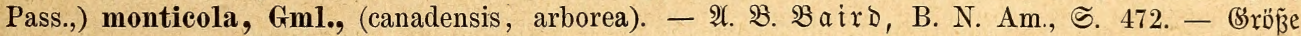

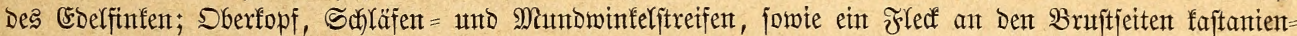

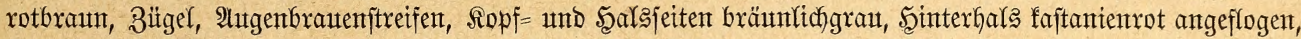

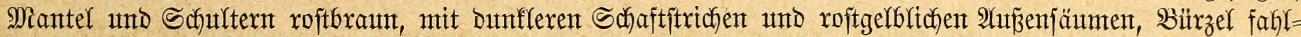

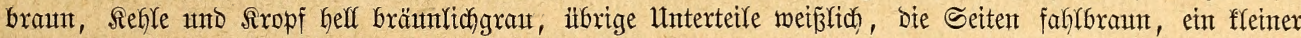

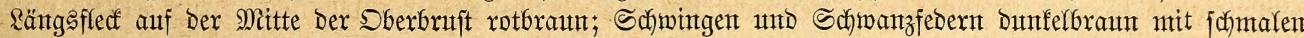

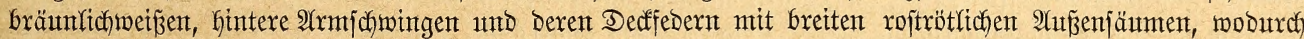

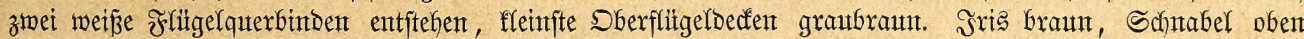

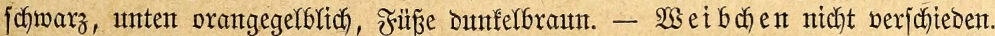

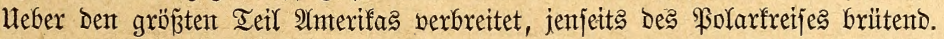

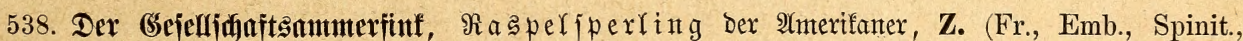

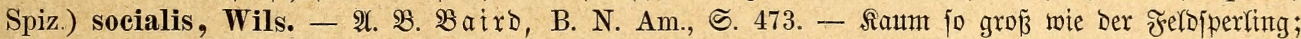

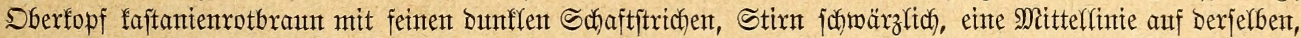

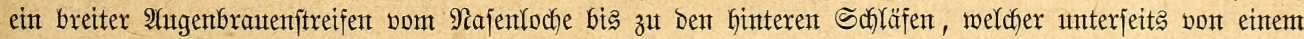

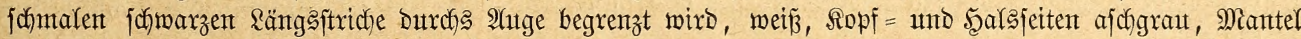

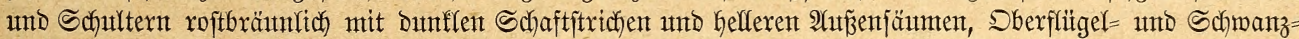

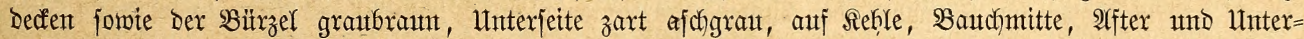

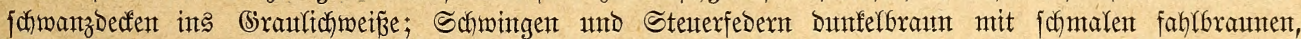

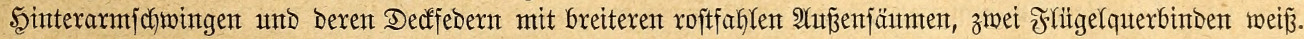

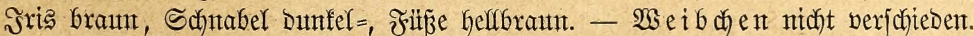

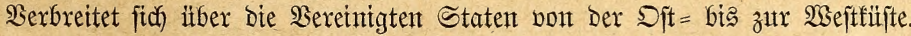

539. Der 3werg = oder Feloammerfinf, Feldfperting Der Amerifaner, Z. (Fr., Emb., Spin.,

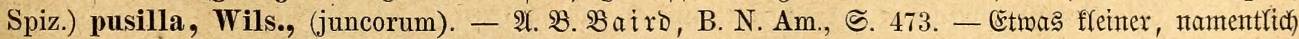

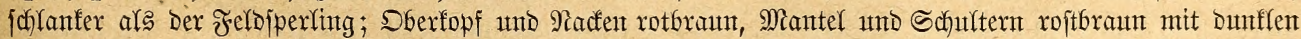
rotbraunen Schaftitrichen, fleinfte Sberflïgeldeden und Sbïrzel graubraun, ein verwajhenter Shrfled rotbraun,

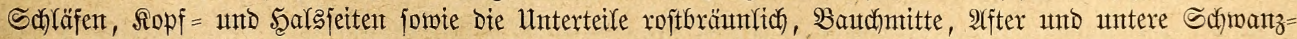

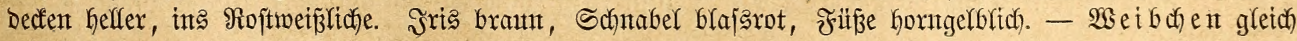
gefärbt.

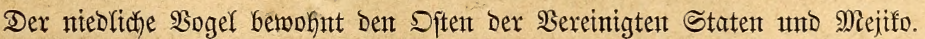

540. Der $\mathfrak{B l a j o a n m e r f i u f , ~ Z . ~ ( E m b . , ~ S p i n . , ~ S p i z . , ) ~ p a l l i d a , ~ S w n . , ~ ( S h a t t u c k i i ) . ~ - ~} \mathfrak{A} . ~ \mathfrak{B}$.

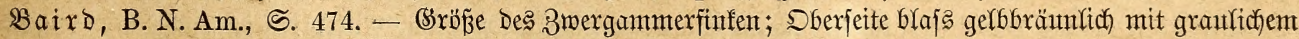

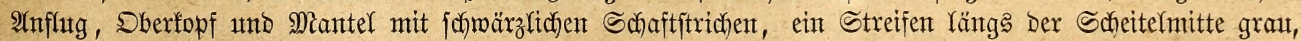

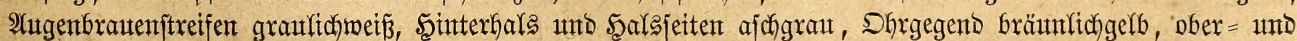




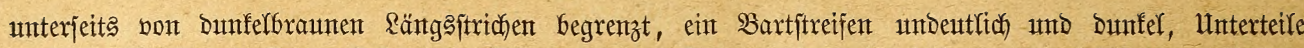

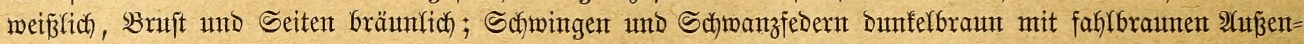

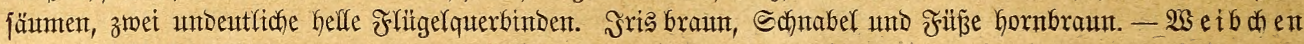
meniger lebbaft gefärbt.

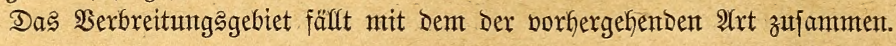

541. Der Sonmeranmerfinf, Z. (Fr., Peucaea, Ammodromus) aestivalis, Licht., (aestiva,

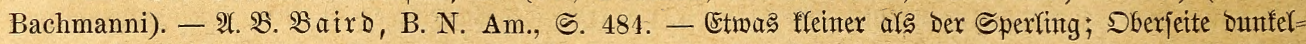

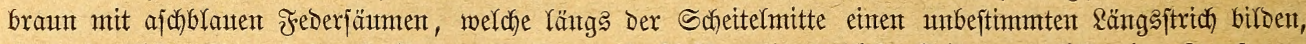

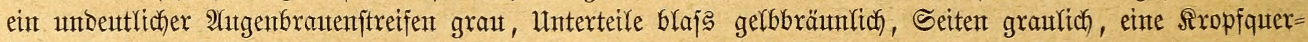

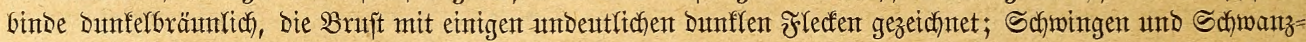

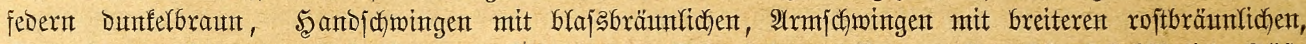

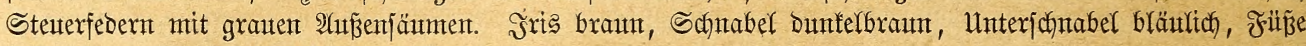
belffafl. - Waeibchen nidft verjodiedent.

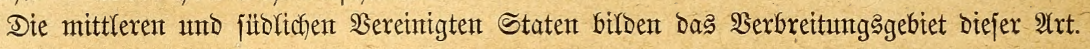

Bintontanmerfinfen int fleinen find bie Sexhenammerfinfen, weldye fith ebenfalfs Durch bie furze Flügelipize unt Den furzen Schwanz auszeidynen, Deghalb audf in eine bejonbere Unterjippe bereinigt worben find.

542. Der \$olaranmerfint, Z. (Emb., Euspiza, P a s s e rculus) aretica, Lath., (sandwichen-

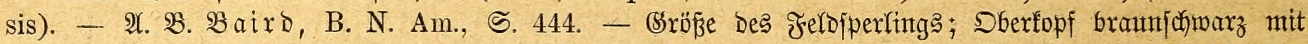

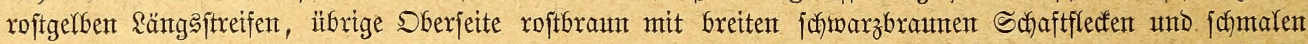

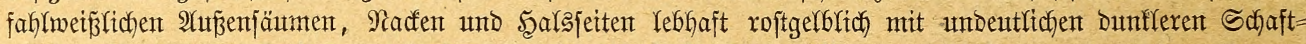

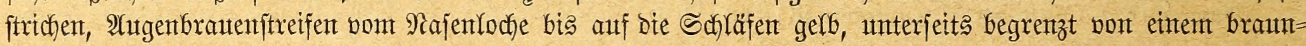

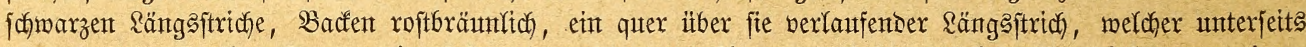

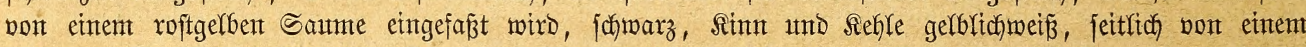

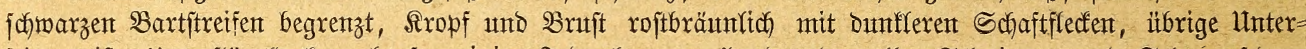

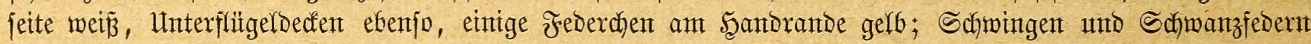

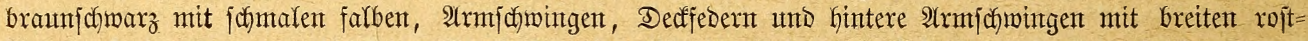

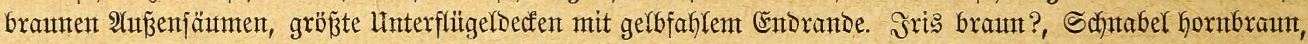

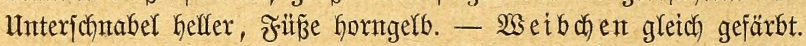

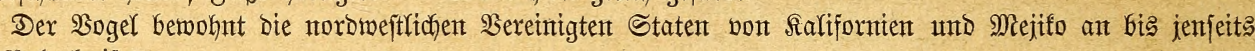
Des Polartreifes.

543. Der Steppenammerfüt, Savannafperling Der Amerifaner, Z. (Fr., Emb., Passerc.) savanna, Wils., (chrysops, anthinus). - 2 . 2 . Baird, B. N. Am., S. 442. - Hnterfheibet fich vont

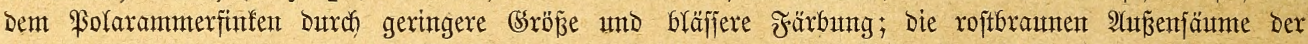

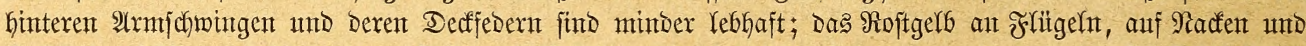

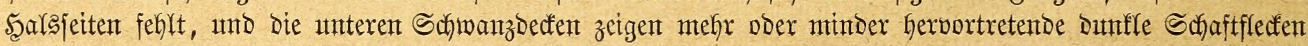
an ber $\mathfrak{W a n z} z$.

Der $\mathfrak{B}$ ogel verbreitet fich ungefähr ebenjo meit wie Der vorhergehende und wandert in 2 Sinter füblich bis B̧atemala hinab.

544. Der \&ethenammerfinf, Z. (Passerc.) alaudinus, Bp. - 2. B. BairD, B. N. Am.,

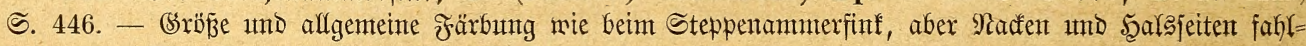

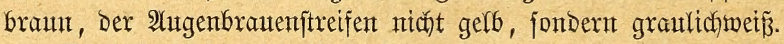

Das Serbreitungsgebiet eritrefft fich) vom hohen Noroweften Amerifas bis nach Ralifornien und Mejifo.

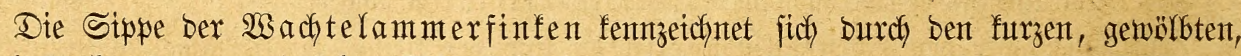

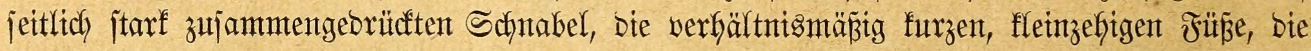
furzen, jtarf gerunbeten Schmingen, melche zujammengelegt nux bis zux Sdhnanzmurzel

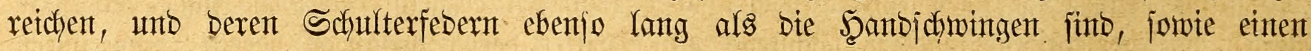
jehr fleinen, jatmalen, janft gerunbeten, aus lanzenförmig zugejpibten Febern bejtehenben Schwanz.

545. Der $\mathfrak{B a d}$ tefammerfinf, Ammodromus (Fr., Coturniculus) manimbe, Licht., (xan-

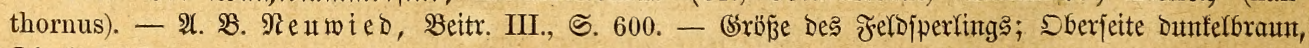

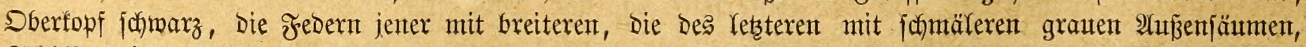

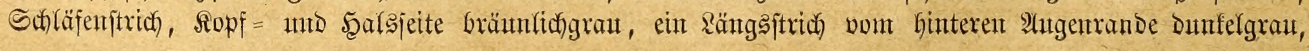




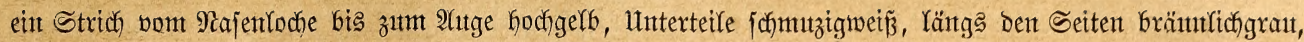

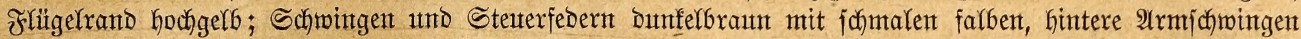

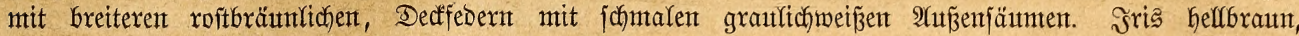

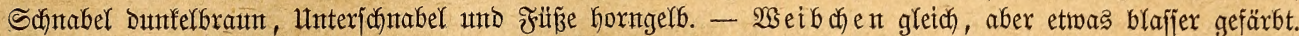

Der 2 ogel verbreitet fich ïber ben größ̈ten Teil Brafiltents bis Gitana.

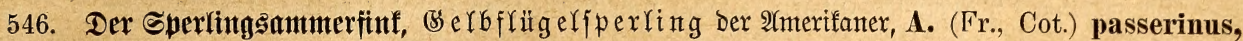

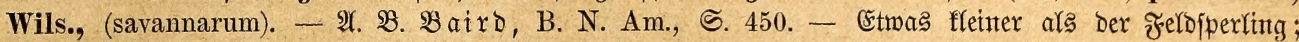

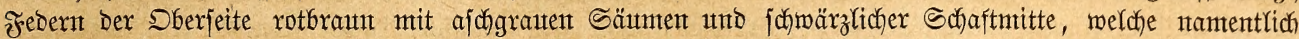

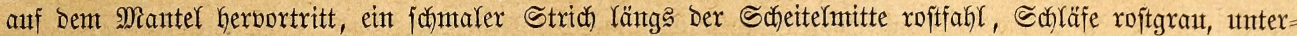

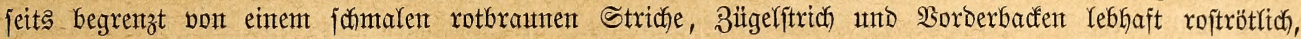

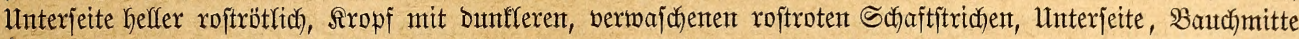

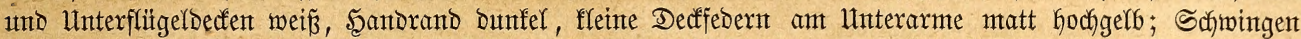

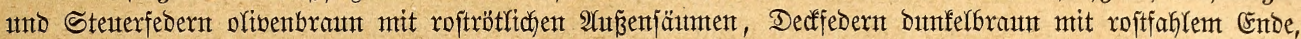
meldes einen roftbraunen Schaftmittelfled zeigt, baker zwei helfe Flïgelquerbinden. Fris braut, Sdhnabel

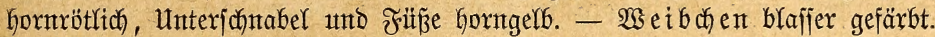

Bemohnt bie mittleren $\mathfrak{B}$ ereinigten Staten fïblich) bis (Satemala hinab.

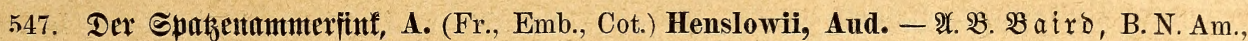

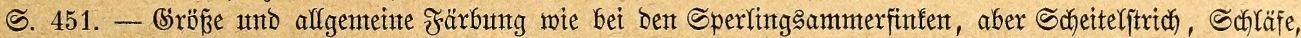

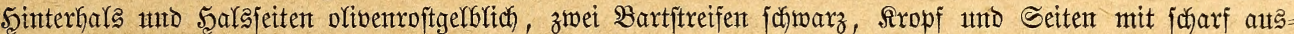

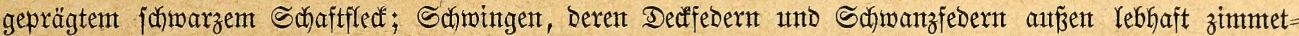

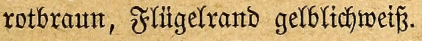

Bemohnt Den Sften Dex Bereinigtent Staten.

548. Der Seenmmerfinf, Seeft $x$ andfint

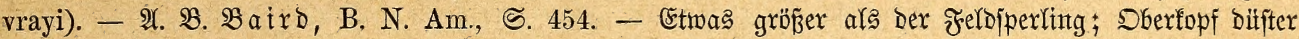

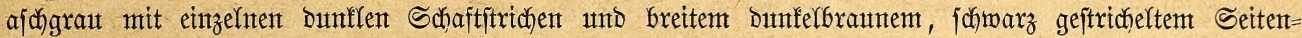
ftreifen, Nadfen roftolivenbräutlich), übrige Sberjeite olivenbraun, Sdyultern tiefbraut mit breitent afd)grauten

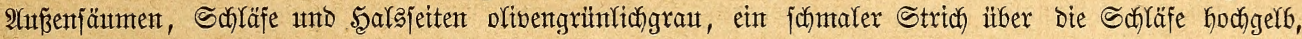

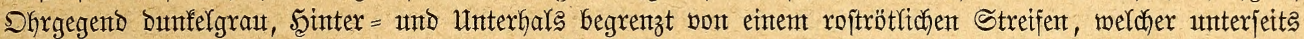

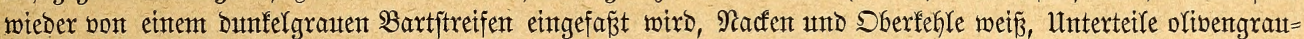

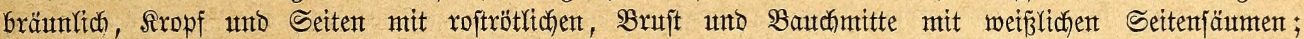

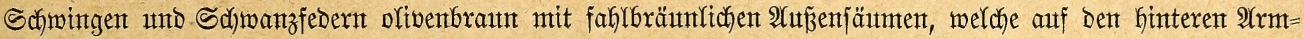

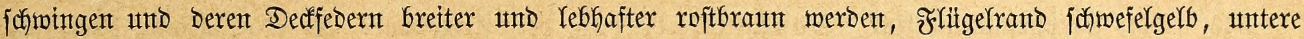

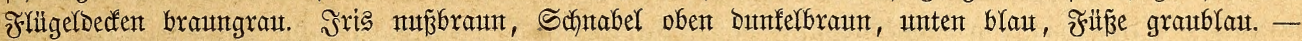

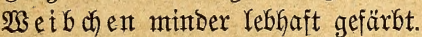

Bemohnt Den Dften Dex Sereinigten Statent.

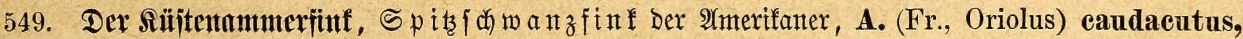

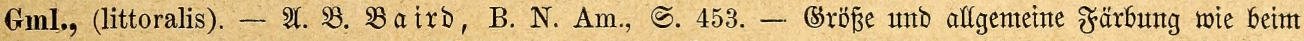

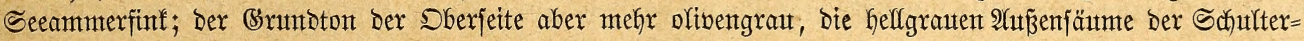

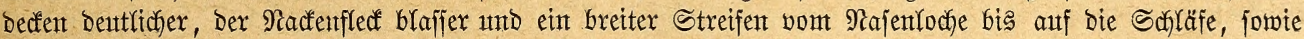
ein zweiter, welcher bie Shrgegent inter = unb Ginterjeits begrenzt, Yebhaft zimmetroftrot, Sropf, Bruft,

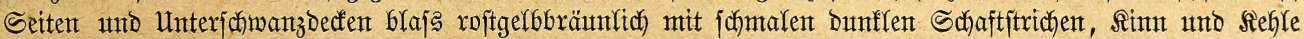

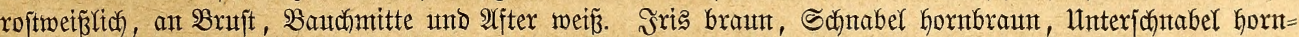
gelb, Jü̈ßje gelbbräunlich). - Weib chen matter gefärbt.

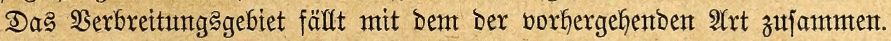

Die Merfmale Der Sdneeammerfinfen finto ber fleine, fegelförmige, oben nur an ber Spitze gebogente Sifnabel, Deffen unterer Ieil ebenjo hody als ber obere, ber ziemlith

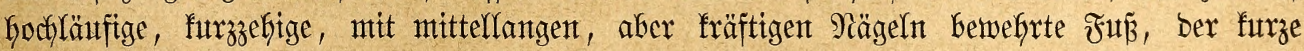
Flïgel, weldyer zujammengelegt Göchjtents ein Drittel Des Schwanzes bebecft, unto unter befjen Schwingen bie zweite bie längjte zu jein pflegt, ber mä̈ìg lange, jeidjt ausge=

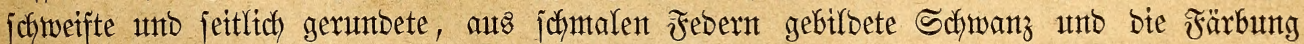
bes (sefiebers, welches auf ber Sberjette mefyr ober mentiger einfarbig unb bunfel, aljo nicht gefledt't ober gejtreift, auf ber Unterjeite bagegent wein ijt.

550. Der Sdneenmmerfinf, Junco (Fr., Struthus, Niphaea) oregonus, Townsend, (hudsonica,

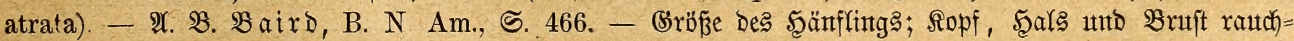




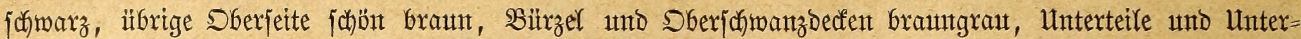

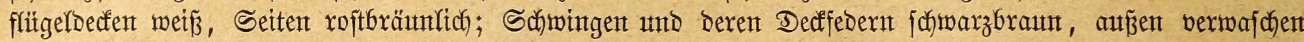

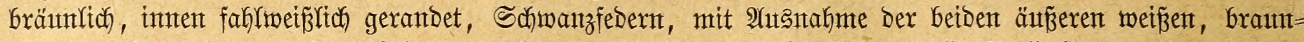

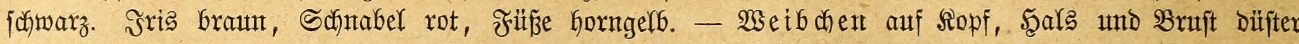
raudfbraun oder grau; ebenjo bas Männtchent int $2 \mathfrak{s}$ interfle i de.

Die weftlichent Sereinigten Staten, ÂA

551. Der (6ranmmmerfinf, J. (Fr.) cinereus, Swns., (phaeonotus). - 2 . $\mathfrak{B}$. $\mathfrak{B}$ atro, B. N.

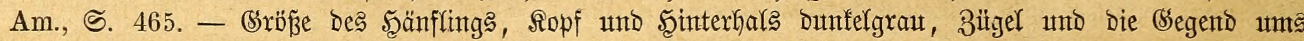

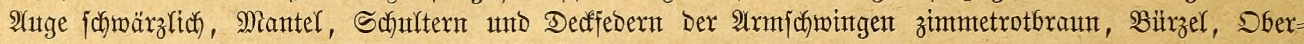

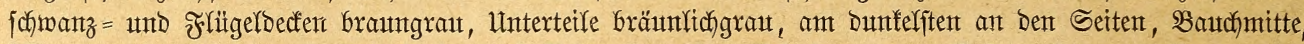

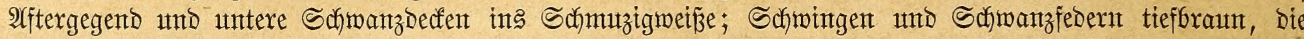

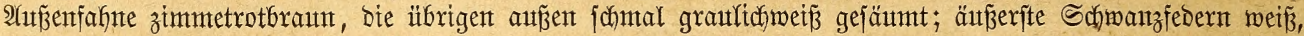

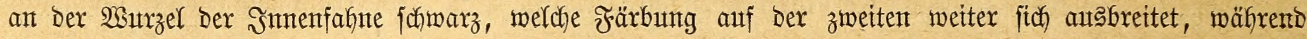

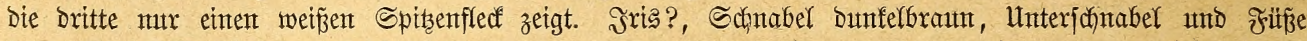

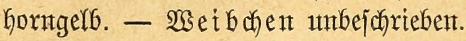

Bisjest mut in Mejiffo aufgefundent.

552. Der $\mathfrak{S i n t e r n m m e r f i n f , ~ S c h n e e v o g e l ~ b e r ~} 2$ mterifanter, J. (Fr., Emb., Struth., Nipha ea)

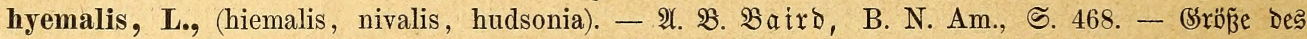

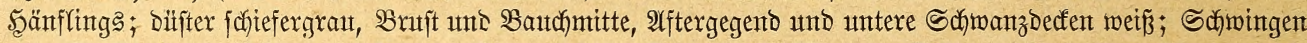

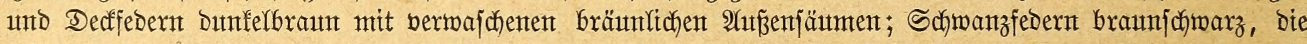

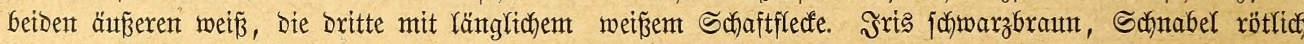

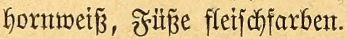

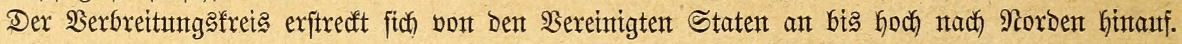

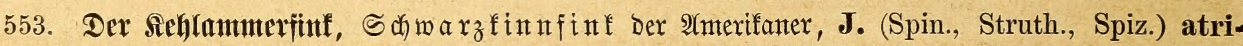

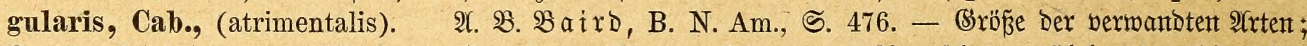

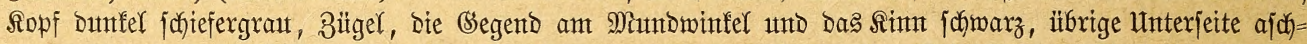

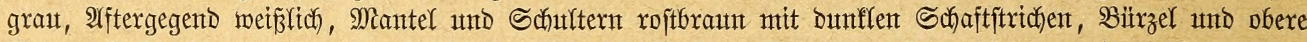

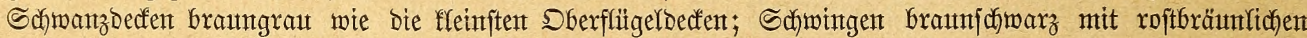

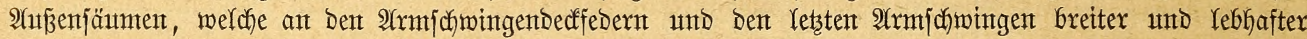

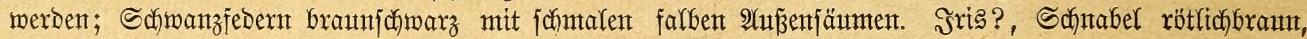
Şiỉ̉e brautt.

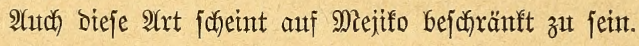

Die Ebelammerfinfen endith haben follanfen, legelförmigen, auf ber Finjte geraben, vorn ziemlich jtarf zulammengebrüdften, ant Munboninfel beutlich eingebogenen Schnabel,

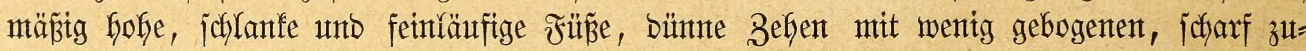
geipitzten Irallen, ziemlich iptbe, zujammengelegt bis über bie oberen Schwanzbedfen herab=

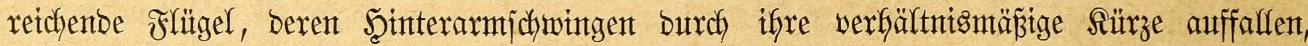
mittellangen, etwas ausgejchntttenen, aus jdymalen, ant snbe mefr ober wentger zugeipitzen Febern gebilbeten Schmantz und ein ziemlich wethes Stefieber, in welchem Scfieferichwarz voer Dunfelblautgrau workerjechen.

554. Der Sdfmutfonmerfinf, Phrygilus, (Fr., Emb.) Gayi, Eud. \& Gervais, (formosa). -

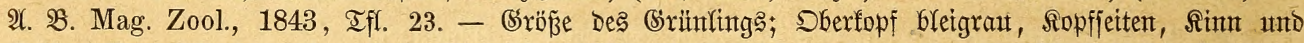

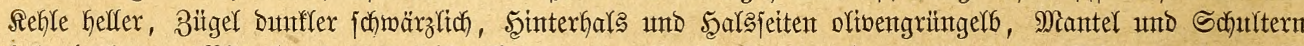

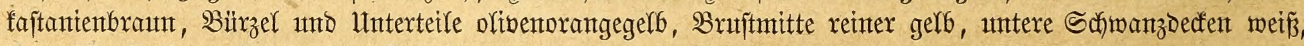

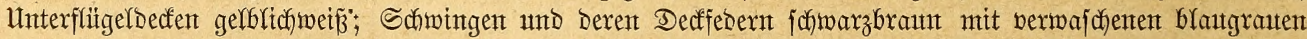

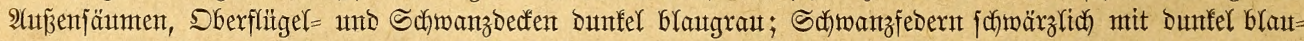

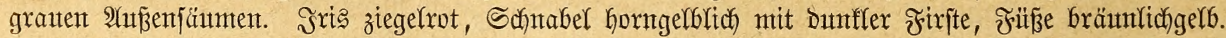

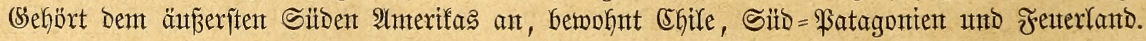

555. Der $\mathfrak{B u f}$ inmmerfinf, Ph. (Fr., Emb., Rhopospiza) fruticeti, Kittl., (luctuosa). - $\mathfrak{e r g r}$.

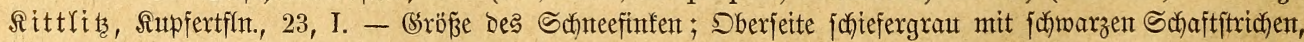

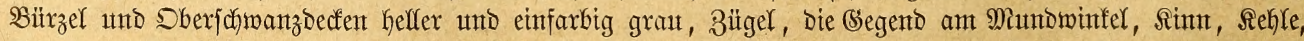

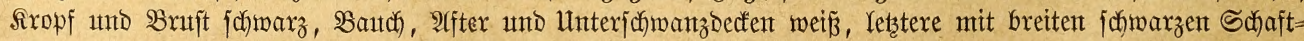

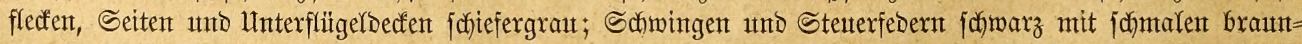
grauten 2 Uน 


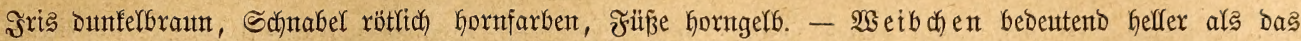

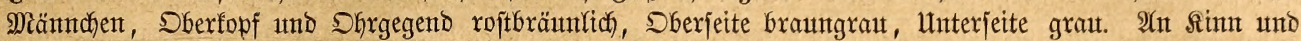

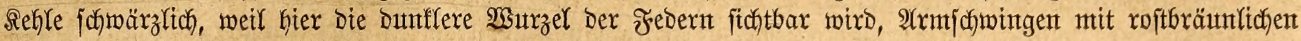

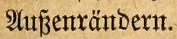

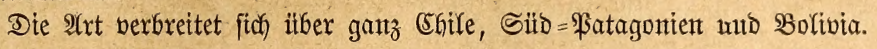

556. Der Tropfentammerfinf, Ph. (Fr., Emb., Passerina) alaudinus, Kittl., (guttata). - $\mathfrak{B}$ ergl.

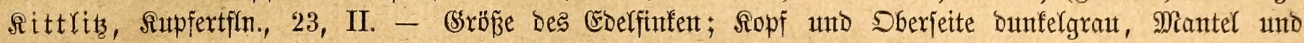

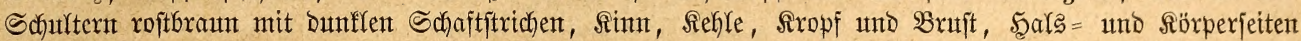

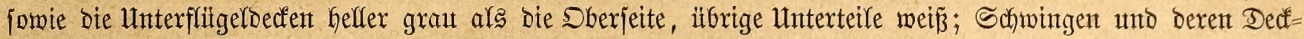

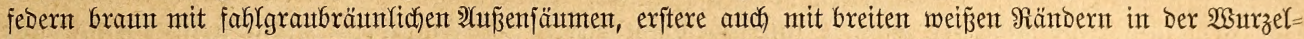

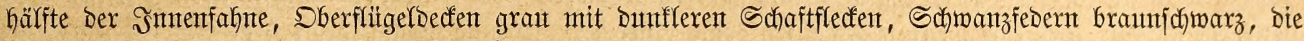

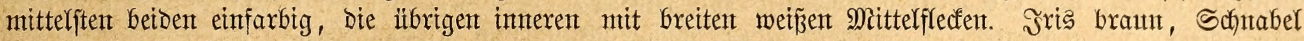

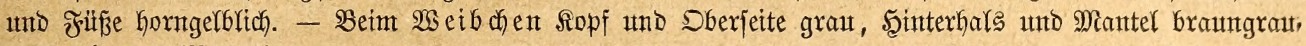
jonft mie das Meämthent.

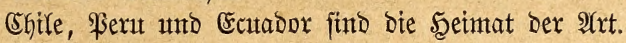

557. Der Sdhieferammerfiut, Ph. (Emb., Tan., Sp., Haplospiza) unicolor, Lafr. - $\mathfrak{\text { Sergl. }}$

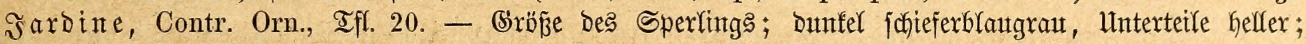

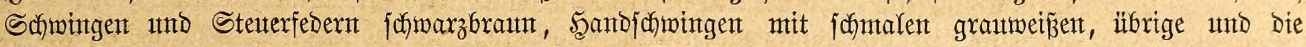

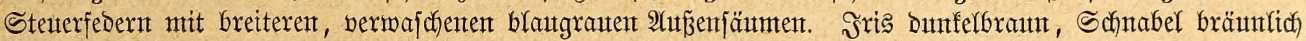

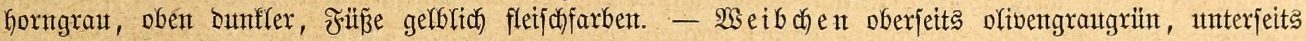

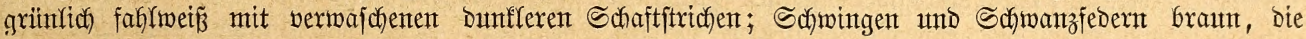

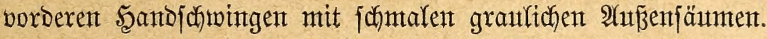

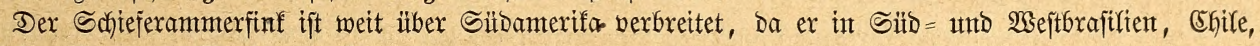
Bolivia, Fert utto Ecutador vorfommt.

558. Der Edelammerfinf, Dittea Der Effitenten, Ph. (Fr., Emb., Dolichonyx, Pipilo, Hedyglossa) diuca, Molina, (griseus, cinereus'. - A. $\mathfrak{B}$. Eud. \& Gervais, Mag. Zool., 1836., Iff. 69. - Brö̈ß̄er

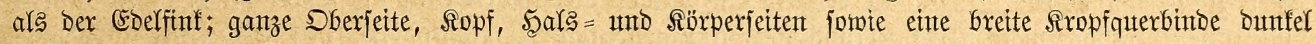

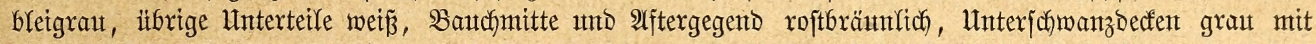

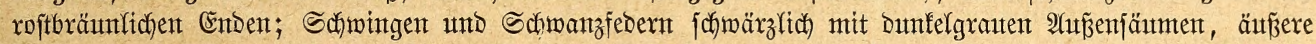

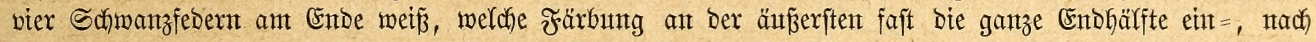

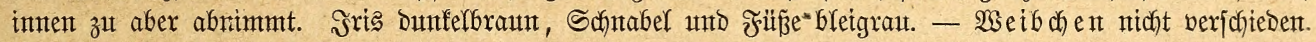

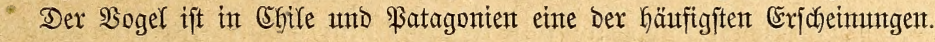

Die 2Ammerfinfen murben burdh bie älteren und neueren $\mathfrak{B}$ ogelfunbigen $2(m e x i f a s$ gut beobarfytet unt ausführlich gejchilbert; wir fint bafher über fie jefr genau unterrichtet. Sie gefören, wie in singange bemerft, 2(merifa autsjchließ̧lich an, werbreiten fich über ben ganzen

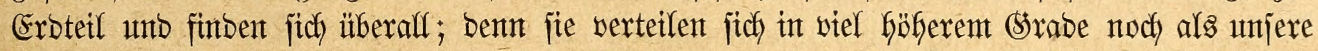
2Immter ïber bie afferwerjchiebenjten Dertlichfeiten. Weitaus bie Miefrzahl wählt jich bujchige

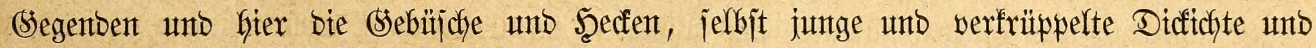

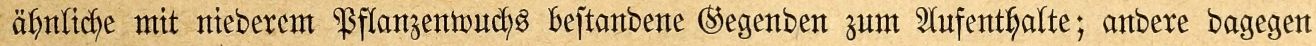
leben in Godjitämmigeren $23 a l b u n g e n$, wieber anbere auf mefr ober wentger faflen Strectent,

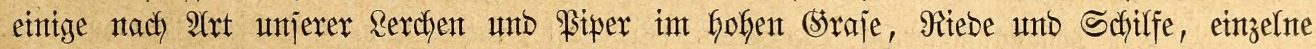
jogar an ber Mieresfüite zwijhen ben Marfen ber Flut unb Ebbe, auf unb zwijhen ben

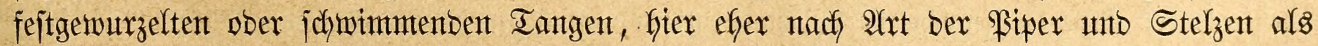

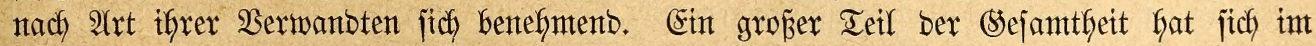

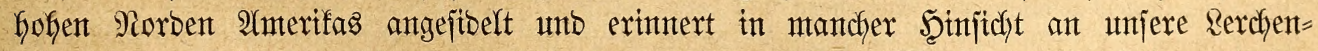
ammtern, weldye befanntlich ebenfalls in ber norbeuropäijchen Mcosfteppe ifyre Seintat Gaben.

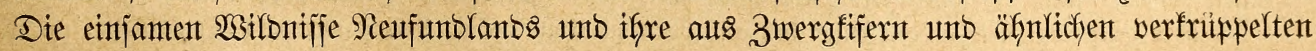

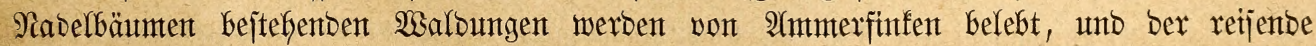
- Forjdyer, welcher jente Segenten unterjudft, begegnet oft auf Mieilen fin faum einer anberent Bogelart als ifnen. Ebenjo triffit mant je nody hod im (sebirge an umb zwar nidst affein

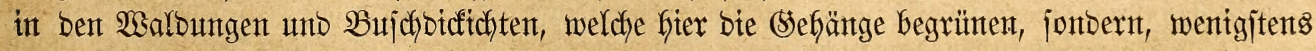

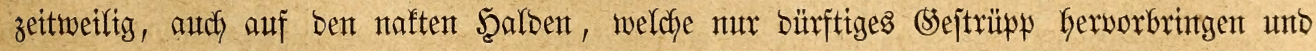




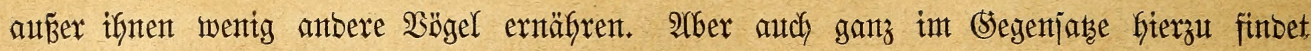

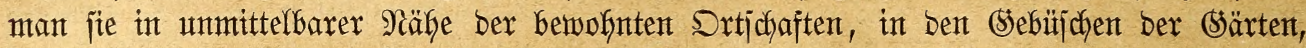

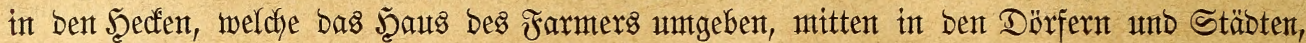

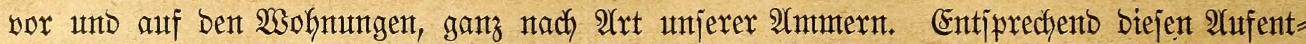

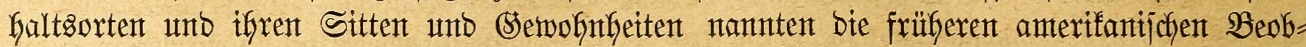

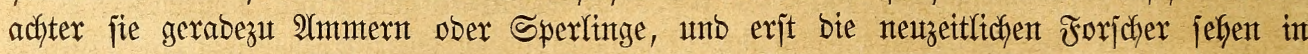

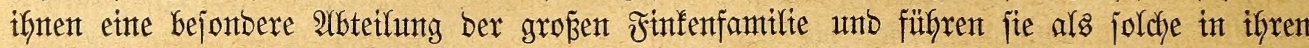
2Berfen auf.

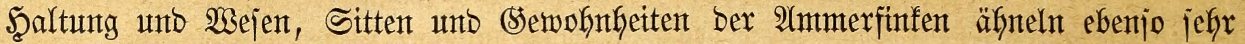

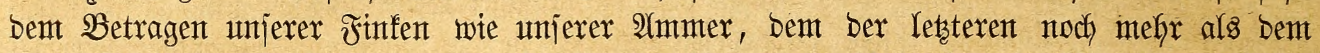

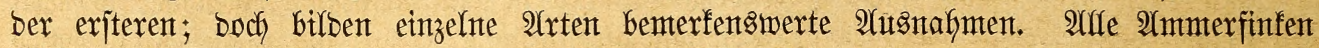

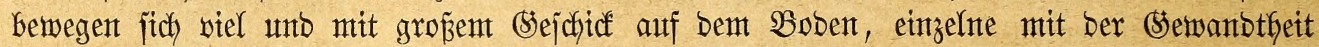

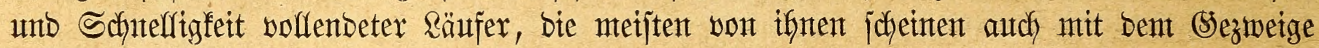
wohl vertraut zu jein, und alfe fliegen annäherno mit berjelben Reidytigfeit wie unjere Finfen

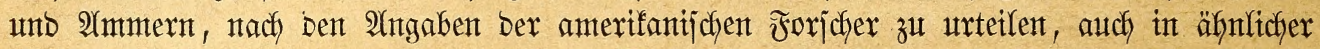
Weije wie bie Yekztgentanten, in bogig welfigen Rinten nemlidh, bald unter rajchem flügel=

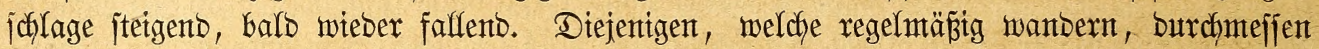

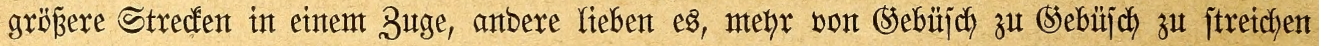
unt fich Dabei mtöglidchit zu verbergen. Sn einer Şinficht übertreffen fie, wentgitens ber

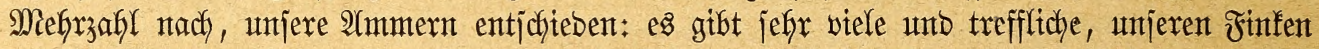
fajt ebenbürtige Sänger unter ifnten. Die einjamen 2Bitoniffe Rabrabors unb Nieufunblandos, bie Sarbungen und Bebuijache Nord = unb Sïbamerifaz, bie Dörfer und Stäbte beiber Şälften Des Eroteils werben belebt unto erfeitert burch Den (sejang biejer Finfen, unt viele

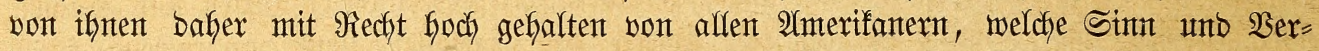

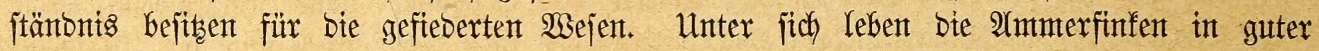

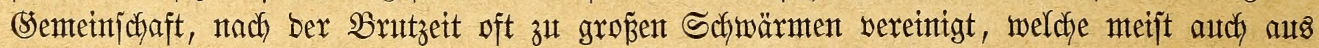

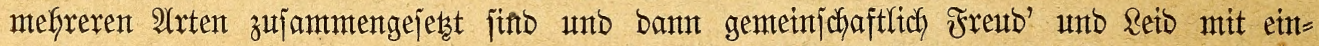
anber teilent. Wä̈frend Der Brutzeit trenten jie jich jefbjtweritäntolich in einzelne Färchen, unb jebes grenzt fich ein gemififes (sebjet gegen anbere Seinesgleichen ab; boch beherbergt

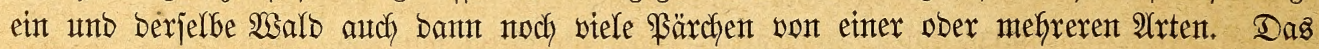

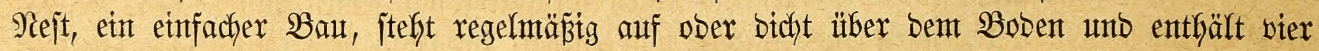
bis jechs auf graulfichem, grünlichem ober bläullichem (srunbe bunfler, meift braun getüpfelte

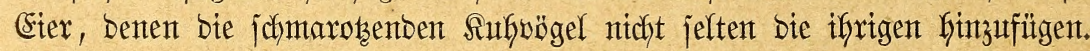

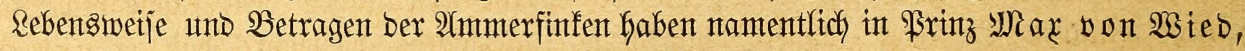

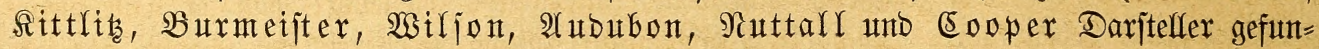

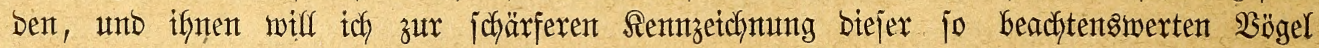
Das Radjytefyente entnefynten. Die Sumpfammerfinfen leben, laut $\mathfrak{B u r m e i f t e r , ~ i n ~}$

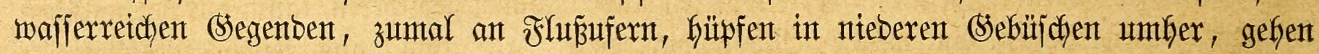
viel auf ben Boben, jutchen jich Giter Rerbtiere unb Sämereien zujanmen, nijten im bich)=

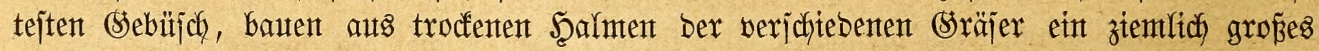

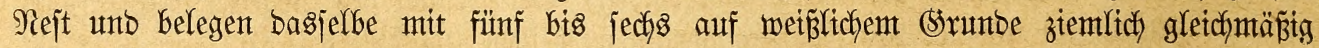

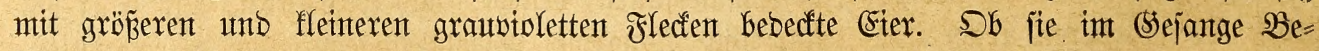
friebigendes leiften, verntag idh) nidft zu jagen. Heber bie (S) rundammerfinfen beridftent

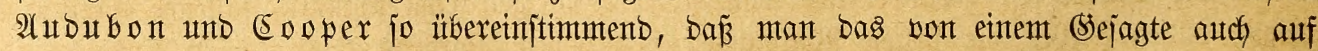

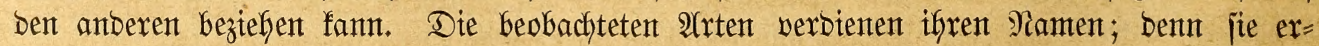

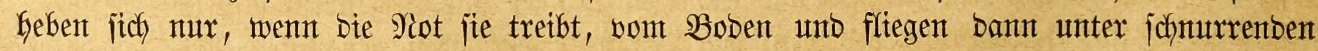
Flügeljeflägen unt fortwähfrentem $\mathfrak{B}$ reiten, Zujammenfaltent unb Wippen bes Schmanzes von einem $\mathfrak{B}$ ujdhe zum anberen, jelten meffr als brei ober sier Mieter it einem Zuge burdh= 


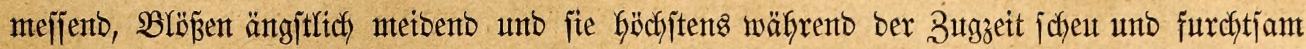
überfliegent. Für gewögnlich laufen und hüpfen jie auf bem $\mathfrak{B}$ oben umber, zwijchen uno Inter Den abgefallenen Blättern, mit benen ify Sleib in ber Färbung übereinjtimmt, nach

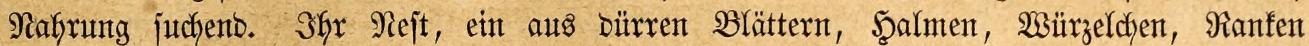
u. bergl. Yeidht zujammengejdjichteter $\mathfrak{B a u}$, jteht wohl verborgen, gewöfnlich in einer Sertiefung

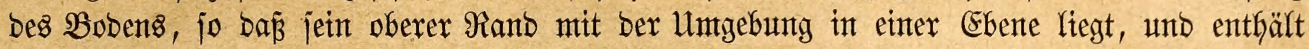

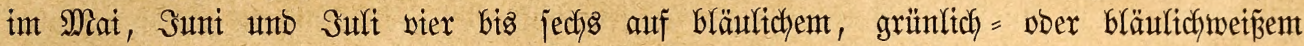
Srumbe mit roten ober braunen Flecfen, Punften unb Scymtzen, gegen bas ftumpfe Ende

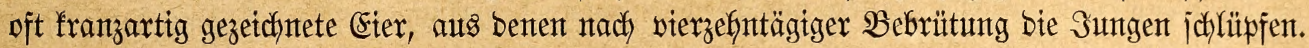

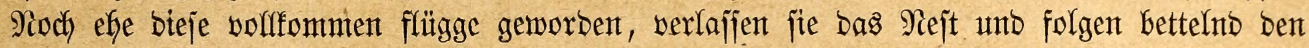
Eltern zu Fuße, bis jie eine geniffe Selbjtändigfeit erlangt haben, fich vereinzeln unb bas einjame Reben Der arlten füfren fönten. (Segen Den Serbjt fin macht jich alt unt jung auf bie Wanberjchaft, ebenfalls einzeln bafinfliegent und nur mit Familienwermanbten fids vereinigend, unb zwar treten bie Weibchen bie Wanberung früher an als bie Männthen. 2uch fie zählen nidyt zu ben Sängern, obnobl fie im Frühlinge einige zujammentängende Töne Gören lajien, fallen aber burch ifre eigentümliche Rodfitimme auf, welche an bas Miauten

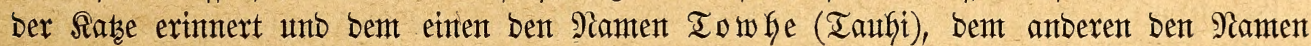
Rakentogel verjchaffit hat.

Den Sern ber Unterfamilie bilben bie aflverbreiteten $\mathfrak{B}$ indenammerfinfen. Sie

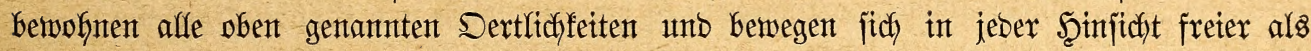

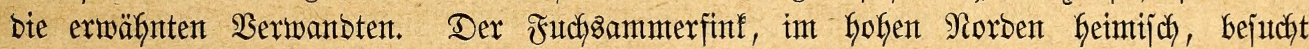

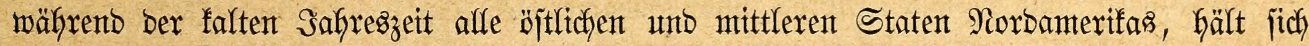
Gier, zu zwei ober brei Familient vereinigt, in Borbölzern, Sebüjchen, Şecfen unt Zäunen auf, bejchäftigt fich ebenfalls viel auf bem Boben, bas abgefalfente Raub burchjuchend, fliegt ungern weit, auch gewöhnlich niebrig über bem Boben fort, aber rajch unt gut, ijt über= haupt ein munterer (sejelf unto erfreut gegen bas Jrühjafy fin burch jeinen trefflicfen, aus vollen, flaren und medjelreidyen Iönen zujammengejesten (sejang, obgleich ex biejen bodh erjt am Brutplatze, in Den öben Milbnifjen Rabrabors mit vollem Feuer vorträgt. Das

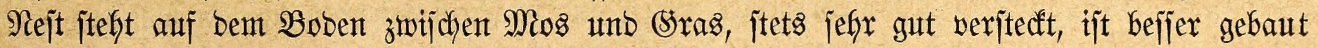

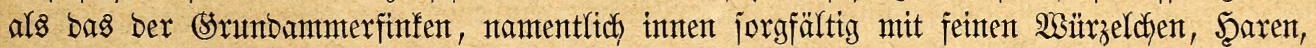
Febern, audf wohl Eiberbunent ausggefüttert unt entfält im Sunt ober Sult vier bis fünf auf büftergrünlidfem Srunbe braun geflectte Eier. Heber ben afmjelammerfinfen mangeln

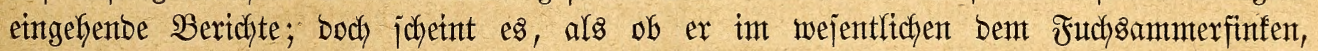

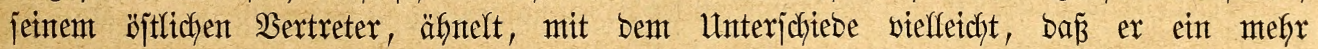

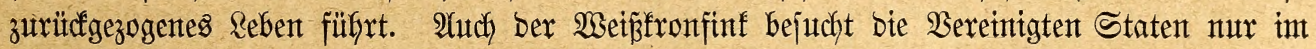
Winter währento jeiner Wanberung; Denn jeine Sceimat füt bie Waldungen Rabrabors, jeine

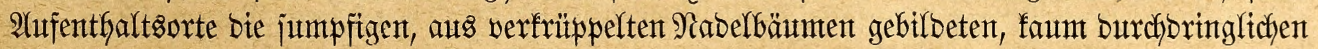

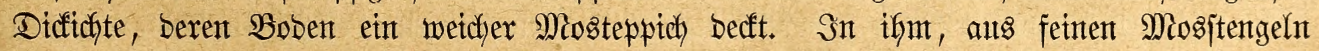

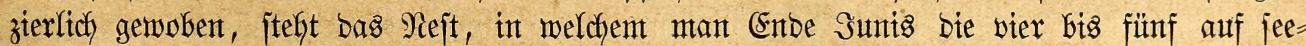
grünem (Srunto braunrot gejprenfelten Eier fintot. Der (Sejang Des 2 ogels, welcher nod)

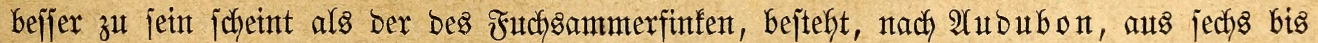
fieben Tönen, berent exiter laut, flar und flangooll, obwohl flagend, unto berent zweiter breiter und minber fejt gerunbet $i j t$, währent bie übrigen einte anmutig faflende Schluí =

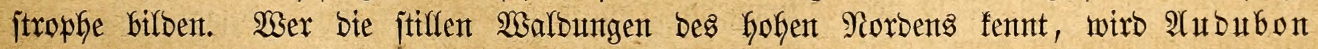

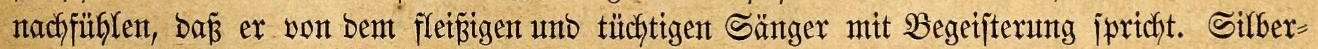
und Solbfronfinf bürfen afs bie wejtlicten $\mathfrak{B}$ ertreter ber oben genannten $\mathfrak{A}$ rt angejefen werben. Beibe erjcheinen im Şerbjte in ben Ebenen Salifornients unt verweilen fier bis zum Mai, um weldye Beit ber erftere jeinen Brutpläzen auf ber Şb̈he ber Sierra Nebaba, 
ber anbere nörbltchen (Segenben fich) zuwenbet, obmof)l beibe auth in bem tieferen falifornten brüten. Snt Winter begegnet man bem Silberfronfinfent überalf, auch in unmittelbarer Nähe ber Wohnungen; Der Soldfronfinf bagegen meibet, objchon ex meijt mit bent Berwandten

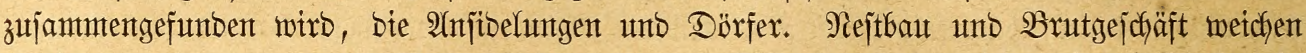

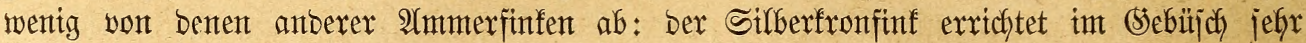

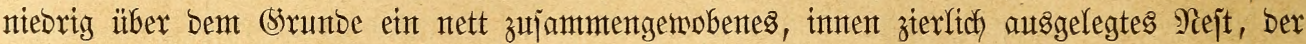
(Solbfronfint baut ein jolches auts gröberen Stoffen, fletbet es aber ebenfalls gut und jauber

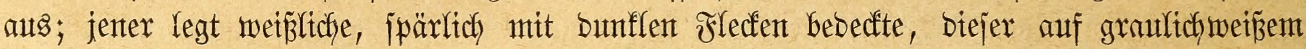

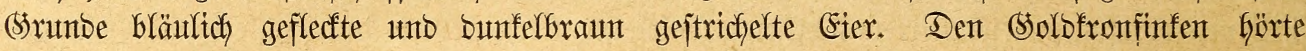
Eooper nidht jungen; bon bem Silberfronfinfen jagt er, baj ber Sejang laut aber furz

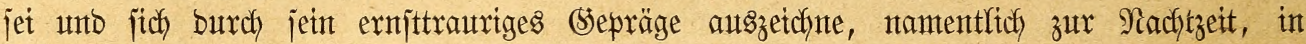
welcher bas riebdjen oft vernommen wirb. Für ben Bäff̈chenammerfinf gill antähernto

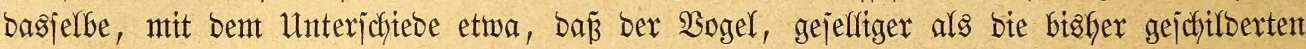

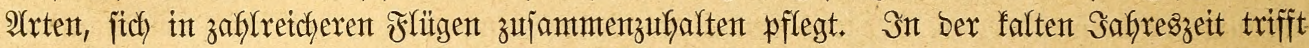
man ifhn in Irupps von breişig bis vierzig Stüd in Borfölzern unto Bebüichen an unto

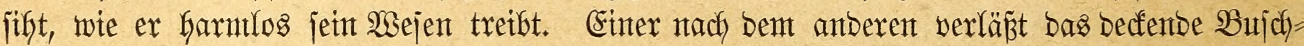
werf, fliegt auf adjt ober zefrn Meter weit ints Frete, um fier Jutter zu juthen, und ver= Gält jich babet volffommen jtill, bis plöblitch, vit ofne erflärliche Unjache, ber ganze Schwarm

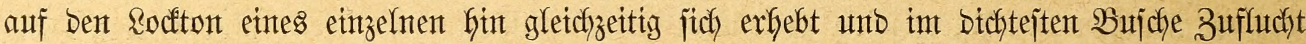
jucht. Doch nur wentge Sefunton, unt einer nach bemt anteren flettert Güpfento aus ber Titefe Des Bujches zu befien höheren 3wetgen empor, und bie Miännchen beginnen ihren Bortrag, einen furzent aber überaus anmutigen, "janft flagenben" (sejantg, welchem man, laut $\mathfrak{A} \mathfrak{a}=$ Dubon, mit Entzücfen zufört, Gald fenten lernt unt body nicht bejdyretben fant. Saunt ijt ex beenbet, io fliegt einter nach Dem anderen mieber ins Frete finaus und treibt es wie

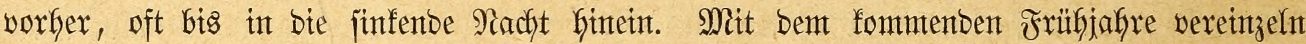

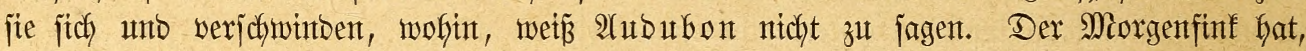

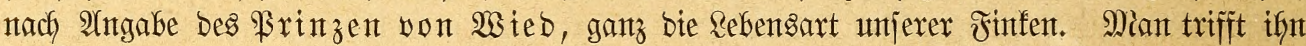

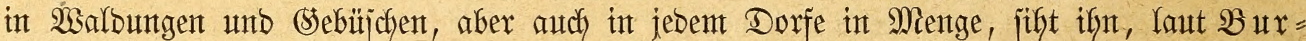

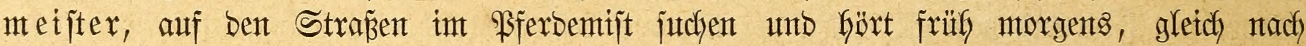
Sonnenaufgang jeine janfte, melobijche Stimme, welche ex von ber Firite bes Daches herab erjchaffen Yäß̈t. "Die Rocfitimme", jagt ber \$srinz, "ijt ein einfacher Raut; jein Stejang

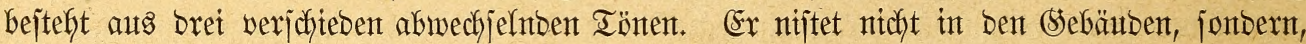

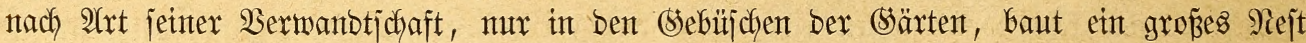

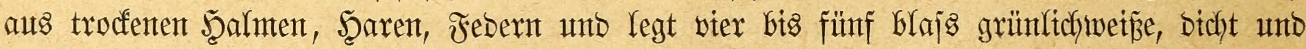
gleidymäpig helf rojtrot getïpfelte Eiter. Bart = unto Strichelammerfinf fint noch wentig be=

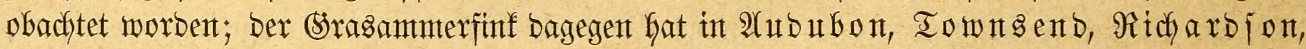
Nuttalf, $\mathfrak{B}$ rewer und Sooper Freunde und Bejchreiber gefunden und zählt baher zu Den ant bejten befannten 2 rten jeiner Familie. Trodfene Witejen, Regben und Felber bilbent

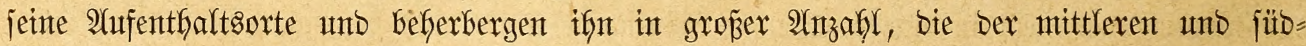
Yicheren Staten auch in Winter, währento er ben Gohen Siorben mit Eintritt ber falten

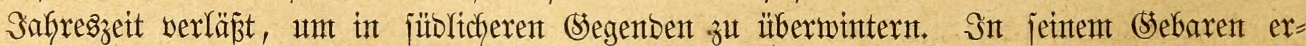
intert ex mefry an Rerchen als an Finfen; Dody pflegt ex fich beim Singen auf Spitzen Der

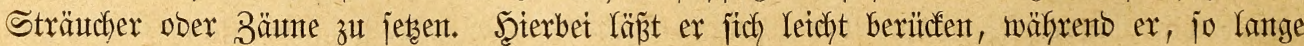
er auf bem Boben umberläuft, ziemlich vorjichtig ijt. Sein Ssejang mirb won alfent Beobachtern gerïfnt und mit bem bes fantartenvogels werglichen, objchon ex in Füfle unto Mandffaltigfeit binter bent prächtigen Riebe unjeres \&ieblingsjängers zurüdffefhen mag. Raut

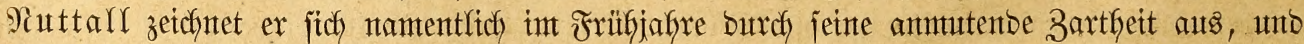

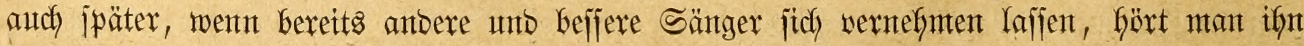




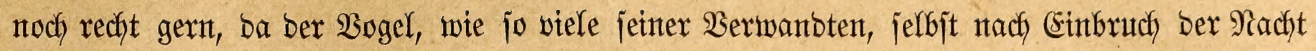
eifrig fintht unto auch bie öbejten (Srünbe in Göchjt anjprechender Weije belebt. Mit Beginn ber Brutzeit gibt es viel Sampi und Streit unter Den Männthen, bis enblich jedes \$ärchen jein Nititgebiet jicf abgegrenzt hat. Snntitten besjelben, meijt wenig verborgen, unter einent (Srasbujche ober verfrüppeltem Strauthe, ntcht feltent audy in blopen Santo, immer aber

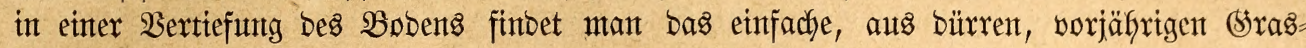

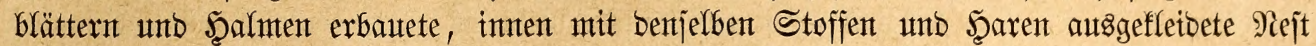

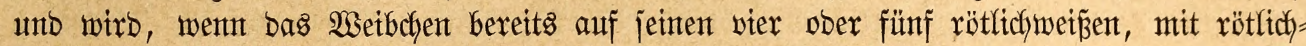

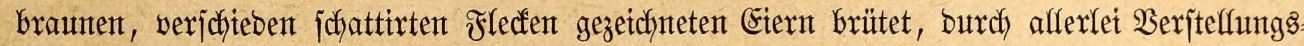
fünjte ober flägliches Bitten zum Weggehen betwogen, body nur, went bas auf jein erb=

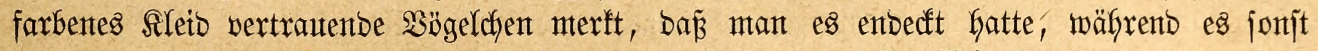
rufig jiben bleibt unb Den Störenfried fajt auf jich treten läjpt. Die Sungen verlajfen balb

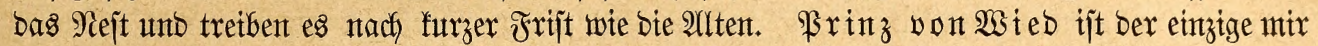
befannte Raturforjcher, weldher bas ben Singammerfinfen von jämtlichen amerifanijchen Bogelfunbigen geipenbete Rob nidjt teilt, jonbern von bem befanntejten Sertreter ber Sruppe

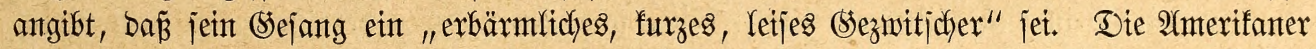
urteilen anbers unb befaupten einjtimmig bas segenteil. Sie zäflen ben Singammerfinfen, went auch ntcht zu ben bejten, jo bodh zu ben guten Sängern ifgres Ranbes. Nitdyt alfein

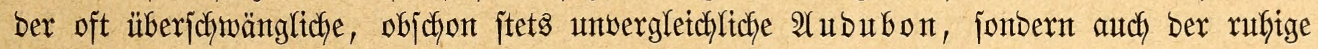

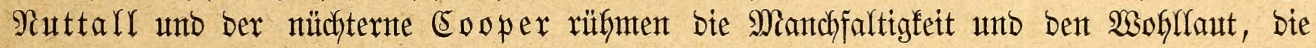
Dauter und das 2injpredjende jeines Stejanges. "Das Ried bes Singantmerfinfen",

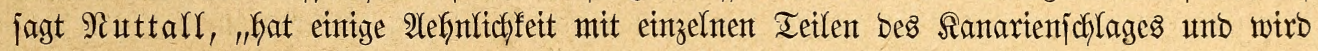
fajt umunterbrodjen vorgetragen vom Tage ber 2 nfunft bes 2 sogels bis zum Beginte bes

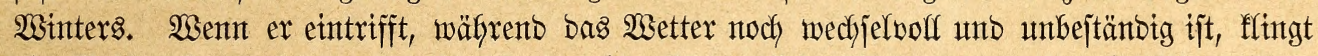
bie Weije ichwermütig unto gefjt oft in ein abjonberfich letjes und zartes Sieflïjter über, welches, wenn mant ifm einige Beit zubört, melobijcher als ber gemöbuliche (sejang und ge=

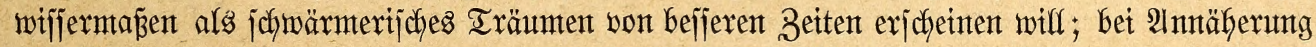

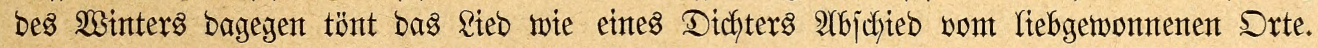
Wenn ber Früfling vorrüht, trägt Der nientals bejonbers lebhafte Sänger jein Rieb lauter

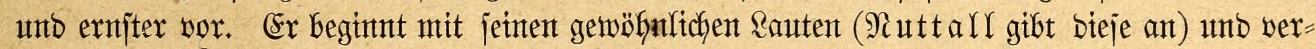
mijdft jie mit einter $2(n z a h l$ triflermber Iöne, erhebt jich aber audy oft über bas (semöbnliche unt änbert jeinen Sejang in höbbjt gefälfiger $\mathfrak{X e i j e ~ a b . ~ W e i l ~ a b e r ~ b e r ~} \mathfrak{B}$ ogel alfgemein ber=

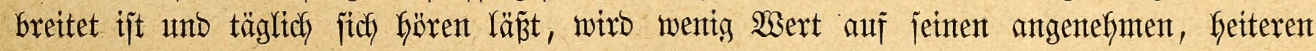

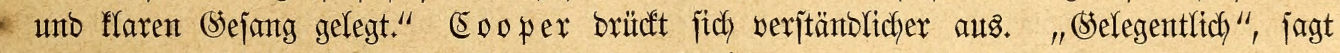
er, "namtentlidf) int Früfjaffre jebt fich ber Sdylagammerfinf (weldyer bie vorker genannte

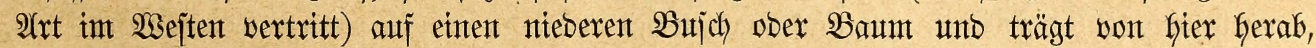
oft eine Stuntbe nach einanber, jeine munteren und anjprectienten Weijen vor. Sebes Rieb ift eine förmlidye, aus etwa einem Dubentb won Tönen bejtebentbe Strophe, wirb aber oft abgeänbert ober gefgt in einte anbere, in äfnlichem Stile unb boch ganz verjchteben vorge= tragente über. Wenn mant einmal Singammerfinfen gebört hat, wiro mant jie jeberzeit wiebererfenten, objchon nicht zwei biejer $\mathfrak{B}$ g̈gel volffommen gleich fingen. Es Gerjat einte

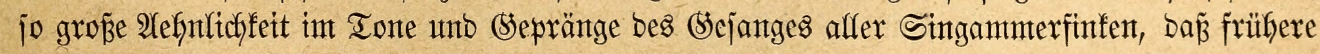

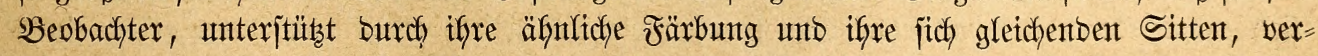

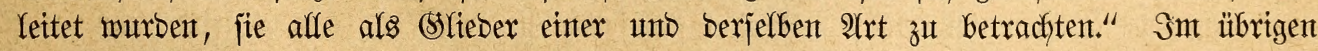
äfneln bie Singammerfinfen ifyen gejdfilberten Serwanbten. Sie fino eher Strid) = als

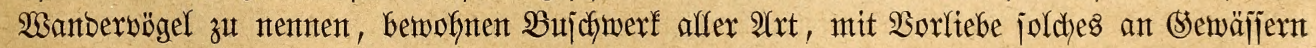

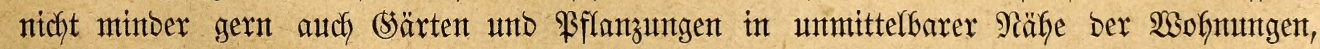

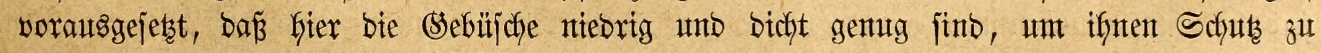


gemäfren, halten fïch ebenfalls viel ant Boben auf unto fliegen ungetn weit in einem Buge.

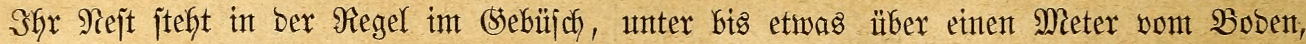
gar nicht jelten aber auds auf resterem jelbjt, unterjchetbet fich int Baut wenig won Den

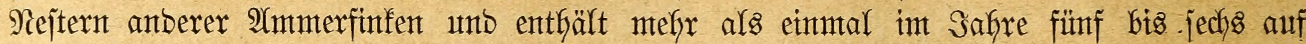

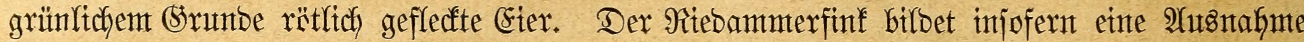

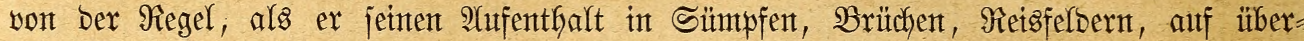
joywemmten Wiejen unto anberen von jtehenbent $\mathfrak{B a f j e r}$ itberfluteten Sertlidbfeiten nimmt unt bier in wejentlichen wie bie noch zu jofilbernben 2 ardhtelammerfinfen lebt. Sein Sejang ift unbebeutent, objcyon ex mit gropent Eifer vorgetragen wirb unb eintge Iriffer entfyält, welche an bie bes fantartentogels erintern. Das Nejt jteft nuf bent Boben an ober in

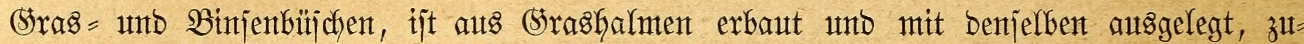
weilen oben teilweije überwölbt unto entbält vier ober fünf weißjliche, rot getïpfelte Eier. Unter ben $\mathfrak{B a u m a m m e r f i n f e n ~ z e t c h e n ~ f i c h ~ b r e i ~ v o n ~ b e n ~ a u f g e f u ̈ b r t e n ~} 2$ (rten burdh ifren (sejang aus: ber Bergs, ber Sommer = unt ber Bmergammerfinf; Die itbrigen atrten fino Stümper. Erjterer trifft gegen 2 (nffang Des Dftober aus jeiner weiter int Norben ge= Yegenten Sceimat in ben mittleren Staten eit, wanbert wohl auth bis zum Sibon Nord = anterifas finab und nimmt währent bes 2 inters an affen ifm einigermaß̧en zuagenton

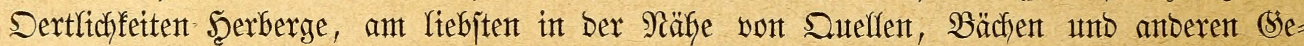

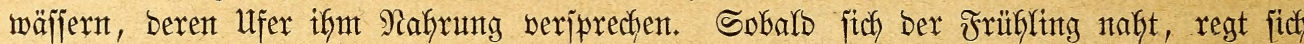

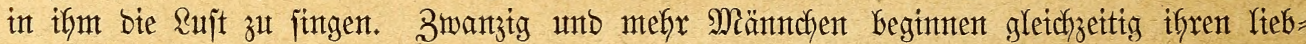

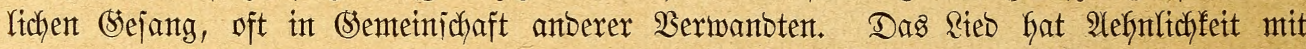
bem bes Boldzeifigs, ift aber mintoer retch an Wechjel, wie auth ber Ton nicht biejelbe

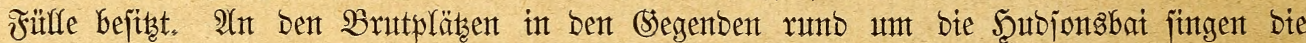
Männchen befjer und lauter als in ber Jrembe. Das Nejt hat nichts abjonberliches; bie Eiter äfnelnt benten des Bejelfichaftsanmerfinfen. Der Sommerammerfinf, cin Bemofner ber mittleren und jüblichen Staten, ijt, Ynut $\mathfrak{B} a d$ mann, "unbebingt ber bejte Sänger

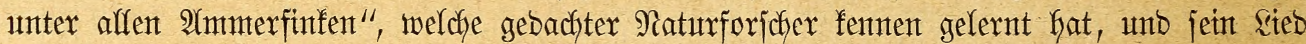

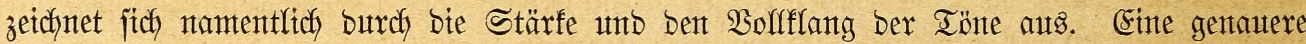

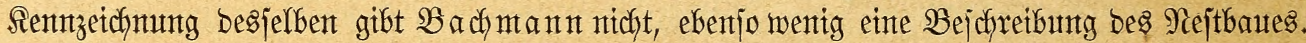
Der 3merganmerfinf, in bent mittlexent unto nörblichent Staten Wanberoogel, pflegt

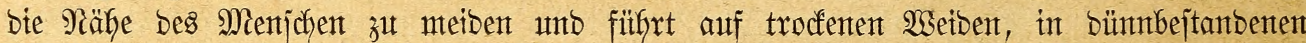

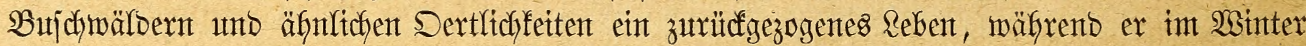
vft in unzäblbaren Scharen, mit Serwantoten bereinigt, auf Wegen unt Felbern erjchent

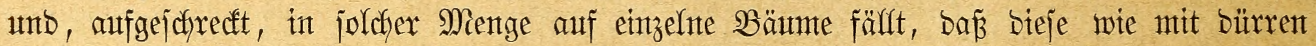

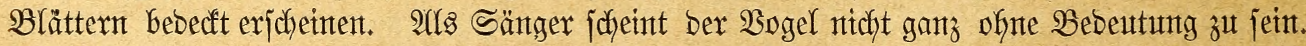

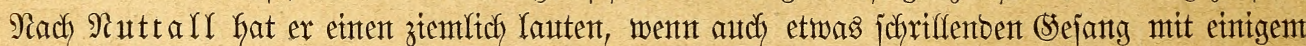

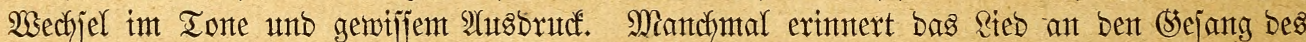

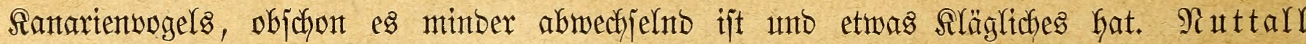
verjichert, einzelne Männthen gefjört zu haben, weldhe in (Sejange betnah mit bem Solozeifige wetteifern fonnten, und bemerft, baj ber 3wergammterfinf wohl wert jei "als ein Singoogel

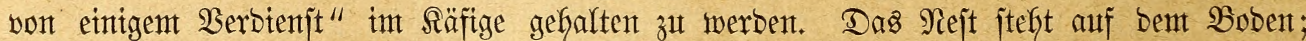

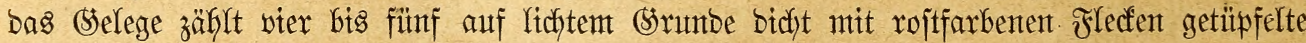

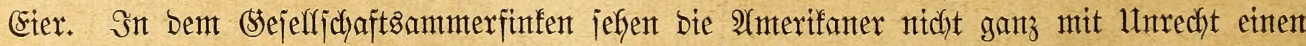
Sperling; bent wie unjer Spats werbreitet jidc jenter itber bas ganze Rant, fibelt fich affer

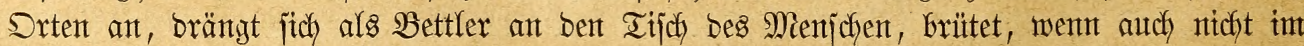

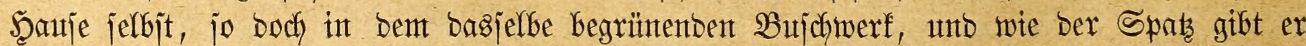
ein Ried zum bejten, weldhes bei Nientand Beifall findet. Nuttall wergleidyt bie J̧aupt= jtrophe mit Dem (Seflingel eintes Beutels voll Sefler, ijt aber noch woflwollento gentug, zu 
jagen, Dẩ einzelne Ieile bes Sejanges an jhywaches, unfertiges Triflern bes Sanarien= vogels erintern. Das (Sanze flinge, meint ex und mit ifm 2 ububon, nicht viel lauter

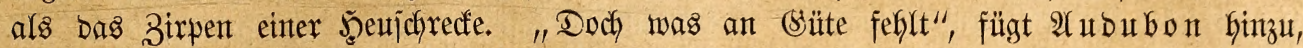
"Das wirb burch bie Mienge exjeţt." (Eine Galbe Stuntbe nach) einanber trägt biejer $2(m m e r=$

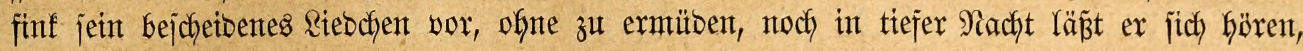
und jelbjt im Winter verftummt er nicht ganz. Das Siejt mirb ber Dertlichfeit angepap̃t unt änbert beshalb in Sejtalt und Bauart; bie (sier find auf glänzend blajggrünem Srumbe helfer ober bunflex braut geflectt, zumat am bicferen Enbe.

Eigentlidje SBobenögel junb Die Rerdhenammerfinfen, unter benen ber Steppen= ober Savantenammerfinf am bejten befannt jein bürjte. Sie bewobnen jteppenartige Randjtriche, Wiejen, Felber und Marichen, leben mefr nach Rerchen = als nach Finfentart, erbeben jich nur gezwungen ober vont Drange zu fungen getrieben in bie \&uft ober auf bie Spike eines niebrigen Strauches, renten Dafür aber mit ber (semandtheit echter Räufer ober mit ber Surtigfeit einter Maus auf ber Erbe Dafint. Furdst= unt Garmlos nähern fie fich unge=

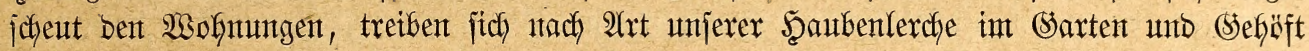
umber ober lajjen jich auf ber Firfte bes Dadjes nieber, unt von fier aus ifren lispelnden, furzen, jaywadjen- und unbebeutenden, objchon nidft unangentebmen (sejang zum bejten zu

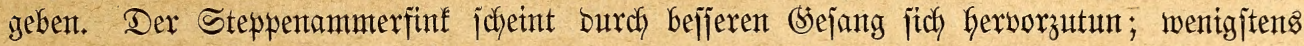

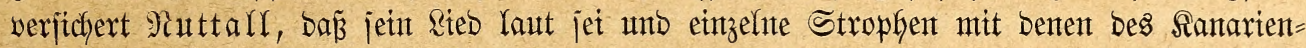

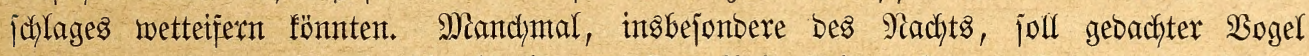

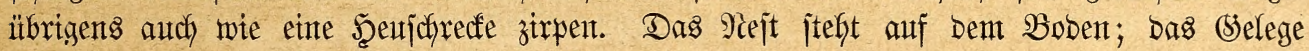
zählt viex bis fünf graultidfe, braun geflectte siter.

Einige $\mathfrak{B a d}$ telammerfinfen, namentlich Sperlings = mo Wadftelammerfinf fübren cinte in wejentlichen gletche sebensineije, andere unterjcheiben fich in Sitten und Sienokn= heiten. See = und Siljitenammerfinf nemlich find biejenigen Arten, welche nur gezmungen bie Seefüjte verlafjen, für gewöhultich aber fier nach alrt ber \$iper jich benefymen. Der Sïjtenammerfinf wäflt vorzugsmeije jalzige Marjchen, welche von ber See regelmäß̈tg überflutet unb Durch bie Ebbe wieber troden gelegt werben, ber Seeammerfinf am liebjten

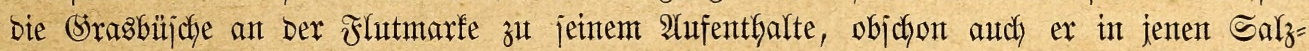
jümpfen nicht feblt. Şier reben beibe in ähnlicher Weife wie ber Watejen = ober Wafjer=

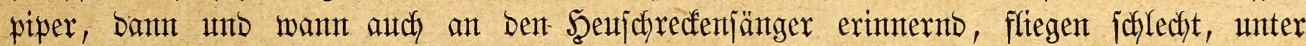

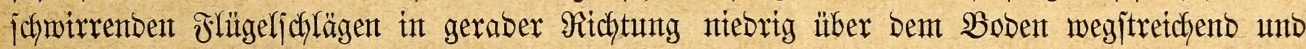

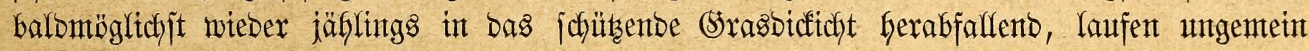
Gurtig Durch Das (Sras, zwijchen Dem blopkgelegten Seetang unt Seegraje umber, friechen

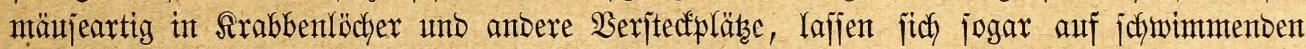
Siraßbüjcheln nteber und mit ben 2 Belfen treiben, entfernen fich von ber Seefüjte überfyaupt

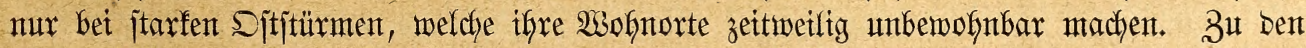

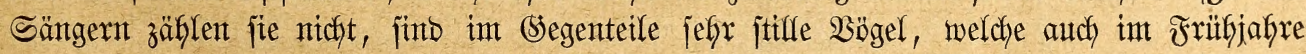
faum einige zujammenbängende flangloje Raute Gervorbringen. Mit Beginn Der Brutzeit berjammeln fie jidf in Menge auf affen exhöheten, nur bei Stürmen teilweije überfluteten, janbigen, mit ausgenorfenen Iangen bebectten Stellen, bauen fich fier jebe geetgnete $\mathfrak{B e r}=$ tief̣ung mit harjchen (sräjern lecthtfertig aus und legen in bas mefyr als bejchetbente Niejt

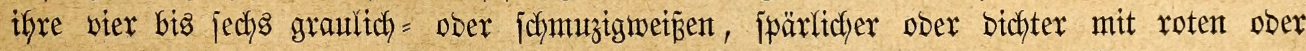
rotbraunen Jlecfen geiprenfelten Eier, bebrïten fie unter Ieilnabme ber Miänndben, un= gemein fejt jitzend, und entfübren bie maugbegende Sungenjchar, noch ehe fie volffommten flügge gemorben ijt, ify jhon in frühejter Sugend alfe Sünjte bes Beritedfens Yefrend. Im Sgerbjte mandern fie weiter nach Sibden finab; Dody berlaffen wohl nur bie wenigiten bie Diereinigten Staten. 
Unter ben Sdyneeammexfinfen find ber Namenterlether ber Sippe unt ber Winterfinf am genautejten beobadytet morben. Der Sctneeammerfinf ijt, nady atngabe Soopers, in Salifornten währento bes winters fait afferorten zu finton, żeht fich

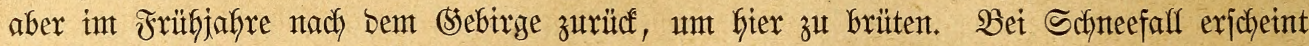

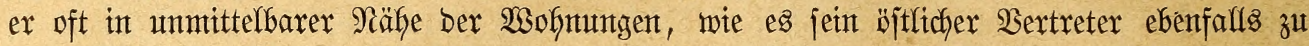

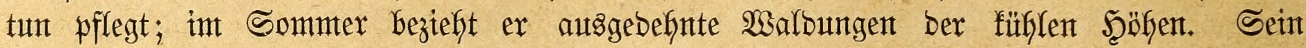

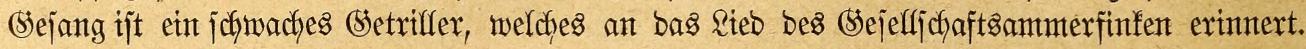

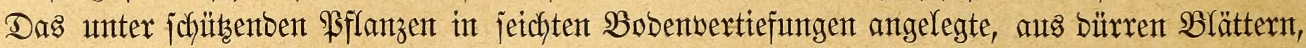
(Sräjern, Würzeldjen und bergleichen exbautete, inten mit feinen (s)räjern unto Jearen aus=

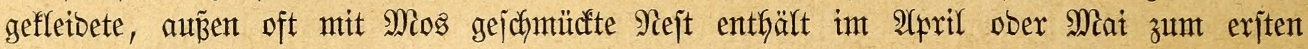

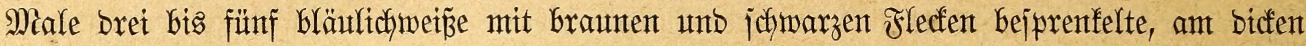
Enbe meijt jefr bicht gezeidfnete Eier. Weit häufiger als ber eben gejdfilberte $\mathfrak{B}$ oger tritt im Siten ber $\mathfrak{B}$ ereinigten Staten ber Winterfinf auf. Währemb bes Sommters bewofnt auth er bie (sebirge, mit Beginn bes Seerbjtes exjdyeint er, meijt plöblich und in Menge, in tieferen Stegenden, treibt fich an Walbränbern, Scedfen unb Bäınen umber, vereintgit jich zu Scharen, welche jtetig zunefynen und unter Utmjtänben zu Iaujenden anwadyjen

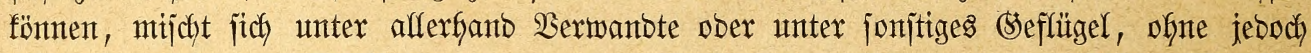
mit eriteren in enge Berbindung zu treten, unt fommt entlich, wenn ber Schntee ifym ben

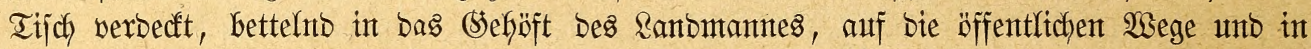

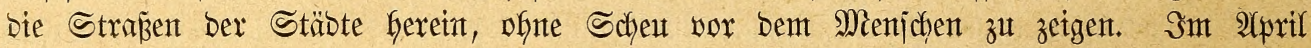

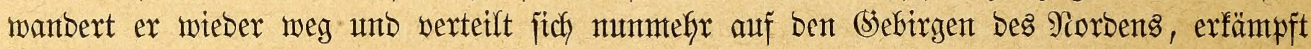
jich Weibchen und Nijtplats, entfaltet jeine eigentümliche Schneepradbt und trägt jeinten ein= fachen aber angenefymen (sejang, welchen (Berfardt Dem Bezmitjcher junger Aanarienbögel

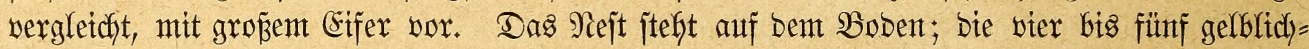

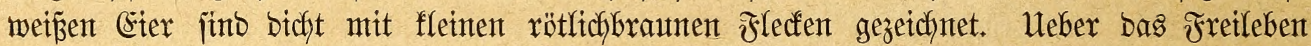
Der EDelammerfinfen wifjen wix fo gut als nidfts. Sie joheinten mit Borltebe niebriges (Sicbiijch zu bemohnen und int wejentlichen biejelbe Rebensmeije zu füfren wie anbere âmmer= finfen, welche ähnliche Dertlichfeiten bebolfern. Der sejang jolf recht gut jein; namentlich Der eigentliche Edelammerfinf miro gerühnt.

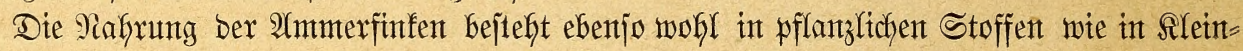

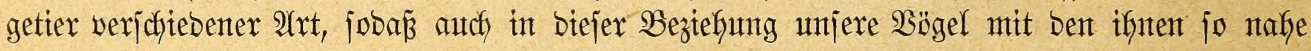

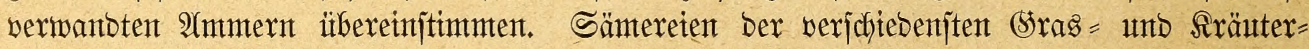
arten bilben im Şerbite und Winter ben Şauptteil ifrex Miablzeiten; außerbem frefien fie (Setreibe, Beren, Inospen unb Srünzeug überfaupt. In ben Sommermonaten entnefmen

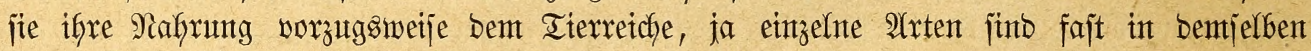

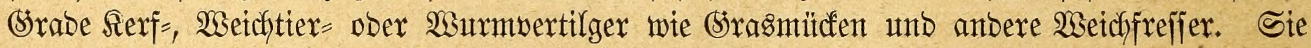

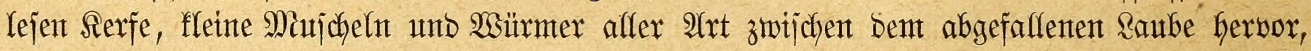
werfen beshalb das lestere nach Droffelart aus einanber und jofarrent förmlich, indem jie burch rajches Bormärtshürpjen bie Blätter ummenten unto wegichleubern, fangen aud

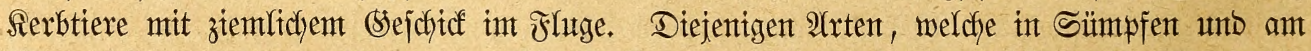
Mere Yeben, erbeuten fier namentlich Wajjergetier unb joheinen bagjelbe zeitweilig in jo

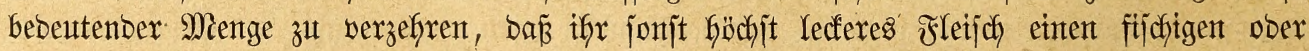
tranigen (sejchmad annimmt unt gerabezu ungeniep̧bar mirb. Nicht mit untredst aljo barf man fie als alleşrefjer bezetdynen.

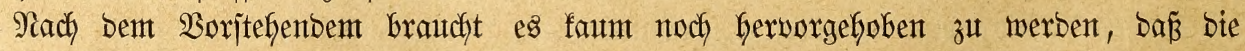

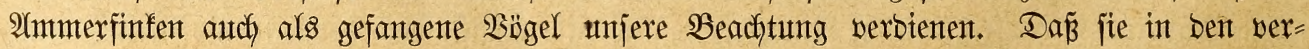
jdhiebenen Schriften Der siebhaber und gemiffer Sdyriftiteller, weldye für Riebhaber jdhreiben, bis jetst faum ober nidft Errwäfnutng gefunben Gaben, wiro Denjenigen nidjt Wamber nefjmen, 


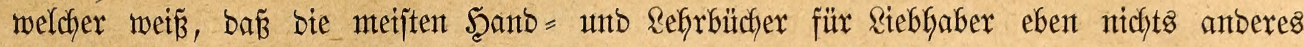

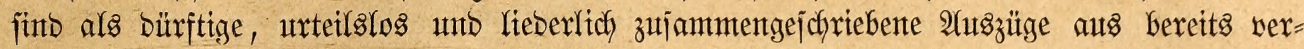
alteten Sachwerfen ober anberen bolfstümlity gebaltenen Bü̈hern, in benen eine Sruppe

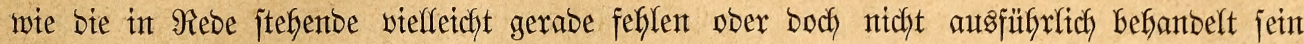
fant. Daj Ginter ben Bergent ober jenjeits des Meres audf nodh Reute unt beziefjentlich

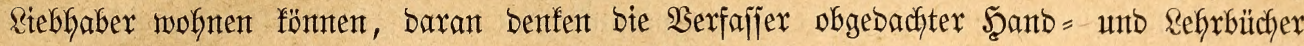

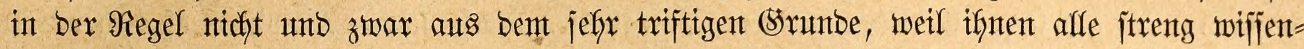

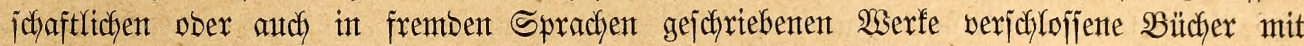
jieben Sigeln. find. Ein Umitano, Dejien bereits (ธ. 108) Erwähmutg gejchaf, trägt zu

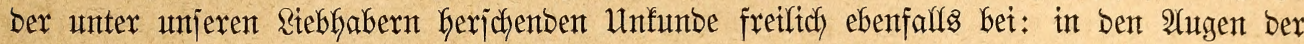
Norbanterifaner verlofnt es fich nitht ber Më̈be, Bögel zu fangen und nach ben $\mathfrak{B e r j a n d}=$ bäfen zu bringen, weldhe nteijt ein unjcheinbares Sefteber haben unb int Sejange mit ben

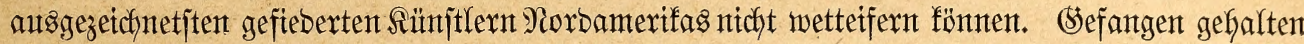

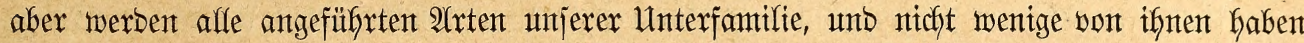

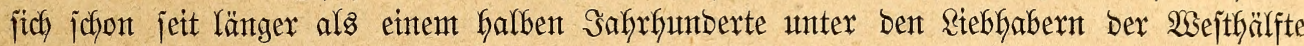
unjerer Erose bie Beachtung und siebe ermorben, weldye fie verbienen. Und audy auf unjere Märfte gelangt ber einte und ber anbere 2tmmerfinf zur Freutbe alfer fantigen; ja in ber

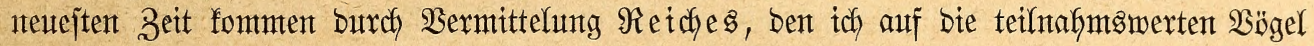
aufmerfjant gemadyt habe, mefy und mefyr 2(rten lebent zu uns Gerüber. Nody int Safre 1866 mur̈te ich befenten, feinen einzigen Winterfinfen Yebend gejehen zu haben: inzwijchen

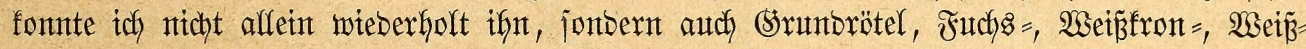

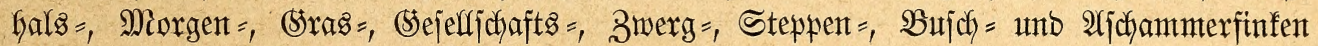
lebent exhalten, pflegen unt beobadyten. Wer aljo über gefangente $\mathfrak{B}$ ögel jdyreiben mill, muर ben 2 mmmerfinten wohy eine Stefle einräumten.

2ltch) in ifyem (Sefangenleben exintern bie 2 (mmerfinfen vielfach an einzelne Mitgliteber unjerer finten und 2 (mmern und zwax an letztere mefy als ant erjtere, objchon jie mit esdel=

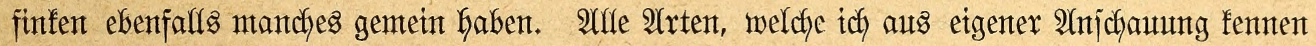
lernte, fint muntere $\mathfrak{B b g e l , ~ w e l d y e ~ f i c h ~ g l a t t ~ u n d ~ z i e r l i d h ~ t r a g e n ~ u n d ~ a n m u t i g ~ b e r w e g e n . ~}$

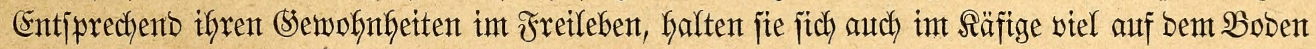
auf, Güpfen hier mit fleinten Sprüngen umber, laufen aud auf furze Streden trippelnto, fajt wie ein \$iper ober eine Rerche Dafin. Dabei pflegen fie ben Sdywanz ein wentig nach oben gejtellt zut tragen und bie Flïgel etwas zu lüftent. Sm Futternapfe joharren fie wie oben

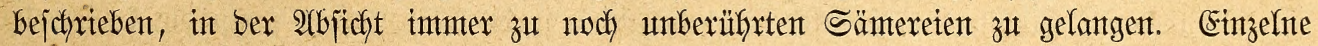

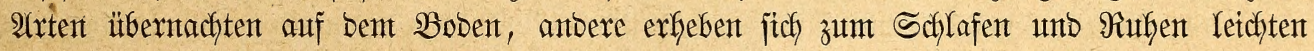

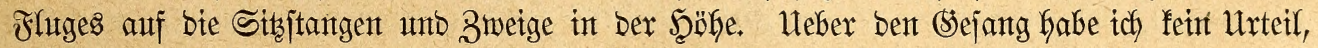
weil id afle $2(r t e n$, welche idh bis jebt pflegte, in Fluggebauter unter einer Menge anberer Bögel fielt, beren Stimmengemirx mux von Den fräftigjten Sängern übertönt wiro. Unter jich unt mit anberen $\mathfrak{B}$ g̈gln bes Fluggebauers leben bie Afntmerfinfen im bejten Eintorjtänonis;

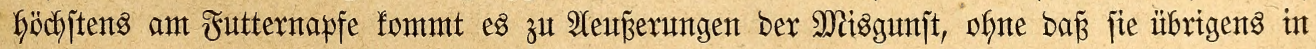

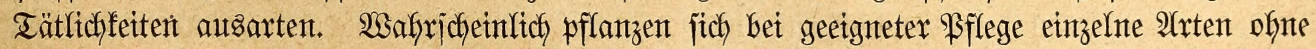

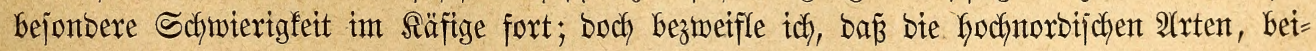

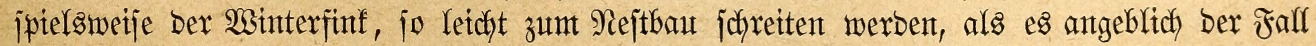
jeth joff. Ess würbe bies wentgitens mit anberweitigen Beobadytungen über hodynorbijche Bögel nicht im Einflange jtehent.

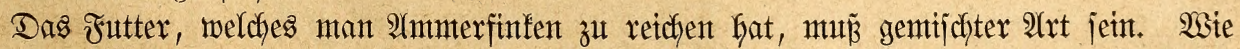

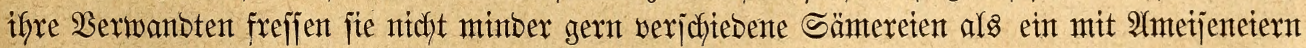

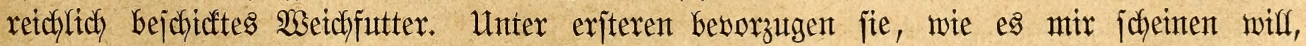
bie fleinteren (sejäme, namentlich aljo Rübjen, Mohn, Scheutrngejäme, Rlleejat, Sras= 


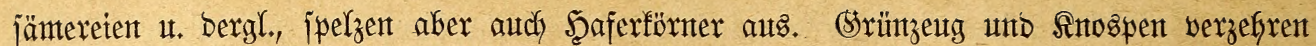

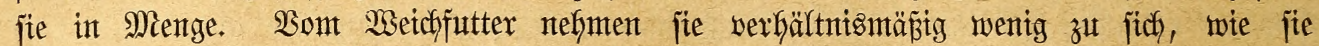
auth, went ifnen Meblwürmer vorgetworfen werben, ntidyt bie (sier bieler Serwanden be= fumben. Sm alfgemeinen barf man jie als gentügiame Bögel bezetchnen; auch focheinen jie bei geeigneter Bflege recht gut in ber Sefangenjchaft auszutbautern.

Einten beftimmten Preis Gaben bie Immerfinfen nicht, weil fie noch siel zu jelten auf umjeren Marft gelangen. Nach meintem Dafürhaltent barf man brei bis fünf Taler für bas Pärchen wohl anlegen.

\section{Antmer.}

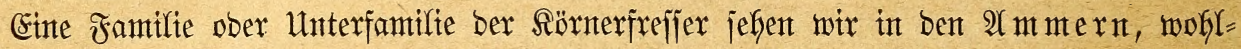

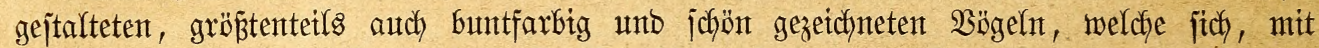

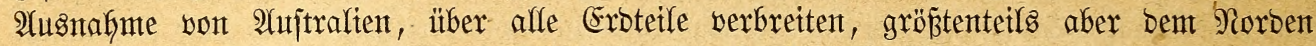
angefören und int allgemeinen burch folgenbe Merfmale fentnzeidynen: Der Schnabel ijt an

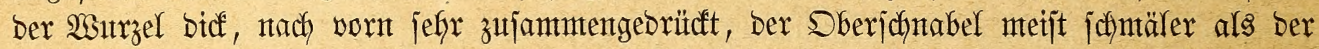
untere, auf ber Firịte fajt gerabe, an ben Sdjnetben jtart eingezogen, vor ber Spitze zu= weifen mit einent jetchten Einjdynttte verjehen, ber Unterjdynabel in ber Mitte ber Sdynetoen=

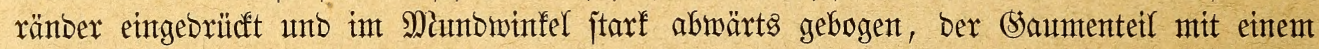

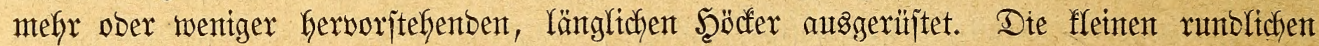

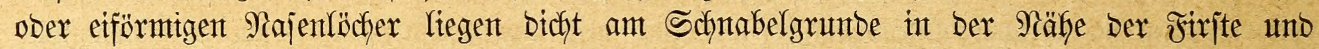
find rüdtwärts von etner fäutigen Schntele umgeben, tetlmeije audy bon zarten Borjten=

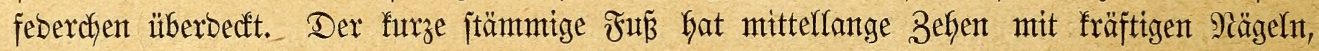
ber Daument bet einzelnen 2̂rtent einen jogenannten Sporen ober eine lange, gerabe ober

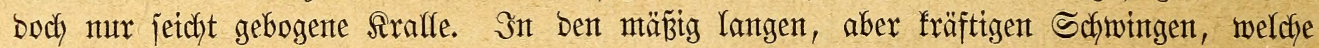
zujammengelegt ein Sechjtel ober Finnftel bes Schwanzes decfen, find bie erjten brei ober vier Schningen unter fich gleich lang, Die zweite ober britte bie längite. Der zitemlich lange, am Enbe auggejchnittente voer gerabe, aber ein wentig abgerunbete Schwantz bejteht aus breiten Febern. Das Aleingefieber ijt ziemlids, bei einzelnen Alrten jefr bidft, jeine Färbung

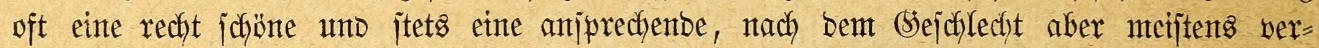

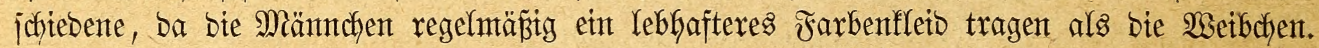

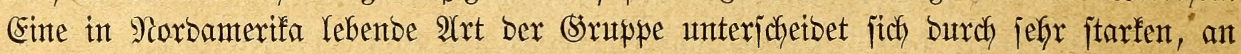
ber Wurzel ausgebaudften, auf ber Finjte breiten, janft gefrünmten Sdynabel, mit fajt

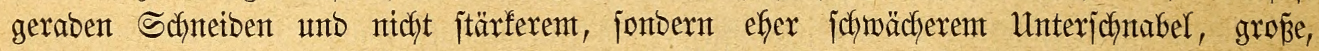

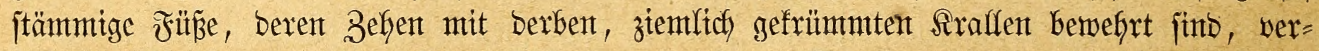

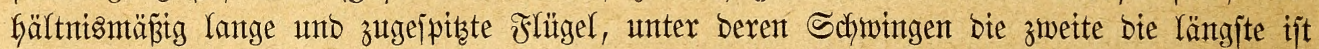

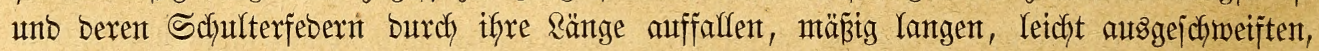
jeitlich abgerumbeten Schwanz ant ein bichtes Sefieder, in meldyem Sdywarz vorherjat, von ben übrigen atmmern und ijt beshalb zum Sertreter ber Sippe ber Irauerammer er= Goben worben.

559. Der 3weifarbennumer, Calamospiza (Emberiza, Corydalina, Dolichonyx) bicolor,

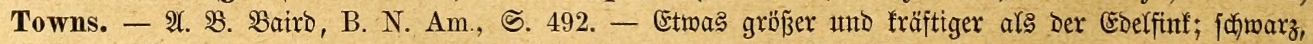

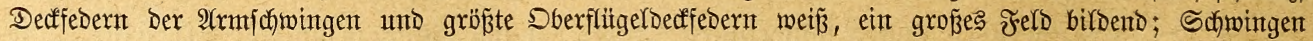

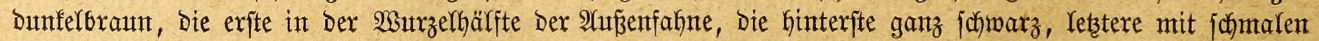

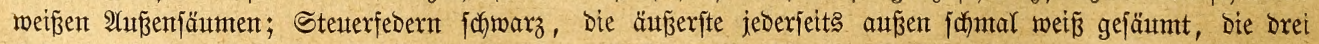

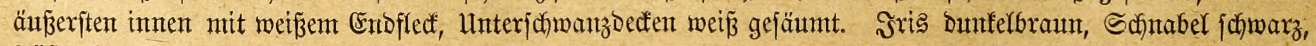

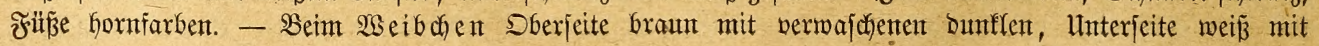




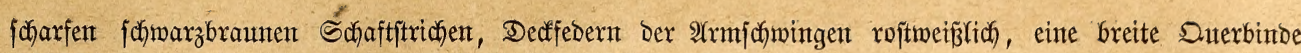

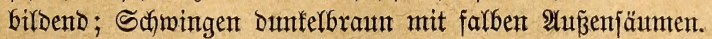

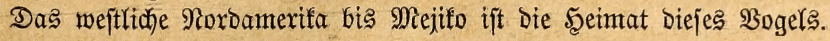

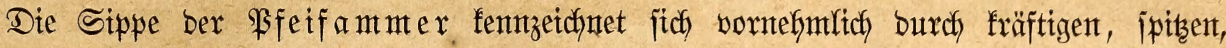

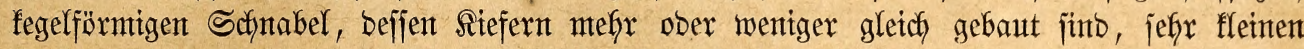

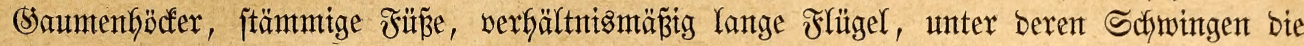

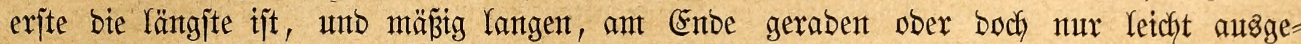
jalyeiften Schmanz.

560. Der Iappentumuter, Drtolanfönig (Ré di ortolani) Der Эtaliener, Euspiza (Emb, Tan., Fr., Xanthornus, Passerina, Granativora) melanocephala, Scopoli, (melanictera, crocea, granativora,

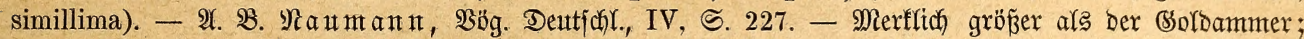

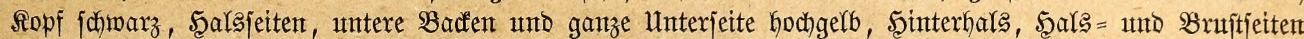
fomie bie Sberjeite lebhaft zimmetroftbraum, bie Febern mit jehr fanmalen graulichen vermajdhenen (Endjäımen;

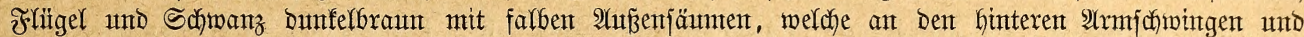

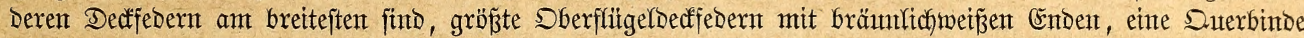

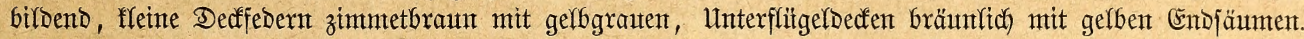

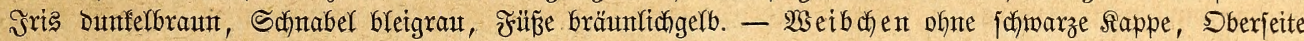

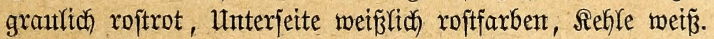

Bewohnt Den Sildoften Europas und Beftaften und verbreitet fich won fier auts bis in bie norbweftlichen

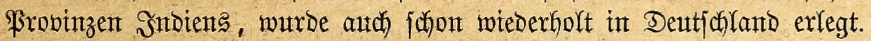

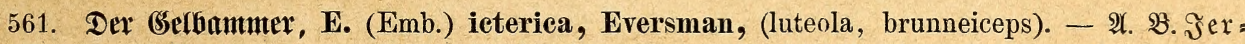
Don, B. of Ind., II, S. 879. - Etwas größjex als Dex Solbammex; Ropf, Rinn, Refle und Siropf lebhaft zimmetrotbraun, Naden und Seinterkals olivengrüngelb, Scalsfeiten, SBürzel und ganze Unterjeite Dunfel

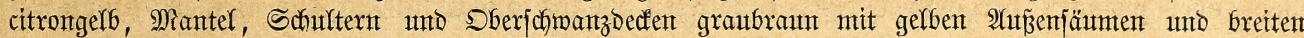

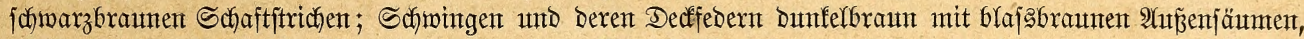

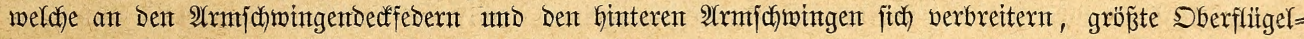

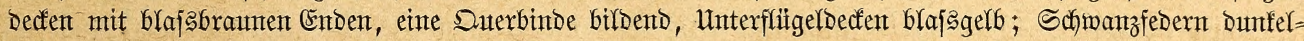

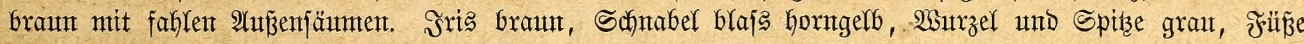

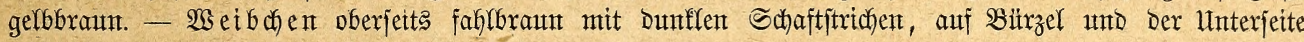
gelb, Sropf unt Seiten roftbräunlich) angeflogent.

Dex $\mathfrak{B o g e l}$ fommt bom mittleren Sibirien an bis Mittelindien und weftlid bis 2ffgantiftan vor, ift aber nux birtlich) berbreitet.

562. Der Sififbammex, Słnarzbrïftchen, E. (Emb., Pass., Spiza) americana, Gml., (Havieollis, mexicana, nigricollis). - 2 . B. Sa

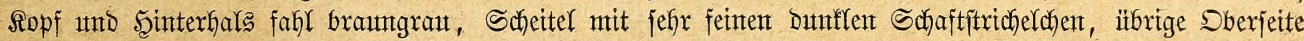

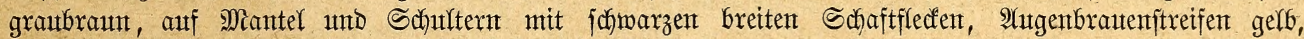

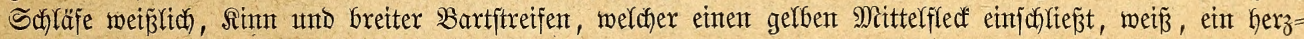

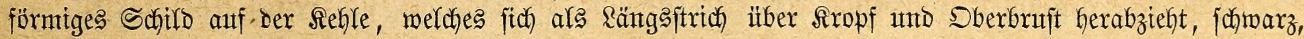

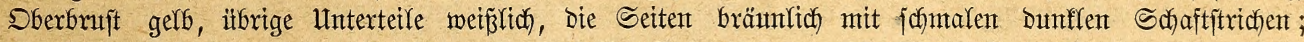

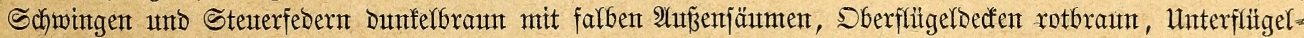

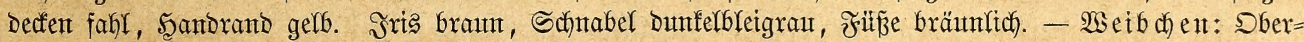

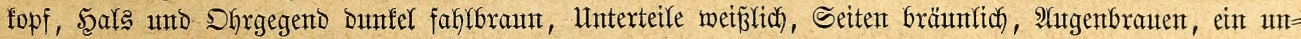
Deutficher Bartitreifen und Sropffledt gelb; Schnabel Gornbraun.

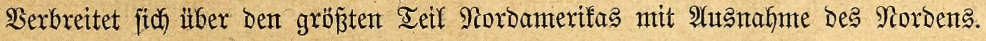

Bei ben $2(m m e r n$ imt engeren Sinte ijt ber Sdynabel werjdfieben lang unt jtarf,

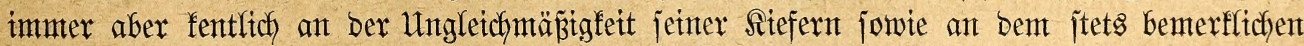

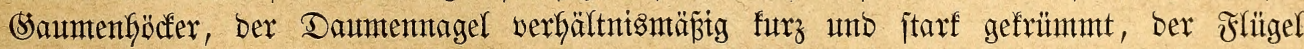

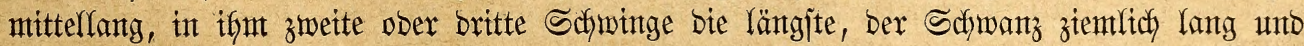
ausgeich weift.

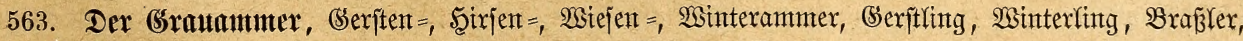

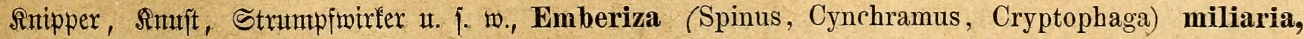

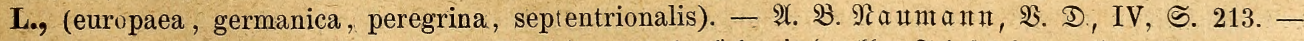

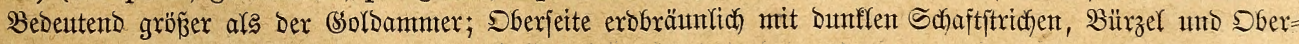




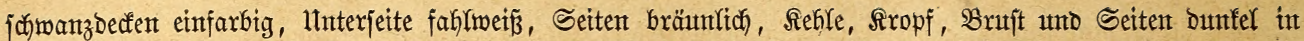

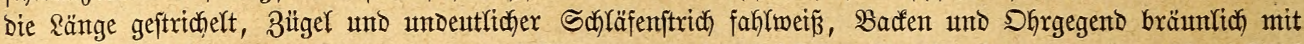

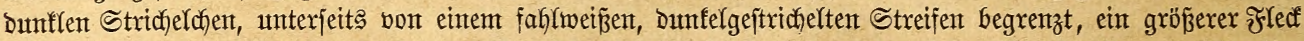

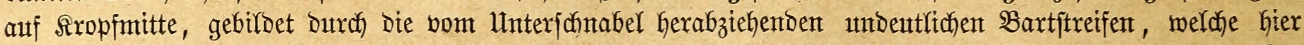

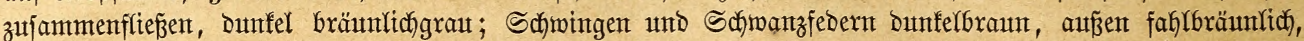

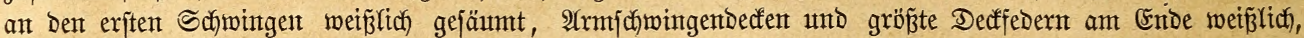

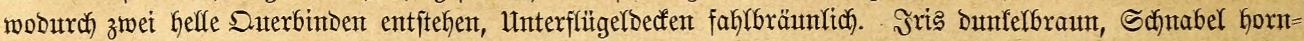

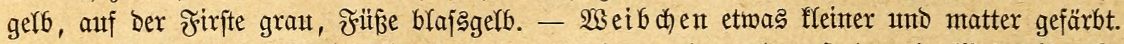

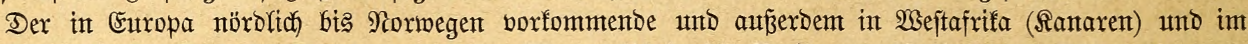

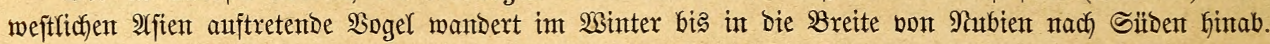

564. Der Bsolonmmer, Atmmer, Emmering, Emmerfing, Emmerits, Bolmer, Belammer, Belb=,

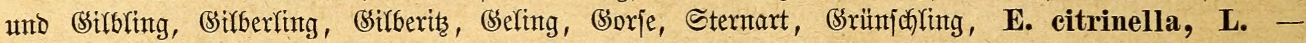

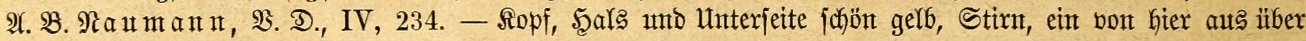

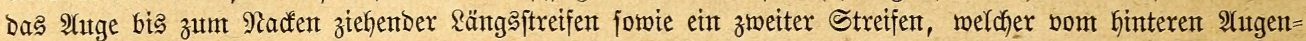

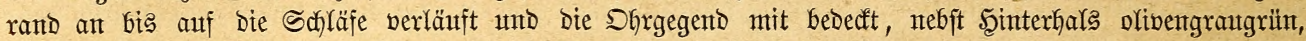

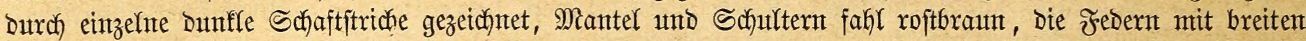

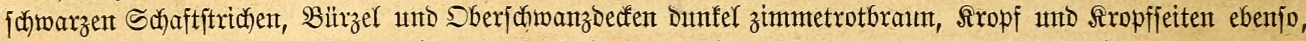

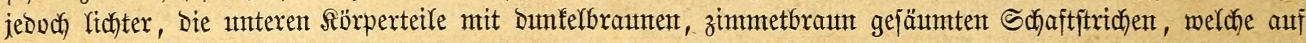

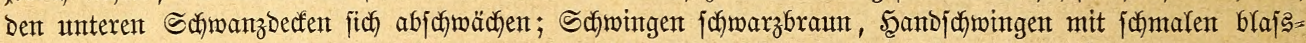
gelben, $\mathfrak{A}$ rmp mit breiten roftbraunent Enden; wodurch eine Duterbinde entfteht, Unterflügeldecten blafs, Scandrand rebhaft

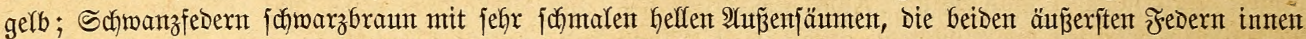

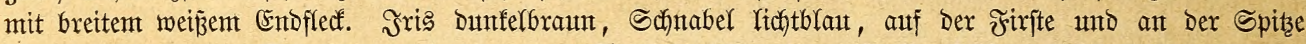

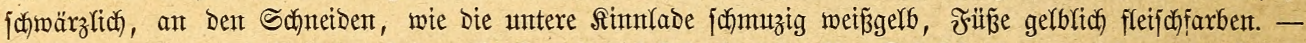

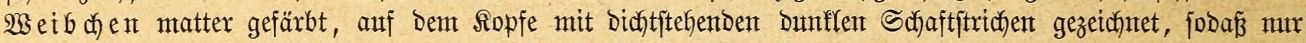

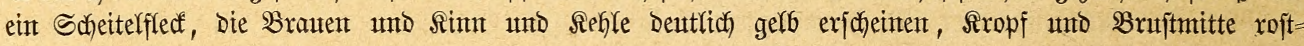
bräunlidügerb.

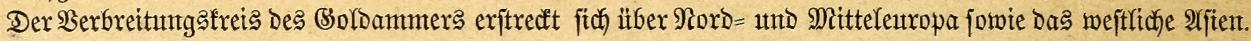

565. Der Cencrutumuter, E. einerea, Strickland, (cineracea). - 2. P. Proc. Zool. Soc. 1836,

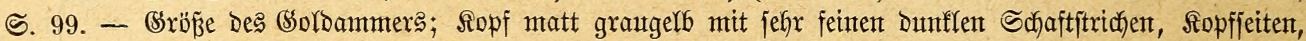

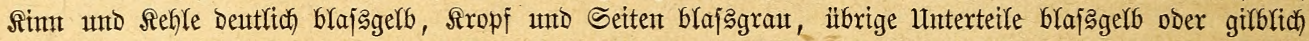

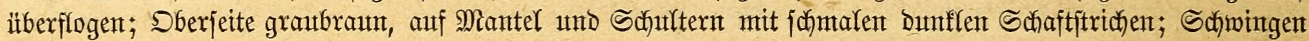

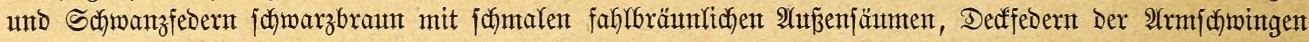

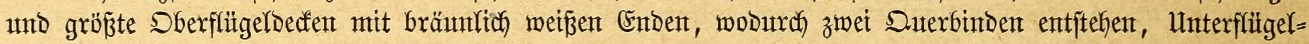

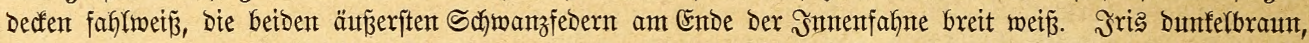

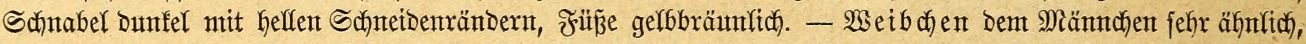

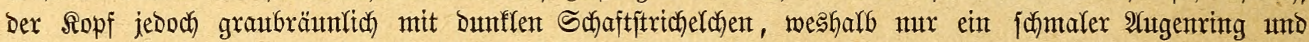

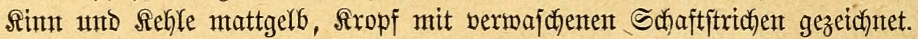

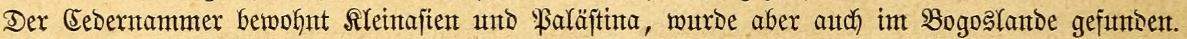

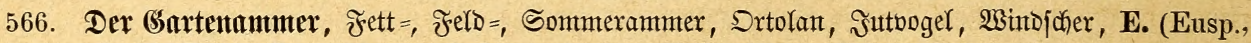
Glycispina) hortulana, L., (chlorocephala, badensis, Tunstalli, malbayensis, pinguescens, delicata,

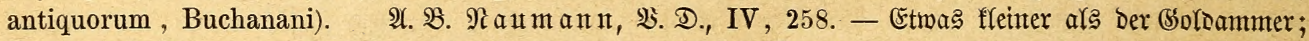

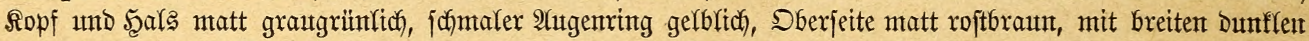

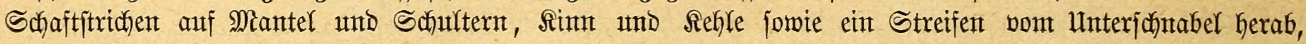

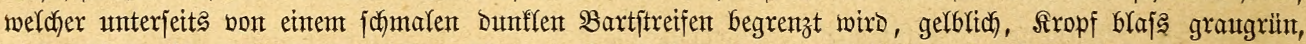

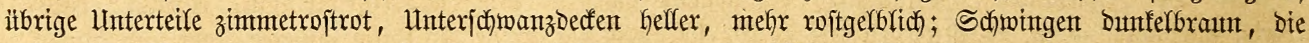

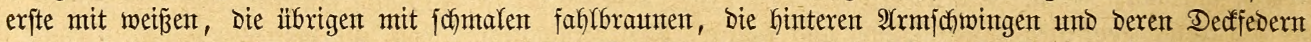

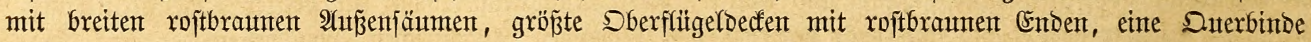

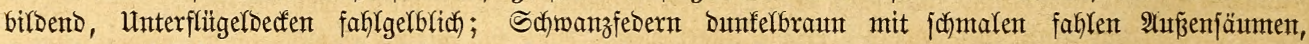

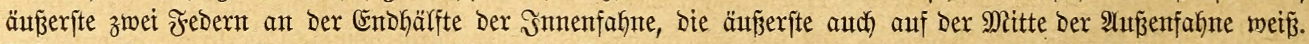

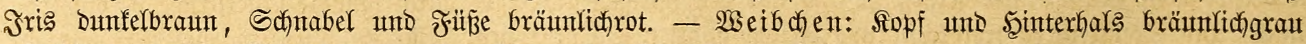

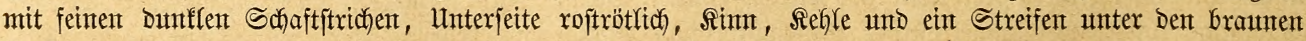

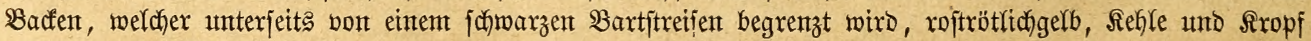
mit feinen Dunflen Sifaftittichen.

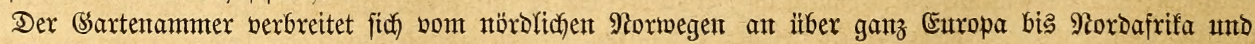
von Weftibirien an bis nach Den 2 seftprobinzen Ditindiens, tritt aber nidjt fo affgemein auf wie ber Boldammer. 
567. Der \$ivitammer, E. (Gl., Fringillaria) eaesia, Cretzschmar, (rufibarba, rufigularis). -

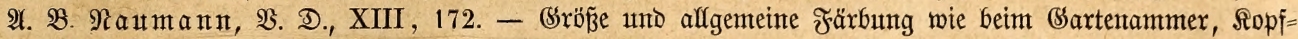

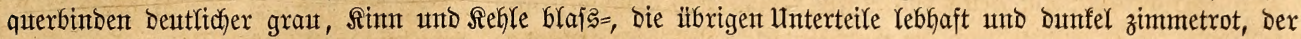

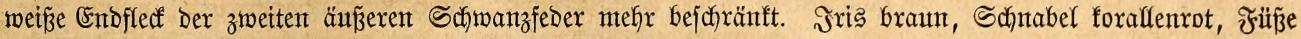

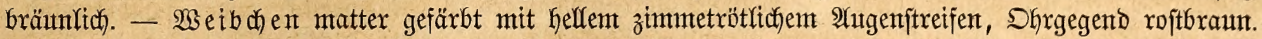

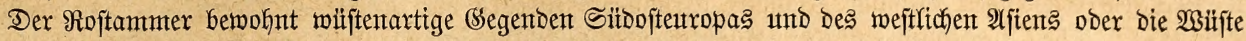

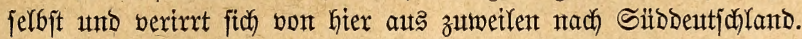

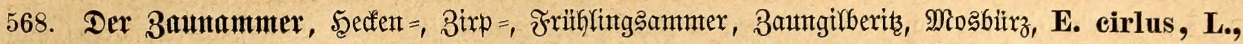

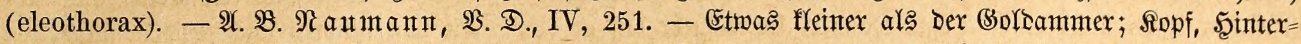

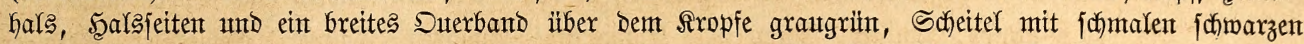

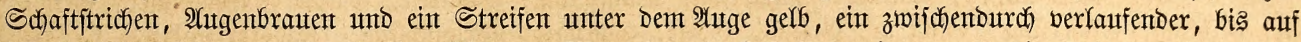
Die Săfäfe reichender 3ügelftreifen fahmarz, Mantel unt Schulttern zimmetrot, bie Febern mit grauten

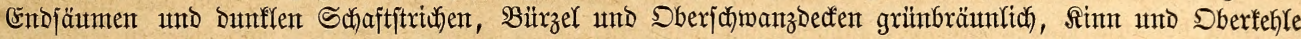

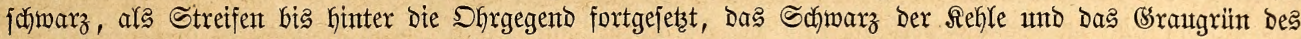

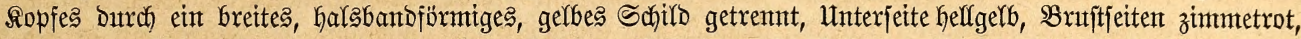

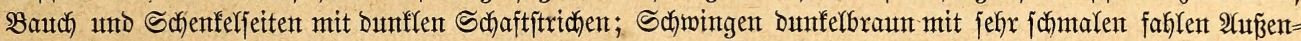

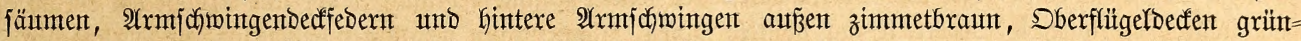

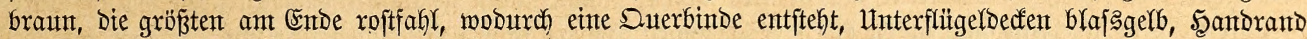

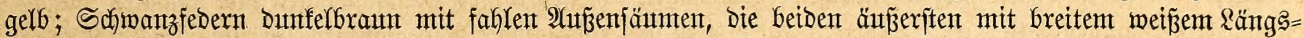

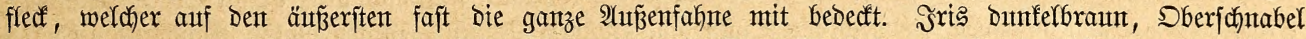

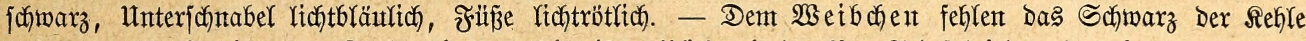
unto ber gelbe Streifen am Ropfe; bie Unterjeite ift gerbfich mit butmflen Schaftftrichen, Der zimmetrote freef ant Dent Brufffeiten bläfier.

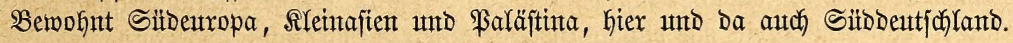

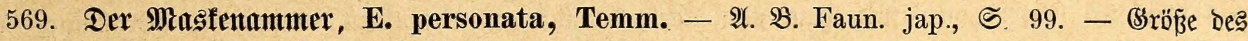

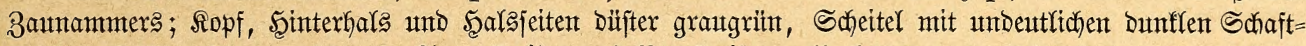

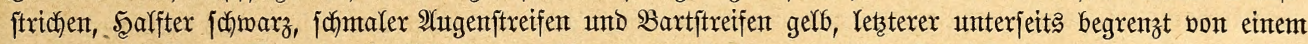
Dunffen Streifen, Mantel und Schultern roftbraut mit breitem Dunffem Schaftftreifen, Bärzel und Sber=

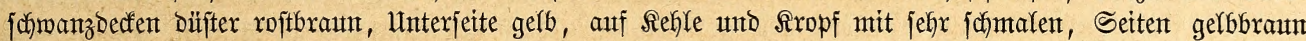

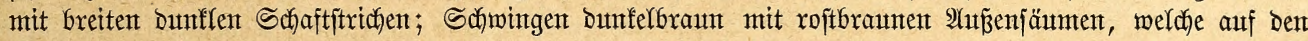

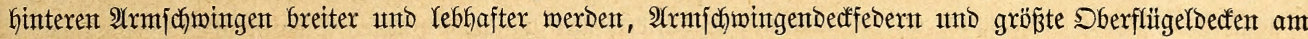

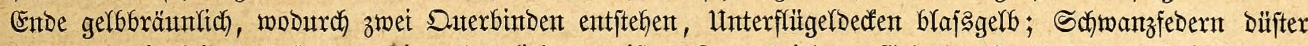

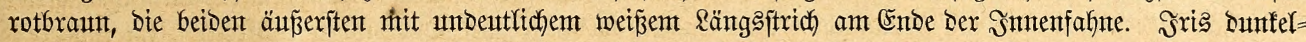

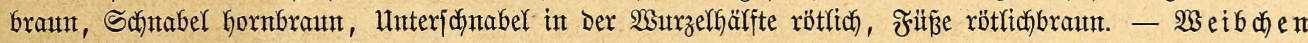

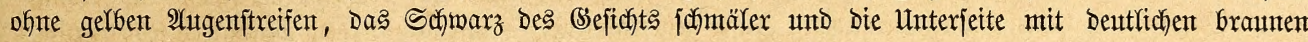
Sdifaftftrident.

Stammt atts ฐapant.

570. Der $\mathfrak{B}$ ujđanmerer, E. spodocephala, Pall., (melanops, chlorocephala). $-\mathfrak{A} . \mathfrak{B}$. Zoog. rossic., II, S. 51. - Dem Miałfentantmer ähnlich, aber fleinter, und der ganze Ropf unt Seals vorderfeits

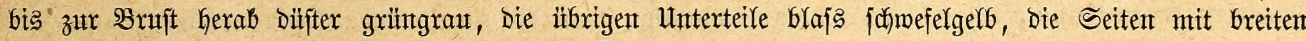

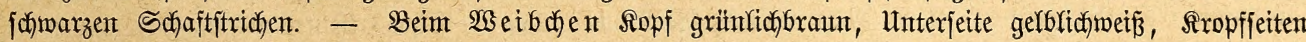
grünticugraut mit Dutmflen S(f)aftflectent.

Sertritt Dent Maßfentammer in Sibirien, Dem Imutrlande, in CGina und Den Sftprobinzen Sndiens.

571. Der 3ipanmer, Bartammer, Steinemmerfing, E. eia, L., (lotharingia, Hordei, cani-

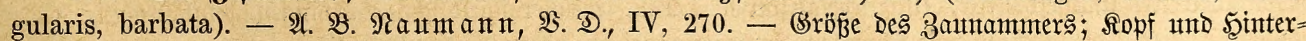

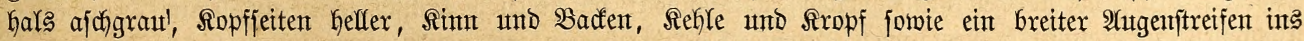

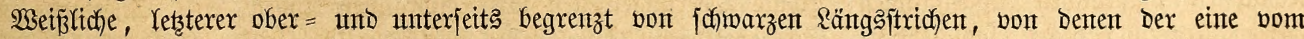

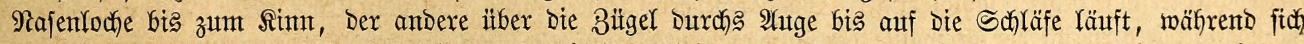
ein Dritter vom Mantowinfel herabziegt unt mit Den itbrigen am Entoe Durch fodmafe Duterftriche verbintet;

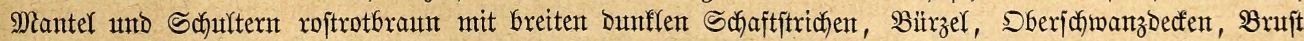

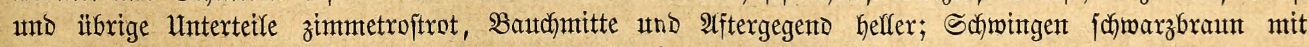

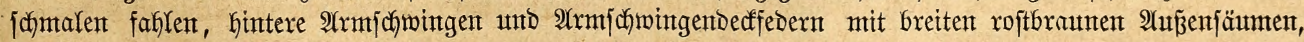

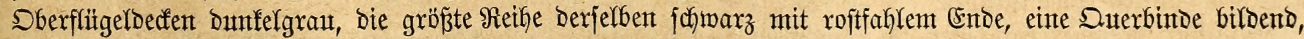

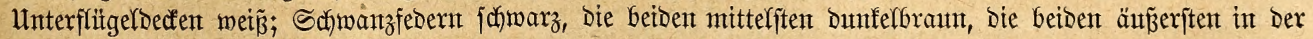

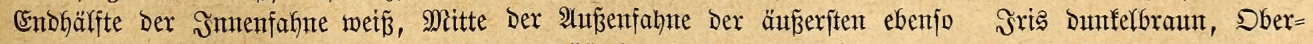

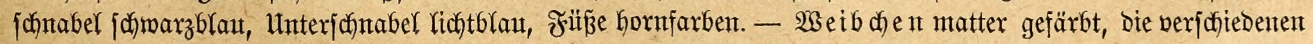


\&ängştreifen bes Ropfes unbentfiderex, Dberfopf braun mit Dunffen Schaftitrichen, ein Mittelftreifen grau,

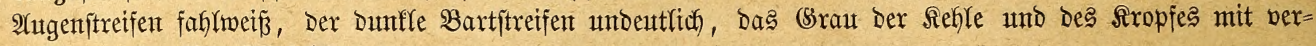
wajchenen bunflen Tilipfeldyen.

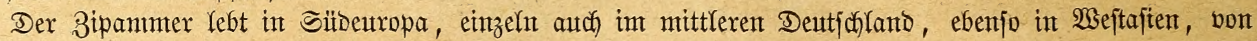
Gier ats bis ins norbmeftlidfe Scimalanagebirge nach) Silben fich verbreitent.

572. Der 5ardenammer, E. ciopsis, Bp., (cioides, pythiornithoides?). - $\mathfrak{\text { T. }}$ : . Faun jap., ङ. 98. - Dem Bipanmer ähnlid, aber fleiner unt im ganzen lebhafter, nemlid dunfler zimmetroftrot

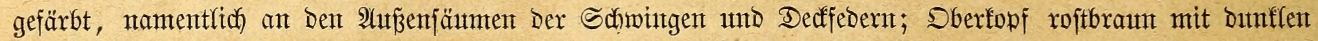

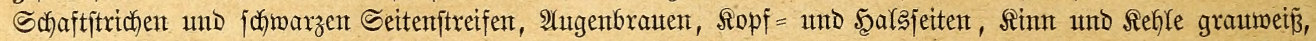

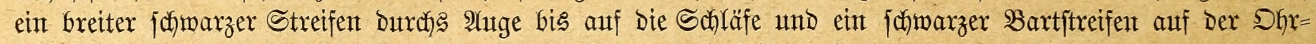

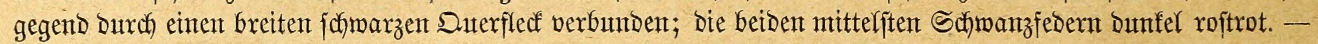

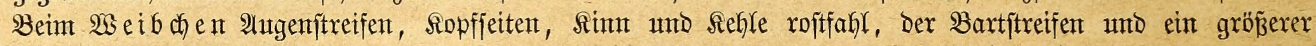
Fledf auf Der Shrgegend Dunfer rotbraut.

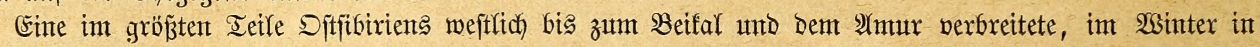

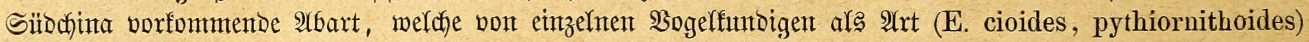

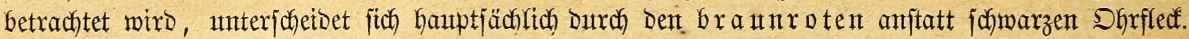

Der Sealdentammer wertritt Den Bipammer in Japan.

573. Der Fidftenummer, E. (Fr.) leucocephala, S. G. Gml., (pithyornus, dalmatica, scla-

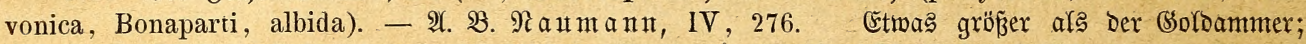

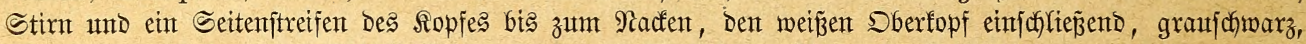

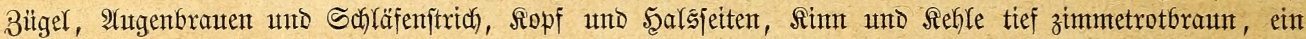

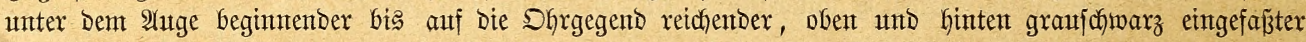

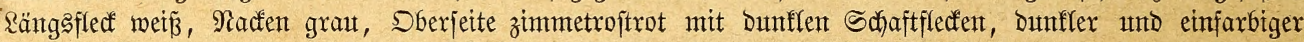

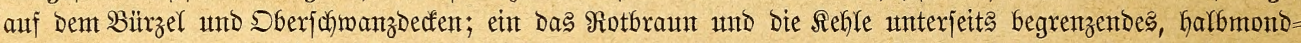

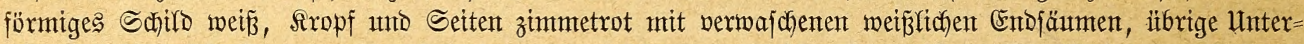

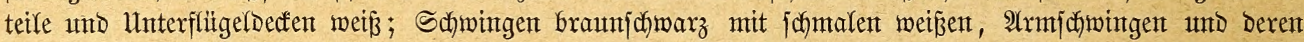

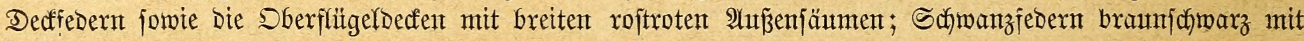

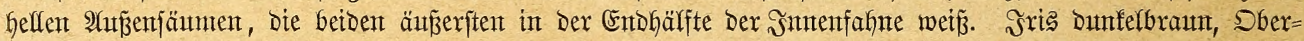

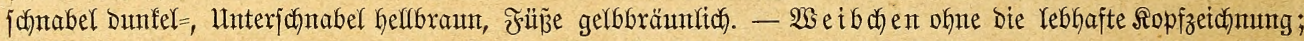

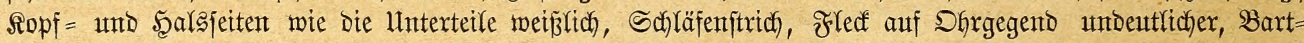

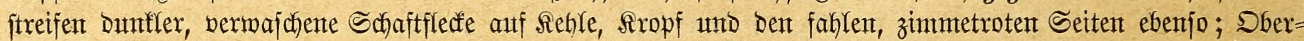

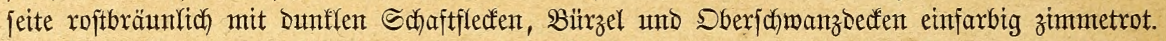

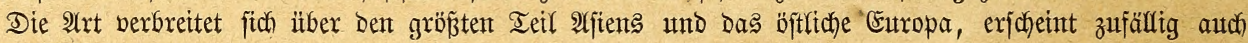
in Deutfich)(anti.

574. Der $\mathfrak{B a f b m m m e r , ~ E . ~ ( H y p o c e n t o r , ~ C y n c h r a m u s ) ~ r u s t i c a , ~ P a l l . , ~ ( b o r e a l i s , ~ l e s b i a , ~ p r o - ~}$

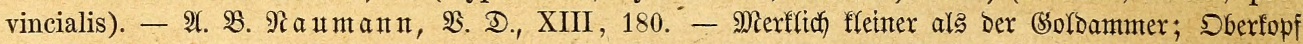

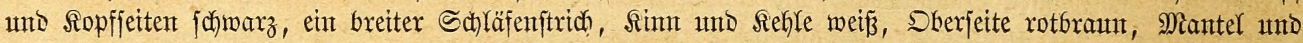
Sd)uftern mit breiten fdwarzen Sdhaftflecfen, ein breites Suterbanto über bem Sropf und untere Seiten

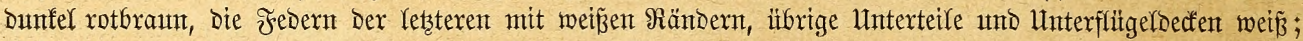

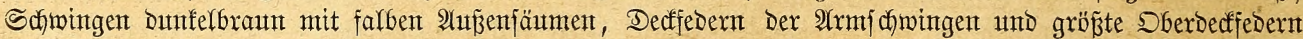

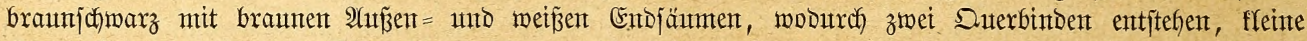
Sberdedfebern rotbraut; Steuterfedern fadwarz, Die beiden mittefften braut gerandet, bie beiden äuberften

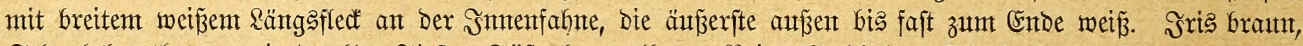

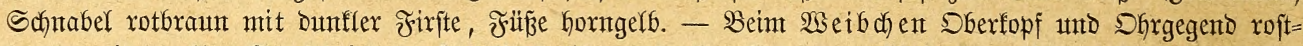

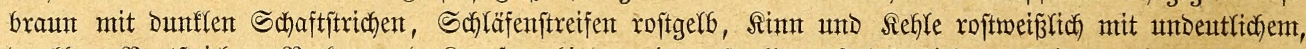

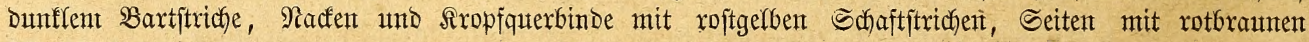
Rängsflectent.

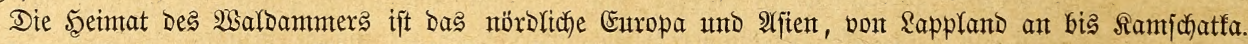

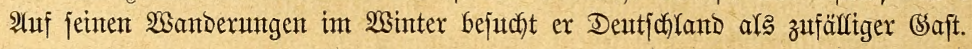

575. Der Feljentumer, E. fueata, Pall. - 2 . 2 . Zoogr. rossic., II, 4 ᄂ. - Dent $\mathfrak{E a l d}=$ ammer fehr ähnlich, aber bie Shrgegend rotbraum, ein fie einfaffenter Streifen, weldjer ant Unterfonnabel

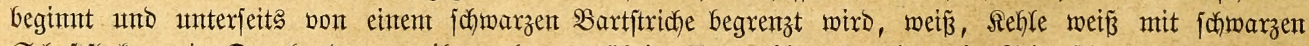

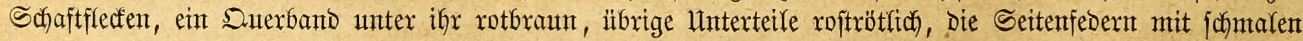

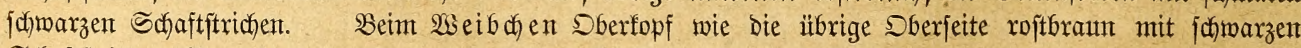

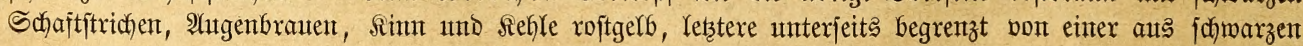




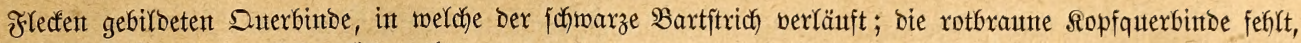
ber Dhrfled" Dagegent ift Deutfich) rotbraut.

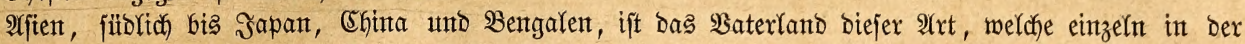
Srim unto int (siriedfentano vorgefontment fein folf.

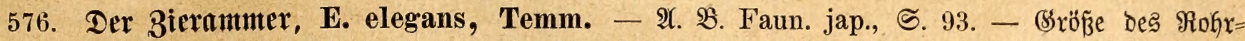

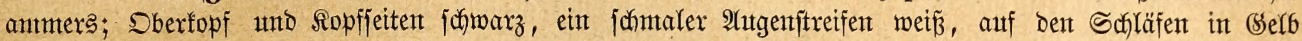

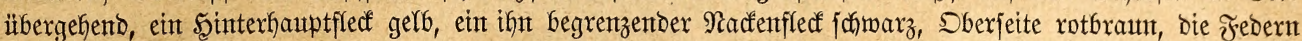

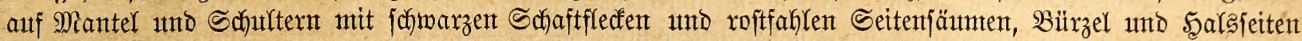

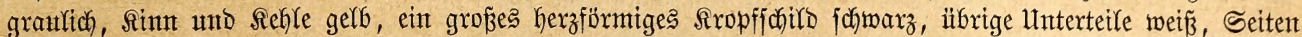

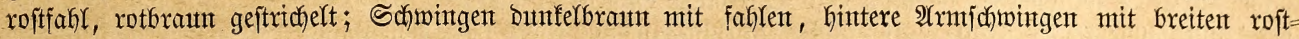

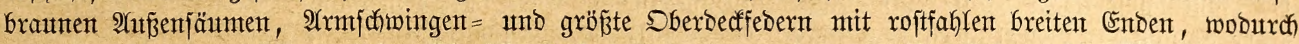

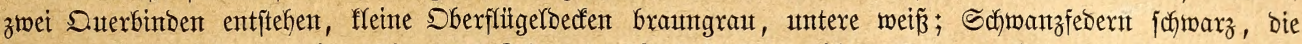

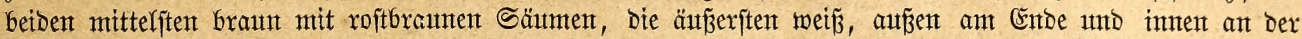

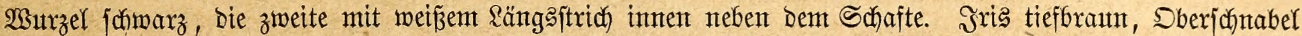

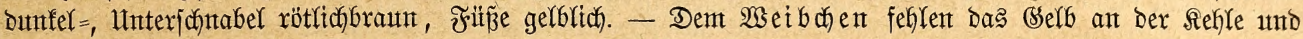

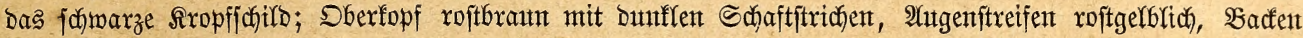
unt Dhrgegent fadwarzbraut.

Japant und 2 tmutrfatto.

577. Der (Sofngratentammer, E. (Hyp.) chrysophrys, Pall. - - $\mathfrak{B}$. Deglant tt tho Berbe,

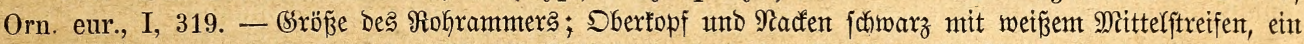
ant oberen 2 tugenrantbe begintenter, über bie Schläfen verfaufenter Streifent gerb, 3ügel unb bie (Begent unter

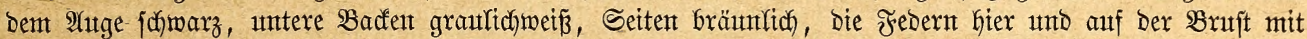

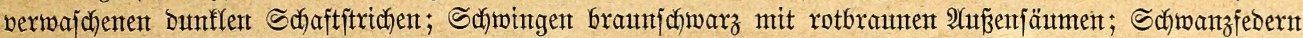

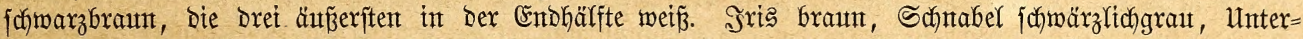

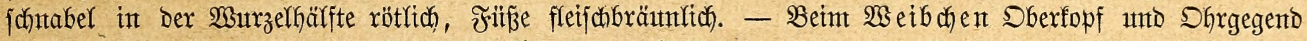

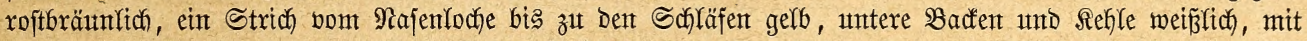

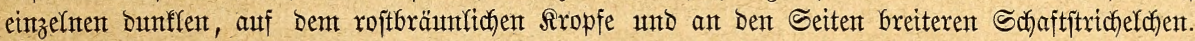

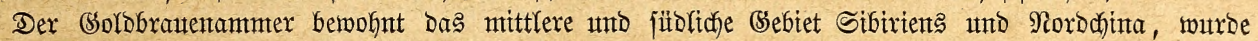
jeoodh einmal bei siffe in einemt Netzè gefangent.

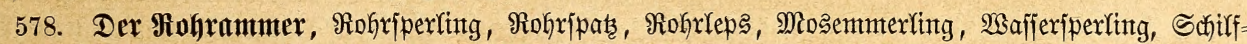
vogel, Schiebchen tr. f. w., E. (Cynchr., Hortulanus, Buscarla, Schoenicola) schoeniclus, L., (arundi-

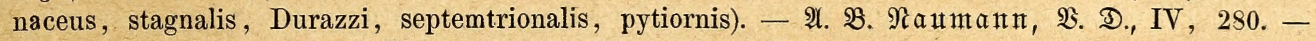

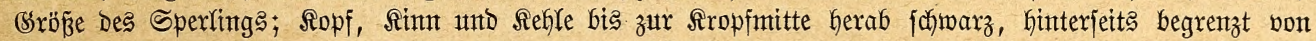

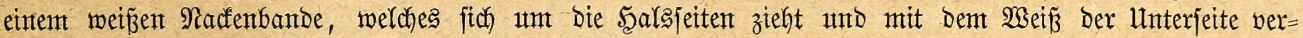

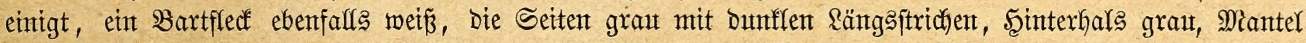

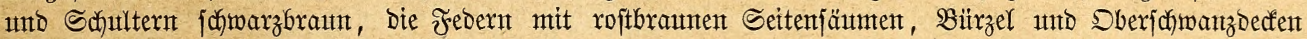

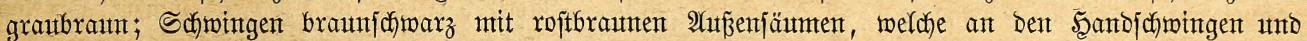

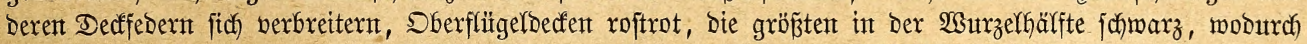

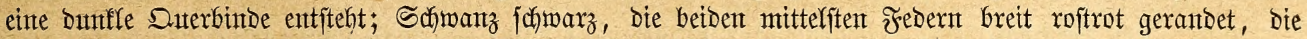

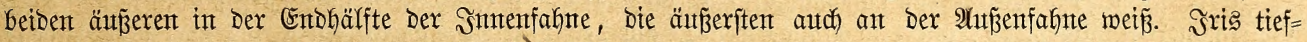

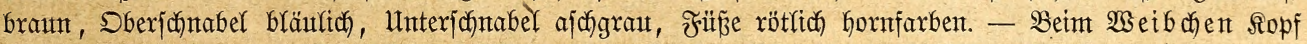

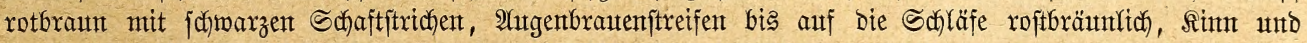

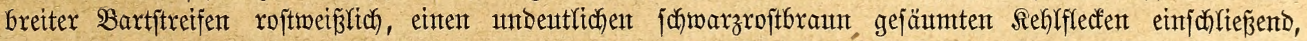

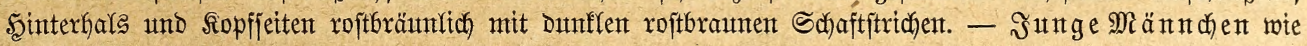
Die 2 seibditent.

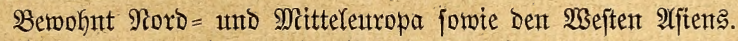

579. Der (5impelantmer, E. (Cynchr., Schön.)) pyrrhuloides, Pall., (palustris, intermedia,

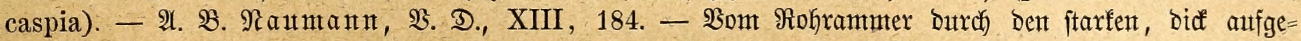

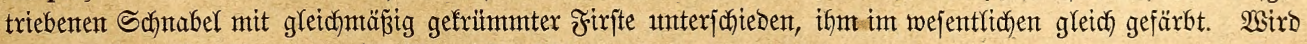

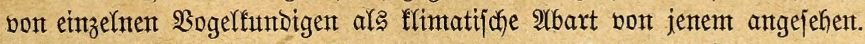

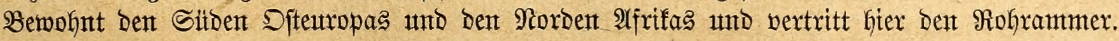

580. Der Sperlinganmmer, E. passerina, Gml., (polaris). - $\mathfrak{A} . \mathfrak{B}$ Midoendorf, Sibirifdue

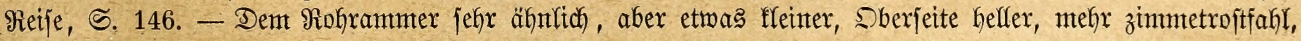

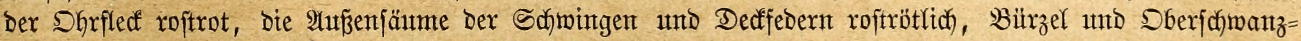

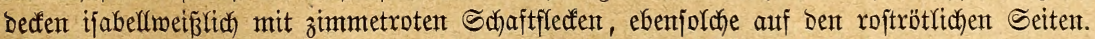

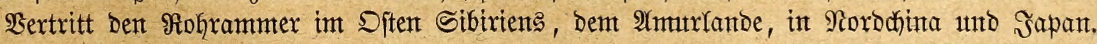


581. Der 3mergammer, E. (Eusp., Cynchr., Ocyris) pusilla, Pall., (sordida, oinops). -

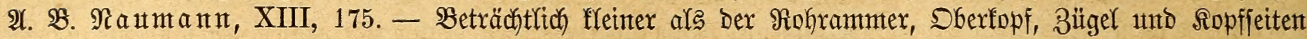

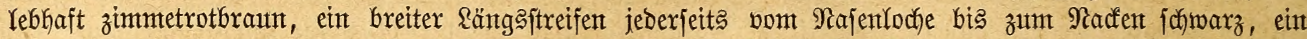

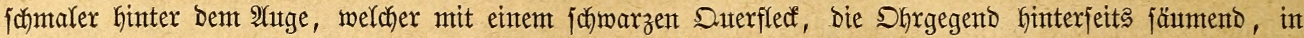
Berbindung fteht, ebenio, ein Duterftreifen an Den Sabsfeiten rötfich, Dberjeite braut, Die. Febern auf

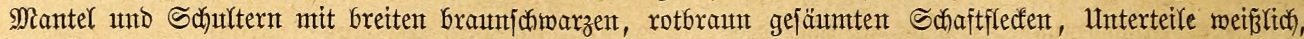

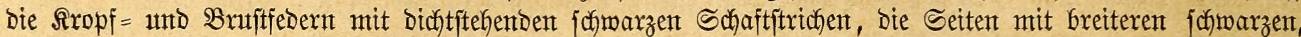

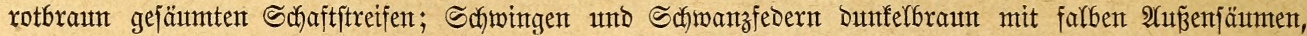

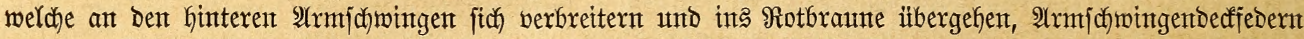

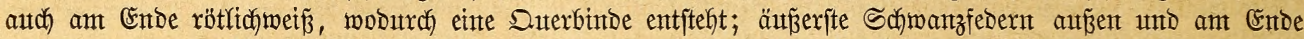

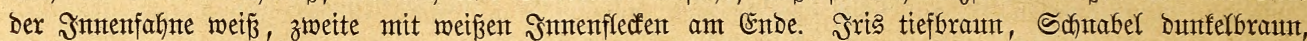

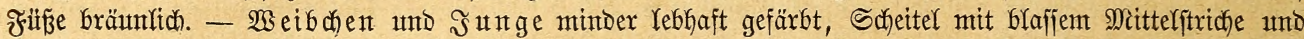

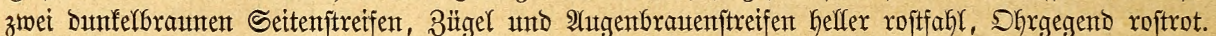

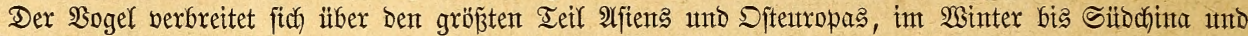

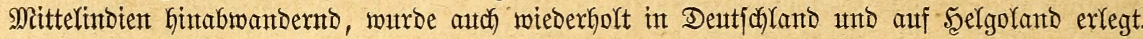

582. Der $\mathfrak{B e i D e n t a m m e r , ~ E . ~ ( E u s p . , ~ H y p . , ~ P a s s e r i n a ) ~ a u r e o l a , ~ P a l l . , ~ ( s i b i r i c a , ~ p i n e t o r u m , ~}$

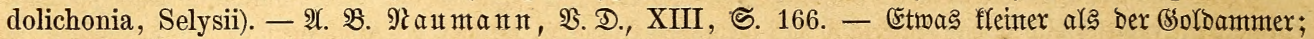
Dherjeite, ein Duterbant unter Der gelfen Refle unt Ropffeiten tief rotbrant, Mantel und Sdyulterfedern

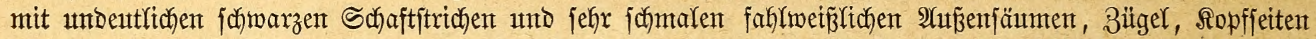

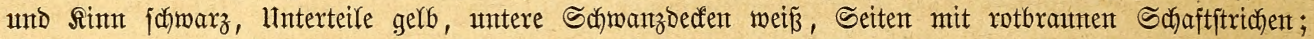

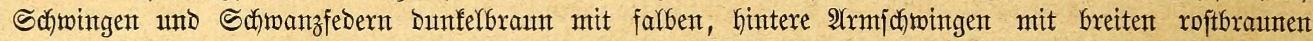

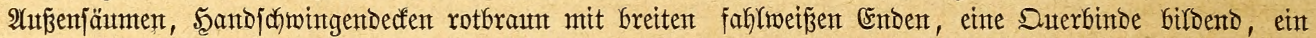

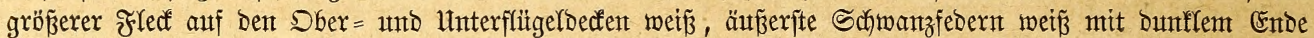

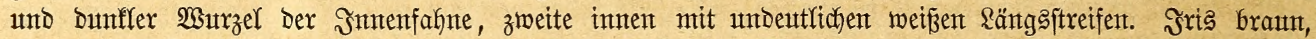

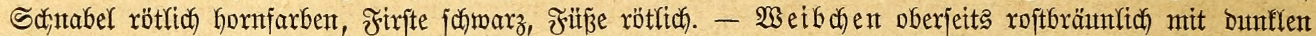

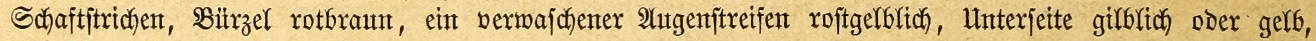

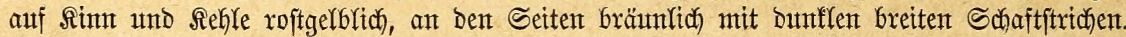

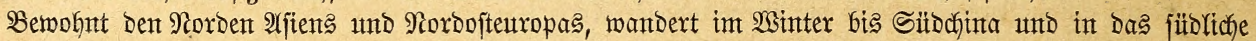
Scimalayagebiet Ginab, verfliegt fich aber zutmeilent auth bis nach Deuttjalanto.

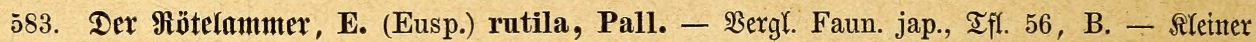

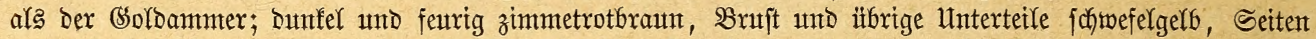

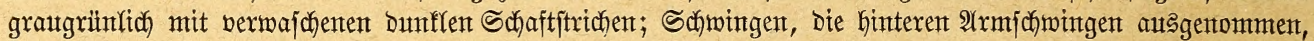

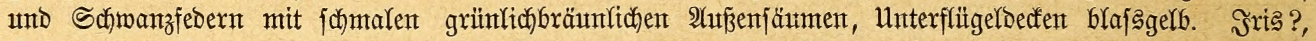

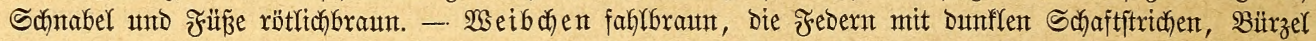

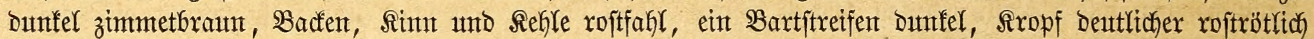
mit bunffent S(h)aftftrid)en, übrige Unterteile blafsgelb, Seiten bräınlich dunfel gę̣treift.

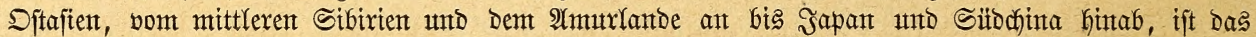
Waterlanto biejer $\mathfrak{2}$ rt.

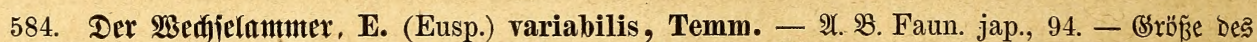

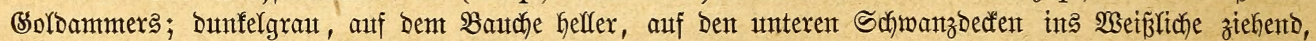
Mantel umb Sdyuttern mit breitent fdiwarzen Sdfaftitrichen; Sdjwingen jobwarzbrautn mit falben, hintere

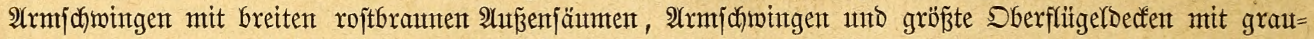

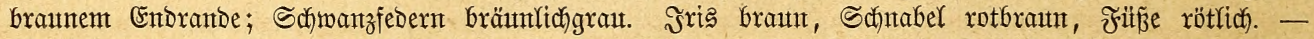

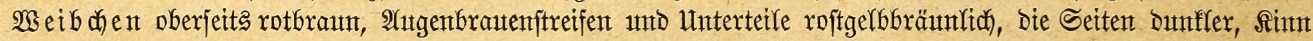

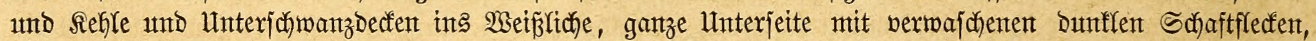

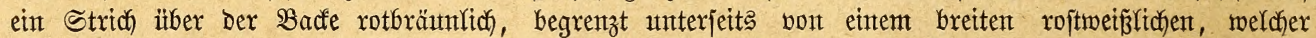

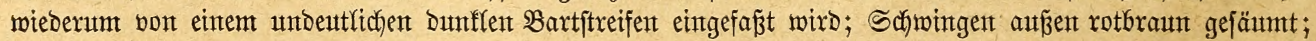
Sadwanzfedern rotbrautn.

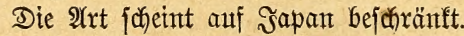

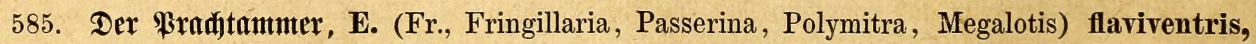
Vieill., (capensis, flavigaster, bicincta, quinquevittata, xanthogastra, albicollis, affinis). $-\mathfrak{A}$. $\mathfrak{B}$.

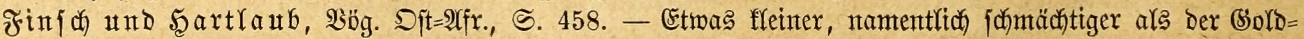

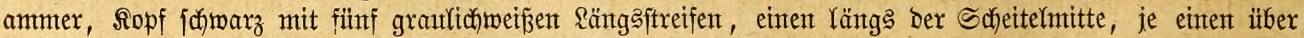

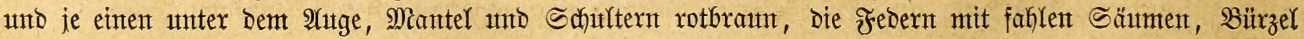

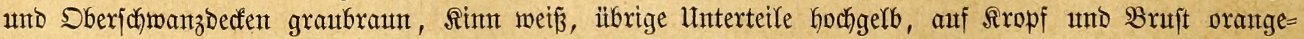

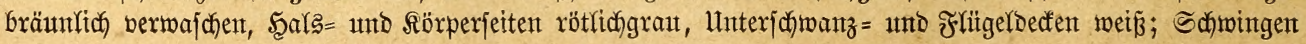




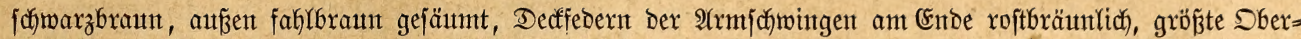

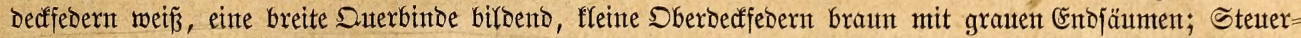

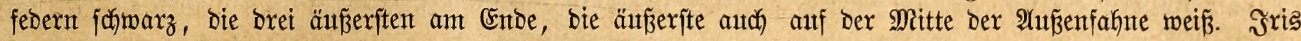

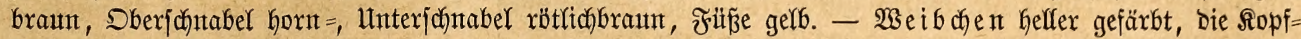
ftreifent $\mathfrak{b l a}\{\mathfrak{s} r o t$.

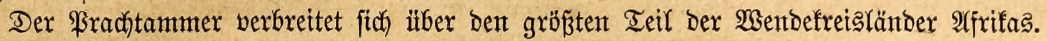

586. Der Streifentummer, E. (Fr., Fringillaria, Polym.) striolata, Licht., (Saharae). - $\mathfrak{A} . \mathfrak{B}$.

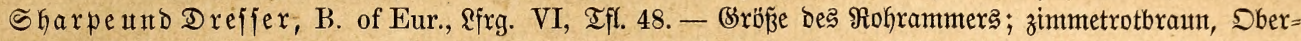

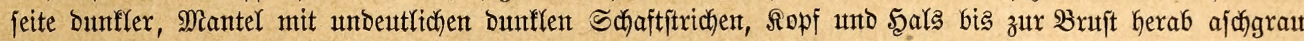

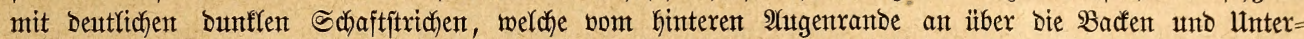

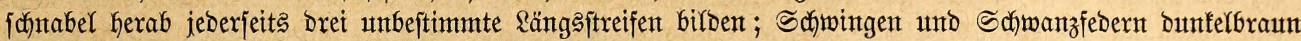

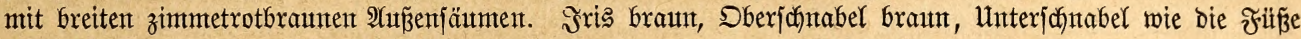
horngelb. - Weibchen matter gefärbt.

Der in 2 Irgerien vorfommente Saharaammer (E. - Polym. - Saharae) interjacidet fich faft nur

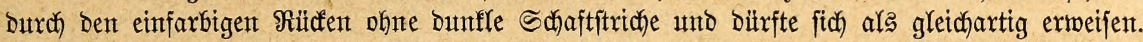

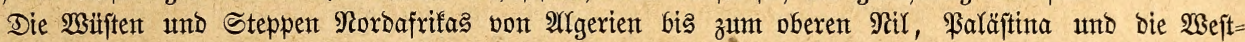

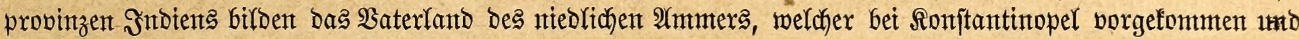
Deshalb z̆t Dent eurropäif́chent $\mathfrak{B}$ ögeln gezählt worbent ift.

587. Der $\mathfrak{B u ̈ i t e n}=$ voer Siebenitreifenammer E. (Fringillaria, Polym.) tahapisi, Smith,

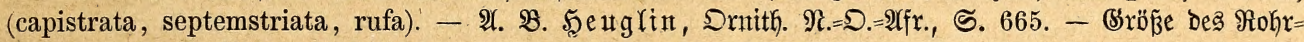

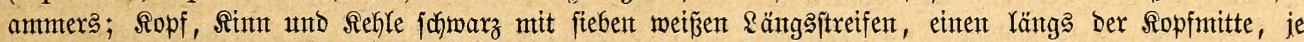

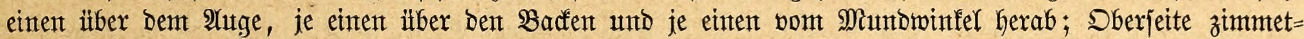

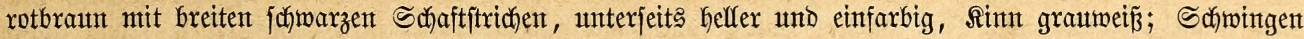

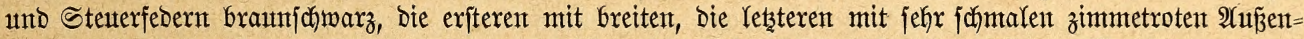

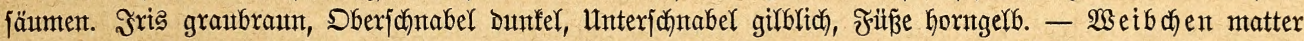

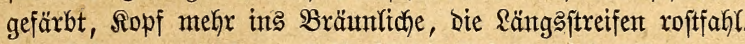

Mittel = unb Inturafrifa ift bie Secimat biefer $\mathfrak{2}$ rt.

588. Der finfferammer, E. (Fringillaria) capensis, L., (erythroptera, caffrariensis, vittata). -

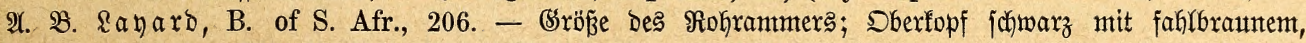

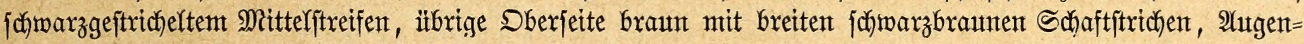

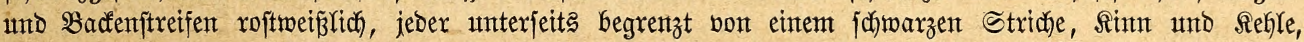

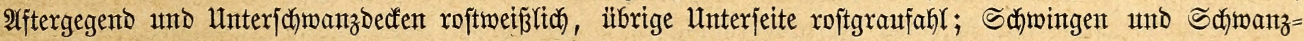

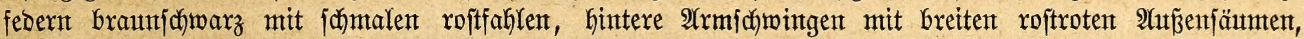

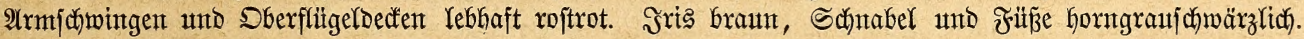

BewoGnt Sitbafrifa.

Schlanfer, geftrectter, jeitlich zujammengebrüdfter Schnabel, befjen Sberfiefer nake ber

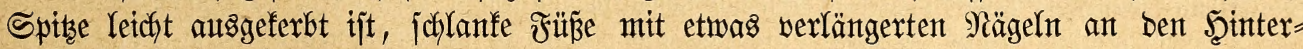
zehen, jefr furze Flügel, breiter, geraber Schwanz und eine auf bem Borberfopfe jitch ex= hebende, aus harigen Febern gebildete Şaube fint bie Merfintale ber Şaubenammer, von benen bis jebt nur eine 2 rtt befannt murbe.

589. Der 5athenanmer, Melophus (Fr., Eusp.) melanicterus, Gml., (Lathami, cristata, sub-

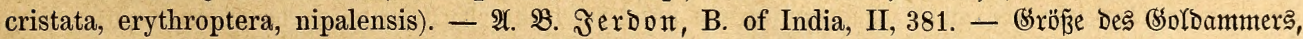

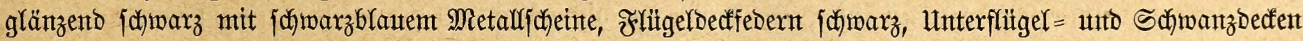

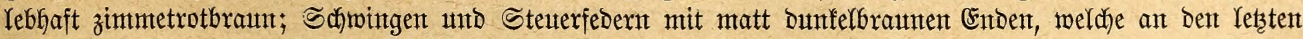

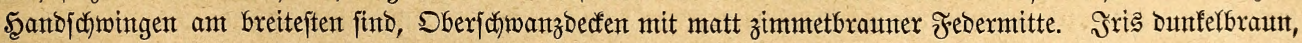

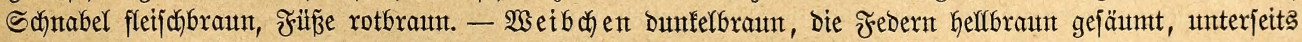

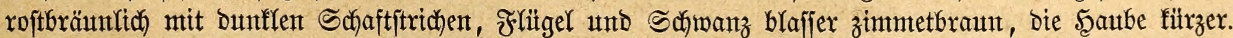

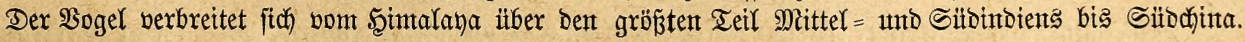

Sporentammer heižen einige bem Norben ber Erobe angehörige, im Siten wie im Weiten vorfommende A(rten ber Familie, weldye jitc fennzeidynen burds itumpffegeligen, jeitlich jefyr zujammengebrïften, an ben Sdynetben jtarf eingezogenen, jtumpfipizigen Sdynabel mit

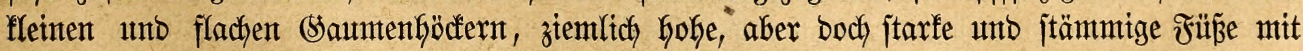

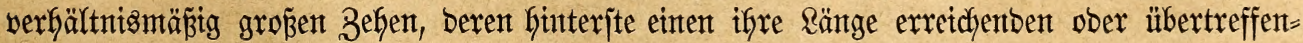




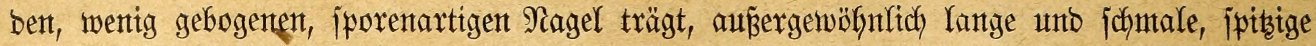
Flïgel, unter beren Sdymingen bie beiben erjten bie längiten jinto, furzen, am Enbe ausge= jaynittenten Sibwanz and ein reiches Feberfleto.

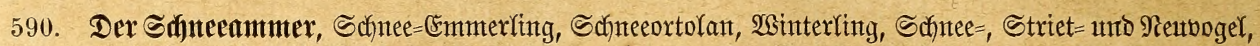
Eiฐammer, Plectrophanes, (E., Passerina) nivalis, L., (montana, mustelina, glacialis, borealis). -

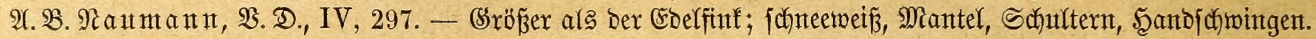

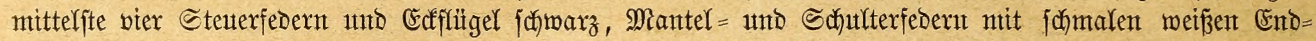

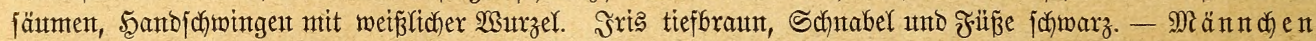

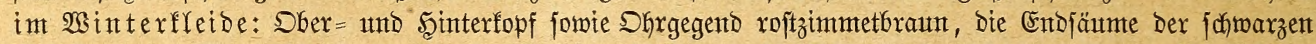
Sdyttter = und Mantelfedern ebemfo, eine Sropfauterbinde und bie Seitent roftgelbfich) angeflogen, bie äuferen

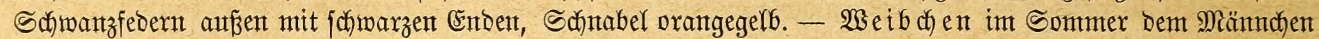

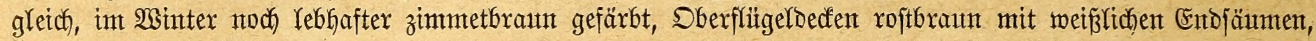
Das Safwarz am Ende Der Schwanzfedern breiter.

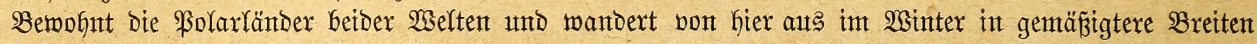

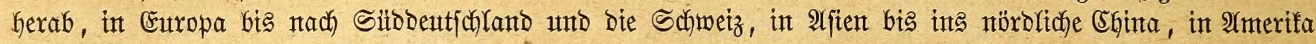
bis in bie mittlerett $\mathfrak{B}$ ereinigten Staten.

591. Der Sporentumuter, Rerchenantmer, Sporenfinf, \&appläntox, PI. (Fr., E., Passerina, Cen-

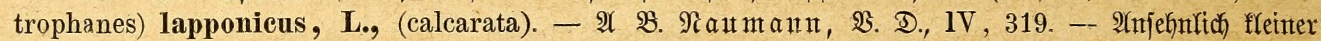

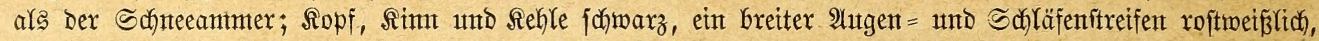

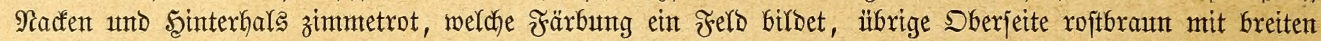

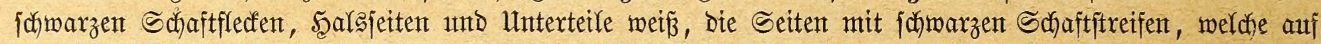

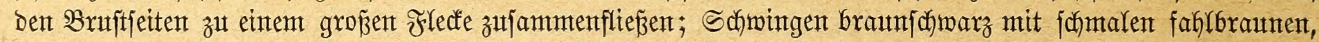

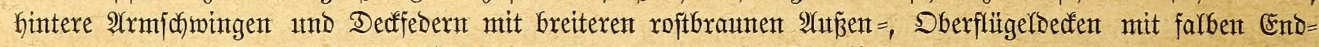

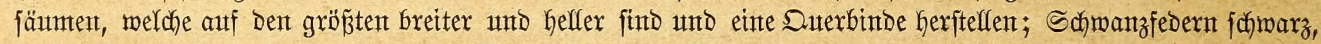

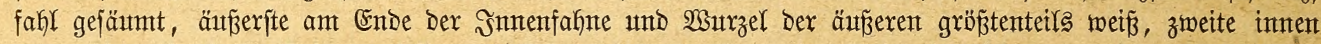

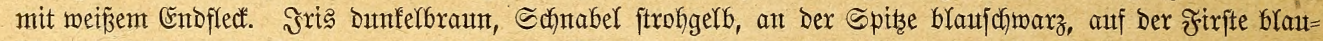

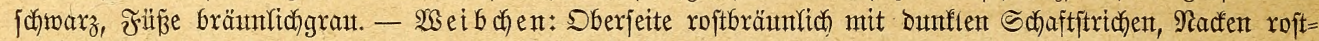

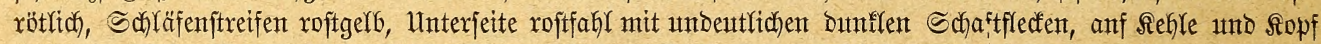

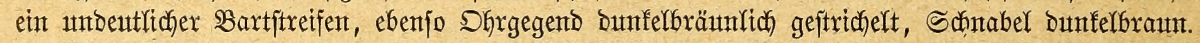

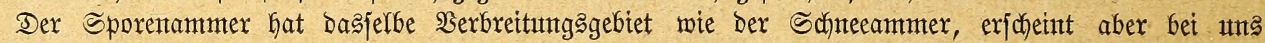
itigleid' feltenter.

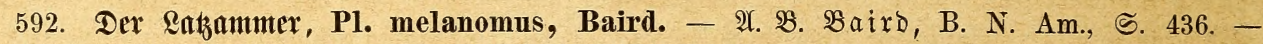

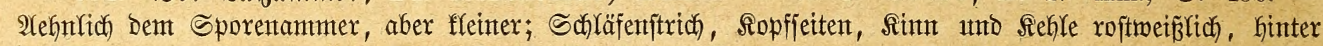

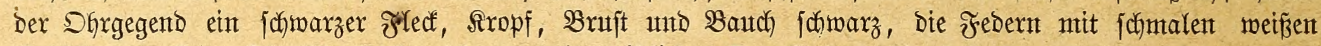

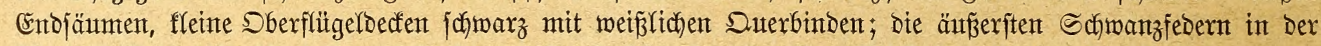

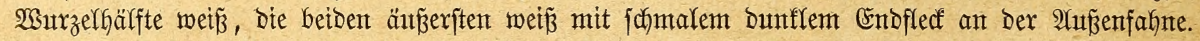

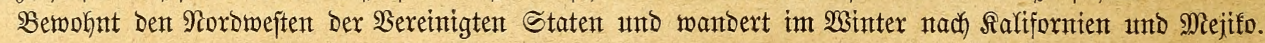

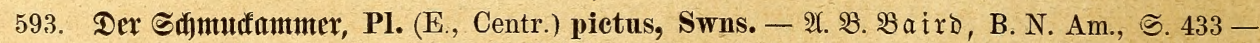

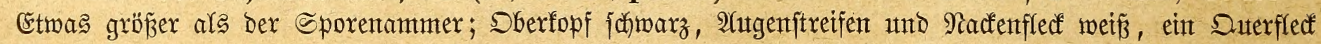

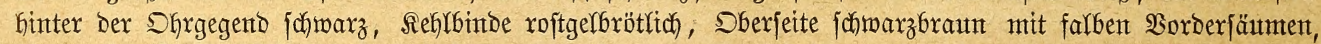

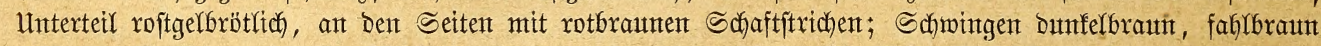

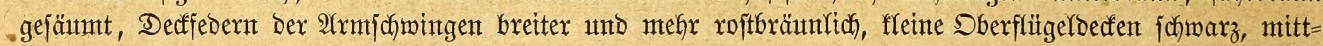

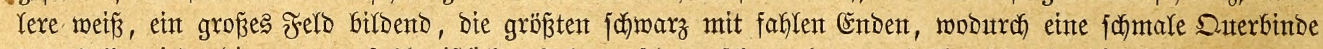

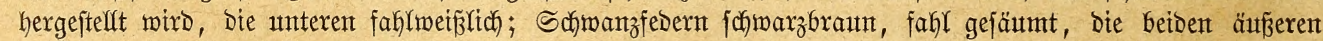

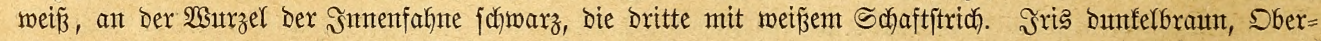

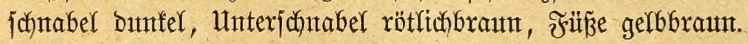

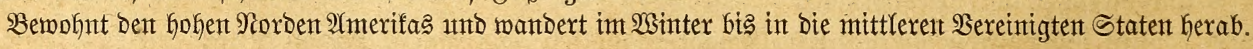

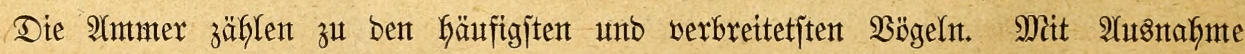
2ujtraliens und ber benachbarten Eilande bewofnen jie affe Eroteile unt in biejen alle

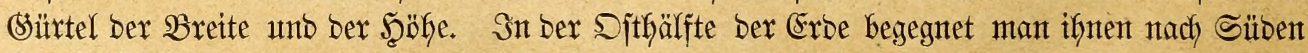

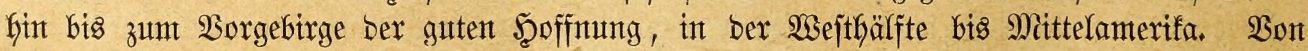

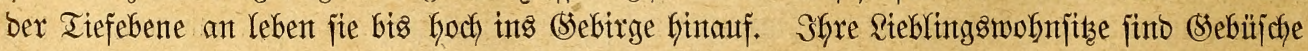

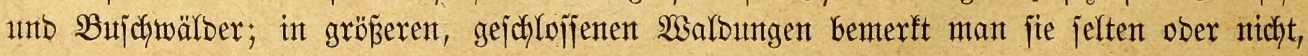




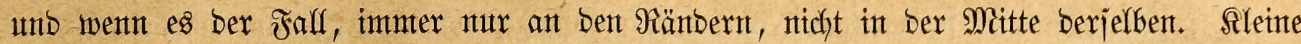

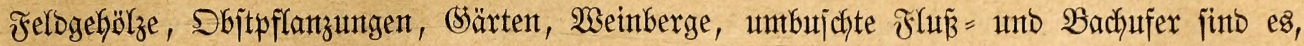

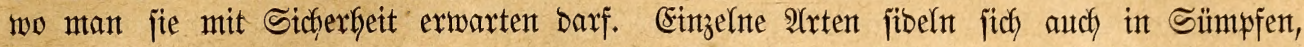

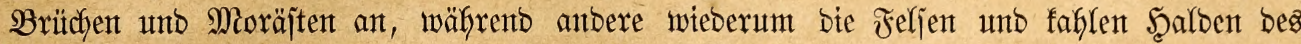

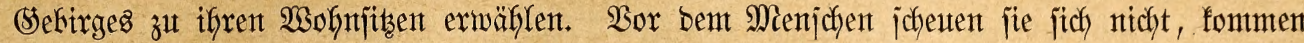

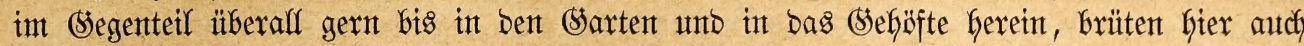
wohl unb zäflen baher zu bent unts ant meiften befreutbeten Rörnerfrefiern.

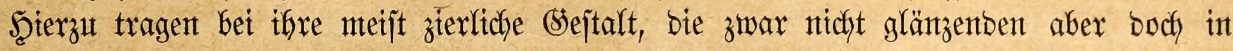

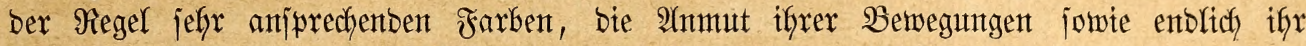
wenn auth bejcheibener, jo boch angentefint ins Shr flingentor (sejantg. Sie zählen zu ben

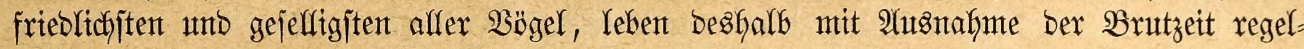

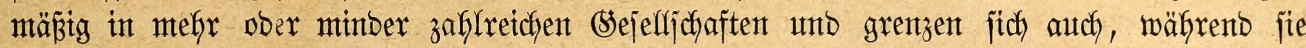

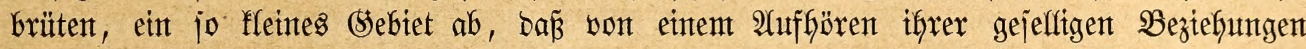

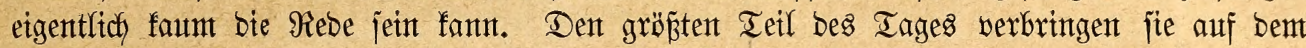

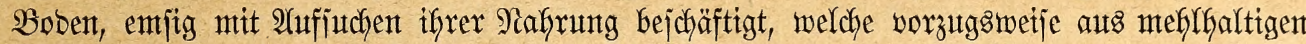

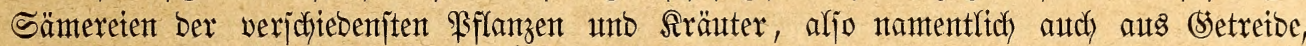

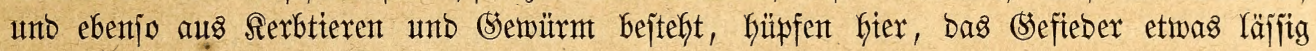

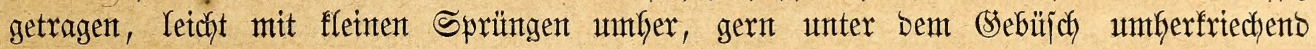

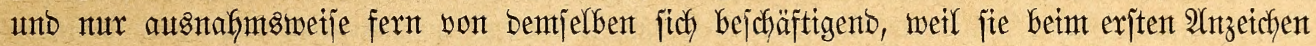

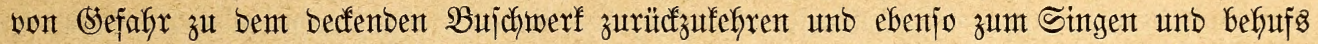

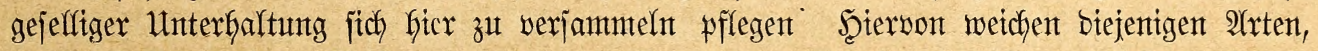
welche Bebirgabfalben, WBüftent unt anbere pflanzentarme Strecfen bewofnten, injofernt ab, als

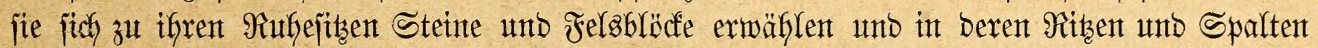

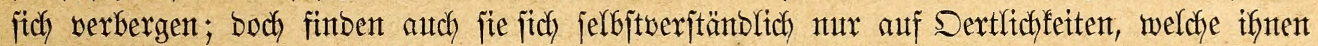
bie Miöglichfeit zum Reben gemähren, b. h. mit nieberen, jamentragenden $\mathfrak{B f l a n z e n , ~ u n t o ~}$

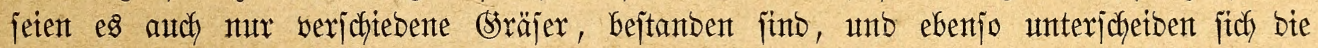
Irten, weldhe ebene Feloer ober aber Süntwfe unt Brüche bemofynen, in gemififer Şinficht

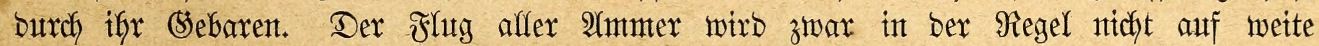

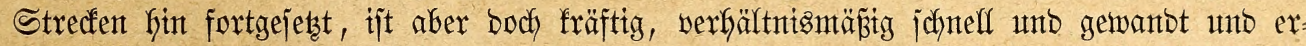

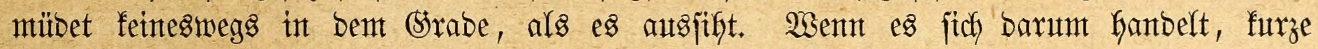

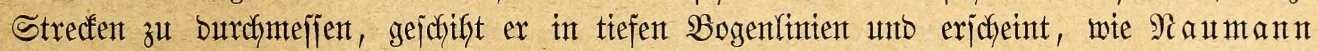
jagt, hü̈pfent unto untgeregelt; beint Durchmefien gröBerer (Entfermutngen bagegent flachen fich

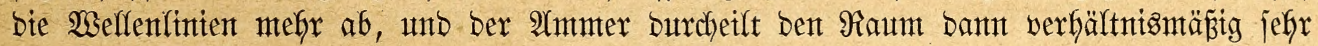

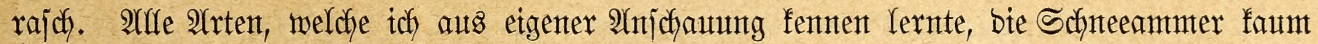

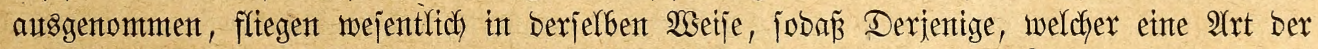

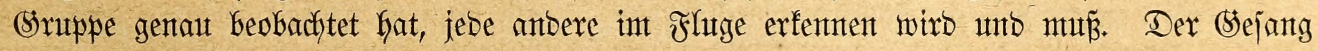
bejteft aus furzen Strophen, weldhe ftets twieberfolt unb häbjitens burch ben Rodfton ver=

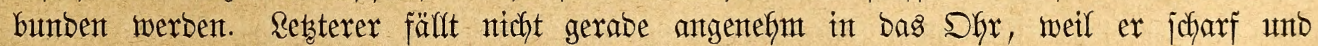

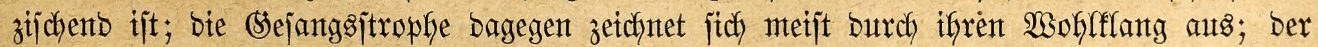

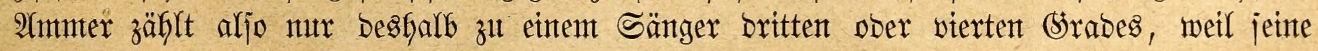
(Sejangşitrophe gar zu futrz ift.

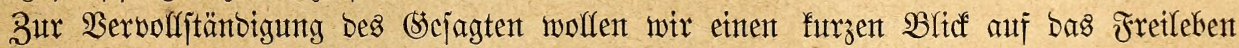
Der einzelnen 2 rten werfen, joweit bies bei bem gegenwärtigen Stanbe unjerer Rentnis

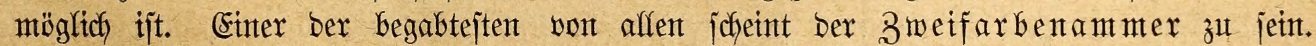
Nuttarl nente ifgn einten ber bejten ober, wie er jagt, "jü̈ßejten" Sänger ber Frairte;

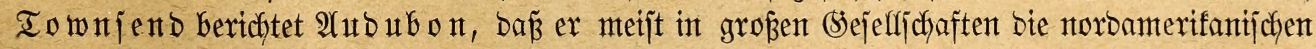
Steppen betwohnt, Yerchenartig auf bene Boben umberfhüpft unt fich mit bent (Srazanmer=

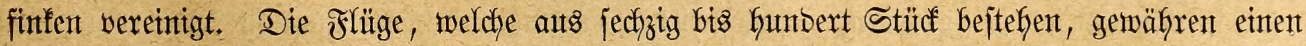




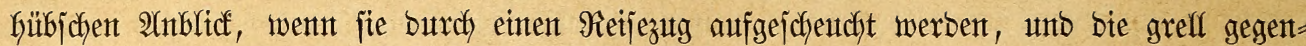

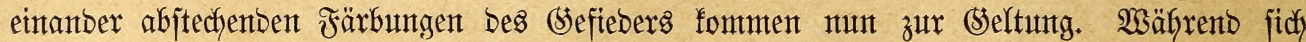

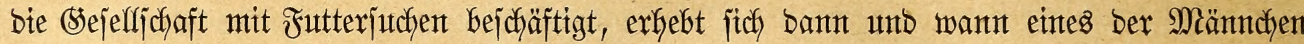

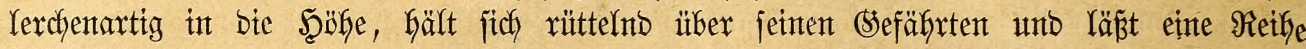

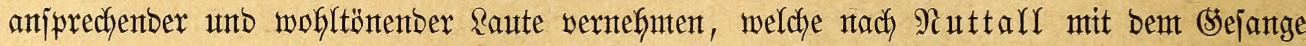

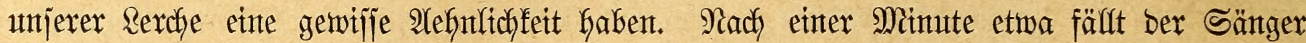

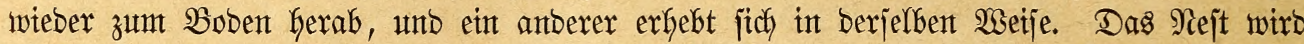

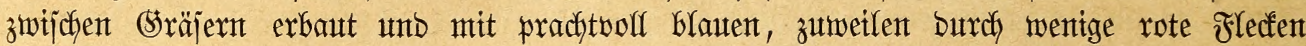

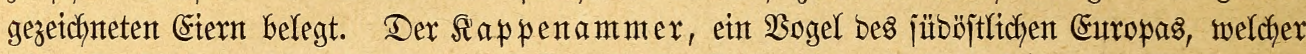

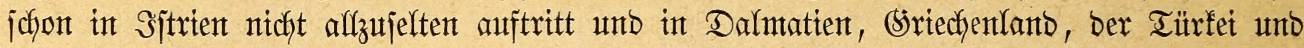

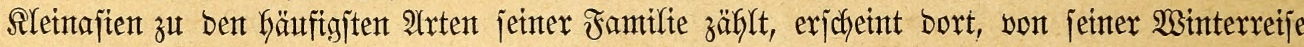

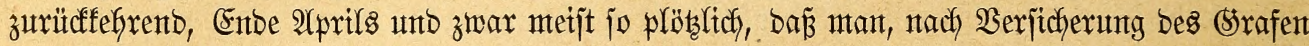

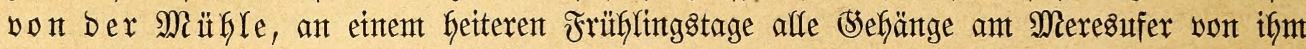

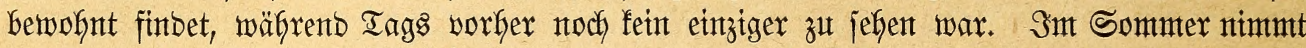

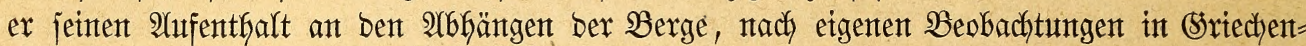

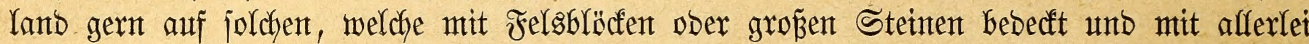

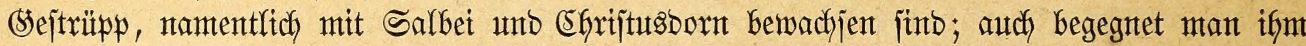

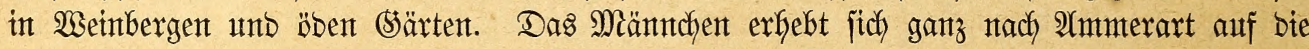

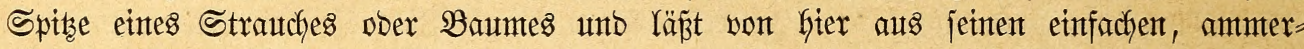

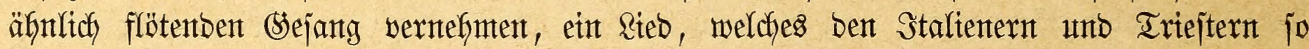

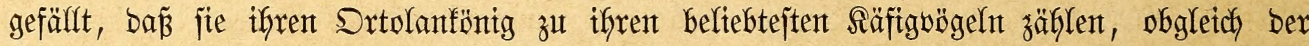
Bejang ben unteres Boldoanmers, went autch etwas an Fitfle ber Töne, jo boch faum an

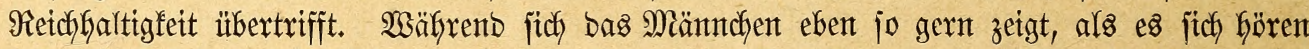

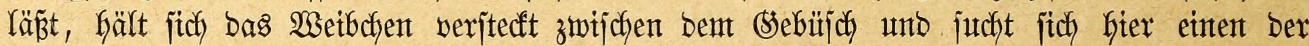

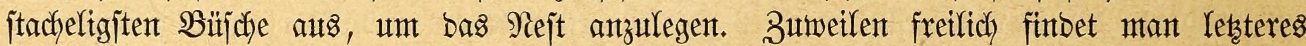

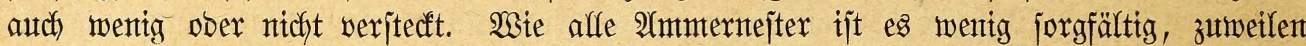

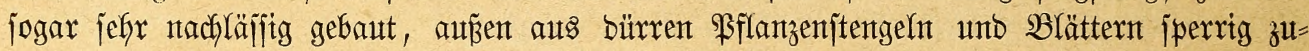

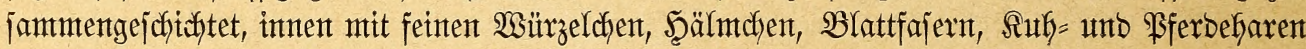

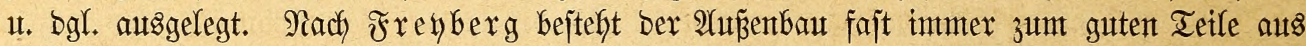
Fajern ber verfaulten 2 gaweblätter; boch werben biejelbent nut bant benutbet, went fie vont Regent ober Taut bentegt worben fitto ober an feutchten Srten gelegen haben. Das Mitte

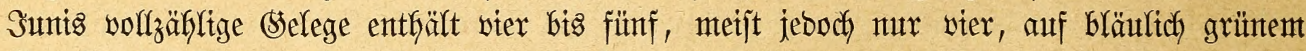

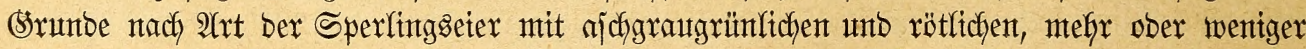
abä̈bernbent Fllecfent gezetdyntete, wentig glänzente Eier. "Dieje", fügt Freyberg hinzu,

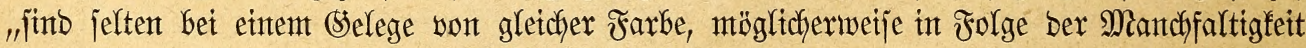

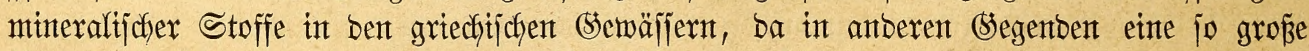
Beränberfidyfeet nicht bemerft worben jein jolf. Das AYeib ber Sungen bejtefft in bent eritent

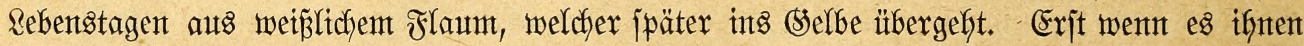

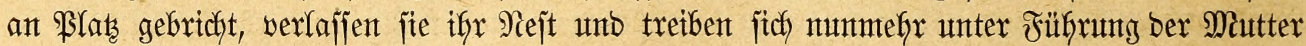

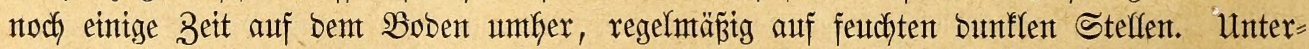

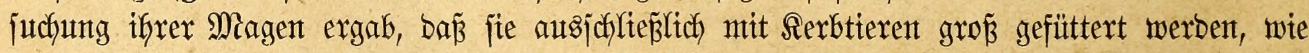

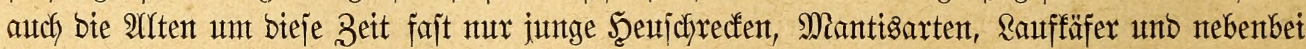

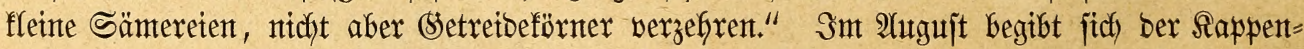

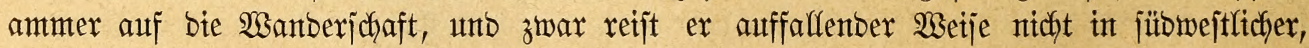

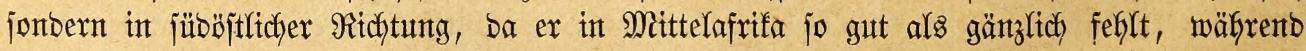

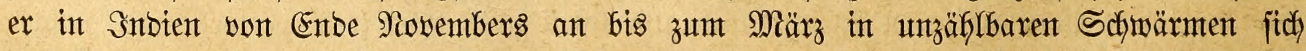

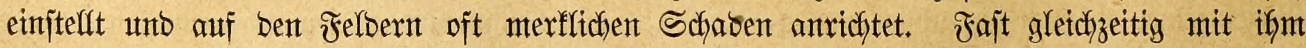

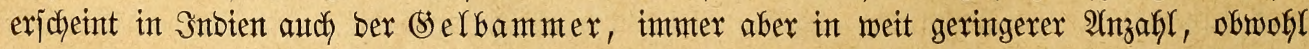




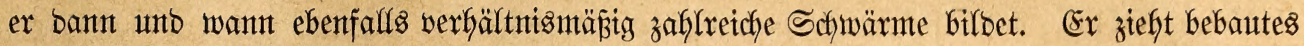

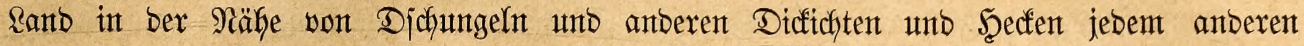

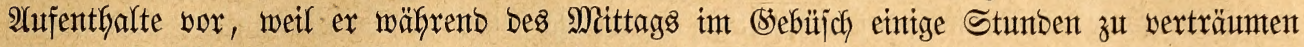
pflegt. Sn 2ffganifitan trifft er int 2(pril ein unt verweilt bajelbjt bis zumt Şerbjt. Nach

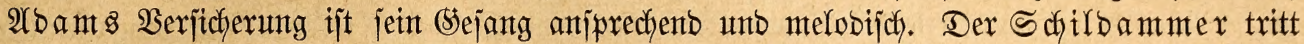

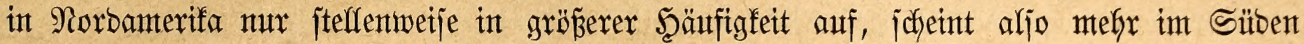
Des Ranbes, insbejontoere in Tejas jeine Seeimat zu haben. Sn ben mittferen Statent

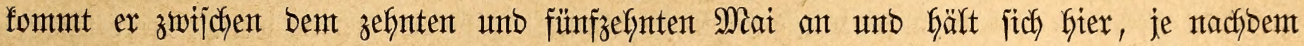
ber Seerbit mtefyr boer wentger günftig, bis zum Septemtber ober Dftober auf. Snt Sunt finbet mant ifgn brütento auf jeinem auz feinen (Sräjern jefr nett erbauteten Nejejte, weldjes

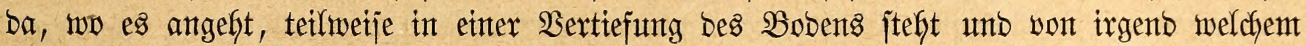
gFflanzenthlatte mefyr ober minber werborgen ober boch überbectt wirb. Die wier bis fünf

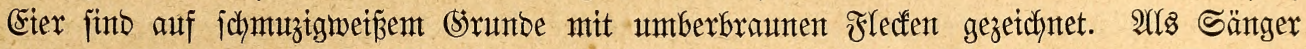

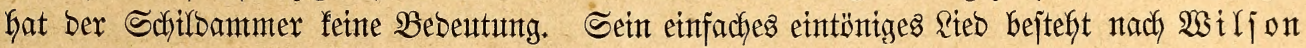

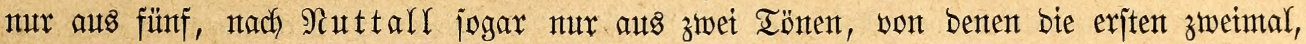
bie anberen breimal wiebergolt unt jente in langjanter, bieje aber in jojntelfer Folge

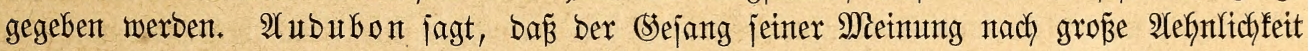
mit bem bes Srauammers habe unt er of́t an biejent erinnert worben jei, went er jenen

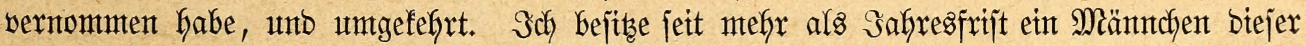

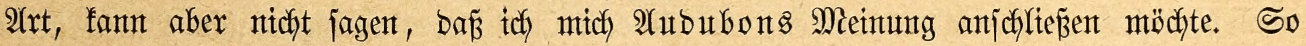

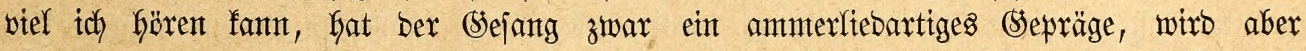

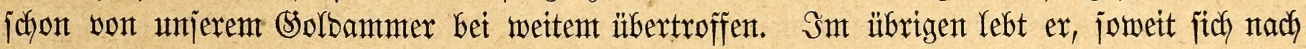

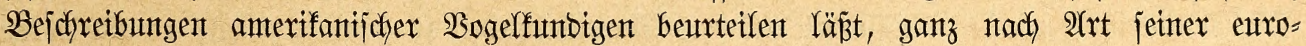

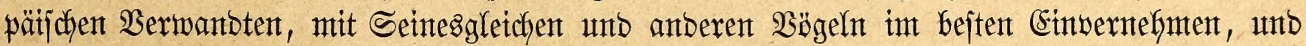

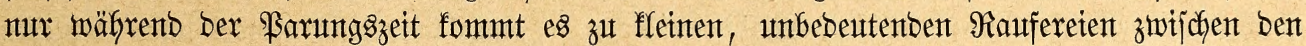

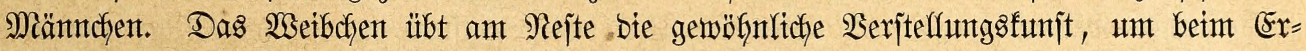
icheinent eines Feinbes biejent jomeit als möglich abzuffaltent.

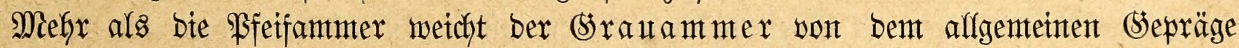

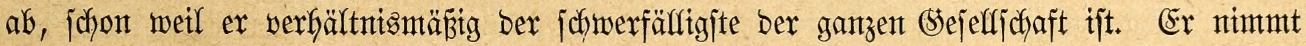

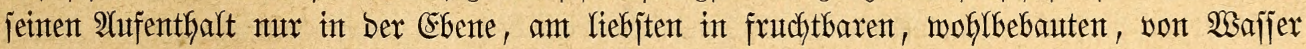

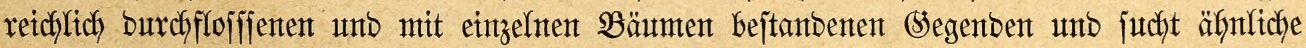

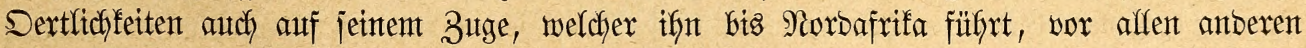

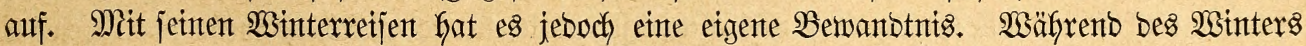

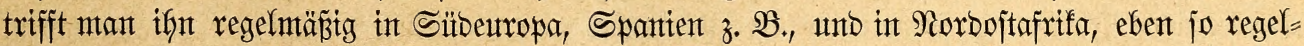

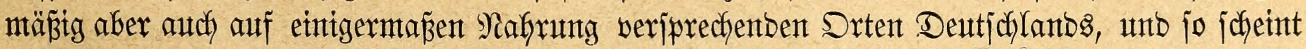

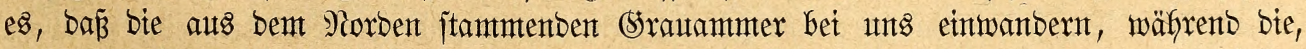

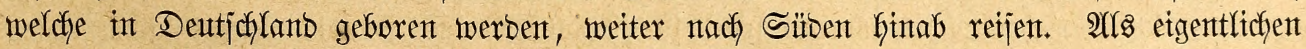

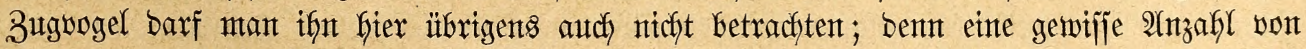
(Sratammtern berweilen jafraus jafreein in Sübeuropa uno brüten Gier ebenjo gut als bei

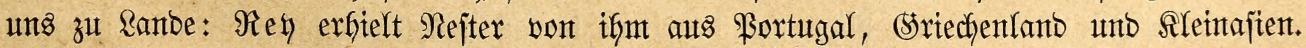

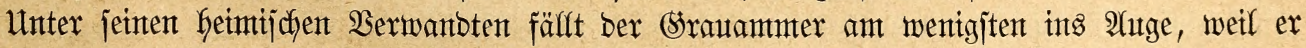

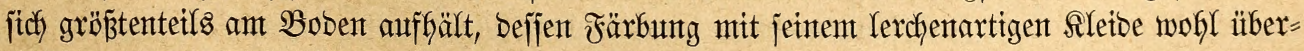

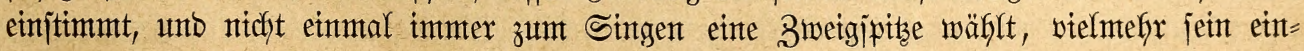

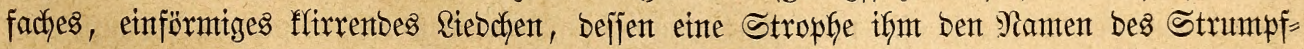

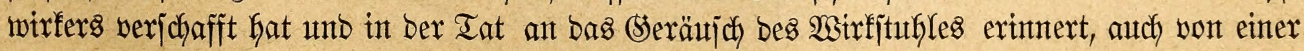

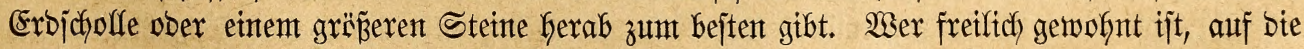

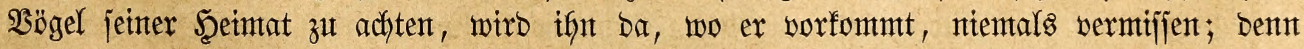

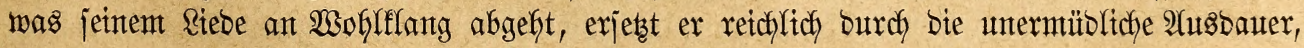


mit welcher er es vorträgt. Âtuch nimmt ex imt Sibent jo eigentümlidye Stellungen an,

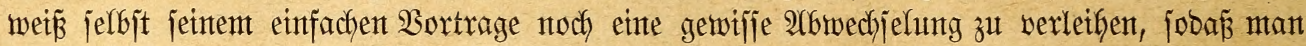

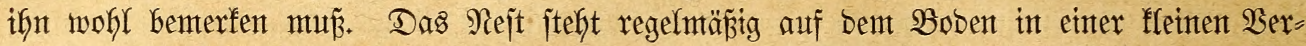
tiefuntg zwifchen (Sräjern ober anberen \$fflanzen, ijt ein gröperer, aus grobent Stoffen, Şalmen, Srä̈ern, Stoppeln, trodfenen Sragblättern, funftlos Gergeridfteter, mur innen eintgermaß̌en glatt unt zierlich ausgelegter Bau und entbält vom 2 (prif an in ben Früblingş= unb erjten

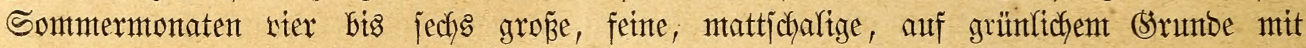

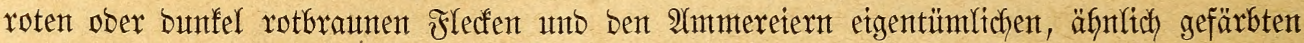

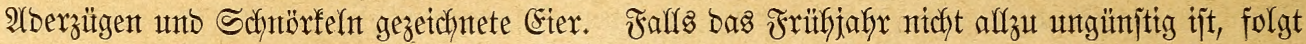
auf bie erjte Brut einte zweite; Die Bermefrung ber Art ijt aljo eine ziemtich bebentende. Unjer (5) oldammex, in mefr als einer Setnjicht für uns das Urbilo ber ganzent sejeflichaft, bewofhnt, wie benterft, fait ganz Europa, objchon ben Göheren Norben unto äuperiten

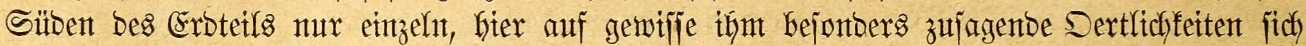

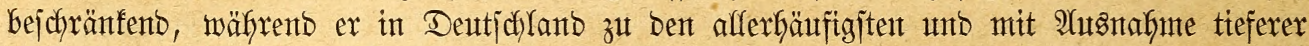

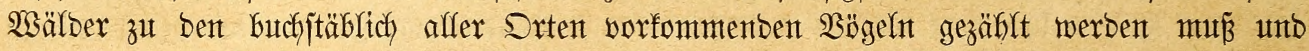

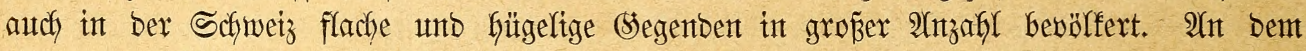

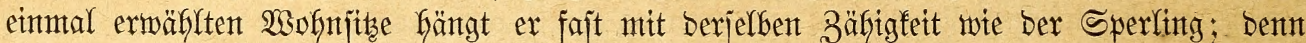

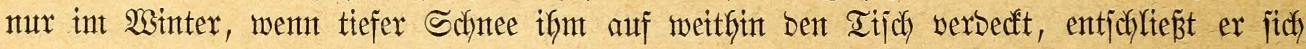
zu furzen Streifzügen in ber 2(Gjicht, günfitigere Sertlicbfeiten aufzujucthen, unt fommt bant auth als gern gejefener Bettler maffenfaft in bie (seböfte unto nor bie Scheunten bes Ranto= mannes. Währento bes Sommers jutbt er jich am liebjten ba jemen Stand, wo (siebüjche unt Felogebölze mit Felbern und Wiejen abwedjeln unt es an eintem Wäfferchen nicht feblt.

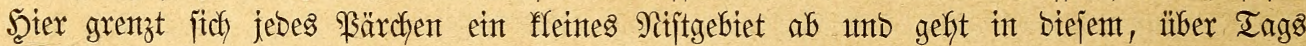

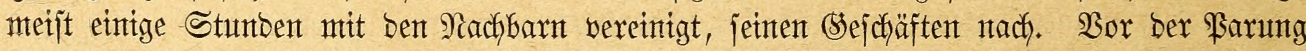
gibt es unter ben Männthen zwar ebenfalfs Streit unto Scaber, zumeilen jogar Sämpfe, weldye mit volfiter Erbitterung gefodjten werben; Dody gejchefhen bieje ausichlieklich in Sachen ber Minne, unt int affgemteintent barf mant ben (5olbammer als einten unjerer friebliebenjten Bögel bezetchnten. Şat jich bas Männchen erit glïfflich ein Weibchen erworben und bas

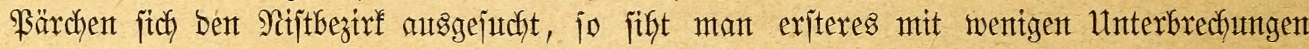
auf eitter ber herworragentojten 3weigjpizen fizen, um fier zu fingen; es idfweigt ïberhaupt

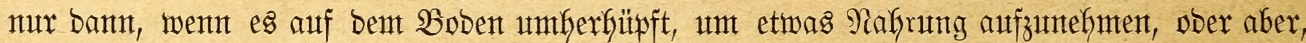

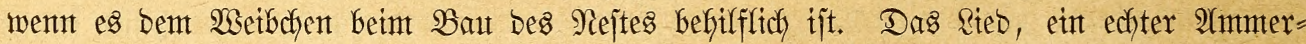
gejang, bejteht aus etner zwar furzen, fïr mein Dhr aber entichiebent wohllautenden Strophe, weldye das $\mathfrak{B o l f}$ jdyon längit, am bejten aber Mojen burdh bie Worte: "Wite, wie Kab" ich) bich lieb!" überjebt hat. Selbjt unter (solbammern gibt es Sïnjtler und Stümper;

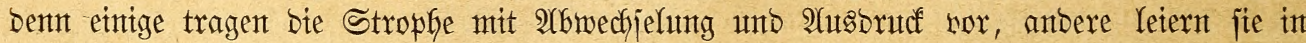
gerabeju langweiliger Weije Ger. Das Nejt wirb int (Sebilich, am. liebjten wohl auf alten,

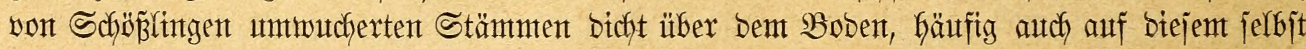

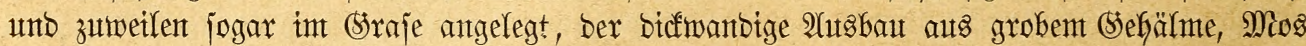

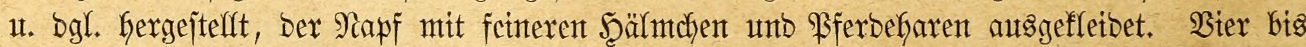
fünf feinjchalige, auf jchntuzigrötfichen, graut= ober trübweiß̄em (Srunbe mit violettgrauen, rötlidfen, rot = ober bunfelbraunten \$unften, Fledfen, Sdymitzen unt Şarzügen gezeidyntete

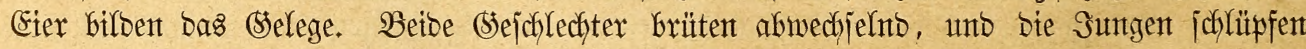
nach) breizehn ober vierzefn Iagen aus, worauf bie Gettern regelmäpigig zux zweiten und unter günjtigen Umitänben zur britten Brut idyreiten. Das erite Belege ijt ppätejtens Ento

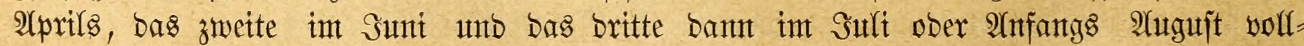
zählig. Sobalo bie Sungen eine gemiffe Selbjtänbigfeit exlangt haben, jodylagen jie fidh ntit anberen in Flitge zufammen, unb went bie Ëltern ifrer Sinberjorgen lebig finto, gejelfen 


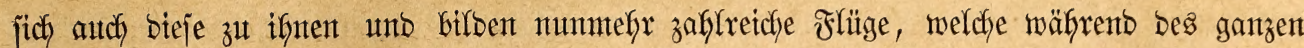

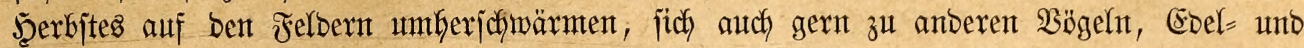

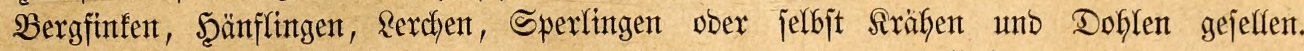
Snwiefern fich bas Reben bes (Eebernammers yon bem unjeres Sorldammers unterjchetiot,

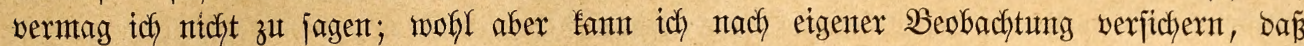

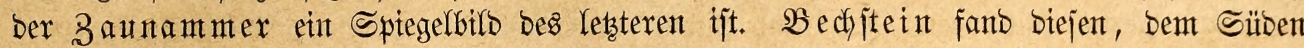

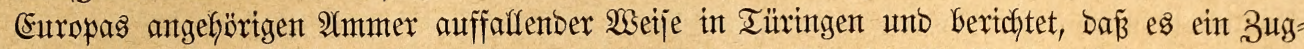

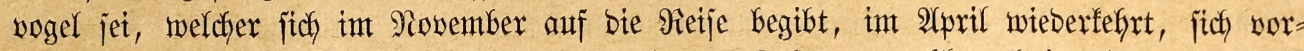

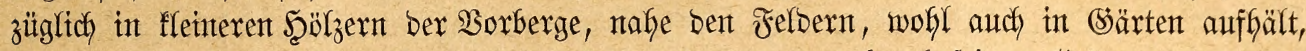

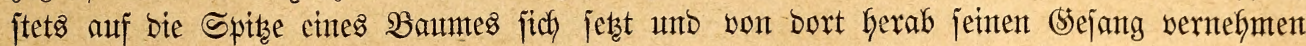

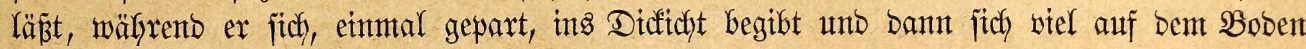

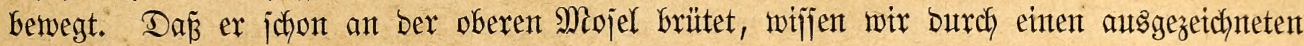

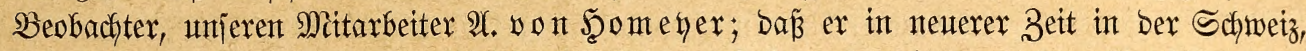

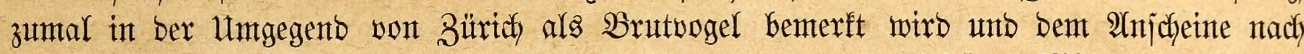

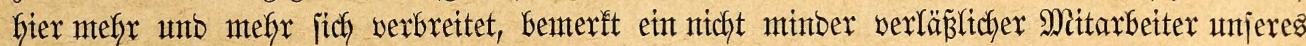

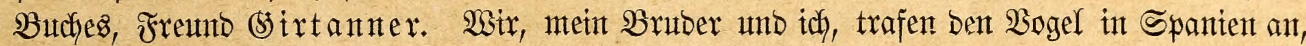
jeboch, nutr in einzelnen Frovinzent, in benten ex häufig war, wähtrent ex in anberen jeltent

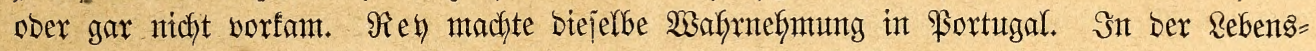

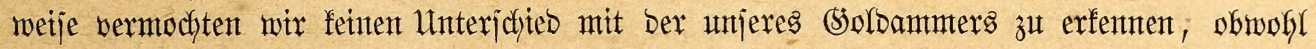

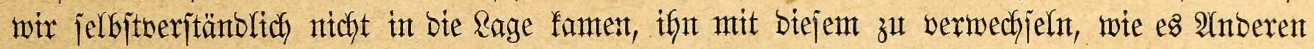
wofhl gejchefen mag; auth Der Siejang erinterte uns burchaus an ben bes Boldoammers,

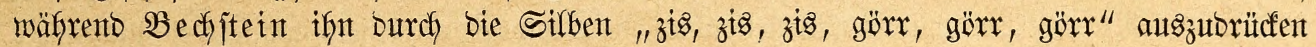
verjutht unb bamit beweift, Dá̉ ex jeinem Shre anbers geffungent habe. Das rejt jtefht,

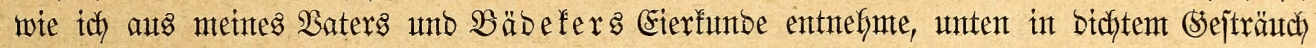
und ift nidyt ganz funftros aus bürren Stroh = unb Srasgfalmen, Mios unb aftem \&aub gebaut, inwentig, wie übfids, mit Iierfaren ausgelegt. Die Eier, brei bis fünf an ber

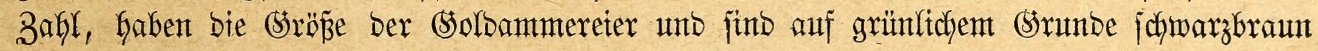
unb ich)warz geäbert, geiprenfelt, gefleceft unb punttirt, inmter aber an ifrex grünen (5rumbfarbe zu erfennen. Der (5artenammer unterichetbet fich zunächjt burch feine

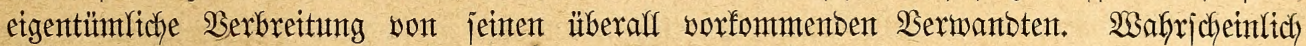

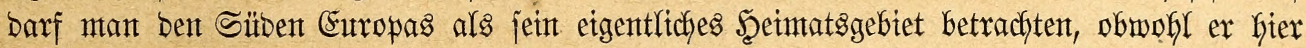

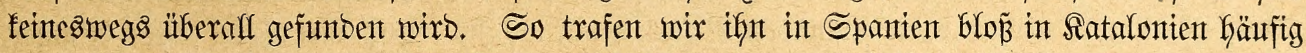

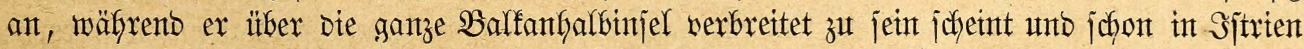

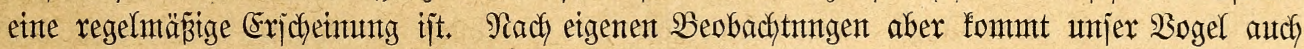

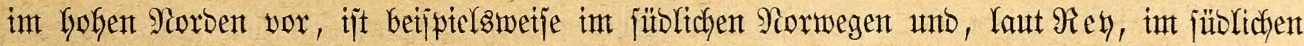

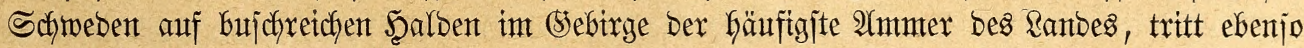

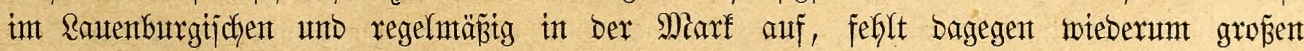

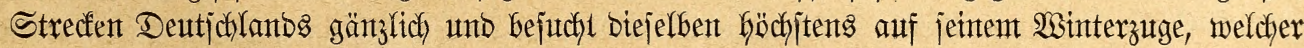

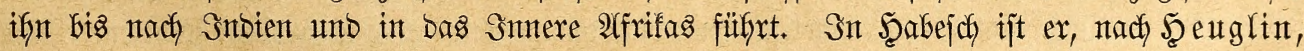

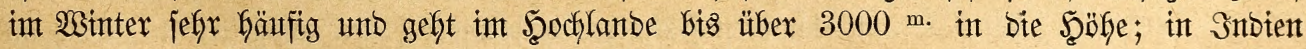

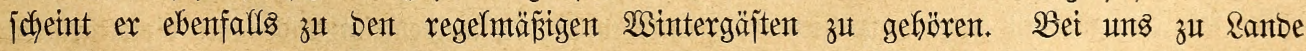

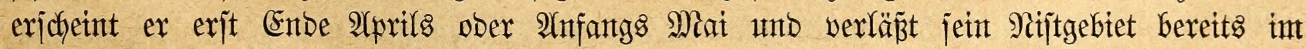

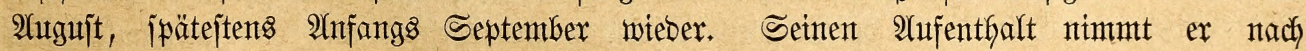

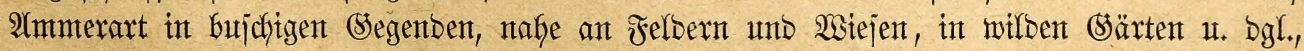

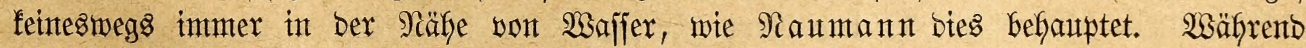

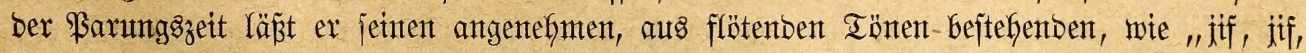

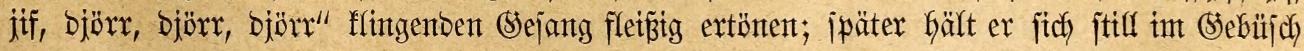

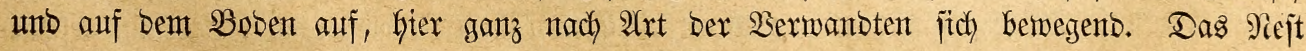


ftefyt bidft auf ber Erbe und hat nidhts abjonberliches, ähnelt vielmefyr bent anberer 9lmmterarten im hohen (5rabe. Un die Mitte bes Miat enthält es viex biz fünf auf bläu=

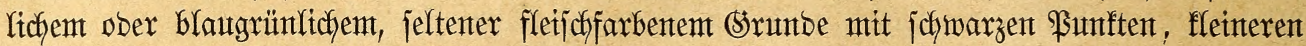
ober größeren Flecfen, furzen ફ̧arzïgen und eintgen grauten Rinten gezeidyntete (Fiter. Der von

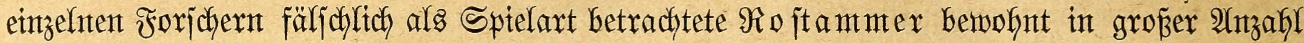

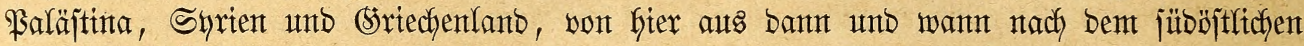

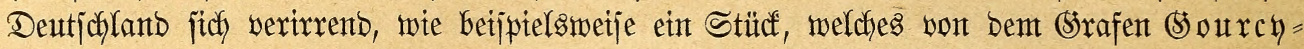
Droitaumont auj Dem Wiener Bogelmarfte gefauft unt eine Beit lang gefangen gebalten

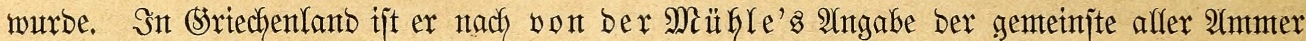

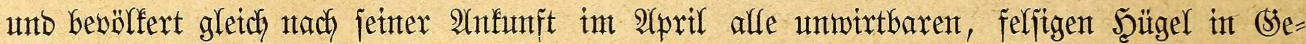

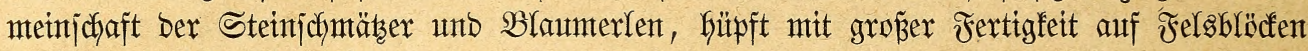
umber und läp̈t jeintent feinen, an ben des (Sartentmmers erinternben, aber wentger flö=

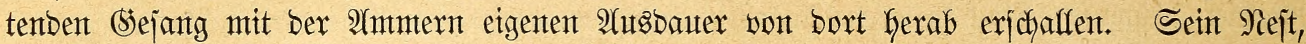
weldyes bem bes (solbammers ähnelt, aber fleiner ijt, wirb finter unto zwijchen Felsblöcfen,

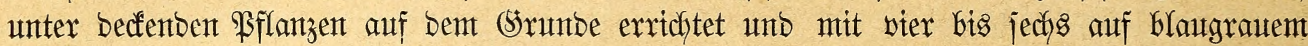

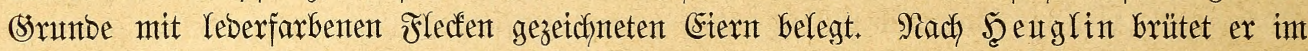

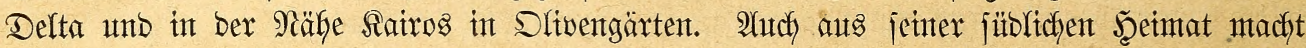

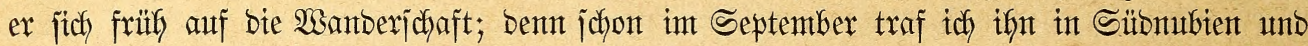
int Rovember und Dezember in Den büntbejtandenten 2 aldoungen am oberen blauten Fluife, jeiner Winterberberge, in groß̈er Mienge an, inmer aber nur auf gemijfen Dertlichfeiten,

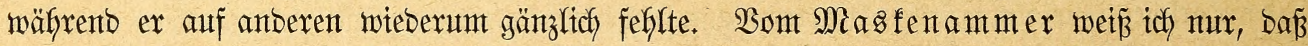
er in Sapan gefangen gefalten wird. Heber ben Bujchammer berichten Rabde, Gerdon und Mi D Dendorf. Erjterer traf bem Bogel einzelıt in Daurien, häufig in Irangbeifalien unt in groperer Menge am mittleren $2(m u x$ an, brütent aud in Den fafylen Soodjpteppen, mojelbjt ex jtets bie wentigen mit niebrigen 2 setben betwachjenten Iarjofjen aufjucht.

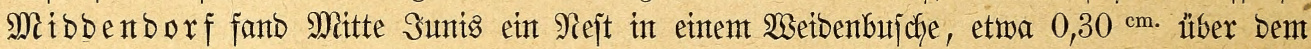
Boben, mit eiförmigen, auf grünlichweipent Srunbe vorzuggmeije ant bicferen Enbe violett gefledten Eitern. In Indien begegntet man bem $\mathfrak{B}$ ogel, mach Sex on, einzeln und jelten in

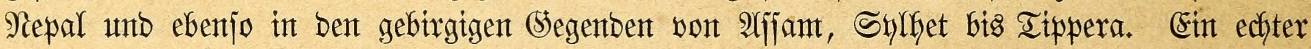

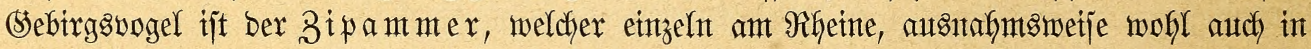
Jranfen und Türtngen, regelmäp̈tg aber in Stalten, Sïtrien, Dalmatien, Sriectyenland, Slein= afien und in bejonbers zaflretcher Menge in Spanten gefunben wirb. Şiex jahen wir ben überaus jchönen $\mathfrak{B o g e l}$ zuerjt in Satalonien in Den höher gelegenten $\mathfrak{B e m b e r g e n ~ u n o ~ z w a r , ~}$ ba wir bieje int Frühjahre bejudyten, pariweije, ant liebjten ba, wo einzelne herabgerifjene Felsblöbe von angebautem ober wilbmadhjendem (sejträuch ungeben waren. Sn ben leżten Seerbjtmonaten trafen wir auf- Dex Sierra গevaba mieber mit ifm zujammen und rernten

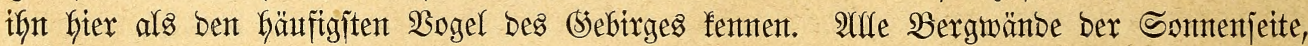
ebenjomohl biejentigen, werdhe in Felder umgemandelt waren, wie bie noch unbebauten, be=

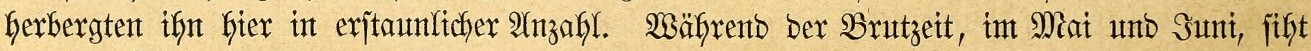

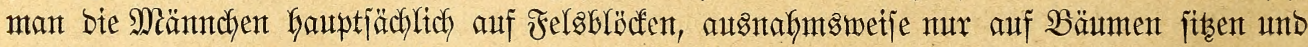
won bort Gerab ifyen einfachen, aber boch nicht unangenehmen (Sejang, welcher etwas eigen=

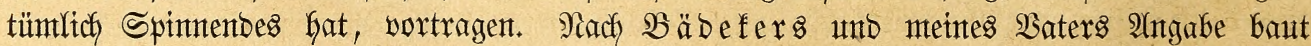

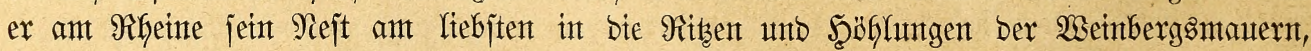
ba no bieje mit niebrigem $\mathfrak{B}$ ujchwerf umgeben werben. Die sier bis fünf Eier find auf grau=

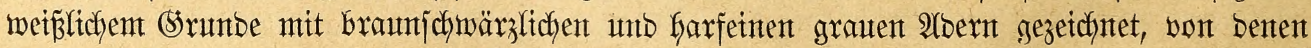

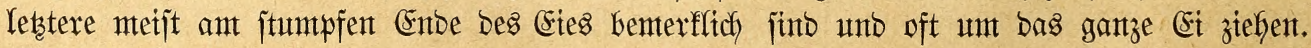

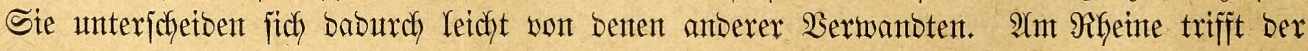

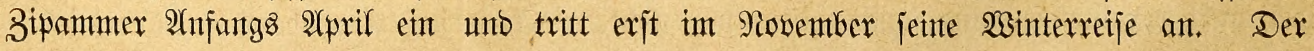




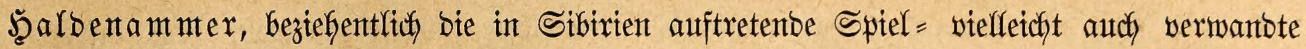

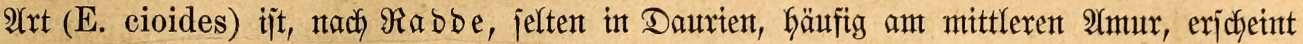

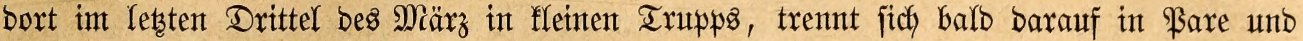

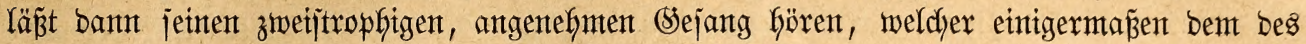

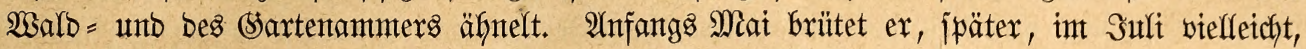

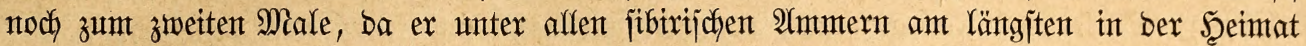
verweilt, einzeln jogar bajelbjt überwintert. WBon jeiner Şeintat Sibirien aus verfliegt jich

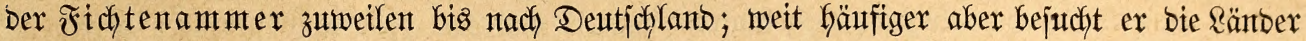

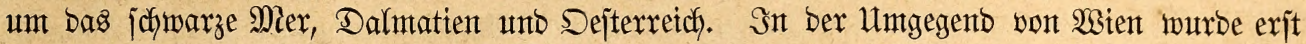

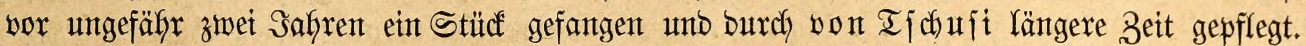

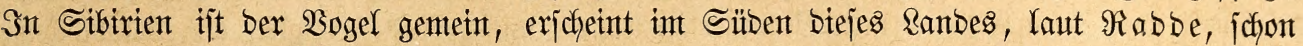
gegent Ëntbe Des Miärz, währeno bez ganzen Sommers an geeigneten Dertffichfeetent werweilent

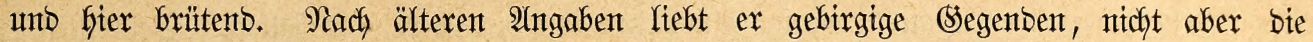

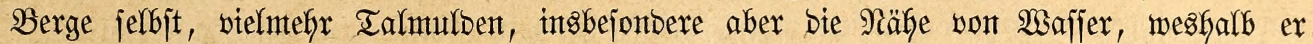

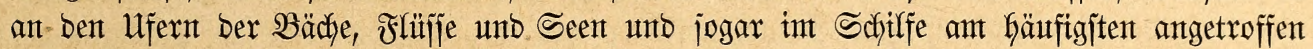
wirb. Seine vier bis fünf trüb rötliddgrauen, braunrot geffedten Eier, welche benen umjeres

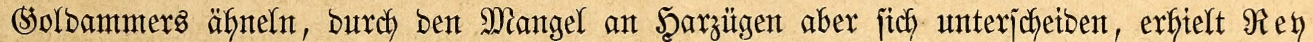
aus Daurient. Der $\mathfrak{B a r b a m m e r , ~ w e l c h e r ~ m i t ~ b e n t ~ F i d y t e n t a m m e r ~ b i e j e l b e ~ S ̧ e i m a t ~ t e i l t , ~}$

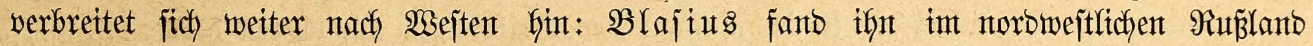

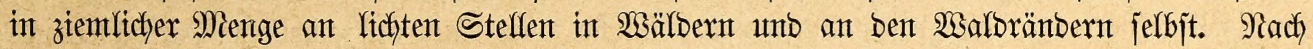

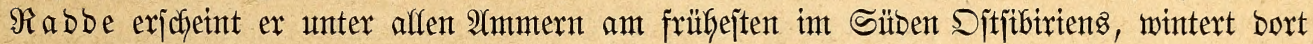

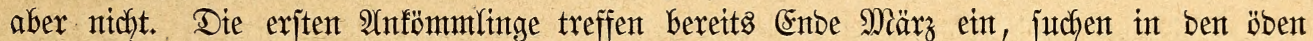

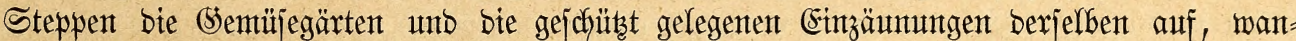

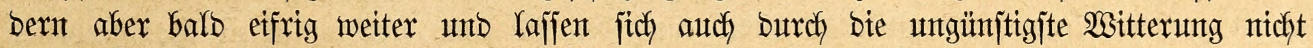

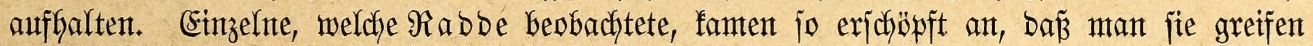
ober leicht mit Steinen töten fonnte. Sielegentfich biejer Wsanberung, aber mur bann,

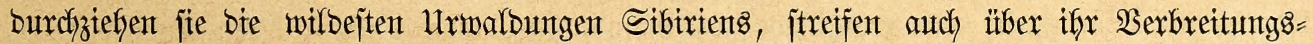
gebiet fintaus unto fommen als verirrte frrentolinge jogar bis zut uns herüber. Zut ifrem

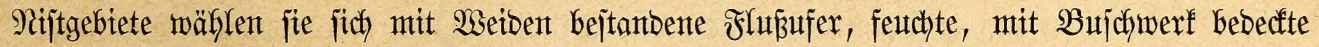

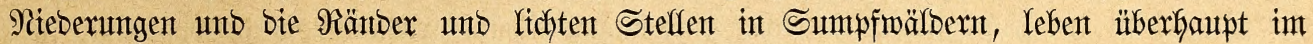

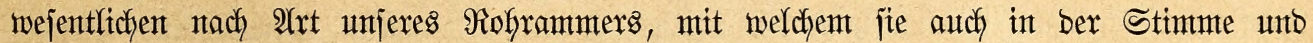

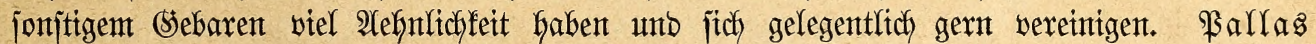
nennt jeine Stimme ein Mittelbing zwijchen ber Des Bip= unto bes Moffrantmers. Das

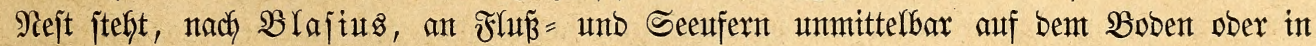

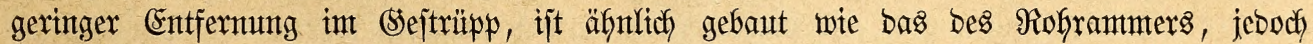

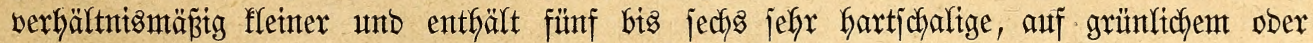

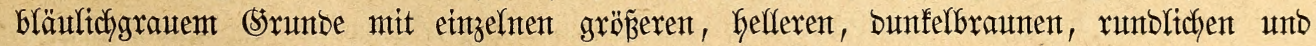
unregefmäß̄igen Flleden, Sdynörfelth unt Şarlinien gezeidhnete Eier. Den Fel jenantmer

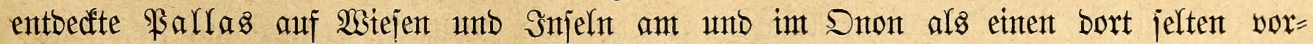

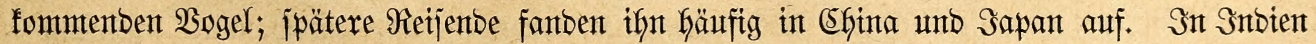

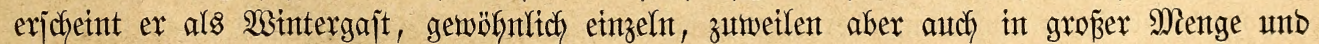

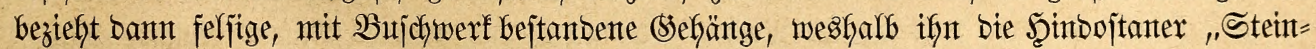

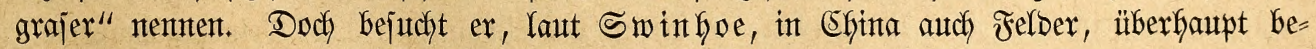

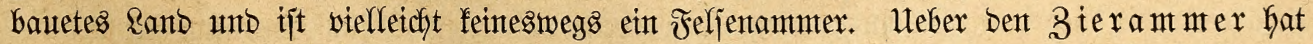

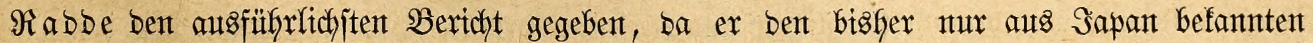

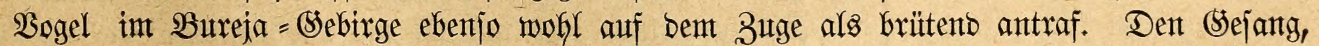
welchent zu Riebe bie Sapaner biejen 2 bgel jefjr gern in Räfigen halten, hat Rabbe leiber nidyt vernommen, uno jomit wifijen wir nicht, wie weit iene SiebGaberei begrünbet ift. 


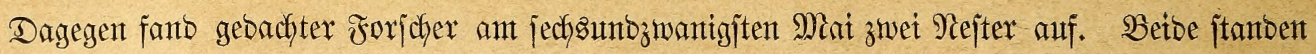
auf bem Boben, waren nus Stengeln, feinen $23 u r z e l n$ und Derben, breiten Sräjern gebaut

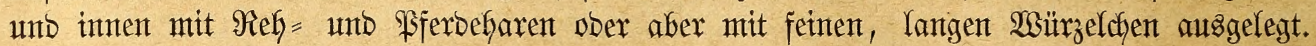

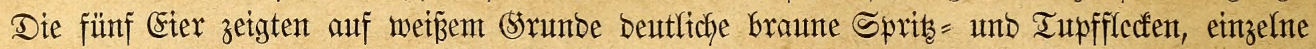

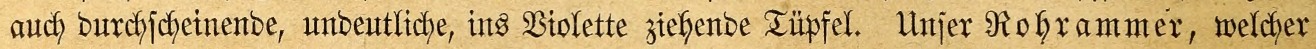

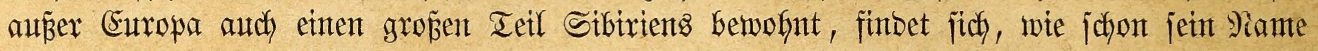

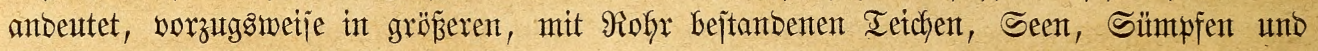
Brüchen, bejonbers bäufig aljo in unjerer norbbentichen Tiefebente und in Scolfand, in

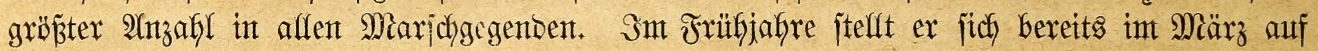
jeinen Brutplätzen ein unto berweilt fier bis zum September unt Sttober, bevor ex fich

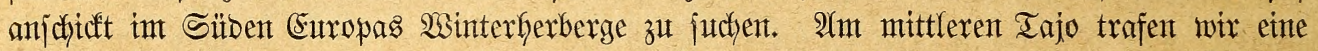

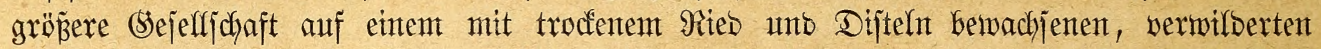

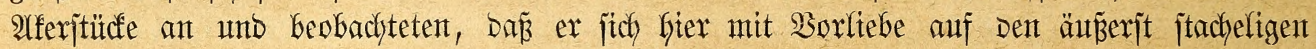

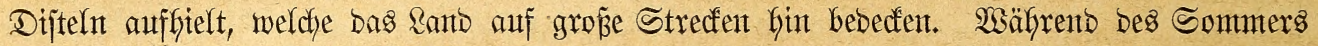
ijt berjelbe Bogel in allen Seen Spantens eine ebenjo bäufige Ericheinung nie in

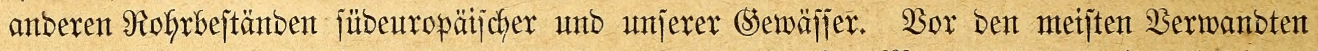

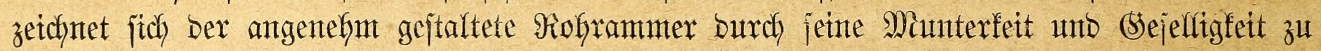

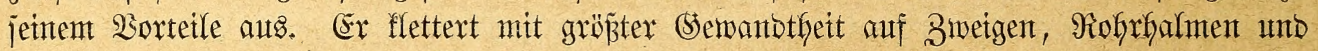

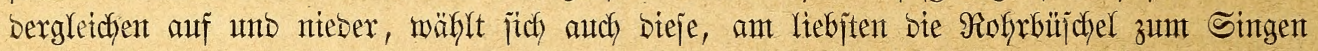

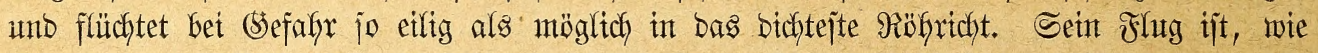
গiaumann treffend jagt, jhytefl und reicht, aber zutfent und hüpfend, als went ex nicht

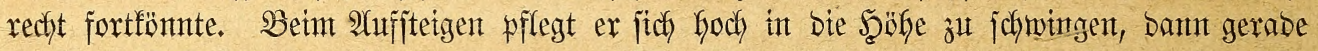
burch Die Euft fortzuftreichen unto vor bem Niteberjitzen jich mefy ober wentiger jenfrecht in

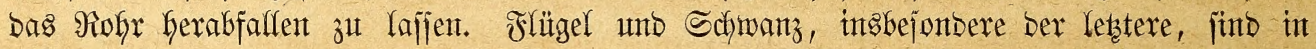
emiger Şeweghng, zuntal währento bes Sejanges, weldyer won ifhm ebenjo eifrig wie won anberen 2 (mmern vorgetragen miro, Yetber aber faum nod) (Sejang jenannt zu merben ber =

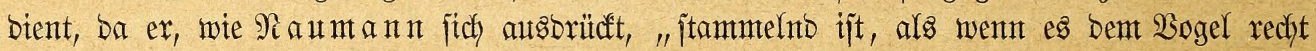

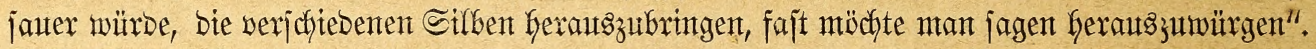

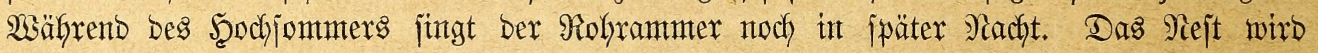

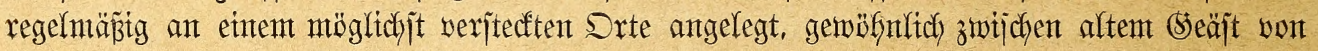

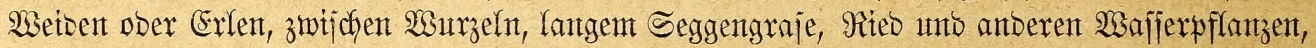

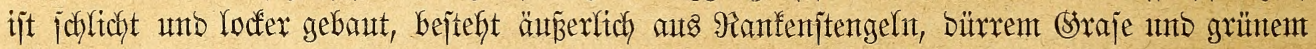

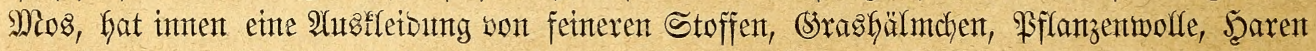

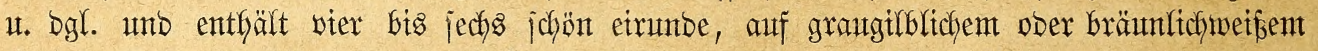
(5rumbe braun gemolfte unb marmorirte, aúperbem mit grauen, jdywarzbraunen ober fdyarzen

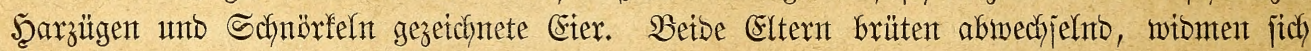

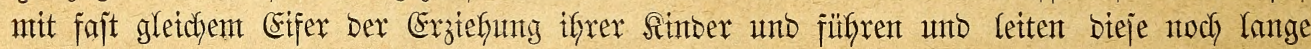

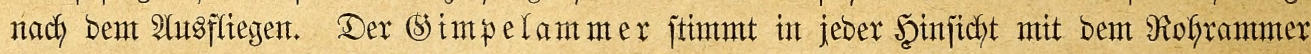

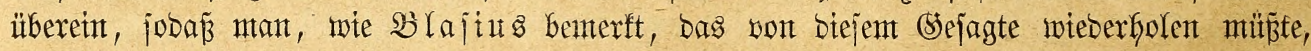

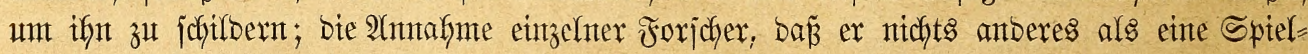

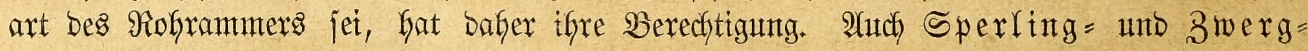

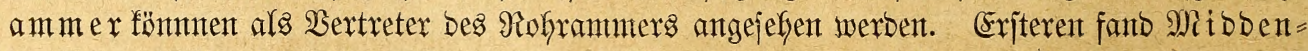

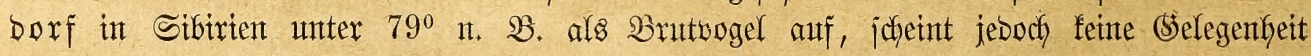
gehabt zu haben, ifn zแ beobadjten, ba er won ber Rebensmeije bes Sogels nicht bas geringjte

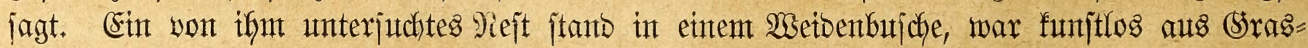

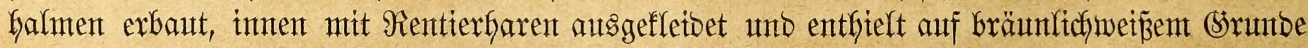
mux um bas ftumpfere Ende mit jchwarzen Strithen und \$umften morgenlänbijchen Sdyrift=

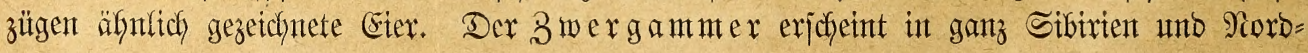




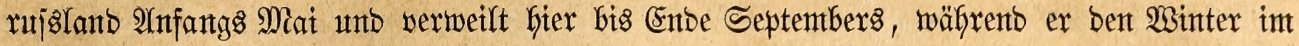

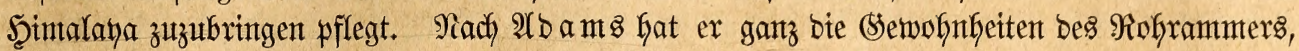

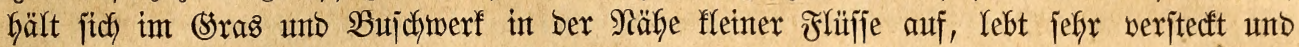
verbreitet fich wahricheinlich viel weiter, als man in Folge biejer Rebensweije vernutet.

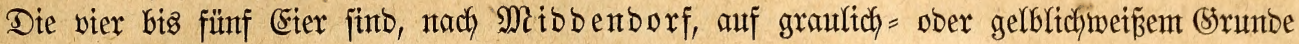

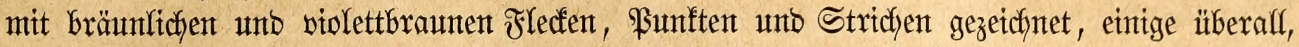
anbere vorzugsweije gegen bas biffere Entbe fin. Weit befjer als bie letztgenannten âtren ijt uns ber $\mathfrak{B}$ eibenamner, eines ber jwönjten Mitgliteber ber ganzen Familie, befannt.

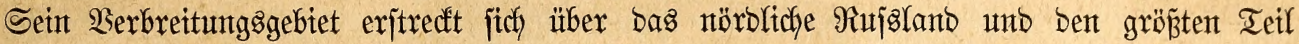

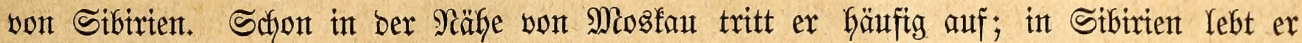

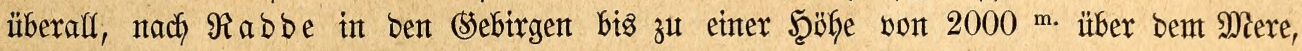

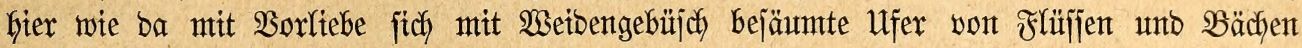

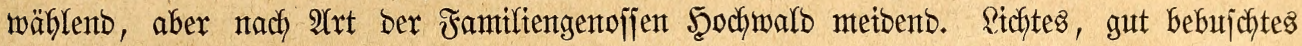

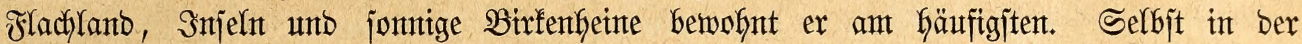

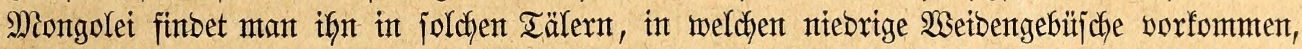

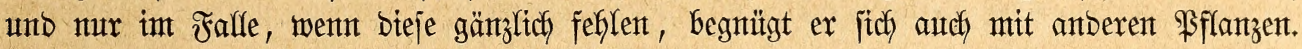
Seine $\mathfrak{B}$ interreije füfyrt ifn bis nach Sïbdfinta und einzeln jogar bis nady Sntien. Der liebliche (Sejang hat brei von einanber abmethenbe Weijen unb bejteft aus Gerlich flötenten

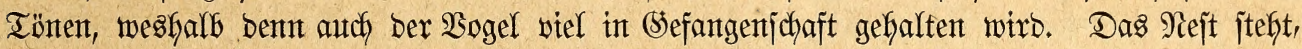
nach Scenfe, auf Dem Boben ober boch nitht hoch Darüber im (Sraje, Sijtrüpp, (Sejträuch, ijt auf einer Utnterlage von trodfenen Sealmen, Blättern unt Semürzel mit feineren Wurzeln, Bajtfajern, (Sraßblättern, auch wohl mit einzelnen Şaren und Febern augigelegt unt entfällt fünf bis jects auf trüb graublautem Brunbe mit bunfelbraunen, fajt jobmarzen Branbfledfen und

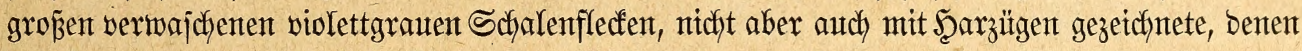

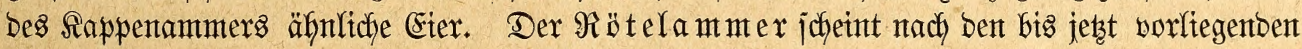

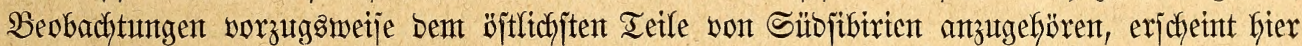

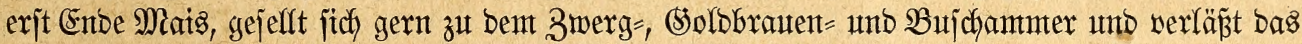

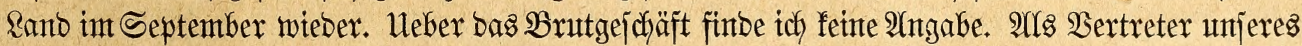

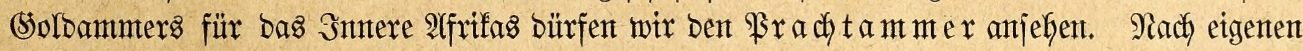

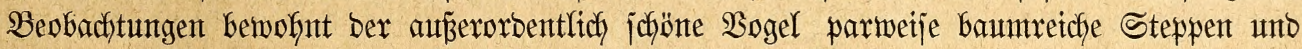
bujchige Ieile ber Urwalbungen, rebt, oft weit von Betwäffern entfernt, ganz nach 2 trt ber Berwanbten, Gat auch einen burchaus ammerartigen, Göbjit unbebeutenben Sejang. Şe uglin bält ifn für einen 3ugoogel, ich bin genetgt, ifn als Stanboogel in ben von ifm betwohnten (Sebieten zu betrachten. Ein edftes Sinto Der $\mathfrak{B u ̈ j t e , ~ G a ̈ l t ~ f i c h ~ b e r ~ v o n ~ m i r ~ n a c h ~ i f y r ~ b e n a n n t e ~}$ Wüftenammer mit Sorliebe auf ben öbejten Stellen Norbojtafrifas auf, gern in ber Nähe von Semäijern, aljo an ben Ufern bes Strontes jelbjt ober aber an ben bürftigen

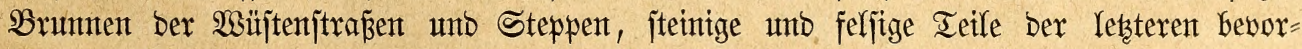

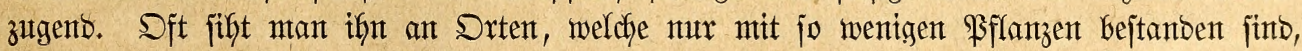

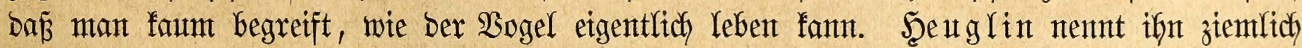
jedühdytern unt flüchtig; ich Gabe bas (segenteil gefumben, ftimme aber genanntem Beobachter

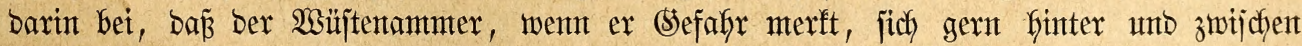
(Sejteinen verjtecft. Wie in ber Sabara lebt er audy in ber norbojtafrifantichen wüjte oft in

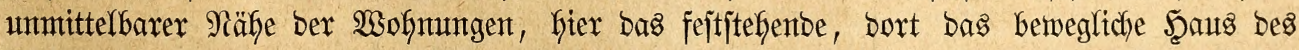
Steppenbemofners zum Mittelpunfte jeines (Sebietes erwäblent. Nejtbau unto Brutgej jedjeinen zur Beit noch gänzlich unbefannt zu jein. Den Siebenjtreifenammer fanben

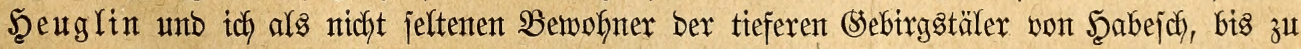

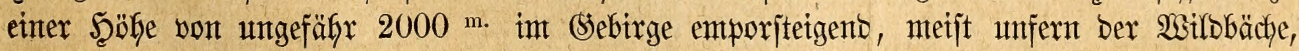

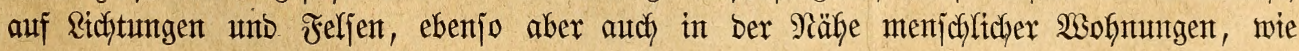




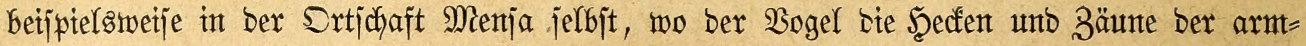

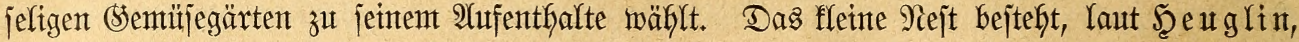
aus Srabhalmen, ijt finter Steinen und Bebüfchen unmittelbar auf bent Boben angelegt unb entfällt zwei bis brei weip̈liche, refymfarben angeflogene Eiter mit bunflen, erbbraunen Flecten, weldye meijt am jtumtsfen Ento franzartig zujanmengebrängt jtehen. Der saffer=

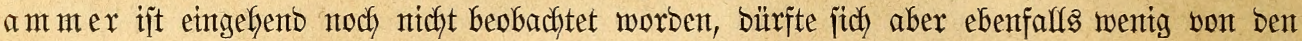
Berwanten unterjchetben. Der Şaubenammer, welcher int wejentlichen wie bie Berwandten

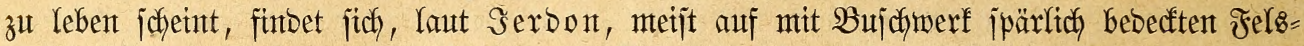

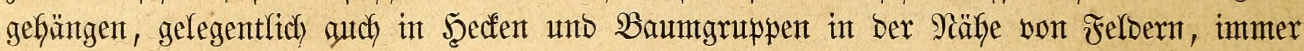
aber nut im Gügeligen Eanbe. Rach SerDons Mieinutng brütet ex nicht in Indien, nach Swinfoe mur einzeln in China, wojelbjt er während bes Winters jefr bäufig auftritt.

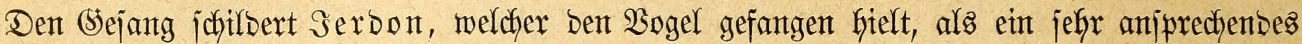
(S)ezirp.

2(rfjährlich fajt, int jtrengen Wintern getwijs, jentet ber Norben Schneeammer nach

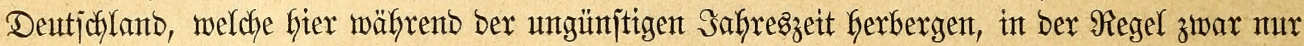
Die Süjte ber Ditjee und ifye Injeln und Dünen bewolfern, gar nitcht jelten aber aud bis

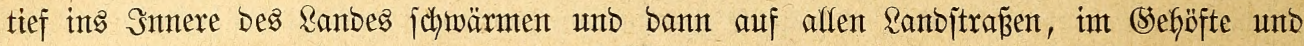
vor ben Scheunten bes Ranbmants ober jelbjt inmitten ber Stäbte jich einjtelfen, um fier

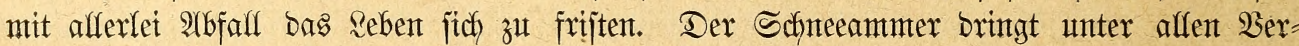

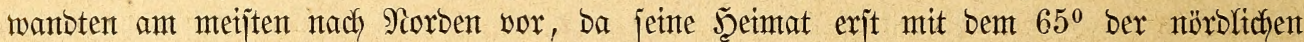

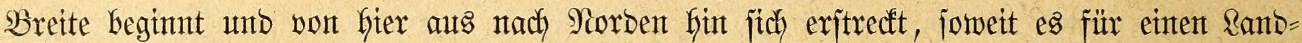
vogel überhaupt möglich ijt zu leben. Sein eigentliches 2 ofngebiet ijt bie Tunbra, nidft aber bie eigentliche Miosjteppe jelbjt, wielmtefgr bie in ifyr fich erfebenden mit (Serölfhalden

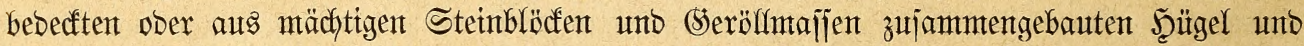

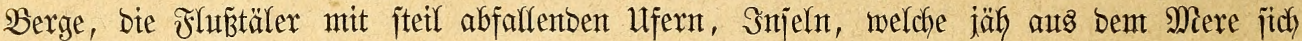
erheben unt ähnliche Sertlichfeitent. Nody auf Spibbergen unb Nowaja Semlja finbet biejer gentügjante $\mathfrak{B}$ ogel, twas er zu jeinem Rebensunterhalte bedarf, und ex ijt es, weldjer jenten Breiten Den beginnenten Jrühlintg fïnbet unt fïch mux zögerno von jeinter armen

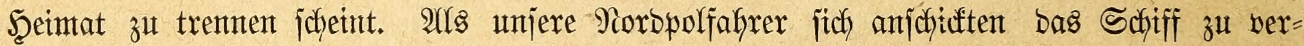
lajjen, weldfes ithnen wäfrend ber Winternacht Şerberge geboten, um bas eifige, mit tiefem

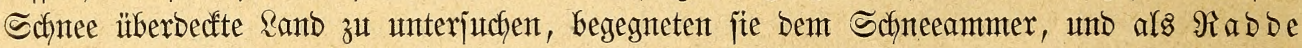
Sibirien Durdyreijte, traf ex biejen $\mathfrak{B o g e l}$ überall, wo bie Randjtraje oft befafyen mirb, noch

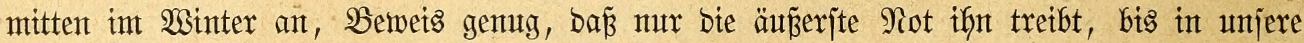
milben Breiten Gerabzufommen. Wie in jeinter (Bejtalt erjecheint ber Schneeammer aud in jeinem

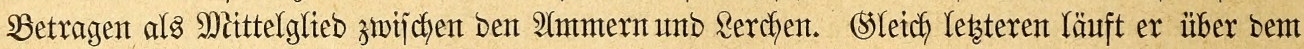
Boben hìt, nidft eigentlich hüpfent, jonbern mefy rentent, unb eher nach âtrt ber Rerdjen

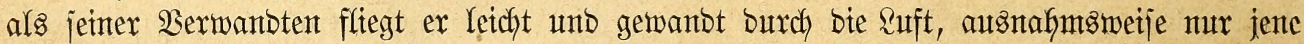

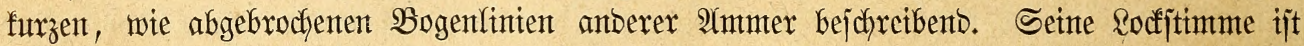
ein helles pfeifentes "Jip" ober flagendes "Zirp", ser Bejang ein Sezmitjcher, welches in einzelnen Tetlen bem stebe ber Felblerche ähnelt, fich aber burch laute, jcharfe, flingente Strophen unterichetdet. Unter jeinen Berwanden zäfilt ber Sdjneeammer wobjl zu ben

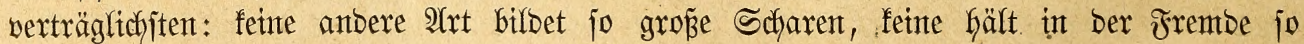
treulich zujammen, unt fetne gexät ant Brutplake jo jelten in Şaber und Streit mit nake=

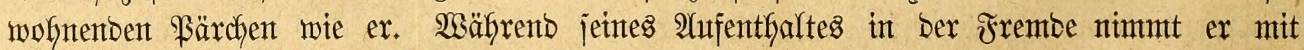
alfent für ifn (sentej̈baren vorlieb, weldyes jich finbet; währent bes furzen Sommers jeiner

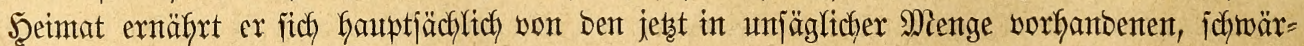

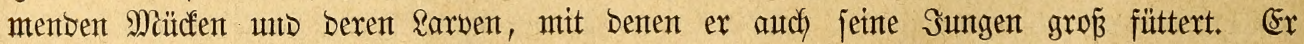
brütet fpät im Safre, ba ex auf Den Brutpläzen jelten vor Mitte Maris eintriffit unb exít 


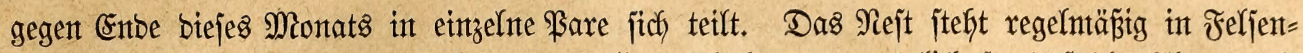
ipalten, zwijchen ober unter Feljen = unb Serölrblödfen, wo möglich jo, baj bie Eltern exjt

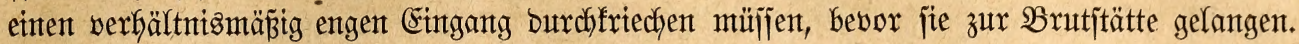

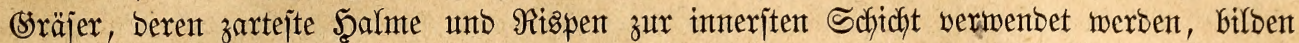

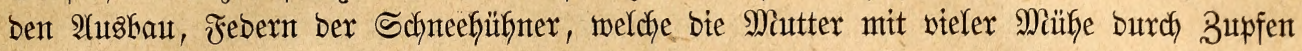

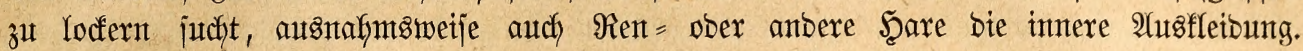

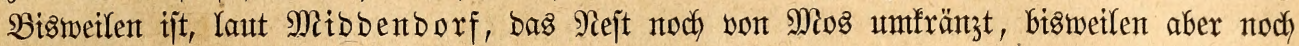

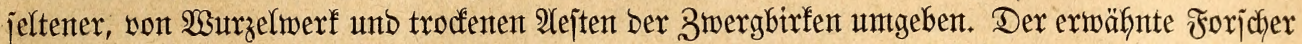
fant am 17. Sunt unter $73^{1} / 2$ Srab nörblicher Breite in affen Nejtern Der Schneeammer Eier, obgletd bas segen noch von feintent beentet war. Täglich murbe ein neutes (Ei gelegt

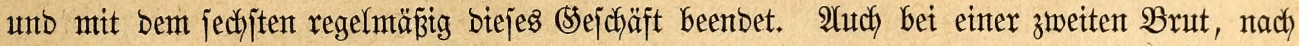
Beritönung Dex erjten, legt ber Sifjeeammer jeine jechs Eier. Sebtere fint nidfyt mur fint= jichtlich ber Färbung, jonbern auch bezïglidy ber Sejtalt jefr verjofjeben, entweber gejtreaft

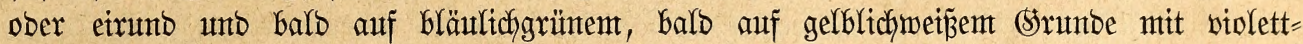
bräunlichen Flecten gezeidyntet. Entoe Sultis begegntet man in jenten hohen Breiten überall

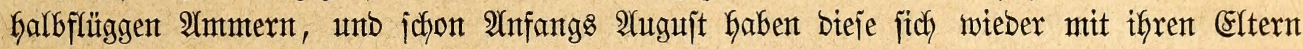
bereinigt unt treten alfgemtach ifre Reije nad) bem Süben an. Der Sporenammer ähnelt in manther Şinjicht bent Berwanton, betwohnt aber im Begenjaze zu ifm mebr bie Tief=

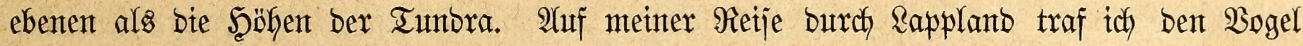
überalf in groperer $2(n z a h l$ und zwar aller Drten, an ben Berghängen ebenjo wohl wie in ben tieferen mit Birfen bejtanbenen Iälern, auf jteinigen wie auf grafigen Stellen. Wenn man ben Sifneeammer als ein Mittelglied zwijchen Rerchent und Âmmern anjehen mag,

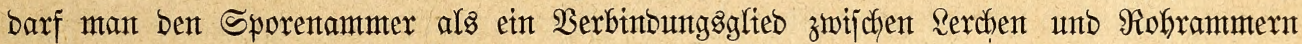
betrachten. Sm Raufen exjcheint ex als Rerche, im Siben als Afmmer, int Fluge vereinigt ex

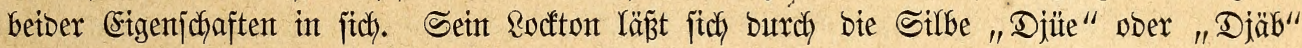
wiebergeben, ber Warmungaruf flingt jperlinggartig wie "Terr"; ber jefr einfache, jeboch nidft unangentefme und in ber oben Tunbra jogar anjprechenbe sejang bejtebt nur aus einter Strophe, in weldyer ber Rocfton oft wieberfefrt. Echt lerchentartig iịt, Dá̉ ber Sporenammer

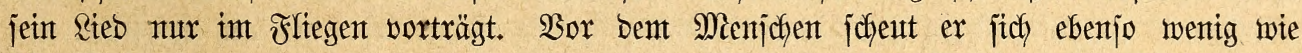
jein Serwanbter, aus bem einfacten Sruntbe, weil er ify, ben Erzfeind affer Tiere, nitht

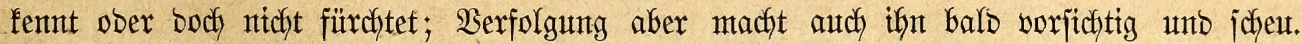

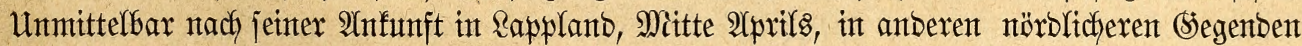
noch) ipäter, idfreitet Der Sporenammer zur Fortpflanzung. Das Nejt jteft ant feudftent

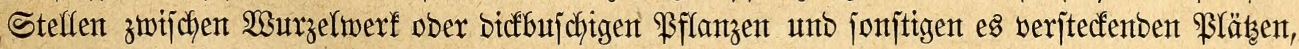

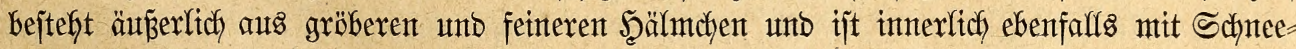
Güfhnerfebern auggefülft. Die fünf bis jechs Eiter zeigen auf bräunlich gelbem ober hell=

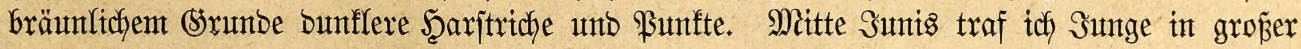
Aftzafil; boch waren bie âtten noch immer mit ber Brut bejdäftigt. Enbe Septembers ober int Dltober tritt alt und jung bie Winterreije an, berübrt auf berjelben aber viel jeltener als ber Sdyneammer umjer Saterlano: bie Miefrzabl jheint im Sitben Sfandi= naviens eine ifgr volffonmen zujagenbe Winterkerberge zu finben. Snwiefern fich bie betoen

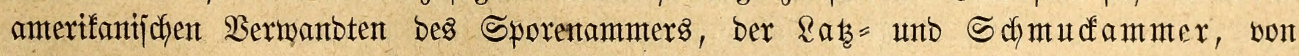

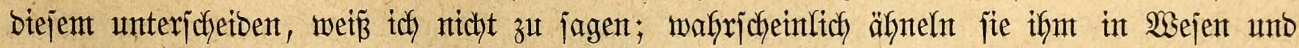
Betragen ebenjo wie in Sejtalt und Färbung.

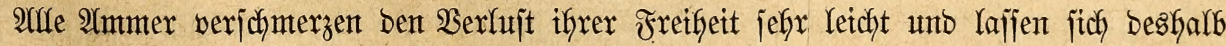
ofne Umitänbe an bie Sefangenjchaft gemöhnen, halten aber feinesmegs jo gut in ify aus,

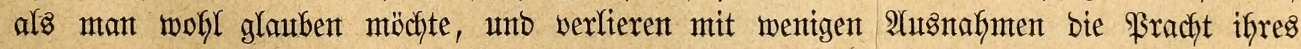

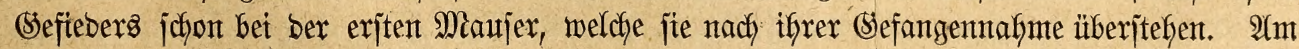


Ginfälligiten finto nach meinen Beobadytungen alfe gelben, am bauterhaftejten affe jdwarzen,

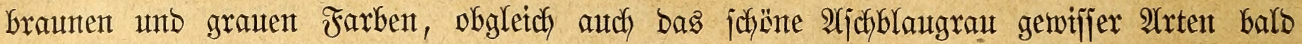
merflidf) werbleidyt. Siappen $=$, Fradft $=$, Sold $=$ Weiben $=$ und Zaunammer legen ichon im erjten Safyre ifrer (Sefangemichaft nach und nach ein Aleid an, weldhes finter bem bejuei=

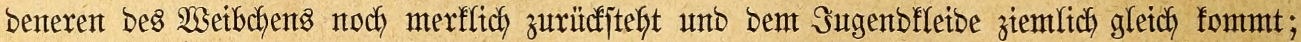

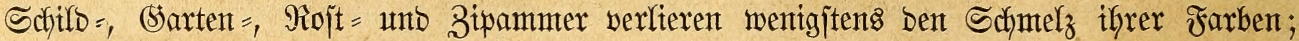

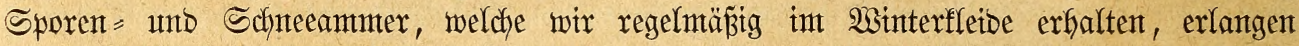

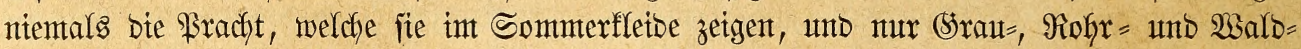

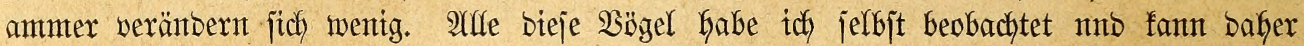
aus eigener Wafhrnefgmung über je urteilen. Sn wie weit sasjelbe für antore 2(rtent gilt, weiz ich niddt, glaube aber Durdh Beraffgemeinerung meiner Beobachtungen auf bie genanntent

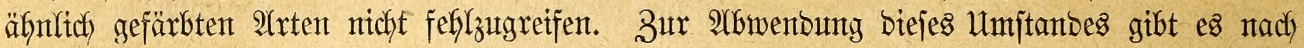
unjeren bisherigen Erfafrungen fein einziges Mittel won irgeno weldyem Erfolge; Denn bie Ilmmter verblafjen ebenjo mofil im freijtehenden Fhthgebauter wie im engen ̊äfige, ebenjo gut bei ber emfachjten wie bet ber jorgfälttigit auggetwählten Nafhrung. Mangel an finreichentom Sontenlicht und gentigento frijcher \&uft ijt jebenfalfs nicht bie einzige Urjache biejer Schmächung;

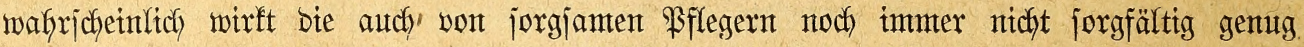

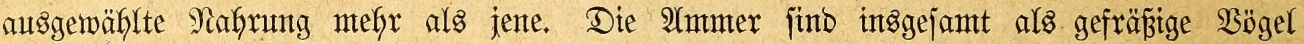
zu bezeidynen; unter ben Sörnerfreffern mintoejtens gibt es wentge, weldje in jo hohem

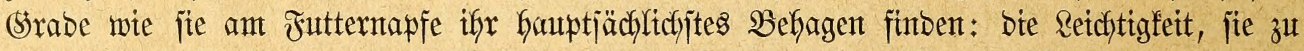
unförmlidfen Jettflumpen zu mäjten, war ja aud bereits ben ÂUten wohl befannt. (Srabe in biejer ausgejprochenten $\mathfrak{A}$ nllage zum Fettwerben aber liegt, entiprechent bem bereits (ऽ. "38.)

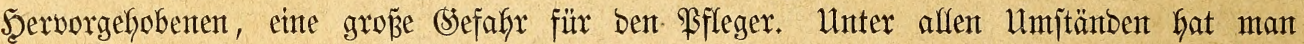

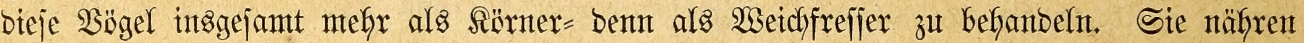
jich alferbings ebenjo wohl won Pflanzen= wie von tierijcyen Stoffen, währent bes Sommers, aljo gerabe in berjentigen Beit, in welcher jie bas \$ractffleid tragen, aber Gauptjächlich von

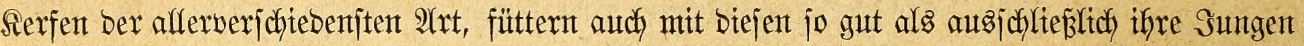

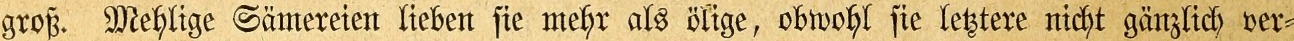

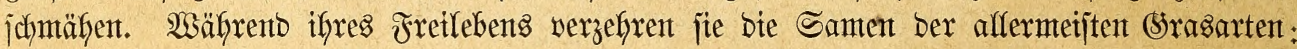

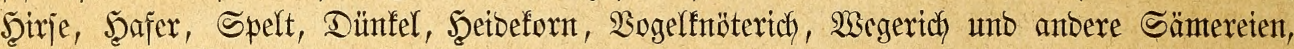
minber gern $\mathfrak{B e i z e n ~ u n b ~ S e x j t e , ~ n o c h ~ u n l i e b e r ~ \Re o g g e n ~ u n t ~ a m ~ a f f e r w e n i g i t e n ~ o ̈ l i g e ~ S a ̈ - ~}$

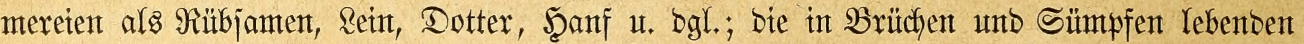

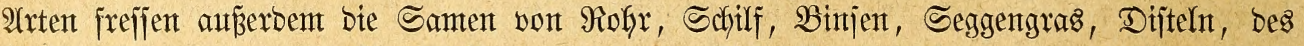
Rofyrgrajes unt anderer Sumpfpflanzen, Denen zu Riebe fie abweidfend von ben Berwanden auch an Scalmt unt YYefren emtporjtetgen; währent bes ganzen Sommers aber genteß̈en jämtliche

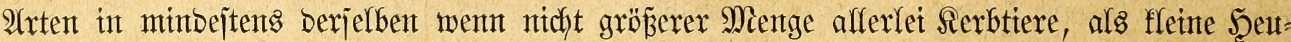

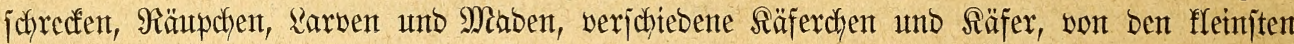

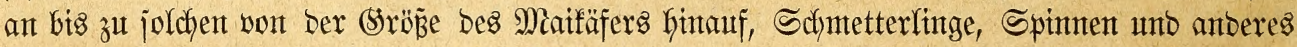

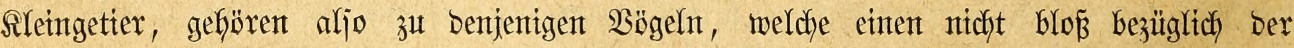
Mienge, jonbern aude) Mantdffaltigfeit reidjen Iijch lieben und vieflectst bebürfen, jolfen fie

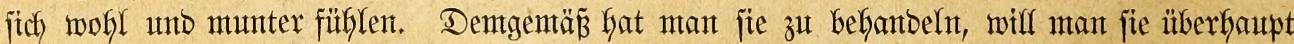
erbalten. In ben meijten Fällen gibt man fich mit ifnen freilich wentg Mähe, tijedt isnen bas einfachjte (Sejäme auf, welches man zur Şanto hat, reidyt ifnen Şafer, zerquetjchten Şanf, Santarienjamten, Şirje und Miofn, Brot = unb Semmelfrumen, glaubt jogar oft afle ifyre Beoürfniffe erfülft zu Gaben, went man ifnen bas sechjteinfche Uniwerjalfutter ober ein äfnliches reicht, unb wumbert fich bann, wenn fie gar nicfit aushalten wolfen, währent

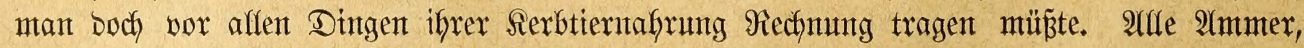

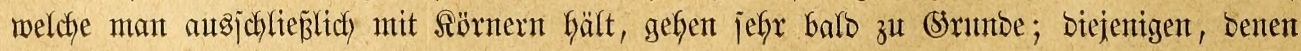




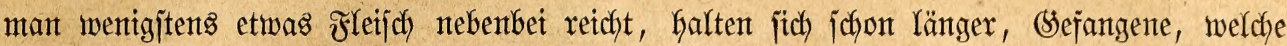

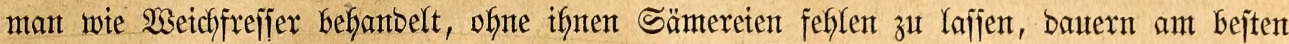

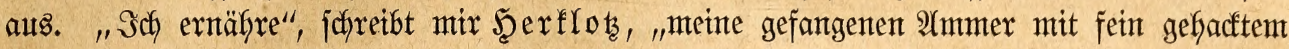

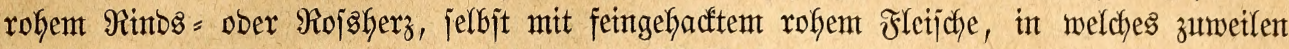

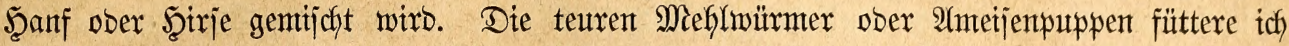

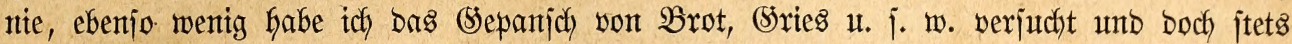

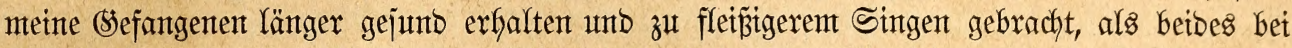

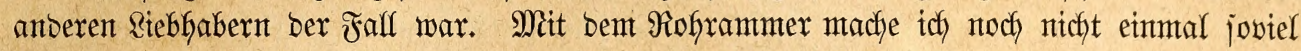
Umitänbe wie mit ben übrigen. Nur bant unb wann bringe ich ifhm von einer Sumtpfjago

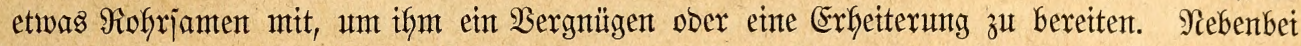

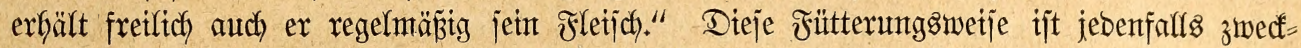
mäß̈iger als bie alfgemein übliche, meines Erachtens aber boch nods immter nidgt bie rechte.

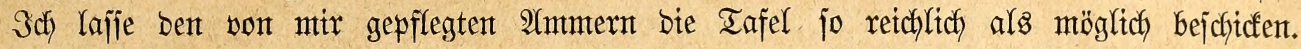

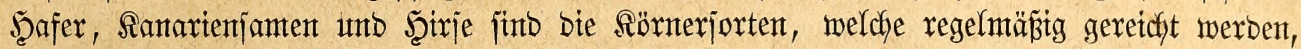

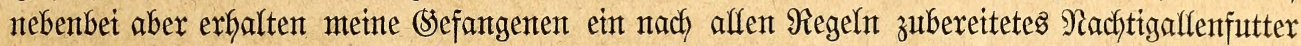

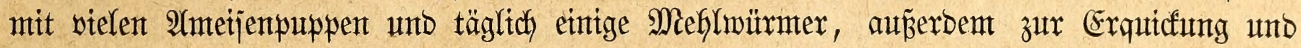

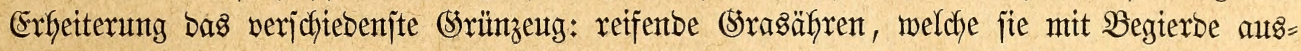

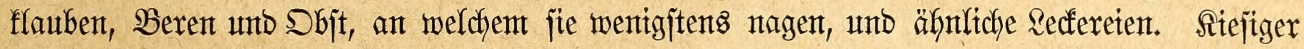

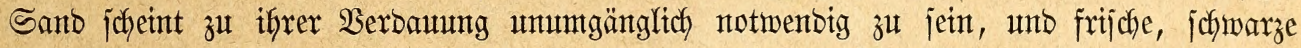

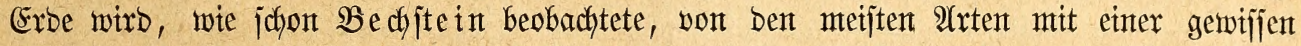
Begierbe gefreifen, nu⿰

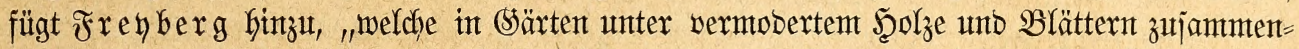

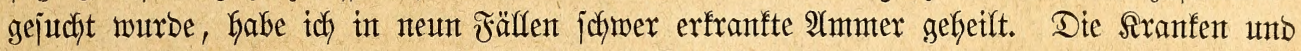

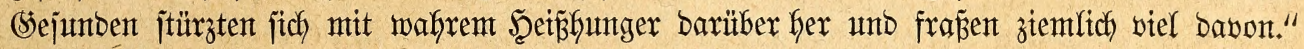

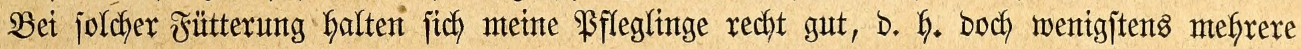
Safre nadeeinatiber.

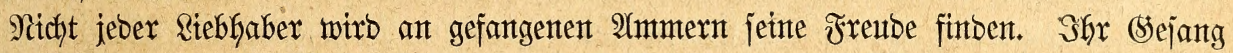

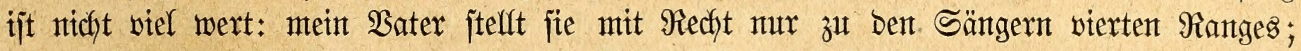
iffr Befieber verbleicht, und won ben Eigenichaften, weldye fie in ber 'Ireeigeit zeigen,

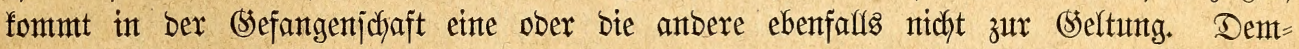

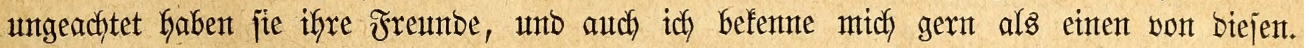
Sie gereichen jebem fruggebauer, für meldhes jie überfaupt ant bejten fich eignten, zu hoher

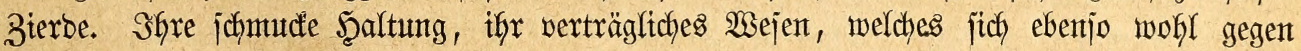

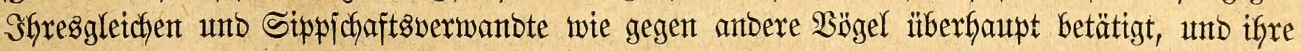
leidgte Züffmbarfeit machen fie mir lieb unto wert; ifge einfacher (sejang erinnert midch ant

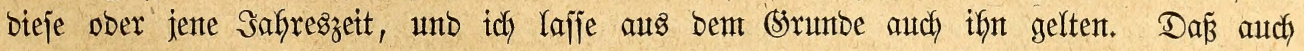
Undere benfen wie idh, beweijen bie nachjtehenten Worte unjeres Mitarbeiters Riebe. "Die

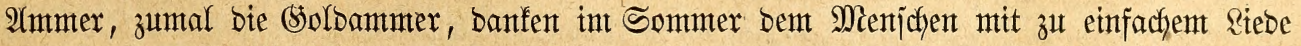

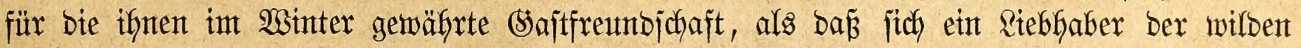

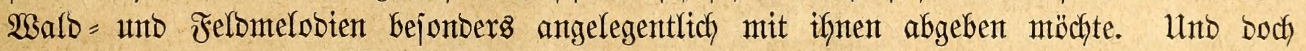

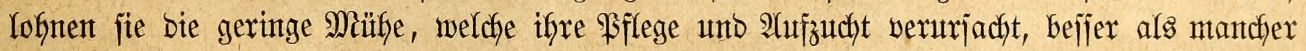

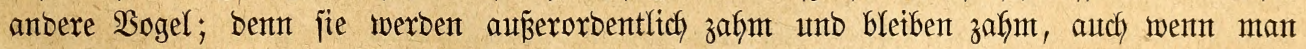
eine Beit lang befhinbert jein jollte, mit iffnen fich zu bejchäftigen. Sch habe viele Safjre

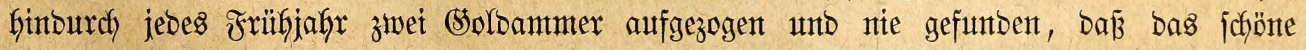

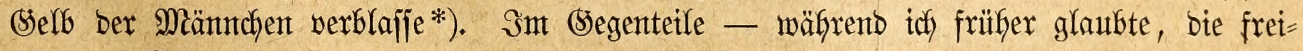

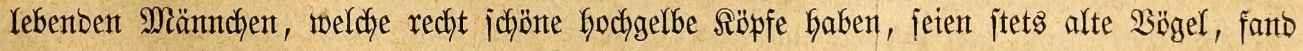

*) Bei meinen Pfleglingen ift bies ftets ber Fanll gewejent. Brm. 


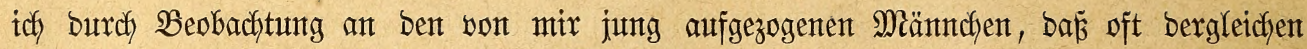
faffen, weldye jofjon nach ber exjten Miaujer volffomment golbgelbe Röpfchen befommen.

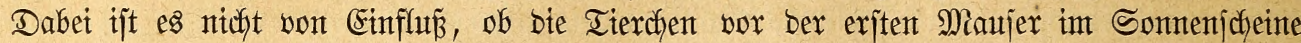
Gängen ober nicht. Zur \$arungszett jint bie 2) welchem bas WSeibchen nicht willfährig ijt, barf man nicht in ben Flugraum lafjen, weil es bie $\mathfrak{B e i b c h e n ~ b e r ~ a l f e r w e r j c h i e b e n i t e n ~} \mathfrak{B}$ ogelarten heftig verfolgt. Sperrt man bagegen ein

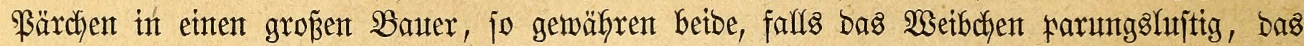

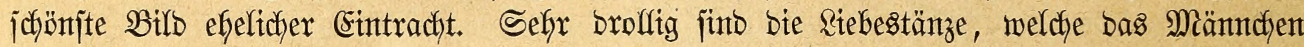
in ben Fltttertagen ausführt. Es hebt ben fopf und ftrüubt bie Scheitelfedern, bläjt jobann

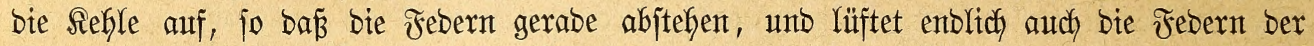
Wangen. In joldyer Weije masfirt, fliegt es an bie Seite bes Wetbrfyens unb verbreft bent

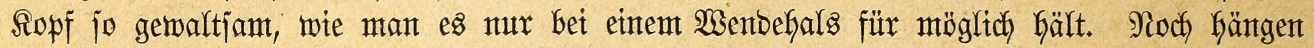
bie Flügel joblaff herab, aber johon beginnen bie Wintungen bes Sopfes und Scarjes bem ganzen Reibe fich mitzuteilen. Zuleţt werben auch bie Flügel mit zurüafigebogenem 2 orber = arme jenfrecht empor gefoben, jo bá ber $\mathfrak{B}$ ogel einem Iagfalter gletcht, welcher bie Flügel jenfredyt bält, fie aber nidjt ganz zujammengejollagen bat. Nunmebr beginnt ber Almmer

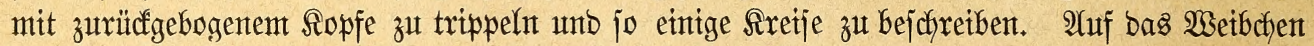

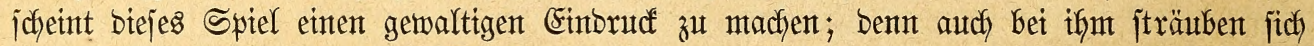

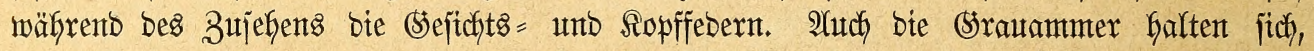
went fie jung aufgezogen murben, aukerorbentlich jaymud, bergelten bie ihnen gemiomete

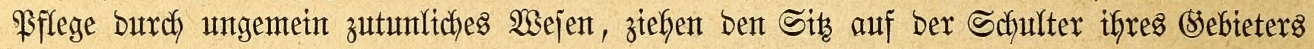

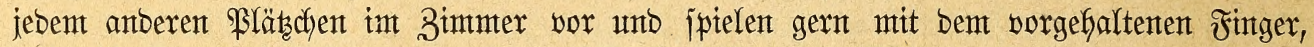
babet bie Febern fträubend und mit ben Flügeln jalagent. Währent bie Soldoammer, welche

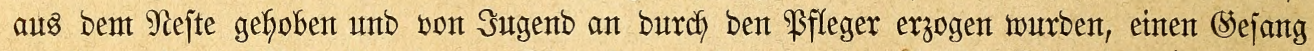
aus ben alferberjchiebenjten Rauten jich zujammenjeben und wäbrjcheinlich gelehrt ober zum Sortrage flemer \&ieber abgerichtet werben fönnten, nefmen aud bie im Simmer gropgge=

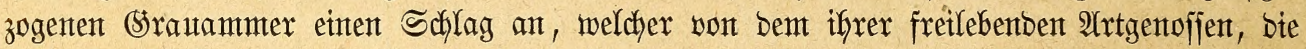

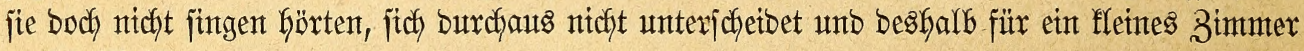
zut jodrifl ijt.

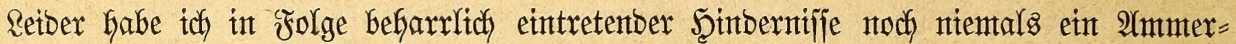
pärchen int Zimmer brïten jefhen, jo oft ich auch bie Einteitung bierzu getroffen batte.

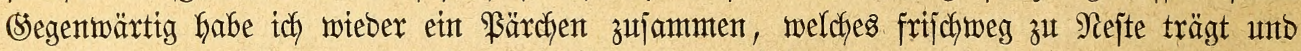

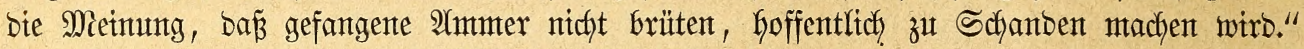

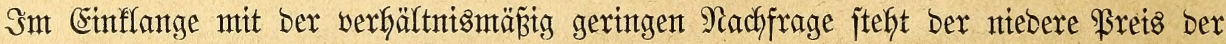

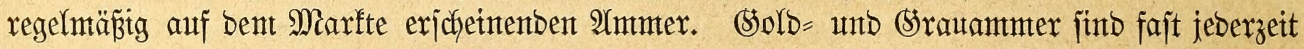

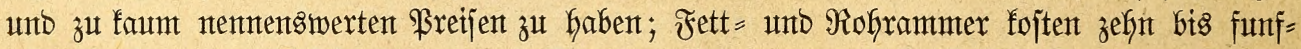
zegnt Srojchen bas Stüdf, Zaut = unt Bipammer etwa anbertfalb Ialer, Rappen =, Sdfilb=,

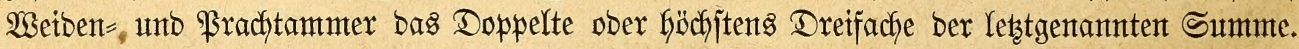

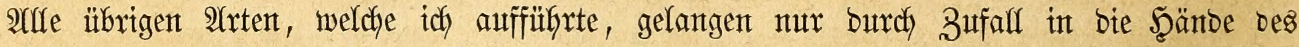
Riebhabers und haben feinen bejtimmten Preis.

\section{Perdent.}

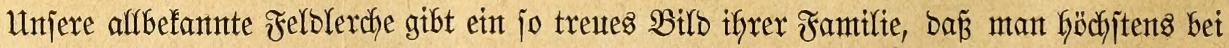
einzelnen 2 rtent ber lezteren in $\mathfrak{B e r l e g e n t h e i t ~ f o m m e n ~ f o ̈ n n t e , ~ f i e ~ z u ~ v e r f e n t e n t . ~ D i e ~ R e r c h e n ~ j i n t o ~}$ gebrungent gebautete $\mathfrak{B o ̈ g e l ~ m i t ~ f u r z e m t ~ o b e r ~ m i t t e l l a n g e m , ~ i t a ̈ r f e r e m ~ o b e r ~ j c y w a ̈ c h e r e m , ~ r u m b e m ~}$ ober feitfich etwas zujammengebrürftem Schnabel, befien Sberteil auf ber Finjte janft fich 


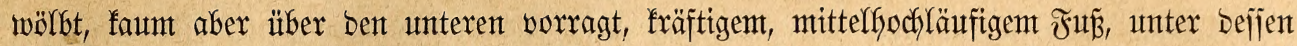

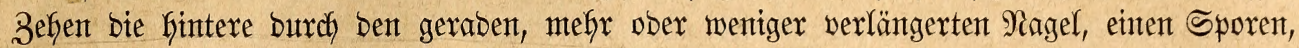

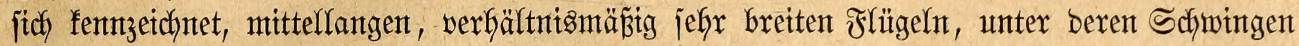
bie britte ober vierte bie längiten find und berèn Sdyulterfebern ben Sdymingen an Ränge fajt gleich fommen, mittellangent ober furzem, jeicht gegabeltem, ebenfalls aus breiten Febern gebilbetem Schwanze und reidyem, erbfarbigem, bei ben meijten $\mathfrak{A}$ rten ziemlith jaymucflojem, aber

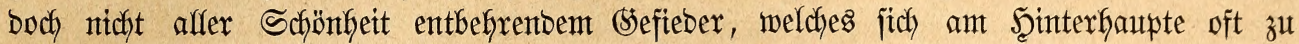
einem Sdyopfe ober einer Şaube verlängert und meift in beiben Siejchlechtern volffomment gleich gefärbt ijt, währento das Sugenbfleit fich Durch jeine Buntheit autzzeichnet.

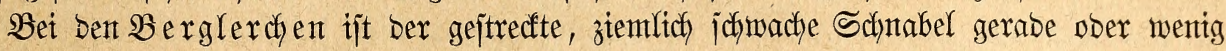

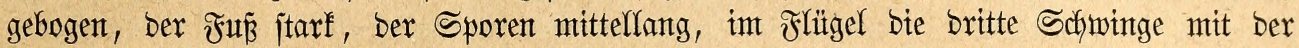
zweiten unt vierten gleidy lang, ber Sdywanz fajt gerabe abgejdynttten, Das (Stefieber bunt unb burch zwei verlängerte Feberbüjche zu beiben Seiten bes Sberfopfes von bem anderer Rerchen unterjofiteden.

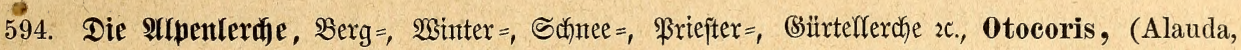
Eremophila, Phileremos, Otocoryx) alpestris, L., (cornuta, virginiana, rufescens, hiemalis, nivalis,

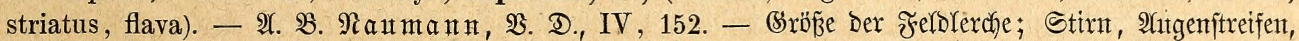

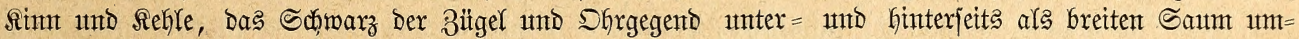

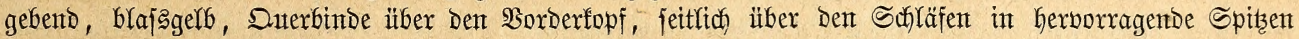

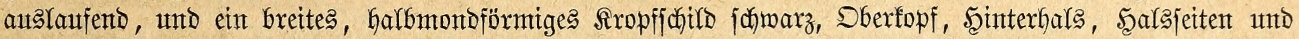

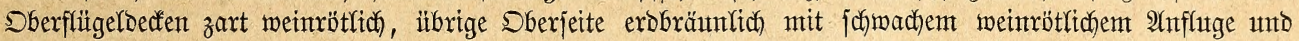

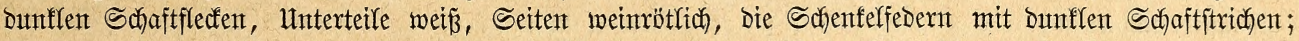

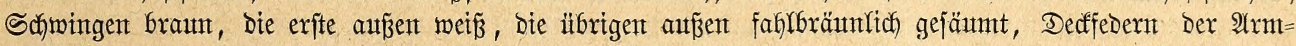

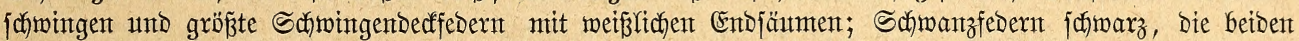

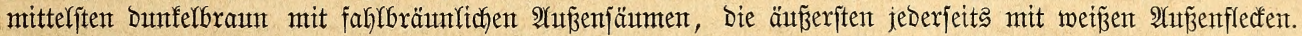

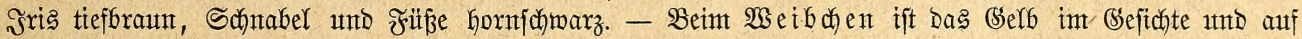

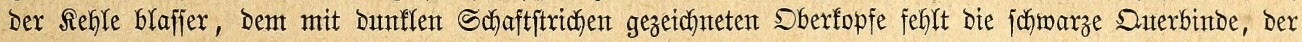

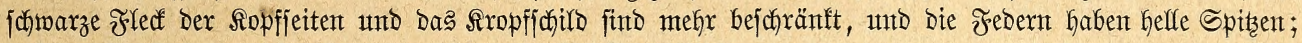

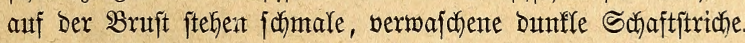

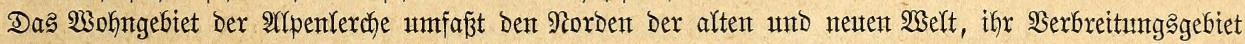

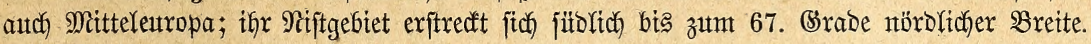

595, Die 5urulerdje, 0. (Al.) chrysolaema, Wagl., (glacialis, rufa, minor, peregrina). -

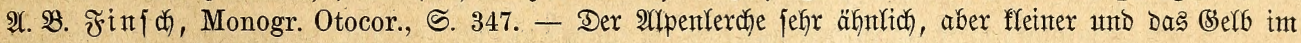
(Beffichte unto auf Der Refle Yebhafter.

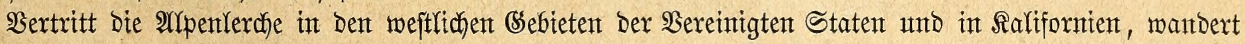

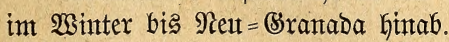

596. Die Dhrlerdje, 0. (Al., Phil.,) penicillata, Gould, (scriba, albigula, larvata). - $\mathfrak{A} . \mathfrak{B}$.

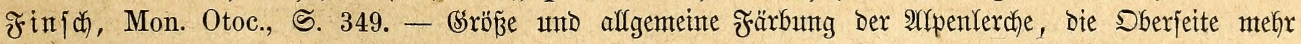

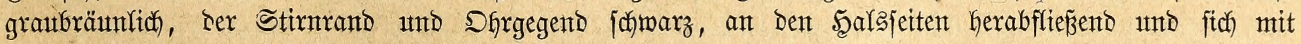

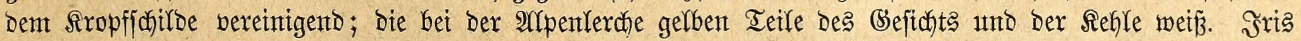

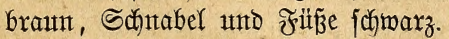

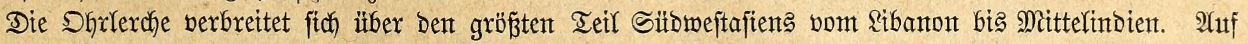
Demt Scimalaya begegnet mant ihr nod) in einter Şöhe von fümftaufento Mieter über bem Mere.

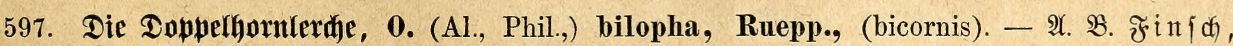

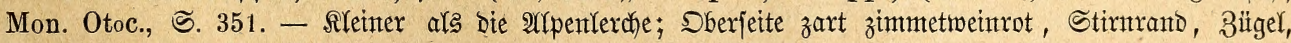

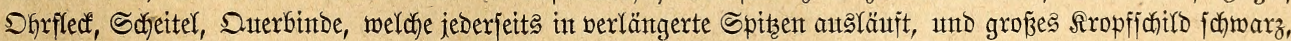

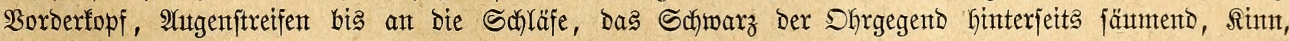

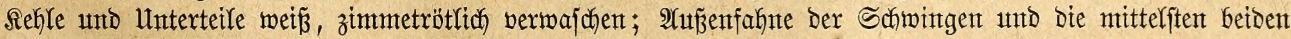

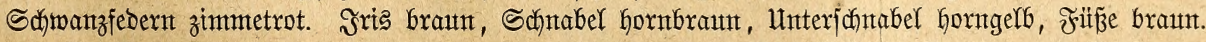

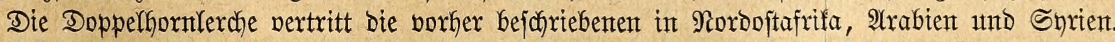

Bei ben Rerchen int engeren Sinnte ijt ber Schnabel mäp̈ig bidf, fajt gerabe, jpitz-

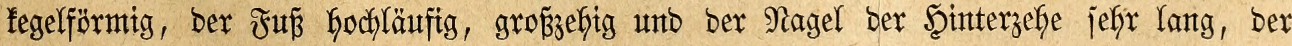




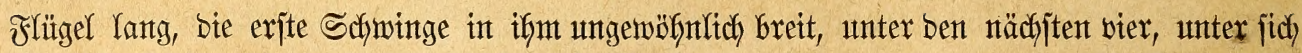

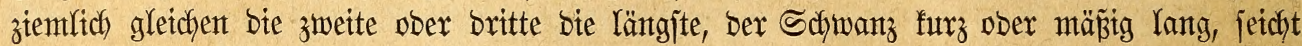
gegabelt, bas Alleingefteber retd') unt mefyr ober weniger geffect't.

598. Die Felolerdide, $\mathfrak{A} d \mathfrak{e} e=$, Sat=, Taglerche, Remarf 2 ., Alanda arvensis, L., (vulgaris, italica, coelipeta, segetum, montana, agrestis, cantarella, triborhynchus, dulcivox, crassirostris, bugiensis, albigularis, tenuirostris, minor, pekinensis, intermedia). - . $\mathfrak{B}$. $\mathfrak{i} \mathfrak{a} \mathfrak{n} \mathfrak{a} \mathfrak{n}, \mathfrak{B} . \mathfrak{D}$, IV, 156. - Sberjeite erobraun, Die Febern mit fahlen Seitenjäumen unt Dunfler fdrmarzbrauner Sahaftmitte, weldhe anf Dem Mantel und Den etwas berlängerten Gollentartigen Febern bes Sberfopfes am

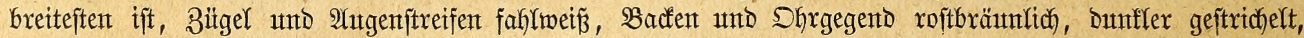
Reble, Sxopf, Dberbruft und Seiten auf roftbräunlidfent (sinnde mit breiteren bunfleren Schaftftrichent

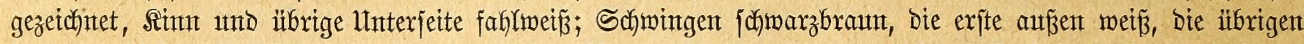

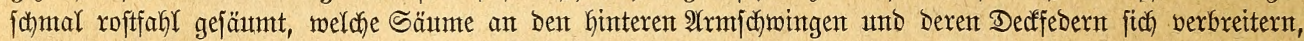

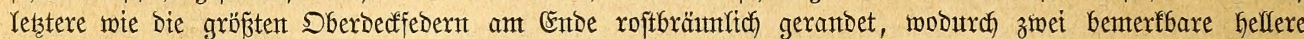

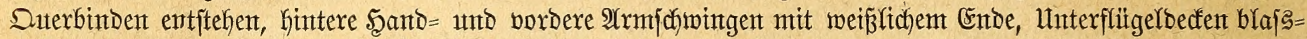

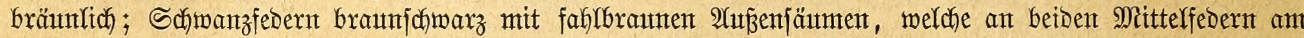

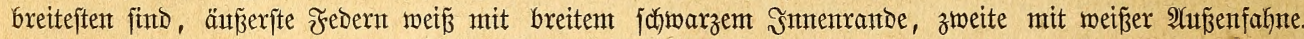

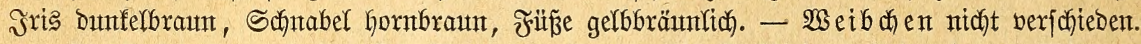

Die Feldrerche verbreitet fich ïber ganz Europa bis Dftfibirien, brïtet it Dex Mitte und im Norben unjeres Eroteiks and wandert im Winter bis Siubafrifia und Sitbinbien fintab.

599. Die 5immtelerdje, A. japonica, Temm. \& Schleg., (coelivox). - श्:. B. Faun. jap., ธ. 87. - Faft ganz wie Die Jelolerche gefärbt und gezeichnet, jeboch fleiner; Dbertopf, Mantel unt

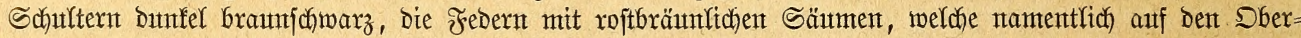

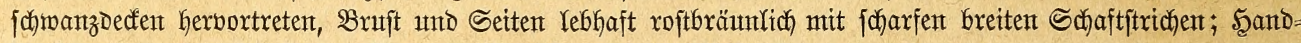

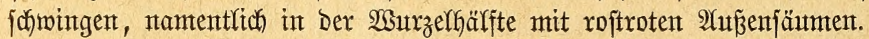

Sextritt unfere Jelolerche in Sitbdjina auf Şainan, Jormoja unt in Japan.

600. Die Iriflerlerife, A. gulgula, Frankl., (gracilis, gangetica, leiopus, malabarica). -

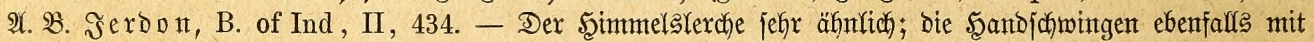

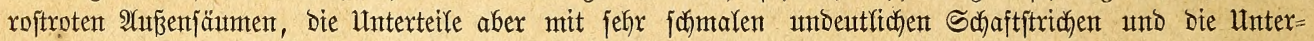
flïgeldecten Deutlič́n ifabelfroftrötliç).

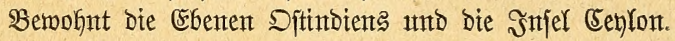

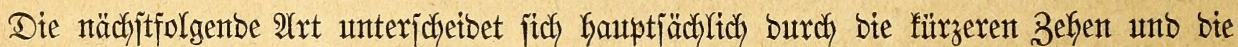
furzze Daumenfrafle won ben eigentfichen Rerchen unb ift besmegent zum $\mathfrak{B}$ ertreter einer bejonberen Sippe ober Unterippe ergoben worben.

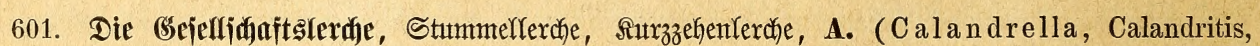
Phil., Melanocorypha, Emberiza) brachydactyla, Leisler, (calandrella, dukhunensis, arenaria, bagheira, olivacea, moreotica, itala, graeca, tenuirostris, gallica). - $\mathfrak{A} . \mathfrak{B}$. $\mathfrak{\Re} a \mathfrak{4} \mathfrak{m} \mathfrak{n}$, $\mathfrak{V} . \mathfrak{D} ., \mathrm{IV}$,

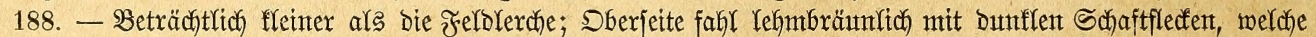

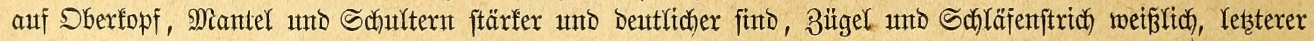
unterjeits von einem Dunflen Striche begrenzt, Shrgegend und Bacfen roftfahl, Dunfel geftridhelt, Unterteile

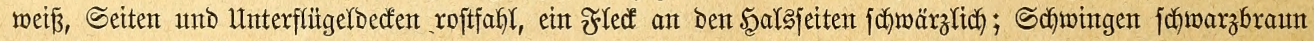

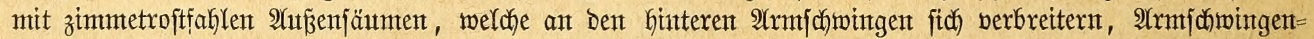

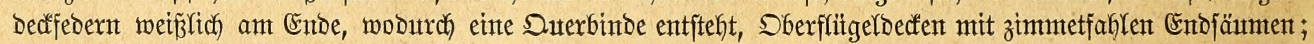

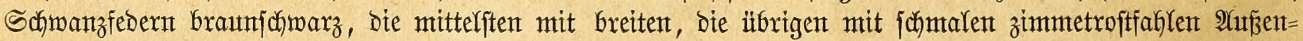

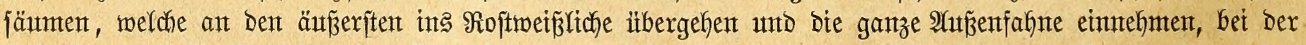

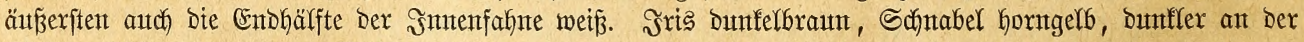

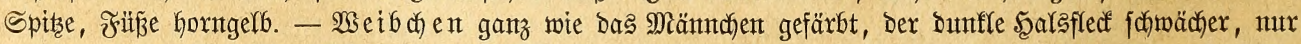

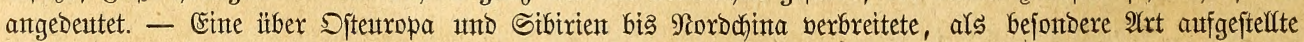

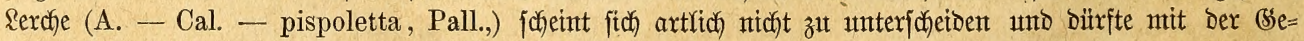

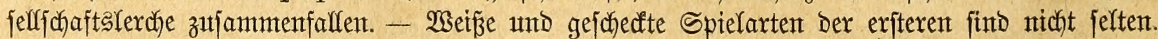

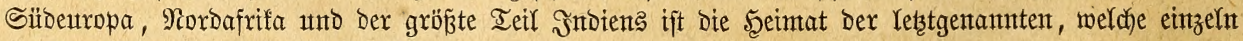
audi) in Deutfdhland und Englanto erlegt wutrde.

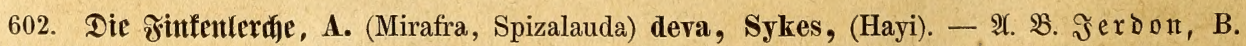

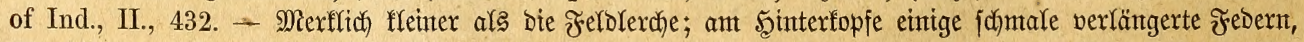
Sberjeite Dunfelforaun mit falbent Borberfäımen, Dhrgegento rötliç braun, ein undeutfiçer Bartftreifen 


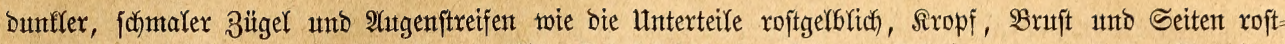

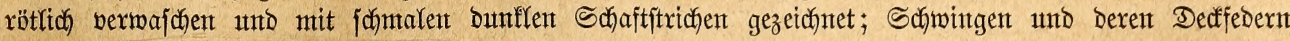

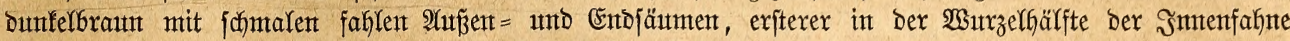

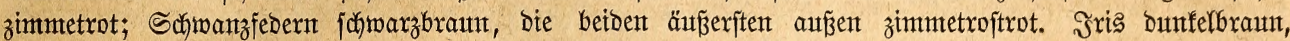

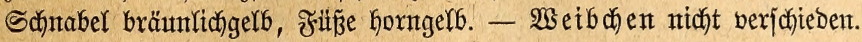

Sebr häuftg in Sïbintbient.

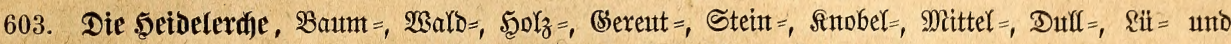

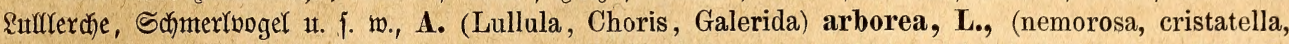

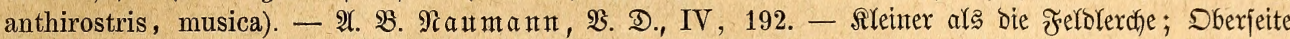

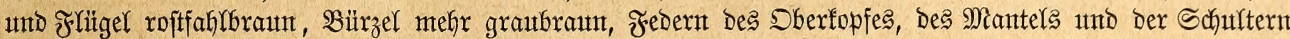

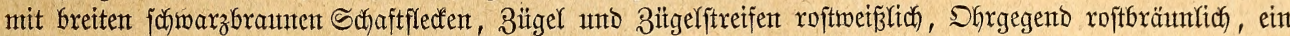

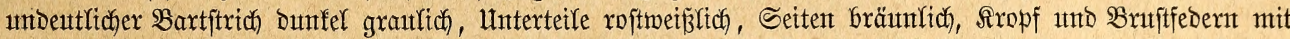

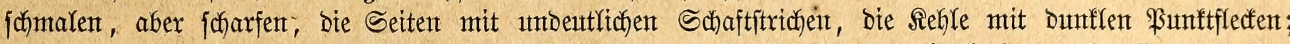

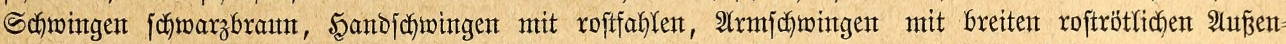

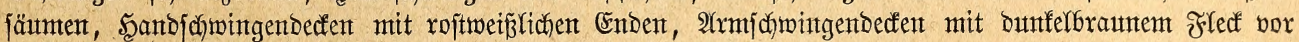

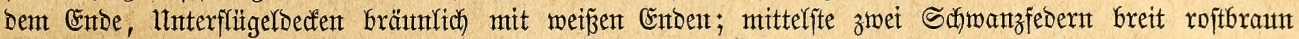

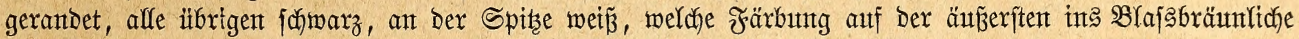

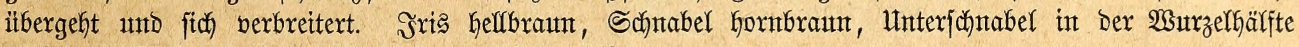

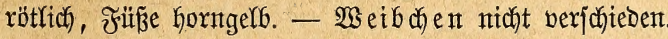

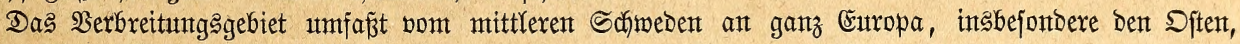
Das weftlide 2 ffien uno Rorbafrita.

604. Die Epiegelferdfe, A. (Phil., Calandr., Melanoc.) sibirica, Gml., (leucoptera):- $-\mathfrak{A} . \mathfrak{B}$.

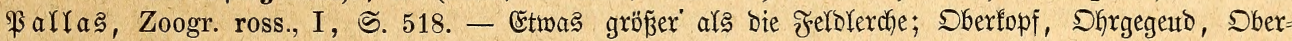

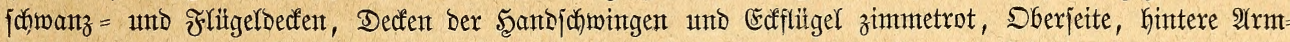

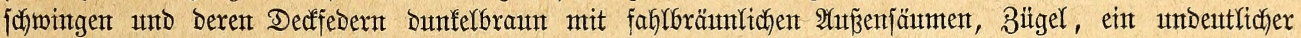

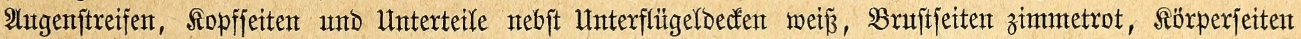

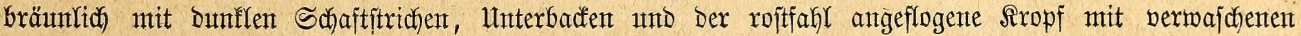

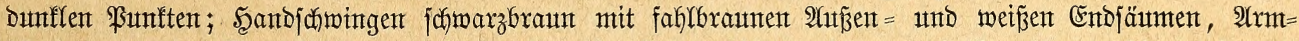

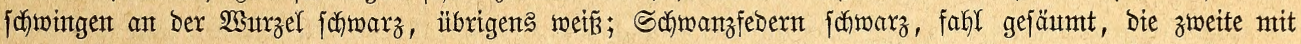

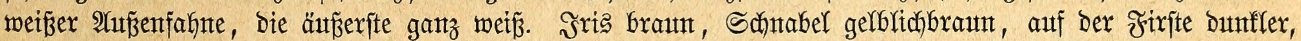

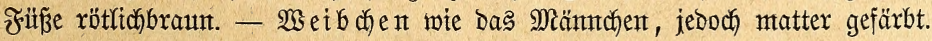

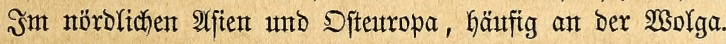

605. Die (Srauterdhe, A. (Caland., Megalophonus) cinerea, Lath., (ruficeps, spleniata, rufi-

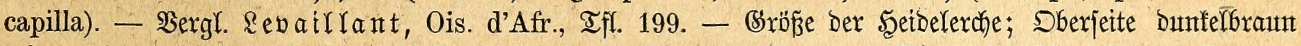

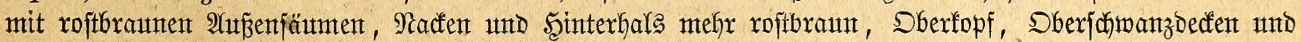

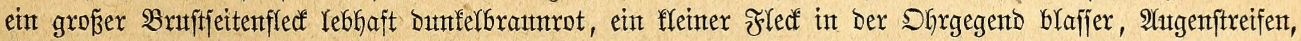

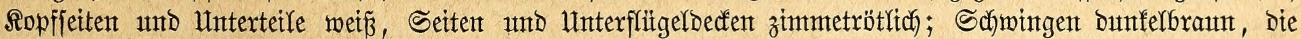

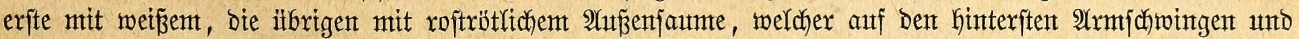

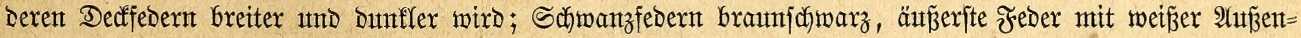

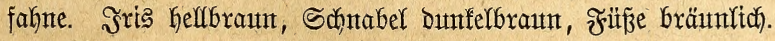

Eine Der gemeinftent $\mathfrak{2}$ rtent Des Raplandes.

Bei ben nadjfolgenden 2 rten ijt ber Sdynabel etwas fräftiger, bie Behen, berent Ginterite

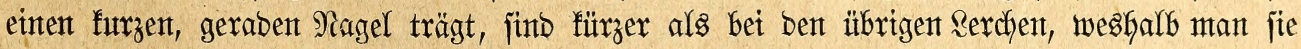
unter bem Namen Sanblerdy en (Ammomanes) in eine bejonbere Sippe bereinigt bat.

606. Die $\mathfrak{B u ̈ i t e n t e r d j e , ~ S ̧ a b e f r e r c h e , ~ A . ~ ( A ~ m m o m a n e s , ~ M e l a n o c . , ~ C a l a n d r . , ~ M i r . ) ~ d e s e r t i , ~}$

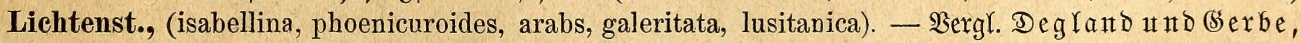

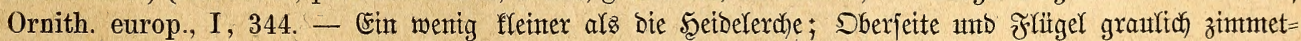

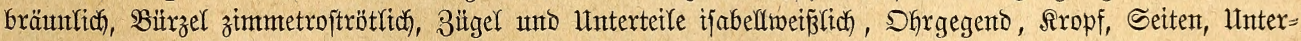

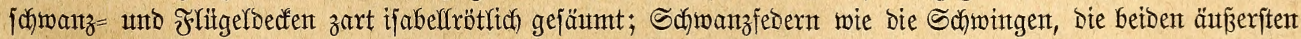

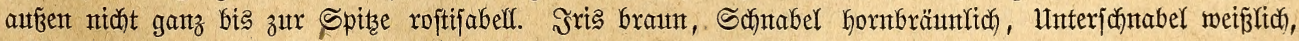

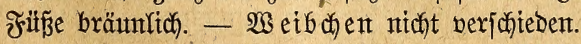

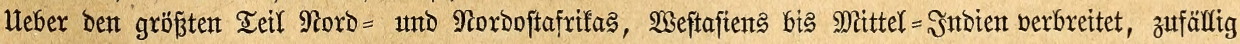
in Sildeutropa.

607. Die Santiferdie, A. (Mel., Ammom.) einetura, Gould, (pallida, elegans, arenicolor). -

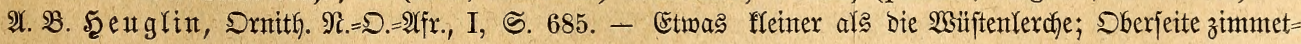




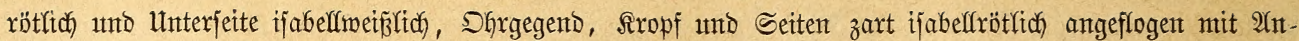

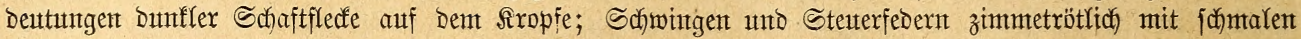

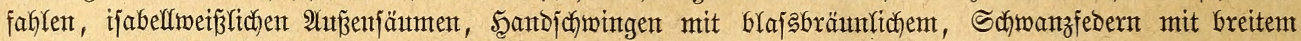

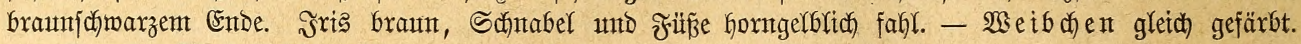

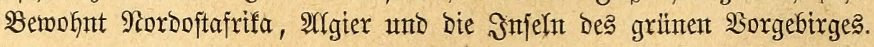

Der ziemlich hohe, jeitlich jtarf zujammengebrüdte Schnabel unb bie hochläufigeren Fün̈e unterjchetben bie nächiftolgenden $2(r t e n$, weldhe ebenfalls in eine bejonbere Siruppe, bie Buj cylerchen (Mirafra), wereinigt worben fint.

608. Die Bujumatolerdje, A. (M irafra, Plocealauda) assamica, Mc. Clell., (typica). -

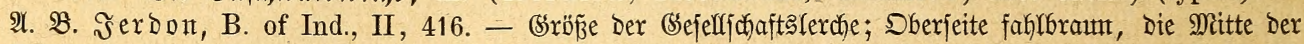

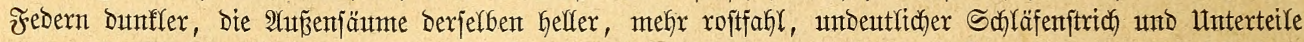

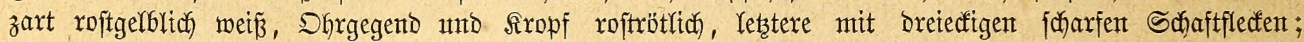
Sdjwingen olibenbraut, nidjt ganz bis zum Ende roftrot, innen breit tiefzimmetrot, Gintere Atrmidjwingen

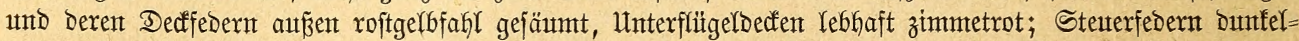

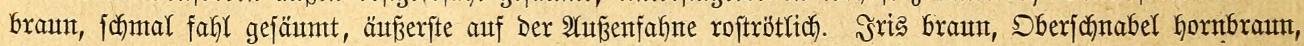

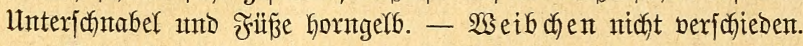

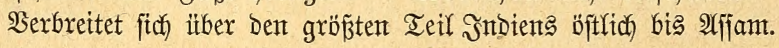

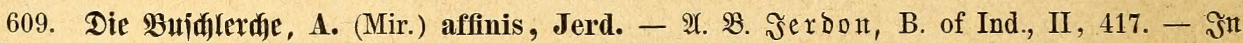

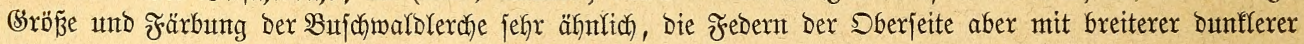

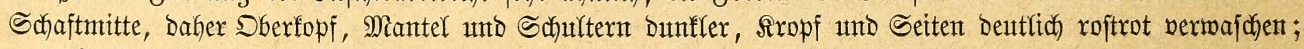

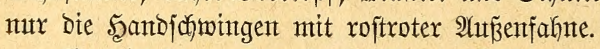

Bertritt bie vorkergehente $\mathfrak{A}$ rt in Sitbintien und auf (Een)lont.

610. Die Sittglerhye, A. (Mir.) cantillans, Jerd., (chendoola, javanica?, Horsfieldi?). - $\mathfrak{A} . \mathfrak{B}$.

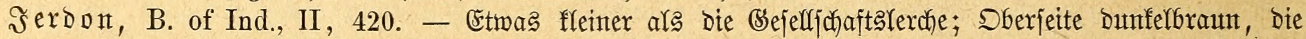

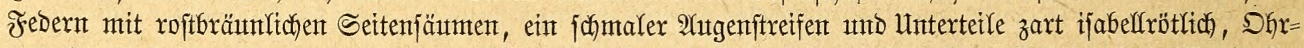

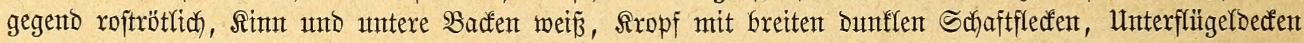

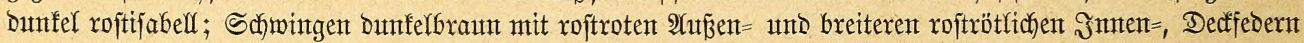

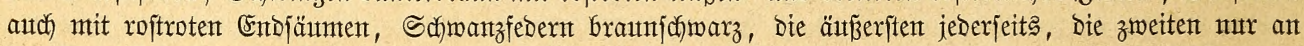

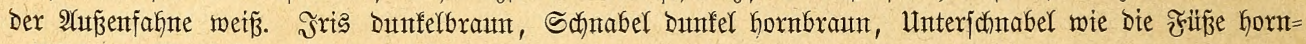

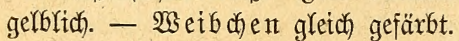

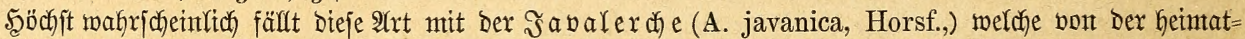

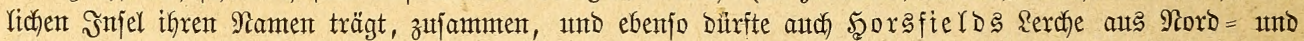

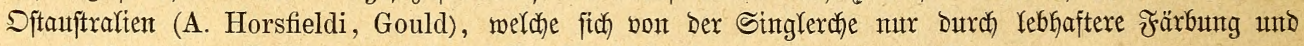

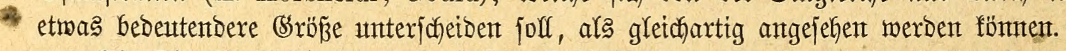

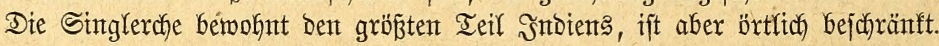

Die betben nächjtfolgenben 2 (rten zeidynen fich burch eigentïmlich bunte Färbunt aus unt fint beshalb zum $\mathfrak{B e r t r e t e r}$ einer Unterjippe, ber $\mathfrak{B}$ untlerchen (Megalophonus), erfoben

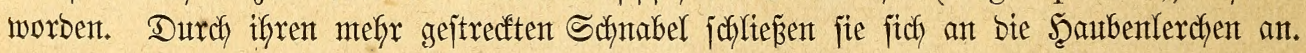

611. Die (Saufellerdie, A. (Megalophonus, Brachonyx) apiata, Vieill., (clamosa, crepitans). Bergl. Revairfant, Ois. d'Afr., Ifl. 194. - Etmą fleiner als bie Sceidelerche; Federn Der Sberjeite

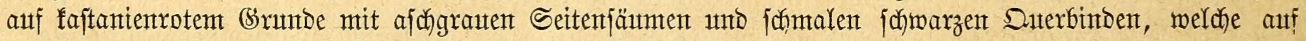

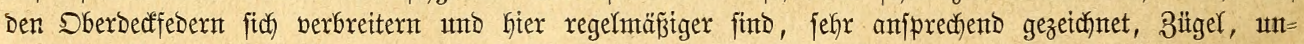

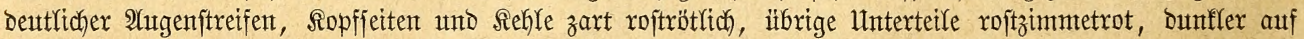

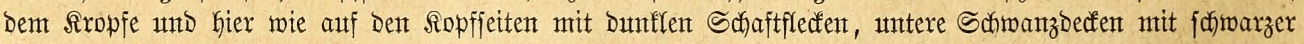

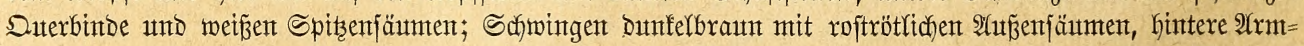

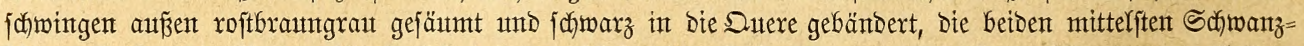

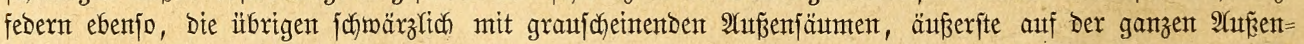

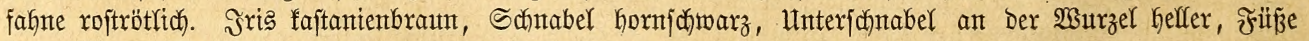
horngelb. - 23 eib dien minder rebhaft gefärbt.

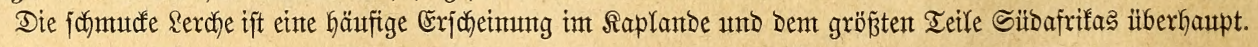

612. Die $\mathfrak{B r a d j l e r d j e , ~ A . ~ ( M i r . , ~ M e g a l o p h . ) ~ p l a n i c o l a , ~ L i c h t . , ~ ( a f r i c a n a , ~ o c c i d e n t a l i s , ~ r o - ~}$

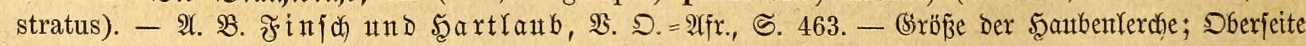

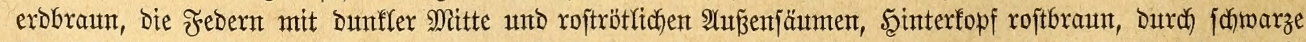

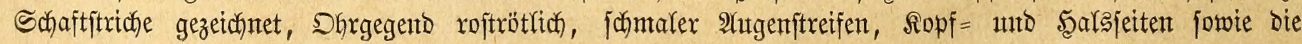




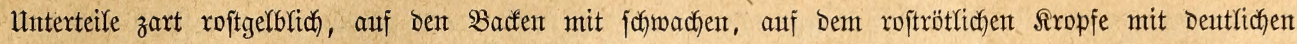

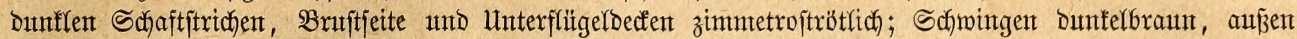

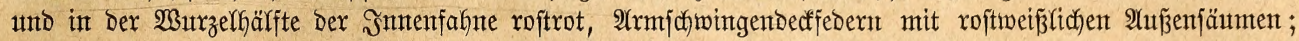

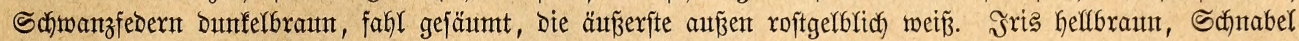

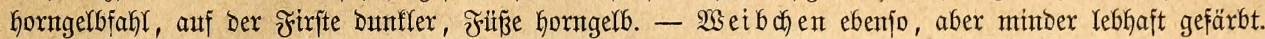

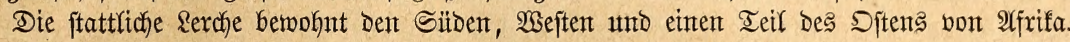

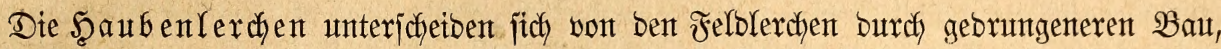
itärfferen, obwofjl noch inmer geftredten, geraben ober janft bogenförmigen Schnabel, jtarfe Füßje mit mittelfangen Zehen unb fajt geraben Daumeniporen, groß̉e breite uno jumtpfe Flügel, in weldyen bie unter fich fajt gletch langen zweite bis fünfte Schminge bie anberen -ïberragen, furzen, gerabe abgejdyntttenen Schwanz und reiches, locferes, auf bent Şinter= fopfe zu einter Şautbe verlängertę (Sefieder.

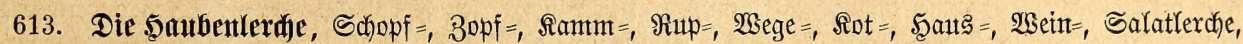
Rürle 1t. f. w., Galerida, (Al., Lullula, Heterops, Certhilauda) cristata, L., (undata, matutina,

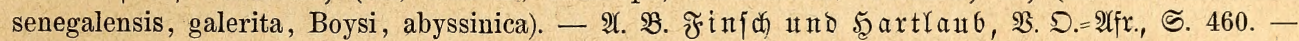

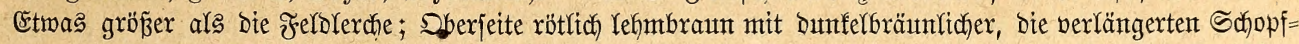

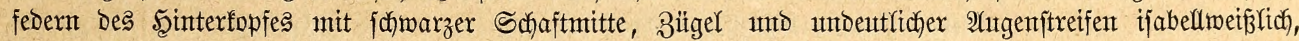

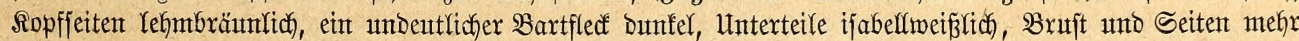

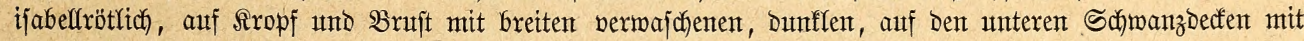

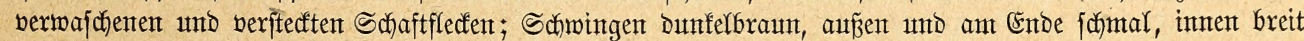

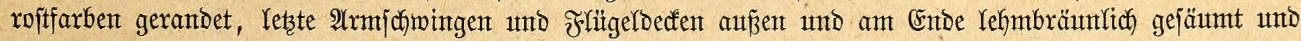

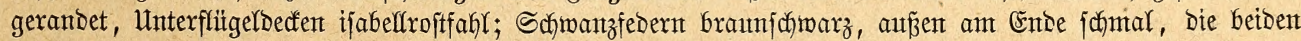

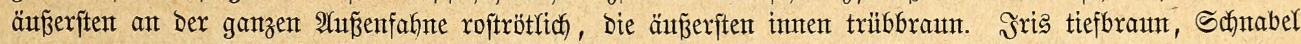

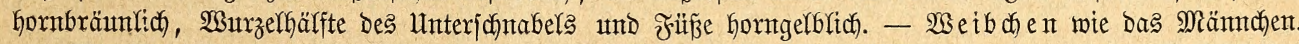

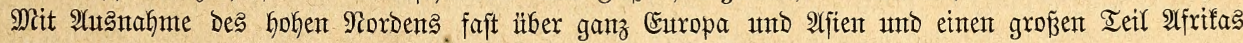
verbreitet.

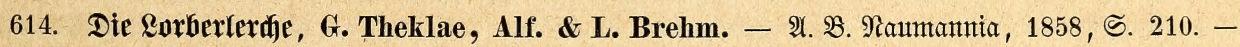

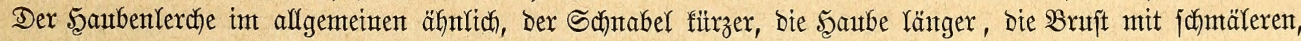

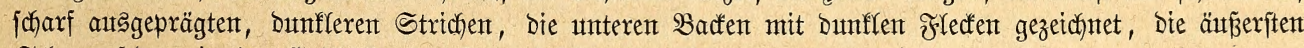
Schwanzfedern in Der Ertohälfte ber Intenfahtte roftrötlich.

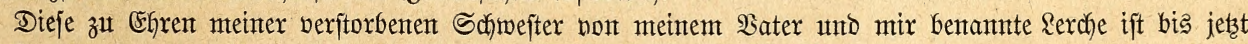

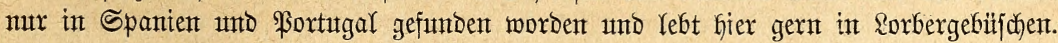

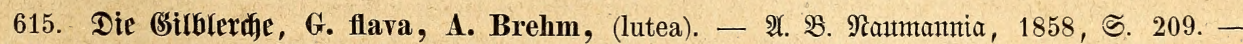

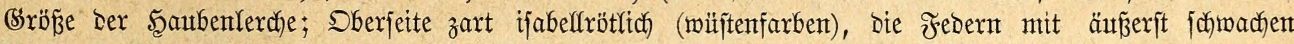

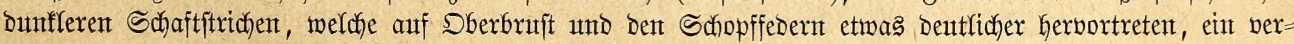

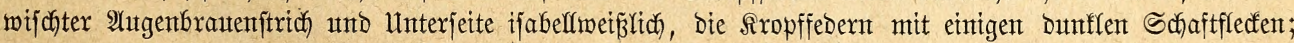

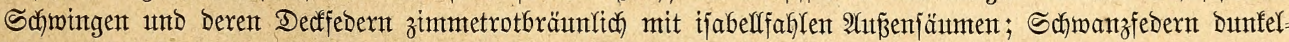

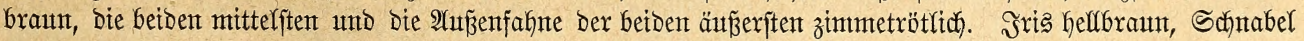

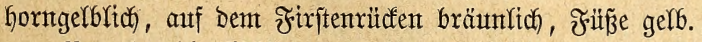

Berwofnt bie Süftent utto Steppent Rabients unt Sitfitdants.

616. Die Droffelferdye, Diffidnabeffexche, G. (Brachonyx, Calendula) erassirostris, Vieill.,

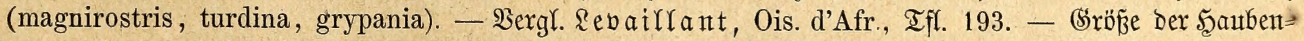

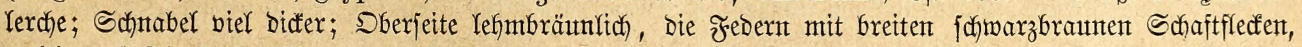

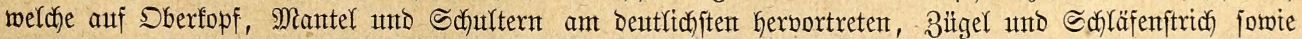
Unterteile weiß̈gefblid, Sropf, \$Bruft und Seitenfedern mit breiten idjwarzbraunen Sdaftfleden, Shrgegento

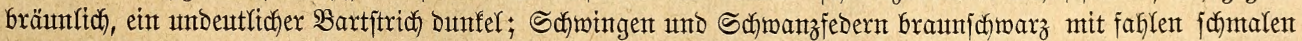

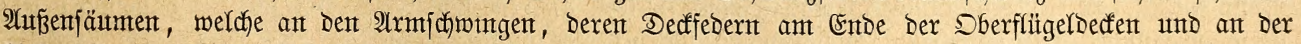

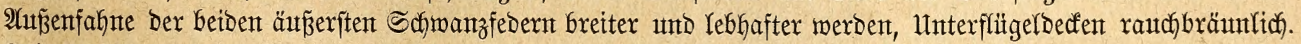

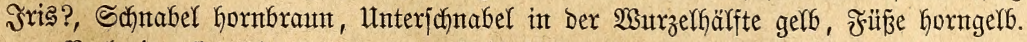

Berbreitet fich) ïber den größ̈ten Teil SüDafrifią.

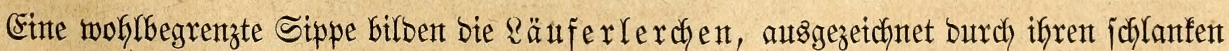

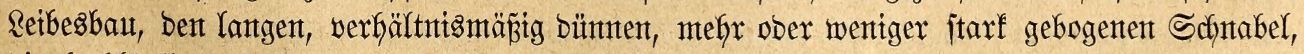

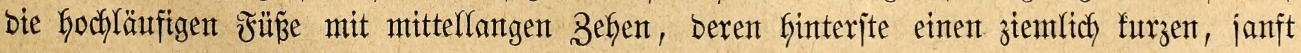


gebogenen Sporen trägt, Fełr lange und breite Flügel, won beren Schwingent bie britte, vierte und fünfte vor ben ïbrigen Gerworjtehen, mäpitg ober ziemlich langen Sdywanz uno reiches, aber glatt antiegentes (Sefieber.

617. Die $\mathfrak{B u ̈ i t e n l a ̈ u f e r t e r c h e , ~ A l a e m o n ~ ( A . , ~ C e r t h i l a u d a ) ~ d e s e r t o r u m , ~ S t a n l e y , ~ ( b i f a s c i a t a , ~}$

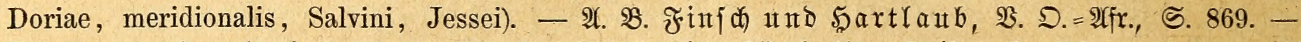

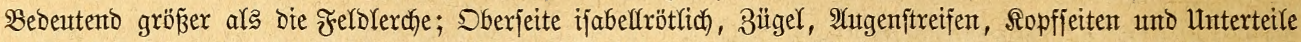

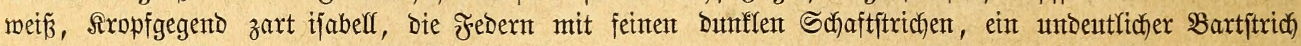

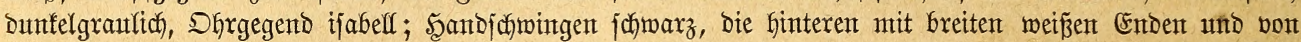

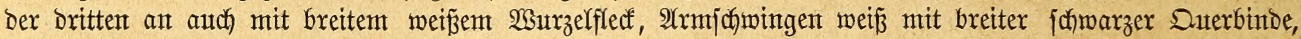

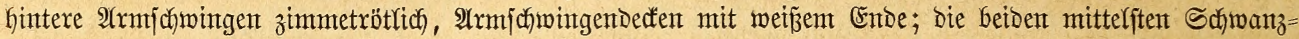

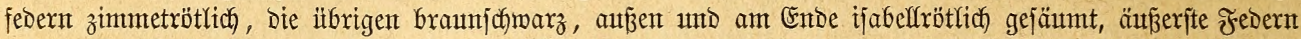

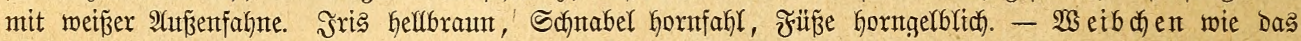

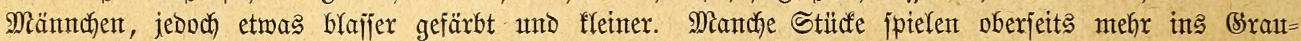

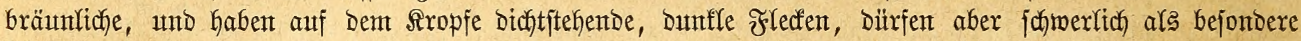
2(rt betrad)tet werbent.

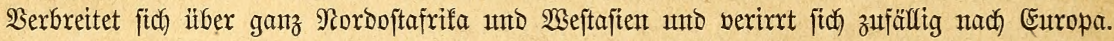

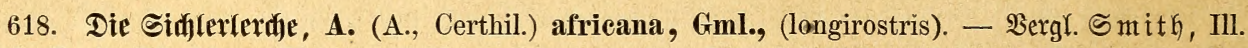
S. Afr. Zool., Ifl. 90. - R̂einer als bie vorhergehentoe, Der Schnaber ftärfer gefrümmt; Dberjeite Dunfel= braun mit roftbraunen verwajchenen Federjä̈men, weldhe am breiteften umb rebhafteiten auf bem Bürzzel

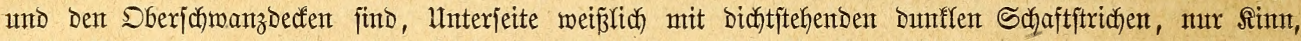

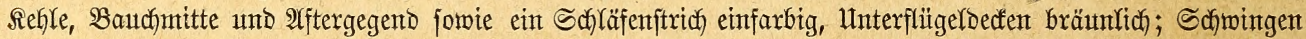

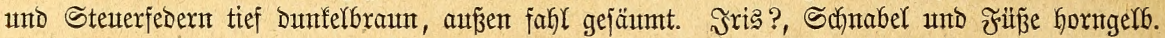

Eine Der häuffigiten $\mathfrak{A}$ rten Sildafrifả.

619. Die Bogenifnabelferdie, A. (A., Certhil.,) Dupontii, Vieill., (ferruginea). - A. $\mathfrak{B}$. Degland und Berbe, Ornith. europ.. I, S. 356. - Größ̈e Der Šaubenterche; Federn Der Dberjeite

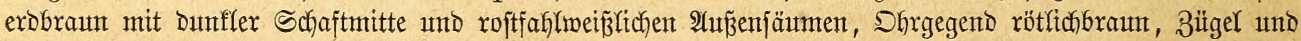

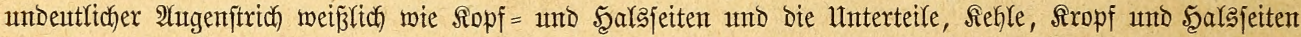

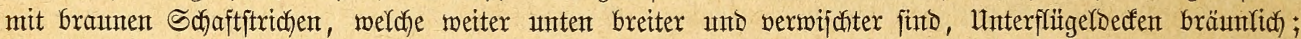

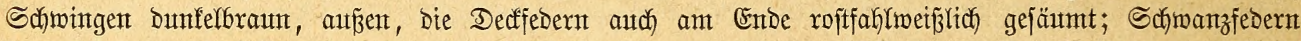

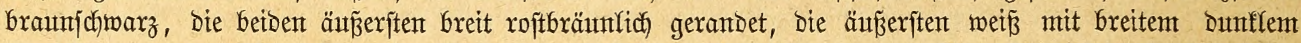

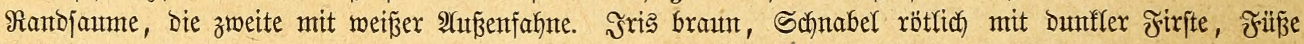
horngelf.

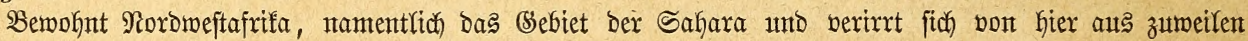
nact) Eutropa.

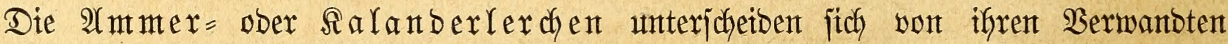
Durch ben georungenen fräftigen $\mathfrak{B a u , ~ D e n ~ a u f f a l l e n t ~ g r o ß ̉ e n , ~ b i c f e n ~ S c h n a b e l , ~ f r a ̈ f t i g e n , ~}$

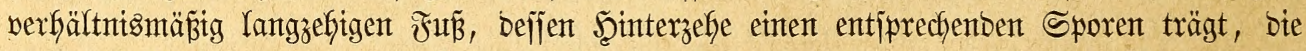

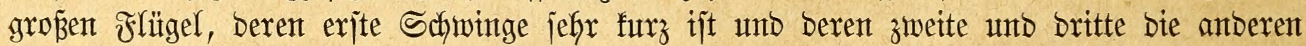
an \&änge überragen, und Den fajt geraben, furzen, faum ausgejdyntttenen Schwanz.

620. Die Salanberterde, Melanocorypha (A.) ealandra, L., (collaris, albigularis, subcalandra,

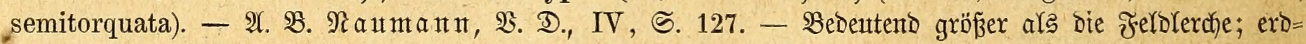

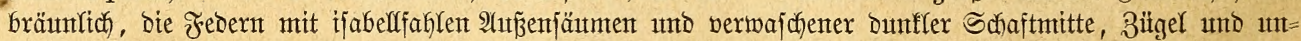

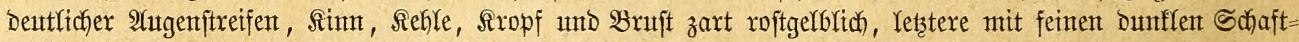

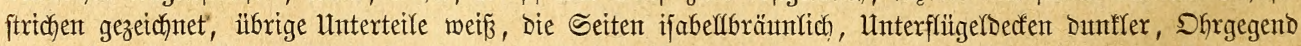

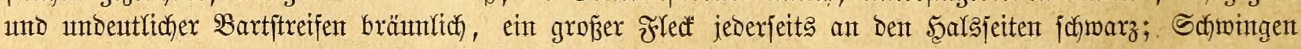

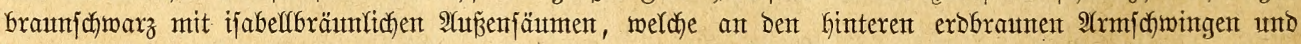

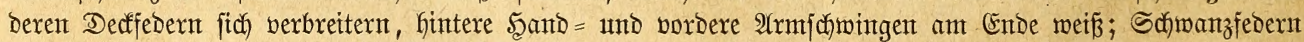

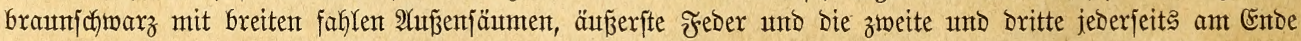

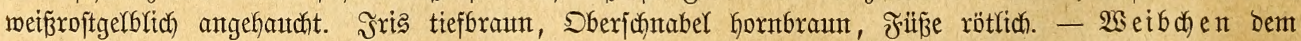

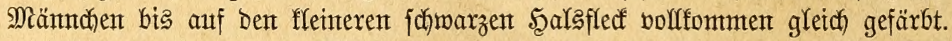

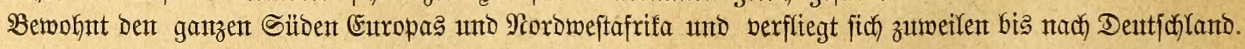

621. Die 5alæhandierảje, M. (A.) bimaculata, Ménetrie, (torquata, alboterminata, rufescens?). -

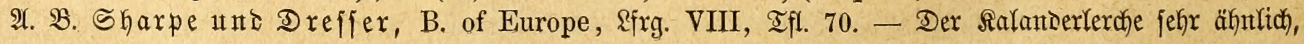




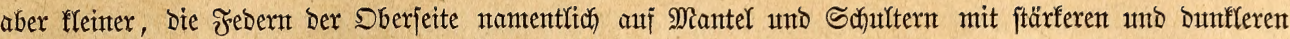

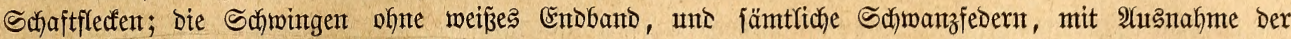
beiben mittelften, an Enbe roftweißjlich.

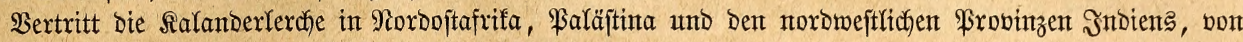
hier auts bis Mittelafien uno Sibirien fich verbreitend.

622. Die Minfrenterdye, M. (A., Tanagra, Saxilauda) yeltoniensis, Forster, (mutabilis, tar-

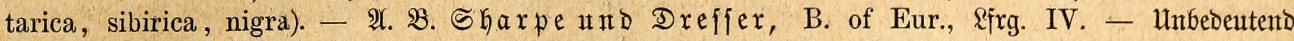

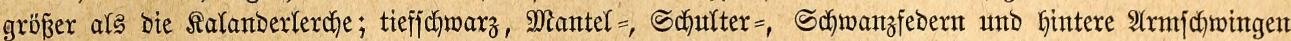

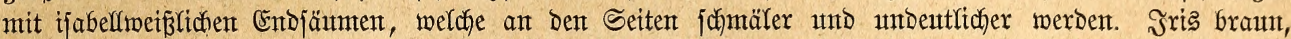

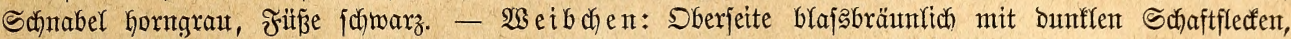

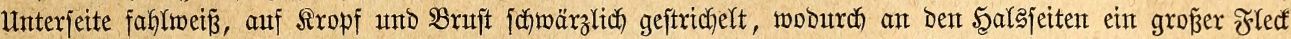

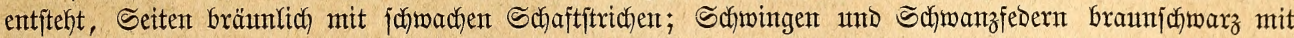

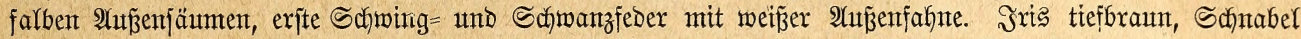

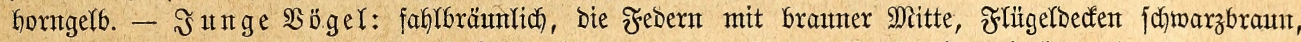

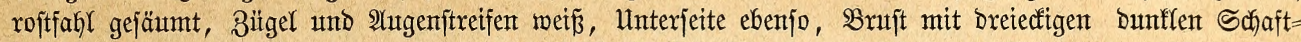

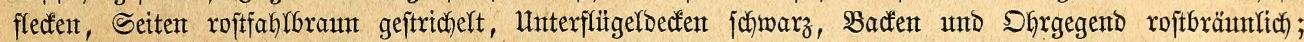

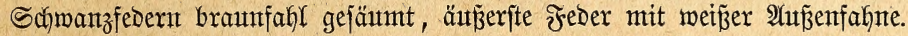

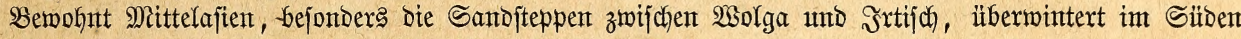

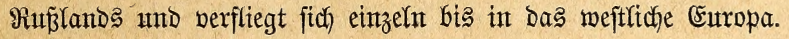

623. Die Steppenterdje, Bai=\&ing, D. i. humbert (seifter ber EGinefen, M. (A.) mongolica, Pall.,

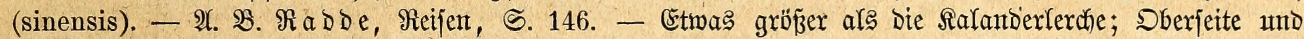

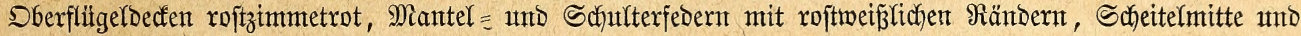

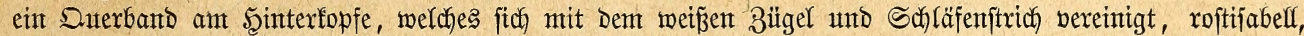
Sa)läfenftrich unterjeits von einem zimmetroten Streifen begrenzt, welcher fich über bie Shrgegent aus=

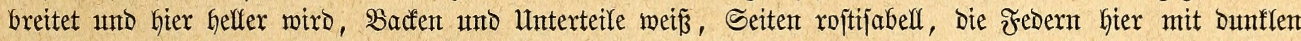

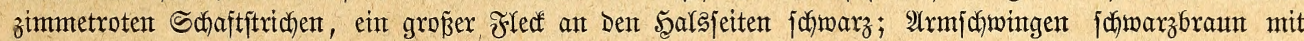

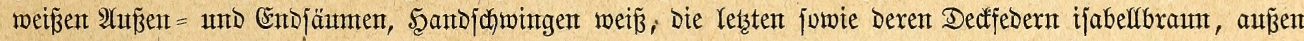

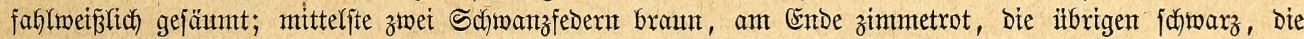
beiden äน

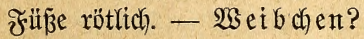

Die Sumpffteppen Mittelafiens füblich vom Baifarfee und die Miongolei find dą $\mathfrak{B a t e r l a n t e ~ b i e f e r ~}$ ftattlicfien \&erche.

Der noch gemaltigere, fajt ebenjo bohe alz lange, jeitlich jtarf zujammengebrürfte, auf

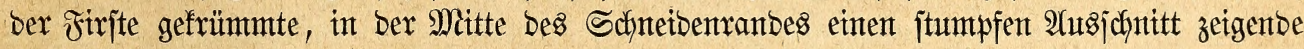

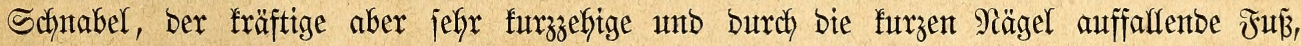
fomie bie langen Flügel, unter beren Schningen bie erjte umb zweite bie längiten fimb, fenzzeidynen bie Falfenlerdyen, bon benen bis jebst nur eine einzige Ât befannt gemorben ijt.

624. Die Intafer = ober Rlepperferdie, Rhamphocoris (A., Melanoc., Jerapterhina, Hierapte-

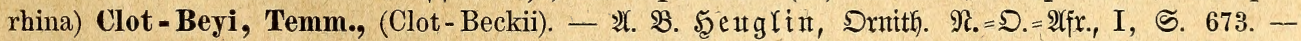

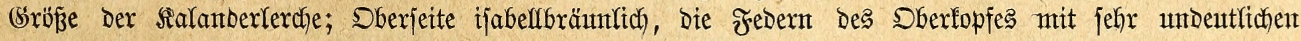

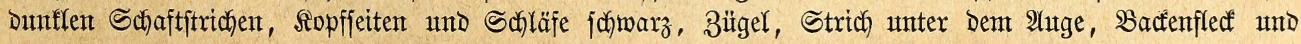

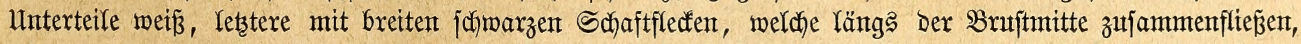

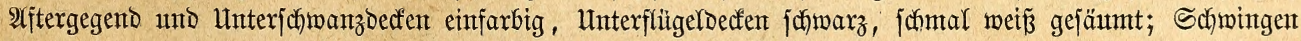

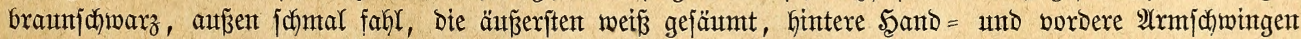

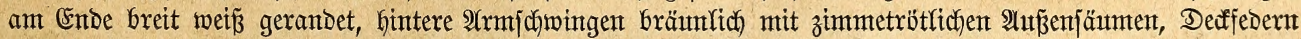

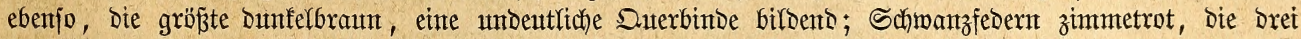

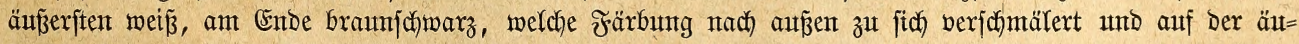

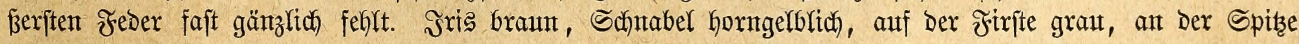
Dunfer, శ̧üße Gornfahl.

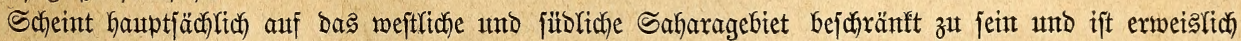
nod) nicht in Befantgenjchaft gehalten worben.

Der furze, jtarfe, jeitlich zujammengebrïnfte, auf ber Firjte merflich gebogene Schnabel, furzläufige unt furzzehige Füß̈e, Deren Daumen nur einen unbebeutenden Sporen trägt, bie breiten, ftarf gerunbeten Flügel, unter beren Sd)wingen bie zweite bis fümfte unter fich 
zientlich gletch lantg into bie längiten fintb, ber furzze, jetcht gegabelte Schmanz unto bas nach

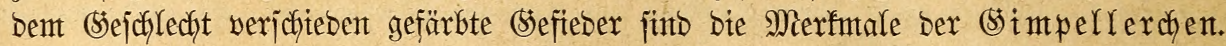

625. Die Sffeflenterdhe, 2 seiß̧ofrlerche, Coraphites (L., Fr., A., Pyrrhulauda) leueotis, Stanl.,

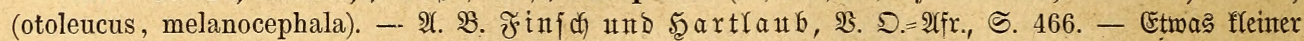

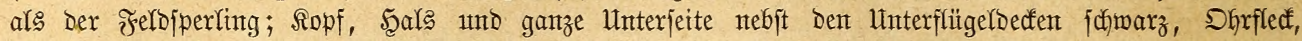

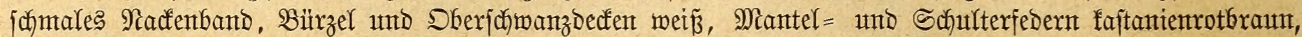

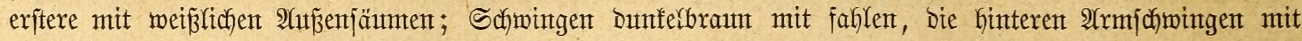

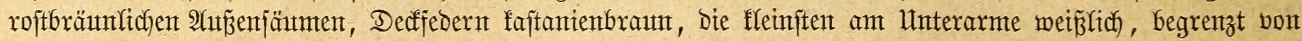

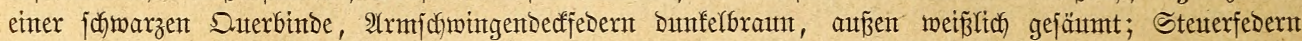

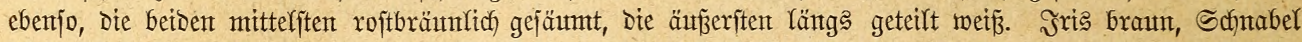

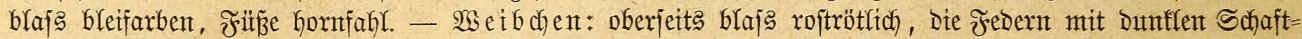

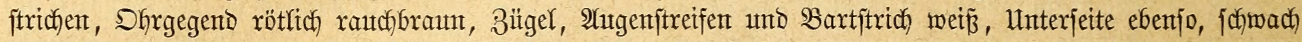
roftrötlich angeflogen, bie Brufffedern mit bräunlichen Edaftfledfen, Bauth, Iffergegeno uno Unteridfmanz= Dedent ichiwarz.

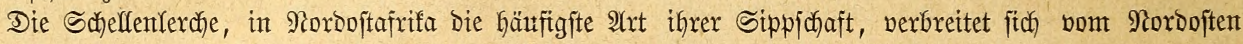

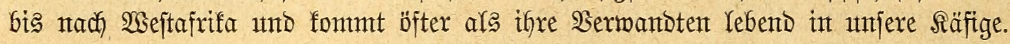

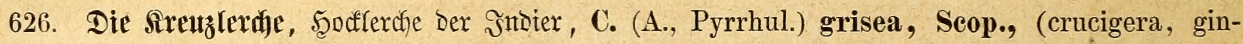

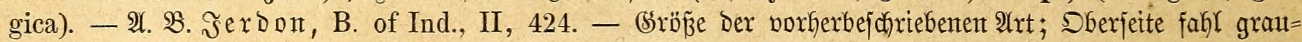

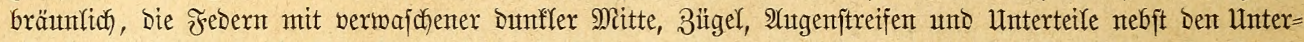

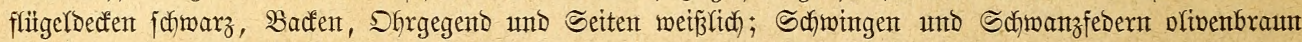

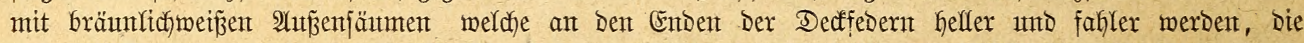

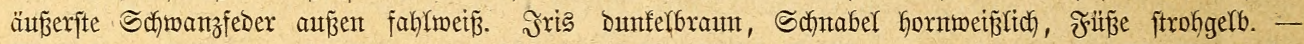

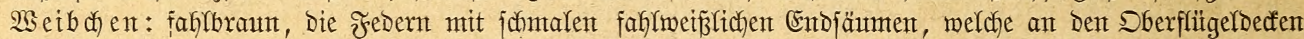

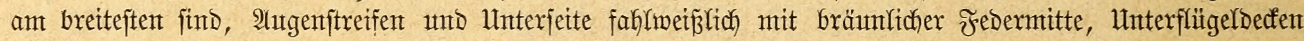

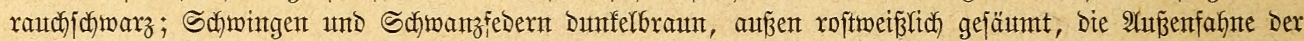

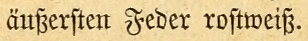

Heber gant Jndien anto (Sen)lont verbreitet.

627. Die Sappenterdje, C. (A., Pyrrhul.,) nigriceps, Gould, (frontalis, albifrons). - Bröß̄e

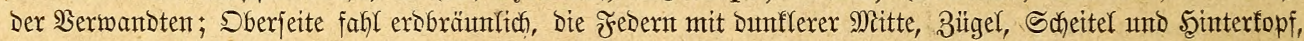

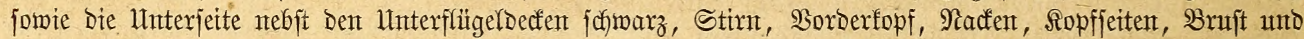

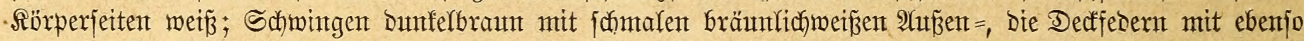

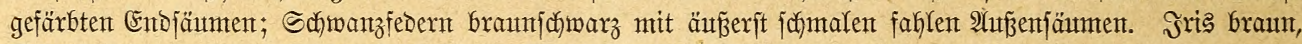

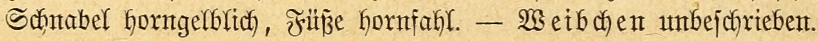

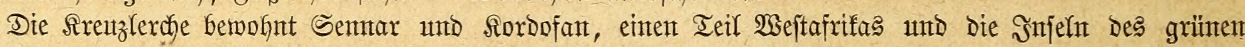
Sorgebirges.

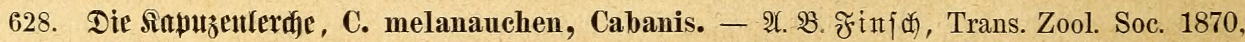

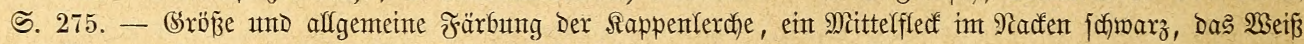

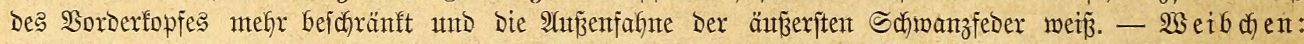

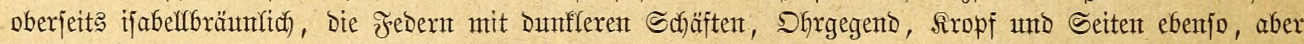

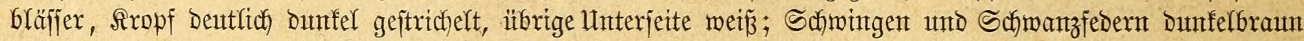

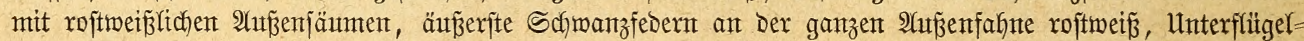
Dedfen rautchidimarz.

Semoght Die Riüftenländer Des roten Meres.

Sbrwofl in affen Eroteifen auftretento unt in affen Siüteln vorfonment, find bie Rerchen boch als Bewohner ber alten 2 selt unt insbejonbere ber nörblichen Erobälfte auf =

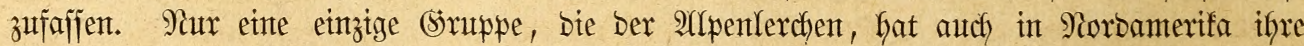

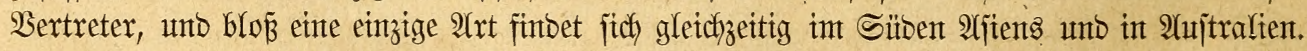

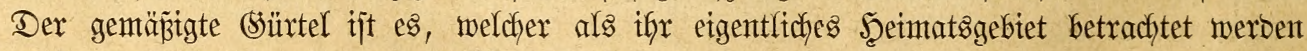

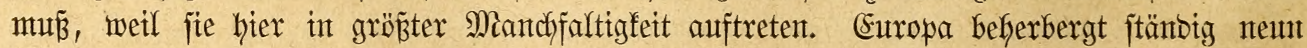

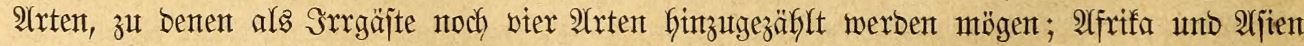

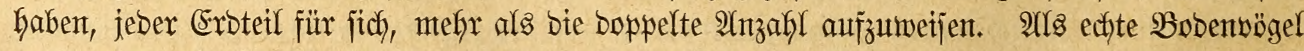
entiprectien bie Rerchent in Der Färbung iffres (Sefiebers ber Segent, in welcher fie reben, und jomit finben mix bie bunfelften 2trten in ben jofwarzen Steppen Silbojteuropas umb 
Afjiens, bie amt helfjten gefärbten bagegen in ben $\mathfrak{B u ̈ j t e n ~} 2$ frifłas unb ben angrenzenben (Siebieten 2fjienz; ja es änbert fich jogar eine und biejelbe (Srunbjorm nach und nach um,

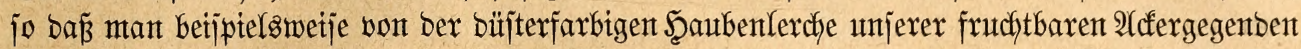

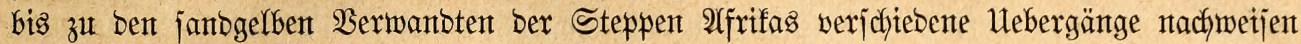

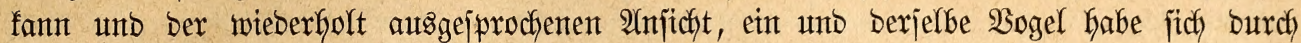

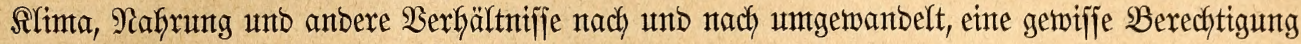
zuiprectjen barf.

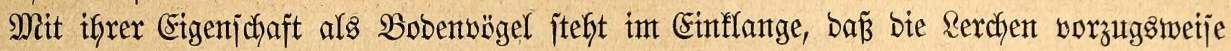
auf baumlerent ober bock mur bürftig mit $\mathfrak{B}$ ujdywerf bejtantenten (Segendent gefunden merben

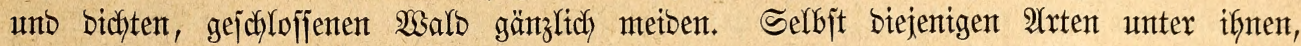

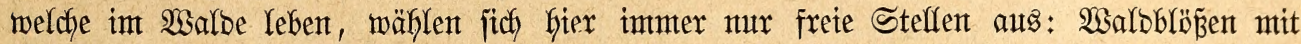

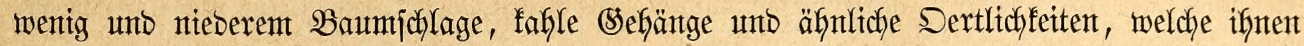

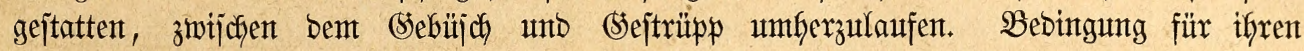

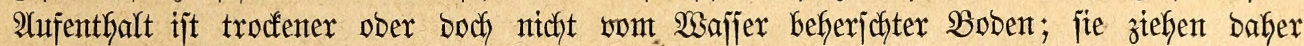
Felber ben Wiejen entjchieben vor unb treten in wajferreichen (segenden bejonbers auf Den trofenteren Sëhen auf. Dem ungendfet bürfen mur bie wentgiten 2 rten won ifnen als

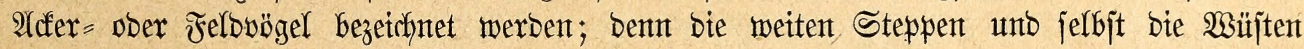

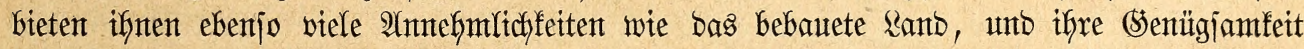
läp̧t jie jelbjt auf ben öbejten Stellen nodh zujagende Wohnjibe finden. Das Fruthtland mit jeinem Ssetreibe, bie Steppen mit ifrent verjefiedenten jamentragenden Srabarten

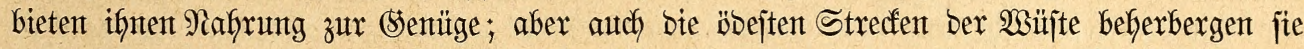
noch, objchon man fier zumeilen jidy vergeblich fragt, in wiefern ifnen bie Miöglichfeit zum Seben gebotent ijt. Snt (sebirgé jteigen jie übrigens nur bis zu getwifjen Şöhen empor, faum über bie (Srenze des Scolzmuthjes jich erhebent.

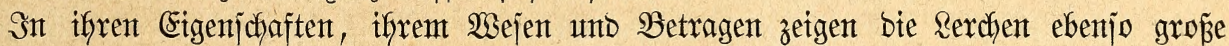
Heberemptimmung wie Ginjictutlich) ifres 2ufentbaltes. Sie find bie Bobentögel unter bent Rörnerfreffern, befjere Räufer als alfe übrigen, gleidyzeitig aber audy treffliche Flieger. Shr

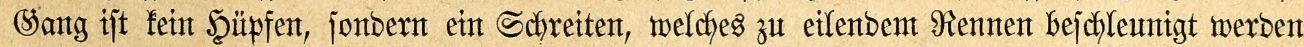

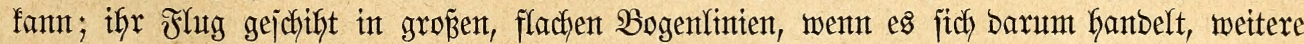
Strecfen zu Durctymeffen, währento bie groß̈en und breiten Flügel beim Spielen unt Singen

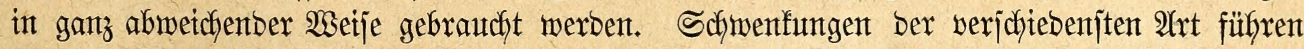

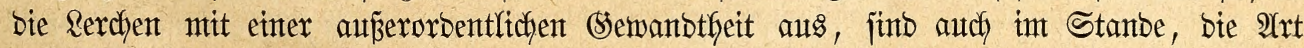
unto Weije ifyres Fluges jeberzeit in eine anbere unzuänbern, unb unterjachetben jich baburch

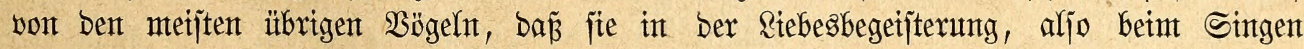
in ber allbefanten Weije aufwärts jteigen, förmlich fletternb, falls man jo jagen barf, wäfrento jie, oben angefommen, langjam unb janft mieber nach unten jdyeben, bant plöblich bie Flügel einziefen und wie ein faffender Stein gegen ben Boben Gerabfallen, unmittelbar über bemielben bie Flügel wieber breitent, um bie Wutcht bes Sturzes zu milbern. IUf

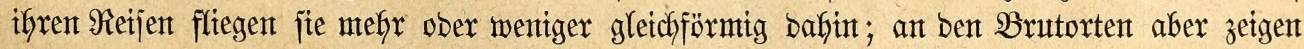
fie bie ermähnten unt noch anbere fïnjte bes Fluges oft in rajdjer Folge nach einanber.

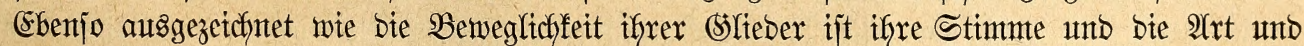

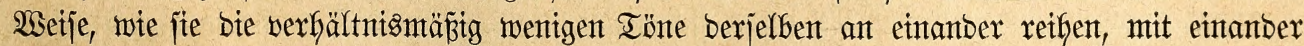
verbinben unb jo einen ununterbrochenen Wedjjel herworzubringen wiffen. Alfe bis jebst

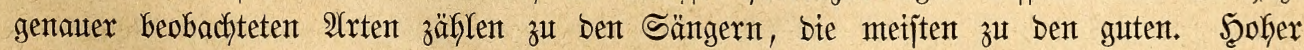
Woblflang, Füfle und Stärfe Der Töne ift ifrem (sejange eigen und verjdaffit ifnen, ints= bejonbere ben beborzugten unter ifnen, überall bie Juneigung bes Menjchen. Die jonjtigen Begabungen erheben fie nicht über anbere Sïrnerfrefjer. Sie fint lebbafte, rufige, benegliche, auch berträgfiche unto außer ber $\mathfrak{B}$ rutzeit friebfertige $\mathfrak{B}$ g̈gel, zeichnen fich aber weber burch 
bejonbere Sinnesjchärfe noch burch Beritand vor ben Finfen und 2lmmern aus. Sit biejen

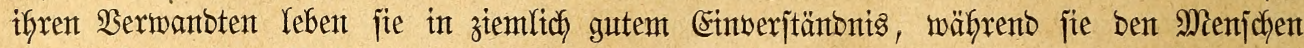
eher metben als aufjuchen, obwohl audch bas letertere jtattfintet und fie ba, wo jie jich jeines

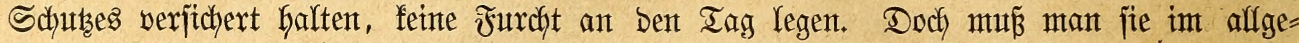
meinen eher als jcheue bent als vertrautensyolle Bögel bezetdynten.

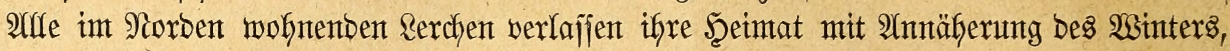
um in jüblicheren (Segenten zettweilig Şerberge zu nefymen. Unjere FelD = unt Setbelerchen z. $\mathfrak{B}$. wandern bis Sïbeuropa und Norbafrifa, wäfrent bie Şautbenterche nur itretcht, nicht aber eigentfich ziteft, indent fie aus höheren (segenben in tiefere, aus fälterent in milloere jich begibt

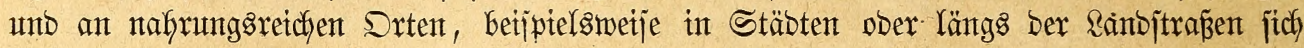

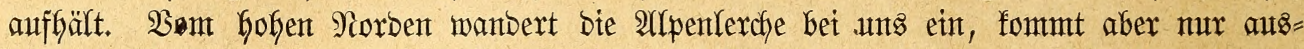

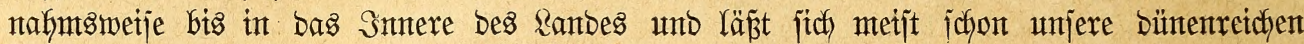

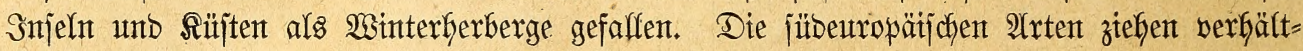

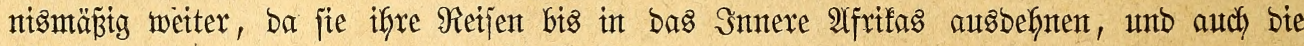

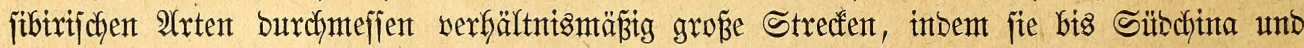
einzelne jelbjt bis nach Inbien vorbringen. Sobals ber Frïfling fich nafht, ftellen alfe

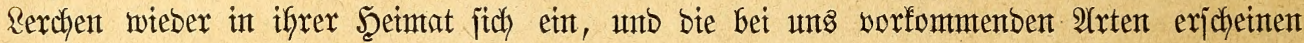

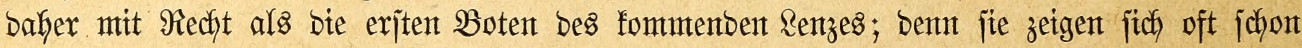

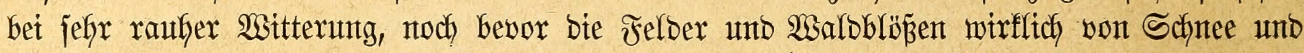
(Eis befreit murben, Gaben bann unter Umjtänben audi viel zu leiben. Sofort nach ifyrer Infunft teilent fich bie Sdywärme, welche währeno des 2 inters treulich zujammengehalten Gatten, in einzelne Bare; bie Männdhen fteigen fingend in bie Ruft, unb bie $\mathfrak{B e i b c h e n ~ i p a ̈ h e n ~}$

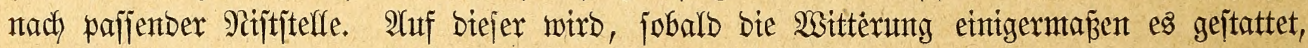

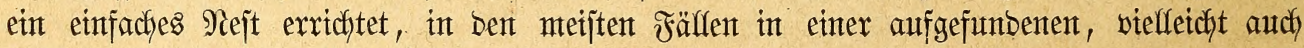
jelbjt ausgejcharrten Bertiefung, weldhe bann notbürftig mit verjchiebenten Bräjern und Sragblättern auggebaut und mit benjelben, mit feineren Stoffen und aüerbem Şaren,

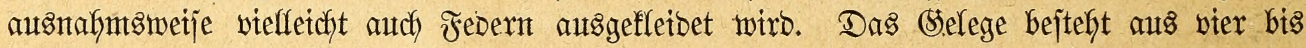
jechs erbfarbenen, D. h. auf trüb gelblich $=$, graulich = ober rötlichneizem (sontube mit bunfleren

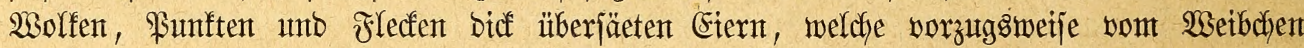

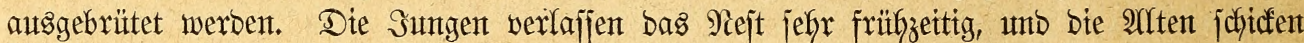
jich unmittelbar, nadjoent jene jelbjtändig geworben fint, wieberum zum Brüten an, jo baß jebes \$ärchen in Rauje Des Sommers minbejtens zwei Bruten aufzieft. Sunge wie थrlte

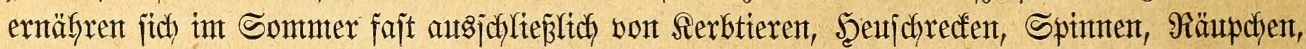

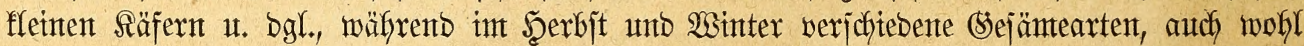

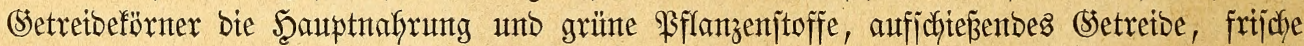

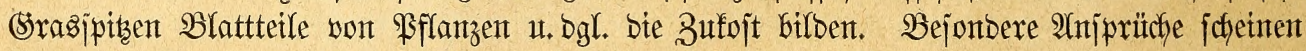

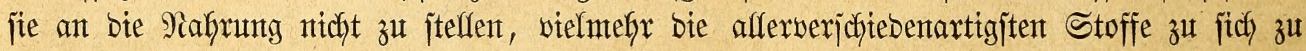
nebmen.

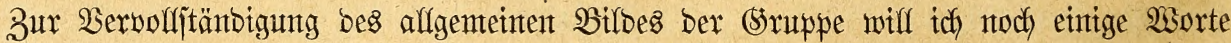
über bie einzelnen 2 (xten finzufïgent. Die $\mathfrak{A}$ lpenterdye bemohnt wäfremb bes Sommers nach eigenen Beobadhtungen alfe Teile bes normegiichen Rapplandes ober Finnmarfens bis

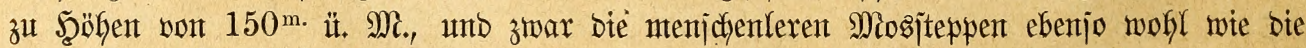
bürftigen (Särten unb Felber um bie (S)eföfte, fibelt fich aljo oft audh in ummittelbarer

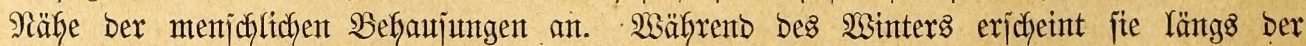

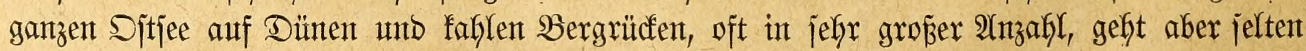
tiefer in bas Rant und berjdyminbet bereits bor ober body mit ber sdyneejdymelze rieber.

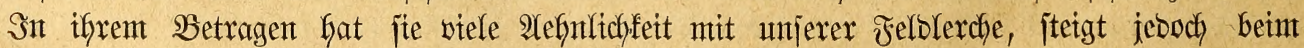
Singen nidft immer in bie Şähe, jonbern jeşt jich, unt ifren Sejang vorzutragen, lieber 


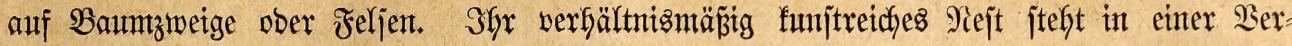
tiefung bes Bobens, wiro innen mit feinen Şalmen, ßflanzenwolle, zarten Samentyüljen nett'auşgelegt unt entbält im Mai vier bis fünf auf gelblichent Srunbe mit feinen, bunfel= farbigeren Stricheldyen, am Ende oft franzartig gezeichnete Eier. Sn guten Sommern brütet

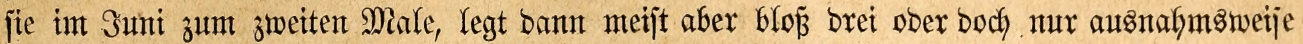

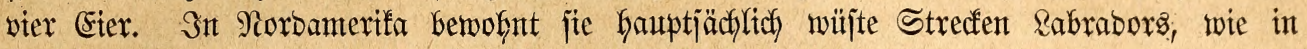
Rappland gen bie গähe ber Seefüjte, weshalb jie von Den bortigen Forjchern gerabezu "Süftenlerche" genannt wirb, triffit in ifrer Şeimat aber erjt im Junt eị uno gelangt

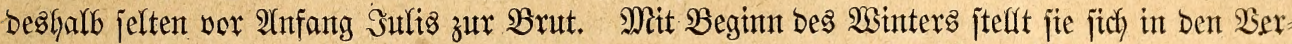
einigten Staten ein, bejteht hier ebenfalls bie Seefinjte ober janbige Felber in ber 9 ähe

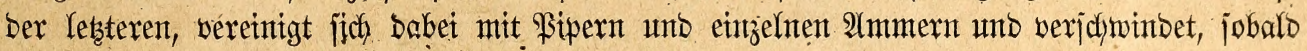

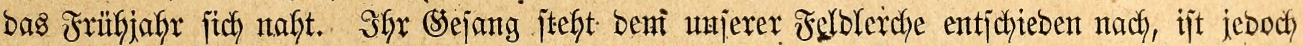

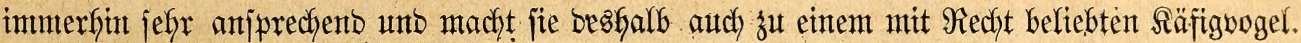

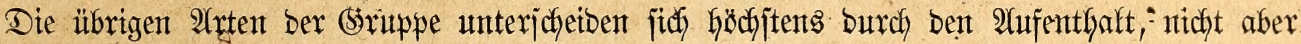
Durch bie Rebensimeije von ber europäijchen Serwanden.

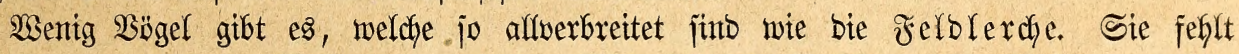

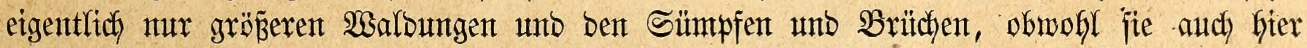
fid) anjibelt, falfs jich in ber. Nähe ber Wafjerflächen einigermaḱen trocfente Stelfen finden. Don Norwegen an bis nach Norbjpanten, Stalien unto Sirechentant, ebenjo aber auds in

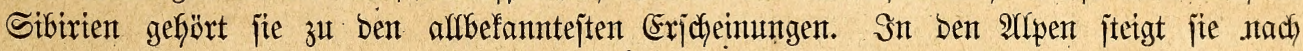
Tid) empor. Felber bilben in Europa ifyren sieblingsanfentbalt; Dody jibelt jie jich auth auf

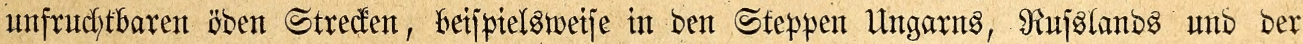

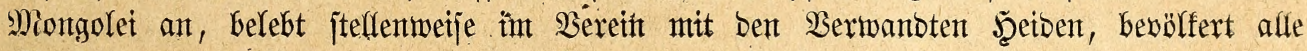

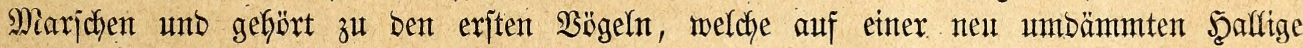

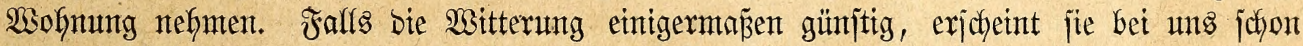

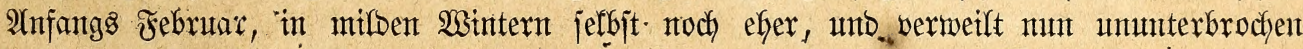

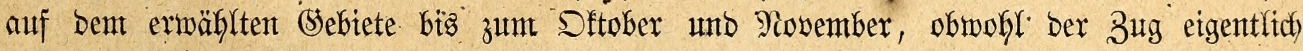
jefon im September beginnt und audy im Früfjahre lange fortbautert, weil bie im Nordent

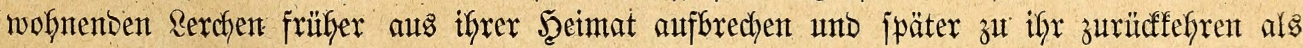
bie unjerigen unb babei mifbere Segenden burdymanbern. Der Bug füfyrt fie bis Silbeuropa,

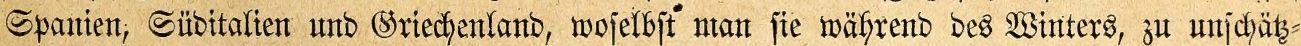
baren Scharen bereinigt, auf affen geetgneten Dertlidffeiten fich umbertreiben fift. Paach Norbafrifa ftreidfen nur wentge Ginüber; bod begegntet man in Unteregypten unto ben

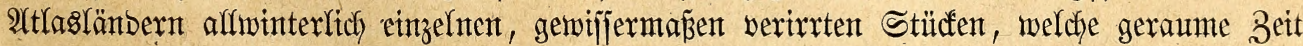

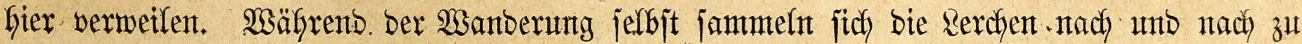

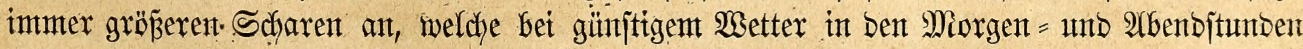
zieben, über Mittag aber auf bie Felder fallen, unt jich zu jättigen. Wibriger, D. h. in ber

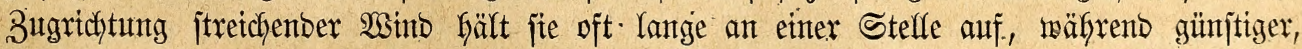

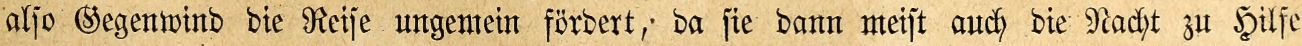

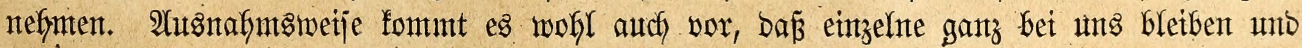
fich jo gut, als es geht, bas Reben frijten. Rebendig, umität, unrufig und gejangeseifrig,

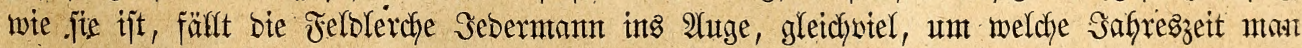
fie beobachtet. So lange fie. ihren Rahrunggegejchäften nachgeht, läuft jie mit furzen Schrittent

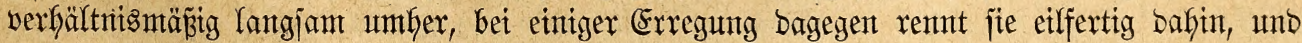
namtentlich beim Ireiben bes Weibdjens zeigt fie ifre ganze Behenbigfeit als Raufvoger. Shr oflug vereinigt in jich alfen Wechjel, beffen ich oben gebacht Gabe. Bald flattert jie langian bicht über bem Boben bafin, balo jagt fie mit betwunberungghürotgex (Semantotheit 
in langen Bogenlinten über grö̈ere Strecfen, balb entlich erhebt fie fich, um zu fingen, in

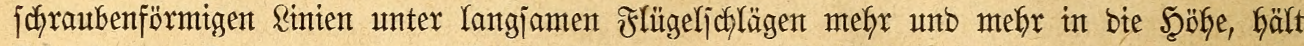
fich, oben angefommen, geraume Beit auf einer unb berjelben Stelle und johnebt bann Langjam zux Tiefe nieber, bis jie endlidy mieber zum Boben jich herabfallen läp̈t. 'Beim Spielen mit bent Weibchent ober beim Streiten mit anberen Männdyen, mit benten fie währento ber Brutzeit in umunterbrodjenem Scaber liegt, ober enblich beim Zanfen mit jonjtigen $\mathfrak{B a ̈ g e l m}$ fanm man ifre volfe (Semandtheit fennen Yernen. Der Rocfton ijt verjefieben, entweber ein icharfes, juntarrenbes "Serr", ober ein Kellpfeifendes "Iri", wieberum entlich eine Witeber=

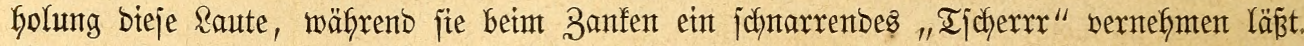
(Sanz anbere saute jetsen iffen (sejang zujammen. Sn ifm bereinigen fidd mehrere helle,

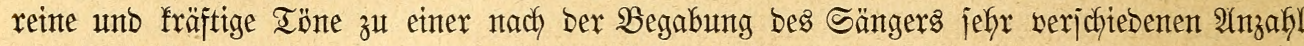
won Strophen, welche bald triffernd, bald wirbelnt, bald wieber lang gezogen und mit mefr

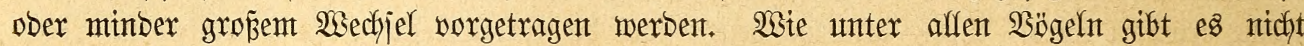

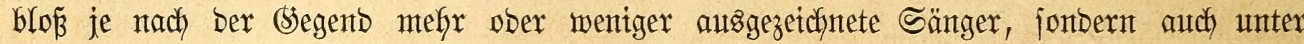

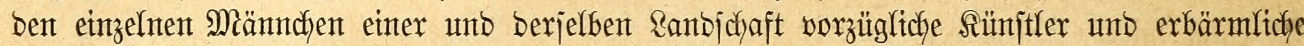
Stümper, joldhe, melche in ununterbrochenem Saechjel ifyre \&ieber vortragen, zu ben eigenen, übltchen Tönen stelfeidft auth nody bie anberer Singwögel aufnefymen, unt Dagegen Männchen, weldye burch das emige Einerlei der Alufeinanberfolge ber Strophen ifres (Sejanges gerabezu ermüben. Die (Sebrïber Mürrer bemerfen, wohl mit Recht, baß́ in ber Gbene das

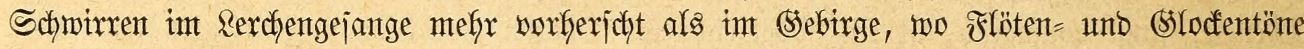
bas \&ieb verjob̈ntern. Şier wie bort aber barf man bie Felblerdye zu unjeren guten Sängern

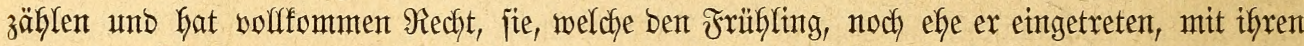

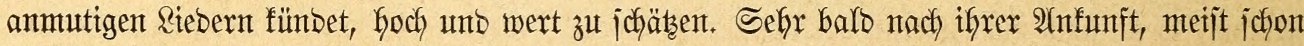

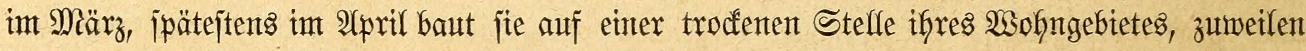
inmitten jumpfiger Wiejen ober jelbjt in SBrüchen, am liebjten abex auf etwas exföhten, Ueberjchwemmungen nicht ausgejebten Felbern unb insbejonbere auf Brachäcfern, Feloreinen und Den mit Sommergetreide, Seüljenfrüdyten und Alee bebauteten Felbern ify einfaches Nejt. Eine fleine Bertiefung, welche jich findet, wirb ermeitert unb gerunbet ober auggeicharrt

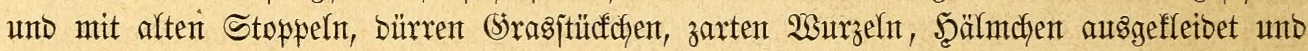

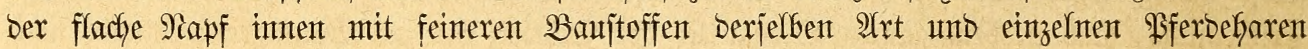
ausgelegt. Die ziemlich groß̈en, in Der Form etwas verjedjebenen Eiet zeigen auf trüb gelblich = ober rötlichweifiem (Strunbe molfenartige 3eichnungen und über biejen in verjchiebener

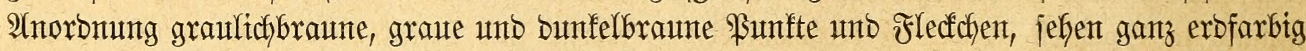
aus und find aus bem Srumbe mur fajwer zu erfennen. Sm itbrigen bietet bas fort= pflanzungsgejchäft unjerex $\mathfrak{B}$ g̈gel nichts abjonberliches, D. h. vont bent affgemeinen abweichendes.

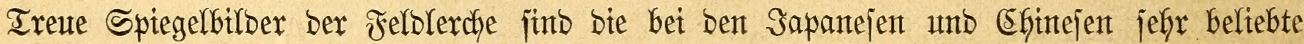
Seimmels = und bie weit über Inbien verbreitete, auf affen grajtgen Şügeln, Biejen uno

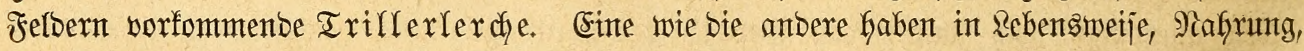
int Sejang unb in ber Fortpflanzung jo viel überemftimmendes mit ber europäijchen Berwanbten, bá̉ man bis jebt wentigitens faum etwas bejonberes vont ifnen jagen fant.

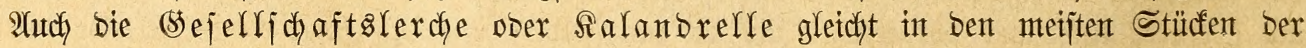

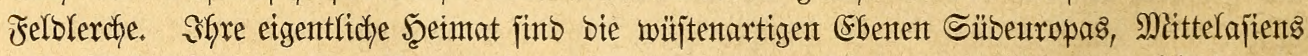

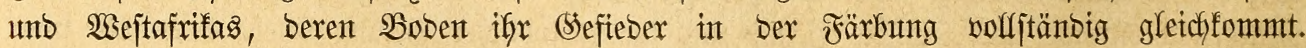
Bon Gier aus manbert fie mit Beginn bes Scerbjtes in zahlretifjen, locfer zujammenfaltenden Flügen nach Imerafrifa, hier bie Srenze des bebaueten unt müjten Ranbes, bie $\mathfrak{W u ̈ j t e ~ u n d ~}$

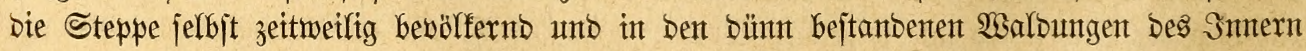
oft zu unjedäbzbaren Sdymärmen jïh) vereinigend. (5)anz in Derjelben Weije tritt jie, laut

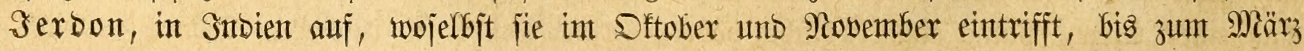


unt 2 (pril berweilt, fich aber mefy auf ben Felbern als auf bent wüiten Stelfen umbertreibt, währento ber ganzen Beit vielfach verfolgt von Fängern unb Schützen, welche fie bes lecteren Fleijches halber majientyaft vertilgen. Sie läuft ebenjo bebende wie bie Felolerche, objchon mefyr trippelnben (Sanges, fliegt gut, aber body nidft jo wedjfelvolf wie jente, bejdyreibt im

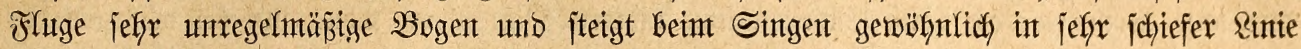
empor. "Shr (Sejang ijt", wie unjer Mitarbeiter $\mathfrak{A}$. von Scomełer, wohl ber bejte Senner affer europäijchen Singbögel, fich ausobrücft, "lauter Stïtfwerf, nichts zujammenfängendes.

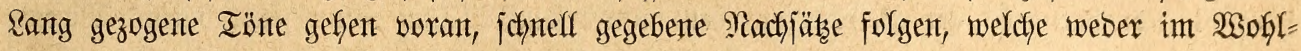
laute noch in Ionfalle zum Bejange paffent. Die lang gezogenen Flötentöne finto jajreient, bie Sdjlupiftrophen bölzern unb ofne Silang. Dabet werben einige Strophen ganz genau

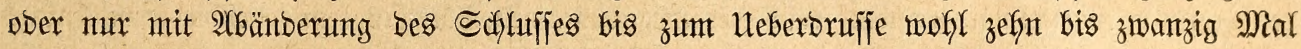

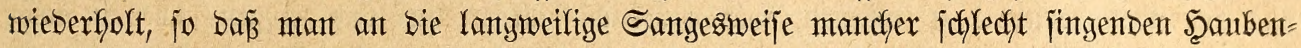

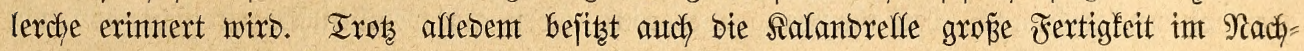

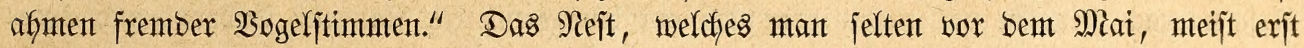

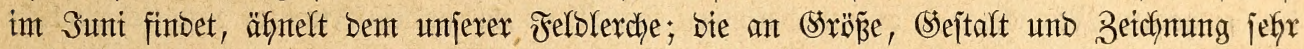

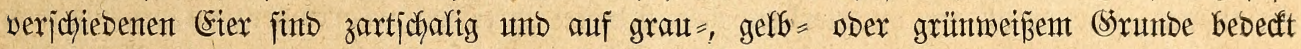
mit grauen Unter = und jefy feinen, engitehenben, graubraunen Dberflecfen und \$ünftchen, welche am bidferen Ende oft in einen frant fich bereinigent. Die Finfenlerche hat, laut Gerbon, affe Eigenjidyaften unt Bemofnheiten ber Felblerdje, betwofnt mit Borliebe grajige Ëbenen, fingt worzüglich, ijt ein ausgezeidyneter Spötter und wirb beshalb gern int Säfige gehalten. Heber ifgre Fortpflanzung weís idh nichts zu jagent. Unzmeifelgaft bie anmutigjte alfer unjerer einteinijchen Rerchen ijt bie Sceibelerdye, ein in gantz Deutjchlanto nirgends jeltener, went audh nidyt überaff vorfommentoer $\mathfrak{B o g e l}$. (Serabe bie öben, unbebaueten Steflen und zmar vorzugsmeije bie bergigen (segenden ober das (s)ebirge jelbjt, aber audh die

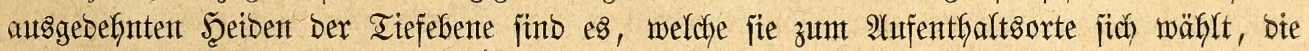

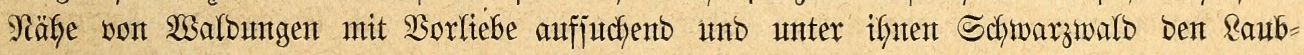

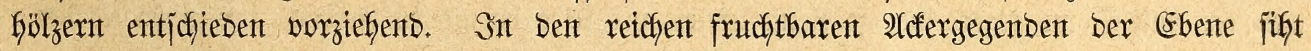

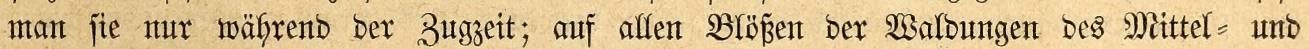
jelbjt Sodjgebirges aber ijt jie, objchon nidft eine genteinte, jo boch einte regelmäpige Exjcheinung, audh in bem ganzen Berggürtel ber Sdyweiz bis zur Baumgrenze fintauf noch überaff anzutreffen. Sie verläß̈t uns etmas früher als bie Felblerche, manbert wie bieje

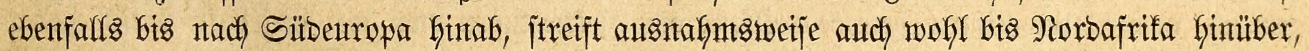
nimmt in Spanten in Den Sebirgşwälbern Setberge utb belebt bieje Dant zu Taujenden,

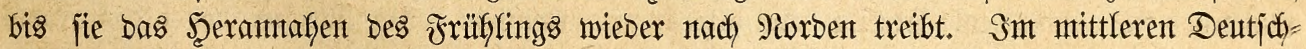
land trifft fie gemöhnlich inmitten bes Februar ant Brutplabe ein, gleidhwiel ob ber Sdynee an Den Berggefängen bereits geịdymolzen ijt ober nitht, und fündet ifyre Freube ïber bie

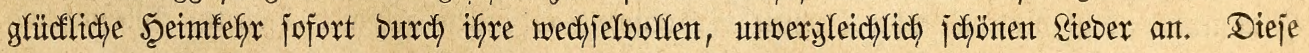
haben alferbings noch immer bas (sepräge bes Rerchengejanges, zeichnen fich aber burch Woblflang, Weichlyeit und Sanftheit, man mödhte jagen Schwermut ber Töne aus, bejtehen. aus mefreren mäpig langen aufeinanberfolgenten Strophen unt werben womöglich noch

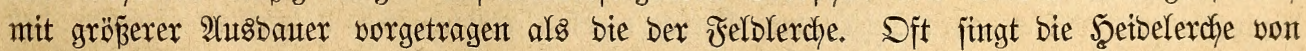

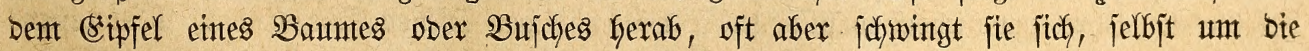

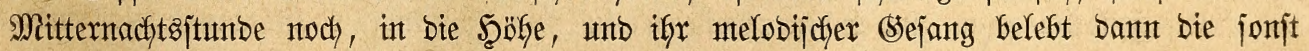

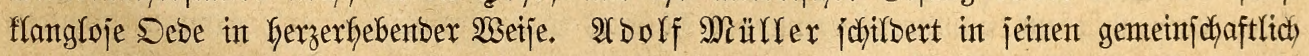
mit jeintem Bruber verfap̧ten "Eharafterzetdyuntgen ber vorzüglichjten beutjchen Singbögel" Das \&ieb ber Scetbelerche mit folgenden 2 orten: "Es bejteft aus einer langjameren Strophe won zefn bis zmölf und mefr tiefen welfenförmigen Flötetönereihen, worauf gerwöhnlich

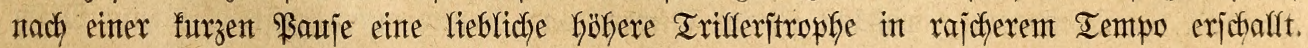


Der von guten Sängern, namentliç von Piachtjchlägern verjchieben gebeugte unt veränberte (Sejang läp̈t fich in jeinem Srumbcharafter auf bie Raute bes melobijchen Rocftones , Rululu"

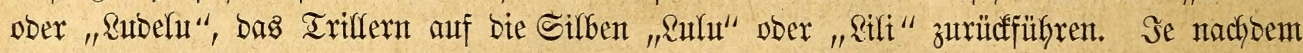

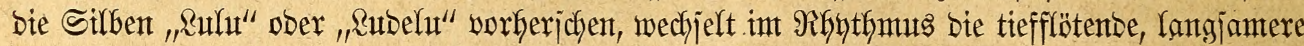
Strophe; audh werben von Nachtjchlägern bismetlen gezogente Iöne zwijchen bie tieferen

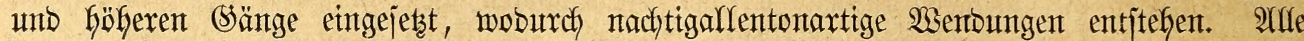

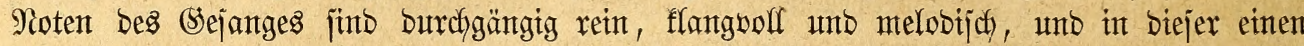

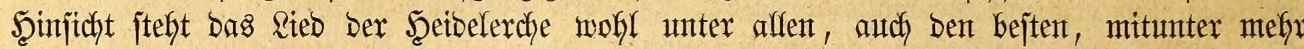
ober minber Sityarfes unb Unreines enthaltenben Soggelgejängen oben an." Jeber (siebirger hält biejes (bejanges halber bie Şeibelerche hoch und wert, und jeber Riebhaber jift in ifyr ben trefflichiten Bimmergenofjen, weldyen bie Rerchenfamilie überhaupt uns liefern fann. Das Sieb ber Salanderlerche ijt ungleich reicher als bas ifrige, füx bas 3immer aber zu laut, bas steb ber Feldlerche abwechjelnber, aber nidht bejonters wohlfautend, ber (sejang ber

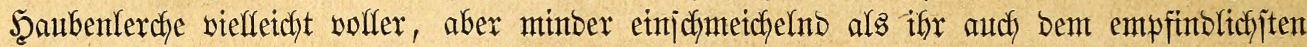

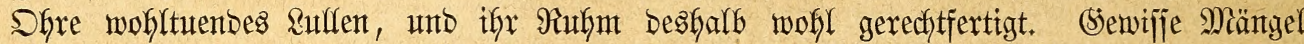
Gat freilidy aud ify (sejang. "Sbgleich fie", bemerft unjer Mittarbeiter $\Re$ öppen, "nicht alle Eigenichaften eines guten Stubenoogels in bem (Srabe wote bie Mionchsgrasmücfe bejitzt, ijt

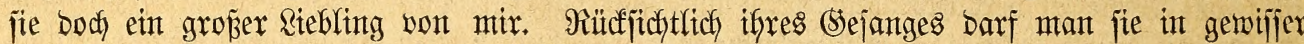
Bezitefung über alfe anberen Singö̈gel jtellen, ba jie in ifren Riebern nidyt einen einzigen unangenefgmen Ion hat. Selbit bie einzeln auşgejtopenen Rochtöne flingen lieblich, uno

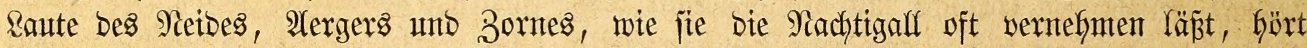
man von ber janften Sceidelerche nicht. Die einzigen (stünde, weabalb ich jie bem Schwarjfopf

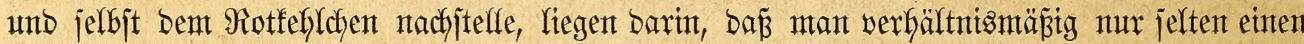
Sänger ifrer $\mathfrak{A}$ rt erfält, weldher fich Durch ente bem werwöfnten Dhre bes siebfabers

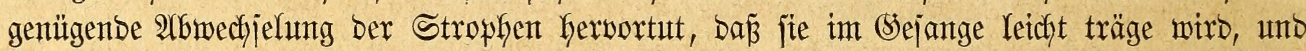

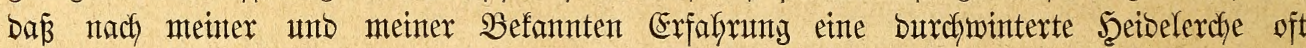

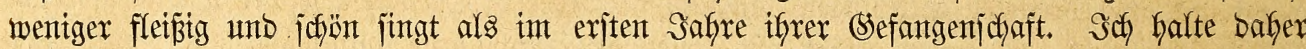
Die Sceibelerdye, weldye idy jederzeit in beliebiger 2 (nzahl befommen fanm, immer nux einen

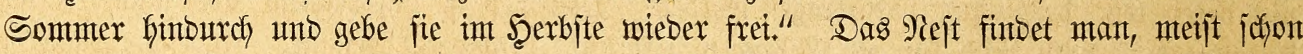

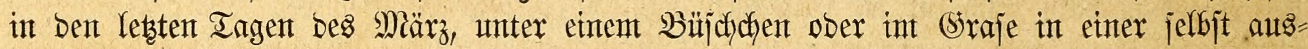
gejcharrten Bertiefung. Dürre Scalme, Srasblätter, Flecíten und Mos bilden ben

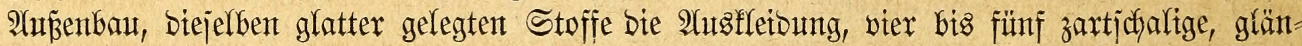
zenbe, auf graumeifem (Sirunbe mit ajchgrauten, graubrauten ober graurötlitchen Flecfen uno Sunften bicht, am jtumpfen Ende oft franzartig gezeidhnete (Eiex bas Bielege, weldyes fait nux vom WSeibchen bebrütet wirb. In günjtigen Sommern macht bas \$ärchen minbejtents zwei, meijt

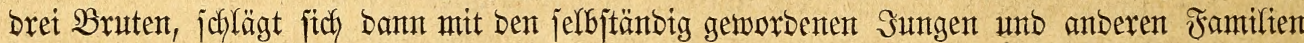
zujammen unb beginnt zu itreichen, Wiejen, Stoppelfelber und andere Sertlichfeiten bejuchend,

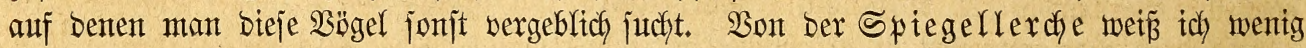
zu jagen. Sie bewohnt, wie angegeben, ben grö̈ten Ieil Sibiriens, Die Tartaret, das

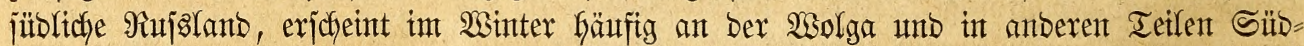

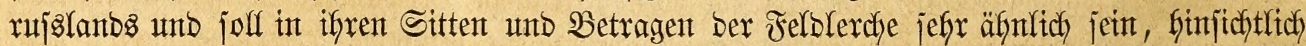

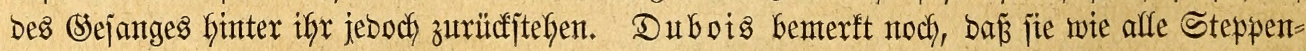

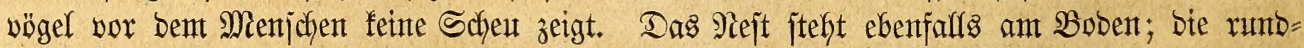
lichen Eier jinto auf gilblichem Srumbe bicht mit grauen, violetten und braunen \$anften

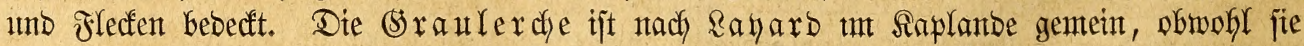
einzelne Siegenben mit bejonberer Borliebe bewofnt, baut ify Rejt in ober neben einem Srasbüjchel und legt bret bis fünf auf gelblidjweiß̧ent Srumbe überall mit braunen und purpurfarbenen Flecten gezeidfnete Eiter. Leber ben (5ejang umb jonjtige Eigenjd)aften 


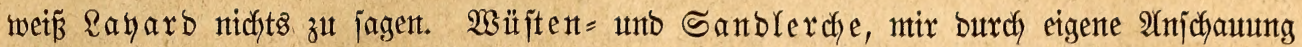

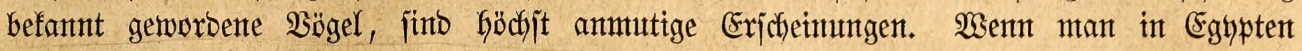
untb Nabient an bie Srenze bes bebauteten Ranbes gefomment ijt, wirb man fier bie eine, bort bie andere $\mathfrak{A}$ rt felten vermifjen. Mit ber $\mathfrak{B u ̈ j}$ te beginnt ify Bebiet, unt jelbjt bie

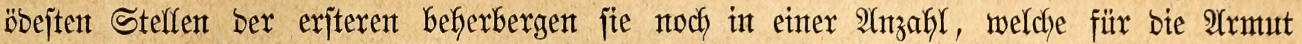

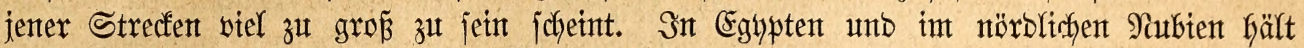

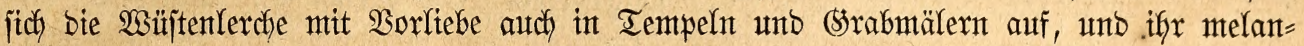

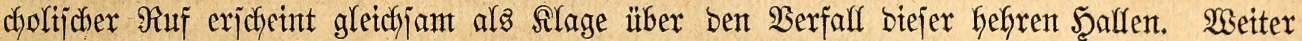
oben in Nubien belebt fie bie ferfïgen 14 fergelänbe bes Stromes, bie pflanzenleren Gabenen zu

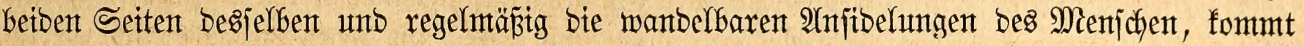

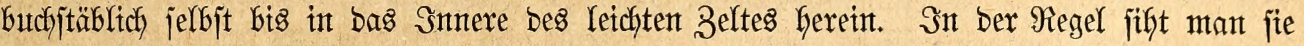
par=, nach ber $\mathfrak{B r u t z e i t}$ familtemweije, jelten in grö̈peren Sejelfjchaften ober Scharen. Sebes

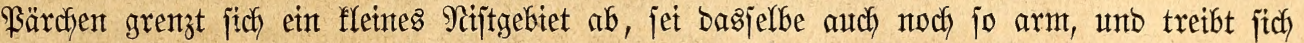
Gier vom Morgen bis zum 2tbento umber, rentenden Rnufes über ben Boben bafinthujdjend ober Yeichtent, obichon etwas jchlaffen Fluges von eintem Ieile bes Wohnfreijes zum anderen fich wentent, bann unb want audf auf einen erfÿhten Stein ober aber auf eine Bujchipibe fich) jetzent, um von Gier aus ifjen unbebententen, mit bent umjerer Feld = ober Sceibelerche in feiner Weije zu bergletchenten, went auth nidft affer 9:nmut baren (Sejantg vorzutragen. Iriftram fantb bas Nejt ber Wüftenterche in ber Sahara und in ben Eintöben von Faläjtina,

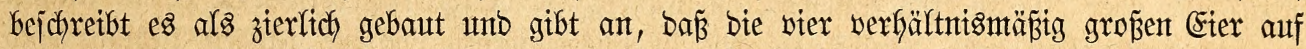

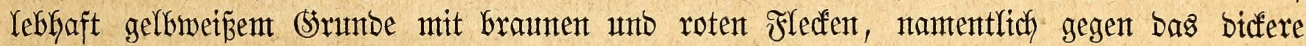

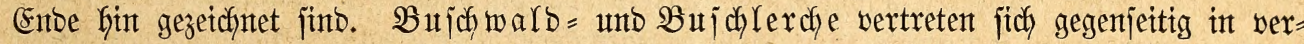

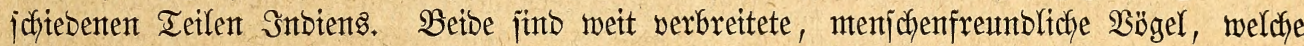
auch in bie (särten hereinfommen, Gier aber mehr ober wentger fich zu verbergen juchen,

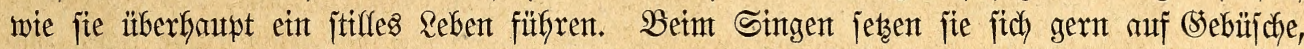

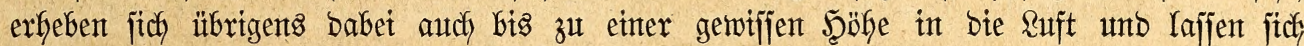
bann mit ausggebreiteten Schmingen langjam hernieber. Der Sejang Der Bujchmalblerdye

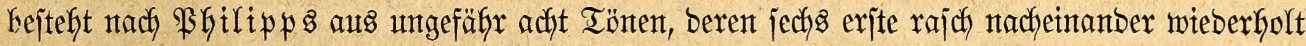
unt beren leţte langjanter vorgetragen werben. Das \&ied ijt anjprectient, aber nicfft fräftig,

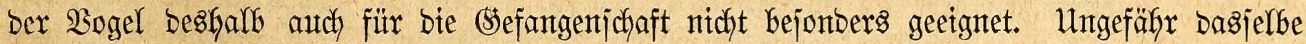

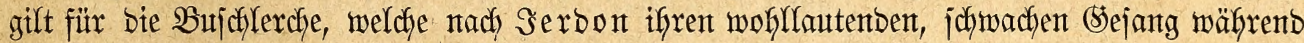

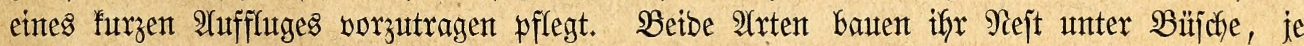

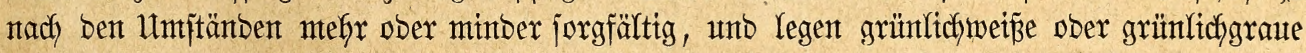
mit büfterbraunen Flecten bebecte Eier. Die Singlerdye bemofnt nach bemjelben Forjcher

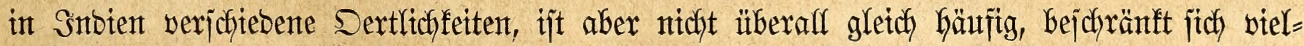
mefy auf gewifje Steflen, insbejonbere auf Wiejen unb jonjtwie mit (Sraz bejtandene Strecten

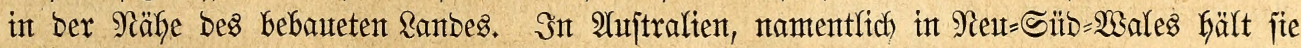
ober ifyre Bermante (A. Horsfieldi), laut (\$ould, ant liebjten auf bergigen (sebängen fict)

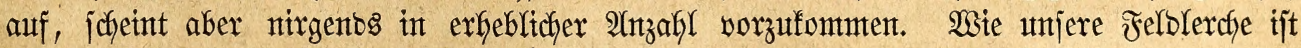

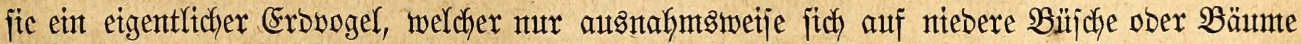

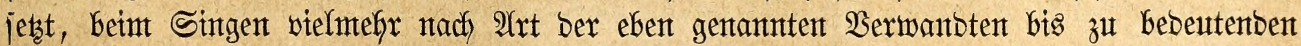

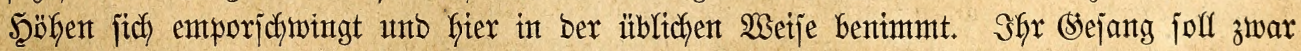
etwas jchnächer jein als ber ber Felblerche, wirb jebods von ben aujtralijchen wie intijchen Jorjchern gleidh hoch gepriejen unt unjere Rerche beshalb audh jefr oft im Räfige gehalten.

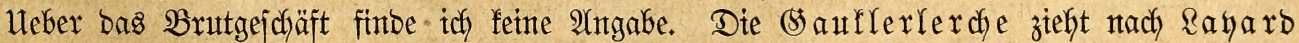
warme, janbige Stellen ber fö̈heren Gbenen anberen vor, ijt baher in ben wejtlichen Ieilen Des Saplanbes Gäufiger als in ben s̈jtlichen und fälft ebenjo burch bie Schönfheit ifyres (Stefiebers, wie burch bie abjonberliche $\mathfrak{A}$ rt bes $\mathfrak{B}$ ortrags ifres einfachen (Sejanges auf. 


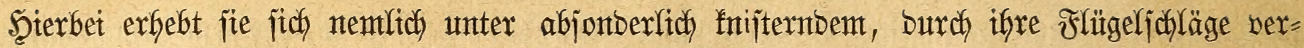

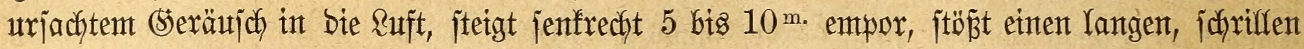
Raut aus und fällt bant wieber wie ein Stein zum $\mathfrak{B}$ oben berab, nach $\mathfrak{B} e r f a u f$ einer ober

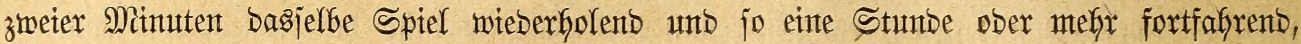
zumal in ber Frühe ober bes 2Abentos.

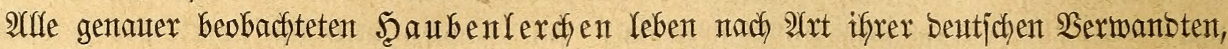

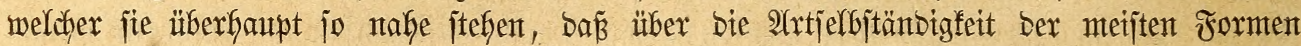
wont biejem ober jentem Forjcher Zweifel ergoben morben fint. Meiner Meinung nadh

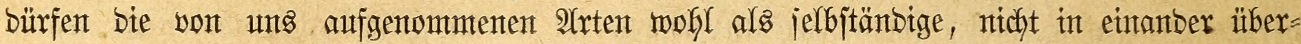

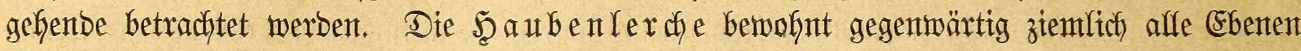

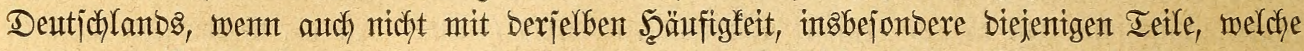

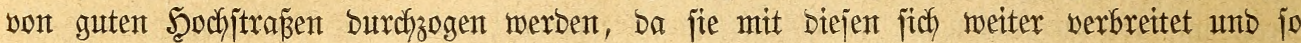

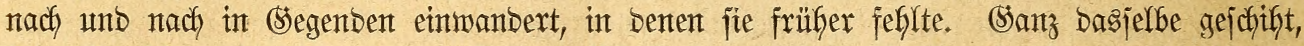
laut Şerflofs, in Untgarn, wo fie Den Eijenbafnen folgt, mit ifynen weiter uno weiter in Ranbesteile vorbringent, welche fie jonjt nur auf bem Buge berüfrte. "Sidh habe", jafreibt

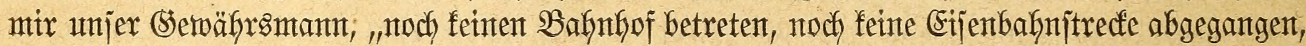
ofgne ifyr zut begegnen, auch feinen anberen 2 bogel fenten gelernt, weldher fith fo oft an

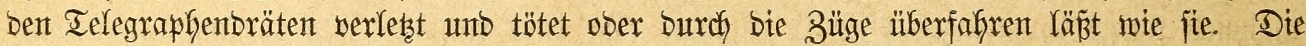

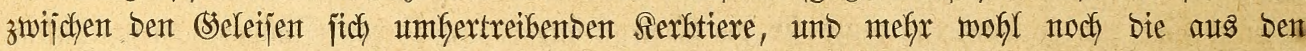

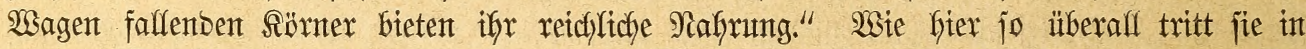

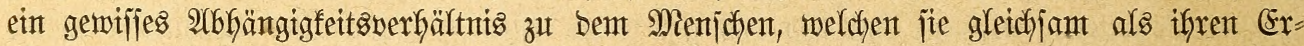

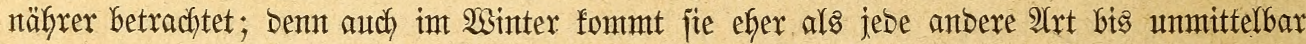

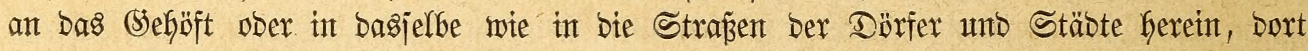

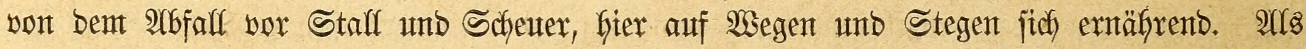

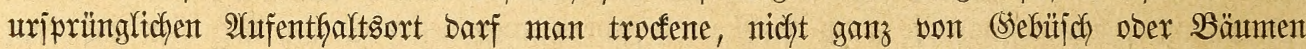

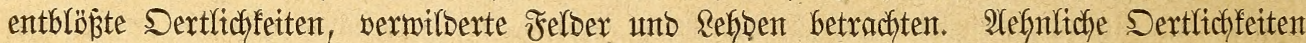

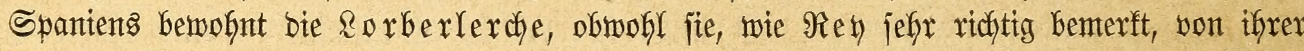

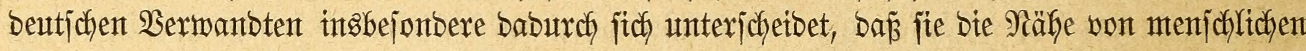

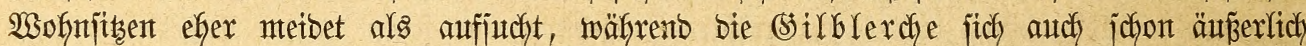

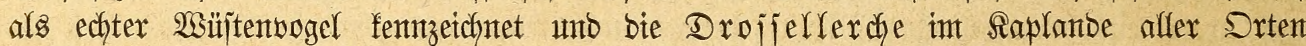

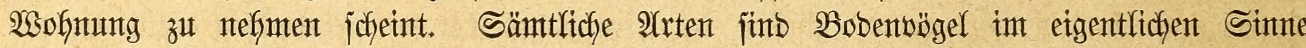
Des 2 Sortes, ergeben fich nur ungern zu furrzent 2ufffluge, fiteigen jelten weit in einem 3uge,

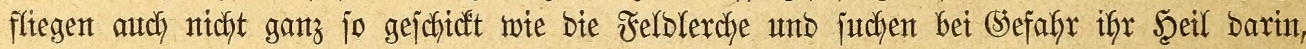

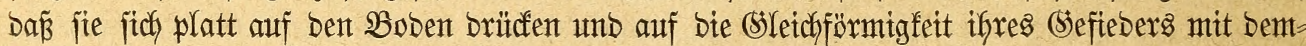

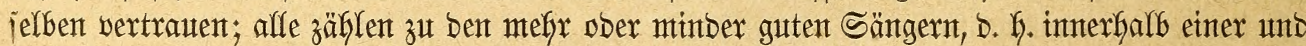

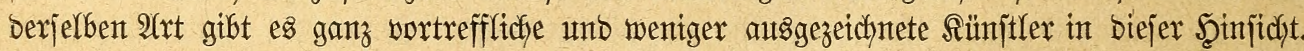
Der Roctton läß̈t fich burrdh bie 2 Sorte "veni, vidi" annäherno wiebergeben; Der Bejantg

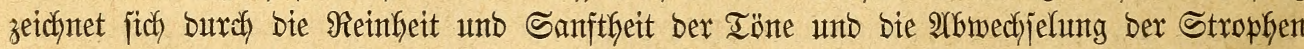
aus, welche getragener unb flötenber als bie ber Felblerche fintb, nitcht jo viele Irilfer haben

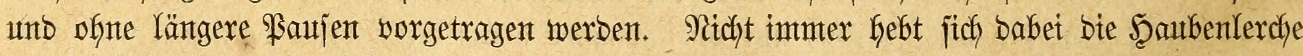

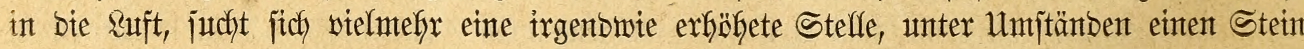
boer einte Scholfe auf und fingt bont biejer herab; bie Riebesbegeifterung aber treibt aud

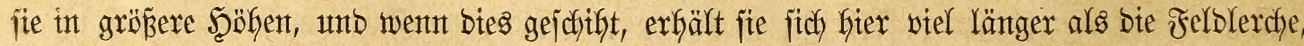

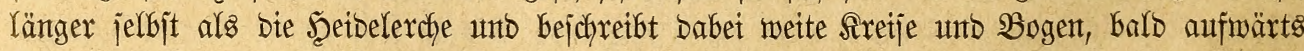
jteigent, balb jich etwas Gerabjentent, balb nach biejer balo nach jenter Richtung jojwanfenten

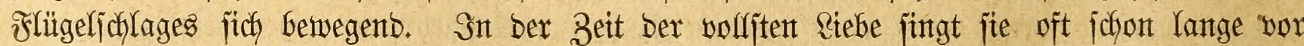

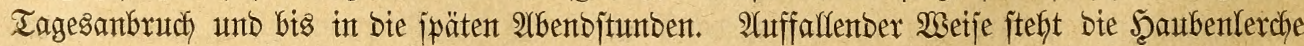

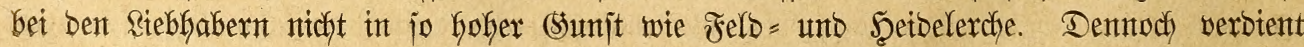




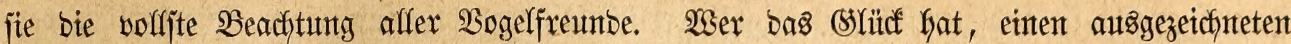

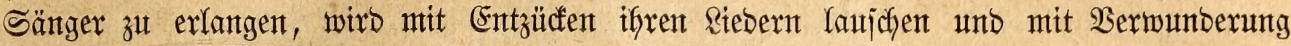

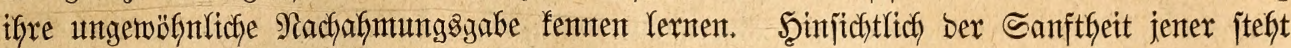

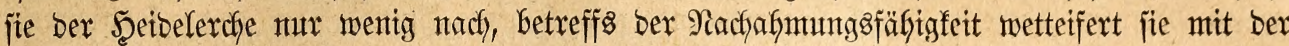
Saranberlerche, wemt jie bieje audy nidft zu erreichen im Stanbe ijt. Uno boch wirb fie

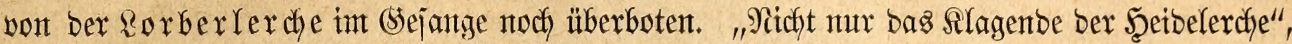
jagt $\mathfrak{A}$. von Şonteyer, "ijt biejer eigen, jonbern fie übertriffit bieje liebe Sängerin gerabe

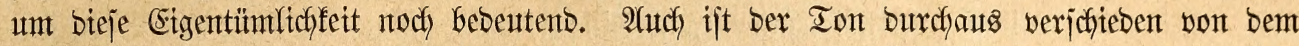
Dex Saubenlerdye, weich, flagento unt filberrein wie bei ber Şeibelerche, aber noch melan= dyolijcher. Der Sortrag iteht mit biejer Ionweije in engiten Bujammenthang: ich fenne faum etwas jhöneres als den gefüflvolfen (Sejang biejer Rerche." Rey, melcher bie Rorber= lerche im füblichen Portugal beokadftete, fann biejer vortrefflichen Schilberung J̧ome yers

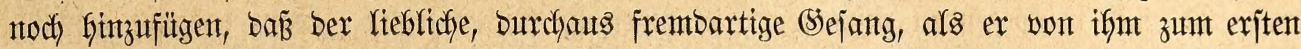
Male in ben öben Sefilben bet Rap Sincent vernommen wurbe, ifnn nidft einmal an mjere

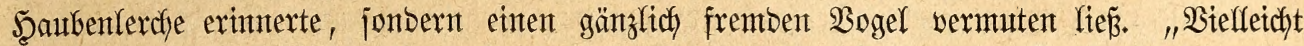

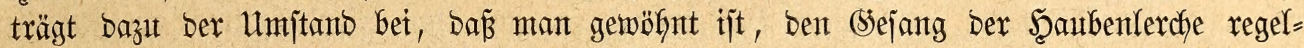

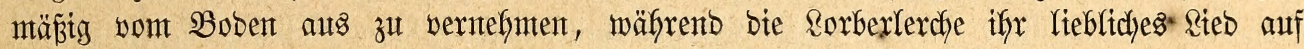

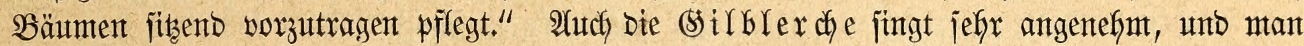
erfennt bies um jo Danffarer, als jie bie jofweigende, an wirflicfyen Sängern arme Wüjte

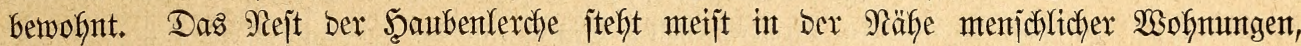
in Semüjegärten, Felbern, Ginter bent (Seföften, zutweilen auds auf altent Refgmtwänben und jelbjt auf Firjten niebriger Strohbächer, ijt fumitlos wie bas anberer Berwanbten und jift einent vom Winbe zujammengemeften Şaufen alter Stoppeln täujchent ähnlich. Dieje, (Sras=

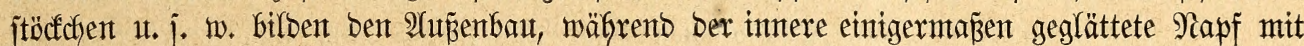
\$ferbefgaren, auşnafymsmeije audy wohl mit Febern ausgelegt mirb. Die vier bis fünf bünt= unb glattjchaligen (Eier jün auf weißent, gelbem ober grünlichem (Srunbe mit grauen

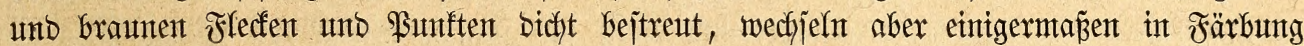

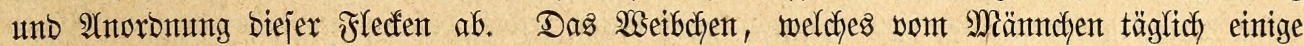

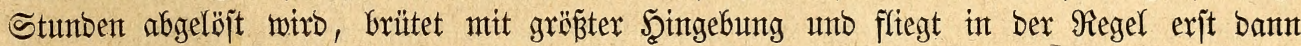
auf, went ein herannafenber Menjch Gereits unmittelbar vor ifm iteft. Das Nejt ber

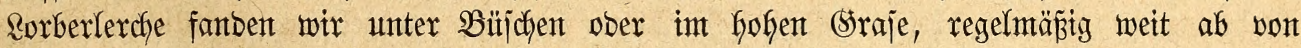
menjehlichen Wofnungen; bie vier bis fïnf Eier, weldye es entfält, erintern wentger an bie Dex Şauben = als an bie ber Scetbelerche, fint glänzento graumeiz mit vermajchenen bunfel= grauten Unter = unt Sberfleffen, weldye ant itumtyfen Enbe wie bet benten ber Şaubenterche oft franzartig zujammenffiežen.

Sämtliche Räıferlerchen ähneln bent Wüjtenläufer ebenjo mie ifyen eigentlidyen Wermanten. Die $\mathfrak{B}$ ïjtenläuferlerche finbet man parweije in ben Wäjten Egyptens, গubiens, bes jtemigen 9 rabiens und Snbiens und zmar ebenjo gut nahe am bebauteten Ranbe als inmitten ber janbigen, fajt baumlojen Flächen, fern bon allem $\mathfrak{B}$ erfehre unt fern

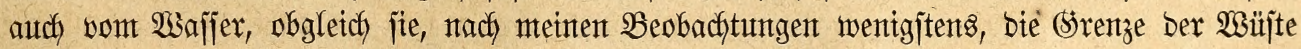

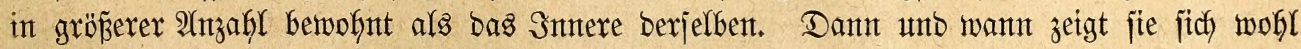
audy auf abgeernteten Felbern, ntemals aber für längere Beit, fonbern inmer nut vorïber= gebento. 2Auf ben früber itarf bejuchten Sarawantenwegen bon Sairo nadh Sues traf ich fie fä̈ufiger an als irgentwo anders; aber aud in গubten tritt jie jtellentweije in einer gemiffient

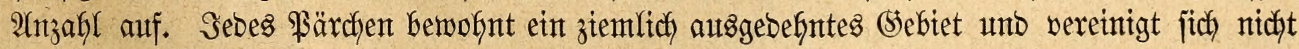
mit jeinen Siachbarn; benn wenn man wirflich einmal mefy als zwei biejer Rerchen in

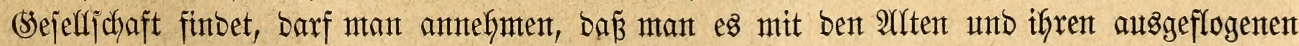

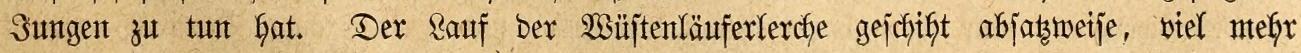


ftranbläufer = als Yerchentartig unb förbert ben $\mathfrak{B}$ ogel außerorbentlich rajch; ber Flug, welcher ielten auf weitfin ausigebefint wiro, ijt letdht, aber flatterno und jedwebento unt exinnert in

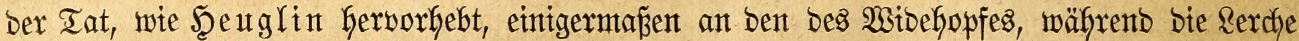
in ber Zeit ifyer siebe jefy oft gantz anbers fich bewegt, nemlich plöblitch mit einigen Flügel=

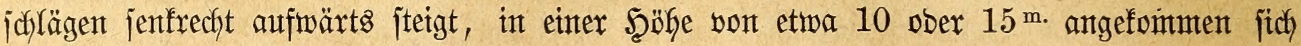

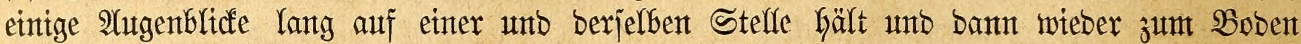

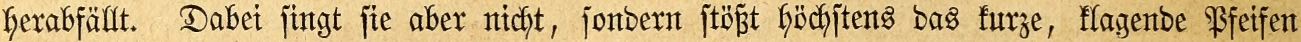
aus, weldyes ifr sodfton zu jein joheint. Zum Singen wählt jie fich meijtens etwas erföhete Punfte ifres (S)biets, Die Spitze eines zujammengemehten Sanbhaufent, einen größeren ober flemeren Stein u. bgl, unt gibt bon ifm herab ifgr jefr einfaches und unbebentendes Rieb zum bejten. Da, wo jie bem Menjchent vertrauen gelernt hat, ijt jie auperorbentlich zutraultch, währent fie an anberen Stellen eine ängitliche Sicheu an ben Tag zu legen pflegt.

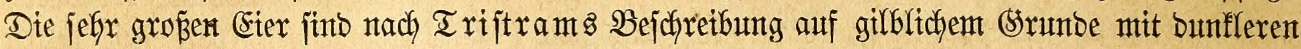
grauten unb bräunlictjen Flecfen bicht, am bicfen Enbe franzartig bebedt, aljo echt jantofarben. Die Sichlerlerche, weldye nach Rayarbs Urteil in ber Rebensweije von ben $\mathfrak{B}$ erwantent

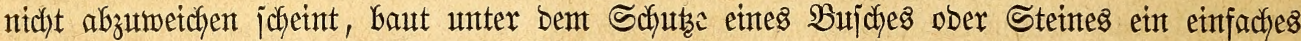
Tejt aus*(Sräjern unt Şaren, fletbet basjelbe intnen mit Febern aus unb belegt es mit brei jayntuzigmeiken, jejwach und fein braum gejprenfelten Eiern.

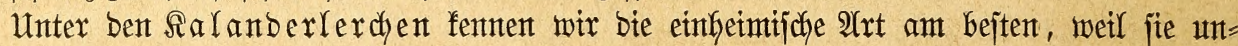
mittelbar an umjerer (Strenze, in Sjtrien, ebenjo bäufig auftritt wie in Sritedhenlant, Slein= ajien, Mittel= unb Sïbitalien, Spanten unb anbererjeits in ben Steppen Sübrujslanos.

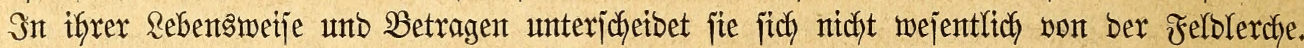
Wite bieje bewohnt jie bie verichiebenjten Dertlichfeiten, bas bebaute Rand ebemjo wohl als bas brach liegento ober veröbete, gejdyloffenen Wald unt feuchte Yitederungen metbent; wie bie Felblerche bält fie fich währent bes Sommers parmeije in einem getwifjen Bebiete auf,

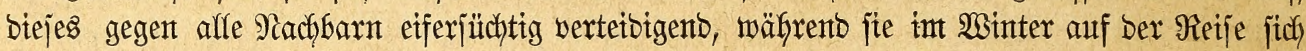
zu ungebeuren Sdyuärmen verjammelt uno bann im Snmen âfrifas voie in Sïbajten oft weite Stredfen förmtlich bebedt. Entiprechent ifrent berben, gebrungenen $\mathfrak{B a u}$ jüts alle $\mathfrak{B e}=$ wegungen fräftig und jelbjt hajtig; bodh habe idh bei ben won mir beobadbteten feinen wejent= Yichen Unterjofied zwijchen ifyren und ber Felblerche Raufen und Fltegen benterft. Sanz aus=

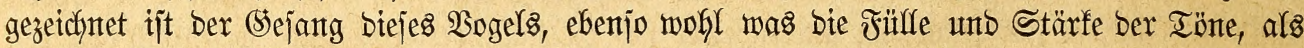

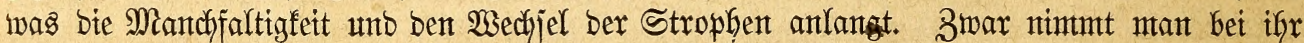

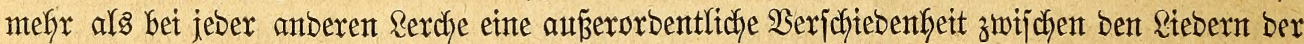

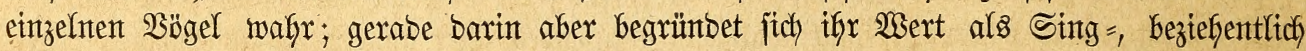

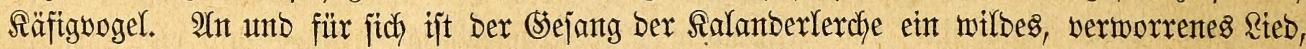
beffen Strophen oft bunt burch einanber getworfen, bald in einer getwiffen Folge an eintanber gereift, balb wieber beliebig aus einatber geriffen werben; aber ber $\mathfrak{B o g e r}$ zählt zu ben ausggezeichnetjten Spöttern, weldhe wix fenten, zu ben gelebrigiten Schülern ber bejten Sänger,

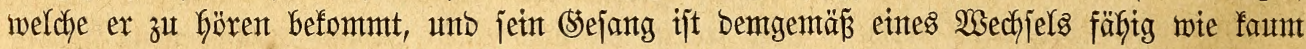
nody ber einer anderen Serche. Eryt in ber neueren Beit babe idy auf meinen mieberkolten Reijen nach bent mitterfänbijchen Mere bie Ralanberlerche würbigen unb ichätzen gelernt, weil idch unter ben vielen Stümpern auth wirflich auggezetchntete Sejangesmeifter Gören fonnte, Sïnjtler erjten Ranges, auf weldhe bie Schitberungen Eettis und bes (Srafen Bourch

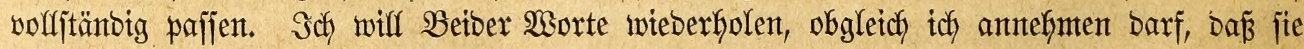
wentgitens burch mein iflujtirtes Tierleben ben meiften meiner sejer befannt jein bürften. "Sowite bie Ralanberlerche alle übrigen Mitglieber ber Familie an Sröß̈e übertrifft", jagt Eetti, "io itberbietet fie biejerben an Sejang: fie fant mit jebem anderen Bogel um ben Borrang itreiten. SGre matürliche Stimme focheint mir ein (sejdymäts von nicht groper 


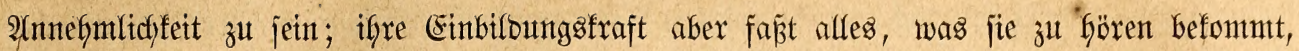

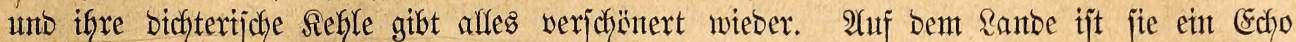

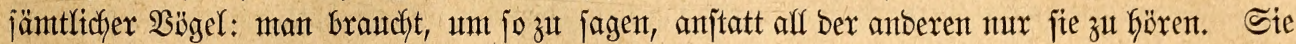

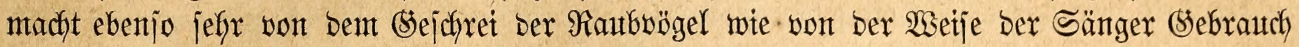
unb verweenbet, in ber \&uft jefjwebenb, Ialjente in eittanber geflochtenter Strophen, Triffer

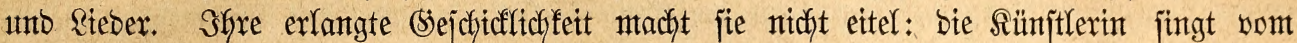

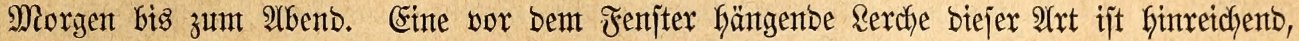
bie ganze Begent zu erheitern; fie iit bie Freube unb ber Stolz bes Şanbwerfers, Das

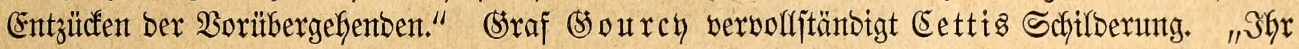

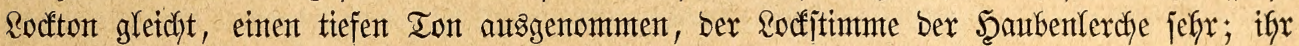

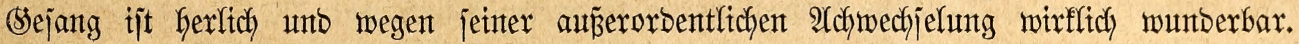

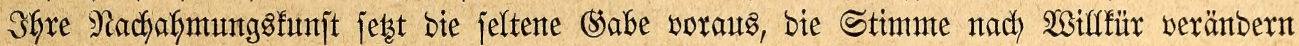

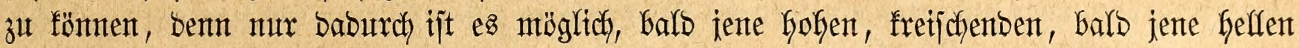

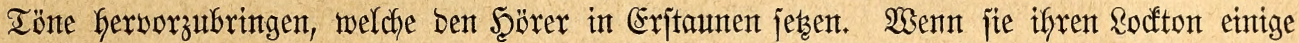
Miale hat Gören lafjen, folgen gewöfnllich einige Strophent aus bemt Bejange ber Bajtarb=

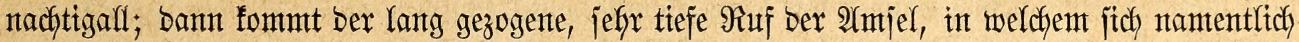

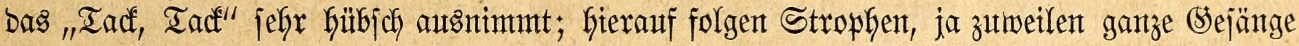

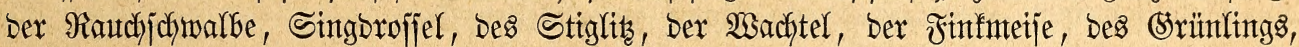

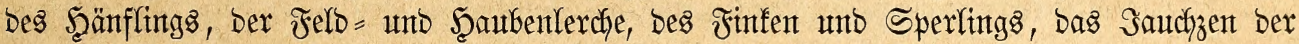

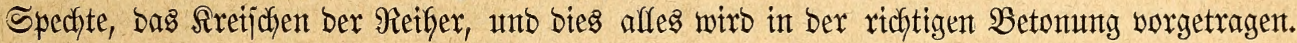

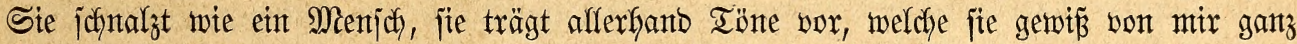

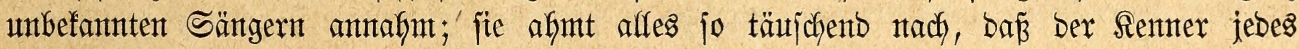

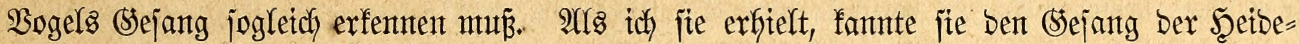

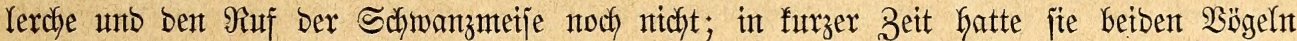

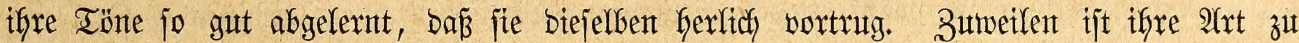

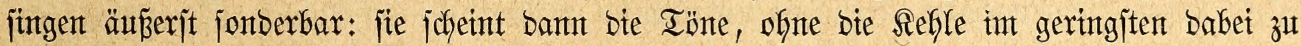
bewegen, turt aus bent Schnaber herauszumerfen." Die eine wie bie anbere bejdyretbung

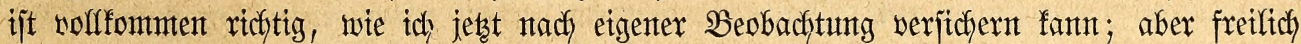

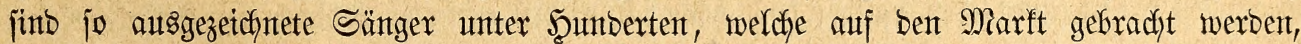
juft ebenjo jeltene Eridjeinungen wie wirflich vorzügliche Sprojifer, Naadjtigaflent ober Spott=

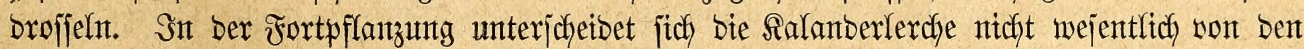
Serwandten. Das aus Stoppelfarmen gebautete, intnen mit feinen (5razblättern, 2 sürzel=

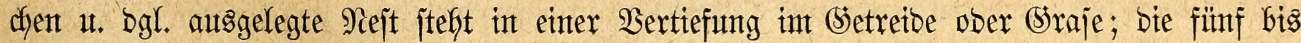

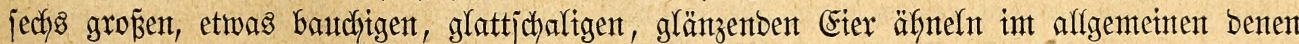

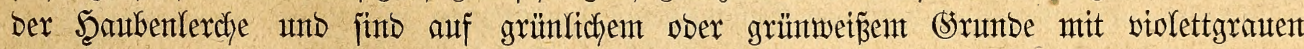

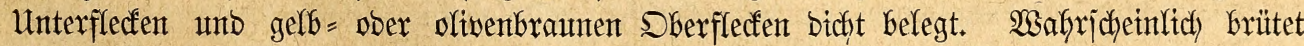

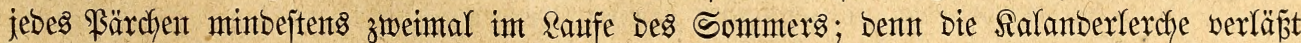

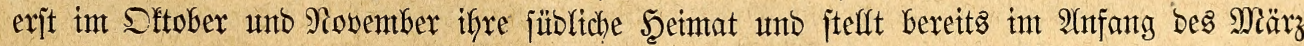
in iffr fich wieber ein, werweilt aber freilich oft noch einen Mionat in ifg, ofgne fich in

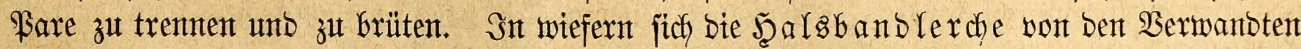

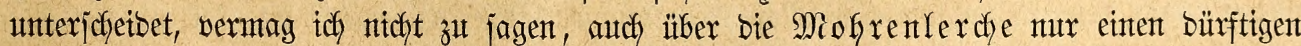

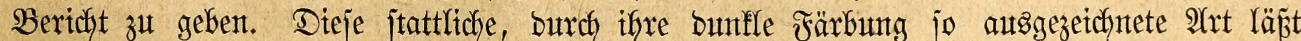

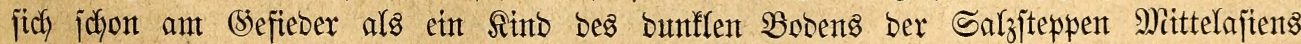
erfennen. Son Gier aus wantert fie mit $\mathfrak{B}$ eginn bes 2 sinters nadf Siliben fint, fammelt fich) bann in Scharen rings um bas faspifdje Mer, bie untere $\mathfrak{S}_{0}$ Iga, bringt aber autch

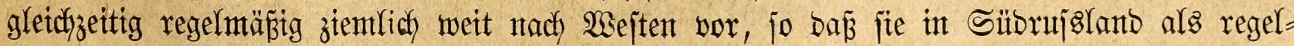

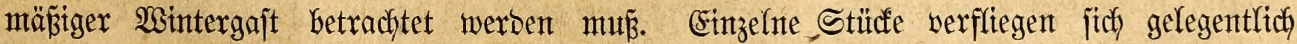

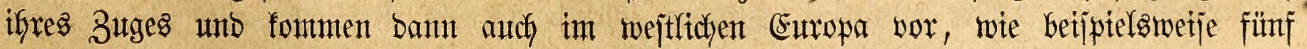




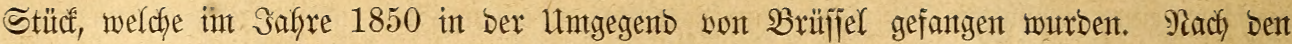

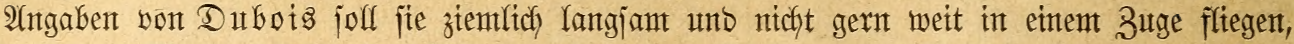
auf threr Wanberjchaft ofne Scheu audf in Den Dörfern und Stäbtent jich zeigen, cinten unbebeutentent ober bodh nidyt guten (Sejang haben, gantz nad) 2(rt ber Serwanbten nijten unb vier bis fünf auf blajs bläultidjem Srunte mit rötlichen Flecfen verjegene Eter haben;

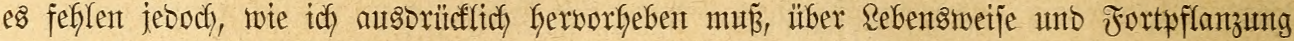
ausfiüfrltche Beobachtungen nodh gänzlich. Beffer fenten wir bie Steppenlerche, welche in

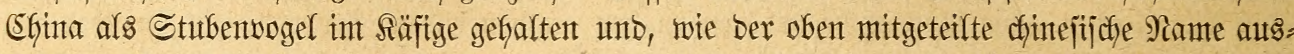

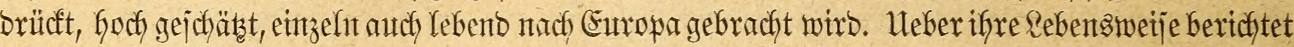

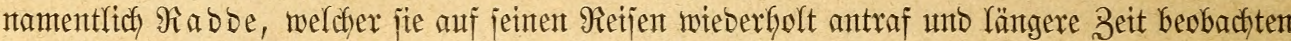
fontnte. Ex fant jie bei Beginn bes Früflings in fleinent Scharen von zefyn bis breip̧itg Stüff in offenen (Segenben, niemals aber auf mit Straudjwert ober 2 arb bebectten Stredfent Sitfibiriens. Bor Sontenuntergang jah ntan bieje (sieịellichaften gantz in ber şeije ber Salanber = unb Spiegelferchen umberichwärmen, gegen Mittag auf Schneejdyntelzen fïch verjammefn, überfaupt ant liebjten an buthfeudfeten Stellen bes öben Steppentbobens fich) aufbalten, ba mo ber Sifnee int 2 inter zujammengewefyt morben war. Die Steppen=

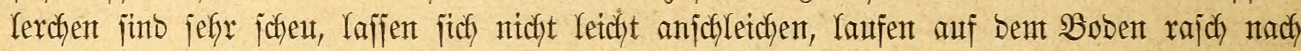

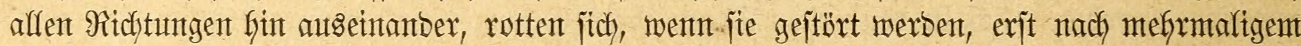

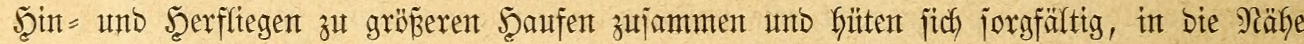

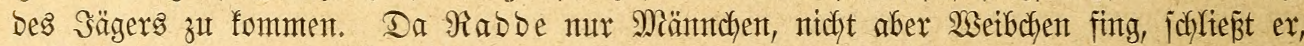

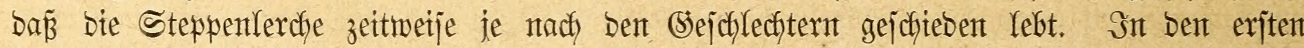
Iagen bes 2lpril Yöjen jich bie Yetzten Flüge, unb man benterft bie Rerchen mur einzeln ober

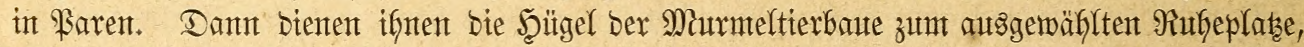

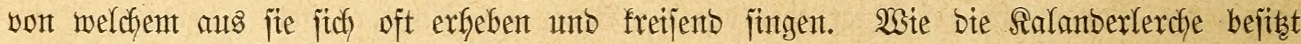
auch bie Steppenlerche ben niebrigen teils rinttelnben, teils flatternben Flitg unt einen äfntlichen (Sejant, welchen jie int Jrïfling blo berjelben 2 (usbauter wie unjere Felblerche vorträgt. Rach volfenbetent Singen läß̈t fie fich plöblich fallent mieber zumt Boben herab.

Heber bie burch ifren mädytigen Schnabel Gëdjit auffallenbe Alepperlerdye, weldye

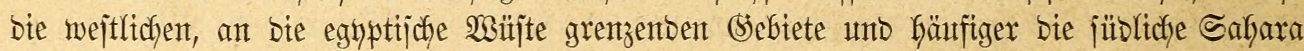

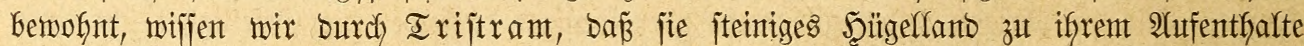
wählt, in fleinen Flügen jich auffält, mit grokéer Sdynelligfeit läuft und fliegt unt jebr

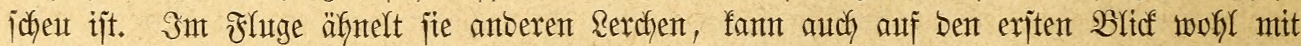

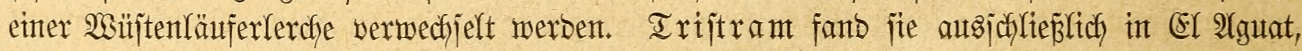
förte audf nidft, "Dañ fie in âfgerient jonjtwo nody borfommt.

Die Schellenlerdhe fand ich in bent oberen Nitlänbern bäufig vor, ba fie nut bem Walbe und meijt int Sebirge fehlt. Dafi fie aud bier vorfonmt, benterft f̧euglin, weldher

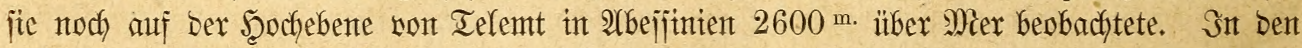
gejchlofienen Waldungen fift mant jie nicht, wohl aber int biun bejtantonten Steppentwalbe,

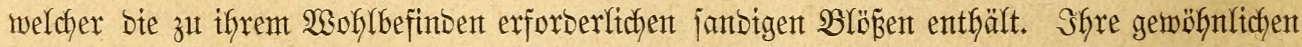

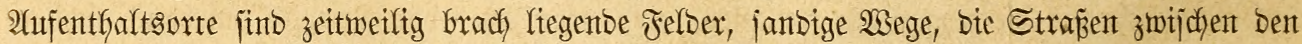
zerjtrent liegenton 20 fnungen ber Dörfer und äfnltche Dertlichfeiten, weldye bürftig mit janten=

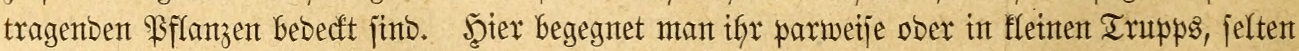

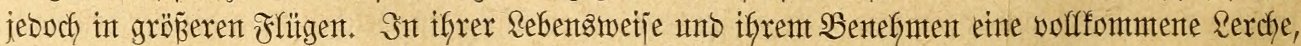
treibt jie jich munter umber unt belebt in anjprectenter SGetje ifr Wobngebtet, bald unge=

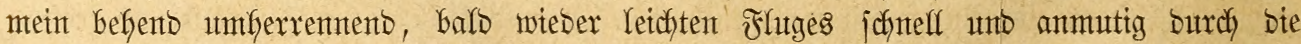

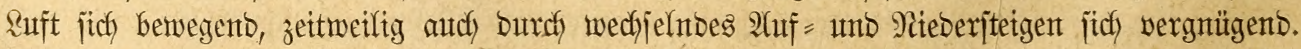

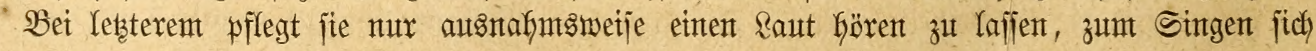




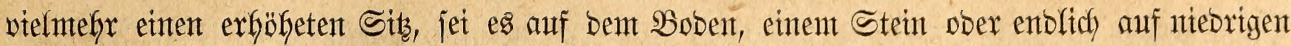
Büichen, fich auszumäblen. Der Sejang ijt unbebentent, trägt aber unverfennbar das Sepräge Des Rerchenliedes. Sebes \$ärchen grenzt jidh ein beftimmtes (sebiet ab, in tweldyem es fein anberes bulbet, unb baut jich wafricheinlidy ebento wie bie indijdye (S) runblerdye in einer

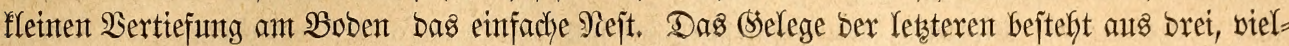

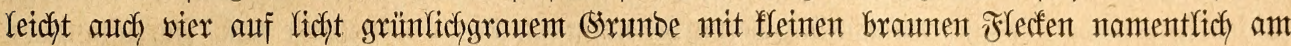
Enbe bidyt bebectten Eiern.

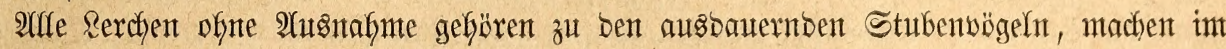

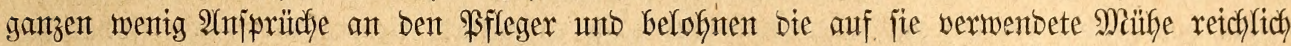

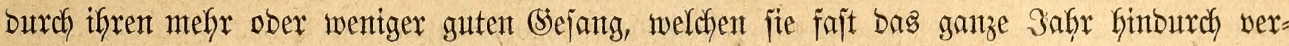

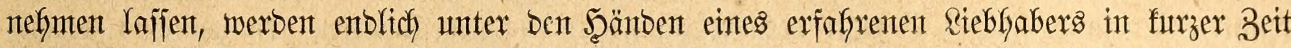

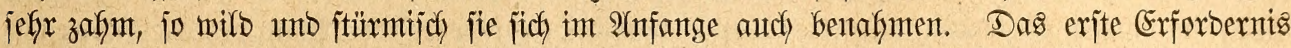

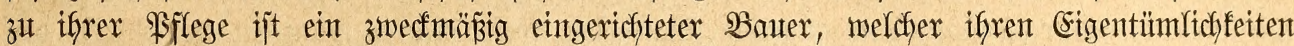
entipridyt und in ber bereits bejchriebenen Weije (ธ. 15) Gergerichtet wirb. Ânjtatt bes Sprungholzes Yegt man zum Bejten ber Füße ber Rerchen joharffürnigen Sand= ober Iuffitein auf Den Säfigboben. Die serchen jizen gern auf jolchen Steinflumpen unt fönten ifyre

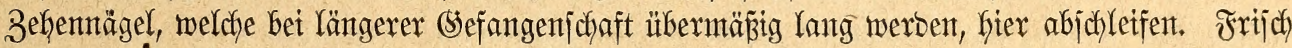
gefangene benefymen jich in ben exiten Iagen ifyer (Sefangenjchaft auperorbentlidy jtürmijac),

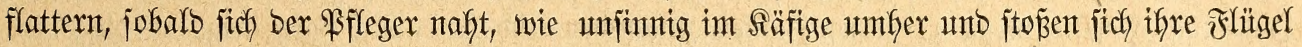
amt (Sitter wunt, rennen jich auch gar nidft affuljelten ben Sopf ein; mant tut baher wobl, fie

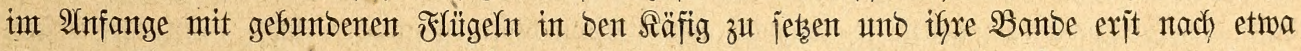

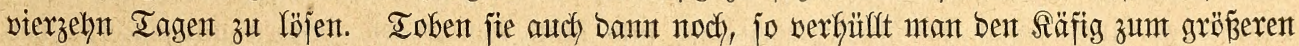
Ieile unb gibt erjt nach und nach mieber sidft. Sft ijt es von ber beiten 2 itrfung, went mant einten Bauter jefyr tief hängt ober auf ben Boben bes Bimmers jtellt. Seidfter als int Säfige gemöhnen fie fid in Zimmer ober im Fluggebauter ein, unt namentlidh, wenn man bereits eine ober bie antore 2 rrt von ifnen gefangen fä̆lt unt bie neu angefommenen zu biejen bringt. Sceibelerchen z. 2 ., meldye mandymal längere Zeit bebürfen, efge jie jich

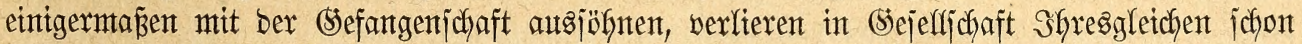
binnen wenigen Iagen alfe Scheu, weldhe jie anfänglich zeigten, gehen fajt unmittelbar nadh Dem Einjeben mit biejen an ben Futternapf und überbeben Den Pfleger jomit aller jonjtigen Sorge. Für bie übrigen Âtrten gillt mefr ober wentiger baģelbe: bie (Sejelligfeit übt einent

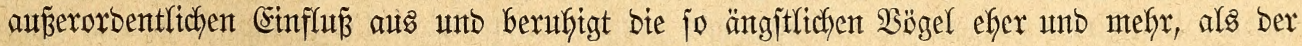
exfahrenjte Pfleger bies zu tun in Stande ijt. Se nachbem man es mit härterent doer

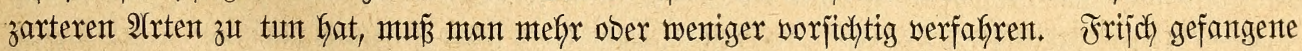

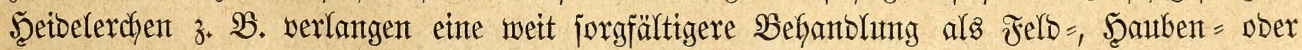

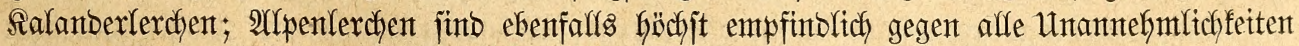

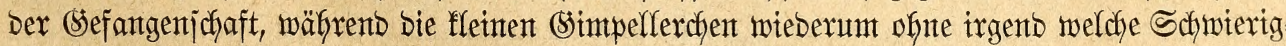
feit fỉch in bie beränberten Umjtänbe fügen unb jichon in bent erjten Iagen jitch int Räfige

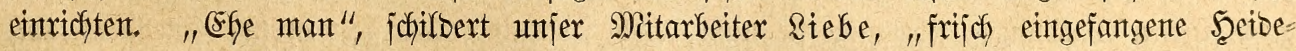

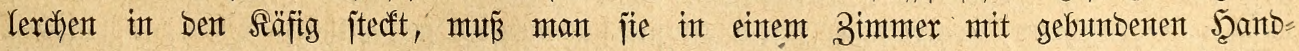
jdymingent acht bis vierzefyn Iage frethajfen, unto zwar barf bas 3immter burchaus nicht zu

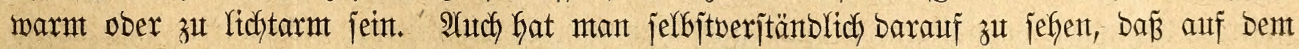

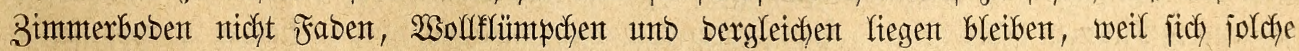

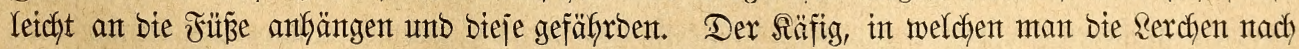

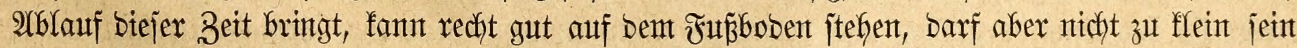

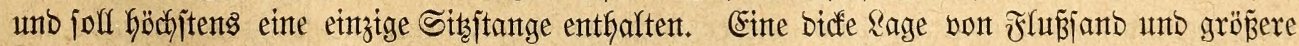
Stüdfe frijhen, feuchtent Rajens ober auth etne Rage frudden Mojes barf nicht fehlen, weil jonjt

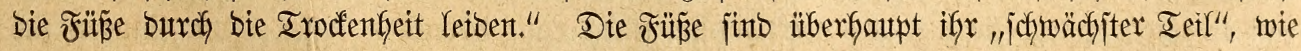




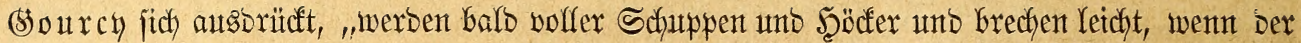

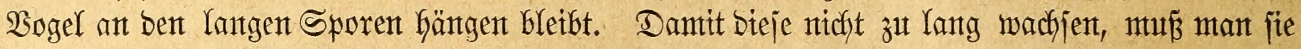

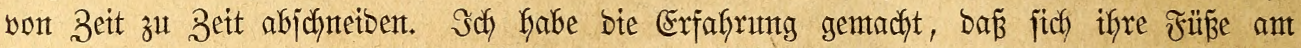

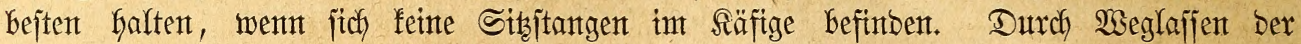
Sprunghölzer unt s̈fteres Baben ber Fü̈̈e, unt ben an ifnen fejtflebenten Santo aufzulbjen

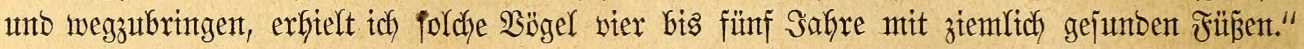
"Sit bie Scetbelerche", fäfhrt ¿iebe fort, "erit einntal an ben Räfig gemöhnt, fo tut mant mohl, fite täglich einte halbe Stunbe in Bimmer umberfliegen zu lafjen, wobet jie jich zwar

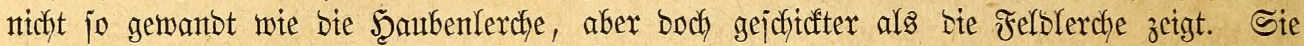
fliegt in ber Stube weit langjamer als jente beiben untfer unb verjucht oft an einer Stelle

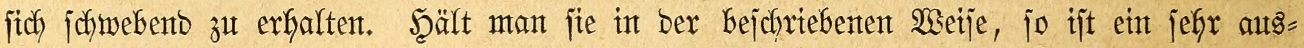
gewäfllt gutes Futter nicht mur nicht nöttg, jonbern jogar jofäblich, ba bie Scetbelerchen, wie

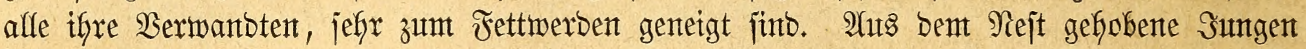
laffen jich inbrigens leidjter aufbringen unb eingemöfnten als alt gefangente, unto bie meiften

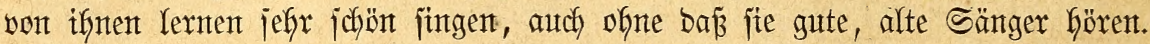

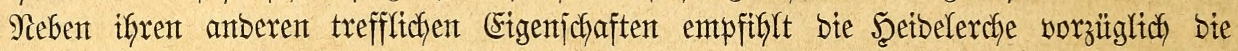
anthängliche Ireue, mit meldyer fie ifrem Serren zugetan ijt. Sch habe noch fetnen Sogel

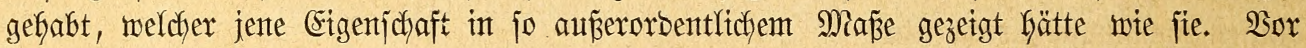

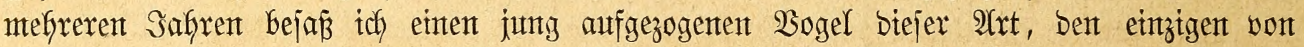
fünf (Sejchwijtern, weldher, zufälfig bem Iobe burch einen Senjentjieb entgangen, bon bent Sceuer hereingebracht worben unt in meine Bfflege gefomment war. Dieje Rerche hatte fich)

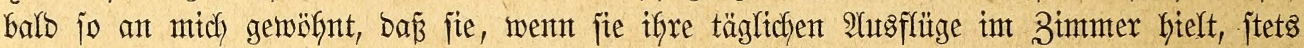

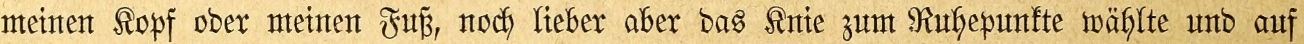
biejent Sizze bie zartejten ifyrer idyntelzenden Weijent lullte. Shne fie int geringjten zu ftören,

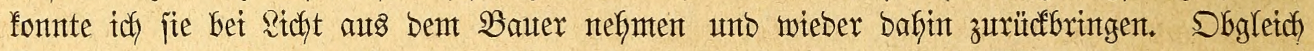
fie von meinter Frau gefüttert wurbe, nafm jie bod) nur von mir Mefliwïrmer an. Sn meiner 2rbmejentheit jang fie mentg, gletchjant jtubirent; fam ich aber nach Şauje, Dant

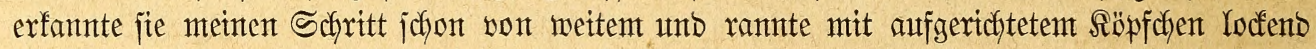

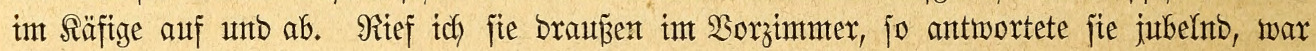

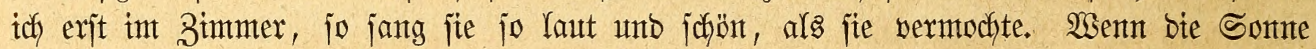

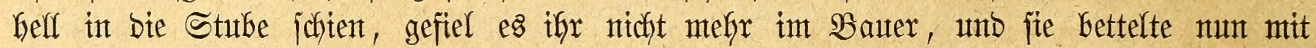
Seberben unto Iönen, bis ich jie Gerauslieś. Selbjt ant jpäten albent, went ich aus einer

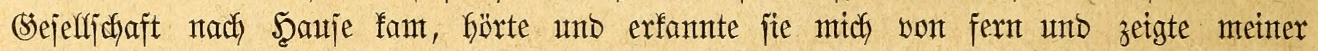

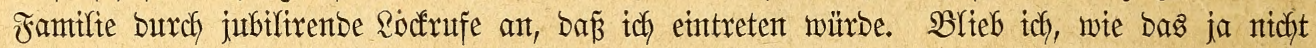
zu wernteiben war, einmal einten ganzen Iag weg, bant wurbe fie untufig, rante jafretent

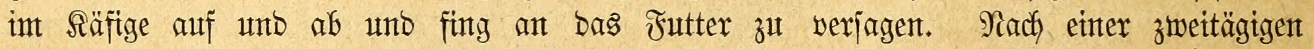

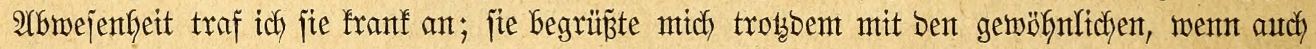
etwas matten Freubenxufen und jich, son mix füttern; am nädjitent Iage war fie wieber

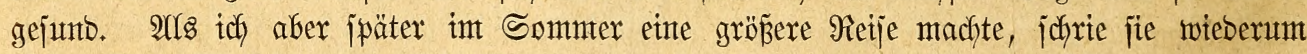

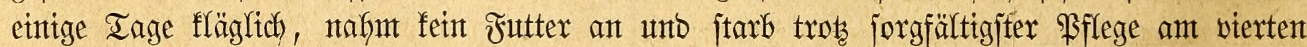
Tage. Sch habe gefliffentlich nite wieber einte Scetbelerche in joldyent (Srabe gezäfmt, weil ify Iod mix jebr nahe gegangen war, und idh fant beshalb nidft jagen, of fich alfe jo innig

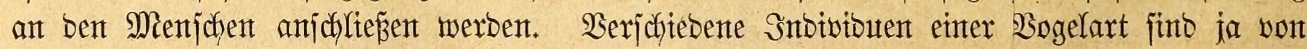
Şauje aus auch berichteben geartet, inmterfin glaube ich aber ben alfgemeinent Satz aus=

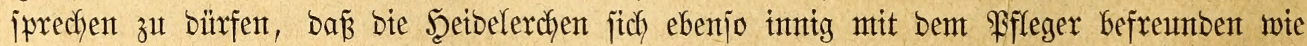

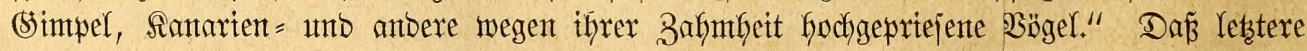
Âtjicht volffommen begrünbet ijt, geft aus anberweitigen Mitteilungen Gervor, welche ich

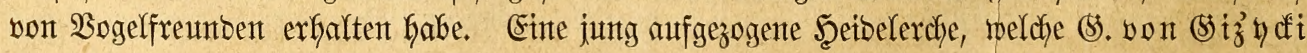




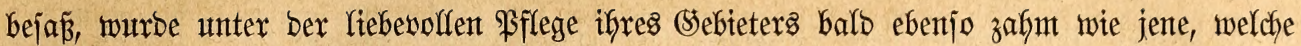

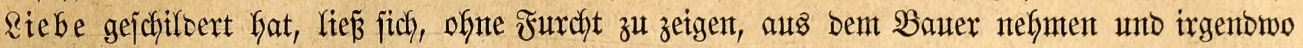
int 3immer nieberjeben, lief unt flog Giex wie ein Scaustier umber, nicht jelten an einem

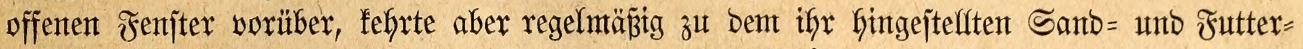

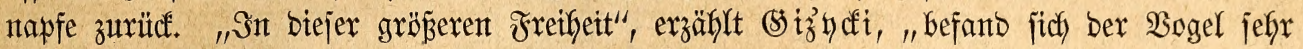

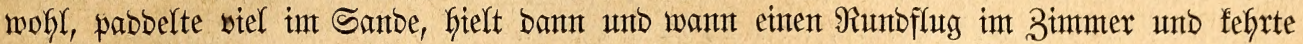

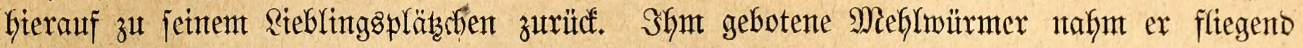
aus ber Şanb. Eintes Morgens befam er einen recht groben, fetten Miefliwum, anjtatt ber flemen, welche jonjt ich ifym auszujuchen pflegte, nafym ifgn audy fofort in Empfang, befielt ifn jeboch längere Beit im Schnabel, midy babei wie bittend anjefend. Sach geraumer

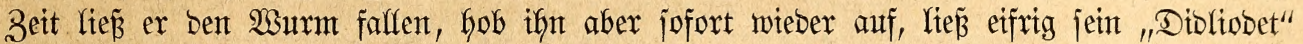

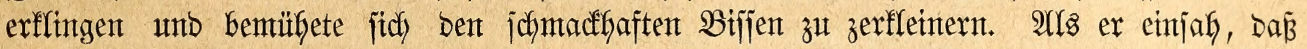
bies ifym zu jojmierig murbe, flog ex exjt um mich herum, lię fich bant auf einem Iijche nieber, willig von mix greifen, Den Mehlwurm äbnefmen uno wartete bes Exfolges jeiner

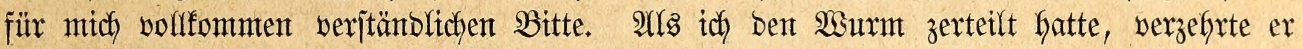
Die eine Scälfte jofort, trug bie anbere auf jeine Rennbafn, frap fie fiter unb forberte mebr.

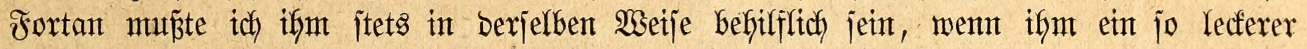
Biffen nicht muntogeredyt wax."

Was füt bie Setbelerche gilt, läß̈t fich audch von ben ïbrigen Ârten ber Familie jagen: fie werben, jung aus bem Rejte genommen, in furzer Frijt ungemein zafm unt ifrem Bfleger innigjt zugetan. Şerflobs beobadtete auf einem fleitent Babnhopfe im Banat eine

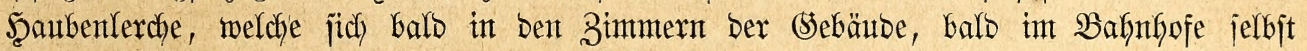
umbertrieb, und bejá̧ längere Beit ein Miänndhen, meldfes mit jeinem trefffich erzogenen

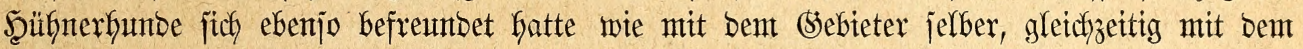

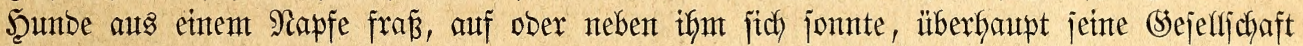

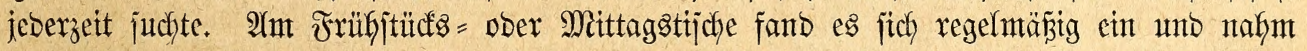

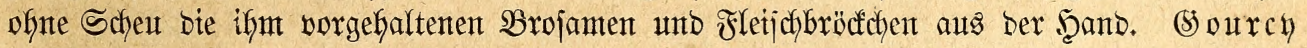
berichtet von ebenjo zahmen Şaubenlerchen. "Sie haben", jagt er, "Die Eigenfyeit, beim" Singen bie Flügel auszubreiten, fitch in ifrem Räfige Gerum zu brehen unt jo ifgre sieber tanzend zu begleiten. Unğemein artig fieht $\mathfrak{e B}$ aus, went jie auf bieje âtrt bie Mienjohen,

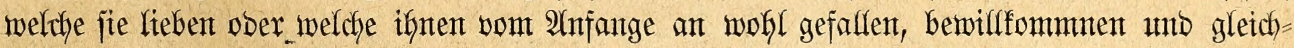
jam grüßen. Da glaubt man oft, bas Tanzen nähme gar fein Ende; bod folgen iffm

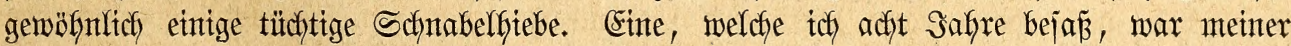
Jrau jo zugethan, baj jie, meine Sattin mochte jtehen, jiben ober gehen, auf bieje zu=

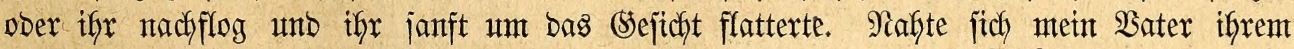
Säfige, fo Görte fie nicht auf zu tanzen und zu jügen." Felblerchen, welche fajt ebenjo fingebent fich zeigten, ungemein zafyme Ralanber = und alfpenlerchen babe ich jelbit gepflegt.

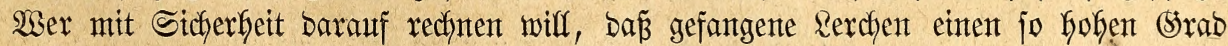

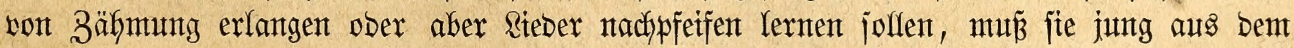

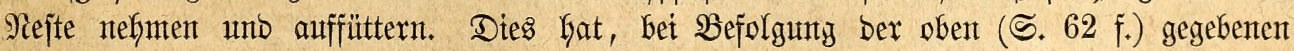

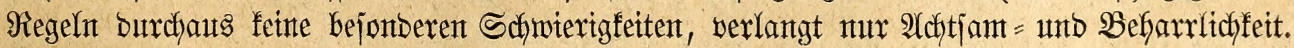

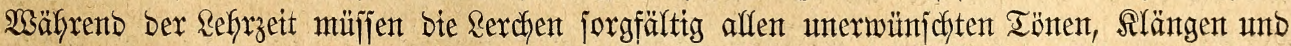
(Seräujchen entrülft werben unb bürfen einzig und affein ben Meijtex Gören, weldher fie lebren jolf; entgegengejetsten Falls nefimen fie nicht affein anberer $\mathfrak{B}$ ögel sieber auf jonbern ebenjo unt=

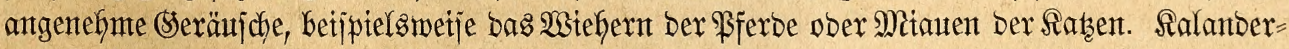
unb Şaubenlerchen werben als bejonbers gelebrig gerüfymt; aber auth bie übrigen 2Yrten, welche wir unts als Sunge verjchaffen fönnen, befunben, wie groż ifgre Niadjafymungsgabe ijt.

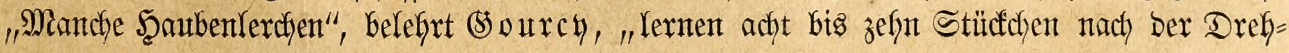




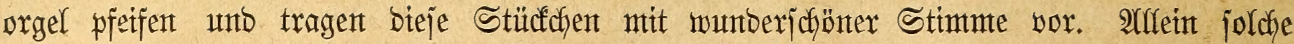

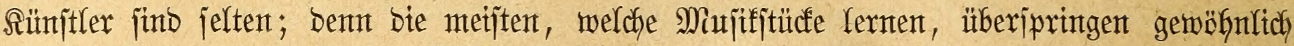

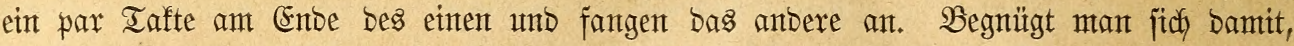
ifgnent wentger beizubringen, io hat man joldhes nicht zut befürchten. Wate jebent abgerich-

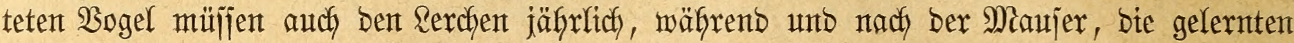

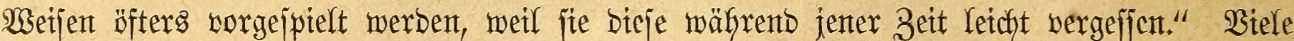
Riebgaber, uno autch id zähle zu biejen, wolfent übrigents von jogenannten geleffrten Rerchen

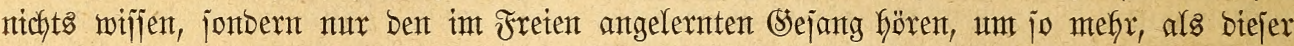

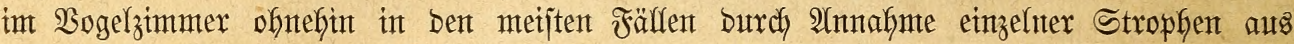

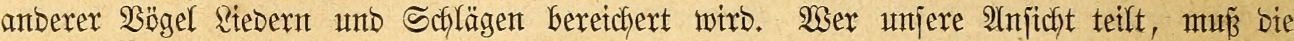

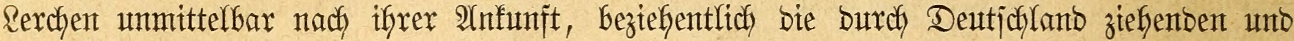

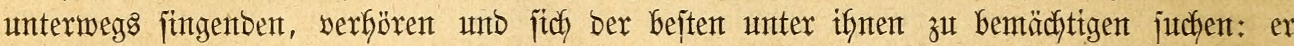
mirb jo zu wirffich ausgezeidyneten Sängern gelantgent.

Bor Bug hat mant bie gefangenen Rerchent ebenio ängitlich) zut hüten als anbere Bügel.

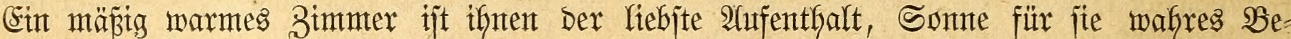

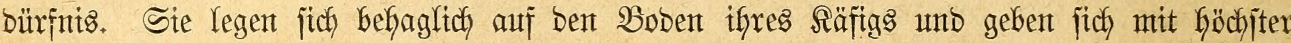

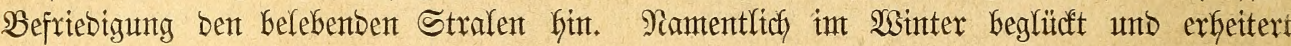
iie jeber Sommenjtral.

Die (Sefangentenfojt Der Rerchen mun ifyremt natürfichent Futter nady Miöglichfeit an=

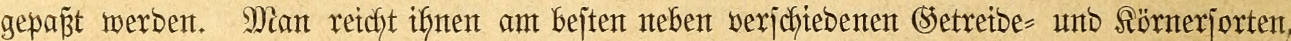

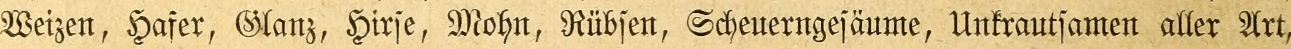

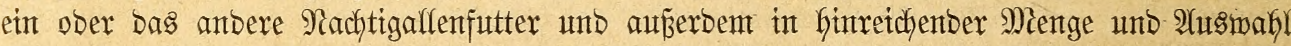

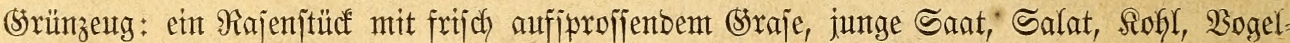
miere $\mathfrak{u}$. DgY. Das (ธ. 40) bejdfriebente Rerchenfutter genügt, 2(Gbwedfjelung aber erfheitert unt belebt. Safanberferchen zerfetzen und verzefrent in furzer Zeit ein ganzes Safathaupt,

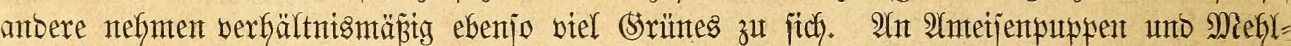
mürmern Darf man feine Rerche Mangel Ketben Lajien, mur ifgr überfaupt jo viele Serbtiere

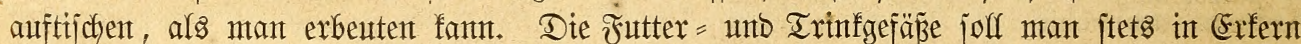
ober Dreffolfen unterbringent, weil bie Rerchen, went jente auf Demt Boben bes Rärigs itefen, in fie fineinjteigen unb bas Frtter bejdyntrzen unt verberben.

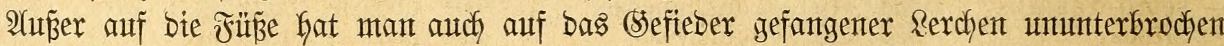

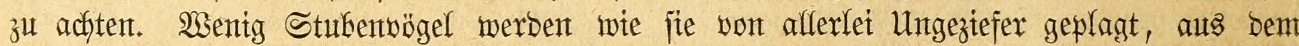

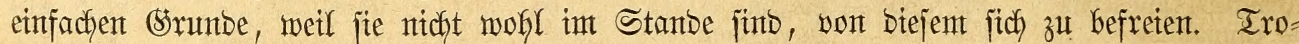

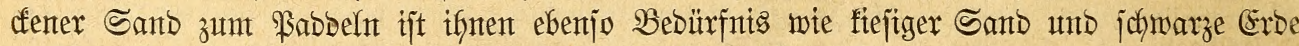

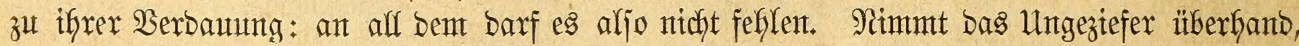
io entfernt mant ben Sand, itreut eine biffe Rage peritiches Snjeftenpulver auf bent Boben

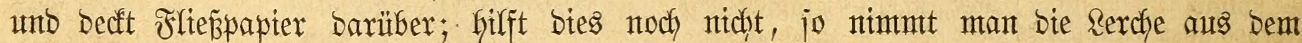
Säfige uno greif̈t zu Dent bereits (ธ. 51) angegebenten Mittel. Reinfidy gefgaltene unto gut geuflegte Rerchent Yeben jechs bis zefjn Safje int Räfige.

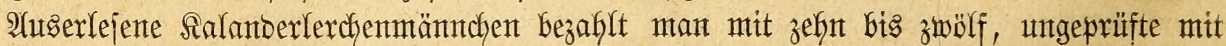

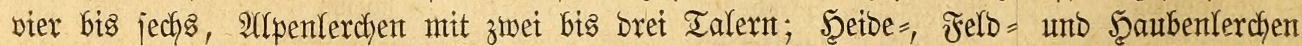

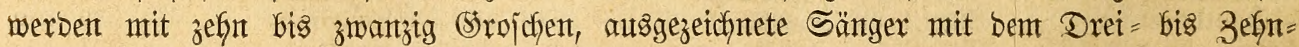
factent bezafilt; alfe übrigen Atrten haben feinent bejtimmten Preiz.

Ende des eriten Bandes. 


\section{$\mathfrak{h e g i f t e r . ~}$}

Aegiothus canescens
- Holboelli
- linarius
Alaemon africana
- desertorum
- Dupontii
Alauda affinis
- apiata
- arborea
- arvensis
- assamica
- brachydactyla
- cantillans
- cinctura
- cinerea
- deserti
- deva
- gulgula
- japonica
- planicola
- sibirica

Amauresthes fringilloides

Amblynura cyanovirens

Ammodromus caudacutus

- Henslowii

manimbe

maritimus

- passerinus

Arremon brumneinuchus

- flavirostris

- semirufus

- semitorquatus

- silens

Acalanthe psittacea

Acanthis canescens

- cannabina

- carduelis

- Holboelli

- linaria

- montium

- spinus

Acrocompsa callophrys

Aegintha temporalis

Agapornis azureus

- cana

- cyanopterus

- guianensis

- pullaria

- xanthops

Aglaia chilensis

- flava

- paradisea

- striata

- viridissima

- vittata

- yeni

Agrophilus haematocephalus
Nr. Seite

261. 363 Aglaius coronatus

260. 363 Aidemosyne modesta

259. 36. Aimophila rufescens

618. 572 Alaemon Jessei

617. 57.2 Alario personatus

619. 572 Alauda africana

609. 570 - agrestis

611. 570 - albigula

603. 569 - albigularis

598. 568 - alpestris

$60<570$ - anthirostris

601. 568 - arenaria

610. 570 - arenicolor

607. 569 - bicornis

605. 569 - bifasciata

606. 569 - bilopha

602. 568 - bimaculata

600. 568 - bugiensis

599. 568 - calandra

612. 570 - calandrella

604. 569 - cantarella

- chendoola

399. 437 - chrysolaema - clamosa

424. 458 - Clot-Beyi

4. coelipeta

549. 533 - coelivox

547. 533 - collaris

545. 532 - cornuta

548. 533 - crassirostris

546. 533 - crepitans

336. 415 - cristata

335. 415 - crucigera

337. 416 - desertorum

334. 415 - dukhunensis

333. 415 - dulcivox

423. 458 - Dupontii

261. 363 - elegans

257. 359 - ferruginea

262. 365 - flava

260. 363 - frontalis

259362 - galerita

258. 359 - gangetica

264. 369 - gingica

383. 429 - glacialis

443. 469 - gracilis

65. 174 - grisea

68. 175 - grypania

69. 175 - hiemalis

69. 175 - Horsfieldi

66. 175 - intermedia

66. 175 - isabellina

372. 423 - italica

379. 424 - leiopus

371. 423 - leucoptera

368. 422 - lusitanica

375. 423 - magnirostris

381. 428 - malabarica

372. 423 - matutina

191. 505 - melanocephala

491. 505 - minor
Nr. Seite

346. 418 Alauda minor

433. 461 - mongolica

517. 527 - montana

617. 572 - mutabilis

229. 333 - nemorosa

618. 572 - nigra

598. 568 - nivalis

596. 567 - pallida

598. 568 - pekinensis

594. 567 - penicillata

603. 569 - rufa

601. 568 - ruficapilla

607. 569 - ruficeps

597. 567 - segetum

617. $57 \cdot 2$ - senegalensis

597. 567 - sinensis

621. 572 - spleniata

598. 568 - tartarica

620. 57. - tenuirostris

601. 568 - triborhyncha

598. 568 - turdina

610. 570 - undata

595. 567 - virginiana

611. 570 - vulgaris

624. $573-$ yeltoniensis

598. 568 Alecto albirostris

599.568 - Dinemelli

620. 572 - erythrorhynchus

594. 567 Alectornis albirostris

598. 568 Amadina acuticauda

611. 570 - annulosa

613. 571 - bicolor

603. 569 - cantans

626. 574 - castaneothorax

617. $57 \cdot 2$ - castanotis

601. 568 - cincta

598. 568 - cucullata

619. 57.2 - cyanovirens

607. 569 - detruncata

619. 572 - erythrocephala

594. 567 - fasciata

627. 574 - fringilloides

613. 571 - frontalis

600. 568 - fuscocrissa

626. 574 - guttata

595. 567 - larvata .

600. 568 - Lathami

626. 574 - lunulata

616. 571 - modesta

594. 567 - nitens

610. 570 - nitida

598. 568 - oryzivora

606. 569 - pectoralis

598. 568 - poënsîs

600. 568 - polyzona

604. 569 - prasina

606. 569 - ruficauda

616. 571 - sanguinolenta

600. 568 - squamifrons

613. 513 Amandava punctulata

625. 574 - punicea

596. 567 Amazona accipitrina
Nr. Seite

598. 568

623. 573

598. 568

622. 573

603. 569

622. 573

594. 567

607. 569

598. 568

596. 567

595. 567

605. 569

605. 569

598. 568

613. 571

623. 573

605. 569

622. 573

598. 568

598. 568

616. 571

613. 571

594. 567

598. 568

622. 573

459. 481

462. 481

460. 481

459. 481

431. 461

428. 4 ti 1

402. 438

406. 438

416. 440

437. 462

429. 4 i 1

400. 438

424. 4.58

418. 440

419. 441

418. 440

399. 437

493. 508

425. 459

436. 462

449. 470

43i. 4 i 2

426. 460

433. 461

514. 524

434. 462

397. 433

417. 440

401. 438

425. 459

422458

454. 471

444. 469

494. ! 08

452. 471

452. 471

31. 159 
Amazona albifrons

- amazonica

- augustus

- auripalliata

- autumnalis

- brasiliensis

- chalcoptera

- cyanogaster

- Dufresniana

- farinosa

- festiva

- Guildingi

- histrio

- leucocephala

- leucogaster

- Levaillantii

- lilacina

- melanocephala

- menstrua

- Pretrei

- pulverulenta

- Sallei

- senilis

- vinacea

- violacea

- vittata

- Vittata

- xanthornus

Ammomanes cinctura

- deserti

- isabellina

Ampelis tersa

Anadorhynchus

- hyazinthinus

- Maximiliani

- dorsalis

- erythropterus

- personatus

- scapulatus

- splendens

Ara alecto

- ararauna

- brasiliensis

- castaneifrons

- erythrochlorus

- glauca

- hyazinthina

- jamaicensis

- maracana

- militaris

Arara aracanga

- auricapilla

- carolinensis

- cayana

- chloroptera

- erythrofrons

- glauca

- hyazinthina

- maracana

- marginata

- patagonica

- purpureodorsalis

- severus

- tricolor

Aratinga acutirostris

- aeruginosa

- aurea

- aurifrons

- caixana

- Carolinae Augustae
Mr. Seite

46. 167 Aratinga carolinensis

60. 170 - chrysocephalus

56. 169 - cruentata

59. 170 - cyanogularis

53. 168 - fasciata

49. 167 - haemorrhous

29. 158 - ludoviciana

21. 156 - ninus

54. 169 - nobilis

58. 170 - pertinax

41. 165 - solstitialis

57. 169 - sosove

23. 157 - virescens

45. 166 - viridissima

25. 157 - xanthoptera

33. 160 Arremon frontalis

51. 168 - superciliaris

24. 157 - torquatus

26. 158 Astragalinus tristis

47. 167 Astrilda cinerea

$58 \quad 170$ - nigricauda

42. 166 - rubriventris

28. 158 - undulata

50. 167 Auripasser luteus

30. 159 Australasia Novae-Hol-

43. 166 landiae

541.532 abyssinica, Fringilla,

545. 532 Pyromelana

607. 569 abyssinicus, Hyphan-

606. 569 tornis, Ploceus

606. 569 accipitrinus, Amazona,

382. 428 Deroptyus, Pionias

100. 211 acuticauda, Amadina,

99. 211 Poëphila

- Munia, S permestes 405, 438

176. 265 acuticaudatus, $\mathrm{C}_{0}$ -

176. 265 nurus, Evopsitta,

179. 266 Psittacara, Psittacus

174. 265 adelaidensis, Platy-

175. 265

173. 265 aestiva, Amazona,

97. 205

105. 212

103. 212

106. 212

106. 212

100. 211

99. 211

102. 212

107. 213

101. 211

102. 212

120. 222

118. 221

116. 221

103. 212

108. 218

100. 211

99. 211

107. 213

19. 154

109. 220

107. 213

106. 212

104. 212

140. 238

123. 222

121. 222

120. 222

124. 223

112. 220 tica, Ploceus Alauda, Ala emo
Chrysotis, Psittacus 64. 171 - Phoenicosoma, Py ranga, Tanagra aestivalis, Fringilla, Peucaea, Zon otrich i a

aethiopicus, Hyphan-

affinis, Alauda, Mira fra

- Eclectus, Tanygnathus

352. 419 aretica, Emberiza, Euspiza, Passerculus, Zonotrichia

541. 532 arcticus, $\mathrm{Pipilo}$ Pyrgita

484496 ardens, Emberiza, Niobe,P enthetria

608. 570 Vidua

- Pyranga

17. 153 arvensis, A lauda

- Euphonia, Tanagra388. 429 ater, Diucopis, Nemosia, Orchesti cus, Saltator, Schiagilis, Chrysotis, Psittacus

Alario,Crithologus, Fringilla

alaudina, Passerculus, Zonotrichia

618. 572

stochlamys, Tanagra

48. 167. aterrimus, Cacatua, M i c r o g lossus, Psittacus

atra, Chalcopsitta, Domicella, Eos, Lorius, Platycercus, Psittacus

Passerina,Phrygilus 556. 535

albicollis, Fringilla, Zonotrichia

527. 529

atrata, Carduelis,

Chrysomitris 273. 371

albifrons, Amazona, atricapilla,D o micella 188. 274 Chry sotis, Psittacus 46. 167 - Estrelda, Habroalbogularis, Loxia, Spermophila, Sporophila

p y g a

atricollis, Fringilla

441. 469

234. 337

290. 384

542. 532

520. 527

509. 519

356. 420

598. 568

329. 412

97. 205

187. 274

Ortygospiza

426. 460
506. 518

459. 481

134. 232

594. 567

274. 376

452. 471

60. 170

176. 265

562. 545

210. 292

301. 395

227. 330

389. 429

428. 461

611. 570

105. 212

603. 569

286. 383 
atricollis, Saltat or, Tanagra

atrigularis, Junco, Spinites, Spizella

assamica, A lauda, Mirafra

astrild,Estrelda, Fringilla, $\mathrm{Hab}$ ropyg a, Loxia

augusta, Amazona, Chrysotis, Oenochrus, Psittacus

aureoflavus, $\mathrm{Hy}$ phantornis, Ploceus

aureola, Emberiza, Euspiza,Hypocentor, Passerina

aureus, Aratinga, C onurus, Psittacus, Sittace

auriceps, Coriphilus, Cyanorhamphus, Euphema, Platycer cus, Psittacus

auripalliata, Amazona, Chrys otis, Psittacus

autumnalis, Amazona, Chrysotis, Psittacu axillaris, Penthetria, Urobrachya, Vidua

Azarae, S al tat or abietina, Crucirostra abyssinica, Galerida

- Taha

Nr. Seite

327. 412 albocristata, Cacatua

albiventris, Calliste alboterminata, Melano-

553. 534 corypha

albus, Psittacus

608. 570 alecto, Ara, Macroglossus, Microglossu alpicola, Passer

438. 468 amazonicus, Psittacus ambiguus, Macrocercus, Psittacus

56. 169 amboinensis, Lorius americana, Carduelis - Pinicola

americanus, Psittacus amoenus, Psittacus

582. 550 angolensis, Cardinalis - Estrelda, Fringilla - Vidua

121. 222 annulatus, Psittacus anthinus, Passerculus anthirostris, Alauda anthopeplus, Palaeornis

182. 267 antiquorum, Emberiza Aourou, Psittacus apicalis, Loriculus

59. 170

approximans, Orynx arabs, Melanocorypha

aracanga, Arara, $\mathrm{Ma}$ crocercus, Psittacus araguira, Emberiza,

504. 518 Fringilla

$3 \cdot 25.412$ arborea, Fringilla

206. 291 archiepiscopus, Tanagra

613. 571 ardesiaca, Sporophila

503. 512 arenaria, Alauda

140. 238 arenicolor, Alauda

acutirostris, Aratinga

Adelaidae, Platycercus adscitus, Psittacus

aenea, Hypochera

157. 260

argentata, Tanagra

161. 261 argentoratensis, Frin-

514. 524 gilla

83. 190 aruensis, Eclectus

equatorialis, Cacatua

aeruginosus, Aratinga Conurus

aestiva, Chrysotis, Psittacus

- Fringilla

23. 222 riza, Hortulanus, Schoenicola

60. 170 asiaticus, Loriculus,

541. 532 Psittacus

aestivalis, Chrysotis

53. 168 ater, Coccoborus

aethiops, Hyphantornis 467. 486 - Microglossus

afer, Euplectes

affinis, Emberiza

- Psittacus

africana, Fringilla

- Fringilla

africanus, Megalophonus, Mirafra agrestis, Alauda albicollis, Emberiza albida, Emberîza 503. 512 - Pipilo

585. 550) atrata, Fringilla

138. 233 atricapilla, Emberiza,

254. 349 Fringilla

511. 519 - Fringilla

- Loxia

612. 570 atricapillus, Psittacus

598. 568 atrigula, Ploceus

585. 550 atrigularis, Cocco-

573. 548 thraustes

627. 574 atrimentalis, Struthus 500. 344

albifrons, Coraphites

albigula,Alauda,Otoco

albigularis, Alauda

- Buserinus

- Melanocorypha

- Petronia

albirostris.Alecto,Alectornis, Dertroides

- Euplectes Rhamphocelus

- Tanygnathus

albispecularis, Tachyphonus
596. 567 atrochalybaeus, Pitylus 320. 411

598. 568 atrococcineus, Rham-

226. 329 phocelus, Rhamphopis 359. 421

620. 572 atrogularis, Linaria 227. 330

295. 386 Aubryanus, Poiocephalus 34. 160

Augustus, Macrocercus,

480. 495 auklandicus, Cyano-

99. 211

18. 154 auranti

Ploceus 470, 486 - notatus

aurantiiventris, Chloris 278. 379 - sappbirinus

345. 418 aurantius, Ploceus $\quad 476.487$ - Sparrmanni
Nr. Seite

9. 152

53. 168

119. 22.

262. 365

476. 487

467. 486

480. 495

350. 419

120. 222

221. 313

509. 519

94. 198

120. 222

145. 239

475. 487 230. 334

526. 529

64. 171

95. 202

81. 190

96. 202

204. 283

203. 280

378. 424

49. 167

330. 412

353. 420

65. 174

152. 256

147. 241

143. 238

140. 238

144. 239

146. 239

145. 239

142. 238

141. 238

74. 185 Bucanetes githigineus 218. 309

95. 202

165. 262

164. 262

166. 263

177. 266

178. 266

454. 471

138. 233

134. 232

133. 231

139. 233

133. 231

138. 233

134. 232

332. 414

331. 414

611. 570

616. 571

145. 239

185. 273

145. 239

184. 273

184. 273 
Brunhilda erythronota Buarremon brunneinuchus

- semirufus

- xanthogenys

Bubalornis niger

Buscarla pytiornis

Buserinus albigularis

- butyraceus

- rufllatus

Banksi, Cacatua, C a lyptorrhynchus, Psittacus

Barklyi, Coracopsis, Psittacus

Barnardi, Platy cercus

Barrabandi, Palaeornis, Platycercus, Polytelis, Psittacus

baya, Nelicurvius, Ploceus

bengalensis, Loxia, Ploceus, Nelicurvius

Bichenovi, Estrelda, Fringilla, Stictoptera

bicolor, Amadina, Spermestes

- Calamospiza,Corydalina, Dolichonyx, Emberiza

- Euethia, Fringilla, Phonipara, Spermophila

Nigrita, Pytelia

bilopha, Alauda, O tocoris

bimaculata, Alauda, Melanocorypha

Bourki, Euphema, Nanodes, Platycercus

brachydactyla, A lauda, Calandrites, Phileremos

- Carpospiza, Fringilla, Petronia, Pyrgita

brasiliensis, Amazona, Chrysotis, Psittacus

- Calliste, Callospiza, Tanagra

- Crithagra, Emberiza,Fringilla, Sycal is

- Rhamphocelus Rhamphopis, Tanagra

brunneinuchus, A rremon, Buarremon, Embernagra

Bufoni, Plictolophus 84.191

butyracea, Buserinus, Chrithagra, Fringilla

Bachmanni, Ammodromus, Fringilla

badensis, Emberiza

badiceps, Psittacus

badius, Psittacus

bagheira, Emberiza
Nr. Seite

455. 471 Banksianus, Psittacus barbadensis, Callospi336. 415 za, Tanagra

337. 416 barbata, Crithagra

336. 415 - Emberiza

460. 481 barbatulatus, Psittacus

578. 549 barbatus, Belurus, $\mathrm{Pa}$ -

226. 329 laeornis

225. 329 batavensis, Psittacus

283. 383 batavica, Psittacula, Psittacus

Baueri, Platycercus,

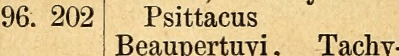

4. 146 phonus

bella, Estrelda, Frin-

164. 262 gilla, Loxia

bengalensis, Euplectes

- Fringilla

178. 266 - Psittacus bengalus,

478. 495 Fringilla

Estrelda,

Bernsteini, C

bicolor, Loxia

480. 495 bicornis, Alauda, Phileremos

bifasciata, Alauda, Cer-

427. 460 thilauda

- Crucirostra, Loxia

402. 438 bimaculatus, Psittacus bicincta, Fringilla, $\mathrm{Po}_{0}$ lymitra

559. 544 bisetis, Psittacus bistrigata, Crithagra bitorquatus, Palaeornis

243. 340 bivittata, Donacola

495510 bivittatum, Phoenicosoma, Pyranga

597. 567 Bonaparti, Emberiza bononiensis, Fringilla

621. 572 borbonica, Coccothraustes

172. 264 borealis, Emberiza

- Linaria

601. 568 bornea, Eos, Lorius borneus, Palaeornis, Psittacus

282. 382 Boysi, Certhilauda, Galerida

brachypterus, Hyphan-

49. 167 tornis, Hyphanturgus, Ploceus

376. 423 brasiliana, Loxia brasiliensis, Ara

230. 334 - Caryothraustes -- Conurus, Eupsittula, Psittacus - Tirica

Brissoni, Fringilla

336. 415 bruneiceps, Emberiza brunnea, Tanagra Buchanani, Emberiza bugiensis, Alauda

225. 329 Buserinus sulfuratus Byroni, Psittacus

540. 532 Calamospiza bicolor 566. 546 Callipsittacus Novae24. 157 Hollandiae

25. 157 Calliste brasiliensis

601. 568 - cayana
Nr. Seite

203. 280 Calliste Desmaresti

- fastuosa

376. 423 - flava

225. 329 - guttata

571. 547 - tatao

138. 233 - tricolor

- Vieilloti

133. 231 - yeni

186. 273 Calyphantria eminentissima

76. 176 - erythrocephala - flavicans

166. 263 - madagascarensis Calyptorrhynchus

344. 418 Banksi

- galeatus

Nr. Seite

375. 423

374. 423

379. 424

380. 424

371. 423

373. 423

377. 423

372. 423

487. 502

488. 503

490. 503

489. 503

96. 202

95. 202

434. 462 Cannabina flavirostris 258, 359

479. 495 - linota 257. 359

456. 472 Cardinalis phoeniceus 313.405

131. 231 - sinuatus 314.405

$\begin{array}{ll}\text { - virginianus } & 312.405\end{array}$

456. 472 Carduelis caniceps 263. 366

187. 274 - elegans 262. 365

407. 439 Carpodacus erythrinus 214. 305

- purpureus 215. 306

597. 567 - roseus 216. 306

$\begin{array}{ll}\text { - sibiricus } & \text { 217. } 306\end{array}$

207. 292 gaster 319.409

134. 232 - viridis $\quad 318.409$

Chlorospingus flavi-

163. 262 - superciliaris $\quad 339.416$

229. 333 Chlorospiza chloris 278. 379

$\begin{array}{ll}130.231 \text { - sinica } & 279.379\end{array}$

$\begin{array}{ll}\text { 416. } 440 \text { - spinoides } & 280.380\end{array}$

Chrysomitris atrata 273. 371

$\begin{array}{ll}356.420 \text { - cucullata } & \text { 271. } 370\end{array}$

573. 548 - icterica $\quad 265.369$

281. 382 - pinus 268.370

$\begin{array}{ll}\text { - psaltria } & 270.370\end{array}$

$\begin{array}{ll}\text { 403. } 438 \text { - spinescens } & \text { 267. } 369\end{array}$

$\begin{array}{ll}574.548 \text { - spinus } & 264.369\end{array}$

590. 552 - Stanleyi $\quad 266.369$

259. 36. - tristis $\quad 269.370$

196. 276 - uropygialis 272. 371

Chrysospiza lutea 293. 385

135. 232 Chrysotis aestiva 64. 171

48. 167

46. 167

60. 170

56. 169

59. 170

53. 168

49. 167

51. 168

44. 166

52. 168

54. 169

58. 170

41. 165

55. 169

57. 169

45. 166

62. 171

63. 171

61. 170

47. 167

42. 166

50. 167

43. 166 


\begin{tabular}{|c|c|c|c|c|c|}
\hline & Nr. Seite & Cacatua Eos & Nr. Spite & & $\begin{array}{r}\text { Nr. Seite } \\
264.369\end{array}$ \\
\hline $\begin{array}{l}\text { Cissopis Leverianus } \\
\text { - minor }\end{array}$ & 332. 414 & - erythrolophus & 78. 190 & - Stanleyi & $\begin{array}{l}264.569 \\
266.369\end{array}$ \\
\hline Citrinella alpina & 274. 376 & - galeata & 95. 202 & - tristis & 269. 370 \\
\hline - barbata & 276. 376 & - galerita & 81. 190 & Carpodacus githagineus & 218. 309 \\
\hline - Lawrenci & 275. 376 & - Gof & 88. 191 & Carpospiza brach & \\
\hline - totta & 277. 376 & - inter & 97. 205 & Nrat a d t & 282. 382 \\
\hline occothraustes mela- & & - Leadbeateri & 86. 191 & - longipennis & 282. 382 \\
\hline & 252. 344 & - leucolophus & 80. 1 & Caryothraustes brasili- & \\
\hline$-\mathbf{p}$ & 51. 344 & $-\mathrm{li}$ & 81. 1 & & 318. \\
\hline & 250.344 & -10 & 83. 1 & - & 319. \\
\hline urus acuticaus & 110. 220 & $-\mathrm{m}$ & 89. 191 & s lapponica & 590.552 \\
\hline eus $=$ & 121. 222 & ccensis & 78. 190 & -1 & 592. \\
\hline - & 24. 2 & $-n$ & 92. 192 & rus au & \\
\hline$-c$ & 118. 221 & - Novae - Hollandiae & 94. 198 & Cert & 72 \\
\hline$-\mathbf{c}$ & 6. 223 & -0 & 79. 190 & - bifascia & 17. \\
\hline arogenys & 21 & -1 & 4. 191 & $-\mathrm{Bc}$ & 1 \\
\hline$-\mathbf{e}$ & 7. 2 & -1 & 89. 1 & $-d e$ & 2 \\
\hline$-\mathbf{h}$ & 1. 2 & 一 & 78. 190 & $-\mathrm{D}$ & \\
\hline$-\mathbf{h}$ & 3. 2 & 一 & 91. 1 & -1 & \\
\hline- & 11 & - & 91 & -1 & \\
\hline-1 & $\begin{array}{l}120.222 \\
128.224\end{array}$ & - & 87. 191 & $\begin{array}{l}-\mathrm{m} \\
-\mathrm{s}\end{array}$ & \\
\hline - luteus & 112. 220 & $-\mathrm{s}$ & 83. 190 & sitta atra & 187. 274 \\
\hline - patagonus (pat & & $-\tilde{T}$ & 82. 190 & $-\mathrm{Be}$ & 187. 274 \\
\hline goni & 109. 220 & Caic & 23. 157 & $-\mathrm{N}$ & 187. 274 \\
\hline-1 & 6. 221 & tra & 25. 1 & $-r$ & 186. \\
\hline-1 & 123. 2 & -1 & 24. 1 & $-\mathrm{s}$ & \\
\hline$-\hat{\mathbf{P}}$ & 122. 2 & serti & 606.569 & Che & \\
\hline$-s$ & 125. 2 & - & 05.569 & $-\mathrm{p}$ & \\
\hline$-\mathbf{s}$ & 119. 2 & - sibiri & 604.569 & Ch & 1 \\
\hline$-v i$ & 7. 2 & tes brachydac- & & Chl & 278. \\
\hline isea & 62 & & 01. 568 & & 9 \\
\hline-1 & 74 & a crass & 616.571 & $-s$ & 27 \\
\hline-1 & 628. & Cal & 95. 202 & honia callop & 383 \\
\hline$-\mathbf{n}$ & 627. & Cal & 376.423 & spingus & \\
\hline Icissi & 73. & - & 376. 423 & & \\
\hline & 77. & $-c$ & 78. 424 & Chl & \\
\hline$-\xi$ & 7.2. & onota & 378. 424 & $\mathrm{Ch}$ & \\
\hline$-\mathbf{i}$ & 74. & - & 379. 424 & - & 530. \\
\hline & & -1 & 77. 4 & Chr & \\
\hline- & & - & 71. 423 & - & \\
\hline-1 & 75. 1 & $-\mathrm{t}$ & 73. 423 & $-n$ & 76 \\
\hline ospingus cris- & & $-\mathrm{y}$ & 72. 423 & $-\mathrm{s}$ & 280. \\
\hline & 304. & albiventris & 376. 423 & omus, Conurus, & \\
\hline$-c$ & 306. & $-c$ & 372. 423 & & \\
\hline$-\mathbf{p}$ & 98 & $-c$ & 80. 424 & hraupis $\mathrm{f}$ & \\
\hline golensis & 227. & -1 & 369. 4 & & 369. \\
\hline - & & -1 & 381. 4 & $\mathrm{Ch}$ & \\
\hline & 224. & aalon australe & 95. 202 & - & 53 \\
\hline$-\mathbf{f}$ & 223. & $-g$ & 95. 202 & $-c$ & \\
\hline$-n$ & 228. & hynchus Cookii & i 96.202 & $-\mathrm{cc}$ & \\
\hline$-\mathbf{S}$ & 226. & $-I$ & 96. 202 & $-\mathrm{c}$ & \\
\hline - si & 222. & $-m$ & 96. 202 & $-c$ & \\
\hline Alar & 229. & $-\mathrm{Te}$ & 92. 202 & $-d$ & \\
\hline ata & 208. & phorus cucu & & $-f$ & \\
\hline C) & 301. & & 307. & $-\varepsilon$ & \\
\hline & & - & & $-\mathrm{j}-2+2 \cdot$ & \\
\hline$-c$ & 298. & - & 0.400 & $-\mathrm{ve}-\mathrm{r}-\mathrm{r}$ & \\
\hline$-\mathbf{v}$ & 300. & $\mathrm{Ca}$ & 274. 376 & - vi & \\
\hline lis & & Cal & 419. 4 & $-v$ & \\
\hline & & -1 & 48 & $-x$ & \\
\hline & & Carc & 269.3 & $-\mathrm{x}$ & \\
\hline & & - & 273. 3 & $\mathrm{Cocc}$ & \\
\hline$-\mathbf{B}$ & & -8 & 262. 3 & - & 248. \\
\hline$-c$ & & $-\mathrm{cu}$ & 271. 370 & $-\mathrm{c}$ & 249. \\
\hline$-c$ & & $-\mathrm{L}$ & & -18 & \\
\hline$-c$ & & -10 & 0. 394 & & \\
\hline$-c$ & & $-\mathrm{m}$ & 39 & & \\
\hline & & $-p$ & & is capi & \\
\hline & & -1 & 270. 370 & & \\
\hline - Eleonora & 82. 190 & - spinoides & 280.380 & Coccopygia Dufresnei & 442. 4 \\
\hline
\end{tabular}


Coccothraustes atrigularis

- borbonica

- canadensis

- cantans

- capensis

- cardinalis

- cayanensis

- chloris

- chrysocephalus

- coerulescens

- collaris

- cyanea

- deformis

- erythrina

- europaeus

- gambiensis

- javensis

- lutea

- melanocephalus

- moluccensis

- oryx (orix)

- oryzivora

- rubricollis

- rufiventris

- scutatus

- sinensis

- sulfuratus

- viridis

Coliuspasser flavoscapulatus

- macrourus

- phoeniceus

- torquatus

Conurus aeruginosus

- auricapillus

- brasiliensis

- calita

- canicollis

- canicularis

- Cassini

- chrysogenys

- chrysophrys

- chrysopterus

- chrysostomus

- coeruleobarbatus

- cyanops

- dorsocoeruleus

- erythrocephalus

- erythrofrons

- fugax

- gregarius

- griseicollis

- griseocephalus

- guianensis

- Illigeri

- leptorhynchus

- ludovicianus

- martinicanus

- modestus

- monachus

- murinus

- ocularis

- palliceps

- passerinus

- phaeton

- phoenicurus

- pondicerianus

- propinquus

- pyrrhopterus

- pyrrhurus গr. Seite।

250. 344

Conurus rubrolarvatus

- rufirostris

403. 438 - rufirostris

213. 303 - severus

406. 438 - squamosus

501. 511 - tiriacula

312. 405 - tovi

318. 409 - tui

278. 379 - tuipara

480. 495 - virescens

320. 411 - xanthogenius

240. 338 - xantholaemus

249. 342 - xanthopterus

250. 344 - xanthopterygius

214. 305 - xanthopterygius

250. 344 Cooki, Platycercus

464. 485 Coracopsis Barklyi

413. 440 - comorensis

223. 329 - mascarina

237. 338 - melanorhyncha

405. 438 - nigra

497. 511 - personata

397. 433 - vaza

315. 408 Coraphites albifrons

247. 342 - frontalis

400. 438 Coriphilus auriceps

397. 433 - cyaneus

222. 329 - discolor

318. 409 - Kuhlii

505. 518 - Notatus

505. 518 - sapphirinus

504. 518 Corvus collurio

508. 519 Corydalina bicolor

123. 222 Corydon galeatus

120. 222 Corys arborea

121. 222 Corythus enucleator

147. 241 - splendens

147. 241 Coturniculus Henslowi

121. 222 - manimbe

146. 239 - passerinus

123. 222 Crithagra bistrigata

123. 222 - brasiliensis

145. 239 - canaria

153. 257 - chrysopyga

165. 262 - cinerea

110. 220 - flavospecularis

176. 265 - Hartlaubii

131. 231 - leucopygia

108. 218 - luteiventris

110. 220 - mosambica

69. 175 - ruficauda

147. 241 - rufobrunnea

143. 238 Crucirostra abietina

117. 221 - leucoptera

107. 213 - minor

108. 218 - pinetorum

118. 221 - rubrifasciata

123. 222 Cryptophaga miliaria

111. 220 Cyanoloxia coerulea

147. 241 - cyanea

147. 241 Cyanolyseos patagonus

123. 222 Cyanorhamphus auk-

161. 261 landicus

69. 175 - auriceps

180. 266 - erythrotis

125. 223 - Malherbi

134. 232 - Novae-Guineae

116. 221 - Novae-Zeelandiae

143. 238 - pacificus

125. 223 - Saisseti
Nr. Seite।

114. 221 Cyanorhamphus unicolor 183. 267

130. 231 Cynchramus miliarius 563. 545

140. 238 - pusillus $\quad 581.550$

106. 212 - pyrrhuloides $\quad 579.549$

126. 223 - rusticus $\quad 574.548$

140. 238 - schoeniclus $\quad 578.549$

144. 239 - septentrionalis $\quad 578.549$

146. 239 - stagnalis 578. 549

145. 239 Cypsnagra hirundinacea 349. 419

142. 238 - ruficollis 349. 419

123. 222 cactorum, C onurus,

123. 222

141. 238 caesia, Emberiza,

69. 175 Fringillaria, Glyci-

141. 238 spina

181. 267 calandra,Alauda, $\mathrm{M} \mathrm{e}$ -

4. 146 lanocorypha

6. 146 callophrys, Acro-

7. 146 compsa, Chloropho-

5. 146 nia, Euphonia,

3. 145 Triglyphidia

174. 265 cana, Poliopsitta,P sit-

tacula, Psittacus 68.175

627. 574 - Tan ag r a, Thraupis 364.421

627. 574 canariensis, Frin-

182. 267 gilla

184. 273 canarius, Crithagra,

203. 280 Fringilla, Serinus 220. 312

185. 273 canescens, Acanthis,

184. 273 Aegiothus, Frin-

181. 267 gilla, Linaria, Linota 261. 363

184. 273 caniceps, Carduelis 263. 366

331. 414 canicollis, Critha-

559. 544 gra, Fringilla, Se-

95. 202

603. 569 rinus

224. 329

Fringilla, Loxia,

547. 533 cantans, Amadina,

244. 340

545. 532 Coecothraustes, Es-

546. 533 trelda, Euodice,

229. 333 Loxia,S permestes

230. 334 Uroloncha

220. 312 cantillans, A la uda,

225. 329

226. 329

Mirafra

406. 438

276. 376 stes, Loxia, Orynx,

225. 329 Pyromelana

228. 330 - Emberiza, Frin-

231. 335 gillaria,

225. 329 capistratus, 0 rch es -

229. 333 ticus, Saltator,

283. 383

206. 291

Tanagra

210. 292 phonus

205. 291 cardinalis, Eclectus,

207. 291

563. 545

248. 342

249. 342

109. 220

Psittacus

carolinensis, Arara, Aratinga, Co nurus, Psittacus

181. 267

castaneofuscus, $\mathrm{H} \mathrm{y}$ phantornis, Ploceus, Textor

182. 267 castaneothorax,Ama-

181. 267 dina, Donacola,

182. 267 Spermestes

181. 267 castanotis, Amadina,

181. 267 Stagonopleura, Tae-

180. 266 niopygia, Zonae-

181. 267
610. 570

501. 511

588. 551

328. 412

309. 400

13. 152

118. 221

477. 488

416. 440

437. 462 
eaudacutus, A m mo d r om us, Fringilla, Oriolus

eayana, Calliste, Callospiza, Tanagra

chalcopterus, Amazona, Pionias, Psittacus

chloris, Chlorospiza, Cocothraustes, Fringilla,Ligurinus, Passer 278. 379

chlorocerea, Domic e lla, Lorius

chloroptera, Arara, Macrocercus,S i t t a c chlorotica, Euphonia, Tanagra

chrysolaema, Alauda, Otocoris

chrysophrys, Emberiza, Hypocentor

cia, Emberiza,

cincta, Amadina, $\mathrm{P}$ o ëphila

cinctura, Alauda, Ammomanes

cinctus, Hyphantornis

cinerea, Alauda, Megalophonus

- Astrilda, Estrelda, Fringilla, $\mathrm{Habro-}$ p y g a

- Emberiza

cinereus, Fringilla, Junco

cingulata, Psittacula, Psittacus

Mr. Seite

549. 533

378. 424

Corneliae, Eclectus

coronata, Emberiza, Zonotrichia

coronatus, Aglajus, Tachyphonus

nyx, Calendula, G alerida

- Fringilla, Go nia phea, Loxia, Sporophila

cristata, Alauda, Gale rida, Heterops, Lullula

386. 429 cristatella, Emberiza, Gubernatrix phospingus, Frin577. 549 gilla, Lophospiza

571. 547 - Lanio, Tachyphonus, Tanagra

429. 461 - Malimbus, Ploceus, Sycobius

607. 569 cruentatus, Aratinga, Conurus, Psittacara, Psittacus, Pyrrhura, Sittace

605. 569 cruentus, C or yphospingus, Lophospiza, Tiaris

439. 468 cucullata, Amadina,

565. 546 Spermestes

- Calyptrophorus, Fringilla, Loxia, Par oaria

ciopsis, Emberiza

ciris, Cyanospiza, Emberiza, Fringilla, Passerina, Spiza

551. 534

70. 176 - Carduelis, Chrys 0-

572. 548 mitris, Fringilla, Pyrrhomitris

culacissi, C o ryllis, Psittacula

299. 394

568. 547

cirlus, Emberiza

citrinella, E m b e r i z a 564. 546

citrinocristatus, $\mathrm{Ca}$ catua.Plictolophus 85.191

Clot-Beyi, Alauda,Melanocorypha, Rhamphocoris

coccinea,D om i cella, Lorius, Psittacus

coccineifrons, $\mathrm{Ch}$ r y sotis

coelebs, Fringilla, Struthus

coerulea, Coccoborus, Cyanoloxia, Fringilla, G onia phea, Guiraca

coerulescens,Estrelda, Fringilla, Habropyga, Laganosticta,P y telia 450. 470

- Saltator

- Spermophila, Sporophila

collaria, Chrys o tis, Psittacus

- Loxia, Spermophila, Sporophila columboides, Palaeornis yanauchen, Do mi cella, Lorius, Psittacus

cyanea, Coccoborus, Coccothraustes, $\mathrm{Cy}-$ anoloxia, Goniaphea, Loxia

$624 \quad 573$

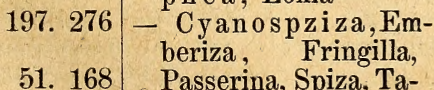

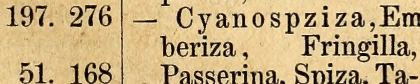
nagra

253. 348 cyanocephalus, $\mathrm{Pa}$ -

laeornis, Psittacus cyanogaster, Amazona, Chrysotis, Pio-

248. 342 nias, Psittacus, Triclaria

cyanogenys (cyanogenia), 1 o micella, Eos, Lorius

cyanogrammus, Tri246. 338 choglossus cyanoptera, Saltator,

44. 166 Tan a gra, Thraupis cyanovirens, Amadina, Amblynura, Erythrura, Geospiza

137. 232 caffer, Icterus
29. 158 crassirostris, Bracho-

595. 567 cristatus, Cory-

Nr. Eeite

caffer, Psittacus

Nr. Seite

33. 160

6. 146 caffra, Chera, Loxia 510. 519

15. 153 caffrariensis, Emberiza 588. 551 caica, Psittacus 23. 157

526. 529 caixana. Aratinga 124. 223 calandrella, Alauda 601. 568

346. 418 calcarata, Emberiza, Fringilla, Plectrophanes

591. 552

616. 571 caledonicus, Platycercus, Psittacus calita, Conurus, My-

246. 342 iopsitta, Psittaca 147. 241 Callispiza punctata 380.424 Calliste guttata 380. 424

613. 571 calthopticus, Psittacus 145. 239 campestris, Fringilla 265. 369

$\begin{array}{ll}\text { 311. } 402 \text { - Fringilla 291. } 385 & \end{array}$

cannabina, Acanthis, Fringilla, Ligurinus, Linota, Passer canadensis, Coccothraustes, Pinicola - Emberiza, Passer - Loxia, Pitylus canicapillus, Passer canicollis, Conurus, Myiopsitta, Sittace

127. 223 canicularis, Conurus, Eupsittula, Psittacus 121. 222 cantarella, Alauda 598. 568

306. 398 capensis, Emberiza, Fringillaria

400. 438 - Hyphantornis, Oriolinus, Oriolus,

307. 399 Ploceus 475.487 585.550 69. 175 capistrata, Emberiza, Fringillaria,Polymitra 587. 551

271. 370 capistratus, Psittacus, Trichoglossus

200. 280

73. 185 - Pitylus 328. 412

206. 291 capitalis, Fringilla 265. 369 capitata, Quelea 482. 496 capitatus, Psittacus 160. 261 cardinalis, Coccothraustes, Fringilla, Loxia, Pitylus

312. 405 - Loxia

249. 342 carduelis, Acanthis, Fringilla, Passer, Spinus

Carolinae Augustae,

298. 394 Aratinga Carolinae, Eclectus

112. 220

15. 153

579. 549

Cassini, Conurus 146. 239

castaneifrons, Ara Macrocercus

106. 212

21. 156 caucasicus, Xanthornus 560.545 caudata, Pyrrhula 217. 306

Cavaignacii, Jerapte-

624. 573

201. 280 cayanensis, Coccothraustes, Fringilla

366. 422 - Psittaca

318. 409

142. 238

48. 167

Psittacus

323. 411

424. 458 ceramensis, Lorius 192. 275

475. 487 ceylonensis, Eclectus 12. 152 cayana, Arara 
\begin{tabular}{cc|l} 
ceylonensis, Eclectus, ${ }^{\text {Rr. Seite }}$ & & coerulea, Tersine \\
Psittacus & 12. 152 & coeruleata, Domicella,
\end{tabular} ceylonicus, Solenoglossus 97.205 chendoola, Alauda $\quad 610.570$ cheet, Lonchura 407. 439 chilensis, Aglaia, Calliste 372. 423 - Fringilla chinensis, Psittacus chiriri, Psittacus chlorion, Fringilla chlorocephala, Emberiza 566. 546

chloronota, Chrysotis chloroptera, Tanagra chloropterus, Psittacus 112. 220 chrysocephalus, Aratinga

- Coccothraustes

120. 222

480. 495

chrysogaster, Psittacula - Tanagra

- Tanagra

chrosogenys, Conurus chrysolophus, Cacatua chrysomelas, Hyphantornis

chrysonota, Callospiza chrysonotus, Vidua chrysophrys, Conurus chrysopogon, Psittacula, Psittovius

chrysops, Emberiza

chrysoptera, Fringilla

chrysopterus, Conurus, Psittacula

chrysopyga, Crithagra, Serinus

chrysopygos, Textor cinerea, Crithagra

- Euphonia

- Pyrrhula, Spermophila

cinereus, Pipilo

cineracea, Emberiza

cinereicollis, Psittacus

cinereola, Pyrrhula, Spermophila cinereus, Pipilo

- Psittacus

cioides, Emberiza

cisalpina, Fringilla

citrinella, Cannabina

Chlorospiza, Fringilla

clamosa, Alauda

Clot-Bekii, Hierapterhina

Clusii, Psittacus

cobaltina, Psittacara

cobaltinus, Psittacus

coccinea, Emberiza,

Pyrrhula

69. 175

368. 422

384. 429

123. 222

85. 191

468. 486

378. 424

505. 518

123. 222

144. 239

543. 532

505. 518

145. 239

225. 329

470. 486

396. 430

233. 337

558. 535

565. 546

147. 241

232. 337

558. 535

1. 145

572. 548

285. 383

274. 376

611. 570

624.573

31. 159

99. 211

26. 158

211. 296

179. 266

coccineus, Rhamphocelus, Rhamphopis

- Vini

coccothraustes, Fringilla, Loxia cochinchinensis, Eos coelestis, Euphonia - Platycercus coelipeta, Alauda coelivox, Alauda

\section{Psittacus}

coeruleobarbatus, Conurus

coeruleofrontatus, Psittacara

coerulescens, Coccothraustes, Pitylus coeruleus, Hylophilus collaris, Alauda

- Coccothraustes - Ploceus

collurio, Corvus

columbiana, Tanagra

columbina Chrysotis, Psittacus

comptus, Tiaris

aris
Cookii, Calyptor-
rhynchus, Psittacus

cornuta, Alauda, Eremophila, Otocoryx

coronatus, Psittacus

- Psittacus Tachyphonus, Tanagra

coulaci, Loriculus

craspedopterus, Euplectes

crassirostris, Alauda

- Pyrgita

crenirostris, Pyrrhula

crepitans, Alauda

crispa, Pyrrhula

crissalis, Fringilla

cristata, Cacatua, Psit-

$$
\text { tacus }
$$

- Emberiza coryphus

cristatella, Alauda

- Cacatua

- Tanagra

Crithagra, barbata crocea, Fringilla

croceus, Plictolophus

crucigera, Alauda

chrysocephalus, Cocco-

thraustes

cubae, Fringilla

cubicularis, Psittacus

cucullatus, Palaeornis

cyanea, Pipracidea cyaneus, Coriphilus,

357. 420 Psittacus

250. 344 cyanocinctus

198. 276
226. 329 coeruleus, Psittacus

Mr. Seite

382. 428

193. 275

65. 262

111. 220

320. 411

340. 417

105. 212

620. 572

240. 338

concolor, Hyphantornis

coryphaea, Pyrrota,

- Emberiza, Lopho-

croccopygia, Poliospiza

crucirostra, Loxia

44. 340

463. 485

466. 486

331. 414

354. 420

50. 167

cyilus, Ploceus

476. 487 Dasyptilus Pesquet

Diucopis fasciat
Domicella atra

96. 202 - atricapilla

- chlorocerca

594. 567 - coccinea

31. 159 - cyanauchen

54. 169 - cyanogenys

- garrula

- Kuhl

74. 185 - reticulata

- riciniata

499. 511 - rubra

598. 568 - scintillata

292. 385 - semilarvata

245. 342 - taitiana

611. 570 Dermophrys flavi-

238. 338

Dermophrys flavi-
prymna

521. 528 - maja

Deroptyus accipitrinus 31. 159

80. 190 Dertroides albirostris 459. 481

589. 551 Dinemellia leucocephala 462.481

Diucopis atra

329. 412

311. 402 Dolichonyx bicolor

603. 569 - griseus

80. 190 Domicella coeruleata

305. 398 Donacola bivittata

225. 329 - castaneothorax

226. 329 - flaviprymna

560. 545 - pectoralis

85. 191 Dryospiza leucopygia

626. 574 - serinus

206. 291 Ducorpsius typus

480. 495

271. 370

130. 231

129. 230

381. 428 cyaneopileata, Psittacula 72. 185

184. 273

185. 273 cyanocephalus, Psittacus 26. 158 cyanochlora, Psittacula 69. 175

191. 275 cyanogaster, Psittacus 199. 279

385. 429 cyanogula, Psittacus 26. 158

161. 261 cyanogularis, Aratinga 126. 223

598. 568 cyanolaemus, Loriculus 74. 185

599. 568 cyanoleucus, Hylophilus 340. 417
Darwinii, Tan a ra

dentata, Gy mnoris Petronia, Pyrgita, Xanthodina

deserti, A lauda Ammomanes, Calandrella, Melanocorypha, Mirafra

desertorum, Alaem o n, Alauda, Certhilauda

559. 544

558. 535

193. 275

416. 440

416. 440

416. 440

417. 440

228. 330

219. 392

90. 191

369. 422

295. 386

Desmaresti, Calliste, 375. 572

deva, A la uda, Spiz-

alauda

diademata, $\mathrm{Ch}$ r y s o tis 52.168

Dinemelli, Alecto, Textor

462. 481 
discolor, Coriphilus, Euphema, Lathamus, Nanodes, Psittacus, Trichoglossus

diuca, Emberiza, Fringilla, Hedyglossa, Phrygilus

domesticus, Fringilla, Pas s er, Pyrgita

Dufresnei (Dufresnianus), Amazona Chrysot is, Psittacus

- Coccopygia, Fringilla, Habropyga,

Ducorpsi, Cacatua, Plictolophus

Dupontii, Alaemon, Alauda, Certhilauda

dalmatica, Fringilla

Daubentoni, Spermophila

decora, Vidua

decorus, Psittacus

deformis, Coccothraustes

delicata, Emberiza

Derbyanus, Palaeornis

Desmaresti, Tanagra

detruncata, Amadina, Fringilla

diadema, Psittacus

diffusus, Passer, Pyrgita

discurus, Psittacus

docilis, Psittacus

dolichonia, Emberiza

domicella, Lorius, Psittacus

dominicanus, Calyptrophorus, Fringilla, Loxia

dominicensis, Chrysotis, Psittacus

- Emberiza

lauda

Doriae, Certhilauda

dorsalis, Aprosmictus,

Platycercus, Psittacus 176. 265 Euspiza americana dorsocoeruleus, Conurus 176. 265 - icterica dubia, Taha 502.512 - melanocephala dukhunensis, Alauda 601. 568 Eclectus arıensis dulcivox, Alauda dumetorum, Embernagra515. 526 - ceylonensis

Durazzi, Emberiza

Eclectus affinis

- cardinalis

- Corneliae

- grandis

- intermedius

- Linnéi

- luconensis

- megalorrhynchus

- Muelleri

- polychlorus

- Westermani

Emberiza aureola

- caesia

- capensis

- chrysophrys

- cia

- cinerea

- ciopsis 598. 568 - Carolinae

Nr. Seite

203. 280

- citrinella

- flaviventri

- fucata

557. 535 - leucocephala

- miliaria

284. 383 - passerina

- personata

- pusilla

- pyrrhuloides

54. 169 - rustica

- rutila

442. 469 - schoeniclus

90. 191 - striolata

- tahapisi

572 - variabilis

573. 548 Embernagraplatensis - rufivirgata

512. 520 - psittacea

64. 171 Euethia bicolor

250. 344 - lepida

566. 546 - pusilla

136. 232 Euphema elegans

348. 419 - petrophila

418. 440 - pulchella

52. 168 - venusta

20. 156 - Annae

130. 231 - callophrys

582. 550 - chlorotica

188. 274 - Gnatho

308. 400 - humilis

$43 \quad 166$ - jamaicensis

- luteicapilla

241. 339 - nigricollis

617. 572 - trinitatis

- violacea

578. 549 - platurus

17. 153 Emberiza affinis

13. 152 - albicollis

15. 153 - albida

12. 152 - americana

10. 152 - amoena

14. 153 - ardens

19. 154 - antiquorum

16. 153 - araguira

18. 154 - arctica

9. 152 - arundinacea

11. 152 - atricapilla

582. 550 - auriceps

567. 547 - badensis

588. 551 - bagheira.

577. 549 - barbata

571. 547 - bicolor

565. 546 - Bonaparti

572. 548 - borealis
- hortulana

229. 333 Erythrura prasina
Nir. Seite

568. 547 Emberiza borealis

564. 546 - brasiliensis

576. 549 - bruneiceps

585. 550 - Buchanani

575. 548 - caffrariensis

566. 546 - calcarata

573. 548 - canadensis

563. 545 - capensis

580. 549 - capistrata

569. 547 - caspia

581. 550 - chlorocephala

579. 549 - chlorocephala

574548 - chrysops

583. 550 - cineracea

578. 549 - cioides

570. 547 - ciris

586551 - coccinea

587. 551 - coronata

584. 550 - cristata

515. 526 - cristata

516. 527 - cristatella

422. 458 - cyanea

423. 458 - cyanopis

243. 340 - delicata

244. 340 - diuca

241. 339 - dolichonia

242. 340 - dominicensis

154. 257 - Durazzi

155. 257 - eleathorax

152. 256 - erythroptera

151. 256 -

153. 257 - erythrophthalma

388. 429 - flavigaster

389. 429 - Gayi

383. 429 - glacialis

386. 429 - grammaca

385. 429 - gramminea

393. 430 - granativora

391. 430 - guttata

395. 430 - Henslowii

390. 429 - Hordei

396. 430 - hyemalis

392. 430 - icterica

384,429 - intermedia

387. 429 - lesbia

394. 430 - leucophrys

562. 545 -- longicauda

561. 545 - lotharingica

560. 545 - luctuosa

10. 152 - luteola

15. 153 - major

12. 152 - malbeyensis

20. 156 - melanocephala

585. 550 - melanops

585. 550 - mexicana

573. 548 - minor

562. 545 - montana

301. 395 - mustellina

509. 519 - nipalensis

566. 546 - nivalis

304. 398 - olivacea

542. 532 - olivacea

578. 549 - oryx, (orix)

526. 529 - palustris

221. 313 - pallida

566. 546 - panayensis

601. 563 - paradisea

571. 547 - picta

559. 544 - pileata

573. 548 - pinetorum

574. 548 - pinguescens
Nr. Seite

590. 552

230. 334

561. 545

566. 546

588. 551

591. 552

537. 531

585. 550

587. 551

579. 549

566. 546

570. 547

543. 532

565. 546

572. 548

299. 394

211. 296

526. 529

311. 402

589. 551

311. 402

298. 394

422. 458

566. 546

558. 535

582. 550

241. 339

578. 549

568. 547

588. 551

589.551

518. 527

585. 550

554. 534

590. 552

530. 529

531. 530

560. 545

556. 535

547. 533

571. 547

552. 534

561. 545

579. 549

574. 548

524. 528

510. 519

571. 547

555. 534

561. 545

512. 520

566. 546

560. 545

570. 547

562. 545

512. 520

590. 552

590. 552

589. 551

590. 552

241. 339

601. 568

497. 511

579. 549

540. 531

509. 519

511. 519

593. 552

528. 529

582. 550

566. 546 
Emberiza pithyornus - platensis

- polaris

- pratensis

- principalis

- provincialis

- pusilla

- pythiornithoides

- quadricolor

- quelea

- quinquevittata

- regia

- rufibarba

- ruficapilla

- rúfigularis

- sandwichensis

- Selysii

- septemstriata

- serena

- Shattuckii

- signata

- simillima

- socialis

- sordida

- subcristata

- Tunstalli

- unalaschcensis

- unicolor

- vidua

- xanthogastra

Emberizoides poliocephalus

Embernagra brunneinucha

- dumetorum

- pyrgitoides

Eolophus roseicapilla

- roseus

Eos ater, atra

- bornea

- cochinchinensis

- cyanogenia

- cyanostriata

- guebiensis

- indica

- Isidori

- orientalis

- puniceus

- reticulata

- riciniata

- rubra

- rubrifrons

- scintillata

- semilarvata

- squamata

- variegata

Eremophila alpestris

- cornuta

Erythrospiza githaginea

- purpurea

- rosea

Erythrostomus macrorhynchus

Erythrura cyanovirens

- Pucherani

Estrelda amandava

- angolensis

- annulosa

- astrild

- atricapilla

- bella
Ni. Seite

573. 548 Estrelda bengalus

515. 526 - Bichenovi

580. 549 - cantans

571. 547 - cinerea

512. 520 - coerulescens

574. 548 - elegans

539. 531 - erythronota

572. 548 - formosa

422. 458 - frontalis

483. 496 - granatina

585. 550 - lipiniana

513. 520 - mariposa

567. 547 - melanogastra

305. 398 - melanogenys

567. 547 - melanopygia

542. 532 - minima

582. 550 - modesta

587. 551 - musica

512. 520 - oculea

540. 531 - Perreinii

509. 519 - phaëton

560. 545 - phoenicotis

538. 531 - polyzona

581. 550 - psittacea

589. 551 - rubricata

566. 546 - rubriventris

523. 528 - rufopicta

557. 535 - sanguinolenta

512. 520 - squamifrons

585. 550 - subflava

515. 526 - temporalis

526 - vinacea

Euodice cantans

336. 415 - malabarica

515. 526 Euphema auriceps

517. 527 - Bourki

91. 191 - chrysostoma

91. 191 - discolor

187. 274 - formosa

196. 276 - haematogaster

198. 276 - haematonota

195. 276 - multicolor

196. 276 - Novae-Zeelandiae

193. 275 - pulcherrima

197. 276 - undulata

198. 276 Euphonia cinerea

11. 152 - coelestis

14. 153 - rufivertex

196. 276 - tibicen

198. 276 Euplectes afer

193. 275 - albirostris

186. 273 - bengalensis

186. 273 - craspedopterus

194. 275 - Edwardsi

193. 275 - erythrops

198. 276 - flammiceps

594. 567 - flaviceps

594. 567 - flavigula

218. 309 - franciscanus

215. 306 - gregarius

216. 306 - ignicolor

- lepidopterus

16. 153 - lepidus

424. 458 - melanogaster

424. 458 - minor

452. 471 - oryx

456. 472 - pseudoryx

428. 461 - pyrrhozona

438. 468 - ranunculaceus

441. 469 - ruber

434. 462 - sanguinirostris
Nr. Seite

456. 472 Euplectes stictus

Nr. Seite

427. 460 - striatus

406. 438 - Sundevallii

439. 468 - taha

450. 470 - xanthomelas

445. 470 Eupsittaca Petzi

455. 471 Eupsittula brasiliensis

453. 471 - canicularis

493. 508 - Petzi

457. 472 Euspiza arctica

455. 471 - aureola

456. 472 - hortulana

451. 471 - Lathami

442. 469 - luteola

439. 468 - pusilla

446. 470 - rutila

433. 461 - variabilis

03. 512

479. 495

497. 511

502. 512

501. 511

122. 222

121. 222

121. 222

122. 222

542. 532

582.550

566. 546

589. 551

561. 545

581. 550

583. 550

584. 550

228. 330 Evopsitta acuticaudata 110. 220

435. 462 - erythrogenys 114. 221

451. 471 - evops 117. 221

458. 472 - Maugei 116. 221

456. 472 elegans, Carduelis 262. 365

425. 459 - Emberiza

423. 458 - Euphema, Na-

448. 470 nodes

438. 468 elegantissima, $\mathrm{E} u$ -

447. 470 phonia, Pipra

444. 469 eminentissima, $\mathrm{Ca}$ -

494. 508 lyphantria, Fou-

444. 469 dia

443. 469 enucleator, Corythus,

449. 470 Fringilla, Loxia, Pi-

406. 438 nicola, Strobilophaga 213. 303

407. 439 erithacus, Psittacus

182. 267 erythrinus, Carpoda- -

17\%. 264 cus, Coccothraustes,

153. 257 Fringilla, Loxia,

203. 280 Pyrrhula

214. 305

149. 254 erythrocephala, Ama-

167. 263 dina, Loxia, Sper-

169. 263 mestes, Sporothlastes 419. 441

170. 264 - Calyphantria, Fou-

181. 267 dia, Fringilla, Plo-

171. 264 ceus

488. 503

148. 242 - Pyrrhula

396. 430 erythrogenys, Belu-

385. 429 rus, Palaeornis

212. 296

- Conurus, Evopsitta 114. 221

385. 429 erythronota, Brun-

503. 512 hilda, Estrelda, Frin-

480. 495 gilla, Uropytelia

479. 495 erythrophthalmus,

499. 511 Emberiza, Fringilla,

497. 511 Pipilo

482. 496 erythrops, Euplectes,

499. 511 Foudia, Hyphantica,

479. 495 Ploceus

480. 495 erythropterus, Apros-

498. 511 mictus, Platycercus,

484. 496 Psittacus, Ptistes

498. 511 erythrorhynchus,

494. 508 Alecto, Textor

492. 507 euops, Conurus, Evo-

508. 512 psitta,Psittacus,Psit-

497. 511 tacara

497. 511 eupatrius, Palaeornis,

497. 511 Psittacus

499. 511 exilis, Coryllis, Lori-

503. 512 culus

489. 503 eburnirostris, Conurus,

483. 496 Psittacus

455. 471

518. 527

482. 496

179. 266

460. 481

122. 222 
Edwardsi, Euplectes

- Loriculus

- Psittacus

eleathorax, Emberiza

elegans, Alauda

- Estrelda, Fringilla, Loxigilla, Marquetia, Zonogastris

- Psittacus

- Psittacus

Eleonora, Cacatua

mberiza, gubernatrix

Eos, cacatua, Plictolophus, Psittacus

episcopus, Caryothraustes

- Tanagra

erubescens, Psittacus

erythraea, Loxia

erythrocephala, Pyranga

erythrocephalus, Conurus, Psittacus

erythrochlorus, Ara

erythrofrons, Arara, Conurus

Arara,

Rr. Seite

497. 511 Fringilla angolensis

74. 185 - angolensis

152. 256 - araguira

568. 547 - arborea

607. 569 - arcuata

$$
\text { - argentoratensis }
$$$$
\text { - astrild }
$$

445. 470 - atrata

31. 159 - atricapilla

156. 260 - atricapilla

82. 190 - atricollis erythroleucus, Psittacus 1. 145 - campestris erythrolophus, Cacatua 78. 190 - campestris erythromelas, Pyranga 351. 419 - canaria

- Tanagra

356. 420 - canescens

erythronotus, Platycercus, Psittacus

erythrophrys, Passer

erythropis, Psittacus

- Pyranga

erythrops, Psittacus

180. 266 - cannabina

289. 384 - canora

49. 167 - capitalis

354. 420 - cardinalis

46. 167 - carduelis

erythroptera, Emberiza 588. 551 - caudacuta

erythropterus, Plictolo-

phus

589. 551 - cayanensis

86. 191 - chilensis

erythrorhyncha, Vidua 512. 520 - chloris

erythrorhynchus, Pitylus

erythrotis, Cyanorhamphus, Platycercus

europaea, Miliaria

europaeus, Coccothraustes

evops, Evopsitta

eximius, Platycercus, Psittacus

Fringilla canariensis

- coelebs

- montifringilla

- spodiogenia

Foudia eminentissima

- erythrocephala

- erythrops

- flavicans

- madagascariensis

Fringilla abyssinica

- aestiva

- aestivalis

- africana

- africana

- alaudina

- albicollis

- Alario

- amandava

- amoena
320. $411 /$ - chrysoptera

181. 267 - ciris

563. 545 - cisalpina

- citrinella

250. 244 - coccothraustes

117. 221 - coerulea

160. 261 - coerulescens

255. 349 - crissalis

253. 348 - cristata

256. 349 - crocea

254. 349 - cubae

487. 502 - cucullata

488. 503 - cucullata

482. 496 - cyanea

490. 503 - dalmatica

489. 503 - detruncata

502. 512 - diuca

541. 532 - domestica

541. 532 - dominicana

254. 349 - Dufresnei

511. 519 - elegans

556. 535 - enucleator

527. 529 - erythrina

229. 333 - erythrocephala

452. 471 - erythronota

301. 395 - erythrophthalma
Nr. Seite

227. 330 Fringilla ferruginea 522.528

456. 472 - flammea 214. 305

304. 398 - flavicollis 294. 386

537. 531 - flavicollis $\quad 562.545$

290. 384 - flavirostris 258. 359

257. 359 - flavoptera $\quad 505.518$

438. 468 - formosa $\quad 453.471$

$550.533--\quad 554.534$

237. 338 - frontalis 493. 508

526. 529 - fruticeti 555.534

426. 460 - funerea 514. 524

625. 574 - Gambelli 525. 529

378. 424 - Gayi 554. 534

541. 532 - georgiana 536. 531

276.376 - githaginea 218. 309

434. 462 - Gnatho 320.411

456. 472 - grammaca 530.529

456. 472 - gramminea $\quad 531.530$

$\begin{array}{ll}\text { 427. } 460 \text { - granatina } & \text { 457. } 472\end{array}$

584. 550 - grisea 282. 382

243. 340 - grisea 292. 385

281. 382 - gutturalis 236. 337

282. 382 - Henslowii $\quad 547533$

249. 342 - hiemalis 552. 534

230. 334 - hispaniolensis 287. 383

225. 329 - hudsonia 552. 534

591.552 - hudsonica $\quad 550.533$

265. 369 - hypoleuca 232. 337

$\begin{array}{ll}291.385 \text { - ictera } & 225.329\end{array}$

220. 312 - icterica 265. 369

261. 363 - ignicolor 498. 511

224. 329 - iliaca 522.528

257. 359 - italica 285. 383

244. 340 - jamaica 396. 430

265. 369 - jugularis 294. 386

312. 405 - juncorum 539. 531

262. 365 - Kawarahiba minor 279. 379

549. 533 - lapponica 591. 552

318. 409 - Lathami 436. 462

528. 529 - laticauda 508. 519

279. 379 - lepida 241. 339

278. 379 - lepidoptera $\quad 494.508$

505. 518 - leucocephala 436. 462

439. 468 - leuconota 403. 438

551. 534 - leucopogon 235. 337

299. 394 - leucopygia $\quad 228.330$

285. 383 - linaria 259. 362

274. 376 - Lincolnii $\quad 535.530$

250. 344 - lineola $\quad 238.338$

248. 342 - linota $\quad 257.359$

450. 470 - lippa 440. 469

246. 342 - littoralis $\quad 549.533$

521. 528 - longirostris 464. 485

304. 398 - ludoviciana 315. 408

560. 545 - lulensis 256. 349

271. 370 - lutea 293. 385

271. 370 - luteiventris 231. 335

$\begin{array}{ll}307.399 \text { - luteola } & \text { 468. } 486\end{array}$

298. 394 - Macgillivrayi 548. 533

573. 548 - macrocerca $\quad$ 507. 518

418. 440 - magellanica 265. 369

558. 535 - majanoides 415.440

284. 383 - manimbe $\quad 545.532$

308. 400 - manyar 479.495

442. 469 - maritima $\quad 548.533$

445. 470 - matutina 528. 529

213. 303 - melanictera 589.551

214. 305 - melanocephala 236. 337

$\begin{array}{ll}\text { 488. } 503 \text { - melanotis } & 442.469\end{array}$

455. 471 - melba $\quad 445.470$

518.527 - melodia $\quad 532.530$ 
Fringilla melpoda

- meruloides

- minima

- montana

- monticola

- montium

- Moreletti

- musica

- Mülleri

- multizona

- neisna

- nisoria

- nitens

- nivalis

- nivalis

- nobilis

- ochracea

- oculea

- oregona

- ornata

- ornata

- oryzivora

- palustris

- panayensis

- paradisea

- passerina

- pennsylvanica

- Perreinii

- petronia

- phaëton

- philippina

- pileata

- pinus

- plumbea

- polyzona

- principalis

- psaltria

- psittacea

- pulchella

- punctulata

- punicea

- purpurea

- pusilla

- pyrrhula

- quelea

- quinticolor

- ranunculacea

- reticulata

- rosea

- rubricata

- rubriventris

- rufa

- rufina

- rufirostris

- russata

- rutilans

- salicicola

- sanguinolenta

- sarda

- savanna

- savannarum

- saxatilis

- sclavonica

- senegalensis

- senegalla

- serinus

- sinensis

- sinica

- socialis

- speciosa

- sphenura
Nr. Seite

440. 469 Fringilla splendens

523. 528 - spinescens

446. 470 - spinoides

291. 385 - spinoides

537. 531 - spinus

258. 359 - squamifrons

255. 349 - striata

228. 330 - striolata

468. 486 - subflava

425. 459 - sylvia

442. 469 - temporalis

408. 439 - tintillon

514. 524 - tobaca

297. 391 - torrida

552. 534 - totta

253. 348 - Townsendii

262. 365 - tristis

435. 462 - troglodytes

550. 533 - ultramarina

235. 337 - undulata

303. 398 - uropygialis

397. 433 - velata

536. 531 - viridis

509. 519 - vitellina

511. 519 - xanthomascalis

546. 533 Fringillaria caesia

527. 529 - capensis

451. 471 - capistrata

281. 382 - flavigaster

458. 472 - rufa

481. 496 - septemstriata

305. 398 - striolata

268. 370 - vittata

233. 337 fallax, Melospiza,

425. 459 Zonotrichia

512. 520 farinosa, Amazona,

270. 370 Chrysotis, Psittacu

423. 458 fuscata, Loxia, Ory-

423. 458 zornis, Padda

421. 457 fasciata, Amadina,

452. 471 Loxia, S permestes,

215. 306 Sporothlastes

539. 531 - Diucopis, Schi-

211. 296 stochlamys, Tanagra

483. 496 fastuosa, Calliste,

443. 469 Tanagra, Tatao

503. 512 ferruginosa, Munia,

419. 441 S permestes

216. 306 festiva, Amazona,

448. 470 Chrysotis, Psittacus

438. 468 flammiceps, Euplectes,

522. 528 Pyromelana

523. 528 flava, Aglaia, Calli-

232. 337 spiza, Calliste, Ta-

288. 384 nagra

288. 384 - Galerida

287. 383 flaveolus, Platycer-

444. 469

287. 383 flavicans, Caly $\mathrm{ph}$ a n-

543. 532 tria, Foudia

546. 533 flavicollis, Fringilla,

297. 391 Gymnoris, Passer,

573. 548 Xanthodina

462. 485 flavifrons, Phoeocepha-

446. 470 lus, Pionias, Psit-

219. 312 tacus

279. 379 flavigula, G y m no r is,

279. 379

538. 531

445. 470

Xanthodina, Passer

422. 458 flavigul aris, $\mathrm{Chlo-}$ rospingus, Pipilopsis
Mr. Seite

Nr. Seite

flavirostris, Arremon 335. 415

267. 369 - Cannabina, Frin-

$\begin{array}{lll}264.369 \text { gilla } & \text { 258. } 359\end{array}$

280. 380 flaviscapulata, Coli-

264. 369 uspasser, Penthe-

494. 508 tria

404. 438 flaviventris, Critha-

586. 551 gra, Loxia

Emberiza, Passe-

253. 348 rina, Polymitra 585. 550

443. 469 - Platycercus, Psit-

255. 349 tacus

227. 330 formosa, Estrelda,

247. 342 Fringilla, Pytelia 453. 471

277. 376 formosus, Euphema,

523. 528 Pezoporus, Psit269. 370 tacus

439. 468 franciscana, Euplec-

514. 524 tes, Loxia, Pyro-

438. 468 melana

227. 330 fringilloides, Ama-

464. 485 dina, A maures-

318. 409 thes, Munia, Ploceus 399. 437

470. 486 frontalis, Amadina,

316. 408 Estrelda, Fringilla,

567. 547 Loxia, Sporopipes 493.508

585. 550 fruticeti, Fringilla,

588. 551 Phrygilus, Rho-

585. 550 pospiza

555. 534

587. 551 fucata, Emberiza 575.548

587. 551 fuliginosus, Pitylus 320. 411

586. 551 fuscans, Munia, Sper-

588. 551 mestes

fuscicapillus, $\mathrm{Pi}$ i $\mathrm{n}$ i-

534. 530 as, Poiocephalus

fuscicollis, Pionias, Psittacus

411. 439

38. 160

58. 170

fuscus, Kieneria, Pi pilo 521. 528

falcirostra, Loxia 209. 292

fasciatus, Psittacus 134. 232

418. 440 ferruginea, Alauda $\quad 619.572$

- Fringilla

330. 412 - Munia

522. 528

415. 440

ferrugineus, Psittacus 125. 223

374. 423 fimbriata, Habropyga 450. 470

fimbriatus, Psittacus 95. 202

415. 440 fimbriolatus, Psittacus 50.167

flamengo, Loxia 213. 303

41. 165 flammea, Fringilla 214. 305

flammigerus, Rham-

$\begin{array}{ll}\text { 499. } 511 \text { phopis } & 363.421\end{array}$

flava, Alauda $\quad 594.567$

flava, Passerina 230. 334

379. 424 flavescens, Icterus 501. 511

615. 571 - Serinus 219.392

flaviceps, Euplectes,

158. 260 Nelicurvius 479.495 - Ploceus 471. 487

490. 503 flavicollaris, Palaeornis 131. 231 flavicollis, Fringilla 562. 545 flavifrons, Psittacus $\quad 63.171$

294. 386 flavigaster, Chloris 278. 379 - Emberiza, Fringillaria

585. 550

35. 160 - Psittacus 163. 262

flavigula, Euplectes $\quad 480.495$

296. 386 - Ploceus 473.487

flavigulus, Psittacus 72. 185

flavinucha, Amazona,

338. 416 Psittacus

59. 170 
flaviprymna, Dermo-
phrys, Donacola, Munia

flavirostris, Psittacus

flavitorques, Palaeornis

Haviventris, Tanagra

flavomareus, Pitylus 319. 409

flavoviridis, Hyphantornis, Ploceus, Textor 465. 486 flavospecularis, Chrithagra

276. 376 Havoscapulatus, Psittacus 39. 161 flavoptera, Fringilla 505. 518 flavus, Saltator formosa, Fringilla - Tanagra

Fraseri, Palaeornis

frenatus, Psittacus

Fringilla, punicea

fringilloides, Tachyphonus

frontalis, Alauda, $\mathrm{Co}$ raphites

- Arremon

- Psittacus

frugilegus, gra

fugax, Conurus

fuliginosa, Vidua

fumigata, Tanagra

funerea, Fringilla, Tiaris

funereus, Psittacus

fuscicollis, Nelicurvius

fuscocrissa, Amadina

fuscus, Psittacus

- Psittacus

Galerida crassirostris

- cristata

- flava

- Theklae

Goniaphea coerulea

- crassirostris

- cyanea

- nigra

- torrida

Gubernatrix cristatella

Gymnoris dentata

- flavicollis

- flavigula

Galerida abyssinica

- Boysi

- lutea

- musica

- nemorosa

Geopsittacus occindentalis

Geospiza cyanovirens

- nivalis

Glossiptila ruficollis

Glycispina caesia

- hortulana

Granativora melanocephala

Guaruba lutea

Guiraca ludoviciana

- melanocephala

- coerulea galeritus, Cacatua
Plictolophus

353. 420

554. 534

379. 424

133. 231

130. 231

315. 408

305. 398

627. 574

336. 415

127. 224

369. 422

110. 220

512. 520

349. 419

514. 524

96. 202

478. 495

425. 459

3. 145

30. 159

616. 571

613. 571

615. 571

614. 571

248. 342

246. 342

249. 342

245. 342

247. 342

311. 402

295. 386

294. 386

296. 386

613. 571

613. 571

615. 571

603. 569

603. 569

150. 255

424. 458

297. 391

34.. 418

567. 547

566. 546

560. 545

112. 220

315. 408

316. 408

248. 342 Psittacus

algulns, Co ryllis Loriculus, Psittacula,

Gambelli, Fringilla Zonotrichia Lorius

Gayi, Emberiza, Fringilla, Phrygilus

githagineus, Bucagilla, Pyrrhula tacara, Psittacus Phonasca loph us Phonasca Zonotrichia Uraeginthus

grandis, Eclectus Lorius, Psittacus Ploceus lauda

Tanagra

gulgula, A lau da
Gyrinorhynchus hypo-

leucus

Gyrola viridissima

ralbula, Hyphan -

tornis, Ploceus, Textor

galeatus, Banksianus, Cacatua, Callicephalus, Callocephalon, Calyptorrhynchus,Corydon,

Plictolophus, Psittacus 95. 202 Psittaculus, Psittacus

garulla, D o mi c ella netes, Carpodacus, Erythrospiza, Frin-

glauca, Anadorhynchus, Ara, Arara, Macrocercus, Psit-

Gnatho, Eu phonia

Goffini, Cacatua, Lophochroa,Plicto-

gracilis, Euphonia,

grammaca, Chondestes, Emberiza, Fringilla, $\mathrm{Z}$ o notrich i gramminea,Emberiza, Fringilla, Poocaetes,

granatina, Estrelda, Fringilla, Mariposa,

- Hyphantornis,

grisea, Alauda, C o ra -

phites, Pyrrhu-

grossus, Loxia Pitylus 321 .

Guatemalae, $\mathrm{C}$ r ry s o ti s55. 169

Guildingi, Amazona, Chry s otis, Psitttcus 57. 169

guira, Hemithraupis, Hylophilus,Motacilla,

N e mosia, Sylvia,

gularis, Calyptrophorus, Coccopsis,

Nemosia,P aroaria,

Tachyphonus,Tanagra

600. 568

Gulielmi, Pionias,

Poiocephalus, Psittacu

guttata, Callis te
232. $337 \begin{gathered}\text { guttata, Loxia, S per- } \\ \text { mospiza }\end{gathered}$

420. 457

Loxia, Stagonopleura

Zonaeginthus

436. 462

Ptturalis, Fringilla,
Pyrrhula,Phonipara, Spermophila, Sporophila

gala, Psittacus

galeata, Muscicapa:

galericulata, Pipra

galerita, Alauda

galeritata, Melano-

81. 190 corypha $\quad 606.569$

gallica, Melanocorypha 601. 568

gambiensis, Coccothraustes, Hyphantornis

464. 485

600. 568

$\begin{array}{lr}\text { georgiana, Fringilla } & 536.531 \\ \text { Gerini, Psittacus } & 44.166\end{array}$

germanica, Miliaria 563. 545

554. 534 gingica, Alauda, Pyrrhulauda

ginginiana, Psittaca 129. 230

glacialis, Alauda $\quad 595.567$

218. 309 - Emberiza 590. 552

glauca, Tanagra 364. 421

glauciceps, Chrysotis 51. 168

gloriosus, Psittacus 156. 260

100. 211 Gnatho, Fringilla 320. 411

Goliath, Microglossus,

393. 430 Psittacus 97. 205 gracilis, Alauda $\quad 600.568$ graeca, Melanocorypha 601. 568

88. 191 gramineus, Pooecetes 531. 530 granativora, Emberiza 560. 545

391. 430 gregarius, Euplectes 484. 496 - Conurus, Psittacula 69. 175 grisea, Fringilla 282. 382

- Fringilla 292. 385

griseicollis, Conurus 147. 241

griseifrons, Psittacula 143. 238

531. 531 griseus, Dolichonyx 558.535

- Microglossus 97. 205

grypania, Alauda $\quad 616.571$

457. 472 guaruba, Psittacus 112. 220

gubernatrix, Emberiza 311. 402

12. 152 guebiensis,Eos,Psittacus 193. 275 - Psittacus 12. 152

guianensis, Agapornis $\quad 69.175$

- Conurus 117. 221

- Maracana, Psittacus 116. 221

gularis, Pyrgita 292. 385

guttata, Emberiza, Passerina

556. 535

guttatus, Pitylus 316. 408

64. 171

- Psittacus 196. 276

guttulata, Calliste, Ixothraupis

341. 417 gutture-luteo, Psittacula, Psittovius

gyrola, Tanagra

380. 424

144. 239

375. 423

438. 468

441. 469

439. 468

442. 469

440. 469

444. 469 
$\begin{array}{lr}\text { Habropyga tempo- } & \text { Rr. Seite } \\ \text { ralis } & 443.469 \\ \text { Haemophila rufescens } & 517.527 \\ \text { Hedymeles ludoviciana315. } 408 \\ \text { melanocephala } & 316.408\end{array}$

leptorrhynehus 108. 218

Hyphantomis abyssinicus

- aureoflavus

- castaneofuscus

- cinctus

- galbula

- grandis

- Iuteolus

- melanocephalus

- nigriceps

- ocularius

- olivaceus

- princeps

- spilonotus

- velatus

\section{- vitellinus}

Hypochera nitens

465. 486

476. 487

477. 488

466. 486

469. 486

463. 485

468. 486

464. 485

472. 487

473. 487

475. 487

474. 487

471. 487

467. 486

470. 486

- fimbriata

- larvata

- nigricauda

- Perreinii

Haplospiza unicolor

Hedyglossa diuca

Heliopsitta lutea

Hemispingus superciliaris

Hemithraupis guira

- ruficeps

Heterops cristatus

Hirundo viridis

Hortulanus arundinaceus

Hylophilus coeruleus

- cyanoleucus

- guira

- ruficeps

- superciliaris

514. 524

450. 470

449. 470

439. 468

451. 471

557. 535

558. 535

112. 220

339. 416

341. 417

342. 418

624. 573 382. 428

578. 549

340. 417

340. 417

341. 417

342. 418

339. 416

Hypacanthis spinoides

- Stanleyi

Hyphantica aethiopica

- erythrops

- haematocephala

- sanguinirostris

Hyphantornis aethiops

- aureus

- aurifrons

- brachypterus

- capensis

- chrysomelas

- concolor

- flavoviridis

- gambiensis

- larvatus

- magnirostris

- modestus

- nigrifrons

- personatus

- subaureus

- textor

Hyphanturgus brachypterus

- ocularius

484. 496

482. 496

482. 496

483. 496

467. 486

476. 487

475. 487

473. 487

475. 487

468. 486

476. 487

465. 486

465. 486
Hyphanturgus personatus

Hypocentor aureola

- chrysophrys

- rusticus

Hypochera aenea

- musica

- ultramarina

habroptilus, Strigops,

Strigopsis, S trin g o p

haematina, Loxia, Spermospiza

haematodes (haematodus), Psittacus, Trichoglossus

haematogaster, Euphema, Platycercus, Psephotus

haematonotus, Euphema, Platy c e rcus, Psephotus

haemorrhous, Aratinga, Conurus, Psittacara

Heermanni, Melospiza, Zonotrichia

Henslowii, A mmodromus, Coturniculus, Emberiza, Fringilla

Ni. Erite

Mr. Seite 468. 486 hirundinacea, Cypsnagra 349. 419 582. 550 - Procnias 382. 428 577. 549 hispaniolensis,Fringilla,

574. 548 Passer

287. 383

514. 524 histrio, Psittacus $\quad$ 197. 276

228. 330 Hodgsoni, Palaeornis 132. 231

514. 524 Hordei, Emberiza 571. 547

Hornemanni, Linaria 261. 363

s 98. 208 Horsfieldi, Alauda, Mirafra 610.570

421457 hudsonia, Fringilla 552. 534 hudsonica, Fringilla 550.533 humeralis, Psittacus 203. 280

200. 280 hypopolius, Nestor, Psittacus 204. 283 hypoxanthus, Psittacus 38. 160

167. 263 Icterus flavescens 501. 511 - olivaceus $\quad 475.487$ Ixothraupis guttulata 380. 424

169. 263 Jerapterhina Cavaignacii 624. 573 Junco phaeonotus 551. 534 - atrigularis $\quad 533.534$

111. 220 - cinereus 551. 534

- hyemalis $\quad 552.534$

533. 530 - oregonus 550.533

icterica, Chrysomitris, Fringilla 265. 369 - Emberiza, Eu s p i z a 561.545

547. 533 icteronotus, $R$ ham -

$\begin{array}{ll}\text { 113. } 220 \text { phocelus } & 3621\end{array}$ icterotis, Platy395. 430. $\begin{gathered}\text { cercus, Psittacus 159. } 261 \\ \text { iliaca,Fringilla, Passer- }\end{gathered}$

23. 157 ella, Zonotrichia 522. 528 incerta, $\mathrm{P}$ sitt a cula

461. 481

humilis, Euphonia,

hyazinthina, Anado-

464. 485 haematuropygius, Psit464. 485 tacus

467. 486 hamburgensis, Loxia,

468. 486 Passer

476. 487 Hansmani, Passer

464. 485 Hartlaubii, Crithagra

Hayi, Mirafra

473. 487 hiemalis, Alauda

473. 487 - Fringilla, Niphaea Psittacus, Psittinus

indica, Coryllis, Loriculus Psittacus

intermedius, Eclectus, Mascarinus, Polychlorus,Psittacodis 10. 152 cispina

566. 546

390. 429 italicus, Fringilla,

Phonasca rhynchus, Ara.Arara, Macrocercus, Psittacus Passer, Pyrgita

jacapa, Rhamphocelus, Rhampho-

99. 211 pis, Tanagra iacarina, Passerina,

285. 383 Spiza, Tanagra, Volatinia

65. 174

74. 185

Junco, Struthus

552. 534

jagoënsis, $\mathrm{P}$ as s e $\mathrm{r}$ jamaicensis, Euphonia

359. 421

302. 397

r-

hypoxanthus, Loxia, haematocephala, $\mathrm{Hy}-$ haematocephalus, Agro-

481. 496 phonia

289. 384 A la u da 599. 568 jendaya, C on urus,

482. 496 Psittacus, Sittace 120. 222 ictera, Fringilla, Serinus 225. 329

491. 505 icterocephalus, Psittacus 61. 170 199. 279 icterophrys, Saltator 324. 411 ignescens, Tanagra 358. 421

167. 263 ignicolor, Euplectes, Fringilla

89. 191 ignita, Lagonosticta

498. 511

446. 470 ignobilis, Loxia 236. 337

291. 385 Illigeri, Conurus, Psit289. 384 tacara, Psittacus, 225. 329 Sittace

107. 213

602. 568 illiniaca, Psittaca 123. 222

594. 567 indica, Eos, Lorius,

552. 533 Psittacus
197. 276 


indicus, Passer
infuscatus, Psittacus
inornata, Tanagra
inornatus, Palaeornis
- Psittacus
interfringillacea, Psit-
tacula
intermedia, Alauda
- Cacatua
- Emberiza -
intermedius, Tany-
gnathus
isabellina, Alauda, Am-
momanes, Melano-
corypha

Isidori, Eos, Lorius

islandicus, Serinus

itala, Melanocorypha

italica, Alauda

italicus, Serinus

jamaica, Fringilla,

Pyrrhuphonia

jamaicensis, Ara

- Chrysotis

janthinus, Psittacus

javanensis, Loxia

javanicus, Palaeornis,

Psittacus

javensis, Coccothraustes

jugularis, Fringilla

- Loxia

- Tanagra

juncorum, Fringilla

Kawarahiba minor,Fringilla

Kieneria fusca

Kuhli, (Kuhlii), Coriphilus, D o micella, Lorius, Psittacula,

Psittacus, Vini

\section{Loxia americana}

- bifasciata

- eurvirostra

- leucoptera

- pityopsittacus

\section{- rubrifasciata}

Lagonosticta coerulescens

- ignita

- larvata

- lateritia

- minima

- rhodopareia

- rubricata

- rufopicta

- senegalla

Lanio cristatus

- cristatus

- tenuirostris

- Vieilloti

Lanius Leverianus

- picatus

Lathamus åzureus

- discolor

- Sparrmanni

Leptolophus auricomis

Leptorrbynchus ruficaudus

leuconota Fringilla

Leucophrys pileatus

Leucopygia ruficollis
Rr. Seite

284. 383 Licmetis nasicus

30. 159 - pastinator

366. 422 - tenuirostris

ensis 73. 185 - semilarvatus,

257. 359 - speciosus

278. 379 - superbus

283. 383 - tricolor

279. 379 - vini

515. 526 - Wallacei

227. 330 Loxia abyssinica

230. 334 - albogularis

259. 362 - astrild

261. 363 - atricapilla

260. 363 - bella

261. 363 - bengalensis

259. 362 - bicolor

258. 359 - bifasciata

268. 370 - brasiliana

259. 362 - caffra

264. 369 - canadensis

277. 376 - canora

261. 363 - cantans

257. 359 - capensis

259. 362 - cardinalis

258. 359 - cardinalis

407. 439 - chloris

412. 439 - coccothraustes

88. 191 - coerulea

86. 191 - collaria

90. 161 - crassirostris

89. 191 - crucirostra

87. 191 - cucullata

418. 440 - minor

327. 412 - sanguinea

539. 531 Lophocoryphus cristatus

279. 379 - cruenta

521. 528 - pileata

Loriculus apicalis

- asiaticus

- coulaci

185. 373 - cyanolaemus

210. 292 - Edwardsi

208. 291 - exilis

206. 291 - galgulus

209. 292 - indicus

205. 291 - philippensis

207. 291 - pumilus

- puniculus

450. 470 - pusillus

446. 470 - rubrifrons

449. 470 - Sclateri

447. 470 - vernalis

446. 470 Lorius amboinensis

448. 470 - ater

448. 470 - borneus

447. 470 - ceramensis

446. 470 - chlorocercus

347. 418 - coccineus

348. 419 - cucullatus

345. 418 - cyanauchen

347. 418 - cyanocinctus

331. 414 - cyanogenia

331. 414 - cyanurus

152. 256 - domicella

203. 280 - grandis

181. 267 - Isidori

94. 198 - indicus

108. 218 - Kuhlii

403. 438 - Novae-Guineae

491. 505 - philippensis

349. 419 - reticulatus
311. 402 - cyanea

304. 398 - dominicana

306. 398 - enucleator

305. 398 - erythraea

74. 185 - erythrina

74. 185 - erythrocephala

74. 185 - falcirostra

74. 185 - fasciata

74. 185 - flamengo

77. 186 - flaviventris

72. 185 - franciscana

74. 185 - frontalis

73. 185 - fuscata

72. 185 - grossa

74. 185 - guttata

76. 185 - guttata

73. 185 - haematina

71. 185 - hamburgensis

75. 185 - hypoxantha

13. 152 - ignobilis

187. 274 - javanensis

196. 276 - jugularis

192. 275 - leucocephala

189. 274 - leucotis

197. 276 - lineola

198. 276 - longicauda

191. 275 - ludoviciana

191. 275 - macroura

195. 276 - maculosa

193. 275 - madagascariensis

188. 274 - maja

12. 152 - malabarica

198. 276 - malacca

197. 276 - melanocephala

185. 273 - melanogastra

192. 275 - musica

187. 274 - naevia

190. 274 - nasuta

196. 276 - nigra
Nr. Seite

198. 276

193. 275

186. 273

194. 275

191. 275

191. 275

190. 274

184. 273

198. 276

465. 486

234. 337

438. 468

412. 439

434. 462

480. 495

407. 439

208. 292

419. 441

510. 519

318. 409

244. 340

406. 438

501. 511

214. 305

312. 405

278. 379

250. 344

248. 342

237. 338

246. 342

206. 291

307. 399

249. 342

308. 400

213. 303

214. 305

214. 305

419. 441

209. 292

418. 440

213. 303

223. 329

498. 511

493. 508

398. 433

321. 411

420. 457

436. 462

421. 457

291. 385

481. 496

236. 337

397. 433

418. 440

414. 440

625. 574

238. 338

505. 518

315. 408

505. 518

419. 441

489. 503

414. 440

407. 439

413. 440

464. 485

503. 512

228. 330

501. 511

247. 342

245. 342 
Loxia nitens

- nitida

- obscura

- oryx

- oryzivora

- phalerata

- plebeja

- prasina

- prasipteron

- progne

- psittacea

- punctularia

- pusilla

- pyrrhula

- regina

- sanguinirostris

- socia

- striata

- sulfurata

- taenioptera

- torrida

- totta

- undulata

- virens

- virginica

Loxigilla elegans

Lullula arborea

- cristata

Iunulata, Amadina

lapponicus, Fringilla, Passerina, Plectrophanes

larvata, Amadina, Habropyga, Lagonosticta, Pytelia

- Paroaria

Lathami, Pa la e ornis

laticauda, Fringilla, Pentheria, Pentheria, Vidua

Lawrenci, Carduelis, Chrysomitris, Citrinella

Leadbeateri, Cacatua, Lophochroa, Plitolophus

lepida, Euethia, Fringilla, Passerina, Phonipara

lepidopterus, Euplectes, Fringilla, Ploceus, Sporopipes

leptorrhynchus, $\mathrm{Co}$ nurus, Henicog n a t h us,Psittacara, Sittace

leucocephala, Amazona, Chrysotis, Psittacus

- Emberiza,

leucogaster, Amazona Caica, Pionias, Psittacus

leucogastroides, $\mathrm{Mu}$ nia, Spermestes

leucolophus, Cacatua, Plictolophus

leucophrys, Emberiza, Zonotrichia

leucoptera, Crucirostra, Loxia
Nr. Seite

514. 524 leucotis, Conurus

434. 462 Microsittace, Psitta-

315. 408 cara, Psittacus, Pyrr-

497. 511 hura

397. 433 - Coraphites, Lo-

501. 511 xia, Pyrrhulauda

236. 337 - Poëphila

422. 458 Levaillanti, Chry-

400. 438 s o t is

510. 519 Leverianus, Bethylus, 213. 303 Cissopis

408. 439 Lincolnii, Fringilla,

210. 292 Melospiza, Passer-

211. 296 culus, Peucaea, $\mathrm{Z}_{0}$ -

480. 495 notrichia

483. 496 lineola, Fringilla, Lo-

492. 507 xia, Pyrrhula, Sper-

403. 438 mophila, Sporo-

222. 329 phila

208. 292 Linnei, Eclectus

247. 342 Psittacus

277. 376 linarius, Acanthis,

409. 439 A egiothus, Frin-

366. 422 gilla, Linota, Spinus

352. 419 linota, Cannabina,

445. 470 Fringilla

603. 569 longicaudatus, $\mathrm{Pa}$ -

613. 571 laeornis, Psittacus

426. 460 lori (lory), Dom i cella, Psittacus

Luciani, Belurus, $\mathrm{Pa}$ -

591. 552 laeornis

luconensis, E c le ctus, Psittacus, Tanygna-

449. 470 thus

308. 400 luctuosus, Pyranga, Tachyphonus

ludoviciana, Сoccoborus, Fringilla, Guiraca, Hedymeles,

$\begin{array}{ll}\text { Loxia } & 315.408 \\ \text { - Pyranga, Tanagra } & 354.420\end{array}$

508. 519

- Pyranga, Tanagr Chrysospiza,

Fringilla, Passer,

86. 191 Pyrgita, Serinus

luteicapilla, $\mathrm{Eu}$ phonia, Phonasca

241. 339 Iuteiventris, Crithagra, Fringilla, Sy calis

494. 508 luteolus, Fringilla, Hyphantornis, Ploceolus, Sitagra 468. 486

luteus, Conurus, Guaruba, Heliopsitta, Psittacus

lacteus, Pyrenestes

45. 166 larvata, Otocoris

573. 548 larvatus, Hyphantornis lateralis, Psittacus

lateritia, Lagonosticta

25. 157 Lathami, Amadina Fringilla

404. 438 - Euspiza

- Ploceus

80. 190 - Psittacus

Leachii, Calyptorrhyn524. 528 chus

Leari, Lophochroa

209. 292 Lecomtei, Psittacus
Nr. Seite

leiopus, Alauda

Nr. Seite

lenocinia, Vidua $\quad 509.519$

lepidus, Euplectes, Philetaerus $\quad 492.507$ - Psittacus 124. 223

625. 574 lesbia, Emberiza $\quad 574.548$

430. 461 leucocephala, Dinemellia 462.481

- Fringilla 436.462

62. 171 - Loxia 414.440

331. 414 leucophaea, Schistochlamys, Tanagra 328. 412 leucophrys, Chlorospingus, Tanagra

535. 530 leucophthalmus, Psittacus

339. 416

- Psittacus

leucopogon, Fringilla,

238. 338 Spermophila leucoptera, Alauda

14. 153 leucopterus, Oriolus, Pyrrota, Tachyphonus 344. 418 leucopygia, Crithagra, Dryospiza, Fringilla. Serinus

257. 359 leucorhynchus, Psittacus 28, 158 Levaillantii, Amazona, Psittacus

33. 160

licmetorhyncha, Caca-

190. 274 tua, Plictolophus

Lichtensteinii, Psitta-

133. 231 cara 126. 223

lilacina, Amazona 51. 168

lineoventer, Munia 409. 439

19. 154 lipiniana, Estrelda 455. 471 lippa, Fringilla, Melpoda 440. 469

345. 418 littoralis, Fringilla 549. 533 longicauda, Emberiza 510. 519 - Loxia 505. 518 longicaudata, Pyrrhula 217. 306

315. 408 longipennis, Carpospiza 282. 382 longirostris, Certhilauda 618. 572 - Fringilla 464. 485 lotharingica, Emberiza 571. 547 luctuosa, Emberiza 555. 534 293. 385 ludovicianus, Aratinga, Conurus, Psittacus,

392. 430 Sittace 118. 221

lugubris, Spermophila 302. 397 lulensis, Fringilla 256.349

231. 335 lunatus, Passer $\quad 295.386$

lusitanica, Alauda $\quad 606.569$

lutea, Coccothraustes 223. 329 - Galerida $\quad 615.571$

luteocapillus, Psittacus 118. 221

luteocristata, Cacatua 83. 190

112. 220 Iuteola, Emberiza, Eu-

282. 382 spiza

561. 545

596. 567

luteolus, Psittacus

60. 170

9. 152 luxuosus, Carduelis 300. 394

447. 470 Melanocorypha bimaculata

( 620.572

483. 496 - yeltoniensis 622.573

203. 280 Melophus melanicterus589. 551 Melopsittacus undu-

96. 202 latus

90. 191 Microglossus ater148. 242

34,160 rimus

97. 205 
Nr. Seite

Montifringilla nivalis 297. 391 Miliaria europaea

Macrocercus ambiguus 101. 211

105. 212 Mirafra affinis

- aracanga

- Augustus

- castaneifrons

- chloropterus

- glaucus

- hyazinthinus

- macao

- makavouanna

- maracana

- militaris

- severus

- tricolor

Macroglossus alecto

Maja sinensis

Malimbus cristatus

Maracana guianensis

Mariposa granatina

- phoenicotis

Marquetia elegans

99. 211 - africana

106. 212 - assamica

103. 212 - cantillans

100. 211 - deserti

99. 211 - Hayi

102. 212 - Horsfieldi

104. $212-$ phoenicuroides

107. 213 Munia acuticauda

101. 211 - ferruginea

106. 212 - ferruginosa

104. 212 - flaviprymna

97. 205 - fringilloides

414. 440 - fuscans

486. 501 - leucogastroides

116. 221 - leuconota

457. 472 - lineoventer

456. 472 - maja

445. 470 - minima

Mascarinus intermedius 10. 152 - molucca

- macrorhynchus

- madagascarensis

- polychlorus

- prasinus

Motacilla guira

- ruficollis

16. 153 - muscadina

7. 146 - oryzivora

9. 152 - punctularia

9. 152 - rubronigra

341. 417 - sinensis

343. 418 - striata

Megalophonus africanus 612. 570 - topela

- apiatus

- cinereus

- occidentalis

- planicola

- rostratus

Megalotis quinquevittatus

Melanocorypha albigularis

- alboterminata

- arabs

- Clot-Beyi

- deserti

- galeritata

- gallica

- graeca

- itala

- isabellina

- pallida

- rufescens

- semitorquata

- sibirica

- subcalandra

- tartarica

- tenuirostris

- torquata

Melospiza fallax

- Heermanni

- Lincolnii

- melodia

- palustris

Melopyrrha nigra

Melpoda lippa

Microglossus alecto

- ater

- Goliath

- griseus

Microsittace leucotis

- pyrrhura

- smaragdina

- vittata
611. 570 - undulata

605. 569 Muscicapa galeata

612. 570 - melanops

612. 570 - rubra

612. 570 Myiopsitta calita

- canicollis

585. 550 - murina

macao, Ara, Macro-

620. 572 cercus, Psittacus,

621. 572 Sittace

606. 569 macroura, Loxia, Pen-

624. 573 theria, Penthe-

606. 569 tria, Vidua

606. 569 madagascarensis

601. 568 Calyphantria, Car-

601. 568 dinalis, Foudia, Loxia

601. 568 - Mascarinus, P sit-

606. 569 tacus

607. 569 magnirostris, Rham-

621. 572 phocelus

620. 572 magnus, Saltator,

604. 569 Tanagra

620. 572 mahali, Philagrus,

622. 573 Ploceus, Plocepasser

601. 568 maja, Dermophrys,

621. 572 Loxia, Munia, Sper-

534. 530 mestes

533. 530 malabarica, Euodice,

535. 530 Loxia, Spermes -

532. 530 tes, Uroloncha

536. 531 malaccensis, Sper-

245. 342 mestes

440. 469 manimbe, A m mo-

97. 205 dromus, Coturni-

97. 205 culus, Fringilla

97. 205 Manyar, Fringilla,

97. 205 Ploceus

128. 224 maracana, Ara, Arara

125. 293 Macrocercus, Sittace

125. 223 maritimns, A m mo-

127. 224 dromus, Fringilla
Nr. Seite

563. 545

563. 545

563. 545

609. 570

612. 570

608. 570

610.570
606.569

602. 568

610. 570

606. 569

405. 438

415. 440

415. 440

416. 440

399. 437

411. 439

404. 438

405. 438

409. 439

414. 440

405. 438

405. 438

405. 438

397. 433

408. 439 melanomus, Plec-

412. 439 trophanes

412. 439 melanorrhynchus,

403. 438 Palaeornis

410. 439 melanonota, Pipri-

409. 439 d e a, Tanagra

350. 419 melanurus, Barra-

350. 419 bandius, Palaeornis,

352. 419 Platycercus,Poly-

147. 241 telis

Nr. Geite

147. 241 melba, Fringilla, Py telia

melodia, Fringilla,

102. 212 Melospiza, Z on otrichia

melpoda, Fringilla, Habropyga

menstruus, Amazona, Pionias, Pionus, Psittacus

meridionalis, $\mathrm{N}$ e s t o $\mathrm{r}$,

7. $146 \begin{gathered}\text { Psittacus } \\ \text { Meyeri, Pionias, }\end{gathered}$ Poiocephalus, Psittacus 39. 161 miliaria, Cryptophaga, Cynchramus, E m beriza, Spinus

563. 545

323. 411

militaris, Ara, Arara, Macrocercus, Psittacus, Sittace

414. 440 minima, Estrelda, Fringilla, Lagonosticta, Pytelia

407. 439 minor, Bethylus, $\mathrm{C}$ is s o p is, Saltator

413. 440 Mitchelli, Trichoglossus

mitratus, Pionias, Psittacus

479. $495 \begin{gathered}\text { modesta, Aidemosyne, } \\ \text { Amadina, Estrelda, }\end{gathered}$

479. 495 modesta, Aidemosyne, Poëphila

445. 470

532. 530

440. 469

26. 158

204. 283

moluccensis, Cacatua, Plictolophus,Psit-

548. 533 tacus

446. 470

332414

202. 280

22. 157

433. 461

78. 190 


\section{monachus, Bolbor- rhynchus, Conurus, Psittacus \\ mongolica, Alauda, Melanocorypha \\ montanus, Fringilla, Pas ser, Pyrgita \\ monticola, Fringilla, Spinites, Spizella, Zonotrichia \\ montifringilla, Frin- gilla, Struthus \\ Muelleri, Eclectus, Psittacodis,Psittacus, Tanygnathus \\ multicolor, Euphema, Platycercus, Pse- photus, Psittacus \\ musica, Crithagra, Estrelda, Fringilla, Hypochera, Loxia, Pholicodoma \\ mystacalis, Zono- trichia}

Macgillivrayi, Fringilla 548. 533 macrocerca, Fringilla, Penthetria

macrolophus, Plictolophus

macropterus, Psittacus macrorhynchus, Calyptorrhynchus

- Erythrostomus,Mascarinus, Psittacus,

Tanygnathus 'Tanygurus, Coliuspasser maculatus, Passer

- Psittacus

maculosa, Loxia

madagascariensis, Psittacula

magellanica, Carduelis,

Chrysomitris,Fringilla magnificus, Psittacus magnirostris, Alauda

- Hyphantornis

- Poiocephalus

magnus, Polychlorus,

Psittacodis, Psittacus

Maitaca, Psittacus

majanoides, Fringilla, Spermestes

major, Pyrrhula - Vidua

malabarica, Alauda malacca, Loxia

- Spermestes

malaccensis, Belocercus, Belurus

- Psittacula, Psittacus, Psittinus

- Psittacus

malachitaceus, Psittacu

malbayensis, Emberiza

Malherbi, Cyanorhamphus, Platycercus

malimbica, Tanagra

makavouanna, Macrocercus

- Psittacus

manillensis, Psittacus
Nr. Seite

marginatus, Arara, Psittacus, Tanygnathus

147. 241

- Tanygnathus

623. 573

marginalis, Chrysomitris

mariposa, Estrelda

291. 385 martialis, Tanagra

martinicanus, Conurus, Psittacus

537. 531 - Psittacus

mascarinus, Coracopsis

256. 349 Psittacus, Vaza matutina, Alauda

18. 154

- Fringilla, Zqnotrichia

Maugei, Evopsitta

Maximiliani, Anado-

170. 264 rhyncha

melanictera, Tanagra

melanocephala, Alauda - Fringilla

228. 330 - Lonchura

- Pipra

- Pyrrhula, thraustes

Cocco-

melanogastra, Estrelda

507.518

melanop is

82. 190 Schistochlamys, Ta-

65. 174 nagra melanops, Emberiza

96. 202 - Muscicapa melanoptera,Psittacula Psittacus, Pyrrhulopsis, Urochroma

16. 153 melanopygia, Estrelda 281. 382 - Tichogrammoptila 112. 220 melanorhyncha, Cora419. 441

68. 175 copsis melanota, Fringilla melanotis Ploceus melanotus Psittacus

265. 369 meridionalis,Certhila

202 - Serinus

616. 571 Merula, surinama

464. 485 meruloides, Fringilla

32. 159 mexicana, Callospiza - Emberiza

9. 152 microptera, Psittacula

22. 157 minima, Munia minimus, Psittacus

415. 440 minor, Alauda

211. 296 -

512. 520 - Cacatua, Lophochroa

600. 568 - Crucirostra

413. 440 - Euplectes

404. 438 - Linaria

- Orynx

138. 233 - Psittacula

- Psittacus

65. 174 - Psittacus

78. 190 - Vidua

21. 156 mississipensis, Tanagra

modesta, Psittacula

modestus,

Hyphan-

182. 267 tornis, Ploceus

486. 501 molucca, Munia

moluccensis, Cocco-

104. 212 thraustes

107. 213 - Lorius

130. 231 montana, Alauda
Ni. Seite

montana, Emberiza montium,Acanthis, Frin-

19. 154 gilia, Linaria, Linota

16. 153 Moreletti, Fringilla

moreotica, Phileremos

456. 472 morotensis, Tanygna-

348. 419 thus mosambica, Crithagra

123. 222 Mülleri, Fringilla

42. 166 multicolor, Psittacus, Trichoglossus

7. 146 multizona, Fringilla

613. 571 murinus, Conurus, Myiopsitta, Psittacus, 528. 529 Sittace

116. 221 muscadina, Munia musica, Galerida

99. 211 mustellina, Emberiza

560. 545 mutabilis, Alauda

625. 574 mystaceus, Psittacus

236. 337 Nemosia guira

412. 439 - pileata

384. 429 - ruificapilla

237. 338 Nestor meridionalis

451. 471 Nigrita bicolor

442. 469 - fusconota

Nanodes Bourki

- discolor

329. 412 - elegans

570.547 - pulchellus

350. 419 - taitianus

- undulatus

- venustus

70. 176 Nelicurvius baya

439. 468 - bengalensis

404. 438 - emberizinus

5. 146 - fuscicollis

442. 469 Nemosia atra

468. 486 - gularis

179. 266 - nigricollis

617. 572 - superciliaris

219. 312 Neochmia phaëton

348. 419 Neornis ruficollis

523. 528 Nestor australis

377. 423 - hypopolius

562. 545 - Novae-Hollandiae

70. 176 - Pesqueti

405. 438 Niobe ardens

66. 175 Niphaea hiemalis

595. 567 - oregona

598. 568 Nymphicus Novae-Hol-

89. 191 landiae

210. 29.2 nasica, Cacatua,Licme-

497. 511 tis, Plictolophus

259. 362 niger, Coracopsis,P sit-

501. 511 tacus, Vaza, Vigorsia

74. 185 nigra, Go niaphea,

48. 167 Loxia, Melopyrrha,

66. 175 Pyrrhula, Spermophila 245. 342

512. 520 nigricephala, Spinda-

352. 419 lis, Tanagra

69. 175 nigriceps, Choraphites, Pyrrhulauda

370.422

464. $485-$ Hyphantornis 472.487

405. 438 nigricollis, Euphonia, Tanagra

384. 429

405. 438 nigrigularis, $\mathrm{Rham}$ -

192. 275 phocelus, Rham-

598. 568 phopis, Tanagra

358. 421 
nigriventris, Pyromelana

nitens, Amadina, Fringilla, Hy pochera, Loxigilla, Philetaerus - Ploceus, Sy c o bius 485. 501

nitidus, Amadina, Loxia, Z onaeginthus 434.462 nivalis, Chionospina Fringilla, Geospiza, Montifringilla

- Emberiza,Passerina Plectrophanes

Novae - Hollandiae, Australasia, Psittacus, Trichoglossus

- Cacatua, Callipsittacus, Calopsitta,Leptolophus, Nymphicus, Palaeornis, Platycercus,Psittacus

\section{Novae - Zeelandiae,} Coriphilus, Cyanorhamphus, Euphema, Platycercus, Psittacus

naevia, Loxia

narcissus, Psittacus

nasuta, Loxia

nasutus, Psittacus

neglectus, Palaeornis

neisna, Fringilla

nemorosa, Alauda, Galerida

Nestor, Psittacus

Nr. Geite

500. 511

Novae-Hollandiae, estor

Orchesticus ater

- capistratus

Ortygospiza atricollis

- polyzona

Oryzornis fuscata

- oryzivora

otocoris alpestris

- bilopha

297. 391 - chrysolaema

- penicillata

590. 552 Ocyris oinops

Oenochrus augustus

- vinaceus

Oraegithus pusillus

199. 279 Oriolinus aurifrons

- capensis

Oriolus capensis

- caudacutus

- leucopterus

94. 198 - textor

Orynx approximans

- capensis

- minor

- xanthomelas

181. 267 Oryzoborus crassirostris

501. 511 - torridus

131. 231 Otocoris albigula

247. 342 - larvata

16. 153 - peregrina

129. 230 - scriba

442. 469 Otocoryx alpestris

- cornuta

603. 569 occidentalis, Geopsit-

204. 283 tacus, Pezoporus

nicobaricus, Palaeornis 139233 ochrocephala, Chryniger, Bubalornis

- Passer

- Psittacus

nigerrima, Tanagra

nigra, Alauda

nigricauda, Astrilda Habropyga

nigricollis, Nemosia, Tanagra

- Passerina

nigrifrons, Hyphantornis, Ploceolus

- Sycobius

nigrigula, Tanagra

nigrigularis, Trichoglossus

nigrirostris, Palaeornis

ninus, Aratinga

nipalensis, Emberiza

- Palaeornis

nisoria, Fringilla, Spermestes

nivalis, Alauda

- Fringilla

nobilis, Aratinga

- Fringilla

notatus, Brotogerys, Psittacus

- Coriphilus

- Psittacus

60. 481

sotis, Psittacus

514. 524 ochroptera, Amazona,

3. 145 Chrysotis, Psittacu 344. 418 ocularius, Hyphan622. 573 tornis, Hyphanturgus, Ploceus

439. 468 oculeus, Estrelda, Fringilla, Zonae-

341. 417 ginthus

562. 545 olivaceus, Hyphantornis, Icterus

467. 486 olivascens, Saltator

486. 501 ophthalmica, Spermo-

341. 417 phila, Sporophila ophthalmicus, Caca-

201. 280 tua, Plic to o p pus
136. 232 oregonus, Fringilla,

128. 224 Junco, Niphaea,

589. 551 Struthus

129. 230 ornata, Fringilla, Sper-

mophila, Sporophila

408. 439

594. 567 - Fringilla, Tiaris

552. 534 - Tanagra, Thraupi

116. 221 oryx , Coccothraustes,

253. 348 Emberiza, Euplectes,

Loxia, Py romelan

145. 239 oryzivora, Amadina,

184. 273 Coccothraustes, Frin-

116. 221 gilla, Loxia, Munia, Oryzornis, Padda obscura, Loxia

copsitta, Lorius, Platycercus, Psittacus

- Cyanorhamphus B rebu, gejangente Bügel. I.
187. 274 obscurus, Psittacus,

181. 267 Vaza
Nr. Seite occidentalis, Megalo-

204. 283 phonus

328. 412 ochracea, Fringilla $\quad 262.365$

26. 460 ocularis, Conurus 123. 222

425. 459 olivacea, Emberiza 601.568

398. 433 - Emberiza, Passeri-

397. 433 na, Spermophila 241. 339

594. 567 olivaceus, Psittacus 19. 154

597. 567 oinops, Ocyris 581. 550

595. 567 orientalis, Eos,Psittacus 11. 152

596. 567 - Quelea 484. 496

581. 550 oryx, Coccothraustes,

56. 169 Emberiza

Psittacus

475. 487 Palaeornis Alexandri 134. 232

475. 487 - columboides 137. 232

475487 - cyanocephalus 131. 231

549. 533 - erythrogenys 139. 233

344. 418 -- eupatrius 129.230

464. 485 - Lathami 135. 232

501. 511 - longicaudatus 138. 233

501. 511 - Luciani 133. 231

501. 511 - melanorrhynchus 136. 232

501. 511 - schisticeps 132.231

130. 231

309. 400

307. 399

310. 400

308. 400

286. 383

290. 384

284. 383

285. 383

289. 334

291. 385

288. 384

287. 383

292. 385

509. 519

504. 518

506. 518

508. 519

505. 518

149. 254

150. 255

317. 408

491. 505

492. 507

324 411 Pheucticus tibialis

Philetaerus socius

239. 333 Phrygilus alaudinus 556. 535

558. 535

555. 534

554. 534

557. 535

213. 303

31. 159

29. 158

21. 156

35. 160

38. 160

32. 159

34. 160

23. 157

25. 157

27. 158

24. 157

26. 158

39. 161

22. 157

20. 156
15. 408 - Meyeri

5. 146 - platurus
397. 433 - menstruus 


\begin{tabular}{|c|c|c|c|c|c|}
\hline Pionias robustus & $\begin{array}{l}\text { Rr. Seite } \\
33.160\end{array}$ & Poëphila cincta & $\begin{array}{l}\text { Mr. Eeite } \\
429.461\end{array}$ & Palaeornis Novae-Hol- & Nr. St \\
\hline & & & & & 94. 198 \\
\hline afiventris & 36. 160 & — modesta & 433. 461 & - parvirostris & 130. 231 \\
\hline negalus & 37. 160 & - personata & 432. 461 & - peristerodes & 137. 232 \\
\hline nilis & & Procnias tersa & 382. 428 & - pondicerianus & 134. \\
\hline olaceus & 30. 159 & Psittacula cana & 68. 175 & - rosaceus & 178. \\
\hline Pipilo & & - cingulata & 70. 176 & - viridimystax & 138. 233 \\
\hline rophthalmus & 518. 527 & - incerta & 65. 174 & - xant & 131. \\
\hline & 521. 528 & - passerina & 69. 175 & Passer alpicola & 297. \\
\hline onyx & 519. 527 & - pull & 66. 175 & - canadensis & 537. 531 \\
\hline Pipridea melanonota & 381. 428 & - roseicollis & 67. 175 & - canicapillus & \\
\hline liginosus & 320. 411 & Psittacus Barklyi & & - cal & \\
\hline & 321. 411 & - comorer & & - carduelis & 262. 365 \\
\hline ereus adelai- & & - erith & 1. 145 & - chl & \\
\hline & 157. 260 & earensis & & $-\mathrm{di}$ & \\
\hline$-\mathrm{a}-\mathrm{s}-\mathrm{a}$ & & $-n$ & 3. 145 & ophrys & 289. 384 \\
\hline- & 182. & - Timn & & - fla & 294. \\
\hline-1 & 164. 262 & - vaza & & - $\mathrm{fla}$ & \\
\hline & 178. 266 & Pyranga aestiva & 352. 419 & - hamburgensis & 291.385 \\
\hline$-\mathbf{I}$ & & & 356. $42_{0}$ & $-\mathrm{Ha}$ & \\
\hline$-\mathrm{e}$ & 79. 266 & - ludovic & 54. & $-\mathrm{hi}$ & \\
\hline & 160. 261 & - rubra & 351. 419 & - ind & 284. 383 \\
\hline-1 & 158. 260 & briceps & 55. 420 & $-\mathrm{lu}$ & 295. $38 t$ \\
\hline-1 & 163. 2 & - saira & 353. 420 & $-1 \mathrm{lu}$ & \\
\hline & 167. 263 & Pyrgita brachydac- & & $-n$ & 281. \\
\hline & & & 282. 382 & $-n i$ & 514. \\
\hline$-\mathrm{i}$ & 159. 261 & $-p$ & 281. & - & \\
\hline-1 & 177. 266 & - rufobrunnea & 283. 383 & lvanicus & 527. \\
\hline & 170. 264 & Pyrom & & $-\mathrm{pe}$ & 281. \\
\hline ndiae & & & 502. & $-p$ & \\
\hline & 180. 266 & - & 501. & -1 & 286. \\
\hline & 161. 261 & -1 & 499. & alensis & 483. 4 \\
\hline-1 & & -1 & & $-\mathrm{s}$ & \\
\hline-1 & 4. & -1 & 503. & $-\mathrm{s}$ & 292. \\
\hline-1 & 34 & -1 & 500. & $-\mathrm{Sp}$ & 253. \\
\hline & & -0 & 497.511 & & \\
\hline$-\mathrm{s}$ & 165. 262 & la erythroce- & & $s$ alaudinus & 544. \\
\hline$-s$ & 173. 2 & & 212. & & 543. \\
\hline & & -1 & & & 542. \\
\hline & 1 & Pyt & 71 & -1 & \\
\hline- & 1 & & 450 & - pal & \\
\hline & & & 453. & -s & 543. \\
\hline Ple & & $-=1$ r $+x+1$ & 449. & $\overline{\mathrm{n}}^{2}$ & \\
\hline & 91. & & & Pass & \\
\hline & & -1 & & $-i$ & \\
\hline & & & & Pas: & \\
\hline & & -1 & 448. & - & 299. \\
\hline Plic & 84. & -1 & & - & \\
\hline & & & & & \\
\hline & 9 & Padd & & - & \\
\hline & 81. & - & 3 & rentris & \\
\hline & & & & & \\
\hline & $\varepsilon$ & anthopeplus & & - & \\
\hline & & & 133. & - & \\
\hline & 7 & -1 & 178. & - & \\
\hline & & -1 & & -1 & \\
\hline & 7 & -1 & 1 & - & \\
\hline & & & & -1 & \\
\hline-1 & & -1 & & -8 - -1 & \\
\hline & 91. & $-f$ & 131. & $-\mathrm{pi}$ & \\
\hline & & $-f$ & 131. & Pent & \\
\hline & & & & & \\
\hline & 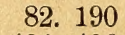 & -1 & 1 & - & \\
\hline ethiopieus & 48 & $-\mathrm{H}$ & 132. & $-n$ & \\
\hline & & $-i$ & 130. & $-r$ & \\
\hline & 4 & $-\mathrm{j}$ & 134. & Pet & \\
\hline & 4 & $-n$ & 17 & -1 & 28 \\
\hline & & $-n$ & 129 & $-d$ & \\
\hline & & & & -1 & \\
\hline & 483. 4 & $\ldots n i$ & 136. & $-\mathbf{r}$ & \\
\hline Poëphlia acuticauda & & - nipalensi & & - stulta & 281. \\
\hline
\end{tabular}




\begin{tabular}{|c|c|c|c|c|c|}
\hline Peucaea aestivalis & $\begin{array}{r}\text { Nr. Seite } \\
541.532\end{array}$ & Platycercus purpureo- & Nr. Seite & Poiocephalus melano- & \\
\hline - Lincolnii & 535. 530 & 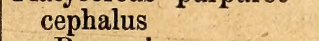 & 162. 262 & cephalus & 24. 157 \\
\hline Pezoporus rufifrons & 162. 262 & - Rayneri & 181. 267 & - Meyeri & 39. 161 \\
\hline - terrestris & 149. 254 & - rosaceus & 178. 266 & - Rueppelli & 40. 161 \\
\hline Phaeocephalus flavifrons & 35.160 & - rufifrons & 162. 262 & - rufiventris & 36. 160 \\
\hline - pachyrrhynchus & 32. 159 & - Stanleyi & 159. 261 & Poliopsitta cana & 68. 175 \\
\hline - Rueppelli & 40. 161 & - tabuensis & 173. 265 & Poliospiza angolensis & 227. 330 \\
\hline - xanthopterus & 39. 161 & - vaza & 5. 146 & - croccopygia & 226329 \\
\hline Phileremos alpestris & 594. 567 & - xanthogaster & 163. 262 & Polychlorus intermedius & S 10.152 \\
\hline - bicornis & 597. 567 & Plectrophanes calcaratus & 591.552 & - magnus & 9. 152 \\
\hline - brachydactylus & 601.568 & Plictolophus aequatorialis & s 83.190 & - Westermani & 11. 152 \\
\hline - moreotica & 601. 568 & - croceus & 85. 191 & Polymitra bicincta & 585. 550 \\
\hline - rufescens & 594. 567 & - Eos & 91. 191 & - capistrata & 587. 551 \\
\hline - scriba & 596. 567 & - erythropterus & 86191 & - flaviventris & 585.550 \\
\hline - sibirica & 604. 569 & - galeatus & 95. 202 & - striolata & 586. 550 \\
\hline - striatus & 594. 567 & - licmetorhynchus & 81. 190 & Polytelis Barrabandi & 178. 266 \\
\hline Philetaerus lepidus & 492. 507 & - macrolophus & 82. 190 & - melanura & 177. 266 \\
\hline - nitens & 514. 524 & - parvulus & 84191 & tes gramineus & 531. 530 \\
\hline Phoenicosoma aestiva & 352. 419 & - rosaceus & 78. 190 & Prioniturus platurus & 20. 156 \\
\hline - Azarae & 353. 420 & Plocealauda typica & 608. 570 & - setarius & 20. 156 \\
\hline - bivittatum & 356. 420 & Ploceolus hypoxanthus & 481. 496 & - Wallacei & 20. 156 \\
\hline - rubra & 351. 419 & - luteolus & 468. 486 & Procnias hirundinacea & $382 \cdot 428$ \\
\hline holicodoma musica & 228. 330 & - nigrifrons & 467. 486 & - ventralis & 382 \\
\hline Iasca Gnatho & 393. 430 & - personatus & 468. 486 & is vittata & 381. 428 \\
\hline ilis & 391. 430 & - vitellinus & 470. 486 & er sordidus & 214. \\
\hline - humilis & 390. 429 & Plocepasser mahali & 491.505 & ea pers & 174. 265 \\
\hline - luteicapilla & 292. 430 & - pileatus & 491. 505 & Psepho & r167. 263 \\
\hline - violacea & 394. 430 & Ploceus atrigula & 478. 495 & - haematonotus & 169. 263 \\
\hline Phonipara bicolor & 243. 340 & - auranticeps & 470. 486 & - haematorrhous & 167. 263 \\
\hline$-c$ & 244. 340 & - aurantius & 476. 487 & lulticolor . & 170. 264 \\
\hline itturalis & 236. 337 & - aureicapillus & 467. 486 & - pulch & 71. 264 \\
\hline-1 & 241. 339 & $-a$ & 476. 487 & $\overrightarrow{\text { Psitt }}$ & \\
\hline $\begin{array}{l}\text { pusilla } \\
\text { inicola americana }\end{array}$ & $\begin{array}{l}242.340 \\
213.303\end{array}$ & $\begin{array}{l}\text { - aur } \\
\text { - aur }\end{array}$ & $\begin{array}{l}480.495 \\
475.487\end{array}$ & Psitt & $\begin{array}{l}147.241 \\
142.238\end{array}$ \\
\hline canadensis & 213. 303 & - brachypterus & 473. 487 & - ginginiana & 129. 230 \\
\hline ionias vinaceicollis & 44. 166 & - capensis & 475. 487 & - illiniaca & 123. 222 \\
\hline Pionopsitta $\mathrm{p}$ & 22. 157 & - castaneofuscus & 477. 488 & - martinicana & 123. 222 \\
\hline Pionus menstruus & 26. 158 & - collaris & 466. 486 & ara acuticaudata & 110. 220 \\
\hline Pipilo ater & 518. 527 & - cristatus & 486. 501 & apilla & 120. 222 \\
\hline reus & 558.535 & - cyclospilus & 471. 487 & $-\mathrm{cob}$ & 99. 211 \\
\hline Pipilopsis flavigularis & 338. 416 & - erythrocephala & 488. 503 & uleofrontata & 111. 220 \\
\hline - semirufus & 337. 416 & - flaviceps & 471. 487 & - euo & 117. 221 \\
\hline - superciliaris & 339. 416 & - flavigula. & 473. 487 & - glauca & 100. 211 \\
\hline Pipra elegantissima & 385. 429 & - flavomarginatus & 470. 486 & - Illigeri & 107. 213 \\
\hline - galericu & 385. 429 & - flav & 465. 486 & orrhyncha & 108. \\
\hline-1 & 384.429 & - frin & 399. 437 & - leu & 128. 224 \\
\hline cidea c & 381.428 & - galbula & 469. 486 & - Lichtensteinii & 126. 223 \\
\hline Pitylus atrochalybaeus & 320.411 & - grandis & 463. 485 & - pa & 109. 220 \\
\hline - canadensis & 318. 409 & - haematocephalus & 482. 496 & - rectirostris & 108. 218 \\
\hline - cardinalis & 312. 405 & $-\bar{T}$ & 491. 505 & - tiriba & 126. 223 \\
\hline - coerulescens & 320.411 & - Lathami & 483496 & - vittata & 127. 224 \\
\hline - erythrorhynchus & 320. 411 & - lepidopterus & 494. 508 & $-x a$ & 141. 238 \\
\hline - guttatus & 316. 408 & - maha & 491. 505 & des tarabe & 50. \\
\hline - melanocephalus & 316. 408 & - melanotis & 468. 486 & Psittacodis intermedius & 10. 152 \\
\hline - personatus & 318. 409 & - modestus & 464. 485 & $-m \varepsilon$ & 9. 152 \\
\hline - poliogaster & 319.409 & - nitens. & 485. 501 & - Westermani & 11. 152 \\
\hline Platycercus Adelaidae & 157. 260 & - ocularius & 473. 487 & - sumatranus & 18. 154 \\
\hline - ater & 187. 274 & - passerinus & 478. 495 & Psittacula azurea & 65. 174 \\
\hline - aucklandicus & 181. 267 & - personatus & 468. 486 & - batavica & \\
\hline - Baueri & 166. 263 & - philippinus & 481. 496 & sogaster & 69.175 \\
\hline - caledonicus & 163. 262 & - ruti & 470. 486 & $-\operatorname{chr}$ & 144. 239 \\
\hline - coelestis & 161. 261 & - spilonotus & 471. 487 & $-\operatorname{chr}$ & 145. 239 \\
\hline - Cooki & 181. 267 & - stictonotus & 471. 486 & - culacissi & 73. 185 \\
\hline - cyanopygius & 175. 265 & - striatus & 478. 495 & - cyaneopileata & 72. 185 \\
\hline - dorsalis & 176. 265 & - textor & 464. 485 & - cyanochlora & 69. 175 \\
\hline - erythronotus & 180. 266 & - velatus & 467. 486 & - cyanoptera & 69.175 \\
\hline & 181. 267 & Poëphila Paddoni & 423. 458 & - galgula & 72.185 \\
\hline - Malherbi & 182. 267 & Poiocephalus Aubryanus & 34.160 & - gregaria & 69. 175 \\
\hline - Novae-Guinae & 187. 274 & — fuscicollis & 38. 160 & - griseifrons & 143. 238 \\
\hline - Novae-Hollandiae & 94. 198 & - Gulielmi & 34. 160 & - guineensis & \\
\hline - pileatus & 162. 262 & - magnirostris & 32. 159 & - gutture-luteo & 144. 239 \\
\hline
\end{tabular}


Psittacula interfringillacea

- Kublii

- leucophthalma

- malaccensis

- melanoptera

- melanoptera

- minor

- modesta

- philippensis

- pileata

- rubricollis

- rubrifrons

- senegalensis

- tiriacula

- tovi

- tui

- tuipara

- viridissima

- xanthopterygia

Psittaculus galgulus

- passerinus

- Sancti Thomae

- tovi

- tui

- vernalis

- virescens

- xanthopterygius

Psittacus accipitrinus

- acuticaudatus.

- adscitus

- aestivus

- aestivus

- affinis

- agilis

- albifrons

- albus

- Alexandri

- amazonicus

- amazonicus

- ambiguus

- amboinensis

- americanus

- amoenus

- annulatus

- Aourou

- aracanga

- ararauna

- asiaticus

- ater

- aterrimus

- atricapillus

- Augustus

- Augustus

-.. aurantius

- aurantius

- aurantius

- aureus

- auricapillus

- auriceps

- auripalliatus

- aurora

- australis

- autumnalis

- autumnalis

- azureus

- badiceps

- badius

- Banksi

- Banksianus

- barbatulatus

\section{Nr. Seite}

185. 273

Psittacus Barrabandi

185. $273-$ batavi

69. 175 - Baueri

65. 174 - bengalensis

70. 176 - bimaculatus

73. 185 - bisetis

74. 185 - borneus

69. 175 - brasiliensis

73. 185 - brasiliensis

22. 157 - cactorum

66. 175 - caffer

73. 185 - caica

37. 160 - caledonicus

140. 238 - calthopticus

144. 239 - canicularis

146. 239 - canus

145. 239 - capensis

69. 175 - capistratus

141. 238 - capitatus

72. 185 - cardinalis

69. 175 - carolinensis

69. 175 - cayanensis

144. 239 - ceylonensis

146. 239 - chalcopteros

75. 185 - chinensis

142. 238 - chiriri

141. 238 - chloropterus

31. 159 - chrysostomus

110. 220 - cinereicollis

161. 261 - cinereus

60. 170 - cingulatus

64. 171 - Clusii

138. 233 - cobaltinus

48. 167 - coccineus

46. 167 - coeruleatus

80. 190 - coeruleus

134. 232 - collarius

60. 170 - columbinus

64. 171 - Cookii

101. 211 - coronatus

176. 265 - coronatus

53. 168 - cristatus

76. 185 - cruentatus

131. 231 - cubicularis

60. 170 - cucullatus

102. 212 - cyanauchen

105. 212 - cyaneus

74. 185 - cyanocephalus

187. 274 - cyanocephalus

97. 205 - cyanogaster

24. 157 - cyanogaster

56. 169 - cyanogula

99. 211 - cyanomelas

9. 152 - cyanopygius

53. 168 - cyanostictus

119. 222 - cyanotis

121. 222 - cyanotus

120. 222 - cyanurus

182. 267. - cyanurus

59. 170 - decorus

64. 171 - diadema

203. 280 - discurus

49. 167 - discolor

53. 168 - docilis

65. 174 - domicella

24. 157 - dominicensis

25. 157 - dorsalis

96. 202 - Dufresnianus

203. 280 - eburnirostris

138. 233 - Edwardsii
Nr. Seite

178. 266 Psittacus elegans

Nr. Seite

186. 273 - elegans

70. 176 - Eos 91.191

166. 263 - erubescens 138,233

131. 231 - erythrocephalus 131. 231

134. 232 - erythrogaster 126. 223

163. 262 - erythroleucus 1. 145

135. 232 - erythronotus 180. 266

49. 167 - erythropis 49.167

121. 222 - erythrops 46.167

124. $223-$ - erythropterus 179.266

33. 160 - euops 117. 221

23. 157 - eupatria 129. 230

163. 262 - eximius 160.261

$\begin{array}{ll}\text { 145. } 239 \text { - farinosus } & 58.170\end{array}$

121. 222 - fasciatus 134. 232

68. 175 - ferrugineus 125.223

69. 175 - festivus 41.165

200. 280 - fimbriatus 95.202

160. 261 - fimbriolatus 50.167

$\begin{array}{ll}\text { 13. } 152 \text { - flavifrons } & 35.160\end{array}$

118. 221 - flavifrons 63. 171

48. 167 - flavigaster 163. 262

12. 152 - flavigulus $\quad 72.185$

29. 158 - Havinuchus $\quad 59.170$

$\begin{array}{ll}\text { 193. } 275 \text { - flavirostris 27. } 158 & \end{array}$

142. 238 - flaviventris 163. 262

112. 220 - flavoscapulatus 39. 161

153. 257 - formosus 149. 254

147. 241 - frenatus 130. 231

1. 145 - frontalis 127. 224

70. 176 - funereus $\quad 96.202$

31. 159 - fuscicollis 32.159

26. 158 - tuscus 3.145

197. 276 - fuscus 30.159

193. 275 - gala 19.154

105. 212 - galeatus 95.202

44. 166 - galeritus $\quad 81.190$

50. 167 - galgulus 72.185

96. 202 - garrulus 192. 275

31. 159 - Gerini 44. 166

54.169 - glaucus $\quad 100.211$

80. 190 - gloriosus 156. 260

126. 223 - Goliath 97. 205

130. 231 - grandis 12.152

198. 276 - guaruba 112.220

191. 275 - guebiensis 12.152

184. 273 - guebiensis 193. 275

26. 158 - guianensis 116. 221

$\begin{array}{ll}\text { 131. } 231 \text { - Guildingi } & \text { 57. } 169\end{array}$

21. 156 - Gulielmi 34.160

199. 279 - guttatus 64.171

26. 158 - guttatus 196.276

166. 263 - gutturalis $\quad$ 44. 166

175. 265 - haematodus 200. 280

196. 276 - haematopus 199. 279

49. 167 - haematuropygius $\quad 89.191$

$\begin{array}{ll}\text { 193. } 275 \text { - histrio 23. } 157 & \end{array}$

27. 158 - histrio 197. 276

193. 275 - humeralis 203. 280

64. 171 - hyazinthinus 99. 211

52. 168 - hypopolius 204. 283

20. 156 - hypoxanthus 38. 160

203. 280 - icterocephalus $\quad 61.170$

130. 231 - icterotis 159. 261

188. 274 - Illigeri 107. 213

43. 166 - incertus $\quad 65.174$

176. 265 - indicus 74.185

54169 - indicus 197. 276

122. 222 - infuscatus $\quad 30.159$

152. 256 - inornatus 123. 222 
Psittacus janthinus - javanicus

- jendaya

- Kuhlii

- lateralis

- Lathami

- Lecomtei

- lepidus

- leucocephalus

- leucogaster

- leucophthalmus

- leucophthalmus

- leucorhynchus

- leucotis

- Levaillantii

- Linnei

- lory

- lucionensis

- ludovicianus

- luteocapillus

- luteolus

- luteus

- luteus

- macao

- macropterus

- macrorhynchus

- maculatus

- madagascariensis

- magnificus

- magnus

- Maitaca

- makavuanna

- malaccensis

- malaccensis

- malachitaceus

- manillensis

- marginatus

- martinicanus

- mascarinus

- Maximiliani

- megalorhynchus

- melanocephalus

- melanopterus

- melanotus

- menstruus

- meridionalis

- Meyeri

- micropterus

- militaris

- minimus

- minor

- minor

- mitratus

- moluccensis

- monachus

- Muelleri

- multicolor

- multicolor

- murinus

- mystaceus

- narcissus

- nasicus

- nasutus

- Nestor

- notatus

- notatus

- Novae-Guineae

- Novae-Hollandiae

- Novae-Hollandiae

- Novae-Zeelandiae

- obscurus
Nr. Seite

12. 152

Psittacus ochrocephalus

134. 232 - ochropterus

120. 222 - olivaceus

185. 273 - orientalis

9. 152 - Osbeckii

203. 280 - pachyrrhynchus

34. 160 - pacificus

124223 - Paradisi

45. 166 - parasiticus

25. 157 - passerinus

69. 175 - patagonus (patago-

$116 \quad 221$ nicus)

28. 158 - pavua

128. $ะ 24$ - pectoralis

33. 160 - pendulus

14. 153 - Pennanti

190. 274 - pertinax

19. 154 - peruvianus

118. 221 - Pesqueti

118. 221 - Petzi

60. 170 - philippensis

60. 170 - philippinarum

112. 220 - phoenicocephalus

102. 212 - phrygius

65. 174 - pileatus

16. 153 - pileatus

112. 220 - piscinator

68. 175 - platurus

96. 202 - poecilorhynchus

9. 152 - poliocar

22. 157 - polychlorus

107. 213 - pondicerianus

65. 174 - porphyrio

78. 190 - Pretrei

21. 156 - pulchellus

130. 231 - pullarius

19. 154 - pulverulentus

42. 166 - pumilus

7. 146 - purpureocephalus

27. 158 - purpureus

16. 153 - purpureus

24. 157 - pyrrhopterus

70. 176 - pyrropygia

179. 266 - radhea

26. 158 - raja

204283 - rectirostris

39. 161 - reticulata

70. 176 - reticulatus

101. 211 - rex

66. 175 - rhodocephalus

48. 167 - riciniatus

66. 175 - robustus

22. 157 - roratus

78. 190 - rosa

147. 241 - rosaceus

18. 154 - roseicollis

170. 264 - ruber

199. 279 - ruber

147. 241 - rubrovarius

134. 232 - rufirostris

131. 231 - rufiventris

92. 192 - sapphirinus

16. 153 - scapulatus

204. 283 - scintillatus

116. 221 - Sebanus

145. 239 - semicollaris

157. 274 - semitorquatus

94. 198 - senilis

199. 279 - setarius

181. 267 - severus

5. 146 - signatus
Nx. Seite

63. 171 P sittacus simplex

Mr. Seite

69. 175

130. 231

9. 152

19. $154-$ sinensis

11. 152 - smaragdinus

134. 232 - solstitialis

32. 159 - Sonnerati

180. 266 - sosove

45. 166 - Sparrmanni

67. 175 - spatuliger

69. 175 - splendidus

109. $220-$ spurius

- streptophorus

9. 152 - sulfureus

75. 185 - taitianus

156. 260 - tarabe

123. 222 - tenuirostris

184. 273 - ternatensis

8. 151 - terrestris

122. 222 - tirica

73. 185 - tovi

89. 191 - torquatus

95. 202 - tricolor

19. 154 - trimaculatus

19. 154 - tui

22. 157 - tui

93. 192 - tuipara

20. 156 - undulatus

63. 171 - Vaillantii

68. 175 - variegatus

9. 152 - varius

134. 232 - ventralis

184. 273 - venustus

47. 167 - vernalis

152. 256 - vernans

66. 175 - versicolorus

58. 170 - Versteri

72. 185 - vibrisca

162. 262 - Vigorsii

26. 158 - vinaceus

192. 275 - violaceus

143. 238 - virescens

75. 185 - viridis

188. 274 - viridis

188. 274 - vittatus

108. 218 - vittatus

65. 174 - xanthops

196. 276 - Zeelandicus

188. 274 - zonarius

131. 231 Psittinus incertus

125. 223

119. 222

129. 230

145. 239

184. 273

20. 156

156. 260

162. 262

$126 \quad 223$

130. 231

83. 190

184. 273

50. 167

92. 192

131. 231

149. 254

140. 238

144. 239

131. 231

104. 212

134. 232

123. 222

146. 239

145. 239

148. 242

145. 239

198. 276

184. 273

42. 166

153. 257

75. 185

51. 168

142. 238

37. 160

135. 232

126. 223

50. 167

30. 159

142. 238

9. 152

166. 263

43. 166

127. 224

62. 171

180. 266

166. 263

65. 174

65. 174

33. 160 Psittovius chrysopogon 144. 239

$\begin{array}{ll}\text { 12. } 152 \text { - gutture-luteo 144. } 239 & 149\end{array}$

131. 231 - tui 146.239

78. 190 - tuipara

67. 175 Psittrichas Pesqueti

145. 239

1. 145 Ptistes coccineopterus 179.266

193. 275 - erythropterus 179. 266

1. 145 Purpureicephalus pileatus162. 262

130. 231 Pyranga Azarae 353. 420

36. 160 - bivittatum $\quad 356.420$

184. 273 - erythrocephala

175. 265 - erythromelas

186. 273 - erythropis

190. 274 - luctuosa

199. 279 Pyrenestes lacteus

165. 262 Pyrgita arctica

28. 158 - crassirostris

20. 156 - dentata

106. 212 - diffusa

48. 167 - domestica
355. 420

351. 419

354. 420

345. 418

282. 382

520. 527

292. 385

295. 386

292. 385

284. 383 
Pyrgita gularis - italica

- lutea

- montana

- salicaria

- simplex

- spadicea

- Swainsonii

Pyrgitopsis Swainsonii Pyrrhomitris cucullata Pyrrhula caudata

- cinerea

- cinereola

- coccinea

- collaris

- crenirostris

- crispa

- erythrina

- githaginea

- gutturalis

- lineola

- longicaudata

- major

- melanocephala

- nigra

- Payreaudi

- peregrina

- pileata

- pusilla

- rubicilla

- rosea

- rufa

- serinus

- sibirica

- thebaica

- torrida

Pyrrhulagra ruficollis

Pyrrhulauda gingica

- grisea

- leucotis

- nigriceps

Pyrrhulinota roseata

Pyrrhulopsis melanopterus

- personata

Pyrrhuloxia sinuata

Pyrrhuphonia jamaica

Pyrrhura cruentata

- leucotis

- vittata

Pyrrota coryphaea

- leucoptera

Pytelia bicolor

- speciosa

- subflava

Pytilus capistratius

- flavocinereus

pacificus, Cyanorhamphus, Platycercus, Psittacus

palliceps, Conurus, Platycercus

pallida, Emberiza, Spinites, Spizella, Zonotrichia

palustris, Fringilla, Melospiza, Passerculus, Spiza, Z o notrichia 536. 53

paradisea, Emberiza, Fringilla, Steganura, Vidua 245. 342 238. 338 214. 305 218. 309 236. 337 238. 338

217. 306 211. 296 237. 338

218. 309

216. 306

626. 574

625. 574

540. 531
Rr. Seite

292. 385 passerina, Conurus, 285. 383 Psittacula, Psit293. 385 taculus, Psittacus 291. 385 - Emberiza

287. 383 Passerinii, Rham292. 385 phocelus

292. 385 passerinus, Ammo292. 385 dromus, Coturni292. 385 culus, Fringilla

271. 370 pastinator, Licmetis, 217. 306 Plictolophus 233. 337 patagonus (patago232. 337 nicus, patachonicus),

211. 296 Arara, Conurus, 244. 340 Cyanolyseus, Psitta-

245. 342

211. 296

211. 296

221. 313

211. 296

211. 296

219. 312

217. 306

218. 309

247. 342

343. 418

626. 574

627. 574

214. 305

70. 176

174. 265

314. 405

396. 430

126. 223

128. 224

127. 224

346. 418

344. 418

495. 510

445. 470

444. 469

328. 412

319. 409 cus, Psittacara, Sittace pavua, Conurus, Psittacus

pectoralis, Amadina, Donacola, Spermestes

penicillata, Alauda, Otocoris

Pennanti, Platycer cus, Psittacus

Perreinii, Estrelda, Fringilla, Habropyga, Pytelia

personata, Em beriza 569. 547 - Poëphila

personatus, Coccothraustes

- Aprosmictus, Coracopsis, Platycercus, Prosopaea, Pyrrhulopsis

pertinax, Aratinga, Conurus, Psittacus, Sittace

Pesqueti, Dasyptilus, Nestor, Psittacus, Psittrichas

petronia, Fringilla, Passer, Pyrgita

petrophila, Euph 38 155. 382

Petzi, Conurus, Eupsittaca,Psittacus, Sittace

phaëton, Estrelda, Fringilla, Neochmia, Uraeg in thus

philippinarum, Cacatua, Plic tolophus, Psittacus

phoeniceus, Cardi$n$ alis

phoenicotis, Estrelda, Mariposa, Uraeginthus

180. 266 pictus, Centrophanes, Emberiza, Plec-

161. 261 trophanes

pileata, Emberiza, Zonotrichia - Nemosia, Tanagra

pileatus, C o ryphos p ingus, Fringilla,

Lophospiza, Passerina 305. 398

pinus, Carduelis, $\mathrm{Chry-}$ so m itris, Fringilla, 511. 519 Linaria
Nr. Ssite

pityopsittacus, Lo x ia 205. 291

planicola, Alauda, Megalophonus

69. 175

580. 549 platensis, Emberiza, Embernagra, Lim-

363. $421 \begin{gathered}\text { nospiza } \\ \text { platurus, Eclectus, }\end{gathered}$

platurus, rus, Psittacus

plumbea, Fringilla, Sporophila poënsis, Amadina, Spermestes

poliogaster, Cary othraustes, Pitylus 319. 409 polychlorus, Eclectus, Mascarinus, Psittacus

polyzona, Amadina, Estrelda, Fringilla, Ortyg ospiza

417. 440

prasina, Amadina,

596. 567 Erythrura, Loxia 422. 458

Pretrei, Amazona,

156. 260 Chrysotis, Psittacus 47. 167

princeps, Hy phantornis, Symplectes

451. 471 principalis, Emberiza

432. 461 progne, Chera, Loxia, Vidua

251. 344 psaltria, Carduelis, Chrysomitris, Fringilla

psittacea, Acalanthe,

174. 265 Erythrura, Estrelda, Fringilla

pulchella, Euphe-

123. 222 ma, Nanodes, Psittacus

pulcherrimus, Euphema, Platycercus, Psephotus

pullaria, Agapornis, Psittacula, Psittacus

punctularia, Loxia, Munia, Spermestes, Uroloncha

purpureus, Carpo-

458472 dacus, Erythrospiza, Fringilla

pusilla, Coryllis,

89. 191 Loriculus

- Cynchramus, Em-

313. 405 beriza, Euspiza

- Emberiza, Fringilla, Spinites, Spizella,

456. 472 Zonotrichia

- Euethia, Phonipara, Tiaris

593. 552 pusillus, Oraegithus, Passer, Pyrrhula,

528. 529 Serinus

474. 487

512. 520

510. 519

270. 370

423. 458

152. 256

171. 264

66. 175

408. 439

215. 306

76. 185

581. 550

539. 531

242. 340

221. 313 yrrhoptera, Brotogerys, Conurus, Psittacus, Trichoglossus

143. 238

pyrrhuloides, Cynchramus, Emberi 268. $370 \mathrm{za}$, Schoenicola

579. 549 
pachyrrhynchus, Phaeocephalus, Psittacus

Paddoni, Poëphila

pallida, Alauda, Melanocorypha

palustris, Emberiza

panayensis, Emberiza, Fringilla

papaverina, Passer

paradisea, Aglaia, Tatao

Paradisi, Psittacus

parasiticus, Psittacus

parvirostris, Palaeornis

parvula, Cacatua, Plic-

tolophus

passerinus, Ploceus

Payreaudi, Pyrrhula

pectoralis, Psittacus

pekinensis, Alauda

pendulus, Psittacus

pennsylvanica, Fringilla, Passer peregrina, Miliaria

- Otocoris

- Pyrrhula

peristerodes, Palaeornis

perrsonatus, Alario

- Hyphantornis, Hyphanturgus, Ploceolus, Ploceus

- Pitylus

peruvianus, Psittacus

petronella, Petronia

phaeonotus, Junco

phaeton, Conurus

phalerata, Loxia

philippensis

- Licmetulus, Loricu-

lus, Psittacula, Psittacus

philippina, Fringilla, Ploceus

phoeniceus, Coliuspasser

phoenicocephalus, Psittacus

phoenicoptera, Vidua

phoenicuroides, Mirafra

phoenicurus, Conurus

phrygius, Psittacus

picatus, Bethylus, Lanius

pileata, Pyrrhula

pileatus, Leucophrys, Plocepasser

- Pionopsitta, Psittacula, Psittaculus, Psittacus

- Platycercus, Psittacus, Purpureicephalus

- Psittacus, Tanygnathus

pinetorum, Crucirostra - Emberiza

pinguescens, Emberiza piscinator, Psittacus pithyornus, Emberiza plebeja, Loxia
Nr. Seite

32. 159 423. 458

plumbeus, Saltator

poecilorhynchus, Psit-

tacus

polaris, Emberiza

607. 569 poliocar, Psittacus

579. 549 poliocephalus, Emberizoides

509. 519 pondicerianus, Belo257. 359 cercus, Belurus, Conurus, Paloeornis, nurus,

371. 423

45. 166 porphyrio, Psittacus

67. 175 praelata, Tanagra

130. 231 prasinus, Mascarinus prasipteron, Loxia

84. 191 pratensis, Emberiza

478. 495 propinquus, Conurus

218. 309 provincialis, Emberiza

9. 152 pseudoryx, Euplectes

598. 568 psittacea, Loxia

75. 185 psittacinus, Saltator, Tanagra

527. 529 Pucherani, Erythrura

563. 545 pulchella, Fringilla

595. 567 pulverulentus, Ama-

211. 296 zona, Psittacus

137. 232 pumilus, Loriculus,

229. 333 Psittacus

punctata, Callospiza

punctulata, Amandava

468. 486 - Fringilla

318. 409 punicea, Amandava,

184. 273 Fringilla

296. 386 - Fringilla

551. 534 puniceus, Eos

180. 266 puniculus, Loriculus

501. 511 purpureocephalus, Pla-

190. 274 tycercus, Psittacus purpureodorsalis, Ara
purpureus, Psittacus

73. 185 - Psittacus

- Rhamphocelus

481. 496

pusilla, Loxia

pyrgitoides, Ember-

504. 518

95. 202

510. 519

pyrrhozona, Euplectes

pyrrhula, Fringilla, Loxia

pyrrhurus, Conurus,

606. 569

Microsittace

125. 223 pyrropygia, Psittacus

19. 154 pythiornithoides, Emberiza

331. 414 pytiornis, Buscarla

211. 296 Quelea capitata

491. 505 - occidentalis

- sanguinirostris

- socia

22. 157 quadricolor, Tachy phonus, Trichothraupis

162. 262 quadricolor, Emberiza quelea, Fringilla

19. 154 quinquevittata, Embe-

205. 291 riza, Megalotis

582. 550 quinticolor, Fringilla

566. 546 Rhamphocelus brasi-

93. 192

liensis

573. 548 - icteronotus

236. 337 - jacapa
Nr. Seite

324. 411 Rhamphocelus magnirostris

63. 171 - nigrigularis

580. 549 - Passerini

68. 175 - sanguinolentus Ramphocoris Clot-

515. $526 \begin{gathered}\text { Beyi } \\ \text { Rhamphocelus albiro- }\end{gathered}$ stris

- coccineus

134. 232 - purpureus

184. 273 Rhamphopis atrococci-

366. 422 neus

9. 152 - coccineus

400. 438 - flammigerus

571. 547 - jacapa

116. 221 - nigrigularis

574. 548 - varians

497. 511 Rhopospiza fruticeti

213. 303 regia, Emberiza, Tetranura, Vidua

320. 411 reticulata, Domi-

424. 458 cella, Eos, Lorius,

423. 458 Psittacus

riciniata, Dom icel-

58. 170 la, Eos, Lorius, Psittacus

72. 185 robustus, Pio nias,

380. 424 Psittacus,

452. 471 roseicapillus, Caca-

421. 457 tua, Eolophus, Plictolophus

452. 471 roseicollis, Psitta-

315. 408 cula, Psittacus

14. 153 roseus, Car podacus,

74. 185 Erythrospiza, Fringilla, Pyrrhula

162. 262 rubra, Domicella Eos, Lorius, Psitta-

cus

26. 158

192. 275 - Phoenicosoma, Py

359. 421 ranga, Tanagra

210. 292 rubricata, Estrelda,

Fringilla, Lagonosticta, Pytelia

517.527

rubriceps, P y rang a rubrifasciata, Cruci-

211. 296 rostra, Loxia

rubronigra, Munia,

125. 223 Spermestes

75. 185 Rueppelli, Phaeocephalus, Pionias,

572. 548 Poiocephalus, Psitta578. 549 cus

482. 496 rufescens, Aimophila,

483. 496 Haemophila

484. 496 ruficapilla, N e mo -

483. 496 sia, Sylvia

484. 496 ruficauda, Amadina, Bathilda, Pytelia

ruficollis, Cypsnagra Leucopygia, Tachy -

422. 458 phonus, Tanagra cilla, Nemosia,

585. 550 Neornis, Pyrrhula-

443. 469 gra, Tanagra, Tanagrella

357. 420 rufiventris, $\mathrm{Pi}$ onias, 362. 421 Poiocephalus, Psitta359. 421 cus
Nr. Scite

360. 421

358. 421

363. 421

361. 421

624. 573

359. 421

357. 420

359. 421

359. 421

357. 420

363. 421

359. 421

358. 421

362. 421

555. 534

513. 520

196. 276

198. 276

33. 160

91. 191

67. 175

216. 306

193. 275

351. 419

448. 470

355. 420

207. 291

412. 439

40. 161

517. 527

342. 418

454. 471

349. 419

343. 418

36. 160 
rufivirgata, Embernag ra

rufobrunnea, Buserinus, Crithagra, Ligurnus, Pyrgita

rufopicta, Estrelda, Lagonosticta, Pytelia

russatus, Fringilla, Passer

rustica, Cynchramus,

Emberiza, Hypocentor

rutila, Emberiza, Euspiza

radhea, Psittacus

raja, Psittacus

ranunculacea, Euplectes, Fringilla

Rayneri, Platycercus

rectirostris, Psittacara Psittacus

regina, Loxia

reticulata, Fringilla

rex, Fsittacus

rhodocephalus, Psittacus

rhodopareia, Lagonosticta

roratus, Psittacus

rosa, Psittacus

rosacea, Cacatua, Plictolophus, Psittacus

rosaceus, Barrabandius, Palaeornis, Platycercus

rosea, Cacatua, Eolophus

roseata, Pyrrhulinota

rostratus, Megalaphonu ruber, Euplectes

- Psittacus

- Saltator, Tachyphonus

rubicilla, Pyrrhula

rubra, Muscicapa

rubricollis, Coccothraustes

- Psittacula

rubrifrons, Chalcopsitta, Eos

- Loriculus, Psittacul

rubritorques, Pentheria, Vidua

rubriventris, Astrilda,

Estrelda, Fringilla

rubrocristatus, Cacatua rubrolarvatus, Conurus

rubrovarius, Psittacus

rufa, Alauda

- Fringilla

- Fringillaria

rufescens, Linaria

- Melanocorypha

- Phileremos

rufibarba, Emberiza

ruficapilla, Alauda

- Emberiza

ruficapillus, Saltator

ruficauda, Crithagra

ruficaudus, Leptorrhynchus
Nr. Seite

ruficeps, Calandrella

516. 527 - Hemithraupis,Hylophilus - Ploceus

283. 383 ruficollis, Tanagra rufidorsalis, Passer rufifrons, Pezoporus,

447. 470 Platycercus rufigularis, Emberiza

288. 384 rufilatus, Buserinus rufina, Fringilla rufirostris, Conurus,

574. 548 Psittacus - Conurus

583. 550 - Fringilla

188. 274 rufiventris, Coccothrau188, 274 stes rufivertex, Euphonia

503. 512 rupestris, Petronia

181. 267 rutilans, Fringilla Saltator atricollis

108. 218 - Azarae

480. 495 - coerulescens

419. 441 - magnus

188. 274 - olivascens

131. 231 - similis

Serinus canarius

448. 470 - hortulanus

12. 152 - pusillus

131. 231 Sitiace ararauna

- chloroptera

78. 190 - glauca

- hyazinthina

- macao

178. 266 - maracana

- militaris

91. 191 - severa

214. 305 - tricolor

612. 570 Spermestes acuti-

89. 503 cauda

1. 145 - bicolor

- cantans

353. 420 - castaneothorax

211. 296 - cucullata

352. 419 - erythrocephala

- fasciats

315. 408 - ferruginosa

66. 175 - fuscans

186. 273 - maja

73. 185 - malabarica

- malaccensis

509. 519 - pectoralis

- poënsis

438. 468 - punctularia

14. 221 - striata

1. 145 - topela

595. 567 - undulata

522. 528 Spermospiza guttata

587. 551 - haematina

259. 362 Sporophila albogu-

621. 572 laris

594. 567 - coerulescens

567. 547 - collaria

605. 569 - gutturalis

305. 398 - hypoleuca

328. 412 - lineola

229. 333 - ophthalmica

108. 218 - ornata
Mir. Eeite

605. 569 Sporopipes frontalis

- lepidopterus $\quad 494.508$

Rr. Erite

342. 418 Stictoptera annulosa 428. 461

470. 486 - Bichenovi 427. 460

528. 529 Stringops habroptilus 98.208

286. 383 Sycalis brasiliensis 230.334

- Iuteiventris

Sycobius cristatus $\quad 486.501$

567. 547 - nitens $\quad 485.501$

288. 383 Saltator ater $\quad 329.412$

523. 528 - cayannensis 323. 411

- cyanoptera 366. 422

130. 231 - flavus

140. 238 - icterophrys $\quad 324.411$

232. 337 - melanopis $\quad 329.412$

- minor $\quad 332.414$

247. 342 - plumbeus 324.411

389. 429 - psittacinus $\quad 320.411$

281. 382 - ruber $\quad 353.420$

288. 384 - ruficapillus $\quad 328.412$

327. 412 - sordidus $\quad 327.412$

325. 412 - validus $\quad 327.412$

326. 412 Saxilauda tartarica $\quad 622.573$

323. 411 Schistochlamys atra 329. 412

324. 411 - fasciata 330. 412

322. 411 - leucophaea 328. 412

220. 312 - melanopis $\quad 329.412$

219. 312 Schoenicola arundinacea 578. 549

221. 313 - pyrrhuloides $\quad 579.549$

105. 212 Senegallus striatus 438.468

103. 212 Serinus canicollis $\quad 224.329$

100. 211 - chrysopygus 225. 329

$\begin{array}{ll}\text { 99. } 211 \text { - flavescens } & 219.312\end{array}$

102. 212 - icterus 225. 329

107. 213 - islandicus $\quad 219.312$

101. 211 - italicus 274. 376

106. 212 - leucopygius 228.330

104. 212 - luteus 293. 385

$\begin{array}{ll}\text { - meridionalis } & 219.312\end{array}$

405. 438 - spinus

402. 438 Sitagra luteola 468.486

406. 438 Sittace aurea 121. 222

416. 440 - canicollis 147.241

400. 438 - cruentata 126. 223

419. 441 - Illigeri 107. 213

418. 440 - jendaya 120. 222

415. 440 - leptorrhyncha 108. 218

411. 439 - leucotis 128. 224

404. 438 - ludoviciana 118. 221

414. 440 - murina 147. 241

407. 439 - patagonica 109. 220

413. 440 - pertiuax 123. 222

417. 440 - Petzi 122. 222

401. 438 - solstitialis $\quad 119.222$

408. 439 - tirica 140.238

412. 439 - tui $\quad 146.239$

403. 438 - tuipara 145. 239

410. 439 - virescens 142.238

409. 439 - vittata 127. 224
- 120

$\begin{array}{ll}420.457 \text { - xanthoptera 141. } 238 & \end{array}$

421. 457 Solenoglossus ceylanicus

97. 205

234. 337 Spermestes majanoides 415. 440

240. 338 - malacca 404. 438

237. 338 - nisoria $\quad 408.439$

236. 337 - scutatus 400.438

232. 337 Spermophaga cyano-

238. 338 rhyncha $\quad 421.457$

239. 338 Spermophila albogularis 234. 337

235. 337 - bicolor 243.340

$\begin{array}{ll}233.337 \text { - cinerea } & 233.337\end{array}$ 


Spermophila cinereola
- coerulescens
- collaria
- Daubentoni
- gutturalis
- hypoleuca
- leucopogon
- lineola
- lugubris
- nigra
- olivacea
- ophthalmica
- ornata
- torquata

Spindalis nigricephala Spinites atrigularis

- monticola

- pallidus

- pusillus

- socialis

Spinus carduelis

- linarius

- miliarius

- viridis

Spiza americana

- amoena

- ciris

- cyanea

- jacarina

- palustris

- unicolor

- versicolor

Spizalauda deva

Spizella atrigularis

- monticola

- pallida

- Shattuckii

- socialis

- pusilla

Sporaeginthus amandava

- subflavus

Sporophila ardesiaca

- crassirostris

- torrida

Sporothlastes erythrocephalus

- fasciatus

Stagonopleura castano tis

- guttata

Steganura paradisea

Strigops habroptilus

Strigopsis habroptilus

Strobilophaga enucleator

Strutbus atrimentalis

- coelebs

- hyemalis

- montifringilla

- oregonus

Sycobius nigrifrons

Sylvia guira

- ruficapilla

Symplectes princeps

saira, P yranga, Tanagra

salicarius, Passer, Pyrgita

Sallei,Amazona,Chrysotis
Rr. Seite

232. 337

240. 338

237. 338

229. 333

236. 337

232. 337

235. 337

238. 338

302. 397

245. 342

241. 339

239. 338

235. 337

240. 338

370. 422

553. 534

537. 531

540. 531

539. 531

538. 531

262. 365

259. 362

563. 545

264. 369

562. 545

301. 395

299. 394

298. 394

302. 397

536. 531

557. 535

300. 394

602. 568

553. 534

537. 531

540. 531

540.531

538. 531

539. 531

452. 471

444. 469

233. 337

246. 342

247. 342

419. 441

418. 440

437. 462

436. 462

511. 519

98. 208

98. 208

213. 303

sanguineus, Cacatua, Lophochroa, Plictolophus

sanguinirostris, Euplectes, Hyphantica, Loxia, Ploceus, Quelea

sanguinolentus,

Rhamphocelus, Tanagra

savanna, Fringilla, Passerculus, $\mathrm{Z}$ o n otrichia

sayaca, Tanagra, Thraupis

scapulatus, Aprosmictus, Platycercus, Psittacus

schisticeps, Palaeorn is

schoeniclus, Cynchramus, Em beriza

scintillata, Chalcopsitta, Do mic ella, Eos, Lorius, Psittacus

Sclateri, Coryllis, Loriculus

Selbyi, Crith a ra

semilarvata, D o m i cella, Eos, Lorius

semirufus, Arremon, Buarremon, Pipilopsis. Tanagra

semitorquatus, Ar remon

- Barnardius, Platycercus, Psittacus senegalus, Poiocephalus, Pionias, Psittacus

senilis, Amazona, Pionias, Psittacus

severa, Arara, Conurus, Macrocercus, Psittacus, Sittace

sibirica, A lauda, Calandrella, Melanocorypha, Phileremos

sibiricus, Carpodacus, Yyrrhula, Uragus

silens, Arremon, Tanagra

similis, Saltat o $r$

sinica, Chlorospiz a, Chloris, Fringil-

553534 la, Ligurinus

253. 348 sinuatus, Car dina-

552. 534 lis, Pyrrhuloxia

256. 349 smaragdinus, $\mathrm{C}_{0}$ -

550. 533 nurus, Microsittace,

486. 501 Psittacus

341. 417 socialis, Emberiza,

342. 418 Fringilla, Spinites,

474. 487 Spizella, Z on otrichia

353. 420 socius, Loxia, Philetaerus

287. 383 solstitialis, Aratinga, 42. 166 Conurus, Psitta-

Mir. Ecite

spilonotus, Hyphan-

tornis, Ploceus

Mr. Seite

87. 191 spinescens, $\mathrm{Chrys} 0$ mitris, Fringilla 267. 369

spinoides, Carduelis, Chlorospiza,

483. 496 Chrysomitris, Hypacanthis

spinus, Acanthis, Carduelis, Chryso mitris, Fringilla, Linaria, Serinus

543. 532 splendens, Aprosmictus, Platycercus 173. 265

365. 422 splendida, Euphema 151. 256 spodiogenia, Fringilla

175. 265 spodocephala, Emberiza

132. 231 spurius, Platycercus, Psittacus

578. 549 Stanleyi, Carduelis, Chrys omitris,

Hypacanthis

162. 262

266. 369

186. 273 striata, Loxia, Munia, Spermestes, Tri-

71. 185 chogrammoptila,

226. 329 Uroloncha 403. 438

- Aglaia, Tanagra 368. 422

194. 275 striolata, Emberiz a, Fringilla, Fringillaria, Polymitra

337. 416 subflava, Estrelda, Fringilla, Habro-

334. 415 pyga, Pytelia, Spo-

334. 415 pyga, Pytelia, Spo-

165. 262 sulfurata, Buserinus, Coccothraustes, Crithagra, Loxia

37. 160 sulfureus, Cacatua, Plictolophus,

28. 158 Psittacus

superciliaris, Arremon, Chlorospingus, Hemispingus, Hylophilus, Nemosia,

604. 569 Pipilopsis surinama, Merula, Turdus, Tachy phonus

217. 306 Swainsonii, Pas ser, Pyrgita, Pyrgitopsis 292. 385

333. 415 Saisseti, Cyanorhamphus 181. 267

$\begin{array}{ll}\text { 322. } 411 \text { salicicola, Fringilla 287. } 383 & \end{array}$ Salvini, Certhilauda 617. 572 Sancti Thomae, Psit-

279. 379 taculus sandwichensis, Emberiza 542. 532 314. 405 sanguinolenta, Amadina, Estrelda, Fringilla 444. 469 sanguinolentus, Uragus 217. 306

125. 223 sapphirinus, Brotogeris,Coriphilus,Psittacus184. 273 sarda, Fringilla 287. 383 savannarum, Fringilla 546. 533

538. 531

492. 507 saxatilis, Fringilla sclavonica, Fringilla scriba, Otocoris, Phileremos scutatus, Coccothrau297. 391 573. 548

596. 567

119. 222 stes, Spermestes 
Sebanus, Psittacus segetum, Alauda Selysii, Emberiza semicollaris, Psittacus semitorquata, Melanocorypha

senegalensis, Alauda

- Fringilla

- Passer

- Phaeocephalus,

Poiocephalus, Psittacula, Psittacus

senegalla, Fringilla, Lagonosticta

septemstriata, Emberiza, Fringillaria

septentrionalis, Cynchramus

septicolor, Tanagra

serena, Emberiza, Vidu

serinus, Dryospiza,

Fringilla, Pyrrhula

setarius, Prioniturus, Psittacus

Shattuckii, Emberiza, Spizella

sibirica, Tanagra

signata, Emberiza

signatus, Psittacus

silvestris, Passer

simillima, Emberiza

simplex, Passer

- Psittacus -

sincialo, Psittacus

sinensis, Alauda

- Coccothraustes

- Fringilla

- Maja

- Munia

- Psittacus

socia, Quelea

Sonnerati, Psittacus

sordida, Emberiza

sordidus, Propasser

- Saltator

sosove, Aratinga, Psittacus

spadicea, Pyrgita

Sparmanni, Brotogeris, Psittacus

- Lathamus

spatuliger, Psittacus

speciosa, Fringilla, Pytelia

speciosus, Lorius

sphenura, Fringilla

spinoides, Fringilla

spiza, Passer

splendens, Corythus

- Fringilla

splendidus, Psittacus

spleniata, Alauda

squamata, Eos

squamifrons, Amadina,

Estrelda, Fringilla

squamosus, Conurus,

Psittacus

stagnalis, Cynchramus

Stanleyi, Platycercus

stictonotus, Ploceus

stictus, Euplectes
Nr. Seite

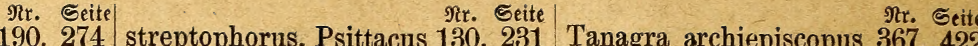

598. 568 striata, Fringilla

582. 550 striatus, Euplectes

199. 279 - Phileremos

- Ploceus

620. 572 - Senegallus

613. 571 strigatus, Chondestes

464. 485 stulta, Petronia

483. 496

subaureus,Hyphantorn corypha

37. 160 subcristata, Emberiza sublarvatus, Textor

404. 438 - argentata

479. 495 - atra

594. 567 - atricollis

478. 495 - auricapilla

438. 468 - axillaris

530. 529 - barbadensis

281. 382 - brasilia

476. 487 - brasiliensis

620 - brunnea

589. 551 - capistrata

470. 486 - chloroptera

350. 419 - chlorotica

446. 470 Suchii, Tachyphonus sulfureus, Xanthophilus 470. 486 - chrysogaster

587. 551 sumatranus, Psittaco-

dis, Tanygnathus

18. 154 - chrysogastra

18. 154 - columbiana

578. 549 Sundevallii, Euplectes 497. 511 - coryphaea

371. 423 superbus, Lorius

191. 275 - cristata

- cristatella phonus

219. 312 Swainsoni, Tanagra

- Trichoglossus

20. 156 sylvia, Fringilla

540. 531 Tachyphonus corona-

622. 573 - cristatus

509. 519 - luctuosus

48. 167 - melaleucus

281. 382 - quadricolor

560. 545 - ruficollis

292385 - surinamus

69. 175 Tanagra cana

130. 231 - cyanoptera

623. 573 - Darwinii

397. 433 - nigricephala

279. 379 - ornata

414. 440 - sayaca

412. 439 - striata

9. 152 Textor alecto

484. 496 - Dinemelli

129. 230 - erythrorhynchus

581. 550 - intermedius

214. 305 Tiaris ornata

327. 412 Trichoglossus, cya-

nogrammus

145. 239 - discolor

292. 385 - haematodes (haematodus)

184. 273 - Mitchelli

348. 419 - cyanea

364. 421 - Desmaresti

199. 279 - episcopus

253. 348 - erythromelas

346. 418 - fasciata

347. 418 - flava

345. 418 - flaviventris

344. 418 - formosa

350. 419 - frugilegus

349. 419 - fumigata

348. 419 - glauca

364. 421 - guira

366. 422 - gularis

369. 422 - gyrola

370. 422 - ignescens

367. 422 - inornata

365. 422 - jacapa

368. 422 - jacarina

459. 481 - jugularis

462. 481 - leucophaea

460. 481 - leucophrys

461. 481 - ludoviciana

303. 398 - magna

- malimbica

201. 280 - martialis

203. 280 - melanictera

200. 280 - melanonota

202. 280 - mississipensis

181. 267 - Novae-Hollandiae 199. 279 - nigerrima

20. 156 Tachyphonus albispecularis

445. 470 - axillaris

191. 275 - Beaupertuyi

422. 458 - capitatus

264. 369 - coryphaeus

253. 348 - fringilloides

213. 303 - gularis

302. 397 - leucopterus

156. 260 - ochropygus

605. 569 - ruficollis

193. 275 - Suchii

- surinamensis

494. 508 - tenuirostris - Vigorsii

126. 223 Taeniopygia castanotis

578. 549 Taha abyssinica

159. 261 - dubia

471. 487 Tanagra aestiva

503. 512 - affinis
345. 418 - nigricollis

330. 412 - nigrigula

344. 418 - nigrigularis

309. 400 - ochropygos

346. 418 - pileata

305. 398 - praelata

310. 400 - psittacina

344. 418 - rubica

348. 419 - ruficollis

343. 418 - -

350. $419--$

348. 419 - saira

345. 418 - sanguinolenta

346. 418 - semirufa

437. 462 - septicolor

503. 512 - sibirica

502. 512 - silens

352. 419 - Swainsoni

388. 429 - tatao
366. 42.

329. 412

327. 412

350. 419

330. 412

376. 423

357. 420

376. 423

347. 418

328. 412

378. 424

386. 429

368. 422

384. 429

354. 420

346. 418

347. 418

305. 398

298. 394

348. 419

364. 421

356. 420

330. 412

374. 423

379. 424

377. 423

379. 424

369. 422

349. 419

364. 421

341. 417

310. 400

375. 423

358. 421

366. 422

359. 421

302. 397

327. 412

328. 412

339. 416

354. 420

323. 411

486. 501

348. 419

560.545

381. 428

329. 412

352. 419

344. 418

341. 417

384. 429

341. 417

358. 421

348. 419

340. 417

366. 422

320. 411

351. 419

343. 418

349. 419

528. 529

353. 420

361. 421

337. 416

371. 423

622. 573

333. 415

364. 421

371. 423
379. 424 
Tanagra tricolor

- unicolor

- variegata

- violacea

- virens

- zena

- zenoides

Tanagrella ruficollis

Tanygnathus affinis

- albirostris

- intermedius

- macrorhynchus

- marginatus

- marginatus

- megalorrhynchus

- morotensis

- Muelleri

- pileatus

- sumatranus

Tatao fastuosa

- paradisea

- tricolor

Tersine coerulea

Tetranura regia

Textor aureoflavus

- castaneofuscus

- chrysopygos

- flavoviridis

- galbula

- melanocephalus

- sublarvatus

- vitellina

Thraupis cana

- cyanoptera

- ornata

- sayaca

Tiaris comptus

- cruenta

- funerea

- pusilla

Tirica brasiliensis

- tiriacula

- virescens

- viridissima

- xanthoptera

Trichoglossus capistratus

- multicolor

- nigrigularis

- pyrrhopterus

- Swainsoni

- taitianus

Trichogrammoptila melanopygia

- striata

Trichotraupis quadricolor

Triclaria cyanogaster

Triglyphidia callophrys

Turdus surinamus

tahapisi, Em beriz a 587 . 551

taitiana, D o mic ella, Nanodes, Psittacus, Trichoglossus

tatao, Callis te, Callospiza, Tanagra

temporalis, Aegintha, Estrelda, Fringilla, $\mathrm{Habropyga}$

tersa,Ampelis,Hirundo Procnias, Tersine

557. 535

394. 430

366. 422

370. 422

370. 422

343. 418

17. 153

18. 154

17. 153

16. 153

16. 153

19. 154

16. 153

16. 153

18. 154

19. 154

18. 154

374. 423

371. 423

373. 423

382. 428

513. 520

476. 487

477. 488

465. 486

469. 486

464. 485

470. 486

470. 486

364. 421

366. 422

367. 422

365. 422

303. 398

306. 398

242. 340

140. 238

140. 238

184. 273
Nr. Seite

373. 423 tersa, Ampelis, P r o c-

352. 419 Theklae, Galerida

470. 486

514. 524

ovius, Sittace

140. 238 taenioptera, Loxia

141. 238 taha, Euplectes

tarabè, Psittacodes,

200. 280 Psittacus

199. 279 tartarica, Alauda, Me-

201. 280 lanocorypha, Saxi-

143. 238 lauda

199. 279 Temminckii, Calyptorrhynchus tenuirostris, Alauda

404. $438-$ Tanio, Tachy

403. 438 - Licmetis, Psittacus

- Melanocorypha

350. 419 ternatensis, Psittacus

21. 156 terrestris, Pezoporus,

383. 429 Psittacus

textor, Hyphantornis, Oriolus, Ploceus

thebaica, Pyrrhula tibicen, Euphonia

184. 273 tintillon, Fringilla tiriacula, Conurus,

371. 423 Psittacula, Tirica tiriba, Psittacara tobaca, Fringilla

443. 469 torquata, Melanocorypha

- Spermophila

382. 428 - Vidua
Rr. Seite

torquatus, Arremon

333. 415

508. 519

281. 382

614. 571 - Passer

317. 408 Townsendii, Fringilla,

2. 145

Passerella

598. 568

190. 274

140. 238 tricolor, Lorius trimaculatus, Psittacus 134. 232

410. 439 troglodytes, Fringilla 439. 468 tui, Psittacus 123. 222

130. 231 turdina, Alauda 616. 571

typica, Plocealauda 608.570

typicus, Barnardius 164. 262

typus, Ducorpsius 90.191

247. 342 Uraeginthus granatinus

- phaëton

457. 472

458. 472

277. 376 - phoenicotis 456. 472

Uropytelia erythronota

455. 471

Uragus sanguinolentus 217. 306

144. 239 - sibiricus 217. 306

Urobrachya axillaris $\quad 504.518$

Urochroma melanoptera 70. 176

$\begin{array}{lll}\text { 104. } 212 \text { Uroloncha cantans 406. } 438 & 407.439\end{array}$

- malabarica 407. 439

$\begin{array}{ll}373.423 \text { - punctularia } & 408.439 \\ 387.429 \text { - striata } & 403.438\end{array}$

unalaschcensis, Emberiza, Z o n o trichia 523.528

269. 370 undulata, Loxia, Munia, Spermestes 409. 439

82. 190 undulatus, Euphema, Melopsittacus, Nanodes, Psittacus

unicolor, Cyanorhamphus, Platy cercus 183. 267

146. 239 - Emberiza, Haplospiza, Phrygilus, Spiza, Tanagra

uropygialis, $\mathrm{Chry}$ somitris

145. 239 ultramarina, Fringilla,

208. 292 Hypochera, Vidua

502. 512 undata, Alauda undulata, Astrilda

50. 167 Fringilla uropygialis, Fringilla Vidua paradisea

622. 573 - principalis

- progne

96. 202 - regia

598. 568 Volatinia jacarina

557. 535

272. 371

514. 524

$613 \quad 571$

438. 468

227. 330

511. 519

512. 520

510. 519

513. 520

302. 397

3. 145

5. 146

92. 192 -

601. 568 Vidua angolensis

131. 231 - ardens

- axillaris

149. 254 - chrysonotus

- decora

464. 485 - erythrorhyncha

218. 309 - fuliginosa

385. 429 - laticauda

255. 349 - lenocinia

- macroura

140. 238 - major

126. 223 - minor

227. 330 - phoenicoptera

512. 520

509. 519

504. 518

505. 518

512. 520

512. 520

512. 520

508. 519

509. 519

505. 518

512. 520

512. 520

510. 519

509. 519

512. 520

240. 338 - serena

509. 519 - torquata 
Vidua ultramarina

Vigorsia nigra

- vaza

Vini coccineus

viridis Hirundo

variabilis, Emberi z a, Euspiza

vaza, Coracopsis. Pla-

tycercus, Psittacus, Vigorsia

velatus, Hyphantornis, Ploceus

venusta, Euphema, Nanodes, Psittacus

vernalis, Coryllis, Loriculus, Psittaculus, Psittacus

versicolor, $\mathrm{Cy}$ ynospiza, Spiza

Vieilloti, Calliste

vinacea, Amazona, Chrysotis, Oenochrus, Psittacus

violacea, Euph onia, Phonasca, Tanagra

violaceus, Amazona, Pionias, Psittacus

virescens, Aratinga, Brotogerys, Conurus, Psittaca, Psittaculus, Psittacus, Sittace, Tirica

virginianus, Cardi nalis

viridis, Cary othraustes, Coccothraustes, Fringilla

vitellinus, Fringilla, Hyphantornis, Ploceolus, Textor

vittata, Amazona, Chrysotis, Psittacus

vittatus, Aratinga Conurus, Microsittace, Psittacara Psittacus, Pyrrhura

vulgaris, $\mathrm{Cocco}$ thraustes

- Pyrrhula

Vaillantii, Psittacus

validus, Saltator

varians, Rhamphopis variegata, Eos, Psittacu

- Tanagra

varius, Psittacus
Nr. Seite

514. 524 vaza, Vigorsia

3. 145 ventralis, Psittacus

5. 146 - Procnias

185. 273 verecunda, Padda

382. 428 vernans, Psittacus vernus, Chrysotis

584. 550 versicolorus, Psittacus Versteri, Psittacus vibrisca, Psittacus

5. 146 vidua, Emberiza Vieilloti, Lanio

467. 486 Vigorsii, Psittacus - Tachyphonus

153. 257 vinacea, Estrelda vinaceicollis, Chrysotis, Pionias

75. 185 vini, Lorius virens, Loxia, Tanagra

300. 394 virginiana, Alauda

377. 423 viridigenalis, Chrysotis

viridigenalis, Chrysotis 51. 168 viridis, Psittacus

50. 167 - Psittacus - Spinus

394. 430 viridissima, Aglaia, Gyrola

30. 159 - Aratinga, Tirica - Psittacula vittata, Aglaia, Calliste, Procnopis - Fringillaria

142. 238. vulgaris, Alauda Wallacei, Lorius

312. 405 - Prioniturus Westermani, Eclectus, Polychlorus, 318. $409 \begin{gathered}\text { Psittacodis } \\ \text { Xanthodina dentata }\end{gathered}$ - flavicollis

470. 486 - flavigula

$\begin{array}{llll}\text { Xanthophilus sulfureus } & 470 & 486 \\ \text { Xanthornus caucasicus } & 560 & 545\end{array}$

43. 166 Xanthornus caucasicus ga, Brotogerys Conurus, Psittacara Sittace, Tirica

127. 224 xanthorrhous, Platycercus, Psephotus

250. 344 xanthocephala, Chrysotis 61. 170 211. 296 xanthogaster, Platycer145. 239 cus

327. 412

362. 421 xar

1952. 419

184. 273

Nr. Seite

5. 146

42. 166

382. 428

397. 433

51. 168

47, 167

142. 238

37. 160

135. 232

512. 520

347. 418

126. 223

346. 418

449. 470

44. 166

184. 273

366. 422

9. 152

166. 263

375. 423

140. 238

69. 175

381. 428

588. 551

598. 568

198. 276

20. 156

11. 152

295. 386

294. 386

296. 386

141. 238
168. 263
61. 170

163. 262 xanthogenius, Conurus 123. 222 xanthogenys, Buarremon

336. 415 xanthomascalis, Fringilla 316.408 xanthomelas, Euplectes, Orynx

xanthops, Agapornis

- Chrysotis, Psittacus xanthopterus, Phaeocephalus

xanthopterygia, Conurus, Psittacula, Psittaculus

xanthopterygius, Conurus 69.175

xanthornus, Ammodromus

545. 532

xanthosomus, Palaeornis 131. 231 yeltoniensis, Alauda, Melan ocorypha

yeni, Aglaia, Callist e, Callospiza

622. 573

Yessei, Alaemon

Zonaeginthus castanotis

372. 423 617. 572

- guttatus

- nitidus

437. 462

436. 462

434. 462

435. 462

Zonotrichia aestivalis 541 . 532 - alaudina 544. 532

- albicollis $\quad 527.529$

- arctica

- coronata

- fallax

542. 532

526. 529

534. 530

525. 529

531. 530

530. 529

533. 530

522. 528

524. 528

535.530

532. 530

537. 531

529. 529

540.531

536. 531

528. 529

539. 531

543. 532

538. 531

523. 528

$\begin{array}{ll}\text { Zonogastris elegans } & 445.470 \\ \text { Zonotrichia aurocapilla } & 526.529\end{array}$

- matutina 528. 529

zonarius, Barnardius,

Platycercus, Psittacus

Zeelandicus, Fsittacus zena, Tanagra

zenoides, Tanagra

zonarius, Passerculus
166. 263

180. 266 370. 422 370. 422 535. 530 


\begin{tabular}{|c|c|c|c|c|c|}
\hline Aderlerche. & $\begin{array}{l}\text { গr. Seite } \\
598.568\end{array}$ & Blajafopffitttich & $\begin{array}{l}\text { Nr. Seite } \\
\text { 161. } 261\end{array}$ & Buntfarbenfint & $\begin{array}{l}\text { Nr. Seite } \\
300 . \quad 394\end{array}$ \\
\hline Prolerpapagei & 8. 151 & Blautarara & 100. 211 & Buntteble & 323. 411 \\
\hline Affamutanga & 54. 169 & Błlaubäntoden & 456. 472 & Buntfopfbabia & 334. 4 \\
\hline Prreftonger & 458. 481 & Blaubart & 41. 165 & Bantjittich & 170. 2 \\
\hline Arlexanderjittich & 134. 232 & Blaubauch & 21. 156 & 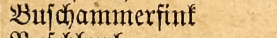 & 555. 5 \\
\hline Slffarblori & 199. 279 & Blauflitgeltantgara & 366. 422 & Bujálerche & 609. 5 \\
\hline Arlpenfint & 297. 391 & Blaugimpelfint & 249. 342 & Bujabinald lerche & 608. 5 \\
\hline arlpenlerche & 594.567 & Blautappe & 167. 263 & Bujadraaldfittich) & 156. 26 \\
\hline शmarant & 446. 470 & Blaufernbeižer & 248. 342 & Buttergimpel & 225. 3 \\
\hline Imtazonenpapagei & 60.170 & Blautopf & 56. 169 & Salita & 147. 2 \\
\hline - Frétres & 47. 167 & Blautfagenlori & 193. 275 & Sallinde & 105. \\
\hline Ylmmerhabia & 333. 415 & Blautfrönät)en & 72. 185 & Sanario & 230. 3 \\
\hline 2tmjelammerfint & 523. 528 & Blaultrone & 42. 166 & Eararauma & 105. 2 \\
\hline Anafan & 106. 212 & Blauratzjittich & 126. 223 & Satanica & 114. 2 \\
\hline Ângolagimper & 227. 330 & Blaumantelfittich) & 176. 265 & Sateita & 109. 2 \\
\hline Ingolahänffing & 227. 330 & Blaunadfenlori & 191. 275 & Sebernammer & 565. 5 \\
\hline Arafanga & 102. 512 & B̧lauorganijt & 381. 428 & (5handana & 129. 2 \\
\hline Irarauma & 105. 212 & B̧laupfäffchent & 240. 338 & (shect)a & 106. 2 \\
\hline $\mathfrak{A}$ trimamu & 184. 273 & Blaujacheitel=[Delpapagei & 19. 154 & Shineje & 412. 4 \\
\hline 2rijiat & 176. 265 & Blauftixnfittich & 111. 220 & Shingolo & 528. 5 \\
\hline 2trfaufag̨zeifig & 270. 370 & Blautoögeldaen. & 396. 430 & (5horoy & 108. 2 \\
\hline Aftrild & 439. 468 & Blautwangenlori & 195. 276 & (5)huculo & 28. 1 \\
\hline Atrasongel & 514. 524 & $\overline{-} \quad$. & 201. 280 & Sicero & 56. 1 \\
\hline 2urorabögelchen & 444. 469 & Bhumenpapagei & 74. 185 & (Sitrinchen & 274. 3 \\
\hline Babaghan & 130. 231 & Shlutbaude)pittich & 167. 263 & Eitrinelle & 275. 3 \\
\hline Bäffictenammerfint & 527. 529 & Blutfinf & 446. 470 & Sitronfinf & 274. 3 \\
\hline Bänderbürzelfint & 433. 461 & B̧lutbänfling & 257. 359 & Sitronbögeldhen & 444. 4 \\
\hline SBailing & 623.573 & Błluthats & 418. 440 & Eitronzeifig & 274. 3 \\
\hline Bamanibaya & 479. 495 & Bhutfinadter & 421. 457 & Eomoren $=2 \mathfrak{a} a \mathfrak{a}$ & 6. 1 \\
\hline Banaros Sittich & 164. 262 & Blutrumpfifttich & 169. 263 & Sorononbleu & 456. 4 \\
\hline Bantooger & 418. 440 & Blutjatnaberneber & 483. 469 & Eorefla & 94. 1 \\
\hline Barettittich & 131. 231 & Blutitixnfittich & 113. 220 & Eornelias Edelpapagei & 15. 1 \\
\hline Bartammer & 571. 547 & Bluttangara & 361. 421 & Eorudt & 68. 1 \\
\hline Bartammerfint & 529.529 & Böhntex & 256. 349 & Sotoro & 46. 16 \\
\hline Bartcitronfint & 276. 376 & Bogenfanabellerche & 619.572 & Sotorra & 147. 2 \\
\hline Bartfinf & 429. 461 & Bonool & 415. 440 & Eotorre & 43. 1 \\
\hline Bartfitticf) & 133. 231 & Bora & 75. 185 & Danlanget & 156. 2 \\
\hline Bartfangara & 341. 417 & Sorjtenfopf & 8. 151 & Diademamazone & 52. 1 \\
\hline Bajtarofittich & 162. 262 & Bourtes Sittich & 172. 264 & Diabentori & 197. 27 \\
\hline Batetiva & 233. 337 & Sradiderche & 612.570 & Diamantogel & 436. 46 \\
\hline Baumlerche & 203. 569 & Srandfinf & 214. 305 & Didfichnabel & 250. 3 \\
\hline Baumiperfing & 586. 383 & Brandweber & 500. 511 & Didfichnaberlerche & 616. 5 \\
\hline- & 437. 531 & Brapiler & 563.545 & Diofich & 483. 4 \\
\hline Baya & 678. 495 & Brautengrüning & 339. 416 & Difterfinf & 262. 3 \\
\hline Becudo & 246. 342 & Braunammerfint & 521.528 & Diuta & 558.5 \\
\hline Beizung Slinto & 72. 185 & Braumflügelammer & 531. 530 & Djullbatla . & 149. 2 \\
\hline Bengelift & 456. 472 & Braunhänffing & 257. 353 & Dohlempapagei & 4. 1 \\
\hline Sergammerfint & 537. 531 & Brauntopf & 38. 160 & intfanter & 308. $4 \mathrm{C}$ \\
\hline Bergfint & 256. 349 & B̧xaunnadenhabia & 336. 415 & Dominifanermioa & 512. 5 \\
\hline Berghänffing & 258. 359 & Braunohrfittich & 127. 224 & Dominifanertwitwe & 512.5 \\
\hline Bergtanarienvogel & 229. 330 & Sraumiperlintg & 291. 385 & Domino & 409. 45 \\
\hline Berglerche & 594.567 & SBreitjobwanzwiba & 508. 519 & Donforo & 36. 16 \\
\hline Bergfittich) & 177. 266 & Breitjadwanzwitwe & 508. 519 & Doppelfarb & 402. 4 \\
\hline Bergiperting & 281. 282 & Briflenpfäffichen & 239. 338 & Doppelfornterche & 597. 5 \\
\hline Bergzeijtg & 259. 362 & Sriflenweber & 473. 487 & Dornammerfint & 517.5 \\
\hline Betet & 138. 233 & emännctyen & 403. 438 & Dornajtrilo & 443. 46 \\
\hline Sindenfehlfpatz & 294. 386 & Bruchanmerfinf & 516.527 & Dor & 165. 2 \\
\hline Bindentangara & 356.420 & Şruchjperfintg & 536.531 & Dreifarbenarara & 104. 21 \\
\hline Birfenzeifig & 259. 362 & Borunfildo & 455. 471 & Dreifarbentangara & 373.42 \\
\hline Bifictof & 248. 342 & Butdofint & 253. 348 & Drofieflerche & 616.57 \\
\hline Bifdjofamebex & 490. 503 & Büffelweber & 460. 481 & Dichindora & 478. 49 \\
\hline 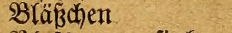 & 238. 338 & Buffonds Rafaou & 84. 190 & Ducorps fiafiadu & 90. 1 \\
\hline SRlajgammerfinf & 540.531 & Bundulfof & 160.261 & Dulferche & 603.56 \\
\hline
\end{tabular}


D)mututuf

Dura

Eselanmerfint

EDelfint

Edelpapagei, Müllexs

EDelfdiläger

sinfarbjittich

Eisammer

Erfenbeinfitticf

(E) fenpapagei

Erisfe

E्fiterfing

(Elfteruögelduen

(5mmering

Emmerits

(5mmerling

(Engeldien

Erofittich

Erzlori

Erzpfäffichen

Erzmeber

శ̋ăcherpapagei

Faribi

Fajänchen

Jajanjittich

శrautfperling

శ̌derzunge

Jeinfitttich

J̌lDammexfint

Jelolerche

Jeldiperting

Feljenammex

folfenittich

శ̌ersfint

Fettammer

Jeutexfint

Feuexflügerfittich

Jeuerjotwanz

Jic) tenammer

fichtengimpel

J̧ichtentrenzidnnabel

Fitchtenzeifig

Jitojofifittich

Finfentönig

fintenterche

శflad)iffint

fllachszeifig

శ̧lammenfinf

శ్lajhenbaum = รangara frauentori

Jricte

Frruchttangara

శrxïbling ammer

テrrïhlingspapagei

Fuchsammerfint

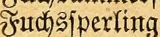

Juch stwebex

Furdientangara

Sagi

(Ballax

Ssanzgrünfittić)

Bartenammex

(Sartenfinf

Saruba

Batterer

Batturama

Sautiflexdie

Seelammer

(Seeling

(Selbammex
Mr. Seite

165. 262 (Selbbatichjittich

130. 231 Selbflügelamazoue

558. 535 (selbflitgelfittic)

253. 348 Belbflitgerfperling

18. 154 Belbhauben = Rafadu

228. 330 Sielbtopf

183. 267 Selbling

590. 552 Befbmantelfori

122. 222 (Selbjacheitel=92mazone

76. 185 Belbjantabel

250. 344 (selbidanabellabia

331. 414 (Selbidultermiba

400. 438 Belbichulterwitme

564. 546 (Selbitei

564. 546 Selbition=9Mohrentopf

564. 546 Selbroangen =92mazone

264. 369 Selbinangen = Iafadu

149. 254 S'eringero

188. 274 Serjtenammer

237. 338 Befellichaftanmerfinf

488. 503 Bejellichaftzlerche

31. 159 Siluberling

131. 231 Bilberit3

438. 468 Ssilblerche

157. 260 Sitrbling

284. 383 Simper

343. 418 Sirtits

153. 257 Bitterflüger

539. 531 Br Labifbetul

598. 568 ङ Sanzflïgel= ßapagei

291. 385 Slanzorganift

539. 531 (S) lanzfittid)

575. 548 S'lanzmeber

109. 220 sslatzentopf

258. 359 Brö̈

566. 546 Soffins Rafadu

498. 511 Bolabi

143. 238 Boldammer

434. 462 (Soldantgenfittic)

573. 548 Boldbärtchen

213. 303 (Sioldbaud

206. 291 (Soldblättdjen

268. 370 Sibldbramammer

173. 265 Bolsbraute

250. 344 Boldbrilftchen

602. 568 Bolbbürzeltangara

259. 362 Soldbiixzelzeiftg

259. 362 Boldint

499. 511 -

343. 418 Ssoldflügelfittich

190. 274 (Soldogirbmeber

291. 355 Boldiehle

369. 422 (Sold fehlgrïning

568. 547 (Soldfimmittic)

75. 185 (Soldfopffittic)

522. 528 (Solbfragen

522. 528 Sold fronenfanarienvogel

477. 488 Sold roneniperling

368. 422 (Soldironfint

132. 231 (Soldmastenjittic)

130. 231 Bsolonadent

115. 221 Soldrïdentangara

566. 546 (SolDjcheitelorganift

253. 348 Boldiperling

112. 220 Solditiglit3

397. 433 Solditirngirlitz

394. 430 Boloftimorganift

611. 570 (Solditimfittich)

564. 546 (Soldtangaxa

564. 546 (Soldwangen = Iafabu

561. 545 Solomeber
Nr. Sette

163. 261

61. 170 Bsoldzitgel

141. 238 Bsolmer

546. 533 Boxje

81. 190 Brantatint

61. 170 Srasammexfinf

564. 546 Srrasfint

192. 275 (Srautammex

63. 171 Srauammerfinf

258. 359 Brauaftrils

335. 415 (Sraubautchfnacter

507. 518 Srauthabia

507. 518 Brauthänfling

168. 263 Sirautarbinal

35. 160 Srautöpfóien

53. 168 Brautleinfinf

83. 190 Brauterche

96. 202 Siraumanter

563. 545 (\$raupfäfficten

538. 531 Srrattangara

601. 568 Sreinerlein

564. 546 Esentadier

564. 546 Srinzling

615. 571 (Sroß̧tehlipaz

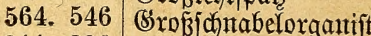

211. 296 (Sroßjidnabeltangara

219. 312 (Sround robit

427. 460 Srünedelpapagei

397. 433 Exïnflïgel = 2 rara

29. 158 Sirinthabia

387. 429 Srïnhänfling

151. 256 Brilnfaroinal

485. 501 Srünling

28. 158 (Sxünj(c)littg

38. 160 (Srïnjdutter = Edelpapaget 17. 153

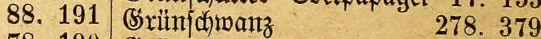

78. 190 (Srïnjđimanzlori 189.274

564. 546 Brïntangara

116. 221 Sritnvogel

242. 340 (Srünwangent $=921 n a z$ one

223. 329 Srïnzügel= $=$ apagei

375. 423

278. 379

51. 168

24. 157

518. 527

577. 549 Brunoroter

$\begin{array}{ll}\text { 241. } 339 & 104.212\end{array}$

55. 169

362. 421 Girtelgrasfin

(Siirtellerche

256. 349 (Sitilding $=24$ tmazone

262. 365 Bultelmis = ßapagei

145. 239 Surliederumg

476. 487 (Sitrab

222. 329 5abia

338. 416 Ђँänfling

144. 239 5ahnich weifmiba

146. 239 5ahnichweifwitwe

244. 340 5ुafenfinf

230. 334 5ूafengimpel

526. 529 5afenternbeif̉er

526. 529 Ђูafentireuzfanaber

123. 222 5ूalbmastenlori

59. 170 รaldenammer

378. 424 5alsbandfinf

392. 430 5arsband lerche

293. 385 5aläbandfittich

269. 370 5alsbantomeber

221. 312 5arrelal

388. 429 5artangara

121. 222 5ुartlaubszeiftg

354. 420 5artidnabel

85. 191 5ूaubenammer

464. 485 5aubenfinf
429. 461

594. 567

70. 175

57. 169

34. 160

154. 257

16. 153

322. 411

257. 359

510. 519

510. 519

213. 303

213. 303

213. 303

213. 303

194. 275

572. 548

418. 440

621. 572

130. 231

466. 486

453. 471

350. 419

225. 329

213. 303

589. 551

304. 398 


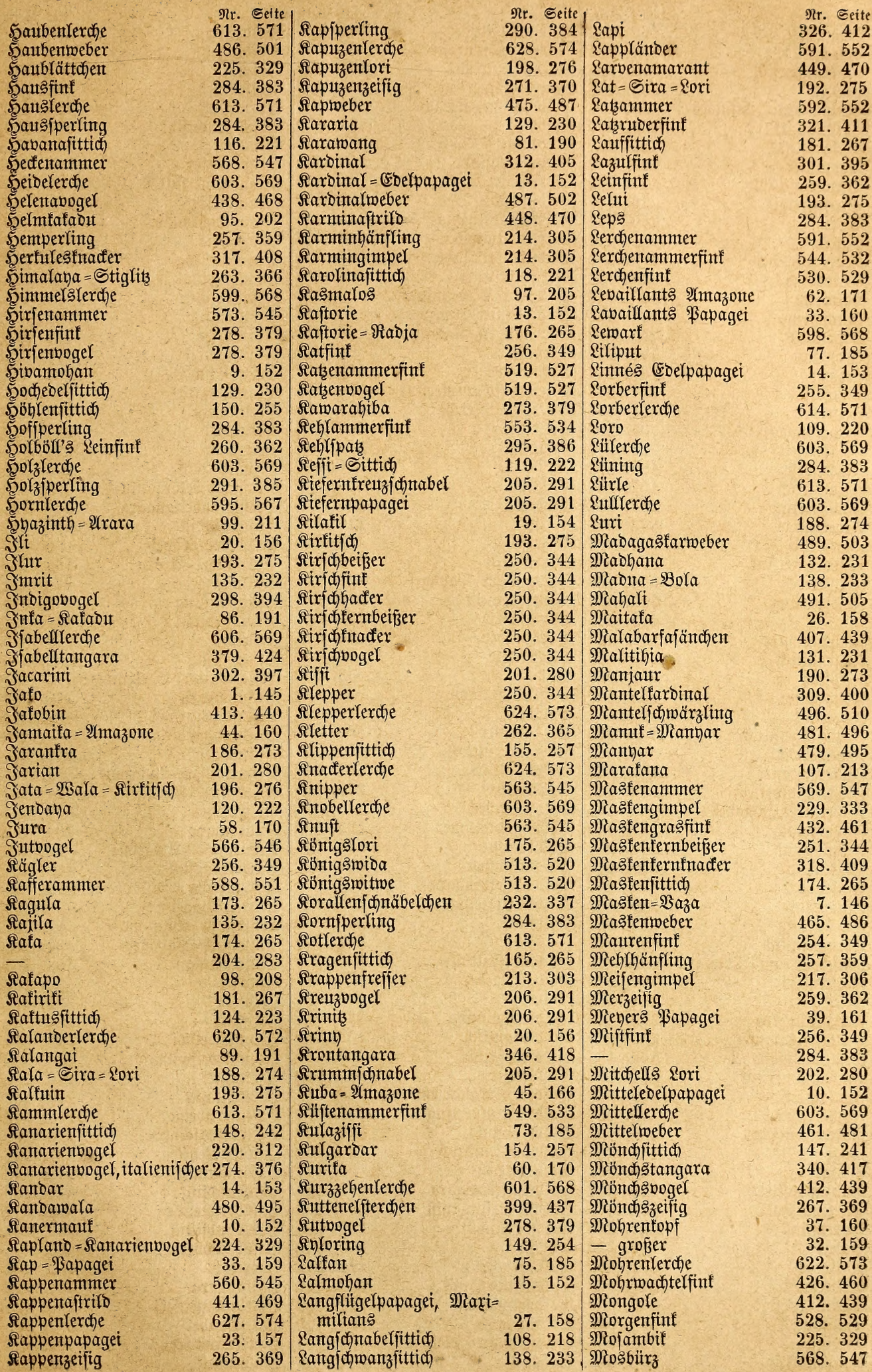


Mosennterling

Motmot = Papageien Mionadud

Miitlex

Matudelfittich

Maijoliperling

Mustatpogel

Nafalnor

Raftaugen $=$ গafabu

Rajen = Rafabut

Netzffïgel

Reubollänoer

Nenoogel

Ninrie

Sonnenorganift

Nontentogel

Nordammerfint

Runxi

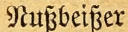

গuß̂tperling

Ninmphe

Shrlerche

Drangeblactionen

Drangentangara

Drangenoogel

Drangeongel

Drangenange

Srtolant

Drtolantönig

Drux

Bahari

Sapa $=$ Sapim

Bapageiengimpel

Papageio

Saptrinf

Sapualori

Garadisamadine

'Saradistangara

Saradismida

Faradismitme

Saratifia

Barisunger

Sierico

Gerlfalstangara

isfäffichen

Sfaffentogel

isflaumentopf

\$haëton

Sietje = ianarie

Solarammerfint

$\mathfrak{B D} \mathcal{L}=($ Sirama

Bortorico = 2 mazone

Frachtammex

Srad) torganift

Prachtjittich

Srachttangara

Sriejterferde

Srinzenweber

Bubarifittich

Buxpurgimpel

\$urpurfardinal

Sirpurfronfint

surpurtangara

Duáfex

Duitter

Rapfinf

Raspeliperfing

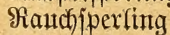

Reistnader

Reisongel

Riedammerfinf
Nr. Seite

578. 549 Riejenmeber

20. 156 Ringelfint

159. 261 Ringelperling

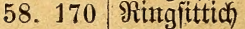

148. 242 Rötelammer

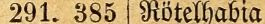

408. 439 Rötelmunie

413. 440 Rötelfperfing

79. 190 Rohrammer

92. 192 Rohrlep:

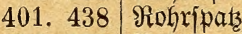

64. 171 Rohriperling

590. 552 -

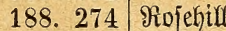

390. 429 Rojella

414. 440 Rojenbrujtfuader

520. 527 Rojengimpel

191. 275 Rojentafadit

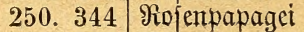

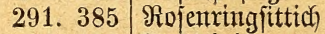

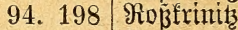

596. 567 ఇoitammer

440. 469 Roittopf = \$apagei

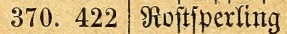

370. 423 Rotachjel

498. 511 Rotbauc) = Mcohrentopf

440. 469 Rotbindentrellzichnabel

566. 546 Rotbrujtamarant

560. 545 Яotbruitlori

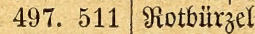

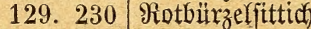

305. 398 Rotbüxzeltangara

218. 309 Rotbug $=$ Amazone

64. 171 Rotedelpapagei

299. 395 Rotfint

190. 274 -

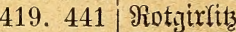

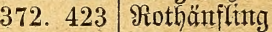

511. 519 Rothaubenfinf

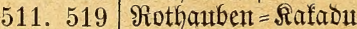

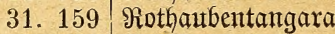

213. 303 Rotfäppchen

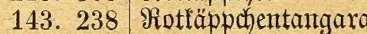

377. 423 Rotfafferfut

234. 337 Rottopfamadine

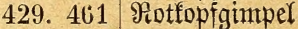

199. 279 Rotfopftaroinal

458. 472 Rotfopfiperling

277. 376 Rotfopftangara

542. 532 Rotfopfweber

74. 185 Rotlarbe

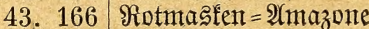

585. 550 Rotpriejter

383. 429 Roticheitelorganift

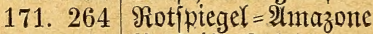

374. 423 Rotitei $\bar{\beta}=$ Rafadu

594. 567 Rotiterzfinf

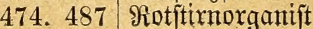

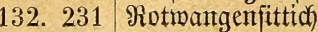

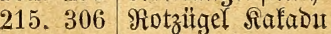

313. 405 Rubinlori

306. 398 Ruberfinf

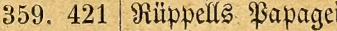

256. 349 Fuplerche

258. 359 Sabtaficca

278. 379 ङängerfinf

538. 531 ङafrantinf

284. 383 Saharaammer

247. 342 Salatrerche

397. 433 Samenfnader

536. 531 Sammetlori

Nr. Seite

463,485

428. 461

291. 385

166. 263

583. 556

337. 416

411. 439

288. 384

578. 549

578. 549

578. 549

291. 385

578. 549

159. 261

160. 261

315. 408

216. 306

91. 191

67. 175

135. 232

205. 291

567. 547

25. 157

283. 383

65. 174

36. 160

207. 291

447. 470

200. 280

450. 470

180. 266

363. 421

64. 171

12. 152

253. 348

458. 472

229. 333

257. 359

305. 398

78. 190

347. 418

73. 185

342. 418

497. 511

419. 441

212. 296

310. 400

285. 383

355. 420

482. 496

114. 221

49. 167

257. 359

389. 429

48. 167

89. 191

454. 471

385. 429

139. 233

87. 191

185. 273

320. 411

40. 161

613. 571

21. 156

228. 330

230. 334

586. 551

613. 571

420. 457

187. 274

Sammettangara

Sammetoogel

Sandlerche

Sangaifu

Sangia

Saphirlori

Sarbobaba

Satlerche

Saunammerfint

Sabannajperling

Schättctien

Sdafari = Mante

Sdarbaya

Sd)arlachbuirzeldaen

Scharfachffïgerfittict

Scharlachtappe

Scharladifopt

Scharlachohr

Sd)arladfichranz

Scharlackfittich

Scharlachtangara

Scharlachmeber

Schellenlerche

Sditebchent

Sdbieferammerfint

Schildanmer

Schillofint

Schildofittich

Schillomida

Schilomitue

Sdjilffint

Schilfuoget

Sdifllerorganif́t

Schilfing

Sdimmertori

Sctixa

Sd)lagammerfint

Salleierbabia

Sd) leierweber

Schmarlanabelfardinal

Sdimerlongel

Sd)metterlingsfinf

Sdinudefamer

Sdimudfammerfint

Sdinuteffittich

Sdnäpperorganift

Sdineeammer

Sdneeaninterfint

Sdineeenmerling

Sdinteefint

Sdineelerche

Santeeortolan

Sanneevogel

Santllpapagei

Sdyurrbärtchen

ธdnönbürzel

Schönfint

Schönfittion

Schopffinf

Schopflerche

Schuppenbrüftchen

ธa)uppentäppchen

Schwalbenlori

Sdimalbentorganift

Schivalbentangara

Sajmarzbädfichen

Sdiwarzgeficitctien

Schinarzgimpelfint

Sd)inarzharshabia

Nr. Seite

358, 421

501. 511 


\begin{tabular}{|c|c|c|c|c|c|}
\hline & Nr. Seite & & Mr. Set & & Nr. Seite \\
\hline 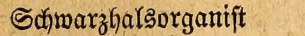 & 384. 429 & Steppenlerche & 623. 573 & Wadjtelfint & 425. 459 \\
\hline opchent & 236. 337 & Sterlits & 262. 365 & SGaldammer & 574. 548 \\
\hline Ṡhwarztinnfint & 553. 534 & Sternart & 564.546 & Waldfinf & 253. 348 \\
\hline Sdimarzfnader & 246. 342 & Stiglit3 & 262. 365 & Warohütteniperling & 292. 385 \\
\hline Sdfwarzfopffnacter & 316. 408 & Stocthänfling & 257. 359 & Walolerdie & 603. 569 \\
\hline Sd)warztopfmeber & 472. 487 & Streifenanmer & 586.551 & Wanatia & 31. 159 \\
\hline (h)warzohx = \$apaget & 26. 158 & Strichelammerfint & 530.529 & Waja & 5. 146 \\
\hline Groarzpapaget & 3. 145 & Strictellori & 196. 276 & Wajiexiperling & 578. 549 \\
\hline (c)marzjonaberfittich & 136. 232 & Strietoogel & 590.552 & $\mathfrak{W a z a}$ & 5. 146 \\
\hline (d) toarzidfulter = (5Del= & & Strohfittich & 158. 260 & Wechielammex & 584. 550 \\
\hline papaget & 16. 153 & Strumpfinirfer & 563.545 & Wegelerche & 613. 571 \\
\hline 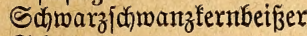 & 252. 344 & Stummellexche & 601. 568 & Weidenammer & 582. 550 \\
\hline d)marztangara & 344. 418 & Stummelfánanz & 424. 458 & Weid & 287. 383 \\
\hline d) twutid & 278. 379 & Stummelivida & 504. 518 & Wei & 613. 571 \\
\hline thoun? & 278. 379 & Stummelmitwe & 504.518 & Weiß̄́ & 430. 461 \\
\hline ammerfinf & 548. 533 & Sumpfammerfintf & 515. 526 & Weī̋̉bärt & 235. 337 \\
\hline ftrandfinf & 548. 533 & Sumpfiperling & 287. 383 & Weiņbaud & 404. 430 \\
\hline erindit & 72. 185 & Sybar & 130. 231 & nfireuz\{d)nabel & 208. 292 \\
\hline tg & 97. 205 & Táglerdie & 598.568 & igelfreuzjantabel & 09. 292 \\
\hline lwebex & 492. 507 & $\underset{\mathfrak{T} a b \mathfrak{a}}{ }$ & 502. 511 & $\mathfrak{W}$ el & 25ั7. 359 \\
\hline mfarb & 371. 423 & Talbalt & 478. 495 & jperfing & 527. 529 \\
\hline enftreifentammer & 587. 551 & Talefa & 139. 233 & Weiß̧̄Gauben = Ratadut & 80. 190 \\
\hline erfajänctient & 407. 439 & Tamala & 166. 263 & Weiñfegle & 226. 329 \\
\hline Ifronfint & 525.529 & Tama & 65. 174 & Ifinf & 524. 528 \\
\hline fdituabel & 406. 438 & Tannenfint & 256. 349 & erche & 625. 574 \\
\hline noit & 72. 185 & Tantenpapaget & 205. 291 & $\mathfrak{W C}$ & 128. 224 \\
\hline gammerfint & 532. 530 & Tamnenbogel & 206. 291 & ngenfittich & 142. 238 \\
\hline gbas & 409. 439 & $\underset{\text { Tagiranga }}{\text { Tana }}$ & 357. 420 & tirn = intazone & 46. \\
\hline Iimpel & 228. 330 & Tarago & 98. 208 & $23 e$ & 175. \\
\hline erche & 610.570 & Tarr & 162. 262 & taftrild & 438. 468 \\
\hline jperfing & 532. 530 & Taubenfials = $\mathfrak{A m} a z$ one & 50. 167 & Wel & 148. 242 \\
\hline & 201. 280 & benfittidy & 137. 232 & man's Edelpapaget & 11. 152 \\
\hline Gfinf & 423. 458 & Teliabaya & 479. 495 & & 434. 462 \\
\hline agofittich & 125. 223 & Tentii & 423. 458 & mener & 563. \\
\hline ten $=\mathfrak{A r a r a}$ & 101. 211 & Tilfo $=$ Ticto & 528. 529 & & 566. \\
\hline & 566.546 & Tiga & 130. 231 & $\mathfrak{W}$ & 184. 273 \\
\hline nexfinf & 541. 532 & Tigerfint & 452. 471 & mmer & 563.545 \\
\hline errotongel & 352. 419 & Tijepirange & 357. 420 & mmerfinf & 552.534 \\
\hline tenfinf & 458. 472 & & 2. 145 & $\mathfrak{W i}$ & 256. 349 \\
\hline $\begin{array}{c}1 \\
-x\end{array}$ & 284. 383 & iflont & 255. 349 & ractie & 594. 567 \\
\hline na & 284. 383 & & 126. 223 & Winterling & 563. \\
\hline senammer & 547. 533 & Tirifa & 140. 238 & - & 590. \\
\hline & 284. 383 & Tiriton & 82. 190 & Won & 177. \\
\hline ling, einkeimifdjer & 435. 462 & Tijajih & 24. 157 & & 503. 511 \\
\hline gsanmerfinf & 546.533 & Tejelixbit & 76. 185 & jeref & 459. 481 \\
\hline & 435. 462 & Topela & 410. 439 & Rafadut & 93. \\
\hline apagei & 69. 175 & $\mathfrak{Z}_{0}$ & 129. 230 & $\mathfrak{W i}$ & 330. \\
\hline & 604. 569 & Totta & 277. 376 & nmer & 587. \\
\hline & 506. 518 & uertangara & 345. 418 & & 218. \\
\hline & 606. 518 & $\mathfrak{I} \mathrm{ro}_{0}$ & 505.518 & $2 \mathfrak{i}$ & 218. \\
\hline ţbaud)munie & 405. 438 & Tro & 505. 518 & fferlerctie & 617. 572 \\
\hline Spitzichnanzfinf & 431. 461 & Trauerzeifig & 269. 370 & $23 i$ & 606.559 \\
\hline & 549. 533 & - & 273. 371 & $26 \mathrm{i}$ & 282. \\
\hline 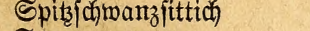 & 110. 220 & Irillerle & 600.568 & trompeter & 218. \\
\hline & 591.552 & $\mathfrak{T} \mathfrak{r}$ & 556.535 & & 256. \\
\hline & 591. 552 & Tropfer & 380. 424 & $3 a$ & 568. \\
\hline & 253. 348 & igammerfin & 534.530 & tgilfberitz & 568. \\
\hline & 302. 397 & $\underset{\text { Tnun }}{\text { Thun }}$ & 262. 365 & rafint & 437. 462 \\
\hline gittich) & 182. 267 & Truppreber & 484. 496 & 3eiftg & 264. 369 \\
\hline ttfinf & 253. 348 & Tut & 146. 239 & 3̌eifiggrïnling & 280. 380 \\
\hline & 262. 365 & Túa & 131. 231 & ig, Stanleys & 266. 369 \\
\hline & 514. 524 & Tut Maitaca & 22. 157 & & 264. 369 \\
\hline ngara & 348. 419 & & 145. 239 & & 256. \\
\hline & 250. 344 & Tulta = Munta & 409. 439 & inter & 576. 549 \\
\hline mmerling & 571. 547 & Türfifin & 152. 256 & & 445. 470 \\
\hline teinfunt & 281. 382 & Tilrfistangara & 376. 423 & & 259.36 \\
\hline & 297. 391 & Unvergleidalidue & 299. 394 & 3ierorganift & 391. 430 \\
\hline thănffing & 258. 359 & Unzertrennlide. & 66. 175 & 3ierfittid & 71. 185 \\
\hline & 603. 569 & hen = \$apagei & 30. 159 & angara & 367. 422 \\
\hline & 281. 382 & & 462. 481 & 3 ie & 264. \\
\hline ppenta & 543. 532 & Wachtelammerfinf & 545. 532 & 3̈immetreiรn & 398. \\
\hline
\end{tabular}


3inntobertantgara

3ipanmer

3irpammer

Bitjcherfing
Rr. Seite

353. 420

568. 547 3meifarbenfd)wärzling

259. 362 3mergammex
Nir. Seite

613. 571 3wergammerfinf

559. 544 3mergelfterling

495. 510 3mergfreuzidinabel

581. 550 3mergiperling
Nr. Seite

539. 531

332. 414

210. 292

289. 384

\section{Bexidtigung.}

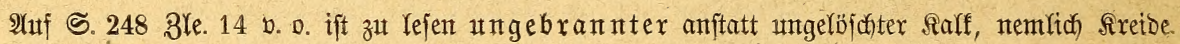




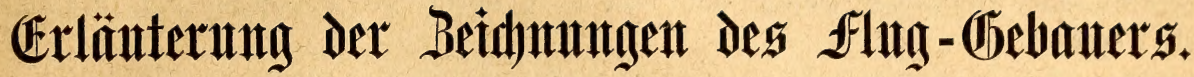

Die Eintichtung unb Ronftuttion bes Fluggebauters ijt in brei B̧latt Beidhnungen, im

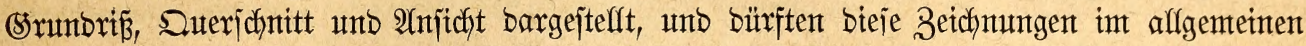

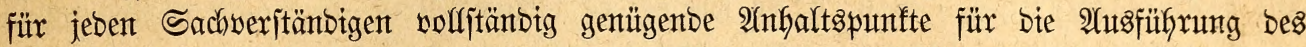

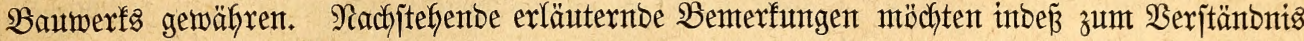
ber Beidyuntgen bettragen.

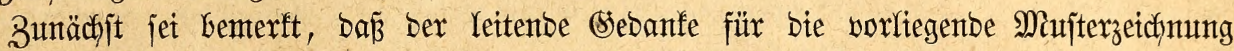
Die Seritellung eines gröperen Fłthgebauters für einen zoologijchen Siarten gemejen ijt, ein

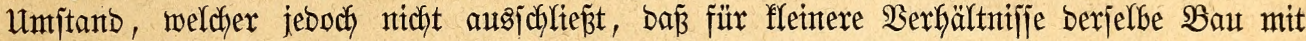

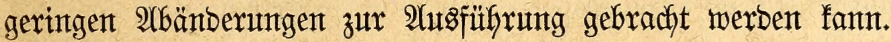

Durch bie gewählte (Sruntoform ijt Gejonbers ber an jeben 2(ufentfaltzont für gefangente

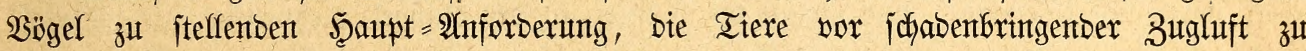

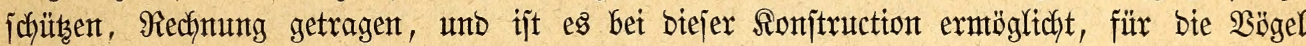
bei jeber mur herjchenden Wintoridytung einen jicheren, jchutgemäfrenten 3uffudftsort zu jchaffen, an weldhem jie ben gefahrbringenden Einflüfjen ber Bugluft jich entzieben fönnen. -

Dex Srunbriz auf B̧latt I zeigt als Srumbform bes Fhthgebauters ein reguläres

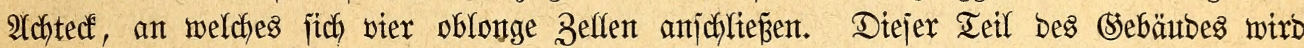
mafito in 3iegelrohbau aufgeführt, Durchweg unterfellert und auf eine ca. $1^{\mathrm{m}}$. hobe slinte gejtellt. - Die 2lbteilungent a, a, a, fieben an ber Zahl, bienten als Winterfäfige, -

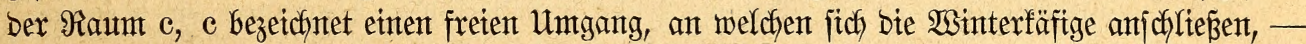

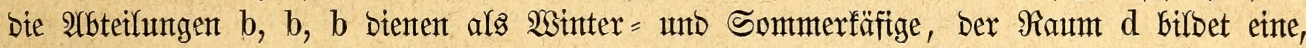

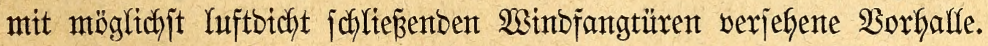

Um bie Räume a, a, a als Winter= unb Sommerfäfige benuben zu fönnen, erhalten

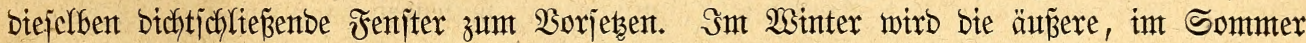
bie nach Dem Intmeren bes Fluggebauters liegento Fenjteröffnung gejchloffen.

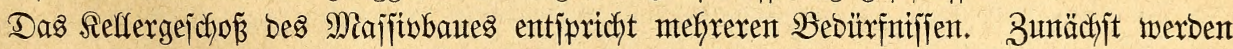

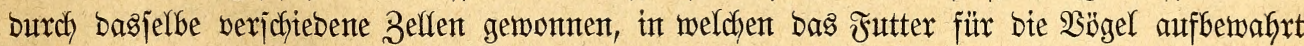
und zubereitet werben fann, - Gauptjächlich jedoch bient bagjelbe für bie Winterzeit als Sceizfammer. - Sn Der Mitte Des Raumes befinbet fich nemlich ein mit einem Mantel

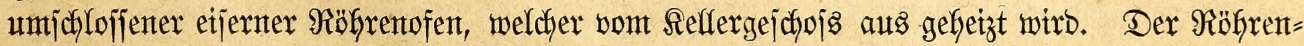
ofen geft, wie aus bem Durchjednitt auf Blatt II erjichtlith, burch ben ganzen interen Raum bes Fluggebauters unb tritt in Sheitelpunft ber Simppel als Schornitein aus ber= jelben heraus.

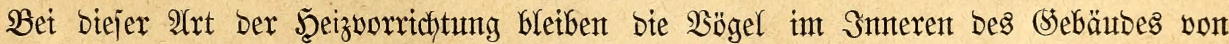

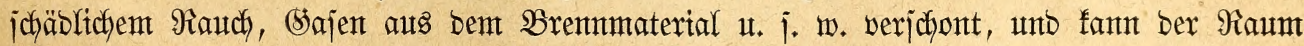
bes Bebauters jelbjt itets rein und jauber gefjaltent werbent.

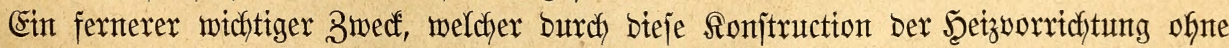

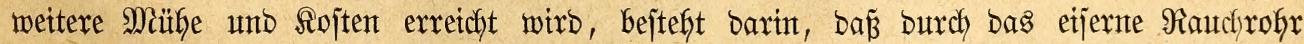
Des Sctornjteins füx bie Winterzett Das Irinf = unt Spülwajfer vorgemärmt wiro.

Sn Der Şöhe Des Şauptgefimies bes Mittelbautes befinbet jich nemlich auf jumiebe=

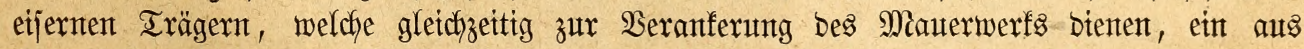

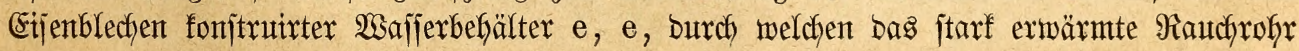


Ginburch geht. Durch eine int Rellergejchojs befindliche Druffpumpe wiro ber Befälter

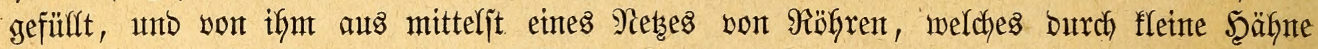

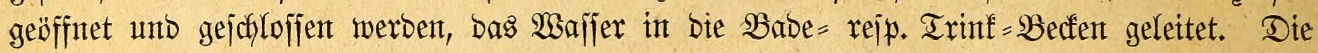

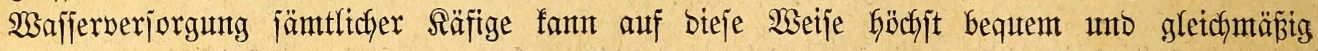
bemirft werdent.

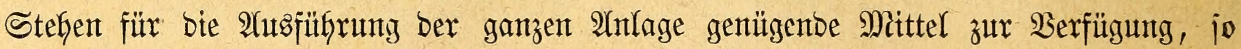
ijt es jelbjtredent, anzuraten, bie Ermärmung ber Winterfäfige mitteljt einer Scei $\tilde{\beta}=$ ober Warm=Wajferketzung zu bewirfen, und auch in biejent Faffe gewährt bas Selfergejchojs einen

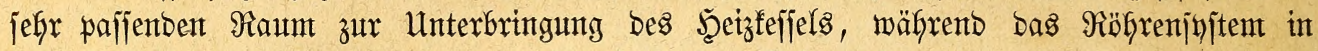
Dent Fuß̄boben bes Umganges c, e, jo wie in ben Seitentwänben angebracht merbent fant.

Die jieben Winterfäfige a, a, werben einfach burch zierliche guzetjerne ङäulen, zmijchen

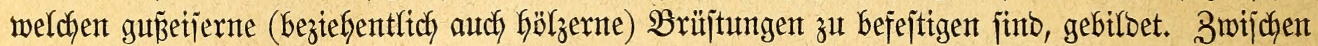
biejen Brüjtungen und einem über ben Säulen als 9 (rchjtrav angebrachten, Durchbrodjenten eijernen Sejimje merben Alavirjaiten eingezogen. Die Dedfe eintes jeben Ssebauers wirb Durch Dratgeflechte Gergejteflt.

Der mit einer leidjt lomitruirten eijernen Suppel überbecfte Mittelbau mirb teilweije

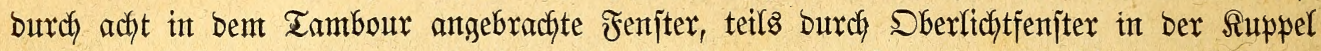
jelbjt vorzüglich beleucfet, unt bienen bie Fenjter in ber §uppel gletchzeitig zur süftung,

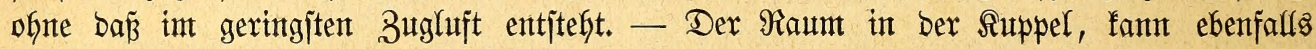
bequent für bie Winterzeit zux 24ufitellung von Säfigen benutzt merben. -

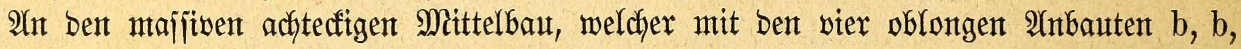

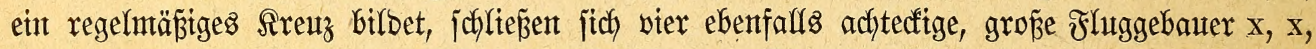
an, weldye jich als Sommerfäfige dharafterijiren. Der Unterbau für bieje Sommerfäfige ijt ebenfallz majfito; einte Unterfellering finbet Gier jeboch nicht jtatt, um in benjelben Baum = und Straudfwerf pflanzen, rejp. unterbringen zu fönnen.

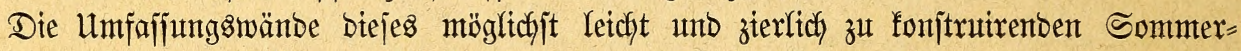
gebauters bejteben aus eijernen Säulen, mit einer auf ber ß̧inte liegenben, burchbrochenent eijernen Brüjtung; auf unt mit ben Säulen wiro ein eijernes Surtgejims verjathaubt,

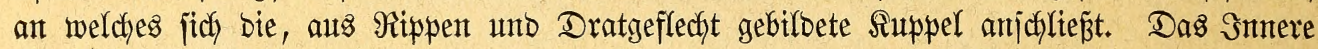
Diejes Sommer = \$sebauers f, f, wirb mit Baumjtämmen, pajfentent Pflanzen u. \%. w. ebenjo

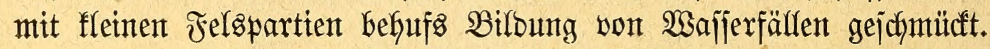

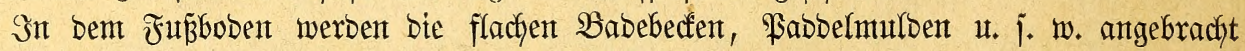
unt zwar Durch Mauterwerf Gergejteflyt. Die in ber Dberanjidft fidftbaren Breter $g$, g,

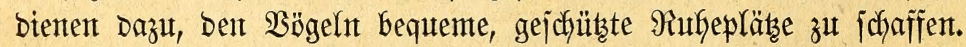

Um aud in biejen Sommertäfigen für alfe Fälle uno bei jeber Wainbrithtung bent

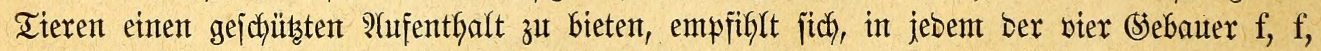

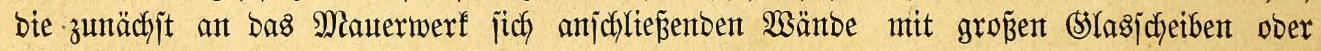
Fenjtern zu juließ̃en. -

2Urfes übrige Dürfte burch Die Zeidfnungen Ginreichento erläutert werben. - 


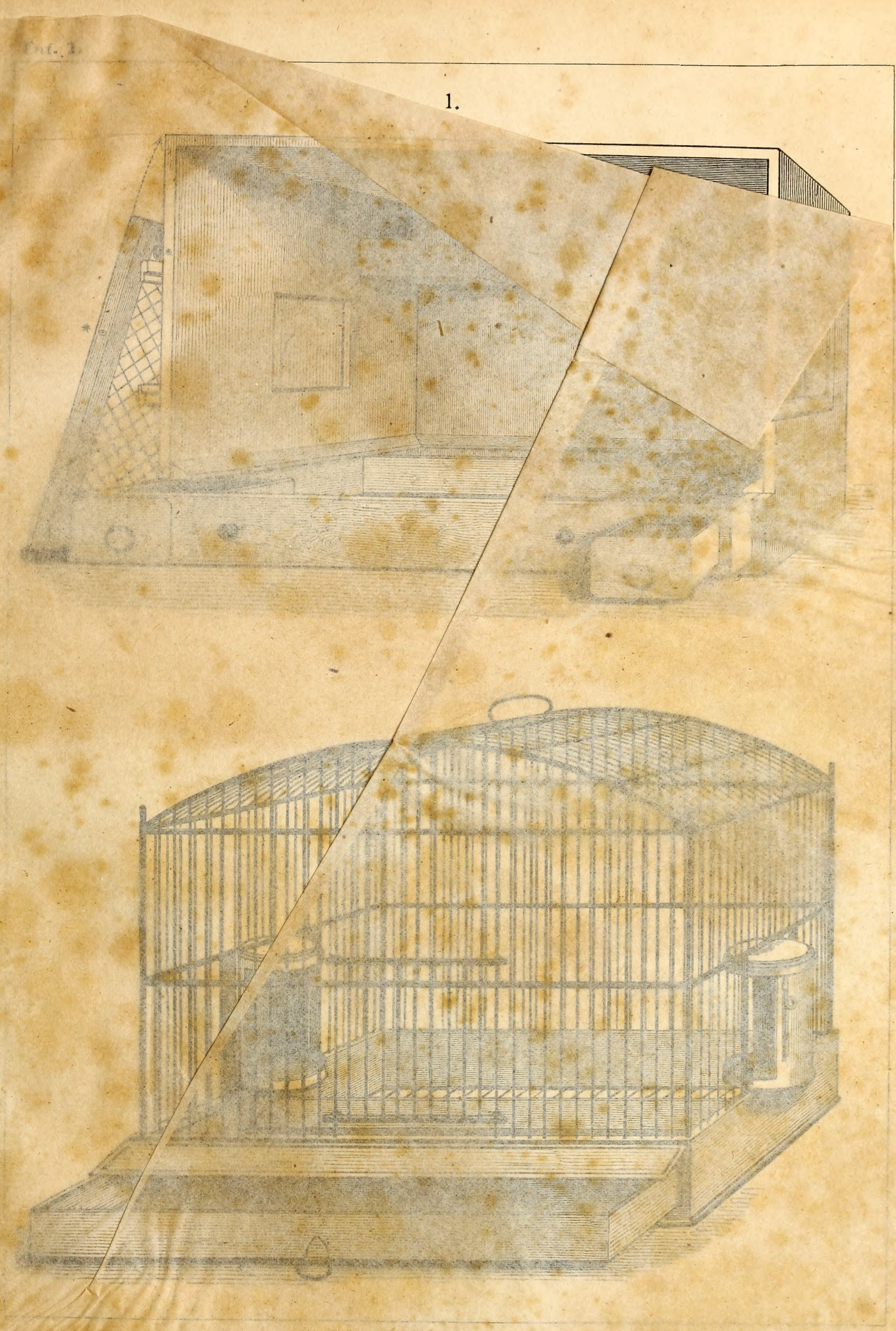

1. Kistenbauer. 2. Zrohwin sutier rimkenbauer. 
Errläuteruntg Der 3eid)nungen Des frug= đ̌ebauters.

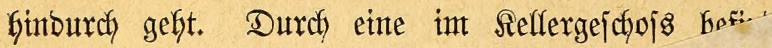
gefülllt, unb von ifmt aus mittelít einpa geöffnet unto gejchlofjen werben Wafferverjoraum beminte

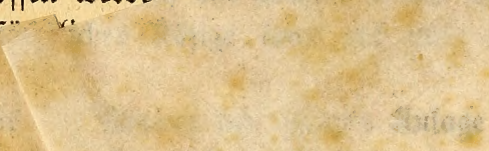

genügentoe Solket zur Bexfigung, is umpe wirb ber Bebaltet retches ourch fieme şuflute

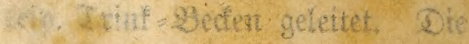

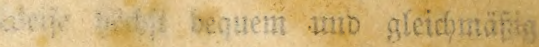

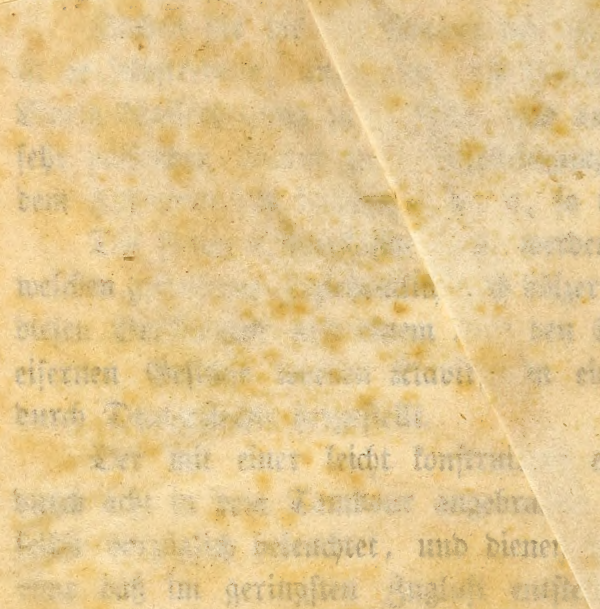

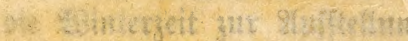

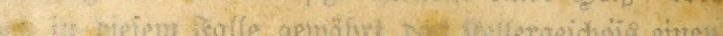

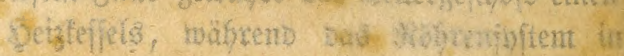
betr Geitermänoen angebridit roerden fam fant burch zierfiche gubeijerne Eirulen, zmtichen.

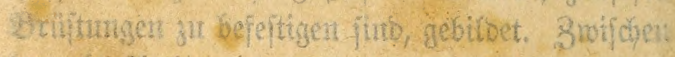

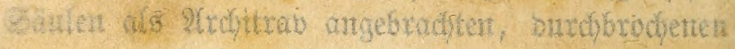

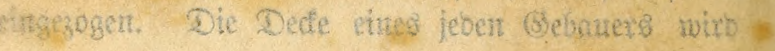

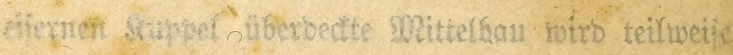

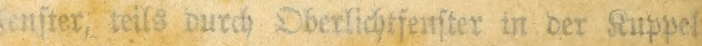

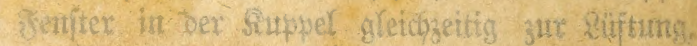
- Dex gium in Det Suptsel, lantr ebenfarfo we fäfigen benut wetbert. -

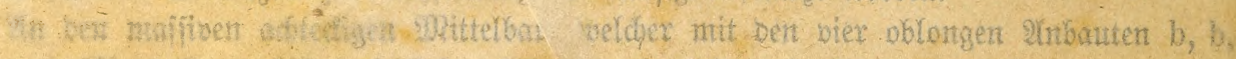

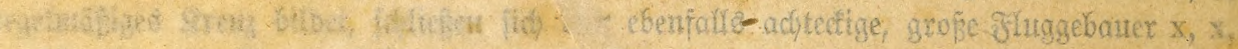

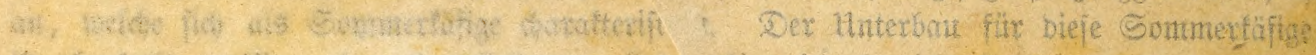

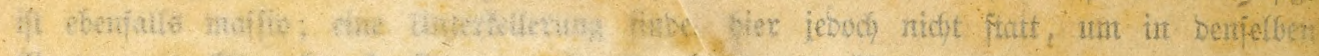

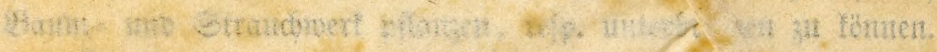

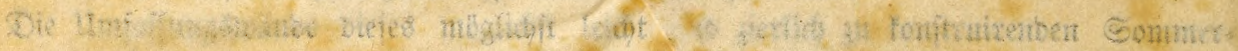

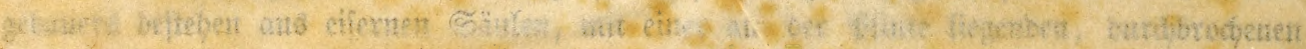

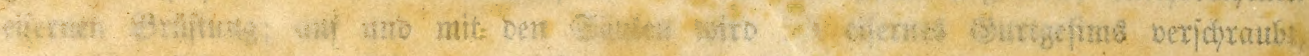

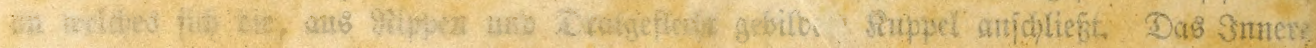

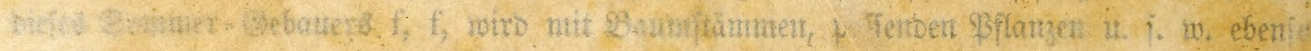

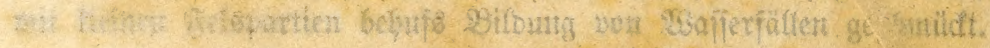

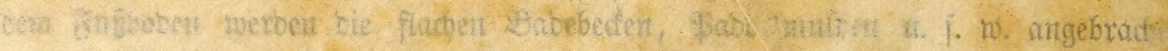

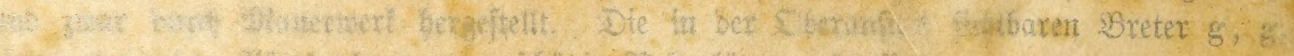

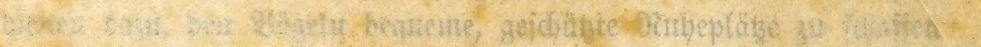

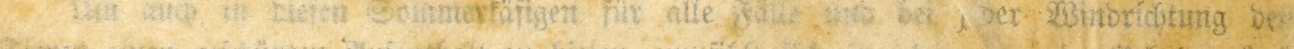

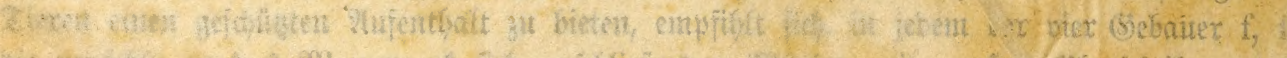
*.

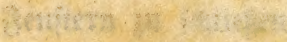

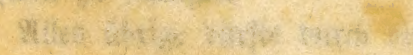


Taf. 1.

1.

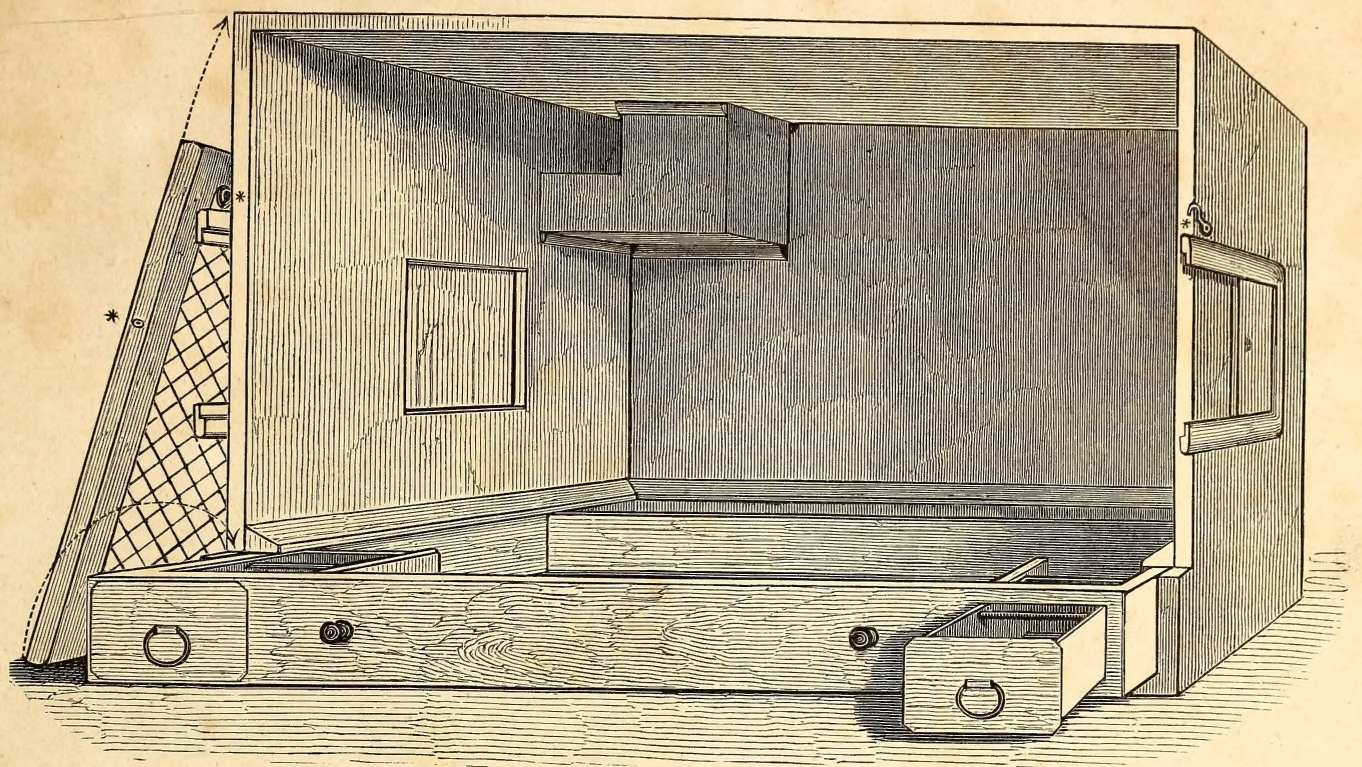

2.

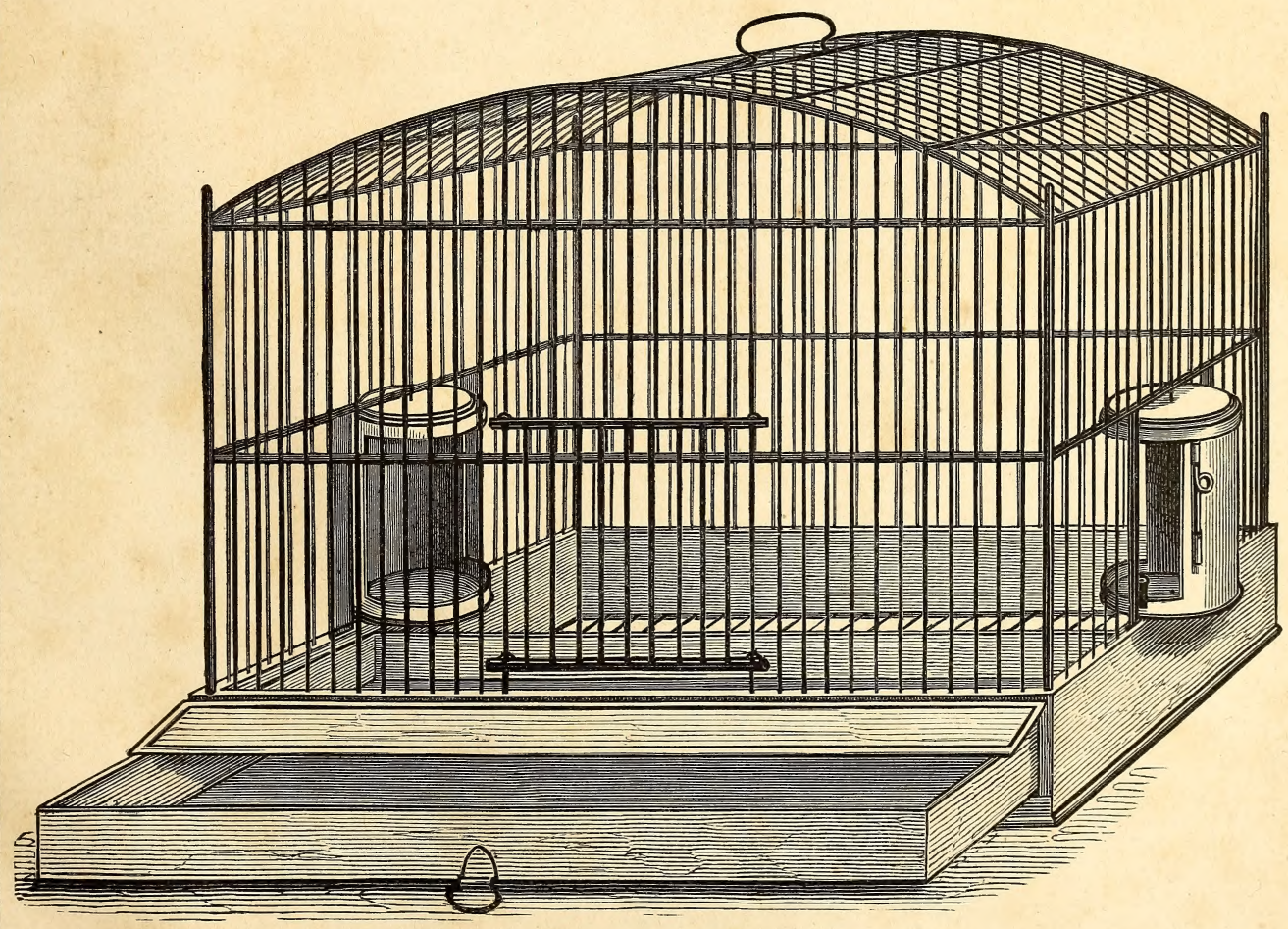

1. Kistenbauter. 2. Brehm'scher Finkenbauter. 
$\therefore$

.

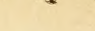

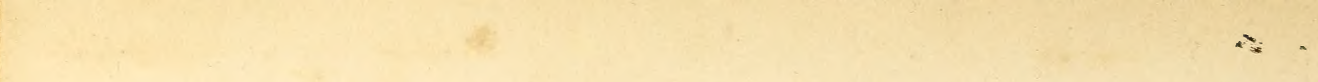

$$
\text { . }
$$




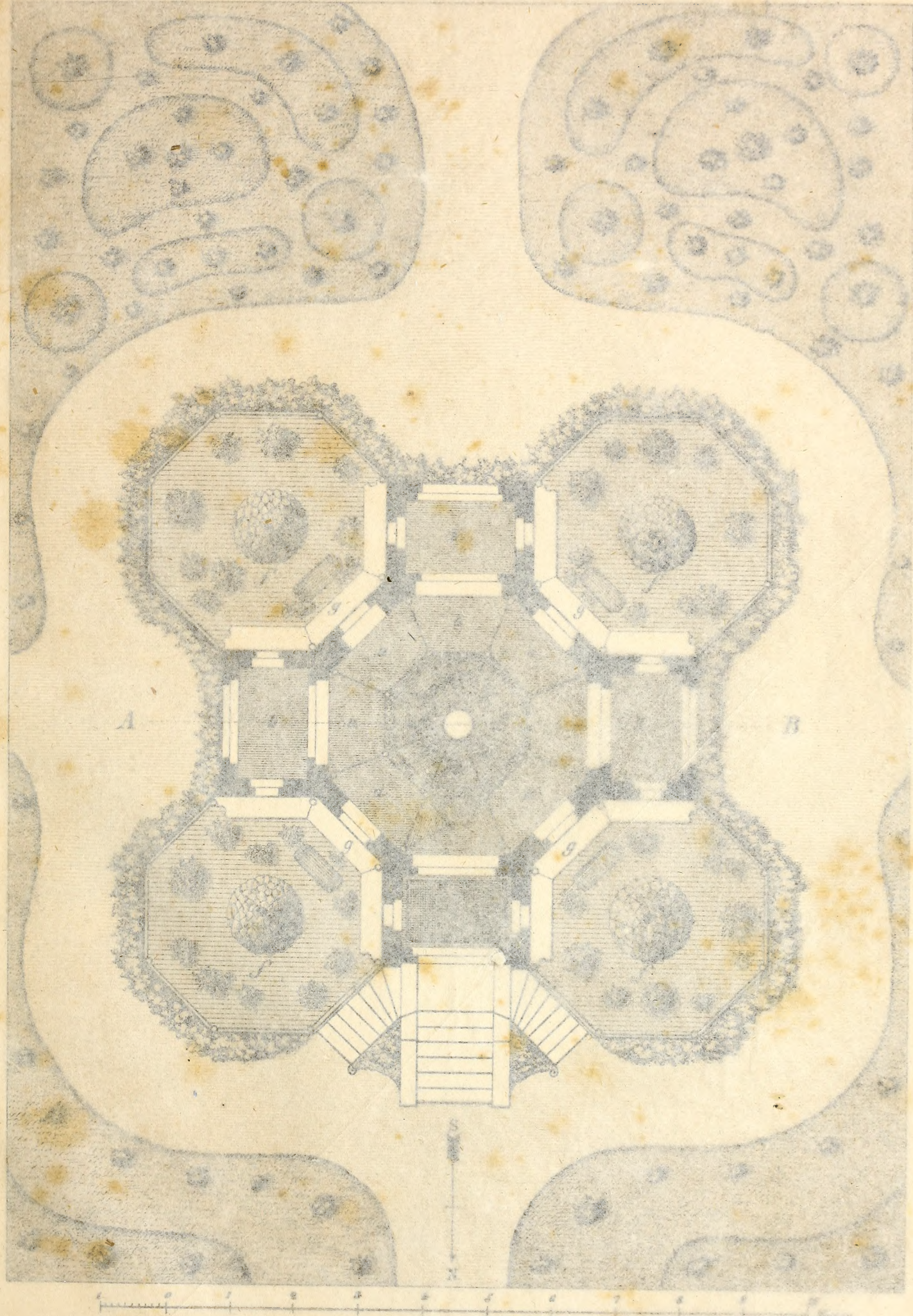

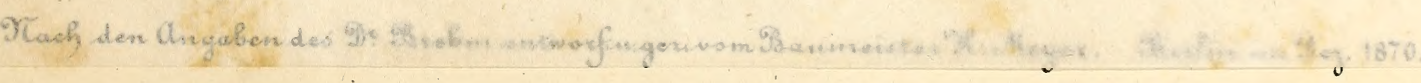

\section{Grundriss des Fluggegebauers.}


$\therefore$

$x^{4}+$

\section{,}
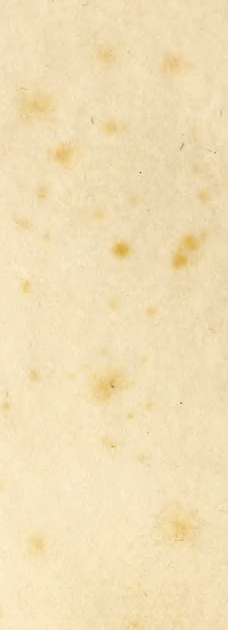

.

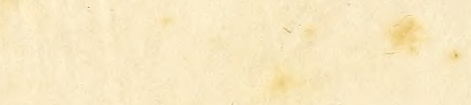




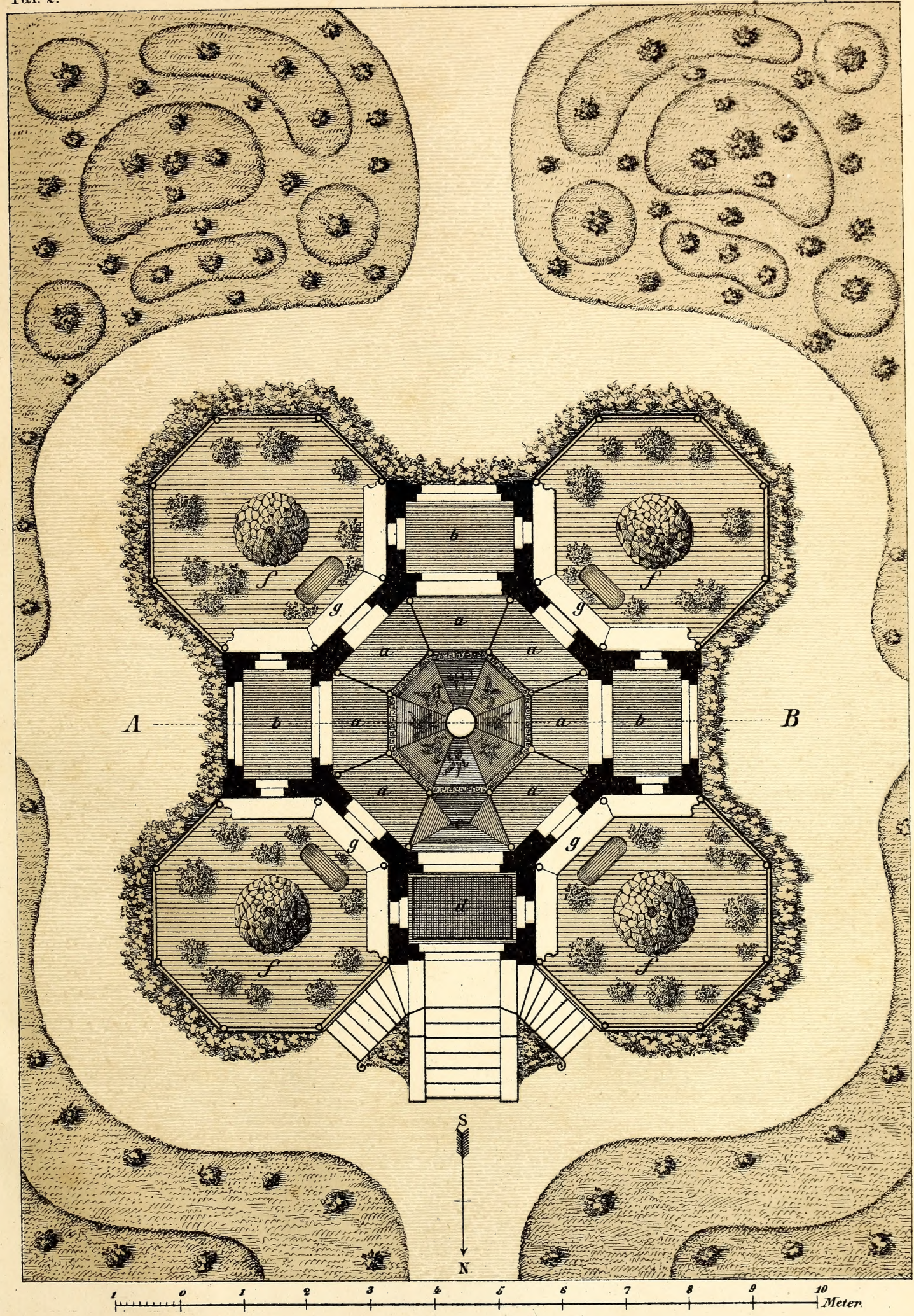

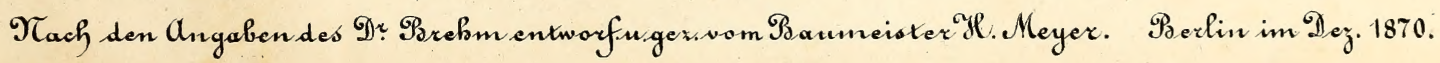


$\therefore$ 


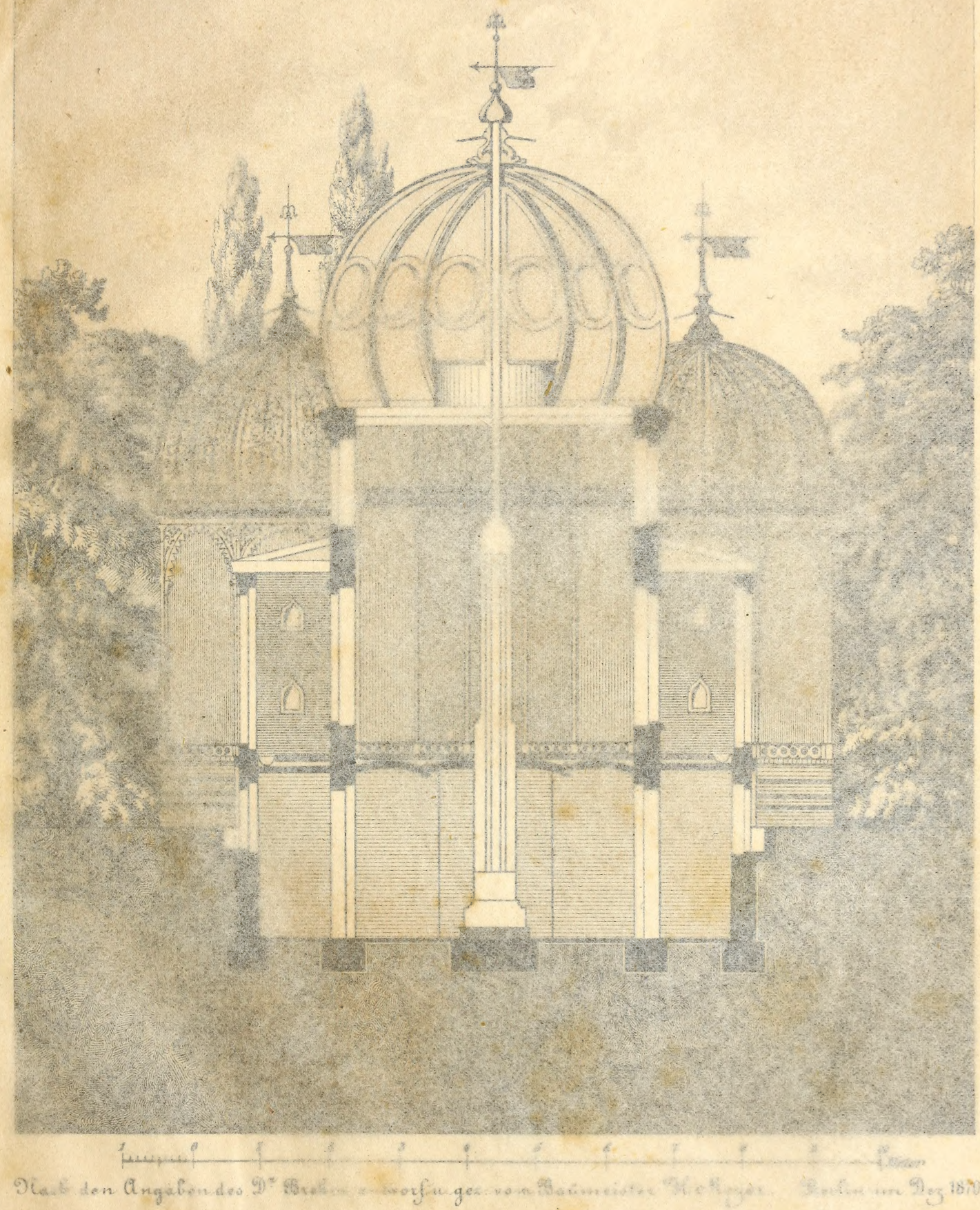

Profil des Flugigebauters nach A B. 


$$
\therefore
$$




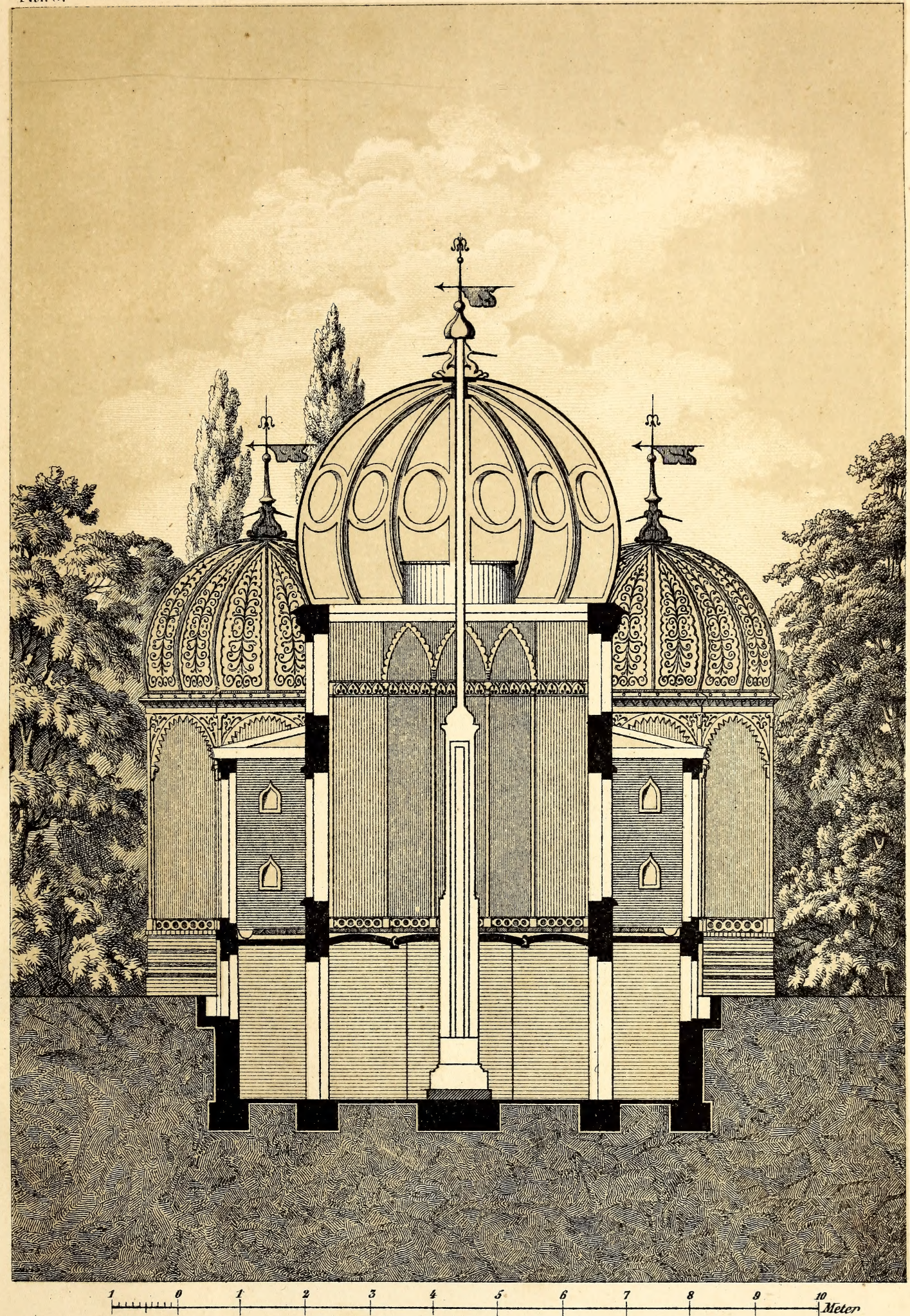

Tack den Angabendes D" Brebmentworfungez vom Baumeioter He Meyer. Berlinim Dez $18 \%$.

Profil des Fluogẹebauers nach A B. 
$\therefore$ 
291
296
344

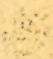


$\therefore$ 
$s^{2}$

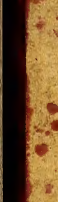

$\rightarrow$ 
